

\section{REVISTA DE DIREITO INTERNACIONAL}

\section{BRAZILIAN JOURNAL OF INTERNATIONAL LAW}

\section{Editores responsáveis por essa edição:}

Professor Marcelo Dias Varella

Professor Nitish Monebhurrun

Profesora Alice Rocha da Silva 
REVISTA DE DIREITO INTERNACIONAL

BRASILIAN JOURNAL OF INTERNATIONAL LAW

Programa de Mestrado e Doutorado em Direito

Centro Universitário de Brasília

Reitor

Getúlio Américo Moreira Lopes

Presidente do Conselho Editorial do UniCEUB

Elizabeth Regina Lopes Manzur

Diretor do ICPD

João Herculino de Souza Lopes Filho

Coordenador do Programa de Mestrado e Doutorado e Editor

Marcelo Dias Varella

\section{Linha editorial}

A Revista de Direito Internacional (RDI) foi criada como instrumento de vinculação de trabalhos acadêmicos relacionados a temáticas tratadas pelo Direito Internacional Público e Privado. A revista é sucessora da Revista Prismas, que foi dividida em dois periódicos (junto com Revista Brasileira de Políticas Públicas), em virtude da quantidade de submissão de artigos e procura. Na busca pelo desenvolvimento e construção de visões críticas a respeito do Direito Internacional, a RDI possui sua linha editorial dividida em dois eixos:

1. Proteção internacional da pessoa humana: abrange questões referentes ao direito internacional ambiental, direito humanitário, internacionalização do direito, além de pesquisas sobre a evolução do direito dos tratados como forma de expansão do direito internacional contemporâneo.

2. Direito Internacional Econômico: abrange questões referentes aos sistemas regionais de integração, direito internacional econômico e financeiro e solução de controvérsias comerciais e financeiras. A RDI busca incentivar a pesquisa e divulgação de trabalhos relacionados as disciplinas voltadas para o estudo do Direito Internacional publicando artigos, resenhas e ensaios inéditos. A revista está aberta às mais diversas abordagens teóricas e metodológicas impulsionando a divulgação, o estudo e a prática do Direito Internacional.

\section{Comitê editorial}

Alice Rocha da Silva, Centro Universitário de Brasília

Cláudia Lima Marques, Universidade Federal do Rio Grande do Sul

José Augusto Fontoura Costa, Universidade de São Paulo

Julia Motte Baumvol, Université d'Evry Val d'Essonne

Nádia de Araújo, Pontíficia Universidade Católica do Rio de Janeiro

Nitish Monebhurrun, Centro Universitário de Brasília

\section{Layout capa}

Departamento de Comunicação / ACC UniCEUB

Diagramação

S2 Books

Disponível em:

www.rdi.uniceub.br

\section{Circulação}

Acesso aberto e gratuito

Matérias assinadas são de exclusiva responsabilidade dos autores.

Citação parcial permitida com referência à fonte. 
Revista de Direito Internacional / Centro Universitário de Brasília, Programa de Mestrado e Doutorado em Direito, volume 12, número 1 - . Brasília : UniCEUB, 2011-

Semestral.

ISSN 2237-1036

Disponível também on-line: http://www.rdi.uniceub.br/

Continuação de: Revista Prismas: Direito, Políticas Públicas e Mundialização. Programa de Mestrado em Direito do UniCEUB.

1. Direito Internacional. 2. Políticas Públicas. 3. Mundialização. I. Programa de Mestrado em Direito do UniCEUB. II. Centro Universitário de Brasília.

CDU 34(05)

Ficha catalográfica elaborada pela Biblioteca Reitor João Herculino

\section{Endereço para Permuta}

\section{Biblioteca Reitor João Herculino}

SEPN 707/907 Campus do UniCEUB

Cep 70790-075 Brasília-DF

Fone: 61 3966-1349

e-mail: biblioteca@uniceub.br 
Crônicas da ATUalidade do Direito Internacional ................................................. 2

Sarah Dayanna Lacerda Martins Lima, Carina Costa de Oliveira e Erika Braga

Crônica 1: O CASO No 12.655 DA CIDH - A primeira submissão de caso de esterilização forçada à Corte Interamericana de Direitos Humanos frente à dimensão global deste crime ...........................2

Crônica 2: Os direitos e os deveres decorrentes do recente contrato assinado entre o Brasil e a Autori-

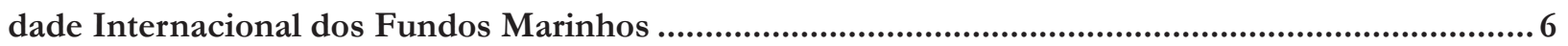

Crônica 3: II Fórum Jurídico dos BRICS: desafios e oportunidades.................................................. 8

Crônicas do Direito Internacional dos Investimentos ............................................12

Nitish Monebhurrun

... E eles descobriram a arbitragem investidor-Estado. .................................................................12

Por que voltar a Kelsen, o jurista do século XX ? ..................................................16 Inocêncio Mártires Coelho

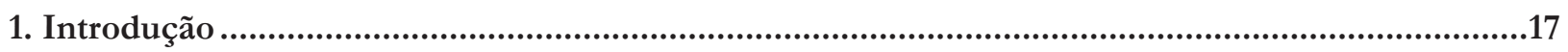

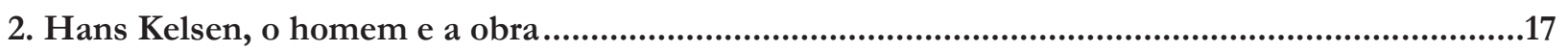

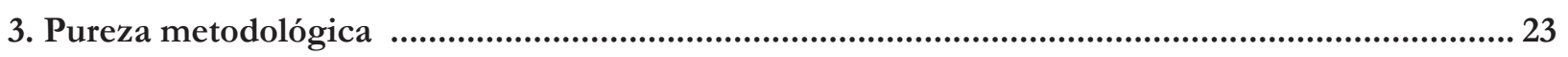

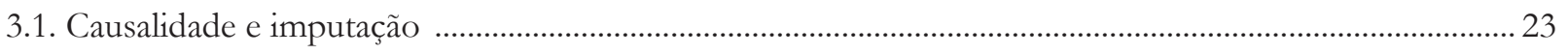

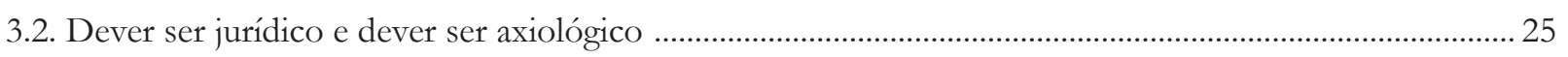

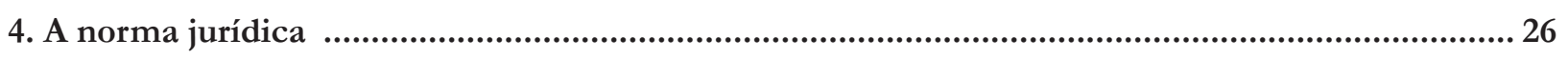

5. Posição perante os dualismos da doutrina tradicional .................................................................. 27

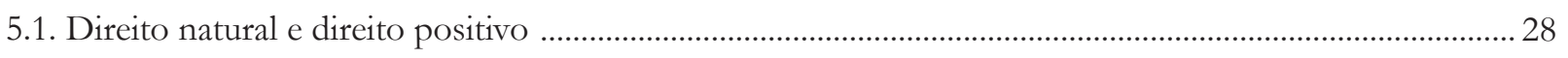

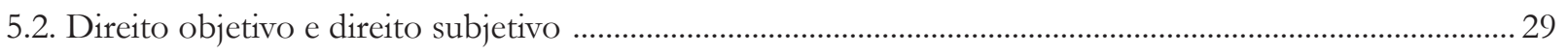

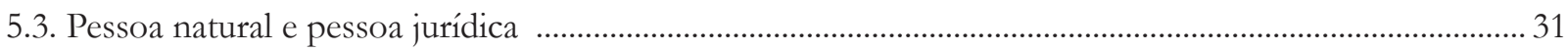

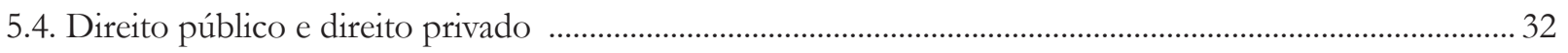

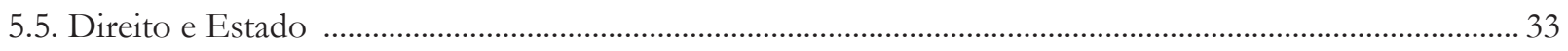

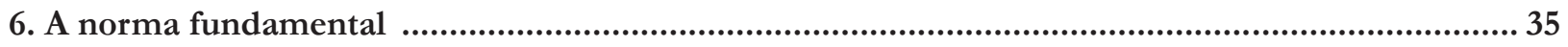

7. A Teoria Pura e o problema da interpretação do direito ................................................................. 37

8. Considerações finais …............................................................................................................ 40

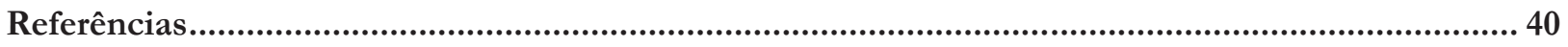




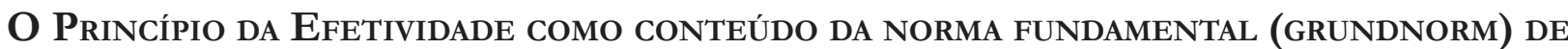

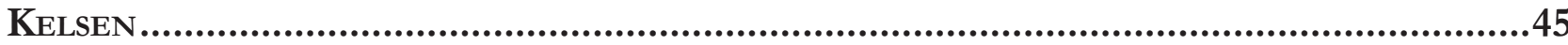

Carlos Alberto Simões de Tomaz e Renata Mantovani de Lima

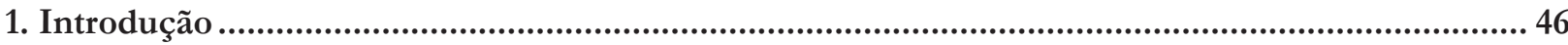

2. Revisitando o projeto de experiência jurídica do positivismo jurídico de Kelsen ......................... 46

3. A norma fundamental como norma (pressu)posta .............................................................50

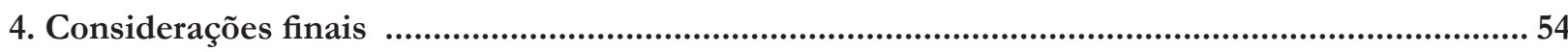

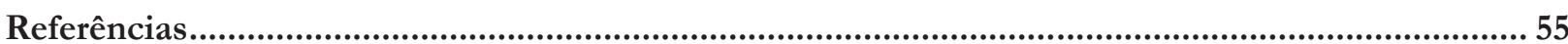

A JURIDIFICAÇÃo DE CONFLITOS POLÍTICOS NO DIREITO INTERNACIONAL PÚBLICO CONTEMPORÂNEO: uma leitura política da paZ pelo direito de Hans Kelsen a Partir do pensamento políTICO DE CLAUDE LEFORT ...........................................................................................57

Arthur Roberto Capella Giannattasio

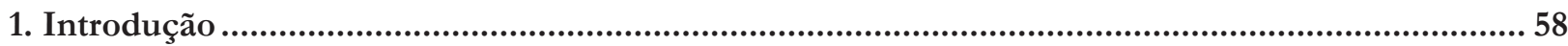

2. Narrativas políticas europeias do pós-segunda guerra mundial e a disputa conceitual pela paz in-

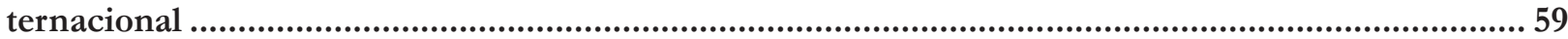

3. Claude Lefort e o vazio normativo do direito político................................................................61

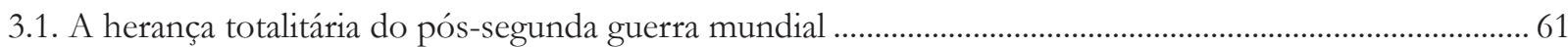

3.2. O esvaziamento normativo como técnica jurídica da política......................................................................... 62

4. A juridificação da paz internacional em Hans Kelsen ............................................................ 64

4.1. A razão prática da razão pura kelseniana: direito como técnica social politicamente independente ........ 64

4.2. O esvaziamento da política pela juridificação internacional da paz ............................................................. 66

5. O sentido político do vazio na técnica jurisdicional internacional kelseniana ............................... 68

5.1. O direito e a organização jurídica da vida pública internacional..................................................................... 68

5.2. O direito internacional público contra o direito estatal mundial ..................................................................... 69

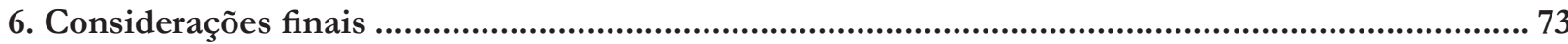

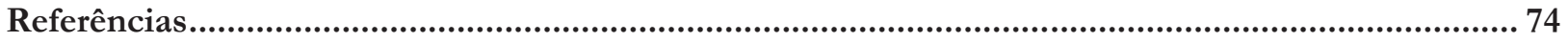

O SINCRETISMO TEÓRICO NA APROPRIAÇÃO DAS TEORIAS MONISTA E DUALISTA E SUA QUESTIONÁVEL UTILIDADE COMO CRITÉRIO PARA A CLASSIFICAÇÃO DO MODELO BRASILEIRO DE INCORPORAÇÃO DE NORMAS INTERNACIONAIS.................................................................78

Breno Baía Magalhães

1. Introdução 79

2. O monismo e o dualismo reconstruído pelos autores nacionais: confusão entre argumentos teóricos e descritivos.

3. O monismo de Kelsen, o dualismo de Triepel e os modelos de incorporação de normas internacionais.

4. A dicotomia monismo/dualismo em sua abordagem descritiva: modelos constitucionais de incorporação de tratados internacionais 
5. O modelo constitucional brasileiro de incorporação de normas internacionais: afinal, somos monistas ou dualistas?

5.1. Inexigibilidade de transformação do tratado em lei nacional, sendo requerido Decreto Executivo para sua

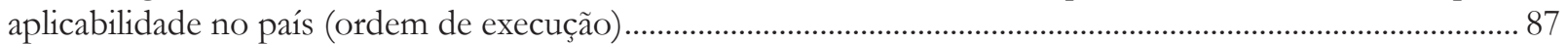

5.2. Os tratados internacionais estão sujeitos ao controle de constitucionalidade .............................................. 89

5.3. Os conflitos entre lei interna e tratados internacionais são solucionados pela prevalência da norma mais recente ou pelo critério da especificidade (com exceção dos tratados internacionais de direitos humanos) . 90

6. Analisando os diferentes tons de monismo brasileiro .................................................................... 92

7. Considerações finais .................................................................................................................... 93

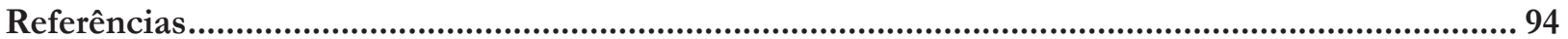

Direito Global em Pedaços: Fragmentação, Regimes e Pluralismo.............................98

Salem Hikmat Nasser

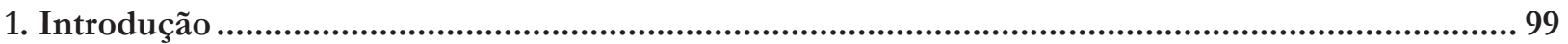

2. Diferenciação funcional - noção de regimes internacionais ...........................................................100

2.1. Regimes na teoria das relações internacionais ....................................................................................... 101

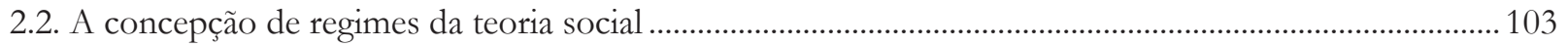

2.3. A fragmentação no direito internacional público......................................................................................... 105

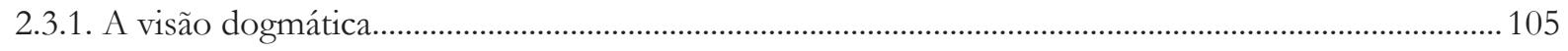

2.3.2. Discursos ou narrativas sobre a fragmentação do direito internacional ............................................. 107

2.4. Coerência e comunicação entre as perspectivas ...................................................................................... 107

3. Governança - Direito e Não-direito - Lugar e Realidade do Direito Internacional .....................108

3.1. Direito e não-direito - pertencimento a um sistema jurídico........................................................................ 110

4. Direito Internacional Público e Fragmentação.............................................................................113

4.1. As determinantes da dupla fragmentação do direito internacional ............................................................. 113

4.2. Dificuldades para a identificação dos regimes jurídicos em direito internacional....................................... 115

4.2.1. O Tema e as representações dos regimes autocontidos ........................................................................ 115

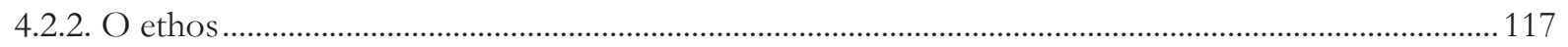

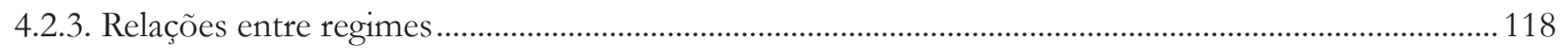

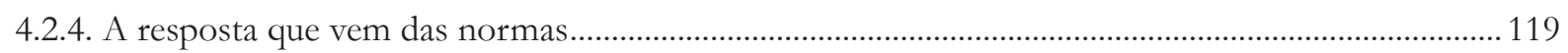

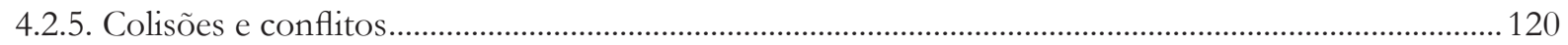

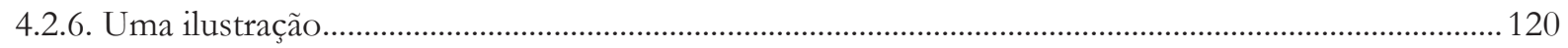

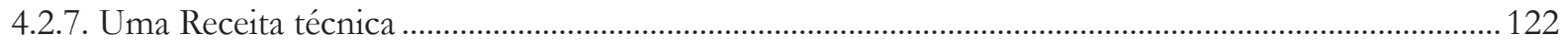

5. Constelação Regulatória Global? ..................................................................................................123

5.1. Dois Pluralismos Jurídicos ou Regulatórios ................................................................................................ 125

5.2. Regulação no espaço internacional ou global .......................................................................................... 126

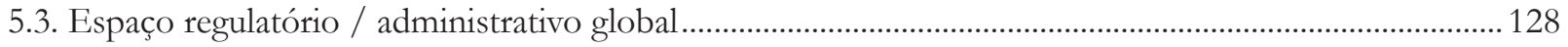

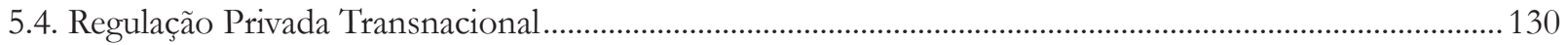


5.5. Mais uma vez, a questão dos limites..... 131

6. Fragmentação, Pluralismo e Rule of Law ................................................................ 131

6.1. Fragmentação do direito internacional público e Rule of Law............................................................ 131

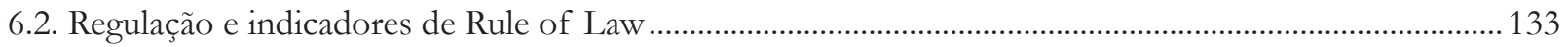

Referências.........................................................................................................................133

Por UMA TEORIA JURÍdiCA DA INTEGRAÇÃo REGIONAL: A INTER-RELAÇÃO DIREITO INTERNO, DIREITO INTERNACIONAL PÚBLICO E DIREITO DA INTEGRAÇÃO ........................................................139 Jamile Bergamaschine Mata Diz e Augusto Jaeger Júnior

1. Introdução. 140

2. A questão do método como fundamento da teoria: há, efetivamente, a necessidade de criar sistemas metodológicos próprios?. 141

3. As fontes do direito da integração regional: uma autonomia ainda a ser determinada 146

3.1. As fontes do direito da integração a partir de uma raiz internacionalista 147

3.2. A inter-relação direito internacional, direito da integração, direito comunitário e direito interno 149

4. A matriz principiológica do direito da integração regional . 151

5. O objeto do direito da integração e a especificidade das relações interestatais 153

5.1. A integração e o elemento território: as fronteiras de um espaço integrado 154

5.2. A formação de um substrato social baseado numa cidadania comum 154

5.3. A irradiação dos efeitos da integração sobre o poder soberano dos Estados 155

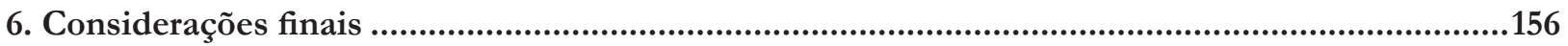

Agradecimento...................................................................................................156

Referências...............................................................................................................157

A TEORIA dA INTERCONSTITUCIONALIDADE: UMA ANÁLISE COM BASE NA AMÉRICA LATINA........... 160 Daniela Menengoti Ribeiro e Malu Romancini

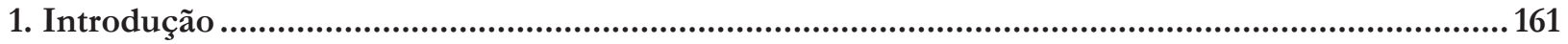

2. Tendências do constitucionalismo global .................................................................. 161

3. A teoria da interconstitucionalidade ................................................................................164

4. O fenômeno do interconstitucionalismo e suas razões de existir na América Latina ..................167

5. O Caso 12.465 - Povo indígena Kichwa de Sarayaku versus Equador e o interconstitucionalismo latino-americano ......................................................................................................170

6. Considerações finais ......................................................................................172

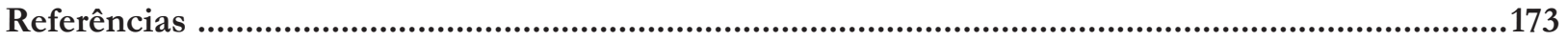


O DIÁLOGO HERMENÊUTICO E A PERGUNTA ADEQUAdA À APLICAÇÃO DOS TRATADOS INTERNACIONAIS DE DIREITOS HUMANOS NO BRASIL: CAMINHOS PARA O PROCESSO DE INTERNACIONALIZAÇÃO

DA CONSTITUIÇÃO...................................................................................... 176

Rafael Fonseca Ferreira e Celine Barreto Anadon

1. Introdução. 177

2. Os tratados internacionais de direitos humanos no imaginário jurídico dominante no Brasil e a ausência de diálogo hermenêutico: olhando o novo com os olhos do velho 178

3. A perspectiva de uma nova racionalidade (hermenêutica) para a normatividade material dos tratados internacionais de Direitos Humanos no Brasil

4. O diálogo hermenêutico e as possibilidades da pergunta adequada como crítica à (in)eficácia dos tratados internacionais de direitos humanos no Brasil.................................................................185

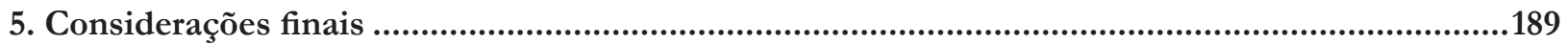

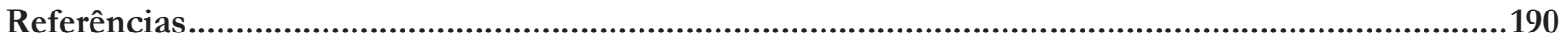

O DIREITO COMPARADO NO STF: INTERNACIONALIZAÇÃO DA JURISDIÇÃO CONSTITUCIONAL BRASI-

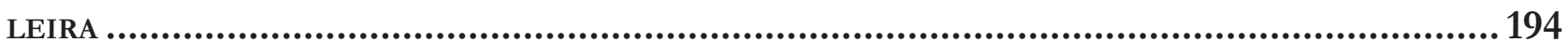

Carlos Bastide Horbach

1. Introdução

2. Funções e métodos do direito comparado ..........................................................................197

3. O elemento estrangeiro na fundamentação jurídico-constitucional.......................................... 200

4. O elemento estrangeiro na jurisdição do Supremo Tribunal Federal ............................................ 205

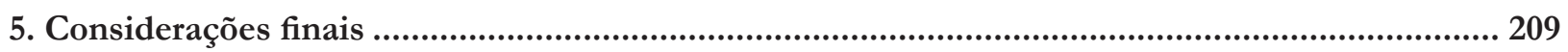

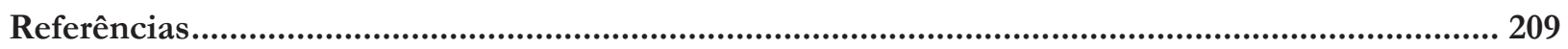

THE PHILOSOPHY OF INTERNATIONAL LAW IN CONTEMPORARY SCHOLARSHIP: OVERCOMING NEGLIGENCE THROUGH THE GLOBAL EXPANSION OF HUMAN RIGHTS .................................. 212

Fabrício Bertini Pasquot Polido, Lucas Costa dos Anjos e Vinícius Machado Calixto

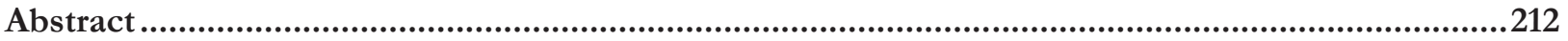

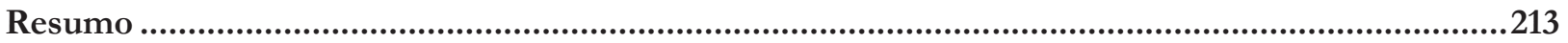

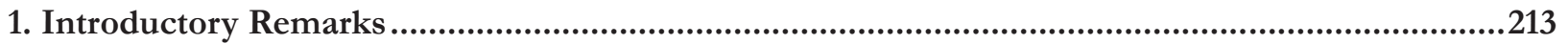

2. The problem of neglect of the philosophy of international law .................................................214

3. Hart and the opportunity cost of his analysis of international law..............................................216

4. The realistic challenge faced by Buchanan and Golove: a response through the global expansion of

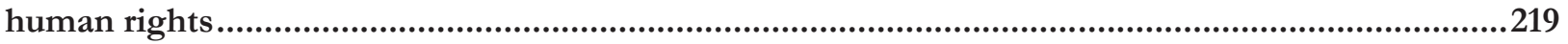

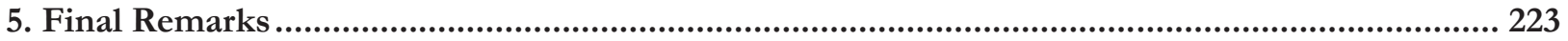

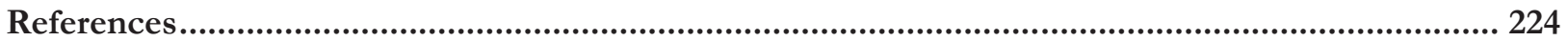


OPORTUNIDADES E DESAFIOS DAS TWAIL NO CONTEXTO LATINO-AMERICANO A PARTIR DE PERSPECTIVAS DOS POVOS INDÍGENAS AO DIREITO INTERNACIONAL .....................................2227

Fernanda Cristina de Oliveira Franco

1. Introdução 228

2. Influências dos povos colonizados em momentos de formação e transformação do direito interna-

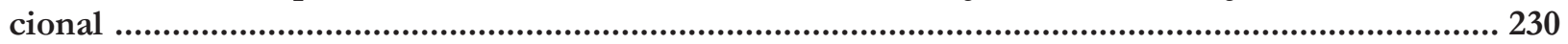

2.1. O encontro entre o nativo americano e o conquistador espanhol: formação ............................................. 230

2.2. O encontro do direito internacional com o Terceiro Mundo: transformação............................................ 232

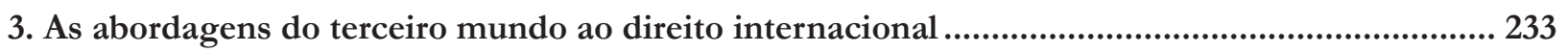

3.1. Relação com outras abordagens críticas ao direito internacional .................................................................. 234

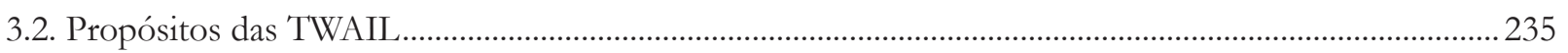

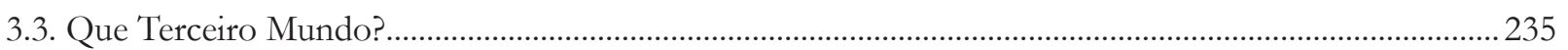

4. Povos indígenas e Twail: diálogos a partir do contexto latino-americano................................. 236

4.1 A presença dos povos indígenas na América Latina e no direito internacional dos direitos humanos .236

4.2. Disputas por recursos naturais: a violência sobre os povos indígenas na região latino-americana ........ 238

4.3. O lugar dos povos indígenas nas TWAIL: estreitando o diálogo ...................................................................239

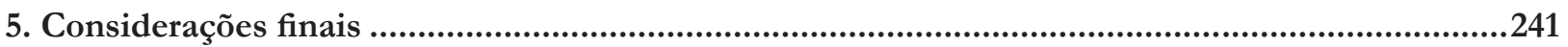

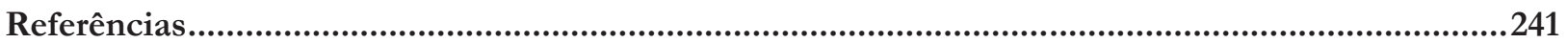

Por QUe uma ANÁLISE ECONÔMICA Do DIREITO INTERNACIONAL PÚBLICO? DESAFIOS E PERSPECTI-

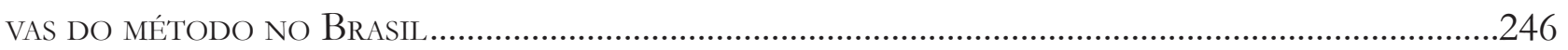

Gustavo Ferreira Ribeiro e Jose Guilherme Moreno Caiado

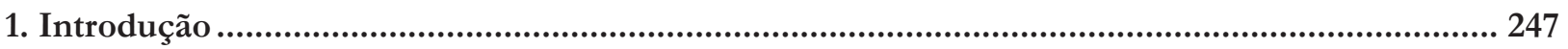

2. A AED como um metodologia e suas particularidades .............................................................. 248

2.1. A análise econômica do direito como um método aplicável ao direito internacional público................248

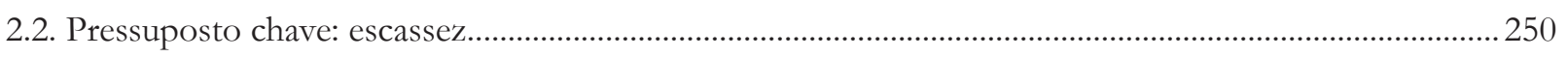

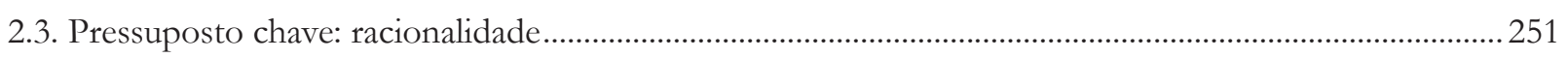

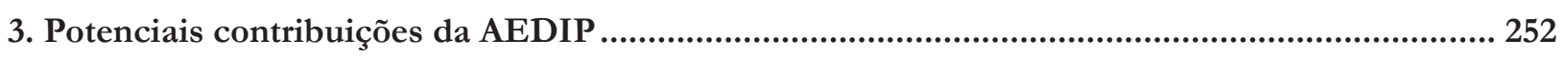

3.1. Tratados: por que se formam? Por que se descumprem? .......................................................................... 253

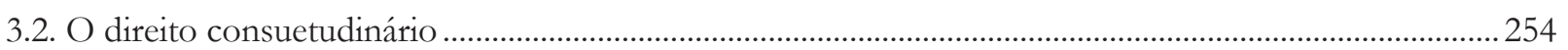

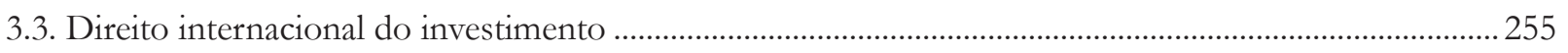

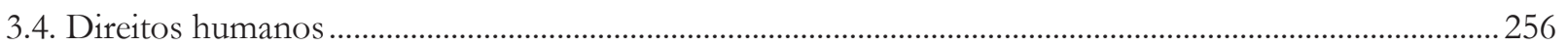

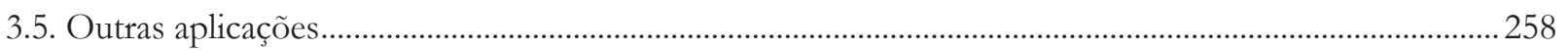

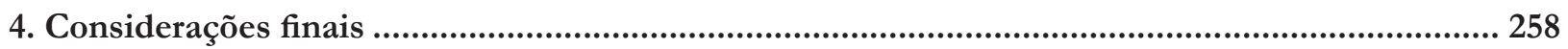

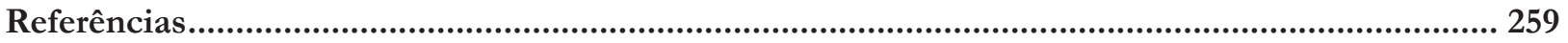


ANÁLISE ECONÔMICA do DIREITO INTERNACIONAL

Michele Alessandra Hastreiter e Luís Alexandre Carta Winter

1. Introdução .

2. O emprego do método da análise econômica no direito internacional ........................................ 264

3. A escassez de recursos e a escolha racional dos estados......................................................... 268

4. Instituições importam: o papel do direito enquanto criador de incentivos .................................. 272

5. Eficiência econômica e rompimento dos tratados internacionais ............................................... 275

6. Ressalvas à eficiência econômica: considerações sobre justiça na análise econômica do direito. ..279

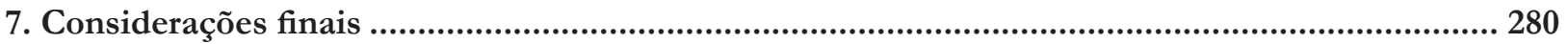

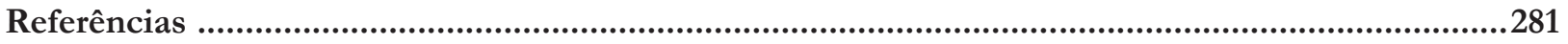

RACIONALIDADE ECONÔMICA E OS ACORDOS BILATERAIS DE INVESTIMENTO........................284

Michele Alessandra Hastreiter e Luís Alexandre Carta Winter

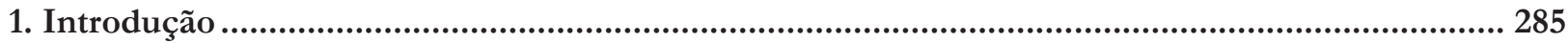

2. A racionalidade econômica dos países signatários de acordos bilaterais de investimento .......... 286

2.1. A perspectiva dos países desenvolvidos........................................................................................................28

2.2. A perspectiva dos países em desenvolvimento ...........................................................................................28

3. Uma nova racionalidade: as mudanças nos acordos bilaterais de investimento .......................... 292

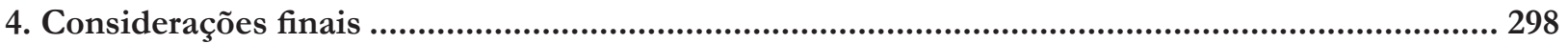

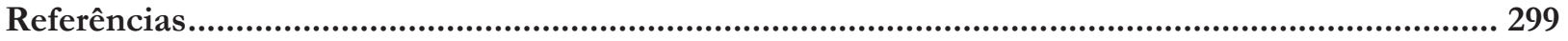

LOOKING FOR A BRICS PERSPECTIVE ON INTERNATIONAL LAW ...................................304

Gabriel Webber Ziero

1. Introduction 305

2. International law and its perspectives: is there a BRICS perspective? 306

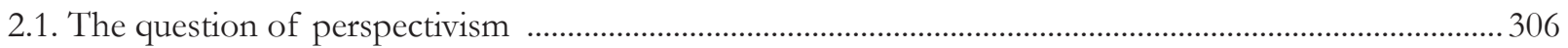

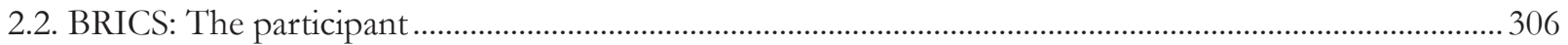

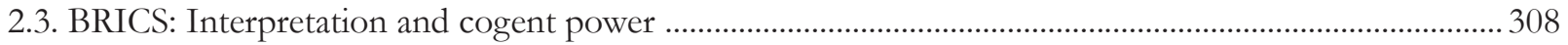

3. International law through the brics lenses …................................................................................. 309

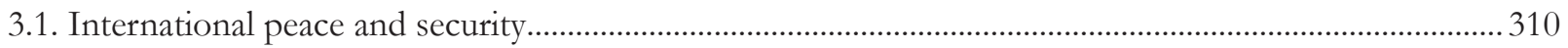

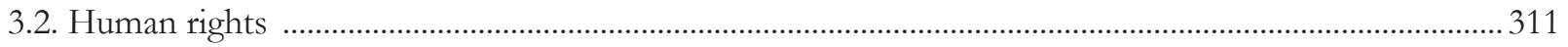

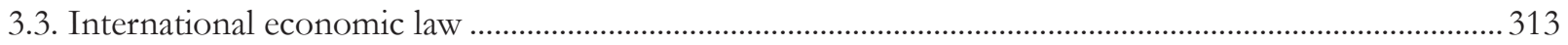

4. The structure of the brics perspective on international law ........................................................316

4.1. International law as the product of multilateral and non-confrontational consensus building ............. 316

4.2. Legal bindingness and precision as a consequence of a multilateral consensus building........................ 318

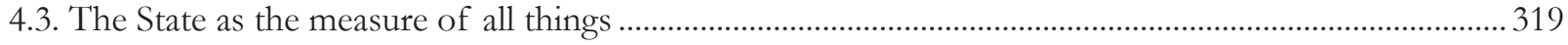




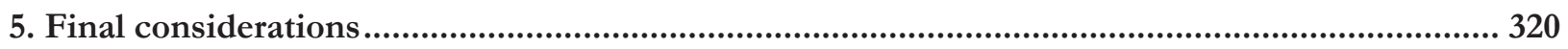

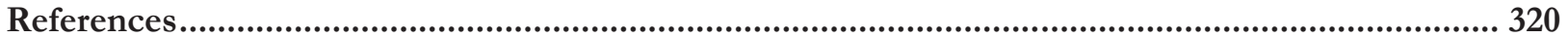

A INFLUÊNCIA DO DIREITO DESPORTIVO TRANSNACIONAL NO ORDENAMENTO JURÍDICO BRASILEIRO: DA REPRODUÇÃO DE NORMAS À APLICAÇÃO DIRETA PELA JURISDIÇÃO ESTATAL......................324

Tiago Silveira de Faria

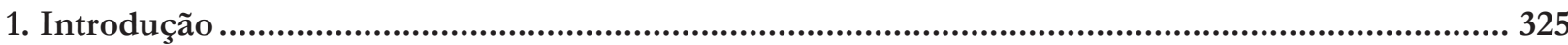

2. Pluralismo jurídico, transnacionalidade e hetero-regulação normativa no âmbito desportivo .... 325

3. A reprodução de normas desportivas transnacionais pelo ordenamento jurídico brasileiro........ 328

4. A aplicação do direito desportivo estrangeiro pela justisdição estatal........................................ 330

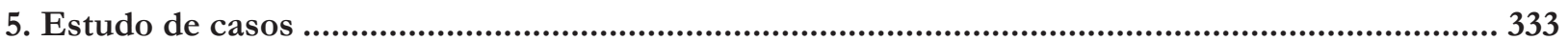

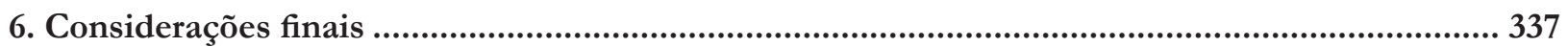

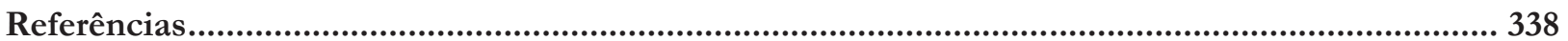

CONVENCIONALIZAÇÃO DO DIREITO CIVIL: A APLICAÇÃO DOS TRATADOS E CONVENÇÕES INTERNA-

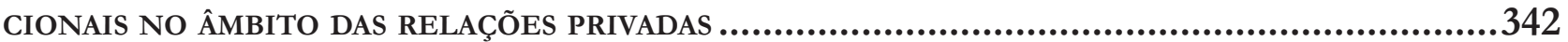

Alexander Perazo Nunes de Carvalho

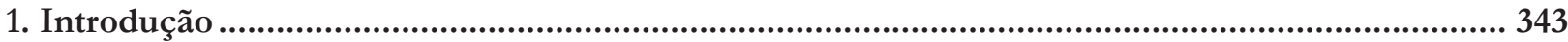

2. A constitucionalização do direito civil............................................................................................... 343

3. A horizontalização dos direitos fundamentais ................................................................................ 347

4. A convencionalização do direito civil .............................................................................................. 349

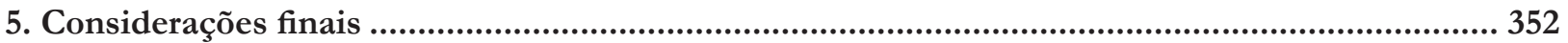

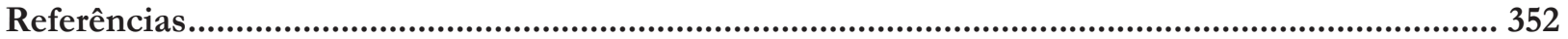

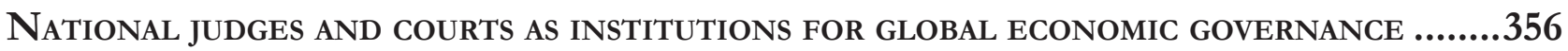

Juízes e tribunais nacionais como instituições para a governança global ....................................... 356

Camilla Capucio

1. Order, International Law and Global Governance: Reconstruction of Relevant Concepts ........ 357

2. Disaggregation of the State and the Review of State Sovereignty: Necessity of a new perspective 358

3. Constitutional perspective to international law: Towards a "cosmopolitan law" ......................... 359

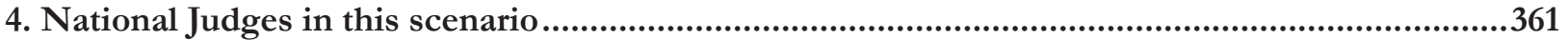

5. WTO and national judjes: is there a possible connection in global economic Governance? ....... 362

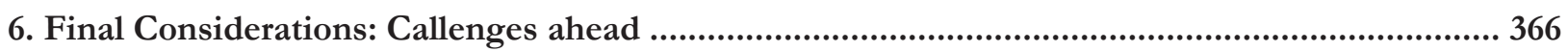

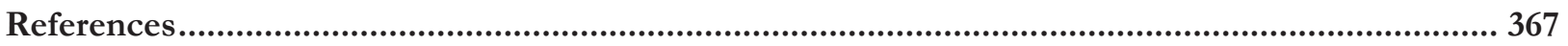

Is Trade Governance Changing? ............................................................................. 371

Alberto do Amaral Júnior 


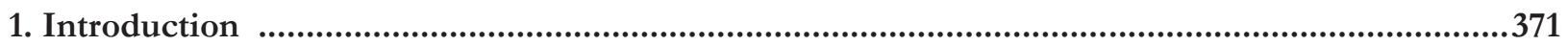

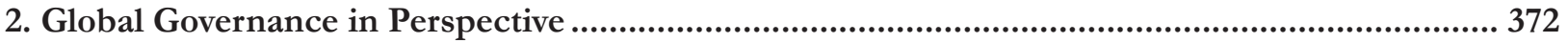

3. WTO and Governance of World Trade ...................................................................................... 372

4. WTO Committee on Regional Trade Agreements ............................................................................ 373

5. Mega-Agreements and a New Configuration of International Trade ......................................... 374

6. Governance in the World Trade ................................................................................................... 379

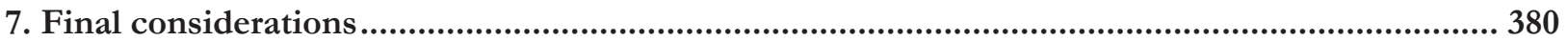

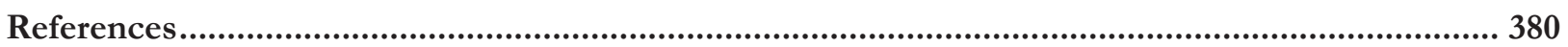

OS FUNDOS ABUTRES: MEROS PARTICIPANTES DO CENÁRIO INTERNACIONAL OU SUJEITOS PERANTE O DIREITO INTERNACIONAL? ............................................................................384

Guilherme Berger Schmitt

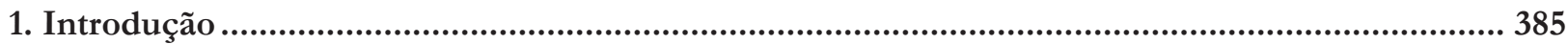

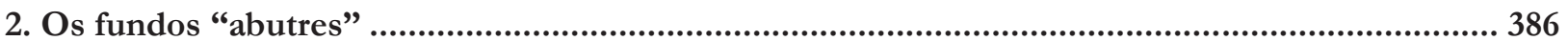

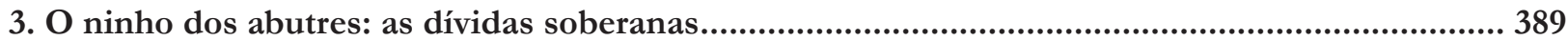

4. O papel dos fundos abutres no cenário internacional.................................................................. 392

5. A personalidade jurídica dos fundos abutres perante o direito internacional ...............................396

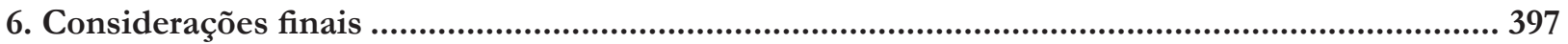

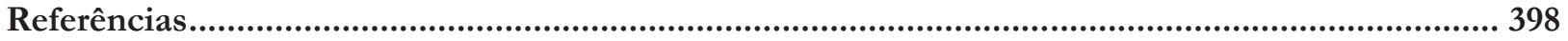

SHAREHOLDER AGREEMENTS IN PUBLICLY TRADED COMPANIES: A COMPARISON BETWEEN THE

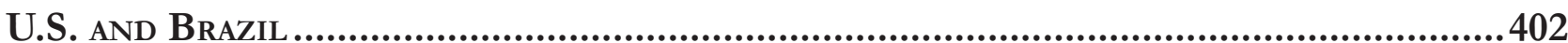
Helena Masullo

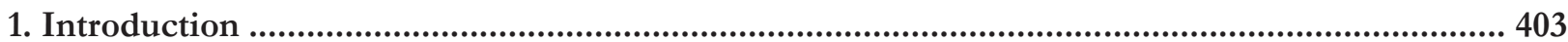

2. The Use and Content of Shareholder Agreements in Brazil Compared to The U.S.................. 405

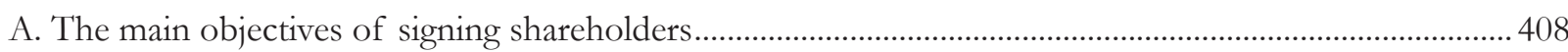

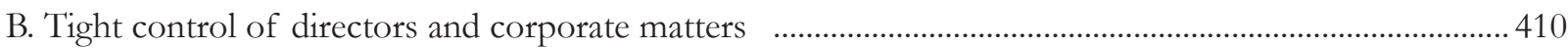

C. Mandatory limitations to the free transferability of shares....................................................................... 412

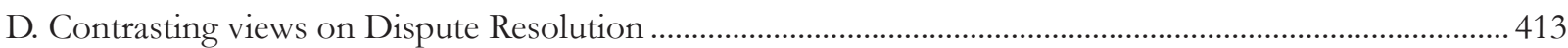

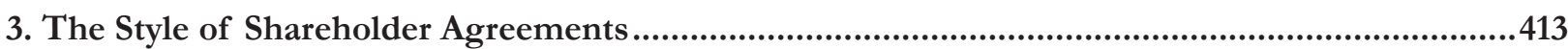

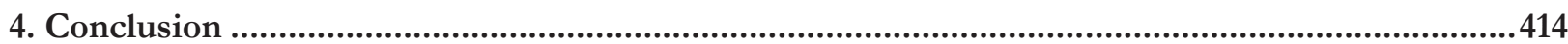

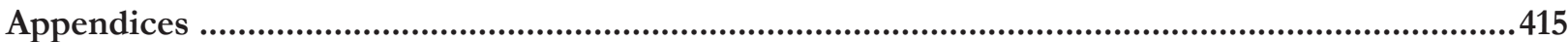

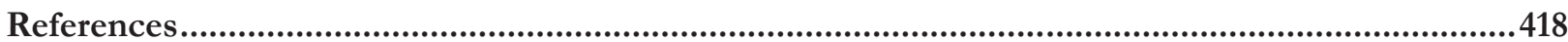

REgUlação Do INVESTIMENTO ESTRANGEIRO DIRETO NO BRASIL: DA RESISTÊNCIA AOS TRATADOS BILATERAIS DE INVESTIMENTO À EMERGÊNCIA DE UM NOVO MODELO REGULATÓRIO ....................421 Fabio Morosini e Ely Caetano Xavier Júnior 
2. A primeira onda regulatória dos investimentos estrangeiros direitos no Brasil: a proposta de recepção de capital estrangeiro via tratados bilaterais de investimento

2.1. O conteúdo dos tratados bilaterais de investimento da década de 90 ........................................................ 423

2.2. Os impasses políticos para a aprovação legislativa dos tratados bilaterais de investimento ..................... 426

3. A segunda onda regulatória dos investimentos estrangeiros direitos no Brasil: a exportação de capital brasileiro e a emergência de um novo modelo de acordo de investimentos.

3.1. Os novos condicionantes econômicos e seus impactos no investimento estrangeiro direito brasileiro 432

3.2. O novo papel do Brasil nas relações de investimento estrangeiro: de país importador a país também ex-

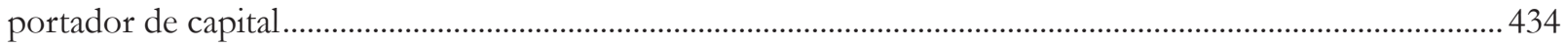

3.2.1. A América do Sul como foco dos investimentos brasileiros ………….............................................. 435

3.2.2. A África como foco dos investimentos brasileiros................................................................................. 435

3.3. A emergência de um modelo brasileiro de acordo de cooperação e facilitação de investimentos .......... 437

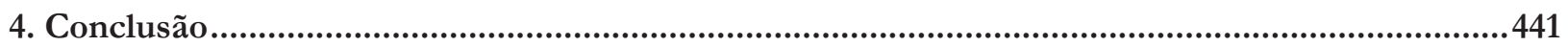

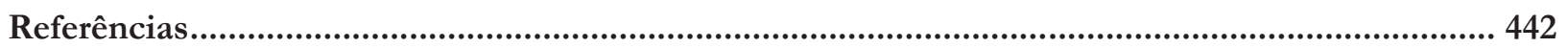

DA QUALIFICAÇÃo JURÍDiCA DAS Distintas FORMAS DE PRESTAÇão TECNOLÓGICA: BREVE ANÁLISE DO MARCO REGULATÓRIO INTERNACIONAL .......................................................449

Daniel Amin Ferraz

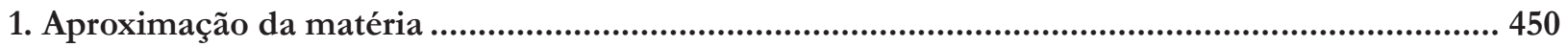

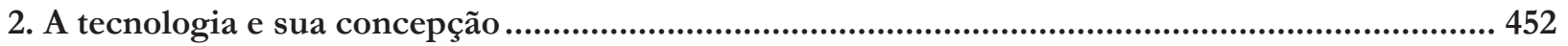

2.1. A tecnologia incorporada e a tecnologia não incorporada às mercadorias ................................................ 452

2.2. Breve enunciado dos diversos tipos de prestação tecnológica ..................................................................... 453

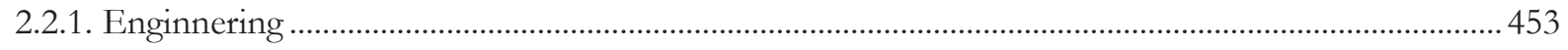

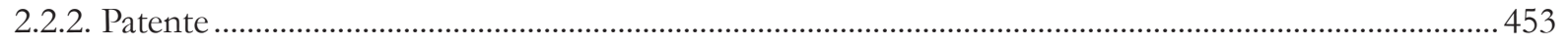

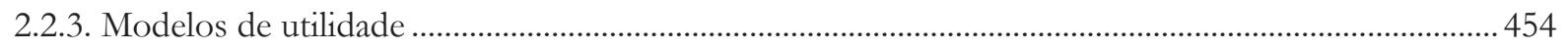

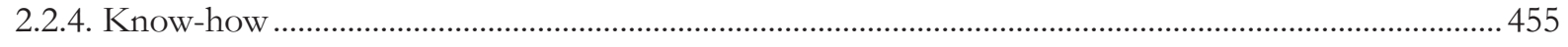

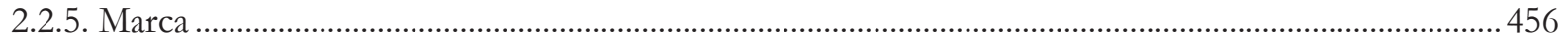

2.2.6. Assistência técnica .......................................................................................................................... 458

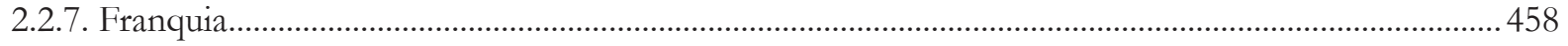

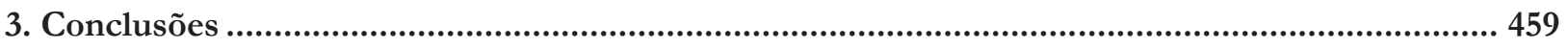

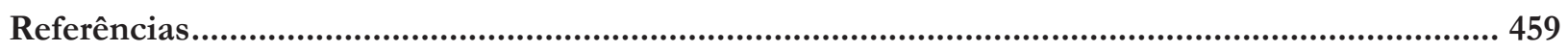

REDEFINING TERRORISM: THE DANGER OF MISUNDERSTANDING THE MODERN WORLD'S GRAVEST THREAT

Jennifer Breedon

1. Introduction

2. Current Laws on "Terrorism." 
3. The Global Community is Afraid to Call Intentional Eliminationism "Genocide" and Still Refuses to Objectively, Accurately Label Modern Extermination Campaigns....

3.1. Unresolved Issues; Gaps in the System; Proposed Changes. ...................................................................... 478

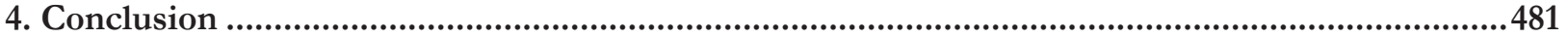

Appendix A - The Proposed Redrafting of the Crime of Genocide to Incorporate Acts of Terror..481

Appendix B - Violations of International Authorities by Terrorist Groups.

As EXECUÇõES SELETIVAS E A RESPONSABILIZAÇÃo DE AGENTES TERRORISTAS

Alexandre Guerreiro

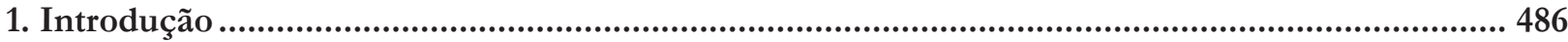

2. Delimitação do conceito e evolução das execuções seletivas...................................................... 487

3. Sobre a fundamentalidade do direito à vida ............................................................................... 489

4. A licitude das execuções de seres humanos em contexto de conflito armado ..............................491

4.1. Condicionantes impostas aos conflitos armados internacionais.................................................................. 491

4.2. Adequação do direito da guerra aos conflitos armados internos................................................................. 494

5. As novas teses desenvolvidas para a realidade do terrorismo e as incongruências que comprometem a legalidade e potenciam a anarquia ................................................................................................. 495

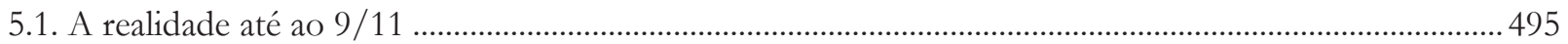

5.2. Das teorias que sustentam o recurso à força para legítima defesa................................................................ 496

5.3. A "terceira via”" às duas espécies de conflitos armados ...................................................................................... 498

5.4. A posição adotada pelo Comitê Internacional da Cruz Vermelha ............................................................. 500

6. Da necessidade de tratar os terroristas como civis e dos cinco requisitos que excluem a ilicitude da

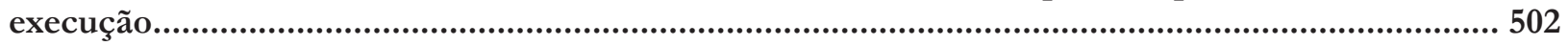

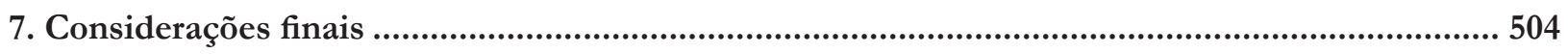

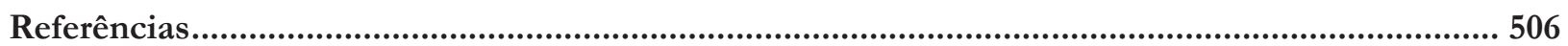

INTERNATIONAL CRIMINALS AND THEIR VIRTUAL CURRENCIES: THE NEED FOR AN INTERNATIONAL EFFORT IN REGULATING VIRTUAL CURRENCIES AND COMBATING CYBER CRIME ..........................512 Joy Marie Virga

1. Introduction .513

2. The Current status of virtual currencies and legal actions involving virtual currencies...............513

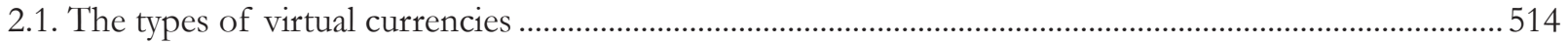

2.2. Legal action taken against organizations that used virtual currencies in national and international criminal

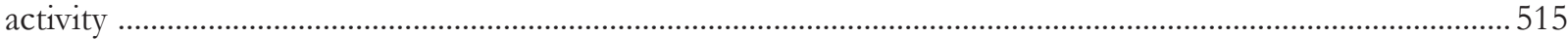

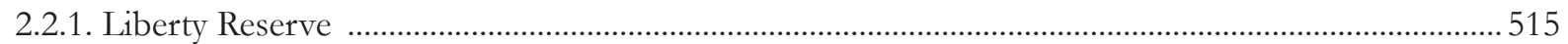

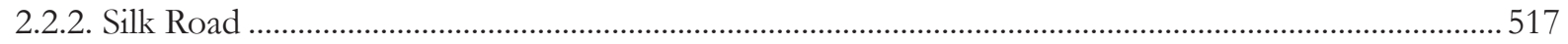

2.3. Regulations of virtual currencies within the United States and other nations ........................................ 518

2.3.1. The United States ................................................................................................................................. 518 
2.3.3. The United Kingdom

3. The Need for International Regulation of Virtual Currencies and How Regulation May Be Approached.....

3.1. Current methods of international regulation of traditional capital and how they may apply to virtual currencies 520

3.1.1. The Financial Action Task Force …………….................................................................................. 520

3.1.2 The World Bank and the International Monetary Fund....................................................................... 522

3.2. Current methods of international regulation of cybercrime and how they may apply crime facilitated by

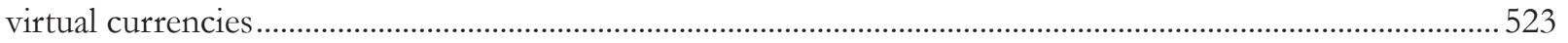

3.2.1. The International Convention on Cybercrime.................................................................................... 523

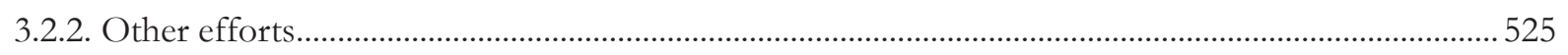

4. Possible Channels for International Regulation of Virtual Currencies ..................................... 525

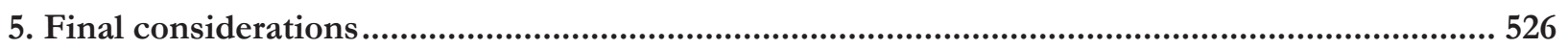

\section{Criminalidad transnacional organizada en el Ámbito del MERCOSUR: ¿HAcia un}

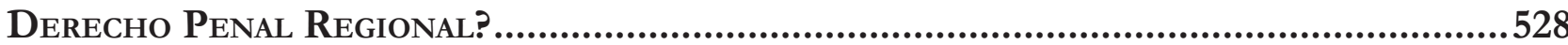

Nicolás Santiago Cordini e Mariano Javier Hoet

1. Intrroducción:

1.1. Marco institucional de la investigación.

1.2. Los procesos de globalización y glocalización en la política criminal........................................................ 529

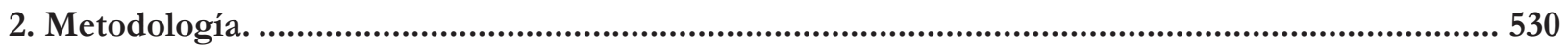

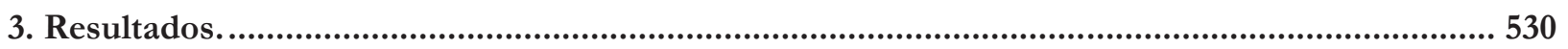

3.1. Primer objetivo: determinar el concepto de "organización”: ¿De qué se trata la criminalidad organizada? ...531

3.2. Segundo objetivo: Determinar el ámbito espacial de la solución jurídica a adoptar: el Derecho Penal Internacional: su status disciplinario.

3.3. Tercer objetivo: determinar posibles factores facilitadores u obstaculizadores para la institucionalización de un Derecho Penal Regional: 534

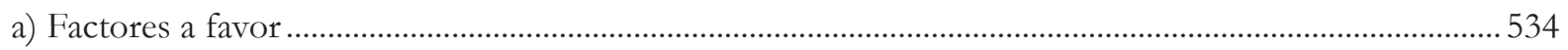

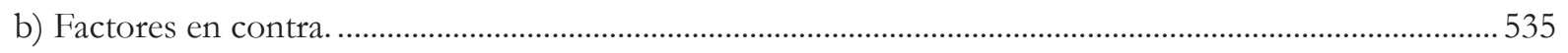

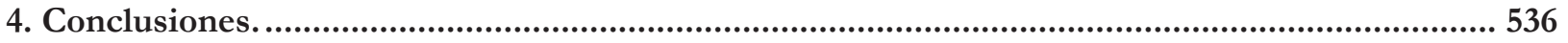

4.1. Teoría del delito como instrumento de análisis: ............................................................................................... 536

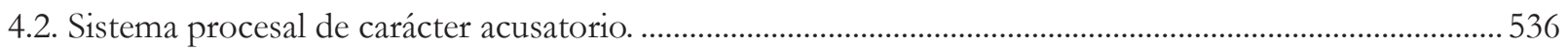

4.3. Respeto a los principios orientadores del Derecho Penal. ........................................................................ 536

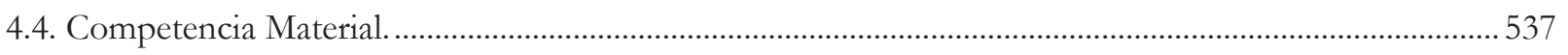

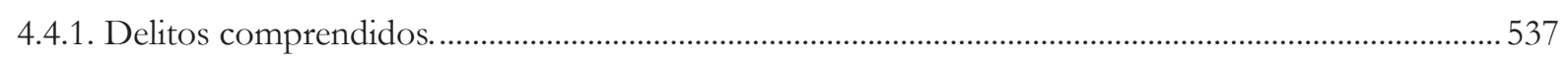

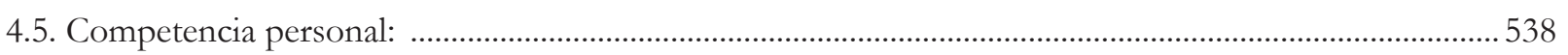

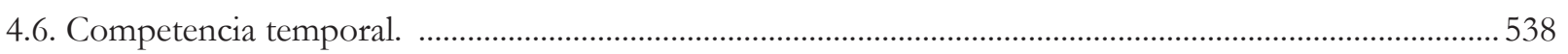

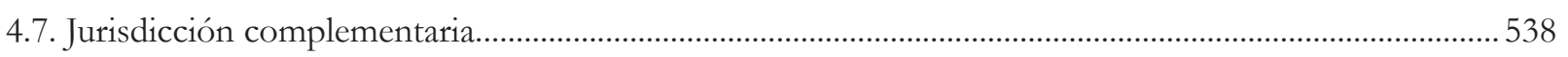




\section{RUMO À INTERNACIONALIZAÇÃO DA PROTEÇÃO PENAL DO MEIO AMBIENTE: DOS ECOCRIMES AO ECOCÍDIO}

Kathia Martin-Chenut, Laurent Neyret e Camila Perruso

1. Introdução 542

2. A impotência atual do direito internacional no tocante à criminalidade ambiental.................... 543

2.1. Uma necessidade crescente de apreender a criminalidade ambiental pelo direito internacional............ 544

2.2. As lacunas do direito internacional em matéria de criminalidade ambiental ............................................ 545

3. A potencialidade futura do direito internacional relativa à criminalidade ambiental .................. 546

3.1. O estabelecimento de uma penalização comum, gradual e racional aos danos ao meio ambiente: dos eco-

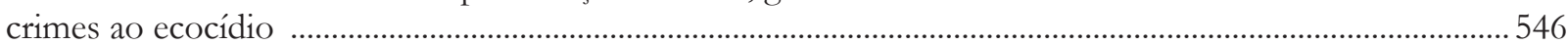

3.2. A imperatividade da prevenção e da repressão da criminalidade ambiental em direito internacional... 547

4. Considerações finais

Referências

Anexo 1. 550

Preâmbulo 550

Capítulo: Disposições gerais 551

Artigo 1 - Terminologia. 551

Artigo 2 - Campo de aplicação 551

Capítulo 2: Definições das infrações 551

Artigo 3 - dos prejuízos ao meio ambiente ……………................................................................................... 551

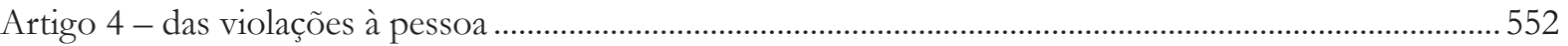

Artigo 5 - participação às infrações ................................................................................................................. 552

Artigo 6 - Responsabilidade penal das pessoas morais .................................................................................... 553

Capítulo 3: Medidas repressivas Seção 1: Sanções.................................................................................................. 553

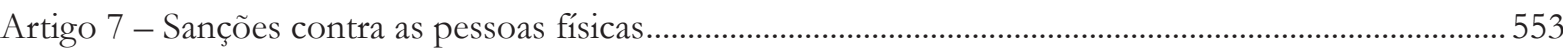

Artigo 8 - Sanções contra as pessoas jurídicas................................................................................................ 553

Artigo 9 - critérios de determinação da sanção das pessoas jurídicas ........................................................... 554

Artigo 10 - Suspensão da execução da sanção, provas e acordos processuais ............................................. 554

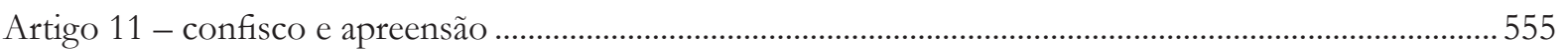

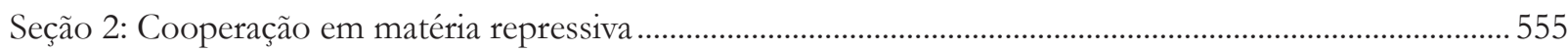

Artigo 12 - Competências nacionais........................................................................................................... 555

Artigo 13 - Investigação e persecução penal.................................................................................................... 556

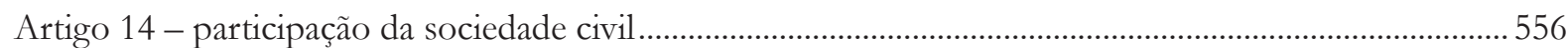

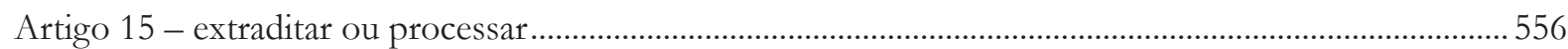

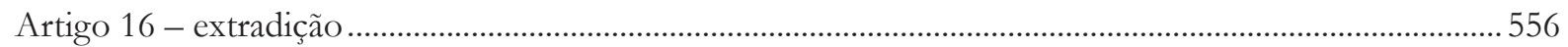

Artigo 17 - Assistência jurídica mútua ………………….................................................................................... 557 
Capítulo 4: Medidas preventivas

Artigo 18 - Cooperação internacional em matéria de prevenção ………………………………………….... 558

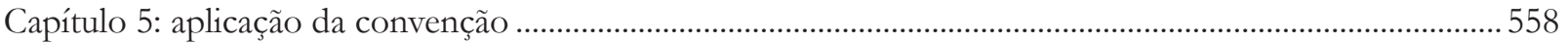

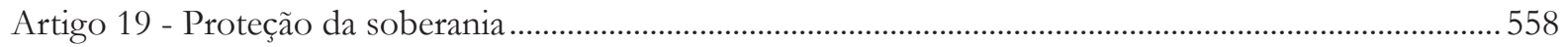

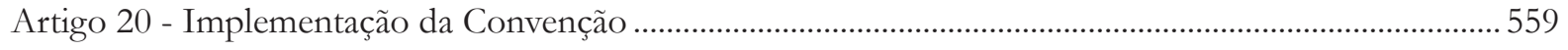

Artigo 21 - Exame do cumprimento das disposições .......................................................................................... 559

Artigo 22 - Solução de controvérsias ............................................................................................................ 559

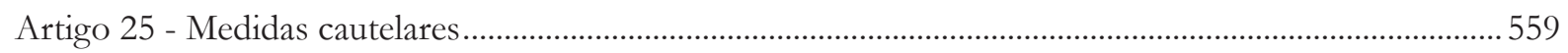

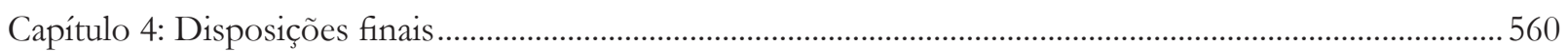

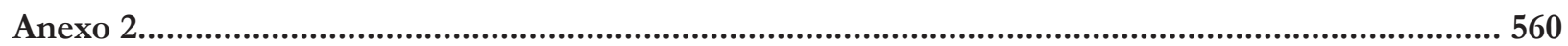

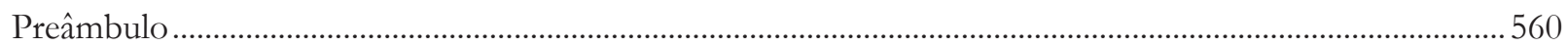

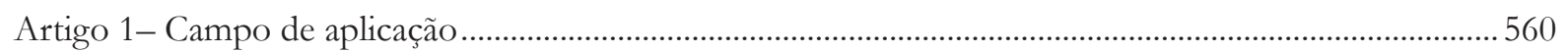

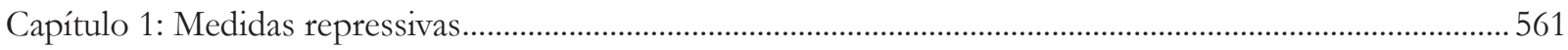

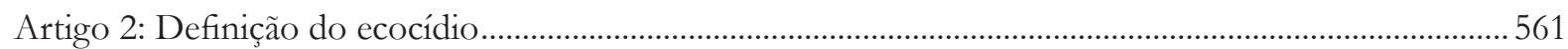

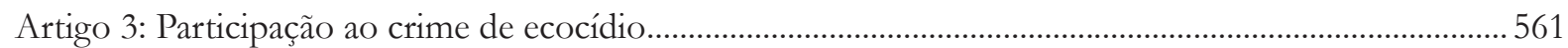

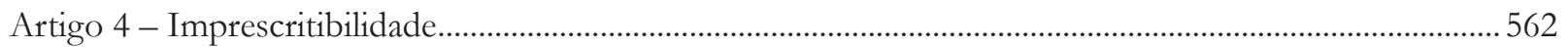

Artigo 5 - Responsabilidade penal das pessoas morais ...................................................................................... 562

Artigo 6 - Sanções contra as pessoas físicas.................................................................................................. 562

Artigo 7: Sanções contra as pessoas morais.................................................................................................... 562

Artigo 8 - Critérios de determinação da sanção das pessoas jurídicas ............................................................... 563

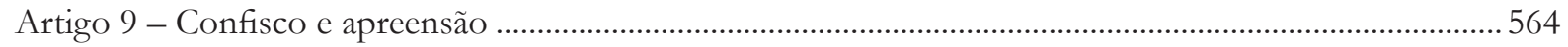

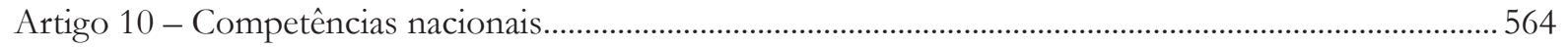

Artigo 11 - Investigação e persecução penal...................................................................................................... 565

Artigo 12 - Participação da sociedade civil...................................................................................................... 565

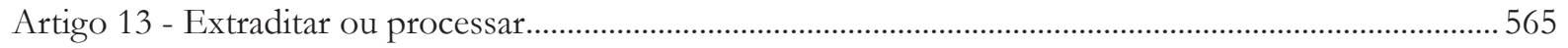

Artigo 14 - Extradição ........................................................................................................................... 565

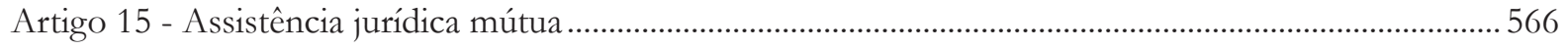

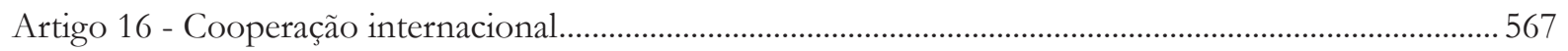

Artigo 17 - Competência do Procurador Internacional do Meio Ambiente ................................................. 567

Artigo 18 - Criação de um Tribunal Penal Internacional do Meio Ambiente ................................................... 567

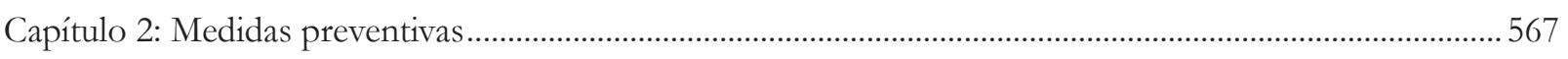

Artigo 19 - A cooperação internacional em matéria de prevenção ………………………………………...... 567

Artigo 20 - Competência do Grupo de Pesquisa e de Investigação para o Meio Ambiente (GREEN)... 568

Capítulo 3: Aplicação da Convenção ....................................................................................................................... 568

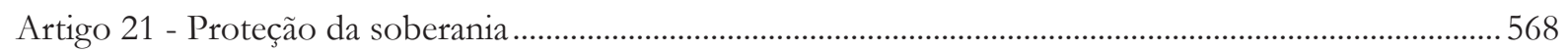

Artigo 22 - Implementação da Convenção ................................................................................................. 568

Artigo 23 - Exame do cumprimento das disposições ........................................................................................ 568 
Artigo 24 - Solução de controvérsias ............................................................................................................ 568

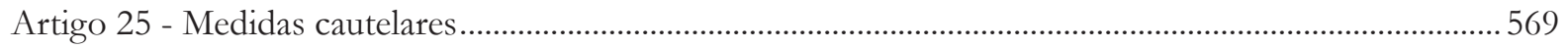

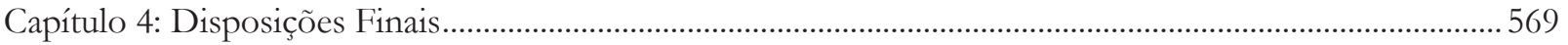

Engaging the U.N. Guiding Principles on Business and Human Rights: the inter-AMERICAN COMMISSION ON HUMAN RIGHTS \& THE EXTRACTIVE SECTOR ..............................571

Cindy S. Woods

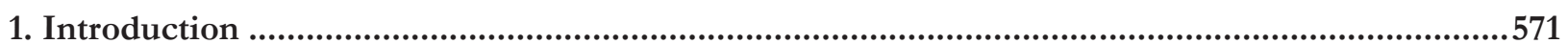

2. The U.N. Guiding Principles on Business and Human Rights ................................................ 573

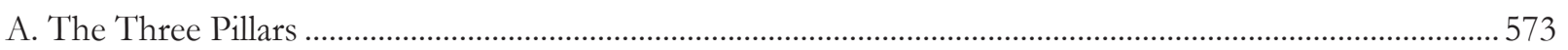

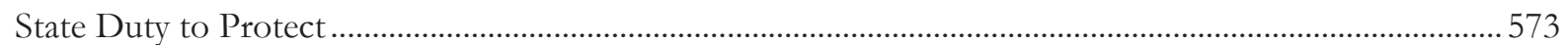

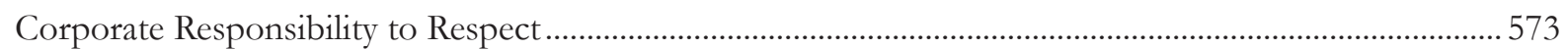

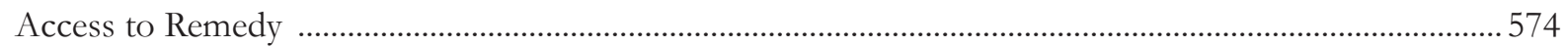

B. Moving Forward: Implementing the Guiding Principles ......................................................................... 574

3. The Inter-American Commission on Human Rights ................................................................ 575

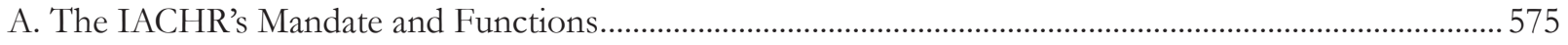

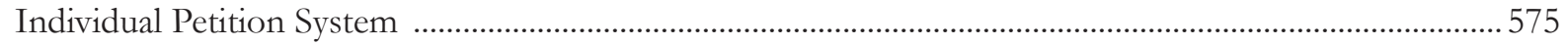

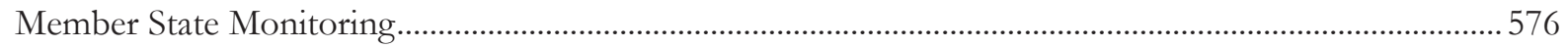

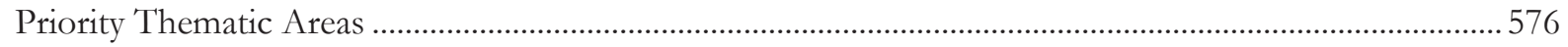

B. Squaring the IACHR's functions with the Guiding Principles ……............................................................ 576

The Guiding Principles Create No New International Obligations ................................................................ 577

The IACHR Has A Mandate To Promote Human Rights ................................................................................ 577

4. The Extractive Sector: Demonstrating the IACHR's Familiarity with Business and Human Rights

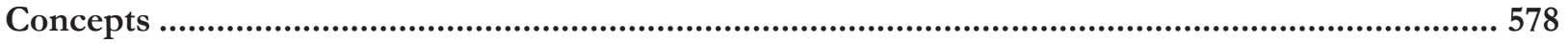

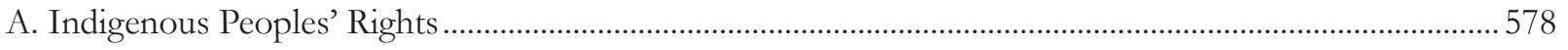

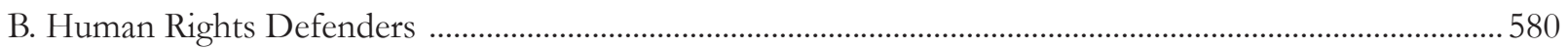

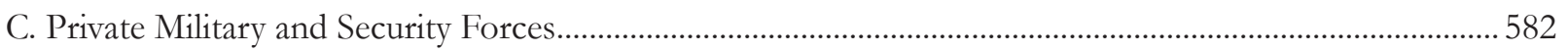

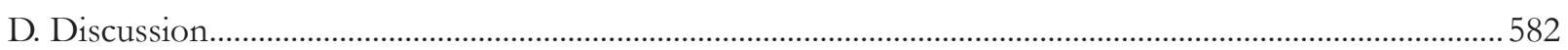

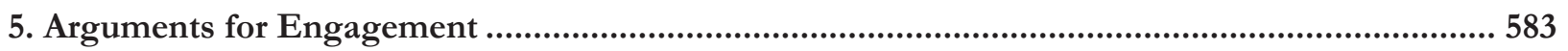

A. The IACHR has been requested to engage with the Guiding Principles .................................................. 583

B. The IACHR has the ability to set normative standards in the field ..............................................................58

C. The IACHR should seek to close increasing accountability gaps ………..................................................... 584

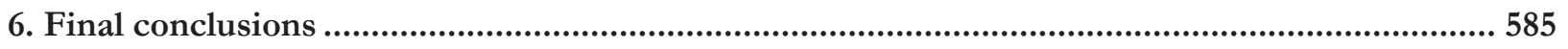

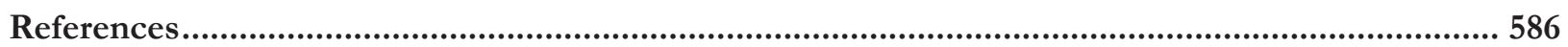


O DIREITO HUMANO À COMUNICAÇÃO PRÉVIA E PORMENORIZADA DAS ACUSAÇÕES NOS PROCESSOS administrativos: O desprezo do Superior Tribunal de Justiça ao Pacto de San José da

Costa Rica e À Corte Interamericana de Direitos Humanos ..................................................590

Daniel Wunder Hachem e Eloi Pethechust

1. Introdução .....

2. Os direitos humanos como elementos integrantes do bloco de constitucionalidade e a hierarquia dos tratados internacionais no Direito brasileiro. 592

3. A descrição prévia e pormenorizada das condutas do acusado no processo administrativo disciplinar como desdobramento dos direitos ao contraditório e à ampla defesa: entre o silêncio da Lei $\mathbf{n}^{\circ}$ 8.112/90 e a previsão expressa do Pacto de San José da Costa Rica 596

4. O posicionamento do Superior Tribunal de Justiça brasileiro sobre o dever de especificação das condutas no ato de instauração do processo administrativo disciplinar 598

5. A aplicação das garantias do art. $8^{\circ}$ do Pacto de San José da Costa Rica aos processos administrativos e a jurisprudência da Corte Interamericana de Direitos Humanos ... 600

6. Considerações finais: a necessidade de adequação da jurisprudência do Superior Tribunal de Justiça e da Administração Pública brasileira ao art. $8^{\circ}$, n. 2, "b" do Pacto de San José da Costa Rica, ao art. 14, item 3, letra a) do Pacto Internacional sobre Direitos Civis e Políticos e à jurisprudência da Corte Interamericana de Direitos Humanos. 603

Referências 605

A responsabilidade internacional do Brasil em faCe do CONTrole de ConVENCionaliDADE EM SEDE DE DIREITOS HUMANOS: CONFLITO DE INTERPRETAÇÃO ENTRE A JURISDIÇÃO DA Corte Interamericana de Direitos Humanos e o Supremo Tribunal Federal quanto a

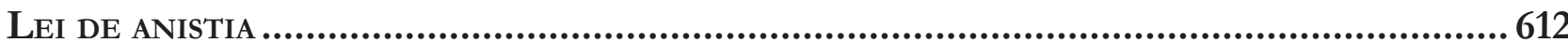

Carla Ribeiro Volpini Silva e Bruno Wanderley Junior

1. Introdução..... 613

2. O Regime militar de 1964-1985 e a violação sistemática dos direitos humanos

3. A polêmica acerca da lei de anistia e a controvérsia entre a posição da Corte Interamericana de Direitos Humanos e a do Supremo Tribunal Federal.

4. Do controle de convencionalidade das leis em face dos tratados de direitos humanos e sua aplicação

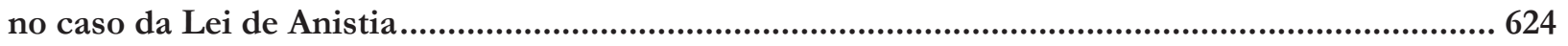

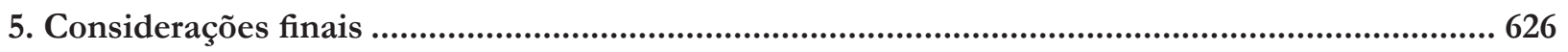

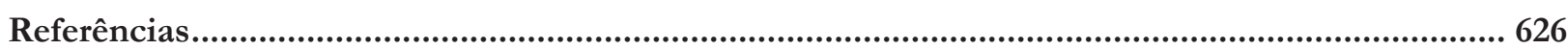

A CriaÇão de um espaÇo de livre residênCIA no Mercosul sob a Perspectiva teleológica DA INTEGRAÇÃo REGIONAL: ASPECTOS NORMATIVOS E SOCIAIS DOS ACORDOS DE RESIDÊNCIA ....... 631

Aline Beltrame de Moura

1. Introdução..... 632

2. A circulação das pessoas nos processos de integração regional

3. A liberdade de circulação no Tratado de Assunção e nas primeiras decisões do Mercosul......... 633

3. Os acordos sobre migração e residência de 2002 
3.1. Os direitos e prerrogativas previstos nos acordos sobre residência para os cidadãos dos estados-parte do Mercosul 637

3.2. A criação de um espaço de livre residência no Mercosul............................................................................. 640

4. Considerações finais ..................................................................................................................... 643

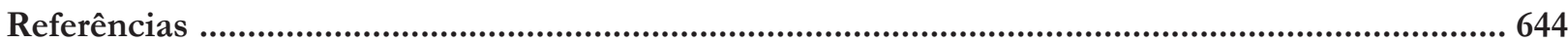

A funcionalização como tendênCia evolutiva do Direito Internacional e sua conTRIBUIÇÃO AO REGIME LEGAL DO BANCO DE DADOS DE IDENTIFICAÇÃO DE PERFIL GENÉTICO NO

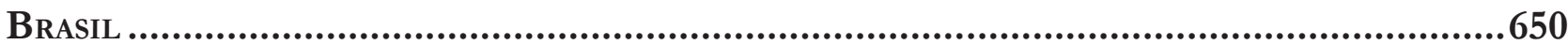

Antonio Henrique Graciano Suxberger

1. Introdução.

2. $\mathrm{O}$ banco de dados de perfil genético e a crítica generalizada à coleta do material biológico no Brasil

3. A juridicidade da coleta compulsória de material genético para fins criminais ............................ 655

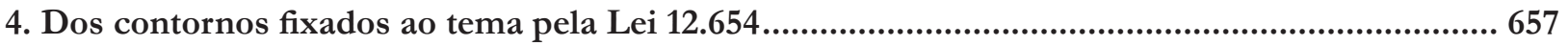

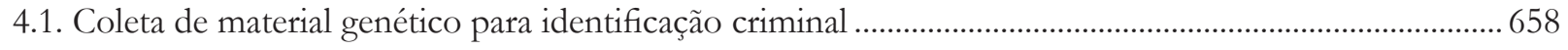

4.2. Coleta de material genético de pessoas condenadas definitivamente......................................................... 659

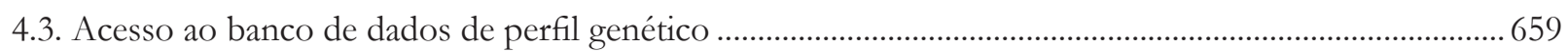

5. A compatibilidade da coleta do material genético do condenado com as garantias do direito ao silêncio e da presunção de inocência ......................................................................................................661

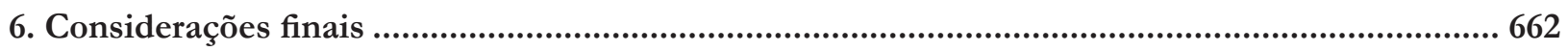

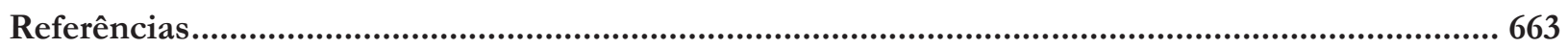

O DIREITO INTERNACIONAL E A PROTEÇÃO DOS DIREITOS DE CRIANÇAS E DE ADOLESCENTES EM

CONFLITO COM A LEI EM MOÇAMBIQUE ...........................................................667

Bernardo Fernando Sicoche

1. Introdução....

2. Conceito e fundamentos teóricos e jurídicos de proteção da criança e do adolescente em conflito com a lei. 670

3. Instrumentos internacionais de proteção da criança e do adolescente em conflito com a lei .... 673

4. Justiça infantil e a proteção de crianças em Moçambique............................................................... 677

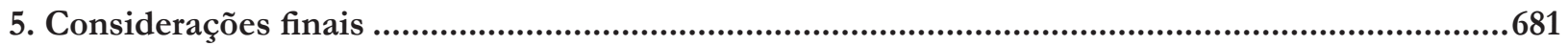

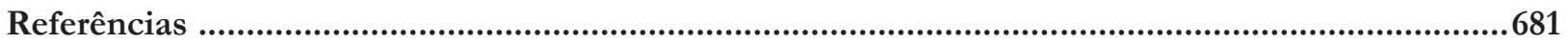

ObTENÇÃo de PROVAS NO EXTERIOR: PARA ALÉM DA LEX FORI E LEX DiligENTIAE...............685

André De Carvalho Ramos

1. Introdução.

2. Produção probatória no exterior e o direito internacional privado

3. Provas e a ordem pública 
4. A "lex diligentiae" na lei de introdução às normas do direito brasileiro e no código Bustamante: o risco do retorno à lex fori

5. A "lex diligentiae" na Convenção da Haia sobre a obtenção de provas no exterior em matéria civil e comercial (1970)

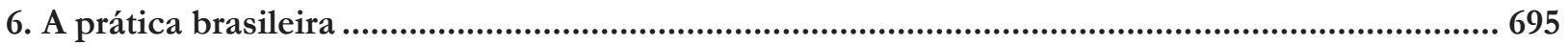

7. As deficiências da dicotomia "lex fori" $\mathrm{x}$ "lex diligentiae"............................................................ 698

8. O giro copernicano: os modelos para aferir o respeito aos direitos envolvidos na produção probatória no exterior.

9. Considerações finais …................................................................................................................ 700

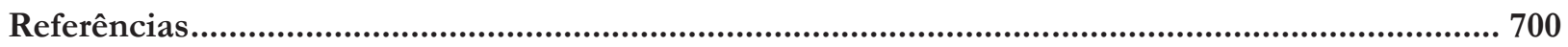

A Slight Revenge and a Growing Hope for Mauritius and the Chagossians: The UNClOS Arbitral Tribunal's Award of 18 March 2015 on Chagos Marine Protected

Area (Mauritius v. United Kingdom) ...........................................................705

Géraldine Giraudeau

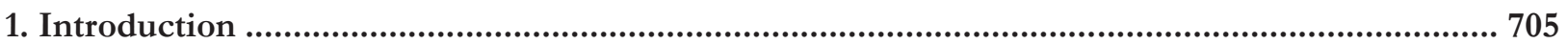

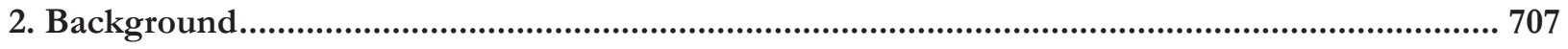

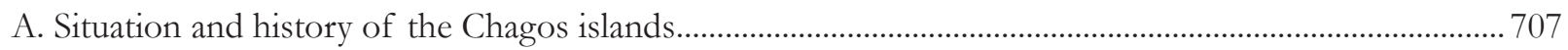

B. Adjudication on compensation and right of return for the Chagossians .................................................... 708

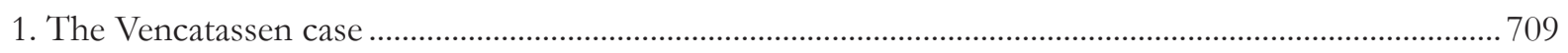

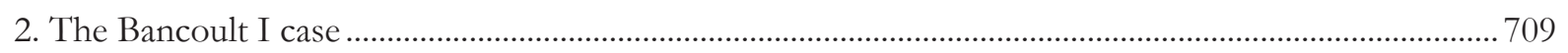

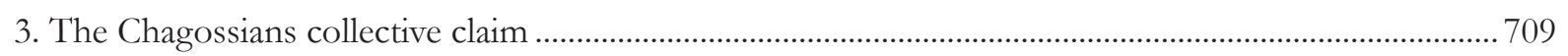

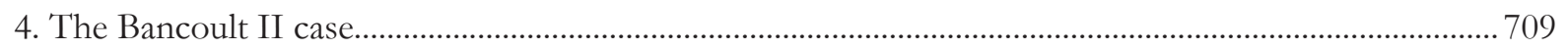

5. The Bancoult III case ......................................................................................................................... 710

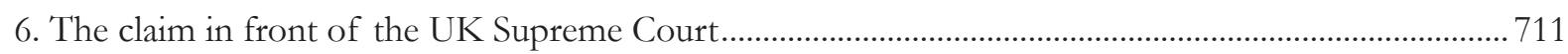

C. The Interstate Dispute over the Chagos islands and the proceedings about the MPA .............................. 711

3. Decision on jurisdiction and clarification on part xv UNCLOS ..............................................713

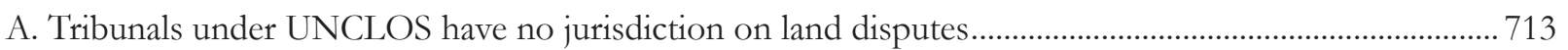

B. The MPA is not only about fisheries and the tribunal has jurisdiction over issues related to these other as-

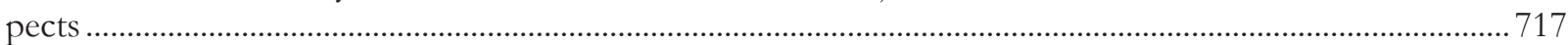

C. The "exchange of views" requirement of article 283 UNCLOS is a procedural condition and must be in-

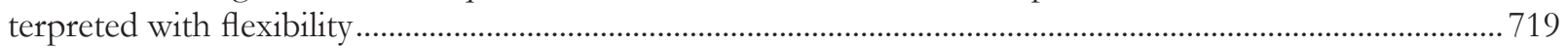

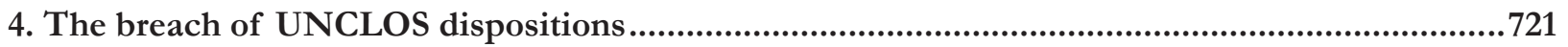

A. The Lancaster House Undertakings are now international obligations ........................................................ 721

B. The interpretation of articles 2(3), 56(2), 194, and 300 UNCLOS ............................................................ 724

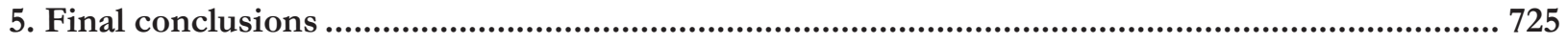

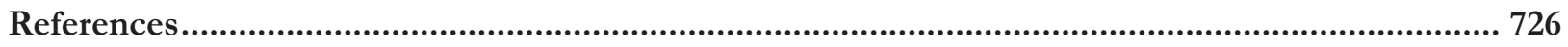




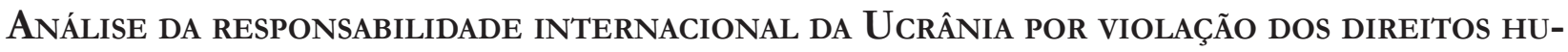
manos Na QUeda do voo da Malaysia Airlines (MH17) ........................................728

Daniela Copetti Cravo

1. Introdução

2. Teste do efetivo controle: afastando a responsabilidade extraterritorial da Rússia .................... 730

3. Responsabilidade da Ucrânia pelo não fechamento do seu espaço aéreo..................................... 732

4. Forum Conveniens: Corte Europeia de Direitos Humanos ........................................................ 734

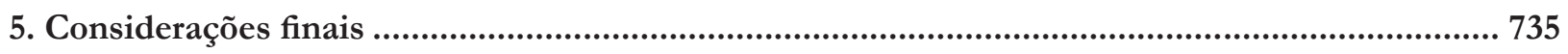

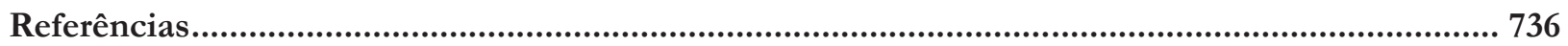

NATUREZa JuRídica do DESENVOLVIMENTo SUSTENTÁVEL NO DIREITO INTERNACIONAL .......739 Pedro Ivo Diniz

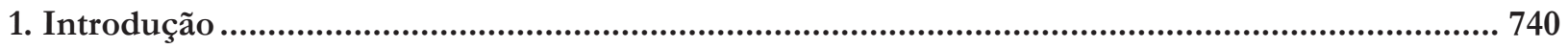

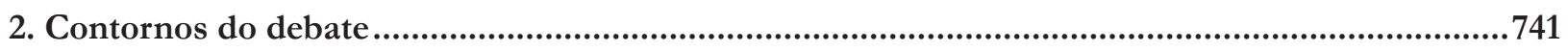

2.1. Desenvolvimento Sustentável como conceito exógeno ao Direito ……………………………………….... 742

2.2. Desenvolvimento Sustentável como "Matriz Conceitual" ............................................................................ 743

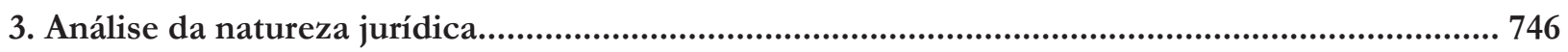

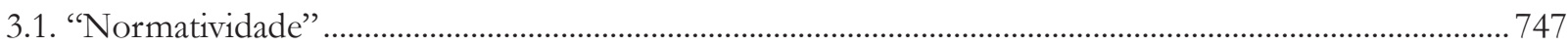

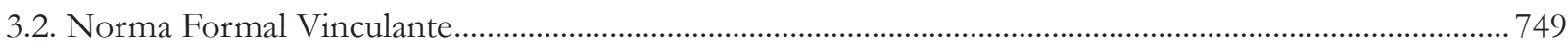

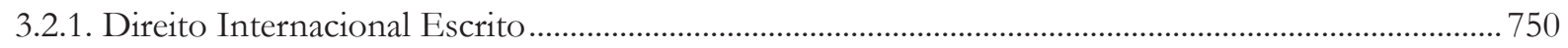

3.2.2. Princípio como Fonte de Direito Internacional........................................................................................ 751

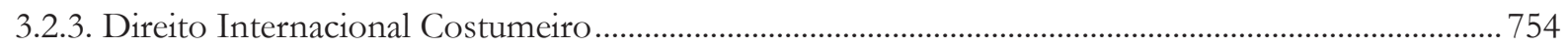

4. Desenvolvimento sustentável como uma obrigação de meio........................................................ 758

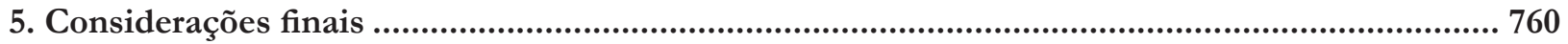

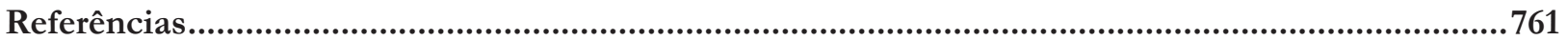

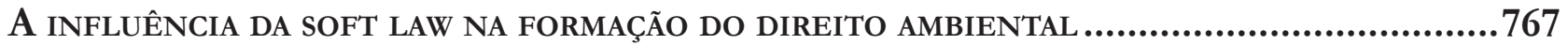

Leonardo da Rocha de Souza e Margareth Anne Leister

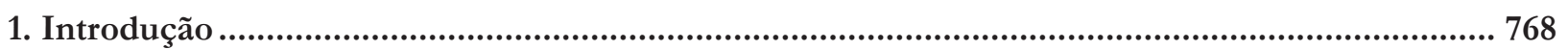

2. Riscos globais e a Soft law como característica da pós-modernidade .......................................... 768

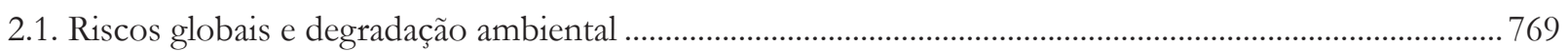

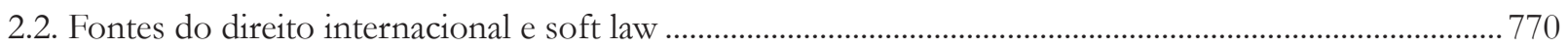

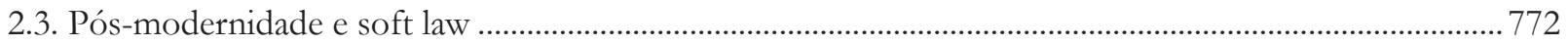

3. A influência das Soft law na formação de normas ambientais internacionais e do direito ambiental

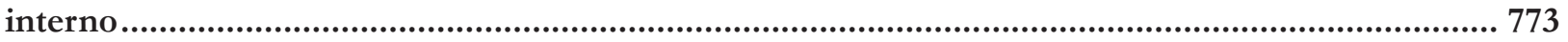

4. A internalização de normas internacionais no direito brasileiro ................................................ 774

5. Influência da opinião pública na formação dos valores ambientais .............................................. 777 


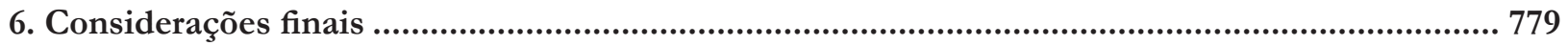

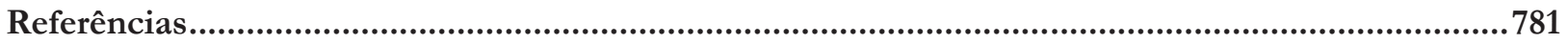

As COMPLICADAS INTER-RELAÇÕES ENTRE OS SISTEMAS INTERNOS E INTERNACIONAIS DE PROTE-

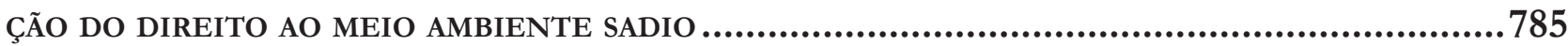

José Adércio Leite Sampaio e Beatriz Souza Costa

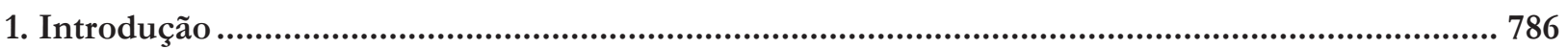

2. Direito ao meio ambiente sadio: um direito humano e direito fundamental ............................. 787

3. As inter-relações entre proteção interna e internacional do direito ao meio ambiente sadio ...... 788

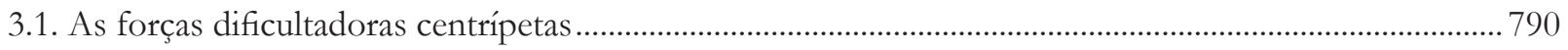

3.1.1. O direito ao meio ambiente sadio em sede do direito internacional dos direitos humanos .............. 790

3.1.2. O direito ao meio ambiente sadio em sede da Organização Mundial do Comércio............................ 791

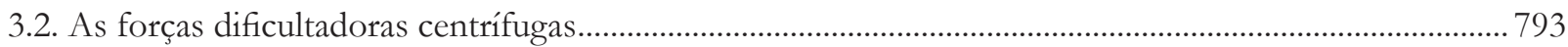

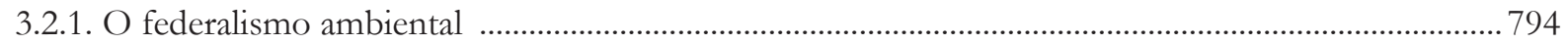

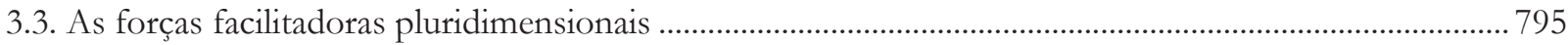

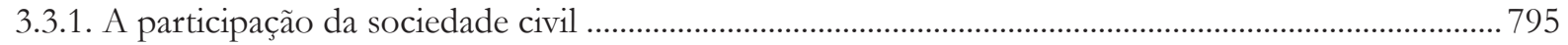

3.3.2. A cooperação internacional........................................................................................................... 797

4. Considerações finais ........................................................................................................................... 798

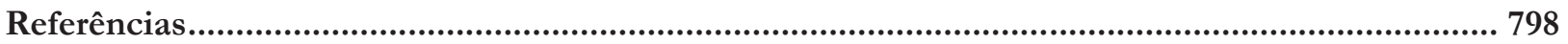

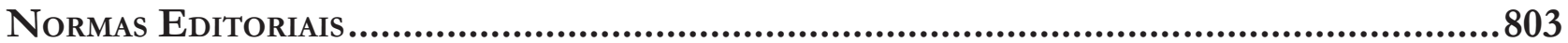




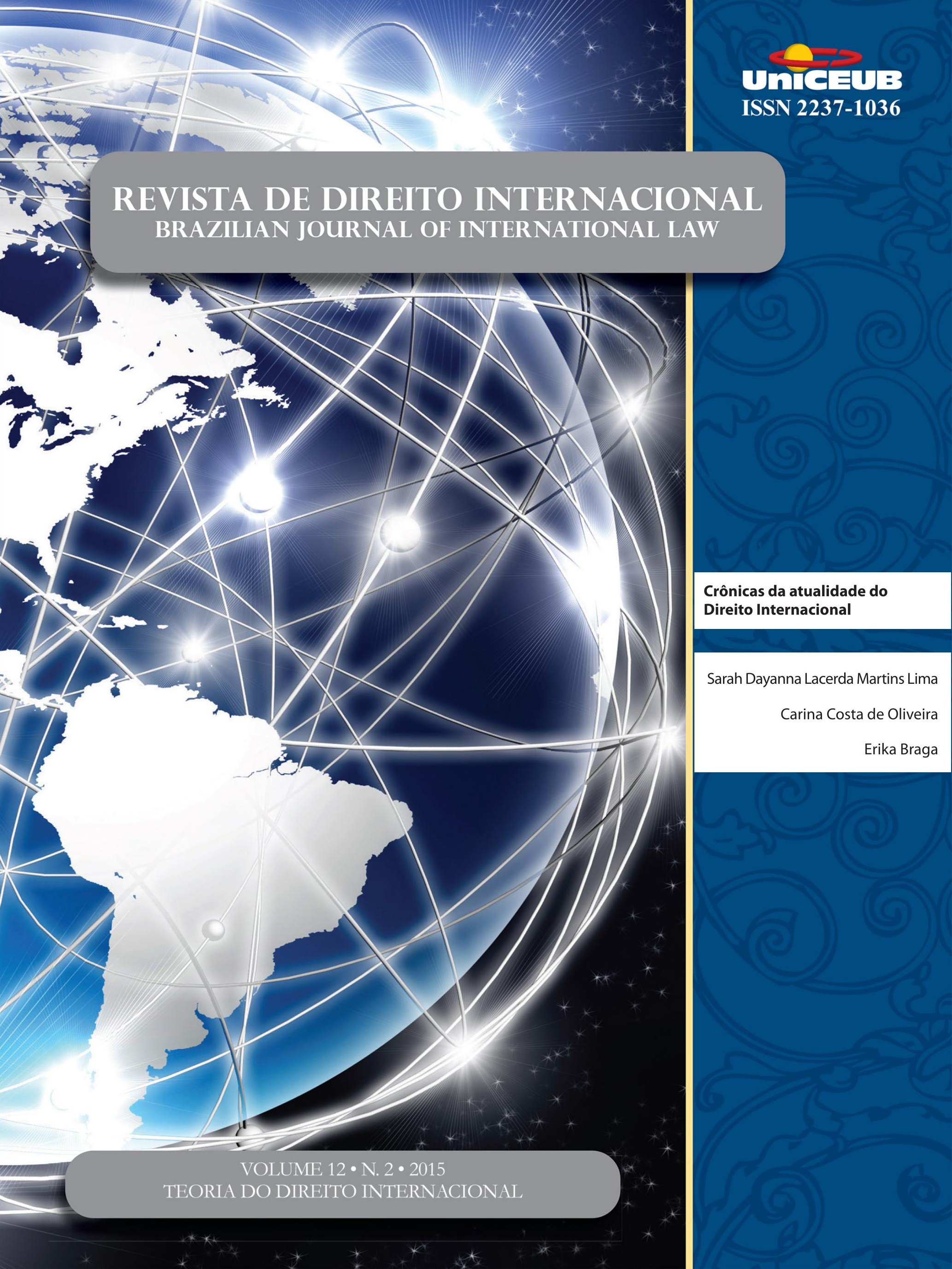




\section{Crônicas da atualidade do Direito Internacional}

Sarah Dayanna Lacerda Martins Lima**

Carina Costa de Oliveira***

Erika Braga****

\section{CRôNICA 1: O CASO No 12.655 DA CIDH - A \\ PRIMEIRA SUBMISSÃO DE CASO DE ESTERILIZAÇÃO FORÇADA à Corte InTeramericana de Direitos Humanos frente À DIMENSÃO GLOBAL DESTE CRIME}

\section{INTRODUÇÃo}

De acordo com o Comunicado de Imprensa 64/15, a Comissão Interamericana de Direitos Humanos (CIDH), submeteu à jurisdição da Corte Interamericana de Direitos Humanos (CorteIDH), em 23 de abril de 2015, o caso $\mathrm{n}^{\mathrm{o}}$ 12.655, em relação à Bolívia. ${ }^{1} \mathrm{O}$ caso refere-se à cirurgia de esterilização, a qual foi submetida a Sr. ${ }^{a}$ I.V. em um hospital público na Bolívia em $1^{\circ}$ de julho de 2000. Esta intervenção, que consiste em uma ligadura de trompas bilateral, resultou na esterilização permanente e forçada da $\mathrm{Sr}^{a}{ }^{a}$ I.V. O procedimento foi feito após uma cesariana, sem o consentimento informado da Sr. ${ }^{a}$ I.V. e sem tratar-se de um caso de emergência. A CIDH concluiu que a cirurgia foi uma violação à integridade física e psicológica da Sr. ${ }^{a}$ I.V., bem como a seus direitos de viver livre de violência e discriminação, de acesso à informação, à privacidade e à vida familiar, compreendendo a autonomia reprodutiva como parte de tais direitos. A Comissão concluiu, ainda, que o Estado não proporcionou à vítima uma resposta judicial eficaz para tais violações. ${ }^{2}$

Em seu Relatório, a Comissão recomendou que o Estado da Bolívia

** Doutoranda em Direito pela Universidade de Coimbra - UC; Mestre em Políticas Públicas pela Universidade Estadual do Ceará - UECE; Bacharel em Direito e especialista em Direito Internacional pela Universidade de Fortaleza - Unifor; Professora de Direito do Centro Universitário Estácio do Ceará. E-mail: sarahlimabr@gmail.com

*** Professora Adjunta da Faculdade de Direito da Universidade de Brasília. Líder do Grupo de Pesquisas em Direito, Recursos Naturais e Sustentabilidade, Gern-UnB. Doutora em Direito pela Universidade Paris II, Panthéon-Assas. E-mail: carina2318@gmail.com

**** Advogada, Mestre em Direito Internacional Econômico (Escola de Direito da Sorbonne, Paris).E-mail: erikabraga@hotmail.com compensasse totalmente a Sr. ${ }^{a}$ I.V. pelas violações proferidas aos seus direitos humanos, levando em conta suas perspectivas e necessidades, incluindo a compensação por danos materiais e morais sofridos; fornecimento de tratamento médico de alta qualidade e individualizado ao Sr. V.I., de acordo com as suas necessidades e adequado para o tratamento de patologias das quais sofre; investigação os fatos relacionados com a esterilização involuntária da Sr. ${ }^{a}$ I.V.; estabelecimento de penalidades que podem ser aplicadas aos responsáveis; adoção de medidas necessárias para prevenir a recorrência de futuros eventos semelhantes; avaliação de políticas e práticas em todos os hospitais em relação à obtenção de consentimento informado dos pa-

\footnotetext{
1 Comunicado de Prensa 64/15: http://www.oas.org/es/cidh/prensa/Comunicados/2015/064.asp

2 A descrição do caso está presente no Informe $N^{o}$ 72/14: http://www.oas.org/es/cidh/ decisiones/corte/2015/12655FondoEs.pdf
} 
cientes; adoção de legislação, políticas públicas e programas para garantir o direito de todas as pessoas não serem objeto de intervenções ou tratamentos sem o seu consentimento informado; investigação das deficiências nas práticas do Judiciário e de seus órgãos auxiliares que permitem atrasos excessivos em processos judiciais e a tomada das medidas necessárias para assegurar o acesso efetivo à justiça, através do devido processo e de uma administração célere e eficiente da justiça.

A Comissão Interamericana submeteu o caso $\mathrm{n}^{\circ}$ 12.655 à jurisdição da CorteIDH em 23 de abril de 2015 por considerar que o Estado da Bolívia não estava em conformidade com as recomendações constantes do Relatório do Fundo. ${ }^{3}$

Este processo vai permitir que o CorteIDH desenvolva jurisprudência sobre as obrigações positivas e negativas dos Estados sobre os direitos de saúde e autonomia sexual e reprodutiva, que, por sua vez, derivam de várias disposições da Convenção Americana de Direitos Humanos. Dessa forma, a Corte pode decidir, pela primeira vez, acerca dos direitos envolvidos em um caso ainda não tratado na sua jurisprudência, ou seja, um caso de esterilização forçada.

O caso $n^{\circ} 12.655$, no entanto, não é um fato isolado no contexto da América Latina. Nos anos de 1990, no Peru, durante a ditadura de Alberto Fujimori (19902000), um dos casos mais impactantes de violação aos direitos humanos foi o da esterilização forçada de cerca de 400 mil pessoas, das quais aproximadamente 350 mil eram mulheres. ${ }^{4}$ Inclusive, recentemente, no dia 14 de maio de 2015, o Ministério Público do Peru reabriu o caso arquivado em janeiro de 2014, no qual pretende apontar as responsabilidades de Fujimori e de seus três Ministros da Saúde (Eduardo Yong, Marino Costa e Alejandro Aguinaga). Já no que toca à realidade do Brasil, estima-se que este país detenha os maiores índices de esterilização do mundo. Embora, no Brasil, não seja comum a utilização da força ou da oferta de vantagens financeiras, dificilmente são fornecidas todas as informações necessárias para um consentimento consciente, o que configura a esterilização como compulsó-

3 Nota de remisión: http://www.oas.org/es/cidh/decisiones/ corte/2015/12655NdeRes.pdf

4 Um dos casos de esterilização forçada mais conhecidos na América Latina é o de María Mamérita Chávez, referente à petição ${ }^{\circ}$ 12.191, apresentada à Comissão Interamericana de Direitos $\mathrm{Hu}-$ manos em 15 de junho de 1999, para a qual foi elaborada uma solução amistosa. ria. Além disso, no contexto brasileiro, assim como em outros países, ainda existem divergências a respeito dos direitos reprodutivos de pessoas portadoras de deficiência mental. ${ }^{5}$

Distante de ser apenas um problema latino-americano e apesar de o caso apresentado ser o primeiro a ser colocado sob a jurisdição da CorteIDH, os crimes de esterilização forçada consistem em graves violações aos direitos humanos, que ferem a autonomia sexual e reprodutiva dos indivíduos, trazendo consequências negativas para a trajetória pessoal, a vida afetiva e a dimensão psicológica de muitas pessoas (principalmente mulheres) ao redor do mundo, tomando, ainda, proporções no campo da economia, da política, da cidadania, dentre outros.

\section{Os DIREITOS REPRODUTIVOS E A DIMENSÃo GLOBAL DOS CRIMES DE ESTERILIZAÇÃO FORÇADA}

Os titulares dos direitos reprodutivos, expressamente nomeados no Plano de Ação do Cairo ${ }^{6}$, são: os casais, os adolescentes, as mulheres (mesmo as solteiras), os homens e as pessoas idosas. Porém, o que se percebe é que, apesar desses direitos estarem estendidos a todos os titulares citados, é para as mulheres que as normas jurídicas e as políticas governamentais estão mais voltadas, destinando a elas não a atribuição de direitos, mas o reconhecimento de deveres reprodutivos. ${ }^{7}$ Este

5 Em 2004, uma sentença judicial emitida no estado de São Paulo autorizou a esterilização de uma mulher de 27 anos com deficiência mental que não tinha filhos, o que claramente desrespeita a lei de planejamento familiar brasileira (Lei $n^{\circ} 9263 / 96$ ) e fere a dignidade humana. Atualmente, embora o Brasil tenha ratificado a Convenção das Nações Unidas sobre os Direitos das Pessoas com Deficiência, a qual estabelece que os incapazes têm o direito de fazer escolhas relacionadas a suas vidas, ainda surgem muitos questionamentos a respeito do reconhecimento dos direitos reprodutivos de indivíduos com deficiência e da possível esterilização dos mesmos.

6 O Plano de Ação do Cairo foi fruto da Conferência Internacional de População e Desenvolvimento (CIPD), realizada entre os dias 5 e 13 de setembro de 1994, na cidade do Cairo. Este programa de ação afirmou os direitos reprodutivos como categoria de direitos humanos já reconhecidos em tratados internacionais, incluindo o direito à escolha livre e responsável do número de filhos e de seu espaçamento, dispondo da informação, educação e meios necessários para tanto.

7 Segundo constatação presente no Relatório da IV Conferência Mundial sobre a Mulher de Pequim (1995), as mulheres estão biológica e psicologicamente mais vulneráveis à violação de seus direitos no campo sexual e reprodutivo do que os homens. No entanto, as normas jurídicas, ao optarem por priorizar esse grupo humano, 
fenômeno acaba por configurar um paradoxo dentro da temática dos direitos reprodutivos, uma vez que as normas que deveriam proteger as mulheres, muitas vezes, acabam por fazê-las vítimas de programas governamentais que violam seus direitos, como no caso dos programas de esterilização. ${ }^{8}$

A esterilização forçada de mulheres configura uma grave violação aos direitos reprodutivos e conforma um domínio de estudos ainda pouco desenvolvido em âmbito jurídico. Apesar da atualidade desta temática (a esterilização forçada de mulheres é praticada, atualmente, em diversas partes do mundo e vários casos já foram levados ao conhecimento das Cortes Internacionais de Direitos Humanos) e de sua transversalidade em relação a diversas questões jurídicas (como, por exemplo, o consentimento para realização de atos médicos, eugenia, crimes de tortura, crimes de genocídio, sanções criminais e salvaguarda da integridade física), ainda são poucas as formulações conclusivas que versam sobre esta temática. Grande parte da doutrina que trata do tema em questão é estrangeira, situando-se, principalmente, nos campos da História e da Saúde Pública. ${ }^{9}$

O reconhecimento dos direitos reprodutivos como direitos humanos fundamentais no campo jurídico internacional implica no reconhecimento da sexualidade e da reprodução como aspectos da vida humana que necessitam ser protegidos por meio de um conjunto de normas e que requerem a implementação de políticas públicas por parte dos Estados, a fim de assegurar o exercício desses direitos.

Os direitos reprodutivos baseiam-se no reconhecimento da capacidade de cada indivíduo de organizar livremente sua vida reprodutiva. Aquilo que atualmente se denomina de direitos reprodutivos diz respeito a uma

imprimem a esta ação um caráter intervencionista e autoritário.

8 Recentemente, desde o ano de 2013, a mídia divulga inúmeros casos de mulheres que morreram ou foram hospitalizadas em estado grave na Índia após participarem dos programas públicos de esterilização.

9 Vide: BROBERG, Gunnar; ROLL-HANSEN, Nils. Eugenics and the Welfare State: Sterilization Policy in Norway, Sweden, Denmark, and Finland. East Lansing: Michigan State University Press, 2005; BRUINIUS, Harry. Better for all the world: The secret history of sterilization and America's quest for racial purity. New York: Vintage Books, 2006; DICK, Erika. Facing Eugenics: Reproduction, sterilization and the politcs of choice. Toronto: University of Toronto Press, 2013; DOWBIGGIN, Ian. The Sterilization Movement and Global Fertility in the Twentieth Century. New York: Oxford, 2008; KLUCHIN, Rebecca M. Fit to be Tied: Sterilization and Reproductive Rights in America, 1950-1980. Rutgers University Press: New Jersey, 2004. problemática que envolve o direito de ter filhos e o direito de não ter filhos. Esses dois direitos opostos (embora conexos) englobam toda uma gama de direitos relativos ao campo reprodutivo: o direito ao aborto legal e o direito a tratamento de fertilidade, o direito a uma saúde reprodutiva de qualidade e o direito ao acesso a métodos contraceptivos, o direito de escolher a quantidade de filhos que deseja ter e o direito de realizar procedimento de esterilização, dentre outros.

Embora muitos progressos já tenham sido alcançados no campo jurídico ${ }^{10}$, graves violações aos direitos reprodutivos ainda persistem em todo o mundo, como é o caso das esterilizações forçadas, que vêm sendo executadas há mais de um século em diversas partes do mundo. ${ }^{11}$

\section{A ESTERILIZAÇÃo FORÇADA COMO FERRAMEN- TAS DOS GOVERNOS PARA ELIMINAR "PROBLEMAS SOCIAIS"}

$\mathrm{Na}$ maioria das culturas do mundo, a fecundidade, a fertilidade, a faculdade reprodutora é vista como uma dádiva. De fato, muitas manifestações de arte antigas trazem imagens de mulheres grávidas como símbolos de beleza e prosperidade, pois delas brotariam novas vidas. Em contraposição, a esterilidade, a incapacidade de procriar, é considerada uma maldição.

A esterilização consiste num método anticoncepcional definitivo, ou cirúrgico, o qual pode ser realizado tanto em homens quanto em mulheres. Na mulher, é realizada por meio da ligadura de trompas, e no homem,

10 Apesar das dificuldades encontradas para que certos valores feministas fossem explicitamente redigidos, após a Conferência do Cairo (1994) e a Conferência Mundial sobre a Mulher (1995), os direitos reprodutivos foram definitivamente legitimados como direitos humanos no âmbito das Nações Unidas, podendo ser compreendidos como direitos que envolvem essencialmente as noções de sexualidade e reprodução, não se tratando meramente do funcionamento do aparelho genital e do processo reprodutivo, mas do reconhecimento de uma vida sexual e reprodutiva gratificante como um direito de cada cidadão, e não como uma mera necessidade biológica. Dessa forma, o indivíduo é livre para desenvolver determinada realização potencial de seu corpo, de viver satisfatoriamente sua sexualidade e de organizar sua vida reprodutiva.

11 Alemanha, Austrália, Bolívia, Brasil, China, Costa Rica, Dinamarca, Eslováquia, Estados Unidos da América, Finlândia, Índia, Nigéria, Panamá, Peru, Portugal, Sri Lanka e Suécia são exemplos de países nos quais pode-se encontrar evidências e denúncias dos crimes de esterilização forçada de mulheres desde o início do século XX. 
por meio da vasectomia.

Assim como com qualquer outro método contraceptivo, a esterilização só deveria ser realizada com total e livre consentimento do indivíduo. No entanto, atualmente, mulheres de todas as partes do mundo são forçadas ou coagidas a se submeteram a procedimentos de esterilização. Casos de esterilização forçada são reportados nas Américas, África, Ásia, Europa e Oceania, e as vítimas raramente alcançam justiça pelas violações sofridas a seus direitos. Seria interessante ter alguns casos concretos dessas regiões.

Embora tanto homens quanto mulheres possam ser submetidos forçadamente à esterilização, as mulheres e meninas continuam a ser desproporcionalmente impactadas, pois a mulher é ainda vista, predominantemente, como um ser reprodutor, cujo caráter maternal a tornaria naturalmente dedicada à procriação e aos cuidados com a prole.

No entendimento da Organização das Nações Unidas, esterilizações realizadas contra a vontade ou sem o conhecimento da paciente podem ser denominadas de duas formas: esterilização forçada e esterilização coativa. A esterilização forçada ocorre quando a mulher não toma conhecimento do procedimento ou não lhe é dada a oportunidade de consentir com o mesmo. ${ }^{12}$ A esterilização coativa, ou compulsória, ocorre por meio da oferta de benefícios financeiros ou outros tipos de incentivos, de táticas de intimidação e do não fornecimento das informações devidas por parte dos profissionais de saúde, a fim de conseguirem o consentimento das mulheres para a realização da cirurgia. ${ }^{13} \mathrm{O}$ termo esterilização involuntária é geralmente utilizado para se fazer menção a

12 E.g.: De acordo com os fatos narrados no caso n ${ }^{\circ} 16.761 / 09$ da Corte Europeia de Direitos Humanos (G.B. e R.B. v. República da Moldávia), com decisão proferida em março de 2013, foi realizada a remoção dos ovários e das trompas de falópio da Sr. ${ }^{a}$ G.B., sem o seu consentimento, após a realização de uma cesariana. A retirada desses órgãos ocasionou sua infertilidade, além de ter acarretado uma menopausa prematura.

13 E.g.: Na década de 1990, os profissionais de saúde peruanos eram coagidos a levar a cabo as políticas antinatalidade implementadas pelo governo. Exigia-se que os médicos realizassem um determinado número de esterilizações por mês, caso desejassem manter os seus empregos. Além de ameaçar e omitir informações, alguns médicos faziam negociações com as mulheres, chegando a dar sacas de grãos em troca da realização do procedimento cirúrgico de esterilização. Atualmente, na Índia, os governos regionais costumam oferecer incentivos como carros e eletrodomésticos aos casais que se apresentam voluntariamente aos programas de esterilização. ambos os tipos de esterilização citados. ${ }^{14}$

Os programas governamentais de esterilização surgiram na Europa e nos Estados Unidos durante a década de 1920, como parte de movimentos eugenistas ${ }^{15}$. Os ordenamentos jurídicos de várias nações autorizavam formalmente a implementação de programas de esterilização, a fim de que determinados grupos de pessoas não se proliferassem.

A Suíça, a Dinamarca e a Suécia foram os primeiros países a legislar acerca da esterilização dos anormais e dos doentes mentais na Europa, em 1929. Entretanto, o exemplo mais drástico de esterilização humana eugênica foi praticado pela Alemanha, em busca da pureza ariana.

Durante as décadas de 1920 e 1930, o governo dos Estados Unidos da América estava convencido de que determinadas condições, como alcoolismo, promiscuidade sexual e pobreza eram hereditárias. Neste período, os profissionais de saúde norte-americanos realizaram esterilizações forçadas em milhares de mulheres pobres, negras e latinas. Em 1927, a Suprema Corte americana validou o direito de os estados esterilizarem seus cidadãos considerados "inapropriados". 16 Em 1941, cerca de 38.087 indivíduos foram esterilizados com base em fundamentos eugenistas.

Entre as décadas de 1960 e 1990, a esterilização forçada foi utilizada como método de controle populacional em alguns países do continente europeu, asiático e latino-americano (Dinamarca, Suécia, Finlândia, Noruega, Índia, China e Peru são exemplos marcantes). A oferta de incentivos e as pressões exercidas por profissionais da saúde e pela própria força policial eram utilizadas para assegurar o consentimento do procedimento cirúrgico.

14 No presente texto, faço uso do termo "esterilização forçada" para me referir, de forma geral, a todas as situações que envolvam a manipulação de mulheres, levando-as a arcar com consequências que não lhes eram desejadas.

15 Os movimentos eugenistas consistem em movimentos sociais baseados nas teorias de eugenia. Eugenia, por sua vez, é um termo criado por Francis Galton (1822-1911), que consiste no estudo dos agentes sob o controle social que podem aprimorar ou empobrecer as qualidades raciais das gerações futuras, seja no aspecto físico ou mental.

16 Buck vs. Bell (1927) é uma decisão da Suprema Corte dos Estados Unidos, redigida pelo Juiz Oliver Wendell Holmes Jr., a partir da qual o Tribunal decidiu que uma lei estadual que permitia a esterilização compulsória dos "inaptos", incluindo os deficientes mentais, não violava a cláusula do devido processo legal da $14^{\text {a }}$ Emenda da Constituição Americana. Esta decisão foi amplamente vista com um endosso à eugenia, uma vez que o Estado almejava o melhoramento da raça humana por meio da eliminação de indivíduos "defeituosos". 
Atualmente, continuam a ser reportados inúmeros casos de esterilização forçada de mulheres e, em muitos países, grupos historicamente discriminados ou socialmente marginalizados compõem os principais alvos das políticas estratégicas dos governos para reduzir o crescimento populacional e eliminar determinados "problemas sociais" que sobrecarregariam as despesas públicas: Mulheres soropositivas; mulheres com deficiência mental; mulheres indígenas e mulheres pertencentes a uma minoria étnica específica (mulheres da etnia Romani, por exemplo).

\section{A base JURÍdica para o ReConheCimento DOS DIREITOS REPRODUTIVOS EM ÂMBITO INTER- NACIONAL}

Em 1968, durante a Conferência de Direitos Humanos das Nações Unidas foi reconhecido o direito humano básico de controle da natalidade, com livre decisão do casal acerca da maternidade e da paternidade livre e responsável.

$\mathrm{Na}$ Conferência Internacional sobre População e Desenvolvimento, realizada na cidade do Cairo em 1994, estabeleceu-se que a comunidade internacional se empenharia em tornar universal o acesso ao planejamento familiar e aos serviços de saúde sexual e reprodutiva até o ano de 2015.

A Plataforma de Beijing, documento internacional elaborado durante a IV Conferência Mundial sobre a Mulher, em 1995, identifica a esterilização forçada como um ato de violência e reconhece os direitos das mulheres de fundarem uma família, de alcançarem altos níveis de saúde sexual e reprodutiva, e de tomar decisões concernentes ao campo reprodutivo, livres de discriminação, coação ou violência.

O Comitê sobre a Eliminação de todas as formas de Discriminação contra a Mulher considera a esterilização forçada como uma forma de violência contra os direitos das mulheres, ferindo sua dignidade humana e suas integridades física e mental.

Segundo Radhika Coomaraswany, relatora especial da Nações Unidas sobre violência contra mulheres, afirma que a esterilização forçada consiste em método cirúrgico de controle da fertilidade feminina, o qual viola a integridade física e mental das mulheres, sendo considerado um ato de extrema violência.
As esterilizações forçadas consistem em graves ofensas aos direitos humanos, podendo ser descritas como atos de tortura e tratamento cruel, desumano e degradante, conforme a Declaração sobre a Proteção de todas as Pessoas contra a Tortura e outros Tratamentos ou Penas Cruéis, Desumanos e Degradantes, de 1975. A esterilização forçada de indivíduos de um determinado grupo social pode, ainda, configurar crime de genocídio, conforme artigo $2^{\circ}$ da Convenção para a Prevenção e a Repressão do Crime de Genocídio, de 1948.

No que tange à esterilização de deficientes mentais, a Convenção Internacional sobre os Direitos das Pessoas com Deficiência, de 2007, contém artigos específicos sobre o tema. O artigo 23 reforça o direito de a pessoa com deficiência formar uma família e controlar sua fertilidade da mesma forma que os demais indivíduos. $\mathrm{O}$ artigo 25 deixa claro que o livre consentimento informado é indispensável na prestação de quaisquer serviços de saúde às pessoas com deficiência. Com base neste documento, o Comitê sobre os Direitos das Pessoas com Deficiência recomenda "a abolição de cirurgia ou tratamento sem o livre consentimento informado do paciente".

Conclui-se que, apesar da existência de um aparato jurídico que fornece base para o reconhecimento dos direitos reprodutivos das mulheres, os crimes de esterilização forçada persistem, configurando graves violações a estes direitos. Assim, o problema da esterilização forçada demonstra, de forma dramática, as dificuldades que mulheres de várias partes do mundo enfrentam no controle de sua vida reprodutiva, de uma forma geral.

\section{Crônica 2: Os direitos e os deVERes DECORRENTES DO RECENTE CONTRATO ASSINADO ENTRE O BRASIL E A Autoridade InTERnACIONAL dos Fundos MARINHOS}

No dia 9 de novembro de 2015, o Brasil, por meio da Companhia de Produção de Recursos Minerais $(\mathrm{CPRM})^{17}$, assinou com a Autoridade Internacional

17 *Professora Adjunta da Faculdade de Direito da Universidade de Brasília. Líder do Grupo de Pesquisas em Direito, Recursos Naturais e Sustentabilidade, Gern-UnB. Doutora em Direito pela Uni- 
dos Fundos Marinhos (International Seabed Authority - ISBA) o primeiro contrato brasileiro de exploração dos fundos marinhos em uma área localizada além da jurisdição nacional ${ }^{18}$. Através desse contrato, o Brasil integrou o pequeno e seleto grupo de Estados com direitos exclusivos de exploração de recursos minerais nos fundos marinhos, área que está sob a gestão da ISBA. Além de ser o primeiro contrato brasileiro, este é o primeiro contrato assinado para a exploração de uma área de aproximadamente 3 mil km2 localizada no Atlântico Sul, mais especificamente no Alto do Rio Grande, por um Estado do Atlântico Sul. Contudo, não haverá apenas direitos. Haverá obrigações que deverão ser cumpridas para que o contrato de exploração possa, no futuro, ser renovado ou ser modificado para um contrato de explotação. Diante desse cenário, é relevante apresentar o contexto da assinatura do contrato assim como os direitos e os deveres que o Brasil terá a partir de sua assinatura.

A ISBA, instituída pela Convenção de Montego Bay, é a Organização responsável pela gestão da exploração dos fundos marinhos na "Área" compreendida pelo solo e pelo subsolo localizados em áreas além da jurisdição nacional ${ }^{19}$. Diversos princípios regulam a exploração desse espaço, podendo ser destacados, particularmente, o princípio do Patrimônio Comum da Humanidade ${ }^{20}$, do uso pacífico da Área ${ }^{21}$ e da proteção do meio ambiente $^{22}$. A regulação do tema é feita pela Convenção de Montego Bay, por recomendações da Comissão Técnica e Jurídica da Autoridade e por regulamentos elaboradas pela ISBA relacionados à exploração de nódulos polimetálicos ${ }^{23}$, de sulfetos polimetálicos ${ }^{24}$ e de crostas

versidade Paris II, Panthéon-Assas.

Disponível em: <http://www.cprm.gov.br/publique/Noticias/ Contrato-assinado-entre-CPRM-e-ISBA-preve-investimentode-11-milhoes-de-dolares-na-exploracao-do-Atlantico-Sul-4113. html?from_info_index=41>. Acesso em: $30 \mathrm{dez} 2015$.

18 Disponível em: <https://www.isa.org.jm/deep-seabed-minerals-contractors?qt-contractors_tabs_alt $=2 \#$ qt-contractors_tabs_ alt $>$. Acesso em: 30 dez 2015.

19 Convenção das Nações Unidas para o Direito do Mar, 1982, Artigo 1o.

20 Convenção das Nações Unidas para o Direito do Mar, 1982, Artigo 136.

21 Convenção das Nações Unidas para o Direito do Mar, 1982, Artigo 141.

22 Convenção das Nações Unidas para o Direito do Mar, 1982, Artigo 145.

23 Autoridade Internacional dos Fundos Marinhos. ISBA/19/C/17. Disponível em: https://www.isa.org.jm/miningcode. Acesso em: 2 jan 2016.

24 Autoridade Internacional para os fundos marinhos. Decision cobaltíferas ${ }^{25}$. Ainda não há normas sobre a explotação desses recursos, o que está sendo objeto de debate no âmbito da ISBA ${ }^{26}$.

O Brasil assinou um contrato para a exploração de crostas ricas em cobalto, níquel, platina, manganês, tálio e telúrio em uma área que está a cerca de $1.500 \mathrm{~km}$ do Rio de Janeiro. Para tanto, foi elaborado um plano de trabalho aprovado previamente pela ISBA ${ }^{27}$. As obrigações brasileiras estão conectadas a esse plano de trabalho que deve ser executado de acordo com as normas da ISBA pelo período de trinta anos. Esse período foi dividido em três fases, com duração de 5 anos cada ${ }^{28}$. De acordo com as informações obtidas no site da CPRM, na primeira fase serão feitos estudos de sonografia física e de ecologia ambiental, enquanto que na segunda serão analisadas as características mineralógicas, estruturais e geomorfológicas da área delimitada. A última fase será destinada à seleção de áreas para a análise da viabilidade econômica, ambiental e técnica dos depósitos minerais identificados ${ }^{29}$.

Entre os direitos pode ser citada a exploração (pesquisa) exclusiva da área delimitada ${ }^{30}$. Entre os deveres, destacam-se: a elaboração de normas relacionadas à exploração de áreas localizadas além da jurisdição nacional, além das normas que regem a exploração em áreas sob a jurisdição nacional; a observância de uma perspectiva de precaução diante dos possíveis riscos da atividade ${ }^{31}$. Os deveres são os desafios que o Brasil

of the Assembly of the International Seabed Authority relating to regulations on prospecting and exploration for polymetallic sulphides in the Area. ISBA/16/A/12/Rev.1, 2010. Disponível em: https://www.isa.org.jm/mining-code. Acesso em: 2 jan 2016.

25 Autoridade Internacional para os Fundos Marinhos. ISBA/18/A/11. Disponível em: https://www.isa.org.jm/miningcode. Acesso em: 2 jan 2016.

26 Sobre o tem aver: <https://www.isa.org.jm/mining-code>. Acesso em: 2 jan 2016.

$27 \mathrm{Na} 20^{\text {a }}$. Sessão Anual do Conselho da ISBA, julho de 2014 (Decisão ISBA/20/C/30). Ver ainda a recomendação da Comissão Técnica e Jurídica da ISBA (ISBA/20/C/17).

28 Disponível em: http://www.cprm.gov.br/publique/Noticias/Contrato-assinado-entre-CPRM-e-ISBA-preve-investimentode-11-milhoes-de-dolares-na-exploracao-do-Atlantico-Sul-4113. html?from_info_index $=41$. Acesso em: 2 de jan 2016.

29 Disponível em: http://www.cprm.gov.br/publique/Noticias/Contrato-assinado-entre-CPRM-e-ISBA-preve-investimentode-11-milhoes-de-dolares-na-exploracao-do-Atlantico-Sul-4113. html?from_info_index=41. Acesso em: 2 jan 2016.

30 Ver sobre o tema: MORE, Rodrigo; SOUZA, Cláudia Maria Rezende. Elevação do Rio Grande: obrigações e responsabilidades. Novas Edições Acadêmicas, 2015.

31 Ver sobre o tema: Regulation 31(2). Regulation 2(2), 5(1) and 31 (5), 33(2) and 5. Ver ainda: TANAKA, Yoshifumi. The international law of the Sea. Cambridge, 2015 , p. 319. 
enfrentará para desenvolver adequadamente o plano de trabalho proposto.

Apesar do possível retorno futuro da atividade, sabe-se que os riscos da atividade não podem ser ignorados ${ }^{32}$. Mesmo que ainda exista uma incerteza científica quanto aos riscos específicos da atividade, não há como negar a possibilidade de efeitos adversos no ecossistema ${ }^{33}$. São necessárias, portanto, medidas de prevenção a possíveis danos que podem ser causados ao meio ambiente marinho. A ISBA elaborou um estudo técnico ${ }^{34}$ que analisa o estado atual e os possíveis riscos da exploração de sulfetos polimetálicos e de crostas cobaltíferas. Esse estudo ainda deve ser aprimorado, mas alerta quanto a alguns dos parâmetros que devem ser seguidos na exploração dos minérios. Por sua vez, o Brasil deve, ainda, organizar a sua legislação interna sobre a exploração da Área. Considerando que nem as normas nacionais aplicáveis a áreas sob a jurisdição nacional são precisas e específicas para a exploração de minérios na plataforma continen$\mathrm{tal}^{35}$, ainda não foram elaboradas normas relacionadas à exploração no âmbito internacional.

Tanto a ISBA quanto os Estados exploradores são limitados no que concerne à gestão do patrimônio comum da humanidade ${ }^{36}$. Não há uma identificação pre-

32 Ver sobre o tema: MORE, Rodrigo; SOUZA, Cláudia Maria Rezende. Elevação do Rio Grande: obrigações e responsabilidades. Novas Edições Acadêmicas, 2015.

33 Ver sobre o tema: Autoridade Internacional para os Fundos Marinhos. Polymetallic Massive Sulphides and Cobalt-Rich Ferromanganese Crusts: Status and Prospects - ISA Technical Study No. 02. Kingston, 2002; HOGLAND, Peter; BEAULIEU, Stace; TIVEY, Marice A.; EGGERT, Roderick G.; GERMAN, Christopher; GLOWKA, Lyle; LIN, Jian. "Deep-sea mining of seafloor massive sulfides". Marine Policy, v. 34, 2010, pp 728-732.

34 ISBA. Polymetallic Massive Sulphides and Cobalt-Rich Ferromanganese Crusts: Status and Prospects - ISA Technical Study No. 02. Kingston, 2002.

35 Ver sobre o tema: OLIVEIRA, C.C. Meio Ambiente Marinho e Direito: exploração e investigação na Zona Costeira, na Plataforma Continental e nos Fundos Marinhos. 1. ed. Curitiba: Juruá Editora, 2015. v. 1. 402p. 36 Ver sobre o tema: KISS, A. "La notion de patrimoine commun de l'humanité". RCADI, t. 175, 1982, p. 103 e s; LODGE, Michael W. "The Common Heritage of Mankind".The International Journal of Marine and Coastal Law, n. 27, 2012, p. 733-742; NOYES, John E. "The common heritage of mankind: past, present, and future". Denv. J. Int'l L. \& Pol'y, n. 20, 447, 2011-2012; BASLAR, Kemal. The Concept of the Common Heritage of Mankind in International Law. Hague: Nijhoff Publishers, 1998; SHACKELFORD, Scott J. "The Tragedy of the Common Heritage of Mankind". Stan Envtl LJ, n. 28, 2009; JOYNER, C. "Legal Implications of the Concept of the Common Heritage of Mankind". Int'l \& Comp. LQ, n. 35, 1986; BARDONNET, D. «Le projet de convention de 1912 sur le Spitsberg et le concept de patrimoine commun de l'humanité». In: Humanité et droit international. Mélanges René-Jean Dupuy. Paris: Pedone, 1991, p. 13. cisa das obrigações de preservação do meio ambiente marinho dos Estados e das Organizações Internacionais, apesar de existir previsão de possível suspenção das atividades em casos de riscos graves, o que ainda não foi utilizado diante de nenhum caso. O Conselho da ISBA tem competência para “ (...) supervisionar e coordenar a implementação dos dispositivos da Parte XI relacionados a qualquer questão de descumprimento das normas aplicáveis" ${ }^{\prime 37}$. O artigo 162 (a) obriga o Conselho da Autoridade a tomar algumas medidas diante de situações emergenciais tais como a suspenção ou a busca pela conformidade da operação a fim de prevenir danos ao meio ambiente marinho. $\mathrm{O}$ regulamento sobre exploração de Nódulos Polimetálicos confirma essa obrigação (art. 32-5). Pode-se citar, também, a possibilidade de estabelecer áreas de interesse particular que não podem ser exploradas pelo Estado contratante. Como exemplo, em 2012, o Conselho da ISBA aprovou o plano de gestão para a Zona Clarion-Clipperton, incluindo o estabelecimento de nove áreas de interesse particu$\operatorname{lar}^{38}$. Trata-se do primeiro plano de gestão ambiental regional ${ }^{39}$. Contudo, esse plano é apenas regional e não se estende ao caso brasileiro.

Pode-se afirmar que, frente a esse contexto, o acesso do Brasil à exploração dos fundos marinhos posiciona o Estado no reduzido rol de países com competências exclusivas para realizar essa atividade. Contudo, adiciona obrigações internacionais dificilmente mensuráveis, o que insere o país em uma área de risco. Este, por sua vez, pode ser mitigado por meio do cumprimento adequado, baseado no princípio da precaução, das obrigações indicadas no plano de trabalho assinado pelo Estado e das normas aplicáveis à exploração de minérios nos fundos marinhos.

\section{Crônica 3: II FóRUM JURÍdICO doS BRICS: DESAFIOS E OPORTUNIDADES}

O Fórum Jurídico dos BRICS é uma plataforma de diálogo de alto nível entre os Estados membros - Brasil, Rússia, Índia, China e África do Sul - para promover a cooperação entre representantes dos governos, juristas,

37 Art. 162(2), a) da Convenção de Montego Bay.

38 ISBA/18/C/22, 26 July 2012, para 1.

39 Ver, ainda, o Relatório da International Seabed Authority, 20 Maio 2014 
pesquisadores e empreendedores. Busca-se um melhor entendimento técnico entre as partes e uma comunicação mais sofisticada entre os respectivos círculos legais, a partir de um processo de cooperação envolvendo as distintas práticas jurídicas, capaz de fortalecer o Estado de Direito e alicerçar decisões políticas, econômicas e culturais, concernentes à agenda revisionista do grupo.

II Fórum Jurídico dos BRICS teve a "Cooperação Jurídica: Rumo a uma Comunidade BRICS de Destino Compartilhado" como tema principal e aconteceu entre os dias 13 e 16 de outubro de 2015 em Xangai. Propôs-se a abordar questões importantes e complexas - tendo em vista, especialmente, as diferentes estruturas jurídicas de cada membro. Consideradas as projeções pessimistas e o ceticismo de muitos $^{40}$, ainda assim, é inegável a existência de um campo de oportunidades reais. Demandam, entretanto, esforços concertados e planejados para que as externalidades positivas possam ser observadas. Foi nesse contexto que três temas direcionaram os trabalhos em Xangai: (i) "On Domestic and International Rule of Law from the Perspective of a Developing Country"; (ii) "Cooperation on Financial Law between the BRICS Countries"; e (iii) "Dispute Resolution Mechanism within BRICS Countries".

Nos debates, um elemento comum emerge, destacando que cada Estado membro, de modo geral, desconhece o sistema legal adotado pelos outros. $\mathrm{O}$ desafio preliminar a ser enfrentado perpassa a implementação de uma metodologia de trabalho que possibilite o aprofundamento do conhecimento técnico recíproco. O primeiro tema, justamente, na busca de uma maior coesão, exerceu essa função ao abordar o Direito Constitucional de cada Estado e seus reflexos no Direito Internacional - o que é basilar para o desenvolvimento desse grupo que pretende aumentar seu peso no sistema internacional multipolar.

Reconhecemos que a lógica dos BRICS não é voltada para dentro, dadas a assimetria do perfil dos 5 paí$\operatorname{ses}^{41}$; o foco é a dimensão política, exercendo pressão para uma ordem econômica mundial mais equilibrada, na qual esses países em desenvolvimento tenham maior representatividade e força no processo decisório, como já o fazem nos resultados econômicos ${ }^{42}$. Entretanto, há

40 Em novembro de 2015 a Goldman Sachs, responsável pela criação do acrônimo BRICS (2001), anunciou o fechamento do fundo de investimento destinado aos BRICS.

41 A dinâmica comercial entre os BRICS representa cerca de $8 \%$ do comércio deles com o mundo.

42 Os membros do BRICS correspondem a, aproximadamente, sinais de que maior atenção deverá ser dada à relação entre os Estados membros.

A criação do Banco dos BRICS (New Development Bank) com sede em Xangai, anunciada em julho de 2015, é um movimento em direção à maior institucionalização do bloco e levanta uma série de questões, inclusive, sobre a possiblidade de desafiar a liderança ocidental e responder ao anacronismo das instituições de Bretton Woods. A avaliação do seu impacto na governança global poderá ser feita apenas a longo prazo, e dependerá, em grande medida, do alinhamento e do trabalho coeso dentro do grupo.

Nesse sentido, um dos objetivos do Fórum foi discutir a necessidade de cooperação em matéria de Direito Financeiro, Tributário e Econômico. É um passo importante e, possivelmente, imprescindível para o êxito desse novo modelo de transação financeira, que se apresenta como alternativa ao Fundo Monetário (FMI) e ao Banco Mundial (BM) para os mercados emergentes. Os Estados membros tendem a adequar suas legislações especificas para facilitar o fluxo de investimentos e de operações societárias - com destaque para as alterações legais já feitas pela China.

Nota-se que, em termos jurídicos, tudo se mostra ainda muito incipiente e regado por incertezas. O próprio desconhecimento recíproco das legislações nacionais dificulta um trabalho de harmonização que, por si só, já é uma tarefa ousada, na medida em que existe um desequilíbrio de poder dentro dos BRICS - em que pese o discurso de igualdade proferido oficialmente. A intenção do Fórum é tentar balancear as forças e propor, num futuro próximo, os ajustes necessários na proporção dos resultados almejados.

Em paralelo, as lacunas existentes no tratado que instituiu o New Development Bank também foram apontadas como um problema que deve ser solucionado com agilidade, por impedirem uma atuação mais pragmática dos atores envolvidos e aumentarem as chances de contenciosos internacionais, diante da omissão e obscuridade que permeia alguns pontos relevantes. É indiscutível que a criação de um banco de desenvolvimento com atuação global constitui

$1 / 3$ da população mundial, são responsáveis por mais de $50 \%$ do crescimento do PIB global nos últimos ano, e estão entre as 10 maiores cotas do FMI (o Brasil está em $10^{\circ}$ lugar, atrás da Índia), apesar de não possuírem proporcional poder de voto (a China, segunda maior economia do mundo, tem apenas 3,81\% do total dos votos). 
numa empreitada das mais desafiadoras, mas o refinamento e a precisão jurídica dos termos acordados deve ser observado pelo corpo diplomático dos Estados, sob a pena de se perderem em um cenário de instabilidade da nova plataforma. Portanto, há muito trabalho a ser feito e um caminho sinuoso pela frente.

Nessa esteira, o último ponto discutido no Fórum foi voltado à possibilidade de criação de um mecanismo de solução de controvérsias para demandas entre os membros dos BRICS. É um tópico controverso, principalmente, em razão do já mencionado desequilíbrio de poder dentro do grupo. Individualmente, cada Estado tem papel e peso distintos na dinâmica geopolítica, refletindo, inevitavelmente, no poder de decisão dentro do bloco. Cada membro defende seus interesses particulares e uma composição nesse campo depende de intensas rodadas de negociação.

À exemplo do Brasil, que não é signatário do ICSID e tem poucos tratados bilaterais de investimento ratificados, a arbitragem de litígios envolvendo o Estado como parte da disputa é algo a ser evitado. Para outros países, como a China, atualmente, essa é uma solução que a beneficia. Na realidade, o peso da balança tende para um lado ou para outro de acordo com a posição do Estado na cadeia produtiva e no fluxo de investimentos; tudo depende se é receptor ou fornecedor de capital. Isso ilustra a complexidade do debate. Tribunal Permanente, Tribunal ad hoc, Câmaras de Arbitragem já existentes, nova Câmara de Arbitragem. São muitas opções e pouco entendimento.

Assim, com um horizonte apontando para desafios e oportunidades, ao fim do II Fórum Jurídico dos BRICS foi assinada a Declaração de Xangai e o Memorando de Entendimento para o estabelecimento de uma aliança entre Universidade de Direito dos membros dos BRICS. Também foram inaugurados o Centro de Treinamento Jurídico dos BRICS e o Instituto de Estudos Jurídicos dos BRICS, representando medidas concretas para fortalecer o diálogo jurídico e enfrentar os obstáculos no percurso da construção de um novo panorama global. Veremos os resultados iniciais, no próximo Fórum, que acontecerá na Índia em 2016. 


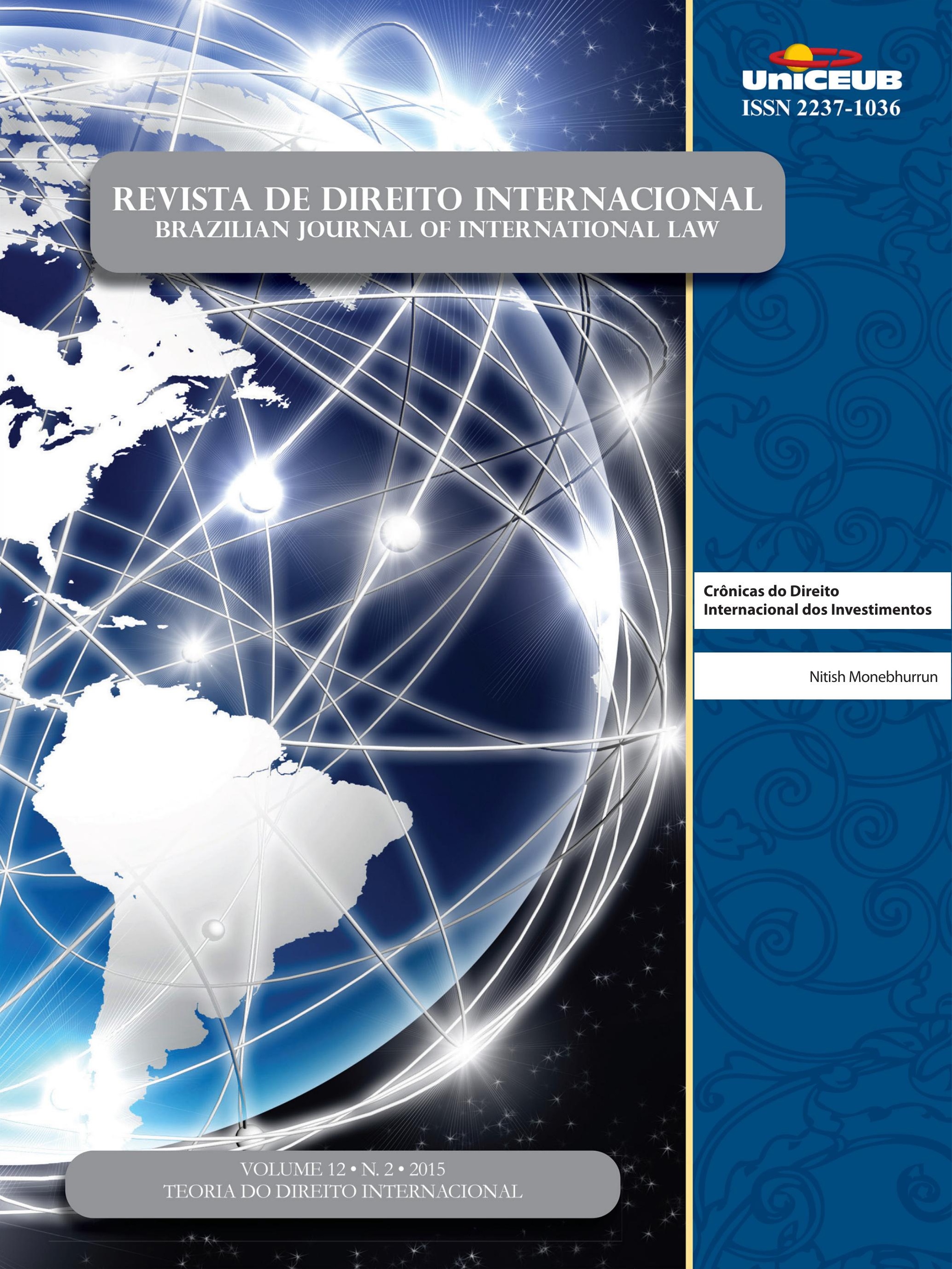




\section{Crônicas do Direito Internacional dos Investimentos}

Nitish Monebhurrun**

\section{... E ELES DESCOBRIRAM A ARBITRAGEM INVESTIDOR- Estado.}

\section{INTRODUÇão}

A atualidade do Direito Internacional Econômico tem sido marcada pelas negociações curiosas entre os Estados Unidos e a União Europeia sobre o Tratado de Livre-Comércio Transatlântico (Transatlantic Free-Trade Agreement, TAFTA): eis porque o tratado está sendo negociado de forma altamente sigilosa, insulado da participação pública e do acesso à informação ao público. Este foi, deveras, informado pela imprensa e, sobretudo, pelos wikileaks. A falta de transparência nas negociações do tratado inquietou e frustrou a opinião pública européia; o aspecto ultra sigiloso não permitiu antever algo de positivo atinente ao acordo econômico — o que despertou uma impressão de traição em um espaço sempre caracterizado por sua abertura democrática. Recentemente, a mobilização da sociedade civil — organizada em um coletivo chamado Stop TAFTA — logrou um abaixo-assinado com aproximadamente três milhões de assinaturas, enviado à Comissão Europeia, para interromper as negociações com o objetivo de declarar o tratado letra morta. Em uma União Europeia cada vez mais questionada, o tratado simboliza o pináculo do ultra liberalismo que muitos - Estados e cidadãos - não querem. O tratado que pretende reger o comércio e os investimentos entre os Estados Unidos e a União Européia foi em especial criticado por conter uma cláusula sobre a arbitragem investidor-Estado no capítulo relativo à proteção dos investimentos. No Direito Internacional dos Investimentos, a maioria dos acordos de proteção dos investimentos prevê a arbitragem entre investidores e Estados como meio de resolução de disputas entre estes: se o investidor estima que os seus diretos protegidos pelo acordo aplicável foram infringidos, ele pode pedir a constituição de um tribunal arbitral que se pronunciará sobre a disputa. Ora, esse mecanismo não é novo e vem caracterizando os acordos sobre a proteção dos investimentos desde os anos 60. E os países europeus foram os primeiros a inclui-lo nos seus respectivos tratados. Trata-se agora de algo comumente admitido e há mais que 3,000 acordos relativos aos investimentos com esse mecanismo de resolução de disputas. Malgrado, ironicamente, parece que é só com o debate sobre o TAFTA que alguns países europeus e os seus cidadãos o descobriram, vislumbrando-o agora como uma aberração jurídica, como uma brecha que limita o poder regulatório do Estado ou como um poder inconcebível e ilegítimo colocado nas mãos dos tribunais arbitrais - instituições que se tornaram repentinamente monstruosas e desconfiáveis. Defronte

** Doutor em Direito Internacional (Escola de Direito de Sorbonne, Paris), Professor de Direito (Centro Universitário de Brasília), Professor Visitante (Programa do Mestrado em Direito Internacional, Universidad de la Sabana, Bogotá).

\footnotetext{
desse ceticismo súbito dos países membros da União Européia em relação a
} 
arbitragem investidor-Estado (2), a Comissão Européia propôs um sistema inovador no Direito Internacional dos Investimentos, um sistema que se baseia em uma jurisdição com duas instâncias — o que, entretanto, foge do espírito de um mecanismo alternativo de resolução de disputas (3).

\section{O CETICISMO REPENTINO dos Países da UnIÃo EUROPÉIA EM RELAÇÃo A ARBITRAGEM INVESTI- DOR-ESTADO}

O recente caso Vattenfall c. Alemanha ${ }^{1}$, ainda pendente, despertou a atenção dos cidadãos da União Européia sobre o poder que muitas empresas multinacionais têm no Direito Internacional dos Investimentos: uma proteção ampla garantida pelos acordos relativos aos investimentos, uma gama de princípios invocáveis para garantir essa proteção, a capacidade de iniciar uma arbitragem - ao contrário dos Estados que sempre atuam como os réus. No referido caso, uma empresa da Suécia, estabelecida na Alemanha decidiu intentar um processo arbitral contra o Estado anfitrião depois da adoção por este de medidas regulatórias em 2011 para gradualmente limitar - e depois interditar - o uso da energia nuclear. A empresa considera que ditas medidas são equiparadas a uma expropriação indireta. O caso configura a dialética agora clássica entre o poder regulatório do Estado anfitrião e a proteção dos investimentos. Em muitos casos, há um conflito potencial entre este poder de polícia para reger o interesse público e o engajamento estatal de proteger o interesse privado dos investidores. Durante muitos anos, isso não foi uma preocupação grande dos países europeus. Não obstante, essa problemática já capturou a atenção de outros países, notadamente aqueles em desenvolvimento, que foram muitas vezes processados pelas empresas oriundas de países europeus pelas mesmas razões invocadas por Vattenfall contra a Alemanha. O que parece ser a atualidade de alguns já se tornou uma banalidade para outros. A arbitragem investidor-Estado está sendo repensado agora que os países europeus estão visualizando-se — como monstros frios resfriados —, na postura do réu contra as poderosas empresas multinacionais americanas. Repentinamente,

1 Vattenfall $A B$ e outros c. Alemanha, CIRDI no. ARB 12/12/12 (caso pendente). percebeu-se que haverá um limite ao poder de regular, que são disputas cabíveis à jurisdição dos próprios países europeus, que as empresas nacionais serão discriminadas por não poder processar os seus Estados pelo sistema de arbitragem ao contrário das empresas estrangeiras, que dito sistema incorre custos elevados ou que há conflitos de interesse potenciais inerentes ao processo arbitral. Em resposta a esses elementos, a Comissão européia propôs um projeto de tratado ${ }^{2}$ cujo capítulo sobre os investimentos revela uma reforma drástica, um renouveau completo da arbitragem investidor-Estado.

\section{A proposta inovadora da União Européia DE UMA JURISDIÇÃO COM DUAS INSTÂNCIAS}

Se a arbitragem é um meio alternativo de resolução de disputas, a proposta da Comissão européia apresenta uma organização institucional para solucionar os litígios que surpreende por sua volta a um classicismo tradicionalmente ignorado no Direito Internacional (dos Investimentos). A arbitragem já era um mecanismo alternativo à resolução de conflitos. A Comissão apresentou uma alternativa à alternativa... A proposta contém, deveras, um sistema quase judicial com duas instâncias: um tribunal de primeira instância ${ }^{3}$ e um tribunal permanente de apelação ${ }^{4}$. O tribunal de primeira instância deve ser composto de 15 juízes, sendo 5 dos países membros da União européia, 5 dos Estados-Unidos e 5 de terceiros Estados. No mesmo espírito, o tribunal de apelação deve ser composto de 6 juízes, 3 europeus, 3 americanos e 3 tendo uma outra nacionalidade. O projeto de tratado mostra-se atento à questão da ética dos membros dos tribunais e prevê, a esse efeito, um código de conduta a ser aplicado ${ }^{5}$. Na realidade, o que resta da arbitragem é apenas o procedimento de submissão das demandas que pode, entre outros, seguir as regras da Convenção de Washington (ICSID) ${ }^{6}$ ou aquelas da Comissão das Nações unidas sobre o Direito do Comércio

2 O capítulo sobre os investimentos do Projeto de Tratado da Comissão da União Européia está disponível em: http://trade. ec.europa.eu/doclib/docs/2015/september/tradoc_153807.pdf

3 Ver o Capítulo II (Comércio nos serviços, investimentos e ecomércio), artigo 9 do projeto de tratado.

4 Ver o Capítulo II (Comércio nos serviços, investimentos e ecomércio), artigo 10 do projeto de tratado.

5 Ver o Capítulo II (Comércio nos serviços, investimentos e ecomércio), anexo II.

6 Ver: artigo 6 (2) (a). 
Internacional (UNCITRAL) ${ }^{7}$. Para o resto, trata-se de um novo mecanismo de resolução de disputas que inexiste no Direito Internacional dos Investimentos. Nesse contexto, uma inversão sistêmica da lógica do contencioso é notável: se a arbitragem até hoje praticada buscava a facilitação do processo a favor do investidor, o sistema proposta pela União Européia concentra-se principalmente na proteção de uma certa margem de manobra dos seus países membros. Por exemplo, o mecanismo de apelação é um antemuro a favor dos Estados que poderão utilizá-lo para pedir que seja infirmada uma decisão de primeira instância — o que esses países

7 Ver: artigo 6 (2) (b). nunca tinham aceito antes, quando uma parte do mundo acadêmico já militava para um sistema similar. Será, seguramente, um meio para rever as decisões que, do ponto de vista dos Estados, desconsideram as questões de interesse público.

Os países que instituíram e elogiaram a arbitragem investidor-Estado - mecanismo, disseram eles, flexível e especializado que permite uma resolução rápida e apolítica de disputas - estão agora menosprezando-a como se um perigo era intrinsecamente inerente a esta. Sendo assim, a mensagem enviada ao resto do mundo e da comunidade jurídica que se entregaram a esse sistema durante décadas contém um cinismo ácido. 


\section{Por que voltar a Kelsen, 0 jurista do século $\mathrm{XX}$ ?*}

\section{Why study Kelsen, a legal writer from the XX century?}

Inocêncio Mártires Coelho**

\section{Resumo}

A teoria Pura do Direito, de Hans Kelsen, é uma teoria do direito positivo; é teoria geral do direito, não uma exposição ou interpretação de uma ordem jurídica particular. Da comparação de todos os fenômenos jurídicos ela busca descobrir a natureza do direito mesmo e determinar sua estrutura e suas formas típicas, independentemente do conteúdo variável que o direito apresenta nas diferentes épocas e nos distintos povos. Assim essa teoria obtém os princípios fundamentais com os quais podemos compreender qualquer ordem jurídica. Avessa a considerações de natureza ética, moral, política, econômica religiosa, etc., ela admite que qualquer conteúdo possa vir a ser direito, desde que uma norma jurídica válida faça desse conteúdo objeto de sua regulação.

Palavras-chave: Natureza. Sociedade. Ser e dever ser. Pureza metodológica. Norma jurídica. Norma fundamental. Jurisprudência normativa. Jurisprudência sociológica. Direito Natural. Direito Positivo. Pirâmide normativa. Fundamentação. Derivação. Interpretação.

\section{Abstract}

The Pure Theory of Law by Hans Kelsen is a theory of positive law; it is general theory of law, not an exhibition or interpretation of a specific lgeal order. It seeks to discover the nature of that law, by comparing different legal phenomena, and determine its structure and its typical forms, regardless of the variable content that Law at different times and in different people. So this theory succeed to identify the fundamental principles with which we can understand any legal order. Averse to ethical, moral, political, religious, economic considerations, it admits that any content might be law, as long as a valid legal rule make that object content of its regulation

Keywords: Nature. Society. Be and must be. Methodological purity. Rule of

* Recebido em 11/02/2016 Aprovado em 11/02/2016

** Possui doutorado, obtido com distinção, na Universidade de Brasília. Atualmente, integra, em caráter permanente, o corpo docente do programa de pós-graduação - mestrado e doutorado - do UniCEUB. E-mail: inocenciocoelho@gmail.com. law. Fundamental norm. Normative jurisprudence. Sociological jurisprudence. Natural Law. Positive Law. Normative pyramid. Rationale Interpretation. 


\section{INTRODUÇÃO}

Somente curvando-nos à sentença de Ortega y Gasset, de que o homem não é um desencarnado, antes um ser situado e datado, um misto de en e circunstância, estaremos em condição de apreender, com um mínimo de segurança e objetividade, os aspectos fundamentais da Teoria Pura do Direito de Hans Kelsen, como expressão do pensamento de um homem concreto, manifestado em um tempo concreto e diante de um mundo igualmente concreto. Enfim, a obra de um ser histórico, de um ser-no-mundo.

Partindo dessa perspectiva da moderna filosofia da existência, que rejeita verdades desligadas das suas coordenadas de tempo e de espaço, intentaremos explicar/ compreender a pureza metodológica que singulariza a obra de Kelsen como "o jurista do século XX", assim considerado tanto pelos seus críticos quanto por seus admiradores. ${ }^{1}$

Sob essa compreensão, nos parece correta a observação de Machado Neto, de que "o pensamento não é uma pura e desinteressada interpretação da realidade, senão que, em certa medida, ele é uma expressão do eu, não somente provinda do trato com as circunstâncias, senão que também circunstancializada, e, por esse modo, igualmente convertida em realidade".

Idêntico entendimento encontramos em Legaz y Lacambra, o qual, situando a Teoria Pura do Direito no seu tempo, assevera que ela é produto de uma época desiludida, de um tempo que acredita na democracia como veículo de essências, mas a esta se aferra como método de convivência; de uma época relativista - prossegue esse mestre espanhol - e, sobretudo, de uma época de profunda desagregação espiritual, onde se impõe a fé em a norma formal como o único patrimônio comum que possibilita a existência do Estado. ${ }^{3}$

As razões históricas e sociais, que potencializaram o formalismo dessa teoria - aspecto a que se aferram todos os seus críticos, em sua maioria leitores aligeirados -, esses "motivos" estão vinculados ao momento mesmo de sua formulação, como anotaremos a seguir.

1 AFTALIÓN, Enrique R. Apresentação. In: KELSEN, Hans. La idea del derecho natural y otros ensayos. Buenos Aires: Losada, 1946. p. 7-11.

2 MACHADO NETO, Antônio Luís. Sociologia do desenvolvimento. Rio de Janeiro: Tempo Brasileiro, 1963. p. 72.

3 LEGAZ Y LACAMBRA, Luis. Horizontes del pensamiento jurídico. Barcelona: Bosch, 1947. p. 459-460.
Produto de um mundo em crise, de um "mundo quebrado", na expressão agônica de Gabriel Marcel, mundo em que coexistiam as mais contrapostas e paradoxais concepções acerca do justo e do injusto, a teoria jurídica de Hans Kelsen teve o mérito de responder ao desafio de seu tempo, situando-se numa posição de tamanha neutralidade axiológica, que pôde "explicar" e "compreender" a existência de todas essas concepções em choque, sendo ao mesmo tempo uma teoria jurídica tanto para a democracia, quanto para o nazi-fascismo e o comunismo, embora nem de longe assumisse esse propósito. Ironicamente, aliás, o próprio Kelsen encarregou-se de "usar" os seus críticos para defender a pureza e o não engajamento político da sua teoria.

Como se mantém completamente alheia a toda a política - anota Kelsen, referindo-se aos seus críticos -, a Teoria Pura do Direito afasta-se da vida real e, por isso, fica sem qualquer valor científico. É esta uma das objeções mais frequentemente levantadas contra ela. Porém, ouve-se também com não menos frequência: a Teoria Pura do Direito não tem de forma alguma possibilidade de dar satisfação ao seu postulado metodológico fundamental e é mesmo tão-só expressão de uma determinada atitude política. Mas qual das afirmações - indaga-se o próprio Kelsen - é verdadeira? Os fascistas declaram-na liberalismo democrático, os democratas liberais ou os sociaisdemocratas consideram-na um posto avançado do fascismo. Do lado comunista é desclassificada como ideologia de um estatismo capitalista, do lado capitalista-nacionalista é desqualificada, já como bolchevismo crasso, já como anarquismo velado. $\mathrm{O}$ seu espírito - asseguram muitos - aparentado com o da escolástica católica; ao passo que outros creem reconhecer nela as características distintivas de uma teoria protestante do Estado e do Direito. E não falta também quem a pretenda estigmatizar com a marca de ateísta. Em suma - conclui o Chefe da Escola de Viena -, não há qualquer orientação política de que a Teoria Pura do Direito se não tenha ainda tornado suspeita. Mas isso precisamente demonstra, melhor do que ela própria o poderia fazer, a sua pureza. ${ }^{4}$

\section{Hans Kelsen, o homem e a obra}

Pondo de lado a instigante e controvertida ideia de que é possível compreender um autor melhor do que ele compreendeu a si mesmo e, inclusive, "completar" a sua obra - ideia que, de resto, possui tanto críticos quanto

4 KELSEN, Hans. Teoria pura do direito. 2. ed. Coimbra: A. Amado, 1962 v. 1. p. ix-x. 
defensores ilustres ${ }^{5}-$, deixemos que o próprio Kelsen nos apresente a sua Teoria Pura do Direito.

A teoria pura do Direito é uma teoria do direito positivo; é teoria geral do direito, não uma exposição ou interpretação de uma ordem jurídica particular. Da comparação de todos os fenômenos que chamamos Direito busca descobrir a natureza do Direito mesmo. Determinar sua estrutura e suas formas típicas, independentemente do conteúdo variável que apresenta nas diferentes épocas e nos distintos povos. Assim ela obtém os princípios fundamentais com os quais podemos compreender qualquer ordem jurídica. Como teoria, seu único propósito é o conhecimento do seu objeto. Ela responde o que é o direito, não o que ele deveria ser. Este último pertence à Política, enquanto que a teoria pura do direito é ciência. Chama-se "pura" porque busca excluir do conhecimento do direito positivo todos aqueles elementos que lhe são estranhos aqui ou acolá. Os limites deste objeto e seu conhecimento devem ficar claramente fixados em dois sentidos: a ciência particular do direito, a disciplina comumente chamada jurisprudência, deve ser distinguida da filosofia da justiça, por um lado, e da sociologia, ou conhecimento da realidade, por outro. ${ }^{6}$

$\mathrm{Na}$ perspectiva da sociologia do conhecimento, não se pode olvidar o que disse Josef Kunz sobre o caráter "vienense" da Teoria Pura do Direito e do Estado, uma abordagem crítica que, integrando as posturas explicativa e compreensiva, adensa e, ao mesmo tempo, refina a interpretação da obra de Kelsen, conforme o lema gnosiológico de Paul Ricoeur - "explicar mais para compreender melhor". ${ }^{7}$

Dessas reflexões de Josef Kunz - que foi aluno de Kelsen, em Viena -, destacamos, à guisa de ilustração, as passagens a seguir, cuja transcrição, um tanto longa, justifica-se pela sua importância para esta linha de raciocínio.

Para compreender completa e profundamente qualquer coisa, é sempre necessário conhecer sua história; conhecer, ademais, o desenvolvimento,

5 GADAMER, Hans-Georg. Herança e futuro da Europa. Lisboa: Edições 70. 1998. p. 64-65; GADAMER, Hans-Georg Hermenentica de la modernidad: conversaciones con Silvio Vietta. Madrid: Trotta, 2004. p. 13; BLEICHER, Josef. Hermenêutica contemporânea. Lisboa: Edições 70, 1992. p. 172

6 KELSEN, Hans. La teoría pura del derecho y la jurisprudência analítica. In: La idea del derecho natural y otros Ensayos. Buenos Aires: Losada, 1946. p. 202-234.

7 RICOEUR, Paul. Explicar e compreender. In: Do texto à ação: ensaios de hermenêutica. Porto: Rés, [198?], p. 163-183; RICOEUR, Paul. Interpretação e/ou argumentação. In: . $O$ Justo: ou a essência da justiça. São Paulo: M. Fontes, 2008. v. 1. p. 153-173. p. 172. a evolução, a situação histórica na qual esteve o autor, e também alguns conhecimentos de sua vida privada, as influências que se exerceram sobre ele, e a formação do seu espírito. Toda grande obra, portanto, constitui uma combinação, contém uma fusão de dois elementos: um, proveniente dos gênio pessoal, o outro, resultado das condições históricas. [...]Para compreender a Teoria Pura do Direito, é necessário ter em conta que o seu autor é austríaco. Não somente austríaco de nascimento, mas também política, histórica e culturalmente. [...]Sua doutrina originou-se na Universidade de Viena e é conhecida no mundo inteiro com o nome de "Escola Vienense".[...] Mais ainda: seu temperamento e sua visão do mundo são de cepa austríaca e vienense. Nós, os vienenses de nascimento, somos católicos no sentido da palavra grega, quer dizer, universalistas. A velha e grande Áustria foi, em uma esfera bem menor, quase uma PanEuropa, quase uma Sociedade das Nações. Somos universalistas, somos tolerantes, antifanáticos. Amamos a paz. Nossa situação geográfica radicase no verdadeiro centro da Europa, no coração do velho continente. Somos democratas, somos liberais, somos individualistas. Os austríacos da velha Áustria e os da pequena República de hoje são quase o único povo europeu que não é em absoluto nacionalista. Somos europeus. A vida cultural é para nós uma necessidade quase mais imperiosa do que nos alimentarmos. Somos os filhos de uma grande e velha cultura.[...]De caráter vienense são a amabilidade e o encanto pessoal de Kelsen; vienense no sentido democrático, liberal, tolerante, antifanático, universalista, relativista. Vienense é o seu entusiasmo pela literatura, o teatro, a música, as viagens, a natureza. ${ }^{8}$

Falando desse terroir austríaco de sua obra, o próprio Kelsen explica que em razão de a antiga monarquia austro-húngara estar composta por dez nações, completamente diferentes quanto à raça, língua, religião e história, era impossível fundar uma unidade sobre qualquer substrato histórico, nem social, nem biológico; que, por isso, a unidade da antiga Áustria consistia de fato no exército, nos funcionários públicos, no Direito comum vigente para todos esses grupos tão diferentes; que, por tudo isso, provavelmente terá sido essa realidade da velha Áustria que lhe sugeriu a tese da identidade entre o Estado e o Direito; e que, finalmente, como essa tese é parte integrante da Teoria Pura do Direito, pode-se dizer em verdade que esta teoria é uma doutrina especificamente austríaca. ${ }^{9}$ (grifos nossos).

Tendo presente essa "revelação" do próprio Kelsen de que a Teoria Pura do Direito é de nacionalidade aus-

8 KUNZ, Josef L. La teoría pura del derecho. México: Universitaria, 1948. p. 9-13.

9 KUNZ, Josef L. La teoría pura del derecho. México: Universitaria, 1948. p. 33. 
tríaca, parece-nos útil - em reforço ao que ele diz enfocar sua obra à luz da regra hermenêutica segundo a qual compreendemos a parte desde o todo e este desde a parte, um cânone interpretativo procedente da antiga retórica e que a hermenêutica moderna transladou da arte de falar para a arte de compreender, com o rótulo de círculo hermenêutico, que alguns estudiosos propõem seja substituído pelas figuras da espiral, da hélice e, mesmo, da bélice cônica, que eles consideram mais condizentes com a abertura e a infinitude do movimento da compreensão. ${ }^{10}$

Esse enfoque se nos mostra adequado porque nesse constante balançar de olhos - mutuamente esclarecedor -, entre o todo e as suas partes, diversas são as acepções do que seja o todo e do que sejam as partes, como se verifica, por exemplo, na relação autor/obra, em que do livro, compreendido até certo ponto, recolhe-se uma imagem parcial do seu autor, a qual nos leva a compreender melhor o texto, que, por sua vez, nos conduz a melhorar o perfil do autor, e assim sucessivamente. ${ }^{11}$

Para mostrar a extensão e a aplicabilidade desse cânone interpretativo, ninguém melhor do que Friedrich Schleiermacher (1768-1834), cuja obra é considerada a pedra fundamental da construção do paradigma hermenêutico. ${ }^{12}$

Assim como a palavra está para a frase, e a frase particular para a sua articulação mais próxima, e esta para a obra mesma, como um elemento em relação a um conjunto e uma parte do todo, assim, por sua vez, cada discurso e cada obra escrita é um particular que apenas pode ser compreendido completamente a partir de um todo ainda maior. Ora, é fácil ver que toda obra é um particular sob um duplo ponto de vista. Cada obra é um particular no domínio da literatura ao qual pertence, e forma com outras obras de mesmo conteúdo um todo a partir do qual ela deve ser compreendida, sob uma referência, a saber, linguística. Mas cada obra é também um particular enquanto ato de seu autor e forma, com as suas outras ações, o todo de sua vida; e, portanto, deve ser compreendida a partir da totalidade de suas ações, naturalmente segundo a medida de sua infuência sobre ela e sua semelhança com ela, sob outra referência, isto é, a pessoal. ${ }^{13}$ (grifo nossos).

10 GADAMER, Hans-Georg. Verdade e método. Petrópolis: Vozes. 1997. v. 1. p. 436-437. Sobre essas distintas figuras geométricas, ver, por todos, MARROU, Henri I. Do conhecimento histórico. Lisboa: Aster, [1978?], p. 16; 79; 81; 225.

11 SCHÖKEL, Luis Alonso; BRAVO, José María. Apuntes de hermenéutica. Madrid: Trotta, 1994. p. 41.

12 LAKS, André; NESCHKE, Ada (Ed.). La naissance du paradigme herméneutique. Lille: Universitaires de Lille, 1990. p. 7-10.

13 SCHLEIERMACHER, Friedrich Daniel Ernst. Herméneutique.
Assim vistas as coisas, isto é, levando-se em conta a biografia, a formação, cada uma e o conjunto das obras de Kelsen ${ }^{14}$, mostra-se infundada a crítica de Machado Neto, ao dizer que, sociologicamente, a Teoria Pura do Direito poderia ser interpretada como retrato de um mundo burguês em decadência e comprometido com as expressões políticas dos partidos liberais. ${ }^{15}$ Em contraposição a esse entendimento, o perspicaz Norberto Bobbio adverte que obras como a de Kelsen não se podem valorar com pautas axiológicas voláteis e acanhadas.

Antes de mais nada - adverte o saudoso mestre de Turim - o valor da obra de um jurista da natureza de Hans Kelsen, de estatura imponente, agrade isso ou não, não se mede com o metro das correntes de opinião que se fazem e desfazem com a mudança dos eventos e das ideologias que os movem, e menos ainda com o metro dos humores e das ‘impressões’ pessoais. Além disso, para dissipar suspeitas, eliminar incompreensões preconceituosas, estabelecer escalas de valores subvertidas e contrapor o que está vivo àquilo que está morto, nada vale mais que uma honesta e franca releitura da obra contestada. ${ }^{16}$

Por isso, no contexto em que se formulou, pode-se dizer que a teoria de Hans Kelsen representou a resposta jurídico-política possível e temporalmente adequada para um momento histórico singularmente dramático, como o foram, por exemplo, nos tempos da chamada "guerra fria", os acordos sobre os arsenais atômicos, celebrados entre os Estados Unidos e a então União Soviética, pactos que não podemos (des)qualificar, aligeiradamente, como espúrias transações ideológicas entre o capitalismo e o comunismo. De resto, nesse terreno, parece que a história não se repete - nem como tragédia, nem como farsa -, antes tem prosseguimento e continuidade, como evidenciam os acertos que, nos primeiros dias de janeiro de 2016, começaram a ser implementados entre as maiores potências nucleares e o governo do Irã, na expectativa de se impedir, por essa via diplomática, que o desenvolvimento do programa atômico desse país venha a descambar na produção de

Lille: Presses Universitaires, 1989. p. 178-179; e SCHLEIERMACHER, Friedrich Daniel Ernst: Hermenêutica. 9. ed. Petrópolis: Vozes, 2012. p. 53.

14 Formação, neste sentido, é um "manter-se aberto para o diferente, para outros pontos de vista mais universais". H GADAMER, Hans-Georg. Verdad y método. Salamanca: Sígueme, 1993. v. 1. p. 46.

15 MACHADO NETO, Antônio Luís. Fundamentación egológica de la teoria general del derecho. Buenos Aires: Eudeba, 1974. p. 43.

16 BOBBIO, Norberto. Direito e poder. São Paulo: UNESP, 2008. p. $22-23$. 
artefatos bélicos, o que colocaria em risco a comunidade internacional. Afinal, não se deve esquecer que as guerras começam quando a palavra perdeu sua batalha.

Se, por esse lado, grande é o mérito da obra de Kelsen, não menos digno de louvor é o reconhecimento de sua teoria como a mais exitosa empreitada para conferir dignidade científica ao saber jurídico, numa época em que, encantados com a objetividade e os êxitos das ciências causal-explicativas, os positivistas - jurídicos ou não - dos mais distintos matizes negaram, peremptoriamente, a existência de uma verdadeira ciência do direito, postura jocosamente manifestada na célebre frase de Julius von Kirchmann, ao dizer que "três palavras retificadoras do legislador e bibliotecas inteiras virariam papeis inúteis". ${ }^{17}$

Sabedor de que a Jurisprudência não era nenhuma ciência natural fundada na indução experimental, e mergulhado num mundo em que "a vigência intelectual predominante identificava a ciência experimental como único saber válido ou pouco menos que isto"18, o jurista prekelseniano deixou-se abater por um complexo de inferioridade teórica, que só começou a ser superado após a intervenção metodologicamente esclarecedora do mestre de Viena. ${ }^{19}$ É o que se lê, a seguir, em João Baptista Machado, tradutor de inúmeras obras e conhecedor profundo do pensamento do mestre de Viena.

\footnotetext{
Pode-se dizer que o colossal esforço de Kelsen trouxe ao pensamento jurídico uma clarificação tal que é possível hoje determinar com rigorosa precisão até onde pode ir a consideração lógicoobjetivante e quais os pontos de vista e os juízos que esta perspectiva já não acolhe nem pode justificar.

Kelsen empreendeu superar o velho complexo de inferioridade da ciência jurídica, fundar o seu caráter científico, determinando-lhe um objeto: as normas jurídicas e as conexões de validade" entre elas, e fixando-lhe um método específico: o método normológico, que se caracteriza por fazer abstração do substrato sociológico do Direito - dos conceitos ético-jurídicos ou político-econômicos e dos fins dos preceitos jurídicos -, limitando a incidência $\mathrm{da}$ visualização àquelas conexões "de validade" e
}

17 VON KIRCHMANN. Julius Hermann. El carácter a-cientifico de la llamada Ciencia del Derecho. In: La Ciencia del Derecho. Buenos Aires: Losada, 1949. p. 247-286. p. 268.

18 Sobre o conceito sociológico de "vigência", ver MORÓN AROYO, Ciriaco. Creencia y vigência In:___. El sistema de Ortega y Gasset. Madrid: Romania, 1968. p. 275-279.

19 MACHADO NETO, Antônio Luís. Fundamentación egológica de la teoria general del derecho. Buenos Aires: Eudeba, 1974. p. 27; MACHADO NETO, Antônio Luís .O problema da ciência do direito. Salvador: Livraria Progresso, 1958. p. 9-18. às relações lógicas entre conceitos fundamentais de natureza formal. ${ }^{20}$

Com esse mesmo reconhecimento, outro jurista de igual porte, Enrique Aftalión, diz que "se Kelsen é credor de um lugar excepcional na história das ideias jurídicas, isso se deve ao fato de ter ministrado aos cientistas do Direito o órganon sem o qual não lhes seria possível expulsar as ideologias e pensar neutralmente o seu objeto", e que "essa abordagem é a lógica jurídica - a lógica do dever ser - cuja descoberta e formulação é o título magno que pode exibir o mestre vienense. ${ }^{21}$ Idêntica exaltação do legado de Kelsen encontramos na Introdução de Mario Losano à edição italiana de $O$ problema da justiça, revelando esse jusfilósofo que, na sua vida de humanista, as obras do grande jurista de Praga acompanharam-no constantemente, estimulando-o sempre, mesmo que muitas vezes por divergência, o que de resto lhe parece inevitável na sucessão das gerações. Mais ainda, prossegue esse mestre italiano, é de se ter presente, a sobrevalorizar a obra Kelsen, que mesmo tendo ele enfrentado mais de meio século de polêmicas, exílios múltiplos e duas guerras mundiais, acabou por ver que a sua doutrina conquistou, na ciência do direito, uma posição bem definida e, em certa medida, definitiva. ${ }^{22}$

Por isso, pode-se dizer que Hans Kelsen incutiu autoconfiança e dignidade científico-epistemológica no saber dos juristas, sem equipará-lo a nenhuma mecânica, uma física ou uma biologia, levar essa ordem de conhecimentos a qualquer tipo de sociologismo e, tampouco, acriticamente, apoiar-se na afirmação rotunda e sonora da sua cientificidade - que a sociedade ingenuamente acata como forma de fugir a uma investigação séria, que ele supõe, por outro lado, desilusória, já que, participando, via de regra, do preconceito positivista, encarna na ciência natural o único modelo possível de ciência". ${ }^{23}$ Sob esse aspecto, Kelsen rejeitou o cientificismo, que, de tão exitoso no desencantamento da natureza, acabou virando pesadelo para os estudiosos das Humanidades, os quais, não podendo comprovar seu conhecimento com experimen-

20 MACHADO, João B. Nota Preliminar. In: KELSEN, Hans. $A$ Justiça e o direito natural. Coimbra: A. Amado, 1963. p. 5-11. p. 7, 1011.

21 AFTALIÓN, Enrique R. Apresentação. In: KELSEN, Hans. La idea del derecho natural y otros ensayos. Buenos Aires: Losada, 1946. p. 7-11. p. 9.

22 LOSANO Mario G. Introdução. In: KELSEN, Hans. O problema da justiça. São Paulo: M. Fontes, 2011. p. 20-38. p. 37-38.

23 MACHADO NETO, Antônio Luís .O problema da ciência do direito. Salvador: Livraria Progresso, 1958. p. 13. 
tos em laboratórios, acabaram sendo relegados ou relegando-se a si mesmos à condição subalterna de cientistas "inexatos" ou de segunda categoria. Isso porque, assinala Gadamer, a autorreflexão lógica das ciências do espírito, que acompanha o seu efetivo desenvolvimento no século XIX, é inteiramente dominada pelo modelo das ciências da natureza, o que nos sugere um simples olhar sobre a história da expressão "ciência do espírito", cujo significado só é familiar através da sua forma no plural. ${ }^{24}$

Nesse contexto, ainda epistemologicamente nebuloso para as ciências do espírito, cresce a importância da Teoria Pura do Direito, na medida em que o seu formulador, seguro da cientificidade do conhecimento jurídico, operou uma verdadeira revolução copernicana nesse domínio cognitivo, como ressaltam, entre outros, o já citado Enrique Aftalión, Fernando García Olano e José Vilanova, na passagem a seguir.

Sua obra - afirmam esses renomados professores
platinos - ocupa um lugar único no pensamento
jurídico contemporâneo e pode-se dizer, sem lugar
a dúvidas, que foi uma abordagem decisiva para a
Teoria Geral do Direito, quer dizer, para o propósito
de desentranhar os conceitos fundamentais,
que se encontram necessariamente em qualquer
ordenamento jurídico e em sua própria estrutura.

Não se veja nessas palavras nenhum elogio gratuito à figura de Hans Kelsen, antes pelo contrário. Juristas e filósofos do Direito da maior expressão, esses pensadores argentinos apenas externam o seu reconhecimento àquele que lançou as bases teóricas para a colocação autônoma do problema epistemológico do direito, numa palavra, a quem certificou a cientificidade dessa ordem de investigação, libertando os juristas daquele abatimento gnosiológico, que os acometeu e aos outros cientistas sociais, até se aperceberem do real estatuto epistemológico do seu campo de conhecimento, onde o explicar respeita o compreender, e as ciências da natureza não "discriminam" as suas irmãs, espirituais. ${ }^{26}$ Afinal - como adverte Bachelard -, apesar de existirem vários métodos científicos, há um só espírito científico e um só tipo de

24 GADAMER, Hans-Georg. Verdad y método. Salamanca: Sígueme, 1993. v. 1 p. 31; GADAMER, Hans-Georg. Verdade e método. Petrópolis: Vozes. 1997. v. 1. p. 39.

25 AFTALIÓN, Enrique R; GARCÍA OLANO, Fernando; VILANOVA, José. Introducción al derecho. Buenos Aires: El Ateneo, 1960. p. 847.

26 DILTHEY, Wilhelm. Introducción a las ciências de espiritu. Madrid: Revista de Occidente, 1956; CASSIRER, Ernst. Las ciências de la cultura. México: Fondo de Cultura Económica, 1982. visão propriamente científica. ${ }^{27}$

A essa luz, vale relembrar, por exemplo, o que nos diz Larenz sobre a especificidade epistemológica da hermenêutica jurídica, em lição aplicável, mutatis mutandis, às Humanidades em geral.

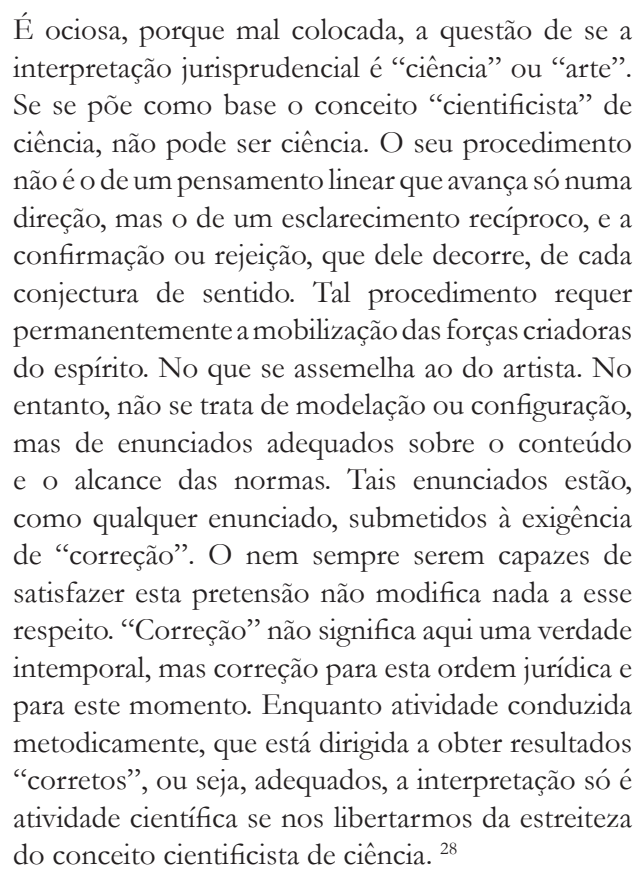

Para superar essa falsa questão epistemológica, bastará que se atente para o "esclarecimento" do mesmo Gadamer, a nos dizer que o verdadeiro problema que as ciências do espírito colocam para o pensamento é que não se consegue compreender corretamente a sua natureza se as medirmos com o padrão de conhecimento progressivo da legalidade; que a experiência do mundo social-histórico não se eleva a uma ciência com o processo indutivo das ciências naturais; que, seja o for que aqui venha a significar ciência, e mesmo que em todo conhecimento histórico esteja incluído o emprego da experiência genérica no respectivo objeto de pesquisa, o conhecimento histórico não aspira, no entanto, a abranger o fenômeno concreto como caso de uma regra geral; que o caso individual não serve simplesmente para confirmar uma legalidade, a partir da qual seja possível, numa reversão prática, fazer previsões; que, para além disso, o seu ideal é compreender o próprio fenômeno na sua concreção singular e histórica; que, enfim, nesse particular, pode influir ainda quanta experiência genérica se quiser, pois o objetivo não é confirmar nem am-

27 BACHELARD, Gaston. A Epistemologia. Lisboa: Edições 70, 1984. p. 139.

28 LARENZ, Karl. Metodologia da ciência do direito. 7. ed. Lisboa: Gulbenkian, 2014. p. 443-444. 
pliar essas experiências, para se chegar ao conhecimento de uma lei do tipo "como se desenvolvem os homens, os povos, os estados", mas sim compreender "como é tal homem, tal povo, tal Estado, o que se fez dele" ou, formulado genericamente, "como isso pode ter ocorrido dessa forma". ${ }^{29}$

Em suma, pela complexidade do evento cognitivo, nem explicar tão-somente e, tampouco, apenas compreender, antes - manejando em conjunto ambos os métodos, numa dialética fina -, explicar mais para compreender melhor. ${ }^{30}$

Voltando a Kelsen, independentemente do juízo que se faça sobre o homem e a sua obra, trata-se de um pensador de tamanho relevo que, em face das suas ideias, não há lugar para atitudes dúbias; ou bem as aprovamos ou bem as rejeitamos - sempre criticamente, é claro -, pois apenas ignorá-las revela pobreza de espírito e autoprivação do conhecimento de uma das mais expressivas contribuições para o avanço do pensamento jurídico e das ideias políticas no século XX, centúria da qual ele foi considerado o jurista por antonomásia - insista-se tanto pelos seus críticos quanto por seus admiradores. ${ }^{31}$ Em suma, ninguém, seja seguidor ou adversário, poderá trabalhar, depois de Kelsen, no campo da teoria do Direito, ignorando a sua obra, assim como toda Filosofia do Direito, a partir dele, terá que ser necessária e essencialmente um "diálogo com Kelsen". ${ }^{32}$

Afinal, são raras, raríssimas mesmo, essas figuras estelares, cuja biografia ostenta o singular atributo de terem transitado, com idêntico fulgor, das rigorosas

29 GADAMER, Hans-Georg. Verdad y método. Salamanca: Sígueme, 1993. v. 1. p. 32-33; GADAMER, Hans-Georg. Verdade e método. Petrópolis: Vozes. 1997. v. 1. p. 40-41.

30 DILTHEY, Wilhelm. Crítica de la razón histórica. Barcelona: Península, 1986. p. 238-286; DILTHEY, Wilhelm e Origens da Hermenêutica._. Textos de Hermenêutica. Lisboa: Res, 1984, p. 149-189; RICOEUR, Paul. Explicar e compreender. In: . Do texto à ação: ensaios de hermenêutica. Porto: Rés, [198?], p. 163-183; RICOEUR, Paul. Interpretação e/ou argumentação. In: . $O$ Justo: ou a essência da justiça. São Paulo: M. Fontes, 2008. v. 1. p. 153-173; RICOEUR, Paul. Interpretação e/ou argumentação. In: . O Justo: ou a essência da justiça. São Paulo: M. Fontes, 2008. v. 1. p. 153-173. p. 172; Sobre a diferença entre esses atos gnosiológicos, ver COMPREENSÃO. In: MORA, José Ferrater. Diccionario de filosofia. Madrid: Alianza, 1986. v. 1. p. 545-548; EXPLICAÇÃO. In: MORA, José Ferrater. Diccionario de filosofia. Madrid: Alianza, 1986. v. 2. p. 1102-1104.

31 AFTALIÓN, Enrique R. Crítica del saber de los juristas. La Plata: Arayú, 1951. p. 152.

32 KUNZ, Josef L. La teoría pura del derecho. México: Universitaria, 1948. p.151-152. formulações de dogmática jurídica às mais apuradas reflexões no campo da teoria política e da filosofia do direito. No caso de Kelsen, merece destaque a jurisdição constitucional, que teve nele o seu principal formulador e o mais aguerrido combatente. ${ }^{33}$

Hans Kelsen - ressalta Josef Kunz - não foi
somente um cientista teórico, mas também um
grande jurisconsulto prático: foi o criador da
Constituição Austríaca de 1920, e atuou durante
dez anos como Juiz Constitucional. Também como
teórico sua obra não se limitou à Ciência do Direito;
contribuiu com importantes e originais abordagens
para a Sociologia, a Ciência Política e a Filosofia.
Finalmente, na Ciência Jurídica - arremata esse
estudioso de Kelsen -, seu trabalho não se restringiu
à Teoria Pura do Direito. Escreveu também obras
de grande valor sobre a técnica do Direito, sobre
política jurídica, sobre Direito constitucional
positivo da República Austríaca, e sobre problemas
de Direito internacional positivo. ${ }^{34}$

Idêntica observação sobre a atividade prática de Kelsen, encontramos em Mario Losano, quando este aborda a postura kelseniana no tema da interpretação do direito. Para esse mestre italiano, haveria contradição no pensamento de Kelsen, na medida em que este, embora sustente que, nesse terreno - como, de resto, em todo o sistema jurídico -, não cabe à ciência do direito fazer juízos de valor, devendo o jurista limitar-se a descrever as possíveis interpretações de uma norma, sem dizer qual delas seria a melhor ou a preferível, essa postura não foi adotada por Kelsen quando ele foi chamado a emitir pareceres em controvérsias jurídico-políticas da maior relevância. ${ }^{35}$

Em suma, independentemente de termos ou não simpatia pela obra e/ou pela figura de Kelsen - como, de resto, em relação a qualquer grande pensador -, ele é daquelas figuras "incontornáveis", sem cujo conhecimento nenhum verdadeiro jurista mostra-se digno dessa qualificação. ${ }^{36} \mathrm{O}$ mesmo se diga no âmbito da fi-

33 KELSEN, Hans. Jurisdição constitucional. São Paulo: M. Fontes, 2003.

34 KUNZ, Josef L. La teoría pura del derecho. México: Universitaria, 1948. p. 116.

35 LOSANO Mario G. Introdução. In: KELSEN, Hans. O problema da justiça. São Paulo: M. Fontes, 2011. p. 20-38. p. 28.

36 Para uma visão externa e aprofundada da obra de Hans Kelsen, ver, entre outros, LEGAZ Y LACAMBRA, Luis. Kelsen: estudio crítico de la teoría pura del derecho y del estado de la Escuela de Viena. Barcelona: Bosch, 1933; EBENSTEIN, William. The pure theory of law. New York: A. M. Kelley, 1969; SICHES, Luís Recaséns. La obra de Hans Kelsen: su teoría pura del derecho y del Estado; y su relativismo axiológico. In:___. Panorama del pensamiento jurídico en el siglo XX. México: Porrua, 1963. v. 1. p. 137-222; GARCÍA 
losofia, no qual, por exemplo, apesar de deplorarmos a militância nazista de Heidegger, não podemos ladear o seu pensamento, sob pena de nos privarmos de conhecer a obra filosófica mais importante do século XX. ${ }^{37}$ A propósito, não devemos esquecer a advertência de Mondolfo sobre a constante vinculação da filosofia com a sua própria história, a qual constitui o processo de sua formação e de seu desenvolvimento. ${ }^{38}$

Se ainda estivesse vivo - ele morreu em 19/4/1973 -, Kelsen teria orgulho em ver que o desenvolvimento da sua justiça constitucional foi o acontecimento mais destacado do Direito Constitucional Europeu da segunda metade do século XX; que, hoje em dia, não se concebe um sistema constitucional que não reserve um lugar sobranceiro para essa instituição; que, na velha Europa, todas as novas Constituições previram a existência de um tribunal constitucional; que o século XX foi o século das cortes constitucionais; e que, enfim, a se julgar pelo seu processo evolutivo, a onda benfazeja da criação desses tribunais, que já adentrou o século XXI, tem tudo para continuar indo em frente, "por mares nunca dantes navegados." 39

\section{Pureza metodológica}

Declarando princípio fundamental de seu método o eliminar da ciência do direito todos os elementos que lhe são estranhos, para combater o que ele considerava um erro da ciência jurídica tradicional do século XIX e princípios do século XX, Hans Kelsen fundou a sua teoria, que denominou pura, como ele mesmo acentua, por ter um único objeto - o direito positivo - e ignorar

AMADO, Juan Antonio. Hans Kelsen y la norma fundamental. Madrid: Marcial Pons, 1996; BOBBIO, Norberto. Direito e poder. São Paulo: UNESP, 2008. VILANOVA, Lourival. Teoria da norma fundamental: comentários à margem de Kelsen. Separata: Anuário do Mestrado em Direito da Faculdade de Direito do Recife, n. 7, jan./dez. 1976; VIOLA, Oscar Luis. Contra Kelsen: revisión crítica de la teoría pura - purísima - del derecho, de Hans Kelsen). Buenos Aires: Astrea, 1975; KUNZ, Josef L. La teoría pura del derecho. México: Universitaria, 1948.

37 FEINMANN, José Pablo. Que es la filosofia? Buenos Aires: Prometeo Libros, 2006. p. 243; e FEINMANN, José Pablo. La filosofiay el barro de la historia. Buenos Aires: Planeta, 2009. p. 347.

38 MONDOLFO, Rodolfo. Problemas e métodos de investigação na história da filosofia. São Paulo: Mestre Jou, [1969] p. 29-34.

39 FAVOREU, Louis. Los tribunales constitucionales. Barcelona: Ariel, 1994. p. 13-14; FERNÁNDEZ RODRÍGUEZ, José Julio. La justicia constitucional Europea ante el siglo XXI. 2. ed. Madrid: Tecnos, 2007. p. 31-34; MARCOU, Jean. Justice constitutionnelle et systèmes politiques. Grenoble: Universitaires de Grenoble, 1997. p. 5. tudo o mais que não responde estritamente à sua definição.

Para ele a ciência jurídica até então estava envolvida por inúmeras confusões e obscuridades, produto da mistura de suas afirmativas e indagações com as de outras disciplinas conexas, mas inteiramente alheias ao seu objeto, como a sociologia, a psicologia, a moral e a política.

Precisava-se empreender, e assim o fez, uma radical eliminação desses elementos contagiantes - por ele reputados não jurídicos e, por isso, espúrios -, para que a ciência do direito cuidasse apenas do seu objeto material especifico, ou seja, do próprio direito positivo, que ele entendia como sistema de normas gerais e individuais.

Para atender a essa exigência metodológica, Kelsen realizou duas ordens de purificação. Primeiramente, separou as ciências naturais das ciências sociais, porque Natureza e Sociedade são realidades totalmente distintas, conforme suas próprias palavras. ${ }^{40}$ Em seguida, empreendeu a chamada purificação juspositiva, anti-jusnaturalista, apartando a Jurisprudência da Ética, da Sociologia, da Psicologia, da Teoria Política e da Teoria da Justiça - saberes que, insista-se, são conexos à Jurisprudência, porém alheios à juridicidade -, para evitar um sincretismo metodológico que obscurece a essência da ciência jurídica e dilui os limites que lhe são impostos pela natureza do seu objeto. ${ }^{41}$

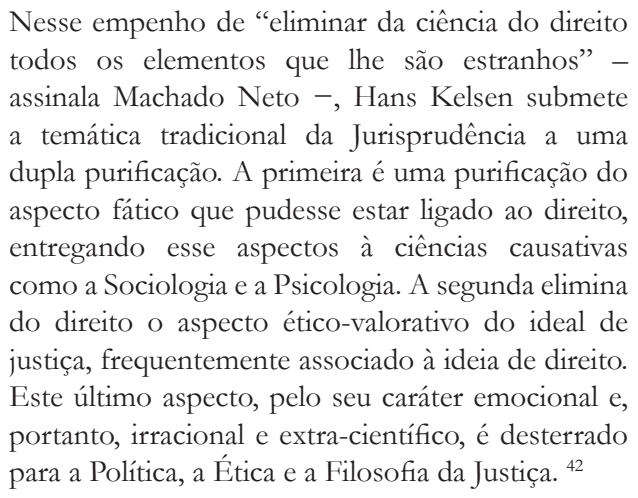

\subsection{Causalidade e imputação}

Separando Natureza e Sociedade, como realidades ou mundos distintos, Kelsen afirma que a primeira é

40 KELSEN Hans. Teoría pura del derecho. Buenos Aires: Eudeba, 1960. p. 16.

41 KELSEN, Hans. Teoria pura do direito. 2. ed. Coimbra: A. Amado, 1962 v. 1. p. 2.

42 MACHADO NETO, Antônio Luís. Fundamentación egológica de la teoria general del derecho. Buenos Aires: Eudeba, 1974. p. 28-29. 
regida pelo princípio da causalidade (leis naturais), enquanto a segunda é dominada pelo princípio da imputação (leis normativas). A propósito, vale registrar que uma das obras mais importantes de Hans Kelsen tem como título "Sociedade e Natureza: uma investigação sociológica", estudo no qual ele ressalta que a noção moderna de causalidade teve sua origem na primitiva ideia de retribuição. ${ }^{43}$

Tanto o princípio da causalidade quanto o da imputação apresentam-se sob a forma de juízos hipotéticos, que relacionam uma condição e uma consequência. Essa, aliás, é a sua única semelhança - assinala Kelsen -, mas, enquanto no primeiro juízo a condição é uma causa, e a consequência, seu efeito, por uma lei de necessidade, sem a interferência de atos humanos, já no segundo juízo não se verifica essa inevitabilidade, estabelecendo-se a relação entre condição e consequência por atos do homem, sob o domínio, portanto, da liberdade.

Ao dualismo irredutível de ser e dever ser - lê-se em Kelsen - corresponde o dualismo metodológico das leis causais, des-critivas do ser, e as normas prescritivas de condutas que instauram um dever ser. $\mathrm{O}$ esquema das leis causais é: Se A é, então é (ou será) B. Na relação entre a condição e a consequência expressa-se a necessidade causal do "ter que " (Müssen). Também nas normas do direito conectase uma condição com uma consequência, pois o direito prescreve uma conduta determinada de uma maneira tal que à conduta oposta - qualificada de antijurídica - enlaça-se uma consequência jurídica chamada sanção. ${ }^{44}$

A distinção está, pois, no sentido do enlace estabelecido pela norma e pela lei natural. Enquanto o juízo que expressa a norma jurídica representa-se pela fórmula "dado A deve ser B", aquele que traduz a lei natural tem a estrutura "dado A será B".

No primeiro juízo, o elemento $A$ é a situação de fato condicionante, e $B$ a conseqüência condicionada, que se imputa à primeira; já no segundo juízo, o elemento $A$ funciona como causa e $B$ como efeito certo (ou provável)..$^{45}$

43 KELSEN, Hans. Sociedad y naturaleza. Buenos Aires: Depalma, 1945 Ver também, KELSEN, Hans. La aparición de la ley de causalidad a partir del principio de retribución. In: La idea del derecho natural y otros ensayos. Buenos Aires: Losada, 1946. p. 53-97. 44 KELSEN, Hans. Contribuciones a la teoría pura del derecho. Buenos Aires: Centro Editor de América Latina, 1969. p. 122-123.

45 Sobre a questão da certeza/probabilidade, no âmbito física moderna, ver, no próprio Kelsen, o estado da arte à época em que ele produziu o texto $O$ surgimento da lei da causalidade a partir do princípio
É o que nos diz ainda o próprio Kelsen, em texto frequentemente citado pelos seus estudiosos.

\begin{abstract}
A regra de Direito, usando o termo em sentido descritivo, é, como a lei natural, um juízo hipotético que atribui uma consequência determinada a uma condição determinada. Mas entre a lei natural e a regra de Direito só existe uma analogia. A diferença está no sentido com que a condição e a consequência estão relacionadas. A lei natural afirma que, quando um fato (a causa) tem lugar, segue-se outro fato (o efeito). A regra de Direito, usando o termo em sentido descritivo, diz que, se um indivíduo se comporta de certa maneira, outro indivíduo deve conduzir-se em determinada forma. A diferença entre a Ciência Natural e a Jurisprudência não está na estrutura lógica das proposições que descrevem o objeto, mas antes no objeto mesmo, e, portanto, no significado da descrição. A Ciência Natural descreve seu objeto - a natureza - em proposições de "ser"; a Jurisprudência descreve o seu objeto - o Direito - em proposições de dever ser. ${ }^{46}$
\end{abstract}

Ademais, enquanto no âmbito da causalidade notamos que "cada causa concreta é, simultaneamente, efeito de outra causa, e cada efeito causa de outro efeito", e assim sucessivamente, sem que se encontre um ponto final nessa cadeia de eventos, já no domínio da imputação o processo é totalmente distinto, pois "a condição à qual se imputa uma consequência moral, religiosa, ou jurídica, não é necessariamente uma consequência imputável a outra condição". ${ }^{47}$ Em suma, como afirma Kelsen, "a série de razões que fundamentam a validade de uma norma não é infinita como as séries de causas e efeitos." 48

Diante do exposto, conclui-se que existe uma contraposição metódica absoluta entre o explicativo e o normativo, fundada na plena disparidade entre ser e dever ser. Trata-se, como afirma Legaz y Lacambra, de "dois mundos separados por um abismo intransponível, porque a sua oposição é lógico-formal e, portanto, impeditiva de se passar de um mundo ao outro." ${ }^{49}$

da retribuição. KELSEN, Hans. La aparición de la ley de causalidad a partir del principio de retribución. In: _. La idea del derecho naturaly otros ensayos. Buenos Aires: Losada, 1946. p. 53-97.

46 KELSEN, Hans. La teoría pura del derecho y la jurisprudência analítica. In: L L L idea del derecho naturaly otros Ensayos. Buenos Aires: Losada, 1946. p. 202-234. p. 217.

47 KELSEN Hans. Teoría pura del derecho. Buenos Aires: Eudeba, 1960. p. 26.

48 KELSEN Hans. Los juicios de valor en la ciencia del derecho. In: _. La idea del derecho natural y otros Ensayos. Buenos Aires: Losada, 1946. p. 239-265 p. 252.

49 Legaz Y LACAMBRA, Luis. Kelsen: estudio crítico de la teoría pura del derecho y del estado de la Escuela de Viena. Barcelona: Bosch, 1933. p. 21. 


\subsection{Dever ser jurídico e dever ser axiológico}

Realizada essa primeira purificação, distinguindo $\mathrm{Na}$ tureza e Sociedade e, consequentemente, separando as ciências naturais das ciências sociais, Kelsen empreendeu uma segunda depuração, esta já no campo normativo, estabelecendo diferença entre o dever ser por seu intrínseco valor (dever ser axiológico), que diz respeito à Moral, ao Direito Natural e à Política, e o dever ser não valorativo, neutral, puramente lógico e, por isso, cientificamente jurídico - o dever ser objeto da Jurisprudência.

Graças a esse esforço em busca do mais completo purismo metodológico, Hans Kelsen pôde atingir, finalmente, o dever ser que, para ele, constitui o conteúdo da norma jurídica, o objeto único, irredutível (mas também não ampliável) da ciência jurídica pura, expungindo do direito o aspecto ético-valorativo do ideal de justiça habitualmente ligado à sua ideia. "O resíduo, isto é, aquilo que deve ser, não por seu intrínseco valor e sim porque constitui o conteúdo das normas jurídicas, é o objeto da ciência jurídica pura". ${ }^{50}$ Daí a sua afirmação - chocante a uma primeira leitura -, de que "todo e qualquer conteúdo pode ser Direito", bastando para isso que a norma que conferiu juridicidade a esse conteúdo tenha sido criada de conformidade com outra, de maior hierarquia - da qual aquela norma extrai sua validade - e, assim, sucessivamente, até a norma fundamental - bipotética - que encerra o processo de fundamentação e fecha o sistema. ${ }^{51}$

Oportuna, na linha desse pensamento de Kelsen, a observação de Soler de que "todo sistema jurídico autolimita não apenas o retrocesso fundante [no sentido expresso acima], mas também o processo dedutivo/derivativo, estabelecendo também aqui um limite além do qual não se pode prosseguir. Num extremo da ordem jurídica positiva está a Constituição, no outro, a coisa julgada; no direito, assim como não há regressus, tampouco

50 VILANOVA, Jose apud MACHADO NETO, Antônio Luís. Fundamentación egológica de la teoria general del derecho. Buenos Aires: Eudeba, 1974. p. 29.

51 KELSEN, Hans. Teoria pura do direito. 2. ed. Coimbra: A. Amado, 1962 v. 2. p. 10; KELSEN, Hans. Teoría general del estado. México: Nacional, 1965. p. 53; e KELSEN, Hans. La idea del derecho natural y otros ensayos. Buenos Aires: Losada, 1946. p. 228: "Uma análise do direito positivo mostra que o procedimento pelo qual se cria uma norma jurídica está regulado por outra norma jurídica. A rigor, frequentemente, outras normas determinam não só o procedimento de criação, mas também, em maior ou menor extensão, o conteúdo da norma a ser criada". há progressus in infinitum, já que a existência deste último seria incompatível com aquela limitação." 52

Dessa maneira, ou seja, dizendo que todo conteúdo pode ser direito ou - o que significa o mesmo -, que uma norma jurídica pode ter qualquer conteúdo -, o chefe da Escola de Viena atingia o fim a que se propusera, eliminando as confusões, que tanto combatera, na teoria tradicional do direito, entre os planos sociológico, filosófico e o estritamente jurídico, sem que, no entanto, negasse o status de investigação científica aos outros saberes - não dogmático-jurídicos - que têm por objeto material a "coisa" direito, tal como esta é conceituada pela Ciência do Direito ou Jurisprudência Normativa. Daí esta afirmação de Kelsen, a respeito das relações entre a Ciência do Direito e a Sociologia Jurídica:

A norma jurídica como expressão de um “dever ser” não é para ele (sociólogo do direito), como é para o jurista, o objeto de seu conhecimento; para o sociólogo é um princípio de seleção. A função da norma jurídica para a sociologia do direito é indicar seu próprio objeto particular, e separá-lo do conjunto dos fatos sociais. Nessa medida, a jurisprudência sociológica pressupõe a jurisprudência normativa. É um complemento da jurisprudência normativa. ${ }^{53}$ (grifo nosso).

Esclarecedoras, nesse particular, são igualmente as reflexões de Miguel Reale sobre os planos e âmbitos do conhecimento do direito, onde ele assinala que a experiência jurídica - conceito bem mais amplo do que o conceito de norma jurídica -, como objeto material comum, pode ser estudada por diferentes "ciências" ou distintos saberes, a depender da perspectiva ou do ponto de vista (=objeto formal) em que se coloquem os seus investigadores.

O Direito, por certo, é um só para todos os que o estudam - diz o mestre do tridimensionalismo jurídico -, havendo necessidade de que os diversos especialistas se mantenham em permanente contato, suprindo e completando as respectivas indagações, sem que isso nos autorize a falar numa única Ciência do Direito, a não ser dando ao termo "Ciência" a conotação genérica de "conhecimento" ou "saber", suscetível de desdobrar-se em múltiplas "formas de saber", em função dos vários "objetos” de cognição que a experiência do Direito logicamente possibilita, seja no plano empírico ou científico-positivo, seja no plano transcendental ou filosófico. ${ }^{54}$

52 SOLER, Sebastin. La interpretación de la Ley. Barcelona: Ariel, 1962. p. 95-96.

53 KELSEN, Hans. La teoría pura del derecho y la jurisprudência analítica. In: La idea del derecho natural y otros Ensayos. Buenos Aires: Losada, 1946. p. 202-234. p. 218.

54 REALE, Miguel. As ciências da realidade jurídica. In: 
Mesmo assim, ou seja, ainda que se troque o conceito específico de norma jurídica - uma regra que impõe, proíbe ou faculta determinadas condutas -, pelo conceito, mais amplo, de experiência jurídica, entendida como aquilo que em dado momento histórico uma sociedade vivencia como direito, em seus elementos essenciais - fáticos, axiológicos e normativos ${ }^{55}$-, ainda assim, qualquer disciplina que pretenda delimitar o seu campo de estudos sobre a "coisa direito", estremando-o de outras ordens de indagações, terá de se referir, prévia e necessariamente, ao Direito sub specie normativitatis e pressupor os conceitos jurídicos fundamentais, pois é somente com a sua normatização - por meio de regras legais ou costumeiras -, que as condutas humanas deixam de ser fatos sociais tout court para se converterem em fatos sociais especificamente jurídicos. ${ }^{56}$ Em síntese, qualquer comportamento só adquire a condição de conduta jurídica quando uma norma, validamente criada, "carimba" esse comportamento como faculdade, prestação, ilícito ou sanção. ${ }^{57}$ Aquilo que não for ou deixar de ser objeto/conteúdo de uma norma jurídica situa-se no "espaço livre de Direito" e, assim, não pode ser objeto de nenhuma abordagem acerca da juridicidade, como, por exemplo, uma Filosofia ou uma Sociologia do Direito . ${ }^{58}$

\section{A NORMA JURÍDICA}

Conseguidas aquelas duas purificações, separados ser e dever ser, e deste eliminado o dever ser axiológico, Kelsen coloca-nos diante da norma jurídica como conceito central da ciência do direito, que surge, assim, como ciência normativa, um saber que tem a norma jurídica positiva - e somente ela - como objeto das suas indagações.

Filosofia do direito. 9. ed. São Paulo: Saraiva, 1982. p. 609-614; REALE, Miguel. Dos planos e âmbitos do conhecimento do direito. In: MACHADO NETO, Antônio Luís; MACHADO NETO, Zahidé (Org.). O Direito e a Vida Social. São Paulo: Nacional, 1966. p. 21-27; REALE, Miguel. Fundamentos da teoria tridimensional do direito. Revista Brasileira de Filosofia, São Paulo, v. 10, n. 4, p. 455-470, out./ nov. 1960.

55 REALE, Miguel. O direito como experiência. São Paulo: Saraiva, 2002. SICHES, Luis Recaséns. La experiencia jurídica. Dianoia, v. 11, n. 11, p. $18-39,1965$.

56 DÍAZ, Elías. Sociología y filosofía del derecho. Madrid: Taurus, 1982. p. $12 ; 183$.

57 MACHADO NETO, Antônio Luís. Teoria geral do direito. Rio de Janeiro: Tempo Brasileiro, 1966. p. 246-247.

58 LARENZ, Karl. Metodologia da ciência do direito. 7. ed. Lisboa: Gulbenkian, 2014. p. 526-527; nota 11.
Convém, todavia, esclarecer que se trata de uma ciência normativa, não porque prescreva normas, o que lhe emprestaria um caráter valorativo que, em absoluto, ela não possui, mas porque tem por objeto normas, as quais a Jurisprudência estuda e descreve com integral neutralidade axiológica. ${ }^{59}$ Entender em contrário seria não compreender o pensamento kelseniano, deformando a sua teoria e desnaturando a sua intenção. Daí esta precisa síntese de Machado Neto, um dos juristas brasileiros que mais se dedicou ao estudo crítico da Teoria Pura do Direito.

\begin{abstract}
Seu objeto é apenas a norma, quer no aspecto estático - nomoestática - quer no dinâmico nomodinâmica, quer na consideração do sistema normativo como um todo coerente, ou na análise dinâmica da produção das normas, em que o direito regula sua própria criação e aplicação. ${ }^{60}$
\end{abstract}

Após haver estabelecido que a ciência jurídica é uma ciência normativa, Kelsen declara que ela estuda o direito sob duplo aspecto - estático e dinâmico -, de vez que o ordenamento jurídico pode ser considerado em estado de repouso - como sistema estabelecido -, assim como em seu movimento - como uma série de atos pelos quais o direito é criado e, em seguida, aplicado. ${ }^{61}$

Qual, entretanto, a natureza dessa norma, que constitui o objeto específico da ciência do direito? É um juízo bipotético, responderá Kelsen; um juízo que exprime o enlace de uma situação de fato condicionante com uma consequência jurídica condicionada. ${ }^{62}$

Afirmando a natureza de juízo hipotético da norma jurídica, Kelsen rejeita a tese tradicional - que sustentava ser a norma um comando, um mandado, uma ordem, um imperativo - não só porque não existe ordem sem vontade real, como também porque as normas jurídicas prescindem desse elemento volitivo para a sua validez. É o que ele nos diz, resumidamente, nas frases reproduzidas a seguir.

Se a regra jurídica é um comando, ela é, por assim dizer, um comando despsicologizado, um comando que não implica uma 'vontade' no sentido psicológico do termo". ${ }^{63}$

59 GARCÍA MÁYNEZ, Eduardo. El problema de la clasificación de las ciências. In: _. Introducción al estudio del derecho. 4. ed. Mexico: Porrúa, 1951. p. 122-123; KALINOWSK, Georges I. Querelle de la science normative. Paris: L.G.D.J., 1969.

60 MACHADO NETO, Antônio Luís. Fundamentación egológica de la teoria general del derecho. Buenos Aires: Eudeba, 1974. p.32-33.

61 KELSEN Hans. Teoría pura del derecho. Buenos Aires: Eudeba, 1960. p. 34.

62 KELSEN Hans. Teoria geral das normas. Porto Alegre: S. A. Fabris, 1986. p. 25-28.

63 KELSEN Hans. Teoria geral do direito e do estado. São Paulo: M. Fontes, 1990. p. 38-40. 


\section{$[\cdots]$}

A conduta humana é sancionada, estatuída ou prescrita por uma regra de direito sem nenhum ato de vontade psíquica. O direito poderia ser denominado uma ordem "despsicologizada. ${ }^{64}$

Em seguida, exigindo que as normas, para pertencerem à esfera do direito, não apenas definam a conduta que constitui a condição de uma sanção, mas também determinem essa mesma sanção, Kelsen as distingue entre normas primárias e normas secundárias, dizendo que a norma primária é aquela que estabelece a relação entre o fato ilícito e a sanção, e a secundária a que prescreve a conduta impeditiva da sanção. ${ }^{65}$

Dessa forma, podemos dar às duas categorias de normas a seguinte formulação:

- Dado nP (não prestação) deve ser S (sanção) - Norma primária

- Dado Ft (fato temporal) deve ser P (prestação) Norma secundária

Compreendido, assim, o direito especificamente como ordem coativa de condutas, vemos que a norma primária é a fórmula pura em que ele consiste, sendo a norma secundária uma verdadeira superfluidade, ou, como prefere dizer o próprio Kelsen, “só um meio técnico para expressar em forma mais breve e acessível o que somente a norma enuncia cabal e corretamente: que ocorrendo a conduta contrária há de acontecer um ato coativo". ${ }^{66}$

Essa é a razão por que Aftalión, Olano e Vilanova, antes citados, analisando o caráter coativo da norma jurídica na concepção kelseniana, chegam a dizer que essa coatividade é a sua diferença específica, sendo a imputação apenas o gênero próximo. ${ }^{67}$

A natureza coativa da norma jurídica não deve, entretanto, ser misturada com elementos que lhe são estranhos, como o medo, o poder, o interesse a reverência ou o respeito, que deformariam seu verdadeiro sentido, porque a sanção jurídica, aquela consequência ligada a um

64 KELSEN, Hans. La idea del derecho naturaly otros ensayos. Buenos Aires: Losada, 1946. p. 222.

65 KELSEN Hans. Teoría pura del derecho. Buenos Aires: Eudeba, 1960. p. 77.

66 AFTALIÓN, Enrique R; GARCÍA OLANO, Fernando; VILANOVA. Introducción al derecho. Buenos Aires: El Ateneo, 1960. p. 855.

67 AFTALIÓN, Enrique R; GARCÍA OLANO, Fernando; VILANOVA. Introducción al derecho. Buenos Aires: El Ateneo, 1960. p. 854 fato condicionante, que singulariza esse tipo de norma, está vinculada estruturalmente ao preceito, sendo irrelevante saber-se quais as razões que determinam o seu cumprimento ou a sua inobservância.

O fato de alguém cumprir ou não um preceito jurídico nenhum valor tem para a sua conceituação qua tale, pois esse preceito continuará a ser o que é independentemente de sua efetiva execução.

Basta ver, por exemplo, que ninguém negará a natureza de norma jurídica ao dispositivo legal que sanciona o furto pela simples razão de existirem ladrões, ou porque um desses criminosos, após cometer o delito (circunstância de fato condicionante), tenha desaparecido até sobrevir a prescrição do crime, a qual, de resto, é objeto de outro preceito jurídico. Em síntese, no mundo ético, diversamente do mundo natural, o descumprimento das normas não constituirá "disposição em contrário", pois enquanto as leis físicas, como sínteses de uma dada experiência, exprimem só o que é, aquilo que efetivamente acontece, as leis morais não recebem as suas verdades das condutas que intentam regular, porque não expressam o que é, mas apenas o que deve ser. Nos domínios da ética, em geral, e do direito, em particular, pelo menos em linha de princípio, a eficácia não é condição de validade ${ }^{68}$, muito embora o próprio Kelsen tenha dito que "não pode negar-se que uma ordem jurídica como um todo, tal como uma norma jurídica singular, perde a sua validade quando deixa de ser eficaz. ${ }^{69}$ Em síntese, como arremata Josef Kunz, a eficácia é a condição da validez; a condição, não a razão, a conditio sine qua non, não a conditio per quam. ${ }^{70}$

\section{Posição PeRANTE OS DUALISMOS Da DoUtRI- NA TRADICIONAL}

Consequência de sua consideração, unificadora e estritamente normativista da ciência jurídica, é a eliminação dos dualismos da doutrina tradicional, tais como direito natural/direito positivo, direito objetivo/direito subjetivo, pessoa natural/pessoa jurídica, direito públi-

68 DEL VECCHIO, Giorgio. Lições de filosofia do direito. Coimbra: Ar. Amado, 1959. v. 2, p. 72.

69 KELSEN, Hans. Teoria pura do direito. 2. ed. Coimbra: A. Amado, 1962. v. 1. p. 40-42.

70 KUNZ, Josef L. La teoría pura del derecho. México: Universitaria, 1948. p. 75. 
co/direito privado, Estado/Direito, pelas razões desenvolvidas a seguir.

\subsection{Direito natural e direito positivo}

Sobre o velho problema do direito natural, aquela ordem intrinsecamente válida, que existiria ao lado e acima do direito positivo, Kelsen concentrou a força de sua argumentação teórica, com o propósito de eliminar de vez com essa antinomia, negando a existência do direito natural em favor do direito positivo como único sistema coativo de condutas. ${ }^{71}$

Ao iniciar seu combate, o mestre de Viena diz que esse dualismo é característico da teoria tradicional do direito, tal como ela foi desenvolvida pela ciência jurídica positivista do século XIX, e que essa dicotomia afeta o sistema em seu conjunto e em cada uma das suas partes. $^{72}$

Trata-se, no entender de Kelsen, de um mero instrumento com o qual a doutrina do direito natural acredita poder resolver o eterno problema da justiça absoluta, dando uma resposta definitiva à questão do bem e do mal nas relações humanas.

Examinando a evolução do pensamento jusnaturalista, Kelsen chega à conclusão de que toda doutrina de direito natural, para ser coerente consigo mesma, deveria revesti-lo de um caráter transcendente, religioso, divino, para que ele seja - como sustentam os seus adeptos - um direito eterno e imutável, diverso, portanto, do direito positivo que, sendo criado pelos homens, é uma realidade histórica, temporal e variável.

\begin{abstract}
Igualmente - adverte Kelsen - só a hipótese de um direito natural estabelecido pela vontade de Deus permite afirmar-se que os direitos subjetivos são inatos ao homem e que possuem um caráter sagrado, com a consequência de que o direito positivo não poderia outorgá-los nem retirá-los do homem, mas tão somente protegê-los e garanti-los. ${ }^{73}$
\end{abstract}

Estamos, assim, diante de uma argumentação que parece irrespondível pelos teóricos do direito natural, que não têm condições para estabelecer a totalidade dos

71 LEGAZ Y LACAMBRA, Luis. Kelsen: estudio crítico de la teoría pura del derecho y del estado de la Escuela de Viena. Barcelona: Bosch, 1933. p. 36-40.

72 KELSEN, Hans. Teoria pura do direito. 2. ed. Coimbra: A. Amado, 1962. v. 1. p. 101.

73 KELSEN Hans. Teoría pura del derecho. Buenos Aires: Eudeba, 1960. p. 103 direitos subjetivos. Ou estes direitos consistem naqueles atributos reconhecidos e protegidos pela ordem jurídica positiva, que seria, então, a sua fonte geradora e garantidora, e, portanto, superior a eles; ou restariam ainda outros tantos direitos, de acordo com a concepção de cada criatura, já que seria impossível uma união de pontos de vista, em ordem a reconhecê-los ou positivá-los numa espécie de "declaração ecumênica" dos direitos humanos.

Levando-se às últimas consequências esse tipo de raciocínio verificaremos que não existe uma, mas diversas doutrinas jusnaturalistas, com a evidente possibilidade de se defenderem teses até mesmo contrapostas, senão mesmo contraditórias.

Daí porque compreendemos, perfeitamente, a utilização dessas doutrinas quer pelas correntes socialistas, na sua condenação da propriedade privada, tida como contrária à Natureza e fonte de todos os males humanos ${ }^{74}$; quer pelos defensores do liberalismo/capitalismo, que entendem deva o Estado proteger essa mesma propriedade, em toda a sua plenitude, porque se trata de um direito natural e imprescritível do homem. ${ }^{75}$

Essas e outras dificuldades e contradições, como a de que o direito positivo encontraria sua justificação e validez no direito natural, sendo assim coisa supérflua e ridícula, tal como - na expressão de Kelsen - "uma iluminação artificial em pleno sol" "76; ou como a afirmação de que a justiça consistiria em dar a cada um o que é seu, mas precisando recorrer ao direito positivo para fornecer o conteúdo desse suum. Tudo isso levou Kelsen a negar validade a esse velho dualismo, dizendo não existir um direito natural, mas apenas teorias de direito natural, o qual não passa de uma máscara atrás da qual se ocul-

74 PROUDHON, Pierre-Joseph. O que é a propriedade? Lisboa: Estampa, 1971. p. 241: “Ora, a propriedade engendra necessariamente o despotismo, o governo do belo prazer, o reino de uma vontade libidinosa: isso faz de tal maneira parte da essência da propriedade que basta, para se convencerem, lembrar o que ela é e o que se passa à nossa volta. A propriedade é o direito de usar e abusar." (grifo nosso).

75 ORGANIZAÇÃO DAS NAÇÕES UNIDAS. Declaração dos Direitos do Homem e do Cidadão. Disponível em: <http://pfdc.pgr. mpf.mp.br/atuacao-e-conteudos-de-apoio/legislacao/direitos-humanos/declar_dir_homem_cidadao.pdf > . Acesso em: 12 fev. 2016. - art. $2^{\circ}$. "A finalidade de toda associação política é a conservação dos direitos naturais e imprescritíveis do homem. Esses direitos são a liberdade, a propriedade, a segurança e a resistência à opressão."

76 KELSEN Hans. Teoría pura del derecho. Buenos Aires: Eudeba, 1960. p. 106 
tam os interesses. ${ }^{77} \mathrm{Um}$ ligeiro percurso pela história do direito natural evidenciará essa diversidade doutrinária, desde a sua compactação em dois grandes blocos teóricos - direito natural clássico e direito natural moderno - , até os refinamentos comparatistas, a distinguirem enfoques diversos num mesmo período histórico. ${ }^{78}$

\subsection{Direito objetivo e direito subjetivo}

Eliminando esse primeiro dualismo - direito natural/direito positivo -, que para Kelsen se mostra de alguma forma imanente e oculto, dedica-se ele ao estudo de outros dualismos, estes patentes e sistemáticos, como a contraposição direito objetivo/direito subjetivo; direito público/direito privado; Estado e direito e outros pares de noções opostas. ${ }^{79}$

Inicialmente, entende Kelsen que deve explicar a natureza de cada um desses dualismos, para, em seguida, esgrimir contra eles a sua argumentação.

Diz ele, por exemplo, que enquanto a oposição entre Direito e Estado tem uma função essencialmente justificadora, e a distinção entre direito objetivo e subjetivo pretende limitar o domínio do direito positivo, a oposição direito público versus direito privado possui significações diferentes e funções ideológicas variadas.

Sendo patente o sentido ideológico da doutrina, no tocante à distinção entre direito subjetivo e direito objetivo, o seu choque com o pensamento kelseniano surge, assim, como algo verdadeiramente axiomático.

Basta partirmos de duas concepções sobre a natureza do direito subjetivo - como a teoria da vontade, de Bernhard Windscheid, ou a teoria do interesse, de Rudolf von lhering - para vermos a sua antinomia com o direito objetivo, entendido e aceito como norma ou conjunto de normas.

Em seu primeiro significado - acentua Kelsen - este dualismo expressa a ideia de que o direito subjetivo é anterior ao direito objetivo, tanto do ponto de vista lógico quanto do cronológico. ${ }^{80}$

77 KELSEN, Hans apud LEGAZ Y LACAMBRA, Luis. Kelsen: estudio crítico de la teoría pura del derecho y del estado de la Escuela de Viena. Barcelona: Bosch, 1933. p. 36.

78 STRAUSS, Leo. Droit Naturel et Histoire. Paris: Flammarion, 1997; SICHES, Luis Recaséns. Iusnaturalismos actuales comparados. Madrid: Universidad de Madrid, 1970.

79 KELSEN Hans. Teoría pura del derecho. Buenos Aires: Eudeba, 1960. p. 113.

80 KELSEN Hans. Teoría pura del derecbo. Buenos Aires: Eudeba,
Seria, assim, o direito subjetivo uma categoria transcendente, superior ao direito objetivo, o qual, como ordem estatal surgida depois, deveria apenas reconhecer, proteger, sancionar o direito subjetivo, que lhe é preexistente.

Após declarar que essa noção é sustentada, em especial, pelos partidários da escola histórica, Kelsen avança para a identificação entre sujeito de direito ou pessoa e direito subjetivo.

Para ele, a rigor, esses conceitos não são mais que dois aspectos da mesma noção, sendo o proprietário titular de um direito subjetivo - o modelo do sujeito de direitos. Ao direito objetivo, se quisesse ser um verdadeiro direito, restaria apenas reconhecer essa personalidade inicial, esse ser independente da ordem jurídica.

Partindo do ponto de vista - sustentado por essa mesma concepção -, de que o direito objetivo é uma norma heterônoma, ao lado do direito subjetivo, e que impõe obrigações e sanções, independentemente, portanto, do âmbito da subjetividade, Kelsen demonstra a contradição existente nesse dualismo, uma vez que "a qualidade de pessoa jurídica é por essência a negação de toda obrigação, a liberdade no sentido de autodeterminação ou de autonomia. ${ }^{81}$

Prosseguindo em sua argumentação, Kelsen denuncia igualmente a função ideológica das noções - que reputa contraditórias entre si - , de direito subjetivo e sujeito de direitos.

Trata-se, no fundo, diz ele, de uma tentativa para manter a ideia de que a propriedade privada é uma categoria transcendente ao direito objetivo, o qual, exatamente por isso, não pode suprimi-la.

Partindo da concepção hegeliana de que o direito subjetivo se identifica com a propriedade, e que esta é o domínio exterior onde se exerce a liberdade ${ }^{82}$, Kelsen demonstrou porque a ideologia do direito subjetivo se sustenta sobre o valor moral da liberdade individual e da autonomia da pessoa, negando foros de ordem jurídica a tudo quanto não garanta essa mesma liberdade, que não proteja os direitos subjetivos.

Dizendo que os teóricos interessam-se mais pelo direito subjetivo do que pelo dever jurídico, embora este

1960. p. 114.

81 KELSEN Hans. Teoría pura del derecho. Buenos Aires: Eudeba, 1960. p. 115.

82 HEGEL, Georg Wilíelm Friedrich. Princípios da filosofia do direito. São Paulo: M. Fontes, 2000. p. 44-46, SS 41-44. 
seja mais importante, já que o direito - como ordem coativa de comportamentos -, tem por função essencial estabelecer uma relação normativa entre a conduta individual e um ato de coação destinado a sancionar essa mesma conduta, Kelsen reduz o direito subjetivo ao direito objetivo.

Para tanto ele coloca em primeiro plano a noção de dever jurídico, que nada mais é do que a mesma norma jurídica considerada do ponto de vista da conduta prescrita a um sujeito determinado.

O dever jurídico, diz Kelsen, "é a norma em sua relação com o indivíduo ao qual ela prescreve certa conduta, vinculando uma sanção à conduta contrária". ${ }^{83}$

Então, verificamos que o dever jurídico é, exatamente, o conteúdo da norma que Hans Kelsen denominou secundária, norma no sentido descritivo da palavra, porque define aquela conduta impeditiva da sanção. ${ }^{84}$ Primária - porque a mais importante - é a norma que estabelece a relação entre o ato ilícito e a sanção, pois a coercibilidade é o traço fundamental do direito como ordem coativa de condutas.

Dessa forma, vemos porque um indivíduo só está obrigado - juridicamente - a adotar certa conduta, quando uma norma faz do comportamento contrário a condição realizadora da sanção. Não por acaso, entre os direitos fundamentais que proclama, reconhece e protege, a nossa Constituição estatui, em seu artigo $5^{\circ}$, incisos II, XXXV LXVIII, respectivamente, que ninguém será obrigado a fazer ou deixar de fazer alguma coisa senão em virtude de lei; que a lei não excluirá da apreciação do Poder Judiciário lesão ou ameaça a direito; e que se concederá habeas corpus sempre que alguém sofrer ou se achar ameaçado de sofrer violência ou coação em sua liberdade de locomoção, por ilegalidade ou abuso de poder.

Noutro dizer, ninguém será coagido - pelo Estado ou pelos particulares -, a se comportar de certa maneira, a não ser que uma norma jurídica defina a conduta contrária como ensejadora de sanção, norma essa que, de outra parte, é suscetível de invalidação judicial se ameaçar ou lesar direito assegurado pela Constituição. É que, no moderno Estado Constitucional de Direito, qualquer

83 KELSEN Hans. Teoría pura del derecho. Buenos Aires: Eudeba, 1960. p. 121

84 KELSEN Hans. Teoría pura del derecho. Buenos Aires: Eudeba, 1960. p. 77. forma de coação - seja estatal ou interindividual - só se reputa legítima se for exercida em estrita obediência ao que estabelece o contrato constitucional. ${ }^{85}$

Fixada a preeminência do dever jurídico em face do direito subjetivo, Hans Kelsen declara que este só existe, em sentido especifico, quando entre as condições determinantes da sanção jurídica figura urna manifestação de vontade, querela ou ação judicial, emanada de um indivíduo lesado em seus interesses por um ato ilícito. Somente nesta hipótese, isto é, quando uma norma jurídica (direito objetivo, portanto) arma o indivíduo do poder de defesa dos seus interesses, é que surge a figura do direito subjetivo. Ora, se este direito (subjetivo) é emanação daquele (objetivo), se ele só existe na medida em que o outro lhe permite essa existência, como então falar-se em dualidade de categorias? Quem dirá, por exemplo, que é possível encontrar-se um direito subjetivo onde não haja um preceito de direito objetivo garantindo-lhe a existência? Ninguém, certamente, nem mesmo os mais ilustres defensores do tradicional dualismo, como Dernburg, por exemplo, para quem os direitos em sentido subjetivo existiam na história muito antes que uma ordem estatal consciente viesse a ser estabelecida. ${ }^{86}$

Após tecer considerações sobre o dever jurídico e o direito subjetivo, Kelsen diz que a Teoria Pura está em condições de resolver o tradicional dualismo direito objetivo/direito subjetivo, pois ambos os direitos são da mesma natureza; que o segundo não é mais do que um aspecto do primeiro, assumindo quer a forma de um dever e de uma responsabilidade - quando o direito objetivo dirige uma sanção contra um indivíduo determinado -, quer a de um direito subjetivo, quando o direito objetivo se põe à disposição de um indivíduo determinado. ${ }^{87}$

85 Sobre a proteção dos direitos fundamentais nas relações entre particulares, ver, na doutrina brasileira, os estudos de SILVA, Virgílio Afonso da. A constitucionalização do Direito: os direitos fundamentais nas relações entre particulares. São Paulo: Malheiros, 2008; SARMENTO, Daniel. Direitos fundamentais e relações privadas. Rio de Janeiro: Lúmen Juris, 2004; VALE, André Rufino do. Eficácia dos direitos fundamentais nas relações privadas. Porto Alegre: S. A. Fabris, 2004; e SOMBRA, Thiago Luís Santos. A eficácia dos direitos fundamentais nas relações jurídico-privadas. Porto Alegre: S. A. Fabris, 2004. Entre os autores estrangeiros, ver CANARIS, Claus-Wilhelm. Direitos fundamentais e direito privado. Coimbra: Almedina, 2003.

86 DERNBURG, Henrich, 1894, apud KELSEN, Hans. Teoría pura del derecho. Buenos Aires: Eudeba, 1960. p. 114.

87 KELSEN Hans. Teoría pura del derecho. Buenos Aires: Eudeba, 1960. p. 122-123. 
Estava, assim, eliminado pela Teoria Pura do Direito mais esse célebre dualismo, já que demonstrada, com fundamento, a redução do direito subjetivo ao direito objetivo, a absorção de um pelo outro. Se a todo o direito deve corresponder uma ação que o assegure, e se essa ação é criatura do direito objetivo, então parece que se há de considerar preeminente o direito objetivo, na sua vertente processual, ficando o direito subjetivo ou direito material na dependência dessa instrumentalização, que lhe provém do direito objetivo. Nesse sentido, vale recordar a expressiva exclamação de Wach, relembrada por Couture: "a pretensão de tutela jurídica não é uma função do direito subjetivo; a pretensão de tutela jurídica é o meio que permite fazer valer o direito, sem ser o direito mesmo." 88

\subsection{Pessoa natural e pessoa jurídica}

Igualmente suprimido pela teoria kelseniana foi o dualismo da doutrina tradicional, que distinguia os sujeitos de direito entre pessoas físicas ou naturais e pessoas jurídicas.

Trata-se de tema amplamente polêmico, que suscita debates desde a simples denominação dos entes coletivos - pessoas morais, pessoas místicas, pessoas abstratas, pessoas ideais, pessoas civis, pessoas coletivas, ou pessoas jurídicas, etc. - , até à explicação da sua natureza, terreno em que se digladiaram juristas da envergadura de Savigny, lhering, Windscheid, Planiol e tantos outros.

Corolário da redução anterior, que no dizer de Aftalión, Olano e Vilanova, aplaina o caminho para esta outra redução ${ }^{89}$, Kelsen empreende a eliminação de mais este dualismo clássico, culminando com a afirmação de que para a Teoria Pura do Direito a pessoa física e a pessoa jurídica são, ambas, a personificação de uma ordem jurídica, de tal modo que não há diferença essencial entre essas duas classes de pessoas, já que a pessoa física é também uma verdadeira pessoa jurídica. ${ }^{90}$

A fim de chegar a essa conclusão categórica, em choque com a teoria tradicional, numa atitude que, de resto, lhe é peculiar, Kelsen concentra seu ataque sobre um

88 DERNBURG, Eduardo J. Couture. Introdução ao estudo do processo civil. Rio de Janeiro: J. Konfino, [200?]. p. 21.

89 AFTALIÓN, Enrique R; GARCÍA OLANO, Fernando; VILANOVA, José. Introducción al derecho. Buenos Aires: El Ateneo, 1960. p. 857.

90 KELSEN Hans. Teoría pura del derecho. Buenos Aires: Eudeba, 1960. p. 128. conceito jurídico fundamental - o sujeito de direitos ou pessoa -, dizendo tratar-se de uma construção artificial, um conceito antropomórfico criado pela ciência jurídica para apresentar o direito de uma maneira sugestiva. ${ }^{91}$

Para tanto, serviu-se Kelsen da teoria positiva que, não obstante haver desenvolvido, apenas parcialmente, sua concepção acerca do problema, já intentara demonstrar que não existia diferença entre pessoa natural e pessoa jurídica.

O homem, diria Kelsen, não é uma noção jurídica, mas biológica, fisiológica e psicológica, não sendo plausível identificá-lo com a pessoa física, nos moldes em que esta é concebida pela teoria tradicional.

"O homem é pessoa (juridicamente falando) na medida em que a sua conduta encontra-se prevista, como faculdade, ou dever, pela ordem jurídica", dizem os citados Aftalión, Olano e Vilanova, que bem compreenderam o sentido da demonstração kelseniana. ${ }^{92}$

Tratava-se, realmente, de um velho equívoco da doutrina tradicional essa crença de que as noções de homem e pessoa, esta juridicamente considerada, se identificavam.

Daí a razão por que as polêmicas giravam apenas em tomo da natureza das pessoas jurídicas, já que inquestionável era a aceitação, quanto às pessoas naturais, de que elas gozavam de atributos jurídicos próprios.

Ora, afirma Kelsen, o homem somente pode transformar-se em um elemento do conteúdo das normas jurídicas, que regulam a sua conduta, quando ele converte alguns de seus atos em objeto de deveres, de responsabilidades ou de direitos subjetivos. O homem - conclui o mestre de Viena - não é essa unidade específica que denominamos pessoa. ${ }^{93}$

É, verdadeiramente, uma realidade natural inarredável, um ser vivente, biológico, que não se confunde, em absoluto, com a noção de pessoa criada pela ciência do direito, que por isso dela poderia prescindir.

Daí porque Kelsen a entende apenas como um instrumento elaborado pela ciência jurídica, um conceito

91 KELSEN Hans. Teoría pura del derecho. Buenos Aires: Eudeba, 1960. p. 125.

92 AFTALIÓN, Enrique R; GARCÍA OLANO, Fernando; VILANOVA, José. Introducción al derecho. Buenos Aires: El Ateneo, 1960. p. 857.

93 KELSEN Hans. Teoría pura del derecho. Buenos Aires: Eudeba, 1960. p. 126. 
que "facilita a descrição do direito, mas não é indispensável, já que é necessário sempre remeter-se às normas que regulam a conduta dos indivíduos ao determinar seus deveres, responsabilidades e direitos subjetivos." 94

Está patente, pois, o objetivo pretendido por Kelsen, de negar atributo jurídico em si para a pessoa física ou natural, que só terá expressão para o Direito na medida em que este lha conceder.

Lembre-se, por exemplo, que houve época, não muito remota na história da Humanidade, em que diversos sistemas jurídicos, consagrando a escravidão, estavam negando qualquer atributo jurídico - personalidade àquelas criaturas físicas.

Equiparados às coisas, nas sociedades escravagistas, ninguém jamais condenou a servidão imposta àqueles seres humanos, muito embora se tratasse de pessoas, juridicamente consideradas, não podendo, portanto, ser objeto, antes apenas sujeitos de direito.

Prosseguindo em sua argumentação, diz Kelsen que as chamadas pessoas jurídicas são em tudo semelhantes às pessoas físicas, designando apenas a unidade de um conjunto de normas, ou seja, um bloco de preceitos jurídicos destinados a reger a conduta de uma pluralidade de indivíduos.

Neste ponto, ele critica a teoria tradicional, porque não faz a distinção necessária, porque real, entre homem e pessoa física; porque afirma haver diferença essencial entre pessoa física e pessoa jurídica, mas é incapaz de reunir as duas sob a noção comum de pessoa jurídica, que é a única existente.

Por isso - como já registramos -, Kelsen diz que para a Teoria Pura do Direito, a pessoa física e a pessoa jurídica são ambas a personificação de uma ordem jurídica, não havendo diferença essencial entre essas duas classes de pessoas, já que a pessoa física é também uma verdadeira pessoa jurídica. ${ }^{95}$

Considerando, entretanto, que essa simples afirmação não resolvia o problema - notadamente o da distinção, consagrada no direito positivo (e.g. Código Civil Brasileiro, artigos $2^{\circ}$ e 45 ), no modo como adquirem personalidade as pessoas naturais e as pessoas jurídicas -, Kelsen declara que os direitos subjetivos, deveres e res-

94 KELSEN Hans. Teoría pura del derecho. Buenos Aires: Eudeba, 1960. p. 126.

95 KELSEN Hans. Teoría pura del derecho. Buenos Aires: Eudeba, 1960. p. 128. ponsabilidades das pessoas jurídicas nada mais são do que os direitos subjetivos, deveres e responsabilidades dos seus componentes, pois as normas jurídicas somente regulam condutas humanas.

A diferença reside, então e exclusivamente, no modo de atuar da ordem jurídica, que confere direitos ou impõe deveres, individualmente, quando se trata das pessoas físicas e, institucionalmente, quando enfoca as pessoas jurídicas.

Por isso, Hans Kelsen declara, exemplificando, que a propriedade e o crédito de uma pessoa jurídica são, na verdade, propriedade e crédito coletivos de seus membros, os quais, todavia, só podem agir em conformidade com as regras jurídicas que regulam a vida do ente coletivo, o que equivale ao atuar da própria entidade, convertida, assim, em um ponto de imputação, pois todos os seus atos são praticados por indivíduos concretos, embora imputados a um sujeito fictício. Tomando como exemplo, outra vez, o nosso Código Civil, lemos em seu artigo 47 , que obrigam a pessoa jurídica os atos dos administradores, exercidos nos limites de seus poderes definidos no ato constitutivo. ${ }^{96}$

\subsection{Direito público e direito privado}

Embora sem a contundência com que investiu contra os dualismos examinados anteriormente, Kelsen também combateu a diferença clássica entre direito público e direito privado, sobre a qual mais de uma centena de critérios já foram propostos, desde a clássica distinção que se encontra no Corpus Juris Civilis - "direito público é o que respeita à organização da coisa pública; privado, o concernente à utilidade dos particulares" -, até as concepções mais recentes, que não consubstanciam sequer uma opinião dominante sobre essa dicotomia. ${ }^{97}$

96 Ver, também, o Código de Defesa do Consumidor (Lei n. 8.078, de 11/9/90) - Art. 28. O juizpoderá desconsiderar a personalidade jurídica da sociedade quando, em detrimento do consumidor, houver abuso de direito, excesso de poder, infração da lei, fato ou ato ilícito ou violação dos estatutos ou contrato social. A desconsideração também será efetivada quando houver falência, estado de insolvência, encerramento ou inatividade da pessoa jurídica provocados por má administração. BRASIL. Lei no 8.078 , de 11 de setembro de 1990. Disponível em: <http://www.planalto.gov.br/ccivil_03/ Leis/L8078.htm>. Acesso em: 12 fev. 2016.

97 Corpus Juris Civilis. Institutionum Juris. Liber Primus. Tít. I, De Justitia, et Jure, $\ 4$. Tomus I, Aug. Taurinorum, Edid. Heredes Sebastiani Bottae, MDCCCXXIX, p. 2: "Publicum jus est, quod ad statum rei Romanae spectat; privatum, quod ad singulorum utilitatem". GARCÍA MÁYNEZ, Eduardo. El problema de la clasificación de las ciências. In: __ Introducción al estudio del derecho. 4. ed. Mexico: Por- 
Para o mestre de Viena, não há falar em distinção nítida entre as duas categorias normativas, pois todo direito constitui formulação da vontade do Estado, existindo, portanto, apenas um direito - o direito público.

Se oposição existe, esta é apenas relativa e intra-sistemática, afirma Kelsen, para quem "a Teoria Pura do Direito, que se coloca sempre em um ponto de vista universalista, e enfoca a ordem jurídica como um todo, pode sem paradoxo ver um ato do Estado tanto num contrato como na sentença de um magistrado, dado que ambos são atos criadores de direito imputáveis à unidade da ordem jurídica." 98

Rejeitava Kelsen, dessa forma, a diferença que a doutrina clássica considerava absoluta, notadamente baseada na célebre distinção entre as índoles dos interesses protegidos, afirmando serem públicas as normas pertinentes ao interesse coletivo, e privados os preceitos atinentes ao interesse individual.

Querer qualificar juridicamente as normas de Direito com referência aos objetivos que elas pretendem alcançar - ironiza Kelsen -, equivaleria a pretender classificar os quadros de um museu de acordo com o seu preço." 99

Realmente, não há por que se distinguir, dada a falta de interesse científico, dentro da ordem jurídica, entre normas de direito público e normas de direito privado. Se o ordenamento é um todo, se somente têm significado e aceitação jurídica as normas assim reconhecidas pelo corpo estatal, não há falar em dualidade normativa válida.

Do exposto, podemos dizer que o direito privado está para o direito público, assim como o direito subjetivo está para o direito objetivo, constituindo, juntos, a totalidade da ordem jurídica, o Direito Positivo, ou seja, aquele direito que é posto ou convalidado pelo Estado.

\subsection{Direito e Estado}

Como consequência essencial do purismo epistemológico kelseniano, temos igualmente a eliminação do dualismo Direito e Estado, defendido tanto pela dou-

rúa, 1951. p. 127-128.

98 KELSEN Hans. Teoría pura del derecho. Buenos Aires: Eudeba, 1960. p. 182

99 KELSEN, Hans. Teoría general del estado. México: Nacional, 1965. p. 106. trina tradicional, como pelos juristas contemporâneos, para os quais é possível encontrar-se Direito Positivo fora do Estado ou até mesmo contra o Estado. ${ }^{100}$

Essa concepção kelseniana, para usarmos as palavras de Miguel Reale, é a máxima expressão da estatalidade do Direito, fundindo Direito e Estado, de tal sorte que o Estado é o Direito (Direito Positivo) e o Direito é o Estado. ${ }^{101}$

Outra, aliás, não poderia ser a posição de Kelsen em face desse problema, por fidelidade à sua própria teoria, sempre oposta a toda e qualquer deformação ideológica do objeto da ciência jurídica.

Entendendo que a oposição Direito versus Estado tinha um sentido essencialmente ideológico, que negava a qualidade de Estado de Direito àqueles ordenamentos jurídicos criadores (do Direito), mas não submetidos à sua própria criatura (o Direito criado), Kelsen voltou-se contra mais esse dualismo, alcançando uma "perspectiva adiáfora que confere a condição de direito tanto ao direito liberal como ao soviético ou ao fascista." 102

Isto não significa, entretanto, que o mestre de Viena considerasse como Estado todo tipo de ordem jurídica, independente da satisfação de certos requisitos mínimos, indispensáveis à configuração do corpo estatal, como, por exemplo, a existência de órgãos centralizados criadores e aplicadores das normas jurídicas.

Daí a sua exigência, para o reconhecimento de um Estado como tal, a superação daquela fase primitiva, pré-estatal de completa descentralização, em que as normas são produto da conduta individual dos sujeitos de direito, aos quais competia comprovar o ilícito e aplicar a respectiva sanção, em defesa de seus interesses lesados.

Nessa fase, a ordem jurídica vigente ainda não pode ser denominada de Estado e, por conseguinte, Direito e Estado não coincidem, já que inexistente um dos termos para essa igualação - precisamente o Estado.

100 REALE, Miguel. Teoria do direito e do estado. São Paulo: Saraiva, 2003. p. 268. REALE, Miguel. Teoria do direito e do estado. São Paulo: M. fontes, 1959. p. 246; TANUGI, Laurent Cohen. Le droit sans l'État. Paris: Quadrige, 1992; e SANTOS, Boaventura de Sousa. Notas sobre a história jurídico-social de Pasárgada. In: O Direito achado na rua. 3. ed. Brasília: UnB, 1990, p.42-47.

101 REALE, Miguel. Teoria do direito e do estado. São Paulo: Saraiva, 2003. p. 245.

102 MACHADO NETO, Antônio Luís. Introdução à ciência do direito. São Paulo: Saraiva,1960. p. 180. 
Posteriormente, entretanto, vencido esse estágio primitivo, estabelecidos os órgãos centrais encarregados da criação e aplicação das normas jurídicas, surge o Estado como ordem coativa da conduta humana, coincidindo com o próprio Direito e constituindo ambos - doravante unificados - um sistema normativo completo. Cronologicamente ou na ordem histórica, portanto, Direito e Estado são distintos, mas uma vez criado o Estado, como ordem jurídico-política centralizada, Direito e Estado se fundem e se confundem numa só e mesma realidade normativa. ${ }^{103}$

Esse Estado, porém, para Kelsen "não é uma realidade natural; não é uma convivência ordenada em um território na unidade de um sistema de Direito, mas é o próprio sistema positivo das normas que deve ser posto como válido em virtude de uma norma hipotética, independentemente da capacidade e da conduta dos homens; é a "unidade da ordem jurídica, isto é, o próprio sistema do Direito Positivo visto como pessoa, como centro de imputabilidade total". ${ }^{104}$

Fundidos, assim, Estado e Direito, Kelsen nega possibilidade a qualquer conhecimento do Estado que não o identifique com o Direito, assim como descarta a forma social de conhecer o Estado, que só é jurídica porque só pode ser conbecido juridicamente pelo jurista. ${ }^{105}$

Nota-se, neste ponto, a absoluta fidelidade de Hans Kelsen ao princípio neokantiano segundo o qual o objeto do conhecimento está imanente no método adotado, que constitui este mesmo objeto.

Com essa tomada de posição, lançava-se ele, fundamentalmente, contra Georg Jellinek, reconhecido por

103 Sobre essa cronologia, não existe consenso, uns dizendo que o Estado precedeu o Direito, outros, que o Direito veio antes e deu forma jurídica ao Estado. Vejamos algumas dessas posições. DECUGIS Henri. Les étapes du droit. Paris: Librairie du Récueil Sirey, 1942. p. 9: "O direito sem a força, disse Ihering duramente, é uma palavra vazia de sentido. Mas essa força, sem a qual o direito não existe, não é necessariamente a força do Estado, como acreditaram equivocadamente [o mesmo] Ihering e outros juristas do século XIX. De fato, o direito surgiu bem antes do Estado. A força constritora que dá à regra seu caráter jurídico pode vir de uma coletividade, como a família ou a tribo primitiva, à qual não podemos chamar de Estado"; MALBERG, R. Carré de. Teoría general del estado. México: UNAM, 2001. p.73: "O direito, enquanto instituição humana, é posterior ao Estado, quer dizer, nasce pelo poder do Estado já formado e, portanto, não pode aplicar-se à formação mesma do Estado."

104 REALE Miguel. Fundamentos do direito. São Paulo: Saraiva, 1998. p. 161.

105 REALE Miguel. Fundamentos do direito. São Paulo: Saraiva, 1998. p. 161 ele como seu "inesquecível mestre" 106 e representante máximo da doutrina dualista, para a qual é possível uma dupla abordagem metodológica acerca do Estado - uma de caráter histórico-social, outra de natureza jurídica. ${ }^{107}$

Tratava-se, ao ver do neokantiano Kelsen, de um absurdo epistemológico acreditar-se que dois métodos distintos pudessem produzir o mesmo objeto.

Daí a reação kelseniana, sustentando a tese de que se o Estado for objeto de conceituação jurídica, como Estado deve ser entendido somente aquilo que possa ser objeto dessa conceituação, ou seja, o Direito ou parte deste. É o que se lê nas duas transcrições a seguir.

Se o objeto de uma Teoria jurídica não pode ser outro senão o próprio Direito, o Estado não pode ser algo diverso do Direito para chegar a ser objeto de uma Teoria do Direito. ${ }^{108}$

Não existe um conceito sociológico do Estado ao lado do conceito jurídico. O duplo conceito do Estado é logicamente impossível, entre outras razões porque não pode haver mais de um conceito para um mesmo objeto. Só há um conceito jurídico do Estado: o Estado como ordem jurídica centralizada. ${ }^{109}$

Está patente, assim, a razão por que Miguel Reale, exaltando a coerência epistemológica do mestre de Viena, afirma que, no sistema kelseniano, tal como o Rei Midas, o jurista converte em Direito tudo o que tomba sob a ação de seus métodos. ${ }^{110}$

Eliminado o dualismo Estado/Direito, Kelsen declara que a Teoria Pura não deixara substituir nada de uma das mais poderosas ideologias destinadas a legitimar o Estado, o que, por outras palavras, equivale a negar a possibilidade dessa legitimação. ${ }^{111}$

Isto, todavia, não implica afirmar a impossibilidade de todas as formas de legitimação, já que outras são perfeitamente aceitáveis, como a política ou a ética, que envolvem juízos de valor de caráter subjetivo.

A impossibilidade referida por Kelsen é somente

106 KELSEN, Hans. Teoría general del estado. México: Nacional, 1965 p. IX.

107 JELLINEK Georg. Teoría General del Estado. México: Continental, 1956. p. 35.

108 KELSEN, Hans. Teoría general del estado. México: Nacional, 1965. p. 8.

109 KELSEN, Hans. Teoría general del estado. México: Nacional, 1965. p. 224.

110 REALE, Miguel. Teoria do direito e do estado. São Paulo: Saraiva, 2003. p. 245.

111 KELSEN, Hans. Teoría pura del derecho. Buenos Aires: Eudeba, 1960. p.188. 
a impossibilidade jurídica, porque a ciência do Direito não está em condições de justificar o Estado pelo Direito ou, o que vem a ser o mesmo, justificar o Direito pelo Estado". ${ }^{112}$

Captado todo o sentido dessa afirmação de Kelsen, é de se louvar a coerência normativa com que ele sustenta a "pureza" da sua teoria nos distintos setores do saber jurídico, não deixando margem ao menor desvio no seu propósito de "construir uma ciência que tenha como único objeto o direito e ignore tudo o que não corresponda estritamente à sua definição." ${ }^{113}$

\section{A NORMA FUNDAMENTAL}

Realizada a unificação Direito-Estado, deflui como consequência lógica, na Teoria Pura, a conclusão de que a ordem jurídica é uma pluralidade de normas, devendo, para sua unidade, repousar em uma norma única, em um único suporte ou fundamento, que dê validade, por igual, a todo o sistema, a todo o ordenamento e a cada uma das suas partes.

\begin{abstract}
A idéia central da teoria do ordenamento - resume Machado Neto - é um conjunto das normas organizador de um sistema coerente, que a estrutura segundo sua maior ou menor generalidade até chegar às normas individualizadas. Dessa maneira a ordem jurídica constitui-se como uma estrutura hierárquica. ${ }^{114}$
\end{abstract}

Constatamos, desde logo, que essas normas estão relacionadas entre si - por fundamentação/derivação -, conforme raciocinemos no sentido ascendente ou descendente de uma hipotética pirâmide, que, integrada por múltiplos degraus normativos, constitui o chamado ordenamento jurídico. ${ }^{115}$

No primeiro caso, tomemos como exemplo uma sentença judicial válida, que autoriza a execução de certa obrigação. Se procurarmos o fundamento desse ato de coação estatal, verificaremos que ela repousa num

112 KELSEN, Hans. Teoría pura del derecho. Buenos Aires: Eudeba, 1960. p. 197.

113 KELSEN, Hans. Teoría pura del derecho. Buenos Aires: Eudeba, 1960. p. 15.

114 MACHADO NETO, Antônio Luís. Fundamentación egológica de la teoria general del derecho. Buenos Aires: Eudeba, 1974. p. 38.

115 MACHADO NETO, Antônio Luís. Teoria geral do direito. Rio de Janeiro: Tempo Brasileiro, 1966. p. 246-247. p. 76: "Foi obra de Adolfo Merkel, depois continuada por Kelsen e completada por Cossio, a teoria da estrutura piramidal do ordenamento jurídico." contrato entre as partes, o qual, por sua vez, foi firmado com base num preceito legal, que se originou da aplicação de uma norma constitucional, esta igualmente elaborada em conformidade com um postulado maior ou anterior.

Raciocinando de maneira inversa, ou seja, partindo do suporte constitucional, veremos que ocorrem derivações sucessivas, até atingirmos a mesma sentença executória daquela obrigação, decisão que sendo um ato individual de coação encerra o processo dessas derivações.

No primeiro exemplo, notamos que existe um processo de fundamentações sucessivas, pelo qual a norma inferior encontra seu fundamento na imediatamente superior, esta, em outra mais alta ainda, e assim por diante. Logicamente, há de chegar o instante em que a última norma positiva será positivamente a última, não sendo possível fundamentá-la em outro preceito de direito positivo, em outro dever ser jurídico. Então, à falta de um fundamento básico, todo o sistema desmoronaria, por não dispor de validade normativa.

Nesse momento, Hans Kelsen lança mão de um postulado gnosiológico do conhecimento jurídico, a chamada norma fundamental hipotética.

Explicando o conceito e a função dessa norma fundamental, Kelsen assinala o que se lê a seguir.

Ao recorrer à noção de norma fundamental, a
Teoria Pura não deseja introduzir um método
novo na ciência do direito, pois se limita a pôr em
relevo uma operação que todo jurista realiza, não
raro inconscientemente, quando depois de ter
descartado o direito natural como fonte de validez
do direito positivo, considera, não obstante, este
direito positivo como uma ordem normativa válida,
e não como um simples dado psicológico que
consiste nas relações de motivação entre dois ou
mais atos. ${ }^{116}$

Essa norma fundamental - à qual, de resto, Hans Kelsen atribuiu diversas denominações ${ }^{117}-$, é a hipótese que permite à ciência jurídica considerar o direito como um sistema de normas válidas. Noutro dizer, é norma que constitui a unidade de uma pluralidade de normas, enquanto representa o fundamento de validade de todas as normas pertencentes a essa ordem normativa; aquela norma que, pelo fato mesmo de situar-se na

116 KELSEN Hans. Teoría pura del derecho. Buenos Aires: Eudeba, 1960. p. $139 / 140$

117 GARCÍA AMADO, Juan Antonio. Hans Kelsen y la norma fundamental. Madrid: Marcial Pons, 1996. p. 11-27. 
base do ordenamento jurídico, há de ser pressuposta, visto que não pode ser posta por nenhuma autoridade, a qual, se existisse e tivesse competência para editá-la, essa autoridade só disporia de tal prerrogativa em razão de uma outra norma de hierarquia ainda mais elevada, e assim sucessivamente; aquela norma, enfim, cuja validade não pode ser derivada de outra e cujo fundamento não pode ser posto em questão. ${ }^{118}$

Aceitando-se essa suposição, de que a norma fundamental é, intrinsecamente, válida, que não precisa buscar fundamentação em nenhuma outra norma anterior ou superior, poderemos considerar válidos todos os atos praticados como derivação dela, desde a promulgação de um preceito constitucional positivo, até a mais individualizada das normas, aquela sentença judicial que autoriza a execução de um contrato firmado entre as partes.

Embora reconhecendo que Hans Kelsen, com sua teoria da norma hipotética fundamental, procurou evitar duas orientações divergentes - recorrer a um princípio de direito natural para fundamentar a validade da ordem jurídica positiva, ou fundar a ordem jurídica sobre um puro fato psicológico, sociológico ou econômico -, Miguel Reale critica o que chamou de "ponto de impasse" da doutrina kelseniana.

Para o mestre paulista, Hans Kelsen, repelindo embora as duas soluções, mas não resolvendo o problema da fundamentação da ordem jurídica, está diante de duas soluções: ou reconhecer que os fatos criam o ideal, os valores, ou reconhecer que é o Fim que o homem tem em vista que dá força normativa aos fatos. ${ }^{119}$

Dizendo que Kelsen admite serem as normas postas materialmente por um fato (por um ato revolucionário, por exemplo), mas que a sua juridicidade não resulta do fato em si, mas da norma fundamental que se supõe ligada a esse fato, Reale verbera o que entende ser um artifício de argumentação do mestre de Viena, mascarando a aceitação de um fundamento de fato, pela referência a um fato só, ao fato inicial constituinte de toda a ordem jurídica... ${ }^{120}$ Nessa mesma linha crítica, Mario Losano afirma que a norma fundamental não é uma

118 KELSEN, Hans. Teoria pura do direito. 2. ed. Coimbra: A. Amado, 1962. v. 2. p. 4.

119 REALE Miguel. Fundamentos do direito. São Paulo: Saraiva, 1998. p. 170.

120 REALE Miguel. Fundamentos do direito. São Paulo: Saraiva, 1998. p. 171. norma em sentido kelseniano - uma norma jurídico-positiva -, o que, a seu ver, reduz a argumentação de Kelsen, no particular, a mero jogo de palavras, que não resolve o problema de fundo, porque se não é jurídica positiva, a norma fundamental é alguma coisa que o jurista aceita com base em sua avaliação de justiça ou de oportunidade, ou seja, com base numa escolha que, para Kelsen, é não-científica porquanto irracional, ou melhor, subjetiva. ${ }^{121}$

Deixando de lado o mérito dessas contestações, preferimos julgar a norma fundamental de Kelsen como condição transcendental - que ela o é - do conhecimento normativo do direito, pouco importando se ela corresponde ou não a uma realidade historicamente comprovável. Aliás, o próprio Kelsen, em obra póstuma, qualificou a sua norma fundamental como "verdadeira" ficção, em termos que vale a pena ler detalhadamente.

A norma fundamental de uma ordem jurídica ou moral positivas [...] não é positiva, mas meramente pensada, e isto significa uma norma fictícia, não o sentido de um real ato de vontade, mas sim de um ato meramente pensado. Como tal, ela é uma pura ou "verdadeira" ficção no sentido da vaihingeriana Filosofia do Como-Se [Hans Vaihinger. Die Philosophie des Als-Ob, 7. e 8. Aufl. Leipzig, 1922 ], que é caracterizada pelo fato de que ela não somente contradiz a realidade, como também é contraditória em si mesma. Pois a suposição de uma norma fundamental - como porventura a norma fundamental de uma ordem moral religiosa: "Deve-se obedecer aos mandamentos de Deus, como determina a primeira Constituição" - não contradiz apenas a realidade, porque não existe tal norma como sentido de um real ato de vontade; ela também é contraditória em si mesma, porque descreve a conferição de poder a uma suprema autoridade da Moral ou do Direito e, com isto, parte de uma autoridade com certeza apenas fictícia - que está mais acima dessa autoridade.

$[\cdots]$

Por conseguinte, é de se observar que a norma fundamental, no sentido da vaihingeriana Filosofia do Como-Se não é hipótese - como eu mesmo, acidentalmente, a qualifiquei -, e sim uma ficção que se distingue de uma hipótese pelo fato de que é acompanhada pela consciência ou, então, deve ser acompanhada, [pela consciência] de que a ela não corresponde a realidade". ${ }^{122}$

121 LOSANO Mario G. Introdução. In: KELSEN, Hans. O problema da justiça. São Paulo: M. Fontes, 2011. p. 20-38. p. 20.

122 KELSEN Hans. Teoria geral das normas. Porto Alegre: S. A. Fabris, 1986. p. 328-329: 
Mesmo ficta e hipotética, essa norma vale como elemento indispensável ao estudo positivista do direito. Abandoná-la seria aceitar o absurdo maior de fundamentar a validade da ordem jurídica sobre um suposto direito natural que, como vimos, socorre-se a todo instante do direito positivo, para fugir as suas próprias contradições, impossibilitado de responder ao quid jus.

Após conceituar a norma fundamental como hipótese necessária a todo estudo positivista do direito, Kelsen afirma que uma ordem jurídica para ser válida precisa que suas normas tenham sido criadas conforme à primeira Constituição, cujo caráter normativo repousa nessa norma fundamental.

Em seguida, declara que a ciência do direito exige certo grau de eficácia dessa mesma ordem jurídica, para reconhecê-la como tal, ou seja, que os fatos se processem, em certa medida, não necessariamente - pois isto seria causalidade ao invés de imputação -, mas de acordo com a ordem estabelecida.

Ao introduzir o requisito eficácia, Kelsen lançou mão de um elemento típico do Direito Internacional - a efetividade - que só reconhece validade às ordens jurídicas nacionais na medida da sua eficácia.

Ao estabelecer o princípio de que uma ordem jurídica para ser válida deve ter certo grau de eficácia - diz Kelsen - nos limitamos a formular uma norma do direito positivo que não pertence a essa ordem jurídica, e sim ao direito internacional. ${ }^{123}$

Qual, então, o motivo desse procedimento kelseniano, fundindo as ordens jurídicas nacional e internacional? Precisamente, o propósito de conseguir a unificação do sistema jurídico universal, com o que a ciência do direito alcançaria a indispensável unidade do seu objeto.

Realmente, se verificarmos que o princípio da efetividade é uma regra do direito internacional, e que ele se constitui, também, ainda que em termos relativos, em norma fundamental das diversas ordens jurídicas nacionais, concluiremos que "o problema da norma fundamental converte-se na questão do fundamento último de uma ordem jurídica total, que compreende todas as ordens jurídicas nacionais." 124

Onde, porém, buscar esse fundamento último e único da ordem jurídica total, que não é possível encontrar

123 KELSEN Hans. Teoría pura del derecho. Buenos Aires: Eudeba, 1960. p. 143.

124 KELSEN Hans. Teoría pura del derecho. Buenos Aires: Eudeba, 1960. p. 145. nas ordens jurídicas parciais?

Kelsen responde, propondo que esse fundamento, que convalida todo o direito internacional, seja buscado no modo de proceder dos Estados.

A norma fundamental do direito internacional, que
por via de consequência resulta ser também a das
diversas ordens jurídicas nacionais subordinadas a
esse direito, é uma norma que confere a qualidade
de fato criador de normas jurídicas ao costume
resultante da conduta recíproca dos Estados. ${ }^{125}$

Com essa concepção colossal de uma única ordem jurídica, que se estenderia por todo o Universo, constituindo um Estado mundial, que ele mesmo reconhece ser teoricamente possível, embora praticamente improvável, Hans Kelsen coroa a sua obra, declarando que a Teoria Pura criou uma condição essencial para lograr a unidade política mundial, sem que isso contrarie o sentido da sua pureza. ${ }^{126}$

\section{A Teoria Pura e o problema da interpre- TAÇÃO DO DIREITO}

Como sabemos, é da natureza do discurso jurídico expressar-se através de normas, ou seja, por meio de palavras/enunciados em que são definidas condutas que, em dado momento, certa comunidade considera positiva ou negativamente valiosas e, por isso, decide prescrever, vedar ou simplesmente permitir, garantindo a sua observância, se necessário, com a imposição de sanções institucionalizadas, porque as normas que as estabelecem são criadas por instituições e a sua aplicação também é levada a cabo por instituições. ${ }^{127}$ Até mesmo as normas consuetudinárias - os costumes jurídicos - manifestam esta substancial dependência do direito em relação à linguagem, porque a conviç̧ão da necessidade jurídica, que é consubstancial à existência dessas espécies normativas, só adquire trânsito social quando é verbalizada sob a forma de um enunciado compreensível pelos membros de determinada comunidade, e vem a ser recepcionada/ reconhecida como regra de direito por juízes e tribunais. ${ }^{128}$

125 KELSEN Hans. Teoría pura del derecho. Buenos Aires: Eudeba, 1960. p. 200.

126 KELSEN Hans. Teoría pura del derecho. Buenos Aires: Eudeba, 1960. p. 204.

127 MORESO, J. J.; VILAJOSANA, J. M. Introducción a la teoría del derecho. Madrid: Marcial Pons, 2004. p. 21-24.

128 HENKEL, Heirich. Derecho y linguaje. In:__. Introducción a la filosofia del derecho. 7. ed. Madrid: Taurus, 1968, p. 85-104; LAR- 
No âmbito da experiência cognitiva do direito, a tomada de posição em face do problema objeto do conhecimento versus conhecimento do objeto não é exclusividade de nenhuma corrente da hermenêutica jurídica, em particular, eis que da Escola da Exegese à Doutrina do Direito Livre, passando pelo Realismo Jurídico norte-americano, não existe nenhuma corrente jusfilosófica de expressão que não tenha a "sua" resposta para essa questão. Se não vejamos: a) a Escola da Exegese, ao dizer que não existe Direito além ou fora da Lei, cabendo ao intérprete tão-somente "extrair" do texto a norma adequada; b) a doutrina do Direito Livre, ao rejeitar essa ideologia legalista e asseverar que a Lei não esgota $\mathrm{o}$ Direito, podendo, inclusive, entrar em conflito com ele, hipótese em que o julgador deverá decidir não apenas extra legem, mas até mesmo contra legem, se isso for necessário para dizer o que for de Direito; c) os adeptos do Realismo Jurídico, enfim, ao garantir que o Direito, em sua concreta existência, o Direito mesmo, não é senão aquilo que decidem os juízes e tribunais, o que significa dizer que - realmente - é o intérprete quem faz a Lei.

Subjacente a isso tudo - o ontológico condicionando o gnosiológico e por este sendo condicionado, à moda de círculo hermenêutico -, acham-se as diferentes respostas filosóficas para a questão radical sobre a essência do direito, a juridicidade como referente externo a nos remeter para o nômeno do direito, independentemente dos fenômenos em que ele se dá a conhecer. ${ }^{129}$

Daí estas considerações de João Baptista Machado sobre a relação entre a essência e a aparência da "coisa direito": os textos legais não determinam ou criam "autonomamente" o jurídico, a juridicidade, sendo, antes, já mera expressão ou tradução dessa juridicidade, a qual, por princípio, e como referente último, está para além deles, está fora deles; e desse referente, da sua "pré-compreensão", tem o intérprete de partir necessariamente se pretende sequer entender esses textos como "jurídicos", como portadores de um sentido jurídico. ${ }^{130}$

ENZ, Karl. Metodologia da ciência do direito. 7. ed. Lisboa: Gulbenkian, 2014. p.504.

129 BONNECASE, Julien. L'École de l'Exégèse en droit civil. Paris: E. De Boccard, 1924. p. 126-181; KANTOROWICZ, Hermann. La lucha por la ciencia del derecho. In: La ciencia del derecho. Buenos Aires: Losada, 1942. p. 361-369; FICHES, Luís Recaséns. El movimiento del realismo jurídico norteamericano. In: Panorama del pensamiento jurídico en el Siglo XX. México: Porrúa, 1963. v. 2. p. 619-642.

130 MACHADO, João Baptista. Introdução ao direito e ao discurso legitimador. Coimbra: Almedina, 1989.p. 205-209.
Por outro lado, desprovidos de uma teoria do direito, que lhes dê sustentação e consistência na seleção dos métodos e princípios adequados à compreensão da realidade jurídica, os intérpretes/aplicadores - premidos pelos problemas a resolver e induzidos pela sua pré-compreensão -, acabam escolhendo os seus instrumentos de trabalho ao sabor de sentimentos e de intuições pessoais, o que, obviamente, não confere racionalidade a essas opções e acaba transmitindo aos cidadãos a ideia de que dizer o direito é, mesmo, algo aleatório ou puramente emocional.

Nesse ambiente de "licenciosidade metodológica", a escolha de um ou de outro método de apreensão/ achamento/realização do direito - literal, histórico, sistemático, teleológico etc. -, até certo ponto é uma decisão arbitrária, dependendo, de fato, do resultado a que o intérprete quer chegar. ${ }^{131}$ Afinal, sempre se poderá dizer, invocando o magistério de Zaccaria, que o método não pode explicar a eleição do método ${ }^{132}$, e pedindo ajuda ao Juiz Holmes, afirmar que é sempre possível se dar forma lógica a qualquer conclusão. ${ }^{133}$

Como, enfim, toda teoria do direito, que se repute digna desse status, não pode elidir a questão crucial da compreensão, interpretação, aplicação, concretização, achamento, enfim, da realização do direito, até porque se trata de algo congênito à própria ideia de experiência jurídica, por tudo isso, a Teoria Pura do Direito também assumiu a "sua" posição em face desse problema, ainda que essa tomada de posição, visualizada na magnitude da obra de Kelsen, pareça ter sido tratada quase en passant, vale dizer, sem a mesma "intensidade" com que ele enfrentou outros temas e problemas do saber jurídico.

Mesmo assim, estudiosos contemporâneos de grande prestígio dizem que esse "descuido hermenêutico" de Hans Kelsen é só aparente, que a sua doutrina da interpretação apresenta singularidades e debilidades, podendo ser usada para subverter a própria concepção kelseniana da estrutura do ordenamento jurídico. Com efeito, se a validade das normas emanadas de tribunais

131 Alguns doutrinadores afirmam que todo juiz - levado pela sua pré-compreensão do justo na causa a decidir -, sentencia antes e, só depois, trabalhando "para trás", sai em busca de fundamentos que sustentem as suas decisões. Ver, Frank, Jerome New. Derecho e incertidumbre. México: Fontamara, 2001. p. 92.

132 ZACCARIA, Giuseppe. Razão jurídica e interpretación. Madrid: Thomson, 2004. p. 337.

133 HOLMES, Oliver Wendell. La senda del derecho. Buenos Aires: Abeledo-Perrot, 1975. p. 29-30. 
supremos - e.g. as cortes constitucionais - não deriva de nenhuma norma sobreposta a eles, mas do fato de que esses tribunais estão situados fora e acima da tradicional tripartição dos poderes, então o que se encontra no vértice da metafórica pirâmide, com que se descreve a estrutura dos ordenamentos jurídicos, não é nenhuma norma fundamental hipotética, mas essas decisões mesmas, de resto dotadas de eficácia erga omnes e efeito vinculante. ${ }^{134}$

Pois bem, voltando ao tema da interpretação na Teoria Pura do Direito, Kelsen afirmou que a decisão judicial - aquela que realiza o direito -, é essencialmente um ato de vontade, não de conhecimento, embora se produza no marco de uma norma previamente dada a conhecer ao intérprete/aplicador do direito. São do mestre de Viena as asserções transcritas a seguir, as quais, de resto, deixam embaraçados todos quantos, numa visão reducionista do pensamento de Kelsen, consideram essa postura hermenêutica - no que abre espaço para a vontade do intérprete -, incompatível com o rigor lógico-formal da Teoria Pura do Direito. Noutro dizer, esses críticos acreditam, romanticamente, compreender Kelsen melhor do que ele compreendeu a si mesmo ${ }^{135}$, nisso olvidando a advertência de Emilio Betti, por exemplo, para quem o objeto da interpretação não é a vontade como tal, mas sempre e apenas a forma na qual essa vontade se concretizou, aquilo que se fez ou que se disse, o feito ou o falado. ${ }^{136}$

Para evitarmos mal entendidos e nos mantermos fieis à genuína função hermenêutica ${ }^{137}$, deixemos que os textos falem por si mesmos, textos que, significativamente, o próprio Kelsen encimou com o título $A$ interpretação como ato de conhecimento ou como ato de vontade. ${ }^{138}$

A interpretação jurídico-científica tem de evitar, com o máximo cuidado, a ficção de que uma norma jurídica apenas permite, sempre e em todos os casos, uma só interpretação: a interpretação "correta". Isto é uma ficção de que se serve a jurisprudência

134 TROPER, Michel. Por una teoria jurídica del estado. Madrid: Dykinso, 2001. p. 63-72.

135 GADAMER, Hans-Georg. Herança e futuro da Europa. Lisboa: Edições 70. 1998. p. 64-65; GADAMER, Hans-Georg Hermeneutica de la modernidad: conversaciones con Silvio Vietta. Madrid: Trotta, 2004. p. 13.

136 BETTI, Emilio. Interpretação da lei e dos atos jurídicos. São Paulo: M. Fontes, 2007. p. XXXVIII.

137 SCHLEIERMACHER, Friedrich Daniel Ernst. Herméneutique. Lille: Presses Universitaires, 1989. p. 122-123.

138 KELSEN, Hans. Teoria pura do direito. 2. ed. Coimbra: A. Amado, 1962. v. 2. p. 292. tradicional para consolidar o ideal da segurança jurídica. Em vista da plurissignificação da maioria das normas jurídicas, este ideal somente é realizável aproximativamente.

$[\ldots]$

A ideia, subjacente à teoria tradicional da interpretação, de que a determinação do ato jurídico a pôr, não realizada pela norma jurídica aplicanda, poderia ser obtida através de qualquer espécie de conhecimento do Direito preexistente, é uma autoilusão contraditória, pois vai contra o pressuposto da possibilidade de uma interpretação.

$[\cdots]$

$\mathrm{Na}$ aplicação do Direito por um órgão jurídico, a interpretação cognoscitiva (obtida por uma operação de conhecimento) do Direito a aplicar combina-se com um ato de vontade em que o órgão aplicador do direito efetua uma escolha entre as possibilidades reveladas através daquela mesma interpretação cognoscitiva.

\section{$[\ldots]$}

Assim como da Constituição, através de interpretação, não podemos extrair as únicas leis corretas, tampouco podemos, a partir da lei, por interpretação, obter as únicas sentenças corretas.

$[\cdots]$

Justamente por isso, a obtenção da norma individual no processo de aplicação da lei é, na medida em que nesse processo seja preenchida a moldura da norma geral, uma função voluntária. ${ }^{139}$

Em face dessas colocações, parece não restar dúvida de que o "positivista", o "formalista", o "rigoroso", o "purista", enfim, o ultra "dogmático" e tão criticado Hans Kelsen, se teoricamente pretendeu excluir fatos e valores da atividade do intérprete/aplicador do direito qua tale, em verdade só o fez aparentemente, porque, mais do que ninguém, ele sabia que esses fatores, sendo imanentes à experiência jurídica, se forem expulsos pela porta dos ordenamentos - concebidos, abstratamente, como sistemas fechados -, a eles retornarão pelas janelas, as quais hão de permanecer necessariamente abertas, para que nelas penetre o sopro vivificador da realidade, em constante transformação. E tais janelas, se nos for permitida essa qualificação, são os "princípios" da Moral, da Política ou do Costume, que o próprio Kelsen reconhece poderem influenciar a produção de normas jurídicas - gerais e individuais - pelas autoridades a tanto legitimadas, como se lê nas passagens a seguir.

139 KELSEN, Hans. Teoria pura do direito. 2. ed. Coimbra: A. Amado, 1962. v. 2. p. 283-298. 
A decisão judicial de um caso concreto, a qual não é a aplicação de uma norma jurídica geral, materialmente definida, que já esteja em vigor, pode ser influenciada por um princípio da Moral, Política ou Costume, que ainda não influenciou até agora, de nenhum modo, a produção do Direito. A norma individual que representa semelhante decisão judicial pode entrar em vigor em virtude do princípio jurídico-positivo-formal da coisa julgada. ${ }^{140}$

Quando uma norma superior é criada com base
em uma norma superior e no marco fixado por ela,
quer se trate de uma lei fundada na Constituição ou
de uma decisão judicial fundada em uma lei, torna-
se claro que o órgão criador da norma inferior não
só leva em conta a norma superior, como também
outras normas não jurídicas relativas à moral,
à justiça ou o que se denomina "bem público",
"interesse do Estado", "progresso". ${ }^{141}$

É precisamente esse "levar em conta" normas não jurídicas, transformando-as em jurídicas no ato de criação do direito - sob a forma de lei ou decisão judicial - que evidencia, a nosso ver, o quanto Hans Kelsen "o jurista por antonomásia" - mesmo empenhado na "purificação" da ciência jurídica, sempre teve presente o papel da realidade da vida do direito, tanto que, para surpresa dos críticos do seu formalismo jurídico, asseverou que não se pode negar que uma ordem jurídica como um todo, tal como uma norma jurídica singular, perde a sua validade quando deixa de ser eficaz: ${ }^{142}$ Afinal, se dos fatos nasce o direito, em razão deles o direito também deixa de existir.

\section{Considerações finais}

Os juristas do século XX, que, mercê da Teoria Pura do Direito, superaram o complexo de inferioridade epistemológica da Jurisprudência em face das ciências naturais, padecem, agora, de uma espécie de desorientação ontognoseológica, já não sabendo ao certo qual é o objeto de suas investigações, tantas e tamanhas são as esquisitices que se entredizem acerca do que é ou deve ser tido como direito.

140 KELSEN Hans. Teoria geral das normas. Porto Alegre: S. A. Fabris, 1986. p. 146.

141 KELSEN, Hans. Teoria pura do direito. 2. ed. Coimbra: A. Amado, 1962. v. 2. p. 170-171.

142 KELSEN, Hans. Teoria pura do direito. 2. ed. Coimbra: A. Amado, 1962. v. 2. p. 40-42.
Ironicamente, embora por caminho diverso, retornam àquilo que os adversários de Kelsen mais criticaram no seu pensamento, a célebre afirmação de que "todo e qualquer conteúdo pode ser direito". Apenas com uma só e grave diferença: os que hoje se autodenominam pospositivistas adotam essa mesma tese - positivista a mais não poder -, embora não saibam que o fazem, nem muito menos por que o fazem. Qualquer semelhança com Monsieur Jourdain é mera coincidência...

Nesse panorama desconcertante e desolador, talvez seja preciso voltar-se a Kelsen, para extrair dele o que for necessário e - dialeticamente - formular uma nova teoria jurídica, uma teoria "repurificadora" do direito. ${ }^{143}$

\section{ReferênCIAS}

AFTALIÓN, Enrique R. Apresentação. In: KELSEN, Hans. La idea del derecho natural y otros ensayos. Buenos Aires: Losada, 1946. p. 7-11.

AFTALIÓN, Enrique R. Crítica del saber de los juristas. La Plata: Arayú, 1951.

AFTALIÓN, Enrique R; GARCÍA OLANO, Fernando; VILANOVA, José. Introducción al derecho. Buenos Aires: El Ateneo, 1960.

BACHELARD, Gaston. A Epistemologia. Lisboa: Edições 70, 1984.

BETTI, Emilio. Interpretação da lei e dos atos jurídicos. São Paulo: M. Fontes, 2007.

BLEICHER, Josef. Hermenêutica contemporânea. Lisboa: Edições 70, 1992. p. 172.

BOBBIO, Norberto. Direito e poder. São Paulo: UNESP, 2008.

BONNECASE, Julien. L'École de l'Exégèse en droit civil. Paris: E. De Boccard, 1924.

BRASIL. Lei $n^{0}$ 8.078, de 11 de setembro de 1990. Di-

143 Sobre esse processo/procedimento dialético, ver POPPER, Karl. Que é a dialética. In: __. Conjecturas e refutações. Brasília: UnB, 1972. p. 345, Nota 5, criticando a visão alargada de Hegel: “ $\mathrm{Na}$ terminologia de Hegel, tanto a tese quanto a antítese são reduzidas, pela síntese, a componentes, e portanto canceladas (negadas, anuladas, afastadas); ao mesmo tempo, são preservadas (guardadas) e elevadas (a um nível superior). Hegel aproveita a ambiguidade da palavra alemã 'Aufgehoben', empregando-a no sentido de redurida a componentes, cancelada, preservada e elevada." 
sponível em: <http://www.planalto.gov.br/ccivil_03/ Leis/L8078.htm>. Acesso em: 12 fev. 2016.

CANARIS, Claus-Wilhelm. Direitos fundamentais e direito privado. Coimbra: Almedina, 2003.

CASSIRER, Ernst. Las ciências de la cultura. México: Fondo de Cultura Económica, 1982

COMPREENSÃO. In: MORA ,José Ferrater. Diccionario de filosofia. Madrid: Alianza, 1986. v. 1. p. 545-548

DECUGIS Henri. Les étapes du droit. Paris: Librairie du Récueil Sirey, 1942.

DEL VECCHIO, Giorgio. Lições de filosofia do direito. Coimbra: Ar. Amado, 1959. v. 2.

DERNBURG, Eduardo J. Couture. Introdução ao estudo do processo civil. Rio de Janeiro: J. Konfino, [200?]..

DÍAZ, Elías. Sociología y filosofía del derecho. Madrid: Taurus, 1982.

DILTHEY, Wilhelm. Origens da Hermenêutica.

Textos de Hermenêutica. Lisboa: Res, 1984. p. 149-189.

DILTHEY, Wilhelm. Crítica de la razón histórica. Barcelona: Península, 1986.

DILTHEY, Wilhelm. Introducción a las ciências de espiritu. Madrid: Revista de Occidente, 1956.

EBENSTEIN, William. The pure theory of law. New York: A. M. Kelley, 1969.

EXPLICAÇÃO. In: MORA, José Ferrater. Diccionario de filosofia. Madrid: Alianza, 1986. v. 2. p. 1102-1104.

FAVOREU, Louis. Los tribunales constitucionales. Barcelona: Ariel, 1994.

FEINMANN, José Pablo. La filosofia y el barro de la bistoria. Buenos Aires: Planeta, 2009.

FEINMANN, José Pablo. Que es la filosofia? Buenos Aires: Prometeo Libros, 2006.

FERNÁNDEZ RODRÍGUEZ, José Julio. La justicia constitucional Europea ante el siglo XXI. 2. ed. Madrid: Tecnos, 2007.

FICHES, Luís Recaséns. El movimiento del realismo jurídico norteamericano. In: Panorama del pensamiento jurídico en el Siglo XX. México: Porrúa, 1963. v. 2. p. 619642.

FRANK, Jerome New. Derecho e incertidumbre. México: Fontamara, 2001.
GADAMER, Hans-Georg Hermenentica de la modernidad: conversaciones con Silvio Vietta. Madrid: Trotta, 2004.

GADAMER, Hans-Georg. Herança e futuro da Europa. Lisboa: Edições 70. 1998.

GADAMER, Hans-Georg. Herança e futuro da Europa. Lisboa: Edições 70. 1998. p. 64-65;

GADAMER, Hans-Georg Hermeneutica de la modernidad: conversaciones con Silvio Vietta. Madrid: Trotta, 2004.

GADAMER, Hans-Georg. Verdad y método. Salamanca: Sígueme, 1993. v. 1.

GADAMER, Hans-Georg. Verdade e método. Petrópolis: Vozes. 1997. v. 1.

GARCÍA AMADO, Juan Antonio. Hans Kelsen y la norma fundamental. Madrid: Marcial Pons, 1996.

GARCÍA MÁYNEZ, Eduardo. El problema de la clasificación de las ciências. In: Introducción al estudio del derecho. 4. ed. Mexico: Porrúa, 1951

HEGEL, Georg Wilíelm Friedrich. Princípios da filosofia do direito. São Paulo: M. Fontes, 2000.

HENKEL, Heirich. Derecho y linguaje. In: . Introducción a la filosofia del derecho. 7. ed. Madrid: Taurus, 1968. p. 85-104.

HOLMES, Oliver Wendell. La senda del derecho. Buenos Aires: Abeledo-Perrot, 1975.

JELLINEK Georg. Teoría General del Estado. México: Continental, 1956.

KALINOWSK, Georges I. Querelle de la science normative. Paris: L.G.D.J., 1969.

KANTOROWICZ, Hermann. La lucha por la ciencia del derecho. In: La ciencia del derecho. Buenos Aires: Losada, 1942. p. 361-369.

KELSEN Hans. Los juicios de valor en la ciencia del derecho. In: . La idea del derecho natural y otros Ensayos. Buenos Aires: Losada, 1946. p. 239-265.

KELSEN Hans. Teoria geral das normas. Porto Alegre: S. A. Fabris, 1986.

KELSEN Hans. Teoria geral do direito e do estado. São Paulo: M. Fontes, 1990. p. 38-40.

KELSEN Hans. Teoría pura del derecho. Buenos Aires: Eudeba, 1960.

KELSEN, Hans. Contribuciones a la teoría pura del derecho. 
Buenos Aires: Centro Editor de América Latina, 1969. p. 122-123.

KELSEN, Hans. Jurisdição constitucional. São Paulo: M. Fontes, 2003.

KELSEN, Hans. La aparición de la ley de causalidad a partir del principio de retribución. In: La idea del derecho natural y otros ensayos. Buenos Aires: Losada, 1946. p. 53-97.

KELSEN, Hans. La idea del derecho natural y otros ensayos. Buenos Aires: Losada, 1946.

KELSEN, Hans. La teoría pura del derecho y la jurisprudência analítica. In: . La idea del derecho natural y otros Ensayos. Buenos Aires: Losada, 1946. p. 202-234. p. 218.

KELSEN, Hans. Teoría general del estado. México: Nacional, 1965.

KELSEN, Hans. Teoria pura do direito. 2. ed. Coimbra: A. Amado, 1962. v. 1.

KELSEN, Hans. Teoria pura do direito. 2. ed. Coimbra: A. Amado, 1962. v. 2.

KUNZ, Josef L. La teoría pura del derecho. México: Universitaria, 1948.

LAKS, André; NESCHKE, Ada (Ed.). La naissance du paradigme herméneutique. Lille: Universitaires de Lille, 1990.

LARENZ, Karl. Metodologia da ciência do direito. 7. ed. Lisboa: Gulbenkian, 2014.

LEGAZ Y LACAMBRA, Luis. Horizontes del pensamiento jurídico. Barcelona: Bosch, 1947.

LEGAZ Y LACAMBRA, Luis. Kelsen: estudio crítico de la teoría pura del derecho y del estado de la Escuela de Viena. Barcelona: Bosch, 1933.

LEGAZ Y LACAMBRA, Luis. Kelsen: estudio crítico de la teoría pura del derecho y del estado de la Escuela de Viena. Barcelona: Bosch, 1933.

MACHADO NETO, Antônio Luís .O problema da ciência do direito. Salvador: Livraria Progresso, 1958. p. 13.

MACHADO NETO, Antônio Luís. Fundamentación egológica de la teoria general del derecho. Buenos Aires: Eudeba, 1974.

MACHADO NETO, Antônio Luís. Introdução à ciência do direito. São Paulo: Saraiva,1960..
MACHADO NETO, Antônio Luís. Sociologia do desenvolvimento. Rio de Janeiro: Tempo Brasileiro, 1963.

MACHADO NETO, Antônio Luís. Teoria geral do direito. Rio de Janeiro: Tempo Brasileiro, 1966.

MACHADO NETO, Zahidé (Org.). O Direito e a Vida Social. São Paulo: Nacional, 1966.

MACHADO, João B. Nota Preliminar. In: KELSEN, Hans. A Justiça e o direito natural. Coimbra: A. Amado, 1963.

MACHADO, João Baptista. Introdução ao direito e ao discurso legitimador. Coimbra: Almedina, 1989.

MALBERG, R. Carré de. Teoría general del estado. México: UNAM, 2001.

MARCOU, Jean. Justice constitutionnelle et systèmes politiques. Grenoble: Universitaires de Grenoble, 1997.

MONDOLFO, Rodolfo. Problemas e métodos de investigação na história da filosofia. São Paulo: Mestre Jou, [1969].

MORESO, J. J.; VILAJOSANA, J. M. Introducción a la teoría del derecho. Madrid: Marcial Pons, 2004.

MORÓN AROYO, Ciriaco. Creencia y vigência In:__ El sistema de Ortega y Gasset. Madrid: Romania, 1968. p. 275-279.

ORGANIZAÇÃO DAS NAÇÕES UNIDAS. Declaração dos Direitos do Homem e do Cidadão. Disponível em: $<$ http://pfdc.pgr.mpf.mp.br/atuacao-e-conteudosde-apoio/legislacao/direitos-humanos/declar_dir_homem_cidadao.pdf $>$. Acesso em: 12 fev. 2016.

POPPER, Karl. Que é a dialética. In: Conjecturas e refutações. Brasília: UnB, 1972. p. inicial-final

PROUDHON, Pierre-Joseph. O que é a propriedade? Lisboa: Estampa, 1971. p. 241.

REALE Miguel. Fundamentos do direito. São Paulo: Saraiva, 1998. p. 170.

REALE, Miguel. As ciências da realidade jurídica. In: . Filosofia do direito. 9. ed. São Paulo: Saraiva, 1982. p. 609-614.

REALE, Miguel. Fundamentos da teoria tridimensional do direito. Revista Brasileira de Filosofia, São Paulo, v. 10, n. 4, p. 455-470, out./nov. 1960.

REALE, Miguel. O direito como experiência. São Paulo: Saraiva, 2002.

REALE, Miguel. Teoria do direito e do estado. São Paulo: 
M. Fontes, 1959.

REALE, Miguel. Teoria do direito e do estado. São Paulo: Saraiva, 2003.

RICOEUR, Paul. Explicar e compreender. In:

Do texto à ação: ensaios de hermenêutica. Porto: Rés, [198?], p. 163-183;

RICOEUR, Paul. Interpretação e/ou argumentação. In: - O Justo: ou a essência da justiça. São Paulo: M. Fontes, 2008. v. 1. p. 153-173;

SANTOS, Boaventura de Sousa. Notas sobre a história jurídico-social de Pasárgada. In: O Direito achado na rua. 3. ed. Brasília: UnB, 1990. p.42-47.

SARMENTO, Daniel. Direitos fundamentais e relações privadas. Rio de Janeiro: Lúmen Juris, 2004.

SCHLEIERMACHER, Friedrich Daniel Ernst. Herméneutique. Lille: Presses Universitaires, 1989.

SCHLEIERMACHER, Friedrich Daniel Ernst: Hermenêutica. 9. Ed. Petrópolis: Vozes, 2012..

SCHÖKEL, Luis Alonso; BRAVO, José María. Apuntes de hermenéutica. Madrid: Trotta, $1994 .$.

SICHES, Luis Recaséns. La experiencia jurídica. Diano$i a$, v. 11, n. 11, p. 18-39, 1965.

SICHES, Luís Recaséns. La obra de Hans Kelsen: su teoría pura del derecho y del Estado; y su relativismo axiológico. In: . Panorama del pensamiento jurídico en el siglo XX. México: Porrua, 1963. v. 1. p. 137-222.

SILVA, Virgílio Afonso da. A constitucionalização do Direi- to: os direitos fundamentais nas relações entre particulares. São Paulo: Malheiros, 2008.

SOLER, Sebastin. La interpretación de la Ley. Barcelona: Ariel, 1962.

SOMBRA, Thiago Luís Santos. A eficácia dos direitos fundamentais nas relações jurídico-privadas. Porto Alegre: S. A. Fabris, 2004.

STRAUSS, Leo. Droit Naturel et Histoire. Paris: Flammarion, 1997

TANUGI, Laurent Cohen. Le droit sans l'État. Paris: Quadrige, 1992.

TROPER, Michel. Por una teoria jurídica del estado. Madrid: Dykinso, 2001.

VALE, André Rufino do. Eficácia dos direitos fundamentais nas relações privadas. Porto Alegre: S. A. Fabris, 2004.

VILANOVA, Lourival. Teoria da norma fundamental: comentários à margem de Kelsen. Separata: Anuário do Mestrado em Direito da Faculdade de Direito do Recife, n. 7, jan./dez. 1976.

VIOLA, Oscar Luis. Contra Kelsen: revisión crítica de la teoría pura - purísima - del derecho, de Hans Kelsen. Buenos Aires: Astrea, 1975.

VON KIRCHMANN. Julius Hermann. El carácter a-cientifico de la llamada Ciencia del Derecho. In: La Ciencia del Derecho. Buenos Aires: Losada, 1949. p. 247-286.

ZACCARIA, Giuseppe. Razão jurídica e interpretación. Madrid: Thomson, 2004. 


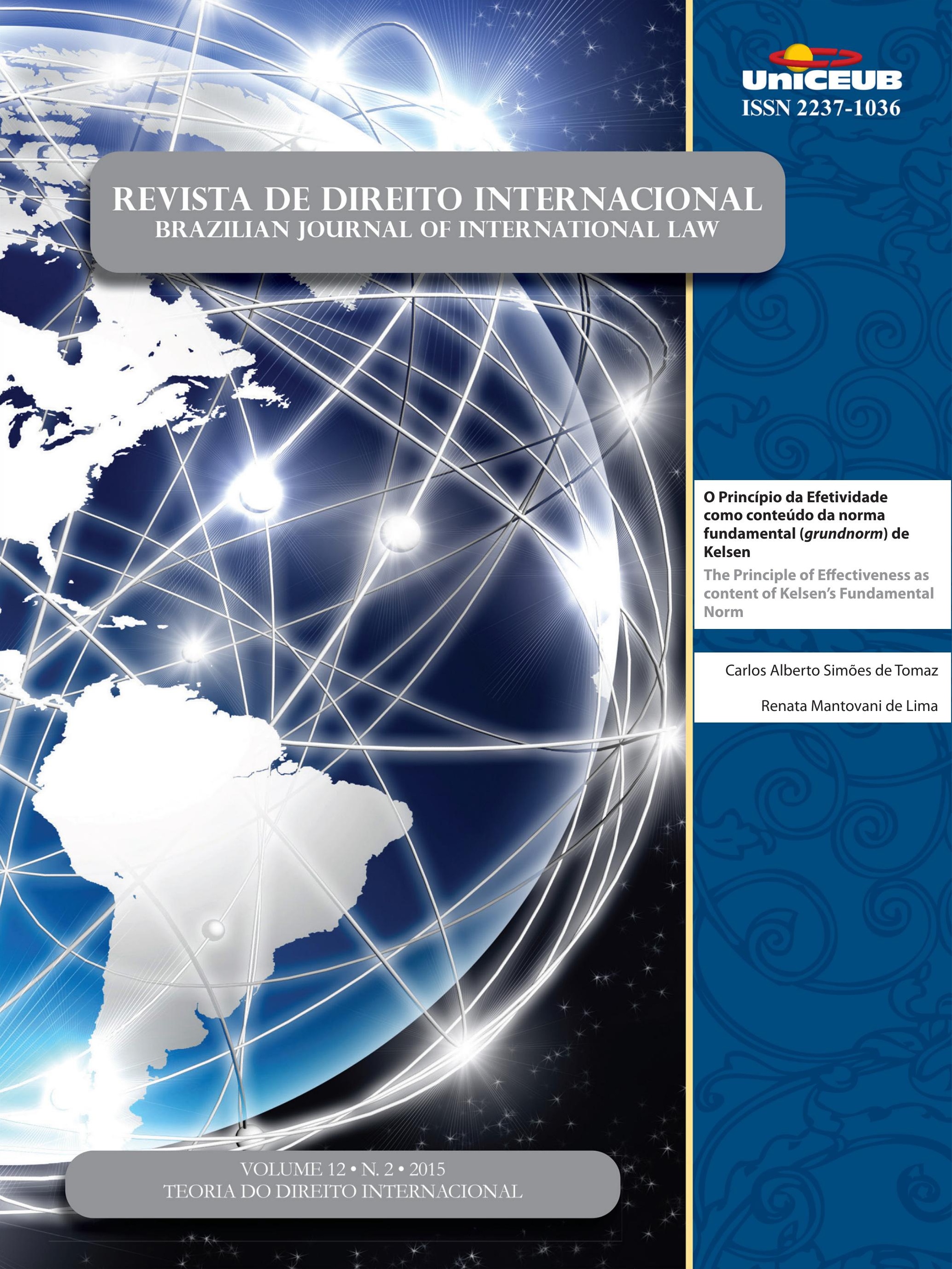




\section{O Princípio da Efetividade como conteúdo da norma fundamental (grundnorm) de Kelsen*}

\section{The Principle of Effectiveness as content of Kelsen's Fundamental Norm}

\section{Resumo}

O artigo visita a Teoria Pura do Direito de Kelsen para discernir a norma fundamental não apenas como um pressuposto lógico hipotético do sistema jurídico, que serve de fundamento de validade de uma constituição, mas para divisá-la, também, como uma norma posta, cujo conteúdo se identifica com o Princípio da Efetividade como norma de Direito Internacional de conformidade com o monismo kelseniano. Nesse sentido, o recurso da lógica dedutiva, impõe-se como basilar para a solução da questão apresentada. A conclusão aposta na circunstância de que a revisão teórica realizada tenha oferecido substratos hermenêuticos para o conteúdo dos atos de reconhecimento de Estado e reconhecimento de governo, que guarnecidos pelo Princípio da Efetividade, dele desbordam para projetar sua validade com base em uma análise valorativa determinada pelo Princípio da Legitimidade não admitida por Kelsen.

Palavras-chave: Teoria pura do direito. Norma fundamental. Princípio da efetividade.

\section{Abstract}

The article visits the Kelsen's Theory Pure of Law in order to discern the fundamental norm not only as a hypothetical logical premise of the legal system, which forms the groundwork of validity of a constitution, but also as a norm of positive law, whose content is identified with the effectiveness principle as a rule of international law in accordance with Kelsen's monism. In this sense, the use of deductive logic, it must be as a foundation for the solution of the question referred. The conclusion believes that the theoretical review carried out has offered hermeneutic substrates for the content of acts of recognition of State and recognition of government, who based on the principle of effectiveness going beyond to design its validity from an evaluative analysis determined by the Legitimacy Principle, not admitted by Kelsen.

Keywords: Theory pure of law. Fundamental norm. Principle of effectiveness. 


\section{INTRODUÇÃO}

As relações entre Estado e Direito e entre as ordens jurídicas nacionais e a ordem internacional sempre constituíram ponto nevrálgico na Teoria do Direito. Hodiernamente, quando as atenções se voltam para se perquirir se a democracia na experiência doméstica depende de uma ordem internacional democrática ou, de modo contrário, se seria a existência de uma ordem internacional democrática que asseguraria a democracia no âmbito interno dos Estados, o pensamento de Kelsen volta à tona - se é que alguma vez deixou de estar em evidência ainda que, aqui e acolá, como ponto de partida, para modernas proposições teoréticas - sobretudo sua postura monista.

Nosso propósito, neste artigo, é revisitar o pensamento de Kelsen, para conceber a norma fundamental (grundnorm) não como uma norma pressuposta, mas como uma norma posta, que possui conteúdo que se encontra projetado no Princípio da Efetividade como norma de Direito Internacional de conformidade com o art. 39 do Tratado de Viena sobre Direito dos Tratados, o que valida o monismo kelseniano.

O objeto da reflexão não é outro senão contribuir para fomentar a discussão sobre o fortalecimento da convivência democrática no âmbito doméstico, bem como na ordem internacional, quando se coloca em evidência os princípios como fonte do Direito Internacional, particularmente, quando se leva a sério o Princípio da Efetividade.

\section{REVISITANDO O PROJETO DE EXPERIÊNCIA JURÍ- DICA DO POSITIVISMO JURÍDICO DE KELSEN}

O positivismo jurídico como projeto para a experiência jurídica irrompeu no Estado Liberal de Direito. Com efeito, expungir do direito qualquer fundamento que não seja o próprio direito - significa dizer: escoimar fundamentos éticos voltados sobremodo para perquirir a respeito da ressonância social da ordem jurídica (eficácia), o que implica questionar se o direito é justo, assim como afastar de sua fundamentação a legitimação (fato), ou resumindo: purificar o direito, afastando dele fundamentos morais e políticos - satisfazia plenamente os ideais do Estado Liberal, que se voltava para um direito seguro, que definindo condutas e delimitando pre- cisamente o âmbito de atuação da autoridade, garantisse o exercício da liberdade.

O Estado de Direito Liberal, erigido sob o influxo da ideologia liberal burguesa, apresentava dois núcleos constitutivos: o primeiro, voltado para proclamar a primazia do indivíduo sujeito de direitos naturais e inalienáveis, inerentes à dignidade da pessoa; e o segundo, decorrente do primeiro, a rigorosa limitação do poder político através de técnicas especiais a fim de garantir o exercício dos direitos individuais. Não foi por outra razão que o Código Prussiano de 1794 (Preussisches Allgemeines Landrecht) continha mais de dezenove mil artigos, numa expressa manifestação de racionalidade, autoconfiança, coroada, segundo faz ver Sobota ${ }^{1}$, com uma proibição geral de interpretação judicial. Sobota chama a atenção para o fato de que não obstante toda vinculação normativa, "este código, supostamente perfeito revelou-se um amontoado de regras desajeitado e às vezes ridículo, superado em suas partes principais antes mesmo de ser publicado"2.

Essa busca por segurança revela a posição doutrinária, então prevalente, que possuía como tese central a ideia de reduzir o direito a uma técnica social, negando-lhe caráter científico, em que o Direito é um instrumento de que o homem se serve para realizar uma finalidade prática. Esvazia-se, assim, o Direito de qualquer outro significado que não seja o de meio para realização de certos fins imediatos, postos pela realidade objetiva concreta. O direito é, simplesmente, útil; nada mais que isso. ${ }^{3}$

É fato: a experiência jurídica não pode se situar fora

1 SOBOTA, Katharina. Não mencione a norma! Tradução de João Maurício Adeodato. Anuário do Mestrado da Faculdade de Direito, Recife, n. 7, p. 251-273, 1995. p. 252.

2 Segundo SOBOTA (SOBOTA, Katharina. Não mencione a norma! Tradução de João Maurício Adeodato. Anuário do Mestrado da Faculdade de Direito, Recife, n. 7, p. 251-273, 1995. p. 252), Franz Wieacker pondera, contudo, no sentido de que esta crítica não deve ofuscar os méritos do Código Geral Prussiano (ALR); inter alia ele realizou um progresso notável na questão da supremacia da lei e da proteção legal (conforme a própria autora registra em nota de rodapé fazendo menção ao pensamento de Wieacker in: Privatreschtgeschichte der Neuzeit. 2. ed., Göttingen, 1967, p. 334). (WIEACKER, 1967 apud SOBOTA, Katharina. Não mencione a norma! Tradução de João Maurício Adeodato. Anuário do Mestrado da Faculdade de Direito, Recife, n. 7, p. 251-273, 1995.)

3 PEDROSA, Maria Bernardette Neves. Filosofia e direito penal: palestra proferida em 23 de novembro de 1972, na Faculdade de Direito da Universidade Federal da Paraíba - UFPB. Separata da: Revista do Ministério Público de Pernambuco, Recife, ano 01, n. 02, 1972. p. 03-04. 
de técnica e de método. Por isso, Bernardette Pedrosa, antiga professora da Faculdade de Direito do Recife, prossegue com propriedade registrando que:

Toda técnica pressupõe uma ciência que lhe corresponde. A técnica médica só é possível porque existe uma ciência da medicina; a técnica econômica, porque há uma ciência da economia; a técnica jurídica, porque existe uma ciência do Direito. Tire-se o fundamento científico da técnica e do que resulta é pura improvisação, a partir da qual os resultados práticos que se pretende alcançar são ocasionais. ${ }^{4}$

Não obstante, o progresso das ciências naturais conduzia ao desprestígio do Direito como ciência e propiciava o vicejamento da concepção reducionista, que se irradiava exatamente em detrimento do pensamento que se voltasse para converter o direito em objeto a conhecer e não a ser manipulado, ou seja, uma visão científica.

Nessa linha, como registra Machado Neto ${ }^{5}$, movidos pela fidelidade ao pensamento naturalista, autores como Picard e Kirchmann colocavam o direito no mesmo espaço das ciências da natureza, culminando, esse último, por negar completamente sua cientificidade. Fato é que, intrinsecamente vinculado ao conceito de natureza humana, possui variações cunhadas na lei divina, no racionalismo ou mesmo histórico-axiológico.

Exatamente nesse espaço, no final do século XIX, que começaram a aparecer as bases para a compreensão e conhecimento do direito como ciência. O positivismo foi onde o direito primeiramente se amparou para garantir sua cientificidade. Em realidade, o positivismo jurídico surge de um esforço em que se busca transformar o estudo do direito em uma perspectiva essencialmente científica.

O positivismo jurídico "partilhava, como doutrina positivista em geral, da aversão à especulação metafísica e a procura de razões finais. Rejeitou quaisquer tentativas dos juristas para discernir e formular uma concepção do direito que transcendesse das realidades empíricas dos sistemas legais existentes". ${ }^{6}$ Deveras, até

4 PEDROSA, Maria Bernardette Neves. Filosofia e direito penal: palestra proferida em 23 de novembro de 1972, na Faculdade de Direito da Universidade Federal da Paraíba - UFPB. Separata da: Revista do Ministério Público de Pernambuco, Recife, ano 01, n. 02, 1972. p. 04-05.

5 MACHADO NETO, Antônio Luís. Teoria da ciência jurídica. São Paulo: Saraiva, 1975. p. 15.

6 BODENHEIMER, Edgar. Ciência do direito. Rio de Janeiro: Forense, 1966. p. 112. o século XIX, a tradição jurídica se amparava numa abordagem filosófica do direito como "uma teoria do que seria justo segundo a própria natureza - com visível intenção demolidora - ao que seria justo segundo a convenção dos homens, estabelecendo assim, as bases de uma justiça imutável e eterna [...] sob a forma de variegadas doutrinas do direito natural..."

A ideia era, portanto, esvaziar o direito de significação moral, depurando-o de ambiguidades numa construção sistêmica que lhe assegurasse autonomia científica, o que ocorreria a partir da definição de seu objeto. Ao declarado escopo, surgem no século XX as contribuições de Kelsen, Ross e Hart marcadas por uma visão empírica do direito dissociado da política e da moral.

Com efeito, em sua Teoria Pura do Direito, Kelsen ${ }^{8}$ considera o ordenamento jurídico estatal como uma estrutura escalonada na qual as normas estariam dispostas, de forma hierarquizada, de tal sorte que a validade de uma norma de escalonamento inferior repousaria numa outra de escalonamento superior que estabelecesse o modo de sua produção. A partir daí, a cientificidade do direito restaria assegurada num esquema metodológico em que a criação de direito sempre implica a aplicação de direito e vice-versa.

A decisão judicial, o ato administrativo e os negócios jurídicos encontram-se na base da pirâmide que representaria o ordenamento jurídico estatal e avultam-se como normas jurídicas de caráter particular que encontrariam fundamento de validade em normas gerais de escalonamento superior, até o último fundamento de validade dentro do sistema estatal que seria a constituição ${ }^{9}$. Essa, a seu turno, encontraria fundamento numa norma que estabelece o dever de se obedecer à constituição. Nas palavras de Kelsen: "devemos conduzir-nos como a Constituição prescreve, quer dizer, de harmonia com o sentido subjectivo do ato de vontade constituinte, de harmonia com as prescrições do autor da Constituição." 10

A norma fundamental (Grundnorm) apresenta-se para Kelsen como condição lógico-transcendental da

7 MACHADO NETO, Antônio Luís. Teoria da ciência jurídica. São Paulo: Saraiva, 1975. p. 14.

8 KELSEN, Hans. Teoria pura do direito. Coimbra: A. Amado, 1979. p. 309-310.

9 KELSEN, Hans. Teoria pura do direito. Coimbra: A. Amado, 1979. p. 324.

10 KELSEN, Hans. Teoria pura do direito. Coimbra: A. Amado, 1979. p. 279. 
possibilidade de atribuição de sentido objetivo ${ }^{11}$, ou seja, como fator de validação jurídica de todos os atos e normas existentes no sistema.

Realmente, a experiência jurídica, para Kelsen, repousa em duas categorias: norma e validade. A juridicidade decorre da atribuição de um sentido objetivo à manifestação de vontade. É esse sentido objetivo que permite se possa distinguir entre a atuação do carrasco ao desferir o golpe mortal e a conduta de um latrocida que para assegurar o fruto do roubo mata sua vítima. O que torna um ato jurídico é algo além do sentido subjetivo que todo ato possui enquanto fenomenologicamente vinculado ao tempo e ao espaço e produto, portanto, de uma manifestação de vontade (sein). É, na verdade, a norma como dever-ser (sollen) que atribui o "sentido de um ato por meio do qual a conduta é prescrita ou especialmente, facultada, no sentido de adjudicada à competência de alguém". ${ }^{12}$

A norma é tomada, assim, como um esquema de interpretação. Como o próprio Kelsen explica:

\begin{abstract}
o juízo em que se enuncia que um ato de conduta humana constitui um ato jurídico (ou antijurídico), é o resultado de uma interpretação específica, a saber, de uma interpretação normativa. Mas também na visualização que o apresenta como um acontecer natural, apenas se exprime uma determinada interpretação, diferente da interpretação normativa: a interpretação causal. A norma que empresta ao ato o significado de um ato jurídico (ou antijurídico) é ela própria produzida por um ato jurídico, que, por seu turno, recebe a sua significação jurídica de uma outra norma. O que faz com que um fato constitua uma execução jurídica de uma sentença de condenação à pena capital e não um homicídio, essa qualidade - que não pode ser captada pelos sentidos - somente surge através da operação mental: confronto com o código penal e com o código de processo penal ${ }^{13}$.
\end{abstract}

A validade da norma decorre, em condições que tais, sob três sentidos imbricados. Pelo primeiro, Kelsen identifica a validade com a existência: "se designarmos a existência específica da norma como a sua $<<$ vigência $>>14$,

11 KELSEN, Hans. Teoria pura do direito. Coimbra: A. Amado, 1979. p. 279.

12 KELSEN, Hans. Teoria pura do direito. Coimbra: A. Amado, 1979. p. 22.

13 KELSEN, Hans. Teoria pura do direito. Coimbra: A. Amado, 1979. p. 20.

14 Na edição portuguesa da Teoria Pura do Direito de 1979, que estamos utilizando, o termo vigência foi usado para traduzir do alemão o étimo Gültigkeit. Parece, efetivamente, que a termo vigência, sobretudo entre nós, mostra-se insuficiente para exprimir o sentido imprimido por Kelsen, o que se percebe diante dos sentidos por ele damos por esta forma expressão à maneira particular pela qual a norma - diferentemente do ser dos fatos naturais - nos é dada ou se nos apresenta."15. O segundo sentido, decorrente do primeiro, atribui à validade a significação de pertinência. A norma é uma estrutura de sentido, mas esse sentido é perceptível em função do sistema no qual ela se insere. Significa dizer, em outras palavras, a norma pertence a certo ordenamento jurídico. Não existe isoladamente. Isolada do todo de que é parte, reduz-se a uma simples proposição que se distingue das demais pela natureza dos conectivos formais (dever-ser) e por isso somente poderá ser objeto de investigação lógica. Se a norma existe somente dentro de determinado sistema, é nele que se deve buscar o modo de sua produção, ou seja, o fundamento de sua validade. Como já assentamos, para Kelsen, o fundamento de validade de uma norma inferior repousa numa norma superior e não em fatos, o que aponta, como com propriedade registra Barzotto ${ }^{16}$, para a conclusão de que Kelsen predica à validade uma relação intranormativa.

Enfim, Kelsen insiste em que validade significa também obrigatoriedade. Segundo ele:

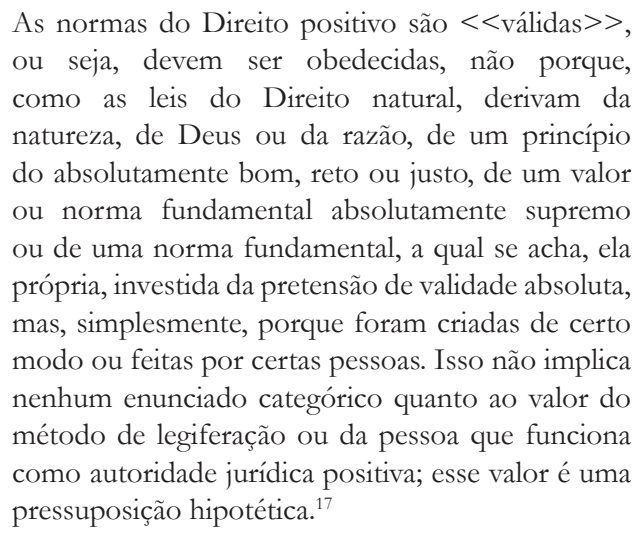

A qualificação de uma norma como jurídica repousa, enfim, em se saber se essa norma é válida, ou seja, se ela encontra fundamento de validade em norma de escalonamento superior que deve, a seu turno, encontrar fundamento de validade na constituição, que, por sua

empregados para a validade. Para Kelsen, a vigência, como fixação positiva da norma, é condição de validade, como é condição de validade sua eficácia (KELSEN, Hans. Teoria pura do direito. Coimbra: A. Amado, 1979. p. 297).

15 KELSEN, Hans. Teoria pura do direito. Coimbra: A. Amado, 1979. p. 29.

16 BARZOTTO, Luis Fernando. O positivismo jurídico contemporâneo: uma introdução a Kelsen, Ross e Hart. São Leopoldo: Unisinos, 2003. p. 38.

17 KELSEN, Hans. Teoria geral do direito e do Estado. São Paulo: M. Fontes, 1992. p. 384. 
vez, encontra fundamento de validade na norma fundamental. Assim, no positivismo kelseniano, a existência não pode ser coisa distinta da validade. O sentido da existência de uma norma é a sua validade, isto é, sua força vinculante de conduta. Essa força ela recebe de outra norma. Nas palavras de Kelsen:

\begin{abstract}
Dizer que uma norma que se refere à conduta de um indivíduo $<<$ vale $>>$ (é $<<$ vigente $>>$ ), significa que ela é vinculativa, que o indivíduo se deve conduzir do modo prescrito pela norma. Já anteriormente, num outro contexto, explicávamos que a questão do porquê é que a norma vale - quer dizer: por que é que o indivíduo se deve conduzir de tal forma - não pode ser respondida com a simples verificação de um fato da ordem do ser, que o fundamento de validade de uma norma não pode ser um tal fato. Do fato de algo ser não pode seguirse que algo deve ser, assim como do fato de algo dever ser não pode seguir-se que algo é. O fundamento de validade de uma norma apenas pode ser outra norma. $^{18}$
\end{abstract}

Kelsen, portanto, mostra-se convencido de que fato não gera direito e de que direito não gera fato. Decompondo seu raciocínio poderíamos considerar, por exemplo, um decreto baixado pelo governador do Estado de Pernambuco prescrevendo que três dias após a sua publicação, para felicidade dos pernambucanos, que é sua missão velar, choverá em todo território do Estado assolado por longa estiagem. Publicado o ato, a pergunta que se avulta é a seguinte: três dias após a publicação choverá em todo Estado de Pernambuco? Decreto é direito. Ele possuiria o condão de gerar o fato? Dificilmente alguém admitirá, considerando que tenha chovido torrencialmente em todo o território do Estado, que foi o decreto que fez chover. Consideremos, contudo, um exemplo mais factível: a norma jurídica que institui um tributo gera fato? Em sala de aula, os alunos gritam de imediato que sim: o pagamento! Para a Teoria Pura do Direito, o pagamento não decorre da norma. O que a norma criou foi apenas a obrigatoriedade de pagar o tributo, isso porque uma norma superior determinou o seu conteúdo no momento de sua aplicação, o que faz prescrevendo determinado conteúdo, vedando-o ou permitindo. Para o positivismo lógico-metodológico, onticamente, o direito apresenta-se com esses conteúdos de onde decorreria o princípio tido por ontológico, que imprimiria, segundo essa visão, tamanha hermeticitude ao sistema, quando tudo que não é juridicamente proibi-

18 KELSEN, Hans. Teoria pura do direito. Coimbra: A. Amado, 1979. p. 267. do, é juridicamente permitido. ${ }^{19}$

A consideração de outro exemplo coloca-nos diante da outra vertente de sustentação da Teoria: a mediação entre o ser e o dever-ser faz-se por meio de norma e não de fato. Com efeito, considerando o disposto nos arts. $2^{\circ}, 6^{\circ}$ e 1.784 do novo Código Civil brasileiro, tem-se que personalidade civil começa com o nascimento com vida e termina com a morte, quando se opera a transmissão dos direitos e dos deveres aos sucessores. Contudo, ali se estabeleceu a hipótese de morte presumida. O que faz com que uma pessoa que faticamente não está comprovadamente morta seja para tanto considerada a ponto de se deflagrar a sucessão? A resposta: a norma. Então a norma atribui um sentido objetivo a ponto de considerar alguém que pode estar vivo, morto. O que a Teoria Pura do Direito quer dizer é que não é a morte que gera o direito de sucessão, mas uma norma que atribuiu esse sentido objetivo a um acontecimento do mundo dos fatos.

Vamos mais além. Sob a validade do Código Civil anterior aos vinte e um anos completos cessava a menoridade e ficava o indivíduo habilitado para todos os atos da vida civil $\left(\right.$ art. $\left.9^{\circ}\right)$. Hoje, o novo Código Civil prescreve que a menoridade termina aos dezoito anos completos $\left(\operatorname{art.~} 5^{\circ}\right)$. Então, o que faz o fato de alguém completar vinte e um anos hoje não gerar mais o direito de gerir, ele próprio, sua pessoa e seus bens? A resposta: um sentido objetivo atribuído por uma norma. Completar vinte e um anos tornou-se, sob a ótica em exame, um fato irrelevante para o direito porque desprovido de sentido objetivo, sentido, pois, jurídico. O sentido objetivo (dever-ser) dirigiu-se para outro fato: o indivíduo completar dezoito anos. Isso pode acontecer porque o novo Código Civil é uma norma válida, isto é, criada com base na aplicação de uma norma superior (a Constituição) que criou o órgão legislativo com competência para fazê-lo, ou seja, confere sentido normativo ao ato a ser criado, com base em uma atribuição de sentido ensejada pela norma fundamental, que se pressupõe, na hipótese, imprimindo logicidade ao sistema (Grundnorm).

19 Na roupagem da Constituição brasileira: ninguém será obrigado a fazer ou a deixar de fazer alguma coisa senão em virtude de lei (Art. $5^{\circ}$, II), descortina uma visão positivista de matiz lógico-metodológico da experiência jurídica, em descompasso com a perspectiva pós-positivista que divisa um maior espectro da juridicidade que não pode se limitar à legalidade formal. BRASIL. Constituição (1988). Constituição da Republica Federativa do Brasil. Disponível em: <http://www. planalto.gov.br/ccivil_03/Constituicao/Constituicao.htm>. Acesso em: 02 fev. 2016. 


\section{A NORMA FUNDAMENTAL COMO NORMA (PRES- SU)POSTA}

A pressuposição da norma fundamental que compele todos à obediência à Constituição não se opera arbitrariamente, alerta Kelsen. Significa dizer que não há possibilidade de escolha quando se interpreta o sentido objetivo de um ato constituinte ou dos atos criados de acordo com a constituição. A norma fundamental é pressuposta em relação a uma constituição inteiramente determinada, em relação à qual se pode interpretar o sentido subjetivo do ato constituinte e dos atos constitucionalmente postos como sendo seu sentido objetivo, isto é, normas jurídicas válidas. ${ }^{20}$

Assim, pode-se afirmar que no sistema jurídico brasileiro, não é válida uma sentença (norma jurídica de caráter particular) que condene alguém à pena de morte, porque essa norma não encontra fundamento de validade na Constituição, que deve ser obedecida porque se pressupõe uma norma, não positivada, que lhe serve de fundamento e que não permite a atribuição de sentido objetivo quanto à pena capital. Da mesma forma, não é uma norma negocial (negócios jurídicos particulares) a compra e venda de trezentos gramas de maconha, porque, igualmente, não se pode atribuir a esse fato um sentido objetivo. $\mathrm{Na}$ linguagem de Kelsen:

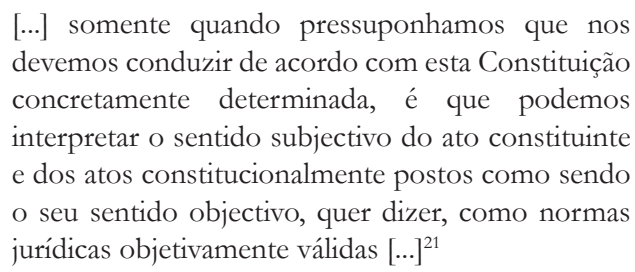

A relação de pertinência assim expressada e inerente à validade afasta, no pensamento kelseniano, qualquer referência a fatos e valores morais. $\mathrm{O}$ que distingue $\mathrm{o}$ ato do Poder Executivo ao baixar uma Medida Provisória que aumenta a carga tributária do ato de um assaltante que, com arma em punho, exige a entrega de certa quantia? Em ambas as hipóteses, deparamo-nos com um fato carregado de sentido subjetivo, mas, quando submetidos ao esquema de interpretação do jurídico (norma), verifica-se que o sistema jurídico predicou sentido objetivo ao primeiro. Não havendo norma a validar a

20 KELSEN, Hans. Teoria pura do direito. Coimbra: A. Amado, 1979. p. 278, passim.

21 KELSEN, Hans. Teoria pura do direito. Coimbra: A. Amado, 1979. manifestação de vontade do assaltante, o fato avulta-se desprovido de sentido objetivo e, portanto, insusceptível de produzir direito. De modo contrário, a manifestação de vontade do chefe do executivo encontra-se validada a partir de uma norma, o que qualifica o ato a produzir direito. Kelsen é convicto, com efeito, de que direito apenas é criado a partir da aplicação de direito. O dever-ser se mostra irredutível do ser. Assim, a medida provisória que instituiu um tributo não geraria nenhum fato, senão a obrigatoriedade de pagar o tributo.

Isso não desloca por completo, na concepção de Kelsen, os fatos do mundo jurídico - e nem poderia já que a eficácia é tomada como condição de validade, ou seja, situam-se igualmente no sistema todos os efeitos da norma. A eficácia encontra-se, assim, em estreita conexão com a validade da norma. Diz respeito à sua executoriedade ou aplicabilidade. De regra, a norma é apta a produzir os efeitos jurídicos determinados. Às vezes, todavia, o legislador condiciona a eficácia ao decurso de certo tempo (vacatio legis), à superveniência de um fato ou de outra norma (norma regulamentar). Em casos tais, a norma existe (é válida na acepção kelseniana), mas não é ainda eficaz.

Kelsen, inteiramente atento à circunstância básica de que, para sua teoria, o que distingue a norma jurídica de outras normas é a possibilidade de conformação da conduta humana sob coerção (dever-ser), já que uma norma "e uma norma jurídica apenas se pretende regular a conduta humana e se regula a conduta humana estabelecendo um ato de coerção como sanção"22, não poderia descurar, contudo, que a eficácia se avulta como condição necessária da validade. E assevera que:

Cada norma individual perde sua validade quando
a ordem jurídica total perde sua eficácia como um
todo. A eficácia da ordem jurídica como um todo é
condição necessária para a validade de cada norma
individual da ordem. Uma conditio sine qua non, mas
não uma conditio per quam. A eficácia da ordem
jurídica total é uma condição, não um fundamento,
para a validade de suas normas constituintes. Essas
normas são válidas não porque a ordem total é
eficaz, mas porque elas são criadas de uma maneira
constitucional. Elas são válidas, porém, apenas sob
a condição de que a ordem total seja eficaz; elas
deixam de ser válidas não apenas quando anuladas
de maneira constitucional, mas também quando a
ordem total deixa de ser eficaz. Em termos jurídicos
não se pode sustentar que os homens devam se
conduzir em conformidade com certa norma, se

22 KELSEN, Hans. Teoria geral do direito e do Estado. São Paulo: M. Fontes, 1992. p. 127. 
a ordem jurídica total, da qual essa norma é parte integrante perdeu a eficácia. ${ }^{23}$

Assim é que, a perda de eficácia de uma constituição, por um golpe, uma revolução ou pelo exercício de poder constituinte por uma assembleia, com a instituição de nova constituição e, portanto, nova ordem, implica que as normas infraconstitucionais anteriores perdem a validade a não ser que adquiram novo fundamento de validade, sendo certo que essa convalidação pode se dar de forma expressa ou tácita. Dessa maneira, fica claro que os órgãos competentes somente poderão aplicar a norma se ela recebeu um novo fundamento de validade.

Decorre, desde aí, uma eficácia em sentido jurídico vinculada à aplicação da norma pelos órgãos competentes, que se distingue da eficácia em sentido sociológico que sob a pretensão de fazer corresponder a conduta prescrita (dever-ser) à conduta efetivamente realizada $($ ser $)$, colocaria a validade da norma em fato e invalidaria a construção kelseniana. Daí porque, sob o prisma da Teoria Pura do Direito, pode-se afirmar que a eficácia, como possibilidade de executoriedade da norma, convive com uma correspondência mínima entre o dever-ser e o ser.

Para Kelsen o fundamento de validade de uma norma repousa em outra norma e não em fato, porque da circunstância de algo ser não se pode derivar um dever ser, em outras palavras: fato não gera direito. Qual, então, o fundamento de validade de uma certa e determinada constituição, se para ele a pirâmide que representa o sistema jurídico se fecha no ápice pela constituição não havendo, portanto, norma acima dela? É com base nessa indagação que Kelsen concebe a norma fundamental (grundnorm) como norma pressuposta e hipotética ${ }^{24}$.

O fundamento de validade de uma constituição não repousaria numa lei natural, em um valor supremo como Deus ou racional como um imperativo categórico absoluto que permita divisar a retidão e a justiça da(s) pessoa(s) envolvidas e do procedimento de elaboração da Constituição. Esse fundamento, conquanto expresse um valor pressuposto e hipotético, imprime sentido objetivo à Constituição.

A maior parte da doutrina, todavia, ao enfrentar a norma fundamental para por aí, ou seja, registra que ela

23 KELSEN, Hans. Teoria geral do direito e do Estado. São Paulo: M. Fontes, 1992. p. 123.

24 KELSEN, Hans. Teoria geral do direito e do Estado. São Paulo: M. Fontes, 1992. p. 384. é um juízo valorativo pressuposto e hipotético. Mas, o que Kelsen quer realmente dizer ao afirmar que a norma fundamental é pressuposta e hipotética? É aqui que reside o âmago da questão, porque efetivamente quem não se debruçar sobre a posição de Kelsen em relação ao Direito Internacional e estabelecer - como ele próprio fez - liame com a norma fundamental, não terá condições de bem equacionar a indagação proposta e continuará simplesmente afirmando que a grundnorm é uma mera hipótese pressuposta para validar uma constituição.

Ocorre que, a circunstância de a norma fundamental ser apontada por Kelsen como uma hipótese pressuposta não significa dizer que ela se reduza a uma proposição formal para validar uma constituição e justificar a Teoria Pura do Direito. Essa norma para Kelsen tem conteúdo que repousa numa norma de Direito Internacional. Se ela tem conteúdo e revela-se como norma de Direito Internacional, então não se reduz apenas a um juízo pressuposto. Pressuposto, na verdade, é o valor que ela encerra - e isso é, a bem da verdade, o que sempre Kelsen fez questão de afirmar ${ }^{25}$ - mas ela existe como norma posta, que possui conteúdo.

Com efeito, a Teoria Pura do Direito considera a norma fundamental (grundnorm) como norma posta. Isso em decorrência do monismo kelseniano que propugna pela supremacia do Direito Internacional sobre o direito estatal. Assim, partindo-se do primado do Direito Internacional, alerta Kelsen que de fato há

uma norma que representa o fundamento de
vigência [entenda-se validade $]^{26}$, das ordens
jurídicas estaduais ${ }^{27}$. Por isso, o fundamento de
vigência da ordem jurídica estadual pode ser
encontrado no Direito internacional positivo.
Nesta hipótese, o fundamento de vigência daquela
ordem jurídica é uma norma posta, não uma

25 KELSEN, Hans. Teoria geral do direito e do Estado. São Paulo: M. Fontes, 1992. p. 384.

26 Na edição portuguesa da Teoria Pura do Direito de 1979, que estamos utilizando, o termo vigência foi usado para traduzir do alemão o étimo Gültigkeit. Parece, efetivamente, que a termo vigência, sobretudo entre nós, mostra-se insuficiente para exprimir o sentido imprimido por Kelsen, o que se percebe diante dos sentidos por ele empregados para a validade. Para Kelsen, a vigência, como fixação positiva da norma, é condição de validade, como é condição de validade sua eficácia (KELSEN, Hans. Teoria pura do direito. Coimbra: A. Amado, 1979. p. 297).

27 A expressão "ordens jurídicas estaduais" utilizada na edição portuguesa ficaria melhor traduzida em português do Brasil por "ordens jurídicas estatais" para não confundir, em face da forma de Estado federativa, com a ordem jurídica dos estados-membros da federação, que aqui identifica o direito estadual. 
simples norma pressuposta. A norma de Direito internacional que representa este fundamento de vigência é usualmente descrita pela afirmação de que, de acordo com o Direito Internacional geral, um governo que, independentemente de outros governos, exerce o efetivo domínio sobre a população de um determinado país, constitui um governo legítimo, e que o povo que vive nesse país sob um tal governo forma um Estado no sentido do Direito Internacional - e isto sem curar de saber se este governo exerce esse domínio efetivo com base numa Constituição por ele revolucionariamente estabelecida. Traduzindo esta mesma ideia na linguagem do Direito: uma norma do Direito internacional geral reconhece a um indivíduo ou a um grupo de indivíduos o poder de, com base na Constituição eficaz, criar e aplicar, como governo legítimo, uma ordem normativa de coerção. Ela legitima assim, para o domínio territorial da sua eficácia real, esta ordem coerciva como ordem jurídica válida, assim como legitima o Estado, no sentido do Direito internacional, a comunidade constituída através desta ordem coerciva - isso sem curar de saber se o governo é legítimo no sentido de uma Constituição anteriormente existente ou se alcançou o poder pela via revolucionária. Esse poder, segundo o Direito internacional, é de considerar como um poder jurídico. Isso significa que o Direito internacional legitima a revolução triunfante como um processo criador de Direito. Se, por esta forma, se reconhece como fundamento de vigência da ordem jurídica estadual uma norma positiva de Direito internacional na sua aplicação à Constituição estadual, sobre cuja base se ergue a ordem jurídica do Estado, então desloca-se o problema da norma fundamental. Com efeito, nesse caso, o fundamento de vigência de uma ordem jurídica estadual não reside numa norma pressuposta mas numa norma jurídico-positivamente estabelecida do Direito internacional. ${ }^{28}$

A norma posta que, na concepção monista serviria de fundamento de validade para a constituição é o Princípio da Efetividade que assim pode ser expressado a partir da construção kelseniana: quando, no seio de uma comunidade, que vive em determinado território, o poder é exercido de forma efetiva a ponto de romper com uma ordem jurídica anteriormente estabelecida, todo ato desse poder produz direito novo. Então, não teria sido o fato ocorrido em 7 de setembro de 1822 (Declaração da Independência), que seria o fundamento de validade da Constituição brasileira de 1824, mas a incidência da norma de Direito Internacional vazada no Princípio da Efetividade que conduz os Estados a agir de determinada maneira (sentido objetivo), qual seja, reconhecer um novo direito (o direito brasileiro) em oposição a um di-

28 KELSEN, Hans. Teoria pura do direito. Coimbra: A. Amado, 1979. p. 301. reito anteriormente existente (o direito português) em ato unilateral conhecido como reconhecimento de Estado.

O raciocínio é o mesmo para o reconbecimento de governo, como ocorreu, por exemplo, após 15 de novembro de 1889, com a Proclamação da República. Contudo, os Estados não se conduziram dessa mesma maneira em relação a um fato ocorrido no Brasil em 1789 - a Insurreição Mineira - exatamente porque ali não se divisou a incidência da norma de Direito Internacional consubstanciada no Princípio da Efetividade. Com efeito, as forças leais à Tiradentes não foram suficientes, ou seja, efetivas o suficiente para romper com a ordem jurídica portuguesa e implantar uma nova ordem apta a criar direito novo. É sob essa compreensão que Kelsen não transfere para os fatos -uma revolução, um golpe de estado ou mesmo uma assembleia constituinte - a validade do direito. Com efeito, os Estados, tal qual as pessoas, pautam suas condutas com base no sentido objetivo que a norma jurídica enseja.

Mas, poder-se-ia perguntar: qual o fundamento de validade da grundnorm? Kelsen não estaria apenas deslocando o problema? O próprio Kelsen não hesitou em registrar:

[...] e, então, levanta-se a questão do fundamento de vigência desta norma e, portanto, a questão do fundamento de vigência da ordem jurídica internacional de que é parte integrante a norma sobre a qual se apoia a autoridade da ordem jurídica estadual, a norma que esta ordem jurídica encontra o seu fundamento imediato de vigência, se bem que não o seu fundamento de vigência último. Este fundamento de vigência apenas pode, então, ser a norma fundamental do Direito internacional que, portanto, é o fundamento mediato de vigência da ordem jurídica estadual. Como genuína norma fundamental, não é uma norma posta mas uma norma pressuposta. Ela representa o pressuposto sob o qual o chamado Direito internacional geral, isto é, as normas, globalmente eficazes, que regulam a conduta de todos os Estados entre si, são consideradas como normas jurídicas que vinculam os Estados. Estas normas são criadas pela via de um costume que é constituído pela conduta efetiva dos Estados, isto é, pela conduta dos indivíduos que, de acordo com as ordens jurídicas estaduais, funcionam como governos. Se elas são pensadas como normas jurídicas vinculantes para os Estados é porque se pressupõe uma norma fundamental que institui o costume dos Estados como fato produtor de Direito. O seu teor é: os Estados, quer dizer, os governos dos Estados, devem conduzir-se nas suas relações mútuas de harmonia com um dado costume dos Estados, ou: a coação de um Estado contra outro deve ser exercida sob os pressupostos e pela forma correspondentes a um dado costume 
dos Estados. É esta a constituição - lógico-jurídica - do Direito internacional. ${ }^{29}$

Advêm, desde aí, duas questões: $\left.1^{a}\right)$ qual o fundamento de validade do Direito Internacional? e $2^{\mathrm{a}}$ ) nos atos de reconbecimento de Estado e reconhecimento de governo os governos não estariam jungidos à observância de um valor pressuposto que colocaria em causa, ao lado do Princípio da Efetividade, do Princípio da Legitimidade.

Equacionando a primeira indagação observamos que a pretensão de fundamentar uma proposição por meio de outra proposição pode-nos conduzir a uma redução ao infinito. Particularmente para a questão objeto de nosso estudo teríamos que indagar: qual o fundamento do Direito Internacional? Alguém poderia, como resposta, afirmar: os direitos humanos, que revestidos de caráter ius cogens ver-se-iam conduzidos ao patamar de imperativo categórico, ao que se poderia facilmente retrucar: e qual o fundamento de validade dos direitos humanos? Leis do Direito natural, que derivam, portanto, da natureza, jusnaturalismo, enfim, de Deus.E poder-se-ia ou não se perguntar: qual o fundamento de validade de Deus? Teríamos, num determinado momento, que renunciar a pretensão de fundamentar e ela seria substituída por uma decisão - uma interrupção dogmática do processo de fundamentação, ou seja, um corte epistemológico como fez Kelsen com sua norma fundamental. Estamos diante do conhecido dilema de Münchbausen ${ }^{30}$.

Contudo, há quem sustente que haveria uma terceira via que nos colocaria numa circularidade. Nesse sentido é a fórmula adotada por Luhmann para quem a validade do direito se assegura mediante a integração recursiva das operações à rede à medida que são diferenciadas pelo seu código binário (lícito/ilícito ou legal/ilegal), sendo certo que "a textualização gera a ilusão da norma ser-em-si-e-por-si (An-und-für-sich-Siens), mas oculta em sua origem a constituição circular. As normas tornam as decisões possíveis porque as decisões tornam as normas possíveis." 31 . Admitida essa terceira hipótese ao problema da fundamentação das ciências lógico-dedutivas, te-

29 KELSEN, Hans. Teoria pura do direito. Coimbra: A. Amado, 1979. p. 301-302.

30 Nesse sentido, ATIENZA, Manoel. As razões do direito: teorias da argumentação jurídica. São Paulo: Landy, 2006. p. 164-165.

31 LUHMANN, Niklas. A restituição do décimo segundo camelo: do sentido de uma análise sociológica do direito. In: ARNAUD, André-Jean; LOPES JR., Dalmy (Org.). Niklas Lubmann: do sistema social à sociologia jurídica. Rio de Janeiro: Lumen Juris, 2004. p. 33-107. p. 37. remos que admitir que se trata de um trilema e não de um dilema. É assim que Hans Albert prefere nomear. ${ }^{32}$

A regressão ao infinito, como uma opção ao problema da fundamentação das ciências lógico-dedutivas, não tem sido levada em consideração porque não conduz a lugar algum. Redunda, como se diz usualmente, em "por água em saco furado", numa referência popular ao "tonel das danaides" (danaidum dolium) da mitologia grega: as danaides, cinquenta filhas de Dânaos, Rei de Argos, foram condenadas pela morte coletiva de seus maridos. A engenhosa justiça dos deuses condenou-as a encherem um tonel sem fundo por toda eternidade.

É preciso, todavia, que se entenda que a interrupção dogmática do processo de fundamentação eleita por Kelsen não pode ser concebida como uma via arbitrária. Trata-se apenas de um corte epistemológico. O que Kelsen quer dizer é que a investigação da ciência do direito vai até o Direito Internacional, acima disso a investigação pode prosseguir no âmbito da metafísica, mais precisamente da filosofia ou da teologia, investigação essa que escaparia dos limites do objeto do Direito.

Impende que se enfrente a segunda indagação. Para Kelsen, efetivamente, a validade do direito não se encontra vinculada a qualquer espécie de juízo de valor: "não significa o reconhecimento de um valor de Justiça que, destarte, não é por forma alguma elevado à categoria de um elemento do conceito de Direito" ${ }^{33}$ E Kelsen prossegue refutando o argumento de Santo Agostinho quando na Cevitas Dei equipara a comunidade jurídica sem justiça a um bando de salteadores para, ao final, sustentar que uma comunidade jurídica que não cultua o verdadeiro Deus, o Deus cristão, não seria justa e portanto, não se equivaleria a um bando de salteadores. Vale a pena conferir a contextualizar exposta por Kelsen:

Na sua Civitas Dei, onde levanta a questão desta
distinção, escreve este autor [referindo-se a Santo
Agostinho]: << Que são os impérios sem Justiça,
senão grandes bandos de salteadores? E são os
bandos de salteadores outra coisa senão pequenos
impérios?>>. Um Estado, ou para Agostinho, uma
comunidade jurídica, não pode existir sem Justiça.
Pois <<o Direito não pode existir onde não exista a
verdadeira Justiça. O que acontece de conformidade
com o Direito, acontece de fato justamente; o que
é feito de uma maneira injusta, não pode acontecer
segundo o Direito>>. O que é, porém, a Justiça?
lut
bert. Tratado da razão crítica. Rio de Janeiro: Tempo
Hans. Teoria pura do direito. Coimbra: A. Amado,


$<<$ Justiça é a virtude que dá a cada um o que é seu (Justitia porro e a virtus est, que sua cuique distribuit). Em que consiste, pois, a Justiça dos homens que rouba o homem ao verdadeiro Deus e o submete aos demônios impuros? Ou não é injusto aquele que subtrai ao comprador um pedaço de terreno e o dá a quem não tem qualquer direito a ele? E é porventura justo aquele que se furta a si próprio ao Senhor por quem foi criado e se põe ao serviço de espíritos maléficos? >> Segundo a concepção que está na base deste raciocínio o Direito é uma ordem de coerção justa e distingue-se, assim, através da Justiça do seu conteúdo, da ordem coercitiva de um bando de salteadores. ${ }^{34}$

Kelsen sustenta, nessa perspectiva, o caráter relativo do juízo de valor com base no qual uma ordem pode ser tida como justa. A ordem jurídica de Roma, porque não fundada no culto e preceitos do Deus judaico-cristão não seria justa ou legítima para Santo Agostinho mas, sem dúvida, o seria para alguém que professasse o credo aos deuses de Roma. E Kelsen conclui absolutamente convencido de que:

\begin{abstract}
Se a Justiça é tomada como o critério da ordem normativa a designar como Direito, então as ordens coercitivas capitalistas do mundo ocidental não são de forma alguma Direito do ponto de vista do ideal comunista do Direito, e a ordem coercitiva comunista da Um ião Soviética não é também de forma alguma Direito do ponto de vista do ideal de Justiça capitalista. Um conceito de Direito que conduz a uma tal consequência não pode ser aceito por uma ciência jurídica positiva. Uma ordem jurídica pode ser julgada como injusta do ponto de vista de uma determinada norma de Justiça. O fato, porém, de o conteúdo de uma ordem coercitiva eficaz poder ser julgado como injusto, não constitui de qualquer forma um fundamento para não considerar como válida essa ordem jurídica. ${ }^{35}$
\end{abstract}

Assim, para Kelsen, a interpretação dos atos praticados em decorrência de uma revolução ou de um golpe de Estado vitoriosos apenas poderia ocorrer sob o prisma de se saber se tais atos decorrem de um poder efetivo que rompeu com a ordem jurídica anteriormente vigente implantando uma nova ordem (Princípio da Efetividade) e nessa perspectiva, imune a uma investigação valorativa, as mais aprimoradas democracias seriam Estados [Estado de Direito, se se preferir, mas a expressão se avultaria carecedora de sentido porque dentro dessa perspectiva formal, todo Estado seria Estado de Direito] tal qual os governos monárquicos absolutistas

34 KELSEN, Hans. Teoria pura do direito. Coimbra: A. Amado, 1979. p. 80-81.

35 KELSEN, Hans. Teoria pura do direito. Coimbra: A. Amado, 1979. p. 81-82. do início da idade moderna, ou os atuais governos das repúblicas autocráticas.

\section{Considerações finais}

$\mathrm{Na}$ verdade, o que transforma uma sociedade em Estado é a existência de um ordenamento jurídico efetivo incidindo sobre a vida de um grupo de pessoas que habitam determinada região. Não se pode cogitar, sem dúvida, da existência de Estado sem Direito e, portanto, é correto afirmar que do ponto de vista formal todo Estado é "Estado de Direito". O exame da matéria não pode se afastar, primeiramente, do aspecto formal.

Porém, toda ordem jurídica encontra-se inserida num contexto existencial, histórico e ideológico. As normas jurídicas não são imunes a valor. Contrariamente, uma conduta é permitida quando ela realiza um valor que o direito faz questão de prescrever, ela [conduta] se torna obrigatória se o valor que realiza é imprescindível para garantir a ordem, e, ainda, a conduta é proibida se realiza valor nocivo ao direito. A eleição de valores volta-se para o alcance dos fins, dos objetivos eleitos pelo Estado, que podem, grosso modo, ser sintetizados num ideal de justiça, que é exigência da política. E, sob tal contextura, quando a análise se volta para o exame do conteúdo da ordem, a questão básica é, sem dúvida, saber se a ordem é justa.

Libertar o conceito de direito do conceito de justiça é difícil, senão impossível, porque ambos estão imbricados e profundamente mergulhados no discurso jurídico-político. Nessa análise, enfocada assim a questão sob o prisma material, a fim de enfrentar o conteúdo da ordem, haverá "Estado de Direito" quando a ordem for justa. Assim, num exame apriorístico e sob uma perspectiva lógica, dada uma ordem jurídica que realiza os valores $a, b, c, d$ e $e$, sendo estes os valores indispensáveis para alcançar o ideal de justiça, estar-se-ia diante de um "Estado de Direito". Se, por outro lado, uma ordem deixa de realizar um daqueles valores, deixaria de ser "Estado de Direito". A conclusão é necessariamente que alguns Estados não são "Estado de Direito" e como ordens jurídicas não legítimas não se revelariam conteúdos interpretativos aptos a chancelar um reconhecimento de Estado ou um reconhecimento de governo.

Mas, inequivocamente, é a relatividade dos valores que constituem substratos interpretativos a fomentarem decisões dos Estados nesse sentido que acarretam tan- 
tos problemas na ordem internacional com, apenas à guisa de um exemplo, a angustiante questão palestina, que revelam o quanto as decisões são definidas em termos de interesses, no âmbito de uma domesticação do direito pela política e pela economia.

\section{ReferênCias}

ATIENZA, Manoel. As razões do direito: teorias da argumentação jurídica. São Paulo: Landy, 2006.

BARZOTTO, Luis Fernando. O positivismo jurídico contemporâneo: uma introdução a Kelsen, Ross e Hart. São Leopoldo: Unisinos, 2003.

BODENHEIMER, Edgar. Ciência do direito. Rio de Janeiro: Forense, 1966.

BRASIL. Constituição (1988) Constituição da Republica Federativa do Brasil. Disponível em: < http:/ / www.planalto.gov.br/ccivil_03/Constituicao/Constituicao.htm $>$. Acesso em: 02 fev. 2016.

HANS, Albert. Tratado da razão crítica. Rio de Janeiro: Tempo Brasileiro, 1976.

KELSEN, Hans. Teoria pura do direito. Coimbra: A. Ama- do, 1979 .

KELSEN, Hans. Teoria geral do direito e do Estado. São Paulo: M. Fontes, 1992.

KIRCHMANN, Julio. La jurisprudencia no es ciencia. Madrid: Instituto de Estudios Políticos, 1961.

LUHMANN, Niklas. A restituição do décimo segundo camelo: do sentido de uma análise sociológica do direito. In: ARNAUD, André-Jean; LOPES JR., Dalmy (Org.). Niklas Lubmann: do sistema social à sociologia jurídica. Rio de Janeiro: Lumen Juris, 2004. p. 33-107.

MACHADO NETO, Antônio Luís. Teoria da ciência jurídica. São Paulo: Saraiva, 1975.

PEDROSA, Maria Bernardette Neves. Filosofia e direito penal: palestra proferida em 23 de novembro de 1972, na Faculdade de Direito da Universidade Federal da Paraíba - UFPB. Separata da: Revista do Ministério Público de Pernambuco, Recife, ano 01, n. 02, 1972.

PICARD, Edmond. O direito puro. Tradução Afonso Celso Furtado Rezende. Campinas: Romana, 2004.

SOBOTA, Katharina. Não mencione a norma! Tradução de João Maurício Adeodato. Anuário do Mestrado da Faculdade de Direito, Recife, n. 7, p. 251-273, 1995. 


\section{A juridificação de conflitos políticos no direito internacional público contemporâneo: uma leitura política da paz pelo direito de Hans Kelsen a partir do pensamento político de Claude Lefort*}

Arthur Roberto Capella Giannattasio **

\section{Resumo}

A partir da proposição de uma reflexão interdisciplinar sobre o pensamento jurídico de Hans Kelsen segundo o pensamento político de Claude Lefort, este texto constrói uma interpretação política da proposta kelseniana para a Paz nas relações internacionais por meio do Direito. Inserto no debate do pós-Segunda Guerra Mundial acerca de uma nova estrutura institucional para o Direito Internacional Público, o Projeto da Paz pelo Direito de Hans Kelsen pode ser compreendido como portando um sentido político pois (i) a técnica jurídica aplicada desenvolve condições para uma convivência Política mediada pelo Direito, e (ii) se trata de uma rejeição consciente do Projeto Político para um Federalismo Mundial. Hans Kelsen percebera a suposta fragilidade do Direito Internacional Público e a revelara como sua virtude: garantir relações internacionais não armadas, não mediante o uso da força centralizada em uma autoridade, mas por um experimentalismo contínuo da arquitetura institucional para reconstituir arranjos jurídicos sensíveis à importância da manutenção e do estímulo reiterado das liberdades política, jurídica, econômica e cultural de cada povo. O texto se sustenta em método qualitativo de análise documental de fontes primárias (documentos históricos) e de fontes secundárias (revisão bibliográfica). A reflexão proposta é relevante, pois propõe compreensão política do pensamento jurídico de Hans Kelsen e insere as instituições judiciárias internacionais contemporâneas em chave explicativa inovadora: instrumentos jurídicos de realização da Política, por meio da mediação não armada da convivência entre diferentes. Essa nova chave de leitura política permite pensar em proposições inovadoras para as instituições jurídicas internacionais contemporâneas.

Palavras-chave: Hans Kelsen. Claude Lefort. Federalismo versus unionis mo. Juridificação. Política 


\section{Abstract}

This text proposes an interdisciplinary debate between Hans Kelsen's legal thought and Claude Lefort political thought, in order to develop a political reading of Hans Kelsen's contribution for the strategies to build Peace in international relations through Law. Hans Kelsen's Peace through Law proposal lies within a post-World War II political debate about new legal institutions for Public International Law and his contribution encompasses a political perspective, because (i) Law is regarded as a technique for Polity-building through Law, and (ii) it is a conscious political choice for a model which refuses the Political Project of a World Federation. Hans Kelsen had perceived the supposed weakness of Public International Law and pointed it as its foremost virtue: ensure non-violent international relations, not through the use of force by a central authority, but via a continuous institutional experimentalism of legal designs which is permanently open to uninterrupted maintenance and incentives of political, legal, economic and cultural freedoms of each people. The text is based on a qualitative documental research of primary sources (historical documents) and secondary sources (literature review). The presented argument is relevant because it points to a possible political sense of Hans Kelsen's legal thought and because it inserts contemporary international judicial institutions within a new analytical key: legal tools for Polity-building, in order to mediate a non-violent relationship. This new analytical key might be the base for further innovative proposal for contemporary international judicial institutions.

Keywords: Hans Kelsen. Claude Lefort. Federalism versus unionism. Juridification.Polity

\section{INTRODUÇÃo}

Este artigo estabelece um diálogo interdisciplinar entre dois autores fundamentais para o pensamento contemporâneo em Direito Internacional Público e Filosofia do Direito (Hans Kelsen) e Filosofia Política (Claude Lefort). Não se trata de tentar compreender estruturalmente o pensamento de um único autor. Antes, seu objetivo é bastante claro: propor um debate entre dois autores - um de Filosofia do Direito, e outro, de
Filosofia Política - com base em elemento normativo concreto: o Direito Internacional Público contemporâneo do pós-Segunda Guerra Mundial.

A reflexão desenvolvida neste texto não pretende se restringir a compreender o pensamento jurídico kelseniano com base no exercício de razão pura, tampouco desenvolver considerações específicas e isoladas sobre todos os limites e possibilidades do pensamento político lefortiano. Busca-se, neste artigo, tratar racionalmente de preocupação prática internacional de construção de condições institucionais de convivência humana, com base em contribuições conceituais trazidas pelos dois autores. Isso permitirá (i) compreender elementos da ordem jurídica internacional contemporânea, e (ii) apontar para uma possível leitura política do pensamento jurídico kelseniano sobre o Direito Internacional Público, e mesmo sobre a própria Teoria Pura do Direito.

Até hoje, a rigor, um debate Kelsen-Lefort não existiu - ele é proposto por este artigo e pretende se desenvolver em textos futuros. Isso não significa que não tenha havido diálogo efetivo entre os autores —, mas não há elementos nos principais textos consultados de um ou de outro que indiquem isso expressamente. Todavia, há que se notar que se tratam de autores europeus do início do século XX e que conviveram por cerca de 49 (quarenta e nove) anos - Hans Kelsen, de origem tcheca, nasceu em 1881 e faleceu em 1973, enquanto que Claude Lefort, de origem francesa, nascem em 1924 e faleceu em 2010.

Há certamente limites no estabelecimento de um diálogo entre os autores. Hans Kelsen é autor contemporâneo de Direito Internacional Público e Filosofia do Direito, ao passo que Claude Lefort é autor contemporâneo de Filosofia Política. Isso implica reconhecer que não apenas são autores de disciplinas diferentes, como também cada um é guiado por tópicos diversas. Enquanto Hans Kelsen trabalha com os limites jurídicos de uma ordem normativa positivada e sua operacionalidade prática para a construção de uma Paz na ordem internacional, Claude Lefort se orienta sobretudo para compreender a formatação do Poder e suas repercussões para a qualidade da tomada de decisão normativa (Direito) e política (Poder).

Todavia, há tentativa de propor reflexão que considere conjuntamente as contribuições de cada um deles a partir de momento histórico comum a ambos: o pós-Segunda Guerra Mundial. Para tanto, confluir alguns 
dos tópicos de ambos os autores, bem como os conceitos fundamentais de cada um deles, permitirá desenvolver pensamento jurídico-crítico sobre o as discussões institucionais acerca do futuro do Direito Internacional Público no pós-Segunda Guerra Mundial.

Desse modo, o presente artigo se sustenta em método qualitativo de análise documental de fontes primárias (documentos históricos do pós-Segunda Guerra Mundial) e de fontes secundárias (revisão bibliográfica da historiografia do pós-Segunda Guerra Mundial e dos textos dos autores mencionados, necessários para compreender a temática), o que permitiu dividir o texto em quatro partes.

A primeira parte contém as principais discussões jurídico-políticas sobre o futuro da Europa no pós-Segunda Guerra Mundial. Elas permitirão compreender tendências da orientação das relações internacionais europeias no período (Federalismo versus Unionismo) como formas de eliminar a ocorrência de novas Guerras na Europa e, posteriormente, no mundo.

A segunda parte trata de elementos fundamentais do pensamento político de Claude Lefort diante das preocupações políticas anti-totalitárias de seu tempo. Com isso enfatiza, no interior do pensamento desse autor, o papel atribuído ao Direito na formatação para a conservação de regimes Políticos. A análise do pensamento lefortiano permitirá estabelecer o conceito de Política como "medida de politicidade" de arranjos institucionais, conforme a qualidade do desenho jurídico a ele conferido em torno da ideia do esvaziamento normativo do Direito.

A terceira parte apresenta o pensamento de Hans Kelsen em sua obra A Pazpelo Direito, de 1944, texto em que o autor propõe, com base em preceitos de sua obra Teoria Pura do Direito $(1934,1960)^{1}$, uma solução jurídica para o problema da construção da Paz Internacional (Juridificação).

Por fim, com base na consideração da "medida de politicidade" e do conceito de Política estabelecidos anteriormente, bem como do contexto dos debates políticos em que o autor escreve, a quarta parte apresentará solução institucional de Hans Kelsen como detentora de um específico sentido político no contexto interna-

1 Razão pela qual aspectos pontuais dessa obra serão rapidamente mencionados nesse texto, naquilo que auxiliarem na construção argumentativa em torno da proposta kelseniana de Paz pelo Direito. cional europeu da época (rejeição do Federalismo) vinculado ao esvaziamento normativo do Direito. E, desse modo, com base na compreensão lefortiana do projeto kelseniano, será possível perceber que a proposta institucional jurisdicional internacional de Hans Kelsen guarda consigo um sentido político não adequadamente salientado pela literatura jurídica.

Ao recusar a solução Federalista, a Juridificação kelseniana das relações internacionais deteria virtude política precisamente por operar, por meio da técnica jurídica, um inovador esvaziamento normativo político e econômico do Direito Internacional. O sentido Político da proposta kelseniana derivara do esforço em construir um ambiente institucional permanente de convivência não-armada - mas simbolicamente conflituoso, em torno da linguagem jurídica da não-violência — entre diferentes. Tratar-se-ia da promoção de um esvaziamento normativo no centro nomogenético voltado, por sua vez, a instaurar lefortianamente a Política por meio do Direito (Internacional Público) nas relações internacionais.

\section{NarRativas POLÍticas EUROPEIAS dO PÓS-SEGUNDA GUERRA MUNDIAL E A DISPUTA CONCEITUAL PELA PAZ INTERNACIONAL}

O período do pós-Segunda Guerra Mundial é usualmente compreendido como inserto em tensão jurídico-política específica. Com a destruição da Europa após as duas Guerras Mundiais, houve uma reordenação das relações internacionais em torno da oposição de modelos de produção econômica e de modelos de vida política portados e representados por duas grandes potências: os Estados Unidos da América e a União das Repúblicas Socialistas Soviéticas, no período conhecido como sendo o da Guerra Fria².

2 A Conferência de Yalta de 1945, na Crimeia, teria sido símbolo dessa modificação de eixo político internacional: não mais a tensão entre países europeus, mas a oposição econômica, política e jurídica entre estadunidenses e soviéticos. Nesse sentido, v. BERSTEIN, Serge; MILZA, Pierre. Histoire de l'Europe contemporaine: de l'héritage de xixe siecle a l'europe d'aujourd'hui. Paris: Hatier, 2002. p. 220-223; BITSCH, Marie-Thérèse. Histoire de la construction européenne: de 1945 a nos jours. Bruxelles : Complexe, 2006. p. 26; 31-32, MATTERA, Alfonso. De la deuxieme guerre mondiale au «projet européen» de Jean Monnet. Revue du Droit de l'Union Européenne, n. 1, p. 5-33, 2002. p. 134-135. 
Todavia, apesar da relevância desse conflito jurídico, político e econômico para o continente europeu, os anos seguintes, ao final da Segunda Guerra Mundial na Europa, foram marcados por uma discussão fundamental em torno do futuro da Europa, a saber, quais seriam os mecanismos jurídico-institucionais mais adequados para impedir a deflagração de novas guerras entre os países europeus: Federalismo ou Unionismo?

Desde o final da Primeira Guerra Mundial, houve clara preocupação em diferentes círculos europeus com a construção da Paz na Europa. Ao menos, cinco nomes podem ser mencionados: Louise Weiss e seu periódico Nova Europa (1918-1934), Richard Coudenhove-Kallergi e suas obras Pan-Europa (1923), A Luta pela Europa (1931) e Europa Unida (1939), Gaston RIOU e suas obras Europa, minha Pátria (1928) e Unir-se, ou Morrer (1929), Aristide BRIAND e seus dois discursos perante a Assembleia Geral da Sociedade das Nações - o Discurso para a União Europeia (1929) e o Discurso à Terceira Sessão Plenária (1930), além de seu Memorandum sobre a Organização de um Regime Federal Europen (1930), redigido em conjunto com Alexis Léger.

Apesar da importância desses primeiros discursos no início do século XX para fomentar e consolidar a percepção acerca da importância de uma Europa Unida jurídica e politicamente para evitar o cometimento de novas guerras, nenhum deles encontrou ressonância institucional no período. Foi apenas com o final da Segunda Guerra Mundial que as perspectivas suscitadas pelos autores foram reabertas na História das Ideias para sustentar a formação de projetos de desenhos institucionais inovadores comprometidos com a formação de uma união da Europa.

As narrativas do pós-Segunda Guerra Mundial preocupadas em unir países Europeus com o objetivo de afastar a possibilidade de novas guerras podem ser organizadas em dois movimentos: o Unionismo e o Federalismo. Estes foram as principais fontes de propostas institucionais concretas voltadas a estabelecer marcos jurídico-políticos para a construção da Paz na Europa e no mundo ${ }^{3}$.

3 BITSCH, Marie-Thérèse. Histoire de la construction européenne: de 1945 a nos jours. Bruxelles : Complexe, 2006. p. 47; CASELLA, Paulo Borba. Comunidade européia e seu ordenamento jurídico. São Paulo: LTr, 1994. p. 77; 84; MATTERA, Alfonso. De la deuxieme guerre mondiale au «projet européen» de Jean Monnet. Revue du Droit de l'Union Européenne, n. 1, p. 5-33, 2002. p. 17-18; MAZOWER, Mark. Dark continent: Europe's twentieth century. London: Penguin, 1998. p. 202-
O Unionismo entendia que, para alcançar a Paz na Europa e no mundo, bastaria estabelecer uma cooperação intergovernamental (política, econômica, militar, entre outras) entre países europeus dentro de uma Organização Internacional — seria assim desnecessário macular o dogma intangível da vontade estatal soberana. Por outro lado, o Federalismo Europeu afirmava que a Paz na Europa e no mundo seria encontrada apenas por meio da adoção de um Estado Federal Europeu — e posteriormente mundial — fundado em Direitos Humanos e Democracia.

Nesse sentido, para o Unionismo, a Paz seria construída por uma Organização Internacional de cooperação intergovernamental, a qual teria como marca institucional fundamental a limitação de suas ações pela Soberania estatal em temas políticos, econômicos, militares, entre outros. Por seu turno, para o Federalismo, a Paz somente seria possível mediante a eliminação imediata da soberania estatal por meio de um Estado Federal Europeu - e depois mundial, o qual substituiria os Estados-nacionais.

Note-se que a primeira proposta tinha por base concepção clássica de Direito Internacional Público, a qual compreende ser a vontade dos Estados o fundamento nomogenético fundamental da vida jurídica internacional. Por esse motivo, para essa perspectiva, o formato jurídico-político do arranjo institucional adequado para aproximar os países deveria ser o de adoção de institutos de cooperação ciosos reciprocamente da Soberania dos Estados.

Ao mesmo tempo, a segunda proposta afastava o Direito Internacional Público como mecanismo apto a construir formas jurídico-institucionais inovadoras de convivência entre os países europeus. Com efeito, ela indicava a necessidade de se constituir um Direito estatal federal que unificasse os países dentro de uma

204; MORAVCSIK, Andrew. The choice for Europe: social purpose and state power from messina to maastricht. London: Routledge, 2005. p. 70; CUNHA, Paulo de Pitta e. Direito institucional da União Européia. Coimbra: Almedina, 2004. p. 38; QUADROS, Fausto de. Direito das comunidades europeias: contributo para o estudo da natureza jurídica do direito comunitário europeu. Lisboa: Almedina, 1984. p. 117; QUERMONNE, Jean-Louis. L'Union Européenne dans le temps long. Paris: SciencesPo, 2008. p. 23; QUERMONNE, Jean-Louis. Le système politique de l'Union Européenne. 8 ed. Paris: Montchrestien, 2010. p. 10-13; RÉAU, Élisabeth du. L'idée d'Europe an XXème siecle: des mythes aux réalités. Bruxelles: Complexe, 2008. p. 167; ROLLAND, Patrice. L'unité politique de l'Europe: histoire d'une idée. Bruxelles: Bruylant, 2006. p. 487; 523; 557. 
arquitetura jurídico-política de um Estado dotado de instrumentos coercitivos que se sobrepusessem à Soberania estatal ${ }^{4}$.

\section{Claude Lefort e o vazio normativo do DIREITO POLÍTICO}

\subsection{A herança totalitária do pós-segunda guer- ra mundial}

No prefácio da primeira edição de sua obra Teoria Pura do Direito, datado de 1934, Hans Kelsen notou que a Primeira Guerra Mundial havia feito o mundo "saltar dos eixos, [pois] as bases da vida social foram profundamente abaladas e, por isso, as oposições dentro dos

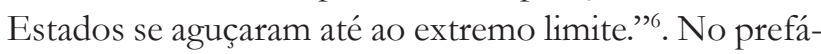
cio da segunda edição da mesma obra, datado de 1960, Hans Kelsen nota que "as coisas não se modificaram muito depois da Segunda Guerra Mundial e das convulsões políticas que dela resultaram."’

O grande embate ideológico do período era a contínua preocupação mundial em alinhar os países em torno de uma entre duas perspectivas - já anunciadas no pós-Primeira Guerra Mundial, mas reforçadas no pós-Segunda Guerra Mundial, com a Conferência de Yalta ${ }^{8}$ : Capitalismo versus Socialismo. Em seu Prefácio à obra Paz pelo Direito, Hans Kelsen reconhece ser essa uma das questões mais candentes de seu tempo — tão forte que infelizmente fazia ignorar a importância da discussão mais fundamental sobre o melhor arranjo jurídico internacional para garantir a Paz Internacional ${ }^{9}{ }^{10}$.

4 GIANNATTASIO, Arthur Roberto Capella. A integração como fenômeno jurídico-político: uma leitura sobre a construção histórica da CECA. 2013. 885. Tese (Doutorado) - Faculdade de Direito do Largo de São Francisco, Universidade de São Paulo, São Paulo, 2013. p. 371-374.

5 É nesse contexto de embates de ideias que escreve Hans Kelsen sua proposta de Paz Internacional pelo Direito, como forma de se opor ao Projeto Federalista. Como o autor examinado se coloca claramente contra este, elementos adicionais do pensamento Federalista serão apresentados a seguir, no item 5.2, infra, como forma de compreender mais completamente a proposta kelseniana.

6 KELSEN, Hans. Teoria pura do direito. 6 ed. São Paulo: M. Fontes, 2000. p. XIV.

7 KELSEN, Hans. Teoria pura do direito. 6 ed. São Paulo: M. Fontes, 2000. p. XVIII.

8 Mencionada no item 2., supra.

9 KELSEN, Hans. A pazpelo direito. São Paulo: M. Fontes, 2011. p. XII.

10 A ser evidenciado no item 4, infra.
Essa discussão sobre as formas jurídico-políticas estatais se mostrava relevante no pós-Segunda Guerra Mundial. Vencido o regime totalitário nazista, a preocupação fundamental do pensamento político desse período consistia em assegurar mecanismos que impedissem a re-instauração de formas novas de dominação totalitária. E esse é precisamente o centro da preocupação do pensamento político de Claude Lefort, na medida em que sua reflexão está voltada a compreender o papel de instituições jurídicas na construção de uma organização jurídico-política desprovida da marca da opressão totalitária $^{11}$.

Desde Hannah Arendt ${ }^{12}$ se reconhece que a experiência totalitária nazista foi produto de uma reorganização jurídico-institucional da ordem política da Alemanha que implicou a retirada jurídica da condição de cidadão dos judeus alemães. A retirada do direito a ter direitos teria sido a origem jurídica da prática de todas as barbaridades contra judeus, na medida em que se eliminara a possibilidade de oposições políticas entre diferentes modos de habitar o mundo na formulação de normas jurídicas e de decisões políticas fundamentais.

Do mesmo modo, Claude Lefort nota que a tendência à realização do mesmo tipo de injustiça totalitária poderia ser verificada no século XX, seja na realização do Socialismo pelo regime soviético, seja na promessa de liberdade capitalista das Democracias liberais.

Se, por um lado, dissidentes nacionais de países componentes da União das Repúblicas Socialistas Soviéticas (Hungria, Polônia, Tchecoslováquia, entre outros) haviam sido continuamente impedidos de manifestar na esfera pública sua insatisfação com o regime central mediante violenta e ostensiva repressão, por outro lado, o Capitalismo das Democracias liberais teria constituído estruturas burocráticas de uma sociedade industrial que igualmente poderiam ensejar uma sutil e paulatina reentrada da lógica totalitária por mecanismos distintos - responsáveis pela dulcificação de formas outras de dominação e pelo progressivo desinteresse social espontâneo pela condução da vida política ${ }^{13}$.

11 LEFORT, Claude. Droit International, Droits de l'Homme et Politique. In:_. Le temps present: écrits 1945-2005. Paris: Belin, 2007. p. 1019-1036. p. 1024.

12 ARENDT, Hannah. Origens do totalitarismo: anti-semitismo, imperialismo, totalitarismo. São Paulo: Companhia das Letras, 2004.

13 LEFORT, Claude. Éléments d'une critique de la bureaucratie. Paris: Gallimard, 1979; LEFORT, Claude. Permanência do teológicopolítico? In: Pensando o político: ensaios sobre democracia, 
Assim, apesar de a dominação totalitária nazista ter sido vencida e repudiada pelo pós-Segunda Guerra Mundial, Claude Lefort diagnostica que os dois regimes jurídico-políticos de seu tempo apresentavam elementos que poderiam ensejar a reintrodução do totalitarismo na condução da vida pública — justificando, assim, o temor kelseniano acima apontado de instabilidades nacional e internacional derivadas das disputas pelo centro no lugar do Poder em cada Estado-nacional e no mundo.

Nesse sentido, Claude Lefort busca critérios que lhe permitam compreender como instituições jurídicas podem contribuir para a construção de um regime de liberdade — isto é, não totalitário — independentemente de um prévio conteúdo normativo político e econômico (Socialismo ou Capitalismo). É dentro desse eixo de preocupações que ele estabelece uma distinção entre regimes juridicamente organizados para a Política e regimes formatados segundo uma diretriz Teológico-Política.

\subsection{O esvaziamento normativo como técnica jurídica da política}

Enquanto roupagem linguística-normativa do projeto político de determinada sociedade, o Direito é índice da maneira pela qual se optou por definir juridicamente o estatuto político de uma sociedade. Em outras palavras, as instituições desenhadas com base na linguagem jurídica designam, por esse preciso arranjo institucional, a formatação escolhida por cada sociedade para a dinâmica a ser adotada nos processos decisórios normativos que se desenvolvem no lugar do Poder.

Assim, é por meio da definição jurídico-institucional da dinâmica que rege a ocupação do lugar do Poder (centro nomogenético) que se permite compreender a forma política adotada por cada sociedade — ou ainda, seu regime político - para reger sua vida pública entre diferentes posições normativas possíveis ${ }^{14}$. O Direito assume, nesse sentido, um papel fundamental na estru-

revolução e liberdade. São Paulo: Paz e Terra, 1991. p. 249-296; LEFORT, Claude. O nome de um. In: CLASTRES, Pierre; LEFORT, Claude; CHAUÍ, Marilena. Discurso da servidão voluntária. São Paulo: Brasiliense, 1999. p. 125-171; e LEFORT, Claude. Repenser la démocratie. In: L Le temps present. écrits 1945-2005. Paris: Belin, 2007. p. 341-346. p. 341-346.

14 LEFORT, Claude. Permanência do teológico-político? In: Pensando o político: ensaios sobre democracia, revolução e liberdade. São Paulo: Paz e Terra, 1991. p. 249-296; p. 262-263. turação da maneira pela qual o regime político tratará o tema da presença ou ausência prévia de posições normativas no centro nomogenético.

Em um regime juridicamente estruturado em uma formatação Política (regime jurídico-Político), o lugar do Poder permanece sempre como um lugar vazio. Este exige uma periódica tensão entre as diferentes posições normativas, de modo a que nenhuma se enraíze no lugar do Poder e com ele se torne Um — ou ainda, de modo que nenhuma posição normativa (política, econômica, cultural, entre outros) se identifique com ele intemporalmente ${ }^{15}$.

Por outro lado, em um regime juridicamente estruturado em uma formatação Teológico-Política (regime jurídico-Teológico-Político), o lugar do Poder jamais se apresenta como um lugar vazio. Ele é previamente ocupado por uma medida normativa que incorpora em si o Poder e que passa a ditar, com base em sua única dimensão existencial, as regras destinadas a reger a vida comum $^{16}$.

Um regime jurídico-Político é caracterizado, desse modo, por um centro nomogenético permanentemente vazio. Esse centro de produção de decisões políticas fundamentais é esvaziado continuamente de prévias posições normativas (políticas, econômicas, culturais, entre outro), pois se reconhece o benefício da ininterrupção das tensões entre as mais plurais formas de se habitar o mundo.

Nesse regime Político, o Direito é percebido como forma de instigação contínua de oposições entre escalas de existência, ou ainda, como fonte de estímulo à nega-

15 A Política não tem, aqui, qualquer relação com a noção de "politicagem", ou barganha de interesses, mas sim com as regras de formatação da vida pública de uma sociedade.

16 LEFORT, Claude. Éléments d'une critique de la bureaucratie. Paris: Gallimard, 1979. p. 25; LEFORT, Claude. Le travail de l'oenvre machiavel. Paris: Gallimard, 1986. p. 735; LEFORT, Claude. Permanência do teológico-político? In: __ Pensando o político: ensaios sobre democracia, revolução e liberdade. São Paulo: Paz e Terra, 1991. p. 249-296; LEFORT, Claude. Machiavel et la veritá effetuale. In: _. Écrire: à l'épreuve du politique. Paris: Calmann-Lévy, 1992. p. 141-179. p. 149; LEFORT, Claude. Entretien avec l'antimythes. In: Le temps present. écrits 1945-2005. Paris: Belin, 2007. p. 223-260. p. 246; LEFORT, Claude. Repenser la démocratie. In: _. Le temps present. écrits 1945-2005. Paris: Belin, 2007. p. 341-346. p. 342; LEFORT, Claude. Aperçu d'un itinéraire: entretien avec Pierre Rosanvallon et Patrick Viveret. In: __. Le temps present. écrits 1945-2005. Paris: Belin, 2007. p. 347-357. p. 351; e LEFORT, Claude. Repenser le politique: entretien avec E. A. El Maleh. In:_Le temps present. écrits 1945-2005. Paris: Belin, 2007. p. 359-367. p. 361. 
tividade mútua entre as diferentes posições normativas, detendo como objetivo a manutenção de um centro normativo vazio. A permanente instabilidade de soluções normativas é o objetivo das instituições jurídicas de formatação da vida pública, as quais são avessas a uma cristalização de autoridade única sobre os demais ${ }^{17}$.

Um regime jurídico-Teológico-Político é caracterizado, por seu turno, por um centro nomogenético permanentemente ocupado de maneira prévia por alguma medida normativa tutora dos Homens (Deus, Homem-Deus, razão de Estado, Revolução, proletariado, razão econômica, entre outros), a qual não admite ser desconsiderada. Ela é compreendida e se afirma como a única escala dotada de legitimidade para proferir, de forma homogênea, um discurso normativo sobre a totalidade social.

Nesse regime Teológico-Político, o Direito é utilizado como instrumento de recusa da negação em nome da conservação permanente da posição normativa que se estabeleceu no lugar do Poder. Ele é utilizado como mecanismo para abafamento e repressão violenta da pluralidade escalar em favor da regra de normalidade estabelecida pela posição normativa enraizada no lugar do Poder. Esta se eleva sobre todas as demais posições normativas possíveis, totaliza-se no centro nomogenético como única medida possível e lidera um projeto de unidimensionalização do social com base em sua própria escala de existência ${ }^{18}$.

17 LEFORT, Claude. Éléments d'une critique de la bureaucratie. Paris: Gallimard, 1979. p. 324; 329; 348; LEFORT, Claude. Le travail de l'oeuvre machiavel. Paris: Gallimard, 1986. p. 727-728; LEFORT, Claude. Permanência do teológico-político? In: Pensando o politico: ensaios sobre democracia, revolução e liberdade. São Paulo: Paz e Terra, 1991. p. 249-296. p. 262-268; LEFORT, Claude. Machiavel et la veritá effetuale. In: ___ Écrire: à l'épreuve du politique. Paris: Calmann-Lévy, 1992. p. 141-179. p. 145; LEFORT, Claude. Entretien avec l'anti-mythes. In: Le temps present. écrits 1945-2005. Paris: Belin, 2007. p. 223-260. p. 252; LEFORT, Claude. Aperçu d'un itinéraire: entretien avec Pierre Rosanvallon et Patrick Viveret. In: _. Le temps present. écrits 1945-2005. Paris: Belin, 2007. p. 347-357. p. 350; 355-356; LEFORT, Claude. Repenser le politique: entretien avec E. A. El Maleh. In: écrits 1945-2005. Paris: Belin, 2007. p. 359-367. p. 361.

18 LEFORT, Claude. Éléments d'une critique de la bureaucratie. Paris: Gallimard, 1979. p. 25; 328-330; LEFORT, Claude. Permanência do teológico-político? In: Pensando o político: ensaios sobre democracia, revolução e liberdade. São Paulo: Paz e Terra, 1991. p. 249-296; LEFORT, Claude. Machiavel et la veritá effetuale. In: . Écrire: à l'épreuve du politique. Paris: Calmann-Lévy, 1992. p. 141-179. p. 149, LEFORT, Claude. Entretien avec l'anti-mythes. In: _L Le temps present: écrits 1945-2005. Paris: Belin, 2007. p. 223-260. p. 237-239; 246-249; LEFORT, Claude. Aperçu d'un
Nem o regime jurídico-Político, nem o regime jurídico-Teológico-Político são desprovidos de politicidade; afinal, ambos são espécies do gênero de regimes políti$\cos (\text { politeia })^{19}$. Em outras palavras, todo regime jurídico-Político e todo regime jurídico-Teológico-Político é um regime jurídico-político, mas nem todo regime jurídico-político (politeia) é um regime jurídico-Político ${ }^{20}$. Todavia, é somente no regime jurídico-Político que se revela a "medida da politicidade" por excelência, isto é, apenas o regime jurídico-Político que detém uma disposição jurídico-institucional excelente que de maneira mais perfeita realiza a "politicidade" 21 , pois nele

[a] ordem social [...] já não está ligada ao poder criador de um personagem excepcional, à sua atividade de ordenador. É a ordem, ao contrário, que regula o poder de todos [...], que impõe um limite à sua vontade de expansão. A ordem é primeira em relação ao poder. A arché pertence na realidade exclusivamente à lei. [...] Toda facção que pretende assegurar-se o monopólio da arché ameaça, por esse golpe contra o equilíbrio das outras forças, a homónoia do corpo social e põe em risco, com isso, a própria existência da cidade. ${ }^{22}$

Observe-se que o Direito é percebido em Claude Lefort como peça fundamental para impactar nos níveis de realização de maior ou menor liberdade política ${ }^{23}$, in-

itinéraire: entretien avec Pierre Rosanvallon et Patrick Viveret. In: Le temps present. écrits 1945-2005. Paris: Belin, 2007. p. 347357. p. 351ç; e LEFORT, Claude. Repenser le politique: entretien avec E. A. El Maleh. In:__. Le temps present. écrits 1945-2005. Paris: Belin, 2007. p. 359-367. p. 362.

19 Como ressalta CARDOSO, Sérgio. Que república? notas sobre a tradição do "governo misto". In: BIGNOTTO, Newton (Org.). Pensar a república. Belo Horizonte: Universidade Federal de Minas Gerais, 2002. p. 27-48. p. 31, há sempre uma confusão inicial quando se refere ao termo "político". Derivado do grego politeia, indica simultaneamente "O gênero dos regimes políticos, [e] uma de suas formas específicas, aquela, justamente, cuja disposição excelente para a realização de sua natureza política, permite assinalá-la com a denominação do gênero.".

20 Nesse sentido, a importância neste texto da distinção gráfica do gênero politeia com "p" minúsculo (regime jurídico-político) e da espécie da Política com "P" maiúsculo (regime jurídico-Político). 21 CARDOSO, Sérgio. Que república? notas sobre a tradição do "governo misto". In: BIGNOTTO, Newton (Org.). Pensar a república. Belo Horizonte: Universidade Federal de Minas Gerais, 2002. p. 27-48. p. 31-32; e ainda LEFORT, Claude. Éléments d'une critique de la bureaucratie. Paris: Gallimard, 1979. p. 125; LEFORT, Claude. Machiavel et la veritá effetuale. In: ___ Écrire: à l'épreuve du politique. Paris: Calmann-Lévy, 1992. p. 141-179. p. 174-176; LEFORT, Claude. Aperçu d'un itinéraire: entretien avec Pierre Rosanvallon et Patrick Viveret. In: ___. Le temps present. écrits 1945-2005. Paris: Belin, 2007. p. 347-357. p. 350.

22 VERNANT, Jean-Pierre. As origens do pensamento grego. 3 ed. São Paulo: Difel, 1981. p. 47.

23 Lembre-se a ressalva feita por WOLFF, Francis. Aristóteles e a 
dependentemente de qualquer prévia opção normativa (política e econômica) - o mesmo ocorrendo com o Direito Internacional Público ${ }^{24}$. Seu papel consistiria em reintroduzir constantemente a pluridimensionalidade da condição humana nos centros de produção normativa e decisória fundamentais e impedir que qualquer um conseguisse se introduzir e se manter com exclusividade no lugar do Poder.

Assim, o vazio juridicamente instaurado em um regime Político teria por objetivo manter permanentemente aberto o centro nomogenético, a fim de que a solução de conflitos escalares fosse viabilizada por meio da estabilidade harmoniosa das instituições, a qual seria constituída e conservada por normas jurídicas positivas. A liberdade apenas seria assegurada por meio de um Direito preocupado em manter um regime Político, isto é, um regime cujo centro nomogenético estaria permanentemente aberto à dissensão e à discórdia estável dentro das instituições.

Por isso, o Direito operaria como estrutura elementar de organização jurídica de uma vida pública conforme a liberdade, ou ainda, um instrumento direcionado para estruturar uma convivência harmônica entre diferentes por meio da Política - o campo do "comum" onde o conjunto das " "atividades e práticas [...] devem ser partilhadas, isto é, [...] não devem ser o privilégio exclusivo de ninguém."”25. Com isso, o Direito se apresenta como um Direito Político, isto é, como um Direito detentor do papel de fundar a Política, ou ainda, de dispor de instituições jurídicas aptas a instaurar um regime de convivência entre diferentes. Esse regime deve ser juridicamente regulamentado para permitir um sistema de relações fundado na liberdade e capaz de impedir o desencadeamento de ações mutuamente destrutivas ${ }^{26}$.

política. São Paulo: Discurso, 1999. p. 7, sobre o uso do grego para designar termos de base da Política: "Já se conseguiu dizer que a filosofia fala grego. É possível. Em todo caso, é certo que a política, sim, fala grego. Não se pode, com efeito, falar de política sem a língua grega: 'tirania', 'monarquia', 'oligarquia', 'aristocracia, 'plutocracia', 'democracia'... todo o nosso vocabulário político saiu dela. E, em primeiro lugar, a própria palavra política. A palavra tanto quanto a coisa. [...]. A política é a prática da polis que se tornou consciente de si própria, ou, inversamente, a investigação sistemática aplicada à polis. É, numa palavra, o livre pensamento de uma vida livre.".

24 LEFORT, Claude. Droit International, Droits de l'Homme et Politique. In:_. Le temps present. écrits 1945-2005. Paris: Belin, 2007. p. 1019-1036. p. 1034-1036.

25 WOLFF, Francis. Aristóteles e a política. São Paulo: Discurso, 1999. p. 10-1.

26 Nesse sentido, v. CARDOSO, Sérgio. Por que república? notas sobre o ideário democrático e republicano. In: (Org.).
O bloqueio do princípio de dominação e de escalada mutuamente destrutiva se daria precisamente pela imediata exclusão de qualquer Um do centro nomogenético. Isso seria possível apenas mediante o uso de técnicas jurídicas voltadas continuamente a (i) esvaziar o centro de produção do Direito de qualquer posição normativa prévia que se pretendesse única, exclusiva e total e (ii) impor que nem um, nem outro, pudesse decidir segundo sua única medida normativa de existência uma regra única das relações.

É precisamente essa compreensão lefortiana da Política que será utilizada a seguir para compreender a proposta kelseniana da Paz pelo Direito — por um Direito (Internacional Público) de caráter Político, ainda, por um Direito (Internacional) Político.

\section{A JURIDIFICAÇÃo dA PAZ INTERNACIONAL EM Hans Kelsen}

\subsection{A razão prática da razão pura kelseniana: direito como técnica social politicamente indepen- dente}

Publicado em 1934, o prefácio da Primeira Edição da obra Teoria Pura do Direito de Hans Kelsen reconhecia que as críticas dirigidas a sua obra derivavam, não dos preceitos Modernos de neutralidade e independência políticas da Ciência (Teoria do Conhecimento e Filosofia da Ciência), mas da preocupação - ainda que de boa-fé - em não querer/conseguir separar Política e Direito. A percepção da Ciência Jurídica insistia em pretender observar na estrutura jurídica a presença de determinada narrativa política de conteúdo religioso, nacional ou de classe ${ }^{27}$, de modo a desvelar alguma parcialidade oculta pelo pensamento jurídico.

Nesse sentido, as críticas endereçadas à proposta teórica pura kelseniana buscavam apontar nela a suspei-

Retorno ao republicanismo. Belo Horizonte: Universidade Federal de Minas Gerais, 2004. p. 45-66. p. 50, LEFORT, Claude. Permanência do teológico-político? In: Pensando o político: ensaios sobre democracia, revolução e liberdade. São Paulo: Paz e Terra, 1991. p. 249-296; VERNANT, Jean-Pierre. As origens do pensamento grego. 3 ed. São Paulo: Difel, 1981. p. 71; e WOLFF, Francis. Aristóteles e a política. São Paulo: Discurso, 1999. p. 7.

27 KELSEN, Hans. Teoria pura do direito. 6 ed. São Paulo: M. Fontes, 2000. p. XII. 
ção de presença de resquícios de qualquer espécie de orientação política:

\begin{abstract}
mas qual das afirmações é verdadeira? Os fascistas declaram-na liberalismo democrático, os democratas liberais ou os sociais-democratas consideram-na um posto avançado do fascismo. Do lado comunista é desclassificada como ideologia de um estatismo capitalista, do lado capitalista-nacionalista é desqualificada, já como bolchevismo crasso, já como anarquismo velado. O seu espírito é - asseguram muitos - aparentado com a da escolástica católica; ao passo que outros creem reconhecer nela as características distintivas de uma teoria protestante do Estado e do Direito. E não falta também quem a pretenda estigmatizar com a marca de ateísta. Em suma, não há qualquer orientação política de que a Teoria Pura do Direito não se tenha ainda tornado suspeita ${ }^{28}$.
\end{abstract}

O final do mesmo prefácio anuncia ser o principal objetivo do autor garantir à Ciência do Direito a independência política necessária para impedir a introdução de conteúdos normativos predeterminados que tornassem o conhecimento jurídico instrumento de qualquer ideologia social. Longe de se tratar de um objetivo derivado de uma intencionalidade de razão pura, a pretensão kelseniana se reveste de caráter racional fundamentalmente prático. Não se tratava de equiparar as Ciências Sociais às Ciências Naturais - como ressalta o próprio autor, ainda no mesmo prefácio, mas sim em ser uma força social intelectual propulsora de sua independência técnica em relação a outras tecnologias de dominação social ${ }^{29}$.

Com efeito, a independência política do conhecimento jurídico seria a única maneira de permitir o progresso de uma técnica jurídica livre ${ }^{30}$. Isso significaria permitir ao Direito que operasse como mecanismo estrutural de convivência mediada de diferentes em sociedade $^{31}$. Ou ainda, nas palavras de Hans Kelsen ${ }^{32}$, como "força social que p[udesse] contrabalançar os interesses

28 KELSEN, Hans. Teoria pura do direito. 6 ed. São Paulo: M. Fontes, 2000. p. XIII.

29 KELSEN, Hans. Teoria pura do direito. 6 ed. São Paulo: M. Fontes, 2000. p. XIV.

30 Livre das clivagens ideológicas fundamentais do pós-Primeira Guerra Mundial, as quais foram mencionadas supra: no âmbito internacional, a oposição entre Federalismo e Unionismo (item 1.), e, no plano nacional, a oposição entre Socialismo e Capitalismo/ Democracias Liberais (item 3.).

31 Nesse sentido, v. CASELLA, Paulo Borba. ABZ: ensaios didáticos. São Paulo: Imprensa Oficial do Estado, 2009. p. 49; e, d CASELLA, Paulo Borba. Prefácio. In: SETTE-CAMARA, José. Poluição de rios internacionais. São Paulo: Quartier Latin, 2011. p. 1119. p. 17.

32 KELSEN, Hans. Teoria pura do direito. 6 ed. São Paulo: M. Fontes, 2000. p. XIV. poderosos [tanto d]aqueles que detêm o poder como aqueles que ainda aspiram ao poder".

O objetivo da pureza se mostra assim como técnica social institucional de contenção da Política fora da determinação do conteúdo normativo do Direito (esvaziamento), de tal forma que o Direito se apresentasse como instrumento de paralisia dos interesses dos poderosos, uma técnica a favor da retirada de qualquer unidimensionalidade do centro normativo.

Datado de 1960, o prefácio da Segunda Edição da mesma obra Teoria Pura do Direito reconhece que os tumultos políticos na Europa não haviam se esgotado no entreguerras e no pós-Segunda Guerra Mundial. Persistia, segundo o autor, a procura em introduzir no Direito conteúdos políticos voltados a afirmar um único Direito como justo, com base em critério de valor predeterminado para o Direito positivo por uma ou outra ideologia social ${ }^{33}$.

Em outras palavras, o autor constatara que, ainda naquele momento, se percebia a busca por corporificar Um único político no Direito. Afinal, o Direito não conseguira ainda se firmar como técnica social estrutural independente dos jogos dos poderosos, a fim de viabilizar a convivência entre diferentes. Dito de outro modo, objeto de disputas por ideologias unidimensionalizantes de dominação social, o Direito ainda não teria conseguido se afirmar como técnica elementar que repudiasse de dentro de si um único centro normativo predeterminado por uma narrativa política específica.

Desse modo, o autor propugna pela necessidade de afirmação do Direito como instrumento institucional de esvaziamento de referenciais normativos prévios. Sua independência político-normativa - ausência de definição prévia de conteúdo normativo dado por uma única e unilateral perspectiva política - seria a chave para garantir o estabelecimento da Política, a virtude da convivência não-armada entre diferentes ${ }^{34}$. O Direito - e o Direito Internacional Público - como centro

33 KELSEN, Hans. Teoria pura do direito. 6 ed. São Paulo: M. Fontes, 2000. p. XVIII.

34 Trata-se, inclusive, da misteriosa virtude da Política, ressaltada no item 4., supra, frequentemente apontada por VERNANT, JeanPierre. As origens do pensamento grego. 3 ed. São Paulo: Difel, 1981. p. 31: "como a ordem pode nascer do conflito entre grupos rivais, do choque das prerrogativas e das funções opostas? Como uma vida comum pode apoiar-se em elementos discordantes? $\mathrm{Ou}$ - para retomar a própria fórmula dos Órficos - como, no plano social, o uno pode sair do múltiplo e o múltiplo do uno?". 
normativamente esvaziado por técnica jurídica não seria veículo de imposição de uma ideologia sobre outra Direito como técnica, mas sem conteúdo.

\subsection{O esvaziamento da política pela juridifica- ção internacional da paz}

Em seu prefácio à obra Pazpelo Direito (1944), Hans Kelsen declara ter sido a insensatez nacionalista responsável pela deflagração das duas Guerras Mundiais no início do século XX. Segundo sua perspectiva, mais importante do que optar nacional ou internacionalmente por um modo de produção econômico Capitalista ou Socialista, o mundo deveria se preocupar em encontrar condições jurídicas para a construção e manutenção da Paz mundial ${ }^{35}$.

Nesse sentido, segundo sua perspectiva, a Ciência do Direito e os juristas deveriam se preocupar em contribuir para um problema mais relevante: aperfeiçoar a técnica social que regula as relações internacionais - o Direito Internacional Público - para afastar o cometimento de novas Guerras. Apenas por meio do aprimoramento da técnica utilizada por esse Direito específico das relações internacionais é que se mostraria possível criar condições institucionais reais de possibilidade de construção e manutenção da Paz mundial ${ }^{36}$.

O centro da proposta kelseniana reside em reconhecer que as duas louváveis propostas apresentadas até o momento, apesar de bem-intencionadas, não conferiam nada mais do que um "pacifismo utópico [...] grave[mente] perigo[so]" ${ }^{37}$ : "o sonho de um Estado Mundial", o qual seria "demais", e a cooperação intergovernamental política no interior de uma Organização Internacional semelhante à "Liga das Nações", a qual fora "muito pouco"38. A primeira iniciativa se encontra na lógica da Federalista, enquanto a segunda está inserida, por sua vez, na narrativa Unionista ${ }^{39}$.

Para além do binômio Federalista e Unionista, o autor apresenta em sua obra dois mecanismos jurídicos

35 KELSEN, Hans. A parpelo direito. São Paulo: M. Fontes, 2011. p. XI-XII.

36 KELSEN, Hans. A pazpelo direito. São Paulo: M. Fontes, 2011. p. XII-XIII.

37 KELSEN, Hans. A paqpelo direito. São Paulo: M. Fontes, 2011. p. XII.

38 KELSEN, Hans. A pazpelo direito. São Paulo: M. Fontes, 2011. p. XII.

39 Como visto no item 2., supra. inovadores: (i) a paz garantida pela perenização institucional da responsabilidade internacional de indivíduos em virtude de violação de Direito Internacional Públi$\mathrm{CO}^{40}$, (ii) a paz garantida por um Tribunal Internacional dotado de jurisdição compulsória no interior de uma Organização Internacional. Para o autor, a introdução de tais mecanismos no Direito Internacional Público seria a solução institucional para assegurar, pelo Direito, a Paz nas relações internacionais ${ }^{41}$.

40 Uma novidade no discurso jurídico internacional à época, pois se compreendia que apenas Estados poderiam ser considerados internacionalmente responsáveis perante o Direito Internacional Público, pois apenas estes eram sujeitos de Direito Internacional Público. Hans Kelsen argumenta que, até aquele momento, apenas em casos isolados - como pirataria ou violação de bloqueio e transporte de artigos contrabandeados — havia uma aceitação da responsabilidade internacional de indivíduos (KELSEN, Hans. A paz pelo direito. São Paulo: M. Fontes, 2011. p. 69-70). A ideia defendida pelo autor - a qual não será desenvolvida neste texto — consiste em constituir Tratados Internacionais que previssem a responsabilidade internacional de indivíduos por atos cometidos enquanto agentes de Estado, bem como órgãos jurisdicionais internacionais que aplicassem as normas jurídicas desses Tratados (KELSEN, Hans. A pazpelo direito. São Paulo: M. Fontes, 2011. p. 79; 102-114). Toda a evolução contemporânea do Direito Internacional Penal com os tribunais internacionais ad boc - o Tribunal Nuremberg, o Tribunal Militar Internacional para o Extremo Oriente, o Tribunal Penal Internacional para Ruanda, o Tribunal Penal Internacional para a Ex-Iugoslávia - e o Tribunal Penal Internacional fundado pelo Estatuto de Roma, de 1998, pode ser compreendida dentro dessa nova lógica de construção do conceito de responsabilidade internacional de indivíduos e de seu reconhecimento mediante um tribunal internacional. Mesmo a proposta contemporânea de um Tribunal Constitucional Internacional após a dita "primavera árabe" talvez se enquadre nessas considerações. Tais temas não serão, contudo, abordados neste artigo, por fugirem ao escopo analítico proposto.

41 Desses dois mecanismos, apenas o segundo será analisado pelo presente texto. Note-se que a ordem jurídica internacional contemporânea é composta pela presença de diferentes Tribunais Internacionais (como a Corte Internacional de Justiça, o Tribunal Internacional do Mar, o Tribunal Penal Internacional, entre outros órgãos judiciais internacionais). Houve, assim, crescente diferenciação e especialização nos séculos XX e XXI de mecanismos pacíficos jurisdicionais de solução de controvérsias internacionais. Todavia, é importante notar que a proposta kelseniana de um tribunal internacional com jurisdição compulsória não foi aceita pelos Estados, os quais preferiram manter a facultatividade da jurisdição internacional. Essa postura limita a aceitação da competência de Tribunais Internacionais à vontade dos Estados, uma vez que a aplicação da jurisdição por Tribunais Internacionais em relação a um Estado depende, afinal, do reconhecimento desta pelo Estado. O artigo 36 do Estatuto da Corte Internacional de Justiça é um exemplo normativo concreto de tal limitação. A essa crescente especialização geográfica e temática de mecanismos pacíficos jurisdicionais de solução de controvérsias internacionais se designou como uma das faces da fragmentação do Direito Internacional Contemporâneo. Associada à facultatividade de jurisdição internacional, essa coexistência de diferentes Tribunais Internacionais é ambiente institucional que cria condições aparentemente contraditórias em 
A ideia fundamental da proposta kelseniana consistia em adensar juridicamente (juridificar) os conflitos internacionais. Por mais que um conflito entre Estados pudesse ter origem em disputas em torno de recursos escassos (origem econômica) ou em pretensões de maior dominação no cenário mundial (origem política), todos poderiam ser entendidos como conflitos jurídicos — isto é, regulados pelo Direito Internacional Público e solucionado por meio da lógica do Direito, mediante instituições jurídicas adequadas ${ }^{42}$.

A perspectiva kelseniana tinha claramente uma preocupação em neutralizar conflitos econômicos e políticos mediante a inserção de tais demandas no interior da linguagem jurídica institucional (Verrechtlichung). A criação de um Tribunal Internacional impediria que a lógica estatal da força e do interesse pudesse ser o recurso de base para solucionar controvérsias internacionais. Afinal, um Tribunal Internacional com jurisdição compulsória expropriaria os Estados da possibilidade de solucionarem, por si só, seus conflitos nas relações internacionais ${ }^{43}{ }^{44}$.

Assim, note-se que a introdução da Paz Internacional pela juridificação de conflitos entre Estados proposta por Hans Kelsen apontava desde já pela necessidade de aperfeiçoamento técnico do Direito Internacional Público. Este deveria parar de operar segundo estruturas de coexistência entre Estados e passar se articular

Direito Internacional, nas quais mais de um Tribunal Internacional é potencialmente competente para processar e julgar uma mesma controvérsia, conforme a vontade/aceitação da jurisdição internacional de cada uma das partes. Nesse sentido. cf. KOSKENNIEMI, Martii. The fate of public international law: between technique and politics. The Modern Law Review, New York, v. 70, n. 1, p. 1-30, Jan. 2007.

42 KELSEN, Hans. A pazpelo direito. São Paulo: M. Fontes, 2011. p. 15-7; 22-30; 43.

43 KELSEN, Hans. A paøpelo direito. São Paulo: M. Fontes, 2011. p. 32-46.

44 Sobre as noções de juridificação como neutralização de conflitos políticos e expropriação de conflitos, v. TEUBNER, Gunther. Verrechtlichung: begriffe, merkmale, grenzen, auswege. In: ZACHER, Hans et al. Verrechtlichung von wirtschaft, arbeit und sozialer solidarität: vergleichend analysen. Baden-Baden: Nomos, 1984. p. 289-344; e TEUBNER, Gunther. Man schritt auf allen Gebieten zur Verrechtlichung: rechtssoziologische theorie im werk Otto Kirchheimers. In: LUTTER, Marcus; STIEFEL, Ernst C.; HOEFLICH, Michael (Hrsg.). Der einfluss deutschsprachiger emigranten auf die recbtentwicklung in den USA und in Deutschland. Tübingen: Mohr Siebeck, 1993. p. 505-520. Indicamos ainda a leitura de GIANNATTASIO, Arthur Roberto Capella. A integração como fenômeno jurídico-político: uma leitura sobre a construção histórica da CECA. 2013. 885. Tese (Doutorado) Faculdade de Direito do Largo de São Francisco, Universidade de São Paulo, São Paulo, 2013. p. 125-33. em torno de mecanismos institucionais de cooperação (Organizações Internacionais) $^{45}$ dotados internamente de organismos jurídicos de solução de controvérsias internacionais - como Tribunais Internacionais.

A opção kelseniana da Paz pelo Direito dialoga diretamente com o projeto jurídico do autor apontado no item anterior.

Tribunais Internacionais seriam ambientes institucionais constituídos pelo Direito Internacional Público e estariam desprovidos de qualquer conteúdo político prévio. De jurisdição compulsória lastreada em vontades estatais conjugadas em Tratado Internacional (pacta sunt servanda), tais Tribunais Internacionais deveriam ser independentes e orientados a atuar de maneira vinculada à ordem jurídica internacional positivada. Nesse sentido, os Tribunais Internacionais seriam o resultado da aplicação da técnica jurídica kelseniana (esvaziamento normativo) nas relações internacionais, de modo a impedir que o Direito (Internacional Público) fosse veículo de preferência prévia de uma posição normativa política ou econômica sobre outra ${ }^{46}$.

Essa solução de Paz Internacional se tratava de inovação jurídica fundamental nos últimos anos da Segunda Guerra Mundial. A amarga experiência do Tratado de Versailles, de $1919^{47}$, deveria ser prudentemente

45 Sobre a distinção entre modelo de coexistência e cooperação, indicamos a leitura de CARRILLO SALCEDO, Juan António. El derecho internacional en un mundo en cambio. Madrid: Tecnos, 1985. p. 183; 185; 188. De CASELLA, Paulo Borba. Tratado de Versalhes na história do direito internacional. São Paulo: Quartier Latin, 2007. p. 17; e CASELLA, Paulo Borba. Fundamentos do direito internacional pós-moderno. São Paulo: Quartier Latin, 2008. p. 189; 228-229; 259. Bem como de FRIEDMANN, Wolfgang. The changing structure of international law. New York: Columbia University, 1964. p. 60; 64. De LAMBERTI, Lucia Baungartner. Reestruturação do direito internacional: reflexões sobre o papel do direito numa ordem mundial em transformação. 1991. f. Dissertação (Mestrado) - Faculdade de Direito, Universidade de São Paulo, São Paulo, 1991.

46 KELSEN, Hans. A pazpelo direito. São Paulo: M. Fontes, 2011. p. 44.

47 Enquanto instrumento jurídico de Paz, o Tratado de Versailles incorporara contraditoriamente uma lógica de dominação dos vencedores sobre os vencidos, a qual seria o epicentro da futura instabilidade internacional que ensejou a Segunda Guerra Mundial. Nesse sentido, mencione-se a título ilustrativo o artigo 227, o qual acusava publicamente o ex-Imperador alemão Guilherme II, Hohenzollern, como o único responsável pela Guerra (violação da moral internacional), e que ele deveria ser julgado por um Tribunal Internacional - cujos membros seriam nomeados pelos EUA, pelo Reino Unido, pela França, pela Itália e pelo Japão, e que deteria competência para determinar a pena a ele aplicável. Ademais, o artigo 231 do mesmo Tratado determinava que a Alemanha e seus aliados eram integralmente responsáveis por todos os danos causados às 
evitada na História ${ }^{48}$ e, consciente dessa necessidade, Hans Kelsen se mostra favorável a operar o Direito Internacional de forma inovadora: a Paz seria construída, não por uma lógica revanchista ${ }^{49}$, mas por meio de uma técnica jurídica precisamente preocupada em retirar do interior de um centro decisório qualquer posição normativa política e econômica predefinida ${ }^{50}$.

Por esse motivo, para o autor, a melhor solução jurídico-institucional para a Guerra seria a adoção de um Tribunal Internacional. Afinal, ele representaria um espaço eminentemente jurídico de solução de controvérsias marcado permanentemente por um vazio normativo político e econômico prévio.

A Paz Internacional seria alcançada, segundo essa perspectiva, por meio de uma juridificação dos conflitos internacionais no interior de uma estrutura judicial internacional compulsória, política e economicamente independente. A Paz pelo Direito significaria, assim, a Paz pela introdução de uma técnica jurídica consciente da necessidade de exclusão permanente de qualquer conteúdo normativo político prévio no centro nomogenético e decisório fundamental.

\section{O SENTIDO POLÍTICO dO VAZIO NA TÉCNICA JURISDICIONAL INTERNACIONAL KELSENIANA}

A juridificação promovida pela proposta kelseniana tinha um sentido político em seu Projeto de promoção da Paz nas relações internacionais. A nova arquitetura institucional internacional proposta se revelava como dotada de politicidade pelo menos em duas camadas de compreensão da proposta: uma, vinculada a um papel Político do Direito de institucionalização de uma vida pública, e outra, relacionada à negação institucional de soluções normativas contextuais enraizadas politicamente.

demais potências aliadas, devendo ser internacionalmente responsáveis para reparar os danos - havendo toda uma minuciosa descrição sobre cláusulas financeiras e comerciais que viabilizariam o pagamento, no tempo, das indenizações.

48 CASELLA, Paulo Borba. Tratado de Versalhes na história do direito internacional. São Paulo: Quartier Latin, 2007. p. 60.

49 Isto é, não pela cristalização jurídica internacional da posição dominante de alguns países sobre outros.

50 KELSEN, Hans. A pazpelo direito. São Paulo: M. Fontes, 2011. p. 45 .

\subsection{O direito e a organização jurídica da vida pública internacional}

O arranjo jurídico do Direito Internacional proposto estaria voltado a promover a expropriação dos meios de solução de conflitos por parte dos Estados. Na medida em que um Tribunal Internacional de jurisdição compulsória passaria a processar e julgar juridicamente situações de violação de normas jurídicas internacionais, não mais os Estados poderiam dispor de maneira lícita do uso da força para solucionar suas controvérsias ${ }^{51}$.

Nesse sentido, o Direito Internacional Público admitiria como mecanismo pacífico de solução de conflitos internacionais, não apenas os mecanismos políticos usuais (negociações diretas, bons ofícios, mediação), ou os instrumentos jurídicos voluntários e não-permanentes da arbitragem. Antes, com base na proposta kelseniana, haveria uma válvula institucional de escoamento das pressões internacionais: um Tribunal permanente, compulsório, independente, marcado por uma estrita atuação de acordo com normas de Direito Internacional Público.

A proposta da Paz pelo Direito reconhece em arranjos institucionais novos dos instrumentos jurídicos a possibilidade de operar como uma forma/formatação renovada da vida das relações internacionais. A previsão de um Tribunal Internacional seria o preciso e precioso ponto de partida institucional permanente para a neutralização da possibilidade de tais disputas implicarem acirramento de conflitos mediante mecanismos não pacíficos (principalmente represálias ${ }^{52}$ ), ou a eclosão de

51 Conferindo, assim, instrumentos jurídicos concretos e factíveis para a realização da Paz e para a proscrição da Guerra como mecanismo jurídico aceito para a solução de conflitos, um aprimoramento em relação ao desenho institucional do Pacto Briand-Kellogg, assinado em Paris, em 1928.

52 Não se podendo ignorar ainda que, em 1934, o Institut de Droit International, na Resolução adotada na Sessão de Paris, já reconhecia, em seus artigos $1^{\circ}$ e 4 , as represálias como ações que derrogam as regras usuais do direito das gentes, sendo proibidas as represálias armadas, tanto como o uso da guerra. Mesmo as represálias não armadas não eram aceitas pelo Direito Internacional Público, conforme o artigo 5 da mesma Resolução, se houvesse a previsão de mecanismos pacíficos de solução de controvérsias (como tribunais ou arbitragem) entre os Estados em disputa, ou enquanto durasse o procedimento de um mecanismo pacífico de solução de controvérsias adotado especificamente para resolver o conflito em questão. Aspecto interessante a ser salientado é que o artigo 8 da mesma Resolução indicava que o exercício de toda represália estaria sujeito a um controle internacional de outros Estados ou de órgãos da (então) Sociedade das Nações. O artigo 9 da mesma Resolução indicava, ainda, que dúvidas sobre a interpretação da Resolução deveriam 
contraposição armada efetiva entre Estados envolvidos.

A virtude política dessa solução inovadora residiria exatamente no fato de que o Tribunal Internacional seria um local forjado pelas ferramentas jurídicas para ser o ponto de encontro obrigatório entre diferentes posições normativas. O sentido político da solução kelseniana seria precisamente este: a manipulação da técnica jurídica jurisdicional para produzir um centro decisório internacional normativamente vazio em termos políticos prévios. Um Tribunal Internacional seria um local de encontro entre diferentes Estados em disputa, no interior do qual eles poderiam estabelecer uma chance renovada para promover um embate simbólico - e não violento - entre as diferentes posições normativas de cada um deles.

A chave de compreensão desse primeiro sentido político do Tribunal Internacional consiste precisamente na ideia maquiaveliana de que "[c] omo possuíam em casa o remédio para o mal, não tinham necessidade de ir buscá-lo em outra parte" ${ }^{93}$. Se o Direito Internacional Público disponibilizava um novo local institucional permanente de realização da oposição entre Estados, — agora —, segundo a linguagem da não violência do Direito, não haveria motivo para os Estados lançarem mão de outros instrumentos.

A confecção jurídica de instituições internacionais engenhosamente desenhadas para absorver e encaminhar as controvérsias entre Estados de acordo com a observância da linguagem do Direito significava, assim:

(i) expulsar da sistemática de solução de conflitos internacionais (a) a usual política diplomática de negociação de interesses do centro normativo e decisório internacional, e (b) a até então reiterada lógica de imposição unilateral de Poder normativo e decisório nas relações internacionais (verticalidade/desigualdade entre Estados) e, ao mesmo tempo;

(ii) criar um espaço Político Internacional permanente e institucionalmente (a) aberto de forma contínua à oposição (1) em igualdade de condições entre os diferentes interessados juridicamente assegurada (horizontalidade/ pé de igualdade entre Estados reconhecida, declarada e garantida pelo Direito), (2) sem prévia assunção de qualquer referencial normativo político e/ou econômico, e (b) dotado da faculdade de produzir decisões a

ser sanadas pela (então) Corte Permanente de Justiça Internacional ou, conforme decisão voluntária dos Estados envolvidos, por Tribunal Arbitral específico.

53 MAQUIAVEL, Nicolau. Comentários sobre a primeira década de Tito Livio. 5 ed. Brasília: Universidade de Brasília, 2008. p. 43. serem compulsoriamente observadas pelos Estados envolvidos.

Assim, por meio do uso da técnica jurídica em âmbito internacional, Hans Kelsen teria proposto a realização institucional da Política ${ }^{54}$ nas relações internacionais por meio do Direito (Internacional Público), de modo a impedir a eclosão de novos conflitos armados entre Estados. A virtude do Direito se encontraria precisamente nesta possibilidade de ser instrumento de criação institucional da Política - e de seu necessário conflito simbólico - para instituir um regime de convivência não armada entre os diferentes povos.

O sentido Político do projeto kelseniano surge, assim, em um primeiro sentido, por ele propor que a técnica jurídica de retirada da (prévia ordem normativa) política (de barganha diplomática) do interior do centro nomogenético internacional de solução de conflitos (esvaziamento) se volte para a construção institucional da Política, em âmbito internacional, como forma nova de organização jurídica de uma vida pública entre diferentes nas relações internacionais.

\subsection{O direito internacional público contra o di- reito estatal mundial}

Essa obra de Hans Kelsen é escrita expressamente como contraposição ao discurso do pós-Segunda Guerra Mundial de construção de uma Federação Europeia e, posteriormente, Mundial. O Federalismo seria não apenas um projeto utópico e de difícil realização prática, mas principalmente um projeto potencialmente tão destrutivo quanto aquele que o Federalismo buscava combater ${ }^{55}$.

Nesse sentido, o autor argumenta ser a criação de um Estado Federal Europeu e mundial a precisa eliminação de uma ordem internacional. Não mais haveria que se falar em Estados se contrapondo em regime entre-nações (internacional), na medida em que haveria apenas um Estado vigendo em todo o mundo. Não se trataria assim de uma confederação de Estados, mas de um único Estado detentor da Soberania em plano mundial, o que eliminaria a possibilidade de se afirmar haver Estados no sentido tradicionalmente atribuído ao termo ${ }^{56}$.

54 No sentido lefortiano, isto é, um sistema de convivência entre diferentes arquitetado institucionalmente para ter em seu centro um vazio normativo prévio.

55 KELSEN, Hans. A parpelo direito. São Paulo: M. Fontes, 2011. p. XII; 5; 9; 11-12.

56 KELSEN, Hans. A pazpelo direito. São Paulo: M. Fontes, 2011. p. 18. 
Mais do que isso, a instauração de uma ordem federal mundial seria, na perspectiva kelseniana, a própria eliminação das condições de possibilidade de um Direito Internacional Público. Com efeito, não mais havendo Estados se relacionando entre si, não mais haveria uma regulação jurídica de uma vida internacional, mas sim uma regulação dada por Direito Estatal Federal mundial. Tratar-se-ia de um Direito nacional constituído por um Tratado Internacional de união dos Estados em um Estado Federal mundial..$^{57}$

Longe de se preocupar simplesmente com a preservação de um campo normativo especial do Direito — o Direito Internacional Público, a observação acima revela uma evidente inquietação com as possíveis consequências jurídicas e políticas de instauração de uma ordem jurídico-política Federal mundial.

A criação de um Estado Federal mundial significaria, em um primeiro movimento, a realização jurídico-institucional em âmbito mundial da forma jurídico-política estatal de organização do social. Em outras palavras, implicaria a realização de escolhas políticas - juridicamente formalizadas em instituições federais - relativas à monopolização legal-burocrática da violência em âmbito mundial, ou ainda, à centralização do uso da força coercitiva em uma agência central, isto é, em um Poder Executivo $^{58}$.

Nesse sentido, um Estado Federal mundial orientaria o Direito para sentido oposto ao do projeto kelseniano exposto no item anterior. De acordo com a precisa lógica jurídico-política típica de um Estado, o Direito (não mais Internacional Público, mas Estatal Federal mundial) trabalharia com o elemento coercitivo para solucionar eventuais controvérsias - uma força policial estatal federal dotada da linguagem da violência. Isso implicaria "uma restrição radical, quando não [a] total destruição, da soberania dos Estados" ${ }^{59}$, resultante de uma contradição no discurso Federalista ${ }^{60}$ que produ-

57 KELSEN, Hans. A pazpelo direito. São Paulo: M. Fontes, 2011. p. 38 .

58 KELSEN, Hans. A pazpelo direito. São Paulo: M. Fontes, 2011. p. 5.

59 KELSEN, Hans. A parpelo direito. São Paulo: M. Fontes, 2011. p. 18.

60 O caráter contraditório e suicida do projeto Federalista é notado também por autores contemporâneos, como WEILER, Joseph H. H. The constitution of Europe: "do the new clothes have an emperor?" and other essays on european integration. Cambridge: Cambridge University, 2005. p. 94: "[i]t would be [...] ironic that an ethos that rejected the nationalism of the Member States gave birth to a zia uma indevida e perigosa analogia entre um Estado mundial e o Estado nacional ${ }^{6162}$.

Para o autor, essa analogia seria perigosa para os povos, ou até mesmo mais perigosa para os povos do que o modelo vigente até o momento. Atribuir o monopólio legal da violência mundial para um único centro executivo poderia também ser fundamento de barbáries entre os povos, a despeito de seu discurso libertário em favor da Paz. Dito de outro modo, em um segundo movimento, apesar de visar à pacificação das relações internacionais, a criação de um Estado Federal mundial poderia ser a base de futuras instabilidades políticas e desmantelar seu próprio objetivo original.

Na perspectiva do autor, um Estado Federal mundial reproduziria precisamente a mesma lógica de afirmação de um Estado nacional: "inclinado a resistir a qualquer restrição a sua independência", o Estado Federal mundial utilizaria todos os recursos disponíveis - inclusive a força - para firmar e afirmar sua integridade Soberana ${ }^{63}$. Em outras palavras, a construção de toda forma de Estado - calcado, sempre, no monopólio legal da violência - implicou a imposição de determinada perspectiva normativa política e econômica sobre as demais $^{64}$, não sendo possível prever algo diferente ${ }^{65}$ com o

new European nation and European nationalism. The problem with the unity vision [within a political union of federal governance] is that its very realization entails its negation.".

61 KELSEN, Hans. A pazpelo direito. São Paulo: M. Fontes, 2011. p. 5 .

62 Nesse sentido, para o Federalismo, apenas um terceiro superior às partes que centralizasse a força poderia superar uma suposta anarquia indesejada e, desse modo, assegurar um sistema internacional. Essa solução estaria fundada em uma indevida projeção do modelo de jurídico-político de organização estatal para as relações internacionais - prática bastante usual dos estudiosos de Direito Internacional Público no início do século XX, cf. KOSKENNIEMI, Martii. The fate of public international law: between technique and politics. The Modern Law Review, New York, v. 70, n. 1, p. 1-30, Jan. 2007.

63 KELSEN, Hans. A pazpelo direito. São Paulo: M. Fontes, 2011. p. $9-10$.

64 Sobre a construção de Estados-nação com base em políticas de uniformização cultural, v. as observações de ANDERSON, Benedict. Comunidades imaginadas: reflexões sobre a origem e a difusão do nacionalismo. São Paulo: Companhia das Letras, 2009; também FERRAJOLI, Luigi. Sobre los derechos fundamentales, cuestiones constitucionales. Revista Mexicana de Derecho Constitucional, México D.F., n. 15, p. 113-36, jul./dic. 2006; e KYMLICKA, Will. Multicultural odysseys: navigating the new international politics of diversity. Oxford: Oxford University, 2007. No caso do Estado brasileiro, mencione-se ainda importante perspectiva proposta por CARVALHO, José Murilo de. A construção da ordem: teatro de sombras. 5 ed. Rio de Janeiro: Civilização Brasileira, 2010.

65 Tentativas de totalização de posições normativas políticas e 
Estado Federal Mundial.

Em outras palavras, a introdução mundial de uma organização jurídico-política estatal Soberana em todo o globo poderia ser instrumento de dominação de determinadas formas jurídicas, políticas, econômicas e culturais sobre outras. Afinal, o consenso necessário para construir um Estado tradicionalmente exigiu a desconsideração da possibilidade de povos determinarem autonomamente seus estatutos jurídicos, políticos, econômicos e culturais em favor da afirmação de uma ordem jurídica e política una em torno do modelo do Estado.

Algumas das propostas do Federalismo Europeu examinado acima podem ser interessantes exemplos desse perigo à autodeterminação jurídica, política, econômica e cultural de povos ${ }^{66}$. Mencione-se aqui apenas o Anteprojeto de Constituição Europeia aprovado no Congresso da União Europeia dos Federalistas, em Roma, em 1948, o qual seria apresentado aos Governos europeus para fundar um futuro Estado Federal Europeu.

Nos artigos $1^{\circ}$ e $2^{\circ}$ desse Anteprojeto, o Federalismo Europeu afirmava a importância de se aprovar uma Carta de Direitos Humanos comum aos povos europeus, a qual seria superior às normas constitucionais dos Estados-membros da Federação. A autonomia política - e não Soberania! — seria garantida aos Estados-membros apenas se estes se organizassem politicamente de acordo com a Constituição Europeia e com os preceitos (Direitos Humanos e Democracia) constantes da Carta de Direitos Humanos ${ }^{67}$.

Mostra-se importante salientar alguns aspectos fundamentais. Em primeiro lugar, a organização de um Estado Federal Europeu não pretendia preservar a Soberania dos Estados-membros - afinal, estaria assegurada apenas a autonomia política, uma vez que a

econômicas encontraram respaldo em aparelhos estatais durante a Segunda Guerra Mundial e após ela na História Contemporânea da Europa. V. nesse sentido a discussão desenvolvida no item 4, supra. 66 Nesse sentido, v. GIANNATTASIO, Arthur Roberto Capella. A integração como fenômeno jurídico-político: uma leitura sobre a construção histórica da CECA. 2013. 885. Tese (Doutorado) - Faculdade de Direito do Largo de São Francisco, Universidade de São Paulo, São Paulo, 2013. p. 354-382.

67 UNION EUROPÉENNE DES FÉDÉRALISTES. Résolutions et Avant-Projet sur la Constitution Européenne: Congrès de Rome, novembre 1948. In: ROLLAND, Patrice (Org.). L'unité politique de l'Europe: histoire d'une idée. Bruxelles: Bruylant, 2006. p. 558575. p. 569. única entidade Soberana seria o Estado Federal Europeu. Em segundo lugar, mesmo essa autonomia política seria desconsiderada pela Federação Europeia, no caso de não conformidade com os preceitos previstos na referida Carta de Direitos Humanos. Inclusive, lembre-se que o ingresso de novos países na Federação Europeia dependeria da satisfação de tais requisitos ${ }^{68}$.

Nesse sentido, em nome da afirmação e da preservação de uma suposta coesão jurídica, política e cultural interna, a Federação Europeia poderia desconsiderar mesmo a limitada autonomia política de Estados-membros em desacordo com um legado da dita civilização europeia. Há nesse ponto uma clara preocupação do Estado Federal Europeu em recusar ao Estado-membro federado a possibilidade de decidir autonomamente seu próprio estatuto jurídico, político, econômico e cultural: apenas a posição normativa política e econômica dos Direitos Humanos e da Democracia poderiam imperar, sendo excluída qualquer possibilidade de se adotar formatações jurídicas, políticas, econômicas e culturais novas conforme posições normativas alternativas.

O Projeto de Paz do Federalismo Europeu fundado nessa imagem unidimensional de Direitos Humanos e Democracia não pretendia se restringir geograficamente à Europa. Desde seu projeto originário do Programa de Hertenstein, de 1946, ele detinha claras pretensões universais: a Europa seria local de testes desse novo modelo, o qual deveria progressivamente ser transplantado e disseminado ao redor do mundo. Tal predisposição à disseminação do fardo civilizador europeu se reafirma em 1947, no Congresso realizado em Montreux ${ }^{69}$ e, em 1948, na Exposição de Motivos do supramencionado Anteprojeto de Constituição Europeia, há a afirmação de que a Federação Europeia teria por missão alterar todas as estruturas políticas e culturais nacionais e internacionais em todo o globo ${ }^{70}$.

68 UNION EUROPÉENNE DES FÉDÉRALISTES. Résolutions et Avant-Projet sur la Constitution Européenne: Congrès de Rome, novembre 1948. In: ROLLAND, Patrice (Org.). L'unité politique de l'Europe: histoire d'une idée. Bruxelles: Bruylant, 2006. p. 558575. p. 560.

69 UNION EUROPÉENNE DES FÉdÉRALISTES. Programme de Montreux: août 1947. In: ROLLAND, Patrice (Org.). L'unité politique de l'Europe: histoire d'une idée. Bruxelles: Bruylant, 2006. p. 489-499. p. 494.

70 UNION EUROPÉENNE DES FÉDÉRALISTES. Résolutions et Avant-Projet sur la Constitution Européenne: Congrès de Rome, novembre 1948. In: ROLLAND, Patrice (Org.). L'unité politique de l'Europe: histoire d'une idée. Bruxelles: Bruylant, 2006. p. 558575. p. 565. 
Com base nessas propostas concretas do Federalismo, pode-se notar a presença de um perigoso princípio de dominação também no Projeto político de Paz do Federalismo mundial. Com Hans Kelsen, é possível concordar que a Paz do Federalismo Europeu parecia "não [ser] muito favorável às intenções daqueles que desejam produzir a paz mundial por métodos que concordam com os princípios da democracia: liberdade e igualdade, aplicadas às relações internacionais" "71, precisamente por ele pretender se organizar jurídica e politicamente de forma avessa à alteridade local de posições normativas, em nome da afirmação universal de um Projeto de Paz civilizatório de origem europeia.

Com base nesses aspectos contextuais. Pode-se compreender a segunda camada de significação política da Paz pelo Direito de Hans Kelsen.

A solução proposta por Hans Kelsen - instituição de uma Organização Internacional articulada em torno de um Poder Judiciário Internacional — seria o mecanismo jurídico internacional mais adequado para a preservação da liberdade em escala mundial e, consequentemente, da autodeterminação dos povos. $\mathrm{E}$ isso porque essa solução exigiria apenas aperfeiçoamento da técnica jurídica do Direito Internacional Público, e não seu abandono por um Direito Estatal Federal.

Com efeito, o autor era consciente da diferença qualitativa entre um Direito Internacional e um Direito Estatal. A aposta no Direito Internacional Público como forma de encaminhamento jurídico-institucional dos conflitos derivados das relações internacionais mantinha a convicção de ser necessário privilegiar sua lógica fundamental de ser uma caixa de ferramentas de instauração de mecanismos de convivência não armada (linguagem da não-violência) entre diferentes povos. Com isso, ele recusava a opção pelo Estado, um mecanismo jurídico cujo pressuposto organizacional fundamental é o exercício centralizado da violência (linguagem da violência).

Em outras palavras, ao manter clara e expressamente a opção pelo Direito Internacional Público, Hans Kelsen sustenta em sua obra Pazpelo Direito uma proposta de encaminhamento de controvérsias internacionais revestida de caráter eminentemente político por se tratar de uma recusa do Estado e de sua estrutura política para

71 KELSEN, Hans. A pazpelo direito. São Paulo: M. Fontes, 2011. p. 5 . as relações internacionais. O sentido político desse projeto kelseniano é entendido, assim, como uma recusa à introdução de um Projeto Político estatizante das Relações Internacionais e do Direto Internacional Público em virtude do reconhecimento da positividade de se pensar ainda em estruturas jurídicas internacionais para essas relações — ainda que essa estrutura devesse ser renovada.

A recusa kelseniana do modelo estatal para as relações internacionais e para o Direito Internacional Público é assim acompanhada pela afirmação da importância de ainda se pensar em um modelo político-institucional juridicamente novo em relação ao modelo internacional clássico: um Tribunal Internacional independente dentro de uma Organização Internacional. Isso implica, desse modo,

(i) rejeitar para as relações internacionais a organização jurídico-política estatal federal mundial em torno de um Poder Executivo Internacional, ou seja, (a) se colocar contra o modelo estatal como padrão a ser idealmente visado e estruturalmente constituído nas relações internacionais, e dessa forma, (b) afirmar a necessidade de se (1) compreender as tais relações fora da chave de compreensão qualitativa estatal (rejeição do Federalismo), e (2) criar juridicamente arranjos institucionais políticos adequados à estrutura internacional — isto é, que não sejam simples transplantes para o âmbito internacional da estrutura jurídico-política institucional dos Estados;

(ii) optar por um instrumento jurídico em desacordo com três aspectos do modelo estatal, saber, (a) a centralização de uso da força em um centro de Poder, (b) a busca e a imposição de uma unidimensionalidade existencial por meio de políticas de uma uniformização cultural em nome de uma unidade derivada de suposta comunidade de valores, precisamente porque percebe não ser viável em âmbito internacional a (c) a eleição a priori de conteúdo normativo político e econômico a figurar no centro de um Poder Executivo;

(iii) articular (a) o legado do Direito Internacional Público como Direito de liberdade nas relações internacionais com (b) a necessidade inovação institucional jurídico-política para a sobrevivência da humanidade, isto é, (a.1) abdicar de formas de ingerência externa e internacional na autodeterminação jurídica, política, econômica e cultural dos diferentes povos, e (a.2) reforçar o papel do Direito Internacional Público como caixa de ferramentas, isto é, como repositório de técnicas jurídicas especializadas de convivência não armada entre os povos que se 
autodeterminaram de maneiras distintas, sem desconsiderar a importância de (b.1) propor uma alteração estrutural profunda do Direito Internacional Público, o qual não deveria mais se centrar nos Estados-nação como sujeitos de Direito, e, com isso, (b.2) introduzir as Organizações Internacionais como novos fóruns internacionais de determinação do sentido normativo e políticos de decisões jurídico-políticas internacionais fundamentais, as quais operariam ativamente no plano internacional ao lado dos Estados ${ }^{72}$.

A proposta kelseniana da Paz pelo Direito reconhece, desse modo, a importância de se operar mudança dramática e profunda estrutura jurídico-institucional das relações internacionais sem, todavia, abandonar a lógica da liberdade do Direito Internacional Público isto é, sem assumir para a regulação das relações internacionais um modelo estatal federal mundial centralizador dos referenciais normativos e políticos. Trata-se, assim, de um consciente discurso político de recusa da forma estatal para as relações internacionais, o qual, por sua vez, possui um profundo sentido jurídico.

Com efeito, o Direito Internacional Público não apenas jamais se tornaria Direito Estatal — isto é, jamais poderia se aproximar dos critérios que caracterizam o Direito do Estado, tais como o monopólio legal da violência, a centralização da produção normativa e de decisões políticas fundamentais - precisamente porque ele não admite se aproximar qualitativamente desse modelo. Se adquirisse contornos Federais, o Direito Internacional Público deixaria de ser propriamente Internacional e passaria a ser, assim, um Direito Estatal Federal Mundial e possível fonte de replicabilidade de conhecidas práticas históricas avessas à espontaneidade local de formações jurídicas, políticas, econômicas e culturais.

Por meio de tal proposta, pode-se afirmar que Hans Kelsen argumentara pela importância de se acreditar na capacidade de agregação política não-estatal da técnica jurídica do Direito Internacional Público. A pureza/o vazio de normatividade no interior do Direito afastaria assim a solução política estatal federal para as relações internacionais contemporâneas e, dessa forma, manteria o reconhecimento da função libertária do Direito Internacional Público enquanto Direito Político de um não Estado.

72 Ou ainda, trabalhar no sentido de promover o início da transição do modelo internacional de coexistência, para o de cooperação, como mencionado no item 4.2, supra.
Em outras palavras, ao institucionalizar um Tribunal Internacional compulsório dentro de uma Organização Internacional marcada pelo vazio normativo político e econômico prévio, o novo arranjo jurídico do Direito Internacional Público do pós-Segunda Guerra Mundial não deveria ter como objetivo se tornar espelho institucional do fenômeno estatal — para, então com isso, tornar mais seguras as relações internacionais.

Pelo contrário. Precisamente por não depender de força para ser cumprido compulsoriamente, o Direito Internacional Público revelaria sua virtude de tornar seguras as relações internacionais, não mediante a ameaça do uso da força, mas sim por meio de uma renovação contínua de sua arquitetura institucional para sempre constituir e reconstituir engenhosos arranjos jurídicos de manutenção e de estímulo das liberdades política, jurídica, econômica e cultural de cada povo.

Por isso mesmo, se se tornasse tão forte quanto um Estado, por meio da Federação Mundial, o Direto Internacional Público perderia seu caráter internacional - e, com isso, sua promessa política de ser o último nicho de reconhecimento, inclusão, preservação e promoção da liberdade internacional dos povos.

\section{Considerações finais}

A partir da proposição de um debate entre o pensamento jurídico de Hans Kelsen e o pensamento filosófico de Claude Lefort, o presente texto pretendeu construir uma interpretação política da proposta kelseniana em torno do aparato jurídico internacional necessário para garantir, no pós-Segunda Guerra Mundial, a construção de condições de possibilidade para uma convivência não-armada entre os povos.

Inserto no debate do pós-Segunda Guerra Mundial acerca de uma nova estrutura institucional para o Direito Internacional Público, o Projeto da Paz pelo Direito de Hans Kelsen pode ser compreendido politicamente pois: (i) utiliza uma técnica jurídica de produção da Política, e (ii) se trata de uma opção consciente por um modelo de juridificação de conflitos distinto do modelo estatal. E, para isso, o texto foi dividido em quatro partes.

$\mathrm{Na}$ primeira parte, foram apresentadas as principais características dos discursos Unionista e Federalista, como modelos propostos no pós-Segunda Guerra 
Mundial para eliminar a ocorrência de novas Guerras na Europa e no mundo. $\mathrm{Na}$ segunda parte, foram expostos elementos fundamentais do pensamento político de Claude Lefort para extrair um conceito de Política como "medida de politicidade" de arranjos institucionais. $\mathrm{Na}$ terceira parte foi mostrada a proposta de Hans Kelsen em sua obra Pazpelo Direito, de 1944, para o problema da construção da Paz Internacional (Juridificação). A quarta parte apresentou como se pode compreender a solução institucional de Hans Kelsen como detentora de um específico sentido político em dois sentidos não adequadamente salientados pela literatura jurídica.

Percebe-se, assim, que, ao manter sua aposta na forma jurídica internacional como melhor solução da técnica jurídica para a Paz nas relações internacionais, Hans Kelsen reconhece em sua proposta a nervura do Direito Internacional Público e propõe que ela seja trabalhada, de modo que, afinal, sua fragilidade se torne sua maior força. Para ele, o novo arranjo jurídico-institucional visando à constituição da Paz Internacional no pós-Segunda Guerra Mundial não deveria jamais esquecer esse legado do Direito Internacional Público: incapaz de deter estrutura institucional semelhante à de um Estado, dever-se-ia rejeitar politicamente qualquer tentativa de transplante estrutural estatal para o Direito Internacional Público.

Mais do que isso. Dever-se-ia reconhecer que a maior segurança nas relações internacionais derivava precisamente da capacidade de o desenho institucional do Direito Internacional Público continuamente se mobilizar enquanto um Direito de liberdade — isto é, um Direito marcado pelo vazio normativo e voltado à mediação institucional juridificada de conflitos de convivência entre diferentes povos. E, desse modo, desprovido do uso da força e tendo reduzido seu cumprimento à dimensão simbólica da linguagem, apenas sua linguagem jurídica normativamente vazia poderia conservar internacionalmente a liberdade política necessária para relações internacionais mais seguras no pós-Segunda Guerra Mundial.

\section{REFERÊNCIAS}

ANDERSON, Benedict. Comunidades imaginadas: reflexões sobre a origem e a difusão do nacionalismo. São Paulo: Companhia das Letras, 2009.
ARENDT, Hannah. Origens do totalitarismo: anti-semitismo, imperialismo, totalitarismo. São Paulo: Companhia das Letras, 2004.

BERSTEIN, Serge; MILZA, Pierre. Histoire de l'Europe contemporaine: de l'héritage de xixe siecle a l'europe d'aujourd'hui. Paris: Hatier, 2002.

BITSCH, Marie-Thérèse. Histoire de la construction européenne: de 1945 a nos jours. Bruxelles : Complexe, 2006.

CARDOSO, Sérgio. Por que república? notas sobre o ideário democrático e republicano. In: ___ (Org.). Retorno ao republicanismo. Belo Horizonte: Universidade Federal de Minas Gerais, 2004. p. 45-66.

CARDOSO, Sérgio. Que república? notas sobre a tradição do "governo misto". In: BIGNOTTO, Newton (Org.). Pensar a república. Belo Horizonte: Universidade Federal de Minas Gerais, 2002. p. 27-48.

CARRILLO SALCEDO, Juan António. El derecho internacional en un mundo en cambio. Madrid: Tecnos, 1985.

CARVALHO, José Murilo de. A construção da ordem: teatro de sombras. 5 ed. Rio de Janeiro: Civilização Brasileira, 2010.

CASELLA, Paulo Borba. ABZ: ensaios didáticos. São Paulo: Imprensa Oficial do Estado, 2009.

CASELLA, Paulo Borba. Comunidade européia e seu ordenamento jurídico. São Paulo: LTr, 1994.

CASELLA, Paulo Borba. Fundamentos do direito internacional pós-moderno. São Paulo: Quartier Latin, 2008.

CASELLA, Paulo Borba. Prefácio. In: SETTE-CAMARA, José. Polvição de rios internacionais. São Paulo: Quartier Latin, 2011. p. 11-19.

CASELLA, Paulo Borba. Tratado de Versalhes na história do direito internacional. São Paulo: Quartier Latin, 2007.

CUNHA, Paulo de Pitta e. Direito institucional da União Européia. Coimbra: Almedina, 2004.

FERRAJOLI, Luigi. Sobre los derechos fundamentales, cuestiones constitucionales. Revista Mexicana de Derecho Constitucional, México D.F., n. 15, p. 113-36, jul./dic. 2006.

FRIEDMANN, Wolfgang. The changing structure of international law. New York: Columbia University, 1964.

GIANNATTASIO, Arthur Roberto Capella. A integração como fenômeno jurídico-politico: uma leitura sobre a con- 
strução histórica da CECA. 2013. 885. Tese (Doutorado) - Faculdade de Direito do Largo de São Francisco, Universidade de São Paulo, São Paulo, 2013.

GIANNATTASIO, Arthur Roberto Capella. Permanência do teológico-político? uma análise do pensamento político do materialismo ateu de Holbach a partir de Claude Lefort. Cadernos Espinosanos, São Paulo, n. 29, p. 88-121, 2013.

INSTITUT DE DROIT INTERNATIONAL. Résolution sur le Régime des représailles en temps de paix. Disponível em: < http://www.idi-iil.org/idiF/resolutionsF/1934_ paris_03_fr.pdf $>$. Acesso em: 19 jun. 2015.

KELSEN, Hans. A pazpelo direito. São Paulo: M. Fontes, 2011.

KELSEN, Hans. Teoria pura do direito. 6 ed. São Paulo: M. Fontes, 2000.

KOSKENNIEMI, Martii. The fate of public international law: between technique and politics. The Modern Law Review, New York, v. 70, n. 1, p. 1-30, Jan. 2007.

KYMLICKA, Will. Multicultural odysseys: navigating the new international politics of diversity. Oxford: Oxford University, 2007.

LAMBERTI, Lucia Baungartner. Reestruturação do direito internacional: reflexões sobre o papel do direito numa ordem mundial em transformação. 1991.Dissertação (Mestrado) - Faculdade de Direito, Universidade de São Paulo, São Paulo, 1991.

LEFORT, Claude. Aperçu d'un itinéraire: entretien avec Pierre Rosanvallon et Patrick Viveret. In: . Le temps present. écrits 1945-2005. Paris: Belin, 2007. p. $347-$ 357.

LEFORT, Claude. Avertissement. In: . Le temps present. écrits 1945-2005. Paris: Belin, 2007. p. 29.

LEFORT, Claude. Droit International, Droits de l'Homme et Politique. In:___. Le temps present. écrits 1945-2005. Paris: Belin, 2007. p. 1019-1036.

LEFORT, Claude. Éléments d'une critique de la bureaucratie. Paris: Gallimard, 1979.

LEFORT, Claude. Entretien avec l'anti-mythes. In: Le temps present. écrits 1945-2005. Paris: Belin, 2007. p. 223-260.

LEFORT, Claude. L'Europe: Civilisation Urbaine. In: Le temps present: écrits 1945-2005. Paris: Belin,
2007. p. 1001-1018.

LEFORT, Claude. La littérature moderne comme expression de l'homme. In: Le temps present. écrits 1945-2005. Paris: Belin, 2007. p. 109-126.

LEFORT, Claude. Le travail de l'oewre machiavel. Paris: Gallimard, 1986.

LEFORT, Claude. Machiavel et la veritá effetuale. In: Écrire: à l'épreuve du politique. Paris: Calmann-Lévy, 1992. p. 141-179.

LEFORT, Claude. O nome de um. In: CLASTRES, Pierre; LEFORT, Claude; CHAUÍ, Marilena. Discurso da servidão voluntária. São Paulo: Brasiliense, 1999. p. 125171.

LEFORT, Claude. Permanência do teológico-político? In: _. Pensando o politico: ensaios sobre democracia, revolução e liberdade. São Paulo: Paz e Terra, 1991. p. 249-296.

LEFORT, Claude. Repenser la démocratie. In: Le temps present: écrits 1945-2005. Paris: Belin, 2007. p. 341-346.

LEFORT, Claude. Repenser le politique: entretien avec E. A. El Maleh. In:__. Le temps present. écrits 19452005. Paris: Belin, 2007. p. 359-367.

LEFORT, Claude. Sur penser la guerre, Clausewitz de Raymond Aron. In: . Le temps present. écrits 1945-2005. Paris: Belin, 2007. p. 321-340.

MAQUIAVEL, Nicolau. Comentários sobre a primeira década de Tito Livio. 5 ed. Brasília: Universidade de Brasília, 2008.

MATTERA, Alfonso. De la deuxieme guerre mondiale au «projet européen» de Jean Monnet. Revue du Droit de l'Union Européenne, n. 1, p. 5-33, 2002.

MAZOWER, Mark. Dark continent. Europe's twentieth century. London: Penguin, 1998.

MORAVCSIK, Andrew. The choice for Europe: social purpose and state power from messina to maastricht. London: Routledge, 2005.

QUADROS, Fausto de. Direito das comunidades europeias: contributo para o estudo da natureza jurídica do direito comunitário europeu. Lisboa: Almedina, 1984.

QUERMONNE, Jean-Louis. Fonctionnalisme. In: BERTONCINI, Yves et al (Org.). Dictionnaire critique de l'Union Européenne. Paris: Armand Colin, 2008. p. 186-187. 
QUERMONNE, Jean-Louis. L'Union Européenne dans le temps long. Paris: SciencesPo, 2008.

QUERMONNE, Jean-Louis. Le système politique de l'Union Européenne. 8 ed. Paris: Montchrestien, 2010.

RÉAU, Élisabeth du. L'idée d'Europe au XXème siecle: des mythes aux réalités. Bruxelles: Complexe, 2008.

ROLLAND, Patrice. L'unité politique de l'Europe: histoire d'une idée. Bruxelles: Bruylant, 2006.

TEUBNER, Gunther. Man schritt auf allen Gebieten zur Verrechtlichung: rechtssoziologische theorie im werk Otto Kirchheimers. In: LUTTER, Marcus; STIEFEL, Ernst C.; HOEFLICH, Michael (Hrsg.). Der einfluss deutschsprachiger emigranten auf die rechtentwicklung in den USA und in Deutschland. Tübingen: Mohr Siebeck, 1993. p. 505-520.

TEUBNER, Gunther. Verrechtlichung: begriffe, merkmale, grenzen, auswege. In: ZACHER, Hans et al. $V$ errechtlichung von wirtschaft, arbeit und sozialer solidarität: vergleichend analysen. Baden-Baden: Nomos, 1984. p. 289-344.

UNION EUROPÉENNE DES FÉDÉRALISTES. Programme d'Hertenstein: Septembre 1946. In: ROL-
LAND, Patrice (Org.). L'unité politique de l'Europe: histoire d'une idée. Bruxelles: Bruylant, 2006. p. 488-489.

UNION EUROPÉENNE DES FÉDÉRALISTES. Programme de Montreux: août 1947. In: ROLLAND, Patrice (Org.). L'unité politique de l'Europe: histoire d'une idée. Bruxelles: Bruylant, 2006. p. 489-499.

UNION EUROPÉENNE DES FÉDÉRALISTES. Résolutions et Avant-Projet sur la Constitution Européenne: Congrès de Rome, novembre 1948. In: ROLLAND, Patrice (Org.). L'unité politique de l'Europe: histoire d'une idée. Bruxelles: Bruylant, 2006. p. 558-575.

VERNANT, Jean-Pierre. As origens do pensamento grego. 3 ed. São Paulo: Difel, 1981.

WEILER, Joseph H. H. European integration legitimacy and mobilizing force: an appraisal. Paris: Universtié PanthéonAssas, 2011.

WEILER, Joseph H. H. The constitution of Europe: "do the new clothes have an emperor?" and other essays on european integration. Cambridge: Cambridge University, 2005.

WOLFF, Francis. Aristóteles e a politica. São Paulo: Discurso, 1999. 


\title{
O sincretismo teórico na apropriação das teorias monista e dualista e sua questionável utilidade como critério para a classificação do modelo brasileiro de incorporação de normas internacionais*
}

\author{
The theoretical syncretism in the \\ appropriation of the monistic and dualistic \\ theories and their questionable utility as a \\ criterion for the classification of the Brazilian \\ model of incorporating international \\ standards
}

Breno Baía Magalhães**

\section{Resumo}

O artigo objetiva analisar a forma como a abordagem descritiva da dicotomia monismo/dualismo é interpretada pelos autores brasileiros e sua incompatibilidade com a prática constitucional. Por meio de revisão bibliográfica da produção teórica de autores brasileiros e de releitura dos autores clássicos sobre o tema, buscaremos cindir a discussão entre monismo e dualismo no direito internacional em duas abordagens: uma teórica, que desenvolve teses acerca da existência ou não de um ordenamento único e outra descritiva, acerca dos modelos constitucionais de incorporação de normas internacionais. Após análise da prática constitucional, chegamos à conclusão de que enquadrar o direito constitucional como monista é insuficiente para descrever o modelo de incorporação de normas internacionais brasileiro.

Palavras-chave: Monismo. Dualismo. Ordenamento único. Modelos de incorporação. Normas constitucionais.

Recebido em 25/09/2015.

Aprovado em 21/11/2015

** Mestre e Doutor pela Universidade Federal do Pará (UFPA), professor da Universidade da Amazônia (UNAMA) e das Faculdades Integradas Brasil Amazônia (FIBRA). Visiting Scholar na Washington College of Law, American University. E-mail: brenobaiamag@gmail.com

\section{Abstract}

This article aims to analyze how the descriptive approach to the dichotomy monism / dualism is interpreted by Brazilian authors and its incompatibility with constitutional practice. Through a literature review of the theoretical work of Brazilian authors and a reinterpretation of the classic authors on the subject, we will seek to split the discussion between monism and dualism in international law on two approaches: a theoretical one, which developed theories about the existence or not of a only juridical order and a descriptive one, about the constitutional models of incorporating international norms. After examination of the constitutional practice, we concluded that to frame the constitutional model as monistic is insufficient 
to describe the Brazilian incorporation model of international norms.

Keywords: Monism. Dualism. Single order. Incorporation models. Constitutional norms

\section{INTRODUÇÃO}

As relações estabelecidas entre o direito internacional e o direito nacional ocupam proeminente lugar na teoria do direito internacional. As sobreditas relações dependem das normas constitucionais e internacionais pertinentes, portanto, ao menos em parte, o direito constitucional indica os meios pelos quais as normativas internacionais se relacionarão com o direito interno ao delimitar as formas de incorporação dos tratados internacionais. Da parte do direito internacional, particularmente no que tange ao direito dos tratados ${ }^{1}$, estipula-se o resguardo da eficácia do tratado quanto aos procedimentos internos de incorporação, ou seja, independentemente dos procedimentos constitucionais internos adotados para a incorporação e as regras que regulamentam possíveis conflitos normativos, o país não poderá utilizá-los como escusas para justificar inadimplemento da norma internacional ${ }^{2}$.

1 No artigo não analisaremos a problemática do costume internacional.

2 Art. 27 da Convenção de Viena sobre o Direito dos Tratados (1969). No âmbito da União Europeia, a CJE decidiu que algumas normas do direito europeu possuem precedência em relação ao direito nacional, ao conferir a possibilidade de as pessoas invocaram nas cortes internas, diretamente, direitos decorrentes das tratativas europeias em Van Gend en Loos v Nederlandse (1963). Pouco tempo depois, a CJE defendeu a supremacia do direito comunitário em Costa v. ENEL (1964), embora nem todas as diretivas gozem de efeito direto (C-91/92, Fancini Dori [1994] ECR 1-3325). FOLSOM, Ralph H. Principles of European Union Law. 3. ed. St. Paul: Thomson, 2011. p. 74-76 e HIX, Simon; HØYLAND, Bjørn. The political system of the European Union. 3. ed. London: P. Macmillan, 2011. p. 84-85. A doutrina do efeito direto poderia indicar a posição monista do direito europeu, mas devemos tomar tal descrição da situação europeia com cautela. Em primeiro lugar, a suposta supremacia, apesar de poder ser transportada para outras realidades institucionais (sistemas internacionais de proteção de direitos humanos, por exemplo), limita-se à integração europeia, e não ao direito internacional em sua inteireza. Em segundo lugar, apesar da tênue diferença, o efeito direito não significa aplicabilidade direta, pois ainda permanece a cargo do ordenamento constitucional estabelecer qual a forma de incorporação das normas europeias e qual seu status no ordenamento jurídico (procedimento interno de incorporação), ressalvando a não contrariedade ao direito europeu. Em terceiro lugar, o princípio da supremacia do direito europeu não foi, amplamente, recepcionado por algumas cortes constitucionais europeias, especialmente
No plano doutrinário, a relação entre direito internacional e nacional é resumida, tradicionalmente, pelo embate de duas perspectivas: o monismo e o dualismo ${ }^{3}$. O monismo advoga a unidade dos ordenamentos interno e internacional, a proeminência do direito internacional em casos de conflitos ${ }^{4}$ e a aplicabilidade direta das normas internacionais (tratados não precisam ser convertidos em lei ordinária nacional $)^{5}$. O dualismo, por

pela corte alemã (Casos Solange I e II), italiana (Caso Frontini) e, mais recentemente, polonesa (K 18/04). Como explicam Delmas-Marty e Hix e Høyland, os tribunais constitucionais europeus não estão dispostos a reconhecer uma hierarquia jurisdicional entre a corte europeia e as constitucionais, dessa forma, mesmo que as normas europeias sejam consideradas, internamente, como supralegislativas, em caso de conflito, a Constituição do Estado sempre prevalecerá. DELMAS-MARTY, Mireille. Por um direito comum. Trad. de Maria Ermantina de Almeida Prado Galvão. São Paulo: M. Fontes, 2004. p. 94 e HIX, Simon; HØYLAND, Bjørn. The political system of the European Union. 3. ed. London: P. Macmillan, 2011. p. 95. A recepção das decisões da CJE acerca da supremacia por parte das referidas cortes (reivindicações concomitantes de discursos de supremacia e de última palavra por parte dos ordenamentos constitucionais e europeu) estimulou o desenvolvimento na Europa de corrente teórica que defende a coexistência de várias Constituições (Neil Maccormick e Neil Walker) ou de uma Constituição Compositiva (Ingolf Pernice) e não uma supraconstitucionalidade monista europeia (tese do ordenamento único). MACCORMICK, Neil. Questioning sovereignty: law, State and nation in the European Commonwealth. Oxford: OUP, 1999. PERNICE, Ingolf. Multilevel constitutionalism and the treaty of Amsterdam: european constitution-making revisited. Common Market Law Review, London, v. 36, n. 4, p. 703-750, 1999. WALKER, Neil. The idea of constitutional pluralism. The Modern Law Review, v. 65, n. 3, p. 317-359, May 2002.

3 A caracterização das teorias, nesse primeiro momento, está baseada na agregação de suas principais consequências práticas, tal como descritas por autores que se ocuparam do tema (e indicados nas notas de rodapé seguintes). Dessa forma, não significa que a breve descrição acima seja compatível ou faça jus às premissas teóricas clássicas, descrição que, inclusive, será questionada ao longo do artigo. Armin Bogdandy considera que o uso da dicotomia também é preponderante entre os autores estrangeiros. VON BOGDANDY, Armin. Pluralism, Direct Effect, and the Ultimate Say. International Journal of Constitutional Law, Oxford, v. 6, n. 3-4, p. 397-413, July/ Oct. 2008. p. 399-400.

4 "International law has primacy over municipal law in both international and municipal decisions". O'CONNELL, Daniel P. The relationship between international law and municipal law. Georgetown Law Journal, New Jersey, v. 48, n. 03, p. 431-485, 1960. p. 432.

5 "[...] the ambition of international law to control the exercise of public power of the state and strengthen the position of the individual remains best expressed in monist theory and is best achieved in states that allow for a socalled monist practice, that is: allow for automatic incorporation". NOLLKAEMPER, André. National Courts and the international rule of law. Oxford: Oxford University, 2012. p. 82. "[...] The monist view holds that international and domestic law are part of a single system, with the result that municipal institutions may apply binding norms of international law (including treaties) just like any other form of domestic law". ALSTINE, Michael P. Van. The role of domestic courts in treaty enforcement. In: SLOSS, David (Org.). The role of domestic courts in treaty enforcement: a compara- 
sua vez, postula a separação dos dois ordenamentos ${ }^{6}$, a superioridade do direito nacional e a exigência de conversão da norma internacional em nacional por meio, geralmente, de uma lei ordinária ${ }^{7}$.

Ambas as teorias são utilizadas por autores do direito constitucional e internacional brasileiro e pelo Supremo Tribunal Federal $(\mathrm{STF})^{8}$ para explicar as relações entre o direito brasileiro e o direito internacional (embora haja preponderância da perspectiva monista) ${ }^{9}$. Dessa forma, a depender da leitura que o autor fizer do conteúdo das normas constitucionais, o Brasil se enquadrará em alguma das teorias e as relações entre ordenamentos serão consequências das respectivas premissas teóricas. Contudo, o panorama normativo brasileiro e a jurisprudência apresentam particularidades que discre-

tive study. Cambridge: Cambridge University, 2009. p. 555-613. p. 564.

6 "Triepel treats the two systems of state law and international law as entirely distinct in nature". STARKE, J. G. Monism and dualism in the theory of international law. British Yearbook of International Law, Oxford, v. 17, p. 66-81, 1936. p. 70.

7 "Since it is always necessary to define the circumstances in which an act of the state legislature or other state organ will be treated as being a declaration of the will of the state, there must be some superior legal norm declaring when this act will bind the state as the expression of its will. Such act, for example ratification of a treaty, is only the condition on which the norm of international law becomes effective for the state". STARKE, J. G. Monism and dualism in the theory of international law. British Yearbook of International Law, Oxford, v. 17, p. 66-81, 1936. p. 72. "A pure dualist approach in contrast, views international and domestic law as separate systems. The consequence is that treaties do not operate of themselves in domestic law; rather, municipal lawmaking bodies must first adapt or adopt domestic law to conform to the international treaty obligations". ALSTINE, Michael P. Van. The role of domestic courts in treaty enforcement. In: SLOSS, David (Org.). The role of domestic courts in treaty enforcement: a comparative study. Cambridge : Cambridge University, 2009. p. 555-613. p. 564.

8 Embora o Ministro Celso de Mello tenha deixado claro que a classificação da Constituição, quanto à aplicabilidade das normas internacionais no plano interno, deve ser extraída de suas próprias normas, sugere que a Constituição, doutrinariamente, poderia enquadrar-se na perspectiva do dualismo moderado. "Sob tal perspectiva, o sistema constitucional brasileiro - que não exige a edição de lei para efeito de incorporação do ato internacional ao direito interno (visão dualista extremada) - satisfar-se, para efeito de executoriedade doméstica dos tratados internacionais, com a adoção de iter procedimental que compreende a aprovação congressional e a promulgação executiva do texto convencional (visão dualista moderada)". MC na ADI 1480 e CR 8279. Deisy Ventrua considera que a posição dualista da interpretação constitucional defendida pelo STF observa-se na consagração da equivalência entre lei interna e tratado internacional, reservando ao direito internacional a mesma regra de solução de conflitos de normas aplicada ao direito interno (lei posterior revoga anterior). VENTURA, Deisy. As assimetrias entre o Mercosul e a União Europeia: os desafios de uma associação inter-regional. São Paulo: Manole, 2003. p. 192-193.

9 A referência pormenorizada dos autores e seu respectivo enquadramento em alguma das duas teorias será aprofundado na seção $\mathrm{X}$ e na nota de rodapé $\mathrm{n}^{\circ} \mathrm{Y}$. pam das premissas elencadas logo acima. São notórias (e serão demonstradas a seguir), por essa razão, as profundas divergências entre os autores nacionais acerca do correto enquadramento de nosso país quanto ao tema das relações entre o direito constitucional e o direito internacional. Os fundamentos da dificuldade classificatória estão no que os autores consideram ser as características e consequências práticas da dicotomia.

Ao questionamento acerca do que significa caracterizar um país como monista ou dualista, é possível elencar três possíveis respostas, partindo-se do pressuposto da viabilidade da dicotomia: 1) significa que um país considera que seu direito constitucional forma um ordenamento unitário com o direito internacional (monismo) ou que ambos os ordenamentos estão separados (dualismo); 2) pode significar que um país adota um modelo de incorporação de normas internacionais que exige a transformação do tratado em lei interna (dualismo), ou que, devidamente incorporado, o tratado será aplicado diretamente pelos órgãos nacionais do país ou, por fim, 3) que, de alguma forma, o processo de incorporação apenas reflete a posição do país a respeito da presença, ou não, de um ordenamento único. O artigo objetiva analisar a pertinência da utilização da dicotomia monismo/dualismo para descrever o modelo de incorporação de normas internacionais no direito brasileiro, ao sugerir que a segunda resposta deve ser dissociada da terceira.

A pesquisa, preponderantemente, bibliográfica, recuperará a construção brasileira sobre a temática, a fim de perquirir a forma com que nossos autores classificam nosso modelo de incorporação, bem como as possíveis limitações dessa classificação. Analisaremos livros, monografias e artigos científicos, bem como decisões do Supremo Tribunal Federal específicas sobre as relações entre direito internacional e constitucional. Em seguida, estudaremos os autores que deram origem à classificação (Hans Kelsen e Heinrich Triepel), com o objetivo de verificar se suas teorias demonstram correlação necessária entre as teses acerca do ordenamento único e os modelos de incorporação a serem adotados pelos Estados. Após a análise da prática constitucional e da jurisprudência do STF, demonstraremos que as categorias do monismo e do dualismo são insuficientes para enquadrar o modelo brasileiro de incorporação de normas internacionais.

Por fim, argumentaremos que a confusão entre uma 
abordagem teórica da dicotomia (tese do ordenamento único) e uma abordagem descritiva (formas de incorporação) dificulta a análise das normas constitucionais brasileiras, porquanto aglutinam o conjunto de críticas e justificativas que podem ser dirigidas à dicotomia (as premissas que subjazem às respostas 1 e 2 acima não são idênticas). Concluiremos que o modelo de incorporação de normas internacionais brasileiro não pode ser descrito como monista (ou suas variações), pois o modelo descritivo não comporta a complexidade constitucional.

\section{O MONISMO E O DUALISMO RECONSTRUÍDO PELOS AUTORES NACIONAIS: CONFUSÃO ENTRE AR- GUMENTOS TEÓRICOS E DESCRITIVOS}

Influenciados pela estrutura clássica do embate entre dualistas e monistas germânicos nos séculos XIX e $\mathrm{XX}$, os autores brasileiros enumeram as características das teorias clássicas utilizando Hans Kelsen e Heinrich Triepel como os principais baluartes de ambas e, de maneira quase metonímica, identificam o monismo com Kelsen e o dualismo com Triepel. Em seguida, os autores brasileiros extraem (e reconstroem) dos autores clássicos o que consideram os principais elementos de cada um de seus posicionamentos.

Dessa forma, de acordo com os autores nacionais ${ }^{10}$,

10 As características foram compiladas com base nos seguintes autores: Carlos Husek, Mirtô Fraga, Mariângela Ariosi, Patrícia Henriques Ribeiro, George Rodrigo Bandeira Galindo, Bruno Pereira, Hee Moon Jo, Celso A. Mello, Pagliarini, Roberto Silva, Luís Roberto Barroso, Valério Mazzuoli. Identificamos, apenas, dois autores que tentam elaborar posições que se distanciam da tradicional abordagem dos autores nacionais. Yamamoto, de um lado, tenta se desvencilhar da dicotomia monismo e dualismo, contextualizando as teorias clássicas com a abordagem sistemática do cientista político David Easton; por meio dela, sugere que ambas não seriam posições teóricas a serem acolhidas de maneira estanque e definitiva, posto dependerem da dinamicidade dos contextos políticos e jurídicos dos sistemas analisados. Portanto, um país não seria monista ou dualista, mas estaria monista ou dualista. Além de confusa, a tese do autor persiste na noção de hierarquia entre fontes normativas de direito internacional e interno e ressuscita, como principal fator para a estipulação das hierarquias, a distinção entre tratado-lei e tratado-contrato. YAMAMOTO, Toru. Direito internacional e direito interno. Porto Alegre: S. A. Fabris, 2000. p. 239. Por outro lado, como a exceção que comprova a regra, Estêvão Couto sustentou a obsolescência do que denominou de teorias do direito internacional clássico (monismo e dualismo) para explicar a relação entre o direito interno e internacional. Ao propor a conjugação do direito internacional com as teorias das relações internacionais, concluiu que as relações entre o dualismo possuiria as seguintes características: 1) cisão rigorosa entre as ordens jurídicas nacionais e internacionais; 2) independência de ordenamentos, porquanto uma ordem jurídica não determina a validade das normas da outra; 3) os ordenamentos formam dois círculos em contato íntimo, mas não sobrepostos; 4) as normas regulam relações sociais diferenciadas e emanam de fontes diversas; 5) para a concepção dualista não podem ocorrer conflitos entre as normas internacionais e nacionais, portanto não se aplicam métodos de solução de conflitos normativos, pois sempre deve ser aplicada a norma interna em detrimento da internacional e 6) tendo em vista que não se relacionam ou conflitam, para a norma internacional ser aplicada no plano nacional pelos órgãos constitucionais, aquela deve ser transformada em direito nacional.

O monismo, por sua vez, se caracterizaria por: 1) todas as normas jurídicas estarem subordinadas entre si, dispostas hierarquicamente; 2) os ordenamentos jurídicos não serem autônomos; 3) inexistir conflito entre normas porque o ordenamento é unificado e unitário, portanto, sempre prevaleceria a norma superior hierarquicamente e 4) não ser necessária a transformação do ato internacional em normas internas.

Os autores atestam, ademais, existir duas subdivisões do projeto monista: a) monismo com primazia do direito interno, que se caracteriza da seguinte maneira: i) por conta da ausência de uma autoridade supra estatal que regule as interações entre os ordenamentos, competiria a cada Estado determinar livremente suas obrigações internacionais, conformando-as como juiz único de sua execução e ii) o direito internacional existe, apenas, em função dos Estados, apesar de importante e b) monismo com primazia do direito internacional: i) ordem jurídica interna deriva da ordem internacional que é suprema e ii) apesar da possibilidade de conflitos, a preponderância

os ordenamentos são complexas e não se encaixam na categorização estanque e excludente das teorias tradicionais, focadas em contextos políticos e sociais superados. Para Couto, as relações ocorrem com base em um continum que denominou de índice de permeabilidade. Analisando os julgados em que o STF e STJ discutiram matérias de direito internacional, o autor observou que a posição dos tribunais acerca da interpretação da norma internacional variava de acordo com sua formação, o objeto de análise e o tempo, o que poria em xeque analisar a relação do direito brasileiro com o direito internacional sob a ótica monista ou dualista. Apesar do valioso diagnóstico, o autor não apresentou novos modelos para superar os clássicos. COUTO, Estêvão Ferreira. A relação entre o interno e o internacional: concepções cambiantes de soberania, doutrina e jurisprudência dos tribunais superiores no Brasil. Rio de Janeiro: Renovar, 2003. 
será do Direito Internacional.

Em relação à análise dos três parágrafos acima, podemos separar em dois os tipos de argumentos enumerados por ambas as teorias de acordo com os autores brasileiros: argumentos referentes à unidade dos ordenamentos jurídicos ${ }^{11}$ e argumentos acerca dos procedimentos de incorporação ${ }^{12}$. Ambos os argumentos não necessariamente caminham de mãos dadas. A construção teórica mais ampla abstrata acerca da natureza das relações entre o direito internacional e nacional do primeiro argumento não exige a constatação de que, no plano constitucional, um país deva adotar um modelo específico de incorporação de normas internacionais, de acordo com o segundo argumento. Pelo caminho inverso, a escolha de um modelo de incorporação por parte de um país não é um indício absoluto de que encampe ou afaste as teses acerca do ordenamento único.

Dessa forma, a reconstrução brasileira das teorias germânicas tende a confundir os dois argumentos (ordenamento único e modelos de incorporação), acarretando problemas quanto à validade dos critérios classificatórios analisados, pois dificulta a identificação de que âmbito argumentativo da dicotomia monismo/dualismo os autores estão a analisar. Dito de outra forma, a classificação do Brasil como um país monista ou dualista, tal como atualmente é feita, falha em demonstrar explicitamente se nosso ordenamento constitucional está contido, ou não, no direito internacional (tese do ordenamento único) ou se adota um modelo de aplicabilidade direta ${ }^{13}$ ou de transformação das normas inter-

11 Do lado dualista, os argumentos seriam os de números 1 a 5; do lado monista, os argumentos de 1 a 3 .

12 Do lado dualista, o argumento de número 6; do lado monista, o argumento de número 4 . O modelo de incorporação de normas internacionais é relevante, ainda, porque a escolha feita pela Constituição pode determinar se uma obrigação internacional poderá ser caracterizada como uma norma jurídica aplicável pelo Poder Judiciário. Um modelo de transformação veda que juízes apliquem a obrigação normativa não veiculada por meio de uma lei ordinária, por exemplo. NOLLKAEMPER, André. National Courts and the international rule of law. Oxford: Oxford University, 2012. p. 68.

13 A aplicabilidade direta de um tratado caracteriza-se pela existência de uma norma interna (geralmente constitucional) que considera o direito internacional como parte do direito nacional, sem a necessidade de uma legislação ordinária implementadora posterior à ratificação para ser aplicado pelo Poder Judiciário interno. NOLLKAEMPER, André. National Courts and the international rule of law. Oxford: Oxford University, 2012. p. 73-74. A ideia de aplicabilidade direta está diretamente ligada ao cânone da autoexecutoriedade (selfexecution) dos tratados internacionais, desenvolvido pela Suprema Corte dos Estados Unidos em Foster \& Elam v. Neilson, 27 U.S (1829), precedente em que afirmou a possibilidade de aplicação de regras nacionais ${ }^{14}$.

Em suma, as teses do ordenamento único não acompanham, necessariamente, um modelo de incorporação. Dessa forma, além de uma leitura superficial do âmbito teórico da dicotomia, os autores nacionais confundem o referido âmbito com as abordagens descritivas do monismo e do dualismo, focadas na diferença entre os processos de incorporação das normas internacionais, sem que, no entanto, discutam sobre a tese mais ampla acerca da unidade dos ordenamentos. Aprofundaremos essa assertiva com mais vagar a seguir.

\section{O MONISMO de KeLSEN, O dUALISMO de Trie- PEL E OS MODELOS DE INCORPORAÇÃO DE NORMAS INTERNACIONAIS}

As teorias clássicas referenciadas acerca das relações entre direito interno e internacional surgiram em um contexto histórico, político e científico específico que remonta ao final do século XIX e muito diferem do contexto constitucional brasileiro atual. O monismo e o dualismo germânicos são frutos de uma época em que o direito buscava se firmar como uma ciência autônoma, seguindo o desenvolvimento das demais ciências iniciado no início do século XIX, ou seja, são reflexos do positivismo científico e da necessidade de firmar o direito como uma categoria apreensível pela metodologia científica das ciências naturais ${ }^{15}$.

extraídas de um tratado sem a necessidade de desenvolvimento legislativo posterior em casos de tratados autoexecutáveis (self-executing), em função do disposto no art. VI da Constituição norte-americana (... all treaties made, or which shall be made, under the authority of the US., shall be the supreme law of the land...). JANIS, Mark Weston. International law. 5. ed. New York: Aspen, 2008. p. 91-95.

14 A transformação das normas internacionais, por sua vez, caracteriza-se pela determinação de que os tribunais nacionais só poderão aplicar um tratado após a edição de lei transformadora do tratado em direito interno, portanto, exige-se necessária ação legislativa posterior. NOLLKAEMPER, André. National Courts and the international rule of law. Oxford: Oxford University, 2012. p. 77-78. Malcolm Shaw, por exemplo, refere-se à necessidade de transformação (transformation) das regras internacionais em direito interno (municipal law), por meio dos meios constitucionais apropriados (como uma lei do Parlamento britânico), para que surtam qualquer efeito dentro da jurisdição nacional. SHAW, Malcolm N. International law. 6. ed. New York: Cambridge University, 2008. p. 139.

15 Martti Koskenniemi postula que as teorias do direito internacional posteriores ao século XVIII (o que inclui o monismo e o dualismo) são respostas liberais aos principais pilares dos teóricos naturalistas. Os últimos defendiam a existência de um conjunto de normas jurídicas vinculantes universais, produzidas, naturalmente, e 
Não obstante o contexto político e social diverso, os autores brasileiros insistem em mesclar os argumentos acerca do ordenamento único com o argumento dos possíveis modelos constitucionais de incorporação das normas internacionais. Para demonstrar a distinção dos argumentos e a impertinência da correlação feita pelos autores brasileiros, precisamos, ainda que brevemente, voltar aos autores clássicos.

Em suma, o monismo kelseniano está ligado à ideia de que o Direito internacional e o direito interno fazem parte de um todo, na medida em que a norma hipotética fundamental dos países que encetam relações de direito internacional público pode ser esboçada, de maneira crua, da seguinte maneira: "que os Estados se regulem por seus costumes". E, para Kelsen, o costume prevalecente nas relações internacionais é o do pacta sunt servanda (tratados são firmados na crença de sua observância de boa-fé pelos pactuantes). A unidade do ordenamento jurídico, portanto, é um pressuposto lógico de dois ordenamentos que intencionam ser caracterizados como jurídicos - se tanto o direito constitucional como o internacional são interpretados como jurídicos, ambos devem compartilhar do mesmo critério de validade. Tendo em vista que o critério de validade de todos os ordenamentos que reivindicam discursos jurídicos é uma norma hipotética fundamental, os ordenamentos constitucionais são considerados como jurídicos, pois podem reconduzir sua validade a uma mesma norma hipotética fundamental internacional ${ }^{16}$.

cognoscíveis pela razão. $\mathrm{O}$ paradigma liberal questiona a existência de uma ordem jurídica natural (não consentida pelo homem) e a parcialidade ideológica de normas jurídicas "naturais" alcançadas, apenas, pelo recurso à razão. Em contrapartida, oferece um modelo em que o direito internacional serve de moldura normativa consensual para as relações entre Estados, a fim de que desenvolvam suas relações políticas. Do ponto de vista da ciência jurídica, o parâmetro liberal exige a limitação do fenômeno jurídico, apenas, àquelas normas oficialmente editadas que poderiam ser caracterizadas como fruto de um acordo de vontades soberanas (a representação jurídica é feita por meio de critérios que diferenciam os sistemas normativos morais e jurídicos). KOSKENNIEMI, Martti. From apology to utopia: the structure of international legal argument. Cambridge: Cambridge University, 2005.

16 A noção de direito internacional de Kelsen, como salientado por Hart, estava baseada na premissa da analogia com o direito interno. HART, Herbert L. A. The concept of law. 2. ed. Oxford: Clarendon, 1994. p. 237. Uma vez que Kelsen delimita a análise do direito às normas identificadas como jurídicas no plano interno, o autor de Viena precisava utilizar os mesmos critérios interpretativos para o plano internacional. No plano interno, normas jurídicas são aquelas que podem ser garantidas por mecanismos coativos institucionalizados de forma autorizada pela comunidade política e globalmente eficazes. No plano internacional, as normas internacionais se caracterizam pelas medidas coativas representadas pelas guerras justas e
De acordo com Kelsen, a violação de uma norma internacional em decorrência dos procedimentos constitucionais de incorporação e do conteúdo material das leis, não pode ser revista pelo direito internacional, uma vez que inexiste norma internacional capaz de revogar a Constituição do país ou obrigar o país a revogar uma lei violadora do direito internacional (critério formal de validade do direito e identidade entre Direito/Estado — o Estado não viola o direito, pois é o próprio direito), nesses casos, são cabíveis, no plano internacional, as sanções internacionais (represálias e guerra justa).

Por outro lado, Kelsen identifica a existência de três possíveis critérios constitucionais para a solução de antinomias: a) direito nacional será sempre aplicado, mesmo em contradição à norma internacional; b) o conflito será solucionado pelo princípio lex posterior derogat priori, mesmo que o tratado internacional ainda esteja em vigor no plano internacional e c) o direito internacional sempre terá precedência sobre o nacional, cabendo aos tribunais internos declarar as leis nacionais violadoras dos tratados como nulas ${ }^{17}$.

No que diz respeito à obrigatoriedade de transformação do direito internacional em nacional como um pressuposto monista, objeto de atenção do artigo, Kelsen é explícito ao afastar a correlação entre aplicabilidade direta de um tratado e a tese do ordenamento único. Para o autor de Viena, a obrigatoriedade de transformação do direito internacional em nacional é uma particularidade do direito positivo constitucional de cada país ${ }^{18}$. $\mathrm{Na}$ inexistência de ressalva constitucional expressa (o autor reconhece que, caso a Constituição obrigue, os tribunais apenas poderão aplicar direito interno), contudo os tribunais seriam competentes para aplicar os tratados diretamente quando assim o puderem ${ }^{19}$.

represálias. KELSEN, Hans. Teoria pura do direito. Trad. João Batista Machado. 7. ed. São Paulo: M. Fontes, 2006 e KELSEN, Hans. Teoria geral do direito e do Estado. São Paulo: Martins Fontes, 2000.

17 KELSEN, Hans. Teoria geral do direito e do Estado. São Paulo: M. Fontes, 2000. p. 539.

18 KELSEN, Hans. Teoria geral do direito e do Estado. São Paulo: M. Fontes, 2000. p. 537.

19 Neste momento de seu texto, Kelsen visivelmente diferencia tratados-normativos de tratados-contratos, pois sustenta, que, no caso de tratados que exigem a emissão de estatuto ou que preveja a criação de regras específicas, a obrigação internacional é a de que sejam editadas normas, especialmente, por meio do Poder Legislativo. Acerca da diferença entre tratados-normativos e tratados-contratos, Hildebrando Accioly caracteriza o primeiro como tratados multilaterais que fixam ou exigem a produção de normas; enquanto os últimos caracterizam-se por regularem interesses recíprocos dos Estados, frutos de concessões mútuas. ACCIOLY, Hildebrando. Manual 
Kelsen afirma que a solução para ambas as situações (critérios para solução de antinomias e aplicabilidade direta dos tratados) "só pode ser respondida pelo direito positivo, não por uma doutrina da natureza do direito internacional ou do direito nacional ou da sua relação mútua" ${ }^{20}$. Como havíamos argumentado, Kelsen separa duas abordagens acerca da dicotomia monismo/ dualismo (uma teórica e outra descritiva), ao defender que seu monismo independe dos critérios de soluções de conflitos e dos procedimentos constitucionais de incorporação dos tratados internacionais.

Portanto, não são as formas de incorporação do ato ou as formas de solução de conflitos que caracterizam o monismo kelseniano, mas a compreensão teórica de que apenas podemos falar de um direito internacional efetivo se pressupusermos que este valida as normas jurídicas nacionais em um único ordenamento, uma vez que o direito internacional determinaria, enquanto ordenamento superior, a norma fundamental permissiva das relações entre os Estados e da validade dos direitos internos ${ }^{21}$.

Triepel $^{22}$, por sua vez, calca sua teoria nas distinções

de direito internacional público. 11. ed. São Paulo: Saraiva, 1976. p. 121. 20 KELSEN, Hans. Teoria geral do direito e do Estado. São Paulo: M. Fontes, 2000. p. 539.

21 Kelsen compreende o dualismo como uma relação entre direito e moral, porque direito internacional e nacional não podem ser tidos como sistemas jurídicos diferentes e mutuamente independentes se as normas de ambos os sistemas forem consideradas válidas para o mesmo espaço e tempo. KELSEN, Hans. Teoria geral do direito e do Estado. São Paulo: M. Fontes, 2000. p. 516. Ou seja, o monismo não se identifica pela ausência de procedimentos formais de incorporação de um tratado além da assinatura, mas pela suposição de que os ordenamentos jurídicos operam pelos mesmos critérios de validade. Se o dualismo sustenta a existência de dois ordenamentos diferenciados separados e independentes, um dos ordenamentos não será jurídico, porquanto a ele se atribui um critério de validade diferenciado. Por essa razão, Kelsen considera que o direito internacional, para o dualismo, seria um ordenamento normativo moral e não jurídico. Alexander Somek reforça o argumento — o monismo é fruto de uma afirmação teórica acerca da defesa de um único e possível critério de validade para o que se considera como fenômeno jurídico. SOMEK, Alexander. Kelsen lives. The European Journal of International Law, v. 18, n. 3, p. 409-451, 2001. p. 424-425. No mesmo sentido, para Jochen von Bernstorff a unidade dos ordenamentos jurídicos seria uma premissa epistemológica apta a dispor todo o material normativo jurídico em um contexto interpretativo lógico. BERNSTORFF, Jochen von. The public international law theory of Hans Kelsen: believing in universal law. Cambridge: Cambridge University, 2010. p. 80. No direito brasileiro, George Galindo já havia chegado a esta conclusão. No entanto, considera que a incorporação seria um ponto prejudicial para a defesa da postura hierárquica kelseniana. Ponto que discordamos. GALINDO, George Rodrigo Bandeira. Tratados internacionais de direitos bumanos e Constituição Brasileira. Belo Horizonte: Del Rey, 2002. p. 65.

22 TRIEPEL, Heinrich. Droit international et droit interne. Paris: Oxford, 1920. p. 19-23. do objeto das relações (rapports régis) e de fontes (sources) existentes entre direito internacional e nacional. Para o jurista alemão, o âmbito das matérias de cada ordem é exclusivo; portanto, a diferença entre os direitos está no conteúdo das relações estabelecidas ${ }^{23}$. O direito internacional estabeleceria uma relação de coordenação entre Estados (a Constituição não pode criar regras de coordenação entre Estados soberanos) e não entre indivíduos, os quais não possuiriam direitos na esfera internacional. Portanto, no que diz respeito às matérias, não há conflitos (concurrence) entre as ordens jurídicas ${ }^{24}$. As regras jurídicas, para o autor, são caracterizadas pelo conteúdo de uma vontade que intenciona limitar a vontade humana de forma obrigatória, portanto, uma vontade superior à individual ${ }^{25}$. A fonte do direito seria a vontade de onde deriva a regra jurídica: no direito interno, a vontade superior é do Estado; no direito internacional, a vontade conjunta e comum dos Estados soberanos ${ }^{26}$.

Para o alemão, ainda que as Constituições disponham que o tratado internacional deva ser considerado como direito interno ou que se torne obrigatório independentemente de outras formalidades (ou seja, Constituições que determinam a aplicabilidade direta do tratado), a separação entre ordenamentos defendida pelo dualismo é, ainda assim, mantida por dois argumentos não excludentes: a) em ambos os casos são necessários atos formais de constituição da vontade interna (como,

23 Ponto contestado por Kelsen, que defendia que o direito internacional poderia regular matérias constitucionais.

24 Os exemplos utilizados pelo autor limitam-se a questões comerciais e tributárias.

25 TRIEPEL, Heinrich. Droit international et droit interne. Paris: Oxford, 1920. p. 28-29.

26 TRIEPEL, Heinrich. As relações entre o direito interno e o direito internacional. Trad. Amílcar de Castro. Revista da Faculdade de Direito da Universidade Federal de Minas Gerais, Belo Horizonte, v. 17, n. 6, p. 07-64, 1966. p. 13-14. A postulação de uma vontade superior comum é um refinamento da tese de que os Estados se obrigam para criar o direito internacional de Jellinek. Para Triepel, a imposição jurídica não ocorre por conta da autolimitação unilateral da soberania, mas da vontade conjunta dos Estados (uma terceira vontade, portanto). Tal união de vontades deve possuir força obrigatória - a vontade comum que surgirá por meio dos acordos geradores do direito entre os Estados. Uma união de vontades, não como, necessariamente, um contrato em que são agregadas vontades opostas, mas como uma vontade concorrente de criar uma regra permanente (vereinbarung). Ou seja, os Estados soberanos criam direito internacional quando demonstram uma vontade concorrente de se submeterem a regras obrigatórias, que limitam as vontades inferiores consideradas individualmente. TRIEPEL, Heinrich. As relações entre o direito interno e o direito internacional. Trad. Amílcar de Castro. Revista da Faculdade de Direito da Universidade Federal de Minas Gerais, Belo Horizonte, v. 17 , n. 6, p. $07-64$, 1966. p. 30-35 
por exemplo, a ratificação) e/ou b) quem determina a equiparação é a própria Constituição, ordem interna que representaria a vontade do Estado ${ }^{27}$. Ao tratar da Constituição "monista" por excelência, a Norte-Americana, que prevê em seu art. VI que os tratados internacionais serão part of the law of the land, Triepel argumenta que tal disposição não significa que não haja, anteriormente, uma proclamação formal do Presidente da República após a ratificação do tratado. Ademais, conclui Triepel, para a aplicação do tratado naquele país foi necessária intervenção estatal anterior ${ }^{28}$, ainda que emanada diretamente da Constituição (fonte de direito interno).

A problemática da necessária incorporação do direito internacional pelo direito constitucional é algo que ambas as teorias lidam de forma semelhante (não idêntica, contudo) ${ }^{29}$. Kelsen afirma que a forma de incorporação depende do direito interno, que pode prescrever um necessário ato de incorporação, como a transformação do tratado em lei interna. Da mesma forma, Triepel sustenta que as ordens de execução são atos necessários para a aplicação interna de um regramento internacional (não necessariamente do tratado). A preocupação de Triepel é com a adaptação de vontades, não com a forma (que pode ser legislativa, por exemplo). Portanto, do pressuposto da unidade de ordenamento não decorre a desnecessidade de atos de transformação pela visão monista; e, igualmente, da hipótese da separação dualista, não decorre a necessidade de uma adaptação decorrente de uma lei formal, bastante qualquer ato constitutivo (decreto de promulgação ou norma constitucional autorizativa).

\section{A DICOTOMIA MONISMO/DUALISMO EM SUA ABOR- DAGEM DESCRITIVA: MODELOS CONSTITUCIONAIS DE INCORPORAÇÃO DE TRATADOS INTERNACIONAIS}

Após a demonstração de que as teorias germânicas de Kelsen e Triepel não acoplam modelos específicos de incorporação das normas internacionais às suas cons-

27 TRIEPEL, Heinrich. As relações entre o direito interno e o direito internacional. Trad. Amílcar de Castro. Revista da Faculdade de Direito da Universidade Federal de Minas Gerais, Belo Horizonte, v. 17, n. 6, p. 07-64, 1966. p. 26.

28 TRIEPEL, Heinrich. As relações entre o direito interno e o direito internacional. Trad. Amílcar de Castro. Revista da Faculdade de Direito da Universidade Federal de Minas Gerais, Belo Horizonte, v. 17, n. 6, p. 07-64, 1966. p. 27.

29 Não podemos deixar de observar que, para Triepel, ainda que o tratado seja aplicado diretamente, a escolha do modelo de incorporação sempre poderá ser justificada pela tese de que os ordenamentos não formam uma unicidade. truções teóricas acerca das teses referentes à existência ou não de um ordenamento único, precisamos reforçar a distinção das diferentes abordagens da dicotomia.

Ao discorrer acerca da dicotomia monismo/dualismo, John Jackson ${ }^{30}$, analisando os impactos políticos da escolha de um modelo de incorporação de normas internacionais no momento da promulgação de uma Constituição e ressaltando as confusões terminológicas da dicotomia, afirma que a distinção monismo/dualismo pode ser interpretada como uma escolha constitucional política acerca dos efeitos dos tratados no plano interno. Afirma o autor que um modelo de aplicabilidade direta do tratado pode, dentre outros argumentos ${ }^{31}$, ser sustentado com base em uma tomada de posição teórica acerca da unidade de ordenamentos jurídicos e consequente superioridade hierárquica do direito internacional ${ }^{32}$. Ou seja, a escolha política constitucional de um modelo de aplicabilidade direta de um tratado independe da posição teórica acerca da tese da unidade, ou não, dos ordenamentos jurídicos, pois a posição teórica pode ser utilizada como um motivo, portanto critério não determinante, para o modelo de incorporação. John Jackson sugere, portanto, que podemos caracterizar, também, a escolha política constitucional pela aplicabilidade direta ou não dos tratados internacionais como uma escolha entre monismo e dualismo.

Mais recentemente, David Sloss ${ }^{33}$ reforça a existência da separação entre as abordagens teóricas e descritivas da dicotomia monismo e dualismo, ainda que ambas sejam pertinentes à relação entre direito internacional e

30 JACKSON, John. Status of treaties in domestic legal systems: a policy analysis. American Journal of International Law, Washington, v. 86, n. 2, p. 310-340, abr. 1992. p. 313-314.

31 O autor elenca, igualmente, as seguintes razões para uma Constituição adotar um modelo de aplicabilidade direta dos tratados: a) atribuir o aumento e garantia da efetividade do direito internacional ao dar aplicação direta aos tratados, diminuindo a possibilidade de as autoridades nacionais o negligenciarem e b) assumir a aplicabilidade direta do tratado serve de exemplo para que outros Estados cumpram, também, suas obrigações internacionais e, por fim, assegura direitos diretamente aplicáveis às pessoas no sistema jurídico quando um tratado contém normas a elas destinadas. JACKSON, John. Status of treaties in domestic legal systems: a policy analysis. American Journal of International Law, v. 86, n. 02, p. 310-340, abr. 1992. p. 322.

32 JACKSON, John. Status of treaties in domestic legal systems: a policy analysis. American Journal of International Law, Washington, v. 86, n. 2, p. 310-340, abr. 1992. p. 321.

33 SLOSS, David. Treaty enforcement in domestic courts: a comparative analysis. In: (Org.). The role of domestic courts in treaty enforcement: a comparative study. Cambridge: Cambridge University, 2009. p. 01-66. 
nacional. Uma das abordagens da dicotomia diz respeito à unidade ou não dos ordenamentos, enquanto outra abordagem descreve os diferentes tipos de modelos constitucionais de incorporação de normas internacionais (aplicabilidade direta ou transformação das normas internacionais $)^{34}$. Quando utilizamos a abordagem descritiva, afirma o autor, não nos comprometemos sobre a relação mais ampla entre direito internacional e nacional, apenas atestamos algo acerca do status do direito internacional no direito interno ${ }^{35}$. Michael Alstine ${ }^{36}$ compartilha da mesma posição.

Especialmente nos estudos norte-americanos ${ }^{37}$ do direito internacional, a linha demarcatória que separa a abordagem teórica da descritiva é mais forte do que a observada em nosso país. O viés pragmático dos estudos norte-americanos acerca do debate entre monismo e dualismo ${ }^{38}$ realçou a distinção que já podia ser identificada nas prescrições teóricas germânicas. A importância

34 Anthony Aust endossa a posição descritiva, na medida em que trata a dicotomia dualismo/monismo de acordo, apenas, com as normas constitucionais que incorporam as obrigações internacionais. Para o referido autor, sob a abordagem dualista, os direitos e obrigações criados pelas normas internacionais não têm efeito na ordem jurídica interna, exceto na medida em que a legislação ordinária atribuir efeito aqueles. Quando a legislação é editada especificamente para tal intento, os direitos e obrigações são, então, considerados como "incorporados" ao direito interno. Por outro lado, a essência da abordagem monista está na pressuposição de que, independentemente da edição de uma lei posterior, um tratado pode tornar-se parte do direito interno, desde que tenha sido celebrado em conformidade com a Constituição e tenha entrado em vigor para o Estado. AUST, Anthony. Handbook of international law. 2. ed. Cambridge: Cambridge University, 2010. p.75-76.

35 Para reforçar o ponto, vamos transcrever excerto do texto de Sloss: "when used in this way (o autor refere-se à abordagem descritiva da dicotomia), the proposition that a particular state is a dualist does not say anything about the general relationship between domestic and international law; it merely says sometbing about the status of international law in the domestic legal system of that state". SLOSS, David. Treaty enforcement in domestic courts: a comparative analysis. In: (Org.). The role of domestic courts in treaty enforcement: a comparative study. Cambridge: Cambridge University, 2009. p. 01-66. p. 06.

36 ALSTINE, Michael P. Van. The role of domestic courts in treaty enforcement. In: SLOSS, David (Org.). The role of domestic courts in treaty enforcement: a comparative study. Cambridge : Cambridge University, 2009. p. 555-613. p. 565.

37 Na Europa, Gordillo faz o mesmo argumento acerca da existência das duas abordagens acerca da dicotomia monismo/dualismo.

38 NIJMAN, Janne; NOLLKAEMPER, Andre. Introduction. In: (Coord.). New perspectives on the divide between international and national law. Oxford: Oxford University, 2007. p. 01-14 e GALINDO, George Rodrigo Bandeira. Revisiting monism's ethical dimension. In: CRAWFORD, James; NOUWEN, Sarah. (Org.). Select proceedings of the European Society of International Law, 2010. Oxford: Hart Publishing, 2012. v. 3. p. 141-153. p. 141. de distinguirmos as diferentes abordagens destina-se à formulação das críticas que podem ser dirigidas a cada uma delas, bem como às formas de justificação dos modelos de incorporação institucionalizados constitucionalmente.

No Brasil, um monista de cunho teórico kelseniano, por conseguinte, defensor da unidade dos ordenamentos jurídicos, não pode classificar a Constituição brasileira como monista tão somente porque o tratado é aplicado diretamente. Além do mais, as justificativas para a defesa do ordenamento único não podem limitar-se ao aspecto descritivo da abordagem dicotômica, ou seja, o modelo de incorporação constitucional será um argumento insuficiente para defender um monismo kelseniano. Os modelos de incorporação das normas internacionais justificam-se, por exemplo, como consequências da estrutura constitucional de separação de poderes $^{39}$.

Ademais, para cada abordagem, um conjunto diferente de críticas precisa ser formulado. Não podemos, por exemplo, argumentar que uma Constituição nega o dualismo de Triepel indicando o modelo de incorporação constitucional. Do ponto de vista da abordagem teórica da dicotomia, as críticas e justificativas de defesa têm de ser dirigidas aos pressupostos das teorias do direito desenvolvidas pelos autores. No caso de Kelsen, ao positivismo formalista e suas prescrições ${ }^{40}$; no caso de Triepel, ao seu voluntarismo e à sua teoria do direito de matriz hegeliana ${ }^{41}$. Por outro lado, para criticarmos as disposições acerca da abordagem descritiva, temos de nos focar nas regras constitucionais que compreendem o modelo de incorporação de normas internacionais (aplicabilidade direta ou transformação).

39 NOLLKAEMPER, André. National courts and the international rule of law. Oxford: Oxford University, 2012. p. 80-82.

40 Identificação entre Direito e Estado (reduzindo o papel da soberania no plano internacional); princípio da eficiência (o reconhecimento de um território como Estado depende, exclusivamente, de critérios do direito internacional); ordenamento jurídico como ordem coativa (normas internacionais identificadas como jurídicas por meio da guerra justa e das represálias); redução do critério único de validade do direito a normas hipotéticas fundamentais (a validade do direito constitucional pode ser reconduzida a uma norma jurídica internacional costumeira).

41 Distinção entre política e direito nas relações internacionais (proeminência do papel da soberania nas relações internacionais, que demarca o campo de atuação do Estado como ente capaz de decidir voluntariamente pela construção das normas jurídicas internacionais); separação de matéria e de fontes entre o direito internacional e interno e direito como vontade soberana (o surgimento de obrigações jurídicas e seu caráter vinculante dependem de manifestações de vontade capazes de subordinar ações). 


\section{O MODELO CONSTITUCIONAL BRASILEIRO DE INCORPORAÇÃO DE NORMAS INTERNACIONAIS: AFI- NAL, SOMOS MONISTAS OU DUALISTAS?}

Nesta seção, iremos nos focar na abordagem descritiva da dicotomia monismo/dualismo. Portanto, nosso foco será no modelo de incorporação de normas internacionais previsto pelo direito constitucional brasileiro e como esse modelo é interpretado pelos autores nacionais ${ }^{42}$. Além da apropriação equivocada e confusa da dicotomia, que insere argumentos justificatórios da abordagem teórica para defender modelos de incorporação, observaremos que os autores brasileiros não chegam a uma conclusão acerca da categorização descritiva do ordenamento brasileiro em monista ou dualista em face da limitação do critério classificatório. A seguir, descreveremos as regras constitucionais brasileiras acerca da incorporação de normas internacional, exporemos a posição dos autores nacionais (portanto, visões que confundem as duas abordagens) e defenderemos a insuficiência da dicotomia descritiva monismo/dualismo

42 Gustavo Binenbojm apresenta uma perspectiva semelhante, mas não idêntica — o autor intenciona compreender a maneira pela qual os teóricos brasileiros se apropriaram dos conceitos "monismo" e "dualismo". Todavia, sua conclusão é a de que, tendo em vista que as teorias apresentam critérios diferenciados para solução dos conflitos normativos, ambas podem ser acolhidas simultaneamente. Do ponto de vista da incorporação e dos mecanismos de internalização dos tratados, por exemplo, o Brasil seria dualista moderado, pois não exige lei específica reproduzindo o tratado por completo, mas o decreto executivo se perfaz como fonte normativa interna autônoma. Por outro lado, do ponto de vista da admissibilidade dos conflitos e seus critérios de solução, o país seria monista moderado, uma vez que o tratado é a fonte normativa operando no ordenamento jurídico BINENBOJM, Gustavo. Monismo e dualismo no Brasil: uma dicotomia afinal irrelevante. Revista da EMERJ, Rio de Janeiro, v. 3, n. 9, p. 180-195, 2000. p. 194-195. Portanto, o autor afirma que as teorias ainda podem servir de ideal regulativo das relações entre ordenamentos jurídicos internos e internacionais. Ponto que discordamos, uma vez que, além de reproduzir a malfadada tentativa de retenção das teorias clássicas pela utilização das adjetivações vazias, a separação entre critérios dualistas e monistas apenas faria sentido se o autor estivesse, necessariamente, tratando de ambas as teorias. Em verdade, Binenbojm lança mão de arquétipos construídos pelos autores brasileiros que os nomearam baseados no que acreditam serem as consequências práticas de teorias formuladas na Alemanha weimariana. Por fim, os critérios apresentados pelo autor, ainda, continuam insatisfatórios e incompletos para explicar a complexa interação entre direito constitucional e internacional. Concordamos, ademais, com Estêvão Couto quando sustenta que as teorias clássicas são inconciliáveis, que suas hipóteses são mutualmente excludentes e que não comportam gradações em suas premissas. COUTO, Estêvão Ferreira. A relação entre o interno e o internacional: concepções cambiantes de soberania, doutrina e jurisprudência dos tribunais superiores no Brasil. Rio de Janeiro: Renovar, 2003. p. 57-58. para caracterizar o modelo brasileiro.

\subsection{Inexigibilidade de transformação do tra- tado em lei nacional, sendo requerido Decreto Executivo para sua aplicabilidade no país (or- dem de execução)}

De acordo com os pressupostos do dualismo, tal qual reconstruído pelos autores nacionais conforme exposto no início do artigo (seção 2), a independência das ordens jurídicas enseja a necessidade de transformação do tratado em direito interno. Tal incorporação teria de ser feita, via de regra, por uma lei que reproduzisse, na íntegra, o tratado internacional. Por sua vez, o monismo consagraria a simples ratificação para aplicação direta do tratado internacional no direito interno, pois o ordenamento seria unitário e o ordenamento internacional, superior hierarquicamente.

A Constituição brasileira, sustentam os autores nacionais, dispõe que os tratados é que são aplicados, diretamente, ao ordenamento jurídico, porquanto as normas constitucionais citam de forma explícita as expressões "tratado" "43, "acordos" ${ }^{44}$ ou "convenções" $" 45$ quando visam dispor sobre atos internacionais que vigem no plano constitucional. Consideram que a citação expressa seria um indício de que as referidas espécies normativas seriam autônomas e aplicáveis por si mesmas.

A característica monista da Constituição seria demonstrada pela aplicação direta e imediata do tratado, sem a necessidade de sua conversão ou transformação legislativa. Contudo, o $\mathrm{STF}^{46}$ considera que, a despeito

43 Cf. art.: $5^{\circ}, \iint 2^{\circ}$ e $3^{\circ}$; art. 49; art. 71, V; art. 84, VIII; art. 102, III, b; art. 105, III, a e art. 109, III, V e $\int 5^{\circ}$. BRASIL. Constituição (1988). Constituição da República Federativa do Brasil. Disponível em: $<$ http://www.planalto.gov.br/ccivil_03/constituicao/ConstituicaoCompilado.htm>. Acesso em: 20 jan. 2016.

44 Art. 178 e 192, III. BRASIL. Constituição (1988). Constituição da República Federativa do Brasil. Disponível em: <http://www.planalto.gov.br/ccivil_03/constituicao/ConstituicaoCompilado.htm>. Acesso em: 20 jan. 2016.

45 Art. $5^{\circ}$, \ $3^{\circ}$; art. 84, VIII e art. 109, V. BRASIL. Constituição (1988). Constituição da República Federativa do Brasil. Disponível em: <http://www.planalto.gov.br/ccivil_03/constituicao/ConstituicaoCompilado.htm>. Acesso em: 20 jan. 2016.

46 BRASIL. Supremo Tribunal Federal. Medida Cautelar na Ação Direta de Inconstitucionalidade. ADI 1480 MC / DF. Tribunal Pleno. Requerente: Confederação Nacional do Transporte; Confederação Nacional da Indústria. Requerido: Presidente da República. Relator: Min. Celso de Mello. Brasília, 04 de setembro de 1997. Disponível em: <http://redir.stf.jus.br/paginadorpub/paginador. jsp?docTP=AC\&docID=347083 . Acesso em: 20 jan. 2016; e BRASIL. Supremo Tribunal Federal. Carta Rogatória. CR 8279 AT. 
da inexistência de um regramento expressamente positivado, a Constituição exigiria a edição de Decreto Executivo para fins de aplicação (promulgação, publicação e executoriedade) do tratado no ordenamento jurídico interno, não obstante o tratado ter sido ratificado pelo Presidente após referendo Congressual. A ratificação executiva não garante, por si só, a incorporação automática do tratado ao sistema normativo brasileiro.

A exigência do Decreto Presidencial para aplicação do tratado internacional seria uma característica do ordenamento constitucional que não se conformaria com o monismo descrito acima, uma vez que a ratificação presidencial não seria suficiente para a aplicação do tratado, ainda que, em tratados multilaterais, os outros Estados estejam cumprindo o mesmo tratado em vigor no plano internacional. A ordem executiva seria uma característica dualista, ainda que "moderada", para os autores, pois não se trataria de uma lei em sentido formal reprodutora do total conteúdo do tratado, contudo, sua justificativa decorreria do processo legislativo de internalização do tratado (equiparação entre lei e tratado) ${ }^{47}$.

Concluímos, anteriormente, que as teses sobre a unidade ou não dos ordenamentos de Triepel e Kelsen independem de uma necessária distinção entre aplicabilidade direta ou transformação do tratado, pois, para Kelsen, a transformação em lei de um tratado internacional em nada altera sua posição monista de superioridade hierárquica do ordenamento internacional e Triepel postulava que manifestações políticas podem indicar a aplicação do tratado diretamente, desde que espelhem a vontade formal governamental ${ }^{48}$. Portanto, no plano teórico (teses do ordenamento único), o decreto de execução do presidente brasileiro não é capaz de marcar a diferença entre monismo e dualismo.

A distinção entre monismo e dualismo calcada no campo da descrição (aplicação direta/transformação)

Tribunal Pleno. Agravante: Coagulantes Argentinos S/A. Relator: Min. Celso de Mello. Brasília, 04 de maio de 2005. Disponível em: < http://stf.jusbrasil.com.br/jurisprudencia/19162742/carta-rogatoria-cr-8279-at-stf>. Acesso em: 20 jan. 2016.

47 ARAÚJO, Nadia de. Direito internacional privado. 3. ed. Rio de Janeiro: Renovar, 2006. p. 114.

48 Utilizando a Constituição norte-americana como exemplo, Triepel afirma que a Constituição manifestaria a vontade de aplicarse o tratado, que, por sua vez, apenas poderia vincular os cidadãos após manifestação formal do Presidente da República (proclamação formal após ratificação). TRIEPEL, Heinrich. As relações entre o direito interno e o direito internacional. Trad. Amílcar de Castro. Revista da Faculdade de Direito da Universidade Federal de Minas Gerais, Belo Horizonte, v. 17, n. 6, p. 07-64, 1966. p. 26-27. não goza de sorte diferente da teórica exposta acima, na medida em que países tradicionalmente dualistas (no sentido descritivo), como Austrália, Canadá e Reino Unido, apresentam uma série de práticas legislativas que não se esgotam na edição de uma lei formal transformadora, são elas: a) scheduling (a lei editada apensa o texto do tratado e determina sua aplicação no direito interno); b) incorporação implícita (mesmo um tratado não transformado pode ter efeito no direito interno se o parlamento houver editado anteriormente leis que sejam consistentes e tratem da mesma questão substantiva) e c) delegação normativa ${ }^{49}$ (o legislativo delega aos órgãos executivos competentes a obrigação de que sua produção normativa seja compatível com o tratado) ${ }^{50}$.

O Scheduling permite que as cortes apliquem o texto do tratado mediante autorização legislativa, ainda que a lei não tenha "traduzido" o tratado em um corpo legislativo. A incorporação implícita permite que o texto do tratado não transformado seja interpretado pelas cortes para, posteriormente, ser compreendido como compatível às leis já existentes. A delegação demonstra que órgãos do país, ainda que não os judiciais, deverão aplicar diretamente o tratado.

Do lado monista, a lógica da aplicação direta do tratado é mitigada por construções judiciais que podem ser representadas pela doutrina da autoexecutoriedade (self-

49 SLOSS, David. Treaty enforcement in domestic courts: a comparative analysis. In: (Org.). The role of domestic courts in treaty enforcement: a comparative study. Cambridge: Cambridge University, 2009. p. 01-66. p. 18; ALSTINE, Michael P. Van. The role of domestic courts in treaty enforcement. In: SLOSS, David (Org.). The role of domestic courts in treaty enforcement: a comparative study. Cambridge: Cambridge University, 2009. p. 555-613. p. 569.

50 Isso para ficarmos apenas na questão dos tratados implementados (por implementados, estamos a nos referir a quaisquer atos oficiais posteriores à ratificação necessários à incorporação final do tratado). Sloss e Alstine, após analisarem relatórios de países ditos dualistas, surpreenderam-se com a influência dos tratados não implementados no país. O grau de permeabilidade dos países é variado, mas Austrália, Índia, e Reino Unido limitam a atividade administrativa por meio de tratados não implementados (ou seja, se o Executivo ratifica o tratado ainda não implementado, tal ato já será suficiente para que se conforme com as prescrições internacionais). Ademais, tratados não incorporados são aplicados por meio das regras do direito comum (Common Law), quando dispõem sobre questões semelhantes. SLOSS, David. Treaty enforcement in domestic courts: a comparative analysis. In: (Org.). The role of domestic courts in treaty enforcement: a comparative study. Cambridge: Cambridge University, 2009. p. 01-66. p. 20-21 e ALSTINE, Michael P. Van. The role of domestic courts in treaty enforcement. In: SLOSS, David (Org.). The role of domestic courts in treaty enforcement: a comparative study. Cambridge : Cambridge University, 2009. p. 555613. p. 609-611. 
-executing). Mesmo em países monistas (Polônia e EUA), o efeito direto dos tratados não é automático quando questões interpretativas e/ou relacionadas ao conteúdo das obrigações internacionais exigem a mediação de uma lei interna regulamentadora daquelas obrigações. Portanto, mesmo em países monistas, não são todos os tratados ou normas oriundas de tratados que possuem aplicabilidade direta ${ }^{51}$.

Assim, o monismo descritivo não é uma carta branca para a aplicabilidade de todos os tratados internacionais. Dessa forma, a exigência de manifestações legislativas posteriores nos países descritos como monistas muito se assemelha às exigências constitucionais de edição de leis ordinárias nos países ditos dualistas, reduzindo a diferença entre as abordagens descritivas.

Pensemos na seguinte situação hipotética: o país M, considerado monista no sentido descritivo, prevê a aplicabilidade direta dos tratados ratificados pelo executivo, autorizados pelo parlamento via decreto e, posteriormente, publicados pelo Presidente, mas acolhe a doutrina de que existem tratados não autoexecutáveis, que exigem legislação posterior. $\mathrm{M}$ ratificou, ao todo, 130 tratados internacionais, sendo que 90 foram interpretados pelas cortes internas como tratados não autoexecutáveis ${ }^{52}$. O país $\mathrm{D}$, de outra ponta, caracterizado como dualista no sentido descritivo, exige, expressamente, em sua Constituição, que as normas internacionais sejam transformadas em direito interno. D ratificou 130 tratados e, desse total, 100 foram incorporados via scheduling, o que constitui, portanto, ato legislativo autorizando a aplicação direta do tratado. Nessa hipótese, qual país seria caracterizado como monista ou dualista?

Os exemplos estendem-se à prática brasileira. Lima Marques e Lixinski ${ }^{53}$ demonstram que as cortes nacionais têm se recusado a aplicar tratados internacionais de

51 SLOSS, David. Treaty enforcement in domestic courts: a comparative analysis. In: (Org.). The role of domestic courts in treaty enforcement: a comparative study. Cambridge: Cambridge University, 2009. p. 01-66. p. 12.

52 No caso hipotético estamos, ademais, suprimindo a existência de tratados que possuem apenas algumas normas não autoexecutáveis, o que poderia fazer aumentar o número de manifestações legislativas do país.

53 MARQUES, Claudia Lima;LIXINSKI, Lucas. Treaty Enforcement by brazilian courts: reconciling myths and ambivalences? Brazilian Yearbook of International Law, Washington, v. 04, n. 1, p. 138169, 2009. p. 164-167. direitos humanos ${ }^{54}$ e econômicos ${ }^{55}$ quando algumas de suas regras não sejam autoexecutáveis, sob a argumentação de que os referidos tratados não geram obrigações diretamente concretizáveis. Portanto, mesmo em nosso país, nem todos os tratados internalizados pelo Decreto Executivo terão aplicação direta, sendo exigida lei em sentido formal. Nesses casos, devemos contabilizar todos os tratados de aplicação direta para nos classificarmos como monista ou dualista?

\subsection{Os tratados internacionais estão sujeitos ao controle de constitucionalidade}

A perspectiva da relação entre ordenamentos jurídicos e a solução de possíveis conflitos atinge ponto sensível quando discutimos a constitucionalidade dos tratados internacionais à luz das teorias clássicas.

De acordo com o dualismo reinterpretado pela doutrina nacional, a questão dos conflitos diretos entre ordenamentos jurídicos não é um problema porque são ordens distintas e, após a incorporação por meio de leis internas, o conflito ocorreria apenas entre fontes internas. A inconstitucionalidade de um tratado (ou melhor, de uma lei que reproduz o tratado) seria possível, tendo em vista a paridade com outros atos normativos infraconstitucionais, porquanto qualquer um deles poderia ser declarado como violador da Constituição estatal. Para a visão monista com prevalência do direito internacional, os tratados internacionais não poderiam ser considerados inconstitucionais com base na Constituição, uma vez que estão dispostos acima daquela hierarquicamente.

Para os autores nacionais, os tratados internacionais ratificados posteriormente à Constituição de 1988 podem violá-la de forma intrínseca (processo de incorporação do tratado) ou extrínseca (normas substantivas da

54 RIO GRANDE DO SUL. Tribunal de Justiça. Apelação Cível. AC 70017102161. Porto Alegre, 26 de outubro de 2006. O tratado em questão era o PIDESC.

55 BRASIL. Tribunal Regional Federal (1. Região). Remessa Ex Officio em Mandado de Segurança. 90.01.16972-4/BA. Terceira Turma. Recorrente: Importadora e Exportadora Latino Americana Ltda. Recorrido: Fazenda Nacional. Relator: Desembargador Federal Tourinho Neto. Brasília, 29 de Abril de 1991. Disponível em: <https:// processual.trf1.jus.br/consultaProcessual/processo.php?proc $=90$ 01169724\&secao=TRF1\&pg=1\&trf1_captcha_id=746be8fceb2c 1c3614a2a5398192652e\&trf1_captcha=cg7h\&enviar=Pesquisar $>$. Acesso em: 20 jan. 2016. O tratado em questão era o de Montevidéu sobre integração econômica. 
Constituição).

O principal dispositivo citado para defender tal posição é o art. art. 102, III, $b$, que prevê a possibilidade de o STF analisar, via Recurso Extraordinário, decisão de tribunais inferiores que declararam a inconstitucionalidade de tratados com base na Constituição da República. Ademais, o STF pode declarar a inconstitucionalidade dos dispositivos que incorporaram os tratados internacionais, que se afiguram como normas internas sujeitas ao controle de constitucionalidade realizado pelo STF: os decretos legislativo e executivo.

Ainda que o tratado seja considerado como uma norma de existência autônoma no ordenamento jurídico (não se exige lei, apenas uma ordem de execução), o tratado está subordinado hierarquicamente à Constituição. O que justificaria a possibilidade de o Brasil, no plano interno, não estar mais vinculado ao tratado, mas, no plano externo, estar sujeito a sanções internacionais.

Dessa forma, apesar de o tratado ser considerado como norma autônoma diretamente aplicável (monismo), ele está, tal qual qualquer norma infraconstitucional, sujeito ao controle de constitucionalidade (dualismo). Portanto, elementos centrais das abordagens descritivas estariam mesclados na prática brasileira.

\subsection{Os conflitos entre lei interna e tratados in- ternacionais são solucionados pela prevalência da norma mais recente ou pelo critério da espe- cificidade (com exceção dos tratados internacio- nais de direitos humanos)}

Para o dualismo teórico, por emanarem da mesma fonte normativa, a internalização do tratado, por meio de lei interna, traz como consequência óbvia a paridade entre as normas. Ou seja, estaríamos lidando com duas leis internas. Para o monismo, seria problemático afirmar a paridade das normas, uma vez que, seja do ponto de vista do monismo interno ou externo, o ordenamento é único e um dos ordenamentos seria hierarquicamente superior e prevaleceria em relação ao outro.

Os autores nacionais afirmam que o tratado, devidamente, internalizado prevalece sobre as leis federais. Portanto, de acordo com tal lógica, o tratado, enquanto norma autônoma, seria, hierarquicamente, superior às normas internas, à exceção da Constituição e os prováveis conflitos seriam solucionados pelo critério hierárquico. Para os autores, tal característica por eles defen- dida estaria inserida na lógica monista com prevalência do direito internacional.

Entretanto, o STF considera que os tratados possuem o mesmo status que as leis federais, sob as seguintes justificativas ${ }^{56}:$ 1) os tratados internacionais não impedem a atividade legislativa do Congresso Nacional, que pode dispor, de forma contrária, ao tratado internalizado anteriormente; 2) O tratado é aplicado sem conversão legislativa, sendo exigida apenas ordem de execução; 3) O Judiciário está apenas adstrito à lei nacional, nesse sentido, caso haja conflito entre lei e tratado, a vinculação judicial é apenas ao produto legislativo interno, mesmo que isso resulte em conflitos no campo da política externa; 4) O art. 98 do CTN não abarca todas as espécies de tratados, apenas aqueles que podem, eventualmente, criar direitos subjetivos, portanto, de impossível revogação legislativa interna, como em um contrato e 5) apenas a Constituição poderia dispor sobre: hierarquia do tratado, formas de solução de conflito e revogação do tratado.

A construção jurisprudencial acima descrita do STF estava baseada na Constituição de 1969.

Quando o STF teve oportunidade de conhecer do tema sob os auspícios da Constituição de 1988, a inclusão de novas normas sobre direito internacional, especialmente, sobre direitos humanos, poderia dar ensejo a uma revisão da jurisprudência anterior. Contudo, nos primeiros vinte anos da Constituição, o mesmo entendimento prevaleceu, porém com alguns acréscimos.

Em 1995, no HC 72.131/RJ, ao analisar a constitucionalidade da prisão do depositário infiel em alienação fiduciária, instituída pelo Decreto-Lei 911/69, o STF, além de reforçar a regra da prevalência da norma mais

56 Os autores brasileiros identificam o RE 80.004/SE (1977) como o precedente que determinou a construção jurisprudencial do STF acerca dos conflitos entre tratados internacionais e leis internas, segundo a regra lei posterior revoga anterior.(BRASIL. Supremo Tribunal Federal. Recurso Extraordinário. RE 80.004/SE. Tribunal Pleno. Recorrente: Belmiro da Silveira Goes. Recorrido: Sebastião Leão Trindade. Relator: Min. Cunha Peixoto. Brasília, 01 de junho de 1977. Disponível em: <http://redir.stf.jus.br/paginadorpub/ paginador.jsp?doc $\mathrm{TP}=\mathrm{AC} \& \operatorname{docID}=175365>$. Acesso em: $20 \mathrm{jan}$. 2016) De acordo com Fraga e Ariosi, em análises dos votos dos ministros no referido acórdão, a diversidade de fundamentos foi notória e nem todas foram convergentes. Portanto, descreveremos, apenas, os pontos dos votos dos ministros que alcançaram uma maioria no tribunal. FRAGA, Mirtô. O conflito entre tratado internacional e norma de direito interno. Rio de Janeiro: Forense, 1998. e ARIOSI, Mariângela. Conflitos entre tratados internacionais e leis internas: o judiciário brasileiro e a nova ordem internacional. Rio de Janeiro: Renovar, 2000. 
moderna, incluiu outra regra para solução de conflitos entre normas constitucionais e tratados: o critério da especialidade.

As argumentações do impetrante baseavam-se na impossibilidade de equiparação do contrato de depósito com a alienação fiduciária em garantia, pois ensejaria a criação de uma nova hipótese de prisão civil por dívidas, estabelecida por via transversa e, ademais, o art. $7^{\circ}, 7$, da Convenção Americana de Direitos Humanos $(\mathrm{CADH})^{57}$, limitava a prisão civil à hipótese do devedor alimentante.

O relator originário do caso, Marco Aurélio, ao conceder a ordem, dividiu sua argumentação em dois pontos. Primeiro, sustentou que alienação fiduciária não se equipararia ao depósito, portanto, não poderia haver prisão. Segundo, afirmou que a Convenção Americana de Direitos Humanos, de nível hierárquico legal, derrogou o Decreto-Lei 911/69, uma vez que o decreto instituidor da CADH (Decreto Executivo 678/92) seria posterior ao Decreto-Lei.

A tese prevalecente, todavia, foi a do Ministro Moreira Alves. O ministro considerou que a Convenção, por ser lei geral, não revogou o Decreto-Lei, lei especial. Compreendeu, ademais, que a Convenção, incorporada posteriormente à $\mathrm{CF} / 88$, não afetaria a norma constitucional do art. $5^{\circ}$, LXVII por força do disposto no $\int 2^{\circ}$ do art. $5^{\circ}$, pois não se admitiria emenda constitucional realizada por via de ratificação de tratado.

Portanto, além do critério temporal (lei posterior revoga anterior), o STF incorporou mais um critério para a solução de conflitos entre tratados e leis internas, o da especialidade. O desenvolvimento de mais um critério para solução de conflitos entre o Decreto-Lei e o Decreto Presidencial parecem demonstrar o caráter não autônomo do tratado, uma vez que, não obstante tenha sido regularmente internalizado posteriormente à lei nacional, não significa que o tratado de direitos humanos será aplicado no plano interno, pois terá de atender ao critério da especialidade, da mesma maneira que qualquer outra lei interna sobre assunto diverso (contrato de alienação fiduciária, no caso), além de ter

57 Artigo $7^{\circ}$ - Direito à liberdade pessoal: 7. Ninguém deve ser detido por dividas. Este princípio não limita os mandados de autoridade judiciária competente expedidos em virtude de inadimplemento de obrigação alimentar. COMISSÃO INTERAMERICANA DE DIREITOS HUMANOS. Convenção Americana Sobre Direitos Humanos. São Jose, 22 nov. 1969. Disponível em: <https://www.cidh.oas.org/basicos/portugues/c. convencao_americana.htm>. Acesso em: 20 jan. 2016. de ser considerada pelo Judiciário como autoexecutável. Trata-se de característica que se aproximaria do dualismo tal qual reconstruído pelos autores nacionais. A suspeita de que a postura do STF poderia enquadrar-se no dualismo, visto pela ótica dos autores brasileiros, ganhou reforço nas manifestações do tribunal na MC na ADI 1480, que afirma a posição dualista moderada do ordenamento brasileiro (não exige transformação do ato internacional mediante lei, sendo suficiente o decreto executivo).

Interessante notar, ademais, que a inserção do art. 5, $\int 2^{\circ}$ não foi suficiente, naquele momento (1995), para sensibilizar a maioria dos ministros ${ }^{58}$ para a constitucionalidade da CADH. Na ocasião, os ministros sustentaram a paridade da $\mathrm{CADH}$ com as leis federais por meio dos seguintes argumentos: 1) a soberania da Constituição Federal e 2) o $₫ 2^{\circ}$, art. $5^{\circ}$ não conferiria aos tratados a possibilidade de emendar a Constituição por procedimento diferenciado daquele estabelecido no art. 60, da $\mathrm{CF} / 88$. Voltaremos a esses argumentos no futuro.

Contudo, em 2008 o STF alterou sua jurisprudência no que se refere à posição dos tratados internacionais de direitos humanos no ordenamento constitucional. Seguindo o voto do Min. Gilmar Mendes, o tribunal considerou que os referidos tratados possuiriam status supralegal.

De acordo com o Ministro, apesar de não poderem afrontar a supremacia da Constituição (continuam sujeitos ao controle de constitucionalidade), os tratados internacionais de direitos humanos são mais importantes que outras tratativas internacionais, bem como mais importantes que as leis ordinárias, por força do art. 5, \$ $2^{\circ}$. A supralegalidade seria o adjetivo, portanto, outorgado aos tratados de direitos humanos devido aos valores inerentes a eles. Como consequência, a relação entre normas supralegais e legais seria a seguinte: as primeiras detêm o poder de paralisar a eficácia jurídica de toda e qualquer disciplina infraconstitucional conflitante.

58 O Ministro Carlos Velloso defendeu que os direitos extraídos dos tratados internacionais de Direitos Humanos possuiriam a mesma força dos direitos fundamentais previstos na Constituição, os quais denominou de direitos fundamentais materiais e formais com base no referido artigo. Cançado Trindade defendeu argumentos semelhantes na Assembleia Constituinte e em trabalho teórico poucos anos depois. TRINDADE, Antonio Augusto Cançado. A proteção internacional dos direitos humanos: fundamentos jurídicos e instrumentos básicos. São Paulo: Saraiva, 1991. p. 629-630. e TRINDADE, Antonio Augusto Cançado. A proteção internacional dos direitos bumanos e o Brasil. 2. ed. Brasília: UnB, 2000. p. 170 e ss. 
Por fim, em face das particularidades expostas até o momento, os autores classificam o Brasil como: monista com prevalência do direito internacional ${ }^{59}$, monista moderado $^{60}$, monismo nacionalista ${ }^{61}$, monismo abrandado $^{62}$, monismo internacionalista dialógico ${ }^{63}$ e dualista moderado $^{64}$.

\section{Analisando os Diferentes tons de MONIS- MO BRASILEIRO}

Os autores nacionais encontram dificuldades para classificar a Constituição brasileira em alguma das categorias dicotômicas. Além de confundir as teses do ordenamento único com a escolha política de um modelo de incorporação, a descrição do modelo constitucional brasileiro não se "encaixa” perfeitamente nos estreitos limites da tradicional abordagem descritiva monista e dualista. Apesar da dificuldade, contudo, podemos observar que a maioria dos autores nacionais posiciona nossa Constituição como monista.

Do lado monista, nossa Constituição seria: nacionalista, com prevalência do direito internacional, moderado, abrandado ou internacionalista dialógico. Do lado

59 FRAGA, Mirtô. O conflito entre tratado internacional e norma de direito interno. Rio de Janeiro: Forense, 1998. p. 114.

60 RODRIGUES, Maurício. Os tratados internacionais de proteção dos direitos e a Constituição. In: TORRES, Ricardo Lobo (Org.). Teoria dos direitos fundamentais. Rio de Janeiro: Renovar, 1999. p. 157-195. p. 164; ARIOSI, Mariângela. Conflitos entre tratados internacionais e leis internas: o judiciário brasileiro e a nova ordem internacional. Rio de Janeiro: Renovar, 2000. p. 183; RIBEIRO, Patrícia Henriques. As relações entre o direito internacional e o direito interno: conflito entre o ordenamento brasileiro e normas do Mercosul. Belo Horizonte: Del Rey, 2001. p. 67. e BARROSO, Luís Roberto. Interpretação e aplicação da Constituição: fundamentos de uma dogmática constitucional transformadora. 6. ed. São Paulo: Saraiva, 2006. p. 19.

61 REZEK, Francisco. Direito internacional público. 11. ed. São Paulo: Saraiva, 2008. p. 04. e SILVA, Roberto Luiz. Direito internacional público. 2. ed. Belo Horizonte: Del Rey, 2005. p. 130.

62 PAGLIARINI, Alexandre Coutinho. Constituição e direito internacional: cedências possíveis no Brasil e no mundo globalizado. Rio de Janeiro: Forense, 2004. p. 43.

63 MAZZUOLI, Valerio de Oliveira. Curso de direito internacional público. 5. ed. São Paulo: Revista dos Tribunais, 2011.

64 ARAÚJO, Nadia de. Direito internacional privado. 3. ed. Rio de Janeiro: Renovar, 2006. p. 158. e BRASIL. Supremo Tribunal Federal. Ação Direta de Inconstitucionalidade. ADI 1480 DF. Tribunal Pleno. Requerente: Confederação Nacional do Transporte; Confederação Nacional da Indústria. Requerido: Presidente da República. Relator: Min. Celso de Mello. Brasília, 26 de junho de 2001. Disponível em: $<$ http://stf.jusbrasil.com.br/jurisprudencia/14819932/acao-diretade-inconstitucionalidade-adi-1480-df-stf $>$. Acesso em: 20 jan. 2016. dualista, a constituição seria, apenas, moderada. Do ponto de vista descritivo, a diversidade de categorias não oferece meios suficientes para uma clara definição acerca do modelo de incorporação adotado pelo Brasil. Afinal, o que podemos apreender desses diferentes tons de monismo?

Tendo em vista que o monismo descritivo caracteriza-se pela aplicabilidade direta do tratado, a primeira pergunta que devemos fazer aos autores defensores do monismo é se há uma diferença quanto ao grau de aplicabilidade dos tratados internacionais, isto é, se o espectro de aplicabilidade dos tratados abrangeria, desde uma aplicabilidade direta até a inaplicabilidade do tratado sem uma lei interna ordinária. Contudo, a resposta é negativa. Os autores nacionais não formulam suas diferentes nomenclaturas tomando com base uma análise empírica da aplicação dos tratados na prática brasileira, seja nos tribunais superiores, seja nos inferiores. Ou seja, se dispuséssemos os diferentes adjetivos do monismo em um continuum de aplicabilidade direta, teríamos dificuldade em posicionar as diferentes adjetivações. Por essa razão, a criação de diferentes nomenclaturas não se justifica por não apresentarem um variável grau de aplicabilidade dos tratados no plano interno.

As diferentes nomenclaturas não se sustentam, igualmente, no plano semântico. O caso mais notório é o da diferença entre monismo abrandado e monismo moderado. $\mathrm{O}$ abrandamento e a moderação são do quê? E em que medida os adjetivos se diferenciam para um autor substituir um pelo outro?

O monismo internacionalista dialógico de Mazzuoli (2011) é intrigante. O autor afirma que o monismo ainda mantém sua posição de superioridade hierárquica frete ao direito interno (portanto, sufragando a hipótese do ordenamento único), mas, no que tange aos tratados de direitos humanos, o monismo deve ser encarado como dialógico, por permitir a aplicação do direito interno nas ocasiões em que esse direito preveja norma mais favorável ao indivíduo (transigência da norma internacional) ${ }^{65}$. O autor pode estar certo quanto à posição do direito internacional dos direitos humanos, mas se a transigência do direito internacional para com a norma mais favorável é característica material de certa qualidade de tratados internacionais (direitos humanos), por que a parte serve para classificar o todo? Ou seja, por que o

65 MAZZUOLI, Valerio de Oliveira. Curso de direito internacional público. 5. ed. São Paulo: Revista dos Tribunais, 2011. p. 90-92. 
monismo, como um todo, é dialógico se apenas uma parcela do direito internacional é explicada por meio dessa característica? Ademais, se a premissa básica do monismo permanece (ordenamento único estruturado de forma hierárquica) a adjetivação "dialógico" parece acrescentar pouco ao conceito, uma vez que a aplicação da norma interna ocorre por uma transigência ou permissão do direito internacional.

Mesmo a caracterização do Brasil como dualista moderado é demais inclusiva, na medida em que pode significar uma moderação que se confunde com a moderação do monismo proposta por outros autores ou mesmo a posição de Rezek, que defende um monismo nacionalista. A confusão quanto aos conjuntos de críticas (ordenamento único/projetos de incorporação) obscurece a linha que, supostamente, separaria essas três classificações (dualista moderado, monista moderado e monista nacionalista), pois não ficam claros os elementos que as diferenciam, nem mesmo as aplicações e consequências práticas da diferença.

George Galindo ${ }^{66}$, por exemplo, sugere o abandono das terminologias monistas e dualistas, por afirmar que nenhum país adota as teorias de maneira completa, sendo suas caracterizações desenvolvidas apenas de forma ideal. $\mathrm{O}$ autor afirma que as adjetivações são perigosas porque podem significar tudo e nada ao mesmo tempo, dependendo do referencial utilizado pelos autores para sustentar sua escolha. Partindo das mesmas premissas, por exemplo, os autores classificam o Brasil como monista moderado ou dualista moderado. Ou seja, o adjetivo "moderado", aposto a quaisquer das teorias, poderia significar a cedência de pressupostos importantes de ambas as teorias, acarretando a confusão conceitual observada nas descrições acima de que, se o país é monista

66 GALINDO, George Rodrigo Bandeira. Tratados internacionais de direitos humanos e Constituição Brasileira. Belo Horizonte: Del Rey, 2002. p. 69-70. Mais recentemente, o autor parece ter reconsiderado, em parte, suas conclusões anteriores. No entanto, George Galindo não sugere o resgate das proposições monistas em suas formulações clássicas, e ressaltadas no presente artigo (hierarquia, coerência, ou supremacia do direito internacional), mas conclama os internacionalistas a uma revisitação das premissas éticas que separam o monismo e o dualismo, no intuito de reavaliarem as premissas transformadoras defendidas por monistas acerca das diversas possibilidades de transformações do direito internacional, em contraposição a uma suposta manutenção da realidade oriunda do pragmatismo dualista. GALINDO, George Rodrigo Bandeira. Revisiting monism's ethical dimension. In: CRAWFORD James; NOUWEN, Sarah. (Org.). Select proceedings of the European Society of International Law, 2010. Oxford: Hart Publishing, 2012. v. 3. p. 141-153. com temperos de dualismo, pode ser qualificado como monista moderado. Ou, caso seja dualista com acentos monistas, o país será dualista moderado ${ }^{67}$. A desmistificação e a complexidade dos ordenamentos e de seus regramentos constitucionais tendem a tornar a dicotomia pouco útil do ponto de vista descritivo ${ }^{68}$.

\section{Considerações finais}

O monismo e o dualismo podem ser caracterizados, tanto como teorias utilizadas para defender a unidade, ou não, dos ordenamentos jurídicos internacionais e constitucionais, quanto como a escolha política feita por uma Constituição sobre as formas de incorporação de tratados internacionais.

Em nosso país, a doutrina confunde os dois conjuntos dicotômicos, empobrecendo a viabilidade analítica da classificação. Ainda que nossa prática seja descrita como monista, a categorização não se sustenta em seu aspecto descritivo (controle de constitucionalidade de tratados, decreto executivo, critérios de solução de conflitos), bem como em seu aspecto tipológico (diferentes tons de monismo).

Em conclusão, enquanto teorias abrangentes, o monismo e o dualismo são insatisfatórios, na medida em que não conseguem dar conta dos problemas que surgem hoje em dia nas questões internacionais e constitucionais, bem como sobre suas relações. Seguindo o afirmado por Armin Von Bogdandy ${ }^{69}$, devem ser completamente abandonadas.

67 Antenor Madruga pontua que a discussão entre monismo e dualismo está limitada a uma noção de incorporação e eficácia das normas internacionais que torna opaca a questão de outras fontes internacionais, como o costume, que não necessita de um reconhecimento formal do Estado. No entanto, o autor não desenvolve sua crítica e não sugere soluções. MADRUGA, Antenor. Constituição Brasileira de 1988: monista ou dualista? Revista de Informação Legislativa. Brasília, v. 45, n. 179, p. 135-140, jul./set. 2008. p. 136.

68 LUPI, André Lipp Pinto Basto. O Brasil é dualista? Anotações sobre a vigência de normas internacionais no ordenamento brasileiro. Revista de Informação Legislativa, Brasília, v. 46, n. 184, p. 29-45, out./dez, 2009. p. 44.

69 VON BOGDANDY, Armin. Pluralism, Direct Effect, and the Ultimate Say. International Journal of Constitutional Law, Oxford, v. 6, n. 3-4, p. 397-413, july/oct. 2008. p. 399-400. 


\section{REFERÊNCIAS}

ACCIOLY, Hildebrando. Manual de direito internacional público. 11. ed. São Paulo: Saraiva, 1976.

ALSTINE, Michael P. Van. The role of domestic courts in treaty enforcement. In: SLOSS, David (Org.). The role of domestic courts in treaty enforcement: a comparative study. Cambridge: Cambridge University, 2009. p. 555-613.

ARAÚJO, Nadia de. Direito internacional privado. 3. ed. Rio de Janeiro: Renovar, 2006.

ARIOSI, Mariângela. Conflitos entre tratados internacionais e leis internas: o judiciário brasileiro e a nova ordem internacional. Rio de Janeiro: Renovar, 2000.

AUST, Anthony. Handbook of international law. 2. ed. Cambridge: Cambridge University, 2010.

BARROSO, Luís Roberto. Interpretação e aplicação da Constituição: fundamentos de uma dogmática constitucional transformadora. 6. ed. São Paulo: Saraiva, 2006.

BERNSTORFF, Jochen von. The public international law theory of Hans Kelsen: believing in universal law. Cambridge: Cambridge University, 2010.

BINENBOJM, Gustavo. Monismo e dualismo no Brasil: uma dicotomia afinal irrelevante. Revista da EMERJ, Rio de Janeiro, v. 3, n. 9, p. 180-195, 2000.

BRASIL. Constituição (1988). Constituição da República Federativa do Brasil. Disponível em: $<$ http:/ /www.planalto.gov.br/ccivil_03/constituicao/ConstituicaoCompilado.htm>. Acesso em: 20 jan. 2016.

BRASIL. Supremo Tribunal Federal. Ação Direta de Inconstitucionalidade. ADI 1480 DF. Tribunal Pleno. Requerente: Confederação Nacional do Transporte; Confederação Nacional da Indústria. Requerido: Presidente da República. Relator: Min. Celso de Mello. Brasília, 26 de junho de 2001. Disponível em: <http://stf.jusbrasil.com.br/jurisprudencia/14819932/acao-direta-deinconstitucionalidade-adi-1480-df-stf $>$. Acesso em: 20 jan. 2016.

BRASIL. Supremo Tribunal Federal. Carta Rogatória. CR 8279 AT. Tribunal Pleno. Agravante: Coagulantes Argentinos S/A. Relator: Min. Celso de Mello. Brasília, 04 de maio de 2005. Disponível em: < http:/ / stf.jusbrasil.com.br/jurisprudencia/19162742/carta-rogatoriacr-8279-at-stf>. Acesso em: 20 jan. 2016.
BRASIL. Supremo Tribunal Federal. Medida Cautelar na Ação Direta de Inconstitucionalidade. ADI 1480 MC / DF. Tribunal Pleno. Requerente: Confederação Nacional do Transporte; Confederação Nacional da Indústria. Requerido: Presidente da República. Relator: Min. Celso de Mello. Brasília, 04 de setembro de 1997. Disponível em: < http://redir.stf.jus.br/paginadorpub/ paginador.jsp?doc $\mathrm{TP}=\mathrm{AC} \& \mathrm{doc} \mathrm{ID}=347083>$. Acesso em: 20 jan. 2016.

BRASIL. Supremo Tribunal Federal. Recurso Extraordinário. RE 80.004/ SE. Tribunal Pleno. Recorrente: Belmiro da Silveira Góes. Recorrido: Sebastião Leão Trindade. Relator: Min. Cunha Peixoto. Brasília, 01 de junho de 1977. Disponível em: < http:/ / redir.stf.jus.br/paginadorpub/paginador.jsp?docTP $=$ AC\&docID $=175365>$. Acesso em: 20 jan. 2016.

BRASIL. Tribunal Regional Federal (1. Região). Remessa Ex Officio em Mandado de Segurança. 90.01.16972-4/ $B A$. Terceira Turma. Recorrente: Importadora e Exportadora Latino Americana Ltda. Recorrido: Fazenda Nacional. Relator: Desembargador Federal Tourinho Neto. Brasília, 29 de Abril de 1991. Disponível em: $<$ https://processual.trf1.jus.br/consultaProcessual/ processo.php? proc $=9001169724 \&$ secao $=$ TRF $1 \& p g=$ 1\&trf1_captcha_id=746be8fceb2c1c3614a2a53981926 52e\&trf1_captcha $=c g 7$ h\&enviar $=$ Pesquisar $>$. Acesso em: 20 jan. 2016.

\section{COMISSÃO INTERAMERICANA DE DIREITOS} HUMANOS. Convenção Americana Sobre Direitos Humanos. São Jose, 22 nov. 1969. Disponível em: <https:// www.cidh.oas.org/basicos/portugues/c.convencao_ americana.htm>. Acesso em: 20 jan. 2016.

COUTO, Estêvão Ferreira. A relação entre o interno e o internacional: concepções cambiantes de soberania, doutrina e jurisprudência dos tribunais superiores no Brasil. Rio de Janeiro: Renovar, 2003.

DELMAS-MARTY, Mireille. Por um direito comum. Trad. de Maria Ermantina de Almeida Prado Galvão. São Paulo: M. Fontes, 2004.

FOLSOM, Ralph H. Principles of European Union law. 3. ed. St. Paul: Thomson, 2011.

FRAGA, Mirtô. O conflito entre tratado internacional e norma de direito interno. Rio de Janeiro: Forense, 1998.

GALINDO, George Rodrigo Bandeira. Revisiting monism's ethical dimension. In: CRAWFORD, James; 
NOUWEN, Sarah. (Org.). Select proceedings of the European Society of International Law, 2010. Oxford: Hart Publishing, 2012. v. 3. p. 141-153.

GALINDO, George Rodrigo Bandeira. Tratados internacionais de direitos bumanos e Constituição Brasileira. Belo Horizonte: Del Rey, 2002.

HART, Herbert L. A. The concept of law. 2. ed. Oxford: Clarendon, 1994.

HIX, Simon; HØYLAND, Bjørn. The political system of the European Union. 3. ed. London: P. Macmillan, 2011.

HUSEK, Carlos Roberto. Curso de direito internacional público. 2. ed. São Paulo: LTr, 1998.

JACKSON, John. Status of treaties in domestic legal systems: a policy analysis. American Journal of International Law, Washington, v. 86, n. 2, p. 310-340, abr. 1992.

JANIS, Mark Weston. International law. 5. ed. New York: Aspen, 2008.

JO, Hee Moon. Introdução ao direito internacional. 2. ed. São Paulo: LTr, 2004.

KELSEN, Hans. Teoria geral do direito e do Estado. São Paulo: M. Fontes, 2000.

KELSEN, Hans. Teoria pura do direito. Trad. João Batista Machado. 7. ed. São Paulo: M. Fontes, 2006.

KOSKENNIEMI, Martti. From apology to utopia: the structure of international legal argument. Cambridge: Cambridge University, 2005.

LUPI, André Lipp Pinto Basto. O Brasil é dualista? Anotações sobre a vigência de normas internacionais no ordenamento brasileiro. Revista de Informação Legislativa, Brasília, v. 46, n. 184, p. 29-45, out./dez, 2009.

MACCORMICK, Neil. Questioning sovereignty: law, State and nation in the European Commonwealth. Oxford: OUP, 1999.

MADRUGA, Antenor. Constituição Brasileira de 1988: monista ou dualista? Revista de Informação Legislativa. Brasília, v. 45, n. 179, p. 135-140, jul./set. 2008.

MARQUES, Claudia Lima;LIXINSKI, Lucas. Treaty enforcement by brazilian courts: reconciling myths and ambivalences? Brazilian Yearbook of International Law, Washington, v. 04, n. 1, p. 138-169, 2009.

MAZZUOLI, Valerio de Oliveira. Curso de direito internacional público. 5. ed. São Paulo: Revista dos Tribunais, 2011.
MELLO, Celso Duvivier de Albuquerque. Curso de direito internacional público. 15. ed. Rio de Janeiro: Renovar, 2004. v. 1.

NIJMAN, Janne; NOLLKAEMPER, Andre. Introduction. In: (Coord.). New perspectives on the divide between international and national law. Oxford: Oxford University, 2007. p. 01-14.

NOLLKAEMPER, André. National courts and the international rule of law. Oxford: Oxford University, 2012.

O'CONNELL, Daniel P. The relationship between international law and municipal law. Georgetown Law Journal, New Jersey, v. 48, n. 03, p. 431-485, 1960.

PAGLIARINI, Alexandre Coutinho. Constituição e direito internacional: cedências possíveis no Brasil e no mundo globalizado. Rio de Janeiro: Forense, 2004.

PERNICE, Ingolf. Multilevel constitutionalism and the treaty of Amsterdam: european constitution-making revisited. Common Market Law Review, London, v. 36, n. 4, p. $703-750,1999$.

REZEK, Francisco. Direito internacional público. 11. ed. São Paulo: Saraiva, 2008.

RIBEIRO, Patrícia Henriques. As relações entre o direito internacional e o direito interno: conflito entre o ordenamento brasileiro e normas do Mercosul. Belo Horizonte: Del Rey, 2001.

RODRIGUES, Maurício. Os tratados internacionais de proteção dos direitos e a Constituição. In: TORRES, Ricardo Lobo (Org.). Teoria dos direitos fundamentais. Rio de Janeiro: Renovar, 1999. p. 157-195.

SHAW, Malcolm N. International law. 6. ed. New York: Cambridge University, 2008.

SILVA, Roberto Luiz. Direito internacional público. 2. ed. Belo Horizonte: Del Rey, 2005.

SLOSS, David. Treaty enforcement in domestic courts: a comparative analysis. (Org.). The role of domestic courts in treaty enforcement: a comparative study. Cambridge: Cambridge University, 2009. p. 01-66.

SOMEK, Alexander. Kelsen lives. The European Journal of International Law, v. 18, n. 3, p. 409-451, 2001.

STARKE, J. G. Monism and dualism in the theory of international law. British Yearbook of International Law, Oxford, v. 17, p. 66-81, 1936. 
TRIEPEL, Heinrich. As relações entre o direito interno e o direito internacional. Trad. Amílcar de Castro. Revista da Faculdade de Direito da Universidade Federal de Minas Gerais, Belo Horizonte, v. 17, n. 6, p. 07-64, 1966.

TRIEPEL, Heinrich. Droit international et droit interne. Paris: Oxford, 1920.

TRINDADE, Antonio Augusto Cançado. A proteção internacional dos direitos humanos e o Brasil. 2. ed. Brasília: UnB, 2000.

TRINDADE, Antonio Augusto Cançado. A proteção internacional dos direitos humanos: fundamentos jurídicos e instrumentos básicos. São Paulo: Saraiva, 1991.

VENTURA, Deisy. As assimetrias entre o Mercosul e a União Europeia: os desafios de uma associação inter-regional. São Paulo: Manole, 2003.

VON BOGDANDY, Armin. Pluralism, Direct Effect, and the Ultimate Say. International Journal of Constitutional Law, Oxford, v. 6, n. 3-4, p. 397-413, july/oct. 2008.

WALKER, Neil. The idea of constitutional pluralism. The Modern Law Review, v. 65, n. 3, p. 317-359, may 2002.

YAMAMOTO, Toru. Direito internacional e direito interno. Porto Alegre: S. A. Fabris, 2000. 


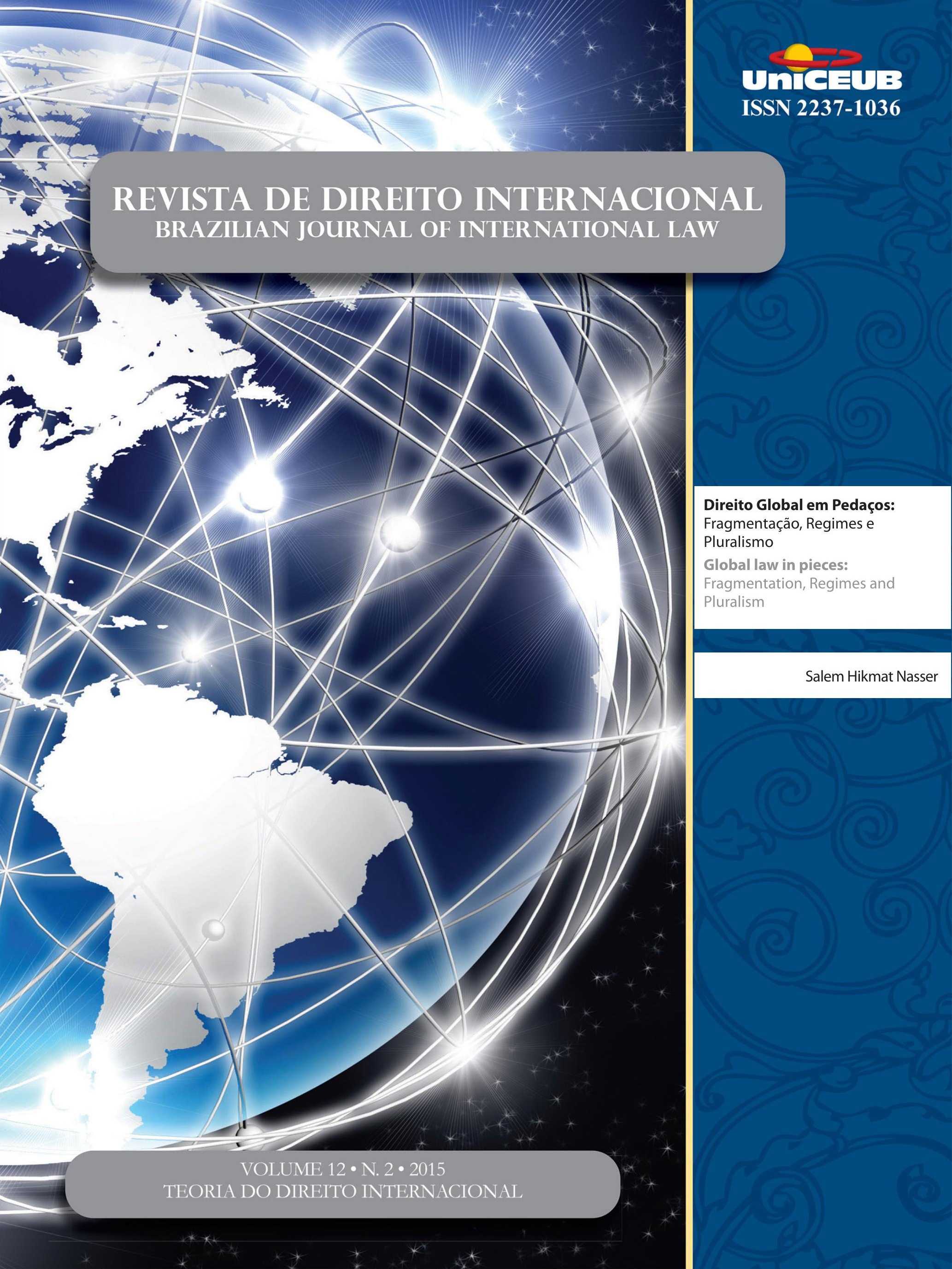




\title{
Direito Global em Pedaços: Fragmentação, Regimes e Pluralismo
}

\author{
Global law in pieces: Fragmentation, Regimes \\ and Pluralism
}

Salem Hikmat Nasser**

\section{Resumo}

A ideia de que a vida passa por um processo de diferenciação funcional, e de que, como consequência, o direito torna-se crescentemente especializado - e talvez se transforme em sua própria natureza - é agora generalizada. Os conjuntos especializados de normas e regulamentos são muitas vezes chamados de regimes, e na esfera internacional, regimes internacionais ou transnacionais. Este artigo lida, primeiro, com três fortes representações de regimes internacionais e discute alguns de seus problemas. Sustenta que, a fim de fazer bom uso da noção de regimes, é necessário ter em mente a diferença entre o jurídico e o não jurídico no contexto amplo de governança. Assim, toma-se primeiramente a noção de regimes como fragmentos de uma ordem jurídica unificada e coerente de Direito Internacional Público e, em seguida, como um ponto de encontro de regulação, de produtos regulatórios, emergentes de ordens jurídicas diversas e também de fontes não jurídicas. Dentro do Direito Internacional Público, regimes são vistos como relacionados ao que se chama de dupla fragmentação de ordem jurídica. Como conjuntos de instrumentos regulatórios dentro de uma regulação global mais ampla, regimes são colocados em relação a dois tipos de pluralismo legal ou regulatório. Ao final faz uma discussão dos problemas de rule of law impostos ao direito internacional pela sua fragmentação e aos problemas equivalentes em relação à regulação global.

Palavras Chave: fragmentação, regimes internacionais, direito global, direito internacional; pluralismo legal.

\section{Abstract}

The idea that life undergoes a process of functional differentiation, and that, consequently, law becomes increasingly specialized - and maybe even transforms in its very nature - is now widespread. The specialized clusters of law or regulation are very often called regimes, in the international arena, international or transnational regimes. This paper deals, first, with three strong representations of international regimes and discusses some of their problems. It argues that, in order to make a good use of the category, it is necessary to keep in mind the differentiation between law and non-law in the wider context of governance. It then turns, firstly, to the notion of regimes as fragments of a unified and coherent public international law order and, secondly, as meeting points of regulations emerging from different 
legal orders as well as from other non-legal sources. Within public international law, regimes are seen as related to what is called the double fragmentation of that legal order. As clusters of regulation within a wider global regulatory order, regimes are put in relation to two types of legal or regulatory pluralism. At the end, it discusses de issues related to the rule of law within international law and its fragmentation process, and also the equivalent issues concerning global regulation.

Keywords: fragmentation; international regimes; global law; international law; legal pluralism.

\section{INTRODUÇão}

A literatura acadêmica mais recente sobre o direito internacional tem sido preenchida com referências a noções como fragmentação, pluralismo e regimes.

Entender o debate nelas centrado e construir conceitos competentes de uma ou outra das noções, de modo a avaliar sua utilidade e ou os riscos que trazem à tona, não são tarefas que se apresentam fáceis.

A literatura, me parece, é rica em incertezas, em confusão e em perspectivas embaralhadas. Nesse ambiente, e para não dizer nada por ora sobre fragmentação e pluralismo, regimes recebem, por vezes, o que parecem ser definições claras, mas que, ao menos em alguns casos, não são apropriadas às construções teóricas em que se inscrevem. Mais do que isso, ainda que se tenha clareza conceitual, é particularmente difícil identificar na prática os regimes tais como são definidos e as suas relações tais como são descritas.

Além dessa fragilidade de conceitos e de consistência, quando se abordam os temas da fragmentação, do pluralismo ou dos regimes, muito cedo se encontra um outro problema de considerável relevância e dificuldade. Esse problema combina a transformação do direito (internacional), a sua relação com outros instrumentos ou sistemas regulatórios e o lugar que ele ocupa na regulação da vida na arena internacional.

$\mathrm{Na}$ verdade, a ideia geral de que direito e regulação ${ }^{1}$

1 Regulação é termo que pode receber mais de um sentido, alguns mais genéricos e outros mais específicos. Pode vir relacionado, por exemplo, ao direito administrativo e referir-se às normas produzidas por órgãos dotados de poder delegado pelo Estado e que organizam determinados setores da economia ou participam de determinadas políticas públicas. Em sentido mais geral, pode significar o ato ou o produto da atividade de criar regras e normas. É nesse sentido mais abrangente, como conjuntos de normas e regras, prescrições, que tendem a se reorganizar em blocos relativamente autônomos para responder à complexidade da vida traz à luz o fato de que as normas pertencentes a um sistema jurídico passam a constituir fragmentos organizados em torno de temas, e de que o direito pertencente a um sistema jurídico se combina com aquele pertencente a outros sistemas, assim como o direito formal se combina com regulação de outras naturezas, de modo a governar áreas específicas da vida.

Os regimes, entendidos em certos sentidos, constituem combinações, áreas de confluência de vários sistemas legais, ou áreas de convergência de direito e de regulação, surgida de uma multiplicidade de fontes, inclusive privadas, e cuja natureza, jurídica ou outra, é objeto de polêmica.

A polêmica é provavelmente o resultado de uma dupla frustração ou de uma dupla ambição: ao descobrirem que o direito - o que usualmente se entende por direito - não regula senão uma pequena porção da vida, juristas sentem a necessidade de alargar o escopo de seu objeto de estudos; frequentemente, no entanto, desconfortáveis ao lidar com o não-direito, sentem a necessidade de chamar direito o que usualmente não seria entendido como sendo tal.

Quer sejam pensados como instâncias de fragmentação de uma ordem jurídica dada ou como elementos de um ambiente regulatório plural, os regimes - jurídicos ou regulatórios e, no nosso caso, internacionais ou transnacionais - representam desafios para a qualidade da ordem jurídica ou do ambiente regulatório, ou seja, desafios à construção do rule of law.

Começo a discussão desses temas com um capítulo que parte da noção de diferenciação funcional e da influência que ela exerce sobre a ideia de regimes jurídicos internacionais ou transnacionais (Capítulo I). Esse capítulo se ocupa essencialmente com explorar três representações fortes dos regimes no espaço internacional ou global e aponta para os seus problemas de inconsistência e de contaminação mútua.

O capítulo II se detém na discussão de um tema que subjaz a compreensão, que aqui se está tentando, do panorama da organização do mundo por normas reunidas em aglomerados em torno de problemas específicos, qual seja a relação entre o direito e a noção de

podem não ser jurídicas, que o termo é usado aqui. Tratarei mais adiante do tema em maior detalhe. 
governança e a necessidade de distinguir o jurídico do não jurídico, de distinguir o que pertence a uma ordem jurídica do que não pertence.

O capítulo III cuida dos regimes enquanto manifestações da fragmentação do direito internacional público. Discuto ali o que identifico como os dois tipos de fragmentação do direito internacional e, após demonstrar a dificuldade de identificar e delimitar os regimes, exploro o modo como o direito internacional resolve os conflitos entre regimes ou dentro de um mesmo regime, conflitos esses que tendem a ser apresentados sob uma luz um pouco distorcida.

Já o capítulo IV lida, primeiramente, com os dois tipos de pluralismo jurídico que identifico no panorama da regulação das relações internacionais ou transnacionais, aquele em que as unidades básicas são as ordens jurídicas e aquele em que são os regimes os elementos constitutivos. Partindo da ideia de que regimes podem ser também pontos de convergência, agregados, de normas e organizações pertencentes a diferentes ordens jurídicas e de outros tipos de regulação, assim como podem, mais raramente, consistir em sistemas fechados de um tipo único de regulação, o capítulo apresenta um quadro das formas de regulação diversas, diferentes, do direito internacional e se vale, para isso, da literatura sobre Global Administrative Law e Transnational Private Regulation.

Finalmente, no capítulo V, discuto a noção de rule of law e as suas funções básicas face a uma ordem jurídica fragmentada, o direito internacional público, e face a um ambiente regulatório global em que a ação regulatória é empreendida por atores diversos e em processos que, impactando o interesse público, não se submetem necessariamente a mecanismos de controle e não estão sujeitos a exigências de transparência e responsividade.

\section{DifERENCIAÇÃo FUNCIONAL - NOÇÃo DE REGI- MES INTERNACIONAIS}

A vida, nos é dito, está ficando crescentemente fragmentada. Por meio de algo chamada 'diferenciação funcional', as sociedades estariam sendo divididas em inúmeros setores organizados em torno de conjuntos de interesses, temas, saberes específicos. Isto seria igualmente verdade para as sociedades nacionais e para aque- la internacional ou global. ${ }^{2}$

Esses segmentos da sociedade demandariam ou tenderiam a produzir, ou ao menos provocariam a produção de regulação setorialmente específica. As normas, regras, e possivelmente as instituições, as organizações ou órgãos, ${ }^{3}$ constitutivos desses conjuntos de regulação específicas a cada setor apareceriam e tenderiam a ser vistas como conjuntos distintos e diferenciados, razoavelmente autônomos.

Esses conjuntos de normas e instituições podem ser vistos, e o serão, como constituindo ou fragmentos de uma única, mas fragmentada ordem jurídica, ou como uma variedade de ordens jurídicas em um ambiente jurídico pluralístico. Eles seriam expressão ou de fragmentação, ou de pluralismo jurídico, ou de ambos. Isto, é claro, se presumido o caráter jurídico das regras ou normas que constituem o conjunto. De outra forma, falar-se-ia de fragmentação de uma ordem regulatória ou de pluralismo regulatório.

Quer sejam entendidos ou percebidos como partes diferenciadas de um único sistema jurídico ou como ordens jurídicas independentes, esses conjuntos regulatórios tendem a ser chamados 'regimes jurídicos'.

Porque a fragmentação da vida e da sociedade não acontece apenas no interior das sociedades domésticas, nacionais, mas é um fenômeno que atinge o que é agora uma esfera social global unificada (em outro sentido), esses regimes jurídicos são também internacionais ou transnacionais ou globais.

É a existência de algo chamado regimes jurídicos ou regulatórios, ou de governança - internacionais - ou transnacionais - que serve como desculpa para o que seguirá nas próximas páginas. No entanto, em ambiente saturado por sábia literatura sobre fragmentação e pluralismo jurídico, talvez haja a necessidade de uma justificação para o que seguirá.

2 Esta é uma famosa afirmação trazida em partes dentro de discussão de GuntherTeuber. Ver, por exemplo, TEUBNER, G. Global Bukowina: Legal Pluralism in the World Society. In: TEUBNER, G (Ed.). Global Law in the World Society. Dartmouth, Aldershot, 1997. p. 3-28; FISHER-LESCANO, ANDREAS; TEUBNER, G. Regime-Collisions? The Vain Search for Legal Unity in the Fragmentation of Global Law.Michigan Journal of International Law, v. 25, p. 999-1046, 2004;

3 Também os termos instituição ou instituições podem cobrir mais de um significado. Eles são usados aqui no sentido que mais se aproxima de organização ou órgão, querendo significar loci institucionais para a produção de normas ou para a sua implementação ou para a solução de controvérsias. 
O fato é que, embora a descrição da realidade que veio sendo discutida seja razoavelmente acurada, muitas variáveis muito importantes permanecem desconhecidas ou sem resposta. Por exemplo, há alguma concepção de direito, subjacente à discussão, que nos dirá se e quando a regulação que constitui o regime é jurídica? Se existe, qual é essa concepção do direito? Há uma aceitação da necessidade de diferenciar a regulação jurídica daquela não-jurídica, ou, ao contrário, dispensa-se essa necessidade? Como é possível identificar uma norma ou uma instituição como pertencente a um regime específico? Como se pode reconhecer os contornos de um regime? Quais os critérios usados, se os há, para identificar o regime como sendo parte de uma ordem jurídica mais ampla, e quais aqueles que o qualificam como uma ordem jurídica autônoma?

Respostas a estas e outras perguntas podem aparecer, explicita ou implicitamente, em parte da literatura sobre fragmentação ou pluralismo. Frequentemente não aparecem ou não se mostram cristalinas ao leitor.

De todo modo, quer as respostas apareçam claras ou não, é fato que essas questões constituem pontos de divergência ou de desencontro entre autores que escrevem sobre os fenômenos da fragmentação, do pluralismo e dos regimes jurídicos ou regulatórios. Ao responderem de modos divergentes a essas questões centrais, ou ao apresentarem atitudes diferentes em relação a elas - alguns ignorando-as como desimportantes, outros respondendo com firmeza e outros ignorando sua existência - os autores estão na verdade construindo ou descrevendo realidades diferentes.

Descrevem realidades diversas quando, ao olharem a partir de perspectivas distintas para algo que existe, levam em conta o que se encontra dentro de seu campo de visão e, claro, excluem o que ali não está. Constroem realidades diferentes quando interpretam e fazem afirmações normativas sobre o que existe e é visto a partir de distintas perspectivas.

Perspectiva é tudo então, ou quase. Pode-se julgar uma teoria, sobre fragmentação, por exemplo, e apontar-lhe falhas ou porque a perspectiva em que encontra sua origem fornece uma visão distorcida, falsa, da realidade, ou porque constrói uma realidade que não guarda relação com o que existe.

Pode-se também apontar falhas numa teoria quando suas conclusões não são consistentes com a perspectiva sobre a qual se supõe que esteja baseada. Há, portanto, uma correspondência ou uma falta de correspondência entre a perspectiva e o real e uma correspondência ou uma falta de correspondência entre as conclusões e as condicionantes fundamentais de uma dada perspectiva.

Para que qualquer julgamento desse tipo possa ser feito, no entanto, deve haver clareza sobre a perspectiva adotada.

Parece-me que há uma cacofonia razoavelmente ensurdecedora que permeia as discussões sobre fragmentação, pluralismo e regimes. Muito frequentemente, conceitos, argumentos, diagnósticos são transportados de uma perspectiva a outra sem muito cuidado com o risco de que não faça qualquer sentido ali, ou com o risco de que desfaça a coerência do ponto de vista para onde é feita a transferência. Por vezes, independentemente do eventual recurso a tais empréstimos inapropriados, algumas leituras são simplesmente desprovidas de coesão interna ou são ao menos pouco convincentes.

A fim de começar a pintar o panorama das discussões relacionadas aos regimes, apresentarei brevemente três representações fortes da noção.

\subsection{Regimes na teoria das relações internacio- nais}

A noção de regimes internacionais apareceu e se desenvolveu primariamente na teoria das relações internacionais. Nesse campo, a publicação em 1983 de um livro editado por Stephen Krasner emoldurou o debate sobre a existência, a definição e as funções de regimes internacionais. $\mathrm{O}$ livro organizou o que era à época o estado da arte na matéria e desde então continuou sendo uma referência necessária para quem quer que estude o tema. ${ }^{4}$

Ali regimes internacionais são vistos como uma possível ferramenta para a explicação do funcionamento das relações internacionais. A discussão é centrada no possível papel dos regimes enquanto variáveis que atuariam como intermediários entre as determinantes causais básicas do comportamento e as resultantes e o efetivo comportamento.

Uma definição é oferecida: regimes seriam 'conjuntos de princípios, normas, regras e procedimentos de tomada de decisão, implícitos ou explícitos, em torno dos quais as expectativas dos atores convergem, em

4 KRASNER, Stephen D (ed.). International Regimes. Ithaca: Cornell University Press, 1983. 
uma dada área das relações internacionais' ${ }^{5}$.

Os termos da definição são assim explicados: 'Princípios são crenças de fato, de causa e de retidão. Normas são padrões de comportamento definidos em termos de direitos e obrigações. Regras são prescrições ou proscrições específicas de ação. Procedimentos de tomada de decisão são práticas prevalentes para a feitura e a implementação de escolhas coletivas ${ }^{6}$. Nem essa definição de regimes nem aquela de suas partes constitutivas é aceita por todos sem restrições. No entanto, podem ser retidas como definições operativas, working definitions 7 e são, em todo caso, definições referenciais.

As posturas que os estudiosos das relações internacionais adotam em relação à definição de regimes, em relação ao papel que estes desempenham e em relação às determinantes de sua existência, variam de acordo com a sua abordagem teórica subjacente, a partir da qual estudam o funcionamento da sociedade internacional. As diferenças podem ser vistas, em essência, como relacionadas ao papel do direito ou da regulação - princípios, normas, regras - nas relações internacionais.

Este aspecto fundamental da concepção de regimes que tem a teoria das relações internacionais aparece claramente: regimes internacionais são normativos, regulatórios, jurídicos, em sua natureza mesma. Falar então sobre regimes 'jurídicos' internacionais seria em certa medida pleonástico. Mas aqui o direito está sendo olhado desde fora, como um produto das dinâmicas que governam as relações na cena internacional e como uma possível condicionante dos comportamentos e resultados. Não se trata de uma discussão jurídica sobre o direito, mas de uma discussão política.

5 KRASNER, Stephen D (ed.). International Regimes. Ithaca: Cornell University Press, 1983, p. 2, tradução nossa. 'sets of implicit or explicit principles, norms, rules, and decision-making procedures around which actors' expectations converge in a given area of international relations'(KRASNER, 1983)"title" : "Structural causes and regime consequences: regimes as intervening variables", "type" : "chapter" \}, "uris" : [ "http://www.mendeley.com/ documents / ?uuid=826f40ad-f706-4e72-8f96-08683c832d4b" ] \} ], "mendeley" : \{ "previouslyFormattedCitation": “(KRASNER, 1983 6 KRASNER, Stephen D (ed.). International Regimes. Ithaca: Cornell University Press, 1983, p. 2, tradução nossa. 'Principles are beliefs of fact, causation and rectitude. Norms are standards of behaviour defined in terms of rights and obligations. Rules are specific prescriptions or proscriptions of action. Decision-making procedures are prevailing practices for making and implementing collective choice' 7 HANSENCLEVER, A.; MAYER, P.; RITTBERGER, V. Theories of international regimes. Cambridge: Cambridge University Press, 1997, p. 13
Outro aspecto importante da discussão neste terreno é o fato de que, apesar da definição geral falar em 'expectativas dos atores', ela está centrada no comportamento e nas expectativas dos Estados. Os Estados são vistos como os atores centrais das relações internacionais e os regimes internacionais são vistos como aqueles conjuntos de princípios, normas, regras e procedimentos de tomada de decisão produzidos pelos Estados e destinados a influenciar as expectativas e o comportamento dos Estados.

Finalmente, devo sublinhar um aspecto central dos regimes tal como definidos aqui: esses conjuntos de princípios, normas etc. governam áreas ou setores específicos das relações internacionais ${ }^{8}$. Está claro, portanto, que a discussão de regimes que faz a teoria das relações internacionais não está preocupada, ao menos não de modo particular, com a existência, função ou unidade de um sistema jurídico constituído pelos vários regimes ou a eles sobreposto.

Enquanto se esforça para explicar as interações entre Estados e identificar o caminho que leva das variáveis causais básicas ao correspondente comportamento ou resultante, a teoria das relações internacionais olha para aglomerados, conjuntos de instrumentos regulatórios organizados em torno de temas específicos tais como segurança, meio ambiente, comércio etc.

Vistos pelos teóricos das relações internacionais, regimes internacionais aparecem essencialmente como conjuntos regulatórios constituídos por normas e organizações que são parte do que se conhece usualmente como direito internacional público, apesar de que nenhum esforço particular é feito para verificar se de fato essas normas e organizações pertencem a essa ordem jurídica e correspondem aos cânones que, aos olhos do próprio direito internacional, fazem desta ordem jurídica um todo coerente.

Esses traços básicos dos regimes internacionais normas e organizações criadas ou produzidas pelos Estados e destinados a regular o comportamento dos Estados, correspondendo às características do direito internacional público, organizadas em torno de temas específicos - são os que resultam da literatura sobre relações internacionais. Mas regimes não precisam necessariamente ser vistos assim e, de fato, não o são sempre,

8 KRASNER, Stephen D (ed.). International Regimes. Ithaca: Cornell University Press, 1983, p. 1 
nem por todos. Outras concepções de regimes internacionais existem.

\subsection{A concepção de regimes da teoria social}

Uma concepção diferente de regimes pode ser encontrada entre aqueles que enxergam a emergência de um direito global que é fragmentado em diversos regimes diferenciados funcionalmente, correspondendo a setores específicos do tecido social ${ }^{9}$.

Essa visão, ancorada numa perspectiva de teoria social, vê o direito como uma realidade transformada. Ele já não seria normativo nem fundado no território. $\mathrm{O}$ direito seria agora cognitivo e desprovido de qualquer capacidade de unidade..$^{10}$ Sua organização tradicional, de acordo com territórios nacionais, estaria dando lugar a um direito fragmentado segundo linhas sociais setoriais, os setores sendo economia, ciência e outros tantos ${ }^{11}$.

Esses regimes setoriais, porque constituiriam esse direito global que é diferente em sua essência mesma, são pensados mais como transnacionais do que como internacionais. ${ }^{12}$

Diferem, ou pensa-se que diferem, dos regimes in-

9 FISHER-LESCANO, ANDREAS; TEUBNER, G. RegimeCollisions? The Vain Search for Legal Unity in the Fragmentation of Global Law. Michigan Journal of International Law, v. 25, 2004, p. 1000 10 FISHER-LESCANO, ANDREAS; TEUBNER, G. RegimeCollisions? The Vain Search for Legal Unity in the Fragmentation of Global Law. Michigan Journal of International Law, v. 25, 2004., p. 1000 11 FISHER-LESCANO, ANDREAS; TEUBNER, G. RegimeCollisions? The Vain Search for Legal Unity in the Fragmentation of Global Law. Michigan Journal of International Law, v. 25, 2004. p. 1006-1007.Diferentemente desta abordagem, Gabriela Garcia Batista Lima explora uma utilidade do conceito de governança originado das relações internacionais como institucionalização para o estudo de um direito que cada vez mais inclui relações não estatais. Assim, aborda a complementaridade e convergência dos conceitos de governança, regimes jurídicos, direito reflexivo, pluralismo jurídico, corregulação e autorregulação, que são colocados como ferramentas para um estudo do direito pós-globalização. Ver LIMA, Gabriela G. B. Conceitos de relações internacionais e teoria do direito diante dos efeitos pluralistas da globalização: governança global, regimes jurídicos, direito refexivo, pluralismo jurídico, corregulação e autorregulação. Revista de Direito Internacional, v.11, n.1, 2014.

12 "The traditional differentiation in line with the political principle of territoriality into relatively autonomous national legal orders is thus overlain by a sectoral differentiation principle: the differentiation of global law into transnational legal regimes, which define the external reach of their jurisdiction along issue-specific rather than territorial lines, and which claim a global validity for them- selves." FISHER-LESCANO, ANDREAS; TEUBNER, G. Regime-Collisions? The Vain Search for Legal Unity in the Fragmentation of Global Law. Michigan Journal of International Law, v. 25, 2004, p. 1009 ternacionais em vários sentidos. A comunidade cognitiva que daria origem ao regime e suas normas não é vista como constituída exclusivamente por Estados. ${ }^{13}$ As normas são, em princípio, pensadas como jurídicas ou legais, mas não precisariam conformar-se aos cânones quer do direito doméstico, nacional, quer do direito internacional. Os destinatários das normas, aqueles cujo comportamento supõe-se que regulem, não seriam os Estados, ou ao menos não apenas os Estados, mas quem quer que seja um membro da comunidade cognitiva ou do setor social em questão ${ }^{14}$.

Porque essa visão dos regimes pressupõe uma transformação na própria natureza do direito, é apenas natural que se espere uma resposta para o que significa serem esses regimes (transnacionais) jurídicos. Essa resposta não se encontra em lugar algum. Ela é, no entanto, de fundamental importância já que para os proponentes desta perspectiva, que pretendem indicar um caminho para a solução das colisões entre os regimes, é muito importante decidir se e quando as normas colidentes são jurídicas e não apenas normas sociais. ${ }^{15}$ De acordo

13 FISHER-LESCANO, ANDREAS; TEUBNER, G. RegimeCollisions? The Vain Search for Legal Unity in the Fragmentation of Global Law. Michigan Journal of International Law, v. 25, 2004., p. 1007-1009. Isso porque há uma consequência indireta da globalização da diferenciação social: "the unity of global law is no longer structure-based, as in the case of the Nation- State, within institutionally secured normative consistency; but is rather process-based, deriving simply from the modes of connection between legal operations, which transfer binding legality between even highly heterogeneous legal orders".FISHER-LESCANO, ANDREAS; TEUBNER, G. Regime-Collisions? The Vain Search for Legal Unity in the Fragmentation of Global Law. Michigan Journal of International Law, v. 25, 2004., p. 1007-1008. Ainda, "[f]or centuries law had followed the political logic of nation-states and was manifest in the multitude of national legal orders, each with their own territorial juris- diction. Even international law, which viewed itself as the contract law of Nation-States, did not depart from this model. The final break with such conceptions was only signaled in the last century with the rapidly accelerating expansion of international organizations and regulatory regimes, which, in sharp contrast to their genesis within international treaties, established themselves as autonomous legal orders. The national differentiation of law is now overlain by sectoral fragmentation". FISHER-LESCANO, ANDREAS; TEUBNER, G. Regime-Collisions? The Vain Search for Legal Unity in the Fragmentation of Global Law. Michigan Journal of International Law, v. 25, 2004., p. 1008.

14 FISHER-LESCANO, ANDREAS; TEUBNER, G. RegimeCollisions? The Vain Search for Legal Unity in the Fragmentation of Global Law. Michigan Journal of International Law, v. 25, 2004, p. 1007-1009. Ver também TEUBNER, 1997.

15 TEUBNER, G. K. P. Two Kinds of Legal Pluralism: Collision of Transnational Regimes in the Double Fragmentation of World Society. In: YOUNG, M. (Ed.). Regime Interaction in International Law: Facing Fragmentation. 1. ed. Cambridge: Cambridge University Press, 
com eles, uma norma jurídica terá sempre precedência sobre uma norma social com que colida ${ }^{16}$.

Os regimes diferenciados funcionalmente são, portanto, pensados como sendo direito, mas seriam a expressão de um direito diferente, organizado em torno de setores cognitivos específicos, não produzido por Estados, não destinado a governar as relações no interior de um determinado território ou as relações entre Estados territorialmente definidos. Eles podem colidir, e argumenta-se que colidem de fato, também com os direitos nacionais, domésticos, e com o direito internacional, já que nem aqueles nem este desaparecem. ${ }^{17}$

Isto traz algum conforto, para quem dele precisar, e indica a existência ou a emergência de um novo tipo de direito que ainda não tem as condições de substituir o antigo, normativo, territorial. Esperar-se-ia, portanto, que esses regimes legais transnacionais não coincidam com aqueles regimes que, no coração do direito doméstico ou do direito internacional, são expressões das características desses sistemas jurídicos, ainda que organizados em torno de áreas ou temas de preocupação específicos.

Regimes jurídicos transnacionais, para serem jurídicos, ou devem pressupor uma definição de direito diferente, de modo a diferenciá-los do que faz jurídicos os regimes que fazem parte do direito internacional público, ou devem pressupor uma definição ampliada, mais inclusiva, que possa abarcar ambos tipos de conjuntos de normas, regras etc.

Num mesmo fôlego, direito do comércio internacional, direito do meio ambiente, lex mercatoria, lex constructionis, lex digitalis, são oferecidos como exemplos desses regimes funcionais que seriam a expressão da fragmentação do direito global. ${ }^{18} \mathrm{~A}$ proliferação de tribunais e cortes internacionais é invocada como prova suple-

2012, p. 52

16 TEUBNER, G. K. P. Two Kinds of Legal Pluralism: Collision of Transnational Regimes in the Double Fragmentation of World Society. In: YOUNG, M. (Ed.). Regime Interaction in International Law: Facing Fragmentation. 1. ed. Cambridge: Cambridge University Press, 2012, p. 52

17 FISHER-LESCANO, ANDREAS; TEUBNER, G. RegimeCollisions? The Vain Search for Legal Unity in the Fragmentation of Global Law. Michigan Journal of International Law, v. 25, 2004, p. 1013. 18 FISHER-LESCANO, ANDREAS; TEUBNER, G. RegimeCollisions? The Vain Search for Legal Unity in the Fragmentation of Global Law. Michigan Journal of International Law, v. 25, 2004, p. 1010-1011; 1013. mentar dessa fragmentação. ${ }^{19}$ Mas todos os exemplos dessa proliferação são tirados do direito internacional público! ${ }^{20}$

De acordo com essa visão, a fragmentação do direito é apenas um reflexo efêmero da fragmentação social. ${ }^{21}$ Qualquer desejo de unidade seria mera ilusão. ${ }^{22}$ No melhor dos casos, pensa-se, normas de conflito permitirão o estabelecimento de redes fluidas entre as unidades em conflito. ${ }^{23}$ No entanto, ainda que assim fosse, parece-me que deveria permanecer inteira a necessidade de se poder reconhecer e delimitar as unidades em questão.

Ou bem o direito do comércio internacional e, por exemplo, a lex constructionis, correspondem a uma única e mesma definição genérica ou não. Se não correspondem, a única justificativa possível para o fato de aparecerem juntos é o fato de demonstrarem a tendência do direito ou da regulação de se tornarem especializados e compartimentalizados. Será realmente possível que o fato de um desses regimes ser parte do direito internacional público não tenha qualquer importância?

Para decidir sobre isso, é preciso verificar o conceito de regime transnacional com que os proponentes dessa perspectiva estão trabalhando. Aquela oferecida é esta:

"A regime is a union of rules laying down particular
rights, duties and powers and rules having to do
with the administration of such rules, including
in particular rules for reacting to breaches. When
such a regime seeks precedence in regard to the
general law, we have a 'self-contained regime,' a
special case of lex specialis."'(FISCHER-LESCANO,

19 FISHER-LESCANO, ANDREAS; TEUBNER, G. RegimeCollisions? The Vain Search for Legal Unity in the Fragmentation of Global Law. Michigan Journal of International Law, v. 25, 2004, p. 1012-1014.

20 FISHER-LESCANO, ANDREAS; TEUBNER, G. RegimeCollisions? The Vain Search for Legal Unity in the Fragmentation of Global Law. Michigan Journal of International Law, v. 25, 2004, passim. 21 FISHER-LESCANO, ANDREAS; TEUBNER, G. RegimeCollisions? The Vain Search for Legal Unity in the Fragmentation of Global Law.Michigan Journal of International Law, v. 25, 2004, p. 1004. Ainda, os autores concluem que nem a criação de hierarquias judiciais, solução apresentada comumente para a fragmentação jurídica, solucionaria a questão, já que tal fragmentação deriva de contradições estruturais sociais. Citam então Luhmann (Die Gesellschaft der Gesellschaft, 1997, p. 1088-96) "[T]hesino f differentiation can never be undone. Paradise is lost".

22 FISHER-LESCANO, ANDREAS; TEUBNER, G. RegimeCollisions? The Vain Search for Legal Unity in the Fragmentation of Global Law. Michigan Journal of International Law, v. 25, 2004, p. 1004 23 FISHER-LESCANO, ANDREAS; TEUBNER, G. RegimeCollisions? The Vain Search for Legal Unity in the Fragmentation of Global Law. Michigan Journal of International Law, v. 25, 2004, p. 1004 


\section{TEUBNER, 2004, p. $1013^{24}$ )}

Essa definição é apresentada como uma demonstração de que esses regimes não pertencem quer ao direito nacional, quer ao direito internacional, porque, nos é dito, suas normas secundárias não correspondem a qualquer dos dois tipos de sistema jurídico. ${ }^{25}$ No entanto, a definição é tomada emprestada de um relatório da Comissão do Direito Internacional (CDI) sobre a fragmentação do direito internacional e faz referência, no relatório, à noção de regimes autocontidos que funcionariam como lex specialis em relação ao direito internacional público geral!

A definição não pode ser aplicada a lex mercatoria, lex constructionis, lex digitalis etc. Os traços gerais da definição - "a union of rules laying down particular rights, duties and powers and rules having to do with the administration of such rules, including in particular rules for reacting to breaches."- podem se aplicar a esses conjuntos normativos como sistemas, jurídicos se quisermos, independentes, mas não como regimes dentro de um sistema jurídico a que não podem pertencer. A ideia de derrogação em relação ao direito geral só poderia querer significar derrogação em relação ao novo direito global que, nos é também dito, não é passível de unidade. ${ }^{26}$

Algumas menções à literatura referencial das relações internacionais a que me referi antes são feitas nessa literatura que chamo de teoria social. ${ }^{27}$ Mas aqui também está claro que os regimes de que uns e outros falam só podem ser coisas totalmente diversas.

Não há nada, além da ideia básica de que conjuntos de normas, regras e procedimentos tendem a surgir e evoluir em torno de áreas e problemas específicos, que una a noção de regimes como concebidos pela teoria das relações internacionais àquela de regimes transnacionais pensados por cientistas sociais como partes de

24 Definição citada de KOSKENNIEMI, Martti.Study on the Function and Scope of the lex specialis Rule and the Question of "Self-Contained Regimes, Preliminary Report by Martti Koskenniemi, Chairman of the Study Group of the ILC. Maio de 2004, p. 9.(KOSKENNIEMI, 2004)

25 FISHER-LESCANO, ANDREAS; TEUBNER, G. RegimeCollisions? The Vain Search for Legal Unity in the Fragmentation of Global Law. Michigan Journal of International Law, v. 25, 2004, p. 1013. 26 FISHER-LESCANO, ANDREAS; TEUBNER, G. RegimeCollisions? The Vain Search for Legal Unity in the Fragmentation of Global Law. Michigan Journal of International Law, v. 25, 2004, p. 1017 27 FISHER-LESCANO, ANDREAS; TEUBNER, G. RegimeCollisions? The Vain Search for Legal Unity in the Fragmentation of Global Law. Michigan Journal of International Law, v. 25, 2004, p. 1011, nota 45. um novo direito global. Além disso, estes últimos se ressentem da falta de uma definição clara, uma que não seja tomada de empréstimo à literatura das relações internacionais ou de estudos estritamente dogmáticos de direito internacional. E, como dito, não há clareza sobre o que significaria serem esses regimes jurídicos.

\subsection{A fragmentação no direito internacional público}

Uma terceira perspectiva a partir da qual se olhou para a noção de regimes é aquela do direito internacional público. Ali regimes são igualmente vistos como conjuntos normativos organizados em torno de áreas específicas, mas constituem partes, fragmentos de um sistema jurídico unificado, coerente. Os princípios, normas, regras e procedimentos de tomada de decisão, assim como as organizações, que podem ser pensados como constituindo conjuntos relativamente articulados ou autocontidos, são todos partes do direito internacional e correspondem aos critérios de reconhecimento estabelecidos por essa ordem jurídica.

\subsubsection{A visão dogmática}

A fragmentação do direito internacional (público) decorre, ao que parece, da sua expansão e de sua crescente especialização e daria lugar, por sua vez, a vários problemas e dificuldades. ${ }^{28}$ Tanto a expansão quanto a especialização dizem respeito às normas e também às instituições ou estruturas organizacionais do direito internacional. ${ }^{29} \mathrm{~A}$ fragmentação é portanto tanto normativa quanto institucional.

A possibilidade de que haja contradições e colisões entre as normas chamadas a regular o comportamento dos sujeitos de direito internacional e de que essas normas venham a ser aplicadas de modo divergente por diferentes tribunais ou instituições internacionais é normalmente apresentada como a principal dificuldade associada à fragmentação dessa ordem jurídica. ${ }^{30} \mathrm{O}$ problema, portanto, é a possibilidade de que um Estado se veja submetido a normas contraditórias ou tenha que

28 RELATÓRIO da Comissão de Direito Internacional, 2006, para. 8-9; 15

29 RELATÓRIO da Comissão de Direito Internacional, 2006, para. 8-9; 13

30 RELATÓRIO da Comissão de Direito Internacional, 2006, para. 8-9; 15 
fazer face a decisões contraditórias emitidas por tribunais ou instituições diferentes, baseando-se em normas pertencentes a diferentes fragmentos ou ramos do direito internacional.

Um caminho para a solução da fragmentação normativa foi ensaiado pela CDI. ${ }^{31}$ Os juristas da Comissão consideraram, por outro lado, que era mais apropriado deixar que a solução para as colisões decorrentes da fragmentação institucional seja buscada pelas próprias instituições. ${ }^{32}$

Regimes são o produto resultante da fragmentação (ou um dos produtos, já que, talvez, nem sempre se assista à formação de regimes autocontidos, mas sim à de simples fragmentos ou mesmo de normas individuais isoladas). ${ }^{33}$ Eles podem ser entendidos como regimes específicos de responsabilidade internacional, ${ }^{34}$ como um conjunto de normas relativas a um tema ou área específicos ou como um sistema mais complexo de normas e estruturas organizacionais voltadas à regulação de um tema. ${ }^{35}$

A solução ensaiada pelo relatório da CDI para os dois principais problemas identificados - a relação entre os regimes e o direito internacional geral e a irritação entre os regimes - começa por adotar a Convenção de Viena sobre o Direito dos Tratados como guia. Isto porque os regimes são sempre, pensa-se, constituídos por e contidos em tratados ou conjuntos de tratados. ${ }^{36}$

Recorre-se em seguida às técnicas clássicas para a solução de antinomias: lex specialis, lex posteriori e hierarquia. ${ }^{37}$ Claro, porque o direito internacional é um tipo específico e especial de ordem jurídica, todas essas téc-

31 RELATÓRIO da Comissão de Direito Internacional, 2006, 2006, p. 248-256

32 Entretanto, indica-se:[d]isputes concerning the operation of the regimes may not always be properly dealt with by the same organs that have to deal with the recognition of claims of rights. Likewise, when conflicts emerge between treaty provisions that have their home in different regimes, care should be taken so as to guarantee that any settlement is not dictated by organs exclusively linked with one of the other of the conflicting regimes. RELATÓRIO da Comissão de Direito Internacional, 2006, pág. 252.

33 RELATÓRIO da Comissão de Direito Internacional, 2006, para. 14. Ver também para. 123-137

34 RELATÓRIO da Comissão de Direito Internacional, 2006, para. 138 - 152. Retornarei a essas possibilidades adiante, no capítulo III.

35 RELATÓRIO da Comissão de Direito Internacional, 2006, para. 159 - 185

36 RELATÓRIO da Comissão de Direito Internacional, 2006, para. 17, 248; 492.

37 RELATÓRIO da Comissão de Direito Internacional, 2006, para 8 nicas funcionam de modo também específico, especialmente a ideia de hierarquia normativa.

É muito importante notar que a todo momento esta perspectiva da fragmentação olha para o direito internacional como uma ordem jurídica unitária, coerente, e olha para o fenômeno dos regimes como um desafio que pode e deve receber uma resposta no âmbito de uma ordem unitária e coerente. É a partir dessa perspectiva que o direito internacional olha para si mesmo, desde dentro.

Desse ponto de vista, regimes são vistos como manifestações de uma tendência, problemática e desafiadora, de fragmentação. O contexto da fragmentação e dos regimes continua sendo a diferenciação funcional da vida, dividindo a sociedade em setores de conhecimento e de interesses. ${ }^{38}$ Aqui, no entanto, para o direito internacional, a diferenciação funcional setorial não distribui diferentes atores em múltiplos núcleos sociais. Aqui, são os Estados que produzem as normas e organizações e, ao mesmo tempo, criam diferentes regimes, temáticos, especiais, de direito internacional. ${ }^{39}$

Isto porque, de acordo com essa visão do direito pelo direito, ainda são os Estados a produzir o direito internacional, assim como são estes os destinatários de suas normas. Apenas, os Estados agem através de diferentes partes de suas burocracias, ou através de uma mesma autoridade responsável pelas relações externas, produzindo diferentes respostas normativas para lidar com diferentes temas de preocupação, adotando e respondendo a diferentes racionalidades.

Encontramos aqui, portanto, a mesma determinante básica para a existência de algo chamado 'regimes jurídicos internacionais' - a fragmentação da vida social em temas específicos de preocupação, de conhecimento, de interação. Apenas, aqui, os regimes de que fala o direito internacional, problemáticos mas ainda assim parte integrante de sua identidade como ordem jurídica, parecem ser essencialmente os mesmos de que fala a literatura sobre teoria das relações internacionais. A diferença central é que esta última ou não se preocupa em estabelecer a natureza jurídica dos princípios, normas, regras, procedimentos de tomada de decisão ou organizações, ou presume essa natureza jurídica; tampouco se preocupa com o pertencimento dessas coisas a um

38 RELATÓRIO da Comissão de Direito Internacional, 2006, para. 7

39 RELATÓRIO da Comissão de Direito Internacional, 2006, para. 493. 
sistema jurídico unificado e coerente.

De todo modo, os regimes de que fala o direito internacional não são os mesmos de que parece falar a teoria social mencionada antes.

\subsubsection{Discursos ou narrativas sobre a fragmen- tação do direito internacional}

A visão jurídica que acaba de ser discutida é dogmática no sentido de que relata a visão que o direito tem de si mesmo e usa a linguagem de que devem se valer os juristas para atuar no direito.

Há abundante literatura, jurídica, sobre fragmentação, que se separa dessa visão dogmática e que tende a discutir o tema desde um ponto de vista mais teórico ou problematizante. ${ }^{40}$ Uma parte dessa literatura discute as narrativas ou os discursos sobre fragmentação e as coloca contra o pano de fundo das construções intelectuais históricas do direito internacional. Uma parte discute os substratos filosóficos ou políticos que informam as escolhas por ou contra a fragmentação ${ }^{41}$. As respostas ou opções teóricas - sistema, constitucionalismo, pluralismo - têm mais a ver com isto do que com o verdadeiro funcionamento do direito internacional.

E, é claro, uma parte importante da literatura lida com instâncias concretas de colisão ou fricção entre re-

40 Ver KOSKENNIEMI, M.; LEINO, P. Fragmentation of International Law ? Leiden Journal of International Law, v. 14, n. 3, p. 553579, 2002; HAFNER, G. Pros and Cons Ensuing from Fragmentation of International Law. Michigan Journal of International Law, v. 25, p. 849-863, 2004; SIMMA, B. Fragmentation in a Positive Light. Michigan Journal of International Law, v. 25, p. 845-847,2012; FISHERLESCANO, ANDREAS; TEUBNER, G. Regime-Collisions? The Vain Search for Legal Unity in the Fragmentation of Global Law. Michigan Journal of International Law, v. 25, p. 999-1046, 2004;ABI SAAB, G. Fragmentation or Unification: Some Concluding Remarks. NYU Journal of International Law and Policy, v. 31, p. 919-933, 1998;DUPUY, P.-M. A Doctrinal Debate in the Globalization Era: On the "Fragmentation" of International Law. European Journal $O$ Legal Studies, v. 1, n. 1, p. 1-20, 2007; JACKSON, J. H. Fragmentation or Unification Among International Institutions: The World Trade Organization. New York Journal of International Law and Politics, v. 31, p. 823-831, 1999.;,SALAMA, R. Fragmentation of International Law: Procedural Issues Arising of the Sea Disputes. Australian and New Zealand Maritime Law Journal, v. 19, p. 24-55, 2005;KOSKENNIEMI, M.; LEINO, P. Fragmentation of International Law ?Leiden Journal of International Law, v. 14, n. 3, p. 553-579, 2002.

41 Ver KOSKENNIEMI, M. Global Legal Pluralism: Multiple Regimes and Multiple Modes of Thought. Palestra proferida em Harvard em 5 de março de 2005;MARTINEAU, A.-C. The Rhetoric of Fragmentation: Fear and Faith in International Law. Leiden Journal of International Law, v. 22, n. 01, p. 1, 2009. gimes, entre regimes específicos, diante de tribunais ou organismos de tomada de decisão específicos. ${ }^{42}$ Alguns tentam oferecer ou discutir matrizes teóricas para a solução de casos concretos. ${ }^{43}$

Parece-me, no entanto, que muitas das explicações teóricas e soluções propostas sofrem de uma imperfeita construção dos problemas concretos e dos modos concretos em que os tribunais são chamados a lidar com os casos de fragmentação. Mais será dito sobre isso à frente.

\subsection{Coerência e comunicação entre as perspec- tivas}

Como mencionado antes, a compreensão da noção de regimes e daquelas conexas, de fragmentação e pluralismo, pode se revelar uma empreitada mais difícil se não são tomadas em conta as diferenças em perspectiva - os substratos teóricos, o propósito da investigação, a questão colocada - e as lógicas internas de cada uma das perspectivas. Pois é certo que cada perspectiva deve ter e manter-se fiel a uma lógica interna.

Alguns podem ter reservas em relação à perspectiva jurídico-dogmática sobre a fragmentação, considerando-a limitada em sua natureza, mas permanece o fato de que ela é uma perspectiva válida; assim como é válida a perspectiva adotada pela teoria social aqui mencionada, quer apreciemos ou não suas conclusões expansivas e revolucionárias.

No entanto, diferenças de perspectiva não são tudo que explica as dificuldades de compreensão. Como mencionei antes, dois problemas ocorrem dentro das e entre as perspectivas.

O primeiro desses é o problema dos empréstimos

42 DUPUY, P.-M. A Doctrinal Debate in the Globalization Era: On the "Fragmentation" of International Law. European Journal O Legal Studies, v. 1, n. 1, p. 1-20, 2007; JACKSON, J. H. Fragmentation or Unification Among International Institutions: The World Trade Organization. New York Journal of International Law and Politics, v. 31, p. 823-831, 1999.;,SALAMA, R. Fragmentation of International Law: Procedural Issues Arising of the Sea Disputes. Australian and New Zealand Maritime Law Journal, v. 19, p. 24-55, 2005

43 HALBERSTAM, D. Local, Global and Plural Constitutionalism: Europe meets the world. 2009. (working paper) Disponível em: http://ssrn.com/abstract=1521016; TEUBNER, G. K. P. Two Kinds of Legal Pluralism: Collision of Transnational Regimes in the Double Fragmentation of World Society. In: YOUNG, M. (Ed.). Regime Interaction in International Law: Facing Fragmentation. 1. ed. Cambridge: Cambridge University Press, 2012. p. 23-54 
inapropriados de conceitos e raciocínios ou de referências cruzadas inapropriadas.

A visão de regimes sustentada pela teoria das relações internacionais discutida acima, não carrega a culpa desse pecado e é mais comumente mero objeto de referências feitas pelas demais perspectivas, referência que são por vezes inofensivas e por vezes prejudiciais.

Em princípio, como dito, essa perspectiva tem mais coisas em comum com aquela do direito internacional público, já que ambas estão centradas nos conjuntos normativos que regulam o comportamento dos Estados. Mas o direito internacional não pode se apoiar sobre ou encontrar suporte na teoria das relações internacionais para qualquer afirmação normativa sobre a natureza jurídica das normas ou sobre seu pertencimento a algum sistema jurídico.

As relações excessivamente liberais têm lugar entre a literatura jurídica e a teoria social específica que explorei acima.

Boa parte da discussão legal faz alguma referência ao trabalho de Teubner e de Fischer-Lescano. ${ }^{44}$ A eles é dado o crédito, com alguma frequência, por haverem em princípio introduzido o tema da fragmentação no campo do direito internacional. ${ }^{45}$ As referências só poderiam ser aceitas se a intenção é de apontar para um outro modo de olhar para fragmentação e regimes, para um conceito diverso de fragmentação e um conceito diverso de regimes, porque o fato é que, ao escreverem sobre regimes, esses autores certamente não falavam de direito internacional público.

E porque este é o caso, Teubner e Fischer-Lescano não poderiam e não deveriam tomar emprestada a definição de regimes autocontidos que foi dada pela CDI em seu relatório sobre fragmentação do direito internacional para descrever algo completamente diferente, que eles concebem como regimes setoriais transnacionais.

Este exemplo relativo ao conceito mesmo de regime, aquela que se espera seja a noção central de um trabalho lidando com colisões de regimes, ilustra o segundo problema que afeta o entendimento de regimes e de fragmentação. Não apenas trata-se do exemplo mais extremo de empréstimo inapropriado, mas consiste também

44 Trata-se da obra já analisada aqui "Regime-collisions: The vain search for legal unity in the fragmentation of global law" de 2004. 45 MARTINEAU, A.-C. The Rhetoric of Fragmentation: Fear and Faith in International Law. Leiden Journal of International Law, v. 22 , n. 01 , p. 1,2009 , nota 8 em uma quebra da coesão interna da perspectiva, de sua lógica interna.

De fato, nenhuma teoria geral consistente sobre a transformação da natureza do direito, sobre a diferenciação funcional do direito, sobre regimes e suas colisões e sobre remédios para as colisões é possível se o conceito de regimes precisa ser tomado emprestado da dogmática do direito internacional e se o conceito pode na melhor das hipóteses cobrir um número limitado de exemplos, superficialmente descritos, de direito fragmentado.

As três perspectivas discutidas acima oferecem representações fortes do tema dos regimes internacionais, ainda que não sejam as únicas possíveis. Muito esquematicamente, é possível dizer que elas anunciam dois grandes modos de enxergar a fragmentação, o pluralismo e a formação de regimes. O primeiro está centrado no papel do Estado como regulador das relações internacionais e, por extensão, na centralidade do direito internacional público. O segundo escapa a essa centralidade do Estado e do direito internacional, ou ao menos não se restringe a ela.

Essa dicotomia fundamental anuncia a escolha central que fiz neste texto, de discutir regimes como manifestações da fragmentação do direito internacional público (capítulo III) e enquanto aglomerados de normas pertencentes a vários sistemas jurídicos e de outros tipos de regulação (capítulo IV).

Antes, no entanto, de proceder a essa discussão central, cabe lidar com uma outra dicotomia que é também anunciada pelas implicações das diferentes perspectivas, qual seja a relação, de oposição ou de combinação, entre a noção de governança e aquela de direito, que chama, por sua vez, a uma discussão sobre a diferenciação entre direito e não-direito.

\section{Governança - Direito e Não-direito - Lugar e Realidade do Direito Internacional}

Antes de voltarmos a atenção aos problemas da perspectiva jurídica sobre regimes, parece-me necessário discutir um tema que corre em paralelo àquele da fragmentação, se não está totalmente entrelaçado com ele. Trata-se da questão da natureza do direito e de seu papel na regulação do mundo, em nosso caso, da sociedade internacional. Abstenho-me aqui de tentar definir 
essa sociedade já que o que se quer é dar à discussão um caráter mais geral.

Tomemos a seguinte questão como ponto de partida: há um lugar, um papel, para o direito num mundo, e num universo de pensamento, dominados pela noção de governança?

Um jurista um pouco mais afim à tradição pode sentir-se, por vezes, e ser visto como um espécime de tempos há muito superados, que desembarca em um novo mundo, mais complexo, em que a língua que fala não guarda qualquer relação com qualquer coisa real ou, no melhor dos casos, descreve uma parte muito insignificante da realidade.

O termo governança, ainda que seja de difícil conceituação - é, de fato uma dessas palavras que, quando as ouvimos, dão-nos a impressão de que sabemos o que significam, mas que, se perguntados, teríamos dificuldades para explicá-las -, ganhou a preferência de muitos e está em todas as bocas. ${ }^{46}$

Governança pode ser entendida de modo mais abstrato, genérico, ou em sentido mais específico, por vezes

46 Ver ABBOTT, K. W.SNIDAL D. Strengthening International Regulation through Transnational New Governance: Overcoming the Orchestration Deficit. Vanderbilt Journal of Transnational Law, p. 1-69, 2009;BÖRZEL, T. A.; HEARD-LAURÉOTE, K. Networks in EU Multi-level Governance: Concepts and Contributions. Journal of Public Policy, v. 29, n. 02, p. 135-151, 2009; DANN, P.; GOLDMANN, M.; BOGDANDY, A.. Developing the Publicness of Public International Law : Towards a Legal Framework for Global Governance Activities. German Law Journal, v. 9, n. 11, p. 1375-1400, 2007; DAVIS, D.; CORDER, H. Globalization, National Democratic Institutions and the Impact of Global Regulatory Governance on Developing Countries. Acta Juridica, v. 09, p. 68-89, 2009.; ESTY, D. C. Good Governance at the Supranational Scale : Globalizing Administrative Law. The Yale Law Journal, v. 115, n. 7, p. 1490-1562, 2011.;HARLOW, C. Global Administrative Law: The Quest for Principles and Values. European Journal of International Law, v. 17, n. 1, p. 187-214, 2006.;HOOGHE, LIESBET; MARKS, G. Unraveling the Central State, but How? Types of Multi-Level Governance. The American Political Science Review, v. 97, n. 2, p. 233-243, 2003; KEYNES, J. M.; LEO, C. Multi-Level Governance and Ideological Rigidity : The Failure of Deep Federalism. Canadian Journal of Political Science, v. 42, n. 1, p. 93-116, 2009; KINGSBURY, B.; KRISCH, S.; STEWART, R.; WIENER, J.B..Global Governance as Administration-National and Transnational Approaches to Global Administrative law. Law and Contemporary Problems, v. 68, n. 3-4, p. 1-13, 2005; KRISCH, N. Introduction: Global Governance and Global Administrative Law in the International Legal Order. European Journal of International Law, v. 17, n. 1, p. 1-13, 2006; MICHAELS, R. The Mirage of Non-State Governance. Utah Law Review, v. 63, p. 1-15, 2010; PIATTONI, S. Multi-level Governance: a Historical and Conceptual Analysis. Journal of European Integration, v. 31, n. 2, p. 163180, 2009; SLAUGHTER, A-M. Everyday Global Governance. Research Library Core, v. 132, n. 1, p. 83-90, 2003; TRUBEK, D. M.; TRUBEK, L. G. New Governance \& Legal Regulation : Complementarity, Rivalry , and Transformation. Columbia Journal of International Law, v. 13, p. 1-26, 2007. carregado. Pode vir acompanhada por adjetivos ou predicados tais como 'nova ${ }^{47}$ ou 'sem governo ${ }^{48}$.

Para nossos propósitos, mais importante do que definir precisamente a governança - tarefa que não tentarei aqui - é entender como a ideia se relaciona com o direito e com seu papel na regulação da vida.

Nesse sentido, podem ser concebidos dois tipos básicos de relação entre as duas noções. Uma que muitas vezes nos fica na mente como uma impressão é a de que de algum modo elas se encontram em posições antagônicas, uma contra a outra, a governança tentando ocupar o lugar do direito e o direito tentando resistir ao invasor.

A segunda, que parece estar mais de acordo com a realidade de hoje e de ontem, na medida em que se queira trabalhar a noção de governança como significando os modos - meios e mecanismos - pelos quais a sociedade é regulada, é a de que o direito é, como sempre foi, parte da governança.

É por esta razão, precisamente, que a questão diz respeito ao lugar ocupado pelo direito na governança da vida - para nossos propósitos, da vida internacional. Uma solução, ou resposta, radical seria a de que o direito não tem um lugar, ou já não tem um lugar.

Mais frequentemente, no entanto, a ênfase na governança como categoria privilegiada é usada para indicar que o direito tem um papel na regulação da vida em sociedade que se encolhe progressivamente, perdendo espaço para outros tipos de meios ou instrumentos regulatórios. ${ }^{49}$

É claro que ambas afirmações - de que ao direito não cabe um papel ou de que esse papel se encolhe podem ser lidas como significando que o direito como o conhecemos está destinado à obsolescência ou a um status menor. E isto, por sua vez, pode levar a duas posturas

47 Ver ABBOTT, K. W.;SNIDAL D. Strengthening International Regulation through Transnational New Governance: Overcoming the Orchestration Deficit. Vanderbilt Journal of Transnational Law, p. 1-69, 2009; TRUBEK, D. M.; TRUBEK, L. G. New Governance \& Legal Regulation: Complementarity, Rivalry, and Transformation. Columbia Journal of International Law, v. 13, p. 1-26, 2007.

48 Ver. SLAUGHTER, A-M. The Real New World Order. Foreign Affairs, v. 76, n. 5, 1997, p. 184.

49 Ver variações de tratamento da relação entre direito e governança em KINGSBURY, B.; KRISCH, S.; STEWART, R.; WIENER, J.B.. Global Governance as Administration-National and Transnational Approaches to Global Administrative law. Law and Contemporary Problems, v. 68, n. 3-4, p. 1-13, 2005. 
básicas na matéria: ou algo diferente do direito está tomando o seu lugar, ou o direito está se transformando em algo que antes não era para dar conta das novas realidades.

No segundo caso, a natureza mesma do direito e o seu conceito seriam vistos como evoluindo. Por exemplo, de modo a poder incluir novas formas de regulação que antes eram dele excluídas.

Nada impede que ambas coisas possam estar acontecendo contemporaneamente: a transformação do direito e sua crescente insignificância. Se a transformação que se concebe é aquela da expansão fagocitária, como pode ser que o direito seja mais do que antes era e, ao mesmo tempo, menos relevante? Simplesmente porque transformando-se deste modo torna-se menos diferenciado.

Parece não haver, portanto, modo de escapar a uma questão fundamental: quer se diga que ao direito não cabe papel, ou que este papel perde em significância, ou que o direito se está transformando, será preciso lidar com o que é, o que era, o que passa a ser e o que não é direito. Essa questão é igualmente inescapável, se não mais, para quem queira sustentar uma visão mais tradicional do papel do direito.

Essa questão é frequentemente, e conscientemente, contornada, evitada. É claro, uma razão muito simples para isso pode se encontrar no fato de que muitos consideram a diferenciação entre direito e não-direito, e o alimentar a dicotomia entre os dois, um exercício fútil ou desprovido de importância.

E essa é uma escolha legítima. No entanto, percebe-se mal como alguém pode abandonar a diferenciação entre direito e não-direito e ao mesmo tempo calçar as botas do jurista, falar a sua língua e adotar suas posturas.

Se o direito não precisa ser diferenciado do que não é, ele é então, potencialmente, tudo e também nada.

Certamente, não faria sentido que um direito assim indiferenciado fosse o objeto de uma perspectiva legal, jurídica, sobre a governança e, para nossos propósitos, sobre fragmentação, pluralismo e regimes, e isto pela simples razão de que não haveria significado relevante para os termos legal ou jurídica já que estes não seriam distinguíveis de não-legal ou não-jurídica. Nenhuma das categorias teria qualquer existência significativa.

Assim, quando se abandona a necessidade de di- ferenciar, está-se adotando uma perspectiva diversa, aquela do cientista político, do sociólogo, do filósofo, do antropólogo etc. Pode-se até mesmo ser um jurista sustentando o argumento de que, para certos propósitos, por exemplo, para observar o comportamento em determinada esfera social e decidir sobre o que a influencia, não há uma razão imperativa de colar sobre esse algo uma etiqueta e chamá-lo direito ou outra coisa.

Em verdade, a perspectiva que se adota tem uma íntima relação com os propósitos perseguidos e com as perguntas que se quer fazer. Está-se preocupado com descrever a realidade de modo mais preciso e dizer quais são os atores relevantes, como interagem e por que o fazem de determinados modos? Ou a preocupação restringe-se a determinar a terminologia correta, os nomes certos para as coisas, direito, regulação, governança? Ou se quer fazer afirmações normativas sobre como as coisas deveriam ser ou se transformar?

Qual será então o propósito de pensar e falar no direito, como parte da governança, se quisermos, e, mais especificamente, quando lidamos com a ideia de regimes?

O ponto de partida é este: existe algo chamado direito que influencia os comportamentos, participa da regulação do espaço social e serve como mecanismo para decidir sobre a correção das condutas e solucionar controvérsias? Se a resposta é positiva, a próxima questão é esta: de modo a entender como o direito faz o que faz, é preciso saber como funciona? E será que o seu modo de funcionar depende da imagem que o direito faz de si mesmo e da linguagem, do código que lhe é interior e específico?

Já que essa linguagem interna, essa lógica interna, diferencia entre o que está dentro do direito e aquilo que está fora, e já que ela determina como o direito realiza suas funções e influencia os comportamentos, nós não podemos dispensar essa diferenciação e ignorá-la se quisermos descrever de modo competente a realidade.

\subsection{Direito e não-direito - pertencimento a um sistema jurídico.}

Esta questão sobre a utilidade e ou a necessidade de diferenciação se traduz, portanto, em duas perguntas que se complementam, uma relativa à natureza do direito e outra relacionada à determinação de que algo, algum tipo de provisão, contido em algum instrumento, 
resultante de um processo de gênese qualquer, é ou não é direito.

Já se usou muita tinta para defender posições que ou tendiam a ser restritivas, protetoras da exclusividade do status jurídico, ou tendiam a ser extensivas, abrindo o domínio do direito a um maior número de categorias, novas de preferência, de prescrições ou linguagem.

$\mathrm{Na}$ arena internacional e fora dela, em todo lugar, na verdade, há uma contínua e permanente discussão sobre serem as prescrições - linguagem normativa, portanto - que não são produzidas pelo Estado, ou que não surgem a partir das fontes reconhecidas do direito, ou que não pretendem ser mandatórias, ou que não contêm obrigações, ou que são de difícil aplicação etc, parte do que se pode considerar direito. Esses fenômenos são por vezes referidos, de modo geral, como sendo o que se chama de soft law. ${ }^{50}$

É claro, como foi dito antes, que essa questão é resolvida de modo diverso segundo o conceito de direito esposado por quem tenta responder. A resposta dependerá de considerar o observador, por exemplo, que o direito é necessariamente constituído por normas, que essas normas devem ser válidas, que essa validade é consequência de procedimentos específicos realizados por atores especialmente autorizados, que a norma precisa ser reconhecida como sendo parte de um sistema jurídico específico etc.

Pode ser, no entanto, que, apesar de despertar debates apaixonados e polêmica, a questão sobre ser algo, em sua natureza, essência ou substância, direito, seja na verdade inútil ou desimportante em certa medida.

Primeiramente, presume-se que a construção de argumentos ou raciocínios para demonstrar ser algo direito é uma necessidade especialmente importante para quem se encontra fora das concepções canônicas do direito. O trabalho de quem quiser concordar com Kelsen, Hart ou Raz fica facilitado ${ }^{51}$.

Mas, de fato, quando se quer e se tenta dizer que algo é direito porque tem efeitos jurídicos, ou porque faz

50 Retomarei essa discussão adiante, no capítulo IV.

51 A noção do que é direito ou como ele pode ser identificado é explorada por esses autores em suas principais obras. Ver, e.g., KELSEN, H. A Teoria Pura do Direito. São Paulo: Martins Fontes, 2009; HART, H. L. A.O conceito de direito.São Paulo: Martins Fontes, 2012; RAZ, Joseph.O conceito de sistema jurídico:uma introdução à teoria dos sistemas jurídicos. São Paulo: Martins Fontes, 2012. com que expectativas convirjam, ou porque dá razões para a ação, ou porque é efetivamente implementado pelos seus destinatários, ainda que esse algo não surja a partir das fontes tradicionais e não seja obrigatório, não se faz mais do que descrever esse algo, falar de seus efeitos e de sua existência real.

Dizer que esse algo é direito não tem qualquer consequência especial. Dizer que esse algo é direito porque afeta os comportamentos e dizer que tanto este algo - outra coisa que não direito - quanto o direito afetam os comportamentos, são afirmações equivalentes e têm exatamente o mesmo peso na descrição da realidade fática.

A questão ganha em importância, no entanto, quando, ao perguntar se algo é direito, estamos de fato perguntando se esse algo pertence a uma ordem jurídica específica. Nesse sentido, há uma diferença entre perguntar se uma prescrição dada, contida em um particular tipo de instrumento, é, falando genericamente, direito em sua natureza, e perguntar se essa prescrição é parte integrante do, digamos, direito internacional público.

É mais fácil avançar o argumento de que determinados tipos de prescrições ou instrumentos podem ser qualificados genericamente de jurídicos, ou legais, do que é demonstrar que pertencem a um sistema jurídico específico, já que, para essa segunda tarefa, é preciso usar a linguagem do próprio sistema.

Para demonstrar o pertencimento a um sistema legal específico, é preciso adotar o ponto de vista interno do sistema, é preciso olhar para o sistema e vê-lo como ele mesmo se olha e enxerga. Em outras palavras, apenas aquilo que o sistema reconhece como the pertencendo pode pretender fazer parte de seu corpo.

Tanto as ordens jurídicas domésticas quanto o direito internacional público tendem a diferenciar entre o que é e o que não é direito recorrendo às noções de obrigatoriedade e de validade das prescrições legais. Há, é verdade, a possibilidade de debater o sentido da obrigatoriedade e a necessidade de que este seja o critério da juridicidade. Mas, ainda que se quisesse dispensar o critério e admitir a existência de prescrições, jurídicas, legais, mas não obrigatórias, permanece o fato de que essas prescrições precisariam ser reconhecidas pelo sistema jurídico como pertencendo ao seu conjunto de prescrições. Para que esse reconhecimento se dê, elas devem ter passado a integrar o sistema através de um 
dos mecanismos, uma das fontes por ele admitidas. ${ }^{52}$

É verdade que é sempre possível sustentar que um sistema jurídico deveria mudar ou que ele já mudou, e que o conjunto tradicional de fontes já não reflete ou não refletiria a realidade do processo de gênese normativa. Tais argumentos, no entanto, ou significam, simplesmente, que algumas prescrições não reconhecidas pelo sistema como sendo direito influenciam o comportamento dos sujeitos do sistema, ou são a expressão de um esforço militante para mudar o sistema jurídico.

Se, no entanto, o sistema já tiver mudado realmente, incorporando, por exemplo, novas fontes ao seu rol, nada muda em substancia já que ainda será o sistema a dizer quando uma prescrição é jurídica e parte integrante sua. ${ }^{53}$

Para nossos propósitos, enquanto olhamos para regimes regulatórios ou legais que operam na esfera internacional, talvez devamos lidar com uma sequência de questões: i) se as prescrições, as normas, as regras, são jurídicas em sua natureza - levando, no entanto, em consideração o fato de que, como dito, essa questão pode ser, em si, menos importante; ii) se as prescrições, normas, regras, pertencem ao direito internacional público ou a outro sistema jurídico conhecido; iii) se pertenceriam a e constituiriam um sistema normativo ou jurídico específico, diferente.

Uma chave-guia para a compreensão do tema geral - a existência e natureza de regimes jurídicos ou normativos internacionais - que corre paralelamente a estas questões sobre a natureza jurídica das prescrições e seu pertencimento a ordens jurídicas, é representada por um outro conjunto de questões: i) pode-se perguntar se um tema dado, amplo ou restrito, é regulado pelo direito internacional público; ii) pode-se perguntar se e como um tema é regulado, ponto; iii) e pode-se perguntar se existe um regime global ou internacional relativo ao tema ou ao problema.

Como a esfera social que estamos observando é a sociedade internacional, a relação entre direito e governança que aparecerá como mais relevante é aquela que tem lugar no cenário internacional ou global. Seria possível olhar para os modos como o direito interno se re-

52 Ver: NASSER, S. H. Fontes e Normas do Direito Internacional: Um Estudo sobre a Soft Law. 2a. ed. São Paulo: Editora Atlas, 2006, p. 59 e ss.

53 Ver: NASSER, S. H. Fontes e Normas do Direito Internacional: Um Estudo sobre a Soft Law. 2a. ed. São Paulo: Editora Atlas, 2006. p. 60 laciona com o que chamaríamos governança global, mas muito provavelmente isso só se poderia fazer - de qualquer modo que não fosse puramente teórico - olhando para sistemas jurídicos domésticos particulares. Não é minha intenção fazê-lo; meu foco será a relação com direito internacional público.

Haverá, é claro, quem nos diga que o direito internacional, como entendido historicamente, é hoje responsável por tão pouco da organização do mundo pós-moderno que mal valeria a pena fazer dele assunto de discussão quanto mais dominar sua linguagem interna. Outros diriam que é justamente essa linguagem interna que está ultrapassada e necessitando transformação para poder lidar com as novas realidades.

Ficamos assim, essencialmente, com duas questões centrais: qual a importância e o papel desempenhado pelo direito internacional e quais são as características, conhecidas e transformadas, do direito internacional?

Em outras palavras, somos convidados a considerar um conjunto de investigações preliminares: vale a pena falar de direito internacional? Esse direito existe? Opera de algum modo significativo? É importante saber de quem regula o comportamento e como o faz? É importante saber quais as suas relações com outros tipos ou conjuntos de regulação?

Não devemos esquecer que a razão de ser disto que se lê é a discussão da noção de regimes. Como exatamente essa discussão se entrelaça com aquela relativa ao lugar do direito na governança?

Se aceitamos a afirmação original de que a vida está ficando (mais) fragmentada e que a essa fragmentação corresponde a formação de conjuntos regulatórios, núcleos de governança se quisermos, então a relação entre direito e o restante da governança não acontece apenas em geral, mas se verá refletida, potencialmente, em cada singular partição da governança da vida.

É por esta razão que mais à frente discutirei o modo como sistemas jurídicos se encontram e se combinam, entre si e com mecanismos regulatórios não-jurídicos, para regular mais efetivamente setores da vida internacional.

Mas essa partição da vida, quer seja fenômeno novo ou antigo, não serve apenas para a compreensão da interação entre sistemas jurídicos e outros tipos de regulação; ela se materializa e reflete também no interior do sistema jurídico, em nosso caso, o direito internacional público. 
Concentrar-me-ei, de início, no direito internacional e seu funcionamento, e discutirei a noção de regime jurídico internacional no interior desse sistema jurídico. Num segundo momento, voltar-me-ei para a discussão dos regimes como lugares de confluência de sistemas jurídicos diversos e de sua combinação com regulação não-jurídica.

\section{Direito Internacional Público e Frag- MENTAÇÃO}

De acordo com sua linguagem interna, o direito internacional é essencialmente, e ainda hoje, uma ordem jurídica interestatal. Seria certamente possível argumentar que, num mundo em que o Estado já não seria ator tão preponderante, um tal sistema jurídico já não estaria adaptado à realidade social. Mas o fato é que a sociedade internacional nunca se constituiu exclusivamente de Estados e o papel crescente de outros atores é apenas mais um aspecto de sua transformação.

O que não mudou ainda é o fato de que o Estado continua a ser o ator principal das relações internacionais. $\mathrm{E}$, ainda que isto viesse a ser provado falso ou equivocado, continua sendo verdade que o direito internacional público é produzido e operado em um sistema composto por Estados. Se houvesse mudança nessa característica essencial, ele seria um outro direito internacional, diferente e diverso. Este direito internacional que conhecemos ainda não desapareceu, ainda que seja, como é o caso para qualquer sistema jurídico, fundado numa ficção.

E a ficção é, neste caso, poderosa. Pode-se sempre discutir se os Estados são verdadeiramente soberanos, se realmente ficam obrigados por normas que aceitaram voluntariamente, se outros atores são ou não são afetados por essas normas etc. Mas continua sendo verdade que o que chamamos de direito internacional continua a surgir - e suas normas criadas - através dos Estados; que ele regula direta e primariamente apenas o comportamento dos Estados, de entes criados pelos Estados, ou entes cujo comportamento os Estados decidem regular; e que há um consenso sobre o que é preciso para que uma norma seja considerada válida e sobre o que é necessário para que uma norma seja aplicável a um Estado ou outro ente.

Quando dois Estados, ou um grupo de Estados, ou organizações e entes por eles autorizados, comparecem perante um tribunal internacional ou outra instância decisória criada pelo direito internacional, pedindo que uma controvérsia seja resolvida de acordo com o direito, tal como este emerge de normas válidas, eles não estão vivendo em algum tipo de mundo bizarro ou falando uma língua morta.

\subsection{As determinantes da dupla fragmentação do direito internacional54}

A ideia de diferenciação funcional da sociedade é, como visto, central às noções de fragmentação do direito e de pluralismo jurídico. De muitos modos, a ideia de que atores sociais emergem e interagem em torno de temas ou problemas específicos é essencial à compreensão do fenômeno que faz reunirem-se em núcleos normas, regras e outros mecanismos regulatórios. De muitos modos, parece impossível conceber ou entender esses núcleos, esses agregados, esses regimes, sem a referência ao tema ou ao problema subjacente.

Essa partição da vida, essa tendência à especialização, é uma força motora por trás da formação de regimes jurídicos ou simplesmente regulatórios. Pensa-se que o tema com que o regime se ocupa, determina ou ao menos corresponde a um ethos, ${ }^{55}$ a objetivos que pairam sobre esse regime e suas normas. ${ }^{56}$

Dependendo da perspectiva a partir da qual se olha para a fragmentação ou, se quisermos, dependendo do tipo de fragmentação de que se está falando, o tema pode ajudar a determinar os entes sobre os quais recai a expectativa de que produzam normas e estruturas organizacionais e os entes que estão autorizados a proceder a tal produção. Também pode ajudar a determinar quais são os atores cujas expectativas supõe-se que o regime atenda e cujos comportamentos supõe-se que regule.

$54 \mathrm{KOCH}, \mathrm{C} . \mathrm{H}$. Globalization of Administrative and Regulatory Practice. Administrative Law Review, v. 54, n. 1, p. 409-414, 2002 e TEUBNER, G. K. P. Two Kinds of Legal Pluralism: Collision of Transnational Regimes in the Double Fragmentation of World Society. In: YOUNG, M. (Ed.). Regime Interaction in International Law: Facing Fragmentation.1. ed. Cambridge: Cambridge University Press, 2012, fazem referência igualmente a uma dupla fragmentação que identificam no direito global, assim como falam de dois tipos de pluralismo. Não se trata dos mesmos fenômenos de que falo eu. Discutirei isso mais em detalhe adiante, no capítulo IV.

55 De acordo com o Merriam-Webster: "the distinguishing character, sentiment, moral nature, or guiding beliefs of a person, group, or institution"

56 V., e. g., KOSKENNIEMI, 2007, passim. 
Como visto, essa relação entre tema e atores pode aparecer mais apropriada à visão que tem a teoria social sistêmica dos regimes como sendo principalmente comunidades epistêmicas e manifestações normativas da fragmentação funcional da sociedade. Para essa perspectiva, os atores que participam da constituição do regime e têm seus comportamentos regulados por suas normas constituem eles mesmos setores diferenciados da sociedade. ${ }^{57}$

Por outro lado, do que vimos da perspectiva da teoria das relações internacionais tradicional a respeito dos regimes, o tema ou a matéria com que lida o regime não pode determinar a categoria de atores relevantes. Segundo essa visão os atores são predeterminados; os Estados são vistos como os atores determinantes das relações internacionais e são quem tende a regular seu próprio comportamento em torno de temas específi$\cos ^{58} \mathrm{O}$ tema pode no máximo provocar a constituição de regimes que reúnam número maior ou menor de Estados ou grupos variáveis de Estados, interessados e concernidos.

O mesmo é também verdade para o direito internacional público. Ali a fragmentação e a multiplicação de regimes é um traço - novo ou crescentemente relevante - de um direito internacional que continua a ser criado pelos Estados e dirigido ao comportamento dos Estados. A diferenciação funcional da sociedade, neste contexto, significa a multiplicação de temas em que a interação entre Estados ocorre e demanda regulação.

É por esta razão, essencialmente, que, no direito internacional, a discussão sobre sua fragmentação está centrada na potencial ocorrência de situações em que Estados se verão sujeitos a normas jurídicas conflitantes, pertencentes a diferentes regimes de direito internacional, e potencialmente submetidos a diferentes procedimentos perante múltiplas instituições aplicadoras do direito relevando, também estas, de regimes distintos.

O fenômeno mais geral de diferenciação setorial na sociedade é filtrado, portanto, e limitado. No caso da teoria das relações internacionais, o filtro é a escolha teórica e disciplinar que é feita: o Estado como o ator

57 FISHER-LESCANO, ANDREAS; TEUBNER, G. RegimeCollisions? The Vain Search for Legal Unity in the Fragmentation of Global Law. Michigan Journal of International Law, v. 25, 2004, p. 1007-1009.

58 KRASNER, S. Structural causes and regime consequences: regimes as intervening variables. In: KRASNER, S. (Ed.). International Regimes. Ithaka/London: Cornell University Press, 1983, p.1. central das interações políticas e sociais. No caso do direito internacional, o filtro é a lógica interna ao sistema jurídico que tem o Estado como o legislador e o sujeito primário.

Para o direito internacional, portanto, a sua fragmentação é devida à diferenciação da vida, sim, mas os efeitos de tal diferenciação sofrem uma limitação na medida em que não pode determinar os atores - legisladores e sujeitos - da regulação setorial específica. Aqueles atores que não os Estados, que estão necessariamente envolvidos no setor social, só afetarão o direito internacional indiretamente e só serão por ele afetados indiretamente, através da ação dos Estados.

Mas as características específicas do direito internacional como ordem jurídica não fazem apenas limitar o modo como a fragmentação se dá dentro do sistema. Essas mesmas características operam também como facilitadoras da fragmentação do sistema, fragmentação esta que, ainda que relacionada com a diferenciação setorial, não é inteiramente determinada por ela.

Em outras palavras, o direito internacional não sofre uma crescente fragmentação apenas porque diferentes temas demandando sua ação reguladora fazem emergir regimes diferenciados, relativamente autônomos, respondendo a lógicas diversas; sofre também um outro tipo de fragmentação, devida ao fato de que cada Estado tem a prerrogativa de decidir se quer ou aceita ser obrigado por cada norma, tratado ou regime. Exclui-se dessa lógica, é claro, as normas, de relativamente recente aceitação, gerais, de ordem pública ou erga omnes.

É claro que, nesse sentido, a fragmentação é uma operação matemática básica: cada um dos Estados decide, ao tomar parte no processo de criação normativa, se e quando quer se ver obrigado por uma norma qualquer, dentre todas aquelas que surgem e se multiplicam em progressão geométrica. Por esta razão, uma questão que pode sempre ser posta - e deve, de fato, ser posta se um estado específico está obrigado por uma norma específica -, continua sendo necessária, mas agora se coloca muito mais vezes.

Há, portanto, um tipo diferente de fragmentação do direito internacional, um em que os fragmentos são os diferentes conjuntos de normas pelos quais cada Estado está obrigado e os diferentes conjuntos normativos que obrigam cada par de Estados e cada grupo de Estados. De fato, cada vez que uma norma é adicionada ou subtraída do conjunto normativo e cada vez que um Estado 
passa a ser obrigado por uma norma ou um conjunto normativo, ou deixa de sê-lo, um fragmento diverso verá a luz.

Quando esses fragmentos são compostos por normas que apresentam algum grau de organicidade, desde que o conjunto apresente algum elemento unificador ou agregador, talvez possam então receber o nome de regimes.

Esse elemento agregador pode ser geográfico, quando, por exemplo, Estados pertencentes a uma mesma região celebram acordos ou se veem obrigados por normas costumeiras regionais, ou pode dizer respeito a categorias de Estados que, ainda que de diferentes regiões do mundo, têm características similares ou interesses afins.

Talvez se pudesse falar então em regime quando se pensasse em algo como um direito internacional da América do Sul, por exemplo, ou como um direito internacional dos países desenvolvidos.

Mas o mais usual seria falar de conjuntos do direito internacional que, ligando Estados de determinadas regiões ou estando aberto a todos os Estados do mundo, trata de temas específicos. Haveria então um regime, sul-americano ou internacional, de proteção dos direitos do homem, um outro de desarmamento, e assim por diante.

Ainda que a questão temática, a diferenciação funcional, pareça ser a chave de compreensão mais usual e mais natural para a existência de regimes, a verdade é que não é exercício fácil identificar e delimitar as fronteiras dos regimes internacionais.

\subsection{Dificuldades para a identificação dos regi- mes jurídicos em direito internacional}

Como vimos, a ideia prevalente é a de que um regime é um agregado de normas e instituições, organizações, regulando um tema ou uma matéria que é objeto de preocupação ou atenção por parte dos Estados e outros atores sociais, governado por um ethos ou lógica específica.

\subsubsection{O Tema e as representações dos regimes autocontidos}

Não há dúvida de que é possível conceber um ilimitado número de temas que constituem preocupações dos Estados. Alguns dos mais tradicionais, dos mais mencionados, são temas abrangentes como o meio ambiente, direitos humanos, segurança internacional, paz e guerra, comércio, desenvolvimento etc.

Um tema, no entanto, não é definido por natureza, mas sim por convenções comunicativas. $\mathrm{O}$ número de temas imagináveis é, assim, infinito. Por isso, a mera existência de um tema, ainda que superficialmente concebido, ainda que se possa conectar a ele uma ou diversas normas de direito internacional, ou não dá lugar à emergência de um regime jurídico, ou, se o fizer, isto criará sérios problemas para as implicações teóricas e práticas da ideia mesma de regimes de direito internacional.

Imaginemos um exemplo. Pode-se conceber alguns temas: a floresta amazônica, desmatamento, mudanças climáticas, meio ambiente. É fácil localizar normas de direito internacional que obrigam conjuntos diversos de Estados e que lidam com esses temas. Pode-se dizer que há um regime para cada um desses temas?

Se o mero fato de que se pode conceber um tema e encontrar normas a ele relativas significar que a cada tema concebido corresponde um regime jurídico de direito internacional, então poderá haver igualmente um número infinito de regimes e qualquer utilidade que o conceito possa ter ficará diminuída ou deverá ser uma utilidade que leve em conta a indeterminação do número total de regimes.

Não apenas isso, mas, com um número infinito de temas, alguns, mais gerais, tenderão a incluir outros, mais específicos. Se para cada tema com normas a ele conectadas há um regime, enfrentar-se-á um cenário de bonecas russas, com regimes contidos em regimes contidos em regimes. E novamente a questão da utilidade da noção se colocaria.

Ataquemos, então, de pronto, a questão da utilidade da noção de regime jurídico internacional.

Penso que se deva começar por isto: os regimes - e a noção - não transformam nem afetam o funcionamento do direito internacional; mais especificamente, eles não alteram o modo como o direito internacional é interpretado e aplicado. ${ }^{59}$ Regimes são antes uma manifestação da estrutura e do funcionamento do direito internacional, agora em sentido diverso, qual seja o meca-

59 Objeções podem ser levantadas contra essa afirmação, mas creio lidar com elas adiante. 
nismo de gênese das suas normas e das suas instituições.

O conceito serve para representar, para explicar, como os Estados podem dar lugar ao nascimento de normas diversas sobre temas diversos e podem criar estruturas organizacionais diversas, talvez guiados por preocupações e por lógicas potencialmente conflitantes.

Os problemas resultantes desse fato básico do direito internacional, que a noção de regimes vem anunciar, são a possibilidade de que normas pertencentes a conjuntos diversos, inspiradas por lógicas diferentes, sejam portadoras de conteúdos contraditórios e a possibilidade de que entes diferentes decidam de modos igualmente conflitantes quando interpretam ou aplicam as normas.

A noção, portanto, não altera a realidade do direito internacional, não altera o modo como são resolvidos os problemas jurídicos; o que ela faz é tentar explicar e retratar essa realidade e apontar os problemas que se pode vir a enfrentar quando da solução de questões jurídicas num sistema assim fragmentado pelos temas e pelas lógicas subjacentes aos temas.

Exploremos primeiramente os regimes enquanto descrição da realidade para depois lidarmos com o modo como se apresentam os problemas e as suas soluções.

Como estamos no âmbito do direito internacional público e da sua fragmentação, é apenas apropriado que recuperemos o tratamento que o relatório da Comissão de Direito Internacional, a que aludi acima, dá aos regimes.

Há três limitações, contidas no tratamento que o relatório dá aos regimes, que devem ser consideradas antes de se seguir adiante. A primeira está no fato de que o relatório se refere a regimes como uma manifestação da fragmentação e não a única, e nem, talvez, a mais importante. A segunda é que o relatório escolhe falar de regimes como decorrentes principalmente, se não exclusivamente, de tratados, deixando assim de fora as normas costumeiras. A terceira está no foco dado à relação que os regimes têm com o direito internacional geral e não tanto à relação dos regimes entre si. Adicione-se a isso tudo o fato de que o relatório qualifica os regimes de que fala: os seus regimes são aqueles chamados de autocontidos.

Estando isso bem claro, podemos ver que o relatório nos diz de três coisas diferentes que podem receber, e recebem, o nome de regimes autocontidos.

Num sentido mais restrito, “...o termo é usado para denotar um conjunto especial de regras secundárias, sob o direito da responsabilidade dos Estados, que pretende ter primazia sobre as normas gerais relativas a consequências de uma violação. "60

Em sentido mais amplo, “...o termo é usado para se referir a conjuntos integrados de regras primárias e secundárias, às vezes também referidos como 'sistemas' ou 'subsistemas' de regras que cobrem algum problema particular diferentemente de como seria coberto sob o direito geral. " $\mathrm{O}$ relatório nos lembra que, quando usado nesse sentido, o termo regimes autocontidos se funde com o viés contratual do direito dos tratados, um viés segundo o qual, havendo norma convencional, não há necessidade de buscar no direito geral e nos costumes outras aplicáveis. ${ }^{62}$

Há ainda um uso, que segundo o Relatório é ocasional, que estende a noção de regimes autocontidos a “...campos inteiros de especialização funcional, de expertise diplomática e acadêmica." ${ }^{\text {(33 }}$ Entende-se que em campos como direito dos direitos humanos, direito da OMC, direito da União Europeia, direito humanitário, direito do espaço, entre outros, regras e técnicas especiais de interpretação e administração são aplicáveis, sempre com o afastamento de princípios divergentes contidos no direito geral. ${ }^{64}$

É-nos dito que o principal efeito desses conjuntos entendidos do modo mais abrangente, como "ramos do direito internacional" é o de prover orientação e direção interpretativas que de algum modo desviam do direito geral. Esse sentido da expressão cobriria "um conjunto amplo de sistemas normativos inter-relacionados" e o "grau em que se pensa que o direito geral é afetado varia

60 RELATÓRIO da Comissão de Direito Internacional, 2006, vide nota 32

61 RELATÓRIO da Comissão de Direito Internacional, 2006, vide nota 33. Os exemplos citados são instrutivos: o regime de cooperação judicial entre o Tribunal Penal Internacional e os Estados Partes ou as técnicas para interpretar a Convenção Europeia de Direitos do Homem como um instrumento de ordem pública europeia.

62 RELATÓRIO da Comissão de Direito Internacional, 2006, p. 68.

63 RELATÓRIO da Comissão de Direito Internacional, 2006, p. 68.

64 RELATÓRIO da Comissão de Direito Internacional, 2006, p. 68 
grandemente. ${ }^{65}$

Perceba-se, primeiramente, que todos os três sentidos em que a expressão costuma ser usada, de acordo com o Relatório, trazem as três limitações a que me referi acima. E perceba-se, em seguida, que só é relativamente mais fácil identificar e delimitar um regime quando ele é pensado mais restritivamente, como no caso do segundo tipo e especialmente no do primeiro tipo.

Mas é preciso notar que esses regimes só são delimitáveis na medida em que o tema de preocupação se combina com outros critérios que, estes sim, dão os contornos da sua aplicação: os Estados que fazem parte do mecanismo específico de responsabilidade ou do subsistema, o tipo de resposta às violações, a instituição encarregada de aplicar a resposta ou as normas do subsistema etc.

Quando, no entanto, se fala de regimes enquanto subsistemas mais amplos, enquanto ramos do direito internacional, a delimitação fica mais difícil de fazer porque o tema - direitos humanos, meio ambiente, comércio etc. - não recebe o apoio dos outros critérios com a mesma precisão ou na mesma medida. $\mathrm{Na}$ verdade, no universo de normas que lidam com cada um desses temas ou preocupações, há várias respostas específicas para diferentes violação e, mais importante, há vários subsistemas que reúnem grupos diversos de Estados e há várias instituições encarregadas da administração de diferentes conjuntos de normas.

Retomemos, para dar concretude à discussão, o exemplo anteriormente citado dos quatro temas relacionados ao ambiental: floresta amazônica, desmatamento, mudanças climáticas e meio ambiente. Pode-se dizer que os três primeiros estão relacionados ao tema geral constituído pelo último, o meio ambiente. É também verdade que todos esses temas têm alguma relação com outros tantos, comércio, direitos humanos, desenvolvimento etc., mas deixemos isto de lado, por enquanto.

Se o meio ambiente é o tema mais abrangente, e as normas e instituições a ele relacionadas constituem o ramo do direito internacional, então entende-se como os conjuntos de normas e organizações conectadas aos demais temas - e tais conjuntos existem, de fato - constituem o que se descreveu como subsistemas interligados dentro do conjunto mais alargado.

65 RELATÓRIO da Comissão de Direito Internacional, 2006, p. 70 e também p. 81
A delimitação, quer do conjunto maior, quer daqueles que, ainda amplos, participam dele, resta por fazer. O fato é que é virtualmente impossível conhecer todas as normas que se referem a cada um dos assuntos e é difícil saber quais as instituições que fazem parte de cada sistema ou subsistema - e mais ainda saber quais as instituições que podem vir a atuar sobre os assuntos, ainda que não tenham sido criadas pelas normas do regime e, portanto, não façam propriamente parte dele.

Como quer que seja, difíceis como são de delimitar, uma boa parte da literatura jurídica internacionalista não parece pronta a dispensar a categoria, ainda que talvez dispensasse o nome, que considera central ao entendimento das fricções e colisões entre diferentes conjuntos de arranjos normativos. Essa literatura reconhece que as fronteiras dos regimes não são necessariamente claras, mas ainda os considera como conjuntos normativos e institucionais reconhecíveis e organizados em torno de um tema e guiados por um ethos.

\subsubsection{O ethos}

Talvez seja então o ethos o critério central que daria aos regimes sua unidade e explicaria a relevância das colisões e fricções potenciais entre regimes, já que, pensa-se, cada um seria guiado por ethos específico e divergente daqueles dos demais.

Mas o que é exatamente o ethos de um regime? ${ }^{36}$ Será uma orientação, uma motivação, que deve ser encontrada no momento em que um regime foi construído ou suas normas criadas? Será o sentido que emerge das normas assim como são? Será a orientação ou a tendência dos Estados e das instituições de interpretar e aplicar as normas de certos modos? Será o resultado concreto da operação do regime, da aplicação de suas normas, do funcionamento de suas instituições?

Suponhamos a existência de um regime jurídico internacional do comércio. E suponhamos que o ethos desse regime seja a ideia de que o comércio deveria ser tão livre quanto possível. Pode-se então tentar verificar se os Estados, quando criavam e enquanto continuamente recriam o regime, atuaram e atuam sob a inspiração, real ou declarada, de caminhar no sentido de uma maior liberdade do comércio.

66 American Heritage Dictionary: "The disposition, character, or fundamental values peculiar to a specific person, people, culture, or movement." 
Ou pode-se tentar identificar no conteúdo normativo, a partir da leitura e interpretação sistemática das normas, a liberdade de comércio como sendo o valor ou o objetivo.

Ou se pode perguntar se as instituições do regime, por exemplo aquelas encarregadas da aplicação das normas e da solução de controvérsias, agem, interpretam e aplicam as normas com uma tendência e o objetivo de fazer resultar uma maior liberdade de comércio.

Finalmente, pode-se perguntar se o regime como um todo e em funcionamento de fato dá lugar a essa liberdade incrementada.

É certo que a formulação do ethos não precisa ser única e indiscutível. Alguém poderia avançar o argumento de que mais e melhor desenvolvimento, quer econômico quer mais geral, é ou deveria ser o ethos do regime de comércio antes ou em substituição à liberdade de comércio, esta última permanecendo apenas se e na medida em que for meio eficaz para atingir o primeiro.

$\mathrm{E}$ as mesmas questões estariam agora postas para este novo ethos estabelecido ou identificado. Conhecer o ethos de um regime é, portanto, uma questão de escolha e perspectiva.

Mas, admitindo que um regime é afetado por algo que poderia ser chamado ethos, como se espera que um regime seja dinâmico e apto a transformar-se e evoluir, não deveria haver impedimento a que o ethos de um regime mude e evolua também.

Além disso, não há nada que diga que não se chegará a respostas divergentes para cada uma das questões concebidas acima: as intenções ou a orientação dos Estados, ainda que apenas declaradas, ao criarem o regime, podem não coincidir com o contido nas normas; uma e outra coisa podem não coincidir com a disposição mental das instituições quando chamadas a interpretar e aplicar as normas; todas ou qualquer uma dessas podem divergir do que efetivamente resulta da operação do regime e de seu funcionamento. $\mathrm{O}$ mesmo regime pode, portanto, ser visto como tendo mais de um ethos.

Ainda que seja difícil delimitar os regimes pelo tema ou pelo ethos, como já se disse, a noção aparece a muitos como necessária e relevante para explicar determinados problemas na relação entre os vários conjuntos. Usualmente, a ênfase é posta na possível relação, de contato, fricção, colisão, entre os diferentes regimes. O ensaio de um mapa alternativo dessas relações pode se revelar útil à investigação.

\subsubsection{Relações entre regimes}

Há ainda um problema que afeta tanto a delimitação dos regimes como as possíveis relações entre eles. Ainda que alguns de seus aspectos já tenham sido mencionados de passagem, vale a pena detalhá-lo um pouco mais aqui.

Considerando que uma norma de direito internacional pode estar presente em mais de um instrumento normativo, assim como pode decorrer de mais de uma fonte, ${ }^{67}$ nada impede que uma norma qualquer faça parte de mais de um regime ou de mais de um subsistema normativo dentro do regime, ou pertença ao mesmo tempo a um regime e ao direito internacional geral.

Mas o que ocorre quando uma norma, formalmente, não faz parte do regime, mas diz respeito à matéria, ao tema, de que ele trata? Pode-se pensar num exemplo: uma norma sobre preservação ambiental de um tipo específico contida num regime de comércio internacional. Essa norma passa a compor o regime do meio ambiente por força de seu tema ou por força da racionalidade ou do bem jurídico que quer proteger?

E o que acontece na via contrária? Aquela mesma norma deixa de pertencer ou pode ser considerada como nunca tendo pertencido ao regime do comércio em que, não obstante, estava inscrita formalmente?

Esses mesmos raciocínios ou perguntas se podem fazer em relação à normas contidas em regimes e em direito internacional geral.

E raciocínios similares podem ser feitos com relação às estruturas organizacionais de administração das normas ou de interpretação e aplicação do direito. Pode

67 Com relação, por exemplo, à possibilidade de uma norma estar ao mesmo tempo contida na Carta das Nações Unidas e no costume internacional, ver a decisão da Corte Internacional de Justiça no caso Nicarágua: "The Court has now to turn its attention to the question of the law applicable to the present dispute. In formulating its view on the significance of the United States multilateral treaty reservation, the Court has reached the conclusion that it must refrain from applying the multilateral treaties invoked by Nicaragua in support of its claims, without prejudice either to other treaties or to the other sources of law enumerated in Article 38 of the Statute. The first stage in its determination of the law actually to be applied to this dispute is to ascertain the consequences of the exclusion of the applicability of the multilateral treaties for the definition of the content of the customary international law which remains applicable." CIJ. Case Concerning Military And Paramilitary Activities in and Against Nicaragua (Nicaragua v. United State of America), Mérito, 1986, \$172). Disponível em: http://www.icj-cij.org/docket/index. php? sum $=367 \& \operatorname{code}=$ nus $\& \mathrm{p} 1=3 \& \mathrm{p} 2=3 \&$ case $=70 \& \mathrm{k}=66 \& \mathrm{p} 3=5$ 
um mesmo órgão pertencer a mais de um regime? Será que esse pertencimento é determinado pelo fato de ter sido criado pelos participantes do regime e através das normas do mesmo?

E para além da questão do pertencimento, pode um órgão ser chamado a aplicar normas que não são pertencentes ao regime de que ele mesmo é parte? E podem instituições que não pertencem especificamente a regimes temáticos serem levadas a aplicarem normas de diferentes regimes?

O fato é que as normas constituindo um regime podem ter criado uma instituição, um órgão, para administrar o tratado ou para resolver disputas dele decorrentes, mas podem igualmente ter referido as controvérsias a uma instituição criada no contexto de um outro regime, ou encarregado essa instituição com a administração das suas normas.

É igualmente certo que controvérsias relativas às normas do regime podem cair sob a jurisdição de um tribunal com competência mais ampla. A Corte Internacional de Justiça é apenas o exemplo mais evidente.

E também é fato que algumas instituições internacionais têm atuação explícita na administração de normas do que poderiam ser vários regimes diferentes, assim como na consecução de seus objetivos. Observe-se, por exemplo, a atuação do Banco Mundial em relação aos temas do meio ambiente, do desenvolvimento, dos direitos humanos, do comércio, dos investimentos internacionais etc.

Essas questões, além de explicitarem a dificuldade de delimitação dos regimes, ao adicionarem às limitações do tema e do ethos para fornecerem as respostas, colocam em evidência problemas relacionados à ideia da relativa autonomia dos regimes, uns em relação aos outros, e às noções aceitas concernentes às colisões e fricções entre eles.

Consideremos quatro candidatos ao status de regime em direito internacional público: o regime da paz e da segurança internacionais, o regime dos direitos humanos, o regime do direito humanitário e o regime do direito penal internacional.

Primeiramente, podemos usar esses candidatos para pensar a questão das fronteiras dos regimes e de seus conteúdos. Pode-se perguntar: o regime internacional da paz e da segurança está limitado às disposições da Carta das Nações Unidas sobre a matéria? Ele inclui os tratados sobre proliferação nuclear? Inclui outros tratados relacionados ao desarmamento? Inclui o direito internacional humanitário? Essas e outras perguntas poderiam ser feitas em relação ao regime dos direitos humanos: por exemplo, ele inclui as regras de direito humanitário? $\mathrm{E}$ as de direito penal internacional?

Em seguida, eles podem nos servir para considerar o tema que eu chamaria de possível sequestro, por parte de um regime, do ethos ou do tema de um outro regime.

Quando o Conselho de Segurança das Nações Unidas cria um tribunal penal internacional ad hoc ou quando refere um caso ao Tribunal Penal Internacional, está agindo de acordo com as regras contidas no regime da paz e da segurança internacionais e salvaguardando o ethos e os objetivos desse regime, ou estará agindo dentro do regime de direito penal internacional e perseguindo os objetivos deste? E nesse caso, o órgão Conselho de Segurança é parte de que regime?; ou pode pertencer a ambos e, a rigor, a tantos outros?

E mais, não estará o Conselho de Segurança sequestrando o ethos do regime do direito penal internacional e instrumentalizando-o, submetendo-o ao ethos politicamente carregado da lógica em que opera esse órgão enquanto ostensivamente busca garantir a paz e a segurança?

Além disso, os exemplos podem ainda iluminar a possibilidade de referências cruzadas entre regimes. $\mathrm{O}$ direito penal internacional, por exemplo, faz referência às normas de direitos humanos e de direito humanitário para definir os crimes a serem julgados e punidos. ${ }^{68}$

\subsubsection{A resposta que vem das normas}

O que resta claro, portanto, é que tanto a conceituação dos regimes quanto a sua delimitação com base nos temas e com base no ethos é virtualmente impossível ou se deve fazer com alto grau de imprecisão.

Também está claro que as complexas relações que se podem verificar entre os candidatos a regimes internacionais, relações que vão muito além das concessões usualmente feitas ao tema das colisões e contatos pela literatura, constituem mais um conjunto de dificuldades

68 Tribunal Internacional para Ruanda. Caso Jean Paul, Sentença, 02.10.1998 (Caso No: ICTR - 96 - 4 - T). Tribunal Penal Internacional para a antiga Iugoslávia. Caso Zlatko Aleksovski, 1999 (Caso no. IT-95-14/1-T) 
no caminho dessa delimitação, se quisermos que seja significativa.

Penso, em vista disso, que, se a noção de regime deve ter alguma chance de se provar útil, é preciso procurar os critérios de sua existência do lado das normas ou dos conjuntos normativos. Serão a identidade e as características das normas que permitirão a determinação do tema para o qual existe um regime e não o contrário.

O único caminho para fazer com que discussão faça sentido é encontrar, se os há, critérios jurídicos para o reconhecimento dos regimes. Só se pode entender os limites, as fronteiras, de regimes autocontidos ou especiais se estes forem determinados desde dentro, pelas normas do regime na medida em que estas determinam o seu campo de aplicação, suas relações com outras normas do regime, com outras normas relacionadas ao mesmo tema, com normas de outros regimes, e na medida em que estabelecem a competência ou reconhecem a jurisdição de tribunais ou outras instituições.

Isto é verdade quer falemos de regimes ou não. Nesse sentido, se o regime tem um ethos ou princípios ou objetivos reconhecíveis, eles serão dados pelas normas. Esta é a delimitação dos regimes desde dentro e, nesse sentido, a diferenciação funcional original, aquela genérica, é apenas indicativa das condicionantes sociológicas da fragmentação funcional. O que é funcional desde dentro é o que faz o regime jurídico.

\subsubsection{Colisões e conflitos}

Falei um pouco acima de relações possíveis entre os conjuntos normativos e organizacionais a que se pode e costuma chamar regimes e que dificultavam a sua delimitação.

Mencionei especialmente a incorporação de uma norma relativa a um tema ou pertencente a um regime por outro regime, lidando com outro tema e a possibilidade de que uma instituição, relacionada ou pertencente a um regime, seja chamada a aplicar normas de outro regime.

Já havia anunciado, no entanto, que ênfase costuma ser posta em possíveis relações de choque ou conflito entre os regimes, que vão além dessas duas. Pensa-se, sobretudo, nas colisões que podem dar lugar a antinomias e a decisões contraditórias e que, portanto, trazem incerteza jurídica.
A primeira possibilidade aventada é a de que um Estado se encontre obrigado por normas contraditórias relevando de distintos regimes. Que esteja, por exemplo, obrigado, por normas do comércio internacional, a liberar o comércio de determinado bem, e obrigado, por normas do direito internacional do meio ambiente, a restringir o comércio do mesmo bem.

A segunda possibilidade é de que diferentes instituições, relacionadas a distintos regimes, sejam chamadas a decidir sobre um mesmo conjunto factual e, aplicando normas contraditórias ou diversas, cheguem a decisões que são, elas também, incompatíveis.

A terceira possibilidade é de que diferentes instituições, talvez igualmente relacionadas a regimes diversos, sejam chamadas a decidir aplicando as mesmas normas, mas as interpretem de modos diversos e, novamente, cheguem a conclusões contraditórias.

Sempre, portanto, se está essencialmente preocupado com a possibilidade de que os conteúdos normativos ou a sua interpretação e aplicação por instituições diversas comandem comportamentos divergentes aos Estados.

É claro que está subentendido aí o risco mais abrangente de que, em um ambiente de inflação normativa, se estabeleça uma incerteza geral sobre normas e instituições que não se coordenam, por pertencerem a regimes, mais uma vez, orientados por racionalidades diversas e voltados para a consecução de objetivos distintos sem que haja esforço ou preocupação de coordenação.

O fato é, no entanto, que esses mesmos problemas se podem apresentar, e se apresentam, no direito internacional, independentemente da noção de regimes e independentemente das noções de tema e de ethos.

Mas é verdade que os regimes podem funcionar como um complicador desse problema e como um multiplicador das ocasiões em que ele vai se apresentar.

Ainda assim, o retrato que se faz desses conflitos muitas vezes apresenta os problemas de modo pouco fidedigno e, de todo modo, as soluções são as mesmas e devem ser buscadas na técnica do direito internacional.

\subsubsection{Uma ilustração}

Um dos casos mais frequentemente citados quando se discute os problemas decorrentes da fragmentação, 
e em que estes apareceriam em toda a sua força, é a sequência de decisões tomadas por tribunais internacionais e tribunais arbitrais nos chamados casos MOX Plant. $^{69}$

Esses são apresentados usualmente como uma ilustração de como o mesmo conjunto de fatos pode ser levado a diversos organismos de solução de controvérsias ou tomada de decisões - fragmentação institucional - que seriam chamados a aplicar de modo conflitante normas pertencentes a regimes diversos - fragmentação normativa - ou as mesmas normas, chegando a resultados divergentes. ${ }^{70}$

É verdade que o ponto de partida factual é o mesmo: a construção de uma fábrica de $\mathrm{MOX}^{71}$ pelo Reino

69 TIDM. Caso Mox Plant. (Irlanda v. Reino Unido), Medidas Cautelares com base no art. 290 \ $5^{\circ}$ da Convenção do Mar das Nações Unidas, No. 10, Ordem 2001/5, 2001;TIDM. Caso Mox Plant. (Irlanda v. Reino Unido), Medidas Cautelares, No. 10, Ordem 2001/3, 2001;CPA. Caso Mox Plant, (Irlanda v. Reino Unido), Ordem no. 1 - Ireland's Amended Statement of Claim, 2002; CPA. Caso Mox Plant, (Irlanda v. Reino Unido), Ordem no. 2 - Tempo Limite para Submissões e pedidos, 2002; CPA. Caso Mox Plant, (Irlanda v. Reino Unido), Ordem No. 3 - Suspensão dos Procedimentos de Jurisdição e Mérito, e Pedidos de Medidas Cautelares, 2003; CPA. Caso Mox Plant, (Irlanda v. Reino Unido), Ordem no. 4 - Outras Suspensões de Jurisdição e Mérito, 2003;CPA. Caso Mox Plant, (Irlanda v. Reino Unido), Ordem no. 5 - Suspensão dos Relatórios Periódicos pelas Partes, 2007;CPA. Caso Mox Plant, (Irlanda v. Reino Unido), Ordem no. 6 - Fim dos Procedimentos, 2008;TCE. Comissão da Comunidade Europeia v. Irlanda, Caso C-459/03, 2006.Disponível em: http://eurlex.europa.eu/LexUriServ/LexUriServ.do?uri=CELEX: 62003CJ0459:EN:PDF.

70 Gabriela Garcia Batista Lima traz outra possibilidade de ilustração desse fenômeno com três casos do Centro Internacional para a Resolução de Conflitos de Investimentos (ICSID). Ainda que sejam individualmente mais simples que o caso aqui analisado, apresentam elementos que evidenciam as mesmas questões nos choques entre âmbitos espaciais ou temáticos de regulação. LIMA, Gabriela G. B. Conceitos de relações internacionais e teoria do direito diante dos efeitos pluralistas da globalização: governança global, regimes jurídicos, direito refexivo, pluralismo jurídico, corregulação e autorregulação. Revista de Direito Internacional, v.11, n.1, 2014. Outro estudo nacional sobre os efeitos da fragmentação na prática do direito internacional é a análise de André Pires Gontijo sobre a "internacionalização do direito na pós-modernidade" observando o sistema interamericano e europeu de direitos humanos. Segundo o autor, ainda que os sistemas regionais de direitos humanos tenham desenvolvido um pano de fundo comum, da proteção à dignidade da pessoa humana, os dois sistemas apontados se encontram em projetos diferentes: o interamericano busca aumentar o acesso do indivíduo ao sistema, enquanto o europeu enfrenta o choque entre demandas econômicas e de direitos humanos. GONTIJO, André P. Os Caminhos Fragmentados da Proteção Humana: o peticionamento individual, o conceito de vítima e o amicus curiae como indicadores do acesso aos sistemas interamericano e europeu de proteção aos direitos humanos. Revista de Direito Internacional, v. 9, n.1, 2012.

71 A sigla corresponde a "mixed oxide fuel".
Unido, em seu território, à qual a Irlanda objetava. E é verdade que ambos países se encontram obrigados por um grande número de normas jurídicas que poderiam ser relevantes para a solução da controvérsia definida de modo assim genérico. Mais especificamente, ambos são partes da Convenção para a proteção do Atlântico nordeste (OSPAR) ${ }^{72}$, ambos são partes da Convenção das Nações Unidas para o Direito do Mar (Convenção do $\mathrm{Mar}^{73}$, e ambos são membros da União Europeia, sendo-lhes, portanto, aplicável o conjunto do direito comunitário.

Enquanto procurava por meios de impedir a existência da fábrica e seu funcionamento, a Irlanda desenvolveu várias reclamações contra o Reino Unido. Uma dessas dizia respeito à quantidade e à qualidade de informações fornecidas por este último. Sentindo, ou argumentando apenas, que a informação não era satisfatória, sustentou que o Reino Unido não cumpria com uma obrigação contida no artigo 9 da convenção OSPAR.

Essa convenção contém uma cláusula de solução de controvérsias que foi invocada pela Irlanda para dar início a um procedimento arbitral ${ }^{74}$. O tribunal arbitral teve de lidar com essa questão jurídica específica, relativa à observância do artigo $9^{\circ}$. E, de modo correspondente, teve que lidar com um universo factual específico que tinha relação direta com a questão jurídica sendo considerada.

A Irlanda também sentiu, ou argumentou, que o Reino Unido violava várias normas da Convenção do Mar e, de acordo com as regras para solução de controvérsias contidas nessa convenção, deu início a um outro procedimento arbitral. Este segundo tribunal arbitral também devia lidar com questões jurídicas específicas, relativas à violação de normas jurídicas materiais específicas e, do mesmo modo, tinha que lidar com o contexto factual a elas relacionado.

Porque sentiu que medidas cautelares eram necessárias, também de acordo com a Convenção do Mar, a Irlanda pediu que o Tribunal Internacional para o Direito do Mar (Tribunal do Mar) as concedesse. ${ }^{75} \mathrm{O}$ Tribunal

72 Disponível em: http://www.ospar.org/content/content.asp?m enu=01481200000000_000000_000000

73 Disponível em: http://dai-mre.serpro.gov.br/atos-internacionais/multilaterais/direito-do-mar/m_487/

74 TIDM. Caso Mox Plant. (Irlanda v. Reino Unido), Memorial da Irlanda, Volume 1, 2002, SS 4.35-4.36.

75 TIDM. Caso Mox Plant. (Irlanda v. Reino Unido). Medidas Cautelares com base no art. 290 \5 $5^{\circ}$ da Convenção do Mar das 
do Mar teve, portanto, que lidar com a questão jurídica relativa a serem ou não devidas as medidas cautelares e, em caso afirmativo, quais deviam ser essas medidas. Precisaria estabelecer seu convencimento sobre estarem presentes as condições factuais para que concedesse a cautela.

Finalmente, porque a Comissão das Comunidades Europeias (Comissão) ${ }^{76}$ considerou que as provisões da Convenção do Mar cuja violação a Irlanda arguia perante o tribunal arbitral haviam sido incorporadas ao direito comunitário, apresentou uma demanda contra a Irlanda perante o Tribunal das Comunidades Europeias ${ }^{77}$ sob a acusação de que a esta teria violado a obrigação de levar qualquer controvérsia relativa a direito comunitário que a opusesse a outro Estado membro da Comunidade às instituições desta última. Aqui também o Tribunal comunitário teve de lidar com uma questão jurídica específica e com os fatos a ela conectados: se a Irlanda havia violado obrigações decorrentes do direito comunitário.

Na verdade, portanto, cada tribunal estava tentando resolver uma questão jurídica diferente, lidando com conjuntos factuais diversos, ainda que relacionados, e tendo que aplicar normas distintas, pertencentes, se quisermos, a diferentes regimes jurídicos. Um dos tribunais arbitrais devia aplicar o artigo $9^{\circ} \mathrm{da}$ convenção OSPAR; o outro, algumas normas da Convenção do Mar, o Tribunal do Mar devia aplicar outras normas da mesma convenção; e o Tribunal das Comunidades Europeias devia aplicar direito comunitário.

O único momento em que os traços problemáticos da fragmentação se mostram mais claramente é aquele do cruzamento entre o tribunal arbitral chamado a aplicar a Convenção do Mar e o Tribunal da Comunidade Europeia. A interação normativa aparece mais claramente, no entanto, apenas porque um regime ou, para ser mais preciso, um sistema jurídico - que em muitas coisas é o equivalente de um sistema jurídico doméstico, fechado -, o direito comunitário, havia incorporado normas que constituem parte daquilo que se poderia olhar como sendo o regime internacional do mar, ou seja, algumas normas da Convenção do Mar.

Nações Unidas, No. 10, Ordem 2001/5, 2001; TIDM. Caso Mox Pant. (Irlanda v. Reino Unido), Medidas Cautelares, No. 10, Ordem 2001/3, 2001.

76 Comissão Europeia - Assuntos Legais, Sumário de Sentenças importantes, Caso C-459/03 (Comissão v. Irlanda), 2006.

77 TCE. Comissão da Comunidade Europeia v. Irlanda, Caso C-459/03, 2006.Disponível em: http://eurlex.europa.eu/LexUriServ/LexUriServ.do?uri=CELEX:62003CJ0459:EN:PDF
O contato ou fricção institucional se manifesta na decisão do tribunal arbitral de suspender o seu trabalho enquanto esperava o Tribunal comunitário tomar a sua decisão. ${ }^{78}$ Essa deferência não é fundada em qualquer crença de que, tendo ambos que aplicar as mesmas normas, o Tribunal comunitário teria precedência sobre o tribunal arbitral já que, de fato, eles não eram chamados a aplicar as mesmas normas ou resolver as mesmas questões jurídicas. A decisão se baseou na crença de que se o Tribunal comunitário viesse a decidir, como afinal decidiu, que a Irlanda havia violado o direito comunitário ao começar o procedimento arbitral, este naturalmente se veria terminado. ${ }^{79}$

\subsubsection{Uma Receita técnica}

Outros tantos exemplos, ao mesmo tempo parecidos e distintos desse dos casos MOX Plant, poderiam ser explorados aqui. Penso, por exemplo, nas decisões relacionadas à importação de pneus usados pelo Brasil. ${ }^{80}$ Ali, decisões divergentes foram tomadas dentro do sistema de solução de controvérsias da OMC e por arbitragem feita no âmbito do MERCOSUL. Mas ali,

78 CPA. Caso Mox Plant, (Irlanda v. Reino Unido), Ordem No. 3 Suspensão dos Procedimentos de Jurisdição e Mérito, e Pedidos de Medidas Cautelares, 2003; CPA. Caso Mox Plant, (Irlanda v. Reino Unido), Ordem no. 4 - Outras Suspensões de Jurisdição e Mérito, 2003;

79 TCE. Comissão da Comunidade Europeia v. Irlanda, Caso C-459/03, 2006.

80 BRASIL. Superior Tribunal Federal. Arguição de Descumprimento de Preceito Fundamental no. 101 (ADPF-101). Portaria DECEX N. 8. Proibição de Pneus Usados. Relatora: Ministra Carmem Lúcia. DF 21.09.2006; OMC. Brazil - Measures Affecting Imports of Retreaded Tyres.,2008 (WT/DS332/16); OMC. Brazil - Measures Affecting Imports of Retreaded Tyres, Status Report by Brazil, 2009 (W'T/DS332/19); OMC, Brazil - Measures Affecting Imports of Retreaded Tyres, Status Report by Brazil,Notification of an Appeal by the European Communities under Article 16.4 and Article 17 of the Understanding on Rules and Procedures Governing the Settlement of Disputes (DSU), and under Rule 20(1) of the Working Procedures for Appellate Review, 2007, (WT/DS332/9), OMC, Brazil - Measures Affecting Imports of Retreaded Tyres, Report of the Appellate Body, 2007,( WT/DS332/AB/R); MERCOSUL. Tribunal Arbitral - Laudo Arbitral de las presentes actuaciones ante este Tribunal Arbitral relativas a la controversia entre la República Oriental del Uruguay (Parte Reclamante, en adelante "Uruguay") y la República Federativa del Brasil (Parte Reclamada, en adelante "Brasil") sobre "Prohibición de Importación de Neumáticos Remoldeados (Remolded) Procedentes de Uruguay, 2006; MERCOSUL. Criação do grupo ad hoc para uma política regional sobre pneus, inclusive reformados e usados -GAHP (MERCOSUL/ GMC EXT/RES. Nº 25/08), 29.06. 2008; CAMEX, Resolução no. $38,22.10 .2007$. 
também, as perguntas jurídicas feitas em cada uma das instâncias eram diversas e comandavam, portanto, a consideração do conjunto factual de modos diversos. O que esses casos mostrariam, no entanto, é a possibilidade do mesmo tipo de problema ocorrer dentro do que, para muitos efeitos, é um e único regime jurídico, o do comércio internacional. Ou, no máximo, é o conflito entre normas e instituições de um regime com aquelas de um seu sub-regime.

O que o caso MOX Plant e os demais que poderíamos conceber nos ensinam, portanto, é que faríamos bem de lidar, numa perspectiva mais ampla, com o direito internacional como uma unidade, como um sistema jurídico coerente, dotado de determinadas características diferenciadoras. Numa perspectiva mais restrita, deveríamos tentar uma descrição mais realista das suas dinâmicas.

A qualquer momento dado, um Estado ou outro sujeito de direito internacional perguntar-se-á se está obrigado por esta ou aquela norma. Talvez não se pergunte se a norma pertence a este ou aquele regime, entre outras razões, porque talvez não faça qualquer diferença. Se descobrir que há contradições concernentes aos direitos e obrigações decorrentes de normas diversas pelas quais está obrigado, tentará resolver isto, se o tentar, primeiramente reconhecendo que essas normas pertencem igualmente a um sistema jurídico que deve ter, e em principio tem, regras secundárias destinadas a lidar com as antinomias.

Quando uma corte internacional ou um tribunal arbitral são chamados a aplicar direito internacional, estarão lidando com uma ou mais questões jurídicas específicas e, para provê-las com respostas, considerarão, primeiro, se têm jurisdição e, em seguida, quais as normas de direito internacionais aplicáveis ao caso. Não precisam, na verdade, decidir se essas normas pertencem a este ou aquele regime jurídico.

Um tribunal pode estar obrigado a aplicar apenas normas que são vistas como pertencendo a um desses regimes simplesmente porque aquelas são as normas para cuja aplicação tem competência e se revelam aplicáveis ao caso concreto que tem diante de si. Um outro tribunal pode ter competência para aplicar, e descobrir aplicáveis a um caso, normas que seriam vistas como pertencendo a diferentes regimes jurídicos. E pode descobrir, enquanto tenta aplicar as normas a casos específicos, que há contradições, antinomias, para a solução das quais recorrerá a normas e técnicas que encontrará no direito internacional.

E tudo isso só será possível porque não há dúvida em relação ao fato de que essas normas e tribunais, ou instituições, são partes integrantes de um único sistema jurídico equipado com algum grau de coerência interna.

\section{Constelação Regulatória Global?}

Se abordamos a matéria pelo lado do tema ou da área específica da vida internacional, ao nos perguntarmos como e pelo que ela é regulada, veremos uma gama de possíveis respostas.

Descobriremos, possivelmente, que o tema é completamente regulado por direito internacional público, o que quereria dizer que toda a regulação relativa ao tema deve ser encontrada dentro do direito internacional e é reconhecida como parte constitutiva desse sistema. Ou descobriremos que a área é regulada por direito internacional e por direito interno. Ou veremos que ao lado das prescrições jurídicas que pertencem ou ao direito internacional, ou ao direito interno, ou a ambos, há outros tipos de regulação, outros instrumentos, cujo caráter ou natureza jurídica podem ser controvertidos e que são produzidos por um ou vários tipos de atores sociais, mas que têm em comum o fato inegável de que regulam efetivamente os comportamentos em setores sociais específicos, entre certos atores, em relação a determinados temas.

Talvez gostemos de pensar que o conjunto de prescrições, normas, que lidam com uma área específica, constitui um regime regulatório, talvez jurídico. Se ignoramos ou consideramos desimportante o exercício de determinar se partes ou o todo das prescrições é direito e se todas elas ou apenas algumas pertencem a este ou aquele sistema jurídico, estaremos escolhendo como único elemento organizador o fato de que aquela regulação se refere a um tema específico.

Se assim fizermos, estaremos nos condenando a apenas descrever como algo é regulado. No entanto, como já se discutiu acima, mesmo esse exercício descritivo estaria incompleto já que não se pode verdadeiramente descrever o modo como algo é regulado passando ao largo da discussão sobre se esta ou aquela prescrição é ou não é obrigatória, se pode ou não pode ser aplicada 
e exigida por um órgão jurisdicional etc.

Alternativamente, como também já se disse acima, podemos considerar que para descrever de modo apropriado o conjunto de normas ou prescrições que lidam com uma área ou tema específico, é preciso decidir se são jurídicas, no sentido de que pertencem a um sistema jurídico, quer seja este o direito internacional público ou um direito nacional, doméstico e, se não pertencem nem a um nem a outro, decidir se são ainda assim jurídicas, porque, por exemplo, parte integrante de um terceiro tipo de sistema jurídico que operaria apenas em torno daquele tema, entre aqueles atores, para um conjunto específico de sujeitos jurídicos.

As opções teóricas são, portanto: i) considerar que cada conjunto regulatório é um sistema jurídico que, ao reconhecer as prescrições relativas ao tema de que trata, lhes dá caráter jurídico. Isto colocaria o problema de saber se as normas pertencentes ao direito internacional ou aos direitos domésticos seriam incorporadas, reproduzidas, no interior da ordem jurídica setorial específica, ou se seriam simplesmente reconhecidas para efeito de aplicação pelas instituições do regime; ii) Considerar que o tema é um ponto de encontro, um ponto de confluência, de sistemas jurídicos diferentes, quando há mais de um envolvido, cujas prescrições regulam juntas o tema ou a matéria específica, em combinação, quando for o caso, com prescrições não-jurídicas e/ou com o que é usualmente chamado regulação privada.

De fato, frequentemente, quando se olha para qualquer tema global, quer seja abrangente - meio ambiente, segurança, comércio etc. - quer restrito, encontra-se direito internacional, o de traços tradicionais, que lide com a matéria; isto quer dizer que serão encontrados tratados e/ou normas costumeiras e/ou princípios gerais de direito, emergindo portanto das fontes reconhecidas da ordem jurídica, que tratem do tema e regulem o campo.

Essas normas serão consideradas válidas e obrigatórias e sua inobservância por parte dos Estados, os sujeitos da ordem jurídica, fará entrar em operação os mecanismos de sua responsabilização. Se houver delegação da função de resolver controvérsias a um organismo com competência, esse organismo interpretará e aplicará as normas aos casos que lhe forem apresentados.

Também é frequente que sejam encontradas outras prescrições, criadas por Estados ou por outros atores, emergindo a partir de fontes outras que não as reco- nhecidas pelo direito internacional, que desempenham um papel na ordenação, na organização da vida e do comportamento em relação àquele tema ou campo específico.

Essas prescrições emergirão de resoluções ou decisões de organismos internacionais, de acordos informais entre os Estados, de códigos de conduta e de um sem-número de outros tipos de instrumentos e mecanismos. Muitos desses, porque são tão próximos da mecânica do direito internacional e estão intimamente ligados à atividade dos Estados e das organizações internacionais, dão lugar a questionamentos sobre a sua natureza jurídica, no sentido de seu pertencimento ou não ao ordenamento jurídico internacional.

Muitas vezes, ver-se-á que o tema específico ou o setor é também ordenado, organizado, regulado pelo que é usualmente chamado regulação privada, arranjos ou acordos privados, códigos de conduta, processos de certificação, redes de contratos etc. ${ }^{81}$

Este tipo de regulação não pode ser suspeito de fazer parte do direito internacional público. Sua natureza jurídica, no entanto, é debatida e suas manifestações são vistas por alguns como pertencentes a uma ordem jurídica global ou transnacional frouxamente definida ou àquele regime ou sistema jurídico ou regulatório especificamente direcionado a um tema.

Finalmente, quase sempre será possível observar que o direito doméstico dos Estados trata do tema ou da área.

Pode-se argumentar que tentar saber ou entender apenas o modo como um direito doméstico, ou apenas como o direito internacional, lida com um tema resultará em uma visão apenas parcial daquele microcosmos regulatório e servirá a propósitos muito limitados. Será aceitável se a intenção for, de fato, trabalhar apenas com propósitos limitados como, por exemplo, quando um tribunal com competência para aplicar apenas direito internacional tiver que responder a uma pergunta jurídica circunscrita a essa ordem jurídica, mas não será

81 Um exemplo de estudo nacional com essa abordagem é o trabalho de Mateus de Oliveira Fornasier e Luciano Vaz Ferreira sobre as normativas internas de conduta nas empresas transnacionais, com capacidade de influência expandida a outros setores, explorada pelos autores como ordem jurídica não-estatal de alta relevância de autoria privada e relevância global. FORNASIER, Mateus de O.; FERREIRA, Luciano V. A regulação das empresas transnacionais entre as ordens jurídicas estatais e não estatais. Revista de Direito Internacional, v. 12, n.1, 2015. 
apropriado se a intenção é descrever de maneira integral o modo como a regulação daquele setor específico se apresenta.

Mais uma vez, no entanto, uma descrição competente da realidade regulatória de um campo, única base sobre a qual propósitos mais ambiciosos podem ser construídos, não pode dispensar a distinções técnicas entre o que é parte do direito internacional e o que não é, combinadas com a descrição afinada do funcionamento do sistema jurídicos e do funcionamento das prescrições dentro do sistema; a determinação do que é parte deste ou daquele sistema jurídico doméstico, também combinada com o funcionamento do sistema e das suas prescrições; a determinação do que é obrigatório, do que não o é, de quem é o produtor de cada prescrição regulatória, de quem é o destinatário da provisões etc.

A realidade regulatória internacional, ou global, ou transnacional, se nos mostra, assim, como um complexo de sistemas jurídicos e de tipos de regulação diversos e como um complexo de temas em torno dos quais normas jurídicas e outros tipos de regulação se aglutinam.

\subsection{Dois Pluralismos Jurídicos ou Regulatórios}

A ideia que nos servia de ponto de partida, a da diferenciação funcional que leva as normas a se aglutinarem em torno de temas ou problemas específicos, quando pensada em relação à vida internacional, nos coloca face a face com dois tipos de pluralismo jurídico. ${ }^{82}$

O primeiro tem como suas unidades básicas os sistemas jurídicos, as ordens jurídicas. Essencialmente, esses sistemas jurídicos são os direitos nacionais e o direito internacional. É possível, no entanto, que alguns queiram incluir entre as ordens jurídicas sistemas cuja natureza jurídica é mais controvertida, entre outras coisas,

82 Como mencionado antes, KORTH e TEUBNER têm um artigo em que falam de dois tipos de pluralismo. Ali, os dois tipos são equivalentes ou correspondem a uma dupla fragmentação do direito global e também a dois tipos de colisão entre normas, ou seja, pluralismo, fragmentação e colisões parecem ser termos intercambiáveis. Os exemplos usados fazem referência a questões de propriedade intelectual em que se discute, num caso, a atribuição de nome de domínio na internet e, no outro, a proteção de saberes tradicionais. Penso que, mais uma vez, os conflitos normativos são equivocadamente identificados e explicados. Segundo os autores, os dois tipos de pluralismo, a dupla fragmentação e os dois tipos de colisão oporiam, primeiramente, diferentes sistemas funcionais e suas normas, e em segundo lugar, direito formal e direitos tradicionais. Como se pode ver, não é o mesmo de que falo eu aqui. por não serem as suas normas produzidas pelos Estados. O exemplo talvez mais evidente é o da Lex mercatoria. Nesse caso, falar-se ia de um pluralismo de sistemas jurídicos ou regulatórios, mas já não seria um pluralismo estritamente jurídico, ou seja, centrado no direito.

Perceba-se que quando se pensa o pluralismo como um espaço de múltiplos sistemas jurídicos, esses sistemas não são definidos pelas suas preocupações temáticas, mas sim pelas suas características sistêmicas. Ou seja, cada ordem jurídica se define pelas respostas que dá a uma série de perguntas que são essencialmente estas: i) qual o seu campo de aplicação territorial ou social? ii) quais os mecanismos que reconhece como aptos a criar normas válidas? iii) quem são os destinatários das normas? iv) Quais são e como operam as instituições criadas pelas normas do sistema?

Essas perguntas podem ser feitas com naturalidade e respondidas com razoável simplicidade em relação aos direitos nacionais, estatais, e ao direito internacional público. Mesmo que se queira incluir sistemas não estatais, e talvez não jurídicos, tais como a Lex mercatoria, as respostas às perguntas permitiriam identificar uma razoável unidade e sistematicidade, apesar de ser esse sistema específico marcado pelo tema, pelo setor da vida que regula, o comércio, diferentemente do que ocorre com os direitos nacionais e com o internacional.

O segundo tipo de pluralismo jurídico internacional que se desenha perante nós, a partir da ideia de diferenciação funcional é um em que as unidades básicas não são os sistemas jurídicos, mas sim os regimes jurídicos, estes sim, como vimos, tendendo a serem definidos pelo tema, pelo problema ou pelo setor regulado.

Como dito, é possível conceber regimes jurídicos ou regulatórios que sejam compostos por apenas um tipo de regulação e que constituam um sistema completo e fechado. Porém, o mais comum será que em torno do tema específico se reúnam, ou venham a incidir conjuntamente, normas oriundas de mais de um sistema jurídico e que essas normas se façam acompanhar igualmente de outros tipos de regulação cujo caráter jurídico será controvertido.

É claro que aquilo que já se apresentava difícil quando se falava de regimes enquanto fragmentos de uma ordem jurídica dada, o direito internacional público, ou seja, a determinação dos confins, dos limites dos regimes, das normas e estruturas institucionais que fazem parte dos regimes, não é tarefa mais simples quando se 
pensa o regime como ponto de confluência de normas e de regulação saídas de sistemas e de fontes diversas.

Aqui, portanto, também se trabalha com zonas de indeterminação. Percebe-se os regimes de modo aproximado, a partir do tema. Como acontecia em relação aos regimes inseridos no direito internacional público, os temas podem ser muito numerosos, ser mais ou menos específicos, se relacionarem uns com os outros dos modos mais variados: em círculos concêntricos, interpenetrando-se, tangenciando-se.

Assim como acontecia com os regimes autocontidos do direito internacional público, pode revelar-se difícil identificar um ethos a comandar a gênese e a operação das normas que lidam com um tema a partir de ordens jurídicas distintas e de outros tipos de regulação. $\mathrm{Na}$ verdade, justamente por constituírem um aglomerado de normas pertencentes a ordens diversas, é ainda mais difícil provar um ethos único.

Pela mesma razão, aqui também são mais prováveis as colisões ou as fricções entre normas ou instâncias de tomada de decisões conectadas a um mesmo tema, para não dizer nada daquelas que existirão entre as normas e instâncias que lidam com temas diversos, pertencentes, se quisermos, a regimes diversos.

Aqui, como lá, seria exercício fútil tentar mapear os regimes existentes. Lá, eu ofereci uma descrição da solução técnica que o direito internacional oferece para as percebidas fricções entre normas e entre órgãos de tomada de decisão - especialmente jurisdicionais - de regimes diversos ou até de um mesmo regime.

No que concerne os regimes entendidos como pontos de convergência de normas jurídicas ou de regulação de diferentes tipos ou pertencentes a diferentes ordens jurídicas, uma solução técnica análoga é concebível, mas não é factível o seu mapeamento e a sua descrição aqui.

Com relação a este segundo tipo de regime, pretendo concentrar esforços em entender, e tentar mapear, justamente os instrumentos ou normas pertencentes ao que venho designando genericamente como outros tipos de regulação.

\subsection{Regulação no espaço internacional ou global}

Como vimos, quando se tenta entender como é ordenada a vida no espaço global, internacional ou transnacional, ou seja, para além e através das fronteiras dos Estados, quando se tenta entender e descrever o que muitos chamam de governança global, tende-se a apontar as limitações do direito internacional público e a observar a sua incapacidade para regular sozinho esse espaço global, evidenciada pela existência de uma pluralidade de outros meios de regulação.

A esta limitação do direito internacional público e a esta oposição entre essa ordem jurídica e os seus concorrentes, sobrepõe-se a percebida limitação do direito, do jurídico estritamente definido, e a sua contraposição a uma noção mais genérica e inclusiva de regulação.

Um modo de representar essa dupla limitação e essa dupla oposição é contrapondo noções genéricas de hard law e soft law, sendo esta última expressão entendida como designando instrumentos normativos - no sentido de conterem prescrições e tenderem a influenciar os comportamentos - mas não vinculantes, não obrigatórios.

Em outro lugar ${ }^{83}$ eu discuti essa contraposição entre as normas jurídicas que compunham o direito internacional público por emergirem de processos de gênese, de mecanismos, de fontes, reconhecidos dessa ordem, e as prescrições contidas em instrumentos normativos, mas não jurídicos, que regulavam os comportamentos na esfera internacional e que eram produzidos ou pelos Estados, ou por organizações internacionais, ou por entes não governamentais.

Mas, para além dessa dicotomia simplista e generalizante, há muitos que vêm tentando descrever de modos diversos a arquitetura do espaço normativo ou regulatório internacional ou partes específicas dele. Usam, para isso, recortes e perspectivas variados. Faço mais adiante uma breve discussão de duas dessas leituras que, por ser uma mais genérica e a outra mais específica, dialogam entre si, e que, por apresentarem bases teóricas mais sólidas, permitem a discussão da noção de regulação nos termos por mim propostos aqui. Trata-se do direito administrativo global ${ }^{84} \mathrm{e} \mathrm{da}$

83 NASSER, S. H. Fontes e Normas do Direito Internacional: Um Estudo sobre a Soft Law. 2a. ed. São Paulo: Editora Atlas, 2006. p. 175. 84 Ver, KINGSBURY, B.; KRISCH, S.; STEWART, R.; WIENER, J.B.. Global Governance as Administration-National and Transnational Approaches to Global Administrative law. Law and Contemporary Problems, v. 68, n. 3-4, p. 1-13, 2005; CAROTTI, B.; SAVINO, M. Global Administrative Law: cases, materials, issues. New York University School of Law, 2008.Disponívelem: http:// iilj.org/GAL/documents/GALCasebook2008.pdf; CASSESE，S. Global Administrative law: An Introduction. Anais da IIJL Conference. 2005. Disponível em: http://www.iilj.org/GAL/documents/GALCasebookBibliography.pdf; CHESTERMAN, S. Global Administrative Law. Working Paper for the S.T. Lee Project on Global Governance.2009 
regulação privada transnacional. ${ }^{85}$

Antes de procedermos com a discussão dessas duas leituras, no entanto, cabem alguns comentários acerca da compreensão e do uso do termo regulação e de outros a ele conectados.

.Disponível em: http://www.ssrn.com/abstract=1435170.; DAVIS, D.; CORDER, H. Globalization, National Democratic Institutions and the Impact of Global Regulatory Governance on Developing Countries. Acta Juridica, v. 09, p. 68-89, 2009; ESTY, D. C. Good Governance at the Supranational Scale: Globalizing Administrative Law. The Yale Law Journal, v. 115, n. 7, p. 1490-1562, 2011; HARLOW, C. Global Administrative Law: The Quest for Principles and Values. European Journal of International Law, v. 17, n. 1, p. 187-214, 2006.; KINGSBURY, B. The Concept of "Law" in Global Administrative Law. European Journal of International Law, v. 20, n. 1, p. 23-57, 2009.; KINGSBURY, B.. Co-Option and Resistance : Two Faces of Global Administrative Law. New York University Journal of International Law and Politics, v. 38, p. 799-827, 2005.; KINGSBURY, B.; KRISCH, S.; STEWART, R.; WIENER, J.B.. Global Governance as Administration-National and Transnational Approaches to Global Administrative law. Law and Contemporary Problems, v. 68, n. 3-4, p. 1-13, 2005; KINGSBURY, B.; KRISCH, S.; STEWART, R. The Emergence of Global Administrative Law. Law and Contemporary Problems, v. 68, p. 15-61, 2005.; KOCH, C. H. Globalization of Administrative and Regulatory Practice. Administrative Law Review, v. 54, n. 1, p. 409-414, 2002.;KRISCH, N. Introduction: Global Governance and Global Administrative Law in the International Legal Order. European Journal of International Law, v. 17, n. 1, p. 1-13, 2006a. KRISCH, N. The Pluralism of Global Administrative Law. European Journal of International Law, v. 17, n. 1, p. 247-278, 2006b. KRISCH, N. Global Administrative Law and the Constitutional Ambition. Law, Society Economy Working Papers. 2009. Disponível em: http://www.lse.ac.uk/collections/law/wps/WPS2009-10_Krisch. pdf; KUO, M.-S. The Concept of "Law" in Global Administrative Law: A Reply to Benedict Kingsbury. European Journal of International Law, v. 20, n. 4, p. 997-1004, 2010.; MARKS, S. Naming Global Administrative Law. New York Journal of International Law and Politics, v. 95, p. 995-1002, 2005.; MCLEAN, J. Divergent Conceptions of the State: Implications for Global Administrative Law. Law and Contemporary Problems, v. 68, n. 3, p. 167-187, 2005.; SANCHEZ, M. R. The Global Administrative Law Project: A review from Brazil. Artigos Direito GV, v. 38, p. 1-14, 2009.; SCHMIDT-ASSMAN, B. E. The Internationalization of Administrative Relations as a Challenge for Administrative Law Scholarship. German Law Journal, v 9, n. 11, 2006.; SHAPIRO, M. Administrative Law Unbounded : Reflections on Government and Governance. Indiana Journal of Legal Studies, v. 8, n. 2, p. 369-377, 2001.

85 Ver ABBOTT, K. W.;SNIDAL D. Strengthening International Regulation through Transnational New Governance: Overcoming the Orchestration Deficit. Vanderbilt Journal of Transnational Law, p. 1-69, 2009; BARTLEY, T. Institutional Emergence in an Era of Globalization: The Rise of Transnational Private Regulation of Labor and Environmental Conditions. American Journal of Sociology, v. 113, n. 2, p. 297-351, 2007.; BENVENISTI, E.; DOWNS, G. W. National Courts Review of Transnational Private Regulation. n. 2003, p. 1-18, 2005. (working paper) Disponível em: http://papers. ssrn.com/sol3/papers.cfm?abstract_id=1742452.; CAFAGGI, F. New Foundations of Transnational Private Regulation.EUI Working Papers. p. 1-40, 2010.
Perceba-se que até aqui a noção vem sendo usada como significando, de modo muito genérico, algo equivalente à organização dos espaços sociais por normas ou regras. Alguns dicionários da língua portuguesa admitem para o termo o sentido de "ato ou efeito de regular" estabelecer normas ou regras" $" 87$. Alguns outros, como Houaiss, consideram que o termo é um neologismo inapropriado, preferindo a ele a palavra regulamentação. ${ }^{88}$

Quando falava acima da contraposição entre direito e a noção genérica de regulação, esta última era justamente entendida como um universo de organização dos comportamentos por normas.

A rigor, o direito faz parte desse universo normativo. A contraposição a que se fez referência é a que opõe o tipo específico de regulação que é o direito, e as qualidades especiais que têm as suas normas, a outros tipos de regulação que, considerados em conjunto, teriam em comum o traço de serem não jurídicos. A limitação a que se fez referência é aquela que toca o direito por sofrer ele a necessidade de que suas normas se adéquem a certos critérios.

Não está dado, no entanto, que o termo regulação seja sempre e necessariamente usado e entendido como o ato ou efeito de regular, de dirigir, de estabelecer regas ou normas ou como o conjunto das regras e normas que operam em um espaço social.

Regulação pode aparecer também como sinônimo de "norma, preceito, regulamento, por que se deve reger o comportamento" 89 , designando, portanto, a norma singularmente considerada.

Parece-me que esse uso é mais especialmente influenciado pelo peso tanto da língua inglesa quanto da cultura jurídica norte-americana. Nestas, o termo, que normalmente aparece no plural, regulations, pode carregar justamente esse sentido de norma singular que, em português, nós chamaríamos normalmente regulamento.

86 Dicionário PRIBERAM de Língua Portuguesa Online. Disponível em: http://www.priberam.pt/dlpo/default.aspx?pal=regu la\%u00e7\%u00e3o;MICHAELIS: Moderno Dicionário da Língua Portuguesa. São Paulo: Companhia Melhoramentos, 1998, p. 1804.

87 Dicionário Priberam de Língua Portuguesa Online. Disponível em: http://www.priberam.pt/dlpo/default. aspx?pal $=$ regula $\%$ u $00 \mathrm{e} 7 \%$ u $00 \mathrm{e} 3 \mathrm{o}$

88 HOUAISS, Antônio e VILLAR, Mauro Salles. Rio de Janeiro: Objetiva, 2001, p. 2418

89 MICHAELIS: Moderno Dicionário da Língua Portuguesa. São Paulo: Companhia Melhoramentos, 1998, p. 1804 
Mas há mais, regulations são definidas como "regras ou outras diretivas emitidas por agências administrativas que devem ter autorização específica para emitir diretivas e, com base nessa autorização, devem usualmente seguir condições prescritas, tais como notificação prévia, em registro público, da ação proposta, e um convite a comentários públicos". ${ }^{90}$

Isto significa que as regras ou outras diretivas a que se faz referência quando se usa o termo regulação, em inglês, são de natureza administrativa, e emanam de agências ou órgãos dotados de poderes específicos para regular ou regulamentar atividades ou setores específicos. Os poderes ou a autorização, supõe-se, são conferidos, delegados, pelo Estado, e a regulação diz respeito a temas de interesse público ou coletivo.

Essa compreensão do termo regulação, que o aproxima do universo do direito administrativo e que deve tanto ao inglês e ao direito norte-americano, é hoje muito usual e se estende a expressões conexas como agências reguladoras, setores regulados etc.

Note-se que essa aproximação entre regulação e direito administrativo não está imune às dúvidas sobre as fronteiras do direito e sobre a distinção entre o jurídico e o não jurídico que aqui se apresentam com cores próprias. Afinal, regulação, como entendida aqui, é direito? É direito administrativo ou de outro tipo? As agências reguladoras ou quaisquer órgãos dotados de poderes de regulação legislam? Se legislam, produzem direito administrativo?

Com muito mais razão, essas dúvidas e essas perguntas se impõem quanto se faz referência às noções de autorregulação e de regulação privada. Com relação a estas, talvez o conforto seja maior em responder pela negativa quanto à natureza jurídica das normas ou das regras, mas aqui também sobrarão perplexidades.

De todo modo, não me interessa especialmente resolver essas questões, quer para a regulação pública, quer para a privada, de outro modo que não seja apontar para a dificuldade e para a possível controvérsia. Interessa sim, um pouco mais, fazer notar que, mesmo em relação à autorregulação e à regulação privada, é usual

90 "rules or other directives issued by administrative agencies that must have specific authorization to issue directives and upon such authorization must usually follow prescribed conditions, such as prior notification of the proposed action in a public record and an invitation for public comment." (GIFIS, Steven H. BARRON'S LAW DICTIONARY, p 425) conectar a noção de regulação àquelas de espaço, de interesse ou de bens públicos ou coletivos.

Essa conexão orienta, em grande medida, tanto a reflexão em torno da chamada regulação privada transnacional quanto aquela que advoga a emergência de um direito administrativo global. Ela será fundamental também para instruir a relação entre essas categorias e as noções de rule of law, de accountability, de transparência, de participação etc.

\subsection{Espaço regulatório / administrativo global}

Tendo em seu centro a ideia da conexão entre os instrumentos ou mecanismos regulatórios internacionais ou transnacionais e o espaço e os interesses públicos, desenvolveu-se uma literatura, especialmente em torno do projeto Global Administrative Law, que identifica a existência de uma governança global da qual "muito ... pode ser entendido e analisado como ações administrativas: criação de regras, adjudicação administrativa entre interesses em competição, e outras formas de decisão e de gerenciamento regulatórios e administrativos". ${ }^{91}$

Essa literatura presume a existência de uma administração transnacional global ${ }^{92}$ que realiza essas ações administrativas, ações que difeririam da criação normativa por tratados e das soluções judiciárias episódicas de disputas, ${ }^{93}$ mas incluiriam a criação de regras e padrões de aplicabilidade geral ${ }^{94}$ bem como a tomada de decisões para o controle e implementação dos regimes regulatórios. ${ }^{95}$

Essa administração global em que se dá a atividade regulatória transnacional e de onde emanam produtos regulatórios dirigidos aos diversos atores, estatais ou não, e

91 “...much of global governance can be understood and analyzed as administrative action: rulemaking, administrative adjudication between competing interests, and other forms of regulatory and administrative decision and management." (tradução nossa). KINGSBURY, KRISCH, STEWART, 2005, p. 17

92 KINGSBURY, B.; KRISCH, S.; STEWART, R. The Emergence of Global Administrative Law. Law and Contemporary Problems, v. 68,2005 , p. 18

93 KINGSBURY, B.; KRISCH, S.; STEWART, R. The Emergence of Global Administrative Law. Law and Contemporary Problems, v. 68,2005 , p. 28

94 KINGSBURY, B.; KRISCH, S.; STEWART, R. The Emergence of Global Administrative Law. Law and Contemporary Problems, v. 68,2005 , p. 42

95 KINGSBURY, B.; KRISCH, S.; STEWART, R. The Emergence of Global Administrative Law. Law and Contemporary Problems, v. 68 , p. $15-61,2005$, p. 23 
destinados a serem aplicados, diretamente ou por implementação estatal, não é nem única nem centralizada.

Pelo contrário, a paisagem da administração transnacional global é marcada pela variedade. E é importante notar que, para essa literatura, a paisagem variada não resulta apenas da variedade de temas e áreas e da diferenciação funcional entre instituições correlata, mas também do caráter multifolhas da administração da governança global. ${ }^{96}$

Especialmente interessante é a lista de tipos de instância em que se realizam as ações administrativas, em que se dá a atividade regulatória, assim como a tomada de decisões para o controle e implementação das normas.

São mencionados cinco tipos. O primeiro é o da administração propriamente internacional realizada pelas instâncias criadas por direito internacional público; dá-se como exemplo a atuação do Conselho de Segurança das Nações Unidas. ${ }^{97}$

O segundo tipo é aquele operado por redes transnacionais e arranjos de coordenação entre Estados ou entes estatais; ${ }^{98}$ o exemplo aqui usado é o do Comitê da Basiléia que, através de regulação de implementação voluntária, organiza as atividades do setor bancário. ${ }^{9}$

O terceiro tipo é o produto da atuação administrativa distribuída, ou seja, operada pelos reguladores nacionais e com efeitos cumulativos e possivelmente extra territoriais. ${ }^{100}$

96 Sobre isso, vale ressaltar as ideias de SLAUGHTER, 2003, p. 9 "(...)it is possible to identify three different types of transnational regulatory networks, based on the different contexts in which they arise and operate. First are those networks of national regulators that develop within the context of established international organizations. Second are networks of national regulators that develop under the umbrella of an overall agreement negotiated by heads of state. And third are the networks that have attracted the most attention over the past decade - networks of national regulators that develop outside any formal framework."

97 KINGSBURY, B.; KRISCH, S.; STEWART, R. The Emergence of Global Administrative Law. Law and Contemporary Problems, v. 68,2005 , p. 21

98 KINGSBURY, B.; KRISCH, S.; STEWART, R. The Emergence of Global Administrative Law. Law and Contemporary Problems, v. 68,2005 , p. 21

99 " (...) the Basle Committee brings together the heads of various central banks, outside any treaty structure, so they may coordinate on policy matters like capital adequacy requirements for banks. The agreements are non-binding in legal form but can be highly effective." KINGSBURY, KRISCH, STEWART, 2005, p. 21 100 KINGSBURY, B.; KRISCH, S.; STEWART, R. The Emergence of Global Administrative Law. Law and Contemporary Problems,
O quarto tipo é produzido por arranjos híbridos em que participam entes estatais e privados; ${ }^{101}$ o exemplo usado para ilustrar esse tipo é o Codex Alimentarius ${ }^{102}$

E, finalmente, o quinto tipo é aquele da ação administrativa operada pelos entes privados diretamente; ${ }^{103} \mathrm{O}$ exemplo usado é o do ISO. ${ }^{104}$

Perceba-se, olhando para os tipos, que, segundo essa literatura, pode-se falar de regulação ainda quando o seu produtor são instituições do direito internacional público. Isso marca o fato de que, ainda que produzida por Estados ou por organizações intergovernamentais, a produção é algo diferente do direito internacional que se encontra nos tratados e nos costumes, ainda que possa ser constituída de normas que determinam o comportamento, inclusive dos Estados.

Qualquer um dos cinco tipos de atividade regulatória global dá lugar a todo um universo passível de estudos, um universo que seria fundamentalmente dependente de estudos de casos concretos. Qualquer teoria geral dependeria desse material empírico, o que explica, de fato, que deem lugar a pesquisas de fôlego que tentam dar conta das manifestações concretas dos problemas e das tendências regulatórias.

O próprio projeto Global Administrative Law, gera continuamente estudos mais específicos. Além dele, é possível mencionar também o projeto Transnational Private Regulation ${ }^{105}$ e o Informal International Law Making. ${ }^{106}$

Faço em seguida uma rápida discussão do primeiro desses projetos apenas, por duas razões básicas. A primeira delas é que, de todos os tipos de regulação con-

v. 68,2005 , p. $21-22$

101 KINGSBURY, B.; KRISCH, S.; STEWART, R. The Emergence of Global Administrative Law. Law and Contemporary Problems, v. 68,2005 , p. 22

102 "O Codex Alimentarius (do latim Lei ou Código dos Alimentos) é uma coletânea de normas alimentares adotadas internacionalmente e apresentadas de modo uniforme." Disponível em: http:/ / www.anvisa.gov.br/divulga/public/alimentos/codex_alimentarius.pdf 103 KINGSBURY, B.; KRISCH, S.; STEWART, R. The Emergence of Global Administrative Law. Law and Contemporary Problems, v. 68 , p. $15-61,2005$, p. $22-23$

104 (...)the private International Standardization Organization (ISO) has adopted over 13,000 standards that harmonize product and process rules around the world. (...)The ISO provides a good example: not only do its decisions have major economic impacts, but they are also used in regulatory decisions by treaty-based authorities such as the WTO." KINGSBURY, KRISCH, STEWART, 2005 , p. $22-23$

105 Sobre o projeto, acessar http://privateregulation.eu/

106 Sobre o projeto, acessar: http://nilproject.org/ 
cebidos por aqueles que trabalham com o espaço regulatório global, a regulação privada é justamente aquela que escapa em maior medida à atuação e à influência dos Estados e, por isso mesmo, apresenta os maiores desafios para as noções usuais de regulação. A segunda razão está em que o projeto é, operando através do estudo de casos concretos de regulação privada, oferece um quadro mais completo do panorama regulatório.

\subsection{Regulação Privada Transnacional}

A noção de regulação privada transnacional é objeto de um projeto contínuo de pesquisa que se desenvolve sob os auspícios do HIIL e já deu lugar à produção de uma abundante literatura. ${ }^{107}$ Essa literatura constitui o referencial na matéria.

Parte-se da constatação de que o que se poderia chamar de função regulatória sofre um duplo processo de deslocamento: do nacional para o transnacional e do público para o privado. Ou seja, a regulação, que era pensada como fenômeno essencialmente doméstico, intraestatal, e decorrente da atividade do próprio Estado, passa gradualmente a ser um fenômeno internacional ou, na preferência dos seus autores, transnacional, e de produção por atores privados.

É evidente que nem a regulação nacional nem aquela pública desaparecem, mas, em circunstâncias cada vez mais numerosas, haverá essa passagem de um nível a outro ou a flutuação entre eles. Tanto uma como outra coisa dependerão da temática, do objeto da regulação e das circunstâncias.

Regulação privada transnacional é assim definida: "um novo corpo de regras, práticas e processos, criado primariamente por atores privados, empresas, ONGs, especialistas independentes, tais como aqueles que determinam padrões técnicos, e comunidades epistêmicas, ou exercendo poderes regulatórios autônomos ou implementando poder delegado, conferido pelo direito internacional ou pela legislação nacional." ${ }^{108}$

107 Publicações disponíveis em: http://privateregulation. eu/?page_id $=30$

108 “... a new body of rules, practices, and processes, created primarily by private actors, firms, NGOs, independent experts like technical standard setters and epistemic communities, either exercising autonomous regulatory powers or implementing delegated power, conferred by international law or by national legislation." CAFAGGI, F. New Foundations of Transnational Private Regulation. EUI Working Papers, 2010., p. 20-21
O espaço da regulação transnacional é visto por essa literatura como composto por uma pluralidade de regimes dedicados a setores diversos das relações sociais. ${ }^{109}$ Esse fato é ilustrado pela discussão que faz em torno da fragmentação do direito internacional público.

Sustenta-se que naquele sistema jurídico o chamado soft law tenha uma função de coordenação entre os vários regimes. ${ }^{110}$ Já na regulação privada transnacional, em contraste, haveria mais fragmentação e competição do que harmonização entre os regimes. ${ }^{111}$ Alguns exemplos são aportados para ilustrar essa competição, entre os quais estariam os regimes da responsabilidade social das empresas, do meio ambiente, da segurança alimentar.

Marca-se, no projeto, a existência de diferenças importantes entre a regulação privada transnacional e o que se chama de regulação privada tradicional: a primeira teria uma ênfase regulatória, e é a esse aspecto que eu dava ênfase acima; na regulação transnacional, haveria também uma variação na identidade dos atores, muitas vezes organizações não governamentais; e, finalmente, ela poderia produzir relevantes efeitos sobre terceiros.

É preciso insistir na importância desses elementos diferenciadores, já que todos eles tendem a marcar o caráter de regulação tal como entendida antes, incidindo sobre o espaço e os interesses públicos e podendo ser inclusive heteronormativa, o ente privado regulado não coincidindo com o ente privado regulador. ${ }^{112}$ Essas marcas inscrevem a regulação privada entre as manifestações do espaço regulatório global. Elas nos informam igualmente sobre o fato de que ainda há regulação de outros tipos, pensada, portanto, com um significado diferente, para além desse universo. $\mathrm{O}$ quadro que traçamos aqui não inclui, assim, por exemplo, a autorregulação ou a regulação privada tradicionais.

Os atores da regulação privada transnacionais podem se encontra em três situações diversas: a de regulador, a de regulado e de beneficiário. ${ }^{113} \mathrm{E}$ a grande variedade de atores envolvidos dá lugar a uma grande

109 CAFAgGI, F. New Foundations of Transnational Private Regulation. EUI Working Papers, 2010, p.8

110 CAFAgGI, F. New Foundations of Transnational Private Regulation. EUI Working Papers, 2010, p. 10

111 CAFAGGI, F. New Foundations of Transnational Private Regulation. EUI Working Papers, 2010, p.4

112 CAFAgGi, F. New Foundations of Transnational Private Regulation. EUI Working Papers, 2010, p.9 e p.13-14

113 CAFAgGI, F. New Foundations of Transnational Private Regulation. EUI Working Papers, 2010, p.13-14 
variedade de regulações que entram em competição. ${ }^{114}$ Por vezes essa variedade origina a formação de organizações multi-stakeholder. ${ }^{115} \mathrm{E}$ sempre há o potencial para tensões entre atores de mesma ou diversas categorias: ONGs, grandes e pequenas empresas, consumidores, trabalhadores, ambiental etc. ${ }^{116}$

Perceba-se que também a regulação privada transnacional é pensada considerando as possíveis colisões entre diferentes regimes. O esforço de descrição que é feito, no entanto, levanta também a possibilidade de tensões internas aos regimes, opondo os atores por eles implicados.

Dos temas, dos atores e das dinâmicas que determinam as suas relações, resultará o tipo de regulação privada, que pode ser voluntária, promovida ou obrigatória, e a sua estrutura, que pode ser contratual, organizacional ou uma que combine elementos das duas. ${ }^{117}$ Quando a estrutura é contratual pode ser constituída por contratos bilaterais (supply chain) ou multilaterais. ${ }^{118}$ Quando é organizacional, pode atender a um modelo associativo ou fundacional. ${ }^{119}$

É muito importante notar que os vários regimes dessa regulação privada transnacional vão surgindo e se multiplicando, em grande medida, como respostas da autonomia privada aos desafios e necessidades regulatórias. Justamente por isso, não estão inseridos num todo que lhes ofereça uma moldura coerente ou unitária. Muito frequentemente, no entanto, estabelecem relações de complementaridade com a regulação pública e veem o direito doméstico operar um preenchimento das lacunas.

\subsection{Mais uma vez, a questão dos limites}

Como mencionado antes, nos regimes regulatórios transnacionais em geral, e naqueles privados em particular, o problema da sua delimitação se coloca com

114 CAFAGGI, F. New Foundations of Transnational Private Regulation. EUI Working Papers, 2010, p.8

115 C CAFAGGI, F. New Foundations of Transnational Private Regulation. EUI Working Papers, 2010, p.11

116 CAFAgGI, F. New Foundations of Transnational Private Regulation. EUI Working Papers, 2010, p.8-9

117 CAFAGGI, F. New Foundations of Transnational Private Regulation. EUI Working Papers, 2010, p.11-14

118 CAFAGGI, F. New Foundations of Transnational Private Regulation. EUI Working Papers, 2010, p. 13

119 CAFAGGI, F. New Foundations of Transnational Private Regulation. EUI Working Papers, 2010, p. 11 igual ou maior força do que acontecia com os regimes do direito internacional público.

Aqui também, quanto mais amplamente se conceber o tema de preocupação, mais imprecisos serão os limites do conjunto de normas que com ele lidam e menos útil será a noção mesma de regime. Aqui também, a delimitação será mais factível na medida em que se puder circunscrever o regime a uma organização específica ou a uma rede particular de contratos.

Como no direito internacional público, obter uma caracterização mais bem delimitada dos regimes na regulação transnacional, privada ou outra, depende da determinação das relações que as normas estabelecem entre si e das competências, estrutura e funcionamento das organizações. $\mathrm{O}$ fato de as normas e instituições lidarem com este ou aquele tema pode ser visto como mero acidente, ou como uma preocupação originária, já que certamente haverá vários regimes, definidos a partir da instituição ou do conjunto específico de normas (ou de contratos, no caso da regulação privada), que se ocupem com um mesmo tema.

Quanto mais amplamente se conceber o regime, e quanto mais se quiser acompanhar a grandeza do tema, mais certo será o encontro da imbricação entre as normas e instituições dos vários tipos de regulação e aquelas do direito internacional e dos direitos domésticos. Essas imbricações podem ser de conflito, é verdade, mas é usual que sejam de complementaridade, de referências cruzadas, de incorporação mútua etc.

\section{Fragmentação, Pluralismo e Rule of Law}

\subsection{Fragmentação do direito internacional pú- blico e Rule of Law}

Os mesmos traços do direito internacional que dão lugar à sua fragmentação, de que a constituição dos chamados regimes autocontidos seria apenas uma das manifestações, são determinantes em fazer do direito internacional um sistema jurídico menos propenso ao rule of law. A fragmentação do direito internacional é, de fato, um dos óbices ao estabelecimento de um alto grau de rule of law. ${ }^{120}$

120 NASSER, S. H. Rule of Law e Direito Internacional: uma nova 
Duas ideias fortes, ao menos, são usualmente postas em relação com o conceito, a noção, o ideal, de rule of law. Uma é que do axioma de que as interações sociais deveriam ser governadas pelo direito resulta que as normas jurídicas deveriam ser conhecidas, claras, públicas, abertas etc. A outra é que o objetivo do ser governado pelo direito é a redução do espaço de arbitrariedade. ${ }^{121}$

Como se sabe, a fragmentação do direito internacional não é apenas um fenômeno natural, dadas as características específicas desse sistema jurídico, mas se relaciona intimamente com a expansão normativa do sistema. Novos conjuntos de normas constituem novos fragmentos, e estes serão mais numerosos na medida em que as normas continuam a se multiplicar.

Nessas condições, conhecer as normas pelas quais o comportamento e as interações sociais deveriam ser governadas se transforma em exercício mais complexo já que em direito internacional é relativamente mais difícil saber quem está obrigado por qual norma. Em um caso particular, com um conjunto específico de fatos e com uma ou um número certo de questões jurídicas claras, decidir se os sujeitos em questão estão obrigados pelas normas aplicáveis, é exercício mais factível.

No entanto, olhando para o sistema jurídico como um todo, conhecer as normas pelas quais o comportamento dos sujeitos é, em geral, regulado, revela-se uma tarefa mais difícil, porque o comportamento de cada sujeito é, na verdade, governado por um conjunto, pessoal, se quisermos, de normas - que pode coincidir, assemelhar-se ou diferir radicalmente dos conjuntos normativos correspondentes a cada um dos demais sujeitos - e porque não há uma necessária coerência entre normas pertencentes ao conjunto que obriga um Estado ou entre normas pertencentes a conjuntos setoriais diversos.

A multiplicação das normas poderia por si só ser vista como um movimento em direção a mais rule of law já que mais da vida estaria sendo governado pelo direito. Isto, no entanto, só pode ser verdade se o volume normativo jurídico aumentado não trouxer consigo a dimi-

aproximação. In: VILHENA, OSCAR; DIMOULIS, D. (Ed.). Estado de Direito e o Desafio do Desenvolvimento. 1. ed. São Paulo: Saraiva, 2011, p. 70.

121 Uma discussão mais abrangente sobre as diferentes concepções de rule of law pode ser encontrada em NASSER, S. H. Rule of Law e Direito Internacional: uma nova aproximação. In: VILHENA, OSCAR; DIMOULIS, D. (Ed.). Estado de Direito e o Desafio do Desenvolvimento. 1. ed. São Paulo: Saraiva, 2011, p. 59-66. nuição da clareza com que se pode saber por quais normas o comportamento de cada sujeito está governado. Essa clareza significa saber quais são as normas, quais os seus destinatários, quais os conteúdos normativos, quando se aplicam e como se relacionam com outras normas.

Não há dúvida de que mais aspectos das relações internacionais entre Estados estão agora submetidos à regulação normativa, jurídica, e, nesse sentido, mas apenas nesse sentido, há uma redução do espaço para o exercício arbitrário do poder por e entre os Estados.

Esse aumento das normas é, no entanto, acompanhado pela dupla fragmentação do direito internacional, em parte devida à diferenciação setorial e em parte constitutiva da natureza do sistema jurídico. Essa dupla fragmentação torna mais difícil a resposta à questão sobre quem está submetido a que normas e quem tem que obrigações e que direitos. Também dificulta o exercício de estabelecer o conteúdo normativo, não apenas das normas particulares, que podem ser menos claras ou mais lacunosas, mas aquele resultante da possibilidade de haver normas contraditórias contemporaneamente obrigatórias e aplicáveis.

A multiplicação das normas jurídicas e a dupla fragmentação representam uma maior complexidade do sistema jurídico internacional. E a maior complexidade amplia o fosso entre atores, Estados, que estão mais bem equipados para lidar com ela e aqueles a quem faltam os meios para fazê-lo.

Essas diferenças nas capacidades para gerenciar complexidade colocam o problema da igualdade dos Estados perante o direito internacional. Não se trata daquela, formal, de acordo com a qual, os Estados, sendo soberanos, podem escolher por quais normas serão obrigados, e também segundo a qual, diante da norma individual, só serão desiguais na medida em que essa desigualdade decorrer de uma escolha soberana.

Trata-se antes daquela igualdade em relação ao sistema jurídico como um todo, uma igualdade que está relacionada à inclusão e à exclusão efetiva dos Estados da constituição, do gerenciamento e da possibilidade de transformação da ordem jurídica.

A complexidade, e a decorrente desigualdade, pode efetivamente excluir os Estados do processo de criação normativa quando, ainda que formalmente partícipes e aptos a expressar sua voz, estão incapacitados para 
construir uma vontade informada e eficaz.

O mesmo pode se dar no processo de identificação das normas e da determinação de que se é ou não se é obrigado, ou seja, da determinação do conteúdo normativo.

Finalmente, a complexidade funciona como barreira à participação efetiva no gerenciamento das diferentes normas jurídicas, especialmente no caso de haver conflitos entre elas, competências distribuídas entre diversas instituições e instâncias múltiplas de tomada de decisões.

\subsection{Regulação e indicadores de Rule of Law}

Aqui, é claro, poder-se-ia falar igualmente das duas ideias ou dos dois princípios relacionados ao rule of law: a possibilidade de saber o que diz o direito ou a regulação - ou seja, saber qual é o comportamento prescrito - e a necessidade de limitar o exercício arbitrário do poder.

Como aqui se trata de conjuntos regulatórios que concentram ou colocam em relação, potencialmente, normas pertencentes ao direito internacional público, pertencentes a um ou mais direitos domésticos e aquelas que não são jurídicas ou não pertencem a qualquer desses sistemas mais claramente reconhecíveis, a avaliação da qualidade do conjunto normativo depende, em parte, mas apenas em parte, da qualidade dos sistemas jurídicos domésticos eventualmente envolvidos e da qualidade acima discutida do direito internacional público.

Naquilo em que não depende da qualidade dos direitos domésticos ou do direito internacional, essa qualidade só pode ser avaliada no caso-a-caso.

Mas será possível falar de qualidade ou de grau de rule of law quando se fala de regulação no sentido em que apareceu acima, e em relação a cada um dos seus tipos básicos de manifestação? Ou seja, como se avalia a qualidade da regulação criada por redes transnacionais, quer sejam públicas, privadas ou híbridas?

Quando lida com a noção geral de governança o com tipos específicos de regulação, a literatura tende a apoiar-se em noções como legitimidade, transparência, accountability, participação, para avaliar ou para colocar os critérios normativos para a qualidade da regulação.
Nenhuma conclusão geral parece ser facilmente acessível, senão que alguns conjuntos regulatórios podem refletir a inclusão de e a participação de atores concernidos - stakeholders- no processo de criação de normas e na avaliação a posteriori das normas, tornando possível uma maior aderência e melhores chances de efetividade para as normas, assim como para seu contínuo desenvolvimento. Outros conjuntos regulatórios podem, ao contrário, refletir as desbalanceadas relações de poder.

É justamente com base no diagnóstico de que se pode verificar um déficit de accountability e de legitimidade no espaço regulatório global, déficit que atinge tanto a ação de atores nacionais com efeitos extraterritoriais, quanto a ação dos reguladores transnacionais, que a literatura a que me referi antes enxerga a necessidade e o começo da emergência de um direito administrativo global.

Esse direito administrativo pode decorrer de mecanismos nacionais que se estendam para a esfera transnacional ou estará contido em mecanismos que são eles mesmos transnacionais. Ele compreenderia "mecanismos, princípios, práticas e entendimentos sociais subjacentes que promovem ou afetam de outro modo a accountability de entes administrativos globais, particularmente assegurando que atinjam padrões adequados de transparência, participação, decisões motivadas e legalidade, e fornecendo revisão efetiva das regras e decisões por eles feitas". ${ }^{122}$

\section{REFERÊNCIAS}

ABBOT'T, K. W.;SNIDAL D. Strengthening International Regulation through Transnational New Governance: Overcoming the Orchestration Deficit. Vanderbilt Journal of Transnational Law, p. 1-69, 2009.

ABI SAAB, G. Fragmentantion or Unification: Some Concluding Remarks. NYU Journal of International Law and Policy, v. 31, p. 919-933, 1998.

BARTLEY, T. Institutional Emergence in an Era of Globalization: The Rise of Transnational Private Regulation of Labor and Environmental Conditions. Ameri-

122 KINGSBURY, B.; KRISCH, S.; STEWART, R. The Emergence of Global Administrative Law. Law and Contemporary Problems, v. 68, p. $15-61,2005$, p. 17. 
can Journal of Sociology, v. 113, n. 2, p. 297-351, 2007. BENVENISTI, E.; DOWNS, G. W. National Courts Review of Transnational Private Regulation. n. 2003, p. 1-18, 2005. (working paper) Disponível em: http://papers.ssrn.com/sol3/papers.cfm?abstract_id $=1742452$.

BÖRZEL, T. A.;HEARD-LAURÉOTE, K. Networks in EU Multi-level Governance: Concepts and Contributions. Journal of Public Policy, v. 29, n. 02, p. 135-151, 2009.

BRASIL. Superior Tribunal Federal. Arguição de Descumprimento de Preceito Fundamental no. 101 (ADPF-101). Portaria DECEX N. 8. Proibição de Pneus Usados. Relatora: Ministra Carmem Lúcia. DF 21.09.2006.

CAFAGGI, F. New Foundations of Transnational Private Regulation. EUI Working Papers. p. 1-40, 2010.

CAROTTI, B.; SAVINO, M. Global Administrative Law: cases, materials, issues. New York University School of Law, 2008. Disponível em: http://iilj.org/ GAL/documents/GALCasebook2008.pdf.

CASSESE, S. Global Administrative law: An Introduction. Anais da IIJL Conference. 2005. Disponível em: http://www.iilj.org/GAL/documents/GALCasebookBibliography.pdf.

CHESTERMAN, S. Global Administrative Law. Working Paper for the S.T. Lee Project on Global Governance. 2009 .Disponível em: http://www.ssrn.com/ abstract $=1435170$.

CIJ. Case Concerning Military And Paramilitary Activities in and Against Nicaragua (Nicaragua v. United State of America), Mérito, 1986, \$172). Disponível em: http://www.icj-cij.org/docket/index.php?sum $=367 \& c$ ode $=$ nus\&p1 $=3 \& \mathrm{p} 2=3 \&$ case $=70 \& \mathrm{k}=66 \& \mathrm{p} 3=5$.

COMISSÃO Europeia - Assuntos Legais, Sumário de Sentenças importantes, Caso C-459/03 (Comissão v. Irlanda), 2006.

CPA. Caso MoxPlant, (Irlanda v. Reino Unido), Ordem no. 1 - Ireland's Amended Statement of Claim, 2002.

CPA. Caso Mox Plant, (Irlanda v. Reino Unido), Ordem no. 4 - Outras Suspensões de Jurisdição e Mérito, 2003.

CPA. Caso Mox Plant, (Irlanda v. Reino Unido), Ordem no. 4 - Outras Suspensões de Jurisdição e Mérito, 2003.

CPA. Caso Mox Plant, (Irlanda v. Reino Unido), Ordem no. 5 - Suspensão dos Relatórios Periódicos pelas Partes, 2007.

CPA. Caso Mox Plant, (Irlanda v. Reino Unido), Ordem no. 6 - Fim dos Procedimentos, 2008.

CPA. Caso Mox Plant, (Irlanda v. Reino Unido), Ordem No. 3 - Suspensão dos Procedimentos de Jurisdição e Mérito, e Pedidos de Medidas Cautelares, 2003.

CPA. Caso Mox Plant, (Irlanda v. Reino Unido), Ordem no. 2 - Tempo Limite para Submissões e pedidos, 2002.

DANN, P.; GOLDMANN, M.; BOGDANDY, A.. Developing the Publicness of Public International Law : Towards a Legal Framework for Global Governance Activities. German Law Journal, v. 9, n. 11, p. 13751400, 2007.

DAVIS, D.; CORDER, H. Globalization, National Democratic Institutions and the Impact of Global Regulatory Governance on Developing Countries. Acta Juridica, v. 09 , p. 68-89, 2009.

Dicionário PRIBERAM de Língua Portuguesa Online. Disponível em: http://www.priberam.pt/dlpo/default. aspx?pal $=$ regula $\%$ u00e $7 \%$ u00e 3 o.

DUPUY, P.-M. A Doctrinal Debate in the Globalization Era: On the "Fragmentation" of International Law. European Journal O Legal Studies, v. 1, n. 1, p. 1-20, 2007.

ESTY, D. C. Good Governance at the Supranational Scale: Globalizing Administrative Law. The Yale Law Journal, v. 115, n. 7, p. 1490-1562, 2011.

FISHER-LESCANO, ANDREAS; TEUBNER, G. Regime-Collisions? The Vain Search for Legal Unity in the Fragmentation of Global Law. Michigan Journal of International Law, v. 25, p. 999-1046, 2004.

FORNASIER, Mateus de O.; FERREIRA, Luciano V. A regulação das empresas transnacionais entre as ordens jurídicas estatais e não estatais. Revista de Direito Internacional, v. 12, n.1, 2015

GIFIS, Steven H. BARRON'S LAW DICTIONARY.

GONTIJO, André P. Os Caminhos Fragmentados da Proteção Humana: o peticionamento individual, o conceito de vítima e o amicus curiae como indicadores do acesso aos sistemas interamericano e europeu de proteção aos direitos humanos. Revista de Direito Internacional, v. 9, n.1, 2012.

HAFNER, G. Pros and Cons Ensuing from Fragmen- 
tation of International Law. Michigan Journal of International Law, v. 25, p. 849-863, 2004.

HALBERSTAM, D. Local, Global and Plural Constitutionalism: Europe meets the world. 2009. (working paper) Disponível em: http://ssrn.com/abstract $=1521016$.

HANSENCLEVER, A.; MAYER, P.; RITTBERGER, V. Theories of international regimes. Cambridge: Cambridge University Press, 1997.

HARLOW, C. Global Administrative Law: The Quest for Principles and Values. European Journal of International Law, v. 17, n. 1, p. 187-214, 2006.

HART, H. L. A.O conceito de direito.São Paulo: Martins Fontes, 2012.

HOOGHE, LIESBET; MARKS, G. Unraveling the Central State, but How? Types of Multi-Level Governance. The American Political Science Review, v. 97, n. 2, p. 233-243, 2003.

HOUAISS, Antônio e VILLAR, Mauro Salles. Rio de Janeiro: Objetiva, 2001, p. 2418.

JACKSON, J. H. Fragmentation or Unification Among International Institutions: The World Trade Organization. New York Journal of International Law and Politics, v. 31, p. 823-831, 1999.

KELSEN, H. A Teoria Pura do Direito. São Paulo: Martins Fontes, 2009.

KEYNES, J. M.; LEO, C. Multi-Level Governance and Ideological Rigidity : The Failure of Deep Federalism. Canadian Journal of Political Science, v. 42, n. 1, p. 93116, 2009.

KINGSBURY, B. The Concept of "Law" in Global Administrative Law. European Journal of International Law, v. 20, n. 1, p. 23-57, 2009.

KINGSBURY, B.. Co-Option and Resistance : Two Faces of Global Administrative Law. New York University Journal of International Law and Politics, v. 38, p. 799 827, 2005.

KINGSBURY, B.; KRISCH, S.; STEWART, R. The Emergence of Global Administrative Law. Law and Contemporary Problems, v. 68, 2005, p. 18.

KINGSBURY, B.; KRISCH, S.; STEWART, R.; WIENER, J.B.. Global Governance as Administration-National and Transnational Approaches to Global Admi- nistrative law. Law and Contemporary Problems, v. 68, n. 3-4, p. 1-13, 2005.

$\mathrm{KOCH}, \mathrm{C} . \mathrm{H}$. Globalization of Administrative and Regulatory Practice. Administrative Law Review, v. 54, n. 1, p. 409-414, 2002.

KOSKENNIEMI, M. Global Legal Pluralism: Multiple Regimes and Multiple Modes of Thought. Palestra proferida em Harvard em 5 de março de 2005.

KOSKENNIEMI, M.; LEINO, P. Fragmentation of International Law? Leiden Journal of International Law, v. 14, n. 3, p. 553-579, 2002.

KOSKENNIEMI, Martti. Study on the Function and Scope of the lex specialis Rule and the Question of "Self-Contained Regimes, Preliminary Report by Martti Koskenniemi, Chairman of the Study Group of the ILC. Maio de 2004, p. 9.

KRASNER, S. Structural causes and regime consequences: regimes as intervening variables. In: KRASNER, S. (Ed.). International Regimes. Ithaka/London: Cornell University Press, 1983.

KRASNER, Stephen D (ed.). International Regimes. Ithaca: Cornell University Press, 1983.

KRISCH, N. Global Administrative Law and the Constitutional Ambition. Law, Society Economy Working Papers. 2009. Disponível em: http:/ /www.lse.ac.uk/collections/law/wps/WPS2009-10_Krisch.pdf.

KRISCH, N. Introduction: Global Governance and Global Administrative Law in the International Legal Order. European Journal of International Law, v. 17, n. 1, p. 1-13, 2006.

KRISCH, N. The Pluralism of Global Administrative Law. European Journal of International Law, v. 17, n. 1, p. 247-278, 2006b.

KUO, M.-S. The Concept of "Law" in Global Administrative Law: A Reply to Benedict Kingsbury. European Journal of International Law, v. 20, n. 4, p. 997-1004, 2010.

LIMA, Gabriela G. B. Conceitos de relações internacionais e teoria do direito diante dos efeitos pluralistas da globalização: governança global, regimes jurídicos, direito refexivo, pluralismo jurídico, corregulação e autorregulação. Revista de Direito Internacional, v.11, n.1, 2014.

MARKS, S. Naming Global Administrative Law. New York Journal of International Law and Politics, v. 95, p. 
995-1002, 2005.

MARTINEAU, A.-C. The Rhetoric of Fragmentation: Fear and Faith in International Law. Leiden Journal of International Law, v. 22, n. 01, p. 1, 2009.

MCLEAN, J. Divergent Conceptions of the State: Implications for Global Administrative Law. Law and Contemporary Problems, v. 68, n. 3, p. 167-187, 2005.

MERCOSUL. Criação do grupo ad hoc para uma política regional sobre pneus, inclusive reformados e usados GAHP ( MERCOSUL/GMC EXT/RES. No 25/08), 29.06. 2008; CAMEX, Resolução no. 38, 22.10.2007.

MERCOSUL. Tribunal Arbitral - Laudo Arbitral de las presentes actuaciones ante este Tribunal Arbitral relativas a la controversia entre la República Oriental del Uruguay (Parte Reclamante, em adelante "Uruguay") y la República Federativa del Brasil (Parte Reclamada, enadelante "Brasil") sobre "Prohibición de Importación de Neumáticos Remoldeados (Remolded) Procedentes de Uruguay, 2006.

MICHAELIS: Moderno Dicionário da Língua Portuguesa. São Paulo: Companhia Melhoramentos, 1998, p. 1804.

MICHAELS, R. The Mirage of Non-State Governance. Utah Law Review, v. 63, p. 1-15, 2010;

NASSER, S. H. Fontes e Normas do Direito Internacional: Um Estudo sobre a Soft Law. 2a. ed. São Paulo: Editora Atlas, 2006.

NASSER, S. H. Rule of Law e Direito International: uma nova aproximação. In: VILHENA, OSCAR; DIMOULIS, D. (Ed.). Estado de Direito e o Desafio do Desenvolvimento. 1. ed. São Paulo: Saraiva, 2011.

OMC, Brasil - Measures Affecting Imports of Retreaded Tyres, Status Report by Brazil, Notification of an Appeal by the European Communities under Article 16.4 and Article 17 of the Understanding on Rules and Procedures Governing the Settlement of Disputes (DSU), and under Rule 20(1) of the Working Procedures for Appellate Review, 2007, (WT/DS332/9).

OMC. Brasil - Measures Affecting Imports of Retreaded Tyres, Status Report by Brazil, 2009 (WT/ DS332/19).

OMC. Brasil - Measures Affecting Imports of Retreaded Tyres., 2008 (WT/DS332/16).

PIATTONI, S. Multi-level Governance: a Historical and Conceptual Analysis. Journal of European Integration, v. 31, n. 2, p. 163-180, 2009.

RAZ, Joseph.O conceito de sistema jurídico:uma introdução à teoria dos sistemas jurídicos. São Paulo: Martins Fontes, 2012

RELATÓRIO da Comissão de Direito Internacional, 2006.

SALAMA, R. Fragmentation of International Law: Procedural Issues Arising of the Sea Disputes.

SANCHEZ, M. R. The Global Administrative Law Project : A review from Brazil. Artigos Direito GV, v. 38, p. 1-14, 2009.

SCHMIDT-ASSMAN, B. E. The Internationalization of Administrative Relations as a Challenge for Administrative Law Scholarship. German Law Journal, v 9, n. 11, 2006.

SHAPIRO, M. Administrative Law Unbounded: Reflections on Government and Governance. Indiana Journal of Legal Studies, v. 8, n. 2, p. 369-377, 2001.

SIMMA, B. Fragmentation in a Positive Light. Michigan Journal of International Law, v. 25, p. 845-847, 2012.

SLAUGHTER, A-M. Everyday Global Governance. Research Library Core, v. 132, n. 1, p. 83-90, 2003.

TCE. Comissão da Comunidade Europeia v. Irlanda, Caso C-459/03, 2006.Disponível em: http:// eurlex.europa.eu / LexUriServ / LexUriServ. do?uri=CELEX:62003CJ0459:EN:PDF

TCE. Comissão da Comunidade Europeia v. Irlanda, Caso C-459/03, 2006.Disponível em: http:// eur-lex.europa.eu / LexUriServ/LexUriServ. do?uri=CELEX:62003J0459:EN:HTML

TEUBNER, G. Global Bukowina: Legal Pluralism in the World Society. In: TEUBNER, G (Ed.). Global Law in the World Society. Dartmouth, Aldershot, 1997. p. 3-28;

TEUBNER, G. K. P. Two Kinds of Legal Pluralism: Collision of Transnational Regimes in the Double Fragmentation of World Society. In: YOUNG, M. (Ed.). Regime Interaction in International Law: Facing Fragmentation. 1. ed. Cambridge: Cambridge University Press, 2012.

TIDM. Caso Mox Pant. (Irlanda v. Reino Unido), Medidas Cautelares, No. 10, Ordem 2001/3, 2001. Di- 
sponível em: http://www.itlos.org/fileadmin/itlos/ documents/cases/case_no_10/Order.03.12.01.E.pdf

TIDM. Caso Mox Plant. (Irlanda v. Reino Unido), Memorial da Irlanda, Volume 1, 2002, \§ 4.35-4.36.

TIDM. Caso Mox Plant. (Irlanda v. Reino Unido), Medidas Cautelares com base no art. $290 \rrbracket 5^{\circ}$ da Convenção do Mar das Nações Unidas, No. 10, Ordem 2001/5, 2001.

TIDM. Caso Mox Plant. (Irlanda v. Reino Unido), Medidas Cautelares com base no art. 290 \5 da Convenção do Mar das Nações Unidas, No. 10, Ordem 2001/5, 2001.
TRIBUNAL Internacional para Ruanda. Caso Jean Paul, Sentença, 02.10.1998 (Caso No: ICTR - 96 - 4 T). International Tribunal for the Prosecution of Persons Responsible for Serious Violations of International Humanitarian Law Committed in the Territory of the Former Yugoslavia,

TRIBUNAL Penal Internacional para a antiga Iugoslávia. Caso Zlatko Aleksovski, 1999 (Caso no. IT95-14/1-T)

TRUBEK, D. M.; TRUBEK, L. G. New Governance \& Legal Regulation : Complementarity, Rivalry, and Transformation. Columbia Journal of International Law, v. 13, p. 1-26, 2007. 


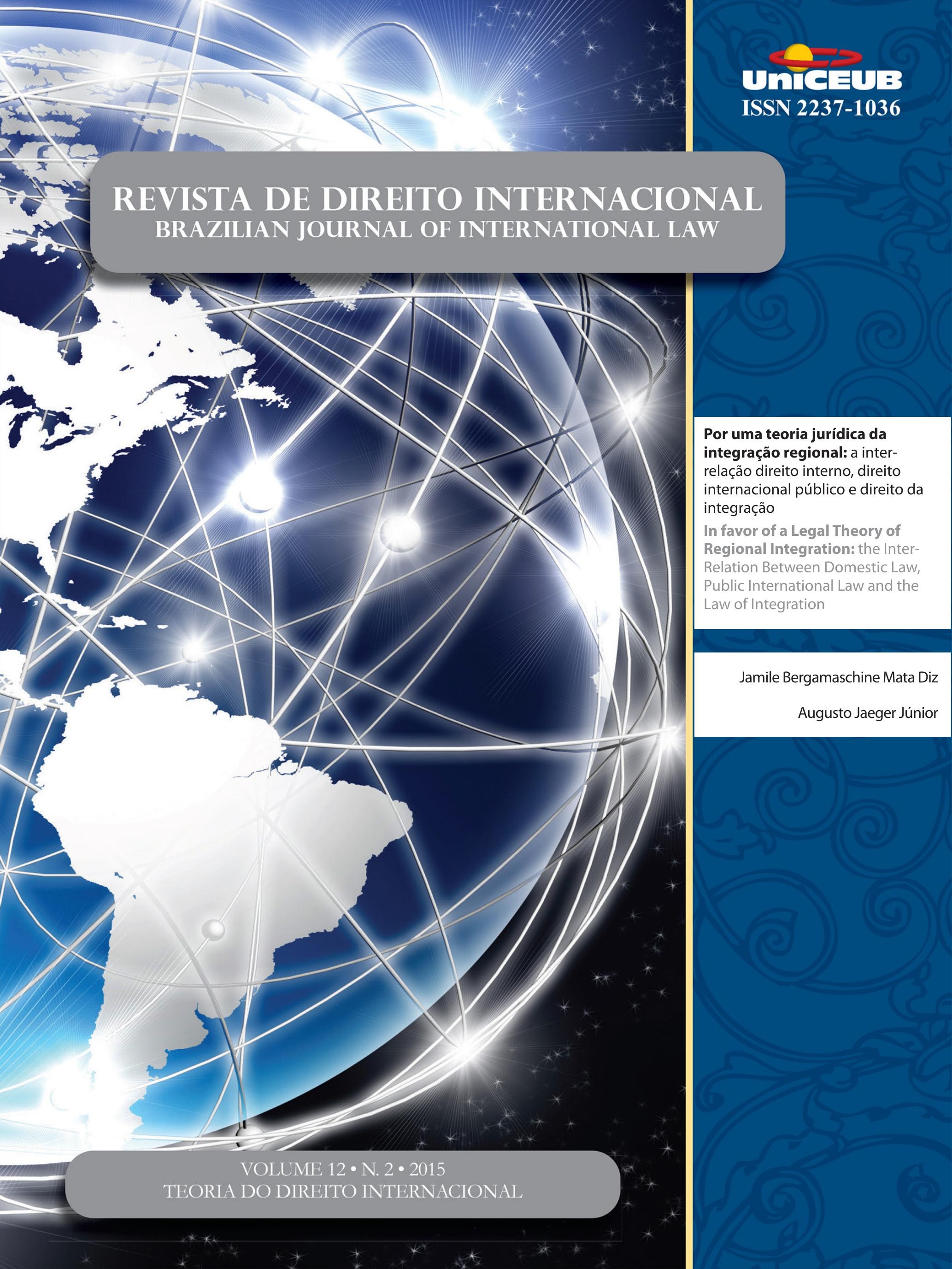




\title{
Por uma teoria jurídica da integração regional: a inter-relação direito interno, direito internacional público e direito da integração*
}

\author{
In favor of a Legal Theory of Regional \\ Integration: the Inter-Relation Between \\ Domestic Law, Public International Law and the \\ Law of Integration
}

Jamile Bergamaschine Mata Diz**

Augusto Jaeger Júnior***

\section{Resumo}

As relações derivadas do processo de integração regional serão analisadas no presente artigo com base na necessidade de formular uma teoria jurídica própria que possa explicar o fenômeno da integração do ponto de vista de método, objeto e fontes próprios. Nesse sentido, o objetivo do presente trabalho será investigar em que medida pode-se determinar a existência de um método específico, de fontes próprias e autônomas, de um objeto predeterminado e de destinatários também singulares que possibilitem verificar a construção e o desenvolvimento de uma teoria jurídica diferenciada dos parâmetros já estabelecidos pelo direito internacional de corte clássico, dado que a análise da integração regional não pode se subjugar aos postulados de um Direito que não explica adequadamente essas novas conformações e blocos. A metodologia utilizada ancorou-se, principalmente, no método indutivo, já que este artigo parte do exame das premissas necessárias para formular uma teoria jurídica da integração fundada na defesa de uma autonomia que o tema merece receber. Conclui-se que o direito da integração utiliza-se dos métodos tradicionais de estudo e pesquisa, bem como de interpretação, ainda que sua aplicação se configure de forma diferenciada, dada a existência de fontes próprias e autônomas. O objeto próprio como elemento da teoria vinculada à presença dos atores estatais também pode ser verificado, especialmente quando analisamos a nova roupagem assumida pelos elementos constitutivos do Estado, com base nas modificações trazidas pela integração regional.

Palavras-chaves: teoria jurídica; direito da integração; direito internacional; União Europeia; Mercosul.

*** Professor Associado da Faculdade de Direito da UFRGS, em Porto Alegre, Brasil, onde leciona as disciplinas de Direito Comunitário e da Integração, Direito Internacional Privado e Direito Internacional Público para a graduação e para a pós-graduação. Bolsista de produtividade em pesquisa do CNPq, Doutor em Direito Comunitário da Concorrência pela UFRGS e Mestre em Direito Internacional pela UFSC. Email: augusto.jaeger@ufrgs.br

\section{Abstract}

The relations derived from the regional integration process are analyzed in this article from the need to formulate its own legal theory that can explain the phenomenon of integration from the point of view of the method, 
object and own sources. In this sense, the objective of this study is to investigate to what extent can determine the existence of a specific method, its own and autonomous sources of a predetermined object and also individual recipients that allow verify the construction and development of a different legal theory of the parameters established by international law classic cut, given that the analysis of regional integration can not subdue the postulates of a right which does not adequately explain these new shapes and blocks. The methodology is anchored mainly on the inductive method, as this study is examining the assumptions necessary to formulate a legal theory of integration based on the defense of autonomy that the subject deserves. We conclude that the right of integration is used from traditional methods of study and research as well as interpretation, although its application is set differently given the existence of own and autonomous sources; the object itself as a theory element linked to the presence of state actors can also be checked, especially when we analyze the new look assumed by the constituent elements of the state, from the changes brought about by regional integration.

Keywords: legal theory; integration law; international law; European Union; Mercosur

\section{INTRODUÇÃo}

A integração regional entendida como a formação de processos de associação interestatais com a finalidade de conformar um sistema comum mediante a convergência de interesses e valores sempre foi objeto de atenção por parte da sociedade e dos acadêmicos das mais diversas áreas. Como tema específico vinculado ao direito internacional, foi pouco a pouco ganhando expressão no âmbito universitário até conformar-se como disciplina autônoma, já que ostenta objeto, métodos e fontes próprios, além de fundamentar-se sobre pressupostos independentes daqueles aplicados pelo direito internacional, conforme será analisado.

A criação de uma comunidade de países que compartam interesses e valores comuns demanda uma análise específica, voltada para o entendimento de questões que não são necessariamente tratadas pelo direito internacional clássico, especialmente quando essa comunidade adota também um sistema normativo e institucional próprio, em que o processo de tomada de decisões realize-se por um esquema completamente diferenciado dos modelos tradicionais existentes, baseados no sistema estatal e, ainda, em que os elementos clássicos da formação do Estado experimentem modificações substanciais, especialmente no que tange ao compartilhamento ou à transferência do exercício de poderes e competências estatais.

A justificativa para o presente trabalho pode ser referendada não somente pela crescente e complexa dimensão da integração regional, merecedora, sem dúvida, de uma teoria própria e autônoma, mas, também, pelo crescente domínio do direito da integração sobre o direito interno.

No momento atual, quando se fala de uma crise da integração à raiz dos problemas gregos, quando alguns anunciam o fim da União Europeia, quando se fala num Mercosul natimorto, quando se questiona a atuação das instituições comunitárias andinas... torna-se importante debruçar-se ainda com maior afinco ao tema, não em vã e estéril tentativa de alçá-lo a uma espécie de redenção e libertação dos fatores políticos e econômicos, mas ao contrário, para entender a integração com base em uma perspectiva jurídica sem isolá-la dos demais aspectos que a compõem; para entender como esse tipo de associação entre Estados resulta numa abordagem diferenciada dos padrões tradicionais; e para defender que a análise da integração regional não possa se subjugar aos postulados de um Direito que não explica, adequadamente, essas novas conformações e blocos. Portanto, o objetivo do presente trabalho será analisar como a integração regional demanda um estudo que leve em consideração as especificidades do processo de associação entre Estados tendentes a conformar um sistema institucional e normativo próprio, diferenciado das organizações internacionais clássicas. O exame se centrará nos elementos teóricos que possam fixar a autonomia do direito da integração face ao direito internacional, devendo o método, o objeto e as fontes constituírem os aspectos principais para que a teoria possa ser formulada. Ainda, os processos de integração analisados serão a União Europeia por encontrar-se em uma etapa mais avançada de integração ao constituir uma união econômica e monetária, e o Mercosul, que conta com a participação do Brasil como Estado-Parte. Portanto, o recorte feito para englobar somente estes dois processos de integração vincula-se ao desenvolvimento das etapas integracionistas conhecidas por ambos os processos. 
A metodologia de trabalho deverá centrar-se nos aspectos principais estabelecidos para uma pesquisa interdisciplinar que envolva temas de direito da integração e de direito internacional, devido, especialmente, ao caráter específico e singular que deve estar presente em toda análise de um sistema jurídico próprio aplicado a um determinado tipo de relação interestatal, como é o caso da formação de processos de integração regional. Nesse sentido, devem-se utilizar métodos que permitam analisar a evolução e desenvolvimento do direito da integração. Os métodos histórico e indutivo permitirão estabelecer as premissas conceituais e práticas aplicadas ao tema escolhido, já que possibilitam os parâmetros necessários para compreender um fenômeno típico do século XX, dado que a análise histórica da integração regional nos permite uma devida compreensão do modo e meio de desenvolvimento dos processos em curso ao reforçar os pontos de contato com os momentos vividos por cada um deles (em especial a União Europeia). A indução parte de um exame das premissas necessárias para formular uma teoria jurídica da integração ancorada na defesa de uma autonomia que o tema merece receber.

\section{A QUESTÃO DO MÉTOdO COMO FUNDAMENTO DA TEORIA: HÁ, EFETIVAMENTE, A NECESSIDADE DE CRIAR SISTEMAS METODOLÓGICOS PRÓPRIOS?}

De início, pode-se afirmar que os estudiosos do Direito aplicam procedimentos e técnicas metodológicas que são empregadas indistintamente a todos os ramos do conhecimento jurídico. A aplicação de métodos de abordagem $^{1}$ de estudo e pesquisa pode dar-se, como no caso das ciências sociais aplicadas, de forma a abarcar uma concepção indutiva, dedutiva, hipótetico-dedutiva, entre outra ${ }^{2}$. Também há métodos tradicionalmente reconhecidos, utilizados para a interpretação dos sistemas jurídicos, tanto de natureza interna como internacional, como é o caso do método teleológico, sistemático e

1 Lakatos e Marconi fazem diferença entre métodos de abordagem e métodos de procedimento, considerando estes últimos como etapas mais concretas de investigação, classificando-os, inclusive, mais como técnica que como método. LAKATOS, Eva Maria; MARCONI, Mariana de Andrade. Fundamentos de metodologia científica: Técnicas de pesquisa. 3 ed. São Paulo: Atlas, 2003.

2 LAKATOS, Eva Maria; MARCONI, Mariana de Andrade. Fundamentos de metodologia científica: Técnicas de pesquisa. 3 ed. São Paulo: Atlas, 2003. gramatical. Neste trabalho, pretende-se realizar uma primeira aproximação aos métodos de estudo e pesquisa que podem ser aplicados ao estudo da integração, dada sua especificidade, bem como aos métodos interpretativos que podem ser utilizados pelo direito da integração, de modo a examinar se haveria ou não a necessidade de criação de métodos próprios completamente diferenciados dos métodos tradicionais, ou se, ao contrário, o que se deve determinar é uma aplicação diferenciada destes.

Os métodos de estudo e pesquisa usualmente empregados na pesquisa em ciências sociais aplicadas são aqui considerados com base no marco teórico apresentado por Lakatos e Marconi, e que podem ser assim sintetizados:

- método indutivo: parte-se de uma premissa menor já cientificamente constatada para uma premissa maior, de modo que "partindo de dados particulares, suficientemente constatados, infere-se uma verdade geral ou universal, não contida nas partes examinadas."

- Método dedutivo: nesse caso, parte-se de uma premissa maior que pode ser, inclusive, capturada da realidade social para que se possa explicar o conteúdo das premissas, de modo a gerar formulações baseadas na certeza. Ainda na esteira de Lakatos e Marconi, os "argumentos indutivos aumentam o conteúdo das premissas, com sacrifício da precisão, ao passo que os argumentos dedutivos sacrificam a ampliação do conteúdo para atingir a certeza"4.

- Método hipótetico-dedutivo: ancorado na análise de Popper ${ }^{5}$, esse método propõe a verificação com base em um problema, que seria testado por uma teoria-tentativa para posteriormente criticar a solução, num esquema de tentativa-erro, de forma a eliminar as possíveis incorreções.

A aplicação desses métodos na pesquisa e no estudo em direito internacional pode ser inferida com base nos estudos apresentados pelos internacionalistas (cite-se, a título de exemplo, Schwarzenberger $\left.{ }^{6}\right)$, preocupados em

3 LAKATOS, Eva Maria; MARCONI, Mariana de Andrade. Fundamentos de metodologia científica: Técnicas de pesquisa. 3 ed. São Paulo: Atlas, 2003, p. 85.

4 LAKATOS, Eva Maria; MARCONI, Mariana de Andrade. Fundamentos de metodologia científica: Técnicas de pesquisa. 3 ed. São Paulo: Atlas, 2003, p. 92.

5 POPPER, Karl S. A lógica da pesquisa cientlfica. 2. ed. São Paulo: Cultrix, 1975.

6 SCHWARZENBERGER, Georg. International Law, Vol. I, second edition, London, 1949 apud RANGEL, Vicente Marotta. 
destacar a importância do método como instrumento essencial para a explicação dos problemas derivados pelo direito das gentes. Nesse sentido, entende Rangel ${ }^{7}$ ao abordar os métodos dedutivos e indutivos como consagradamente "adotados" pelo direito internacional, pois "amplamente difundidos, conhecem-se argumentos favoráveis a um e outro método tanto quanto os inconvenientes que a adoção exclusiva de um deles acarreta", defendendo uma aplicação simultânea de ambos os métodos, ainda que acabe por ocorrer a prevalência de um deles.

Rangel aponta ainda que "O problema que estamos a considerar oferece peculiaridades no que tange à pesquisa $\mathrm{e}$ ao ensino do direito das gentes. Deles emanam dificuldades precisas." ". Nesse sentido, dois aspectos interessantes são mencionados pelo autor, o primeiro se refere ao influxo das questões de política internacional sobre o Direito e o segundo se vincula à propagação do domínio internacional sobre as políticas internas, dado que

a área de aplicação do direito internacional penetra, de forma progressiva, em setores que tradicionalmente eram reservados ao direito interno dos Estados. Ela o faz de maneira envolvente à medida que se atenuam as rígidas barreiras outrora erguidas entre os dois ordenamentos jurídicos ${ }^{9}$.

Os problemas derivados da aplicação de métodos tradicionais ao estudo da integração — partindo-se da consideração que os mesmos também não podem ser ab initio aplicados indiscriminadamente ao direito internacional, conforme apontado alhures — se vinculam notadamente às modificações trazidas pela integração no que tange à formação de um sistema institucional e normativo próprio, distinto daqueles sistemas que foram ao longo do tempo criados pelo direito internacional. Fácil é observar que o estudo do funcionamento de uma organização internacional clássica, como é o caso das Organizações das Nações Unidas (ONU), não pode ser completamente semelhante ao estudo de uma organização de integração, como é o caso da União Europeia, dada uma das características principais deste tipo organizacional, que é a transferência de poderes e competências em dimensão mais alargada da que até

Direito e Relações internacionais. $2^{a}$. Ed. São Paulo: Editora RT. 1981, p. 273.

7 RANGEL, Vicente Marotta. Direito e Relações internacionais. 2a. Ed. São Paulo: Editora RT. 1981, p. 273.

8 RANGEL, Vicente Marotta. Direito e Relações internacionais. 2a. Ed. São Paulo: Editora RT. 1981, p. 275.

9 RANGEL, Vicente Marotta. Direito e Relações internacionais. $2^{a}$. Ed. São Paulo: Editora RT. 1981, p. 276. então vinha sendo outorgada às organizações internacionais. Ao possibilitar aos Estados-membros que as instituições nascidas com base nessa organização possam decidir — em e para os próprios Estados — sobre as políticas públicas que hão de se aplicar internamente, o funcionamento destas (por exemplo, no que tange ao peso e ponderação de votos ou a formação de maiorias simples, absolutas ou relativas) não pode ser compreendido com base na clássica concepção adotada pelo direito internacional, apesar das dificuldades encontradas pelos teóricos para vislumbrar pontos de semelhança entre o direito da UE e outros sistemas, conforme apontam Cryer et all ${ }^{10}$ :

Walkers indaga se a legislação da UE exige novas ferramentas de análise e nova forma de construção teórica, e nós concordamos que é uma pergunta que vale a pena explorar ( ... . . Se a legislação da UE deve ser abordada com uma nova compreensão teórica e metodológica própria, deve-se questionar se a roda precisa ser reinventada, e ao descrever a UE como um sistema sui generis não responde à questão em que medida ela se assemelha a outro sistema (...).

O método adotado para o estudo da integração não pode ser aplicado, portanto, de modo idêntico àquele utilizado para o direito internacional. A especificidade do método reside, justamente, na conformação diferenciada trazida por um mercado comum ou interno e pode ser explicada com base nas questões vinculadas, por exemplo, à vigência simultânea ou à incorporação imediata das normas do bloco, sem que haja, necessariamente, a criação de órgãos e instituições supranacionais, como é o caso do Mercosul.

Além disso, a própria questão da supranacionalidade, que será verificada posteriormente neste artigo, demanda uma sistemática metodológica diferenciada que não pode ser, de forma direta e imediata, trasladada ao plano do direito da integração.

Contudo, não se nega neste artigo que o método de pesquisa usado para compreender o fenômeno da in-

10 No original: Walkers wonders whether EU law requires its own new tools of analysis and new form of theory building, and we agree that is a question worth exploring (...). If EU law is to be approached with an understanding of theroy and methodology, it must be questioned whether the wheel need to be reinvented, and to describe the EU as a sui generis system does not answer the question of in what it resembles other system, or amounts to a theorical shrug of the shoulders when it comes dealing with insights from other areas of study. CRYER, Robert, et all. Research methodologies in EU and International Law. Oxford and Portland: Hart Publishing, 2011, p. 20. 
tegração deva ser absolutamente distinto dos métodos tradicionais empregados pelo Direito, mas sim que deve haver uma aplicação específica que leve em consideração aspectos intrínsecos dos processos de integração regional, sem descuidar o caráter inovador de alguns destes aspectos, conforme será abordado posteriormente neste trabalho. Tal aplicação específica significa que os métodos considerados tradicionais pela ciência jurídica devem adaptar-se ou até mesmo amoldar-se à nova realidade criada pelos espaços interestatais de associação, como é o caso da União Europeia e do Mercosul. Nesse mesmo sentido, expressa López ${ }^{11}$ :

a construção europeia, agora referida especificamente à UE, é uma nova realidade; mais especificamente, podemos definir como um processo dinâmico (e inacabado) a criação de um novo espaço territorial a partir do direito, a partir dos direitos, dos EstadosMembros. A supraestatalidade é a própria essência da União e o dado crucial em que reside a novidade que nos obriga a ajustar a metodologia. Do ponto de vista da teoria de fontes se aprecia claramente este fato, se falamos sobre a complexidade ordinamental, a existência de diferentes sistemas em uma mesma área de validade territorial. Realmente a experiência europeia poderia remeter-se para o direito constitucional do federalismo, mas sua própria singularidade não permite uma transposição perfeita de categorias.

O autor afirma que

certamente já começa a tornar-se evidente que esta nova realidade exige novos princípios, uma metodologia até então inexplorada. E não pode ser de outra forma, por duas razões: a diversidade de tradições de partida e pioneirismo de seu objeto. Desta síntese resulta um novo corpo em que há partes, entre outros, do direito alemão, do francês e do britânico. ${ }^{12}$

11 No original: La construcción europea, referida ahora específicamente a la UE, es una nueva realidad; más concretamente la podemos definir como un proceso dinámico (e inacabado) de creación de un nuevo espacio territorial a partir del derecho, a partir de los derechos, de los Estados miembros. La supraestatalidad es la verdadera esencia de la Unión y el dato crucial en el que radica la novedad que nos obliga a ajustar la metodología. Desde el punto de vista de la teoría de las fuentes se aprecia con toda claridad este hecho si hablamos de la complejidad ordinamental, de la existencia de diferentes ordenamientos en un mismo ámbito de validez territorial. Realmente la experiencia europea podría remitirse al Derecho constitucional del federalismo pero su misma singularidad no permite hacer una transposición perfecta de categorías. LOPEZ, Enrique Guillen. Metodología del Derecho Constitucional Europeo: Un derecho Constitucional para la integración política de Europa. Del pluralismo ideológico. Revista de Derecho Constitucional Europeo, n. 12, UGR, 2009, p. 154.

12 No original: Ciertamente ya comienza a hacerse evidente que esta nueva realidad requiere principios nuevos, una metodología hasta ahora inexplorada. Y no puede ser de otro modo por dos ra-
Para que se possa efetivamente fixar as bases - ainda que sem pretensão de esgotar o tema, dada a complexidade do mesmo - de métodos que podem ser utilizados para o estudo e pesquisa da integração interestatal, deve-se, primeiramente, em breve aproximação, definir quais são os principais métodos atualmente aplicados no estudo da integração. De modo geral, considera-se que a abordagem metodológica tradicionalmente empregada pelos estudiosos do direito internacional vem sendo amplamente replicada nos estudos da integração, conforme ressalta López. ${ }^{13}$

Portanto, faz-se necessário defender que se pode fixar como métodos de abordagem aqueles já utilizados pelas ciências sociais aplicadas de modo geral e, especificamente, para o estudo e a pesquisa em Direito, mas que, no caso da integração regional, deve ser adaptado de forma que permita abarcar as inovações trazidas pelo direito da integração, notadamente a institucionalidade e normatividade trazidas por esse tipo de associação interestatal. A adaptação defendida neste artigo deve ser compreendida como um esforço do pesquisador em estabelecer as premissas que surgem do direito da integração, ainda que enraizadas no direito internacional, segundo será posteriormente investigado.

No que tange aos métodos interpretativos, em geral, os autores mencionam a interpretação teleológica-axiológica entendida como aquela que "ativa a participação do intérprete na configuração do sentido. Seu movimento interpretativo, inversamente da interpretação sistemática que também postula uma cabal e coerente unidade do sistema, parte das consequências avaliadas das normas e retorna para o interior do sistema"14; a interpretação sistemática considerada como processo que "a partir do sistema externo da lei, portanto nas conclusões retiradas da localização de um preceito em determinado livro, seção ou conexão de parágrafos, da

zones: la diversidad de las tradiciones de partida y lo pionero de su objeto. De la síntesis resulta un nuevo cuerpo en el que hay piezas, entre otros, del derecho alemán, del francés y del británico. LOPEZ, Enrique Guillen. Metodología del Derecho Constitucional Europeo: Un derecho Constitucional para la integración política de Europa. Del pluralismo ideológico. Revista de Derecho Constitucional Europeo, n. 12, UGR, 2009, p. 156.

13 LOPEZ, Enrique Guillen. Metodología del Derecho Constitucional Europeo: Un derecho Constitucional para la integración política de Europa. Del pluralismo ideológico. Revista de Derecho Constitucional Europeo, n. 12, UGR, 2009, p. 156

14 FERRAZ JÚNIOR, Tércio Sampaio. Introdução ao Estudo do Direito: técnica, decisão, dominação. $6^{a}$ ed. - São Paulo: Atlas, 2008, p. 266. 
sua configuração com proposição autônoma ou como mera parte de uma proposição" ${ }^{15}$, não podendo-se considerar um norma isolada de seu contexto normativo, atribuindo-lhe um sentido dentro de um sistema complexo; ainda apontam a interpretação gramatical e a interpretação histórica ${ }^{16}$.

Uma análise reducionista e tradicional dos métodos interpretativos aplicados tradicionalmente pelo Direito, enquanto ciência, não pode explicar como os Estados tendem a associar-se, formando uma institucionalidade distinta daquelas adotadas pelo direito internacional, através de suas organizações. Basicamente, a aplicação tradicional não permite, por exemplo, estabelecer em que medida e porque decidem os Estados transferir competências e poderes para uma organização supranacional.

Pois bem, para a compreensão de um método interpretativo de aplicação (e não de criação) para o direito da integração pode-se adotar um recorte singular a partir de distintas variáveis, entre elas: i) a análise dos sistemas normativos de integração com base em cada processo integrador; ii) a análise das decisões emanadas dos órgãos de solução de controvérsias naqueles processos de integração regional que contam com um sistema judicial próprio; iii) com base na atuação das instituições legislativas e da formação de um processo legislativo específico para a criação de normas comuns, entre outras.

De forma a validar a possibilidade do emprego de métodos interpretativos tradicionais, mas aplicados de forma diferenciada para o estudo do direito da integração, escolheu-se neste artigo a análise das decisões emanadas do Tribunal Arbitral do Mercosul, onde desponta, ainda que não exclusivamente, o uso do método teleológico e do método sistemático. No caso do método teleológico, ao analisar o primeiro laudo arbitral sob o Protocolo de Brasília ${ }^{17}$, I Laudo Arbitral, TADM, Mon-

15 CANARIS, Claus-Wilhelm. Pensamento Sistemático e Conceito de sistema na Ciência do Direito. $3^{\mathrm{a}}$ ed. - Lisboa: Fundação Calouste Gulbenkian, 2002, p. 158.

16 Não será feita no presente artigo uma análise aprofundada das questões relativas a todos os tipos e classificações dos métodos intepretativos, dado não ser o objetivo do mesmo. Contudo, recomenda-se a leitura de MAXIMILIANO, Carlos. Hermenêutica e aplicação do Direito. 19a ed. - Rio de Janeiro: Forense, 2002; BETTI, Emilio. Interpretação da Lei e dos atos jurídicos: teoria geral e dogmática. Trad.: Karina Janinni. $2^{\mathrm{a}}$ ed. - São Paulo: Martins Fontes, 2007; STRECK, Lenio Luiz. Hermenêutica Jurídica e(m) Crise. $10^{a}$. ed. Porto Alegre: Livraria do Advogado, 2010, entre outros.

17 Tratou-se de caso em que foi objetada uma norma brasileira que internalizou regras do Mercosul no ordenamento jurídico na- tevidéu, 28 de abril de 1999, a linha de argumentação seguida pelo Tribunal reconhece o papel central da liberação comercial no cumprimento dos fins e objetivos do Mercosul, a natureza inseparável das vertentes tarifária e não tarifária e a obrigação de eliminar totalmente as restrições em ambas, bem como os cinco Anexos do TA, congruentes com essa interpretação, contêm obrigações concretas e autoexequíveis, e nenhuma norma expressa derrogou a obrigação de proceder ao desmantelamento não tarifário, subsistindo o sistema do TA e as obrigações nascidas com ele, apesar de haver sofrido modificações, especialmente decorrentes da expiração do prazo originalmente pactado para o alcance do mercado comum. Essa seria a conclusão com base em uma interpretação harmônica do sistema, congruente e não contraditória com os fins e objetivos declarados e acordados pelas partes.

Em conclusão, decidiu o Tribunal que a controvérsia situava-se no conjunto normativo do Mercosul, que contra ele devia ser invocada uma incompatibilidade de um ordenamento nacional, que os instrumentos do processo de integração devem ser interpretados em forma teleológica, tendo em conta os fins, objetivos e princípios do sistema de integração, mesmo na ausência de normas de caráter supranacional, bem como que o TA e seu sistema normativo contêm disposições que fixam objetivos e princípios que estabelecem obrigações concretas para os Estados, entre as quais se inclui o programa de liberação comercial que deve ser completado tanto em relação às medidas tarifárias quanto às não tarifárias.

A necessidade de ser interpretado o Tratado de Assunção e a normativa do Mercosul funcional ou teleologicamente, enquanto mecanismo de integração, para desestimar medidas nacionais que sejam contrárias ao objetivo final neles estabelecidos foi uma constante encontrada nos laudos arbitrais, até o nono, que torna a esses métodos, como se lê no seu item 19. Esse laudo, IX Laudo Arbitral, TADM, Montevidéu, 4 de abril de 2003, por sinal, no item 26, apresenta um outro método, chamado lógico-sistemático, que prega o atendimento

cional, assim o Comunicado n. 37/97, que estabelecia e consolidava a lista de capítulos e produtos da Nomenclatura Comum do Mercosul sujeitos a licença não automática ou a licença automática com condições especiais. A alegação é que o Comunicado piorava e agravava as condições de acesso ao mercado brasileiro de produtos argentinos, estabelecendo medidas administrativas equivalentes a restrições. 
aos princípios do Mercosul de gradualismo, flexibilidade e equilíbrio, consagrados no preâmbulo do Tratado de Assunção, que deveriam presidir a progressiva concretização, através da normativa vinculadora emanada dos órgãos do Mercosul, dos enunciados programáticos e princípios gerais essencialmente encerrados no corpo do Tratado ${ }^{18}$.

Já a aplicação do método sistemático foi enfatizada na Primeira opinião consultiva ${ }^{19}$, OC n. 1/2007, TPR, Assunção, 3 de abril de 2007, com base nas inovações advindas com o Protocolo de Olivos. A pergunta abarcava, exclusivamente, questões atinentes à interpretação jurídica da normativa do Mercosul e se vinculava com causa que estivesse tramitando no Poder Judiciário do Estado-parte solicitante, com o que restavam cumpridas as exigências do Protocolo de Olivos para a submissão de opinião consultiva. Ainda, segundo o item A, 3, a aceitação da questão considerava a sua transcendental importância para assentar os sólidos cimentos do conceito, natureza e objetivo das opiniões consultivas dentro do processo de integração, dado o contexto da consulta, e segundo o item B, 1, a função do tribunal nos casos em tela consistia em interpretar a norma comunitária desde o ponto de vista jurídico, vale dizer, buscar o significado para precisar o seu alcance, ainda que uma opinião consultiva não seja obrigatória, nem vinculante para o juiz nacional consultante. No mesmo item, lembram os interpretadores que na União Europeia, um recurso semelhante é sempre vinculante.

No item C, 1, buscando resolver já a questão, o tribunal informa que "as três características básicas do então direito comunitário são: i) a aplicação imediata, ii) o efeito direto, iii) a prevalência normativa sobre o direito

18 JAEGER JUNIOR, Augusto. Metodologia jurídica europeia e mercosulista: considerações fundamentais. Revista da Secretaria do Tribunal Permanente de Revisão do Mercosul. Assunção: Secretaria do Tribunal Permanente de Revisão do Mercosul, a. 2, n. 3, mar. 2014. p. 117-157. Disponível em: http://www.revistastpr. com/index.php/rstpr/article/view/87/66, acesso em 13 mar 2015. 19 Em 2007, surgiu a primeira opinião consultiva do TPR. Uma juíza de primeira instância do cível e do comercial de primeiro grau da jurisdição de Assunção, Paraguai, via Corte Suprema de Justiça do Paraguai, em autos em que litigavam duas empresas privadas, a argentina Laboratorios Northia Sociedad Anónima e a paraguaia Norte Sociedad Anónima, endereçou uma questão ao TPR. Ela girava em torno da prevalência do Protocolo de Buenos Aires sobre Jurisdição Internacional em Matéria Contratual, uma norma integracionista, sobre uma lei nacional paraguaia, que determinava o devido respeito, por essa, à eleição de jurisdição contratualmente estabelecida entre as partes, em conformidade com o artigo $4^{\circ}$. de tal Protocolo, sustentando a primazia do tratado sobre a lei. interno", no momento em que cita o jurista espanhol Ricardo Alonso García e os seus comentários ao caso Costa/ENEL, do TJCE, de 1964, que determinou uma origem pretoriana aos preceitos acima, especialmente o terceiro. Para esse dissertante, pende novamente o TPR ao método comparativo. Evidentemente, o TPR tinha a oportunidade de uma criação também pretoriana para inseri-las dentro do regime jurídico e da metodologia jurídica mercosulistas.

Mais adiante, no item E, 4, que discutia a prevalência da norma de direito da integração sobre a ordem pública nacional e internacional, novamente a jurisprudência do TJCE é citada, em especial o caso Dieter Krombach, de 28 de março de $2000^{20}$.

$\mathrm{Na}$ sequência, antes de estimar a interpretação do articulado do Protocolo de Buenos Aires, informa o tribunal que este foi aprovado e ratificado por todos os Estados-partes do Mercosul, e que, por essa razão, estaria legitimado para angariar prevalência sobre a lei nacional de todos os Estados. E no mesmo item F, 3, informa que o Protocolo de Santa Maria, invocado no processo para ser aplicado, não o poderia ser, dado que, ainda, não se encontra em vigor. Essa conclusão é bastante simplória, mas muito representativa para a formação de uma metodologia jurídica mercosulista, especialmente porque reafirma que nem mesmo uma norma do Mercosul, em comparação com as normas do direito internacional público, não é dispensada do processo de ratificação pelos Estados-partes para que entre em vigor.

Então, no item E do voto do árbitro Nicolás Becerra, lê-se que "os Protocolos de Direito internacional privado são convenções internacionais, mas convenções muito particulares porque estão contidas em decisões do Mercosul - que têm caráter obrigatório segundo o Protocolo de Ouro Preto - e por terem sido adotadas no marco de um processo de integração. Esses dados são fundamentais no momento de fixar a interpretação de suas normas. É verdade que se tem que seguir o processo de incorporação previsto em cada Estado - dado que ainda não existe uma instância supranacional legiferante da que pudessem derivar normas como estas destinadas a sua aplicação direta nos países-membros -, mas uma vez em vigor essas convenções devem interpretar-se e aplicar-se em função das finalidades do Mercosul" e objetivos que os Estados-partes assumiram

20 STJCE, assunto Dieter Krombach v. André Bamberski, C-07/98, 28 de março de 2002. 
explícita e implicitamente ao adotarem tais normas, assim segundo um método nesse laudo chamado de interpretação sistemática, global.

Enfim, em conclusão, o TPR afirma que a cláusula atributiva de competência jurisdicional contida no contrato realizado entre as duas empresas confrontadas na lide era válida, posto que as normas do Mercosul internalizadas prevalecem sobre as normas do direito interno dos Estados-partes, sejam elas de direito interno propriamente dito ou de direito internacional público e privado, e, assim, o caso foi respondido pelo TPR muito mais pela elucidação do aparente conflito entre duas fontes normativas diversas aplicáveis, o Protocolo de Buenos Aires e uma lei nacional paraguaia, do que por uma real interpretação de uma norma do Mercosul ${ }^{21}$.

Percebe-se, portanto, que os métodos interpretativos podem ser aplicados ao estudo do direito da integração, contudo, devem considerar - ainda que não esteja exclusivamente apartada de uma concepção já amplamente adotada - as peculiariedades inerentes à normatividade gerada pelo processo integrador, justamente pelo reconhecimento das fontes jurídicas próprias emanadas do mesmo, tema que será abordado à continuação.

\section{As FONTES DO DIREITO DA INTEGRAÇÃO REGIO- NAL: UMA AUTONOMIA AINDA A SER DETERMINADA}

O reconhecimento de um direito da integração próprio e autônomo pode ser comprovado, ainda, pela coexistência de um sistema de fontes jurídicas, estabelecidas nos tratados constitutivos e cujo enunciado fixa quais serão os atos que servirão de sustento para o ordenamento jurídico integracionista. As características fornecidas pelas fontes servem como um elemento agregador para a afirmação da existência de um direito próprio, afastando-se das posições tradicionalistas que renegam a autonomia de dito direito. A peculiaridade do regime jurídico adotado pelos Estados para a formação da associação inter-regional acaba por implicar numa particular forma de produção normativa, em diferentes

21 JAEGER JUNIOR, Augusto. Metodologia jurídica europeia e mercosulista: considerações fundamentais. Revista da Secretaria do Tribunal Permanente de Revisão do Mercosul. Assunção: Secretaria do Tribunal Permanente de Revisão do Mercosul, a. 2, n. 3, mar. 2014. p. 117-157. Disponível em: http://www.revistastpr. com/index.php/rstpr/article/view/87/66, acesso em 13 mar 2015. âmbitos, que determinam aos Estados participantes um dever de cumprimento que, apesar de aceito por estes, pode ver-se debilitado, em maior ou menor medida, pela ausência dos mecanismos institucionais necessários (como é o caso do Mercosul). Não obstante, essa debilidade não resulta em negação expressa do direito da integração como um direito próprio, senão que reforça a falta de coercibilidade como premissa necessária que pode impedir o avanço do processo integrador a etapas mais profundas. Conforme ressaltado por Pallares,

os processos de integração têm como resultado a produção de normas legais para regular essas ações coletivas. Ao mesmo tempo, eles refletem um fluxo constante de interações entre Estados participantes e outros sujeitos destinatários de tais normas, e destacam o desenvolvimento de uma diversidade de funções próprias de verdadeiras estruturas orgânicas de natureza administrativa ${ }^{22}$.

A defesa de um direito do Mercosul próprio e autônomo já havia sido defendida, em 2004, ocasião em que afirmamos, na esteira de Perez Otermin ${ }^{23}$,

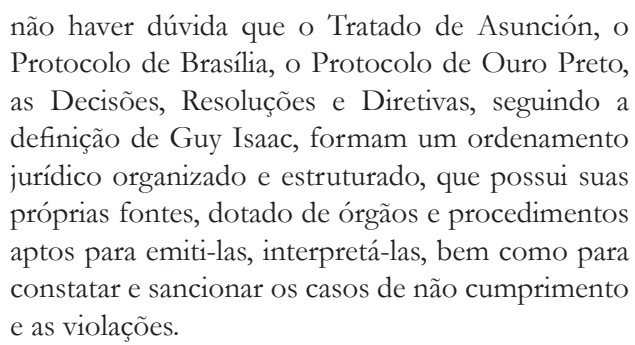

No mesmo sentido, o IX Laudo Arbitral, TADM, Montevidéu, 04 de abril de 2003, sobre medidas de Estímulo à industrialização de lã, utilizou a definição de

22 No original: Los procesos de integración tienen como resultado la producción de normas jurídicas destinadas a regular dichas acciones colectivas. $\mathrm{Al}$ mismo tiempo, reflejan un flujo permanente de interacciones entre los Estados participantes y otros sujetos destinatarios de tales normas y ponen de manifiesto el desarrollo de una diversidad de funciones propias de verdaderas estructuras orgánicas de índole administrativa. PALLARES, Beatriz y AGUZIN, Luiz. El régimen de incorporación de los tratados en el derecho interno. Congreso Internacional de Cultura y Sistemas jurídicos comparados. Instituto de Investigaciones Jurídicas. UNAM, México, 2004, p. 23, disponible em http://www.juridicas.unam.mx/inst/ evacad/eventos/2004/0902/mesa3/76s.pdf, acesso en 15 dec 2004 23 No original: no puede caber duda que el Tratado de Asunción, el Protocolo de Brasilia, el Protocolo de Ouro Preto, las Decisiones, Resoluciones y Directivas, siguiendo la definición de Guy Isaac, forman un ordenamiento jurídico organizado y estructurado, que posee sus propias fuentes, dotado de órganos y procedimientos aptos para emitirlas, interpretarlas, así como para constatar y sancionar los casos de incumplimiento y las violaciones. PEREZ OTERMÍN, Jorge. El Mercado Común del Sur. Desde Asunción a Ouro Preto: aspectos jurídico-institucionales. Montevideo: Fundación de Cultura Universitaria, 1995, p. 195. 
Isaac ${ }^{24}$ para afirmar a existência de um direito próprio, com um ordenamento jurídico individualizado.

A discussão sobre a validade do tratado como superior à norma de direito interno representa uma ligação intrínseca com a própria criação do então direito comunitário, embora não se possa ignorar que este representa um produto direto de uma determinada época e para uma determinada região, contudo, ao irradiar efeitos concretos e para além das fronteiras da UE, alcançou, num certo sentido, uma abrangência universal, isto é, apesar de aplicar-se diretamente aos membros e instituições da UE, pode, sim, alcançar relações que se formam fora do espaço europeu.

Nesse sentido, os princípios orientadores do processo de integração descritos nas linhas seguintes são importantes para a compreensão de como as fontes do direito, em um sistema integrado que envolve estados soberanos podem determinar o grau de cumprimento e a implementação do acervo normativo, considerando-se, especialmente, se este pertence ao direito interno ou se ancora-se numa formação supranacional ou até mesmo internacional.

\subsection{As fontes do direito da integração a partir de uma raiz internacionalista}

Há certo consenso na doutrina em relação ao rol de fontes do direito internacional, desglosado no art. 38 do Estatuto da Corte Internacional de Justiça, que, assim, prevê: tratados internacionais, costume internacional, princípios gerais de direito, decisões dos tribunais internacionais de justiça enquadradas como fonte jurisprudencial e a doutrina. Há ainda outras classificações que englobam, por exemplo, também as decisões de organizações internacionais, as decisões de tribunais de arbitragem e os atos unilaterais ${ }^{25}$.

Como tal, o Tratado que institui um processo de associação entre os Estados, na modalidade de cooperação

24 Vale a pena citar o pensamento de Isaac para quem "Llamamos orden jurídico al conjunto organizado y estructurado de normas jurídicas, que poseen sus propias fuentes, dotado de órganos y procedimientos aptos para emitirlas, interpretarlas, así como constatar y sancionar sus incumplimientos y violaciones." ISAAC, Guy. Manual de Derecho Comunitario general. $5^{a}$ edición. Madrid: Ed. Ariel, 2000, p. 155.

25 Vide como exemplo a análise feita por NASSER, Salem Hikmat. Fontes e normas do direito internacional: um estudo sobre a soft law. São Paulo: Atlas, 2006. ou na modalidade de integração, diferencia-se dos tratados internacionais de natureza clássica, constitutivo das organizações internacionais globais. Um tratado clássico pode ser definido, conforme preceitua a Convenção de Viena dos Direitos dos Tratados, como um "acordo internacional concluído entre os Estados na forma escrita e regida pelo direito internacional, que pode consistir em um único instrumento, tanto como dois ou mais instrumentos conexos, qualquer que seja sua denominação específica."

A definição clássica de tratados não inclui qualquer referência à forma de associação ou relações entre os estados, mas genericamente determina submissão às regras do direito internacional. Considerando-se a definição já referida, pode-se observar que esta não logra alcançar a produção normativa derivada da formação de processos de integração regional, ainda que os acordos baseados no direito internacional sejam considerados como fontes originárias do sistema normativo integrador.

Depois de citar as fontes do direito internacional, resta investigar, de forma sucinta, o sistema das fontes do direito da União Europeia. Em primeiro momento, cabe perguntar sobre os atos normativos relevantes da UE que especificam fontes. Qual seria a importância de se determinar o sistema das fontes do direito da União, se ele parece, à primeira vista, conformar-se pelos tratados constitutivos e outros acordos responsáveis pelo "alicerce" do sistema normativo comum? A criação de um sistema comunitário de fontes normativas é, particularmente, importante para determinar a natureza dos atos das instituições comunitárias e para compreender o alcance e os efeitos surgidos com base em uma ordem jurídica diferente da ordem internacional e das normas que compõem o direito nacional dos Estados-Membros. Molina del Pozo salienta a importância de se definir as fontes jurídicas da UE, como meio de determinar o âmbito de validade das regras. Para este autor,

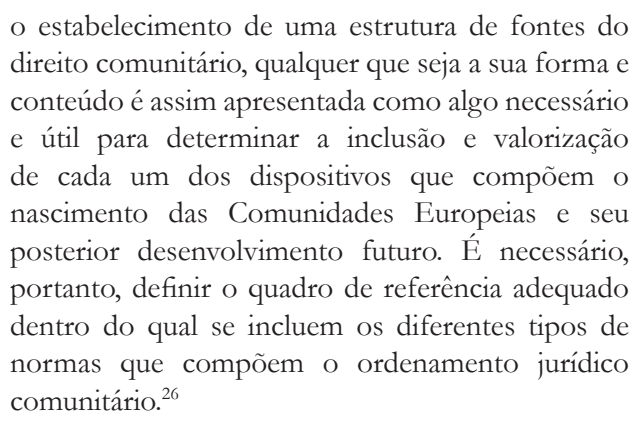

26 No original: El establecimiento de una estructuración de las fuentes del Derecho comunitario, sea cual sea su forma y contenido, se presenta, pues, como algo necesario y útil a la hora de determinar 
As principais fontes do direito da União são formadas com base no estabelecimento de tratados constitutivos (TCECA e TCEE), tratados de adesão - relacionados com as alterações derivadas da introdução de novos membros por ocasião de cada rodada de ampliação - e os tratados que foram feitos para a formação e desenvolvimento de uma união econômica, monetária e jurídica, aqueles que aportaram novos instrumentos jurídicos para a realização do mercado comum, bem como para o funcionamento das instituições (são os chamados Tratado da União Europeia, firmados em Maastricht, Amsterdam, Nice e Lisboa).

Como fonte de direito primário, os tratados estabelecem as principais ações das instituições, dos órgãos, dos Estados-Membros, atingindo, inclusive, as condutas que devem ser observadas pelos cidadãos. Como dito acima, para muitos, os Tratados poderiam ser considerados como verdadeira "Constituição", ao enquadrar as normas comunitárias em um sistema jurídico próprio distinto dos sistemas nacionais e internacional.

Fazendo uma breve análise da legislação da UE, podemos dizer que as normas originárias da UE, embora surgidas de uma fonte convencional (o tratado), resultam de atos jurídicos interestatais que envolvem sujeitos próprios de um sistema de coordenação avançado ${ }^{27}$, ou em certos casos até mesmo de subordinação, ao determinar a matriz de incidência das demais normas que compõem a ordem comunitária. Os tratados constitutivos e outros instrumentos criam obrigações para os Estados dentro de um quadro formal de direito internacional, mas que também têm efeitos que ultrapassam a conformação clássica internacionalista, já que criam um novo sistema legal - comunitário - com suas características próprias, do qual surgem regras fundamentais, com hierarquia superior à norma nacional e que fundam um conjunto de normas jurídicas a ele subordinado: o direito secundário, composto pelos regulamentos, diretivas e decisões emanados das instituições comunitárias e que

la inserción y valoración de cada uno de los actos dispositivos que configuran el nacimiento de las Comunidades Europeas y todo su posterior desarrollo. Es conveniente, por tanto, fijar el marco referencial apropiado dentro del cual habrían de incluirse las diferentes tipologías de normas que conforman el ordenamiento jurídico comunitario. MOLINA DEL POZO, Carlos F. Manual de Derecho de la Comunidad Europea. $4^{\text {a }}$ ed. Madrid: Dijusa, 2002, p. 457.

27 ARBUET-VIGNALI, Heber. Claves jurídicas de la Integración. En los sistemas del MERCOSUR y la Unión Europea. Santa Fe: Ed. Rubinzal-Culzoni, Santa Fe, 2004, p. 185. se regem por princípios singulares ${ }^{28}$, conforme será analisado posteriormente.

Em relação ao direito da integração no âmbito do Mercosul, as normas originárias compreendem, essencialmente, o Tratado de Assunção, o Protocolo de Brasilia, o Protocolo de Ouro Preto, conforme o art. 41 do Protocolo de Ouro Preto e nos termos do art. 19 do Protocolo de Brasíliaa ${ }^{29}$. Apesar de não estarem expressamente mencionados em ambos os artigos, tanto o Protocolo de Olivos como o Protocolo de Las Leñas, bem como o Protocolo de Santa Maria, devem ser considerados como fonte de direito originário ${ }^{30}$. Também os acordos firmados com outras organizações e/ou sistemas de integração e o Mercosul, bem como aquelas firmados com os estados associados, caso do Peru, Chile, Bolívia etc., podem ser considerados fontes originárias do direito mercosulista.

Esses instrumentos devem ser considerados como mandamentos de máxima observância, o que implica que todas as outras normas do MERCOSUL devem a eles se submeter, atuando como uma fonte primária para a aplicação e execução dos objetivos delineados pelos estados partícipes. Normas fundamentais ou constitutivas de objetivos pontuais do MERCOSUL são responsáveis por projetar um sistema de produção de normas e procedimentos de aplicação dos atos produzidos pelos órgãos comuns, embora o processo sub-regional do Cone Sul careça de instituições comunitárias com competências definidas para aplicar e garantir o devido cumprimento das normas por eles produzidas ${ }^{31}$.

O Tratado do Mercosul possui base claramente internacionalista ${ }^{32}$, mas os seus objetivos foram expressa-

28 MATA DIZ, Jamile B. MERCOSUR: orígen, fundamentos, normas y perspectivas. Curitiba: Juruá, 2007, p. 228.

29 DROMI, Laura San Martino. De la nueva historia del Derecho. A propósito del objeto, método y fuentes del Derecho del MERCOSUR. Buenos Aires: Ed. Ciudad Argentina, 1997, p. 108110.

30 Para Díaz Labrano os Protocolos de las Leñas e de Santa María são normas derivadas porque apesar de adotar a forma de protocolos internacionais "son de carácter instrumental para operativizar el proceso de integración o para armonizar jurídicamente la legislación de los Estados Parte." Mientras que los acuerdos de complementación económica son, para este autor, normas originarias. DÍAZ LABRANO, Roberto Ruiz. Integración y Derecho. Buenos Aires: Ed. Ciudad Argentina, 1998, pp. 521-522.

31 MATA DIZ, Jamile B. MERCOSUR: orígen, fundamentos, normas y perspectivas. Curitiba: Juruá, 2007, p. 245.

32 PEÑA, Felix. Reglas de juego, instituciones e integración económica: Reflexiones en una perspectiva del MERCOSUR. Fundación BankBoston, oct. 2002, disponível em http:// 
mente definidos com base na concepção de um processo de integração regional, divergindo, portanto, de uma natureza meramente cooperativa. As normas derivadas dos órgãos do Cone Sul também se caracterizam por uma abrangência menor do que aquela vinculada ao direito internacional. Ainda que atuem para além das fronteiras nacionais, devem ser plenamente respeitadas pelos Estados-Membros, porque foram criadas e aceitas espontaneamente. Os resultados dos acordos interestatais, tais como os firmados no âmbito do MERCOSUL, devem irradiar e propagar efeitos não só nos Estados mas também sobre as pessoas.

O problema de um sistema de fontes reside nas diferentes interpretações adotadas pelos Estados-membros do MERCOSUL, cujas Constituições nacionais têm distinções quanto à preponderância de ato externo formulado por um órgão supraestatal ${ }^{33}$. $\mathrm{O}$ resultado das assimetrias, sem dúvida, pode determinar o avanço ou retrocesso do processo de integração e prejudicar ou favorecer a formação de um sistema institucional supranacional.

A instituição de um sistema de fontes do MERCOSUL, caso seja considerado como um processo complexo de integração regional, diferenciado de um mero processo de cooperação econômica, é essencial para fixar o grau de aplicabilidade das regras comuns, estabelecendo uma "hierarquia" entre as normas de direito interno e as normas comunitárias, embora a regulação específica e própria do sistema integrador possa reforçar e acentuar a divisão de poderes entre as organizações regionais e os Estados-Membros que a formam. A distinção entre a ordem supranacional, proveniente de instituições comuns, e a ordem interna é essencial para localizar e corrigir o nível de efetividade e observância das regras produzidas por tais instituições ${ }^{34}$. Assim, a aplicação das regras comunitárias no âmbito dos Estados-Membros é inegavelmente mais consistente e impositiva, do ponto de vista da obrigação de cumprimento por parte dos estados, do que aquela resultante da maioria dos atos internacionais convencionais ${ }^{35}$.

www.fundacionbankboston.com.ar/inst/sec10/docs-felixpena/ articulos/2002-10-reglas-instituciones.doc, acesso em 12 set 2008.

33 MATA DIZ, Jamile B. MERCOSUR: orígen, fundamentos, normas y perspectivas. Curitiba: Juruá, 2007.

34 Para a distinção entre as fontes intra e extra-estatais recomenda-se a leitura de GALATERIA, Luigi; STIPO, Massimo. Manuale di Diritto Amministrativo. Roma: Ed. Torino, 1995, p. 36-40.

35 MATA DIZ, J. B. MERCOSUR: orígen, fundamentos, normas y perspectivas. Curitiba: Juruá, 2007.
A doutrina majoritária ${ }^{36}$ entende que o Mercosul é um processo amparado pelos princípios da integração, uma vez que está em uma zona intermediária entre a cooperação e a comunitarização, sendo considerado, portanto, como um processo de integração que pretende chegar a formar um mercado comum. A integração seria o instrumento adequado para regular o comportamento dos Estados-Membros e das pessoas - públicas e privadas - bem como dos atos ditados pelos órgãos do processo no âmbito do Mercosul. No entanto, esse direito, por sua singularidade e aspecto inovador, está consubstanciado pelos limites da ordem interna de cada particípe e como tal circunstância determina a necessidade de mandamentos imperativos para fazer cumprir a norma acordada nos órgãos integradores.

\subsection{A inter-relação direito internacional, direito da integração, direito comunitário e direito in- terno}

O direito da integração provém de relações específicas de cada estado, com os seus objetivos próprios e diferenciados daqueles aplicados pelo direito internacional público, embora, em certos momentos, possa utilizar-se de fontes jurídicas internacionais como método interpretativo e como forma de regulação ${ }^{37}$ (nesse caso, queremos dizer, principalmente, direitos humanos, direito comercial, resolução de conflitos etc.), de modo que suas funções possam ser salvaguardados pelas autoridades do Estado dos Estados-Membros em conjunto com os órgãos intergovernamentais (na ausência, por exemplo, de uma corte ou tribunal). ${ }^{38}$

Tanto no caso da União Europeia (em maior medi-

36 Vide por todos DÍAZ LABRANO, Roberto Ruiz. Diferencias Institucionales en los distintos esquemas de integración. In: Integración Eurolatinoamericana. MOLINA DEL POZO, Carlos F. (coord.). Buenos Aires: Ed. Ediciones Ciudad Argentina, 1996. 37 Essa regulação ocorre principalmente através da harmonização legislativa entendida como "a existência de esforços consistentes dos Estados-membros com vistas à adoção de normas coerentes e simétricas, não se podendo olvidar que em situações pontuais as exceções seriam bem toleradas." MORAES, Isaias Albertin de; MORAES, Flávia Albertin de; MATTOS, Beatriz R. Bessa. O Mercosul e a importância de uma legislação ambiental harmonizada. Revista de Direito Internacional, Brasília, v. 9, n. 3, 2012, p. 100.

38 GATTINONI DE MUJÍA, Maria C. El diálogo entre el juez de la jurisdicción nacional y el juez comunitario - Un análisis de la revisión prejudicial en Europa y en América Latina. Jornadas de Derecho Internacional. Organización de los Estados Americanos, Academia Diplomática del Perú. Lima, 17 al 20 de noviembre de 2003 (formato paper). 
da) como do MERCOSUL (em menor medida), a integração manifesta-se por regras de produção em diversas áreas, determinando aos Estados participantes no processo de integração uma obrigação de cumprimento que pode, contudo, resultar enfraquecida pela ausência de mecanismos institucionais comuns. No entanto, isso não resulta em falta de reconhecimento - especialmente no caso do Mercosul - de um direito específico e próprio, apenas torna-se ponto de destaque a falta de coercibilidade necessária para avançar na implementação de um mercado comum. Em igual sentido, assim manifesta Díaz Labrano ${ }^{39}$ :

além de qualquer discussão ou ceticismo sobre o direito que emana do MERCOSUL, a realidade se impôs e é fácil perceber com nítidos perfis a existência de um ordenamento jurídico de integração especial: direito da integração, que vem promovendo alterações substanciais na relacionamento dos Estados Partes e dos cidadãos no espaço integrado, ao mesmo tempo coloca o MERCOSUL como uma entidade jurídica que tem intensamente se relacionado com Estados e blocos semelhantes.

Pode parecer paradoxal a existência de um direito que não forneça os instrumentos jurídicos e os imperativos legais para conformar um substrato normativo que venha a determinar e limitar a atuação do estado que participa de um espaço multinacional integrado. A realidade nos leva a aceitar não só a existência desse direito, mas defender até mesmo sua aplicabilidade, mesmo que ainda não integralmente observado pelos Estados.

Se considerarmos o Mercosul como um processo de integração, não meramente de cooperação, devemos, também, compreender que este define-se por um sistema normativo, que não é internacional nem nacional - ainda que nasça ou se origine de um acordo internacional - mas que avança no sentido de estabelecer uma ordem jurídica própria. Vale ressaltar que o Mercosul não é produto de uma entidade estatal única, sendo, por outro lado, resultado da vontade política, econômica,

39 No original: Más allá de cualquier discusión o escepticismo en torno del derecho emanado del MERCOSUR, la realidad se ha impuesto y es fácil percibir con perfiles nítidos la existencia de un ordenamiento jurídico especial de integración: el derecho de la integración, que viene impulsando transformaciones sustanciales en el reracionamiento de los Estados Parte y de los ciudadanos en el espacio integrado, al mismo tiempo de ubicar al MERCOSUR en una entidad con personalidad jurídica que desarrolla una intensa actividad con Estados y bloques similares. DÍAZ LABRANO, Roberto Ruiz. Integración y Derecho. Buenos Aires: Ed. Ciudad Argentina, 1998, p. 524. social de um conjunto de estados ${ }^{40}$. Além disso, não se pode negar que a distinção entre direito da integração, direito internacional e direito interno envolve uma abordagem complexa e multifacetada, que merece, por sua vez, um tratamento teórico também diferenciado.

A formação de um direito da integração deve responder rapidamente às questões levantadas pelo desenvolvimento do processo de integração e deve ser capaz de regular a conduta dos envolvidos, determinar o nível de observância das normas, controlar a atuação dos órgãos comuns e, finalmente, determinar as sanções devidas em caso de descumprimento do acervo normativo. Mas como um sistema normativo será aplicado se não existem instituições que possam garantir o funcionamento pleno e eficaz de tal sistema? Será que o direito da integração consegue "fazer cumprir" as normas adotadas pelos partícipes sem um quadro institucional que venha a assegurar o devido funcionamento e aplicação das normas desse direito advindas?

Claro está que um ordenamento comunitário prima, incondicionalmente, sobre toda e qualquer norma estatal, incluídas as de natureza constitucional, em virtude de suas características especificamente originais. Os critérios de estrita juridicidade que informam o direito comunitário determinam que, contrariamente ao que ocorre no direito internacional ou no direito da integração, a mera manutenção em vigor de uma norma contrária àquele direito resulte em afronta ao princípio da primazia, resultando numa violação direta do direito comunitário ${ }^{41}$. O direito comunitário baseia-se, conforme será analisado posteriormente, em três princípios básicos e elementares: a primazia, a aplicabilidade imediata e o efeito direto ${ }^{42}$, determinados, em maior ou menor

40 SAVID-BAS, Luis I. Los actos obligatorios de los órganos del MERCOSUR, los sistemas constitucionales y la división republicana de poderes. In: Chile y el MERCOSUR en América Latina. IRIGOIN BARRENNE, Jeannete (coord.). Santiago: Ed. Jurídica de Chile, 1999, p. 221.

41 MONSANTO, Alberto. Dimensión jurídico-institucional del MERCOSUR. In: Estado, Mercado y Sociedad en el MERCOSUR, vol. I. LAREDO, Iris (org.). Rosario: Editorial Universidad Nacional de Rosario, 1993.

42 "Na União Europeia (...) vigora um direito específico e peculiar que é o Direito Comunitário, de caráter supranacional e dotado das seguintes características: aplicabilidade direta (vale dizer que a norma do bloco não necessita ser internalizada nos ordenamentos jurídicos dos Estados), primazia frente às normas nacionais (naqueles eventos em que, caso as normas nacionais conflitem com as normativas do bloco, sempre terão primazia as primeiras) e a uniformidade na interpretação e na aplicação das normativas." GOMES, Eduardo Biachi. Integração econômica no MERCOSUL: opiniões 
medida, nos tratados constitutivos.

O direito da integração, ao contrário, não obedece os pressupostos jurídicos do direito comunitário. Não se deve olvidar a existência de sistema de princípios cuja força imperativa radicaria nos elementos citados, senão que se determinam com base no binômio direitos internos/direito internacional público. ${ }^{43}$ Isso ocorre porque, em algumas circunstâncias, dependendo da etapa de integração em que os estados se encontram, há uma carência de mecanismos institucionais aptos a garantir a criação, execução e o controle tanto dos atos nacionais quanto intergovernamentais (adotados no âmbito dos órgãos), além de não possuir um sistema jurídico complexo como é o caso do direito comunitário; mas, nem por isso se pode considerá-lo como um mero apêndice do direito internacional público.

A doutrina internacionalista tradicional geralmente reconhece, apenas, dois resultados qualitativamente expressos pelos processos de integração: a cooperação e a comunitarização. No entanto, não se pode ignorar que há um estágio intermediário entre os dois processos, cuja manifestação se expressa pelo direito de integração. Caracterizá-lo como um elemento relacionado com o direito internacional (processo de cooperação) determinaria uma distorção da natureza específica das normas produzidas no âmbito de processos de integração subregionais, conforme as conclusões apresentadas pelo Informe final produzido no Seminário sobre "Las normas de Derecho Originario y Derivado del MERCOSUR", em seu item 13

\footnotetext{
Aceitar a possibilidade da existência de novas categorias de direito, além daquelas atualmente vigentes, o que resultaria na aceitação da existência de um direito regional, diferente do direito internacional público, direito comunitário e do direito interno. ${ }^{44}$
}

consultivas e a democratização no acesso ao tribunal permante de revisão. Revista de Direito Internacional, Brasília, v. 10, n 1, jan./ jul. 2013, p. 131.

43 CALIGIURI AMMENDIOLA, Eugenio R. FIGUEROA VEJAR, Alejandro A. Los principios de primacía y operatividad en el Derecho Comunitario como fundamento para la integración Latinoamericana. American Diplomacy, vol. 5, n. 01, North Carolina, invierno 2000.

44 No original: Aceptar la posibilidad de la existencia de nuevas categorías de derecho además de las actualmente vigentes, lo que redundaría en la aceptación de la existencia de un derecho regional, diferente del Derecho Internacional Público, del Derecho Comunitario y del Derecho interno. Seminario Las normas de Derecho Originario y Derivado del MERCOSUR - Su incorporación a los ordenamientos jurídicos de los Estados Partes. Secretaria del Merco-
Caso se adote um método jurídico científico, moldado pelas crescentes mudanças sociais, pode-se afirmar que, no caso do Mercosul, apesar das deficiências e problemas, existe um processo inclusivo que vai além das fronteiras da cooperação, abrangendo áreas de significativo valor social (por exemplo, as normas relativas a direitos sociais e outros de natureza fundamental que se consubstanciam em Declarações, Decisões etc.).

\section{A MATRIZ PRINCIPIOLÓGICA DO DIREITO DA IN- TEGRAÇÃO REGIONAL}

Os princípios do direito da integração nascem do direito internacional, mas, posteriormente, adquirem natureza própria, como é o caso da gradualidade, da flexibilidade e do equilíbrio, todos eles calcados, em maior ou menor medida, no princípio do tratamento diferenciado; bem como os princípios da primacía, da aplicabilidade imediata e do efeito direito no caso do direito europeu. A interpretação e aplicação dos referidos princípios ocorre em concordância com o objetivo especificado por cada processo de integração, considerando-se as assimetrias existentes no âmbito interno destes processos. Além disso, conforme ressalta Arbuet-Vignali ${ }^{45}$,

\begin{abstract}
ao aparecer um processo de integração mais profundo, que requer um novo sistema jurídico para ordenar-se, volta-se a atualizar a necessidade de princípios, mais do que como uma resposta doutrinária, como uma exigência da prática e para permitir desenvolver, ordenar e encaminhar corretamente a vontade política dos Estados no sentido de integrar-se, obrigando-se profundamente sem confundir-se num novo Estado que os abarque, nem perder sua independência (...) Os processos de integração profunda seriam muito difíceis de concretizar sem sólidos princípios que lhes assistissem
\end{abstract}

sur, CARI/Argentina, BID/INTAL, Fundación Konrad Adenauer, Uruguay, 26-27 setembro 2002, p. 3 (formato paper).

45 No original: $\mathrm{Al}$ aparecer un proceso de integración más profundo, que requiere un nuevo sistema jurídico para ordenarse, se vuelve a actualizar la necesidad de principios, más que como una respuesta doctrinal, como una exigencia de la práctica y para permitir desarrollar, ordenar y encauzar correctamente la voluntad política de los Estados en el sentido de integrarse, obligándose profundamente sin confundirse en un nuevo estado que los abarque, ni perder su independencia (...) Los procesos de integración profunda serían muy difícil de concretar sin principios sólidos que les asistieran. ARBUET-VIGNALI, Heber. Claves jurídicas de la Integración - En los sistemas del MERCOSUR y la Unión Europea. Ed. Rubinzal-Culzoni, Santa Fe, 2004, p. 338. 
Em muitas partes do Tratado de Assunção (TA), pode-se encontrar, implícita o explicitamente, os princípios que servem como condutores do processo de integração. De maneira geral, esses princípios referem-se às condições necessárias para o devido desenvolvimento do mercado comum, caso do princípio da não discriminação (art. 8, d) que deve ser aplicado no Programa de Liberação Comercial para o Paraguai e o Uruguai (art. 6); na transparência aplicada na coordenação das políticas nacionais de modo a garantir condições equitativas de comércio con terceiros países y assegurar que seja aplicada condições iguais no tratamento comercial extrazona (art. 4); princípio da reciprocidade de direitos e deveres entre os Estados (art. 2); entre outros ${ }^{46}$.

A importância dos princípios de gradualidade, flexibilidade e equilíbrio foi analisada e ressaltada por distintos autores, considerando-se, também, que o princípio da reciprocidade encontraria-se, ainda que implicitamente, incluído no rol de princípios previsto no TA. Ainda conforme Gross Spiel" ${ }^{47}$, "los principios de gradualidad, flexibilidad y equilibrio informan, dan sentido y contenido a todo el proceso de creación y conformación del MERCOSUR, y deben ser aplicados en cada etapa y negociación relativa a los Derechos y deberes de las partes."

O princípio da gradualidade deve ser entendido como a adoção de maneira gradual e progressiva dos postulados que regem um mercado comum. Previsto anteriormente pelo Tratado de Montevideu de 1960 e também pelo de 1980. Esse princípio define as etapas necessárias para o desenvolvimento por etapas do processo de integração. Conforme especifica Ventura ${ }^{48}$, esse princípio pode ser interpretado tanto num plano vertical, em que o início de uma nova etapa estaria condicionada ao termo da etapa precedente, quanto num plano horizontal, vinculado à coordenação de distintos instrumentos que subjazem às etapas consecutivas.

O princípio da flexibilidade, como bem expressa o próprio nome, determina uma margem de manobra para que os Estados possam adotar e cumprir as obriga-

46 ESTRELA FARIA, José A. O Mercosul: princípios, finalidades e alcance do Tratado de Assunção. Ministério das Relações Exteriores, Brasília, 1993, p. 3-8.

47 GROSS ESPIELL, Hector. Tratado de Asunción: una aproximación a su problemática jurídica. Rev. de la Facultad de Derecho de Montevideo, n. 01, jul./dic. 1991, p. 21.

48 VENTURA, Deisy. As assimetrias entre o Mercosul e a Uniao Europeia. Sao Paulo: Ed. Manole, 2002, p. 44. ções relacionadas com o sistema jurídico fixado no TA, de uma maneira elástica e menos rígida. Como princípio previsto no Tratado de 1992, a flexibilidade se manifesta mais na forma que no conteúdo propriamente dito dos atos jurídicos mercosurlistas, ainda que não se pode desconhecer a excessiva flexibilidade adotada pelos Estados na formulação de um sistema institucional que resulte em maior segurança jurídica.

O princípio do equilíbrio visa garantir condições de igualdade entre todos os Estados partes. Claro está que o objetivo principal consiste em evitar os conflitos derivados que surgem da aplicação das diferentes legislações nacionais e por práticas comerciais de natureza claramente protecionista e distorsiva do mercado comum. Contudo, o equilíbrio não deve buscar, necessariamente, uma completa uniformidade entre a ordem interna nacional e a ordem comum, mas deve servir para corrigir as "assimetrias" surgidas no decorrer do processo de integração ${ }^{49}$. O tratamento desigual entre os Estados-partes não supõe, per si, um tratamento discriminatório, já que, em algumas ocasiões, um determinado país necessita de um tempo maior e/ou circunstâncias mais maleáveis para adequar-se à normativa comum quando comparado com os demais estados. O limite da igualdade deve ser formulado pelos próprios signatários do Tratado e pode ser garantido pela adoção de normas de caráter obrigatório que estabeleçam prazos ou condições de cumprimento especial por parte do membro favorecido ${ }^{50}$.

Finalmente, o princípio da reciprocidade possibilita adotar mecanismos de controle de aplicação de normas e instrumentos pelos Estados partes, assegurando que a incorporação da normativa comum seja realizada de maneira equivalente e recíproca entre todos os signatários. Além disso, torna-se elemento intrínseco à própria existência do mercado comum ao permitir o desenvolvimento do reconhecimento mútuo. Esse princípio deve ser interpretado com os demais princípios, especialmente o do equilíbrio, já que se inclui no quadro geral de vantagens e concessões mútuas dadas aos países

49 MATA DIZ, Jamile B. MERCOSUR: orígen, fundamentos, normas y perspectivas. Curitiba: Juruá, 2007, p. 156.

50 Lorezentti faz distinção entre os princípios estruturais: o respeito à ordem democrática; respeito pelos direitos humanos; desenvolvimento econômico com justiça social; proteção ambiental e transparência do mercado, e os princípios processuais: a gradualidade; reciprocidade e solidariedade. $\mathrm{O}$ autor refere-se ainda aos princípios relativos à liberdade de circulação de pessoas. LORENZETTI, Ricardo. Sistema jurídico del MERCOSUR. Rev. Jurisprudencia Argentina, Tomo E, Buenos Aires: Ed. La Ley, 1998, p. 1258-1275. 
participantes do processo de integração ${ }^{51}$.

Em relação aos princípios da União Europeia, pode-se citar, sem ânimo de esgotar o tema, aqueles que conformam a supranacionalidade normativa sendo atributos de tal modalidade de integração:

1) A primacía implica que, em caso de conflito, as normas comunitárias devem aplicar-se com prevalência sobre as nacionais, qualquer que seja a hierarquia ou posição das normas e com prescindência de aprovação interna posterior. Em outros termos, significa que, em caso de contradição entre uma norma comunitária e uma norma de direito interno, deve prevalecer a norma comunitária ${ }^{52}$. Essa supremacía incondicional e absoluta do direito comunitário fundamenta-se em sua natureza de ordenamento jurídico autônomo e é consequência direta da aplicabilidade imediata e do efeito direto, já que esses princípios determinam que as normas comunitárias sejam aplicadas de maneira geral, uniforme e incondicionada em todos os estados participantes, revogando, em caso de controvérsia, as normas de direito interno opostas ou contrárias às de direito comunitário. ${ }^{53}$

2) Efeito direito: o efeito direto ou aplicabilidade direta está intimamente relacionado com a aplicabilidade imediata e alude à capacidade do direito comunitário de gerar direitos e obrigações para os estados, instituições e cidadão. Seu efeito refere-se à possibilidade de que toda e qualquer pessoa possa demandar ao juiz nacional a aplicação do direito originário e derivado e a obrigação dos juízes de aplicar as normas comunitárias, qualquer que seja a legislação nacional do país, tanto nas relações entre particulares, como naquelas feitas entre estes e os Estados, bem como nas de natureza interestatal ${ }^{54}$. A doutrina $a^{55}$ e a jurisprudência fazem distinção entre

51 Sobre a incompatibilidade entre a reciprocidade e o tratamento diferenciado deve-se citar a TABARÉ, Vasquez y BIZZOZERO, Lincoln. La construcción del MERCOSUR: diagnóstico y evaluación de lo acordado. BID/INTAL, Buenos Aires, 1994, p. 12.

52 Neste sentido conforme ressalta Vidigal ao comentar a sentença Costa Enel emitida pelo então Tribunal de Justiça da Comunidade Europeia, "Consagra-se, pois, no Direito Comunitário, o chamado Princípio da Supremacia e do Efeito Direto, o que eleva os Tratados que instituem a Comunidade à condição de verdadeira Carta Constitucional". VIDIGAL, Erick. O regime jurídico das integrações político-econômicas regionais. Revista de Direito Internacional, Brasília, v. 8, n. 2, jul./dez. 2011, p. 103.

53 MATA DIZ, Jamile B. El sistema de incorporación de normas en el MERCOSUR: la supranacionalidad plena y la vigencia simultánea. Rev. Ius et Praxis, vol. 10, n. 02, Chile: Universidad de Talca, ago./dic. 2005, p.227 - 260.

54 MOLINA DEL POZO, Carlos F. Manual de Derecho de la Comunidad Europea. $4^{\text {a }}$ ed. Madrid: Dijusa, 2002, p. 822.

55 PALACIO GONZÁLEZ, Jose. El efecto directo: ¿Un con- o efeito direto horizontal, compreendido como a possibilidade de que o particular possa invocar as normas comunitárias tanto frente aos Estados como em relação a outro particular; e o efeito direto vertical: representa o fundamento inicial da construção do princípio, ao pregar a possibilidade de invocar as normas ante o estado que infringe ou não internaliza a norma comunitária.

3) Aplicabilidade imediata: a aplicabilidade imediata de uma norma comunitária implica que esta adquire automaticamente status de direito positivo na ordem interna dos Estados-membros, sem que haja procedimento nacional de incorporação ou internalização de norma ao ordenamento jurídico interno. Os poderes e órgãos dos Estados estão obrigados a aplicar as normas comunitárias, não podendo invocar razões de ordem constitucional ou supralegal para não fazê-lo. Na UE, o direito comunitário, em seu conjunto, goza de aplicabilidade imediata e se integra aos ordenamentos jurídicos nacionais pelo simples fato de ser a norma publicada no Diário Oficial da União Europeia.

\section{O OBJETO DO DIREITO DA INTEGRAÇÃO E A ES- PECIFICIDADE DAS RELAÇÕES INTERESTATAIS}

Os destinatários de um processo de integração serão sempre os cidadãos, a sociedade em geral, mas seus sujeitos são os entes estatais, reunidos numa espécie de associação tendente a criar vínculos mais profundos que aqueles estabelecidos num tratado internacional. Nesse sentido, os sujeitos da integração são os Estados - na mesma acepção do direito internacional público - mas a integração modifica substancialmente os elementos clássicos utilizados para a definição destes, ao possibilitar a livre circulação de pessoas, bens, serviços e capital.

Num sistema de cooperação interestatal clássico, calcado nos postulados do direito internacional, as transformações não afetam, na essencialidade, a todos os elementos do Estado, já que não acarreta, em geral, uma mutação no território e na população, ainda que possa modificar, em maior ou menor grau, o exercício do poder soberano por esse Estado, na medida em que, ao integrar-se a outro sujeito de direito internacional (seja Estado ou organização internacional), deverá submeter-

cepto en crisis? Revista Comunidad Europea, año XXVIII, n. 8-9. Madrid: Ed. Aranzadi, 2001, p. 34-44. 
-se aos objetivos que compõem o acordo de associação ou adesão. Mas, mesmo nesse caso, o Estado continua com a integralidade do poder soberano, pois será o encarregado de decidir ou não pela respectiva participação na integração.

Num sistema de comunitarização, fundado nas premissas do direito da integração e ainda mais no direito comunitário, as transformações afetam, em maior medida, os elementos do Estado, uma vez que os resultados pretendidos supõem a criação de um arcabouço normativo destinado ao cumprimento dos objetivos de uma integração mais profunda. Assim, esse sistema pode estipular, por exemplo, modificações estruturais no território por meio da abertura das fronteiras com a consequente livre circulação; na população, ao promover um fluxo indefinido de "nacionais" e "estrangeiros", e garantir igualdade de tratamento para todos os habitantes dos Estados partícipes da integração, inclusive chegando a uma concepção elástica de "nacional" e até mesmo "cidadão"; e finalmente, uma alteração significativa na acepção clássica de soberania, especificamente no exercício das competências e poderes estatais, ao criar um sistema de decisão amparado em instituições e normas de natureza supranacionais, que deverão exercer as funções e tarefas que foram delegadas por estes Estados. É valido recordar que, obviamente, o Estado continua no exercício da soberania que lhe é inerente, mas deverá "compartilhá-la" com os demais Estados integrantes do processo associativo. Ainda, o Estado também poderá decidir pela participação ou não nesse tipo de integração e, por isso, discordamos dos autores que afirmam haver uma perda de soberania ${ }^{56}$.

Assim, o chamado "Ente" supranacional representa, em verdade, a junção da vontade de distintos Estados em compartilhar mecanismos e decisões de índole política e jurídica destinadas a fortalecer o papel e a atuação dos partícipes nas relações exteriores em geral, além de estabelecer direitos e garantias que venham a aperfeiçoar o sistema normativo protetivo dos direitos fundamentais destes mesmos Estados.

\subsection{A integração e o elemento território: as fronteiras de um espaço integrado}

56 MATA DIZ, Jamile B.; MARTINS, Thiago Penido. Por uma reinterpretação dos elementos do Estado a partir da criação e consolidação dos processos de integração regional. In: Direito Internacional. RAIZER, Valeska; Del'Olmo, Florisbal. XXIII Congresso do CONPEDI. Aracaju, junho 2015 (no prelo).
A permeabilidade das fronteiras possibilita que a integração possa atingir o objetivo estrutural e funcional de facilitar que os fatores produtivos, vinculados ao mercado, possam lograr maior liberalidade na circulação e consequente comercialização dos bens e produtos. Sob o prisma da circulação de pessoas, os obstáculos devem ser removidos de forma a promover e garantir a igualdade de direitos e o tratamento não discriminatório, tal e como aplicado na União Europeia.

No caso específico dos processos de integração, torna-se importante analisar, também, a questão da livre circulação sob a perspectiva da "derrubada" dos limites territoriais, ao expurgar a necessidade de controles mais rigorosos sobre a mobilidade transfronteiriça, em quaisquer de seus aspectos. Agora, deve-se ressaltar desde já que não há eliminação propriamente dita das fronteiras, mas a adoção de critérios flexíveis de mobilidade que permitam maior circulação dos fatores produtivos e pessoais. Conforme expressa Papadodima, "as mudanças associadas com as novas funções de fronteiras internacionais supõem que elas são agora mais permeáveis aos movimentos e fluxos transfronteiriços, apesar das fronteiras internacionais permanecerem bem demarcadas." ${ }^{57}$

\subsection{A formação de um substrato social baseado numa cidadania comum}

A criação de uma cidadania europeia traz importantes reflexos para as relações existentes entre os conceitos de povo, território e soberania. Segundo o preceito contido no artigo 20 do Tratado de Funcionamento da União Europeia (TFUE), toda pessoa considerada como nacional de qualquer dos Estados-Membros adquirirá, sem prejuízo de sua nacionalidade, a cidadania europeia, razão pela qual se tornam titulares de direitos e deveres perante a referida comunidade de Estados, tais como o direito de livre circulação e residência em qualquer dos territórios dos Estados-Membros, o direito de votar e ser votado nas eleições do Parlamento Europeu, bem como nas eleições do Estado-Membro em que estiver residindo, de buscar proteção e amparo em

57 No original: "Los cambios asociados a las nuevas funciones de las fronteras internacionales, hacen asumir que son ahora más permeables a los movimientos y flujos transfronterizos, aunque los límites internacionales continúan siendo bien demarcados." PAPADODIMA, Zampeta. Las fronteras regionales: la materia de migraciones en la Geopolítica contemporánea. Cuadernos geográficos de la Universidad de Granada, n 48. Granada: UGR, 2011, p. 193. 
qualquer Estado-Membro, mesmo que inexista órgão representativo do Estado de sua nacionalidade, direito de peticionar aos órgãos públicos, dentre outros ${ }^{58}$.

Agora bem, uma questão relevante vinculada à cidadania e a livre circulação de pessoas se refere ao tratamento não discriminatório que deve imperar em todo o território europeu. O Tratado da União Europeia obriga os países-membros da UE a lutar ativamente contra a discriminação, não somente contra a discriminação por nacionalidade, senão também por gênero, raça, origem étnica, religião ou crença religiosa, idade, incapacidade ou inclinação sexual. A Carta dos Direitos Fundamentais da União Europeia (CDF-2007) proíbe ademais a discriminação por características genéticas, cor de pele, idioma, ou ideias políticas ou de outro tipo, bem como pelo "vínculo" a uma minoria nacional. Também a Carta sublinha a igualdade ante a lei e a proibição da discriminação.

\subsection{A irradiação dos efeitos da integração sobre o poder soberano dos Estados}

O elemento mais contravertido no debate sobre os processos de integração está relacionado com a questão de transferência de competências ou cessão da soberania que, em tese, pode ser desenvolvida por cada Estado. Ao estabelecer as mudanças na estrutura interna dos Estados membros de um processo de integração regional, principalmente político, institui-se um novo modelo de formação estatal que, de certa maneira, influi no conceito clássico de soberania. Mas, a integração regional não é definitivamente incompatível com a soberania nacional. A potestade de um país não será menos absoluta, porque a força do poder soberano vincula-se à participação na própria integração regional. As relações do direito comunitário, por exemplo, não negam nem excluem a soberania. Ao contrário, conformam um marco ampliado, que estende ou prolonga o poder soberano de um Estado, já que agora há uma "compatibilidade" com o poder soberano de outros Estados membros.

Assim, pode-se observar que a integração aumenta, qualitativamente, a soberania dos países integrantes

58 MATA DIZ, Jamile B.; LEMOS Jr., Eloy. O direito fundamental à livre circulação de pessoas: as transformações nos elementos do Estado advindas dos processos de integração regionais. In: Sistema Jurídico e Direitos fundamentais individuais e Coletivos. MENEZES, Wagner; DEL'OLMO, Florisbal (coord.). Florianópolis: CONPEDI, 2012, p. 888-898. do processo e que a mesma não pode subsistir como conceito que imponha um obstáculo à liberdade de associação entre os Estados. É mister que se proceda à revisão do termo, procurando desmaterializar a afirmação assumida pelos defensores do Estado clássico de que a soberania é a razão primeira para a existência de uma Nação. É diferente a relação internacional entre Estados no marco do regionalismo puro ${ }^{59}$, pois neste a vinculação é de independência e autonomia, mais do que de soberania, porque o direito internacional se coordena direta e automaticamente ao direito interno de cada país.

No caso de processos de integração, a mudança nos conceitos de soberania aplicada em cada um dos Estados membros dependerá do grau de integração atingido, com o qual se pode reconhecer um "partilhar de soberania" mais ou menos aprofundado, segundo o sistema de integração que se deseja atingir com a associação interestatal. A discussão em torno do compartilhamento de competências se centra, principalmente, na questão de determinar se os Estados, enquanto integrados num espaço institucional unificado, determinam a constituição de elementos dissociativos da soberania nacional, perdendo parte das funções estatais tradicionais.

Devemos enfatizar que a concepção da soberania como um valor jurídico-político materializado pela independência e autonomia dos Estados, originou-se a partir dos supostos do chamado Estado-nação, durante os séculos XVIII e XIX, mas que conseguiu uma grande expansão modificativa a partir do século XIX e XX. A questão também demanda maiores reflexões sobre se o compartilhamento se refere ao conteúdo formal da soberania e das conseguintes competências ou funções estatais, ou se se refere ao exercício das competências

59 Deblock y Brunelle fazem distinção entre regionalismo e regionalização ao afirmar que "Le régionalisme peut être considéré, dans le sens étroit du terme, comme une option de politique comérciale, à côté du multilatéralisme et du bilatéralisme, et ensuite, comme un moyen de favoriser la coopération économique et une plus grande intégration institutionelle entre les pays concernés, dans une région donnée, et en fin comme une forme particulière d'alliance en vue de promouvoir des intérêts communs et certains intérêts stratégiques particuliers sur la scène économique internationale. La régionalisation renvoie à la concentration et à l'intensification des échanges, commerciaux ou financiers, de même qu'à l'élargissement et à l'approfondissement des réseaux financiers, de production, de communication et de mise en marché des produits dans une région donnée." DEBLOCK, Christian; BRUNELLE, Dorval. Lé régionalisme économique international: de la prèmiere à la deuxième génération. Tous pour un ou chacun pour soi. FORTMANN, Maurice et all. (org.). Québec: Institut québécois des hautes études internationales, 1996, pp. 271-316. 
dadas às instituições, fazendo com estas continuem pertencendo ao Estado, podendo ser executadas pelas instituições comunitárias ${ }^{60}$.

A partilha de competências entre os Estados e as instituições supranacionais se dá, basicamente, pela própria vontade daqueles ao fixar as matérias que serão atribuídas às esferas supranacionais. $\mathrm{O}$ debate se refere ao questionamento da própria divisão ou compartilhamento entre os poderes estatais e supranacionais, já que se fala de transferência das competências estatais ou transferência de seu exercício e que, apesar de ser uma discussão vigente, não desperta maiores dúvidas quando os países-membros de uma Comunidade estabelecem normas a partir de uma raiz institucional comunitária: o poder legislativo comum. Não obstante, cabe indagar sobre a formação de instituições e técnicas de criação de um direito supraestatal, com base em pressupostos conceituais da supranacionalidade e de seus respectivos atributos.

\section{Considerações finais}

O principal aspecto que restou evidenciado, com base nas experiências teóricas e práticas vinculadas ao tema da integração regional, foi a necessidade de estabelecer os pressupostos para a construção de uma teoria própria e autônoma que pudesse explicar a consequente evolução e o desenvolvimento, mesmo que fragmentado, deste tipo de associação interestatal. No intuito, conforme fixado na introdução deste artigo, de compatibilizar os reais mecanismos usados pelos Estados quando decidem criar um espaço integrado, diferenciado das tradicionais e clássicas fórmulas baseadas no direito internacional.

Nesse sentido, vale ressaltar que o debate sobre a autonomia do direito da integração, ao compará-lo com o direito da União Europeia, pode ser, ainda, estabelecido com base na perspectiva de ser este direito da integração evoluído, aperfeiçoado, presente na União Europeia, enfatizando-se ainda ser a questão intergovernamentalidade versus supranacionalidade a nota distintiva entre ambas as espécies de Direito. Com base nessa constatação, pode-se afirmar

60 MATA DIZ, Jamile B.; MARTINS, Thiago Penido. Por uma reinterpretação dos elementos do Estado a partir da criação e consolidação dos processos de integração regional. In: Direito Internacional. RAIZER, Valeska; Del'Olmo, Florisbal. XXIII Congresso do CONPEDI. Aracaju, junho 2015 (no prelo). que a autonomia do direito da integração, sob a perspectiva teórica, pode embasar-se no já tradicional esquema de etapas econômicas e naquele apresentado pela teoria das relações internacionais, mas deve ir além, ao consubstanciar os pressupostos jurídicos que venham a compreender e categorizar tal ramo do Direito.

Em primeira aproximação, repise-se, teórica, pode-se afirmar ter o direito da integração método, princípios, objeto e fontes próprios, condizentes, então, com sua autonomia em relação ao direito internacional e até mesmo ao direito da União. Ao caracterizar os processos de integração, numa configuração teórica jurídica, quer estejam situados em zonas mais ou menos desenvolvidas de integração (ou seja, podem classificar-se desde uma união aduaneira até uma união política), entre a comunitarização e a internacionalização das normas, encontrando-se, portanto, sob a égide do direito da integração, entendido este como um plexo de normas descritivas de uma conduta para a comunitarização, mas que também não se enquadram no direito internacional. Prima-se pelo reconhecimento de um sistema próprio, ainda que compartilhe mecanismos e fontes do direito internacional, mas que permite aos Estados associados integrar-se num acordo com disposições comuns, sem que tenha especificamente adotado a supranacionalidade num sentido amplo. As diferenças estruturais entre as instituições supranacionais, as organizações de integração e as relações de cooperação (internacional) resultam na diversidade da natureza jurídica, das funções, competências e alcance das atribuições de cada uma delas.

Finalmente, nesse breve escorço teórico, delineamos alguns dos pressupostos que devem ser levados em consideração quando defende-se uma autonomia do direito da integração que seja capaz, ainda que de forma incipiente, de explicar e analisar devidamente o fenômeno da integração interestatal.

\section{Agradecimento}

A coautora agradece ao Programa Erasmus + Jean Monnet Chair activities 2015 - EAC/A04/2014 pelo financiamento dado para a realização da presente pesquisa no marco do projeto 565401-EPP-1-2015-1-BREPPJMO-CHAIR. O coautor agradece ao CNPq, que financiou a realização da presente pesquisa no Programa de Pós-Graduação em Direito da UFRGS no marco de uma Bolsa de Produtividade em Pesquisa. 


\section{REFERÊNCIAS}

ARBUET-VIGNALI, Heber. Claves jurídicas de la Integración en los sistemas del MERCOSUR y la Unión Europea. Santa Fe: Ed. Rubinzal-Culzoni, Santa Fe, 2004.

BETTTI, Emilio. Interpretação da Lei e dos atos jurídicos: teoria geral e dogmática. Trad.: Karina Janinni. $2^{\mathrm{a}}$ ed. - São Paulo: Martins Fontes, 2007.

CALIGIURI AMMENDIOLA, Eugenio R. FIGUEROA VEJAR, Alejandro A. Los principios de primacía y operatividad en el Derecho Comunitario como fundamento para la integración Latinoamericana. American Diplomacy, vol. 5, n. 01, North Carolina, invierno 2000.

CANARIS, Claus-Wilhelm. Pensamento sistemático e conceito de sistema na Ciência do Direito. $3^{\mathrm{a}} \mathrm{ed}$. Lisboa: Fundação Calouste Gulbenkian, 2002.

CRYER, Robert et all. Research methodologies in EU and International Law. Oxford and Portland: Hart Publishing, 2011.

DEBLOCK, Christian; BRUNELLE, Dorval. Lé régionalisme économique international: de la prèmiere à la deuxième génération. In : Tous pour un ou chacun pour soi. FORTMANN, Maurice et all (org.). Québec: Institut québécois des hautes études internationales, 1996, pp. 271-316.

DÍAZ LABRANO, Roberto Ruiz. Diferencias Institucionales en los distintos esquemas de integración. In: Integración Eurolatinoamericana. MOLINA DEL POZO, Carlos F. (coord.). Buenos Aires: Ed. Ediciones Ciudad Argentina, 1996.

DÍAZ LABRANO, Roberto Ruiz. Integración y Derecho. Buenos Aires: Ed. Ciudad Argentina, 1998.

DROMI, Laura San Martino. De la nueva historia del Derecho: a propósito del objeto, método y fuentes del Derecho del MERCOSUR. Buenos Aires: Ed. Ciudad Argentina, 1997.

ESTRELA FARIA, José A. O Mercosul: principios, finalidades e alcance do Tratado de Assunção. Ministerio das Relações Exteriores, Brasília, 1993.

FERRAZ JÚNIOR, Tércio Sampaio. Introdução ao Estudo do Direito: técnica, decisão, dominação. $6^{a}$ ed. - São Paulo: Atlas, 2008.
GALATERIA, Luigi; STIPO, Massimo. Manuale di Diritto Amministrativo. Roma: Ed. Torino, 1995.

GATTINONI DE MUJÍA, Maria C. El diálogo entre el juez de la jurisdicción nacional y el juez comunitario - Un análisis de la revisión prejudicial en Europa y en América Latina. Jornadas de Derecho Internacional. Organización de los Estados Americanos, Academia Diplomática del Perú. Lima, 17 al 20 de noviembre de 2003 (formato paper).

GOMES, Eduardo Biachi. Integração econômica no MERCOSUL: opiniões consultivas e a democratização no acesso ao tribunal permante de revisão. Revista de Direito Internacional, Brasília, v. 10, n 1, jan./jul. 2013.

GROSS ESPIELL, Hector. Tratado de Asunción: una aproximación a su problemática jurídica. Revista de la Facultad de Derecho de Montevideo, n. 01, jul./dic. 1991.

ISAAC, Guy. Manual de Derecho Comunitario general. $5^{a}$ edición. Madrid: Ed. Ariel, 2000.

JAEGER JUNIOR, Augusto. Metodologia jurídica europeia e mercosulista: considerações fundamentais. Revista da Secretaria do Tribunal Permanente de Revisão do Mercosul. Assunção: Secretaria do Tribunal Permanente de Revisão do Mercosul, a. 2, n. 3, mar. 2014. p. 117-157. Disponível em: http://www.revistastpr.com/index.php/rstpr/article/view/87/66, acesso em 13 mar 2015.

LAKATOS, Eva Maria; MARCONI, Mariana de Andrade. Fundamentos de metodologia científica: Técnicas de pesquisa. 3 ed. São Paulo: Atlas, 2003.

LOPEZ, Enrique Guillen. Metodología del Derecho Constitucional Europeo: Un derecho Constitucional para la integración política de Europa. Del pluralismo ideológico. Revista de Derecho Constitucional Europeo, n. 12, UGR, 2009.

LORENZETTI, Ricardo. Sistema jurídico del MERCOSUR. Revista Jurisprudencia Argentina, Tomo E, Buenos Aires: Ed. La Ley, 1998.

MATA DIZ, Jamile B. El sistema de incorporación de normas en el MERCOSUR: la supranacionalidad plena y la vigencia simultánea. Rev. Ius et Praxis, vol. 10, n. 02, Chile: Universidad de Talca, ago./dic. 2005.

MATA DIZ, Jamile B. MERCOSUR: orígen, fundamentos, normas y perspectivas. Curitiba: Juruá, 2007. 
MATA DIZ, Jamile B.; LEMOS Jr., Eloy. O direito fundamental à livre circulação de pessoas: as transformações nos elementos do Estado advindas dos processos de integração regionais. In: Sistema Jurídico e Direitos fundamentais individuais e Coletivos. MENEZES, Wagner; DEL'OLMO, Florisbal (coord.). Florianópolis: CONPEDI, 2012, p. 888-898.

MATA DIZ, Jamile B.; MARTINS, Thiago Penido. Por uma reinterpretação dos elementos do Estado a partir da criação e consolidação dos processos de integração regional. In: Direito Internacional. RAIZER, Valeska; Del'Olmo, Florisbal. XXIII Congresso do CONPEDI. Aracaju, junho 2015 (no prelo).

MAXIMILIANO, Carlos. Hermenêutica e aplicação do Direito. 19a ed. - Rio de Janeiro: Forense, 2002.

MOLINA DEL POZO, Carlos F. Manual de Derecho de la Comunidad Europea. $4^{a}$ ed. Madrid: Dijusa, 2002.

MONSANTO, Alberto. Dimensión jurídico-institucional del MERCOSUR. In: Estado, Mercado y Sociedad en el MERCOSUR. LAREDO, Iris (org.). Rosario: Editorial Universidad Nacional de Rosario, 1993.

MORAES, Isaias Albertin de; MORAES, Flávia Albertin de; MATTOS, Beatriz R. Bessa. O Mercosul e a importância de uma legislação ambiental harmonizada. Revista de Direito Internacional, Brasília, v. 9, n. 3, 2012.

NASSER, Salem Hikmat. Fontes e normas do direito internacional: um estudo sobre a soft law. São Paulo: Atlas, 2006.

PALACIO GONZÁLEZ, Jose. El efecto directo: ¿Un concepto en crisis? Revista Comunidad Europea, año XXVIII, n. 8-9. Madrid: Ed. Aranzadi, 2001.

PALLARES, Beatriz y AGUZIN, Luiz. El régimen de incorporación de los tratados en el derecho interno. Congreso Internacional de Cultura y Sistemas jurídicos comparados. Instituto de Investigaciones Jurídicas. UNAM, México, 2004, p. 23, disponible em http://www.juridicas.unam.mx/inst/evacad/even- tos/2004/0902/mesa3/76s.pdf, acesso en 15 dec 2004

PAPADODIMA, Zampeta. Las fronteras regionales: la materia de migraciones en la Geopolítica contemporánea. Cuadernos geográficos de la Universidad de Granada, n 48. Granada: UGR, 2011, p. 193.

PEÑA, Felix. Reglas de juego, instituciones e integración económica: Reflexiones en una perspectiva del MERCOSUR. Fundación BankBoston, oct. 2002, disponível em http://www.fundacionbankboston.com. ar/inst/sec10/docs-felixpena/articulos/2002-10-reglas-instituciones.doc, acesso em 12 set 2008.

PEREZ OTERMÍN, Jorge. E1 Mercado Común del Sur - desde Asunción a Ouro Preto: aspectos jurídico-institucionales. Montevideo: Fundación de Cultura Universitaria, 1995.

POPPER, Karl S. A lógica da pesquisa científica. 2. ed. São Paulo: Cultrix, 1975.

RANGEL, Vicente Marotta. Direito e Relações internacionais. $2^{a}$. Ed. São Paulo: Editora RT. 1981.

SAVID-BAS, Luis I. Los actos obligatorios de los órganos del MERCOSUR, los sistemas constitucionales y la división republicana de poderes. In: Chile y el MERCOSUR en América Latina. IRIGOIN BARRENNE, Jeannete (coord.). Santiago: Ed. Jurídica de Chile, 1999.

Seminario Las normas de Derecho Originario y Derivado del MERCOSUR - Su incorporación a los ordenamientos jurídicos de los Estados Partes. Secretaria del Mercosur, CARI/Argentina, BID/INTAL, Fundación Konrad Adenauer, Uruguay, 26-27 setembro 2002, p. 3 (formato paper).

STRECK, Lenio Luiz. Hermenêutica Jurídica e(m) Crise: uma exploração hermenêutica da construção do Direito. 10a . ed. Porto Alegre: Livraria do Advogado, 2010.

TABARÉ, Vasquez y BIZZOZERO, Lincoln. La construcción del MERCOSUR: diagnóstico y evaluación de lo acordado. BID/INTAL, Buenos Aires, 1994. 


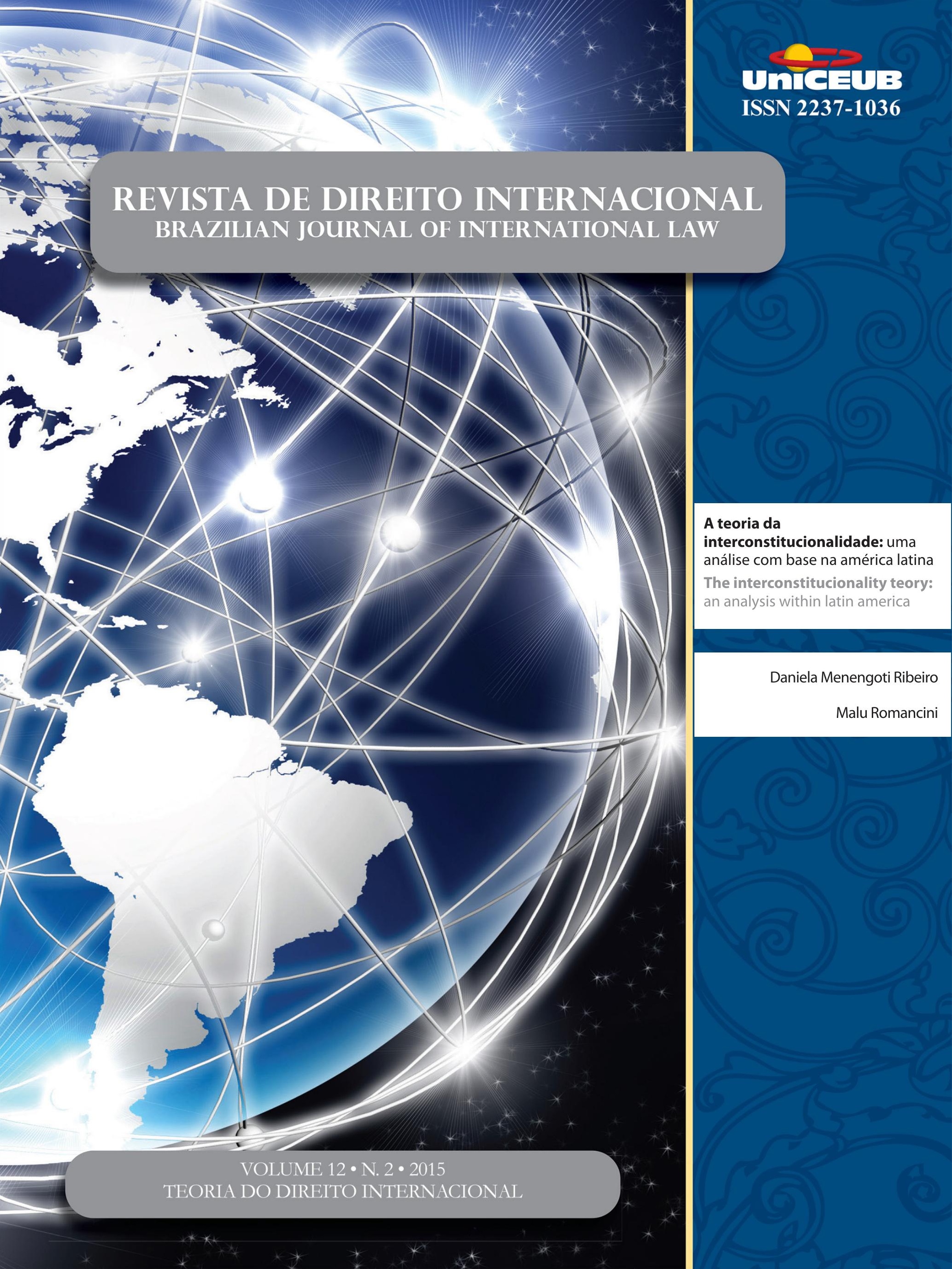




\title{
A teoria da interconstitucionalidade: uma análise com base na américa latina*
}

\section{The interconstitucionality teory: an analysis within latin america}

\author{
Daniela Menengoti Ribeiro** \\ Malu Romancini***
}

** Daniela M. Ribeiro é Professora do Programa de Mestrado em Ciências Jurídicas, graduação em Direito e Especialização EAD da Unicesumar. Pesquisadora da FUNADESP. Coordenadora/Líder do Grupo de Pesquisas (CNPq) "Internacionalização do direito: dilemas constitucionais e internacionais contemporâneos". Doutora em Direito-Relações Econômicas Internacionais pela Pontifícia Universidade Católica de São Paulo (PUC/SP) com período de pesquisa (doutorado sanduíche) na Université Paris 1 - Panthéon-Sorbonne, França. Mestre em Direito-Relações Internacionais, pela Universidade Federal de Santa Catarina (UFSC), com período de pesquisa no Mestrado em Integrazione Europea da Università Degli Studi Padova, Itália. Bolsista CNPq no mestrado e no doutorado. Especialista em Comercio Internacional y Inversiones, pela Universidad de Buenos Aires (UBA), Argentina. Especialista em Direito e Negócios Internacionais pela Universidade Federal de Santa Catarina (USFC).

*** Malu Romancini é Mestre em Direitos da Personalidade pela Unicesumar - Centro Universitário de Maringá-PR (2014-2015). Pósgraduada em Direito do Estado, com ênfase em Direito Constitucional, pela Universidade Estadual de Londrina (2013-2014). Bacharel em Direito pela Faculdade Maringá (2012). Bacharel em Secretariado Executivo Trilíngue pela Universidade Estadual de Maringá (2010). É advogada atuante, especialmente nas áreas de Direito Civil, Direito do Consumidor, Direito do Trabalho, Direito Empresarial, Direito Tributário, dentre outros. Atuou como professora de Direito Processual Civil na Fafiman Mandaguari (2014). Atualmente é professora de Direito Empresarial na Faculdade Alvorada, em Maringá (2015). Emails: daniela.mene ngoti@ gmail.com e maluromancini@gmail.com

\section{Resumo}

A presente pesquisa tem como objetivo estudar e compreender o fenômeno do interconstitucionalidade para demonstrar a efetividade dessa abordagem interconstitucional no âmbito da América Latina, o que se fará por meio de estudo de um caso julgado pela Corte Interamericana de Direitos Humanos. Utilizar-se-á o método dedutivo, instrumentos de pesquisa bibliográfica e análise jurisprudencial. Os resultados da pesquisa proposta neste artigo apontaram que a Teoria do Interconstitucionalidade, reconhecida inicialmente no sistema jurídico europeu, pode ser, também, identificada no contexto da América Latina, no âmbito do Sistema Interamericano de Direitos Humanos. Portanto, este artigo permitiu concluir que, em razão da conversação entre ordens jurídicas internacionais e da semelhança cultural, o interconstitucionalismo encontra alicerce para se desenvolver, e, ademais, permite maior proteção dos direitos dos indivíduos. O estudo do fenômeno do interconstitucionalismo em casos da Corte Interamericana de Direitos Humanos é inédito, cumprindo com seu caráter inovador e constituindo importante e rica fonte de informação com relevância acadêmica em razão da pujante internacionalização do direito, que implica na modificação da estrutura constitucional e na interação entre ordens jurídicas.

Palavras-chave: Interconstitucionalidade. América Latina. Corte Interamericana de Direitos Humanos.

\section{Abstract}

This research aims to study and understand the phenomenon of interconstitucionality to effectively demonstrate interconstitucional this approach in Latin America, which will be done through a case study judged by the Inter-American Court of Human Rights. It will use the deductive method, and instruments of literature research and jurisprudential analysis. The results of this research showed that the theory of interconstitucionality initially recognized only in the European legal system, can also be identified in the context of Latin America, in the inter-American Human Rights System. Therefore, this study concluded that because of the conversation between international legal systems and also cultural similarity, the interconstitucionalism finds ground to develop itself, and, moreover, allows greater protection of 
people's rights. The study of the interconstitucionalism in cases of the Inter-American Court of Human Rights is unprecedented, consisting the innovative character of this paper. Therefore, it constitutes an important and rich source of information with academic relevance due to the vigorous internationalization of law, which implies in the modification of constitutional structure and the interaction between legal systems.

Keywords: Interconstitucionalism. Latin America. Inter-American Court of Human Rights.

\section{INTRODUÇão}

A globalização e o consequente fortalecimento do direito internacional com o sentimento de mudança e troca de experiências que se instauraram no globo trouxeram uma evolução positiva considerável em relação aos direitos humanos e, dentro destes, os direitos da personalidade. Em razão disso, iniciou-se um processo de acentuada integração da sociedade mundial e, assim, os problemas relacionados aos direitos da personalidade - aqueles que são inerentes aos seres humanos tornaram-se impossíveis de ser amparados somente no âmbito doméstico dos Estados devido à importância de sua efetivação e tutela.

É nesse contexto que o direito constitucional inicia, assim, um processo de transformação desde o século passado, em que houve preocupação com os novos desafios de um direito que transcendeu as fronteiras dos Estados para diversas ordens jurídicas. Esse fenômeno foi denominado por por J. J. Canotilho como "interconstitucionalismo" que pode ser compreendido, de maneira breve, como a utilização de conversações constitucionais, bem como o estudo das relações interconstitucionais de concorrência, convergência, justaposição e conflitos de várias constituições e de vários poderes constituintes no mesmo espaço político.

É a partir dessa proposição que a presente pesquisa propõe-se a analisar se a Teoria Interconstitucionalidade proposta por Canotilho vem sendo utilizada no âmbito da Corte Interamericana de Direitos Humanos, como uma forma de fortalecimento e efetivação da tutela de problemas constitucionais envolvendo os direitos da personalidade.

Para tanto, o presente artigo busca analisar as ten- dências do Constitucionalismo global. Assim, abordar-se-á a mudança no Direito Constitucional tradicional e no Direito Internacional clássico, para tentar encontrar um direito intermediário, que melhor se encaixe com os problemas globais atuais.

Para tal, tratar-se-á da construção de um constitucionalismo global e da intensificação e da legitimação do interconstitucionalismo para a tutela dos direitos inerentes aos seres humanos. Por fim, dentro do mesmo tópico, será analisada a presença desse fenômeno na Europa - União Europeia - e - América Latina - Organização dos Estados Americanos.

A terceira e última parte deste estudo tratará da análise de um caso prático em que se percebe a presença do interconstitucionalismo no Sistema Interamericano de Direitos Humanos, a fim de demonstrar a sua ocorrência na América Latina.

\section{TendênCias do CONSTitucionalismo global}

O cenário que se instaurou ano mundo pós a Segunda Guerra fez com que a sociedade internacional buscasse um ambiente baseado na paz, na harmonia e na proteção mais efetiva dos direitos das pessoas. Com isso, surgiu a necessidade premente de cooperação internacional para alcançar interesses comuns, e neste contexto, começou a delinear-se um fenômeno, que posteriormente seria chamado de globalização.

Para Anthony Giddens, um dos primeiros autores a conceituar o termo,

[a] globalização, em suma, é uma complexa
variedade de processos, movidos por uma mistura
de influências políticas e econômicas. [...] Ela é
mais que o mero pano de fundo para políticas
contemporâneas: tomada como um todo, a
globalização está transformando as instituições das
sociedades em que vivemos. ${ }^{1}$

Essas mudanças provocaram o fortalecimento do direito internacional e trouxeram à tona o questionamento quanto o tradicional conceito de direito constitucional. Canotilho ${ }^{2}$ explica que a questão atual que

1 GIDDENS, Anthony. A terceira via: reflexões sobre o impasse político atual e o futuro da sociela-democracia. Tradução de Maria Luiza X. de A. Borges. Rio de Janeiro: Record, 2000, p. 43

2 CANOTILHO, J. J. Gomes. "Brancosos" e interconstitucionalidade: itinerários dos discursos sobre a historicidade constitucional. 2. ed. Almedina: Coimbra, 2008. p.190. 
se coloca à Constituição e ao direito constitucional é saber se pode-se continuar a considerar adequado um conceito de Constituição nos moldes de Luhmann, qual seja, pura e simplesmente como um horizonte de sentido dotado de instruções para uso suficiente de prática.

\section{Canotilho assevera que:}

[...] mesmo na era da globalização, o problema de constitucionalizar uma ordem política e econômica através do direito continua a residir na assimetria entre a "responsabilidade" imposta pelo Estado de direito democrático no plano político, social e econômico, e as suas reais capacidades de actuação, agora num contexto global crescentemente compressor da modelação jurídico-política estatal em matéria de segurança, de liberdade e do próprio direito ${ }^{3}$.

A tese de Luhmann é de que o conceito de Constituição é simplesmente uma reação à diferenciação entre direito e política, ou, em outras palavras, à total separação de ambos os sistemas de funções e à consequente necessidade de uma religação entre eles ${ }^{4}$. O que Luhmann faz, em poucas palavras, é separar o homem do sistema.

Ademais, Luhman afirma que a Constituição deve ser entendida como "[...] uma inovação de origem política no interior do próprio sistema do direito" ${ }^{5}$. O autor explica que pode haver confusão ao se pensar que, no passado, havia a ideia, apenas, de leis particularmente importantes e fundamentais, mas não a ideia de que houvesse uma lei que serviria de medida da conformi-

3 CANOTILHO, J. J. Gomes. "Brancosos" e interconstitucionalidade: itinerários dos discursos sobre a bistoricidade constitucional. 2. ed. Almedina: Coimbra, 2008. p. 22.

4 LUHMANN, Niklas. A constituição como Aquisição Evolutiva. Tradução realizada a partir do original ("Verfassung als evolutionäre Errungenschaft”. In: Rechthistorisches Journal . Vol. IX, 1990, pp. 176 a 220), cotejada com a tradução italiana de F. Fiore ("La costituzione come acquisizione evolutiva". In: ZAGREBELSKY, Gustavo. PORTINARO, Pier Paolo. LUTHER, Jörg. Il Futuro della Costituzione. Torino: Einaudi, 1996), por Menelick de Carvalho Netto, Giancarlo Corsi e Raffaele De Giorgi. Notas de rodapé traduzidas da versão em italiano por Paulo Sávio Peixoto Maia (texto não revisado pelo tradutor), p. 04.

5 LUHMANN, Niklas. A constituição como Aquisição Evolutiva. Tradução realizada a partir do original ("Verfassung als evolutionäre Errungenschaft". In: Rechthistorisches Journal . Vol. IX, 1990, pp. 176 a 220), cotejada com a tradução italiana de F. Fiore ("La costituzione come acquisizione evolutiva". In: ZAGREBELSKY, Gustavo. PORTINARO, Pier Paolo. LUTHER, Jörg. Il Futuro della Costituzione. Torino: Einaudi, 1996), por Menelick de Carvalho Netto, Giancarlo Corsi e Raffaele De Giorgi. Notas de rodapé traduzidas da versão em italiano por Paulo Sávio Peixoto Maia (texto não revisado pelo tradutor), p. 06. dade ou não conformidade ao direito de todas as outras leis e atos jurídicos. Essa posição particular, entretanto, somente adveio após a Declaração da Independência Americana de $1776^{6}$.

Nesse sentido, Canotilho afirma que o "[...] risco de a Constituição não estar em condições de continuar a ser compreendida como estatuto jurídico do político torna-se agora indisfarçável"’. E continua a explicar que"[...] mesmo que haja um Legal Transplant8 da ideia constitucional a nível global, nem por isso a Constituição poderá aspirar a ser mais do que é: um texto útil para direitos e políticas simbólicas".

Luigi Ferrajoli concorda que há um problema de salvaguarda dos direitos dos indivíduos a nível global, uma vez que, segundo ele, o mundo vive atualmente à mercê de um "vazio de direito público internacional":

a falta de uma esfera pública internacional no sentido aqui definido é a grande lacuna dramaticamente revelada pelas tragédias desses anos: pelas guerras, por tantos crimes contra a humanidade, pelo crescimento das desigualdades e pelas devastações ambientais. À crise dos Estados e, portanto, ao papel das esferas públicas nacionais, não correspondeu a construção de uma esfera pública à altura dos processos de globalização em curso. Faltam, ou são de todo débeis, não somente as garantias dos direitos solenemente proclamados, ou seja, a previsão de proibições e obrigações a eles correspondentes, mas também as instituições internacionais dedicadas às funções de garantia, quer dizer, à salvaguarda da paz, à mediação dos conflitos, à regulação do mercado e à tutela dos direitos e dos bens fundamentais de todos ${ }^{10}$.

6 LUHMANN, Niklas. A constituição como Aquisição Evolutiva. Tradução realizada a partir do original "Verfassung als evolutionäre Errungenschaft”. In: Rechthistorisches Journal . Vol. IX, 1990, pp. 176 a 220), cotejada com a tradução italiana de F. Fiore ("La costituzione come acquisizione evolutiva". In: ZAGREBELSKY, Gustavo. PORTINARO, Pier Paolo. LUTHER, Jörg. Il Futuro della Costituzione. Torino: Einaudi, 1996), por Menelick de Carvalho Netto, Giancarlo Corsi e Raffaele De Giorgi. Notas de rodapé traduzidas da versão em italiano por Paulo Sávio Peixoto Maia (texto não revisado pelo tradutor), p. 06.

7 CANOTILHO, J. J. Gomes. "Brancosos" e interconstitucionalidade: itinerários dos discursos sobre a historicidade constitucional. 2. ed. Almedina: Coimbra, 2008, p. 190.

8 Pode ser traduzido como um transplante legal/legitimado.

9 CANOTILHO, J. J. Gomes. "Brancosos" e interconstitucionalidade: itinerários dos discursos sobre a historicidade constitucional. 2. ed. Almedina: Coimbra, 2008, p. 190.

10 FERRAJOLI, Luigi. Democracia, estado de direito e jurisdição na crise do estado nacional. Disponível em: <file:///D:/PC\%20Malu/Pessoal/Mestrado/Disserta\%C3\%A7\%C3\%A3o/FERRAJOLI $\% 20$ DIREITO \%20DO\%20ESTADO\%202013.pdf>. Acesso em: 03 jun. 2015, p. 09. 
Pode-se notar a preocupação do autor quanto à questão da efetividade do direito internacional, de modo que difere-se do direito interno, principalmente porque este tem formas de imposição e possui coercibilidade, enquanto aquele funda-se na voluntariedade dos Estados. Em outras palavras, o direito interno dos Estados possui meios de coação, meios de ser respeitado e o direito internacional é uma jurisdição voluntária, isto é, os Estados não são obrigados a se submeterem às suas normas, a não ser que seja de sua livre vontade fazê-lo. E, uma vez submetidos à uma jurisdição internacional, o Estado fica vinculado e pode ser repreendido por meio de embargos econômicos, dentre outras sanções.

Nesse contexto, deve-se repensar a ordem internacional, em um cenário em que a globalização gerou efeitos tão significativos. O que se percebe é que o direito constitucional viu-se obrigado a andar conjuntamente com o direito internacional, conforme assevera Canotilho:

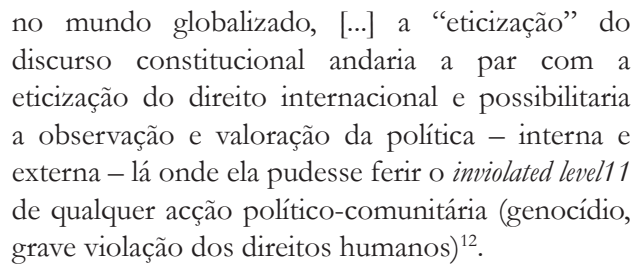
discurso constitucional andaria a par com a eticização do direito internacional e possibilitaria a observação e valoração da política - interna e externa - lá onde ela pudesse ferir o inviolated level11 de qualquer acção político-comunitária (genocídio, grave violação dos direitos humanos) ${ }^{12}$.

Diante dessa problemática, tentou-se conduzir este estudo de modo a encontrar uma solução para esse "vazio de direito público" ao qual se refere Ferrajoli. Primeiramente, deve-se modificar o direito constitucional, para o fim de que o constitucionalismo se adapte ao cenário jurídico global verificado atualmente. Canotilho afirma que as fronteiras entre o direito constitucional e o direito internacional estreitaram-se a tal ponto que hoje se trata do direito constitucional internacional e do direito internacional constitucional ${ }^{3}$.

Eis aqui a questão central deste estudo: como resolver esse problema? Diante da globalização e da modificação da condição da soberania estatal frente ao direito internacional, o interconstitucionalismo se mostra uma alternativa eficaz para o fim de tutelar os direitos dos cidadãos - em especial os direitos da personalidade - em um âmbito internacional?

11 Pode ser traduzido como nível inviolável das ações dos países. 12 CANOTILHO, J. J. Gomes. "Brancosos" e interconstitucionalidade: itinerários dos discursos sobre a historicidade constitucional. 2. ed. Almedina: Coimbra, 2008, p. 191-192.

13 CANOTILHO, J. J. Gomes. "Brancosos" e interconstitucionalidade: itinerários dos discursos sobre a historicidade constitucional. 2. ed. Almedina: Coimbra, 2008, p. 285.
A globalização e a fragmentação de interesses, a pluralização dos âmbitos sociais, o pluralismo das fontes do direito e a multiplicidade de formas de autoridades modificaram o conceito clássico de soberania. Para Ferrajoli, a matriz jusnaturalista do conceito embasou a concepção positivista do Estado e caracteriza um resquício do mundo jurídico pré-moderno. ${ }^{14}$

Nesse contexto, Duarte afirma que as transformações global ou comunitariamente (pela Comunidade/ União Europeia) impostas aos mecanismos estatais culminam em uma necessária reformulação a respeito do próprio conceito de Estado ${ }^{15}$.

Deve haver, conjuntamente, um reformulação das constituições dos Estados que deverão modificar-se no sentido de fornecer "[...] o conjunto de parâmetros básicos. Isso é o que se pensa em termos de Constituição, como um mecanismo capaz de lidar com os influxos gerados pela globalização" ${ }^{\prime 1}$.

Nesse sentido, Engelmann alerta que as Constituições deverão conter o conteúdo mínimo, ou seja, prever os parâmetros básicos, se tornando um mecanismo flexível para lidar com as inquietações que possam vir a aparecer no mundo globalizado ${ }^{17}$.

O que se percebe é que o Estado, mesmo que lhe sejam dadas atribuições, tem sua ação prejudicada no âmbito internacional, em um contexto globalmente interligado. Ferrajoli sustenta que, dessa forma, diminuem as possibilidades de controle dos Estados sobre a economia, sempre mais autônoma no mercado global ${ }^{18}$.

Canotilho, corroborando o pensamento de Ferrajoli,

14 Ver a respeito em: FERRAJOLI, Luigi. A soberania no mundo moderno: nascimento e crise do Estado nacional. Tradução de Carlo Coccioli e Márcio Lauria Filho. Revisão da tradução de Karina Jannini. 2. ed. São Paulo: Martins Fontes, 2007.

15 DUARTE, Écio Oto Ramos. Entre constitucionalismo cosmopolita e pluriversalismo internacional: neoconstitucionalismo e ordem mundial. Rio de Janeiro: Lumen Juris, 2014, p. 16.

16 DUARTE, Écio Oto Ramos. Entre constitucionalismo cosmopolita e pluriversalismo internacional: neoconstitucionalismo e ordem mundial. Rio de Janeiro: Lumen Juris, 2014, p. 120.

17 ENGELMANN, Wilson. A crise constitucional: a linguagem e os direitos humanos como condição de possibilidade para preservar o papel da Constituição no mundo globalizado. In: MORAIS, José Luis Bolzan de (Org.) O Estado e suas crises. Porto Alegre: Livraria do Advogado, 2005, p. 242.

18 FERRAJOLI, Luigi. Democracia, estado de direito e jurisdição na crise do estado nacional. Disponível em: <file:///D:/PC\%20Malu/Pessoal/Mestrado/Disserta\%C3\%A7\%C3\%A3o/FERRAJOLI $\% 20$ DIREITO \%20DO\%20ESTADO\%202013.pdf>. Acesso em: 03 jun. 2015, p. 05. 
assevera que o Estado tornou-se um "herói local", uma vez que

[...] quem quiser compreender o lugar e o sentido da Constituição terá de apelar para um patriotismo constitucional de inclusividade. Isso significa uma Constituição aberta a outros espaços, aberta a outras pessoas, aberta a outras normas, aberta a conflitos e consensos, aberta à sobreposição experiencial de consensos $^{19}$.

Nessa perspectiva, tratar-se-á da compreensão e da aplicação, na América Latina, da Teoria da Interconstitucionalidade, visando verificar a sua aplicabilidade para a proteção mais eficaz dos direitos dos cidadãos.

\section{A teoria DA INTERCONSTITUCIONALIDADE}

Inicialmente, é preciso compreender a proposta da análise desse fenômeno trazida por Canotilho, que se refere a um processo de construção do constitucionalismo europeu a ser estudado com base na Teoria de Interconstitucionalidade. Essa teoria, a princípio, estuda as relações interconstitucionais de concorrência, convergência, justaposição e conflitos de várias constituições e de vários poderes constituintes no mesmo espaço político ${ }^{20}$.

O constitucionalista português explica que a Teoria da Interconstitucionalidade já teve precedentes tanto na ordem jurídica medieval quanto na articulação da Constituição Federal em consonância com as constituições estatais $^{21}$.

No período medieval, podia se observar a convivência de diversas ordens jurídicas ao mesmo tempo em um só território ou região. Da mesma maneira, quando se observa a inter-relação entre as constituições estatais - de um Estado federativo - em detrimento da Constituição Federal, há um entrelaçamento, bem como uma justaposição entre ordens jurídicas - nesse caso, de ordem constitucional sobre ordem infraconstitucional.

Nesses Estados compostos, como é o caso do Brasil,

19 CANOTILHO, J. J. Gomes. "Brancosos" e interconstitucionalidade: itinerários dos discursos sobre a historicidade constitucional. 2. ed. Almedina: Coimbra, 2008. p.197.

20 CANOTILHO, J. J. Gomes. "Brancosos" e interconstitucionalidade: itinerários dos discursos sobre a historicidade constitucional. 2. ed. Almedina: Coimbra, 2008. p. 265-266.

21 CANOTILHO, J. J. Gomes. "Brancosos" e interconstitucionalidade: itinerários dos discursos sobre a bistoricidade constitucional. 2. ed. Almedina: Coimbra, 2008. p. 266. está sempre presente a articulação dos seguintes princípios: o princípio da sobreposição de ordens jurídicas ${ }^{22}$, o princípio da autonomia das unidades integrantes ${ }^{23}$ e o princípio da participação24 no poder central ${ }^{25}$.

Assim, pode-se afirmar que fenômeno do interconstitucionalismo teve suas origens nos ordenamentos medievais. No entanto, o interconstitucionalismo, que se trata neste estudo, é aquele que se percebe nos moldes atuais de concorrência, convergência e conflitos entre diversos poderes constituintes convivendo no mesmo espaço político.

A Teoria da Interconstitucionalidade enfrenta, dentre outros problemas, o da articulação entre constituições e da afirmação de poderes constituintes com fontes e legitimidades diversas ${ }^{26}$.

Para melhor entender esse fenômeno, é preciso estudar seus elementos básicos. O primeiro deles é a autodescrição, que significa dizer que "[...] autodescritivamente, os textos constitucionais nacionais conservam a memória e a identidade política e, quando inseridos numa rede interconstitucional, assumem-se sempre como autorreferência" ${ }^{27}$.

Em outras palavras, as constituições dos Estados não desaparecerão, mas sofrerão mudanças ao serem inseridas no contexto da rede interconstitucional. Isso porque o Estado deve "obedecer" as normativas internacionais, porém sem perder sua memória e identidade política.

Antonio Carlos Wolkmer defende a identidade cultural de uma região em suas constituições, a constituição não deve ser tão somente uma matriz
geradora de processos políticos, mas uma resultante
de correlações de forças e de lutas sociais em um
dado momento histórico do desenvolvimento da

22 No que diz respeito à sobreposição da ordem constitucional sobre a ordem infraconstitucional.

23 A autonomia das unidades integrantes é vislumbrada uma vez que os Estados podem elaborar suas constituições estatais.

24 E o princípio da participação do poder central se traduz em duas premissas: a primeira delas diz respeito à delegação de poder do poder central para os periféricos - no caso os Estados.

25 CANOTILHO, J. J. Gomes. "Brancosos” e interconstitucionalidade: itinerários dos discursos sobre a historicidade constitucional. 2. ed. Almedina: Coimbra, 2008. p. 266-267.

26 CANOTILHO, J. J. Gomes. "Brancosos" e interconstitucionalidade: itinerários dos discursos sobre a historicidade constitucional. 2. ed. Almedina: Coimbra, 2008, p. 267-268.

27 CANOTILHO, J. J. Gomes. "Brancosos" e interconstitucionalidade: itinerários dos discursos sobre a historicidade constitucional. 2. ed. Almedina: Coimbra, 2008. p. 269. 
sociedade. Enquanto pacto político que expressa a pluralidade, ela materializa uma forma de poder que se legitima pela convivência e coexistência de concepções divergentes, diversas e participativas ${ }^{28}$.

Para Peter Häberle, a Constituição deve ser concebida como cultural, pois não é somente um ordenamento jurídico voltado aos juristas, tampouco um mero texto jurídico, mas sim uma expressão de uma situação cultural e instrumento de autorrepresentação do povo ${ }^{29}$. Logo, a interpretação constitucional, sendo concebida como um produto cultural e aberto, deve pressupor um exercício de participação democrática ${ }^{30}$.

Esse caráter autodescritivo faz com que haja a manutenção do valor e da função das constituições estaduais. Canotilho explica esse processo por meio de uma metáfora, uma vez que afirma que as constituições dos Estados desceram do "castelo" para a "rede", mas não perderam as funções identificadoras pelo fato de, agora, estarem interligadas umas com as outras ${ }^{31}$.

Outra característica da interconstitucionalidade é o texto interorganizativo, o que implica a necessidade autodescritiva da organização superior, no caso europeu, da organização da União Europeia ${ }^{32}$.

Outros doutrinados, a exemplo de Mireille Delmas-Marty, estudam esse fenômeno de universalização das normas jurídicas denominado pela autora como "internacionalização dos direitos", cuja finalidade consiste em propor e analisar o fenômeno de aproximação dos sistemas jurídicos, mas não propriamente de sugerir uma unificação. ${ }^{33}$

28 WOLKMER, Antonio Carlos. Pluralismo crítico e perspectivas para um novo constitucionalismo na América Latina. In: WOLKMER, Antonio Carlos; MELO, Milena Petters. (Orgs.). Constitucionalismo latino-americano: tendências contemporâneas. Curitiba: Juruá, 2013, p. 19.

29 HÄBERLE, Peter; HABERMAS; Jürgen; FERRAJOLI, Luigi. VITALE, Ermanno. La constitucionalización de Europa. México: Instituto de Investigaciones Jurídicas de la UNAM, 2004. p. 25.

30 LEAL, Mônia Clarissa Hennig. La noción de constitución abierta de peter haberle como fundamento de una jurisdicción constitucional abierta y como presupuesto para la intervención del amicus curiae en el derecho brasileño. In: Estudios Constitucionales, Año 8, $\mathrm{N}^{\mathrm{o}}$ 1, 2010 , pp. 283 - 304.

31 CANOTILHO, J. J. Gomes. "Brancosos" e interconstitucionalidade: itinerários dos discursos sobre a historicidade constitucional. 2. ed. Almedina: Coimbra, 2008, p. 269.

32 CANOTILHO, J. J. Gomes. "Brancosos" e interconstitucionalidade: itinerários dos discursos sobre a historicidade constitucional. 2. ed. Almedina: Coimbra, 2008, p. 270.

33 Ver a respeito em: DELMAS-MARTY, Mireille. Les forces imaginantes $d u$ droit: le relaatif et l'universel. Paris, França: Seuil, 2004.
Também o constitucionalista alemão Peter Häberle afirma que "[...] hoje o Estado Constitucional e o Direito Internacional transformam-se em conjunto. $\mathrm{O}$ Direito constitucional não começa onde cessa o Direito Internacional". E continua sustentando também o “[...] contrário, ou seja, o Direito Internacional não termina onde começa o Direito Constitucional.”34

Porém, em contrapartida à interconstitucionalidade, o transconstitucionalismo teorizado por Marcelo Neves é a que mais se enquadra, no âmbito da América Latina, de paradigma à teoria apresentada por Canotilho. $\mathrm{O}$ transconstitucionalismo é caracterizado como uma relação transversal permanente entre ordens jurídicas em torno de problemas constitucionais comuns, como é o caso das questões que envolvem os direitos fundamentais e direitos humanos, por exemplo ${ }^{35}$.

O viés transconstitucionalista de Neves importa na relação de complementaridade entre as inúmeras ordens jurídicas existentes por meio da relação entre identidade e alteridade, no momento em que procuram reconstruir sua identidade por meio do entrelaçamento transconstitucional e rearticular com base na alteridade.

Nesse sentido, Neves fala em "conversação" ou "diálogo" entre Cortes, que podem ser vislumbrados em vários níveis, como por exemplo, o diálogo entre o Tribunal de Justiça das Comunidades Europeias (supranacional) e os Tribunais dos Estados-membros.

Neves aponta que a peculiaridade do transconstitucionalismo é o fato de o autor não abordar somente o entrelaçamento jurídico, mas também o fato de as ordens jurídicas se entrelaçarem no plano reflexivo de suas estruturas normativas, não havendo que se falar em hierarquia entre elas. Além disso, ele afirma que o fenômeno faz emergir uma "fertilização constitucional cruzada", isto é, as cortes passam a citar-se, não como precedentes, mas como autoridade persuasiva. Sendo assim, o que ocorre é um diálogo constitucional de aprendizagem recíproca ${ }^{36}$.

Portanto, o que caracteriza o transconstitucionalismo é o entrelaçamento de ordenamentos e normativas de órgãos internacionais, órgãos transnacionais, versus

34 HÄBERLE, Peter. Estado constitucional cooperativo. Rio de Janeiro: Renovar, 2007, pp. 11 - 12

35 NEVES, Marcelo. Transconstitucionalismo. São Paulo: Martins Fontes, 2013, p. XXI.

36 NEVES, Marcelo. Transconstitucionalismo. São Paulo: Martins Fontes, 2013, p. 118-119. 
tribunais internos dos Estados, dentre outros. O que se espera é um diálogo entre as ordens constitucionais conflitantes, por meio das chamadas pontes de transição, para o fim de que ambas troquem conhecimentos e citem-se umas às outras como forma de precedentes.

Assim, tendo comparado as principais características do interconstitucionalismo, bem como do transconstitucionalismo, parece correto afirmar que o fenômeno do interconstitucionalismo se mostra como uma alternativa mais adequada, em um cenário em que "[...] as decisões dos Estados têm cada vez mais efeitos extraterritoriais, em virtude das interdependências globais. Consequentemente, acabam por vincular, de forma crescente, pessoas diferentes daquelas que participaram na recolha dos titulares da decisão" 37 .

Isso porque, a ideia central é demonstrar que, o que se apresenta viável é a apreciação do interconstitucionalismo, fenômeno visível nos ordenamentos jurídicos, em razão do entrelaçamento de ordenamentos por causa da globalização e do fortalecimento do direito internacional.

Corroborando esse pensamento, preceitua Canotilho que

[...] claramente se compreendeu que uma sociedade funcionalmente diferenciada é também uma sociedade de organização e das organizações. Ora, as organizações atuam como actores corporativos. [...] Neste contexto, mantêm-se as pretensões de direção do Estado. Mas, com uma grande diferença: em vez do velho "estado heroico", hierarquicamente intervencionista, deve erguer-se o "Estado pós-heróico" - o Estado supervisor que, através de uma direção contextualizada (ou seja, através de uma autovinculação), proporciona, mas não determina, as convenções-quadro para a prossecução do bem comum ${ }^{38}$.

O que o autor português quis dizer é que o Estado deve mudar de figura nessa sociedade internacional, se levantando simplesmente como o supervisor e determinando mormente as normas padrões para sua sociedade.

No entanto, ao se tratar da Teoria da Interconstitucionalidade, tem-se que esta não se resume a um pro-

37 CANOTILHO, J. J. Gomes. "Brancosos" e interconstitucionalidade: itinerários dos discursos sobre a bistoricidade constitucional. 2. ed. Almedina: Coimbra, 2008. p. 291.

38 CANOTILHO, J. J. Gomes. "Brancosos" e interconstitucionalidade: itinerários dos discursos sobre a historicidade constitucional. 2. ed. Almedina: Coimbra, 2008. p. 147-148. blema de interorganizatividade entre os Estados. Ela é também uma Teoria de Interculturalidade Constitucionaß ${ }^{39}$.

Por interculturalidade entende-se como o conjunto de propostas de convivência democrática entre diferentes culturas, visando à integração entre elas sem anular sua diversidade, pelo contrário, essa proposta incentiva o potencial criativo e vital resultante da relações entre diferentes agentes e seus respectivos contextos ${ }^{40}$.

O próprio artigo 98 da Constituição boliviana de 2009 define interculturalidade, ao afirmar que a diversidade cultural constitui a base essencial do Estado Plurinacional Comunitário e que a "[...] interculturalidade é o instrumento para a coesão e a convivência harmônica e equilibrada entre todos os povos e nações. Assim, a interculturalidade terá lugar com respeito às diferenças e na igualdade de condições" ${ }^{\prime 4}$.

Vasconcelos esclarece que "[...] a questão da interculturalidade ultrapassou os limites dos países hegemônicos a partir do final do Século XX com o crescimento dos processos globalizadores mercantis operados por instituições transnacionais e a diminuição do poder dos estados-nações" ${ }^{42}$.

A interculturalidade jurídica pode ser conceituada como a convivência democrática de diversas ordens constitucionais, desde que permaneçam suas características básicas e sua essência. Assim, dentro do aspecto da cultura, ao se interligar com a Teoria do Interconstitucionalismo, surge a interculturalidade comunitária, que consiste nessa convivência de culturas em uma comunidade ou região. Porém, essa rede de interconstitucio-

39 CANOTILHO, J. J. Gomes. "Brancosos" e interconstitucionalidade: itinerários dos discursos sobre a bistoricidade constitucional. 2. ed. Almedina: Coimbra, 2008. p. 271.

40 FLEURI, Reinaldo Matias. In Palestra Proferida no V Colóquio Internacional Paulo Freire - 2005. Disponível em: <www.paulofreire.org.br/Textos/ fleuri_2005_recife_resumo_e_texto_completo.pdf>. Acesso em: 06 jun. 2015.

41 "Artículo 98. I. La diversidad cultural constituye la base esencial del Estado Plurinacional Comunitario. La interculturalidad es el instrumento para la cohesión y la convivencia armónica y equilibrada entre todos los pueblos y naciones. La interculturalidad tendrá lugar con respeto a las diferencias y en igualdad de condiciones. II. El Estado asumirá como fortaleza la existencia de culturas indigena originario campesinas, depositarias de saberes, conocimientos, valores, espiritualidades y cosmovisiones. III. Será responsabilidad fundamental del Estado preservar, desarrollar, proteger y difundir las culturas existentes en el país." Constituição Federal da Bolívia. Artigo 98. Disponível em: $<$ http://pdba.georgetown.edu/Constitutions/Bolivia/bolivia09. html>. Acesso em: 17 jun. 2015.

42 VASCONCELOS, Luciana Machado de. Interculturalidade. Disponível em: <http://www.cult.ufba.br/maisdefinicoes/INTERCULTURALIDADE.pdf>. Acesso em: 08 jun. 2015. p. 02. 
nalidade enfrenta um problema complexo, que se traduz na articulação de paradigmas de diversos de poderes constituintes ${ }^{43}$.

A interconstitucionalidade sugere, ainda, intersemioticidade, no sentido de que esse fenômeno se preocupa, também, com a investigação e descoberta de um conjunto de regras respeitantes à produção e interpretação dos textos constitucionais dos Estados e dos respectivos discursos e práticas sociais com elas relacionados. Assim, se pode afirmar, que as Constituições nacionais são dimensões relevantes de uma bermenêutica jurídica europeia ${ }^{44}$.

Percebe-se, com essa observação de Canotilho, que a interconstitucionalidade permite a manutenção da identidade dos Estados e que suas constituições não agirão mais de forma isolada, mas sim farão parte de um sistema de hermenêutica jurídica europeia.

Nesse contexto, assevera Canotilho que a interconstitucionalidade e a interculturalidade abrem espaço para o pluralismo de intérpretes, aberto e racionalmente crítico ${ }^{45}$. Nesse sentido, o interconstitucionalismo pareceu um fenômeno de aplicabilidade não somente no contexto europeu, mas em toda a perspectiva global atual.

\section{O FENÔMENO DO INTERCONSTITUCIONALISMO E suas razões de existir na América Latina}

A partir desse momento da pesquisa, passa-se a estudar se há a presença do fenômeno do interconstitucionalismo no âmbito da América Latina. Primeiramente, em razão da identidade cultural e da existência de pontos de convergência dentre os ordenamentos constitucionais dos Estados e, posteriormente, em razão da existência de um Sistema Interamericano de Direitos Humanos que possui jurisdição sobre os Estados latino-americanos.

A América Latina como um todo construiu sua his-

43 CANOTILHO, J. J. Gomes. "Brancosos" e interconstitucionalidade: itinerários dos discursos sobre a historicidade constitucional. 2. ed. Almedina: Coimbra, 2008, p. 275.

44 CANOTILHO, J. J. Gomes. "Brancosos" e interconstitucionalidade: itinerários dos discursos sobre a bistoricidade constitucional. 2. ed. Almedina: Coimbra, 2008, p. 277.

45 CANOTILHO, J. J. Gomes. "Brancosos" e interconstitucionalidade: itinerários dos discursos sobre a bistoricidade constitucional. 2. ed. Almedina: Coimbra, 2008, p. 279. tória com identidades culturais, uma vez que os Estados foram colonizados por espanhóis ou portugueses. Além disso, todos os Estados são historicamente recentes, em comparação com a Europa, e muitos tiveram regimes ditatoriais que perduraram até meados dos anos $60 \mathrm{ou}$ mais.

Acerca do que significa identidade cultural, Renato Seixas preceitua:

a identidade cultural é formada com diferentes
elementos culturais que podem ter distintos
significados intertextuais para cada indivíduo ou
grupo social. São elementos culturais os valores
sociais e os modos de pensar, os costumes e o
estilo de vida, as instituições, a história comum,
os grupos étnicos, o meio ambiente natural e
cultural, os pressupostos filosóficos subjacentes
às relações sociais e outros elementos a que certa
sociedade atribui significados culturais intertextuais
específicos. Com base em elementos como esses, o
indivíduo e o grupo social formam a convicção de
que compartilham uma cultura ${ }^{46}$.

Maria Luisa Ortiz Alvarez afirma que falar acerca de identidade latino-americana implica

\section{[...] remontar à época colonial e traçar uma trajetória que se estende até os dias atuais, observando como os diferentes períodos históricos operaram a re- significação do termo, a partir da conservação de determinados traços e da negociação, exclusão e inclusão de outros. $O$ encontro entre europeus e índios, povos portadores de culturas díspares, até antagônicas em certos aspectos, é tido como o momento inicial das transformações que conduziram à ideia de um "modo latino-americano de ser" ${ }^{\prime \prime 7}$.}

Percebe-se que, à época da colonização, os povos colonizados absorveram quase totalmente a cultura europeia colonizadora, diferenciando-se a América Central, que absorveu mais a cultura americana da América do Sul, que integralizou a cultura ocidental, advinda dos europeus.

Nesse contexto, é necessário trazer a importância da figura de Simón Bolívar, que mostrou-se um dos principais articuladores dos processos de independência e de pós-independência. Ademais, foi notória sua contri-

46 SEIXAS, Renato. Identidade Cultural da América Latina: conflitos culturais globais e mediação simbólica. Disponível em: < http://www.usp. br/prolam/downloads/2008_1_4.pdf >. Acesso dia: 16/07/2015, p. 98.

47 ALVAREZ, Maria Luisa Ortiz. (Des) construção da identidade latino-americana: heranças do passado e desafios futuros. Disponível em: $<$ http://unb.revistaintercambio.net.br/24h/pessoa/temp/anexo/1/231/427.pdf>. Acesso em: 16 jul. 2015, p. 02. 
buição para construir uma identidade entre os Estados latino-americanos.

Entretanto, conforme expõe Alvarez, esse ideário pretendia ir mais além, à medida que Bolívar manifestava seu sonho de ver a América unida em uma só nação, que teria um só governo que confederaria todos os diferentes Estados da região ${ }^{48}$.

Apesar de suas ideias revolucionárias não terem encontrado efetivação na América Latina, Bolívar influenciou o "modo latino-americano de ser", inclusive, tendo seu nome incluído em diversas constituições dos Estados latino-americanos, ditas constituições Bolivarianas, como a da Venezuela e do Equador.

Quanto ao contexto histórico da região, Flávia Piovesan destaca a existência dos regimes ditatoriais e da transição política de tais regimes à democracia. O primeiro período foi marcado por inúmeras violações de direitos e liberdades, e o segundo período caracterizou-se pela tentativa de consolidar o efetivo respeito aos direitos humanos ${ }^{49}$.

Como consequência disso, após a caída dos regimes ditatoriais, as constituições passaram a se abrirem para incorporaram o novo comunitarismo internacional, admitindo a celebração de tratados de integração entre Estados para conformar organizações supraestatais e interestatais.

Com o advento da Convenção Americana de Direitos Humanos em 1978, dos 11 Estados que ratificaram a Convenção na época, menos da metade possuía governos eleitos de forma democrática. Assim, havia dificuldade para o Sistema Interamericano de Direitos Humanos em lidar com tal paradoxo: como proteger os direitos humanos em um espaço onde não havia inicialmente abertura para a tríade Democracia - Estado de Direito - Direitos Humanos ${ }^{50}$.

Nesse sentido, são notórias as semelhanças entre os Estados da América Latina, inclusive, porque refletem

48 ALVAREZ, Maria Luisa Ortiz. (Des) construção da identidade latino-americana: heranças do passado e desafios futuros. Disponível em: $<$ http://unb.revistaintercambio.net.br/24h/pessoa/temp/anexo/1/231/427.pdf>. Acesso em: 16 jul. 2015, p. 02.

49 PIOVESAN, Flavia. Direitos humanos e justiça internacional: um estudo comparativo dos sistemas regionais europeu, interamericano e africano. $2^{a}$ ed. São Paulo: Saraiva, 2011, p. 123-124.

50 PIOVESAN, Flavia. Direitos humanos e diálogo entre jurisdições. In: Revista Brasileira de Direito Constitucional - RBDC, n. 19, p. 67-93, jan-jun, 2012. uma integração quase que natural. Em outras palavras, ao se comparar a integração latino-americana com a integração europeia, percebe-se que há muito mais pontos de convergência no primeiro em detrimento do segundo. Isso porque os cidadãos latino-americanos se reconhecem uns nos outros, em sua cultura, em seu modo de viver, na variedade de nações dentro de um mesmo Estado. Assim, pode-se afirmar que, no que se refere à identidade e integração entre os Estados, a América Latina mostra-se bastante integrada.

Peter Häberle acredita que a Constituição deve ser concebida como cultural, pois não deve representar somente um ordenamento jurídico voltado aos juristas, mas sim traduzir uma situação cultural e servir como instrumento de autorrepresentação de seu povo ${ }^{51}$.

Assim, percebe-se que, hoje, as constituições dos Estados da América Latina, além de serem a expressão da cultura local e perfazerem-se como instrumento de autorrepresentação de seu povo, também estão em consonância. Em outras palavras, as constituições latino-americanas possuem diversos pontos de convergência.

A Teoria de Häberle transcendeu o continente europeu e chegou à América Latina com o intuito de ajudar o processo não somente de integração política, mas também cultural, buscando desenvolver a concepção de um "direito constitucional comum".

Nesse cenário, que a Teoria da Interconstitucionalidade ganha forma e razão de existir. Isso porque, segundo Canotilho, essa teoria estuda as relações interconstitucionais de concorrência, convergência, justaposição e conflitos de várias constituições e de vários poderes constituintes no mesmo espaço político ${ }^{52}$.

Em primeiro lugar, cumpre destacar que a interconstitucionalidade que se observa e se propõe com este estudo, no âmbito da América Latina, é diferente daquela que ocorre na Europa. Isso porque a Europa está inserida na União Europeia, que é uma organização internacional sui generis, sendo diferenciada de qualquer outra OI. Assim, observa-se na UE um sistema jurídico único - supranacional, de alta integração e imposto para todos os Estados membros.

51 HÄBERLE, Peter; HABERMAS; Jürgen; FERRAJOLI, Luigi. VITALE, Ermanno. La constitucionalización de Europa. México: Instituto de Investigaciones Jurídicas de la UNAM, 2004, p. 25.

52 CANOTILHO, J. J. Gomes. "Brancosos" e interconstitucionalidade: itinerários dos discursos sobre a historicidade constitucional. 2. ed. Almedina: Coimbra, 2008, p. 265-266. 
Por outro lado, na América Latina, tem-se a Organização dos Estados Americanos - uma organização internacional mais regular, ou seja, com características mais comuns às demais OI's. Em outras palavras, a OEA não possui um sistema jurídico próprio imposto a todos os membros. Tem-se, na verdade, a Convenção Americana de Direitos Humanos e dois órgãos que são responsáveis por fiscalizar, aplicar e fazer cumprir as suas determinações, quais sejam, a Corte e a Comissão Interamericana de Direitos Humanos.

Assim, a dinâmica da América Latina funciona da seguinte forma: os Estados membros da OEA, e que ratificaram a Convenção Americana, estão sujeitos às normas nela contidas. Dessa forma, estão também submetidos à jurisdição da Corte e da Comissão.

Nesse sentido, os Estados membros, bem como a CIDH podem submeter casos para serem julgados pela Corte IDH, desde que cumpridos os requisitos determinados pela legislação da OEA. Dentre os requisitos, pode-se mencionar o fato de terem se exaurido as vias internas do Estado, ou seja, o referido caso transitou em julgado e não há mais possibilidade de recorrer a quaisquer órgão superior do Estado membro - artigo 61.2 da Convenção $0^{53}$. Ademais, o caso deve versar sobre matéria objeto de proteção da Convenção, isto é, inerente a direitos humanos, pois esta é a competência da Corte $\mathrm{IDH}$ - conforme artigo 34 da Convenção ${ }^{54}$.

Nesse diapasão, a Corte IDH cumpre papel parecido com o do Tribunal de Justiça das Comunidades Europeias. Isso porque, quando um caso é submetido à análise e julgamento na Corte IDH, esta faz um controle de convencionalidade entre as leis do Estado membro que foram aplicadas no caso concreto e as normas contidas na Convenção, conforme preceitua o artigo 62.3 da Convenção ${ }^{55}$. Esse artigo dita que a Corte

53 "Artículo 61 1. Sólo los Estados Partes y la Comisión tienen derecho a someter un caso a la decisión de la Corte. 2. Para que la Corte pueda conocer de cualquier caso, es necesario que sean agotados los procedimientos previstos en los artículos 48 a 50." Disponível em: <http://www.oas.org/dil/ esp/tratados_B-32_Convencion_Americana_sobre_Derechos_Humanos.htm>. Acesso em: 17 jun. 2015.

54 "Artículo 34 La Comisión Interamericana de Derechos Humanos se compondrá de siete miembros, que deberán ser personas de alta autoridad moral y reconocida versación en materia de derechos humanos." Disponível em: $<$ http://www.oas.org/dil/esp/tratados_B-32_Convencion_Americana_sobre_Derechos_Humanos.htm>. Acesso em: 17 jun. 2015.

55 "Artículo 62 [...] 3. La Corte tiene competencia para conocer de cualquier caso relativo a la interpretación y aplicación de las disposiciones de esta Convención que le sea sometido, siempre que los Estados Partes en el caso hayan reconocido o reconozcan dicha competencia, ora por declaración especial, como se tem competência para conhecer qualquer caso relativo à interpretação e aplicação das disposições da Convenção Americana de Direitos Humanos que lhe seja submetido, sempre que os Estados partes no caso tenham reconhecido ou reconheçam dita competência, seja por declaração especial, seja por convenção especial.

Dessa forma, quando um Estado ou a CIDH submete algum caso para ser julgado pela Corte IDH, o interconstitucionalismo está de fato ocorrendo, o que se verifica por meio de três premissas.

Para que se possa compreender tais premissas, é necessário uma retrospectiva acerca do fenômeno do interconstitucionalismo. Conforme já explanado, a Teoria da Interconstitucionalidade, segundo Canotilho, estuda as relações interconstitucionais de concorrência, convergência, justaposição e conflitos de várias constituições e de vários poderes constituintes no mesmo espaço político ${ }^{56}$.

As relações de concorrência se dão no sentido de concomitância, convivência, simultaneidade, coexistência de ordens jurídicas. Por exemplo, na OEA há diversos Estados e cada um possui a sua ordem jurídica constitucional própria. Ademais, o próprio Sistema Interamericano de Direitos Humanos possui a sua ordem jurídica internacional própria. Assim, elas coexistem e se inter-relacionam.

No que se refere à convergência, tem-se no sentido de afinidade, identidade, concordância, coincidência, consonância, harmonia. Isso porque as constituições dos Estados da América Latina possuem diversos pontos de convergência, em razão da colonização e história semelhantes. Além disso, essas constituições devem estar em consonância e harmonia com a Convenção Americana dentro do SIDH.

As relações de justaposição traduzem-se no fato de que o SIDH, muitas vezes, sobrepõe a sua ordem jurídica aos ordenamentos constitucionais dos Estados membros. A legitimidade dessa ação ocorre mormente porque os Estados-membros assim o quiseram, quando aceitaram a jurisdição do SIDH.

No que se refere a relações de conflitos de várias

indica en los incisos anteriores, ora por convención especial." Disponível em: $<$ http://www.oas.org/dil/esp/tratados_B-32_Convencion_Americana_sobre_Derechos_Humanos.htm>. Acesso em: 17 jun. 2015.

56 CANOTILHO, J. J. Gomes. "Brancosos" e interconstitucionalidade: itinerários dos discursos sobre a bistoricidade constitucional. 2. ed. Almedina: Coimbra, 2008. p. 265-266. 
constituições e de vários poderes constituintes, tem-se que cada Estado membro tem sua Constituição e, mesmo que hajam pontos de convergência, cada um possui suas especificidades, direitos que tutelam mais ferozmente, e outros que se tutela de forma mais branda.

Explicadas tais relações, chega-se às três premissas que demonstram a presença do interconstitucionalismo na América Latina. A primeira delas diz respeito à relação de justaposição de ordens jurídicas, que ocorre justamente pelo fato do aceite por parte dos Estados membros da jurisdição do SIDH. Em outras palavras, no momento em que o Estado membro aceita fazer parte do SIDH, ele se submete às suas normas. Sendo assim, o ordenamento constitucional interno do Estado passa a não ser mais a última instância, mas sim o ordenamento internacional. Importante frisar que não se trata de mais uma instância recursal, mas de uma justaposição entre ordens jurídicas, na qual a ordem internacional se sobreporá à ordem interna. Também não se trata somente da imposição das decisões da Corte aos tribunais nacionais com competências constitucionais, mas também de revisão da jurisprudência dos Estados membros à luz das decisões da Corte.

A segunda premissa pela qual percebe-se a presença do interconstitucionalismo vai mais além do que uma "simples" justaposição. Essa premissa refere-se à aplicação de norma constitucional de Estado diverso daquele que é parte no processo ao caso concreto, semelhante ao que ocorre no sistema europeu. Para que se possa compreender tal situação, imagina-se que um caso ocorrido do Equador, envolvendo desrespeito aos direitos humanos dos indígenas, foi submetido a julgamento na Corte IDH. No decorrer do julgamento, os juízes da Corte IDH reparam que a legislação constitucional boliviana é mais protetiva com relação aos direitos dos indígenas. Assim, a Corte IDH aplica o direito constitucional boliviano ao caso equatoriano, mesmo que a Bolívia não seja parte desta lide.

Por fim, a terceira premissa diz respeito à utilização, por parte da Corte IDH, de jurisprudências de Cortes de Direitos Humanos que não fazem parte do sistema interamericano, como por exemplo, a Corte Europeia de Direitos Humanos, para fundamentar suas decisões.

Esses casos vêm sendo percebidos ultimamente quando da análise da jurisprudência da Corte IDH e traduzem claramente a presença do interconstitucionalismo no SIDH, visando conceder maior proteção aos direitos humanos dos indivíduos.

\section{O Caso 12.465 - Povo indígena Kichwa de Sarayaku Versus Equador e o intercons- TITUCIONALISMO LATINO-AMERICANO}

Analisar-se-á, nesta seção, um caso julgado pela Corte Interamericana de Direitos Humanos com a finalidade de confirmar a hipótese proposta por este estudo, qual seja, constatar a presença do fenômeno interconstitucionalismo no âmbito da América Latina. ${ }^{57}$

O caso n ${ }^{\circ} 12.465$ - PUEBLO INDÍGENA KICHWA DE SARAYAKU VS. ECUADOR referia-se principalmente à concessão de uma permissão por parte do Estado equatoriano dada a certa empresa petrolífera privada para realizar atividades de exploração petroleira no território do Povo Indígena Kichwa de Sarayaku, na década de 90 , sem que se houvesse consultado previamente tal povo e sem qualquer consentimento por parte da comunidade indígena. Assim, iniciaram-se as explorações e seus efeitos foram de tamanha monta que repercutiram em todo o mundo.

Dentre os efeitos desse ato, tem-se o risco de morte da população indígena, que ficou um período sem poder buscar meios de subsistência, além de ter seus direitos de circulação e de expressar sua cultura violados. Ademais, o dano ambiental causado pela empresa CGC resta inestimável, uma vez que utilizaram-se de explosivos de alto poder em vários pontos do território indígena, construíram portos, destruíram cavernas e fontes d'água nativas, rios subterrâneos utilizados pela comunidade para consumo próprio, além de derrubar incontáveis árvores e plantas de grande valor ambiental e de subsistência para os Kichwa ${ }^{58}$.

Nesse sentido, a CIDH apontou as possíveis violações por parte do Estado equatoriano, quais sejam, direito de consulta e propriedade indígena, direito de livre circulação, de expressão de sua cultura, direito ao

57 O Caso 12.051 - Karen Atala e filhas vs. Chile, que versa acerca do direito à livre orientação sexual, bem como direito à vida privada sem interferência, também revela a ocorrência do fenômeno do interconstitucionalismo. Nesse caso, a Corte Interamericana não realizou diálogos somente com a ordem constitucional dos Estados membros da OEA e que ratificaram o Pacto de San José da Costa Rica, mas também com a Corte Europeia de Direitos Humanos. 58 Informações extraídas da sentença da Corte IDH. CORTE INTERAMERICANA DE DIREITOS HUMANOS. CASO PUEBLO INDÍGENA KICHWA DE SARAYAKU VS. ECUADOR. SENTENCA DE 27 DE JUNHO DE 2012. Disponível em: $<$ http://www.corteidh.or.cr/docs/casos/articulos/seriec_245_esp. pdf $>$. Acesso em: 22 jun. 2015. 
meio ambiente, direito à vida e integridade física, direito à liberdade, direito à garantia e proteção judicial, dentre outros.

Dentre os direitos supracitados que foram violados, é claro que se encontram diversos direitos da personalidade. Os principais deles são o direito à vida e à integridade física, que, nesse caso, a Corte entendeu como violados porque o Estado violou seu dever de garantir o respeito ao direito de propriedade e, consequentemente, permitiu o uso de explosivos no território indígena, o que ocasionou uma situação permanente de perigo à vida e à sobrevivência desse povo. Ademais, colocou em risco o direito desse povo de preservar e transmitir seu legado cultural ${ }^{59}$.

Ao final, a Corte IDH concluiu que é obrigação do Estado garantir o direito à consulta prévia do povo indígena antes de conceder permissões para adentrar e explorar seu território. Como fundamentação dessa decisão, a Corte utilizou-se de jurisprudências de diversos países da América Latina, dentre eles Argentina, Bolívia, Chile, Colômbia, México, Nicarágua, Paraguai, Peru, Venezuela, Belize e Brasil.

Citou a Constituição Nacional da República Argentina, de 1994, que, em seu artigo 75.17, reconhece a preexistência étnica e cultural dos povos indígenas argentinos e das pessoas jurídicas de duas comunidades ${ }^{60}$.

Aduziu, também, que, na Bolívia, a Constituição Política do Estado, de 2009. Reconhece o direito dos povos indígenas a serem consultados mediante procedimentos apropriados quando houver medidas legislativas ou administrativas que os afetem, conforme disposição do artigo 30, II, 15. Ademais, o Tribunal Constitucional da Bolívia se pronunciou em diversas oportunidades acerca do direito à consulta prévia. No Chile, de forma semelhante, há lei própria para tutelar tais direitos - Lei 19.253 (Lei Indígena) ${ }^{61}$.

59 Informações extraídas da sentença da Corte IDH. CORTE INTERAMERICANA DE DIREITOS HUMANOS. CASO PUEBLO INDÍGENA KICHWA DE SARAYAKU VS. ECUADOR. SENTENCA DE 27 DE JUNHO DE 2012. Disponível em: $<$ http://www.corteidh.or.cr/docs/casos/articulos/seriec_245_esp. pdf $>$. Acesso em: 22 jun. 2015, p. 72-73.

60 Informações extraídas da sentença da Corte IDH. CORTE INTERAMERICANA DE DIREITOS HUMANOS. CASO PUEBLO INDÍGENA KICHWA DE SARAYAKU VS. ECUADOR. SENTENCA DE 27 DE JUNHO DE 2012. Disponível em: $<$ http://www.corteidh.or.cr/docs/casos/articulos/seriec_245_esp. pdf >. Acesso em: 22 jun. 2015, p. 45.

61 Informações extraídas da sentença da Corte IDH. CORTE
A Constituição Política da Colômbia, por sua vez, estabelece, no parágrafo do artigo 330, que a exploração dos recursos naturais em territórios indígenas não podem ser feitas de modo a desrespeitar a integridade cultural, social e econômica das comunidades. Ademais, a Corte valeu-se da interpretação da sentença T-129/11, parágrafo 5.1 proferida pela Corte Constitucional da Colômbia ao aduzir que é dever do Estado garantir e aplicar real e efetivamente o direito fundamental de consulta prévia das comunidades étnicas, pois diante disto, poderá se chegar a um ponto intermediário de diálogo intercultural no qual os povos possam exercer seu direito de autonomia frente aos modelos econômicos baseados na economia de mercado ${ }^{62}$.

A Constituição Mexicana igualmente dispõe que o Estado deve promover a igualdade de oportunidades dos indígenas e eliminar qualquer prática discriminatória $^{63}$.

De forma semelhante, a Constituição da Nicarágua positiva, no Título IV, artigo 89, que as comunidades indígenas têm direito a preservar e desenvolver sua identidade cultural na unidade nacional. Ademais, o Estado reconhece o gozo, uso e disfrute das águas e bosques pelas comunidades indígenas ${ }^{64}$.

A Constituição do Paraguai de 1992 estabelece, em seu artigo 64, que os povos indígenas têm direito à propriedade comunitária da terra, em extensão e qualidade suficientes para a conservação e desenvolvimento de suas formas peculiares de vida ${ }^{65}$.

INTERAMERICANA DE DIREITOS HUMANOS. CASO PUEBLO INDÍGENA KICHWA DE SARAYAKU VS. ECUADOR. SENTENCA DE 27 DE JUNHO DE 2012. Disponível em: $<$ http://www.corteidh.or.cr/docs/casos/articulos/seriec_245_esp. pdf >. Acesso em: 22 jun. 2015, p. 45.

62 CORTE INTERAMERICANA DE DIREITOS HUMANOS. CASO PUEBLO INDÍGENA KICHWA DE SARAYAKU VS. ECUADOR. SENTENCA DE 27 DE JUNHO DE 2012. Disponível em: <http://www.corteidh.or.cr/docs/casos/articulos/ seriec_245_esp.pdf>. Acesso em: 22 jun. 2015, p. 47, 56 e 58.

63 Informações extraídas da sentença da Corte IDH. CORTE INTERAMERICANA DE DIREITOS HUMANOS. CASO PUEBLO INDÍGENA KICHWA DE SARAYAKU VS. ECUADOR. SENTENCA DE 27 DE JUNHO DE 2012. Disponível em: $<$ http://www.corteidh.or.cr/docs/casos/articulos/seriec_245_esp. pdf>. Acesso em: 22 jun. 2015, p. 45.

64 Informações extraídas da sentença da Corte IDH. CORTE INTERAMERICANA DE DIREITOS HUMANOS. CASO PUEBLO INDÍGENA KICHWA DE SARAYAKU VS. ECUADOR. SENTENCA DE 27 DE JUNHO DE 2012. Disponível em: <http://www.corteidh.or.cr/docs/casos/articulos/seriec_245_esp. pdf>. Acesso em: 22 jun. 2015, p. 46.

65 Informações extraídas da sentença da Corte IDH. CORTE 
A Constituição Bolivariana da Venezuela, de 1999, também dispõe, em seu artigo 120, que o aproveitamento dos recursos naturais nos habitats indígenas por parte do Estado não podem lesionar a integridade cultural, social e econômica destes ${ }^{66}$.

A Corte Suprema de Belize assinalou o reconhecimento ao direito à terra dos povos indígenas bem como a reflexão dos princípios internacionais relativos aos $\operatorname{mesmos}^{67}$. E, no Brasil, o julgado federal da Seção Judiciária do Maranhão afirmou que o Estado não pode desconhecer a proteção constitucionalmente garantida como um dos objetivos fundamentais da República Federativa do Brasil, que busca promover o bem de todos, sem preconceitos de qualquer origem, conforme disposto no artigo $3^{\circ}$, IV da Constituição Federal.

Além disso, a Corte utilizou também como fundamento o Convênio 169 da OIT, que prevê a consulta prévia aos povos indígenas antes de efetuar qualquer procedimento em suas terras, e a Convenção de Viena da Organização das Nações Unidas - ONU.

Percebeu-se, ao estudar esse caso, que há um interconstitucionalismo inerente à segunda premissa explanada neste artigo, qual seja, referente à aplicação, por parte da Corte IDH, de norma constitucional de Estado diverso daquele que é parte no processo ao caso concreto. Isso porque o caso em comento versava sobre determinada comunidade indígena do Equador e como fundamentação para a sentença, a Corte utilizou-se de diversas normas constitucionais e jurisprudências de Supremas Cortes dos Estados da América Latina para solucionar a lide. Tudo isso para encontrar a legislação

INTERAMERICANA DE DIREITOS HUMANOS. CASO PUEBLO INDÍGENA KICHWA DE SARAYAKU VS. ECUADOR. SENTENCA DE 27 DE JUNHO DE 2012. Disponível em: $<$ http://www.corteidh.or.cr/docs/casos/articulos/seriec_245_esp. pdf>. Acesso em: 22 jun. 2015, p. 46.

66 Informações extraídas da sentença da Corte IDH. CORTE INTERAMERICANA DE DIREITOS HUMANOS. CASO PUEBLO INDÍGENA KICHWA DE SARAYAKU VS. ECUADOR. SENTENCA DE 27 DE JUNHO DE 2012. Disponível em: $<$ http://www.corteidh.or.cr/docs/casos/articulos/seriec_245_esp. pdf>. Acesso em: 22 jun. 2015, p. 46.

67 Corte Suprema de Belice, Aurelio Cal por derecho propio y en nombre de la Comunidad Maya de Santa Cruz y otros Vs. Procurador General de Belice y otros, casos 171 y 172 de 2007. Sentencia de 18 de octubre de 2007. Ver mais em: CORTE INTERAMERICANA DE DIREITOS HUMANOS. CASO PUEBLO INDÍGENA KICHWA DE SARAYAKU VS. ECUADOR. SENTENÇA DE 27 DE JUNHO DE 2012. Disponível em: <http://www.corteidh. or.cr/docs/casos/articulos/seriec_245_esp.pdf>. Acesso em: 22 jun. 2015, p. 47. mais protetiva com relação aos direitos da personalidade e aplicá-la ao caso concreto, propiciando, assim, maior efetividade aos direitos dos indivíduos.

\section{Considerações finais}

Preliminarmente, esta pesquisa objetivou estudar o fenômeno do interconstitucionalismo, surgido no âmbito europeu para, posteriormente, trazê-la para a realidade latino-americana. Assim, o problema principal deste artigo consistia em descobrir se existiriam perspectivas e albergue para o desenvolvimento de um interconstitucionalismo latino-americano e se ele, efetivamente, ocorria no âmbito da Corte Interamericana de Direitos Humanos, bem como se mostraria eficaz na tutela dos direitos da personalidade.

Apesar de este não ser tão aprimorado quanto o Sistema europeu, percebeu-se que haveria possibilidade de ocorrência do interconstitucionalismo o Sistema Interamericano de Direitos Humanos. Isso porque, uma vez que os Estados decidem fazer parte da Organização dos Estados Americanos, bem como tomam a decisão de ratificar a Convenção Americana de Direitos Humanos, fatalmente, se tornam parte em um sistema internacional. Assim, ficam subordinados a tais normas internacionais, e, dessa forma, fatalmente ocorrerá inter-relação entre ordens jurídicas, na medida em que, quando um caso é levado ao Sistema Interamericano, coexistirão e interagirão normas nacionais e internacionais.

Portanto, quedou-se claro neste artigo a possibilidade da ocorrência de interconstitucionalidade na América Latina. Para confirmar tal hipótese, a última parte do estudo visou constatar e comprovar a ocorrência do interconstitucionalismo no Sistema Interamericano de Direitos Humanos por meio da análise de um caso concreto.

Concluiu-se que a Comissão e a Corte Interamericana de Direitos Humanos utilizam-se do interconstitucionalismo dentro do Sistema Interamericano de Direitos Humanos. Isso porque, em suas decisões, percebe-se que é feito um estudo de direito comparado bastante minucioso e aprofundado nos ordenamentos jurídicos, que inclui as Cortes Supremas e as Constituições nacionais, bem como as normativas internacionais, como por exemplo, a Convenção Americana, com o intuito de buscar o fundamento mais apropriado e protetivo aos direitos da personalidade e aplicá-lo ao caso concreto. 
Assim, percebe-se que há um diálogo interconstitucional no Sistema Interamericano de Direitos Humanos. Portanto, ao final, após o estudo casuístico, verificou-se que o interconstitucionalismo mostrou-se como um meio eficaz para aprimoração e efetivação dos direitos da personalidade. Pode-se afirmar isso com base na seguinte justificativa: por meio do diálogo entre ordens jurídicas, é possível não somente observar os erros e acertos de cada sistema, mas também aprimorar e verificar quais normas e/ou jurisprudências são mais protetivas aos direitos da personalidade e aplicá-las ao caso concreto.

A grande inovação e aprimoramento na utilização dessa prática consiste no fato de que o interconstitucionalismo permite que os julgadores não fiquem restritos à aplicação da legislação do Sistema Interamericano de Direitos Humanos, apenas. Ao contrário, os julgadores da Comissão e da Corte IDH possuem certa liberdade para realizar pesquisa a fim de procurar em outras legislações constitucionais e jurisprudências de Cortes Superiores, a norma mais protetiva ao caso concreto e aplicá-las às lides, permitindo, assim, maior proteção e efetividade na tutela dos direitos humanos.

\section{REFERÊNCIAS}

aLVAREZ, Maria Luisa Ortiz. (Des) construção da identidade latino-americana: heranças do passado e desafios futuros. Disponível em: <http://unb.revistaintercambio.net. br/24h/pessoa/temp/anexo/1/231/427.pdf $>$. Acesso em: 16 jul. 2015.

CANOTILHO, J. J. Gomes. "Brancosos" e interconstitucionalidade: itinerários dos discursos sobre a historicidade constitucional. 2. ed. Almedina: Coimbra, 2008.

CONSTITUIÇÃO FEDERAL DA BOLÍVIA. Disponível em: <http://pdba.georgetown.edu/Constitutions/Bolivia/bolivia09.html>. Acesso em: 17 jun. 2015.

CONVENÇÃO AMERICANA SOBRE DIREITOS HUMANOS. Disponível em: <http://www.oas.org/ dil/esp/tratados_B-32_Convencion_Americana_sobre_Derechos_Humanos.htm>. Acesso em: 17 jun. 2015.

CORTE INTERAMERICANA DE DIREITOS HUMANOS. CASO PUEBLO INDÍGENA KICHWA
DE SARAYAKU VS. ECUADOR. SENTENCAA DE 27 DE JUNHO DE 2012. Disponível em: <http:// www.corteidh.or.cr/docs/casos/articulos/seriec_245_ esp.pdf>. Acesso em: 22 jun. 2015.

DELMAS-MARTY, Mireille. Les forces imaginantes du droit: le relaatif et l'universel. Paris, França: Seuil, 2004.

DUARTE, Écio Oto Ramos. Entre constitucionalismo cosmopolita e pluriversalismo internacional: neoconstitucionalismo e ordem mundial. Rio de Janeiro: Lumen Juris, 2014.

ENGELMANN, Wilson. A crise constitucional: a linguagem e os direitos humanos como condição de possibilidade para preservar o papel da Constituição no mundo globalizado. In: MORAIS, José Luis Bolzan de (Org.) O Estado e suas crises. Porto Alegre: Livraria do Advogado, 2005.

FERRAJOLI, Luigi. A soberania no mundo moderno: nascimento e crise do Estado nacional. Tradução de Carlo Coccioli e Márcio Lauria Filho. Revisão da tradução de Karina Jannini. 2. ed. São Paulo: Martins Fontes, 2007.

- Democracia, estado de direito e jurisdição na crise do estadonacional.Disponívelem: < file:///D:/PC\%20Malu/ Pessoal/Mestrado/Disserta\%C3\%A7\%C3\%A3o/ FERRAJOLI\%20DIREITO \%20DO \%20ESTADO\%202013.pdf>. Acesso em: 03 jun. 2015.

FLEURI, Reinaldo Matias. In Palestra Proferida no V Colóquio Internacional Paulo Freire - 2005. Disponível em: <www.paulofreire.org.br/Textos/ fleuri_2005_recife_resumo_e_texto_completo.pdf $>$. Acesso em: 06 jun. 2015.

GIDDENS, Anthony. A terceira via: reflexões sobre o impasse político atual e o futuro da sociela-democracia. Tradução de Maria Luiza X. de A. Borges. Rio de Janeiro: Record, 2000.

HÄBERLE, Peter. Estado constitucional cooperativo. Rio de Janeiro: Renovar, 2007.

; HABERMAS; Jürgen; FERRAJOLI, Luigi. VITALE, Ermanno. La constitucionalización de Europa. México: Instituto de Investigaciones Jurídicas de la UNAM, 2004.

LEAL, Mônia Clarissa Hennig. La noción de constitución abierta de peter haberle como fundamento de una jurisdicción constitucional abierta y como presupuesto para la intervención del amicus curiae en el derecho brasileño. In: Estudios Constitucionales, Año 8, No 1, 2010, pp. 283 - 304. 
LUHMANN, Niklas. A constituição como Aquisição Evolutiva. Tradução realizada a partir do original ("Verfassung als evolutionäre Errungenschaft”. In: Rechthistorisches Journal. Vol. IX, 1990, pp. 176 a 220), cotejada com a tradução italiana de F. Fiore ("La costituzione come acquisizione evolutiva". In: ZAGREBELSKY, Gustavo. PORTINARO, Pier Paolo. LUTHER, Jörg. Il Futuro della Costituzione. Torino: Einaudi, 1996), por Menelick de Carvalho Netto, Giancarlo Corsi e Raffaele De Giorgi. Notas de rodapé traduzidas da versão em italiano por Paulo Sávio Peixoto Maia (texto não revisado pelo tradutor), p. 04.

NEVES, Marcelo. Transconstitucionalismo. São Paulo: Martins Fontes, 2013.

PIOVESAN, Flavia. Direitos humanos e diálogo entre jurisdições. In: Revista Brasileira de Direito ConstitucionalRBDC, n. 19, p. 67-93, jan-jun, 2012.
Direitos humanos e justiça internacional: um estudo comparativo dos sistemas regionais europeu, interamericano e africano. $2^{a}$ ed. São Paulo: Saraiva, 2011.

SEIXAS, Renato. Identidade Cultural da América Latina: conflitos culturais globais e mediaģão simbólica. Disponível em: <http://www.usp.br/prolam/downloads/2008_1_4. pdf>. Acesso dia: 16/07/2015, p. 98.

VASCONCELOS, Luciana Machado de. Interculturalidade. Disponível em: < http://www.cult.ufba.br/maisdefinicoes/INTERCULTURALIDADE.pdf $>$. Acesso em: 08 jun. 2015.

WOLKMER, Antonio Carlos. Pluralismo crítico e perspectivas para um novo constitucionalismo na América Latina. In: WOLKMER, Antonio Carlos; MELO, Milena Petters. (Orgs.). Constitucionalismo latino-americano: tendências contemporâneas. Curitiba: Juruá, 2013. 


\section{O diálogo hermenêutico e a pergunta adequada à aplicação dos tratados internacionais de direitos humanos no Brasil: caminhos para o processo de internacionalização da constituição*}

Rafael Fonseca Ferreira**

Celine Barreto Anadon***

* Recebido em 19/10/2015.

Aprovado em 03/12/2015

** Doutor e Mestre em Direito Público pela Universidade do Vale do Rio dos Sinos UNISINOS; Especialista em Comércio Exterior e Relações Internacionais pela Universidade de Caxias do Sul - UCS. Professor efetivo da Universidade Federal do Rio Grande - FURG. E-mail: rafaelferreira@furg.br

*** Mestranda em Direito e Justiça Social pela Universidade Federal do Rio Grande - FURG; Especialista em Direito Público pela Anhanguera/Uniderp. Procuradora do Município de São José do Norte/RS. E-mail: celine_anadon@yahoo.com.br

\section{Resumo}

O objetivo deste artigo consiste em recompor a paisagem entre o direito interno e o direito internacional com base no fenômeno da constitucionalização do direito internacional proporcionado pela Constituição Federal de 1988 e a recepção dos tratados internacionais de direitos humanos. O trabalho é guiado por uma análise de caráter fenomenológico-hermenêutica, com base no referencial teórico de Gadamer e na ideia de diálogo, estruturado sob a dinâmica da pergunta e da resposta. No início, elabora-se uma crítica dirigida à deficiência teórico-interpretativa do imaginário jurídico dominante que, tanto na doutrina como na jurisprudência do STF, consegue superar a lógica do discurso formal do status hierárquico-normativo (positivista) na aplicação dos tratados internacionais de direitos humanos no Brasil antes e depois da introdução do $\int 3^{\circ}$ no art. $5^{\circ}$ pela Emenda Constitucional $n^{\circ} 45 / 2004$. Diante desse cenário, mais do que uma proposta de diálogos interjurisdicionais, com base na crítica hermenêutica do diálogo, objetiva-se, mais profundamente, demonstrar que existem outros caminhos para a normatividade dos tratados internacionais de direitos humanos os quais transcendem a simples redução da definição de sua posição hierárquica ou de uma comunicação entre cortes nacionais e internacionais. Por fim, sob a desconstrução do paradigma hierárquico-normativista de caráter positivista, busca-se demonstrar a adequada compreensão (teórico-normativa) e dialógica entre Constituição e tratados internacionais de direitos humanos como novos horizontes da normatividade constitucional e do processo de internacionalização do Direito.

Palavras-chave: Diálogo hermenêutico. Constituição. Tratados internacionais de direitos humanos. Internacionalização do direito. 


\section{Abstract}

This article aims restore the landscape between domestic law and international law from the phenomenon of the constitutionalisation of international law afforded by Federal Constitution of 1988 and the reception of the international human rights treaties. The work is guided by a phenomenological hermeneutic analysis from Gadamer theoretical framework and the idea of dialogue, structured under the dynamic of question and answer. At first, is elaborated a critical directed to the deficiency theoretical-interpretive of the dominant legal imaginary that, both in doctrine and in the Supreme Court jurisprudence, manages to overcome the logic of formal discourse hierarchical-normative status (positivist) in the application of international human rights treaties in Brazil before and after the introduction of $₫ 3$ in article 5 by Constitutional Amendment no. 45/2004. In this scenario, more than a proposal for interjurisdictional dialogue, based on hermeneutical critical dialogue, the objective is to more deeply demonstrate that there are other ways for the normativity of international human rights treaties which transcend the simple reduction of the definition of their hierarchical status or of a communication between national and international courts. Finally, under the deconstruction of hierarchical-normativist paradigm positivist character, it seeks to demonstrate the adequate understanding (theoretical-normative) and dialogical between Constitution and international human rights treaties as new horizons of constitutional normativity and Law internationalization process.

Keywords: Hermeneutic dialogue. Constitution. International human rights treaties. Law internationalization.

\section{INTRODUÇÃo}

A busca por novas possibilidades de internacionalização do Direito, considerando o Brasil em que as forças sociais sofrem com os desvios políticos e jurídicos, por vezes mais com seus interesses privados e com a manutenção do status de poder, recomenda melhor debate. Com efeito, a abordagem do tema dos "diálogos interjurisdicionais" traz algumas preocupações, em particular, o crescimento da discricionariedade judicial e o pragmaticismo de algumas metodologias.
Não obstante isso, a proposta do trabalho caminha no sentido do aprimoramento teórico e normativo do constitucionalismo do Brasil, pois a Constituição brasileira ainda revela muitos espaços de concretização e afirmação em matéria de direitos humanos, os quais precisam ser desvelados com base em uma qualificada exploração hermenêutica. Nesse sentido, a Constituição ocupa lugar central na profusão da normatividade, embora requeira melhor compreensão em razão da (in) capacidade hermenêutica do imaginário jurídico contemporâneo, às vezes, orientado para respostas de funcionalização do Direito e da Justiça e nem tanto pela densificação das práticas teóricas.

Buscando evidenciar as limitações do processo de compreensão sobre o horizonte, ainda não explorado, da normatividade constitucional, o tema dos tratados internacionais de direitos humanos ${ }^{1}$ assume papel fundamental. Buscando ilidir algumas dificuldades aplicativas, no horizonte começam a surgir algumas propostas como a dos diálogos interjurisdicionais ${ }^{2}$. Contudo, o vetor de investigação filosófica com base em Gadamer é também o diálogo, porém o diálogo hermenêutico (filosófico) àquele oriundo da provocação dinâmica da pergunta e da resposta enquanto modo-de-ser capaz de estreitar a relação entre o perguntar e compreender para conferir real dimensão à experiência hermenêutica ${ }^{3}$.

1 Ao longo do trabalho, optou-se pela expressão "tratados internacionais de direitos humanos" por ser mais abrangente, contemplando os demais instrumentos internacionais de mesma natureza.

2 GARCÍA ROCA, Javier. El diálogo entre el Tribunal Europeo de Derechos Humanos y los tribunales constitucionales en la construcción de un orden público europeo. Teoría y Realidade Constitucional, Madrid, n. 30, p. 183-224, 2012. p. 183-224; NOGUEIRA ALCALÁ, Humberto. Diálogo interjurisdiccional, control de convencionalidad y jurisprudencia del Tribunal Constitucional en período 2006-2011. Estudios Constitucionales, Santiago, v. 10, n. 2, p. $57-$ 140, 2012; BUSTOS GISBERT, Rafael. Diálogos jurisdiccionales en escenarios de pluralismo constitucional: la protección supranacional de los derechos en Europa. In: MAC-GREGOR, Eduardo Ferrer; LELO DE LARREA, Arturo Zaldívar (Coord.). La ciencia del derecho procesal constitucional: estudios en homenaje a Héctor Fix-Zamudio en sus cincuenta años como investigador del derecho. México: UNAM, 2008. (Derechos humanos y tribunales internacionales, 9). p. 753775; e BUSTOS GISBERT, Rafael. Pluralismo constitucional y diálogos jurisprudenciales. México: Porrúa, 2012. BURGORGUE-LARSEN, Laurence. De l'internationalisation du dialogue des juges: missive doctrinale à l'attention de Bruno Genevois. In: BADINTER, Robert et al. Le dialogue des juges: mélanges en l'honneur du président Bruno Genevois. Paris: Dalloz, 2009. p. 95-130. Disponível em: <http://www.univ-paris1.fr/fileadmin/IREDIES/Contributions_en_ligne/L._BURGORGUE-LARSEN/M\%C3\%A9langes/ LBL_M\%C3\%A9langes_Genevois-1.pdf>. Acesso em: 17 out. 2015.

3 GADAMER, Hans-Georg. Verdade e método I: traços funda- 
A ideia do Diálogo em Gadamer está assentada na (dia)lógica de que: é somente por meio do outro (pro-vocação ${ }^{4}$ por aquilo que nos interpela - textos, discursos, lógicas etc.) que entendemos, já que, por meio do outro, podemos encontrar uma autocrítica à nossa compreensão histórica ${ }^{5}$, a qual opera como teste permanente do elemento fundamental do ser humano, a compreensão. Com efeito, é a pergunta e não a resposta, o vetor crítico capaz de estranhar aquilo que é tido como premissa inarredável ou que está ancorada em pressupostos inautênticos, pois somente assim é que se permitirá a abertura para novas expectativas de sentido, é desafio crítico de nossa experiência. É assim porque toda a verdadeira experiência (dialógica) é um confronto, em que se opõe o novo ao antigo e nunca se sabe se o novo prevalecerá ao fim de tornar-se experiência. Então, movemo-nos pelas perguntas, nem tanto pelas respostas.

Assim, as críticas hermenêuticas, a seguir lançadas, são uma instigação à necessidade de inauguração de uma nova paisagem (hermenêutica), a qual já deveria ter se iniciado a partir da Constituição de 1988. No fundo, as críticas se dirigem ao tratamento - talvez inautêntico - dispensado aos tratados e convenções de direitos humanos no Brasil, seja por ocasião da introdução do $\$ $3^{\circ}$ no art. $5^{\circ}$ da Constituição Federal via Emenda Constitucional (EC) n 45/2004, seja por ocasião dos julgamentos proferidos pelo plenário do Supremo Tribunal Federal (STF), as quais não são produto de provocação, mas de manutenção de análises reducionistas de verificação de status normativo, em que se escondem os discursos ideológicos de soberania e centralidade estatal ${ }^{6}$.

Por isso, romper com essas estruturas liberais-individualistas de Direito reivindica que o sentido de qualquer 'diálogo' deverá ser hermenêutico em oposição à pragmática dos diálogos de sistema de justiça ou interju-

mentais de uma hermenêutica filosófica. 12. ed. Trad. Flávio Paulo Meurer. Petrópolis: Vozes, 2012. p. 487-9.

4 Pro-vocação no sentido de chamar o outro a nossa vocação básica de ser humano, interpretar. Cf. GALÁN, Pedro Cerezo. Reivindicación del diálogo. Madri: Real Academia de Ciencias Morales y Políticas, 1997.

5 GADAMER, Hans-Georg. O problema da consciência histórica. Tradução Paulo César Duque Estrada. 2. ed. Rio de Janeiro: FGV, 2003. p. 12-13.

6 MORAIS, José Luis Bolzan de; VIEIRA, Gustavo Oliveira. Estado e constituição em tempos de abertura: a crise conceitual e a transição paradigmática num ambiente intercultural. Revista de Estudos Constitucionais, Hermenêtica e Teoria do Direito, v. 5, n. 2, p. 133-140, jul./dez. 2013. p. 133-140. risdicionais que não se constituem compreensão senão justificativa funcional da subjetividade ou otimização da atividade jurisdicional ${ }^{7}$, referendando o velho discurso. Ao contrário disso, o diálogo hermenêutico é capaz de linguisticamente se comprometer com a produção do discurso adequado ao caráter democrático e emancipatório dos direitos humanos para afirmar novos horizontes de compreensão que superam a ideologia hierárquico-formal, a afirmação de espaços de poder das elites e a estagnação dos direitos humanos.

\section{OS TRATADOS INTERNACIONAIS DE DIREITOS HUMANOS NO IMAGINÁRIO JURÍDICO DOMINANTE NO BRASIL E A AUSÊNCIA DE DIÁLOGO HERMENÊU- TICO: OLHANDO O NOVO COM OS OLHOS DO VELHO}

A premissa de partida é a de que a pergunta dialógica sobre a normatividade dos tratados internacionais de direitos humanos no Brasil deveria caminhar no sentido de recuperar sua importância no movimento de constitucionalização pós-Segunda Guerra e no rompimento com os regimes autoritários da América Latina. Isso porque a história institucional dos direitos humanos não se resume à positivação na ordem interna dos Estados, mas compreende um fenômeno mais complexo do ponto de vista político, filosófico e jurídico. Com efeito, as respostas produzidas pelo imaginário jurídico brasileiro, por não serem produto de verdadeiro diálogo, parecem não dar conta desse paradigma, senão apenas da afirmação do processo de positivação formal de cunho liberal-individualista, o qual desnuda a lógica de que não há direito internacional vinculante, mas, em última ratio, sempre e somente direito interno ou, no máximo, direito internacional 'nacionalizado'.

Assim, por exemplo, das correntes que conferiam status de hierarquia legal à tese da hierarquia supralegal dos tratados e convenções de direitos humanos no Brasil, a racionalidade linear que lhes comum é a da herança positivista de matriz kelseniana (hierárquico-normativista) orientada pela presença do Estado como

7 Neste sentido, confira a pontual e extensa crítica as principais teses sobre os diálogos interjurisdicionais em: FERREIRA, Rafael Fonseca. Diálogos hermenêuticos em direitos humanos: em busca da(s) pergunta(s) adequadas(s) para a aplicação dos tratados internacionais de direitos humanos no Brasil. Disponível em: <http://www. repositorio.jesuita.org.br/handle/UNISINOS/3693>. Acesso em: 15 out. 2015. 
única fonte racional de onde ele emana ${ }^{8}$ e que las fuentes jurídicas son siempre directamente vinculantes, las no jurídicas no lo son hasta que una forma jurídica positiva no las reconoce como fuentes del Derecho ${ }^{9}$, em que, nessas condições, o direito internacional não pode ser considerado vinculante ${ }^{10}$.

O desvelamento dos discursos positivistas (normativistas) trazem, em sua essência, a defesa de um controle e da qualidade conteudística, em especial, das decisões judiciais em relação a Constituição e aos Tratados de Direitos Humanos, mormente, com base no paradigma normativo inaugurado em $1988 \mathrm{com}$ base na dignidade da pessoa humana, na promoção do bem-estar social e, nas relações internacionais, a prevalência dos direitos humanos e a defesa dos direitos fundamentais.

Isso porque, aparentemente, boa parcela da comunidade jurídica, incluindo-se o próprio Supremo Tribunal Federal, tem revelado dificuldades em lidar com o tema dos tratados internacionais de direitos humanos, reduzindo o debate, no mais das vezes, à definição do status normativo dos instrumentos internacionais na ordem jurídica interna, sem maiores aprofundamentos teóricos acerca de seu papel ou de seu conteúdo na história institucional do Direito contemporâneo.

A malfadada emenda que introduziu o $\int 3^{\circ}$ no art. $5^{\circ}$ da Constituição brasileira em detrimento do modelo parece não ter sido percebida de forma crítica, nada obstante a advertência de Cançado Trindade quando a apontou como um retrocesso em relação ao modelo aberto consagrado pelo $\int 2^{\circ}$ do mesmo artigo e por colocar em risco a interrelação ou indivisibilidade dos direitos protegidos em nosso país ${ }^{11}$.

Tinha razão Cançado Trindade, uma vez que as incertezas e dificuldades trazidas pela referida emenda se confirmaram, em particular, por exemplo, naquelas teses que passaram a advogar a possibilidade do controle de convencionalidade ${ }^{12}$. A tese de Mazzuoli, não obs-

8 KELSEN, Hans. Teoria pura do direito. Trad. João Baptista Machado. 8. ed. São Paulo: M. Fontes, 2009. p. 246 et seq.

9 PÉREZ LUÑO, Antonio Enrique. El desbordamiento de las fuentes del derecho. Madrid: La Ley, 2011. p. 21.

10 LOSANO, Mario G. Sistema e estrutura no Direito: o século XX. Trad. Luca Lamberti. São Paulo: M. Fontes, 2010. v. 2. p. 54-55.

11 CANÇADO TRINDADE, Antônio Augusto. Desafios e conquistas do direito internacional dos direitos bumanos no início do século XXI. 410-411. Disponível em: <http://www.oas.org/dil/ esp $/ 407490 \% 20$ cancado $\% 20$ trindade $\% 20$ OEA $\% 20$ CJI $\% 20 \% 20$. def.pdf\#page=5\&zoom $=$ auto,0,497> . Acesso em: 17 out. 2015 .

12 MAZZUOLI, Valério. Curso de direito internacional público. 3. ed. São Paulo: RT, 2009. p. 374; MAZZUOLI, Valério. O controle jurisdi- tante o autor defenda o status hierárquico constitucional dos tratados de direitos humanos, estruturou-se sob as insuficiências da supralegalidade adotada pelo Supremo Tribunal Federal em razão da nova interpretação requerida pela nova emenda constitucional. Nesse contexto, o modelo de controle de convencionalidade defendido parte de uma obrigatória e hierárquica distinção entre o controle de constitucionalidade e de convencionalidade (supralegalidade), qualificado como 'duplo controle vertical $^{13}$, num aparente controle meramente semântico-formalista ${ }^{14}$. De outro lado, a também internacionalista Flávia Piovesan, embora sempre tenha divergido da paridade entre tratado internacional de direitos humanos e a legislação federal, como base no art. $5^{\circ}, \int 2^{\circ}$ da Constituição de 1988 sempre defendeu a hierarquia constitucional dos tratados de direitos humanos, porém não abrindo mão do discurso hierárquico-formal ${ }^{15}$, não é por menos que sustenta a existência de duas categorias de tratados internacionais de proteção de direitos humanos: os materialmente constitucionais e os materiais e formalmente constitucionais, embora todos sejam, no mínimo, materialmente constitucionais ${ }^{16}$.

Longe de qualquer ousadia em olvidar a importância doutrinária dos autores mencionados, é preciso convir que essas teses, involuntariamente, além de referendarem o paradigma positivista-normativista, reforçam a imprópria cisão entre direitos humanos e fundamentais. Com efeito, a crítica hermenêutica revele que não se pode descuidar da história institucional do Direito legada pelo movimento constitucional pós-Segunda Guerra, onde o fundamento mínimo é o de que os direitos humanos orientam a materialidade (e legitimidade) constitucional, razão pela qual não podem ser condicionados

cional da convencionalidade das leis. 2. ed. São Paulo: Revista dos Tribunais, 2011. (Direito e Ciências afins, v. 4). p. 39.

13 MAZZUOLI, Valério. O controle jurisdicional da convencionalidade das leis. 2. ed. São Paulo: Revista dos Tribunais, 2011. (Direito e Ciências afins, v. 4). p. 116.

14 Advirta-se que, genuinamente, o controle de convencionalidade consiste na atuação de um tribunal internacional com o objetivo de controlar se as normas locais acatam ou não as convenções internacionais de sua competência, sem que isso implique, no caso da CIDH, modificação direta do direito interno, cassação de ato normativo e, por consequência, uma quarta instância de decisão sobre o efeito das leis dos países. Cf. HITTERS, Juan Carlos. Control de constitucionalidad y control de convencionalidad: comparación: criterios fijados por la Corte Interamericana de Derechos Humanos. Estudios Constitucionales, v. 7, n. 2, p. 109-128, 2009. p. 110-112.

15 PIOVESAN, Flávia. Direitos humanos e o direito constitucional internacional. 13. ed. São Paulo: Saraiva, 2102. p. 115.

16 PIOVESAN, Flávia. Direitos humanos e o direito constitucional internacional. 13. ed. São Paulo: Saraiva, 2102. p. 139. 
aos desvios dos discursos hierárquico-normativistas.

Também, seria importante consignar que nunca se questionou a constitucionalidade do $\int 3^{\circ}$ introduzido pela EC no 45/2004 na Constituição Federal, nem mesmo para se buscar, talvez, uma melhor solução mediante as técnicas interpretativas da interpretação conforme a Constituição ou da nulidade parcial sem redução de texto em controle de constitucionalidade. Não é juridicamente aceitável a manutenção de uma emenda que não atingiu o fim que se propugnou, bem como trouxe mais dúvidas e insegurança jurídica, mormente no que tange à ineficácia dos $\iint 1^{\circ}$ e $2^{\circ}$ do mesmo artigo, a reafirmação da cisão teórica entre direitos humanos e fundamentais e a contrariedade a toda principiologia constitucional.

Os direitos humanos possuem um caráter próprio e diferenciado que fundaram um novo espaço no constitucionalismo contemporâneo, conquistado em face dos Estados e não impostos por eles ${ }^{17}$, de forma que a cisão teórica em relação aos direitos fundamentais representa uma negação de seu processo de formação histórica ${ }^{18}$. A relação "genética" e dialógica perguntará sempre pela dimensão superior e transpositiva ${ }^{19}$ dos direitos humanos que se antecipa a qualquer discurso sobre direitos fundamentais. Dessa forma, a diferença entre direitos humanos e fundamentais é apenas na linguagem (ontológica), em que a compreensão acerca dos direitos fundamentais deverá sempre ser uma compreensão dos direitos humanos.

No fundo, as dificuldades aplicativas dos $\iint 1^{\circ}$ e $2^{\circ}$ do art. $5^{\circ}$ da Constituição para a doutrina que não se desapegou do paradigma liberal-individualista, resultou no efeito colateral da reivindicação - imprópria — de um dispositivo que pudesse esclarecer ou dirimir qualquer celeuma ${ }^{20}$. Por isso, a introdução do $₫ 3^{\circ}$ no art. $5^{\circ}$ da Constituição inserido pela EC no 45/2004 do ponto de vista dialógico constitui-se numa resposta sem adequada pergunta, na medida em que sempre as preocu-

17 DELMAS-MARTY, Mireille. Por um direito comum. Trad. Maria Ermantina de Almeida Prado Galvão. São Paulo: M. Fontes, 2004. p. X.

18 COMPARATO, Fábio Konder. A afirmação histórica dos direitos bumanos. 5. ed. São Paulo: Saraiva, 2007.

19 MELGARÉ, Plínio. Direitos humanos: uma perspectiva contemporânea: para além dos reducionismos tradicionais. Revista de Informação Legislativa, Brasília, v. 39, n. 154, p. 71-92, abr./jun. 2002. p. 73.

20 LAFER, Celso. A internacionalização dos direitos humanos: constituição, racismo e relações. Barueri: Manole, 2005. p. 15-16. pações interpretativas tenham se dedicado ao aspecto formal do status normativo dos tratados internacionais de direito humanos, a instituição de uma emenda ritualística para a questão, na forma em que recepcionada, não pode ser comemorada como avanço normativo-material sobre o tema.

Outrossim, uma breve análise da jurisprudência do plenário do Supremo Tribunal Federal pós-Constituição de 1988 também é suficiente para reforçar as dificuldades interpretativas impostas pelo paradigma hierárquico-normativista no que tange ao tema da eficácia dos tratados internacionais de direitos humanos no Brasil ${ }^{21}$. Observe que, até o ano da promulgação da Constituição de 1988 e mesmo até o primeiro julgamento que envolveu a questão da hierarquia dos tratados internacionais, em geral na ordem jurídica brasileira pós-1988, o posicionamento do Supremo Tribunal Federal vigente desde $1977^{22}$ sempre foi no sentido da bierarquia legal dos tratados internacionais sem qualquer distinção de natureza do instrumento.

Do Habeas Corpus no 72.131/RJ (1995) ${ }^{23}$ onde referendou-se a tese da hierarquia legal dos tratados internacionais de direitos humanos aos Recursos Extraordinários $n^{\circ} 466.343 / \mathrm{SP}$ e $349.703 / \mathrm{RS}$ e o Habeas Corpus $\mathrm{n}^{\circ}$ 87.585/TO e 92.566/SP (2008) em que passou a reinar a tese da supralegalidade daqueles instrumentos, a racionalidade formal da "irrecusável supremacia da Constituição" em relação a qualquer instrumento internacional sempre foi preponderante ${ }^{24}$. Mesmo no julgamento do

21 Utilizando-se a ferramenta eletrônica de busca de jurisprudência disponível no próprio site do Tribunal (www.stf.jus.br), com base na combinação das expressões "tratados internacionais + direitos humanos + hierarquia", o resultado objetivo, dentro da proposta, foi de 11 (onze) acórdãos em 01/06/2014. Cf. FERREIRA, Rafael Fonseca. Diálogos hermenêticos em direitos humanos: em busca da(s) pergunta(s) adequadas(s) para a aplicação dos tratados internacionais de direitos humanos no Brasil. Disponível em: <http://www. repositorio.jesuita.org.br/handle/UNISINOS/3693>. Acesso em: 15 out. 2015. p. 59-101.

22 BRASIL. Supremo Tribunal Federal. Recurso Extraordinário. RE $n^{\circ} 80004$ SE. Tribunal Pleno. Recorrente: Belmiro da Silveira Goes. Recorrido: Sebastião Leão Trindade. Relator: Min. Xavier de Albuquerque. Brasília, 1 de junho de 1977. Disponível em: <http:// stf.jusbrasil.com.br/jurisprudencia/14614120/recurso-extraordinario-re-80004-se>. Acesso em: 11 out. 2015.

23 BRASIL. Supremo Tribunal Federal. Habeas Corpus. HC $n^{\circ}$ 72131 RJ. Tribunal Pleno. Paciente: Lairton Almagro Vitoriano da Cunha. Coator: Tribunal de Justiça do Estado do Rio de Janeiro. Relator: Min. Marco Aurélio. Brasília, 23 de novembro de 1995. Disponível em: <http://redir.stf.jus.br/paginadorpub/paginador. jsp?docTP=AC\&docID=73573 > . Acesso em: 11 out. 2015.

24 Essa premissa ainda pode ser constatada nos julgamentos em 
Habeas Corpus no 79.785/RJ (2000) em que o Ministro Sepúlveda Pertence esboçou a possibilidade da defesa da tese que diferenciasse os tratados internacionais de direitos humanos como materialmente constitucionais, ainda sim nessa concepção os tratados estariam abaixo da Constituição ${ }^{25}$.

Nos julgados de 2008, o STF, por maioria, superou a tese da hierarquia legal dos tratados em geral, passando a acolher a tese proposta pelo Ministro Gilmar Mendes da supralegalidade dos tratados internacionais de direitos humanos, quando não submetidos ao rito do $₫ 3^{\circ}$ do art. $5^{\circ}$, ficando vencida a tese da hierarquia constitucional defendida pelo Ministro Celso de Mello.

A tese da supralegalidade vingou por exclusão "formal". Isso porque, segundo o voto do Ministro Gilmar Mendes, seria impossível conferir status supraconstitucional aos tratados de direitos humanos em razão da dificuldade imposta pela supremacia formal e material da Constituição, inviabilizando o controle de constitucionalidade e, na mesma esteira, o status constitucional dos tratados de direitos humanos, ora esvaziado pela introdução do $\int 3^{\circ}$ no art. $5^{\circ}$ da Constituição. A tese da hierarquia legal, dominante até aquele momento na

plenário do STF: BRASIL. Supremo Tribunal Federal. Ação Direta de Inconstitucionalidade. ADI MC n 1480 DF. Tribunal Pleno. Requerente: Confederação Nacional do Transporte; Confederação Nacional da Indústria. Requerido: Presidente da Republica; Congresso Nacional. Relator: Min. Celso de Melo. Brasília, 04 de setembro de 1997. Disponível em: <http://redir.stf.jus.br/paginadorpub/ paginador.jsp?doc $\mathrm{TP}=\mathrm{AC} \& \mathrm{doc} \mathrm{ID}=347083>$. Acesso em: 09 set. 2016; BRASIL. Supremo Tribunal Federal. Recurso Extraordinário. RE $n^{\circ} 206482$ SP. Tribunal Pleno. Recorrente: Ministério Público Federal. Recorrido: Pedro Luiz de Oliveira. Relator: Min. Maurício Corrêa. Brasília, 27 de maio de 1998. Disponível em: < http://stf. jusbrasil.com.br/jurisprudencia/14698605/recurso-extraordinariore-206482-sp> Acesso em: 09 set. 2016; BRASIL. Supremo Tribunal Federal. Habeas Corpus. HC $n^{\circ} 77527$ MG. Tribunal Pleno. Paciente: João Cordoval de Barros. Coator: Tribunal de Alçada do Estado de Minas Gerais. Relator: Min. Marco Aurélio. Brasília, 23 de setembro de 1998. Disponível em: <http://stf.jusbrasil.com.br/ jurisprudencia/14698138/habeas-corpus-hc-77527-mg>. Acesso em: 09 set. 2016; BRASIL. Supremo Tribunal Federal. Recurso Ordinário em Habeas Corpus. RHC nº 81.319/GO. Tribunal Pleno. Recorrente: Nilo Lottici Júnior. Recorrido: Relator do RE no 299401. Relator: Min. Celso De Mello. Brasília, 24 de abril de 2002. Disponível em: <http://stf.jusbrasil.com.br/jurisprudencia/774659/ habeas-corpus-hc-81319-go>. Acesso em: 09 set. 2016.

25 BRASIL. Supremo Tribunal Federal. Recurso Ordinário em Habeas Corpus. RHC no 79785 RJ. Tribunal Pleno. Recorrente: Jorgina Maria de Freitas Fernandes. Recorrido: Ministério Público Federal. Relator: Min. Sepúlveda Pertence. Brasília, 29 de março de 2000. Disponível em: <http://redir.stf.jus.br/paginadorpub/paginador.jsp?docTP=AC\&docID=102661 >. Acesso em: 11 out. 2015. p. 301. jurisprudência do Tribunal, em razão da alteração imposta pela EC no 45/2004, também teria ficado cada vez mais difícil de ser sustentada $a^{26}$; por fim, restou a tese da hierarquia supralegal, que, para o Ministro, lhe parecia a mais consistente, uma vez que os tratados sobre direitos humanos não submetidos à regra do $\ 3^{\circ}$, diante de seu caráter especial em relação aos demais atos normativos internacionais, seriam dotados de um atributo de supralegalidade, isto é, estariam abaixo da Constituição, mas acima das demais normas legais ${ }^{27}$.

O voto divergente do Ministro Celso de Mello não se desapegou da questão formal como predominante, basta observar que sua tese, ao não reconhecer superioridade formal dos tratados, teria que apostar numa saída de segundo nível a partir da do $\int 2^{\circ}$ do art. $5^{\circ}$ da Constituição, o qual enquanto cláusula geral de recepção autorizaria o reconhecimento de que os tratados internacionais de direitos humanos possuem hierarquia constitucional, passando a integrarem-se ao conjunto normativo configurador do bloco de constitucionalida$\mathrm{de}^{28}$. A tese seria perfeita se não fossem suas incompatibilidades em relação ao próprio $\int 3^{\circ}$, uma vez que não foi debatida sua (in)constitucionalidade, bem como, por outro lado, a própria a ideia de bloco de constitucionalidade em nível secundário (abaixo da Constituição), enquanto solução alternativa para uma dificuldade formal.

Diante desse quadro, a crítica necessária verticaliza com todas as teses estiveram intimamente ligadas às condições procedimentais instituídas pelo $\int 3^{\circ}$ do art. $5^{\circ}$ da Constituição, em que tratados de direitos humanos recepcionados antes e pós-Emenda tem sua função aplicativa condicionada à formalização receptiva do legislador num modo ou noutro. Por isso, nem mesmo os

26 BRASIL. Supremo Tribunal Federal. Recurso Extraordinário. RE $n^{\circ}$ 466343. Tribunal Pleno. Recorrente: Banco Bradesco S/A. Recorrido: Luciano Cardoso Santos. Relator: Min. Cezar Peluso. Brasília, 03 de dezembro de 2008. Disponível em: <http://redir.stf.jus. $\mathrm{br} /$ paginadorpub/paginador.jsp?docTP $=\mathrm{AC} \& \operatorname{doc} \mathrm{ID}=595444>$. Acesso em: 11 out. 2015.

27 BRASIL. Supremo Tribunal Federal. Recurso Extraordinário. RE $n^{\circ}$ 466343. Tribunal Pleno. Recorrente: Banco Bradesco S/A. Recorrido: Luciano Cardoso Santos. Relator: Min. Cezar Peluso. Brasília, 03 de dezembro de 2008. Disponível em: <http://redir.stf.jus. $\mathrm{br} /$ paginadorpub/paginador.jsp?docTP $=\mathrm{AC} \& \operatorname{docID}=595444>$. Acesso em: 11 out. 2015.

28 BRASIL. Supremo Tribunal Federal. Recurso Extraordinário. RE $n^{\circ}$ 466343. Tribunal Pleno. Recorrente: Banco Bradesco S/A. Recorrido: Luciano Cardoso Santos. Relator: Min. Cezar Peluso. Brasília, 03 de dezembro de 2008. Disponível em: <http://redir.stf.jus. $\mathrm{br} /$ paginadorpub/paginador.jsp?docTP $=\mathrm{AC} \& \operatorname{docID}=595444>$. Acesso em: 11 out. 2015. 
diálogos interjurisdicionais conseguiriam superar essa dificuldade, uma vez que a dependência do protagonismo judicial seria insuficiente democraticamente para ilidir essas premissas hierárquico-normativas.

Assim, de forma objetiva, a racionalidade dominante não prescinde do aspecto sistemático da ordem jurídica e da supremacia (formal) constitucional de influência kelseniana, olvidando o caráter hermenêutico dos direitos humanos e a normatividade (material) da Constituição, deixando de responder satisfatoriamente a pergunta dialógica posta pela própria autonomia normativo-material da Constituição e pelo direito internacional dos direitos humanos. É o novo com os olhos do velho. Por isso a adequada pergunta ou sua provocação tem a finalidade de romper com esse discurso monológico formado doutrinária e jurisprudencialmente no Brasil e que obscurece a diálogo na/para a internacionalização da Constituição.

\section{A perspectiva de UMA NOVA RACIONALIDADE (HERMENÊUTICA) PARA A NORMATIVIDADE MATE- Rial dos tratados internacionals De Direitos Humanos no BrasiL}

A necessária relação dialógica entre Direitos Humanos, Estado de Direito e Constituição tem por finalidade superar a mera dimensão axiológica dos direitos humanos para elevá-los a condição de possibilidade jurídica e política dos Estados de Direito e de suas Constituições, inclusive, no sentido de se constituir uma esfera capaz de repassar o arbítrio da jurisdição interna de cada Estado ${ }^{29}$.

Daí porque sob a razão hermenêutica não se pode compartilhar a ideia de que a defesa da especialidade dos direitos humanos e sua influência no movimento constitucional pós-Segunda Guerra tenha pretendido colocar os tratados de direitos humanos, por exemplo, no nível intermediário (supralegalidade), na medida em que constituem, por si, a própria medida legitimidade constitucional.

O desafio da pergunta constitucionalmente/convencionalmente adequada, autonomizadora e vinculante do direito internacional dos direitos humanos mediado

29 PÉREZ LUÑO, Antonio Enrique. Derechos humanos, estado de derecho y constituición. 10. ed. Madrid: Tecnos, 2010. p. 131. pela Constituição, tem em sua estrutura a necessidade de aproximação das fontes e a des(hierarquização) das ordens jurídicas interna e internacional. As fronteiras entre o direito constitucional e o direito internacional devem estreitar-se apontando para uma progressiva constitucionalização do direito internacional revelando uma dialética com o conteúdo de mesma natureza advindo das organizações internacionais, pactos e convenções de direitos humanos ${ }^{30}$. A recomposição da paisagem ${ }^{31}$ implica numa estrutura (hermenêutica) favorecedora de 'pontes de transição' das habituais referências estatal e lógico-sistemática das (des)ordens às novas dimensões interpretativo-normativas do Direito (constitucional) consolidadoras de um espaço jurídico e democrático comuns em matéria de direitos humanos.

É consenso que a positivação dos direitos fundamentais indica o resultado de uma opção democraticamente instituída pelo Estado na defesa dos direitos humanos, os quais determinam, mais do que orientam, a sua vinculação (e de seus agentes) seja contra atos normativos ou mesmo não-normativos, internos e internacionais. Porém, os discursos formalistas e estatalistas não podem segurar a substancialização que o debate exige, sobretudo, ao se considerar que as controvérsias sobre os direitos humanos decorrem da possibilidade de leituras diversas do conceito, da pluralidade conflituosa de interpretações/concretizações das normas e da incongruência prática dos diferentes tipos de direitos humanos ${ }^{32}$.

Por isso adverte Häberle que a unidade, coerência e hierarquia do sistema jurídico não podem ser corolário de um único princípio dominante e do qual mecanicamente se derivam os demais. No Estado Constitucional, que é o Estado de uma 'sociedade aberta', o sistema jurídico e seus postulados básicos exigem de seu intérprete uma atitude aberta e um modo-de-ser hermenêutico como instância crítica — baseado em um processo dinâmico baseado em alternativas práticas e num pensamento de possibilidades — em detrimento de um monopólio metodológico cerrado e hermético ${ }^{33}$.

30 CANOTILHO, J. J. Gomes. "Brancosos" e a interconstitucionalidade: itinerários dos discursos sobre a historicidade constitucional. 2. ed. Lisboa: Almedina, 2008. p. 285.

31 Expressão usada por Delmas-Marty. In: DELMAS-MARTY, Mireille. Por um direito comum. Trad. Maria Ermantina de Almeida Prado Galvão. São Paulo: M. Fontes, 2004.

32 NEVES, Marcelo. Transconstitucionalismo. São Paulo: M. Fontes, 2009. p. 256.

33 HÄBERLE, Peter. Pluralismo y constituición: estúdios de teoria 
O tema direitos humanos requer a máxima prudência histórica, especialmente em países, como o Brasil, onde seu tratamento teórico e normativo dá nítidos indicativos de não ter atingido um nível autêntico dos discursos, aprisionado nas 'compreensões' baseadas em preconceitos improdutivos ou modelos autoritários, os quais somente servem para a reprodução da desigualdade social. Nesse cenário, há muito espaço (hermenêutico) para recuperar a tradição (autêntica), com base em um exercício fenomenológico, buscando ilidir aquilo que foi perdido na pretensa objetividade da regra e na subjetividade dos intérpretes, nos discursos autoritários ou de ocasião, responsáveis por obscurecerem a normatividade dos direitos humanos e das Constituições.

As novas possibilidades que reivindicam o pluralismo oriundo da interrelação entre Constituição e tratados internacionais de direitos humanos dependem de uma adequada compreensão dialógico-hermenêutica — de um acontecer estruturado e comprometido com a alteridade crítica do outro - e não de uma "metodologia" de diálogos que coloca a verdade como produto uma subjetividade assujeitadora e autoritária.

O que se quer destacar é que o Diálogo como modo de ser hermenêutico é capaz de produzir a verdade como acontecer histórico (não dedutivo) resultado da mediação da experiência linguística entre passado e presente. Trata-se de um acontecer que ocorre como crítica à produção artificial das verdades científicas das metodologias tradicionais de intepretação, dependentes do protagonismo do sujeito. Para o diálogo hermenêutico, nós pertencemos à história e não a história que nos pertence, logo, não é possível negar o caráter vinculativo entre os fatos históricos e a filosofia constitucional após a Segunda Guerra. A tradição que nos condiciona é insuscetível de manipulação arbitrária.

A crítica dialógica volta-se, portanto, contra a inadequada opção do legislador constitucional derivado em procedimentalizar a admissão dos tratados internacionais de direitos humanos em detrimento da norma constitucional originária de admissão automática daqueles instrumentos. Ao lado disso, também se tem em mira o consequente entendimento do Supremo Tribunal Federal quanto ao caráter de supralegalidade dos tratados internacionais de direitos humanos quando não recepcionados pela nova regra constitucional. Quaisquer delas, a opção do legislador e o entendimento do STF,

constitucional de la sociedad aberta. Madrid: Tecnos, 2002. ao objetificarem a tradição, acabaram sufocar as expectativas de sentido sobre o tema, deixando ao alvedrio da subjetividade dos 'intérpretes' o acoplamento ad hoc escolhas políticas e jurídicas descontextualizadas de nossa realidade histórica, ofuscando o verdadeiro compromisso dos direitos humanos nessa quadra da história.

No Direito, enquanto ciência interpretativa, a prática dominante, ainda, acredita no modo dedutivo de conhecimento das hermenêuticas clássicas e/ou em metodologias especiais (diálogos interjurisdicionais, por exemplo) para salvar as insuficiências interpretativas do imaginário jurídico, as quais por não contarem com enraizamento ontológico-hermenêutico comprometem a continuidade consentânea da história ${ }^{34}$. $\mathrm{Na}$ medida em que cada intérprete pretende contar sua melhor história (filosofia da consciência), o Direito se enfraquece institucionalmente, recaindo numa espécie de instrumentalização pragmático-formal.

A crítica aos diálogos interjurisdicionais caminha nesse sentido, conforme se observa com base em Vergottini quando destaca que o "el diálogo parece haberse convertido en uno de los fetiches históricos que se evocan para esconder improvisaciones comparatísticas a menudo carentes de fundamento y, en todo o caso, científicamente impropias" ${ }^{35}$. O diálogo, nessas condições, longe de um processo comparativo, ou mesmo dialógico, "non forman parte de los lugares comunes a los que nos ha acostumbrado la fácil y acrítica vulgata de la globalización" ${ }^{36}$, o que há é "una utilización unilateral de contribuiciones del outro" ${ }^{37}$, reconhecendo-se ao juiz a liberdade de inspirar-se em precedentes ou previsões constitucionais de outros, distintas de situações mais concretas de cada país ${ }^{38}$.

Por isso, talvez, albergados nessa crítica, poderiam compreender-se algumas das propostas de diálogos interjurisdicionais, quando lidas sem a devida ontologização, por exemplo: García Roca, Alcalá e Bustos Gisbert $^{39}$ no texto La comunicación entre ambos sistemas

34 DWORKIN, Ronald. O império do direito. Trad. Jefferson Luiz Camargo. 2. ed. São Paulo: M. Fontes, 2007. p. 272.

35 VERGOTTINI, Giuseppe De. Más allá del diálogo entre tribunales. Madrid: Civitas, 2010. p. 63.

36 VERGOTTINI, Giuseppe De. Más allá del diálogo entre tribunales. Madrid: Civitas, 2010. p. 41.

37 VERGOTTINI, Giuseppe De. Más allá del diálogo entre tribunales. Madrid: Civitas, 2010. p. 188.

38 VERGOTTINI, Giuseppe De. Más allá del diálogo entre tribunales. Madrid: Civitas, 2010. p. 197.

39 Oportuno destacar que cada um destes autores desenvolvem, 
y las características del diálogo ${ }^{40}$, onde propõem, nas relações entre as Cortes Internacionais de Direitos Humanos (CIDH e TEDH), o diálogo como medida de aproximação metodológica, de reciprocidade ou consenso regional, numa perspectiva pedagógica capaz de atingir o maior número de sujeitos implicados na tutela de direitos humanos ${ }^{41}$; por sua vez, Alcalá também aborda o tema do diálogo interjurisdicional ${ }^{42}$ defendendo que a internacionalização do diálogo dos juízes é uma manifestação da desnacionalização do diálogo, funcionando numa espécie de crítica aos juízes tradicionalmente vinculados a um território, aos seus procedimentos e normas ${ }^{43}$; ainda, na literatura internacional, a francesa Laurence Burgorgue-Larsen, trabalha com a internacionalização do diálogo de juízes ${ }^{44}$ como medida de internacionalização dos sistemas e dos comportamentos judiciários nacionais ${ }^{45} \mathrm{em}$ que o juiz doméstico precisa abrir-se para o amplo leque das manifestações, tanto da internacionalização como do recuo das fron-

também, autonomamente pesquisas nesta mesma linha teórica. 40 O texto constitui-se do Capítulo I da obra de GARCÍA ROCA, Javier et al. (Orgs.). El diálogo entre los sistemas europeo y americano de derechos humanos. Madrid: Civitas, 2012. Cf. GARCÍA ROCA, Javier; NOGUEIRA ALCALÁ, Humberto; BUSTOS GISBERT, Rafael. La comunicación entre ambos sistemas y las características del diálogo. In: __ et al. (Org.). El diálogo entre los sistemas europeo y americano de derechos humanos. Madrid: Civitas, 2012. p. 66-107.

41 GARCÍA ROCA, Javier; NOGUEIRA ALCALÁ, Humberto; BUSTOS GISBERT, Rafael. La comunicación entre ambos sistemas y las características del diálogo. In: ___ et al. (Org.). El diálogo entre los sistemas europeo y americano de derechos humanos. Madrid: Civitas, 2012. p. 66-100. p. 66.

42 NOGUEIRA ALCALÁ, Humberto. Diálogo interjurisdiccional, control de convencionalidad y jurisprudencia del Tribunal Constitucional en período 2006-2011. Estudios Constitucionales, Santiago, v. 10, n. 2, p. 57-140, 2012.

43 NOGUEIRA ALCALÁ, Humberto. Diálogo interjurisdiccional, control de convencionalidad y jurisprudencia del Tribunal Constitucional en período 2006-2011. Estudios Constitucionales, Santiago, v. 10, n. 2, p. $57-140,2012$. p. 58.

44 BURGORGUE-LARSEN, Laurence. De l'internationalisation du dialogue des juges: missive doctrinale à l'attention de Bruno Genevois. In: BADINTER, Robert et al. Le dialogue des juges: mélanges en l'honneur du président Bruno Genevois. Paris: Dalloz, 2009. p. 95-130. Disponível em: < http://www.univ-paris1.fr/fileadmin/IREDIES/Contributions_en_ligne/L._BURGORGUELARSEN/M\%C3\%A9langes/LBL_M\%C3\%A9langes_Genevois-1.pdf $>$. Acesso em: 17 out. 2015.

45 BURGORGUE-LARSEN, Laurence. De l'internationalisation du dialogue des juges: missive doctrinale à l'attention de Bruno Genevois. In: BADINTER, Robert et al. Le dialogue des juges: mélanges en l'honneur du président Bruno Genevois. Paris: Dalloz, 2009. p. 95-130. Disponível em: <http://www.univ-paris1.fr/fileadmin/IREDIES/Contributions_en_ligne/L._BURGORGUELARSEN/M\%C3\%A9langes/LBL_M\%C3\%A9langes_Genevois-1.pdf>. Acesso em: 17 out. 2015. teiras territoriais ${ }^{46}$; no mesmo sentido apontam as ideias de Delmas-Marty, quando fala do caminho percorrido pelos juízes na refundação dos poderes, em que a internacionalização dos juízes nacionais e o aumento da jurisdicionalização do direito internacional constituirão um duplo fenômeno que contribui para o equilíbrio dos poderes numa futura ordem mundial ${ }^{47}$, apontando, assim, para a mundialização como fenômeno para além do direito internacional e do Estado-Nação, deslocando para os juízes a mediação (dialética) entre o geral e o particular, do risco da ordem hegemônica e da desordem impotente ${ }^{48}$.

Poder-se-ia cogitar, por certo, que os diálogos entre sistemas regionais e/ou interjurisdicionais serão, talvez, um passo futuro, porém não sem antes resolverem-se os problemas de maturidade democrática e constitucional como é o caso do Brasil. Algumas das propostas de diálogo referidas e que começam a influenciar a doutrina nacional ${ }^{49}$ parecem não superar os velhos problemas do positivismo, especialmente, aqueles oriundos do âmbito da práxis interpretativa, pois, no fundo, a pragmática dos diálogos interjurisdicionais quer apostar no protagonismo judicial como drible à formalidade conceitual e legislativa do sistema e as dificuldades produtivas da doutrina. Obviamente, a intenção não seria desqualificar quaisquer das proposições teóricas, tampouco o valioso trabalho de seus respectivos autores, senão apenas traçar características e identificar algumas dificuldades das ideias de diálogo fora de um contexto hermenêutico (filosófico), conteudístico, em última análise.

Por isso se afirma que existe espaço para o desenvolvimento de outras narrativas sob uma nova perspectiva

46 BURGORGUE-LARSEN, Laurence. De l'internationalisation du dialogue des juges: missive doctrinale à l'attention de Bruno Genevois. In: BADINTER, Robert et al. Le dialogue des juges: mélanges en l'honneur du président Bruno Genevois. Paris: Dalloz, 2009. p. 95-130. Disponível em: <http://www.univ-paris1.fr/fileadmin/IREDIES/Contributions_en_ligne/L._BURGORGUELARSEN/M\%C3\%A9langes/LBL_M\%C3\%A9langes_Genevois-1.pdf>. Acesso em: 17 out. 2015.

47 DELMAS-MARTY, Mireille. Les forces imaginantes $d u$ droit: la refondation des pouvoirs. Paris: Seuil, 2007. v. 3. p. 42.

48 DELMAS-MARTY, Mireille. Les forces imaginantes $d u$ droit: le relatif et l'universel. Paris: Seuil, 2004. v. 1. p. 414.

49 Por exemplo, SALDANHA, Jânia Maria Lopes. Novas geometrias e novos sentidos: internacionalização do direito e internacionalização do diálogo dos sistemas de justiça. In: STRECK, Lenio Luiz; ROCHA, Leonel Severo; ENGELMANN, Wilson. Constituição, sistemas sociais e hermenêtica. São Leopoldo: UNISINOS, 2012. (Anuário do Programa de Pós-Graduação em Direito da UNISINOS: Mestrado e Doutorado, 9). p. 137-160. p. 137-160. 
dialógico-hermenêutica entre fontes (Constituição e tratados e convenções de direitos humanos) em detrimento do encobridor debate de cunho hierárquico-normativista. É importante consignar que não é atitude metodológica (pragmática) dos diálogos interjurisdicionais ou sua dependência do protagonismo do sujeito-intérprete que modificará a normatividade constitucional dos tratados de direitos humanos no Brasil, uma vez que não se estará a discutir os problemas estruturais (hermenêuticos) de compreensão dos direitos humanos no constitucionalismo contemporâneo, senão encontrando apenas uma saída para evitar esse enfrentamento. Logo, se aposta no sentido de que é preciso revolver o chão linguístico, que sustenta essa tradição inautêntica, para buscar revelar a essência das novas faces (interpretativas) da normatividade jurídica que poderá, inclusive, apontar para uma tese verdadeiramente hermenêutica para a aplicação dos tratados internacionais de direitos humanos no Brasil, como por exemplo, àquela obtida da noção interpretativa de bloco de constitucionalidade ${ }^{50}$.

Nesse particular, é preciso fortalecer o caráter produtivo da normatividade constitucional, inclusive, no que diz respeito a sua própria internacionalização. $\mathrm{O}$ Direito deverá trilhar caminhos que possam institucionalmente desvelar a face normativa, invasora da legalidade e fundadora do espaço público democrático da Constituição. As análises teóricas apontam que é possível se construir uma nova racionalidade para excetuar ou ultrapassar a lógica hierárquica dominante que reduz o papel dos tratados internacionais de direitos humanos através da abertura constitucional.

\section{O DIÁLOGO HERMENÊUTICO E AS POSSIBILIDA- DES DA PERGUNTA ADEQUADA COMO CRÍTICA À (IN)EFICÁCIA DOS TRATADOS INTERNACIONAIS DE DIREITOS HUMANOS NO BRASIL}

A mudança de racionalidade é um processo complexo e que encontra uma série de resistências, especialmente, por demandar a necessidade de revisar pressupostos - por vezes inautênticos — que sustentam os

50 FERREIRA, Rafael Fonseca; LIMBERGER, Temis. O diálogo hermenêutico como horizonte de uma nova paisagem no Direito: crítica à racionalidade autoritária dispensada aos tratados de direitos humanos no Brasil. In: SOUZA SILVA, Karine de; ARARUNA SANTIAGO, Nestor Eduardo (Org.). Direito constitucional, direitos bumanos e direito internacional. Barcelona: Laborum, 2015. p. 155-176. discursos. Na realidade, para se falar em diálogo (hermenêutico) essa necessidade de revisar pressupostos é condição de possibilidade, pois, como restou evidenciado, é preciso se entregar ao fenômeno dialógico para o acontecer produtivo da verdade que orienta o discurso epistemológico, é um modo-de-ser.

Em se tratando de direitos humanos no Brasil, algumas questões mostraram-se fulcrais quando criticadas no viés da hermenêutica filosófica, em especial, sob o arranjo do diálogo. Embora, no âmbito desse trabalho, a proposta seja demonstrar as possibilidades de analisar o tema sob a perspectiva hermenêutica, temas como o do bloco de constitucionalidade, do controle de convencionalidade, da impossibilidade de cisão entre direitos humanos e direitos fundamentais e da força normativa e autonômica da Constituição encontrarão novos horizontes de compreensão e assim um espaço aberto para melhor desenvolvimento epistemológico-hermenêutico.

Isso porque o desenvolvimento de uma proposta que vise contemplar a historicidade do processo de formação das fontes e ordens jurídicas dentro de uma nova paisagem jurídica pressupõe antes de tudo, para evitar o pragmatismo e o relativismo, dar sentido a estrutura interpretativa dos discursos por meio da fenomenologia hermenêutico-dialógica ao fim de superar a discussão meramente semântico-instrumental da linguagem do tema dos direitos humanos.

O atual cenário global tem revelado uma pressão mais acentuada pela internacionalização do Direito, como medida de potencialização dos canais de comunicação e, por consequência, como uma tendência de democratização interpretativa em benefício das possibilidades de alinhamento político, econômico e, também, jurídico, especialmente, em tempos de busca da autonomia do Direito. Com efeito, a preocupação com o modo pela qual tem se dado essa busca por esses movimentos de interrelação reside o espaço para se trabalhar a reestruturação do sistema de fontes e se constituir critérios interpretativos movidos por elementos comuns (democracia e direitos humanos) como resposta às demandas de interesse da sociedade contemporânea. As novas demandas dessa sociedade não podem eficazmente serem enfrentadas por uma única ordem jurídica estatal no âmbito do respectivo território ${ }^{51}$ ou mesmo pela depen-

51 NEVES, Marcelo. Transconstitucionalismo. São Paulo: M. Fontes, 2009. p. XXI. 
dência de uma racionalidade autoritária e impositiva que não se estrutura sob premissas partilháveis.

Logo, qualquer ideia que reivindique a comunicação intersistemas de Direito, como repercussão de um movimento da internacionalização do Direito ou como promessa de renovação dos sistemas de Direito, ainda atrelados de maneira geral à ideia ultrapassada do Estado-Nação, não passam de paliativos às medidas de segurança jurídica e de resistência às arbitrariedades ${ }^{52}$ políticas e jurídicas dos próprios Estados. Sob a ótica hermenêutica, a prescindibilidade da hierarquização das ordens (interna/internacional), enquanto o fundamento básico dos discursos reducionistas e arbitrários de exceção aos direitos humanos é um elemento chave para o novo modo de produção e normatividade jurídicas na recomposição da paisagem do Direito, reconstruídos com base nos diálogos hermenêuticos.

Outrossim, não se pode deixar de consignar que o próprio monismo kelseniano sempre foi dependente da ideia de escalonamento, já que somente se afirmaria como possível em razão da ausência de positividade do direito internacional, lembrando que o Direito em sua teoria é um sistema de normas válidas. Em diversas passagens, quando trata do direito internacional, Kelsen ainda se preocupe em criticar os pluralistas que concebem duas personalidades jurídicas ao Estado, afirma que não passa de uma instância de legitimação jurídica e moral dos Estados em suas relações mútuas no âmbito externo, a qual somente quando vislumbrada conjuntamente (monisticamente) com o direito interno é que se torna possível concebê-la como parte de uma unidade sistemática e inconflitível de normas ${ }^{53}$.

Advirta-se que para Kelsen em regra geral as normas de direito internacional são sempre incompletas, pois sua normatividade plena seria sempre dependente da suplementação do direito nacional onde encontraria o elemento pessoal ${ }^{54}$ (sujeito/destinatário). Por isso é que as concepções doutrinárias vigentes como também as decisões do Supremo Tribunal Federal ainda se considerem como avançadas, de um modo ou de outro, não

52 NEVES, Marcelo. Transconstitucionalismo. São Paulo: M. Fontes, 2009. p. 116.

53 KELSEN, Hans. Teoria geral do direito e do Estado. Trad. Luís Carlos Borges. 4. ed. São Paulo: M. Fontes, 2005. p. 531 et seq.; KELSEN, Hans. Teoria pura do direito. Trad. João Baptista Machado. 8. ed. São Paulo: M. Fontes, 2009. p. 348.

54 KELSEN, Hans. Teoria geral do direito e do Estado. Trad. Luís Carlos Borges. 4. ed. São Paulo: M. Fontes, 2005. p. 488. ultrapassam a ideia positivística de Kelsen, do normativismo semântico.

Para a doutrina dos direitos humanos, a superação desse imaginário se constitui num dos grandes desafios contemporâneos, como se observa na crítica de Pérez Luño dirigida àqueles que defendem os direitos humanos sob uma concepção meramente axiológica, mormente quando se está diante de sistemas normativos forjados na dogmática positivista do século XIX, isto é, no mais das vezes não invocáveis ou justicializáveis por não estarem positivados direta e imediatamente ${ }^{55}$.

O não reconhecimento dos direitos humanos como autênticos direitos (validados formalmente - positivados), sob a ótica metodológica dominante é determinante para o paradoxo dual (valores éticos versus normas jurídicas), especialmente, ao se prescindir do caráter deôntico que está em sua origem. É de se convir que o estatalismo combinado com a ausência de diálogo hermenêutico em sede de direitos humanos desprestigia o seu caráter universalista, suscetibilizando-os a fragmentação e ao enfraquecimento de seu caráter normativo (e interpretativo).

$\mathrm{Na}$ superação desse paradigma fragmentário, o processo de defesa de uma racionalidade alternativa ou transversal ${ }^{56}$ como o diálogo hermenêutico abre um espaço (normativo) favorável e criativo destinado a albergar a pluridimensionalidade dos direitos humanos ${ }^{57}$, ordenando interpretativamente o espaço ${ }^{58}$.

As possibilidades de um diálogo, de uma 'conversação constitucional ${ }^{159}$, devem ser vistas como medidas críticas do olhar hermenêutico contra as restrições da autoridade hierárquica de caráter nacional, convencional ou comunitária, de modo que a reivindicação de um direito acessível a todos, ao fim de consagrá-lo como verdade compartilhada ${ }^{60}$, como são os direitos huma-

55 PÉREZ LUÑO, Antonio Enrique. Derechos humanos, estado de derecho y constituición. 10. ed. Madrid: Tecnos, 2010. p. 595.

56 Alternativa ou transversal no sentido de uma excetuação às lógicas dos modelos tradicionais de ordens jurídicas (verticais e/ ou horizontais) e onde o diálogo hermenêutico atua como vetor de transformação dessa nova face de normatividade (tradução nossa).

57 NEVES, Marcelo. Transconstitucionalismo. São Paulo: M. Fontes, 2009. p. 235 et. seq.

58 DELMAS-MARTY, Mireille. Les forces imaginantes du droit: le pluralisme ordonné. Paris: Seuil, 2006. v. 2. p. 26.

59 NEVES, Marcelo. Transconstitucionalismo. São Paulo: M. Fontes, 2009. p. XXV.

60 DELMAS-MARTY, Mireille. Por um direito comum. Trad. Maria Ermantina de Almeida Prado Galvão. São Paulo: M. Fontes, 2004. 
nos.

Nesse ponto, hermenêutica (filosófica) e epistemologia parecem se conectar, na medida em que o diálogo que estruturam a adequada razão ontológica dos direitos humanos, formando uma comunidade de experiências linguísticas (comunidade de diálogo ou entendimento) ${ }^{61}$ facilitando o desenvolvimento epistemológico. A razão hermenêutica que sempre se antecipa, quando autêntica, pavimenta os desafios como aqueles propostos por Delmas-Marty quando diz que o segredo da reinvenção de um direito comum passa por uma reflexão sobre as lógicas jurídicas, especialmente, a do formalismo racional do Direito, em que a arbitrariedade se encontra ignorada, dotada de 'eficácia simbólica' que não permite pensar o múltiplo, ora reduzido à alternativa binária ${ }^{62}$ ou a influência 'tranquilizadora' da unidade e da estabilidade do espaço normativo identificado com a autoridade do Estado e numa ordem normativa organizada em torno da $l e i^{63}$.

Então, essas são apenas algumas das objetivas confissões de que a hierarquia lógico-sistemática tida em Kelsen, em que uma norma fundamental assegura a unidade e a validade do todo e, mesmo ao longo da pirâmide, supostamente de forma linear e estável, não dá conta da complexidade do cenário contemporâneo, em particular, de um direito constitucional que reclama a normatividade de sua face internacionalizada. Assim, inclusive, seria mais conveniente falar em 'pirâmides inacabadas ou hierarquias descontínuas', não porque tenha desaparecido toda a hierarquia, mas porque mudou o desenho ${ }^{64}$ de produção da normatividade em benefício da fertilização recíproca entre direito constitucional e direito internacional. É preciso romper com a absolutização da lógica sistemático-formal e do monólogo cientificista, que não admite ‘co/ordenação' entre direito interno e internacional ${ }^{65}$, ao fim de dar continuidade

prefácio.

61 GADAMER, Hans-Georg. Verdade e método I: traços fundamentais de uma hermenêutica filosófica. 12. ed. Trad. Flávio Paulo Meurer. Petrópolis: Vozes, 2012. passim.

62 DELMAS-MARTY, Mireille. Por um direito comum. Trad. Maria Ermantina de Almeida Prado Galvão. São Paulo: M. Fontes, 2004. Prefácio.

63 DELMAS-MARTY, Mireille. Por um direito comum. Trad. Maria Ermantina de Almeida Prado Galvão. São Paulo: M. Fontes, 2004. p. 46.

64 GADAMER, Hans-Georg. Verdade e método I: traços fundamentais de uma hermenêutica filosófica. 12. ed. Trad. Flávio Paulo Meurer. Petrópolis: Vozes, 2012. p. 86.

65 DELMAS-MARTY, Mireille. Por um direito comum. Trad. Maria ao processo inacabado de 'constitucionalização' e 'internacionalização’ da normatividade ${ }^{66}$.

As incertezas e insuficiências teóricas das relações hierárquicas (interno-internacional) e das 'tradicionais técnicas' ineficazes oriundas dessa relação, como por exemplo, margem de apreciação nacional e primazia da norma mais favorável, não estimulam o adequado espaço para repensar outras possibilidades de consolidação da internacionalização do direito constitucional no mundo globalizado, mormente se continuar a apostar na primazia da ordem estatal nacional de matiz kelseniano.

A recomposição da paisagem, portanto, passa-se pela possibilidade de se criar condições de desenvolver uma racionalidade transversal ou alternativa estruturante, a partir da Constituição - nem vertical, nem horizontal ${ }^{67}$ - e que tem no diálogo hermenêutico a condição favorecedora de 'pontes de transição' das habituais referências estatal e lógico-sistemática das (des)ordens, rompedora dos dilemas tradicionais (monismo/pluralismo) e que busque ilidir o distanciamento da 'significação teórica da realização prática dos direitos humanos ${ }^{\prime 68}$. De outro lado, a manutenção do atual cenário continuará a nos deixar reféns de um constitucionalismo autista, provinciano e autossuficiente, ou caminharemos para um constitucionalismo imperial como última ratio do social $^{69}$, refratário a multiplicidade de sistemas institucionais existentes (regionais, locais, supraestatais, entre outros) ${ }^{70} \mathrm{e}$, sobretudo, às dimensões interpretativo-normativas do Direito.

O diálogo nesse cenário vem resgatar o modo de ser democrático e produtivo da interpretação do/no

Ermantina de Almeida Prado Galvão. São Paulo: M. Fontes, 2004. p. 86.

66 DELMAS-MARTY, Mireille. Por um direito comum. Trad. Maria Ermantina de Almeida Prado Galvão. São Paulo: M. Fontes, 2004. p. 88 .

67 DELMAS-MARTY, Mireille. Les forces imaginantes du droit. le pluralisme ordonné. Paris: Seuil, 2006. v. 2. p. 37.

68 PÉREZ LUÑO, Antonio Enrique. Derechos humanos, estado de derecho y constituición. 10. ed. Madrid: Tecnos, 2010. p. 597.

69 NEVES, Marcelo. Transconstitucionalismo. São Paulo: M. Fontes, 2009. p. 51.

70 BUSTOS GISBERT, Rafael. Diálogos jurisdiccionales en escenarios de pluralismo constitucional: la protección supranacional de los derechos en Europa. In: MAC-GREGOR, Eduardo Ferrer; LELO DE LARREA, Arturo Zaldívar (Coord.). La ciencia del derecho procesal constitucional: estudios en homenaje a Héctor Fix-Zamudio en sus cincuenta años como investigador del derecho. México: UNAM, 2008. (Derechos humanos y tribunales internacionales, 9). p. 753775. p. 754. 
Direito, na medida em que prescinde das dicotomias tradicionais isolacionistas (interno-internacional, direitos humanos-direitos fundamentais, p. ex.), para empreender numa substancializadora modalidade dialógica e construtiva baseada na colaboração e enriquecimento recíproco, objetivando a criação de um espaço jurídico comum em matéria de direitos humanos ${ }^{71}$.

Por certo, a questão é mais complexa, não se trata de desprestigiar os textos, mas de como se lida com eles, é uma questão de compreensão que, como já destacado, é um acontecimento histórico-linguístico que dá conta de nossos projetos de sentido. Na realidade, o tempo, a historicidade, é a verdadeira fonte do Direito, pois é o elemento que constitui e condiciona o intérprete num movimento implicado que vincula passado-presente-futuro. Não há espaço para abstrações ou subjetivismos, há sempre um sentido que orienta a compreensão e do qual não se pode prescindir sob o prisma hermenêutico. Assim é, toda e qualquer interpretação que não partilha sentidos, ou quaisquer teorias que não conseguem superar a relação sujeito-objeto e a discricionariedade positivista.

Todavia, a dificuldade de 'pensar o múltiplo' ou de qualificar a constituição da normatividade jurídica, são efeitos colaterais da ordem monológica, precisa, silogística e de valores homogêneos ${ }^{72}$. Por isso, é que o compromisso dos constitucionalistas e dos intérpretes em geral, com o Direito não lhes exime de considerar a normatividade emergente dos tratados e convenções, mormente, em razão do caráter ontológico de sua fundamentação: os direitos humanos.

Além de estar em jogo a possibilidade de uma internacionalização do direito constitucional com o diálogo hermenêutico, está, também, pressuposta a necessidade de transformação cognitiva do Direito em todas as suas faces, ao fim de dar cabo daquilo que Delmas-Marty estabelece como uma das características da refundação dos poderes: la refondation des pouvoirs institués (exécutif, législatif et judiciaire) appele en effet de nowvelles articulations entre

71 GARCÍA ROCA, Javier; NOGUEIRA ALCALÁ, Humberto; BUSTOS GISBERT, Rafael. La comunicación entre ambos sistemas y las características del diálogo. In: __ et al. (Org.). El diálogo entre los sistemas europeo y americano de derechos humanos. Madrid: Civitas, 2012. p. 66-107. p. 73 et. seq.

72 DELMAS-MARTY, Mireille. Por um direito comum. Trad. Maria Ermantina de Almeida Prado Galvão. São Paulo: M. Fontes, 2004. p. 202. compétences internationales et nationales ${ }^{73}$.

Assim, no que se pode concordar com Alcalá, por certo o desafio está em superar as resistências provocadas por preconceitos, juízos prévios e paradigmas de pensamento arraigados em nossa cultura jurídica ${ }^{74}$, mas, no entanto, a solução não se encontra numa internacionalização do comportamento dos juízes e tribunais, senão no modo de como se constrói o Direito. Seria um grande erro envidar esforços para manutenção do velho paradigma subjetivista, isto é, que a mudança do sujeito seja suficiente para um novo olhar democrático para o Direito.

O caminho para novos horizontes hermenêuticos que dê cabo da necessária interrelação entre direito internacional e constitucional não implica em se socorrer de abstrações ou de argumentos de confronto formal e material, pois eles furtam a possibilidade de aprendizado recíproco entre fontes e sistemas de direito e renunciam a mediação horizôntica que se dá no diálogo. As dicotomizações e abstrações desse jaez, servem, apenas, para opor lo constitucionalmente necessário y lo constitucionalmente accesorio sem, contudo, realizar a Constituição, propriamente dita, como fuente del Derecho - origen mediata e inmediata de derechos y de obligaciones ${ }^{75}$, suas preocupações são de ordem metodológico-sistemáticas, não hermenêuticas.

Então, o traçado aponta no sentido de se buscar nova racionalidade baseada na valorização de nosso modo de ser dialógico e dos princípios constituídos a partir de padrões e conquistas democraticamente construídas pelo constitucionalismo contemporâneo e nem tanto por metodologias funcionais de justiça. Por isso, essas 'novas lógicas' autorizam trilhar por um novo caminho, não mais limitadamente monológico, mas abertamente dialógico e transparente ${ }^{76}$ e que possa dar conta

73 '[...] a refundação dos poderes instituídos (executivo, legislativo e judicial), chamado, na verdade, de novas articulações entre competências nacionais e internacionais' (Tradução nossa). In: DELMAS-MARTY, Mireille. Les forces imaginantes du droit: la refondation des pouvoirs. Paris: Seuil, 2007. v. 3. p. 33.

74 NOGUEIRA ALCALÁ, Humberto. Diálogo interjurisdiccional, control de convencionalidad y jurisprudencia del Tribunal Constitucional en período 2006-2011. Estudios Constitucionales, Santiago, v. 10 , n. 2 , p. $57-140,2012$. p. 60.

75 RUBIO LLORENTE, Francisco. La forma del poder: estudios sobre la constituición. Madrid: Centro de Estudios Constitucionales, 1997. p. 50 et seq.

76 DELMAS-MARTY, Mireille. Por um direito comum. Trad. Maria Ermantina de Almeida Prado Galvão. São Paulo: M. Fontes, 2004. p. 203. 
da adequada normatividade emergente da Constituição e do processo de internacionalização do Direito nessa quadra da história. Esta possibilidade de um nova face de pluralismo ordenado convida a abandonar a oposição binária entre relação hierárquica (subordinação de um sistema para outro) e a relação não hierárquica (coordenação) para considerar um processo de produtivo e sustentável de Direito.

\section{Considerações finais}

A proposição hermenêutica desenvolvida neste trabalho visa fomentar o caráter transformativo e autônomo do Direito na realidade contemporânea, não mais dependente de práticas que afirmem a onipresença do Estado e da Lei, a hierarquia formal dos sistemas e a subjetividade assujeitadora dos intérpretes. As aproximações entre sistemas e fontes de Direito como produto de uma reciprocidade que condiciona a coordenação de formas democráticas de construção do direito tem nos diálogos hermenêuticos sua condição de possibilidade sustentável e coerente. A harmonização que resulta de um adequado diálogo hermenêutico de longe é uma busca por unificação hierárquica, senão um efeito da reconstrução da adequada compreensão da normatividade constitucional com a adição interpretativa dos tratados e convenções dos direitos humanos, sem, contudo, reduzi-los a uma categoria legal típica do ideal liberal-individualista.

A pergunta sobre a normatividade dos instrumentos internacionais de direitos humanos no Brasil, enquanto fontes de aproximação internacional do Direito e de ampliação da normatividade constitucional, reivindica a mudança de racionalidade para novos horizontes interpretativos, sob o risco de ficarem segregados a um papel secundário dentro do sistema.

O desafio da pergunta constitucionalmente/convencionalmente adequada em sede de direitos humanos é hermenêutico e, por isso, tem em sua estrutura a necessidade de uma compreensão historicamente comprometida com a aproximação das fontes e a des(hierarquização) das ordens jurídicas interna e internacional. Então, se há um novo modelo de Direito, também há a necessidade, em contraposição às teorias e 'hermenêuticas de bloqueio ${ }^{977}$, de um novo modo de compreensão da normatividade jurídica, a partir premissas (democráticas) compreensivo-estruturantes e multidialogais, mais rígidas e coerentes, inclusive, do que os imperialismos piramidais de cunho eminentemente formais.

O Direito e o Estado precisam se preparar para esse rompimento umbilical que não implica em separação absoluta, mas numa distinção necessária e indicadora de que a supremacia não é o único critério. Assim, permitirá aflorar uma das vertentes contributivas da autonomia do Direito na complexidade social, tocada pela reconfiguração das relações entre tempo e espaço (pluralismo), das quais o Direito não está (nem poderia estar) imune enquanto fenômeno social.

A relação de reciprocidade crescente entre direito internacional e direito constitucional implica num movimento que reclama, sobretudo, uma transformação do modo de produção e interpretação do/no Direito, mormente, ao se considerar o dever dos Estados e da sociedade em geral com os direitos humanos. Por essa simples razão, não se pode fazer o cumprimento das obrigações depender estritamente da própria organização estatal, mas também de outros aportes (hermenêuticos) para (des)integração dessa 'ordem' e recomposição de uma nova paisagem ao imaginário jurídico. A internacionalização da Constituição implica que la Constituición material se nutre boy de normas situadas más allá de los Estados y, por tanto, escapan a la posibilidad de definición unilateral por parte de una sola entidad estatal ${ }^{7}$, em que se pode verificar, à vista disso, um espaço de convivência político-jurídico entre os participantes da comunidade, o qual se guia muito mais por relações de coordenação e colaboração (aprendizagem mútua) do que por relações de hierarquia.

O diálogo, enquanto modo de ser hermenêutico, é capazes de criar as condições adequadas para pergun-

77 STRECK, Lenio Luiz. Reflexões hermenêuticas acerca do papel (dirigente) da Constituição do Brasil e os (velhos) obstáculos à concretização dos direitos fundamentais/sociais. In. CLÈVE, Clèmerson Merlin; SARLET, Ingo Wolfgang; PAGLIARINI, Alexandre Coutinho (Coord.). Direitos humanos e democracia. Rio de Janeiro: Forense, 2007. p. 385-405. p. 403.

78 BUSTOS GISBERT, Rafael. Diálogos jurisdiccionales en escenarios de pluralismo constitucional: la protección supranacional de los derechos en Europa. In: MAC-GREGOR, Eduardo Ferrer; LELO DE LARREA, Arturo Zaldívar (Coord.). La ciencia del derecho procesal constitucional: estudios en homenaje a Héctor Fix-Zamudio en sus cincuenta años como investigador del derecho. México: UNAM, 2008. (Derechos humanos y tribunales internacionales, 9). p. 753775. p. 754. 
tar sobre a legitimidade das práticas e metodologias que não conseguem preencher o espaço havido pela tensão entre a plenitude de ordem jurídica e sua supremacia (hierárquico-normativista) e o processo de ampliação da normatividade constitucional englobante do direito internacional. E, nesse espaço, se inserem os direitos humanos e seus instrumentos internacionais de proteção como componentes da formação-consolidação de uma nova racionalidade hermenêutica para uma realidade jurídica pluridimensional de caráter constitucional e internacionalizada hermeneuticamente comprometida.

\section{REFERÊNCIAS}

BRASIL. Supremo Tribunal Federal. Ação Direta de Inconstitucionalidade. ADI MC $n^{\circ} 1480 \mathrm{DF}$. Tribunal Pleno. Requerente: Confederação Nacional do Transporte; Confederação Nacional da Indústria. Requerido: Presidente da Republica; Congresso Nacional. Relator: Min. Celso de Melo. Brasília, 04 de setembro de 1997. Disponível em: < http://redir.stf.jus.br/paginadorpub/ paginador.jsp?doc $\mathrm{TP}=\mathrm{AC} \& \mathrm{doc} \mathrm{ID}=347083>$. Acesso em: 09 set. 2016.

BRASIL. Supremo Tribunal Federal. Habeas Corpus. HC $n^{\circ} 72131$ RJ. Tribunal Pleno. Paciente: Lairton Almagro Vitoriano da Cunha. Coator: Tribunal de Justiça do Estado do Rio de Janeiro. Relator: Min. Marco Aurélio. Brasília, 23 de novembro de 1995. Disponível em: <http://redir.stf.jus.br/paginadorpub/paginador. jsp?docTP=AC\&docID=73573>. Acesso em: 11 out. 2015.

BRASIL. Supremo Tribunal Federal. Habeas Corpus. HC $n^{\circ} 77527$ MG. Tribunal Pleno. Paciente: João Cordoval de Barros. Coator: Tribunal de Alçada do Estado de Minas Gerais. Relator: Min. Marco Aurélio. Brasília, 23 de setembro de 1998. Disponível em: <http://stf. jusbrasil.com.br/jurisprudencia/14698138/habeascorpus-hc-77527-mg>. Acesso em: 09 set. 2016.

BRASIL. Supremo Tribunal Federal. Recurso Extraordinário. RE $n^{\circ} 206482$ SP. Tribunal Pleno. Recorrente: Ministério Público Federal. Recorrido: Pedro Luiz de Oliveira. Relator: Min. Maurício Corrêa. Brasília, 27 de maio de 1998. Disponível em: < http://stf.jusbrasil. com.br/jurisprudencia/14698605/recurso-extraordinario-re-206482-sp>. Acesso em: 09 set. 2016.
BRASIL. Supremo Tribunal Federal. Recurso Extraordinário. RE $n^{\circ}$ 466343. Tribunal Pleno. Recorrente: Banco Bradesco S/A. Recorrido: Luciano Cardoso Santos. Relator: Min. Cezar Peluso. Brasília, 03 de dezembro de 2008. Disponível em: <http://redir.stf.jus.br/paginadorpub/paginador.jsp?docTP $=$ AC\&docID $=595444>$. Acesso em: 11 out. 2015.

BRASIL. Supremo Tribunal Federal. Recurso Extraordinário. RE $n^{\circ} 80004$ SE. Tribunal Pleno. Recorrente: Belmiro da Silveira Goes. Recorrido: Sebastião Leão Trindade. Relator: Min. Xavier de Albuquerque. Brasília, 1 de junho de 1977. Disponível em: <http:/ / stf.jusbrasil.com.br/jurisprudencia/14614120/recursoextraordinario-re-80004-se >. Acesso em: 11 out. 2015.

BRASIL. Supremo Tribunal Federal. Recurso Ordinário em Habeas Corpus. RHC n 79785 RJ. Tribunal Pleno. Recorrente: Jorgina Maria de Freitas Fernandes. Recorrido: Ministério Público Federal. Relator: Min. Sepúlveda Pertence. Brasília, 29 de março de 2000. Disponível em: <http://redir.stf.jus.br/paginadorpub/paginador. jsp?doc'TP=AC\&docID=102661 $>$. Acesso em: 11 out. 2015.

BRASIL. Supremo Tribunal Federal. Recurso Ordinário em Habeas Corpus. RHC $n^{\circ} 81.319 /$ GO. Tribunal Pleno. Recorrente: Nilo Lottici Júnior. Recorrido: Relator do RE no 299401. Relator: Min. Celso De Mello. Brasília, 24 de abril de 2002. Disponível em: < http:/ / stf.jusbrasil.com.br/jurisprudencia/774659/habeascorpus-hc-81319-go >. Acesso em: 09 set. 2016.

BURGORGUE-LARSEN, Laurence. De l'internationalisation du dialogue des juges: Missive doctrinale à l'attention de Bruno Genevois. In: BADINTER, Robert et al. Le dialogue des juges: mélanges en l'honneur du président Bruno Genevois. Paris: Dalloz, 2009. p. 95-130. Disponível em: <http://www.univ-paris1.fr/ fileadmin/IREDIES/Contributions_en_ligne/L._ BURGORGUE-LARSEN/M\%C3\%A9langes/ LBL_M\%C3\%A9langes_Genevois-1.pdf>. Acesso em: 17 out. 2015.

BUSTOS GISBERT, Rafael. Diálogos jurisdiccionales en escenarios de pluralismo constitucional: la protección supranacional de los derechos en Europa. In: MAC-GREGOR, Eduardo Ferrer; LELO DE LARREA, Arturo Zaldívar (Coord.). La ciencia del derecho procesal constitucional: estudios en homenaje a Héctor FixZamudio en sus cincuenta años como investigador del derecho. México: UNAM, 2008. (Derechos humanos y 
tribunales internacionales, 9). p. 753-775.

BUSTOS GISBERT, Rafael. Pluralismo constitucional y diálogos jurisprudenciales. México: Porrúa, 2012.

CANÇADO TRINDADE, Antônio Augusto. Desafios e conquistas do direito internacional dos direitos bumanos no início do século XXI. 410-411. Disponível em: $\quad<$ http://www.oas.org/dil/esp/407490\%20cancado $\% 20$ trindade $\% 20$ OEA $\% 20$ CJI $\% 20 \% 20$.def. pdf\#page $=5 \& z o o m=$ auto, $0,497>$. Acesso em: 17 out. 2015.

CANOTILHO, J. J. Gomes. "Brancosos" e a interconstitucionalidade: itinerários dos discursos sobre a historicidade constitucional. 2. ed. Lisboa: Almedina, 2008.

COMPARATO, Fábio Konder. A afirmação histórica dos direitos humanos. 5. ed. São Paulo: Saraiva, 2007.

DELMAS-MARTY, Mireille. Les forces imaginantes $d u$ droit: la refondation des pouvoirs. Paris: Seuil, 2007. v. 3.

DELMAS-MARTY, Mireille. Les forces imaginantes $d u$ droit: le pluralisme ordonné. Paris: Seuil, 2006. v. 2.

DELMAS-MARTY, Mireille. Les forces imaginantes $d u$ droit: le relatif et l'universel. Paris: Seuil, 2004. v. 1.

DELMAS-MARTY, Mireille. Por um direito comum. Trad. Maria Ermantina de Almeida Prado Galvão. São Paulo: M. Fontes, 2004.

DELMAS-MARTY, Mireille. Três desafios para um direito mundial. Trad. Fauzi Hassan Choukr. Rio de Janeiro: Lumen Júris, 2003.

DWORKIN, Ronald. O império do direito. Trad. Jefferson Luiz Camargo. 2. ed. São Paulo: M. Fontes, 2007.

FERREIRA, Rafael Fonseca. Diálogos hermenêuticos em direitos humanos: em busca da(s) pergunta(s) adequadas(s) para a aplicação dos tratados internacionais de direitos humanos no Brasil. Disponível em: <http://www.repositorio.jesuita.org.br/handle/UNISINOS/3693>. Acesso em: 15 out. 2015.

FERREIRA, Rafael Fonseca; LIMBERGER, Temis. O diálogo hermenêutico como horizonte de uma nova paisagem no Direito: crítica à racionalidade autoritária dispensada aos tratados de direitos humanos no Brasil. In: SOUZA SILVA, Karine de; ARARUNA SANTIAGO, Nestor Eduardo (Org.). Direito constitucional, direitos humanos e direito internacional. Barcelona: Laborum, 2015. p. $155-176$.
GADAMER, Hans-Georg. O problema da consciência histórica. Tradução Paulo César Duque Estrada. 2. ed. Rio de Janeiro: FGV, 2003.

GADAMER, Hans-Georg. Verdade e método I: traços fundamentais de uma hermenêutica filosófica. 12. ed. Trad. Flávio Paulo Meurer. Petrópolis: Vozes, 2012.

GALÁN, Pedro Cerezo. Reivindicación del diálogo. Madri: Real Academia de Ciencias Morales y Políticas, 1997.

GARCÍA ROCA, Javier. El diálogo entre el Tribunal Europeo de Derechos Humanos y los tribunales constitucionales en la construcción de un orden público europeo. Teoría y Realidade Constitucional, Madrid, n. 30, p. 183-224, 2012.

GARCÍA ROCA, Javier; NOGUEIRA ALCALÁ, Humberto; BUSTOS GISBERT, Rafael. La comunicación entre ambos sistemas y las características del diálogo. In: et al. (Org.). El diálogo entre los sistemas europeo y americano de derechos humanos. Madrid: Civitas, 2012. p. 66-107.

HÄBERLE, Peter. Pluralismo y constituición: estúdios de teoria constitucional de la sociedad aberta. Madrid: Tecnos, 2002.

HIT'TERS, Juan Carlos. Control de constitucionalidad y control de convencionalidad: comparación: criterios fijados por la Corte Interamericana de Derechos Humanos. Estudios Constitucionales, v. 7, n. 2, p. 109-128, 2009.

KELSEN, Hans. Teoria geral do direito e do Estado. Trad. Luís Carlos Borges. 4. ed. São Paulo: M. Fontes, 2005.

KELSEN, Hans. Teoria pura do direito. Trad. João Baptista Machado. 8. ed. São Paulo: M. Fontes, 2009.

LAFER, Celso. A internacionalização dos direitos humanos: constituição, racismo e relações. Barueri: Manole, 2005.

LOSANO, Mario G. Sistema e estrutura no direito: o século XX. Trad. Luca Lamberti. São Paulo: M. Fontes, 2010. v. 2.

MAZZUOLI, Valério. Curso de direito internacional público. 3. ed. São Paulo: RT, 2009.

MAZZUOLI, Valério. O controle jurisdicional da convencionalidade das leis. 2. ed. São Paulo: Revista dos Tribunais, 2011. (Direito e Ciências afins, v. 4).

MELGARÉ, Plínio. Direitos humanos: uma perspectiva contemporânea: para além dos reducionismos tradicionais. Revista de Informação Legislativa, Brasília, v. 39, n. 154, p. 71-92, abr./jun. 2002. 
MORAIS, José Luis Bolzan de; VIEIRA, Gustavo Oliveira. Estado e constituição em tempos de abertura: a crise conceitual e a transição paradigmática num ambiente intercultural. Revista de Estudos Constitucionais, Hermenêutica e Teoria do Direito, v. 5, n. 2, p. 133-140, jul./ dez. 2013.

NEVES, Marcelo. Transconstitucionalismo. São Paulo: M. Fontes, 2009.

NOGUEIRA ALCALÁ, Humberto. Diálogo interjurisdiccional, control de convencionalidad y jurisprudencia del Tribunal Constitucional en período 2006-2011. Estudios Constitucionales, Santiago, v. 10, n. 2, p. 57-140, 2012.

PÉREZ LUÑO, Antonio Enrique. Derechos bumanos, estado de derecho y constituición. 10. ed. Madrid: Tecnos, 2010.

PÉREZ LUÑO, Antonio Enrique. El desbordamiento de las fuentes del derecho. Madrid: La Ley, 2011.

PIOVESAN, Flávia. Direitos humanos e o direito constitucional internacional. 13. ed. São Paulo: Saraiva, 2102.
RUBIO LLORENTE, Francisco. La forma del poder: estudios sobre la constituición. Madrid: Centro de Estudios Constitucionales, 1997.

SALDANHA, Jânia Maria Lopes. Novas geometrias e novos sentidos: internacionalização do Direito e internacionalização do diálogo dos sistemas de justiça. In: STRECK, Lenio Luiz; ROCHA, Leonel Severo; ENGELMANN, Wilson. Constituição, sistemas sociais e hermenêutica. São Leopoldo: UNISINOS, 2012. (Anuário do Programa de Pós-Graduação em Direito da UNISINOS: Mestrado e Doutorado, 9). p. 137-160.

STRECK, Lenio Luiz. Reflexões hermenêuticas acerca do papel (dirigente) da Constituição do Brasil e os (velhos) obstáculos à concretização dos direitos fundamentais/sociais. In. CLÈVE, Clèmerson Merlin; SARLET, Ingo Wolfgang; PAGLIARINI, Alexandre Coutinho (Coord.). Direitos humanos e democracia. Rio de Janeiro: Forense, 2007. p. 385-405.

VERGOTTINI, Giuseppe De. Más allá del diálogo entre tribunales. Madrid: Civitas, 2010. 


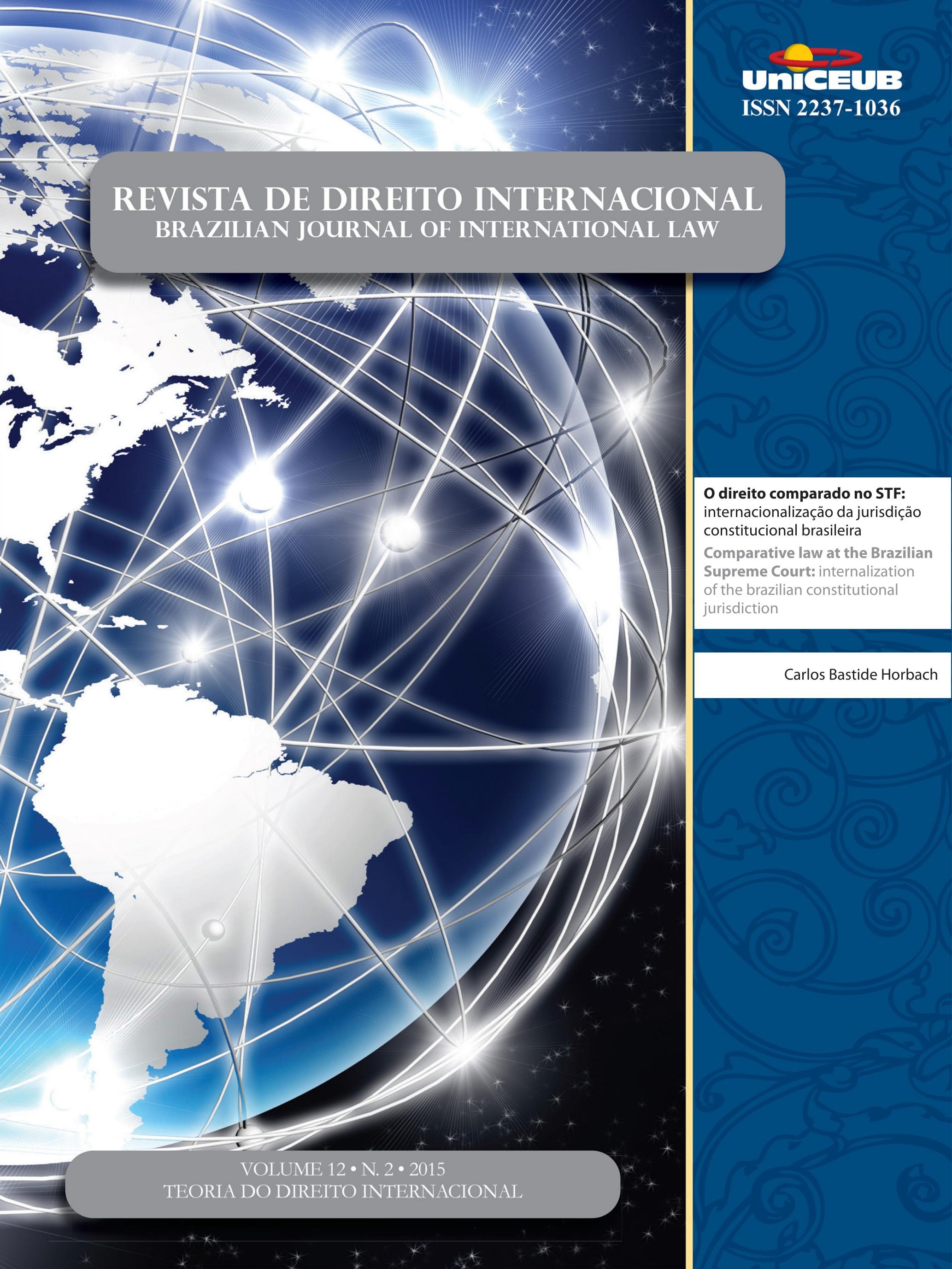




\title{
O direito comparado no STF: internacionalização da jurisdição constitucional brasileira*
}

\author{
Comparative law at the Brazilian Supreme \\ Court: internalization of the brazilian \\ constitutional jurisdiction
}

Carlos Bastide Horbach**

\section{Resumo}

O presente trabalho busca analisar a utilização do direito comparado pelo Supremo Tribunal Federal. O texto sumariza as principais discussões teóricas sobre o método comparativo e sobre sua aplicação à jurisdição constitucional, para avaliar a correção do uso de fontes estrangeiras pelos Ministros do STF, especialmente nos acórdãos sobre pesquisa com células-tronco embrionárias e sobre a união civil entre pessoas do mesmo sexo.

Palavras-chave: Direito comparado. Jurisdição constitucional. Internacionalização do direito.

\section{Abstract}

This paper intends to analyze the use of comparative law by the Brazilian Federal Supreme Court (STF). It summarizes the main theoretical debates about the comparative method and discusses how this method applies to constitutional jurisdiction, using this data to evaluate the correctness of the foreign sources use by STF justices and studying especially two opinions of the Court: the stem cells case and the same sex civil unions case.

Keywords: Comparative law. Constitutional jurisdiction. Internalization of law.

* Recebido em 25/10/2015.

Aprovado em 03/11/2015

** Autor convidado é Professor Doutor de Direito Constitucional da Faculdade de Direito da Universidade de São Paulo - USP, Professor do Programa de Mestrado e Doutorado em Direito do Centro Universitário de Brasília UniCEUB, Doutor em Direito do Estado pela USP, Mestre em Direito do Estado e Teoria do Direito pela UFRGS e Advogado. E-mail: carloshorbach@uol.com.br

*** BRASIL. Decreto $\mathrm{N}^{\circ} 848$, de 11 de outubro de 1890. Disponível em: <http://www. planalto.gov.br/ccivil_03/decreto/1851-1899/ d848.htm>. Acesso em: 20 jan. 2016.

\section{INTRODUÇÃo}

"Os estatutos dos povos cultos e especialmente os que regem as relações jurídicas na República dos Estados Unidos da América do Norte, os casos de common law e equity, serão também subsidiários da jurisprudência e processo federal"'. Com essas palavras, o art. 386 do Decreto n 848, de 11 de

1 BRASIL. Decreto No 848, de 11 de outubro de 1890. Disponível em: <http://www.planalto. 
outubro de 1890, responsável pela organização da Justiça Federal, indicava o caminho seguro a ser seguido pelos intérpretes da nascente ordem institucional republicana que se instalava no Brasil.

Tal diploma, forjado pela mente jurídica de Campos Salles, pode ser considerado o marco inicial na jurisdição constitucional brasileira ${ }^{2}$, uma vez que definia os poderes do Supremo Tribunal Federal, entre eles incluindo o de apreciar a validade de atos frente à Constituição, como se pode verificar do disposto - seguindo a técnica legislativa de então - no parágrafo único do inciso II do seu art. $9^{\circ} .^{3}$

Desse modo, a jurisdição constitucional brasileira nasce sob o influxo marcante do direito estrangeiro, em especial do direito norte-americano, como bem marcado pelo texto do Decreto 848. Ante o transplante abrupto de instituições republicanas e presidencialistas para um ambiente cultural orientado por anos e anos de práticas constitucionais monárquicas e parlamentaristas - ou pseudoparlamentaristas, como prefeririam alguns críticos do Segundo Reinado ${ }^{4}$, natural que a doutri-

gov.br/ccivil_03/decreto/1851-1899/d848.htm>. Acesso em: 20 jan. 2016.

2 Registre-se que se trata do marco inicial da jurisdição constitucional brasileira, ou seja, da atividade jurisdicional voltada ao exercício do controle de constitucionalidade; mas não se tem, no decreto em questão, o surgimento do controle de constitucionalidade no Brasil, já que no Império a Assembleia Geral exercia constantemente o controle de constitucionalidade sobre as leis provinciais e o Conselho de Estado igualmente confrontava as leis com o texto constitucional de 1824, promovendo até mesmo decisões de interpretação conforme a constituição (LOPES, José Reinaldo de Lima. O Oráculo de Delfos: o conselho de Estado no Brasil-Império. São Paulo: Saraiva, 2010. p. 198 e ss.).

3 "Paragrapho único. Haverá também recurso para o Supremo Tribunal Federal das sentenças definitivas proferidas pelos tribunais e juízes dos Estados: a) quando a decisão houver sido contraria á validade de um tratado ou convenção, á applicabilidade de uma lei do Congresso Federal, finalmente, á legitimidade do exercício de qualquer autoridade que haja obrado em nome da União - qualquer que seja a alçada; b) quando a validade de uma lei ou acto de qualquer Estado seja posta em questão como contrário à Constituição, aos tratados e às leis federaes e a decisão tenha sido em favor da validade da lei ou acto; c) quando a interpretação de um preceito constitucional ou de lei federal, ou da cláusula de um tratado ou convenção, seja posta em questão, e a decisão final tenha sido contraria, á validade do título, direito e privilegio ou isenção, derivado do preceito ou cláusula.(BRASIL. Decreto $N^{o} 848$, de 11 de outubro de 1890. Disponível em: <http://www.planalto.gov.br/ccivil_03/decreto/1851-1899/d848.htm>. Acesso em: 20 jan. 2016)

4 Para um exame do sistema parlamentar do Império e suas críticas: HORBACH, Carlos Bastide. O parlamentarismo no Império do Brasil (II): representação e democracia. Revista de Informação Legislativa, Brasília, v. 44, n. 1747, p. 213-231, abr./jun. 2007. na e a jurisprudência de países experimentados nessas "novidades" fossem a fonte mais fácil e confiável na interpretação e na aplicação da ordem constitucional da República.

Tanto foi assim, que a simples leitura dos primeiros constitucionalistas republicanos deixa esse fator em relevo. Registrando as matrizes estrangeiras, Pedro Lessa, por exemplo, explicita as fontes de sua pesquisa sobre o Poder Judiciário na Constituição de 1891, publicada em 1915:

e como a doutrina entre nós conta por enquanto um número quase nulo de expositores, e a jurisprudência, incipiente e vacilante, pouco subsídio, ou amparo, pode prestar, forçoso me foi recorrer aos comentadores e aos julgados do país cujas instituições políticas serviram de modelo às nossas, os Estados Unidos da América do Norte, valendo-me, também, não raro, dos exegetas e da jurisprudência de uma nação que nos precedeu no perfilhar os lineamentos principais da obra de Hamilton, Madison e Jay, a República Argentina. Existindo no primeiro desses países uma grande massa de precedentes, de verdades gerais induzidas da observação dos fatos, de deduções dessas verdades, de sentenças proferidas sobre uma imensa variedade de pleitos, de notações e comparações dos resultados de interpretações e aplicações diversas desta modalidade do direito constitucional, criada pelos norte-americanos, e adotada em grande parte por nós, fora imperdoável falta estudar nossa lei fundamental sem as lições dos constitucionalistas e dos juízes da América do Norte". ${ }^{5}$

A jurisprudência do Supremo Tribunal Federal, no início da República, também é marcada pelos argumentos norte-americanos ou mesmo de países da América Latina com maior experiência constitucional republicana, como a Argentina. Por exemplo, no julgamento de um dos mais importantes casos da segundo década do século XX, que envolvia liberdade de imprensa e a decretação de estado de sítio, a Suprema Corte brasileira fundamenta sua decisão nas lições de sua correspondente nos Estados Unidos.

$\mathrm{Na}$ vigência de estado de sítio decretado pelo Poder Executivo, a polícia proibiu a publicação de discursos parlamentares na imprensa; proibição que foi afastada por meio de ordem concedida em habeas corpus impetrado por Ruy Barbosa perante o STF. Amparado pela decisão sob enfoque, o jornal O Imparcial publicou discursos de diversos Senadores, o que resultou na prisão

5 LESSA, Pedro. Do poder judiciário. Brasília: Senado Federal, 2003. edição fac-similar. p. 6. 
de todos os membros de sua redação, ato contra o qual Ruy Barbosa ajuizou novo habeas corpus no STF.

Esse segundo feito foi o HC 3.539, relator originário Ministro Pedro Lessa e relator para o acórdão o Ministro Enéas Galvão, julgado na sessão de 9 de maio de 1914. Tanto o voto vencido do relator originário quanto o condutor da maioria - formada para denegar a ordem - utilizaram amplamente fontes estrangeiras para analisar o ponto fulcral da controvérsia, qual seja, a constitucionalidade da decretação do estado de sítio. Nos votos sobram menções a nomes como Cooley, Thayer, Taylor e Willoughby, bem como deles constam referências a precedentes da Suprema Corte americana. ${ }^{6}$

Esse precedente não é caso isolado. O acúmulo de referências estrangeiras é uma das características mais constantes dos votos de Ministros do STF, seja nos primeiros anos da República, seja em suas fases de consolidação democrática, em seus momentos de crise institucional, seja nos dias de hoje.

A própria jurisdição constitucional evoluiu, legislativa e jurisprudencialmente, sob a égide das experiências estrangeiras, de modo que, gradualmente, essa evolução passa a ser refletida na origem dos autores e dos precedentes citados nos votos, os quais, cada vez menos, se referem a nomes americanos, trocando-os por autores e cortes da Europa. ${ }^{7}$

Assim, é possível dizer que a jurisdição constitucional brasileira que nasce no final do século XIX e no início do século XX teve seu exercício marcado pelo direito estrangeiro, sendo o recurso a normas, autores e precedentes de outros países ainda um de seus traços marcantes no início do século XXI.

Pois, no mesmo momento em que a jurisdição constitucional brasileira dava seus primeiros passos - a virada do século XIX para o XX -, outro campo da ciência jurídica ganhava sistematização e autonomia: o direito comparado.

6 HORBACH, Carlos Bastide. Ministro Pedro Lessa: memória Jurisprudencial. Brasília: Supremo Tribunal Federal, 2007. p. 99-101.

7 Essa constatação é verificável não só no Brasil, mas em todo o mundo. Evidencia-se uma significativa diminuição da importância da Constituição da Filadélfia no processo de elaboração de novos textos constitucionais, os quais acabam sofrendo hoje maior influxo das constituições europeias do pós-guerra ou mesmo de textos mais recentes, como a Constituição da África do Sul ou a Carta Canadense de Direitos e Liberdades (cf. LAW, David S.; VERSTEEG, Mila. The declining influence of the United States Constitution. New York University Law Review, New York, v. 87, n. 3, p. 761-858, June 2012).
$\mathrm{O}$ ato de nascimento dessa nova seara de estudos jurídicos é o Congresso Internacional de Direito Comparado, ocorrido em Paris no ano de 1900, o qual proclamou como objetivo da disciplina em formação a busca dos princípios gerais de direito reconhecidos pelos países civilizados, identificando o fundo comum da ciência jurídica. ${ }^{8}$ A meta geral do direito comparado, nos termos postos no Congresso, seria a descoberta de um direito comum legislativo e a formação de um estoque comum de soluções jurídicas para os problemas, idênticos ou semelhantes, experimentados pelos diferentes países reunidos. ${ }^{9}$

O desenvolvimento do direito comparado nos 112 anos que sucederam o famoso Congresso de Paris transformou seus objetivos e incrementou seus métodos, agregando maior rigor científico nas comparações jurídicas. Saiu-se da busca dos elementos normativos comuns, marcante da fase constitutiva no início do século XX, para uma tentativa utópica de unificação mundial do direito no período entre guerras; chegando-se, após a Segunda Grande Guerra, na preponderância dos estudos de metodologia do direito comparado. ${ }^{10} \mathrm{E}$, atualmente, o direito comparado se insere nos cenários da globalização ${ }^{11}$ e da internacionalização do direito. ${ }^{12}$

Em outras palavras, o modo como ocorrem as trocas entre experiências jurídicas diversas sofreu uma significativa evolução. A comparação do início do século XX não mais se verifica nos dias atuais, em que os métodos e os objetivos do direito comparado são outros, notadamente diferentes.

Resta saber se essa alteração do quadro geral do direito comparado se faz sentir no exercício da jurisdição constitucional brasileira, a qual - como antes ressaltado - tem como característica desde sua origem à forte assimilação de elementos doutrinários e jurisprudenciais estrangeiros.

Ou seja, o objeto material do presente artigo é a

8 ANCEL, Marc. Utilidade e método do direito comparado. Porto Alegre: S. A. Fabris, 1980. p. 29.

9 ZWEIGERT, Konrad; KÖTZ, Hein. Introduction to comparative law. 3. ed. Oxford: Clarendon, 2011. p. 59.

10 ANCEL, Marc. Utilidade e método do direito comparado. Porto Alegre: S. A. Fabris, 1980. p. 33-39.

11 WATT, Horatia Muir. Globalization and comparative law. In: REIMANN, Matthias; ZIMMERMANN, Reinhard (Ed.). The $O x$ ford Handbook of Comparative Law. Oxford: Oxford University, 2006. p. $579-607$.

12 DELMAS-MARTY, Mireille. Les forces imaginantes du droit: le relatif et l'universel. Paris: Editions du Seuil, 2004. 
utilização de fontes estrangeiras pelo Supremo Tribunal Federal no exercício da jurisdição constitucional pós1988; enquanto o objeto formal - a perspectiva com base na qual o objeto material é examinado - será a moderna metodologia do direito comparado.

Assim, será possível avaliar qual o rigor científico e metodológico do STF na utilização de argumentos de direito estrangeiro na solução de controvérsias originalmente tuteladas pelo direito brasileiro e que com base nele devem ser decididas.

Para tanto, serão inicialmente apresentadas as funções e os métodos do direito comparado na atualidade, atentando-se para as peculiaridades do direito constitucional comparado. Em seguida, proceder-se-á à apresentação dos argumentos favoráveis e contrários à utilização de fontes estrangeiras como fundamento de decisões na jurisdição constitucional, tomando-se como referência o peculiar debate sobre o tema travado nos Estados Unidos. Por fim, o estudo focará duas decisões recentes do Supremo Tribunal Federal, ambas de altíssima repercussão, buscando identificar quais os métodos de direito comparado utilizados pelos Ministros e quais as consequências do uso de fontes estrangeiras na atual jurisdição constitucional brasileira.

\section{Funções E MÉtodos do diREITO COMPARADO}

Função e método são questões indissociáveis. Definida a função, possível se torna a identificação do método mais adequado a persegui-la. Destarte, o direito comparado somente será bem compreendido se corretamente identificadas as suas funções, em especial aquelas consentâneas com o objeto deste artigo: a utilização de fontes estrangeiras pela jurisdição constitucional. Com tal definição funcional, poderá ser fixado o padrão metodológico que servirá de base para o exame, ao final, dos precedentes do STF, avaliando-se o rigor científico com que os Ministros lançam mão de fundamentos de direito estrangeiro.

Questionar as funções do direito comparado consiste em buscar resposta para a seguinte pergunta: por que comparar? Das diferentes aproximações a essa questão, é possível identificar uma função primária do direito comparado, correspondente ao conhecimento dos ordenamentos estrangeiros e à aquisição de novos elementos cognitivos, que permitem atingir finalidades teóricas e práticas; tais finalidades são consideradas a função secundária da comparação, ou seja, a utilização concreta das informações obtidas por meio do emprego dos métodos de comparação. ${ }^{13}$

Zweigert e Kötz sistematizam de modo um pouco mais didático essas funções secundárias, apresentando cinco objetivos específicos do moderno direito comparado.

Inicialmente, o direito comparado tem como objetivo propiciar ao jurista o conhecimento pleno da sua ciência, que não se limita a técnicas de interpretação e aplicação das normas de seu ordenamento nacional, mas compreende também a descoberta de modelos de prevenção e de solução dos conflitos sociais. Assim, o primeiro fim da comparação é a geração, mediante a compreensão das normas estrangeiras, de um maior número de alternativas para a solução de problemas concretos com que se depara o jurista. O direito comparado, pois, enriquece o suprimento de soluções do jurista, qualificando-o para a preservação da paz social. ${ }^{14-15}$

A segunda função do direito comparado seria, na visão dos autores alemães, o auxílio ao legislador. "Legisladores ao redor do mundo têm percebido que em muitos assuntos boas leis não podem ser produzidas sem o recurso do direito comparado, seja na forma de estudos gerais ou na de relatórios especialmente produzidos sobre o tópico em questão". ${ }^{16}$ Essa, aliás, é certamente a mais antiga das funções do direito comparado, pois "sempre se pensou que o conhecimento dos direitos estrangeiros era de importância primeira para o legislador", como demonstram as obras de Platão e Aristóteles. ${ }^{17}$

13 SCARCIGLIA, Roberto. Introducción al derecho constitucional comparado. Madrid: Dykinson, 2011. p. 70.

14 ZWEIGERT, Konrad; KÖTZ, Hein. Introduction to comparative law. 3. ed. Oxford: Clarendon, 2011. p. 15.

15 Scarciglia, com fundamento em Ackerman, registra que esse movimento de acúmulo de conhecimentos por meio do direito comparado tem levado a uma verdadeira revolução macrocomparativa: “o fenômeno - definido com a expressão 'revolução macrocomparativa' - vai incidir não só no modo - e nos lugares - de conhecimento do direito estrangeiro, mas vai também favorecer novas combinações de formantes (neo-formants), reconhecíveis ao comparatista mediante o auxílio da história, pela cultura de um povo, pela evolução das fórmulas políticas ou por outros fatores que, combinados entre si, incidem no jogo de formantes" (SCARCIGLIA, Roberto. Introducción al derecho constitucional comparado. Madrid: Dykinson, 2011. p. 74).

16 ZWEIGERT, Konrad; KÖTZ, Hein. Introduction to comparative law. 3. ed. Oxford: Clarendon, 2011. p. 16.

17 ANCEL, Marc. Utilidade e método do direito comparado. Porto 
Numa terceira função, o direito comparado seria um instrumento de interpretação do direito nacional. ${ }^{18} \mathrm{E}$, nessa perspectiva, a questão ganha importância, em especial quando se projeta no campo da jurisdição constitucional, ou seja, a importância do direito comparado na interpretação das constituições nacionais.

A grande questão que se põe nessa terceira função é a de saber como e quando o intérprete está habilitado a invocar uma solução estrangeira para dar sentido a um dispositivo de seu ordenamento, o que poderá variar desde a confirmação ou auxílio de um argumento até a inserção de orientação completamente nova e não raro dissociada do teor literal do dispositivo a ser interpretado.

Desde os primeiros comparatistas, algumas balizas foram introduzidas para o exercício dessa função do direito comparado. Duas orientações para o juiz, no uso do direito estrangeiro, são já difundidas no início do século XX: tal uso só se justifica quando necessário a colmatar uma lacuna e que a solução encontrada seja harmônica com o direito interno. ${ }^{19}$

Zweigert e Kötz registram, ainda, que os tribunais alemães são refratários a interpretações com base no direito estrangeiro e que a Corte de Cassação francesa é "surda" a qualquer argumento que leve em consideração o direito comparado; enquanto países como Portugal e Grécia são notadamente abertos ao influxo exterior. Isso sem contar a constante troca de experiências que se verifica entre os países da Commonwealth britânica, em especial Inglaterra, Canadá e Austrália. ${ }^{20}$

Em quarto lugar, o direito comparado apresenta-se como uma ferramenta de formação jurídica. "O direito comparado fornece ao estudante de direito toda uma nova dimensão, da qual ele pode aprender a respeitar culturas jurídicas específicas de outros povos, ele pode ainda compreender melhor seu próprio ordenamento, pode desenvolver os padrões críticos aptos a propiciar

Alegre: S. A. Fabris, 1980. p. 18-20.

18 ZWEIGERT, Konrad; KÖTZ, Hein. Introduction to comparative law. 3. ed. Oxford: Clarendon, 2011. p. 18.

19 SCARCIGLIA, Roberto. Introducción al derecho constitucional comparado. Madrid: Dykinson, 2011. p. 78.

20 ZWEIGERT, Konrad; KÖTZ, Hein. Introduction to comparative law. 3. ed. Oxford: Clarendon, 2011. p. 19. Note-se que os exemplo de ordenamentos abertos à interpretação baseada em direito comparado ou são de países culturalmente muito próximos - os da Commonwealth -, ou são de países juridicamente periféricos, como Portugal e Grécia, os quais já utilizaram o direito comparado na edição de suas normas. o incremento desse seu ordenamento, podendo compreender também como as regras jurídicas são condicionadas por fatos sociais", ${ }^{21}$

Por fim, o direito comparado tem como função preparar os processos de unificação do direito no plano internacional ou supranacional. Quando se procura elaborar leis modelo ou diretrizes comunitárias, não se pode formular os enunciados ideais e esperar que eles sejam adotadas pelos diferentes países. É preciso, acima de tudo, identificar quais são os princípios comuns de todos os ordenamentos dos países envolvidos, tornando as normas internacionais ou supranacionais palatáveis à cultura jurídica de cada Estado. ${ }^{22}$

Dessas funções ou desses objetivos do direito comparado e tendo em vista o objeto do presente estudo - qual seja, sua utilização na jurisdição constitucional -, é possível afirmar que as mais interessantes são a primeira e a terceira, respectivamente relacionadas com o aprimoramento do jurista - que aumenta seu rol de soluções possíveis para enfrentar problemas concretos - e com a utilização do direito estrangeiro na interpretação do direito nacional.

Entretanto, não se pode deixar de lado as funções específicas que a doutrina aponta para uma peculiar variante do direito comparado, aquela que se dedica à comparação constitucional. Jorge Miranda, explicitando as razões de ser do direito constitucional comparado, apresenta a seguinte síntese:

"Ligado ao Direito constitucional de cada Estado,
é múltipla a razão de ser do trabalho comparativo:

1. $\left.{ }^{\circ}\right)$ Mostrar a proveniência de qualquer instituto nele introduzido, identificando o sistema donde é oriundo, figurando o modo de recepção, enumerando as transformações sofridas na passagem de um sistema a outro, inclusivamente explicando as causas da recepção;

2..$^{\circ}$ Dissipar dúvidas quanto à origem de algum instituto explicando que, apesar de semelhante a um que se encontra noutro país, não pôde ter sido colhido neste, pois que, na realidade, se foi buscar a um terceiro país ou até nasceu no sistema em análise sem influências estranhas;

3. $\left.{ }^{\circ}\right)$ No caso de se tratar de instituto de que não se possa dizer ter sido importado de um Direito estrangeiro ou nacional de outra época, assinalar como procedem frente a idênticos problemas

21 ZWEIGERT, Konrad; KÖTZ, Hein. Introduction to comparative law. 3. ed. Oxford: Clarendon, 2011. p. 21.

22 ZWEIGERT, Konrad; KÖTZ, Hein. Introduction to comparative law. 3. ed. Oxford: Clarendon, 2011. p. 24-25. 
de regulamentação diferentes sistemas jurídicoconstitucionais". ${ }^{23}$

Tais considerações evidenciam, na verdade, um especial emprego das funções tradicionais do direito comparado às questões do direito constitucional, o que permite concluir que, ocorrendo identidade - ou, pelo menos, proximidade - das funções, haverá igual relação com as questões de método.

Desde sua sistematização, na virada do século XIX para o século XX, o direito comparado tem buscado identificar a metodologia mais adequada a promover seus fins, havendo na atualidade não um consenso, mas somente uma aceitação mais ampla e difundida de um desses métodos, o qual não se coloca infenso a críticas. ${ }^{24}$

Assim, desenvolveram-se diferentes aproximações metodológicas no direito comparado, traduzidas, por exemplo, no método problemático, no método casuístico, no método factual e no método funcional, ${ }^{25} \mathrm{O}$ qual enfatiza a função que determinada categoria, regra ou instituto desempenha em seu ordenamento, habilitando a comparação com categorias, regras ou institutos funcionalmente semelhantes.

Esse método funcional é hoje o mais acatado pela doutrina comparatista. Zweigert e Kötz chegam a afirmar que:

o princípio metodológico básico de todo o direito comparado é o da funcionalidade. Desse princípio básico decorrem todos os outros que determinam a escolha dos direitos a comparar, o escopo da comparação, a criação de um sistema de direito comparado e assim por diante. Incomparáveis não podem ser utilmente comparados, e em matéria jurídica somente são comparáveis as coisas que preenchem a mesma função. ${ }^{26}$

Entretanto, essa busca das funções idênticas ou semelhantes não é tarefa facilmente desenvolvida. Existem inúmeros requisitos para que a comparação funcio-

23 MIRANDA, Jorge. Sobre o direito constitucional comparado. Revista de Direito Constitucional e Internacional, São Paulo, v. 14, n. 55, p. 243-260, abr./jun., 2006. p. 243 e ss.

24 Para uma análise crítica do método funcional: MICHAELS, Ralf. The functional method of Comparative Law. In: REIMANN, Matthias; ZIMMERMANN, Reinhard (Ed.). The Oxford Handbook of Comparative Law. Oxford: Oxford University, 2006. p. 339-382. p. 339.

25 SCARCIGLIA, Roberto. Introducción al derecho constitucional comparado. Madrid: Dykinson, 2011. p. 88.

26 ZWEIGERT, Konrad; KÖTZ, Hein. Introduction to comparative law. 3. ed. Oxford: Clarendon, 2011. p. 34. nal seja possível. Inicialmente, a aproximação funcional exige do comparatista a erradicação de pré-compreensões oriundas de seu sistema nativo. Depois, exige um conhecimento do sistema de fontes dos ordenamentos objeto da comparação; conhecimento que se estende pela amplitude que essas fontes tenham em cada um desses ordenamentos. Ademais, o modo como as fontes são compreendidas e como as normas são vivenciadas adquire relevo evidente, buscando-se não o direito posto, mas sim o direito em ação, na expressão dos autores anglo-saxônicos; ou ainda não só o direito vigente, mas principalmente o "direito vivente", para usar a expressão cara aos italianos. ${ }^{27}$

Ante tal quadro, a formação do jurista que procede à comparação passa a ser um elemento fundamental. Não só sua formação jurídica, mas igualmente sua formação humanística, no que toca, por exemplo, ao domínio do idioma dos países estrangeiros em que desenvolve seu estudo. Essas condições preliminares à comparação são tão enfatizadas, que autores tradicionais do direito comparado defendem constantemente a necessidade de "viagens de comparação", nas quais os juristas teriam condições de investigar in loco o funcionamento do direito estrangeiro, num processo de completa inserção em sua vida cultural, política, institucional, etc. ${ }^{28}$

$\mathrm{Na}$ atualidade, com as inovações da comunicação global, essa inserção no ambiente normativo estrangeiro pode prescindir da realização da "viagem" a que se referiam os autores clássicos, por mais interessantes e agradáveis que possam ser tais experiências. $\mathrm{Na}$ verdade, é possível ter acesso aos mais variados dados e às mais completas informações de diferentes sistemas jurídicos sem a necessidade de se vivenciar, no seu dia a dia e in loco, o funcionamento de suas instituições.

Porém, esse aspecto deixa em relevo o variado grau de informações que devem ser reunidas para o desen-

27 Essas necessárias implicações da atividade de comparação são resumidas no seguinte trecho de Roberto Scarciglia: "Porém, como pode o jurista perceber em sua totalidade o termo a comparar? É necessário que siga algumas regras. Deve-se ter em conta estas cinco: a) o termo a comparar deve ser estudado tal e como aparece na realidade; b) o termo de comparação deve ser examinado em suas fontes originais; c) o termo a comparar deve ser estudado na complexidade e totalidade das fontes do direito; e) o termo a comparar deve ser interpretado segundo o método hermenêutico do ordenamento a que pertence" (SCARCIGLIA, Roberto. Introducción al derecho constitucional comparado. Madrid: Dykinson, 2011. p. 94).

28 ANCEL, Marc. Utilidade e método do direito comparado. Porto Alegre: S. A. Fabris, 1980. p. 111. 
volvimento de um estudo comparado, o qual se inicia exatamente com essa compreensão ampla da cultura jurídico-institucional e da vida social dos países envolvidos, num processo que - mais uma vez nas palavras de Zweigert e Kötz - exige "imaginação e disciplina". ${ }^{29}$

Sem esses elementos de compreensão global dos ordenamentos, a simples justaposição de várias regras não é direito comparado, mas sim seu passo preliminar. A partir dessa justaposição é que começa o trabalho mais árduo em qualquer comparação, que igualmente diz com a identificação de diferenças nas aparentes semelhanças. ${ }^{30}$

No próximo estágio, afastadas as falsas congruências, busca a comparação efetivamente construir um sistema, o qual mantém a vinculação necessária com os aspectos funcionais que pautam o direito comparado:

\begin{abstract}
O direito comparado está de modo muito próximo conectado com as modernas tendências das ciências sociais quando questiona qual pode ser a função das instituições jurídicas nos diferentes países, antes de perguntar qual é sua estrutura doutrinária, e igualmente quando ordena as soluções dos vários sistemas sobre bases realísticas, testando-as a partir de sua capacidade de reagir às necessidades sociais que buscam satisfazer. ${ }^{31}$
\end{abstract}

Para tanto, é preconizado um procedimento metodológico, resumido em três ações elementares: conhecer, compreender e comparar. A essas três, alguns autores agregam a fase da aplicação de resultados, que é contingente, pois variável de acordo com as finalidades do estudo. Nas duas funções acima indicadas - ampliação do rol de soluções à disposição do jurista e auxílio na interpretação do direito nacional - essa fase de aplicação de resultados estará presente.

Tais fases são subsequentes, no sentido de uma constituir a base para a seguinte; bem como são complementares, já que todas existem em função das outras. ${ }^{32}$

Seguindo esses passos, tendo por orientação a funcionalidade dos institutos e procedendo a comparações metodologicamente respaldadas, pode o jurista lograr atingir, de modo realmente satisfatório, os objetivos do

29 ZWEIGERT, Konrad; KÖTZ, Hein. Introduction to comparative law. 3. ed. Oxford: Clarendon, 2011. p. 37.

30 ZWEIGERT, Konrad; KÖTZ, Hein. Introduction to comparative law. 3. ed. Oxford: Clarendon, 2011. p. 43.

31 ZWEIGERT, Konrad; KÖTZ, Hein. Introduction to comparative law. 3. ed. Oxford: Clarendon, 2011. p. 45.

32 SCARCIGLIA, Roberto. Introducción al derecho constitucional comparado. Madrid: Dykinson, 2011. p. 92. direito comparado, em especial no que toca ao aprimoramento de seu próprio ordenamento.

Não ser pode deixar de considerar, como faz Ackerman, ${ }^{33}$ que o direito constitucional comparado está em sua fase inicial, ainda mais se contrastado com as comparações que tradicionalmente são feitas no âmbito do direito privado. Nesse contexto de gênese da comparação no direito público, sempre se corre o risco de assumir-se premissas falsas, que conduzirão - por certo - a conclusões igualmente falsas. Exemplos dessas premissas falsas são o que Ackerman chama de nominalismo e de particularismo. O primeiro induz o estudioso a aproximar institutos que guardam o mesmo nome - e o exemplo dado é o de corte constitucional, sob cujo nome podem se esconder instituições das mais variadas - e o segundo faz com que o exame comparado procure inserir de tal forma o objeto de análise em seu contexto original, que despreza suas naturais conexões com o mundo exterior. ${ }^{34}$

Por fim, resta lembrar a advertência de Scarciglia acerca dos riscos de um procedimento de comparação não amparado pela metodologia adequada:

\begin{abstract}
sem um enfoque metodológico sério, o estudioso corre o risco de não levar a cabo nenhuma atividade de comparação real, incorrendo mais na realização de atividades em sua maior parte ornamentais, sem nenhum valor epistemológico. ${ }^{35}$
\end{abstract}

\section{O ELEMENTO ESTRANGEIRO NA FUNDAMENTA- ÇÃO JURÍDICO-CONSTITUCIONAL}

Visto o modo como o direito comparado deve ser produzido para que tenha valor científico, para que se apresente metodologicamente adequado ao cumprimento de suas funções, resta analisar outra questão de enorme importância, qual seja, a da legitimidade e da relevância do uso do elemento estrangeiro na fundamen-

33 ACKERMAN, Bruce. The rise of world constitutionalism. Virginia Law Review, Charlottesville v. 83, n. 4 p. 771-798, May. 1997. p. 794.

34 Esse risco do nominalismo já é apontado também por Marc Ancel, num perspectiva geral do direito comparado: "é preciso sobretudo não confiar nas traduções apressadas e naqueles que chamamos de falsos amigos. É preciso não traduzir common law por direito comum e a equity inglesa não é a equidade continental, não mais do que a preventive detention, que constitui um internamento e segurança, não é a nossa prisão preventiva" (cf. ANCEL, Marc. Utilidade e método do direito comparado. Porto Alegre: S. A. Fabris, 1980. p. 111).

35 SCARCIGLIA, Roberto. Introducción al derecho constitucional comparado. Madrid: Dykinson, 2011. p. 94. 
tação jurídica praticada em determinado ordenamento nacional.

Numa perspectiva histórica - e o aspecto histórico não pode deixar de ser considerado no processo de comparação ${ }^{36}$-, essa relevância, muitas vezes, é evidente, decorrendo da própria origem das normas de um dado ordenamento. A ênfase na experiência norte-americana verificada no nascimento da República brasileira é prova disso.

Entretanto, há outros elementos, de ordem pragmática e teórica, que contribuem para a caracterização dessa relevância do direito estrangeiro na solução de controvérsias de um dado ordenamento. Esses Elementos, aliás, não deixam de sofrer críticas, em especial em realidades nacionais, como a norte-americana, por exemplo, em que o uso de referências estrangeiras converteu-se em verdadeiro tabu..$^{37 / 38}$

Essas críticas serão a seguir apresentadas, para se isolar suas decorrências para a prática a ser desenvolvida no cotidiano da jurisdição constitucional, bem como para se verificar sua higidez teórica.

36 MIRKINE-GUETZÉVITCH, B. L'histoire constitutionnelle comparée. Annales de l'Institut de Droit Comparée de la Université de Paris, Paris, n. 1, p. 85-98, 1936. p. 85-98. Segundo o autor, "o direito constitucional comparado deve sempre ser estudado no quadro da história política".

37 Ainda que, como aponta Vicki C. Jackson, essa prática era por demais acolhida desde as origens da jurisdição da Suprema Corte norte-americana, sendo exemplo disso até mesmo o célebre caso Marbury v. Madison, ou mesmo em casos mais recentes, como o igualmente célebre Miranda v. Arizona, em que, após analisar o direito de outros quatro países de língua inglesa, a corte decidiu no sentido de incrementar os direitos dos cidadãos americanos contrainterrogatórios abusivos por parte das autoridades policiais (JACKSON, Vicki C. Progressive Constitutionalism and Transnational Legal Discourse. In: BALKIN, Jack M.; SIEGEL, Reva B. (Ed.). The Constitution in 2020. New York: Oxford University Press, 2009. p. 285-297. p. 286-288).

38 Nesse mesmo sentido, Cheryl Saunders: "reference by courts to foreign law in determining constitutional questions is presently a controversial practice in the United States. The controversy should be kept in perspective, however. Reference to foreign law in the course of constitutional adjudication in the United States is not a recent phenomenon, nor is it confined to the Supreme Court. Most members of the current Court have referred to comparative sources, at some stage, for a reason other than to dismiss the legitimacy of reliance on them. At least four justices also have made extra-judicial remarks that appear to endorse the use of comparative constitutional law in some circumstances. Based on present indications, it seems likely that references by U.S. judges to foreign law will increase, if cautiously, although changes pending in the composition of the Supreme Court make prediction risky" (SAUNDERS, Cheryl. The use and misuse of comparative constitutional law. Indiana Journal of Global Legal Studies, Indiana, v. 13, n. 1, p. 37-76, Winter 2006. p. 39).
No estágio atual do debate que se tem nos Estados Unidos sobre esse tema, as posições se apresentam como radicais e acaloradas. Como registra Vicki C. Jackson, a discussão acerca do uso de referências estrangeiras nos tribunais americanos adquiriu um quê de simbólico, sendo tal uso considerado como representativo de tudo o que determinados juristas têm identificado como errado no proceder da Suprema Corte nos últimos anos, incluindo suas atividades contramajoritárias - tão presentes na jurisprudência do STF - e também certo caráter elitista que teria assumido a Corte, distanciando-se de suas raízes americanas. Por outro lado, os defensores dessas referências estrangeiras não as tomam como questão fundamental, mas somente como mais um elemento de um processo amplo de interpretação constitucional. ${ }^{39}$

As críticas às fontes estrangeiras são verbalizadas, na Suprema Corte norte-americana, notadamente pelo Justice Antonin Scalia, em especial após a decisão de alguns casos - em especial Lawrence v. Texas e Roper v. Simmons - em que a utilização de fontes estrangeiras foi introduzida de modo mais explícito, a partir das contribuições do Justice Anthony Kennedy. ${ }^{40-41}$

As objeções de Scalia podem ser resumidas nos seguintes aspectos: a) as fontes estrangeiras são irrelevantes para o originalismo, aqui considerado - em linhas gerais - como o método de interpretação que busca determinar as intenções e sentidos originais do texto constitucional americano, tal como definidos pelos framers de

39 JACKSON, Vicki C. Progressive Constitutionalism and Transnational Legal Discourse. In: BALKIN, Jack M.; SIEGEL, Reva B. (Ed.). The Constitution in 2020. New York: Oxford University Press, 2009. p. 285-297. p. 285.

40 Para um exame de perfil mais jornalístico sobre a participação de Kennedy nos chamados "Seminários de Salzburg" e do reflexo disso nas decisões da Suprema Corte, ver: TOOBIN, Jeffrey. The nine: inside the secret world of the Supreme Court. New York: Anchor Books, 2008. p. 3045 e ss.

41 A reação à utilização de fontes estrangeiras não se limitou à própria Suprema Corte norte-americana. Em 2005, tramitou na House of Representatives, a Câmara baixa do Congresso dos Estados Unidos, um projeto de lei - o chamado Constitution Restoration Act (HR 1070, 109th Congress - 2005) - determinando que, na interpretação da Constituição, os Tribunais americanos estariam proibidos de fazer uso de "qualquer constituição, lei, norma administrativa, ordem executiva, diretiva, política, decisão judicial, ou qualquer outra ação de qualquer Estado estrangeiro ou organização ou agência internacional; com exceção do direito constitucional ou do common law ingleses praticados até o momento da adoção da Constituição dos Estados Unidos" (TUSHNET, Mark. The 'Constitution Restoration Act' and judicial independece: some observations. Case Western Reserve Law Review, Ohio, v. 56, n. 4, p. 1071-1082, 2006). 
1787; b) a utilização de fontes estrangeiras não é democrática, uma vez que o Estado nacional que recebe a influência não toma parte na produção desse direito, nem na escolha e no controle de seus juízes, cujas decisões são internalizadas; e c) a utilização de fontes estrangeiras aumenta a discricionariedade judicial, possibilitando a escolha arbitrária de normas estrangeiras que se amoldem à argumentação desenvolvida pelo julgador, num processo que o Chief Justice Roberts, na sua sabatina perante o Senado americano, chamou de cherry-picking. ${ }^{42}$

Retirando-se a crítica relativa ao originalismo, que, dadas as suas particularidades, pode ser restringida ao cenário americano, restam as questões relacionadas com a falta de legitimidade e com a falta de método na utilização das fontes estrangeiras, sendo esses os dois pontos fulcrais a serem examinados.

Quanto à primeira crítica, a da legitimidade, é possível afirmar que as fontes estrangeiras não são tomadas isoladamente e transplantadas para o ordenamento nacional, passando a adquirir o mesmo valor das normas nacionais. Ou seja, as leis nacionais definitivamente não são, por meio desse processo, substituídas pelas leis estrangeiras, não sendo o recurso ao direito comparado uma forma de subversão da ordem jurídica de um país.

$\mathrm{Na}$ verdade, existem diferentes níveis de recurso ao direito estrangeiro, por meio da comparação. Cheryl Saunders sistematiza a questão fixando uma escala que vai do uso moderado de fontes estrangeiras (soft use) a um uso intensivo (hard use). Próximo do polo do uso moderado, encontram-se práticas como a referência a situações empíricas ou a afirmação da correção do direito interno mediante sua comparação com o estrangeiro; enquanto próximos do polo oposto, o do hard use, estão os casos em que o emprego do direito estrangeiro contribui mais significativamente para modelar a decisão que é prolatada pela Corte nacional, incluindo a importação de fundamentos de uma corte estrangeira, recurso ao direito estrangeiro para a interpretação do texto constitucional nacional ou mesmo, no extremo,

42 JACKSON, Vicki C. Progressive Constitutionalism and Transnational Legal Discourse. In: BALKIN, Jack M.; SIEGEL, Reva B. (Ed.). The Constitution in 2020. New York: Oxford University Press, 2009. p. 285-297. p. 286-287. A frase de Roberts é, exatamente, no sentido de que "by cherry-picking foreign law, you can find anything you want". Ou como afirmou o próprio Scalia na decisão de Ropers v. Simmons, "to invoke alien law when it agrees with one's own thinking, and ignore it otherwise, is not reasoned decisionmaking, but sophistry". o transplante judicial de norma, instituto ou prática estrangeiros. ${ }^{43}$ Podem ser inseridas, igualmente, no campo do hard use, as práticas que levam à chamada fertilização cruzada (cross-fertilizartion), consideradas como um estímulo externo que promove avaliações do direito interno, levando à sua evolução. Tal evolução envolve adaptação pelo sistema jurídico receptor das influências externas, que adquirem novos contornos, de modo que o novo desenvolvimento é um produto distinto, mas organicamente vinculado a esse sistema. ${ }^{44}$

A questão da legitimidade será, pois, mais ou menos grave se a utilização do direito estrangeiro estiver mais próximo do polo do hard use ou do soft use, respectivamente. Entretanto, de qualquer modo, a crítica da legitimidade democrática do uso de fontes estrangeiras somente seria verdadeiramente efetiva se se estivesse num quadro em que se apresentasse como uma imposição ao Juiz e não como uma opção de aprimoramento do raciocínio judiciário. ${ }^{45}$

No que toca à segunda questão, a da falta de critérios, é ela superada pela simples utilização dos métodos e procedimentos do direito comparado, tal como apresentados no tópico anterior. O recurso à técnica comparativa, nos moldes fixados cientificamente, coloca em xeque a prática do cherry-picking, expondo as fragilidades dos recursos arbitrários a este ou àquele ordenamento específico.

Somente por meio do uso de métodos claros e de procedimentos seguros é que pode a jurisdição constitucional enfrentar tal ordem de desafios à utilização do direito estrangeiro, em perspectiva comparada, na fundamentação de suas decisões. ${ }^{46}$

43 SAUNDERS, Cheryl. The use and misuse of comparative constitutional law. Indiana Journal of Global Legal Studies, Indiana, v. 13, n. 1, p. 37-76, Winter 2006. p. 50.

44 BELL, John. The relevance of foreign examples to legal development. Duke Journal of Comparative \& International Law, v. 21, n. 2, p. 431-460, Winter 2011. p. 434

45 JACKSON, Vicki C. Progressive Constitutionalism and Transnational Legal Discourse. In: BALKIN, Jack M.; SIEGEL, Reva B. (Ed.). The Constitution in 2020. New York: Oxford University Press, 2009. p. 285-297. p. 287.

46 Mais uma vez, as lições de Cheryl Saunders: "the second principal ground of opposition to the use of comparative sources in constitutional adjudication concerns methodology. This is potentially a more serious issue for those common law countries in which the practice is readily employed. The debate in the United States has had the effect of focusing attention on two distinct dimensions of the methodology of the use of comparative constitutional law by courts: the process of judicial reasoning and the methodology of comparative law. Each intersects with and may be further fueled by 
As críticas que são feitas, portanto, não se dirigem propriamente à prática da utilização de elementos estrangeiros, mas sim ao modo como se dá essa utilização. Seja porque inexiste critério no estabelecimento das comparações - que são mero e caprichoso ato de cherry-picking, para utilizar a jocosa expressão dos americanos -; seja porque as fontes estrangeiras são tomadas em preponderância às fontes nacionais, invertendo-se seu valor relativo; seja ainda porque esses exercícios de comparação ocorrem em ambientes constitucionais pretensamente refratários à experiência estrangeira, como no caso muito específico dos Estados Unidos após a onda originalista dos anos 80 .

Afastadas, assim, as críticas que impediriam o uso do direito estrangeiro e o emprego do método comparado,

other intense contemporary controversies over, respectively, judicial activism and what has been described as 'critical comparative law' reflecting a new 'appreciation of diversity'. Significant defects in either judicial or comparative method have the potential to undermine the legitimacy of recourse to foreign law in constitutional adjudication on grounds of misuse, rather than use. A second question for judicial method concerns the greater potential for manipulative use of foreign legal sources. Most obviously, this might take the form of unjustifiable selectivity in the choice of sources, by jurisdiction or by item, deliberately or by inadvertence. Justice Scalia identified the problem in typically colorful terms in his opinion in Roper: 'To invoke alien law when it agrees with one's own thinking, and ignore it otherwise, is not reasoned decisionmaking, but sophistry'. The phenomenon of 'cherry-picking' is well-recognized. Yash Ghai, for example, described the approach of Hong Kong courts to foreign cases in the early years of the Hong Kong Bill of Rights as 'not very consistent; they are invoked when they support the position preferred by the court, otherwise they are dismissed as irrelevant.' Of course, selection of sources emanating from a home jurisdiction can be manipulated as well, but the practice can be more readily detected and the principles of selection are more settled, if often difficult to apply. A second, distinct dimension of the methodological challenges presented by the use of foreign law in constitutional adjudication is inherent in the very activity of comparative law. First, and most obviously, there are threshold problems of obtaining access to foreign sources and being able to use and understand them, in terms both of language and the legal concepts used. But the central challenge of comparative method is to understand the legal experience of other jurisdictions in sufficient depth to be able to properly determine its relevance and to include it in the reasoning process. This is a complication that, by and large, is not present when a court relies on a variety of sources from within the home jurisdiction. Notoriously, it demands understanding of the relevant context from which a foreign comparative source derives, requiring consideration of political, social, economic, historical, or other cultural factors. Arguably the problem is exacerbated by the particular difficulty of acquiring contextual understanding of a constitution, which to a greater extent than other laws, is likely to be embedded in the life of its national community and may have evolved over an extended period of time" (SAUNDERS, Cheryl. The use and misuse of comparative constitutional law. Indiana Journal of Global Legal Studies, Indiana, v. 13, n. 1, p. 37-76, Winter 2006. p. 67). resta examinar as razões que o justificam, ou seja, o que legitima esse uso e até mesmo o incentiva.

A aceitação do uso do elemento estrangeiro acaba dependendo de aspectos pragmáticos e teóricos. Os primeiros são os mais evidentes e podem ser associados às próprias funções do direito comparado, em especial àquelas que se projetam sobre sua utilização na jurisdição constitucional: o aumento de soluções à disposição do jurista e o auxilio na interpretação do direito nacional.

Essas razões pragmáticas, porém, não seguem uma lógica muito clara, sendo difícil estabelecer uma razão pela qual um direito estrangeiro passa a ser mais influente em determinado ordenamento, eliminando ou diminuindo os influxos de outro elemento externo previamente considerado. Como explicar, por exemplo, a migração gradual do direito constitucional brasileiro das fontes originariamente americanas, passando pelo direito constitucional político dos franceses e chegando num quadro atual de recurso constante ao direito constitucional alemão, de matriz mais filosófica?

Essas alterações decorrem de fatores empíricos, que envolvem personagens específicos, responsáveis pela divulgação desse ou daquele ordenamento; bem como dizem com as circunstâncias em que se encontram os ordenamentos dos quais se retiram os modelos, que podem ter momentos de maior ou menor projeção internacional.

As experiências concretas indicam, na linha do argumentado por John Bell, que o desenvolvimento jurídico depende mais de pessoas do que de ideias; que esse desenvolvimento não envolve a incorporação automática de institutos estrangeiros, mas sim a conformação de novos modelos normativos autóctones que são inspirados pelo modelo estrangeiro; e que a extensão da influência estrangeira depende do modo como seus modelos são apresentados no país receptor e do clima de abertura de sua comunidade jurídica para o novo. Nesse quadro, ganha importância a figura dos juristas que promovem essa interação entre os ordenamentos, os quais por diferentes fatores pessoais têm contato com esta ou aquela novidade estrangeira e igualmente dispõem de recursos para introduzi-las nas práticas locais. ${ }^{47}$

47 "From these examples, we have seen that academics, legislators and users of the law do not confine their attention to national boundaries. Problems are not confined to those boundaries and are often neither texts nor principles. [...] Academics often play more than one role. Academics across all of the jurisdictions often be- 
Mas a atuação desses juristas como vetores da introdução de elementos estrangeiros depende, igualmente, da reputação dos ordenamentos com os quais tiveram contato, o que decorre sim do seu prestígio cultural - o que é de difícil mensuração -, mas que também deriva de fatores de relevância, relacionados com os problemas específicos que se pretendem solucionar internamente. Por exemplo, é natural que um país saindo de uma ditadura totalitária busque elementos de outros países que já passaram pelo mesmo problema histórico e institucional, o que justifica, por exemplo, a influência alemã no desenvolvimento do direito húngaro no período pós-comunista. Finalmente, essa reputação dependerá também da proximidade entre o sistema estrangeiro e aquele que recebe a influência, sendo mais forte o vínculo se pertencem à mesma família de direitos. ${ }^{48}$

Quanto à questão da proximidade, é importante anotar que sua determinação nem sempre é possível e que a avaliação dessas conexões dependerá de fatores múltiplos, em especial no campo do direito constitucional. ${ }^{49}$ Roberto Scarciglia, por exemplo, não aceita a utilização do modelo de famílias jurídicas - amplamente divulgado a partir dos anos 1950 por meio da obra de René David ${ }^{50}$ - ao direito constitucional, uma vez que teriam sido desenvolvidas sob a égide de um pensamento privatista. ${ }^{51}$

Ante essas circunstâncias, o direito constitucional

came law reformers, judges, and politicians. [...] They do not just publish and hope that they will be noticed, but have the means of making their voices heard. Their later appointments put them in an excellent position to implement the ideas they had developed in their academic careers" (BELL, John. The relevance of foreign examples to legal development. Duke Journal of Comparative \& International Law, v. 21, n. 2, p. 431-460, Winter 2011. p. 448-449).

48 BELL, John. The relevance of foreign examples to legal development. Duke Journal of Comparative \& International Law, v. 21, n. 2, p. 431-460, Winter 2011. p. 451.

49 Isso não significa que os critérios de proximidade não devam ser estritamente definidos, muito antes pelo contrário. Isso porque, como registra Mark Tushnet, os trabalhos de direito constitucional comparado são, não raro, "insuficientemente sensíveis às diferenças nacionais, que geram divergências nos direitos constitucionais locais. Ou, em outras palavras, os acadêmicos do direito constitucional comparado tendem para uma implícita, mas insuficientemente defendida, preferência por uma aproximação universalista do estudo jurídico comparativo em relação à particularista" (TUSHNET, Mark. Comparative constitutional law. In: REIMANN, Matthias; ZIMMERMANN, Reinhard (Ed.). The Oxford Handbook of Comparative Law. Oxford: Oxford University, 2006. p. 1225-1257. p. 1256).

50 DAVID, René. Os grandes sistemas do direito contemporâneo. 2. ed. São Paulo: M. Fontes, 1993. p. 16 e ss.

51 SCARCIGLIA, Roberto. Introducción al derecho constitucional comparado. Madrid: Dykinson, 2011. p. 87. comparado está aberto a novos referenciais de proximidade entre sistemas jurídicos e, em consequência, entre suas jurisdições constitucionais. É em tal perspectiva que se coloca o esquema proposto por Bruce Ackerman reunindo dois modelos de constituição que promovem tipos distintos de jurisdição constitucional: as constituições que assinalam novos começos, "marcos simbólicos de uma grande transição na vida política de uma nação"; e as constituições federalistas, cujo traço fundamental é "a existência de múltiplos centros de poder, num constante projeto de intensiva coordenação". ${ }^{52}$ Tais tipos de constituição gerariam, respectivamente, formas redentoras ou coordenadoras de jurisdição constitucional. ${ }^{53}$

De qualquer forma, adotando-se a tradicional sistematização das famílias jurídicas - que, apesar das críticas, é bastante aceita ${ }^{54}$ - ou se buscando novos critérios de reunião de experiências constitucionais diversas, o fato é que o requisito da proximidade é fundamental na utilização das técnicas do direito constitucional comparado. ${ }^{55}$

Por fim, há, ainda, a questão das justificações teóricas que emprestam valor em si mesmo às fontes estrangeiras, defendendo sua influência independentemente de relação direta com o ordenamento nacional.

Nesse sentido, Jeremy Waldron apresenta dois argumentos para que as fontes estrangeiras sejam tratadas como justificativas para as decisões das cortes nacionais: inicialmente, o sistema estrangeiro ofereceria um exemplo de metodologia para a solução de conflitos no que objetivamente não se tem novidade em relação às tradicionais funções do direito comparado - e, ainda, promoveria um ideal de justiça, de tratamento igualitário, no que sim há uma novidade em relação ao que até agora foi analisado. Na busca desse tratamento justo e igualitário, "os cidadãos reclamam que os mesmos princípios gerais de direito devem conduzir aos mesmos resultados práticos, apesar de diferenças geográficas e institucionais". ${ }^{56}$

52 ACKERMAN, Bruce. The rise of world constitutionalism. Virginia Law Review, Charlottesville, v. 83, n. 4, p. 771-798, May. 1997. p. 778.

53 ACKERMAN, Bruce. The rise of world constitutionalism. Virginia Law Review, Charlottesville, v. 83, n. 4, p. 771-798, May. 1997. p. 796.

54 MIRANDA, Jorge. Manual de direito constitucional. 4. ed. Coimbra: Coimbra, 1990. v. 1. p. 104.

55 SCARCIGLIA, Roberto. Introducción al derecho constitucional comparado. Madrid: Dykinson, 2011. p. 78-79.

56 WALDRON, Jeremy. Foreign law and the modern ius gentium. 
Com os cuidados, orientações e fundamentos expostos ao longo desse item, o elemento estrangeiro se apresenta minimamente respaldado no exercício da jurisdição constitucional, ficando apto a afastar as críticas que são feitas a seu uso e possibilitando reais aprimoramentos para os ordenamentos receptores.

\section{O elemento estrangeiro Na JURISDIÇÃo do Supremo Tribunal Federal}

Analisados os padrões teóricos e as discussões mais pragmáticas acerca da utilização do direito comparado, seja em linhas gerais, seja especificamente no que toca do direito constitucional; cabe agora verificar como essa prática se apresenta nos julgamentos atuais do Supremo Tribunal Federal brasileiro, no exercício de sua jurisdição constitucional.

Para tanto, serão a seguir examinados dois julgados da Suprema Corte brasileira, para se verificar se as referências feitas a fontes estrangeiras passam pelos crivos metodológicos e legitimadores antes apontados. Serão, pois, estudados os acórdãos da ADI 3.510 ${ }^{57}$, Rel. Min. Ayres Britto, DJe de 28.05.2010 - em que o STF apreciou a constitucionalidade da Lei de Biossegurança -; e da ADPF $132^{58}$, Rel. Min. Ayres Britto, DJe de 14.10.2011 - na qual a Suprema Corte reconheceu efeitos jurídicos a uniões homoafetivas.

Tal análise não tem como objetivo promover uma avaliação individual dos argumentos ou das razões expostas em cada voto, mas simplesmente destacar como os elementos estrangeiros foram utilizados na formação da ratio decidendi de cada Ministro, de modo objetivo, impessoal.

Harvard Law Review, Cambridge, v. 119, n. 1, p. 129-147, Nov. 2005. p. 129 e ss.

57 BRASIL. Supremo Tribunal Federal. Ação Direta de Inconstitucionalidade. ADI 3510/DF. Tribunal Pleno. Requerente: Procurador-Geral da República. Requerido: Presidente da Republica. Relator: Min. Ayres Britto. Brasília, 29 de maio de 2008. Disponível em: <http://redir.stf.jus.br/paginadorpub/paginador. jsp?docTP=AC\&docID=611723>. Acesso em: 20 jan. 2016.

58 BRASIL. Supremo Tribunal Federal. Argüição de Descumprimento de Preceito Fundamental. ADPF 132/RJ. Tribunal Pleno. Requerente: Governador do Estado do Rio de Janeiro. Requerido: Procurador-Geral do Estado do Rio de Janeiro. Relator: Min. Ayres Britto. Brasilia, 05 de maio de 2011. Disponível em: < http://redir.stf.jus. $\mathrm{br} /$ paginadorpub $/$ paginador.jsp?doc $\mathrm{TP}=\mathrm{AC} \& \mathrm{doc} \mathrm{ID}=628633>$. Acesso em: 20 jan. 2016.
$\mathrm{Na}$ ADI $3.510^{59}$, os primeiros recursos a elementos estrangeiros se fizeram presentes no voto da Ministra Ellen Gracie, cuja argumentação parte da referência ao Human Fertilization and Embriology Act, editado pelo parlamento britânico em 1990. Não há, na manifestação em questão, uma justificativa técnica acerca da escolha desse diploma normativo ou mesmo das conexões genéricas entre a experiência do Reino Unido e a do Brasil. Quanto às fontes, o caso britânico é basicamente analisado com base na obra de Letícia da Nóbrega Cesarino, intitulada Nas fronteiras do "bumano": os debates britânico e brasileiro sobre a pesquisa com embriões, texto esse que é uma pesquisa na área das ciências sociais e da antropologia e não um texto jurídico.

Em seguida, no mesmo feito, o voto do Ministro Menezes Direito é pródigo em referências estrangeiras. O exame se inicia com menções a dados oficiais acerca do direito inglês e australiano; isso sem que o voto indique quais são as semelhanças e as diferenças que tornam a comparação mais ou menos adequada a auxiliar na controvérsia posta ao STF. Depois, a argumentação passa pelo exame de um relatório da Assembleia Nacional francesa, do qual é destacado trecho específico da manifestação de um único deputado, a qual corrobora as razões do voto do Ministro. Cita, ainda, com base em site da internet, as normas de países que proíbem a pesquisa com células-tronco - como Alemanha, Itália, Áustria e Polônia -, sumarizando suas disposições. Há também uma breve referência à Lei francesa $n^{\circ} 2004-$ 800 , relativa à bioética. Tendo como fonte o site do Parlamento britânico, o Ministro Menezes Direito cita a lei já mencionada no voto da Ministra Ellen Gracie; para na sequência dedicar um parágrafo para cada um dos ordenamentos dos seguintes países: Suécia, Espanha, Portugal, Bélgica e Canadá. Em um único parágrafo, o voto menciona as regras japonesas, chinesas, sul-coreanas e de Cingapura. Para finalmente arrematar as considerações sobre experiências estrangeiras analisando os casos norte-americano - em que os ordenamentos dos diferentes Estados são citados num único parágrafo - e australiano.

59 BRASIL. Supremo Tribunal Federal. Ação Direta de Inconstitucionalidade. ADI 3510/DF. Tribunal Pleno. Requerente: Procurador-Geral da República. Requerido: Presidente da Republica. Relator: Min. Ayres Britto. Brasília, 29 de maio de 2008. Disponível em: <http://redir.stf.jus.br/paginadorpub/paginador. jsp?docTP $=$ AC\&docID=611723 $>$. Acesso em: 20 jan. 2016. 
Já o voto do Ministro Ricardo Lewandowski contém um item dedicado ao tema Células embrionárias bumanas no direito comparado. Nele há menções à experiência francesa - a partir de um artigo de Brigitte Mintier, publicado na obra coletiva Células-tronco humanas: aspectos cientificos, éticos e jurídicos, coordenada pelo padre jesuíta Julio Luis Martinez -; e às experiências holandesa, alemã e espanhola, sempre a partir de artigos publicados na mesma obra coletiva. No caso da Alemanha, há, também, menção a artigo de Erik Parens, sobre a política de pesquisa com células-tronco. O item específico do voto, porém, apresenta em sequência essas referências, sem conduto identificar um fio condutor da análise comparada; não explicitando, igualmente, o porquê do exame daqueles ordenamentos específicos. No item seguinte do voto, relativo às limitações das pesquisas, novamente são apresentados dados de elementos normativos estrangeiros, seja por meio de artigos doutrinários, seja por meio da menção a dispositivos legais.

O Ministro Joaquim Barbosa, por sua vez, analisa, em seu voto - com maior ou menor profundidade normas dos ordenamentos inglês, francês, espanhol, belga e suíço, sempre com base nos textos legais - os quais apresenta explicitamente no texto ou em notas de rodapé, algumas no idioma original -, para concluir da seguinte maneira:

enfim, esses são apenas alguns exemplos, colhidos do direito comparado, que demonstram a preocupação dos países europeus com a pesquisa envolvendo células-tronco embrionárias. Vê-se que as legislações estrangeiras têm ao menos três pontos em comum: o primeiro, referente à obrigatoriedade de que os embriões sejam utilizados em pesquisas que visem ao bem-comum; o segundo, que sejam utilizados apenas embriões excedentes dos processos de fertilização in vitro, o que, em outras palavras, significa a proibição de que sejam criados embriões para este fim; e, por último, que haja o consentimento expresso dos genitores.

Nessa ordem de ideias, parece-me que a legislação brasileira segue os critérios mínimos que têm sido exigidos por outros países que permites pesquisa envolvendo células-tronco embrionárias. ${ }^{60}$

Ainda que o voto não indique as razões de escolha dos ordenamentos mencionados, nem os contextualize

60 BRASIL. Supremo Tribunal Federal. Ação Direta de Inconstitucionalidade. ADI 3510/DF. Tribunal Pleno. Requerente: Procurador-Geral da República. Requerido: Presidente da Republica. Relator: Min. Ayres Britto. Brasília, 29 de maio de 2008. Disponível em: <http://redir.stf.jus.br/paginadorpub/paginador. jsp?docTP=AC\&docID=611723 > . Acesso em: 20 jan. 2016. histórica e socialmente, há nele uma orientação clara de comparação, com o intuito de retirar dela orientações comuns que indiquem a essência de um instituto ou a solução comum a um problema igualmente compartilhado por distintos países.

O voto do Ministro Marco Aurélio apresenta, em linhas bastante gerais, informações acerca do tratamento normativo da matéria em dezoito países - são eles: África do Sul, Alemanha, Austrália, China, Cingapura, Coréia do Sul, Espanha, Estados Unidos, França, Índia, Israel, Itália, Japão, México, Reino Unido, Rússia, Suíça e Turquia -, tendo como bases fontes da internet.

Por fim, o então Presidente do STF, Ministro Gilmar Mendes, inicia seu voto com um exame comparado não do tema de fundo da discussão na ADI $3.510^{61}$, mas sim acerca do papel do Tribunal enquanto instituição, comparando-o à Suprema Corte americana e ao Tribunal Constitucional Federal alemão, para concluir, com base em Robert Alexy, que "o parlamento representa o cidadão politicamente, o tribunal constitucional argumentativamente". Trata-se, por certo, do estabelecimento de relações entre instituições que guardam peculiaridades muito próprias, sendo oriundas de contextos sociais, políticos, culturais e constitucionais radicalmente distintos. $^{62}$

Segue o voto do Ministro Gilmar Mendes fazendo considerações acerca da jurisprudência do Tribunal Constitucional Federal alemão em matéria de direitos fundamentais; considerações essas embasadas em obras

61 BRASIL. Supremo Tribunal Federal. Ação Direta de Inconstitucionalidade. ADI 3510/DF. Tribunal Pleno. Requerente: Procurador-Geral da República. Requerido: Presidente da Republica. Relator: Min. Ayres Britto. Brasília, 29 de maio de 2008. Disponível em: <http://redir.stf.jus.br/paginadorpub/paginador. jsp?docTP $=$ AC\&docID=611723> . Acesso em: 20 jan. 2016.

62 Basta, para compreender essas diferenças fundantesm - que talvez sejam óbices a uma comparação -, voltar às considerações de Bruce Ackerman em "The rise of world constitutionalism". Será o STF, de fato, uma "corte redentora" relacionada com uma constituição representativa de um "novo começo", ou estará ele mais atrelado ao conceito de "corte de coordenação", característica de um ambiente normativo federal? Essa resposta é fundamental para se analisar a pertinência das referências à obra de Alexy para fins de fundamentação ou de legitimação da atuação do Supremo Tribunal brasileiro. Para Ackerman, a autoridade do Tribunal Constitucional Federal alemão decorre da autoridade simbólica da Lei Fundamental de Bonn como marco de superação do nazismo (ACKERMAN, Bruce. The rise of world constitutionalism. Virginia Law Review, Charlottesville, v. 83, n. 4, p. 771-798, May. 1997. p. 779). É possível incorporar suas técnicas, sem que o STF tenha como objeto de trabalho um texto que goze de semelhante status? 
doutrinárias e decisões jurisprudenciais alemãs, todas analisadas em suas versões originais.

Igualmente no tema específico das células-tronco, o voto sob enfoque adentra na seara dos elementos estrangeiros. Cita a legislação - sempre diretamente e a partir de suas versões originais - da Alemanha, da Austrália, da França, da Espanha - complementada pela citação de duas sentenças, muito provavelmente do Tribunal Constitucional espanhol, ainda que o voto não o explicite - e do México. Não há, porém, nessa análise o propósito de apurar referenciais comuns que orientem a compreensão do tema em debate, tratando-se, exclusivamente, de uma descrição dos textos legais estrangeiros.

No segundo julgado a ser analisado, o da ADPF $132^{63}$, as referências ao direito estrangeiro se iniciam com o voto do Ministro Luiz Fux, que menciona duas obras de Ronald Dworkin, para afirmar que suas reflexões sobre o direito constitucional norte-americano são "perfeitamente aplicáveis ao direito constitucional brasileiro". Entretanto o voto não explicita como as reflexões dos tribunais e dos juristas norte-americanos em torno da XIV Emenda à Constituição de 1787 que impôs, em 1868, o dever de observância à cláusula do devido processo legal aos poderes estaduais - são coordenadas com dispositivos muito mais específicos e detalhados, como aqueles constantes da moderna Constituição brasileira. Igualmente, não há preocupação, na linha do preconizado pelos comparatistas, com a caracterização das diferenças ou semelhanças entre os contextos sociais, culturais e institucionais em que as duas ordens jurídicas são aplicadas.

Em seguida, o voto menciona obra doutrinária espanhola sobre a alteração do Código Civil da Espanha que permitiu o casamento entre pessoas do mesmo sexo. Nessa perspectiva há a contribuição do direito estrangeiro a partir da doutrina, que analisa situação jurídica de modificação legislativa bastante diversa daquela que se promovia, por meio do julgado em andamento, no âmbito do Poder Judiciário.

O próximo elemento significativo de direito estran-

63 BRASIL. Supremo Tribunal Federal. Argüição de Descumprimento de Preceito Fundamental. ADPF 132/RJ. Tribunal Pleno. Requerente: Governador do Estado do Rio de Janeiro. Requerido: Procurador-Geral do Estado do Rio de Janeiro. Relator: Min. Ayres Britto. Brasília, 05 de maio de 2011. Disponível em: <http://redir.stf.jus. $\mathrm{br} /$ paginadorpub/paginador.jsp?docTP $=\mathrm{AC} \& \operatorname{doc} \mathrm{ID}=628633>$. Acesso em: 20 jan. 2016. geiro que se pode verificar no julgamento da ADPF 132 consta do primeiro voto do Ministro Gilmar Mendes (fls. 121 e seguintes do acórdão), o qual anota que "a doutrina nacional não tem se ocupado, talvez como devesse, de um dispositivo que consta do Direito Comparado, talvez a sua matriz esteja na Lei Fundamental de Bonn, que fala do direito que cada indivíduo tem de autodesenvolvimento, Selbst Entfaltung seiner Persönlichkeit, quer dizer, autodesenvolvimento de sua personalidade". Entretanto, tal concepção oriunda do direito alemão não é esmiuçada, nem é demonstrado como se projeta sua aplicação ao direito brasileiro, como esse direito ao autodesenvolvimento da personalidade decorre das normas da Constituição de 1988.

Traz o voto, por fim, à colação mais uma vez a lição de Alexy, segundo a qual o Tribunal Constitucional representa o cidadão argumentativamente.

No segundo voto do Ministro Gilmar Mendes, que consta do acórdão (fls. 144 e seguintes), há um item específico sobre direito comparado, baseado quase que exclusivamente na obra União homoafetiva. Direitos acessórios e novos direitos, de Fábio Oliveira de Vargas, bem como em dois sites, um de uma associação ativista da causa homossexual nos Estados Unidos e outro sobre legislação alemã. Esse breve exame é concluído com as seguintes considerações:

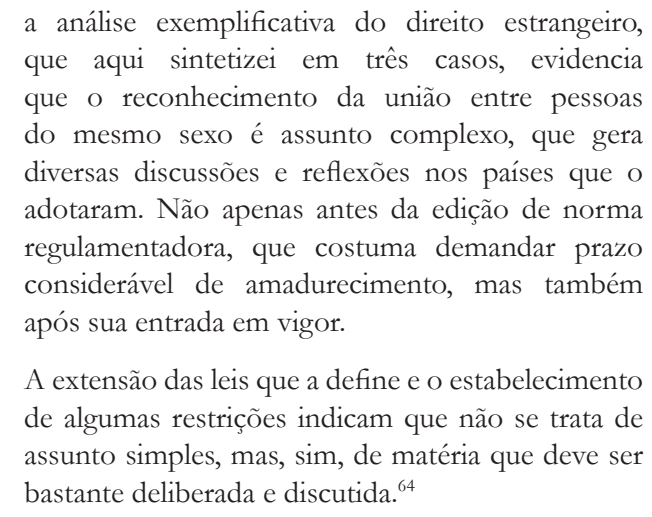

Tal trecho parece evidenciar que, com a análise de elementos estrangeiros, se pretendeu atingir um dos objetivos do direito comparado, qual seja, a identificação das diferenças para que, afastadas, seja possível vislum-

64 BRASIL. Supremo Tribunal Federal. Argüição de Descumprimento de Preceito Fundamental. ADPF 132/RJ. Tribunal Pleno. Requerente: Governador do Estado do Rio de Janeiro. Requerido: Procurador-Geral do Estado do Rio de Janeiro. Relator: Min. Ayres Britto. Brasília, 05 de maio de 2011. Disponível em: <http://redir.stf.jus. $\mathrm{br} /$ paginadorpub/paginador.jsp?docTP $=\mathrm{AC} \& \operatorname{docID}=628633>$. Acesso em: 20 jan. 2016. 
brar a essência do problema jurídico a resolver, a solucionar.

O Ministro Marco Aurélio, por sua vez, iniciou seu voto citando a discussão acerca da descriminação da homossexualidade na Inglaterra, ou seja, a abolição das leis penais que tipificavam como delito as condutas homossexuais; ressaltando as conclusões de Herbert L. A. Hart acerca das relações entre direito, liberdade e moralidade.

Já o Ministro Celso de Mello introduz elemento estrangeiro em sua argumentação ao destacar importância do "direito à busca da felicidade" para a solução da controvérsia dos autos; princípio esse que retira da Declaração de Independência dos Estados Unidos, a partir de dois trabalhos acadêmicos norte-americanos. $O$ voto cita vários julgados da Suprema Corte americana, nos quais as decisões tiveram como apoio retórico esse postulado de busca da felicidade; sem, contudo, apresentar com detalhes seus contornos fáticos ou as teses jurídicas neles enfrentadas.

O voto, ainda, cita que a "busca da felicidade" foi positivada nas Constituições do Japão (1947), França (preâmbulo do texto de 1958) e do Reino do Butão (2008); países que, certamente, têm compreensões bastante diversas do que seja esse direito fundamental; compreensões igualmente distintas da matriz norte-americana e do que se concebe no Brasil. ${ }^{65}$

65 Nesse específico argumento da "busca da felicidade", a diferença fundamental que existe entre uma análise exclusivamente literal dos ordenamentos e o exame funcional, social e historicamente compreensivo, que deve pautar as comparações, fica explícito. Não se discute que Estados Unidos, França, Japão e Butão contêm em seus ordenamentos constitucionais o mencionado "direito à busca da felicidade"; esse é o law in the books, o direito vigente desses quatro países. Mas a pergunta fundamental do comparatista deveria ser como esse enunciado normativo se projeta sobre a questão em análise, ou seja, sobre o reconhecimento jurídico de uniões entre pessoas do mesmo sexo. Em outras palavras, como o "direito à busca da felicidade" ampara homossexuais nesses quatro ordenamentos, como essa garantia se apresenta na forma de law in action, de "direito vivente". No caso concreto, se a análise literal permitiu que os ordenamentos norte-americano, francês, japonês e butanês fossem utilizados como reforço da fundamentação do voto do Ministro Celso de Mello, o exame funcional demonstraria - como de fato demonstra - que o "direito à busca da felicidade" nesses países em nada amparava, à época do julgamento, o reconhecimento jurídico de uniões homoafetivas. Inicialmente, os Estados Unidos, berço da afirmação de Thomas Jefferson sobre a "busca da felicidade", tinham, quando da decisão do STF, um panorama bastante complexo no tema. Dos 51 estados americanos, 29 estados expressamente proibiam as uniões entre pessoas do mesmo sexo em suas Constituições e 9 estados as proibiam por meio de leis locais. Havia, ainda,
Concluído o breve estudo desses dois importantes precedentes do STF, é possível afirmar que os elementos estrangeiros são, ordinariamente, utilizados sem maiores critérios metodológicos, se considerados os padrões fixados pelo direito comparado moderno.

Ainda que a maioria dos exames tenha um fundo funcionalista, custa percebê-lo. Porém, não se tem uma preocupação contumaz com contextualizações, não há justificativa das razões que levam à citação deste ou daquele ordenamento estrangeiro - e aí se misturam fontes exteriores com autoridade maior ou menor, que se intercalam indistintamente -, não se enfatiza a ocorrência de eventuais fertilizações cruzadas (cross-fertilizations), não se busca estudar o direito vivente (law in action), mas preponderantemente o direito vigente (law in the books) e, na maioria das vezes, as citações são meras ilustrações, que não passam - para utilizar as palavras anteriormente citadas de Scarciglia ${ }^{66}$ - de "partes ornamentais" dos acórdãos. ${ }^{67}$

desde 1996, legislação federal - o Defense of the Marriage Act-DOMA - que proibia aos órgãos da União o reconhecimento de uniões homoafetivas; legislação essa que somente foi afastada por decisão da Suprema Corte no caso United States v. Windsor, de 2013. Na França, a legalização do casamento homossexual somente ocorreu em abril de 2013, muito depois da decisão do STF. No Japão, por sua vez, o "direito à busca da felicidade" também não atinge uniões entre pessoas do mesmo sexo, que não são reconhecidas como juridicamente válidas, delas não se originando direitos. Por fim, no Reino do Butão, onde também a todos é assegurado o "direito à busca da felicidade", o Código Penal de 2011 tipifica, em seus arts. 213 e 214, o crime de "sexo não natural", no qual as práticas homossexuais são enquadradas. Ou seja, o reconhecimento que o direito butanês dá às uniões homoafetivas é o da criminalização, radicalmente distante do propugnado no voto ora em comento. Assim, trazer à colação tais ordenamentos como reforços na defesa da concessão de efeitos jurídicos a uniões entre pessoas do mesmo sexo é, no mínimo, técnica e metodologicamente inadequado. BRASIL. Supremo Tribunal Federal. Argüição de Descumprimento de Preceito Fundamental. ADPF 132/RJ. Tribunal Pleno. Requerente: Governador do Estado do Rio de Janeiro. Requerido: Procurador-Geral do Estado do Rio de Janeiro. Relator: Min. Ayres Britto. Brasília, 05 de maio de 2011. Disponível em: <http://redir.stf.jus.br/paginadorpub/paginador. jsp?docTP=AC\&docID=628633 > . Acesso em: 20 jan. 2016.

66 SCARCIGLIA, Roberto. Introducción al derecho constitucional comparado. Madrid: Dykinson, 2011. p. 94.

67 As conclusões de Cheryl Saunders, ao analisar acórdãos da High Court australiana não são muito diferentes, o que talvez sirva para indicar uma tendência na qual se insere a prática insipiente do STF no uso do direito comparado. A autora australiana indica que, em linhas gerais, a High Court entende os propósitos do uso do direito estrangeiro, porém "it was less comfortable, however, with other demands of comparative law: deeper contextual analysis, where required, and examination of the rationale for the selection of particular foreign sources. It may be that in cases where foreign law is used extensively, a more explicit rationale for selection would be helpful, not only to expose to critical examination the criterion that is used 


\section{Considerações finais}

Do que foi até aqui analisado, os seguintes pontos podem ser destacados à guisa de conclusão:

a) o direito constitucional brasileiro tradicionalmente é permeável à contribuição do direito estrangeiro, por meio da importação de institutos e por meio da abertura de sua jurisdição constitucional ao método comparado;

b) tal método comparado exige do jurista o domínio de uma série de técnicas, bem como o emprego de cuidados específicos no tratamento dos ordenamentos em comparação; especialmente no que diz com a observância das funções dos institutos, bem como do contexto cultural, social, institucional e histórico em que foram desenvolvidos e em que são vivenciados;

c) no plano específico da jurisdição constitucional, as críticas que ordinariamente são feitas ao emprego de elementos estrangeiros de fundamentação dizem mais com o modo como é procedido do que com tal emprego considerado em si mesmo; o que reforça a necessidade da correta utilização da metodologia comparada nos processos de decisão;

d) a aceitação maior, ou menor, de uma influência estrangeira depende de vetores pessoais - considerados aqui os juristas responsáveis pela promoção do uso do elemento exterior no direito interno -, de vetores objetivos relacionados com a reputação do ordenamento estrangeiro e ainda de vetores teóricos, relacionados com a fundamentação filosófica última das trocas de experiências por meio da jurisdição constitucional, num postulado de tratamento igualitário dos cidadãos de diferentes países, submetidos a princípios gerais semelhantes;

e) nesse contexto, a experiência do Supremo Tribunal Federal brasileiro na utilização do direito comparado ainda se encontra aquém dos padrões teóricos fixados pelos modernos estudos e práticas comparatistas, normalmente faltando-lhe o aprofundamento do conhecimento dos ordenamentos estrangeiros de que lança mão em suas fundamentações e ficando constantemente alheio a exercícios de compreensão mais abrangente

and to identify inconsistencies in its application, in order to preclude misuse, but also to secure a more complete measure of the benefit of foreign experience" (SAUNDERS, Cheryl. The use and misuse of comparative constitutional law. Indiana Journal of Global Legal Studies, Indiana, v. 13, n. 1, p. 37-76, Winter 2006. p. 74). desses mesmos ordenamentos e, por fim, muitíssimo raramente adentrando no campo da comparação propriamente dita.

Esses pontos realçam a necessidade de uma revisão ampla do modo como o STF desenvolve seus argumentos de direito comparado, buscando-se a introdução de uma metodologia que permita a seus Ministros identificar quais os ordenamentos cuja proximidade com o brasileiro admite comparação, como as fontes desses ordenamentos devem ser analisadas pela Corte - com ênfase no direito vivente (law in action) - e quais os pressupostos teóricos comuns que tornam a utilização desses referenciais útil e legítima.

Somente assim a Suprema Corte brasileira poderá cumprir vocação que está na sua gênese e que lhe dá característica enriquecedora, qual seja, a sua abertura natural ao diálogo jurídico internacional, por meio do direito comparado.

\section{REFERÊNCIAS}

ACKERMAN, Bruce. The rise of world constitutionalism. Virginia Law Review, Charlottesville, v. 83, n. 4, p. 771-798, May. 1997.

ANCEL, Marc. Utilidade e método do direito comparado. Porto Alegre: S. A. Fabris, 1980.

BALKIN, Jack M.; SIEGEL, Reva B. (Ed.). The Constitution in 2020. New York: Oxford University Press, 2009.

BELL, John. The relevance of foreign examples to legal development. Duke Journal of Comparative \& International Law, v. 21, n. 2, p. 431-460, Winter 2011.

BRASIL. Decreto $N^{0} 848$, de 11 de outubro de 1890. Disponível em: <http://www.planalto.gov.br/ccivil_03/ decreto/1851-1899/d848.htm>. Acesso em: 20 jan. 2016.

BRASIL. Supremo Tribunal Federal. Ação Direta de Inconstitucionalidade. ADI 3510/DF. Tribunal Pleno. Requerente: Procurador-Geral da República. Requerido: Presidente da Republica. Relator: Min. Ayres Britto. Brasília, 29 de maio de 2008. Disponível em: <http:/ / redir.stf.jus.br/paginadorpub/paginador. jsp?docTP $=$ AC\&docID $=611723>$. Acesso em: 20 jan. 2016. 
BRASIL. Supremo Tribunal Federal. Argüição de Descumprimento de Preceito Fundamental. ADPF 132/ RJ. Tribunal Pleno. Requerente: Governador do Estado do Rio de Janeiro. Requerido: Procurador-Geral do Estado do Rio de Janeiro. Relator: Min. Ayres Britto. Brasília, 05 de maio de 2011. Disponível em: $<$ http:/ / redir.stf.jus.br/paginadorpub/paginador. jsp?docTP $=$ AC\&docID $=628633>$. Acesso em: 20 jan. 2016.

DAVID, René. Os grandes sistemas do direito contemporâneo. 2. ed. São Paulo: M. Fontes, 1993.

DELMAS-MARTY, Mireille. Les forces imaginantes $d u$ droit: le relatif et l'universel. Paris: Editions du Seuil, 2004.

HORBACH, Carlos Bastide. Ministro Pedro Lessa: memória Jurisprudencial. Brasília: Supremo Tribunal Federal, 2007.

HORBACH, Carlos Bastide. O parlamentarismo no Império do Brasil (II): representação e democracia. Revista de Informação Legislativa, Brasília, v. 44, n. 1747, p. 213-231, abr./jun. 2007.

JACKSON, Vicki C. Progressive Constitutionalism and Transnational Legal Discourse. In: BALKIN, Jack M.; SIEGEL, Reva B. (Ed.). The Constitution in 2020. New York: Oxford University Press, 2009. p. 285-297.

LAW, David S.; VERSTEEG, Mila. The declining influence of the United States Constitution. New York University Law Review, New York, v. 87, n. 3, p. 761-858, June 2012.

LESSA, Pedro. Do poder judiciário. Brasília: Senado Federal, 2003. edição fac-similar.

LOPES, José Reinaldo de Lima. O Oráculo de Delfos: o conselho de Estado no Brasil-Império. São Paulo: Saraiva, 2010.

MICHAELS, Ralf. The functional method of Compara- tive Law. In: REIMANN, Matthias; ZIMMERMANN, Reinhard (Ed.). The Oxford Handbook of Comparative Law. Oxford: Oxford University, 2006. p. 339-382.

MIRANDA, Jorge. Sobre o direito constitucional comparado. Revista de Direito Constitucional e Internacional, São Paulo, v. 14, n. 55, p. 243-260, abr./jun., 2006.

MIRANDA, Jorge. Manual de direito constitucional. 4. ed. Coimbra: Coimbra, 1990. v. 1.

MIRKINE-GUETZÉVITCH, B. L'histoire constitutionnelle comparée. Annales de l'Institut de Droit Comparée de la Université de Paris, Paris, n. 1, p. 85-98, 1936.

SAUNDERS, Cheryl. The use and misuse of comparative constitutional law. Indiana Journal of Global Legal Studies, Indiana, v. 13, n. 1, p. 37-76, Winter 2006.

SCARCIGLIA, Roberto. Introducción al derecho constitucional comparado. Madrid: Dykinson, 2011.

TOOBIN, Jeffrey. The nine: inside the secret world of the Supreme Court. New York: Anchor Books, 2008.

TUSHNET, Mark. Comparative constitutional law. In: REIMANN, Matthias; ZIMMERMANN, Reinhard (Ed.). The Oxford Handbook of Comparative Law, Oxford: Oxford University, 2006. p. 1225-1257.

TUSHNET, Mark. The 'Constitution Restoration Act' and judicial independece: some observations. Case Western Reserve Law Review, Ohio, v. 56, n. 4, p. 1071-1082, 2006.

WALDRON, Jeremy. Foreign law and the modern ius gentium. Harvard Law Review, Cambridge, v. 119, n. 1, p. 129-147, Nov. 2005.

WATT, Horatia Muir. Globalization and comparative law. In: REIMANN, Matthias; ZIMMERMANN, Reinhard (Ed.). The Oxford Handbook of Comparative Law. Oxford: Oxford University, 2006. p. 579-607.

ZWEIGERT, Konrad; KÖTZ, Hein. Introduction to comparative law. 3. ed. Oxford: Clarendon, 2011. 


\title{
The philosophy of international law in contemporary scholarship: overcoming negligence through the global expansion of human rights*
}

\author{
A filosofia do direito internacional no estudo \\ contemporâneo: a superação negligência \\ através da expansão global dos direitos \\ humanos
}

\author{
Fabrício Bertini Pasquot Polido ** \\ Lucas Costa dos Anjos *** \\ Vinícius Machado Calixto ****
}

* Recebido em 31/10/2015.

Aprovado em 07/12/2015

** Professor Adjunto de Direito Internacional da Faculdade de Direito e Ciências do Estado da Universidade Federal de Minas Gerais (UFMG). Professor do corpo permanente do Programa de Pós-Graduação em Direito. Doutor em Direito Internacional pela Faculdade de Direito da Universidade de São Paulo. Foi Pesquisador Visitante - nível Pós- Doutorado - do Max-Planck Institute for Comparative and International Private Law, Hamburgo, Alemanha. É Membro do Comitê de Direito Internacional Privado e Propriedade Intelectual da International Law Association (ILA), Sociedade de Direito Internacional Econômico e da Associação Americana de Direito Internacional Privado. Email: fpolido@gmail.com

*** Mestrando e bacharel em Direito pela Universidade Federal de Minas Gerais (UFMG), com formação complementar pela Baylor University School of Law. Especialista em Direito Internacional pelo Centro de Direito Internacional (CEDIN). Bolsista CAPES e membro do Grupo de Estudos Internacionais de Propriedade Intelectual, Internet e Inovação (GNet). E-mail: lucascostaanjos@gmail.com

**** Mestrando em Direito pela Universidade Federal de Minas Gerais (UFMG), vinculado à área de estudo Ordem Jurídica Transnacional e Tecnlogias. Pós-Graduando em Direito Desportivo e Negócios do Esporte pelo Centro de Direito Internacional (CEDIN). Bacharel em Direito pela Universidade de Brasília (UnB). Pesquisador do Projeto Referências da Secretaria Nacional de Alto Rendimento do Ministério do Esporte/UFRGS. E-mail: viniciusmcalixto@gmail.com

\section{Abstract}

This paper aims to analyze the relative neglect often given to international law under philosophy of law studies. Within this context, the relationship between law and reasoning, in the light of the international realm, is taken in a broader level to understand the role played by this field of knowledge in H.L.A. Hart's The Concept of Law, among other works of reference. With the consolidation of normative and jurisprudential work of several international fora, such as the United Nations, its affiliate agencies, and many international courts other than the International Court of Justice, international law has given rise to several legal phenomena worth understanding through a philosophical perspective. Regardless of the field of study, whether humanitarian law, international economic law, or transnational justice, the social and political role international law plays nowadays has been growing exponentially.Notwithstanding its importance, there is a current negligence to the philosophy of international law among authors from all over the world. Despite researching fields such as distributive justice, group justice and transnational justice, not enough thought is put into understanding current legal theories behind international law, neither into the possibility of conceiving a moral theory in the context of legal pluralism. In view of these main issues, the article aims not only to examine international law as a viable field of study for the philosophy of law in the context of legal pluralism, but also to further understand its developmental consequences for the international order. Therefore, this article analyzes with remarkable concern the importance of the global expansion of human rights in order to better examine the role that international human rights can play in the definition of a international legal order.

Keywords: Legal pluralism. Transnational justice. Human rights. 


\section{RESUMO}

Este trabalho tem como objetivo analisar a relativa negligência, muitas vezes do direito internacional estudos de filosofia direito. Dentro deste contexto, a relação entre direito e do raciocínio, à luz do domínio internacional, é tomada em um nível mais amplo para entender o papel desempenhado por este campo de conhecimento a luz de "O Conceito de Direito", de Hart, entre outras obras de referência. Com a consolidação do trabalho normativo e jurisprudencial de vários fóruns internacionais, como a família onusiana, o direito internacional deu origem a vários fenômenos jurídicos que podem ser compreendidos através de uma perspectiva filosófica. Independentemente do campo de estudo, se direito humanitário, direito econômico internacional, ou a justiça transnacional, o direito internacional desempenha um crescente papel social e político. $\mathrm{O}$ artigo tem como objetivo não só para examinar o direito internacional como um campo viável de estudo para a filosofia do direito no contexto do pluralismo jurídico, mas também para entender melhor as suas consequências para o desenvolvimento para a ordem internacional. Portanto, este artigo analisa com notável preocupação a importância da expansão global dos direitos humanos, a fim de examinar melhor o papel que os direitos humanos internacionais podem desempenhar na definição de uma ordem jurídica internacional.

Palavras-chave: Pluralismo jurídico. A justiça transnacional. Direitos humanos.

\section{INTRODUCTORY REMARKS}

Scholarly circles in international law and philosophy of law have been experiencing the very striving task to revive the foundations of the philosophical thought and explain what may be considered the core concerns of both subjects nowadays: power, authority, moral, justice, adjudication, coercion, enforcement, and obligations ${ }^{1}$. This necessary approximation is not only a

1 See, for instance, BUCHANAN, Allen; GOLOVE, David. Philosophy of international law. In: COLEMAN, Jules L.; HIMMA, Kenneth Einar; SHAPIRO, Scott J. The Oxford handbook of jurisprudence and philosophy of law. Oxford: Oxford University, 2002. p. 868934. p. 868 et seq; FINNIS, John. Natural law: the classical tradition. In: COLEMAN, Jules L., HIMMA, Kenneth, SHAPIRO, Scott. The Oxford handbook of jurisprudence and philosophy of law. Oxford: Oxford University, 2002. p. 1-39; TESSON, Fernando R. Philosophy of in- matter of academic convenience, but it is rather an extraordinary opportunity for scholars to critically reflect on the main contemporary theories involving the nature and philosophical justification of conceptual and normative issues of international law and its institutions.

A first methodological concern appears to be the investigation of the main existing concepts and understandings of normativity and how they are associated to international legal order and the main roles of the international regulatory, law-making and adjudicatory institutions. Secondly, philosophy of international and its theoretical proponents would be very prepared to design theoretical proposals for analysis of the key interactions between law, morality and politics within the international legal order, challenging, for instance, the mainstream approach of global governance in international law.

Further, philosophy of international law could be better adjusted to formulate critical inputs to the current state of art of the academic debate surrounding legal positivism, realism in international relations, natural law and new non-positivist circles in international legal scholarship ${ }^{2}$. The potential merger between two traditional subjects in legal studies can overcome the outdated plain discussions about the relationship between international law and municipal law (usually based on a voluntary return to the Manichaeism of monism vs. dualism), or about the decentralized nature of international legal order, often conceived as the main constraint for legitimacy and enforcement.

Any sound criticism would then be justified by the impetus of a theory sufficient to explain the foundations of international law and able to ascertain the normative parameters for their proper interpretation of normative issues (e.g. justice, moral, adjudication, legitimacy) in international law and enforcement of international rules by the existing institutions (international organizations, international courts and national courts themselves). In doing so, philosophy of international law (and revisited

ternational law. In: MAY, Larry; BROWN, Jeff (Ed.). Philosophy of law: classic and contemporary readings. Chichester: Wiley-Blackwell, 2010, p. 187-199. p. 187; BESSON, Samantha; TASIOULAS, John. Introduction. In: ___ (Ed.). The philosophy of international law. New York: Oxford University, 2010. p. 1-32. p. 1 et seq;

2 Critically, see the opposing views in GOLDSMITH, Jack L.; POSNER, Eric A. The limits of international law. New York: Oxford University, 2005; and DWORKING, Ronald. 'A new philosophy for international law. Philosophy and Public Affairs, v. 41, n. 1, p. 2-30, Winter 2013. 
proposals for the philosophical foundations of international law) will constitute a very important key for the comprehension of the dynamics of the more interdependent international community.

It may assist us to deviate from the old risks (and obsession) to associate the existing international legal order to a set or bundle of national legal orders, based on voluntarism and state-centered perspectives, both taken as core arguments for the justification for the functioning of a rudimentary international system of states

This paper is an attempt to tackle some of the pending issues related to contemporary research agenda of philosophy of international law. It is based on the analysis of Jeremy Waldron's paper, entitled “International Law: a Relatively Small and Unimportant Part of Jurisprudence"? ${ }^{3}$, and Allen Buchanan and David Golove's "The Philosophy of International Law", in which various aspects of the current scholarly international legal debate are addressed. This subject is particularly relevant with regard to the parallels Waldron establishes with the work of H.L.A. Hart, The Concept of Law $w^{5}$,inwhich he questions the analysis that Hart develops about the validity of international law as a systematic and singular branch of law.

Buchanan and Golove, on the other hand, agree that there is a certain neglect of the philosophy of international law, thus remarking in their paper some issues that are currently discussed in academic circles in the field of political philosophy, but not of philosophy of international law, such as distributive justice and transnational justice, for example.

In this context, rather than simply understand the reasons why there is some theoretical negligence in relation to the study of the philosophy of international law, this paper investigates the current trends on the analysis

3 WALDRON, Jeremy. International law: 'a relatively small and unimportant' part of jurisprudence? NYU School of Law, Public Law Research Papern. 13-56, p. 209-223, Oct. 2013. Available at: <http:// papers.ssrn.com/sol3/papers.cfm?abstract_id $=2326758>$. Accessed on: 5 apr. 2015.

4 BUCHANAN, Allen; GOLOVE David. Philosophy of international law. In: COLEMAN, Jules L.; HIMMA, Kenneth Einar; SHAPIRO, Scott J. The Oxford handbook of jurisprudence and philosophy of law. Oxford: Oxford University, 2002. p. 868-934.

5 HART, H. L. A. The concept of law. 2. ed. New York: Oxford University, 1994. p. 213-237. Available at: <http://nw18.american. $\mathrm{edu} / \sim$ dfagel/Class\%20Readings/Hart/International\%20Law $\% 20$ Chapter $\% 20$ From $\% 20$ Concept $\% 20$ of $\% 20$ Law.pdf>. Accessed on: 3 apr. 2015. of the nature of international law, admitted as a legal theory for international law, and the possibility of conceiving a moral theory in the context of international law.

Our proposal of analysis for these core issues of research is presented in five sections. In addition to this first introductory item, the second item analyzes the problem of neglect of the philosophy of international law, from the perspective of authors such as Buchanan and Golove,andby contextualizing their work with the authoritative work of other theorists on the subject.The third item explores the criticism proposed by Waldron with regard to Hart, the so-called opportunity costs involved in the lack of analyzing international law throughout in his work. In section four, we analyze the key aspects ofthe challenges faced by Buchanan and Golovewithin the domain of international law nowadays. In our concluding remarks, we stress the importance of the recent changesoccurring in the field of international law, as well as trends for its future development.

\section{THE PROBLeM OF NEgLeCt OF THE PHILOSOPHY OF INTERNATIONAL LAW}

InThe Philosophy of InternationalLaw, Buchanan and Golove argue what they call a“curious neglect"conferred on the philosophy of international law. According to the authors, contemporary political philosophers already tend to neglect international relations in their studies, having even less to say about the philosophy of international law.Most contemporary philosophers of law sometimes even act as if there were not an international legal system to be theorized ${ }^{6}$.

Samantha Besson and John Tasioulas also raise this neglect with regard to the philosophy of international

6 According to Buchanan and Golove: "Contemporary political philosophers trend to neglect international relations.Contemporary philosophers of law usually have even less to say about the philosophy of international law.Rawls's work has dominated political philosophy for more than a quarter of a century, but only recently has he extended his theory to the international sphere, And then only in the rather skeletal fashion. The contemporary major philosophers of law largely proceed to if there were in Legal international system to be theorized about". BUCHANAN, Allen; GOLOVE, David. Philosophy of international law. In: COLEMAN, Jules L.; HIMMA, Kenneth Einar; SHAPIRO, Scott J. The Oxford handbook of jurisprudence and philosophy of law. Oxford: Oxford University, 2002. p. 868-934. p. 868. 
law, which ended up being left behind at a period to which the authors refer as the rebirth of the philosophy of law (since 1960, through the works of Hart and Rawls) ${ }^{7}$. Previously to the current scholarship discussing philosophical foundations of international law, some authors contended that the fundamental neglect was associated to the way how legal education spread a vague and flat approach on the role of international law and international institutions: instruments to commerce and diplomacy ${ }^{8}$.

The main criticism is also consistent with observations that Jeremy Waldron makes with regard to Hart's work,International Law: a Relatively Small and Unimportant Part of Jurisprudence.Among the remarks made by Waldron in relation to Hart's ideas in Chapter X of The Concept of Law, one could notice the neglect in relation to international law. To Waldron, Hart's omission impaired international law's theoretical appeal, particularly because he could have better contributed to the debate on the interface with legal philosophy.

According to Hart, with regard to his conception of the theorization international law:

\begin{abstract}
It resembles, as we have said, in form though not at all in content, a simple regime of primary or customary law. Yet some theorists, in their anxiety to defend against the skeptic the title of international law to be called 'law', have succumbed to the temptation to minimize these formal differences, and to exaggerate the analogies, which can be found in international law to legislation or other desirable formal features of municipal law?.
\end{abstract}

Therefore, the author then made an effort to address the "issue" of an emergent field of study in the philosophy of law. Despite Hart's efforts, his assertions were based on a considerably different international scenario than the one exiting by the time Buchanan and Golove published their research.

To further exemplify Hart's contention, the author

7 According to Besson and Tasioulas: "Yet it is the case that, until comparatively recently, the post-1960 revival of cool philosophy has tended to neglect international law". BESSON, Samantha; TASIOULAS, John.Introduction. In: __ (Ed.). The philosophy of international law.New York: Oxford University, 2010. p. 1-32. p. 17.

8 DUMBAUD, Edward. The place of philosophy in international law. University of Pennsylvania Law Review, Philadelphia, v. 83, n. 5, p. 590-606, 1935.

9 HART, H. L. A. The concept of law. 2. ed. New York: Oxford University, 1994. p. 232. Available at: <http://nw18.american. edu/ dfagel/Class $\% 20$ Readings/Hart/International $\% 20$ Law $\% 20$ Chapter $\% 20$ From $\% 20$ Concept $\% 20$ of $\% 20$ Law.pdf>. Accessed on: 3 apr. 2015. points out that:

[...] Though it is consistent with the usage of the last 150 years to use the expression 'law' here, the absence of an international legislature, courts with compulsory jurisdiction, and centrally organized sanctions have inspired misgivings, at any rate in the breasts of legal theorists. ${ }^{10}$.

In addition, there is even a more problematic fact, which is that the minority of political philosophers that seek to extend their normative vision to the field of international relations, for the most part, have ceased to be explicit about the role of positive theory in this attempt. According to Buchanan and Golove, the way is clear even for the development of a moral theory of international law. According to the authors, the structure of a moral theory of international law would consist of the following elements, basically comprising moral grounds, accomplishment of goals, legitimacy and enforcement:

The fundamental structure of a normative theory of international law, the ideal theory, would consist of the following elements: (1) an account of the moral point, or goals of the institution of international law, the most fundamental moral values it ought to serve, (2) an articulation of the moral reasons for supporting the institution of international law as a means of achieving those goals or serving those values, (3) the specification of the conditions under which the international legal system would be legitimate, at least in the sense of there being an adequate justification for the processes of creating and enforcing the rules of the system,(4) a statement ofand justification for the most important substantive principles of the system. ${ }^{11}$

Buchanan and Golove listed three factors responding for this relative underdeveloped state of the philosophy of international law. First, the fact that scholars neglect institutional moral theory. This means that the core moral principles of international law would necessarily be difficult to be institutionalized due to the fact that their eventual abandonment (to implement other institutional principles case by case, for example) is pro-

10 HART, H. L. A. The concept of law. 2. ed. New York: Oxford University, 1994. p. 214. Available at: <http://nw18.american. edu/ dfagel/Class $\% 20$ Readings/Hart/International $\% 20$ Law $\% 20$ Chapter $\% 20$ From $\% 20$ Concept $\% 20$ of $\% 20$ Law.pdf $>$. Accessed on: 3 apr. 2015.

11 BUCHANAN, Allen; GOLOVE, David. Philosophy of international law. In: COLEMAN, Jules L.; HIMMA, Kenneth Einar; SHAPIRO, Scott J. The Oxford handbook of jurisprudence and philosophy of law. Oxford: Oxford University, 2002. p. 868-934. p. 881-882. 
hibitive and too restrictive ${ }^{12}$.

The second factor would be directly related to the realist theory of international relations ${ }^{13}$, to which the moral theoretical approach of international relations and, therefore, of international law, would be futile. More recently, even though realism has been challenged by several critics regarding its most important assumptions, and, more systematically, by liberal positivist theories, it is precisely its pessimistic implications for normative initiative that persist. This is particularly relevant with regard to political philosophers and legal philosophers who are not intimate with the main weaknesses of this theory (realism). ${ }^{14}$

Finally, many authors tend to project a disparaging perspective of the philosophy of international law in their works. Buchanan and Golove assert that, in the very least, this field of law is described only as a pale shadow of what we call a legal system ${ }^{15}$. The most extreme form of this point of view, the legal nibilism ${ }^{16}$, even

12 BUCHANAN, Allen; GOLOVE, David. Philosophy of international law. In: COLEMAN, Jules L.; HIMMA, Kenneth Einar; SHAPIRO, Scott J. The Oxford handbook of jurisprudence and philosophy of law. Oxford: Oxford University, 2002. p. 868-934. p. 870.

13 According to Amado Luiz Cervo, the fundamentals of realistic theory of international relations may be rejected by the very honor student of the area: "Realism, for example, paved the way to success in intellectual universities and media from around the world, so incomparable.Disqualification this theoretical current begins with the evidence of its origin in the United States at the beginning of the Cold War, for this reason establishing the State as the main agent of international relations and security as primary motivation of external action.Realism suggests the world interests, values and Western standards of conduct.Realism is not free nor explains international relations as you want. Sometimes you may agree to certain nations face the realism teaches Parola.He adds that his morale was excluded from the beginning. Why would international relations not move against realism, which is capable of producing the unjust order?." CERVO, Amado Luiz. Concepts in International Relations. Journal of International Politics, Basingstoke, v. 51, n. 2, p. 8-25, 2008. Available at: <http://www.scielo.br/pdf/rbpi/v51n2/v51n2a02>. Accessed on: 5 apr. 2015.

14 BUCHANAN, Allen; GOLOVE, David. Philosophy of international law. In: COLEMAN, Jules L.; HIMMA, Kenneth Einar; SHAPIRO, Scott J. The Oxford handbook of jurisprudence and philosophy of law. Oxford: Oxford University, 2002. p. 868-934. p. 871.

15 BUCHANAN, Allen; GOLOVE, David. Philosophy of international law. In: COLEMAN, Jules L.; HIMMA, Kenneth Einar; SHAPIRO, Scott J. The Oxford handbook of jurisprudence and philosophy of law. Oxford: Oxford University, 2002. p. 868-934. p. 871.

16 According to Buchanan and Golove: "There are two ways the legal Nihilist view can be understood: as an analytic claim about the features a system of rules must have if it is to constitute the legal system, paired with the assertion that what we call international law does not satisfy those conditions; or as a claim that a system of rules is not a legal system unless its rules effectively constrain or denies the existence of international law as a field of law.

\section{HART AND THE OPPORTUNITY COST OF HIS ANALYSIS OF INTERNATIONAL LAW}

In a similar fashion to Buchanan and Golove's critique, Jeremy Waldron focuses his analysis on the ideas supported by Hart in Chapter X of The Concept ofLaw. The title of Waldron's article is a prelude of the criticism made against Hart, who would have lost an opportunity to effectively contribute to theoretical foundations of the legal nature of the international order. Hart could have explored the differences between the so-called municipal legal systemsandinternationallegal systems ${ }^{17}$. According to Jeremy Waldron:

The real harm lies in the opportunity costs of Hart's negligence.What we miss is what might have been done.[...]It is a pity that the author of The Concept of Law ran out of steam or inclination before doing this in his last chapter, for it deprived us not only of comparable insights, but of an example that might have inspired some of Hart's followers in jurisprudence to take up and pursue this challenge ${ }^{18}$.

Addressing the foundations of a legal system, Hart asserts the existence of two minimum conditions necessary and sufficient for the existence of a legal system. First, the rules of behavior valid according to the ultimate criteria of validity must be generally obeyed. Second, its officials must effectively accept the rules of change and adjudication as common public standards

determine the behavior of those to whom the rules are directed, along with the assertion that international law is not effective." BUCHANAN, Allen; GOLOVE, David. Philosophy of international law. In: COLEMAN, Jules L.; HIMMA, Kenneth Einar; SHAPIRO, Scott J. The Oxford handbook of jurisprudence and philosophy of law. Oxford: Oxford University, 2002. p. 868-934. p. 877.

17 Waldron also explains this distinction, defining municipal legal systems such as those belonging to a particular state, such as France or New Zealand, as opposed to an international legal system (WALDRON, Jeremy. International law: 'a relatively small and unimportant' part of jurisprudence? NYU School of Law, Public Law Research Paper n. 13-56, p. 209-223, Oct. 2013. p. 209. Available at: $<$ http://papers.ssrn.com/sol3/papers.cfm?abstract_id $=2326758>$. Accessed on: 5 apr. 2015.)

18 WALDRON, Jeremy. International law: 'a relatively small and unimportant' part of jurisprudence? NYU School of Law, Public Law Research Paper n. 13-56, p. 209-223, Oct. 2013. p. 222-223. Available at: <http://papers.ssrn.com/sol3/papers.cfm?abstract_ $\mathrm{id}=2326758>$. Accessed on: 5 apr. 2015. 
of official behavior ${ }^{19}$. According to Hart, what would then be the status of international law? That is the question he does not answer in The Concept ofLaw.According to the author, international law does not have secondary rules, an organized legislature and courts with compulsory jurisdiction ${ }^{20}$.

The absence of these Institutions means that the rules for states resemble that simple form of social structure, consisting only of primary rules of obligation, which when we find it among societies of individuals, we are accustomed to contrast with a developed legal system ${ }^{21}$.

In this sense, Hart asserts that international law lacks the secondary rules of change and adjudication which provide for legislature and courts and also a unifying rule of recognition specifying sources of law, with a general criteria for the identification of its rules ${ }^{22}$.

Although the author affirms that we must free ourselves from the assumption that international law must necessarily contain a fundamental norm, Hart rejects the commonly made analogies between international law and domestic law. For him, the rules on operation of international law do not form a system, but a simple set of rules ${ }^{23}$.

According to Hart, the international legal order would be considered primitive:

Both forms of doubt arise from an adverse comparison of international law with municipal

19 HART, H. L. A. The concept of law. 2. ed. New York: Oxford University, 1994. p.116. Available at: <http://nw18.american. $\mathrm{edu} / \sim$ dfagel/Class\%20Readings/Hart/International\%20Law $\% 20$ Chapter $\% 20$ From $\% 20$ Concept $\% 20$ of $\% 20$ Law.pdf $>$. Accessed on: 3 apr. 2015.

20 HART, H. L. A. The concept of law. 2. ed. New York: Oxford University, 1994. p.216. Available at: <http://nw18.american. $\mathrm{edu} / \sim$ dfagel/Class $\% 20$ Readings/Hart/International $\% 20$ Law $\% 20$ Chapter $\% 20$ From $\% 20$ Concept $\% 20$ of $\% 20$ Law.pdf $>$. Accessed on: 3 apr. 2015.

21 HART, H. L. A. The concept of law. 2. ed. New York: Oxford University, 1994. p. 213-237; p. 214. Available at: <http://nw18. american.edu/ $\sim$ dfagel/Class $\% 20$ Readings/Hart/International $\% 20$ Law $\% 20$ Chapter $\% 20$ From $\% 20$ Concept $\% 20$ of $\% 20$ Law.pdf $>$. Accessed on: 3 apr. 2015.

22 HART, H. L. A. The concept of law. 2. ed. New York: Oxford University, 1994. p.214. Available at: <http://nw18.american. $\mathrm{edu} / \sim \mathrm{dfagel} /$ Class $\% 20$ Readings/Hart/International $\% 20$ Law $\% 20$ Chapter $\% 20$ From $\% 20$ Concept $\% 20$ of $\% 20$ Law.pdf $>$. Accessed on: 3 apr. 2015.

23 HART, H. L. A. The concept of law. 2. ed. New York: Oxford University, 1994. p.236. Available at: <http://nw18.american. $\mathrm{edu} / \sim \mathrm{dfagel} /$ Class $\% 20$ Readings/Hart/International $\% 20 \mathrm{Law} \% 20$ Chapter $\% 20$ From $\% 20$ Concept $\% 20$ of $\% 20$ Law.pdf $>$. Accessed on: 3 apr. 2015. law, which is taken of the clear, standard example of what law is. The first has its roots deep in the conception of the law fundamentally as matter of orders backed by threats, and contrasts the character of the rules of international law with those of municipal law.The second form of doubt springs from the obscure belief that States are fundamentally incapable of being the subjects of the legal obligation, and contrasts the character of the subjects of international law with those of municipal law ${ }^{24}$.

More than criticism, the text of Jeremy Waldron appears to be, in reality, an expression of regret regarding the superficiality with which Hart depicted the international legal system in 1961. Much of the critical appraisal formulated by Waldron is explained by the fact that he is a contemporary author, who may refer to theories published and events occurred after Hart's work to base his assumptions. Amongst the examples, one could remark the operation and own life of Vienna Convention on the Law of Treaties (1969) or even a more outstanding performance of the International Court of Justice in recent decades. The complex processes leading to the emergence of other standing international courts after the 1960s at multilateral and regional levels are also plausible evidences to excuse Hart's arguable negligence or missing opportunity ${ }^{25}$.

24 HART, H. L. A. The concept of law. 2. ed. New York: Oxford University, 1994. p. 216. Available at: <http://nw18.american. edu/ dfagel/Class $\% 20$ Readings/Hart/International $\% 20$ Law $\% 20$ Chapter $\% 20$ From $\% 20$ Concept $\% 20$ of $\% 20$ Law.pdf $>$. Accessed on: 3 apr. 2015.

25 Previous to Hart, the old scholarship dealing with the foundations of philosophy of international law was inevitably influenced by monists and dualists. For instance, Eduard Dumbaud (DUMBAUD, Edward. The place of philosophy in international law. University of Pennsylvania Law Review, Philadelphia, v. 83, n. 5, p. 590-606, 1935. p. 606-607), resorted to Hans Kelsen and Dionisio Anzilotti to formulate his main claims: "International law is international; it is not the internal law of a super-state or of a multitude of states, a composite structure like "criminal law" or "contracts", a conglomeration of rules prevailing in many jurisdictions with respect to a common subject-matter. It is a universal unity, having its own constitution and community, made up of independent states. (2) That the fundamental norm is binding must be shown upon moral or political extralegal grounds.' Here may be considered the facts of international intercourse, the pressure of commercial needs and humanitarian desires'; (3) What the content of the fundamental norm is must be ascertained by observation. It includes the rule pacta sunt servanda; (4) The fundamental norm prescribes how law is to be made. Sources so referred to are convention, custom and general principles of law.'(5) International law sets the orbit within which states may exercise their jurisdiction. The doctrine that the jurisdiction of states is not unlimited, embracing the whole world, but has definite boundaries is one of the chief contributions of Anglo-American legal thought to the science of international law."; (6) International law is not the source of state law and power, but a limitation on it; just as states in the American union derive authority from their own constitutions but are curbed by the federal Constitution." If the monistic construction 
Hart recognizes that the analogies between domestic law and international law may in the future become more consistent. In his words:

Perhaps international law is at present in a stage of transition towards acceptance of this and other forms, which would bring it nearer in structure to a municipal system. If, and when, this transition is completed the formal analogies, which at present seem thin and even delusive, would acquire substance, and the skeptic's last doubts about the legal 'quality' of international law may then be laid to rest.

In his paper, Waldron argues against this perspective of absence of primary and secondary rules, stating, for example, that international law would comprise secondary rules, in line with Hart's concept of secondary rules. The difference is that these rules would not be exactly the same as those of municipal legal systems.Still, the very definition of secondary rules by Hart would nowadays be adjusted to international law ${ }^{26}$.

Waldron refers to the International Court of Justice as a basis to challenge Hart's assertion, sustaining that the court does not act as sole an arbitrator in its current decisions. The Court has a deep-rooted role in public international law, it has a continuous participation to the international norm setting, it achieved prestige among States and international organizations, and it passes significant decisions and is composed fairly evenly ${ }^{27}$.

Furthermore, Waldron mentions the distinct nature of law making in the international legal system, in comparison to municipal legal systems.Even though they operate differently and not in centralized manner, i.e., in a single body of legislative power, contractual and

bringing international law and the internal law of every state within the same legal system is to be preserved, it must be on the basis of common dependence upon a bigher norm."

26 "Hart's basic idea is quite simple.Primary rulesare rules of conduct; they tell you what you are legally obligated to do (or refrain from) and what consequences attach to obedience or disobedience. Thus, the criminal law rules that prohibit theft, forbid certain conduct and provide for penalties for violating the prohibition. Technically, the class of secondary rules includes everything except primary rules. The category ofsecondary rules includes legal rules that allow for the creation, extinction, and alteration of primary rules; these secondary rules arepower-conferringrules. Thus, contract law empowers individuals LEGAL theory lexicon.primary and secondary rules. Available at: <http://lsolum.typepad.com/legal_theory_lexicon/2004/06/legal_theory_le_2.html>. Accessed on: 5 apr. 2015.

27 WALDRON, Jeremy. International law: 'a relatively small and unimportant' part of jurisprudence? NYU School of Law, Public Law Research Paper n. 13-56, p. 209-223, Oct. 2013. p. 216. Available at: $<$ http://papers.ssrn.com/sol3/papers.cfm?abstract_id=2326758>. Accessed on: 5 apr. 2015. voluntary creation of obligations are also present in the negotiation and conclusion of treaties:

Individuals in the municipal order may enter into contracts, so states in the international order may enter into treaties and vary their obligations to one another accordingly.Such powers would be unintelligible if the international order were just the system a primary rules.So Hart is not entitled to infer - as he does - that the international order is just a system of primary rules (so far the legal change is concerned) from the fact that it has no parliament. ${ }^{28}$

Ruti Teitel also refutes the international law negative sustained by Hart. In her own words:

International law has been changing in directions
that arguably bring it closer, in its forms and ways
of operation, to domestic law. For example, this
can be said of international law's development of
processes and institutions of judicialization and
of the centralization of its sanctions. Even more
important, this can be said with regard to the degree
to which international law has emergent potential
for the kind of applicability and direct effect on
individuals that domestic law routinely displays. It
follows, therefore, that around the world, courts are
engaging more often with foreign sources in their
constitutional jurisprudence

Some conclusions can be drawn from these premises. Despite relying on different structures and forms of systematization for the creation and enforcement of obligations, this aspect does not imply that the international order and the internal order are necessarily disparate, neither impossible to complement one another. In fact, as it occurs in municipal law, the international order is comprised by rules produced by international agents, is shaped by previously determined and existing jurisdictions and by critical jurisprudence, either by a voluntary inclination or by consensus.

Another point argued by Waldron is that systemic legal orders are an element present in greater or lesser degree in any order entity, even in municipal legal syste$\mathrm{ms}^{30}$.According to the author's claims inHuman Rights:

28 WALDRON, Jeremy. International law: 'a relatively small and unimportant' part of jurisprudence? NYU School of Law, Public Law Research Paper n. 13-56, p. 209-223, Oct. 2013. p. 217. Available at: $<$ http://papers.ssrn.com/sol3/papers.cfm?abstract_id=2326758>. Accessed on: 5 apr. 2015.

29 TEITEL, Ruti G. Humanity's law. New York: Oxford University, 2011. p. 187-188.

30 WALDRON, Jeremy. International law: 'a relatively small and unimportant' part of jurisprudence? NYU School of Law, Public Law Research Paper n. 13-56, p. 209-223, Oct. 2013. p. 220. Available at: $<$ http://papers.ssrn.com/sol3/papers.cfm?abstract_id=2326758>. Accessed on: 5 apr. 2015. 
a Critique of the Raz. / Rawls Approach ${ }^{31}$, one could acknowledge a greater development of the international systematization of issues pertaining to fundamental rights, in particular with regard to a "human concern" approach,such as sustained by Joseph Raz and John Rawls $^{32}$ :

The human concern approach', rights are designated as human rights because they are rights whose violation is the proper concern of all humans. [...] For some adherents of the human concern approach, the relevant human concern about rights is not just a matter of disapproving of their violation. It is practical political concern: these theorists say that human rights are rights whose violations appropriately elicits action on the part of the rest of humanity against the violators. More specifically, views of this kind focus on the response of governments and international agencies. The idea is that we can define a class of rights such that no government, nor any other human agency or organization, is even required or permitted to say that the violation of one of these rights is none of their business, no matter where it occurs ${ }^{33}$.

This approach can be criticized due to other reasons, although it reasonable to agree with Waldron's belief that it can provide an interesting basis for the definition of human rights ${ }^{34}$.

Scott J. Shapiro and Ona A. Hathaway, in their paper entitled Outcasting: Enforcement in Domestic and International Law $w^{35}$, address the neglect of international law in Hart's theory and the question of whether or not international law is law.

31 WALDRON, Jeremy. Human rights: a critique of the raz/rawls approach. NYU School of Law, Public Law Research Paper, N. 13-32, June 2013. Available at: <http://papers.ssrn.com/sol3/papers. cfm?abstract_id=2272745>. Accessed on: 5 apr. 2015.

32 According to Waldron: WALDRON, Jeremy. Human rights: a critique of the raz/rawls approach. NYU School of Law, Public Law Research Paper, N. 13-32, June 2013. p. 3. Available at: < http://papers.ssrn.com $/$ sol3 $/$ papers.cfm?abstract_id $=2272745>$. Accessed on: 5 apr. 2015.

33 WALDRON, Jeremy. Human rights: a critique of the raz/rawls approach. NYU School of Law, Public Law Research Paper, N. 13-32, June 2013. p. 2. Available at: <http://papers.ssrn.com/sol3/papers. cfm?abstract_id $=2272745>$. Accessed on: 5 apr. 2015.

34 The author appears to be sympathetic, however, with the "human carrier approach" which purports human rights as those carried by and belonging to all individuals by virtue of their humanity. WALDRON, Jeremy. Human rights: a critique of the raz/rawls approach. NYU School of Law, Public Law Research Paper, N. 13-32, June 2013. p.2. Available at: <http://papers.ssrn.com/sol3/papers. cfm?abstract_id=2272745>. Accessed on: 5 apr. 2015.

35 HATHAWAY, Oona A; SHAPIRO, Scott J. Outcasting: enforcement in domestic and international law. Yale Law Journal, Connecticut, v. 1, n. 2, p. 252-349, Nov. 2011
Shapiro and Hathaway support that the traditional critique of international law is based on a limited and inaccurate understanding of law enforcement. Critics assume that a regime is law if this system relies on internal enforcement mechanisms of its own rules employing force and intimidation through violence to enforce their own rules. The authors call this conception of Modern State Conception ${ }^{36}$.

Shapiro and Hathaway assert the necessity to overcome this conception. In their words:

\begin{abstract}
We are able to see that allowing the Modern State Conception to set the terms of the debate over international law leads us to ask and answer the wrong questions. Yes, very little of international law meets the Modern State Conception of international law-very little (if any) of it is enforced through brute physical force deployed by an institution enforcing its own rules. But what is interesting is not so much what international law is not, but what it is. And that is law that operates almost entirely through outcasting and external enforcement. ${ }^{37}$
\end{abstract}

The authors recognize the importance to overcome the Modern State Conception in order to conceive an international legal order, and the concept of outcasting is fundamental in this attempt. Addressing the human rights field, they affirm that:

Human rights scholarship, in particular, has highlighted the ways in which states are sometimes publicly singled out for their violations of human rights laws as a nonviolent means of discouraging law-breaking behavior ${ }^{38}$.

\section{The realistic Challenge faced by Bucha- NAN AND GOLOVE: A RESPONSE THROUGH THE GLOBAL EXPANSION OF HUMAN RIGHTS}

In an attempt to discuss the possibilities of contemporary conception of a moral theory of international law, Buchanan and Golove face the challenges presented by the criticism already settled by realism. In his

36 HATHAWAY, Oona A.; SHAPIRO, Scott J. Outcasting: enforcement in domestic and international law. Yale Law Journal, Connecticut, v. 1, n. 2, p. 252-349, Nov. 2011. p. 258.

37 HATHAWAY, Oona A.; SHAPIRO, Scott J. Outcasting: enforcement in domestic and international law. Yale Law Journal, Connecticut, v. 1, n. 2, p. 252-349, Nov. 2011. p. 302.

38 HATHAWAY, Oona A.; SHAPIRO, Scott J. Outcasting: enforcement in domestic and international law. Yale Law Journal, Connecticut, v. 1, n. 2, p. 252-349, Nov. 2011. p. 309. 
analysis, Buchanan and Golove maintain that realism in its pure positivist facade is a descriptive and explanatory account of the nature of the international relations. The authors draw an implication called "meta-ethics" of the descriptive-explanatory theory, namely, that morality would not apply to international relations ${ }^{39}$.

However, most authors who are affiliated to a descriptive and explanatory approach assert an important moral inference, even when denying the application of moral principles to international relations in general the inference that State leaders should act on their own interests without regard to any moral constraint.

According to the views of two prominent theorists of legal realism who sought to analyze the international context, Jack L. Goldsmith and Eric Posner, States would act from political choices, thus being guided by a prudential bias. In line with this thought, international law could be seen by means of the states' self-interest, corroborated by political decision-making activities in a rational fashion. These choices represent a specific type of policy, which is based on precedent, tradition, interpretation and other practices and concepts that are familiar to domestic law ${ }^{40}$.

Buchanan and Golove maintain that, for realism, the nature of international relations excludes morality in this sphere. Hence, a moral theory of international law would be an exercise of futility ${ }^{41}$.

The authors distinguish a positive variant of realism, called "fiduciary realism", which describes the international relations as a Hobbesian state of war. Along with this view, responsible state officials should act only in order to maximize the survival prospects of their States, regardless of any moral constraints. Fiduciary realists are not moral, neither skeptical nihilists. They believe

39 BUCHANAN, Allen; GOLOVE, David. Philosophy of international law. In: COLEMAN, Jules L.; HIMMA, Kenneth Einar; SHAPIRO, Scott J. The Oxford handbook of jurisprudence and philosophy of law. Oxford: Oxford University, 2002. p. 868-934. p. 873.

40 According to Goldsmith and Posner: "It is politics, but a special kind of politics, one that relies heavily on precedent, tradition, interpretation and other practices and concepts familiar from domestic law". GOLDSMITH, Jack L.; POSNER, Eric A. The limits of international law.New York: Oxford University, 2005; and DWORKING, Ronald. A new philosophy for international law. Philosophy and Public Affairs, v. 41, n. 1, p. 2-30, Winter 2013. p. 202.

41 BUCHANAN, Allen; GOLOVE, David. Philosophy of international law. In: COLEMAN, Jules L.; HIMMA, Kenneth Einar; SHAPIRO, Scott J. The Oxford handbook of jurisprudence and philosophy of law. Oxford: Oxford University, 2002. p. 868-934. p. 873. that State officials have obligations to their people, but to obey these obligations they require the rejection of any moral restraint in relation with other States.Fiduciary realists disregard other moral principles besides the fundamental moral obligation, that is, to serve the interests of the State itself $f^{42}$.

Under this Hobbesian context, described by positive realism, international relations include the following features, according to the analysis of Buchanan and Golove:

a.There is no global sovereign, no supreme arbiter capable of enforcing rules of peaceful cooperation.b.There is (approximate) equality of power, such that no one state can permanently dominate all others;c.The fundamental preference of states is to survive; d.Given conditions (a) and (b), what is rational for each state to do is to strive by all means to dominate others in to avoid being dominated (to rely on what Hobbes calls 'the principle of anticipation'); .In a situation in which each party rationally anticipates that it is rational for others to dominate, without constraints on the means they use to do so, moral principles are inapplicable. ${ }^{43}$

Indeed, Goldsmith and Posner argue that the best explanation to understand when and why States obey the rules of international law would not be because the States internalized this law, or because they have the habit of acting in a specific way, or even supported by moral reasons, but simply because they act according to their own interests. ${ }^{44}$

According to Buchanan and Golove, the positivist realism assumes questionable empirical generalizations about the international sphere, while the fiduciary realism takes into account these empirical generalizations and concludes that the State authority will disregard any moral restraint in order to achieve the interests of the State. $^{45}$

42 BUCHANAN, Allen; GOLOVE, David. Philosophy of international law. In: COLEMAN, Jules L.; HIMMA, Kenneth Einar; SHAPIRO, Scott J. The Oxford handbook of jurisprudence and philosopby of law. Oxford: Oxford University, 2002. p. 868-934. p. 873.

43 BUCHANAN, Allen; GOLOVE, David. Philosophy of international law. In: COLEMAN, Jules L.; HIMMA, Kenneth Einar; SHAPIRO, Scott J. The Oxford handbook of jurisprudence and philosophy of law. Oxford: Oxford University, 2002. p. 868-934. p. 872.

44 GOLDSMITH, Jack L.; POSNER, Eric A. The limits of international law.New York: Oxford University, 2005. p. 225.

45 BUCHANAN, Allen; GOLOVE, David. Philosophy of international law. In: COLEMAN, Jules L.; HIMMA, Kenneth Einar; SHAPIRO, Scott J. The Oxford handbook of jurisprudence and philosophy of law. Oxford: Oxford University, 2002. p. 868-934. p. 874. 
Buchanan and Golove assert that most of the interesting work in international relations over the past two decades indicates that the international relations are not, in fact, a Hobbesian context of war of one against all.According to recent studies, there are stable patterns of peaceful cooperation and effective supranational regimes, some bilateral, some regional and some genuinely global in scope - including military alliances defense, financial systems, trade agreements, structures for scientific, environmental agreements and international media to human rights, economic development and disaster relief.

Furthermore, the ability to make credible commitments for peaceful cooperation is a valuable asset to the states and individuals. The techniques for building trust are varied and ubiquitous. According to Buchanan and Golove, survival is not an issue, not the only question, in various contexts of state interaction.States are also not equal in power and, as a result, their vulnerability is a concrete factor. Powerful states can take risks in an effort to build cooperation and they can minimize the risks acting in a cooperative manner, as the costs of betraying their trust may be great.

The moral minimalism, in turn, argues that the distinction between international law and national law is that the latter is comprised of a framework of rules for those who share the same purposes, while the former does not.However, as generally observed elsewhere, in a liberal society domestic public order cannot be based on shared purposes other than security and justice.So the moral minimalism must answer for what reason the lack of shared purpose precludes the normative theory of international law, but not a liberal domestic society.

The claim that there is a nuclear concept of justice capable of providing the basis for a theory of morally robust international law is an empirical claim about the extent of moral disagreement beyond the borders of States. It is possible to argue, however, that there is, in fact, a global culture expanding human rights, reflecting a growing consensus on a conception of justice based on the recognition of equality and freedom of all people and a fair conception of sovereignty susceptible to limitations. ${ }^{46}$.According to this view, the notion

46 In this sense, it is worth mentioning the Article 1 of the Universal Declaration of Human Rights: Art. 1:All human beings are born free and equal in dignity and rights. They are endowed with reason and conscience and should act towards one another in a spirit of brotherhood. UNITED NATIONS. The Universal Declaration of of equality and freedom expressed in the main human rights conventions may provide the basis for the development of a moral theory of international law, whose content is substantial.

In fact, the international legal system already includes principles, practices and institutions that are contributing to the emergence of a greater consensus on the content of human rights standards.For example, the various processes and mechanisms by which the enforcement of human rights has been monitored, including the operation of the UN Human Rights Council and Committees covering the 1966 Covenants on Civil and Political Rights and Economic, Social and Cultural Rights ${ }^{47}$. These processes contribute to the formation of broadly shared beliefs and certainty about the content of human rights.

On the other hand, it is important to notice that the emergence of a culture in the global expansion of human rights has flowered in the context of the consolidation of human rights in states constitutions. In this sense, United States constitution had a profound impact upon the development of international human rights law. Besides assisting in the clarification of these rights, the American constitution has helped to shape the norms found in the principal international human rights instruments ${ }^{48}$.

However, it is remarkable the differences between the provisions of the constitution and the international human rights instruments. Some rights expressly included in the international instruments are not found in the text of the American constitution and many others have far wider scope than their United States consti-

Human Rights. Available at: <http://www.un.org/en/documents/ udhr/>. Accessed on: 20 jan. 2015. In the 1930s, the scholarship recognized the emergent landscape for "humanitarian and social legislation" in international law and how this trend would be linked to the "end of law", such as contended by Edward Dumbaud, DUMBAUD, Edward. The place of philosophy in international law. University of Pennsylvania Law Review, Philadelphia, v. 83, n. 5, p. 590-606, 1935. p. 605: "Self-assertion and clinging to abstract legal rights can find no better illustration than that afforded by the dominant doctrine of state sovereignty in international law. Yet a growing mass of social and humanitarian legislation in the international field shows that the world is awake to the necessity of protecting social interests by means of legal machinery".

47 UNITED NATIONS HUMAN RIGHTS. United Nations Human Rights Council. Available at: <http://www.ohchr.org/en/hrbodies/hrc/pages/hrcindex.aspx>. Accessed on: 20 jan. 2015.

48 LILLICH, Richard B. The United States constitution and international human rights law. Harvard Human Rights Journal, London, v. 3, p. 53-81, Spring 1990. p. 56. 
tutional counterparts ${ }^{49}$. The argument advocated by Buchanan and Golove about the existence of a culture in global expansion of human rights is also evident in the transconstitutionalism theory addressed by Marcelo Neves $^{50}$. He argues that the human rights claim to be valid for the system legal world of multiple levels, so to any existing legal order in world society.

In this sense, the field of human rights, which was once seen as a domestic issue, today is addressed under multiple overlapping orders not only concentrated at the state level, but also at international, supranational, transnational and local levels.

James Griffin, writing about the autonomy of international law of human rights, argues that the transition process from human moral rights to positivized human rights is still ongoing and entails a return to the original ideas of lack of separation between law and moral. ${ }^{51}$

Marcelo Neves discusses the theory called by him "multidimensional transconstitutionalism of human rights" and places them on the border of the legal system, binding it to a moral inclusion and dissent:

It should be noted that the conditions for the emergence of human rights in modern society is related to the emergence of a structural dissent, concerning not only the plurality of communicational spheres with pretense of autonomy (systemic complexity), but also the heterogeneity of expectations, interests and values of individuals and groups.In this sense, it is defining the concept of human rights, to set it as normative expectations of generalized legal inclusion under conditions of structural dissent of society worldwide. Therefore, human rights are located on the border of the legal system, binding it to a moral of inclusion and dissent, which circulates with relevance in the global society of the present, in competition with other moral standards ${ }^{52}$.

In order to explain the multidimensional nature of human rights and the emergence of what Buchanan

49 LILLICH, Richard B. The United States constitution and international human rights law. Harvard Human Rights Journal, London, v. 3, p. 53-81, Spring 1990. p. 57.

50 NEVES, Marcelo. Transconstitucionalismo. São Paulo: M. Fontes, 2009. p. 253.

51 GRIFFIN, James. Human rights and the autonomy of international law. In: BESSON, Samantha;TASIOULAS, John.(Ed.). The philosophy of international law.New York: Oxford University, 2010. p. 339-356.

52 NEVES, Marcelo. Transconstitucionalismo. São Paulo: M. Fontes, 2009. p. 255. (free translation). and Golove call an expansion of the global culture of human rights, Marcelo Neves analyses an array of judicial cases that demonstrated that human rights issues permeate various legal systems.

In 2005, the U.S. Supreme Court ruled on Roper v. Simmons ${ }^{53}$, a case which discussed the possibility of applying the death penalty to a juvenile, taking into account the prohibition to cruel and unusual punishments established at Eighth Amendment of the American Constitution. ${ }^{54}$ After being sentenced to death by the jury, the Supreme Court,in a tight scrutiny (5-4), the death penalty was removed, having been argued in the vote ofJusticeAnthony Kennedy that the United States were alone in a world that has turned against the death penalty for juveniles. The decision, demonstrated the possibilities of coordination between national law and established practice outside the domestic sphere in the context of constitutional dialogue $e^{55}$.

At this point, it is worth mentioning that the Supreme Court decision had a great reverberation, resulting in the revocation of dozens of death sentences directed to individuals who committed crimes when they were still juveniles. This approach reveals how moral values conceived by the international community are penetrating domestic legal orders and rejects the critique of realist theory about the supposedly little exogenous influence of the human rights on state behavior ${ }^{56}$.

Marcelo Neves, discussing this case, also mentions the analysis of Jeremy Waldron on the issue.Waldron sees the decision of the American judges from the reconstruction of the old concept of jus gentium, indicating the formation of a set of knowledge that can be referenced each other.In the words of Marcelo Nevesin a free translation:

From this argument, Waldron argues that the citation of foreign and international law by the US Supreme Court should not be seen as a random practice in pieces unrelated, but as a model for

53 UNITED STATES. Supreme Court of the United States. Roper, Superintendent, Potosi Correctional Center vs. Simmons. n. 03-633. Available at: <http://www.deathpenaltyinfo.org/u-s-supreme-court-roper-v-simmons-no-03-633>. Accessed on: 20 jan. 2015.

54 NEVES, Marcelo. Transconstitucionalismo. São Paulo: M. Fontes, 2009. p. 257.

55 NEVES, Marcelo. Transconstitucionalismo. São Paulo: M. Fontes, 2009. p. 258.

56 POSNER, Eric; GOLDSMITH, Jack. L. The Limits of International Law. Oxford: Oxford University, 2005; and DWORKING, Ronald. A new philosophy for international law. Philosophy and Public Affairs, v. 41, n. 1, p. 2-30, Winter 2013. p. 133. 
action in connection network between various legal systems, for the solution common problems.

Another practical example that illustrates the expansion of global culture of human rights is the case Hazel Tau $\times$ Glaxo and Boehringer ${ }^{57}$,related to the claim access to medication to combat HIV before the Commission of the South African Competition.In this case, the decision of the South Antitrust Commission, based on national law, was favorable to the applicants, arguing that the excessive price of antiretroviral drugs is directly responsible for premature, predictable and avoidable deaths of people living with HIV, including both children and adults. ${ }^{58}$

It is clear, thereby, that in a matter of intellectual property, which brings elements of national, international and transnational law, it becomes even more clear the need to elevate the discussion to a point where they do not opt for a simple solution based on the prevalence of a particular legal system over another.Marcelo Neves treats this issue as follows, in a free translation:

In addition to lead to discussion of the problem
of the horizontal effects of fundamental rights in
the transnational context, surpassing the national
level, this discussion points to the intertwining
issues between regulatory orders. The simple
internationalist appeal to a generous interpretation
of the TRIPS agreement, or exclusive reliance
transnational model of self-regulation and, finally,
the argument by a final state solution based
on the sovereignty of the people, appear not
complex enough in such cases. The respective
orders legitimacy limits may not also be the last
argument to exclude them from the process of
finding a consistent solution and socially adequate.
Without theultima ratiopresent in any of the orders,
the solution regarding the transnational human
rights, in the case mentioned, shows that the
key is to restrictthe expansive nature of certain
legal orders over others (avoid the danger of the
dedifferentiation), as well how to limit the expansion
of regulatory orders and their organizations
working towards the expansion of the exclusion
and the destruction of the chemical the person
biopsychic support

Therefore, the distinction that Buchanan and Golove present about transnational justice principles - that

57 UNITED STATES. Supreme Court of the United States. Hazel Tau vs. Glaxo and Boehringer. Available at: <http://www.tac.org. za/Documents/DrugCompaniesCC/HazelTauAndOthersVGlaxoSmithKlineAndOthersStatementOfComplaint.doc $>$. Accessed on: 20 jan. 2016.

58 NEVES, Marcelo. Transconstitucionalismo. São Paulo: M. Fontes, 2009. p. 267. would be related to the rights and duties between members of the same state or between the government and the members of state should be recognized by international law as universal - it is possible to recognize that the progress of international law involves the expansion of transnational justice and the expansion of global culture of human rights has a decisive role $\mathrm{e}^{59}$ and 60.

Facing the humanity Law as an emerging transnational legal order, Vicki Jackson argues "we now live in a world of multiple legal orders where there is not centralization, or monopoly, or a hierarchy of interpretative authority, and where interpretative legitimacy is a concept that pertains to non-state actors as well" ${ }^{\prime 61}$.

\section{Final Remarks}

As it can be seen, the architecture of international law and the philosophy of law still have room for further development.The institutionalization of principles, the expansion of human rights and the case law of sedimentation in international courts have raised more reflection and discussion on this topic.

Increasingly, contemporary authors like Jeremy Waldron, Allen Buchanan and David Golove, among others, have been contributing to a review of juridical

59 BUCHANAN, Allen; GOLOVE, David. Philosophy of international law. In: COLEMAN, Jules L.; HIMMA, Kenneth Einar; SHAPIRO, Scott J. The Oxford handbook of jurisprudence and philosophy of law. Oxford: Oxford University, 2002. p. 868-934. p. 887.

60 According to Buchanan and Golove, the justification oh human rights can be presented as (1) principles whose effective institutionalization maximizes overall utility, (2) as required for the effectiveness of other important rights, (3) as needed to satisfy basic needs that are universal to all human beings, (4) as needed to nurture fundamental human capacities that constitute or are instrumentally valuable for well-being or human flourishing, (5) as required by respect for human dignity, (6) as the institutional embodiment of a 'common good conception of justice' according to which each member of society's good counts, (7) as required by the most fundamental principle of morality, the principle of equal concern and respect for persons, (8) as principles that would be chosen by parties representing individuals in a 'global original position' behind a 'veil of ignorance', and (9) as necessary conditions for the intersubjective justification of political principles and hence as a requirement for political legitimacy BUCHANAN, Allen; GOLOVE, David. Philosophy of international law. In: COLEMAN, Jules L.; HIMMA, Kenneth Einar; SHAPIRO, Scott J. The Oxford handbook of jurisprudence and philosophy of law. Oxford: Oxford University, 2002. p. 868-934. p. 889.

61 TEITEL, Ruti G. Humanity's law. New York: Oxford University, 2011. p. 187. 
and philosophical theories in vogue on the nature of international law.Whether due to State interests, whether to the advancement of the international organizations' agenda, this debate has also increased its attention to the issue in main international forums.

Although there is stillthe need for better understanding of the relationship between the various currents of international law and international relations, it is possible to understand that the expansion of human rights indicates from the outset the possibility of designing a moral theory within the framework of international law. The existence of a global culture expanding human rights is directly related to convergence towards a nuclear common conception of justice, and moral progress of international law through the improvement of institutionalization of the principles and by forming mechanisms that enable its effective application.

The international human rights are currently much more integrated with the consolidation of institutions as the Human Rights Council and the European Court of Human Rights. To the extent that it increases forms of access to international courts, converging regulatory regimes transnational in nature and advancing the performance of subjects and actors in the international order, there are also new conflicts and contradictions to the theorists of the philosophy of law, which comes to contribute to the determination of these concepts and inconsistencies.

\section{References}

BESSON, Samantha; TASIOULAS, John.Introduction. In: (Ed.). The philosophy of international law. New York: Oxford University, 2010. p. 1-32.

BUCHANAN, Allen; GOLOVE David. Philosophy of international law. In: COLEMAN, Jules L.; HIMMA, Kenneth Einar; SHAPIRO, Scott J. The Oxford handbook of jurisprudence and philosophy of law. Oxford: Oxford University, 2002. p. 868-934.

CERVO, Amado Luiz. Concepts in International Relations. Journal of International Politics, Basingstoke, v. 51, n. 2, p. 8-25, 2008. Available at: <http://www.scielo.br/ pdf/rbpi/v51n2/v51n2a02>. Accessed on: 5 apr. 2015.

DUMBAUD, Edward. The place of philosophy in international law. University of Pennsylvania Law Review, Philadelphia, v. 83, n. 5, p. 590-606, 1935.
DWORKING, Ronald. A new philosophy for international law. Philosophy and Public Affairs, v. 41, n. 1, p. 2-30, Winter 2013.

FINNIS, John. Natural law: the classical tradition. In: COLEMAN, Jules L., HIMMA, Kenneth; SHAPIRO, Scott. The Oxford handbook of jurisprudence and philosophy of law. Oxford: Oxford University, 2002. p. 1-39.

GOLDSMITH, Jack L.; POSNER, Eric A. The limits of international law.New York: Oxford University, 2005.

GRIFFIN, James. Human rights and the autonomy of international law. In: BESSON, Samantha;TASIOULAS, John.Introduction. (Ed.). The philosophy of international law.New York: Oxford University, 2010. p. 339-356.

HART, H. L. A. The concept of law. 2. ed. New York: Oxford University, 1994. Available at: <http://nw18. american.edu/ dfagel/Class\%20Readings/Hart/International $\% 20$ Law $\% 20$ Chapter $\% 20$ From $\% 20$ Concept $\% 20$ of\%20Law.pdf>. Accessed on: 3 apr. 2015.

HATHAWAY, Oona A; SHAPIRO, Scott J. Outcasting: enforcement in domestic and international law. Yale Law Journal, Connecticut, v. 1, n. 2, p. 252-349, Nov. 2011.

LEGAL theory lexicon.Primary and secondary rules. Available at: <http://lsolum.typepad.com/legal_theory_lexicon/2004/06/legal_theory_le_2.html>. Accessed on: 5 apr. 2015.

LILLICH, Richard B. The United States constitution and international human rights law. Harvard Human Rights Journal, London, v. 3, p. 53-81, Spring 1990.

NEVES, Marcelo. Transconstitucionalismo. São Paulo: M. Fontes, 2009.

TEITEL, Ruti G. Humanity's law. New York: Oxford University, 2011.

TESSON, Fernando R. Philosophy of international law. In: MAY, Larry; BROWN, Jeff (Ed.). Philosophy of law: classic and contemporary readings. Chichester: Wiley-Blackwell, 2010. p. 187-199.

UNITED NATIONS HUMAN RIGHTS. United Nations Human Rights Council. Available at: <http://www. ohchr.org/en/hrbodies/hrc/pages/hrcindex.aspx>. Accessed on: 20 Jan. 2015.

UNITED NATIONS. The Universal Declaration of $\mathrm{Hu}$ man Rights. Available at: <http://www.un.org/en/documents/udhr/>. Accessed on: 20 Jan. 2015. 
UNITED STATES. Supreme Court of the United States. Roper, Superintendent, Potosi Correctional Center vs. Simmons. n. 03-633. Available at: <http://www.deathpenaltyinfo.org/u-s-supreme-court-roper-v-simmonsno-03-633>. Accessed on: 20 Jan. 2015.

UNITED STATES. Supreme Court of the United States. Hazel Tau vs. Glaxo and Boehringer. Available at: <http://www.tac.org.za/Documents/DrugCompaniesCC/HazelTauAndOthersVGlaxoSmithKlineAndOthersStatementOfComplaint.doc $>$. Accessed on: 20 Jan. 2016.
WALDRON, Jeremy. Human rights: a critique of the raz/rawls approach. NYU School of Law, Public Law Research Paper, N. 13-32, June 2013. Available at: $<$ http://papers.ssrn.com/sol3/papers.cfm?abstract_ id $=2272745>$. Accessed on: 5 apr. 2015.

WALDRON, Jeremy. International law: 'a relatively small and unimportant' part of jurisprudence? NYU School of Law, Public Law Research Paper n. 13-56, p. 209223, Oct. 2013. Available at: <http://papers.ssrn.com/ sol3 $/$ papers.cfm?abstract_id $=2326758>$. Accessed on: 5 apr. 2015. 


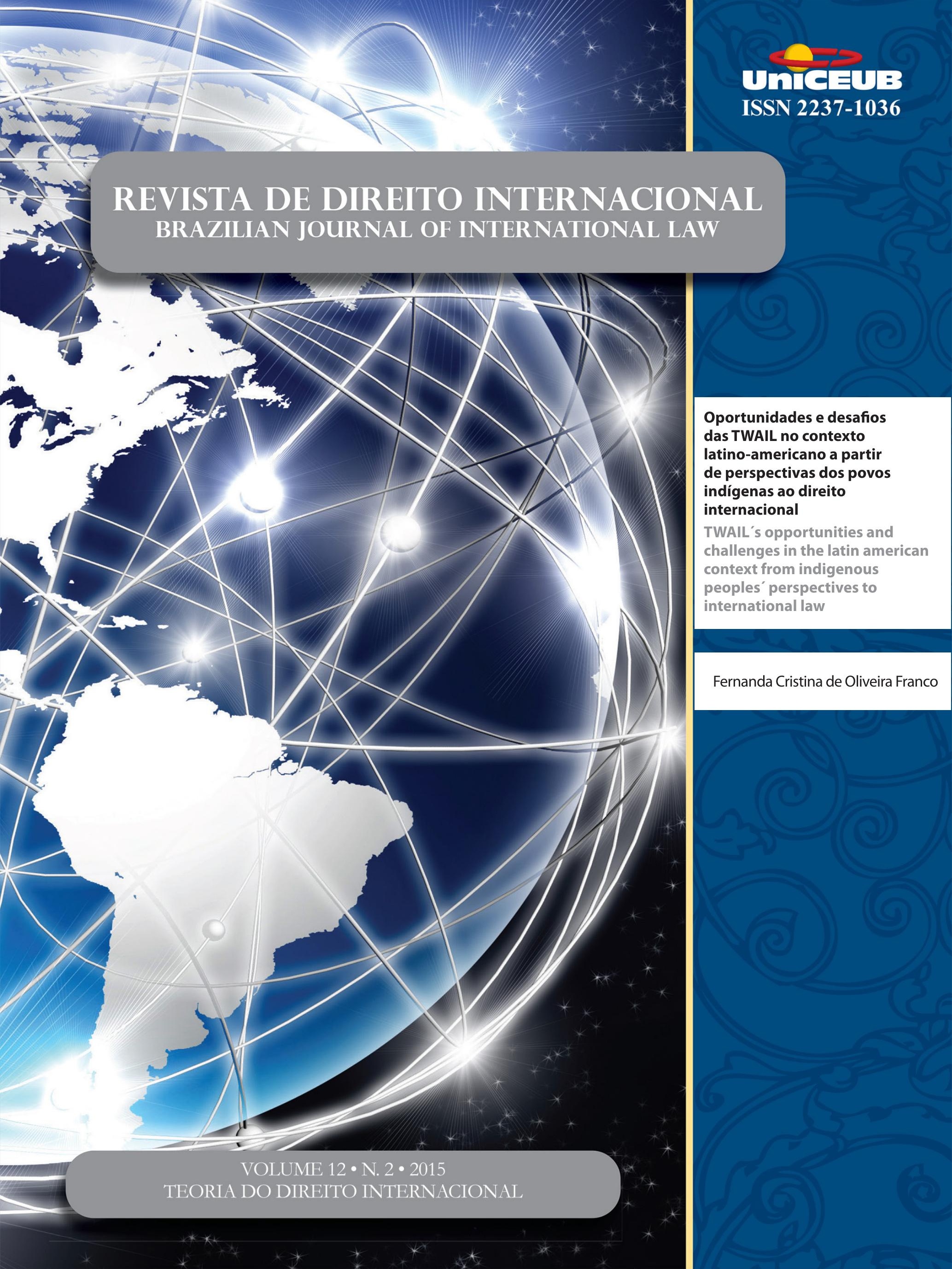




\title{
Oportunidades e desafios das TWAIL no contexto latino-americano a partir de perspectivas dos povos indígenas ao direito internacional*
}

\author{
TWAIL's opportunities and challenges in \\ the latin american context from indigenous \\ peoples' perspectives to international law
}

Fernanda Cristina de Oliveira Franco **

\section{Resumo}

As TWAIL são atualmente uma das mais destacadas abordagens críticas ao direito internacional. Paradoxalmente, tornaram-se elas próprias alvo de críticas, uma das quais aponta sua frágil consideração acerca do processo de marginalização dos povos indígenas perante o direito internacional. $\mathrm{O}$ presente artigo objetiva analisar oportunidades e desafios de releituras das TWAIL no contexto latino-americano com base em perspectivas dos povos indígenas ao direito internacional. A segunda parte resgata o marco dos estudos legais (pós)coloniais para ilustrar como os povos indígenas e do Terceiro Mundo se relacionaram com o direito internacional em momentos de formação e transformação da disciplina. A terceira, expõe peculiaridades e propósitos das TWAIL e a quarta considera em que medida os povos indígenas desafiam e oportunizam releituras das TWAIL no contexto latino-americano, especialmente por se tratar da região que abriga expressiva diversidade de povos, que assumem destacado protagonismo nas instâncias de direito internacional. A Corte Interamericana é comparativamente a que oferece pronunciadas decisões sobre direitos indígenas, mas, ainda assim, é região que prossegue compactuando com ações que violentamente afetam esses povos, especialmente diante da ofensiva da exploração dos recursos naturais nos territórios tradicionais. Conclui-se que a aproximação desses elementos é teoricamente pertinente e que o desafio não é apenas o de compreender as TWAIL, mas sobretudo reinterpretá-las sob o vislumbre de que possam expressar e aprimorar o potencial transformador e de realização da justiça que se constrói na América Latina por meio das expressões indígenas.

Palavras-chave: TWAIL. Estudos legais (pós)coloniais. Direitos dos povos indígenas. Corte Interamericana de Direitos Humanos. Direito internacional na América Latina.

* Recebido em 30/10/2015.

Aprovado em 02/12/2015

** Doutoranda em Direito pelo Programa de Pós-Graduação em Ciências Jurídicas da UFPB. Mestre pelo mesmo programa. Bacharel em Direito pela Universidade de São Paulo. E-mail: ffranco.cristina@gmail.com.

\section{Abstract}

The TWAIL are currently one of the most prominent critical approaches to international law. Paradoxically, they have become themselves target 
of criticism, one of which points out its fragile consideration of indigenous people's marginalization under international law. This article aims to analyze opportunities and challenges for TWAIL's readings in the Latin American context from an indigenous peoples' perspective to international law. The second part acknowledges the (post)colonial legal studies framework to illustrate how was the relationship between indigenous and Third World peoples in moments of international law`s formation and transformation. The third exposes TWAIL's peculiarities and purposes. The fourth discusses the extent to which indigenous peoples challenge and offer opportunities for TWAIL's readings in the Latin American context, especially because it is a region that is home of a significant diversity of peoples, who take prominent role in instances of international law. The Inter-American Court is comparatively the one that offers pronounced decisions on indigenous rights, but that, even so, it is a region that continues to condone actions that violently affect indigenous peoples, especially before the threat of natural resources exploitation at traditional territories. It concludes that bringing these elements closer is a theoretically pertinent move and that the challenge is to not only understand TWAIL but rather reinterpret them under the glimpse that they can express and enhance the transformative and justice achievement potential that are built in Latin America throughout indigenous expressions.

Keywords: TWAIL. (Post)colonial legal studies. Indigenous peoples rights. Inter-American Court of Human Rights. International law in Latin America.

\section{INTRODUÇÃo}

O estudo do direito internacional tem, ao longo do tempo, se complexificado devido à multiplicidade de atores e temas com que passa a dialogar, como também em razão da profusão de vertentes teóricas e metodológicas por meio das quais passa a ser investigado ${ }^{1}$. Tais

1 No final da década de 1990 foram catalogados os seguintes métodos de direito internacional: 1) positivismo legal; 2) Escola New Haven; 3) processo legal internacional; 4) estudos críticos legais; 5) direito internacional e relações internacionais; 6) abordagem feminista do direito internacional e 7) law and economics. Conforme RATNER, Steven; SLAUGHTER, Anne-Marie. Symposium on method in international law: appraising the methods of international law: a prospectus for readers. American Journal of International Law, Washington, v. 93, n. 2, p. 291-302, 1999. análises permitem tanto reforçar leituras tradicionais do passado como também contrariar ou desconcertar interpretações estabelecidas por essas mesmas leituras. Essa última maneira de enfocar a disciplina é característica das abordagens críticas ao direito internacional, que buscam ressignificar seus principais fundamentos e doutrinas de forma a que se torne mais justo para aqueles que normalmente dele estiveram excluídos ou marginalizados ${ }^{2}$.

Uma das abordagens críticas que ultimamente tem expandido sua influência nas análises do direito internacional são as chamadas Abordagens do Terceiro Mundo ao Direito Internacional (Third World Approaches to International Law - TWAIL), cujas leituras miram a disciplina de forma provocativa a seus fundamentos clássicos, questionando suas heranças ortodoxas e, principalmente, tornando críticas as narrativas que reduziram os povos do Terceiro Mundo ${ }^{3}$ a objetos de dominação e poder. Uma de suas principais influências são os estudos (pós)coloniais ${ }^{4}$. Sob tal orientação, as TWAIL consideram em que medida as realidades coloniais e imperiais $s^{5}$ do direito internacional forjaram seus fundamentos, bem como de que modo suas principais doutrinas trataram de excluir e marginalizar o conhecimento e as formas organizativas dos povos não europeus domi-

2 GALINDO, George Rodrigo Bandeira. Para que serve a história do direito internacional? Revista de Direito Internacional, Brasília, v. 12, n. 1, p. 338-354, 2015. p. 343-345.

3 O termo Terceiro Mundo é atribuído originalmente a Alfred Sauvy, economista e jornalista anti-colonialista francês. Em geral, a denominação foi usada para designar um grupo de Estados "menos desenvolvidos" economicamente quando em comparação aos países do chamado Primeiro Mundo. O Segundo Mundo foi termo usado para designar os países alinhados ao bloco do regime comunista soviético da época. SAUVY, Alfred. Trois mondes, une planete. L'observateru, Paris, n. 118, p. 14, 14 aout 1952. Disponible dans: <http://www.homme-moderne.org/societe/demo/ sauvy/3mondes.html>. Accès: 06 out. 2015.

4 Nos debates iniciais sobre a terminologia adequada para nomear este campo de estudos, foram profusas as discussões e controvérsias geradas pelo uso do prefixo "pós", vez que indicaria a superação do colonialismo, constatação equivocada para muitos que alegavam a persistência das relações coloniais. Para ilustrar essa controvérsia, utiliza-se aqui o "pós" entre parêntesis. Veja KUMAR, Vidya S. A. A proleptic approach to postcolonial legal studies? a brief look at the relationship between legal theory and intellectual history. Law, Social Justice and Global Development Journal, n. 2, 2003. p. 03. Available in: <https://www2.warwick.ac.uk/fac/soc/law/elj/lgd/2003_2/ kumar>. Access: Jan. 22, 2016.

5 Para Edward Said, o colonialismo seria sempre a consequência do imperialismo, razão pela qual apresentam-se como conceitos interligados, correlatos e decorrentes. SAID, Edward W. Cultura e imperialismo. Trad. Denise Bottmann. São Paulo: Companhia das Letras, 2011. p. 42. 
nados durante a expansão colonial. Ao mesmo tempo, acabam por revelar como a participação desses povos inferiorizados no processo colonial foi fundamental em momentos de formação e transformação da disciplina.

Entretanto, ainda que as TWAIL tenham elaborado críticas cada vez mais reconhecidas pela comunidade acadêmica internacional, também têm sido elas próprias alvo de críticas, que atestam, por exemplo, não terem avançado para além da crítica, ou mesmo não terem considerado apropriadamente a posição marginal ou a situação de exclusão a que diversos grupos como mulheres, camponeses, povos indígenas e tribais foram submetidos no direito internacional ${ }^{6}$. Por essa razão, atualmente se encontram desafiadas a reformular a abrangência do conceito Terceiro Mundo para que comporte toda a diversidade e pluralidade que lhe é inerente. Particularmente, alega-se que, embora tenham discutido o problema da diferença cultural no contexto do encontro colonial, elas não articularam a noção, categoria e voz dos povos indígenas de forma satisfatória ou apropriada ${ }^{7}$.

De fato, historicamente as TWAIL construíram diálogos mais estreitos com os contextos africanos e asiáticos e apenas recentemente começam a ser discutidas por internacionalistas da região latino-americana. A América Latina, por sua vez, é a região no mundo na qual os povos indígenas representam relevante sujeito marginalizado que, apesar dos pesares, conquistou marcos de reconhecimento normativo e instâncias de participação política nas estruturas do direito internacional regional e global ${ }^{8}$. O protagonismo dos povos indígenas

6 Veja descrição sucinta das críticas às TWAIL em: CUMBERLAND, Emily. Call for Submissions for Symposium on Third World Approaches to International Law (TWAIL). Washington: American Society of International Law, March 2015. Available in: < http://www.asil. org/blogs/call-submissions-symposium-third-world-approachesinternational-law-twail>. Access: Jan. 22, 2016.

7 MUNARRIZ, Gerardo J. Rhetoric and reality: the world bank development policies, mining corporations, and indigenous communities in Latin America. International Community Law Review, v. 10, p. 431-443, 2008. p. 442.

8 Os dois instrumentos normativos globais sobre povos indígenas são a Convenção 169 da OIT e a Declaração das Nações Unidas sobre os direitos dos povos indígenas (DDPI). Dentre os órgãos das ONU dedicados à questão indígena destaque-se o Fórum Permanente das Nações Unidas sobre questões indígenas (UNPFII); A Relatoria Especial sobre os povos indígenas e o Mecanismo de Peritos. Regionalmente na OEA, há a Relatoria Regional sobre os Povos Indígenas e o sistema de petições do Sistema Interamericano de Direitos Humanos. Discute-se ainda regionalmente o texto da Declaração Americana sobre o Direito dos Povos Indígenas, com participação direta dos povos indígenas na discussão do texto. latino-americanos na construção do arcabouço normativo internacional que lhe é pertinente é reconhecido globalmente, considerando-se inclusive que esta contribuição afetou a forma como o direito internacional passou a ser aplicado aos povos indígenas do mundo todo?

Jurisdicionalmente, a Corte Interamericana de direitos humanos é órgão com decisões pronunciadas acerca dos direitos indígenas, mais do que qualquer outra Corte Internacional, o que leva à constatação de que, quando comparada a outras regiões do mundo, esta tomou a dianteira no reconhecimento legal dos direitos indígenas, pelo menos em termos normativos ${ }^{10}$. Entretanto, as violações a seus direitos prosseguem ocorrendo especialmente em razão da continuidade de um tipo contemporâneo de colonialismo extrativista ${ }^{11}$ que não encontra obstáculos para a exploração dos recursos naturais, cujas maiores reservas ainda existentes encontram-se justamente nos territórios tradicionais.

Diante dessas considerações, o presente artigo objetiva analisar oportunidades e desafios de releituras das TWAIL no contexto latino-americano considerando, para tanto, perspectivas dos povos indígenas ao direito internacional. Parte dos estudos (pós)coloniais, um dos principais marcos conceituais de influência das TWAIL, para destacar de que forma os povos colonizados participaram, ainda que, em posição marginal e excludente, em dois momentos históricos distintos de formação e transformação das principais doutrinas do direito internacional. A segunda parte do artigo aprofunda o estudo sobre as características e propósitos das TWAIL, a fim de entender com mais propriedade essa escola crítica, teórica e metodológica de direito internacional. Por fim, a terceira parte analisa em que medida o contexto latino-americano desafia e oportuniza a aproximação

9 ENGLE, Karen. The elusive promise of indigenous development: rights, culture, strategy. Durham: Duke University, 2010. p. 01.

10 Veja por exemplo, DULITZKY, Ariel E. Quando os afrodescendentes se tornaram "povos tribais": o sistema interamericano de direitos humanos e as comunidades negras rurais. Meritum, Belo Horizonte, v. 6, n. 2, p. 57-138, jul./dez. 2011. Veja também PASQUALUCCI, Jo M. International Indigenous Land Rights: a critique of the Jurisprudence of the Inter-American Court of Human Rights in light of the United Nations Declaration on the Rights of Indigenous Peoples. Wisconsin International Law Journal, v. 27, n. 01, p. 51-98, 2009.

11 Sobre as diversas tipologias do colonialismo, consulte SHOEMAKER, N. A Typology of Colonialism. Available in: <http://historians.org/publications-and-directories/perspectives-on-history/ october-2015/a-typology-of-colonialism\#.VinyWqK7OG4.facebook>. Access: Oct. 24, 2015. 
das TWAIL e povos indígenas, argumentando que essa releitura deve ir além de mera transposição das TWAIL ao contexto. Ao contrário, a tarefa é reinterpretá-las de forma a que sejam capazes de expressar e aprimorar o potencial transformador e de realização da justiça que se constrói na região por meio das expressões indígenas.

\section{INFLUÊNCIAS DOS POVOS COLONIZADOS EM MOMENTOS DE FORMAÇÃO E TRANSFORMAÇÃO DO DIREITO INTERNACIONAL}

\subsection{0 encontro entre o nativo americano e o conquistador espanhol: formação}

As análises (pós)coloniais ao direito internacional, consideradas sob o ponto de vista histórico, são relativamente recentes. Comparadas às ciências sociais em geral, a influência desses estudos no direito se deram tardiamente. Para alguns, esse envolvimento tardio seria surpreendente, visto ser impossível desconsiderar que o direito foi a frente de batalha na relação colonial. Por outro lado, apontam ser tal distanciamento compreensível, na medida em que destrinchar os aspectos da relação entre direito e (pós)colonialismo poderia inconvenientemente romper com interpretações jurídicas consolidadas ${ }^{12}$. Sob a influência de tais estudos, identifica-se que a história da relação entre direito internacional e o mundo não europeu é importante porque, por meio dela, é possível demonstrar em que medida os povos colonizados influenciaram no processo de desenvolvimento de uma série de doutrinas de direito internacional, destacando como foram criadas justamente por meio desse encontro ${ }^{13}$.

Oferecem novos parâmetros de análise à disciplina, partindo do entendimento de que há um ethos eurocêntrico que marca suas origens ${ }^{14}$. Esse ethos eurocêntrico

12 FITZPATRICK, Peter; DARIAN-SMITH, Eve. The laws of the postcolonial: an insistente introduction. In: (Eds.) Laws of the Postcolonial. Ann Arbour: University of Michigan Press, 1999. p. 1-18. p.10.

13 ANGHIE, Antony; CHIMNI, B. S. Third world approaches to international law and individual responsability in internal conflicts. Chinese Journal of International Law, v. 2, n. 1, p. 77-103, 2003. p. 84.

14 ESLAVA, Luis; PAHUJA, Sundhya. Beyond the (post)colonial: TWAIL and the everyday life of international law. Journal of Law and Politics in Africa, Asia and Latin America, v. 45, n. 2, p. 195-221, 2012. p.196. teria reforçado para que práticas, identidades e formas organizativas de sociedades não europeias permanecessem de fora dos principais fundamentos do direito internacional ${ }^{15}$. Nesse sentido, os internacionalistas que focam suas análises nas perspectivas (pós)coloniais adotam abordagem diferente da positivista, tendo como principal preocupação mostrar como o direito internacional positivista subordinou povos não europeus, bem como identificar de que forma teria sido utilizado como instrumento que legitimou a expansão do império europeu por meio do regime colonial ${ }^{16}$.

Uma das análises a que os estudos legais (pós)coloniais dão curso mostra como os nativos americanos foram, desde o momento do encontro do conquistador espanhol, excluídos do reino da soberania, destituídos, assim, do requisito fundamental para fazer parte da sociedade das nações. Por outro lado, destacam como foram eles a principal contraparte em oposição à qual o embrião do direito internacional (o jus gentium) foi gerado. Revelam, ainda, como a polarização entre o eu (o colonizador, por quem e para quem o direito internacional é feito) e o outro (os povos colonizados e excluídos do direito internacional) justificou o ímpeto de verdadeira missão civilizatória sobre o outro indígena, cujo objetivo era transformar os nativos em civilizados e cristãos, para que, a partir de então, pudessem ser integrados à comunidade das nações, à imagem e semelhança do $e$.

Curiosamente, é com atenção às considerações a respeito do outro indígena que os teólogos espanhóis da Universidade de Salamanca ${ }^{17}$, considerados por muitos internacionalistas como os precursores do direito internaciona ${ }^{18}$, estabeleceram as bases do que viria a se tornar o direito internacional. Rompendo com interpretações tradicionais, tais teólogos advogaram em defesa dos indígenas, insistindo em sua humanidade, bem

15 ANGHIE, Antony. The evolution of international law: colonial and postcolonial realities. Third World Quaterly, v. 27, n. 5, p. 739-753, 2006. p. 739.

16 ANGHIE, Antony. Finding the peripheries: sovereignty and colonialism in nineteenth-century international law. Harvard International Law Journal, v. 40, n. 1, p. 01-71, 1999. p. 01-04.

17 Dentre eles destaque-se os escritos de Bartolomé de Las Casas (1484-1566), Francisco de Vitória (1483/92-1546) e Domingo de Soto (1494-1560), que contribuíram cada qual à sua maneira e em diferentes posições políticas para construir a diferença colonial e configurar tanto os interesses dos nativos como o dos espanhóis na relação colonial.

18 KOSKENNIEMI, Martti. Empire and International Law: The Real Spanish Contribution. University of Toronto Law Journal, v. 61, p. 01-36, 2011. p. 04. 
como em seus direitos de propriedade e jurisdição. Em sua célebre lição De Indies et de Jure Belli (Os Índios e o Direito da Guerra), Francisco de Vitória argumenta que, mesmo levando em conta a suposição de que os índios fossem ineptos e rudes, mesmo assim não haveria justificativas para negar-lhes o domínio, tampouco declará-los como escravos ${ }^{19}$.

Alguns internacionalistas mais modernos ${ }^{20}$ admiraram o impulso humanitário das preleções dos teólogos espanhóis e sua propensão em discutir o império à luz do direito natural e das nações. Entretanto, acima de tudo, foram admirados por defenderem o direito dos indígenas simultaneamente ao estabelecimento de regras para o comércio espanhol e o proselitismo nos novos territórios conquistados, o que seria um caso exemplar de tomada de consciência contra os excessos causados por seu próprio país, ao mesmo tempo de expressa defesa do movimento de expansão colonial ${ }^{21}$.

Anthony Anghie, autor ligado às TWAIL, ao tecer sua crítica às lições de Vitória afirma que o teólogo não estava tão interessado no problema da ordem entre dois Estados soberanos, mas antes com o problema da criação de ordem entre duas sociedades pertencentes a dois sistemas culturais diferentes. Esta sim, a diferença cultural, teria sido crucial para a versão de soberania de Vitória, que atestou que os indígenas não seriam soberanos em razão de serem não civilizados e não cristãos ${ }^{22}$.

Dessa forma, a ausência do reconhecimento da diferença cultural precede e formata profundamente a doutrina da soberania, que, tradicionalmente, indica que uma soberania já estabelecida lide com o problema da diferença cultural internamente ${ }^{23}$. Consequentemente,

19 VITÓRIA, Francisco de. Os índios e o direito da guerra. Trad. Ciro Mioranza. Ijuí: Editora Ijuí, 2006. (Clássicos do Direito Internacional). p. 58.

20 Nomeadamente James Scott Brown. Uma das mais renomadas figuras do moderno direito internacional, James Brown Scott (18661943) publicou o livro "The Spanish Origin of International Law. Francisco De Vitoria and His Law of Nations", de 1934, sustentando que as doutrinas de Vitória são, na verdade, o primeiro trabalho a abordar o direito das nações, que viria a ser o direito internacional do mundo cristão e do mundo em geral.

21 KOSKENNIEMI, Martti. Empire and International Law: the real spanish contribution. University of Toronto Law Journal, v. 61, p. 01-36, 2011. p. 02-04.

22 ANGHIE, Antony. Francisco de Vitoria and the colonial origins of international law. Social and Legal Studies, London, v. 5, n. 3, p. 321-336, 1996. p. 332.

23 ANGHIE, Antony. The evolution of international law: colonial and postcolonial realities. Third World Quaterly, v. 27, n. 5, p. 739-753, 2006. p. 742 . as diferenças culturais foram relegadas ao âmbito interno dos Estados soberanos, ficando a ordem internacional "livre" de enfrentar tal problema. Isso afetou, profundamente, não só o direito internacional e seu inadequado tratamento à questão da diferença cultural, como também aos povos indígenas, engolidos que foram pelos Estados nacionais, ficando sujeitos e submetidos ao exercício da soberania de cada Estado-nação.

Por essa razão, Anghie atesta que a construção de Vitória, que identifica o outro como bárbaro, cria um objeto contra o qual a soberania pode expressar seu total poder, perpetrando violência não mediada, justificada como meio de conversão, salvação e civilização do nativo contra ele mesmo ${ }^{24}$. Afirma, ainda, Anghie que, decidindo-se pelo mundo colonial como não soberano, o direito internacional teria criado por si mesmo o grande projeto de trazer o mundo marginalizado ao reino da soberania, civilizando o incivilizado e desenvolvendo técnicas jurídicas e instituições necessárias para essa grande missão civilizatória. Em última análise, essa construção revelaria como o vocabulário do direito internacional, longe de ser neutro e abstrato, seria baseado na história de subordinação e marginalização de culturas nativas ${ }^{25}$.

Note-se ainda que, na história do direito internacional, tornar o outro civilizado significou torná-lo de acordo com a imagem dos europeus sobre si mesmos, revelando nesse caso o direito internacional como produto da história e da cultura europeia, incluindo os não europeus num universo de conceitos europeus ao afastar qualquer forma de identidade nativa ${ }^{26}$. Como resultado, os povos indígenas e suas formas particulares de organização ficaram de fora das principais doutrinas do direito internacional, como a da soberania ${ }^{27}$ e da nacionalida-

24 ANGHIE, Antony. Francisco de Vitoria and the colonial origins of international law. Social and Legal Studies, London, v. 5, n. 3, p. 321-336, 1996. p. 333.

25 No original, o autor usa o termo extinção de "culturas alienígenas" (alien cultures), que parece impróprio a nosso ver, pois inverte o lugar de fala, já que, do ponto de vista do nativo, do indígena, o que se extinguiu não foram as culturas alienígenas, como menciona o autor, mas sim as culturas indigenas. ANGHIE, Antony. Francisco de Vitoria and the colonial origins of international law. Social and Legal Studies, London, v. 5, n. 3, p. 321-336, 1996. p. 333.

26 KOSKENNIEMI, Martti. The gentle civilizer of nations: the rise and fall of international law 1870-1960. Cambridge: Cambridge University, 2004. p. 127-135.

27 Segundo Anghie, a doutrina da soberania consistiu em parte dos mecanismos que expulsaram sociedades não europeias do reino da soberania e poder. ANGHIE, Antony. Finding the peripheries: sovereignty and colonialism in nineteenth-century international law. 
$\mathrm{de}^{28}$, ocupando desde sempre posição marginal nas relações internacionais, cujos efeitos são sentidos até hoje.

\subsection{O encontro do direito internacional com o Terceiro Mundo: transformação}

Se o momento do encontro entre o nativo americano e o conquistador espanhol é considerado o início do período colonial, seu término é identificado com o período do pós-Segunda Guerra Mundial, momento em que antigas colônias, sobretudo na África e na Ásia, paulatinamente adquiriram autonomia política e soberania nacional, libertando-se da dominação colonial. Assim, a partir da década de 1950 e com maior ênfase nas décadas de 1960 e 1970, o direito internacional é cobrado a regular, para muito além das tradicionais questões sobre o uso da força, guerra e paz, novo e amplo universo trazido pela entrada na sociedade das nações de novos Estados oriundos do Terceiro Mundo. Revela-se um direito internacional inadaptado frente à nova realidade, que cobrava transformações para que fosse capaz de responder aos novos desafios.

Atente-se que, até então, o direito internacional havia congregado Estados europeus mais ou menos equitativos, tendo como principal intuito a preservação da 'civilização' e dos estados cristãos ${ }^{29}$. Todavia, com a entrada dos países do Terceiro Mundo na sociedade das nações, esse balanço equitativo entre os Estados foi rompido e as condições entre os membros da comunidade internacional se tornou bastante heterogênea. Assim, o direito internacional não se adequava mais como produto de determinada comunidade histórica (europeia), composto por membros com níveis comparáveis de desenvolvimento, mas ao contrário, desiguais e diversos, situação diante da qual não tinha repertório, tampouco instrumentos adequados para lidar ${ }^{30}$.

Harvard International Law Journal, v. 40, n. 1, p. 01-71, 1999. p. 741.

28 Para que o formato da nação se tornasse universal foram feitos diversos esforços, de modo a assegurar que formas não nacionais de organização política e social fossem mantidas como não universais, tanto para permitir sua dominação como para manter sua inclusão como não sujeitos de direito. Veja PAHUJA, Sandhya. The postcoloniality of international law. Harvard International Law Journal. v. 46, n. 2, p. 459-469, summer 2005. p. 463.

29 SHAW, Malcolm N. International law. 6. ed. Cambridge: Cambridge University, 2008. p. 27.

30 FLORY, Maurice. Adapting international law to the development of the Third World. Journal of African Law, v. 26, p. 12-20, 1982. p. 15.
Alegava-se que a mais importante diferença e que mais afetaria o papel do "novo" direito internacional da época seria a desigualdade entre estágios de crescimento econômico dos "velhos" e "novos" Estados, despontando o desenvolvimento como tema predominante do moderno direito internacional. Ademais, proliferaram-se métodos e canais legais que teriam como objetivo a consolidação de uma ordem legal internacional estável, sendo do interesse dos Estados mais fracos do Terceiro Mundo estabelecer tais canais legais, mais do que canais puramente políticos, uma vez que estariam claramente em larga desvantagem nesses últimos ${ }^{31}$.

Em razão dessas novas formas de resolução de conflitos, o direito internacional tornou-se alvo privilegiado de juristas do Terceiro Mundo, especialmente porque, a partir de então, as injustiças poderiam ser resolvidas no âmbito das relações e do direito internacional. Nessa esteira, ganharam impulso estudos legais de internacionalistas que passaram a advogar em defesa dos interesses dos povos do Terceiro Mundo. Delineia-se período histórico expressivo na configuração de vertente emancipatória da disciplina, já que, durante esse momento, adquire um duplo caráter, transformando gradualmente sua função de instrumental jurídico exclusivamente de regulação para um instrumental jurídico também e, sobretudo, de libertaçã $0^{32}$.

De modo geral, diversas foram as reivindicações dos países do Terceiro Mundo, contribuindo para dar densidade e novos contornos a princípios previamente existentes, como por exemplo o da autodeterminação e da soberania permanente sobre os recursos naturais, bem como lançando as bases de um novo direito: o direito ao desenvolvimento ${ }^{33}$. Ainda, pleiteando a instauração de uma nova ordem econômica internacional (NOEI) ${ }^{34}$,

31 FATOUROS, A. A. International law and the third world. Virginia Law Review, v. 50, n. 05, p. 783-823, jun. 1964. p. 791.

32 CANÇADO TRINDADE, Antônio Augusto. A bumanização do direito internacional. Belo Horizonte: Del Rey, 2006. p. 110.

33 No direito positivo, o direito ao desenvolvimento encontra-se previsto na Declaração do Direito ao Desenvolvimento. Assembleia Geral da ONU Resolução 41/128. UNITED NATIONS. Declaration on the Right to Development. 4 Dec. 1986. Available in: <http://www. un.org/documents/ga/res/41/a41r128.htm>. Access: Feb. 4, 2016. 34 A Declaração para o Estabelecimento de uma Nova Ordem Econômica Internacional (NOEI) foi adotada pela Assembleia Geral das Nações Unidas em 1974 e cobrou uma reestruturação da ordem internacional em direção a uma maior equidade para os países em desenvolvimento. Documento UNITED NATIONS. Declaration on the Establishment of a New International Economic Order. May. 1974. Available in: <http://www.un-documents.net/s6r3201.htm>. Access: Feb. 4, 2016. 
que fosse capaz de proteger a independência e soberania dos novos Estados. Sublinhe-se, contudo, não se tratar de repúdio à ordem jurídica já existente, mas sim de reivindicações por transformações situadas no interior da ordem jurídica já existente ${ }^{35}$.

Dentre diversos resultados, os novos formatos normativos reivindicados pelo Terceiro Mundo acabaram por fortalecer no direito internacional a categoria coletiva dos povos, sendo que tanto os direitos à autodeterminação, à soberania permanente sobre os recursos naturais e ao desenvolvimento firmaram-se muito mais como direito dos povos do que como direito dos Esta$\operatorname{dos}^{36}$. Nesse sentido, conforme afirma Baxi, a partir de então a reformulação do direito internacional contemporâneo não pôde mais ser entendida apenas como a história do direito das nações (law of nations) à completa exclusão do direito dos povos (law of peoples) ${ }^{37}$.

Os teóricos responsáveis por argumentos traçados desde a perspectiva dos interesses do Terceiro Mundo são considerados os precursores das Abordagens do Terceiro Mundo ao Direito Internacional (TWAIL) ${ }^{38}$. Suas análises enfatizaram que o direito internacional não era estranho aos países pré-coloniais do Terceiro Mundo, ainda que nunca tivessem tido contato prévio com o direito internacional eurocêntrico. Identificaram para isso rico corpo de doutrina e princípios nos sistemas legais e culturais de países colonizados que faziam

35 BUIRETTE-MAURAU, Patricia. La participation du Tiers-Monde a l'elaboration du droit international. Paris: Librairie Générale de Droit et de Jurisprudence, 1983. p. 19-35.

36 Para uma visão crítica a respeito do direito dos povos, veja CRAWFORD, James. The rights of peoples: 'peoples' or 'governments'? In: _ (Ed). The rights of peoples. Oxford: Oxford University, 2001. p. 55-68. p. 56. O autor problematiza a questão ao indagar se o direito internacional teria tomado para si a tarefa de conferir direito a grupos e comunidades contra os Estados que essas pessoas constituem e contra os governos destes mesmos Estados. Isso porque, para o autor, se a frase direito dos povos tiver algum significado independente, ele deve conferir direitos aos povos contra seus próprios governos, o que soaria problemático para a estrutura clássica do direito internacional.

37 BAXI, Upendra. What may the 'Third World' expect from international law? Third World Quarterly, v. 27, n. 5, p. 713-725, 2006. p. 720 .

38 Dentre os teóricos da TWAIL I, cujos trabalhos remontam à década de 1970, encontram-se por exemplo Mohammed Bedjaoui, Upendra Baxi, R.P. Anand, T.O. Elias, dentre outros. O próprio pioneiro na defesa do Direito ao Desenvolvimento como direito humano, o jurista senegalês Keba M’Baye, pode ser tido também como representante deste grupo, na medida em que, já na década de 1970 defendia, por meio da afirmação do direito internacional ao desenvolvimento, os interesses das antigas colônias africanas durante o processo de descolonização. alusão a regras de diálogo e negociações entre nações ${ }^{39}$. Constituem assim o que a doutrina nomeia de fase I das TWAIL ou TWAIL I.

\section{As ABORDAGENS DO TERCEIRO MUNDO AO DI- REITO INTERNACIONAL}

Nas últimas décadas, as escolas de direito internacional se diversificaram, surgindo, basicamente, duas grandes tendências opostas, uma delas reconhecida como corrente majoritária (mainstream) e outra cuja proposta celebra a busca por novas formas de abordar o direito internacional que não aquela tradicionalmente realizada (newstream). Essa segunda vertente, nomeada 'Novas Abordagens ao Direito Internacional' (New Approaches to International Law - NAIL), configura movimento acadêmico que surgiu oficialmente na década de 1980 com o intuito de promover perspectivas críticas, alternativas e oposicionistas ao direito internacional e sua corrente majoritária ${ }^{40}$.

As TWAIL encontraram inspiração nas NAIL, cujo objetivo é destacar bias, ideologias, controvérsias doutrinárias e conceituais presentes no direito internacional. No momento de sua origem ${ }^{41}$, o próposito das TWAIL foi discutir novas formas de pensar a relação entre o direito internacional público e o direito econômico internacional, bem como sobre questões de riqueza e pobreza. Além disso, dedicaram-se a mapear abordagens anteriores do Terceiro Mundo ao direito internacional, com vistas a entender em que medida as críticas, por exemplo, ao formalismo e à soberania que estavam em ascensão nos países desenvolvidos seriam ou não igualmente relevantes para os países do Terceiro Mundo. Ainda, preocuparam-se em analisar como a história

39 ANGHIE, Antony; CHIMNI, B.S. Third world approaches to international law and individual responsability in internal conflicts. Chinese Journal of International Law, v. 2, n. 1, p. 77-103, 2003. p. 80-81. 40 O trabalho seminal das NAIL é atribuído a David Kennedy, especialmente por meio da obra KENNEDY, David. International legal structures. Baden-Baden: Nomos, 1987. Bem como, posteriormente, pela obra de KOSKENNIEMI, Martti. From apology to utopia: the structure of international legal argument . Cambridge: Cambridge University, 1989. As NAIL são retomadas no trabalho de KENNEDY, David. When renewal repeats: thinking against the box. York Journal of International Law and Politics, v. 32, n. 2, p. 335500, Winter 2000.

41 O surgimento oficial das TWAIL situa-se no momento da realização da Conferência "New Approaches to Third World Legal Studies" (1997). 
do direito internacional era contada e, dessa forma, re-examinar seus fundamentos históricos ${ }^{42}$.

Desde então as TWAIL têm se firmado como escola de pensamento, como método de direito internacio$\mathrm{nal}^{43}$, como comunidade intelectual e epistêmica, como movimento acadêmico ${ }^{44}$, como abordagem peculiar ao direito internacional ${ }^{45}$, dentre várias outras denominações que mostram a diversidade de abordagens que lhe dá nome.

\subsection{Relação com outras abordagens críticas ao direito internacional}

As abordagens críticas ao direito internacional são aquelas que buscam iluminar pontos até então obscuros ou pouco abordados pela mainstream positivista e liberal ${ }^{46}$. O interessante das teorias críticas é que geram conflito e estimulam o debate, na medida em que descrevem um mesmo objeto (direito internacional) por ângulos opostos e múltiplos, revelando face excludente e de dominação, ainda que sem desacreditar, pelo contrário, na renovação do direito internacional que seja condizente com a promessa de proteção do pluralismo na vida internacional $l^{47}$.

42 GATHII, James Thuo. TWAIL: A brief history of its origins, its decentralized network, and a tentative bibliography. Trade Law and Development, v. 3, n. 1, p. 27-64, 2011. p. 29-30.

43 OKAFOR, Obiora C. Critical third world approaches to international law (TWAIL): theory, methodology, or both? International Community Law Review, v. 10, p. 371-378, 2008. p. 378.

44 PARMAR, Pooja. TWAIL: an epistemological inquiry. International Community Law Review, v. 10, p. 363-370, 2008. p. 364.

45 ANGHIE, Antony; CHIMNI, B. S. Third world approaches to international law and individual responsability in internal conflicts. Chinese Journal of International Law, v. 2, n. 1, p. 77-103, 2003. p. 102.

46 Chimi lista dentre elas as abordagens: (i) realista - cuja maior influência vem de Hans Morgenthau, prevê que o rule of law internacional é submetido à política internacional, baseada em relações de poder; (ii) liberal - defendem que o direito internacional assume papel fundamental na manutenção da ordem na sociedade internacional e que facilita uma resposta colaborativa para problemas chave da sociedade internacional; (iii) crítica - identifica vários problemas nas abordagens realista e liberal; e (iv) feminista - incorporou muitos insights da abordagem crítica desafiando o direito internacional a partir de uma perspectiva de gênero e (v) abordagem do Terceiro Mundo - que guarda afinidades com as perspectivas críticas e feministas. CHIMNI, B. S. Legitimating the international rule of law. In: CRAWFORD, J.; KOSKENNIEMI, M. (Ed.). The Cambridge companion to international law. Cambridge University, 2012. p. 290-308. p. 295-300.

47 MÉGRET, Frédéric. International law as law. In: CRAWFORD, J.; KOSKENNIEMI, M. (Ed.). The Cambridge companion to international law. Cambridge University, 2012. p. 64-92. p. 81.
De acordo com Chimni, as TWAIL guardam relações mais estreitas com as perspectivas crítica e feminis$\mathrm{ta}^{48}$. Embora se reconheça que as três sejam genericamente abordagens críticas ao direito internacional, cada qual configura universo particular e parte de premissas próprias. Consideradas as diferenças, o que as une é que compartilham o entendimento do direito internacional não como elemento neutro ou acima das relações de poder, mas ao contrário, como política e culturalmente originado e orientado.

Com a abordagem feminista, compartilham entendimentos comuns, por exemplo, em relação ao fato de ambas entenderem que o direito internacional se consolidou com base em conceitos, vocabulários e instituições problemáticas aos grupos subalternos ${ }^{49}$, sejam eles mulheres ou povos dos países do Terceiro Mundo. Por outro lado, as TWAIL divergem das perspectivas feministas por entenderem que elas não apreciaram, suficientemente, a íntima relação entre capitalismo, imperialismo e direito internacional ${ }^{50}$.

Provavelmente, a maior crítica às TWAIL seja justamente ao fato de que focam sua análise na crítica, sem elevar o nível das respostas e propostas em alternativa ao que criticam ${ }^{51}$. Defensores das TWAIL alegam, todavia, que elas não buscam apenas criticar, mas também oferecer possibilidades para o futuro do direito internacional, tendendo a imaginar e predizer as formas pelas quais o direito internacional se comportaria frente ao Terceiro Mundo, ou parte dele, no longo prazo ${ }^{52}$.

48 CHIMNI, B. S. Legitimating the international rule of law. In: CRAWFORD, J.; KOSKENNIEMI, M. (Ed.). The Cambridge companion to international law. Cambridge University, 2012. p. 290-308. p. 299. 49 O conceito de subalterno foi cunhado pelo italiano Gramsci e se refere a uma pessoa ou grupo em situação de inferioridade e excluída da hegemonia do poder. Tal conceito foi resgatado pelo grupo de estudos (pós)coloniais conhecido como Subaltern Studies, cujas reflexões tiveram como primeiro objetivo produzir análises históricas nas quais os grupos subalternos fossem vistos como sujeitos da história e não apenas como objetos de dominação. LUDDEN, David (Org). Reading subaltern studies: critical history, contested meaning and the globalization of South Asia. London: Anthem, 2002. p. 15.

50 CHIMNI, B. S. Legitimating the international rule of law. In: CRAWFORD, J.; KOSKENNIEMI, M. (Ed.). The Cambridge companion to international law. Cambridge University, 2012. p. 290-308. p. 299. 51 GORDON, Seth. Indigenous rights in modern international law from a critical third world perspective. American Indian Law Review, v. 31, p. 401-424, 2006. p. 413.

52 OKAFOR, Obiora C. Critical third world approaches to international law (TWAIL): theory, methodology, or both? International Community Law Review, v. 10, p. 371-378, 2008. p. 373. 
Em suma, alega-se que as TWAIL destacaram, com sucesso, relações coloniais e imperiais que monopolizaram a elaboração e destinação do direito internacional sem, entretanto, terem conseguido até agora oferecer agenda positiva para reformar ou transformar o direito internacional com vistas a efetivar a realização dos propósitos aos quais almejam.

\subsection{Propósitos das TWAIL}

As TWAIL se caracterizam mais pelas diferenças internas e diversidade de pontos abordados do que por unidade de discurso e propósitos. Ainda assim, guardam entre si elementos de coerência e unidade, expressos em ideais mais ou menos comuns. De forma geral, dedicam-se a tornar possível a construção de um direito internacional sob a perspectiva daqueles que normalmente ficaram de fora da construção desse direito. Com isso, propõe repensar os modos tradicionais de ler e escrever o direito internacional, bem como sintonizá-lo a lugares e sujeitos alijados do processo de sua construção ${ }^{53}$.

Uma das formas por meio das quais se valem para construir suas análises é considerar não apenas as perspectivas dos Estados (como os realistas e positivistas fazem) ou dos indivíduos (como os liberais e naturalistas fazem), mas especialmente dos povos, normalmente identificados com os povos do 'Terceiro Mundo"54, já que defendem que para as TWAIL o direito internacional faz sentido apenas no contexto da história viva desses povos ${ }^{55}$. Isso quer dizer que o cotidiano dos povos marginalizados do Terceiro Mundo é foco comum e o intuito é desvendar os conhecimentos julgados como hierarquicamente inferiores que radicam justamente na experiência por eles vivida.

Advém daí forma particular de aprender com a vida das pessoas e privilegiar conhecimentos locais, validando o engajamento com os interesses, preocupações, histórias e lutas que foram relegadas às margens do direito internacional como consequência do colonialismo e do

53 ESLAVA, Luis; PAHUJA, Sundhya. Beyond the (post)colonial: TWAIL and the everyday life of international law. Journal of Law and Politics in Africa, Asia and Latin America, v. 45, n. 2, p. 195-221, 2012. p. 02.

54 RAJAGOPAL, Balakrishnan. International law and social movements: challenge of theorizing resistance. Columbia Journal of Transnational Law. v. 41, n. 2, p. 396-433, 2003. p. 401.

55 ANGHIE, Antony; CHIMNI, B. S. Third world approaches to international law and individual responsability in internal conflicts. Chinese Journal of International Law, v. 2, n. 1, p. 77-103, 2003. p. 78. imperialismo ${ }^{56}$. Nesse sentido, a intenção desses estudiosos é contribuir com a construção de um tipo de saber que amplie os limites do pensamento ocidental, agregando outros conhecimentos, com vistas à construção de um direito internacional verdadeiramente universal, ou melhor, pluriversal ${ }^{57}$, que crie condições de diálogo e convivência entre os múltiplos e interconectados povos que se relacionam sob a égide da sociedade global, superando de vez as heranças coloniais que marcaram as relações entre eles.

\subsection{Que Terceiro Mundo?}

Muito se indaga a respeito da pertinência do uso da terminologia 'Terceiro Mundo' em épocas contemporâneas, uma vez que a composição política do contexto da Guerra Fria que lhe deu origem já não mais subsiste. $\mathrm{Na}$ esteira crítica do termo, surgem proposições que celebram construções de uma humanidade comum a todos os povos da terra - expressão nomeada por Baxi de 'um-mundismos5. Adverte o professor indiano que para as proposições baseadas no 'um-mundismo', o fenômeno 'Terceiro Mundo' de fato ou nunca existiu, ou então é apenas uma categoria que congrega massivas histórias de desapontamentos e fracassos descoloniais.

Todavia, mesmo diante do fato de ser considerada categoria 'fora de moda' para diversos círculos intelectuais, os estudiosos ligados às TWAIL insistem no seu uso, sustentando ser importante para uma releitura do direito internacional em termos de maior justiça e inclusã ${ }^{59}$. Assim, afirmam que a categoria Terceiro Mundo continua a ser relevante, sobretudo em razão do potencial que tem para revelar a ordem hierárquica da comunidade internacional. Permite identificar e localizar suas

56 PARMAR, Pooja. TWAIL: an epistemological inquiry. International Community Law Review, v. 10, p. 363-370, 2008. p. 365.

57 RAJAGOPAL, Balakrishnan. Postdevelopment as a vision for a third world approach to international law. In: ANNUAL MEETING AMERICAN SOCIETY OF INTERNATIONAL LAW, 94. Washington, 2000. Proceedings...Washington: ASIL, 2000. p. 306-307. p. 307. Veja também: CHIMNI, B. S. Legitimating the international rule of law. In: CRAWFORD, J.; KOSKENNIEMI, M. (Ed.). The Cambridge companion to international law. Cambridge: Cambridge University, 2012. p. 290-308.

58 BAXI, Upendra. What may the 'Third World' expect from international law? Third World Quarterly, v. 27, n. 5, p. 713-725, 2006. p. 714 .

59 GALINDO, George Rodrigo Bandeira. A volta do terceiro mundo ao direito internacional. Boletim da Sociedade Brasileira de Direito Internacional, v.1, n. 119-124, p. 46-68, ago./dez. 2013. p. 46. 
raízes histórico-culturais na experiência do colonialismo e do imperialismo, duas dimensões que não são totalmente capturadas quando se adota outros termos como por exemplo "em desenvolvimento", ou "Sul Global"

Em síntese, a opção das TWAIL pela continuidade no uso do 'Terceiro Mundo' procura desvincular o termo do tradicional contexto de nações que pertencem a um grupo de países economicamente periféricos e atrasados para reeditá-lo como expressão de contraponto e resistência à ordem internacional hegemônica (e injusta) sobre o globo ${ }^{61}$.

\section{Povos Indígenas e TwaIL: DIÁlogos a PAR- TIR DO CONTEXTO LATINO-AMERICANO}

\subsection{A presença dos povos indígenas na América Latina e no direito internacional dos direitos humanos}

Estima-se que os povos indígenas representem 370 milhões de pessoas presentes em cerca de 90 países de todos os continentes. Constituem 5 por cento da população mundial, mas representam 15 por cento dos pobres do mundo, o que demonstra como são desproporcionalmente afetados quando comparados à população não indígena ${ }^{62}$. A América Latina é região particularmente rica e diversa em termos de presença de povos indígenas. Calcula-se que sejam em torno de 800 povos, com uma população próxima de 45 milhões de pessoas, que se caracterizam por sua ampla diversidade demográfica, social, territorial e política, que vive desde situações de isolamento voluntário até grandes assentamentos urbanos ${ }^{63}$.

60 RAJAGOPAL, Balakrishnan. Locating the Third World in Cultural Geography. Third World Legal Studies, v. 15, n. 2, p. 01-20, 1999. p. 03.

61 MUTUA, Makau. What it TWAIL? In: ANNUAL MEETING AMERICAN SOCIETY OF INTERNATIONAL LAW, 94. Washington, 2000. Proceedings...Washington: ASIL, 2000. p. 31-39. p. 35-36.

62 Fórum Permanente das Nações Unidas sobre Questões Indígenas: State of Indigenous Peoples. UNITED NATIONS. State of the worlds indigenous peoples. New York: United Nations, 2009. Available in: <http://issuu.com/uniccanberra/docs/state_of_world_s_indigenous_peoples/1>. Access: Oct. 05, 2015.

63 COMISSÃO ECONÔMICA PARA A AMÉRICA LATINA E O CARIBE. Os povos indígenas na América Latina: avanços na última década e desafios pendentes para a garantia de seus direitos. Nações
Como sujeitos de direito internacional, seu reconhecimento é relativamente recente. As primeiras movimentações nesse caminho datam da década de 1970, quando organizações indígenas nacionais começaram a ganhar densidade política em vários países, incluindo Canadá, Estados Unidos, Austrália e diversos países da América Latina ${ }^{64}$. Os resultados dessa intensa luta por reconhecimento ficaram evidentes nas últimas décadas, quando efetivamente emergiram como sujeitos no regime do direito internacional dos direitos humanos. Vencendo inúmeros obstáculos, o fato é que os direitos dos indígenas se tornaram parte relativamente ampla e permanente da agenda intergovernamental de direitos humanos nas últimas décadas. O padrão internacional se fortaleceu consideravelmente, resultando: (i) em instrumentos de direitos humanos especificamente direcionados à regulamentação dos direitos dos povos indígenas (Convenção 169 da OIT sobre Povos Indígenas e Tribais (1989), Declaração da ONU sobre os Direitos dos Povos Indígenas (2007), Projeto de Declaração Americana sobre os Direitos dos Povos Indígenas); (ii) na incorporação de alguns desses direitos em instrumentos outros de direitos humanos (Convenção sobre a Diversidade Biológica (1992), Convenção sobre a proteção e promoção da diversidade das expressões culturais (2005)); (iii) na interpretação da possibilidade de proteção dos direitos indígenas sob instrumentos de direitos humanos de aplicação geral (Declaração Universal dos Direitos Humanos (1948), Convenção Americana de Direitos Humanos (1969), Pacto Internacional de Direitos Econômicos, Sociais e Culturais (1966)).

Vale destacar que não há uma definição fixa adotada internacionalmente sobre o significado do termo 'povos indígenas', havendo várias definições e discussões sobre como deve ser entendido. A principal polêmica e o motivo de contestações por parte dos Estados se deram em razão do significado específico que o termo povos adquire no direito internacional ao atribuir-lhes direito à autodeterminação ${ }^{65}$. A Convenção 169 da OIT tratou,

Unidas: Santiago do Chile, 2015. p. 06.

64 ENGLE, Karen. The elusive promise of indigenous development: rights, culture, strategy. Durham: Duke University, 2010. p. 17.

65 O status de povo teoricamente lhes garante o direito à autodeterminação, conforme o artigo 1 (1) do Pacto Internacional dos Direitos Civis e Políticos e dos Econômicos, Sociais e culturais, ambos com igual redação. BRASIL. Decreto no 592, de 6 de julho de 1992. Atos Internacionais. Pacto Internacional sobre Direitos Civis e Políticos. Promulgação. Disponível em: < http://www.planalto.gov.br/ccivil_03/decreto/1990-1994/D0592.htm>. Acesso em: 20 out 2015. 
assim, de limitar esse entendimento, assegurando que a utilização do termo "povos" pelo documento não seria interpretada no sentido de ter implicação alguma aos direitos que poderiam ser conferidos a esse termo no direito internacional ${ }^{66}$. Já a DDPI foi mais abrangente $\mathrm{e}$ finalmente reconheceu o direito dos povos indígenas à autodeterminação ${ }^{67}$.

Por sua vez, o termo indigena se refere amplamente aos descendentes vivos dos habitantes da terra no período pré-invasão europeia e que hoje são dominados por outros, constituindo povos, nações ou comunidades culturalmente distintas, que foram engolidas pelas sociedades coloniais nascidas das forças do império e da conquista $^{68}$. De acordo com a Convenção 169 da OIT, os povos indígenas são aqueles assim considerados pelo fato de descenderem de populações que habitavam região pertencente ao país na época da conquista ou da colonização e que conservam suas próprias instituições sociais, econômicas, culturais e políticas, ou parte de$\operatorname{las}^{69}$.

Contudo, por abranger uma série de características não exaustivas, não existe uma definição amplamente aceita acerca do que venha a ser indígena, razão pela qual o direito internacional e as Nações Unidas corroboram, jurídica e politicamente, a moderna tendência de tomar a ideia sobre quem é ou não indígena com base no princípio da autoidentificação. Assim, a Convenção assegura que a consciência da identidade indígena ou tribal será considerada como critério fundamental para determinar os grupos aos que se aplicam as disposições do documento $^{70}$.

66 Redação conforme artigo 01 (3) da DDPI. NAÇÕES UNIDAS. Declaração das Naçoes Unidas sobre os Direitos dos Povos Indígenas. Rio de Janeiro, 2008. Disponível em: <http://www.un.org/esa/ socdev/unpfii/documents/DRIPS_pt.pdf $>$. Acesso em: 20 out 2015.

67 NAÇÕES UNIDAS. Declaração das Nações Unidas sobre os Direitos dos Povos Indígenas. Rio de Janeiro, 2008. Disponível em: <http:// www.un.org/esa/socdev/unpfii/documents/DRIPS_pt.pdf $>$. Acesso em: 20 out. 2015.

68 ANAYA. S. J. International human rights and indigenous peoples: the move toward the multicultural state. Arizona Journal of International and Comparative Law, v. 21. n. 1, p. 15-61, 2004. p. 3.

69 Redação conforme artigo 1 (b). Disponível em: BRASIL. Decreto no 5051, de 19 de abril de 2004. Promulga a Convenção no 169 da Organização Internacional do Trabalho - OIT sobre Povos Indígenas e Tribais. Disponível em: <http://www.planalto.gov.br/ ccivil_03/_ato2004-2006/2004/decreto/d5051.htm>. Acesso em: 20 out. 2015.

70 De acordo com o artigo 2 da Convenção 169 da OIT. BRASIL. Decreto no 5051, de 19 de abril de 2004. Promulga a Convenção no 169 da Organização Internacional do Trabalho - OIT sobre Povos
Normativamente, há uma multiplicidade de estruturas possíveis para a reivindicação dos direitos dos povos indígenas ${ }^{71}$, diante da qual alguns autores discutem se o arcabouço dos direitos humanos e o padrão trazido por ele bastaria de forma satisfatória para contemplar os complexos problemas que enfrentam ou se, ao contrário, novas categorias legais seriam necessárias ${ }^{72}$. Independentemente da discussão, o fato é que a grande maioria das reivindicações atuais sobre a questão em âmbito internacional são delineadas com base no regime dos direitos humanos. Nesse sentido, é que Anne Orford constata atuarem os direitos humanos como canais por onde o direito internacional consegue encontrar aberturas de mediação com outros tipos de direito $^{73}$. Essa maior abertura dos direitos humanos implica inegavelmente na confrontação de valores, sentidos e significados contidos na tradicional/original doutrina dos direitos humanos com os novos valores, sentidos e significados que chegam por meio da abertura ao diálogo com outras culturas. Os povos indígenas são um dos exemplos desses outros que, ao serem alcançados pelos direitos humanos, não só sofrem a transformação de traduzirem suas visões para a linguagem jurídica, como também influenciam na elaboração desta linguagem jurídica que busca alcançá-los. Prosseguem nesse formato de forma controversa, especialmente em razão da insuficiência do sistema em implementar e assegurar direitos a esses grupos ${ }^{74}$.

A Corte Interamericana de Direitos Humanos tem sido órgão jurisdicional dedicado a analisar casos envolvendo violações de direitos indígenas, peticionados especialmente

Indígenas e Tribais. Disponível em: < http://www.planalto.gov.br/ ccivil_03/_ato2004-2006/2004/decreto/d5051.htm>. Acesso em: 20 out. 2015.

71 São elas: (1) reivindicações baseadas em direitos humanos e não discriminação; (2) reivindicações de minorias; (3) reivindicações de autodeterminação; (4) reivindicações históricas de soberania; e (5) reivindicações sui generis como povos indígenas, incluindo aquelas baseadas em tratados ou outros acordos entre povos indígenas e estados. KINGSBURY, Benedict. Reconciling five competing conceptual structures of indigenous peoples' claims in international and comparative law. New York University Journal of International Law and Policy, v. 34, p. 189-250, 2001. p.190.

72 KINGSBURY, Benedict. Reconciling five competing conceptual structures of indigenous peoples' claims in international and comparative law. New York University Journal of International Law and Policy, v. 34, p. 189-250, 2001. p. 193.

73 ORFORD, Anne. Ritual, Mediation and the International Law of the South, Griffith Law Review, v.16, p. 353-374, 2007. p. 354.

74 MIRANDA Lillian Aponte. Indigenous peoples as international lawmakers, Journal of International Law, v. 32, n. 1, p. 203-263, 2010. p. 225. 
quando a jurisdição doméstica seja falha ou inexistente, ou então quando não há vontade política para torná-la efetiva. De maneira geral, os julgados da Corte têm, normalmente, expandido a interpretação da Convenção Americana de forma a fazer respeitar o direito dos povos indígenas a permanecer ou retornar a seus territórios tradicionais, de serem consultados apropriadamente em assuntos que lhes afetem diretamente, bem como em assegurar que exerçam suas práticas culturais, espirituais e de convivência harmônica com seus territórios e recursos naturais. Trata-se de construção jurisprudencial de destaque, já que, diferentemente de sua contraparte Africana, a Convenção Americana postulou basicamente direitos individuais sem apontar os correspondentes direitos coletivos dos $\operatorname{povos}^{75}$. Ademais, a quantidade e qualidade das decisões sobre a questão indígena prolatadas pela Corte não encontra correspondência em qualquer outra Corte Internacional ${ }^{76}$.

Observa-se, todavia, que a despeito das decisões serem consideradas paradigmáticas na expansão da jurisprudência internacional sobre os direitos dos povos indígenas, estando geralmente de acordo com os mais novos princípios trazidos pelo texto da Declaração das Nações Unidas sobre os direitos dos povos indígenas (2007), um tema em particular permanece aquém do que assegura a Declaração, qual seja, o tema do acesso aos recursos naturais. Trata-se de questão relevante que ameaça a integridade dos povos na região atualmente. Nessa área, a Corte Interamericana tem permitido aos Estados direitos residuais no acesso e exploração desses recursos em detrimento dos direitos dos povos indígenas $^{77}$. Normalmente resultam dessa omissão ou permis-

75 PASQUALUCCI, Jo M. The evolution of international indigenous rights in the inter-american human rights system. Human Rights Law Review, v. 6, n. 2, p. 281-322, 2006. p. 283.

76 Os casos analisados pela Comissão Interamericana sobre os povos indígenas também são diversos. Aqui está se referindo apenas aos casos julgados (sentença de mérito) pela Corte, dentre os quais é possível mencionar: Caso Yakye Axa Indigenous communities vs. Paraguay (junho/2015); Caso Indigenous Communities Kuna of Madungandí e Emberá de Bayano e seus membros vs. Panama (outubro/2014); Caso Norín Catrimán et al. (Mapuche Indigenous People) vs. Chile (maio/2014); Caso Kichwa Indigenous People of Sarayaku vs. Ecuador (junho/2012); Caso Xákmok Kásek Indigenous communities vs. Paraguay (Agosto/2010); Caso Sawhoyamaxa Indigenous Community vs. Paraguay (Março/2006); Caso Mayagna (Sumo) Awas Tingni Community v. Nicaragua (Agosto/2001). Essa lista aumenta quando inclui petições dos povos tribais, que se apropriam e beneficiam do mesmo arcabouço criado para os povos indígenas, a exemplo do Caso Saramaka People vs. Suriname (Novembro/2007).

77 PASQUALUCCI, Jo M. International Indigenous Land Rights: a critique of the Jurisprudence of the Inter-American Court of Hu- sividade ofensivas aos territórios tradicionais de atores não indígenas responsáveis por empreender ações de exploração dos recursos naturais, cujos efeitos colaterais são extremante danosos para a sobrevivência física e cultural desses povos. Nessa área, a Corte tem sido acusada de apresentar apenas uma defesa retórica aos $\operatorname{povos}^{78}$.

\subsection{Disputas por recursos naturais: a violência sobre os povos indígenas na região latino-ame- ricana}

De fato, a despeito das proteções trazidas pelo regime dos direitos humanos, presencia-se uma cena internacional marcada por diversos conflitos envolvendo povos indígenas e ofensivas que os ameaçam constantemente. Na América Latina, os conflitos se dão expressivamente em virtude das disputas pelos recursos naturais abundantes tanto na região como nos territórios indígenas, locais que normalmente representam a última fronteira de exploração das indústrias extrativas e de geração de energia.

O conflito intensifica-se em razão da disputa — simbólica, cultural, axiológica, teleológica - pelo uso dos recursos naturais, vez que, se por um lado as indústrias os enxergam como 'recurso', como matéria prima para a geração de seu "produto" mercadológico, os povos indígenas veem esses mesmos elementos como fonte de sua sobrevivência física, social, cultural e espiritual. Entram em colisão com a visão indígena processos de exploração econômica que coisificam a natureza como 'recurso natural' e os contabiliza como insumo da produção econômica ${ }^{79}$. Estabelece-se o conflito entre a le-

man Rights in light of the United Nations Declaration on the Rights of Indigenous Peoples. Wisconsin International Law Journal, v. 27, n. 01, p. 51-98, 2009. p. 54.

78 ANTKOWIAK, Thomas M. Rights, resources, and rhetoric: indigenous peoples and the Inter-American Court. University of Pennsylvania. Journal of International Law, v. 35, n. 1, p. 113-187, 2014. p. 187.

79 Os exemplos de conflitos com a participação dos Estados nacionais com a presença de corporações transnacionais são inúmeros e ocorrem na maior parte dos países da América Latina. Cite-se apenas para ilustrar alguns casos de construção de Hidrelétricas: Hidroaysen na Patagônia Chilena; Chan-75, no Panamá; La Parota, no México, Belo Monte, no Brasil. Destaque-se as intensas atividades mineradoras de corporações Canadenses e Chinesas no Peru; o gasoduto entre os Bolívia-Brasil que destruiu vastas áreas do território dos Chiquitanos; no Equador, conflitos sobre a exploração de petróleo em território do Shuar e dos Sarayaku, dentre outros casos abundantes na literatura. 
gitimidade de atuação do Estado como agente de desenvolvimento e o direito dos povos indígenas de terem direito às suas terras, territórios e recursos naturais que possuem e ocupam tradicionalmente ${ }^{80}$. $\mathrm{Na}$ base do uso e regulação dos recursos, está o direito internacional, arena da luta entre o imperativo da exploração dos recursos e da proteção dos direitos humanos dos povos indígenas.

Nesse ponto, vale abrir um parêntesis para mencionar que um dos propósitos das TWAIL é justamente revelar inconsistências e unilateralidades do direito internacional, dedicando-se a enfrentar o tema das contradições internas ao buscar as origens das discrepâncias entre linguagens utilizadas nos diferentes ramos ou regimes internacionais como, por exemplo, o fato de o direito internacional se dedicar à regulamentação e promoção dos direitos humanos, mas, por outro lado, destinar pouca atenção quando a prática do comércio internacional ou das ações de desenvolvimento econômico consistentemente violam aqueles direitos ${ }^{81}$.

Destaque-se que as ações de exploração de recursos naturais a que se faz menção são normalmente expressas em termos de desenvolvimento nacional e envolvem íntima colaboração do Estado às ações das corporações, contrariando compromissos legais internacionalmente assumidos de proteção aos direitos territoriais dos povos indígenas $^{82}$. Revelam a violência estrutural a que esses povos estão submetidos no contexto do desenvolvimento global, cujos impactos negativos tornam mais grave seu quadro histórico de vulnerabilidade e marginalização ${ }^{83}$. A séria devastação e abusos causados

80 Conforme artigo 26 (1) da DDPI. NAÇÕES UNIDAS. Declaração das Nações Unidas sobre os Direitos dos Povos Indígenas. Rio de Janeiro, 2008. Disponível em: <http://www.un.org/esa/socdev/ unpfii/documents/DRIPS_pt.pdf $>$. Acesso em: 20 out. 2015.

81 BADARU, Opeoluwa A. Examining the utility of third world approaches to international law for international human rights law. International Community Law Review, v. 10, p. 379-387, 2008. p. 383.

82 Sobre a ação das corporações em territórios indígenas e sua responsabilização perante o direito internacional veja: MIRANDA, Lillian Aponte. The hybrid state-corporate enterprise and violations of indigenous land rights: theorizing corporate responsibility and accountability under international law. Lewis e Clark. Law Review, v. 11, n. 01 , p. $135-183,2007$. p. 147.

83 Sobre o impacto dos grandes projetos de desenvolvimento sobre os povos indígenas veja: Relatório do Relator Especial sobre a situação dos direitos humanos e liberdades fundamentais dos povos indígenas, Rodolfo Stavenhagen, E/CN.4/2003/90 21, Janeiro, 2003. STAVENHAGEN, Rodolfo. Relatório sobre a situação dos direitos bumanos e liberdades fundamentais dos povos indigenas. 2003. Disponível em: <http://www.unhchr.ch/huridocda/huridoca.nsf/e06a5300f9 0fa0238025668700518ca4/30f0fcfc1eb1b247c1256d09003152b2/\$ na região por projetos de danosos impactos refletem a continuidade de uma relação colonial e de exploração dos territórios dos povos indígenas, que permanecem excluídos dos centros de regulação dessa dinâmica ${ }^{84}$.

Na prática, mesmo diante do reconhecimento como sujeitos de direitos humanos, continuam sendo violentados sistematicamente, situação diante da qual é possível dizer que os povos indígenas sofrem duplamente o impacto das práticas coloniais, pois, além de sofrerem o processo colonial externo, também sofrem os efeitos de um tipo de colonialismo interno, que na maior parte das legislações nacionais os submete a um regime da tutela estatal. Esse tipo interno é ainda ocasionado em razão de ações ou omissões dos governos dos Estados nacionais dentro dos quais estão inseridos e da percepção das sociedades nacionais que os acusa de representarem impedimentos à livre circulação do capital e ao projeto de "modernidade" que está por detrás dos grandes empreendimentos. Alega-se que vivem outro tempo, algo como pré-capital, realidade que pertence ao pré-moderno e assim são vistos como oriundos de um tempo passado, rotulados de arcaicos e atrasados, parte de uma forma de vida a ser superada ${ }^{85}$.

Curiosamente, embora essas evidências possam ser perfeitamente trazidas à tona por meio das ferramentas analíticas oferecidas pelas TWAIL, e mesmo diante de serem os povos indígenas importantes protagonistas de ações de resistência contra uma ordem internacional injusta, as TWAIL pouco ou quase nada disseram sobre eles. Essa débil consideração é apontada atualmente como uma lacuna a ser enfrentada por estas abordagens.

\subsection{O lugar dos povos indígenas nas TWAIL: es- treitando o diálogo}

A razão do frágil diálogo entre as TWAIL e os povos indígenas pode ser investigada sob algumas hipóteses. Uma das linhas de investigação pode se orientar pelo fato de as TWAIL, por terem sofrido influências das análises marxistas (binárias) de classe, não terem apro-

FILE/G0310544.pdf>. Acesso em: 14 out. 2015.

84 MUNARRIZ, Gerardo J. Rhetoric and reality: the world bank development policies, mining corporations, and indigenous communities in Latin America. International Community Law Review, v. 10, p. 431-443, 2008. p. 431; 442.

85 As palavras são de Chaterjee, a respeito dos povos colonizados, mas perfeitamente aplicáveis ao contexto dos povos indígenas. CHATTERJEE, Partha. Colonialismo, modernidade e política. Trad. Fábio Figueiredo. Salvador: EDUFBA, 2004. p. 71. 
priadamente elaborado categorias capazes de lidar com pluralidades como gênero, raça e etnia ${ }^{86}$. Outra razão pode ser devida ao tênue diálogo das TWAIL no contexto latino-americano, região rica, diversa e combativa em termos de presença e atuação dos povos indígenas.

Argumenta-se não ser essa aproximação em desacordo com os propósitos das TWAIL, pois, se de fato se declaram como contraponto que exerce o direito internacional a partir de sua face emancipatória ${ }^{87}$, como abordagem dirigida principalmente a moldar a lei internacional favoravelmente aos que foram tradicionalmente excluídos e marginalizados por ela, como preocupadas em escavar os conhecimentos subordinados ${ }^{88}$, então seguramente desempenham papel importante na projeção das vozes e visões dos povos indígenas no direito internacional.

Mas de que forma a categoria 'Terceiro Mundo' poderia entrar em diálogo com os povos indígenas, se estes nunca se identificaram nesses termos? Como os povos indígenas podem se identificar com a ideia de Terceiro Mundo se resta incerta e obscura sua participação nesse universo? Gordon opina que ainda que os povos indígenas possam não se identificar com o sentido do senso comum sobre o Terceiro Mundo, certamente eles se encaixam na situação de, assim como os povos do Terceiro Mundo, também terem sido eles vitimizados em razão do processo colonial.

Dessa forma, segundo o autor, desde que o Terceiro Mundo e os povos indígenas compartilhem características comuns, como por exemplo, de terem sido sujeitos à dominação por um sistema legal internacional que os destituiu de poder, as ferramentas oferecidas pelas TWAI podem entrar em diálogo com a realidade dos povos indígenas, na tentativa de explicar a situação indígena perante o direito internacional e em identificar como o atual sistema falhou e provavelmente continue

86 Na opinião de Singh, as omissões das histórias dos povos tribais seriam reflexo de certa insensibilidade do teórico indiano B. S. Chimni, que mais bem conceitualizou as TWAIL no contexto indiano. Veja: SINGH, Prabhakar. Indian International law: from a colonized apologist to a subaltern protagonist. Leiden Journal of International Law, v. 23, p. 79-103, 2010. p. 95. Chimni dedicou-see análises marxistas de direito internacional, conforme. CHIMNI, B. S. Marxism and international law: a contemporary analysis. Economic and Political Weekly, v. 34, n. 6, p. 337-349, Fev. 6-12, 1999.

87 CHIMNI, B. S. The past, present and future of international law: a critical third world approach. Melbourne Journal of International Law, v. 8, n. 2, p. 499- 515, 2007. p. 500.

88 ANGHIE, Antony. LatCrit and TWAIL. California Western International Law Journal, v. 42, p. 311-319, 2012. p. 312. a falhar diante deles ${ }^{89}$. Por essa razão, entende Munarriz que as TWAIL representam valioso instrumental por meio do qual pode ser possível compreender a cumplicidade do direito internacional com a violência que foi (e ainda é) cometida contra os povos indígenas. Opina o autor que essa compreensão passa justamente pelo reconhecimento dos povos indígenas pelas TWAIL $^{90}$.

Considere-se, contudo, que, em razão da recente aproximação das TWAIL ao contexto latino-americano, ainda se elabora como de fato poderiam representar novo instrumental teórico e metodológico capaz de abordar o processo de exclusão e subalternidade a que foram submetidos os povos indígenas, bem como em que medida seriam eficazes para que as vozes e visões desses povos pudessem ser amplificadas no direito internacional, especialmente em assuntos nos quais os povos indígenas oferecem reconhecida contribuição, como é o caso de temas como desenvolvimento sustentável, biodiversidade, conhecimento tradicional, patrimônio genético e cultural, recursos naturais e mudança climática $^{91}$.

Provavelmente, um grande desafio ao se traçar as linhas desse diálogo se dê diante do fato de, conforme destaca Lorca, o direito internacional tradicionalmente não oferecer aos internacionalistas situados na periferia ferramentas analíticas adequadas para compreender o significado e usos do direito internacional em seus con-

89 GORDON, Seth. Indigenous rights in modern international law from a critical third world perspective. American Indian Law Review, v. 31, p. 401-424, 2006. p. 404.

90 MUNARRIZ, Gerardo J. Rhetoric and reality: the world bank development policies, mining corporations, and indigenous communities in Latin America. International Community Law Review, v. 10, p. 431-443, 2008. p. 435.

91 O conhecimento indígena já é considerado fundamental em domínios como a agricultura, conservação da biodiversidade, gestão dos recursos naturais, medicina tradicional e desenvolvimento sustentável. Agora, são cada vez mais reconhecidos como importante fonte de conhecimento sobre mudanças climáticas. Veja mais em: UNITED NATIONS EDUCATIONAL, SCIENTIFIC AND CULTURAL ORGANIZATION. At Geneva meeting, UNESCO affirms its commitment to indigenous peoples Rights. 2015. Available in: <http://www.unesco.org/new/en/media-services/single-view/ news/at_geneva_meeting_unesco_affirms_its_commitment_to_indigenous_peoples_rights/\#.VhVJJvlViko>. Access: Set. 01, 2015. Outro reconhecimento da importância dos povos indígenas em: Climate Change - is it the Indigenous Peoples who have the answers? Veja mais em: LUNDIN, John. Climate change: is it the indigenous peoples who have the answers? July, 2013. Available in: <http:// thedemocraticdaily.com/2013/07/27/climate-change-indigenouspeoples-answers/\#sthash.N0EZmviQ.AaXfsjOi.dpuf>. Access: Set. 01, 2015. 
textos particulares ${ }^{92}$. Por isso, deve-se considerar o risco de que quando categorias teóricas de direito internacional são transpostas para a América Latina, normalmente são reduzidas à recepção, imitação, ou na melhor das hipóteses, contribuição para o legado da disciplina ${ }^{93}$. Em se tratando das TWAIL, essa tendência pode ser revertida, especialmente porque encontram sentido exatamente na valorização do uso e significados do direito internacional exercido a partir do contexto local (a imagem do international law from below ${ }^{94}$ ), cujo sentido está radicado nas expressões dos grupos periféricos.

No contexto latino-americano, essas expressões estão bem representadas nas lutas cotidianas por reconhecimento e de resistência travadas pelos povos indígenas, inclusive por meio de canais normativos, políticos e jurisdicionais presentes na estrutura do direito internacional, especialmente os disponibilizados pelo regime internacional dos direitos humanos.

\section{Considerações finais}

As leituras críticas ao direito internacional a partir das Abordagens do Terceiro Mundo trouxeram diferentes perspectivas ao estudo da disciplina, complexificando e tornando diversas suas possibilidades de análise. Destacam não apenas o que o direito internacional contingenciou, mas também os conhecimentos por ele subjugados que, em última análise, estiveram presentes de uma forma ou de outra na construção de suas principais doutrinas. Nesse sentido, a vitalidade do discurso oferecido pelas TWAIL permite acentuar com originalidade nova concepção normativa que almeja trazer vozes e visões periféricas ao centro de produção e exercício do direito internacional a fim de torná-lo mais justo globalmente.

Provavelmente o maior desafio em relação a como considerar esses saberes subjugados e suas variadas ex-

92 LORCA, Arnulf B. International law in Latin America or latin american international law? rise, fall, and retrieval of a tradition of legal thinking and political imagination. Harvard International Law Journal, v. 47, n. 1, p. 283-305, Winter 2006. p. 283.

93 LORCA, Arnulf B. International law in Latin America or latin american international law? rise, fall, and retrieval of a tradition of legal thinking and political imagination. Harvard International Law Journal, v. 47, n. 1, p. 283-305, Winter 2006. p. 285.

94 A expressão é título do livro do professor Balakrishinan Rajagopal (2003). A reversão do mapa mundi é uma das imagens que caracteriza os estudos (pós)coloniais. pressões ocorre em razão de o direito internacional não ter vocabulário apropriado para dar conta dessa diversidade, ainda que se reconheça que, por sua essência universal, tenha todos os atributos teóricos que permitiriam esse desenvolvimento. A despeito dessas limitações, há avanços que indicam transformações nas interpretações da disciplina, principalmente no âmbito do regime jurídico internacional dos direitos humanos. Nele, os povos indígenas têm contribuído para expansões normativas e interpretativas do direito internacional que consideram suas peculiaridades como povos culturalmente distintos.

No contexto da América Latina, o uso, exercício e potencialização dos direitos dos povos ganham destaque, sendo, consequentemente, região na qual as TWAIL encontram oportunidades para enfrentar a debilidade de não terem considerado com mais propriedade a posição marginal desses grupos perante o direito internacional. Por ser uma região na qual esse assunto é exercitado de forma expressiva nas instâncias do direito internacional dos direitos humanos, encontram aí farto material vivo de investigação, capaz de lhes orientar na tarefa de superar a fragilidade em relação à consideração dos indígenas, com vistas a aprimorarem-se como contraponto emancipatório de direito internacional.

O desafio está não apenas em reproduzir ou transpor as TWAIL ao contexto latino-americano, mas, sobretudo, reinterpretá-las para que possam contribuir para refinar e amplificar o potencial transformador e de realização de justiça que se cria e exerce regionalmente com base nas expressões indígenas. Esse desafio envolve abordar o direito internacional não apenas do ponto de vista de seu próprio imaginário fundacional, mas especialmente do ponto de vista do imaginário conflitivo que surge quando, em cumprimento a seu ethos universal, alcança diferentes povos e culturas, para tornar-se, destarte, instrumental valioso no almejado diálogo entre os povos.

\section{REFERÊNCIAS}

ANAYA, S. J. International human rights and indigenous peoples: the move toward the multicultural state. Arizona Journal of International and Comparative Law, v. 21, n. 1, p. 15-61, 2004. 
ANGHIE, Antony; CHIMNI, B. S. Third world approaches to international law and individual responsability in internal conflicts. Chinese Journal of International Law, v. 2, n. 1, p. 77-103, 2003.

ANGHIE, Antony. Finding the peripheries: sovereignty and colonialism in nineteenth-century international law. Harvard International Law Journal, v. 40, n. 1, p. 01-71, 1999.

ANGHIE, Antony. Francisco de Vitoria and the colonial origins of international law. Social and Legal Studies, London, v. 5, n. 3, p. 321-336, 1996.

ANGHIE, Antony. LatCrit and TWAIL. California Western International Law Journal, v. 42, p. 311-319, 2012.

ANGHIE, Antony. The evolution of international law: colonial and postcolonial realities. Third World Quaterly, v. 27, n. 5, p. 739-753, 2006.

ANTKOWIAK, Thomas M. Rights, resources, and rhetoric: indigenous peoples and the Inter-American Court. University of Pennsylvania. Journal of International Law, v. 35, n. 1, p. 113-187, 2014.

BADARU, Opeoluwa A. Examining the utility of third world approaches to international law for international human rights law. International Community Law Review, v. 10, p. 379-387, 2008.

BAXI, Upendra. What may the 'Third World' expect from international law? Third World Quarterly, v. 27, n. 5, p. 713-725, 2006.

BRASIL. Decreto no 592, de 6 de julho de 1992. Atos Internacionais. Pacto Internacional sobre Direitos Civis e Políticos. Promulgação. Disponível em: < http://www. planalto.gov.br/ccivil_03/decreto/1990-1994/D0592. htm>. Acesso em: 20 out. 2015.

BRASIL. Decreto no 5051, de 19 de abril de 2004. Promulga a Convenção no 169 da Organização Internacional do Trabalho - OIT sobre Povos Indígenas e Tribais. Disponível em: < http://www.planalto.gov.br/ccivil_03/_ ato2004-2006/2004/decreto/d5051.htm>. Acesso em: 20 out. 2015.

BUIRETTE-MAURAU, Patricia. La participation $d u$ Tiers-Monde a l'elaboration du droit international. Paris: Librairie Générale de Droit et de Jurisprudence, 1983.

CANÇADO TRINDADE, Antônio Augusto. A humanização do direito internacional. Belo Horizonte: Del Rey, 2006.
CHATTERJEE, Partha. Colonialismo, modernidade e politica. Trad. Fábio Figueiredo. Salvador: EDUFBA, 2004.

CHIMNI, B. S. Legitimating the international rule of law. In: CRAWFORD, J.; KOSKENNIEMI, M. (Ed.). The Cambridge companion to international law. Cambridge University, 2012. p. 290-308.

CHIMNI, B. S. Marxism and international law: a contemporary analysis. Economic and Political Weekly, v. 34, n. 6, p. 337-349, Fev. 6-12, 1999.

CHIMNI, B. S. The past, present and future of international law: a critical third world approach. Melbourne Journal of International Law, v. 8, n. 2, p. 499- 515, 2007.

COMISSÃO ECONÔMICA PARA A AMÉRICA LATINA E O CARIBE. Os povos indígenas na América Latina: avanços na última década e desafios pendentes para a garantia de seus direitos. Santiago do Chile: Nações Unidas, 2015.

CRAWFORD, James. The rights of peoples: 'peoples' or 'governments'? In: (Ed). The rights of peoples.

Oxford: Oxford University, 2001. p. 55-68.

CUMBERLAND, Emily. Call for Submissions for Symposium on Third World Approaches to International Law (TWAIL). Washington: American Society of International Law, March 2015. Available in: <http://www.asil. org/blogs/call-submissions-symposium-third-worldapproaches-international-law-twail>. Access: Jan. 22, 2016.

DULITZKY, Ariel E. Quando os afrodescendentes se tornaram "povos tribais": o sistema interamericano de direitos humanos e as comunidades negras rurais. Meritum, Belo Horizonte, v. 6, n. 2, p. 57-138, jul./dez. 2011.

ENGLE, Karen. The elusive promise of indigenous development: rights, culture, strategy. Durham: Duke University, 2010.

ESLAVA, Luis; PAHUJA, Sundhya. Beyond the (post) colonial: TWAIL and the everyday life of international law. Journal of Law and Politics in Africa, Asia and Latin America, v. 45, n. 2, p. 195-221, 2012.

FATOUROS, A. A. International law and the third world. Virginia Law Review, v. 50, n. 05, p. 783-823, jun. 1964.

FITZPATRICK, Peter; DARIAN-SMITH, Eve. The laws of the postcolonial: an insistente introduction. In: (Eds.) Laws of the Postcolonial. Ann Arbour: Uni- 
versity of Michigan Press, 1999. p. 1-18.

FLORY, Maurice. Adapting international law to the development of the Third World. Journal of African Law, v. 26, p. 12-20, 1982.

GALINDO, George Rodrigo Bandeira. A volta do terceiro mundo ao direito internacional. Boletim da Sociedade Brasileira de Direito Internacional, v. 1, n. 119-124, p. 46-68, ago./dez. 2013.

GALINDO, George Rodrigo Bandeira. Para que serve a história do direito internacional? Revista de Direito Internacional, Brasília, v. 12, n. 1, p. 338-354, 2015.

GATHII, James Thuo. TWAIL: a brief history of its origins, its decentralized network, and a tentative bibliography. Trade Law and Development, v. 3, n. 1, p. 27-64, 2011.

GORDON, Seth. Indigenous rights in modern international law from a critical third world perspective. American Indian Law Review, v. 31, p. 401-424, 2006.

KINGSBURY, Benedict. Reconciling five competing conceptual structures of indigenous peoples' claims in international and comparative law. New York University Journal of International Law and Policy, v. 34, p. 189-250, 2001.

KOSKENNIEMI, Martti. Empire and International Law: the real spanish contribution. University of Toronto Law Journal, v. 61, p. 01-36, 2011.

KOSKENNIEMI, Martti. The gentle civilizer of nations: the rise and fall of international law 1870-1960. Cambridge: Cambridge University, 2004.

KUMAR, Vidya S. A. A proleptic approach to postcolonial legal studies? a brief look at the relationship between legal theory and intellectual history. Law, Social Justice and Global Development Journal, n. 2, 2003. Available in: <https://www2.warwick.ac.uk/fac/soc/law/elj/ lgd/2003_2/kumar>. Access: Jan. 22, 2016.

LORCA, Arnulf B. International law in Latin America or latin american international law? rise, fall, and retrieval of a tradition of legal thinking and political imagination. Harvard International Law Journal, v. 47, n. 1, p. 283-305, Winter 2006

LUDDEN, David (Org). Reading subaltern studies: critical history, contested meaning and the globalization of South Asia. London: Anthem, 2002.

LUNDIN, John. Climate change: is it the indigenous peoples who have the answers? July, 2013. Available in: <http://thedemocraticdaily.com/2013/07/27/ climate-change-indigenous-peoples-answers/\#sthash. NoEZmviQ.AaXfsjOi.dpuf>. Access: Set. 01, 2015.

MÉGRET, Frédéric. International law as law. In: CRAWFORD, J.; KOSKENNIEMI, M. (Ed.). The Cambridge companion to international law. Cambridge: Cambridge University, 2012. p. 64-92.

MIRANDA, Lillian Aponte. Indigenous peoples as international lawmakers. Journal of International Law, v. 32, n. 1, p. 203-263, 2010.

MIRANDA, Lillian Aponte. The hybrid state-corporate enterprise and violations of indigenous land rights: theorizing corporate responsibility and accountability under international law. Lewis e Clark Law Review, v. 11, n. 01, p. 135-183, 2007.

MUNARRIZ, Gerardo J. Rhetoric and reality: the world bank development policies, mining corporations, and indigenous communities in Latin America. International Community Law Review, v. 10, p. 431-443, 2008.

MUTUA, Makau. What it TWAIL? In: ANNUAL MEETING AMERICAN SOCIETY OF INTERNATIONAL LAW, 94., Washington, 2000. Proceedings...Washington: ASIL, 2000. p. 31-39.

NAÇÕES UNIDAS. Declaração das Nações Unidas sobre os Direitos dos Povos Indígenas. Rio de Janeiro, 2008. Disponível em: <http://www.un.org/esa/socdev/unpfii/ documents/DRIPS_pt.pdf>. Acesso em: 20 out. 2015.

OKAFOR, Obiora C. Critical third world approaches to international law (TWAIL): theory, methodology, or both? International Community Law Review, v. 10, p. 371378, 2008.

ORFORD, Anne. Ritual, Mediation and the International Law of the South, Griffith Law Review, v. 16, p. 353374, 2007.

PAHUJA, Sandhya. The postcoloniality of international law. Harvard International Law Journal. v. 46, n. 2, p. 459469, summer 2005.

PARMAR, Pooja. TWAIL: an epistemological inquiry. International Community Law Review, v. 10, p. 363-370, 2008.

PASQUALUCCI, Jo M. International Indigenous Land Rights: a critique of the Jurisprudence of the InterAmerican Court of Human Rights in light of the Uni- 
ted Nations Declaration on the Rights of Indigenous Peoples. Wisconsin International Law Journal, v. 27, n. 01, p. 51-98, 2009.

PASQUALUCCI, Jo M. The evolution of international indigenous rights in the inter-american human rights system. Human Rights Law Review, v. 6, n. 2, p. 281-322, 2006.

RAJAGOPAL, Balakrishnan. International law and social movements: challenge of theorizing resistance. Columbia Journal of Transnational Law, v. 41, n. 2, p. 396-433, 2003.

RAJAGOPAL, Balakrishnan. Locating the Third World in Cultural Geography. Third World Legal Studies, v. 15, n. 2, p. 01-20, 1999.

RAJAGOPAL, Balakrishnan. Postdevelopment as a vision for a third world approach to international law. In: ANNUAL MEETING AMERICAN SOCIETY OF INTERNATIONAL LAW, 94., Washington, 2000. Proceedings...Washington: ASIL, 2000. p. 306-307.

RATNER, Steven; SLAUGHTER, Anne-Marie. Symposium on method in international law: appraising the Methods of International Law: a prospectus for readers. American Journal of International Law, Washington, v. 93, n. 2, p. 291-302, 1999.

SAID, Edward W. Cultura e imperialismo. Trad. Denise Bottmann. São Paulo: Companhia das Letras, 2011.

SAUVY, Alfred. Trois mondes, une planete. L'observateru, Paris, n. 118, p. 14, 14 aout 1952. Disponible dans: <http://www.homme-moderne.org/societe/demo/ sauvy/3mondes.html>. Accès: 06 out. 2015.

SHAW, Malcolm N. International Law. 6. ed. Cambridge: Cambridge University, 2008.

SHOEMAKER, N. A Typology of Colonialism. Available in: <http://historians.org/publications-and-directori- es/perspectives-on-history/october-2015/a-typologyof-colonialism\#.VinyWqK7OG4.facebook>. Access: Oct. 24, 2015.

SINGH, Prabhakar. Indian international law: from a colonized apologist to a subaltern protagonist. Leiden Journal of International Law, v. 23, p. 79-103, 2010.

STAVENHAGEN, Rodolfo. Relatório sobre a situação dos direitos humanos e liberdades fundamentais dos povos indigenas. 2003. Disponível em: <http://www.unhchr.ch/huridocda/huridoca.nsf/e06a5300f90fa023802566870051 8ca4/30f0fcfc1eb1b247c1256d09003152b2/\$FILE/ G0310544.pdf>. Acesso em: 14 out. 2015.

UNITED NATIONS EDUCATIONAL, SCIENTIFIC AND CULTURAL ORGANIZATION. At Geneva meeting, UNESCO affirms its commitment to indigenous peoples Rights. 2015. Available in: <http://www.unesco. org/new/en/media-services/single-view/news/at_geneva_meeting_unesco_affirms_its_commitment_to_ indigenous_peoples_rights/\#.VhVJJvlViko>. Access: Set. 01, 2015.

UNITED NATIONS. Declaration on the Establishment of a New International Economic Order. May. 1974. Available in: <http://www.un-documents.net/s6r3201.htm>. Access: Feb. 4, 2016.

UNITED NATIONS. Declaration on the Right to Development. 4 Dec. 1986. Available in: <http://www. un.org/documents/ga/res/41/a41r128.htm>. Access: Feb. 4, 2016.

UNITED NATIONS. State of the worlds indigenous peoples. New York: United Nations, 2009. Available in: <http:/ / issuu.com/uniccanberra/docs/state_of_world_s_indigenous_peoples/1>. Access: Oct. 05, 2015.

VITÓRIA, Francisco de. Os indios e o direito da guerra. Trad. Ciro Mioranza. Ijuí: Editora Ijuí, 2006. (Clássicos do Direito Internacional). 


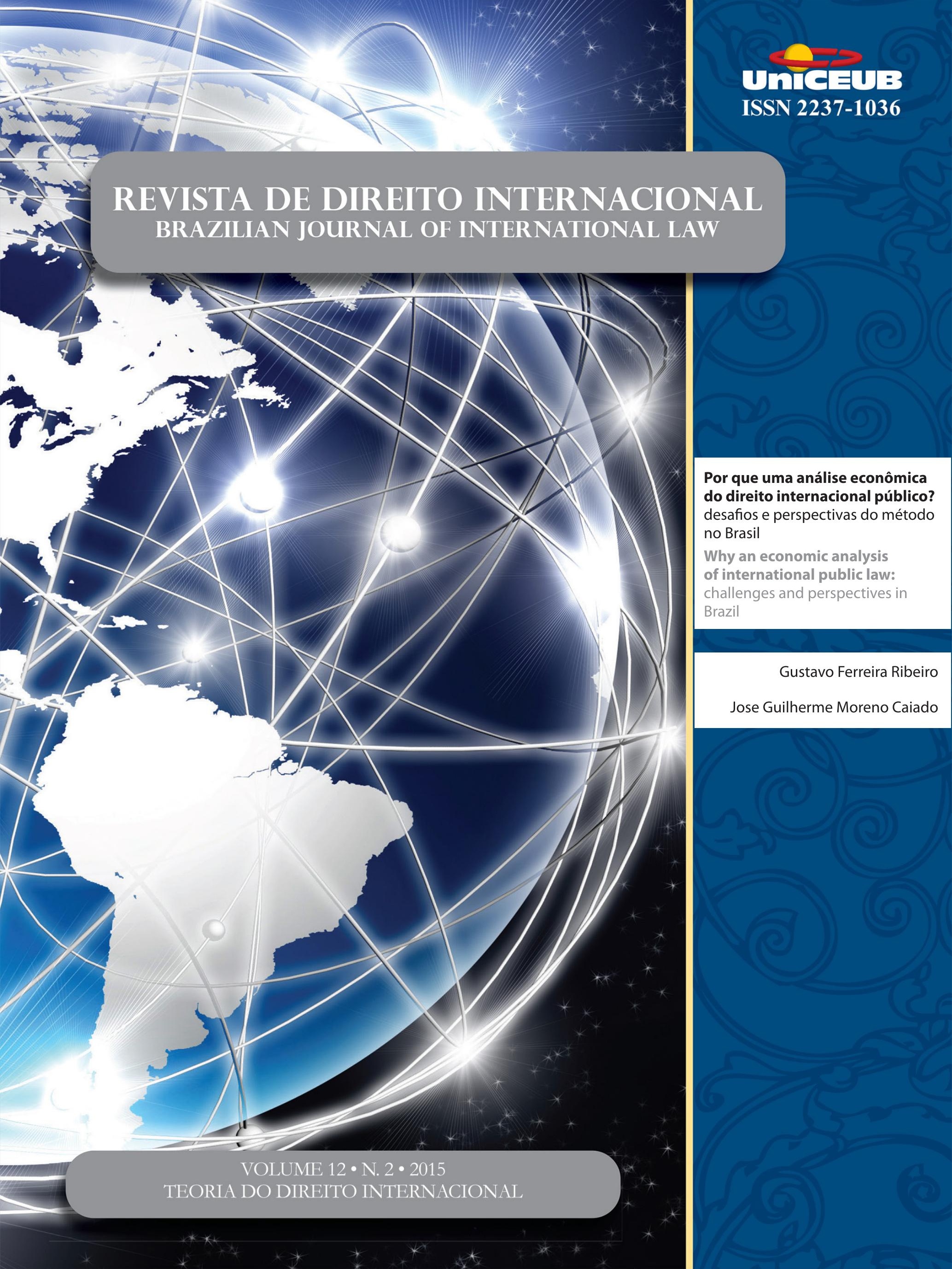




\title{
Por que uma análise econômica do direito internacional público? desafios e perspectivas do método no Brasil*
}

\author{
Why an economic analysis of international \\ public law: challenges and perspectives in \\ Brazil
}

\author{
Gustavo Ferreira Ribeiro** \\ Jose Guilherme Moreno Caiado***
}

\section{Resumo}

o objetivo deste artigo é esclarecer o método, desafios e perspectivas da análise econômica do direito internacional público (AEDIP) no Brasil. O método vem sendo utilizado nas academias norte-americana, de forma precursora, e europeia, mais recentemente. No Brasil, é diminuto o número de docentes, publicações e grupos de pesquisa nesse campo. Há naturalmente uma questão temporal (formação de massa crítica) para sua introdução, mas também barreiras de linguagem e compreensão de seus limites e possibilidades. Na essência, a AEDIP é uma transposição da consolidada análise econômica do direito doméstico, com adaptações, para o plano internacional. Ao se utilizar de uma abordagem interdisciplinar por meio de conceitos econômicos, como escassez e racionalidade, o método contribui para explicar o direito (positivo, "ser"), prescrever soluções (normativo, "dever-ser") e visualizar as potenciais consequências das interpretações das normas no mundo real (hermenêutica). Partindo de dois problemas selecionados acerca da origem material das fontes do direito internacional (tratados e costumes) e de duas áreas específicas (investimentos internacionais e direitos humanos), esclarecem-se neste artigo essas abordagens. Conclui-se pela indispensável visão proporcionada pela AEDIP como mais uma das luzes sobre a "catedral" do direito internacional, e a possibilidade de se superarem os obstáculos cognitivos do método.

Palavras-chave: Direito internacional público. Direito e economia. Análise econômica. Academia brasileira.

* Recebido em 16/11/2015

Aprovado em 08/12/2015

** Autor Convidado: Professor do Programa de Mestrado e Doutorado em Direito - UniCEUB, Brasília. E-mail: Gustavo.Ribeiro@uniceub.br

*** Autor Convidado: Doutorando do Institute of Law and Economics, Universidade de Hamburgo. E-mail: Jose.Caiado@ile-graduateschool.de

\section{Abstract}

This paper aims at clarifying the method, challenges and perspectives of the law and economics of public international law (LEPIL) in Brazil. The method has been used in the North American, at earliest, and in the European academy, more recently. In Brazil, the number of faculty, publications, and research groups in the area is meager. Naturally, there is a temporal issue over the formation of a critical mass to deal with the method, but also 
language and comprehension barriers about its possibilities and limits. In the essence, LEPIL is the transposition of the consolidated law and economics - as applied to domestic law - to the international realm, with adaptations. While using an interdisciplinary approach, drawing from economic concepts, such as scarcity and rationality, the method serves to explain international law (positive, "be"), prescribe solutions (normative, "should be"), and predict the consequences of interpretation in the real world (hermeneutics). By focusing in two selected problems about the material origin of sources of international law (treaties and customs) and two specific areas (international investments and human rights), this article clarifies these approaches. The paper concludes about the indispensable vision supplied by LEPIL, as one of lights on the "cathedral" of international law, and the possibility of overcoming its cognitive hurdles.

Keywords: Public international law. Law and economics. Economic analysis of law. Brazilian academy.

\section{INTRODUÇão}

Este $\operatorname{artigo~}^{1}$ oferece razões para que se desenvolvam, catedralmente, ${ }^{2}$ estudos e pesquisas por meio da análise econômica aplicada ao direito internacional público (AEDIP), sob uma perspectiva da academia brasileira. Inicialmente, explicam-se as particularidades da análise econômica do direito (AED), esclarecendo o que ela adiciona às discussões de direito internacional público (DIP). Como argumento central, vê-se o papel imprescindível da AEDIP como um olhar adicional para o jurista, auxiliando-o na compreensão do fenômeno jurídico internacional de forma amplificada.

\footnotetext{
1 Uma versão preliminar e sintética deste artigo foi apresentada no II Workshop do grupo de pesquisa Direito Global e suas Alternativas Metodológicas, em 2014, a ser publicada nos anais do evento (no prelo, 2016). A presente versão compreende um esforço dos autores de expandir e examinar mais detalhadamente conceitos centrais da disciplina, bem como sua aplicação a certas áreas de direito material. $2{ }^{4}$ Neologismo não tem, seguramente, qualquer conotação ecumênica, mas se inspira na célebre passagem de Calabresi e Melamed de se lançar uma visão adicional sobre um problema para que se tenha uma melhor compreensão do todo. E é, apenas, mais uma das visões possíveis. Veja-se CALABRESI, Guido; MELAMED, A. Douglas. Property rules, liability rules, and inalienability: one view of the cathedral. Harvard Law Review, v. 85, n. 6, p. 1089-1128, Abr. 1972. p. 1089-1090, nota de rodapé 2 .
}

Como panorama geral, embora existam pelo menos dezesseis grupos de pesquisa ${ }^{3}$ em AED no Brasil, a academia brasileira vem só recentemente incursionado na AEDIP 4 . Os poucos manuais ou coletâneas de AED escritos ou traduzidos para o vernáculo pouco auxiliaram nessa construção. ${ }^{5}$ Eles simplesmente não dedicam um

$3{ }^{5}$ Ao se pesquisar, como termo exato, "direito e economia" nos campos nome, linha de pesquisa ou palavra-chave dos grupos certificados e atualizados no Diretórios de Grupos de Pesquisa no Brasil do CNPQ, localizaram-se dezesseis grupos, com distintos escopos e origens: Análise Econômica do Direito (PUC/PR); Centro de Estudos Jurídico-Econômicos e de Gestão do Desenvolvimento (UFSC); Controladoria e Finanças (UNIFAL/MG); Direito Constitucional nas Relações Privadas (UNIFOR); Direito e Desenvolvimento (FEEVALE), Direito e Economia (FGV); Direito e Economia (IDP); Direito e Economia do Petróleo, Gás e outras Fontes de Energias (UCAM); Direito Estado e Sociedade (UFRN); Estado, Sociedade e Relações Jurídicas Contemporâneas (FURB); Estruturas dos Sistemas Tributários e suas Implicações no Desenvolvimento e na Performance do Comércio Exterior dos Países do BRIC: Lições e Soluções (UCB/DF); História e direito: da civilização ao desenvolvimento no Brasil 1750-1930 (USP); Núcleo de Direito, Economia e Governança (FGV); Núcleo de Estudos em Direito Economia, NEDE-DF (UniCEUB); O Papel das Agências Reguladoras no Desenvolvimento da Infraestrutura (UCAM); Propriedade Intelectual, Inovação e Desenvolvimento (UCAM). Dados disponíveis em: < http://lattes.cnpq.br/web/dgp>. Acesso em: 26 out. 2015. Apenas pelos nomes não é possível a identificação de qualquer um dos grupos com dedicação à AED do DIP.

$4{ }^{6}$ Reconhece-se o quão indeterminado possa vir a ser o termo "academia brasileira". Acadêmicos brasileiros no Brasil? Acadêmicos, nacionais ou estrangeiros, que lecionam no Brasil? Adotou-se como critério artigos de acadêmicos, independentemente de sua nacionalidade, com algum tipo de vinculação a uma IES no Brasil. Vejam-se: BELONIEL, Daniel; SALAMA, Bruno. Towards an intellectual property bargaining theory: the post-wto era. University of Pennsylvania Journal or International Law, v. 32, n. 1, p. 265-368, 2010; SANTOS, Alexandre Leite. O direito internacional público como jogo institucional. Economic Analysis of Law Review, v. 1, n. 2, p. 179-195, July/Dez. 2010; RIBEIRO, Gustavo Ferreira. The legality of trade sanctions based on human rights violations: an analysis through law and economics. Economic Analysis of Law Review, v. 3, n. 2, p. 260-281, Dez. 2012; CAIADO, José Guilherme Moreno. From coordination to collaboration: explaining international disputes over tariff classification. Economic Analysis of Law Review, v. 3, n. 1, p. 95-108, Jun. 2012; ELTZ, Magnum Koury de Figueiredo. Uma abordagem da análise econômica do direito para os danos ambientais transfronteiriços. Economic Analysis of Law Review, v. 3, n. 1, p. 40-56, Jun. 2012.

5 Em ordem cronológica: TIMM, Luciano (Org.). Direito e economia. Porto Alegre: Livraria do Advogado, 2008 (contendo um capítulo específico de direito internacional privado, sob a autoria do professor Paulo Caliendo); SALAMA, Bruno Meyerhof (Org.). Direito e economia: textos escolhidos. São Paulo: Saraiva, 2010. (Direito em Debate); COOTER, Robert; ULEN, Thomas. Direito e economia. 5. ed. Porto Alegre: Bookman, 2010. RIBEIRO, Gustavo Ferreira; GICO JR, Ivo T. (Org.). O jurista que calculava. Curitiba: CRV, 2013; TIMM, Luciano (Org.). Direito e economia no Brasil. 2. ed. São Paulo: Atlas, 2014. (contendo um capítulo específico de direito internacional privado, sob a autoria da professora Nádia de Araújo). 
único capítulo sobre o tema.

Decerto, ao menos três motivos contribuem para explicar o cenário mencionado. Em primeiro lugar, esse é um campo novo de pesquisa, exigindo algum tempo para que os grupos especializados em AED e/ou DIP, respondam com publicações e trabalhos na área. Em segundo lugar, o método utiliza, ao se interpolar com a ciência econômica, premissas como racionalidade, escassez, bem-estar, eficiência, teoria dos jogos e ferramentas matemáticas pouco conhecidas na tradição do ensino do DIP, e por que não, do direito, no Brasil. Como resultado, há uma carência de docentes e publicações com viés interdisciplinar que poderiam impulsionar seu uso. ${ }^{6}$ Por fim, mesmo se apropriando desses conhecimentos, existem desentendimentos acerca das possibilidades e limites do método, o que pode dificultar seu uso e aceitação por parte da academia.

As escolas norte-americanas possuem maior familiaridade com a $\mathrm{AEDIP}^{7}$, uma vez que é precursora da AED de forma geral ${ }^{8}$. Já a tradição europeia, assim como a brasileira, é menos aberta ao método, embora o quadro venha se alterando. Aaken, quanto ao cenário europeu, reconhece a sua "quase totalmente negligenciada" utilização. A autora credita essa ausência à tensão da visão kantiana do direito internacional com o pensamento consequencialista e a percepção de que a principal função do jurista é o trabalho dogmático-doutrinário. ${ }^{?}$

6 Aliás, parece ser um problema de "mão dupla", podendo-se dizer que aos economistas também lhes falta maior compreensão da argumentação jurídica e das categorias axiológicas do direito.

7 Sem se pretender qualquer tipo de exaustão, citam-se como seminais: SYKES, Alan O. Protectionism as a "safeguard": a positive analysis of the gatt "escape clause" with normative speculations. University of Chicago Law Review, v. 58, n. 1, p. 255-306. winter 1991; DUNOFF, Joel L.; TRACHTMAN, Jeffrey P. Economic analysis of international law. Yale Journal of International Law, v. 24, n. 1, p. 1-59, winter 1999; BHANDARI, Jagdeep S.; SYKES, Alan O. (Org.). Economic dimensions in international law comparative and empirical perspectives. Cambridge: CUP, 1998. Mais recentemente, GOLDSMITH, Jack L.; POSNER, Eric A. The limits of international law. Oxford: OUP, 2005; TRACHTMAN, Joel P. The economic structure of international law. Cambridge: HUP, 2008; GUZMAN, Andrew T. How international law works. Oxford: OUP, 2008; TRACHTMAN, Joel P. The future of international law: global government. Cambridge: CUP, 2013. POSNER, E. A.; SYKES, A. O.; POSNER, Eric A; SYKES, Alan O. Economic foundations of international law. Cambridge: HUP, 2013.

$8{ }^{10} \mathrm{Não}$ é objetivo deste artigo citar a numerosa literatura de AED nos Estados Unidos, mas deve-se apenas se lembrar as contribuições de Coase, Becker e Williamson, para a formação da área.

$9{ }^{11}$ VAN AAKEN, Anne. Opportunities for and limits to an economic analysis of international economic law. Law and Economics Re-
O artigo se desenvolve, inicialmente, por localizar a AEDIP como um método e expondo dois de seus pressupostos chave: escassez e racionalidade. $\mathrm{Na}$ sequência, investe-se na aplicação da AEDIP em problemas relativos às fontes do direito internacional (tratados e costumes) e a dois de seus campos específicos (investimentos e direitos humanos). Conclui-se por reconhecer os benefícios e desafios do método, conquanto superáveis, que resultariam em uma aproximação salutar da academia brasileira com o vanguardismo no estudo do direito internacional.

\section{A AED COMO UM METOdOLOGIA E SUAS PAR- TICULARIDADES}

\subsection{A análise econômica do direito como um mé- todo aplicável ao direito internacional público}

Os métodos na ciência jurídica são objeto de intenso debate e divergência. Em simpósio realizado em 1999, no contexto da academia norte-americana, Ratner e Slaughter retomaram esse debate secular indicando a AED como um dos sete métodos aplicados a problemas de direito internacional. ${ }^{10}$

A enumeração ${ }^{11}$ parece agrupar, sem maior rigor, escolas, métodos e movimentos ao colocá-los conjuntamente. Reflete uma opção pragmática dos organizadores que chegam mesmo a se questionar se o DIP possui um único ou múltiplos métodos. ${ }^{12}$ Para eles, a preocupação do simpósio sobre o que era um método era menos o de associá-lo a uma teoria geral de direito internacional que pudesse explicar a natureza do DIP, mas o de buscar, na prática, como cada método responderia a problemas específicos. Nessa sistemática,

search Paper Series, v. 9, n. 31, 2010. p. 2.

10 12RATNER, Steven R.; SLAUGHTER, Anne Marie. Appraising the methods of international law: a prospectus for readers. American Journal of International Law, v. 93, n. 2, p. 291-302, April 1999. p. 300.

11 Além da AED (ou law and economics), enumeraram-se: o positivismo; o da escola de New Haven; o processo legal internacional (international legal process); os estudos jurídicos críticos (Critical Legal Studies - CLS); o método que combina o direito internacional e as relações internacionais.

$12{ }^{14}$ RATNER, Steven R.; SLAUGHTER, Anne Marie. Appraising the methods of international law: a prospectus for readers. American Journal of International Law, v. 93, n. 2, p. 291-302, April 1999. p. 299. 
ofereceu-se um mesmo problema para os representantes de cada "método" para que eles determinassem, entre outras coisas, "porquê o direito é daquela maneira", "qual deveria ser o direito" e "qual é o direito" aplicável ao caso. ${ }^{13}$ Como se sugerirá neste artigo, as perguntas refletem as perspectivas positiva, normativa e hermenêtica, com distintas visões sobre os limites e possibilidades de contribuição da AEDIP.

A AED, em si, é descrita como um método que, na sua vertente aplicada ao direito interno, provou-se altamente relevante e duradoura, sob duas formas. A positival descritiva, que serve para explicar as normas como reflexo de resultados economicamente mais eficientes. A normativa, que possibilita avaliar propostas de mudanças nas normas, instando a adoção daquelas que maximizam a riqueza. O método seria frequentemente entendido por abarcar a teoria dos jogos e a escolha pública e, na área internacional, teria estreado com estudos de questões internacionais de comércio e meio-ambiente. A AED possuiria, ademais, relação próxima ao método que conjuga direito internacional e relações internacionais ao dar prioridade ao comportamento racional dos atores. $^{14}$

A categorização entre AED com perspectiva positival descritiva e normativa remonta períodos mais longínquos, própria da epistemologia das ciências sociais, com transposição específica ao direito e ao DIP. Em conferência realizada uma década após a norte-americana, sob os auspícios da Sociedade de Direito Internacional Econômico (SIEL), Aaken relembra que, tradicionalmente, existem três perspectivas de estudar o direito com reflexo direto na abordagem dos juristas. Com alusão ao pioneirismo classificatório de Kantorowicz, cita a autora a perspectiva sociológica (ciência positiva, descritiva), a normativa (ciência normativa) e a doutrinária. Para a autora, partindo do ponto de vista do observador, as perspectivas sociológica e normativa da AEDIP funcionam como uma visão externa, mais característica das ciências sociais. Já à visão interna corresponderia a perspectiva doutrinária, comumente aplicada por juristas para a inter-

13 15RATNER, Steven R.; SLAUGHTER, Anne Marie. Appraising the methods of international law: a prospectus for readers. American Journal of International Law, v. 93, n. 2, p. 291-302, April 1999. p. 292.

$14{ }^{16}$ RATNER, Steven R.; SLAUGHTER, Anne Marie. Appraising the methods of international law: a prospectus for readers. American Journal of International Law, v. 93, n. 2, p. 291-302, April 1999. p. 294, 300. pretação das normas. ${ }^{15}$

A autora reforça o caráter da perspectiva sociológical positiva como descritiva, explanatória e preditiva. De forma geral, nela se desenvolve uma hipótese que deve ser empiricamente testada. Já a abordagem normativa inclui, no caso do DIP, a questão de como ele deve ser (lege ferenda). Em um nível mais geral, aproxima-se da filosofia ao se questionar quais objetivos deve o DIP buscar (eficiência, paz, justiça, sustentabilidade). Em seu nível mais específico, pode ser usado para se pensar como conceber instituições internacionais (em sentido amplo: organizações, tratados, softlaw) tendo em vista certos objetivos, inclusive a efetividade da norma internacional. Finalmente, a abordagem doutrinária teria relação com a aplicação do direito (bermenêutica) e, no caso singular do DIP, com os artigos 31 e 32 da Convenção de Viena dos Direitos dos Tratados (CVDT). ${ }^{16}$

Ao fazer a categorização em três perspectivas, não teve a autora intenção de considerá-las estanques. Pelo contrário. Sugere que as perspectivas são intimamente interconectadas. A abordagem positiva pode resultar em uma crítica normativa. Ou seja, ao se descrever algo (pela ciência positiva) afloram seus benefícios e problemas, podendo se sugerir aproveitamentos e mudanças; o esforço normativo (p.e. na concepção de políticas públicas e instituições internacionais), por sua vez, necessita da descrição sociológica (ciência positiva) se se quer levar em conta os efeitos de normas no mundo real.

Até esse ponto, parece que Aaken entende não haver maiores dificuldades no papel das ciências sociais (incluindo a economia) a contribuir pelas interconexões das perspectivas. Porém, sobre a terceira abordagem (hermenêutica), revela a autora maior divergência entre a tradição europeia (refratária ao uso de outras disciplinas que não o direito) a e norte-americana (familiar ao uso das ciências sociais no direito) com reflexos no DIP. Ao mesmo tempo, admite Aaken certo contrassenso na tradição continental. Afinal, certos métodos interpretativos (como o teleológico, prescrito no artigo 31(1), in fine da CVDT, "[...] à luz de seu objetivo e finalidade") não apenas deixa aberto uma janela para conhecimentos das ciências sociais (positivos ou normativos) mas mesmo de-

$15{ }^{17}$ VAN AAKEN, Anne. Opportunities for and limits to an economic analysis of international economic law. Law and Economics Research Paper Series, v. 9, n. 31, 2010. p. 4.

$16{ }^{18}$ VAN AAKEN, Anne. Opportunities for and limits to an economic analysis of international economic law. Law and Economics Research Paper Series, v. 9, n. 31, 2010. p. 6. 
manda-o. $\mathrm{O}$ mesmo ocorreria com relação à argumentação de natureza consequencialista e certos princípios como o da proporcionalidade e da necessidade, encontrados no General Agreement on Trade and Tariffs (GAT'T) e na Convenção Europeia de Direitos Humanos. Esses métodos e princípios funcionariam como "canais" ou "janelas" para se acomodar os cânones da "escolha racional" e os paradigmas das ciências sociais, como a economia. $^{17}$

Em sessão própria, este artigo retomará as classificações e suas aplicações na AEDIP. Porém, duas ressalvas são esclarecedoras ao se tomar a AEDIP como um método, distinguindo-o de outras abordagens envolvendo a economia e o direito internacional.

A primeira é que o uso da economia pode ser meramente acessório à aplicação da regra jurídica. Pense-se, por exemplo, no caso envolvendo o Brasil e os Estados Unidos, na Organização Mundial do Comércio (OMC), sobre a concessão de subsídios pelo governo norte-americano aos seus agricultores. Uma vez considerado proibido, o cálculo do dano que o programa de subsídios norte-americanos ao algodão causou à indústria nacional de diversos países faz apenas uso instrumental da economia. Da mesma forma, quando se autorizou, no mesmo contencioso, que o Brasil retaliasse produtos norte-americanos até um determinado valor (gatilho), a potencial lista de produtos oferecidas pelo Brasil se fundava em um cálculo econômico (elasticidade-renda) de cada um dos produtos da lista.

A segunda observação se direciona à classificação do direito em disciplinas e a associação da AED àquelas vistas como pertencentes exclusivamente ao campo do direito internacional econômico (DIE), i.e., comércio, investimentos e finanças internacionais. ${ }^{18}$ Ainda que o DIE seja um campo fértil para a AED (seja nas perspectivas positiva, normativa e/ou doutrinária), outras áreas

$17{ }^{19}$ VAN AAKEN, Anne. Opportunities for and limits to an economic analysis of international economic law. Law and Economics Research Paper Series, v. 9, n. 31, 2010. p. 7-8.

$18{ }^{20}$ Embora seja igualmente complexo definir qual é o campo do direito internacional econômico. Da academia norte-americana e europeia vejam-se, respectivamente: CHARNOVITZ, Steve. What is international economic law? Journal of International Economic Law, v. 14, n. 1, p. 3-22, 2014. CARREAU, Dominique; FLORY, Thiébault; JULLIARD, Patrick. Droit internacional èconomique. Paris: Persée, 1990. No caso do Brasil, encontra-se, no prelo, abrangente pesquisa empírica dos professores Fabio Costa Morosini (UFRGS) e Michelle Ratton Sanchez Badin (FGV), sobre o escopo de campo do DIE, com base nos currículos lattes dos professores que se auto intitulam como pertencentes à disciplina. não percebidas como diretamente econômicas também podem ser. Ratner e Slaughter mencionam que a Corte de Justiça Internacional (CIJ) vem há muito tempo considerando a eficiência econômica como um conceito chave em seus julgamentos, citando especificamente, em sua ilustração, o caso da delimitação das plataformas continentais trazidos àquela Corte. ${ }^{19}$

Exposta a AEDIP como um método e suas perspectivas, as próximas seções avançam na elaboração de dois de seus pressupostos chave (escassez e racionalidade).

\subsection{Pressuposto chave: escassez}

A economia é tida como a ciência que trata da alocação de recursos escassos. Qualquer manual ou livro consistente de introdução à economia enfatizará, de uma outra maneira, a escassez como um fato.

Assim, Cooter e Ulen relembram a consagrada definição de ciência econômica em Robbins: trata-se do estudo do "comportamento humano como uma relação entre fins e meios escassos que poderiam ser usados de modo alternativo". ${ }^{20}$ Pindick e Rubinfeld dão sonoridade (e simplicidade) à definição, aludindo à canção dos Rolling Stones de que "não se pode conseguir sempre [tudo] aquilo que se deseja". ${ }^{21}$ No campo do direito, Holmes e Sustein já salientaram a dupla relação entre escassez e direitos: (i) direitos dependem da existência de recursos; e (ii) governos e juízes escolhem rotineiramente como alocá-los, sendo que a escolha de se proteger alguns resulta no abandono de outros. ${ }^{22}$ São centenas de variações na literatura para se descrever uma realidade: os recursos na sociedade, doméstica ou internacional, são escassos e há escolhas a serem feitas.

As inferências são imediatas para o plano internacional. Não há recursos suficientes no mundo para, ao mesmo tempo, saciar a fome mundial, eliminar a poluição do mar, conservar as florestas, eliminar o desemprego, acolher refugiados, eliminar o tráfico internacional

$19{ }^{21}$ RATNER, Steven R.; SLAUGHTER, Anne Marie. Appraising the methods of international law: a prospectus for readers. American Journal of International Law, v. 93, n. 2, p. 291-302, April 1999. p. 300.

$20{ }^{22}$ COOTER, Robert; ULEN, Thomas. Direito e economia. 5. ed. Porto Alegre: Bookman, 2010. p. 35.

$21{ }^{23}$ PINDYCK, Robert S.; RUBINFELD, Daniel L. Microeconomia. 7. ed. São Paulo: Pearson, 2010. p. 4.

$22{ }^{24}$ HOLMES, Stephen; SUNSTEIN, Cass R. The cost of rights: why liberty depends on taxes. New York: WW Norton, 1999. capítulo 5 . 
de crianças, garantir a paz, entre outros. Escolhas serão feitas e as discussões passam pela legitimidade dessas escolhas e de como os atores, se se deseja atingir o objetivo com o menor desperdício possível de recursos, podem maximizar os resultados pretendidos.

Outra questão nessa transposição é a da identidade dos atores que, assumidamente e racionalmente, realizam essas escolhas em um mundo escasso. O DIP concede intensa primazia ao papel do Estado, uma coletividade, em sua análise. O que significaria racionalidade e como pensá-la nesse contexto?

\subsection{Pressuposto chave: racionalidade}

O método econômico faz uso do conceito de racionalidade e, por consequência, da escolha racional (rational choice), comumente empregado nas ciências sociais. Os atores são racionais e suas ações são pautadas por cálculos de custos e benefícios de acordo com seus interesses ou preferências. Diz-se que os atores (os mais variados possíveis) buscam maximizar o resultado final do cálculo (benefício líquido), de acordo com essas preferências.

Não se tratam de cálculos puramente monetários e passa despercebido pelos juristas a idiossincrasia de que a própria ordem jurídica se funda na ideia de gerar custos e benefícios que influenciam o balanceamento dos cálculos pelos atores. A sanção (administrativa, civil ou penal) pode ser pensada como uma forma de se criar custos, ao desincentivar condutas dos agentes. Normas premiais induzem o inverso. Da mesma forma, decisões judiciais geram uma espécie de segunda ordem de efeitos na sociedade sinalizando o que é ou não aceitável, sendo a de primeira ordem aquela específica ao caso concreto, entre as partes. Não há aqui, reforce-se, o intento de se desenvolver os meandros desses pressupostos, mas simplesmente de sugerir transposições para a AEDIP.

Decerto, a racionalidade permite que o pesquisador entenda o comportamento de diversos atores como racionais, ainda que esses não sejam formalmente reconhecidos como sujeitos de direito internacional. Assim, mesmo que grande parte da literatura da AEDIP tenha por objeto de pesquisa o comportamento estatal, seja como formulador ou objeto da norma jurídica, também é possível analisar o comportamento, bem como o impacto de uma determinada norma sobre o comportamento de várias outras coletividades: organizações internacionais, grupos governamentais informais, organizações-não-governamentais, tribunais internacionais e domésticos e empresas multinacionais.

Ao fazer simplificações, como em qualquer método, e considerar o Estado como a unidade de análise racionalizadora, sem desagregá-la, a AEDIP nada mais faz do que uma redução metodológica. O mesmo ocorre em outras abordagens. Nas relações internacionais, similarmente, a unidade de análise "Estado" é tida como dada (taken as given). Na escola realista, o foco é no Estado que busca maximizar seu poder no plano internacional, ${ }^{23}$ colocando-se de lado o papel dos grupos domésticos internos na formação dos interesses. De forma análoga, mas com foco em elementos outros que o poder, os institucionalistas também veem o estado como uma "caixa preta", conferindo pouca ênfase à influência de grupos políticos domésticos.

O questionamento de como as preferências e/ou interesses dos Estados são forjados conduzem a inúmeras discussões que podem ser introduzidas em modelos mais sofisticados. Se se prefere uma abordagem político-econômica, pode-se entender a racionalidade da ação estatal com base em um conjunto de forças domésticas, o que é estudo do campo denominado Escolha Pública (Public Choice) ou de outras escolas das relações internacionais (Liberal Theory).

Mas ao se considerar o Estado (unidade de análise) como um ente racional, paralelos serão possíveis para se entender o significado do agir racional. Por exemplo, se se pensa nas razões às quais Estados celebram tratados, como sugere Guzman, Estados celebram tratados pelo mesmo motivo que indivíduos celebram contratos: obter um excedente cooperativo e garantir o curso de uma conduta presente e futura. ${ }^{24}$ Oportunamente, este artigo retomará esses exemplos.

\subsection{Crítica aos pressuposto racional}

Se da escassez não decorrem críticas plausíveis, a ideia de racionalidade de atores, entretanto, é há muito

$23{ }^{25}$ NOGUEIRA, João Pontes; MESSARI, Nizar. Teoria das relações internacionais. São Paulo: Elsevier, 2005. p. 23-24.

$24{ }^{26}$ GUZMAN, Andrew T. How international law works. Oxford: OUP, 2008. p. 121. São simplificações, reduções, opções metodológicas que funcionam para possibilitar uma análise, mas que não passam despercebidas da crítica da própria AEDIP. GOLDSMITH, Jack L.; POSNER, Eric A. The limits of international law. Oxford: OUP, 2005. p. 4-7. DUNOFF, Joel L.; TRACHTMAN, Jeffrey P. Economic analysis of international law. Yale Journal of International Law, v. 24, n. 1, p. 1-59, winter 1999. p. 16. 
criticada. ${ }^{25}$ Essa tendência, comum em estudos sobre a escolha racional no direito doméstico, na qual se reconhecem lapsos, comportamentos impulsivos e limitações cognitivas dos indivíduos avança, igualmente, sobre a AEDIP.

De acordo com Broude, a abordagem behaviorista diverge da AEDIP "clássica", primeiro por trabalhar com conceitos lastreados em pesquisas empíricas, e também porque os resultados dessas pesquisas demonstram as limitações do conceito de racionalidade, tão caro aos estudiosos da análise econômica. Segundo os argumentos de Broude, a ideia de racionalidade da análise econômica estaria tão desgastada, que a análise behaviorista deveria se aproximar mais da sociologia que da análise econômica racional. Esse behaviorismo sociológico, na opinião de Broude, poderia abrir novas frentes de pesquisa no estudo do DIP, podendo ser aplicado para compreender o comportamento de três tipos de atores: (i) o estado como ator unitário; (ii) coletividades internacionais de tomada de decisões; e (iii) o indivíduo como tomador de decisões de cunho internacional. ${ }^{26}$ Embora pertinente o argumento, entende-se que não há na AEDIP uma exclusão a priori dessas dimensões. Como já se mencionou, trata-se muito mais

$25{ }^{27} \mathrm{Um}$ bom resumo é a discussão de Mark Blaug sobre o postulado da "racionalidade" como sacrossanta, ultra empirista e, como próprio Popper admitiu, falsa. BLAUG, M. The methodology of economics: or how economists explain. 2. ed. Cambridge: CUP, 1992. p. 229-236.

$26{ }^{28}$ BROUDE, Tomer. Behavioral International Law. Hebrew University of Jerusalem International Law Forum Research Paper, n. 12-13, p. 1-85, 2013. doi: 10.2139/ssrn.2320375. De fato, as possibilidades são múltiplas o incremento de experimentos, nos quais se simula, em laboratório ou em campo, o comportamento e a reação de diferentes atores a determinadas situações parece ser uma tendência. Entretanto, ainda que esses métodos possam ser valiosos para se estudar o comportamento de, por exemplo, negociadores internacionais durante as tratativas para assinatura de um acordo, sua aplicação a entes mais complexos, como o Estado e OIs, esbarra na dificuldade de se comparar a ação de tal ente à "falhas" habitualmente observadas no comportamento do indivíduo. Uma das soluções propostas, a de individualizar o comportamento dos estados, pode ser encontrada no trabalho de Hafner-Burton e outros, que analisa uma possível correlação entre a escolha de mecanismos de execução de tratados internacionais e o nível de senioridade dos negociadores americanos. Segundo os autores, quanto mais sênior o negociador, menor a preocupação com tais mecanismos. HAFNER-BURTON, Emilie M.; LEVECK, Brad L.; VICTOR, David G. Strategic enforcement: results from an elite survey experiment on international trade agreements. SSRN Electronic Journal, Aug. 2012. doi: 10.2139/ ssrn.2132948. Available at: <https://www.researchgate.net/publication/256031577_Strategic_Enforcement_Results_from_an_ Elite_Survey_Experiment_on_International_Trade_Agreements $>$. Access: Feb. 09, 2016. de uma questão de enfoque, de modelagem e do tipo de problema que se quer analisar.

Não é por menos, que, atenuando a crítica acerca do papel da teoria racional para a compreensão do direito internacional, Aaken sugere que a abordagem behaviorista pode oferecer argumentos e conclusões complementares aos resultados da análise econômica. Por exemplo, trazendo insights acerca da pretensão de Estados, representados na figura de seus negociadores, de assinarem tratados internacionais. Segundo a autora, a teoria behaviorista sugere que a vinculação de negociações de diferentes tratados (bens manufaturados, produtos agrícolas, serviços, meio-ambiente), como no caso da OMC, pode ser um empecilho à conclusão das tratativas, porque indivíduos tendem a supervalorar suas concessões, e subestimar aquelas feitas pela outra parte. Se essa supervaloração já tem implicações em um contrato simples entre duas partes, ela se potencializa em contratos múltiplos que precisam ser negociados simultaneamente entre partes diversas. Outro problema, baseado na teoria contratual, diz respeito aos benefícios de flexibilidade nos contratos, que é comumente defendida pela teoria racional. De acordo com Aaken, há uma tendência de que as partes interpretem a seu favor cláusulas demasiadamente abertas, o que pode levar a comportamentos contra produtivos do ponto de vista da criação esperada de valor pelo contrato. Assim, as recomendações da teoria behaviorista acerca da rigidez contratual podem diferir daquelas da teoria racional pura. $^{27}$

$\mathrm{Na}$ seção subsequente, apresentado o método da AEDIP e os pressupostos da escassez e racionalidade, sugerem-se contribuições do método a problemas específicos.

\section{Potencials contribuições da AEDIP}

A presente seção expõe, principalmente, quatro aplicações da AEDIP. Nas duas primeiras, ilustra-se a teoria das fontes do direito internacional público vista sob o olhar da teoria racional: por que certas formas jurídicas surgem e quando estas serão preferidas sobre outras (tratados e costumes, nos exemplos dados). Nas

$27{ }^{29}$ VAN AAKEN, Anne. Behavioural international law and economics. Harvard International Law Journal, n. 55, p. 421-481, summer 2014. 
duas seguintes a AEDIP é aplicada à determinadas áreas do DIP: direito internacional dos investimentos e direitos humanos. Em cada um dos exemplos, apontam-se a qualidade da abordagem em positiva, normativa ou hermenêutica, retomando-se as distinções anteriores. Como fechamento do bloco, enumeram-se outras possíveis aplicações.

\subsection{Tratados: por que se formam? Por que se descumprem?}

Fonte formal do DIP, os tratados são definidos como um acordo internacional concluído por escrito entre Estados e regido pelo Direito Internacional, podendo se consubstanciar em um único ou múltiplos instrumentos. As variações terminológicas (como convenções) são irrelevantes, sendo esse o conceito encontrado na Convenção de Viena dos Direitos dos Tratados. Do texto convencional se desenvolve boa parte do dogmatismo jurídico acerca dessa fonte; por assim dizer, as regras sobre a conclusão e a entrada em vigor, a possibilidade de reservas, a observância, a aplicação e a interpretação dos tratados.

Em uma de suas aplicações, a AEDIP pode ser utilizada para se desvendar a origem dos tratados. Por que Estados se engajam na celebração de tratados? Ou qual a origem material dos tratados? ${ }^{28}$

Trata-se da perspectiva positiva da AEDIP que nos ajuda a compreender essas indagações, amparando-se na dinâmica racional Estatal. Alguns autores utilizam a teoria dos contratos, que já recebeu bastante atenção por parte da literatura doméstica de análise econômica, nesse esforço. Como sugere Trachtman, tratados devem ser vistos como análogos aos contratos domésticos porque são, também, acordos entre partes com a intenção de criar-se um documento juridicamente vinculante com direitos e obrigações que modelem o comportamento futuro das partes. ${ }^{29}$

\footnotetext{
$28{ }^{30}$ A distinção entre fonte formal e material dos tratados é didaticamente feita pelo professor Guido Soares com a analogia de uma pessoa que busca água para matar sua sede: "vai à fonte (fonte formal), sem ter de preocupar-se com a indagação de sua origem mais profunda (fonte material), ou seja, se a mesma vem de lençóis freáticos, [...] do ciclo de água da terra, [...] a partir do big-bang que formou o universo [...]"SOARES, Guido Fernando Silva. Curso de direito internacional público. 2. ed. São Paulo: Atlas, 2004. v. 1. p. 54.

$29{ }^{31}$ DUNOFF, Joel L.; TRACHTMAN, Jeffrey P. Economic analysis of international law. Yale Journal of International Law, v. 24, n. 1, p. 1-59, winter 1999. p. 23.
}

Ainda sob o pensar positivo, a AEDIP oferece ferramentas sobre as razões pelas quais os tratados são descumpridos e como a racionalidade da inobservância se afeiçoa. Ao se abordar contratos a partir da teoria dos preços, argumenta-se que o preço (custo) de violação é o elemento principal da observância. Esse preço seria composto por dois elementos. Em primeiro lugar, a quantidade ou valor dos danos que um determinado Estado teria de arcar em caso de inobservância. Em segundo lugar, a probabilidade de condenação. Essa, por sua vez, seria afetada pela capacidade de se (i) identificar um comportamento ilícito, e de se (ii) provar sua existência perante o tribunal competente. Se a resultante da composição (multiplicação) das variáveis valor e probabilidade for demasiadamente baixa, podem se esperar incentivos baixos para o cumprimento das obrigações firmadas.

Porém, em uma sociedade global anárquica, horizontal - sem autoridade central - pode-se mesmo especular se o tratado teria o condão de induzir observância (cumprimento) das obrigações internacionais com base apenas na composição das variáveis acima. Transposto para a linguagem jurídica, vem à tona o tradicional problema da "ausência" de sanção e enforcement do DIP.

Não é por menos que Guzman teoriza sobre a existência de três " $R$ " (reputação, reciprocidade e retaliação) como componentes necessários à análise sobre a observância das obrigações internacionais. A reputação é definida como a avaliação sobre o comportamento passado de um determinado ator para se prever seu futuro comportamento. Assim, uma "sanção" reputacional se refere ao custo imposto ao Estado quando sua reputação é atingida negativamente. Não se tratam de punições no sentido estrito, mas a ideia da perda de credibilidade do Estado frente a seus pares. Quando um Estado observa (cumpre) um tratado transmite uma mensagem de que tem boa vontade em honrar suas obrigações. Essa boa reputação teria valor ao tornar mais críveis e menos custosos novos compromissos com esse Estado. ${ }^{30}$ Colocado simplificadamente, acredita-se em quem goza de boa reputação, sendo o inverso também verdadeiro. A reciprocidade, similarmente, não representa uma "sanção" direta ao violador, mas uma resposta ao descumprimento do violador original: um Estado cessa o cumprimento de suas obrigações (descontinua a reciprocidade) quando a violação original não mais atende

$30{ }^{32}$ GUZMAN, Andrew T. How international law works. Oxford: OUP, 2008. p. 33. 
a seus interesses. Finalmente, a retaliação possuiria o intento direto de punir o violador, perpassando pelas formas de sanções econômicas, diplomáticas ou mesmo militares. $^{31}$

Também dessa visão descritiva, são trazidos conceitos de incompletude dos contratos causada por conhecimento insuficiente das partes ou por cálculo estratégico no momento das negociações. ${ }^{32}$ Nesse ponto, extrapola-se a mera narrativa do tratado como fonte material do DIP e se investiga a questão das variações obrigacionais dos tratados (precisas, imprecisas, de melhores esforços etc.).

Pode se chegar a uma situação, assim segue o argumento, em que os custos de transação na negociação contratual sejam muito elevados e as partes decidam empregar termos vagos que carecem de interpretação, ou simplesmente ignorem certos possíveis comportamentos ou situações futuras que demonstrem necessidade de regulação. Os juristas rotulam o resultado dessa dinâmica como cláusulas abertas, conceitos indeterminados ou a ideia de ambiguidade construtiva dos tratados (constructive ambiguity). Haveria, portanto, na esfera bermenêutica e como prescrição normativa a possibilidade de que os tribunais empreguem uma regra que, alegadamente, as partes teriam alcançado nas negociações. Alternativamente, que se determinem sanções que poderiam levar a um comportamento similar ao que teria sido estabelecido pelas partes, colocando-as na mesma posição caso as obrigações tivessem sido cumpridas. ${ }^{33}$

Paradoxalmente, em uma perspectiva normativa, alguns estudiosos afirmam que, em certas circunstâncias, a inobservância de determinada obrigação contratual poderia ser mais eficiente do que o desempenho da obrigação pactuada no tratado. ${ }^{34}$ Os economistas se utilizam de certos conceitos de eficiência (Pareto e Kaldor-

$31{ }^{33}$ GUZMAN, Andrew T. How international law works. Oxford: OUP, 2008. p. 33-34.

$32{ }^{34}$ SANTOS, A. L. O direito internacional público como jogo institucional. Economic Analysis of Law Review, v. 1, n. 2, Dez. 2010, p. 186, 193.

33 35 Para uma análise mais detalhada acerca da aplicação dessa teoria ao direito internacional. PAUWELYN, Joost. Optimal protection of international law: navigating between European absolutism and American voluntarism. Cambridge: CUP, 2008.

$34{ }^{36}$ SYKES, Alan O. Protectionism as a "safeguard": a positive analysis of the gatt "escape clause" with normative speculations. University of Chicago Law Review, v. 58, n. 1, p. 255-306. winter 1991. Para uma análise mais recente, ver SCHROPP, Simon. A. B. Trade policy flexibility and enforcement in WTO: a law and economics analysis. Cambridge: CUP, 2009.
-Hicks) $)^{35}$ para estabelecer o porquê de ser a quebra um resultado eficiente (efficient breach), atendidas certas condições. $^{36}$

Ao mesmo tempo, exerce-se uma crítica normativa por meio da descrição positiva, no sentido de que a quebra eficiente pode afetar o núcleo duro da teoria dos tratados, ou seja, a noção de que os tratados têm de ser obedecidos. ${ }^{37}$ Dessa leitura, afirmariam os juristas: "pacta sunta servanda".

\subsection{O direito consuetudinário}

$\mathrm{Na}$ dogmática internacionalista, o direito consuetudinário é definido como uma de suas fontes formais. Da leitura do artigo 38 do Estatuto da Corte Internacional de Justiça, advém o conceito tradicional do costume como prova de uma prática geral aceita como sendo o direito. A doutrina, com variantes, distingue dois elementos dessa definição: (i) a prática consistente entre os Estados; e (ii) a opinio iuris, elemento subjetivo associado à consciência ou aceitação do costume como sendo o direito.

Encontram-se bem documentados os enigmas acerca da definição e prova do costume (duração, abrangência da prática, significado da opinio iuris). A abordagem dogmática, entretanto, empenha poucos esforços em explanar a razão do surgimento dos costumes internacionais, podendo-se questionar até mesmo se teria essa função, ao tomar o costume como fonte formal e não material. $^{38}$

A AEDIP positiva, por outro lado, retoma a proble-

35 A lição de SEN é um bom ponto de partida sobre os diversos conceitos de eficiência. Veja-se: SEN, Amartya. On ethics and econom ics. Malden: Blackwell, 1987. p. 31-40, sem se olvidar da leitura de suas diversas notas de rodapé.

36 Trazido para a linguagem jurídica, o debate é feito à luz da colisão de princípios (por exemplo, o pacta sunt servanda e o rebus sic stantibus). Como consequência, poder-se-ia argumentar que o direito internacional deveria permitir a violação da obrigação em tais casos. $37{ }^{39}$ Entretanto, os autores argumentam que, no direito interno esse também é um problema e que a doutrina concluiu que ao permitir quebra eficientes pode-se estimular as partes a celebrar contratos que não existiriam em sua ausência. DUNOFF, Joel L.; TRACHTMAN, Jeffrey P. Economic analysis of international law. Yale Journal of International Law, v. 24, n. 1, p. 1-59, winter 1999. p. 24-26. $38{ }^{40}$ Estar-se-á aqui incorrendo nos riscos das generalizações. Relevante estudo sobre métodos no direito internacional e a conjugação de explicações dogmáticas e realistas sobre o costume internacional é encontrada em LUPI, André Lipp Pinto Basto. Os métodos no direito internacional. São Paulo: Lex, 2007. p. 173-201. 
mática de se explicar o costume como fonte material do DIP. Em uma das pioneiras abordagens, Goldsmith e Posner rejeitam argumentos de jusnaturalismo e de moralidade para justificar a origem do costume. Adentram o comportamento dos Estados, por meio da teoria dos jogos, para elucidar quatro lógicas possíveis e subjacentes ao surgimento do costume. A primeira, coincidência de interesses, sugere que as regularidades de comportamento associadas ao costume são meros resultados de condutas individuais auto interessadas dos Estados, sem qualquer relevância quanto à ação tomada por outros. A segunda, coerção, tem a ver com o poderio de um Estado (ou coalizão) em forçar ou ameaçar outros pares em se engajar em atos que não fariam, absente a coerção. A terceira (cooperação verdadeira) e a quarta (coordenação) lógicas envolveriam algum grau de incremento de ganhos para os Estados em ações concertadas mas teriam pouco poder explicativo para justificar o costume como uma prática persistente da comunidade internacional, senão em situações particulares com poucos Estados. ${ }^{39}$ Em outras palavras, não haveria costume na esfera internacional fora das hipóteses em que todos fazem parte daquela prática. No extremo do argumento, descartar-se-ia mesmo a noção de jus cogens e a possibilidade de se referir a violação de costumes a Estados que não tenham inequivocamente se comportado como entendendo ser aquele costume o próprio direito.

Guzman, por outro lado, afasta-se da espinhosa questão de buscar a origem do costume. Assume o fato de que tribunais internacionais, como a CIJ, reconhecem um conjunto de costumes na sociedade internacional. Nesse sentido, busca desvendar, também, na perspectiva positiva, em que grau os costumes afetam o comportamento estatal, sugerindo similaridade entre as forças dos "R" presente nos tratados e nos costumes. Tanto as obrigações previstas nos tratados quanto as derivadas do costume gerariam custos aos violadores, seja por perda de reputação, retirada de reciprocidade ou alguma ação retaliatória. Falhas em observar costumes ditos como postos sinalizariam a intenção de um Estado em ignorar obrigações internacionais e faria, em um jogo de continua interação dos Estados ao longo

$39{ }^{41}$ GOLDSMITH, Jack L.; POSNER, Eric A. A theory of customary international law. University of Chicago Law Review, Chicago, v. 66, p. 1133-1177, 1999. p. 1114-1115. Um contra-argumento é apresentado na lição de Schacte de que três ou quatro Estados com frota naval foram responsáveis pela elaboração da maior parte do (costumeiro) Direito do Mar. Veja-se GUZMAN, Andrew T. How international law works. Oxford: OUP, 2008. p. 189. do tempo, que a cooperação futura seja mais custosa (custo reputacional). Já a violação acerca do costume sobre o tratamento de diplomatas estrangeiros ${ }^{40}$ poderia significar a retirada da reciprocidade por outros Estados. Por fim, a inobservância dos costumes acerca de direitos humanos pode, sob a forma de custos de retaliação, desfechar sanções, como comerciais. Além disso, Guzman afirma que os custos de violação dos costumes seriam mais elevados do que os presentes em "meras normas" internacionais que não adquiriram status de costume, embora reconheça a dificuldade em se separar os costumes do que denomina "meras" normas. ${ }^{41}$

Exercitados com a AEDIP, explicações sobre a origem de duas fontes precípuas do DIP, a próxima seção adentra campos específicos de aplicação do método.

\subsection{Direito internacional do investimento}

Sornarajah define o investimento estrangeiro como aquele que "envolve a transferência de ativos tangíveis e intangíveis de um país a outro, com o propósito de utilizá-los neste país gerando riqueza por meio do controle total ou parcial do proprietário dos ativos". ${ }^{42} \mathrm{No}$ jargão jurídico, os direitos envolvendo esse fluxo de capital é estudado sob a disciplina Direito Internacional dos Investimentos.

A literatura é farta. Nela se expõe o potencial conflito entre os interesses dos investidores e as pretensões regulatórias dos países receptores de capital. Ampliada, ostenta esse campo ponderações sobre interesses e ideologias conflitantes entre o Norte e o Sul, países desenvolvidos e em desenvolvimento, embora, recentemente, essa divisão tenha perdido apelo. ${ }^{43}$

Diversas tentativas foram empreendidas em se estabelecer regras sobre investimentos estrangeiros, sendo o gênero Acordos Internacionais de Investimentos (International Investments Agreements - II $A)^{44}$ utilizado para

$40 \quad{ }^{42}$ Acrescentemos: hoje consubstanciado em tratados como a Convenção de Viena das Relações Diplomáticas.

$41{ }^{43}$ GUZMAN, Andrew T. How international law works. Oxford: OUP, 2008. p. 190-193.

$42{ }^{44}$ SORNARAJAH, M. The international law of foreign investment. 3. ed. Cambridge: CUP, 2010. p. 8.

$43{ }^{45}$ A divisão de capital no mundo moderno é muito mais complexa. Basta se pensar o caso do Brasil que, na última década, vêm assumindo uma posição de exportador de capital, buscando o seu próprio modelo de proteção de seus investidores no exterior.

$44{ }^{46}$ Terminologia utilizada pela United Nations Conference on Trade and Development (UNCTAD). 
denominar tanto os acordos bilaterais (BITS), quanto os regionais e multilaterais. Conforme dados da UNCTAD existiram 2.556 desses acordos em vigor (2015), sendo significativa a categoria dos BITS (89\%). ${ }^{45}$

A AEDIP pode ser utilizada em diversas questões sobre o campo do Direito Internacional do Investimento. Como sintetiza SASSE, a estória tradicional dos BITs, quanto a sua origem material, é a de que Estados receptores e investidores estrangeiros buscam gerar algum tipo de excedente (atração de investimento e proteção, respectivamente), por meio desses acordos. Fato, inclusive, que, empiricamente, ainda não se encontra provado. Um número de estudos não conseguiu confirmar os efeitos positivos dos BITS em termos de atração de investimentos. ${ }^{46}$ Há mesmo quem indique, como Montilla, a partir de uma abordagem racionalista (teoria da agência), efeitos negativos, capturados na linguagem econômica como externalidades, que investimentos estrangeiros podem ter em países da África Sub-Sariana. ${ }^{47}$

A abordagem positiva de SASSE, não obstante, indica que os BITs devem trazer, de algum modo, benefícios para as partes e influenciar suas condutas. Do ponto de vista do investidor estrangeiro, o autor localiza os benefícios nos aumentos de custos de violação pelos Estados receptores, em, pelo menos, dois modos. O primeiro se deve à forma particular dos Estados poderem ter seus ativos sequestrados em outros países (em caso de arbitragem); o segundo, pelo custo reputacional, em caso de

$45 \quad{ }^{47}$ Os dados podem ser extraídos do site interativo da UNCTAD: UNITED NATIONS CONFERENCE ON TRADE AND DEVELOPMENT. International Investment Agreements Navigator. Available at: <http://investmentpolicyhub.unctad.org/IIA $>$. Access: Out. $15,2015$.

$46 \quad{ }^{48}$ SASSE, Jan Peter. An economic analysis of bilateral investment treaties. Hamburgo: Gabler, 2011. p. 67.

$47{ }^{49}$ No centro da análise desse autor está a ideia de que o direito à propriedade local, com elementos coletivistas, coloca o chefe da tribo em posição possivelmente oportunista em relação aos demais usuários da terra. Estes podem, assim, ter seus interesses mal representados em uma eventual negociação acerca das condicionalidades do investimento. $\mathrm{Na}$ ausência de instrumentos jurídicos locais para fazer valer as pretensões desses usuários, Montilla busca soluções tanto em instrumentos de formulação de tratados de investimento, de interpretação do direito do investimento estrangeiro, bem como na atuação de grupos internacionais sobre o financiamento estatal de tais atividades de aquisição de terra por meio de investimento, como forma de garantir direitos humanos internacionalmente reconhecidos. MONTILLA FERNÁNDEZ, Luis Tomás. Land policies and labour markets in Sub-Saharan Africa: a law and economics analysis. IDS Bulletin, v. 43, n. 6, p. 78-89, 2012. doi: 10.1111/j.17595436.2012.00381.x. violação, frente a outros investidores e Estados-pares. ${ }^{48}$ Como se vê, trata-se de uma aplicação a um campo específico do outrora discutido por Guzman, sobre o funcionamento dos " $\mathrm{R}$ " no direito internacional. ${ }^{49}$

Ainda em uma abordagem descritiva, todavia para explicar a natureza dos BITs como contratos incompletos, Aaken chama a atenção para a incerteza das partes sobre o futuro e os elevados custos na redação do acordo. Destarte, são instrumentos que necessitam de flexibilização. Entretanto, e esse é um ponto de vista mais interessante ao aplicador do direito, a autora classifica a possibilidade da já mencionada quebra eficiente como extralegal. Argumenta que um instrumento de flexibilidade intralegal pode levar a resultados semelhantes, sem a necessidade de modificações no acordo. Os instrumentos intralegais, por sua vez, poderiam ser classificados em explícitos e implícitos. Os explícitos estariam contidos no próprio texto do tratado, tais como regras de exceção contratual. Os implícitos seriam por meio de tribunais e outros mecanismos de interpretação a posteriori que possam vir a, em uma análise de caso concreto, interpretar as regras de maneira a se adequar à nova realidade que possa justificar a violação contratual. Dessa forma, juízes ou outras pessoas designadas pelo tratado poderiam lidar com problemas de incompletude contratual que tenham porventura levado as partes a contratar em termos vagos ou a deixarem lacunas. Uma das soluções, segundo a autora, nesse viés hermenêutico, seria abrir uma porta, com base na interpretação do direito internacional do investimento estrangeiro, para outros campos do direito internacional, como o direito ao meio ambiente ou os direitos humanos..$^{50}$

\subsection{Direitos humanos}

Estudiosos do DIP se deparam com o idealismo não se inferindo necessariamente viés negativo dessa afirmação - e inquirições sobre o campo dos Direitos Humanos na esfera internacional. Sua evolução, força normativa, observância, diferenças entre modelos re-

48 SASSE, Jan Peter. An economic analysis of bilateral investment treaties. Hamburgo: Gabler, 2011. p. 84.

$49{ }^{51}$ Sasse, predominantemente, cita Guzman como parte de seu esforço explanatório. SASSE, Jan Peter. An economic analysis of bilateral investment treaties. Hamburgo: Gabler, 2011.

$50{ }^{52}$ VAN AAKEN, Anne. Smart flexibility clauses in international investment treaties and sustainable development: a functional view. Journal for World Investment and Trade, v. 15, n. 5-6, p. 827-861, 2014. 
gionais e multilaterais, bem como as possíveis implicações para a noção de soberania dos Estados contribuem para que o campo seja polêmico e instigante.

Há quem diga que a AEDIP teria pouco a contribuir, porquanto seus pressupostos (escassez racionalidade e eficiência) colidiriam diretamente com o próprio cerne do campo. Por outro lado, autores relembram a questão dos custos dos direitos ${ }^{51}$ e, no plano internacional, apontam uma verdadeira falta de efetividade dos tratados de direitos humanos. Avançam mesmo, em outro extremo, ao propor a substituição da linguagem de direitos humanos para a de bem-estar humano. ${ }^{52}$

Uma questão inicial seria a de buscar as razões para Estados ratificarem tratados de direitos humanos. Goldsmith e Posner reconhecem-na como um verdadeiro quebra-cabeça. Admitem, desde o início, a diversidade de razões para que Estados se interessem por condições fora de seu território o que pode mesmo estar associado à presença de seus nacionais no exterior, laços religiosos ou étnicos. ${ }^{53}$ Partem, também, do pressuposto que os modernos tratados de direitos humanos (pós Segunda Grande Guerra) não influenciaram significativamente o comportamento dos Estados e se perguntam por que, então, Estados gastam tempo, esforços e recursos para ratificá-los? De um lado, não faria sentido tradicionais democracias liberais ratificá-los. Tampouco, Estados autoritários o fazerem, uma vez que não possuem intenção de cumpri-los. ${ }^{54}$

Os autores não generalizam uma resposta. Ao analisarem especificamente o Pacto Internacional dos Direitos Civis e Políticos, indicam que para democracias liberais haveria um baixo custo associado à sua ratificação, pois já estão em conformidade com o previsto no tratado. Já para os Estados autoritários a falta de mecanismos formais de coação (retaliação) serviria para explicar sua inclinação em ratificá-los. Mesmo ao ponderarem a possibilidade de incorrer em custos reputacionais por

$51{ }^{53}$ HOLMES, Stephen; SUNSTEIN, Cass R. The cost of rights: why liberty depends on taxes. New York: WW Norton, 1999.

$52{ }^{54} \mathrm{O}$ argumento central é que a linguagem de bem-estar (welfare) possuiria maior suporte internacional e filosófico e que a linguagem dos tratados de direitos humanos seria, ao mesmo tempo, rígida e vaga, para guiar as correspondentes políticas públicas. Veja- POSNER, Eric A. Human welfare, not human rights. Columbia Law Review, v. 108, p. 1758-1802, 2008. p. 1758-1763.

$53{ }^{55}$ GOLDSMITH, Jack L.; POSNER, Eric A. The limits of international law. Oxford: OUP, 2005. p. 110-111.

$54{ }^{56}$ GOLDSMITH, Jack L.; POSNER, Eric A. The limits of international law. Oxford: OUP, 2005. p. 127. descumprimento, não haveria maiores diferenças em se ter ou não ratificado o tratado, porquanto ONGs e mídia se encarregariam de estabelecer esse custo reputacional. Os mecanismos do tratado (monitoramento e relatórios) adicionariam apenas custos marginais à violação. Quanto aos benefícios, os autores entendem estar associados ao estabelecimento de um código de conduta ou mesmo um standard civilizatório que poderosas democracias liberais entendem importante propagar. Os benefícios aos Estados cumpridores se associariam ao recebimento de ajudas (acesso a recursos e fóruns do qual não participariam) e a redução de ameaças ou pressões por seguirem este código. ${ }^{55}$

Decerto, as explicações não param por aí. Há, também, a tentativa de atribuir a existência de cooperação relativa a direitos humanos (com ou sem tratados) pelo cálculo sobre os efeitos adversos que uma crise de direitos humanos no exterior pode, eventualmente, ter sobre outros Estados. Uma maneira de se modelar esse problema se dá novamente pela linguagem das externalidades. ${ }^{56}$ Pense-se em uma situação contemporânea envolvendo o Brasil. Dada a proximidade geográfica entre Brasil e Haiti, caso as condições dos direitos humanos no Haiti atinjam níveis muito baixos, parte da população local poderia emigrar e vir para o Brasil - como de fato está ocorrendo -, trazendo efeitos (positivo e negativos) no país. ${ }^{57}$ Esse fluxo poderia desencadear, em um primeiro momento, uma ação cooperativa de recepção desses imigrantes e, em se alterando a percepção dos benefícios, ações tendentes a controlá-lo ou mesmo cessá-lo. Não deve ser uma surpresa que essa mesma linha de raciocínio, seguindo uma perspectiva racional, seja utilizada na atual crise imigratória envolvendo a Europa e os imigrantes das regiões africanas e do oriente médio.

$55{ }^{57}$ GOLDSMITH, Jack L.; POSNER, Eric A. The limits of international law. Oxford: OUP, 2005. p. 128.

$56{ }^{58}$ Para uma análise detalhada do uso do conceito de racionalidade no campo dos direitos humanos, bem como sua crítica, ver MCGREAL, Daragh. Essays on the law and economics of international buman rights law. Hamburgo: Staats- und Universitätsbibliothek Hamburg, 2013.

$57{ }^{59}$ Alguns alegariam que o motivo do Estado brasileiro se interessar pelas péssimas condições da população da República do Haiti seria meramente altruístico. Para outros, uma forma de ganho reputacional visando fazer parte do seleto grupo de países pertencentes ao membros permanentes do Conselho de Segurança da ONU. Não se afirma neste artigo que a emigração traria prejuízos ao Estado brasileiro. Certamente, uma complexa análise de custos e benefícios poderia apontar quais grupos sociais se beneficiam e se prejudicam pela entrada de mão-de-obra, efeitos na seguridade social, entre outros efeitos. 
Por mais polêmicas que sejam, aqui apenas se quer reforçar o argumento das externalidades como possível fundamento para explicar a ação racional de estados ao regular os direitos humanos. Assumindo-se a escassez de recursos, serve também como um alerta para as possíveis consequências dos cursos racionais das condutas dos Estados.

\subsection{Outras aplicações}

Como se vê, o menu da AEDIP é vasto e oferece um horizonte a mais, sendo aplicado a diversos campos do direito internacional. Tanto em sua parte geral, como em áreas de direito material.

Há trabalhos que discutem a formação e o papel de Organizações Internacionais, ${ }^{58} \mathrm{o}$ papel do soft law, ${ }^{59}$ a fragmentação do direito internacional, ${ }^{60}$ a possibilidade e aplicações de um direito internacional da concorrência, ${ }^{61}$ desenvolvimento econômico e propriedade intelectual, ${ }^{62}$ entre outros.

Este artigo apenas sinalizou alguma destas abordagens e de que forma o método pode contribuir nesse debate.

\section{Considerações finais}

Como introduzido, a academia brasileira de DIP ainda está em um estágio modesto em relação à AEDIP.

$58{ }^{60}$ DUNOFF, Joel L.; TRACHTMAN, Jeffrey P. Economic analysis of international law. Yale Journal of International Law, v. 24, n. 1, p. 1-59, winter 1999. TRACHTMAN, Joel P. The economic structure of international law. Cambridge: HUP, 2008. GUZMAN, A. International organizations and the Frankenstein problem. European Journal of International Law, v. 24, n. 4, 2013, p. 999-1025.

$59{ }^{61}$ VOIGT, Satefan. The economics of informal international law: an empirical assessment. In: PAUWELY, Joost; WOUTERS, Ramses A. (Ed.). Informal international lawmaking. Oxford: Oxford University, 2012. p. 81-105.

$60{ }^{62}$ VAN AAKEN, Anne. Defragmentation of public international law through interpretation: a methodological proposal. Indiana Journal of Global Legal Studies, v. 16, n. 2, p. 483-512, 2009. p. 483-512. RIBEIRO, Gustavo Ferreira. The legality of trade sanctions based on human rights violations: an analysis through law and economics. Economic Analysis of Law Review, v. 3, n. 2, p. 260-281, Dez. 2012.

$61{ }^{63}$ GUZMAN, Andrew T. Antitrust and international regulatory federalism. New York University Law Review, v. 76, p. 1142-1163, Oct. 2001. GUZMAN, Andrew T. Is international antitrust possible? New York University Law Review, v. 73, p. 1501-1548, Nov. 1998. p. 15011548.

$62{ }^{64}$ COOTER, Robert D; SCHAEFER, Hans-Bernd. Solomon's knot: how law can end the poverty of nations. Princeton: PUP, 2011.
Há um baixo número de publicações, grupos de pesquisa e o ensino do método é praticamente ignorado nas instituições de ensino superior brasileiras.

Há uma questão prévia, não desenvolvida no artigo, mas salutar de ser tocada. Deve-se reconhecer que o ensino do direito no Brasil - consideração essa ampla, não apenas ao campo do DIP - é marcada, no bacharelado, predominantemente, pela memorização. Isso é parcialmente um reflexo de um mecanismo de reprodução: os professores tendem a repetir os métodos de aprendizagem aos quais foram expostos. ${ }^{63}$ A resultante é uma estrutura de incentivos perversa com pouco espaço para métodos como a AEDIP.

A discussão se a AEDIP é um método ou não já se encontra praticamente superada. Tanto a academia norte-americana quanto a europeia tomam o método como existente. A primeira de uma forma pragmática, uma vez que a inter-relação das ciências sociais com o direito já ocorre há mais tempo. A última com mais precaução, principalmente, quanto a uma maior reserva do papel do jurista à abordagem hermenêutica, porém com menos resistência ao uso positivo e normativo da AEDIP.

Parece, entretanto, desafiador, mas superável, o problema de linguagem. A construção de uma ponte que possa transmitir ao jurista o vocabulário e o modo de pensar do economista deve ser feita, incluindo boas noções de escassez, racionalidade, maximização, eficiência (Pareto, Kaldor-Hicks), quebras eficientes de contratos, externalidades, análise de custos e benefícios, custos de transação, noções sobre teoria dos jogos, em uma lista que poderia ser aumentada. O mesmo devendo ser dito ao economista que pretenda se aproximar do vocabulário jurídico, dos valores axiológicos do direito e do modus operandi do jurista.

Nesse artigo, procurou-se refletir sobre esse exercício apontando caminhos para se pensar as possibilidades da AEDIP na análise das fontes do direito internacional (tratados e costumes), assim como no seu aproveitamento a campos temáticos (direito internacional dos investimentos e direitos humanos).

63 Existem razões associadas à proliferação de instituições, exames de ordem, concursos públicos que informam esta constatação. MARINHO, Maria Edelvacy Pinto; RIBEIRO, Gustavo Ferreira. Aplicação do método de role-playing em problemas interdisciplinares: direito e economia. In: MEZZAROBA, Orides; TAVARES NETO, José Querino; VASCONCELOS, Silvia Andréia (Orgs.). Direito, educação, ensino e metodologia jurídicos. Florianópolis: FUNJAB, 2013. p. 360-374. 
Dada a massa crítica de estudantes e pesquisadores já ocupados com a análise econômica do direito, com temas de relações internacionais, e de direito internacional, e a variedade de instituições brasileiras que possuem cursos nessas áreas, pode haver um ambiente favorável ao desenvolvimento dessa nova abordagem nos próximos anos. Pesquisadores e estudantes interessados no tema, entretanto, carecem de mais publicações, inclusive de manuais em português sobre a disciplina e sobre o estado da pesquisa internacional. A falta de um ou mais grupos de pesquisa de análise econômica do direito internacional também chama a atenção e começa a ser remediada. Isso poderia, sem dúvida, ajudar a estreitar os laços acadêmicos do Brasil com instituições estrangeiras e pesquisadores que já se ocupam do tema. Poderia, também, ajudar a definir uma agenda nacional de pesquisa que inclua temas de interesse do Brasil e dos brasileiros.

Isso resultaria em uma aproximação mais significativa com centros de vanguarda no campo do DIP que passam, cada vez mais, a se comunicar por meio desse método e linguagem.

\section{REFERÊNCIAS}

BELONIEL, Daniel; SALAMA, Bruno. Towards an intellectual property bargaining theory: the post-wto era. University of Pennsylvania Journal or International Law, v. 32, n. 1, p. 265-368, 2010.

BHANDARI, Jagdeep S.; SYKES, Alan O. (Org.). Economic dimensions in international law comparative and empirical perspectives. Cambridge: CUP, 1998.

BLAUG, M. The methodology of economics: or how economists explain. 2. ed. Cambridge: CUP, 1992.

BROUDE, Tomer. Behavioral international law. Hebrew University of Jerusalem International Law Forum Research Paper, n. 12-13, p. 1-85, 2013. doi: 10.2139/ssrn.2320375.

CAIADO, José Guilherme Moreno. From coordination to collaboration: explaining international disputes over tariff classification. Economic Analysis of Law Review, v. 3, n. 1, p. 95-108, Jun. 2012.

CALABRESI, Guido; MELAMED, A. Douglas. Property rules, liability rules, and inalienability: one view of the cathedral. Harvard Law Review, v. 85, n. 6, p. 10891128, Abr. 1972.
CARREAU, Dominique; FLORY, Thiébault; JULLIARD, Patrick. Droit internacional èconomique. Paris: Persée, 1990.

CHARNOVITZ, Steve. What is international economic law? Journal of International Economic Law, v. 14, n. 1, p. 3-22, 2014.

COOTER, Robert D.; SCHAEFER, Hans-Bernd. Solomon's knot: how law can end the poverty of nations. Princeton: PUP, 2011.

COOTER, Robert; ULEN, Thomas. Direito e economia. 5. ed. Porto Alegre: Bookman, 2010.

DUNOFF, Joel L.; TRACHTMAN, Jeffrey P. Economic analysis of international law. Yale Journal of International Law, v. 24, n. 1, p. 1-59, winter 1999.

ELTZ, Magnum Koury de Figueiredo. Uma abordagem da análise econômica do direito para os danos ambientais transfronteiriços. Economic Analysis of Law Review, v. 3, n. 1, p. 40-56, Jun. 2012.

GOLDSMITH, Jack L.; POSNER, Eric A. A theory of customary international law. University of Chicago Law Review, Chicago, v. 66, p. 1133-1177, 1999.

GOLDSMITH, Jack L.; POSNER, Eric A. The limits of international law. Oxford: OUP, 2005.

GUZMAN, Andrew T. Antitrust and international regulatory federalism. New York University Law Review, v. 76, p. 1142-1163, Oct. 2001.

GUZMAN, Andrew T. How international law works. Oxford: OUP, 2008.

GUZMAN, Andrew T. Is international antitrust possible? New York University Law Review, v. 73, p. 1501-1548, Nov. 1998.

GUZMAN, Andrew. International organizations and the Frankenstein problem. European Journal of International Law, v. 24, n. 4, p. 999-1025, 2013.

HAFNER-BURTON, Emilie M.; LEVECK, Brad L.; VICTOR, David G. Strategic enforcement: results from an elite survey experiment on international trade agreements. SSRN Electronic Journal, Aug. 2012. doi: 10.2139/ ssrn.2132948. Available at: <https://www.researchgate. net/publication/256031577_Strategic_Enforcement_ Results_from_an_Elite_Survey_Experiment_on_International_Trade_Agreements $>$. Access: Feb. 09, 2016. 
HOLMES, Stephen; SUNSTEIN, Cass R. The cost of rights: why liberty depends on taxes. New York: WW Norton, 1999.

LUPI, André Lipp Pinto Basto. Os métodos no direito internacional. São Paulo: Lex, 2007.

MARINHO, Maria Edelvacy Pinto; RIBEIRO, Gustavo Ferreira. Aplicação do método de role-playing em problemas interdisciplinares: direito e economia. In: MEZZAROBA, Orides; TAVARES NETO, José Querino; VASCONCELOS, Silvia Andréia (Orgs.). Direito, educaşão, ensino e metodologia jurídicos. Florianópolis: FUNJAB, 2013. p. 360-374.

MCGREAL, Daragh. Essays on the law and economics of international human rights law. Hamburgo: Staats- und Universitätsbibliothek Hamburg, 2013.

MONTILLA FERNÁNDEZ, Luis Tomás. Land policies and labour markets in Sub-Saharan Africa: a law and economics analysis. IDS Bulletin, v. 43, n. 6, p. 78-89, 2012. doi: 10.1111/j.1759-5436.2012.00381.x.

NOGUEIRA, João Pontes; MESSARI, Nizar. Teoria das relações internacionais. São Paulo: Elsevier, 2005.

OETER, Stefan. Legitimacy of customary international law. In: EGER, Thomas; OETER, Stefan; VOIGT, Stefan (Ed.). Economic analysis of international law: contributions to the XIIIth Travemünde symposium on the economic analysis of law (March 29-31, 2012). Tübingen: Mohr Siebeck, 2012. p. 1-22.

PAUWELYN, Joost. Optimal protection of international law: navigating between european absolutism and american voluntarism. Cambridge: CUP, 2008.

PINDYCK, Robert S.; RUBINFELD, Daniel L. Microeconomia. 7. ed. São Paulo: Pearson, 2010.

POSNER, Eric A. Human welfare, not human rights. Columbia Law Review, v. 108, p. 1758-1802, 2008.

POSNER, Eric A.; SYKES, Alan O. Economic foundations of international law. Cambridge: HUP, 2013.

RATNER, Steven R.; SLAUGHTER, Anne Marie. Appraising the methods of international law: a prospectus for readers. American Journal of International Law, v. 93, n. 2, p. 291-302, April 1999.

RIBEIRO, Gustavo Ferreira. The legality of trade sanctions based on human rights violations: an analysis through law and economics. Economic Analysis of Law
Review, v. 3, n. 2, p. 260-281, Dez. 2012.

RIBEIRO, Gustavo Ferreira; GICO JR, Ivo T. (Org.). O jurista que calculava. Curitiba: CRV, 2013.

RUGGIE, John Gerard; BURLEY, Anne-Marie (Ed.). Multilateralism matters: the theory and praxis of an institutional form. New York: Columbia Universtity, 1993.

SALAMA, Bruno Meyerhof (Org.). Direito e economia: textos escolhidos. São Paulo: Saraiva, 2010. (Direito em Debate).

SANTOS, Alexandre Leite. O direito internacional público como jogo institucional. Economic Analysis of Law Review, v. 1, n. 2, p. 179-195, July/Dez. 2010.

SASSE, Jan Peter. An economic analysis of bilateral investment treaties. Hamburgo: Gabler, 2011.

SCHROPP, Simon. A. B. Trade policy flexibility and enforcement in WTO: a law and economics analysis. Cambridge: CUP, 2009.

SEN, Amartya. On ethics and economics. Malden: Blackwell, 1987.

SOARES, Guido Fernando Silva. Curso de direito internacional público. 2. ed. São Paulo: Atlas, 2004. v. 1.

SORNARAJAH, M. The international law of foreign investment. 3. ed. Cambridge: CUP, 2010.

SYKES, Alan O. Protectionism as a "safeguard": a positive analysis of the gatt "escape clause" with normative speculations. University of Chicago Law Review, v. 58, n. 1, p. 255-306. winter 1991.

TIMM, Luciano (Org.). Direito e economia no Brasil. 2. ed. São Paulo: Atlas, 2014.

TIMM, Luciano (Org.). Direito e economia. Porto Alegre: Livraria do Advogado, 2008.

TRACHTMAN, Joel P. The economic structure of international law. Cambridge: HUP, 2008.

TRACHTMAN, Joel P. The future of international law: global government. Cambridge: CUP, 2013.

UNITED NATIONS CONFERENCE ON TRADE AND DEVELOPMENT. International Investment Agreements Navigator. Available at: <http://investmentpolicyhub.unctad.org/IIA>. Access: Out. 15, 2015.

VAN AAKEN, Anne. Behavioural international law and economics. Harvard International Law Journal, n. 55, 
p. 421-481, summer 2014.

VAN AAKEN, Anne. Defragmentation of public international law through interpretation: a methodological proposal. Indiana Journal of Global Legal Studies, v. 16, n. 2, p. 483-512, 2009.

VAN AAKEN, Anne. International investment law between commitment and flexibility: a contract theory analysis. Journal of International Economic Law, v. 12, n. 2, p. 507-538, 2009.

VAN AAKEN, Anne. Opportunities for and limits to an economic analysis of international economic law. Law and Economics Research Paper Series, v. 9, n. 31, 2010.

VAN AAKEN, Anne. Smart flexibility clauses in international investment treaties and sustainable development: a functional view. Journal for World Investment and Trade, v. 15, n. 5-6, p. 827-861, 2014.

VOIGT, Satefan. The economics of informal international law: an empirical assessment. In: PAUWELY, Joost; WOUTERS, Ramses A. (Ed.). Informal international lawmaking. Oxford: Oxford University, 2012. p. 81-105. 


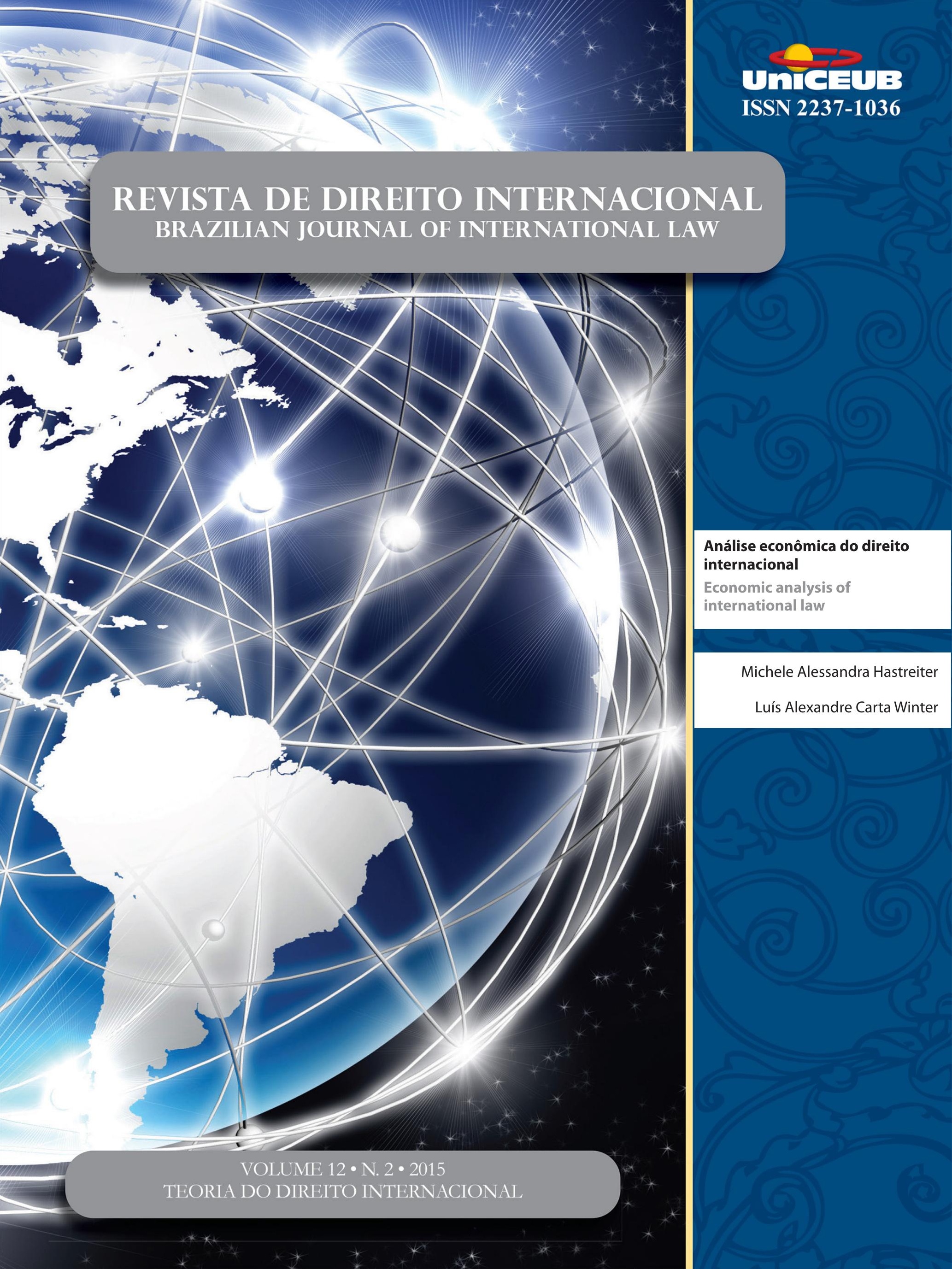




\title{
Economic analysis of international law
}

\author{
Michele Alessandra Hastreiter** \\ Luís Alexandre Carta Winter***
}

\section{Resumo}

O objetivo deste artigo é demonstrar como o método da análise econômica do Direito (AED) pode ser empregado para auxiliar a compreensão do Direito Internacional Público. Para tanto, inicia-se investigando possíveis razões para a resistência que o método tem tido por parte de estudiosos do Direito Internacional. $\mathrm{Na}$ sequência, passa-se à análise dos pressupostos da AED - a escassez de recursos, a racionalidade econômica, a resposta a incentivos e eficiência - exemplificando maneiras de empregá-los para análise de questões específicas de Direto Internacional. Por fim, faz-se uma breve consideração acerca das preocupações com a justiça - valor axiológico que não pode ser esquecido na busca pela eficiência. Conclui-se que a AED pode ser uma ferramenta útil à compreensão do Direito Internacional e de seus institutos, razão pela qual deveria ser utilizada com mais frequência por estudiosos da disciplina.

Palavras-Chave: Análise Econômica do Direito; Direito Internacional Público; Teoria da Escolha Racional; Incentivos; Eficiência.

\section{Abstract}

This article aims to demonstrate how Economic Analysis of Law can be used to improve the understanding of International Law. At first, it starts investigating possible reasons for resistance on the economic method by scholars of International Law field. After that, it analyses the application of economics' assumptions - such as the scarcity of resources, economic rationality, incentives and efficiency - on examples of International Law problems. Finally, it presents a brief account of concerns with justice - the main axiological value of Law, that cannot be forgotten in the pursuit of efficiency. As conclusion, the Economic Analysis of Law can be a useful tool for understanding International Law and its institutions, which is why it should be more frequently used by scholars of the discipline.

Keywords: Economic Analysis of Law; International Law; Rational Choice; Efficiency; Incentives.

*** Luís A. C. Winter é Doutor pela USP. Professor do PPGD da PUCPR. Professor titular da PUCPR; UNICURITIBA e da FAMEC. Coordenador do NEADI. Emails: michele.hastreiter@gmail.com eluisalexandrecartawinter@

yahoo.com.br

\section{Recebido em 29/10/2015}

** Michele Hastreiter é Advogada. Mestranda em Direito Econômico e Socioambiental na Pontifícia Universidade Católica do Paraná (PUCPR). E professora da UNICURITIBA. 


\section{INTRODUÇÃO}

A análise econômica do Direito (AED) é um método de análise da ciência Jurídica com crescente relevância. No entanto, embora seja amplamente difundido em outras searas, seu emprego ainda é incipiente no Direito Internacional. Este artigo tem como objetivo demonstrar que as ferramentas e conceitos do método econômico podem ser úteis à disciplina. Em especial, algumas das características definidoras do Direito Internacional Público fazem dele um ramo em que os pressupostos econômicos encontram especial pertinência.

O Direito Internacional Público é um ramo do Direito que emerge com base na cooperação entre Estados Soberanos e na ausência de uma autoridade central. As razões para a formação de estruturas complexas de cooperação, por meio de regras deste ramo do Direito, sem que haja um governo mundial forçando os países a cooperarem entre si, é uma questão que sempre intrigou os estudiosos da disciplina. Ao se considerar Estados soberanos como agentes racionais - conforme definição da racionalidade econômica autointeressada -, todas as suas decisões podem ser analisadas com a ajuda dos pressupostos de tomada de decisão da AED. Isto inclui as decisões de Direito Internacional Econômico, de modo especial - já que o ramo segue a lógica econômica por si só - mas também pode auxiliar a compreensão de certos institutos de Direitos Humanos, de Direito Internacional Ambiental, normas sobre Relações Diplomáticas e Consulares, questões acerca do Direito Internacional do Trabalho, entre outros. Em suma, ao se compreender a AED como um método para a análise de escolhas, toda e qualquer decisão pode ser medida em função de seus postulados. Seguindo a corrente voluntarista do Direito Internacional Público, a adesão as suas regras e previsões nada mais é do que uma decisão - livre e soberana -, sendo plenamente cabível, portanto, o emprego da análise.

A AED empregada neste estudo não pressupõe que os objetivos da norma sejam sempre econômicos, nem mesmo pretende sustentar que os objetivos econômicos possam ser o fundamento último do Direito. Não há dúvidas de que a ciência jurídica pauta-se em fundamentos de natureza axiológica, e a busca pela justiça - qualquer que seja o conceito de justiça empregado - emerge como uma preocupação central. Isso não contradiz, no entanto, a pertinência da AED, já que ela constrói um método de pensamento que permite medir a capacidade da norma de atingir os seus resultados, quaisquer que sejam eles. Dessa forma, a definição dos objetivos do Direito é questão política que precede à decisão dos Estados racionais de se engajarem em negociações para formação de normas de Direto Internacional. A AED é ferramenta importante, porém, para prever a capacidade das instituições criadas de atingir estes objetivos, ou ainda para mensurar, antes da redação de um determinado Tratado, o tipo de estrutura da norma internacional que facilitaria o alcance dos objetivos propostos.

O presente artigo, portanto, visa elucidar os pressupostos do método econômico, demonstrando como ele pode ser aplicado ao estudo do Direito Internacional. Para tanto, inicia-se com considerações acerca do emprego do método à análise do Direito Internacional Público, levando em conta as peculiaridades da disciplina. Posteriormente, discorre-se sobre cada um dos pressupostos da AED (escassez de recursos, racionalidade econômica, incentivos e eficiência), exemplificando a aplicabilidade de cada um ao Direito Internacional Público. Ao final, espera-se ter contribuído para a difusão do método na análise do Direito Internacional, de tal forma que estudos futuros possam utilizar de seus pressupostos para avaliar normas internacionais específicas.

\section{O EMPREGO DO MÉTODO DA ANÁLISE ECONÔ- MICA NO DIREITO INTERNACIONAL}

A economia é a ciência das escolhas humanas ${ }^{1}$. A análise econômica é uma análise de escolhas - e, assim, as teorias econômicas que servem para explicar o processo de tomada de decisão podem ser úteis em outras searas - seja, por exemplo, na política, na sociologia ou no Direito ${ }^{2}$. A análise econômica do direito (AED) consiste na aplicação do "instrumental analítico e empírico da economia, em especial da microeconomia e da economia do bem-estar social, para se tentar compreender, explicar e prever as implicações fáticas do ordenamento jurídico, bem como da lógica (racionalidade) do próprio ordenamento"3. Trata-se, portanto, da análise do Direi-

1 COASE, Ronald. The firm, the marked and the law. Chicago: The University of Chicago Press, 1988. p. 1.

2 COASE, Ronald. The firm, the marked and the law. Chicago: The University of Chicago Press, 1988, p. 3

3 GICO JR., Ivo. Metodologia e Epistemologia da Análise Econômica do Direito. Economic Analysis of Law Review, v. 1, n. 1, p. 7-33, jan./jun.2010. Disponível em: http://portalrevistas. ucb.br/index.php/EALR/article/view/1460/1110. Acesso em: 21 out. 2014. p. 18. 
to realizada através de métodos econômicos ${ }^{4}$.

Embora a AED esteja ganhando espaço nos debates jurídicos desde a década de $1970^{5}$, o Direito Internacional manteve-se alheio ao método até os primeiros anos do Século XXI, quando alguma bibliografia sobre o assunto começou a ser produzida. Trata-se de uma resistência curiosa, até mesmo porque no estudo das Relações Internacionais - disciplina estreitamente relacionada ao Direito Internacional - a utilização do método econômico e de muitos de seus pressupostos já está há tempos incrustada nos debates entre suas diferentes correntes teóricas ${ }^{7}$. Em verdade, tanto o realis$\mathrm{mo}^{8}$ quanto o liberalismo ${ }^{9}$ se interconectam diretamen-

4 A interconexão entre Direito e Economia pode ser classificada em dois grupos: a abordagem conhecida como "Direito e Economia" tem em Ronald Coase o seu expoente e tem seu foco principal nos problemas econômicos, considerando o Direito e as instituições na medida em que elas afetam as atividades econômicas; a análise econômica do Direito, por sua vez, centra-se no Direito, definindo o uso do instrumental econômico como um método pelo qual o Direito pode ser analisado. A análise econômica do Direito foi "inventada" por Richard Posner, em 1970. Além dele, Guido Calabresi é também um importante nome na análise econômica do Direito. A contribuição dos três autores é vista como relevante para uma análise interdisciplinar de Direito e Economia e, sobretudo, para o estudo do Direito sob o enfoque do método econômico. Cf. MARCIANO, Alain; RAMELLO, Giovanni B. Consent, Choice and Guido Calabresi's heterodox economic analysis of law. Law and Contemporary Problems, v. 77, n. 97, p. 97-116, 2014. Disponível em: http://scholarship.law.duke.edu/cgi/viewcontent. cgi? article $=4400 \&$ context $=$ lcp. Acesso em: 15 nov. 2014.

5 O trabalho considerado fundador da análise econômica do Direito é o de Richard Posner. (POSNER, Richard A. Economic Analysis of Law. 9th edition. New York: Wolters Kluwe Law \& Business, 2014).

6 POSNER, Eric A.; SYKES, Alan O. Economic Foundations of International Law. Cambridge: Harvard University Press, 2013. p. 12.

7 Sobre as correntes teóricas de Relações Internacionais, ver em: CASTRO, Thales. Teoria das relações internacionais. Brasília: FUNAG, 2012; SALDANHA, Eduardo. Teoria das Relações Internacionais. Curitiba: Juruá, 2005.

8 Uma das primeiras teorias explicativas das relações internacionais - o realismo - parte da premissa do Estado como um ator que busca racionalmente a maximização de seu poder. Não obstante, a teoria enfoca majoritariamente questões de segurança e acaba concluindo que a cooperação internacional é muito difícil e que o Direito Internacional não influencia a conduta dos estados. Cf. COSTA, José Augusto Fontoura. Do GATT à OMC: a perspectiva neoliberal institucionalista. Universitas: Relações Internacionais, Brasília, v. 9, n. 2, p. 25-53, jul./dez. 2011. Disponível em: http://www.publicacoesacademicas.uniceub.br/index.php/relacoesinternacionais/ article/view/1413. Acesso em: 19 dez. 2014; STEIN, Arthur. Why nations cooperate: circumstances and choice in international relations. New York: Cornell University Press, 1990. p. 6; GUZMAN, Andrew T. How international law works: a rational choice theory. Oxford: Oxford University Press, 2008. p. 18.

9 As escolas liberais de Relações Internacionais defendem a ex- te com as ideias e métodos econômicos, aplicando há muito tempo a analogia das relações internacionais com mercados competitivos e utilizando-se de ferramentas como a Teoria dos Jogos (e em especial, o Dilema do Prisioneiro ${ }^{10}$ ) para a análise das estratégias internacionais ${ }^{11}$. Pode-se dizer, assim, que a resistência do Direito Internacional em utilizar do método econômico não se justifica e pode ser atribuída a confusões e preconceitos quanto ao método que merecem esclarecimento.

Por uma questão de escolha de critério ${ }^{12}$, entende-se o Direito Internacional Público como a disciplina jurídica que rege as relações entre os Estados e os demais sujeitos de Direito Internacional. É importante destacar, porém, que, apesar de regular o comportamento dos sujeitos - e, por isso, atender ao propósito fundamental do Direito, que é o de regular os comportamentos nas sociedades humanas ${ }^{13}$ (tal qual o famoso brocardo latino Ubi societas, ibi ius) -, o Direito Internacional difere do Direito doméstico em muitos aspectos ${ }^{14}$ : nele,

istência de outras forças pulverizadas no interior e exterior dos Estados que exercem um papel nas Relações Internacionais (como as empresas transnacionais e os investidores estrangeiros, por exemplo) e partem da pressuposição da racionalidade, porém de forma mais flexível do que os realistas. Mais sobre isto, ver em: CASTRO, Thales. Teoria das relações internacionais. Brasília: FUNAG, 2012 e COSTA, José Augusto Fontoura. Do GATT à OMC: a perspectiva neoliberal institucionalista. Universitas: Relações Internacionais, Brasília, v. 9, n. 2, p. 25-53, jul./dez. 2011. Disponível em: http://www.publicacoesacademicas.uniceub.br/index.php/ relacoesinternacionais/article/view/1413. Acesso em: 19 dez. 2014. p. 27.

10 A história original do Dilema do Prisioneiro narra à situação de dois suspeitos de um crime que foram presos pela polícia e interrogados separadamente. A polícia não tem provas para condenálos, o que abre a possibilidade para que um deles confesse e, com isso, tenha uma pena mais leve, condenando o outro a pena maior. Porém, se ambos confessarem, serão condenados à pena máxima. Se nenhum dos dois confessar, adotando uma estratégia de cooperação, ambos teriam uma pena menor. O Dilema do Prisioneiro pode ser empregado de forma análoga aos Estados nas Relações Internacionais para explicar as vantagens da adoção de posturas cooperativas. Sobre isto, sugere-se a leitura de: AXELROD, Robert. A evolução da cooperação. São Paulo: Leopardo Editora, 2010. p. 6.

11 STEIN, Arthur. Why nations cooperate: circumstances and choice in international relations. New York: Cornell University Press, 1990, p. 10-11.

$12{ }^{11}$ São o critérios: sujeitos do direito internacional; objeto da norma internacional e o da forma de produção da norma internacional. PEREIRA, André Gonçalves e QUADROS, Fausto de. Manual de Direito Internacional Público, 3a.ed. Coimbra: Almedina, 1995, p. 26-31.

13 NASSER, Salem Hikmat. Rule of law e Direito Internacional: uma nova aproximação. In: VIEIRA, Oscar Vilhena; DIMOULIS, Dimitri (Org.). Estado de Direito e o Desafio do Desenvolvimento. São Paulo: Saraiva, 2011. p. 59.

14 Neste sentido, Hans Kelsen chama o Direito Internacional de 
inexiste uma autoridade central e superior - tal qual um governo mundial; tampouco, há poder legislativo constituído ou uma única estrutura judiciária coesa, nem sequer um poder dotado de força e coerção responsável por implementar e aplicar o Direito ${ }^{15}$. Nesse sentido, muitos teóricos juspositivistas negavam o caráter jurídico do Direito Internacional ${ }^{16}$, uma vez que, para eles, o Direito necessariamente emanaria do Estado.

Não é cabível criticar esse posicionamento, hoje não mais em voga e notavelmente equivocado ${ }^{17}$. É bem verdade, porém, que a AED é movimento que se filia ao positivismo, o que pode ser uma das razões pelas quais os estudiosos do Direito Internacional tenham resistido a ela ${ }^{18}$. Ocorre que, quando se afirma que a AED é

"ordenamento jurídico primitivo". Ver em: KELSEN, Hans. Teoria Pura do Direito. Tradução de J. Cretella Jr. e Agnes Cretella. 9. ed. São Paulo: Revista dos Tribunais, 2013. p. 183.

15 NAS NASSER, Salem Hikmat. Rule of law e Direito Internacional: uma nova aproximação. In: VIEIRA, Oscar Vilhena; DIMOULIS, Dimitri (Org.). Estado de Direito e o Desafio do Desenvolvimento. São Paulo: Saraiva, 2011. p. 66.

16 O posicionamento de Herbert Hart destaca-se nesse sentido. $\mathrm{O}$ autor afirma que o Direito se constitui com base nas regras primárias (que determinam deveres e obrigações) e regras secundárias (que atribuem poderes - como o de alteração - no qual um corpo de indivíduos pode introduzir novas regras primárias - e de julgamento ou adjudicação - que concede poderes aos indivíduos para proferir determinações dotadas de autoridade acerca da violação de regras primárias). O autor, então, sustenta, no tocante ao Direito Internacional, que, "embora seja compatível com os usos dos últimos 150 anos, a utilização aqui da expressão 'direito', a ausência de um poder legislativo internacional, de tribunais com jurisdição obrigatória e de sanções centralmente organizadas tem inspirado desconfianças, pelo menos no espírito dos teorizadores do direito. A ausência dessas instituições significa que as regras aplicáveis aos Estados se assemelham àquela forma simples de estrutura social, composta, apenas, de regras primárias de obrigação, a qual, quando as descobrimos nas sociedades de indivíduos, nos acostumámos a contrastar com um sistema jurídico desenvolvido. É, na verdade, sustentável, como iremos demonstrar, que o Direito Internacional não só não dispõe de regras secundárias de alteração e de julgamento que criam um poder legislativo e tribunais, como ainda lhe falta uma regra de reconhecimento unificadora que especifique as fontes do Direito e que estabeleça critérios gerais de identificação de suas regras. Essas diferenças são na verdade flagrantes e a questão 'é o Direito Internacional realmente Direito?' não pode ser posta de lado." (Cf. HART, Herbert L. A. O conceito de Direito. Tradução de A. Ribeiro Mendes. 3. ed. Lisboa: Fundação Calaouste Gulbekian, 2001. p. 230).

17 Basta que se note que a lei que advém do Processo Legislativo é apenas uma das fontes do Direito até mesmo no direito interno e as normas jurídicas podem advir de costumes, do exercício da autonomia privada manifesto por contratos, de princípios gerais, entre outros (REALE, Miguel. Lições Preliminares de Direito. 27. ed. São Paulo: Saraiva, 2002. p. 143).

18 DUNOFF, Joffrey L.; TRACHTMAN, Joel P. Economic Analysis of International Law: An Invitation and a Caveat. April 20, 1998. Disponível em: http://papers.ssrn.com/sol3/papers. positivista, o positivismo a que se está referindo é o positivismo científico de Augusto Comte, e não o juspositivismo jurídico. A AED é positivista na medida em que dá ênfase ao empirismo - ainda que esta análise sirva para o desenvolvimento de críticas normativas ${ }^{19}$. Como destacado por Ivo Gico Júnior, o propósito da AED é adotar um método científico lógico e empiricamente verificável (como defendia o positivismo de Comte), sem, contudo, "adotar a postura xenófoba e hermética que afastou o juspositivismo do Positivismo filosófico e eliminou o diálogo entre o Direito e as outras ciências" ${ }^{20}$ durante o período em que este pensamento esteve em voga.

Em verdade, a ausência de um poder central no Direito Internacional apenas reforça a pertinência da AED à disciplina, posto que o método mostra-se especialmente útil quando as decisões dos agentes são tomadas em um contexto mercadológico. Ao contrário das situações de contexto hierárquico, que são regidas por regras de comando, as relações regidas em um contexto de mercado caracterizam-se pela livre interação dos agentes, que barganham entre $\mathrm{si}^{21}$. $\mathrm{O}$ mercado consiste em um mecanismo de realização de trocas que, a princípio, não é controlado por qualquer dos agentes individualmente, mas sim o resultado de interações espontâneas entre eles ${ }^{22}$. De modo geral, pode-se dizer que as relações internacionais em muito se assemelham aos mercados privados ${ }^{23}$. Assim como os mercados, o sistema internacional é formado pela interação de agentes

cfm?abstract_id=73688. Acesso em: 22 out. 2014, p. 7.

19 DUNOFF, Joffrey L.; TRACHTMAN, Joel P. Economic Analysis of International Law: An Invitation and a Caveat. April 20, 1998. Disponível em: http://papers.ssrn.com/sol3/papers. cfm?abstract_id=73688. Acesso em: 22 out. 2014, p. 7.

20 GICO JR., Ivo. Metodologia e Epistemologia da Análise Econômica do Direito. Economic Analysis of Law Review, v. 1, n. 1, p. 7-33, jan./jun.2010. Disponível em: http://portalrevistas. ucb.br/index.php/EALR/article/view/1460/1110. Acesso em: 21 out. 2014. p. 11-12

21 GICO JR., Ivo. Metodologia e Epistemologia da Análise Econômica do Direito. Economic Analysis of Law Review, v. 1, n. 1, p. 7-33, jan./jun.2010. Disponível em: http://portalrevistas. ucb.br/index.php/EALR/article/view/1460/1110. Acesso em: 21 out. 2014. p. 22.

22 SANTOS, Alexandre Leite dos. O Direito Internacional Público como jogo institucional. Economic Analysis of Law Review, v. 1, n. 2, p. 179-195, jul./dez. 2010. Disponível em: http://portalrevistas.ucb.br/index.php/EALR/article/view/1\%20EALR $\% 20$ 174/1\%20EALR\%20174. Acesso em: 10 nov. 2014. p. 184.

23 DUNOFF, Joffrey L.; TRACHTMAN, Joel P. Economic Analysis of International Law: An Invitation and a Caveat. April 20, 1998. Disponível em: http://papers.ssrn.com/sol3/papers. cfm?abstract_id=73688. Acesso em: 22 out. 2014, p. 10. 
autointeressados - em grande maioria, os Estados - que negociam entre si em um ambiente sem hierarquia.

Afirmar que as relações internacionais se assemelham a mercados privados não significa - frise-se - pautar as relações internacionais nos valores de mercado e desvinculá-las da moral, como a crítica de Michael San$\mathrm{del}^{24}$ sobre os limites morais do mercado indicou. Em verdade, afirmar que uma determinada troca ocorre em um ambiente de mercado não significa que essa troca deva ter sido feita considerando valores pecuniários, desvalorizando qualquer característica intrínseca do bem barganhado ${ }^{25}$. Ao contrário, como bem sustentou Ivo Gico Júnior ${ }^{26}$, a referência ao mercado na juseconômia significa, simplesmente, uma delimitação do contexto social no qual os agentes tomam as decisões de forma livre, barganhando com os demais para obter o que desejam por meio da cooperação. Trata-se de um ambiente que difere de um contexto hierárquico, onde existem regras de comando que limitam e conduzem os agentes. Os ativos transacionados pelos Estados em um contexto mercadológico são bastante peculiares às relações internacionais: em vez de bens ou serviços, os Estados negociam componentes de poder ${ }^{27}$. Isso, contudo, não invalida a lógica mercadológica destas transações.

Para formalizar as negociações realizadas, a analogia das relações entre Estados com uma relação de mercado pode ser estendida, comparando os tratados internacionais com contratos ${ }^{28}$. Os tratados internacionais são a principal fonte de Direito Internacional - e eles possuem muitas características semelhantes aos contratos. Assim como os contratos, os tratados também são fon-

24 SANDEL, Michael J. O que o dinheiro não compra: os limites morais do mercado. Tradução de Clóvis Marques. Rio de Janeiro: Civilização Brasileira, 2013. p. 12.

25 GICO JR., Ivo. Metodologia e Epistemologia da Análise Econômica do Direito. Economic Analysis of Law Review, v. 1, n. 1, p. 7-33, jan./jun.2010. Disponível em: http://portalrevistas. ucb.br/index.php/EALR/article/view/1460/1110. Acesso em: 21 out. 2014. p. 23.

26 GICO JR., Ivo. Metodologia e Epistemologia da Análise Econômica do Direito. Economic Analysis of Law Review, v. 1, n. 1, p. 7-33, jan./jun.2010. Disponível em: http://portalrevistas. ucb.br/index.php/EALR/article/view/1460/1110. Acesso em: 21 out. 2014. p. 23.

27 SANTOS, Alexandre Leite dos. O Direito Internacional Público como jogo institucional. Economic Analysis of Law Review, v. 1, n. 2, p. 179-195, jul./dez. 2010. Disponível em: http://portalrevistas.ucb.br/index.php/EALR/article/view/1\%20EALR $\% 20$ 174/1\%20EALR\%20174. Acesso em: 10 nov. 2014. p. 185

28 POSNER, Eric A.; SYKES, Alan O. Economic Foundations of International Law. Cambridge: Harvard University Press, 2013, p. 29. tes de direitos e obrigações entre as partes - e apenas entre as partes; além disso, ambos têm seu fundamento de validade no acordo de vontade entre as partes celebrantes $^{29}$.

Percebe-se, assim, a pertinência da analogia - que, naturalmente, não é perfeita. Há importantes diferenças entre as relações entre Estados e as de mercado, a começar pelas peculiaridades dos interesses estatais como será enfocado quando da análise da racionalidade dos Estados. O que se nota, porém, é que o Direito Internacional, tal qual o Direito doméstico, carece de teorias explicativas baseadas em metodologia de estrutura analítica mais consistente ${ }^{30}$, razão pela qual a AED pode auxiliar a suprir esta dificuldade. Neste mesmo sentido, defende Jeffrey L. Dunoff e Joel P. Trachtman ${ }^{31}$, que afirmam que o Direito Internacional "tem combinado uma cuidadosa descrição doutrinária, mostrando o Direito como ele é, com prescrições infundadas para concluir como o Direito deveria ser" - problema este que pode ser mitigado com o emprego da AED.

Outra possível razão pela qual a pesquisa em Direito Internacional tem resistido à AED decorre de uma associação do método com correntes econômicas conservadoras e libertárias, que consideram os valores de mercado acima de qualquer outro valor ${ }^{32}$. Trata-se de uma associação equivocada, já que compactuar dessa ideologia não é um pré-requisito para o uso do método econômico na análise do Direito e não é verdade que nenhuma consideração moral tem espaço na AED. É bem verdade que o Direito é uma conjugação indissociável entre fato, valor e norma ${ }^{33}$ de tal forma que a aná-

29 DUNOFF, Joffrey L.; TRACHTMAN, Joel P. Economic Analysis of International Law: An Invitation and a Caveat. April 20, 1998. Disponível em: http://papers.ssrn.com/sol3/papers. cfm?abstract_id=73688. Acesso em: 22 out. 2014, p. 23

30 SANTOS, Alexandre Leite dos. O Direito Internacional Público como jogo institucional. Economic Analysis of Law Review, v. 1, n. 2, p. 179-195, jul./dez. 2010. Disponível em: http://portalrevistas.ucb.br/index.php/EALR/article/view/1\%20EALR $\% 20$ 174/1\%20EALR\%20174. Acesso em: 10 nov. 2014. p. 180

31 "International legal scholarship too often combines careful doctrinal description - here is what the law is - with unfounded prescription: here is what the law should be." DUNOFF, Joffrey L.; TRACHTMAN, Joel P. Economic Analysis of International Law: An Invitation and a Caveat. April 20, 1998. Disponível em: http://papers.ssrn.com/sol3/papers.cfm?abstract_id=73688. Acesso em: 22 out. 2014, p. 2, tradução livre.

32 DUNOFF, Joffrey L.; TRACHTMAN, Joel P. Economic Analysis of International Law: An Invitation and a Caveat. April 20, 1998. Disponível em: http://papers.ssrn.com/sol3/papers. cfm?abstract_id=73688. Acesso em: 22 out. 2014, passim.

33 REALE, Miguel. As três acepções fundamentais da palavra 
lise jurídica não pode ocorrer em um vazio axiológico. No entanto, tampouco a economia é uma ciência alheia a preocupações de cunho ético: o caráter conscientemente não ético comumente atribuído à economia moderna é algo que contraria a própria natureza da ciência econômica, que, em sua origem histórica, foi concebida como um ramo da ética ${ }^{34}$.

Portanto, utilizar a AED não significa desprezar considerações de cunho moral ou ético, mas sim refutar a perspectiva de que os resultados esperados de uma determinada regra serão atingidos, apenas, porque, assim, intuitivamente, acredita o operador do Direito. Como bem destacou Vinícius Klein ${ }^{35}$, o que une os praticantes da AED é "O inconformismo com a visão de que uma análise jurídica presa a justificações formais abstratas e desatentas ao mundo real é suficiente para o enfrentamento dos problemas jurídicos".

O uso da análise econômica do Direito, portanto, não significa um afastamento do direito ao seu objetivo de perseguição da justiça - muito embora muitas sejam as concepções de justiça possíveis. Ao contrário, Guido Calabresi ${ }^{36}$ afirma que não há desculpas para a análise econômica do Direito eximir-se das considerações sobre justiça. Porém, como bem ressaltado por Ivo Gico Júnior ${ }^{37}$, "para que tenhamos uma compreensão plena do fenômeno jurídico e para que os supostos critérios de justiça sejam operacionalizáveis, é necessário que antes sejamos capazes de responder à simples pergunta: a norma X é capaz de alcançar o resultado social desejado $\mathrm{Y}$ dentro de nosso arcabouço institucional?”. A interconexão entre Direito e Economia é importante no debate

Direito. Revista da Faculdade de Direito da USP, v. 44, p. 68-78, jan. 1949. Disponível em: http://www.revistas.usp.br/rfdusp/article/view/66108/68718. Acesso em: 29 out. 2014. passim.

34 Neste sentido cabe a observação pertinente de Amartya Sen, destacando que até mesmo Adam Smith, o "pai da economia moderna", foi professor de filosofia moral na Universidade de Glasgow. (SEN, Amartya. Sobre Ética e Economia. Tradução de Laura Teixeira Motta. São Paulo: Companhia das Letras, 1999. p. 9).

35 KLEIN, Vinícius. Posner é a única opção? In: RIBEIRO, Márcia Carla Pereira; KLEIN, Vinícius (Coord.). O que é análise econômica do Direito: uma introdução. Belo Horizonte: Fórum, 2011. p. 177.

36 CALABRESI, Guido. The cost of accidents: a legal and economic analysis. New Haven; London: Yale University Press, 1970. p. 25.

37 GICO JR., Ivo. Metodologia e Epistemologia da Análise Econômica do Direito. Economic Analysis of Law Review, v. 1, n. 1, p. 7-33, jan./jun.2010. Disponível em: http://portalrevistas. ucb.br/index.php/EALR/article/view/1460/1110. Acesso em: 21 out. 2014. p. 15 sobre a justiça das instituições internacionais, portanto, já que permite trazer as consequências do fenômeno jurídico para o centro do debate, em razão do poder preditivo da análise econômica ${ }^{38}$.

A análise econômica do Direito exige que sejam observadas certas premissas fundamentais: a escassez de recursos, a racionalidade autointeressada dos agentes, a existência de incentivos e o equilíbrio, ou eficiência, econômica. Por esse motivo, passa-se, agora, a uma análise sobre como cada uma destas premissas pode ser aplicada ao Direito Internacional.

\section{A ESCASSEZ De RECURSOS E A ESCOLHA RACIO- NAL DOS ESTADOS}

A primeira premissa a ser destacada quando se enfoca a análise econômica do Direito é o fato de que, embora os desejos dos seres humanos sejam ilimitados, o mundo possui recursos escassos para realizá-los ${ }^{39}$. Se não fosse a escassez de recursos, não haveria problemas ou escolhas econômicas, uma vez que todas as necessidades seriam satisfeitas - fossem elas quais fossem ${ }^{40}$. Ivo Gico Júnior ${ }^{41}$ salienta que, neste contexto, sequer haveria conflito e o Direito seria desnecessário, já que as pessoas não precisariam competir para satisfazerem suas necessidades conflitantes em um mundo de recursos ilimitados.

No mundo real, porém, a escassez de recursos impõe à sociedade que escolha entre alternativas possíveis e excludentes. Toda escolha gera um custo de oportunidade (tam-

38 SALAMA, Bruno Meyerhof. O que é pesquisa em Direito e Economia? Cadernos Direito GV, v. 5, n. 2, mar. 2008. Disponível em: http://bibliotecadigital.fgv.br/dspace/bitstream/handle $/ 10438 / 2811 /$ caderno $\% 2520$ direito $\% 252022$.pdf? sequence $=1$. Acesso em: 22 out. 2014. p. 14

39 PINHEIRO FILHO, Francisco Renato Codevila. Teoria da agência (problema agente-principal). In: RIBEIRO, Márcia Carla Pereira; KLEIN, Vinícius (Coord.). O que é análise econômica do Direito: uma introdução. Belo Horizonte: Editora Fórum, 2011. p. 98.

40 GICO JR., Ivo. Metodologia e Epistemologia da Análise Econômica do Direito. Economic Analysis of Law Review, v. 1, n. 1, p. 7-33, jan./jun.2010. Disponível em: http://portalrevistas. ucb.br/index.php/EALR/article/view/1460/1110. Acesso em: 21 out. 2014. p. 22.

41 GICO JR., Ivo. Metodologia e Epistemologia da Análise Econômica do Direito. Economic Analysis of Law Review, v. 1, n. 1, p. 7-33, jan./jun.2010. Disponível em: http://portalrevistas. ucb.br/index.php/EALR/article/view/1460/1110. Acesso em: 21 out. 2014. p. 22. 
bém chamado de trade off), o qual pode ser definido como "a segunda alocação factível mais interessante para o recurso, mas que foi preterida" ${ }^{42}$. Para escolher entre as opções possíveis, os indivíduos ponderam custos e benefícios de cada curso de ação - decidindo pela opção que atende melhor os seus interesses e, ponderando, inclusive, sobre os ganhos esperados na alternativa desprezada. Nesse contexto, Ivo Gico Júnior ${ }^{43}$ afirma que a conduta dos agentes econômicos é racional maximizadora - isto é, os indivíduos tendem a agir de forma a maximizar suas utilidades, visando extrair o máximo de satisfação possível para si com o menor custo.

É importante destacar que o termo "utilidade" deve ser entendido como a satisfação extraída de uma dada escolha, sem necessariamente que tal conceito se restrinja a questões materiais, muito menos monetárias ${ }^{44}$. Embora essa perspectiva comporte ressalvas que serão oportunamente endereçadas, a teoria econômica supõe que os agentes racionais escolherão sempre a alternativa que lhes proporcionar mais utilidade - isto é, satisfação maximizando seus interesses, sem, contudo, fazer juízos de valor sobre que interesses são estes ${ }^{45}$.

A racionalidade econômica mostra-se um dos conceitos de maior utilidade à análise do Direito Internacional, justamente por ser este um ramo do Direito que emerge sem que exista um Estado para impô-lo e que é composto por regras criadas pelos Estados para si mes-

42 GICO JR., Ivo. Metodologia e Epistemologia da Análise Econômica do Direito. Economic Analysis of Law Review, v. 1, n. 1, p. 7-33, jan./jun.2010. Disponível em: http://portalrevistas. ucb.br/index.php/EALR/article/view/1460/1110. Acesso em: 21 out. 2014. p. 22.

43 GICO JR., Ivo. Metodologia e Epistemologia da Análise Econômica do Direito. Economic Analysis of Law Review, v. 1, n. 1, p. 7-33, jan./jun.2010. Disponível em: http://portalrevistas. ucb.br/index.php/EALR/article/view/1460/1110. Acesso em: 21 out. 2014. p. 22.

44 GICO JR., Ivo. Metodologia e Epistemologia da Análise Econômica do Direito. Economic Analysis of Law Review, v. 1, n. 1, p. 7-33, jan./jun.2010. Disponível em: http://portalrevistas. ucb.br/index.php/EALR/article/view/1460/1110. Acesso em: 21 out. 2014. p. 27.

45 Richard Posner, neste sentido, destaca que a racionalidade não deve ser confundida com egoísmo, já que o bem-estar de outros pode ser parte da satisfação de certos indivíduos; tampouco deve ser confundida com o calculismo consciente, já que a racionalidade é medida por sua conformidade à escolha racional, que não se confunde com o estado mental do agente (até animais podem ser considerados racionais); ainda, a racionalidade não se confunde com a onisciência - já que não exige que os indivíduos tenham todas as informações possíveis para fazerem suas escolhas e admite que a capacidade das pessoas de processarem informações é limitada. (cf. POSNER, Richard A. Economic Analysis of Law. 9th edition. New York: Wolters Kluwe Law \& Business, 2014). mos, como resultado de um processo de cooperação ${ }^{46}$. Douglas C. North ${ }^{47}$, um dos grandes nomes da AED, já havia se questionado sobre as condições em que a cooperação voluntária pode existir sem a solução bobbesiana de um Estado coercitivo para obrigar os agentes a cooperarem. A perspectiva da escolha racional fornece uma resposta simples para esta questão, que também intrigou diversos juristas que se dedicam ao estudo do Direito Internacional ${ }^{48}$.

Fato é que embora alguns teóricos tenham expressado ceticismo quanto ao Direito Internacional, pela ausência de governo mundial a conceder-lhe coercitividade, a regra do Direito Internacional é o seu cumprimento - e não sua violação - e, como afirmou Louis Henkin, "quase todas as nações observam quase todos os princípios de Direito Internacional e quase todas as suas obrigações na maior parte do tempo" ${ }^{\text {"49 }}$. De acordo com os teóricos da escolha racional - que partem de uma perspectiva voluntarista do Direito Internacional ${ }^{50}$ - os Estados conformam-se às suas normas e incorrem em custos para sua negociação e formulação porque entendem que este é o meio mais eficiente de atingir

46 SANTOS, Alexandre Leite dos. O Direito Internacional Público como jogo institucional. Economic Analysis of Law Review, v. 1, n. 2, p. 179-195, jul./dez. 2010. Disponível em: http://portalrevistas.ucb.br/index.php/EALR/article/view/1\%20EALR $\% 20$ 174/1\%20EALR\%20174. Acesso em: 10 nov. 2014. p. 182-183

47 NORTH, Douglass C. Institutions, institutional change and economic performance. New York: Cambridge University Press, 1990. p. 14.

48 Um bom resumo das diferentes explicações doutrinárias pode ser encontrado em: $\mathrm{KOH}$, Harold Hongiu. Why do nations obey international law? Yale law school faculty scholarship. Disponível em: http://digitalcommins.law.yale.edu/fss_papers/2101. Acesso em: 31 dez. 2014.

49 "Almost all nations observe almost all principles of international law and almost all of their obligations almos all of the time". (HENKIN, Louis apud KOH, Harold Hongiu. Why do nations obey international law? Yale law school faculty scholarship. Disponível em: http://digitalcommins.law.yale.edu/fss_papers/2101. Acesso em: 31 dez. 2014).

50 Há um debate antigo acerca do fundamento do Direito Internacional, que opõe, de um lado, os teóricos do Direito Natural e, de outro os que fundamentam a ordem internacional no consentimento dos membros da comunidade internacional, de forma voluntária. A esta segunda corrente nos filiamos. Sobre o tema, recomenda-se a leitura de: VERDROSS, Alfred. O fundamento do Direito Internacional. Revista de Direito Internacional, Brasília, v. 10, n. 2, 2013, p. 1-33. 
os seus próprios interesses ${ }^{51}$. Goldshmit e Posner ${ }^{52}$ foram bastante assertivos neste sentido, afirmando que o "Direito Internacional surge a partir da ação racional dos Estados para maximizar seus interesses, tendo por base sua percepção dos interesses dos outros Estados e a distribuição de poder entre eles". No mesmo sentido, assente Andrew Guzman ${ }^{53}$, para quem os Estados não têm nenhuma predisposição a seguir o Direito Internacional - sendo que o farão apenas se entenderem que tal conduta maximizará os seus interesses.

A perspectiva dos Estados como agentes racionais pressupõe que os Estados são autointeressados - e conseguem identificar claramente os seus interesses (ou preferencias estatais) ${ }^{54}$, moldando suas escolhas de modo a satisfazê-los. Obviamente, a presunção do comportamento estatal como autointeressado - ou mesmo do comportamento humano como autointeressado - é uma simplificação. De fato, afirmar que os Estados são agentes autointeressados é uma afirmação que exige uma série de ressalvas. Joeest Pauwelyn ${ }^{55}$ afirma que os Estados não perseguem um objetivo único, mas sim uma série de objetivos, como atender ao interesse público, defender certos valores ou ainda buscar poder geopolítico. Além disso, os Estados não são atores unitários e quando se enfoca toda a ampla gama de indivíduos que compõem um dado país, pode haver interesses conflitantes.

Robert Scott e Paul Stephan ${ }^{56}$ sustentam que a noção dos Estados como formadores do Direito Internacional é uma abstração, já que os Estados são formados por pessoas e agem por meio de pessoas. A perspectiva

51 SANTOS, Alexandre Leite dos. O Direito Internacional Público como jogo institucional. Economic Analysis of Law Review, v. 1, n. 2, p. 179-195, jul./dez. 2010. Disponível em: http://portalrevistas.ucb.br/index.php/EALR/article/view/1\%20EALR $\% 20$ 174/1\%20EALR\%20174. Acesso em: 10 nov. 2014. p. 183

52 "International law emerges from states acting rationally to maximize their interests given their perceptions of the interest of other states and the distribution of state power" (GOLDSMITH, Jack; POSNER, Eric A. The Limits of International Law. New York: Oxford University Press. p. 3, tradução livre).

53 GUZMAN, Andrew T. How international law works: a rational choice theory. Oxford: Oxford University Press, 2008. p. 17.

54 GUZMAN, Andrew T. How international law works: a rational choice theory. Oxford: Oxford University Press, 2008. p. 17

55 PAUWELYN, Joost. Optimal protection of international law: navigating between European Absolutism and American voluntarism. Cambridge: Cambridge University Press, 2008. p. 74.

56 SCOTT, Robert E.; STEPHAN, Paul B. The limits of Leviathan: contract theory and the enforcement of international law. Cambridge: Cambridge University Press, 2006, p. 29. da escolha racional deve enfocar, então, a decisão dos representantes dos Estados, os quais podem, por vezes, ter incentivos para atender a interesses que não se alinham com os interesses dos Estados enquanto ente coletivo. Não obstante, estes representantes são submetidos a uma espécie de seleção natural em razão do escrutínio ao qual suas decisões são submetidas e "decisões ruins, não sempre, mas frequentemente, levam ao surgimento de novos líderes" ${ }^{\prime 57}$. Ainda que, de forma simplificada, portanto, pode-se dizer que os Estados, por meio de seus representantes, dão forma ao Direito Internacional conforme percebem que, ao fazê-lo, satisfarão de forma mais adequada os seus interesses.

Ressalta-se, desde logo, que, embora se sustente que a escolha racional pode ser uma das explicações para a existência e efetividade do Direito Internacional, não se pretende neste artigo sustentar que a perspectiva da escolha racional é a única possível para compreendê-lo. Ao contrário, trata-se apenas de um modelo suficientemente plausível para justificar a análise do Direito Internacional através do método econômico. Nesse sentido, muitos pensadores denominados juseconomistas defendem que qualquer ramo do Direito pode ser avaliado em termos econômicos - do direito contratual ao constitucional, do direito ambiental ao direito de família - na medida em que envolvem a tomada de decisões feita por agentes ${ }^{58}$. É fato, porém, que a aplicação da lógica econômica se mostra muito mais simples no enfoque do Direito Internacional Econômico e das regulações de comércio e investimentos estrangeiros, por exemplo, do que para uma análise do Direito Internacional Humanitário ou do Direito Internacional dos Direitos Humanos.

Qualquer que seja o ramo, porém, é de se ressaltar que o interesse a ser maximizado não precisa ser, necessariamente, econômico. Assim, ainda que se acredite que o surgimento do Direito Internacional dos Direitos Humanos possa ser explicado por uma difusão construtivista $^{59}$ de normas e valores compartilhados, a escolha

57 "Bad choices result, not inevitably but frequently in new leaders". (SCOT'T, Robert E.; STEPHAN, Paul B. The limits of Leviathan: contract theory and the enforcement of international law. Cambridge: Cambridge University Press, 2006, p. 25).

58 GICO JR., Ivo. Metodologia e Epistemologia da Análise Econômica do Direito. Economic Analysis of Law Review, v. 1, n. 1, p. 7-33, jan./jun.2010. Disponível em: http://portalrevistas. ucb.br/index.php/EALR/article/view/1460/1110. Acesso em: 21 out. 2014. p. 18

59 Estes ramos talvez sejam melhor explicados pelo enfoque 
de determinados arranjos (multilaterais, bilaterais ou regionais, por exemplo) ou de determinadas estruturas de proteção (com a possibilidade de reclamação direta pelos indivíduos em caso de violação, com tal possibilidade intermediada por uma Comissão Estatal ou apenas reconhecendo capacidade postulatória aos Estados) pode ser explicada em função de uma decisão racional emanada pelos Estados que os leva a crer que uma dada estrutura propiciará uma melhor difusão de tais valores compartilhados. Em outras palavras, a decisão racional dos agentes pode pressupor mais do que apenas objetivos egoísticos. Até mesmo o altruísmo pode, em última análise, ser compreendido em função da racionalidade econômica autointeressada ${ }^{60}$.

Não obstante, a própria teoria econômica ressalva o postulado da racionalidade absoluta. Os teóricos da Nova Economia Institucional, por exemplo, embasam suas perspectivas na premissa de racionalidade limita$\mathrm{da}^{61}$. Isso significa que, conforme afirmou Douglass North, os indivíduos nem sempre possuem todas as informações necessárias para tomar a decisão que maximize o resultado de suas escolhas ${ }^{62}$, tampouco agem de forma absolutamente racional, sendo influenciados por

dado pelo construtivismo, teoria das Relações Internacionais que se baseia na ideia da existência de normas e valores compartilhados que moldam o comportamento dos Estados, mais do que apenas as relações de poder. Sobre o construtivismo, recomenda-se a leitura de CASTRO, Thales. Teoria das relações internacionais. Brasília: FUNAG, 2012. Disponível em: http://www.funag.gov.br/ biblioteca/dmdocuments/Teoria_das_Relacoes_Internacionais_ de_Thales_Castro.pdf. Acesso em 15 de dezembro de 2014.

60 Neste contexto, Douglas North (cf. NORTH, Douglass C. Institutions, institutional change and economic performance. New York: Cambridge University Press, 1990. p. 21) destacou que o altruísmo pode ser considerado como uma outra faceta da visão racional-maximizadora (o indivíduo altruísta obtém satisfação ao contribuir para o bem estar dos demais - e por isto, sua conduta altruísta é, em verdade, um meio para aumentar sua própria satisfação). Assim também pensa Richard Posner, quando afirma que o a satisfação (ou até mesmo a miséria) de um pode ser essencial para a satisfação do outro. (Cf. POSNER, Richard A. Economic Analysis of Law. 9th edition. New York: Wolters Kluwe Law \& Business, 2014).

61 O reconhecimento da limitação da racionalidade humana é questão enfocada por Márcia Carla Pereira Ribeiro, que destaca a assimetria informacional e as características inatas dos seres humanos como falhas de racionalidade que precisam ser ponderadas na análise econômica. Ver em: RIBEIRO, Márcia Carla Pereira. Racionalidade Limitada. In: RIBEIRO, Márcia Carla Pereira; KLEIN, Vinícius (Coord.). O que é análise econômica do Direito: uma introdução. Belo Horizonte: Editora Fórum, 2011. p. 67.

62 NORTH, Douglass C. Institutions, institutional change and economic performance. New York: Cambridge University Press, 1990. p. 8. ideologias e dogmas e por limitações em sua capacidade intelectual para processar, organizar e utilizar as informações de que dispõem ${ }^{63}$.

Além disso, sem fugir dos postulados econômicos, é também possível questionar o autointeresse como única conduta racional possível. Amartya Sen ${ }^{64}$, por exemplo, considerou um patente absurdo a rejeição de qualquer concepção de motivação ética como irracional. Para o autor:

A racionalidade da escolha é sobretudo uma
questão de basear nossas escolhas - explícita ou
implicitamente - em um argumento que podemos
sustentar de forma reflexiva se o submetermos à
análise crítica. O método da escolha racional, nessa
visão, está fundamentalmente ligado a conformar
nossas escolhas à investigação crítica das razões
para fazê-las. As exigências essenciais da escolha
racional referem-se a submetermos nossas escolhas
- de ações bem como de objetivos, valores e
prioridades - à análise arrazoada ${ }^{65}$.

As vantagens do método econômico não recaem, portanto, em sua capacidade de descrever perfeitamente a racionalidade por trás de cada comportamento dos agentes individualmente tomados, mas sim na capacidade preditiva que o uso da racionalidade - de forma instrumental - pode proporcionar ${ }^{66}$. Isto porque ainda que a maximização do autointeresse não seja de fato a forma pela qual os Estados sempre agem, não se pode deixar de notar que os Estados não estão completamente alienados desta percepção ${ }^{67}$, e tais considerações são ponderadas na tomada de decisões estatais. Além disso, ainda que se adote uma concepção mais abrangente de racionalidade, como a sugerida por Amartya Sen, o

63 NORTH, Douglass C. Institutions, institutional change and economic performance. New York: Cambridge University Press, 1990. p. 20-25.

64 SEN, Amartya. A ideia de justiça. Tradução de Denise Bottmann e Ricardo Doninelli Mendes. São Paulo: Companhia das Letras, 2009. p. 199.

65 SEN, Amartya. A ideia de justiça. Tradução de Denise Bottmann e Ricardo Doninelli Mendes. São Paulo: Companhia das Letras, 2009. p. 193.

66 SALAMA, Bruno Meyerhof. O que é pesquisa em Direito e Economia? Cadernos Direito GV, v. 5, n. 2, mar. 2008. Disponível em: http://bibliotecadigital.fgv.br/dspace/bitstream/handle $/ 10438 / 2811 /$ caderno $\% 2520$ direito $\% 252022$.pdf? sequence $=1$. Acesso em: 22 out. 2014. p. 19-20.

67 No mesmo sentido, afirma Amartya Sen, para quem o importante "não é a suposição de que as pessoas sempre agem de forma racional, mas a ideia de que as pessoas não estão completamente alienadas das exigências da racionalidade (mesmo que se enganem de vez em quando ou não consigam seguir os ditames da razão em todos os casos)". (SEN, Amartya. A ideia de justiça. Tradução de Denise Bottmann e Ricardo Doninelli Mendes. São Paulo: Companhia das Letras, 2009. p. 191). 
posicionamento da escolha racional continua sendo útil para mensurar a pertinência entre os meios escolhidos e os objetivos propostos em uma norma.

Assim, a despeito das importantes ressalvas quanto à racionalidade autointeressada dos Estados, pode-se dizer que eles criarão normas de Direito Internacional (assinando um Tratado, por exemplo) quando perceberem que estarão - de alguma forma - em uma situação melhor, fazendo parte dessa estrutura de cooperação do que ao se recusarem a participar. Isso implica, por decorrência lógica, uma cessão de poderes e liberdades em prol de um objetivo maior. Porém, após a assinatura dos tratados, sempre haverá a tentação de descumpri-lo - o que também é explicado pela Teoria Econômica.

A ferramenta do Dilema do Prisioneiro é útil para compreender esta estrutura: agindo de forma egoísta e autointeressada, é possível que os países alcancem resultados melhores em um primeiro momento do que ao mitigarem seus interesses individuais e cooperarem internacionalmente. No entanto, os atores internacionais não se relacionam uma única e isolada vez - como os prisioneiros acusados de um delito único da história original do Dilema do Prisioneiro. Em verdade, na sociedade contemporânea, suas relações tornam-se iteradas, o que os impulsiona a adotar estratégias cada vez mais cooperativas.

Para Robert Axelrod ${ }^{68}$ a ameaça implícita de uma retaliação contra a traição do outro em uma interação futura funciona como um estímulo para que os agentes cooperem. No exemplo do Dilema do Prisioneiro original, se os dois prisioneiros encontram-se novamente, é provável que aquele que foi traído na interação anterior decida retaliar: nesse caso, ambos sairão prejudicados. Assim, a melhor estratégia, quando há a possibilidade de uma nova interação, é o estabelecimento de um ciclo ininterrupto de cooperação.

Ademais, as relações entre países possuem a peculiaridade de serem amplamente observadas por terceiros Estados, de tal forma que a adoção de uma estratégia adequada de cooperação é importante para a construção da reputação do país, o que afetará a escolha da estratégia dos demais em relacionamentos futuros69. Além disso, os Tratados Internacionais também podem servir para alterar as recompensas, tornando uma

68 AXELROD, Robert. A evolução da cooperação. São Paulo: Leopardo Editora, 2010.

69 AXELROD, Robert. A evolução da cooperação. São Paulo: Leopardo Editora, 2010, p. 140 traição mais custosa, de modo que a cooperação vem a ser a melhor escolha. Assim, quando as relações são iteradas, os direitos estão bem estabelecidos, a punição para a detração é grande e os prejuízos reputacionais sensíveis, a possibilidade de cumprimento de Tratados cresce exponencialmente.

A existência de normas de Direito Internacional criadas prevalentemente pelos Estados e com graus variados de efetividade fazem com que as condutas dos agentes que atuam na sociedade internacional (Estados, organizações internacionais, indivíduos, empresas, organizações não governamentais, entre outros) sejam influenciadas pela existência deste arcabouço jurídico internacional. O papel das normas de Direito Internacional como influenciadora de determinados comportamentos pode ser analisado a partir de outro pressuposto da AED: agentes racionais respondem a incentivos.

\section{INSTITUIÇÕES IMPORTAM: O PAPEL DO DIREITO ENQUANTO CRIADOR DE INCENTIVOS}

Dando continuidade à análise de custos e benefícios realizadas pelos agentes econômicos para a tomada da decisão racional-maximizadora, tem-se que muitos são os fatores ponderados pelos agentes no cálculo preditivo de seus resultados. Estes fatores podem ser chamados de incentivos ou desincentivos para a adoção de um comportamento determinado. Assim, uma outra importante premissa da AED é a de que as pessoas respondem a incentivos ${ }^{70}$.

A economia clássica restringia a análise dos custos de produção no cálculo decisório do agente econômico. Em outras palavras, considerava que o agente, ao optar por um determinado curso de ação, desconsiderava os custos em etapas de negociação, formulação e execução de contratos ou resoluções de disputas, por exemplo. Segundo Oliver Williamson ${ }^{71}$, tais fatores compõem os chamados custos de transação, e sua desconsideração pelas teorias econômicas clássicas era semelhante à des-

70 GICO JR., Ivo. Metodologia e Epistemologia da Análise Econômica do Direito. Economic Analysis of Law Review, v. 1, n. 1, p. 7-33, jan./jun.2010. Disponível em: http://portalrevistas. ucb.br/index.php/EALR/article/view/1460/1110. Acesso em: 21 out. 2014. p. 22.

71 WILLIAMSON, Oliver. The Economic Institutions of Capitalism - Firms, Markets, Relational Contraction. New York: The Free Press, 1985. p. 18-19. 
consideração do atrito nos cálculos de Física realizados por estudantes da educação fundamental. Porém, tal qual um cálculo físico que desconsidera o atrito, um cálculo econômico que desconsidera os custos de transação leva a conclusões irreais. Um dos pontos fulcrais da aplicação do método econômico aos estudos do Direito despontou, portanto, quando a corrente teórica denominada Nova Economia Institucional (NEI) surgiu para suprir esta falha da economia clássica, estabelecendo que a decisão dos agentes é influenciada, também, pelos custos de transação.

O pensamento da NEI tem como precursor Ronald Coase, em seu texto "The Problem of the Social Cost" Nele, o autor abordou as chamadas externalidades: situações em que as ações de determinados agentes (especificamente, as empresas) produzem efeitos que transbordam o escopo de sua atividade, afetando negativamente terceiros - o que o autor chamou de "custo social". Coase sugeriu, então, uma visão alternativa à que vinha sendo defendida por Arthur Cecil Pigou ${ }^{73}$, para quem o modo adequado para lidar com as externalidades seria a intervenção estatal, atribuindo ao Estado o papel de corretor das escolhas individuais por meio de medidas de incentivo para as boas escolhas e de desincentivo para as que resultassem em efeitos negativos (ou na redução de bem-estar). Para Ronald Coase ${ }^{74}$, as vantagens supervenientes da regulação governamental estavam sendo superestimadas e nem sempre levariam a solução mais eficiente. $\mathrm{O}$ autor acreditava que as partes envolvidas poderiam - sozinhas e mediante livre negociação - chegar à solução mais adequada para lidar com as externalidades, desde que as transações ocorressem sem custos, os direitos das partes estivessem bem definidos e os resultados das ações judiciais pudessem ser previstos com facilidade ${ }^{75}$.

Com base nesse artigo - que se tornou um dos mais citados de todos os tempos tanto no Direito quanto na economi ${ }^{76}$ - difundiu-se o chamado Teorema de Coase,

72 COASE, Ronald. O problema do custo social. The Latin American and Caribbean Journal of Legal Studies, v. 13, n. 1, article 9, 2008.

73 PIGOU, Arthur Cecil. The Economics of Welfare. Londres: Macmillan and CO. Limited, 1932.

74 COASE, Ronald. O problema do custo social. The Latin American and Caribbean Journal of Legal Studies, v. 13, n. 1, article 9, 2008. p. 15.

75 COASE, Ronald. O problema do custo social. The Latin American and Caribbean Journal of Legal Studies, v. 13, n. 1, article 9, 2008

76 KLEIN, Vinícius. Teorema de Coase. In: RIBEIRO, Már- cuja formulação mais conhecida pode ser assim descrita "numa situação de custos de transação zero, a alocação final de um bem, obtida por meio da barganha entre as partes, será sempre eficiente, não importa a configuração legal acerca da propriedade deste bem"77. Douglas C. North, nesse mesmo sentido, destaca a conclusão lógica emanada com base no Teorema: "quando há custos de transação, as instituições importam" ${ }^{78}$.

Segundo Douglas C. North $^{79}$, as instituições são restrições criadas pelos seres humanos, que estruturam as relações humanas. Podem ser consideradas instituições as regras, leis, acordos, tratados e convenções, por exemplo. As instituições afetam os custos de transação em um dado sistema econômico, e por isto precisam ser consideradas na tomada de decisões feita pelos agentes. É este o ponto fulcral da análise econômica do Direito: por meio das regras jurídicas, criam-se incentivos ou desestimula-se o exercício de determinadas atividades, direcionando as escolhas dos indivíduos. Como bem destacou Bruno Salama ${ }^{80}$ "as instituições importam, no fundo, porque os indivíduos e organizações reagem aos incentivos por elas criados".

A percepção de que o Direito pode ser uma ferramenta de incentivos não é nova: o Direito Penal, por exemplo, parte do pressuposto de que, ao estabelecer suas penas, elevam-se os custos da prática de delitos e, portanto, a incidência de sua ocorrência tende a diminuir ${ }^{81}$. Por outro lado, outros ramos do Direito destinam-se a estimular certos comportamentos para que as pessoas o pratiquem, trazendo mais bem-estar à sociedade como um todo. A análise econômica do

cia Carla Pereira; KLEIN, Vinícius (Coord.). O que é análise econômica do Direito: uma introdução. Belo Horizonte: Fórum, 2011. p. 71

77 KLEIN, Vinícius. Teorema de Coase. In: RIBEIRO, Márcia Carla Pereira; KLEIN, Vinícius (Coord.). O que é análise econômica do Direito: uma introdução. Belo Horizonte: Fórum, 2011. p. 71

78 NORTH, Douglass C. Institutions, institutional change and economic performance. New York: Cambridge University Press, 1990. p. 12.

79 NORTH, Douglass C. Economic Performance through Time. American Economic Review. American Economic Association, v. 84, n. 3, p. 359-368, jun. 1994. p. 360.

80 SALAMA, Bruno Meyerhof. Sete enigmas do desenvolvimento em Douglas North. In: VIEIRA, Oscar Vilhena; DIMOULIS, Dimitri. (Org.). Estado de direito e o Desafio do Desenvolvimento. São Paulo: Saraiva, 2011. p. 45.

81 POSNER, Eric A.; SYKES, Alan O. Economic Foundations of International Law. Cambridge: Harvard University Press, 2013, p. 18. 
Direito permite ponderar quais as condutas que estão sendo induzidas por uma determinada norma - bem como auxilia o Direito a atuar, ao mesmo tempo, como um instrumento de estímulo a realização de transações benéficas e de mitigação das ações prejudiciais ${ }^{82}$.

Conceber o Direito Internacional como uma estrutura de incentivos é útil, em primeiro lugar, porque as regras de Direito Internacional vinculam os seus próprios formuladores - ou seja, os Estados signatários de um tratado, ao mesmo tempo em que elaboram suas regras, também estipulam a estrutura de incentivos que culmina em sua observância ou seu descumprimento. É de se notar, portanto, que a estrutura de incentivos que emerge a partir das regras de Direito Internacional se assemelha à solução proposta por Coase ao problema das externalidades: os agentes transacionam livremente entre si para chegar a um consenso sobre a melhor forma de lidar com as condutas de uns Estados que direta ou indiretamente - afetam outros.

Tendo em vista os elevados custos de transação em uma disputa internacional, a definição prévia desta estrutura de incentivos é uma das razões pelas quais os Estados se envolvem em negociações internacionais. Ao considerarem descumprir um tratado firmado, os países terão que ponderar sobre os custos envolvidos nas punições que eles mesmos estipularam no instrumento firmado, nas retaliações permitidas pelo Direito Internacional e, ainda, no prejuízo reputacional incorrido pela quebra de uma estrutura de cooperação - o que pode prejudicar a capacidade dos países de realizar novas iniciativas de cooperação que lhe seriam úteis no futuro. Tais situações emergem como desincentivos à ruptura do acordo firmado. Não obstante, é importante compreender que a existência da regra de Direito Internacional é apenas um dos muitos incentivos que um Estado possui para agir de uma forma determinada - e a escolha dos Estados dependerá de vários fatores (além do Direito Internacional). Em alguns casos, como bem salientou Andrew Guzman ${ }^{83}$, o Direito Internacional serve apenas como um pequeno incentivo para a adoção de um determinado comportamento.

82 SHAPIRO, Mário Gomes. Repensando a relação entre Estado e Direito: os limites do paradigma Rule of Law e a relevância das alternativas institucionais. In: VIEIRA, Oscar Vilhena; DIMOULIS, Dimitri. Estado de Direito e o desafio do Desenvolvimento. São Paulo: Saraiva, 2011, p. 225.

83 GUZMAN, Andrew T. How international law works: a rational choice theory. Oxford: Oxford University Press, 2008. p. 15
É notório, também, que os incentivos ao cumprimento estabelecidos pelo Direito Internacional são propositadamente maiores em alguns casos do que em outros. Tome-se como exemplo a faculdade conferida por certos instrumentos internacionais para que atores privados (indivíduos ou empresas) acionem diretamente os instrumentos de solução de controvérsias, alegando o descumprimento de regras de direito material internacional. Na seara dos Direitos Humanos, apenas a Convenção Europeia de Direitos Humanos estabelece esta possibilidade de modo pleno ${ }^{84}$. Por outro lado, quase todos os mais de 3.000 acordos bilaterais de investimentos existentes no mundo conferem ao investidor o direito de processar o Estado receptor do investimento em foros arbitrais internacionais por violações a regras de proteção da propriedade ${ }^{85}$. A razão para esta diferença também pode ser compreendida em função da estrutura de incentivos que os acordos estabelecem.

Os acordos de investimento são quase que exclusivamente bilaterais - e a história desse ramo do Direito demonstrou enorme dificuldade nas negociações multilaterais sobre a matéria. Os Tratados de Direitos Humanos, por sua vez, são quase sempre multilaterais e com aspiração universal ${ }^{86}$. A criação de uma estrutura muito rígida para proteção dos direitos humanos poderia ser um desincentivo à ampla adesão ao tratado, o que seria um objetivo preliminar deste ramo do Direito Internacional: como ainda existem discordâncias culturais acerca de quais os direitos humanos efetivamente devem ser garantidos, antes de demandar o cumprimento, é conveniente que o maior número de países concorde com os princípios de Direitos Humanos elencados nos instrumentos internacionais. Em outras palavras, para esse ramo do Direito Internacional, conseguir adesão universal aos seus postulados é o objetivo prioritário e, diante disto, punições muito altas para suas violações

84 Sobre o peticionamento individual às Cortes Regionais de Direitos Humanos, sugere-se a leitura de: GONTIJO, André Pires. Os caminhos fragmentados da proteção humana: o peticionamento individual, o conceito de vítima e o amicus curiae como indicadores do acesso aos sistemas interamericano e europeu de proteção dos direitos humanos. Revista de Direito Internacional, Brasília, v. 9, n. 4, 2012, p. 7-25

85 Sobre os acordos bilaterais de investimentos estrangeiros, sugere-se a leitura de: MONEBHURRUN, Nitish. Crônicas do Direito Internacional dos Investimentos. Revista de Direito Internacional, Brasília, v. 11, n.1, 2014, p. 10-18; MONEBHURRUN, Nitish. Crônicas do Direito Internacional dos Investimentos. Revista de Direito Internacional, Brasília, v. 12, n. 1, 2015, p. 32-36

86 GUZMAN, Andrew T. How international law works: a rational choice theory. Oxford: Oxford University Press, 2008. p. 157 
poderiam servir como desincentivo à adesão a tais instrumentos - razão pela qual são evitadas.

Não por acaso, o sistema europeu de Direitos Humanos é o mais avançado na possibilidade de reclamações diretas por indivíduos. As democracias europeias já cumprem, de modo geral, muito mais efetivamente com as obrigações previstas nas Convenções de Direitos Humanos, não incorporando obrigações muito maiores do que aquelas que já fazem parte de sua estrutura jurídica interna quando aderem a estes acordos. Os postulados defendidos como Direitos Humanos já estão arraigados em seus sistemas jurídicos internos e em seu arcabouço moral e cultural. Por isso, podem avançar um pouco mais ao estabelecer um meio de solução de controvérsias mais estruturado, permitindo reclamações individuais.

As negociações do Direito Internacional dos Investimentos Estrangeiros englobam, por outro lado, menos Estados, o que lhes permitiria, em tese, pensar em uma estrutura mais apropriada às idiossincrasias de cada relação. Além disso, seu enfoque protetivo recai basicamente sobre as noções de direito de propriedade - que se tornaram bastante aceitas internacionalmente, especialmente após a derrocada do comunismo. Além disso, há incentivos para que os países concordem com um grau mais elevado de proteção ao investidor internacional: ao protegerem a propriedade estrangeira e os ativos dos investidores, os Estados esperam criar uma estrutura de proteção tal que induza o comportamento dos investidores internacionais também, estimulando-os a investir. Em verdade, os Acordos bilaterais de Proteção e Promoção Recíproca de investimentos estrangeiros só existem em razão da crença disseminada entre os países em desenvolvimento de que assinar esses acordos é um incentivo para o recebimento de capital estrangeiro em seu território ${ }^{87}$. Caso tais regras fossem transpostas ao cenário multilateral, se perderia a sensação de criação de uma vantagem comparativa ao assinar acordos de investimento. Isso explica porque o multilateralismo foi uma estratégia fracassada neste âmbito do Direito Internacional.

O que se nota, portanto, é que o Direito Interna-

87 Sobre a decisão dos países assinarem acordos bilaterais de investimento, ver em GUZMAN, Andrew. Why LDCs sign treaties that hurt them: explaining the popularity of bilateral investment treaties. Virginia Journal of International Law, v. 38, n. 639, p. 639-688, 1998. Disponível em: http://papers.ssrn.com/sol3/papers.cfm?abstract_id=2176003. Acesso em: 4 nov. 2014. cional pode servir tanto para incentivar seus próprios formuladores a agirem em uma direção determinada quanto para a criação de uma estrutura de incentivos que impulsione a conduta de terceiras partes, com vistas à obtenção de benefícios pelos Estados signatários. Compreender quais os incentivos criados por uma regra de Direito Internacional é, portanto, mais um dos benefícios da aplicação do método da AED à disciplina.

\section{EFICIÊNCIA ECONÔMICA E ROMPIMENTO dOS TRATADOS INTERNACIONAIS}

Nos contextos em que a interação dos agentes é livre - ou seja, em um contexto de mercado (como, conforme já se destacou, é o cenário internacional) -, a AED pressupõe que os agentes transacionarão entre si até que os custos de cada troca se igualem aos benefícios auferidos, hipótese na qual há uma situação de equilíbrio, em que todos os desperdícios envolvidos na troca foram eliminados. Diz-se que, quando o equilíbrio foi alcançado, está-se diante de um resultado eficiente, conforme o critério chamado de "Ótimo de Pareto" $"$.

O Ótimo de Pareto não foi inicialmente desenvolvido para enfocar as instituições, mas sim a distribuição de recursos em sistemas produtivos ${ }^{89}$. Assim, uma determinada forma de organizar a produção seria considerada eficiente quando não fosse possível produzir mais de um determinado bem sem produzir menos de outro bem. Aplicando essa mesma fórmula às instituições, tem-se que uma determinada configuração será considerada eficiente quando não for possível modificá-la para melhorar a condição de algumas pessoas sem que, para isso, outras pessoas fiquem em uma situação pior ${ }^{90}$.

Ocorre que, para que o critério paretiano de eficiência pudesse ser atingido, a capacidade de negociação das partes deveria ser ilimitada: ou seja, as partes conseguiriam negociar de forma perfeita, prevendo todas as contingências

88 O Ótimo de Pareto é assim chamado porque é o critério de eficiência econômica defendido por Vilfredo Pareto em seu livro "Manual de Economia Politica". (Cf. DOMINGUES, Victor Hugo. Ótimo de Pareto. In: RIBEIRO, Márcia Carla Pereira; KLEIN, Vinícius (Coord.). O que é análise econômica do Direito: uma introdução. Belo Horizonte: Editora Fórum, 2011. p. 40).

89 RAWLS, John. A Theory of Justice. Cambridge: Harvard College, 1999. p. 66.

90 RAWLS, John. A Theory of Justice. Cambridge: Harvard College, 1999. p. 66. 
possíveis e sem que houvesse a possibilidade de circunstâncias imprevisíveis alterarem o combinado. Naturalmente, não é este o cenário das negociações internacionais. Isto faz com que os Tratados Internacionais precisem ter uma flexibilidade mínima para que possa ser ajustados à uma eventual mudança de circunstâncias. Por outro lado, flexibilidade demais pode levar a um enfraquecimento das obrigações assumidas - razão pela qual um adequado equilibrio precisa ser encontrado ${ }^{91}$.

Ademais, pelo critério paretiano de eficiência, há uma grande dificuldade para a propositura de mudanças (legislativas ou de políticas públicas, por exemplo), já que dificilmente estas mudanças são neutras - e sempre haverá perdedores ou vencedores. Assim, o critério de Pareto, quando aplicado ao Direito, precisa ser complementado por outra métrica da eficiência, o chamado critério de Kaldor-Hicks, que defende que haverá eficiência nas trocas econômicas ainda que haja vencedores e perdedores - desde que os primeiros possam compensar os segundos ${ }^{92}$.

Em outras palavras, um Tratado será eficiente quando os vencedores ganham mais do que os perdedores perdem. Mesmo o critério de Kaldor-Hicks não está isento de críticas, mormente no tocante as considerações de justiça, por vezes ignoradas na análise da eficiência. De fato, não há qualquer garantia de que situações consideradas eficientes serão, também, justas. Não obstante, a ineficiência sempre gera injustiça ${ }^{93}$, o que justifica a preocupação em eliminá-la com o auxílio da AED.

Em outras palavras, se alguém pode melhorar sua situação sem piorar a situação de ninguém, deve poder fazê-lo e o Direito deve criar mecanismos para isso. Diretamente relacionado a esse debate, está a teoria do "rompimento eficiente", presente na análise econômica

91 AAKEN, Anne Van. International Investment Law and Rationalist Contract Theory. Disponível em: http://iilj.org/courses/ documents/2009Colloquium.Session2.Aaken.pdf Acesso em 26 de dezembro de 2015.

92 SALAMA, Bruno Meyerhof. O que é pesquisa em Direito e Economia? Cadernos Direito GV, v. 5, n. 2, mar. 2008. Disponível em: http://bibliotecadigital.fgv.br/dspace/bitstream/handle $/ 10438 / 2811 /$ caderno $\% 2520$ direito $\% 252022$.pdf? sequence $=1$. Acesso em: 22 out. 2014. p. 24.

93 As situações que são Pareto-ineficientes necessariamente serão também injustas, já que se alguém pode melhorar sua situação sem prejudicar ninguém, deve poder fazê-lo. Ver em: GICO JR., Ivo. Metodologia e Epistemologia da Análise Econômica do Direito. Economic Analysis of Law Review, v. 1, n. 1, p. 7-33, jan./jun.2010. Disponível em: http://portalrevistas.ucb.br/index.php/EALR/article/view/1460/1110. Acesso em: 21 out. 2014. p. 23 dos contratos e que também pode ser transposta para o Direito Internacional. O rompimento eficiente ocorre quando as circunstâncias fazem com que os ganhos de se romper um acordo sejam maiores do que os de cumpri-lo e relaciona-se intimamente com os conceitos de eficiência de Pareto e de Kaldor Hicks.

Pela lógica paretiana, a eficiência seria atingida no "momento exato de equilíbrio em que todas as ações a serem tomadas não incrementam a condição dos agentes sem prejudicar os demais" ${ }^{94}$. O critério de Kaldor Hicks flexibiliza tal situação ao afirmar que, quando os ganhos gerais forem superiores, a parte que ganha mais deve compensar o perdedor de modo a manter a eficiência. Aplicando o critério ao rompimento eficiente dos tratados internacionais, tem-se que seria possível aos países violarem acordos firmados desde que as outras partes fossem compensadas pelo prejuízo sofrido. Ao admiti-lo, os Tratados Internacionais adquiririam a necessária flexibilidade quanto à mudanças de circunstâncias, em razão da supramencionada dificuldade para a elaboração de Tratados com a garantia da eficiência paretiana. Essa ideia parte do pressuposto de que um Tratado Internacional não é sacrossanto, e só deve ser cumprido quando o seu cumprimento é o caminho mais benéfico a todas as partes envolvidas.

A possibilidade de aplicação do rompimento eficiente ao Direito Internacional não é, contudo, aceita sem ressalvas. De modo geral, tem-se que autores fundados na perspectiva voluntarista tendem a aceitá-lo, ao passo que os teóricos de inspiração jusnaturalista são muito resistentes a aplicá-lo. Joost Pauwelyn ${ }^{95}$ comparou essas duas perspectivas, percebendo uma prevalência dos juristas da primeira corrente entre os norte-americanos (razão pela qual rotulou a corrente de "voluntarismo americano") e da segunda corrente entre os europeus (intitulando o pensamento de "absolutismo Europeu"). Em seu trabalho, o autor classificou as regras de Direito Internacional conforme um trabalho clássico da AED formulado por Guido Calabresi e Douglas Melamed ${ }^{96}$,

94 DOMINGUES, Victor Hugo. Ótimo de Pareto. In: RIBEIRO, Márcia Carla Pereira; KLEIN, Vinícius (Coord.). O que é análise econômica do Direito: uma introdução. Belo Horizonte: Editora Fórum, 2011. p. 40.

95 PAUWELYN, Joost. Optimal protection of international law: navigating between European Absolutism and American voluntarism. Cambridge: Cambridge University Press, 2008. p. 32.

96 CAlABRESI, Guido; MELAMED, A. Douglas. Property Rules, Liability Rules and Inalienability: One View of the Cathedral (1972). Faculty Scholarship Series, Paper 1983. Dis- 
que categorizaram as diferentes formas de assegurar direitos ${ }^{97}$ pelo Estado. Existiriam assim direitos inalienáveis (que não podem ser livremente transacionados), direitos de propriedade (os quais podem ser negociados e transacionados, desde que com o consentimento do proprietário) e regras de responsabilidade ou liability (na qual o direito pode ser apropriado por qualquer pessoa, desde que se disponha a indenizar o anterior titular do direito, ora desapropriado) ${ }^{98}$.

Na perspectiva europeia, todo o Direito Internacional seria composto por regras de direito inalienáveis o que se coaduna com a própria origem da disciplina, no pensamento de Hugo Grotius, para quem o Direito Internacional correspondia ao direito natural ${ }^{99}$. $\mathrm{O}$ voluntarismo americano, por sua vez, convencido da perspectiva da escolha racional dos estados em formarem o Direito Internacional, levaria à crença de que o seu cumprimento ocorreria apenas e tão somente quando fosse esta a melhor estratégia, após uma análise de custo-benefício feita pelos Estados. Dessa forma, as normas de Direito Internacional seriam apenas e tão somente regras de liability.

Assim, enquanto para os autores baseados no absolutismo europeu, as considerações sobre o rompimento eficiente seriam tidas como imorais, para os voluntaristas americanos, o rompimento eficiente seria não apenas plenamente admitido, como também recomendável, já que aumentaria o bem-estar de todos sem deixar ninguém em uma situação pior $^{100}$.

ponível em: http://digitalcommons.law.yale.edu/cgi/viewcontent. cgi? article $=3043 \&$ context $=$ fss_papers. Acesso em: 15 nov. 2014 .

97 Os autores usam a expressão "entitlements" ao invés da expressão "rights", uma vez que o objetivo da análise era o de discernir diferentes tipos de direitos baseados na proteção concedida pelo Estado. A diferenciação entre os termos, contudo, se perde na tradução para o português.

98 Em relação aos direitos considerados inalienáveis ou protegidos por regras de responsabilidade, exige-se uma maior intervenção estatal (seja na defesa destes direitos que não podem ser transacionados nem mesmo com a autorização de seus titulares, seja para determinar montantes indenizatórios apropriados para os direitos assegurados apenas por regras de responsabilidade), ao passo que os direitos de propriedade admitem a livre-transação. (CALABRESI, Guido; MELAMED, A. Douglas. Property Rules, Liability Rules and Inalienability: One View of the Cathedral (1972). Faculty Scholarship Series, Paper 1983. Disponível em: http://digitalcommons. law.yale.edu $/$ cgi $/$ viewcontent.cgi article $=3043 \&$ context $=$ fss_papers. Acesso em: 15 nov. 2014, passim).

99 PAUWELYN, Joost. Optimal protection of international law: navigating between European Absolutism and American voluntarism. Cambridge: Cambridge University Press, 2008. p. 32.

100 PAUWELYN, Joost. Optimal protection of international
De modo geral, porém, pode-se dizer que nem o voluntarismo americano, nem o absolutismo europeu são capazes de explicar o Direito Internacional como um todo. Há normas com diferentes graus de obrigatoriedade no Direito Internacional contemporâneo - e, portanto, a teoria do rompimento eficiente não pode ser aplicada de modo despreocupado em toda a disciplina.

De fato, ao categorizar as normas de Direito Internacional em função de sua obrigatoriedade, Pauwelyn ${ }^{101}$ afirma que, em geral, as obrigações de Direito Internacional não podem ser consideradas inalienáveis: os Estados negociam os tratados que assinam e, portanto, transacionam sobre os direitos que tais instrumentos preveem. Mesmo após a celebração dos tratados, os acordos não são escritos em pedra e podem ser alterados, renegociados, ou denunciados. A exceção seriam as chamadas normas de jus cogens, definidas pela Convenção de Viena como "uma norma aceita e reconhecida pela comunidade internacional dos Estados como um todo, como norma da qual nenhuma derrogação é permitida e que só pode ser modificada por norma ulterior de Direito Internacional geral da mesma natureza" ${ }^{\text {102 }}$. Tais normas poderiam ser classificadas como inalienáveis e, portanto, insuscetíveis de serem descumpridas de modo justificado, nem mesmo sob supostas alegações de eficiência. Não obstante, elas também podem ser modificadas por normas posteriores da mesma natureza, o que, apesar de dificultar, não elimina por completo a possibilidade de serem objeto de transações.

Por outro lado, a Convenção de Viena também prevê expressamente o princípio do pacta sunt servanda, ao estabelecer, em seu artigo 26, que "todo tratado em vigor obriga as partes e deve ser cumprido por elas de boa fé" ${ }^{103}$. Isso faz com que Pauwelyn ${ }^{104}$ sustente que a

law: navigating between European Absolutism and American voluntarism. Cambridge: Cambridge University Press, 2008. p. 36.

101 PAUWELYN, Joost. Optimal protection of international law: navigating between European Absolutism and American voluntarism. Cambridge: Cambridge University Press, 2008, p. 86 102 Artigo 53 - BRASIL. Planalto. Decreto $\mathbf{n}^{\mathbf{0}}$ 7.030, de 14 de dezembro de 2009. Brasília, 14 de dezembro de 2009. Disponível em: http://www.planalto.gov.br/ccivil_03/_Ato2007-2010/2009/ Decreto/D7030.htm. Acesso em: 17 nov. 2014

103 Artigo 26 - BRASIL. Planalto. Decreto $\mathbf{n}^{\mathbf{0}}$ 7.030, de 14 de dezembro de 2009. Brasília, 14 de dezembro de 2009. Disponível em: http://www.planalto.gov.br/ccivil_03/_Ato2007-2010/2009/ Decreto/D7030.htm. Acesso em: 17 nov. 2014

104 PAUWELYN, Joost. Optimal protection of international law: navigating between European Absolutism and American voluntarism. Cambridge: Cambridge University Press, 2008, p. 88 
maior parte dos direitos consagrados pelo Direito Internacional possuem a característica de direitos de propriedade - e da mesma forma que ninguém pode se apropriar de uma casa sem a permissão de seu proprietário, um direito assegurado internacionalmente depende da concordância de seu "proprietário" para que possa ser mitigado.

Dessa forma, não seria permitido o descumprimento de uma obrigação internacional sob uma alegação de eficiência: seria necessário o consentimento da outra parte ou uma renegociação do tratado para que o descumprimento fosse lícito. Tanto é assim que a International Law Comission, em seus artigos sobre a responsabilidade dos Estados pelo descumprimento do Direito Internacional, já sustentou que a obrigação prioritária de um Estado ao descumprir uma regra de Direito Internacional é a de reestabelecer a situação anterior (e não de compensar a parte prejudicada) ${ }^{105}$. Tome-se como exemplo a invasão da embaixada estadunidense no Irã em 1979: não era suficiente que o governo iraniano oferecesse uma compensação financeira pela ruptura de obrigações de Direito Internacional no tocante à inviolabilidade diplomática; era preciso que os reféns fossem libertados e o prédio, bem como seus documentos, devolvidos aos Estados Unidos.

Assim, em geral, uma norma de Direito Internacional deve ser cumprida ou renegociada. Ao mesmo tempo em que suas obrigações não foram cravadas em pedra e não são imutáveis, tampouco há espaço para que um descumprimento unilateral, ainda que compensado, seja considerado lícito. Não obstante, há um ramo do Direito Internacional contemporâneo que parece ser uma exceção, composto quase que exclusivamente por normas de liability e, portanto, contemplando plenamente a tese voluntarista: o Direito Internacional dos Investimentos Estrangeiros.

105 O artigo 35 do modelo elaborado pela ILC sustenta que "Um Estado responsável pela violação de uma obrigação internacional é obrigado a restituição, isto é, reestabelecer a situação que existia antes de seu ato ilícito ter sido praticado, considerando qu a restituição: a) não é materialmente impossível; b) não envolve um fardo desproporcional em razão da escolha pela restituição e não pela compensação". ("Article 35. Restitution. A State responsible for an internationally wrongful act is under an obligation to make restitution, that is, to re-establish the situation which existed beore the wrongful act was committed, provided and to the extent that restitution: a) is not materially impossible; b) does not involve a burden out of all proportion to the benefit deriving from restitution instead of compensation"). http://legal.un.org/ilc/texts/instruments/english/commentaries/9_6_2001.pdf
De fato, Pauwelyn conclui que o Direito Internacional dos Investimentos Estrangeiros é um dos raros sub-ramos do Direito Internacional a utilizar das regras de liability ${ }^{106}$, admitindo, portanto, a aplicação da teoria do rompimento eficiente. Em verdade, é de se registrar que o rompimento eficiente de um acordo composto por regras de liability não é, propriamente dito, um rompimento do acordo. Joost Pauwelyn ${ }^{107}$ bem esclareceu essa imprecisão terminológica, ao afirmar que, - dentro de um sistema de regras de liability -, a ação daquele que opta por violar o comportamento previsto pagando a indenização correspondente não é, efetivamente, uma ruptura do pacta sunt servanda. Em realidade, o próprio acordo faculta as partes escolherem entre seguirem a conduta prevista (por exemplo, não expropriar) ou pagar a indenização correspondente (que, no caso dos acordos de investimentos, deve ser pronta, adequada e efetiva).

Dessa forma, os acordos bilaterais de investimento garantiriam a eficiência na medida em que permitiriam que os países administrassem os investimentos estrangeiros de forma livre - desde que indenizando os investidores quando adotassem medidas que lhes são desfavoráveis. O critério paretiano seria atendido, adotando o sistema de compensação de Kaldor-Hicks.

Essa constatação, contudo, não permite concluir que o simples fato dos acordos bilaterais de investimento preverem expressamente as possibilidades da violação de suas regras mediante compensação é suficiente para garantir eficiência ao sistema de proteção dos investidores internacionais. Em primeiro lugar, os acordos formados por meio de regras de liability exigem que uma corte estabeleça os montantes indenizatórios devidos, para assegurar que a compensação seja adequada. Esta avaliação, porém, pode não ocorrer de modo adequado. Segundo Pauwelyn ${ }^{108}$, as cortes podem errar no montante indenizatório tanto para mais quanto para menos:

106 PAUWELYN, Joost. Optimal protection of international law: navigating between European Absolutism and American voluntarism. Cambridge: Cambridge University Press, 2008, p. 114

107 PAUWELYN, Joost. Optimal protection of international law: navigating between European Absolutism and American voluntarism. Cambridge: Cambridge University Press, 2008, p. 10.

108 "Under-compensation does not fully compensate the victim, thereby making the transfer Pareto undesirable and potentially overall inefficient; over-compensation pays the victim more than she is harmed and is said to deter efficient breach". (PAUWELYN, Joost. Optimal protection of international law: navigating between European Absolutism and American voluntarism. Cambridge: Cambridge University Press, 2008, p. 63-64). 
[...] a compensação a menor não ressarce totalmente a vítima, fazendo com que a troca seja indesejável sob a perspectiva de Pareto e potencialmente ineficiente; a compensação excessiva, por outro lado, concede a vítima mais do que ela sofreu e pode desestimular o rompimento eficiente.

No que tange ao Direito Internacional dos Investimentos Estrangeiros, existem diversas críticas quanto à confiabilidade do sistema de solução de controvérsias existente, sobretudo quando se fala do ICSID (International Centre of Settlement of Investment Disputes), sistema erigido pelo Banco Mundial para solucionar as disputas entre os investidores e os Estados ${ }^{109}$. Montantes excessivos de indenização desestimulam a escolha dos Estados pelo rompimento eficiente - o que resulta em uma situação indesejada no tocante a maximização do bem estar coletivo (o Estado deixa de adotar uma medida de interesse público pelo receio da excessiva indenização) $)^{110}$. Indenizações insuficientes não compensam a empresa lesada - e, portanto, não são capazes de fazer cumprir o objetivo maior dos acordos, que é o de proteger os investidores.

A assimetria de poder é, também, uma questão importante quando se discutem as regras de liability no Direito Internacional: países como os Estados Unidos - com todo seu poder econômico e militar - são muito diferentes de países como Bangladesh, por exemplo. Utilizando-se do exemplo de Joost Pauwelin ${ }^{111}$, pode-se dizer que um acordo entre estes dois países seria semelhante a um contrato privado entre a Microsoft e um indivíduo vivendo abaixo da linha da pobreza. Há um grande risco de que o rompimento eficiente funcione apenas para o mais rico, que tem condições para pagar as indenizações. $\mathrm{O}$ mais pobre pode romper o Tratado e não pagar a indenização correspondente; ou abster-se de rompê-lo - mesmo quando seria mais eficiente fazê-lo - por não poder arcar com as sanções. Nos dois

109 Gus Van Harten é o autor da principal crítica, afirmando que o sistema de solução de controvérsias geraria incentivos para decisões pró-investidor. Neste sentido, ver em: HARTEN, Gus Van. Investment Treaty Arbitration and Public Law. Oxford: Oxford University Press, 2007.

110 MARRELLA, Fabrizio. MARBOE, Irmgard. "Efficient Breach" and Economic Analysis of International Investment Law. Transnational Dispute Management. v. 4, i.6, November, 2007. Disponível em: https://arca.unive.it/retrieve/ handle/10278/33386/19852/econ\%20an\%20IEL\%20marrellamarboetv4-6-article14.pdf Acesso em 26 de dezembro de 2015.

111 PAUWELYN, Joost. Optimal protection of international law: navigating between European Absolutism and American voluntarism. Cambridge: Cambridge University Press, 2008, p. 71. casos, a eficiência paretiana não é atingida, razão pela qual sua aplicação merece ressalvas.

\section{Ressalvas À EFICIÊNCIA ECONÔMICA: CONSI- DERAÇÕES SOBRE JUSTIÇA NA ANÁLISE ECONÔMICA DO DIREITO.}

Como já se viu, não são todas as normas de Direito Internacional que comportam a análise da eficiência. Mesmo no que diz respeito ao Direito Internacional dos Investimentos Estrangeiros - que, como se viu, é um dos raros ramos compostos por regras de liability -, pode-se dizer que há ressalvas prementes a serem feitas sobre a utilização do critério paretiano de eficiência.

Note-se, em um primeiro momento, que existem muitas situações que podem ser consideradas como "Ótimos de Pareto" - de tal forma que há diferentes formas de alocar direitos e deveres em acordos internacionais que podem ser consideradas eficientes. O Ótimo de Pareto é neutro quanto a distribuição inicial de recursos, de tal forma que "um estado pode estar no ótimo de Pareto havendo algumas pessoas na miséria extrema e outras nadando em luxo, desde que os miseráveis não possam melhorar suas condições sem reduzir o luxo dos ricos" $" 112$.

No que diz respeito ao Direito Internacional, a postura paretiana insensível ao atual estágio de distribuição de recursos mostra-se inaceitável, uma vez que permite a perpetuação de uma desigualdade que é intolerável à maior parte das pessoas que vivem nos países de menor nível de desenvolvimento, ignora o fato de que muitas das vantagens percebidas hoje pelas economias desenvolvidas têm sua origem histórica em um período no qual as pessoas do Terceiro Mundo não tinham voz ativa na determinação dos arranjos globais e, ainda, permite que poucos desfrutem de muito mais recursos do que o necessário para incrementar a produtividade global, ao passo que muitos, por outro lado, são privados do essencial ${ }^{113}$.

O grande problema é que o critério de Pareto parte de assunções utilitaristas, sem preocupações distributivas $^{114}$, o que faz com que por si só não possa ser

112 SEN, Amartya. Sobre Ética e Economia. Tradução de Laura Teixeira Motta. São Paulo: Companhia das Letras, 1999. p. 33. 113 FRANCK, Thomas M. Fairness in International Law and Institutions. New York: Oxford University Press, 1995. p. 20.

114 SEN, Amartya. Sobre Ética e Economia. Tradução de 
considerado um critério razoável para a análise das instituições jurídicas. De fato, é extremamente necessário determinar se é possível que uma parte melhore sua situação sem prejudicar as demais, mas quando se conclui que o equilíbrio já está em curso, é preciso completar a análise com algo mais. A eficiência não encerra os debates sobre a pertinência de determinadas regras jurídicas - que precisam, também, levar em consideração as urgentes questões relativas à justiça e à equidade.

Não obstante, como bem afirmou Guido Calabresi "é muito mais fácil descrever instâncias de injustiça do que exemplos de justiça" e "nós estamos muito mais certos de que um processo em particular ou seus resultados são injustos do que alguns arranjos particulares são justos em um sentido positivo" ${ }^{115}$. Assim, quando empregado o método econômico, a análise da justiça de determinados arranjos deve complementar a análise, servindo como um meio de veto para estruturas internacionais injustas, apesar de eficientes.

\section{Considerações finais}

O Direto Internacional Público é um ramo do Direito peculiar: diante da inexistência de um governo mundial, suas decisões são tomadas em um contexto mercadológico - ou seja, mediante a livre transação de seus agentes (em especial, Estados Soberanos). Justamente por isto, a AED pode contribuir para identificar as razões para escolha dos Estados, os incentivos por ela criados e a eficiência dos arranjos formados pelas partes que, conjuntamente, estabelecem uma estrutura de cooperação.

A primeira contribuição da AED ao Direito Internacional é a de fornecer uma explicação para o seu funcionamento, a despeito da inexistência de uma autoridade central para forçar o seu cumprimento: a teoria da escolha racional fornece uma resposta factível para a decisão dos Estados de engajarem-se em negociações internacionais e assinarem acordos internacionais. Eles o fazem porque entendem que, ao fazê-lo, reúnem maiores condições de atingir seus objetivos (seja eles quais

Laura Teixeira Motta. São Paulo: Companhia das Letras, 1999. p. 35. 115 "It is much easier to describe instances of injustice than examples of justice. We are much surer that particular processes or results are unfair than that particular arrangements are just in some positive sense" (CALABRESI, Guido. The cost of accidents: a legal and economic analysis. New Haven; London: Yale University Press, 1970. p. 25, tradução livre). forem). Em outras palavras, percebem que a adesão a compromissos de caráter internacional é a estratégia que maximiza seus interesses.

Essa maximização de interesses decorre, sobretudo, da percepção de que os Tratados Internacionais são instituições - criadas pelos próprios Estados - que alteram a estrutura de incentivos dos agentes que atuam na arena internacional. Assim, os Estados podem aderir a compromissos de caráter internacional porque pretendem estimular os demais países a agirem nos termos do acordo, ou porque pretendem criar regras que estimulem terceiras partes (indivíduos ou empresas, por exemplo) a adotarem comportamentos determinados.

Por fim, a teoria econômica defende que os Estados transacionarão entre si até que ninguém mais possa melhorar sua situação sem prejudicar a de outro agente - situação esta conhecida como Ótimo de Pareto. Esse critério serve de estímulo às negociações internacionais - e ainda sustenta que alguns arranjos podem ser quebrados em prol da eficiência. Muito embora essa perspectiva não mereça acolhida em todos os ramos do Direito Internacional, funciona perfeitamente para explicar o funcionamento específico do Direito Internacional dos Investimentos Estrangeiros, por exemplo, no qual a ruptura de um padrão de proteção (por exemplo, a expropriação) não é proibida per se, mas exige-se, apenas, o pagamento de indenização.

Por fim, nota-se que a AED não deve se imiscuir de preocupações com a justiça das instituições internacionais. Porém, identificar se uma dada situação é justa é tarefa difícil e demasiadamente subjetiva. Assim, o que se sugere é que a injustiça - muito mais facilmente identificável - seja empregada como ferramenta de veto para estruturas internacionais que, apesar de eficientes, não podem ser toleradas.

Dessa forma, o presente artigo teve como objetivo demonstrar como os pressupostos da AED podem ser utilizados para análise de institutos de Direito Internacional. Não se pretende ter esgotado a temática, mas apenas elucidado alguns dos componentes do método econômico com especial ênfase à sua aplicabilidade no Direito Internacional, em razão do silêncio sobre a temática nas pesquisas brasileiras. Espera-se, com isso, inspirar novas e mais profundas análises que discorram sobre sub-ramos ou institutos específicos da disciplina com a ajuda dos postulados econômicos. 


\section{ReferênCIAS}

AAKEN, Anne Van. International Investment Law and Rationalist Contract Theory. Disponível em: http:/ /iilj.org/courses/documents/2009Colloquium. Session2.Aaken.pdf Acesso em 26 de dezembro de 2015.

BRASIL. Planalto. Decreto $\mathbf{n}^{\mathbf{0}} \mathbf{7 . 0 3 0}$, de 14 de dezembro de 2009. Brasília, 14 de dezembro de 2009. Disponível em: http://www.planalto.gov.br/ccivil_03/_ Ato2007-2010/2009/Decreto/D7030.htm Acesso em: 17 nov. 2014

CALABRESI, Guido. The cost of accidents: a legal and economic analysis. New Haven; London: Yale University Press, 1970.

CASTRO, Thales. Teoria das relações internacionais. Brasilia: FUNAG, 2012

COASE, Ronald. The firm, the marked and the law. Chicago: The University of Chicago Press, 1988.

COSTA, José Augusto Fontoura. Do GATT à OMC: a perspectiva neoliberal institucionalista. Universitas: Relações Internacionais, Brasília, v. 9, n. 2, p. 25-53, jul./ dez. 2011. Disponível em: http://www.publicacoesacademicas.uniceub.br/index.php/relacoesinternacionais/ article/view/1413 Acesso em: 19 dez. 2014

DOMINGUES, Victor Hugo. Ótimo de Pareto. In: RIBEIRO, Márcia Carla Pereira; KLEIN, Vinícius (Coord.). O que é análise econômica do Direito: uma introdução. Belo Horizonte: Editora Fórum, 2011.

DUNOFF, Joffrey L.; TRACHTMAN, Joel P. Economic Analysis of International Law: An Invitation and a Caveat. April 20, 1998. Disponível em: http:// papers.ssrn.com/sol3/papers.cfm?abstract_id $=73688$ Acesso em: 22 out. 2014.

GICO JR., Ivo. Metodologia e Epistemologia da Análise Econômica do Direito. Economic Analysis of Law Review, v. 1, n. 1, p. 7-33, jan./jun.

GOLDSMITH, Jack; POSNER, Eric A. The Limits of International Law. New York: Oxford University Press.

GONTIJO, André Pires. Os caminhos fragmentados da proteção humana: o peticionamento individual, o conceito de vítima e o amicus curiae como indicadores do acesso aos sistemas interamericano e europeu de pro- teção dos direitos humanos. Revista de Direito Internacional, Brasília, v. 9, n. 4, 2012, p. 7-25

GUZMAN, Andrew T. How international law works: a rational choice theory. Oxford: Oxford University Press, 2008.

GUZMAN, Andrew. Why LDCs sign treaties that hurt them: explaining the popularity of bilateral investment treaties. Virginia Journal of International Law, v. 38, n. 639, p. 639-688, 1998. Disponível em: http://papers. ssrn.com/sol3/papers.cfm?abstract_id=2176003 Acesso em: 4 nov. 2014.

HART, Herbert L. A. O conceito de Direito. Tradução de A. Ribeiro Mendes. 3. ed. Lisboa: Fundação Calaouste Gulbekian, 2001.

HENKIN, Louis apud $\mathrm{KOH}$, Harold Hongiu. Why do nations obey international law? Yale law school faculty scholarship. Disponível em: http://digitalcommins. law.yale.edu/fss_papers/2101 Acesso em: 31 dez. 2014.

KELSEN, Hans. Teoria Pura do Direito. Tradução de J. Cretella Jr. e Agnes Cretella. 9. ed. São Paulo: Revista dos Tribunais, 2013.

KLEIN, Vinícius. Posner é a única opção? In: RIBEIRO, Márcia Carla Pereira; KLEIN, Vinícius (Coord.). O que é análise econômica do Direito: uma introdução. Belo Horizonte: Fórum, 2011

$\mathrm{KOH}$, Harold Hongiu. Why do nations obey international law? Yale law school faculty scholarship. Disponível em: http://digitalcommins.law.yale.edu/ fss_papers/2101Acesso em: $31 \mathrm{dez} .2014$.

MARCIANO, Alain; RAMELLO, Giovanni B. Consent, Choice and Guido Calabresi's heterodox economic analysis of law. Law and Contemporary Problems, v. 77, n. 97, p. 97-116, 2014. Disponível em: http:/ / scholarship.law.duke.edu/cgi/viewcontent. cgi? article $=4400 \&$ context $=$ lcp Acesso em: 15 nov. 2014.

MARRELLA, Fabrizio. MARBOE, Irmgard. "Efficient Breach" and Economic Analysis of International Investment Law. Transnational Dispute Management. v. 4, i.6, November, 2007. Disponível em: https:// arca.unive.it/retrieve/handle/10278/33386/19852/ econ $\% 20$ an $\% 20$ IEL $\% 20$ marrella-marboetv4-6-article14.pdf Acesso em 26 de dezembro de 2015.

MONEBHURRUN, Nitish. Crônicas do Direito Internacional dos Investimentos. Revista de Direito Inter- 
nacional, Brasília, v. 11, n.1, 2014, p. 10-18

MONEBHURRUN, Nitish. Crônicas do Direito Internacional dos Investimentos. Revista de Direito Internacional, Brasília, v. 12, n. 1, 2015, p. 32-36

NASSER, Salem Hikmat. Rule of law e Direito Internacional: uma nova aproximação. In: VIEIRA, Oscar Vilhena; DIMOULIS, Dimitri (Org.). Estado de Direito e o Desafio do Desenvolvimento. São Paulo: Saraiva, 2011.

NORTH, Douglass C. Institutions, institutional change and economic performance. New York: Cambridge University Press, 1990.

NORTH, Douglass C. Economic Performance through Time. American Economic Review. American Economic Association, v. 84, n. 3, p. 359-368, jun. 1994.

PAUWELYN, Joost. Optimal protection of international law: navigating between European Absolutism and American voluntarism. Cambridge: Cambridge University Press, 2008.

PEREIRA,André Gonçalves e QUADROS, Fausto de. Manual de Direito Internacional Público, 3a.ed. Coimbra: Almedina, 1995.

PINHEIRO FILHO, Francisco Renato Codevila. Teoria da agência (problema agente-principal). In: RIBEIRO, Márcia Carla Pereira; KLEIN, Vinícius (Coord.). O que é análise econômica do Direito: uma introdução. Belo Horizonte: Editora Fórum, 2011.

POSNER, Eric A.; SYKES, Alan O. Economic Foundations of International Law. Cambridge: Harvard University Press, 2013.

POSNER, Richard A. Economic Analysis of Law. 9th edition. New York: Wolters Kluwe Law \& Business, 2014.

REALE, Miguel. As três acepções fundamentais da palavra Direito. Revista da Faculdade de Direito da USP, v. 44, p. 68-78, jan. 1949. Disponível em: http://www. revistas.usp.br/rfdusp/article/view/66108/68718 Acesso em: 29 out. 2014.

REALE, Miguel. Lições Preliminares de Direito. 27. ed. São Paulo: Saraiva, 2002.

SALAMA, Bruno Meyerhof. O que é pesquisa em Direito e Economia? Cadernos Direito GV, v. 5, n. 2, mar. 2008. Disponível em: http://bibliotecadigital.fgv.br/dspace/bitstream/handle/10438/2811/ caderno $\% 2520$ direito $\% 252022$.pdf? sequence $=1$ Acesso em: 22 out. 2014.

SANDEL, Michael J. O que o dinheiro não compra: os limites morais do mercado. Tradução de Clóvis Marques. Rio de Janeiro: Civilização Brasileira, 2013.

SANTOS, Alexandre Leite dos. O Direito Internacional Público como jogo institucional. Economic Analysis of Law Review, v. 1, n. 2, p. 179-195, jul./dez. 2010. Disponível em: http://portalrevistas.ucb.br/index. php/EALR/article/view/1\%20EALR\%20174/1\%20 EALR\%20174 Acesso em: 10 nov. 2014.

SEN, Amartya. Sobre Ética e Economia. Tradução de Laura Teixeira Motta. São Paulo: Companhia das Letras, 1999. p. 9.

SEN, Amartya. A ideia de justiça. Tradução de Denise Bottmann e Ricardo Doninelli Mendes. São Paulo: Companhia das Letras, 2009.

STEIN, Arthur. Why nations cooperate: circumstances and choice in international relations. New York: Cornell University Press, 1990.

VERDROSS, Alfred. O fundamento do Direito Internacional. Revista de Direito Internacional, Brasília, v. 10, n. 2, 2013, p. 1-33.

WILLIAMSON, Oliver. The Economic Institutions of Capitalism - Firms, Markets, Relational Contraction. New York: The Free Press, 1985 


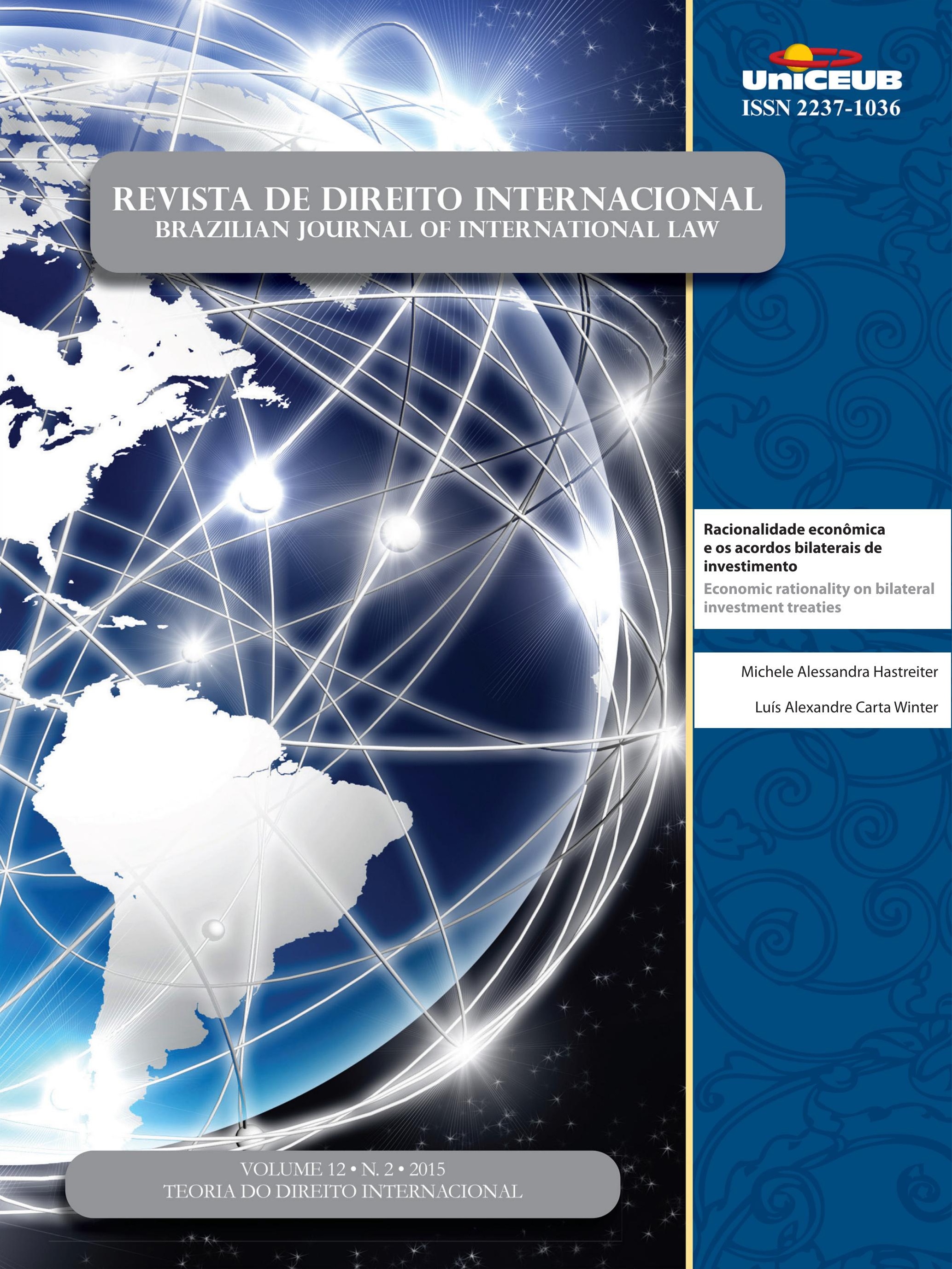




\title{
Racionalidade econômica e os acordos bilaterais de investimento*
}

\section{Economic rationality on bilateral investment treaties}

\author{
Michele Alessandra Hastreiter** \\ Luís Alexandre Carta Winter***
}

\section{Resumo}

Este artigo analisa a decisão dos países de celebrar acordos internacionais de investimento sob o prisma da racionalidade econômica, com o objetivo de mensurar a adequação da postura brasileira sobre o tema. Por meio do método dedutivo de abordagem e utilizando-se do ferramental teórico da Análise Econômica do Direito (AED) e de referencial bibliográfico, o estudo conclui que a decisão racional dos estados de celebrarem acordos de investimento não pode mais ser mensurada sob um paradigma dicotômico, que opõe, de um lado, países desenvolvidos e exportadores de capital e, do outro, países em desenvolvimento e receptores do investimento externo. Em um novo cenário no qual a definição de país investidor e país receptor de investimento torna-se mais nebulosa, a perspectiva racional autointeressada pode demandar acordos de caráter mais equilibrados do que aqueles difundidos na década de 1990, sendo compatível, portanto, com a tendência observada de reformulação das principais disposições desses acordos - caminho este que parece estar sendo trilhado pelo Brasil ao engajar-se recentemente em negociações sobre o tema. Sustenta-se, assim, a possibilidade do Brasil assumir a liderança no processo de reformulação das normas sobre a matéria no cenário internacional.

* Recebido em 17/09/2015

Aprovado em 07/12/2015

** Mestre em Direito pela Pontifícia Universidade Católica do Paraná. Professora de Direito Internacional Público e Privado no Centro Universitário Curitiba (UNICURITIBA). Membro da Comissão de Direito Econômico da Ordem dos Advogados do Brasil - Seção do Paraná. Membro do Núcleo de Estudos Avançados em Direito Internacional (NEADI) da PUCPR. Advogada e Administradora Internacional de Negócios, graduada pela Pontifícia Universidade Católica do Paraná e pela Universidade Federal do Paraná, respectivamente. Email: michele.hastreiter@gmail.com.

*** Doutor pela USP. Professor do PPGD da PUCPR. Professor titular da PUCPR; UNICURITIBA e da FAMEC. Coordenador do Núcleo de Estudos Avançados em Direito Internacional (NEADI - PUCPR). E-mail: luisalexandrecartawinter@yahoo.com.br.
Palavras-chave: Acordos bilaterais de investimento. Racionalidade econômica. Análise econômica do direito. Direito internacional do investimento estrangeiro. Teoria da escolha racional.

\section{Abstract}

This article examines the decision made by countries to conclude bilateral investment treaties through the prism of economic rationality, in order to measure the adequacy of the Brazilian position on the subject. Through deductive approach and using the theoretical tools of Economic Analysis of Law and bibliographic research, the study concludes that the rational decision of the states to conclude investment agreements can no longer be measured in a dichotomous paradigm, opposing on the one hand, developed countries as capital exporters and on the other hand, developing countries as recipients of foreign investment. In this new scenario, the rational and self-interested perspective can demand a more balanced agreement than those 
broadcasted in the 1990s and is compatible, therefore, with the trend to recast the main provisions of these agreements - a path that seems to be the one that Brazil chose while negotiating recently on the subject.

Keywords: Bilateral investment treaties. Economic rationality. Economic analysis of law. International law of foreign investment. Rational choice theory.

\section{INTRODUÇÃO}

O presente estudo tem como objetivo analisar, por meio do pressuposto da racionalidade econômica, as razões pelas quais os países engajam-se na negociação e assinatura de acordos bilaterais de investimentos estrangeiros - um dos mais polêmicos temas de Direito Internacional Econômico na atualidade.

Trata-se de uma sistemática de regulação amplamente difundida nas últimas décadas. Embora o primeiro desses acordo de proteção e promoção de investimentos tenha sido celebrado entre Alemanha e Paquistão, em 1959¹ foi na década de 1990 - quando o mainstream econômico defendia que o desenvolvimento seria o resultado de um regime que permitisse que os atores de mercado transacionassem livremente, nacional e internacionalmente - que esses acordos encontraram o cenário ideal para sua disseminação. Em 1990, eram 446 os acordos bilaterais existentes no mundo ${ }^{2}$. Ao final de 2013, havia 3.236 acordos sobre a temática em vigor, sendo 2.902 acordos bilaterais de proteção e outros 334 acordos de outras naturezas, dentre os quais os acordos regionais ou de livre comércio que também abordam a matéria $^{3 .}$

Embora não sigam um padrão único, esses acordos possuem regras comuns, que representam a essência do

1 GERMANY. Treaty between the Federal Republic of Germany and Pakistan for the prootion and protection of investments. Available in: <http:/ / investmentpolicyhub.unctad.org/Download/TreatyFile/1387>. Access: Out. 29, 2014

2 SCANDIUCCI FILHO, José Gilberto. O Brasil e os acordos bilaterais de investimentos. In: AMARAL JÚNIOR, Alberto do; SANCHEZ, Michelle Ratton. Regulamentação internacional dos investimentos: algumas lições para o Brasil. São Paulo: Aduaneiras, 2007. p. 271-302. p. 279.

3 UNITED NATIONS CONFERENCE ON TRADE AND DEVELOPMENT. World Investment Report 2014: investing in the SDGs: an action plan. New York: United Nations, 2014. Available in: <http://unctad.org/en/publicationslibrary/wir2014_en.pdf>. Access: Sept. 8, 2014
Direito Internacional do Investimento contemporâneo ${ }^{4}$ Além disso, boa parte deles também estabelece um consentimento arbitral genérico por parte dos países signatários, que podem ser demandados por quaisquer empresas provenientes dos países com quem possuem acordos bilaterais perante uma corte arbitral, para solucionar as controvérsias oriundas desses acordos.

A intensa celebração desses acordos a partir da década de 1990 se aliava à crença na cartilha para o desenvolvimento econômico propugnada pelo Consenso de Washington e foi um dos sinais da vitória do capitalismo ocidental sobre as economias planificadas socialistas e comunistas. Por isso, eles se consagraram, em suma, como instrumentos voltados à proteção dos direitos de propriedade dos investidores. Na prática, porém, o sistema de regulação gerou efeitos inesperados em razão do excesso de proteção que concedeu aos investidores sem qualquer exigência de contrapartida. Há indícios de que, ao tentar equilibrar a balança compensando a fragilidade do investidor, os acordos tenham, na realidade, feito com que a balança pendesse para o outro lado, gerando, assim, uma assimetria em prol do capital internacional. Além disto, como os acordos quase sempre eram celebrados entre países desenvolvidos e países em desenvolvimento, o fluxo de investimentos que cobriam era unilateral - o que gerava um desequilíbrio nas obrigações assumidas pelos países signatários ${ }^{5}$. Isso fez com que os acordos se tornassem preocupações para governos, ONGs e acadêmicos.

O que se nota, porém, é que, a despeito das dificuldades para aprovação de instrumentos multilaterais so-

4 As regras sobre Expropriação (direta e indireta), o Tratamento Nacional, o Tratamento da Nação Mais Favorecida e o Tratamento Justo e Equitativo, por exemplo, estão presentes na quase totalidade dos acordos. Sobre o conteúdo típico dos acordos, sugere-se a leitura de: MONEBHURRUN, Nitish. Crônicas do direito internacional dos investimentos. Revista de Direito Internacional, Brasília, v. 11, n. 1, p. 10-18, 2014. p. 10-18; ARENHART, Fernando Santos. Investimento estrangeiro: o padrão de tratamento justo e equitativo e o papel da boa fé. Revista de Direito Internacional, Brasília, v. 10, n. 1, p. 154-169, 2013. p. 154-169; POSTIGA, Andréa Rocha. A emergência do direito administrativo global como ferramenta de regulação transnacional do investimento estrangeiro direto. Revista de Direito Internacional. Brasília, v. 10, n. 1, p. 171-193, 2013. p. 171-193; DOLZER, Rudolf; SCHREUER, Christoph. Principles of international investment law. Oxford: Oxford University, 2012; SORNARAJAH, M. The international law on foreign investment. Cambridge: Cambridge University, 2010.

5 Acerca desse desequilíbrio, ver: MONEBHURRUN, Nitish. Essay on unequal treaties and modernity throgh the example of bilateral investment treaties. Revista de Direito Internacional, Brasilia, v. 11, n. 1, p. 202-214, 2014. 
bre a matéria, os acordos bilaterais de investimento têm sido prática corriqueira nas negociações internacionais contemporâneas. Ainda que haja uma crescente preocupação com a abrangência e excessiva proteção concedida aos investidores em algumas de suas cláusulas, fato é que os acordos são extremamente disseminados e são uma ferramenta institucional significativa para regulação da economia globalizada. Diante desse cenário, mostra-se importante compreender por que os países assinam esses acordos.

Essa análise reveste-se de especial pertinência em um momento em que o Brasil revisa sua postura acerca da matéria. Seguindo a tendência mundial, o Brasil assinou quatorze acordos dessa natureza na década de 1990, sem, contudo, ratificá-los. Desde então, o país tem sido uma notória exceção no sistema de regulação internacional sobre a temática, já que não se encontra vinculado a nenhum acordo. Apesar disso, é uma das economias que mais atrai o capital internacional. Não obstante, em 2013, o país anunciou o início de negociações bilaterais com países africanos e latino-americanos. Em 30 de março de 2015, anunciou a celebração de Acordo de Cooperação e Facilitação de Investimentos com Moçambique. Em 01 de abril de 2015, o país assinou um acordo semelhante com a Angola. Em 28 de maio de 2015, o mesmo acordo foi assinado com o México. Em 23 de novembro de 2015, o país assinou acordo com o Chile. Além desses países, o Brasil também negocia a assinatura de tais acordos com a África do Sul, Argélia, Colômbia, Malaui, Marrocos, Peru e Tunísia ${ }^{6}$.

Embora esses acordos assinados ainda estejam pendentes de ratificação, a recente mudança de perspectiva sobre a temática reacende os debates sobre o tema no país. Compreender o que está por trás da decisão de engajar-se em negociações de acordos bilaterais de investimento mostra-se útil para avaliar a adequação da postura brasileira. Assim, o presente artigo, com a ajuda dos postulados teóricos da Análise Econômica do Direito, busca estabelecer o que norteia a decisão racional dos países signatários desses acordos, tanto dos países

6 Estas informações encontram-se disponíveis no site do Itamaraty. BRASIL. Ministério das Relações Exteriores. Acordo BrasilMéxico de Cooperação e Facilitação de Investimentos: Cidade do México, 26 de maio de 2015. Brasília: MRE, 27 maio 2015. Disponível em: $<$ http://www.itamaraty.gov.br/index.php?option=com_conten $\mathrm{t} \&$ view $=$ article $\& i d=9890$ :acordo-brasil - mexico-de-cooperacaoe-facilitacao-de-investimentos-cidade-do-mexico-26-de-maio-de$2015 \&$ catid $=42 \&$ lang $=$ pt-BR\&Itemid $=280>$. Acesso em: 03 fev. 2016.

desenvolvidos, como os em desenvolvimento, para, ao fim, enfocar a mudança de racionalidade exigida em um contexto no qual as diferenças entre países investidores e receptores de investimento tornam-se mais nebulosas. Para isso, sugere-se que há uma nova racionalidade possível, pautada na perspectiva do "véu da ignorância" de John Rawls, já que a teoria estabelece como agentes racionais podem concordar com princípios equilibrados de justiça distributiva quando desconhecem sua posição perante os demais. Sustenta-se, assim, que há uma tendência dos acordos internacionais de investimento se tornarem mais equilibrados na medida em que as posições dos países como investidores ou receptores de capital não é mais tão clara. O modelo de acordo brasileiro corrobora essa perspectiva.

\section{A racionalidade EConômica dos países SIGNATÁRIOS DE ACORDOS BILATERAIS DE INVESTI- MENTO}

Um dos postulados do pensamento econômico é o da racionalidade econômica. A ideia de racionalidade econômica parte da premissa de que os desejos dos seres humanos são ilimitados, mas o mundo possui escassos recursos para realizá-los. Assim, a escassez de recursos impõe aos agentes que escolham, entre alternativas possíveis e excludentes, onde aplicar esses recursos. Para escolher entre as opções possíveis, os indivíduos ponderam custos e benefícios de cada curso de ação - decidindo pela opção que atende melhor os seus interesses. Nesse contexto, a conduta dos agentes econômicos é racional maximizadora - isto é, os indivíduos tendem a agir de forma a maximizar suas utilidades, visando extrair o máximo de satisfação possível para si com o menor custo.

A aplicação do pressuposto da racionalidade econômica ao Direito é um dos postulados da Análise Econômica do Direito, método que consiste na aplicação do:

\begin{abstract}
instrumental analítico e empírico da economia, em especial da microeconomia e da economia do bemestar social, para se tentar compreender, explicar e prever as implicações fáticas do ordenamento jurídico, bem como da lógica (racionalidade) do próprio ordenamento. ${ }^{7}$
\end{abstract}

7 GICO JR., Ivo. Metodologia e epistemologia da análise econômica do direito. Economic Analysis of Law Review, v. 1, n. 1, p. 7-33, Jan./ June 2010. p. 18. Available in: <http://portalrevistas.ucb.br/index. 
Trata-se de uma perspectiva especialmente interessante ao Direito Internacional, ramo do Direito que se desenvolve em um ambiente de anarquia, na ausência de um Estado hobbesiano para forçar uma cooperação entre as partes.

Aplicando a perspectiva da escolha racional aos acordos internacionais de investimento, pode-se dizer que os países assinarão acordos de investimento quando perceberem que estarão - de alguma forma - em uma situação melhor fazendo parte dessa estrutura de cooperação do que ao se recusarem a participar. Em verdade, precisamente, no tocante aos acordos de investimento, Robert Scott e Paul Stephan ${ }^{8}$ destacam que essa cooperação movida pela racionalidade tornou-se de tal forma elevada que o corpo de normas por eles originado é hoje um dos exemplos mais evidentes do fortalecimento do Direito Internacional, que, paulatinamente, está construindo o seu próprio "Leviatã".

Considerando que os acordos internacionais de investimento são tradicionalmente celebrados entre países desenvolvidos e em desenvolvimento - e que esses países têm objetivos diferentes nas negociações de investimento - compreender o porquê dos Estados estarem aderindo a esse sistema de proteção do capital internacional exige que se vislumbre as perspectivas desses países separadamente.

\subsection{A perspectiva dos países desenvolvidos}

O relacionamento entre países desenvolvidos e suas empresas domésticas remete-nos a períodos longínquos

php/EALR/article/view/1460/1110>. Access: Out. 21, 2014. 8 SCOTT, Robert E.; STEPHAN, Paul B. The limits of Leviathan: contract theory and the enforcement of international law. Cambridge: Cambridge University, 2006. p. 3.

9 Nesse sentido, os autores afirmam que "o Direito Internacional era soft, no sentido de que não existia um Leviatã hobbesiano para sancionar o seu descumprimento. A nova abordagem, de modo contrário, autoriza a exequibilidade privada, emprega tribunais independentes e cortes para forçar o seu cumprimento e concede poderes a esses tribunais na mesma medida em que as cortes domésticas possuem para fazer valer suas decisões. O Direito Internacional tornouse hard, com o seu próprio Leviatã". No original: "International law was soft, in the sense that there existed no Hobbesian Leviathan to sanction default. The new approach, in contrast, allow private enforcement, employs independent tribunals and courts to do the enforcing, and empowers those tribunals and courts to wield the same array of tools that domestic courts traditionally use to compel compliance with their decisions. International law has become hard law, with its own Leviathan." (SCOTT, Robert E.; STEPHAN, Paul B. The limits of Leviathan: contract theory and the enforcement of international law. Cambridge: Cambridge University, 2006. p. 3.) na história. Há quem afirme que o alinhamento entre investidor e Estado foi crucial para os objetivos expansionistas do período colonial, o que se mostra, particularmente, evidente no relacionamento de países europeus com as Companhias das Índias Orientais ${ }^{10}$. Atualmente, porém, as empresas não mais representam uma longa manus dos Estados para tratar de questões comerciais, como faziam outrora. Em verdade, as corporações de hoje transformaram-se em grandes centros de poder, tendo, muitas vezes, uma "política externa própria"11. Apesar disto, os Estados continuam defendendo os interesses de suas empresas externamente.

A decisão do Estado nacional de intervir em favor de seus investidores, não apenas após a ocorrência de uma violação concreta, mas de forma proativa pela negociação de acordos internacionais - despendendo para isto, tempo e outros recursos escassos - pode ter múltiplas explicações. Uma das primeiras razões pelas quais os Estados podem decidir apoiar suas empresas internacionalmente é geopolítica: segundo Celso Albuquerque de $\mathrm{Mello}^{12}$, a presença de empresas nacionais no exterior aumenta o prestígio político do Estado, razão pela qual as empresas transnacionais contam com o apoio diplomático de seus Estados nacionais.

Além disso, uma das consequências inexoráveis do acirramento do processo de globalização são as externalidades econômicas promovidas pelo cada vez mais livre fluxo de bens, pessoas, serviços e capitais. Externalidades são os efeitos que a conduta de determinados agentes produz sobre terceiros ${ }^{13}$. Quando um Estado receptor expropria um investidor estrangeiro, ele está diminuindo a quantidade de recursos disponíveis no Estado doméstico da empresa, na medida em que o investimento realizado baseava-se na expectativa legítima de poder repatriar os lucros obtidos ${ }^{14}$.

10 MILES, Kate. The origins of international investment law. Cambridge: Cambridge University, 2013. p. 45-47.

11 MELLO, Celso Albuquerque de. Direito internacional econômico. Rio de Janeiro: Renovar, 1993. p. 108-109.

12 MELLO, Celso Albuquerque de. Direito internacional econômico. Rio de Janeiro: Renovar, 1993. p. 109.

13 Externalidades negativas acontecem quando uma pessoa se dedica a uma atividade que trás benefícios privados, mas que causa prejuízos a outros (por exemplo, a poluição de uma fábrica), ao passo que as externalidades positivas, surgem quando uma pessoa desempenha uma ação que beneficia os outros. (POSNER, Eric A.; SYKES, Alan O. economic foundations of international law. Cambridge: Harvard University, 2013. p. 19).

14 É por isso que a presunção de que o ingresso de capital do exterior é importante pelo impacto positivo que produz ao balanço de pagamentos merece ressalvas. O estudo de S. M. Cunningham, por exemplo, indica que os montantes repatriados podem ser até duas vezes maiores 
Além disso, o enfraquecimento da empresa expropriada também pode afetar o desempenho da matriz no Estado doméstico, comprometendo sua performance econômica. Esta é uma externalidade negativa que os Estados domésticos podem buscar endereçar através dos instrumentos de proteção dos investidores. Dessa forma, manter suas empresas fortes internacionalmente pode ser importante para o desenvolvimento interno do país de origem da empresa.

É possível, porém, que a decisão de suportar as empresas internacionalmente possa ter embasamentos que nem sempre resistem a um juízo arrazoado de razão pública ${ }^{15}$. Como bem sustentou Douglas North ${ }^{16}$, muitas vezes é a parte com maior poder de barganha que vê seus interesses prevaleceram na formação das instituições, ao contrário da maximização do bem-estar coletivo - o que gera uma economia ineficiente. A teoria de Mancur Olson ${ }^{17}$ sobre a escolha pública também contribui para esta compreensão, na medida em que o autor esclarece o papel dos diferentes grupos de interesses na formação das decisões governamentais: embora existam grandes grupos de interesse na sociedade que permanecem inertes e, portanto, incapazes de

do que o aporte inicial de capital, o que indica que embora a repercussão inicial possa ser positiva, o capital estrangeiro pode contribuir para tornar o balanço de pagamentos do país receptor deficitário - e o do emissor de investimentos superavitário - no longo prazo. Nesse sentido, ver: CUNNINGHAM, S. M. Multinationals and restructuring in Latin America. In: DIXON, Chris; DRAKAKIS-SMITH, David; WATTS, Doug (Ed.). Multinational corporations and the third world. New York: Routledge, 1986. v. 11. p. 39-65.

15 O conceito de razão pública foi expresso por John Rawls, que a considera como uma ideia do que é politicamente razoável, tendo em vista que os indivíduos têm concepções diferentes religiosas, filosóficas e morais, para que um governo democrático possa direcionar suas ações. (RAWLS, John. O direito dos povos. Tradução de Luís Carlos Borges. São Paulo: M. Fontes, 2001. p. 173). Amartya Sen defende, de modo semelhante, a "argumentação racional pública" fundada na ideia de democracia formada com o "governo por meio do debate" (SEN, Amartya. A ideia de justiça. Tradução de Denise Bottmann e Ricardo Doninelli Mendes. São Paulo: Companhia das Letras, 2009. p. 09).

16 NORTH, Douglass C. Economic performance through time. American Economic Review, v. 84, n. 3, p. 359-368, June 1994. p. 360.

$17 \mathrm{O}$ autor afirma que pequenos grupos privilegiados com interesses especiais têm poder desproporcional quando comparado a grandes grupos. Como exemplo, o ator cita que um grupo pequeno composto por industriais oligopolistas desejando uma isenção tributária pode por vezes ver o seu objetivo ser atendido mesmo quando a maior parte da população perde como um resultado disto. Os grupos menores e privilegiados podem, frequentemente, vencer grupos grandes - ao contrário do que deveria acontecer em uma democracia porque geralmente são mais organizados e ativos do que os grupos grandes, como a sociedade civil. (Neste sentido, ver em: OLSON, Mancur. The logic of collective action: public goods and the theory of groups. Cambridge: Harvard University, 1965. p. 127-128). pressionar o governo para a obtenção de políticas que lhe são favoráveis, outros, por diversos motivos, ainda que menores em número e com interesses que propiciam menores ganhos globais, conseguem se organizar melhor e encontram meios para influenciar mais fortemente as decisões governamentais. É necessário, nesse sentido, destacar o enorme poder de barganha de certos investidores internacionais, que podem fazer valer suas pressões inclusive mediante uma influência direta sobre os representantes dos Estados, pela corrupção e pelo suborno, ou por meio de contribuições empresariais às campanhas políticas com exigências explícitas ou veladas de contrapartida ${ }^{18}$.

De toda sorte, como se viu da análise do conteúdo desses acordos, fato é que eles estabelecem obrigações apenas para os Estados receptores do investimento, de tal forma que uma vez que o Estado doméstico tenha firmado tal compromisso, ele se exime de maiores preocupações com o investimento. Tais acordos contam, em sua maioria, com mecanismos de solução de controvérsia que concedem aos investidores o poder de acionar o Estado receptor diretamente, reduzindo as preocupações do Estado doméstico inclusive quando há uma violação concreta. Percebe-se, assim, que após incorrer nos custos transacionais para a negociação e celebração dos acordos, os Estados investidores apenas se beneficiam da assinatura de tais instrumentos, não assumindo nenhuma obrigação adicional - especialmente nos acordos firmados sob os moldes tradicionais e entre um país claramente investidor e outro exclusivamente receptor de capital.

Assim, nas relações bilaterais em que os países desenvolvidos são essencialmente emissores de investimentos, não é difícil explicar as razões pelas quais celebram os acordos de investimento. Explicar porque os países em desenvolvimento aderem a tais compromissos - nos quais, se não possuem investimentos externos a proteger, são os únicos detentores de obrigações mostra-se, portanto, uma questão mais complexa.

\subsection{A perspectiva dos países em desenvolvi- mento}

Os países em desenvolvimento sempre se opuseram aos padrões de tratamento a investidores estrangeiros defendidos pelos países desenvolvidos. Essa oposição

18 STIGLITZ, Joseph E. Globalização: como dar certo. São Paulo: Companhia das Letras, 2007. p. 308. 
foi, inclusive, um dos temas centrais do movimento conhecido como Nova Ordem Econômica Internacional (NOEI), que buscava, na Assembleia Geral das Nações Unidas, rever padrões de Direito Internacional Consuetudinário considerados contrários aos interesses dos novos países independentes ${ }^{19}$. Essa oposição também ficou evidente nas tentativas de negociação multilateral sobre o tema. Por isso, a disseminação dos acordos bilaterais de investimento entre países em desenvolvimento e desenvolvidos pode parecer difícil de explicar.

Andrew Guzman ${ }^{20}$ buscou explicar a popularidade dos acordos bilaterais de investimento a partir, exatamente, dessa perspectiva. $\mathrm{O}$ autor sustenta, então, que o comportamento dos países em desenvolvimento pode ser explicado pela constatação da existência de uma "inconsistência dinâmica", a qual pode ser definida como:

\begin{abstract}
a situação na qual uma decisão política futura, que faz parte de um plano ideal formulado em data inicial, não é mais ideal do ponto de vista de uma data posterior, ainda que nenhuma informação nova tenha aparecido no mesmo período" 21 .
\end{abstract}

Eric Posner e Alan Sykes ${ }^{22}$ também conceituam essa inconsistência temporal, afirmando que, em um determinado momento, os governos identificam que um determinado curso de ação é mais favorável, mas as circunstâncias podem mudar e essa opção pode não ser mantida em um novo contexto.

No que diz respeito aos investimentos estrangeiros, tem-se que é importante que o Estado adote medidas para parecer atrativo aos investidores internacionais. No entanto, após a realização do investimento, o Estado não precisa mais preocupar-se em manter as condições com as quais se comprometeu para atraí-lo, sendo suficiente que não as piore tanto a ponto de não conseguir manter o investimento em seu território. Uma vez que um investimento tenha sido realizado, o desinvestimen-

19 COSTA, José Augusto Fontoura. Direito internacional do investimento estrangeiro. Curitiba: Juruá, 2010. p. 169.

20 GUZMAN, Andrew. Why LDCs sign treaties that hurt them: explaining the popularity of bilateral investment treaties. Virginia Journal of International Law, v. 38, n. 639, p. 639-688, 1998. Available in: $<$ http://papers.ssrn.com/sol3/papers.cfm?abstract_id=2176003>. Access: Nov. 4, 2014.

21 GUZMAN, Andrew. Why LDCs sign treaties that hurt them: explaining the popularity of bilateral investment treaties. Virginia Journal of International Law, v. 38, n. 639, p. 639-688, 1998. p. 644. Available in: <http://papers.ssrn.com/sol3/papers.cfm?abstract_ id=2176003 > . Access: Nov. 4, 2014.

22 POSNER, Eric A.; SYKES, Alan O. economic foundations of international law. Cambridge: Harvard University, 2013. p. 19. to geralmente não pode ser feito de forma completa: quando os investidores montam uma fábrica, por exemplo, os custos já foram feitos e não podem ser recuperados simplesmente desmontando a operação. Assim, os incentivos necessários para a manutenção do investimento no país são menores do que para sua atração, o que faz com que os Estados sejam tentados a agir de forma oportunista, prometendo um tratamento determinado e mudando o seu comportamento após a realização do investimento.

Porém, os investidores não desconhecem essa inconsistência dinâmica e ela os desestimula a investir e, como o Estado receptor precisa do investimento estrangeiro para suas necessidades de desenvolvimento, ela se torna um problema. Os Estados não conseguem firmar um compromisso crível quanto ao tratamento a ser concedido para o investidor dentro de sua regulação doméstica - já que os investidores temem que o governo possa mudar a lei após a realização do investimento, ou que os tribunais domésticos não apliquem as regras que beneficiam os investidores ${ }^{23}$. Assim, os países em desenvolvimento não conseguem - apenas com sua regulação doméstica - oferecer uma segurança jurídica que estimule os investidores a investir.

Em outras palavras, os governos têm incentivos para explorar o investidor que já realizou investimentos irrecuperáveis (aumentando os impostos, criando exigências regulatórias ou expropriando o investimento), mas essa situação prejudica o governo antes da realização dos investimentos, uma vez que aumenta os riscos percebidos pelos investidores, reduzindo o montante de recursos recebido ${ }^{24}$. Os acordos funcionam, nesse contexto, como um meio de estabelecer um compromisso crível entre o Estado receptor e o Estado doméstico do investimento, garantindo a manutenção das condições do investimento e padrões de tratamento e proteção ao investidor internacional.

Em razão do pacta sunt servanda, uma vez que tenha se comprometido com o padrão de tratamento disposto no acordo, os Estados não podem mais alterar os padrões unilateralmente, dependendo, para isso, do consentimento do outro Estado-parte (o Estado doméstico

23 POSNER, Eric A.; SYKES, Alan O. economic foundations of international law. Cambridge: Harvard University, 2013. p. 279.

24 POSNER, Eric A.; SYKES, Alan O. economic foundations of international law. Cambridge: Harvard University, 2013 p. 279. 
do investidor $)^{25}$. Além disso, uma violação ao acordo representa um ilícito internacional, sujeitando o Estado à responsabilidade internacional e às sanções previstas no acordo. Assim, apesar de estabelecerem onerosos compromissos aos países em desenvolvimento, os acordos seriam um meio de superar as dificuldades que esses países teriam para atrair o capital internacional.

Não obstante, Andrew Guzman ${ }^{26}$ afirma que se nenhum país em desenvolvimento tivesse assinado os acordos bilaterais de investimento, os investidores estrangeiros investiriam a despeito dessa inconsistência dinâmica. Embora reconheça que esta é uma questão que dependeria de confirmação empírica, o autor afirma que se trata de uma suposição razoável, já que os países em desenvolvimento são atrativos para os investidores por razões diferentes da atração exercida por países desenvolvidos (disponibilidade de matéria prima ou mão de obra barata, por exemplo). Assim, um país em desenvolvimento geralmente não é uma opção de investimento alternativa a um país desenvolvido, mas sim a outro país em desenvolvimento. Se os países em desenvolvimento atuassem coletivamente resistindo a esses acordos, o efeito prático não seria uma escassez de recursos para essas economias, mas um aumento do preço pago pelos investidores por investir em tais localidades ${ }^{27}$.

Além disso, como a existência de mecanismos de proteção é, apenas, um dos fatores considerados pelos investidores na decisão sobre onde aplicarem seu capital, se não houvesse países oferecendo a estrutura de proteção dos acordos bilaterais, os investimentos aconteceriam mesmo assim - e os países teriam mais liberdade para gerenciá-los. Guzman compara essa situação a de um cartel: os países em desenvolvimento, mantendo-se unidos e em cooperação, poderiam aumentar o preço dos investimentos realizados em seu

25 DIAS, Bernadete de Figueiredo. A abordagem do Direito ao Desenvolvimento nos Tratados sobre Investimentos. In: AMARAL JÚNIOR, Alberto do (Org.). Direito internacional e desenvolvimento. Barueri: Manole, 2005. p. 253-269. p. 199.

26 GUZMAN, Andrew. Why LDCs sign treaties that hurt them: explaining the popularity of bilateral investment treaties. Virginia Journal of International Law, v. 38, n. 639, p. 639-688, 1998. p. 644. Available in: <http://papers.ssrn.com/sol3/papers.cfm?abstract_ id $=2176003>$. Access: Nov. 4, 2014.

27 GUZMAN, Andrew. Why LDCs sign treaties that hurt them: explaining the popularity of bilateral investment treaties. Virginia Journal of International Law, v. 38, n. 639, p. 639-688, 1998. p. 675. Available in: <http://papers.ssrn.com/sol3/papers.cfm?abstract_ id $=2176003>$. Access: Nov. 4, 2014. território, sujeitando-os a uma interferência maior do Estado receptor ${ }^{28}$. Porém, assim como em um cartel, há incentivos para que um país isoladamente rompa com essa cooperação, visando aumentar os investimentos que recebe ao oferecer uma vantagem comparativa à oferecida pelos demais.

A conduta dos países em desenvolvimento pode ser explicada, nesse contexto, com a ajuda do "Dilema do Prisioneiro", ferramenta desenvolvida dentro do estudo de Teoria dos Jogos para tratar de situações em que os indivíduos procuram seus próprios interesses, sem o auxílio de uma autoridade central para forçar uma cooperação ${ }^{29}$ - tal qual o cenário internacional. A história original do Dilema do Prisioneiro narra a situação de dois suspeitos de um crime que foram presos pela polícia e interrogados separadamente. A polícia não tem provas para condená-los, o que abre a possibilidade para que um deles confesse e, com isso, tenha uma pena mais leve, porém condenando o outro a pena maior. Porém, se ambos confessarem, serão condenados à pena máxima. Se nenhum dos dois confessar, adotando uma estratégia de cooperação, ambos teriam uma pena menor.

De acordo com Andrew Guzman ${ }^{30}$, quando atuavam coletivamente nos foros internacionais - especialmente na Assembleia Geral da ONU -, os países em desenvolvimento cooperavam entre si e, assim, conseguiram reduzir o nível de exigências de proteção do investidor feito pelo Direito Internacional costumeiro, tendo uma liberdade maior para gerenciar os investimentos recebidos e podendo, assim, extrair deles um maior benefício. Não obstante, os países - ao mesmo tempo competiam entre si por investimento, de tal forma que possuíam incentivos para "trair" os demais, assinando acordos bilaterais de investimento que representariam uma vantagem comparativa na atração do capital internacional. Ocorre, porém, que a deserção de um país impulsionou os demais a seguirem no mesmo caminho - e uma vez que os acordos tornaram-se altamente dis-

28 GUZMAN, Andrew. Why LDCs sign treaties that hurt them: explaining the popularity of bilateral investment treaties. Virginia Journal of International Law, v. 38, n. 639, p. 639-688, 1998. p. 675. Available in: <http://papers.ssrn.com/sol3/papers.cfm?abstract_ id $=2176003>$. Access: Nov. 4, 2014.

29 AXELROD, Robert. A evolução da cooperação. São Paulo: Leopardo, 2010. p. 6.

30 GUZMAN, Andrew. Why LDCs sign treaties that hurt them: explaining the popularity of bilateral investment treaties. Virginia Journal of International Law, v. 38, n. 639, p. 639-688, 1998. Available in: $<$ http://papers.ssrn.com/sol3/papers.cfm?abstract_id=2176003 $>$. Access: Nov. 4, 2014. 
seminados (como são hoje, com cerca de 3.000 acordos celebrados), a vantagem comparativa desapareceu - e os países encontram-se numa situação pior do que estariam se tivessem continuado cooperando.

Em suma, tem-se que a ampla disseminação dos acordos bilaterais de investimento é o resultado de uma incapacidade dos países em desenvolvimento cooperarem entre si, tendo sucumbido à tentação da deserção. Essa postura competitiva dos países em desenvolvimento os impulsiona a fornecer mais e mais proteção aos investidores internacionais ${ }^{31}$, o que os deixa em uma situação pior do que a que estariam se tivessem resistido a esses acordos coletivamente, defendendo uma regulação que fosse mais favorável aos seus interesses. Essa competição por investimento levaria a uma concessão cada vez maior de proteção aos investidores até que o benefício obtido pelos Estados do investimento se aproximaria do zero ${ }^{32}$.

Naturalmente, a existência de mecanismos de proteção do investidor não é a única - nem mesmo a principal - motivação para o investimento. Segundo Colen, Maertens e Swinnen, na prática, há apenas uma pequena contribuição dos acordos bilaterais na atração dos investimentos - sendo que os incentivos econômicos (como o tamanho do mercado, a existência de recursos naturais, a abertura ao comércio internacional, por exemplo) e as politicas internas parecem ser mais importantes na decisão do investidor ${ }^{33}$. Os autores ${ }^{34}$ citam $^{-}$

31 GUZMAN, Andrew. Why LDCs sign treaties that hurt them: explaining the popularity of bilateral investment treaties. Virginia Journal of International Law, v. 38, n. 639, p. 639-688, 1998. p. 682. Available in: <http://papers.ssrn.com/sol3/papers.cfm?abstract_ id=2176003 > . Access: Nov. 4, 2014.

32 GUZMAN, Andrew. Why LDCs sign treaties that hurt them: explaining the popularity of bilateral investment treaties. Virginia Journal of International Law, v. 38, n. 639, p. 639-688, 1998. p. 671. Available in: <http://papers.ssrn.com/sol3/papers.cfm?abstract_ $\mathrm{id}=2176003>$. Access: Nov. 4, 2014.

33 COLEN, Liesbeth; MAERTENS, Miet; SWINNEN, Johan. Determinants of foreign direct investment flows to developing countries: the role of international investment agreements. In: SCHUTTER, Olivier de; SWINNEN, Johan; WOUTERS, Jan (Ed). Foreign direct investment and buman development: the law and economics of international investment agreements. London: Routledge, 2013. p. $142-162$.

34 COLEN, Liesbeth; MAERTENS, Miet; SWINNEN, Johan. Determinants of foreign direct investment flows to developing countries: the role of international investment agreements. In: SCHUTTER, Olivier de; SWINNEN, Johan; WOUTERS, Jan (Ed). Foreign direct investment and human development: the law and economics of international investment agreements. London: Routledge, 2013. p. $142-162$. p. 152. o Brasil como indicador de que não há relação necessária entre a atração de investimento e a assinatura de APPRIs: o país figura entre os maiores receptores de investimento (o Brasil está em $5^{\circ}$ lugar no ranking dos países que mais recebem capital estrangeiro ${ }^{35}$ ), embora tenha sido resistente à assinatura de instrumentos internacionais de proteção aos investidores. No entanto, o Dilema do Prisioneiro de Guzman ajuda até mesmo a explicar a inexistência de uma correlação imediata entre o recebimento de capital e a existência dos mecanismos de proteção: a disseminação dos acordos aniquila seus efeitos enquanto vantagem comparativa aos olhos dos investidores, de tal forma que os acordos falham em seu papel de promoção de investimentos.

A perspectiva defendida por Guzman não é, contudo, aceita sem ressalvas. Ryan Bubb e Susan Rose-Ackerman ${ }^{36}$ discordam do autor: afirmam que a resistência inicial dos países em desenvolvimento ao Direito Internacional Costumeiro foi uma ação oportunista desses países - que, logo após terem conquistado sua independência, decidiram extrair o máximo de valor possível dos investimentos feitos no período colonial, cujos compromissos envolvidos não se sentiam obrigados a honrar. Após, automaticamente, passaram a respeitar os direitos de propriedade - preocupados até mesmo com sua reputação internacional caso continuassem expropriando os investidores. Os acordos internacionais de investimento, então, serviriam como um meio para um país fazer uma ruptura clara com seu comportamento no passado, fornecendo aos investidores motivos para acreditar em sua disposição renovada pela proteção de direitos de propriedade.

No mesmo sentido, defendem Eric Posner e Alan Sykes $^{37}$, para quem é possível que a resistência do mundo em desenvolvimento ao direito internacional costumeiro seja conciliável com a proposição de que os acordos bilaterais trazem benefícios aos países receptores. $\mathrm{Na}$ realidade, quando batalhavam na ONU sobre

35 UNITED NATIONS CONFERENCE ON TRADE AND DEVELOPMENT. World Investment Report 2014: investing in the SDGs: an action plan. New York: United Nations, 2014. p. 15. Available in: <http://unctad.org/en/publicationslibrary/wir2014_ en.pdf>. Access: Sept. 8, 2014.

36 BUBB, Ryan J.; ROSE-ACKERMAN, Susan. BITs and bargains: strategic aspects of bilateral and multilateral regulation of foreign investment. International Review of Law and Economics, v. 27, n. 3, p. 291-311, Sept. 2007. p. 302.

37 POSNER, Eric A.; SYKES, Alan O. economic foundations of international law. Cambridge: Harvard University, 2013. p. 283. 
as regras do Direito costumeiro, os países estavam se referindo ao direito aplicável à expropriação de investimentos já realizados - antes da assinatura de qualquer acordo internacional. Assim, os países em desenvolvimento podem ter adotado uma estratégia de explorar esses investimentos já realizados, confiando na proteção fraca do Direito costumeiro, mas podem ter percebido que as oportunidades para essa exploração diminuiria na medida em que todos os investimentos fossem expropriados ou depreciados - sendo que, nesse contexto, assinar os acordos bilaterais seria importante para garantir um renovado influxo de capital internacional dali em diante.

Ryan Bubb e Susan Rose-Ackerman ${ }^{38}$ refutam, ainda, a presunção de os acordos bilaterais de investimento deixam os países em desenvolvimento em uma posição pior do que estariam se tivessem coletivamente resistido a eles, uma vez que a disseminação dos acordos pode ser positiva aos países em desenvolvimento, desde que o fortalecimento das garantias ao investidor gere um aumento no fluxo global de capital que seja suficiente para compensar a perda na capacidade dos Estados extraírem valor dos investimentos feitos em seu território.

José Alvarez ${ }^{39}$ por sua vez, afirma que embora o primeiro acordo bilateral tenha sido firmado em 1959, os países em desenvolvimento só passaram a aceitá-los de forma entusiasmada na década de 1990, quando os esforços para modificar as regras de Direito Internacional costumeiro perante a ONU já haviam cessado. Nesse mesmo período, após a queda do Muro de Berlim, os países também começaram a adotar medidas internas liberalizantes ao capital privado, o que denota que as razões para a ratificação estão mais relacionadas a uma mudança de entendimento dos países em desenvolvimento sobre o tema do que por uma questão de detração em um Dilema do Prisioneiro propriamente dita. Além disso, muitos países se viram compelidos a assinar tais acordos não apenas para atrair mais IED, mas sim para sinalizar ao FMI a seriedade com a qual estariam comprometidos em suas exigências de ajuste estrutu-

38 BUBB, Ryan J.; ROSE-ACKERMAN, Susan. BITs and bargains: strategic aspects of bilateral and multilateral regulation of foreign investment. International Review of Law and Economics, v. 27, n. 3, p. 291-311, Sept. 2007. p. 302.

39 ALVAREZ, José E. The once and future foreign investment regime. In: ARSANJANI, Mahnoush $\mathrm{H}$. et al. (Ed.). Looking to the future: essays on international law in honor of W. Michael Reisman. Netherlands: Koninklijke Brill, 2011. p. 608-648. $\mathrm{ral}^{40}$. Outra motivação residiria nas reformas regulatórias, já que haveria uma crença de que ao assinar um APPRI, os países estariam tornando também a legislação nacional mais estável e previsível - embora Tom Ginsburg tenha realizado estudo empírico que aponta precisamente na direção contrária ${ }^{41}$.

Seja qual for a explicação correta, porém, fato é que mesmo os países desenvolvidos têm reconhecido que os acordos tornaram-se excessivamente onerosos para os países signatários, o que tem levado à uma tendência de revisão e modificação de suas cláusulas. Essa tendência também pode ser explicada com a ajuda da racionalidade econômica, mas com o complemento da filosofia de John Rawls, que trouxe uma nova luz a perspectiva do comportamento autointeressado.

\section{UMA NOVA RACIONALIDADE: AS MUDANÇAS NOS ACORDOS BILATERAIS DE INVESTIMENTO}

A falta de flexibilidade nos modelos de acordos de investimento vem sendo alvo de inúmeras críticas e esses acordos, recentemente, passaram a ser reformulados visando um maior equilíbrio em suas disposições. Um dos pioneiros nas reformas dos modelos do acordo foi os Estados Unidos, que acabou surpreendido pelos perigos do instrumento - que se tornou um aspecto preponderante de sua política externa após o governo Reagan ${ }^{42}$ - quando se viu envolvido em disputas arbi-

40 ALVAREZ, José E. The once and future foreign investment regime. In: ARSANJANI, Mahnoush $\mathrm{H}$. et al. (Ed.). Looking to the future: essays on international law in honor of W. Michael Reisman. Netherlands: Koninklijke Brill, 2011. p. 608-648.

41 Tom Ginsburg dedicou-se a analisar o impacto dos APPRIs na regulação doméstica e concluiu que, em verdade, a adoção dos acordos bilaterais de investimento piora a qualidade do Rule of Law doméstico. A explicação encontrada pelo autor é a de que a presença de alternativas internacionais às regras e cortes locais reduzem o incentivo para melhorias institucionais locais. O Poder Judiciário, por exemplo, não se sente compelido a melhorar sua qualidade temendo a concorrência da arbitragem privada - ao contrário, ele - via de regra - satisfaz-se com a diminuição da demanda. Ademais, justamente porque as instituições internacionais servem como substituto as locais, mitigando o impacto das instituições internas deficientes na atração de investimentos, o incentivo para investir em reformas institucionais é reduzido. Nesse sentido, recomenda-se a leitura de: GINSBURG, Tom. International substitutes for domestic institutions: bilateral investment treaties and governance. International Review of Law and Economics, v. 25, p. 107-123, 2005.

42 RUTTEMBERG, Valerie H. The United States bilateral investment treaty program: variations on the model. Journal of International Law, v. 9, p. 121-143, 1987. p. 121. Available in: <http://scholarship. 
trais que questionavam suas medidas domésticas. $\mathrm{O}$ acordo de investimentos celebrado no âmago do NAFTA (North American Free Trade Agreement) fez com que o País percebesse, pela primeira vez, o caráter recíproco dos compromissos firmados, já que seu sistema interno foi desafiado pelos padrões de proteção que esses acordos impunham, em especial nos casos Methanex Corp $v$. EUA, R. Loewen e Loewen Corp v. EUA e Mondev International Ltd v. EU $A^{43}$. Essa preocupação se intensificou após os trágicos acontecimentos de 11 de setembro de 2001, quando o Congresso estadunidense percebeu a possibilidade dos acordos internacionais de investimento firmados pelos Estados Unidos restringirem medidas de segurança adotadas pelo governo norte-americano em determinados setores que afetam investidores estrangeiros no país ${ }^{44}$.

Além disso, nos últimos tempos, e, em especial, após a crise econômica de 2008, as diferenças entre países exportadores e investidores de capital tornaram-se mais nebulosas, já que muitos países em desenvolvimento passaram a ser importantes exportadores de capital. Em verdade, antes da crise de 2008, os países desenvolvidos eram, ao mesmo tempo, os maiores emissores e destinatários de investimento, ao passo que os países em desenvolvimento eram quase exclusivamente receptores do capital internacional. Em 2012 - pela primeira vez na história - as economias em desenvolvimento atraíram mais investimento do que os países desenvolvidos: 52\% do capital que circulou naquele ano dirigiu-se as economias em desenvolvimento ${ }^{45}$; o mesmo ocorreu em 2013, quando 54\% do capital circulante foi destinado

law.upenn.edu $/$ cgi $/$ viewcontent. $\operatorname{cgi}$ ?article $=1639 \&$ context $=j i 1>$. Access: Nov. 15, 2014.

43 Nos três casos, medidas regulatórias internas estadunidenses foram questionadas por investidores. Ainda que não tenha saído derrotado de nenhuma disputa, os Estados Unidos perceberam, a partir delas, a possibilidade de serem questionados elos instrumentos - que até então eram vistos apenas sob a perspectiva da proteção de seus investimentos no exterior. Para mais detalhes sobre os casos, ver em: FONSECA, Karla Closs. Investimentos estrangeiros: regulamentação internacional e acordos bilaterais. Curitiba: Juruá, 2008. p. 150-154.

44 WEISS, Martin A. CRS report for congress: the US bilateral investment treaty program: an Overview. April 24, 2007. Available in: <https://www.hsdl.org/?view\&did=716235>. Access: Nov. 21, 2014.

45 UNITED NATIONS CONFERENCE ON TRADE AND DEVELOPMENT. World Investment Report 2013: global valeu chains: investment and trade for development. New York: United Nations, 2013. p. 9. Available in: <http://unctad.org/en/PublicationsLibrary/wir2013_en.pdf>. Access: Dez. 02, 2013. às economias em desenvolvimento ${ }^{46}$. As economias em desenvolvimento também aumentaram sensivelmente sua participação enquanto economias investidoras, tendo alcançado 39\% do fluxo mundial de capital em 2013 - um aumento significativo aos $12 \%$ a que correspondiam os investimentos provenientes dessas mesmas economias no início dos anos $2000^{47}$.

Além da superação parcial da dicotomia entre países investidores e países receptores de capital, há, também, uma dificuldade grande em garantir que um determinado estado será apenas investidor ou apenas receptor do investimento em razão do chamado forum shopping. Segundo Gus Van Harten e Martin Loughlin ${ }^{48}$, os acordos internacionais de investimento oferecem oportunidades abundantes para a prática do forum shopping - que consiste na possibilidade de as empresas escolherem os locais para se instalarem e se incorporarem considerando onde terão uma maior proteção jurídica. Isso significa que uma empresa pode decidir realizar um determinado investimento em um território por meio de uma subsidiária localizada no local que possua o acordo bilateral com a estrutura mais generosa de proteção - já que determinados critérios para definir a empresa como nacional sequer exigem o desempenho efetivo de atividades num país determinado, bastando para isto que nele tenha ocorrido sua incorporação.

Assim, torna-se muito mais difícil para um país ter certeza se os seus interesses em uma determinada negociação são de, exclusivamente, um país receptor ou emissor de investimentos. Isso faz com que as preocupações com esse sistema não sejam mais tão polarizadas. Não são apenas as grandes potências que abrigam empresas que investem no exterior; tampouco apenas as economias pobres e em desenvolvimento precisam

46 UNITED NATIONS CONFERENCE ON TRADE AND DEVELOPMENT. World Investment Report 2014: investing in the SDGs: an action plan. New York: United Nations, 2014. p. 9. Available in: <http://unctad.org/en/publicationslibrary/wir2014_ en.pdf $>$. Access: Sept. 8, 2014.

47 UNITED NATIONS CONFERENCE ON TRADE AND DEVELOPMENT. World Investment Report 2014: investing in the SDGs: an action plan. New York: United Nations, 2014. p. 9. Available in: <http://unctad.org/en/publicationslibrary/wir2014_ en.pdf>. Access: Sept. 8, 2014.

48 HARTEN, Gus Van; LOUGHLIN, Martin. Investment treaty arbitration as a species of global administrative law. The European Journal of International Law, v. 17, n. 1, p. 121-150, 2006. Available in: <http://www.uni-potsdam.de/fileadmin/projects/jur-zimmermann/LV_2010_2011/Koll_Van_HartenLoughlin_Investment_ Arbitration_as_GAL.pdf>. Access: Nov. 4, 2014. 
se preocupar com a extensão dos benefícios concedidos aos investidores internacionais. Isso faz com que a lógica da racionalidade econômica que contempla o posicionamento de países desenvolvidos e em desenvolvimento em separado precise ser revista.

A teoria de justiça de John Rawls se mostra relevante para essa análise, na medida em que promove um aperfeiçoamento na teoria da escolha racional que pode ajudar a explicar a mudança nos acordos de investimento. Em verdade, o próprio autor afirma que "a teoria de justiça é uma parte, talvez a mais importante, da teoria da escolha racional" 49 . Sua pertinência ao debate ora apresentado decorre da busca do autor pela formação de uma estrutura de cooperação que enfoca precisamente a relevância da justiça nas instituições sociais. Para o autor, "a justiça é a maior virtude das instituições sociais" $" 50$ e as teorias econômicas, leis e instituições devem ser rejeitadas quando forem injustas, já que uma injustiça só é tolerável se for o único meio para evitar uma injustiça ainda maior. Essa perspectiva alinha-se ao proposto por Guido Calabresi ${ }^{51}$, em seu enfoque à análise econômica, quando afirma que, embora seja difícil de mensurar a justiça objetivamente, ela não pode deixar de ser considerada na avaliação das normas jurídicas.

O que John Rawls ${ }^{52}$ propõe são princípios de justiça que seriam aceitos por indivíduos livres, racionais e mutuamente desinteressados, visando maximizar o seu autointeresse, em uma situação hipotética com limitações especiais que levaria a formação de uma concepção de justiça imparcial. Essa situação hipotética é chamada pelo autor de "posição original" - a qual corresponderia à situação de estado natureza, tipicamente defendida pelos teóricos contratualistas tradicionais como Hobbes, Locke e Rousseau. A posição original de Rawls, contudo, não se caracteriza como um estado histórico real ou como uma condição cultural primitiva, mas sim como um exercício hipotético ${ }^{53}$ cuja característica central é a presença do "véu da ignorância". Isto é, nas palavras de

49 RAWLS, John. A theory of justice. Cambridge: Harvard College, 1999. p. 16.

50 RAWLS, John. A theory of justice. Cambridge: Harvard College, 1999. p.3.

51 CALABRESI, Guido. The cost of accidents: a legal and economic analysis. London: Yale University, 1970. p. 35.

52 RAWLS, John. A theory of justice. Cambridge: Harvard College, 1999. p. 13.

53 RAWLS, John. A theory of justice. Cambridge: Harvard College, 1999. p. 12.
John Rawls ${ }^{54}$ :

Entre as características essenciais dessa situação é a de que ninguém conhece seu lugar na sociedade, sua classe social ou status, nem sabe nada sobre sua fortuna ou sobre a distribuição de seus bens ou aptidões, sua inteligência, sua força, e outros. Eu ainda presumo que as partes sequer sabem quais suas concepções sobre o bem e outras propensões psicológicas. Os princípios de justiça são escolhidos sob um véu da ignorância.

Ou seja, na posição original, os agentes nada sabem sobre sua posição na sociedade, de tal forma que não possuem meios para considerarem-se relevantemente diferentes dos demais e, assim, beneficiarem-se de uma eventual posição privilegiad $a^{55}$. Como ninguém está em uma posição superior de barganha, os princípios escolhidos para reger a sociedade - sob o véu da ignorância - seriam justos ${ }^{56}$.

Para John Rawls ${ }^{57}$, as partes, na posição original, elegeriam dois princípios de justiça, quais sejam: a) o princípio da igualdade - segundo o qual todos deveriam as mesmas liberdades básicas; b) o princípio da diferença que sustenta que as desigualdades econômicas e sociais só são justas quando resultam em benefícios para todos e, particularmente, para os membros menos favorecidos da sociedade. Nesse contexto, o autor defende a adoção de uma estratégia conhecida na Teoria dos Jogos que é a do maximin - ou seja, a regra do máximo mínimo ${ }^{58}$. Trata-se de uma escolha estratégica que elege, dentre os piores resultados possíveis, aquele que resulta no menor prejuízo.

Em outras palavras, por temerem estar em uma situação menos favorecida, os indivíduos, sob o véu da ignorância, decidiriam garantir que teriam um mínimo de benefícios suficientemente satisfatório. Assim, con-

54 RAWLS, John. A theory of justice. Cambridge: Harvard College, 1999. p. 12.

55 ALMEIDA, Fábio Portela Lopes. Análise jurídica da economia. Revista do Mestrado em Direito da Universidade Católica de Brasilia, Brasília, v. 1, n. 1, p. 49-101, 2007. p. 69. Disponível em: <http:// portalrevistas.ucb.br/index.php/rvmd/article/viewArticle/2617>. Acesso em: 15 dez. 2014.

56 SANDEL, Michael J. Justiça: o que é fazer a coisa certa? Tradução de Heloísa Matias e Maria Alice Máximo. 12. ed. Rio de Janeiro: Civilização Brasileira, 2013. p. 178.

57 RAWLS, John. A theory of justice. Cambridge: Harvard College, 1999. p. 14.

58 ALMEIDA, Fábio Portela Lopes. Análise jurídica da economia. Revista do Mestrado em Direito da Universidade Católica de Brasília, Brasília, v. 1, n. 1, p. 49-101, 2007. p. 69. Disponível em: <http:// portalrevistas.ucb.br/index.php/rvmd/article/viewArticle/2617>. Acesso em: 15 dez. 2014. 
cordariam que os tratamentos diferenciados só deveriam ser admitidos quando resultassem numa redução da desigualdade - e não em sua acentuação ${ }^{59}$.

Nas negociações internacionais de investimento, pensa-se que a posição original seria alcançada quando os países em negociação não soubessem se estarão na posição de investidores ou de receptores de investimentos, de tal forma que suas diferenças posicionais não afetassem a predileção por uma determinada estrutura do acordo em detrimento de outra. É por isso que José Alvarez $^{60}$ afirma que, na medida em que mais países em desenvolvimento tornam-se investidores, os países aproximam-se da posição original de Rawls - já que passam a ter interesses na proteção de suas indústrias externamente, ao passo que, os países desenvolvidos começam a preocupar-se em garantir a manutenção de um espaço regulatório tal que lhe permita adotar medidas e políticas públicas sem serem questionados em cortes internacionais quando estiverem na posição de receptores do investimento. A regra do maximin poderia ser entendida como um meio para o estabelecimento de acordos que contivessem disposições que privilegiassem os países receptores de investimento - em especial os de menor nível de desenvolvimento - suas necessidades desenvolvimentistas e os interesses de sua população.

É importante notar que o maximin de Rawls consiste em uma defesa da equidade que não deve ser confundida com as noções de igualdade que deram substrato para o pensamento comunista ou, ainda, para alguns aspectos da NOEI e dos debates sobre o Direito Internacional do Desenvolvimento na década de 1960 e 1970. A teoria do maximin não pressupõe que a distribuição dos recursos na sociedade deve ser igual - independentemente dos efeitos que esta igualdade distributiva gerará na produtividade ou na capacidade da sociedade de aumentar a soma dos bens disponíveis ${ }^{61}$. Ao contrário, a teoria expressamente autoriza a distribuição desigual de recursos que leva a um aumento no montante geral de riqueza, desde que com isso, seja possível beneficiar especialmente aqueles que estão na posição mais frágil na sociedade. Esta perspectiva autoriza que o Estado

59 FRANCK, Thomas M. Fairness in international law and institutions. New York: Oxford University, 1995. p. 18.

60 ALVAREZ, José. The public international law regime governing international investment law. Hague: The Hague Academy of International Law, 2011. p. 35.

61 FRANCK, Thomas M. Fairness in international law and institutions. New York: Oxford University, 1995. p. 19. receptor do investimento continue tendo maiores encargos do que o Estado investidor, ou mesmo do que a empresa estrangeira - desde que se verifique que tais medidas serão efetivamente compensadas por investimentos capazes de gerar resultados benéficos ao desenvolvimento da economia receptora.

Não obstante, o próprio Rawls relutou na aplicação de sua teoria no tocante ao Direito Internacional em sua obra "O Direito dos Povos" 62 . Em verdade, o Princípio da Diferença (maximin) está ausente de sua concepção de justiça para a sociedade internacional, já que o autor entende que a intervenção internacional deve servir apenas para auxiliar os países a criarem instituições liberais - já que os infortúnios de alguns países decorreriam exclusivamente de sua má organização política (e não de uma escassez de recursos ${ }^{63}$. Além disso, o autor coloca em dúvida a obrigação moral dos países mais ricos com os mais pobres na seara internacional - onde não haveria uma comunidade global ${ }^{64}$.

Joffrey Dunoff e Joel Trachtman ${ }^{65}$ concordaram com essa perspectiva, ao aplicar os pressupostos da escolha racional ao Direito Internacional, defendendo que o Direito Internacional não funciona como os sistemas domésticos, nos quais é comum que os indivíduos se disponham a conceder autoridade para decisões alocativas institucionais que visem uma distribuição de recursos. Na sociedade internacional, essa solidariedade é - segundo os autores - menos firme: há uma sensação menor de valores compartilhados, uma menor disposição para aceitar os custos de decisões que geram prejuízos no curto prazo pelo benefício de uma vida em sociedade - o que faria com que os Estados tivessem uma menor predisposição para a celebração de acordos sob a ótica do "véu da ignorância".

Não obstante, a integração global constante tem elevado o sentimento de solidariedade da esfera internacional. É o que sustenta Thomas Franck ${ }^{66}$, para quem

62 RAWLS, John. O direito dos povos. Tradução de Luís Carlos Borges. São Paulo: M. Fontes, 2001.

63 RAWLS, John. O direito dos povos. Tradução de Luís Carlos Borges. São Paulo: M. Fontes, 2001. p. 142.

64 RAWLS, John. O direito dos povos. Tradução de Luís Carlos Borges. São Paulo: M. Fontes, 2001. p. 119.

65 DUNOFF, Joffrey L.; TRACHTMAN, Joel P. Economic analysis of international law: an invitation and a caveat. April 20, 1998. p. 37. Available in: <http://papers.ssrn.com/sol3/papers.cfm?abstract_ $\mathrm{id}=73688>$. Access: Out. 22, 2014.

66 FRANCK, Thomas M. Fairness in international law and institutions. New York: Oxford University, 1995. p. 5. 
há um sentimento crescente de comunidade global que tornaria perfeitamente justificável a aplicação do maximin nas alocações de recursos internacionais. Para o autor, desde a chegada do homem ao espaço, quando se percebeu a pequenez da Terra como o único habitat possível a todos os homens diante da imensidão do universo, a autopercepção das pessoas ao redor do mundo quanto a suas interconexões enquanto humanidade - um conjunto de seres humanos com anseios, aspirações e necessidades semelhantes e interligadas - tem crescido $^{67}$. Dentro desse contexto, é possível acatar os postulados da racionalidade - reconhecendo que os Estados seguirão o Direito Internacional quando os benefícios de fazê-lo excederem os custos - mas admitindo que escolha racional não precisa decorrer de cálculo de custo-benefício egoístico acerca de regras particulares, mas sim em uma análise mais ampla e profunda, baseada no impulso de solidariedade e cooperação que move as nações ao se sentirem todas como membros de um mesmo clube ${ }^{68}$.

De fato, diversas questões inter-relacionam e conectam as pessoas dos mais diferentes lugares do mundo atualmente. As diferenças econômicas e de padrões de vida entre os países - que sempre existiram - tornaram-se menos suportáveis com o advento das comunicações instantâneas e as reinvindicações por igualdade alcançam escala global ${ }^{69}$. Além disso, problemas sem fronteiras - como a crise ambiental e o terrorismo, por exemplo - suscitam a percepção do planeta como um todo conectado e interligado na busca por um futuro comum. Pensa-se, assim, que as condições para a aplicação do maximin na esfera internacional - se já não existem - estão cada vez mais próximas. Em verdade, o critério de Rawls tem sido utilizado em relatórios da ONU para reforçar a opinião de que, na cooperação internacional pelo desenvolvimento, deve ser dada prioridade àqueles em situação marginalizada, de forma a favorecer os grupos mais vulneráveis da sociedade ${ }^{70}$.

67 FRANCK, Thomas M. Fairness in international law and institutions. New York: Oxford University, 1995. p. 5.

$68 \mathrm{KOH}$, Harold Hongiu. Why do nations obey international law? Yale law school faculty scholarship. p. 2062. Available in: <http://digitalcommins.law.yale.edu/fss_papers/2101>. Access: Dez. 31, 2014. 69 MELLO, Celso Albuquerque de. Direito internacional econômico. Rio de Janeiro: Renovar, 1993. p. 12.

70 OLIVEIRA, Silvia Menicucci. Financiamento internacional do desenvolvimento: seu papel na implementação do direito ao desenvolvimento. In: AMARAL JUNIOR, Alberto. Direito internacional e desenvolvimento. Barueri: Manole, 2005. p. 219-252. p. 223.
Nessa perspectiva, acredita-se que as conexões entre os países hoje e o "véu da ignorância" que recai sobre negociadores na celebração de acordos de investimento em que a posição das partes não é mais tão definida torna possível uma busca por acordos que tenham como objetivo concretizar globalmente o desenvolvimento econômico sustentável e harmônico entre os Estados, pois esta pode ser, além de uma questão ética e moral, também uma questão necessária à busca pelo melhor interesse dos países individualmente - inclusive os mais desenvolvidos.

A tendência de reforma nos acordos de investimento aponta nessa direção. O modelo elaborado pela Noruega, por exemplo, concatena ideais desenvolvimentistas com a necessidade de proteção dos investidores internacionais ${ }^{71}$. $\mathrm{O}$ mesmo pode ser dito do modelo brasileiro: os acordos assinados recentemente diferem do modelo da década de 1990 até no nome. Os tradicionais "Acordos de Promoção e Proteção de Investimentos" encontram-se agora sob a roupagem de "Acordo de Cooperação e Facilitação de Investimentos", e suas previsões são substancialmente diferentes em diversos aspectos.

Pautado no diálogo intergovernamental, o acordo cria obrigações tanto para Estados receptores do investimento (por meio das garantias de proteção) quanto para o Estado de origem do investidor (que devem participar ativamente de debates e do compartilhamento de oportunidades para expansão dos investimentos, trocar informações e participar de agendas temáticas para facilitação de investimentos recíprocos) ${ }^{72}$. Além disso, o acordo também inova por estabelecer obrigações de responsabilidade social corporativa aos investidores, que devem comprometer-se com o respeito aos direitos humanos, manter políticas de governança corporativa e absterem-se de práticas nocivas à economia receptora ${ }^{73}$.

71 73KINGDOM OF NORWAY. Agreement between the Kingdom of Norway and for the promotion and protection of investments. Available in: <http://www.italaw.com/sites/default/files/archive/ita1031.pdf > Access: Nov. 15, 2014.

72 BRASIL. Ministério das Relações Exteriores. Acordo BrasilMoçambique de Cooperação e Facilitacãa de Investimentos (ACFI): Maputo, 30 de março de 2015. Brasília: MRE, 30 mar. 2015. Disponível em: $<$ www.itamaraty.gov.br/index.php?option $=$ com_content\&view $=$ ar ticle $\&$ id $=8511 \&$ catid $=42 \&$ Itemid $=280 \&$ lang $=p t-B R>$. Acesso em: 2 set. 2015

73 MONEBHURRUN, Nitish. Crônicas do direito internacional dos investimentos. Revista de Direito Internacional, Brasília, v. 12, n. 1, p. 32-36, 2015. p. 32-36. 
A decisão brasileira de celebrar acordos de investimento nesse momento, mesmo depois de ter expressamente refutado os acordos assinados na década de 1990, advém da nova posição do país nesses embates: é cada vez mais comum que empresas brasileiras invistam no exterior ${ }^{74}$. É de se destacar, em relação a esse contexto que algumas empresas brasileiras já foram impactadas por medidas hostis adotadas por governos vizinhos. Em 2006, o presidente boliviano Evo Morales anunciou a expropriação de investimentos estrangeiros no setor de petróleo e gás natural de seu país, incluindo, dentre as empresas expropriadas, uma subsidiária holandesa da Petrobrás. Além disto, em 2008, a empresa Odebrecht e a FURNAS foram expulsas do Equador pelo presidente Rafael Correa, em razão de problemas encontrados pelo governo na hidrelétrica São Francisco ${ }^{75}$. A proteção dos investidores nacionais torna-se, assim, uma preocupação a ser considerada pelo governo brasileiro.

Porém, ao contrário do que se poderia supor, o Brasil não está negociando apenas com países nos quais o fluxo de investimentos é unilateral. Apesar dos acordos assinados com países africanos representarem uma resposta à demanda de grandes empresas - em especial construtoras - brasileiras que participam de grandiosos projetos no continente, o Brasil assinou acordo também com o México, mesmo sendo o principal destino de investimentos mexicanos na América Latina ${ }^{76}$. Da mesma forma, o fluxo de investimentos entre o Brasil e Chile é recíproco ${ }^{77}$. Assim, pode-se dizer que o Brasil encontra-se coberto pelo "véu da ignorância" nessas situações,

74 O estoque de investimentos do Brasil no exterior subiu de \$42bilhões em 2001 para U\$266,3 bilhões em 2013. Nesse sentido, ver em: BANCO CENTRAL DO BRASIL. Capitais brasileiros no exterior: ano base 2012. Disponível em: <http://www4.bcb.gov.br/rex/ CBE/Port/ResultadoCBE2012p.pdf>. Acesso em: 04 dez. 2013.

75 MACHADO, Artur Andrade da Silva. O caso Odebrecht e o dilema da liderança regional brasileira. Meridiano 47. Disponível em: <http://periodicos.unb.br/index.php/MED/article/ view/851/519>. Acesso em: 17 nov. 2015.

76 BRASIL. Ministério das Relações Exteriores. Acordo BrasilMéxico de Cooperação e Facilitação de Investimentos: Cidade do México, 26 de maio de 2015. Brasília: MRE, 27 maio 2015 Disponível em: $<$ http://www.itamaraty.gov.br/index.php?option=com_conten $\mathrm{t} \&$ view $=$ article $\& i d=9890$ :acordo-brasil - mexico-de-cooperacaoe-facilitacao-de-investimentos-cidade-do-mexico-26-de-maio-de$2015 \&$ catid $=42 \&$ lang $=$ pt $-B R \&$ Itemid $=280>$. Acesso em: 03 fev. 2016.

77 BRASIL. Ministério do Desenvolvimento, Indústria e Comércio Exterior. Brasil e Chile assinam acordo de cooperação e facilitação de investimentos. Brasil: MDIC, nov. 2015. Disponível em: <http://www. mdic.gov.br/sitio/interna/noticia.php?area $=5 \&$ noticia $=14186>$. Acesso em: 07 dez. 2015. pois precisou pensar em um acordo que englobasse suas demandas tanto como país receptor de investimentos quanto como investidor.

O que se nota, portanto, é que os acordos de investimento não devem ser abolidos. Ao contrário, os acordos são uma solução cooperativa entre Estados receptores e investidores para um problema real: a falta de confiabilidade dos investidores nas instituições domésticas dos países em que investem - o que acaba por desestimular o ingresso de capital especialmente necessário aos países mais pobres, que também são os que despertam maiores desconfianças quanto à qualidade de seus sistemas institucionais. Contudo, uma vez que se reconhecem os benefícios da cooperação, é preciso reconhecer que esta não se restringe a um modelo único. Em verdade, "quando a cooperação produz ganhos, muitos arranjos são possíveis"

Pautando-se nos pressupostos de maximin defendidos por Rawls, pode-se pensar em acordos de investimento calibrados com diferentes níveis de obrigações conforme o nível de desenvolvimento do país signatário - de modo semelhante às disposições do GATT que atribuem responsabilidades diferenciadas para os países menos desenvolvidos ${ }^{79}$. Pode ser desejável incluir, como fez o modelo brasileiro, obrigações para as empresas investidoras entre as disposições dos acordos, modificando seu o caráter unilateral que, até então, estabelece apenas deveres para os Estados receptores do investimento. Dar continuidade às iniciativas de revisão das cláusulas abertas, como a do tratamento justo e equitativo e da expropriação indireta, evitando que continuem

78 SEN, Amartya; KLIKSBERG, Bernardo. As pessoas em primeiro lugar: a ética no desenvolvimento e os problemas do mundo globalizado. Tradução de Bernardo Ajzemberg e Calos Eduardo Lins da Silva. São Paulo: Companhia das Letras, 2010. p. 19.

79 Há, no GATT, um total de 25 previsões diferenciadas para países em desenvolvimento, contidas nos artigos XVIII, XXXVI, XXXVII e XXXVIII. Tais medidas incluem o estabelecimento de oportunidades para aumentar o comércio nos países em desenvolvimento (artigos XXXVI.2, XXXVI.3, XXXVI.4, XXXVI.5, XXXVII.1(a), XXXVII.4, XXXVIII.2(c),(e); medidas de flexibilidade quanto aos compromissos, ações e uso dos instrumentos (artigos XXXVI.8, XVIII,7(a), XVIII.8 e XVIII.13) e previsões acerca da salvaguarda dos interesses de países em desenvolvimento (artigos XXXVI.5, XXXVI.7, XXXVI.9, XXXVII.1(b),(c), XXXVII.2, XXXVII.3, XXXVII.5, XXXVIII.1, XXXVIII.2(a), (b), (d), (f)). Nesse sentido, ver em: WTO. Special and differential treatment provisions. WORLD TRADE ORGANIZATION. Special and differential treatment provisions. Geneve: WTO, 2015. Available in: $<$ https://www.wto.org/english/tratop_e/devel_e/dev_special_differential_provisions_e.htm>. Access: Nov. 12, 2015. 
sendo percebidas como uma caixa-preta de onde podem emergir indesejadas surpresas para os países signatários ${ }^{80}$, é também importante.

Uma mudança nos acordos de investimento é desejável e possível, não apenas por um desejo de uma sociedade internacional mais justa e equilibrada, mas também porque esse caminho é o mais indicado a ser tomado pelos Estados, concebidos como agentes econômicos racionais que desconhecem sua posição nas negociações de investimento. A partir do momento que os agentes em negociação percebem que sua racionalidade posicional pode ser variável - ora podendo ser um Estado investidor desejoso da proteção de seus empresários nacionais, ora um receptor do investimento, necessitando manter um espaço razoável para o "direito de regular" - um novo horizonte se abre para esses acordos, que devem se tornar cada vez mais equilibrados e menos intrusivos.

\section{Considerações finais}

O presente artigo permitiu concluir que a decisão dos países de participar de acordos bilaterais de investimento pode ser mensurada com base no pressuposto da racionalidade econômica. Em outras palavras, os países devem se engajar nas negociações desses acordos quando perceberem que estão em uma melhor situação em fazê-lo do que estariam sem esse instrumento de regulação internacional.

Essa análise pode ser útil para ponderar sobre a mudança de perspectiva brasileira quanto ao tema: apesar de ter assinado 14 acordos na década de 1990, o país optou por não ratificá-los em 2002. Hoje, porém, negocia acordos pautados em uma lógica distinta, mais equilibrados às necessidades dos países receptores e emissores de investimento do que os acordos tradicionais. Nota-se, assim, que, se em 2002, com a análise de custo-benefício realizada pelo governo brasileiro concluiu-se por uma desnecessidade desses instrumentos, há uma série de fatos novos a serem considerados atualmente e é preciso rediscutir o assunto.

80 WALLACE, Perry. International investment law and arbitration, sustainable development, and Rio+20: improving corporate institutional and state governance. Sustainable Development Law and Policy, v. 12, n. 3, p. 22-28; 55-56, 2012. p. 23. Available in: $\quad<$ http://digitalcommons.wcl.american.edu/cgi/viewcontent. coi $P$ article $=1535 \&$ context $=$ sdlp $>$. Access: Jan. 29, 2015.
Em um primeiro momento, um novo cenário para os acordos está se formando e, paulatinamente, as grandes potências têm dado abertura para rediscutir os acordos de investimento, reformando seus modelos para incluir disposições mais equilibradas, com maiores considerações aos interesses dos Estados receptores. Além disso, a visão de que os acordos são irrelevantes para o Brasil tomando-o por um país exclusivamente receptor de capital e com fatores de atração relevantes (tais como um grande mercado doméstico e uma legislação liberal para regular nacionalmente o investimento estrangeiro, o que justifica o recebimento de grande influxo de capital a despeito do não fornecimento das garantias internacionais de proteção) - não se sustenta diante da percepção de que o país se torna, cada vez mais, uma economia exportadora de capital.

Dentro desse contexto, entende-se que o país não pode mais manter-se alheio ao papel importante dos acordos de investimento na proteção das empresas nacionais contra riscos políticos e institucionais nos países em que investem. Essa maior proteção, porém, não necessariamente precisa ser pautada sob uma lógica egocêntrica do país investidor, mas sim com a devida atenção às necessidades também da economia receptora, posto que o Brasil está em uma posição em que compreende e possui interesses nos dois lados do jogo. Em muitos casos, pode-se dizer que o Brasil é, verdadeiramente, um agente coberto pelo "véu da ignorância" na posição original pensada por Rawls - em condições, portanto, de elaborar acordos alinhados com as ideias de justiça ponderadas pelo autor e pautados na lógica do maximin.

Com seu novo modelo, pensa-se que o país poderia assumir a liderança de um processo de reforma do Direito Internacional dos Investimentos Estrangeiros, atuando de modo preocupado em garantir um sistema eficiente e equilibrado de proteção dos investidores que seja também solidário às necessidades desenvolvimentistas das economias receptoras. O país está numa posição privilegiada para isso justamente porque não se comprometeu com os acordos formulados sob a lógica do Consenso de Washington na década de 1990, estando livre para estabelecer um modelo novo sem amarras com compromissos internacionais anteriormente firmados. Além disto, seu poder de barganha é considerável nos debates sobre investimento: justamente por ter fatores atrativos em sua economia que lhe permitem atrair capital mesmo na ausência de um acordo, o 
país pode usar da ameaça de abandonar as negociações quando elas não estiverem caminhando na direção de seus interesses - o que não ocorre com as economias que apostam nos acordos internacionais de investimento como meios para criarem fatores de atração às suas economias.

Assim, a postura brasileira pode servir para dar força ao processo de reforma nos acordos globais, pautando-se numa perspectiva ampliada de desenvolvimento e atuando de modo solidário aos interesses dos países mais pobres. Trata-se, ao mesmo tempo, um imperativo moral e também uma estratégia que pode servir ao Brasil sob uma perspectiva de maximização racional: fazer parte de um acordo equilibrado traria mais benefício aos seus investidores locais do que manter-se distante dessa estrutura de proteção; por outro lado, na condição de receptor de capitais, o Brasil precisa assegurar um devido espaço para a elaboração de políticas públicas de desenvolvimento nacionais e para medidas de regulação movidas por interesses públicos, razão pela qual não deve concordar com propostas de acordo que repetem a lógica altamente intrusiva dos acordos bilaterais tradicionais.

É de se destacar, também, a importância da regulação internacional dos investimentos estrangeiros em um cenário de intensificação da criação de normas positivas em âmbito internacional, uma vez que a existência desses acordos serve para trazer clareza e segurança jurídica para relações econômicas cada vez mais frequentes no cenário global.

O que se nota, portanto, no cenário atual das negociações de investimento é que existe uma janela de oportunidade para que a adesão à regulação internacional dos investimentos estrangeiros possa ser repensada pelas autoridades brasileiras. Percebe-se que o Brasil já está caminhando nessa direção com seu novo modelo de acordo. É uma mudança de perspectiva importante e, muito embora, os acordos ainda estejam pendentes de ratificação e sua eficácia e impactos ainda precisem ser mensurados, a mera celebração desses novos modelos é um marco não só na política externa brasileira, mas para todo o Direito Internacional dos Investimentos Estrangeiros.

\section{REFERÊNCIAS} economia. Revista do Mestrado em Direito da Universidade Católica de Brasília, Brasília, v. 1, n. 1, p. 49-101, 2007. Disponível em: <http://portalrevistas.ucb.br/index. $\mathrm{php} / \mathrm{rvmd} /$ article/viewArticle/2617>. Acesso em: 15 dez. 2014.

ALVAREZ, José E. The once and future foreign investment regime. In: ARSANJANI, Mahnoush H. et al. (Ed.). Looking to the future: essays on international law in honor of W. Michael Reisman. Netherlands: Koninklijke Brill, 2011. p. 608-648.

ALVAREZ, José. The public international law regime governing international investment law. Hague: The Hague Academy of International Law, 2011.

ARENHART, Fernando Santos. Investimento estrangeiro: o padrão de tratamento justo e equitativo e o papel da boa fé. Revista de Direito Internacional, Brasília, v. 10, n. 1, p. 154-169, 2013.

AXELROD, Robert. A evolução da cooperação. São Paulo: Leopardo, 2010.

BANCO CENTRAL DO BRASIL. Capitais brasileiros no exterior: ano base 2012. Disponível em: <http://www4. bcb.gov.br/rex/CBE/Port/ResultadoCBE2012p.pdf >. Acesso em: 04 dez. 2013.

BRASIL. Ministério das Relações Exteriores. Acordo Brasil-México de Cooperação e Facilitação de Investimentos: Cidade do México, 26 de maio de 2015. Brasília: MRE, 27 maio 2015 Disponível em: <http://www.itamaraty. gov.br $/$ index.php?option $=$ com_content\&view $=$ artic le\&id =9890:acordo-brasil-mexico-de-cooperacao-efacilitacao-de-investimentos-cidade-do-mexico-26-demaio-de-2015\&catid $=42 \&$ lang $=$ pt-BR\&Itemid $=280>$. Acesso em: 03 fev. 2016.

BRASIL. Ministério das Relações Exteriores. Acordo Brasil-Moçambique de Cooperação e Facilitação de Investimentos (ACFI): Maputo, 30 de março de 2015. Brasília: MRE, 30 mar. 2015. Disponível em: <www.itamaraty.gov.br/ index.php?option $=$ com_content\&view $=$ article\&id $=85$ $11 \&$ catid $=42 \&$ Itemid $=280 \&$ lang $=p t-B R>$. Acesso em: 2 set. 2015.

BRASIL. Ministério do Desenvolvimento, Indústria e Comércio Exterior. Brasil e Chile assinam acordo de cooperação e facilitação de investimentos. Brasil: MDIC, nov. 2015. Disponível em: <http://www.mdic.gov.br/sitio/inter$\mathrm{na} /$ noticia.php?area $=5 \&$ noticia $=14186>$. Acesso em: 
07 dez. 2015.

BUBB, Ryan J.; ROSE-ACKERMAN, Susan. BITs and bargains: strategic aspects of bilateral and multilateral regulation of foreign investment. International Review of Law and Economics, v. 27, n. 3, p. 291-311, Sept. 2007.

CALABRESI, Guido. The cost of accidents: a legal and economic analysis. London: Yale University, 1970.

COLEN, Liesbeth; MAERTENS, Miet; SWINNEN, Johan. Determinants of foreign direct investment flows to developing countries: the role of international investment agreements. In: SCHUTTER, Olivier de; SWINNEN, Johan; WOUTERS, Jan (Ed). Foreign direct investment and human development: the law and economics of international investment agreements. London: Routledge, 2013. p. 142-162.

COSTA, José Augusto Fontoura. Direito internacional do investimento estrangeiro. Curitiba: Juruá, 2010.

COSTA, José Augusto Fontoura. Modelos de Solução de Controvérsias Investidor-Estado: os mecanismos nacionais e internacionais. In: AMARAL JÚNIOR, Alberto do; SANCHEZ, Michelle Ratton. Regulamentação internacional dos investimentos: algumas lições para o Brasil. São Paulo: Aduaneiras, 2007. p. 325-354.

CUNNINGHAM, S. M. Multinationals and restructuring in Latin America. In: DIXON, Chris; DRAKAKIS-SMITH, David; WATTS, Doug (Ed.). Multinational corporations and the third world. New York: Routledge, 1986. v. 11. p. 39-65.

DIAS, Bernadete de Figueiredo. A abordagem do direito ao desenvolvimento nos tratados sobre investimentos. In: AMARAL JÚNIOR, Alberto do (Org.). Direito internacional e desenvolvimento. Barueri: Manole, 2005. p. 253-269.

DOLZER, Rudolf; SCHREUER, Christoph. Principles of international investment law. Oxford: Oxford University, 2012.

DUNOFF, Joffrey L.; TRACHTMAN, Joel P. Economic analysis of international law: an invitation and a caveat. April 20, 1998. Available in: <http://papers.ssrn.com/ sol3 $/$ papers.cfm?abstract_id $=73688>$. Access: Out. 22, 2014.

FONSECA, Karla Closs. Investimentos estrangeiros: regulamentação internacional e acordos bilaterais. Curitiba: Juruá, 2008.
FRANCK, Thomas M. Fairness in international law and institutions. New York: Oxford University, 1995.

GERMANY. Treaty between the Federal Republic of Germany and Pakistan for the prootion and protection of investments. Available in: <http://investmentpolicyhub.unctad.org/ Download/TreatyFile/1387>. Access: Out. 29, 2014.

GICO JR., Ivo. Metodologia e epistemologia da análise econômica do direito. Economic Analysis of Law Review, v. 1, n. 1, p. 7-33, Jan./June 2010. Available in: <http:// portalrevistas.ucb.br/index.php/EALR/article/ view/1460/1110>. Access: Out. 21, 2014.

GINSBURG, Tom. International substitutes for domestic institutions: bilateral investment treaties and governance. International Review of Law and Economics, v. 25, p. 107-123, 2005.

GUZMAN, Andrew. Why LDCs sign treaties that hurt them: explaining the popularity of bilateral investment treaties. Virginia Journal of International Law, v. 38, n. 639, p. 639-688, 1998. Available in: <http://papers.ssrn. com $/$ sol3 $/$ papers.cfm?abstract_id $=2176003>$. Access: Nov. 4, 2014.

HARTEN, Gus Van. Investment treaty arbitration and public law. Oxford: Oxford University, 2007.

HARTEN, Gus Van; LOUGHLIN, Martin. Investment treaty arbitration as a species of global administrative law. The European Journal of International Law, v. 17, n. 1, p. 121-150, 2006. Available in: <http://www.unipotsdam.de/fileadmin/projects/jur-zimmermann/ LV_2010_2011/Koll_Van_HartenLoughlin_Investment_Arbitration_as_GAL.pdf>. Access: Nov. 4, 2014.

INTERNATIONAL CENTRE FOR SETTLEMENT OF INVESTMENT DISPUTES. The ICSID Caseload: Statistics (Issue 2014-2). Washigton: ICSID, 2014. Available in: <https://icsid.worldbank.org/apps/ICSIDWEB/resources/Documents/ICSID $\% 20 W$ Web $\% 20$ Stats $\% 202014-2 \% 20$ (English).pdf $>$. Access: Nov. 23, 2014.

KINGDOM OF NORWAY. Agreement between the Kingdom of Norway and for the promotion and protection of investments. Available in: <http://www.italaw.com/sites/ default/files/archive/ita1031.pdf>. Access: Nov. 15, 2014.

$\mathrm{KOH}$, Harold Hongiu. Why do nations obey international law? Yale law school faculty scholarship. Availa- 
ble in: <http://digitalcommins.law.yale.edu/fss_papers/2101>. Access: Dez. 31, 2014.

KULICK, Andreas. Global public interest in international investment law. Cambridge: Cambridge University, 2012.

MACHADO, Artur Andrade da Silva. O caso Odebrecht e o dilema da liderança regional brasileira. $\mathrm{Me}$ ridiano 47. Disponível em: <http://periodicos.unb.br/ index.php/MED/article/view/851/519>. Acesso em: 17 nov. 2015.

MELLO, Celso Albuquerque de. Direito internacional econômico. Rio de Janeiro: Renovar, 1993.

MILES, Kate. The origins of international investment law. Cambridge: Cambridge University, 2013.

MONEBHURRUN, Nitish. Crônicas do direito internacional dos investimentos. Revista de Direito Internacional, Brasília, v. 11, n. 1, p. 10-18, 2014.

MONEBHURRUN, Nitish. crônicas do direito internacional dos investimentos. Revista de Direito Internacional, Brasília, v. 12, n. 1, p. 32-36, 2015.

MONEBHURRUN, Nitish. Essay on unequal treaties and modernity throgh the example of bilateral investment treaties. Revista de Direito Internacional, Brasilia, v. 11, n. 1, p. 202-214, 2014.

NORTH, Douglass C. Economic performance through time. American Economic Review, v. 84, n. 3, p. 359-368, June 1994.

OLIVEIRA, Silvia Menicucci. Financiamento internacional do desenvolvimento: seu papel na implementação do direito ao desenvolvimento. In: AMARAL JUNIOR, Alberto. Direito internacional e desenvolvimento. Barueri: Manole, 2005. p. 219-252.

OLSON, Mancur. The logic of collective action: public goods and the theory of groups. Cambridge: Harvard University, 1965.

PINHEIRO FILHO, Francisco Renato Codevila. Teoria da agência: problema agente-principal. In: RIBEIRO, Márcia Carla Pereira; KLEIN, Vinícius (Coord.). O que é análise econômica do direito: uma introdução. Belo Horizonte: Fórum, 2011. v. 1. p. 97-109.

POSNER, Eric A.; SYKES, Alan O. Economic foundations of international law. Cambridge: Harvard University, 2013.

POSTIGA, Andréa Rocha. A emergência do direito administrativo global como ferramenta de regulação transnacional do investimento estrangeiro direto. Revista de Direito Internacional. Brasília, v. 10, n. 1, p. 171-193, 2013.

RAWLS, John. A theory of justice. Cambridge: Harvard College, 1999.

RAWLS, John. O direito dos povos. Tradução de Luís Carlos Borges. São Paulo: M. Fontes, 2001.

RUTTEMBERG, Valerie H. The United States bilateral investment treaty program: variations on the model. Journal of International Law, v. 9, p. 121-143, 1987. Available in: <http://scholarship.law.upenn.edu/cgi/ viewcontent. cgi ?article $=1639 \&$ context $=$ jil $>$. Access: Nov. 15, 2014.

SANDEL, Michael J. Justiça: o que é fazer a coisa certa? Tradução de Heloísa Matias e Maria Alice Máximo. 12. ed. Rio de Janeiro: Civilização Brasileira, 2013.

SCANDIUCCI FILHO, José Gilberto. O Brasil e os acordos bilaterais de investimentos. In: AMARAL JÚNIOR, Alberto do; SANCHEZ, Michelle Ratton. Regulamentação internacional dos investimentos: algumas lições para o Brasil. São Paulo: Aduaneiras, 2007. p. 271-302.

SCHILL, Stephan W. The mutilateralization of international investment law. Cambridge: Cambridge University, 2009.

SCOTT, Robert E.; STEPHAN, Paul B. The limits of Leviathan: contract theory and the enforcement of international law. Cambridge: Cambridge University, 2006.

SEN, Amartya; KLIKSBERG, Bernardo. As pessoas em primeiro lugar: a ética no desenvolvimento e os problemas do mundo globalizado. Tradução de Bernardo Ajzemberg e Calos Eduardo Lins da Silva. São Paulo: Companhia das Letras, 2010.

SEN, Amartya. A ideia de justiça. Tradução de Denise Bottmann e Ricardo Doninelli Mendes. São Paulo: Companhia das Letras, 2009.

SORNARAJAH, M. The international Law on Foreign Investment. Cambridge: Cambridge University, 2010.

STIGLITZ, Joseph E. Globalização: como dar certo. São Paulo: Companhia das Letras, 2007.

TAYLOR, Matthew. Philip Morris v Australia: the challenges of investor-state arbitration. Available in: <http://www.mallesons.com/publications/marketAlerts/2011/International-Arbitration-Update-November-2011/Pages/Philip-Morris-v-Australia-the-challen- 
ges-of-investor-state-arbitration.aspx>. Access: Aug. 26, 2014.

UNITED NATIONS CONFERENCE ON TRADE AND DEVELOPMENT. World Investment Report 2013: global valeu chains: investment and trade for development. New York: United Nations, 2013. Available in: <http://unctad.org/en/PublicationsLibrary/ wir2013_en.pdf>. Access: Dez. 02, 2013.

UNITED NATIONS CONFERENCE ON TRADE AND DEVELOPMENT. World Investment Report 2014: investing in the SDGs: an action plan. New York: United Nations, 2014. Available in: <http://unctad.org/ en/publicationslibrary/wir2014_en.pdf>. Access: Sept. 8, 2014.

WALLACE, Perry. International investment law and arbitration, sustainable development, and Rio +20 : improving corporate institutional and state governance. Sustainable Development Law and Policy, v. 12, n. 3, p. 22-28; 55-56, 2012. Available in: <http://digitalcommons.wcl.american.edu/cgi/viewcontent. cgi?article $=1535 \&$ context $=$ sdlp $>$. Access: Jan. 29, 2015.

WEISS, Martin A. CRS report for congress: the US bilateral investment treaty program: an overview. April 24, 2007. Available in: <https://www.hsdl. org/?view\&did=716235>. Access: Nov. 21, 2014.

WOUTERS, Jan; DUQUET, Sanderijn; HACHEZ, Nicolas. International investment law: the perpetual search for consensus. In: SCHUTTER, Olivier de; SWINNEN, Johan; WOUTERS, Jan. Foreign direct investment and human development: the law and economics of international investment agreements. London: Routledge, 2013. p. 25-69. 


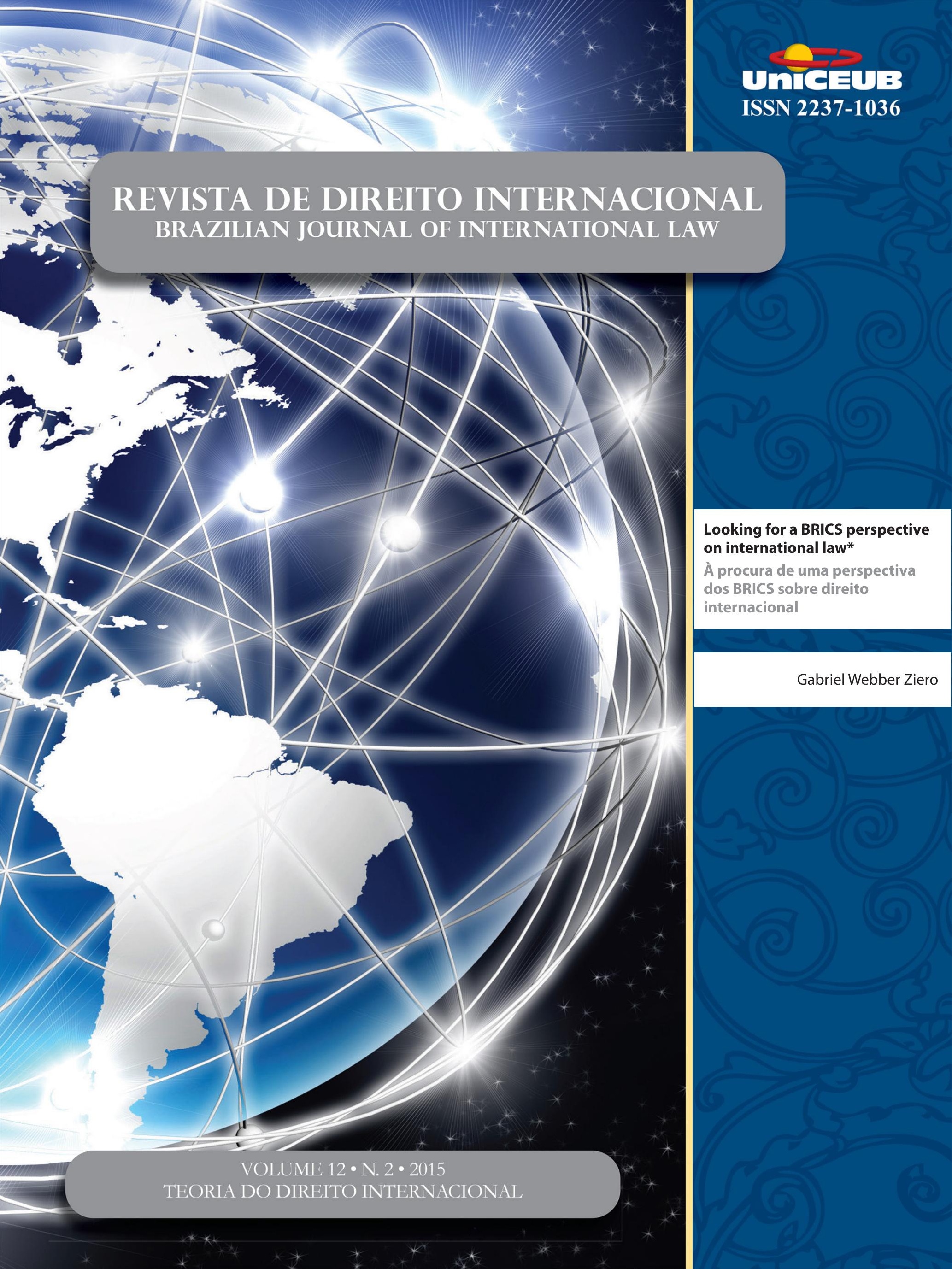




\title{
Looking for a BRICS perspective on international law*
}

\section{À procura de uma perspectiva dos BRICS sobre direito internacional}

Gabriel Webber Ziero*

\begin{abstract}
The aim of this paper is to analyze whether there is a BRICS perspective on international law and what would be its main features. In the first part, the investigation inquires, based on Nietzsche's theory of perspectivism, what a perspective is and whether the BRICS fulfils these theoretical thresholds necessary to possess a perspective on international law. After answering positively to this question, the areas of international peace and security, human rights as well as international economic law are scrutinized in order to verify how the BRICS perceives international law. The first two fields were chosen given the fact that they are the fundaments of the international legal system established after 1945, while the latter is related to the area where the BRICS has been focusing its attention since its creation. In a third moment, based on the findings of the previous sections, the structural fundaments of the group's perspective on international law are identified. Finally, it is possible to conclude that the BRICS perspective on international law is based and shaped by the continuous interactions between the fields of international relations and international law present in the consensus-building process in international organizations as well as by the concept of state sovereignty. These findings allow filling the gap in legal research on the BRICS and better understanding its approach to international law.
\end{abstract}

Keywords: BRICS. Public international law. Perspective. International peace and security. Human rights. International economic law.

\section{Resumo}

O objetivo deste artigo é analisar se existe uma perspectiva dos BRICS quanto ao direito internacional e quais seriam as suas principais características. Na primeira parte, com base na teoria do perspectivismo de Nietzsche, busca-se definir o que é uma perspectiva, bem como se os BRICS preenchem os critérios teóricos necessários para ter uma perspectiva acerca do direito internacional. Após responder positivamente a essa questão, as áreas de paz e segurança internacional, direitos humanos, bem de direito econômico internacional são analisadas a fim de verificar como os BRICS lidam com direito internacional. Os dois primeiros campos foram escolhidos tendo em vista o fato de que eles são os fundamentos do sistema jurídico internacional estabelecido após 1945, enquanto o terceiro está relacionado com a área 
onde os BRICS têm focado a sua atenção desde a sua criação. Em um terceiro momento, com base nos resultados das seções anteriores, os fundamentos estruturais da perspectiva do grupo acerca do direito internacional são identificados. Finalmente, é possível concluir que a perspectiva dos BRICS quanto ao direito internacional se baseia e é moldada pelas interações contínuas entre os domínios das relações internacionais e do direito internacional presente no processo de construção de consenso no seio das organizações internacionais, bem como pelo conceito de soberania do Estado. Tais conclusões permitem preencher a lacuna na pesquisa jurídica sobre os BRICS e ajudam a compreender melhor como os BRICS lidam com o direito internacional.

Palavras-chave: BRICS. Direito internacional público. Perspectiva. Paz e segurança internacional. Direitos humanos. Direito internacional econômico.

\section{INTRODUCTION}

The financial market often designates investment scenarios using acronyms, such as CIVETS (Colombia, Indonesia, Vietnam, Egypt, Turkey and South Africa) and VISTA (Vietnam, Indonesia, South Africa, Turkey and Argentina). This was also the case when in the beginning of the second millennium an investment forecast of Jim O'Neill created the expression BRIC, which was nothing more than a short form to address Brazil, Russia, India and China as a group of countries in an economic prognosis. ${ }^{1}$ Yet, differently than the other acronyms, the BRIC countries promoted their development as a group and established their own diplomatic channel in order to coordinate their actions in the most different fields of the international arena. ${ }^{2}$

The integration of the group in the international scenario started in a sideline meeting of Foreign Ministers during the $61^{\text {st }}$ United Nations General Assembly (UNGA) in 2006 and has been concretized in 2009 at the first BRIC Summit of Heads of States in Yekaterinburg (Russia). Moreover, the most significant moments for the establishment

1 O'NEILL, Jim. Building better global economic BRICs. New York: Goldman, Sach, Nov. 2001. (Global Economics Paper, n. 66). Available on: <http://www.goldmansachs.com/our-thinking/archive/ archive-pdfs/build-better-brics.pdf>. Access: Oct. 16, 2015.

2 REIS, Maria E. F. BRICS: genesis and evolution. In: PIMENTEL, José Vicente de Sá (Ed.). Brazil, BRICS and the international agenda. Brasília: FUNAG, 2013. p. 47-71 p. 51. of the group as an actor in the international arena were the integration of South Africa in 2011 and the subsequent creation of the New Development Bank (NDB) as well as the BRICS Contingent Reserve Agreement (CRA) in 2014. Therefore, fifteen years after they were first named as a group by O'Neill and after South Africa joined the group, Brazil, Russia, India, China and South Africa, or simply the BRICS, represent more than forty percent of the world's population and their added Gross Domestic Product (GDP) corresponds to more than one quarter of the world's economy. ${ }^{3}$ The group thus became an important player of international relations with the capacity to shape processes and outcomes in the international arena, which are commonly inserted within the international legal framework.

However, although the BRICS has become a trend topic in the last years in what regards academic publications, ${ }^{4}$ few are the analyses of the group departing from and within the field of public international law. This is why this paper wants to investigate how the BRICS, as a group and prominent player in international relations, perceives international law. An inquiry about such a BRICS perspective is relevant not only due to the lack of research related to this topic, but also because the levels of institutionalization and cooperation within or through the group are increasing each year. Moreover, it is via the domain of public international law, i.e. "the aggregate of the legal norms governing international relations" ${ }^{5}$, that these actions are and will be expressed.

In order to conduct such investigation, this paper analyzes primary sources drafted by the five countries as a group, such as declarations, statements and plans of action issued by the BRICS Summits of Heads of States, and is divided into three parts. The first one analyzes by means of Nietzsche's philosophy on perspectivism whether the BRICS, as a group, can have its own perspective on international law. The next section aims

3 RUSSIA. Presidency. Official Website of Russia's Presidency in BRICS: BRICS in numbers. 2015. Available on: <http://en.brics2015.ru/infographics/20150301/24260.html>. Access: Oct. 16, 2015.

4 See, for example: REWIZORSKI, Marek (Ed.). The European Union and the BRICS: complex relations in the Era of Global Governance. New York: Springer, 2015. FERDINAND, Peter. Rising powers at the UN: an analysis of the voting behaviour of BRICS in the General Assembly. Third World Quarterly, v. 35, n. 3, p. 376-391, May 2014. KIRTON, John. BRICS evolving institutional identity: explaining the brics summit's solid strengthening success. International Organizations Research Journal, v. 10, n. 2, p. 9-31, Jun. 2015.

5 GUGGENHEIM, Paul. Traité de droit international. Genève: Libraire Georg, 1967. p. 1. 
to explore such BRICS perspective on international law addressing three areas of the discipline, which are: the two core goals of the post-World War II international order, i.e. international peace and security and human rights, as well as international economic law, as this is the area on which the BRICS has been concentrating its efforts since its creation. Finally, the third part puts forward the framework, i.e. the basic ideas that underlie the identified BRICS perspective on international law.

\section{INTERNATIONAL LAW AND ITS PERSPECTIVES: IS THERE A BRICS PERSPECTIVE?}

International law regulates a broad range of issues, from the deep seabed until the outer space, as well as a myriad of actors, such as states, international organization or non-state armed groups. ${ }^{6}$ As a consequence of these innumerous interactions with, within and through the framework of international law, it is possible to indentify several theoretical approaches towards such regulatory regime. For instance, theories approaching international law through the lenses of fragmentation, ${ }^{7}$ feminism ${ }^{8}$ and TWAIL, give an idea that international law can be accessed from uncountable angles, i.e. perspectives. Nevertheless, in front of such scenario a question comes-up: What counts as a perspective?

In order to answer the above mentioned question as well as to verify if there is a BRICS perspective on international law, this section briefly presents Nietzsche's theory of perspectivism in order to understand what a perspective is and how it can be identified. After that, based on the identified elements, upon which a perspective is built, this section scrutinizes whether it can be affirmed that there is a BRICS perspective on international law.

\subsection{The question of perspectivism}

6 SHAW, Malcolm. International law. Cambridge: Cambridge University, 2008. p. 2.

7 KOSKENNIEMI, Martti; LEINO, Päivi. Fragmentation of international law? postmodern anxieties. Leiden Journal of International Law, v. 15, n. 3, p. 553-579, Sept. 2002.

8 KUOVO, Sari; PEARSON, Zoe (Ed.). Feminist perspectives on contemporary international law: between resistance and compliance? Oxford: Hart, 2011.

9 MUTUA, Makau. What it TWAIL? In: ANNUAL MEETING AMERICAN SOCIETY OF INTERNATIONAL LAW, 94., Washington, 2000. Proceedings... Washington: ASIL, Apr. 2000. p. 31-39.
Debates related to a theory of perspective can be traced back to Nietzsche's philosophy where the question of perspectivism (Perspektivismus) is related to the interpretation that a person or group gives to the world that surrounds it. ${ }^{10}$ This idea departs from the understanding that the world does not possesses "any features that are in principle prior to and independent of interpretation". ${ }^{11}$ Moreover, during such hermeneutic process, the subject tries to compel others to accept its worldview as a norm. ${ }^{12}$ In the field of international law, especially during the legalization process, ${ }^{13}$ it is possible to witness the presence of different perspectives on a certain topic or the discipline as a whole, which are put forward by different actors involved in it. For example, during the negotiation process for the creation of the International Criminal Court groups of states as well as movements from civil society presented their views trying to influence the drafting process in order to have their perspectives on international criminal law and justice enshrined in the final treaty. ${ }^{14}$

From the idea of perspectivism, it is possible to identify three decisive elements, which are necessary to be present in order for a specific perspective on something to exist. They are: the participants (persons or group); their interpretation and the cogent power that they give to their worldview. Hence, in order to address the question whether a BRICS perspective on international law exists, this paper shall analyze the group through these three lenses.

\subsection{BRICS: The participant}

Nietzsche's theory of perspectivism is structured on as well as departs from an individual or group, which

10 NIETZSCHE, Friedrich. The will to power. New York: Vintage Books, 1967. p. 267.

11 NEHAMAS, Alexander. Nietzsche: life as literature. Cambridge: Harvard University, 1985. p. 45.

12 NIETZSCHE, Friedrich. The will to power. New York: Vintage Books, 1967. p. 267.

13 This paper adopts the expression "international legalization process" put forward by Abbot and Sindal as it has a broader meaning than the expression "international law-making process". It embodies not only aspects related to the creational process of a certain rule, but also includes normativity considerations, such as the degree of bindingness and precision of the rule. See: ABBOT, Kenneth; SINDAL, Duncan. Hard and soft law in international governance. International Organization, v. 53, n. 3, p. 421-453, Jun. 2000.

14 KIRSCH, Philippe; HOLMES, John T. The Rome Conference on an International Criminal Court: The Negotiating Process. The American Journal of International Law, v. 93, n. 1, p. 2-12, Jan. 1999. 
perceives the world that surrounds it. ${ }^{15}$ It has to be noted that the term "group" implies the presence of a shared interpretation of a subject as well as a certain degree of coordination among its members. Consequently, in order to verify whether there is a BRICS perspective, it is necessary to analyze how the BRICS, as a group, addresses international law and not the individual perspective of its members. Therefore, this section aims at providing a concise analysis of the BRICS members perception of the forum trying to identify common areas and not to investigate the degree of differences among the participants or the causes of such.

In what regards the required degree of coordination, it can be observed that the group has been structuring its relations via an informal legalization strategy, ${ }^{16}$ meaning that the BRICS sets aside some formalities, which are characteristic for the traditional ways in which international cooperation is shaped. For example, instead of establishing an international organization via an international agreement under international law with the presence of at least one organ with an independent will from its members ${ }^{17}$ in order to enhance its strategies regarding cooperation and coordination of policies, the BRICS are in the process of creating a virtual secretariat $^{18}$ responsible for a joint BRICS website designated "to strengthen comprehensive cooperation between the Member States" ${ }^{\prime 1}$. Moreover, the group has an extensive practice in the use of memoranda of understanding, i.e. documents that do not create rights and obligations under international law among its signatories, for example between governmental agencies, state-owned banks and ministries traditionally not involved in the classical international legalization process. ${ }^{20}$ Such lack of legally

15 NIETZSCHE, Friedrich. The will to power. New York: Vintage Books, 1967. p. 267.

16 PAUWELYN, Joost. Informal international lawmaking: framing the concept and research questions. In: PAUWELYN, Joost; WESSEL, Ramses; WOUTERS, Jan (Ed.). Informal international lawmaking. Oxford: Oxford University, 2012. p. 13-34.

17 SCHERMERS, Henry G.; BLOKKER, Niels M. International institutional law. Leiden: M. Nijhoff, 2011. p. 37.

18 UNIVERSITY OF TORONTO. VII BRICS summit: $2015 \mathrm{Ufa}$ Declaration. Ufa, July 9, 2015. Available on: <http://www.brics.utoronto.ca/docs/150709-ufa-declaration_en.html>. Access: Oct. 17, 2015. (Hereinafter: Ufa Declaration), point 77.

19 UNIVERSITY OF TORONTO. Memorandum of understanding on the creation of the joint BRICS Website. Ufa, July 9, 2015. Available on: <http://www.brics.utoronto.ca/docs/150709-website-en. html>. Access: Oct. 17, 2015. Preamble.

20 A list of all memorandums of understanding among the BRICS is UNIVERSITY OF TORONTO. BRICS Information Centre. Available on: <http://www.brics.utoronto.ca/>. Access: Oct. 17, 2015. binding sources, in particular a founding treaty, which in the area of international law is perceived as one of the requirements for the characterization of an international organization, does not impair the possibility to consider the BRICS as a group in the terms of Nietzsche's theory. Differently than the strict requirements put forward by international legal scholarship in order to determine if a group of countries is an international organization, Nietzsche's theory of perspectivism does not require a high level of formalism. Nevertheless, it is important to mention that since 2014 the role played by legally binding documents governed by international law has been increasing with the BRICS agreements creating the NDB as well as the BRICS Contingent Reserve in 2014 and the agreement on cooperation in the field of culture in $2015 .^{21}$

In what regards the shared interpretation, it needs to be observed that the BRICS participants do not always fully agree or support each other's positions. ${ }^{22}$ This was for example the case of the Bali Agreement (2013) ${ }^{23}$ related to the Doha Round at the World Trade Organization (WTO), where India blocked the negotiations for a certain period and almost undermined the trade deal, which was supported by the other BRICS countries. ${ }^{24}$ Nevertheless, although differences exist, the will to act together, as a group, addressing particular issues provides the BRICS with an opportunity to create and strengthen the coordination between its members, as it is required by Nietzsche's theory. As an example of this, it is possible to mention the BRICS countries common efforts via the forum to reform the global economic/ financial architecture. ${ }^{25}$ Furthermore, the group's inte-

21 UNIVERSITY OF TORONTO. Agreement between the governments of the BRICS states on cooperation in the field of culture. Ufassia, July 9, 2015. Available on: <http://www.brics.utoronto.ca/ docs/150709-culture-agreement-en.html>. Access: Oct. 17, 2015

22 COOPER, Andrew; FAROOQ, Assif. Testing the club dynamics of the BRICS: the new development bank from conception to establishment. International Organizations Research Journal, v. 10, n. 2, p. 32-44, Jun. 2015. p. 3.

23 BRAGA, Erika. Um panorama sobre as negociações do Pacote de Bali e os seus desdobramentos no âmbito da OMC. Brazilian Journal of International Law. v. 12, n. 2, p. 16-20, dez. 2014.

24 WTO MINISTERIAL CONFERENCE, 9., 2013, Bali, 2013. Proceedings... Valencia: Instituto de Tecnología y Alimentos Agroquímica, 2014. Available at: <https://www.wto.org/english/ thewto_e/minist_e/mc9_e/balipackage_e.htm>. Access: Oct. 21, 2015.

25 COOPER, Andrew; FAROOQ, Assif. Testing the club dynamics of the BRICS: the new development bank from conception to establishment. International Organizations Research Journal, v. 10, n. 2, p. 32-44, Jun. 2015. 
gration is based on the self-identification of its members as emergent economies, ${ }^{26}$ which also corresponds to the image, which other players have of them. ${ }^{27} \mathrm{Mo}-$ reover, the BRICS bases itself on a non-confrontational approach, ${ }^{28}$ where consensus does not only play a relevant role during the decision-making process, but also at the selection of the themes to be addressed. Consequently, the group understands itself as "a major platform for dialogue and cooperation" 29 that aims to become a "full-fledged mechanism of current and long-term coordination on a wide range of key issues of the world economy and politics" 30 .

The theory of perspectivism requires the presence of shared interpretations and a degree of coordination among the members of a group and does not look at the formalities that are usually essential in the area of international institutional law. Also, it does not require a complete harmony in opinions or the absence of differences among the participants of a group. Therefore, it is possible to affirm that the BRICS satisfies the theoretical requirements to be called a group according to Nietzsche's theory, in the sense that it "acts as the

26 For example: UNIVERSITY OF TORONTO. Joint statement of the BRIC countries' leaders. Yekaterinburg, June 16, 2009. Available on: $<$ http://www.brics.utoronto.ca/docs/090616-leaders.html>. Access: Oct. 17, 2015. (Hereinafter: Yekaterinburg Statement), point 15; UNIVERSITY OF TORONTO. Sanya Declaration. Sanya, Apr. 14, 2011. Available on: <http://www.brics.utoronto.ca/docs/110414leaders.html>. Access: Oct. 17, 2015. (Hereinafter: Sanya Declaration), points 5, 6, 7, 15, 16; UNIVERSITY OF TORONTO. The 6th BRICS summit: Fortaleza Declaration. Fortaleza, July 15, 2014. Available on: <http://www.brics.utoronto.ca/docs/140715-leaders. html>. Access: Oct. 17, 2015. (Hereinafter: Fortaleza Declaration), points 3, 5, 8, 11.

27 See, for example: KEUKELEIRE, Stephan et al. The EU Foreign Policy towards the BRICS and other emerging powers: objectives and strategies. Brussels: European Parliament, Oct. 2009. Available on: $<$ https:/ / www.google.com.br/url?sa $=\mathrm{t} \& \mathrm{rct}=\mathrm{j} \& \mathrm{q}=\&$ esrc $=\mathrm{s} \&$ sourc $\mathrm{e}=$ web\&cd $=1 \& \mathrm{cad}=$ rja\&uact $=8 \& v e d=0$ hUKEwi $4 \mathrm{mcvBtuDKAh}$ XIgZAKHfztAEIQFggfMAA\&url=http $\% 3 \mathrm{~A} \% 2 \mathrm{~F} \% 2 \mathrm{Fwww}$.europarl.europa.eu $\% 2$ Fcommittees $\% 2$ Fen $\% 2$ Fstudiesdownload.html $\%$ 3FlanguageDocument $\% 3$ DEN $\% 26$ file $\% 3 D$ 49151\&usg=AFQjCN G5J6ipEQ5iXvDSwbAi01VZhesbPQ\&sig2=NWyUUYcBlZeAT EH_ed07PA>. Access: Oct. 16, 2015.

28 UNIVERSITY OF TORONTO. Sanya Declaration. Sanya, Apr. 14, 2011. Available on: <http://www.brics.utoronto.ca/ docs/110414-leaders.html>. Access: Oct. 17, 2015. point 6.

29 UNIVERSITY OF TORONTO. Sanya Declaration. Sanya, Apr. 14, 2011. Available on: <http://www.brics.utoronto.ca/ docs/110414-leaders.html>. Access: Oct. 17, 2015. point 6.

30 UNIVERSITY OF TORONTO. BRICS and Africa: partnership for development, integration and industrialization, eThekwini Declaration. Durban, Mar. 27, 2013. Available on: <http://www. brics.utoronto.ca/docs/130327-statement.html>. Access: Oct. 17, 2015. (Hereinafter: eThekwini Declaration). point 21. hub that irons out differences and illustrates how [...] diversity does not entail divergence or conflict"31. As a consequence, in order to conclude whether the BRICS has a perspective on international law, it is necessary to verify if the group tries to compel other actors to follow its interpretations regarding the world.

\subsection{BRICS: Interpretation and cogent power}

Besides the necessity of an agent, which can be an individual or a group, the theory of perspectivism requires that this actor interprets the surrounding world and tries to compel others to accept this interpretation as a blueprint to build their understandings. ${ }^{32}$ In the case of the BRICS, it is possible to perceive that the group aims at complementing global governance ${ }^{33}$ by developing as well as proposing solutions to the current challenges faced by the structures of the international system, which in its view are endowed with a lack of legitimacy and representation. ${ }^{34}$ Moreover, according to the group's interpretation, the current multi-polar international scenario has to "based on international law, equality, mutual respect, cooperation, coordinated action and collective decision-making of all States" ${ }^{\prime 35}$.

The BRICS strategy to gain support for its inter-

31 TSINGOU, Eleni. Club governance and the making of global financial rules. Review of International Political Economy, v. 22, n. 2, p. 225-256, Mar. 2015. p. 232. See also: KIRTON, John. BRICS evolving institutional identity: explaining the BRICS summit's solid strengthening success. International Organizations Research Journal, v. 10, n. 2, p. 9-31, Jun. 2015. p. 13.

32 NIETZSCHE, Friedrich. The will to power. New York: Vintage Books, 1967. p. 267.

33 REIS, Maria E. F. BRICS: genesis and evolution. In: PIMENTEL, José Vicente de Sá (Ed.). Brazil, BRICS and the international agenda. Brasília: FUNAG, 2013. p. 47-71. p. 56.

34 UNIVERSITY OF TORONTO. Joint statement of the BRIC countries' leaders. Yekaterinburg, June 16, 2009. Available on: < http:// www.brics.utoronto.ca/docs/090616-leaders.html>. Access: Oct. 17, 2015. point 3; UNIVERSITY OF TORONTO. Sanya Declaration. Sanya, Apr. 14, 2011. Available on: <http://www.brics.utoronto.ca/ docs/110414-leaders.html>. Access: Oct. 17, 2015. points 8, 15; UNIVERSITY OF TORONTO. Fourth BRICS summit: Delhi Declaration. New Delhi, Mar. 29, 2012. Available on: <http://www.brics. utoronto.ca/docs/120329-delhi-declaration.html>. Access: Oct. 17, 2015. (Hereinafter: Delhi Declaration), point 25; UNIVERSITY OF TORONTO. The 6th BRICS summit: Fortaleza Declaration. Fortaleza, July 15, 2014. Available on: <http://www.brics.utoronto.ca/ docs/140715-leaders.html>. Access: Oct. 17, 2015. point 5.

35 UNIVERSITY OF TORONTO. 2nd BRIC summit of heads of state and government: joint statement. Brasília, Apr. 15, 2010. Available on: <http://www.brics.utoronto.ca/docs/100415-leaders.html>. Access: Oct. 17, 2015. (Hereinafter: Brasília Statement), point 2. 
pretation of the international scenario by other players, and therefore to make its interpretation valid, has been to focus its attention on a particular area of global governance where the group plays an important role, namely the financial/economical architecture. The BRICS approach towards this agenda can be found in its critics to the way that international financial institutions dealt with the 2008 economic crisis and with its spillover effects. According to the group, the Group of Eight (G-8) and the Bretton Woods institutions, especially the International Monetary Fund (IMF) and the World Bank (WB), are not representative enough and incapable to propose solutions to the crisis given the lack of representation of emergent economies and developing countries in their structures. ${ }^{36}$

Consequently, the BRICS advocated for the placement of the debate related to the economic crisis in the Group of Twenty (G-20), which it sees as a more representative forum, ${ }^{37}$ as well as called for and supports the reform processes of the IMF and the WB. ${ }^{38}$ Nevertheless, the BRICS went a step further in the process of compelling other actors to follow its interpretations by giving a follow-up to its open critics to the already established world financial structure. This was when the group, in 2014, signed the constitutive treaty of the New Development Bank (NDB) in order to aid all

36 UNIVERSITY OF TORONTO. Sanya Declaration. Sanya, Apr. 14, 2011. Available on: <http://www.brics.utoronto.ca/ docs/110414-leaders.html>. Access: Oct. 17, 2015. point 15.

37 UNIVERSITY OF TORONTO. Fourth BRICS summit: Delhi Declaration. New Delhi, Mar. 29, 2012. Available on: <http://www. brics.utoronto.ca/docs/120329-delhi-declaration.html>. Access: Oct. 17, 2015. point 7 .

38 UNIVERSITY OF TORONTO. Joint statement of the BRIC countries' leaders. Yekaterinburg, June 16, 2009. Available on: <http:// www.brics.utoronto.ca/docs/090616-leaders.html>. Access: Oct. 17, 2015. point 3; UNIVERSITY OF TORONTO. 2nd BRIC summit of heads of state and government: joint statement. Brasília, Apr. 15, 2010. Available on: <http://www.brics.utoronto.ca/docs/100415-leaders. html>. Access: Oct. 17, 2015. point 10; Sanya Declaration, point 15; UNIVERSITY OF TORONTO. Fourth BRICS summit: Delhi Declaration. New Delhi, Mar. 29, 2012. Available on: < http://www. brics.utoronto.ca/docs/120329-delhi-declaration.html>. Access: Oct. 17, 2015. point 8; UNIVERSITY OF TORONTO. BRICS and Africa: partnership for development, integration and industrialization, eThekwini Declaration. Durban, Mar. 27, 2013. Available on: <http://www.brics.utoronto.ca/docs/130327-statement.html>. Access: Oct. 17, 2015. point 13; UNIVERSITY OF TORONTO. The 6th BRICS summit: Fortaleza Declaration. Fortaleza, July 15, 2014. Available on: <http://www.brics.utoronto.ca/docs/140715leaders.html>. Access: Oct. 17, 2015. point 18; UNIVERSITY OF TORONTO. VII BRICS summit: 2015 Ufa Declaration. Ufa, July 9, 2015. Available on: <http://www.brics.utoronto.ca/docs/150709ufa-declaration_en.html>. Access: Oct. 17, 2015. point 12. emergent countries that "continue to face significant financing constraints to address infrastructures gaps and sustainable development needs" 39 . Consequently, this institution can be seen as an attempt from the BRICS to gain support as well as to compel other countries to adopt the group's understandings, i.e. the critical perspective on the existing international financial/economic architecture.

Building on Nietzsche's philosophy of perspectivism as well as on the examples brought forward by this section, it can be affirmed that there is a BRICS perspective on international law. It could be identified in a first moment that the group has a particular approach towards the international arena, which can be differentiated from the ones adopted by its members. Moreover, it could be noticed that the BRICS expresses its interpretations not only via discursive means, such as diplomatic declarations, but also through actions, for example by creating the NDB, aiming at compelling and gaining support from other players. Nevertheless, it is not possible to have a clear image and understanding of how the BRICS perspective on international law looks like just by assessing the elements that form the idea of perspectivism. In order to discover this, it is necessary to dive into BRICS practice and to relate it to international law.

\section{INTERNATIONAL LAW THROUGH THE BRICS LENSES}

At a first glance it is difficult to dissociate the BRICS perspective on international relations from its perspective on international law. Nevertheless, aiming at verifying how the BRICS perceives international law, it is necessary to engage in a deeper analysis of the BRICS interpretation of the international system, especially by assessing how the group perceives the fundaments of today's international (legal) order.

In 1945, the United Nations Charter launched the basis for the international system of the post-World War II focusing on two main areas: maintenance of international peace and security and human rights. ${ }^{40}$ Since

39 UNIVERSITY OF TORONTO. The 6th BRICS summit: Fortaleza Declaration. Fortaleza, July 15, 2014. Available on: <http:// www.brics.utoronto.ca/docs/140715-leaders.html>. Access: Oct. 17, 2015. point 11 .

40 See for example Article 1 of the UN Charter. 
then these ideas have been influencing how different actors interpret international law. As a consequence, it seems relevant to verify how the BRICS addresses these topics in order to have a better idea of how it perceives international law. This is done in the first two subsections of this part. Moreover, as mentioned above, the BRICS has been concentrating its actions on a particular area of global governance, which is the economic/ financial architecture, consequently, in a third moment, it is investigated how the group approaches the area of international economic law, a very important pillar of the globalized world order.

\subsection{International peace and security}

The maintenance of international peace and security is the main objective of the United Nations (Article 1(1) of the UN Charter) and the Security Council is the organ with the primary, but not exclusive, ${ }^{41}$ responsibility to ensure that this goal is achieved (Article 24(1) of the UN Charter). According to the BRICS, the issue of international peace and security has to be assessed in accordance with its indivisible nature ${ }^{42}$ in the sense that the area of international peace and security does not only involve questions directly related to the threat or use of force by a state, but also a broader range of factors that might affect the sovereignty of a country, such as economic interference, terrorism etc. ${ }^{43}$ This approach can also be seen since the beginning of the 1990's in the practice of the UN Security Council and General Assembly that have expanded their interpretations of

41 In the Wall Opinion the International Court of Justice has stated based on Article 12 of the UN Charter that the General Assembly can deal in parallel with issues related to the question of international peace and security. See: Legal Consequences of the Construction of a Wall in the Occupied Palestinian Territory, Advisory Opinion, I. C. J. Reports 2004, p. 136, para. 27.

42 UNIVERSITY OF TORONTO. The 6th BRICS summit: Fortaleza Declaration. Fortaleza, July 15, 2014. Available on: <http:// www.brics.utoronto.ca/docs/140715-leaders.html>. Access: Oct. 17, 2015. point 27; UNIVERSITY OF TORONTO. VII BRICS summit: 2015 Ufa Declaration. Ufa, July 9, 2015. Available on: <http:// www.brics.utoronto.ca/docs/150709-ufa-declaration_en.html>. Access: Oct. 17, 2015. point 8 .

43 UNIVERSITY OF TORONTO. The 6th BRICS summit: Fortaleza Declaration. Fortaleza, July 15, 2014. Available on: <http:// www.brics.utoronto.ca/docs/140715-leaders.html>. Access: Oct. 17, 2015. point 27. See also: SALMON, Trevor. The nature of peace and security. In: MATHER, Alexander; BRYDEN, John (Ed.). Encyclopedia of life support systems, regional sustainable development. Paris: UNESCO, 2009. p. 259-276. p. 259. the term "threat to peace" present in the UN Charter. ${ }^{44}$

Moreover, according to the BRICS, the achievement of a sustainable peace ${ }^{45}$ is only possible if it is based on a "comprehensive, concerted and determined approach, based on mutual trust, mutual benefit, equity and cooperation" 46 , which has to rely on "generally recognized principles and rules of international law"47. For instance, the group structures its normative benchmark regarding the area of international peace and security on the UN Charter as well as on the UN Declaration on Principles of International Law concerning Friendly Relations and Cooperation among States in accordance with the Charter of the United Nations. ${ }^{48}$ The BRICS approach towards this fundament of the current international legal order bases on generally recognized principles and rules of international law and can be clearly noticed in the way the group has been dealing with the topics of terrorism ${ }^{49}$ and conflicts, such as in Syria, Afghanistan and Ukraine.

In the case of terrorism, the BRICS puts forward that the UN plays a key-role by acting as a coordinator of the efforts related to the fight against terrorism ${ }^{50}$ always in ac-

44 TALMON, Stefan. The security council as world legislature. The American Journal of International Law, v. 99, n. 1, p. 175-193, Jan. 2005. p. 181.

45 UNIVERSITY OF TORONTO. VII BRICS summit: 2015 Ufa Declaration. Ufa, July 9, 2015. Available on: <http://www.brics.utoronto.ca/docs/150709-ufa-declaration_en.html>. Access: Oct. 17, 2015. points 6-9.

46 UNIVERSITY OF TORONTO. VII BRICS summit: 2015 Ufa Declaration. Ufa, July 9, 2015. Available on: <http://www.brics.utoronto.ca/docs/150709-ufa-declaration_en.html>. Access: Oct. 17, 2015. point 9 .

47 UNIVERSITY OF TORONTO. VII BRICS summit: 2015 Ufa Declaration. Ufa, July 9, 2015. Available on: <http://www.brics.utoronto.ca/docs/150709-ufa-declaration_en.html>. Access: Oct. 17, 2015. point 6 .

48 UNIVERSITY OF TORONTO. BRICS and Africa: partnership for development, integration and industrialization, eThekwini Declaration. Durban, Mar. 27, 2013. Available on: <http://www. brics.utoronto.ca/docs/130327-statement.html>. Access: Oct. 17, 2015. point 21; UNIVERSITY OF TORONTO. The 6th BRICS summit: Fortaleza Declaration. Fortaleza, July 15, 2014. Available on: $<$ http://www.brics.utoronto.ca/docs/140715-leaders.html>. Access: Oct. 17, 2015. point 27; UNIVERSITY OF TORONTO. VII BRICS summit: 2015 Ufa Declaration. Ufa, July 9, 2015. Available on: <http://www.brics.utoronto.ca/docs/150709-ufa-declaration_ en.html>. Access: Oct. 17, 2015. point 6.

49 Since the first BRICS Summit in 2009, the topic of terrorism has always been addressed by the group.

50 UNIVERSITY OF TORONTO. Sanya Declaration. Sanya, Apr. 14, 2011. Available on: <http://www.brics.utoronto.ca/ docs/110414-leaders.html>. Access: Oct. 17, 2015. point 11; UNIVERSITY OF TORONTO. The 6th BRICS summit: Fortaleza Dec- 
cordance with principles and norms of international law, ${ }^{51}$ "including the UN Charter, international refugee and humanitarian law, human rights and fundamental freedoms" $"$. The same approach can be found when the group addresses conflict situations. The centrality of the UN has been affirmed since the first time the group has addressed a conflict, which was the situation in Libya..$^{53}$ Also the necessity to act within the limits set by international law, for example, respect for states sovereignty and territorial integrity ${ }^{54}$ are constantly mentioned by the group when addressing similar situations. Moreover, the BRICS has been highlighting the importance of national dialogue ${ }^{55}$ and "compliance with the UN Charter and universally recognized human rights and fundamental freedoms ${ }^{" 56}$ as necessary steps for the

laration. Fortaleza, July 15, 2014. Available on: <http://www.brics. utoronto.ca/docs/140715-leaders.html>. Access: Oct. 17, 2015. point 48 .

51 UNIVERSITY OF TORONTO. 2nd BRIC summit of heads of state and government: joint statement. Brasília, Apr. 15, 2010. Available on: <http://www.brics.utoronto.ca/docs/100415-leaders.html>. Access: Oct. 17, 2015. point 23; UNIVERSITY OF TORONTO. Fourth BRICS summit: Delhi Declaration. New Delhi, Mar. 29, 2012. Available on: <http://www.brics.utoronto.ca/docs/120329-delhideclaration.html>. Access: Oct. 17, 2015. point 25.

52 UNIVERSITY OF TORONTO. VII BRICS summit: 2015 Ufa Declaration. Ufa, July 9, 2015. Available on: <http://www.brics.utoronto.ca/docs/150709-ufa-declaration_en.html>. Access: Oct. 17, 2015. point 27 .

53 UNIVERSITY OF TORONTO. 2nd BRIC summit of heads of state and government: joint statement. Brasília, Apr. 15, 2010. Available on: <http://www.brics.utoronto.ca/docs/100415-leaders.html >. Access: Oct. 17, 2015. point 10.

54 E.g. in what regards the conflict in Syria: UNIVERSITY OF TORONTO. Fourth BRICS summit: Delhi Declaration. New Delhi, Mar. 29, 2012. Available on: <http://www.brics.utoronto.ca/ docs/120329-delhi-declaration.html>. Access: Oct. 17, 2015. point 21; UNIVERSITY OF TORONTO. BRICS and Africa: partnership for development, integration and industrialization, eThekwini Declaration. Durban, Mar. 27, 2013. Available on: <http://www. brics.utoronto.ca/docs/130327-statement.html>. Access: Oct. 17, 2015. point 26; UNIVERSITY OF TORONTO. The 6th BRICS summit: Fortaleza Declaration. Fortaleza, July 15, 2014. Available on: $<$ http://www.brics.utoronto.ca/docs/140715-leaders.html>. Access: Oct. 17, 2015. point 37.

55 UNIVERSITY OF TORONTO. Fourth BRICS summit: Delhi Declaration. New Delhi, Mar. 29, 2012. Available on: <http://www. brics.utoronto.ca/docs/120329-delhi-declaration.html>. Access: Oct. 17, 2015. point 21; UNIVERSITY OF TORONTO. BRICS and Africa: partnership for development, integration and industrialization, e'Thekwini Declaration. Durban, Mar. 27, 2013. Available on: <http://www.brics.utoronto.ca/docs/130327-statement.html>. Access: Oct. 17, 2015. points 26, 29, 30; Fortaleza Declaration, points 32, 37, 43, 44.

56 UNIVERSITY OF TORONTO. The 6th BRICS summit: Fortaleza Declaration. Fortaleza, July 15, 2014. Available on: <http:// www.brics.utoronto.ca/docs/140715-leaders.html>. Access: Oct. 17, 2015. point 44 . achievement of a sustainable peace in conflict situations. Furthermore, it is important to highlight that this approach is also applied to cases such as the Ukraine ${ }^{57}$ and Syria, ${ }^{58}$ which are highly sensitive for the BRICS members, especially Russia that is actively involved in both scenarios. This fact that the group follows its line also in issues that involve one of its members and not only in other cases such as Afghanistan ${ }^{59}$ shows the integrity of such approach.

Consequently, in the area of international peace and security it is possible to highlight that the BRICS has a broad understanding of what might be considered a threat to international peace and states' sovereignty, which embodies not only the use of force, but also other forms of coercion. Furthermore, the group puts forward the necessity to assess situations in this context based on generally recognized principles of international law.

\subsection{Human rights}

The respect for human rights is the other pillar of the post-World War II international system, which was laid-down by the UN Charter and afterwards confir-

57 UNIVERSITY OF TORONTO. The 6th BRICS summit: Fortaleza Declaration. Fortaleza, July 15, 2014. Available on: <http:// www.brics.utoronto.ca/docs/140715-leaders.html>. Access: Oct. 17, 2015. point 44; UNIVERSITY OF TORONTO. VII BRICS summit: 2015 Ufa Declaration. Ufa, July 9, 2015. Available on: <http:// www.brics.utoronto.ca/docs/150709-ufa-declaration_en.html>. Access: Oct. 17, 2015. point 43.

58 UNIVERSITY OF TORONTO. Fourth BRICS summit: Delhi Declaration. New Delhi, Mar. 29, 2012. Available on: < http://www. brics.utoronto.ca/docs/120329-delhi-declaration.html>. Access: Oct. 17, 2015. point 21; UNIVERSITY OF TORONTO. BRICS and Africa: partnership for development, integration and industrialization, eThekwini Declaration. Durban, Mar. 27, 2013. Available on: <http://www.brics.utoronto.ca/docs/130327-statement.html>. Access: Oct. 17, 2015. point 26; UNIVERSITY OF TORONTO. VII BRICS summit: 2015 Ufa Declaration. Ufa, July 9, 2015. Available on: <http://www.brics.utoronto.ca/docs/150709-ufa-declaration_en.html>. Access: Oct. 17, 2015.point 36.

59 UNIVERSITY OF TORONTO. Fourth BRICS summit: Delhi Declaration. New Delhi, Mar. 29, 2012. Available on: < http://www. brics.utoronto.ca/docs/120329-delhi-declaration.html>. Access: Oct. 17, 2015. point 23; UNIVERSITY OF TORONTO. BRICS and Africa: partnership for development, integration and industrialization, e'Thekwini Declaration. Durban, Mar. 27, 2013. Available on: <http://www.brics.utoronto.ca/docs/130327-statement.html>. Access: Oct. 17, 2015. point 29; UNIVERSITY OF TORONTO. The 6th BRICS summit: Fortaleza Declaration. Fortaleza, July 15, 2014. Available on: <http://www.brics.utoronto.ca/docs/140715leaders.html>. Access: Oct. 17, 2015. point 42; UNIVERSITY OF TORONTO. VII BRICS summit: 2015 Ufa Declaration. Ufa, July 9, 2015. Available on: <http://www.brics.utoronto.ca/docs/150709ufa-declaration_en.html>. Access: Oct. 17, 2015. point 42. 
med by the 1948 Universal Declaration on Human Rights. Since then, the international community has been working on the establishment of an international legal and institutional human rights framework, which according to the BRICS has as its cornerstone "the principle of equitable and mutually respectful cooperation of sovereign states" $"$. Besides that, the group puts forward that in order for states to protect, respect and fulfill their human rights obligations as well as "to treat all human rights, including the right to development, in a fair and equal manner, on the same footing and with the same emphasis" ${ }^{61}$, it is necessary that the human rights agenda is not politicized. ${ }^{62}$

In the area of human rights the BRICS devotes its attention to a particular topic, namely the (right to) development that is closely connected with the group's major focus, i.e. the financial/economic architecture of the international system. In this setting, the former UN Millennium Development Goals (MDG), which were replaced by the UN Sustainable Development Goals (SDG), are perceived by the group as a fundamental milestone reached by the international society in dealing with human rights. ${ }^{63}$ According to the BRICS, these goals can only be achieved by poor and developing nations by means of cooperation (technical, economical, etc.) for the establishment of policies aiming at developing in a sustainable way their economies without disregarding groups in need of social protection, ${ }^{64}$ as put forward by MDG number 8 and SDG numbers 16

60 UNIVERSITY OF TORONTO. VII BRICS summit: $2015 \mathrm{Ufa}$ Declaration. Ufa, July 9, 2015. Available on: < http://www.brics.utoronto.ca/docs/150709-ufa-declaration_en.html>. Access: Oct. 17, 2015. point 10 .

61 UNIVERSITY OF TORONTO. The 6th BRICS summit: Fortaleza Declaration. Fortaleza, July 15, 2014. Available on: <http:// www.brics.utoronto.ca/docs/140715-leaders.html>. Access: Oct. 17, 2015. point 28 .

62 UNIVERSITY OF TORONTO. The 6th BRICS summit: Fortaleza Declaration. Fortaleza, July 15, 2014. Available on: <http:// www.brics.utoronto.ca/docs/140715-leaders.html>. Access: Oct. 17, 2015. point 28; UNIVERSITY OF TORONTO. VII BRICS summit: 2015 Ufa Declaration. Ufa, July 9, 2015. Available on: < http:// www.brics.utoronto.ca/docs/150709-ufa-declaration_en.html>. Access: Oct. 17, 2015. point 10.

63 UNIVERSITY OF TORONTO. Fourth BRICS summit: Delhi Declaration. New Delhi, Mar. 29, 2012. Available on: <http://www. brics.utoronto.ca/docs/120329-delhi-declaration.html>. Access: Oct. 17, 2015. point 35 .

64 UNIVERSITY OF TORONTO. 2nd BRIC summit of heads of state and government: joint statement. Brasília, Apr. 15, 2010. Available on: <http://www.brics.utoronto.ca/docs/100415-leaders.html>. Access: Oct. 17, 2015. point 15. and $17,{ }^{65}$ as well as by the UN Charter (Articles 1(3), 55 and 56) and other international treaties, such as the International Covenant on Economic, Social and Cultural Rights (ICESCR). Moreover according to the group, sustainable growth has to be embedded not only in the MDG/SDG framework, but also has to be entrenched in other soft law documents, such as the Agenda 21 and Rio Principles on Sustainable Development, as well as in multilateral treaties. ${ }^{66}$

Furthermore, the BRICS structures its approach towards the interconnections between the areas of human rights, environmental law and economic law on the principle of common but differentiated responsibilities, ${ }^{67}$ which was put forward in the Rio Declaration on 1992 by merging the concepts of positive discrimination from Article 2 of the International Covenant on Economic, Social and Cultural Rights (ICESCR) with the preferential treatment of developing countries present on Article XVIII of the General Agreement on Tariffs and Trade (GATT). ${ }^{68}$ The principle of common but differentiated responsibilities addresses, among other issues, the necessity for international cooperation with

65 UNIVERSITY OF TORONTO. 2nd BRIC summit of heads of state and government: joint statement. Brasília, Apr. 15, 2010. Available on: <http://www.brics.utoronto.ca/docs/100415-leaders.html>. Access: Oct. 17, 2015. point 18; eThekwini Declaration, point 38; UNIVERSITY OF TORONTO. VII BRICS summit. 2015 Ufa Declaration. Ufa, July 9, 2015. Available on: <http://www.brics.utoronto.ca/docs/150709-ufa-declaration_en.html>. Access: Oct. 17, 2015. point 66 .

66 UNIVERSITY OF TORONTO. Joint statement of the BRIC countries' leaders. Yekaterinburg, June 16, 2009. Available on: <http:// www.brics.utoronto.ca/docs/090616-leaders.html>. Access: Oct. 17, 2015. point 7; UNIVERSITY OF TORONTO. Sanya Declaration. Sanya, Apr. 14, 2011. Available on: <http://www.brics.utoronto.ca/ docs/110414-leaders.html>. Access: Oct. 17, 2015. point 23; UNIVERSITY OF TORONTO. The 6th BRICS summit: Fortaleza Declaration. Fortaleza, July 15, 2014. Available on: <http://www.brics. utoronto.ca/docs/140715-leaders.html>. Access: Oct. 17, 2015. point 54.

67 UNIVERSITY OF TORONTO. Sanya Declaration. Sanya, Apr. 14, 2011. Available on: <http://www.brics.utoronto.ca/ docs/110414-leaders.html>. Access: Oct. 17, 2015. point 23; UNIVERSITY OF TORONTO. The 6th BRICS summit: Fortaleza Declaration. Fortaleza, July 15, 2014. Available on: <http://www.brics. utoronto.ca/docs/140715-leaders.html>. Access: Oct. 17, 2015. point 54; UNIVERSITY OF TORONTO. VII BRICS summit: 2015 Ufa Declaration. Ufa, July 9, 2015. Available on: <http://www.brics. utoronto.ca/docs/150709-ufa-declaration_en.html>. Access: Oct. 17, 2015. point 66 .

68 SCHRIJVER, Nico. The evolution of sustainable development in international law: inception, meaning and status. Leiden: M. Nijhoff, 2008. p. 178-184. 
the low-income countries (LIC), ${ }^{69}$ which base their economies in the revenue of commodities. ${ }^{70}$ Consequently, the BRICS built on this principle its strategy to address its responsibility towards LIC as well as to pressure the reform of the international financial/economic architecture that currently allows "volatility in food and other commodity prices" ${ }^{\text {"11 }}$, which are harmful to developing countries.

In short, it is possible to see that the BRICS concentrate its efforts concerning human rights issues on the question of cooperation with developing states based on the MDG/SDG framework as well as on the principle of common but differentiated responsibilities. Therefore, it is likely that the BRICS-sponsored NDB will play a significant role in the group's cooperation strategy for the support of developing and LIC countries to achieve the SDG. ${ }^{72}$ This focus on the topic of development might by some be seen as a contradiction to the BRICS aim of a non-politicized human rights agen$\mathrm{da}$, as development policies are decisively defined by a political choice. However, when analyzing the BRICS approach to the right to development, it becomes clear that it is understood rather as a right owned by states, which facilitates inter-state cooperation ${ }^{73}$ and contributes to creating a more equal world order. The BRICS does thus not attach great importance to human rights

69 UNIVERSITY OF TORONTO. BRICS and Africa: partnership for development, integration and industrialization, eThekwini Declaration. Durban, Mar. 27, 2013. Available on: <http://www. brics.utoronto.ca/docs/130327-statement.html>. Access: Oct. 17, 2015. point 38. See also the International Law Association New Delhi Declaration of Principles of International Law relating to Sustainable Development, circulated as UN Doc. A/57/329 (2002). 70 UNIVERSITY OF TORONTO. BRICS and Africa: partnership for development, integration and industrialization, eThekwini Declaration. Durban, Mar. 27, 2013. Available on: <http://www. brics.utoronto.ca/docs/130327-statement.html>. Access: Oct. 17, 2015. point 38 .

71 UNIVERSITY OF TORONTO. BRICS and Africa: partnership for development, integration and industrialization, eThekwini Declaration. Durban, Mar. 27, 2013. Available on: <http://www. brics.utoronto.ca/docs/130327-statement.html>. Access: Oct. 17, 2015. point 38 .

72 UNIVERSITY OF TORONTO. The 6th BRICS summit: Fortaleza Declaration. Fortaleza, July 15, 2014. Available on: <http:// www.brics.utoronto.ca/docs/140715-leaders.html>. Access: Oct. 17, 2015. point 11.

73 UNIVERSITY OF TORONTO. The 6th BRICS summit: Fortaleza Declaration. Fortaleza, July 15, 2014. Available on: <http:// www.brics.utoronto.ca/docs/140715-leaders.html>. Access: Oct. 17, 2015. point 28; UNIVERSITY OF TORONTO. VII BRICS summit: 2015 Ufa Declaration. Ufa, July 9, 2015. Available on: <http:// www.brics.utoronto.ca/docs/150709-ufa-declaration_en.html>. Access: Oct. 17, 2015. point 10. with a particular focus on the individual as this may expose states, including its members, to criticism and thus hamper the possibilities for cooperation between states. Centering its actions on inter-state cooperation allows the BRICS to use the human rights agenda, especially the right to development, as a way to strengthen its objectives with regard to the reform of the international economic system, which is seen as a major obstacle for the realization of such right for all nations.

\subsection{International economic law}

After analyzing the areas of international peace and security as well as human rights, it becomes relevant to scrutinize the way in which the BRICS approaches themes related to the field of international economic law, due to the fact that its main area of action is in the international system's financial/economic architecture. Moreover, since the group's first summit macroeconomic issues have been at the top of the BRICS' agenda and deliberations. ${ }^{74}$ Consequently, such analysis can contribute to specify how the BRICS perspective on international law looks like. In order to present in a clear way the group's posture towards such area of international law, this part is divided into two sections, one addressing regulatory issues related to commodity prices and international trade (a), while the second section tackles the BRICS main claim, the reform of the Bretton Woods institutions (b).

a. Commodity price regulation and international trade

As mentioned before, the BRICS understands that the volatility in commodity prices is a threat to developing countries and LIC as the stability of these prices is fundamental not only for the national economy of these states, but also for a well-functioning global economy. ${ }^{75}$ Moreover, taking into account the 2008 international economic crisis and the end of the commodities' supercycle, the BRICS, as in its approach regarding the

74 KIRTON, John. BRICS evolving institutional identity: explaining the brics summit's solid strengthening success. International Organizations Research Journal, v. 10, n. 2, p. 9-31, Jun. 2015. p. 14.

75 UNIVERSITY OF TORONTO. Sanya Declaration. Sanya, Apr. 14, 2011. Available on: <http://www.brics.utoronto.ca/ docs/110414-leaders.html>. Access: Oct. 17, 2015. point 17; UNIVERSITY OF TORONTO. Fourth BRICS summit: Delhi Declaration. New Delhi, Mar. 29, 2012. Available on: <http://www.brics. utoronto.ca/docs/120329-delhi-declaration.html>. Access: Oct. 17, 2015. point 38 . 
MDG/SDG, advocates for the strengthening of international cooperation among states envisaging improving the dialogue between producers and consumers' nations as well as to support developing countries. ${ }^{76}$ As a consequence of these actions, the BRICS, from a legal point of view, puts forward the necessity to improve regulations regarding commodity prices, for example in ensuring access to "reliable and timely information on demand and supply" "77 by countries in order to make international, regional and national markets more stable and less subject to recessions. ${ }^{78}$

A further element that the BRICS sees as fundamental to have a more stable market on commodities is a strong multilateral trading system coordinated and lead by the World Trade Organization (WTO) ${ }^{79}$ based on principles like inclusiveness, ${ }^{80}$ transparency, ${ }^{81}$ equal

76 UNIVERSITY OF TORONTO. 2nd BRIC summit of heads of state and government: joint statement. Brasília, Apr. 15, 2010. Available on: <http://www.brics.utoronto.ca/docs/100415-leaders.html>. Access: Oct. 17, 2015. point 13; Sanya Declaration, point 17; UNIVERSITY OF TORONTO. Fourth BRICS summit: Delhi Declaration. New Delhi, Mar. 29, 2012. Available on: <http://www.brics. utoronto.ca/docs/120329-delhi-declaration.html>. Access: Oct. 17, 2015. point 38 .

77 UNIVERSITY OF TORONTO. Sanya Declaration. Sanya, Apr. 14, 2011. Available on: <http://www.brics.utoronto.ca/ docs/110414-leaders.html>. Access: Oct. 17, 2015. point 17.

78 UNIVERSITY OF TORONTO. 2nd BRIC summit of heads of state and government: joint statement. Brasília, Apr. 15, 2010. Available on: <http://www.brics.utoronto.ca/docs/100415-leaders.html>. Access: Oct. 17, 2015. point 13; UNIVERSITY OF TORONTO. Sanya Declaration. Sanya, Apr. 14, 2011. Available on: <http://www. brics.utoronto.ca/docs/110414-leaders.html>. Access: Oct. 17, 2015. point 17; UNIVERSITY OF TORONTO. Fourth BRICS summit. Delhi Declaration. New Delhi, Mar. 29, 2012. Available on: $<$ http://www.brics.utoronto.ca/docs/120329-delhi-declaration. html>. Access: Oct. 17, 2015. point 38.

79 UNIVERSITY OF TORONTO. Joint statement of the BRIC countries' leaders. Yekaterinburg, June 16, 2009. Available on: < http:// www.brics.utoronto.ca/docs/090616-leaders.html>. Access: Oct. 17, 2015. point 5; UNIVERSITY OF TORONTO. 2nd BRIC summit of heads of state and government: joint statement. Brasília, Apr. 15, 2010. Available on: <http://www.brics.utoronto.ca/docs/100415leaders.html>. Access: Oct. 17, 2015.point 14; UNIVERSITY OF TORONTO. III BRICS summit: 2015 Ufa Declaration. Ufa, July 9, 2015. Available on: <http://www.brics.utoronto.ca/docs/150709ufa-declaration_en.html $>$. Access: Oct. 17, 2015. point 21.

80 UNIVERSITY OF TORONTO. 2nd BRIC summit of heads of state and government: joint statement. Brasília, Apr. 15, 2010. Available on: <http://www.brics.utoronto.ca/docs/100415-leaders.html>. Access: Oct. 17, 2015. point 14.

81 UNIVERSITY OF TORONTO. BRICS and Africa: partnership for development, integration and industrialization, eThekwini Declaration. Durban, Mar. 27, 2013. Available on: <http://www. brics.utoronto.ca/docs/130327-statement.html>. Access: Oct. 17, 2015. point 15 UNIVERSITY OF TORONTO. The 6th BRICS summit: Fortaleza Declaration. Fortaleza, July 15, 2014. Available on: opportunities, ${ }^{82}$ fair participation in global economy, financial and trade affairs ${ }^{83}$ and common but differentiated responsibilities. ${ }^{84}$ Consequently, international trade agreements establishing plurilateral initiatives that are not in consonance with such principles and do not seek for an inclusive and constructive outcome are disapproved by the group. ${ }^{85}$ Nevertheless, regional trade agreements that seek to make markets more open to trade and transparent in accordance with WTO rules are seen by the BRICS as an important asset to the multilateral trading system, ${ }^{86}$ where the WTO dispute settlement system is a "cornerstone of the security and predictability" 87 .

Therefore, in a nutshell, the BRICS pushes for a more inclusive international trade system based on multilateral organization, such as the W'TO. Also, the group advocates for more state-made regulations aiming at bringing certainty, transparency and stability to commodity prices and to international trade. ${ }^{88}$ For example, the

<http://www.brics.utoronto.ca/docs/140715-leaders.html>. Access: Oct. 17, 2015. point 21.

82 UNIVERSITY OF TORONTO. 2nd BRIC summit of heads of state and government: joint statement. Brasília, Apr. 15, 2010. Available on: <http://www.brics.utoronto.ca/docs/100415-leaders.html>. Access: Oct. 17, 2015. point 14; UNIVERSITY OF TORONTO. The 6th BRICS summit: Fortaleza Declaration. Fortaleza, July 15, 2014. Available on: <http://www.brics.utoronto.ca/docs/140715leaders.html>. Access: Oct. 17, 2015. point 21.

83 UNIVERSITY OF TORONTO. 2nd BRIC summit of heads of state and government: joint statement. Brasília, Apr. 15, 2010. Available on: $\quad<$ http://www.brics.utoronto.ca/docs/100415-leaders.html >. Access: Oct. 17, 2015. point 14; Fortaleza Declaration, point 21.

84 UNIVERSITY OF TORONTO. BRICS and Africa: partnership for development, integration and industrialization, eThekwini Declaration. Durban, Mar. 27, 2013. Available on: <http://www. brics.utoronto.ca/docs/130327-statement.html>. Access: Oct. 17, 2015.point 15; UNIVERSITY OF TORONTO. The 6th BRICS summit: Fortaleza Declaration. Fortaleza, July 15, 2014. Available on: $<$ http://www.brics.utoronto.ca/docs/140715-leaders.html>. Access: Oct. 17, 2015. point 21.

85 UNIVERSITY OF TORONTO. Fourth BRICS summit: Delhi Declaration. New Delhi, Mar. 29, 2012. Available on: < http://www. brics.utoronto.ca/docs/120329-delhi-declaration.html>. Access: Oct. 17, 2015. point 16 .

86 UNIVERSITY OF TORONTO. The 6th BRICS summit: Fortaleza Declaration. Fortaleza, July 15, 2014. Available on: <http:// www.brics.utoronto.ca/docs/140715-leaders.html>. Access: Oct. 17, 2015. point 21; UNIVERSITY OF TORONTO. VII BRICS summit: 2015 Ufa Declaration. Ufa, July 9, 2015. Available on: <http:// www.brics.utoronto.ca/docs/150709-ufa-declaration_en.html>. Access: Oct. 17, 2015. point 21.

87 UNIVERSITY OF TORONTO. The 6th BRICS summit: Fortaleza Declaration. Fortaleza, July 15, 2014. Available on: <http:// www.brics.utoronto.ca/docs/140715-leaders.html>. Access: Oct. 17, 2015. point 21.

88 For an analysis of the interrelations between the WTO system 
(quasi) confidential negotiations of the Transatlantic Trade and Investment Partnership (TTIP) between the United States and the European Union and the Trans-Pacific Partnership (TPP) between twelve countries, from a BRICS perspective, have to be qualified as non-transparent and non-inclusive process, which might undermine the central role of the WTO as a multilateral organization responsible for managing world commerce. $^{89}$

\section{b. Reform of the Bretton Woods institutions}

According to the BRICS, the international financial architecture, established in the aftermath of the World War II by the Bretton Woods institutions, i.e. the IMF and the WB, has as its main function the establishment and maintenance of a stable, predictable and integrated international monetary system..$^{90}$ Since its creation in $2009,{ }^{11}$ the group has been defending a reform of such institutions due to the fact that the structure of these institutions does not reflect the current state of affairs of the global economy, where emergent and developing countries play a significant role. ${ }^{92}$ Not living up to this reality contributes to an increase of the legitimacy deficit of these institutions. ${ }^{93}$ As a consequence, the BRICS

and regional trade agreements, see: CAPUCIO, Camilla. WTO and regionalism in the 21st century: strategy to impose normative models? Brazilian Journal of International Law, v. 12, n. 2, p. 337-347, Aug. 2014.

89 For a deeper analysis on the impacts of the TTIP and the TPP on the WTO system, see: HAUFBAUER, Gary C.; ISAACS, Cathleen. How will TTP and TTIP Change the WTO System? Journal of International Economic Law, v. 18, n. 3, p. 679-696, Aug. 2015.

90 UNIVERSITY OF TORONTO. Joint statement of the BRIC countries' leaders. Yekaterinburg, June 16, 2009. Available on: < http:// www.brics.utoronto.ca/docs/090616-leaders.html>. Access: Oct. 17, 2015. point 3; UNIVERSITY OF TORONTO. Fourth BRICS summit: Delhi Declaration. New Delhi, Mar. 29, 2012. Available on: $<$ http://www.brics.utoronto.ca/docs/120329-delhi-declaration. html>. Access: Oct. 17, 2015. point 8; UNIVERSITY OF TORONTO. BRICS and Africa: partnership for development, integration and industrialization, eThekwini Declaration. Durban, Mar. 27, 2013. Available on: <http://www.brics.utoronto.ca/docs/130327statement.html>. Access: Oct. 17, 2015. point 13.

91 UNIVERSITY OF TORONTO. Joint statement of the BRIC countries' leaders. Yekaterinburg, June 16, 2009. Available on: < http:// www.brics.utoronto.ca/docs/090616-leaders.html>. Access: Oct. 17, 2015. point 3.

92 UNIVERSITY OF TORONTO. 2nd BRIC summit of heads of state and government: joint statement. Brasília, Apr. 15, 2010. Available on: <http://www.brics.utoronto.ca/docs/100415-leaders.html>. Access: Oct. 17, 2015 point 11.

93 UNIVERSITY OF TORONTO. Joint statement of the BRIC countries' leaders. Yekaterinburg, June 16, 2009. Available on: < http:// www.brics.utoronto.ca/docs/090616-leaders.html>. Access: Oct. 17, 2015. point 3; UNIVERSITY OF TORONTO. Sanya Declaration. has advocated for the placement of negotiations regarding global economic governance and macroeconomic policies in the G-20 that is a more inclusive and representative arena than the IMF and the WB. ${ }^{94}$

As a consequence of this plea for more inclusiveness in the international financial architecture, the BRICS puts forwards that a reform of those institutions has to be structured upon four pillars. ${ }^{95}$ The first one is democratic and transparent decision-making given the current lack of legitimacy and representation of the Bretton Woods institutions. ${ }^{96}$ The second pillar is a solid legal basis, instead of self-regulations and soft law instruments to regulate the financial market, aiming at ensuring more stability and predictability. ${ }^{97}$ The strengthening of risk management and supervisory practices as well as the coordination between national and international regulatory institutions represent the other two pillars of the groups' framework for the reform of the IMF and the WB. ${ }^{98}$

Based on these ideas, the BRICS advocates that a plan of reform of the Bretton Woods institutions "requires first and foremost a substantial shift in voting participation in decision making" 99 in order for them

Sanya, Apr. 14, 2011. Available on: <http://www.brics.utoronto.ca/ docs/110414-leaders.html>. Access: Oct. 17, 2015. point 15.

94 UNIVERSITY OF TORONTO. Sanya Declaration. Sanya, Apr. 14, 2011. Available on: <http://www.brics.utoronto.ca/ docs/110414-leaders.html>. Access: Oct. 17, 2015. point 14; UNIVERSITY OF TORONTO. Fourth BRICS summit: Delhi Declaration. New Delhi, Mar. 29, 2012. Available on: <http://www.brics. utoronto.ca/docs/120329-delhi-declaration.html>. Access: Oct. 17, 2015. point 7 .

95 UNIVERSITY OF TORONTO. Joint statement of the BRIC countries' leaders. Yekaterinburg, June 16, 2009. Available on: < http:// www.brics.utoronto.ca/docs/090616-leaders.html>. Access: Oct. 17, 2015. point 4 .

96 UNIVERSITY OF TORONTO. Joint statement of the BRIC countries' leaders. Yekaterinburg, June 16, 2009. Available on: < http:// www.brics.utoronto.ca/docs/090616-leaders.html>. Access: Oct. 17, 2015. point 4; Brasília Statement, point 11.

97 UNIVERSITY OF TORONTO. Joint statement of the BRIC countries' leaders. Yekaterinburg, June 16, 2009. Available on: <http:// www.brics.utoronto.ca/docs/090616-leaders.html>. Access: Oct. 17, 2015. point 4; UNIVERSITY OF TORONTO. 2nd BRIC summit of heads of state and government: joint statement. Brasilia, Apr. 15, 2010. Available on: <http://www.brics.utoronto.ca/docs/100415-leaders. html>. Access: Oct. 17, 2015. point 13.

98 UNIVERSITY OF TORONTO. Joint statement of the BRIC countries' leaders. Yekaterinburg, June 16, 2009. Available on: <http:// www.brics.utoronto.ca/docs/090616-leaders.html>. Access: Oct. 17, 2015. point 4 .

99 UNIVERSITY OF TORONTO. 2nd BRIC summit of heads of state and government: joint statement. Brasília, Apr. 15, 2010. Available on: <http://www.brics.utoronto.ca/docs/100415-leaders.html $>$. 
to reflect the global economy scenario in a better way. According to the BRICS, this initial movement will foster transparency and allow countries that are nowadays underrepresented (e.g. emergent economies, developing and African Sub-Saharan states) to play a greater role in the IMF and the WB and make their voice heard in these forums. ${ }^{100}$ Nevertheless, it is important to mention that the BRICS proposal does not advocate for the abolishment of the quota system upon which these institutions are structured. ${ }^{101}$

So far, the reform process of the IMF and the WB has been perceived by the group as deeply disappointing ${ }^{102}$ and risking to "fade into obsolescence"103. Consequently, the BRICS sponsored the New Development Bank has to be interpreted as an institution set to complement the structures of the financial architecture, which until now could not be reformed in order to be more inclusive, democratic and representative. This means, as put forward by the group, that the NDB aims at helping emergent economies and developing countries to over-

Access: Oct. 17, 2015. point 11.

100 UNIVERSITY OF TORONTO. Joint statement of the BRIC countries' leaders. Yekaterinburg, June 16, 2009. Available on: <http:// www.brics.utoronto.ca/docs/090616-leaders.html>. Access: Oct. 17, 2015. point 3; UNIVERSITY OF TORONTO. Fourth BRICS summit: Delhi Declaration. New Delhi, Mar. 29, 2012. Available on: $<$ http://www.brics.utoronto.ca/docs/120329-delhi-declaration. html>. Access: Oct. 17, 2015. point 8; UNIVERSITY OF TORONTO. BRICS and Africa: partnership for development, integration and industrialization, eThekwini Declaration. Durban, Mar. 27, 2013. Available on: <http://www.brics.utoronto.ca/docs/130327statement.html>. Access: Oct. 17, 2015. point 13.

101 UNIVERSITY OF TORONTO. The 6th BRICS summit: Fortaleza Declaration. Fortaleza, July 15, 2014. Available on: <http:// www.brics.utoronto.ca/docs/140715-leaders.html>. Access: Oct. 17, 2015. point 18 .

102 UNIVERSITY OF TORONTO. VII BRICS summit: 2015 Ufa Declaration. Ufa, July 9, 2015. Available on: < http://www. brics.utoronto.ca/docs/150709-ufa-declaration_en.html>. Access: Oct. 17, 2015. point 19. See also: UNIVERSITY OF TORONTO. Fourth BRICS summit: Delhi Declaration. New Delhi, Mar. 29, 2012. Available on: <http://www.brics.utoronto.ca/docs/120329-delhideclaration.html>. Access: Oct. 17, 2015. point 9; UNIVERSITY OF TORONTO. BRICS and Africa: partnership for development, integration and industrialization, eThekwini Declaration. Durban, Mar. 27, 2013. Available on: <http://www.brics.utoronto.ca/ docs/130327-statement.html>. Access: Oct. 17, 2015. point 13; UNIVERSITY OF TORONTO. The 6th BRICS summit: Fortaleza Declaration. Fortaleza, July 15, 2014. Available on: <http://www. brics.utoronto.ca/docs/140715-leaders.html>. Access: Oct. 17, 2015. point 18 .

103 UNIVERSITY OF TORONTO. 2nd BRIC summit of heads of state and government: joint statement. Brasília, Apr. 15, 2010. Available on: <http://www.brics.utoronto.ca/docs/100415-leaders.html>. Access: Oct. 17, 2015. point 11. come the constraints imposed by the current international financial architecture that block the realization of investments in the area of infrastructure necessary to achieve a sustainable pattern of development. ${ }^{104}$

\section{THE STRUCTURE OF THE BRICS PERSPECTIVE ON INTERNATIONAL LAW}

After analyzing how the BRICS perceives and deals with different fields of international law, this section identifies the structures of the BRICS perspective on international law. It is divided into three parts aiming at covering, from a BRICS point of view, the international legalization process as well as the role of states, international organizations and individuals in international law.

\subsection{International law as the product of multila- teral and non-confrontational consensus buil- ding}

The reading of the BRICS documents through the lenses of international peace and security, human rights and international economic law appoints to a framework upon which the BRICS perspective on international law is structured. The first characteristic of this approach is the reliance by the BRICS on multilateral international organizations, such as the UN and the WTO. According to the group, these organizations that allow states to undertake multilateral negotiations on global problems with actors from different backgrounds should have a central place in the global governance structure. ${ }^{105}$

104 UNIVERSITY OF TORONTO. The 6th BRICS summit: Fortaleza Declaration. Fortaleza, July 15, 2014. Available on: <http:// www.brics.utoronto.ca/docs/140715-leaders.html>. Access: Oct. 17, 2015. point 11 .

105 UNIVERSITY OF TORONTO. Sanya Declaration. Sanya, Apr. 14, 2011. Available on: <http://www.brics.utoronto.ca/ docs/110414-leaders.html>. Access: Oct. 17, 2015. point 8; UNIVERSITY OF TORONTO. Fourth BRICS summit: Delhi Declaration. New Delhi, Mar. 29, 2012. Available on: <http://www.brics. utoronto.ca/docs/120329-delhi-declaration.html>. Access: Oct. 17, 2015. point 7; UNIVERSITY OF TORONTO. BRICS and Africa: partnership for development, integration and industrialization, eThekwini Declaration. Durban, Mar. 27, 2013. Available on: <http://www.brics.utoronto.ca/docs/130327-statement.html>. Access: Oct. 17, 2015. point 20; UNIVERSITY OF TORONTO. The 6th BRICS summit: Fortaleza Declaration. Fortaleza, July 15, 2014. Available on: <http://www.brics.utoronto.ca/docs/140715leaders.html>. Access: Oct. 17, 2015. points 5, 10, 25. 
From a BRICS perspective on international law, the reasons why decisions should be adopted in multilateral settings is related to the fact that they are more inclusive and democratic institutions in which developing countries have more space for action than in other organizations that currently suffer from a legitimacy deficit, such as the IMF. ${ }^{106}$ The roots of such plea can be found in the Declaration on the Establishment of a New International Economic Order, which already in the 1970's proposed a "full and effective participation on the basis of equality of all countries in the solving of world economic problems in the common interest of all"107. Moreover, this understanding was shared by the Report of the Commission of Experts of the President of the United Nations General Assembly on Reforms of the International Monetary and Financial System presented in the year of the first BRICS Summit, which attested the non-democratic nature of the global financial/economic architecture, especially the IMF and the WB, and proposed to give "a greater voice for developing countries" 108 , something that is possible in multilateral organizations, such as the UN and the WTO.

In this search for the achievement of a common ground among the different players, which might take conflicting positions in multilateral settings, a BRICS perspective suggests the use of a non-confrontational approach based on consensus and open to all the members of the international community without any kind of distinction. ${ }^{109}$ This means,

106 UNIVERSITY OF TORONTO. 2nd BRIC summit of heads of state and government: joint statement. Brasília, Apr. 15, 2010. Available on: <http://www.brics.utoronto.ca/docs/100415-leaders.html>. Access: Oct. 17, 2015. point 11; UNIVERSITY OF TORONTO. Fourth BRICS summit: Delhi Declaration. New Delhi, Mar. 29, 2012. Available on: <http://www.brics.utoronto.ca/docs/120329-delhideclaration.html>. Access: Oct. 17, 2015. point 9; UNIVERSITY OF TORONTO. BRICS and Africa: partnership for development, integration and industrialization, eThekwini Declaration. Durban, Mar. 27, 2013. Available on: <http://www.brics.utoronto.ca/ docs/130327-statement.html>. Access: Oct. 17, 2015. point 18; UNIVERSITY OF TORONTO. VII BRICS summit: 2015 Ufa Declaration. Ufa, July 9, 2015. Available on: <http://www.brics.utoronto.ca/docs/150709-ufa-declaration_en.html>. Access: Oct. 17, 2015.point 18 .

107 UNITED NATIONS. General Assembly. Declaration on the establishment of a new international economic order. New York: UN, May 1974 Available in: <http://www.un-documents.net/s6r3201.htm>. Access: Fev. 05, 2016. para. 4 (c).

108 UNITED NATIONS. General Assembly. Report of the commission of experts of the president of the United Nations General Assembly on reforms of the international monetary and financial system. New York: UN, 21 Sept. 2009. Available on: <http://www.un.org/ga/econcrisissummit/docs/FinalReport_CoE.pdf>. Access: 17 Oct. 2015.

109 UNIVERSITY OF TORONTO. Sanya Declaration. Sanya, if the adoption of a decision might raise a conflict among the participants, it is preferable not to approve it. Consequently, it is possible to identify the role played by several principles such as horizontality, pragmatism and collective decision-making underlined by such non-confrontational approach, i.e. unanimous decisions, which also guide the BRICS countries when they are deliberating within the group. ${ }^{110}$

For instance, one of the most sensible topics within the BRICS, the reform of the UN system, shows the importance and respect of the non-confrontational approach within the group. When the wide-open and expressive support given by the group to the admission of Russia as a member of the World Trade Organization ${ }^{111}$ is compared with the encouragement regarding the reform of the UN, particularly the Security Council, it is rather modest and cannot be explicitly found in any of the BRICS declarations. Until now, the BRICS just agreed to support the aspirations of Brazil, India and South Africa "to play a greater role" in the organization. ${ }^{112}$ Thus, these countries defending the reform of

Apr. 14, 2011. Available on: <http://www.brics.utoronto.ca/ docs/110414-leaders.html>. Access: Oct. 17, 2015. point 6.

110 UNIVERSITY OF TORONTO. Sanya Declaration. Sanya, Apr. 14, 2011. Available on: <http://www.brics.utoronto.ca/ docs/110414-leaders.html>. Access: Oct. 17, 2015. point 6.

111 UNIVERSITY OF TORONTO. 2nd BRIC summit of heads of state and government: joint statement. Brasília, Apr. 15, 2010. Available on: <http://www.brics.utoronto.ca/docs/100415-leaders.html>. Access: Oct. 17, 2015. point 14; UNIVERSITY OF TORONTO. Sanya Declaration. Sanya, Apr. 14, 2011. Available on: <http://www. brics.utoronto.ca/docs/110414-leaders.html>. Access: Oct. 17, 2015. point 26; UNIVERSITY OF TORONTO. Fourth BRICS summit: Delhi Declaration. New Delhi, Mar. 29, 2012. Available on: $<$ http://www.brics.utoronto.ca/docs/120329-delhi-declaration. html>. Access: Oct. 17, 2015. point 15. The Russian Federation is a WTO member since 2012.

112 UNIVERSITY OF TORONTO. Joint statement of the BRIC countries' leaders. Yekaterinburg, June 16, 2009. Available on: < http:// www.brics.utoronto.ca/docs/090616-leaders.html>. Access: Oct. 17, 2015. point 14; UNIVERSITY OF TORONTO. 2nd BRIC summit of heads of state and government: joint statement. Brasília, Apr. 15, 2010. Available on: <http://www.brics.utoronto.ca/docs/100415leaders.html>. Access: Oct. 17, 2015. point 4; UNIVERSITY OF TORONTO. Sanya Declaration. Sanya, Apr. 14, 2011. Available on: $<$ http://www.brics.utoronto.ca/docs/110414-leaders.html>. Access: Oct. 17, 2015. point 8; UNIVERSITY OF TORONTO. Fourth BRICS summit: Delhi Declaration. New Delhi, Mar. 29, 2012. Available on: <http://www.brics.utoronto.ca/docs/120329-delhideclaration.html>. Access: Oct. 17, 2015. point 26; UNIVERSITY OF TORONTO. BRICS and Africa: partnership for development, integration and industrialization, eThekwini Declaration. Durban, Mar. 27, 2013. Available on: <http://www.brics.utoronto.ca/ docs/130327-statement.html>. Access: Oct. 17, 2015. point10; UNIVERSITY OF TORONTO. The 6th BRICS summit: Fortaleza 
the Security Council aiming at making it more culturally and geographically representative are looking for other forums to discuss this topic, for example, the Group of Four (G-4), which is formed by Brazil, Germany, India and Japan.

Hence, it can be put forward that the harmony and common understanding among state actors about international law as well as "the need for universal adherence to principles and rules of international law in their interrelation and integrity, discarding the resort to 'double standards' and avoiding placing interests of some countries above others" ${ }^{\prime 13}$ represents the basis of the BRICS perspective on international law. Departing from this baseline, the BRICS approaches questions related to the issues of legal bindingness and precision, which can be perceived in the way that the group relates to the fields of international economic law (pleas for more specific regulations) and international peace and security (reliance on general principles of international law).

\subsection{Legal bindingness and precision as a conse- quence of a multilateral consensus building}

When approaching the area of international economic law, the BRICS advocates for more international regulations based on a determined set of underlying principles in order to replace soft law agreements or self-regulatory initiatives aiming at achieving more certainty, predictability and stability in the system. ${ }^{114}$ However, the same reasoning does not hold true when consensus is not present within the BRICS, as in the case of questions regarding international peace and security. As a consequence, the BRICS perspective pushes for a

Declaration. Fortaleza, July 15, 2014. Available on: <http://www. brics.utoronto.ca/docs/140715-leaders.html>. Access: Oct. 17, 2015. point 25 .

113 UNIVERSITY OF TORONTO. VII BRICS summit: 2015 Ufa Declaration. Ufa, July 9, 2015. Available on: <http://www.brics. utoronto.ca/docs/150709-ufa-declaration_en.html>. Access: Oct. 17, 2015. point 6 .

114 UNIVERSITY OF TORONTO. Joint statement of the BRIC countries' leaders. Yekaterinburg, June 16, 2009. Available on: <http:// www.brics.utoronto.ca/docs/090616-leaders.html>. Access: Oct. 17, 2015. point 3; UNIVERSITY OF TORONTO. Fourth BRICS summit: Delhi Declaration. New Delhi, Mar. 29, 2012. Available on: <http://www.brics.utoronto.ca/docs/120329-delhi-declaration. html>. Access: Oct. 17, 2015. point 8; UNIVERSITY OF TORONTO. BRICS and Africa: partnership for development, integration and industrialization, eThekwini Declaration. Durban, Mar. 27, 2013. Available on: <http://www.brics.utoronto.ca/docs/130327statement.html>. Access: Oct. 17, 2015. point 13. more flexible and vague approach towards international law by referring to concepts such as general principles of international law that allow a greater room for maneuver to states to use diplomatic arrangements. ${ }^{115}$

Yet, the BRICS approach to the international legalization cannot be understood through the binary division between hard/specific vs. soft/vague international law, as the group's perspective on international law and issues regarding normativity, especially the degrees of legal bindingness and precision are a "question of more or less". ${ }^{116}$ This means, according to a BRICS perspective the process of legalization is determined by the relations between international politics and international law, in the sense that the first limits the second's autonomy, while the latter gives sense to the former. ${ }^{117}$ Consequently, it is during the consensus-building process, which is embedded in the field of international politics, where different players by engaging themselves in a common discursive setting end-up by shaping the normative outcome, i.e. the levels of bindingness (hard or soft) and precision of the norm aiming at giving sense and legitimacy to their actions. ${ }^{118}$ Nevertheless, it is important to detach the notions of bindingness and precision. Although it is possible to perceive in the BRICS

115 UNIVERSITY OF TORONTO. Joint statement of the BRIC countries' leaders. Yekaterinburg, June 16, 2009. Available on: < http:// www.brics.utoronto.ca/docs/090616-leaders.html>. Access: Oct. 17, 2015. point 12; UNIVERSITY OF TORONTO. 2nd BRIC summit of heads of state and government: joint statement. Brasília, Apr. 15, 2010. Available on: <http://www.brics.utoronto.ca/docs/100415leaders.html>. Access: Oct. 17, 2015. point 2; UNIVERSITY OF TORONTO. Sanya Declaration. Sanya, Apr. 14, 2011. Available on: $<$ http://www.brics.utoronto.ca/docs/110414-leaders.html>. Access: Oct. 17, 2015. points 7, 11; UNIVERSITY OF TORONTO. Fourth BRICS summit: Delhi Declaration. New Delhi, Mar. 29, 2012. Available on: <http://www.brics.utoronto.ca/docs/120329-delhideclaration.html>. Access: Oct. 17, 2015. points 4, 25; UNIVERSITY OF TORONTO. BRICS and Africa: Partnership for development, integration and industrialization, eThekwini Declaration. Durban, Mar. 27, 2013. Available on: <http://www.brics.utoronto. ca/docs/130327-statement.html>. Access: Oct. 17, 2015. points 1, 21; UNIVERSITY OF TORONTO. The 6th BRICS summit: Fortaleza Declaration. Fortaleza, July 15, 2014. Available on: <http:// www.brics.utoronto.ca/docs/140715-leaders.html>. Access: Oct. 17, 2015. points 2, 27.

116 WEIL, Prosper. Towards relative normativity in international law? The American Journal of International Law, v. 77, n. 3, p. 413-442, Jul. 1983. p. 421.

117 ABBOT, Kenneth; SINDAL, Duncan. Hard and soft law in international governance. International Organization, v. 53, n. 3, p. 421 453, Jun. 2000. p. 455.

118 RISSE, Thomas; ROPP, Stephen; SIKKINK, Kathrin. The persistent power of human rights: from commitment to compliance. Cambridge: Cambridge University, 2013. p. 6. 
practice the use of vague expressions, such as general principles of international law, this does not mean that these terms have a low level of bindingness, as is the case with the principle of self-determination, which is a general principle of international law with an erga omnes character. ${ }^{119}$

Consequently, it can be noticed that the BRICS perspective on international law reflects the group's consensus building process, which is centered on the non-confrontational character aiming at granting plenty of space for the states involved. Therefore, it is possible to affirm that the levels of legal precision, which might be seen as constraints of states' actions, are intrinsically related to the degree of consensus among the participants.

\subsection{The State as the measure of all things}

Another characteristic of the BRICS perspective on international law, even though recognizing the importance of multilateral organization, ${ }^{120}$ is the preference for a Westphalian approach, ${ }^{121}$ which centers all the debates and actions regarding the discipline in one of its players, the state, and in the ideas correlated to it, such as sovereignty, states' equality and non-intervention. ${ }^{122}$

119 East Timor (Portugal v. Australia), Judgment, I. C. J. Reports 1995, p. 90. para. 29. See also: Legal Consequences of the Construction of a Wall in the Occupied Palestinian Territory, Advisory Opinion, I. C. J. Reports 2004, p. 136. para. 87.

120 UNIVERSITY OF TORONTO. Sanya Declaration. Sanya, Apr. 14, 2011. Available on: <http://www.brics.utoronto.ca/ docs/110414-leaders.html>. Access: Oct. 17, 2015. point 8; UNIVERSITY OF TORONTO. Fourth BRICS summit: Delhi Declaration. New Delhi, Mar. 29, 2012. Available on: <http://www.brics. utoronto.ca/docs/120329-delhi-declaration.html>. Access: Oct. 17, 2015. point 7; UNIVERSITY OF TORONTO. BRICS and Africa: partnership for development, integration and industrialization, eThekwini Declaration. Durban, Mar. 27, 2013. Available on: <http://www.brics.utoronto.ca/docs/130327-statement.html>. Access: Oct. 17, 2015. point 20; UNIVERSITY OF TORONTO. The 6th BRICS summit: Fortaleza Declaration. Fortaleza, July 15, 2014. Available on: <http://www.brics.utoronto.ca/docs/140715leaders.html>. Access: Oct. 17, 2015. points 5, 10, 25.

121 GROTE, Rainer. Westphalian System. Max Planck Encyclopedia of Public International Law. Oxford: Oxford University, 2006.

122 UNIVERSITY OF TORONTO. Fourth BRICS summit: Delhi Declaration. New Delhi, Mar. 29, 2012. Available on: <http://www. brics.utoronto.ca/docs/120329-delhi-declaration.html>. Access: Oct. 17, 2015. point 21; UNIVERSITY OF TORONTO. BRICS and Africa: partnership for development, integration and industrialization, eThekwini Declaration. Durban, Mar. 27, 2013. Available on: <http://www.brics.utoronto.ca/docs/130327-statement.html>. Access: Oct. 17, 2015. point 26; UNIVERSITY OF TORONTO.
Consequently, the international arena, in the group's view, should be a space where its main actors, the states, can have plenty of space and few limits to implement their maneuvers. Therefore, states' interests, which are shaped through the consensus-building process via international politics, play a determining role in limiting the functions of multilateral organizations.

The importance of international law as a shaping factor of states' interests in such context has already been put forward by Virally. ${ }^{123}$ According to him, the manifestations of states' sovereignty in the domain of international organizations are a decisive factor in defining not only the functional limits, but also the practice of these institutions. ${ }^{124}$ This idea can be perceived in the BRICS perspective on international law, when the group puts forward its views and proposals regarding the reform of the Bretton Woods institutions, tackling not only their structure and aiming at granting more representation to emergent economies and developing countries, ${ }^{125}$ but also their practices, such as in the selection process of their heads and executives. ${ }^{126}$

Besides, it is also important to mention that individuals do not play a relevant role in the BRICS perspective on international law, even though their protection via the framework of international human rights law is one of the pillars of the international legal system. ${ }^{127}$ Moreover, according to the group's perspective, the international human rights framework has to be seen through the lenses of "the

The 6th BRICS summit: Fortaleza Declaration. Fortaleza, July 15, 2014. Available on: <http://www.brics.utoronto.ca/docs/140715leaders.html>. Access: Oct. 17, 2015. point 37.

123 VIRALLY, Michel. La notion de fonction dans la théorie de l'organisation internationale. In: ___. Le droit international en devenir: essais écrits au fil des ans. Paris: Universitaires de France, 1990. p. $277-300$.

124 VIRALLY, Michel. La notion de fonction dans la théorie de l'organisation internationale. In: ___. Le droit international en devenir: essais écrits au fil des ans. Paris: Universitaires de France, 1990. p. 277-300. See also: SCHERMERS, Henry G.; BLOKKER, Niels M. International institutional law. Leiden: M. Nijhoff, 2011. p. 17-22.

125 See, for example: UNIVERSITY OF TORONTO. The 6 th BRICS summit: Fortaleza Declaration. Fortaleza, July 15, 2014. Available on: <http://www.brics.utoronto.ca/docs/140715-leaders. html>. Access: Oct. 17, 2015. point 18.

126 UNIVERSITY OF TORONTO. Joint statement of the BRIC countries' leaders. Yekaterinburg, June 16, 2009. Available on: <http:// www.brics.utoronto.ca/docs/090616-leaders.html>. Access: Oct. 17, 2015. point 3 .

127 UN Charter, Articles 1 and 55. See also: MERON, Theodor. International law in the age of human rights: general Course on public international law. Leiden: Hague Academy of International Law, 2004. p. $9-403$. 
principle of equitable and mutually respectful cooperation of sovereign states" ${ }^{\prime 28}$, which contrasts with the idea established at the international level that such rights "are not a web of inter-State exchanges of mutual obligations, [but] endowment of individuals" ${ }^{\prime 29}$. Furthermore, even though recognizing the interconnection and interdependence of all human rights, ${ }^{130}$ the BRICS mainly focus its attentions on the right to development, which in its perspective can be understood more as a right owned by states rather than by individuals as put forward by the UN Declaration on the Right to Development.

Moreover, from the BRICS Summits' documents it is possible to perceive that in the few mentions in which the group deals with individuals living on their territories, it bases its approach on the concept of people-to-people contact (or connectivity). ${ }^{131}$ This expression is restrictively used to express the group's aim to foster the cooperation within itself in the areas of education and culture. In order to bolster the people-to-people connectivity, the group has signed during the Ufa Summit an international treaty that has as one of its goals to facilitate the rapprochement of BRICS' peoples via inter-state cooperation. ${ }^{132}$

Therefore, it is possible to affirm that a BRICS perspective on international law is structured and shaped

128 UNIVERSITY OF TORONTO. VII BRICS summit: 2015 Ufa Declaration. Ufa, July 9, 2015. Available on: <http:/ /www.brics. utoronto.ca/docs/150709-ufa-declaration_en.html>. Access: Oct. 17, 2015. point 10 .

129 UNITED NATIONS. Human Rights Committee, General Comment 24 (52), General comment on issues relating to reservations made upon ratification or accession to the Covenant or the Optional Protocols thereto, or in relation to declarations under article 41 of the Covenant, U.N. Doc. CCPR/C/21/Rev.1/Add.6 (1994). Minneapolis: University of Minnesota, 2004. Available in: <https://www1.umn.edu/humants/ gencomm/hrcom24.htm>. Access: Fev. 05, 2016 para. 17.

130 UNIVERSITY OF TORONTO. The 6th BRICS summit: Fortaleza Declaration. Fortaleza, July 15, 2014. Available on: <http:// www.brics.utoronto.ca/docs/140715-leaders.html>. Access: Oct. 17, 2015. point 28.

131 UNIVERSITY OF TORONTO. Fourth BRICS summit: Delhi Declaration. New Delhi, Mar. 29, 2012. Available on: <http:// www.brics.utoronto.ca/docs/120329-delhi-declaration.html>. Access: Oct. 17, 2015. point 40; UNIVERSITY OF TORONTO. The 6th BRICS summit: Fortaleza Declaration. Fortaleza, July 15, 2014. Available on: <http://www.brics.utoronto.ca/docs/140715-leaders. html>. Access: Oct. 17, 2015. point 56; UNIVERSITY OF TORONTO. VII BRICS summit: 2015 Ufa Declaration. Ufa, July 9, 2015. Available on: <http://www.brics.utoronto.ca/docs/150709ufa-declaration_en.html >. Access: Oct. 17, 2015. point 56.

132 UNIVERSITY OF TORONTO. Agreement between the governments of the BRICS states on cooperation in the field of culture. Ufassia, July 9, 2015. Available on: <http://www.brics.utoronto.ca/ docs/150709-culture-agreement-en.html>. Access: Oct. 17, 2015. by the continuous interactions between the fields of international relations, represented by the consensus-building process, and international law, which is used to give form to the commitments. Moreover, the idea of state sovereignty with all its manifestations, such as the notions of non-intervention and horizontality in states' relations, play a significant role for the group's perspective. As a consequence, the BRICS approaches towards different areas of international law vary in accordance with the consensus-building processes in multilateral organizations, but always share as a "lowest common denominator" a state-centrist character.

\section{Final considerations}

Nowadays the BRICS are a key-actor in the international scenario and the levels of cooperation and institutionalization within the group are increasing each year. Therefore, this paper had as its goals to identify whether there is a BRICS perspective on international law and how it is structured. After all, it is possible to conclude that there is a BRICS' perspective on international law.

As a product of its time, which is still in its very early stages, the BRICS can be seen as an actor embodied with the aim to change the world order, which uses international law either as a way to legitimize its discourse when pleading for a more inclusive international financial/economic architecture or to consolidate its achievements, as in the case of the agreement establishing the NDB. Moreover, the BRICS prioritize an international law that can be seen as the outcome of the consensus-building process held at multilateral organizations, which at the same time grants plenty of space for states to participate as well as to make their objections. Therefore, the BRICS perspective relies on a strong state-centrist approach towards the most different areas of international law, including the ones commonly characterized as centered in the individual, such as the field of human rights.

\section{References}

ABBOT, Kenneth; SINDAL, Duncan. Hard and soft law in international governance. International Organization, v. 53, n. 3, p. 421-453, Jun. 2000. 
BRAGA, Erika. Um panorama sobre as negociações do Pacote de Bali e os seus desdobramentos no âmbito da OMC. Brazilian Journal of International Law. v. 12, n. 2, p. 16-20, dez. 2014.

CAPUCIO, Camilla. WTO and regionalism in the 21 st century: strategy to impose normative models? Brazilian Journal of International Law, v. 12, n. 2, p. 337-347, Aug. 2014.

COOPER, Andrew; FAROOQ, Assif. Testing the club dynamics of the BRICS: the new development bank from conception to establishment. International Organizations Research Journal, v. 10, n. 2, p. 32-44, Jun. 2015.

FERDINAND, Peter. Rising powers at the UN: an analysis of the voting behaviour of BRICS in the General Assembly. Third World Quarterly, v. 35, n. 3, p. 376391, May 2014.

GROTE, Rainer. Westphalian System. Max Planck Encyclopedia of Public International Law. Oxford: Oxford University, 2006.

GUGGENHEIM, Paul. Traité de droit international. Genève: Libraire Georg, 1967.

HAUFBAUER, Gary C.; ISAACS, Cathleen. How will TTP and TTIP Change the WTO System? Journal of International Economic Law, v. 18, n. 3, p. 679-696, Aug. 2015.

KEUKELEIRE, Stephan et al. The EU Foreign Policy towards the BRICS and other emerging powers: objectives and strategies. Brussels: European Parliament, Oct. 2009. Available on: <https://www.google.com.br/url?sa=t\& $\mathrm{rct}=\mathrm{j} \& \mathrm{q}=\&$ esrc $=\mathrm{s} \&$ source $=$ web\&cd $=1 \& \mathrm{cad}=\mathrm{rja} \& u a c$ $\mathrm{t}=8 \& v e d=0$ ahUKEwi4mcvBtuDKAhXIgZAKHfztA EIQFggfMAA\&url=http $\% 3 \mathrm{~A} \% 2 \mathrm{~F} \% 2 \mathrm{Fwww}$.europarl. europa.eu $\% 2 \mathrm{Fcommittees} \% 2 \mathrm{Fen} \% 2 \mathrm{~F}$ studiesdownlo ad.html\%3FlanguageDocument $\% 3$ DEN $\% 26$ file $\% 3 \mathrm{D} 4$ 9151\&usg=AFQjCNG5J6ipEQ5iXvDSwbAi01VZhes bPQ\&sig2=NWyUUYcBlZeATEH_ed07PA>. Access: Oct. 16, 2015.

KIRSCH, Philippe; HOLMES, John T. The Rome Conference on an International Criminal Court: The Negotiating Process. The American Journal of International Law, v. 93, n. 1, p. 2-12, Jan. 1999.

KIRTON, John. BRICS evolving institutional identity: explaining the BRICS summit's solid strengthening success. International Organizations Research Journal, v. 10, n. 2, p. 9-31, Jun. 2015.
KOSKENNIEMI, Martti; LEINO, Päivi. Fragmentation of international law? postmodern anxieties. Leiden Journal of International Law, v. 15, n. 3, p. 553-579, Sept. 2002.

KUOVO, Sari; PEARSON, Zoe (Ed.). Feminist perspectives on contemporary international law: between resistance and compliance? Oxford: Hart, 2011.

MERON, Theodor. International law in the age of buman rights: general Course on public international law. Leiden: Hague Academy of International Law, 2004.

MUTUA, Makau. What it TWAIL? In: ANNUAL MEETING AMERICAN SOCIETY OF INTERNATIONAL LAW, 94., Washington, 2000. Proceedings...Washington: ASIL, Apr. 2000. p. 31-39.

NEHAMAS, Alexander. Nietæsche: life as literature. Cambridge: Harvard University, 1985.

NIETZSCHE, Friedrich. The will to power. New York: Vintage Books, 1967.

O’NEILL, Jim. Building better global economic BRICs. New York: Goldman, Sach, Nov. 2001. (Global Economics Paper, n. 66). Available on: <http://www.goldmansachs.com/our-thinking/archive/archive-pdfs/build-better-brics.pdf>. Access: Oct. 16, 2015.

PAUWELYN, Joost. Informal international lawmaking: framing the concept and research questions. In: PAUWELYN, Joost; WESSEL, Ramses; WOUTERS, Jan (Ed.). Informal international lawmaking. Oxford: Oxford University, 2012. p. 13-34.

REIS, Maria E. F. BRICS: genesis and evolution. In: PIMENTEL, José Vicente de Sá (Ed.). Brazil, BRICS and the international agenda. Brasília: FUNAG, 2013. p. 47-71.

REWIZORSKI, Marek (Ed.). The European Union and the BRICS: complex relations in the Era of Global Governance. New York: Springer, 2015.

RISSE, Thomas; ROPP, Stephen; SIKKINK, Kathrin. The persistent power of human rights: from commitment to compliance. Cambridge: Cambridge University, 2013.

RUSSIA. Presidency. Official Website of Russia's Presidency in BRICS:BRICS in numbers. 2015. Available on: < http:/ / en.brics2015.ru/infographics/20150301/24260.html>. Access: Oct. 16, 2015.

SALMON, Trevor. The nature of peace and security. In: MATHER, Alexander; BRYDEN, John (Ed.). Encyclopedia of life support systems, regional sustainable development. 
Paris: UNESCO, 2009. p. 259-276.

SCHERMERS, Henry G.; BLOKKER, Niels M. International institutional law. Leiden: M. Nijhoff, 2011.

SCHRIJVER, Nico. The evolution of sustainable development in international law: inception, meaning and status. Leiden: M. Nijhoff, 2008.

SCHUTTER, Olivier de. International human rights law: cases, materials and commentary. Cambridge: Cambridge University, 2010.

SHAW, Malcolm. International law. Cambridge: Cambridge University, 2008.

TALMON, Stefan. The security council as world legislature. The American Journal of International Law, v. 99, n. 1, p. 175-193, Jan. 2005.

TSINGOU, Eleni. Club governance and the making of global financial rules. Review of International Political Economy, v. 22, n. 2, p. 225-256, Mar. 2015.

UNITED NATIONS. General Assembly. Report of the commission of experts of the president of the United Nations General Assembly on reforms of the international monetary and financial system. New York: UN, 21 Sept. 2009. Available on: <http://www.un.org/ga/econcrisissummit/docs/ FinalReport_CoE.pdf>. Access: 17 Oct. 2015.

UNITED NATIONS. General Assembly. Declaration on the establishment of a new international economic order. New York: UN, May 1974. Available in: <http://www.undocuments.net/s6r3201.htm>. Access: Fev. 05, 2016.

UNITED NATIONS. Human Rights Committee, General Comment 24 (52), General comment on issues relating to reservations made upon ratification or accession to the Covenant or the Optional Protocols thereto, or in relation to declarations under article 41 of the Covenant, U.N. Doc. CCPR/C/21/Rev.1/Add.6 (1994). Minneapolis: University of Minnesota, 2004. Available in: <https:// www1.umn.edu/humanrts/gencomm/hrcom24.htm>. Access: Fev. 05, 2016.

UNIVERSITY OF TORONTO. 2nd BRIC summit of heads of state and government: joint statement. Brasília, Apr. 15, 2010. Available on: <http:/ /www.brics.utoronto.ca/ docs/100415-leaders.html>. Access: Oct. 17, 2015.

UNIVERSITY OF TORONTO. Agreement between the governments of the BRICS states on cooperation in the field of culture. Ufassia, July 9, 2015. Available on: <http://www. brics.utoronto.ca/docs/150709-culture-agreement-en. html>. Access: Oct. 17, 2015.
UNIVERSITY OF TORONTO. Agreement on the New Development Bank. Fortaleza, July 15, 2014. Available on: $<$ http://www.brics.utoronto.ca/docs/140715-bank. html>. Access: Oct. 17, 2015.

UNIVERSITY OF TORONTO. BRICS and Africa: partnership for development, integration and industrialization, eThekwini Declaration. Durban, Mar. 27, 2013. Available on: <http://www.brics.utoronto.ca/ docs/130327-statement.html>. Access: Oct. 17, 2015.

UNIVERSITY OF TORONTO. Fourth BRICS summit: Delhi Declaration. New Delhi, Mar. 29, 2012. Available on: <http://www.brics.utoronto.ca/docs/120329-delhi-declaration.html>. Access: Oct. 17, 2015.

UNIVERSITY OF TORONTO. Joint statement of the BRIC countries' leaders. Yekaterinburg, June 16, 2009. Available on: <http://www.brics.utoronto.ca/ docs/090616-leaders.html>. Access: Oct. 17, 2015.

UNIVERSITY OF TORONTO. Memorandum of understanding on the creation of the joint BRICS Website. Ufa, July 9, 2015. Available on: <http://www.brics.utoronto.ca/ docs/150709-website-en.html> Access: Oct. 17, 2015.

UNIVERSITY OF TORONTO. Sanya Declaration. Sanya, Apr. 14, 2011. Available on: <http://www.brics.utoronto.ca/docs/110414-leaders.html>. Access: Oct. 17, 2015.

UNIVERSITY OF TORONTO. The 6th BRICS summit: Fortaleza Declaration. Fortaleza, July 15, 2014. Available on: <http://www.brics.utoronto.ca/docs/140715leaders.html>. Access: Oct. 17, 2015.

UNIVERSITY OF TORONTO. VII BRICS summit: 2015 Ufa Declaration. Ufa, July 9, 2015. Available on: $<$ http://www.brics.utoronto.ca/docs/150709-ufa-declaration_en.html>. Access: Oct. 17, 2015.

VIRALLY, Michel. La notion de fonction dans la théorie de l'organisation internationale. In: __. Le droit international en devenir: Essais écrits au fil des ans. Paris: Universitaires de France, 1990. p. 277-300.

WEIL, Prosper. Towards relative normativity in international law? The American Journal of International Law, v. 77, n. 3, p. 413-442, Jul. 1983.

WTO MINISTERIAL CONFERENCE, 9., 2013, Bali, 2013. Proceedings... Valencia: Instituto de Tecnología y Alimentos Agroquímica, 2014. Available at: <https:// www.wto.org/english/thewto_e/minist_e/mc9_e/ balipackage_e.htm> Access: 21 Oct. 2015. 


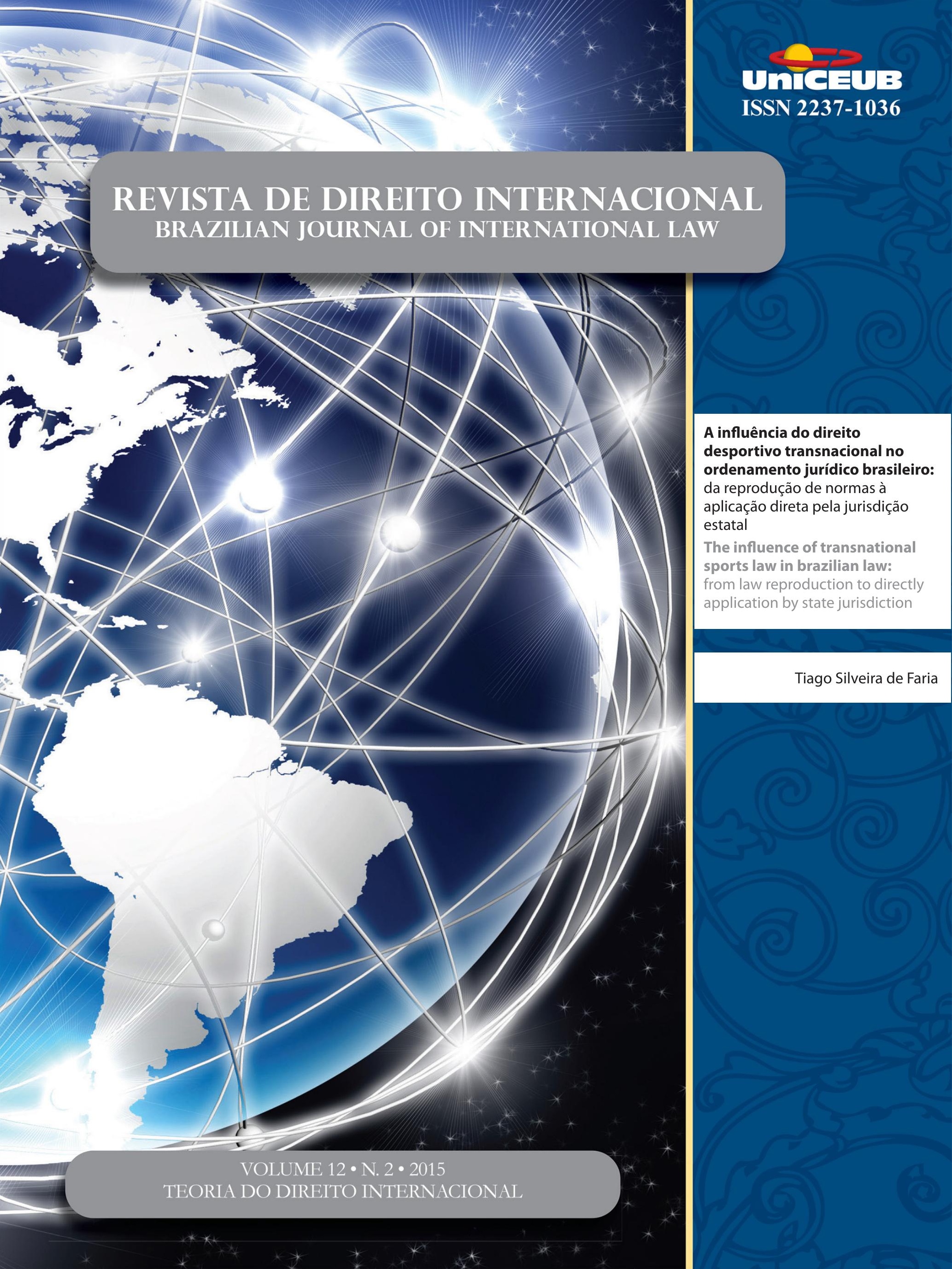




\title{
A influência do direito desportivo transnacional no ordenamento jurídico brasileiro: da reprodução de normas à aplicação direta pela jurisdição estatal*
}

\author{
The influence of transnational sports law in \\ brazilian law: from law reproduction to directly \\ application by state jurisdiction
}

Tiago Silveira de Faria**

\section{Resumo}

O artigo pretende analisar a influência do direito desportivo transnacional no ordenamento jurídico brasileiro, seja com base na reprodução de normas transnacionais oriundas das federações esportivas internacionais, por meio do processo legislativo convencional, seja por meio da aplicação direta do direito desportivo estrangeiro pela jurisdição estatal, este mais complexo e envolvendo uma necessária exposição do pluralismo jurídico, da fragmentação do direito e da hetero-regulação normativa que permeia o âmbito jurídico-desportivo. Posteriormente, ao se estudar a peculiar regra de conexão prevista na legislação desportiva estatal, abordar-se-á os elementos, os limites e os eventuais obstáculos para a aplicação do direito desportivo estrangeiro em território pátrio, assim como os possíveis critérios para solução de conflitos normativos, encerrando-se com estudo de casos, opção metodológica principal deste trabalho.

Palavras-chave: Direito desportivo transnacional. Brasil. Jurisdição estatal.

\section{Abstract}

The article aims to analyze the influence of transnational Sports Law in the Brazilian legal system, whether from the reproduction of transnational norms deriving from international sports federations through conventional legislative process, either through direct application of foreign Sports Law by the State jurisdiction, this case more complex, involving a necessary display of legal pluralism, fragmentation of law and hetero-normative regulation that pervades the legal and sports context. Later, when studying the peculiar connection rule in State Sports Legislation, will address them elements, limits and possible obstacles to the application of foreign Sports Law on home territory and the possible criteria for conflict resolution regulatory, ending up with a case study, main methodological option of this work.

Keywords: Transnational sports Law. Brazil. State jurisdiction.

** Especialista em Direito Empresarial pela PUCRS. Mestrando em Direito pela UNISINOS. Articulista e professor de Direito Desportivo. Advogado. E-mail: tiagosdefaria@ gmail.com
Recebido em 07/09/2015 Aprovado em 01/11/2015 


\section{SUMÁRIO}

1 Introdução; 2 Pluralismo jurídico, transnacionalidade e hetero-regulação no âmbito desportivo; 3 A reprodução de normas desportivas transnacionais pelo ordenamento jurídico brasileiro; 4 A aplicação direta do direito desportivo estrangeiro pela jurisdição estatal; 5 Estudo de casos; 6 Conclusão; Referências.

\section{INTRODUÇÃO}

No desporto, floresce um fenômeno semelhante ao que os teóricos da lex mercatoria têm identificado no campo do comércio internacional: a existência de ordenamentos jurídicos privados e autônomos em relação ao Estado, dentro de um pluralismo que caracteriza a pós-modernidade global. Em verdade, a globalização é caracterizada pelo fatos dos Estados não serem mais os centros do poder, doravante dispersos em uma sociedade fragmentada. ${ }^{1}$

Essa constatação traz à tona que, para o estudo das fontes do direito, é preciso voltar-se, também, para a produção normativa por grupos sociais particulares, segmentos da sociedade que, de forma crescente, competem com o poder legiferante do Estado-nação. ${ }^{2}$ Nessa concepção, o direito não se reduz a um conjunto de normas emanadas pelo Estado.

O direito desportivo talvez seja um dos exemplos mais claros de duplicidade das fontes normativas (hetero-regulação), porquanto, no mesmo sistema, gravitam normas de origem estatal e de origem privada, nem sempre em harmonia, mas que demonstram o pluralismo intrínseco a essa disciplina. De um lado, as normas "oficiais" do Estado-nação brasileiro; de outro, as normas transnacionais das federações esportivas internacionais. É possível dizer que essa normatividade transversal limita o poder e a soberania dos Estados, dentro dessa complexa rede transnacional que não conta mais com o direito estatal como única referência funcional, mas

1 JAYME, Erik. O direito internacional privado do novo milênio: a proteção da pessoa humana face à globalização. Cadernos do programa de pós-graduação em Direito, Porto Alegre, v. 1, n. 1, p. 133-146, mar. 2003. p. 86.

2 TEUBNER, Gunther. A Bukowina global sobre a emergência de um pluralismo jurídico transnacional. Revista de Ciências Sociais e Humanas, Piracicaba, v. 14, n. 33, p. 9-31, jan./abr. 2003. p. 10-11. baseia-se em diversos níveis de normatividade. ${ }^{3}$

A esse conjunto de normas desportivas transnacionais, originadas das federações esportivas internacionais, tem-se atribuído o neologismo de lex sportiva, de forma similar à lex mercatoria e outros fenômenos jurídicos similares.

Interessante notar que a influência da normatividade desportiva transnacional, perante o Estado-nação brasileiro, tem dois vieses: a reprodução de suas normas pelo ordenamento jurídico nacional; a aplicação direta da legislação transnacional pela jurisdição estatal.

A reprodução das normas transnacionais da Fédération Internationale de Football Association - FIFA pelo ordenamento jurídico brasileiro, e.g., demonstra a grande influência que, na fragmentação do direito, uma entidade desportiva privada pode alcançar ante a ordem jurídica "oficial".

De outra parte, a aplicação direta da normatividade desportiva transnacional em território pátrio, por meio de um elemento de conexão bastante peculiar, explicita a pluralidade de fontes normativas e reforça o poder dos regimes jurídicos autônomos na sociedade atual.

No entanto, quais são os elementos, limites e eventuais obstáculos para a aplicação do direito desportivo transnacional pela jurisdição estatal brasileira? Essas questões que, doravante, pretende-se explicitar, tendo por referencial teórico o pluralismo jurídico ordenado de Mireille Delmas-Marty.

\section{Pluralismo jurídico, transnacionalidade E HETERO-REGULAÇÃO NORMATIVA NO ÂMBITO DESPORTIVO}

Entre os valores básicos da pós-modernidade, destacam-se o pluralismo lato sensu, pluralismo de estilos de vida e a negação de uma pretensão universal à maneira própria de ser. Expressa a convivência, lado a lado, dos diferentes, do estrangeiro e dos contrapostos. A pluralidade reaparece como um valor jurídico (Rechtswert). $\mathrm{Na}$

3 TEIXEIRA, Anderson Vichinkeski. Qual a função do estado constitucional em um constitucionalismo transnacional? In: STRECK, Lenio Luiz; ROCHA, Leonel Severo; ELGELMANN, Wilson (Org.). Constituição, sistemas sociais e bermenêutica: anuário do Programa de Pós-Graduação em Direito da UNISINOS. Porto Alegre: Livraria do Advogado, 2012. v. 9, p. 9-32. p. 9-10. 
linguagem do direito, o pluralismo significa ter à disposição alternativas, opções, possibilidades. ${ }^{4}$

A ascensão de ordens jurídicas privadas deslocadas do poder estatal é um ponto marcante e inegável da contemporaneidade, ainda que o direito (clássico) se oponha ferrenhamente à multiplicidade pela sua vocação a uma ordem unificada e hierarquizada. ${ }^{5}$ Assim, a tese do monismo jurídico encontra-se muito distante da realidade e da complexidade contemporânea. Com efeito, para o estudo das fontes do direito,

\begin{abstract}
deve ser ressaltado o poder normativo dos grupos sociais particulares, que nos dias de hoje se configuram como uma realidade solar. [...] Esses grupos sociais são fontes de normas, pois têm o poder de criar suas próprias ordenações jurídicas que garantem a consecução dos fins que pretendem atingir. [...] Como exemplo de ordenamentos jurídicos dos grupos sociais particulares podemos citar: o direito desportivo. ${ }^{6}$
\end{abstract}

O esporte, entendido com um fragmento autônomo da sociedade, exige uma enorme demanda por normas regulatórias, mas que não pode ser suprida por instituições vinculadas ao Estado-nação. Em vez disso, esse subsistema da sociedade satisfaz sua própria demanda recorrendo ao direito autônomo, i.e., criando seu próprio direito substantivo e suas fontes normativas, distantes da esfera legislativa nacional e dos tratados internacionais.

Para Gunther Teubner, só é possível compreender o pluralismo jurídico em sua real dimensão se abandonarmos a suposição de que o direito global extrai sua validade somente de processos legislativos e de sanções estatais, derivados de fontes jurídicas internas ao Estado ou de fontes jurídicas internacionais oficialmente sancionadas. Nessa linha, o direito global demanda uma exegese de fontes arquitetada em termos pluralistas, convergindo a sua atenção para processos espontâneos de formação do direito, que compõem uma nova espécie

4 JAYME, Erik. Visões para uma teoria pós-moderna do direito comparado. Cadernos do programa de pós-graduação em Direito, Porto Alegre, v. 1, n. 1, p. 115-131, mar. 2003. p. 118-119.

5 DELMAS-MARTY, Mireille. Três desafios para um direito mundial. Tradução de Fauzi Hassan Choukr. Rio de Janeiro: Lumen Juris, 2003. p. 99.

6 SIQUEIRA JR., Paulo Hamilton. Teoria do direito. 3. ed. São Paulo: Saraiva, 2012. p. 54.

7 TEUBNER, Gunther. Colisões de regimes: a busca vã por unidade jurídica na fragmentação do direito global. Revista Brasileira de Estudos Constitucionais, Belo Horizonte, v. 6, n. 21, p. 105-155, jan./ mar. 2012. p. 117. apartada do instituído pelos Estados. ${ }^{8}$

Essas ordens constituem-se "em autonomia relativa diante do Estado-nação, bem como diante da política internacional, setores distintos da sociedade mundial que produzem a partir de si mesmos ordenamentos jurídicos globais sui generis."”

Segundo Teubner, a fragmentação do direito na pós-modernidade transparece o fato incontroverso de que o Estado "deixou de ser o fundamento único de validade do poder e da lei". ${ }^{10} \mathrm{O}$ direito oficial do Estado não detém o monopólio das atenções, doravante disperso na fragmentação das diversas racionalidades sociais vigentes. ${ }^{11}$

Como Janus, deus romano das mudanças e tradições, "O pluralismo se apresenta agora com duas faces [...] direito e sociedade." 12

A globalização reforçou, ainda mais, o crescimento social e econômico do fenômeno esportivo, que é, por sua própria natureza, universal. Nesse contexto, Lorenzo Casini ${ }^{13}$ manifesta que o esporte tem criado uma série de regras jurídicas e de instituições esportivas transnacionais que se equiparam a uma ordem jurídica autônoma: "[...] which legal scholarship has varyingly referred to as 'International Sports Law', 'Global Sports Law' and lex sportiva (thus drawing a patent analogy with the lex mercatoria governing international trade)."

E prossegue o mesmo autor com a seguinte assertiva:

8 TEUBNER, Gunther. A Bukowina global sobre a emergência de um pluralismo jurídico transnacional. Revista de Ciências Sociais e Humanas, Piracicaba, v. 14, n. 33, p. 9-31, jan./abr. 2003. p. 11.

9 TEUBNER, Gunther. A Bukowina global sobre a emergência de um pluralismo jurídico transnacional. Revista de Ciências Sociais e Humanas, Piracicaba, v. 14, n. 33, p. 9-31, jan./abr. 2003. p. 10.

10 TEUBNER, Gunther. A Bukowina global sobre a emergência de um pluralismo jurídico transnacional. Revista de Ciências Sociais e Humanas, Piracicaba, v. 14, n. 33, p. 9-31, jan./abr. 2003. p. 23.

11 TEUBNER, Gunther. As duas faces de Janus: pluralismo jurídico na sociedade pós-moderna. In:___ (Org.). Direito, sistema e policontexturalidade. Piracicaba: UNIMEP, 2005. p. 79-104. p. 81.

12 TEUBNER, Gunther. As duas faces de Janus: pluralismo jurídico na sociedade pós-moderna. In:___ (Org.). Direito, sistema e policontexturalidade. Piracicaba: UNIMEP, 2005. p. 79-104. p. 81.

13 CASINI, Lorenzo. Sports law: a global legal order? Law \& Society Forum, Honolulu, 2012. p. 03. Disponível em: <http://ssrn.com/ abstract $=2079857>$. Acesso em: 07 jun. 2015. 
As far as international regimes consist of 'sets of implicit and explicit principles, norms, rules, and decision-making procedures around which actor expectations converge in a given issue-area', sports legal orders can be likened to the internationallevel 'private regimes', i.e. those regimes that are voluntarily formed and should be conceptually located beyond the mechanisms typically arising in international law. ${ }^{14}$

É nesse cenário que a lex sportiva se destaca entre os regimes jurídicos privados transnacionais, com a lex mercatoria e a lex digitalis. ${ }^{15}$

A lex mercatoria é a pioneira no tema, remontando à Idade Média, quando comerciantes a desenvolveram como um remédio jurídico à multiplicidade de leis feudais que inviabilizavam a segurança jurídica comercial. ${ }^{16}$

A lex sportiva constitui um fenômeno jurídico similar, porém, no âmbito do esporte, compreendendo o conjunto de normas desportivas transnacionais produzidas por organizações desportivas privadas como a Fédération Internationale de Football Association - FIFA. ${ }^{17}$

O conceito de norma transnacional (ainda) é bastante discutido doutrinariamente. Philip Jessup ${ }^{18}$, um dos primeiros juristas a empregar o termo em sua obra Transnational Law, de 1965, definiu norma transnacional como todo direito que regula ações ou eventos que transcendem as fronteiras nacionais, incluindo o direito internacional público e privado.

Essa concepção, todavia, foi alvo de críticas por destacar as tradicionais disciplinas de direito internacional, muito ligadas ao conceito dogmático de fonte estatal, embora Jessup já ressaltasse, à época, a complexidade da sociedade e a insuficiência desses ramos para tratar dos incipientes fenômenos jurídicos.

Hodiernamente, o direito transnacional caracteriza-se mais por sua "desterritorialização", com ênfase nas

14 CASINI, Lorenzo. Sports law: a global legal order? Law \& Society Forum, Honolulu, 2012. p. 05. Disponível em: <http://ssrn.com/ abstract $=2079857>$. Acesso em: 07 jun. 2015.

15 TEUBNER, Gunther. A Bukowina global sobre a emergência de um pluralismo jurídico transnacional. Revista de Ciências Sociais e Humanas, Piracicaba, v. 14, n. 33, p. 9-31, jan./abr. 2003. p. 11.

16 CASINI, Lorenzo. Sports law: a global legal order? Law \& Society Forum, Honolulu, 2012. p. 37. Disponível em: <http://ssrn.com/ abstract $=2079857>$. Acesso em: 07 jun. 2015.

17 LATTY, Franck. La lex sportiva: recherche sur le droit transnational. Leiden: Nijhoff, 2007. p. 37.

18 JESSUP, Philip C. Direito transnacional. Tradução de Carlos Ramires Pinheiro da Silva. São Paulo: Fundo de Cultura, 1965. p. 12. novas formas de relações jurídicas além do estado. A respeito, Roger Cotterrell lembra que o direito transnacional é conceitualmente distinto do nacional e internacional, "because its primary sources and addressees are neither nation state agencies nor international institutions founded on treaties or conventions, but private (individual, corporate or collective) actors involved in transnational relations." 19

A peculiaridade do direito desportivo, por sua vez, reside na hetero-regulação normativa, porquanto no mesmo sistema gravitam normas nacionais (de fonte estatal) e transnacionais (de fonte privada), nem sempre em harmonia. ${ }^{20}$

A natureza normativa híbrida é especialmente verificável no desporto, como lembra Casini': "The answer is that sports law is now far from being understood from a private law perspective alone, because it presents, rather, a mixed nature, in which a regulatory framework based on private autonomy constantly interacts with public law norms."

Temas antes regulados prioritariamente pelo direito doméstico, de forma crescente, passam a ser tutelados pelo direito transnacional, com base em normas com caráter extraterritorial. Trata-se de um novo cenário, marcado pela expansão do direito global, com uma intensificação dos processos transnacionais, em que o direito estatal se internacionaliza a partir da maior interação com regimes jurídicos privados. ${ }^{22}$ Criam-se arranjos institucionais para traduzir esses fenômenos jurídicos para a realidade local. É por meio desses processos contínuos de interação que se configura a identidade de um direito internacional como um direito próprio e sua efetividade torna-se interesse dos Estados e dos demais atores privados. Nem mesmo países mais isolados,

19 COTTERRELL, Roger. What is Transnational Law. Law \& Social Inquiry, London, v. 37, n. 2, p. 500-524, March 2012. Disponível em: <http://papers.ssrn.com/sol3/papers.cfm?abstract_ id=2021088 $>$. Acesso em: 04 ago. 2015.

20 No Brasil, por exemplo, temos a regulação estatal (Lei 9.615/98 - Lei Pelé). No âmbito internacional, os estatutos e regulamentos da FIFA. BRASIL. Lei 9.615, de 24 de marco de 1998. Institui normas gerais sobre desporto e dá outras providências. Disponível em: <http://www.planalto.gov.br/ccivil_03/LEIS/L9615consol.htm>. Acesso em: 26 jul. 2015.

21 CASINI, Lorenzo. Sports law: a global legal order? Law \& Society Forum, Honolulu, 2012. p. 18. Disponível em: <http://ssrn.com/ abstract $=2079857>$. Acesso em: 07 jun. 2015.

22 VARELLA, Marcelo D. Internacionalização do direito: direito internacional, globalização e complexidade. 2012. 606 f. Tese (LivreDocência em Direito Internacional) - Faculdade de Direito, Universidade de São Paulo, São Paulo, 2012. p. 105. Disponível em: $<$ https://www.uniceub.br/media/186548/MVarella.pdf >. Acesso em: 03 nov. 2015. 
como Coreia do Norte, Cuba ou Albânia, conseguem se manter alheios. ${ }^{23}$

Os subsistemas jurídicos, porém, nem sempre avançam na mesma direção, tampouco na mesma velocidade. Certos ramos do direito, como o desportivo, internacionalizam-se com maior rapidez, fruto da forte influência transnacional a que seu subsistema está acoplado. Há um progressivo intercruzamento normativo na construção dos direitos nacionais, uma pluralidade de ordens normativas que se comunicam, embora sem o clássico sistema hierarquizado. ${ }^{24}$

A par da atual multiplicidade de fontes normativas, não é possível prescindir da forma tradicional de regulamentação normativa (estatal), modelo que igualmente não para de se construir e reforçar. ${ }^{25}$

Mireille Delmas-Marty consegue conjecturar, na aparente profusão anárquica de normas, oriundas das mais diferentes fontes, uma possibilidade de ordenamento, pois a abundância normativa da atualidade não representa necessariamente uma desregulamentação nem a submissão ou supressão do poder legiferante estatal, "mas um reemprego das normas segundo outros dispositivos, mais opacos e mais complexos". ${ }^{26}$ Longe de reduzir o papel cabível ao direito, esse fenômeno marca a aparição de um novo processo de encadeamento de normas, lastreado na fragilidade do princípio hierárquico.

De fato, no Brasil, a principal legislação desportiva estatal (Lei 9.615/98) prevê, de forma expressa, a hetero-regulação normativa, consoante a disposição legal do $\int 1^{\circ}$ do art. $1^{\circ}$ : "A prática desportiva formal é regulada por normas nacionais e internacionais e pelas regras de prática desportiva de cada modalidade, aceitas pelas respectivas entidades nacionais de administração do desporto." 27

23 VARELLA, Marcelo D. Internacionalização do direito: direito internacional, globalização e complexidade. 2012. 606 f. Tese (LivreDocência em Direito Internacional) - Faculdade de Direito, Universidade de São Paulo, São Paulo, 2012. p. 315. Disponível em: $<$ https://www.uniceub.br/media/186548/MVarella.pdf $>$. Acesso em: 03 nov. 2015.

24 DELMAS-MARTY, Mireille. Les forces imaginantes du droit II: le pluralisme ordonné. Paris: Seuil, 2006.

25 DELMAS-MARTY, Mireille. Três desafios para um direito mundial. Tradução de Fauzi Hassan Choukr. Rio de Janeiro: Lumen Juris, 2003. p. 80.

26 DELMAS-MARTY, Mireille. Les forces imaginantes du droit II: le pluralisme ordonné. Paris: Seuil, 2006. p. 72-73.

27 BRASIL. Lei 9.615, de 24 de marco de 1998. Institui normas gerais
É possível vislumbra-se duas formas distintas de aplicação das normas transnacionais desportivas em território pátrio: 1) a reprodução (parcial ou total) de normas desportivas transnacionais pelo ordenamento jurídico-desportivo brasileiro; 2) aplicação direta daquelas normas pelo juiz por meio de critérios provenientes do direito internacional privado, este último caso de maior complexidade.

Ambas as hipóteses podem ser inseridas no que Delmas-Marty denomina de pluralismo ordenado, em que, embora haja o reconhecimento da diversidade, marca heterogênea da ordem jurídica contemporânea, busca-se uma resposta à complexidade jurídica mundial, delineando as possibilidades de harmonização normativa sem a ilusória pretensão de unificá-la. ${ }^{28}$

\section{A RePRODUÇÃo DE NORMAS DESPORTIVAS TRANSNACIONAIS PELO ORDENAMENTO JURÍDICO BRASILEIRO}

Com uma frequência crescente, tem-se observado a reprodução de normas desportivas transnacionais, especialmente da FIFA, pela legislação estatal brasileira, por meio do processo legislativo ordinário.

Mireille Delmas-Marty classifica essas relações estabelecidas entre os diferentes sistemas jurídicos de internormatividade. São técnicas de relação e intercâmbio normativo num sentido prático, notadamente no que a autora francesa denomina de processos de "imitação", i.e., diferentes ordenamentos jurídicos buscando inspiração em outros para a produção normativa. ${ }^{29}$ É o direito privado transnacional como fonte de inspiração do direito estatal.

Convém registrar que o direito transnacional ingressa em cada país de maneira distinta, em geral com adequações às respectivas culturas e ordens jurídicas nacionais. A internacionalização de normas envolve um processo dinâmico e complexo de interações, em que a norma pode ser internalizada, no âmbito doméstico,

sobre desporto e dá outras providências. Disponível em: $<$ http:// www.planalto.gov.br/ccivil_03/LEIS/L9615consol.htm>. Acesso em: 26 jul. 2015.

28 DELMAS-MARTY, Mireille. Les forces imaginantes du droit II: le pluralisme ordonné. Paris: Seuil, 2006. p. 7-10.

29 DELMAS-MARTY, Mireille. Les forces imaginantes du droit II: le pluralisme ordonné. Paris: Seuil, 2006. p. 42. 
de forma quase idêntica à originária ou totalmente remodelada. ${ }^{30}$

No caso do Brasil, as normas desportivas transnacionais vêm sendo reproduzidas pelo ordenamento jurídico brasileiro de forma muito similar às originárias, o que demonstra o reconhecimento estatal da especialidade do subsistema desportivo privado transnacional.

Nesse sentido, o artigo 27-B da Lei 9.615/98 - Lei Pelé, inclú́do pela Lei $12.395 / 11^{31}$, é um exemplo claro dessa ilação:

Art. 27-B. São nulas de pleno direito as cláusulas de contratos firmados entre as entidades de prática desportiva e terceiros, ou entre estes e atletas, que possam intervir ou influenciar nas transferências de atletas ou, ainda, que interfiram no desempenho do atleta ou da entidade de prática desportiva, exceto quando objeto de acordo ou convenção coletiva de trabalho.

A previsão legal supratranscrita retrata, de maneira geral, a regra constante do art. 18 BIS do regulamento de transferência de jogadores da FIFA ${ }^{32}$, vigente desde a edição de 2008, que proíbe a interferência de terceiros em contratos de trabalho e transferências de atletas: "No club shall enter into a contract which enables the counter club/counter clubs, and vice versa, or any third party to acquire the ability to influence in employment and transfer-related matters its independence, its policies or the performance of its teams."

Da mesma forma, o artigo 29-A, introduzido na ordem jurídico-desportiva estatal pela citada Lei $12.395 / 11$, reproduz o mecanismo de solidariedade ${ }^{33}$

30 VARELLA, Marcelo D. Internacionalização do direito: direito internacional, globalização e complexidade. 2012. 606 f. Tese (LivreDocência em Direito Internacional) - Faculdade de Direito, Universidade de São Paulo, São Paulo, 2012. p. 115-116. Disponível em: $<$ https://www.uniceub.br/media/186548/MVarella.pdf $>$. Acesso em: 03 nov. 2015.

31 BRASIL. Lei 12.395, de 16 de março de 2011. Altera as Leis nos 9.615 , de 24 de março de 1998, que institui normas gerais sobre desporto. Disponível em: < http://www.planalto.gov.br/ccivil_03/_ ato2011-2014/2011/lei/112395.htm>. Acesso em: 09 ago. 2015.

32 FÉDÉRATION INTERNATIONALE DE FOOTBALL ASSOCIATION. Regulation on the status and transfer of players. Zurique, 2015. Disponível em: <http://resources.fifa.com/mm/ document/affederation/administration/01/06/30/78/statusinhalt_en_122007.pdf>. Acesso em: 26 jul. 2015.

33 Se um jogador é transferido onerosamente de clube durante a vigência do contrato de trabalho, $5 \%$ do valor a ser pago pelo clube cessionário (contratante) ao clube cedente deverá ser separado e distribuído entre os clubes que formaram o jogador entre os 12 e os 23 anos de idade. Este é o mecanismo de solidariedade (solidarity mechanism), instituto que visa compensar financeiramente os clubes que participaram da formação do atleta, o que torna possível a um pequeno clube brasileiro receber, anos mais tarde, uma participação "importado" do artigo 21 e do anexo V do regulamento de transferência de jogadores da entidade máxima do futebol, cujo inteiro teor está disponível no sítio oficial da FIFA desde a edição 2005.

Nesses casos, a legislação transnacional da FIFA foi adotada voluntariamente, de maneira planejada e com esforços de harmonização, pelo Estado-nação brasileiro. Tal incorporação da legislação transnacional ocorre por meio de "intermediários".

$\mathrm{Na}$ definição de Shaffer ${ }^{34}$, intermediários são pessoas físicas ou jurídicas, públicas ou privadas, que podem atuar em nível nacional ou regional, oferecendo múltiplas "portas de entrada" para a legislação transnacional. Eles ajudam a traduzir, adaptar e contextualizar as normas transnacionais aos contextos locais. Esses intermediários incluem representantes do governo, prestadores de serviços, acadêmicos, organizações não-governamentais, entidades privadas, líderes de movimentos sociais etc.

Em território pátrio, podemos identificar a Confederação Brasileira de Futebol - CBF, associação privada sem fins lucrativos, como a grande intermediária para o processo de incorporação da lex FIFA ao ordenamento jurídico brasileiro, juntamente, em nível regional, com as federações desportivas estaduais e os clubes. A CBF, igualmente, possui influência no Congresso Nacional, com deputados e senadores atentos aos seus interesses. $^{35}$

Não há dúvida de que a reprodução de normas transnacionais da FIFA, pelo ordenamento jurídico estatal brasileiro, é a melhor forma de prevenir conflitos e harmonizar os diferentes regimes jurídicos. Porém, isso nem sempre é possível, quer pela grande disparidade da dinâmica de produção normativa, quer pela divergência de interesses.

financeira sobre a vultosa venda de um atleta entre grandes clubes europeus.

34 SHAFFER, Gregory. Transnational legal process and state change: opportunities and constraints. Nova Iorque: Universidade of Minnesota, 2012. (Legal Studies Research Paper Series Research Paper, n. 1028). p. 35-36. Disponível em: <http://papers.ssrn.com/sol3/papers.cfm?abstract_id=1901952>. Acesso em: 26 jul. 2015.

35 REBELLO, Aiuri; CRUZ, José. "Bancada da bola" faz, pressão e tira CBF de projeto sobre dividas dos times. Brasília, 29 abr. 2014. Disponível em: <http://esporte.uol.com.br/futebol/ultimas-noticias/2014/04/29/bancada-da-bola-faz-pressao-e-tira-cbf-de-projeto-sobre-divida-dos-times.htm>. Acesso em: 26 jul. 2015. 


\section{A APLICAÇÃO DO DIREITO DESPORTIVO ESTRANGEIRO PELA JUSRISDIÇÃO ESTATAL}

A Constituição Federal de 1988 é relativamente omissa em relação à aplicação, em território pátrio, do direito estrangeiro, excetuando-se a incorporação de normas internacionais relativas a direitos humanos (art. $5^{\circ}, \int 2^{\circ}$, da $\mathrm{CF} / 88$ ), às convenções e aos tratados (art. 49, inciso I, e art. 84, inciso VIII, da CF/88), que estão especialmente contemplados, mas que retratam matéria majoritariamente de direito internacional público.

Para o restante do direito internacional e transnacional, todavia, são frequentes os questionamentos acerca do alcance dessas normas no direito interno, as quais tampouco figuram no rol legislativo do art. 59 da $\mathrm{CF} / 88{ }^{36}$

Nem mesmo para as organizações internacionais, assim entendidas aquelas que detêm alguma participação governamental, eg., ONU, OTAN, Mercosul etc., a situação é clara. Como lembra Dallari, ${ }^{37}$

\begin{abstract}
Se o acúmulo de discussão, embora volumoso, não possibilitou ainda que a legislação, doutrina $\mathrm{e}$ jurisprudência convergissem no reconhecimento de posição incontroversa para a disciplina da recepção das normas convencionais, no caso das decisões de organizações internacionais, tal debate nem sequer ganhou corpo.
\end{abstract}

A problemática adentra no campo do direito internacional privado - DIPr, que cuida de classificar ou qualificar a situação jurídica e determinar o direito aplicável à espécie. Em outras palavras, indica a lei material (nacional ou estrangeira) incidente no caso concreto.

No Brasil, a principal fonte interna do DIPr é a Lei de Introdução às Normas do Direito Brasileiro (LINDB), Decreto-Lei 4.657/42. ${ }^{38}$

O direito brasileiro está submetido ao princípio da territorialidade moderada/mitigada, i.e., no nosso território aplica-se, em regra, a lei brasileira. Havendo, no entanto, um elemento de conexão, aplica-se o direito

36 BENJAMIN, Daniela Arruda. A aplicação dos atos de organizações internacionais no ordenamento jurídico brasileiro. Brasília: Funag, 2014. p. 107.

37 DALLARI, Pedro B. A. Constituição e relacõoes internacionais. 2. ed. São Paulo: Saraiva, 2003. p. 119.

38 BRASIL. Decreto-Lei 4.657, de 04 de setembro de 1942. Lei de Introdução às normas do Direito Brasileiro. Disponível em: <http:/ / www.planalto.gov.br/ccivil_03/decreto-lei/Del4657.htm>. Acesso em: 31 jul. 2015. estrangeiro, desde que, nos termos do 17 da LINDB, as leis, atos e sentenças de outro país, bem como quaisquer declarações de vontade, não ofendam a soberania nacional, a ordem pública e os bons costumes. Por elemento ou regra de conexão entende-se as normas de direito internacional privado que indicam o direito aplicável às várias situações jurídicas conectadas a mais de um sistema legal. ${ }^{39}$

As principais regras de conexão estão dispostas na Lei de Introdução às Normas do Direito Brasileiro. No entanto, a vetusta legislação data de 1942 e a Lei 12.376/2010 apenas alterou seu campo de incidência, outrora restrito ao Código Civil..$^{40}$ Desse modo, o anacronismo da LINDB em relação aos novos fenômenos que permeiam o direito internacional privado exige a ampliação do foco de atenção para outras fontes normativas. ${ }^{41}$

Entre as normas de ligação previstas em legislações esparsas, encontra-se a regra de conexão desportiva disposta no $\int 1^{\circ}$ do art. $1^{\circ}$ da Lei 9.615/98: “A prática desportiva formal é regulada por normas nacionais e internacionais e pelas regras de prática desportiva de cada modalidade, aceitas pelas respectivas entidades nacionais de administração do desporto."

É preciso, no entanto, fazer uma importante distinção. A norma de conexão desportiva não tem a característica maniqueísta típica dos elementos de ligação do DIPr, mas um caráter holístico integrativo. Assim, essa regra de conexão não visa propriamente dirimir conflitos de leis no espaço, para muitos o cerne do direito internacional privado, e sim facultar a aplicação do direito desportivo internacional concomitantemente com a legislação nacional. $\mathrm{O}$ art. $3^{\circ}$, inciso III, da Lei Pelé reforça a hetero-regulação (nacional e internacional) do Direito Desportivo e seu caráter integrativo. ${ }^{42}$

39 DOLINGER, Jacob. Direito internacional privado: parte geral. 11. ed. Rio de Janeiro: Forense, 2014. p. 297.

40 Então denominada Lei de Introdução ao Código Civil (LICC). 41 BASSO, Maristela. Curso de direito internacional privado. 3. ed. São Paulo: Atlas, 2013. p. 49.

42 Art. $3^{\circ} \mathrm{O}$ desporto pode ser reconhecido em qualquer das seguintes manifestações:[...] III - desporto de rendimento, praticado segundo normas gerais desta Lei e regras de prática desportiva, nacionais e internacionais, com a finalidade de obter resultados e integrar pessoas e comunidades do País e estas com as de outras nações. BRASIL. Lei 9.615, de 24 de marco de 1998. Institui normas gerais sobre desporto e dá outras providências. Disponível em: <http:// www.planalto.gov.br/ccivil_03/LEIS/L9615consol.htm>. Acesso em: 26 jul. 2015. 
Como destaca Álvaro Melo Filho ${ }^{43}$,

Em suma, é a própria lei brasileira sobre desporto que impõe a obediência e acatamento às normas internacionais, o que implica no reconhecimento da autonomia desportiva dos entes internacionais, sem malferir ou derruir a soberania nacional.

Esse caráter integrativo permite estabelecer processos de coordenação normativa, segundo a linha teórica de Delmas-Marty, especialmente o que denomina de "harmonização por aproximação", que são movimentos ascendentes e descendentes entre o direito interno e o direito transnacional, uma troca normativa propensa à cooperação entre as diferentes fontes do direito. ${ }^{44}$ Essa forma de interação tem uma hierarquia dinâmica de ajustamentos e reajustamentos sucessivos. Ao mesmo tempo em que o Estado tende a manter uma margem nacional de aplicação de seu direito, ele também quer a aproximação com o estrangeiro, criando uma verdadeira dinâmica de forças que resultam em uma hierarquia que não é necessariamente de cima para baixo, mas que está em constante mutação. ${ }^{45}$

A norma de conexão desportiva brasileira parece se encaixar nesse conceito, sendo indireta e sui generis. Indireta porque não resolve o problema de direito material subjacente, apenas indica a legislação aplicável. Já a peculiaridade reside no fato de que, em vez de resolver o conflito de leis no espaço, tipificando as hipóteses e indicando uma única legislação aplicável, essa norma de conexão, paradoxalmente, amplia o direito material incidente e remete a solução, ainda que indiretamente, para a análise do caso concreto.

Note-se, ademais, que a regra de ligação desportiva é abstrata em relação ao direito estrangeiro aplicável, ao mencionar simplesmente "normas internacionais", o que, no singular ramo do direito desportivo, subentende-se o ordenamento jurídico-desportivo produzido pelas federações desportivas internacionais, a lex sportiva, e não as normas desportivas decorrentes do "direito oficial" dos demais Estados-nação.

Mas, como antes mencionado, a análise da eventual aplicação da lei desportiva estrangeira, concomitante-

43 MELO FILHO, Álvaro. O novo direito desportivo. São Paulo: Cultural Paulista, 2002. p. 70.

44 DELMAS-MARTY, Mireille. Les forces imaginantes du droit II: le pluralisme ordonné. Paris: Seuil, 2006. p. 70-100.

45 VELHO, Rafael Rott de Campos. O Mercosul e a política ambiental: modelos, inconsistências e alternativas. Revista de Direito Internacional, Brasília, v. 9, n. 3, p. 103-128, 2012. p. 110. mente ou não com a legislação nacional, dar-se-á no momento em que o órgão judicante apreciar o caso concreto. Isso porque pode haver antinomias entre a legislação nacional e internacional que impeçam a aplicação simultânea de ambas de modo harmônico, como parece ser o intuito da lei (mens legis).

Por antinomia jurídica tem-se a oposição que ocorre entre duas normas contraditórias, emanadas de autoridades competentes num mesmo âmbito normativo. Tercio Sampaio Ferraz Junior ainda acrescenta o fato de que o sujeito deve ficar em uma posição insustentável pela ausência ou inconsistência de critérios aptos a solucionar a incongruência, distinguindo, assim, a antinomia real (insolúvel) da antinomia aparente (solúvel). ${ }^{46}$

Um exemplo típico de conflito entre a lex FIFA e a legislação desportiva brasileira está no prazo máximo estipulado para o primeiro contrato profissional de um atleta de futebol. De acordo com o artigo 29 da Lei 9.615/98 - Lei Pelé:

Art. 29. A entidade de prática desportiva formadora do atleta terá o direito de assinar com ele, a partir de 16 (dezesseis) anos de idade, o primeiro contrato especial de trabalho desportivo, cujo prazo não poderá ser superior a 5 (cinco) anos.

Já o regulamento de transferências da FIFA só admite contratos profissionais, para menores de 18 anos, com prazo máximo de 03 (três) anos. É o que dispõe o artigo 18, item 2, in fine, do indigitado regulamento: "Players under the age of 18 may not sign a professional contract for a term longer than three years. Any clause referring to a longer period shall not be recognized."

Interessante notar que, dada a complexidade da norma de conexão desportiva, pode-se dizer que o direito privado internacional não está adequadamente preparado para enfrentar determinados conflitos normativos, especialmente quando o caso concreto atrai a competência jurisdicional da FIFA. ${ }^{47}$ Aqui, no entanto, restringir-se-á o estudo da aplicação do direito desporti-

46 FERRAZ JUNIOR, Tercio Sampaio. Introdução ao estudo do direito: técnica, decisão, dominação. 7. ed. São Paulo: Atlas, 2013. p. 179. 47 Via de regra, quando há algum "elemento internacional" envolvido, i.e., quando as partes em litígio (atletas, clubes, etc.) pertencem a diferentes associações (países, protetorados, etc.). Vide art. $1^{\circ}$ do regulamento de transferência da FIFA. FÉDÉRATION INTERNATIONALE DE FOOTBALL ASSOCIATION. Regulation on the status and transfer of players. Zurique, 2015. Disponível em: $<$ http://resources.fifa.com/mm/document/affederation/administration/01/06/30/78/statusinhalt_en_122007.pdf>. Acesso em: 26 jul. 2015. 
vo estrangeiro pela jurisdição estatal aos casos que não envolvam um "conflito de competência" com a entidade máxima do futebol, cujos critérios para a resolução de litígios são distintos e sui generis.

De outra parte, a legislação desportiva brasileira não estabelece nenhum tipo de critério para a solução de eventuais antinomias existentes entre as normas internas e internacionais, colocando-as, ainda que indiretamente, em um mesmo plano hierárquico da lei ordinária nacional ( $\int 1^{\circ}$ do art. $1^{\circ}$ da Lei 9.615/98).

Irrelevante, assim, que a Fédération Internationale de Football Association (FIFA) seja uma associação privada de direito suíço, já que a legislação desportiva brasileira não faz distinção hierárquica entre suas próprias normas ordinárias e as transnacionais, justamente por compreender a sistemática desportiva mundial, em que as entidades privadas internacionais exercem um controle global sobre os respectivos esportes. Tal fato, aliás, é corroborado pela proteção constitucional conferida às organizações desportivas pelo art. 217, inciso I, da Carta Federal de $1988 .^{48}$

Partindo-se do pressuposto de que ambas as legislações estão num mesmo âmbito hierárquico e normativo, quais os critérios para a solução de eventuais antinomias?

Considerando o fato de que não existe propriamente um conflito de competência, mas apenas de direito material aplicável (nacional ou internacional), em tese, não há óbice para a resolução dos conflitos normativos por meio de critérios historicamente corporificados pela legislação nacional e internacional, sobretudo os critérios da especialidade (lex specialis derogat generalis), cronológico (lex posterior derogat priori) e hierárquico ${ }^{49}$ (lex superior

48 Art. 217. É dever do Estado fomentar práticas desportivas formais e não-formais, como direito de cada um, observados: I - a autonomia das entidades desportivas dirigentes e associações, quanto a sua organização e funcionamento. BRASIL. Constituição (1988). Constituição da Republica Federativa do Brasil. Disponível em: <http:/ / www.planalto.gov.br/ccivil_03/Constituicao/Constituicao.htm>. Acesso em: 3 fev. 2016.

49 O critério hierárquico tem sido mais utilizado para resolver as antinomias em nível interno, especialmente no embate entre a legislação desportiva estatal e a Constituição Federal, v.g., vínculo desportivo (art. 28, \5 50 inciso II, da Lei 9.615/98) e o livre exercício da profissão (art. 5, inciso XIII, da CF/88). BRASIL. Constituição (1988). Constituição da Republica Federativa do Brasil. Disponível em: <http://www.planalto.gov.br/ccivil_03/Constituicao/Constituicao. htm>. Acesso em: 3 fev. 2016. Sobre o tema, consultar: FARIA, Tiago Silveira de. A persistência da inconstitucionalidade do vínculo desportivo na lei 12.395/2011. Jornal Trabalbista Consulex, Brasília, v. derogat inferiori). Essas regras resolveriam as antinomias aparentes.

Para as antinomias reais, assim entendidas aquelas em que há também conflito entre os próprios critérios, e.g., norma anterior-especial e outra posterior-geral, a doutrina elaborou metarregras: 1) lex inferiori non derogat priori superiori; 2) lex posteriori generalis non derogat priori speciali. ${ }^{50}$

Segundo Martti Koskenniemi, os critérios de solução de conflitos normativos, oriundos do "direito tradicional", são igualmente úteis no campo internacional: "This is why it is useful to have regard to the wealth of techniques in the traditional law for dealing with tensions or conflicts between legal rules and principles." 51 Aliás, as regras de especialidade e cronológica são amplamente empregadas pelo direito internacional, enquanto o critério de hierarquia é menos utilizado. $^{52}$

Evidentemente, para viabilizar a análise das possíveis soluções para os conflitos normativos, de acordo com as regras citadas, torna-se imperiosa a estrita observância do art. 14 da LINDB $^{53}$, pois, em regra, o juiz não conhece a lei estrangeira (exceção ao brocardo jurídico iura novit curia) e a prova do texto e da vigência incumbe à parte que alega.

O desconhecimento da legislação estrangeira, da regra de conexão desportiva, assim como a vontade de aplicar a lex fori, talvez sejam os principais motivos para o receio e a desconformidade de aplicação das normas desportivas estrangeiras pela jurisdição estatal. A respei-

28, p. 6-8, 2011.

50 FERRAZ JUNIOR, Tercio Sampaio. Introdução ao estudo do direito: técnica, decisão, dominação. 7. ed. São Paulo: Atlas, 2013. p. 178. 51 KOSKENNIEMI, Martti. Fragmentation of international law: difficulties arising from the diversification and expansion of international law. In: INTERNATIONAL LAW COMMISSION, 58., 2006. Report of the Study Group of the International Law Commission... Geneve: United Nations, 2006. p. 15-16. Available at: <http://legal. un.org/ilc/documentation/english/a_cn4_1682.pdf>. Access : 3 Feb. 2016.

52 KOSKENNIEMI, Martti. Fragmentation of international law: difficulties arising from the diversification and expansion of international law. In: INTERNATIONAL LAW COMMISSION, 58., 2006. Report of the Study Group of the International Law Commission... Geneve: United Nations, 2006. p. 20. Available at: <http://legal. un.org/ilc/documentation/english/a_cn4_1682.pdf>. Access : 3 Feb. 2016.

53 Art. 14.Não conhecendo a lei estrangeira, poderá o juiz exigir de quem a invoca prova do texto e da vigência. BRASIL. DecretoLei 4.657, de 04 de setembro de 1942. Lei de Introdução às normas do Direito Brasileiro. Disponível em: < http://www.planalto.gov.br/ ccivil_03/decreto-lei/Del4657.htm>. Acesso em: 31 jul. 2015. 
to, lembra Gaudemet-Tallon, ${ }^{54}$

Ora, a vontade de aplicar sua própria lei, sem mesmo vislumbrar a possibilidade de aplicar uma lei estrangeira, me parece ser a característica de uma ordem jurídica ainda imatura, que quer se impor de forma imperialista ao invés de procurar uma boa coordenação internacional.

No mesmo sentido, não parece antiquada a visão de Clóvis Beviláqua, ${ }^{55}$
Para que seja possível determinar, com isenção de espírito, qual a sede de uma relação de direito, é necessário partir dessa ideia de elevada de uma comunhão de direitos entre os diferentes povos, que se acham em contato frequente. Essa comunhão de direito realiza-se pelo acordo dos Estados em admitir que possam ser aplicadas, por seus juízes, leis originariamente estrangeiras, o que não é absolutamente resultado de simples benevolência, ato revogável de uma vontade arbitrária, mas consequência natural do desenvolvimento próprio do direito.

Torna-se relevante, assim, a par da previsão hetero-regulativa da legislação esportiva brasileira, o estudo de casos de aplicação das normas desportivas transnacionais pela jurisdição estatal, na medida em que a matéria (ainda) transita em um caminho nebuloso, reforçando a necessidade de pesquisa empírica. Afinal, como ressalta José Rodrigo Rodriguez" "Não há crítica do direito sem análise das instituições reais, ou seja, sem pesquisas empíricas que as sustentem [...]."

\section{Estudo de CAsos}

A essência do estudo de caso consiste em iluminar uma decisão ou um conjunto de decisões: por que elas são tomadas, como elas são implementadas e com que resultado.

A escolha de casos múltiplos tem vantagens metodológicas em comparação com o projeto de caso único, pois é considerado mais robusto pela lógica da replica-

54 GAUDEMET-TALLON, Héléne. Le pluralisme en droit international privé: richesses et faiblesses (le funambule et l'arc-en-ciel) : cours general. Leiden: M. Nijhoff, 2006. (Recueil des Cours de l' Académie de Droit International de la Haye, n. 312).p. 269.

55 BEVILÁQUA, Clóvis. Princípios elementares de direito internacional privado. Rio de Janeiro: Rio, 1978. p. 273.

56 RODRIGUEZ, José Rodrigo. Fuga do direito: um estudo sobre o direito contemporâneo a partir de Franz Neumann. São Paulo: Saraiva, 2009. p. 140. ção. ${ }^{57}$ Após a descoberta de um resultado, a prioridade subsequente é replicá-lo.

Para Robert Yin ${ }^{58}$, “cada estudo de caso individual consiste em um estudo completo, no qual a evidência convergente é procurada em relação aos fatos e às conclusões do caso; as conclusões de cada caso são, então, consideradas a informação que precisa ser replicada."

Por outro lado, não há que se confundir pesquisa de levantamento ou amostragem com estudo de caso, pois esse método emprega a generalização analítica, enquanto aquela o método de generalização estatística. No estudo de caso, o pesquisador busca generalizar um conjunto determinado de resultados, pela lógica de replicação, a alguma teoria mais ampla (generalização analítica). ${ }^{59}$

O âmbito do presente estudo de casos concentrar-se-á em decisões oriundas da justiça comum de primeira e de segunda instâncias do Estado do Rio Grande do Sul. No que toca à seleção dos casos, a triagem foi realizada por meio de pesquisa jurisprudencial no sítio oficial do Tribunal de Justiça do Rio Grande do Sul - TJRS ${ }^{60}$, pelo método de "palavras-chave". ${ }^{61}$ Em que pese os casos selecionados representem processos públicos, os nomes das partes foram omitidos com a transcrição apenas das respectivas letras iniciais.

A análise do caso iniciará pela sentença de primeira instância mediante a elaboração de um relatório. Posteriormente, far-se-á a transcrição, ipsis litteris, do ponto nevrálgico da decisão, com o intuito de dar maior confiabilidade ao estudo; por fim, as conclusões conectadas à teoria de base. Na sequência, será apresentada a decisão de segunda instância com a manutenção ou reforma da sentença originária e a exposição da ratio decidendi.

57 HERRIOT, Robert E.; FIRESTONE, William A. Multisite qualitative policy research: optimizing description and generalizability. Florida: Educational Researcher, 1983. p. 14-19.

58 YIN, Robert K. Estudo de caso: planejamento e métodos. Trad. Ana Thorell. 4. ed. Porto Alegre: Bookman, 2010. p. 80.

59 YIN, Robert K. Estudo de caso: planejamento e métodos. Trad. Ana Thorell. 4. ed. Porto Alegre: Bookman, 2010. p. 66.

60 RIO GRANDE DO SUL. Tribunal de Justiça. Pesquisa de Jurisprudência. Porto Alegre, 2015. Disponível em: < http://www.tjrs.jus. br/site/>. Acesso em: 2 ago. 2015.

61 Selecionada a pesquisa de jurisprudência "inteiro teor", com a seguintes palavras-chave: "regulamento e FIFA". Posteriormente, fez-se uma nova triagem analítica dos casos a partir das decisões disponíveis. Para acesso às sentenças de primeira instância, utilizou-se o link "consulta processual" inserindo os números dos processos de segundo grau disponíveis e acesso aos links "ver dados de primeiros grau" e "ver sentença". 
O primeiro caso trazido à baila será o denominado "caso-piloto", 62 , assim entendido aquele que abarca a teoria de base de forma mais abrangente possível, buscando-se, após, a replicação em outro caso similar.

Primeiro caso: Processo no 001/1.10.0280529-6. ${ }^{63}$

\section{Relatório:}

T. V. e G. C., dizendo-se agentes de jogadores de futebol, ajuizaram ação judicial de cobrança contra o atleta R. C. O. Narraram os autores terem firmado com o réu, em 26 de julho de 2009, contrato de prestação de serviços, com exclusividade, em todos os assuntos pertinentes a sua carreira de jogador de futebol profissional, pelo prazo determinado de dois anos. A remuneração dos agentes foi estipulada, contratualmente, em $10 \%$ dos rendimentos brutos auferidos pelo atleta por contratos de trabalho firmados durante a vigência do contrato de agenciamento. Os agentes aduziram que o atleta descumpriu o contrato de agenciamento ao firmar, sem o conhecimento daqueles, contrato de trabalho com um clube húngaro e, posteriormente, com dois clubes brasileiros, igualmente sem lhes pagar a remuneração estipulada.

O atleta demandado, por sua vez, alegou que os autores não prestaram os serviços contratados, notadamente não tiveram qualquer participação nos contratos de trabalho firmados pelo réu durante a vigência do contrato de agenciamento. Aduziu, ainda, a ilegitimidade específica do autor G. C. para exercer a profissão de agente de jogadores, já que não seria credenciado junto às entidades desportivas pertinentes.

$\mathrm{Na}$ fundamentação da sentença, o magistrado atestou a incontrovérsia da contratação dos agentes pelo atleta, passando a analisar a atividade de agente de jogadores exercida pelos autores. No tema, a sentença considerou que ambos os agentes não tinham as credenciais necessárias para exercer o ofício, nos termos do art. 104, incisos I e III, do Código Civil. ${ }^{64}$

62 YIN, Robert K. Estudo de caso: planejamento e métodos. Trad. Ana Thorell. 4. ed. Porto Alegre: Bookman, 2010. p. 118-119.

63 RIO GRANDE DO SUL. Tribunal de Justiça. Processo Civil. Processo 001/1.10.0280529-6. Decima Sexta Vara Cível. Autores: Tomás Vier; Gabriel Caraver. Réu: Rychely Cantanhede de Oliveira. Porto Alegre, 15 de janeiro de 2013. Disponível em: <http:// www.tjrs.jus.br/site_php/consulta/download/exibe_doc1g_oracle.php?id_comarca=porto_alegre\&ano_criacao $=2013 \& \mathrm{cod}_{-}$ documento=130792\&tem_campo_tipo_doc $=S>$. Acesso em: 2 ago. 2015.

64 Art. 104. A validade do negócio jurídico requer: I - agente ca-
Para tanto, o julgador referiu que deve ser observada, no caso em exame, a legislação especial que regula as relações contratuais atinentes às atividades desportivas, especificamente a Lei 9.615/98 - Lei Pelé, que prevê, em seu artigo $1^{\circ}, \Omega 1^{\circ}$, a obediência de normas nacionais e internacionais.

Transcreve-se o trecho o ponto nevrálgico da sentença para o presente estudo:

[...] Tais regras específicas ditadas por lei ou mesmo regulamentos internacionais, no caso, possui plena vigência no ordenamento jurídico brasileiro, pois, além do próprio país assim prever, como frisado no artigo $1^{\circ}, \int 1^{\circ}$, inciso I (sic) da Lei Pelé, o próprio artigo $9^{\circ}$ da Lei de Introdução às Normas do Direito Brasileiro - LINDB, alterada pela Lei 12.376 de 2010, é enfático ao afirmar que quando a obrigação depende de forma essencial, esta deverá ser observada, admitindo-se as peculiaridades de lei estrangeira quanto aos requisitos extrínsecos do ato.

Imperioso frisar, ainda, que os regulamentos estrangeiros, leis e atos de outros países apenas não terão eficácia no caso de ofensa à soberania nacional, a ordem pública e os bons costumes (artigo 17, Lei 12.376/2010), o que não é o caso dos autos.

Então, não há qualquer impeditivo legal para não observância de ato editado pela FIFA no que tange à capacidade de pessoas físicas para agenciamento de jogadores perante clubes desportivos, os quais devem estar devidamente cadastrados para desempenho destas atividades.

Os autores não são agentes credenciados junto à Federação Internacional, consoante se observa na relação acostada pelo próprio réu (folhas 71 a 96).

Portanto, não poderiam os demandantes exercer qualquer agenciamento de jogadores perante clubes nacionais ou internacionais ou entabular qualquer negociação contratual para a atividade como representante do réu. É o que se infere junto ao Regulamento da FIFA, órgão que administra a modalidade de negociações entre jogadores de futebol e clubes agenciados por terceiros, documento juntado pelo réu às folhas 98 a 113, cumprindo o que preceitua o artigo 14 da LINDB exceção ao aforismo iuria novit curia. $[\text {... }]^{65}$

paz; [...] III - forma prescrita ou não defesa em lei. BRASIL. Lei $N^{o}$ 10.406, de 10 de janeiro de 2002. Institui o Código Civil. Disponível em: <http://www.planalto.gov.br/ccivil_03/leis/2002/L10406. htm>. Acesso em: 03 fev. 2016.

65 RIO GRANDE DO SUL. Tribunal de Justiça. Processo Civil. Processo 001/1.10.0280529-6. Decima Sexta Vara Cível. Autores: Tomás Vier; Gabriel Caraver. Réu: Rychely Cantanhede de Oliveira. Porto Alegre, 15 de janeiro de 2013. Disponível em: <http:// www.tjrs.jus.br/site_php/consulta/download/exibe_doc1g_oracle.php?id_comarca $=$ porto_alegre\&ano_criacao $=2013 \& \mathrm{cod}_{-}$ documento $=130792 \&$ tem_campo_tipo_doc $=S>$. Acesso em: 2 
Assim fundamentando, a sentença considerou o contrato de agenciamento nulo, julgando improcedente a demanda.

\section{Conclusões:}

A sentença aplicou o direito estrangeiro, especificamente os regulamentos da FIFA, mediante a regra de conexão estabelecida no art. $1^{\circ}, \int 1^{\circ}$, da Lei 9.615/98. Em uma interpretação sistemática da legislação brasileira e internacional: Código Civil (art. 104), Lei Pelé (art. 1º,$\$$ $1^{\circ}$ ) e Regulamentos da FIFA, buscou-se a compatibilidade num todo estrutural, em um paralelo da teoria das fontes. ${ }^{66}$

O decisum referiu, ainda, que o réu trouxe a prova da existência do direito estrangeiro (Regulamento da FIFA), cumprindo com a exigência inserta no art. 14 da $\operatorname{LINDB}^{67}$, e que o indigitado regulamento não contrariava o art. 17 da $\operatorname{LINDB}^{68}$, motivo pelo qual não haveria óbice a sua aplicação de forma concomitante e harmônica com a legislação nacional (ausência de antinomias ou ofensa à ordem pública e a soberania).

Para a sentença, como a validade do negócio jurídico requer agente capaz e forma prescrita ou não defesa em lei (art. 104 do CC), ratificada a forma essencial pelo art. $9^{\circ}$ da LINDB, os autores não cumpriram com a exigência de credenciamento junto ao órgão que regula a atividade (FIFA), nos termos do regulamento dessa entidade aplicável por força do art. $1^{\circ}, \sqrt{ } 1^{\circ}$, da Lei Pelé.

Da sentença de primeira instância, houve interposição de recurso de apelação. ${ }^{69} \mathrm{O}$ acórdão manteve a sen-

ago. 2015.

66 FERRAZ JUNIOR, Tercio Sampaio. Introdução ao estudo do direito: técnica, decisão, dominação. 7. ed. São Paulo: Atlas, 2013. p. 256. 67 Art. 14.Não conhecendo a lei estrangeira, poderá o juiz exigir de quem a invoca prova do texto e da vigência. BRASIL. DecretoLei 4.657, de 04 de setembro de 1942. Lei de Introdução às normas do Direito Brasileiro. Disponível em: <http:/ /www.planalto.gov.br/ ccivil_03/decreto-lei/Del4657.htm>. Acesso em: 31 jul. 2015.

68 Art. 17. As leis, atos e sentenças de outro país, bem como quaisquer declarações de vontade, não terão eficácia no Brasil, quando ofenderem a soberania nacional, a ordem pública e os bons costumes. BRASIL. Decreto-Lei 4.657, de 04 de setembro de 1942. Lei de Introdução às normas do Direito Brasileiro. Disponível em: <http:/ / www.planalto.gov.br/ccivil_03/decreto-lei/Del4657.htm>. Acesso em: 31 jul. 2015

69 RIO GRANDE DO SUL. Tribunal de Justiça. Recurso de apelação Cível. Processo Cível $n^{0} 70054439807$. Décima Sexta Câmara Cível. Recorrentes: Tomás Vier; Gabriel Caraver. Recorrido: Rychely Cantanhede de Oliveira. Relator: Des. Paulo Sergio Scarparo. Porto Alegre, 25 de julho de 2013. Disponível em: <http:// www.tjrs.jus.br/site_php/consulta/download/exibe_documento. php?ano $=2013 \&$ codigo $=1248582>$. Acesso em: 2 ago. 2015. tença de improcedência, mas por motivo diverso: ausência de comprovação dos serviços prestados e quebra do princípio da boa-fé objetiva. Quanto à fundamentação da sentença recorrida antes transcrita, o acórdão assim dispôs:

[...]Nesse ponto, convém salientar que não se deixa de reconhecer a razoabilidade do argumento - trazido aos autos pelo demandado a acolhido pela sentenciante - de que haveria nulidade do contrato, em razão de não serem os demandantes credenciados junto à FIFA. Afirmam os réus que haveria nulidade do contrato por não terem os autores credenciamento, bem como por inobservância das normas administrativas dessa entidade, no que pertine à utilização de formulários padronizados de contratação entre agente e atleta e entre agente e clubes de futebol associadas.

Todavia, independentemente das regras e formalidades da FIFA, releva, no caso ora sob a análise, é relevante notar que a validade de todo e qualquer contrato, no âmbito do direito privado, pressupõe que sejam observados tanto a função social do contrato quanto o princípio da boa-fé objetiva (arts. 421 e 422 do Código Civil). [... $]^{70}$

Desse modo, embora o acórdão tenha adotado fundamentos diversos para julgar improcedente a demanda, não invalidou a ratio decidendi a quo. Convém registrar, por fim, que o processo transitou em julgado sem recurso para as instâncias superiores (STJ e STF).

Segundo caso: Processo no $001 / 1.06 .0246425-4^{71}$

Relatório:

B. C. F., na condição de agente de jogadores autorizado pela FIFA, ajuizou ação de indenização contra o atleta C. C. D., alegando, em suma, que o jogador profissional lhe outorgou poderes, com exclusividade, para representá-lo em negociações com clubes de futebol europeus. O autor aduziu que, após diversas tratativas, trouxe uma proposta de trabalho para o atleta requerido de um clube italiano, que fora aceita pelo jogador. No

70 RIO GRANDE DO SUL. Tribunal de Justiça. Recurso de apelação Cível. Processo Cível no 70054439807. Décima Sexta Câmara Cível. Recorrentes: Tomás Vier; Gabriel Caraver. Recorrido: Rychely Cantanhede de Oliveira. Relator: Des. Paulo Sergio Scarparo. Porto Alegre, 25 de julho de 2013. Disponível em: <http:// www.tjrs.jus.br/site_php/consulta/download/exibe_documento. php?ano $=2013 \&$ codigo $=1248582>$. Acesso em: 2 ago. 2015 .

71 RIO GRANDE DO SUL. Tribunal de Justiça. Apelação Cível. Processo 001/1.06.0246425-4. Terceira Vara Cível Autor: Bernardo Chlaem Filho. Réu: Christian Corrêa Dionisío. Porto Alegre, 09 de fevereiro de 2007. Disponível em: <http://www.tjrs.jus.br/site_php/ consulta/download/exibe_doc1g_oracle.php?id_comarca=porto_ alegre\&ano_criacao $=2007 \&$ cod_documento $=126719 \&$ tem_campo_tipo_doc $=S>$. Acesso em: 2 ago. 2015. 
entanto, o atleta decidiu, de última hora, não concretizar a oferta laboral, optando por entabulá-la com outro clube da Alemanha, por meio de agente desportivo diverso, descumprindo, assim, a cláusula de exclusividade concedida. Desse modo, o autor postulou, a título de indenização por dano material, pagamento da comissão a que teria direito no clube italiano, equivalente a $10 \%$ do valor do contrato de trabalho ofertado e recusado pelo atleta; pleiteou, ainda, indenização por danos morais diante do abalo à sua imagem e credibilidade no mercado desportivo.

C. C. D., em contestação, alegou que o autor, enquanto agente de jogadores credenciado pela FIFA, não cumpriu com as exigências insertas no regulamento que norteia a atividade. $\mathrm{O}$ atleta reconheceu que o autor, de fato, trouxe uma proposta inicial de trabalho de um clube italiano, mas que teria recusado; uma segunda proposta trazida pelo autor, do mesmo clube e com melhores condições financeiras, não continha carimbo e assinatura dos dirigentes responsáveis, elementos mínimos de credibilidade, motivo pelo qual teria igualmente rejeitado e optado por encetar contrato de trabalho com outro clube europeu, por meio de outro agente. Por fim, aduziu que a comissão de 10\% sobre o contrato de trabalho só seria devida em caso de concretização do negócio com o clube italiano, o que não ocorreu.

A lide comportou julgamento antecipado, pela ausência de provas em audiência, na forma do art. 330, inciso I, do Código de Processo Civil.

$\mathrm{Na}$ fundamentação da sentença, o magistrado considerou que o regulamento de agentes de jogadores da FIFA era aplicável ao caso dos autos e que o autor efetivamente descumpriu diversos preceitos contidos nesse regulamento. Aduziu, ainda, que a atividade de agente de jogadores é de risco, sendo devida a remuneração somente em caso de efetivação do contrato de trabalho. No caso dos autos, o autor só demonstrou a existência de negociações preliminares, sem um desfecho positivo do pacto laboral.

Transcreve-se o trecho o ponto nevrálgico da sentença para o presente estudo:

[...] De pronto destaco que, não obstante os argumentos lançados pelo autor, no sentido de que a legislação a ser aplicada ao caso dos autos deva primar pelos ditames da lei civil em geral, é inevitável, como supedâneo das razões de decidir, a aplicação do Regulamento dos Agentes de Jogadores de fls. 48/60, expedido pela FIFA, trazido aos autos através de tradução por profissional juramentado.

Com isso, não há o afastamento do ordenamento jurídico pátrio, mas a observância do que já foi regulamentado pelo órgão competente à atividade desportiva, naquilo que não afrontar os preceitos e princípios que regem o ordenamento jurídico nacional. Em outras palavras, se aplica a Lei Nacional (Constituição Federal e Código Civil), mas também se considera o regulamento da entidade internacional, FIFA, no que não afrontar os preceitos e princípios dispostos no ordenamento jurídico pátrio. [...]

Por isso, a observância das normas específicas, ainda que não niveladas à lei civil, para dirimir as controvérsias advindas da relação entre o agente e o jogador de futebol. [... $]^{72}$

Assim, com base no descumprimento do regulamento de agentes de jogadores da FIFA, cujos artigos afrontados são irrelevantes para o presente estudo, e diante da ausência de concretização do contrato de trabalho entre o atleta e o clube italiano, o juiz julgou a ação indenizatória improcedente.

\section{Conclusões}

Houve a aplicação do direito desportivo estrangeiro pelo juiz nacional, especificamente o regulamento de agentes de jogadores da FIFA, trazido aos autos por tradutor juramentado. Todavia, não foi mencionada a existência de algum elemento de conexão para a incidência direta daquela normatividade transnacional. Optou-se, diante da anomia da legislação estatal brasileira acerca da atividade de agente de jogadores, por aplicar as normas da FIFA, naquilo que não afrontasse os preceitos e princípios do ordenamento jurídico nacional, em uma interpretação indireta do art. 17 do LINDB. Por fim, a par da aplicação dos regulamentos da FIFA, fez-se uma consideração sobre uma (suposta) hierarquia da lei estatal brasileira em relação à lei privada estrangeira.

Da sentença de primeira instância, houve interposição de recurso de apelação. ${ }^{73} \mathrm{O}$ acórdão manteve a

72 RIO GRANDE DO SUL. Tribunal de Justiça. Apelação Cível. Processo 001/1.06.0246425-4. Terceira Vara Cível Autor: Bernardo Chlaem Filho. Réu: Christian Corrêa Dionisío. Porto Alegre, 09 de fevereiro de 2007. Disponível em: <http://www.tjrs.jus.br/site_php/ consulta/download/exibe_doc1g_oracle.php?id_comarca=porto_ alegre\&ano_criacao $=2007 \&$ cod_documento $=126719 \&$ tem_campo_tipo_doc=S>. Acesso em: 2 ago. 2015.

73 RIO GRANDE DO SUL. Tribunal de Justiça. Recurso de apelação Cível. Processo Cível 70019936756. Quinta Câmara Cível. Recorrentes: Bernardo Chlaem Filho. Recorrido: Christian Corrêa Dionisío. Relator: Des. Paulo Roberto Felix. Porto Alegre, 04 de junho de 2008. Disponível em: <http://www.tjrs.jus.br/site_php/consulta/ download $/$ exibe_documento.php? ano $=2008 \&$ codigo $=700574>$. 
sentença de improcedência, pelos seus próprios fundamentos, com a transcrição, ipsis litteris, de toda a fundamentação originária.

Convém registrar, por fim, que houve a interposição de recurso especial pelo autor para o Superior Tribunal de Justiça - STJ, inadmitido pelo TJRS por questões processuais. Contra essa decisão de inadmissibilidade recursal, o autor interpôs, ainda, agravo de instrumento para o STJ, sendo negado provimento ao recurso por decisão monocrática, ${ }^{74}$ igualmente por questões processuais que são despiciendas à controvérsia objeto do presente estudo, com o consequente trânsito em julgado.

\section{Considerações finais}

A fragmentação do direito é uma marca da sociedade contemporânea, especialmente pelo surgimento de setores sociais especializados, que reclamam para si um direito autônomo com as suas próprias regras e instituições. Segmentos da sociedade que, de forma crescente, competem com o poder legiferante do Estado-nação. Assim, o direito não se reduz a um conjunto de normas emanadas pelo Estado, mas reclama um pluralismo de fontes normativas. É como um rio caudaloso que, após uma forte chuva, arrasta a tudo e a todos.

Nesse contexto, novos fenômenos jurídicos, que caracterizam o direito global, ganham força, v.g., a lex sportiva, ordenamento jurídico-desportivo transnacional produzido por entidades privadas sem participação governamental.

Tais ordens jurídicas privadas, que procuram se manter afastadas do direito oficial do Estado-nação, paradoxalmente, estão influenciando a legislação estatal, quer pela reprodução de normas transnacionais mediante processos legislativos convencionais, quer pela aplicação direta do direito desportivo estrangeiro.

Sob a perspectiva do Estado brasileiro, esses proces-

Acesso em: 3 fev. 2016.

74 BRASIL. Superior Tribunal de Justiça. Agravo de instrumento. AI n 1.155.400 - RS (2009/0025521-9). Agravante: Bernardo Chlaen Filho. Agravado: Christian Corrêa Dionisío. Decisão monocrática. Relator: Min. Honildo Amaral de Mello Castro. Brasília, 17 de julho de 2009. Disponível em: <https://ww2.sti.jus.br/processo/revista/ documento $/$ mediado $/$ ?componente $=\mathrm{MON} \&$ sequencial $=5784530$ $\&$ num_registro $=200900255219 \&$ data $=20090807 \&$ tipo $=0 \&$ format $\mathrm{o}=\mathrm{PDF}>$. Acesso em: 9 ago. 2015. sos de reprodução da normatividade jurídico-desportiva transnacional e de aplicação direta pela jurisdição estatal traduzem-se em tentativas de harmonização do direito oficial com o direito desportivo transnacional, criando-se arranjos institucionais para traduzi-lo ou aplicá-lo internamente. $^{75}$

No entanto, quanto à aplicação do direito desportivo transnacional pela jurisdição estatal, ainda há certa recalcitrância por uma série de motivos, dentre eles o desconhecimento da peculiar regra de conexão desportiva e seu funcionamento, assim como uma vontade, quiçá natural, de aplicar a lex fori escudada pela segurança do brocardo iura novot curia.

O estudo empírico de casos, porém, revelou que a jurisdição estatal, incisivamente de primeira instância, tem aplicado as normas transnacionais desportivas em uma leitura contemporânea do pluralismo jurídico, conquanto por meio de critérios disformes.

$\mathrm{O}$ primeiro caso conectou-se à teoria de base de forma mais abrangente, utilizando a norma de conexão desportiva de acordo com a mens legis, ou seja, buscando a compatibilidade e a aplicação concomitante de normas desportivas nacionais e transnacionais. A decisão de segunda instância (acórdão), embora tenha reconhecido expressamente a razoabilidade dos fundamentos da sentença originária quanto à aplicação do direito desportivo transnacional, optou por utilizar argumentos diversos para manter a improcedência da demanda, calcados exclusivamente no Código Civil.

Já no segundo caso estudado, a sentença de primeira instância aplicou as normas desportivas estrangeiras de forma concomitante à legislação estatal, naquilo que não a afrontasse, mas sem mencionar o elemento de conexão para a aplicação do direito desportivo estrangeiro. Referiu, ademais, uma (suposta) hierarquia entre a legislação civil brasileira em relação às normas desportivas transnacionais: lex superior derogat inferiori. A decisão de segunda instância (acórdão), nesse caso, manteve a sentença de improcedência pelos seus próprios fundamentos, com a transcrição, ipsis litteris, de toda a fundamentação originária.

A despeito de certa discrepância na ratio decidendi dos casos analisados, percebe-se que a legislação desportiva transnacional ganha espaço no ordenamento jurídico

75 DELMAS-MARTY, Mireille. Les forces imaginantes du droit II: le pluralisme ordonné. Paris: Seuil, 2006. p. 69. 
estatal, tanto pela reprodução de normas transnacionais por meio do processo legislativo convencional, quanto pela aplicação direta da normatividade desportiva estrangeira pela jurisdição nacional.

Assim, paradoxalmente, é o direito "oficial" do Estado-nação que, deliberadamente, cede espaço para a normatividade transnacional, enquanto esse subsistema mantém-se equidistante do ordenamento jurídico estatal, com sua pretensão de autonomia e auto-regulação.

\section{REFERÊNCIAS}

BASSO, Maristela. Curso de direito internacional privado. 3. ed. São Paulo: Atlas, 2013.

BENJAMIN, Daniela Arruda. A aplicação dos atos de organizações internacionais no ordenamento jurídico brasileiro. Brasília: Funag, 2014.

BEVILÁQUA, Clóvis. Princípios elementares de direito internacional privado. Rio de Janeiro: Rio, 1978.

BRASIL. Constituição (1988). Constituição da Republica Federativa do Brasil. Disponível em: < http:/ / www.planalto.gov.br/ccivil_03/Constituicao/Constituicao.htm>. Acesso em: 3 fev. 2016.

BRASIL. Decreto-Lei 4.657, de 04 de setembro de 1942. Lei de Introdução às normas do Direito Brasileiro. Disponível em: <http://www.planalto.gov.br/ccivil_03/ decreto-lei/Del4657.htm>. Acesso em: 31 jul. 2015.

BRASIL. Lei 12.395, de 16 de março de 2011. Altera as Leis nos 9.615, de 24 de março de 1998, que institui normas gerais sobre desporto. Disponível em: <http:/ / www.planalto.gov.br/ccivil_03/_ato2011-2014/2011/ lei/112395.htm>. Acesso em: 09 ago. 2015.

BRASIL. Lei 9.615, de 24 de marco de 1998. Institui normas gerais sobre desporto e dá outras providências. Disponível em: <http://www.planalto.gov.br/ccivil_03/ LEIS/L9615consol.htm>. Acesso em: 26 jul. 2015.

BRASIL. Lei $N^{0}$ 10.406, de 10 de janeiro de 2002. Institui o Código Civil. Disponível em: <http://www.planalto. gov.br/ccivil_03/leis/2002/L10406.htm>. Acesso em: 03 fev. 2016.

BRASIL. Superior Tribunal de Justiça. Agravo de instrumento. AI no 1.155.400 - RS (2009/0025521-9). Agravante: Bernardo Chlaen Filho. Agravado: Christian
Corrêa Dionisío. Decisão monocrática. Relator: Min. Honildo Amaral de Mello Castro. Brasília, 17 de julho de 2009. Disponível em: < https://ww2.stj.jus.br/processo $/$ revista $/$ documento $/$ mediado $/$ ?componente $=\mathrm{M}$ ON\&sequencial $=5784530 \&$ num_registro $=200900255$ $219 \&$ data $=20090807 \&$ tipo $=0 \&$ formato $=P D F>$. Aces so em: 9 ago. 2015.

CASINI, Lorenzo. Sports law: a global legal order? Law \& Society Forum, Honolulu, 2012. Disponível em: $<$ http://ssrn.com/abstract $=2079857>$. Acesso em: 07 jun. 2015.

COTTERRELL, Roger. What is Transnational Law. Law \& Social Inquiry, London, v. 37, n. 2, p. 500-524, March 2012. Disponível em: <http://papers.ssrn.com/ sol3/papers.cfm?abstract_id $=2021088>$. Acesso em: 04 ago. 2015.

DALLARI, Pedro B. A. Constituição e relações internacionais. 2. ed. São Paulo: Saraiva, 2003.

DELMAS-MARTY, Mireille. Les forces imaginantes $d u$ droit II: le pluralisme ordonné. Paris: Seuil, 2006.

DELMAS-MARTY, Mireille. Três desafios para um direito mundial. Tradução de Fauzi Hassan Choukr. Rio de Janeiro: Lumen Juris, 2003.

DOLINGER, Jacob. Direito internacional privado: parte geral. 11. ed. Rio de Janeiro: Forense, 2014.

FARIA, Tiago Silveira de. A persistência da inconstitucionalidade do vínculo desportivo na lei 12.395/2011. Jornal Trabalbista Consulex, Brasília, v. 28, p. 6-8, 2011.

FÉDÉRATION INTERNATIONALE DE FOOTBALL ASSOCIATION. Regulation on the status and transfer of players. Zurique, 2015. Disponível em: < http:// resources.fifa.com/mm/document/affederation/administration/01/06/30/78/statusinhalt_en_122007. pdf>. Acesso em: 26 jul. 2015.

FERRAZ JUNIOR, Tercio Sampaio. Introdução ao estudo do direito: técnica, decisão, dominação. 7. ed. São Paulo: Atlas, 2013.

GAUDEMET-TALLON, Héléne. Le pluralisme en droit international privé: richesses et faiblesses (le funambule et l'arc-en-ciel): cours general. Leiden: M. Nijhoff, 2006. (Recueil des Cours de l' Académie de Droit International de la Haye, n. 312).

HERRIOT, Robert E.; FIRESTONE, William A. Multisite qualitative policy research: optimizing description and 
generalizability. Florida: Educational Researcher, 1983.

JAYME, Erik. O direito internacional privado do novo milênio: a proteção da pessoa humana face à globalização. Cadernos do programa de pós-graduação em Direito, Porto Alegre, v. 1, n. 1, p. 133-146, mar. 2003.

JAYME, Erik. Visões para uma teoria pós-moderna do direito comparado. Cadernos do programa de pós-graduação em Direito, Porto Alegre, v. 1, n. 1, p. 115-131, mar. 2003.

JESSUP, Philip C. Direito transnacional. Tradução de Carlos Ramires Pinheiro da Silva. São Paulo: Fundo de Cultura, 1965.

KOSKENNIEMI, Martti. Fragmentation of international law: difficulties arising from the diversification and expansion of international law. In: INTERNATIONAL LAW COMMISSION, 58., 2006. Report of the Study Group of the International Law Commission... Geneve: United Nations, 2006. Available at: <http://legal. un.org/ilc/documentation/english/a_cn4_1682.pdf> . Access: 3 Feb. 2016.

LATTY, Franck. La lex sportiva: recherche sur le droit transnational. Leiden: Nijhoff, 2007.

LATTY, Franck. Transnational sports law. The International Sports Law Journal, Haye, n. 1-2, p. 34-38, Jan./April 2011.

MELO FILHO, Álvaro. O novo direito desportivo. São Paulo: Cultural Paulista, 2002.

REBELLO, Aiuri; CRUZ, José. "Bancada da bola" faz pressão e tira CBF de projeto sobre dividas dos times. Brasília, 29 abr. 2014. Disponível em: < http:/ / esporte.uol.com. br/futebol/ultimas-noticias/2014/04/29/bancada-dabola-faz-pressao-e-tira-cbf-de-projeto-sobre-dividados-times.htm>. Acesso em: 26 jul. 2015.

RIO GRANDE DO SUL. Tribunal de Justiça. Apelação Cível. Processo 001/1.06.0246425-4. Terceira Vara Cível Autor: Bernardo Chlaem Filho. Réu: Christian Correa Dionísio. Porto Alegre, 09 de fevereiro de 2007. Disponível em: <http://www.tjrs.jus.br/site_php/ consulta/download/exibe_doc1g_oracle.php?id_ comarca $=$ porto_alegre\&ano_criacao $=2007 \& c o d$ documento=126719\&tem_campo_tipo_doc $=S>$. Acesso em: 2 ago. 2015.

RIO GRANDE DO SUL. Tribunal de Justiça. Pesquisa de Jurisprudência. Porto Alegre, 2015. Disponível em: $<$ http://www.tjrs.jus.br/site/>. Acesso em: 2 ago. 2015.
RIO GRANDE DO SUL. Tribunal de Justiça. Processo Civil. Processo 001/1.10.0280529-6. Decima Sexta Vara Cível. Autores: Tomás Vier; Gabriel Caraver. Réu: Rychely Cantanhede de Oliveira. Porto Alegre, 15 de janeiro de 2013. Disponível em: < http:// www.tjrs.jus.br/site_php/consulta/download/exibe_ doc1g_oracle.php?id_comarca=porto_alegre\&ano_ criacao $=2013 \&$ cod_documento $=130792 \&$ tem_campo_tipo_doc $=S>$. Acesso em: 2 ago. 2015.

RIO GRANDE DO SUL. Tribunal de Justiça. Recurso de apelação Cível. Processo Civel 70019936756. Quinta Câmara Cível. Recorrentes: Bernardo Chlaem Filho. Recorrido: Christian Correa Dionísio. Relator: Des. Paulo Roberto Felix. Porto Alegre, 04 de junho de 2008. Disponível em: < http://www.tjrs.jus. br/site_php/consulta/download/exibe_documento. php?ano $=2008 \&$ codigo $=700574 \mathrm{P}$. Acesso em: $3 \mathrm{fev}$. 2016.

RIO GRANDE DO SUL. Tribunal de Justiça. Recurso de apelação Cível. Processo Civel n ${ }^{\circ} 70054439807$. Décima Sexta Câmara Cível. Recorrentes: Tomás Vier; Gabriel Caraver. Recorrido: Rychely Cantanhede de Oliveira. Relator: Des. Paulo Sergio Scarparo. Porto Alegre, 25 de julho de 2013. Disponível em: < http://www.tjrs.jus. br/site_php/consulta/download/exibe_documento. php?ano $=2013 \&$ codigo $=1248582>$. Acesso em: 2 ago. 2015.

RODRIGUEZ, José Rodrigo. Fuga do direito: um estudo sobre o direito contemporâneo a partir de Franz Neumann. São Paulo: Saraiva, 2009.

SHAFFER, Gregory. Transnational legal process and state change: opportunities and constraints. Nova Iorque: Universidade of Minnesota, 2012. (Legal Studies Research Paper Series Research Paper, n. 10-28). Disponível em: <http://papers.ssrn.com/sol3/papers.cfm?abstract_ id $=1901952>$. Acesso em: 26 jul. 2015.

SIQUEIRA JR., Paulo Hamilton. Teoria do direito. 3. ed. São Paulo: Saraiva, 2012.

TEIXEIRA, Anderson Vichinkeski. Qual a função do estado constitucional em um constitucionalismo transnacional? In: STRECK, Lenio Luiz; ROCHA, Leonel Severo; ELGELMANN, Wilson (Org.). Constituição, sistemas sociais e hermenêutica: anuário do Programa de PósGraduação em Direito da UNISINOS. Porto Alegre: Livraria do Advogado, 2012. v. 9, p. 9-32.

TEUBNER, Gunther. As duas faces de Janus: plura- 
lismo jurídico na sociedade pós-moderna. In: (Org.). Direito, sistema e policontexturalidade. Piracicaba: UNIMEP, 2005. p. 79-104.

TEUBNER, Gunther. Colisões de regimes: a busca vã por unidade jurídica na fragmentação do direito global. Revista Brasileira de Estudos Constitucionais, Belo Horizonte, v. 6, n. 21, p. 105-155, jan./mar. 2012.

TEUBNER, Gunther. A Bukowina global sobre a emergência de um pluralismo jurídico transnacional. Revista de Ciências Sociais e Humanas, Piracicaba, v. 14, n. 33, p. 9-31, jan./abr. 2003.

VARELLA, Marcelo D. Internacionalização do direito: di- reito internacional, globalização e complexidade. 2012. 606 f. Tese (Livre-Docência em Direito Internacional) - Faculdade de Direito, Universidade de São Paulo, São Paulo, 2012. Disponível em: <https://www.uniceub. br/media/186548/MVarella.pdf $>$. Acesso em: 03 nov. 2015.

VELHO, Rafael Rott de Campos. O Mercosul e a política ambiental: modelos, inconsistências e alternativas. Revista de Direito Internacional, Brasília, v. 9, n. 3, p. 103128, 2012.

YIN, Robert K. Estudo de caso: planejamento e métodos. Trad. Ana Thorell. 4. ed. Porto Alegre: Bookman, 2010. 


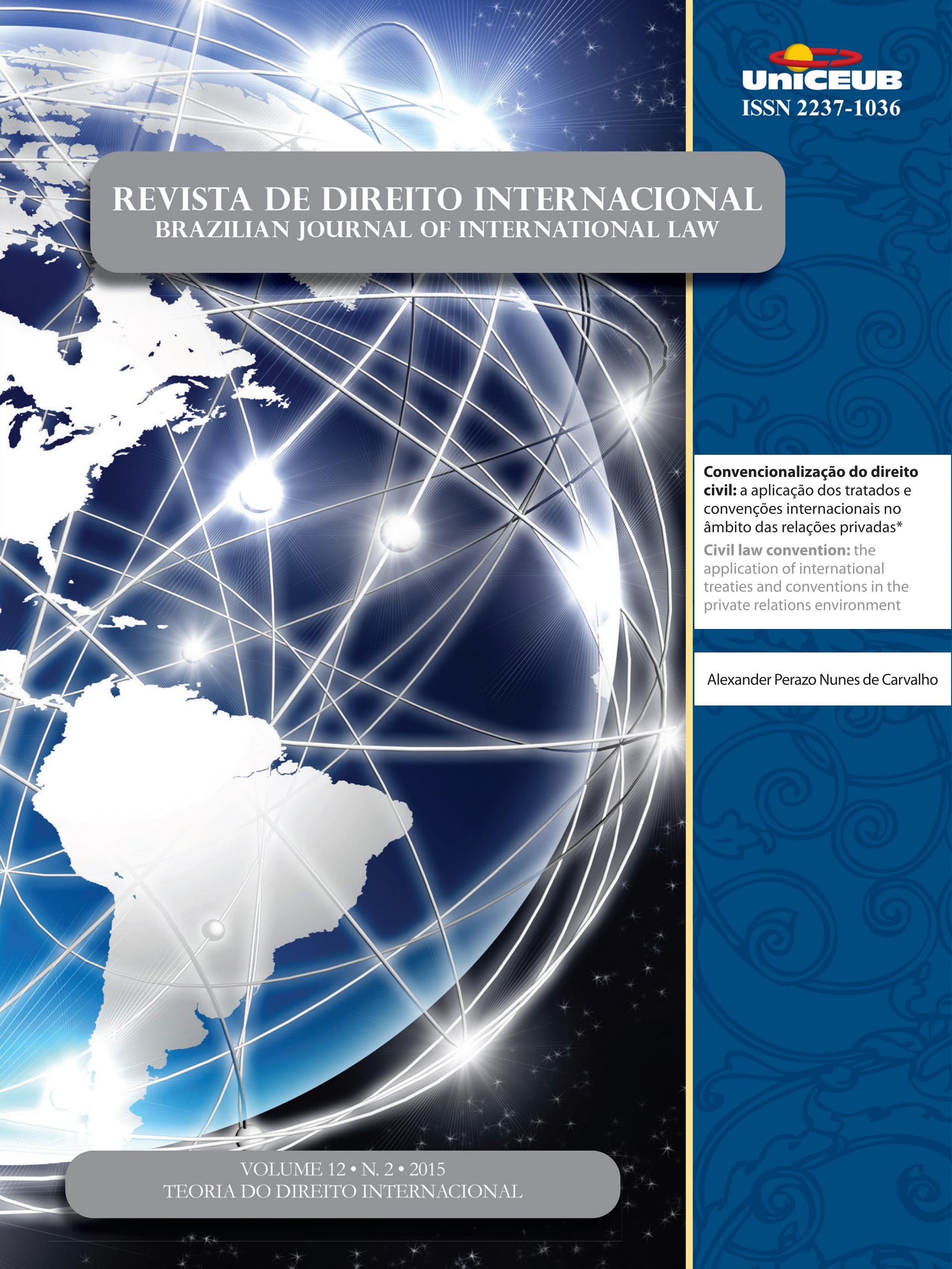




\section{Convencionalização do direito civil: a aplicação dos tratados e convenções internacionais no âmbito das relações privadas*}

\author{
Civil law convention: the application of \\ international treaties and conventions in the \\ private relations environment
}

Alexander Perazo Nunes de Carvalho**

\section{Resumo}

O objetivo deste artigo é analisar a aplicação dos tratados e convenções internacionais no âmbito das relações de Direito Civil. Sabe-se que o artigo $5^{\circ}, \int 3^{\circ}$, da Constituição Federal de 1988, acrescentado pela Emenda Constitucional $n^{\circ} 45 / 04$, passou a disciplinar que os tratados e convenções internacionais sobre direitos humanos que forem aprovados, em cada Casa do Congresso Nacional, em dois turnos, por três quintos dos votos dos respectivos membros, serão equivalentes às Emendas Constitucionais. Por outro lado, o Supremo Tribunal Federal já entendeu que os tratados e convenções internacionais sobre direitos humanos não submetidos às formalidades constitucionais suso mencionadas, têm eficácia supralegal, situados, portanto, em uma posição imaginária entre a Constituição Federal e as leis infraconstitucionais. Não por outra razão, as normas de Direito Civil devem se submeter, além do indispensável controle de constitucionalidade, também a um controle de convencionalidade, em relação a tratados e a convenções que versam sobre direitos humanos. No presente artigo, inicialmente, apresenta-se um breve panorama sobre a constitucionalização do Direito Civil e a nova hermenêutica das relações privadas. Em seguida, e em virtude desse viés constitucional, analisa-se o fenômeno da horizontalização dos direitos fundamentais, com a aplicação direta dos direitos fundamentais às relações privadas, embora sem descurar de especificidade do Direito Civil. Como conclusão, analisa-se a aplicação dos tratados e convenções internacionais no âmbito das relações privadas, compreendendo o fenômeno da convencionalização do Direito Civil, , inclusive diante da redação do artigo 13 do novo Código de Processo Civil - Lei no 13.105, de 16 de março de 2015.

Palavras-chave: Constitucionalização do direito civil. Eficácia horizontal das relações privadas. Convencionalização do direito civil.

\section{Abstract}

The objective of this article is to analyze the application of international treaties and conventions in the Civil Law relations.The Federal Constitution of 1998 , in its 5 th article, $3^{\text {rd }} \int$, added by the Constitutional Amendment 
45/04 established that international human rights treaties and conventions that were approved by both houses of National Congress, in two turns, by at least $3 / 5$ votes will be equivalent to the Constitutional Amendments. On the other hand, the Federal Supreme Court has already disciplined that international human rights treaties and conventions that have not followed the steps described above, have supralegal efficacy. Therefore they are located in an imaginary place between the Federal Constitution and the infraconstitutional laws. For this reason, the norms of Civil Laws shall be subordinated to a conventional control in relation with human rights treaties and conventions besides the obvious constitutional controls. In this article, there will be a brief overview about Civil Laws as it relate to the Constitution and the new private relations hermeneutics. After this introduction, because of this constitutional bias, we will analyze the horizontal phenomena of fundamental rights with its direct application in the private relations, without losing Civil Laws specificities. Concluding this article analyzes the application of international treaties and conventions in the private relations environment including the conventionalization of Civil Laws and considering the article $13^{\text {th }}$ wording of the new Civil Code Process - Law 13.105, from march 16 ${ }^{\text {th }}, 2015$.

Keywords: Civil law and constitution. Horizontal efficience of private relations. Civil law convention.

\section{INTRODUÇÃo}

O presente artigo defende a hipótese de aplicação dos tratados e convenções internacionais no âmbito das relações privadas. Tal estudo baseia-se nas transformações do Direito Civil, como um fenômeno que se operou ao longo da história.

Assim, sabe-se que, na fase do liberalismo jurídico, rompendo com o regime absolutista e seus privilégios, surge o Estado da legalidade e da liberdade, em conjunto com a fase da codificação do Direito Civil. Para os Oitocentistas, a codificação seria suficiente para regular toda a vida da sociedade civil, como lei maior da comunidade, de forma igualitária.

A concepção de então passou a ser o respeito integral à lei e aos contratos, principal fonte das obrigações civis. A lei, tratando a todos como iguais, possuía natureza geral e impessoal, sendo a vontade a fonte única para o nascimento de direitos e obrigações.

No Brasil, era esta, em linhas gerais, a visão do Direito Civil no Código de 1916. O Estado não estava presente nas relações individuais, até mesmo porque se pregava a soberania do indivíduo, com a própria autonomia decorrente do contrato, cuja visão estática, ignorava as desigualdades econômicas entre as partes, sempre baseado numa ética meramente individualista.

Após as sucessivas crises que surgiram após a Segunda Guerra Mundial, adveio a necessidade de se repensar as técnicas de proteção a pessoa humana, passando o Estado a legislar, ainda que de forma desordenada, sobre matérias que antes eram afeitas ao Direito Civil, criando uma denominada "legislação de emergência". O Código Civil perdia, paulatinamente, a sua função de "Constituição do Direito Privado", ocasião em que os textos constitucionais começavam a trazer princípios que antes eram encontrados somente nas leis civis, tais como a função social da propriedade, organização da família, limites da atividade econômica etc.

Nesse diapasão, a constitucionalização do Direito Civil surge para representar a busca de seu fundamento de validade numa perspectiva constitucional, tendo como ponto basilar a releitura de seus institutos e possuindo como parâmetro a dignidade da pessoa humana.

Ainda nessa esteira de pensamento, delineia a noção, ainda tímida, de horizontalização dos direitos fundamentais (Drittwirkung), impondo novos desafios ao civilista contemporâneo. Por sua vez, a noção de convencionalização do Direito Civil, com a aplicação dos tratados e convenções internacionais às relações privadas, representa nova dimensão axiológica que, por sua vez, deve direcionar a realização do Direito Civil, em seus variados planos, justificando, sobremaneira, o presente estudo.

\section{A CONSTItUCIONALIZAÇÃo do diREITO CIVIL}

O processo evolutivo do Direito encontra-se profundamente associado à própria evolução humana e, consequentemente, à vida em sociedade. Hoje, há uma maior atuação do Estado em áreas que, no passado, eram tradicionalmente privadas. Dessa forma, o denominado Direito Civil Constitucional reflete a análise da aplicação de normas constitucionais, isto é, de natureza 
pública, em situações eminentemente privadas, regidas pelo Direito Privado. Despontou-se, assim, a exigência de que as condutas individuais não prejudicassem o interesse coletivo, para que estivessem de acordo com o equilíbrio e o bem-estar social.

Sabe-se que o Direito Civil, durante a sua trajetória no mundo romano-germânico, tradicionalmente, foi considerado como o locus normativo do indivíduo, e, de todos os ramos do Direito, este era considerado, como o mais distante do Direito Constitucional. Em vez da Constituição Política, havia uma constituição do homem comum, máxime após o processo de codificação liberal. Seu gradativo desenvolvimento atravessa desde a história do Direito Romano-Germânico, há cerca de dois mil anos, parecendo contrário às transformações sociais, políticas e econômicas. Assim, as relações jurídicas interpessoais, em especial o Direito das Obrigações, estariam imunes às mudanças históricas, estando, permanentemente, válidos os princípios e as regras imemoriais, independentemente da espécie de constituição política vigente. ${ }^{1}$

O termo "constitucionalização do Direito Civill" alcançou expressiva importância na atualidade, estimulando pesquisas e debates no universo acadêmico jurídico, vinculando-se às aquisições culturais da hermenêutica contemporânea, tais como a força normativa dos princípios, a diferenciação entre princípios e regras, a interpretação de acordo com o texto constitucional, entre outros aspectos. Esse processo de constitucionalização do Direito Civil refere-se às mudanças de valores, substituindo o indivíduo pela pessoa. A liberdade individual passa a ser sobrepujada pela solidariedade social. Como expõe Caio Mário, "é tempo de reconhecer que a posição ocupada pelos Princípios Gerais de Direito passou a ser preenchida pelas normas constitucionais, notadamente pelos Direitos Fundamentais".

O processo de constitucionalização do Direito Privado torna-se, portanto, sob determinados aspectos, a superação da perspectiva que considerava o ordenamento jurídico dividido em dois mundos antagônicos: o Direito Público e o Direito Privado. Impõe-se, assim, repercorrer as razões que criaram essa diferenciação,

1 LÔBO NETTO, Paulo Luiz. Constitucionalização do direito civil. Revista de Informação Legislativa, Brasília, v. 36, n. 141, p. 99-100, jan./mar. 1999.

2 PEREIRA, Caio Mário da Silva. Instituições de direito civil. 20. ed. Rio de Janeiro: Forense, 2004. v. 1. p. 23. seu desenvolvimento, com a análise das justificativas que provocaram a contemporânea relativização dessa diferenciação. ${ }^{3}$

É relevante ressaltar que o objetivo de uma constitucionalização do Direito Civil está em uma reconstrução do Direito Privado, que passa a se basear nos valores constitucionais, destinados à satisfação dos direitos fundamentais. Segundo Freitas e Pires, "a constitucionalização do direito, em outros termos, seria a irradiação das normas e dos valores constitucionais a todos os tecidos do Direito." ${ }^{4}$

Gustavo Tepedino, salienta que:

A inclusão dos institutos de direito civil, como
contrato, propriedade e família, na agenda atinente à
ordem pública associa-se à irradiação dos princípios
constitucionais nos espaços de liberdade individual.
Com efeito, a partir da interferência da Constituição
no âmbito antes reservado à autonomia privada, uma
nova ordem pública há de ser construída, coerente
com os fundamentos e objetivos fundamentais da
República. Afinal, o código civil é o que a ordem
pública constitucional permite que possa sê-lo.
E a solução interpretativa do caso concreto só se
afigura legítima se compatível com a legalidade
constitucional.5

Assim, estabelece Pedro Luiz Netto Lôbo ${ }^{6} 0$ que a constitucionalização "é o processo de elevação ao plano constitucional dos princípios fundamentais do direito civil, que passam a condicionar a observância pelos cidadãos, e a aplicação pelos tribunais, da legislação infraconstitucional."

Destarte, o fenômeno da constitucionalização do Direito, como um todo, representa um processo que está em efervescência desde o fim da Segunda Guerra Mundial (1939-1945), por intermédio, da criação

3 FACCHINI NETO, Eugênio. A constitucionalização do direito privado. Revista do Instituto do Direito Brasileiro, Lisboa, Ano 1, n. 1, p. 185-243, 2012. p. 187.

4 FREITAS, Riva Sobrado de; PIRES, Mixilini Chemin. A constitucionalização do direito civil e a ampliação de direitos subjetivos fundamentais: uma análise em torno do direito de propriedade. In: SIMPÓSIO INTERNACIONAL DE DIREITO, 3., 2012, Chapecó. Dimensões materiais e eficácias dos direitos fundamentais. Joaçaba: Unoesc, 2012. v. 1. p. 1-25. p. 3-4. Disponível em: < http://editora. unoesc.edu.br/index.php/simposiointernacionaldedireito/article/ view/2287>. Acesso em: 12 jan. 2013.

5 TEPEDINO, Gustavo; SCHREIBER, Anderson. A garantia da propriedade no direito brasileiro. Revista da Faculdade de Direito de Campos, Rio de Janeiro, Ano 6, n. 6, p. 101-121, jun. 2005. p. 102.

6 LÔBO NETTO, Paulo Luiz. Constitucionalização do direito civil. Revista de Informação Legislativa, Brasília, v. 36, n. 141, p. 99-100, jan./mar. 1999. p. 100. 
do Tribunal Constitucional da Alemanha (1949), por exemplo, que, por sua vez, reconheceu a carga valorativa da Constituição. Logo, foi a partir daquela época que surgiu um novo constitucionalismo entre as nações de tradição jurídica romano-germânica. A concepção que assenta toda essa nova ordem jurídica parte do pressuposto essencial de que a dignidade da pessoa humana representa o sustentáculo de todos os outros princípios constitucionais. ${ }^{7}$

Por amor ao argumento, cabe salientar que, no âmbito das relações privadas, como narra Cristiano Chaves de Farias e Nelson Rosenvald, no Estado Liberal,

o Direito Civil esteve liberto da incidência da norma constitucional. O Direito Constitucional se restringia a cuidar da organização política e administrativa do Estado, relegando para o Código Civil a tarefa de disciplinar as relações privadas. ${ }^{8}$

Assim, a Constituição, de forma alguma, participava das relações privadas as quais estavam regulamentadas por uma legislação ordinária, surgida ao redor do Código Civil, visando garantir a segurança jurídica em atendimento aos interesses burgueses.

Dessa maneira, a Constituição Federal de 1988 teria criado novos parâmetros hermenêuticos que demandavam por uma readequação das normas em curso à nova realidade constitucional. Mas não se referia tão somente a analisar o instituto da recepção das antigas normas com relação à nova Carta Política. Referia-se a aplicar o Direito de acordo com o "espírito" da Constituição fundamentada em sua principiologia, cujo destaque está no princípio da dignidade da pessoa humana. Assim, o ordenamento infraconstitucional será válido se estiver adequado aos princípios constitucionais, em que serão reconhecidas ou mesmo consagradas somente as normas que estiverem de acordo com esse padrão.

O Direito Civil, passaria da regulamentação da atividade
econômica individual, entre homens livres e iguais,
para a regulamentação da vida social, onde quer que
a personalidade humana melhor se desenvolva e sua
dignidade seja mais amplamente tutelada. ${ }^{10}$

7 MIRANDA, Daniel Gomes. Constitucionalização do direito privado e a função social do contrato e da propriedade na empresa. 2010. 130 f. Dissertação (Mestrado) - Programa de Pós-Graduação em Direito, Faculdade de Direito, Universidade Federal do Ceará, Fortaleza, 2010. p. 24-25.

8 FARIAS, Cristiano Chaves de; ROSENVALD, Nelson. Curso de direito civil. 13. ed. São Paulo: Atlas, 2015. v. 1. p. 33.

9 SAMPAIO JÚNIOR, Rodolpho Barreto. Da liberdade ao controle: os riscos do novo direito civil brasileiro. Belo Horizonte: PUC Minas Virtual, 2009. p. 71.

10 SAMPAIO JÚNIOR, Rodolpho Barreto. Da liberdade ao controle:
Para a Escola de Direito Civil Constitucional, defende-se um Novo Direito Civil, despatrimonializado e socializado. As relações privadas devem pautar-se na dignidade humana, visando à solidariedade entre os homens.

Assim, pensar o Direito Civil com um viés constitucional passou a representar, basicamente, a introdução de princípios e regras constitucionais nas relações privadas, e, dessa forma, injetar-se nessas relações valores e fundamentos superiores para que

os princípios fundamentais do direito civil, elevados ao plano constitucional, passassem a ser por ele condicionados; de outra forma, ficariam submetidos aos fundamentos de validade constitucionalmente estabelecidos ${ }^{11}$.

Portanto, a sua constitucionalização, como salienta Sampaio Júnior:

[...] deve ser entendida no sentido de que a legislação civil infraconstitucional encontra na Constituição da República o seu fundamento de validade, como hoje é reconhecido pela Teoria Geral do Direito, e não que os institutos civis tratados pela Carta Política teriam migrado para o Direito Público ${ }^{12}$.

Nesse sentido, realiza-se a inversão referencial na ordem jurídico-privada existente. Da regulamentação privada, oriunda do Código Civil, classificando a estrutura normativa em dois eixos-unitários: o privado e o público, colocando-os como direitos antagônicos e destinados a segmentos sociais bem distintos, parte-se para uma análise das relações privadas com um enfoque constitucional. Assim, seria possível aos Direitos Público e Privado uma reunificação visando o benefício do ser humano inserido nas mais variadas espécies de sociedades. Logo, o Código Civil decai e perde sua centralidade, uma vez que a atribuição unificadora do sistema, em todos os seus aspectos, passa a ser exercida pela Constituição Federal de 1988. Este é o escopo da constitucionalização, isto é, colocar o direito positivo sob a tutela do texto constitucional, como é dito, "interpretar o Direito Civil com olhos voltados a Constituição

os riscos do novo direito civil brasileiro. Belo Horizonte: PUC Minas Virtual, 2009. p. 73.

11 PASTRE, Daniel Fernando. Efetividade socioeconômica dos processos de autorização estatal nas concentrações empresariais. 2009. 159 f. Dissertação (Mestrado) - Programa de Mestrado em Direito Empresarial e Cidadania, Centro Universitário Curitiba, Curitiba, 2009. Disponível em: <http://dominiopublico.mec.gov.br/download/teste/ arqs/cp116732.pdf $>$. Acesso em: 7 jan. 2013. p. 13.

12 SAMPAIO JÚNIOR, Rodolpho Barreto. Da liberdade ao controle: os riscos do novo direito civil brasileiro. Belo Horizonte: PUC Minas Virtual, 2009. p. 75. 
Federal"13.

Objetiva-se, portanto, uma reconstrução do Direito Privado, agora fundamentado em valores constitucionais, para que sejam atendidos os direitos fundamentais, bem como a efetivação da consolidação de um Estado Democrático de Direito. Assim, se a legislação civil atritar com os princípios e as regras constitucionais, ela deve ser considerada revogada (por não ter sido recepcionada) se foi editada antes da Constituição, ou inconstitucional, se foi editada após a sua promulgação. ${ }^{14}$

Vale ressaltar que não se busca hoje delimitação clara dos espaços até contrapostos. Se anteriormente existia a disjunção, há atualmente a unidade hermenêutica que compreende o texto constitucional como o elemento direcionador de desenvolvimento e aplicação da legislação civil. É significativa a transformação de atitude, em que o jurista deverá interpretar o Código Civil de acordo com a Constituição Federal e não o contrário, como era praticado no passado e que, equivocadamente, ainda ocorre em alguns casos restritos.

A mudança de atitude também envolve certa dose de humildade epistemológica. O Direito Civil sempre disponibilizou os conceitos e as classificações que eram utilizados como base para o reconhecimento dos diversos ramos do Direito Público (entre eles, o Constitucional). Nesse sentido, descobre-se a necessidade dos civilistas em trabalhar as categorias fundamentais da Constituição, pois sem esta inteiração, a interpretação do Código e das leis civis podem tornar-se equivocadas. ${ }^{15}$

Entretanto, a mais importante inovação da Constituição, contudo, refere-se aos direitos fundamentais.

13 FREITAS, Riva Sobrado de; PIRES, Mixilini Chemin. A constitucionalização do direito civil e a ampliação de direitos subjetivos fundamentais: uma análise em torno do direito de propriedade. In: SIMPÓSIO INTERNACIONAL DE DIREITO, 3., 2012, Chapecó. Dimensões materiais e eficaciais dos direitos fundamentais. Joaçaba: Unoesc, 2012. v. 1. p. 1-25. p. 3-4. Disponível em: < http:// editora.unoesc.edu.br/index.php/simposiointernacionaldedireito/ article/view/2287>. Acesso em: 12 jan. 2013.

14 FREITAS, Riva Sobrado de; PIRES, Mixilini Chemin. A constitucionalização do direito civil e a ampliação de direitos subjetivos fundamentais: uma análise em torno do direito de propriedade. In: SIMPÓSIO INTERNACIONAL DE DIREITO, 3., 2012, Chapecó. Dimensões materiais e eficaciais dos direitos fundamentais. Joaçaba: Unoesc, 2012. v. 1. p. 1-25. p. 4-5. Disponível em: <http:// editora.unoesc.edu.br/index.php/simposiointernacionaldedireito/ article/view/2287>. Acesso em: 12 jan. 2013.

15 LÔBO NETTO, Paulo Luiz. Constitucionalização do direito civil. Revista de Informação Legislativa, Brasília, v. 36, n. 141, p. 99-100, jan./mar. 1999.
Além de conter em sua estrutura um elenco amplo e generoso de direitos individuais, políticos, sociais, difusos e coletivos, de acordo com a tendência internacional de proteção desses direitos, tornou-os "cláusula pétrea expressa", impedindo-os de sofrerem alteração por parte do poder constituinte derivado. A própria estruturação interna da Constituição, ao contrário do que ocorria na antiga ordem constitucional, inseriu os direitos fundamentais em sua parte inicial antes mesmo das normas sobre a organização do Estado e, nesse sentido, indica a enorme relevância proporcionada a esses direitos, possuidores, a partir de então, de uma indisputável primazia axiológica. ${ }^{16}$

Dessa maneira, a posição hierárquica superior da Carta Constitucional para a edição das suas normas, e porque estas, por uma escolha consciente do legislador constituinte, informam também junto as relações privadas, permitem, como dito, que se considerem a Constituição como novo centro do Direito Privado, em condições para consolidar as suas partes e a informar seu conteúdo. Em vez de um ordenamento descentralizado e fragmentado, tem-se um sistema aberto, em cujo núcleo principal está a Constituição. A unidade do ordenamento, não somente no sentido lógico-formal, mas também no substantivo, está alterada, pois a Constituição agrega e fundamenta toda a enorme estrutura de normas editadas pelo nada econômico legislador atual. ${ }^{17}$

Facchini $\mathrm{Neto}^{18,}$, sobre a constitucionalização do Direito Privado diz:

\footnotetext{
Da constitucionalização do Direito Civil decorre a migração, para o âmbito privado, de valores constitucionais, dentre os quais, como verdadeiro primus inter paris, o princípio da dignidade da pessoa humana. Disso deriva, necessariamente, a chamada repersonalização do Direito Civil, ou visto de outro modo, a despatrimonialização do direito civil.
}

Assim, um novo processo de "despatrimonialização" do Direito Civil ocorre com base na da funcionalização das relações intersubjetivas a princípios-valores como os da dignidade da pessoa humana, da justiça social e da igualdade. Representa o que Facchini Neto

16 SARMENTO, Daniel. Direitos fundamentais e relaçoes privadas. 2. ed. Rio de Janeiro: Lumen Juris, 2010. p. 85.

17 SARMENTO, Daniel. Direitos fundamentais e relações privadas. 2. ed. Rio de Janeiro: Lumen Juris, 2010. p. 75.

18 FACCHINI NETO, Eugênio. Reflexões histórico-evolutivas sobre a constitucionalização do direito privado. In: SARLET, Ingo Wolfgang. (Org). Constituição, direitos fundamentais e direito privado. Porto Alegre: Livraria do Advogado, 2003. p. 11-60. p. 32. 
chama de "repersonalização do direito civil ou visto de outro modo, a despatrimonialização do direito civil". O homem se torna o núcleo do sistema jurídico, tanto em nível do direito público, quanto no privado. Assim, reconhece-se que a Constituição passou a tutelar a vida privada e o Código Civil, por sua vez, passou a ter uma característica eminentemente política, objetivando relacionar o Direito Público com o Privado, a sociedade com Estado e o Direito Civil com a Constituição. ${ }^{19}$

Resta claro, diga-se, que as relações civis ainda possuem um intenso conteúdo patrimonializante, basta verificar, por exemplo, os conceitos tradicionais de propriedade e contrato, mas, como afirmado, essa concepção majoritariamente patrimonialista do Direito Civil quase sempre se choca com os valores presentes na dignidade da pessoa humana, adotados no texto constitucional.

Assim, o desafio que se coloca aos civilistas é a capacidade de ver as pessoas em toda a sua dimensão ontológica e, por meio dela, o seu patrimônio. Impõe-se a materialização dos sujeitos de direitos, que são mais do que apenas titulares de bens. A restauração da primazia da pessoa humana, nas relações civis, passa a ser a condição primeira de adequação do direito à realidade e aos fundamentos constitucionais.

\section{A HORIZONTALIZAÇÃo DOS DIREITOS FUNDA- MENTAIS}

Com os olhos atentos a essa nova visão do Direito Civil, sabe-se, por sua vez, que o $\int 1^{\circ}$, do artigo $5^{\circ}$ da Constituição Federal de 1988 ainda determinou que as normas definidoras de direitos fundamentais tenham aplicabilidade imediata, ou seja, além de eficácia plena, devem possuir, também, vigência automática, sendo, inclusive, autoaplicáveis. Resta, porém, indagar contra quem os direitos fundamentais podem ser opostos.

Assim, percebe-se que os direitos fundamentais atuam como uma limitação à atuação dos governantes

19 CAGLIARI, Cláudia Taís Siqueira. A função social do contrato como forma de efetivação dos direitos fundamentais nas relações entre particulares. 2007. 230 f. Dissertação (Mestrado) - Programa de Pós-Graduação em Direito, Área de Concentração em Direitos Sociais e Políticas Públicas, Universidade de Santa Cruz do Sul, Roma, 2007. Disponível em: <http://www.unisc.br/portal/images/stories/mestrado/ direito/dissertacoes/2007/claudia_tais_cagliari.pdf $>$. Acesso em: 17 dez. 2014. em relação aos governados, em uma nítida relação vertical entre o Estado e o indivíduo, seja por meio de uma abstenção estatal (direitos de primeira dimensão), uma ação (segunda dimensão) ou em favor dos meta-individuais (direitos de terceira dimensão). Não por outra razão, os direitos fundamentais podem não ser exercidos, porém nunca renunciados, pois historicidade, universalidade, inalienabilidade, imprescritibilidade e a própria irrenunciabilidade são caraterísticas determinantes dos ditos direitos fundamentais.

Por outro lado, com esse olhar no Direito Civil Constitucional, cogita-se, hoje, da aplicação dos direitos fundamentais ${ }^{20}$ também nas relações jurídicas entre indivíduos, interpretando-se as relações privadas com um viés constitucional e possibilitando, assim a manutenção do equilíbrio da justiça também nas prefaladas relações privadas (Drittwirkung).

De fato, ao expandir os efeitos das relações privadas para uma concepção constitucional ${ }^{21}$, naturalmente, fez surgir também uma ampliação dos direitos fundamentais para além de uma relação cidadão-Estado, adquirindo uma dimensão objetiva de aplicação dos direitos fundamentais "de validade universal, de conteúdo indeterminado e aberto, e que não pertence nem ao Direito Público, nem ao Direito Privado, mas compõe a abóbada de todo o ordenamento jurídico enquanto direito constitucional de cúpula"22

Assim, o Direito Privado passa também a

conhecer o fenômeno do poder e da autoridade para condicionar suas relações, não sendo apenas do poder público do ataque contra a liberdade de manifestação do indivíduo e a dignidade da pessoa humana ${ }^{23}$

20 Ainda hoje, toda a discussão sobre a incidência dos direitos fundamentais às relações privadas se restringe aos direitos individuais. A questão concernente à possibilidade de vinculação dos particulares aos direitos sociais não trabalhistas, direitos políticos e direitos transindividuais, apesar de relevantíssima, ainda não despertou a merecida atenção da doutrina, o que não significa dizer que tais direitos não teriam nenhum tipo de eficácia no âmbito das relações privadas.

21 Segundo Lorenzetti, o Direito Privado é Direito Constitucional aplicado, pois nele se detecta o projeto de vida em comum que a Constituição tenta impor; o Direito Privado representa os valores sociais de vigência efetiva. LORENZETTI, Ricardo Luis. Normas fundamentales de derecho privado. Trad. de Vera Maria Jacob de Fradeira. São Paulo: Revista dos Tribunais, 1998.

22 LORENZETTI, Ricardo Luis. Normas fundamentales de derecho privado. Trad. de Vera Maria Jacob de Fradeira. São Paulo: Revista dos Tribunais, 1998. p. 587.

23 QUEIROZ, André Luiz Tomasi de. Teorias da horizontalização dos direitos fundamentais. Disponível em: <http://www.flaviotartuce. adv.br/artigosc/horizontal_and.doc>. Acesso em: 01 dez. 2014. 


\section{Para Daniel Sarmento,}

a extensão dos direitos fundamentais às relações privadas é indispensável no contexto de uma sociedade desigual, na qual a opressão pode provir não apenas do Estado, mas de uma multiplicidade de atores privados, presentes em esferas como o mercado, a família, a sociedade civil e a empresa24

Em outro diapasão, não é possível entender o Estado Democrático sem a proteção (também constitucional) da autonomia privada. Assim, o paradoxo da democracia, ${ }^{25} \mathrm{em}$ uma tentativa de alcançar o "governo do povo", resta por expulsar o indivíduo que, colocado frente a problemas cada vez mais complexos, necessita de uma ação individual com suficiente liberdade, na crença de que isso produzirá um efeito conjunto que, no futuro, seja melhor para todos.

Nessa dualidade de posições, ou seja, de um lado a autonomia privada, indispensável, como dito, em um Estado Democrático de Direito e base estrutural do Direito Civil, e, por outro lado, a premissa que se encontra perfeitamente possível a aplicação dos direitos fundamentais ao âmbito do direito privado, fez com que surgissem várias teorias acerca da vinculação dos particulares aos direitos fundamentais, pois, é certo que a forma de incidência dos direitos fundamentais para os particulares não pode ser igual para os poderes públicos, em razão das diferenças ontológicas entre ambos.

Nesse estudo, adota-se a teoria da eficácia horizontal direta que surge, de forma tímida, na Alemanha, na década de 50, pela tese de Hans Carl Nipperdey. ${ }^{26}$ Segundo o mencionado autor, embora alguns direitos fundamentais previstos na Constituição alemã vinculem apenas o Estado, outros, pela sua natureza, podem ser invocados diretamente nas relações privadas, independentemente de qualquer mediação por parte do legislador, revestindo-se de oponibilidade erga omnes.27

Assim, hoje, e como já dito, não se pode conceber o Direito Privado como um sistema independente, dis-

24 SARMENTO, Daniel. Direitos fundamentais e relações privadas. 2. ed. Rio de Janeiro: Lumen Juris, 2010. p. 185.

25 Cf. BOBBIO, Noberto; PONTARA, Giuliano; VECA, Salvatore. Crisis de la democracia. Barcelona: Ariel, 1985.

26 Cf. Sarmento, a primeira manifestação de Nipperdey sobre essa teoria foi produzida em 1950, num artigo sobre a igualdade do homem e da mulher em relação ao salário. Mas é em seu livro sobre a parte geral do Direito Civil Alemão que o autor traz uma abordagem sobre a questão. SARMENTO, Daniel. Direitos fundamentais e relações privadas. 2. ed. Rio de Janeiro: Lumen Juris, 2010.

27 SARMENTO, Daniel. Direitos fundamentais e relações privadas. 2. ed. Rio de Janeiro: Lumen Juris, 2010. p. 204. sociado das premissas maiores da constitucionalização do Direito Civil. Adotar a teoria da aplicação imediata dos direitos fundamentais às relações privadas significa abandonar, de vez, a velha dicotomia público privado.

Cumpre destacar, no entanto, que a aplicação imediata dos direitos fundamentais nas relações privadas não significa desconsiderar as especificidades das relações privadas, não sendo possível, portanto, transplantar o particular para a posição de sujeito passivo nos mesmos moldes que se faz com os poderes públicos.

Com efeito, não se trata, por assim dizer, de uma teoria radical, já que não se prega a desconsideração da liberdade individual das pessoas. Assim, os particulares são titulares de direitos fundamentais e contra eles não seria possível atribuir toda a esfera restritiva que essas normas possuem em face do Estado, ao passo que são imbuídos da proteção constitucional de autodeterminação.

Conforme preleciona Daniel Sarmento, "a teoria da eficácia imediata não logrou grande aceitação na Alemanha, mas é majoritária na Espanha e em Portugal". ${ }^{28}$ Perlingieri, por sua vez, aduz que

[...] a norma constitucional pode, também sozinha (quando não existirem normas ordinárias que disciplinem a fattispecie em consideração), ser a fonte da disciplina de uma relação jurídica de direito civil. [...] Assim, a normativa constitucional não deve ser considerada sempre e somente como mera regra hermenêutica, mas também como norma de comportamento, idônea a incidir sobre o conteúdo das relações entre situações subjetivas, funcionalizando-as aos novos valores 29

Dessa maneira, com a aplicação direta da teoria dos direitos fundamentais às relações privadas, a Constituição pode demonstrar sua eficácia de forma dúplice ou binária, pois esse método se concretiza quando o Poder Judiciário, em sua atuação típica, resolve o caso concreto utilizando-se da legislação ordinária (em um método de aplicação indireta), mas ao mesmo tempo, aplica também, em razão de sua normatividade, de forma direta os princípios constitucionais ao caso concreto.

Ora, sabe-se que o constituinte brasileiro foi omisso quanto à vinculação expressa dos particulares aos direitos fundamentais, porém, como já foi dito, o $\int 1^{\circ}$, do

28 SARMENTO, Daniel. Direitos fundamentais e relaçoes privadas. 2. ed. Rio de Janeiro: Lumen Juris, 2010. p. 206.

29 PERLINGIERI, Pietro. Perfis do direito civil. Trad. de Maria Cristina de Cico. Rio de Janeiro: Renovar, 1999. p. 11. 
artigo $5^{\circ}$ da Charta Política estabelece que "as normas definidoras dos direitos e garantias individuais têm aplicação imediata", não gerando dúvidas, data maxima venia, quanto à aplicação de forma direta dos direitos fundamentais às relações privadas. Nesse sentido, destaca Daniel Sarmento,

com efeito, qualquer posição que se adota em relação à controvérsia em questão não pode se descurar da moldura axiológica delineada pela Constituição de 1988, e do sistema de direitos fundamentais por ela hospedado. Não há dúvida, neste ponto, que a Carta de 88 é intervencionista e social, como o seu generoso elenco de direitos sociais e econômicos (arts. $6^{\circ}$ e $7^{\circ}, \mathrm{CF}$ ) revela com eloquência. Trata-se de uma Constituição que indica, como primeiro objetivo fundamental da República, "construir uma sociedade livre, justa e solidária" (art. $3^{\circ}, \mathrm{I}, \mathrm{CF}$ ) e que não se ilude com a miragem liberal de que é o Estado o único adversário dos direitos humanos.

[...] A Constituição brasileira é francamente incompatível com a tese radical, adotada nos Estados Unidos, que simplesmente exclui a aplicação dos direitos individuais sobre as relações privadas. $^{30}$

Assim, inconteste que se, como dito, a compreensão de que o fundamento da dignidade da pessoa humana representa o centro de gravidade da ordem jurídica que, por sua vez, legitima e condiciona todo o direito positivado, a adoção da teoria da eficácia direta dos direitos fundamentais nas relações privadas é medida que se impõe, uma vez que não reconhecê-la ou condicioná-la à vontade do legislador ou, por último, limitar o seu alcance à interpretação das cláusulas gerais e conceitos jurídicos indeterminados do direito privado, significa, simplesmente, retirar a dignidade da pessoa humana do epicentro axiológico da ordem constitucional brasileira.

Argumenta-se como precedente no Supremo Tribunal Federal para a adoção da teoria direta, o julgamento do RE 158215-4/RS, no ano de 1996, possuindo como Relator o Min. Marco Aurélio, no qual discutia-se um caso em que associados de uma cooperativa haviam sido excluídos, como punição, sem direito de defesa, tendo o julgado entendido que "na hipótese de exclusão de associado decorrente de conduta contrária aos estatutos, impõe-se a observância do devido processo legal, viabilizando o exercicio da ampla defesa".31

30 SARMENTO, Daniel. Direitos fundamentais e relações privadas. 2. ed. Rio de Janeiro: Lumen Juris, 2010. p. 237.

31 BRASIL. Supremo Tribunal Federal. Recurso Extraordinário. RE $n^{0} 158215-4$ RS. Segunda Turma. Relator: Min. Marco Aurélio. Brasília, 07 de junho de 1997. Disponível em: <http://www.stf.jus.
Ainda no ano de 1996, o Supremo Tribunal Federal também entendeu, no RE 161.243-6/DF, cujo Relator foi o Min. Carlos Velloso, que o trabalhador brasileiro, empregado na empresa Air France, deveria ter o reconhecimento dos mesmos direitos trabalhistas assegurados no Estatuto do Pessoas da Empresa, que em princípio, somente beneficiava os empregados de nacionalidade francesa. ${ }^{32}$

Mais recentemente, o STF, com relatoria do Min. Gilmar Mendes, no RE 201819/RJ, entendeu pela ampla aceitação dos direitos fundamentais de forma direta nas relações privadas, diante da União Brasileira de Compositores que também havia excluído do seu quadro de sócios determinado compositor, sem que a este fossem asseguradas as garantias constitucionais da ampla defesa e do contraditório, destacando o Voto do Min. Celso de Mello, que assim se manifestou:

É por essa razão que a autonomia privada - que
encontra claras limitações e ordem jurídica - não
pode ser exercida em detrimento ou com desrespeito
aos direitos e garantias de terceiros, especialmente
aqueles positivados em sede constitucional, pois a
autonomia da vontade não confere aos particulares,
no domínio de sua incidência e atuação, o poder
de transgredir ou de ignorar as restrições postas e
definidas pela própria Constituição, cuja eficácia
e força normativa também se impõem aos
particulares, no âmbito de suas relações privadas,
em tema de liberdades fundamentais33

Por esses acórdãos, não resta dúvidas de que o Supremo Tribunal Federal tem amplamente aceito a aplicação direta dos direitos fundamentais na resolução de conflitos privados, independentemente da mediação do legislador ou de aplicação das cláusulas abertas.

\section{A Convencionalização do direito CiVIL}

br/arquivo/informativo/documento/informativo34.htm>. Acesso em: 04 fev. 2016.

32 BRASIL. Supremo Tribunal Federal. Recurso Extraordinário. RE $n^{\circ}$ 161.243-6/DF. Segunda Turma. Recorrente: Roberto de Figueiredo Caldas e outros. Recorrida: Compagnie Nationale Air France. Relator: Min. Carlos Velloso. Brasília, 29 de outubro de 1996. Disponível em: <http://redir.stf.jus.br/paginadorpub/paginador.jsp?docTP=AC\&docID=213655>. Acesso em: 04 fev. 2016. 33 BRASIL. Supremo Tribunal Federal. Recurso Extraordinário. RE $n^{0}$ 201-819-8 RJ. Segunda Turma. Recorrente: União Brasileira de Compositores. Recorrido: Arthur Rodrigues Villarinho Relator: Min. Gilmar Mendes. Brasília, 11 de outubro de 2005. Disponível em: $<$ http://redir.stf.jus.br/paginadorpub/paginador. http://redir.stf. jus.br/paginadorpub/paginador.jsp?doc TP $=\mathrm{AC} \& \operatorname{doc} \mathrm{ID}=388784$ >. Acesso em: 04 fev. 2016. 
Com base na constitucionalização do Direito Civil e na própria horizontalização das normas fundamentais, acima comentadas, restou claro que a reinterpretação do Direito Privado passa, necessariamente, pela Constituição Federal. E, agora, nessa linha de raciocínio, o art. $5^{\circ}$, $\int 3^{\circ}$, da Constituição Federal de 1988, acrescentado pela Emenda Constitucional no 45/04, passou a aduzir que os "tratados e convençôes internacionais sobre direitos bumanos que forem aprovados, em cada Casa do Congresso Nacional, em dois turnos, por três quintos dos votos dos respectivos membros, serão equivalentes às emendas constitucionais".

Assim, inconteste pensar que os tratados e convenções internacionais - que versem sobre direitos humanos que foram aprovados no quórum acima (em dois turnos, por três quintos dos votos dos respectivos membros) - passam a ser equiparados às Emendas Constitucionais e, assim, são perfeitamente aplicáveis no âmbito das relações privadas. Exemplo disso é a Convenção sobre os direitos das pessoas com deficiência, assinada em Nova Iorque, em 30.03.07, e aprovadas pelo Decreto Legislativo $n^{\circ} 186 / 08$, sendo incorporada ao ordenamento jurídico com status de norma constitucional e perfeitamente aplicável, portanto, às relações privadas, pelas razões já elencadas neste artigo.

Porém, nesse diapasão, convém indagar se os demais tratados e convenções internacionais que versem sobre direitos humanos, mas anteriores à Emenda Constitucional $\mathrm{n}^{\circ} 45 / 04$, ou que não foram submetidos às formalidades indicadas para a sua aprovação, ou, por derradeiro, os tratados e convenções internacionais comuns, poderiam ser aplicados, aprioristicamente, às relações privadas?

Inicialmente e sem amarras, cabe menção às lições de Marcelo Varella, ao mencionar que o direito contemporâneo passa por um momento de transição, que acompanha a própria globalização.

\footnotetext{
Esse processo é influenciado pela ampliação da complexidade dos direitos nacionais dos Estados e do direito internacional, e tem como resultado a alteração da lógica normativa do direito internacional clássico. Neste sentido, parece-nos claro que vivemos em um período de transição. Já é possível dizer que a lógica tradicional do direito internacional não é mais aplicável aos dias de hoje. No entanto, também é possível verificar que ainda não há uma nova lógica consolidada ${ }^{34}$
}

34 VARELLA, Marcelo D. Direito internacional público. 5. ed. São Paulo: Saraiva, 2014. p. 28.
Para melhor compreensão do tema, pode-se afirmar que se vivencia, hoje em dia, e a par da constitucionalização do direito interno, a aplicação de um Direito Constitucional Internacional e, conforme preleciona Flávia Piovesan,

por Direito Constitucional Internacional
subentende-se aquele ramo do Direito no qual
se verifica a fusão e a interação entre o Direito
Constitucional e o Direito Internacional, interação
que assume um caráter especial quando esses dois
campos do Direito buscam resguardar um mesmo
valor - o valor da primazia da pessoa humana
- concorrendo na mesma direção e sentido. Ao
tratar da dinâmica da relação entre a Constituição
brasileira e o sistema internacional de proteção
dos direitos humanos, objetiva-se não apenas
estudar os dispositivos do Direito Constitucional
que buscam disciplinar o Direito Internacional
dos Direitos Humanos, mas também desvendar
o modo pelo qual este último reforça os direitos
constitucionalmente assegurados, fortalecendo os
mecanismos nacionais de proteção dos direitos da
pessoa humana35

Assim, o Supremo Tribunal Federal, em relação aos tratados e convenções internacionais que versem sobre direitos humanos, fixou orientação sobre o tema, no Recurso Extraordinário no 466.343/SP, entendendo que o Pacto de San José da Costa Rica (Convenção Americana de Direitos Humanos, aprovada antes do advento da Emenda Constitucional no 45/04) foi acolhido com status supralegal no ordenamento jurídico interno, pairando acima da legislação infraconstitucional, mas devendo respeitar, por outro lado, a norma constitucional.

No voto do Ministro Gilmar Mendes, depreende-se a seguinte orientação:

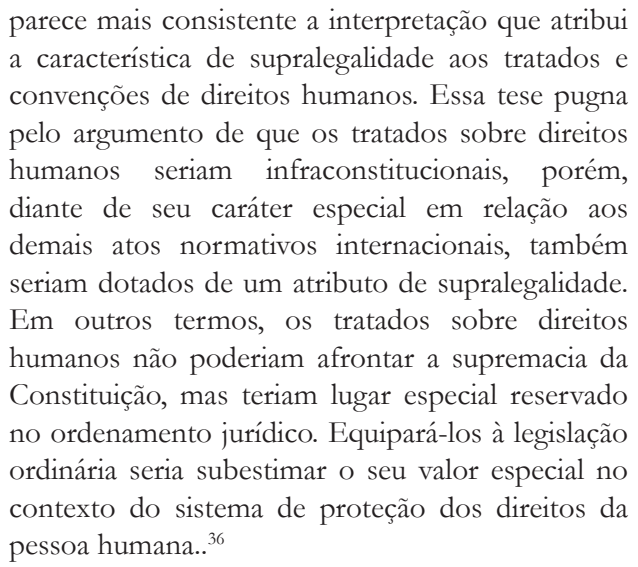

35 PIOVESAN, Flávia. Direitos humanos e o direito constitucional internacional. 14. ed. São Paulo: Saraiva, 2014. p.78-79.

36 BRASIL. Supremo Tribunal Federal. Recurso Extraordinário. RE $n^{0}$ 466.343-1 SP. Tribunal Pleno. Recorrente: Banco Bradesco S/A. Recorrido: Luciano Cardoso Santos. Relator: Min. Cezar Pelu- 
Dessa maneira, a Corte deliberou que as proteções humanitárias contidos na Convenção Americana de Direitos Humanos estão posicionadas acima das normas do Código Civil, afastando, portanto, a eficácia da legislação infraconstitucional e, demonstrando a força da compreensão judicial sobre o tema, foi editada a Súmula Vinculante $\mathrm{n}^{\circ} 25$, alertando que "é ilícita a prisão civil do depositário infiel, qualquer que seja a modalidade de depósito".

Inaugurou-se, assim, a par da adequação das normas de Direito Civil à Carta Política, um movimento de convencionalização de suas normas, devendo se adequar aos tratados e convenções internacionais que disponham sobre direitos humanos, mesmo que não tenham sido submetidos às formalidades de aprovação necessárias para se ter natureza de uma Emenda Constitucional.

Nessa linha de raciocínio, até mesmo as normas de Direito Civil precisam se harmonizar, mantendo uma compatibilidade vertical, tanto com o Texto Constitucional, quanto com os tratados e convenções internacionais de direito humanos.

E, sendo assim, detectada uma eventual incompatibilidade da norma infraconstitucional com um tratado de diretos humanos, sobreleva a suspensão de sua eficácia, respeitando a própria especialidade da convenção 37.

Segundo Valério Mazzuoli,

Desta inovação advinda da EC 45 veio à tona (e passou a ter visibilidade entre nós) um novo tipo de controle das normas de Direito interno: o controle de convencionalidade das leis, que nada mais é que o processo de compatibilização vertical (sobretudo material) das normas domésticas com os comandos encontrados nas convenções internacionais de direitos humanos. À medida que os tratados de direitos humanos ou são materialmente constitucionais (art. $5^{\circ}, \sqrt{\mathbb{2}}$ ) ou material e formalmente constitucionais (art. $5^{\circ}$, $\int 3^{\circ}$ ), é lícito entender que o clássico 'controle de constitucionalidade' deve agora dividir espaço com esse novo tipo de controle ('de convencionalidade') da produção e aplicação da normatividade interna.38

Por derradeiro, com a incidência, inclusive, do artigo 13 do novo Código de Processo Civil ${ }^{39}$ - Lei no 13.105 ,

so. Brasília, 22 de novembro de 2006. Disponível em: < http://www. stf.jus.br/imprensa/pdf/re466343.pdf>. Acesso em: 04 fev. 2016.

37 FARIAS, Cristiano Chaves de; ROSENVALD, Nelson. Curso de direito civil. 13. ed. São Paulo: Atlas, 2015. v. 1. p. 47.

38 MAZZUOLI, Valerio de Oliveira. Curso de direito internacional público. 8. ed. São Paulo: Revista dos Tribunais, 2014. p. 411.

39 Art. 13. A jurisdição civil será regida pelas normas processuais brasileiras, ressalvadas as disposições específicas previstas em de 16 de março de 2015 - que representa, no mínimo, uma tendência atual, uma última, porém não menos importante, reflexão merece ser feita: a convencionalização do Direito Civil também estaria sujeita aos tratados internacionais comuns, mesmo que não versassem sobre direitos humanos?

Primeiramente, convém assinalar que o Supremo Tribunal Federal ainda não avançou sobre o tema, porém de acordo ainda com Mazzuoli,

sabe-se que os tratados internacionais comuns
(aqueles que versam sobre temas alheios aos direitos
humanos) também têm status superior ao das leis
internas. Se bem que não equiparados às normas
constitucionais, os instrumentos convencionais
comuns têm hierarquia supralegal em nosso país. 40

Isso porque, de acordo com a Convenção de Viena sobre o Direito dos Tratados, de 1969, ratificada pelo Brasil pelo Decreto ${ }^{\circ} 7030 / 09$, todo tratado obriga as partes e deve ser cumprido por elas de boa-fé (art. 26) e uma parte não pode invocar as disposições de seu direito interno para justificar o inadimplemento de um tratado (art. 27), a não ser que essa violação fosse manifesta e dissesse respeito a uma norma de seu direito interno de importância fundamental (art. 46).

Para tal situação, seria uma espécie de controle de supralegalidade, como exposto ainda por Mazzuolii ${ }^{41}$

Tais tratados (comuns) também servem de paradigma ao controle das normas infraconstitucionais, posto estarem situados acima delas, com a única diferença (em relação aos tratados de direitos humanos) que não servirão de paradigma do controle de convencionalidade (expressão reservada aos tratados com nível constitucional), mas do controle de supralegalidade das normas infraconstitucionais.

Assim, mesmo as normas de Direito Privado, ao eventualmente contrariarem um tratado comum, também, estarão sujeitas a um controle de convencionalidade (supralegalidade), uma vez que referido tratado se encontra acima delas. Frise-se que, apesar da polêmica que envolve o assunto, a nova redação do artigo 13 do CPC, delineia, ao menos, uma tendência nesse sentido, ao salientar que a jurisdição civil será regida pelas nor-

tratados, convenções ou acordos internacionais de que o Brasil seja parte. BRASIL. Lei ñ 13.105, de 16 de marco de 2015. Disponível em: <http://www.planalto.gov.br/ccivil_03/_ato2015-2018/2015/lei/ 113105.htm>. Acesso em: 03 fev. 2016.

40 MAZZUOLI, Valerio de Oliveira. Curso de direito internacional público. 8. ed. São Paulo: Revista dos Tribunais, 2014. p. 421.

41 MAZZUOLI, Valerio de Oliveira. Curso de direito internacional público. 8. ed. São Paulo: Revista dos Tribunais, 2014. p. 421. 
mas processuais brasileiras, ressalvadas as disposições específicas em tratados, convenções ou acordos internacionais.

\section{Considerações finais}

Certamente, como demonstrado neste artigo, o civilista do Século XXI deve comprometer-se com o projeto constitucional, que elegeu a dignidade da pessoa humana, a solidariedade social e a igualdade material como princípios e fundamentos de toda a ordem jurídica. A visão do Direito Civil como fonte de relações unicamente privadas, tem, paulatinamente, se distanciado da realidade, fazendo com que surja uma unidade hermenêutica, despontando a Constituição como ápice conformador da elaboração e aplicação também da legislação privada.

Essa onda de solidariedade social, portanto, fez com que as relações patrimoniais fossem revisitadas, visando à repersonalização ou despatrominialização do Direito Civil, de forma a garantir um mínimo de dignidade aos partícipes dessa relação jurídica.

Assim, como foi visto neste artigo, a repersonalização do Direito Civil representou uma transformação de direcionamento das normas presentes no ordenamento jurídico nacional, passando da esfera do individual para o social, objetivando a proteção da vida e a dignidade da pessoa humana.

Dessa maneira, os direitos fundamentais passaram a representar o núcleo para todos os outros direitos, pois lograram ser entendidos como direitos que emanam fundamentalmente sobre os demais, devido à origem constitucional.

Pelo exposto, com o advento da Constituição Federal de 1988, calcada pelo ideário de justiça e solidariedade e, tendo a dignidade da pessoa humana como Fundamento do Estado Democrático de Direito, tornou-se necessária a aplicação direta dos direitos fundamentais no âmbito privado, objetivando dar a esses direitos a sua máxima efetividade.

Em contrapartida, pode-se antever que a aplicação direta dos direitos fundamentais às relações privadas não exclui, decerto, a obrigação do Poder Judiciário de interpretar e eventualmente aplicar as normas jurídicas do Direito Privado, de índole infraconstitucional, como, verbi gratia, as cláusulas gerais da boa-fé objetiva, desde que respeitados, num primeiro momento, os direitos fundamentais. Em relação a esse cotejo, deve o Judiciário, preliminarmente, mirar os valores constitucionais - que possui no sistema dos direitos fundamentais o seu eixo central - e caso não seja possível a aplicação de norma infraconstitucional, deve o órgão jurisdicional exercer o controle de constitucionalidade incidental da norma, afastando o preceito viciado face ao Parâmetro Constitucional.

Em virtude dessa nova visão constitucional do Direito Privado, exsurgiu, por sua vez, a convencionalização do Direito Civil, no que tange à análise de sua compatibilidade vertical aos tratados e convenções internacionais que versem sobre direitos humanos, quando aprovados, em cada Casa do Congresso Nacional, em dois turnos, por três quintos dos votos dos respectivos membros, pois são equivalentes às Emendas Constitucionais, como é o caso, como visto, da Convenção sobre os direitos das pessoas com deficiência, assinada em Nova Iorque, em 30.03.07, e aprovadas pelo Decreto Legislativo $\mathrm{n}^{\mathrm{o}} 186 / 08$.

Por outro lado, tendo com pano de fundo o Direito Civil Constitucional, restou demonstrado que os demais tratados e convenções internacionais que versem sobre direitos humanos, anteriores à Emenda Constitucional $n^{\circ} 45 / 04$ ou que não foram submetidos às formalidades indicadas para a sua aprovação e, inclusive, os tratados e convenções internacionais comuns (aqueles que versam sobre temas alheios aos direitos humanos), também se submetem ao controle de convencionalidade, em virtude da previsão contida no artigo 27 da Convenção de Viena sobre o Direito dos Tratados, de 1969, ratificada pelo Brasil pelo Decreto $n^{\circ} 7030 / 09$, sendo certo que a nova redação do artigo 13 do novo Código de Processo Civil, Lei no 13.105 , de 16 de março de 2015, representa, para se dizer o mínimo, nitidamente, uma tendência no avanço desse tema.

\section{ReferênCIAS}

BOBBIO, Noberto; PONTARA, Giuliano; VECA, Salvatore. Crisis de la democracia. Barcelona: Ariel, 1985.

BONAVIDES, Paulo. Curso de direito constitucional. 29. ed. São Paulo: Malheiros, 2014. 
BRASIL. Lei n 13.105, de 16 de marco de 2015. Disponível em: <http://www.planalto.gov.br/ccivil_03/_ato20152018/2015/lei/113105.htm>. Acesso em: 03 fev. 2016.

BRASIL. Supremo Tribunal Federal. Recurso Extraordinário. RE $n^{0}$ 158215-4 RS. Segunda Turma. Relator: Min. Marco Aurélio. Brasília, 07 de junho de 1997. Disponível em: <http://www.stf.jus.br/arquivo/informativo/documento/informativo34.htm>. Acesso em: 04 fev. 2016.

BRASIL. Supremo Tribunal Federal. Recurso Extraordinário. RE $n^{\circ}$ 161.243-6/DF. Segunda Turma. Recorrente: Roberto de Figueiredo Caldas e outros. Recorrida: Compagnie Nationale Air France. Relator: Min. Carlos Velloso. Brasília, 29 de outubro de 1996. Disponível em: <http://redir.stf.jus.br/paginadorpub/ paginador.jsp?doc'TP $=\mathrm{AC} \& \operatorname{doc} \mathrm{ID}=213655>$. Acesso em: 04 fev. 2016.

BRASIL. Supremo Tribunal Federal. Recurso Extraordinário. RE $n^{0}$ 201-819-8 RJ. Segunda Turma. Recorrente: União Brasileira de Compositores. Recorrido: Arthur Rodrigues Villarinho Relator: Min. Gilmar Mendes. Brasília, 11 de outubro de 2005. Disponível em: <http://redir.stf.jus.br/paginadorpub/paginador. http://redir.stf.jus.br/paginadorpub/paginador. jsp?doc'TP=AC\&docID=388784 > . Acesso em: 04 fev. 2016.

BRASIL. Supremo Tribunal Federal. Recurso Extraordinário. RE $n^{\circ}$ 466.343-1 SP. Tribunal Pleno. Recorrente: Banco Bradesco S/A. Recorrido: Luciano Cardoso Santos. Relator: Min. Cezar Peluso. Brasília, 22 de novembro de 2006. Disponível em: < http://www.stf.jus. br/imprensa/pdf/re466343.pdf $>$. Acesso em: 04 fev. 2016.

CAGLIARI, Cláudia Taís Siqueira. A função social do contrato como forma de efetivação dos direitos fundamentais nas relações entre particulares. 2007. 230 f. Dissertação (Mestrado) - Programa de Pós-Graduação em Direito, Área de Concentração em Direitos Sociais e Políticas Públicas, Universidade de Santa Cruz do Sul, Roma, 2007. Disponível em: <http://www.unisc.br/portal/images/ stories/mestrado/direito/dissertacoes/2007/claudia_ tais_cagliari.pdf>. Acesso em: 17 dez. 2014.

FACCHINI NETO, Eugênio. A constitucionalização do direito privado. Revista do Instituto do Direito Brasileiro, Lisboa, Ano 1, n. 1, p. 185-243, 2012.
FARIAS, Cristiano Chaves de; ROSENVALD, Nelson. Curso de direito civil. 13. ed. São Paulo: Atlas, 2015. v. 1.

FREITAS, Riva Sobrado de; PIRES, Mixilini Chemin. A constitucionalização do direito civil e a ampliação de direitos subjetivos fundamentais: uma análise em torno do direito de propriedade. In: SIMPÓSIO INTERNACIONAL DE DIREITO, 3., 2012, Chapecó. Dimensões materiais e eficaciais dos direitos fundamentais. Joaçaba: Unoesc, Chapecó, 2012. v. 1. p. 1-25. Disponível em: <http://editora.unoesc.edu.br/index.php/simposiointernacionaldedireito/article/view/2287>. Acesso em: 12 jan. 2013.

HESSE, Konrad. Derecho constitucional y derecho privado. Madrid: Cuadernos Civitas, 1995.

LÔBO NETTOO, Paulo Luiz. Constitucionalização do direito civil. Revista de Informação Legislativa, Brasília, v. 36, n. 141, p. 99-100, jan./mar. 1999.

LORENZETTTI, Ricardo Luis. Normas fundamentales de derecho privado. Trad. de Vera Maria Jacob de Fradeira. São Paulo: Revista dos Tribunais, 1998.

MAZZUOLI, Valerio de Oliveira. Curso de direito internacional público. 8. ed. São Paulo: Revista dos Tribunais, 2014.

MENDES, Gilmar Ferreira. Direitos fundamentais e controle de constitucionalidade: estudos de direito constitucional. 3. ed. São Paulo: Saraiva, 2004.

MIRANDA, Daniel Gomes. Constitucionalização do direito privado e a função social do contrato e da propriedade na empresa. 2010. 130 f. Dissertação (Mestrado) - Programa de PósGraduação em Direito, Faculdade de Direito, Universidade Federal do Ceará, Fortaleza, 2010.

PASTRE, Daniel Fernando. Efetividade socioeconômica dos processos de autorização estatal nas concentrações empresariais. 2009. 159 f. Dissertação (Mestrado) - Programa de Mestrado em Direito Empresarial e Cidadania, Centro Universitário Curitiba, Curitiba, 2009. Disponível em: <http://dominiopublico.mec.gov.br/download/teste/ arqs/cp116732.pdf $>$. Acesso em: 7 jan. 2013.

PEREIRA, Caio Mário da Silva. Instituições de direito civil. 20. ed. Rio de Janeiro: Forense, 2004. v. 1.

PERLINGIERI, Pietro. Perfis do direito civil. Trad. de Maria Cristina de Cico. Rio de Janeiro: Renovar, 1999.

PIOVESAN, Flávia. Direitos bumanos e o direito constitucional internacional. 14. ed. São Paulo: Saraiva, 2014. 
QUEIROZ, André Luiz Tomasi de. Teorias da horizontalização dos direitos fundamentais. Disponível em: <http:// www.flaviotartuce.adv.br/artigosc/horizontal_and. doc>. Acesso em: 01 dez. 2014.

SAMPAIO JÚNIOR, Rodolpho Barreto. Da liberdade ao controle: os riscos do novo direito civil brasileiro. Belo Horizonte: PUC Minas Virtual, 2009.

SARMENTO, Daniel. Direitos fundamentais e relaçoos privadas. 2. ed. Rio de Janeiro: Lumen Juris, 2010.
TEPEDINO, Gustavo; SCHREIBER, Anderson. A garantia da propriedade no direito brasileiro. Revista da Faculdade de Direito de Campos, Rio de Janeiro, Ano 6, n. 6, p. 101-119, jun. 2005.

VARELLA, Marcelo D. Direito internacional público. 5. ed. São Paulo: Saraiva, 2014.

VON MÜNCH, Ingo. Drittwirkung de derechos fundamentales em Alemania. In: SALVADOR CODERCH, Pablo (Org.). Associaciones, derechos fundamentales y autonomia privada. Madrid: Civitas, 1997. p. 25-53. 


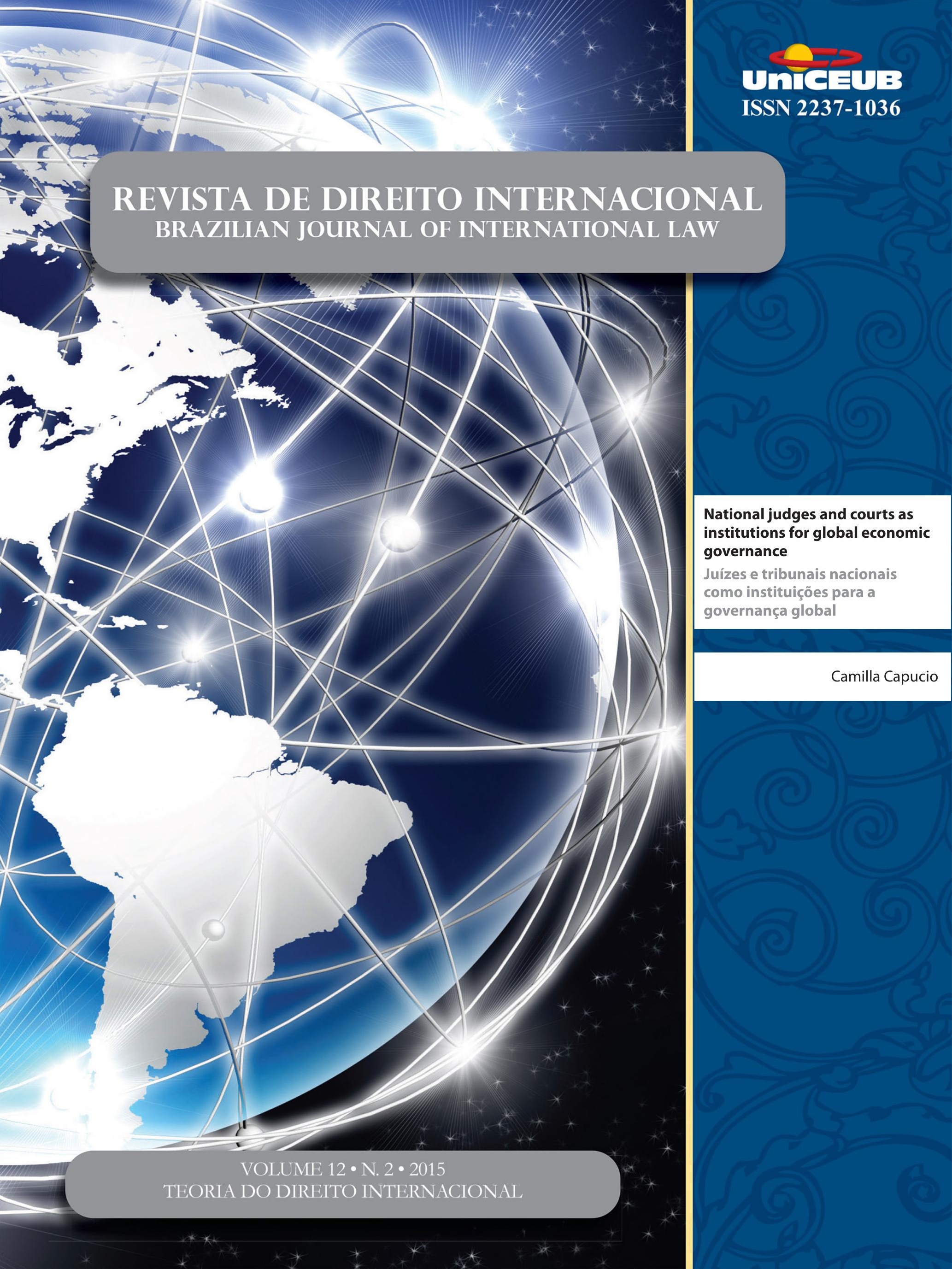




\title{
National judges and courts as institutions for global economic governance*
}

\author{
Juízes e tribunais nacionais como \\ instituições para a governança global
}

Camilla Capucio**

\begin{abstract}
This paper aims to explore the relationship between national judges and courts and the international economic order, from the perspective of global economic governance. It is proposed, therefore, the thesis that there is room and need for active participation of these bodies as institutions of global governance, through four sections. The first section presents concepts such as international order and global governance, guiding to the succeeding reflections. The second part enters into the question of disaggregation of State and its consequences in international trade relations. Third section deals with the perspective of constitutionalism and cosmopolitan law as a project for global order, and the layers of multilevel trade governance encompassing multilateral, regional and national levels of norms and institutions. Fourth part discusses the role of national courts, understood as having also an international authority, in international economic order. Fifth section focuses on the relation between national judiciary and the multilateral rules and WTO Dispute Settlement Mechanism decisions. This thesis explored in the paper is an attempt to overcome the perspective of classic international law that erects a wall of separation between international order and domestic order, in what consists its main value, as a new perspective for international law as a broader instrument for global governance.
\end{abstract}

Keywords: National Courts. Global Economic Governance. Multilevel Trade Governance. International Order. World Trade Organization. Dispute Settlement.

* Recebido em 21/09/2015

Aprovado em 02/11/2015

** Doutoranda pela Faculdade de Direito da Universidade de São Paulo -USP. Mestre em Direito pela Faculdade de Direito da Universidade Federal de Minas Gerais - UFMG, com experiência de estudos realizados na Universitá di Bologna - UNIBO. Ex-bolsista do CNPq. Advogada e Consultora Jurídica. Professora de Graduação em Direito no Centro Universitário UNA. Professora de cursos de Pós-Graduação latu senso (Escola Paulista de Direito e Faculdades Promove). Coordenadora da linha temática sobre o Mecanismo de Solução de Controvérsias da OMC, do Núcleo de Estudos em Tribunais Internacionais - NETI-USP. Email: ccapucio@usp.br.

\section{Resumo}

Este trabalho tem como objetivo explorar a relação entre os juízes e os tribunais nacionais e a ordem econômica internacional, a partir da perspectiva da governança econômica global. Propõe-se, portanto, a tese de que não apenas há espaço para, mas há necessidade de necessidade de participação ativa destes órgãos como instituições de governança global, por meio de cinco seções. A primeira seção apresenta conceitos como ordem internacional e governança global, orientando as reflexões seguintes. A segunda parte adentra na questão da desagregação do Estado e as suas consequências nas relações comerciais internacionais. A terceira seção trata da perspectiva do constitucionalismo e do direito cosmopolita como um projeto para a 
ordem global, e as camadas de governança em vários níveis para o comércio, abrangendo níveis multilaterais, regionais e nacionais de normas e instituições. A quarta parte discute o papel dos tribunais nacionais, entendidos como tendo também uma autoridade internacional, na ordem econômica internacional e a quinta seção, por fim, explora a relação entre o poder judiciário nacional e as decisões do Mecanismo de Solução de Controvérsias da OMC. Esta tese explorada no trabalho é uma tentativa de superar a perspectiva do Direito Internacional clássico, que ergue uma rígida separação entre a ordem internacional e ordem interna, no que consiste o seu valor principal, como uma nova perspectiva para o direito internacional como um instrumento mais amplo para a governança global.

Palavras-chave: Órgãos Jurisdicionais Nacionais. Governança Econômica Global. Governança Econômica De Vários Níveis. Ordem Internacional. Organização Mundial Do Comércio. Solução De Controvérsias.

\section{Order, International LaW and Global Governance: Reconstruction of Relevant CONCEPTS}

Aiming to initiate the discussion on the place for national judges and courts in global governance, and therefore in global economic governance, it is necessary to reflect about certain concepts, theoretical grounds upon which this paper is based. Initially, we must address the concept of order, and its relationship with International Law and global governance.

According to the conception of Redley Bull, order in a broad sense means the manner in which things related to each other, according to some pattern. Worth noting that order is not necessarily synonymous with law, and in this sense the author seeks to remove the normative element of the definition of order, though not disregarding its role in creating order. ${ }^{1}$ In this perspective, we take the vision of international order as " $a$

1 BULL, Hedley. The Anarchical Society: a study of order in world politics. 3. ed. Basingstoke; New York: Palgrave, 2002. p. 7. "I have sought deliberately to find a definition of order in social life that excludes the conception of rules. This is because, for reasons discussed in Chapter 3, I believe order in social life can exist in principle without rules, and that it is best to treat rules as a widespread, and nearly ubiquitous means of creating order in human society, rather than as part of the definition of order itself." pattern of activity that sustains the elementary or primary goals of the society of states, or international society" ${ }^{2}$ Therefore, international order is a pattern of social actions purposely oriented, to achieve primary objectives of the international society, a society of states which necessarily requires that states has common values and interests. ${ }^{3}$

To our objectives, the most important feature of BuLL's work lies in the differentiation between international society and world society, because it brings the necessity to consider rules, norms and institutions that lies beyond the state, and rethink about the management of change within international legal and normative structure of global order. In his conception, international society means a society of states, meanwhile in a broader sense, by world order BuLL means "those patterns or dispositions of human activity that sustain the elementary or primary goals of social life among mankind as a whole" 4

In this sense, it is at utmost relevant the idea that order among mankind as a whole is wider, more fundamental, more primordial and morally prior than order among states. ${ }^{5}$ The figure of state loses its primacy as we reach the concept of world order, and becomes a path for achieving global common values and interests.

Applying this idea to international economic order, there is an undeniable necessity to include other actors, new institutions and multiple dimensions to the classic analysis of economic international law, encompassing a broader view of the members of the economic community - possible by the lens of global economic governance.

On a similar perspective, JAmes Rosenau argues that, although with close relation to world order ${ }^{6}$ and

2 BULL, Hedley. The Anarchical Society: a study of order in world politics. 3. ed. Basingstoke; New York: Palgrave, 2002. p. 8.

3 BULL, Hedley. The Anarchical Society: a study of order in world politics. 3. ed. Basingstoke; New York: Palgrave, 2002. p. 11.

4 BULL, Hedley. The Anarchical Society: a study of order in world politics. 3. ed. Basingstoke; New York: Palgrave, 2002. p. 19.

5 BULL, Hedley. The Anarchical Society: a study of order in world politics. 3. ed. Basingstoke; New York: Palgrave, 2002. p. 21.

6 ROSENAU, James. Govenance without Government. In: ROSENAU, James; CZEMPIEAL, Ernst-Otto. Govenance, Order and Change in World Politics. Cambridge: Cambridge University Press, 1992. p. 1-29. Specially on the complex relation between order and governance, the author explicates that "In sum, governance and order are clearly interactive phenomena. As intentional activities designed to regularize the arrangements whicg sustain world affairs, governance obviously shapes the nature of the prevailing global order. It could not do so, if the patters constituting the order did not facilitate governanxe. Thus order is both a precondition and a consequence of government. Neither comes firts qand each helps explain the 
government, governance refers to a more encompassing phenomenon that embraces not only governmental institutions but also informal, non-governmental and sub-national mechanisms. Governance is an inter-subjective system of rules, with its construction, contents and application shared by multiple actors. ${ }^{7}$

At the same time, Mark ZaCHER points out that we are facing the fall of the Westhalian order's paradigm, and the rise of a new architecture of the global world. ${ }^{8}$ In a changing world order, states are becoming "increasingly enmeshed in a network of interdependencies and regulatory/ collaborative arrangements" ${ }^{\prime}$, and to this webs of commitments it may be added, as a recent novelty, the peoples acknowledgement of their common risks and future, recognizing each other increasingly as part of humankind. ${ }^{10}$

In this crisis of paradigm, institutions assume an essential role in global governance, as it becomes an attempt to conceive rules and mechanisms of management to regulate complex multi-dimensions situations. The importance of the institutions has not been unnoticed by the authors, that recognize it empirically ${ }^{11}$ and normatively. ${ }^{12}$ Institutions may be comprehended as expression of collaboration and exercising functions of global order in international society ${ }^{13}$, and have un-

othet. There can be no governance without order and there can be no order without governance (unless periods of disorder are regarded as forms of order)." p. 8 7 ROSENAU, James. Govenance without Government. In: ROSENAU, James; CZEMPIEAL, Ernst-Otto. Govenance, Order and Change in World Politics. Cambridge: Cambridge University Press, 1992. p. 1-29.

8 ZACHER, Mark. The Decaying pillars of the Westphalian temple: Implications for International Order and Governance. In: ROSENAU, James; CZEMPIEAL, Ernst-Otto. Governance, Order and Change in World Politics. Cambridge: University Press, 1992. p. 58-101.

9 ZACHER, Mark. The Decaying pillars of the Westphalian temple: Implications for International Order and Governance. In: ROSENAU, James; CZEMPIEAL, Ernst-Otto. Governance, Order and Change in World Politics. Cambridge: Cambridge University Press, 1992. p. 58-101. p. 60.

10 ZACHER, Mark. The Decaying pillars of the Westphalian temple: Implications for International Order and Governance. In: ROSENAU, James; CZEMPIEAL, Ernst-Otto. Governance, Order and Change in World Politics. Cambridge: University Press, 1992. p. 58-101. p. 111.

11 ROSENAU, James. Govenance without Government. In: ROSENAU, James; CZEMPIEAL, Ernst-Otto. Govenance, Order and Change in World Politics. Cambridge: Cambridge University Press, 1992. p. 1-29.

12 BULL, Hedley. The Anarchical Society: a study of order in world politics. 3. ed. Basingstoke; New York: Palgrave, 2002.

13 BULL, Hedley. The Anarchical Society: a study of order in world politics. 3. ed. Basingstoke; New York: Palgrave, 2002. p. 71. "Symbolize the existence of an international society that is more than the sum of its members, to give substance and performance to their deniable role in "governing globalization". ${ }^{14}$

In what regards to global economic governance, economic aspects of this increasingly enmeshed network caused by globalization urges for effective global governance, beyond formal structures that have been ineffective in developing and protecting the values and interests of stakeholders in the global economy. ${ }^{15}$

It is necessary, for this approach, to conceive international economic law and international normative phenomenon in a broader perspective, encompassing new protagonists and structures that were once only considered in international politics, understood before as a completely different and hermetic field, as we contend that national judges are essential pillars to global governance, as we will further develop.

\section{Disaggregation of the State and the Re- View of State Sovereignty: Necessity of a NEW PERSPECTIVE}

The reality brought by globalization in its multiple dimensions resulted in a rupture with the "dogma" of State's unity in international law ${ }^{16}$, triggering the disaggregation of the State as the initial platform for its analysis in world order. As ANDrew Hurrel emphasizes, this dominant perspective with liberal origins includes the novelty of giving ontological primacy to individuals and groups within the State, and comprises an increase of transnational relations that involve different parts of the state acting together with private actors,

collaboration in carrying out the political functions of international society".

14 MISTRAL, Jacques. Globalization Needs better Governance. Politique Étrangère, v. 5, p. 153-162, 2008. Available at: <http:// www.cairn.info/revue-politique-etrangere-2008-5-page-153.html>. Access on: 15 set. 2015.

15 BRADLOW, Daniel D. Framework For Assessing Global Economic Governance. Boston College Law Review, v. 54, n. 3, p. 971-1003, 2013.

16 Commenting the phenomenon of decay of the traditional concept of sovereignty in international law and the unity of state itself, Cf: FERRAJOLI, Luigi. A soberania no mundo moderno: nascimento e crise do Estado Nacional. São Paulo: M. Fontes, 2002. "Falar em 'Estados soberanos', se já não é aceito no plano da teoria do direito, também não o é no plano da teoria política. De fato, o que entrou irreversivelmente em crise, bem antes do atributo da soberania, é precisamente seu sujeito: o Estado nacional unitário e independente, cuja identidade, colocação e função precisam ser repensadas à luz da atual mudança, de fato e de direito, das relações internacionais.". 
and with bodies of other states. ${ }^{17}$

Hence, States cannot be conceived any longer as artificial units constructing its relations, but as an aggregate of elements, such as its legislative, executive and judicial branches, civil society, NGOs and firms that influence the formulation of global governance. Therefore, the same transformation forces that demands changes broadly in traditional international law have been remodeling States radically, demanding an urgent review on the definitions and consequences of sovereignty nowadays.

According to Anne Marie Slaughter, changes in the concept of sovereignty are necessary in view of the new reality of international society. The Westphalian sovereignty is no longer effective to explain the ambiguous role of States in the construction of the global order. Thus, there must take place a new interpretation of sovereignty, related to the ability to participate in international and transgovernmental regimes, networks and institutions increasingly necessary for the achievement of the goals of the global society. Therefore, the new sovereignty is related to the ability to participate in joint efforts, and to be in connection to the rest of the world. ${ }^{18}$

In fact, the transformation observed in the traditional idea of sovereignty is responding to changes in the international system and international relations, opening space for the performance of its institutions as architectures of global governance and reaffirming (this new type of) sovereignty. In other words,

\begin{abstract}
the state is no longer an interlocking set of government institutions in its domestic affairs, with sovereignty lodged in the people, and a unitary entity in its foreign relations, with sovereignty a fundamental attribute of its statehood. Instead, its internal and external face begin to mirror one another, as sovereignty becomes inextricably interwoven with accountability. ${ }^{19}$
\end{abstract}

A clear example of this scenario is the formation of governance networks in response to threats that also follow a logical increasingly rectified. ${ }^{20}$ Once the-

17 HURREL, Andrew. On Global Order: Power, Values and the Constitution of International Society. Oxford University Press, 2007. p. 115-116.

18 SLAUGHTER, Anne-Marie. Sovereignty and Power in a Networked World Order. Standford Journal of International Law, v. 40, p. 283-327, 2004.

19 HELFER, Laurence R; SLAUGHTER, Anne-Marie. Toward a Theory of Effective Supranational Adjudication. Yale Law Journal, v. 107, n. 2, p. 273-391, 1998. p. 388

20 SLAUGHTER, Anne-Marie. Sovereignty and Power in a Net- se governance networks share information, coordination and implementation efforts, beneficial effects are created for the world order. There is a movement of deterioration of the linking of state organs to traditional sovereignty, to domestic normativity and to national interests, as they start to be understood as institutions of global governance, linked to a relational sovereignty - owing respect to the global community.

As Andrew Hurrel suggests, "institutions, including state institutions, should not be seen as representatives of sovereign power or as embodiments of a particular community, but rather as functional bodies that compete with one another to provide efficient solutions to governance problems". ${ }^{21}$ National judges and tribunals are one of these institutions, that although needing to comply with legitimacy and accountability frameworks, must be conscious about its role in resolving governance demands.

In this perspective, in one hand there is an urgent necessity to encompass stakeholders of global economic governance in the administration of its dimensions, as the formal position of states in international forums searching for the development of solutions to problems in international economic order, may no longer be seen as representing the complex spectrum of its actors. On the other hand, national judges and courts may contribute as institutions for global economic governance. ${ }^{22}$

\section{Constitutional perspective to internatio- NAL LAW: TOWARDS A "COSMOPOLITAN LAW"}

With the "failure" of statehood paradigm, some perspectives have been developed to replace its gap

worked World Order. Standford Journal of International Law, v. 40, p. 283-327, 2004.

21 HURREL, Andrew. On Global Order: Power, Values and the Constitution of International Society. Oxford University Press, 2007. p. 115.

22 PETERSMANN, Ernst-Ulrich. Multi-Level Judicial Trade Governance without Justice? On the Role of Domestic Courts in the WTO Legal and Dispute Settlement System. European University Institute, Department of Law, EUI Working Paper LAW n. 2006/44. Available at: < http://cadmus.eui.eu/handle/1814/3/ browse? value $=$ PETERSMANN, + Ernst-Ulrich\&type $=$ author $>$. Access on: 15 set. 2015. p. 8; PETERSMANN, Ernst-Ulrich. The Future of the WTO: From Authoritarian Mercantilism to Multilevel Governance for the Benefit of Citizens. Asian Journal of WTO \& International Health Law and Policy, v. 6, n. 1, p. 45-80, mar. 2011. 
as a project for world order. ${ }^{23}$ In this context, we will briefly describe the perspective of constitutionalism and cosmopolitan law as a project for global order, and the layers of multilevel trade governance encompassing multilateral, regional and national levels of norms and institutions.

Albeit there are multiple different definitions, JÜRGEN Habermas presents the perspective of constitutionalization as directly connected to the Kantian cosmopolitan law "project", intended to transform international law as a law of states into cosmopolitan law of individuals. ${ }^{24}$ The conception of cosmopolitanism introduced by KANT is related to the idea of "public use of reason", and the notion of cosmopolitan right as an entitlement to dialogue and participate in cosmopolitan society. ${ }^{25}$

DAvid Held use this notion as background to defend a "layered cosmopolitan perspective" that lead to a cosmopolitan law embracing global, regional, national, and local forms of power and authority, centered on citizenships as human beings entitled to equal liberty and to multiple forms of governance founded on deliberation and consent. ${ }^{26}$

The idea of constitutionalization is used in the context of multilateral trading system in reference to (a) the WTO institutional architecture; (b) the process of judicial balance operated by WTO dispute settlement; and/or (c) the primacy of a set of normative commitments. ${ }^{27}$

23 Other main perspectives of analysis of contemporary international law, besides the perspective of constitutionalism, are (a) the fragmentation of international law and (b) the legal pluralism. For more details, Cf: KOSKENNIEMI, Martii. The Fate of Public International Law: Between Technique and Politics. Modern Law Review, v. 70, n. 1, p. 1-30, jan. 2007.

24 HABERMAS, Jürgen. Does the Constitutionalization of International Law Still Have a Chance? In: HABERMAS, Jürgen. The Divided West. Cambridge: Polity Press, 2006. p. 115-193. p. 115-124. 25 HELD, David. Principles of cosmopolitan order. Chaper 2. In: BROCK, Gillian; BRIGHOUSE, Harry. (Ed.) The Political Philosophy of Cosmopolitanism. Cambridge: Cambridge University Press, 2005. p. 18, 26, 27.

26 HELD, David. Principles of cosmopolitan order. Chaper 2. In: BROCK, Gillian; BRIGHOUSE, Harry. (Ed.) The Political Philosophy of Cosmopolitanism. Cambridge: Cambridge University Press, 2005. p. 10-27. p. 11.

27 DUNOFF, Jeffrey L. Why Constitutionalism Now? Text, Context and the Historical Contingency of Ideas. Journal of International Law and International Relations, v. 1, p. 191-211, 2005. In the first use of the idea: JACKSON, John. The Jurisprudence of GATT and the WTO. Cambridge: Cambridge University Press, 2000. In the second use of the idea: CASS, Deborah Z. "The "Constitutionali-
Therefore, choosing the multilateral trading system as a platform for reflecting about international economic order, is necessary to design a clear connection between the constitutional paradigm and the cosmopoli$\tan$ ideal $^{28}$, which is possible by the means of the layers of multilevel trade governance ${ }^{29}$, as an integration and interpenetration between national, regional and global institutions for constructing and applying international economic order. ${ }^{30}$

zation" of International Trade Law: Judicial Norm-Generation as the Engine of Constitutional Development in International Trade'. European Journal of International Law, v. 12, n. 1, p. 39-75, 2001. p. 42. In the third use of the idea: PETERSMANN, Ernst-Ulrich. How to Constitutionalize International Law and Foreign Policy for the Benefit of Civil Society? Michigan Journal of International Law, v. 20, p. 1-30, 1998. p. 13; PETERSMANN, Ernst-Ulrich. Human Rights, International Economic Law and Constitutional Justice: A Rejoinder. European Journal of International Law, v. 19, n. 5, p. 955-960, 2008. PETERSMANN, Ernst-Ulrich. Multilevel Judicial Governance as Guardian of the Constitutional Unity of International Economic Law. Loyola of Los Angeles International and Comparative Law Review, v. 30, n. 3, p. 367-418, 2008.

28 CHARNOVITZ, Steve. WTO Cosmopolitics. New York University Journal of International Law \& Politics, v. 34, p. 299-354, 2002. Arguing that WTO needs more "cosmopolitics," which the author defines as global political action transcending a strict state-to-state, or multilateral, basis."

29 SLAUGHTER, Anne-Marie. BURKE-WHITE, William. Future of International Law Is Domestic (or, the European Way of Law). Harvard International Law Journal, v. 47, p. 327-352, 2006. HSUEH, Ching-wen. Direct Effect, WTO Compliance Mechanism and the Protection for Individuals: Lessons Learned from the EC. Asian Journal of WTO \& International Health Law and Policy, v. 4, n. 2, p. 521-556, Sept. 2009. PETERSMANN, Ernst-Ulrich. From the Hobbesian International Law of Coexistence to Modern Integration Law: The WTO Dispute Settlement System. Journal of International Economic Law, v. 1, n. 2, p. 175-198, 1998. PETERSMANN, Ernst-Ulrich. Multilevel Judicial Governance as Guardian of the Constitutional Unity of International Economic Law. Loyola of Los Angeles International and Comparative Law Review, v. 30, n. 3, p. $367-$ 418, 2008. PETERSMANN, Ernst-Ulrich. The Future of the WTO: From Authoritarian Mercantilism to Multilevel Governance for the Benefit of Citizens. Asian Journal of WTO \& International Health Law and Policy, v. 6, n. 1, p. 45-80, mar. 2011.

30 Albeit with some conceptual differences, this perspective may be connected to the "global administrative law" KINGSBURY, Benedict; KRISCH, Nico. Introduction: Global Administrative Law. European Journal of International Law, v. 17, n. 1, p. 1-13, 2006. STEWART, Richard B.; BADIN, Michelle R. S. The World Trade Organization: multiple dimensions of global administrative law. International Journal of Constitutional law, v. 9, p. 556-586, 2011. and to the "multisystem of regulation of international trade" THORSTENSEN, Vera; PRADO, Victor Luiz. O Multissistema Da Regulação Do Comércio Global: Proposta De Novo Referencial Teórico e Nova Metodologia de Análise. In: BAPTISTA, Luiz Olavo; FERRAZ JUNIOR, Tercio Sampaio. Novos caminhos do século XXI: direito internacional, filosofia jurídica e política, dogmática jurídica e direitos fundamentais: uma homenagem a Celso Lafer. Curitiba: Juruá, 2013. 


\section{National Judges in this scenario}

International Courts and Tribunals have increasing relevance in global order, since they are institutionalized agents of interpretation and application of international law, beyond the primary will of states. Beyond the emergence of international courts and tribunals in the past decades ${ }^{31}$, it is possible to recognize in the international reality a phenomenon of "bybridization of the application of international law", which would indicate an increasing merger of domestic laws and its institutions - among them especially the judiciary- in the concretion of international law. ${ }^{32}$

Therefore, they may be placed as part of a system of multilevel global governance, "as part of a system of multilevel global governance in which the national and international levels are more deeply intertwined than ever before." ${ }^{33}$ Although often ignored in their role in the enforcement of international law, national courts are also vital elements of creating, implementing and enforcing international rules and dealing with global governance challenges.

It is relevant to revisit the theory of "role splitting" (dedoublement fonctionelle) created by GeOrges ScELle, which impacted on the work of many authors. Beyond the theories of monism and dualism, Georges SCELLE envisioned that the relationship between the spheres of domestic and international normativity should be understood by using the functional capacity of internal actors - among them the national judges - to ensure the effectiveness of the international order. ${ }^{34}$ That is, domestic courts integrates itself as part of international law, facing the organic lack of international law, without failing to perform their own competencies, and becoming thus (inter)national judges and courts.

In a scenario of spectacular organic development of the international system, accompanied by an expansion of density limits and rules of international law, in a ' $\mathrm{glo}$ balization of law ${ }^{35}$, the actuality of his theory is revea-

31 CHARNEY, Jonathan. Is International Law threatened by multiple international tribunals? Recueil des Cours. Collected Courses of the Hague Academy of International Law, v. 271, p. 101-382, 1998. p. 116.

32 BURKE-WHITE, William W. International Legal Pluralism. Michigan Journal of International Law, v. 25, p. 963-979, 2004. p. 975-7 33 BURKE-WHITE, William W. International Legal Pluralism. Michigan Journal of International Law, v. 25, p. 963-979, 2004. p. 977

34 SCELLE, Georges. Regle generales du droit de la paix. Recueil des cours de l'Academie de La Haye, v. 46, p. 327-696, 1933. p. 356-359

35 DUPUY, Pierre-Marie. Unité d'Application du Droit à led, since have been given increased opportunities for domestic courts to play a substantial role as means of safeguarding world order. ${ }^{36}$

From the perspective of Antonio Cassese, these opportunities come in two facets. First, in the case of treaties that expressly provide to the contracting parties the power to exercise jurisdiction with a vocation to universality, giving national courts the power to act as an organ of international society. Secondly, there are situations in which the need for action arises directly from national judges in the face of international inertia, subrogating itself as legitimate enforcers of international rules, in an attempt to replace the collective enforcement of international bodies and acting as true organs of the international society.

In another perspective, EyAL BENVENISTI and GEORGE W. Downs call attention to the changes and consequences of the current scenario in which are national judges and Courts. Given the jurisidicization, evidenced by the proliferation of international courts and tribunals and expansion of their reach, there is the increasing role of international judicial bodies on issues that come into the powers previously reserved to the domestic law. Thus, in this context the position of national courts would have changed "instinctively" or "strategically", once they discovered that the most efficient way to maintain their inner space of deliberation would be ensuring that their judgments are complementary rather than conflicting with other national and international decisions, leading them to a kind of "tacit coordination". ${ }^{37}$

YUVAL SHANY also recognizes the evolution of recent decades, in the increasing of participation of national courts in contributing to development of international law, although seeing its role as an activity increasingly more technical:

\begin{abstract}
a number of national courts have adopted a more international law friendly attitude and have started applying international law with greater frequency, in what appears to be a professional and credible manner (even in politically-charged cases involving their own governments). ${ }^{38}$
\end{abstract}

l'Echelle Globale et Responsabilité des Juges. European Journal of Legal Studies, v. 1, n. 2, p. 245-269, 2007.

36 CASSESE, Antonio. Remarks on Scelle's Theory of "Role Splitting" (dedoublement fonctionnel) in International Law. European Journal of International Law, v. 1, n. 1, p. 210-231, 1990. p. 228

37 BENVENISTI, Eyal; DOWNS, George W. National Courts, Domestic Democracy, and the Evolution of International Law. European Journal of International Law, v. 20, n. 1, p. 59-72, 2009. p. 61 38 SHANY, Yuval. No Longer a Weak Department of Power? Reflections on the Emergence of a New International Judiciary. Eu- 
Pierre-Marie Dupuy stress that this growing cooperation between the domestic and international courts is related to a gradual change in the self-perception of national judges about their participation in a larger totality, and their responsibilities as such. ${ }^{39}$ In this view, the responsibilities of the national courts, therefore, are not limited to cooperation with International Courts, nor to the factual and prevailing application of international norms to the facts presented to them internally, but to a shared sense of universal normativity and its axiological content. It presupposes, certainly, a substantial degree of knowledge of the international legal system by these agents, and an internal functional independence that enables them to exercise their "dual" role evidenced by Georges SCELle.

Defending a larger performance for domestic courts as deliverers of justice, ERnst-Ulrich Petersman also stress that the exercise of multilevel governance by national judges and courts at the legal dimension require a complex hermeneutical exercise, assuming their responsibility of fulfilling obligations present in international laconic texts, recognizing certain hierarchy in the international system -derived from erga omnes and jus cogens categories- and applying the principle of systemic interpretation erected by the Vienna Convention of the Law of Treaties. ${ }^{40}$

Beyond the legal dimension, Christopher WhytoCK aims to construct a methodology for assessing domestic courts participation in global governance by a systematic analysis of the global governance functions of domestic courts, on an interdisciplinary perspective. ${ }^{41}$ This "governance-oriented analysis", argues that domestic courts perform two global governance functions, first allocating governance authority, and second determining rights and obligations of transnational actors.

At one side, by allocating properly adjudicative, prescriptive, and enforcement authority, and on the other

ropean Journal of International Law, v. 20, n. 1, p. 73-91, 2009. p. 75-6 39 DUPUY, Pierre-Marie. Unité d'Application du Droit à l'Echelle Globale et Responsabilité des Juges. European Journal of Legal Studies, v. 1, n. 2, p. 245-269, 2007.

40 PETERSMANN, Ernst-Ulrich. Multi-Level Judicial Trade Governance without Justice? On the Role of Domestic Courts in the WTO Legal and Dispute Settlement System. European University Institute, Department of Law, EUI Working Paper LAW n. 2006/44. Available at: < http://cadmus.eui.eu/handle/1814/3/ browse? value $=$ PETERSMANN, + Ernst-Ulrich\&type $=$ author $>$. Acess on: 15 set. 2015. p. 8-9.

41 WHYTOCK, Christopher A. Domestic Courts and Global Governance. Tulane Law Review, v. 84, p. 67-124, 2010. side, by producing concrete decisions and delivering justice on transnational and global matters, domestic courts impact deeply not only on litigants, but also on global welfare. Ignoring its place in world order would be to ignore a potential force for properly addressing global challenges.

\section{WTO AND NATIONAL JUDJES: IS THERE A POS- SIBLE CONNECTION IN GLOBAL ECONOMIC GOVER- NANCE?}

Although there is no formal institutional linkage between the levels of judicial protection of global economic governance in international trade, ${ }^{42}$ we argue that national courts may contribute to the application of W'TO obligations, and especially to the concretization of the WTO Dispute Settlement decisions. ${ }^{43}$

As a general statement, there is no doubt that individuals may pursue existing rights in national court systems by legislation that implemented international rules. Although the distinction between direct and indirect applicability of international rules cannot be ignored, ${ }^{44}$ the question of guaranteeing effective legal protection of the rights and interests of the individual in the international trading system is a matter of crucial interest. ${ }^{45}$

Thus, as basic judicial protection of the individual is part of the rule of law, and is present not only in national but also international legal instruments, international economic matters may also be subject to national judicial analysis. In the European Union context, for example, there have been recognized a fundamental right to export or import, as derived from the freedom of profession, the right to equal treatment, the protec-

42 HILF, Meinhard. Role Of National Courts In International Trade Relations. Michigan Journal of International Law, v. 18, p. 321356, 1997.

43 PETERSMANN, Ernst-Ulrich. Multi-Level Judicial Trade Governance without Justice? On the Role of Domestic Courts in the WTO Legal and Dispute Settlement System. European University Institute, Department of Law, EUI Working Paper LAW n. 2006/44. Available at: < http://cadmus.eui.eu/handle/1814/3/ browse value $=$ PETERSMANN, + Ernst-Ulrich\&type $=$ author $>$. Acess on: 15 set. 2015. p. 18-19

44 ZHANG, Xin. Domestic Effect of the WTO Agreement in China: Trends and Implications. The Journal of World Investment,v. 3, p. $912-937,2002$. p. 321.

45 HILF, Meinhard. Role Of National Courts In International Trade Relations. Michigan Journal of International Law, v. 18, p. 321356, 1997. 
tion of property, and the freedom to pursue trade or business, which may be relevant to international trade. Accordingly, courts have derived a fundamental right to export or import in this context, although this right should be interpreted bearing in mind its social function and respecting a broad discretionary space to Community institutions. ${ }^{46} 47$

As mentioned above, national judges may play a double role, as they are not only enforcers of national law but may also be regarded as genuine enforcers of international instruments. This "deconcentrated enforcement" is a valid logic for economic global governance, and should be regarded less cautiously by the government of WTO members. ${ }^{48}$

As describes Meinhalf Hilf, this path would enhance the legitimacy of international trade rules and its compliance:

It is in the self-interest of the WTO and othe international organizations who set and apply international rules, that these rules be applied as effectively as possible to the grass-root relations of the individual operators. The more national courts become involved in the implementation of international rules, the more the relevant international institutions will gain domestic political support and thus, legitimacy. Only such support can guarantee effective implementation and faithful compliance in the long run. Such support is essential for the legitimization of new international rules. Accordingly, internationalism should have its firm roots at home. ${ }^{49}$

WTO Agreements are almost silent in what regards to the role of national courts in international trade dispute resolution. Nevertheless, specific clauses ${ }^{50}$ mention national judicial authorities, such as Article $\mathrm{X}$ of GATT ${ }^{51}$ and Articles 41 to 50 of TRIPS Agreement,

46 HILF, Meinhard. Role Of National Courts In International Trade Relations. Michigan Journal of International Law, v. 18, p. 321356, 1997. PETERSMANN, Ernst-Ulrich. Constitutional Functions and Constitutional Problems of International Economic Law, Progress and Undercurrents in Public International Law, v. 3, 1, 387 (1991). 47 Case C-280/93, Germany v. Council, 1994 E.C.R. 1-4973, 1-4974-78. Case 52/81, Faustv. Commission, 1982 E.C.R. 3745.

48 HILF, Meinhard. Role Of National Courts In International Trade Relations. Michigan Journal of International Law, v. 18, p. 321356, 1997.

49 HILF, Meinhard. Role Of National Courts In International Trade Relations. Michigan Journal of International Law, v. 18, p. 321356, 1997. p. 326.

50 Other examples are the Article 3 of the Antidumping Agreement, Article 23 of Subsidies Agreement and Article XX Agreement on Government Procurement.

51 Article X:3.(b). "[...] b) Each contracting party shall maintain,
${ }^{52}$ regarding enforcement of intellectual property rights,

or institute as soon as practicable, judicial, arbitral or administrative tribunals or procedures for the purpose, inter alia, of the prompt review and correction of administrative action relating to customs matters. Such tribunals or procedures shall be independent of the agencies entrusted with administrative enforcement and their decisions shall be implemented by, and shall govern the practice of, such agencies unless an appeal is lodged with a court or tribunal of superior jurisdiction within the time prescribed for appeals to be lodged by importers; Provided that the central administration of such agency may take steps to obtain a review of the matter in another proceeding if there is good cause to believe that the decision is inconsistent with established principles of law or the actual facts.". Available at: < https://www.wto.org/english/docs_e/ legal_e/gatt47_01_e.htm>.

52 Specially these clauses are relevant to the thesis: "Article 41. 1. Members shall ensure that enforcement procedures as specified in this Part are available under their law so as to permit effective action against any act of infringement of intellectual property rights covered by this Agreement, including expeditious remedies to prevent infringements and remedies which constitute a deterrent to further infringements. These procedures shall be applied in such a manner as to avoid the creation of barriers to legitimate trade and to provide for safeguards against their abuse. [...] 4. Parties to a proceeding shall have an opportunity for review by a judicial authority of final administrative decisions and, subject to jurisdictional provisions in a Member's law concerning the importance of a case, of at least the legal aspects of initial judicial decisions on the merits of a case. However, there shall be no obligation to provide an opportunity for review of acquittals in criminal cases. 5. It is understood that this Part does not create any obligation to put in place a judicial system for the enforcement of intellectual property rights distinct from that for the enforcement of law in general, nor does it affect the capacity of Members to enforce their law in general. Nothing in this Part creates any obligation with respect to the distribution of resources as between enforcement of intellectual property rights and the enforcement of law in general. Article 42 Fair and Equitable Procedures. Members shall make available to right holders civil judicial procedures concerning the enforcement of any intellectual property right covered by this Agreement. Defendants shall have the right to written notice which is timely and contains sufficient detail, including the basis of the claims. Parties shall be allowed to be represented by independent legal counsel, and procedures shall not impose overly burdensome requirements concerning mandatory personal appearances. All parties to such procedures shall be duly entitled to substantiate their claims and to present all relevant evidence. The procedure shall provide a means to identify and protect confidential information, unless this would be contrary to existing constitutional requirements. [...] Article 44. Injunctions 1.The judicial authorities shall bave the authority to order a party to desist from an infringement, inter alia to prevent the entry into the channels of commerce in their jurisdiction of imported goods that involve the infringement of an intellectual property right, immediately after customs clearance of such goods. Members are not obliged to accord such authority in respect of protected subject matter acquired or ordered by a person prior to knowing or having reasonable grounds to know that dealing in such subject matter would entail the infringement of an intellectual property right. [...] Article 45 Damages 1. The judicial authorities shall have the authority to order the infringer to pay the right holder damages adequate to compensate for the injury the right holder has suffered because of an infringement of that person's intellectual property right by an infringer who knowingly, or with reasonable grounds to know, engaged in infringing activity. [...] Article 46 Other Remedies. In order to create an effective deterrent to infringement, the judicial authorities shall bave the authority to order that goods that they have found to be infringing be, without compensation of any sort, disposed of outside the channels of commerce in such a manner as to avoid any harm caused to the right holder, or, unless this would be contrary to existing constitutional requirements, destroyed. The judicial authorities shall also have the authority to order that materials and implements 
providing for "expeditious remedies to prevent infringements and remedies which constitute a deterrent to further infringements". ${ }^{53}$

More importantly, W'TO members have a large space of discretion in how they may choose to respond to their obligations under its agreements and specially how they may choose to implement a decision from the WTO Dispute Settlement System, and thus judicial authorities are not ab initio excluded from implementation processes.

Since WTO Agreements do not have express reference to its applicability/ invocability in the legal systems of its members, it is commonly recognized that this definition has been left to each national legal system. ${ }^{54}{ }^{55}$ Notwithstanding WTO members have generally

the predominant use of which has been in the creation of the infringing goods be, without compensation of any sort, disposed of outside the channels of commerce in such a manner as to minimize the risks of further infringements. In considering such requests, the need for proportionality between the seriousness of the infringement and the remedies ordered as well as the interests of third parties shall be taken into account. In regard to counterfeit trademark goods, the simple removal of the trademark. unlawfully affixed shall not be sufficient, other than in exceptional cases, to permit release of the goods into the channels of commerce. PROVISIONAL MEASURES Back. Article 50 1. The judicial authorities shall have the authority to order prompt and effective provisional measures: (a) to prevent an infringement of any intellectual property right from occurring, and in particular to prevent the entry into the channels of commerce in their jurisdiction of goods, including imported goods immediately after customs clearance; (b) to preserve relevant evidence in regard to the alleged infringement. 2. The judicial authorities shall have the authority to adopt provisional measures inaudita altera parte where appropriate, in particular where any delay is likely to cause irreparable harm to the right holder, or where there is a demonstrable risk. of evidence being destroyed. [...]”. Available at: <https://www.wto.org/ english/tratop_e/trips_e/t_agm4_e.htm>.

53 Article 41.1. TRIPS Agreement. Available at: <https://www. wto.org/english/tratop_e/trips_e/t_agm4_e.htm>.

54 "[...] Como regra geral, o próprio efeito direto das normas da OMC dependerá da estrutura constitucional e do status concedidos aos tratados pela ordem jurídica de cada Membro. [...] Na OMC, entretanto, não há regras que gerem efeitos diretos, para a esfera normativa nacional dos Membros, das decisões do OSC ou das interpretacõoes eventualmente adotadas pelos painéis e pelo OAp." BARRAL, Welber. Solução de controvérsias na Organização Mundial do Comércio. Brasília: Fundação Alexandre de Gusmão, 2007. p. 70 .

55 Petersmann has a different view in this matter, stressing that from article $\mathrm{X}$ of GATT it is possible to extract the obligation to ensure access to national jurisdiction for violations of multilateral rules: "Even though WTO law provides for a multilevel legal and dispute settlement system protecting also individual 'access to justice' in domestic courts (cf. GATT Article X and numerous other WTO provisions), many governments limit their domestic legal and judicial accountability for harmful violations of their WTO obligations by insisting that domestic courts should not protect domestic citizens against violations of WTO obligations and WTO dispute settlement rulings to the detriment of adversely affected citizens seeking judicial remedies in domestic courts." PETERSMANN, Ernst-Ulrich. Multilevel Governance Problems of the World Trading System beyond the denied direct applicability/invocability of WTO agreements, ${ }^{56}$ some of the most influential members in international trade (US, EU/EC, Japan) sought to evade from their ordinary practice regarding the applicability of international treaties in order to deny direct effects to WTO Law on their courts. ${ }^{57}$

By way of illustration, the fact that other WTO members do not concede direct applicability/invocability was one of the arguments used by the European Court of Justice to deny these effects to WTO Agreements, and this line of reasoning tends to be used by other members. ${ }^{58}$ Thus, it builds up a tautological reasoning that leads to widening the trend of limiting the possibility of exercising legitimate rights by global economic stakeholders (consumers, importers, exporters, etc.) towards national judicial authorities.

WTO Conference at Bali 2013. Journal of International Economic Law, v. 17 , p. 233-270, 2014. p. 248.

56 "Indeed, it appears that among the countries that, as a matter of principle, deny direct effect to WTO Agreements are all the major trading members of the WTO, namely the US, the EU, Canada, Japan, China, and so on. And yet they represent roughly 70 to 75 per cent of world trade. Through this lens, the denial of direct effect to the WTO agreements becomes more massive. At the same time, this approach evidences that the reasons cannot be exclusively legal. It is all the more true that some of these WTO members, such as the EU, could, according to the structure of their legal systems, eas-ily accommodate direct effect, at least for some provisions of WTO law, meeting the usual substantive requirements for granting direct effect.” FABRI, Hélène Ruiz. Is There a Case - Legally and Politically - for Direct Effect of WTO Obligations? European Journal of International Law, v. 25, n. 1, p. 151-173, 2014. p. 155.

57 "However, it is necessary to explore the underlying rationale for the EC, the United states and Japan to reject the direct invocability of the WTO Agreement regardless of their traditions and the obvious advantages. There are three argument against direct effect. First, the recognition of direct effect will undermine the sovereignty enjoyed by the Member and, in particular, by the legislature. The United States is the typical example. Second, such recognition will deprive legislative and administrative bodies of political flexibility and make their actions more susceptible to challenges by private parties. The ECJ holds this position. Third, the nature and structure of the WTO Agreement are flexible and not mandatory or precise enough to confer rights on private parties. The EC and Japan take such a view. [...] In conclusion, the group of leading world trading entities deviate from their normal position and specifically deny the direct invocability of the WTO Agreements or adopt a more restrictive attitude toward their domestic application." ZHANG, Xin. Domestic Effect of the WTO Agreement in China: Trends and Implications. The Journal of World Investment, v. 3, p. 912-937, 2002. p. 923. 58 Portugal v. Council (Rec.1999, p.I-8395), Case C-149/96, 23 nov. 1999. para. 44. "Admittedly, the fact that the courts of one of the parties consider that some of the provisions of the agreement concluded by the Community are of direct application whereas the courts of the other party do not recognise such direct application is not in itself such as to constitute a lack of reciprocity in the implementation of the agreement (Kupferberg, paragraph 18)." 
Conceptually, one should not ignore the distinction between applicability/invocability conferred to certain international treaty in a given national order and the applicability/invocability awarded to decisions of an adjudicative system or body created by that treaty. While there may be a tendency to treat these instruments similarly, obligations under the WTO agreements and those arising from decisions of the WTO Dispute Settlement System have remarkably different nature, as states ERnst-Ulrich Petersman:

In addition to the "primary" international legal obligations of each WTO Member to implement its WTO obligations in good faith and "ensure the conformity of its laws, regulations and administrative procedures with its obligations as provided in the annexed Agreements" (Article XVI.4 WTO Agreement), the adoption of WTO panel and Appellate Body findings by the DSB entails "secondary" obligations.

- to "secure the withdrawal of the measures concerned if these are found to be inconsistent with the provisions of any of the covered agreements" (Article 3 DSU), either "immediately" or within "a reasonable period of time" (cf Article 21.3 DSU) depending, inter alia, on whether compliance with WTO law requires legislative, administrative or judicial measures;

- if WTO treaty benefits continue to be nullified after the end of the implementation period, to accept either "a mutually satisfactory adjustment

(Article 26.1 DSU), including voluntary compensation as a "temporary measure" pending "full implementation of a recommendation to bring a measure into conformity with the covered agreements" (Article 22.1 DSU), or "suspension of concessions or other obligations" as a remedy aimed at rebalancing reciprocal WTO rights and obligations and inducing compliance with WTO law. ${ }^{59}$

According to this line of interpretation, there is an “independent" obligation to comply with WTO Dispute Settlement decisions. In this context, we may recall three relevant characteristics of WTO Dispute Settle-

59 PETERSMANN, Ernst-Ulrich. Multi-Level Judicial Trade Governance without Justice? On the Role of Domestic Courts in the WTO Legal and Dispute Settlement System. European University Institute, Department of Law, EUI Working Paper LAW n. 2006/44. Available at: < http://cadmus.eui.eu/handle/1814/3/ browse ?value $=$ PETERSMANN, + Ernst - Ulrich $\&$ type $=$ author $>$. Acess on: 15 set. 2015. p. 15-16. ment decisions: (i) legality, ${ }^{60}$ (ii) bindingness ${ }^{61}$ and (iii) undeterminedness (open character of the commands of the decisions, which are undetermined but determinable). ${ }^{626364}$

Decisions of the WTO Dispute Settlement System are thus expressed as commands of results, by requiring that the measure recognized as in disconformity be brought in conformity to multilateral obligations. The choice of means by which the result expected is achieved is to be determined by the member, in its discretionary space.

60 "The decisions are binding, and bring about legal consequences; the mechanism, in sum, is an integral part of Public International Law, and orients itself by the due process of law, what is endowed with significance and relevance". TRINDADE, Antônio Augusto Cançado. International law for humankind: towards a new jus gentium (II). General course on public international law. Recueil des cours, v. 317, p. 9-312, 2005. p. 205.

61 "In my view, these clauses over whelmingly imply, in the light of the practices of GATT, that the legal effect of an adopted panel report is the international law obligation to perform the recommendation or to comply with the "rulings" of the panel or appellate report." JACKSON, John. International Law Status of WTO Dispute Settlement Reports: Obligation to Comply or Option to Buy Out? American Journal of International Law, v. 98, p. 109-125, 2004. p. 115.

62 "[...] while a panel may suggest ways of implementing its recommendation, the choice of means of implementation is decided, in the first instance, by the Member concerned" WTO. WTO. Panel Report, United States - Anti Dumping Measures on Stainless Steel Plate in Coils and Stainless Steel Sheet and Strip from Korea. WT/DS179/R, 22 dez. 2000. para. 8.8.

63 " $[\mathrm{T}]$ he choice of the method of implementation rests with the implementing Member. However, the implementing Member does not have an unfettered right to choose any method of implementation. Besides being consistent with the Member's WTO obligations, the chosen method must be such that it could be implemented within a reasonable period of time in accordance with guidelines contained in Article 21.3(c). Objectives that are extraneous to the recommendations and rulings of the DSB in the dispute concerned may not be included in the method if such inclusion were to prolong the implementation period. Above all, it is assumed that the implementing Member will act in "good faith" in the selection of the method that it deems most appropriate for implementation of the recommendations and rulings of the DSB." WTO. Award of the Arbitrator, European Communities - Export Subsidies on Sugar (Arbitration under Article 21.3(c) of the DSU). WT/DS265/33, WT/ DS266/33, WT/DS283/14, 28 out. 2005. para. 69.

64 "Although Members generally have discretion to determine their means of implementation, this discretion is not without bounds. Saying that selecting the means of implementing the recommendations and rulings of the DSB is the prerogative of the implementing member is not at all the same as saying that "anything goes". To declare otherwise would be to allow implementing Members the discretion also to pursue implementation measures that needlessly and unduly extend the reasonable period of time needed for implementation. And this would be contrary to the objective of Article 21.3 of the DSU." Award of the Arbitrator, European Communities - Customs Classification of Frozen Boneless Chicken Cuts (Arbitration under Article 21.3(c) of the DSU). WT/DS269/13, WT/DS286/15, 20 fev. 2006. para. 56 
With regard to national implementation mechanisms, these may involve the action of one or more branches of government. Although implementation measures with the participation of the judiciary are not common, they cannot be discarded from the systematic implementation of WTO members.

Thus, if the measures constituting violation of multilateral rules may emanate from organs of the three branches of government, ${ }^{65}{ }^{66}$ it is reasonable to assume that implementation may require measures from all these powers. ${ }^{67}$ For instance, in the case Brazil- Measures Affecting Imports of Retreaded Tyres, national judiciary had enrolled a relevant part in implementing the WTO Dispute Settlement ruling, and it was recognized by the arbitrator as a legitimate measure. ${ }^{68}$

65 " $[. .$.$] the United States, of course, carries responsibility for ac-$ tions of both the executive and legislative departments of government." WTO. Appellate Body Report, United States - Standards for Reformulated and Conventional Gasoline. WT/DS2/AB/R, 29 abr. 1996. p. 28.

66 "The United States, like all other Members of the WTO and of the general community of states, bears responsibility for acts of all its departments of government, including its judiciary." WTO. Appellate Body Report, United States - Import Prohibition of Certain Shrimp and Shrimp Products. WT/DS58/AB/R, 22 out. 2001. para. 173.

67 "We note that a WTO Member "bears responsibility for acts of all its departments of government, including its judiciary." This is supported by Article 18.4 of the Anti-Dumping Agreement, Article XVI:4 of the WTO Agreement, and Article 27 of the Vienna Convention, The judiciary is a state organ and even if an act or omission derives from a WTO Member's judiciary, it is nevertheless still attributable to that WTO Member. Thus, the United States cannot seek to avoid the obligation to comply with the DSB's recommendations and rulings within the reasonable period of time, by relying on the timing of liquidation being "controlled by the independent judiciary.” WTO. Appellate Body Report, United States - Measures Relating to Zeroing and Sunset Reviews (Recourse to Article 21.5 of the DSU by Japan). WT/DS322/AB/RW, 29 ago. 2008. para. 182.

68 "In previous arbitrations, implementing Members have usually proposed either legislative or regulatory means to implement DSB recommendations and rulings. However, I do not consider that implementation through the judiciary can be a priori excluded from the range of permissible action that can be taken to implement DSB recommendations and rulings and bring about compliance with a Member's obligations under the covered agreements. The degree of government control may well be different with respect to the executive, the legislative, and the judiciary branches of power. Implementation action, whether it is taken by the legislature, or the judiciary, may not be executed in the way envisaged by the government. Yet the possibility of failure to achieve the intended compliance has not been regarded by previous arbitrators as a reason to question the permissibility of implementation by means of legislation, nor, in my view, does it exclude judicial action from the range of a permissible means of implementation. [...]" WTO. Brazil - Measures Affecting Imports of Retreated Tyres (Arbitration under Article 21.3(c) of the Understanding on Rules and Procedures Governing the Settlement
Last but not least, ERnST-Ulrich Petersman contends that a different approach of the matter by governments, improving the potential of its national courts in ruling disputes regarding certain private rights, by means of establishing effective remedies in WTO related matters, could prevent WTO disputes, reducing transaction costs and enhancing the rule of law. ${ }^{69}$

While facing certain skepticism, there is no legal impossibility or formal obstacle to enhancing the role of national judges in economic global governance, although this requires a consciousness of their responsibilities as such. However, as we conceive national judges and courts like institutions for global economic governance, many theoretical and practical questions arise. It is not our intention to answer or to exhaust the enumeration of these questions on this opportunity, but we contend that future reflections shall be constructed from the dimensions of (a) knowledge, (b) legitimacy and (c) accountability.

\section{Final Considerations: Callenges ahead}

Throughout this paper we developed the thesis that there is room and need for active participation of national judiciary authorities as institutions of global economic governance. Transformations in the architecture of the global world order has brought the necessity to consider rules, norms and institutions that lies beyond the state, and rethink about the management of change within international legal and normative structure of global order.

Applying this idea to international economic order, it is recognizable the necessity to include other actors, new institutions and multiple dimensions to the classic analysis of economic international law, encompassing a broader view of the members of the economic community - possible by the lens of global economic governance.

of Disputes). WT/DS332/16, 29 ago. 2008. para 68.DS332: Brazil - Measures Affecting Imports of Retreaded Tyres (Complainant: European Communities)

69 PETERSMANN, Ernst-Ulrich. Multi-Level Judicial Trade Governance without Justice? On the Role of Domestic Courts in the WTO Legal and Dispute Settlement System. European University Institute, Department of Law, EUI Working Paper LAW n. 2006/44. Available at: < http://cadmus.eui.eu/handle/1814/3/ browse ?value $=$ PETERSMANN, + Ernst-Ulrich\&type $=$ author $>$. Acess on: 15 set. 2015. p. 19. 
Regarding judicial structures, in this new paradigm, there is a movement of deterioration of the linking of state organs to traditional sovereignty, to domestic normativity and to national interests, as they start to be understood as institutions of global governance, linked to a relational sovereignty - owing respect to the global community.

In exercising their double role, as part of national apparatus and as part of global architecture, domestic judges must be aware of their "responsibility" towards other subjects beyond its national boundaries, and must properly have knowledge on the international legal system. This task brings implicit challenges, in the process of dominating international economic law and "language" without falling into the technicism and in the development of abilities to translate it in local, national and regional levels.

In dealing with legitimacy, many preoccupations arise in the ways of connecting institutions to citizens. National courts primarily earn its authority from States, but once comprehended as part of world order, they shall conquer its respect and authority from citizens and stakeholders of international economic community.

It is relevant in this matter the use of procedural mechanisms such as amicus curiae and public sessions in which judges have contact with underrepresented interests and points of view. It may also be necessary to discuss the processes of choosing these judges, as although representing a functional authority, they cannot always rupture with potential influences of their personal, philosophical and political background in exercising their power.

Last but not least, regarding the third dimension it is necessary to discuss the connections between national courts and the global public sphere, in which stakeholders shall be able to get involved on an ongoing process of accountability. Mechanisms of participation, transparency, evaluation and complaint need to be explored, as bridges between the performance of national courts and the global economic order.

As the thesis developed in the paper is an attempt to overcome the perspective of classic international law that erects a wall of separation between international order and domestic order, it aims to contribute to a new perspective for international law as a broader instrument for global governance. International economic law, although with distinct features and exactly be- cause it covers a variety of stakeholders having a broad spectrum of interests, should not be excluded from this perspective of multilevel global governance.

\section{References}

BENVENISTI, Eyal; DOWNS, George W. National Courts, Domestic Democracy, and the Evolution of International Law. European Journal of International Law, v. 20, n. 1, p. 59-72, 2009.

BARRAL, Welber. Solução de controvérsias na Organização Mundial do Comércio. Brasília: Fundação Alexandre de Gusmão, 2007.

BRADLOW, Daniel D. Framework For Assessing Global Economic Governance. Boston College Law Review, v. 54, n. 3, p. 971-1003, 2013.

BUERGENTHAL, Thomas. Self-executing and nonself-executing treaties in national and international law. Recueil des cours, v. 235, p. 303-400, 1992.

BULL, Hedley. The Anarchical Society: a study of order in world politics. 3. ed. Basingstoke; New York: Palgrave, , 2002.

BURKE-WHITE, William W. International Legal Pluralism. Michigan Journal of International Law, v. 25, p. 963979, 2004.

CASS, Deborah Z. "The "Constitutionalization" of International Trade Law: Judicial Norm-Generation as the Engine of Constitutional Development in International Trade'. European Journal of International Law, v. 12, n. 1, p. 39-75, 2001.

CASSESE, Antonio. Remarks on Scelle's Theory of "Role Splitting" (dedoublement fonctionnel) in International Law. European Journal of International Law, v. 1, n. 1, p. 210-231, 1990.

CHARNEY, Jonathan. Is International Law threatened by multiple international tribunals? Recueil des Cours. Collected Courses of the Hague Academy of International Law, v. 271, p. 101-382, 1998.

CHARNOVITZ, Steve. WTO Cosmopolitics. New York University Journal of International Law \& Politics, v. 34, p. 299-354, 2002.

DUNOFF, Jeffrey L. Why Constitutionalism Now? Text, Context and the Historical Contingency of Ideas. 
Journal of International Law and International Relations,v. 1, p. 191-211, 2005.

DUPUY, Pierre-Marie. Unité d'Application du Droit à 1'Echelle Globale et Responsabilité des Juges. European Journal of Legal Studies, v. 1, n. 2, p. 245-269, 2007.

FABRI, Hélène Ruiz. Is There a Case - Legally and Politically - for Direct Effect of WTO Obligations? European Journal of International Law, v. 25, n. 1, p. 151-173, 2014.

FERRAJOLI, Luigi. A soberania no mundo moderno: nascimento e crise do Estado Nacional. São Paulo: M. Fontes, 2002.

HABERMAS, Jürgen. Does the Constitutionalization of International Law Still Have a Chance? In: HABERMAS, Jürgen. The Divided West. Cambridge: Polity Press, 2006. p. 115-193.

HELD, David. Principles of cosmopolitan order. Chaper 2. In: BROCK, Gillian; BRIGHOUSE, Harry. (Ed.) The Political Philosophy of Cosmopolitanism. Cambridge: Cambridge University Press, 2005. p. 10-27.

HELFER, Laurence R; SLAUGHTER, Anne-Marie. Toward a Theory of Effective Supranational Adjudication. Yale Law Journal, v. 107, n. 2, p. 273-391, 1998.

HILF, Meinhard. Role Of National Courts In International Trade Relations. Michigan Journal of International Law, v. 18, p. 321-356, 1997.

HURREL, Andrew. On Global Order: Power, Values and the Constitution of International Society. Oxford University Press, 2007.

HSUEH, Ching-wen. Direct Effect, WTO Compliance Mechanism and the Protection for Individuals: Lessons Learned from the EC. Asian Journal of WTO \& International Health Law and Policy, v. 4, n. 2, p. 521-556, Sept. 2009.

JACKSON, John. International Law Status of WTO Dispute Settlement Reports: Obligation to Comply or Option to Buy Out? American Journal of International Law, v. 98, p. 109-125, 2004.

JACKSON, John. The Jurisprudence of GATT and the WTO. Cambridge: Cambridge University Press, 2000.

KINGSBURY, Benedict; KRISCH, Nico. Introduction: Global Administrative Law. European Journal of International Law, v. 17, n.1, p. 1-13, 2006.
KOSKENNIEMI, Martii. The Fate of Public International Law: Between Technique and Politics. Modern Law Review, v. 70, n. 1, p. 1-30, Jan. 2007.

MISTRAL, Jacques. Globalization Needs better Governance. Politique Étrangère, v. 5, p. 153-162, 2008. Available at: <http:/ /www.cairn.info/revue-politique-etrangere-2008-5-page-153.html>. Access on: 15 set. 2015.

PETERSMANN, Ernst-Ulrich. From the Hobbesian International Law of Coexistence to Modern Integration Law: The WTO Dispute Settlement System. Journal of International Economic Law, v. 1, n. 2, p. 175-198, 1998.

PETERSMANN, Ernst-Ulrich. How to Constitutionalize International Law and Foreign Policy for the Benefit of Civil Society? Michigan Journal of International Law, v. 20, p. 1-30, 1998.

PETERSMANN, Ernst-Ulrich. Human Rights, International Economic Law and Constitutional Justice: A Rejoinder. European Journal of International Law, v. 19, n. 5, p. 955-960, 2008.

PETERSMANN, Ernst-Ulrich. Multilevel Governance Problems of the World Trading System beyond the WTO Conference at Bali 2013. Journal of International Economic Law, v. 17, p. 233-270, 2014.

PETERSMANN, Ernst-Ulrich. Multilevel Judicial Governance as Guardian of the Constitutional Unity of International Economic Law. Loyola of Los Angeles International and Comparative Law Review, v. 30, n. 3, p. 367 418, 2008.

PETERSMANN, Ernst-Ulrich. Multi-Level Judicial Trade Governance without Justice? On the Role of Domestic Courts in the WTO Legal and Dispute Settlement System. European University Institute, Department of Law, EUI Working Paper LAW n. 2006/44. Available at: < http://cadmus.eui.eu/handle/1814/3/ browse? value $=$ PETERSMANN, + Ernst Ulrich\&type $=$ author $>$. Acess on: 15 set. 2015.

PETERSMANN, Ernst-Ulrich. The Future of the WTO: From Authoritarian Mercantilism to Multilevel Governance for the Benefit of Citizens. Asian Journal of WTO \& International Health Law and Policy, v. 6, n. 1, p. 45-80, mar. 2011.

ROSENAU, James. Govenance without Government. In: ROSENAU, James; CZEMPIEAL, Ernst-Otto. Govenance, Order and Change in World Politics. Ambridge: Cambridge University Press, 1992. p. 1-29. 
SCELLE, Georges. Regle generales du droit de la paix. Recueil des cours de l'Academie de La Haye, v. 46, p. 327-696, 1933.

SHANY, Yuval. No Longer a Weak Department of Power? Reflections on the Emergence of a New International Judiciary. European Journal of International Law, v. 20, n. 1, p. 73-91, 2009.

SLAUGHTER, Anne-Marie. Sovereignty and Power in a Networked World Order. Standford Journal of International Law, v. 40, p. 283-327, 2004.

SLAUGHTER, Anne-Marie. BURKE-WHITE, William. Future of International Law Is Domestic (or, the European Way of Law). Harvard International Law Journal, v. 47, p. 327-352, 2006.

STEWART, Richard B.; BADIN, Michelle R. S. The World Trade Organization: multiple dimensions of global administrative law. International Journal of Constitutional law, v. 9, p. 556-586, 2011.

THORSTENSEN, Vera; PRADO, Victor Luiz. O Multissistema Da Regulação Do Comércio Global: Propo- sta De Novo Referencial Teórico e Nova Metodologia de Análise. In: BAPTISTA, Luiz Olavo; FERRAZ JUNIOR, Tercio Sampaio. Novos caminhos do século XXI: direito internacional, filosofia jurídica e política, dogmática jurídica e direitos fundamentais: uma homenagem a Celso Lafer. Curitiba: Juruá, 2013.

TRINDADE, Antônio Augusto Cançado. International law for humankind: towards a new jus gentium (II). General course on public international law. Recueil des cours, v. 317, p. 9-312, 2005.

WHYTOCK, Christopher A. Domestic Courts and Global Governance. Tulane Law Review, v. 84, p. 67-124, 2010.

ZACHER, Mark. The Decaying pillars of the Westphalian temple: Implications for International Order and Governance. In: ROSENAU, James; CZEMPIEAL, Ernst-Otto. Governance, Order and Change in World Politics. Cambridge: University Press, 1992. p. 58-101.

ZHANG, Xin. Domestic Effect of the WTO Agreement in China: Trends and Implications. The Journal of World Investment, v. 3, p. 912-937, 2002. p. 923. 


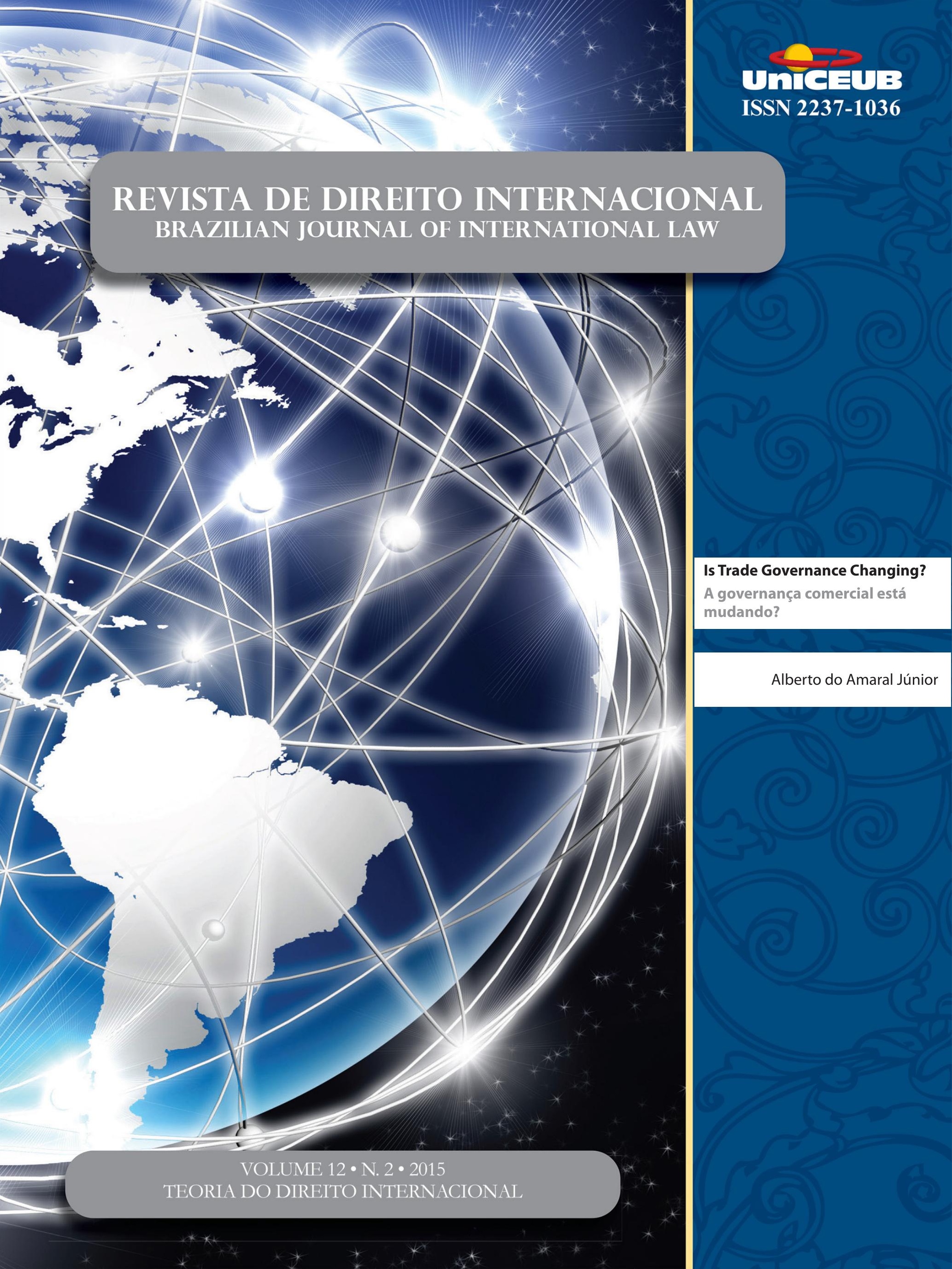




\title{
Is Trade Governance Changing?*
}

\section{A governança comercial está mudando?}

\author{
Alberto do Amaral Júnior**
}

\begin{abstract}
A constellation of PTAS either increases the scope of the WTO rules or regulates subject-matters not belonging to the multilateral trading system. More recently, negotiations of the mega-agreements, a label coined to mean agreements encompassing a vast majority of the world wealth, has brought together effects not yet fully assessed. This article investigates the impact of those shifts for trade governance. I argue that there is an ongoing shift in the governance of the world trade. Its most relevant aspects will be analyzed below.
\end{abstract}

Keywords: Governance. Trade. WTO. Mega-agreements. Preferential trade agreements.

\section{Resumo}

Uma constelação de PTAS aumenta tanto no âmbito de aplicação das regras da OMC como regula os assuntos que não pertencem ao sistema de comércio multilateral. Mais recentemente, as negociações dos mega-acordos, um rótulo cunhado para significar acordos que abrangem a grande maioria da riqueza mundial, reuniu efeitos ainda não totalmente avaliados. Este artigo investiga o impacto dessas mudanças para a governança do comércio. Eu argumento que há uma mudança em curso na governação do comércio mundial.

Palavras-chave: Governança. Comércio. OMC. Mega-acordos. Acordos comerciais preferenciais.

\section{INTRODUCTION}

It is a common place to say that the WTO's creation during the Uruguay Round had crucial importance for the world trading system. Indeed, a rudimentary institutional apparatus in force in the GATT age was too feeble to grapple with a great deal of transformation that the international trade confronted in the early 90's. At its inception, WTO signified the apogee of a long process initiated in the 40's, when policy-makers of more than twenty countries attributed to the GATT the role of third pillar of the newly international economic order. In 1995, WTO achieved to figure as the institutional landmark of a carefully cherished ideal. It crystallizes the hope of governing a globalized world in accordance with multilateral legal

** Amaral Júnior, Alberto, professor of International Law of the University of São PauloBrazil.E-mail: aamaralj@uol.com.br
* Recebido em 23/10/2015

Aprovado em 10/12/2015 
rules. Over time, preferential trade agreements (PTAs) disseminated too fast in all corners of the globe. A constellation of PTAs either increases the scope of the WTO rules or regulates subject-matters not belonging to multilateral trading system. More recently, negotiations of the mega-agreements, a label coined to mean agreements encompassing a vast majority of the world wealth, has brought together effects not yet fully assessed. This article investigates the impact of those shifts for trade governance. I argue that there is an ongoing shift in the governance of world trade. Its most relevant aspects will be analyzed below.

\section{Global Governance in Perspective}

The meaning of the concept of governance is equated with: "all that happens or would have to happen in order to resolve the collective problems of a set of actors in satisfactory ways" 1 . In accordance with Claus Offe "governance would be a game without losers leading to achievement of good results. Questions of power, distribution and conflict are cast aside in the pursuit of depoliticization. Participants in the discourse on governance scorn the significance of conflicts of interest and values that take place in the public outside the negotiation room"'.

We must take a step forward to grasp in Andrew Hurrell's words about the hybrid nature of the present international society. According to the author, we are witnessing:

[...] a huge increase in the scope, density and intrusiveness of rules and norms that are made at international level but affects how domestic societies are organized; the ever-greater involvement of new actors in global governance; the move toward the coercive enforcement of global rules; and a fundamental changes in political, legal, and moral understandings of state sovereignty and of the relationship between the state and the citizen, and the international community. A large number of factors have disturbed this picture and have pushed global order back from a broadly Westphalian direction ${ }^{3}$.

1 OFFE, Claus. Governance: an empty signifier? Constellations, New York, v. 16, n. 4, p. 550-562, Dec. 2009. p. 557.

2 OFFE, Claus. Governance: an empty signifier? Constellations, New York, v. 16, n. 4, p. 550-562, Dec. 2009. p. 557-558.

3 HURRELL, Andrew. International law 1989-2010: a performance appraisal. In: CRAWFORD, James; NOUWEN, Sarah (Ed.). Select proceedings of the European Society of International Law. Oxford:
These included: (1) the renewed salience of security, the re-valorization of national security as a value that can and - for a dispiritingly large number of people - should trump ideas of universal human rights, and a renewed preoccupation with warfighting and counter-insurgency; (2) the continued or renewed power of nationalism, no longer potentially containable politically or analytically in a box marked ethnic conflict but manifest in the identity politics and foreign policy actions of the major states in the system; (3) the renewed importance of nuclear weapons as central to major power relations, to the structure of regional security complexes, and in the construction of great power hierarchies and the distribution of seats at top tables; (4) the national and transnational power of religion (both aspects matter); and (5) the quiet return of balance of power as both a motivation for state policy (as with US policies in Asia) and as an element in the foreign policy of all second-tier states - not hard balancing and the building up of hard power; but soft balancing either in the form of attempts explicitly to de-legitimize US hegemony, to argue for alternative conceptions of legitimacy, and to reflect demands for status and recognition ${ }^{4}$.

\section{WTO and Governance of World Trade}

Created at the end of the Uruguay Round, the World Trade Organization (WTO) strengthened governance in world trade. Protectionism in the early 80's took countries to fear the erosion of benefits obtained through the multilateral trading system. Governments needed to overcome unilateral actions derived from unsuitable use of trade defense measures, highly noxious for a stable international economy. To this end, the Uruguay Round was lunched in 1986, in Punta del Este. It lasted 8 years, being successfully finished in April 1994, in Morocco. The fall of the Berlin wall and the breakup of the Soviet Union set the stage for WTO to come to the fore. From an institutional angle, a full-fledged centralization of the world trading system was necessary. The limited GATT Secretariat hosted in Geneva was no longer congenial for the new demands from developed and developing countries. In this view, the WTO implies, simultaneously, continuity and break with the past. On the one hand, continuity is noticeable in the reception of GATT principles and acceptance of economic liberalization agree-

Hart Publishing, 2012. v. 3. p. 4.

4 HURRELL, Andrew. International law 1989-2010: a performance appraisal. In: CRAWFORD, James; NOUWEN, Sarah (Ed.). Select proceedings of the European Society of International Law. Oxford: Hart Publishing, 2012. v. 3. p. 9. 
ments previously negotiated. On the other hand, break occurs when the GATT rules are not sufficient to cope with tensions generated by globalization.

The acceleration of interdependence and interpenetration of markets shifted the trade agenda and demanded a new institutional apparatus. Agreements negotiated in the Uruguay Round on agriculture, trade in services, intellectual property rights and investment measures related to trade are evidences of the enlargement and the deepening of the world trading system.

WTO differs from the Bretton Woods institutions. The IMF and the World Bank deal with financial resources and their decision-making process is based on the weighted vote. The WTO, on the contrary, is a set of rules wherein the financial contribution of each member does not count. Devised shortly after the upshot of the Cold War, WTO symbolizes a joint effort of the vast majority of states to govern international trade through primary and secondary rules. The former provide for rights and obligations of members and the latter indicate criteria for a rule to belong to the multilateral trading system, grant power to institutional bodies for changing rules and adjudicating disputes. However, in the course of the Uruguay Round negotiators aimed at thickening of decision-making process and the diplomatic initiative. Ministerial conferences are in charge of making new agreements, amending existing treaties and providing binding interpretations for WTO rules. The Dispute Settlement Body and the Mechanism for Trade Policy Review are composed of diplomats performing the functions of settling disputes and scrutinizing domestic trade policies. Even after having begun a dispute, a political solution can always bring it to an end. Concomitantly, secondary rules regulated in detail procedures to be followed for settling a dispute. Composed of jurists, the Appellate Body was entrusted with the mission to revise the dispute from a legal perspective. The legal thickening of the Dispute Settlement Understanding in the Uruguay Round is a measure of confidence building essential to guarantee security and predictability of the world trading system.

The WTO law presents two simultaneous processes: unification and primacy of the WTO rules. Unification has to do with the enlarging of the validity domain of the WTO agreements. With the time passing, it has become a nearly universal organization. At the same time, the principle of single undertaking irradiates effects on a global scale as opposed to the fragmentation resulted from the Tokyo Round. The most-favored nation clause and the national treatment principle, particular expression of non-discrimination in international trade, go in the same direction. Banning unilateralism support efforts for unification of rules. The aspiration of primacy of the multilateral trading system comes from controlling protectionist behaviors that eventually arise out of regional trade agreements. In the same vein, the WTO provisions are in search of making the world trade law consistent with normative subsystems under the WTO supervision. There would be an economic coherence to the extent that open regionalism served as an intermediary phase of the globalization process.

\section{WTO Committee on Regional Trade Agreements}

Under the GATTT 1947, Contracting Parties had to notify the Secretariat that they have concluded a regional trade agreement. Thereafter, a working group would be created to ascertain its consistency with Article XXIV and eventually recommend any change. However, these working groups did not reach to fulfill their functions for the sake of lacking parameters for judgment. Hence, the verification on whether a regional agreement was compatible with the multilateral trading system normally failed. In order to resolve this inconvenience, the General Council decided, on February 6, 1996, that the Committee on Regional Trade Agreements ought to play the following functions: (i) to examine the compatibility of regional trade agreements with WTO provisions in conformity with rules, procedures and terms of reference adopted by the Council on Trade in Goods (Article XXIV of GATT), the Council on Trade in Services (Article V of GATS), or the Committee on Trade and Development (enabling clause), and to present its report to pertinent body for appropriate action; (ii) to consider how due reports must be prepared on such agreements and formulate recommendations; (iii) to develop, if necessary, procedures to facilitate and enhance the examination process; (iv) to take account of systemic implications of these agreements and regional initiatives for international trade; (v) to issue suitable recommendations to the General Council; (vi) to accomplish any additional function that the General Council assigned to it and to prepare annual reports on 
its activities to the General Council. As far as systemic issues were concerned, the Secretariat elaborated proposals and documents. The Committee had to examine them taking into consideration the WTO provisions by means of horizontal analysis of the regional trade agreements' economic aspects.

At 1998 Geneva Ministerial Conference, the WTO members expressed their concern about excessive cases notified to the Committee on Regional Agreements and its incapacity to perform a compatibility analysis. In the Checklist Issues document for the 1999 Seattle Ministerial Conference, the lack of substantive progress in the work of the Committee on Regional Agreement was discussed. In the Doha Round, a new text about the compatibility analysis of Regional Trade agreements came to be debated and approved. However, its entry into force will only take place at the end of the Doha Round. The WTO members designed a transparency mechanism for regional trade agreements that tends to streamline the compatibility verification procedure of regional trade agreements with W'TO rules. The inherent weakness of that procedure makes it incapable to suitably perform its function.

\section{Mega-Agreements and a New Configura- TION OF INTERNATIONAL TRADE}

Among plentiful preferential trade agreements concluded over the last decades, negotiations involving the Mega-Regional Trade Agreements have gained even greater strength. Such agreements could be defined as deep integration partnerships between countries or regions with large participation in both world trade and foreign direct investment and in which two or more parties serve as logistic centers for global value chains ${ }^{5}$. For Draper, Lancey and Ramkolowan the mega-agreements are trade partnerships negotiated by three or more countries or regional groupings whose member collectively account for at least $25 \%$ of world trade 6 . Further,

5 MELÉNDEZ-ORTIZ, Ricardo. Mega-regionals: what is going on? In: WORLD ECONOMIC FORUM. Mega-regional trade agreements: game-changers or costly distractions for the World Trading System? Global Agenda Council on Trade and Foreign Direct Investment, Report 160414, jul. 2014. p. 6.

6 DRAPER, Peter; LACEY, Simon; RAMKOLOWAN, Yash. Mega-regional trade agreements: implications for the African, Caribbean, and the Pacific Countries. ECIPE. Brussels: European Centre for those agreements intend to regulate themes that have not yet been addressed at the WTO level. If successfully adopted, those agreements will significantly impact the international trade regime. In order to cast light on the regulation of international trade in the XXI century, I briefly analyze the three most important agreements under negotiation. Those agreements are, respectively, the Trans-Pacific Partnership (TPP), the Trans-Atlantic Trade and Investment Partnership (TTIP) and the Regional Comprehensive Economic Partnership (RCEP).

The Trans-Pacific Partnership - TPP - connects 11 economies of Asia and the Pacific to the US economy ${ }^{7}$. Currently, the TPP encompasses the following countries: Brunei, New Zealand, Chile, the United States, Australia, Canada, Japan, Malaysia, Mexico, Peru, and Vietnam. Despite the huge economic, demographic and strategic differences, the adoption of a broad trade agreement that comprised all those countries has always been the common target that guided the negotiations. After five years of consultations, states signed a final version of the treaty on the October 5, 2015. The TPP has been the deepest plurilateral trade agreement made since the Uruguay Round in 1994. It will account for $36.3 \%$ of the world GDP and $25.5 \%$ of the world trade.

From the US perspective, the TPP means a commitment to Asian countries and a strong decision to maintain the American influence in the region. Once implemented, the TPP will reaffirm the US status as one of the largest players in the global trade with the ability to dictate terms that will conduct trade in the coming decades. The greatest advances of TPP are in the regulatory field. Initiatives devoted to fostering regulatory coherence amongst countries received special attention. In this perspective, the TPP aims to be the legal and institutional framework that will guide the creation of global value chains in the Asia and Pacific region ${ }^{8}$.

International Political Economy, 2014. Available at: < http://www. ecipe.org/app/uploads/2014/12/OCC22014_pdf>. Accessed: 25 nov. 2015.

7 THORSTENSEN, Vera; FERRAZ, Lucas (Coord.). A multiplicaşão dos acordos preferenciais de comércio e o isolamento do Brasil. Instituto de Estudos para o Desenvolvimento Industrial: junho, 2013. Disponível em: <http://retaguarda.iedi.org.br/midias/ artigos/51d18e9168afa9d0.pdf>. Acesso em: 25 nov. 2015.

8 JANK, Marcos. Impacto do TPP no Brasil será profundo e exige uma reação. Folha de São Paulo, São Paulo, 7 out. 2015. Disponível em: $<$ http://www1.folha.uol.com.br/mercado/2015/10/1691040-impacto-do-ttp-no-brasil-sera-profundo-e-exige-uma-reacao.shtml $>$. Acesso em: 25 nov. 2015. 
The TPP agreement is divided into 30 chapters covering a wide range of issues such as: trade in goods, trade defense, customs cooperation, rules of origin, sanitary and phytosanitary measures, technical barriers to trade, market access, trade in services, financial services, e-commerce, telecommunication, temporary entry for business agents, protection of foreign investments, intellectual property, labor and environmental standards, government procurement, competition, trade facilitation, regulatory coherence, regional integration, transparency and anticorruption.

Due to the nature of this article, my intention is not to detail all regulatory changes at issue, but simply to underline their importance for the governance of the multilateral trading system. The chapter on dispute settlement, for instance, created a fast mechanism whereby both complainants and respondents are allowed to resort, at any time, to alternative dispute settlement methods, namely good offices, mediation and arbitration. The TPP Dispute Settlement mechanism was based on the Dispute Settlement Understanding at the WTO level. Retaliation is a recourse that is at disposal to disputants if one of them breaches its obligations. When a dispute arises from violation of a common obligation between the TPP and other trade agreement, including those belonging to multilateral trading system, parties are free to choose which rules will be employed to settle their dispute. In principle, the TPP mechanism for dispute settlement does not take primacy over others. However, the choice for one system implies necessarily the exclusion of other possibilities. In case of disputes concerning common obligations between WTO agreements and the TPP provisions, the TPP panel may invoke the WTO Appellate Body consolidated jurisprudence. The TPP panels may be composed not only of experts in international trade but also of experts in the litigation subject. In this connection, there is a likelihood for a more balanced dispute settlement, without a commercial bias, on labor and environmental standards as well as in the sphere of anticorruption measures. It is noteworthy that TPP Dispute Settlement mechanism only regulates disputes between States whilst Investor-State Dispute Settlement applies exclusively to the commitments under the TPP Investment Chapter?.

9 UNITED STATES TRADE REPRESENTATIVE. The TransPacific Partnership: leveling the playing field for American workers and American Business. USTR. Available at: <https://ustr.gov/tpp/>. Accessed: 25 nov. 2015.
The TPP contains safeguards that grant governments the capacity to enact legal norms about public health, security and the environment. Measures taken to protect such values do not constitute indirect expropriation. As for rules of origin, $45 \%$ of imported cars and $40 \%$ of spare parts ought to be manufactured in one TPP country to benefit from tariff exemption within the bloc. In NAFTA, those requirements are, respectively, of $62,5 \%$ and $60 \%{ }^{10}$. Undeniably, the TPP countries are pursuing a more deep productive integration. With respect to labor standards are concerned, States Parties reaffirmed the right to form trade unions, to a minimum wage, to safe labor and decided to prohibit forced and children labor. In other words, the TPP obliges states parties to accept and safeguard fundamental labor rights recognized by the International Labor Organization (ILO) ${ }^{11}$. The Environment Chapter embraces norms on climate change, subsidies to fishery, conservation of fauna and flora, trade in environmental services and goods etc. Of note is the specific procedure to settle disputes about environmental obligations.

Finally, the chapter on intellectual property received a decisive influence of the US domestic law. In reality, there was no direct increase in the period of protection established in the TRIPs agreement. Nevertheless, as states parties should adjust the patent term to compensate unexpected delays in its concession, the period of protection may surpasses 20 years. The TPP is the first trade agreement that protected biological medicines such as: vaccines, bloody products, allergenic extracts, human tissues and cells for transplantation. For such cases, negotiators provided two ways of protection. The first one ensures a minimum period of 8 years for data and undisclosed information protection. The second one is formed by a combination of the protection of 5 years of data and undisclosed information plus other administrative and regulatory procedures. On the basis of considerations above, a conclusion is unavoidable: the TPP advanced in comparison to any other preferential trade agreement already made. To enter into force, the Trans-Pacific Partnership still needs to be approved

10 BRIGES WEEKLY. After TPP Deal Reached in Atlanta, Focus Shifts to Ratification. BRIDGES, v. 19, n. 33, 8 Oct. 2015. Available at: <http://www.ictsd.org/sites/default/files/review/bridgesweekly19-33.pdf>. Accessed: 25 nov. 2015.

11 UNITED STATES TRADE REPRESENTATIVE. The TransPacific Partnership: leveling the playing field for American workers and American Business. USTR. Available at: <https://ustr.gov/tpp/>. Accessed: 25 nov. 2015. 
by the Legislative Power of all signatories. South Korea, Taiwan, Philippines and Colombia have demonstrated interest in adhering to TPP.

The Trans-Atlantic Trade and Investment Partnership (TTIP) is an attempt to harmonize trade relations between the US and the EU. As the most important mega-agreement in negotiation, the TTIP accounts for $45 \%$ of world GDP ${ }^{12}$. Both the United States and the European Union strive to set in motion a comprehensive trade agreement aimed at liberalizing trade and eliminating non-tariff barriers. Diplomats and policy-makers are in pursuit of high standards to make compatible and possibly to harmonize rules on trade in goods and services, investments and bidding procedures on both sides of the Atlantic ${ }^{13}$. Negotiations are divided into three baskets: market access; regulation and non-tariff barriers; and norms. The market access takes priority to rules of origin, removal of all duties and customs charges on industrial and agricultural products with special treatment to the most sensitive sectors and liberalization of trade in services ${ }^{14}$. Since the basket on rules has dealt with measures of trade defense; regarding investments there is a concern with guarantees of protection against expropriation, free transfer of funds, fair and equitable treatment; government procurement; financial regulation; the deepening of the international regime on intellectual property rights and an increase in the effectiveness of coercive measures either against acts related to physical products or actions perpetrated in the digital environment. A goal carefully nourished is reconciling the US and the EU regimes of geographical indications as well as labor and environmental standards. Innovations include provisions to forbid the

12 MELÉNDEZ-ORTIZ, Ricardo. Mega-regionals: what is going on? In: WORLD ECONOMIC FORUM. Mega-regional trade agreements: game-changers or costly distractions for the World Trading System? Global Agenda Council on Trade and Foreign Direct Investment, Report 160414, jul. 2014.

13 DRAPER, Peter; MÉLENDEZ-ORTIZ, Ricardo. The TransPacific Partnership (TPP) and the Trans-Atlantic Trade and Investment Partnership (TTIP): key issues and potential impact on members. In: WORLD ECONOMIC FORUM. Mega-Regional Trade Agreements: game-changers or costly distractions for the World Trading System? Global Agenda Council on Trade and Foreign Direct Investment, Report 160414, jul. 2014.

14 DRAPER, Peter; MÉLENDEZ-ORTIZ, Ricardo. The TransPacific Partnership (TPP) and the Trans-Atlantic Trade and Investment Partnership (TTIP): key issues and potential impact on members. In: WORLD ECONOMIC FORUM. Mega-Regional Trade Agreements: game-changers or costly distractions for the World Trading System? Global Agenda Council on Trade and Foreign Direct Investment, Report 160414, jul. 2014. p. 16. exploitation of both illegal timber and fishery ${ }^{15}$. Discussions related to non-tariff barriers embrace measures to harmonize existing rules in both parties with a view to simplifying procedures and design a permanent regime for regulatory cooperation. Shifts shall occur in cyber security, information technology, nanotechnology and electrical cars ${ }^{16}$.

Foreign direct investments have aroused great interest in the European society, principally in the investor-state dispute settlement terrain. The European Commission lunched a public consultation on this matter with the scope to define solid basis for negotiations ${ }^{17}$. Around 150.000 people took part in the public consultation that occurred from March to July 2015. The main target consisted in achieving a balance between the investors' interests and the right to regulate investments in favor of public interest $t^{18}$. Afterwards, on September 16, 2015, the European Commission proposed a new mechanism for dispute settlement on investments. It was recommended an investments tribunal composed of a first instance chamber and a chamber of appeal. Investors could sole lodge complaints founded on three arguments: (i) expropriation without compensation; (ii) denial to justice; or (III) specific discrimination on the grounds of race, gender etc ${ }^{19}$.

15 DRAPER, Peter; MÉLENDEZ-ORTIZ, Ricardo. The TransPacific Partnership (TPP) and the Trans-Atlantic Trade and Investment Partnership (TTIP): key issues and potential impact on members. In: WORLD ECONOMIC FORUM. Mega-Regional Trade Agreements: game-changers or costly distractions for the World Trading System? Global Agenda Council on Trade and Foreign Direct Investment, Report 160414, jul. 2014. p. 16.

16 DRAPER, Peter; MÉLENDEZ-ORTIZ, Ricardo. The TransPacific Partnership (TPP) and the Trans-Atlantic Trade and Investment Partnership (TTIP): key issues and potential impact on members. In: WORLD ECONOMIC FORUM. Mega-Regional Trade Agreements: game-changers or costly distractions for the World Trading System? Global Agenda Council on Trade and Foreign Direct Investment, Report 160414, jul. 2014. p. 24.

17 EUROPEAN COMISSION. Preliminary report: online public consultation on investment protection and investor-to-state dispute settlement (ISDS) in the Transatlantic Trande and investment partnership agreement. EC. 2014a. Available at: <http://trade. ec.europa.eu/doclib/docs/2014/july/tradoc_152693.pdf>. Accessed: 25 nov. 2015.

18 EUROPEAN COMISSION. Consultations: online public consultation on investment protection and investor-to-state dispute settlement (ISDS) in the Transatlantic Trade and investment partnership agreement. EC. 2014b. Available at: < http://trade.ec.europa. $\mathrm{eu} /$ consultations/index.cfm?consul_id $=179>$. Accessed: 25 nov. 2015.

19 EUROPEAN COMISSION. Commission proposes new investment court system for TTIP and other EU trade and investment negotiations. EC. 2015. Available at: < http://trade.ec.europa.eu/doclib/press/index. 
That proposal runs the risk of not being accepted after the inclusion in the TPP of a proposal creating an investor-state dispute settlement mechanism, at the US initiative. Moreover, groups of civil society will likely contest the negative effects of such agreement on food security, public health and human rights protection. Birbeck and Botwright argue that the recent public wave of preoccupation over the TTIP echoes themes hotly discussed in the 1999 WTO Ministerial Conference held in Seattle ${ }^{20}$. Initially aimed for completion by end 2014, the TTIP negotiations are still in course. Surely, the TPP's adoption will give a new impetus to the TTIP and RCEP negotiations.

The Regional Comprehensive Economic Partnership (RCEP) gathers the ten member countries of the Association of Southeast Asian Nation (ASEAN) and six countries with which that association has free trade agreements (Australia, China, India, Japan, New Zealand and South Korea). The RCEP is the more populous mega-agreement comprising more than half of world population $^{21}$. India and China, two key members of BRICS, only participate in this mega-agreement ${ }^{22}$. Similar partnership seeks to give rise to a modern, wide and mutually beneficial agreement which regulates trade in goods and services, investment, technical and economic cooperation, intellectual property, competition, dispute settlement and further topics identified in the course of negotiations ${ }^{23}$. The RCEP negotiations find support in the Guiding Principles and Objectives for Negotiating the Regional Comprehensive Economic

cfm?id=1364>. Accessed: 25 nov. 2015.

20 BIRKBECK, Carolyn; BOTWRIGHT, Kimberley. The future of the global trade and investment architecture: pursuing sustainable development in the global economy: overview of issues, challenges and debates. e15initiative. Geneva: International Centre for Trade and Sustainable Development (ICTSD) and World Economic Forum, 2015. Available at: <http://e15initiative.org/publications/the-future-of-the-global-trade-and-investment-architecture/> Accessed: 25 nov. 2015.

21 UNITED NATIONS CONFERENCE ON TRADE AND DEVELOPMENT. World Investment Report 2014. UNCTAD. Available at: <http://unctad.org/en/PublicationsLibrary/wir2014_ en.pdf $>$. Accessed: 25 nov. 2015.

22 STEPHENSON, Sherry. Impact of Mega-Regionals on the Asia-Pacific Region. In: WORLD ECONOMIC FORUM. MegaRegional Trade Agreements: game-changers or costly distractions for the World Trading System? Global Agenda Council on Trade and Foreign Direct Investment, Report 160414, jul. 2014. p. 34.

23 AUSTRALIAN DEPARTMENT OF FOREIGN AFFAIRS AND TRADE. Regional comprehensive economic partnership negotiations. DFTA. Available at: <www.dfat.gov.au/fta/rcep/>. Accessed: 25 nov. 2015.
Partnership, adopted on November 20, 2012. According to this document, such an agreement shall respect the following guidelines:

1. The RCEP will be consistent with WTO, notably with GATS article V and GATT article XXIV;

2. The RCEP will maintain a profound engagement with ASEAN and simultaneously recognize peculiarities surrounding each participant;

3. The RCEP will contribute to increase the degree of transparency of trade and investments amongst countries and promote their insertion in global and regional supply chains;

4. Taking into account the different levels of development, the RCEP will foresee appropriate forms of flexibility, including provisions for special and differential treatment;

5. The ASEAN Free Trade Agreements (FTAs) and the bilateral/plurilateral Free Trade Agreements between and among participating countries will continue to exist and no provision in the RCEP agreement will detract from the terms and the conditions in them;

6. Any state that had made a free trade agreement with ASEAN is permitted to participate in the RCEP negotiations as long as it complies with terms and conditions previously established. The RCEP agreement will also have an open accession clause to enable the participation of any ASEAN FTA partner that did not participate in the RCEP negotiations and any other external economic partners after the completion of the RCEP negotiations;

7. Provisions for technical assistance and capacity building may be available to developing and leastdeveloped countries that are participating in the RCEP. This is done in order enable all parties to fully participate in negotiations, implement obligations and enjoy the RCEP benefits.

8. The negotiations on trade in goods, trade in services, investments and other areas will be conducted to secure a balanced and comprehensive result ${ }^{24}$

In the light of those principles, it is worth noting that both the RCEP and TPP fabric indicate two different concepts toward integration project. As noted by Dupont, the RCEP incorporates the nesting dynamic concept whose purpose is to push for economic integration without setting a clear priority among treaties concluded by states parties. The TPP, on the contrary, follows the concept of multilateralization dynamics

24 ASSOCIATION OF SOUTHEAST ASIAN NATIONS. Guiding principles and objectives for negotiating the regional comprehensive economic partnership. ASEAN. Available at: < http://www10.iadb.org/intal/intalcdi/PE/CM\%202013/11581.pdf>. Accessed: 25 nov. 2015. 
whereby the new agreement must replace those in force. Both concepts aim to harmonize economic integration among countries approaches, but whereas the nesting dynamic preserves regulatory diversity, multilateralization dynamics tend to eliminate $\mathrm{it}^{25}$. Countries like Brunei, Malaysia, Singapore, Vietnam, Australia, Japan and New Zealand participate in both TPP and RCEP. Due to this conceptual discrepancy, Dupont alerts for a clash between North American and Chinese interests in the region $^{26}$.

Since the RCEP has been launched in 2012, nine negotiations rounds happened. During this time, eleven working groups and subgroups have been created in order to advance themes such as: investments; trade in goods and services; intellectual property, competition; legal and institutional issues; rules of origin; customs procedures; trade facilitation, sanitary and phytosanitary measures; technical barriers to trade and economic cooperation $^{27}$.

In recent negotiations, governments sought to integrate intellectual property to investments towards better protecting the investors' rights. Delicate issues arise in themes such as: tariff reduction for goods; methodology to liberalize services and investments; the level of investor's protection and the enlargement of the partnership's scope ${ }^{28}$. A successful RCEP would help expand even more the added-value chains in the Southeast Asia by means of integrating India and Asian

25 DUPONT, Cedric. Asian +, RCEP and TPP: a clash of integration concepts. In: BALDWIN, Richard; KAWAI, Mashiro; WIGNARAJA, Ganeshan. The future of the world trading system: asian perspectives. London: Center For Economic Policy Research (CEPR), 2013. Available at: <http://www.voxeu.org/sites/default/files/Future_World_Trading_System.pdf $>$. Accessed: 25 nov. 2015.

26 DUPONT, Cedric. Asian +, RCEP and TPP: a clash of integration concepts. In: BALDWIN, Richard; KAWAI, Mashiro; WIGNARAJA, Ganeshan. The future of the world trading system: asian perspectives. London: Center For Economic Policy Research (CEPR), 2013. p. 115. Available at: <http://www.voxeu.org/sites/default/ files/Future_World_Trading_System.pdf $>$. Accessed: 25 nov. 2015. 27 NEW ZELAND. Ministry of Foreign Affairs and Trade. Regional Comprehensive Economic Partnership (RCEP). MFAT. Available at: <http://www.mfat.govt.nz/Trade-and-Economic-Relations/2Trade-Relationships-and-Agreements/RCEP/>. Accessed: 25 nov. 2015.

28 XIAO, Yifei. Competitive Mega-regional Trade Agreements: Regional Comprehensive Economic Partnership (RCEP) vs. Trans-Pacific Partnership (TPP). College Undergraduate Research Electronic Journal - CUREJ. University of Pennsylvania, 2015. Available at: $<$ http:/ / repository.upenn.edu/cgi/viewcontent.cgi?article $=1227 \&$ context $=$ curej $>$. Accessed: 25 nov. 2015. members ${ }^{29}$. Nonetheless, the RCEP negotiations will of course take time until it is completed. The table below summarizes the main characteristics of the regional trade mega-agreements in relation to membership, global coverage and purposes.

\section{Tableau 1 -}

\begin{tabular}{|c|c|c|c|c|}
\hline \multicolumn{5}{|c|}{ Mega Regional Trade Agreements } \\
\hline Nome & Members & $\begin{array}{c}\text { Global } \\
\text { Coverage }\end{array}$ & Scope & Timeline \\
\hline $\begin{array}{l}\text { Trans- } \\
\text { Pacific } \\
\text { Partnership } \\
\text { (TPP) }\end{array}$ & $\begin{array}{l}\text { Australia, } \\
\text { Brunei } \\
\text { Darussalam, } \\
\text { Canada, } \\
\text { Chile, Japan, } \\
\text { Malaysia, } \\
\text { Mexico, } \\
\text { New Zea- } \\
\text { land, Peru, } \\
\text { Singapore, } \\
\text { Vietnam, } \\
\text { United } \\
\text { States. }\end{array}$ & $\begin{array}{l}3.6 \% \text { of } \\
\text { world GDP, } \\
25.5 \% \text { of } \\
\text { the world } \\
\text { trade }(2014)\end{array}$ & $\begin{array}{l}\text { Compre- } \\
\text { hensive } \\
\text { market } \\
\text { access; } \\
\text { trade in } \\
\text { goods; trade } \\
\text { defense, } \\
\text { rules of } \\
\text { origin; SPS; } \\
\text { TBT; trade } \\
\text { in services; } \\
\text { investment, } \\
\text { intellectual } \\
\text { property; } \\
\text { government } \\
\text { procure- } \\
\text { ment; } \\
\text { State-owned } \\
\text { Enterprises; } \\
\text { environ- } \\
\text { ment; labor; } \\
\text { capac- } \\
\text { ity building; } \\
\text { horizontal } \\
\text { issues; } \\
\text { including } \\
\text { regulatory } \\
\text { coherence, } \\
\text { regional } \\
\text { integration, } \\
\text { transpar- } \\
\text { ency, and } \\
\text { develop- } \\
\text { ment. }\end{array}$ & $\begin{array}{l}\text { Based on } \\
\text { the } 2005 \\
\text { Trans-Pacif- } \\
\text { ic Strategic } \\
\text { Economic } \\
\text { Partnership. } \\
\text { The United } \\
\text { Nations } \\
\text { joins in } \\
\text { 2008. First } \\
\text { round TPP } \\
\text { negotiations } \\
\text { were held } \\
\text { in 2010. On } \\
\text { 5, October } \\
\text { 2015, } \\
\text { participants } \\
\text { concluded } \\
\text { nego- } \\
\text { tiations. } \\
\text { The Parts } \\
\text { need now } \\
\text { to secure } \\
\text { ratification } \\
\text { in their } \\
\text { respective } \\
\text { domestic } \\
\text { legislatures } \\
\text { before entry } \\
\text { into force }\end{array}$ \\
\hline
\end{tabular}

29 STEPHENSON, Sherry. Impact of Mega-Regionals on the Asia-Pacific Region. In: WORLD ECONOMIC FORUM. MegaRegional Trade Agreements: game-changers or costly distractions for the World Trading System? Global Agenda Council on Trade and Foreign Direct Investment, Report 160414, jul. 2014. p. 35. 


\begin{tabular}{|c|c|c|c|c|}
\hline $\begin{array}{l}\text { Trans- } \\
\text { atlantic } \\
\text { Trade and } \\
\text { Investment } \\
\text { Partnership } \\
\text { (TTIP) }\end{array}$ & $\begin{array}{l}\text { United } \\
\text { States and } \\
\text { European } \\
\text { Union }\end{array}$ & $\begin{array}{l}30 \% \text { global } \\
\text { merchandise } \\
\text { trade, } 40 \% \\
\text { world trade } \\
\text { in services; } \\
\text { nearly half } \\
\text { of global } \\
\text { GDP (2013) }\end{array}$ & $\begin{array}{l}\text { Market } \\
\text { access; ser- } \\
\text { vices, public } \\
\text { procure- } \\
\text { ment, rules } \\
\text { of origin, } \\
\text { regulatory } \\
\text { coherence, } \\
\text { standards, } \\
\text { mutual } \\
\text { recognition, } \\
\text { TBTs, sus- } \\
\text { tainable de- } \\
\text { velopment; } \\
\text { energy; } \\
\text { intellectual } \\
\text { property, } \\
\text { geographi- } \\
\text { cal indica- } \\
\text { tions; } \\
\text { completion; } \\
\text { investment. }\end{array}$ & $\begin{array}{l}\text { Nego- } \\
\text { tiations } \\
\text { launched in } \\
\text { July } 2013 \text {. } \\
\text { Initially } \\
\text { aimed for } \\
\text { comple- } \\
\text { tion by end } \\
2014 \text {. }\end{array}$ \\
\hline $\begin{array}{l}\text { Regional } \\
\text { Compre- } \\
\text { hensive } \\
\text { Economic } \\
\text { Partnership } \\
\text { (RCEP) }\end{array}$ & $\begin{array}{l}\text { Australia, } \\
\text { Brunei, } \\
\text { China, } \\
\text { Myanmar, } \\
\text { Cambodia, } \\
\text { India, Indo- } \\
\text { nesia, Laos, } \\
\text { Malaysia, } \\
\text { Philippines, } \\
\text { Singapore, } \\
\text { Thailand, } \\
\text { Vietnam, Ja- } \\
\text { pan, South } \\
\text { Korea } \\
\text { and New } \\
\text { Zealand. }\end{array}$ & $\begin{array}{l}\text { Almost half } \\
\text { the world } \\
\text { popula- } \\
\text { tion, } 30 \% \\
\text { of global } \\
\text { GDP, over } \\
25 \% \text { world } \\
\text { exports. }\end{array}$ & $\begin{array}{l}\text { Goods, } \\
\text { trade in } \\
\text { services, } \\
\text { investment, } \\
\text { eco- } \\
\text { nomic and } \\
\text { technical } \\
\text { cooperation, } \\
\text { intellectual } \\
\text { property, } \\
\text { competition } \\
\text { and dispute } \\
\text { settlement. }\end{array}$ & $\begin{array}{l}\text { Launched in } \\
\text { November } \\
2012 . \text { Ne- } \\
\text { gotiations } \\
\text { ongoing. }\end{array}$ \\
\hline
\end{tabular}

Source: BIRKBECK, Carolyn; BOTWRIGHT, Kimberley ${ }^{30}$

\section{Governance in the World Trade}

A new way of governing world trade appears to be emerging. The WTO creation in 1994 signaled a process of centralization of world trading system that started with the GAT'T's adoption in 1947. The system experienced a gradual increase in its complexity that culminated with the concentration of the main international trade rules under the WTO framework. However, over the last twenty years that trend has moved at the oppo-

30 BIRKBECK, Carolyn; BOTWRIGHT, Kimberley. The future of the global trade and investment architecture: pursuing sustainable development in the global economy: overview of issues, challenges and debates. e15initiative. Geneva: International Centre for Trade and Sustainable Development (ICTSD) and World Economic Forum, 2015. Available at: <http://e15initiative.org/publications/the-future-of-the-global-trade-and-investment-architecture/> Accessed: 25 nov. 2015. p. 25. site direction. Initially, an extraordinary expansion of preferential trade agreements and later an uncommon negotiation of mega-agreements have reconfigured the governance in world trade. Nowadays, the current decentralization of the world trading system sounds to exhibit some of the following features:

1. A multi-level governance. Three levels seem outright visible. In the multilateral field, WTO is the major guardian of economic liberalization rules approved in several trade rounds. It successfully shaped the legal framework for the international trade in the 90's. Since then, its strength has been progressively undermined. This legacy rendered obsolete insofar as a gulf has been formed between a plethora of regulatory demands, notably from developed and developing countries, and the capacity of the WTO system to respond them. That profound paralysis lies in factors such as: the large amount of WTO members, the prevailing mechanism of single understanding that requires an overall consensus as a condition for a trade round to finish and the rise of short-term interest to the detriment of longterm goals. In the aftermath of second World War, for example, the new international economic order founded on the US attitude in emphasizing long-term interests. In the late 40's, the US consented protectionism in Europe prior to consolidation of a full liberal order, as the European Payment Union displays. The WTO function tends to be limited to what has been already accorded. Trade rounds with broad agendas seem unlikely to happen in the near future. The Doha Round was perhaps the last gasp of a cycle that experienced an ever greater sophistication.

The second layer of trade governance finds expression in the so-called mega-agreements which gather developed and developing countries and concentrate the most relevant share of the world economy. They are shaped to institute new regulatory spaces that harmonize rules at a threshold hitherto unknown. The third level of governance encompasses a multitude of preferential trade agreements, of a lesser scale, that may be of distinct size and varied degrees of normative deepness.

2. Centralization and decentralization. As regards world trade, I discern low-intensity and highintensity regulation. A low-intensity regulation addresses traditional topics of international trade, albeit financial positive results are evident. A high-intensity regulation focuses on matters not yet regulated at multilateral level or deepened in an unprecedented way those already regulated. The World Trade Organization has become the venue of lowintensity regulation whilst PTAs and megaagreements enact high-intensity regulation. 
Centralization and decentralization coexist at different speed and eventually play a complementary role. The DSB is required to settle disputes that may arise between states that are Parties of diverse agreements.

3. Fragmentation. On the contrary of the supposed coherence that should be governing the world trade system at the end of the Uruguay Round, the situation now is much more diversified. A plurality of rules endowed with no coincidental domains of spatial validity and emanated from different governments depicts an intricate portrait where disparities and normative collision coexist without a superior instance to settle disputes. A conflict between a decision made by the WTO Body and a mechanism for settling disputes instituted by a preferential trade agreement or mega-agreement will not ensure prevalence of the former as observers were used to believe. The WTO itself has witnessed a fragmentation while regulatory coherence is being negotiated at the level of mega-agreements. Not always conflicts between primary and secondary norms can take place. Sometimes, rules may coexist through a mutual recognition. In the realm of Trans-Atlantic Partnership the mutual recognition of technical rules is on the agenda.

4. The clash between an instrumental and a solidaristic logic. Multinational enterprises unsatisfied with meager advances in the liberalization process after the Uruguay Round put pressure on national governments to negotiate the constitution of far-flung markets for their goods and services. PTAs and megaagreements somewhat reflect that plea. Even though the instrumental logic has been the dominant one, the solidaristic logic manifests itself in the claim for environmental and labor standards. The former is top-down while the latter is bottom-up opened to a grassroots social participation.

5. A power imbalance. In the vast majority of cases, PTAs and mega-agreements join developed and developing countries. It is usual that the most powerful export its rules to a broader context in a way that the other states parties will incorporate them.

6. Inequality among insiders and outsiders. Developing and least developed countries which do not participate in PTAs and megaagreements will have their difficulties increased when they try to export to nations where tariff and non-tariff barriers have been reduced drastically or wholly eliminated.

7. An exacerbation of political power. Even though no one doubts that only a few countries actually took part in the rule making-process in the WTO, this International Organization partially neutralized political power of developed states through the single-undertaking principle. A trade round sole finishes by means of a general consent of the WTO members. In smaller groups of countries, like PTAs and some mega-agreements, huge discrepancies in political power operate on behalf of developed states. The Trans-Atlantic Trade and Investment Partnership is the most prominent exception.

8. The strengthening of global value chains. PTAs and mega-agreements encourage and are encouraged by global value chains. In a world where production is increasingly deterritorialised, goods and services depend on a close cooperation of economic agents located in different countries.

\section{Final considerations}

This article intends to show the change in governance of world trade. My assumption is that it is of a structural nature and has far-reaching consequences. It affects, at the same time, international law and politics on a world scale. I deemed fundamental not only to expose the main traits of the TTIP and RCEP ongoing negotiations as well as the TPP's conclusion, but also to draw remarks on this process that is powerfully shifting the system originally crafted more than six decades ago.

\section{References}

ASSOCIATION OF SOUTHEAST ASIAN NATIONS. Guiding principles and objectives for negotiating the regional comprehensive economic partnership. ASEAN. Available at: <http://www10.iadb.org/intal/intalcdi/PE/ CM\%202013/11581.pdf>. Accessed: 25 nov. 2015.

AUSTRALIAN DEPARTMENT OF FOREIGN AFFAIRS AND TRADE. Regional comprehensive economic partnership negotiations. DFTA. Available at: <www.dfat. gov.au/fta/rcep/>. Accessed: 25 nov. 2015.

BIRKBECK, Carolyn; BOTWRIGHT, Kimberley. The future of the global trade and investment architecture: pursuing sustainable development in the global economy: overview of issues, challenges and debates. e15initiative. Geneva: International Centre for Trade and Sustainable Development (ICTSD) and World Economic Forum, 2015. Available at: <http://e15initiative.org/publications/the-future-of-the-global-trade-and-investment- 
architecture/>. Accessed: 25 nov. 2015.

BRIGES WEEKLY. After TPP Deal Reached in Atlanta, Focus Shifts to Ratification. BRIDGES, v. 19, n. 33, 8 Oct. 2015. Available at: <http://www.ictsd.org/sites/ default/files/review/bridgesweekly19-33.pdf > . Accessed: 25 nov. 2015.

DRAPER, Peter; LACEY, Simon; RAMKOLOWAN, Yash. Mega-regional trade agreements: implications for the African, Caribbean, and the Pacific Countries. ECIPE. Brussels: European Centre for International Political Economy, 2014. Available at: <http://www.ecipe.org/ app/uploads/2014/12/OCC22014_pdf>. Accessed: 25 nov. 2015.

DRAPER, Peter; MÉLENDEZ-ORTIZ, Ricardo. The Trans-Pacific Partnership (TPP) and the Trans-Atlantic Trade and Investment Partnership (TTIP): key issues and potential impact on members. In: WORLD ECONOMIC FORUM. Mega-Regional Trade Agreements: game-changers or costly distractions for the World Trading System? Global Agenda Council on Trade and Foreign Direct Investment, Report 160414, jul. 2014.

DUPONT, Cedric. Asian +, RCEP and TPP: a clash of integration concepts. In: BALDWIN, Richard; KAWAI, Mashiro; WIGNARAJA, Ganeshan. The future of the world trading system: asian perspectives. London: Center For Economic Policy Research (CEPR), 2013. Available at: <http://www.voxeu.org/sites/default/files/Future_World_Trading_System.pdf $>$. Accessed: 25 nov. 2015.

EUROPEAN COMISSION. Commission proposes new investment court system for TTIP and other EU trade and investment negotiations. EC. 2015. Available at: <http:// trade.ec.europa.eu/doclib/press/index.cfm?id $=1364>$. Accessed: 25 nov. 2015.

EUROPEAN COMISSION. Consultations: online public consultation on investment protection and investor-to-state dispute settlement (ISDS) in the Transatlantic Trade and investment partnership agreement. EC. 2014b. Available at: <http://trade.ec.europa.eu/ consultations/index.cfm?consul_id=179>. Accessed: 25 nov. 2015.

EUROPEAN COMISSION. Preliminary report: online public consultation on investment protection and investor-to-state dispute settlement (ISDS) in the Transatlantic Trande and investment partnership agreement.
EC. 2014a. Available at: <http://trade.ec.europa.eu/ doclib/docs/2014/july/tradoc_152693.pdf>. Accessed: 25 nov. 2015 .

HURRELL, Andrew. International law 1989-2010: a performance appraisal. In: CRAWFORD, James; NOUWEN, Sarah (Ed.). Select proceedings of the European Society of International Law. Oxford: Hart Publishing, 2012. v. 3.

JANK, Marcos. Impacto do TPP no Brasil será profundo e exige uma reação. Folha de São Paulo, São Paulo, 7 out. 2015. Disponível em: <http://www1.folha.uol.com. br/mercado/2015/10/1691040-impacto-do-ttp-nobrasil-sera-profundo-e-exige-uma-reacao.shtml $>$. Acesso em: 25 nov. 2015.

MELÉNDEZ-ORTIZ, Ricardo. Mega-regionals: what is going on? In: WORLD ECONOMIC FORUM. Mega-regional trade agreements: game-changers or costly distractions for the World Trading System? Global Agenda Council on Trade and Foreign Direct Investment, Report 160414, jul. 2014.

NEW ZELAND. Ministry of Foreign Affairs and Trade. Regional Comprehensive Economic Partnership (RCEP). MFAT. Available at: < http://www.mfat.govt.nz/Tradeand-Economic-Relations/2-Trade-Relationships-andAgreements/RCEP/>. Accessed: 25 nov. 2015.

OFFE, Claus. Governance: an empty signifier? Constellations, New York, v. 16, n. 4, p. 550-562, Dec. 2009.

STEPHENSON, Sherry. Impact of Mega-Regionals on the Asia-Pacific Region. In: WORLD ECONOMIC FORUM. Mega-Regional Trade Agreements: game-changers or costly distractions for the World Trading System? Global Agenda Council on Trade and Foreign Direct Investment, Report 160414, jul. 2014.

THORSTENSEN, Vera; FERRAZ, Lucas (Coord.). A multiplicação dos acordos preferenciais de comércio e o isolamento do Brasil. Instituto de Estudos para o Desenvolvimento Industrial: junho, 2013. Disponível em: < http://retaguarda.iedi.org.br/midias/artigos/51d18e9168afa9d0. pdf>. Acesso em: 25 nov. 2015.

UNITED NATIONS CONFERENCE ON TRADE AND DEVELOPMENT. World Investment Report 2014. UNCTAD. Available at: <http://unctad.org/en/PublicationsLibrary/wir2014_en.pdf $>$. Accessed: 25 nov. 2015. 
UNITED STATES TRADE REPRESENTATIVE. Regional Comprehensive Economic Partnership The Trans-Pacific Partnership: leveling the playing field (RCEP) vs. Trans-Pacific Partnership (TPP). College for American workers and American Business. USTR. Undergraduate Research Electronic Journal - CUREJ. Available at: <https://ustr.gov/tpp/>. Accessed: 25 University of Pennsylvania, 2015. Available at: <http:// nov. 2015.

XIAO, Yifei. Competitive Mega-regional Trade Agreements: repository.upenn.edu/cgi/viewcontent.cgi?article $=122$ 7\&context $=$ curej>. Accessed: 25 nov. 2015. 


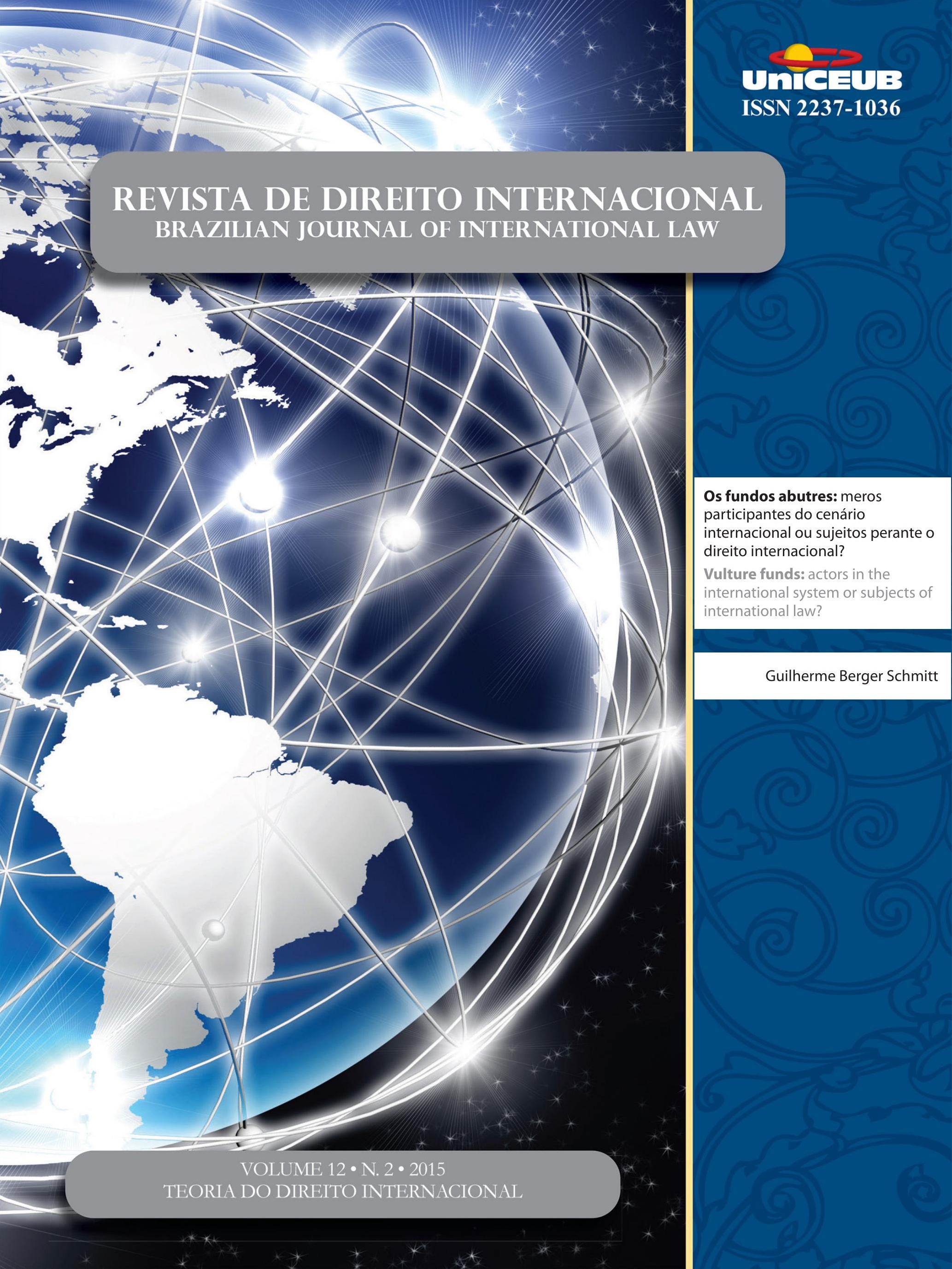




\title{
Os fundos abutres: meros participantes do cenário internacional ou sujeitos perante o direito internacional?*
}

\author{
Vulture funds: actors in the international \\ system or subjects of international law?
}

Guilherme Berger Schmitt**

\section{Resumo}

O objetivo deste artigo é analisar a atuação dos chamados fundos "abutres" no cenário internacional, nomeadamente no âmbito das dívidas soberanas, perquirindo, com isso, a caracterização jurídica desses fundos perante o direito internacional público. Para tanto, primeiro apresentamos uma definição desses atores específicos, caracterizando-os a partir da sua atuação na seara internacional. Em seguida, analisamos a evolução dos institutos econômicos e jurídicos que hoje permitem o modo de operação dos fundos abutres, alinhavando breves explicações acerca da imunidade jurisdicional dos Estados e da titularização dos créditos das dívidas soberanas. Após a sua caracterização e a explicação do seu contexto de atuação, passamos à análise do papel exercido por esses fundos no âmbito internacional, demonstrando o seu papel de reguladores do mercado das dos créditos das dívidas soberanas. Finalmente, discutimos a possibilidade da atribuição da personalidade jurídica desses atores perante o direito internacional público. Concluímos que o ingresso desses fundos, no âmbito das dívidas soberanas, resultou, diretamente dos "incentivos" jurídico-econômicos presentes na época do seu ingresso no cenário internacional, permitindo o seu modo de operação atualmente empregado. Também é possível concluir que os fundos "abutres" podem ter, com algumas ressalvas, um papel positivo no âmbito das dívidas soberanas e, consequentemente, a possibilidade de ter a si atribuída a característica de direitos de sujeito internacional, embasando as novas teorias da quebra de paradigmas do direito internacional público atual.

Palavras-chave: Fundos abutres. Dívida soberana. Reestruturação da dívida soberana. Imunidade jurisdicional do estado. Sujeitos de direito internacional.

* Recebido em 31/10/2015

Aprovado em 24/11/2015

** Advogando Miliitante. Mestre em Ciências Jurídico-Políticas pela Faculdade de Direito da Universidade de Coimbra. E-mail: gbschmitt@ outlook.com.

\section{Abstract}

The purpose of this article is to analyze the role of vulture funds in the modern international relations, particularly in the context of sovereign debts, thus investigating the nature of these funds towards the international law. To do so, we defined these specific actors, characterizing them through the investigation of their actions in the international system. After that, we analyzed the evolution of the economic and legal institutions that now 
allowed the modus operandi of the vulture funds, throughout brief explanations of the jurisdictional immunity of States and the sovereign debt credits securitization. After their characterization and operational contextualization, we move to the analysis of the international role presented by these funds, demonstrating its role as regulators of the market in the credits of sovereign debt. Finally, we discussed the possibility of granting to these funds legal personality as subjects of international law. We conclude that the international emergence of these funds occurred as a direct result of the legal-economic "incentives" established at the time of their admission into the international system. We also concluded that the vulture funds could have, with some exceptions, a positive role in the context of sovereign debts, and, consequently, a legal personality as subjects of international law. This could indicate that the intricate role of the vulture funds in the international scenario surpass the restricted scope of the sovereign debts, proving the new theories of international law.

Keywords: Vulture funds. Sovereign debt. Sovereign debt restructuring. State immunity. Subjects of international law.

\section{INTRODUÇÃo}

A fim de comprar máquinas agrárias, em 1979, a República da Zâmbia requisitou um empréstimo interestatal de 15 milhões de dólares junto à Romênia. ${ }^{1}$ Não obstante a natureza daquela relação, é possível afirmar que o governo da Zâmbia anteviu que o empréstimo tomado resultaria em uma dívida superior ao valor acordado inicialmente, isto é, previu que o débito poderia aumentar devido à aplicabilidade de quaisquer juros contratuais previstos. Parece improvável, porém, que o governo zambiano pudesse imaginar, na época, que aquela dívida interestatal embasaria, quase trinta anos depois, a reivindicação judicial de um débito superior a 55 milhões de dólares.

O governo da Zâmbia, tampouco, poderia antever, sem dúvida, que aquela pretensão judicial partiria de um fundo privado com sede nas Ilhas Virgens Britânicas e, muito menos, que a pretensão concretizar-se-ia,

1 Cfr. GOREN, Jonathan. State-to-State debts: sovereign immunity and the "vulture" hunt. The George Washington International Law Review, Washington, v. 41, n. 3, p. 681-708, 2010. p. 681. em parte, sob a jurisdição de um Estado estrangeiro. ${ }^{2}$ Certamente, em situações similares, ficaram igualmente atônitos os governantes de diversos outros Estados soberanos que sofreram com estas inesperadas investidas. ${ }^{3}$

Isso porque - como soberanos e protagonistas do direito das gentes ${ }^{4}$ - os Estados sempre gozaram de amplos privilégios e imunidades perante outros membros da comunidade internacional. É difícil imaginar, pois, que os governantes estatais e até mesmo os autores jusinternacionalistas clássicos pudessem, algum dia, admitir um cenário no qual uma entidade privada tivesse poderes não só para os "enfrentar" judicialmente, mas, também, para manter - abertamente e por meio da ordem legal de uma jurisdição estrangeira — um Estado soberano sob as suas "garras". Hoje, porém, a situação é diferente.

A diluição das fronteiras estatais, claramente acelerada pela globalização, acabou por revelar a interdependência estabelecida entre os diversos atores internacionais ${ }^{5}$, tornando imprudente negar a forte influência que

2 Conquanto o direito de cobrança dos autores tenha sido reconhecido, o processo judicial não teve o desfecho por eles esperado, pois embora tenham requerido 55 milhões de dólares, a Corte responsável pelo caso acabou por conceder aos autores, em audiência realizada em abril de 2007, "somente" 15,5 milhões de dólares, que ainda representaram um excelente lucro quando comparado aos 3,2 milhões pagos pelo direito de cobrança da dívida. Veja-se, a respeito, AREWA, Olufunmilayo B. Vultures, hyenas, and african debt: private equity and Zambia. Northwestern Journal of International Law and Business, Chicago, v. 29, n. 3, p. 643-674, July/Sept. 2009. p. 646. 3 A lista de Estados que sofreram com investidas judiciais de fundos privados é grande. Podemos listar, não exaustivamente, países como: Argentina, Brasil, Peru, Zâmbia, Equador, Congo, Libéria e diversos outros. Cfr. SCHUMACHER, Julian; TREBESCH, Christoph; ENDERLEIN, Henrik. Sovereign defaults in court: the rise of creditor litigation 1976-2010. Social Science Research Network, June 2013. p. 37-38. Available at: <http://www.scu.edu/business/economics/upload/SovereignDefaultsinCourt.pdf $>$. Accessed on: 16 dec. 2015.

4 Embora dividam os holofotes com outros sujeitos de emergente importância, se não maior, pois muito se fala a respeito da superação do modelo estatal de Vestefália e do crescente reconhecimento dos indivíduos como sujeitos primários de direito internacional, os Estados ainda podem ser considerados - como grande parte da doutrina assim o faz - como a espinha dorsal da comunidade internacional. Vejam-se, sobre o assunto, inter alia, MACHADO, Jónatas Eduardo Mendes. Direito internacional: do paradigma clássico ao pós-11 de setembro. 2. ed. Coimbra: Coimbra, 2004. p. 213-215; ALMEIDA, Francisco Ferreira de. Direito internacional público. 2. ed. Coimbra: Coimbra, 2003. p. 200-201; CASSESE, Antonio. International law in a divided world. Oxford: Clarendon Press, 1986. p. 74-77; SHAW, Malcolm N. International law. 6. ed. Cambridge: Cambridge University Press, 2008. p. 197 e ss; BRITO, Wladmir. Direito internacional público. Coimbra: Coimbra, 2008. p. 333-334.

5 Cfr., a propósito, MACHADO, Jónatas Eduardo Mendes. Direito 
os entes privados exercem hoje no cenário internacional, inclusive sobre os Estados soberanos. ${ }^{6}$ Não é de se estranhar, portanto, que as ações internacionais destes fundos vêm sendo acompanhadas de perto pela mídia, pela comunidade acadêmica jusinternacionalista e por Organizações e personalidades internacionais. O caso que entrelaçou a República da Argentina e o fundo de investimento MNL Capital, por exemplo, que ainda está se desenrolando em tribunais nacionais e internacionais, vem atraindo muita atenção, sendo rotulado, inclusive, como o "julgamento do século".

Note-se que, muito embora a sua presença não tenha sido bem-vinda pela sociedade internacional como um todo, e que não haja dúvida acerca da nebulosidade ético-moral das suas ações, parece certo que esses novos atores já possuem um papel definido no cenário internacional, com grande parte da sua prática fundamentada em normas legais, sejam internas ou internacionais. Por outro lado, a caracterização desses fundos abutres como sujeitos perante o Direito Internacional ainda parece padecer de exatidão. É, portanto, nessa conjectura que este estudo pretende analisar o papel e a atuação desses fundos na sociedade internacional, auxiliando na caracterização da natureza desses novos atores perante o Direito Internacional.

\section{Os FUNDOS "ABUtRES"}

Não é novidade o fato de que, recentemente, a mídia internacional passou a destacar com maior intensidade a ação dos chamados fundos "abutres" no cenário internacional. ${ }^{7}$ Atualmente, não é raro, portanto, deparar-se

internacional: do paradigma clássico ao pós-11 de setembro. 2. ed. Coimbra: Coimbra, 2004. p. 465-466.

6 A influência econômica destes atores pode ser percebida com clareza, por exemplo, no contexto da atuação dos fundos "abutres" nas dívidas soberanas, nomeadamente nos casos que envolvam países fragilizados e altamente endividados, uma vez que estes países não apresentam, em geral, resistência às investidas destes fundos. Cfr., sobre este ponto, PROCTOR, Charles. Vulture funds and sovereign debt: the Zambian experience. Journal of South African Law, Philadelphia, n. 4, p. 629-641, 2007. p. 629. Acerca da influência dos atores privados no cenário internacional e, inclusive, sobre o Direito Internacional, veja-se, inter alia, GARCIA, Frank J. Globalization, power, states, and the role of law. Boston College Law Review, Boston, v. 54, n. 3, 903-919, 2013. p. 908.

7 Em meados de 2005, as ações dos fundos “abutres" já permeavam as notícias internacionais, porém, em 2007, com a conclusão do caso que envolveu o fundo de investimento Donegal e a República da Zâmbia, o assunto passou a frequentar as manchetes internacio- com diversas reportagens, publicadas nos mais variados jornais de renome internacional, que utilizam esta alcunha pejorativa como chamariz à atuação global destes novos atores. O termo é utilizado e repetido, por meio da sua tradução literal, em diferentes línguas, mantendo o núcleo e o "valor" inicialmente atribuídos à expressão. ${ }^{8}$

As reportagens apresentadas - muitas vezes parciais e com agendas secundárias ${ }^{9}$ - , todavia, normalmente relacionam a ação destes fundos somente a aspectos políticos, não apresentando, assim, análises jurídicas ou econômicas da sua ação no cenário internacional. A classificação mais aprofundada desses fundos - que envolve aspectos jurídicos, econômicos, sociais e, por vezes, morais - parece ter ficado a cargo da comunidade acadêmica. Isso porque, diversos autores já contribuíram à identificação destes novos atores econômicos, bem como à análise dos reflexos que as ações destes fundos geram no âmbito jurídico, nomeadamente no cenário internacional.

Note-se, assim, que, embora largamente utilizado,

nais com maior intensidade Segundo uma reportagem do Financial Times, se pesquisássemos no mecanismo de busca Google as palavras "Sheehan" e "vulture funds", encontraríamos, em 2007, mais de 62 mil resultados referentes à pesquisa. Nesse sentido, cfr. HURLEY, Gail. Taming the vultures: are new measures enough to protect debt relief gains? Belgiui: Eurodad, dez. 2008. p. 4. Available at: < http:// eurodad.org/uploadedfiles/whats_new/reports/the $\% 20$ rise $\% 20$ of $\% 20$ the $\% 20$ vulture $\% 20$ layout.pdf $>$. Accessed on: 16 dec. 2015. Desde o final de 2011, porém, com o desenrolar das decisões proferidas nos casos que se desenvolveram a partir da moratória argentina de 2001, as mídias internacionais foram "dominadas" pela grande onda de atenção que as ações destes fundos vêm atraindo. $\mathrm{O}$ efeito do caso do "século" não se limita, porém, somente às notícias referentes ao específico caso da Argentina. Hoje, no início de 2014, ao realizar a mesma pesquisa feita pelo Financial Times em 2007, ou seja, no mesmo mecanismo de busca e com as mesmas palavras, deparamo-nos com mais de 2 milhões de resultados acerca dos fundos "abutres".

8 Vejam-se, por exemplo, os termos fonds vautours, fondos buitres e geierfonds, que são utilizados, respectivamente, pela mídia francesa, espanhola e alemã.

9 Com inúmeros interesses secundários em jogo, assim como diversos outros tópicos que são objetos centrais dos debates que fazem parte do cenário internacional, o assunto que envolve os fundos "abutres" não pode ser pinçado dos jogos políticos internos e internacionais. Não é de se estranhar, destarte, que diversas reportagens acerca dos fundos "abutres", que se encontram vinculadas nas mídias internacionais, inclusive em jornais de destaque, estão repletas de informações e opiniões parciais. É o caso, geralmente, dos artigos publicados nos meios de informação ligados aos Estados que sofreram diretamente com a ação destes fundos. É o que ocorre, igualmente, nas notícias que são de autoria de indivíduos diretamente vinculados às partes envolvidas nas querelas dos fundos abutres. 
o termo "fundo abutre" não reflete, ainda, uma classificação oficial, tampouco incontestável. É possível afirmar, contudo, que os fundos de investimento que recebem esse rótulo apresentam algumas características em comum. Assim, caso fosse necessário apresentá-los de maneira breve e simplista, poderíamos afirmar que os fundos "abutres" nada mais são do que credores secundários, normalmente organizados sobre a forma de fundos de hedge, que obtêm seu lucro por meio da especulação e da cobrança de títulos de dívidas soberanas. ${ }^{10}$ Seria possível afirmar, ademais, que a busca lucrativa desses fundos se dá, geralmente, pela via judicial. ${ }^{11}$

É importante salientar, destarte, que essa nomenclatura nada mais é do que um rótulo utilizado para identificar, de maneira negativa, credores que empregam, comumente, um determinado modus operandi no âmbito internacional. Alguns autores refutam, portanto, a utilização dessa expressão, referindo-se aos investidores como distressed debt investors.12 Outros, inclusive, não

10 Cfr., a propósito AREWA, Olufunmilayo B. Vultures, hyenas, and african debt: private equity and Zambia. Northwestern Journal of International Law and Business, Chicago, v. 29, n. 3, p. 643-674, July/ Sept. 2009. p. 647; SILVA, Alexandre Pereira da; PEREIRA, Mariana Yante Barrêto. "Fundos abutres" vs. Estados nacionais: soberania e atuação do Tribunal Internacional do Direito do Mar a partir do caso da fragata libertad. Revista de Direito Internacional, Brasília, v. 10, n. 1, 2013. p. 138.

11 Sobre este ponto, vejam-se, inter alia, NGUYEN, Davy V.H. Too Big to Fail? Towards a Sovereign Bankruptcy Regime. Cornell International Law Journal, New York, v. 45, n. 3, p. 697-723, 2012. p. 699; AVERY, Ryan E. Out of the desert and to the Oasis: legislation on predatory debt investing. University of Miami International and Comparative Law Review, Miami, v. 18, n. 2, p. 267-290, 2011. p. 276; BROOMFIELD, Elizabeth. Subduing the vultures: assessing government caps on recovery in sovereign debt litigation. Columbia Business Law Review, washington, v. 2010, n. 2, p. 473-528, 2010. p. 475; MONTELEONE, Theresa A. A vulture's gamble: high-stakes interpretation of sovereign debt contracts in NML Capital, Ltd v Republic of Argentina. Capital Markets Law Journal, Oxford, v. 8, n. 2, p. 149-165, 2013. p. 154.

12 Vejam-se, a título exemplificativo, GOREN, Jonathan. Stateto-State debts: sovereign immunity and the "vulture" hunt. The George Washington International Law Review, Washington, v. 41, n. 3, p. 681-708, 2010. p. 681; SOOKUN, Devi. Stop vulture fund lawsuits: a handbook. London: Commonwealth Secretariat, 2010. p. 7. A utilização de termos imparciais também se faz presente em documentos estatais oficiais. Em português, por exemplo, podemos encontrar o emprego da expressão "Fundo de Situação Especial" para referir aos chamados "fundos abutres". Cfr., neste sentido, BRASIL. Ministério das Relações Exteriores. Comunicado Conjunto dos Presidentes dos Estados Partes do Mercosul. \24. Disponível em: <http://www.itamaraty.gov.br/index.php?option $=$ com_content $\&$ view $=$ article\&id $=3$ 250:comunicado-conjunto-dos-presidentes-dos-estados-partes-domercosul-brasilia-7-de-dezembro-de-2012\&catid $=42 \&$ lang $=$ pt-BR\&Itemid=280>. Acesso em: 15 dez. 2015. utilizam rótulo algum, remetendo-se aos fundos apenas pela sua classificação maior, isto é, referindo-se aos investidores como fundos de hedge que atuam no mercado internacional.

Dessa forma, devido à falta de padronização em sua nomenclatura, o entendimento das particularidades destes fundos se faz de suma importância, uma vez que a compreensão aprofundada das características destes novos atores econômicos pode prevalecer sobre qualquer termo a eles aplicado, permitindo ao leitor, assim, identificar um núcleo comum em diferentes rótulos.

Para tanto, parece fundamental entender, primeiramente, a natureza desses atores como fundos de investimento per se, ou seja, entender o seu funcionamento como um fundo de hedge. ${ }^{13}$ Isso porque, parece correto afirmar que grande parte do modo de operação empregado pela "espécie" dos "abutres" deriva diretamente das características intrínsecas ao modelo de operação aplicado pelos fundos de hedge.

Nesse sentido, de maneira extremamente breve, é possível afirmar que os fundos de hedge são particularmente conhecidos por proporcionar um alto retorno ${ }^{14}$ de investimento a um restrito ${ }^{15}$ grupo de investidores. Ressalte-se, que a presença desses característicos fundos de investimento não é inédita, tampouco recente, no âmbito privado, pois esses fundos especializaram-se, numa das vertentes do seu modo de operação, na compra de débitos de empresas que se encontram em dificuldades, uma vez que a emergência na venda dos títulos desses empreendimentos, em situações críticas, pode gerar descontos atraentes sobre o preço dos seus títulos de crédito. Mediante o início do processo de falência ou, em alguns casos, inclusive, perante a simples ameaça de falência dessas empresas, os credores primários podem reagir negativamente à possível desvalorização das ações questão em sua posse, optando, assim,

13 Cfr. NGUYEN, Davy V. H. Too big to fail? Towards a sovereign bankruptcy regime. Cornell International Law Journal, New York, v. 45, n. 3, p. 697-723, 2012. p. 699; SILVA, Alexandre Pereira da; PEREIRA, Mariana Yante Barrêto. "Fundos abutres" vs. Estados nacionais: soberania e atuação do Tribunal Internacional do Direito do Mar a partir do caso da fragata libertad. Revista de Direito Internacional, Brasília, v. 10, n. 1, 2013. p. 138.

14 Veja-se LO, Andrew W. Risk management for hedge funds: introduction and overview. Financial Analysts Journal, Stanford, v. 57, n. 6, p. 16-33, Nov./Dec. 2001. p. 16-17.

15 Cfr. FUNG, William; HSIEH, David A. Empirical characteristics of dynamic trading strategies: the case of hedge funds. Review of Financial Studies, Oxford, v. 10, n. 2, p. 75-302, 1997. p. 281. 
pela venda dos créditos e não pela continuação do seu investimento prévio. ${ }^{16}$

A situação criada pelo stress dessas empresas é vista pelos fundos de hedge, diferentemente do que ocorre com outros fundos tradicionais, como uma oportunidade de investimento. Isto porque, quando realizada abaixo do preço integral, a compra de títulos de créditos empresariais pode gerar uma alta taxa de lucratividade em curtos períodos de tempo. A aposta na recuperação ou, inclusive, na renovação dessas empresas, que pode se dar, respectivamente, antes ou após o processo de falência, pode gerar altos retornos aos investidores que souberem gerir, corretamente, as suas aplicações.

Note-se, porém, que essa específica via de aplicação só tem possibilidade de maximizar o retorno dos seus investidores se a compra dos créditos for efetuada quando estes se encontram em baixa, isto é, em situações críticas. Portanto, o primeiro grande traço característico desses fundos (ao menos quando nos referimos ao mercado empresarial e das dívidas soberanas), refere-se à posição que eles ocupam, relativamente, aos credores e ao mercado de débitos. Os fundos de investimento não são credores primários ou originários, pelo contrário, eles adquirem seus débitos por meio dos mercados secundários, quando os títulos se encontram à venda por preços abaixo do seu valor nominal.

A agressiva e oportunista estratégia desses fundos pode facilitar, de certo modo, uma oposição ética às suas ações, uma vez que esses fundos lucram enquanto outros investidores, nomeadamente os primários, são obrigados a realizar sacrifícios financeiros e materiais. ${ }^{17}$ Porém, embora alguma resistência inicial possa existir, a sua atuação encontra grande aceitação e defesa interna, uma vez que esses fundos têm importante papel na manutenção dos mercados econômicos internos. ${ }^{18}$

16 Cfr LHABITANT, François-Serge. Handbook of hedge funds. England: J. W. and Sons, 2011. p. 226-227.

17 Veja-se LHABITANT, François-Serge. Handbook of hedge funds. England: J. W. and Sons, 2011. p. 215.

18 A participação dos fundos de bedge no processo de falência empresarial pode ser interessante para todos envolvidos, pois, segundo alguns autores, a presença dos fundos de bedge nesses processos pode auxiliar na manutenção do equilíbrio dos poderes entre as partes presentes no processo da falência e, por vezes, inclusive, na própria recuperação das empresas devedoras. O equilíbrio entre as partes envolvidas no processo é benéfico especialmente para aqueles pequenos fundos ou acionistas privados que não possuem um poder aquisitivo equiparável às grandes empresas. Isto porque, os fundos de hedge, além de possuir grande poder aquisitivo, possuem experiência nestes processos, o que acaba por equilibrar o poder entre a parte
Grande parte das discussões referentes à presença dos fundos "abutres" nos âmbitos privados encontra-se, porém, afastada ou desligada de fatores sociais ou éticos, circunscrevendo-se, assim, a fatores puramente econométricos. ${ }^{19}$ Entrementes, a presença e a atuação desses fundos no mercado internacional incitam debates mais profundos que envolvem, além das questões econômicas, aspectos morais, jurídicos e, mais importante, humanos. Isso porque, diferentemente do que ocorre no âmbito privado (no qual a integridade dos credores e dos devedores é protegida internamente pelas leis de falência), as ações dos fundos "abutres" no mercado das dívidas soberanas ainda não se encontram diretamente limitadas ou reguladas, sejam por normas internas ou internacionais. Inexistem, por exemplo, normas ou institutos que garantam, nessa específica situação, a proteção dos Estados altamente endividados, tampouco existem normas que garantam proteção aos cidadãos desdesses Estados que se encontrem em situação crítica.

Assim, embora compartilhem das características gerais dos fundos de investimento de hedge, os fundos que atuam no mercado internacional apresentam algumas especificidades próprias, que em muito advêm do seu particular âmbito de atuação, destacando-os dos restantes fundos de investimento e, inclusive, de outras variações de fundos hedge. A presença e atuação desses fundos no âmbito internacional, por exemplo, diferentemente do que ocorre nos mercados internos, não pa-

devedora e os pequenos acionistas. Ver, nesse sentido, WEI, Jiang; KAI, Li; WEI, Wang. Hedge funds and chapter 11. The Journal of Finance, v. 67, n. 2, p. 513-559, 2012. p. 513; 555; 556. As empresas, por seu lado, podem ser beneficiadas com a participação dos fundos de hedge no processo de falência devido à provável lucratividade que os fundos podem atingir caso as empresas se recuperem, seja durante o processo ou, nos piores casos, com uma renovação após a falência. Muitos dos fundos de bedge são geridos por profissionais capacitados, com larga experiência no âmbito empresarial, que, como novos acionistas destas empresas "necessitadas", passam a buscar a sua recuperação a fim de garantir o retorno do seu investimento inicial. Vejam-se, nesse sentido, WOLLASTON, Andrew. The growing importance of debt in European corporate transactions. Insolvency Intelligence, London, v. 18, n. 10, p. 145-149, 2005. p. 147-148; YAP, Suniati. Investing in chapter 11 companies: vultures or white knights?. Southewestern Journal of Law and Trade in the Americas, California, v. 2, p. 153-174, Mar./Apr. 1995. p. 153-155; 174.

19 É importante salientar, porém, que existem exceções que, inclusive, argumentam que os comportamentos destes fundos estão em consonância com o ambiente no qual eles se inserem. Cfr. CARSON, Scott Alan. Vulture investors, predators of the $90 \mathrm{~s}$ : an ethical examination. Journal of Business Ethics, Berlin, v. 17, n. 5, p. 543-555, 1998. p. 555. 
rece encontrar muitos defensores. Não é de se estranhar, portanto, que, conquanto os agressivos fundos de hedge já fossem identificados como "abutres" dos mercados internos, foram exatamente as suas atuações nos mercados internacionais - nomeadamente no mercado das dívidas soberanas - que renderam maior conexão destes fundos com o seu adjetivo pejorativo.

Isso porque, se a busca por lucros em detrimento do desenvolvimento de alguns Estados já não bastasse para prejudicar a reputação desses fundos no cenário internacional, o caminho por eles trilhado soma-se aos argumentos utilizados por aqueles que se opõem às ações desses fundos. Os abutres são aves facilmente reconhecidas pela sua cor e pelo seu característico hábito de caça. Muito paciente, o abutre geralmente sobrevoa sua presa até que ela se apresente indefesa ou morta, para, então, alimentar-se da sua fragilizada presa ou da carcaça deixada por outros animais. Os chamados fundos "abutres" são igualmente conhecidos por averiguar e esperar pacientemente para "atacar" as suas fragilizadas presas, nesse caso, países que se encontrem em situações emergenciais.

O sucesso da caçada desses "predadores" econômicos, porém, igualmente ao ocorrido com as aves de rapina, não depende somente da escolha das suas presas, pois o momento da investida é igualmente importante e deve ser meticulosamente calculado. Não é de se estranhar, pois, que os fundos "abutres" sejam reconhecidamente responsáveis por "atacar" países agraciados pelo programa de incentivo à recuperação dos países altamente endividados (HIPC) $)^{20}$.

20 Em 2010 estimava-se que credores privados haviam conseguido mais de um bilhão de dólares em julgamentos favoráveis face aos países mais pobres do mundo. Em relação a esse grande grupo de credores privados, os fundos "abutres" são responsáveis por $65 \%$ dos processos iniciados perante os chamados HIPC. Segundo os fundos "abutres", seus ataques aos países agraciados por esses programas de recuperação se fundamentam no fato de que os países atacados — antes altamente endividados — passam a ter, após o alívio das dívidas, externas, condições de cumprir com as obrigações financeiras previamente adquiridas. Em 2007, por exemplo, o fundo de investimento Donegal acionou judicialmente o governo da Zâmbia devido a um débito de 42 milhões de dólares. Curiosamente, a quantia requerida era equivalente a todo o alívio da dívida que o governo da Zâmbia havia recebido no ano anterior ao processo. A este respeito, veja-se: ZAMBIA loses 'vulture fund' case. BBC News, London, Feb 15, 2007. Available at: < http://www. scu.edu/business/economics/upload/SovereignDefaultsinCourt. pdf $>$. Accessed on: 16 dec. 2015. Vejam-se SCHUMACHER, Julian; TREBESCH, Christoph; ENDERLEIN, Henrik. Sovereign defaults in court: the rise of creditor litigation 1976-2010. Social Science Research Network, June 2013. Available at: <http://news.bbc.
Além do mais, ao buscar a maximização dos seus lucros, os fundos "abutres" negam-se a participar das reestruturações dos débitos, uma vez que essas negociações envolvem, geralmente, a redução dos débitos.

Esses fundos apresentam-se, assim, como um tipo específico de credor, compreendendo-se no grupo dos chamados hold-out creditors. 21 Isso porque, mediante uma oportunidade de troca dos títulos, durante uma reestruturação de dívida, os fundos "abutres" "seguram" seus títulos a fim de buscar uma oportunidade mais rentável. Essa "oportunidade" mais rentável, conforme já dito, é geralmente atingida pela via judiciária ou, ainda, por meio de negociações alavancadas pela ameaça dos processos. As ações desses chamados hold-out creditors obstruem, destarte, conforme se verá adiante, o bom andamento da reestruturação das dívidas dos Estados devedores. Certamente, o atraso das reestruturações pode prejudicar a economia desses Estados, refletindo, diretamente, no bem-estar dos seus cidadãos.

Não é à toa, portanto, que o termo "fundos abutres", que é claramente utilizado de maneira pejorativa, foi largamente difundido pela comunidade internacional. A alusão ao grande predador no termo utilizado para caracterizar estes fundos é, portanto, geralmente utilizada em referência à sua nefasta maneira de atuar.

\section{O NINHO DOS ABUTRES: AS DÍVIDAS SOBERANAS}

Não há dúvida de que a principal característica dos fundos "abutres" e a principal diferença destes para os demais fundos de hedge, nomeadamente com relação àqueles que atuam internamente, advêm da escolha do seu âmbito, ou mercado, de atuação. Ao contrário do que ocorre com a generalidade dos fundos de hedge, os fundos "abutres" buscam o retorno do investimento dos seus integrantes por meio da especulação do mer-

co.uk/2/hi/business/6365433.stm>. Accessed on: 16 dec. 2015. p. 3; BROOMFIELD, Elizabeth. Subduing the vultures: assessing government caps on recovery in sovereign debt litigation. Columbia Business Law Review, Washington, v. 2010, n. 2, p. 473-528, 2010. p. 475. Veja-se, para uma lista dos países que se "qualificaram para, são elegíveis ou potencialmente elegíveis, e que podem querer receber ajuda da Iniciativa HIPC", IMF. Debt Relief Under the Heavily Indebted Poor Countries (HIPC) Initiative Factsheet. HIPC Initiative (2013).

21 Cfr. WHEELER, Christopher C.; ATTARAN, Amir. Declawing the vulture funds: rehabilitation of a comity defense in sovereign debt litigation. Stanford Journal of International Law, Stanford, v. 39, p. 253-284, 2003. p. 254. 
cado das dívidas soberanas.

Porém, embora o mercado das dívidas soberanas apresente contexto muito mais complexo do que aquele presente nos mercados internos, o modus operandi empregado pelos "abutres" não se distancia, em muito, daquele utilizado internamente, uma vez que ambos se caracterizam como credores secundários. Isso, porque, no cenário internacional, os títulos de débito soberanos são adquiridos pelos fundos "abutres" em um mercado paralelo, geralmente por um valor inferior ao preço nominal dos débitos. ${ }^{22}$

Encontrando seus primórdios no período posterior à Segunda Guerra Mundial, o mercado das dívidas soberanas se estabeleceu a partir dos acordos de Bretton Woods, que, inicialmente, foram elaborados, a fim de assegurar a estabilidade econômica internacional no caótico cenário econômico internacional de período caótico 1945, garantindo aos Estados a possibilidade de alavancar a sua economia interna por meio de arrecadações externas de empréstimos oficiais e supranacionais. Em meados da década de 70 , porém, o cenário internacional presenciou uma radical mudança nos padrões econômicos internacionais. Os empréstimos, que antes eram assegurados pelo FMI, passaram a ser concedidos por bancos comerciais norte-americanos e europeus. ${ }^{23}$

Com a crise latino-americana de 1980 e, consequentemente, com as diversas moratórias dos países endividados, os bancos credores passaram a renegociar e remanejar as dívidas soberanas em um mercado secundário. ${ }^{24}$ Ressalte-se que, diferentemente do que ocorre

22 No caso que envolveu a República da Zâmbia, por exemplo, a dívida inicial adquirida em 1979 era de 15 milhões de dólares americanos. Os títulos da dívida soberana, porém, foram comprados, em 1999, por um fundo privado identificado como um fundo "abutre", por 3,2 milhões de dólares (enquanto a dívida corrigida atingia, aproximadamente, a quantia de 30 milhões de dólares). Entrementes, o fundo de investimento cobrou judicialmente, em 2007, uma quantia de mais de 55 milhões de dólares. Se considerarmos que o valor total do débito atingia, em 1999, 44 milhões de dólares (números identificados no litígio, compostos pela correção do valor total mais os juros), é possível afirmar que o pagamento realizado fundo de investimento não chegou a $7,5 \%$ do valor real da dívida. O julgamento final acabou por conceder 15 milhões de dólares ao fundo Donegal. A quantia concedida, mesmo longe dos 55 milhões pretendidos, representou uma margem de lucro de mais de $480 \%$ sobre o valor do investimento inicial.

23 Cfr. HAYS II, James M. "The Sovereign Debt Dilemma. Brooklyn Law Review, New York, v. 75, n. 3, p. 905-933, 2010. p. 913.

24 O governo norte-americano adotou, por meio da sua Reserva Federal, uma política de aumento das taxas de juros nominais. Essa nova política conseguiu combater as taxas de inflação, reduzindo- hoje, na época, apesar das diversas declarações de moratórias dos devedores e das diversas reestruturações das dívidas soberanas, pouquíssimas ações judiciais alimentaram-se dos conflitos. Isso porque, inicialmente, as dívidas eram apenas negociadas entre os próprios bancos e, ademais, os Estados gozavam de imunidades jurisdicionais que ainda encontram algum (muito embora pouco) respaldo em doutrinas absolutistas. ${ }^{25}$

A titularização dos créditos das dívidas soberanas, estabelecida pelo "Plano Brady"26, contudo, transfor-

as substancialmente. A nova política, somada à redução da inflação norte-americana, resultou em um aumento acentuado nas taxas de juros reais previstos nos acordos de débito. $\mathrm{O}$ aumento nas taxas de juros norte-americanas atingiu especialmente os Estados devedores latino-americanos, pois a maioria dos empréstimos concedidos a estes países tinha uma taxa de juros flutuante, ou seja, a taxa de juro cobrada seguia a variação do mercado. Cfr. HAYS II, James M. "The Sovereign Debt Dilemma. Brooklyn Law Review, New York, v. 75, n. 3, p. 905-933, 2010. p. 913; EDWARDS, Sebastian. Crisis and reform in Latin America: from despair to hope. New York: Oxford University, 1995. p. 22; GOLDMAN, Samuel E. Mavericks in the market: the emerging problem of hold-outs in sovereign debt restructuring. UCL A Journal of International Law and Foreign Affairs, California v. 5, p. 159-197, 2000. p. 61; POWER, Philip J. Sovereign debt: the rise of the secondary market and its implications for future restructurings. Fordham Law Review, New York, v. 64, n. 6, p. 2071-2077, Sept./ Mar. 1996.

25 O movimento de aplicação das imunidades jurisdicionais do Estado teve, inicialmente, uma fase que é, geralmente, expressada pela doutrina como "absoluta". Alguns autores relutam, porém, em utilizar o adjetivo, ao menos sem apontar as suas particularidades. Isto porque, segundo estes autores, as imunidades jurisdicionais do Estado não foram, nem durante a sua primeira fase de aplicação, "absolutas". MADRUGA observa, por exemplo, que nos casos de ações relativas a imóveis nunca se estranhou a submissão do Estado estrangeiro ao forum rei sitae. SHAW igualmente afirma que há alguma limitação à teoria absoluta das imunidades jurisdicionais do Estado. Segundo o autor " [t] here is some limitation to the absolute immunity rule to the extent that a mere claim by a foreign sovereign to have an interest in the contested property would have to be substantiated before the English court would grant immunity. Since this involves some submission by the foreign sovereign to the local jurisdiction, immunity is not unqualifiedly absolute". Alguns autores empregam, pois, termos alternativos para expressar a aplicação absoluta das imunidades jurisdicionais do Estado. Termos como "imunidade plena" e "imunidade extensiva" são encontrados na doutrina como alternativas ao termo "imunidade absoluta". Vejam-se, neste sentido, MADRUGA FILHO, Antenor Pereira. $A$ renúncia à imunidade de jurisdição pelo Estado brasileiro e o novo direito da imunidade de jurisdição. São Paulo: Renovar, 2003. p. 178; SHAW, Malcolm N. International law. 6. ed. Cambridge: Cambridge University Press, 2008. p. 703; CARVALHO, Geraldes de. Da imunidade jurisdicional dos Estados estrangeiros. Colectânea de Jurisprudência, Ano 10, Tomo IV, 1985, p. 35-37.

26 De maneira sintética, o plano propunha o agrupamento de todas as dívidas de um determinado devedor, para, então, mediante um desconto no débito total, transformá-las em títulos "Brady" que poderiam ser livremente oferecidos e transacionados pelo público geral. Após a securitização das dívidas, as obrigações originais do 
mou a antiga pequena e, relativamente, homogênea classe de credores em uma classe muito maior e mais diversificada. ${ }^{27}$ Não seria exagero, destarte, afirmar que a expansão do mercado secundário e a facilidade da comercialização dos títulos securitizados são responsáveis por espalhar a titularidade das dívidas soberanas por milhares de credores que variam de enormes instituições a simples investidores privados. Note-se, ademais, que esse processo foi acelerado pelo processo de globalização, uma vez que o fácil acesso a informações mundiais, a interdependência política e, principalmente, econômica, que se estabeleceram no cenário internacional, facilitaram, por um lado, a compra e o acesso dos investidores a novas oportunidades de investimentos; e, por outro lado, dificultaram o reconhecimento e a identificação destes credores. ${ }^{28}$

Porém, não seria correto responsabilizar, exclusivamente, aquelas mudanças político-econômicas pela problematização atual das reestruturações soberanas. A evolução nos arquétipos jurídicos, nomeadamente com relação à cobrança das dívidas soberanas, foi essencial à permissibilidade legal do atual modus operandi utilizado pelos fundos "abutres".

Destarte, se os fundos "abutres" estabeleceram o seu "ninho" no cenário internacional após a grande de 1980 e a titularização dos créditos das dívidas soberanas, certamente é possível afirmar que as evoluções jurídicas, nomeadamente dos paradigmas relativos à imunidade jurisdicional do Estado, detêm parcela substancial na proliferação e na possibilidade da permanência destes fundos no seu novo "habitat". Isso porque, seja com base nas normas consuetudinárias, seja com

país devedor, que se encontravam sob a forma de diversos contratos, eram extintas. Cfr. FISCH, Jill; GENTILE, Caroline. Vultures or vanguards?: the role of litigation in sovereign debt restructuring. Emory Law Journal, Atlanta, v. 53, n. 1043, p. 1047-1116, 2004. p. 1071; POWER, Philip J. Sovereign debt: the rise of the secondary market and its implications for future restructurings. Fordham Law Review, New York, v. 64, n. 6, p. 2071-2077, Sept./ Mar. 1996.

27 Vejam-se, HAYS II, James M. "The Sovereign Debt Dilemma. Brooklyn Law Review, New York, v. 75, n. 3, p. 905-933, 2010, p. 912915; POWER, Philip J. Sovereign debt: the rise of the secondary market and its implications for future restructurings. Fordham Law Review, New York, v. 64, n. 6, p. 2071-2077, Sept./ Mar. 1996. p. 2763.

28 A reestruturação do débito de títulos soberanos argentinos em 2001 envolveu, por exemplo, uma negociação com centenas de milhares de credores que possuíam, ao todo, mais de cento e quarenta tipos de títulos regidos por diversas moedas e leis diferentes. Cfr. WAIBEL, Michael. Sovereign defaults before International courts and tribunals. Cambridge: Cambridge University, 2011. p. 16. base nas normas internas ${ }^{29}$, hoje não há hesitação por grande parte da doutrina em afirmar que as normas de Direito Internacional que versam sobre as imunidades jurisdicionais do Estado devem ser aplicadas à luz da interpretação e aplicação restrita, sendo vistas como uma garantia essencial ao bom funcionamento do mercado econômico internacional, pois a prática evita "distorções de concorrência causadas pelo recurso abusivo à imunidade soberana dos Estados por parte das entidades públicas envolvidas na prática de atos de comércio." 30

Não há dúvidas, portanto, que a doutrina das imunidades jurisdicionais do Estado têm uma íntima relação com a presença dos fundos "abutres" no cenário internacional, bem como com o funcionamento do modo de operação por eles empregado, pois a manutenção da existência desses atores, como entidades econômicas, incita a busca pela alternativa mais lucrativa que estes fundos possam conseguir. A alternativa mais rentável para estes fundos se dá, por certo, por meio da busca do ressarcimento dos seus investimentos pela via judicial, operação esta que seria extremamente ineficiente caso as imunidades jurisdicionais do Estado ainda fossem "absolutas". Note-se que outros institutos como a cortesia internacional, a teoria do ato do Estado e as normas anti-champerty também poderiam representar um duro golpe econômico aos procedimentos dos fundos abutres, mas a história parece apontar em sentido contrário. $^{31}$

29 A nova tendência da aplicação qualificada das imunidades jurisdicionais do Estado foi, assim, ancorada principalmente pelo estabelecimento de leis internas como o Foreign Sovereign Immunities Act (FSIA), proclamado em 1972 nos Estados Unidos da América, e o State Immunity Act, que logo seguiu a legislação norte-americana, sendo proclamado em 1976 no Reino Unido. Não obstante o seu caráter internacional, também se faz importante mencionar aqui as legislações regionais como, por exemplo, a Convenção Europeia sobre a Imunidade dos Estados, de 1972. Para uma visão mais aprofundada sobre estas legislações internas, vejam-se DOLINGER, Jacob. A imunidade jurisdicional dos Estados. Revista de informação legislativa, Brasília, v. 19, n. 76, p. 5-64, 1982. p. 20-36; PELLET, Alain; DINH, Nguyen Quoc; DAILLIER, Patrick. Direito internacional público. Lisboa: Calouste Gulbenkian, 2003. p. 462-463.

30 A aplicação restritiva das imunidades jurisdicionais do Estado sempre encontrou refúgio nas cortes de países europeus como a Itália, a Bélgica e a Suíça. A disparidade da aplicação das teorias das imunidades jurisdicionais do Estado encadeou, inclusive, a negação de uma norma consuetudinária relativa à aplicação absoluta das imunidades jurisdicionais do Estado. Ver, entre outros, SALIBA, Aziz Tuffi. A imunidade absoluta de jurisdição de Estados: sólida regra costumeira" ou mito? Revista Brasileira de Direito Público, Belo Horizonte, v. 3, n. 8, p. 17-51, 2005. p. 21-23.

31 Vejam-se Allied Bank International v. Banco Crédito Agrícola (757 F.2d 516). UNITED STATES. Court of Appeals. Al- 
Diversos foram os desenrolares jurídicos, internos ou externos, que colaboraram, portanto, à proliferação da ação dos fundos "abutres" no cenário internacional. Os casos que envolveram a República da Costa Rica e o Banco Allied International, por exemplo, não só marcaram o âmbito das dívidas soberanas por caracterizar-se como um dos primeiros casos que envolveram a ação dos chamados hold-out creditors, mas, também, devido às suas decisões proferidas, pois o resultado dos julgamentos já apresentava em seu contexto alguns "incentivos" à aparição dos fundos "abutres".

Isso porque, embora, inicialmente, as decisões tenham acatado a invocação das defesas soberanas, o resultado do litígio, que começou a atrair a atenção da comunidade financeira de Nova York, colaborou, pelo contrário, à erosão da aplicação de doutrinas como a cortesia internacional e a doutrina do Ato do Estado. A linha de interpretação, que afirmou que a "recusa" à participação nas reestruturações soberanas representa um direito legítimo dos credores, solidificou-se nas decisões subsequentes às decisões dos litígios que envolveram o Banco Allied International. ${ }^{32}$ Essas decisões afirmaram, inclusive, que as pretensões desses credores e os meios por eles utilizados não afetavam a recuperação econômica dos Estados devedores.

Assim, além da clara evolução jurídica em favor dos fundos "abutres" nesses casos, essas decisões, também, podem ser vistas como uma defesa "moral" à atuação dos "abutres", uma vez que muitos argumentos atuais, que se mostram contrários a esta classe de investidores, afirmam que a recusa à participação destes fundos nas reestruturações soberanas acaba por dificultar a recuperação econômica dos Estados. As decisões proferidas no caso Allied e o reflexo das mesmas nos julgamen-

lied Bank International vs. Banco Credito Agricola. Setence March 18, 1985. Available at: <http://www.leagle.com/decision/198512737 57F2d516_11184/ALLIED\%20BANK\%20INTERN.\%20v.\%20 BANCO\%20CREDITO\%20AGRICOLA $>$. Accessed on: 16 dec. 2015; e CIBC Bank and Trust Co. (CAYMAN) Ltd v. Banco Central do Brasil (886 F. Supp. 1105), UNITED STATES. District Court. CIBC Bank and Trust co. vs. Banco Central do Brasil. Setence May 9, 1995. Available at: <http://www.leagle.com/decision/19951991 886FSupp1105_11830/CIBC $\% 20$ BANK $\% 20 \& \% 20$ TRUST $\% 20$ CO. $\% 20 \mathrm{v} . \% 20 \mathrm{BANCO} \% 20 \mathrm{CENT} \%$ 20do\%20BRASIL>. Accessed on: 16 dec. 2015.

32 Para uma descrição mais detalhada acerca das decisões subsequentes ao caso Allied, cfr., entre outros, FISCH, Jill; GENTILE, Caroline. Vultures or vanguards?: the role of litigation in sovereign debt restructuring. Emory Law Journal, Atlanta, v. 53, n. 1043, p. 1047-1116, 2004. p. 1085 e ss. tos subsequentes "incentivaram" a cultura dos fundos "abutres", que identificaram uma situação favorável à busca de lucros no mercado das dívidas soberanas internacionais.

\section{O PAPEL dOS FUNDOS ABUTRES NO CENÁRIO INTERNACIONAL}

O envolvimento desses fundos com o mercado das dívidas soberanas acarreta uma gama de consequências que vai além dos fatores econométricos envoltos nos processos internos. Já ultrapassamos o entendimento de que os Estados se identificavam como entidades autônomas, independentes e completas por si só. Pelo contrário, a evolução do conceito da soberania e os princípios presentes no modelo internacional pós-westfaliano destacam a subordinação dos Estados ao Direito Internacional e aos valores por ele empregados, como, por exemplo, o respeito aos direitos humanos. É por isso que se refuta, hoje, a ideia do Estado como entidade moral, caracterizando-o, longe disso, como um meio institucional que atende a um fim mais importante: a proteção dos direitos fundamentais dos seus cidadãos. ${ }^{33}$

O jogo especulativo dos fundos "abutres" envolve, pois, princípios e questões mais intrincadas do que aquelas vistas no cenário interno. A satisfação econômica desses fundos pode levar à negação de direitos básicos que deveriam ser assegurados a milhares de indivíduos. Em um país como a Zâmbia, por exemplo, em que a situação financeira é extremamente instável, a investida dos fundos "abutres" pode ser um obstáculo à melhoria do bem-estar da própria população. Em 2007, quando o governo da Zâmbia se encontrava sob as investidas desses fundos, o conselheiro presidencial e consultor da OXFAM, Martin Kalunga-Banda, relatou que o pagamento da dívida requerida pelos fundos "abutres" era equivalente ao custo do tratamento médico de mais de cem mil cidadãos. ${ }^{34}$

Não é de se estranhar, portanto, conforme já dito, que a atuação dos fundos abutres não foi bem recepcio-

33 Cfr MACHADO, Jónatas Eduardo Mendes. Direito internacional: do paradigma clássico ao pós-11 de setembro. 2. ed. Coimbra: Coimbra, 2004. p. 214.

34 O dinheiro cobrado pelos fundos "abutres", segundo o conselheiro presidencial, também se destinava à contratação de recursos humanos, como professores e enfermeiras, e à construção de infraestruturas básicas ao Estado. 
nada pela mídia e por diversos órgãos internacionais. ${ }^{35}$ Assim, a comunidade acadêmica vem apresentando diversas propostas que visam limitar, amplamente ou pontualmente, a atuação dos fundos abutres no cenário internacional. Essas propostas variam desde a inserção de cláusulas de ação coletiva (CAC) nos títulos de débito soberanos ${ }^{36}$ até a realização de lobbys de diversas ONG's, a fim de obter a aprovação de legislações internas voltadas à coibição da ação dos fundos de hedge nos tribunais nacionais. Essas propostas, por exemplo, encontraram aceitação por alguns políticos britânicos e norte-americanos, que propuseram, respectivamente, a legislação conhecida como "Developing Country Debt (Restriction of Recovery) Bill' e o projeto conhecido como "Stop 'Vulture' Funds Act" (Stop Very Unscrupulous Loan Transfers from Underprivileged Countries to Rich, Exploitive Funds $A c t)$.

É importante salientar, porém, que, em que pese a importância dessas legislações na defesa dos países pobres e altamente endividados, que normalmente são alvos dos fundos "abutres", muitas das propostas apresentadas pela comunidade internacional almejam coibir por completo a ação destes fundos no cenário internacional. Estas propostas não consideram, portanto, a importância que esses fundos podem ter no cenário das dívidas soberanas. Hoje já não é possível negar que, como fazem parte desse âmbito, esses fundos já apresentam papel no cenário das dívidas soberanas.

Contudo, para compreender o papel dos fundos "abutres" no âmbito das dívidas soberanas, faz-se importante, primeiramente, entender como funcionam as reestruturações dessas dívidas, uma vez que esse processo se apresenta como o único instituto que pode, em caso de real necessidade, ser benéfico a todas as partes envolvidas. Isso porque, diferentemente do que ocorre nos mercados econômicos internos, os Estados soberanos que não tem condições de pagar as suas dívidas só

35 Os fundos de investimento, por outro lado, rebatem as acusações e referem-se a si próprios por meio de termos neutros e, portanto, menos agressivos, afirmando, ao contrário, que os Estados devedores "são responsáveis pela erosão do sistema jurídico, devido ao seu desrespeito pelo Estado de Direito" e pela falta de pagamento de débitos legítimos. Cfr. BOSCO, David. The debt frenzy. Foreign Policy, Washington, n. 161, p. 36-42, July/Aug. 2007. p. 38-39. Veja-se DING, Yilin. Absolute, restrictive, or something more: did Beijing choose the right type of sovereign immunity for Hong Kong?. Emory International Law Review, Atlanta, v. 26, p. 997-1037, 2012. p. 1008. 36 Cfr. HASELER, Sonke. Collective action clauses in international sovereign contracts: whence the opposition?. Journal of Economic Surveys, New Jersey, v. 23, n. 5, p. 882-923, 2009. p. 885 e ss. podem recorrer a duas vias: a moratória ou a reestruturação das suas obrigações.

Não existe, portanto, um instituto de "falência" ao qual os Estados possam recorrer. ${ }^{37}$ Assim, o termo "reestruturação da dívida soberana" refere-se a "qualquer mudança realizada nos pagamentos previamente acordados, seja após a declaração de moratória ou, até mesmo, mediante a ameaça da falta de pagamentos". ${ }^{38}$ Desse modo, qualquer mudança nos acordos que regem o débito soberano pode ser considerada como uma reestruturação dos títulos desta dívida. Devido à falta de um instituto específico para reger esse processo, atualmente, embora diversos institutos de recuperação soberana tenham sido propostos, estas reestruturações ainda ocorrem de maneira "voluntária".39

Pode parecer ingênuo adjetivar essas reestruturações como "voluntárias", visto que nenhum investidor, em bom juízo ou de bom grado, acataria, voluntariamente, um corte de $70 \%$ no valor total dos seus créditos, fato que ocorreu, por exemplo, na recente reestruturação da dívida Grega. ${ }^{40}$ Faz-se importante, pois, esclarecer que essa voluntariedade, quando vinculada às reestruturações soberanas, somente expressa uma decisão que foi tomada em mútuo acordo das partes. ${ }^{41}$ Não significa dizer, pois, que os credores tenham poder suficiente para decidir, exclusivamente, acerca da concessão, ou não, da reestruturação das dívidas.

Assim, o sucesso das reestruturações dos débitos soberanos requer, muitas vezes, sacrifícios mútuos. ${ }^{42}$

37 BLACKMAN, Jonathan I.; MUKHI, Rahul. The evolution of modern sovereign debt litigation: vultures, alter egos, and other legal fauna. Law and Contemporany Problems, Durham, v. 73, p. 47-61, 2010. p. 48.

38 WAIBEL, Michael. Sovereign defaults before International courts and tribunals. Cambridge: Cambridge University, 2011. p. 14.

39 A expressão "reestruturação da dívida soberana" refere-se às mudanças realizadas em pagamentos previamente acordados. Estas mudanças podem ser realizadas após a moratória de um Estado ou mediante uma ameaça de moratória. WAIBEL, Michael. Sovereign defaults before international courts and tribunals. Cambridge: Cambridge University, 2011. p. 14.

40 GULATI, Mitu. Sovereign debt after 2013: things will never be the same again. Capital Markets Law Journal, Oxford v. 8, n. 2, p. 117-120, 2013. p. 117.

41 WAIBEL, Michael. Sovereign defaults before international courts and tribunals. Cambridge: Cambridge University, 2011. p. 14.

42 A crise de 1980, por exemplo, só pode ser resolvida devido ao reconhecimento, por parte dos bancos credores, da necessidade da realização de sacrifícios mútuos. POWER, Philip J. Sovereign debt: the rise of the secondary market and its implications for future restructurings. Fordham Law Review, New York, v. 64, n. 6, p. 20712077, Sept./Mar. 1996. p. 2705. 
Essas reestruturações, que têm por objetivo o remanejamento das obrigações estatais perante os credores, normalmente envolvem a elaboração de uma nova e, mais espaçada, agenda de pagamentos ou, sendo esta a opção mais buscada pelos devedores, a redução do valor total da dívida.

Os fundos "abutres", contudo, geralmente optam pela busca integral dos títulos por meio de ações judiciais. Diversos autores afirmam que a recusa apresentada pelos fundos "abutres" acaba por dissuadir a participação de outros credores na reestruturação voluntária apresentada pelos devedores. ${ }^{43}$

O caos causado por uma provável vitória judicial contra os países devedores pode dificultar ainda mais a reestruturação das dívidas ou, pior, danificar, severamente, a sua economia e suas futuras negociações. Isso porque, os demais credores podem, mediante uma ação judicial dos fundos "abutres", iniciar ações, a fim de salvar-se de mais prejuízos, seja vendendo seus títulos de débito no mercado secundário ou buscando também a via judiciária. ${ }^{44} \mathrm{~A}$ venda dos títulos de débito em plena crise e, por conseguinte, com baixos preços, pode piorar a situação financeira do devedor e, assim, a sua capacidade de pagar os seus débitos, uma vez que as vendas realizadas no mercado secundário, nesta determinada situação, refletem na credibilidade dos títulos e nas taxas de juros dos futuros empréstimos. ${ }^{45} \mathrm{~A}$ busca da cobrança pela via judicial, por outro lado, pode desencadear um efeito dominó, levando outros credores à provável alimentação deste ciclo vicioso.

Note-se, contudo, que muito embora esses fundos apresentem capacidade de disrupção nos processos de reestruturação das dívidas soberanas, não podemos negar as diversas teses que afirmam que a participação desses fundos no âmbito internacional pode sobrepujar o caos geralmente causado por estes nas reestruturações soberanas.

Alguns autores afirmam que, devido à sua preferên-

43 WHEELER, Christopher C.; ATTARAN, Amir. Declawing the vulture funds: rehabilitation of a comity defense in sovereign debt litigation. Stanford Journal of International Law, Stanford, v. 39, p. 253-284, 2003. p. 254.

44 NGUYEN, Davy V. H. Too big to fail? towards a sovereign bankruptcy regime. Cornell International Law Journal, New York, v. 45, n. 3, p. 697-723, 2012. p. 699.

45 NGUYEN, Davy V. H. Too big to fail? towards a sovereign bankruptcy regime. Cornell International Law Journal, New York, v. 45, n. 3, p. $697-723,2012$. p. 699. cia pela compra dos títulos de débito por meio dos mercados secundários, os fundos abutres acabam garantindo a liquidez dos mercados de débitos, apresentando-se como reguladores do mercado secundário. ${ }^{46}$

Outros autores afirmam que a presença dos fundos abutres no cenário internacional funciona como um contrapeso à falta de um instituto de falência específico nesse âmbito, garantindo que os Estados possam cancelar os pagamentos das obrigações previamente adquiridas, simplesmente por ser mais fácil escolher a moratória das suas dívidas em vez de empregar as medidas que seriam necessárias para continuar com os pagamentos acordados. ${ }^{47}$

Não há dúvida alguma de que a declaração de uma moratória soberana tem reflexos em diversos campos estatais, isto é, na política, na economia e, até mesmo, na reputação do Estado. Portanto, alguns autores defendiam a ideia de que as consequências políticas e econômicas da declaração de uma moratória eram suficientes, por si só, para coibir os Estados de declarar uma moratória "oportunista". ${ }^{48}$ Atualmente, porém, o entendimento parece ser outro. As consequências econômicas não são graves o suficiente para reprimir os opportunistic deffault's. O recente caso da Argentina comprova essa nova teoria. Tido por muitos como uma moratória oportunista, a República da Argentina vem sofrendo com a sua saga judicial com os fundos "abutres", uma vez que as consequências econômicas não parecem ter surtido efeito suficiente a ponto de refrear a moratória em primeiro lugar. ${ }^{49}$

Assim, se a ameaça das sanções ainda deve fazer-se presente no ambiente das dívidas soberanas, e as consequências econômicas que advêm da inadimplência de uma moratória não são suficientes para coibir a ação deliberada dos Estados, atualmente, a ameaça sancionatória deve ser aplicada pelos próprios credores. Di-

46 Cfr. WHEELER, Christopher C.; ATTARAN, Amir. Declawing the vulture funds: rehabilitation of a comity defense in sovereign debt litigation. Stanford Journal of International Law, Stanford, v. 39, p. 253-284, 2003. p. 254.

47 FISCH, Jill; GENTILE, Caroline. Vultures or vanguards?: the role of litigation in sovereign debt restructuring. Emory Law Journal, Atlanta, v. 53, n. 1043, p. 1047-1116, 2004. p. 1048.

48 NGUYEN, Davy V. H. Too big to fail? towards a sovereign bankruptcy regime. Cornell International Law Journal, New York, v. 45, n. 3, p. 697-723, 2012. p. 708-711.

49 Sobre este ponto, veja-se, inter alia, BAER, Werner Baer; MARGOT, Diego Margot; MONTES-ROJAS, Gabriel. Argentina's default and the lack of dire consequences. Economia Aplicada, Ribeirão Preto, v. 15, n. 1, p. 131-146, jan./mar. 2011. p. 137-140. 
ferentemente do passado, porém, os credores podem pressionar os Estados devedores por meio da utilização dos tribunais nacionais para buscar os seus direitos de cobrança. Nesse sentido, a presença dos "abutres" no cenário das dívidas soberanas poderia justificar-se, em caso de moratórias oportunistas, uma vez que esses fundos têm vasta experiência nestes litígios, bem como a possibilidade de lançar-se numa "saga" jurídica contra os soberanos, ao contrário dos outros credores privados individuais, que não teriam condições de suportar tamanha tarefa. Desse modo, a presença dos "abutres" se faria importante não só nos casos de moratórias oportunistas, mas, também, em casos nos quais as reestruturações sejam necessárias, porém apresentem termos extremamente prejudiciais às partes credoras minoritárias. ${ }^{50}$ Ademais, geralmente, os fundos "abutres" não estão sujeitos às pressões políticas dos Estados devedores e, inclusive, dos seus próprios Estados, tornando-os, assim, "livres" para litigar contra os devedores. ${ }^{51}$

Precisamos nos perguntar, porém, até que ponto a presença e a consequente ameaça desses fundos cumpre o objetivo que lhes é atribuído. Certamente, o pagamento que a Grécia realizou em benefício dos bold-out creditors demonstra que os Estados devedores estão cientes de que estes fundos, provavelmente, vão servir de balanço às moratórias ou reestruturações. Parece-nos, porém, que os devedores poderiam simplesmente pagar àqueles identificados como riscos à reestruturação. Nesse caso, somente os "abutres" lucrariam com a sua posição de vantagem perante os outros devedores.

Ademais, nessa situação, outros credores também seriam incentivados a segurar os seus créditos e não participar das reestruturações oferecidas, situação que poderia gerar, assim, uma disrupção desnecessária e encadear um efeito dominó nas reestruturações soberanas. Cabe salientar, também, que os fundos "abutres" ainda têm como objetivo principal a lucratividade em detrimento do desenvolvimento de alguns Estados. Com certeza a ação desses fundos não ficaria atrelada às moratórias oportunistas, pelo contrário, se incentivados, os fundos "abutres" passariam a negar a sua participação

50 Cfr. FISCH, Jill; GENTILE, Caroline. Vultures or vanguards?: the role of litigation in sovereign debt restructuring. Emory Law Journal, Atlanta, v. 53, n. 1043, p. 1047-1116, 2004. p. 1052, 1115.

51 Cfr BROOMFIELD, Elizabeth. Subduing the vultures: assessing government caps on recovery in sovereign debt litigation. Columbia Business Law Review, Washington, v. 2010, n. 2, p. 473-528, 2010. p. 514 em qualquer negociação, até mesmo naquelas realmente necessárias.

Outras bandeiras também têm sido levantadas em defesa da participação dos fundos "abutres" no âmbito das dívidas soberanas, nomeadamente com relação ao reflexo que as suas ações espargem no governo dos HIPC. Alguns autores afirmam que as ações desses fundos têm revelado grandes esquemas de corrupção nesses Estados. ${ }^{52} \mathrm{O}$ caso que se desenvolveu com base no litígio contra o Congo é um perfeito exemplo deste inusitado papel dos fundos "abutres". ${ }^{53} \mathrm{O}$ esquema, que envolvia, inclusive, funcionários de alto escalão do governo congolense - como, por exemplo, o presidente e o seu filho - nunca haveria de ser descoberto caso não fossem os vastos recursos investigativos do fundo "abutre".

$\mathrm{Na}$ tentativa de encontrar bens penhoráveis, que serviriam de garantia à sua ação judicial, o fundo "abutre" Elliott Associates acabou revelando esquema de corrupção estabelecido pelo governo do Congo, apontando mais de 82 mil dólares em fraudes. Segundo indícios revelados no caso, o governo congolense havia montado uma rede de empresas fictícias a fim de mascarar transações petrolíferas corruptas. Novamente, a "liberdade" política desses fundos apresentou-se como fator positivo no desempenho desse papel, uma vez que as autoridades locais não desvendariam as redes corruptas daquele país, especialmente devido à participação dos funcionários de alto escalão do governo.

Não podemos entrar em erro, neste artigo, e atribuir esses papéis aos fundos "abutres" sem analisar as consequências que estas atuações trazem ao âmbito das dívidas soberanas. Não cabe aqui, porém, analisar a razão pela qual os fundos realizam as suas investigações. O fato de a ação ser um meio ao fim lucrativo dos fundos não descaracteriza a consequência benéfica do

52 Veja-se BROOMFIELD, Elizabeth. Subduing the vultures: assessing government caps on recovery in sovereign debt litigation. Columbia Business Law Review, Washington, v. 2010, n. 2, p. 473-528, 2010. p. 516-517.

53 Na tentativa de encontrar bens penhoráveis, que serviriam de garantia à sua ação judicial, o fundo "abutre" Elliott Associates acabou revelando um esquema de corrupção estabelecido pelo governo do Congo, apontando mais de 82 mil dólares em fraudes. Segundo indícios revelados no caso, o governo congolense havia montado uma rede de empresas fictícias a fim de mascarar transações petrolíferas corruptas. AVERY, Ryan E. Out of the desert and to the oasis: legislation on predatory debt investing. University of Miami International and Comparative Law Review, Miami, v. 18, n. 2, p. 267-290, 2011. 
ato. Cabe aqui, porém, afirmar que muitas vezes os próprios fundos acabam gerando ações corruptas no meio do processo. Certamente, o litígio iniciado pelo fundo "abutre" Donegal teve o mérito de revelar o sistema corrupto anterior, porém, no decorrer deste processo, o próprio fundo de investimento, conforme indicam os autos, acabou utilizando processos corruptos para ter acesso aos títulos de débito soberanos. ${ }^{54}$

Conforme dissemos, não cabe desmerecer o ato benéfico realizado pelos fundos "abutres", mas não devemos esquecer, porém, que o retorno lucrativo é o primeiro e único objetivo desses fundos. A sua contribuição à transparência dos governos adquire natureza contraditória, portanto, quando os métodos empregados por esses fundos, desencadeiam corrupção ou estrago ainda maior para os Estados devedores. Ademais, segundo alguns autores, parece que as agências multinacionais cada vez mais estão voltadas a reduzir a corrupção nesses países altamente endividados. As organizações lideradas pelo Banco Mundial, FMI, por exemplo, têm implementado procedimentos destinados a aumentar a transparência das ações destes países. Não podemos negar que os fundos "abutres" chamaram a atenção para esses problemas e com isso os investidores retém os seus créditos, porém, devido ao estabelecimento dos programas de transparências destes órgãos internacionais, a corrupção poderá ser agora identificada durante as fases de reestruturação, seja com ou sem a participação dos fundos "abutres". ${ }^{55}$

54 Após a compra dos créditos da dívida externa zambiense, em 1999, o fundo abutre tentou entrar em negociações com o governo da Zâmbia. O fundo de investimento apresentou várias propostas de conversão da dívida que foram, incialmente, rejeitadas pela República da Zâmbia. Finalmente em 2003 o fundo abutre conseguiu realizar um acordo com o governo da Zâmbia. O acordo - que, segundo o governo da Zâmbia, havia sido confeccionado de maneira ilegal e por meios corruptos - foi essencial à estratégia do fundo Donegal. Isto porque, o acordo serviu para confirmar a validade da dívida do governo da Zâmbia perante o fundo e, mais importante, impediu que o governo da zambiense pudesse requerer o benefício da imunidade jurisdicional. O acordoprevia, expressamente, que "The Republic of Zambia irrevocably and unconditionally: (a) agrees that if Donegal brings proceedings against it or its assets in relation to this Agreement or the Debt, no immunity from those proceedings (including without limitation, suit, attachment prior to judgment, other attachment, the obtaining of judgment, execution or other enforcement) will be claimed by or on behalf of itself or with respect to its assets: (b) waives any such right of immunity which it or its assets now has or may subsequently acquire" Donegal International, Ltd. "Website do fundo de investimento Donegal.” Disponível em: <http:/ / www.donegalinternational.net/>. Acesso em: 21 ago. 2013.

55 Veja-se, neste sentido, AVERY, Ryan E. Out of the desert and to the oasis: legislation on predatory debt investing. University of $\mathrm{Mi}$ ami International and Comparative Law Review, Miami, v. 18, n. 2, p. 267-
Assim, não obstante os argumentos apresentados em prol da presença desses fundos no cenário internacional, a comunidade acadêmica continua a apresentar diversas propostas desenhadas, a fim de impedir a ação destes fundos no âmbito das dívidas soberanas, especialmente a fim de impedir a ação dos fundos "abutres" perante aqueles países que se encontram em situações extremamente críticas.

\section{A PERSONALIDADE JURÍDICA DOS FUNDOS ABU- TRES PERANTE O DIREITO INTERNACIONAL}

Muito embora algumas poucas normas e institutos do direito internacional geral tenham se desenvolvido nas últimas décadas, grande parte dos seus conceitos basilares clássicos não parecem ter acompanhado o mesmo rito evolucionário. Para alguns autores, por exemplo, são pessoas jurídicas de direito internacional público os Estados soberanos (aos quais se equiparam a Santa Sé) e as organizações internacionais em sentido estrito. Os primeiros sendo possuindo uma personalidade jurídica originária, enquanto os segundos possuem a personalidade derivada.

Não têm, portanto, para esses autores, personalidade jurídica os indivíduos, tampouco as empresas. Isso porque, segundo algumas teses, para que a ideia se torne científica, e não meramente "declamatória", seria necessário que os aspirantes a tal posição dispusessem, ao menos, "da prerrogativa ampla de reclamar, nos foros internacionais, a garantia de seu direito, e que tal qualidade resultasse de norma geral", e não de acordos tópicos do seu Estado pátrio com as cortes internacionais. ${ }^{56}$

Outros, contudo, afirmam, categoricamente, a consideração do indivíduo como unidade primaria e sujeito por excelência do direito internacional, observando, inclusive, à emergência de outros sujeitos internacionais, de natureza intergovernamental, supranacional, não governamental, bem como de sujeitos especiais, ou, ainda, atípicos. ${ }^{57}$

\section{0, 2011. p. 281-282.}

56 RESEK, Fransisco. Direito internacional público. 14. ed. São Paulo: Saraiva, 2013.

57 MACHADO, Jónatas Eduardo Mendes. Direito internacional: do paradigma clássico ao pós-11 de setembro. 2. ed. Coimbra: Coimbra, 2004; BROWNLIE, Ian. Principles of public international law. Oxford: Oxford University, 2003. p. 61-63. 
Assim, tendemos a refutar as extremas doutrinas clássicas, concordando com aquelas outras advindas da escola sociológica, defendendo, contudo, não somente a classificação dos indivíduos como sujeitos de direito internacional, mas sim a caracterização de outros entes que também podem assumir um papel de extrema importância no cenário internacional. Afinal, aqueles que podem ser considerados como membros da comunidade internacional, por serem destinatários diretos das suas normas, também o devem ser considerados como sujeitos de direito internacional. ${ }^{58}$ Ainda mais que, conforme refletido em um famoso dictum do Tribunal Internacional de Justiça, no parecer de Reparação dos prejuízos sofridos ao serviço das Nações Unidas, os sujeitos de direito, em um sistema jurídico, não necessariamente precisam ser idênticos quanto à sua natureza ou ao alcance dos seus direitos. Não existindo, assim, qualquer proibição quanto à coexistência de uma multiplicidade de sujeitos de direito internacional, que se distinguem por estatutos jurídicos diferentes e uma personalidade jurídica mais ou menos caracterizada. ${ }^{59}$ Por certo, não poderão ser, assim, considerados, contudo, de outra forma senão como pessoas jurídicas com personalidades derivadas.

As constantes tentativas de refrear a ação dos fundos abutres por meio de normas internacionais demonstram, claramente, a possibilidade de esses novos atores serem, direta e especificamente, afetados por normas internacionais, levando à crença de que esses atores poderão sim (se é que já não podem) ser considerados como sujeitos de direito internacional. Pesa, ainda, para a clara possibilidade, o fato de que esses atores, por vezes, e de certa forma, acabam garantindo, inclusive, o cumprimento das normas internacionais por parte dos Estados. Essas afirmações encontram respaldo, ainda, nas novas teses que vêm apontando uma drástica mudança nos paradigmas do direito internacional, ainda que estas ainda se encontrem em fase embrionária.

Essas novas teses afirmam que a globalização foi responsável por realocar os poderes político-econômicos, antes pertencentes somente aos Estados, entre os diversos atores do cenário internacional, levando ao entendimento de que, embora os argumentos da "mor-

58 PELLET, Alain; DINH, Nguyen Quoc; DAILLIER, Patrick. Direito internacional público. Lisboa: Calouste Gulbenkian, 2003. p. 412-413.

59 PELLET, Alain; DINH, Nguyen Quoc; DAILLIER, Patrick. Direito internacional público. Lisboa: Calouste Gulbenkian, 2003. p. 413 te" do Estado sejam exagerados, em alguns aspectos, a globalização enfraqueceu os Estados, deixando-os mais vulneráveis às forças globais. ${ }^{60}$

Sem dúvida, se analisarmos o comportamento do cenário internacional, nomeadamente na seara das dívidas soberanas, é possível afirmar os fundos "abutres" já passaram de meros coadjuvantes para atores principais, que hoje certamente se encontram sob os holofotes do cenário internacional. Sem dúvida, se os Estados realmente estão sendo enfraquecidos pelo processo de globalização, também é possível afirmar que outros atores estão prontos para preencher essa lacuna de poder, explorando e moldando as relações internacionais por meio do exercício da sua influência em situações oportunistas. ${ }^{61}$

A erosão dos institutos jurídicos que protegiam a soberania dos Estados, em muito acelerada devido às decisões políticas passadas, e o estabelecimento das condições econômicas ideais para a proliferação dos fundos "abutres" demonstram, claramente, embora em um âmbito limitado, a verificação da tendência da mudança do paradigma internacional já defendido por alguns autores.

Se acatarmos como verdadeira essa linha interpretativa que afirma a mudança do paradigma jurídico internacional que tem o Estado como objeto central para um paradigma que coloca ao centro as entidades corporativas, podemos afirmar que a presença e a proliferação dos fundos "abutres" no cenário internacional deixam de ser resultado de uma descompassada evolução entre o cenário econômico e o cenário político-jurídico, passando a ser, na verdade, um sinal da tendência que está a se instaurar no cenário internacional. Certamente, a coibição da atuação desses fundos, nesse cenário, pode tornar-se mais complicada.

\section{Considerações finais}

Em suma, no mínimo, devemos admitir que os fundos "abutres" já protagonizam papel de destaque no

60 Cfr GARCIA, Frank J. Globalization, power, states, and the role of law. Boston College Law Review, Boston, v. 54, n. 3, p. 903-919, 2013. p. 903.

61 GARCIA, Frank J. Globalization, power, states, and the role of law. Boston College Law Review, Boston, v. 54, n. 3, p. 903-919, 2013. p. 911. 
âmbito das dívidas soberanas, possuindo, caso a caso, e com algumas ressalvas, importante papel no cenário das dívidas soberanas. A afirmação categórica da sua personalidade jurídica, contudo, ainda não encontra respaldo nos clássicos conceitos jusinternacionalistas, o que, tendo em vista as constantes mudanças trazidas pelo novo cenário internacional globalizado, não nos parecem obstáculo à sua caracterização como tal em um futuro extremamente próximo, se não já presente.

\section{REFERÊNCIAS}

ALMEIDA, Francisco Ferreira de. Direito internacional público. 2. ed. Coimbra: Coimbra, 2003.

AREWA, Olufunmilayo B. Vultures, hyenas, and african debt: private equity and Zambia. Northwestern Journal of International Law and Business, Chicago, v. 29, n. 3, p. 643674, July/Sept. 2009.

AVERY, Ryan E. Out of the desert and to the oasis: legislation on predatory debt investing. University of Miami International and Comparative Law Review, Miami, v. 18, n. 2, p. 267-290, 2011.

BAER, Werner Baer; MARGOT, Diego Margot; MONTES-ROJAS, Gabriel. Argentina's default and the lack of dire consequences. Economia Aplicada, Ribeirão Preto, v. 15, n. 1, p. 131-146, jan./mar. 2011.

BLACKMAN, Jonathan I.; MUKHI, Rahul. The evolution of modern sovereign debt litigation: vultures, alter egos, and other legal fauna. Law and Contemporany Problems, Durham, v. 73, p. 47-61, 2010.

BOSCO, David. The debt frenzy. Foreign Policy, Washington, n. 161, p. 36-42, July/Aug. 2007.

BRASIL. Ministério das Relações Exteriores. Comunicado Conjunto dos Presidentes dos Estados Partes do Mercosul. Disponível em: <http://www.itamaraty.gov.br/ index.php?option $=$ com_content\&view $=$ article\&id $=3$ 250:comunicado-conjunto-dos-presidentes-dos-estados-partes-do-mercosul-brasilia-7-de-dezembro-de$2012 \&$ catid $=42 \&$ lang $=p t-B R \& I t e m i d=280>$. Acesso em: 15 dez. 2015.

BRITO, Wladmir. Direito internacional público. Coimbra: Coimbra, 2008.

BROOMFIELD, Elizabeth. Subduing the vultures: as- sessing government caps on recovery in sovereign debt litigation. Columbia Business Law Review, Washington, v. 2010, n. 2, p. 473-528, 2010.

BROWNLIE, Ian. Principles of public international law. Oxford: Oxford University, 2003.

CARSON, Scott Alan. Vulture investors, predators of the 90s: an ethical examination. Journal of Business Ethics, Berlin, v. 17, n. 5, p. 543-555, 1998.

CARVALHO, Geraldes de. Da imunidade jurisdicional dos Estados estrangeiros. Colectânea de Jurisprudência, v. 10, n. 4, p. 33-37, 1985.

CASSESE, Antonio. International law in a divided world. Oxford: Clarendon, 1986.

DING, Yilin. Absolute, restrictive, or something more: did Beijing choose the right type of sovereign immunity for Hong Kong?. Emory International Law Review, Atlanta, v. 26, p. 997-1037, 2012.

DOLINGER, Jacob. A imunidade jurisdicional dos Estados. Revista de Informação Legislativa, Brasília, v. 19, n. 76, p. 5-64, 1982.

EDWARDS, Sebastian. Crisis and reform in Latin America: from despair to hope. New York: Oxford University, 1995.

FISCH, Jill; GENTILE, Caroline. Vultures or vanguards?: the role of litigation in sovereign debt restructuring. Emory Law Journal, Atlanta, v. 53, n. 1043, p. 1047-1116, 2004.

FUNG, William; HSIEH, David A. Empirical characteristics of dynamic trading strategies: the case of hedge funds. Review of Financial Studies, Oxford, v. 10, n. 2, p. 75-302, 1997.

GARCIA, Frank J. Globalization, power, states, and the role of law. Boston College Law Review, Boston, v. 54, n. 3, p. 903-919, 2013.

GOLDMAN, Samuel E. Mavericks in the market: the emerging problem of hold-outs in sovereign debt restructuring. UCLA Journal of International Law and Foreign Affairs, California v. 5, p. 159-197, 2000.

GOREN, Jonathan. State-to-State debts: sovereign immunity and the "vulture" hunt. The George Washington International Law Review, Washington, v. 41, n. 3, p. 681708, 2010.

GULATI, Mitu. Sovereign debt after 2013: things will never be the same again. Capital Markets Law Journal, 
Oxford v. 8, n. 2, p. 117-120, 2013.

HASELER, Sonke. Collective action clauses in international sovereign contracts: whence the opposition?. Journal of Economic Surveys, New Jersey, v. 23, n. 5, p. 882 923, 2009.

HAYS II, James M. The sovereign debt dilemma. Brooklyn Law Review, New York, v. 75, n. 3, p. 905-933, 2010.

HURLEY, Gail. Taming the vultures: are new measures enough to protect debt relief gains? Belgiui: Eurodad, dez. 2008. Available at: <http://eurodad.org/uploadedfiles/whats_new/reports/the $\% 20$ rise $\% 20$ of $\% 20$ the $\% 20$ vulture $\% 20$ layout.pdf $>$. Accessed on: $16 \mathrm{dec}$. 2015.

LHABITANT, François-Serge. Handbook of hedge funds. England: J. W. and Sons, 2011.

LO, Andrew W. Risk management for hedge funds: introduction and overview. Financial Analysts Journal, Stanford, v. 57, n. 6, p. 16-33, Nov./Dec. 2001.

MACHADO, Jónatas Eduardo Mendes. Direito internacional: do paradigma clássico ao pós-11 de setembro. 2. ed. Coimbra: Coimbra, 2004.

MADRUGA FILHO, Antenor Pereira. A renúncia à imunidade de jurisdição pelo estado brasileiro e o novo direito da imunidade de jurisdição. São Paulo: Renovar, 2003.

MONTELEONE, Theresa A. A vulture's gamble: high-stakes interpretation of sovereign debt contracts in NML Capital, Ltd v Republic of Argentina. Capital Markets Law Journal, Oxford, v. 8, n. 2, p. 149-165, 2013.

NGUYEN, Davy V. H. Too big to fail? towards a sovereign bankruptcy regime. Cornell International Law Journal, New York, v. 45, n. 3, p. 697-723, 2012.

PELLET, Alain; DINH, Nguyen Quoc; DAILLIER, Patrick. Direito internacional público. Lisboa: Calouste Gulbenkian, 2003.

POWER, Philip J. Sovereign debt: the rise of the secondary market and its implications for future restructurings. Fordham Law Review, New York, v. 64, n. 6, p. 2071-2077, Sept./Mar. 1996.

PROCTOR, Charles. Vulture funds and sovereign debt: the zambian experience. Journal of South African Law, Philadelphia, n. 4, p. 629-641, 2007.

RESEK, Fransisco. Direito internacional público. 14. ed. São Paulo: Saraiva, 2013.
SALIBA, Aziz Tuffi. A imunidade absoluta de jurisdição de Estados: sólida regra costumeira ou mito? Revista Brasileira de Direito Público, Belo Horizonte, v. 3, n. 8, p. 17-51, 2005.

SCHUMACHER, Julian; TREBESCH, Christoph; ENDERLEIN, Henrik. Sovereign defaults in court: the rise of creditor litigation 1976-2010. Social Science Research Network, June 2013. Available at: <http://www.scu. edu/business/economics/upload/SovereignDefaultsinCourt.pdf>. Accessed on: 16 dec. 2015.

SHAW, Malcolm N. International law. 6. ed. Cambridge: Cambridge University, 2008.

SILVA, Alexandre Pereira da; PEREIRA, Mariana Yante Barrêto. "Fundos abutres" vs. Estados nacionais: soberania e atuação do Tribunal Internacional do Direito do Mar a partir do caso da fragata libertad. Revista de Direito Internacional, Brasília, v. 10, n. 1, 2013.

SOOKUN, Devi. Stop vulture fund lawsuits: a handbook. London: Commonwealth Secretariat, 2010.

UNITED STATES. Court of Appeals. Allied Bank International vs. Banco Credito Agrícola. Setence March 18, 1985. Available at: <http://www.leagle.com/decision/ 19851273757F2d516_11184/ALLIED\%20BANK\%20 INTERN.\%20v.\%20BANCO \%20CREDITO \%20 AGRICOLA>. Accessed on: 16 dec. 2015.

UNITED STATES. District Court. CIBC Bank and Trust co. vs. Banco Central do Brasil. Setence May 9, 1995. Available at: <http://www.leagle.com/decision/1995199 1886FSupp1105_11830/CIBC\%20BANK\%20\&\%20 TRUST\%20CO.\%20v.\%20BANCO $\% 20$ CENT. $\% 20$ do\%20BRASIL>. Accessed on: 16 dec. 2015.

WAIBEL, Michael. Sovereign defaults before international courts and tribunals. Cambridge: Cambridge University, 2011.

WEI, Jiang; KAI, Li; WEI, Wang. Hedge funds and chapter 11. The Journal of Finance, v. 67, n. 2, p. 513-559, 2012.

WHEELER, Christopher C.; ATTARAN, Amir. Declawing the vulture funds: rehabilitation of a comity defense in sovereign debt litigation. Stanford Journal of International Law, Stanford, v. 39, p. 253-284, 2003.

WOLLASTON, Andrew. The growing importance of debt in european corporate transactions. Insolvency Intelligence, London, v. 18, n. 10, p. 145-149, 2005. 
YAP, Suniati. Investing in chapter 11 companies: vultures or white knights?. Southewestern Journal of Law and Trade in the Americas, California, v. 2, p. 153-174, Mar./ Apr. 1995.
ZAMBIA loses 'vulture fund' case. BBC News, London, Feb 15, 2007. Available at: <http://www.scu.edu/business/economics/upload/SovereignDefaultsinCourt. pdf $>$. Accessed on: 16 dec. 2015. 


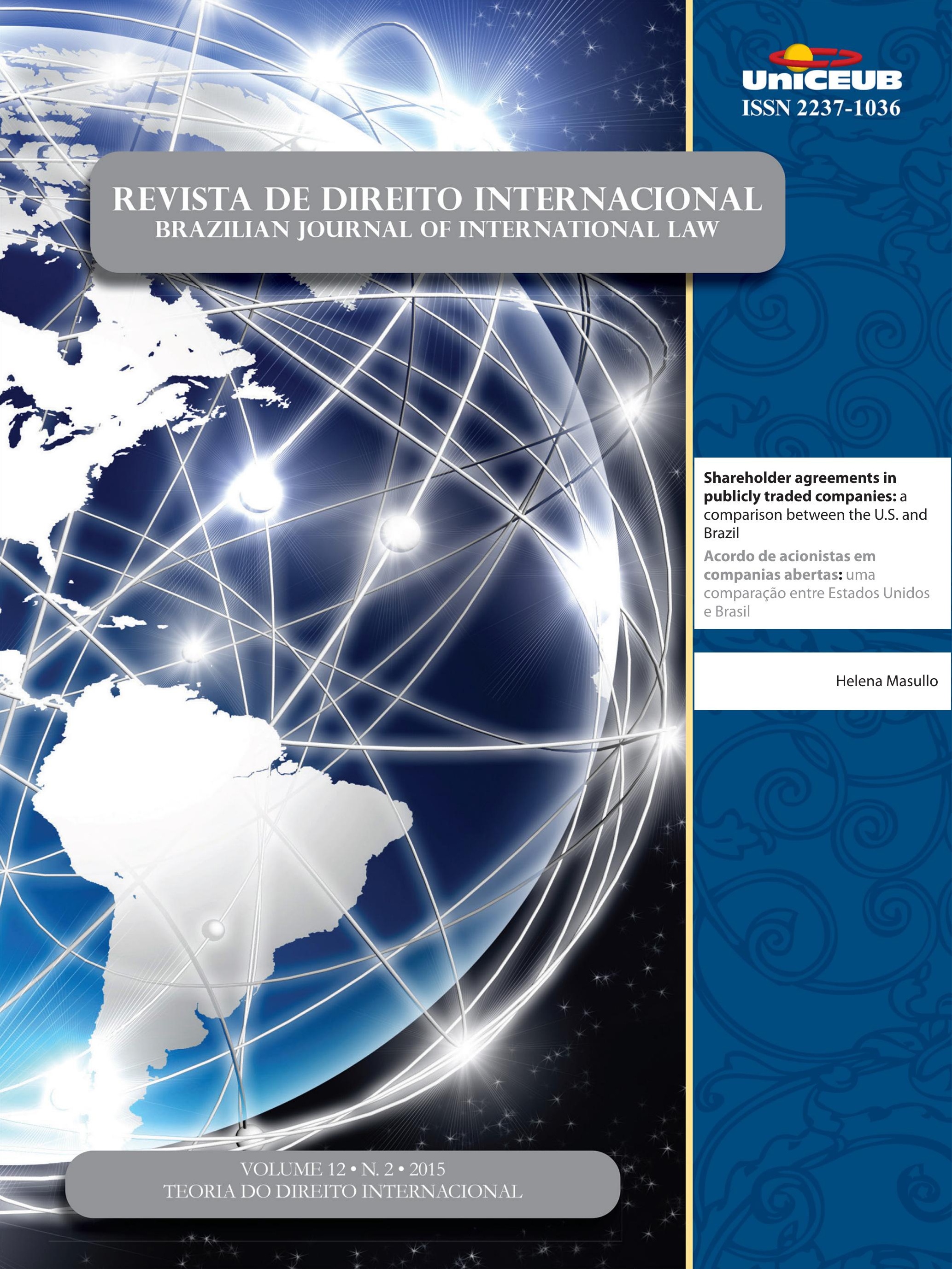




\section{Shareholder agreements in publicly traded companies: a comparison between the U.S. and Brazil*}

\author{
Acordo de acionistas em companias abertas: \\ uma comparação entre Estados Unidos e Brasil
}

Helena Masullo**

\begin{abstract}
We know remarkably little about the use of shareholder agreements in publicly held companies. This article builds upon empirical evidence to advance the theoretical understanding in comparative law of how and why shareholders agreements are used by publicly traded firms. It also contributes to the existing literature on comparative contract design. The evidence suggests great divergence in the incidence and content of shareholder agreements in both countries. Consistent with prior studies, we find that shareholder agreements are frequent in Brazilian corporate culture, where they are used to coordinate corporate decision-making and bind directors' votes, in such a way that the best corporate governance practices are being disregarded. But while conventional wisdom suggests that U.S. public corporations do not have shareholders agreements, such understanding is inaccurate. Nevertheless, the existing agreements differ from their Brazilian counterparts in that they are usually used in order to achieve a specific corporate transaction. Many findings of this study are surprising and challenge the current thinking in terms of contract design. For example, it finds no major stylistic differences between the agreements of the two countries, which contradicts the prevailing belief that U.S. contracts are necessarily longer than those of civil-law countries. Moreover, while arbitration appears as the preferred method of dispute resolution in Brazil, U.S. parties opt for judicial dispute resolution with greater frequency, mostly in Delaware and New York courts.
\end{abstract}

Keywords: Shareholder agreement. Empirical research. Contract design and business law.

\section{Resumo}

Sabe-se pouco sobre o uso de acordos de acionistas em companhias abertas. Este artigo utiliza evidências empíricas para progredir a compreensão teórica em direito comparado sobre a razão e a maneira pelas quais acordos de acionistas são utilizadas por companhias de capital aberto. O artigo também traz contribuições à literatura existente em direito contratual. As evidências sugerem que existe uma diferença relevante em relação à existência e ao conteúdo de acordos de acionistas no Brasil e nos Es- 
tados Unidos. Coerente com estudos anteriores, descobrimos que acordos de acionistas são frequentes na cultura corporativa brasileira, em que eles são utilizados para coordenar decisões corporativas e vincular os votos dos administradores, de modo que as melhores práticas de governança corporativa muitas vezes são desconsideradas. Embora a visão convencional indique que as companhias abertas norte-americanas não possuem acordos de acionistas, tal visão é imprecisa. Não obstante, os acordos existentes no cenário norte-americano diferem daqueles utilizados por companhias brasileiras, uma vez que aqueles são normalmente utilizados para concretizar determinada operação societária. Diversas descobertas desse estudo são surpreendentes e desafiam o entendimento atual em termos de estilo contratual. Por exemplo, verificam-se poucas diferenças estilísticas entre os acordos de acionistas dos dois países, o que contradiz o entendimento prevalecente de que os contratos norte-americanos são necessariamente mais longos do que aqueles proveniente de países de civil law. Além disso, enquanto a arbitragem parece ser o método preferido de resolução de disputas no Brasil, os norte-americanos optam por resolver disputas no âmbito judicial com maior frequência, sobretudo nas cortes de Delaware e Nova Iorque.

Palavras-Chave: Acordos de Acionistas. Pesquisa Empírica. Direito Societário e Contratual.

\section{INTRODUCTION}

We know remarkably little about the use of shareholder agreements in publicly held companies. The existing corporate law literature generally focuses on shareholder agreements entered into by shareholders of privately held corporations ${ }^{1}$. However, such agreements are far absent in the context of listed corporations. This article shows that shareholder agreements are present in publicly traded firms of both civil law and common law countries and contributes to the enrichment of the literature on this relevant corporate tool.

A shareholder agreement is a contract that governs

1 VENTORUZZO, Marco. Why Shareholders' Agreements are not used in U.S. Listed Corporations: a Conundrum in Search of an Explanation. Penn State Law Research Paper, n. 42, 2013; CARVALHOSA, Modesto. Acordo de acionistas: homenagem a Celso Barbi Filho. São Paulo: Saraiva, 2011. EIZIRIK, Nelson. A lei das S/A comentada. Cidade: Editora, 2011. the relationship among shareholders through specific rights and duties not included in the articles of incorporation or bylaws of the company. It typically regulates the manner in which shareholders vote and establish restrictions on the free transferability of shares. Since shareholders agreements are generally governed by the rules of contract law, they are endowed with greater flexibility vis-à-vis other organizational documents.

This study is based on a sample of hand-collected shareholder agreements entered into by Brazilian and U.S. publicly traded firms between 2010 and 2012. It analyzes all relevant clauses of a shareholder agreement, investigating the following issues: voting agreements, provisions concerning the election of directors, restrictions on director's corporate powers, limitations on the free transferability of shares, the identity of the shareholders of the company and method of dispute resolution.

The study focused on a period of three years for two main reasons: to collect a relevant sample of documents and to deal with technical issues regarding the collection and availability of date. EDGAR's electronic database does not have a specific field for shareholder agreements, so that the author had to use the "full-text search" field to find such documents. Such a time restriction helped to limit the number of documents collected. To illustrate, in the short period of three years the author had to analyze more than 8.000 documents to collect a sample of 69 shareholder agreements. Additionally, the period of 2010 to 2012 was specifically chosen to provide a current review on this corporate instrument and Brazilian studies conducted in previous years.

This provides the best comparative analysis of shareholder agreements of public companies in different countries. The author opted to compare the U.S. and Brazil to identify similarities and differences between contrasting corporate contexts. Brazil is a jurisdiction where, according to the existing literature ${ }^{2}$, shareholder agrrements play a key role in corporate governance. In contrast, although the U.S. is the jurisdiction with the largest equity markets and the focus of corporate gover-

2 GORGA, Érica. Changing The Paradigm Of Stock Ownership From Concentrated Towards Dispersed Ownership? Evidence From Brazil And Consequences For Emerging Countries. Northwestern Journal of International Law \& Business, v. 29, p. 439-462-463, 2009; ALDRIGHI, Dante Mendes; MAZZER NETO, Roberto. Estrutura de propriedade e de controle das empresas de capital aberto no Brasil. Revista de Economia Politica, v. 25, p. 115-132, 2005. 
nance literature, U.S. shareholder agreements are mostly employed in relation to corporate transactions, addressing specific issues. In this framework, the study aims to identify and explore possible effects of shareholder agreements on the best corporate governance practices.

The results of this study challenge the conventional wisdom that shareholder agreements are not used in U.S. public corporations. Although rare, this study finds that such agreements are employed in several contexts by these companies, though mostly in connection with specific corporate transactions, such as voting agreements signed in connection with the closing of a merger agreement. Moreover, the evidence shows that Brazilian public companies commonly use shareholder agreements to provide for central issues of corporate governance, in such a way that they are truly frequent in Brazilian corporate culture.

After examining their incidence in both countries, the author explores different hypotheses to explain why in Brazil shareholder agreements are vastly used by public companies while in the United States they are not. One possible explanation is that the tradition of concentrated control in Brazilian companies has encouraged non-controlling shareholders to enter into agreements to establish (or share) corporate control. On the contrary, shareholders of U.S. public companies do not recognize the same value in shareholder agreements. This may be explained by the relatively dispersed capital structure of U.S. companies. After all, to sign an agreement, a limited group of shareholders is necessary and each of them must have a significant number of shares, in such a way that they will be able to make relevant decisions together. For example, if a shareholder owns $15 \%$ of the corporation shares, but the next largest shareholders own less than $1 \%$, it would be inefficient for the block holder to seek an agreement with the other shareholders. Accordingly, this study compares how shareholder agreements impact the companies' control in regimes with different capital structures.

Furthermore, the two legal systems differ in their legal treatment of shareholders agreements. The article indicates that, unlike the Brazilian legal framework, which promotes the use of shareholder agreements, U.S. law deters companies from using such agreements. It also discusses other potential explanations for the different incidence of shareholder agreements in both countries.
The best corporate governance practices reflect individual and collective interests of shareholders, as well as the interests of the stakeholders of the company (as employees, customers, suppliers, creditors etc.). According to the Brazilian Institute of Corporate Governance (IBGC), corporate governance is

The system by which organizations are managed,
monitored and encouraged, involving the
relationship between owners, board of directors,
executive officers and control bodies. The best
corporate governance practices convert principles
into objective recommendations, aligning interests
in order to preserve and optimize the value of
the organization, facilitating access to capital and
contributing to its longevity ${ }^{3}$.

The best practices require respect for the following principles: transparency, accountability, equity and corporate responsibility ${ }^{4}$. The protection of minority shareholders is one of the basic conditions for an environment that fosters the best corporate governance practices, as it ensures fairness between shareholders and prevent the expropriation of rights by controlling shareholders.

In this vein, this study argues that shareholder agreements may operate in the same or in the opposite direction of the best corporate governance practices, depending on their purpose and use. Taking this into account, this study shows that U.S. agreements do not restrict rights and obligations of the shareholders and of the management as much as the Brazilian agreements. For instance, while many Brazilian companies seek to use shareholder agreements to bind the votes of corporate directors, U.S. agreements do not contain similar provisions. This is consistent with related work by Erica Gorga and Marina Gelman, which describes what they see as negative uses of shareholder agreement in Brazil. As an example, they state that shareholder agreements that create limitations to the board of directors are being used in such a way that the responsibility to act with independence and commitment in the full exercise of the Board is annulled 5 . In this sense, the study indicates

3 IBCG. Governança Corporativa. Available at: <http://www.ibgc. org.br/Secao.aspx?CodSecao $=17>$

4 IBCG. Governança Corporativa. Available at: <http://www.ibgc. org.br/Secao.aspx?CodSecao $=17>$.

5 GORGA, Érica; GELMAN, Marina. O esvaziamento crescente do conselho de administração como efeito da vinculação de seu voto a acordos de acionistas no Brasil. In: INSTITUTO BRASILEIRO GOVERNANÇA CORPORATIVA, 13, 2012, São Paulo. Anais... São Paulo, 2012. 
that a shareholder agreement may run over corporate law and market rules obliging protection of minority shareholders and compliance with the best corporate governance practices, as equal treatment of shareholders and fulfillment of the duties of loyalty and care by the directors and officers.

Nevertheless, there is significant debate in the literature about the merits of shareholder agreements. For example, Morten Bennedsen and Daniel Wolfenzon suggest that a shareholder agreement may be beneficial for minority shareholders, when granting veto powers on certain matters that must be deliberated by the general meeting ${ }^{6}$. Furthermore, other studies suggest that it would be more difficult for a group of shareholders who entered into an agreement to extract private benefits of control, as opposed to one controlling shareholder ${ }^{7}$. In this sense, the agreement enables companies to maintain an intermediate level between a single controlling shareholder and an extremely diffuse control of capital. Consequently, it helps to reduce agency costs through management oversight by the signing shareholders and prevents the expropriation of minority shareholders' rights $^{8}$. Thus, joint control through shareholder agreements has some promise as a mechanism to reduce private benefits of control' .

Besides analyzing the typical rights and duties included in shareholder agreements of Brazilian and U.S. public firms and their incidence in both countries, this article will explore the contractual style of the agreements. There are theoretical discussions that claim that U.S. contracts are overly descriptive and detailed, as analyzed by Thomas Lundmark and John Langbein. The main finding of this study contradicts the current thinking on contractual style in the sense that U.S. contracts are inherently longer. It attests that there are no

6 WOLFENZON, Daniel; BENNEDSEN, Morten. The Balance of Power in Closely Held Corporations. Journal of Financial Economics, v. 58, p. 113 - 139, 2000.

7 HANSMANN, Henry; PARGENDLER, Mariana; GILSON, Ronald J. Regulatory Dualism as a Development Strategy: Corporate Reform in Brazil, the United States, and the European Union. Stanford Law Review, Stanford, v. 63, p. 475-498, 2011.

8 HANSMANN, Henry; PARGENDLER, Mariana; GILSON, Ronald J. Regulatory Dualism as a Development Strategy: Corporate Reform in Brazil, the United States, and the European Union. Stanford Law Review, Stanford, v. 63, p. 475-498, 2011.

9 HANSMANN, Henry; PARGENDLER, Mariana; GILSON, Ronald J. Regulatory Dualism as a Development Strategy: Corporate Reform in Brazil, the United States, and the European Union. Stanford Law Review, Stanford, v. 63, p. 475-498, 2011. relevant differences between shareholder agreements of Brazil, a civil law country, and the U.S., a common law country, as they are similar in length.

The goal of this study is to document the use and content of shareholder agreements in Brazilian public companies and compare it to the U.S. context, taking into account best corporate governance practices. Based on this goal, it pursues a comparative analysis that takes into consideration quantitative and qualitative aspects of the data collected. As a result, hypotheses are proposed to explain its main findings, in such a way that the comparative literature on corporate law is not only contested, but also enriched.

This article proceeds as follows. Part II presents the empirical evidence on the use and content of shareholder agreements of public companies in the U.S. and Brazil, in light of existing corporate law scholarship and taking into account possible effects on the best corporate governance practices. Part III outlines the main features of the design of shareholder agreement in both countries. Part IV draws conclusions and calls for discussion on the use of shareholder agreements in comparative law.

\section{The Use and Content of Shareholder Agreements in Brazil Compared to The U.S.}

The empirical evidence collected by the author ${ }^{10}$ demonstrates that, between 2010 and 2012, 54 publicly held Brazilian companies signed 64 shareholder agreements ${ }^{11}$. In the U.S., in this same period, approximately 69 shareholder agreements were signed by 65 U.S. public companies. Until December 2012, there were approximately 353 listed corporations in Brazil ${ }^{12}$, while in

10 The study involves hand-collected data available from the shareholder agreements filed with CVM and with SEC. The author collected all Brazilian shareholder agreements signed between 2010 and 2012, considering that CVM's electronic database has a specific field indicating all existing shareholder agreements of Brazilian public companies. In relation to U.S. shareholder agreements, the author collected a sample of the agreements signed between 2010 and 2012, as EDGAR's electronic database does not have a specific field for shareholder agreements, in such a way that the author had to use the "full-text search" field to find such documents. See infra Table 1 and Table 2.

11 Of them, 39 companies were listed on a special segment of BM\&FBOVESPA.

12 The World Bank, World Development Indicators: Stock markets, 
the U.S. there were approximately 4,102 publicly held companies ${ }^{13}$. Illustratively, this means $1,58 \%$ of U.S. publicly companies entered into a shareholder agreement in the period analyzed, while in Brazil, in the same period, this number represents $15,29 \%$ of Brazilian public companies. Taking these numbers into account, it is possible to infer that Brazilian publicly held companies use shareholder agreements far more than the U.S listed corporations, in which such a corporate tool is not as typical.

The empirical study confirms that shareholder agreement are intensely employed in Brazil, by means of clauses that coordinate corporate decision-making, bind directors' votes and intensely limit the free transferability of shares. By contrast, in the U.S., shareholders sign an agreement in order mainly to achieve a corporate transaction, predominantly establishing rules to govern the election of directors and the transferability of shares.

Considering that shareholder agreements are commonly identified in the Brazilian context, a number of studies have analyzed the use of such instrument. Érica Gorga empirically demonstrated that since the 1990s the use of shareholder agreements has greatly increased in Brazil ${ }^{14}$. Similarly, a study conducted in 2001 by Dante Mendes Aldrighi and Roberto Mazzer Neto concluded that shareholder agreements are a widespread practice among Brazilian companies ${ }^{15}$.

However, there is little American literature that addresses the theme of shareholder agreement in U.S. public companies, as noted by Marco Ventoruzzo ${ }^{16}$. This may be explained by the fact that, in the U.S., shareholder agreements are commonly used by closed corporations. Nevertheless, although rare, the present study proves that they are identified in publicly held companies, mainly in some specific transactions, as the entrance of an investment fund in the company.

2014. Available at: <http://wdi.worldbank.org/table/5.4>. (last updated June 15, 2014).

13 The World Bank, World Development Indicators: Stock markets, 2014. Available at: <http://wdi.worldbank.org/table/5.4> . (last updated June 15, 2014).

14 GORGA, Érica. Direito societário atual. Rio de Janeiro: Elsevier, 2013.

15 ALDRIGHI, Dante Mendes; MAZZER NETO, Roberto. Estrutura de propriedade e de controle das empresas de capital aberto no Brasil. Revista de Economia Política, v. 25, p. 115-132, 2005.

16 CLARK, Robert. Corporate Law. Litte, Brown, 1986.
There are different hypotheses to explain why listed companies in the U.S. employ shareholder agreements with comparatively little frequency. The first hypothesis relates to the historical predominance of dispersed ownership in U.S. public corporations. This is the classic thesis of Adolf Berle and Gardiner Means, who found that there is lack of a satisfactory number of holders with a substantial percentage of shares in U.S publicly held corporations that would be able to represent a block of control or, at least, a relevant block of common stock $^{17}$. Most of the times, a shareholder agreement is only beneficial when there is a limited group of shareholders with a significant number of shares that will be able to take relevant decisions together. For example, if a shareholder owns $20 \%$ of the corporation shares, but the next largest shareholders own less than $1 \%$, it would be futile or inefficient for the block holder to seek an agreement with the other shareholders ${ }^{18}$.

Ownership dispersion is identified in the majority of U.S. public companies. In 1929, some companies already had a high level of dispersion of the capital stock, meaning that the sum of the shares of the twenty largest shareholders accounted for somewhere around 5\% of the total capital stock of the company ${ }^{19}$. Nevertheless, there is an ongoing debate in the U.S. corporate literature that discusses the current trend toward ownership concentration in that context.

Clifford G. Holderness conducted a study that proves the existence of shareholders holding significant percentage of shares in U.S. public companies ${ }^{20}$. He believes that the level of ownership concentration in the U.S. is similar to that observed in other countries ${ }^{21}$. In a sample of 375 companies, $96 \%$ of them have block holders, that is, shareholders who have at least $5 \%$ of the company's shares ${ }^{22}$. Ronald J. Gilson and Jeffrey N.

17 BERLE Adolf A.; MEANS, Gardiner C. The Modern Corporation and Private Property. New Brunswick: Transaction, 1967. p. 47-65.

18 VENTORUZZO, Marco. Why Shareholders' Agreements are not used in U.S. Listed Corporations: a Conundrum in Search of an Explanation. Penn State Law Research Paper, n. 42, 2013.

19 BERLE, Adolf A.; MEANS, Gardiner C. A moderna sociedade anônima e a propriedade privada. Rio de Janeiro: Nova Cultural, 1988.

20 HOLDERNESS Clifford G. The Myth of Diffuse Ownership in the United States. Review of Financial Studies, v. 22, n. 4, p. 13781379, 2009.

21 HOLDERNESS Clifford G. The Myth of Diffuse Ownership in the United States. Review of Financial Studies, v. 22, n. 4, p. 13781379, 2009.

22 HOLDERNESS Clifford G. The Myth of Diffuse Ownership in the United States. Review of Financial Studies, v. 22, n. 4, p. 1378- 
Gordon have also questioned the prevalence of dispersed ownership in the U.S. They state that is common to find institutional investors with a relevant number of shares in U.S. public companies ${ }^{23}$. They note that, in 2011 , institutional investors had, approximately, $70 \%$ of the shares of the ten thousand largest public companies in the U.S. ${ }^{24}$.

However, although a recent trend toward ownership concentration is emerging in the U.S, it is clear that this is still far from the ownership concentration identified in Brazilian companies. In most Brazilian companies, one or more shareholders share corporate control, meaning that they have, at least, $51 \%$ of the company's shares. According to Dante Mendes Aldrighi and Roberto Mazzer Neto, on average, shareholder agreements of Brazilian companies involve three members and result in a concentration of more than $80 \%$ of the voting rights ${ }^{25}$. This number clearly contrasts with the $5 \%$ threshold used in Holderness's study. In this sense, equity ownership of U.S. companies may, indeed, impact the use of shareholder agreements.

The second hypothesis for the low use of shareholder agreements in U.S. public companies is the fact that most minority shareholders with significant shares of the company are institutional investors. Such investors, usually, do not want to limit their freedom to sell their shares or to vote in general meetings ${ }^{26}$. After all, most institutional investors have fiduciary duties related to the exercise of their vote ${ }^{27}$, in such a way that they cannot limit this right by means of a shareholder agreement.

Indeed, the evidence shows that clauses that restricted the vote of shareholders were mostly absent from the U.S. However, rules that establish the election of the

1384, 2009.

23 GORDON, Jeffrey N.; GILSON, Ronald J. The Agency Costs of Agency Capitalism: Activist Investors and the Revaluation of Governance Rights. Columbia Law Review, v. 113, p. 863-866, 2013.

24 GORDON, Jeffrey N.; GILSON, Ronald J. The Agency Costs of Agency Capitalism: Activist Investors and the Revaluation of Governance Rights. Columbia Law Review, v. 113, p. 863-866, 2013.

25 ALDRIGHI, Dante Mendes; M. NETO, Roberto. Estrutura de propriedade e de controle das empresas de capital aberto no Brasil. Revista de Economia Política, v. 25, p. 115-132, 2005.

26 VENTORUZZO, Marco. Why Shareholders' Agreements are not used in U.S. Listed Corporations: a Conundrum in Search of an Explanation. Penn State Law Research Paper, n. 42, 2013.

27 GORDON, Jeffrey N.; GILSON, Ronald J. The Agency Costs of Agency Capitalism: Activist Investors and the Revaluation of Governance Rights. Columbia Law Review, v. 113, p. 863-879-881, 2013. directors and limit the free transferability of shares were identified. This may indicate that, for institutional investors, a shareholder agreement might work as an efficient tool to influence the governance of the company and to guarantee their investment through clauses that limit the free transferability of shares to other shareholders.

The third hypothesis is the lack of extensive cross-holdings among listed corporations ${ }^{28}$. Interlocking participations among major shareholders in different companies would be an incentive to use shareholder agreements, since these shareholders would enter into these agreements in such a way that one of them would have control on the voting shares of one company while the other would control the other company.

As forth hypothesis, in the U.S. there are legal rules that prevent publicly held companies from using shareholder agreements ${ }^{29}$. First, minority shareholders are highly protected by law, in such a way that a relevant holder of the company would face high costs to sign a shareholder agreement with a large number of small holders. Secondly, block holders are subjected to a number of rules, as the Williams Act ${ }^{30}$. According to this Act, the beneficial owners of $5 \%$ or more of common stock must disclose their participations, indicating also the purpose of further acquisitions of the company's shares $^{31}$. Possibly, the members of a shareholder agreement may be considered a group for disclosure purposes. However, some investors might be unwilling to reveal their strategies of capital investing, creating a disincentive to sign of shareholder agreements.

Another example is identified in Delaware's Corporation Act, section 203, that provides that stockholders who acquire beneficial ownership of more than $15 \%$ of the stock of the company without prior approval of the board of directors turn into interested stockholders. In this sense, they cannot enter into business combinations, as mergers, with the corporation for a period of 3

28 GORDON, Jeffrey N.; GILSON, Ronald J. The Agency Costs of Agency Capitalism: Activist Investors and the Revaluation of Governance Rights. Columbia Law Review, v. 113, p. 863-881, 2013. 29 VENTORUZZO, Marco. Why Shareholders' Agreements are not used in U.S. Listed Corporations: a Conundrum in Search of an Explanation. Penn State Law Research Paper, n. 42, 2013.

30 VENTORUZZO, Marco. Why Shareholders' Agreements are not used in U.S. Listed Corporations: a Conundrum in Search of an Explanation. Penn State Law Research Paper, n. 42, 2013.

31 Securities Exchange Act of 1934 (48 Stat. 881, 15 U.S.C. 78a$78 \mathrm{kk})$. 
years without supermajority approvals ${ }^{32}$.

This forth hypothesis arises from Mark Roe's thesis. According to Roe, the dispersed ownership of U.S. companies is the result of political decisions motivated by the fear of concentrating economic power ${ }^{33}$. He believes that shareholder's activism is inhibited by legal norms ${ }^{34}$, in such a way that if such rules did not exist, the ownership structure in the U.S. would be more concentrated and, as a result, property would not have been separated from control ${ }^{35}$.

In this same vein, Black believes that the ownership structure in the U.S. can be explained by legal norms. He says that institutional investors are not active shareholders because they face information costs to decide which governance matters they will support, as well as to organize themselves in collective action to influence the directors of the company ${ }^{36}$. Black states that legal norms exacerbate this problem for hindering acquisition of a relevant number of shares, collective action of institutional investors and capability to choose directors to the Board ${ }^{37}$. Thus, shareholder agreements may be prevented in the context of U.S. public corporations for the reason that legal norms are not friendly to its usual purpose of collective action.

This legal landscape really differs from the one identified in Brazil, where the legal framework contributes to the signing of shareholder agreements by public companies. For example, when the Brazilian Corporation Law was changed in 2001, by Law 10.303/2001, norms related to shareholder agreement were modified to formally bind directors to such agreements ${ }^{38}$.

Finally, the last hypothesis is that U.S. shareholders have alternatives to shareholder agreement to strengthen their positions in the company. In the U.S., con-

32 DEL. CODE ANN. tit. 8, \$ 203 (2001).

33 ROE, Mark J. Strong managers, weak owners: the political roots of american corporate finance. Cambrigde: Harward Law, 1994. p. 24.

34 ROE, Mark J. Strong managers, weak owners: the political roots of american corporate finance. Cambrigde: Harward Law, 1994. p. 13-15.

35 ROE, Mark J. Strong managers, weak owners: the political roots of american corporate finance. Cambrigde: Harward Law, 1994. p. 24.

36 BLACK, Bernard S. Shareholder Activism and Corporate Governance in the United States. The New Palgrave Dictionary of Economics and the Law, v. 3, p. 459-475, 1998.

37 BLACK, Bernard S. Shareholder Activism and Corporate Governance in the United States. The New Palgrave Dictionary of Economics and the Law, v. 3, p. 459-475, 1998.

38 See Brazilian Corporation Law (Law 6.404), art. 118. trolling shareholders increasingly use dual-classes shares structures, which may be taking the place of the shareholder agreement ${ }^{39}$. This reason seems to be only applicable to U.S. companies, since although Brazilian corporations can create preferred shares, shareholder agreements are still used.

\section{A. The main objectives of signing shareholders}

In Brazil, the study shows that most of the agreements were signed by shareholders that aimed to constitute a block of control. The reasons for the formation of a block of control are several; as establishment of shared control, enter of a strategic shareholder in the company, organization of the family power and creation of joint ventures. In the Brazilian context, a control block is formed through the contribution of, at least, $51 \%$ of the voting shares of the company, which are necessary to the achievement of the absolute majority of the votes in the general meetings.

It was identified that in 44 Brazilian agreements (68,75\% of the total analyzed) the signing shareholders have more than $50 \%$ of the ordinary capital of the company. This data may indicate a change in the ownership structure of Brazilian companies, which is becoming more dispersed. Typical shareholder agreements used to be signed between the controlling shareholder and the minority shareholders, which desired to protect their economic interest in the company. However, such agreements are now being celebrated between minority shareholders who do not dispose of the power of control of the company individually, but, by means of a shareholder agreement, acquire this power ${ }^{40}$. Gorga corroborates this evidence of the article. She believes that the recent tendency of dispersed capital structure of Brazilian companies favored the creation of formal coalition between the shareholders, by means of shareholder agreements that are essential to the corporate governance of the company ${ }^{41}$.

39 VENTORUZZO, Marco. Why Shareholders' Agreements are not used in U.S. Listed Corporations: a Conundrum in Search of an Explanation. Penn State Law Research Paper, n. 42, 2013.

40 CARVALHOSA, Modesto. Acordo de acionistas: homenagem a Celso Barbi Filho. São Paulo: Saraiva, 2011.

41 GORGA, Érica. Corporate Control \& Governance after a Decade from "Novo Mercado": Changes in Ownership Structures and Shareholder Power in Brazil. Yale Law \& Economics Research Paper, n. 502, 2014. 
It was not possible to identify the stake of the shareholders of U.S. companies. However, the study revealed that in American agreements the parties do not establish themselves as a control block. This contrasts to what has been identified in Brazil, where the shareholders clearly state that they must be jointly considered the controlling shareholder of the company. It seems that the shareholders of a U.S. company do not have this aim of creating a block of control. Contrariwise, they are mainly motivated to have some specifics rights guaranteed, as electing a director of the company, and not to jointly act as a block.

These evidences lead to the following hypothesis: Brazil is moving towards dispersed control in public companies, which may be explained by the role assumed by Novo Mercado, a special listing segment of BM\&FBOVESPA, the main stock exchange in Brazil, in which common stock overlap preferred stock and rules that protect the minority shareholders are continuously preventing a single shareholder to command the company ${ }^{42}$. BM\&FBOVESPA has three special listing segments: Level 1, Level 2 and Novo Mercado. These segments were launched to foster the best corporate governance practices in the capital markets, since a company listed in one of these segments must comply with stricter requirements regarding corporate governance ${ }^{43}$. The requirements include disclosure and transparency duties (all segments), maintenance of a certain degree of free-float (all segments), unified term of two years maximum to all directors (Level 2 and Novo Mercado), presence of independent directors (Novo Mercado), voting rights granted to non-voting shareholders in some matters (Level 2) or the rule one-share-one-vote (Novo Mercado), tag-along rights (Level 1, Level 2 and Novo Mercado), obligation to hold a tender offer in some events (Level 2 and Novo Mercado) and adherence to the Market Arbitration Panel (Level 2 and Novo Mercado $)^{44}$. Novo Mercado is considered the most rigo-

42 GORGA, Érica. Changing The Paradigm Of Stock Ownership From Concentrated Towards Dispersed Ownership? Evidence From Brazil And Consequences For Emerging Countries. Northwestern Journal of International Law \& Business, v. 29, p. 439-462, 2009.

43 BOVESPA. O que são segmentos de listagem. Available at: <http://www.bmfbovespa.com.br/pt-br/servicos/solucoes-paraempresas/segmentos-de-

listagem/o-que-sao-segmentos-de-listagem.aspx?Idioma=pt-br $>$. 44 BOVESPA. O que são segmentos de listagem. Available at: $<$ http://www.bmfbovespa.com.br/pt-br/servicos/solucoes-paraempresas/segmentos-de-

listagem/o-que-sao-segmentos-de-listagem.aspx?Idioma=pt-br $>$. rous segment for being the only segment that requires the one-share-one-vote rule and tag-along for all minority shareholders at the same price paid for the shares of the controlling shareholder.

Canellas and Leal analyzed the structure of propriety and control of the Brazilian companies listed at BM\&FBOVESPA between 2004 and $2006^{45}$ and also concluded that dispersed ownership has increased in Brazil, especially at Novo Mercado ${ }^{46}$.

In this context, shareholder agreements are seen as effective mechanisms to establish control power. In the study, it is noticed that these agreements are commonly used by shareholders holding small values of shares when comparing to the percentage held by a major shareholder, which is typically $51 \%$ or more of the total stock of the company. These shareholders enter into an agreement in order to form a control block representing the majority of shares or, at least, to create a relevant group of shareholders that will make decisions together.

A shareholder agreement may be positive when it allows Brazilian companies to maintain an intermediate level of capital distribution between a single controlling shareholder and an extremely diffused control. The agreement may ensure stability to a group of shareholders that jointly hold the control of the company, preventing the creation of new coalitions and the appearance of desertions that would destabilize the control group ${ }^{47}$. In this sense, such corporate tool facilitates the implementation of joint control and inhibits ownership concentration by a single majority shareholder that could easily expropriate minority shareholder rights ${ }^{48}$. Additionally, this tool can help reduce agency costs, since the shareholders that signed the agreement may be more efficient in supervising the management of the company when compared to the supervision of a single shareholder.

45 LEAL, Ricardo P. C.; CANELLAS, Thiago Costa. Evolução da Estrutura de Controle das Empresas Listadas na Bovespa entre 2004 e 2006, 387 Relatórios Coppead 01, 18-19 (2009).

46 LEAL, Ricardo P. C.; CANELLAS, Thiago Costa. Evolução da Estrutura de Controle das Empresas Listadas na Bovespa entre 2004 e 2006, 387 Relatórios Coppead 01, 18-19 (2009).

47 GOMES, Armando; NOVAES, Walter. Multiple Large Shareholders in Corporate Governance 26 (February 17, 1999) (unpublished manuscript) (on file with author).

48 HANSMANN, Henry; PARGENDLER, Mariana; GILSON, Ronald J. Regulatory Dualism as a Development Strategy: Corporate Reform in Brazil, the United States, and the European Union. Stanford Law Review, Stanford, v. 63, p. 475-498, 2011. 
However, a legal problem arises when a shareholder agreement establishing a block of control leads to violations of best corporate governance practices. This takes place when the agreement removes key corporate decisions from the minority shareholders and the managers of the company. Controlling shareholders feel uncomfortable to grant powers to minority shareholders, fearing that their intrusion in the course of business will cause mismanagement and loss of control, which could negatively impact the value of the company's shares. Accordingly, ownership concentration through a shareholder agreement may create an agency problem between the largest holders and the minority shareholders as the company's control remains with a restricted group of shareholders that is not concerned with the interests of the minority.

La Porta, Lopes-de-Silanes and Shleifer believe that the structure of propriety and control of public companies is the result of the legal protection granted to minority shareholders ${ }^{49}$. In such countries where minorities are legally protected and where the enforcement is effective, corporate ownership tends to be less concentrated ${ }^{50}$.

Although the Brazilian capital market is advancing in the protection of minority rights and moving towards dispersed ownership, which can be mainly explained by the creation of special listing segments at BM\&FBOVESPA, ownership in Brazil is still concentrated. Gorga has demonstrated that concentrated ownership rises in those listing segments where the rule one-share-one-vote does not exist $\mathrm{t}^{51}$. In other words, dispersed ownership is only relevant at the Novo Mercado segment. In this sense, moving away from the Novo Mercado, the law is still insufficient in the protection of minority shareholders ${ }^{52}$. Such inadequate legal protection is mainly identified in the move away of the rule one-share-one-vote, which is enabled by the use of some mechanisms, as preferred shares ${ }^{53}$.

49 LA PORTA, Rafael; LOPES-DE-SILANES, Florencio; SHLEIFER, Andrei. Corporate Ownership Around the World. Journal of Finance, Cambridge, v.2, 1999.

50 ALDRIGHI, Dante Mendes; M. NETO, Roberto. Estrutura de propriedade e de controle das empresas de capital aberto no Brasil. Revista de Economia Política, v. 25, p. 115-132, 2005.

51 GORGA, Érica. Changing The Paradigm Of Stock Ownership From Concentrated Towards Dispersed Ownership? Evidence From Brazil And Consequences For Emerging Countries. Northwestern Journal of International Law \& Business, v. 29, p. 439-463, 2009.

52 ALDRIGHI, Dante Mendes; MAZZER NETO, Roberto. Estrutura de propriedade e de controle das empresas de capital aberto no Brasil. Revista de Economia Política, v. 25, p. 115-132, 2005.

53 ALDRIGHI, Dante Mendes; MAZZER NETO, Roberto. Es-
The research leads to the conclusion that companies listed in Novo Mercado do not necessarily comply with rules concerning the protection of minority shareholders, since shareholder agreements may violate the proportionality between political power and economic rights. Although the study shows that $46 \%$ of the analyzed Brazilian companies are listed in Novo Mercado, $60 \%$ of them represent a block of control that owns more than $50 \%$ of the company's capital and $80 \%$ of them establish voting obligations that relocate the voting power between shareholders, as the previous meeting mechanism, deliberations in the general meetings that depend on the previous manifestation of specific shareholders and obligation to vote jointly in general meetings. In this sense, shareholder agreements are overriding stricter listing segment rules.

The study further analyzed who were the parties to the shareholder agreement in both countries. The shareholder that was most identified in Brazil was Brazilian legal entities (41 agreements, equivalent to 59,42\%), while private individuals were identified in 37 contracts $(57,81 \%)$. In the U.S., legal entities were identified in 59 agreements $(85,5 \%)$ and private individuals in 36 $(52,17 \%)$. Though the study brings only a sample of the shareholder agreements of public companies in both countries, the state presence in Brazilian agreements is evident. In 11 Brazilian agreements (17,18\%) state presence is identified, by means of pension funds (as FUNCEF), state actors and BNDES. This may indicate the relevance of public financial support to Brazilian companies and this finding may collaborate with further studies on this matter.

\section{B. Tight control of directors and corporate matters}

The election of directors is intensely ruled by shareholder agreements in both countries, in the sense that such tool becomes relevant in the establishment of conditions to the corporate governance of the company. The study shows that 44 Brazilian agreements (68,75\%) create conditions to the election of the members of the board of directors by the shareholders. In the U.S., 57 agreements $(82,60 \%)$ have such clause.

Both Brazilian and American corporate law provide that shareholders must elect the directors of the com-

trutura de propriedade e de controle das empresas de capital aberto no Brasil. Revista de Economia Política, v. 25, p. 115-132, 2005. 
pany in general meetings. Thus, a shareholder agreement that seeks to regulate the director's election must have a clause that obliges the signatory shareholders to jointly exercise their vote in such general meetings. Therefore, agreements that regulate the election of directors consist in a voting agreement.

Besides establishing the election of directors, the agreements analyzed settled mandatory provisions to the board of directors. These provisions were more identified in Brazil than in the U.S. as 25 Brazilian agreements $(39 \%)$ have such provisions. Particularly, 15 of them imposed the election of the executive officers of the company by the shareholders, although according to the article 142 of the Brazilian Corporate Law the officers' election is an exclusive competency of the board of directors ${ }^{54}$. Curiously, 13 of such 15 agreements are listed in a special segment of BM\&FBOVESPA (Level 1, Level 2 and Novo Mercado). In this sense, not only corporate law is being infringed, but also market rules that demand the independence of directors.

Gorga and Gelman studied the rise of Brazilian shareholder agreements that restrict directors' vote through the so called "umbrella clauses". Such clauses allow the previous control of directors' decisions by the shareholders party to the agreement ${ }^{55}$. The article corroborates such discovery as it shows that the "previous meeting" mechanism was verified in 42 Brazilian companies $(65,62 \%)$ signed between 2010 an 2012. In 25 of such agreements (39\%), the previous meeting extends to the deliberations of the board of directors. This means that previously of any directors' meeting the shareholders have the power to decide how the directors elected by them will vote.

In 2007, the umbrella clauses were used by approximately $38 \%$ of the Brazilian shareholder agreements that bounded directors ${ }^{56}$. In 2012 this number increased, as clauses were identified in approximately $67 \%$ of the agreements ${ }^{57}$. This means a rise of $76 \%$ of umbrella clauses in the Brazilian context ${ }^{58}$.

54 Brazilian Corporation Law (Law 6.404), art. 142.

55 GORGA, Érica. Direito societário atual. Rio de Janeiro: Elsevier, 2013. p. 197-198.

56 GORGA, Érica. Direito societário atual. Rio de Janeiro: Elsevier, 2013. p. 197-198.

57 GORGA, Érica. Direito societário atual. Rio de Janeiro: Elsevier, 2013. p. 197-198.

58 GORGA, Érica. Direito societário atual. Rio de Janeiro: Elsevier, 2013. p. 197-198.
In such framework, Brazilian shareholder agreements seem to be indeed operating in the opposite direction of the best corporate governance practices. Shareholder agreements that establish limitations to the board of directors have been used as a mechanism of annulment of the duties of independence and commitment in the full exercise of the Board. This absence of independence may be even illegal when matters that must be exclusively deliberated by the directors are not an exception to umbrella clauses, as provided by art. 142 of the Brazilian Corporate Law ${ }^{59}$. After all, the interests of the controlling shareholders cannot be presumed to be in accordance with the corporate interest of the company itself. This situation, therefore, contrasts with the expected development of the Brazilian securities market and with the promotion of the best practices of corporate governance, as it requires independence to the board of directors.

In the U.S. agreements, such mandatory provisions towards directors were mostly not identified. Only 7 agreements $(10,14 \%)$ limited Director's power, but in a less restrictive way than the one identified in Brazilian agreements. This context may be explained by two reasons. First, in the U.S., fiduciary duties of directors cannot be easily expropriated by a shareholder agreement, since they are not bounded to restrictions on their vote imposed by shareholders ${ }^{60}$, which contrasts with paragraphs 7 and 8 of the article 118 of the Brazilian Corporate Law, which binds directors' votes to shareholder agreements ${ }^{61}$. Secondly, the company itself is part of American shareholder agreements, what means that obligations created towards the company end up obligating its managers. Thus, it would not be necessary to create direct obligations to the managers of the company.

In relation to corporate decisions, Brazilian voting agreements are intensely used to influence the deliberations of the general meetings and of the board of directors. The previous meeting stands out as a mechanism that restrict such decision-making bodies. As have been demonstrated above, it was used in 42 Brazilian agree-

59 GORGA, Érica. Direito societário atual. Rio de Janeiro: Elsevier, 2013. p. 197-198.

60 Corporation Law Committee of the Association of the Bar of the City of New York, The Enforceability and Effectiveness of Typical Shareholders Agreement Provisions, 65 The Business Lawyer 1153, 1163 (2010).

61 Brazilian Corporation Law (Law 6.404), art. 118. 
ments $(65,62 \%)$ analyzed in the study. In this sense, shareholder agreements assume a central position in the corporate governance of Brazilian publicly held companies, which goes beyond the election of directors.

The wild range of deliberations subjected to the previous meeting excels. As an example, $59,5 \%$ of the previous meetings identified in Brazilian agreements occur previously of any meeting of the general meeting of shareholders and of the board of directors. By means of such clause, the shareholders party to the agreement will meet and decide not only how themselves will vote on general meetings, but also how the directors elected by them will vote on the board of directors. In this sense, not only the independence of directors is harmed, but also the corporate rule one-share-one-vote, since the previous meeting relocates the voting power between shareholders ${ }^{62}$. Once again we identify the legal problem associated with Brazilian shareholder agreements: they are overriding the best corporate governance practices, as the rule one-share-one-vote, the principle of equal treatment for all shareholders and the independence of directors.

Voting agreements not related to the election of directors were almost not identified in the American context. Particularly, the previous meeting mechanism was not identified. Such assessment leads to the conclusion that although voting agreements are allowed by American corporate law, they are not as explored as in Brazil.

This situation may be explained by the legal competency granted to the general meeting in U.S. companies. As an example, in the Delaware Corporation Law the right to vote of the shareholders is essentially limited to the election of directors and to the approval of amendments to the bylaws, mergers and acquisitions, sell of all assets of the company and spontaneous dissolution of the company ${ }^{63}$. However, only the election of directors and amendments to the bylaws do not require the prior approval of the board of directors ${ }^{64}$. In contrast, art. 122 of the Brazilian Corporate Law provides an extensive number of matters that must be exclusively deliberated by the shareholders of the company ${ }^{65}$. Also,

62 GORGA, Érica. Corporate Control \& Governance after a Decade from "Novo Mercado": Changes in Ownership Structures and Shareholder Power in Brazil. Yale Law \& Economics Research Paper, n. 502, 2014.

63 DEL. CODE ANN. tit. 8, \$S 109211 (2001).

64 DEL. CODE ANN. tit. 8, \$S 109211 (2001).

65 Brazilian Corporation Law (Law 6.404), art. 122. in art. 121 of such Brazilian law it is established that the general meeting has the power to decide on all business related to the "corporate purpose" of the company ${ }^{66}$. Thus, the competences of the general meeting in both countries seem to be a reasonable explanation on why voting agreements are differently explored in Brazil and in the U.S.

\section{Mandatory limitations to the free transferabi- lity of shares}

Clauses that limit the free transferability of shares stands out in both countries, although in Brazil they are more often used. Particularly, three types of clauses excelled, which were: tag-along, right of first refusal and lock up. Such clauses are usually employed to guarantee the investment of the shareholders in the company or to prevent the sudden withdrawn of any shareholder of the company and the consequent entrance of a new shareholder that could mislead business.

The tag-along clause was used by 30 Brazilian agreements (46,87\%) and by 19 U.S. agreements (27,53\%). On its turn, the right of first refusal was identified in 42 agreements from Brazil $(65,6 \%)$ and in 15 from the U.S. $(21,73 \%)$. Finally, the lock up clause was employed by 18 Brazilian contracts $(28,12 \%)$ and by 12 U.S. contracts $(17,39 \%)$. Other clauses were identified in both contexts, as call, put and drag-along. However, they do not represent a relevant number in the analyzed agreements.

The use of clauses limiting the free transfer of shares indicates a concern of shareholders to maintain and stabilize their interest in the company. This finding raises the question if such clauses would be legitimate in an environment of public traded shares, mostly in the special listing segments of BM\&FBOVESPA in which free-float levels are mandatory. For example, in Level 1, Level 2 and Novo Mercado companies must comply with the requirement of $25 \%$ of the its shares in free float. However, the study indicates that $33 \%$ of the analyzed companies listed in these segments have shareholder agreements signed between shareholders representing more than $75 \%$ of the company's capital, in such a may that limiting the free transferability of shares ends up preventing the fulfillment of free-float mandatory rules.

66 Brazilian Corporation Law (Law 6.404), art. 121. 
Moreover, in Brazil, clauses limiting the free transfer of shares may result in unpredictable conflicts. On the one hand, the lock up clause may benefit the current shareholders of the company, since it prevents sudden fluctuations in the share price. On the other hand, it ends up restricting the liquidity of shares of "locked up" shareholders, in such a way that the restriction may impact the price of the company's shares proportionally to the number of shares of the "locked up" stockholders, as illiquidity usually affect stock prices.

It can also be noticed that U.S. agreements use standstill provisions. Standstill clauses intend to discourage any hostile acquisition of the company. It usually provides for previous approval of any relevant acquisition offer by the company and prevents submission and approval of offers by the shareholders. This clause was identified in $23 \%$ of the U.S. shareholder agreements. The standstill clause was only identified in U.S. shareholder agreements, which may be explained by the fact that the U.S. corporate context is more dispersed than the Brazilian context; meaning that American companies are more subjected to hostile acquisitions than Brazilian corporations, since the last usually have a controlling shareholder or block of control.

\section{Contrasting views on Dispute Resolution}

In Brazil, the dispute resolution method most used was arbitration. The arbitration was established in 50 agreements $(78,12 \%)$, while the judiciary was identified in 14 agreements $(21,88 \%)$. Such data indicates that Brazilian companies do not trust the judiciary to resolve any corporate disputes, mainly for its slowness and lack of technical expertise. In this context, arbitration appears to be a good solution, since it rapidly set a qualified body to deal with any corporate dispute. Moreover, this can be explained by that fact that many of the companies analyzed were listed in Level 2 and Novo Mercado of BM\&FBOVESPA, where adherence to the Market Arbitration Panel is mandatory.

In its turn, in the U.S., the judiciary prevails. In 49 U.S. agreements $(71 \%)$ the judiciary was chosen to resolve any issue that arises from the agreement. The arbitration only appeared in 5 agreements $(7,25 \%)$. Thus, American shareholders seem to trust their judiciary. However, only the courts of two states were mainly selected by such shareholders, which were the courts of
New York and the courts of Delaware, what may be explained by the judgments of such courts in matters of corporate law and by its technical team.

Concerning the applicable law to the contract, in Brazil, to govern obligations, the law of the country where they are constituted shall be applicable ${ }^{67}$. No Brazilian shareholder agreement has indicated the applicable law to the contract, because Brazilian law is automatically applied to national agreements. Particularly, in relation to shareholder's agreements, the Brazilian Corporation Law, a federal law, is the main regulatory norm and cannot be derogated by any state's law ${ }^{68}$. On the contrary, in the U.S., the shareholders may choose which law will be applicable to their agreement. The laws most chosen were Delaware's corporate law $(55,07 \%)$ and New York's corporate law $(26,08 \%)$.

The preference for the little state of Delaware may be explained by its reformist regime, which is sought by shareholders or managers who desire to guarantee a high value for the shares of their company, since the law of such state sets a higher protection to minority shareholders and contributes to global efficiency ${ }^{69}$.

\section{The Style of Shareholder Agreements}

Besides analyzing the use and content of shareholder agreement, the article contributes to the examination of the design of shareholder agreements in different countries. In general, American and Brazilian agreements have the same extension. It can be even observed that they have clauses that are really similar to each other, as the definitions clause. Hence, the study proved that stylistically the agreements from both countries are not as different as usually believed.

This finding contrasts with the literature on agreements' design in comparative law. Authors believe that, in Brazil, as in most European civil law countries, contracts are less long than U.S. agreements ${ }^{70}$. This could be

67 Law of Introduction to the Civil Code (Decree-Law No. 4657), art. 9 .

68 Brazilian Corporation Law (Law 6.404).

69 HANSMANN, Henry; PARGENDLER, Mariana; GILSON, Ronald J. Regulatory Dualism as a Development Strategy: Corporate Reform in Brazil, the United States, and the European Union. Stanford Law Review, Stanford, v. 63, p. 475-498, 2011.

70 LUNDMARK, Thomas. Verbose Contracts. American Journal of Comparative Law, Michigan, v. 49, p. 121, 2001; LANGBEIM, John 
explained by the predictability of civil law, which provides general rules for the signing of agreements, has a gap-filling role and guarantees specific enforcement in any dispute ${ }^{71}$. Taking into account these variances between civil law and common law, there are theoretical discussions that claim that U.S. contracts are overly descriptive and detailed.

Thomas Lundmark, for example, points to the following factors as responsible for the redundancy of U.S. contracts $^{72}$ : (i) limited solutions for the granting of compensatory damages in the case of breach of contract, (ii) the informal and oral tradition of common law, (iii) the jurisdictional diversity following federalism, and (iv) the preference for private arrangement of business.

The first factor pointed out by Lundmark rises from the fact that common law countries do not grant specific performance to the parties of an agreement, what obliges them to entirely rely on a legal proceeding ${ }^{73}$. Moreover, the second factor prevents the parties of U.S. contracts from trusting documentary evidence, since witnesses have a larger role in common law countries. On the contrary, in civil law countries, a controversy arising from an agreement would be mainly solved by documentary evidence ${ }^{74}$. The third factor of Lundmark refers to the federalist system of the U.S. He states that the main issue of this factor is not on the state's substantial law, but rather in the state's procedural law, which is verbose and does not even guarantee specific performance ${ }^{75}$. At last, the forth factor relates to the fact that American businessman do not trust the State to solve their disputes. Therefore, they prefer to over detail the agreement and guarantee dispute resolution in the private sphere ${ }^{76}$.

John H. Langbein also states that U.S. contracts are more complex ${ }^{77}$. He justifies this statement by the third

H. Comparative Civil Procedure and the Style of Complex Contracts. American Journal of Comparative Law, v. 35, p. 381, 1987.

71 LUNDMARK, Thomas. Verbose Contracts. American Journal of Comparative Law, Michigan, v. 49, p. 121-124, 2001.

72 LUNDMARK, Thomas. Verbose Contracts. American Journal of Comparative Law, Michigan, v. 49, p. 121-123, 2001.

73 LUNDMARK, Thomas. Verbose Contracts. American Journal of Comparative Law, Michigan, v. 49, p. 121-124, 2001.

74 LUNDMARK, Thomas. Verbose Contracts. American Journal of Comparative Law, Michigan, v. 49, p. 121-126, 2001.

75 LUNDMARK, Thomas. Verbose Contracts. American Journal of Comparative Law, Michigan, v. 49, p. 121-130, 2001.

76 LUNDMARK, Thomas. Verbose Contracts. American Journal of Comparative Law, Michigan, v. 49, p. 121-131, 2001.

77 LANGBEIM, John H. Comparative Civil Procedure and the factor of Lundmark. Langbein says that, in the U.S., civil procedure is inefficient, because it is expensive, unpredictable and do not discourage lawsuits, unlike the European civil law systems, which are more efficient and predictable ${ }^{78}$.

The present article questions the continued relevance of these authors' assumptions, at least in the context of shareholder agreements. The study did not find any relevant stylistic difference between shareholder agreements of Brazil and the U.S. In length, they are really similar. Also, some clauses are identically used. As an example, the definitions clause, which is a customary practice of American corporate law, is being intensely used in Brazil. The data collected indicates that 40 Brazilian agreements (62,5\%) and 36 U.S. agreements $(52,17 \%)$ present such clause and have more than 30 definitions. This may be explained by the increasing flow of deals between American and Brazilian companies, as well as by the globalization of Brazil's companies, which are increasingly opening offices in other countries or being listed in American stock exchanges.

\section{Conclusion}

This empirical and comparative study intended to investigate the use and content of shareholder agreements of Brazilian and U.S. publicly held companies in order to analyze how the Brazilian experience diverges from a different corporate context.

Initially, the article proved that public traded companies, including U.S. corporations, use shareholder agreements. Secondly, it showed that while in Brazil such corporate instrument provides for central issues of corporate governance, in the U.S. they are mostly employed in relation to corporate transactions, mainly establishing conditions to the election of directors and restrictions to the free transferability of shares. Particularly, in Brazil, the previous meeting mechanism is widely used to bind the vote of the signing shareholders and also of the directors of the company. On the contrary, in U.S. agreements, this voting restriction was not iden-

Style of Complex Contracts. American Journal of Comparative Law, v. 35, p. 381-392, 1987.

78 LANGBEIM, John H. Comparative Civil Procedure and the Style of Complex Contracts. American Journal of Comparative Law, v. 35, p. 381-392, 1987. 
tified. American voting agreements almost do not limit shareholder voting or restrict directors' duties, being essentially used to elect directors. Thirdly, the study demonstrated that Brazilian shareholders establish a block of control by means of a shareholder agreement. This may indicate a rise of dispersed ownership in Brazil's capital market. In the Brazilian context, the article leads to the conclusion that shareholder agreements are overriding the best corporate governance practices, in such a way that corporate laws are infringed, as the protection of minority shareholders and the duties of care and loyalty of directors and officers, and market rules are disrespected.

Fourthly, it evidences the preference of Brazilian shareholders for arbitration as dispute resolution method, while U.S. shareholders trust the judiciary, predominantly Delaware and New York courts.

Lastly, the article revealed that the design of shareholder agreements in both countries is really similar, since there are no relevant stylistic differences between them. This finding demystifies the belief that U.S. contracts are necessarily longer than those from civil law countries.

Beyond questioning dominant assumptions about the role of shareholder agreements in public corporations, the conclusions of this article open a space for discussing shareholder agreements in comparative law.

\section{Appendices}

Table 1: Main Aspects of Brazilian Shareholder Agreements

\begin{tabular}{|c|c|c|}
\hline Company & $\begin{array}{c}\text { Date of Signa- } \\
\text { ture }\end{array}$ & $\begin{array}{c}\text { Listing Seg- } \\
\text { ment }\end{array}$ \\
\hline $\begin{array}{c}\text { ALLIS PARTICIPAÇÕES } \\
\text { S.A. }\end{array}$ & $07 / 02 / 2011$ & OTC Mkt. \\
\hline $\begin{array}{c}\text { AMIL PARTICIPACOES } \\
\text { S.A. }\end{array}$ & $26 / 10 / 2012$ & OTC Mkt. \\
\hline $\begin{array}{c}\text { AREZZO INDÚSTRIA } \\
\text { E COMÉRCIO S.A. }\end{array}$ & $06 / 01 / 2011$ & Novo Mercado \\
\hline $\begin{array}{c}\text { AREZZO INDÚSTRIA } \\
\text { E COMÉRCIO S.A. }\end{array}$ & $06 / 01 / 2011$ & Novo Mercado \\
\hline $\begin{array}{c}\text { BCO BTG PACTUAL } \\
\text { S.A. }\end{array}$ & $29 / 02 / 2012$ & Standard \\
\hline BCO DAYCOVAL S.A. & $21 / 11 / 2011$ & Level 2 \\
\hline BCO INDUSVAL S.A. & $30 / 03 / 2011$ & Level 2 \\
\hline BCO INDUSVAL S.A. & $07 / 11 / 2011$ & Level 2 \\
\hline
\end{tabular}

\begin{tabular}{|c|c|c|}
\hline $\begin{array}{l}\text { BCO MERCANTIL DO } \\
\text { BRASIL S.A. }\end{array}$ & $22 / 10 / 2010$ & Standard \\
\hline $\begin{array}{c}\text { BCO PANAMERICANO } \\
\text { S.A. }\end{array}$ & $26 / 07 / 2010$ & Level 1 \\
\hline $\begin{array}{c}\text { BCO PANAMERICANO } \\
\text { S.A. }\end{array}$ & $31 / 01 / 2011$ & Level 1 \\
\hline BCO PINE S.A. & 09/09/2011 & Level 2 \\
\hline $\begin{array}{l}\text { BRASIL INSURANCE } \\
\text { PARTICIPAÇÕES E AD- } \\
\text { MINISTRAÇÃO S.A }\end{array}$ & $27 / 03 / 2010$ & Novo Mercado \\
\hline $\begin{array}{l}\text { BRASIL TRAVEL TU- } \\
\text { RISMO E PARTICIPA- } \\
\text { ÇÕES S.A. }\end{array}$ & $30 / 04 / 2012$ & Novo Mercado \\
\hline BRASKEM S.A. & $08 / 02 / 2010$ & Level 1 \\
\hline $\begin{array}{l}\text { CIA CELG DE PARTI- } \\
\text { CIPACOES - CELGPAR }\end{array}$ & $01 / 08 / 2011$ & Standard \\
\hline $\begin{array}{c}\text { CIA ENERGETICA } \\
\text { DE MINAS GERAIS - } \\
\text { CEMIG }\end{array}$ & $01 / 08 / 2011$ & Level 1 \\
\hline $\begin{array}{l}\text { COMPANHIA DE } \\
\text { LOCAÇÃO DAS AMÉ- } \\
\text { RICAS }\end{array}$ & $27 / 02 / 2012$ & Novo Mercado \\
\hline $\begin{array}{c}\text { CONCESSIONARIA } \\
\text { RIO-TERESOPOLIS } \\
\text { S.A. }\end{array}$ & $25 / 04 / 2011$ & OTC Mkt. \\
\hline COPERSUCAR S.A. & $20 / 06 / 2011$ & Novo Mercado \\
\hline $\begin{array}{l}\text { DESENVIX ENERGIAS } \\
\text { RENOVÁVEIS S.A. }\end{array}$ & 08/03/2012 & Bovespa Mais \\
\hline DIMED S.A. & $12 / 01 / 2012$ & Standard \\
\hline $\begin{array}{c}\text { ECORODOVIAS } \\
\text { INFRAESTRUTURA E } \\
\text { LOGÍSTICA S.A. }\end{array}$ & $22 / 01 / 2010$ & Novo Mercado \\
\hline
\end{tabular}

Table 1: (continued)

\begin{tabular}{|c|c|c|}
\hline Company & $\begin{array}{c}\text { Date of Signa- } \\
\text { ture }\end{array}$ & $\begin{array}{c}\text { Listing Seg- } \\
\text { ment }\end{array}$ \\
\hline $\begin{array}{c}\text { ECORODOVIAS } \\
\text { INFRAESTRUTURA E } \\
\text { LOGISTICA S.A. }\end{array}$ & $27 / 12 / 2012$ & Novo Mercado \\
\hline $\begin{array}{c}\text { EVEN CONSTRUTORA } \\
\text { E INCORPORADORA } \\
\text { S.A. }\end{array}$ & $06 / 08 / 2012$ & Novo Mercado \\
\hline $\begin{array}{c}\text { FRIGOL FOODS PAR- } \\
\text { TICIPAÇÕES S.A. }\end{array}$ & $08 / 03 / 2012$ & Standard \\
\hline $\begin{array}{c}\text { HIDROVIAS DO BRA- } \\
\text { SIL S.A. }\end{array}$ & $27 / 03 / 2012$ & Standard \\
\hline HYPERMARCAS S.A. & $23 / 06 / 2010$ & Novo Mercado \\
\hline $\begin{array}{c}\text { INDUSTRIAS ROMI } \\
\text { S.A. }\end{array}$ & $05 / 11 / 2012$ & Novo Mercado \\
\hline JBS S.A. & $26 / 01 / 2010$ & Novo Mercado \\
\hline JSL S.A. & $19 / 03 / 2010$ & Novo Mercado \\
\hline $\begin{array}{c}\text { KROTON EDUCA- } \\
\text { CIONAL S.A. }\end{array}$ & $28 / 09 / 2012$ & Novo Mercado \\
\hline
\end{tabular}




\begin{tabular}{|c|c|c|}
\hline $\begin{array}{c}\text { KROTON EDUCA- } \\
\text { CIONAL S.A. }\end{array}$ & $28 / 11 / 2012$ & Novo Mercado \\
\hline MANABI S.A. & $31 / 05 / 2011$ & Standard \\
\hline MANABI S.A. & $22 / 08 / 2012$ & Standard \\
\hline MARCOPOLO S.A. & $31 / 03 / 2012$ & Level 2 \\
\hline $\begin{array}{c}\text { MARFRIG ALIMEN- } \\
\text { TOS S.A. }\end{array}$ & $05 / 08 / 2010$ & Novo Mercado \\
\hline MARISA LOJAS S.A. & $31 / 03 / 2010$ & Novo Mercado \\
\hline $\begin{array}{c}\text { MILLS ESTRUTURAS E } \\
\text { SERVIÇOS DE ENGE- } \\
\text { NHARIA S.A. }\end{array}$ & $11 / 02 / 2011$ & Novo Mercado \\
\hline $\begin{array}{c}\text { MONTICIANO PAR- } \\
\text { TICIPACOES S.A. }\end{array}$ & $08 / 07 / 2010$ & OTC Mkt. \\
\hline $\begin{array}{c}\text { NADIR FIGUEIREDO } \\
\text { IND E COM S.A. }\end{array}$ & $31 / 10 / 2011$ & Standard \\
\hline $\begin{array}{c}\text { NET SERVICOS DE } \\
\text { COMUNICACAO S.A. }\end{array}$ & $21 / 12 / 2012$ & Level 2 \\
\hline $\begin{array}{c}\text { NET SERVICOS DE } \\
\text { COMUNICACAO S.A. }\end{array}$ & $21 / 12 / 2012$ & Level 2 \\
\hline $\begin{array}{c}\text { PARANA BCO S.A. } \\
\text { PORTOBELLO S.A. }\end{array}$ & $25 / 05 / 2011$ & Level 1 \\
\hline $\begin{array}{c}\text { QGEP PARTICI- } \\
\text { PAÇÕES S.A. }\end{array}$ & $17 / 04 / 2011 / 2011$ & Novo Mercado \\
\hline
\end{tabular}

\begin{tabular}{|c|c|c|}
\hline $\begin{array}{c}\text { USINAS SID DE MINAS } \\
\text { GERAIS S.A.- USIMI- } \\
\text { NAS }\end{array}$ & $16 / 01 / 2012$ & Level 1 \\
\hline $\begin{array}{c}\text { USINAS SID DE MINAS } \\
\text { GERAIS S.A.- USIMI- } \\
\text { NAS }\end{array}$ & $18 / 02 / 2011$ & Level 1 \\
\hline $\begin{array}{c}\text { VIA VAREJO S.A. (GLO- } \\
\text { BEX UTILIDADES S.A.) }\end{array}$ & $01 / 07 / 2010$ & Standard \\
\hline $\begin{array}{c}\text { VIGOR ALIMENTOS } \\
\text { S.A. }\end{array}$ & $19 / 06 / 2012$ & Novo Mercado \\
\hline
\end{tabular}

Source: Own Elaboration based on electronic survey.

Table 2: Main Aspects of U.S. Shareholder Agreements

\begin{tabular}{|c|c|c|}
\hline Company & $\begin{array}{l}\text { Date of Signa- } \\
\text { ture }\end{array}$ & Listing \\
\hline $\begin{array}{c}\text { SCHIFF NUTRITION } \\
\text { INTERNATIONAL, } \\
\text { INC. }\end{array}$ & $14 / 10 / 2010$ & NYSE \\
\hline $\begin{array}{c}\text { PARKWAY PROPER- } \\
\text { TIES, INC. } \\
\end{array}$ & $5 / 6 / 2012$ & NYSE \\
\hline $\begin{array}{l}\text { GREENMAN TECH- } \\
\text { NOLOGIES, INC. }\end{array}$ & $30 / 04 / 2012$ & OTC Mkt. \\
\hline $\begin{array}{c}\text { KENNEDY-WILSON } \\
\text { HOLDINGS, INC. }\end{array}$ & $13 / 08 / 2010$ & NYSE \\
\hline $\begin{array}{l}\text { CHINA BCT PHARMA- } \\
\text { CY GROUP, INC. }\end{array}$ & 2011 & OTC Mkt. \\
\hline $\begin{array}{l}\text { BUCYRUS INTERNA- } \\
\text { TIONAL, INC. }\end{array}$ & $19 / 02 / 2010$ & NASDAQ \\
\hline $\begin{array}{c}\text { ASCENT SOLAR } \\
\text { TECHNOLOGIES, INC. }\end{array}$ & $12 / 08 / 2011$ & NASDAQ \\
\hline HCP, INC. & $13 / 12 / 2010$ & NYSE \\
\hline CTC MEDIA,INC. & $20 / 05 / 2011$ & NASDAQ \\
\hline WATSCO, INC. & $27 / 04 / 2012$ & NYSE \\
\hline $\begin{array}{l}\text { TTM TECHNOLOGIES, } \\
\text { INC. }\end{array}$ & 09/04/2010 & NASDAQ \\
\hline $\begin{array}{l}\text { CHINDEX INTERNA- } \\
\text { TIONAL, INC. } \\
\end{array}$ & $14 / 06 / 2010$ & NASDAQ \\
\hline $\begin{array}{c}\text { THOMAS PROPERTIES } \\
\text { GROUP, INC. }\end{array}$ & $29 / 05 / 2012$ & NYSE \\
\hline $\begin{array}{c}\text { PEOPLE'S LIBERA- } \\
\text { TION, INC. } \\
\end{array}$ & $22 / 02 / 2012$ & OTC Mkt. \\
\hline $\begin{array}{c}\text { HALCÓN RESOURCES } \\
\text { CORPORATION }\end{array}$ & $06 / 12 / 2012$ & NYSE \\
\hline $\begin{array}{l}\text { BONDS.COM GROUP, } \\
\text { INC. }\end{array}$ & $11 / 01 / 2010$ & OTC Mkt. \\
\hline $\begin{array}{l}\text { BONDS.COM GROUP, } \\
\text { INC. }\end{array}$ & $19 / 10 / 2010$ & OTC Mkt. \\
\hline $\begin{array}{l}\text { BONDS.COM GROUP, } \\
\text { INC. }\end{array}$ & 05/12/2011 & OTC Mkt. \\
\hline $\begin{array}{l}\text { BONDS.COM GROUP, } \\
\text { INC. }\end{array}$ & $02 / 02 / 2011$ & OTC Mkt. \\
\hline $\begin{array}{l}\text { SILGAN HOLDINGS } \\
\text { INC. }\end{array}$ & $12 / 04 / 2011$ & NASDAQ \\
\hline
\end{tabular}

\begin{tabular}{|c|c|c|}
\hline Company & $\begin{array}{l}\text { Date of Signa- } \\
\text { ture }\end{array}$ & $\begin{array}{l}\text { Listing Seg- } \\
\text { ment }\end{array}$ \\
\hline QUALICORP S.A. & $01 / 09 / 2010$ & Novo Mercado \\
\hline RAIA DROGASIL S.A. & $10 / 11 / 2011$ & Novo Mercado \\
\hline $\begin{array}{c}\text { RENOVA ENERGIA } \\
\text { S.A. }\end{array}$ & 19/08/2011 & Level 2 \\
\hline $\begin{array}{c}\text { RENOVA ENERGIA } \\
\text { S.A. }\end{array}$ & $06 / 11 / 2012$ & Level 2 \\
\hline $\begin{array}{c}\text { SAO CARLOS EM- } \\
\text { PREEND E PARTICIPA- } \\
\text { COES S.A. }\end{array}$ & $31 / 10 / 2011$ & Novo Mercado \\
\hline SARAIVA S.A. & $27 / 09 / 2011$ & Level 2 \\
\hline SPRINGER S.A. & $31 / 07 / 2012$ & Standard \\
\hline $\begin{array}{l}\text { SUL } 116 \text { PARTICIPA- } \\
\text { COES S.A. }\end{array}$ & $12 / 08 / 2010$ & OTC Mkt. \\
\hline $\begin{array}{l}\text { SUZANO PAPEL E } \\
\text { CELULOSE S.A. }\end{array}$ & $30 / 05 / 2011$ & Level1 \\
\hline TECHNOS S.A. & $31 / 05 / 2011$ & Novo Mercado \\
\hline $\begin{array}{l}\text { ULTRAPAR PARTICIPA- } \\
\text { COES S.A. }\end{array}$ & $01 / 04 / 2011$ & Novo Mercado \\
\hline $\begin{array}{l}\text { UNICASA INDÚSTRIA } \\
\text { DE MÓVEIS S.A. }\end{array}$ & $14 / 03 / 2012$ & Novo Mercado \\
\hline $\begin{array}{l}\text { UNIVERSO ONLINE } \\
\text { S.A. }\end{array}$ & $27 / 01 / 2011$ & Level 2 \\
\hline $\begin{array}{l}\text { UNIVERSO ONLINE } \\
\text { S.A. }\end{array}$ & $27 / 01 / 2011$ & Level 2 \\
\hline
\end{tabular}




\begin{tabular}{|c|c|c|}
\hline $\begin{array}{c}\text { AMN HEALTHCARE } \\
\text { SERVICES, INC. }\end{array}$ & $28 / 07 / 2010$ & NYSE \\
\hline $\begin{array}{c}\text { INTERLINE BRANDS, } \\
\text { INC. }\end{array}$ & $07 / 09 / 2012$ & NYSE \\
\hline $\begin{array}{c}\text { DEERFIELD CAPITAL } \\
\text { CORP }\end{array}$ & 2011 & NASDAQ \\
\hline $\begin{array}{c}\text { TEGAL CORPORA- } \\
\text { TION }\end{array}$ & $12 / 07 / 2012$ & NASDAQ \\
\hline $\begin{array}{c}\text { CARPENTER TECH- } \\
\text { NOLOGY CORPORA- } \\
\text { TION }\end{array}$ & $29 / 02 / 2012$ & NYSE \\
\hline EXPRESS, INC. & $23 / 04 / 2011$ & NYSE \\
\hline $\begin{array}{c}\text { REAL GOODS SOLAR, } \\
\text { INC. }\end{array}$ & $19 / 12 / 2011$ & NASDAQ \\
\hline $\begin{array}{c}\text { TRIUMPH GROUP, } \\
\text { INC. }\end{array}$ & $23 / 03 / 2010$ & \\
\hline
\end{tabular}

Table 2: (continued)

\begin{tabular}{|c|c|c|}
\hline Company & $\begin{array}{l}\text { Date of Signa- } \\
\text { ture }\end{array}$ & Listing \\
\hline $\begin{array}{l}\text { ACADIA HEALTH- } \\
\text { CARE COMPANY INC. }\end{array}$ & $01 / 11 / 2011$ & NASDAQ \\
\hline $\begin{array}{l}\text { MEDIA GENERAL, } \\
\text { INC. }\end{array}$ & $24 / 05 / 2012$ & NYSE \\
\hline $\begin{array}{l}\text { RECOVERY ENERGY, } \\
\text { INC. }\end{array}$ & $23 / 06 / 2010$ & NASDAQ \\
\hline $\begin{array}{l}\text { URANIUM RESOURC- } \\
\text { ES, INC. }\end{array}$ & $01 / 03 / 2012$ & NASDAQ \\
\hline $\begin{array}{l}\text { TRIDENT MICROSYS- } \\
\text { TEMS, INC. }\end{array}$ & $28 / 04 / 2011$ & OTC Mkt. \\
\hline QUIKSILVER, INC. & $09 / 08 / 2010$ & NYSE \\
\hline $\begin{array}{c}\text { BIOFUEL ENERGY } \\
\text { CORP }\end{array}$ & $24 / 09 / 2010$ & NASDAQ \\
\hline $\begin{array}{l}\text { APPLIED NATURAL } \\
\text { GAS FUELS, INC. }\end{array}$ & $24 / 03 / 2010$ & OTC Mkt. \\
\hline $\begin{array}{l}\text { TEXAS RARE EARTH } \\
\text { RESOURCES CORP }\end{array}$ & $21 / 01 / 2011$ & OTC Mkt. \\
\hline $\begin{array}{c}\text { GRAHAM PACKAGING } \\
\text { COMPANY INC. }\end{array}$ & $10 / 02 / 2010$ & NYSE \\
\hline SPIRIT AIRLINES,INC. & $01 / 06 / 2011$ & NASDAQ \\
\hline $\begin{array}{l}\text { WALKER\& } \\
\text { DUNLOP,INC. }\end{array}$ & $20 / 12 / 2010$ & NYSE \\
\hline $\begin{array}{l}\text { WESCO AIRCRAFT } \\
\text { HOLDINGS,INC. }\end{array}$ & $27 / 07 / 2011$ & NYSE \\
\hline $\begin{array}{l}\text { BOOZ ALLEN HAM- } \\
\text { ILTON HOLDING } \\
\text { CORPORATION }\end{array}$ & 08/11/2010 & NYSE \\
\hline $\begin{array}{l}\text { ALLISON TRANSMIS- } \\
\text { SION HOLDINGS, INC. }\end{array}$ & $12 / 03 / 2012$ & NYSE \\
\hline $\begin{array}{l}\text { REGIONAL MANAGE- } \\
\text { MENT CORP }\end{array}$ & $27 / 03 / 2012$ & NYSE \\
\hline
\end{tabular}

\begin{tabular}{|c|c|c|}
\hline $\begin{array}{c}\text { MIDSTATES PETRO- } \\
\text { LEUM COMPANY, INC. }\end{array}$ & $24 / 04 / 2012$ & NYSE \\
\hline GSE HOLDING,INC. & $15 / 02 / 2012$ & NYSE \\
\hline $\begin{array}{c}\text { MEDQUIST HOLD- } \\
\text { INGS INC. }\end{array}$ & $04 / 02 / 2011$ & NASDAQ \\
\hline $\begin{array}{c}\text { SOLAR ENERTECH } \\
\text { CORP }\end{array}$ & $07 / 01 / 2010$ & OTC Mkt. \\
\hline SMTC CORPORATION & $05 / 01 / 2012$ & NASDAQ \\
\hline $\begin{array}{c}\text { HYSTER-YALE MA- } \\
\text { TERIALS HANDLING, } \\
\text { INC. }\end{array}$ & $28 / 09 / 2012$ & NYSE \\
\hline $\begin{array}{c}\text { EXPEDIA, INC. } \\
\text { INC. }\end{array}$ & $20 / 12 / 2011$ & NASDAQ \\
\hline $\begin{array}{c}\text { NACCO INDUSTRIES } \\
\text { MANNING AND } \\
\text { NAPIER INC. }\end{array}$ & $28 / 09 / 2012$ & NYSE \\
\hline $\begin{array}{c}\text { IRONCLAD PERFOR- } \\
\text { MANCE WEAR CORP }\end{array}$ & $14 / 12 / 2012$ & OTC Mkt. \\
\hline $\begin{array}{c}\text { TAL INTERNATIONAL } \\
\text { GROUP,INC. }\end{array}$ & $23 / 03 / 2012$ & NYSE \\
\hline ZIX CORPORATION & $28 / 12 / 2012$ & NASDAQ \\
\hline
\end{tabular}

Table 2: (continued)

\begin{tabular}{|c|c|c|}
\hline Company & $\begin{array}{c}\text { Date of Signa- } \\
\text { ture }\end{array}$ & Listing \\
\hline EXPEDIA, INC. & $20 / 12 / 2011$ & NASDAQ \\
\hline $\begin{array}{c}\text { OPTIONS MEDIA } \\
\text { GROUP HOLDINGS, } \\
\text { INC. }\end{array}$ & $16 / 04 / 2010$ & OTC Mkt. \\
\hline BLACKROCK, INC. & $15 / 11 / 2010$ & NYSE \\
\hline $\begin{array}{c}\text { TURKPOWER CORP } \\
\text { (NOW: ZINCO DO } \\
\text { BRASIL, INC.) }\end{array}$ & $28 / 06 / 2011$ & OTC Mkt. \\
\hline TRIPADVISOR, INC. & $20 / 12 / 2011$ & NASDAQ \\
\hline RSC HOLDINGS INC. & 06/10/2011 & NYSE \\
\hline $\begin{array}{l}\text { HIGH PLAINS GAS, } \\
\text { INC. }\end{array}$ & $18 / 11 / 2011$ & OTC Mkt. \\
\hline $\begin{array}{c}\text { WONDER AUTO } \\
\text { TECHNOLOGY, INC. }\end{array}$ & $05 / 10 / 2011$ & OTC Mkt. \\
\hline $\begin{array}{c}\text { LPL INVESTMENT } \\
\text { HOLDINGS, INC. }\end{array}$ & $23 / 11 / 2010$ & NASDAQ \\
\hline $\begin{array}{c}\text { BRAZIL FAST FOOD } \\
\text { CORP }\end{array}$ & $22 / 12 / 2010$ & OTC Mkt. \\
\hline $\begin{array}{c}\text { LUMOS NETWORKS } \\
\text { CORP. }\end{array}$ & $31 / 10 / 2011$ & NASDAQ \\
\hline $\begin{array}{l}\text { WUHAN GENERAL } \\
\text { GROUP (CHINA), INC. }\end{array}$ & $13 / 12 / 2010$ & OTC Mkt. \\
\hline $\begin{array}{l}\text { TALON INTERNA- } \\
\text { TIONAL, INC. }\end{array}$ & $30 / 07 / 2010$ & OTC Mkt. \\
\hline
\end{tabular}

Source: Own Elaboration based on electronic survey. 


\section{ReferenCES}

ALDRIGHI, Dante Mendes; MAZZER NETO, Roberto. Estrutura de propriedade e de controle das empresas de capital aberto no Brasil. Revista de Economia Politica, v. 25, 2005.

BERLE Adolf A.; MEANS, Gardiner C. The Modern Corporation and Private Property. New Brunswick: Transaction, 1967.

BERLE, Adolf A.; MEANS, Gardiner C. A moderna sociedade anônima e a propriedade privada. Rio de Janeiro: Nova Cultural, 1988.

BLACK, Bernard S. Shareholder Activism and Corporate Governance in the United States. The New Palgrave Dictionary of Economics and the Law, v. 3, 1998.

Brazilian Corporation Law (Law 6.404).

BOVESPA. O que são segmentos de listagem. Available at: <http://www.bmfbovespa.com.br/pt-br/servicos/ solucoes-para-empresas/segmentos-de-listagem/oque-sao-segmentos-de-listagem.aspx?Idioma $=$ pt-br $>$

CARVALHOSA, Modesto. Acordo de acionistas: homenagem a Celso Barbi Filho. São Paulo: Saraiva, 2011. EIZIRIK, Nelson. A lei das S / A comentada. Cidade: Editora, 2011.

CLARK, Robert. Corporate Law. Litte, Brown, 1986.

Corporation Law Committee of the Association of the Bar of the City of New York, The Enforceability and Effectiveness of Typical Shareholders Agreement Provisions, 65 The Business Lawyer (2010).

DEL. CODE ANN. (2001).

GOMES, Armando; NOVAES, Walter. Multiple Large Shareholders in Corporate Governance 26 (February 17, 1999).

GORDON, Jeffrey N.; GILSON, Ronald J. The Agency Costs of Agency Capitalism: Activist Investors and the Revaluation of Governance Rights. Columbia Law Review, v. 113, 2013.

GORGA, Érica. Changing The Paradigm Of Stock Ownership From Concentrated Towards Dispersed Ownership? Evidence From Brazil And Consequences For Emerging Countries. Northwestern Journal of International Law \& Business, v. 29, 2009.
GORGA, Érica; GELMAN, Marina. O esvaziamento crescente do conselho de administração como efeito da vinculação de seu voto a acordos de acionistas no Brasil. In: INSTITUTO BRASILEIRO GOVERNANÇA CORPORATIVA, 13, 2012, São Paulo. Anais... São Paulo, 2012.

GORGA, Érica. Direito societário atual. Rio de Janeiro: Elsevier, 2013.

GORGA, Érica. Corporate Control \& Governance after a Decade from "Novo Mercado": Changes in Ownership Structures and Shareholder Power in Brazil. Yale Law \& Economics Research Paper, n. 502, 2014.

HANSMANN, Henry; PARGENDLER, Mariana; GILSON, Ronald J. Regulatory Dualism as a Development Strategy: Corporate Reform in Brazil, the United States, and the European Union. Stanford Law Review, Stanford, v. 63, 2011.

HOLDERNESS Clifford G. The Myth of Diffuse Ownership in the United States. Review of Financial Studies, v. 22 , n. 4, 2009.

IBCG. Governança Corporativa. Available at: http:// www.ibgc.org.br/Secao.aspx?CodSecao=17

LANGBEIM, John H. Comparative Civil Procedure and the Style of Complex Contracts. American Journal of Comparative Law, v. 35, 1987.

LA PORTA, Rafael; LOPES-DE-SILANES, Florencio; SHLEIFER, Andrei. Corporate Ownership Around the World. Journal of Finance, Cambridge, v.2, 1999.

Law of Introduction to the Civil Code (Decree-Law No. 4657).

LEAL, Ricardo P. C.; CANELLAS, Thiago Costa. Evolução da Estrutura de Controle das Empresas Listadas na Bovespa entre 2004 e 2006, 387 Relatórios Coppead 01, (2009).

LUNDMARK, Thomas. Verbose Contracts. American Journal of Comparative Law, Michigan, v. 49, 2001;

ROE, Mark J. Strong managers, weak owners: the political roots of american corporate finance. Cambrigde: Harward Law, 1994.

Securities Exchange Act of 1934 (48 Stat. 881, 15 U.S.C. 78a-78kk). 
VENTORUZZO, Marco. Why Shareholders' Agreements are not used in U.S. Listed Corporations: a Conundrum in Search of an Explanation. Penn State Law Research Paper, n. 42, 2013.

WOLFENZON, Daniel; BENNEDSEN, Morten. The
Balance of Power in Closely Held Corporations. Journal of Financial Economics, v. 58, 2000.

The World Bank, World Development Indicators: Stock markets, 2014. Available at: <http://wdi.worldbank.org/ table/5.4>. 


\section{Regulação do investimento estrangeiro direto no Brasil: da resistência aos tratados bilaterais de investimento à emergência de um novo modelo regulatório*}

\author{
Foreign direct investment regulation in \\ Brazil: from resistance to investment bilateral \\ treaties to the emergence of a new regulatory \\ model
}

* Recebido em 15/09/2015

Aprovado em 10/11/2015

** Professor da Faculdade de Direito da Universidade Federal do Rio Grande do Sul (UFRGS), onde coordena o Centro para Direito, Globalização e Desenvolvimento. Ph.D. e mestre em Direito Internacional pela University of Texas at Austin, e Master em Direito e Globalização Econômica pela Université de Paris 1/Sciences Po - Paris. Bolsista Produtividade em Pesquisa Nível 2 do CNPq. E-mail: fabio. morosini@ufrgs.br

*** Professor de Direito Internacional da Universidade Federal Rural do Rio de Janeiro (UFRRJ). Doutorando em Direito Internacional pela Faculdade de Direito da Universidade de São Paulo (USP). Mestre em Direito Internacional pela Universidade do Estado do Rio de Janeiro (UERJ) e pela Universidade de Londres. Advogado. E-mail: ely.jr@uol.com.br
Fabio Morosini **

Ely Caetano Xavier Júnior***

\section{Resumo}

O objetivo deste artigo é analisar o desenvolvimento regulatório do Brasil em matéria de investimento estrangeiro. Em comparação com outros países em desenvolvimento, o Brasil por anos gozou da reputação de um rebelde na regulação de investimentos estrangeiro direto (IED). Na década de 90, quando o mundo parecia caminhar pacificamente para regulação de investimento via tratados bilaterais de investimento (TBIs), o Brasil colocou toda a sua rebeldia na resistência a esse modelo, sob o argumento de que tal tipo de regulação confrontava dispositivos de sua Constituição. Desafiando o argumento de que TBIs seriam necessários para atrair investimentos, a inexistência desse padrão regulatório não ofuscou o interesse de investidores estrangeiros no país, que se manteve como um dos principais destinatários de IED. Entretanto, mudanças na economia doméstica e internacional alavancaram empresas brasileiras para outros países, principalmente ao sul do continente e na África, fazendo com que os formuladores da política brasileira de investimentos reelaborassem a estratégia nacional. Nesse contexto, um novo modelo regulatório emerge novamente de maneira rebelde, agora não pela negação dos modelos em vigor, mas pela singularidade de seus termos. Esse novo modelo dialoga com a chamada crise de legitimidade do regime global de investimentos e promove relações de investimento mais equilibradas e cooperativas. As análises apresentadas no artigo partem de documentos primários (regulação nacional e internacional) e secundários (literatura especializada).

Palavras-chave: Investimento estrangeiro direto. Modelos regulatórios. Brasil. Acordos de investimento.

\section{Abstract}

The goal of this article is to analyze the regulatory evolution of foreign investment in Brazil. In comparison with its peers, Brazil has enjoyed for 
years the reputation of a rebel regarding the regulation of foreign direct investment (FDI). In the 90s, when the world seemed to peacefully agree on the regulation of investment via bilateral investment treaties (BITs), Brazil expressed all its insurgence by resisting to this model, arguing that that such agreements confronted provisions of its Constitution. Challenging the view that BITs were necessary to attract investments, the absence of this regulatory instrument has not overshadowed the interest of foreign investors in the country, which remained one of the main recipients of FDI. However, changes in domestic and international economy boosted Brazilian companies to other countries in the south of the continent and in Africa, what led Brazilian investment policymakers to redesign the national strategy. In this context, a new regulatory model emerges again in a rebellious fashion, which is now based not on the denial of the models in place, but rather on the uniqueness of its terms. This new model addresses the so-called legitimacy crisis of the global regime of investments and promotes more balanced and cooperative investment relations. The analyses developed in this paper depart from primary (national and international regulation) and secondary documents (specialized literature).

Keywords: Foreign direct investment. Regulatory models. Brazil. Investment agreements.

\section{INTRODUÇÃo}

Ao longo dos anos, o Brasil tem sido um protagonista na circulação de riquezas por meio do investimento estrangeiro direto. De acordo com os últimos cinco relatórios de investimentos estrangeiros da Conferência das Nações Unidas para o Comércio e o Desenvolvimento (UNCTAD, sigla em inglês), observa-se que o Brasil oscila entre a quarta e a décima quarta posições de um total de vinte países avaliados, relativamente à atração de investimentos. ${ }^{1}$ Ainda que o Brasil não ocupe o mesmo papel de destaque enquanto país de origem dos investimentos, observa-se, entretanto, significativo

1 No relatório de 2010, o Brasil ocupava a $14^{\mathrm{a}}$ posição. No relatório de 2013, o Brasil ocupava a $4^{a}$ posição. Nos relatórios de 2011 e 2012, o país permaneceu na $5^{a}$ posição. No relatório de 2014, o Brasil ocupou a $7^{\text {a }}$ posição. No relatório de 2015, o Brasil passou para a $6^{a}$ posição. Nos relatórios anteriores, o ranking não está disponível e/ou o Brasil não consta entre os principais importadores de capital estrangeiro. crescimento da internacionalização de empresas brasileiras acompanhado de aumento do investimento brasileiro direto no exterior. ${ }^{2}$

Ao mesmo tempo, nota-se que a posição de destaque do Brasil enquanto país receptor de investimentos estrangeiros, está ancorada, fortemente, na dinâmica das relações Norte-Sul, em que países do Norte se instalam em economias periféricas como o Brasil para explorar seus recursos naturais e gozar de custos de transação reduzidos. Por outro lado, o incremento dos investimentos estrangeiros oriundos de nacionais brasileiros apontam para, longe de uma reversão dessa lógica, a emergência de uma nova categoria de análise pautada no Sul como investidor. Chama-se atenção, nesse contexto, que uma parcela significativa dessas novas relações são Sul-Sul.

O presente artigo busca explorar a posição do Brasil na regulamentação dos investimentos estrangeiros, seja como receptor ou exportador de capital. Indaga-se como o direito brasileiro tem se moldado às pressões por acordos internacionais de investimento estrangeiro. Isso significa examinar dois tipos de dinâmica: a primeira delas, na década de 90, impulsionada por economias desenvolvidas interessadas em investir no Brasil e oferecer padrões de proteção aos seus nacionais; e a segunda dinâmica mais perceptível a partir de meados dos anos 2000, liderada pela indústria brasileira interessada em proteger seus negócios em países de destino do seu capital, notadamente na América do Sul e, mais recentemente, na África.

Sustentamos a tese de que o Brasil passa por um período de transição regulatória que vai da resistência em assumir compromissos internacionais no padrão dos tratados bilaterais de investimento (TBIs) ao protagonismo no desenho de um novo modelo de acordo de investimento com características desenhadas a partir de diferentes interesses e preocupações.

$\mathrm{O}$ artigo pauta-se em pesquisa documental sobre materiais primários e secundários e está estruturado em duas grandes partes, com subdivisões. A primeira parte explora o que chamaremos, neste artigo, de primeira onda de acordos de investimento envolvendo o Brasil. Identificamos o conteúdo dessas regras, sua tramitação

2 BANCO CENTRAL DO BRASIL. Capitais brasileiros no exterior. Disponível em: <http://www4.bcb.gov.br/rex/cbe/port/cbe. asp>. Acesso em: 14 set. 2015; FUNDAÇÃO DOM CABRAL. Ranking FDC das multinacionais brasileiras 2014: a força da marca Brasil na criação de valor internacional. [S.1]: FDC, 2014. p. 29. 
legislativa e a resistência do governo brasileiro em ratificar esses compromissos internacionais. A segunda parte do artigo avança para a segunda onda de acordos de investimentos, que está, fortemente, associada à aproximação do Brasil com o Sul global e a busca por instrumentos regulatórios alternativos de investimento estrangeiro.

\section{A primeira onda RegulatóRIa dos INVES- TIMENTOS ESTRANGEIROS DIREITOS NO BRASIL: A PROPOSTA DE RECEPÇÃO DE CAPITAL ESTRANGEIRO VIA TRATADOS BILATERAIS DE INVESTIMENTO}

Em matéria de regulação de investimento estrangeiro, ressalta-se que, desde 1960, o Brasil já era parte do Acordo sobre Garantia de Investimentos, celebrado com os Estados Unidos, ${ }^{3}$ o qual - diversamente dos tratados bilaterais de investimento - se ocupa, exclusivamente, sobre a garantia dos riscos políticos, não apresentando disposições sobre a proteção dos investimentos estrangeiros. ${ }^{4}$ Foi nesse período, também, que o primeiro Tratado Bilateral de Investimento foi assinado, entre Alemanha e Paquistão, ${ }^{5}$ iniciando uma nova e modernamente a mais popular tendência em matéria de regulação de investimento estrangeiro no mundo. ${ }^{6}$

Durante as décadas de 80 e 90, era possível se observar a disseminação dos tratados bilaterais de investi-

3 BRASIL. Decreto no 57.943, de 10 de março de 1966. Promulga o Acordo de Garantia de Investimentos com os Estados Unidos da América. Diário Oficial [da] República Federativa do Brasil, Poder Executivo, Brasília, DF, 16 mar. 1966. Seção 1, p. 2815. Embora o acordo contenha previsão de mecanismo arbitral, sua utilização é restrita aos Estados partes para controvérsia que possa constituir matéria de Direito Internacional Público, estando excluídos os assuntos que permaneçam exclusivamente dentro da jurisdição interna de um Estado soberano. Além disso, o acordo expressamente exclui do mecanismo arbitral as "reivindicações decorrentes de desapropriação de bens de investidores privados estrangeiros", exceto se restar configurada denegação de justiça. MAGALHÃES, José Carlos de. Acordos bilaterais de promoção e proteção de investimentos. Revista de Arbitragem e Mediação, São Paulo, v. 6, n. 20, p. 53-65, 2009.

4 NUSDEO, Ana Maria de Oliveira. A experiência do Decreto n ${ }^{\circ}$ 57.943 como acordo de garantia de investimentos entre Brasil-EUA. In: AMARAL JÚNIOR, Alberto do; SANCHEZ, Michelle Ratton (Coord.). Regulamentação internacional dos investimentos: algumas lições para o Brasil. São Paulo: Aduaneiras, 2007. p. 303-321. p. 320.

5 Alemanha - Paquistão TBI, assinado em 25 de novembro de 1959, Bundesgesetzblatt, Pt II, No 33 (6 julho 1961).

6 A bibliografia sobre BITs é absolutamente abundante. De forma geral, veja BROWN, Chester (Ed.). Commentaries on selected model investment treaties. Oxford: Oxford University Press, 2013. mento em diversos países. Nessa época, o Brasil assinou quatorze Acordos de Proteção e Promoção Recíproca de Investimentos, denominação pela qual ficaram conhecidos os tratados bilaterais de investimento celebrados com Alemanha (1995), Bélgica/Luxemburgo (1999), Chile (1994), Coreia do Sul (1995), Cuba (1997), Dinamarca (1995), Finlândia (1995), França (1995), Itália (1995), Países Baixos (1998), Portugal (1994), Reino Unido (1994), Suíça (1994) e Venezuela (1995). ${ }^{7}$

Tais tratados bilaterais de investimento apresentavam estrutura muito semelhante. ${ }^{8}$ Em todos eles, estão presentes os dispositivos sobre: (a) definições de investimento, investidor e território, (b) admissão de investimentos, (c) promoção dos investimentos, (d) padrões de proteção dos investimentos, (e) nacionalização, expropriação e indenização, (f) livre transferência e repatriação dos investimentos, (g) solução de controvérsias entre Estados partes, (h) solução de controvérsias entre investidores e Estados, e (i) vigência e denúncia do tratado. Vejamos mais detalhadamente o conteúdo desses tratados.

\subsection{O conteúdo dos tratados bilaterais de inves- timento da década de 90}

A análise mais detalhada de alguns dispositivos centrais dos tratados bilaterais de investimento com o Brasil se torna importante para a compreender a posição brasileira sobre o tema. ${ }^{9}$ Todos os acordos assinados pelo Brasil contêm um artigo, no qual são determinadas,

7 MAGALHÃES, José Carlos de. Acordos bilaterais de promoção e proteção de investimentos. Revista de Arbitragem e Mediação, São Paulo, v. 6, n. 20, p. 53-65, 2009. p. 53. Os tratados estão acessíveis na base de dados do Sistema de Atos Internacionais do Ministério das Relações Exteriores, que pode ser acessado em $<$ dai-mre.serpro. gov.br>. Em 1999, o acordo com Bégica/Luxemburgo foi assinado com a União Econômica Belgo-Luxemburguesa.

8 Todavia observa-se que questões como proteção do meio ambiente, desenvolvimento sustentável, direitos trabalhistas, responsabilidade corporativa e direitos humanos - incluídos na nova geração de acordos internacionais de investimento - não foram objeto de previsão nos acordos assinados pelo Brasil.

9 A Consultoria Legislativa da Câmara dos Deputados realizou, por ocasião da tramitação desses acordos no Congresso Nacional, uma análise mais geral dos dispositivos principais desses tratados. Nesse sentido, cf. AZEVEDO, Débora Bittah. Os acordos para a promoção e a proteção recíproca de investimentos assinados pelo Brasil. Brasília: Câmara dos Deputados, 2001. Em relação ao conteúdo desses tratados, cf. também SCANDIUCCI FILHO, José Gilberto. O Brasil e os acordos bilaterais de investimentos. In: AMARAL JÚNIOR, Alberto do; SANCHEZ, Michelle Ratton (Coord.). Regulamentação internacional dos investimentos: algumas lições para o Brasil. São Paulo: Aduaneiras, 2007. p. 271-301. 
entre outras, as definições de investimento e investidor. Confira-se, a título de exemplo, o artigo $1^{\circ}$ do Acordo de Promoção e Proteção Recíproca de Investimentos celebrado com a Alemanha:

\section{Artigo 1}

\section{Para os efeitos do presente Acordo:}

1. O termo "investimentos" significa toda espécie de haveres investidos ou reinvestidos por um investidor de uma Parte Contratante no território da outra, de acordo com a legislação desta última, e inclui, em particular, ainda que não exclusivamente:

a) a propriedade de bens móveis e imóveis, bem como quaisquer outros direitos reais, tais como hipotecas e penhoras;

b) as ações, quotas ou outras formas de participação societária;

c) os direitos sobre créditos ou quaisquer outros direitos sobre obrigações com valor econômico relativos a um investimento;

d) os direitos de propriedade intelectual, tais como direitos de autor, patentes, modelos registrados, desenhos e modelos industriais, marcas, nomes comerciais, informações não divulgadas, processos tecnológicos, know-how e fundo de comércio, e

e) as concessões de direito público, inclusive concessões para pesquisa, exploração e extração de recursos naturais.

A alteração da forma pela qual os bens foram investidos não afeta a sua qualificação como investimento.

2. O termo "rendimentos" designa as quantias geradas por um investimento, em um determinado período, tais corno lucros, dividendos, juros, royalties, ou outras formas de remuneração.

\section{O termo "investidores" designa:}

a) as pessoas físicas que tenham a nacionalidade de uma das Partes Contratantes em conformidade com sua Constituição e que realizem um investimento no território da outra Parte Contratante, e

b) as pessoas jurídicas, as sociedades comerciais ou outras sociedades e associações, com ou sem personalidade jurídica, que tenham sede no território de uma das Partes Contratantes, constituídas de acordo com a sua respectiva legislação interna, independentemente de terem suas atividades fins lucrativos, e que realizem um investimento no território da outra Parte Contratante.

4. O termo "território" designa o território de cada Parte Contratante, compreendendo a plataforma continental e a zona econômica exclusiva, sobre o qual a Parte Contratante em questão possa, de acordo com o Direito Internacional, exercer direitos soberanos ou jurisdição.
Verifica-se que a definição de investimentos contida no tratado celebrado com a Alemanha possui uma referência bastante ampla a "toda espécie de haveres investidos ou reinvestidos por um investidor" no território do outro Estado contratante. ${ }^{10}$ Em seguida, o dispositivo apresenta rol exemplificativo dos ativos que são considerados investimentos, alertando que a definição "inclui, em particular, ainda que não exclusivamente" os tipos de ativos listados. Nota-se que, em nenhum momento, a definição distingue investimento direto e de investimento indireto.

A definição de investimentos adotada no acordo celebrado com a Alemanha é extremamente semelhante, com exceção de irrisórias alterações de redação, às definições contidas nos demais acordos celebrados. Ressalte-se, contudo, que o acordo celebrado com a Coreia do Sul apresenta, no rol exemplificativo, um tipo bastante amplo de investimento, definido como "quaisquer direitos conferidos por lei ou contrato relacionados a um investimento".

Em relação à definição de investidor, o acordo celebrado com a Alemanha utiliza o critério da nacionalidade para as pessoas físicas e o critério do local da incorporação somado ao critério da sede para as pessoas jurídicas. O mesmo padrão é observado na maioria dos outros tratados bilaterais assinados pelo Brasil, com algumas exceções. ${ }^{11}$

Outro dispositivo de crucial importância para os tratados bilaterais de investimento é o que regula os padrões de tratamento do investidor estrangeiro. De maneira geral, os tratados celebrados pelo Brasil dedicam de um a três artigos - com algumas variações - para

10 SCANDIUCCI FILHO, José Gilberto. O Brasil e os acordos bilaterais de investimentos. In: AMARAL JÚNIOR, Alberto do; SANCHEZ, Michelle Ratton (Coord.). Regulamentação internacional dos investimentos: algumas lições para o Brasil. São Paulo: Aduaneiras, 2007. p. 271-301. p. 283. De acordo com o autor, no caso brasileiro, "optou-se pelo critério mais amplo possível: todas as formas de investimento oriundas da outra Parte são protegidas pelo acordo" (grifo do autor).

11 Nos tratados celebrados com Dinamarca e Reino Unido, o critério do domicílio é utilizado como alternativa ao critério da nacionalidade para a definição do investidor pessoa física. Nos mesmos tratados, a definição de investidor pessoa jurídica se restringe ao critério do local da incorporação. Os tratados celebrados com França, Suíça e Venezuela a definição é muito semelhante àquela do acordo com a Alemanha, exceto pela inclusão do critério do controle da pessoa jurídica. No acordo celebrado com os Países Baixos, utiliza-se, também, o critério do controle da pessoa jurídica, mas não há menção ao critério da sede da pessoa jurídica. No tratado celebrado com a Itália, verifica-se menção expressa às empresas públicas. 
tratar, entre outros assuntos: (a) do tratamento da nação mais favorecida, (b) do tratamento nacional, (c) do tratamento justo e equitativo, (d) da garantia de proteção e segurança, e (e) das exceções pela participação em blocos econômicos. ${ }^{12}$

No acordo celebrado com os Países Baixos, a redação estabelece - sem maiores detalhes - a obrigação de assegurar ao investidor estrangeiro o padrão de tratamento justo e equitativo. ${ }^{13} \mathrm{O}$ mesmo paradigma de redação é utilizado nos demais tratados bilaterais celebrados pelo Brasil, existindo, especificamente no caso dos tratados celebrados com Países Baixos e Dinamarca, menção ao tratamento justo e equitativo, também, no preâmbulo do acordo.

Os tratados celebrados com Chile, Cuba e França apresentam modulação na previsão do padrão de tratamento justo e equitativo, determinando que ele seja assegurado "em conformidade com os princípios do Direito Internacional”. De maneira análoga, o acordo celebrado com a Venezuela faz referência à garantia do tratamento justo e equitativo "em conformidade com as normas e princípios do Direito Internacional".

Interessante notar que o acordo celebrado com a França inclui, em seu artigo $3^{\circ}$, alguns exemplos de violações do padrão de tratamento justo e equitativo, entre os quais estão incluídos: (a) restrições à compra e ao transporte de matérias-primas e matérias auxiliares, energia e combustíveis; (b) obstáculos à venda e transporte dos produtos no interior do país e para o exterior; (c) restrições à compra de meios de produção e de exploração de qualquer espécie; e (d) quaisquer outras medidas de efeito análogo.

Os dispositivos sobre solução de controvérsias entre Estado hospedeiro e investidor estrangeiro presentes

12 SCANDIUCCI FILHO, José Gilberto. O Brasil e os acordos bilaterais de investimentos. In: AMARAL JÚNIOR, Alberto do; SANCHEZ, Michelle Ratton (Coord.). Regulamentaşão internacional dos investimentos: algumas lições para o Brasil. São Paulo: Aduaneiras, 2007. p. 271-301. p. 284-87.

13 SCANDIUCCI FILHO, José Gilberto. O Brasil e os acordos bilaterais de investimentos. In: AMARAL JÚNIOR, Alberto do; SANCHEZ, Michelle Ratton (Coord.). Regulamentação internacional dos investimentos: algumas lições para o Brasil. São Paulo: Aduaneiras, 2007. p. 271-301. p. 284-285. Segundo a análise empreendida pelo autor, "é evidente que a aplicação desse dispositivo enseja razoável subjetividade em sua interpretação. A classificação de uma medida ou norma legal como 'justa' e/ou 'equitativa' depende de critérios que podem variar de acordo com cada situação, para dizer o mínimo". nos tratados bilaterais assinados pelo Brasil apresentam, por sua vez, menor grau de uniformidade na redação. $\mathrm{O}$ artigo $8^{\circ}$ do Acordo de Promoção e Proteção Recíproca de Investimentos celebrado com o Chile fornece, entretanto, algumas indicações de disposições recorrentes nos outros acordos. Tal dispositivo apresenta um roteiro básico para a solução de controvérsias, que consiste em: (1) realização de consultas mútuas para alcançar uma solução amigável, (2) escolha irreversível (fork-in-the-road), por parte do investidor estrangeiro, entre (a) os tribunais nacionais do Estado hospedeiro ou (b) a arbitragem internacional, (3) optando-se pela arbitragem, escolha, por parte do investidor estrangeiro, entre utilização (a) do ICSID ou, quando necessário, de seu Mecanismo Suplementar ou (b) da arbitragem ad hoc de acordo com as regras da Comissão das Nações Unidas sobre o Direito do Comércio Internacional (UNCITRAL), e (4) execução de eventual laudo arbitral de acordo com o Direito nacional.

Esse roteiro é quase integralmente reproduzido nos tratados bilaterais celebrados com Bélgica/Luxemburgo, Coreia do Sul, Dinamarca, Finlândia, Reino Unido e Suíça, exceto pela possibilidade de o investidor estrangeiro, tendo, previamente, optado pela submissão da controvérsia ao tribunal nacional competente no Estado hospedeiro, desistir do processo antes de proferida qualquer decisão e, então, submeter a controvérsia à arbitragem internacional.

Em relação aos possíveis fóruns para a realização do procedimento arbitral, o tratado celebrado com Bélgica/Luxemburgo inclui as alternativas da Câmara de Comércio Internacional de Paris e da Câmara de Comércio de Estocolmo. O acordo com o Reino Unido, por sua vez, traz como alternativa apenas a Câmara de Comércio Internacional de Paris. Os tratados assinados com Itália e Portugal preveem a utilização da arbitragem ad hoc ou no ICSID, sem fazer referência à possibilidade de utilização de seu Mecanismo Suplementar. O tratado com a Alemanha, por outro lado, prevê a utilização da arbitragem ad hoc enquanto ambos os Estados partes não tiverem aderido à Convenção de Washington. Já o tratado com a Venezuela prevê a utilização da arbitragem ad hoc apenas quando o ICSID ou seu Mecanismo Suplementar não estiverem, por algum motivo, acessíveis. No acordo celebrado com Cuba, há, apenas, a previsão de utilização da arbitragem ad hoc de acordo com as regras da UNCITRAL. 
É interessante a redação adotada, a esse respeito, no tratado bilateral celebrado com os Países Baixos, no qual se faz referência apenas à conciliação e à arbitragem, tanto no âmbito interno quanto no âmbito internacional. Outro dispositivo peculiar é observado no acordo celebrado com Bélgica/Luxemburgo, em que se admite o pedido de instauração do procedimento arbitral por parte do Estado hospedeiro, o qual deve solicitar por escrito ao investidor que designe a organização à qual será submetida a controvérsia.

Em resumo, ainda que se concorde com a doutrina especializada no sentido de que os tratados bilaterais de investimento servem para assegurar um certo grau de uniformidade com relação aos standards que governam as relações de investimento entre o país de origem do investimento e os vários países de destino do investimento, ${ }^{14}$ é bastante evidente que o interesse preponderante desses instrumentos é a proteção do investidor, como se percebe da análise das cláusulas mencionadas. Portanto, o país de destino do investimento que se compromete com esses tratados deve antes se certificar de que a redução do seu policy space é compensada pelas oportunidades de investimento geradas.

\subsection{Os impasses políticos para a aprovação le- gislativa dos tratados bilaterais de investimento}

Apesar das semelhanças estruturais e substanciais dos tratados bilaterais de investimentos assinados pelo Brasil, apenas os acordos celebrados com Alemanha, Chile, França, Portugal, Reino Unido e Suíça foram encaminhados por mensagens do Presidente da República para ratificação pelo Congresso Nacional. ${ }^{15}$ No entanto, os procedimentos de ratificação de todos esses acordos - apesar das diferenças de redação e tramitação - enfrentaram resistências no Poder Legislativo. ${ }^{16}$

O Governo brasileiro não parece ter adotado um critério geográfico para a escolha de quais acordos

14 SCHILL, Stephan W. The multilateralization of International Investment Law. Cambridge: Cambridge University Press, 2014. p. 91.

15 Os projetos de decreto legislativo são os seguintes: PDC $\mathrm{n}^{\circ}$ 396/00 (Alemanha), PDC no 366/96 (Chile), PDC no 395/00 (França), PDC no 365/96 (Portugal), PDC no 367/96 (Reino Unido) e PDC n 348/96 (Suíça).

16 SCANDIUCCI FILHO, José Gilberto. O Brasil e os acordos bilaterais de investimentos. In: AMARAL JÚNIOR, Alberto do; SANCHEZ, Michelle Ratton (Coord.). Regulamentaşão internacional dos investimentos: algumas lições para o Brasil. São Paulo: Aduaneiras, 2007. p. 271-301. p. 301 deveriam ser encaminhados ao Congresso Nacional. Foram deixados de lado acordos com países europeus (Bélgica/Luxemburgo, Dinamarca, Finlândia, Itália e Países Baixos), asiáticos (Coreia do Sul) e latino-americanos (Cuba e Venezuela). A análise dos dados do Banco Central do Brasil sobre o estoque de investimentos estrangeiros no Brasil nos anos de 1995 e 2000 (Tabela 1) demonstra que o Governo parece ter dado prioridade aos acordos celebrados com países que possuíam maior participação nos investimentos estrangeiros realizados no Brasil, a exemplo de Alemanha, França e Reino Unido. Entretanto, acordos celebrados com países como Itália e Países Baixos nunca foram submetidos ao Congresso Nacional, ainda que a participação desses países nos investimentos realizados no Brasil fosse maior do que aquela de países como Chile e Portugal.

Tabela 1 - Estoque de investimentos estrangeiros diretos no Brasil (em US\$ milhões) em 1995 e 2000.

\begin{tabular}{|l|r|r|r|r|}
\hline \multirow{2}{*}{ Países } & \multicolumn{2}{|c|}{1995} & \multicolumn{2}{c|}{2000} \\
\cline { 2 - 5 } & valor & percentual & valor & percentual \\
\hline Alemanha & $\mathbf{5 8 2 8 , 0 4}$ & $\mathbf{1 3 , 9 8}$ & $\mathbf{5 1 1 0 , 2 4}$ & $\mathbf{4 , 9 6}$ \\
\hline $\begin{array}{l}\text { Bélgica/ } \\
\text { Luxem- } \\
\text { burgo }\end{array}$ & 966,28 & 2,32 & 1690,76 & 1,64 \\
\hline Chile & $\mathbf{2 3 8 , 3 7}$ & $\mathbf{0 , 5 7}$ & $\mathbf{2 2 8 , 1 3}$ & $\mathbf{0 , 2 2}$ \\
\hline $\begin{array}{l}\text { Coreia do } \\
\text { Sul }\end{array}$ & 3,81 & 0,01 & 179,64 & 0,17 \\
\hline Cuba & 0,71 & $<0,01$ & 0,08 & $<0.01$ \\
\hline Dinamarca & 84,91 & 0,20 & 478,10 & 0,46 \\
\hline Finlândia & 123,30 & 0,30 & 180,62 & 0,18 \\
\hline França & $\mathbf{2 0 3 1 , 4 6}$ & $\mathbf{4 , 8 7}$ & $\mathbf{6 9 3 0 , 8 5}$ & $\mathbf{6 , 7 3}$ \\
\hline Itália & 1258,56 & 3,02 & 2507,17 & 2,43 \\
\hline $\begin{array}{l}\text { Países } \\
\text { Baixos }\end{array}$ & 1545,80 & 3,71 & 11055,33 & 10,73 \\
\hline Portugal & $\mathbf{1 0 6 , 6 1}$ & $\mathbf{0 , 2 6}$ & $\mathbf{4 5 1 2 , 1 0}$ & $\mathbf{4 , 3 8}$ \\
\hline $\begin{array}{l}\text { Reino } \\
\text { Unido }\end{array}$ & $\mathbf{1 8 6 2 , 6 1}$ & $\mathbf{4 , 4 7}$ & $\mathbf{1 4 8 7 , 9 5}$ & $\mathbf{1 , 4 4}$ \\
\hline Suíça & $\mathbf{2 8 5 1 , 3 0}$ & $\mathbf{6 , 7 5}$ & $\mathbf{2 2 5 2 , 0 5}$ & $\mathbf{2 , 1 9}$ \\
\hline Venezuela & 1,02 & $<0,01$ & 19,08 & 0,02 \\
\hline $\begin{array}{l}\text { Total de in- } \\
\text { vestimentos } \\
\text { estrangeiros }\end{array}$ & 41695,62 & 100,00 & 103014,51 & 100,00 \\
\hline $\begin{array}{l}\text { Fonte: Banco } \\
\text { dos bilaterais de investimento foram submetidos à apreciação do } \\
\text { Congresso Nacional. }\end{array}$ & & & \\
\hline
\end{tabular}

Os motivos que levaram o Governo a encaminhar os tratados bilaterais de investimentos ao Congresso Nacional podem ser extraídos, por exemplo, da Mensagem no 1.158 , de 15 de dezembro de 1994, que submetia 
o acordo celebrado com Portugal à apreciação do Poder Legislativo. $\mathrm{Na}$ exposição de motivos anexa ao documento, esclarece-se que:

acordos para a promoção e proteção contra riscos não comerciais constituem hoje relevantes fatores de atração do capital estrangeiro. [...] O Governo brasileiro, por conseguinte, com o objetivo de sinalizar à comunidade financeira internacional uma postura receptiva ao investimento estrangeiro [...] criou, em março de 1992, Grupo de Trabalho Interministerial encarregado de elaborar modelo de acordo para a promoção e a proteção de investimentos estrangeiros. Em setembro de 1992, o Ministério das Relações Exteriores, e o então Ministério da Economia, Fazenda e Planejamento aprovaram texto-padrão de acordo sobre a matéria, o qual tem sido gradativamente adaptado às tendências internacionais nessa área. Desde então, número significativo de países vêm propondo formalmente ao Brasil a negociação de acordos para a promoção e a proteção recíproca de investimentos. ${ }^{17}$

$\mathrm{Na}$ Mensagem no 8, de 5 de janeiro de 1995, que encaminhou ao Congresso Nacional o acordo celebrado com o Reino Unido, a exposição de motivos informava que, ao longo das negociações, o modelo de acordo inicialmente aprovado pelo Governo foi "adaptado a padrões mais realistas, os mais próximos possíveis dos recomendados pela Organização para a Cooperação e o Desenvolvimento Econômico (OCDE)". ${ }^{18} \mathrm{O}$ objetivo dos tratados era "garantir a introdução no ordenamento jurídico nacional de regras compatíveis com a política nacional de atração de investimentos estrangeiros diretos", ${ }^{19}$ como se observa da Mensagem no 652, de 9 de junho de 1997, que encaminhou o acordo celebrado com a França para apreciação do Congresso Nacional. Por ocasião do encaminhamento do acordo celebrado com a Alemanha, por meio da Mensagem $n^{\circ} 755$, de 25 de junho de 1998, a exposição de motivos reconhecia o avanço trazido pelas reformas constitucionais da or-

17 BRASIL. Exposição de Motivos no 612/MRE, de 12 de dezembro de 1994. Diário do Congresso Nacional, Brasília, v. 50, n. 4, p. 404, 6 jan. 1995. Seção 1. Idêntica justificativa foi apresentada para a submissão do acordo celebrado com o Chile, cf. BRASIL. Exposição de Motivos no 613/MRE, de 12 de dezembro de 1994. Diário do Congresso Nacional, Brasília, v. 50, n. 4, 6 jan. 1995. p. 408

18 BRASIL. Exposição de Motivos no 642/MRE, de 27 de dezembro de 1994. Diário do Congresso Nacional, Brasília, v. 50, n. 21, 31 jan. 1995. p. 1486. Nos mesmos termos, foi apresentada a mensagem que encaminhou o acordo celebrado com a Suíça, cf. BRASIL. Exposição de Motivos no 643/MRE, de 28 de dezembro de 1994. Diário do Congresso Nacional, Brasília, v. 52, n. 24, 19 fev. 1997. p. 4350. 19 BRASIL. Exposição de Motivos no 227/MRE, de 5 de junho de 1997. Diário da Câmara dos Deputados, Brasília, v. 52, n. 113, 1 jul. 1997. p. 18178. dem econômica, realizadas ao longo dos anos 90, mas ressaltava igualmente a "necessidade de também o Brasil conferir maior transparência e estabilidade à legislaçãonacional aplicável ao capital estrangeiro, mediante a celebração de acordos para a promoção e proteção de investimentos". ${ }^{20}$

Registre-se que, em paralelo à tramitação dos tratados bilaterais de investimento assinados pelo Brasil, o Congresso Nacional, também, analisou o Protocolo de Buenos Aires, que tratava da promoção e proteção de investimentos provenientes de Estados não partes do MERCOSUL. ${ }^{21} \mathrm{O}$ acordo tinha como objetivo harmonizar os princípios gerais aplicáveis por cada um dos Estados partes aos investimentos estrangeiros extrazona, estabelecendo bases normativas para a eventual negociação de tratados de investimento com terceiros Estados. ${ }^{22}$ Esclareceu a Mensagem n ${ }^{0} 749$, de 6 de julho de 1995, que encaminhou o Protocolo de Buenos Aires para o Congresso Nacional, que o acordo "estabelece, assim, parâmetros máximos de concessões que podem ser estendidas a investimentos realizados por investidores de Estados não membros do Mercosul". ${ }^{23}$

Durante a tramitação na Câmara dos Deputados, os acordos de investimentos receberam quase sempre pareceres favoráveis da Comissão de Constituição e Justiça e de Cidadania (CCJC), ${ }^{24}$ da Comissão de Finanças e

20 BRASIL. Exposição de Motivos no 230/MRE/MF, de 22 de junho de 1998. Diário da Câmara dos Deputados, Brasília, v. 53, n. 111, 7 jun. 1998. p. 17657.

21 MERCOSUL. Conselho do Mercado Comum. Decisão no 11, de 5 de agosto de 1994. Protocolo sobre promoción y protección de inversiones provenientes de Estados no partes del Mercosur. Disponível em: <http://www.bcb.gov.br/Rex/SGT4/Ftp/DEC_11_1994. pdf $>$. Acesso em: 19 jan. 2016.

22 COSTA, José Augusto Fontoura. Proteção e promoção do investimento estrangeiro no Mercosul uma ferramenta para a implementação de um bom clima de investimentos? Revista Brasileira de Política Internacional, Brasília, v. 49, n. 2, p. 60-77, 2006. p. 68.

23 BRASIL. Exposição de Motivos no 369/MRE, de 30 de junho de 1995. Diário da Câmara dos Deputados, Brasília, v. 56, n. 95, 21 jun. 2001. p. 30526. No Congresso Nacional, o Protocolo de Buenos Aires tramitou como Projeto de Decreto Legislativo no 301/99.

24 No caso do acordo celebrado com o Reino Unido, cf. BRASIL. Câmara dos Deputados. Parecer da Comissão de Constituição e Justiça e Redação, de 8 de janeiro de 1997 [ao Projeto de Decreto Legislativo no 367 de 1996]. Diário da Câmara dos Deputados, Brasília, v. 60, n. 78, 4 maio 2000. p. 21702. Da mesma forma, em relação ao acordo celebrado com o Chile, cf. BRASIL. Câmara dos Deputados. Parecer da Comissão de Constituição e Justiça e Redação, de 8 de janeiro de 1997 [ao Projeto de Decreto Legislativo no 366 de 1996]. Diário da Câmara dos Deputados, Brasília, v. 59, n. 184, 6 nov. 1999. p. 52684. 
Tributação (CFT) ${ }^{25}$ e da Comissão de Desenvolvimento Econômico, Indústria e Comércio (CDEIC) ${ }^{26}$

Entretanto, na Comissão de Relações Exteriores e de Defesa Nacional (CREDN), os acordos encontraram resistências desde o início da tramitação, ainda que os pareceres tenham, por fim, indicado a aprovação dos projetos. Nesse sentido, a análise realizada no caso do acordo celebrado com o Reino Unido apontou os dois principais aspectos controversos: a compensação por expropriação e a solução de controvérsias entre investidor e Estado. ${ }^{27}$

De acordo com a manifestação parlamentar, a "forma de indenização definida no texto precisa ser confrontada com alguns dos preceitos constitucionais vigentes acerca da desapropriação de imóveis urbanos e rurais". ${ }^{28}$ Embora a regra seja o pagamento de indenização por expropriação em dinheiro, a Constituição Federal admite - em determinadas circunstâncias - seu pagamento em títulos da dívida pública ou em títulos da reforma agrária, de maneira que "como não se ressalvaram, no texto do acordo as particularidades previstas na [Constituição Federal], podemos imaginar que o investidor estrangeiro poderia, em caso de conflito futuro, pretender a aplicação do texto acordado". ${ }^{29}$

25 Em relação à da Comissão de Tributação e Finanças, a conclusão pela não implicação da matéria com aumento ou diminuição da receita ou da despesa públicas pode ser observada, por exemplo, no parecer de avaliação do acordo celebrado com a Alemanha. BRASIL. Câmara dos Deputados. Parecer da Comissão de Tributação e Finanças, de 6 de agosto de 2003 [ao Projeto de Decreto Legislativo $\mathrm{n}^{\circ} 366$ de 2000]. Diário da Câmara dos Deputados, Brasília, v. 68, n. 126, 12 ago. 2003. p. 37396.

26 A manifestação favorável da Comissão de Desenvolvimento Econômico, Indústria e Comércio pode ser constatada, por exemplo, no caso do acordo celebrado com o Reino Unido. BRASIL. Câmara dos Deputados. Parecer da Comissão de Desenvolvimento Econômico, Indústria e Comércio, de 13 de fevereiro de 1997 [ao Projeto de Decreto Legislativo no 367 de 1996]. Diário da Câmara dos Deputados, Brasília, v. 53, n. 94, 3 jun. 1998. p. 15007.

27 GARCIA NETO, Paulo Macedo. Investment arbitration in Brazil: the landscape of investment arbitration in Brazil and why Brazil should become a more important player in the investment arbitration arena. In: LEVY, Daniel de Andrade; BORJA, Ana Gerdau de; PUCCI, Adriana Noemi. Investment protection in Brazil. Alphen aan den Rijn: Wolters Kluwer, 2013. p. 3-16. p. 5-6.

28 BRASIL. Câmara dos Deputados. Parecer da Comissão de Relações Exteriores e Defesa Nacional [ao Projeto de Decreto Legislativo no 367 de 1996]. Exposição do Deputado Luiz Gushiken. Diário da Câmara dos Deputados, Brasília, v. 60, n. 78, 4 maio 2000. p. 21692.

29 BRASIL. Câmara dos Deputados. Parecer da Comissão de Relações Exteriores e Defesa Nacional [ao Projeto de Decreto Legislativo no 367 de 1996]. Exposição do Deputado Luiz Gushiken. Diário da Câmara dos Deputados, Brasília, v. 60, n. 78, 4 maio 2000. p.
Além de estabelecer o pagamento da indenização pela expropriação de terras para fins da reforma agrária em moeda conversível, quando o pagamento realizado, na mesma hipótese, seria em títulos da divida agrária resgatáveis em até 20 anos, os tratados bilaterais de investimento assinados pelo Brasil "estabeleciam o compromisso com a livre transferência de recursos, independentemente da disponibilidade de divisas pelo país, o que, obviamente, representava um tratamento diferenciado em relação ao dispensado aos nacionais". ${ }^{30}$

Em relação à solução de controvérsias entre Estado e investidor, afirma-se, no parecer da Comissão de Relações Exteriores e Defesa Nacional (CREDN) da Câmara dos Deputados, que "as normas contrariam regra de direito internacional consuetudinário tradicionalmente adotada pelo Brasil, o princípio do esgotamento de recursos internos". ${ }^{31} \mathrm{O}$ acesso direito do investidor estrangeiro à arbitragem internacional colocaria o particular em igualdade com o Estado brasileiro, o que representaria uma "proteção de investidores internacionais em detrimento de políticas e interesses nacionais". ${ }^{32}$

De maneira semelhante, é criticada no parecer parlamentar a possibilidade de alteração do foro no decorrer do processo, por escolha do investidor, alertando-se que, em função da cláusula da nação favorecida, a

21692. Nesse sentido, cf. a conclusão de LUÍS, Daniel Tavela; ANDRADE, Luis Antonio Gonçalves. Expropriation in Brazilian Law: an international standard? In: LEVY, Daniel de Andrade; BORJA, Ana Gerdau de; PUCCI, Adriana Noemi. Investment protection in Brazil. Alphen aan den Rijn: Wolters Kluwer, 2013. p. 107-126, p. 124, no sentido de que "it can be argued that Brazil has a standard of protection against expropriation that is similar to the one provided for in international law. Foreign investors and Brazilian nationals both have the same procedural and substantial rights under Brazilian law. The substantial rights conferred to by Brazilian law are close to the ones set forth by international law, but two main differences should be pointed out: (i) Brazilian courts have a limited assessment of issues related to expropriation - in principle, they are only allowed to discuss the quantum of indemnification due, and; (ii) payment of the amount due by the State entity responsible for the taking may not be made prior to the taking, as in some cases it may be made by "orders of cash release".

30 ALVES, André Gustavo de Miranda Pineli. As relações de investimento direto entre o Brasil e os países de seu entorno. In: (Org.). Os BRICS e seus vizinhos: investimento direto estrangeiro Brasília: IPEA, 2014. p. 13-169. p. 31, nota 17.

31 BRASIL. Câmara dos Deputados. Parecer da Comissão de Relações Exteriores e Defesa Nacional [ao Projeto de Decreto Legislativo no 367 de 1996]. Exposição do Deputado Luiz Gushiken. Diário da Câmara dos Deputados, Brasília, v. 60, n. 78, 4 maio 2000. p. 21693.

32 ALVES, André Gustavo de Miranda Pineli. As relações de investimento direto entre o Brasil e os países de seu entorno. In: (Org.). Os BRICS e seus vizinhos: investimento direto estrangeiro Brasília: IPEA, 2014. p. 13-169. p. 31. 
mesma prerrogativa poderia ser estendida, independentemente de previsão expressa nos outros tratados aos países, com os quais o Brasil viesse a celebrar acordos sobre investimentos. ${ }^{33}$

Algumas das críticas dirigidas aos tratados bilaterais assinados pelo Brasil acabaram por dar margem à proposição de emendas substitutivas pelos parlamentares. Exemplos dessas emendas podem ser observados no projeto de decreto legislativo que aprovaria o texto do acordo celebrado com a Alemanha. ${ }^{34}$ Também durante a apreciação do acordo celebrado com a Alemanha, o parecer do relator na Comissão de Tributação e Finanças apresentou críticas à amplitude do conceito de investimento empregado no texto do acordo e à cláusula de livre transferência dos recursos. ${ }^{35}$

Com as crescentes críticas aos tratados bilaterais de investimentos no Congresso Nacional, o Poder Executivo decidiu retirar os projetos de ratificação dos tratados da tramitação na Câmara dos Deputados. ${ }^{36}$ Repercutindo as controvérsias do projeto de Acordo Multilateral de Investimentos $(\mathrm{MAI})^{37}$ que se discutia à época, a

33 BRASIL. Câmara dos Deputados. Parecer da Comissão de Relações Exteriores e Defesa Nacional [ao Projeto de Decreto Legislativo no 367 de 1996]. Exposição do Deputado Luiz Gushiken. Diário da Câmara dos Deputados, Brasília, v. 60, n. 78, 4 maio 2000. p. 21696.

34 O projeto de decreto legislativo continha os seguintes dispositivos: "Art. $2^{\circ} \mathrm{O}$ disposto no $\ 2^{\circ}$ do art. $4^{\circ}$ do Acordo [sobre expropriação] somente será aplicado no que não contrariar os casos previstos na Constituição Federal, especialmente o inciso III do $\$ 4^{\circ}$ do art. 182, e o art. 184. Art. $3^{\circ}$ A expressão "a pedido do investidor", contida no art. 10 do Acordo [sobre solução de controvérsias entre Estado e investidor], é interpretada no sentido de que o recurso à arbitragem internacional depende, necessariamente, da anuência do Governo brasileiro, quando os investimentos forem realizados em território nacional. Art. $4^{\circ}$ Os compromissos assumidos nesse Acordo terão que se submeter à regulamentação prevista no art. 172 da Constituição Federal". BRASIL. Câmara dos Deputados. Projeto de Decreto Legislativo no 396 de 2000: substitutivo adotado pela Comissão [de Economia, Indústria e Comércio]. Diário da Câmara dos Deputados, Brasília, v. 58, n. 126, 12 ago. 2003. p. 37783.

35 BRASIL. Câmara dos Deputados. Parecer da Comissão de Tributação e Finanças, de 21 de julho de 2003 [ao Projeto de Decreto Legislativo no 396 de 2000. Diário da Câmara dos Deputados, Brasília, v. 58, n. 126, 12 ago. 2003. p. 37795-37796.

36 SIQUEIRA, Marcelo Gustavo Silva. Direito do investimento e inovação tecnológica: o histórico regulatório da transferência de tecnologia no Brasil em face das cláusulas de proteção dos acordos bilaterais de investimentos. 2012. 199 f. Dissertação (Mestrado) - Faculdade de Direito, Universidade do Estado do Rio de Janeiro, Rio de Janeiro, 2012. p. 146-149.

37 Também descrito como uma "global bill of rights" dos investidores, o MAI era visto como um instrumento de proteção do capital estrangeiro que não garantia nenhum direito ao Estado hospedeiro, fulminando qualquer comprometimento com o desenvolvimento.
Mensagem $\mathrm{n}^{\circ}$ 1.081, de 11 de dezembro de 2002, que requeria a retirada do acordo celebrado com o Chile da tramitação no Congresso Nacional, reconhecia que os tratados bilaterais de investimentos assinados pelo Brasil haviam deixado de refletir as tendências do cenário internacional, ${ }^{38}$ nos seguintes termos:

A partir de 1997 testemunhou-se crescente questionamento quanto ao chamado Acordo Multilateral de Investimentos (Multilateral Agreement on Investments - MAI, na sigla em inglês), que vinha sendo negociado no âmbito da OCDE. Os dispositivos que aquele instrumento contemplava foram avaliados como um conjunto demasiado abrangente de direitos e prerrogativas que estariam sendo concedidos às empresas multinacionais, em detrimento da jurisdição do Estado e da própria socie-

A forte resistência dos países em desenvolvimento levou ao afastamento dos principais atores que conduziam o processo de negociação do MAI, o qual acabou por ser suspenso em 1998. Veja SUBEDI, Surya P. International Investment Law: reconciling policy and principle. Oxford: Hart Publishing, 2008. p. 41. A desconsideração pelos reflexos sociais dos investimentos também foi criticada por Wartha: "Die spürbare Dominanz des Wirtschaftlichen, die den Bürger zum Konsumenten reduziert und mit einer, Abdankung der Politk' einhergebt, kann nicht der Weg für die Zufunft sein". WARTHA, Udo. Das Multilaterale Abkommen über Investitionen (MAI). In: SCHACHTSCHNEIDER, Karl Albrecht (Org.). Rechtsfragen der Weltwirtschaft. Berlin: Duncker und Humblot, 2002. p. 359-433. p. 433. No mesmo sentido, veja FONSECA, Karla Closs. Investimentos estrangeiros: regulamentação internacional e acordos bilaterais. Curitiba: Juruá, 2008. p. 49. É importante observar que a desistência das negociações do MAI em virtude da pressão dos países em desenvolvimento foi sucedida por uma onda de negociações bilaterais, em que os países em desenvolvimento adotaram uma postura competitiva pela atração de investimentos dos países exportadores de capital. O resultado das negociações foi uma "race to the bottom", materializada na concessão de privilégios bastantes amplos para o capital estrangeiro. GUZMAN, Andrew T. Why LDCs sign treaties that hurt them: explaining the popularity of bilateral investment treaties. Virginia Journal of International Law, Virginia, v. 38, p. 639-688, 1997. p. 687.

38 No entendimento de José Augusto Fontoura Costa, "a estrutura do projeto e seu caráter de ampla liberalização e proteção deram espaço para o surgimento de preocupações efetivas com a manutenção de controles soberanos". COSTA, José Augusto Fontoura. Direito internacional do investimento estrangeiro. Curitiba: Juruá, 2010. p. 251. Nesse sentido, a Mensagem $n^{\circ} 1.084$, de 11 de dezembro de 2002, sobre o acordo celebrado com a França, em sua exposição de motivos, reconhecia que: "embora o Governo tenha oferecido argumentos para dirimir dúvidas e esclarecer questões levantadas no Congresso, é forçoso constatar que os acordos, por um lado, nunca encontrou [sic.] o respaldo político necessário para sua aprovação e, por outro, deixaram de refletir as tendências que hoje prevalecem no cenário internacional". BRASIL. Exposição de Motivos no 403 DSF/ARC/DEI - MRE - PEXT EFIN, de 5 de dezembro de 2002. Diário da Câmara dos Deputados, Brasília, v. 57, n. 184, 13 dez. 2002. p. 54415. A exposição de motivos é idêntica àquelas presentes nas mensagens do Poder Executivo que retiraram de tramitação os outros tratados bilaterais de investimento assinados pelo Brasil. 
dade. Dessa evolução resultou um declínio do apoio político àquelas negociações, particularmente por parte de alguns países europeus, movimento que culminou com o colapso do processo negociador. O Governo brasileiro participava como Observador das negociações da OCDE. Setores do Congresso Nacional passaram a ecoar fortemente as críticas formuladas àquele projeto $\mathrm{e}$ os [acordos de proteção e promoção de investimentos] assinados pelo Brasil começaram a ser vistos como uma espécie de versão bilateral do MAI e, como tal, não merecedores de endosso político. ${ }^{39}$

A decisão de retirar os tratados bilaterais de investimento da tramitação no Congresso Nacional decorreu de proposta formulada pela comissão instituída em 2002, durante a transição presidencial entre Fernando Henrique Cardoso e Luiz Inácio Lula da Silva, para avaliar os tratados bilaterais de investimento assinados pelo país. ${ }^{40}$

De maneira semelhante aos tratados bilaterais, o Protocolo de Buenos Aires foi retirado de tramitação no Congresso Nacional pela Mensagem no 162, de 8 de abril de 2004, cuja exposição de motivos repisa os aspectos controversos identificados pelos parlamentares, concluindo que "o referido Protocolo não contempla aspectos considerados prioritários para o Governo brasileiro sobre o tema da proteção e promoção de investimentos estrangeiros". ${ }^{41}$ Os motivos do Poder Executivo para interromper a tramitação do Protocolo de Buenos Aires no Congresso Nacional ficaram registrados nos seguintes termos:

no que diz respeito à "indenização para desapropriação", o Protocolo estipula pagamento "pronto, adequado e efetivo" aos investidores estrangeiros, ao passo que os nacionais brasileiros, por força da Constituição de 1988, têm de ser compensados, em casos de desapropriação, por instrumentos financeiros de longa maturação. No capítulo referente a "transferências de recursos para o exterior", o Protocolo não contempla as salvaguardas existentes na legislação brasileira à repatriação de capitais estrangeiros. Outra

39 BRASIL. Exposição de Motivos no 399 DSF/ARC/DE-I MRE - PEXT EFIN, de 5 de dezembro de 2002. Diário da Câmara dos Deputados, Brasília, v. 57, n. 184, 13 dez. 2002, p. 54411.

40 ALVES, André Gustavo de Miranda Pineli. As relações de investimento direto entre o Brasil e os países de seu entorno. In: (Org.). Os BRICS e seus vizinhos: investimento direto estrangeiro Brasília: IPEA, 2014, p. 13-169, p. 31.

41 BRASIL. Exposição de Motivos no 77/DCM/AFEPA/DAMI-MRE-MSUL, de 26 de março de 2004. Diário da Câmara dos Deputados, Brasília, v. 59, n. 64, 23 abr. 2004. p. 18374. dificuldade do Protocolo reside no capitulo referente à "solução de controvérsias", uma vez que estipula a renúncia à jurisdição interna para a solução de eventuais conflitos com investidores estrangeiros. ${ }^{42}$

É interessante observar que, no âmbito do MERCOSUL, apenas o Brasil deixou de ratificar o Protocolo de Buenos Aires. ${ }^{43}$ De todo modo, o Protocolo de Buenos Aires - assim como o Protocolo de Colônia, que dispunha sobre os investimentos provenientes de Estados partes do MERCOSUL - acabou por ser revogado pela Decisão CMC no 30/2010, que aprovou as diretrizes para a negociação de um novo acordo de investimentos para a região. ${ }^{44}$

Em resumo, a análise empreendida permite observar uma tendência historicamente conservadora do Brasil no que se refere aos acordos internacionais para a regulação dos investimentos estrangeiros. Alguns fatores - no plano internacional - acabaram por endossar a posição brasileira. Em paralelo à análise do Congresso Nacional, por exemplo, discutia-se, no âmbito da Organização para Cooperação e Desenvolvimento Econômico (OCDE), o projeto de Acordo Multilateral de Investimentos (MAI), que - em virtude da resistência dos países em desenvolvimento e das organizações não governamentais - acabou sendo abandonado no final da década de 90. É inegável que a postura brasileira se revelou, quando cotejada com a retrospectiva históri-

42 BRASIL. Exposição de Motivos no 77/DCM/AFEPA/DAMI-MRE-MSUL, de 26 de março de 2004. Diário da Câmara dos Deputados, Brasília, v. 59, n. 64, 23 abr. 2004. p. 18374.

43 O Protocolo de Buenos Aires foi ratificado pela Argentina (Lei $\mathrm{n}^{\circ}$ 24.554, de 13 de setembro de 1995), pelo Paraguai (Lei $\mathrm{n}^{\circ}$ 593, de 15 de junho de 1995) e pelo Uruguai (Lei $\mathrm{n}^{\circ}$ 17.531, de 30 de julho de 2002), mas nunca entrou em vigor pela ausência da ratificação do Brasil. O Protocolo de Colônia, que regulamentava os investimentos intrazona, nunca foi ratificado pelos Estados partes do MERCOSUL, de acordo com as informações do Ministério das Relações Exteriores do Paraguai, responsável por receber o depósito dos instrumentos de ratificação. Nesse sentido, cf. PARAGUAI. Ministerio de Relaciones Exteriores. Estado de ratificaciones y vigencias de tratados y protocolos del Mercosur y Estados Asociados. Disponible en: $<$ http://www.mre.gov.py/v1/Adjuntos/ mercosur/mercosurprincipal.htm>. Acceso en: 8 nov. 2014.

44 VASCONCELOS, Raphael Carvalho de; SUÑÉ, Natasha. O Direito dos Investimentos no Mercosul: realidade e possibilidades. In: RIBEIRO, Marilda Rosado de Sá (Org.). Direito internacional dos investimentos. Rio de Janeiro: Renovar, 2014. p. 159-178. p. 175. Para uma análise de aspectos de política econômica, cf. FLÔRES JUNIOR, Renato G. Investimento direto estrangeiro no Mercosul: uma visão geral. AMARAL JÚNIOR, Alberto do; SANCHEZ, Michelle Ratton (Coord.). Regulamentação internacional dos investimentos: algumas lições para o Brasil. São Paulo: Aduaneiras, 2007. p. 199-225. 
ca, mais prudente do que conservadora. Isso porque, ao longo das últimas décadas, o regime internacional de regulação dos investimentos estrangeiros foi submetido a um processo de amadurecimento e reconstrução, que se materializa - por exemplo - nos novos modelos de tratados bilaterais de investimento. ${ }^{45} \mathrm{Na}$ esfera regional, igualmente relevantes para dar suporte à posição brasileira foram os diversos procedimentos arbitrais instaurados contra a Argentina no âmbito do International Centre for Settlement of Investment Disputes (ICSID), em virtude da crise econômica pela qual o país passou após 2001 e o engessamento do seu policy space por força dos acordos bilaterais de investimento. ${ }^{46}$ Mais recentemente, a sensação de ressurgimento de posturas nacionalistas na América Latina - culminando na denúncia da Convenção de Washington por Bolívia, Equador e Venezuela - contribuiu para o debate sobre a compatibilidade do regime internacional dos investimentos com a soberania dos Estados hospedeiros. ${ }^{47}$ Além disso, muitos dos países latino-americanos têm denunciado com certa frequência os tratados bilaterais de investimento dos quais faziam parte. ${ }^{48}$ Nesse aspecto, destaca-se como principal justificativa para a denúncia o argumento da incompatibilidade desses tratados com as constituições

45 Diversos modelos de tratados de investimento são comentados na obra de BROWN, Chester (Ed.). Commentaries on selected model investment treaties. Oxford: Oxford University Press, 2013. Em relação especificamente a um modelo europeu, cf. a edição especial do The Journal of World Investment and Trade, com especial destaque para BUNGENBERG, Marc; REINISCH, August. The anatomy of the (invisible) EU model BIT: an introduction. The Journal of World Investment and Trade, London, v. 15, n. 3-4, p. 375-378, 2014.

46 Giogio Sacerdoti comenta a crise argentina nos seguintes termos: "de-dollarization of that economy, the restructuring of public debt and the freezing of public tariffs have been challenged by foreign investors as being in breach of relevant BITs entered into by the Argentine Republic in the previous decade. In these cases, the Argentine Republic has invoked the crisis as the basis for its claim that the relevant BIT provisions were inapplicable". SACERDOTI, Giorgio. BIT protections and economic crises: limits to their coverage, the impact of multilateral financial regulation and the defence of necessity. ICSDI Review, Oxford, v. 28, n. 2, p. 351-383, 2013. José Enrique Alvarez, por sua vez, analisa os casos envolvendo a Argentina sob a ótica da fragmentação e da inconsistência da arbitragem internacional dos investimentos. ALVAREZ, José Enrique. The public international law regime governing international investment. Recueil des Cours, Haye, v. 344, p. 195-541, 2009. p. 377-404.

47 GARCÍA-BOLÍVAR, Omar E. Sovereignty v. investment protection: back to Calvo? ICSID Review, Oxford, v. 24, n. 2, p. 464-488, 2009.

48 UNITED NATIONS CONFERENCE ON TRADE AND DEVELOPMENT. Denunciation of the ICSID Convention and BITs: impact on investor-State claims. IIA Issues Note, Geneva, n. 2, p. 1-10, Apr. 2010. p. 1-2. recentemente aprovadas por esses países. ${ }^{49}$

No plano nacional, é possível reconhecer, nos aspectos controversos identificados pelo Congresso Nacional durante a apreciação dos projetos para aprovação desses acordos, os fundamentos que conduziram o Brasil à rejeição dos tratados bilaterais de investimento. Dentre os aspectos controversos, é possível destacar (a) a preocupação com a limitação da soberania nacional, (b) a incompatibilidade entre o regime de expropriação previsto nos acordos e as disposições constitucionais sobre desapropriação, (c) a utilização de uma definição bastante ampla de investimento, (d) a previsão absoluta da livre transferência de recursos e (e) a possibilidade de escolha pelo investidor estrangeiro de mecanismo de arbitragem internacional envolvendo o Estado brasileiro. ${ }^{50}$

No plano interno, deve-se destacar igualmente o embate de forças políticas no âmbito do Congresso Nacional, que continha minoria organizada na oposição aos tratados bilaterais de investimentos. ${ }^{51}$ Em contrapartida, a ratificação desses tratados - embora importante para o Ministério de Relações Exteriores - assumia papel secundário nas demais áreas do governo. Essa relativa ausência de uma posição clara do Poder Executivo abriu espaço para que minoria organizada pudesse avançar sua posição no Congresso Nacional. ${ }^{52}$

Além disso, as diretrizes de proteção do investidor estrangeiro contidas nos tratados bilaterais de investimentos foram - com exceção da previsão de arbitragem internacional entre investidores e Estado - incorpo-

49 ALVES, André Gustavo de Miranda Pineli. As relações de investimento direto entre o Brasil e os países de seu entorno. In: (Org.). Os BRICS e seus vizinhos: investimento direto estrangeiro Brasília: IPEA, 2014. p. 13-169. p. 30. Lembra o autor que "no caso do Equador, por exemplo, a nova Constituição, promulgada em 2008, estabelece que o país não pode tomar parte em tratados internacionais nos quais abra mão de soberania, concedendo jurisdição a cortes arbitrais internacionais, no caso de controvérsias entre o Estado e entes privados".

50 KALICKI, Jean; MEDEIROS, Suzana. Investment arbitration in Brazil. Arbitration International, Oxford, v. 24, n. 3, p. 423-446, 2008. p. 432-433.

51 CAMPELLO, Daniela; LEMOS; Leany. The non-ratification of bilateral investment reaties in Brazil: a sotry of conflict in a land of cooperation. Review of International Political Economy, London, p. 1-32, 2015. doi: 10.1080/09692290.2014.987154. p. 23.

52 Os esforços dessa minoria organizada foram capitaneados pelo Partido dos Trabalhadores, que - em seguida - chegaria ao poder. CAMPELLO, Daniela; LEMOS; Leany. The non-ratification of bilateral investment reaties in Brazil: a sotry of conflict in a land of cooperation. Review of International Political Economy, London, p. 1-32, 2015 doi: 10.1080/09692290.2014.987154. p.18-9. 
radas ao ordenamento jurídico brasileiro por meio de reformas internas na política econômica e na estrutura regulatória infralegal. Nesse sentido, por exemplo, o Conselho Monetário Nacional e o Banco Central do Brasil realizaram revisões em suas normas sobre investimentos estrangeiros, tratando de aspectos como a livre transferência de recursos investidos no país. ${ }^{53}$

Além de registrar a percepção de que os tratados bilaterais de investimentos concediam um "conjunto demasiado abrangente de direitos e prerrogativas" aos investidores estrangeiros, a Mensagem $\mathrm{n}^{\circ} 1.083$, de 11 de dezembro de 2002, que solicitava a retirada de tramitação do acordo celebrado com a Suíça, apresentava o argumento da desnecessidade dos tratados bilaterais de investimento para o Brasil, que mantinha sua posição de importador de capitais estrangeiros. ${ }^{54}$

\section{A SEgUNDA ONDA REgULATÓRIA DOS INVES- TIMENTOS ESTRANGEIROS DIREITOS NO BRASIL: A EXPORTAÇÃO DE CAPITAL BRASILEIRO E A EMER- GÊNCIA DE UM NOVO MODELO DE ACORDO DE INVESTIMENTOS}

Verifica-se que, em primeiro momento, o Brasil resistiu fortemente à tendência quase que universal de celebrar tratados de investimento nos moldes dos TBIs. Nesse período o Brasil caracterizava-se, sobretudo, como um país receptor de capital estrangeiro. Nos últimos anos, entretanto, observa-se novo posicionamento do Brasil relativamente ao tema dos investimentos e sua regulação. O fortalecimento da economia brasileira favoreceu a internacionalização de empresas brasileiras - principalmente em países da América do Sul e África - o que demanda do país a criação de um arcabou-

53 CAMPELLO, Daniela; LEMOS; Leany. The non-ratification of bilateral investment reaties in Brazil: a sotry of conflict in a land of cooperation. Review of International Political Economy, London, p. 1-32, 2015. doi: 10.1080/09692290.2014.987154. p. 22.

54 "A inexistência de acordos do gênero não tem afetado a posição do Brasil como importante receptor de investimentos internacionais, sobretudo de investimentos diretos, cujos fluxos de entrada encontram-se entre os mais altos no grupo dos países em desenvolvimento. Explicam esse notável desempenho a estabilidade das regras jurídicas no âmbito doméstico e a força intrínseca que a economia brasileira passou a demonstrar a partir de 1994." BRASIL. Exposição de Motivos no 401 DSF/ARC/DE-I - MIRE - PEXT EFIN, de 5 de dezembro de 2002. Diário da Câmara dos Deputados, Brasília, v. 57, n. 184, 13 dez. 2002, p. 54414 ço jurídico protetivo para os investidores nacionais. $\mathrm{O}$ que se observa, portanto, é uma pressão exercida sobre o governo por parte do setor privado nacional para aprovação de um modelo de marco regulatório de investimentos para inicialmente ser aplicado nas relações econômicas entre o Brasil e outros países em desenvolvimento.

\subsection{Os novos condicionantes econômicos e seus impactos no investimento estrangeiro direito brasileiro}

Os desenvolvimentos estruturais da economia brasileira, materializados em fatores como o aumento do volume de negócios na bolsa de valores, ${ }^{55}$ a multiplicação de oferta pública inicial de ações (IPOs), ${ }^{56}$ a alteração da legislação contábil com um alinhamento aos padrões internacionais, ${ }^{57}$ a minimização dos riscos de investimentos e o aumento de transparência e segurança nas transações empresariais ${ }^{58}$ são indicativos do "ingresso do país na seleção das economias com mercado

55 O índice da bolsa de valores (Ibovespa) oscilava entre 10.000 e 26.000 pontos no período de 1997 a 2004; após 2005, o índice passou a alcançar patamares entre 33.000 a 65.000 pontos. Informações cf. BOLSA DE VALORES DE SÃO PAULO. Índice Bovespa: Ibovespa. Disponível em: <http://www.bmfbovespa.com.br/indices $/$ ResumoIndice.. aspx? Indice $=$ IBOVESPA\&Opcao $=0 \&$ idioma $=$ pt-br>. Acesso em: 14 nov. 2014.

56 Entre 2004 e 2013, a Comissão de Valores Mobiliários efetuou o registro de uma média anual de 23 editais de ofertas públicas de ações, excluídas as ofertas de outros títulos mobiliários. COMISSÃO DE VALORES MOBILIÁRIOS. Registro de ofertas públicas. Disponível em: <http://www.cvm.gov.br/port/registro/FormRegistro.asp>. Acesso em: 14 nov. 2014.

57 BRASIL. Lei $\mathrm{n}^{\circ}$ 11.638, de 28 de dezembro de 2007. Altera e revoga dispositivos da Lei $\mathrm{n}^{\circ}$ 6.404, de 15 de dezembro de 1976, e da Lei $n^{\circ}$ 6.385, de 7 de dezembro de 1976, e estende às sociedades de grande porte disposições relativas à elaboração e divulgação de demonstrações financeiras. Diário Oficial [da] República Federativa do Brasil, Poder Executivo, Brasília, 28 dez. 2007. Seção 1, p. 2. ANTUNES, Maria Thereza Pompa et al. A adoção no Brasil das normas internacionais de contabilidade IFRS: o processo e seus impactos na qualidade da informação contábil. Revista de Economia e Relações Internacionais, São Paulo, v. 10, n. 20, p. 5-19, 2012.

58 BRASIL. Lei $\mathrm{n}^{\circ}$ 12.414, de 9 de junho de 2011. Disciplina a formação e consulta a banco de dados com informações de adimplemento, de pessoas naturais ou de pessoas jurídicas, para formação de histórico de crédito. Diário Oficial [da] República Federativa do Brasil, Poder Executivo, Brasília, 10 jun. 2011. Seção 1, p. 2. BRASIL. Lei $\mathrm{n}^{\circ} 12.846$, de $1^{\circ}$ de agosto de 2013 . Dispõe sobre a responsabilização administrativa e civil de pessoas jurídicas pela prática de atos contra a administração pública, nacional ou estrangeira, e dá outras providencias. Diário Oficial [da] República Federativa do Brasil, Poder Executivo, Brasília, DF, 2 ago. 2013. Seção 1, p. 1. 
maduro". ${ }^{59}$

No que se refere, exclusivamente, aos investimentos estrangeiros diretos, como se observa na Figura 1, tais desenvolvimentos estruturais se traduzem, por exemplo, em um acentuado crescimento - especialmente nos últimos dez anos - do estoque de investimentos estrangeiros no Brasil. Nesse âmbito, a análise do estoque anual de investimentos estrangeiros diretos na economia nacional revela crescimento contínuo e moderado do estoque de investimentos estrangeiros até 1994. Após uma redução da presença de capitais estrangeiros em 1995, observa-se nova tendência de crescimento até 2001. Recuperando-se de um recuo no estoque de investimentos estrangeiros diretos em 2002, inaugurou-se, na economia brasileira, novo ciclo de crescimento mais acentuado no estoque de capitais estrangeiros até 2007. Em 2008, evidencia-se uma nítida queda da presença do investimento estrangeiro direto no país, em resposta à crise financeira mundial. Entre 2009 e 2010, percebe-se o aumento vertiginoso do estoque de capital estrangeiro no país, com uma tendência de crescimento mais moderado a partir de 2010.

Figura 1 - Evolução do estoque de investimentos estrangeiros diretos no Brasil (1980-2013)

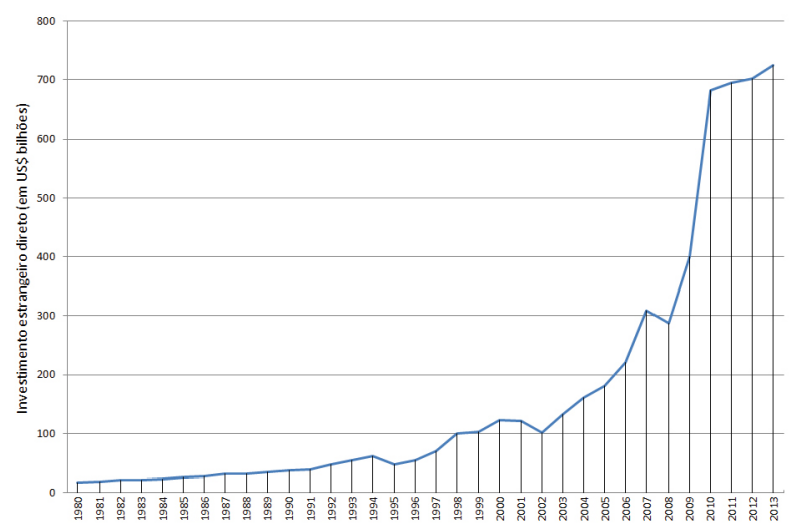

Fonte: Conferência das Nações Unidas para o Comércio e o Desenvolvimento (UNCTAD)

Outros dados econômicos parecem fortalecer o argumento de desnecessidade dos acordos internacionais de investimentos para atração de capitais estrangeiros pelo Brasil. De acordo com a Conferência das Nações Unidas para o Comércio e o Desenvolvimento (UNCTAD), por exemplo, o Brasil representa um dos principais destinos mundiais e regionais de investimentos estrangeiros. No ano de 2014, o Brasil ficou em sexto

59 TREVISAN, Antoninho Marmo. Brasil: um emergente seguro. Revista de Direito Bancário e do Mercado de Capitais, São Paulo, v. 11, n. 41, p. 49-55, 2008. p. 55. lugar na classificação mundial dos principais países receptores de investimentos estrangeiros diretos, com um influxo total de aproximadamente 62 bilhões de dólares americanos ${ }^{60}$ Apesar de uma pequena redução do fluxo de investimentos em relação ao ano anterior, o Brasil continua sendo o maior receptor de investimentos na América Latina. ${ }^{61} \mathrm{Na}$ avaliação das empresas transnacionais, o Brasil aparece em quinto lugar como destino de investimentos no período de 2014 e $2016 .{ }^{62}$

Após o arquivamento dos projetos pelo Congresso Nacional, a Câmara de Comércio Exterior (CAMEX) institui um grupo de trabalho interministerial, em setembro de 2003, para apresentar opções de encaminhamento a ser dado aos acordos de investimentos assinados pelo Brasil. O grupo de trabalho recomendou a renegociação dos acordos com os parceiros estratégicos do Brasil, de maneira que, em agosto de 2005, a Câmara de Comércio Exterior (CAMEX) estabeleceu novo grupo de trabalho interministerial para definir linguagens alternativas para as cláusulas centrais dos tratados bilaterais de investimentos. Em 2007, o Conselho de Ministros da Câmara de Comércio Exterior (CAMEX) aprovou as diretrizes de negociação contidas no relatório do grupo de trabalho, as quais sugeriam: (a) a renegociação dos acordos de investimento no âmbito de Mercado Comum do Sul (MERCOSUL); (b) a negociação prioritária de acordos de investimento com países da América do Sul e (c) a negociação fora da região apenas no contexto de acordos comerciais mais amplos. ${ }^{63}$

Em 2010, as autoridades brasileiras deram início a

60 UNITED NATIONS CONFERENCE ON TRADE AND DEVELOPMENT. World Investment Report 2015: reforming international investment governance. Geneva: United Nations, 2015. p. 5. O país não figura, entretanto, entre os principais exportadores mundiais de capital.

61 Em 2013, o influxo total de investimentos estrangeiros diretos no Brasil foi de aproximadamente 64 bilhões de dólares americanos. UNITED NATIONS CONFERENCE ON TRADE AND DEVELOPMENT. World Investment Report 2014: investing in the SDGs: an action plan. Geneva: United Nations, 2014. p. 4. De acordo com a UNCTAD, "in Brazil, the sharp fall of FDI in the primary sector was compensated by an increase in FDI in manufacturing and services, keeping total flows similar to 2013 levels". UNITED NATIONS CONFERENCE ON TRADE AND DEVELOPMENT. World Investment Report 2015: reforming international investment governance. Geneva: United Nations, 2015. p. 3.

62 UNITED NATIONS CONFERENCE ON TRADE AND DEVELOPMENT. World Investment Report 2014: investing in the SDGs: an action plan. Geneva: United Nations, 2014. p. 28.

63 BRASIL. Ministério de Relações Exteriores. O Brasile os acordos de promoção e proteção de investimentos: uma perspectiva histórica. set. 2008. Slides. p.18-21. 
negociações de um novo tratado bilateral de investimento com o Chile. ${ }^{64} \mathrm{~A}$ intenção do governo era utilizar um possível acordo com os chilenos como modelo para assinatura de outros tratados de investimento, ${ }^{65}$ mas as negociações permaneceram sem resultados concretos. Evidencia-se com essa iniciativa que o Brasil tem adotado postura de liderança regional na América do Sul, a qual, em certa medida, "abre outros fóruns de possibilidades para o país, como aqueles do BRICS (Brasil, Rússia, Índia, China e África do Sul) e do Ibas (Índia, Brasil e África do Sul)" ${ }^{66} \mathrm{O}$ desejo de buscar novos mercados não tem, entretanto, invalidado a estratégia de afirmação regional do país. ${ }^{67}$

\subsection{O novo papel do Brasil nas relações de in- vestimento estrangeiro: de país importador a país também exportador de capital}

Há alguns anos, a doutrina já fazia referência à mudança de papel do Brasil no cenário econômico, reconhecendo que o país "is not only a recipient of FDI and therefore a potential respondent in investor-state arbitrations; in addition, Brazilian companies are increasingly investing abroad" ${ }^{68}$ Trata-se de observar que,

64 GARCIA NETO, Paulo Macedo. Investment arbitration in Brazil: the landscape of investment arbitration in Brazil and why Brazil should become a more important player in the investment arbitration arena. In: LEVY, Daniel de Andrade; BORJA, Ana Gerdau de; PUCCI, Adriana Noemi. Investment protection in Brazil. Alphen aan den Rijn: Wolters Kluwer, 2013. p. 3-16. p. 6-7. O autor enumera outras iniciativas de negociação envolvendo o Brasil, registrando que "since 2011, Canada has sought to sign a BIT with Brazil, but the negotiations have not started yet. The same is the case with the EU. Moreover, during the 2000s, Brazil signed eleven memorandums of understanding regarding the promotion of commerce and investment with Chile, Suriname, Nicaragua, Korea, Singapore, Libya, Uzbekistan, Guiana, South Africa, Venezuela and Kenya". 65 BRASIL busca acordos de proteção e promoção. Veja, 14 nov. 2010. Disponível em: <http://veja.abril.com.br/noticia/economia/ brasil-busca-acordos-de-protecao-e-promocao $>$. Acesso em: $6 \mathrm{fev}$. 2014.

66 BADIN, Michelle Ratton Sanchez; CARVALHO, Marina Amaral Egydio de; RORIZ, João Henrique Ribeiro. Os acordos regionais e preferenciais de comércio do Brasil com o seu entorno. In: BAUMANN, Renato; OLIVEIRA, Ivan Tiago Machado (Org.). Os BRICS e seus vizinhos: comércio e acordos regionais. Brasília: Ipea, 2014. p. 55-101. p. 59.

67 BADIN, Michelle Ratton Sanchez; CARVALHO, Marina Amaral Egydio de; RORIZ, João Henrique Ribeiro. Os acordos regionais e preferenciais de comércio do Brasil com o seu entorno. In: BAUMANN, Renato; OLIVEIRA, Ivan Tiago Machado (Org.). Os BRICS e seus viqinhos: comércio e acordos regionais. Brasília: Ipea, 2014. p. 55-101. p. 60.

68 KALICKI, Jean; MEDEIROS, Suzana. Investment arbitration in Brazil. Arbitration International, Oxford, v. 24, n. 3, p. 423-446, 2008. p. 440. Citam os exemplos de Petrobras, Companhia Vale do além dos efeitos na atração de capitais estrangeiros, os desenvolvimentos estruturais da economia brasileira também permitiram fortalecimento das empresas brasileiras, que puderam atingir diferentes graus de internacionalização. ${ }^{69}$

Os dados estatísticos da Conferência das Nações Unidas para o Comércio e o Desenvolvimento (UNCTAD) permitem observar o aumento do estoque dos investimentos brasileiros diretos no exterior (Figura 2). No âmbito dos investimentos brasileiros diretos no exterior, observa-se estabilidade até 2003 , quando se inicia tendência de crescimento continuado do estoque de investimentos no exterior. Entre 2003 e 2013, o estoque de investimentos brasileiros diretos no exterior aumentou $434,3 \%$ e, entre 2012 e 2013, esse aumento foi de aproximadamente $26 \%$. Em comparação com os dados da Figura 1, o estoque de investimentos estrangeiros diretos no Brasil cresceu 445,6\% na última década (20032013) e 3,2\% no último ano (2012-2013).

Figura 2 - Evolução do estoque de investimentos brasileiros diretos no exterior (1980-2013)

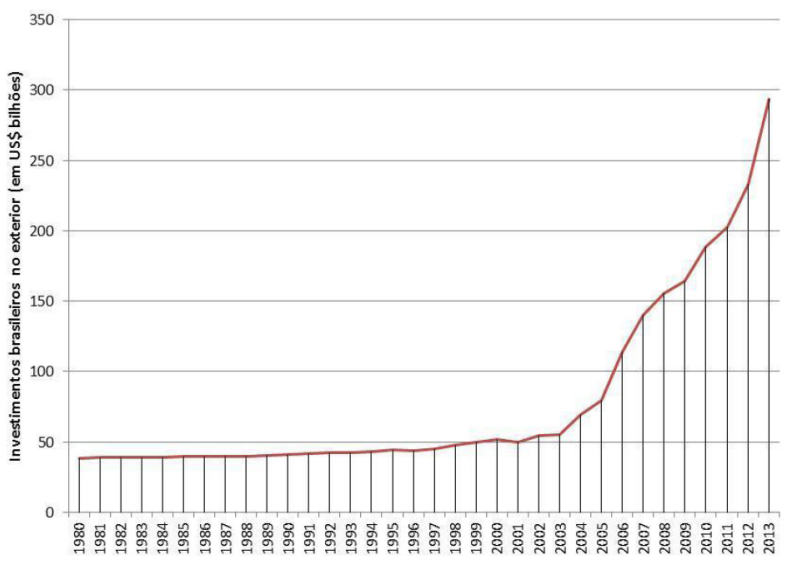

Fonte: Conferência das Nações Unidas para o Comércio e o Desenvolvimento (UNCTAD)

Rio Doce, Odebrecht, Gerdau, Camargo Correa e Companhia Siderúrgica Nacional (CSN).

69 MELLO, Celso D. de Albuquerque. Direito Internacional Econômico. Rio de Janeiro: Renovar, 1993; RIBEIRO, Marilda Rosado de Sá. As empresas transnacionais e os novos paradigmas do comércio internacional. In: DIREITO, Carlos Alberto Menezes; TRINDADE, Antônio Augusto Cançado; PEREIRA, Antônio Celso Alves (Coord.). Novas perspectivas do direito internacional contemporâneo: estudos em homenagem ao professor Celso D. de Albuquerque Mello. Rio de Janeiro: Renovar, 2008. p. 455-492; MENDES, Marcos José Martins. O direito internacional dos investimentos: o caso do mercado brasileiro de biocombustíveis. 2011. 313 f. Dissertação (Mestrado) - Faculdade de Direito, Universidade do Estado do Rio de Janeiro, Rio de Janeiro, 2011. p. 33. 


\subsubsection{A América do Sul como foco dos investi- mentos brasileiros}

Mais do que o destaque na política econômica brasileira, a América do Sul tem recebido intensos fluxos negociais das empresas transnacionais brasileiras. Uma análise da dispersão geográfica das empresas brasileiras no mundo demonstra que $75,8 \%$ das empresas brasileiras com presença no exterior em 2013 tinham subsidiárias ou franquias em países sul-americanos. ${ }^{70}$ Além disso, dos treze países com maior número de empresas brasileiras, oito são países da América do Sul, ${ }^{71}$ os quais são escolhidos por $52,9 \%$ das empresas brasileiras para estabelecimento da primeira subsidiária ou franquia no exterior. ${ }^{72}$

Segundo o relatório de 2013 dos investimentos brasileiros no exterior da Confederação Nacional da Indústria, as empresas transnacionais brasileiras consideram Argentina, China e México como os principais parceiros estratégicos, com os quais o Brasil deveria celebrar acordos de investimentos. ${ }^{73} \mathrm{~A}$ indicação dos países América do Sul como alvos dos acordos internacionais de investimentos pode decorrer também das posturas nacionalistas observadas mais recentemente em alguns países da região.

No entanto, a ausência de acordos internacionais de investimentos tem sido contornada pelas empresas com uma estratégia de triangulação dos investimentos brasileiros no exterior. Uma das possibilidades para as empresas transnacionais brasileiras é a realização do "treaty shopping", que consiste na estruturação das operações internacionais por meio de subsidiárias que se enquadrem

70 FUNDAÇÃO DOM CABRAL. Ranking FDC das multinacionais brasileiras 2014: a força da marca Brasil na criação de valor internacional. [S.1]: FDC, 2014. p. 29. Os demais percentuais de empresas brasileiras com subsidiárias ou franquias no exterior são: $66,7 \%$ na América do Norte, 54,6\% na Europa, 37,9\% na Ásia, 28,8\% na África, $27,3 \%$ na América Central e Caribe, $22,7 \%$ no Oriente Médio e $15,2 \%$ na Oceania.

71 FUNDAÇÃO DOM CABRAL. Ranking FDC das multinacionais brasileiras 2014: a força da marca Brasil na criação de valor internacional. [S.I]: FDC, 2014, p. 27. Os países com maior número de empresas brasileiras são: Estados Unidos da América com 39 empresas, Argentina com 33, Chile com 28, Uruguai com 24, Colômbia com 23, Peru com 23, México com 22, China com 19, Venezuela com 16, Paraguai com 15, Portugal com 15, Bolívia com 14 e Reino Unido com 14.

72 FUNDAÇÃO DOM CABRAL. Ranking FDC das multinacionais brasileiras 2014: a força da marca Brasil na criação de valor internacional. [S.I]: FDC, 2014. p. 31.

73 CONFEDERAÇÃO NACIONAL DA INDÚSTRIA. Relatório dos investimentos brasileiros no exterior 2013: recomendações de políticas públicas para o Brasil. Brasília: CNI, 2013. p. 65. no conceito de nacionais de Estados partes de acordos internacionais de investimentos. Nesse âmbito, os Países Baixos possuem um relevante destaque histórico, tendo em vista a ampla gama de tratados bilaterais de investimentos ratificados pelo país. ${ }^{74}$

Outro mecanismo de triangulação utilizado pelas empresas transnacionais brasileiras parece ser a escolha de países com tributação favorecida (paraísos fiscais) ou regimes fiscais privilegiados. Muitas vezes, o receptor do capital brasileiro no exterior não é o destinatário final do investimento, mas apenas um intermediário do setor financeiro, que viabiliza o investimento final. ${ }^{75}$

\subsubsection{A África como foco dos investimentos bra- sileiros}

Especialmente a partir de 2003, com o governo de Luiz Inácio Lula da Silva, a política externa brasileira passou a atribuir maior relevância às relações diplomáticas com a África. Nesse sentido, a análise do Banco Mundial e do Instituto de Pesquisa Econômica Aplicada (IPEA) ressalta dois argumentos convergentes para fundamentar a política de reaproximação com a África: "o primeiro enfatiza as afinidades culturais e históricas diretas com o povo negro do continente africano e as transferências culturais. O segundo privilegia as afinidades étnicas e culturais com os países lusófonos da África". ${ }^{76}$

Assim, verificou-se, entre 2003 e 2010, a construção de uma estratégia política de reaproximação com os países africanos, por meio de medidas que incluíram o fortalecimento da diplomacia presidencial com o aumento de visitas à África, a inauguração de missões e postos diplomáticos, o rece-

74 VAN OS, Roos; KNOTTNERUS, Roeline. Dutch bilateral investment treaties: a gateway to 'treaty shopping' for investment protection by multination companies. Amsterdam: Stichting Onderzoek Multinationale Ondernemingen, 2011. p. 4-6. Na avaliação do Ministério das Relações Exteriores dos Países Baixos, as dezesseis filiais de empresas latino-americanas existentes naquele país em 2009 movimentaram aproximadamente 127 milhões de euros. Dessas empresas, oito eram brasileiras, com destaque para a Petrobrás que estabeleceu um escritório em Rotterdam em 2010. VAN NIEKERK, Nico (Coord.). Buscando novas relações: avaliação da política externa dos Países Baixos para a América Latina: informe especial sobre o Brasil. Haia: IOB, 2013. (IOB Avaliação n. 382). p. 86.

75 VILAS-BÔAS, Júlia Covre. A presença de empresas brasileiras na África: incentivos, atrativos e motivações. 2014. 162 f. Dissertação (Mestrado) - Instituto de Relações Internacionais, Universidade de Brasília, Brasília, 2014. p. 38.

76 INSTITUTO DE PESQUISA ECONÔMICA APLICADA. Ponte sobre o Atlântico: Brasil e África Subsaariana: parceira sul-sul para o crescimento. Brasília: IPEA, 2011. p. 29. 
bimento de visitas oficiais autoridades africanas no Brasil, a renegociação da dívida de diversos países do continente, o desenvolvimento de iniciativas de cooperação com envolvimento em fóruns com países em desenvolvimento, ${ }^{77} \mathrm{O}$ apoio técnico para a implementação de programas de transferência de renda e de redução de pobreza ${ }^{78}$ e o fomento a projetos de assistência técnica em áreas como agricultura, medicina tropical e energia. ${ }^{79}$

Em relação à política comercial, o período foi caracterizado pelo aumento de feiras de negócios apoiadas pelo governo, ${ }^{80}$ pelo aumento das linhas de crédito públicas e dos programas de financiamento estatais ${ }^{81} \mathrm{e}$ pelos incentivos governamentais à atuação de empresas brasileiras na África. ${ }^{82}$ De acordo com os dados do Banco Mundial e do IPEA, metade dos projetos de desenvolvimento internacional administrados pela Agência Brasileira de Cooperação (ABC) em 2009 era destinada a países africanos. Em 2010, quase 60\% dos projetos eram destinados à África, totalizando mais de $22 \mathrm{mi}$ lhões de dólares empregados em cooperação. ${ }^{83}$

77 Alguns desses fóruns são a Comunidade dos Países de Língua Portuguesa (CPLP), o Fórum de Diálogo Índia-Brasil-África do Sul (IBAS) e a Cúpula América do Sul-África (ASA). INSTITUTO DE PESQUISA ECONÔMICA APLICADA. Ponte sobre o Atlantico: Brasil e África Subsaariana: parceira sul-sul para o crescimento. Brasília: IPEA, 2011. p. 44-45.

78 Gana foi um dos primeiros países a solicitar apoio técnico do governo brasileiro para e implementação de programas como o Fome Zero e o Bolsa Família. INSTITUTO DE PESQUISA ECONÔMICA APLICADA. Ponte sobre o Atlantico: Brasil e África Subsaariana: parceira sul-sul para o crescimento. Brasília: IPEA, 2011. p. 45.

79 INSTITUTO DE PESQUISA ECONÔMICA APLICADA. Ponte sobre o Atlântico: Brasil e África Subsaariana: parceira sul-sul para o crescimento. Brasília: IPEA, 2011. p. 43-51.

80 VILAS-BÔAS, Júlia Covre. A presença de empresas brasileiras na África: incentivos, atrativos e motivações. 2014. 162 f. Dissertação (Mestrado) - Instituto de Relações Internacionais, Universidade de Brasília, 2014. p. 60.

81 Destaque-se, nesse âmbito, o papel do Banco Nacional de Desenvolvimento Econômico e Social (BNDES) e da Caixa Econômica Federal (CEF). INSTITUTO DE PESQUISA ECONÔMICA APLICADA. Ponte sobre o Atlântico: Brasil e África Subsaariana: parceira sul-sul para o crescimento. Brasília: IPEA, 2011. p. 85.

82 VILAS-BÔAS, Júlia Covre. A presença de empresas brasileiras na Africa: incentivos, atrativos e motivações. 2014. 162 f. Dissertação (Mestrado) - Instituto de Relações Internacionais, Universidade de Brasília, Brasília, 2014. p. 78-79. O incentivo governamental foi materializado na forma de aquisição pela BNDESPAR de participações acionárias em subsidiárias no exterior de empresas brasileiras. Outro mecanismo foi o fomento aos programas de incentivo às exportações. INSTITUTO DE PESQUISA ECONÔMICA APLICADA. Ponte sobre o Atlântico: Brasil e África Subsaariana: parceira sul-sul para o crescimento. Brasília: IPEA, 2011. p. 84-85.

83 INSTITUTO DE PESQUISA ECONÔMICA APLICADA.
A reaproximação política com os países africanos ocorreu em paralelo a um aumento da presença de empresas brasileiras naquele continente. O balanço oficial do governo no período de 2003 a 2010 registrou, a respeito dessa internacionalização, o papel dos investimentos brasileiros na África:

empresas brasileiras já estão entre as principais investidoras em países africanos. No mercado libio, por exemplo, firmas do País detêm uma carteira de investimentos de mais de US\$ 6 billhões. A presença brasileira também é forte nos setores de mineração - a Vale opera em quase todos os países do continente - e de energia, neste caso por meio da Petrobras, atuante em Angola, Libia, Namíbia, Tanzânia e principalmente na Nigéria. Investimentos brasileiros possibilitaram, ainda, significativas melhorias na infraestrutura física da África. Empreiteiras como Andrade Gutierrez, ARG, Queiroz Galvão e Odebrecht, em alguns casos com financiamento do Banco Nacional de Desenvolvimento Econômico e Social (BNDES) e da Câmara de Comércio Exterior (Camex), desenvolveram obras rodoviárias no Camarões, na Guiné, na Argélia, na Mauritânia e em Gana; portos e aeroportos na Lỉbia, em Moçambique e no Djibuti; e uma rede de metrô em Trípoli, capital da Libia. ${ }^{84}$

O governo de Dilma Rousseff parece ter mantido a estratégia de reaproximação com os países africanos. ${ }^{85} \mathrm{Em}$ sua primeira viagem presidencial, a chefe de Estado participou de encontro do Fórum de Diálogo Índia-Brasil-África do Sul (IBAS) e realizou visitas a Angola e Moçambique. $\mathrm{Na}$ análise do Banco Mundial e do Instituto de Pesquisa Econômica Aplicada, "trata-se de uma forte mensagem política que confirma que a África continuará a ser prioridade na agenda" da política externa brasileira. ${ }^{86}$

Os dados mais recentes da Fundação Dom Cabral

Ponte sobre o Atlantico: Brasil e África Subsaariana: parceira sul-sul para o crescimento. Brasília: IPEA, 2011. p. 45.

84 BRASIL. Balanço de Governo 2003-2010. Brasília: Dez. 2010. Disponível em: <http://www.balancodegoverno.presidencia.gov. br>. Acesso em: 24 nov. 2013. p. 36. Outros dados sobre a presença das empresas brasileiras na África são apresentados em INSTITUTO DE PESQUISA ECONÔMICA APLICADA. Ponte sobre o Atlântico: Brasil e África Subsaariana: parceira sul-sul para o crescimento. Brasília: IPEA, 2011. p. 85-93.

85 João Marcelo Conte Cornetet pondera que "o atual governo segue com os mesmos objetivos na esfera internacional mantidos pelo anterior - incluindo a obtenção de desenvolvimento por meio da diversificação de parceiros comerciais e a afirmação do Brasil como líder regional -, mas a diplomacia de Dilma busca esses objetivos com menos ativismo e com mais limitações externas." CORNETET, João Marcelo Conte. A política externa de Dilma Rousseff: contenção na continuidade, Conjuntura Austral, Porto Alegre, v. 5, n. 24, p. 111-150, 2014. p. 111.

86 INSTITUTO DE PESQUISA ECONÔMICA APLICADA. Ponte sobre o Atlântico: Brasil e África Subsaariana: parceira sul-sul para o crescimento. Brasília: IPEA, 2011. p. 44. 
sobre a dispersão geográfica das transnacionais brasileiras no exterior indicam que $28,8 \%$ das empresas nacionais têm subsidiárias ou franquias na África, ${ }^{87}$ que também é escolhida por 5,9\% das empresas para o estabelecimento da primeira unidade no exterior. ${ }^{88} \mathrm{Em}$ 2013, as empresas brasileiras tinham presença comercial em 22 países do continente africano. ${ }^{89}$

Entre 2000 e 2010, as exportações brasileiras para a África aumentaram de 1,3 para 9,1 bilhões de dólares, demonstrando - na análise do Banco Mundial e do Instituto de Pesquisa Econômica Aplicada - "que a África havia se tornado uma alternativa viável para os investidores brasileiros"..$^{90}$ Mantendo a tendência de crescimento, as exportações brasileiras para a África alcançaram o patamar de 12.2 bilhões de dólares em 2012, havendo uma inversão da tendência em 2013, quando as exportações somaram 11 bilhões de dólares (Tabela 2). Entretanto, o movimento de queda em 2013 também foi observado no volume total das exportações brasileiras.

Tabela 2 - Volumes das exportações brasileiras (em US\$ milhões) para os cinco principais destinos da África e participação do continente africano no volume mundial de exportações.

\begin{tabular}{|l|r|r|r|r|r|}
\hline Destino & $\mathbf{2 0 0 9}$ & $\mathbf{2 0 1 0}$ & $\mathbf{2 0 1 1}$ & $\mathbf{2 0 1 2}$ & $\mathbf{2 0 1 3}$ \\
\hline Mundo & 152.995 & 197.356 & 256.039 & 242.580 & 218.230 \\
\hline África & 8.591 & 9.135 & 12.124 & 12.210 & 11.084 \\
\hline Argélia & 714 & 839 & 1.494 & 1.170 & 1.200 \\
\hline Angola & 1.333 & 9.444 & 1.074 & 1.145 & 1.271 \\
\hline $\begin{array}{l}\text { África do } \\
\text { Sul }\end{array}$ & 1.260 & 1.304 & 1.681 & 1.765 & 1.836 \\
\hline Egito & 1.444 & 1.966 & 2.424 & 2.712 & 2.202 \\
\hline Nigéria & 1.067 & 857 & 1.192 & 1.067 & 876 \\
\hline $\begin{array}{l}\text { África/ } \\
\text { Mundo }\end{array}$ & $5.62 \%$ & $4.63 \%$ & $4,74 \%$ & $5.03 \%$ & $4,58 \%$ \\
\hline
\end{tabular}

Fonte: Organização das Nações Unidas (Comtrade/United Nations
Statistics Division) $)^{91}$

Em relação aos investimentos brasileiros no exterior, o montante de capitais brasileiros na África não é determinado com precisão, em razão da metodologia declaratória utilizada pelo Banco Central do Brasil no censo de capitais brasileiros no exterior e da utilização de mecanismos de triangulação de investimentos em paraísos fiscais. ${ }^{92}$ Nesse sentido, os dados do Banco Central do Brasil não apresentam as informações de todos os países do continente africano, com exceção de Angola, que tem papel de destaque nos fluxos de comércio e investimento com o Brasil.

O aumento e a consolidação de empresas brasileiras, em países da América do Sul, e África repercutem na demanda do setor privado nacional por um arcabouço normativo protetivo desses investimentos. ${ }^{93}$ As demandas vão desde estruturas locais nesses países para quem os investidores brasileiros podem dirigir suas duvidas e reclamações, padrões de tratamento do investimento, a mecanismos de solução de controvérsias entre investidor e Estado hospedeiro. Curiosamente, o Brasil parece ter optado por uma estratégia regulatória alternativa aos modelos de acordos de investimentos existentes, como veremos na seção seguinte.

\subsection{A emergência de um modelo brasileiro de acordo de cooperação e facilitação de investi- mentos}

Ao final de 2013, o Ministério do Desenvolvimento, Indústria e Comércio Exterior (MDIC) iniciou as negociações de um novo modelo de acordo internacional de investimentos com Angola, Argélia, Marrocos,

91 ORGANIZAÇÃO DAS NAÇÕES UNIDAS. Titulo. Local: Editora, ano.

92 IGLESIAS, Roberto Magno; COSTA, Katarina. O investimento direto brasileiro na África. Rio de Janeiro: CINDES, 2011. (Textos CINDES, n. 27).p. 14.

93 Além disso, as empresas brasileiras com atuação no continente africano demandavam maior grau de proteção para aumentar a competitividade frente às empresas chinesas, o que motivou o governo brasileiro a desenvolver um modelo de acordo que contivesse um agenda de cooperação técnica. SOUZA, Renato Rezende de Campos. Acordos de cooperação e facilitação de investimentos [informação verbal]. In: Brasil e os Acordos bilaterais de promoção de investimentos. AMCHAM São Paulo, 30 de abril de 2015. 
Moçambique, ${ }^{94}$ África do Sul, Nigéria e Tunísia ${ }^{95}$ como parte de uma "iniciativa brasileira de estabelecer acordos de investimentos com países dos continentes africano e sul-americano". ${ }^{96}$ De acordo com as informações da Presidência da República na mensagem anual ao Congresso Nacional de 2014, os acordos propostos pelo Brasil tem alcançado boa receptividade dos países africanos:

\begin{abstract}
No que diz respeito às negociações internacionais, foram aprovadas pela Câmara de Comércio Exterior (Camex) novas diretrizes para a negociação de Acordos de Cooperação e Facilitação de Investimentos (ACFI). Esse modelo tem sido bem recebido pelos países africanos e há possibilidade de conclusão dos acordos nesses países. Tal modelo foi apresentado para Moçambique, Angola, África do Sul, Malaui, Argélia e Nigéria. ${ }^{97}$
\end{abstract}

A decisão de negociar acordos de investimentos com os países africanos reflete a conscientização por parte do governo brasileiro de que o país possui atualmente uma inegável posição de país exportador de capital. ${ }^{98}$ Nesse aspecto em especial, os dados econômicos da

94 BRASIL. Ministério do Desenvolvimento, Indústria e Comércio Exterior. Missão brasileira negocia acordos de investimento com Angola e Moçambique. Brasília, 09 out. 2012. Disponível em: $<$ http://www.desenvolvimento.gov.br/sitio/interna/noticia. php?area $=1$ \&noticia $=12727>$. Acesso em: 28 jan. 2014; BRASIL. Ministério do Desenvolvimento, Indústria e Comércio Exterior. Godinho: Brasil apoiará não somente negociações bilaterais e regionais, mas também multilaterais. Brasília, 26 out. 2013. Disponível em: <http://www.desenvolvimento.gov.br/sitio/ interna/noticia. php?area $=5$ \&noticia $=12765>$. Acesso em: 18 dez. 2013. BRASIL. Ministério do Desenvolvimento, Indústria e Comércio Exterior. Missão ao Marrocos gera US\$4,8 milhões em negócios e expectativas de vendas, 4 dez. 2013. Disponível em: <http://www.mdic.gov.br/sitio/interna/noticia.php?area $=1 \&$ noticia $=12863>$. Acesso em: 28 jan. 2014. 95 DANTAS, Iuri; PARAGUASSU, Lisandra. Múltis brasileiras investem cada vez mais em paraísos fiscais. O Estado de São Paulo, 21 set. 2014. Disponível em: <http://economia.estadao.com.br/noticias/geral,multis-brasileiras-investem-cada-vez-mais-em-paraisosfiscais, 1563549>. Acesso em: 03 mar. 2015.

96 BRASIL. Ministério do Desenvolvimento, Indústria e Comércio Exterior. Godinho analisa momento de oportunidades no comércio exterior. Brasília, 25 out. 2013. Disponível em: <http://www.mdic. gov.br $/$ sitio $/$ interna $/$ noticia.php?area $=5 \&$ noticia $=12762>$. Acesso em: 14 jan. 2014. De acordo com as informações do Secretário de Comércio Exterior, "estes acordos que estamos buscando seriam instrumentos de apoio para os investidores brasileiros atuarem no exterior. Estamos propondo tratar de temas relevantes e práticos, do dia a dia, como concessão de vistos e outros que afetam o processo de decisão sobre o investimento".

97 BRASIL. Mensagem ao Congresso Nacional, 2014: 4ª Sessão Legislativa Ordinária da $54^{a}$ Legislatura. Brasília: Presidência da República, 2014. p. 41.

98 VILAS-BÔAS, Júlia Covre. Os investimentos brasileiros na África no governo Lula: um mapa. Meridiano 47, v. 12, n. 128, p. 3-9, 2011.
UNCTAD apontam o continente africano como principal destino das empresas transnacionais brasileiras. ${ }^{99}$

De acordo com as informações divulgadas pelo governo durante a elaboração e negociação do modelo de acordo brasileiro, o país parece estar atento às tendências internacionais e procurou formular uma minuta com dispositivos mais equilibrados, como informou o Secretário de Comércio Exterior em audiência da Comissão de Relações Exteriores e Defesa Nacional da Câmara dos Deputados, conforme registro em ata que ficou assim redigida:

no campo dos investimentos, [o Secretário de Comércio Exterior] sublinhou que, após período de rejeição do modelo tradicional de acordos de investimento - como consubstanciado em alguns acordos assinados pelo Executivo brasileiro na década de 1990, mas não aprovados pelo Congresso Nacional -, o País, já na condição de receptor de investimentos estrangeiros e de importante investidor no exterior, havia formulado modelo próprio para acordos de facilitação de investimento, aprovado pela Câmara de Comércio Exterior, prevendo maior equilíbrio entre as partes envolvidas. Relatou que esse formato de acordo avançava rapidamente em tratativas com alguns países africanos onde já havia presença de investimentos de empresas brasileiras..$^{100}$

De acordo com as informações prestadas pelo Ministério do Desenvolvimento, Indústria e Comércio Exterior (MDIC), mediante consulta formulada sob a égide da Lei n ${ }^{\circ} 12.527$, de 18 de novembro de 2011, que dispõe sobre a garantia de acesso à informação, o atual

99 De acordo com as informações da UNCTAD, "Brazilian FDI to Africa has been on the rise in recent years, with public financial institutions playing an important role in bringing the country's investors closer to Africa. Among these, the Brazilian Development Bank (BNDES) deserves special mention as its incentives and disbursements to sub-Sabaran Africa have increased strongly over the past decade. It has played a key role in the expansion of Brazilian TNCs into the new African ethanol industry, in countries such as Angola, Ghana and Mozambique". UNITED NATIONS CONFERENCE ON TRADE AND DEVELOPMENT. World Investment Report 2013: Global value chains: investment and trade for development. Geneva: United Nations, 2013. p. 5. No mesmo sentido, as informações do Ministério do Desenvolvimento, Indústria e Comércio Exterior apontam que "esses acordos serão muito importantes para o fortalecimento da presença de empresas brasileiras no continente e para promover o intercâmbio comercial". BRASIL. Ministério do Desenvolvimento, Indústria e Comércio Exterior. Brasil está ativo em todas as frentes de negociações comerciais. Brasília, 13 nov. 2013. Disponível em: <http://www.desenvolvimento.gov.br/sitio/interna $/$ noticia.php?area $=5 \&$ noticia $=12815>$. Acesso em: 8 jan. 2014. 100 BRASIL. Câmara dos Deputados. Comissão de Relações Exteriores e de Defesa Nacional. Ata da 42a Reunião Ordinária de Audiência Pública realizada em 13 de Novembro de 2013. Diário da Câmara dos Deputados, Brasília, v. 68, n. 214, 3 dez. 2013. p. 57126. 
modelo brasileiro de Acordo de Cooperação e Facilitação de Investimentos (ACFI), contempla (a) mecanismos para a prevenção de controvérsias, ${ }^{101}$ (b) estratégias de melhoria da governança institucional e (c) cláusulas de responsabilidade social corporativa. A resposta apresentada pelo Departamento de Negociações Internacionais do MDIC foi formulada nos seguintes termos:

está baseado nos seguintes pilares, já aprovados pela Câmara de Comércio Exterior (CAMEX): i) a melhoria da governança institucional; ii) agendas temáticas para cooperação e facilitação dos investimentos; e iii) mecanismos para mitigação de riscos e prevenção de controvérsias, não estando atrelado a nenhum modelo internacional. Além disso, a proposta destaca-se por seu caráter modulável e flexível. Assim, por meio de agendas temáticas de cooperação e facilitação de investimentos, o texto deverá ser adaptado ao interlocutor e às necessidades manifestadas por investidores brasileiros. Outra característica do acordo são as cláusulas de responsabilidade social corporativa que incluem compromissos com padrões de conduta empresarial responsável. Por oportuno, ressalta-se que a formalização de tais acordos ainda se insere no âmbito das negociações internacionais. ${ }^{102}$

Em 2015, foi realizada a assinatura de Acordos de Cooperação e Facilitação de Investimentos com Moçambique, Angola, México, Maláui e Colômbia. ${ }^{103}$ De

101 Sobre a prevenção de controvérsias, cf. CARVALHO, Romulo Soares Brillo. O segundo tempo do regime internacional dos investimentos: a nova geração de tratados e a prevenção de controvérsias investidorEstado. 2011. 144 f. Dissertação (Mestrado) - Faculdade de Direito, Universidade do Estado do Rio de Janeiro, Rio de Janeiro, 2011. p. 129 , afirmando que "as controvérsias estão gerando laudos arbitrais que inovam na interpretação dos tratados, levando diversos países a reexaminar e reconsiderar o enquadramento e a extensão das obrigações neles contidos. No plano das deficiências, há a demora (o tempo costuma ser calculado não em meses, mas em pares de anos), o custo elevado, os questionamentos quanto à sua legitimidade para arbitrar questões sensíveis de política pública, e os prejuízos que causam à relação de longo prazo entre os investidores estrangeiros e o Estado hospedeiro. Esse cenário impulsiona a busca por outros instrumentos para solucionar os conflitos envolvendo investidores e Estados hospedeiros".

102 BRASIL. Ministério do Desenvolvimento, Indústria e Comércio Exterior. Departamento de Negociações Internacionais. Sistema Eletrônico do Serviço de Informações ao Cidadão: e-SIC. Brasília: MDIC, fev, 2015. Disponível em: <http://www.acessoainformacao.gov.br/ sistema/site/index.html?ReturnUrl $=\% 2$ fsistema $\% 2 \mathrm{f}>$. Acesso em: 06 nov. 2015. sob o protocolo no 52750000051201466.

103 BRASIL. Ministério das Relações Exteriores. Acordo BrasilMoçambique de Cooperação e Facilitação de Investimentos (ACFI). Maputo, 30 mar. 2015. (Nota à imprensa, no 99). Disponível em: $<$ http://www.itamaraty.gov.br/index.php?option=com_content acordo com o Ministério do Desenvolvimento, Indústria e Comércio Exterior, outros acordos estão em negociação com África do Sul, Argélia, Chile, Colômbia, Marrocos, Nigéria, Peru e Tunísia. ${ }^{104}$

Embora uma análise crítica dos Acordos de Cooperação e Facilitação de Investimentos transcenda o escopo da análise ora proposta, ${ }^{105}$ é necessário comentar algumas características fundamentais do modelo desenvolvido pelo Brasil: (a) o desenho da gestão institucional do acordo; (b) a sistemática para resolução de eventuais controvérsias no âmbito do acordo; (c) as regras de proteção dos investidores estrangeiros e (d) a incorporação de temas sensíveis no âmbito do acordo.

Do ponto de vista da gestão institucional, o Acordo de Cooperação e Facilitação de Investimentos se fundamenta na criação de pontos focais (ombudsmen) com a função de promover a interlocução entre o governo de um país e os investidores estrangeiros instalados em seu território. ${ }^{106}$ Esses pontos focais deverão, também, interagir entre si e com as demais autoridades dos respectivos Estados, de modo a prevenir e buscar resolver as eventuais reclamações dos investidores. Os pontos focais devem atender às recomendações do comitê conjunto e a ele e relatar suas atividades. $\mathrm{O}$ comitê conjunto, segundo órgão de gestão institucional criado pelos acordos brasileiros, será composto por representantes governamentais dos Estados partes. Entre as atribui-

\&view $=$ article\&id $=8511$ :acordo-brasil-mocambique-de-cooperacao-e-facilitacao-de-investimentos-acfi-maputo-30-de-marco-de$2015 \&$ catid $=42 \&$ Itemid $=280 \&$ lang $=p t-B R>$. Acesso em: 14 abr. 2015. BRASIL. Ministério das Relações Exteriores. Acordo Brasil-Angola de Cooperação e Facilitação de Investimentos. Luanda, 1º de abril 2015. (Nota à imprensa $\mathrm{n}^{\circ}$ 104). Disponível em: <http://www.itamaraty. gov.br/index.php?option $=$ com_content $\&$ view $=$ article $\&$ id $=8520: \mathrm{a}$ cordo-brasil-angola-de-cooperacao-e-facilitacao-de-investimentosacfi-luanda-1 - de-abril-de- $2015 \&$ catid $=42 \&$ Itemid $=280 \&$ lang $=$ ptBR>. Acesso em: 14 abr. 2015.

104 BRASIL. Ministério do Desenvolvimento, Indústria e Comércio Exterior. Acordo de Cooperação e Facilitação de Investimentos. São Paulo, 2015. 18 slides, color. p. 17. Arquivo com os autores.

105 Para uma análise dos Acordos de Cooperação e Facilitação de Investimentos (ACFIs), cf. MOROSINI, Fabio; BADIN, Michelle Ratton Sanchez. The Brazilian Agreement on Cooperation and Facilitation of Investments (ACFI): a new formula for international investment agreements? Investment Treaty News, Winnipeg, v. 6, n. 3, 2015; COSTA, José Augusto Fontoura. Os ACFIs e a (falta de) proteção dos investidores. Valor Econômico, São Paulo, 30 jul. 2015. 106 No caso do Brasil, a função foi atribuída à Câmara de Comércio Exterior (CAMEX); em Moçambique, o órgão encarregado será o Conselho de Investimentos e, em Angola, a Secretaria de Estado de Cooperação do Ministério das Relações Exteriores desempenhará a função de ponto focal. 
ções do comitê conjunto, cujo regulamento ainda deverá ser definido pelos Estados partes, é possível destacar (a) o monitoramento e a implementação do acordo, discutindo oportunidades de expansão da cooperação e buscando a concretização da agenda temática de negociação estabelecida no acordo, ${ }^{107} \mathrm{e}$ (b) a busca de solução amigável dos conflitos sobre investimentos e a eventual definição de um mecanismo de arbitragem entre Estados. Tanto os pontos focais quanto o comitê conjunto deverão promover a troca de informações sobre oportunidades de investimento e legislação de interesse dos investidores.

Em relação ao mecanismo de solução de controvérsias, eventual reclamação do investidor estrangeiro deve ser apresentada ao ponto focal do Estado hospedeiro para que se busque uma solução negociada. Se não for alcançada uma solução negociada, o acordo prevê uma segunda etapa: a apresentação da reclamação do investidor, unicamente por intermédio do governo de seu Estado de origem, ao comitê conjunto, que deverá avaliar o caso em até sessenta dias prorrogáveis por igual período. Nos termos do acordo, os representantes do investidor e de entidades não governamentais poderão "sempre que possível" participar do procedimento de diálogo e consulta bilateral. ${ }^{108}$ Evidenciou-se, com a assinatura do Acordo de Cooperação e Facilitação de

107 O artigo $8^{\circ}$ do Acordo de Cooperação e Facilitação de Investimentos assinado com Angola estabelece a agenda temática para discussão pelo comitê conjunto. Os resultados das discussões poderão resultar em protocolos adicionais ao acordo ou em instrumentos jurídicos próprios. De acordo como a primeiro anexo do acordo, a agenda temática com Angola inclui os seguintes eixos temáticos; (a) facilitação da remessa de divisas, (b) vistos, (c) legislação ambiental e regulamentos técnicos, e (d) intercâmbios institucionais e troca de experiências sobre a regulação de determinados setores. BRASIL. Ministério das Relações Exteriores. Acordo Brasil-Angola de Cooperação e Facilitação de Investimentos. Luanda, $1^{\circ}$ de abril 2015. (Nota à imprensa $\mathrm{n}^{\circ}$ 104). Disponível em: <http://www.itamaraty.gov.br/index. php?option $=$ com_content $\&$ view $=$ article $\&$ id $=8520$ :acordo-brasilangola-de-cooperacao-e-facilitacao-de-investimentos-acfi-luanda1 -de-abril-de- $2015 \&$ catid $=42 \&$ Itemid $=280 \&$ lang $=p t-B R>$. Acesso em: 14 abr. 2015.

$108 \mathrm{O}$ artigo $7^{\circ}$ do acordo assinado com Angola determina que as partes incentivarão o envolvimento do setor privado nos assuntos do acordo e o artigo $4^{\circ}$ determina que o setor privado e representantes de entidades não governamentais "poderão ser convidados" a participar dos trabalhos do comitê conjunto. BRASIL. Ministério das Relações Exteriores. Acordo Brasil-Angola de Cooperação e Facilitação de Investimentos. Luanda, $1^{\circ}$ de abril 2015. (Nota à imprensa $\mathrm{n}^{\circ}$ 104). Disponível em: <http://www.itamaraty.gov.br/index. php?option $=$ com_content $\&$ view $=$ article $\&$ id $=8520$ :acordo-brasilangola-de-cooperacao-e-facilitacao-de-investimentos-acfi-luanda1 -de-abril-de- $2015 \&$ catid $=42 \&$ Itemid $=280 \&$ lang $=p t-B R>$. Acesso em: 14 abr. 2015.
Investimentos, a manutenção da posição brasileira de resistência à arbitragem de investimentos entre investidor estrangeiro e Estado hospedeiro. Desse modo, na persistência de uma controvérsias, admite-se, apenas, a arbitragem entre Estados, cuja definição e implementação depende da atuação do comitê conjunto.

No que se refere às disposições materiais, o acordo busca garantir um tratamento dos investidores estrangeiros equivalente ao dos investidores nacionais e dos investidores de terceiros países, tanto na fase de estabelecimento do investimento quando na fase de condução dos negócios no Estado hospedeiro. Os investidores contam, também, com proteção contra expropriação de seus investimentos, exceto se a expropriação ocorrer de maneira não discriminatória por utilidade ou interesse públicos e, observado o devido processo legal, for acompanhada por pagamento sem demora de indenização justa, adequada e efetiva, equivalente ao valor de mercado do empreendimento. Além disso, o acordo também trata da transparência das medidas administrativas que possam afetar os investimentos estrangeiros e da garantia de transferência de recursos relacionados ao investimento. ${ }^{109}$

Com referência aos temas sensíveis relativos aos investimentos estrangeiros, o acordo determina que os investidores estrangeiros devem "se empenhar em realizar o maior nível possível de contribuições aos desenvolvimento sustentável do Estado receptor e da comunidade local". Além disso, o segundo anexo ao acordo traz conjunto de padrões e princípios de responsabilidade social corporativa, dentre os quais se destacam o respeito aos direitos humanos, o fortalecimento dos recursos humanos locais, a adoção de boas práticas de governan-

109 É importante notar que, no acordo celebrado com Angola, por exemplo, não foram estabelecidas definições essenciais para o conteúdo do acordo, havendo apenas uma remissão para o ordenamento jurídico de cada um dos Estados partes. BRASIL. Ministério das Relações Exteriores. Acordo Brasil-Moçambique de Cooperação e Facilitação de Investimentos (ACFI). Maputo, 30 mar. 2015. (Nota à imprensa no 99). Disponível em: <http://www.itamaraty. gov.br $/$ index.php?option $=$ com_content $\& v i e w=\operatorname{article} \& i d=851$ 1:acordo-brasil-mocambique-de-cooperacao-e-facilitacao-de-investimentos-acfi-maputo-30-de-marco-de-2015\&catid=42\&Itemi$\mathrm{d}=280 \&$ lang $=\mathrm{pt}-\mathrm{BR}>$. Acesso em: 14 abr. 2015. BRASIL. Ministério das Relações Exteriores. Acordo Brasil-Angola de Cooperação e Facilitação de Investimentos. Luanda, $1^{\circ}$ de abril 2015. (Nota à imprensa $\mathrm{n}^{\circ}$ 104). Disponível em: < http://www.itamaraty.gov.br/index. php?option $=$ com_content\&view $=$ article $\&$ id $=8520$ :acordo-brasilangola-de-cooperacao-e-facilitacao-de-investimentos-acfi-luanda1 -de-abril-de- $2015 \&$ catid $=42 \&$ Itemid $=280 \&$ lang $=p t-B R>$. Acesso em: 14 abr. 2015. 
ça corporativa e a abstenção de ingerência na política interna dos países envolvidos. Embora a abordagem seja inovadora se comparada à generalidade dos acordos internacionais de investimentos, há alguns aspectos críticos como a ausência de um mecanismo de reporting, o silêncio sobre os aspectos relativos à corrupção e a manutenção do valor jurídico da responsabilidade social corporativa em uma zona cinzenta. ${ }^{110}$

Embora os dispositivos do Acordo de Cooperação e Facilitação de Investimentos mereçam uma análise mais detalhada e o sucesso do modelo dependa de sua utilização pelos Estados partes, é inegável que sua assinatura "legitima o Brasil a atuar mais ativamente nas discussões internacionais sobre o tema". ${ }^{111}$ Trata-se, nesse aspecto, de um avanço para o tema da regulação dos investimentos estrangeiros no Brasil.

\section{Conclusão}

Do ponto de vista regulatório, o artigo demonstrou a saga pela elaboração de um marco jurídico para governar as relações de investimento estrangeiro envolvendo o Brasil. Durante a década de 90, houve importantes movimentações no Brasil em torno da ratificação de tratados bilaterais de investimento, que visavam muito claramente a proteção do investidor em detrimento do policy space do país hospedeiro do investimento. Em resposta a esse tipo de dinâmica, oriunda principalmente das grandes potências exportadoras de capital do século $\mathrm{XX}$, o Brasil resistiu a ingressar no regime dos tratados bilaterais de investimento. Destaca-se como suas principais razões a inconformidade com as disposições

110 MONEBHURRUN, Nitish. A inclusão da responsabilidade social das empresas nos novos Acordos de Cooperação e Facilitação de Investimentos do Brasil: uma revolução. Revista de Direito Internacional, Brasília, p. 32-38, v. 12, n. 1, 2015. De acordo com o autor, "o Estado brasileiro, que sempre mostrou grande ceticismo em relação ao Direito Internacional dos Investimento, assina, com esses acordos, a sua entrada nesse universo jurídico, e o faz com laudável arrojo ao conferir — tão esperadas — obrigações aos investidores, pelo princípio da responsa- bilidade social das empresas". MONEBHURRUN, Nitish. A inclusão da responsabilidade social das empresas nos novos Acordos de Cooperação e Facilitação de Investimentos do Brasil: uma revolução. Revista de Direito Internacional, Brasília, v. 12, n. 1, p. 32-38, 2015. p. 34.

111 NASSER, Rabih; SATO, Nathalie Tiba. O novo modelo brasileiro de acordos de investimento. Valor Econômico, São Paulo. 12 maio 2015. Disponível em: <http://www.valor.com.br/ opiniao/4045196/o-novo-modelo-brasileiro-de-acordos-de-investimento>. Acesso em: 14 maio 2015. sobre compensação por expropriação e solução de controvérsias entre investidor e Estado. Mesmo sem aderir ao modelo regulatório padrão - nos termos de um TBI, o país tem se destacado como uma das economias que mais atrai investimentos estrangeiros diretos. Tal pode ser explicado pela existência de um regime político e economia relativamente estáveis, um judiciário confiável, além de um grande mercado consumidor. Nesse caso, qualquer tipo de pressão para ratificação de tratados bilaterais de investimento parece ter se tornado moot.

Por outro lado, o crescente volume de capitais exportados pelo Brasil é reconhecido como uma mudança de paradigma da economia brasileira, de maneira que "the tables have thus changed. Accordingly, it is now time for Brazil to set in motion policy changes to reflect this paradigmatic shift, and equip its national investor with adequate protections abroad'. ${ }^{112}$ A proteção das empresas brasileiras que investem no exterior tem se mostrado como o principal argumento de boa parte da doutrina brasileira para a defesa da adesão do Brasil aos tratados bilaterais de investimento ${ }^{113}$. Nesse sentido, pressionado pelo setor

112 BENTO, Lucas. Time to join 'BIT Club'? Promoting and protecting Brazilian investments abroad. The American Review of International Arbitration, New York, v. 24, n. 2, p. 271-324, 2013. p. 324. Em tradução livre: $\mathrm{O}$ jogo virou. Dessa forma, é o momento de o Brasil colocar em prática mudanças políticas para refletir essa mudança de paradigma e equipar o investidor nacional com proteções adequadas no exterior.

113 Nesse sentido: "conclui-se pela necessidade da adesão brasileira à Convenção de Washington e, por oportuno, pelas assinaturas e ratificações de Tratados Bilaterais de Promoção e Proteção de Investimentos com os países que sejam os principais destinos dos nossos investidores privados, sobretudo com àqueles que têm uma política e legislação instáveis, conferindo, assim, maior segurança às empresas nacionais em sua atuação transfronteiriça" (CAETANO, Fernanda Araújo Kallás e. Direito internacional dos investimentos na atualidade: uma análise da posição brasileira. E-civitas: Revista Científica do Departamento de Ciências Jurídicas, Políticas e Gerenciais do UNI-BH, Belo Horizonte, v. 3, n. 2, p. 1-16, jul. 2010. p. 15), "the arguments supporting Brazilians joining the investment arbitration world have been more focused on the fact that this is important to keep the inflow of investments. However, the flip side of the coin should be exploited more. The fact that the Brazilian companies are becoming more multinational and need to have their investments protected should be investigated more" (GARCIA NETO, Paulo Macedo. Investment arbitration in Brazil: the landscape of investment arbitration in Brazil and why Brazil should become a more important player in the investment arbitration arena. In: LEVY, Daniel de Andrade; BORJA, Ana Gerdau de; PUCCI, Adriana Noemi. Investment protection in Brazil. Alphen aan den Rijn: Wolters Kluwer, 2013. p. 3-16. p. 14-15), “o novo modelo de TBIs baseados na cooperação Sul-Sul pode trazer importantes vantagens ao governo brasileiro, na medida em que (a) aumentaria a proteção às empresas brasileira que investem no exterior; (b) permitiria que o Brasil firmasse tratados preocupados com o desenvolvimento de 
privado nacional que busca proteção para os seus negócios no exterior, observa-se um movimento alinhando setor privado e governo para elaboração de um marco jurídico de proteção do investidor brasileiro no exterior. Ainda que elaborado para endereçar as preocupações do empresariado brasileiro nos mercados da América do Sul e África, tem-se notícia de que o Brasil considera adotar esse modelo de acordo de investimento para negociar com outros países, inclusive com os Estados Unidos.

Estudos mais recentes, entretanto, suavizam a tônica de proteção dos investidores no novo modelo de acordo de investimento brasileiro. Segundo Morosini e Sanchez Badin, a alternativa regulatória brasileira deve ser entendida como um produto de narrativas cruzadas: como um movimento de contestação contra relações econômicas desiguais cristalizadas no modelo tradicional de TBIs; como uma busca por alternativas ao debate atual sobre reengenharia do regime global de investimentos; e como uma tentativa de criar um modelo de acordo de investimento genuinamente brasileiro, que seja sensível às limitações constitucionais internas e responsivo às aspirações do país enquanto uma economia emergente. ${ }^{114}$

A efetiva contribuição desse novo modelo brasileiro ainda precisa ser testada na prática, tendo em vista que a eficácia das inovações do modelo fica dependente de sua ratificação pelo Brasil. ${ }^{115}$ Desde já há espaço

seus parceiros; (c) serviria como um elemento de manutenção da liderança brasileira entre os países do Sul" (LERNER, Diego Fraga. Os regimes jurídicos de proteção ao investimento estrangeiro direto: o papel desempenhando pelos países emergentes. 2009. 121 f. Dissertação (Mestrado) - Faculdade de Direito, Universidade Federal do Rio Grande do Sul, Porto Alegre, 2009. p. 103), "[o aumento da participação das empresas brasileiras no mundo] poderia ser seguido de uma agenda de regulação propriamente jurídica para garantir os investimentos nacionais no exterior" (LUÍS, Daniel Tavela. Proteção do investimento estrangeiro: o sistema do Centro Internacional para a Resolução de Disputas Relativas ao Investimento (CIRDI) e suas alternativas. 2013. 189 f. Dissertação (Mestrado) - Faculdade de Direito, Universidade de São Paulo, São Paulo, 2013. p. 23).

114 MOROSINI, Fabio; BADIN, Michelle Ratton Sanchez. The Brazilian Agreement on Cooperation and Facilitation of Investments (ACFI): a new formula for international investment agreements? Investment Treaty News, Winnipeg, v. 6, n. 3, 2015.

115 Cumpre ressaltar que até novembro de 2015, os Acordos de Cooperação e Facilitação de Investimentos assinados pelo Brasil não foram submetidos ao Congresso Nacional para apreciação, nos termos do que determina a Constituição Federal. MOROSINI, Fabio; BADIN, Michelle Ratton Sanchez. The Brazilian Agreement on Cooperation and Facilitation of Investments (ACFI): a new formula for international investment agreements? Investment Treaty News, Winnipeg, v. 6, n. 3, 2015, argumentando que as inovações do modelo de acordo brasileiro dependem de sua implementação, um para argumentar que o modelo brasileiro contribui com novos fundamentos regulatórios, amparado na ideia de cooperação e alinhado aos movimentos de política externa brasileira de parceria com o Sul global. Ademais, o afastamento dos mecanismos de solução de controvérsias investidor-Estado, um dos focos da resistência brasileira aos antigos acordos, para adoção de abordagens negociais previstas nos mecanismos de prevenção de controvérsias corrobora essa linha de argumentação.

O que fica evidente, ao fim e ao cabo, é que o Brasil, por meio da regulação, tem respondido às pressões externas e internas para adesão ao regime internacional de investimento estrangeiro, ora para resisti-lo e preferir soluções nacionais, ora para integrá-lo em novas bases.

\section{ReferênCiAs}

ALVAREZ, José Enrique. The public international law regime governing international investment. Recueil des Cours, Haye, v. 344, p. 195-541, 2009.

ALVES, André Gustavo de Miranda Pineli. As relações de investimento direto entre o Brasil e os países de seu entorno. In: ___ (Org.). Os BRICS e seus vizinhos: investimento direto estrangeiro. Brasília: IPEA, 2014. p. 13-169.

ANTUNES, Maria Thereza Pompa et al. A adoção no Brasil das normas internacionais de contabilidade IFRS: o processo e seus impactos na qualidade da informação contábil. Revista de Economia e Relaçôes Internacionais, São Paulo, v. 10, n. 20, p. 5-19, 2012.

AZEVEDO, Débora Bittah. Os acordos para a promoção e a proteção recíproca de investimentos assinados pelo Brasil. Brasília: Câmara dos Deputados, 2001.

BADIN, Michelle Ratton Sanchez; CARVALHO, Marina Amaral Egydio de; RORIZ, João Henrique Ribeiro. Os acordos regionais e preferenciais de comércio do Brasil com o seu entorno. In: BAUMANN, Renato; OLIVEIRA, Ivan Tiago Machado (Org.). Os BRICS e seus vizinhos: comércio e acordos regionais. Brasília: Ipea, 2014. p. 55-101.

BANCO CENTRAL DO BRASIL. Capitais brasileiros no exterior. Disponível em: <http://www4.bcb.gov.br/rex/

desafio que recai fortemente na capacidade de cooperação e coordenação das partes envolvidas e suas agências. 
cbe/port/cbe.asp>. Acesso em: 14 set. 2015.

BENTO, Lucas. Time to join 'BIT Club’? Promoting and protecting Brazilian investments abroad. The American Review of International Arbitration, New York, v. 24, n. 2, p. 271-324, 2013.

BOLSA DE VALORES DE SÃO PAULO. Índice Bovespa: Ibovespa. Disponível em: < http://www.bmfbovespa.com.br/indices/ResumoIndice.aspx? Indice $=\mathrm{IB}$ OVESPA\&Opcao=0\&idioma=pt-br $>$. Acesso em: 14 nov. 2014.

BRASIL busca acordos de proteção e promoção. Veja, 14 nov. 2010. Disponível em: <http://veja.abril.com. $\mathrm{br} /$ noticia/economia/brasil-busca-acordos-de-protecao-e-promocao>. Acesso em: 6 fev. 2014.

BRASIL. Balanço de Governo 2003-2010. Brasília: Dez. 2010. Disponível em: <http://www.balancodegoverno. presidencia.gov.br>. Acesso em: 24 nov. 2013.

BRASIL. Câmara dos Deputados. Comissão de Relações Exteriores e de Defesa Nacional. Ata da 42a Reunião Ordinária de Audiência Pública realizada em 13 de Novembro de 2013. Diário da Câmara dos Deputados, Brasília, v. 68, n. 214, 3 dez. 2013.

BRASIL. Câmara dos Deputados. Parecer da Comissão de Constituição e Justiça e Redação, de 8 de janeiro de 1997 [ao Projeto de Decreto Legislativo no 366 de 1996]. Diário da Câmara dos Deputados, Brasília, v. 59, n. 184, 6 nov. 1999.

BRASIL. Câmara dos Deputados. Parecer da Comissão de Constituição e Justiça e Redação, de 8 de janeiro de 1997 [ao Projeto de Decreto Legislativo no 367 de 1996]. Diário da Câmara dos Deputados, Brasília, v. 60, n. 78, 4 maio 2000.

BRASIL. Câmara dos Deputados. Parecer da Comissão de Desenvolvimento Econômico, Indústria e Comércio, de 13 de fevereiro de 1997 [ao Projeto de Decreto Legislativo no 367 de 1996]. Diário da Câmara dos Deputados, Brasília, v. 53, n. 94, 3 jun. 1998.

BRASIL. Câmara dos Deputados. Parecer da Comissão de Relações Exteriores e Defesa Nacional [ao Projeto de Decreto Legislativo no 367 de 1996]. Exposição do Deputado Luiz Gushiken. Diário da Câmara dos Deputados, Brasília, v. 60, n. 78, 4 maio 2000.

BRASIL. Câmara dos Deputados. Parecer da Comissão de Tributação e Finanças, de 21 de julho de 2003 [ao Projeto de Decreto Legislativo no 396 de 2000. Diário da
Câmara dos Deputados, Brasília, v. 58, n. 126, 12 ago. 2003.

BRASIL. Câmara dos Deputados. Parecer da Comissão de Tributação e Finanças, de 6 de agosto de 2003 [ao Projeto de Decreto Legislativo no 366 de 2000]. Diário da Câmara dos Deputados, Brasília, v. 68, n. 126, 12 ago. 2003.

BRASIL. Decreto no 57.943, de 10 de março de 1966. Promulga o Acordo de Garantia de Investimentos com os Estados Unidos da América. Diário Oficial [da] República Federativa do Brasil, Poder Executivo, Brasília, DF, 16 mar. 1966. Seção 1, p. 2815.

BRASIL. Exposição de Motivos no 77/DCM/AFEPA/ DAM-I-MRE-MSUL, de 26 de março de 2004. Diário da Câmara dos Deputados, Brasília, v. 59, n. 64, 23 abr. 2004.

BRASIL. Exposição de Motivos no 227/MRE, de 5 de junho de 1997. Diário da Câmara dos Deputados, Brasília, v. 52, n. 113, 1 jul. 1997.

BRASIL. Exposição de Motivos no 230/MRE/MF, de 22 de junho de 1998. Diário da Câmara dos Deputados, Brasília, v. 53, n. 111, 7 jun. 1998.

BRASIL. Exposição de Motivos no 369/MRE, de 30 de junho de 1995. Diário da Câmara dos Deputados, Brasília, v. 56, n. 95, 21 jun. 2001.

BRASIL. Exposição de Motivos no 399 DSF/ARC/ DE-I - MRE - PEXT EFIN, de 5 de dezembro de 2002. Diário da Câmara dos Deputados, Brasília, v. 57, n. 184, 13 dez. 2002.

BRASIL. Exposição de Motivos no 401 DSF/ARC/ DE-I - MIRE - PEXT EFIN, de 5 de dezembro de 2002. Diário da Câmara dos Deputados, Brasília, v. 57, n. 184, 13 dez. 2002.

BRASIL. Exposição de Motivos no 403 DSF/ARC/ DEI - MRE - PEXT EFIN, de 5 de dezembro de 2002. Diário da Câmara dos Deputados, Brasília, v. 57, n. 184, 13 dez. 2002.

BRASIL. Exposição de Motivos nº 612/MRE, de 12 de dezembro de 1994. Diário do Congresso Nacional, Brasília, v. 50, n. 4, p. 404, 6 jan. 1995. Seção 1.

BRASIL. Exposição de Motivos nº 613/MRE, de 12 de dezembro de 1994. Diário do Congresso Nacional, Brasília, v. 50, n. 4, 6 jan. 1995.

BRASIL. Exposição de Motivos no 642/MRE, de 27 de dezembro de 1994. Diário do Congresso Nacional, Brasília, v.50, n. 21, 31 jan. 1995. 
BRASIL. Exposição de Motivos n ${ }^{\circ}$ 643/MRE, de 28 de dezembro de 1994. Diário do Congresso Nacional, Brasília, v. 52, n. 24, 19 fev. 1997.

BRASIL. Lei $n^{\circ}$ 11.638, de 28 de dezembro de 2007. Altera e revoga dispositivos da Lei $n^{0}$ 6.404, de 15 de dezembro de 1976, e da Lei no 6.385, de 7 de dezembro de 1976, e estende às sociedades de grande porte disposições relativas à elaboração e divulgação de demonstrações financeiras. Diário Oficial [da] República Federativa do Brasil, Poder Executivo, Brasília, 28 dez. 2007. Seção 1, p. 2.

BRASIL. Lei no 12.414, de 9 de junho de 2011. Disciplina a formação e consulta a banco de dados com informações de adimplemento, de pessoas naturais ou de pessoas jurídicas, para formação de histórico de crédito. Diário Oficial [da] República Federativa do Brasil, Poder Executivo, Brasília, 10 jun. 2011. Seção 1, p. 2.

BRASIL. Lei $\mathrm{n}^{\circ} 12.846$, de $1^{\circ}$ de agosto de 2013. Dispõe sobre a responsabilização administrativa e civil de pessoas jurídicas pela prática de atos contra a administração pública, nacional ou estrangeira, e dá outras providencias. Diário Oficial [da] República Federativa do Brasil, Poder Executivo, Brasília, DF, 2 ago. 2013. Seção 1, p. 1.

BRASIL. Mensagem ao Congresso Nacional, 2014: $4^{a}$ Sessão Legislativa Ordinária da 54 ${ }^{\mathrm{a}}$ Legislatura. Brasília: Presidência da República, 2014.

BRASIL. Ministério das Relações Exteriores. Acordo Brasil-Angola de Cooperação e Facilitação de Investimentos. Luanda, $1^{\circ}$ de abril 2015. (Nota à imprensa $\mathrm{n}^{\circ}$ 104). Disponível em: <http://www. itamaraty.gov.br/index.php?option $=$ com_content\&vi ew $=$ article $\&$ id $=8520$ :acordo-brasil-angola-de-cooperacao-e-facilitacao-de-investimentos-acfi-luanda-1-deabril-de-2015\&catid $=42 \&$ Itemid $=280 \&$ lang $=p t-B R>$. Acesso em: 14 abr. 2015.

BRASIL. Ministério das Relações Exteriores. Acordo Brasil-Moçambique de Cooperação e Facilitação de Investimentos (ACFI). Maputo, 30 mar. 2015. (Nota à imprensa $\mathrm{n}^{\circ}$ 99). Disponível em: < http://www.itamaraty.gov.br/ index.php?option $=$ com_content $\&$ view $=$ article $\&$ id $=8$ 511:acordo-brasil-mocambique-de-cooperacao-e-facilitacao-de-investimentos-acfi-maputo-30-de-marco-de$2015 \&$ catid $=42 \&$ Itemid $=280 \&$ lang $=p t-B R>$. Acesso em: 14 abr. 2015.

BRASIL. Ministério de Relações Exteriores. O Brasil e os acordos de promoção e proteção de investimentos: uma perspec- tiva histórica. set. 2008. Slides.

BRASIL. Ministério do Desenvolvimento, Indústria e Comércio Exterior. Missão brasileira negocia acordos de investimento com Angola e Moçambique. Brasília, 09 out. 2012. Disponível em: <http://www.desenvolvimento.gov. $\mathrm{br} / \mathrm{sitio} /$ interna $/$ noticia.php?area $=1$ \&noticia $=12727>$. Acesso em: 28 jan. 2014.

BRASIL. Ministério do Desenvolvimento, Indústria e Comércio Exterior. Godinho: Brasil apoiará não somente negociações bilaterais e regionais, mas também multilaterais. Brasília, 26 out. 2013. Disponível em: <http:// www.desenvolvimento.gov.br/sitio/ interna/noticia. php?area $=5 \&$ noticia $=12765>$. Acesso em: 18 dez. 2013.

BRASIL. Ministério do Desenvolvimento, Indústria e Comércio Exterior. Missão ao Marrocos gera US\$ 4,8 milhões em negócios e expectativas de vendas, 4 dez. 2013. Disponível em: <http://www.mdic.gov.br/sitio/interna/ noticia.php?area $=1 \&$ noticia $=12863>$. Acesso em: 28 jan. 2014.

BRASIL. Ministério do Desenvolvimento, Indústria e Comércio Exterior. Godinho analisa momento de oportunidades no comércio exterior. Brasília, 25 out. 2013. Disponível em: <http://www.mdic.gov.br/sitio/interna/ noticia. php?area $=5 \&$ noticia $=12762>$. Acesso em: 14 jan. 2014.

BRASIL. Ministério do Desenvolvimento, Indústria e Comércio Exterior. Brasil está ativo em todas as frentes de negociações comerciais. Brasília, 13 nov. 2013. Disponível em: <http://www.desenvolvimento.gov.br/sitio/interna $/$ noticia.php?area $=5 \&$ noticia $=12815>$. Acesso em: 8 jan. 2014.

BRASIL. Ministério do Desenvolvimento, Indústria e Comércio Exterior. Departamento de Negociações Internacionais. Sistema Eletrônico do Serviço de Informações ao Cidadão: e-SIC. Brasília: MDIC, fev, 2015. Disponível em: <http://www.acessoainformacao.gov.br/sistema/ site $/$ index.html?ReturnUrl $=\% 2$ fsistema $\% 2 f>$. Acesso em: 06 nov. 2015.

BRASIL. Ministério do Desenvolvimento, Indústria e Comércio Exterior. Acordo de Cooperação e Facilitação de Investimentos. São Paulo, 2015. 18 slides, color.

BROWN, Chester (Ed.). Commentaries on selected model investment treaties. Oxford: Oxford University Press, 2013.

BUNGENBERG, Marc; REINISCH, August. The anatomy of the (invisible) EU model BIT: an introduction. 
The Journal of World Investment and Trade, London, v. 15, n. 3-4, p. 375-378, 2014.

CAETANO, Fernanda Araújo Kallás e. Direito internacional dos investimentos na atualidade: uma análise da posição brasileira. E-civitas: Revista Científica do Departamento de Ciências Jurídicas, Políticas e Gerenciais do UNI-BH, Belo Horizonte, v. 3, n. 2, p. 1-16, jul. 2010.

CAMPELLO, Daniela; LEMOS; Leany. The non-ratification of bilateral investment reaties in Brazil: a sotry of conflict in a land of cooperation. Review of International Political Economy, London, p. 1-32, 2015. doi: 10.1080/09692290.2014.987154.

CARVALHO, Romulo Soares Brillo. O segundo tempo do regime internacional dos investimentos: a nova geração de tratados e a prevenção de controvérsias investidor-Estado. 2011. 144 f. Dissertação (Mestrado) - Faculdade de Direito, Universidade do Estado do Rio de Janeiro, Rio de Janeiro, 2011.

COMISSÃO DE VALORES MOBILIÁRIOS. Registro de ofertas públicas. Disponível em: <http://www.cvm. gov.br/port/registro/FormRegistro.asp>. Acesso em: 14 nov. 2014.

CONFEDERAÇÃO NACIONAL DA INDÚSTRIA. Relatório dos investimentos brasileiros no exterior 2013: recomendações de políticas públicas para o Brasil. Brasília: CNI, 2013.

CONFERÊNCIA DAS NAÇÕES UNIDAS PARA O COMÉRCIO E O DESENVOLVIMENTO. n. do evento., ano do evento, local. Titulo do documento. Local: Editora, ano.

CORNETET, João Marcelo Conte. A política externa de Dilma Rousseff: contenção na continuidade. Conjuntura Austral, Porto Alegre, v. 5, n. 24, p. 111-150, 2014.

COSTA, José Augusto Fontoura. Direito internacional do investimento estrangeiro. Curitiba: Juruá, 2010.

COSTA, José Augusto Fontoura. Os ACFIs e a (falta de) proteção dos investidores. Valor Econômico, São Paulo, 30 jul. 2015.

COSTA, José Augusto Fontoura. Proteção e promoção do investimento estrangeiro no Mercosul uma ferramenta para a implementação de um bom clima de investimentos? Revista Brasileira de Politica Internacional, Brasília, v. 49, n. 2, p. 60-77, 2006.

DANTAS, Iuri; PARAGUASSU, Lisandra. Múltis brasi- leiras investem cada vez mais em paraísos fiscais. O Estado de São Paulo, 21 set. 2014. Disponível em: <http://economia.estadao.com.br/noticias/geral,multis-brasileirasinvestem-cada-vez-mais-em-paraisos-fiscais, 1563549>. Acesso em: 03 mar. 2015.

FLÔRES JUNIOR, Renato G. Investimento direto estrangeiro no Mercosul: uma visão geral. AMARAL JÚNIOR, Alberto do; SANCHEZ, Michelle Ratton (Coord.). Regulamentação internacional dos investimentos: algumas lições para o Brasil. São Paulo: Aduaneiras, 2007. p. 199-225.

FONSECA, Karla Closs. Investimentos estrangeiros: regulamentação internacional e acordos bilaterais. Curitiba: Juruá, 2008.

FUNDAÇÃO DOM CABRAL. Ranking FDC das multinacionais brasileiras 2014: a força da marca Brasil na criação de valor internacional. [S.1]: FDC, 2014.

GARCIA NETO, Paulo Macedo. Investment arbitration in Brazil: the landscape of investment arbitration in Brazil and why Brazil should become a more important player in the investment arbitration arena. In: LEVY, Daniel de Andrade; BORJA, Ana Gerdau de; PUCCI, Adriana Noemi. Investment protection in Brazil. Alphen aan den Rijn: Wolters Kluwer, 2013. p. 3-16.

GARCÍA-BOLÍVAR, Omar E. Sovereignty v. investment protection: back to Calvo? ICSID Review, Oxford, v. 24, n. 2, p. 464-488, 2009.

GUZMAN, Andrew T. Why LDCs sign treaties that hurt them: explaining the popularity of bilateral investment treaties. Virginia Journal of International Law, Virginia, v. 38, p. 639-688, 1997.

IGLESIAS, Roberto Magno; COSTA, Katarina. O investimento direto brasileiro na África. Rio de Janeiro: CINDES, 2011. (Textos CINDES, n. 27)

INSTITUTO DE PESQUISA ECONÔMICA APLICADA. Ponte sobre o Atlântico: Brasil e África Subsaariana: parceira sul-sul para o crescimento. Brasília: IPEA, 2011.

KALICKI, Jean; MEDEIROS, Suzana. Investment arbitration in Brazil. Arbitration International, Oxford, v. 24, n. 3, p. 423-446, 2008.

LERNER, Diego Fraga. Os regimes jurídicos de proteção ao investimento estrangeiro direto: o papel desempenhando pelos países emergentes. 2009. 121 f. Dissertação (Mestrado) - Faculdade de Direito, Universidade Federal do 
Rio Grande do Sul, Porto Alegre, 2009.

LUÍS, Daniel Tavela. Proteção do investimento estrangeiro: o sistema do Centro Internacional para a Resolução de Disputas Relativas ao Investimento (CIRDI) e suas alternativas. 2013. 189 f. Dissertação (Mestrado) - Faculdade de Direito, Universidade de São Paulo, São Paulo, 2013.

MAGALHÃES, José Carlos de. Acordos bilaterais de promoção e proteção de investimentos. Revista de Arbitragem e Mediação, São Paulo, v. 6, n. 20, p. 53-65, 2009.

MELLO, Celso D. de Albuquerque. Direito Internacional Econômico. Rio de Janeiro: Renovar, 1993.

MENDES, Marcos José Martins. O direito internacional dos investimentos: o caso do mercado brasileiro de biocombustíveis. 2011. 313 f. Dissertação (Mestrado) - Faculdade de Direito, Universidade do Estado do Rio de Janeiro, Rio de Janeiro, 2011.

MERCOSUL. Conselho do Mercado Comum. Decisão $n^{\circ} 11$, de 5 de agosto de 1994. Protocolo sobre promoción y protección de inversiones provenientes de Estados no partes del Mercosur. Disponível em: < http://www.bcb. gov.br/Rex/SGT4/Ftp/DEC_11_1994.pdf>. Acesso em: 19 jan. 2016.

MONEBHURRUN, Nitish. A inclusão da responsabilidade social das empresas nos novos Acordos de Cooperação e Facilitação de Investimentos do Brasil: uma revolução. Revista de Direito Internacional, Brasília, v. 12, n. 1, p. 32-38, 2015.

MOROSINI, Fabio; BADIN, Michelle Ratton Sanchez. The Brazilian Agreement on Cooperation and Facilitation of Investments (ACFI): a new formula for international investment agreements? Investment Treaty News, Winnipeg, v. 6, n. 3, 2015.

NASSER, Rabih; SATO, Nathalie Tiba. O novo modelo brasileiro de acordos de investimento. Valor Econômico, São Paulo. 12 de maio de 2015. Disponível em: < http:/ / www.valor.com.br/opiniao/4045196/o-novo-modelobrasileiro-de-acordos-de-investimento $>$. Acesso em: 14 maio 2015.

NUSDEO, Ana Maria de Oliveira. A experiência do Decreto $\mathrm{n}^{\circ} 57.943$ como acordo de garantia de investimentos entre Brasil-EUA. In: AMARAL JÚNIOR, Alberto do; SANCHEZ, Michelle Ratton (Coord.). Regulamentação internacional dos investimentos: algumas lições para o Brasil. São Paulo: Aduaneiras, 2007. p. 303-321.
PARAGUAI. Ministerio de Relaciones Exteriores. Estado de ratificaciones y vigencias de tratados y protocolos del Mercosur y Estados Asociados. Disponible en: <http://www. mre.gov.py/v1/Adjuntos/ mercosur/mercosurprincipal.htm>. Acceso en: 8 nov. 2014.

RIBEIRO, Marilda Rosado de Sá. As empresas transnacionais e os novos paradigmas do comércio internacional. In: DIREITO, Carlos Alberto Menezes; TRINDADE, Antônio Augusto Cançado; PEREIRA, Antônio Celso Alves (Coord.). Novas perspectivas do direito internacional contemporâneo: estudos em homenagem ao professor Celso D. de Albuquerque Mello. Rio de Janeiro: Renovar, 2008. p. 455-492.

SACERDOTI, Giorgio. BIT protections and economic crises: limits to their coverage, the impact of multilateral financial regulation and the defence of necessity. ICSDI Review, Oxford, v. 28, n. 2, p. 351-383, 2013.

SCANDIUCCI FILHO, José Gilberto. O Brasil e os acordos bilaterais de investimentos. In: AMARAL JÚNIOR, Alberto do; SANCHEZ, Michelle Ratton (Coord.). Regulamentação internacional dos investimentos: algumas lições para o Brasil. São Paulo: Aduaneiras, 2007. p. 271-301.

SCHILL, Stephan W. The multilateralization of International Investment Law. Cambridge: Cambridge University Press, 2014.

SIQUEIRA, Marcelo Gustavo Silva. Direito do investimento e inovação tecnológica: o histórico regulatório da transferência de tecnologia no Brasil em face das cláusulas de proteção dos acordos bilaterais de investimentos. 2012. 199 f. Dissertação (Mestrado) - Faculdade de Direito, Universidade do Estado do Rio de Janeiro, Rio de Janeiro, 2012.

SOUZA, Renato Rezende de Campos. Acordos de cooperação e facilitação de investimentos [informação verbal]. In: Brasil e os Acordos bilaterais de promocão de investimentos. AMCHAM São Paulo, 30 de abril de 2015.

SUBEDI, Surya P. International Investment Law: reconciling policy and principle. Oxford: Hart Publishing, 2008.

TREVISAN, Antoninho Marmo. Brasil: um emergente seguro. Revista de Direito Bancário e do Mercado de Capitais, São Paulo, v. 11, n. 41, p. 49-55, 2008.

UNITED NATIONS CONFERENCE ON TRADE AND DEVELOPMENT. Denunciation of the ICSID Convention and BITs: impact on investor-State claims. 
ILA Issues Note, Geneva, n. 2, p. 1-10, Apr. 2010.

UNITED NATIONS CONFERENCE ON TRADE AND DEVELOPMENT. World Investment Report 2013: Global value chains: investment and trade for development. Geneva: United Nations, 2013.

UNITED NATIONS CONFERENCE ON TRADE AND DEVELOPMENT. World Investment Report 2014: investing in the SDGs: an action plan. Geneva: United Nations, 2014.

UNITED NATIONS CONFERENCE ON TRADE AND DEVELOPMENT. World Investment Report 2015: reforming international investment governance. Geneva: United Nations, 2015.

VAN NIEKERK, Nico (Coord.). Buscando novas relações: avaliação da política externa dos Países Baixos para a América Latina: informe especial sobre o Brasil. Haia: IOB, 2013. (IOB Avaliação n. 382).

VAN OS, Roos; KNOTTNERUS, Roeline. Dutch bilateral investment treaties: a gateway to 'treaty shopping' for investment protection by multination companies. Amsterdam: Stichting Onderzoek Multinationale Ondernemingen, 2011.

VASCONCELOS, Raphael Carvalho de; SUÑÉ, Natasha. O direito dos investimentos no Mercosul: realidade e possibilidades. In: RIBEIRO, Marilda Rosado de Sá (Org.). Direito internacional dos investimentos. Rio de Janeiro: Renovar, 2014.

VILAS-BÔAS, Júlia Covre. A presença de empresas brasileiras na Africa: incentivos, atrativos e motivações. 2014. 162 f. Dissertação (Mestrado) - Instituto de Relações Internacionais, Universidade de Brasília, Brasília, 2014.

VILAS-BÔAS, Júlia Covre. Os investimentos brasileiros na África no governo Lula: um mapa. Meridiano 47, v. 12 , n. 128 , p. 3-9, 2011.

WARTHA, Udo. Das Multilaterale Abkommen über Investitionen (MAI). In: SCHACHTSCHNEIDER, Karl Albrecht (Org.). Rechtsfragen der Weltwirtschaft. Berlin: Duncker und Humblot, 2002. p. 359-433. 


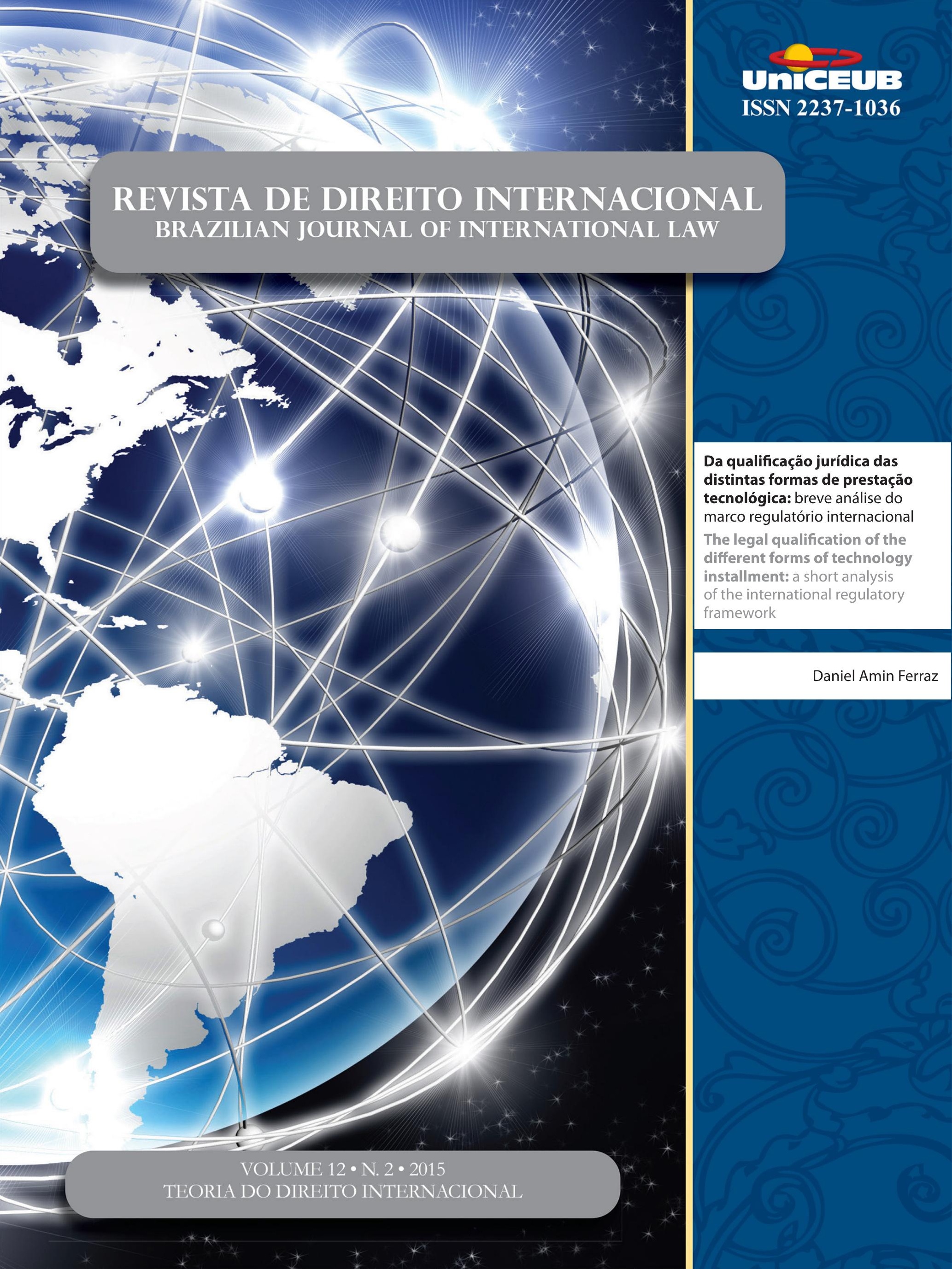




\section{Da qualificação jurídica das distintas formas de prestação tecnológica: breve análise do marco regulatório internacional*}

\section{The legal qualification of the different forms of technology installment: a short analysis of the international regulatory framework}

\section{Resumo}

A transferência de tecnologia e o acesso a esse insumo consistem em elementos fundamentais para o desenvolvimento da atividade humana concebida no âmbito da organização civil e para o exercício de uma diversidade de atividades econômicas. No entanto, em função da diversidade das formas de prestações tecnológicas, inexiste conceito internacional minimamente uniforme de tecnologia. A inexistência dessa premissa compromete a regulação de negócios jurídicos em que uma parte se mostra mais vulnerável que a outra, especialmente quando se concebe negociação entre empresas multinacionais ou de nacionalidades diferentes, já que haveria uma assimetria entre elas. Dado esse contexto, o presente artigo, tendo como escopo o marco regulatório internacional, visa qualificar, juridicamente, as distintas formas de prestação tecnológica, a fim de que um entendimento minimamente uniforme seja sedimentado. Tal entendimento, possibilitará o desenvolvimento da discussão relativa à regulação estatal dos contratos de transferência de tecnologia e à otimização da prestação contratual entre as empresas. Além disso, a partir de uma base conceitual satisfatória, poder-se-á conceber harmonização legislativa da matéria relativa à prestação tecnológica, que, atualmente, se mostra ausente.

Palavras-chave: Contratos. Transferência de tecnologia. Formas de prestação tecnológica. Marco regulatório internacional.

\section{Abstract}

The technology transfer and the access to this input consist in fundamental elements to the development of the human activity designed in the scope of civil organization and to the exercise of diversified economic transactions. However, due to the diversity of the technology installment forms, a minimum international concept of technology is absent. The absence of this concept compromises the regulation of legal transactions in which one part of the contract is more vulnerable than the other, especially when a negotiation is designed between multinational companies or from different countries, for there would exist an asymmetry between those parts. In this

\footnotetext{
** Autor convidado; Mestre em Direito Empresarial, Universidade de Coimbra, Portugal; Doutor em Direito Internacional - Empresarial Internacional, Universidad de València, Espanha; Professor do Programa de Mestrado/Doutorado do UniCEUB, Brasília - DF; Advogado.

E-mail: daniel.amin@afcadvogados.adv.br.
}

\section{Recebido em 09/11/2015}

Aprovado em 02/12/2015 
context, the present article, in the scope of the international regulatory framework, crave to legally qualify the distinct forms of technology installment, so that a minimally uniform understanding of the matter is settled. This understanding will enable the development of the discussion regarding the state regulation of technology transfer and regarding the optimization of the technology installment between companies. Besides that, from this satisfactory conceptual base, it will be possible to design a legal harmonization of the matter regarding the technology transfer, which nowadays is absent.

Keywords: Contracts. Technology transfer. Forms of technology installment. International regulatory framework.

\section{Aproximação da matéria}

O acesso à tecnologia, incorporada ao capital, aos bens ou ao conhecimento, é condição do exercício das distintas atividades econômicas e constitui elemento determinante na capacidade competitiva das empresas ${ }^{1}$.

Os contratos de transferência de tecnologia constituem a forma normal de acesso a esse fator de produção (a tecnologia de desenvolvimento). Assim, os inves-

1 Importa referir que, no presente artigo, as expressões empresa e empresário serão utilizadas como sinônimas, seguindo a teoria empresarial adotada no Direito Europeu continental e, posteriormente, adotada em outras partes do globo. Observe-se que ainda que pese o entendimento de doutrina pátria no sentido da adoção da teoria empresarial no Brasil, entende-se que este não ocorreu, uma vez que presente em nossa legislação de cunho mercantilista a distinção entre empresário (agente que desenvolve a atividade econômica e qualificado como pessoa de direito); estabelecimento mercantil (objeto de direito utilizado pelo empresário para o exercício de sua atividade - instrumento de exercício da mesma) e, finalmente, empresa (qualificada como a mera atividade desenvolvida pelo empresário, utilizando-se do estabelecimento). Dessa forma, a empresa seria, também, qualificada como objeto de direito e não sujeito. Ademais, para ser qualificada como objeto de direito mercantil, deverá ser equiparada a mercadoria, o que determinaria a possibilidade de sua negociação de forma independente e autônoma. Assim, deverá a empresa possuir valor intrínseco e ser passível de negociação de forma independente de outros bens (exemplo, para a qualificação da empresa como objeto de direito mercantil seria a existência dos contratos de franquia, em que, ademais da transferência de tecnologia, o franqueador transfere ao franqueado parte de sua empresa). Para aprofundamento quanto à caracterização jurídica da empresa e a adoção, pelo Direito Europeu continental da teoria empresarial, veja-se, por todos: CARVALHO, Orlando de. Critério e estrutura do estabelecimento comercial: o problema da empresa como objecto de negócios. Coimbra: Atlântida, 1967. timentos em longo prazo em investigação e tecnologia constituem um dos mecanismos fundamentais para que uma economia industrializada mantenha sua taxa de conhecimento e sua quota de inserção no comércio internacional ${ }^{2}$.

Grande parte dos contratos de transferência de tecnologia é elaborada entre empresários originários de países industrializados e tecnologicamente avançados, permitindo constituir-se uma cooperação recíproca.

Contudo, com certa frequência, esses contratos são praticados entre empresas de desigual capacidade econômica e tecnológica, principalmente multinacionais e empresas nacionais. Ademais, muitas das vezes entre empresários de países industrializados (detentores da tecnologia) e empresários de países em desenvolvimento (receptores da tecnologia). Sempre que a capacidade de negociação da empresa adquirente e da empresa cedente for desigual, estarão criadas as condições para o desequilíbrio contratual ${ }^{3}$.

Tal situação é agravada pela prática comum de transferência da tecnologia pelos pacotes tecnológicos, sendo difícil para o adquirente o conhecimento de todos os elementos que fazem parte da tecnologia adquirida. Tal condição gera a eterna dependência econômica e tecnológica do adquirente com relação ao cedente. Todas essas restrições, quando praticadas em larga escala, são suscetíveis, até mesmo, de afetar a independência econômica dos Estados ${ }^{4}$.

2 GARCÍA-CASTRILLÓN, Carmen Otero. Las patentes en el comercio internacional. Madrid: Dykinson, 1997. p. 70.

3 Importa referir que ganha relevância, neste contexto, a classificação econômica dos contratos, elaborada pelo renomado jurista italiano Messineo. Hoje em dia, a classificação do autor sofreu atualizações, passando por novas categorizações. Assim, as prestações tecnológicas estariam agrupadas em uma nova categoria, os contratos de transferência de tecnologia. Para aprofundamento quanto a classificação econômica dos contratos, ver: MESSINEO, Francesco. Manuale di diritto civile e commerciale. 6. ed. Padova: Cedam, 1943. p. 361 e ss.; FERRAZ, Daniel Amin. Dos contratos internacionais do comércio: regime geral. In: (Org.). Contratação internacional: algumas espécies de contratos mercantis. Curitiba: CRV, 2014. p. 9-32. p. 19 e ss.

4 "El sistema financiero se internacionalizó. Y eso tuvo un efecto inmenso en el mundo, entre otras razones porque limitó, en la práctica, la capacidad de los Estados nacionales, incluso de los más poderosos, para regular los flujos de capital. Los bancos centrales resultaron pequeños ante la velocidad con que se realizan los flujos privados de transferencia de capital". CARDOSO, Fernando Henrique. La globalización y los desafíos de la democracia en el plano internacional. Foreign Affairs, Ciudad de México, v. 2, n. 1, p. 108-113, primavera de 2002. p. 109 e ss. 
Por constatar as características acima elencadas, especialmente a partir do final dos anos 60 do século passado, em um número considerável de países em desenvolvimento, adotou-se legislação específica no domínio da transferência de tecnologia.

De maneira geral, tais legislações (que têm base na carta de Direitos e Deveres Econômicos dos Estados aprovados pela Assembleia Geral das Nações Unidas) conferem poderes de intervenção aos Estados.

A intervenção, por exemplo, poderia estar caracterizada de forma múltipla: a) necessidade de autorização estatal para a celebração de contratos de transferência de tecnologia entre empresas nacionais e estrangeiras; b) imposição de determinadas cláusulas previstas em lei no âmbito dos contratos; c) proibição de condições restritivas para o adquirente da tecnologia; d) imposição de cláusulas favoráveis a empresa nacional ou ao país acolhedor da tecnologia (principalmente em matéria de formação de recursos humanos, utilização de recursos locais, preservação do meio ambienteetc) $)^{5}$.

Não obstante, sabe-se hoje que a simples intervenção do Estado com o fim de limitar a realização dos contratos de transferência de tecnologia não é a estratégia mais benéfica, já que gera atraso no desenvolvimento tecnológico e social para todos os países periféricos.

A transferência de tecnologia deriva de distintas necessidades para o desenvolvimento das atividades humanas (organização da sociedade civil) e empresariais. Assim, pode se dar em virtude do investimento estrangeiro, envolvendo a construção ou instalação de estabelecimentos e equipamentos industriais (tecnologia incorporada ao capital); venda de bens de capital ou bens intermediários (tecnologia incorporada ao capital); trabalho humano qualificado, incluindo a assistência técnica e a formação técnica (tecnologia incorporada ao conhecimento); informação, de natureza técnica e comercial, protegida pelos direitos da propriedade industrial, exemplo maior a patente ${ }^{6}$ etc.

5 No sentido da dependência econômica dos países da periferia capatalista com relação aos países de economia central, ver: FERRAZ, Daniel Amin. A concentração empresarial no contexto da economia internacional. In: (Org.). Direito empresarial: marco jurídico de internacionalização das empresas brasileiras. Curitiba: CRV, 2012. p. 10-31. p. 10 e ss.

6 SANTOS, António Marques dos. Transferência internacional de tecnologia, economia e direito: alguns problemas gerais. Lisboa: Centro de Estudos Fiscais, 1984. (Cadernos de Ciência e Técnica de Fiscal, 132). p. 22 e ss.
Para o progresso de uma dada sociedade civil organizada, é fundamental seu adequado desenvolvimento tecnológico. Não há dúvida alguma de que o progresso tecnológico é um dos fatores decisivos para o desenvolvimento, pois, sem progresso técnico, não há que se falar em competitividade industrial ${ }^{7}$.

A colaboração entre empresas mediante intercâmbios de técnicas e conhecimentos é uma constante no contexto atual do comércio mundial, sendo elemento essencial para a disseminação dos processos tecnológicos.

Como nota introdutória, é importante salientar que algumas premissas devem ser asseguradas para adequada compreensão do fenômeno da transferência de tecnologia.

Assim, etimologicamente, tecnologia é termo genérico que compreende diversas características específicas, distintas umas das outras, que, normalmente, constituem manifestações da propriedade industrial, mesmo quando são tratadas no marco regulatório da propriedade intelectual.

Por outro lado, quanto à forma de disponibilização, a tecnologia pode ser transferida, definitivamente, mediante compra e venda, contra pagamento de preço, ou; simplesmente, ser objeto de direito de utilização ou exploração temporária, mediante pagamento de royalty.

Ademais, pode se dar de forma isolada, ou vinculada a uma operação de compra e venda de determinado bem ou serviço. Há que se falar, nesse caso, que o contrato objeto de tal operação será qualificado como negócio jurídico de natureza mercantil, ainda que no âmbito de uma operação obrigacional ${ }^{8}$.

Diversamente, a tecnologia pode ser transferida por meio de uma operação societária, na forma de contribuição para a constituição de capital’.

7 PERALES, Rafael. Mercosury Comunidad Europea: la cooperación científico-tecnológica. 2. ed. Buenos Aires: Ciudad Argentina, 1998. p. 135.

8 Neste ponto é importante referir que o Direito Obrigacional, como sub-ramo autônomo do direito privado, serviria, supletivamente, a toda a matéria contratual, seja ela civil, mercantil ou trabalhista. Desta forma, estaria o mesmo qualificado como teoria geral de todo o direito contratual, seja ele em que âmbito se apresentar, limitada sua aplicação, tão somente, pela qualificação do direito privado. Veja-se, neste sentido: VARELA, João de Matos Antunes. Das obrigações em geral. 8. ed. Coimbra: Almedina, 1994.

9 Nesse caso, o negócio jurídico praticado será qualificado como negócio societário. Assim, a integralização de capital por meio da incorporação tecnológica será qualificada como negócio jurídico de natureza societária, seja plurilateral (sociedades mercantis em geral) 
Portanto, a diversidade de formas de transferência de tecnologia dificulta sua definição, ademais de, muitas das vezes, gerar dependência para os agentes (empresários nacionais) que atuam nos países em desenvolvimento.

\section{A tecnologia e sUA CONCEPÇÃo}

Para a busca de uma concepção uniforme sobre tecnologia, dois elementos devem ser considerados. Assim, o primeiro seria a ausência de legislação internacional uniforme sobre a matéria. Dessa forma, necessário será a verificação das legislações nacionais para a caracterização da oferta tecnológica.

Outro ponto importante a destacar como obstáculo à compreensão do presente instituto jurídico é que a tecnologia pode incorporar inúmeras outras prestações, tais como o know-how, técnicas novas, respostas para a observação dos sistemas técnicos etc ${ }^{10}$.

Uma tentativa importante na unificação do Direito aplicável à transferência de tecnologia foi a inclusão, no Acordo da OMC, do anexo relativo aos aspectos do direito de propriedade intelectual, relacionados com o comércio ${ }^{11}$, tema que tradicionalmente havia estado ausente nos debates e trabalhos do GATT.

O acordo contém normas específicas a respeito das seguintes matérias tecnológicas: Direitos de autor e direitos conexos; Programas de computador; Marcas; Indicação de procedência e denominação de origem; Desenho industrial; Patente; Circuitos integrados; Know-how; normas para solução de conflitos entre os países-membros e; meio de controle de práticas de não concorrência nos contratos de licenciamento.

ou estatutária (quando envolva sociedade anônima). Veja-se, quanto a natureza do negócio jurídico societário: BROSETA PONT, Manuel. Manual de derecho mercantil. 10. ed. Madrid: Tecnos, 2000. p. 177 e ss.

10 SULLIVAN, Neil F. Technology transfer: making the most of your intellectual property. Cambridge: Cambridge University Press. p. 5.

11 Acordo OMC, Anexo 1C. CONSELHO DAS COMUNIDADES EUROPEIAS. Decisão 94/800/CE Conselho de 22 de Dezembro de 1994 relativa à celebração, em nome da Comunidade Europeia e em relação às matérias da sua competência, dos acordos resultantes das negociações multilaterais do Uruguay Round (1986/1994). Jornal Oficial das Comunidades Europeias, Bruxelas, v. 37, L336, p. 1-2, 23 dez. 1994. Disponivel em: < http://eur-lex.europa. eu/legal-content/PT/TXT/HTML/?uri=CELEX:31994D0800\&f rom $=$ PT $>$. Acesso em: 22 jan. 2016.
Nos termos do art. $7^{\circ}$ do referido anexo, a proteção e observância do direito de propriedade intelectual deve contribuir para a promoção da inovação tecnológica e a transferência e difusão da tecnologia, em benefício recíproco dos produtores e dos usuários de conhecimentos tecnológicos, favorecendo o bem-estar social e econômico.

Para tanto, esse é um marco multilateral de princípios, normas e disciplinas tendentes a reduzir as dificuldades e obstáculos no comércio internacional. Fomenta, paralelamente, a proteção eficaz dos direitos de propriedade intelectual e industrial. Ademais, é uma tentativa de harmonização de interpretações quanto ao domínio tecnológico.

$\mathrm{Na}$ esteira da busca de uma melhor definição da prestação tecnológica, classificações podem ser elaboradas.

\subsection{A tecnologia incorporada e a tecnologia não incorporada às mercadorias}

Basicamente, existem dois tipos de operações que permitem melhor definição de transferência de tecnologia.

Por um lado, as partes podem realizar operação com tecnologia incorporada nas transferências de mercadorias ou; por outro lado, realizar operações com transferência de tecnologia de isolamento, como operacõoes invisíveis, nos termos utilizados pela OMC.

$\mathrm{Na}$ segunda categoria, estariam compreendidas as operações de transferência de tecnologia com contribuição para a constituição de capital, v.g., com a criação de um grupo de sociedades de base contratual ${ }^{12}$.

Normalmente, quando um bem é objeto de compra e venda, o vendedor já incluiu no preço final o custo da pesquisa, estudos, decisões etc. Ao pagar o preço solicitado o comprador está, em última instância, realizando o pagamento do custo da tecnologia utilizada na fabricação do bem.

Em tais casos, não se pode falar em contrato de

12 Nesse sentido: ANTUNES, José Manuel Oliveira; MANSO, José António Costa. Relações internacionais e transferência de tecnologia. Coimbra: Almedina, 1993. p. 8 e ss. Para uma definição de grupos de sociedades de base contratual, ver FERRAZ, Daniel Amin. Grupo de sociedades: instrumento jurídico de organização da empresa plurisocietária. Revista de Direito Internacional, Brasilia, v. 12, p. 495509, 2014. 
transferência de tecnologia propriamente dito, vez que a mesma seria parte indissociável da mercadoria negociada. Assim, estaria qualificado um autêntico contrato de compra e venda internacional de mercadorias.

Não obstante, é muito frequente que, além das mercadorias vendidas (por exemplo, máquinas e equipamentos), se transfiram outros benefícios que não fazem parte do custo das mesmas, tais como: direito de uso de uma marca, patente, serviços de assistência técnica etc. Assim, nestes casos, com o contrato de compra e venda internacional de mercadorias, coexistiria um contrato de transferência de tecnologia.

Por outro lado, quando os recursos técnicos são objeto de transmissão separada de uma compra e venda de mercadorias, aparece o genuíno contrato de transferência de tecnologia.

Por sua vez, certos benefícios da tecnologia podem ser objeto de bem de atribuição definitiva, ou seja, de venda a varejo por um preço, direito de licença ou concessão de uso ou exportação, mediante o pagamento de royalty.

Por conseguinte, não é tarefa fácil realizar classificação das distintas prestações susceptíveis de adequar-se no termo genérico transferência de tecnologia.

\subsection{Breve enunciado dos diversos tipos de pres- tação tecnológica}

Várias são as formas de prestação tecnológica, gerando reflexos quanto à formulação e natureza dos negócios jurídicos praticados. No presente estudo, seria impossível aprofundamento sobre todas as espécies de prestação tecnológica. Contudo, algumas categorias contratuais deverão ser analisadas, para melhor compreensão da matéria.

\subsubsection{Enginnering}

Assim, o enginnering constitui conjunto de trabalhos e estudos de caráter técnico, econômico e de investigação, normalmente feitos por uma empresa ou departamento especializado, para a realização de determinado projeto industrial. Muitas vezes o negócio jurídico se materializa em projetos e relatórios técnicos.

Em relação a essa categoria contratual, há, no mínimo, duas espécies contratuais: a) consulting-engineering e; b) comercial-engineering.

a) Entende-se por consulting-engineering a operação por meio da qual a empresa consultora (empresa de engenharia) concorda em atuar como conselheira técnica, perante o pagamento de um valor pré-determinado, para a execução de projeto específico. A consultoria estabelecerá os planos e especificações do projeto, examinará as propostas apresentadas pelo executor do projeto, promoverá as inspeções e supervisões dos trabalhos.

b) Por sua parte, os contratos de comercial-engineering têm por objetivo o acompanhamento e a realização de obra imaterial, tipicamente intelectual, conjuntamente com a execução de outras prestações materiais, tais como o fornecimento de mercadorias e equipamentos e/ou a execução dos trabalhos técnicos ${ }^{13}$.

Finalmente, ponto relevante é do tratamento aduaneiro nas operações de contratos internacionais de engineering. Do ponto de vista da alfândega o negócio jurídico engloba, tão somente, os trabalhos e estudos destinados à fabricação de uma instalação ou produto industrial, tratando-se de operações anteriores à aquisição do produto final. Dessa forma, o regime fiscal deverá acompanhar tal qualificação, dispensado o negócio jurídico de incidência fiscal.

\subsubsection{Patente}

A patente é um privilégio legal, concedido ao inventor, que lhe permite fabricar, utilizar e/ou vender determinado bem ou processo, com a exclusão de terceiros, de forma exclusiva e por tempo determinado ${ }^{14}$.

$\mathrm{Na}$ generalidade dos ordenamentos jurídicos, é evidente a existência de um claro interesse público na proeminência de um sistema de proteção das invenções, isto

13 HERNÁNDEZ RODRÍGUEZ, Aurora. Los contratos internacionales de construcción. Granada: Comares, 1999. p. 102 e ss.

14 Ponto controverso quanto à temática ora apresentada, é o de se saber a titularidade da invenção em uma relação laboral, se do empregador ou do empregado. No presente momento não seria possível desenvolver tal temática, já que fugiria do objetivo do presente estudo. Contudo, para um aprofundamento sobre o tema, veja-se: GÓMEZ ABELLEIRA, Francisco Javier. Litigios entre empresario y trabajador sobre patentes, secretos industriales y derechos de autor en los Estados Unidos. Santiago de Compostela: Universidade da Coruña, 1999. p. 50 e ss. 
é, de um sistema de patentes. O interesse se baseia na função que esse sistema desempenha, que não é outro senão a promoção e desenvolvimento das invenções ${ }^{15}$.

O fenômeno da globalização, por sua vez, traz a necessidade de um aprofundamento na discussão da matéria. O tratamento dos direitos de propriedade industrial, no marco do Direito do comércio internacional, oscila entre sua configuração territorial e a globalização das relações comerciais. Essa última circunstância introduziu a necessidade de rentabilidade dos investimentos realizados por empresas de pesquisa. Essas coordenadas se manifestam em diferentes momentos da regulamentação internacional dos direitos de propriedade industrial $^{16}$.

Para o Tribunal de Justiça de Luxemburgo (TJUE), tal privilégio é justificável como uma concessão ao inventor de um direito exclusivo de comercialização/licenciamento do bem, permitindo, com o monopólio da exploração, a recompensa ao inventor por seus esforços criativos $^{17}$. Tem como objetivo específico a garantia ao titular de tal direito de utilizar sua invenção com vistas a fabricação e comercialização de produtos industriais de forma exclusiva, durante prazo determinado.

Contudo, importa salientar que o sistema de patentes não é feito com o fim único de gerar exclusividade para o inventor. A exclusividade, ainda que exista, é entendida somente como uma recompensa ao inventor pelo trabalho realizado. O sistema pretende, assim, contribuir para o desenvolvimento tecnológico e científico dos povos, já que os processos de invenção serão arquivados nos órgãos concedentes da patente e divulgados para a comunidade científica mundial.

A patente tem a natureza jurídica de objeto de direito. Tal natureza jurídica lhe permite ser objeto de

15 GARCÍA-CASTRILLÓN, Carmen Otero. Las patentes en el comercio internacional. Madrid: Dykinson, 1997. p. 353 e ss.

16 JIMÉNEZ BLANCO, Pilar. El derecho aplicable a la protección internacional de las patentes. Granada: Comares, 1998. p. 43.

17 UNIÃO EUROPEIA. Tribunal de Justiça. Centrafarm BV; Adriaan de Peijper vs. Sterling Drug Inc. Caso 15/74. Setença, 31 de outubro de 1974. Disponível em: < http://eur-lex.europa.eu/legalcontent/PT/TXT/PDF/?uri=CELEX:61974CJ0015\&from=FR >. Acesso em: 22 jan. 2016;. EUROPEAN UNION. Court of Justice. Merck. \& Co. Inc. vs Stephar BV; Petrus Stephanus Exler. Reference for a preliminary ruling: Arrondissementsrechtbank Rotterdam - Netherlands. - Patents - Pharmaceutical products. Case 187/80. Sentence, 14 July 1981. Disponível em: <http://eur-lex.europa.eu/legal-content/EN/TXT/HTML/?uri=CELEX:61980CJ0187\&from=FR $>$. Acesso em: 22 jan. 2016. transmissão por venda ou concessão temporal de uso. A licença se aperfeiçoa no momento em que a oferta é aceita por um sujeito determinado que, por sua vez, adquire o compromisso de pagar a indenização preten$\operatorname{dida}{ }^{18}$.

A concessão de licença de patente é a transferência temporal do direito de uso ou de exploração da invenção patenteada, mediante o pagamento de royalty, o qual poderá ser fixo ou variável.

O Regulamento CEE no 2349/84, de 23 de julho de 1984, definia a licença de patentes como a autorização pelo titular de uma patente (licenciante) a outra pessoa (licenciado) para que explore a invenção patenteada por um ou mais modelos de exploração previstos no direito de patentes, em particular a fabricação, utilização e comercialização ${ }^{19}$.

\subsubsection{Modelos de utilidade}

Por sua vez, as invenções que consistem em dar a um objeto nova configuração, estrutura ou constituição, que resulte em alguma vantagem sensível para uso ou fabricação, pode ser protegida como modelo de utilida$\mathrm{de}^{20}$. Pode-se citar como bens protegidos os utensílios, ferramentas, aparelhos, dispositivos ou partes dele que atendam a esses requisitos ${ }^{21}$.

18 CORREA, Carlos M.; BERGEL, Salvador D. Patentes y competencia. Buenos Aires: Rubinzal Culzoni, 1996. p. 111.

19 COMMISSION OF THE EUROPEAN COMMUNITIES. Commission Regulation No. 2349/84/EEC of 23 July 1984 on the application of Article 85(3) of the Treaty to certain categories of patent licensing agreements as corrected by OJL 113 of 1985. Disponível em: <http:// www.wipo.int/wipolex/en/details.jsp?id=1431>. Acesso em: 22 jan. 2016. Este Regulamento esteve em vigor até 31 de março de 1996, sendo substituído pelo Regulamento CE 240/96 da Comissão, de 31 de janeiro de 1996, o qual foi publicado no DO n ${ }^{\circ} \mathrm{L} 31$, de 9 de fevereiro de 1996. COMISSÃO DAS COMUNIDADES EUROPEIAS. Regulamento (CE) n. ${ }^{\circ} 240 / 96$ da Comissão, de 31 de janeiro de 1996, relativo à aplicação do ${ }^{\circ} 3$ do artigo 85 do Tratado a certas categorias de acordos de transferência de tecnologia. Jornal Oficial das Comunidades Europeias, Bruxelas, v. 39, n. L31, p. 2-13, 9 fev. 1996. Disponivel em: <http:/ / eur-lex.europa.eu/legal-content/ PT/TXT/PDF/?uri=CELEX:31996R0240\&rid=3>. Acesso em: 22 jan. 2016.

20 Para uma diferenciação dos requisitos das patentes e dos modelos de utilidade, ver: VILALTA NICUESA, Aura Esther; MÉNDEZ TOMÁS, Rosa M. Acciones para la protección de patentes y modelos de utilidad. Barcelona: Bosch, 2000. p. 9 e ss.

21 No seio da União Europeia, a proteção mediante patentes se realiza por intermédio de dois sistemas: os sistemas nacionais; e o sistema europeu de patentes.Assim, o sistema de patente nacional foi harmonizado, no âmbito da UE, mediante a adesão progressiva ao Convênio de Munique, que trata da Patente Europeia, de 5 de oou- 
Definindo melhor a forma dos objetos que são suscetíveis de registro como modelo de utilidade, caberia indicar que:

a) deverão consistir em uma forma espacial, devendo ser qualificadas como coisas móveis;

b) deverão ter uma configuração determinada. Por não possuir essa característica, a matéria líquida ou gasosa, ou a matéria sólida carente desta

tubro de 1973, onde também constam como signatários, ademais, dos Estados-membros da UE, a Suíça, Liechtenstein e Mônaco. O sistema europeu é constituído de dois Convênios sobre patentes, o referido Convênio de Munique e o Convênio de Luxemburgo sobre patente comunitária, de 15 de dezembro de 1975 que, na atualidade compõe o Acordo em matéria de patentes comunitárias, também firmado em Luxemburgo, em 15 de dezembro de 1989.

O convênio de Munique não criou um direito uniforme de proteção, senão permitiu obter-se uma proteção para tantos estados partes do convênio quanto deseje o solicitante. Este sistema se caracteriza pela flexibilidade, ainda que apresente inconvenientes por sua complexidade e elevados custos. Ademais, não prevê a existência de um tribunal com competência no âmbito europeu para dirimir litígios em matéria de patentes, o que representa elevado risco de que os tribunais dos estados-membros solucionem os conflitos de forma divergente.

Ainda que distintos, os objetivos dos Convênios de Munique e Luxemburgo são complementários. O primeiro pretende racionalizar a expedição das patentes mediante estabelecimento de procedimento centralizado, gerido pela Oficina Europeia de Patentes de Munique. Dessa forma, o convênio está aberto para a adesão de todo Estado europeu. Tal convite deverá partir do Conselho de Administração da Organização Europeia de Patentes. Por seu turno, o segundo pretende alcançar os objetivos do mercado único, especialmente quanto à igualdade de condições de concorrência e livre circulação de mercadorias.

O sistema de patentes na Europa foi elaborado, assim, mediante convênios internacionais. Isso se deve ao fato de essas iniciativas terem sido adotadas em uma época em que a UE ainda não tinha competência legal para regulamentar a matéria em seu âmbito. Todavia, trata-se de fase já superada. Assim, o TJUE reconheceu (sentença de 13 de julho de 1995. Assunto C-350/92. Reino da Espanha c/ Conselho) a competência da UE para intervir no âmbito das patentes, desde que tal intervenção contribua para realizar um dos objetivos dos Tratados de Constituição: a livre circulação de mercadorias, ou o estabelecimento de condições não falseadas de concorrência.

A Comissão entendeu necessário fazer um balanço da situação em matéria de patentes comunitárias e sistemas de patentes na Europa. Com tal fim, elaborou um Livro Verde, no qual analisa as carências derivadas da ausência de uma vertente comunitária correspondente ao sistema europeu de patentes, ademais dos obstáculos para sua eventual entrada em vigor. Em seguida, aborda as questões, derivadas de sua ausência, sob a ótica técnico-jurídica e política, tais como a harmonização complementária do direito de patentes no contesto comunitário.

Finalmente, o Livro Vede persegue triplo objetivo: a) facilitar uma visão geral da situação em matéria de inovação por meio do regime de patentes na UE; b)avaliar a necessidade de adoção de novas ações comunitárias e/ou modificar os regimes atuais; c) explorar a forma e o conteúdo possível de tais novas ações. configuração, por exemplo os pós industriais, não poderão ser registrados como modelo de utilidade;

c) poderão ser bidimensional ou tridimensional;

d) finalmente, há de ter uma forma perceptível pelos sentidos ${ }^{22}$.

\subsubsection{Know-how}

Outro contrato que é importante mencionar é o contrato Know-how, já que boa parte da tecnologia produzida, hoje em dia, se dá por seu intermédio ${ }^{23}$.

Assim, no seio da UE, para sua definição, o regulamento CE 240/96, de 31 de janeiro de $1996^{24}$, determina que Know-how é um conjunto de informações técnicas secretas, substanciais e identificadas de forma apropriada, devendo levar em conta o seguinte:

a) O termo informações técnicas secretas significa que o conjunto de Know-how não é normalmente conhecido nem facilmente acessível, de modo que parte de seu valor consiste na licença temporal que sua

22 OTERO LASTRES, José Manuel. Derecho y tecnología: curso sobre innovación y transferencia. Barcelona: Ariel, 1990. p. 159.

23 MASSAGUER FUENTES, José. El contrato de licencia de Knowhow. Barcelona: J. M. Bosh, 1999. p. 67.

24 Regulamento (CE) no 240/96 da Comissão, de 31 de janeiro de 1996, relativo a aplicação do apartado 3 do artigo 85 do Tratado a determinadas categorias de acordos de transferência de tecnologia (Texto pertinente aos fins do EEE), DO n ${ }^{\circ}$ L 031 de 09/02/1996. COMISSÃO DAS COMUNIDADES EUROPEIAS. Regulamento (CE) n. ${ }^{\circ}$ 240/96 da Comissão, de 31 de janeiro de 1996, relativo à aplicação do $n^{\circ} 3$ do artigo 85 do Tratado a certas categorias de acordos de transferência de tecnologia. Jornal Oficial das Comunidades Europeias, Bruxelas, v. 39, n. L31, p. 2-13, 9 fev. 1996. Disponivel em: $<$ http://eur-lex.europa.eu/legal-content/PT/TXT/PDF/?uri=CE LEX:31996R0240\&rid=3>. Acesso em: 22 jan. 2016, alterado pela Ata relativa às condições de adesão da República Checa, da República da Estônia, da República do Chipre, da República da Letônia, da República da Lituânia, da República da Hungria, da República de Malta, da República da Polônia, da República da Eslovênia e da República Eslava, e das adequações dos Tratados nos quais se fundamenta a União - Anexo II COMUNIDADE EUROPEIA. Acto relativo às condições de adesão da República Checa, da República da Estónia, da República de Chipre, da República da Letónia, da República da Lituânia, da República da Hungria, da República de Malta, da República da Polónia, da República da Eslovénia e da República Eslovaca e às adaptações dos Tratados em que se funda a União Europeia: Anexo II: Lista a que se refere o artigo 20 do Acto de Adesão. Jornal Oficial das Comunidades Europeias, Bruxelas, v. 40, n. L236, p. 53-178, 23 set. 1996. Disponivel em: < http://eurlex.europa.eu/resource.html?uri=cellar:2578ec46-e068-4949-b290fbd013e18e6c.0010.02/DOC_3\&format=PDF>. Acesso em: 22 jan. 2016. 
comunicação confere ao licenciado;

b) O termo substancial significa que o Know-how contém informações úteis. No momento da formação do acordo, este servirá para melhorar a competitividade do licenciado, permitindo-lhe, por exemplo, conectar-se a um novo mercado, tendo incluídas vantagens comparativas com relação à concorrência;

c) O termo identificadas significa que o Know-how é descrito ou registra-se em suporte material da forma que é possível comprovar se cumpre os requisitos de confidencialidade, substancialidade e, se seria suficiente para garantir que não restrinja a liberdade do licenciado de explorar sua própria tecnologia.

Portanto, o contrato de know-how será qualificado como aquele em que o obrigado transfere determinada tecnologia (o transferente), ao receptor da mesma tecnologia, contra pagamento de uma remuneração ${ }^{25}$.

Importa ressaltar que essa operação de transferência, com o transferente licenciando seus conhecimentos secretos, substanciais e identificados em favor do receptor da tecnologia, será qualificada como operação de cessão de direito de propriedade industrial: o cedente se compromete a transferir, de forma plena, seu direito sobre o bem imaterial; em contraprestação, o cessionário paga o preço, normalmente em dinheiro ${ }^{26}$.

Finalmente, com relação a licença de Know-how, ressalta-se que, em virtude da ausência de marco regulatório harmonizado sobre a matéria, ademais da complexidade do contrato com essa natureza jurídica, as operações de licença devem ser muito bem planejadas e pactuadas em minúcias, agravada tal dificuldade, ainda, pela natureza secreta do conhecimento tecnológico que se transmite ${ }^{27}$.

\subsubsection{Marca}

Entende-se como marca todo sinal ou dispositivo que distingue, ou serve para distinguir no mercado, pro-

25 JACQUET, Jean-Michel; DELEBECQUE, Philippe. Droit $d u$ commerce international. 2. ed. Paris: Dalloz, 1999. p. 193.

26 MIGUEL ASENSIO, Pedro A. de. Contratos internacionales sobre propiedad industrial. 2. ed. Madrid: Civitas, 2000. p. 70.

27 CHULIÁ VICENT, E.; BELTRÁN ALANDETE, T. Aspectos jurídicos de los contratos atípicos. 4. ed. Barcelona: J. M. Bosh, 1999. v. 1. p. 255. dutos e serviços de outros similares ${ }^{28}$.

Também são consideradas marcas as palavras, as imagens, figuras, símbolos e gráficos; letras, cifras e suas combinações; as formas tridimensionais, entre as que se incluem as embalagens, a forma do produto ou sua apresentação; e qualquer combinação de sinais ou meios antes mencionados.

As marcas registradas cumprem inúmeras funções nas economias modernas, dentre elas sua valoração financeira como bem imaterial. Entretanto, sua função essencial decorre de sua capacidade distintiva. As demais funções das marcas se subordinam ao seu caráter distintivo $^{29}$.

Ponto importante, derivado da característica distintiva, é o papel que a marca desempenha na regulação e transparência do mercado. Constitui, assim, mecanismo relevante para a tutela e proteção dos consumidores. Para tanto, não se pode esquecer que a marca cumpre um conjunto de funções no sistema jurídico. E entre essas funções se encontra sua função de indicar a procedência empresarial ao consumidor, a qualidade de seus produtos e serviços. A marca gera, assim, correto funcionamento do sistema de livre concorrência, permitindo que os consumidores obtenham informações fidedignas sobre a origem dos produtos e serviços pretendidos $^{30}$.

O Regulamento CEE 40/94, de 20 de dezembro de $1993^{31}$, modificado pelo Regulamento CEE 1992/2003 ${ }^{32}$, sobre a Marca Comunitária, contêm uma

28 Para uma distinção entre marca, nome comercial, rótulos, patentes e modelos de utilidade, ver: VILALTA NICUESA, Aura Esther; MÉNDEZ TOMÁS, Rosa M. Acciones para la protección de patentes y modelos de utilidad. Barcelona: Bosch, 2000. p. 11 e ss.

29 ZUCCHERINO, Daniel R.; MITELMAN, Carlos O. Marcas y patentes en el GATT. Buenos Aires: Abeledo-Perrot, 1997. p. 80 e ss. 30 CASADO CERVIÑO, Alberto. Derecho de marcas y protección de los consumidores: el tratamiento del error del consumidor. Madrid: Tecnos, 2000. p. 75. Ver, ainda: FRÍGOLA RIERA, Antonio. Confusión entre marcas y protección a los consumidores. In: MARTÍN MUÑOZ, Alberto J. (Coord.). Propiedad industrial y competencia desleal: perspectiva comunitaria, mercados virtuales y regulación procesal. Madrid: Instituto de Empresa, 2001. p. 305-334. p. 305-321.

31 CONSELHO DAS COMUNIDADES EUROPEIAS. Regulamento (CE) n. ${ }^{\circ}$ 40/94 do Conselho, de 27 de dezembro 1994, sobre a marca comunitária. Jornal Oficial das Comunidades Europeias, Bruxelas, v. 37, n. L11, p. 1-36, 14 jan. 1994. Disponivel em: <http:// eur-lex.europa.eu/legal-content/PT/TXT/PDF/?uri=CELEX:319 94R0040\&from=PT $>$. Acesso em: 22 jan. 2016.

32 CONSELHO DAS COMUNIDADES EUROPEIAS. Regulamento (CE) n. ${ }^{\circ}$ 1992/2003 do Conselho, de 27 de Outubro de 2003, que altera o Regulamento (CE) n. ${ }^{\circ} 40 / 94$ sobre a marca comuni- 
definição idêntica à estabelecida na Diretiva 89/104, relativa a aproximação das legislações dos Estados-membros em matéria de marcas ${ }^{33}$. Determina que todos sinais que possam ser objeto de representação gráfica, em particular as palavras, incluídos os nomes de pessoas, as letras, as cifras, a forma de produção ou de sua apresentação, com a condição de que tais sinais sejam apropriados para distinguir os serviços e produtos de um empresário dos de outro empresário, podem ser caracterizados como marca ${ }^{34 / 35}$.

O Tribunal de Luxemburgo (TJUE) aponta que o direito de marcas tem por objetivo proteger os titulares contra as atuações de terceiros que provoquem risco de confusão nos consumidores, tentado tirar proveito, indevido, da reputação atribuída à marca de titularidade de outrem ${ }^{36}$.

Percebe-se, assim, que sua função essencial seria ga-

tária, a fim de ter em conta a adesão da Comunidade Europeia ao Protocolo referente ao Acordo de Madrid relativo ao registo internacional de marcas, aprovado em Madrid em 27 de Junho de 1989. Jornal Oficial das Comunidades Europeias, Bruxelas, v. 46, n. L296, p. 1-5, 14 nov. 2003. Disponivel em: <http://eur-lex.europa.eu/legal-content $/ \mathrm{PT} / \mathrm{TXT} / \mathrm{PDF} /$ ?uri=CELEX:32003R1992\&rid=1>. Acesso em: 22 jan. 2016.

33 CONSELHO DAS COMUNIDADES EUROPEIAS. Primeira Directiva 89/104/CEE do Conselho de 21 de Dezembro de 1988 que harmoniza as legislações dos Estados-Membros em matéria de marcas. Jornal Oficial das Comunidades Europeias, Bruxelas, v. 32, n. L40, p. 1-7, 11 fev. 1989. Disponivel em: < http://eur-lex.europa. eu/legal-content/PT/TXT/PDF/?uri=CELEX:31989L0104\&fro $\mathrm{m}=\mathrm{PT}>$. Acesso em: 22 jan. 2016.

34 Coexistindo com as distintas marcas nacionais (cuja regulamentação no âmbito interno da Diretiva 89/104 estabeleceu normas de harmonização), a marca comunitária, criada pelo Regulamento 40/94, permite a proteção marcaria em todo o território da UE, sem a necessidade de registro em todos os Estados-membros. CONSELHO DAS COMUNIDADES EUROPEIAS. Primeira Directiva 89/104/CEE do Conselho de 21 de Dezembro de 1988 que harmoniza as legislações dos Estados-Membros em matéria de marcas. Jornal Oficial das Comunidades Europeias, Bruxelas, v. 32, n. L40, p. 1-7, 11 fev. 1989. Disponivel em: <http://eur-lex.europa.eu/legal-content/ PT/TXT/PDF/?uri=CELEX:31989L0104\&from=PT>. Acesso em: 22 jan. 2016.

35 A marca comunitária apresenta as seguintes singularidades: a) disponibilidade comunitária; b) coexistência; c) necessidade de registro para ser dotada de proteção; d) atribuição de direito público. Ver, nesse sentido: MARTÍN MATEO, Ramón; DÍEZ SÁNCHEZ, Juan José. La marca comunitária: derecho publico. Madri: Trivium, 1996. p. 45 e ss.

36 UNIÃO EUROPEIA. Tribunal de Justiça. IHT Internationale Heiztechnik Gmb; Uwe Danzinger vs Ideal-Standard GmbH; Wabco Standard GmbH. Caso 9/93. Setença, 22 de junho de 1994. Disponível em: <http://curia.europa.eu/juris/showPdf.jsf?text $=\&$ docid $=989$ 86\&pageIndex $=0 \&$ doclang $=\mathrm{pt} \&$ mode $=1$ st $\&$ dir $=\& o c c=$ first $\&$ part $=1 \&$ cid $=748212>$. Acesso em: 22 jan. 2016. rantir aos consumidores a identificação da origem do produto, permitindo-lhes distinguir, sem confusão, esse produto dos que tem outra procedência ${ }^{37}$.

Quanto à natureza jurídica, as marcas são qualificadas como bens móveis, suscetíveis de cessão por todos os meios reconhecidos no Direito. Assim, será possível a realização de sua transferência por contrato de compra e venda; o licenciamento de seu uso; seu oferecimento em garantia de operação de mútuo ou ser objeto de direitos reais.

As licenças de marca têm idêntica natureza com as licenças de patentes. O licenciante/titular do direito e o licenciado tem plena liberdade para estabelecer os pactos que desejam, sempre que não sejam contrários à lei, à moral e à ordem pública. A licença consistirá, para tanto, na atribuição de direito a utilização da marca cedida na condição pactuada, em troca de contraprestação ${ }^{38 .}$

A licença implica a autorização do titular da marca a outra pessoa para que se utilize desta, de forma exclusiva ou não, nos produtos que fabrique ou comercialize, em troca do pagamento de royalt.

É importante ressaltar que, como todas as demais prestações tecnológicas, a licença de marcas pode estar caracterizada como um instrumento contratual que fundamente a constituição de um grupo de sociedades de base contratual.

Finalmente, o contrato de licença de marca desempenha importante papel no quadro da organização empresarial atual, tanto entre empresas pertencentes a um grupo econômico, como entre empresas independentes. Especialmente, é muito comum no âmbito dos acordos de licença de fabricação, ligada ao uso de tecnologia patenteada e de know-how, nos acordos de franquia industrial ou de serviços, ou podem também formar parte dos acordos de joint venture ${ }^{39}$, havendo a concessão do uso de marcas como um negócio acessó-

37 UNIÃO EUROPEIA. Tribunal de Justiça. Centrafarm BV; Adriaan de Peijper vs. Sterling Drug Inc. Caso 15/74. Setença, 31 de outubro de 1974. Disponível em: < http://eur-lex.europa.eu/legalcontent/PT/TXT/PDF/?uri=CELEX:61974CJ0015\&from=FR>. Acesso em: 22 jan. 2016. p. 21 e ss.

38 ECHARRI, Alberto; PENDÁS, Angel. La transferencia de tecnología. Madrid: Fundación Confemetal, 1999. p. 81.

39 Sobre a natureza jurídica dos contratos de Joint Venture, veja-se: FERRAZ, Daniel Amin. Joint Ventures e contratos internacionais. Belo Horizonte: Mandamentos, 2001. 
rio ao principa ${ }^{40} /{ }^{41}$.

\subsubsection{Assistência técnica}

O código de liberalização de operações invisíveis e correntes da OCDE concebe a assistência técnica como uma atividade relacionada a produção e distribuição de bens e serviços em todos os seus graus, e que inclui, por exemplo, consulta e visita de peritos, preparação de planos e projetos, supervisão de fabricação, estudo de mercado e formação profissional.

Às vezes é mais complicado distinguir a assistência técnica do know-how, sobretudo quando realizada sem vinculação a alguma operação de importação, consistindo, simplesmente, na transmissão de conhecimento 'por meio de assessoramento técnico, formação de pessoal, deslocamento de especialistas etc.

A nota diferenciadora entre uma e outra prestação é o caráter secreto e não divulgado que, habitualmente, possui a operação de Know-how, enquanto a assistência técnica não é mais que uma ajuda ou assessoramento para a implementação e correta aplicação de determinados conhecimentos técnicos não secretos.

Assim, estaria definida a assistência técnica como o contrato pelo qual o transferente da tecnologia se compromete a fornecer ao receptor informações e experiência técnicas não secretas, mas cujo conhecimento e absorção exigiriam do receptor esforço ou investimento consideráveis, superiores aos fundos dispensados e pagos ao transferente para aquisição da tecnologia ${ }^{42}$.

40 BAEZA ORTUÑO, Maria Teresa. La licencia de marca. Madrid: Marcial Pons, 2000. (Colección Garrigues \& Andersen). p. 234-235. 41 A utilização da mesma marca por empresas pertencentes a um dado grupo econômico se realiza, na maioria das vezes, por meio de acordos de licença. Com efeito, em um grupo, por sua própria estrutura, é frequente que a produção e a distribuição se repartam entre as distintas empresas do grupo, de tal modo que uma empresa possa utilizar-se da marca de outra. Normalmente, o mesmo se instrumentaliza não por intermédio de uma cessão de marca, mas sim mediante a outorga de licenças de uso. Em especial, a figura da licença de uso de marca é habitual quando a empresa que está à frente do grupo econômico é titular de todas as marcas utilizadas pelos demais membros do grupo, constituindo-se, assim, na empresa que controla o uso destes signos pelo grupo econômico. Veja-se, nesse sentido: CHAVANNE, A.; BURST, J. J. Droit de la propriété industrielle. 5. ed. Paris: Librairies Sirey, 1998. p. 665.

42 GOMEZ SEGADE, J. A. El secreto industrial (Know-bow): concepto y protección. Madrid: Tecnos, 1974. p. 154. Ver, ainda: GOMEZ SEGADE, J. A. Tecnología y derecho: estudios jurídicos del prof. José Antonio Gómez Segade recopilados con ocasión de la conmemoración de los XXV años de cátedra. Madrid: Marcial Pons,

\subsubsection{Franquia}

O contrato de franquia caracteriza-se como outro importante instrumento que fundamenta operações de transferência de tecnologia.

Importa ressaltar, antes de nada, a discussão existente na franquia para sua possível qualificação como instrumento de transferência de tecnologia ou como instrumento de distribuição. Assim, parte da doutrina os qualificaria como negócios de distribuição, por entender que esta seria sua cláusula essencial. Assim, a transferência de tecnologia seria negócio assessório ao principal, a distribuição ${ }^{43}$.

Por outro lado, entende-se que o contrato de franquia apresenta diversas modalidades que não se referem somente à distribuição de produtos. Assim, em função do tipo de prestação do sistema de franquia ao cliente final, cabe realizar uma tripla distinção.

A franquia industrial, que constitui normalmente um acordo entre fabricante e franqueado, e se destina à fabricação de produtos pelo fraqueado. A franquia de distribuição, na qual o sistema se orienta a comercialização de produtos e, finalmente; a franquia de serviços, a qual busca a prestação de serviços pelo franqueado ${ }^{44}$.

O contrato de franquia é negócio jurídico complexo, com múltipla variação de conceitos e formações, podendo ser utilizado, inclusive, como mecanismo de limitação da concorrência ${ }^{45 / 46}$.

Interessante ainda é fazer referência às características do contrato de franquia, entendido como contrato socialmente e juridicamente típico e nominado ${ }^{47}$, com-

2001.

43 GOMES, Orlando. Contratos. 15. ed. Rio de Janeiro: Forense, 1995. p. 458 e ss.

44 FERNÁNDEZ ROZAS, José Carlos (Ed.). Derecho del comercio internacional. Madrid: Eurolex, 1996. p. 332-333.

45 HERNANDO GIMÉNEZ, Aurora: El contrato de franquicia de empresa. Madrid: Civitas, 2000. p. 59 e ss.

46 Para aprofundamento da franquia no contexto do direito da concorrência, ver: ECHEBARRÍA SÁENZ, Joseba A. El contrato de franquicia. Madrid: McGraw-Hill, 1995. p. 179 e ss MARTÍN TRILLA, Esther; ECHARRI ARDANAZ, Alberto. La franquicia: aplicación práctica y jurídica. Navarra: Aranzadi, 2000. p. 19 e ss.

47 Os contratos podem ser qualificados como típicos e atípicos, nominado e inominados, tanto juridicamente como socialmente. Assim, um contrato será socialmente típico quando possua assentamento de sua prática negocial. Se não possui tal assentamento dizse socialmente atípico. Por outro lado, será juridicamente típico se possuir legislação específica sobre o mesmo, que tenha o condão de traçar as características essências do tipo contratual. Ainda que 
plexo, sinalagmático, consensual, obrigatório, oneroso, intuitu personae, de trato sucessivo e duração determinada, geralmente por adesão e mercantil ${ }^{48}$.

Finalmente, para concluir este ponto é importante referir que, apesar de haver sido feita uma breve apresentação da tipologia das distintas prestações suscetíveis de transferência de tecnologia, não se pode afirmar que a tecnologia se subdivide em uma série de compartimentos e setores independentes uns dos outros. Pelo contrário, na atividade prática ou no comércio internacional, se manifesta de forma composta e concomitante.

Por isso mesmo, o normal é que um mesmo contrato contemple diversas prestações tecnológicas, todas elas enquadradas sob o gênero transferência de tecnologia, independente do título que as partes queriam adjudicar ao instrumento. Assim, deverá o intérprete analisar o conteúdo de cada uma das disposições em particular, a fim de determinar o regime jurídico aplicável ao caso in concreto.

Por outro lado, uma categoria concreta pode comportar a realização de prestações adicionais. Pensa-se, por exemplo, em um contrato de licença de patente em que, ademais de dar ao licenciado o direito de fabricar, deve-se fornecer conhecimentos (know-how) e acessoriamente posterior para o perfeito desenvolvimento do produto (assistência técnica), com instruções precisas e incorporadas a um suporte técnico (planos, fórmulas, etc.).

Concluindo esse ponto, têm-se vários tipos contratuais que fundamentam juridicamente as prestações tecnológicas, figuras que, muitas vezes, existem concomitantemente e podem gerar diminuição, ou falseamento, da concorrência no mercado.

existente legislação, contudo sem que a mesma determine as características essências do contrato, será o mesmo juridicamente atípico. Por outro lado, a qualificação de um determinado contrato como nominado ou inominado não diz respeito a sua tipicidade, mas sim a existência de um nomen iuris. Assim, um contrato será socialmente nominado se assentado na prática um nome específico. Por outro lado, se não existente tal prática, será socialmente inominado. Por sua vez, será juridicamente nominado se existente um nome para o contrato determinado por lei. Por outro lado, será juridicamente inominado se não existente um nome contratual definido em lei. Portanto, seria possível a existência de um contrato juridicamente nominado, socialmente nominado, porém juridicamente atípico, mas socialmente típico (exemplo seria o contrato de leasing). Veja, no sentido da classificação dos contratos em socialmente e juridicamente, nominado e inominado, típico e atípico: VASCONCELOS, Pedro Paes de. Contratos atípicos. Coimbra: Almedina, 1995.

48 RUIZ PERIS, Juan I. Los tratos preliminares en el contrato de franquicia. Navarra: Aranzadi, 2000. p. 85.

\section{Conclusões}

As variadas formas de transferência de tecnologia exploradas nessa oportunidade demonstram que qualquer regulação estatal que represente interferência à liberdade de contratar e à autonomia da vontade deve se basear em conceito minimamente uniforme de tecnologia.

Nesse sentido, as atividades econômicas consubstanciadas nos contratos, também, devem ser orientadas com base nesse mencionado conceito uniforme de tecnologia, a fim de que a sociedade civil possa se beneficiar dos frutos provenientes dos contratos de transferência de tecnologia.

Somente a partir do conhecimento suficientemente sedimentado do conceito de tecnologia e das formas contratuais que promovem a sua transferência, poder-se-á conceber a discussão quanto à possibilidade ou não de interferência estatal no âmbito dos contratos de transferência de tecnologia, ou discussões relativas à harmonização legal dessa matéria na esfera internacional.

Percebe-se que tal harmonização conceitual, seja doutrinal ou legislativa, encontra-se, ainda, distante da realidade fática. Finalmente, importa ressaltar que a consolidação da definição de prestação tecnológica, ademais de suas formas de transferência, é elemento essencial para o fortalecimento dos países em desenvolvimento.

\section{ReferênCias}

ANTUNES, José Manuel Oliveira; MANSO, José António Costa. Relações internacionais e transferência de tecnologia. Coimbra: Almedina, 1993.

BAEZA ORTUÑO, Maria Teresa. La licencia de marca. Madrid: Marcial Pons, 2000. (Colección Garrigues \& Andersen).

BONETE PERALES, Rafael. Mercosur y Comunidad Europea: la cooperación científico-tecnológica. 2. ed. Buenos Aires: Ciudad Argentina, 1998.

BROSETA PONT, Manuel. Manual de derecho mercantil. 10. ed. Madrid: Tecnos, 2000.

CARDOSO, Fernando Henrique. La globalización y los desafíos de la democracia en el plano internacional. Foreign Affairs, Ciudad de México, v. 2, n. 1, p. 108-113, 
primavera de 2002.

CARVALHO, Orlando de. Critério e estrutura do estabelecimento comercial: o problema da empresa como objecto de negócios. Coimbra: Atlântida, 1967.

CASADO CERVIÑO, Alberto. Derecho de marcas y protección de los consumidores: el tratamiento del error del consumidor. Madrid: Tecnos, 2000.

CHAVANNE, A.; BURST, J. J. Droit de la propriété industrielle. 5. ed. Paris: Librairies Sirey, 1998.

CHULIÁ VICENT, E.; BELTRÁN ALANDETE, T. Aspectos jurídicos de los contratos atípicos. 4. ed. Barcelona: J. M. Bosh, 1999. v. 1.

COMISSÃO DAS COMUNIDADES EUROPEIAS. Regulamento (CE) n. ${ }^{\circ}$ 240/96 da Comissão, de 31 de janeiro de 1996, relativo à aplicação do $n^{\circ} 3$ do artigo 85 do Tratado a certas categorias de acordos de transferência de tecnologia. Jornal Oficial das Comunidades Europeias, Bruxelas, v. 39, n. L31, p. 2-13, 9 fev. 1996. Disponivel em: <http://eur-lex.europa.eu/legal-content/ $\mathrm{PT} / \mathrm{TXT} / \mathrm{PDF} /$ ?uri=CELEX:31996R0240\&rid=3>. Acesso em: 22 jan. 2016.

COMMISSION OF THE EUROPEAN COMMUNITIES. Commission Regulation No. 2349/84/EEC of 23 July 1984 on the application of Article 85(3) of the Treaty to certain categories of patent licensing agreements as corrected by OJL 113 of 1985. Disponível em: <http://www.wipo. int/wipolex/en/details.jsp?id=1431>. Acesso em: 22 jan. 2016

COMUNIDADE EUROPEIA. Acto relativo às condições de adesão da República Checa, da República da Estónia, da República de Chipre, da República da Letónia, da República da Lituânia, da República da Hungria, da República de Malta, da República da Polónia, da República da Eslovénia e da República Eslovaca e às adaptações dos Tratados em que se funda a União Europeia: Anexo II: Lista a que se refere o artigo 20 do Acto de Adesão. Jornal Oficial das Comunidades Europeias, Bruxelas, v. 40, n. L236, p. 53-178, 23 set. 1996. Disponível em: <http://eur-lex.europa.eu/ resource.html?uri=cellar:2578ec46-e068-4949-b290-fbd013e18e6c.0010.02/DOC_3\&format=PDF $>$. Acesso em: 22 jan. 2016.

CONSELHO DAS COMUNIDADES EUROPEIAS. Decisão 94/800/CE Conselho de 22 de Dezembro de 1994 relativa à celebração, em nome da Comunidade
Europeia e em relação às matérias da sua competência, dos acordos resultantes das negociações multilaterais do Uruguay Round (1986/1994). Jornal Oficial das Comunidades Europeias, Bruxelas, v. 37, L336, p. 1-2, 23 dez. 1994. Disponível em: <http://eur-lex.europa.eu/legalcontent/PT/TXT/HTML/?uri=CELEX:31994D0800 $\&$ from $=$ PT $>$. Acesso em: 22 jan. 2016.

CONSELHO DAS COMUNIDADES EUROPEIAS. Primeira Directiva 89/104/CEE do Conselho de 21 de Dezembro de 1988 que harmoniza as legislações dos Estados-Membros em matéria de marcas. Jornal Oficial das Comunidades Europeias, Bruxelas, v. 32, n. L40, p. 1-7, 11 fev. 1989. Disponível em: <http://eur-lex.europa. eu/legal-content/PT/TXT/PDF/?uri=CELEX:31989 L0104\&from=PT>. Acesso em: 22 jan. 2016.

CONSELHO DAS COMUNIDADES EUROPEIAS. Regulamento (CE) n. ${ }^{\circ}$ 1992/2003 do Conselho, de 27 de Outubro de 2003, que altera o Regulamento (CE) n. ${ }^{\circ}$ 40/94 sobre a marca comunitária, a fim de ter em conta a adesão da Comunidade Europeia ao Protocolo referente ao Acordo de Madrid relativo ao registo internacional de marcas, aprovado em Madrid em 27 de Junho de 1989. Jornal Oficial das Comunidades Europeias, Bruxelas, v. 46, n. L296, p. 1-5, 14 nov. 2003. Disponível em: <http://eur-lex.europa.eu/legal-content/PT/TXT/ $\mathrm{PDF}$ ? ?uri=CELEX:32003R1992\&rid=1>. Acesso em: 22 jan. 2016.

CONSELHO DAS COMUNIDADES EUROPEIAS. Regulamento (CE) n. ${ }^{\circ}$ 40/94 do Conselho, de 27 de dezembro 1994, sobre a marca comunitária. Jornal Oficial das Comunidades Europeias, Bruxelas, v. 37, n. L11, p. 1-36, 14 jan. 1994. Disponível em: <http://eur-lex. europa.eu/legal-content/PT/TXT/PDF/?uri=CELE X:31994R0040\&from=PT>. Acesso em: 22 jan. 2016.

CORREA, Carlos M.; BERGEL, Salvador D. Patentes y competencia. Buenos Aires: Rubinzal Culzoni, 1996.

ECHARRI, Alberto; PENDÁS, Angel. La transferencia de tecnología. Madrid: Fundación Confemetal, 1999.

ECHEBARRÍA SÁENZ, Joseba A. El contrato de franquicia. Madrid: McGraw-Hill, 1995.

ESPAÑA. Ley n 32, de 10 de noviembre, 1988, de Marcas. Disponível em: <http://www.wipo.int/wipolex/es/details.jsp?id=1314>. Acesso em: 22 jan. 2016.

EUROPEAN UNION. Court of Justice. Merck \& Co. Inc. vs Stephar BV; Petrus Stephanus Exler. Reference for 
a preliminary ruling: Arrondissementsrechtbank Rotterdam - Netherlands. - Patents - Pharmaceutical products. Case 187/80. Sentence, 14 July 1981. Disponível em: $<$ http://eur-lex.europa.eu/legal-content/EN/TXT/ HTML/ ?uri=CELEX:61980CJ0187\& from $=F R>$. Acesso em: 22 jan. 2016.

FERNÁNDEZ NOVOA, Carlos. Derecho de marcas. Madrid: Montecorvo, 1990.

FERNÁNDEZ ROZAS, José Carlos (Ed.). Derecho del comercio internacional. Madrid: Eurolex, 1996.

FERRAZ, Daniel Amin. Grupo de sociedades: instrumento jurídico de organização da empresa plurisocietária. Revista de Direito Internacional, Brasilia, v. 12, p. 495-509, 2014.

FERRAZ, Daniel Amin. A concentração empresarial no contexto da economia internacional. In: (Org.). Direito empresarial: marco jurídico de internacionalização das empresas brasileiras. Curitiba: CRV, 2012. p. 10-31.

FERRAZ, Daniel Amin. Dos contratos internacionais do comércio: regime geral. In: (Org.). Contratação internacional: algumas espécies de contratos mercantis. Curitiba: CRV, 2014. p. 9-32.

FERRAZ, Daniel Amin. Joint Ventures e contratos internacionais. Belo Horizonte: Mandamentos, 2001.

FRÍGOLA RIERA, Antonio: Confusión entre marcas y protección a los consumidores. In: MARTÍN MUÑOZ, Alberto J. (Coord.). Propiedad industrial y competencia desleal: perspectiva comunitaria, mercados virtuales y regulación procesal. Madrid: Instituto de Empresa, 2001. p. 305-334.

GARCÍA-CASTRILLÓN, Carmen Otero. Las patentes en el comercio internacional. Madrid: Dykinson, 1997.

GOMES, Orlando. Contratos. 15. ed. Rio de Janeiro: Forense, 1995.

GÓMEZ ABELLEIRA, Francisco Javier. Litigios entre empresario y trabajador sobre patentes, secretos industriales y derechos de autor en los Estados Unidos. Santiago de Compostela: Universidade da Coruña, 1999.

GOMEZ SEGADE, J. A. El secreto industrial (Know-how): concepto y protección. Madrid: Tecnos, 1974.

GOMEZ SEGADE, J. A. Tecnología y derecho: estudios jurídicos del prof. José Antonio Gómez Segade recopilados con ocasión de la conmemoración de los XXV años de cátedra. Madrid: Marcial Pons, 2001.
HERNÁNDEZ RODRÍGUEZ, Aurora. Los contratos internacionales de construcción. Granada: Comares, 1999.

HERNANDO GIMÉNEZ, Aurora. El contrato de franquicia de empresa. Madrid: Civitas, 2000.

JACQUET, Jean-Michel; DELEBECQUE, Philippe. Droit du commerce international. 2. ed. Paris: Dalloz, 1999.

JIMÉNEZ BLANCO, Pilar. El derecho aplicable a la protección internacional de las patentes. Granada: Comares, 1998.

MARTÍN MATEO, Ramón; DÍEZ SÁNCHEZ, Juan José. La marca comunitária: derecho publico. Madri: Trivium, 1996.

MARTÍN TRILLA, Esther; ECHARRI ARDANAZ, Alberto. La franquicia: aplicación práctica y jurídica. $\mathrm{Na}$ varra: Aranzadi, 2000.

MASSAGUER FUENTES, José. El contrato de licencia de Know-how. Barcelona: J. M. Bosh, 1999.

MESSINEO, Francesco. Manuale di diritto civile e commerciale. 6. ed. Padova: Cedam, 1943.

MIGUEL ASENSIO, Pedro A. de. Contratos internacionales sobre propiedad industrial. 2. ed. Madrid: Civitas, 2000.

ORGANIZAÇÃO MUNDIAL DO COMÉRCIO. Acordo sobre aspectos dos direitos de propriedade intelectual relacionados ao comércio. Disponível em: <https://bvc.cgu. gov.br/bitstream/123456789/2357/1/acordo_trips. pdf>. Acesso em: 22 jan. 2016

OTERO LASTRES, José Manuel. Derecho y tecnología: curso sobre innovación y transferencia. Barcelona: Ariel, 1990.

RUIZ PERIS, Juan I. Los Tratos preliminares en el contrato de franquicia. Navarra: Aranzadi, 2000.

SANTOS, António Marques dos. Transferência internacional de tecnologia, economia e direito: alguns problemas gerais. Lisboa: Centro de Estudos Fiscais, 1984. (Cadernos de Ciência e Técnica de Fiscal, 132).

SULLIVAN, Neil F. Technology transfer: making the most of your intellectual property. Cambridge: Cambridge University Press.

UNIÃO EUROPEIA. Tribunal de Justiça. Centrafarm BV; Adriaan de Peijper vs. Sterling Drug Inc. Caso 15/74. Setença, 31 de outubro de 1974. Disponível em: < http:// eur-lex.europa.eu/legal-content/PT/TXT/PDF/?uri= CELEX:61974CJ0015\&from=FR>. Acesso em: 22 jan. 2016. 
UNIÃO EUROPEIA. Tribunal de Justiça. IHT Internationale Heiztechnik Gmb; Uwe Danzinger vs Ideal-Standard GmbH; Wabco Standard GmbH. Caso 9/93. Setença, 22 de junho de 1994. Disponível em: < http://curia.europa.eu $/$ juris $/$ showPdf.jsf?text $=\&$ docid $=98986 \&$ pageIn $\operatorname{dex}=0 \&$ doclang $=$ pt\&mode $=1$ st\&dir $=\&$ occ $=$ first\&part $=1 \&$ cid $=748212>$. Acesso em: 22 jan. 2016.

UNIÃO EUROPEIA. Tribunal de Justiça. Reino da Espanha; República Helénica vs Conselho da União Europeia. Caso 350/92. Setença, 13 de julho de 1995. Disponível em: <http://eur-lex.europa.eu/legal-content/PT/ TXT/PDF/?uri=CELEX:61992CJ0350\&from $=$ PT $>$.
Acesso em: 22 jan. 2016.

VARELA, João de Matos Antunes. Das obrigações em geral. 8. ed. Coimbra: Almedina, 1994.

VASCONCELOS, Pedro Paes de. Contratos atípicos. Coimbra: Almedina, 1995.

VILALTA NICUESA, Aura Esther; MÉNDEZ TOMÁS, Rosa M. Acciones para la protección de patentes y modelos de utilidad. Barcelona: Bosch, 2000.

ZUCCHERINO, Daniel R.; MITELMAN, Carlos O. Marcas y patentes en el GATT. Buenos Aires: AbeledoPerrot, 1997. 


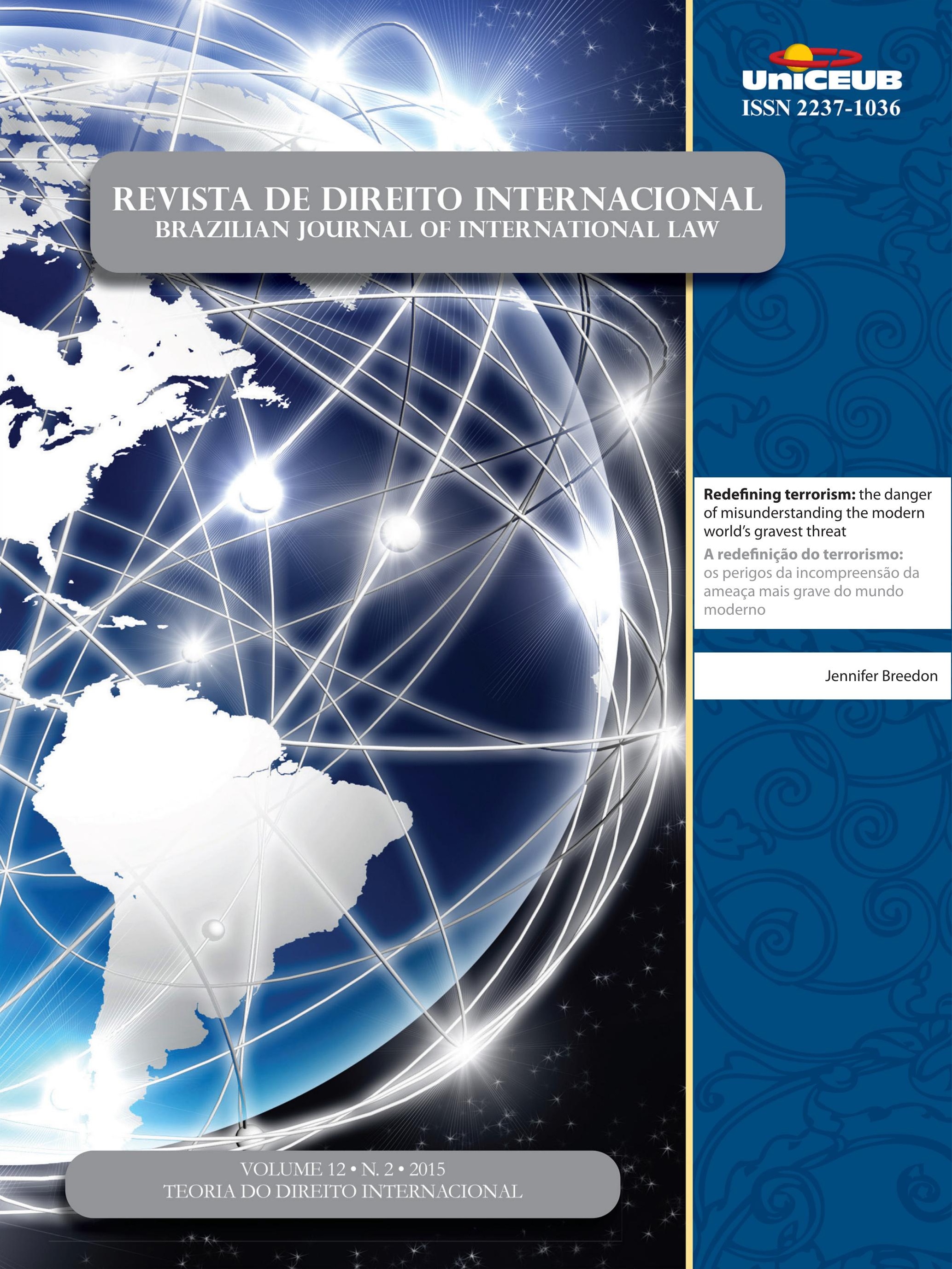




\title{
Redefining terrorism: the danger of misunderstanding the modern world's gravest threat*
}

\author{
A redefinição do terrorismo: os perigos da \\ incompreensão da ameaça mais grave do \\ mundo moderno
}

\section{Jennifer Breedon**}

"The Security Council of the United Nations calls upon all Member States to ... [c] ooperate, particularly through bilateral and multilateral arrangements and agreements, to prevent and suppress terrorist attacks and take action against perpetrators of such acts ... [understanding] the need to enhance coordination of efforts on national, subregional, regional and international levels in order to strengthen a global response to this serious challenge and threat to international security."

"The [adopted legal concept of 'terrorism'] is imprecise; it is ambiguous; and above all it [currently] serves no operative legal purpose." Richard Baxter

\section{Abstract}

The international community has been, and remains, unable to prevent episodes of mass murder resulting for modern-day terrorist ideologies due to three basic failures: (1) the failure to face the problem squarely and understand its real nature, (2) the failure to recognize that it is possible to prevent mass murder of individuals, and (3) the failure to act once knowledge of the violent intent of perpetrators is recognized. This paper will face these challenges by uncovering the fundamental issues underlying the failure of the international community to adopt a uniform and transnational definition of modern-day terrorism boldly and honestly. Terrorism must be codified in a manner that is consistent with its modern forms and acceptable to the global community's regional definitions and differences by highlighting the similarity and allowing for extraterritorial prosecution to prevent such acts in an ad hoc tribunal. This paper will address the following issues: (1) It will highlight the need for universal codification of modern terrorism in order to prevent and prosecute modern terrorists by analyzing current forms of international law regarding terrorism; (2) Then, it will identify the objective intentions of modern extremist organizations by highlighting several ongoing threats and how such threats relate to international legal principles; and (3) finally, after highlighting the gaps in the current legal system involving modern terrorism, it will use the existing conventions on "terrorism" to posit a universal definition that should be agreeable to all UN Member States in efforts to combat the spread of violent extremism. If the world continues to fear political "incorrectness" it will never understand the motives of mo- 
dern extremist groups today. Most modern "terrorist" organizations operate with the same genocidal intent seem throughout history when certain groups sought to annihilate or eliminate entire groups of human beings. If the global community fails to reach a consensus on a uniform codification of terrorism under international law, it will remain nearly impossible to prevent a massive loss of human life. To provide justification for its premise, this article will take a brief look at five of the most prevalent modern "terrorist" organizations that pose the gravest threat to humanity in our time.

Keywords: Terrorism. Transnational law. Rule of law. Genocide.

\section{Resumo}

A comunidade internacional tem sido, e continua a ser, incapaz de evitar episódios de mortes em massa resultante e modernas ideologias terroristas, devido a três falhas básicas: (1) não-enfrentamento do problema de forma direta e de compreensão da sua verdadeira natureza, (2) a falha em reconhecer que é possível para evitar o assassinato em massa de indivíduos, e (3) a omissão, uma vez conhecida as intenções violentas dos agressores. Este trabalho enfrentará esses desafios, descobrindo as questões fundamentais subjacentes ao fracasso da comunidade internacional em adotar uma definição uniforme e transnacional contra o terrorismo, com coragem e honestidade. Este artigo irá abordar as seguintes questões: (1) Seá destacado a necessidade de codificação universal do terrorismo moderno, a fim de prevenir e reprimir atos contemporâneos, analisando as formas atuais do direito internacional sobre o terrorismo; (2) Em seguida, identifica-se as intenções objetivas de organizações extremistas modernas, destacando várias ameaças e como tais ameaças dizem respeito a princípios legais internacionais; e (3) finalmente, depois de destacar as lacunas do actual sistema jurídico envolvendo terrorismo moderno, usa-se as convenções existentes sobre o "terrorismo" para postular uma definição universal que deve ser aceitável por todos os Estados Membros das Nações Unidas. Se o mundo continua a temer "incorreção" político que ela nunca vai entender os motivos de grupos extremistas modernos hoje. Se a comunidade global não conseguir chegar a um consenso sobre uma codificação uniforme do terrorismo, continuará a ser quase impossível evitar uma enorme perda de vidas humanas. Para justificar a sua premissa, este artigo realiza uma breve análise das organizações que mais se destacam atualmente.

Palavras chaves: Terrorismo. Direito transnacional. Estado de Direito. Genocídio.

\section{INTRODUCTION}

Governments and media entities label many forms of violence as "terrorism." The negative connotation this term carries with it does little to resolve the fundamental threat of this modern form of mass violence. All that a "terrorism" label does is perpetuate fear while offering no real understanding of the underpinnings of this treat. Governments and militaries remain paralyzed against this global threat of "terrorism"- a term that still has no universal definition. ${ }^{2}$ The faces of violence and war have changed drastically as threats of terror continue, but the international community has failed to reexamine unconventional warfare in order to understand the extent of the terrorist threat. Therefore, non-state actors - such as violent extremist organizations - are able to act with impunity, just as genocidal State Officials leaders did prior to World War Two and the codification of international crimes at the Nuremburg Tribunals. ${ }^{3}$ On the most basic level, the current definitions of terrorism generally possess the following elements: (1) violence or the threat of violence, (2) stealth conflict, (3) political motivation, (4) intent to frighten, and the (5) targeting of civilians. ${ }^{4}$ These ele-

2 When widespread acts of systematic violence are carried out by non-state actors, the default label attached to such acts is "terrorism" yet the international community has yet to solidify any uniform definition outlining the criminal elements of the act so that it can be prosecuted on an international level. Regional organizations and state governments have delineated acceptable definitions of "terrorism" in their respective territories, since most times, "terrorism" is whatever a government or "legitimate" authority wants it to be: from secessionism to political graffiti. Cite

3 Mary Ellen O'Connell, Richard F. Scott \& Naomi Rott-Ariaza, The International Legal System 509 (Robert C. Clark et al. eds., 6th ed. 2010). Despite the various conventions that address forms of "terrorist acts," none have yet been able to thwart the cancerous growth that organized group violence poses today. David Luban, Julie R. O'Sullivan \& David P. Stewart, International and Transnational Criminal Law 677 (Vicki Been et al. eds., Aspen Publishers 2010). The existing treaties relating to terrorism fall short of establishing a universal system to prevent the atrocities that are continuing to occur at the hands of certain terrorist organizations.

4 Luban, supra note 5, at 670-71 (emphasis added). 
ments are simply inaccurate and incomplete. What is needed is factual codification that takes an honest look at the goals and motivation of modern extremist organizations in order to prosecute and prevent the main perpetrators. ${ }^{5}$ While the current laws governing terrorism were drafted in the 1960s and 1970s when sporadic "acts of violence" were carried out for political purposes, extremist organizations today pose greater threats of mass violence through unconventional warfare and the proliferation of nuclear weapons necessitating a realistic transnational look into the goals and motivations of such organizations. ${ }^{6}$

This paper will identify the objective intentions of modern extremist groups (that governments label "terrorists") by highlighting how modern "terrorist acts" fall under codified and universal international criminal laws, rendering a new title or uniform definition unnecessary. In his book entitled Worse Than War, Daniel Goldhagen discusses the duty that individuals, institutions, and governments have to preserve humanity against repeated campaigns where groups or governments have sought to eliminate entire people groups through mass murder or forced displacement (which this paper will refer to as "eliminationist campaigns"). ${ }^{7}$ He states that the international community has been unable to prevent episodes of mass murder because it fails to understand the real nature of eliminationist campaigns, and then once the violent intent of the mass murderers is understood, they have failed to act in order to prevent. ${ }^{8}$ Government definitions of "terrorism" purposely fail to account for the true intentions of these violent groups.

5 Daniel Jonah Goldhagen, Worse Than War: Genocide, Eliminationism, and the Ongoing Assault on Humanity 550 (Public Affairs Publisher, 1st ed. 2009) (discussing the importance of preventative measures to combat campaigns bent on the annihilation and elimination of nations, religions, or groups).

6 Reuven Young, Defining Terrorism: The Evolution of Terrorism as a Legal Concept in International Law and its influence on Definitions in Domestic Litigation, 29 B. C. Int'l \& Comp. L. Rev. 23, 28-29 (2006). See Luban, supra note 5, at 680 (quoting David Luban, The Way on Terrorism and the End of Human Rights, 22 Phil. \& Pub. Poly. Q. 9 (2002) (stating that "Given the unique and heightened danger that suicide terrorists pose, a stronger response that grant potential terrorists fewer rights may be justified."); See also Goldhagen, supra note 6, at 512. In 2006, criminal law professor, Thomas Weigend, noted that the types of terrorism which transcend national boundaries are easier to combat through international cooperation which can only be achieved by first agreeing upon a universal definition of terrorism. Thomas Weigend, The Universal Terrorist, $912 \mathrm{~J}$. Int. Crim. Justice 4(5), 1 (Nov. 1, 2006).

7 Goldhagen, supra note 6, at xi.

8 Goldhagen, supra note 6, at xi.
If the current network of sovereign states comprising the international legal system continues to fear political "incorrectness" or place proper criminal labels on the violence, it will never be able to prevent future occurrences of eliminationism or protect the innocent lives that we know are already targets. ${ }^{9}$

\section{Current Laws on “Terrorism.”}

The first time the global community attempted a uniform definition of terrorism was in 1937 through the adoption of a convention at the League of Nations. ${ }^{10}$ Since 1963, the international community has elaborated fourteen universal legal instruments attempting to prevent terrorist acts. ${ }^{11}$ In 1972, the Sixth Legal Committee of the United Nations (UN) General Assembly attempted a universal definition of terrorism but, once again, failed to reach a consensus. ${ }^{12}$ Finally, in lieu of a universal, over-arching definition of terrorism, the UN passed numerous conventions to address types of violent acts of terror involving civil aviation, the taking of hostages, certain types of bombing, and the transnational organized financing of terror acts. ${ }^{13}$ The UN Security Council

9 Bruce Hoffman, Inside Terrorism, in Global Affairs 192, 205 (Columbia University Press) (Michelle Baird et al. eds., 3d ed. Thomson Wadsworth 2007).

10 League of Nations Convention on the Prevent and Punishment of Terrorism, Council on Foreign Rel., http://www.cfr.org/ terrorism-and-the-law/league-nations-convention-prevention-punishment-terrorism/p24778 (last visited Feb. 11, 2015). O'Connell, supra note Erreur : source de la référence non trouvée, at 59-61. (That convention never came into force because two years later, the second World War was launched resulting in the replacement of the League of Nations with the United Nations in 1945. See History: From the League of Nations to the United Nations, UN Office at Geneva, http://www.unog.ch/80256EDD006AC19C/\%28httpPag es\%29/242056AEA671DEF780256EF30037A2A8?OpenDocume nt (last visited Feb. 11, 2015).

11 See Luban, supra note 5, at 669-70 (stating that one study counted 109 different definitions of terrorism between 1936 and 1981 even noting how the UN, itself, has differing definitions, which is likely because Security Council resolutions are subject to vetostate approval and are binding as international law while General Assembly resolutions are easier to pass and not considered binding on their face); See also The United Nations Global CounterTerrorism Strategy, G.A. Res 60/288, U.N. Doc. A/RES/60/288 (Sept. 20, 2006).

12 Bruce Hoffman, Inside Terrorism, in Global Affairs 192, 205 (Columbia University Press) (Michelle Baird et al. eds., 3d ed. Thomson Wadsworth 2007).

13 Convention on Offences and Certain Other Acts Committed on Board Aircraft, signed at Tokyo on 14 September 1963. (Deposited with the Secretary-General of the International Civil 
has also addressed the issue of terrorism delineation and prevention by declaring that UN Member States are individually obligated to prevent violence resulting from "terrorist" activities. ${ }^{14}$ It noted a close connection between international terrorism and transnational organized crime which this paper agrees should be amended into the Transnational Organized Crime Convention. ${ }^{15}$

The conflicting definitions of "terrorism" amongst regional actors displays the gaps in opinion of terrorism, but also shows how the universally undefined principle is used as political rhetoric to downgrade any violence with which the government cannot prosecute or prevent. For example, the European Union (EU) defines terrorism as, "criminal acts carried out by non-state or state actors, individuals, or groups that use some form of violence irrespective of the result, committed with the intention to intimidate a civilian population, or compel a government, military, or other formal institution in doing or abstaining from doing something, or another purpose." ${ }^{\text {"T }}$ The Organization of Islamic

Aviation Organization), available at https://treaties.un.org/Pages/ DB.aspx?path=DB/studies/page2_en.xml; Conventions on Terrorism Involving Civil Aviation (passed in 1963, Convention for the Suppression of Unlawful Seizure of Aircraft of 1970, 1971, Terrorism involving Civil Aviation of 2010; 1979 International Convention against the Taking of Hostages; 1997 International Convention for the Suppression of Terrorist Bombings; International Convention for the Suppression of the Financing of Terrorism 1999, International Convention for the Suppression of Acts of Nuclear Terrorism 2005.

14 S. C. Res. 1373 (2001), S/Res/1373 (Sept. 28, 2001) Adopted by the Security Council at its 4385th meeting, on 28 September 2001.

15 S. C. Res. 1373 (2001), S/Res/1373 (Sept. 28, 2001) Adopted by the Security Council at its 4385th meeting, on 28 September 2001. at 4; See also Transnational Organized Crime Convention art. 3 (2) (a)(d), Nov. 15, 2000, 40 I.L.M. 335 (2001); G.A. Res. 55/383 at 25, art. 3 (2000); U.N. Doc. A/RES/55/25 at 4, art. 3 (2001) "an offence is transnational in nature if: (a) it is committed in more than one state; (b) it is committed in one state but a substantial part of its preparation, planning, direction or control takes place in another state; (c) it is committed in one state but involves an organized criminal group that engages in criminal activities in more than one state; or (d) it is committed in one state but has substantial effects in another state., art. 6 (a)(i) criminal offences, when committed intentionally [under this convention, include] the conversion or transfer of property, knowing that such property is the proceeds of crime, for the purpose of concealing or disguising the illicit origin of the property or of helping any person who is involved in the commission of the predicate offence to evade the legal consequences of his or her action." 6 (b)(i) "the acquisition possession or use of property, knowing, at the time of receipt, that such property is the proceeds of crime." Art. 23(b) the use of physical force, threats or intimidation to interfere with the exercise of official duties by a justice or law enforcement official.

16 The Nature of Terrorism: Defining terrorism within the EU
Cooperation (OIC) defines terrorism as the following:

[A]ny act of violence or threat thereof notwithstanding its motives or intentions perpetrated to carry out an individual or collective criminal plan with the aim of terrorizing people or threatening to harm them or imperiling their lives, honor, freedoms, security or rights or exposing the environment or any facility or public or private property to hazards or occupying or seizing them, or endangering a national resource, or international facilities, or threatening the stability, territorial integrity, political unity or sovereignty of independent States. ${ }^{17}$

The Association of Southeast Asian Nations (ASEAN) drafted its own convention on "counter terrorism" but failed to specifically define "terrorism." 18 It merely referred to "terrorism" as understood through various international conventions and used rhetoric that obligated its own member states to cooperate with each other in order to prevent instances of "terrorist acts." It proposed an extradition cooperation treaty and continues to mandate that its signatories identify the root causes of terrorism to form effective countermeasures. ${ }^{19}$ Another interesting approach is the Russian

16 (June 28, 2007), available at http://www.transnationalterrorism. eu/tekst/publications/European\%20Definitions.pdf. For an excellent overview on the current attempts to define terrorism and a global context of each specific definition, see Young, supra note 6. The EU's final "Framework Decision," adopted by the EU Member States in 2002, "offer[ed] a firm foundation for an internationally accepted definition of terrorism encompassing elements of other international conventions and keeping it broad enough to 'reflect the normative consensus that terrorism undermines the State and the political process, The Nature of Terrorism: Defining terrorism within the EU, at 11 .

17 Organization of the Islamic Conference (OIC), Convention of the Organisation of the Islamic Conference on Combating International Terrorism, art. 1 (2), July 1, 1999, Annex to Resolution No: 59/26-P, available at http://www.refworld.org/docid/3de5e6646.html (last visited Feb. 11, 2015). This convention was adopted at the Organization of the Islamic Conference's twenty-sixth session of the Islamic conference of foreign ministers in Ouagadougou, Burkina Faso, in July 1999.

18 ASEAN Convention on Counter-Terrorism, Jan. 13, 2007, in Documents on Combatting Transnational Crime and Terrorism: A Compilation of ASEAN Declarations, Joint Declarations, and Statements on Combatting Transnational Crime and Terrorism 61, 61-68 (ASEAN Secretariat Public Outreach and Civil Society Division, Copyright Association of Southeastern Asian Nations, 2012), available at http://www.asean.org/resources/publications/ asean-publications/item/asean-documents-on-combating-transnational-crime-and-terrorism (Follow link "ASEAN Documents on Combating Transnational Crime and Terrorism" and then click on "Download" to pdf).

19 Id. preamble (discussing the "grave danger posed by terrorism to innocent lives, infrastructure and the environment, regional and international peace and stability as well as to economic develop- 
Federation's laws regarding counter-terrorism, as it reaches beyond the borders of Russia if the government believes that "terrorist" activities are affecting Russia or the Russian political system. ${ }^{20}$ The International Tribunal for Rwanda (ICTR) discussed terrorism in its founding statute giving it the power to prosecute the following offenses:

[C]ommitting or ordering to be committed serious violations of Article 3 common to the Geneva Conventions of 12 August 1949 for the Protection of War Victims, and of Additional Protocol II thereto of 8 June 1977. These violations shall include, but shall not be limited to: a) Violence to life, health and physical or mental well-being of persons, in particular murder as well as cruel treatment such as torture, mutilation or any form of corporal punishment; b) Collective punishments; c) Taking of hostages; d) Acts of terrorism; e) Outrages upon personal dignity, in particular humiliating and degrading treatment, rape, enforced prostitution and any form of indecent assault; f) Pillage; g) The passing of sentences and the carrying out of executions without previous judgement pronounced by a regularly constituted court, affording all the judicial guarantees which are recognised as indispensable by civilised peoples; $\mathrm{h}$ ) Threats to commit any of the foregoing acts. ${ }^{21}$

Similarly, the International Criminal Tribunal for the Former Yugoslavia (ICTY) attempted to discuss and define the crime of terror in the Stanislav Galic case stating that

[e]lements of the Crime of Terror include: (1) Acts of violence directed against the civilian population or individual civilians not taking direct part in hostilities causing death or serious injury to body or health within the civilian population; (2) The

ment"). "Subject to the consent of the Parties concerned, Parties shall cooperate to address the root causes of terrorism and conditions conducive to the spread of terrorism to prevent the perpetration of terrorist acts and the propagation of terrorist cells." Id. art. VI (2) (emphasis added).

20 See Federal Law No. 35-FZ of 6 March 2006 on Counteraction Against Terrorism, Adopted by the State Duma on Feb. 26, 2006, Endorsed by the Federation Council on March 1, 2006, available at http://www.coe.int/t/dlapil/codexter/Source/country_profiles/ legislation/CT\%20legislation $\% 20-\% 20$ Russian $\% 20$ Federation.pdf. In Russia, terrorism is defined as the "practices of influencing the decisions of government, local self-government or international organizations by terrorizing the population or through other forms of illegal violent action . . . [using any] ideology of violence. Id., at art. 3. The definition of terrorist activity is even broader and includes the following acts: propaganda of terrorist ideas, dissemination of materials or information which call to terrorist activity, justify or support the need for such activity, and also "informational or other types of aiding and abetting with regard to planning, preparation or implementation of a terrorist act." Id.

21 S.C. Res. 955, art. 4, U.N. Doc. S/Res/955 (Nov. 8, 1994); 33 I.L.M. 1598 (1994). offender willfully made the civilian population or individual civilians not taking direct part in hostilities the object of those acts of violence; (3) The above offence was committed with the primary purpose of spreading terror among the civilian population. ${ }^{22}$

Acts of terrorism can be currently prosecuted by the international criminal tribunals for the former Yugoslavia (ICTY) and Rwanda (ICTR) only if they amount to crimes against humanity and/ or war crimes (see Arts. 2, 3, and 5 of the ICTY Statute and Arts. 3 and 4 of the ICTR Statute). The only exception is the Special Tribunal for Lebanon (STL), which has jurisdiction over terrorist acts (see Art. 2(a) of the STL Statute). However, the Special Tribunal acts under Lebanese domestic law and not international law. The International Criminal Court (ICC) does not have jurisdiction over terrorism as a distinct crime. Terrorism is also excluded from the list of war crimes provided in Article 8 of the Rome Statute of the International Criminal Court. The only manner in which the International Criminal Court could exercise jurisdiction over acts of terrorism is if terrorist acts would amount to another crime over which the Court has jurisdiction (for instance, crimes against humanity under Article 7 of the Rome Statute). ${ }^{23}$

Although these definitions contain basic similarities, they fail to account for any religious inspiration, and therefore, are unable to delineate the actual intention (or mens rea) of modern day extremist organizations since they do not consider religious or eschatological aspirations as goals of said organizations. This paper argues that modern violent extremist groups intend to commit international crimes (such as genocide, conspiracy to commit genocide, and crimes against humanity) that are already universally defined, thus rendering the necessity to determine a universal definition of "terrorism" legally moot. ${ }^{24}$

Legal scholars that have proposed definitions based on the regional elements of "terrorism" understand this crucial gap and have attempted to propose general guidelines

22 Prosecutor v. Galic, Case No. IT-98-29-T, Judgment, \ 4 (Int'l Crim. Trib. for the Former Yugoslavia Dec. 5, 2008). "The Prosecution is required to prove not only that the Accused accepted the likelihood that terror would result from the illegal acts . but that that was the result which he specifically intended [as] [t] he crime of terror is a specific-intent crime." Id.

23 Terrorism, Int'l Crimes Database, http://www.internationalcrimesdatabase.org/Crimes/Terrorism (last visited Feb. 1, 2015); Rome Statute of the International Criminal Court, supra note Erreur : source de la référence non trouvée.

24 (Dan) The BBC has stopped using the term terrorism and gone with the idea that a bombing is a bombing, a shooting is a shooting, and "terrorism" is a term used by states to inspire fear. 
for future attempts to universally codify terrorism. ${ }^{25}$ Two examples are Ben Saul, a law and policy scholar, and Susan Tiefenbrun. Saul proposed the following definition: (1) Any serious, violent, criminal act intended to cause death or serious bodily injury, or to endanger life including by acts against property; (2) committed outside an armed conflict; (3) for a political, ideological, religious or ethnic purpose; and (4) intended to: (a) create extreme fear; and (b) seriously intimidate a population; or (c) unduly compel a government or an international organization to do or to abstain from doing any act. Saul notes in his proposal that "advocacy, protest, dissent or industrial action which is not intended to cause death, serious bodily harm or serious risk to public health or safety does not constitute a terrorist act."26 This would preclude future "terrorist labels" to populations exercising their inherent right to self-determination. Along similar lines, Tiefenbrun proposed five abstract elements of terrorism: (1) The perpetration of any violence; (2) targeting of innocent civilians; (3) intent to cause violence; (4) for the purpose of causing fear, coercing or intimidating an enemy; (5) "in order to achieve some political, military, ethnic, ideological, or religious goal". ${ }^{27}$

There is a discernable distinction between organized violent extremism and rebellion movement contained within a population for purely self-determination purposes within that delineated territory. ${ }^{28}$ Global powers have historically championed violence in pursuit of political aims (or violence for the cause of "self-determination") since the age of colonialization and imperialism came to an end. ${ }^{29}$ In 1949, the revised codification of the Geneva Conventions highlighted the changing face of political opposition and violence today. "Wars known as 'wars of national liberation' form a general exception to violence with domestic political aims that many label as "terrorist acts." 31 However, "even when

25 O'Connell, supra note 4, at 60.

26 The Nature of Terrorism: Defining terrorism within the EU, supra note 53, at 14 (emphasis added).

27 The Nature of Terrorism: Defining terrorism within the EU, supra note 53, at 14 (emphasis added). at 15 (emphasis added).

28 See Bruce Hoffman, Inside Terrorism, in Global Affairs, supra note Erreur : source de la référence non trouvée, at 206-09 (discussing the inevitable trajectory of terrorism if it remains undefined).

29 Bruce Hoffman, Inside Terrorism, in Global Affairs, supra note Erreur : source de la référence non trouvée, at 205-217.

301987 Additional protocol Geneva convention (pg 1323-1324)) Geneva Convention, http://www.icrc.org/eng/war-and-law/treaties-customary-law/geneva-conventions/

31 For a thorough and compelling report on the various faces of intra-national or domestic terrorism see The Nature of Terrorism: Defining terrorism within the EU, supra note 37. UN Charter art. the use of force is legally and morally justified, the right of self-determination has its limits." ${ }^{32}$

The philosophical intentions of modern extremists mirror the language of eliminationist campaigns that led to prior instances of genocide. ${ }^{33}$ Transnational terrorism naturalizes national boundaries and involves groups whose intent is to operate beyond national boundaries through the use of violence. ${ }^{34}$ Violent Extremists

1, para. 2; On the basis of this principle, the $\mathrm{UN}$ has been induced to adopt a supportive position towards peoples fighting in the exercise of their right of self-determination. This point of view, which has repeatedly been confirmed in resolutions and declarations, is now universally recognized. This would allow proper prosecution of people who commit a crime through the use of political violence since violent uprising is inspired by the view that political freedoms are somehow restriction by the incumbent government in a sovereign state. It is important to keep in mind that one of the main contentions preventing the international community from accepting a universal definition is the, now commonplace, quip that "one man's terrorist is another man's 'freedom fighter," originally coined in Gerald Seymour, Harry's Game (1975). Once such example of this displaced and politically motivated labeling is the situation in the eastern parts of Ukraine as rebel groups seek to separate from the rule of the Western-influenced Kiev government and live under Russian custom, laws, and leadership. See Anthony Deutsch \& Gabriela Baczynska, Malaysia: Dutch Report Suggest MH-17 shot down from ground, Reuters (Sept. 9, 2014, 1:41 PM), http://www. reuters.com/article/2014/09/09/us-ukraine-crisis-mh17-investigation-idUSKBN0H40LM20140909. MH17 Verdict: Real Evidence Points to US-Kiev Cover-up of Failed "False Flag", Twenty-First Century Wire \& Global Res. (July 17, 2014), http://www.globalresearch.ca/mh17-verdict-real-evidence-points-to-us-kiev-coverup-of-failed-false-flag/5393317; see also Tyler Durden, Ukraine Releases YouTube Clip "Proving" Rebels Shot Down Malaysian Flight MH-17, zerohedge.com (July 17, 2014, 7:46 PM), http:// www.zerohedge.com/news/2014-07-17/ukraine-releases-youtubeclip-proving-rebels-shot-down-malaysian-flight-mh-17.

$32 I d$. at 205. The UN's "encouragement for wars of national liberation and the right of self-determination" renders any attempt to prosecute episode of systematic violence moot as it counteracts the UN's purpose in promoting self-determination. See Hoffman, Inside Terrorism, in Global Affairs, supra note Erreur : source de la référence non trouvée, at 212-17. The broad generalizations of acts that have been associated with the current-accepted definitions of terrorism (as fear for political change) have caused any resolution that aims to prevent such violence impracticable to incorporate on a domestic level, as state governments would be incapable of integrating legislation to prosecute liberation movements who intend secessionist strategies. Id.

33 The term "transnational" means "violating another nation's territorial sovereignty or operating in or involving more than one country; extending or going beyond national boundaries." See "Transnational" Definition, Merriam-Webster Dictionary, http:// www.merriam-webster.com/dictionary/transnational, (last visited Feb. 11, 2015) (stating that "transnational" means "operating in or involving more than one country").

34 Ex (Naturalizes national boundaries. We also champion the SPLA, who operated from Ethiopia and Kenya with the intent of using violence in Sudan to overthrow the government. ) Understanding that modern extremist organizations seek to recast and refashion their world 
today that follow certain eschatological ideologies intend solely "to bring about global dominance and international governance through the use of violence and mass extermination aimed at civilians who do not abide by their ideas of religious rule". ${ }^{35}$ Therefore, the current definitions and conventions of "terrorism" are no longer applicable to acts that the modern world considers "terrorism." Organizations such as the Islamic State of Iraq and the Levant (more commonly known as ISIS) ultimately seek to bring about political domination through the creation of a global Islamic Government (or "Caliphate") as evidenced in the 2014 speech of its self-proclaimed Caliph (leader), Abu Bakr al Baghdadi. ${ }^{36}$

under their own versions of "international justice" often resulting in the creation a new global empire, is an important concept to understand in codifying a modern definition of this form of terrorism. Goldhagen, supra note Erreur: source de la référence non trouvée, at 492 (noting that certain forms of Political Islam have elements that exacerbate eliminationist tactics such as the religious consecration of Allah's goals to which slavish devotion is due, the reflexive and insistence public demonization of its opponents, and a culture of death that glorifies those who die or kill others in the name of Allah's law). For a great explanation about the vast majorities of Muslim populations that fear such extremism, see Yasmine Hafiz, Muslims worldwide fear the rise of Islamic Extremism, Huffington Post (updated July 23, 2014 11:59 AM), http://www. huffingtonpost.com/2014/07/02/muslims-against-extremism-pewsurvey_n_5551693.html.

35 The intent of violent Eliminationist campaigns is often documented or promulgated in their publicized statements or charters See e.g. Adolf Hitler, Mien Kampf (1927); see also e.g. Hamas Leader Khaled Mash'al at a Damascus Mosque: “The Nation of Islam Will Sit at the Throne of the World and the West will be full of remorse when it's too late": No. 1087, MEMRI Special Dispatch Series (Feb. 7, 2006), www.memri.org/bin/articles.cgi?Area $=$ sd\&ID=SP1 08706\&Page $=$ archivesMarija Ristic, ICJ rejects Genocide Claims of Serbia and Croatia, supra note 29 (displaying that although the ICJ found that the act of genocide had been established, the intentional element of genocide was lacking. Here, the Genocide Convention's element that a perpetrator possess an "intent to destroy, in whole or in part, a national, ethnical, racial or religious group as such" is essential to such a finding and is considered "dolus specialis," meaning specific intent, id.); Recently, the International Court of Justice concluded that genocide could not occur in a court of lawif the mental element (mens rea or intent) of genocide elements was not met-despite an overt act of genocide and thousands of deaths.

36 See Amir Abdallah, URGENT Video: ISIS releases Abu Baker al-Baghdadi sermon in Mosul Grand Mosque, Iraqi News (July 5, 2014), bttp:/ / mon. iraqinews.com/features/urgent-video-isis-releases-abu-baker-al-baghdadi-sermon-mosul-grand-mosque/. Al-Baghdadi was head saying (translated to English), "Allah the Most High says: And I did not create the jinn (demon-possessed humans and animals) and mankind except to worship Me. And He ordered us, Blessed and Exalted be $H e$, to fight His enemies and set out in Jihad in His cause in order to achieve that and establish the Religion. Allah the Most High says: Fighting has been enjoined upon you while it is hateful to you. And He the Most High says: And fight them until there is no fitnah and [until] the religion, all of it, is for Allah. O people, verily the Religion of Allah, Blessed and High be $\mathrm{He}$, will not be established and this purpose for which Allah has created us will be attained except by ruling by the L aw of Allah and legislating to it and establisbing the limits (of Allab). This verily will not except by battle and
Jus Cogens (or peremptory norms) refer to "certain fundamental, overriding principles of international law, from which no derogation is ever permitted." ${ }^{37}$ One such Jus Cogens crime is the Crime of Genocide; which all nations have generally accepted as international criminal intent and behavior. The term "genocide" was first used by Raphael Lemkin in his book, Axis Rule in Occupied Europe, published in late 1944. ${ }^{38}$ In 1948following the devastation of the genocidal campaign that sparked World War Two-the young UN defined genocide on a universal level in the 1948 Convention on the Prevention and Punishment of the Crime of Genocide in order to prevent such mass violence whether attempted in times of peace or war. ${ }^{3940}$ However, legal and political scholars feared that getting hung up on genocidal definitions coined in the wake of Nazi gas chambers would miss the opportunity to prevent modern forms of genocide. ${ }^{41}$ Genocidal boundaries must be reestablished to face the threats of nuclear power in the hands

authority." Id. (quoting the Quran, suras 51:56, $21: 26$ \& 8:39); see also Criminal Complaint of the United States against Shannon Conley, at 7, 1 12. "Conley said ISIS was 'going to try to make Syria and Iraq the beginnings of a calipha (ph)." "Id. 37 Richard D. Kearney \& Robert E. Dalton, The Treaty on Treaties, 64 Am. J. Int'l L. 495, 535 (1970). There have been three general categories of Jus Cogens: (1) the threat or use of force in violation of the United Nations' principles, (2) acts or omissions whose suppression is required by international law, and (3) international crimes so characterized by international law. The four basic international crimes (as characterized by international law) are (1) crimes against humanity, (2) war crimes, (3) genocide, and (4) the crime of aggression. Id. Those who violate such norms are condemned as "common enemies of all mankind and all nations have an equal interest in their apprehension and prosecution regardless of their 'state' status or willingness to accede to a treaty," Demjanjuk v. Petrovsky, 776 F.2d 571 (1985).

38 William A. Schabas, Convention for the Prevention and Punishment of the Crime of Genocide, UN Legal Affairs (2008), http:// legal.un.org/avl/pdf/ha/cppcg/cppcg_e.pdf, (stating that even though "genocide" appears in the drafting history of the Charter of the International Military Tribunal, the final text of that instrument uses the cognate term "crimes against humanity" to deal with the persecution and physical extermination of national, ethnic, racial and religious minorities, and therefore, the Genocide Convention was the first true codification of the crime on an international level). 39 Convention on the Prevention and Punishment of the Crime of Genocide, G.A. Res. 260 (III), at art. 1, U.N. Doc. A/78/277 (Dec. 9, 1948) [hereinafter Genocide Convention].

40 See Schabas, supra note 37 (stating that that genocide is a crime under international law which the civilized world condemns). Many scholars argue that the global community considers genocide to be the worst of all international crimes.

41 Gregory Stanton, Create a United Nations Genocide Prevention Focal Point and Genocide Prevention Center, GenocideWatch. net, http://www.genocidewatch.org/images/Prevention-Create_a_ United_Nations_Genocide_Prevention_Focal_Point_and_Genocide_Prevention_Center.pdf (proposing a UN-funded center to identify and prevent modern-day genocidal crimes). 
of extremist organizations. The current elements of genocide-accepted by the 193 member states of the $\mathrm{UN}$ and prosecuted by the International Criminal Court as a crime of universal jurisdiction-include "the deliberate killing of a large group of people, especially those of a particular ethnic group or nation [...] committed with intent to destroy, in whole or part a national, ethnic, racial, or religious group [...] [including] complicity in the commission of act." ${ }^{42}$ As familiar as this egregious criminal ideology may sound to those witnessing the modern scourge of "terrorism" those responsible to produce uniform prosecutorial and preventative methods are paralyzed from producing protective laws by the moral considerations of accepting the perpetrators' ideology. ${ }^{43}$ Definition, in a legal sense, must only "require [...] specifying what it is [one is] examining." "Facing a fact must not be muddled by moral considerations or attempts to clarify the pure intention of the religious ideology from which such violent organizations are operating. During the Crusades and Spanish Inquisition of the 1400s, that religious ideology was enforced Catholicism. Today, it is fundamental Islamic theology. Many Arab leaders in nations that have a majority Muslim population have taken steps to thwart the spread of Islamic militants involved in violent extremism. ${ }^{45}$ The international community must do the same. This is a present-day issue so it must be dealt with squarely, but need not be offensive to any single religion which does not purport to accept the acts of the few.

42 Genocide Convention art. 1; see also Prosecutor v. Jean-Paul Akayesu, Case No. ICTR-96-4-T Judgment (Sept. 2, 1998) (emphasis added).

43 See Goldhagen, supra note Erreur : source de la référence non trouvée, at 8 (stating that "[w]e must consult the corrective lenses of others. We must look at mass killings using impartial criteria. We must keep distinct the tasks of definition ... explanation ... . and moral evaluation ... [and] approach the phenomenon with the willingness to think it through systematically and from the beginning." Id.)

44 See Goldhagen, supra note Erreur : source de la référence non trouvée, at 8.

45 One example of Muslim leaders renouncing such violence under the guise of Islam is Egyptian President Abdel Fattah el-Sisi who stated (in his 2015 New Year's speech in Al Azhar University that addressed top Sunni clerics), "it is not possible that 1.6 billion people [reference to the world's Muslims] should want to kill the rest of the world's inhabitants - that is 7 billion-so that they themselves may live." Ali Sina, The Dilemma of Islamic Terrorism, faithfreedom.org (Jan. 26, 2015), http://www.faithfreedom.org/ the-dilemma-of-islamic-terrorism/. "Sisi did not blame Abu Ghraib, Israel, nor made other silly excuses for Islamic terrorism. He blamed the 'ideology' of it." Id.

\section{The Global Community is Afraid to Call InTEntional Eliminationism "Genocide" and Still Refuses to Objectively, Accurately Label Modern Extermination Campaigns.}

The sovereign community of states failed to prevent the 1994 eliminationist campaign in Rwanda, and despite the tribunals that have addressed the aftermath, it is still failing to prevent mass murder due to misunderstood labels and political correctness. Beginning in March 1994, an extremist group of the Rwandan Hutu population took over a UN peacekeeping mission in Kigali with the intention to annihilate the population of Rwandan Tutsis within their territorial control. ${ }^{46}$ Prior to the commencement of the Hutu extermination agenda, the UN peacekeeping mission leader, Canadian General Roméo Dallaire, received the information of an informant saying that Hutu extremists were planning to kill all Tutsis and diplomats. ${ }^{47}$ Dallaire conjured a plan to raid the military bunkers of the Hutu extremists, but when he informed Kofi Annan at the UN headquarters of his plan, he was immediately told to stand down and that a military raid of any Rwandan group was "outside the scope of his peacekeeping mission." ${ }^{\prime 48}$ Further, the UN told him that his only course of action was to inform the Rwandan government of what Dallaire's informant had relayed to him, despite knowing that many government officials were part of the Hutu plot. ${ }^{49}$ Although

46 Cite (Supported by the "legitimate" Rwandan government, by the way. And by machetes sent from the US, which recognized the legitimacy of the Rwandan government.)

47 Dallaire's book Shake Hands with the Devil is also a good source, but very depressing. I believe he attempted suicide once or twice after returning to Quebec.

48 The Ghosts of Rwanda, PBS Frontline (2014), http://www. pbs.org/wgbh/pages/frontline/shows/ghosts/.

49 The Ghosts of Rwanda, PBS Frontline (2014), http://www. pbs.org/wgbh/pages/frontline/shows/ghosts/. The UN forces in Rwanda had issued at least ten clear warnings to the UN of the 'Hutu power' and plans; During this time, the UN General Assembly passed a resolution entitled "Human Rights and terrorism, G.A. Res. 48/122, U.N. Doc. A/RES/48/122 (1994); "The UN Security Council met in secret after the start of the violence. At this meeting Britain urged that UNAMIR should pull out (and later blocked an American proposal to send in a fact-finding mission when the death toll had reached six figures). Council members resisted admitting 'that the mass murder being pursued in front of the global media was in fact 'genocide.' Genocide involved action no-one wanted to take. Once it was inescapably clear that genocide was indeed going on, it was too late. (The United States, at this point, had actually banned its officials from using the term.)" Information on the Genocide in Rwanda, Peace Pledge Union, http://www.ppu. org.uk/genocide/g_rwanda1.html (last visited Feb. 1, 2015. This 
the UN passed resolutions condemning the violence, even the strongest Security Council resolution purposefully omitted the word "genocide," because if the term "genocide" had been used, the international community would have been legally obliged to act to "prevent and punish" the perpetrators. ${ }^{5051}$ When the targeted population was being destroyed in mass numbers, those in power to help ignored the genocide except for the select men and women who gave everything to save innocent civilian lives, such as Senegalese Captain Mbaye Diagne and American missionary, Carl Wilkins. ${ }^{52}$ With no action from the global community over 800,000 human beings were slaughtered in the course of 100 days. ${ }^{53}$

"The definition of 'genocide' was clearly an international sticking-point [during this time], and because so many were unwilling to classify the atrocities as a 'genocide,' the global community - that had the means and might to stop the violence-remained purposely powerless. ${ }^{54}[\ldots]$. Today, international legal actors working to prevent and prosecute violent extremism refuse to pair the labels of Islamic eschatology with the current campaigns of elimination, and therefore, are committing the same purposeful blindness as the apathetic UN of 1994. The truth is that all mass murder campaigns contain similar elements but very unique intricate motivations and that should be addressed during the prosecution phase. Although Rwanda was "state-sponsored terrorism," (whereas extremist organizations are generally non-state or quasi-state actors), it could have been

website provides a detailed, but concise timeline of the events in Rwanda (Statement by the president of the Security Council, S/ PRST/1994/21. 30 April 1994) ("[SC] calls on the leadership of both parties to condemn publicly such attacks and to commit themselves to ensuring that persons who instigate or participate in such attacks are prosecuted and punished," S/PRST/1994/21).

$50 \quad I d$.

$51 \quad I d$.

52 Id.

53100 Days of Slaughter, PBS, http://www.pbs.org/wgbh/ pages/frontline/shows/evil/etc/slaughter.html (last visited Feb. 1, 2015).

54 Id. (emphasis added). Peace Pledge Union Information on Genocide in Rwanda, Peace Pledge Union, http://www.ppu.org.uk/genocide/g rwanda1.html (last visited July 23, 2014) (stating that "[t]he UN Security Council met in secret after the start of the violence and.. At this meeting Britain urged that UNAMIR should pull out (and later blocked an American proposal to send in a fact-finding mission when the death toll had reached six figures). Council members resisted admitting 'that the mass murder being pursued in front of the global media was in fact genocide': genocide involved action noone wanted to take. Once it was inescapably clear that genocide was indeed going on, it was too late. (The United States, at this point, had actually banned its officials from using the term). prevented by squarely facing the published intentions of the Hutu perpetrators and properly labeling the violence "genocide" rather than hiding behind a wall of "sovereignty" and political correctness. While the Hutu extremists used machetes to commit the acts, modern extremists seek the use and proliferation of nuclear weapons. ${ }^{55}$ As the next section will illustrate, the most widespread and influential extremists (or "terrorists") operate with the intent to commit genocide. ${ }^{56}$

Extremist organizations committing systematic violence are guilty of the crime of genocide and the intent to commit genocide. Following the Islamic Revolution in Iran that ushered in the political rule of Ayatollah Khomeini, Iranian religious leaders decided to create a militant wing of Shi'a Islamic extremists in Lebanon whose foundational ideologies would include viewing Iran as the "vanguard and new nucleus of the leading Islamic State in the world [...] [Abiding] by the orders of [...] Khomeini." ${ }^{57}$ This militant wing of Shi'a extremists became known as Hezbollah and was led primarily by Sheik Hassan Nasrallah. ${ }^{58}$ The global reach of Hezbollah's activities illustrates the expertise of extremists in masking their end goals by "becom[ing] experts in the art of concealing their activities." ${ }^{59} \mathrm{He}-$ zbollah covertly operates throughout Europe, the Middle East, Southeast Asia, Africa, and North America. ${ }^{60}$ Nasrallah, the Hezbollah leader throughout the 1980s, restated Hezbollah's goals saying, "[w]e do not believe in multiple Islamic Republics; we do believe however in a single Islamic world governed by a central government" (the "caliphate" mentioned above). ${ }^{61}$ Hezbollah

\section{Goldhagen, supra note 10.}

56 See Goldhagen, supra note Erreur : source de la référence non trouvée, at 496.

57 Matthew Levitt, Hezbollah: The Global Footprint of Lebanon's Party of God 11-12 (Georgetown University Press, 2013).

58 Id. Hezbollah operates with direct Iranian funding and was trained by Iran's Islamic Revolutionary Guard Corp-Qods force. Id. See also Adam Goldman \& Ellen Nakashima, CIA and Mossad killed senior Hezbollah figure in car bombing, Wash. Post (Jan. 30, 2015, 10:14 PM), http://www.washingtonpost.com/world/national-security/cia-and-mossad-killed-senior-hezbollah-figure-in-carbombing/2015/01/30/ebb88682-968a-11e4-8005-1924ede3e54a_ story.html.

59 Levitt, supra note Erreur : source de la référence non trouvée, at xii. Matthew Levitt spent ten years researching the transnational criminal activities of Hezbollah because information on such organizations is very difficult to find through their covert methods of operations, id.

60 Id.

61 See B.B.C. Monitoring: Al-Manar, Sept. 27, 2002 (cited in Deborah Passner, Hassan Nasrallah: In his own words, frontpagemag. 
believes that Shi'a Muslims possess a duty to create the Caliphate, and therefore, Hezbollah's operations serve Shi'a rebel organizations all over the world whose ideologies mirror their own. ${ }^{62}$

Iran considers Hezbollah its main Shi'a extremist proxy that will ultimately bring about carnage that allows a Shi'a ruled Islamic Caliphate to usher in the return of the Mahdi. ${ }^{63}$ Iran even supports Sunnis when it fits with Iran's geopolitical interests. (keep? Cite?) Hassan Nasrallah, the leader of Hezbollah stated that "America will remain the nation's chief enemy and the greatest Satan [...] [and that] Israel will always be, for us, a cancerous growth that needs to be eradicated." ${ }^{64} \mathrm{He}$ continued, stating that likeminded extremist organizations are "not interested in our own personal security [...] [but rather daily hopes] more than anything to be killed for the sake of Allah." ${ }^{\prime 566}$ While its military and terrorist threats currently remain largely unknown, Hezbollah has been a cunning adversary, and prior to September 11, 2001,

com (July 26, 2006), http://archive.frontpagemag.com/Printable. aspx?ArtId=3227).

62 See e.g. Levitt, supra note 111, at 288 (stating that throughout the 1990s, Hezbollah documented its strategic support of radical Shi'a groups in Tunisia, Kuwait, Saudi Arabia, Egypt, Pakistan, and Yemen). It would not be surprising to discover that Hezbollah's significant resources helped to fund and prepare for the military coup in Yemen where Shia extremist Houthi group ousted the Yemeni Parliament and President.

63 Id. at 8-9.

64 B.B.C. Monitoring: Al-Manar, Hassan Nasrallah, supra note 116.

65 Levitt, supra note Erreur : source de la référence non trouvée, at 7 (discussing Hezbollah's media outlet in Lebanon: Al-Manar TV program).

66 Id. at 288. Since 2012, the United States has also seen a resurgence of activity by Iran's Islamic Revolutionary Guard Corps' Qods Force (IRGC-QF), the Iranian Ministry of Intelligence and Security (MOIS), and Tehran's ally Hezbollah; On January 23, 2013, the Yemeni Coast Guard interdicted an Iranian ship carrying weapons and explosives likely destined for Houthi rebels, U.S. State Department Country Reports on Terrorism, April 2014, http://www.state.gov/r/pa/prs/ps/2014/04/225406.htm (last visited Feb. 7, 2015) (emphasis added to show Iranian and Hezbollah involvement in recent Houthi takeover in Yemen). On February 5, 2013, the Bulgarian government publically implicated Hezbollah in the July 2012 Burgas bombing that killed five Israelis and one Bulgarian citizen, and injured 32 others, id. On March 21, 2013, a Cyprus court found a Hezbollah operative guilty of charges stemming from his surveillance activities of Israeli tourist targets in 2012, id. And on December 30, 2013, the Bahraini Coast Guard interdicted a speedboat attempting to smuggle arms and Iranian explosives likely destined for armed Shia opposition, id.; See also Isabel Kershner \& Anne Bernard, Missile Attack kills 2 Israeli soldiers near Lebanon: Hezbollah claims responsibility, N.Y. Times (Jan. 28, 2015). http:// www.nytimes.com/2015/01/29/world/middleeast/israel-lebanonhezbollah-missile-attack.html?_r $=0$.
Hezbollah had targeted and killed more Americans than any other modern terrorist organization. ${ }^{67}$

Next, the Islamic Resistance Movement (known more commonly as Hamas) began its operations in the Gaza Strip in 1986 as an organization intent upon destroying the State of Israel and replacing the territory known as Israel with Palestine once all Israelis were killed or captured, or deported. ${ }^{68}$ The goal of Hamas remains the desire to "conquer evil, break its will, and annihilate it." ${ }^{69}$ Hamas identifies "evil" as the nation-state of Israel and its allies. ${ }^{70}$ Merriam-Webster defines annihilate as "(1) to destroy something or someone completely, (2) to cause to cease to exist, (3) to reduce to nothing." ${ }^{\prime 1}$ The annihilation of an entire nation and religion is at the forefront of Hamas' Charter and Covenant which fostered its initial creation. ${ }^{72}$ Hamas was voted into political power in the Gaza Strip in 2006 by promising civilians access to water, but since then has utilized its extensive war chest to plan rocket launches and declare war against the State of Israel targeting Israel's civilians and using its own civilians as bait to gain international sympathy and garner universal support against Israel. ${ }^{7374}$ Hamas' opinion towards peace

67 Levitt, supra note Erreur : source de la référence non trouvée, at 358 (stating that Hezbollah likely went underground for planning once America's "War on Terror" sought to annihilate Osama bin Laden's al-Qaeda).

68 See e.g. Dali Halevi \& Elad Benari, Hamas Marks Independence Day with Genocide Video, Israel Nat'l News (July, 2014) (showing a video and what they desire to do with Israeli citizens that are not murdered); See also Caroline Alexander, Hamas Releases End of Hope Video to Mark Israel Independence, Bloomberg News (May 6, 2014, 3:53 PM), http://www.bloomberg.com/news/2014-05-06/ hamas-releases-end-of-hope-video-to-mark-israeli-independence. html.

69 The Charter of the Islamic Resistance Movement, chap. 2, art. 9, trans. Muhammad Maqdsi, available at http://www.palestinestudies.org/files/pdf/jps/1734.pdf (last visited Nov. 11, 2014) [hereinafter Hamas Charter]. "The nation of truth is absent and the nation of evil has been established; as long as Islam does not take its rightful place in the world arena everything will continue to change for the worse.” Id. (citing The Quran, Sura 2:251).

70 Id.

71 "Annihilate" Definition, Merriam-Webster Dictionary, http:// www.merriam-webster.com/dictionary/annihilate (last visited Feb. 11, 2015).

72 See Hamas Charter, supra note 124.

73 See id., art. 16 (emphasis added) (stating that Hamas believes their goal is to "train the Muslim generation in our area, an Islamic training that depends on ... careful study of the enemy's ability, current events, and new trends, studying the analysis and commentaries on it'). (to what end?) Hamas' mode of operation is written in their charter to know political trends and that media and the UN will report civilian casualties, Hamas Charter art.

74 Hamas has not only conducted violent strikes against the state 
initiatives is codified in their charter:

[International peace] conferences are nothing but a form of enforcing the rule of the unbelievers. There is no solution to the Palestinian Problem except by Jihad. The initiatives, options, and international conferences [on establishing peace in Palestine and a two-state solution with Israel] are a waste of time and a kind of child's play. ${ }^{75}$

Several journalists working in Gaza during a time of conflict with Israel noted that it is "undisputable that Gaza militants [members of Hamas Al-Qassam Brigade] operate in civilian areas, draw return fire to civilian structures, and [...] benefit in the diplomatic arena from the rising casualties [of their own people]." ${ }^{\prime 76}$ The journalists also noted that Hamas encouraged its residents not to flee their homes when Israel had warned Palestinian residential areas that there was an impending strike. ${ }^{77}$ Further, although Hamas "prepared extensively for war," it did not build any civilian bomb shelters but rather utilized civilian locations and hospitals as areas to conduct media interviews in direct violation of the Geneva Convention. ${ }^{78}$ Even as the official elected representative of the Palestinian civilians, Hamas' goal has not shifted to caring for their civilian population, but remains intent on annihilating Israel and tarnishing Israel to the international community despite the loss of Palestinian lives. After over 2,000 Palestinians had been killed in Hamas' war against Israel ${ }^{79}$, Hamas still

of Israel or her sympathizers (August 2014 of Hamas carrying out public executions of Palestinian civilians they believed were allied with Israel) but also on other sects of Islamic leadership in the land of Palestine ("Jund Ansar Allah is, or was, an armed Salafist jihadist organization in the Gaza Strip. On August 14, 2009, the group's spiritual leader, Sheikh Abdel Latif Moussa, announced during Friday sermon the establishment of an Islamic emirate in the Palestinian territories attacking the ruling authority, the Islamist group Hamas, for failing to enforce Sharia law. Hamas forces responded to his sermon by surrounding his Ibn Taymiyya mosque complex and attacking it. In the fighting that ensued, 24 people (including Sheikh Abdel Latif Moussa himself), were killed and over 130 were wounded." (Al-Quds Al-Arabi (London), August 19, 2009.).

75 Hamas Charter, supra note 124, art. 13.

76 Simon Plosker, Foreign Journalists Acknowledge Hamas' Human Shields Tactics, Honest Reporting (July 23, 2014), http://honestreporting.com/foreign-journalists-acknowledge-hamas-humanshields-tactics/.

77 Id.

78 Id.; see also Hamas backers spend fortunes on rockets and tunnels while Gazans live in misery, Fox News (Aug. 8, 2014) http:// www.foxnews.com/world/2014/08/08/hamas-backers-spend-fortunes-on-rockets-and-tunnels-while-gazans-live-in-misery/.

79 See Hamas admits kidnapping of Israeli Teens, USA Today (Aug. 21, 2014), http://www.usatoday.com/story/news/ world/2014/08/21/hamas-kidnapping-israeli-teens/14406827/ (displaying that the event which triggered the 2014 conflict was, in- declared victory in the 2014 Gaza conflict. ${ }^{80}$ The deaths of civilians, including children, are no concern to Hamas as was observed in an article during the 2014 Gaza-Israeli: ${ }^{81}$

Hamas on Tuesday rejected an Egyptian ceasefire proposal that was supported by Western governments and the Arab League and had been accepted by Israel.

Why would Hamas insist on continuing the fight when it is faring so poorly? The only plausible answer is stomach-turning: The Islamic movement calculates that it can win the concessions it has yet to obtain from Israel and Egypt not by striking Israel but by perpetuating the killing of its own people in Israeli counterattacks. More than 200 people, including a number of children, have already died in Gaza; Hamas probably calculates that more deaths will prompt Western governments to pressure Israel to grant Hamas's demands. ${ }^{82}$

The civilians living in Hamas-controlled territories

deed, perpetuated by Hamas).

80 The Reasons Why Israel's Military Is In Such A Tough Fight, NPR (July 25, 2014, 10:52 PM), http://www.npr.org/blogs/ parallels/2014/07/24/334893877/the-reasons-why-israels-military-is-in-such-a-tough-fight; See also the Geneva Conventions (which ones) "The parties to a conflict shall not direct the movement of the civilian population or individual civilians in order to attempt to shield military objectives from attacks or to shield military operations" "the presence or movements of the civilian population or individual civilians shall not be used to render certain points or areas immune from military operations, in particular in attempts to shield military objectives from attacks or to shield, favour or impede military operations."

81 See Hamas is playing a dangerous game with Gazan lives, Wash. Post (July 15, 2014), http://www.washingtonpost.com/ opinions / hamas-is-playing-a-dangerous-game-with-gazanlives/2014/07/15/cc5f101e-0c3b-11e4-8c9a-923ecc0c7d23_story. html?wpmk=MK0000203 (noting that one must wonder why Hamas would refuse to honor or recognize a cease fire with Israel when their civilians were faring so poorly against the IDF); see also Plosker, Hamas' Human Shields Tactics, supra note Erreur : source de la référence non trouvée (stating that even when warnings from Israeli officials to evacuate reach Palestinian civilians, oftentimes, the innocent cannot escape because Hamas-as an elected representative of the Palestinian civilians-blocks radio broadcasts or tells their fleeing civilians that Israel is blocking the exits or that they cannot leave through such an exit); See Rosen, Targeting Enemy Forces in the War on Terror: Preserving Civilian Immunity, supra note Erreur : source de la référence non trouvée (stating that the Protocol I to the Geneva Conventions of 1949 is fundamentally flawed and that the current law governing targeting is fundamentally defective; it allows terrorist and insurgent groups to gain strategic and tactical advantages through their own noncompliance with the law and their adversaries' observance of it).

82 Hamas is playing a dangerous game with Gazan lives, Wash. Post (July 15, 2014), http://www.washingtonpost.com/ opinions / hamas-is-playing-a-dangerous-game-with-gazanlives/2014/07/15/cc5f101e-0c3b-11e4-8c9a-923ecc0c7d23_story. html?wpmk=MK0000203. 
know this as evidenced by the drop in positive ratings according to recent polls conducted in Gaza, ${ }^{83}$ and the world now understands the extent Hamas was willing to go to perpetuate international condemnation against Israel given that almost 2,200 people died as a result of Hamas' refusal adopt the proposed cease-fires. Regardless of one's stance on the situation involving Israel and Palestine, the intent to exterminate any people, ethnic group, nationality, or religion directly conflicts with the laws prohibiting genocide and crimes against humanity, which have been signed and acceded to by all 196 member and observer states of the UN-including the State of Palestine in $2014 .^{84}$

Quasi-state actors such as Hamas and Hezbollah have been able to gain forms of political power in their respective territories. However, both organizations continue to have the shared goal of annihilating entire nations or people groups using violence or extermination. ${ }^{85}$ To these organizations, such goals outweigh all desire to abide by international laws and respect for human rights and dignity and therefore, the definitions of modern-day terrorist organizations should fit their stated intent and refuse to allow them political office over civilians with such eliminationism intentions. The next section will cover non-state organizations whose similar intentions span across borders and have no legitimate state alliance.

83 See Muslims Worldwide Fear the Rise of Islamic Extremism: Pew Survey, Huffington Post (Updated July 23, 2014, 11:59 AM), http://www.huffingtonpost.com/2014/07/02/muslims-againstextremism-pew-survey_n_5551693.html (showing that "Hamas has fallen out of favor in Palestine since 2007, when 62 percent of Palestinians viewed them positively. Now, in 2014, only 35 percent reported a favorable opinion, with 53 percent on record as having an unfavorable opinion. In the Gaza Strip, which is controlled by Hamas, 63 percent of people have a negative opinion of the group, which is up from 2013, when only 54 percent reported unfavorable views," id.); Mariano Castillo, Chelsea J. Carter \& Salma Abdelaziz, Captured, Killed or missing? Fate of Israeli soldier remains unknown, CNN (Aug. 6, 2014, 12:02 PM), http://www.cnn.com/2014/08/01/ world/meast/mideast-crisis/ (speaking of how Hamas broke a peaceful ceasefire in 90 minutes with a suicide bomber placing their civilians in more danger exposing them to defensive fire).

84 List of Accession or Ratification to the Genocide Convention, UN Treaties, available at https://treaties.un.org/Pages/showDetails.aspx?objid $=0800000280027 \mathrm{fac}$ (last visited Feb. 1, 2015) (displaying that Palestine acceded to the Genocide Convention in 2014). 85 See William Booth, While Israel held its fire, the militant group Hamas did not, Wash. Post (July 15, 2014), http://www.washingtonpost.com/world/middle_east/while-israel-held-its-fire-the-militant-group-hamas-did-not/2014/07/15/116fd3d7-3c0f-4413-94a92ab16af1445d_story.html.
The notion of violent Jihad carried out by extremist groups was not widespread until the mid to late twentieth century, when Osama bin Laden-whom many consider to be the founder of transnational violent jihad-founded the movement. ${ }^{86}$ After fighting and defeating the Soviet forces in Afghanistan in the 1980s, bin Laden moved back to his home, Saudi Arabia to build up an army that would seek to fight and eradicate "un-Islamic" governments by purging. ${ }^{87} \mathrm{Al}$-Qaeda also worked to forge alliances with other organizations such as the "International Islamic Front for Jihad against the Jews and Crusaders," Hezbollah, the Harakat ul-Ansar, and others. ${ }^{88}$ (Bin Laden established training base in Sudan around 1992, at the same time as Sudan had Iranian revolutionary guards training forces in the country. I believe Bin Laden was linked to the attempted assassination of Hosni Mubarak in Addis Ababa in 1995.)

Suleiman Abu Geith, Al-Qaeda's spokesman stated, at one point, that Al-Qaeda had "the right to kill 4 million Americans-2 million of them children-and to exile twice as many and wound and cripple hundreds of thousands." ${ }^{89}$ This intent displays the beliefs of modern jihadists that ("peaceful") Muslims who follow the Quran, live good lives, and believe in peace, family, and stability are to be declared "apostates" and should be condemned to Hell. A more pragmatic way of phra-

86 Joel C. Rosenberg, Inside the Revolution 8, 108-09 (Tyndale House Publishers, Inc., 2011).

87 Id. at 109; See also Al-Qaeda, Infoplease.com, http://www. infoplease.com/spot/al-qaeda-terrorism.html\#ixzz3DUUbDNkY (last visited Nov. 9, 2014).

88 Id.

89 Suleiman Abu Gheith, In the Shadow of Lances, MEMRI Special Dispatch Series-No. 388 (June 12, 2002), www.memri.org/ bin/articles.cgi? ID=sp38802\#_edn1; At another point, in response to the spread of al-Qaeda and violent jihad, Hassan al-Tarabi (the religious leader in Sudan) issued a fatwa that "Muslims who try to question or doubt the Islamic justifiability of [violent] jihad are hereby classified as 'hypocrites' who are no longer Muslims, and also 'apostates' from the religion of Islam; and they will be condemned permanently to the fire of Hell." This statement comes from the religious leader of Sudan--the country that housed the first and primary headquarters of al-Qaeda and recently sentenced a Christian mother to death for "apostasy," displaying the intended consequences of those whom the extremists consider "apostates." Meriam Ibrahim Meet Pope Francis after Escaping Sudan, NBC News (July 24, 2014), http://www.nbcnews.com/news/world/christianmeriam-ibrahim-meets-pope-francis-after-escaping-sudan-n163681. "Because [Miriam Ibrahim also] married a Christian, she was also sentenced to 100 lashes for apostasy," id. She was forced to take her 20-month-old son into her cell in a Sudanese prison for women and gave birth to her second child, Maya, while her legs were in shackles," id. 
sing their intent is global domination and control over all those whom they consider enemies of Allah. Al-Qaeda's primary alliances-which also included representatives of the government of Iran-maintained the common purpose of working together against their perceived enemies: the United States, Israel, and the nationals of both states. ${ }^{90}$ All U.S. nationals are targets for attack and mass casualties, and al-Qaeda has equipped — through funding or donating weapons — other extremist organizations who share the same intent to target an entire nationality. Today, al-Qaeda operates through various branches. Although some are of more imminent concern, one of the most dangerous is al-Qaeda in the Arabian Peninsula (AQAP) that mainly operates in Yemen and is purported to gain a stronger foothold since its main area rival—-the Shiite extremist Houthis group-has ousted the Yemeni government, leaving AQAP the only other governing "option" in the country. ${ }^{91}$ Further, the AQAP has been forging ties with the Islamic State (known more commonly as ISIS or ISIL) who has started training and recruiting in certain parts of Yemen. ${ }^{92}$

With the rise of ISIS, ironically, al-Qaeda has been quick to publically denounce the ISIS reign, but the underpinnings of their operation parallel those of ISIS seeking the annihilation of certain (national groups/ states) ethnic or religious groups. ${ }^{93}$ The global community is wise to ignore the attempts of al-Qaeda to separate themselves from ISIS as its self-proclaimed leader, Abu Bakr al-Baghdadi, rose from al-Qaeda's roots and only recently renamed the group the Islamic State of Iraq and Syria or "The Levant." mly established in al-Qaeda's theology. ${ }^{95}$ Many of the

90 Bin Laden: al Qaeda, PBS.org, http://www.pbs.org/wgbh/ pages/frontline/shows/binladen/who/alqaeda.html (last visited Aug. 31, 2014).

91 Tim Lister \& Paul Cruickshank, Yemen takeover threatens downward sectarian spiral; al Qaeda set to benefit, CNN (Jan. 21, 2015, updated 6:09 PM), http://www.cnn.com/2015/01/21/world/yemen-houthis-alqaeda/.

92 Id.

93 See Amir Abdallah, URGENT Video: ISIS releases Abu Bakr al-Baghdadi sermon in Mosul Grand Mosque, Iraqi Nat'l News (July 5, 2014), http://www.iraqinews.com/features/urgent-video-isisreleases-abu-bakr-al-baghdadi-sermon-mosul-grand-mosque/.

94 Colin Freeman, The Jihadist behind the takeover of Mosul and how America let him go, Telegraph.co.uk (June 11, 2014, 12:13 PM BST), http://www.telegraph.co.uk/news/worldnews/middleeast/ iraq/10891700/Iraq-crisis-the-jihadist-behind-the-takeover-of-Mosul-and-how-America-let-him-go.html.

95 Id.; See also Obama Iraq Combat Mission Ends by Aug. 31, Newsday (Feb. 27, 2009, 6:23 PM), http://www.news- terrorists that were freed from the American prison in Iraq-Abu Ghraib-were believed to have headed to Syria, where they proved decisive in turning al-Qaeda into the pre-eminent rebel movement, now known as ISIS, in the fight against Syrian President Bashar Assad. ${ }^{96}$ (more substance for this assertion) A Middle Eastern news source stated that, as of June 2014, ISIS was composed of several factions of extremist organizations including a "rebranded al-Qaeda," Sadam Hussein's Baath Party, and other Sufi Islamists. ${ }^{97}$

The group currently has about 7,000 fighters in northern Syria, including volunteers from Britain, Canada, the United States, and Europe. ${ }^{98}$ Baghdadi has called on Muslims around the world to flock to territories under his control to fight and build an Islamic state. ${ }^{99}$ In a recording posted online, Baghdadi declared he wants to turn the enclave his fighters have carved out in the heart of the Middle East into a "magnet for militants." (State what legitimate

day.com/news/nation/obama-iraq-combat-mission-ends-byaug-31-2010-1.895115. "The new al-Qaeda was rebranded in 2006 as the Islamic State in Iraq (ISI), id.; see also Joseph Klein, Leader of jihadist onslaught released, Frontpage Mag (June 16, 2014), http:// www.frontpagemag.com/2014/joseph-klein/leader-of-jihadist-onslaught-in-iraq-released-on-obamas-watch/.

96 The Jihadist behind the takeover of Mosul and how America let him go, see supra text accompanying note 147.

97 Obama's "up to 300 US military advisers" won't stop ISISSunni entrenchment in Iraq, DEBKAfile (June 19, 2014, 9:13 PM) (stating that the Islamists advancing on Baghdad are not one, but two armies: The Al Qaeda element has been joined by a hodgepodge of Sufi groups, Saddam Hussein's old Baath Party guard, and UStrained Sunni Awakening Council tribes).

98 Id.; Such has been ISIS's brutality in Syria that it has even alienated other al-Qaeda affiliated groups, and prompted numerous reports that it is at least partly a creation of President Assad's intelligence services, designed to discredit and disunite the rebel movement (id) That does not square with Baghdadi's known-hatred of Shia Muslims, the sect to which Mr. Assad belongs. Like most other al-Qaeda extremists, Baghdadi views Shias as apostates, be they those in Syria or those in the Shia-majority government in Baghdad, id.; see also Leila Fadel, U.S. hands over Tariq Aziz, other detainees to custody of Iraqi government, Wash. Post (July 14, 2010), http:// www.washingtonpost.com/wp-dyn/content/article/2010/07/14/ AR2010071401604.html.

99 Shelby Lin Erdman, Who is the ISIS? CNN (June 12, 2014), http://www.cnn.com/2014/06/12/world/meast/who-is-the-isis (stating that Baghdadi served four years in a U.S. prison camp in Iraq where he almost certainly developed a network of contacts and honed his ideology before being released in 2009).; See also Mohammed Tawfeeq \& Hamdi Alkhshali, Report: ISIS kills 270 at Syrian gas field, CNN (July 18, 2014), http://www.cnn.com/2014/07/18/ world/meast/iraq-isis-christians-threatened/.

100 Amir Abdallah, URGENT Video: ISIS releases Abu Bakr alBaghdadi sermon in Mosul Grand Mosque, Iraqi Nat'l News, supra note 21. 
is) The goal of the Islamic State is mass destruction and imperialization of legitimate states and individuals through violence and carnage. ${ }^{101}$ The threat of the ISIS has been underestimated by United States and now has spread beyond the boundaries of any manageable crisis. ${ }^{102}$ The Secretary General of the OIC, Iyad Ameen Madani, has condemned the actions of ISIS against innocent Muslim and Christian Iraqi citizens in Mosul and Nineveh including the forced deportation under the threat of execution; thus further tearing apart the social fabric of the Iraqi people. ${ }^{103}$ In the United States, the Federal Bureau of Investigation arrested a woman named Shannon Conley, who had a significant relationship and knowledge of ISIS. She was detained before leaving the country and her intelligence provided information useful in understanding the methods of ISIS recruiting. ${ }^{104}$ Conley stated she has no interest in doing humanitarian work and that violent Jihad was the only answer to correct the wrongs against the Muslim world." 105 This shows that extremist organizations also feed on the sympathetic sentiments of young westerners - to protect the plight of Muslims against injustice even though most Muslims have no desire to wage violence or commit murder. ${ }^{106}$ According to Conley, it was acceptable to attack or kill westerners when engaged in "defensive Jihad" since ISIS operates under its own truth that all targets of violence and murder are acceptable if they abide by "man-made laws that are not grounded in [Allah's] law."107 This intent justifies the murder of almost any legally

101 Facing fines or death, Christians flee Mosul, CNN (July 19, 2014), http://www.cnn.com/2014/07/19/world/meast/christiansflee-mosul-iraq/.

102 See e.g. ISIS magazine claims group has enslaved and sold Yazidi women and kids, Fox News (Oct. 13, 2014), http://www. foxnews.com/world/2014/10/13/isis-magazine-claims-group-hasenslaved-and-sold-yazidi-women-and-kids/.

103 OIC Condemns ISIS threats and forced displacement of Christians in Iraq, Org. of Islamic Cooperation (July 17, 2014), http://www.oic-oci.org/oicv2/topic/?t_id=9241\&t_ ref $=3695 \& l a n=$ en. Madani added that this forced displacement is a crime that cannot be tolerated; and that the practices of ISIS have nothing to do with Islam and its principles that call for justice, kindness, fairness, freedom of faith and coexistence, id.

104 Michael Martinez, Ana Cabrera \& Sara Weisfeldt, Colorado woman gets 4 years for wanting to join ISIS, CNN (Jan. 24, 2015, updated 9:29 AM), http://www.cnn.com/2015/01/23/us/colorado-woman-isis-sentencing/index.html.

105 FBI Criminal Complain Shannon Conley, at 5 (7).

106 FBI Criminal Complain Shannon Conley, at 6 (8).

107 FBI Criminal Complain Shannon Conley,. at 4. innocent individual they deem an apostate to their religious doctrine.

Next, the media has generally ignored the lesser-funded extremist organizations that fully support ISIS's rise, such as Boko Haram. ${ }^{108}$ Operating primarily in Nigeria, Boko Haram rose to infamy with the kidnapping and exploitation of nearly 300 young school-girls. ${ }^{109}$ While the world watches IS, Boko Haram declared an Islamic Caliphate in Nigeria amidst a government that has remained powerless to stop this extremist group. ${ }^{110}$ Nigerian government troops have fled while Boko Haram implements its harsh version of Islamic law on approximately 3 million civilians, which includes ongoing beheadings and forced induction of children into its own military forces, in direct violation of Geneva Conventions and international legal principles. ${ }^{111}$ The group's self-proclaimed leader, Abubakar Shakau, addressed the community in Gwoza - a city that Boko Haram conquered - claiming to be responsible for over 1,000 deaths of the "mostly Christian community" in only one day's time. ${ }^{112}$ Shakau is one of the prominent Islamic jihadi leaders that welcomed the rise of ISIS and has emulated al-Baghdadi's brutal reign. ${ }^{13}$ Although the Cairo Declaration in Islam contends that "taking hostages under any form or for any purpose is expres-

108 See Elias Meseret, Africa agrees to send 7,500 troops to fight Boko Haram, Assoc. Press (Jan. 31, 2015 2:24 PM EST), http:/ / bigstory.ap.org/article/8199f64eda1b475b873164943ec84e6d/africaagrees-send-7500-troops-fight-boko-haram.

109 Robert Windrem, While the World Watches ISIS, Boko Haram declares its own Caliphate ion Nigeria, NBC News (Sept. 15, 2014, 4:39 AM), http://www.nbcnews.com/storyline/missingnigeria-schoolgirls/while-world-watches-isis-boko-haram-declaresits-own-caliphate-n202556.

110 Robert Windrem, While the World Watches ISIS, Boko Haram declares its own Caliphate ion Nigeria, NBC News (Sept. 15, 2014, 4:39 AM), http://www.nbcnews.com/storyline/missingnigeria-schoolgirls/while-world-watches-isis-boko-haram-declaresits-own-caliphate-n202556.

111 Robert Windrem, While the World Watches ISIS, Boko Haram declares its own Caliphate ion Nigeria, NBC News (Sept. 15, 2014, 4:39 AM), http://www.nbcnews.com/storyline/missingnigeria-schoolgirls/while-world-watches-isis-boko-haram-declaresits-own-caliphate-n202556

112 Robert Windrem, While the World Watches ISIS, Boko Haram declares its own Caliphate ion Nigeria, NBC News (Sept. 15, 2014, 4:39 AM), http://www.nbcnews.com/storyline/missingnigeria-schoolgirls/while-world-watches-isis-boko-haram-declaresits-own-caliphate-n202556

113 Robert Windrem, While the World Watches ISIS, Boko Haram declares its own Caliphate ion Nigeria, NBC News (Sept. 15, 2014, 4:39 AM), http://www.nbcnews.com/storyline/missingnigeria-schoolgirls/while-world-watches-isis-boko-haram-declaresits-own-caliphate-n202556 
sly forbidden," 114 Boko Haram has gone widely unpunished. ${ }^{115}$

The desire of Boko Haram to join and celebrate the work of ISIS highlights the necessity for the global community to codify transnational terrorism in order to prevent a transnational genocidal alliance of extremist organizations intent on annihilating those they deem to be apostates or evil..$^{116}$ While most international conventions seeks to hold "state" actors responsible for "state-sponsored" criminal acts, the chart displayed shows that militant groups which align with no legitimate state still commit mass atrocities that the global community denounces through international conventions. These extremist organizations must be held accountable to the same international standards in a court of universal jurisdiction. ${ }^{117}$ While such organizations are not parties to the treaties or conventions, this should not preclude them from being tried as international criminals. Innocent lives and civilian well-being are not as important to these extremist organizations as the end goal of building the Islamic Caliphate (or global government) by "cleansing" humanity of all "apostate" Muslims, Jews, Christians, and even entire nations (such as Israel or the United States). ${ }^{118}$

The gravest danger this world faces is modern extremism perpetuated by radical Islamists. ${ }^{119}$ These orga-

114 Boko Haram's treatment of Captured Nigerian girls detailed in new report, Fox News (Oct. 27, 2014), http://www.foxnews. com/world/2014/10/27/boko-haram-treatment-captured-nigerian-girls-detailed-in-new-report/; see also Cairo Declaration on $\mathrm{Hu}$ man Rights in Islam, art. 21 "(a) Human beings are born free, and no one has the right to enslave, humiliate, oppress or exploit them, and there can be no subjugation but to Allah the Almighty."

115 Windrem, supra note Erreur : source de la référence non trouvée.

116 Goldhagen, supra note Erreur : source de la référence non trouvée, at 293-96.

117 In the next section, the crimes that militant organizations carry out on a systematic basis will be highlighted. See United States Department of State: National Consortium for the Study of Terrorism and Responses to Terrorism: Annex of Statistical Information, http://www.state.gov/j/ct/rls/crt/2013/224831.htm (last visited Feb. 16, 2015).

118 Look into this: Often it seems innocent lives and civilian wellbeing are not as important as State goals of maintaining security and order and repressing dissent. E.g. South Africa from 1948-1994 or even US maintaining security by baiting previously innocent civilians into terrorist plots such as Portland Christmas bombing plot a few years ago created by FBI.

119 But cf. Goldhagen, supra note Erreur : source de la référence non trouvée, at 97-99 (which displays that unlike modern extremist groups who know the human nature of their victims, Hitler's forces and Hutu militants would demonize their enemies to garner nizations are well aware of the human nature of their targets: whether they be Muslims, Jews, Christians, or others, and yet they still perpetuate the mass murder without needing to dehumanize their victims for justification. According the Pew Research Center there are approximately 2.2 billion Christians in the world; 1.6 billion Muslims ( $99 \%$ of whom would be considered "moderate" and therefore apostate Muslims to the extremist Salafists or other radical Islamist factions); and 13.9 million Jews. ${ }^{120}$ If the promulgated goals of modern-day extremist organizations are evaluated in realistic data, this means that in order to "cleanse" this world bringing about the final Caliphate, radical groups are willing and poised to kill (according to their specific Charters) any or all of the following populations: (1) 1.58 billion Muslims that don't believe in violent jihad and extremism; (2) 320 million people living in the United States (the "Great Satan") ${ }^{121}$; (3) 8.3 million people living in Israel ${ }^{122}$; (4) 2,213,900,000 Christians and Jews; and worst of all (5) 3,813,900,000 "apostate" Muslims, Christians, and Jews in total. If ever there was a number that indicated the intent to commit genocide, nearly 4 billion human lives (over half of the world's current population ${ }^{123}$ ) is it.

\subsection{Unresolved Issues; Gaps in the System; Pro- posed Changes.}

Rather than learning from the patterns of historical precedent to prevent brutal atrocities, the global community appears to prioritize sovereignty over protecting the defenseless. ${ }^{124}$ Right now the biggest gap in the global legal system revolves around the interplay between maintaining state sovereignty while attempting to quell a threat that knows no boundaries. Upholding state sovereignty and preventing bloodshed do not have to be mutually exclusive. The problem with maintaining state

support).

120 Pew-Templeton Global Research Futures Project of 2012, http://www.globalreligiousfutures.org/questions (last visited Feb 1, 2015).

121 U.S. and World Population Clock, http://www.census.gov/ popclock/ (last visited Feb. 1, 2015).

122 On eve of 2015, Israel's population hits 8.3 million, jpost Jan. 16, 2015)http://www.jpost.com/Israel-News/Culture/Oneve-of-2015-Israels-population-hits-83-million-386178.

123 U.S. and World Population Clock, supra note 185.

124 At least, Sovereignty seems more important than preventing murder until after innocent blood has been shed as was evidenced in the Rwanda genocide and resolutions claiming to uphold sovereignty. 
sovereignty in spite of the mass threat to the powerless civilians is that it leaves those who could rescue the innocent paralyzed beyond the tipping point where too many lives have been taken to ignore the situation any longer. ${ }^{125}$ The truth is that those who do not learn from the past are doomed to repeat it. Now, this does not mean that sovereignty is not to be recognized and protected. It means that upholding sovereignty over innocent bloodshed can no longer be a foundational or practical aspect of a global community that seeks "international peace and security." ${ }^{126}$ The main threat to international peace, security, and stability today-as stated above - is transnational terrorism; which is modern day genocide to an extent this world has yet to witness.

Those who commit acts of transnational terrorism must be put on explicit notice that perpetual violence carried out by non-state aggressors will be prosecuted under international law by legitimate courts who uphold the rule of law. ${ }^{127}$ If the legitimate state governments do not accept that modern extremism is the equivalent of genocide, then these violent organizations will defeat legitimate judicial systems by committing atrocities with impunity. To understand the roots of an organization, one must look objectively at its promulgated goals whether they are based in a religion or a secular ideology. ${ }^{128}$ This is a critical first step for lawmakers and officials in attempting to prevent further mass murder by transnational terrorists. ${ }^{129}$ The proliferation of weapons of mass destruction and nuclear materials make any illegitimate group-no matter how small—a real threat to civilians. ${ }^{130}$ These groups will continue to act with impunity by committing terrorist acts under a generic term which remains universally undefined. The

125 See Goldhagen, supra note Erreur : source de la référence non trouvée, at 11, 26-27.

126 UN Charter preamble; see also U.N. Charter art. 2, para. 4.

127 See Protocol Additional to the Geneva Conventions of 12 August 1949 relating to the Protection of Victims of Non-International Armed Conflicts, June 8, 1977 (discussing how fears of state sovereignty infringement has prevented states from enacted procedures to implement Geneva conventions regarding the protection of civilians in a conflict that is not of an international character. This shows that state sovereignty fears often limit prevention of atrocities against civilians on various levels, id.)

128 Goldhagen, supra note Erreur : source de la référence non trouvée, at 25-27.

129 Id. at 588 (discussing the importance of preventative measure to reduce eliminationist and mass murder campaigns).

130 Id. at 511-12 (stating how the proliferation of nuclear materials to non-state actors makes their existence and intended goals a much greater, imminent threat to international stability, peace, and security of the global population). extremists' system of illegitimate power struggles seeks to overpower the legitimate governmental structures of the "state" system which could undoubtedly result in the tearing down of the legitimate entities who are paralyzed to prosecute transnational crimes.

Today the word "terrorism" is used to refer to any form of violence that cannot be categorized, no matter how egregious the atrocities and no matter what the intent of the perpetrators has become. ${ }^{131}$ The current test for determining terrorism is more of an "impact test." One asks what the impact of the violent act had on the civilians. However, to prevent terrorist acts, the universal definition should adopt an "intent test."132133 "Islamic terrorists carry out acts of genocidal intent and war against bumanity with impunity as non-state actors because most international conventions criminalizing their actions mainly mandate relationships between states and state officials rather than non-state organizations". ${ }^{134}$ This failure to objectively look at the perpetrator's intent leaves those with the power to prosecute and define the atrocities unable to do so due to the progressive forces that believe such objective methods offends a religious doctrine. ${ }^{135}$ In an excellent article by Asra Nomani, a Muslim American, this paralysis of refusing to align any form of political Islam with modern terrorist acts is a real issue, and one that must be addressed in the quest to define it universally. ${ }^{136}$

131 See Thomas Weigend, The Universal Terrorist, supra note Erreur : source de la référence non trouvée, at 1.

132 But cf. Goldhagen, supra note Erreur : source de la référence non trouvée, at 510 (purporting to classify transnational terrorists as Political Islamists given the misleading identification that such groups solely intend political power, rather than asserting their global domination aspirations).

133 The preceding chart displays only a few of the most notorious "extremist" organizations and offers proof that such organizations are inciting, intending, and carrying out some of the most condemned acts of violence against the global civilians and political communities. Without properly defining the crimes of such actors, the international community has and will be paralyzed to stop the atrocities being committed. The evidence of refusal to adopt such a definition is displayed by the rise of ISIS throughout the Middle East and the number of civilians who have been murdered or retreated into hiding as the world waits by the television for the next move of such atrocious individuals.

134 Thomas L. Friedman, Say it like it is, N.Y. Times (Jan. 20, 2015), http://www.nytimes.com/2015/01/21/opinion/thomasfriedman-say-it-like-it-is.html?_r=0.

135 See e.g. ASEAN Convention on Counter-Terrorism, supra note Erreur : source de la référence non trouvée, preamble, ("Reaffirming that terrorism cannot and should not be associated with any religion, nationality, civilisation or ethnic group.').

136 Asra Q. Nomani, Meet the honor brigade, an organized campaign to silence debate on Islam, Wash. Post (Jan. 16, 2015), http://www.washingtonpost.com/opinions/meet-the- 
It is the largest gap in the current system and the reason that terrorism has yet to be defined and proactively suppressed on a universal level. Nomani writes that,

[t]his is largely because of the rising power and influence of the 'ghairat brigade,' an honor corps that tries to silence debate on extremist ideology in order to protect the image of Islam. It meets even sound critiques with hideous, disproportionate responses. The campaign began, at least in its modern form, 10 years ago in Mecca, Saudi Arabia, when the Organization of Islamic Cooperation - a mini-United Nations comprising the world's 56 countries with large Muslim populations, plus the Palestinian Authority — tasked thenSecretary General Ekmeleddin Ihsanoglu with combating Islamophobia and projecting the "true values of Islam." During the past decade, a loose honor brigade has sprung up, in part funded and supported by the OIC through annual conferences, reports and communiques. ${ }^{137}$

As stated, this is not an article to combat a religion. On the contrary, it has become common knowledge that most religious Muslims do not follow or prescribe, at all, to the philosophy of violence in the name of Allah. ${ }^{138}$ However, the factual reality is that every terrorist group mentioned above as well as those operating in many major cities and threatening the free world all operate under a form of Islam. ${ }^{139}$ In order to define "terrorism" and prosecute the perpetrators, it is necessary to study, understand, and proclaim the mens rea of the offenders without fear of public scrutiny. The "fear" that results from terrorist attacks is not from the "terrorists" themselves, but from the progressive ideologists that use incidents of premediated murder as a platform to condemn all who dare to study the perpetrators by their stated goals. ${ }^{140}$ In order to comprehend the full extent of the extremist threat, it is important to understand the mode of operation and methodology behind the "typical terrorist" actions. Preventative mea-

honor-brigade-an-organized-campaign-to-silence-critics-ofislam/2015/01/16/0b002e5a-9aaf-11e4-a7ee-526210d665b4_story. html (emphasis added).

137 Id.

138 Dean Obeidallah, Are All Terrorists Muslims? It's Not Even Close, The Daily Beast (Jan. 14, 2015), http://www.thedailybeast. com/articles/2015/01/14/are-all-terrorists-muslims-it-s-not-evenclose.html.

139 Quran, Sura 9:73, ("Strive hard against the unbelievers and the hypocrites and be unyielding to them; and their abode is hell, and evil is their destination.").

140 See 'Guns don't kill people, Americans kill people,' Fox News (Nov. 13, 2015), http://www.foxnews.com/entertainment/2013/11/06/michael-moore-guns-dont-kill-people-americans-kill-people/ sures should incorporate a substantial knowledge of the individuals' intent who currently engage in transnational acts of terror.

The UN Office of the Special Adviser on The Prevention of Genocide has stated that " $\mathrm{t}] \mathrm{o}$ prevent genocide and genocidal conflicts, it is critically important to understand their root causes." ${ }^{141}$ Whether the root causes lie within a secular manifesto (such as Hitler's "Mien Kampf”) or a religious doctrine (such as certain sayings of Muhammad found in particular Hadith literature) it is important to understand the root causes of the violence and where it stems from, so that further bloodshed can be foreseen and prevented without fear or denial of a religious tie that the organizations, themselves, profess to follow. ${ }^{142}$ Any uniform attempt extremism should include the creation of tribunals that would have jurisdiction over crimes of genocide carried out by extremists. ${ }^{143}$ "Tribunals are [generally] set up outside the situs of [a] conflict], both because of security concerns and because [] an outside court, staffed largely by outsiders, would have the advantages of impartiality, credibility, and expertise that would be lacking in compromised or decimated national legal systems." ${ }^{144}$ This tribunal will have specific prosecutorial duties and universal jurisdiction so that affected states may appeal for aid, protection, and prosecution. ${ }^{145}$

141 Preventing Genocide: Office of The Special Adviser on The Prevention of Genocide, un.org, http://un.org/en/preventgenocide/adviser/genocide_prevention.shtml (last visited Feb. 9, 2015); See also Geneva Conventions, General introduction to the commentary on Additional Protocol II, which discusses that most noninternational armed conflicts tend to be organized groups operating against a government in a "single state" which limits the applicability of the Geneva Convention principles protecting civilians only to domestic "rebel" groups rather than extremist organizations.

142 See e.g. O’Connell, supra note Erreur : source de la référence non trouvée, at 520 (discussing the difficulties in defining and prosecuting terrorism).

143 For an example of a current international convention that illustrates this approach, see The Convention on Transnational Organized Crime, G.A. Res. 55/25, A/RES/55/25 (2001).

144 O'Connell, supra note Erreur : source de la référence non trouvée, at 504 .

145 It should not be set up in the west so detached from the origination of modern extremism, but would be better suited to operate in the following states: Jordan, The United Arab Emirates, Egypt, Kuwait, India, South Africa, or Turkey. Due to the violent nature of many organizations against those who attempt to prevent it, the tribunal should be in an undisclosed location. 


\section{Conclusion}

At the UN Millennium Follow-up World Summit of $2005,{ }^{146}$ Heads of State unanimously affirmed that "each individual State has the responsibility to protect its populations from genocide, war crimes, ethnic cleansing and crimes against humanity." 147 They agreed that, when appropriate, the international community should assist states in exercising that responsibility by building their protection capacities before crises and conflict break out. ${ }^{148}$ However, when a state is "manifestly failing" to protect its population from the four specified crimes, then the international community must be prepared to take collective action, through the Security Council and in accordance with the Charter of the UN. ${ }^{149}$ When the United States declared a "war on terror" the global community was given a "false sense of security" which has continued through the Obama Administration. ${ }^{150}$

A legitimate nation-state attempting to dominate the world as Hitler's Germany sought to during the 1930s, is not the main genocidal threat to international security today now that nuclear weapons have advanced to a point that provides terrorist savages with the capabilities to commit mass murder with a single strike. ${ }^{151}$ The current definitions of terrorism are, therefore, not sufficient since the violence and beheadings are not perpetrated mainly to spread fear nor are they carried out to gain political momentum. Many modern terrorist

146 The 2005 World Summit, 14-16 September 2005, was a follow-up summit meeting to the United Nations' 2000 Millennium Summit

147 Mission Statement, UN: Office of the Special Adviser on the Prevention of Genocide, http://www.un.org/en/preventgenocide/ adviser/ (last visited Feb. 16, 2015).

148 See e.g. William J. Aceves, Liberalism and International Legal Scholarship: The Pinochet Case and the Move Toward a Universal System of Transnational Law Litigation, 41 Harv. Int'l L.J. 129 (discussing why there needs to be international consensus for prosecuting crimes of genocide and humanity).

149 Mission Statement, UN: Office of the Special Adviser on the Prevention of Genocide, supra note 210.

150 See Polish Foreign Minister admits US alliance has become harmful, Assoc. Press (June 22, 2014), http:/ /www.bing.com/r/1F/ CsAtd? $\mathrm{a}=1 \& \mathrm{~m}=\mathrm{EN}-\mathrm{US}$ (stating that recordings obtained from a private conversation displayed that Poland's strong alliance with the U.S. was worthless and "harmful because it creates a false sense of security" with a weakened leadership).

151 See Hoffman, supra note Erreur : source de la référence non trouvée, at 204-06 (showing that many extremists transnational organizations operate with genocidal intent and not an intent that seeks mainly to "incite fear for political purposes.") organizations possess the intent to exterminate, eliminate, and control. ${ }^{152}$ The world may see fear spread as a consequence of the growth of extremism, but these international criminal groups certainly intend not to merely incite fear (as the legal community currently sees "terrorist acts"), but rather, such organized violent groups intent to toss out the notions of civilization as we know it, and instill a form of global governance that oppresses and terrorizes those it subjects to its control and domination. ${ }^{153}$ Underestimating the threat of such genocidal campaigns, allowing them to remain unchallenged, enables them to achieve unprecedented power, unchallenged and unprosecuted in their quest to eliminate and exterminate mass numbers of innocent people. ${ }^{154}$

\section{Appendix A - The Proposed Redrafting of the Crime of Genocide to Incorporate Acts OF TERROR.}

I. The following shall be punishable as Genocide or Acts of Eliminationism:

a) intent to destroy, in whole or in part, a national, ethnical, racial or religious group, in the following manner: (1) Killing members of the group; (2) Causing serious bodily or mental harm to members of the group; (3) Deliberately inflicting on the group conditions of life calculated to bring about its physical destruction in whole or in part; (4) Imposing measures intended to prevent births within the group. ${ }^{155}$

b) Subjugation to violent and forced religious indoctrination

c) Purpose of global domination or mass extinction of any protected class of civilians including but not limited to: (a) Any national group; (b) Ethnic group; (c) Racial group; (d) Religious group; or (e) Gender group.

152 http://www.huffingtonpost.com/jim-wallis/5-things-toknow-about-is_b_6768668.html, Goldhagen, supra note Erreur : source de la référence non trouvée, at 498-99; Levitt, supra note Erreur: source de la référence non trouvée.

153 See Young, supra note Erreur : source de la référence non trouvée.

154 See e.g. Thomas L. Friedman, Say it like it is, supra note 197. 155 Rome Statute of the International Criminal Court, supra note Erreur : source de la référence non trouvée, art. 6. 
d) Recognizing that International Humanitarian laws protecting civilians must apply to transnational and unilateral violence carried out by non-state actors. Therefore, the global community agrees to amend the Geneva Conventions Protocol to include non-state extremism in its list of violators in order to subject them to the same Geneva Provisions.

e) Accepting the campaigns of self-determination. Do not Label Secession Movements As Terrorism.

II. The Foregoing acts shall be prosecuted as genocide and eliminationism campaigns in an individual capacity without regard to "state" status, non-state affiliation, political affiliation, or any other internationally recognized identifying mark.

- RehabilitationProgramsIn limited circumstances, member states and tribunal representatives shall agree to promote rehabilitative programs, where appropriate, to provide social reintegration of persons involved in the commission of terrorism if such individual was subject to duress, coercion, lack of age of consent or any other situation which the tribunal deems appropriate to allow for rehabilitation with the sole purpose of preventing the perpetration of terrorist acts in the future.

\section{APPENDiX B - Violations Of INTERNATIONAL Authorities by Terrorist Groups}

\begin{tabular}{|c|c|c|c|c|c|}
\hline Covenant & $\underline{\text { Hamas }}$ & $\underline{\text { ISIS }}$ & $\begin{array}{c}\underline{\mathrm{Al}-} \\
\text { Qaeda }\end{array}$ & $\frac{\text { Boko }}{\text { Haram }}$ & $\frac{\text { Hezbol- }}{\underline{\text { lah }}}$ \\
\hline $\begin{array}{l}\text { Genocide Conven- } \\
\text { tion arts. II (a) \& III } \\
\text { (b) \& (d), "genocide } \\
\text { means any of the } \\
\text { following acts com- } \\
\text { mitted with intent to } \\
\text { destroy, in whole or } \\
\text { in part, a national, } \\
\text { ethnical, racial or } \\
\text { religious group . . } \\
\text { [including] [k]illing } \\
\text { members of the } \\
\text { group; Conspiracy } \\
\text { to commit genocide; } \\
\text { Direct and public } \\
\text { incitement to com- } \\
\text { mit genocide." }\end{array}$ & X1 & $\mathbf{X}$ & $\mathbf{X} 2$ & X3 & X4 \\
\hline
\end{tabular}

(Human Rights Treaties) ICCPR art. 9(1) "[E]veryone has the right to freedom of thought, conscience and religion; this right includes freedom to change his religion or belief and freedom ... to manifest his religion or belief, in worship, teaching, practice, or observance." ICESCR art. 12

(1) \& (2) (d) States

Parties to the present Covenant recognize the right of everyone to the enjoyment of the highest attainable standard of physical and mental health. ... [and shall take] steps ... to achieve the full realization of this right [including] (d) The creation of conditions which would assure to all medical service and medical attention in the event of sickness.

Geneva Convention Common Article 3 (1) 1231(a)-(d) \& Additional Protocol II: “(1) Persons taking no active part in the hostilities. . . [shall] be treated humanely.

To this end, the following acts are and shall remain prohibited ... violence to life and person, in particular murder of all kinds, mutilation, cruel treatment and torture; taking of hostages; the passing of sentences and the carrying out of executions without previous judgment pronounced by a regularly constituted court, affording all the judicial guarantees which are recognized as indispensable by civilized peoples."

(Footnotes)

1 See Caroline Alexander, Hamas Releases End of Hope Video to 
Mark Israel Independence, Bloomberg News (May 6, 2014, 3:53 PM), http://www.bloomberg.com/news/2014-05-06/hamas-releasesend-of-hope-video-to-mark-israeli-independence.html (showing how Hamas released a video displaying its intent to commit mass genocide and displacement and take over Israeli territory).

2 See 9/11 Attacks, History Channel, http://www.history.com/ topics/9-11-attacks (last visited Feb. 16, 2015) (displaying the attacks committed by individuals acting in direct violation of the Genocide Convention and Geneva).

3 See Elias Meseret, Africa agrees to send 7,500 troops to fight Boko Haram, AP (Jan. 31, 2015 2:24 PM EST), http://bigstory. ap.org/article/8199f64eda1b475b873164943ec84e6d/africa-agreessend-7500-troops-fight-boko-haram.

4 See e.g. Deborah Passner, Hassan Nasrallah: In his own words, Frontpage Mag (July 26, 2006), http://archive.frontpagemag.com/ Printable.aspx?ArtId=3227.

5 See Simon Plosker, Foreign Journalists Acknowledge Hamas Human Shield Tactics, supra note Erreur : source de la référence non trouvée.

6 Facing fines or death, Christians flee Mosul, supra note Erreur : source de la référence non trouvée.
7 Bin Laden: al Qaeda, PBS.org, http://www.pbs.org/wgbh/ pages/frontline/shows/binladen/who/alqaeda.html (last visited Aug. 31, 2014).

8 Robert Windrem, While the World Watches ISIS, Boko Haram declares its own Caliphate ion Nigeria, NBC News (Sept. 15, 2014, 4:39 AM), http://www.nbcnews.com/storyline/missing-nigeriaschoolgirls/while-world-watches-isis-boko-haram-declares-its-owncaliphate-n202556

9 See e.g. B.B.C. Monitoring: Al-Manar, Hassan Nasrallah, supra note 116.

10 See Marc Schulman, Tel Aviv Diary: Public Executions in Gaza Reveal the True Nature of Hamas, Newsweek (Aug. 22, 2014, 12:46 PM), http://www.newsweek.com/tel-aviv-diary-public-executionsgaza-reveal-true-nature-hamas-266271.

11 See Boko Haram's treatment of Captured Nigerian girls detailed in new report, supra note Erreur : source de la référence non trouvée.

12 See Adam Goldman \& Ellen Nakashima, CIA and Mossad killed senior Hezbollah figure in car bombing, supra note Erreur : source de la référence non trouvée. 


\section{As execuções seletivas e a responsabilização de agentes terroristas*}

\section{Targeted killings and the liability of terrorist actors}

Alexandre Guerreiro**

\section{Resumo}

Com o presente artigo é proposta a análise à crescente prática, no âmbito da luta contra o terrorismo, de execuções seletivas por alguns Estados, no que diz respeito à sua legalidade e licitude. Para este efeito, é feito um enquadramento histórico-político genérico da evolução da adoção de condutas que visam a concretização de execuções seletivas e outro de âmbito jurídico alusivo às situações em que um Ser Humano pode ser privado da vida. Deste modo, e com base na análise das normas internacionais em vigor, da jurisprudência mais relevante e também da doutrina que ou se pronuncia sobre o assunto ou contribui para a presente investigação, são dissecadas as duas atuais teses de conflitos armados e o terceiro modelo que tem vindo a ser reivindicado por um número residual de Estados como forma de legitimarem um quadro de supressão de todos os direitos básicos de pessoas de quem se suspeita estarem envolvidas em atos de terrorismo (concretizados ou a concretizar). Assim, é desenvolvida uma análise crítica no decorrer do artigo que concluirá que as execuções seletivas em contexto de luta contra o terrorismo constituem práticas ilícitas e violam o Direito Internacional propondo-se, como alternativa, que os terroristas sejam integrados no conceito de civil, qualidade esta que perdem se estiverem preenchidos cinco requisitos.

Palavras-chaves: Execuções seletivas, terrorismo, conflitos armados, terceira via.

\section{Abstract}

(With the present article it is suggested an assessment to legality and lawfulness of the growing international practice of targeted killings, most of them justified within the context of the fight against terrorism by different countries. To this end, it is made a general historical and political framework regarding the evolution of the adoption of actions concerning targeted killings as well as the legal context according to which a person can be deprived of his/her life. Thereby, and considering the standards laid down in international law rules currently in force and also the most relevant jurisprudence and doctrine that deal with the present subject or that, at some extent, provide important means to support the present research, the two current official models of armed conflicts are dissected on this ar- 
ticle. The same goes to the third model which is supported by a minimum number of States and takes into account the elimination of all basic rights to persons suspect of being involved in terrorist acts (committed or to be committed).Thus, a critical analysis is set along the present article which will come to the conclusion that targeted killings are unlawful and, consequently, contravene international law. Therefore, an alternative is suggested according to which terrorists shall be considered civilians unless five requirements are met.

Keywords: Targeted killings, terrorism, armed conflicts.

\section{INTRODUÇÃO}

A tendência de emergência de novas, diversificadas e sofisticadas ameaças transversais contra a segurança dos Estados perante a crescente evolução do fenômeno de globalização concorre para o aumento do alerta e da adoção de mecanismos que, mais do que atenuar os danos causados pelos agentes criminosos, visam aumentar as possibilidades de evitar o sucesso de qualquer tentativa de realização de atos passíveis de comprometer o bem-estar da sociedade.

Apesar de não se tratar de um conceito recente ${ }^{1}$, dúvidas subsistem quanto ao significado preciso da palavra terrorismo. A multiplicidade de ocasiões em que esse termo é aplicado contribui mais para o adensamento das dúvidas em torno dos atores cujo modo de atuação merece integrar o conceito de terrorismo do que para a delimitação e compreensão do flagelo $^{2}$. Não

1 Com efeito, a palavra terrorismo deriva do verbo latino terrere, sendo invocado, pelo menos, desde o século XIV. Nesse sentido, cfr. SCHMID, Alex P. The definition of terrorism. In: SCHMID, Alex P. (Ed.). The routledge handbook of terrorism research. New York: Routledge, 2011. p. 39-98 e 41-42.

2 Alguns autores alertam para a impossibilidade de consenso da comunidade internacional quanto à definição de "terrorismo", alegando que são utilizados, em simultâneo, centenas de significados para esse conceito. Para uma análise profunda à evolução do conceito "terrorismo" e à forma como se distingue de outros fenômenos, cfr. NOGUEIRA, Patrícia. O terrorismo transnacional e suas implicações no cenário internacional. Universitas: Relações Internacionais, Brasília, v. 2, n. 2, p. 221-244, jul./dez. 2004; SCHMID, Alex P. The definition of terrorism. In: SCHMID, Alex P. (Ed.). The routledge handbook of terrorism research. New York: Routledge, 2011. p. 39-98; NASCIMENTO, Álisson Reis. Violência e terrorismo. Universitas: Relações Internacionais, Brasília, v. 10, n. 1, p. 1-14, jan./jun. 2012; GANOR, Boaz. Introduction to multidimensional warfare: defining terrorism, defining war. In: GANOR, Boaz. (Ed.). Global alert: the obstante essa realidade, a utilização do termo a situações em que pessoas eram executadas por atores que não as autoridades oficiais de um país, devido a, por exemplo, questões políticas, surgiu, pela primeira vez, na Rússia, no século XIX, marcando o que David C. Rapoport identifica como sendo a "primeira de quatro vagas do terrorismo moderno"3.

Num tempo em que o mundo sente as consequências da "quarta vaga" do terrorismo moderno (de matriz religiosa $)^{4}$, o flagelo tem vindo a assumir uma importância extraordinária face a outras tipologias de crimes, uma vez que, um pouco por todo o mundo, vão-se sucedendo os atos com o objetivo de atingir as bases em que as sociedades encontram estabilidade, mais concretamente por via da tensão social e da instabilidade política em Estados que os agentes agressores definem como alvos. Para esse efeito, importa não esquecer que o terrorismo pode ser inspirado por diversas motivações e assumir diversas formas, não se tratando, de modo algum, de um fenômeno estanque ${ }^{5}$.

Nesse contexto, é cada vez mais recorrente ouvir-se falar em targeted killings, ou execuções seletivas, tratando-se de uma expressão cuja aplicação não se resume ao terrorismo, manifestando-se, igualmente, em variadas situações, tais como operações policiais com recursos a franco-atiradores contra um ou mais alvos civis que levam a cabo assaltos e utilizam as vítimas como escudos humanos e ainda em ações militares que visam a eliminação de agentes associados a esse conceito tão

rationality of modern islamist terrorism and the challenge to the liberal democratic world. New York: Columbia University, 2015. p. 4-23. Paralelamente, outros acrescentam que o conceito de terrorismo tornou-se difuso durante o período que David C. Rapoport denomina de "segunda vaga". Cfr. WEINBERG, Leonard et al. The challenges of conceptualizing terrorism. Terrorism and Political Violence, v. 16. n. 4, p. 777-794, 2004. p. 778.

3 A identificação, a caracterização e a análise às quatro vagas pode ser consultada em RAPOPORT, David C. The four waves of modern terrorism. In: CRONIN, Audrey Kurth; LUDES, James M. (Ed.). Attacking terrorism: elements of a grand strategy. Washington: Georgetown University, 2004. p. 46-73.

4 Nesse sentido, cfr. RAPOPORT, David C. The four waves of modern terrorism. In: CRONIN, Audrey Kurth; LUDES, James M. (Ed.). Attacking terrorism: elements of a grand strategy. Washington: Georgetown University, 2004. p. 61-68.

5 Esse assunto pode ser mais aprofundado em GANOR, Boaz. GANOR, Boaz. Terrorist organisation typologies and the probability of a boomerang effect. Studies in Conflict and Terrorism, v. 31, n. 4, p. 269-283, 2008; MARSDEN, Sarah V.; SCHMID, Alex P. Typologies of terrorism and political violence. In: SCHMID, Alex P. (Ed.). The routledge handbook of terrorism research. New York: Routledge, 2011. p. $158-200$. 
vago e indeterminado como é o terrorismo (nacional ou transnacional) ou até mesmo líderes políticos e militares de países terceiros.

Assim, o presente artigo propõe uma reflexão sobre o instituto das execuções seletivas, mais concretamente no que diz respeito à sua definição e evolução histórica, à legalidade e à licitude dessa prática. Acresce, ainda, uma análise crítica à forma como o terrorismo é relacionado com o direito da guerra, recorrendo-se, para esse efeito, à análise a teses jurisprudenciais e doutrinárias que permitirão concluir que as execuções seletivas no âmbito do combate ao terrorismo constitui uma prática ilícita que viola o direito internacional.

\section{Delimitação do Conceito e eVolução das EXECUÇÕES SELETIVAS}

De modo a separar o instituto da execução seletiva de outros como a execução resultante de uma pena de morte ou as diversas tipologias de homicídio, importa identificar os cinco elementos do tipo que compõem o primeiro, sendo esse o que nos propomos a analisar: as execuções seletivas quando praticadas por Estados e não por entidades privadas (pessoas singulares, coletivas ou grupos de crime organizado).

Para se estar perante uma execução seletiva é necessário que se verifique (i) o uso da força de forma letal (ii) contra seres humanos (iii) especificamente selecionados (iv) com o intuito premeditado e deliberado de lhes tirar a vida e (v) não se encontrarem os alvos detidos pela entidade que os pretende executar, o Estado ${ }^{6}$.

Dissecando cada um desses elementos, podemos acrescentar que, relativamente ao uso da força de forma

6 É possível encontrar definições diferentes do conceito de execução seletiva, umas mais simplistas que outras. Cfr. TESÓN, Fernando R. Targeted Killing in War and Peace: a Philosophical Analysis. In: FINKELSTEIN, Claire (Ed.). Targeted killings: law and morality in an asymmetrical world. Oxford: Oxford University, 2012. p. 403-433. p. 404. Contudo, os elementos que compõem a noção de execução seletiva aproximam-se, regra geral, dos referidos neste artigo e igualmente adotados por MELZER, Nils. Targeted killing in international law. New York: Oxford University, 2008. p. 3-8; OTTO, Roland. Targeted killings and international law: with special regard to human rights and international humanitarian law. Heidelberg: Springer, 2012. p. 9-22; GODFREY, Brenda L. Authorization to kill terrorist leaders and those who harbor them: an international analysis of defensive assassination. San Diego International Law Journal, v. 4, p. 491-512, 2003. letal, não se resume ao conceito a armas de fogo ou armas brancas, sendo nele admitidos quaisquer outros meios (envenenamento, raide aéreo, força física, entre outros) passíveis de causarem a morte a um ser humano.

Por outro lado, não se integram nesse instituto casos de negligência ou mesmo de dolo eventual nem de qualquer causa de exclusão de ilicitude, sendo sempre necessário que se verifique dolo direto. Assim, afastam-se dos casos de execução seletiva as situações em que a morte da vítima constitua um dano colateral da conduta que o agente visou alcançar.

Paralelamente, a ação tem de incidir contra indivíduos especificamente selecionados, excluindo-se da noção de execução seletiva os casos de ataque a grupos indiscriminados de pessoas ou alvos não especificados ${ }^{7}$. Uma execução seletiva tem como base uma ordem administrativa (Chefe de Estado) ou militar (alta patente das Forças Armadas) - logo, extrajudicial - não decorrendo esta ação do cumprimento de uma decisão de uma autoridade judicial por se presumir que esses casos resumem-se a situações em que o alvo já se encontra detido e aguarda o cumprimento de uma pena de morte por meio de um meio específico de execução dessa pena.

Contudo, para efeitos de responsabilidade, devemos admitir a hipótese de, futuramente ou em casos pontuais, os tribunais poderem vir a validar execuções seletivas sem as sujeitarem a condições de cumprimento (ex.: independentemente da forma como seja executada a pena quando o agente não está detido e/ou sem que o alvo tenha direito a um processo com garantias de defesa). Nessas situações, por atentarem contra a dignidade da pessoa humana, estaremos, também, perante execuções seletivas.

Embora já se pratiquem desde que a humanidade assiste à disputa de poder entre seres humanos - sendo mesmo uma tática de guerra por excelência como forma de fragilizar o inimigo atentando contra indivíduos com características e funções estratégicas -, a crescente proteção dada aos Direitos Humanos, desde meados do século XIX, aumentou a censura e condenação às execuções seletivas em virtude do perigo de banalização em que consistiam tais práticas, correndo o risco de se converterem em ação primordial dificilmente justificada.

7 O que não afasta os casos de execuções seletivas contra um ou mais alvos simultaneamente. 
Não obstante a consolidação da tendência global em favor do não cometimento desse tipo de atos considerados degradantes, alguns países não só não aderiram a esta campanha como fazem da política de execuções seletivas uma prática comum na sua agenda perante terceiros.

Um desses exemplos é Israel, que, a 9 de Novembro de $2000^{8}$, assumiu oficialmente a política de execuções seletivas. Ainda que tenda a justificar essa prática com a proteção e existência do próprio Estado - luta que iniciou desde a sua independência ${ }^{9}$ e que conheceu um marco significativo rumo à sua adoção oficial com o atentado contra onze atletas israelitas que participaram das Olimpíadas de Munique, em 1972, por um grupo de palestinianos - a condução de execuções seletivas contra alvos de diferentes origens tem vindo a conhecer um aumento exponencial ao longo dos últimos quatorze anos, sob o pretexto de ser um mal necessário contra alegados terroristas palestinos ou, por exemplo, para evitar que o Irã desenvolva uma política nuclear para fins não pacíficos ${ }^{10}$. Essas justificações carecem, em muitos casos, de elementos que permitam reconhecer legitimidade, por mínima que seja, à atuação das autoridades israelitas.

Apesar de outros Estados prosseguirem a política de execuções seletivas, encontrando-se entre eles a China, a Rússia e o Paquistão, os Estados Unidos da América (doravante EUA) serão, muito provavelmente, o país com maior registo de execuções seletivas ${ }^{11}$. O evento determinante que serviu de motivação para que as administrações estadunidenses adotassem este método

8 Mais concretamente no decorrer da segunda intifada (Al-Aqsa) e após o assassinato do ativista da Fatah, Hussein Abayat. Cfr. AMNESTY INTERNATIONAL. Israel and the occupied territories: state assassinations and other unlawful killings. 2001. Available at: $<$ https://www.amnesty.org/en/documents/MDE15/005/2001/en/>. Access in: Feb. 10, 2016.

9 Nesse sentido, recorde-se que, logo a 17 de Setembro de 1948, meses após o reconhecimento da sua independência, militantes judeus emboscaram e assassinaram o mediador sueco da Organização das Nações Unidas, Folke Bernadotte, em Jerusalém, e mantiveram tal prática contra alvos árabes até à guerra de 1967. Cfr. MELZER, Nils. Targeted killing in international law. New York: Oxford University, 2008. p. 27 e ss.

10 RAVIV, Dan. U. S. pushing Israel to stop assassinating Iranian nuclear scientists. CBS News. 1 mar. 2014. Available at: <http:// www.cbsnews.com/news/us-pushing-israel-to-stop-assassinatingiranian-nuclear-scientists/>. Access in: Feb. 10, 2016.

11 OTTO, Roland. Targeted killings and international law: with special regard to human rights and international humanitarian law. Heidelberg: Springer, 2012. p. 1-8. como prática comum teve lugar a 11 de Setembro de 2001, com os ataques comandados pela Al-Qaeda contra o World Trade Center e o Pentágono com uma alegada quarta tentativa frustrada.

Após os ataques da Al-Qaeda contra as missões diplomáticas estadunidenses em Nairobi e Dar es Salaam, em Agosto de 1998, e contra o navio-de-guerra USS Cole, em Outubro de 2000, o 9/11 criou o mote que os EUA necessitaram para legitimar a maior campanha de contraterrorismo da história da humanidade ${ }^{12}$, incluindo o recurso a execuções seletivas. Nesse sentido, recorde-se que, logo a 14 de Setembro de 2001, o Congresso autorizou o presidente George W. Bush a utilizar "toda a força necessária e apropriada contra todas as naçooes, organizações ou pessoas que ele [o Presidente] determine que planeou, autorizou, cometen on auxilion os ataques terroristas" ${ }^{13}$.

Segundo notícias avançadas pela imprensa estadunidense ainda em Setembro 2001, o Presidente Bush autorizou a Central Intelligence Agency a desencadear "ações encobertas letais", ou execuções seletivas, com o objetivo de eliminar a rede da $\mathrm{Al}-\mathrm{Q} a e d a^{14}$. Finalmente, assumiria publicamente, nesse mesmo dia, numa declaração em puro tom revivalista dos westerns, que "Osama bin Laden é procurado: vivo ou morto"15. Esse acontecimento acaba por marcar o início de uma nova era do conceito de execuções seletivas, perdurando até hoje e podendo vigorar indefinidamente ao ponto de vingar numa ordem internacional crescentemente receosa dos imprevisíveis efeitos do fenômeno terrorista.

Com uma agenda externa voltada claramente para

12 Um enquadramento mais pormenorizado com uma análise relativamente à aplicação dos modelos de conflito armado e de aplicação do estatuto de prisioneiro de guerra a membros de grupos terroristas pode ser lido em PEREIRA, Maria da Assunção Vale. A "guerra contra o terrorismo": um novo tipo de conflito armado?. In: GÓMEZ, Mariano J. Aznar (Coord.). Estudios de derecho internacional y derecho europeo en homenaje al Professor Manuel Pérez González. Valencia: Tirant lo Blanch, 2012. t. 1. p. 491-520.

13 UNITED STATES. Public Law 107-40. Available at: <http:// www.gpo.gov/fdsys/pkg/PLAW-107publ40/pdf/PLAW107publ40.pdf>. Access in: Feb. 10, 2016.

14 WOODWARD, Bob. CIA Told to Do 'Whatever Necessary' to Kill Bin Laden. The Washington Post, 21 out. 2001. Available at: <http://www.washingtonpost.com/wp-dyn/content/article/2007/11/18/AR2007111800655.html>. Access in: Feb. 10, 2016.

15 HARNDEN, Toby. Bin Laden is wanted: dead or alive, says Bush. The Telegraph. 18 sept. 2001. Available at: <http://www.telegraph.co.uk/news/worldnews/asia/afghanistan/1340895/BinLaden-is-wanted-dead-or-alive-says-Bush.html>. Access in: Feb. 10, 2016. 
o combate ao terrorismo, os EUA desencadearam um número indeterminado de execuções sumárias, a esmagadora maioria dos quais por meio de aeronaves não tripuladas (vulgarmente designados drones) ${ }^{16}$. Só em palcos como o Paquistão, a Somália, o Afeganistão e o Iémen, os EUA conduziram, entre 2002 e 2014, pelo menos, 550 ataques (estando outros 110 sujeitos a confirmação), que provocaram cerca de 5.230 mortes (dos quais 1.225 civis e 250 crianças) e 2.090 feridos $^{17}$.

O recurso às execuções seletivas apresenta uma dicotomia de elevado grau de complexidade: por um lado, sacrificam-se as vidas dos agentes sob o pretexto de pretenderem evitar-se a morte de vidas humanas inocentes; por outro lado, ainda que se elimine a vida de um (potencial) terrorista, a sua execução implica a morte de um ser humano que é privado da sua vida sem ser submetido a julgamento, condenado ou sequer abatido na sequência de uma ordem judicial, dependendo puramente de uma autorização administrativa.

No fundo, a execução do agente é preventiva, baseada em presunções e partindo do princípio que, no futuro, determinada pessoa iria, com total grau de certeza, levar a cabo um ato terrorista e que esse ato era suscetível de provocar danos significativos.

\section{Sobre A FUndAMENTALIDADE do DiREITO À VIDA}

Seguindo-se a doutrina de Karel Vasak ${ }^{18,} \mathrm{o}$ direito à vida constitui a base fundamental dos direitos humanos, em particular os de primeira geração, sendo com base

16 É compreensível o recurso a aeronaves não tripuladas dadas as incalculáveis vantagens que trazem a quem deles beneficia: evita o destacamento de humanos para o teatro de operações - reduzindo, consequentemente, o número de baixas -, verifica-se uma menor exposição face ao inimigo, implica um menor investimento em recursos, permite a condução de ataques à distância e diminui o número de pessoas envolvidas nas operações. Com a evolução tecnológica, é provável que o centro da decisão tenda a passar por um menor número de pessoas, o que permitirá concentrar os poderes e a responsabilidade no Supremo Comandante das Forças Armadas.

17 A classificação dada a estas operações (habitualmente com Muito Secreto) condiciona o acesso público a todas as operações que são conduzidas pelos EUA contra terceiros, não existindo, sequer, em muitas destas situações, reivindicação oficial da autoria de tais ataques.

18 VASAK, Karel. A 30-year struggle: the sustained efforts to give force of law to the Universal Declaration of Human Rights. The UNESCO Courier. v. 30, p. 28-32, Nov. 1977. p. 29. nele que decorrem todos os outros ${ }^{19}$. Não obstante a importância do direito à vida para garantir a essência humana, esse direito não é incondicional, entendendo-se que a privação da vida humana é justificada em situações em que o recurso a essa solução evite um dano maior, como são os casos de legítima defesa, ou no contexto de um conflito armado ou eventos em que a ponderação de interesses justifique o sacrifício.

O direito à vida é reconhecido aos seres humanos em instrumentos como o Pacto Internacional sobre Direitos Civis e Políticos como "inerente à pessoa humana" tendo "todo o indivíduo [...] direito à vida" ${ }^{20}$. Neste sentido, assiste-se ainda à crescente universalização do princípio da proibição de privação da vida humana de forma arbitrária, fenômeno esse que ao ficar consagrado no Pacto $^{21}$ concorre para o seu reconhecimento e consolidação como princípio de jus cogens ${ }^{22}$. Ressalve-se, todavia, que o direito à vida, per se, não constitui um princípio de jus cogens, por não ser um direito absoluto, uma vez que são reconhecidas causas excepcionais de admissibilidade de privação da vida humana (por exemplo, a aplicação de pena de morte $)^{23}$.

Além dos instrumentos de aplicação universal, como o Pacto Internacional sobre Direitos Civis e Políticos ou a Declaração Universal dos Direitos Humanos ${ }^{24}$, im-

19 GUERREIRO, Alexandre. A resistência dos estados africanos à jurisdição do Tribunal Penal Internacional. Coimbra: Almedina, 2012. p. 120. 20 Artigo $3^{\circ}$ da Declaração Universal dos Direitos Humanos. ORGANIZAÇÃO DAS NAÇÕES UNIDAS. Declaração Universal dos Direitos Humanos: adotada e proclamada pela resolução 217 A (III) da Assembléia G Geral das Nações Unidas em 10 de dezembro de 1948 Geral das Nações Unidas em 10 de dezembro de 1948. Brasília, 1998. Disponível em: <http://unesdoc.unesco.org/ images/0013/001394/139423por.pdf>. Acesso em: 10 fev. 2016.

21 Artigo $6 .^{\circ}$, n. $^{\circ} 1$ do Pacto. NAÇÕES UNIDAS. Pacto Internacional sobre os Direitos Civis e Políticos. Disponível em: <http://www.gddc. $\mathrm{pt} /$ direitos-humanos/textos-internacionais-dh/tidhuniversais/ cidh-dudh-direitos-civis.html>. Acesso em: 10 fev. 2016.

22 OTTO, Roland. Targeted killings and international law: with special regard to human rights and international humanitarian law. Heidelberg: Springer, 2012. p. 195-201. MELZER, Nils. Targeted killing in international law. New York: Oxford University, 2008. p. 214-221. KRETZMER, David. Targeted killing of suspected terrorists: extrajudicial executions or legitimate means of defence?. The European Journal of International Law, New York, v. 16, n. 2, p. 171-212, 2005. p. 185

23 Artigo 6. $^{\circ}$ do Pacto. ORGANIZAÇÃO DAS NAÇÕES UNIDAS. Pacto Internacional sobre os Direitos Civis e Politicos. Disponível em: $<$ http://www.gddc.pt/direitos-humanos/textos-internacionais-dh/ tidhuniversais/cidh-dudh-direitos-civis.html>. Acesso em: $10 \mathrm{fev}$. 2016.

24 Inicialmente designada "Declaração Universal dos Direitos do Homem", em castelhano, o crescente reconhecimento de direitos 
porta ter em conta outros de âmbito meramente regional, mas, ainda assim, fundamentais para, considerando o relativismo cultural, compreender a valoração dada à vida humana em zonas distintas do globo de modo a afastar argumentos que visem defender a imposição universalizante de uma visão monopolista do direito à vida por parte de algumas potências mundiais ${ }^{25}$.

Assim, a Carta Africana dos Direitos Humanos e dos Povos reconhece, no artigo $4 .^{\circ}$, que "a pessoa humana é inviolável" e acrescenta que "todo o ser humano tem direito ao respeito da sua vida", pelo que "ninguém pode ser arbitrariamente privado desse direito". Também a Convenção Interamericana de Direitos do Homem reconhece que a "pessoa tem o direito ao respeito da sua vida", o qual "deve ser protegido pela lei”, não podendo ninguém "ser privado da vida arbitrariamente" 26.

Paralelamente, no mesmo sentido segue a Declaração de Direitos do Homem do Islã, que defende, no seu artigo 1. ${ }^{\circ}$, al. a), que "a vida humana é sagrada e inviolável e todo o esforço deverá ser feito para protegê-la”.

Por sua vez, a Convenção (europeia) para a Proteção dos Direitos do Homem e das Liberdades Fundamentais adota uma redação diferente das restantes ao substituir a proibição de arbitrariedade pela de intencionalidade na privação de vida ${ }^{27}$ indicando-se expressamente os casos excepcionais em que tal pode, ainda assim, ocorrer ${ }^{28}$.

às mulheres e a consequente intenção de eliminar fatores passíveis de prolongarem a discriminação com base no gênero precipitaram a revisão da terminologia, mais concretamente de Derechos del Hombre para Derechos Humanos, em 1952, por via da Resolução 548 (VI) da Assembleia-Geral das Nações Unidas. Portugal nunca procedeu, oficialmente, à mesma alteração, embora a Declaração já tenha a nova terminologia reconhecida por órgãos de soberania como a Assembleia da República.

25 Com efeito, o fato de, à altura em que foi celebrada a Declaração, o número de Estados independentes ser manifestamente menor do que aquele que temos atualmente, acabou "por ser determinante para a criação de sistemas regionais próprios de proteção de Direitos Humanos, baseados nos valores e tradições locais, alguns dos quais com vista a evitar a aplicação de instrumentos universais". Cfr. GUERREIRO, Alexandre. A resistência dos estados africanos à jurisdição do Tribunal Penal Internacional. Coimbra: Almedina, 2012. p. 108. 26 Artigo $4 .^{\circ}$, n. ${ }^{\circ}$ 1. ORGANIZAÇÃO DOS ESTADOS AMERICANOS. Convenção Americana sobre Direitos Humanos: assinada na Conferência Especializada Interamericana sobre Direitos Humanos, San José, Costa Rica, em 22 de novembro de 1969. Disponível em: <https://www.cidh.oas.org/basicos/portugues/c.convencao_ americana.htm>. Acesso em: 10 fev. 2016.

27 Artigo 2. ${ }^{\circ}$, n. ${ }^{\circ}$ 1. ORGANIZAÇÃO DOS ESTADOS AMERICANOS. Convenção Europeia dos Direitos do Homem. Disponível em: $<$ http://www.echr.coe.int/Documents/Convention_POR.pdf $>$. Acesso em: 10 fev. 2016.

28 Artigo 2. ${ }^{\circ}$ n. ${ }^{\circ}$ 2. ORGANIZAÇÃO DOS ESTADOS AMER-
A vida enquanto direito fundamental das pessoas encontra-se, ainda, protegida noutros instrumentos internacionais como o Código de Conduta para os Funcionários Responsáveis pela Aplicação da Lei (1979), que impõe sobre as forças de defesa e de segurança os deveres de "cumprir, a todo o momento, o dever que a lei lhes impõe, servindo a comunidade e protegendo todas as pessoas contra atos ilegais" 29 e de "respeitar e proteger a dignidade humana, manter e apoiar os direitos fundamentais de todas as pessoas" ${ }^{30}$ só podendo "empregar a força quando tal se afigure estritamente necessário" 31.

Nesse quadro, os Princípios Básicos sobre a Utilização da Força e de Armas de Fogo pelos Funcionários Responsáveis pela Aplicação da Lei (1990) preveem que o emprego da força deve ser excepcional e o recurso a meios letais constitui uma medida extrema apenas passível de se constituir como opção "quando um suspeito ofereça resistência armada, ou quando, de qualquer forma, coloque em perigo vidas alheias e não haja suficientes medidas menos extremas para o dominar ou deter".

De acordo com o que tem sido a prática generalizada, parece ser consensual o entendimento que define cinco situações cuja verificação atesta a violação de um princípio que, ao não ser respeitado, denuncia um caso de privação da vida humana de forma arbitrária, o que sucede quando ${ }^{32}$ :

a) a força letal possa ser aplicada contra as pessoas sem que exista uma lei que disponha e limite os termos e as circunstâncias excepcionais

ICANOS. Convenção Europeia dos Direitos do Homem. Disponível em: <http://www.echr.coe.int/Documents/Convention_POR.pdf $>$. Acesso em: 10 fev. 2016.

29 Artigo $1 .^{\circ}$. ORGANIZAÇÃO DAS NAÇÕES UNIDAS. Código de Conduta para os Funcionários Responsáveis pela Aplicação da Lei. Disponível em: <http://www.gddc.pt/direitos-humanos/textosinternacionais-dh/tidhuniversais/dhaj-pcjp-18.html>. Acesso em: 10 fev. 2016.

30 Artigo 2.․ ORGANIZAÇÃO DAS NAÇÕES UNIDAS. Código de Conduta para os Funcionários Responsáveis pela Aplicaşão da Lei. Disponível em: <http://www.gddc.pt/direitos-humanos/textosinternacionais-dh/tidhuniversais/dhaj-pcjp-18.html>. Acesso em: 10 fev. 2016.

31 Artigo $3 .^{\circ}$. ORGANIZAÇÃO DAS NAÇÕES UNIDAS. Código de Conduta para os Funcionários Responsáveis pela Aplicação da Lei. Disponível em: <http://www.gddc.pt/direitos-humanos/textosinternacionais-dh/tidhuniversais/dhaj-pcjp-18.html>. Acesso em: 10 fev. 2016.

32 INTERNATIONAL COMMITTEE OF THE RED CROSS. Fundamental rules of humanitarian law applicable in armed conflicts. International Review of the Red Cross, v. 8, n. 206, p. 247-249, Sept./Out. 1978. p. 247-249. 
em que tal possa ocorrer (violação do princípio da legalidade);

b) a força letal seja utilizada sem ter como base causas punitivas (violação do princípio da justificação);

c) a execução seja causada por força letal que exceda o necessário para manter, restaurar ou impor a lei e a ordem em determinadas circunstâncias ou quando não seja o meio necessário para garantir a proteção de vidas humanas (violação do princípio da necessidade);

d) o uso da força seja desproporcional face ao perigo atual (violação do princípio da proporcionalidade);

e) não sejam tomadas medidas preventivas ou cautelares antes da execução quando as autoridades tenham a possibilidade e os meios para o fazer (violação do princípio da precaução).

Nesse quadro, uma execução seletiva tenderá a considerar-se legítima quando não viole nenhum dos princípios referidos. Todavia, refira-se que dificilmente colherá algum apoio uma aplicação dessas regras de forma abstrata, devendo ser analisados isoladamente em cada caso concreto, por poderem ocorrer eventos que se situem em "zonas cinzentas" no que à legalidade e ilegalidade das execuções diz respeito.

\section{A LiCiTUde dAs EXECUÇões de SERES hUMA- NOS EM CONTEXTO DE CONFLITO ARMADO}

\subsection{Condicionantes impostas aos conflitos ar- mados internacionais}

A privação da vida humana de forma arbitrária ou intencional constitui um princípio de jus cogens incompatível com as execuções seletivas ${ }^{33}$, mesmo apesar de a vida humana não ser um direito absoluto ${ }^{34}$. Apesar de, por regra,

33 MELZER, Nils. Targeted killing in international law. New York: Oxford University, 2008. p. 184-189 e 220-221.

34 A questão da vida como direito absoluto foi discutida, por exemplo, na Corte Internacional de Justiça, no âmbito do processo "Legalidade da Ameaça ou Uso de Armas Nucleares", no qual o juiz Weeramantry recorda que o direito à vida não é um direito absoluto, uma vez que executar um alvo militar em contexto de guerra constitui uma exceção ao direito à vida. Cfr. CORTE INTERNACION- dever ser protegida, existem determinadas situações em que a vida de determinados seres humanos não carece de proteção total pela qualidade que têm num determinado contexto - embora, ainda assim, deva ser sempre dada primazia à detenção e julgamento dessas pessoas e só excepcionalmente o uso letal da força deverá ser utilizado.

Além de situações tipicamente justificadas por causas de exclusão da ilicitude ${ }^{35}$, os contextos de conflitos armados dão, por regra, origem à perda de um número de vidas humanas significativa, muitas das quais de legalidade bastante questionável. De fato, recorde-se que desde a segunda metade do século XIX que o objetivo da guerra deixou de ser "dizimar o inimigo", tendo "os Estados criado normas internacionais que procuram limitar os efeitos dos conflitos armados por razões humanitárias" por meio da restrição e utilização proporcional dos meios e métodos de guerra, da proteção de pessoas que não participam ou deixaram de participar ${ }^{36}$ no conflito armado e ainda da preservação da dignidade dos participantes evitando sofrimento ou consequências desnecessárias ${ }^{37}$.

AL DE JUSTIÇA. CORTE INTERNACIONAL DE JUSTIÇA. Parecer divergente do Juiz, Weeramantry de 8 de julbo de 1996: legalidade da ameaça ou uso de armas nucleares. Disponível em: <http://www. icj-cij.org/docket/files/95/7521.pdf>. Acesso em: 8 jan. 2016. p. 507. Igualmente relevante é o consenso entre Estados como Reino Unido, Holanda e França no sentido de o direito à vida não ser um direito absoluto. Cfr. CORTE INTERNACIONAL DE JUSTIÇA. CORTE INTERNACIONAL DE JUSTIÇA. Carta datada de 16 de junho de 1995 do Conselheiro Jurídico do Ministério dos Assuntos Exteriores e da Commonwealth do Reino Unido da Grã-Bretanha e Irlanda do Norte, juntamente com os comentários escritos do Reino Unido: legalidade da ameaça ou uso de armas nucleares. Disponível em: <http://www.icj-cij. org/docket/files/95/8802.pdf>. Acesso em: 8 jan. 2016. \$3.100; CORTE INTERNACIONAL DE JUSTIÇA. CORTE INTERNACIONAL DE JUSTICA. Carta datada de 16 de junho de 1995 do Ministro dos Negócios Estrangeiros do Reino dos Países Baixos juntamente com a declaração escrita do governo dos Países Baixos: legalidade da ameaça ou uso de armas nucleares. Disponível em: <http://www.icj-cij.org/ docket/files/95/8690.pdf>. Acesso em: 8 jan. 2016. \$27; CORTE INTERNACIONAL DE JUSTIÇA. CORTE INTERNACIONAL DE JUSTIÇA. Carta datada de 20 de junho de 1995 do Ministro dos Negócios Estrangeiros da República Francesa juntamente com a declaração escrita do governo da República Francesa: legalidade da ameaça ou uso de armas nucleares. Disponível em: <http://www.icj-cij.org/docket/ files/95/8701.pdf>. Acesso em: 8 jan. 2016. p. 38.

35 Como a legítima defesa e o estado de necessidade.

36 Artigo 57. ${ }^{\circ}$ do I Protocolo Adicional às Convenções de Genebra (1977). ORGANIZAÇÃO DAS NAÇÕES UNIDAS. Protocolo I Adicional às Convenções de Genebra de 12 de Agosto de 1949 relativo à Protecção das Vitimas dos Conflitos Armados Internacionais. Disponível em: $<$ http://www.gddc.pt/direitos-humanos/textos-internacionais-dh/ tidhuniversais/dih-prot-I-conv-genebra-12-08-1949.html>. Acesso em: 10 fev. 2016

37 Para uma leitura sobre a evolução histórica do direito da guerra 
Estamos, assim, perante o jus in bello (ou direito da guerra), cujas regras passam a garantir uma relativa bumanização do conflito armado e definem que a guerra deve terminar o mais breve possível a partir do momento em que é iniciada e o seu objetivo deve limitar-se à concretização do objetivo que motivou um Estado a declarar e a conduzir contra a guerra contra outro Estado ${ }^{38}$. E, dependendo do contexto, até a morte do inimigo deve ser evitada ${ }^{39}$, já que o objetivo primordial da guerra deve ser estritamente militar ${ }^{40}$ e não causar necessariamente a morte aos que nela participam - embora este seja um dos resultados prováveis e tolerados na guerra.

Se, por um lado, "os membros [da Organização das Nações Unidas] deverão abster-se nas suas relações internacionais de recorrer à ameaça ou ao uso da força"

e do direito internacional humanitário e uma análise crítica à regulamentação dos conflitos armados, cfr. ALVES, Lucas Garcia. A necessidade de regulamentação dos conflitos armados para o reestabelecimento da democracia. Revista de Direito Internacional, Brasília, v. 9, n. 2, p. 45-67, jul./dez. 2012.

38 Artigo 52. ${ }^{\circ}$, n. 2 do I Protocolo Adicional às Convenções de Genebra (1977). ORGANIZAÇÃO DAS NAÇÕES UNIDAS. Protocolo I Adicional às Convenções de Genebra de 12 de Agosto de 1949 relativo à Protecção das Vitimas dos Conflitos Armados Internacionais. Disponível em: <http://www.gddc.pt/direitos-humanos/textos-internacionais-dh/tidhuniversais/dih-prot-I-conv-genebra-12-08-1949.html>. Acesso em: 10 fev. 2016.

39 Alguns autores estadunidenses tendem a defender a total permissibilidade para executar elementos das Forças Armadas inimigas independentemente do risco que representem. Se é verdade que com o início da guerra os combatentes de cada adversário constituem alvos legítimos do ponto de vista militar, nunca é demais recordar situações de (provável) rendição nas quais, apesar de as partes se encontrarem em guerra, combatentes poderão deixar de ser uma ameaça e, desse modo, iniciarem a fase de transição para um regime de proteção ao abrigo da III Convenção de Genebra (1949). Entende-se, por esse motivo, que a menos que seja, no mínimo, possível esperar um ataque ou uma resposta armada da parte de um grupo de combatentes, caso se equacione a hipótese de rendição (mesmo, por exemplo, em situações de desvantagem no terreno) deverá ser dada a primazia ao não ataque ao inimigo. No sentido de defesa da total permissibilidade para atacar alvos humanos, cfr. MAXWELL, Colonel Mark "Max". Rebutting the civilian presumption: playing whack-a-mole without a mallet? In: FINKELSTEIN, Claire (Ed.). Targeted killings: law and morality in an asymmetrical world. Oxford: Oxford University, 2012. p. 31-59. p. 38; CORN, Geoffrey. Mixing apples and hand grenades: the logical limit of applying human rights norms to armed conflict. Journal of International Humanitarian Legal Studies, Leiden, v. 1. n. 1, p. 52-94, 2010. p. 52-94.

40 Artigo 48. ${ }^{\circ}$ do Protocolo I Adicional às Convenções de Genebra. ORGANIZAÇÃO DAS NAÇÕES UNIDAS. Protocolo I Adicional às Convenç̃es de Genebra de 12 de Agosto de 1949 relativo à Protecção das Vitimas dos Conflitos Armados Internacionais. Disponível em: $<$ http://www.gddc.pt/direitos-humanos/textos-internacionais-dh/ tidhuniversais/dih-prot-I-conv-genebra-12-08-1949.html>. Acesso em: 10 fev. 2016 contra outro membro ${ }^{41}$, poderá assistir aos Estados o direito à guerra (ou jus ad bellum), quando se encontrem preenchidas condições (nem todas consensualmente aceites) que legitimem a condução da "guerra justa" ${ }^{42}$, e ainda de legítima defesa ${ }^{43}$.

Independentemente de haver ou não guerra justa, uma vez iniciado um conflito armado, prevalecem as regras do direito da guerra. Sublinham-se, para esse efeito, os dois modelos clássicos aplicáveis às duas situações distintas reconhecidas universalmente como conflito armado: o modelo de conflito armado internacional (entre Estados ${ }^{44}$ ) e o modelo de conflito armado não-internacional (quando ocorram no território de um Estado, entre as suas Forças Armadas e Forças Armadas dissidentes ou grupos armados organizados ${ }^{45}$ ).

No âmbito de uma guerra travada entre dois ou mais Estados, os atores envolvidos no conflito armado veem ser-lhes aplicáveis as limitações previstas na IV Convenção de Genebra (1949) que, em sede de direito da guerra, tem, conforme referido, como principal

41 Artigo 2. ${ }^{\circ}$, n. ${ }^{\circ} 4$ da Carta da ONU. ORGANIZAÇÃO DAS NAÇÕES UNIDAS. Carta das Nações Unidas: assinada em São Francisco a 26 de junho de 1945. Disponível em: <http://www.gddc.pt/direitos-humanos/textos-internacionais-dh/tidhuniversais/onu-carta. html>. Acesso em: 10 fev. 2016.

42 Para mais sobre esse tema, cfr. HUBERT, Don. The Responsibility to Protect: Supplementary Volume to the Report of the International Commission on Intervention and State Sovereignty. Ottawa: International Development Research Centre, 2001. p. 139-143; JOHNSON, James Turner. Just War, As It Was and Is. First Things, Jan. 2005. Available at: <http://www.firstthings.com/article/2005/01/ just-waras-it-was-and-is>. Accessed on: Feb. 10, 2016.

43 Artigo $51 .^{\circ}$ da Carta das Nações Unidas. ORGANIZAÇÃO DAS NAÇÕES UNIDAS. Carta das Nações Unidas: assinada em São Francisco a 26 de junbo de 1945. Disponível em: <http://www.gddc. $\mathrm{pt} /$ direitos-humanos/textos-internacionais-dh/tidhuniversais/onucarta.html>. Acesso em: 10 fev. 2016.

44 De acordo com o artigo 2. ${ }^{\circ}$ da IV Convenção de Haia relativa às Leis e Costumes da Guerra Terrestre (de 1899 e regulamentada em 1907). BRASIL. Câmara dos Deputados. Decreto n ${ }^{\circ} 378$, de 15 de outubro de 1935. Disponível em: <http:/ /www2.camara.leg.br/legin/ fed/decret/1930-1939/decreto-378-15-outubro-1935-557435-publicacaooriginal-77825-pe.html>. Acesso em: 10 fev. 2016.

45 Artigos 3. ${ }^{\circ}$ comum às Convenções de Genebra I a IV (1949): ORGANIZAÇÃO DAS NAÇÕES UNIDAS. Convenção IV, Convenção de Genebra Relativa à Proteção das Pessoas Civis em Tempo de Guerra, de 12 de Agosto de 1949. Disponível em: <http://www.gddc.pt/ direitos-humanos/textos-internacionais-dh/tidhuniversais/dihconv-IV-12-08-1949.html>. Acesso em: 10 fev. 2016. E 1. ${ }^{\circ}$ do II Protocolo Adicional às Convenções de Genebra (1977). ORGANIZAÇÃO DAS NAÇÕES UNIDAS. Protocolo I Adicional às Convenções de Genebra de 12 de Agosto de 1949 relativo à Protecção das Vitimas dos Conflitos Armados Internacionais. Disponível em: <http://www.gddc. $\mathrm{pt} /$ direitos-humanos/textos-internacionais-dh/tidhuniversais/dihprot-I-conv-genebra-12-08-1949.html>. Acesso em: 10 fev. 2016. 
objetivo a humanização da guerra. Nesse sentido, a Convenção consagra desde logo a proteção da população civil e das pessoas civis "contra os perigos resultantes de operações militares" 46 e o seu direito, "em todas as circunstâncias, ao respeito da sua pessoa, da sua honra, dos seus direitos de família" ${ }^{47}$.

Paralelamente, assume particular importância a proibição de "ofensas contra a vida e integridade física" de "pessoas que não tomem parte diretamente nas hostilidades" $"$. As pessoas que não participem nas hostilidades estão, para todos os efeitos, protegidas, constituindo crimes de guerra a condução de ataques (das mais diversas formas) contra tais pessoas, conforme resulta da aplicação dos arts. $146 .^{\circ}$ e $147 .^{\circ}$ da IV Convenção de Genebra ${ }^{49}$.

Por ter como intuito a maior redução possível do impacto da guerra sobre os civis, afigura-se fundamental a distinção entre combatentes e civis, afirmando-se esse princípio como uma das principais bases do Direito Internacional Humanitário ${ }^{50}$. Estabelecendo o Direito Internacional Humanitário a distinção entre pessoas

46 Artigo 51. ${ }^{\circ}$, n. ${ }^{\circ}$ 1. ORGANIZAÇÃO DAS NAÇÕES UNIDAS. Convenção IV, Convenção de Genebra Relativa à Proteção das Pessoas Civis em Tempo de Guerra, de 12 de Agosto de 1949. Disponível em: <http://www.gddc.pt/direitos-humanos/textos-internacionais-dh/ tidhuniversais/dih-conv-IV-12-08-1949.html>. Acesso em: 10 fev. 2016.

47 Artigo $27 .^{\circ}$, n. ${ }^{\circ}$ 1. ORGANIZAÇÃO DAS NAÇÕES UNIDAS. Convenção IV, Convenção de Genebra Relativa à Proteção das Pessoas Civis em Tempo de Guerra, de 12 de Agosto de 1949. Disponível em: $<$ http://www.gddc.pt/direitos-humanos/textos-internacionais-dh/ tidhuniversais/dih-conv-IV-12-08-1949.html>. Acesso em: $10 \mathrm{fev}$. 2016.

48 Artigo $3{ }^{\circ}$, n. $^{\circ}$ 1, al. c). ORGANIZAÇÃO DAS NAÇÕES UNIDAS. Convenção IV, Convenção de Genebra Relativa à Proteção das Pessoas Civis em Tempo de Guerra, de 12 de Agosto de 1949. Disponível em: <http://www.gddc.pt/direitos-humanos/textos-internacionais-dh/tidhuniversais/dih-conv-IV-12-08-1949.html>. Acesso em: 10 fev. 2016.

49 Crimes imprescritíveis, por aplicação do n. 1 do artigo $1 .^{\circ}$ da Convenção sobre a Imprescritibilidade dos Crimes de Guerra e dos Crimes Contra a Humanidade (1968). ORGANIZAÇÃO DAS NAÇÕES UNIDAS. Convenção IV, Convenção de Genebra Relativa à Proteç̧ão das Pessoas Civis em Tempo de Guerra, de 12 de Agosto de 1949. Disponível em: <http://www.gddc.pt/direitos-humanos/textosinternacionais-dh/tidhuniversais/dih-conv-IV-12-08-1949.html>. Acesso em: 10 fev. 2016.

50 Emanam desse princípio disposições como as que regulam a identificação de objetivos militares ou o estatuto de prisioneiros de guerra. Cfr. CASSESE, Antonio. Expert Opinion On Whether Israel's Targeted Killings of Palestinian Terrorists is Consonant with International Humanitarian Law. Stop Torture. Available at: <http:// www.stoptorture.org.il/files/cassese.pdf>. Access in: Feb. 10, 2016. p. 2. protegidas e não protegidas, com a possibilidade de determinados ataques contra as últimas serem tolerados - como a execução ${ }^{51}$-, importa identificar que pessoas se integram numa e noutra qualidade.

Para esse efeito, recorde-se que o artigo $51 .^{\circ}$ da IV Convenção de Genebra já dispõe que gozam de proteção "a população civil e as pessoas civis" - sendo o conceito de "civill" delimitado negativamente como "toda a pessoa não pertencente” às Forças Armadas, a milícias, a corpos voluntários de resistência ou a um levantamento popular ${ }^{52}$. Conforme disposto nos artigos $43 .^{\circ}$ e $44 .^{\circ}$, n. ${ }^{\circ} 3$, do Protocolo I Adicional às Convenções de Genebra, de 1977, são combatentes os membros das Forças Armadas ${ }^{53}$ de uma Parte envolvida num conflito e ainda, no âmbito do artigo 4. ${ }^{\circ}$ da III Convenção de Genebra de 1949, os (i) comandados por uma pessoa responsável pelos seus subordinados, (ii) estabelecem emblemas distintivos reconhecíveis à distância e (iii) dirigem ataques abertamente, já não (iv) conduzem as suas operações em respeito pelas leis e costumes da guerra.

Nesse quadro, e uma vez que civis que não participem nas hostilidades entre duas partes contratantes estão protegidos e gozam de imunidade, não podem estes serem presos, processados ou condenados ${ }^{54}$ Em sentido oposto, civis que participem nas hostilidades gozam de proteção, mas não gozam de imunidade e podem ser atacados nos mesmos termos que os beligerantes,

51 Sempre tendo como base os princípios da necessidade militar e da proporcionalidade e as proibições de quartel, de matar à traição, de perfídia ou de utilização de determinadas armas. Em suma, também na execução em contexto de guerra existem limites impostos aos participantes no conflito. Cfr. OTTO, Roland. Targeted killings and international law: with special regard to human rights and international humanitarian law. Heidelberg: Springer, 2012. p. 243-262.

52 Artigos $50 .^{\circ}$ da IV Convenção de Genebra e, por remissão, 4. ${ }^{\circ}$ A, números 1, 2, 3 e 6 da III Convenção de Genebra. O artigo 1. ${ }^{\circ}$ das regulações à IV Convenção de Haia de 1899 (regulamentada em 1907) estabelece os quatro critérios que, uma vez preenchidos, integram uma coletividade armada na categoria de combatentes.

53 Sobre o conceito de combatente, cfr. OTTO, Roland. Targeted killings and international law: with special regard to human rights and international humanitarian law. Heidelberg: Springer, 2012. p. 222233.

54 Artigos $70 .^{\circ}$ da IV Convenção de Genebra. ORGANIZAÇÃO DAS NAÇÕES UNIDAS. Convenção IV, Convenção de Genebra Relativa à Proteção das Pessoas Civis em Tempo de Guerra, de 12 de Agosto de 1949. Disponível em: <http://www.gddc.pt/direitos-humanos/textosinternacionais-dh/tidhuniversais/dih-conv-IV-12-08-1949.html>. Acesso em: 10 fev. 2016; e 25. ${ }^{\circ}$ das regulações à IV Convenção de Haia. BRASIL. Câmara dos Deputados. Decreto n ${ }^{\circ} 378$, de 15 de outubro de 1935. Disponível em: <http://www2.camara.leg.br/legin/ fed/decret/1930-1939/decreto-378-15-outubro-1935-557435-publicacaooriginal-77825-pe.html>. Acesso em: 10 fev. 2016 
voltando a gozar de proteção assim que abandonem as hostilidades ${ }^{55}$.

\subsection{Adequação do direito da guerra aos confli- tos armados internos}

Por sua vez, o modelo de conflito armado não internacional tem como principal razão de existir o preenchimento de possíveis lacunas que alguns Estados poderiam invocar para justificarem qualquer tipo de ação tomada contra atores beligerantes a operar no seu próprio território ${ }^{56}$, para efeitos da III Convenção de Genebra e do II Protocolo Adicional às Convenções, de 1977, e contra os quais quisessem impor a sua justiça com base no princípio da soberania dos Estados, consagrado no artigo 2. ${ }^{\circ}$, n. 4 da Carta das Nações Unidas, que reconhece exclusividade de cada Estado na gestão dos assuntos internos - e também no fato de a IV Convenção de Haia de 1899 (revista em 1907) se aplicar a conflitos armados internacionais ${ }^{57}$.

Paralelamente, o poder político de cada Estado evidenciava relutância em conferir outro trato aos seus opositores armados não estatais que não fosse o dado a autores de crimes comuns ${ }^{58}$, tendendo a rejeitar os esforços do Comitê Internacional da Cruz Vermelha para prestar assistência às vítimas de conflitos internos por interpretar tal pretensão como tentativa de ingerência nos seus assuntos internos ${ }^{59}$.

55 CASSESE, Antonio. Expert Opinion On Whether Israel's Targeted Killings of Palestinian Terrorists is Consonant with International Humanitarian Law. Stop Torture. Available at: <http://www. stoptorture.org.il/files/cassese.pdf>. Access in: Feb. 10, 2016. p. 7. 56 Sobre o estatuto de grupos armados a operar num Estado, cfr. OTTO, Roland. Targeted killings and international law: with special regard to human rights and international humanitarian law. Heidelberg: Springer, 2012. p. 234-243.

57 Regra esta que integra o direito internacional consuetudinário, tratando-se de um princípio de jus cogens que vincula todos os Estados. GREENWOOD, Christopher. International law and the preemptive use of force: Afghanistan, Al-Qaida, and Iraq. San Diego International Law Journal, v. 4, p. 7-37, 2003. p. 10.

58 Os Estados rejeitam reconhecer o estatuto de combatente a entidades beligerantes ativas no seu território por não quererem que estas gozem do mesmo estatuto e privilégios dos militares dos próprios Estados, nomeadamente poderem vir a usufruir das prerrogativas dos prisioneiros de guerra ou das imunidades dos combatentes em tempo de guerra. Cfr. KRETZMER, David. Targeted killing of suspected terrorists: extra-judicial executions or legitimate means of defence?. The European Journal of International Law, New York, v. 16, n. 2, p. 171-212, 2005. p. 197.

59 MELZER, Nils. Targeted killing in international law. New York: Oxford University, 2008. p. 252.
Uma vez que o objeto que o Direito Internacional Humanitário visa proteger incide nos indivíduos e que a valoração destes não varia em função do território ou do gênero de conflito em que se encontram - importando aqui recordar que as Convenções surgem na sequência das atrocidades cometidas durante as I e II Guerras Mundiais -, bem como a crescente emergência do princípio de jurisdição universal ${ }^{60}$ o grau de censura global face a crimes cometidos contra as pessoas é exatamente igual independentemente do palco onde se verifiquem.

Por esse motivo, aplicam-se exatamente as mesmas disposições referidas no âmbito do modelo do conflito armado internacional, acrescentando-se, porém, a presença do artigo $3 .^{\circ}$ comum às Convenções de Genebra I a IV que pretende afastar quaisquer dúvidas relativamente à aplicação dos valores a proteger em sede de um conflito armado, independentemente de onde este se verifique $^{61}$, estabelecendo proibições concretas contra

60 De acordo com o princípio da jurisdição universal, qualquer Estado tem legitimidade para perseguir e julgar crimes jus cogens ou crimes que "afetam os interesses da comunidade mundial como um todo porque ameaçam a paz e segurança da Humanidade e chocam a consciência da Humanidade". Cfr. BASSIOUNI, M. Cherif. BASSIOUNI, M. Cherif. International criminal law: sources, subjects and contents. 3. ed. Leiden: M. Nijhoff, 2008. v. 1. p. 176; ESCARAMEIA, Paula. Lição de síntese: que direito internacional público temos nos nossos dias? In: ESCARAMEIA, Paula. O Direito internacional público nos princípios do século XXI. Coimbra: Almedina, 2009. p. 26-30. Entende-se, aqui, que os crimes jus cogens criam obrigações para os Estado face à comunidade internacional, pelo que, tendo os Estados um interesse jurídico na sua proteção, estas são obrigações erga omnes. Foi esta a posição da Corte Internacional de Justiça no âmbito do processo Barcelona Traction, Light and Power Company. Cfr. CORTE INTERNACIONAL DE JUSTIÇA. 1970. Sentença de 5 de fevereiro, Bélgica vs. Espanha. Disponível em: < http:/ /www.icj-cij. org/docket/files/50/5387.pdf>. Acesso em: 8 jan. 2016. p. 32.

61 Embora uma leitura imediata deste artigo sugira que a sua aplicação se resuma apenas a situações de "conflito armado que não apresente um caráter internacional e que ocorra no território de uma das Altas Partes contratantes", autores como Nils Melzer tendem a ver como imaterial e não necessariamente obrigatório o requisito da territorialidade (não apenas relativamente à circunscrição do conflito a um território como também que esse território pertença a uma Alta Parte contratante). Desse modo, este artigo poderá ser aplicável a situações em que um Estado desencadeie operações militares contra um grupo armado situado no território de um outro Estado. Cfr. MELZER, Nils. Targeted killing in international law. New York: Oxford University, 2008. p. 257-261. No entanto, é importante sublinhar que esta extensão territorial pode ter lugar quando esse grupo armado tem uma agenda manifestamente política e militar contra aquele Estado - e não propriamente de ataque primordial a civis como forma de atingir o Estado, como sucede no terrorismo - e os agentes, sobretudo a linha de comando, devem ter maioritariamente nacionalidade ou afinidade com o Estado que visam atacar, encontrando-se no território de um terceiro Estado, não por partilharem uma agenda contra o Estado alvo (caso em que poderíamos estar 
as pessoas num território onde se verifique um conflito armado de natureza não internacional.

Conforme sublinha Nils Melzer, «pela primeira vez, grupos armados cuja beligerância não havia sido reconbecida por um Estado soberano opositor e que não tinham qualquer filiação ou ligação a um outro Estado soberano puderam ser "partes" num conflito armador. Desse modo, se, por um lado, essas entidades passaram a ser sujeitos de direitos e obrigações resultantes de direito internacional pactício, por outro lado, o princípio até então dominante de Estado soberano com jurisdição absoluta sobre o seu território perdeu parte significativa da sua razão de $\operatorname{ser}^{62}$ dando força à supervisão de Estados terceiros.

Desse modo, não subsistem dúvidas sobre a preocupação comum a todos os homens de proteger ou minimizar a exposição dos indivíduos a conflitos armados, assistindo-se a um esforço geral no sentido de humanizar a guerra e promover todas as medidas necessárias com vista à censura e punição daqueles que violem essas regras e cometam atos qualificados e entendidos universalmente como crimes de guerra. Demonstração dessa preocupação geral e da universalização dessa visão é dada pelo fato de as Convenções de Genebra contarem com a adesão de 196 Estados soberanos ${ }^{63}$.

Assim, regra geral, as execuções seletivas e as execuções contra grupos indiscriminados não encontram base legal, uma vez que não integram o objetivo estritamente militar da guerra e não há lugar a julgamento prévio dos alvos visados.

Contudo, as execuções seletivas serão admissíveis no contexto de conflito armado se: (i) fizerem parte das hostilidades, (ii) contribuírem efetivamente para alcançar uma vantagem concreta e direta sem que exista alternativa não letal, (iii) sejam direcionadas contra um indivíduo que não esteja sujeito a proteção, (iv) não produzam danos colaterais excessivos, (v) sejam suspensas quando o alvo se render ou abandonar as hostilidades e (vi) não recorram a meios e métodos de guerra proibidos por força das Convenções de Direito Internacional Humanitário. ${ }^{64 .}$

perante uma situação de guerra), mas devido à falta de capacidade do Estado acolhedor para afastar a presença de grupos armados do seu território.

62 MELZER, Nils. Targeted killing in international law. New York: Oxford University, 2008. p. 52-53.

63 O número de Estados-Parte nos Protocolos Adicionais é manifestamente menor face aos que ratificaram as Convenções de Genebra.

64 Exemplos disso são a perfídia, o recurso a armas proibidas e

\section{As NOVAS TESES DESENVOLVIDAS PARA A REA- LIDADE DO TERRORISMO65 E AS INCONGRUÊNCIAS QUE COMPROMETEM A LEGALIDADE E POTENCIAM A ANARQUIA}

\subsection{A realidade até ao $9 / 11$}

Até ao início do século XXI, era consensual a ideia de que as Convenções de Genebra e correspondentes Protocolos Adicionais incidiam sobre todas as possíveis formas de conflito armado. Todavia, os atentados terroristas ocorridos, sobretudo, no final do século XX já haviam motivado acesa discussão nos mais variados fóruns internacionais mesmo sendo resolvidas as questões, até então, como se de conflitos armados puros se tratassem - constatando-se que grupos terroristas que ataquem Estados que não aquele onde se encontram sedeados (e a partir do qual desencadeiam ações) não se enquadram em qualquer dos dois modelos de conflito armado passando a ser apelidados de "combatentes ilegais"

A problemática torna-se mais complexa do que pode parecer à primeira vista, uma vez que, conforme salienta Antonio Cassese, «não existe um "estatuto intermédio" entre o de combatente e o de civil» pelo que «o uso do termo "combatente ilegal" é uma designação abreviada útil para descrever os civis que peguem espontaneamente em armas sem estarem autorizados

ainda a condução das execuções seletivas por entidades não combatentes.

65 Uma vez que o conceito "terrorismo" é comumente utilizado de forma tão ampla que abarca movimentos revolucionários, subversivos e até a oposição política, resumimos o nosso objeto de estudo ao terrorismo desencadeado além fronteiras ou dirigido contra cidadãos ou residentes de um terceiro Estado que não aquele onde se encontram sedeados esses grupos. Neste sentido, GANOR, Boaz. Terrorist organisation typologies and the probability of a boomerang effect. Studies in Conflict and Terrorism, v. 31, n. 4, p. 269-283, 2008; MARSDEN, Sarah V.; SCHMID, Alex P. Typologies of terrorism and political violence. In: SCHMID, Alex P. (Ed.). The routledge handbook of terrorism research. New York: Routledge, 2011. p. 158-200. 66 O conceito "combatente ilegal" ou unlawful combatant foi, pela primeira vez, usado no processo Ex parte Quirin, de 1942, no qual o Supremo Tribunal Federal confirmou a jurisdição do Tribunal Militar estadunidense de julgar 8 espiões alemães nos EUA durante a II Guerra Mundial. ESTADOS UNIDOS. Suprema Corte. 1942. Sentença de 31 de julho. Ex Parte Quirin e outros. Disponível em: <https://supreme.justia.com/cases/federal/us/317/1/case.html>. Acesso em: 8 jan. 2016. \$317 U.S. 31-37; OTTO, Roland. Targeted killings and international law: with special regard to human rights and international humanitarian law. Heidelberg: Springer, 2012. p. 326328 . 
a fazế-lo pelo direito internacional) ${ }^{67}$. Assim, tem "caráter exclusivamente descritivo" e "não pode ser usado para provar ou corroborar a existência de uma terceira categoria de pessoas: em tempo de guerra, uma pessoa ou é combatente ou civil; tertium non datur ${ }^{368}$.

Por um lado, poder-se-ia admitir que o ataque de um grupo armado a partir de um determinado Estado e dirigido contra um terceiro deverá conduzir à responsabilização do Estado onde se encontra a referida organização, uma vez que esse Estado exerce soberania e jurisdição sobre o seu território. Sucede que, se adotar semelhante entendimento, a proposta poderá não ser a mais adequada para gerir situações em que um Estado não consiga garantir a soberania de facto no seu território (Estados falhados) ${ }^{69}$.

Todavia, ataques cometidos por grupos terroristas poderão ser imputados ao Estado a partir dos quais conduzem as suas ações na eventualidade de esse mesmo Estado apoiar ou exercer o controle do grupo terrorista $^{70}$ - a exemplo do que sucedeu com o apoio do Afeganistão à Al-Qaeda e que levou ao 9/11. Na eventualidade de tal suceder, será de admitir que estes atos se incluam na categoria de "ataque armado" previsto no artigo 51. ${ }^{\circ}$ da Carta das Nações Unidas.

Simultaneamente, questiona-se se, nessas condições, os grupos armados de inspiração terrorista assumem a qualidade de "civil" por não se enquadrarem no conceito de "combatente" ao abrigo das disposições de Direito Internacional Humanitário. É, de fato, possível

67 CASSESE, Antonio. Expert Opinion On Whether Israel's Targeted Killings of Palestinian Terrorists is Consonant with International Humanitarian Law. Stop Torture. Available at: <http://www. stoptorture.org.il/files/cassese.pdf $>$. Access in: Feb. 10, 2016.

68 CASSESE, Antonio. Expert Opinion On Whether Israel's Targeted Killings of Palestinian Terrorists is Consonant with International Humanitarian Law. Stop Torture. Available at: < http://www. stoptorture.org.il/files/cassese.pdf>. Access in: Feb. 10, 2016.

69 Relativamente à responsabilização dos Estados pela conduta de atores não estatais no seu território, será de consultar a jurisprudência da Corte Internacional de Justiça no âmbito do processo Corfu Channel (United Kingdom of Great Britan and Northern Ireland v. Albania) que responsabiliza a Albânia por ataques com minas contra a Marinha britânica no Canal de Corfu, em 1946. No mesmo sentido também vai a resolução do Conselho de Segurança das Nações Unidas n. ${ }^{\circ} 471$ (1980), que condenou Israel a pagar indenizações a palestinianos vítimas de tentativas de homicídio perpetradas por colonos judeus.

70 KRETZMER, David. Targeted killing of suspected terrorists: extra-judicial executions or legitimate means of defence?. The European Journal of International Law, New York, v. 16, n. 2, p. 171-212, 2005. p. 187. concluir que, para efeitos da IV Convenção de Haia de 1899 (regulamentada em 1907), se, por um lado, estes grupos são (i) comandados por uma pessoa responsável pelos seus subordinados, (ii) estabelecem emblemas distintivos reconhecíveis à distância e (iii) dirigem ataques abertamente, já não (iv) conduzem as suas operações em respeito pelas leis e costumes da guerra ${ }^{71}$.

Relativamente a esse último elemento, a natureza das atividades e os fins prosseguidos por grupos terroristas transnacionais comprometem o preenchimento desse requisito por incidirem quase exclusivamente na intenção deliberada de provocar a morte a civis como forma de atingir os interesses de um Estado. E, ainda que esse último critério estivesse cumprido, o fato de grupos terroristas não integrarem as Forças Armadas de um Estado envolvido num conflito afasta o preenchimento do quarto requisito ${ }^{72}$.

\subsection{Das teorias que sustentam o recurso à força para legítima defesa}

Importa, porém, recordar a doutrina Caroline, desenvolvida a partir de um incidente entre um navio estadunidense denominado Caroline e as Forças Armadas da Grã-Bretanha, em 1837, sendo a fórmula criada quando, após o navio em apreço ter sido destruído pela marinha britânica sob a justificação de tal ato tratar-se de “auto-preservação e legítima defesa legais", o Secretário de Estado estadunidense Daniel Webster ter afirmado que «o uso de legítima defesa deve estar confinado a situações nas quais um Governo consiga demonstrar que a "necessidade daquela legitima defesa é imediata, avassaladora e não deixa outra alternativa nem outro momento para decidir"». A doutrina ficaria completa com o aditamento do critério de exigência de proporcionalidade no uso da força ${ }^{73}$, encontrando-se a teoria desenvolvida a partir deste caso refletida no arti-

71 OTTO, Roland. Targeted killings and international law: with special regard to human rights and international humanitarian law. Heidelberg: Springer, 2012. p. 227-233.

72 KRETZMER, David. Targeted killing of suspected terrorists: extra-judicial executions or legitimate means of defence?. The European Journal of International Law, New York, v. 16, n. 2, p. 171-212, 2005. p. 191.

73 Sobre a doutrina Caroline, cfr. GREENWOOD, Christopher. International law and the pre-emptive use of force: Afghanistan, Al-Qaida, and Iraq. San Diego International Law Journal, v. 4, p. 7-37, 2003. p. 12-13. GODFREY, Brenda L. Authorization to kill terrorist leaders and those who harbor them: an international analysis of defensive assassination. San Diego International Law Journal, v. 4, p. 491-512, 2003. p. 495-500. 
go $51 .^{\circ}$ da Carta da $\mathrm{ONU}^{74 .}$

Não menos importante é também o contributo da teoria desenvolvida durante a Guerra Fria pela doutrina anglosaxónica e batizada pela doutrina alemã de Nadelstichtaktik, que significa "tática da alfinetada" e é igualmente conhecida como "teoria da acumulação de eventos"75. Segundo essa doutrina, cada ataque concreto perpetrado (ou picada da agulha) por um grupo armado, ainda que não possa ser qualificado, isoladamente, como ataque armado, pode ser equiparado a um ataque armado se se atender aos atos realizados como um todo, o que obriga o Estado vítima a responder com recurso à força. Em suma, à luz desta teoria, vários ataques conduzidos pela mesma entidade não estatal podem servir de motivação para uma resposta armada por parte do Estado visado, ainda que essa resposta deva sempre atender aos princípios exigidos para os conflitos armados em geral, mais concretamente o princípio da proporcionalidade ${ }^{76}$.

A teoria Nadelsticbtaktik acabou por ser aproveitada e adaptada pela doutrina israelense para justificar ataques contra alvos terroristas ${ }^{77}$. Todavia, sublinhe-se que essa teoria não constitui uma regra de direito internacional, não sendo, por isso, vinculativa para toda a Comunidade - ainda que se possa sustentar que a Corte Internacional de Justiça considerou essa teoria nos casos Nicarágua $v$. Estados Unidos da América e República Democrática do Congo v. $U g a n d a^{78}$ - e a doutrina israelense peca ao se desviar

74 GODFREY, Brenda L. Authorization to kill terrorist leaders and those who harbor them: an international analysis of defensive assassination. San Diego International Law Journal, v. 4, p. 491-512, 2003. p. 501.

75 BROWNLIE, Ian. International law and the use of force by states. Oxford: Clarendon, 1963. p. 278-279. HIGGINS, Rosalyn. The development of International Law through the political organs of the United Nations. London: Oxford University, 1963. p. 201; WITTIG, Peter. Der Aggressionsbegriff im internationalen Sprachgebrauch. In: SCHAUMANN, Wilfried. Völkerrechtliches gewaltverbot und friedenssicherung. Baden-Baden: Nomos Verlagsgesellschaft, 1971. p. 33-73. p. 55.

76 FEDER, Norman Menachem. Reading the FEDER, Norman Menachem. Reading the UN charter conotatively: toward a new definition of armed attack. New York. University Journal of International Law and Politics, v. 19, n. 2, p.395-432, winter 1987. p. 415-416.

77 BLUM, Yehuda Z. The Legality of state response to acts of terrorism. In NETANYAHU, Benjamin (Ed.). Terrorism: how the west can win. New York: Farrar, 1986. p. 133-138. p. 136.

78 KATTAN, Victor. Israel, hezbollah and the conflict in lebanon: an act of aggression or self-defense? Human Rights Brief, v. 14, n. 1, p. 26-30, 2006. p. 27. De uma forma mais evidente, os argumentos do Juiz Schwebel apontam nesse sentido. Cfr. CORTE INTERNACIONAL DE JUSTIÇA. Nicarágua v. Estados Unidos da América: Voto do conceito original, uma vez que na Nadelstichtaktik se enfatiza o fato de ser necessário verificar-se o apoio (ou no mínimo a falta de vontade em agir) do Estado a partir do qual os agentes conduzem os ataques ${ }^{79}$.

Ainda que tal hipótese se admita, não serão sustentáveis posições que tentem aplicar o paradigma do conflito armado ao terrorismo transnacional, sobretudo quando justificado com o direito à legítima defesa, uma vez que, no parecer consultivo da Corte Internacional de Justiça, em sede do processo Legal Consequences of the Construction of a Wall in the Occupied Palestinian Territory, o Tribunal foi peremptório ao manifestar-se contra tamanha pretensão quando afirmou que apenas um ataque perpetrado por um Estado pode constituir o tipo de ataque armado contemplado no artigo 51. ${ }^{\circ}$ da Carta das Nações Unidas ${ }^{80}$.

Face ao exposto, a menos que um grupo terrorista transnacional combata ao lado do Estado onde se encontra sedeado ou beneficie do seu apoio desse mesmo Estado - situação em que a organização terrorista seria considerada combatente e os seus membros poderiam constituir-se como objetos de ataques e alvos de execuções seletivas - os membros dessa organização são civis, gozando de todas as prerrogativas que a estes assistem, mesmo que se encontrem a orquestrar ou preparar um ataque ou tenham acabado de cometê-lo ${ }^{81}$.

de vencido do Juiz Schwebel de 27 de junho 1986. Disponível em: $<$ http://www.icj-cij.org/docket/files/70/6523.pdf>. Acesso em: 8 jan. 2016. p. 268-269.

79 BROWNLIE, Ian. International law and the use of force by states. Oxford: Clarendon, 1963. p. 278-279; HIGGINS, Rosalyn. The development of International Law through the political organs of the United Nations. London: Oxford University, 1963. p. 201.

80 CORTE INTERNACIONAL DE JUSTIÇA. Parecer separado do Juir Higgins de 9 de julho de 2004: consequências legais da edificação de um muro no território palestiniano ocupado. Disponível em: <http://www.icj-cij.org/docket/files/131/1681.pdf>. Acesso em: 8 jan. 2016. p. 83; CORTE INTERNACIONAL DE JUSTIÇA. Parecer separado do Juiz. Kooijmans de 9 de julho de 2004: consequências legais da edificação de um muro no território palestiniano ocupado. Disponível em: <http://www.icj-cij.org/docket/files/131/1683. pdf $>$. Acesso em: 8 jan. 2016. p. 97-98; CORTE INTERNACIONAL DE JUSTIÇA. Parecer Separado do Juiz Buergenthal de 9 de julbo de 2004: consequências legais da edificação de um muro no território palestiniano ocupado. Disponível em: <http://www.icj-cij.org/ docket/files/131/1687.pdf>. Acesso em: 8 jan. 2016. p. 109-111. Todavia, há quem recorde que o já referido caso Caroline demonstra que a ameaça tinha origem num ato não estatal e que este não era protegido ou apoiado pelos EUA. Cfr. GREENWOOD, Christopher. International law and the pre-emptive use of force: Afghanistan, Al-Qaida, and Iraq. San Diego International Law Journal, v. 4, p. 7-37, 2003. p. 17.

81 Presume-se que se se encontrarem a executar um ataque, as 
Conforme defendido por alguns autores, a exclusão do terrorismo transnacional dos dois modelos de conflitos armados reconhecidos internacionalmente poderá levar os terroristas a beneficiarem da chamada revolving door theory ou "teoria da porta giratória", que significa que os agentes usufruem "do melhor dos dois mundos - uma vez que podem permanecer civis a maior parte do tempo e apenas colocar em risco a sua proteção como civis quando estiverem a conduzir um ato terrorista"82.

Quem sustenta essa linha de raciocínio tende a defender que terroristas só podem ser visados enquanto combatentes se fizerem parte das hostilidades. Todavia, é importante recordar que grupos terroristas não podem ser qualificados como combatentes por, pelo menos, não conduzirem as suas operações em respeito pelas leis e costumes da guerra e ser sempre de sublinhar que, ainda que possa tratar-se de mera coincidência, a maior parte dos autores que defendem que membros de grupos terroristas podem ser constituídos alvos militares legítimos provêm de Estados como EUA e Israel provavelmente os dois países com mais registros de execuções seletivas contra alvos (alegadamente) terroristas.

\subsection{A "terceira via" às duas espécies de conflitos armados}

Com base na tese referida, o 9/11 daria o mote necessário aos EUA para poderem finalmente agir em conformidade após a declaração de "guerra ao terrorismo", o que se traduziu, pela primeira vez, na história contemporânea estadunidense, na condução de guerra

autoridades do Estado alvo reajam nos mesmos termos em que reagiriam como se o ataque fosse perpetrado por entidades a operar no seu território, procurando, na medida do possível, neutralizá-lo. 82 KRETZMER, David. Targeted killing of suspected terrorists: extra-judicial executions or legitimate means of defence?. The European Journal of International Law, New York, v. 16, n. 2, p. 171-212, 2005. p. 193. Também nesse sentido, PARKS, W. Hays. Air War and the Law of War. Air Force Law Review, v. 32, n. 1, p. 1-225, 1990. p. 118-121; WATKIN, Colonel K. W. Combatants, unprivileged belligerents and conflicts in the 21st century: background paper prepared for the informal high-level expert meeting on the reaffirmation and development of international humanitarian law, cambridge, January 27-29, 2003. Harvard: HPCR, 2003. Available at: < http://www. hpcrresearch.org/sites/default/files/publications/Session2.pdf > . Access in: Feb. 10, 2016. A questão é ainda levantada pela Comissão Interamericana de Direitos Humanos, embora tenha decidido pela inderrogabilidade das regras previstas pelo direito da guerra. Cfr. COMISSÃO INTERAMERICANA DE DIREITOS HUMANOS. Report on terrorism and human rights: executive summary. 2002. Available at: <http://www.cidh.oas.org/Terrorism/Eng/exe.htm>. Access in: Feb. 10, 2016. p. 69-80. contra membros de uma organização: a Al-Qaeda (juntamente com os Talibã) e, posteriormente, também os grupos a ela filiados. Essa "guerra" acabou por ser justificada com o direito à guerra e o direito à autodefesa no âmbito do artigo 51. ${ }^{\circ}$ da Carta da ONU ${ }^{83}$.

Apesar de o Governo Talibã que controlava o Afeganistão ter sido deposto, esse movimento, bem como a Al-Qaeda, mantiveram-se ativos: os Talibãs, por meio do combate armado contra o novo poder político afegão com o objetivo de conquistá-lo; a Al-Qaeda, por meio da orquestração e condução de ataques terroristas contra interesses ocidentais um pouco por todo o mundo, quer pela sua autoria quer por meio de grupos filiados, de meros simpatizantes da causa jihadista ou de "lobos solitários". O terrorismo de matriz islamista conquistou, então, seguidores um pouco por toda a parte, expandindo-se no Oriente Médio e também para o continente africano.

A emergência e alastramento galopantes do jih adismo assumiram proporções tais que tornaram-se numa das principais ameaças a Estados falhados como o Iraque, o Iémen e a Somália. O jihadismo tornou-se um meio muito bem apoiado (financeira e logisticamente) ${ }^{84}$ para qualquer grupo de pessoas conseguir chegar ao poder (ou conquistá-lo por meio da influência ganha junto dos que não o integram), aproveitando-se da ignorância popular, das parcas condições socioeconômicas ou, simplesmente, do ódio contra as culturas ocidentais.

Dada a incapacidade dos grupos jihadistas para combaterem os principais alvos dos seus ataques, os Estados ocidentais, em igualdade de circunstâncias, o modus operandi por excelência passou a incluir atentados contra interesses aparentemente vulneráveis desses países - missões diplomáticas, empresas, cidadãos nacionais e pessoas ligadas ao poder aliadas ou favoráveis aos Estados que se pretende atacar.

As baixas provocadas até ao momento por grupos

83 Não seria a primeira vez que o artigo $51 .^{\circ}$ da Carta da ONU seria utilizado para justificar ações dessa natureza, tendo já sido invocado, no passado, por Israel e EUA, como se recorda em GREENWOOD, Christopher. International law and the pre-emptive use of force: Afghanistan, Al-Qaida, and Iraq. San Diego International Law Journal, v. 4, p. 7-37, 2003. p. 16. GODFREY, Brenda L. Authorization to kill terrorist leaders and those who harbor them: an international analysis of defensive assassination. San Diego International Law Journal, v. 4, p. 491-512, 2003. p. 501.

84 Praticamente sempre com o apoio ministrado pela Arábia Saudita e pelo Qatar, curiosamente, parceiros privilegiados (em matéria militar e energética) daqueles que declaram "guerra ao terrorismo". 
terroristas da matriz islamista são incalculáveis, com grave prejuízo para as populações civis - mortos, feridos graves, deslocados internos e refugiados - e para os próprios Estados - os valores investidos por EUA e União Europeia em esforços de combate contra grupos terroristas aumentaram exponencialmente desde o 11 de Setembro.

Uma vez que o direito da guerra justifica os ataques conduzidos contra órgãos militares e respectivos aliados de um Estado inimigo, até à deposição do Governo Talibã, no Afeganistão, os membros da Al-Qaeda, por participarem dos esforços de guerra, constituíam alvos privilegiados das forças militares que combateram neste país. Todavia, com a queda do poder Talibã no Afeganistão, a guerra contra a Al-Qaeda que encontrava correspondência no direito internacional ${ }^{85}$ tornou-se ilícita com a tomada de posse do Governo transitório afegão, a 19 de Junho de 2002.

Uma vez que, conforme referido, os membros de grupos terroristas (afiliados ou não à Al-Qaeda) não são combatentes, afigurou-se de suprema importância justificar a continuação da beligerância e a presença nos teatros de operações. Manteve-se, assim, a "guerra contra o terrorismo", a qual passou a visar entidades cujos membros são considerados civis.

Para sustentar essa "guerra", foi desenvolvido, oficialmente, pelos EUA o terceiro modelo de conflito armado, segundo o qual os membros de grupos terroristas não são nem combatentes, nem civis, são "combatentes ilegais", uma vez que não se distinguem da população civil e nem respeitam as leis e os costumes da guerra mas conduzem ataques contra Estados soberanos. De acordo com essa teoria, membros de grupos terroristas não gozam de qualquer direito, proteção, imunidade ou privilégio de prisioneiros de guerra e podem ser atacados/executados sempre que forem encontrados, mesmo que não participem nas hostilidades ${ }^{86}$.

Sucede que o terceiro modelo de conflito armado apresenta falhas de tal forma graves que não é possível aceitá-lo como válido ou minimamente justo. Com efeito, contraria os esforços desenvolvidos pela Humanidade ao longo de mais de um século e meio a hipótese de

85 GREENWOOD, Christopher. International law and the preemptive use of force: Afghanistan, Al-Qaida, and Iraq. San Diego International Law Journal, v. 4, p. 7-37, 2003. p. 25.

86 MAXWELL, Colonel Mark "Max". Rebutting the civilian presumption: playing whack-a-mole without a mallet? In: FINKELSTEIN, Claire (Ed.). Targeted killings: law and morality in an asymmetrical world. Oxford: Oxford University, 2012. p. 31-59. p. 46-49. seres humanos, independentemente do grau de beligerância e radicalização, não poderem gozar de quaisquer direitos, nem mesmo o de presunção de inocência, de serem detidos e julgados ou sequer a beneficiarem do princípio de jus cogens segundo o qual ninguém pode ser privado da sua vida humana de forma arbitrária ${ }^{87}$. No fundo, seres humanos deixam de ser humanos.

Paralelamente, ao declarar "guerra ao terrorismo", o Governo estadunidense identificou como adversários “a Al-Qaeda e os seus afiliados"88, "qualquer grupo terrorista de alcance global" 89 ou, simplesmente, o "terrorismo", não sendo feitas distinções entre "os terroristas" e "aqueles que os acolham ou lhes prestem auxílio" Nesse aspeto, concorda-se com Nils Melzer quando o autor afirma que «estas descrições extensivas dificilmente vão de encontro aos requisitos minimos para se ser "parte no conflito" ", uma vez que o conflito deverá resumir-se a grupos organizados suficientemente identificáveis com base em critérios objetivos (e não vagos), não podendo «fenômenos, sejam eles o terrorismo, o capitalismo, o nazismo, o consumo de drogas ou a pobreza, ser "parte num conflito" ${ }^{91 .}$

Finalmente, com o fim do conflito armado no Afeganistão e consequentes ações de grupos terroristas, as execuções seletivas passaram a constituir o método por excelência dos EUA para combater um fenômeno de aplicação material consideravelmente ampla ${ }^{92}$, sem que

87 OTTO, Roland. Targeted killings and international law: with special regard to human rights and international humanitarian law. Heidelberg: Springer, 2012. p. 77-78; MCMAHAN, Jeff. Targeted Killing: Murder, Combat or Law Enforcement. In: FINKELSTEIN, Claire (Ed.). Targeted killings: law and morality in an asymmetrical world. Oxford: Oxford University, 2012. p. 135-155. p. 147; ARABI, Abhner Youssif Mota; FERREIRA, Marcello Caio Ramon e Barros; CARVALHO, Felipe Fernandes de. Terrorismo, direito penal do inimigo e constitucionalismo: a incongruência com o estado democrático de direito. Universitas Jusm, Brasília, v. 23, n. 1, p. 11-22, jan./jun. 2012. p. 20.

88 FOGARTY, Gerard P. Is Guantanamo Bay undermining the war on terror?. Parameters, n. 39, p. 59-67, autumn 2005. p. 54-71.

89 LEIA na íntegra o discurso de Bush no Congresso dos EUA. Folha de São Paulo, São Paulo, 21 set. 2001. Disponível em: <http:// www1.folha.uol.com.br/folha/mundo/ult94u29639.shtml>. Acesso em: 8 jan. 2016.

90 UNITED STATES. Department of State. U.S. national security strategy: strengthen alliances to defeat global terrorism and work to prevent attacks against us and our friends. Available at: $<$ http://2001-2009.state.gov/r/pa/ei/wh/15423.htm>. Access in: Feb. 10, 2016.

91 MELZER, Nils. Targeted killing in international law. New York: Oxford University, 2008. p. 262-263.

92 Constate-se que mesmo crimes contra a propriedade perpetrados por grupos pro-ambientalistas e ativistas da causa animal são passíveis de integrar o conceito de terrorismo. Cfr. HOUSE 
na grande maioria dos casos sejam medidas as consequências reais de tais ações. Com efeito, as execuções seletivas são conduzidas por militares e mediante instruções administrativas de elementos ligados ao poder político, sem envolver, em circunstância alguma, o poder judicial e sem que haja lugar a um julgamento dos alvos (nem mesmo à revelia)

Ainda nesse sentido, refira-se que os alvos selecionados acabam por ser eliminados sem nunca abandonarem o estatuto de meros suspeitos cujos nomes integram uma lista classificada designada Joint Prioritized Effects List (ou, simplesmente, JPEL), com o lema "matar ou capturar", que tem como base informações obtidas pelos Serviços de Inteligência estadunidenses ${ }^{93}$ - independentemente do grau da verosimilhança das notícias recolhidas sobretudo com precedentes como os que motivaram a invasão do Iraque, em 2003.

Não obstante, por norma, não são medidas as consequências de um ataque executado com recurso a uma aeronave não tripulada, atingindo, inúmeras vezes, civis confundidos com os alvos ${ }^{94}$ ou outros que nunca foram sequer suspeitos e acabam por ser danos colaterais apenas por se encontrarem no local errado à hora errada ${ }^{95}$.

Os fatos evidenciam a banalização das execuções seletivas em detrimento de outros meios alternativos que atenuem os danos para a população civil e garantam meios de defesa mínimos e humanizáveis aos potenciais suspeitos ou alegados autores materiais. Com efeito, a bem da dignidade da pessoa humana e pelo tremendo sacrifício que o desenvolvimento da Humanidade, ao longo dos séculos, conheceu, é incompatível com todos os princípios consagrados no Direito Internacional Humanitário qualquer prática que (i) condene alguém por um ato que ainda não foi cometido ou tentado e que

COMMITTEE ON NATURAL RESOURCES. Statement of James F. Jarboe: Eco-terrorism and Lawlessness on the National Forests: Hearing Before the Subcomm. 12 Feb. 2002. Available at: <http:// naturalresources.house.gov/uploadedfiles/jarboe_2.12.02.pdf $>$. Accessed on: Feb. 10, 2016.

93 FINKELSTEIN, Claire. Targeted killing as preemptive action. In: FINKELSTEIN, Claire. (Ed.). Targeted killings: law and morality in an asymmetrical world. Oxford: Oxford University, 2012. p. 156-182.

94 Cfr. ALMASMARI, Hakim. Yemen says U.S. drone struck a wedding convoy, killing 14. CNN, New York, 13 Dec. 2013. Available at: <http://edition.cnn.com/2013/12/12/world/meast/yemen-u-s-drone-wedding/>. Accessed on: Feb. 10, 2016.

95 Cfr. US UNLEASHES three days of drone strikes on Yemen, 55 killed. 21 abr 2014. Available at: <http://rt.com/usa/droneyemen-dozens-dead-880/>. Accessed on: Feb. 10, 2016. (ii) assuma a pena (seja ela ou não de morte) como primeira opção e evite o julgamento fora de um contexto claro de guerra que, como já se constatou, apenas pode ocorrer entre Estados ou entre um Estado e um grupo armado a operar no seu território.

Não parecem oferecer dúvidas que tais atuações violam o artigo $11 .^{\circ}$ da Declaração Universal dos Direitos Humanos, instrumento promovido pelos EUA, que prevê que "toda a pessoa acusada de um ato delituoso presume-se inocente até que a sua culpabilidade fique legalmente provada no decurso de um processo público em que todas as garantias necessárias de defesa lhe sejam asseguradas".

\subsection{A posição adotada pelo Comitê Internacio- nal da Cruz Vermelha}

Face ao exposto, será de rejeitar o terceiro modelo de conflito armado sugerido por escolas estadunidenses e israelitas, uma vez que, se a definição de "conflito armado" desenvolveu-se lentamente até à sua consolidação durante mais de um século, alterar o seu escopo e alargá-lo de tal forma ao ponto de legitimar a execução de seres humanos ${ }^{96}$ com base em suspeições (ou até mesmo alegadas "provas sólidas") sem um julgamento justo constituiria a negação de todo um sistema que tanto custou a conceber e a desenvolver em favor da Humanidade.

Todavia, não será também possível ficarmos indiferentes à evolução da realidade global, à sofisticação de atores dedicados à criminalidade transnacional (na qual se inclui o terrorismo) e ainda à possível proteção conferida a essas entidades. Se, por um lado, as execuções seletivas comprometem a dignidade a que têm direito aqueles que se constituem como alvos, por outro lado, não será tolerável permitir que se organizem e atuem com total impunidade. Tal, também resultaria na negação do sistema de valores referido anteriormente.

Com base nisso, e como forma de tentar dar resposta às necessidades de esclarecer o significado do que é ter "participação direta nas hostilidades", à luz da realidade internacional pós-9/11, o Comitê Internacional da Cruz Vermelha apresentou, em 2009, um estudo aprofundado sobre o tema, da autoria de Nils Melzer, intitulado Interpretive Guidance on the Notion of Direct Parti-

96 Ideia partilhada em MELZER, Nils. Targeted killing in international law. New York: Oxford University, 2008. p. 269. 
cipation in Hostilities under International Humanitarian Law ${ }^{97}$.

Para esse efeito, o Comitê procede, desde logo, a uma primeira distinção entre Forças Armadas dissidentes e outros grupos armados organizados. Se as primeiras são compostas por antigos militares que combatem um Estado, já os segundos recrutam membros primordialmente entre a população civil mas desenvolvem um grau de organização militar suficiente para conduzir hostilidades em nome de uma parte no conflito, ainda que nem sempre disponha dos mesmos meios, intensidade ou nível de sofisticação das Forças Armadas ${ }^{98}$. O Guia acrescenta que o termo "outros grupos armados" organizados abrange exclusivamente a ala militar de atores não estatais ${ }^{99}$.

Por outro lado, um membro de um grupo armado organizado e um civil distinguem-se pelo desempenho (ou não) de funções de combate de forma contínua ${ }^{100}$. Assim, para que um indivíduo seja qualificado como membro de um grupo armado organizado (ou beligerante) e, como tal, possa constituir-se como alvo legítimo de um ataque é necessário que preencha três requisitos:

97 INTERNATIONAL COMMITTEE OF THE RED CROSS. Interpretive Guidance on the Notion of Direct Participation in Hostilities under International Humanitarian Law: Adopted by the Assembly of the International Committee of the Red Cross on 26 February 2009. International Review of the Red Cross, v. 90, n. 872, p. 991-1047, Dec. 2008. Available at: <http://www.icrc.org/eng/assets/files/other/irrc-872-reports-documents.pdf $>$. Access in: Feb. 10, 2016.

98 INTERNATIONAL COMMITTEE OF THE RED CROSS. Interpretive Guidance on the Notion of Direct Participation in Hostilities under International Humanitarian Law: Adopted by the Assembly of the International Committee of the Red Cross on 26 February 2009. International Review of the Red Cross, v. 90, n. 872, p. 991-1047, Dec. 2008. Available at: <http://www.icrc.org/eng/assets/files/other/irrc-872-reports-documents.pdf $>$. Access in: Feb. 10, 2016. p. 1006-1007.

99 INTERNATIONAL COMMITTEE OF THE RED CROSS. Interpretive Guidance on the Notion of Direct Participation in Hostilities under International Humanitarian Law: Adopted by the Assembly of the International Committee of the Red Cross on 26 February 2009. International Review of the Red Cross, v. 90, n. 872, p. 991-1047, Dec. 2008. Available at: <http://www.icrc.org/eng/assets/files/other/irrc-872-reports-documents.pdf $>$. Access in: Feb. 10, 2016. p. 1002-1003; 1006-1007.

100 INTERNATIONAL COMMITTEE OF THE RED CROSS. Interpretive Guidance on the Notion of Direct Participation in Hostilities under International Humanitarian Law: Adopted by the Assembly of the International Committee of the Red Cross on 26 February 2009. International Review of the Red Cross, v. 90, n. 872, p. 991-1047, Dec. 2008. Available at: < http://www.icrc.org/eng/assets/files/other/irrc-872-reports-documents.pdf $>$. Access in: Feb. 10, 2016. p. 1007.
- $\quad$ pertencer a um grupo organizado, porque para se exercer funções de combate de forma contínua é necessário que se integre um grupo armado organizado ${ }^{101}$;

- o grupo organizado a que pertence tem de conduzir hostilidades ${ }^{102103}$;

- o beligerante tem de ter participação direta nas hostilidades conduzidas pelo grupo a que pertence ${ }^{104}$.

Com essas regras, busca-se manter a regra de o beligerante gozar de proteção semelhante ao de um civil e, simultaneamente, pretende-se diferenciá-lo do estatuto de que gozam os combatentes e os beligerantes em sede de conflito armado internacional e não internacional, respetivamente, que podem ser alvo de ataques legítimos enquanto durarem as hostilidades.

No entanto, cria-se a exceção de o beligerante ficar desprotegido apenas quando, assumidamente, vier a tomar parte nas hostilidades - ainda que o conceito de hostilidade acabe por determinar que a solução proposta praticamente só possa ser aplicada quando estes grupos armados tomarem ações diretamente contra as Forças Armadas de um Estado definido como alvo.

101 INTERNATIONAL COMMITTEE OF THE RED CROSS. Interpretive Guidance on the Notion of Direct Participation in Hostilities under International Humanitarian Law: Adopted by the Assembly of the International Committee of the Red Cross on 26 February 2009. International Review of the Red Cross, v. 90, n. 872, p. 991-1047, Dec. 2008. Available at: <http://www.icrc.org/eng/assets/files/other/irrc-872-reports-documents.pdf $>$. Access in: Feb. 10, 2016. p. 1007.

102 INTERNATIONAL COMMITTEE OF THE RED CROSS. Interpretive Guidance on the Notion of Direct Participation in Hostilities under International Humanitarian Law: Adopted by the Assembly of the International Committee of the Red Cross on 26 February 2009. International Review of the Red Cross, v. 90, n. 872, p. 991-1047, Dec. 2008. Available at: <http://www.icrc.org/eng/assets/files/other/irrc-872-reports-documents.pdf $>$. Access in: Feb. 10, 2016. p. 1007.

103 Embora não exista uma definição concreta da noção de "hostilidades", existe o entendimento de que esse conceito integra operações militares e não apenas meros ataques conduzidos contra $O$ adversário, podendo incluir atos que visem as Forças Armadas do Estado inimigo. Cfr. MELZER, Nils. Targeted killing in international law. New York: Oxford University, 2008. p. 269-275.

104 INTERNATIONAL COMMITTEE OF THE RED CROSS. Interpretive Guidance on the Notion of Direct Participation in Hostilities under International Humanitarian Law: Adopted by the Assembly of the International Committee of the Red Cross on 26 February 2009. International Review of the Red Cross, v. 90, n. 872, p. 991-1047, Dec. 2008. Available at: < http://www.icrc.org/eng/assets/files/other/irrc-872-reports-documents.pdf $>$. Access in: Feb. 10, 2016. p. 1019-1021. 
Em suma, não se responsabiliza e desprotege o beligerante pelas ações hostis do grupo a que pertence, mesmo quando assuma que acompanha ou apoia um determinado grupo armado organizado, mas apenas quando for ele próprio a participar nas hostilidades ${ }^{105}$. E, mesmo nos casos em que planeje um ataque, não é certo que se enquadre no requisito da participação direta, uma vez que tem de haver um nexo causal entre um ato específico e o dano passível de resultar, ora desse ato, ora de uma operação militar da qual esse ato constitua parte integral ${ }^{106}$.

Esse conjunto de requisitos é acusado pela doutrina estadunidense de proteger jihadistas e outros indivíduos que apoiem grupos terroristas (incluindo por meio da produção de equipamentos passíveis de serem utilizados nos seus ataques) se não forem eles os autores materiais das hostilidades do seu grupo ${ }^{107}$. Acrescentam, ainda, para esse efeito, que o Comentário ao Protocolo I Adicional às Convenções de Genebra reforça o valor atribuído à relação entre o objetivo de causar dano e a possibilidade de um ato poder resultar nesse mesmo dano $^{108}$.

105 INTERNATIONAL COMMITTEE OF THE RED CROSS. Interpretive Guidance on the Notion of Direct Participation in Hostilities under International Humanitarian Law: Adopted by the Assembly of the International Committee of the Red Cross on 26 February 2009. International Review of the Red Cross, v. 90, n. 872, p. 991-1047, Dec. 2008. Available at: <http://www.icrc.org/ eng/assets/files/other/irrc-872-reports-documents.pdf $>$. Access in: Feb. 10, 2016.

106 INTERNATIONAL COMMITTEE OF THE RED CROSS. Interpretive Guidance on the Notion of Direct Participation in Hostilities under International Humanitarian Law: Adopted by the Assembly of the International Committee of the Red Cross on 26 February 2009. International Review of the Red Cross, v. 90, n. 872, p. 991-1047, Dec. 2008. Available at: < http://www.icrc.org/eng/assets/files/other/irrc-872-reports-documents.pdf $>$. Access in: Feb. 10, 2016. p. 1019.

107 MAXWELL, Colonel Mark "Max". Rebutting the civilian presumption: playing whack-a-mole without a mallet? In: FINKELSTEIN, Claire (Ed.). Targeted killings: law and morality in an asymmetrical world. Oxford: Oxford University, 2012. p. 31-59. p. 51; CORN, Geoffrey; JENKS, Chris. Two sides of the combatant coin: untangling direct participation in hostilities from belligerent status in non-international armed conflicts. University of Pennsylvania Journal of International Law, v. 33. n. 2, p. 313-362, 2011.

108 Para uma breve leitura a críticas feitas à tese de Nils Melzer para o Comitê Internacional da Cruz Vermelha, Cfr. MAXWELL, Colonel Mark "Max". Rebutting the civilian presumption: playing whack-a-mole without a mallet? In: FINKELSTEIN, Claire (Ed.). Targeted killings: law and morality in an asymmetrical world. Oxford: Oxford University, 2012. p. 31-59. p. 49-54.

\section{DA NECESSIDADE DE TRATAR OS TERRORISTAS COMO CIVIS E DOS CINCO REQUISITOS QUE EX- CLUEM A ILICITUDE DA EXECUÇÃO}

Ao contrário das teses que apontam fragilidades à solução proposta pelo Comitê Internacional da Cruz Vermelha, entendemos que a doutrina consagrada no Guia Interpretativo será aquela que se aproxima, de entre as disponíveis, de um sistema mais justo e de acordo com os valores desenvolvidos ao longo dos séculos em defesa da dignidade da pessoa humana - designadamente, a proteção da vida humana, a proteção de inocentes contra danos desproporcionais ou injustificados, o princípio da presunção de inocência, o direito a um julgamento justo e até mesmo o do Estado de Direito ${ }^{109}$.

O simples fato de não haver acordo ou o mínimo consenso ao nível doutrinário quanto ao entendimento sobre (i) quem pode ser alvo de ataque fora das situações previstas nas Convenções de Genebra de 1949 e respetivos Protocolos Adicionais, (ii) em que circunstâncias e (iii) com que meios podem ser atacados os alvos demonstra que o comportamento adotado oficialmente por um número demasiado residual de Estados e de forma reiterada há pouco mais de uma década não pode ser entendido como passível de formar costume.

Por esse motivo, entendemos ser necessário intensificar o debate antes de se consagrar, oficialmente, um terceiro estatuto de conflito (armado ou não), seja por meio de um novo Protocolo Adicional às Convenções de Genebra ou por meio de outros instrumentos, e/ ou o mesma seja assumido como prova de uma prática geral sobre o Direito, formando costume ${ }^{110}$.

Paralelamente, entendemos que, na ausência de consenso internacional em torno dos conflitos que

109 Ideia partilhada em MELZER, Nils. Targeted killing in international law. New York: Oxford University, 2008. p. 239.

110 Embora não exista um critério quantificável que permita universalizar o conteúdo de um Tratado ou uma Convenção, será possível integrá-lo no direito consuetudinário internacional se aqueles forem ratificados ou os seus princípios adotados por um número muito elevado de partes e tanto a jurisprudência internacional como a doutrina partilharem o mesmo entendimento quanto à sua aplicação. A opinio juris pode ser dada por meio de consenso em fora ou organizações internacionais. Cfr. ESCARAMEIA, Paula. Quando o Mundo das Soberanias se transforma no Mundo das Pessoas. In: ESCARAMEIA, Paula. O Direito Internacional Público nos Princípios do Século XXI. Coimbra: Almedina, 2009. p. 183; MELZER, Nils. Targeted killing in international law. New York: Oxford University, 2008. p. 181. 
oponham atores estatais a entidades não estatais a conduzirem ações nos mesmos termos que os grupos envolvidos em atos terroristas transnacionais (contra alvos primordialmente civis, sem recurso ao confronto armado e de forma pontual), o quadro normativo existente já prevê mecanismos que visam combater a impunidade de atores que atentem contra interesses de terceiros.

Com efeito, as regras aplicáveis aos conflitos armados internacional e não internacional são, na verdade, regimes excepcionais face ao modelo de Aplicação da Lei adotado para as forças e serviços de defesa e de segurança ${ }^{111}$, uma vez que as primeiras duas só vigoram no âmbito de uma situação passível de ser caracterizada como conflito armado (e enquanto esta durar) e o último é de aplicação permanente em territórios com funcionários responsáveis pela Aplicação da Lei.

Assim, embora seja reconhecida como direito internacional costumeiro ${ }^{112}$ e, conforme anteriormente referido, já tenha sido invocada em casos precedentes, parece não se justificar a aplicação da regra excepcional do artigo 51. ${ }^{\circ}$ da Carta da ONU às situações em apreço se não estivermos perante uma situação de cobertura dada por um Estado-Membro da ONU - embora alguns autores entendam que o artigo 51. ${ }^{\circ}$ deva ser aplicado a qualquer ataque físico contra o território de um Estado, não apenas porque por altura da concepção da Carta a temática do terrorismo era alvo de uma abordagem diferente, como se se entender que existam razões para esperar a continuação de ataques futuros a partir da mesma fonte, sendo a motivação a necessidade de proteção e não a retaliação ${ }^{113}$.

Nesses termos, execuções seletivas conduzidas por Estados contra alvos que não reúnam condições suficientes para se integrarem no conceito de alvo militar ou fora do quadro de conflito armado só poderão ter lugar quando estiverem preenchidos os seguintes cinco requisitos:

a) a execução seletiva for absolutamente necessária para evitar uma ameaça real ${ }^{114}$, atual e con-

111 Ou modelo law enforcement.

112 PICKARD, Daniel. Legalizing'assassination? terrorism, the central intelligence agency, and international law. Georgia Journal of International and Comparative Law, v. 30, n. 1, p. 1-34, 2001. p. 18-19.

113 GODFREY, Brenda L. Authorization to kill terrorist leaders and those who harbor them: an international analysis of defensive assassination. San Diego International Law Journal, v. 4, p. 491-512, 2003. p. 502-504; 507-509.

114 É preciso avaliar se o agente que pretende conduzir o ataque creta para o Estado atuante ${ }^{115}$, nomeadamente estando em causa a vida de terceiros;

b) o autor material tentar concretizar o ataque que cria essa ameaça;

c) a execução seletiva dirigir-se apenas contra os autores materiais do ataque;

d) existirem garantias de que os danos colaterais serão mínimos ou que os interesses a proteger serão sempre superiores face aos danos colaterais que legitimamente se estima que venham a ocorrer;

e) todas as tentativas para impedir o alvo de conduzir o ataque forem infrutíferas ${ }^{116 .}$

No âmbito dessa tese, indivíduos associados a grupos terroristas transnacionais devem sempre beneficiar do estatuto de civil, pelo que não podem ser constituídos como alvos de ataques por parte de atores estatais e devem, em contrapartida, ser desencadeadas todas as ações necessárias junto do Estado a partir do qual operam para que se proceda à detenção dos agentes (e não apenas potenciais agentes) sempre que seja praticada uma ação que preencha os elementos de um determinado tipo de crime.

Assim, deverá privilegiar-se a detenção dos agentes - quer pelas forças e serviços de segurança do Estado onde estes se encontram, quer em coordenação com forças e serviços de segurança do Estado vítima, mas sempre sem que seja violada a soberania do Estado acolhedor -, os quais, com ou sem extradição, devem sempre ter direito a um julgamento justo nos mesmos termos que qualquer outro crime ${ }^{117}$.

reúne os dois elementos fundamentais para que uma ameaça possa ser real (a intenção de executar a ação e a capacidade para concretizá-la) ou se, apenas, tem um deles (a mera intenção desacompanhada de meios adequados).

115 Informações recolhidas pelos serviços de informações não podem servir de meio de prova se a ameaça não se materializar.

116 Poder-se-ia questionar se não serão de considerar, também, as situações em que o ataque seja previsível, as forças e serviços de segurança comuniquem esse cenário muito provável ao Estado e este não faça tudo o que devia fazer para evitar que ataques destes se materializassem. Contudo, entendemos que não devemos aceitar tal interpretação, não só por poder verificar-se uma situação de manifesta impossibilidade do Estado para investir em mecanismos de defesa suficientemente sofisticados como tal argumento poderia potenciar a aposta em ideologias fundamentalistas em matéria de defesa e segurança ao ponto de se ignorarem direitos, liberdades e garantias em prol do coletivo - como já sucede, aliás, em algumas sociedades.

117 Em favor da condução de ação militar preemptiva, embora com limites, cfr. GREENWOOD, Christopher. International law 
Afinal, o terrorismo não pode constituir um tipo de crime tão especial que se equipare a conflitos armados ${ }^{118}$ e que beneficie de um regime semelhante a estes quando não estamos, como já referido, perante um conflito armado, no sentido que 196 Estados the quiseram dar, mas, sim, perante atos criminosos passíveis de serem resolvidos pelos meios tradicionais ${ }^{119}$.

Neste quadro, e a título de exemplo, se, por um lado, seria legítima a condução de uma execução seletiva contra Osama bin Laden quando os EUA declararam guerra aos Talibã, que governavam o Afeganistão, e à Al-Qaeda - que se enquadrou no conceito de combatente para efeitos das Convenções de Genebra de 1949 -, com a tomada de posse do novo poder político afegão, a 19 de Junho de 2002, os EUA perderam legitimidade para conduzirem uma execução seletiva contra bin Laden.

Desse modo, a operação contra o complexo de Abbottabad, a 2 de Maio de 2011, foi ilegítima, ilícita e violou o Direito Internacional, na medida em que:

a) perante a ausência de guerra efetiva, uma execução seletiva contra Osama bin Laden só poderia ter tido lugar se estivessem preenchidas as cinco condições do modelo de Aplicação da Lei - o que não sucedeu;

b) deveria ter havido coordenação entre os EUA e o Paquistão para que este desenvolvesse iniciativas que levassem à detenção de Osama bin Laden e, posteriormente, se considerassem os termos de uma possível extradição com vista à realização de um julgamento justo;

c) poderá equacionar-se a hipótese de essa intervenção constituir um ato de agressão contra o Paquistão, na medida em que foi conduzida uma ação militar em solo paquistanês sem o consentimento deste Estado ${ }^{120 .}$

and the pre-emptive use of force: Afghanistan, Al-Qaida, and Iraq. San Diego International Law Journal, v. 4, p. 7-37, 2003. p. 36. GODFREY, Brenda L. Authorization to kill terrorist leaders and those who harbor them: an international analysis of defensive assassination. San Diego International Law Journal, v. 4, p. 491-512, 2003. p. 503. 118 Nem mesmo crimes contra o Estado como a espionagem ou violação do segredo de Estado, são geridos como o caso do terrorismo, pese embora a gravidade dos mesmos.

119 A título de exemplo, o tráfico de seres humanos ou de estupefacientes.

120 Embora não exista uma definição concreta do que constitui um ato de agressão, não poderá ser-se indiferente ao conjunto de critérios previstos no novo artigo $8 .^{\circ}$ bis introduzido no Estatuto de Roma a 11 de Junho de 2010, após a Assembleia de Estados-Parte

\section{Considerações finais}

A tendência de recurso a execuções seletivas compromete os esforços desenvolvidos ao longo de mais de 150 anos de afirmação e consolidação do Direito Internacional Humanitário ao provocar um nível elevado de mortes, ofensas à integridade física e destruição injustificadas. Ao contrário do que os autores de execuções seletivas procuram justificar, as motivações que inspiram tais atos e os fundamentos invocados carecem de necessidade militar (enquanto princípio de Direito) dada a desproporcionalidade dos meios face ao grau da ameaça e a ausência de um quadro legal que justifique a realização de execuções seletivas.

Desse modo, é sem surpresa que se assiste às tentativas de legitimar uma prática censurável por meio da retórica ou de manobras de diversão criadas para o efeito. Contudo, constata-se que a associação da autodefesa em nome da segurança e do princípio da necessidade militar às execuções seletivas constitui (mais) uma tentativa de invocar a excepção como forma de justificar uma conduta que é desconforme as leis e costumes da guerra - prática que se imortalizou com a doutrina adotada na Prússia entre o final do século XIX e o início do século XX denominada Kriegsraison ${ }^{121}$.

Recorde-se, aliás, que até os tribunais estadunidenses, quando criaram o conceito de "combatente ilegal" defenderam que este está sujeito a "captura e detenção como prisioneiro de guerra, mas, adicionalmente, será sujeito a julgamento e sanção por tribunais militares por atos que demonstrem que a sua beligerância é ilícita"122. A constatação em favor da detenção e sujeição do "combatente ilegal" a julgamento, que lhe permita usufruir das garantias de defesa consagradas pelos sistemas legais de um Estado de Direito, significa que nem sequer a gênese do termo permite justificar a realização de execuções seletivas, apoiando antes a detenção e o julgamento dos agentes - independentemente de virem a ser condenados a pena de morte - e quando exista uma base concreta de acusação.

No mesmo sentido, as execuções seletivas que se-

realizada em Kampala, Uganda.

121 Para mais sobre o tema, Cfr. MELZER, Nils. Targeted killing in international law. New York: Oxford University, 2008. p. 279 e ss. 122 Tradução nossa a partir de ESTADOS UNIDOS. Suprema Corte. 1942. Sentença de 31 de julho. Ex Parte Quirin e outros. Disponível em: <https://supreme.justia.com/cases/federal/ us/317/1/case.html>. Acesso em: 8 jan. 2016. p. 317 U. S. 4, §9. 
jam motivadas pela obrigação de um Estado em garantir a defesa e a segurança da sociedade ${ }^{123}$ - como forma de antecipação de crimes que se crê poderem ser cometidos no futuro (precrimes) -, bem como a noção de combatente ilegal, não encontram qualquer base de sustentação ${ }^{124}$, quer ao nível da jurisprudência internacional, quer na opinio juris - com excepção feita a autores estadunidenses e israelitas, que se encontram isolados nessa matéria ${ }^{125}$-, concluindo-se que se tratam de mecanismos que violam o Direito Internacional Humanitário ${ }^{126}$. Em suma, a realização de execuções seletivas encontra a sua justificação apenas na decisão política e em correntes internas dos Estados que as prosseguem.

Conforme sugerido por Craig Martin, as execuções seletivas poderão levar à interpretação flexível do princípio da autodefesa. O uso da força contra atores não estatais, conforme defendido por EUA e Israel, fragiliza o regime jus ad bellum passando a permitir violações de direitos humanos ao mesmo tempo que garantem impunidades ${ }^{127}$. Por esse motivo, deverá ser trilhado o caminho no sentido de deslegitimar as execuções seletivas no presente para que, futuramente, não seja dada

123 Ao contrário da tese desenvolvida pela "doutrina Bush" que sustenta o princípio da autodefesa preventiva ou preemptiva, a jurisprudência da Corte Internacional de Justiça é categórica ao afirmar que só pode ser admitido o recurso à autodefesa como resposta a um ataque armado. Nesse sentido, cfr. CORTE INTERNACIONAL DE JUSTIÇA. 2003. Sentença de 6 de novembro, República Islâmica do Irã v. Estados Unidos da América. Disponível em: <http://www.icjcij.org/docket/files/90/9715.pdf>. Acesso em: 8 jan. 2016. \$61-64; CORTE INTERNACIONAL DE JUSTIÇA. 2005. Sentença de 19 de dezembro, República Democrática do Congo v. Uganda. Disponível em: $<$ http://www.icj-cij.org/docket/files/116/10455.pdf>. Acesso em: 8 jan. 2016. \$143-147.

124 Sobre o estatuto dos "combatentes ilegais", cfr. OTTO, Roland. Targeted killings and international law: with special regard to human rights and international humanitarian law. Heidelberg: Springer, 2012. p. 331-340. Verificar

125 Saliente-se que a Corte Internacional de Justiça, no âmbito do processo Military and Paramilitary Activities in and against Nicaragua (Nicarágua v. Estados Unidos da América), pronunciou-se no sentido de condenar atos de visem condenar não combatentes a penas de morte sem julgamento prévio e ainda de executarem alvos selecionados, incluindo magistrados, membros das forças e serviços de segurança, entre outros. Cfr. CORTE INTERNACIONAL DE JUSTIÇA. 1986. Sentença de 27 de junho, Nicarágua v. Estados Unidos da América. <Disponível em: http://www.icj-cij.org/docket/files/70/6503. pdf $>$. Acesso em: 8 jan. 2016. \$255.

126 Nesse sentido, OTTO, Roland. Targeted killings and international law: with special regard to human rights and international humanitarian law. Heidelberg: Springer, 2012. p. 340-347.

127 MARTIN, Craig. Going Medieval: Targeted Killing, Self-Defence and the Jus Ad Bellum Regime. In: FINKELSTEIN, Claire (Ed.). Targeted killings: law and morality in an asymmetrical world. Oxford: Oxford University, 2012. p. 223-252. p. 248-252. qualquer justificação para se usar a força diretamente contra um Estado ${ }^{128}$ sob pretexto de se prosseguir um bem maior ${ }^{129}$ sem que exista uma ameaça concreta, real e atual ${ }^{130}$.

Nesse quadro e como forma de evitar a concretização de doutrinas consequencialistas aventureiras que acabam mais por provocar um retrocesso no direito com instrumentos contemporâneos do que fazer justiça no verdadeiro sentido da palavra - ou mesmo a adoção de um conceito de utilidade questionável (como o proposto pelo Comitê Internacional da Cruz Vermelha -, o modelo de Aplicação de Lei deverá prevalecer e impor-se como primordial.

Do mesmo modo, deverá ser dada prioridade à cooperação entre Estados no sentido de garantir a realização de justiça e um julgamento digno a civis que não integram Forças Armadas nem uma parte que esteja em guerra e pertencem a grupos de crime organizado com motivações político-ideológicas mas que não são, nunca, beligerantes no sentido dado pelas Convenções de Haia e de Genebra.

Certo é que cabe à Comunidade Internacional a tomada de posições que visem a reposição da legalidade por parte de Estados que prosseguem a política de execuções seletivas com base em Direito criado e aplicado em violação do Direito Internacional. De fato, o papel da Comunidade Internacional enquanto justiceira da legalidade assume importância única, uma vez que, como sustenta Hans Kelsen, aos Estados é reconhecido o poder de criar Direito com a condição de o fazerem em respeito pelo Direito Internacional - pois cabe ao Direito Internacional o reconhecimento da legalidade do Direito interno, sob pena de os Estados incorrerem em ilícito e serem alvos de sanções por via de represálias ou da guerra ${ }^{131}$.

No entanto, porque a norma criada em violação do Direito Internacional mantém-se válida, mesmo do ponto de vista internacional, uma vez que inexiste no Direito Internacional geral qualquer procedimento com

128 MARTIN, Craig. Going Medieval: Targeted Killing, Self-Defence and the Jus Ad Bellum Regime. In: FINKELSTEIN, Claire (Ed.). Targeted killings: law and morality in an asymmetrical world. Oxford: Oxford University, 2012. p. 223-252. p. 248.

129 A beleza está nos olhos de quem a vê.

130 Casos há em que a ameaça também só está nos olhos de quem a vê.

131 KELSEN, Hans. Teoria pura do direito. Tradução de João Baptista Machado. 2. ed. Coimbra: Almedina, 2008. p. 358-361. 
vista à sua anulação, uma anulação só poderá ser possível por meio do Direito Internacional pactício ou por meio da aplicação das referidas sanções que obriguem os Estados a corrigirem o seu posicionamento ${ }^{132}$. Existirá coragem internacional para isso?

\section{REFERÊNCIAS}

ALMASMARI, Hakim. Yemen says U.S. drone struck a wedding convoy, killing 14. CNN, New York, 13 Dec. 2013. Available at: <http://edition.cnn. com/2013/12/12/world/meast/yemen-u-s-dronewedding/>. Access in: Feb. 10, 2016.

ALVES, Lucas Garcia. A necessidade de regulamentação dos conflitos armados para o reestabelecimento da democracia. Revista de Direito Internacional, Brasilia, v. 9, n. 2, p. 45-67, jul./dez. 2012.

AMNESTY INTERNATIONAL. Israel and the occupied territories: state assassinations and other unlawful killings. 2001. Available at: <https://www.amnesty.org/en/documents/MDE15/005/2001/en/>. Access in: Feb. 10, 2016.

ARABI, Abhner Youssif Mota; FERREIRA, Marcello Caio Ramon e Barros; CARVALHO, Felipe Fernandes de. Terrorismo, direito penal do inimigo e constitucionalismo: a incongruência com o estado democrático de direito. Universitas Jusm, Brasília, v. 23, n. 1, p. 11-22, jan./jun. 2012.

BASSIOUNI, M. Cherif. International criminal law: sources, subjects and contents. 3. ed. Leiden: M. Nijhoff, 2008. v. 1.

BLUM, Yehuda Z. The Legality of state response to acts of terrorism. In NETANYAHU, Benjamin (Ed.). Terrorism: how the west can win. New York: Farrar, 1986. p. 133-138.

BRASIL. Câmara dos Deputados. Decreto $n^{0} 378$, de 15 de outubro de 1935. Disponível em: <http://www2.

132 A fim de legitimar o alargamento do âmbito de aplicação do artigo $51 .^{\circ} \mathrm{da}$ Carta da ONU, alguns autores, essencialmente estadunidenses, têm defendido a sua revisão. Cfr. GODFREY, Brenda L. Authorization to kill terrorist leaders and those who harbor them: an international analysis of defensive assassination. San Diego International Law Journal, v. 4, p. 491-512, 2003. p. 510-512. GREENWOOD, Christopher. International law and the pre-emptive use of force: Afghanistan, Al-Qaida, and Iraq. San Diego International Law Journal, v. 4, p. 7-37, 2003. p. 8-9. camara.leg.br/legin/fed/decret/1930-1939/decreto378-15-outubro-1935-557435-publicacaooriginal77825-pe.html>. Acesso em: 10 fev. 2016.

BROWNLIE, Ian. International law and the use of force by states. Oxford: Clarendon, 1963.

CASSESE, Antonio. Expert Opinion On Whether Israel's Targeted Killings of Palestinian Terrorists is Consonant with International Humanitarian Law. Stop Torture. Available at: <http://www.stoptorture.org.il/files/cassese.pdf $>$. Access in: Feb. 10, 2016.

\section{COMISSÃO INTERAMERICANA DE DIREITOS} HUMANOS. Report on terrorism and buman rights: executive summary. 2002. Available at: <http://www.cidh. oas.org/Terrorism/Eng/exe.htm>. Access in: Feb. 10, 2016.

CORN, Geoffrey. Mixing apples and hand grenades: the logical limit of applying human rights norms to armed conflict. Journal of International Humanitarian Legal Studies, Leiden, v. 1. n. 1, p. 52-94, 2010.

CORN, Geoffrey; JENKS, Chris. Two sides of the combatant coin: untangling direct participation in hostilities from belligerent status in non-international armed conflicts. University of Pennsylvania Journal of International Law, v. 33. n. 2, p. 313-362, 2011.

CORTE INTERNACIONAL DE JUSTIÇA. 1970. Sentença de 5 de fevereiro, Bélgica vs. Espanha. Disponível em: <http://www.icj-cij.org/docket/files/50/5387. pdf $>$. Acesso em: 8 jan. 2016.

CORTE INTERNACIONAL DE JUSTIÇA. 1986. Sentença de 27 de junho, Nicarágua v. Estados Unidos da América. <Disponível em: http://www.icj-cij.org/docket/files/70/6503.pdf>. Acesso em: 8 jan. 2016.

CORTE INTERNACIONAL DE JUSTIÇA. 2003. Sentença de 6 de novembro, República Islâmica do Irã v. Estados Unidos da América. Disponível em: <http://www.icjcij.org/docket/files/90/9715.pdf>. Acesso em: 8 jan. 2016.

CORTE INTERNACIONAL DE JUSTIÇA. 2005. Sentença de 19 de dezembro, República Democrática do Congo v. Uganda. Disponível em: <http://www.icj-cij.org/ docket/files/116/10455.pdf>. Acesso em: 8 jan. 2016.

CORTE INTERNACIONAL DE JUSTIÇA. Carta datada de 16 de junho de 1995 do Conselheiro Jurídico do Ministério dos Assuntos Exteriores e da Commonwealth do Reino Unido da Grã-Bretanha e Irlanda do Norte, juntamente com os 
comentários escritos do Reino Unido: legalidade da ameaça ou uso de armas nucleares. Disponível em: <http://www. icj-cij.org/docket/files/95/8802.pdf $>$. Acesso em: 8 jan. 2016.

CORTE INTERNACIONAL DE JUSTIÇA. Carta datada de 16 de junho de 1995 do Ministro dos Negócios Estrangeiros do Reino dos Paises Baixos juntamente com a declaração escrita do governo dos Países Baixos: legalidade da ameaça ou uso de armas nucleares. Disponível em: <http://www. icj-cij.org/docket/files/95/8690.pdf $>$. Acesso em: 8 jan. 2016.

CORTE INTERNACIONAL DE JUSTIÇA. Carta datada de 20 de junho de 1995 do Ministro dos Negócios Estrangeiros da República Francesa juntamente com a declaração escrita do governo da República Francesa: legalidade da ameaça ou uso de armas nucleares. Disponível em: <http://www. icj-cij.org/docket/files/95/8701.pdf>. Acesso em: 8 jan. 2016.

CORTE INTERNACIONAL DE JUSTIÇA. Nicarágua v. Estados Unidos da América: Voto de vencido do Juiz Schwebel de 27 de junho 1986. Disponível em: <http:/ / www.icj-cij.org/docket/files/70/6523.pdf $>$. Acesso em: 8 jan. 2016.

CORTE INTERNACIONAL DE JUSTIÇA. Parecer divergente do Juiz. Weeramantry de 8 de julho de 1996: legalidade da ameaça ou uso de armas nucleares. Disponível em: <http://www.icj-cij.org/docket/files/95/7521.pdf >. Acesso em: 8 jan. 2016.

CORTE INTERNACIONAL DE JUSTIÇA. Parecer Separado do Juiz. Buergenthal de 9 de julho de 2004: consequências legais da edificação de um muro no território palestiniano ocupado. Disponível em: <http://www. icj-cij.org/docket/files/131/1687.pdf $>$. Acesso em: 8 jan. 2016.

CORTE INTERNACIONAL DE JUSTIÇA. Parecer separado do Juiz. Higgins de 9 de julho de 2004: consequências legais da edificação de um muro no território palestiniano ocupado. Disponível em: <http://www.icj-cij.org/ docket/files/131/1681.pdf>. Acesso em: 8 jan. 2016.

CORTE INTERNACIONAL DE JUSTIÇA. Parecer separado do Juiz Kooijmans de 9 de julho de 2004: consequências legais da edificação de um muro no território palestiniano ocupado. Disponível em: <http://www.icj-cij. org/docket/files/131/1683.pdf $>$. Acesso em: 8 jan. 2016.
ESCARAMEIA, Paula. Lição de síntese: que direito internacional público temos nos nossos dias? In: ESCARAMEIA, Paula. O Direito internacional público nos princípios do século XXI. Coimbra: Almedina, 2009. p. 2630 .

ESCARAMEIA, Paula. Quando o Mundo das Soberanias se transforma no Mundo das Pessoas. In: ESCARAMEIA, Paula. O Direito internacional público nos princípios do século XXI. Coimbra: Almedina, 2009. p. inicial-final.

ESTADOS UNIDOS. Suprema Corte. 1942. Sentença de 31 de julho. Ex Parte Quirin e outros. Disponível em: <https://supreme.justia.com/cases/federal/ us/317/1/case.html>. Acesso em: 8 jan. 2016.

FEDER, Norman Menachem. Reading the UN charter conotatively: toward a new definition of armed attack. New York University Journal of International Law and Politics, v. 19, n. 2, p.395-432, winter 1987.

FINKELSTEIN, Claire. Targeted killing as preemptive action. In: FINKELSTEIN, Claire. (Ed.). Targeted killings: law and morality in an asymmetrical world. Oxford: Oxford University, 2012. p. 156-182.

FOGARTY, Gerard P. Is Guantanamo Bay undermining the war on terror?. Parameters, n. 39, p. 59-67, autumn 2005.

GANOR, Boaz. Introduction to multidimensional warfare: defining terrorism, defining war. In: GANOR, Boaz. (Ed.). Global alert: the rationality of modern islamist terrorism and the challenge to the liberal democratic world. New York: Columbia University, 2015. p. 4-23.

GANOR, Boaz. Terrorist organisation typologies and the probability of a boomerang effect. Studies in Conflict and Terrorism, v. 31, n. 4, p. 269-283, 2008.

GODFREY, Brenda L. Authorization to kill terrorist leaders and those who harbor them: an international analysis of defensive assassination. San Diego International Law Journal, v. 4, p. 491-512, 2003.

GREENWOOD, Christopher. International law and the pre-emptive use of force: Afghanistan, Al-Qaida, and Iraq. San Diego International Law Journal, v. 4, p. 7-37, 2003.

GUERREIRO, Alexandre. A Resistência dos estados africanos à jurisdição do Tribunal Penal Internacional. Coimbra: Almedina, 2012.

HARNDEN, Toby. Bin Laden is wanted: dead or ali- 
ve, says Bush. The Telegraph. 18 sept. 2001. Available at: <http://www.telegraph.co.uk/news/worldnews/asia/ afghanistan/1340895/Bin-Laden-is-wanted-dead-oralive-says-Bush.html>. Accessed on: Feb. 10, 2016.

HIGGINS, Rosalyn. The development of International Law through the political organs of the United Nations. London: Oxford University, 1963.

HOUSE COMMITTEE ON NATURAL RESOURCES. Statement of James F. Jarboe: Eco-terrorism and Lawlessness on the National Forests: Hearing Before the Subcomm. 12 Feb. 2002. Available at: $<$ http:// naturalresources.house.gov/uploadedfiles/jarboe_2.12.02.pdf>. Accessed on: Feb. 10, 2016.

HUBERT, Don. The Responsibility to Protect: Supplementary Volume to the Report of the International Commission on Intervention and State Sovereignty. Ottawa: International Development Research Centre, 2001.

INTERNATIONAL COMMITTEE OF THE RED CROSS. Fundamental rules of humanitarian law applicable in armed conflicts. International Review of the Red Cross, v. 8, n. 206, p. 247-249, Sept./Out. 1978.

INTERNATIONAL COMMITTEE OF THE RED CROSS. Interpretive Guidance on the Notion of Direct Participation in Hostilities under International Humanitarian Law: Adopted by the Assembly of the International Committee of the Red Cross on 26 February 2009. International Review of the Red Cross, v. 90, n. 872, p. 9911047, Dec. 2008. Available at: <http://www.icrc.org/ eng/assets/files/other/irrc-872-reports-documents. pdf $>$. Access in: Feb. 10, 2016.

JOHNSON, James Turner. Just War, As It Was and Is. First Things, Jan. 2005. Available at: <http://www.firstthings.com/article/2005/01/just-waras-it-was-andis>. Access in: Feb. 10, 2016.

KATTAN, Victor. Israel, hezbollah and the conflict in lebanon: an act of aggression or self-defense? Human Rights Brief, v. 14, n. 1, p. 26-30, 2006.

KELSEN, Hans. Teoria pura do direito. Tradução de João Baptista Machado. 2. ed. Coimbra: Almedina, 2008.

KRETZMER, David. Targeted killing of suspected terrorists: extra-judicial executions or legitimate means of defence?. The European Journal of International Law, New York, v. 16, n. 2, p. 171-212, 2005.

LEIA na íntegra o discurso de Bush no Congresso dos EUA. Folba de São Paulo, São Paulo, 21 set. 2001. Di- sponível em: <http://www1.folha.uol.com.br/folha/ mundo/ult94u29639.shtml>. Acesso em: 8 jan. 2016.

MARSDEN, Sarah V.; SCHMID, Alex P. Typologies of terrorism and political violence. In: SCHMID, Alex P. (Ed.). The routledge handbook of terrorism research. New York: Routledge, 2011. p. 158-200.

MARTIN, Craig. Going Medieval: Targeted Killing, Self-Defence and the Jus Ad Bellum Regime. In: FINKELSTEIN, Claire (Ed.). Targeted killings: law and morality in an asymmetrical world. Oxford: Oxford University, 2012. p. 223-252.

MAXWELL, Colonel Mark "Max". Rebutting the civilian presumption: playing whack-a-mole without a mallet? In: FINKELSTEIN, Claire (Ed.). Targeted killings: law and morality in an asymmetrical world. Oxford: Oxford University, 2012. p. 31-59.

MCMAHAN, Jeff. Targeted Killing: Murder, Combat or Law Enforcement. In: FINKELSTEIN, Claire (Ed.). Targeted killings: law and morality in an asymmetrical world. Oxford: Oxford University, 2012. p. 135-155.

MELZER, Nils. Targeted killing in international law. New York: Oxford University, 2008.

NASCIMENTO, Álisson Reis. Violência e terrorismo. Universitas: Relações Internacionais, Brasília, v. 10, n. 1, p. 1-14, jan./jun. 2012.

NOGUEIRA, Patrícia. O terrorismo transnacional e suas implicações no cenário internacional. Universitas: Relações Internacionais, Brasília, v. 2, n. 2, p. 221-244, jul./dez. 2004.

ORGANIZAÇÃO DAS NAÇÕES UNIDAS. Carta das Nações Unidas: assinada em São Francisco a 26 de junho de 1945. Disponível em: <http://www.gddc.pt/direitoshumanos/textos-internacionais-dh/tidhuniversais/ onu-carta.html>. Acesso em: 10 fev. 2016.

ORGANIZAÇÃO DAS NAÇÕES UNIDAS. Código de conduta para os funcionários responsáveis pela aplicação da lei. Disponível em: <http://www.gddc.pt/direitos-humanos/textos-internacionais-dh/tidhuniversais/dhajpcjp-18.html>. Acesso em: 10 fev. 2016.

ORGANIZAÇÃO DAS NAÇÕES UNIDAS. Convenção IV, Convenção de Genebra Relativa à Proteç̧ão das Pessoas Civis em Tempo de Guerra, de 12 de Agosto de 1949. Disponível em: <http://www.gddc.pt/direitos-humanos/textos-internacionais-dh/tidhuniversais/dih-convIV-12-08-1949.html>. Acesso em: 10 fev. 2016. 
ORGANIZAÇÃO DAS NAÇÕES UNIDAS. Declaração Universal dos Direitos Humanos: adotada e proclamada pela resolução 217 A (III) da Assembléia G Geral das Nações Unidas em 10 de dezembro de 1948 Geral das Nações Unidas em 10 de dezembro de 1948. Brasília, 1998. Disponível em: <http://unesdoc.unesco. org/images/0013/001394/139423por.pdf>. Acesso em: 10 fev. 2016.

ORGANIZAÇÃO DAS NAÇÕES UNIDAS. Pacto Internacional sobre os Direitos Civis e Políticos. Disponível em: $<$ http:/ /www.gddc.pt/direitos-humanos/textos-internacionais-dh/tidhuniversais/cidh-dudh-direitos-civis. html >>. Acesso em: 10 fev. 2016.

ORGANIZAÇÃO DAS NAÇÕES UNIDAS. Pacto Internacional sobre os Direitos Civis e Políticos. Disponível em: $<$ http://www.gddc.pt/direitos-humanos/textos-internacionais-dh/tidhuniversais/cidh-dudh-direitos-civis. html>. Acesso em: 10 fev. 2016.

ORGANIZAÇÃO DAS NAÇÕES UNIDAS. Protocolo I Adicional às Convenções de Genebra de 12 de Agosto de 1949 relativo à Protecção das Vitimas dos Conflitos Armados Internacionais. Disponível em: <http://www.gddc.pt/direitoshumanos/textos-internacionais-dh/tidhuniversais/dihprot-I-conv-genebra-12-08-1949.html>. Acesso em: 10 fev. 2016.

ORGANIZAÇÃO DOS ESTADOS AMERICANOS. Convenção Americana Sobre Direitos Humanos: assinada na Conferência Especializada Interamericana sobre Direitos Humanos, San José, Costa Rica, em 22 de novembro de 1969. Disponível em: <https://www.cidh.oas. org/basicos/portugues/c.convencao_americana.htm>. Acesso em: 10 fev. 2016.

ORGANIZAÇÃO DOS ESTADOS AMERICANOS. Convenção Europeia dos Direitos do Homem. Disponível em: $<$ http://www.echr.coe.int/Documents/Convention_ POR.pdf>. Acesso em: 10 fev. 2016.

OTTO, Roland. Targeted killings and international law: with special regard to human rights and international humanitarian law. Heidelberg: Springer, 2012.

PARKS, W. Hays. Air War and the Law of War. Air Force Law Review, v. 32, n. 1, p. 1-225, 1990.

PEREIRA, Maria da Assunção Vale. A "guerra contra o terrorismo": um novo tipo de conflito armado?. In: GÓMEZ, Mariano J. Aznar (Coord.). Estudios de derecho internacional y derecho europeo en homenaje al Professor Manuel
Pérez González: Valencia: Tirant lo Blanch, 2012. t. 1. p. 491-520.

PICKARD, Daniel. legalizing'assassination? terrorism, the central intelligence agency, and international law. $G e-$ orgia Journal of International and Comparative Law, v. 30, n. 1, p. 1-34, 2001.

RAPOPORT, David C. The four waves of modern terrorism. In: CRONIN, Audrey Kurth; LUDES, James M. (Ed.). Attacking terrorism: elements of a grand strategy. Washington: Georgetown University, 2004. p. 46-73.

RAVIV, Dan. U. S. pushing Israel to stop assassinating Iranian nuclear scientists. CBS Newss. 1 mar. 2014. Available at: <http://www.cbsnews.com/news/uspushing-israel-to-stop-assassinating-iranian-nuclearscientists/>. Access in: Feb. 10, 2016.

SCHMID, Alex P. The definition of terrorism. In: SCHMID, Alex P. (Ed.). The routledge handbook of terrorism research. New York: Routledge, 2011. p. 39-98.

TESÓN, Fernando R. Targeted Killing in War and Peace: a Philosophical Analysis. In: FINKELSTEIN, Claire (Ed.). Targeted killings: law and morality in an asymmetrical world. Oxford: Oxford University, 2012. p. 403-433.

UNITED STATES. Department of State. U.S. national security strategy: strengthen alliances to defeat global terrorism and work to prevent attacks against us and our friends. Available at: <http://2001-2009.state.gov/r/ pa/ei/wh/15423.htm>. Access in: Feb. 10, 2016.

UNITED STATES. Public Law 107-40. Available at: <http://www.gpo.gov/fdsys/pkg/PLAW-107publ40/ pdf/PLAW-107publ40.pdf>. Access in: Feb. 10, 2016.

US UNLEASHES three days of drone strikes on Yemen, 55 killed. 21 abr 2014. Available at: <http:// rt.com/usa/drone-yemen-dozens-dead-880/>. Accessed on: Feb. 10, 2016.

VASAK, Karel. A 30-year struggle: the sustained efforts to give force of law to the Universal Declaration of $\mathrm{Hu}-$ man Rights. The UNESCO Courier. v. 30, p. 28-32, Nov. 1977.

WATKIN, Colonel K. W. Combatants, unprivileged belligerents and conflicts in the 21st century: background paper prepared for the informal high-level expert meeting on the reaffirmation and development of international humanitarian law, cambridge, January 27-29, 2003. Harvard: HPCR, 2003. Available at: <http://www.hpcrresearch. 
$\mathrm{org} /$ sites/default/files/publications/Session2.pdf $>$. Accessed on: Feb. 10, 2016.

WEINBERG, Leonard; PEDAHZUR, Ami; HIRSCHHOEFLER, Sivan. The challenges of conceptualizing terrorism. Terrorism and Political Violence, v. 16. n. 4, p. 777-794, 2004.

WITTIG, Peter. Der Aggressionsbegriff im internatio- nalen Sprachgebrauch. In: SCHAUMANN, Wilfried. Völkerrechtliches gewaltverbot und friedenssicherung. BadenBaden: Nomos Verlagsgesellschaft, 1971. p. 33-73.

WOODWARD, Bob. CIA Told to Do 'Whatever Necessary' to Kill Bin Laden. The Washington Post, 21 out. 2001. Available at: <http://www.washingtonpost.com/wpdyn/content/article/2007/11/18/AR2007111800655. html>. Accessed on: Feb. 10, 2016. 


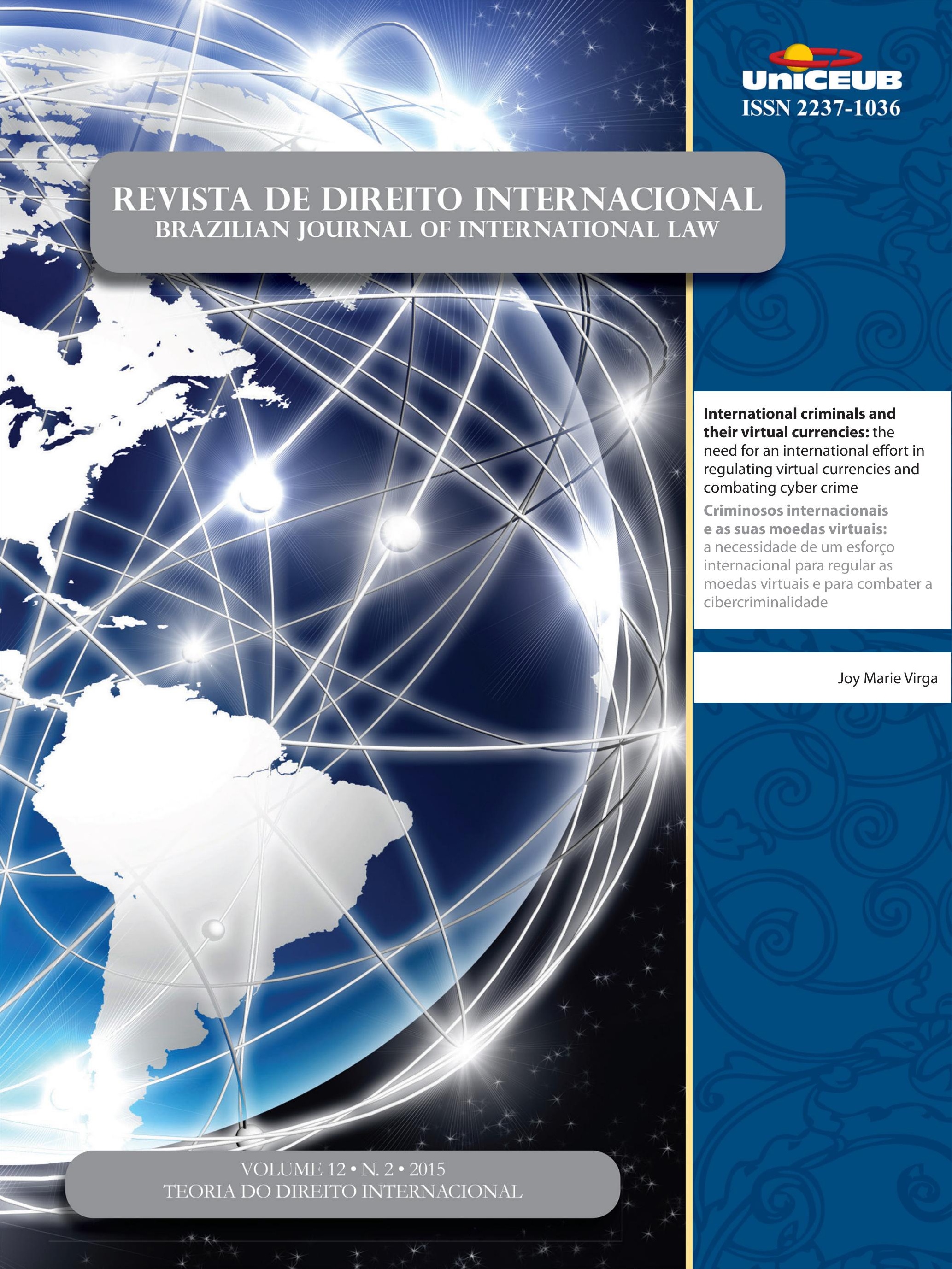




\section{International criminals and their virtual currencies: the need for an international effort in regulating virtual currencies and combating cyber crime*}

\author{
Criminosos internacionais e as suas moedas \\ virtuais: a necessidade de um esforço \\ internacional para regular as moedas virtuais e \\ para combater a cibercriminalidade
}

oy Marie Virga**

\section{Abstract}

Technology is constantly evolving and making our lives easier. Since the advent of the Internet, new technologies have developed that make the world smaller and bring people across the continents closer together. However, these new technologies also create a new medium for criminal activity. One example of these new technologies is virtual currencies. While virtual currencies have many benefits, they also create many opportunities for crimes such as money laundering. Virtual currencies are not controlled by any state entity, they allow users to transfer goods anonymously, and they cross borders effortlessly via the Internet. All these characteristics make it difficult for individual states to regulate virtual currencies in isolation. This article will discuss these issues and how international cooperation is necessary in order to effectively counteract cybercriminals who utilize virtual currencies to evade national law enforcement. First, this article will discuss what virtual currencies are and how they work. Next, the article will discuss recent law enforcement actions of various nations to shutdown operations that use virtual currencies to finance criminal activity. This article will then discuss how virtual currencies are moved through various institutions and used to assist criminals in carrying out illicit activity. It will look at how these institutions were taken down through concerted international efforts. Third, I will briefly discuss how various nations regulate virtual currencies domestically. This article will then analyze the need for international regulation of virtual currencies and discuss possible avenues for regulating virtual currencies internationally. The article will discuss how traditional international financial standards and an existing cybercrime treaty may apply to virtual currencies in their present forms. Finally, this article will recommend a method for international cooperation in regulating virtual currencies to reduce the amount of cybercrime.

Keywords: International. International law. International crime. Cybercrime. Virtual currencies. Bitcoin. Silk road. Money laundering. Technology. Crime. Virtual money.

\footnotetext{
** J.D. Candidate 2016, American University Washington College of Law; M.B.A. 2013 Stony Brook University. The author thanks Professor Srilal Perera for providing guidance and support throughout the writing process for

this article. E-mail: joymarie.virga@gmail.com.
}

Recebido em 01/09/2015 Aprovado em 06/10/2015 


\section{INTRODUCTION}

Virtual currencies have been around since at least 2008, but a federal court only just held that the Securities and Exchange Commission has jurisdiction over virtual currencies on September 18, 2014. ${ }^{1}$ In SEC v. Shavers the court held a Texas man liable for the loss he caused investors through a Bitcoin Ponzi scheme. ${ }^{2}$ This decision provides protection for investors of virtual currencies within the borders of the United States, but does nothing to protect investors from schemes that originate abroad. ${ }^{3}$ This lack of international regulation of virtual currencies opens up investors to fraudulent activities while creating a safe space to finance criminal activities. ${ }^{4}$

International bodies have come out in favor of international regulation of virtual currencies. ${ }^{5}$ The Japanese Finance Minister stated that regulation of crypto currencies should involve international cooperation in order to avoid potential loopholes. ${ }^{6}$ Additionally, a recent paper by the Organisation for Economic Co-operation and Development cited a need for some form of best practice agreement to provide consumer protection of

1 SEC v. Shavers, 13-cv-00416, 2014 US Dist LEXIS $130781 * 22$ (E.D. Tex. Sept. 18, 2014) (deciding that virtual currencies fall within the definition of a security under the Securities and Exchange Act); see Peter M.J. Gross, A History of Virtual Currencies: Why Bitcoins Shouldn't Surprise You, CFA Institute, Jan. 10, 2014, http:/ / annual.cfainstitute.org/2014/01/10/a-history-of-virtual-currencywhy-bitcoins-shouldnt-surprise-you/ (outlining the history of virtual currencies).

2 Shavers, 2014 US Dist. LEXIS 130781 at * 20, 22 (finding that virtual currencies fall under the definition of an investment contract of the Securities and Exchange Act).

3 See SEC v. Shavers, at *22, 28-29 (finding reasonable grounds to issue an injunctions because of the likelihood of defendant repeating offensive behavior).

4 See generally Virtual Currencies: Key Definitions and Potential AML/CFT Risks 9 (June 2014) http://www.fatf-gafi.org/media/ fatf/documents/reports/virtual-currency-key-definitions-and-potential-aml-cft-risks.pdf (stating that virtual currencies are particularly vulnerable to money laundering and terrorist financing abuse because they are traded anonymously and on the internet).

5 Eric Naing, International bodies see need for virtual currency regulation, CG Roll Call Washington Bank Briefing, (July 22, 2014) (stating that the Organisation for Economic Cooperation and Development, the Financial Action Task Force, and the European Banking Authority have all stated a need for regulation of virtual currencies).

6 Sophie Knight, Japan says any Bitcoin regulation should be international, Reuters (Feb. 27, 2014), http://www.reuters. com/article/2014/02/27/us-bitcoin-mtgox-japan-idUSBREA1Q0I520140227 (discussing Japan's reaction to the closing of Mt. Gox, formerly the world's largest Bitcoin exchange). crypto currencies and prevent money laundering. ${ }^{7}$

This article will argue that there is a strong need for international regulations of virtual currencies in order to deter crime and fraud. It will give background information on why regulation of virtual currencies, specifically international regulation, is important. First, I will briefly describe how virtual currencies work and discuss the types of virtual currencies. Second, I will discuss recent law enforcement actions led by various nations to shutdown operations using virtual currencies to fund criminal activity. This article will discuss how virtual currencies were moved through various institutions and used to assist criminals in carrying out illicit activity. This article will then discuss how these institutions were taking down. Third, I will briefly discuss how various nations regulate virtual currencies within their borders.

This article will then explore and analyze the importance of international regulation of virtual currencies and possible methods for regulating these currencies internationally. I will discuss how traditional international financial standards and an existing cybercrime treaty may apply to virtual currencies in their present forms. Finally, this article will recommend a method for international cooperation in regulating virtual currencies to reduce the instances of cybercrime.

\section{The Current status of Virtual currencies AND LEGAL ACTIONS INVOLVING VIRTUAL CURRENCIES}

While all virtual currencies are digital currencies, not all digital currencies are virtual currencies. ${ }^{8}$ Virtual currencies are a digital representation of value that can be exchanged through the Internet for goods and services. ${ }^{9}$ However, virtual currencies have no physical coun-

7 Adrian Blundell-Wignall, The Bitcoin Question: Currenc; versus Trust-less Transfer Technology: OECD Working; Papers on Finance, Insurance and Private Pensions, 17; OECD Publishing, http://www.oecd.org/daf/fin/ financial-markets/The-BitcoinQuestion-2014.pdf (exploring policy issues related to crypto-currencies).

8 Andrew Wagner, Digital v. Virtual Currencies, Bitcoin Magazine Aug. 22, 2014, available at https://bitcoinmagazine. com/15862/digital-vs-virtual-currencies/ (explaining the difference between digital and virtual currencies).

9 Vitual Currencies, supra note 4, at 4 (defining virtual currencies and explaining the difference between virtual currencies and other currencies). 
ter part with legal status and are largely unregulated. ${ }^{10}$ Fiat currencies, also known as "real money" or "national currencies," are the coin and paper money that a nation assigns as its legal tender. ${ }^{11}$ E-money is a digital representation of fiat money used to electronically transfer money that has a legal tender status. ${ }^{12}$ Digital money refers to both e-money and virtual money. ${ }^{13}$ Since, e-money has a legal standard and is thus already regulated by nations, the focus of this article will be on virtual currencies. ${ }^{14}$ In order to understand this issue, it is important to understand the types of virtual currencies and how they function.

\subsection{The types of virtual currencies}

Virtual currencies can be open or closed and centralized or decentralized. ${ }^{15}$ Open virtual currencies have an equivalent value with fiat money and can be exchanged back and forth. ${ }^{16}$ Closed virtual currencies are intended for a particular on-line domain and will not be discussed in this article. ${ }^{17}$ Centralized virtual currencies have a singular administrative authority that issues the curren-

10 European Central Bank (ECB), Virtual Currency Schemes,5 (Oct 2012), available at http://www.ecb.int/pub/pdf/other/virtualcurrencyschemes201210en.pdf (visited Apr 10, 2013)(discussing the difference between virtual currencies and electronic money is the lack of a legal status and physical counterpart).

11 Virtual Currencies, supra note 4 , at 4 (stating that fiat is customarily used and accepted as a medium of exchange in the issuing country and is also referred to as real currency, real money or national currency).

12 Id.; European Commission, E-money, Banking and Finance, http://ec.europa.eu/finance/payments/emoney/index_ en.htm (Jan. 21, 2015 10:05PM) (explaining that e-money is the digital equivalent of cash and can be stored electronically on an electric device or a server).

13 Virtual Currencies, supra note 4, at 4; see also Sandeep Dave, et al., Symposium, Getting Ready for Digital Money: A Roadmap, Imperial College London, 6 (2014) available at http://icg.citi.com/ $\mathrm{icg} / \mathrm{sa} /$ digital_symposium/docs/DigitalMoneyIndex30012014.pdf (providing examples of digital currencies like the M-Pesa in Kenya, and Paypal).

14 See Virtual Currencies, supra note 4, at 4 (stating that e-money is the digital representation of fiat money).

15 Id. at 4-5 (discussing in depth the differences between the types of virtual currencies).

16 Id. at 4 (providing examples of open currencies such as Bitcoin and WebMoney).

17 Id. at 4-5 (stating that closed virtual currencies are popular on sites like Amazon.com or Massively Multiplayer Online Role-Playing Games and include World of Warcraft Gold. All closed virtual currencies are also centralized); Virtual Currency Schemes, supra note 10, at 13 (explaining that closed virtual currencies have "almost no link to the real economy). cy, establishes rules, and generally controls the system. ${ }^{18}$ The exchange rate for centralized virtual currencies can be floating-determined by supply and demand-or pegged — fixed by the central authority. ${ }^{19}$ Decentralized virtual currencies, more commonly known as cryptocurrencies, have no central administrative authority and therefore no oversight. ${ }^{20}$ These currencies are math-based, meaning they are distributed among a network of individuals who validate the transaction by running an algorithm. ${ }^{21}$ Altcoin refers to all virtual currencies that are both open and convertible, the most popular of which is Bitcoin. ${ }^{22}$ These virtual currencies can be swapped for other virtual or fiat currencies through an exchanger. ${ }^{23}$ An exchanger is a person or entity that is in the business of exchanging virtual and fiat currencies for a fee and accepts a wide range of payments, including cash, credit cards and wire transfers. ${ }^{24}$

Altcoins are created through a process called mining. ${ }^{25}$ Mining requires many computers on a peer-to-peer network working together to solve an algorithm. ${ }^{26}$ The purpose of the algorithm is to maintain transparency in the public ledger, which tracks how many altcoins each user owns. ${ }^{27}$ In order to encourage users to

18 Virtual Currencies, supra note 4, at 5 (stating that centralized virtual currencies have a central administrator).

19 Id. (explaining that the exchange rate maybe either pegged or floating).

20 Id.; Virtual Currency Schemes, supra note 10, at 27 (asserting that decentralized virtual currencies exist where there is no central organizer).

21 Virtual Currencies, supra note 4, at 5, 14 (stating that decentralized virtual currencies are also called cryptocurrencies because they use cryptography).

22 Id. at 6; see also Kerry Lynn Macintosh, How to Encourage Global Electronic Commerce: The Case for Private Currencies on the Internet, 11 Harv. J. L. \& Tech. 733, 750 (1998)(detailing how a private market place of currencies would lead to an optimal number of currencies operating within a global electronic marketplace among niche currencies within their own submarket).

23 Virtual Currencies, supra note 4, at 7 (explaining that individuals usually use exchangers to deposit or withdraw money from virtual currency accounts).

24 Id.(describing an exchanger as "a person or entity engaged as a business in the exchange of virtual currency for real currency, funds, or other forms of virtual currency for a fee.”).

25 Castle, Beginner's Guide to Mining Litecoin, Dogecoin, and other Bitcoin Variants, PC World May 6, 2014, http://www.pcworld.com/article/2151261/beginners-guide-to-mining-litecoindogecoin-and-other-bitcoin-variants.html (asserting that all Altcoins, like Bitcoin, are created through process called mining).

26 Id. (explaining that this process is called cryptography).

27 Id.; Virtual Currency Schemes, supra note 10, at 24 (asserting that the mining process validates transactions by using computer power to find valid solutions to complex math problems and is the 
run these algorithms, users are rewarded with altcoins for doing so. ${ }^{28}$ Mining of Bitcoins has become so lucrative in recent years that companies have designed chips solely for this purpose. ${ }^{29}$ As a result, a normal desktop computer will not be able to compete. ${ }^{30}$ However, other altcoins are much less popular and more accessible to the average user. ${ }^{31}$

The benefits of virtual currencies are many. ${ }^{32}$ Virtual currencies could create a common medium of exchange, which would simplify international negotiations. ${ }^{33}$ A common medium of exchange would reduce or eliminate currency exchange fees, which are present in exchanges of fiat money. ${ }^{34}$ Additionally, exchanges of virtual currencies do not incur the same transaction costs that traditional debit and credit card purchases do, which could lead to lower costs for micro transactions like one time music downloads. ${ }^{35}$ Furthermore, virtual currencies could facilitate financial inclusion of the un- and under-banked. ${ }^{36}$

Because open currencies, like Bitcoin or Altcoin, can be exchanged for real currencies, they are vulnerable to fraud. ${ }^{37}$ Tools called anonymisers are used to further increa-

only way to create new coins).

28 Castle, supra note 25; Virtual Currency Schemes, supra note 10 , at 24 (discussing how, in the Bitcoin scheme, people who volunteer to partake in this activity are rewarded with 50 newly created Bitcoins each time their computer solves an equation).

29 Castle, supra note 25. See also Virtual Currency Schemes, supra note 10 , at 21 (stating that the money supply is determined by a type of mining that depends on the resources, electricity and CPU time, the miner devotes to solve the mathematical problems).

30 "Even the burliest desktop PC with huge gaming GPUs won't be able to generate enough money mining bitcoin to cover the cost of the electricity used in the process." Id.

31 Id. (stating that many Altcoins use an algorithm called script, which can be solved on a personal computer to receive Altcoins. Altcoins can then be used to purchase Bitcoins).

32 See generally, Macintosh, supra note 22 , at 756, 762, 783-84(describing how virtual currencies would greatly reduce or eliminate exchange fees, increase privacy and serve as more stable stores of value than national currencies).

33 Id. at 756 (explaining that a user pays a one time exchange fee for the virtual currency, they may buy products freely within the cyber market place without worrying about additional fees that traditional currencies would incur).

34 Id. (detailing the process in which international transactions increase expenses by incurring negotiation costs and bank fees).

35 Virtual Currencies, supra note 4, at 9 (explaining that traditional debit and credit card purchases are associated with higher transactions costs than virtual currency transactions).

36 Id. (stating that virtual currencies can facilitate financial inclusion as new virtual currency services are developed).

37 Id.; see also Adrian Blundell-Wignall, The Bitcoin Question, Currency Versus Trust-Less Transfer Technology, Organisation for Economic Cooperation and Development, 8 available at http://www.oecd.org/daf/fin/financial-markets/The-Bitcoin- se anonymity by obscuring the source of an altcoin transaction. ${ }^{38}$ For example, Dark Wallet is a web browser extension, currently available on Google Chrome, which enables users to remain anonymous in Bitcoin transactions. ${ }^{39}$ This increase in anonymity coupled with the absence of a central oversight body and the global reach of virtual currencies makes them an attractive resource for criminals to reach beyond national borders and escape regulation. ${ }^{40}$ Various national governments have already engaged in national and international efforts to identify and shutdown various criminal organizations that utilized virtual currencies to fund their operations. ${ }^{41}$ These concerted efforts will be discussed in the following section.

\subsection{Legal action taken against organizations that used virtual currencies in national and international criminal activity}

To date, there have been a few instances of nations, working alone or in concert, successfully bringing actions against criminals who use virtual currencies to facilitate crime. In this section I will discuss these cases to provide information on how criminals utilize virtual currencies and to demonstrate the international nature of these schemes.

\subsubsection{Liberty Reserve}

The case of Liberty Reserve is the biggest on-line money laundering case thus far. ${ }^{42}$ Liberty Reserve was designed to avoid regulatory scrutiny and assist criminals in distributing, storing and laundering proceeds collected from fraud,

Question-2014.pdf (stating that the authentication process of Bitcoin opens the way for fraud).

38 Virtual Currencies, supra note 4, at 6 (explaining that anonymisers are tools or services designed to obscure the source of a transaction); Federal Bureau of Intelligence, Intelligence Assessment, (U) Bitcoin Virtual Currency: Unique Feature Present Distinct Challenges for Deterring Illicit Activity, (Apr. 14, 2012), 5 (discussing the various ways Bitcoin user can increase anonymity, including the use of an anonmyzer).

39 Virtual Currencies, supra note 4, at 6 (providing examples of anonymisers such as Tor, Dark Wallet and Bitcoin Laundry).

40 Id. at 9-10. See also Blundell-Wignall, supra note 37, at 13 (asserting that a main purpose for Bitcoins is to carry out illicit activities due to the 'anonymity factor').

41 See generally, Virtual Currencies, supra note 4, at 10-12 (detailing the cases of Liberty Reserve, Western Express International, and the Silk Road).

42 Id. at 10 (explaining that Liberty Reserve was taken down by effectively cutting it out of the US Financial System). 
identity theft, narcotics trafficking, child pornography and other crimes. ${ }^{43}$ It laundered over 6 billion in US Dollars amongst more than a million users. ${ }^{44}$

Liberty Reserve was identified by the United States Department of Treasury as a financial institution primarily concerned with money laundering. ${ }^{45}$ Liberty Reserve created virtual currencies called the "Liberty Reserve Dollar" or "Liberty Reserve Euro"46 which users bought in exchange for national currencies. ${ }^{47}$ Once a user had access to Liberty Reserve Funds, the funds can be transferred to any of the accounts within the system. ${ }^{48}$ All transactions were anonymous and only the account number was visible, however, with an additional fee, even this could be redacted. ${ }^{49}$ Users could then withdraw funds by sending their Liberty Reserve currency to an exchanger, which then sent a bank wire or other transfer method to the user's bank account. ${ }^{50}$

In 2004, Liberty Reserve was being run out of an apartment in Brooklyn, New York but in 2006 was re-registered in Costa Rica, ${ }^{51}$ a country sometimes refer-

43 Id. (stating that Liberty Reserve facilitates anonymous and untraceable transactions). See also, FBI, supra note 38, at 6 (referencing a cybercriminal who would only accept Bitcoin, WebMoney or Liberty Reserve as payment).

44 Virtual Currencies, supra note 4, at 10 (explaining that Liberty Reserve handled about 55 million illicit transactions).

45 Department of Treasury, Treasury Identitfies Virtual Currency Provider Libery Reserve as a Finanacial Institution of Primary Money Laundering Concern Under USA Patriot Act Section 331, May 28, 2013, available at http://www.treasury.gov/press-center/ press-releases/Pages/j11956.aspx (using \ 311 of the USA Patriot Act to support this finding).

46 Department of Treasury, Notice of Finding that Liberty Reserve SA Is a Financial Institution of Primary Money Laundering Concern, available at http://www.fincen.gov/statutes_regs/ files/311--LR-NoticeofFinding-Final.pdf, 3 Therein after, "DOT Notice of Finding"] (finding that Liberty reserve maintained a Dollar for Dollar and Euro for Euro exchange to back their virtual currencies). See also Macintosh, supra note 22, at 759 (suggesting that using a strong national currency to back the Liberty Reserve virtual currency establishes a level of legitimacy).

47 DOT Notice of Finding supra, note 46, at 3 (stating that an exchanger transfers the value to a national currency).

48 Id. See also, Treasury Identifies Virtual Currency, supra note 45 (finding that transfers can be made instantly and anonymously).

49 DOT Notice of Finding supra, note 46, at 3 (asserting that users can pay an addition fee for greater anonymity). See also, Treasury Identifies Virtual Currency, supra note 45 (stating that users can pay an additional "privacy fee").

50 DOT Notice of Finding supra, note 46, at 3 (explaining that exchangers exchange funds through a bank or non bank wire transfer and charge a commission).

51 Id. at 5 (citing registration information from the Liberty Reserve website). red to as a money-laundering hub. ${ }^{52}$ Costa Rica is often used by foreign institutions primarily to send funds to and from other sovereignties in "bulk cash shipments" or off shore companies..$^{53}$ Liberty Reserve's blog explained that the reason for the change in country registration was because Costa Rica does not have a mutual legal assistance treaty with the United States. ${ }^{54}$ After Liberty Reserve learned that it was being investigated by United States law enforcement agencies, Liberty Reserve pretended to shut down in Costa Rica but continued to operate through various shell companies and moving millions of dollars through accounts in other countries such as Australia, China, Morocco, Cyprus, Spain among others. ${ }^{55}$

Liberty Reserve took no steps to verify the identities of their users who regularly used unquestionably false names, such as "Hacker Account," with undoubtedly false addresses, like "123 Fake Main Street." ${ }^{\text {"6 }}$ Liberty Reserve's exchangers also had little to no verification or monitoring of clients. ${ }^{57}$ Liberty Reserve recommended exchangers to its users that were generally unlicensed money transmitting businesses running out of countries with little governmental oversight or regulation of money laundering such as Russia, Malaysia, Vietnam and Nigeria. ${ }^{58}$ The use of exchangers enabled Liberty Reserve to avoid collecting information on its users such as banking information, which would create a paper trail. ${ }^{59}$

52 See Maguerite Cawley, Authorities Investigate Costa Rica Money Laundering Linked to Venezuela Govt., In Sight Crime, June 28, 2013 http://www.insightcrime.org/news-briefs/authorities-investigate-costa-rica-venezuela-money-laundering-connections (asserting that Costa Rica is the top money laundering nation in Central America); See also Tom Hays, Feds: Costa Rica a hub for money laundering, Salon, May 29, 2013 http://www.salon.com/2013/05/29/ feds_costa_rica_a_hub_for_money_laundering_ap/ (claiming that Liberty Reserve is just the latest to take advantage of Costa Rica's lax regulations).

53 DOT Notice of Finding supra, note 46, at 5 (stating that Money Laundering in Costa Rica occurs in formal and informal financial sectors).

54 Id. at 6 (citing the Liberty Reserve blog).

55 irtual Currencies, supra note 4, at 11 (listing the nations in which Liberty Reserve operated).

56 Id. at 10 (presenting the false names and addresses of Liberty Reserve users).

57 DOT Notice of Finding supra, note 46, at 9 (finding that although Liberty Reserve claimed to verify user identity, the only verification practiced was that of a working e-mail).

58 Virtual Currencies, supra note 4, at 10 (asserting that Liberty Reserve used exchangers to evade collecting user information).

59 Id. at 10 (claiming that Liberty Reserve's use of exchangers allowed it to evade collecting bank account information of users). 
After a joint investigation by the United States and Costa Rica, the founder and owner of Liberty Reserve, Arthur Budovsky, was arrested in Spain and the site was shut down. ${ }^{60}$

\subsubsection{Silk Road}

Silk road was a hidden website designed off of the eBay model but functioned as a global black market where users could buy and sell illegal weapons, drugs, stolen identity information and other illicit goods. ${ }^{61} \mathrm{Un}$ like Liberty Reserve, Silk Road did not create its own virtual currency but used the crypto currency Bitcoin as the only accepted currency. ${ }^{62}$ Silk Road was launched in January 2011 and allegedly generated around 1.2 billion US Dollars in sales and commissioned around $80 \mathrm{mi}-$ llion US Dollars through illegal transactions. ${ }^{63}$

By accepting only Bitcoin and operating on the Tor Network Silk Road was able to maintain anonymity. ${ }^{64}$ The Tor Network is an underground network of computers on the Internet that obscures IP addresses by routing transactions through numerous computers and wrapping them in encryptions. ${ }^{65}$ Users were also able to increase anonymity by using anonymisers, which were built into the Silk Road system and made it nearly impossible to link a user's payment with any Bitcoins leaving the site. ${ }^{66}$

The sites founder and operator, Ross William Ulbricht, was arrested in San Francisco in October 2013 and indicted in New York in February 2014. ${ }^{67} \mathrm{He}$ faces char-

60 Vitalik Buterin, Liberty Reserve Shutdown for Money Laundering, Bitcoin Magazine, May 25, 2013 https://bitcoinmagazine. com/4954/liberty-reserve-shut-down-for-money-laundering/ (stating Liberty Reserve has been shut down and its owner arrested in Spain.)

61 United States v. Ulbricht, 31 F. Supp. 3d 540, 546-48 (S.D.N.Y 1970) (discussing the facts of the case); Virtual Currencies, supra note 4, at 11 (explaining the facts of the case).

62 Ulbricht, 31 F. Supp. 3d 547 (finding that Silk Road was used to launder proceeds through Bitcoin).

63 Virtual Currencies, supra note 4, at 11 (asserting that hundreds of millions of dollars were laundered through these illicit activities).

64 Id. (explaining that this allowed users to maintain anonymity). See also, FBI supra note 38, at 6 (asserting that Silk Road also enabled its users to communicate anonymously).

65 Virtual Currencies, supra note 4, at 6 (discussing how the Tor Network is used to conceal IP addresses).

66 Id. at 11-12 (describing how a transaction went through a "complex, semi-random series of dummy transactions").

67 Id. at 11 (stating that the government seized the website and about 173,991 Bitcoins). ges of narcotics trafficking, computer hacking, money laundering and conspiracy ${ }^{68}$ Although Ulbricht argues that the relevant money laundering statute is not broad enough to cover Bitcoin, the judge ruled that the statute did cover Bitcoin because they carry value. ${ }^{69}$

However, shortly after Ulbricht's arrest and the shutting down of Silk Road, Silk Road 2.0 popped up. ${ }^{70}$ Fortunately, Silk Road 2.0 was also recently shut down after the November 14, 2014 arrest of Blake Benthall. ${ }^{71}$ The government filed a complaint against Benthall, who took over after Ulbricht was arrested, seeking to indict him under the same charges as Ulbright. ${ }^{72}$ Silk Road 2.0 had over 13,000 listings for controlled substances. ${ }^{73}$ The take down of Silk Road 2.0 was part of a coordinated effort between the United States Justice Department's Criminal Division, the United State Attorney's Office for the Southern District of New York, and Europol's European Cybercrime Centre and Eurojust. ${ }^{74}$ But like Ulbricht, Benthall was operating within the United States-San Francisco specifically. ${ }^{75}$

\subsubsection{Western Express International}

The take down of Western Express International involved an eight-year investigation conducted by the United States Secret Service and the Manhattan District Attorney's Office. ${ }^{76}$ Western Express International was

68 United States v. Ulbricht, 31 F. Supp. 3d 540, 546 (S.D.N.Y 1970) (citing the Grand Jury indictment).

69 Id. at 548 (finding that the purpose of Bitcoin is to carry value and act as a medium of exchange).

70 Dune Lawrence, Silk Road 2.0 Shut Down by FBI, Just Like Its Black Market Predecessor, Bloomburg Business Week, Nov. 6, 2014, http://www.businessweek.com/articles/2014-11-06/silkroad-2-dot-0-shut-down-by-fbi-just-like-its-black-market-predecessor (calling Silk Road 2.0 a copy cat of the Silk Road).

71 Julianne Pepitone, FBI Arrests Alleged 'Silk Road 2.0' Operator Blake Banthall, NBC News, Nov. 16, 2014, http://www.nbcnews.com/tech/security/fbi-arrests-alleged-silk-road-2-0-operatorblake-benthall-n242751 (asserting that Benthall was arrested for running a "Black Market Bazaar").

72 Lawrence, supra note 70 (stating that Benthal will faces of narcotics trafficking; money laundering, and computer hacking).

73 Id. (asserting that the website had more than 13,000 listings for controlled substances).

74 FBI, More Than 400 .Onion Addresses, Including 'Dark Market' Sites, Targeted as Part of Global Enforcement Action on Tor Network, Nov. 7, 2014, available http://www.fbi.gov/news/ pressrel/press-releases/more-than-400-.onion-addresses-includingdozens-of-dark-market-sites-targeted-as-part-of-global-enforcement-action-on-tor-network (listing the agencies involved in the takedown).

75 Lawrence, supra note 70 (stating that Benthal is from San Francisco).

76 Virtual Currencies, supra note 4, at 12 (recalling the facts of 
a multinational, Internet based cyber crime group. ${ }^{77}$ The hub of the operation was a New York corporation that operated as a "virtual currency exchanger and unregistered money transmitter to coordinate and facilitate the Internet payment methods used by the criminal enterprise, and to launder the group's proceeds." 78

Western Express International was one of the largest currency exchangers in the United States and exchanged 15 million US Dollars and provided knowledge and support via its websites on strategies to move money anonymously and elude reporting requirements. ${ }^{79}$ The group was composed of buyers, venders and cybercrime service providers located in a number of countries spanning from the United States to the Ukraine and Eastern Europe. ${ }^{80}$ Western Express exchanged WebMoney and e-Gold — centralized open currencies ${ }^{81}$ — for US Dollars and charged a commission for the transaction. ${ }^{82}$ The buyers would steal identities to buy expensive goods, which they would then sell. ${ }^{83}$ Buyers also committed crimes such as larceny and fraud and accumulated proceed from credit card fraud in the amount of about 5 million US Dollars. ${ }^{84}$ The venders sold almost 100,000 stolen credit cards and other personal information via the Internet. ${ }^{85}$ The international transactions of the buyers' and venders' illicit activities went largely un-scrutinized because e-Gold and WebMoney, as virtual currencies, are unregulated. ${ }^{86}$ The cyber crime service providers assisted the buyers and sellers in their criminal activity by providing computer services. ${ }^{87}$

the investigation).

77 Id. (calling Western Express a multinational, internet-based, cybercrime group); People v. W. Express Int'l Inc., 19 N.Y. 3d 652, 655 (N.Y. Ct. App. 2012)(reiterating the facts of the case).

78 Virtual Currencies, supra note 4, at 12 (stating the purpose of Western Express).

79 Id. (explaining that money was laundered through WebMoney and e-Gold).

80 Id. (describing the operations of Western Express International).

81 Id. at 4-5 (explaining that money was laundered through WebMoney and e-Gold).

82 People v. W. Express Int'l Inc., 19 N.Y. 3d 652, 655 (N.Y. Ct.

App. 2012) (finding that Western Express international charged commission between two to five percent).

83 Virtual Currencies, supra note 4, at 12 (stating that buyers bought expensive goods, which they then fenced).

84 Id. (listing other crimes buyers committed).

85 Id. (describing the activities of vendors in the organization of Western Express).

86 People v. W. Express Int'l Inc., 19 N.Y. 3d 652, 655 (N.Y. 2012) (recalling the facts of the case).

87 Virtual Currencies, supra note 4, at 12 (discussing the role of service providers within Western Express International).
The owner and operator of Western Express International plead guilty to money laundering, fraud and conspiracy offenses in February 2013 in New York State. ${ }^{88}$ Additionally, several other defendants plead guilty in 2009 and three others were convicted in June 2013. ${ }^{89}$ In all, fifteen defendants were convicted for crimes committed under the auspices of Western Express International. ${ }^{90}$ These defendants were a mix of United States and Foreign nationals, although most were operating within the United States. ${ }^{91}$ One of them, Egor Shevelev, was one of the premier vendors and a Ukrainian national residing in the Ukraine. ${ }^{92}$ Although the United States has no extradition treaty with the Ukraine, he was apprehended while on vacation in Greece. ${ }^{93}$

\subsection{Regulations of virtual currencies within the United States and other nations}

Although virtual currencies were the main element in all of the above mentioned cybercrime schemes, they remain largely unregulated within the borders of nation states. This part will look at how virtual currencies fit into the legal framework of the United States, the United Kingdom and Japan. The nations were chosen not just because of their role in the world's financial markets, but also because of their approach, or lack thereof, to regulating virtual currencies.

\subsubsection{The United States}

None of the laws of the United States explicitly outline how virtual currencies fit into United States regu-

88 Id. (recalling facts of the case)

89 Id. (naming other defendants involved in the case).

90 Manhattan District Attorney, Western Express Cybercriminals Convicted at Trial Sentenced to Significant State Prison Time, Aug. 8, 2013, [herein after, "Manhattan DA, Western Express Cybercriminals Convicted"] available at http://manhattanda.org/ press-release/western-express-cybercriminals-convicted-trial-sentenced-significant-state-prison-time (stating that 15 defendants were convicted).

91 See id. (providing the nationalities of the defendants and their locations of operation).

92 Id. (asserting Shevelev as a premier vender operating out of his home in the Ukraine).

93 Manhattan DA, Western Express Cybercriminals Convicted, supra note 90 (stating that Shevelev could not be arrested in the Ukraine but was arrested on vacation in Greece); Jeff Pohlman and Andrea Day, Busted! Inside one massive cybercrime ring, CNBC (Sept. 12, 2013, 2:06PM), http://www.cnbc.com/id/101029866 (discussing how Shevelev was outside the reach of United States authorities while inside of the Ukraine but was put on a watch list). 
latory framework. However, judges have ruled in recent years that virtual currencies do qualify as money ${ }^{94}$ for the purposes of money laundering and that virtual currencies meet the definition of an investment contract. ${ }^{95}$ Under the Securities Act of 1934, an investment contract is a security and therefore, virtual currencies fall under the auspices of the Securities and Exchange Commission. ${ }^{96}$

\subsubsection{Japan}

The Minister of Japan recently stated that currency under Japan's jurisdiction refers to only coins or notes issued by the Bank of Japan and that virtual currencies do not qualify as a legitimate currency in Japan. ${ }^{97}$ Officials from Japan's Financial Services Agency and Finance Ministry told reporters that virtual currencies do not fall within their purview and the Bank of Japan is only studying the virtual currency phenomenon. ${ }^{98}$ Japan further stated that it does not plan on taking any steps towards regulating virtual currencies. ${ }^{99}$ The Vice Finance Minister of Japan stated that any regulation of virtual currencies should "involve international cooperation to avoid loopholes." 100

\subsubsection{The United Kingdom}

Currently, there are no regulations of virtual currencies in the United Kingdom. ${ }^{101}$ However, in August

94 United States v. Ulbricht, 31 F. Supp. 3d 540, 569 (S.D.N.Y 1970) (comparing Bitcoin to Euros and Dollars).

95 Memorandum Decision Regarding the Courts Subject Matter Jurisdiction at 3, SEC v. Shavers, 13-cv-00416, 2014 US Dist. LEXIS 130781 (E.D. Tex. Sept. 18, 2014) (finding that virtual currencies fall within the definition of a security under the Securities and Exchange Act).

9615 U.S.C. $\int 77 b$; Memorandum Decision Regarding the Courts Subject Matter Jurisdiction at 3, SEC v. Shavers, 13-cv-00416, 2014 US Dist. LEXIS 130781 (E.D. Tex. Sept. 18, 2014) (holding that the Securities and Exchange Commission has jurisdiction over virtual currencies).

97 Knight, supra note 6 (quoting Japanese officials that do not consider Bitcoin to be a currency).

98 Id. (stating that Japanese officials are not taking any action after the fall of Mt. Gox).

99 Japan's ruling party won't regulate Bitcoin for now, Reuters June 19, 2014), http://www.reuters.com/article/2014/06/19/ japan-bitcoin-idUSL4N0P01LS20140619 (discussing that Japan has no intention to regulate virtual currencies).

100 Knight, supra note 6 (quoting the Vice Finance Minister of Japan).

101 Jane Wild, UK Taxman, police and spies look at Bit-
2014, the United Kingdom's Chancellor of the Exchequer stated that the United Kingdom will look into how virtual currencies could or should be regulated. ${ }^{102}$ As of now, Bitcoins have been classified as a single purchase voucher and are subject to a ten to twenty percent value added tax. ${ }^{103}$

\section{The Need for International Regulation of Virtual Currencies and How Regulation May Be Approached}

The willingness of certain governments to organize concerted efforts to investigate and prosecute on-line financial institutions that utilize virtual currencies to operate their criminal activities is a great start. However, many risks are associated with virtual currencies. Although representatives of many governmental agencies in the United States and abroad believe that virtual currencies provide many benefits, many of these representatives are still warning banks and investors to stay away from virtual currencies until they can be better regulated. ${ }^{104}$ Still, regulation of virtual currencies

coin threat, Financial Times, Mar. 13, 2013, http://www. ft.com/cms/s/2/42ca6762-bbfc-11e2-82df-00144feab7de. html\#axzz2pdQoiDZO (explaining that Bitcoin is currently unregulated by any authority in the United Kingdom).

102 Anna Irrera, U.K. to Examine Virtual Currency Regulation, Wall St. J. Aug. 6, 2014, http://blogs.wsj.com/digits/2014/08/06/ uk-to-examine-virtual-currency-regulation/ (recognizing the important of virtual currencies, the UK Chancellor of the Exchequer stated he will look into how virtual currencies could of should be regulated).

103 Chris Skinner, The challenge of being a Bitcoin trader, Financial Services Blog, Nov. 13, 2013, http://thefinanser.co.uk/fsclub/2013/11/the-challenge-of-being-a-bitcoin-trader.html (stating that if an investor wanted to sell Bitcoin for more than $£ 77,000$, the investor would need to register for a value added tax).

104 European Banking Authority, EBA warns consumers on virtual currencies, Dec. 12, 2013, available at https://www.eba.europa. eu/-/eba-warns-consumers-on-virtual-currencies (warning consumers that virtual currencies are not protected); Eric Naing, International bodies see need for virtual currency regulation, CG Roll Call Washington Bank Briefing, (July 22, 2014) (naming various international organizations that cite a need for international regulation of virtual currencies); SEC, Investor Alert: Ponzi Schemes Using Virtual Currencies, SEC Pub. No. 153 (7/13). http://www.sec. gov/investor/alerts/ia_virtualcurrencies.pdf (advising investors to look out for Ponzi Schemes involving virtual currencies); Government Accountability Office, Virtual Currencies: Emerging Regulatory Law, Law Enforcement and Consumer Protection Challenges, Report to the Committee on Homeland Security and Government Affaits, U.S. Senate, 1, 22 May 2014, available at http:// www.gao.gov/assets/670/663678.pdf (explaining that virtual cur- 
remains a difficult task because of the anonymity factor, which makes them so attractive to criminal elements in the first place. ${ }^{105}$

While authorities hope that the law enforcement actions mentioned above would deter cybercriminals who think they can escape prosecution because they are operating outside of United States' borders, there are nations where cybercriminals could evade prosecution from United States authorities. ${ }^{106}$ Additionally, many cases where authorities were successful in prosecuting cybercriminals, a certain level of international cooperation was required. ${ }^{107}$ Therefore, as the government of Japan has asserted, regulation of virtual currencies should involve international coordination to ensure that loopholes are minimized. ${ }^{108}$ While it is tempting to concentrate on the most popular of the virtual currencies, Bitcoin, most criminal activity has been conducted through other types of virtual currencies. ${ }^{109}$

An additional difficulty is presented when balancing the need to protect users from fraud and to deter crime with the benefit of promoting an emerging technology. ${ }^{110}$ This section will analyze possible strategies of regulating virtual currencies internationally in a manner that respects this balance.

\subsection{Current methods of international regulation of traditional capital and how they may apply to virtual currencies}

rencies offer lower transaction costs and faster transfers but are also subject to volatile prices and attract illicit activity).

105 Blundell-Wignall, supra note 37, at 13 (stating "[...]a raison d'etre for Bitcoins is to carry out illegal activities due to the 'anonymity factor"').

106 See Manhattan DA, Western Express Cybercriminals Convicted, supra note 90 (quoting the New York District Attorney).

107 Vitalik Buterin, Liberty Reserve Shutdown for Money Laundering, Bitcoin Magazine, May 25, 2013 https://bitcoinmagazine. com/4954/liberty-reserve-shut-down-for-money-laundering/ (stating that the takedown of liberty reserve was the product of a join investigation.)

108 Knight supra note 6 (citing the Japanese Vice Finance Minister).

109 FBI, supra note 38, at 6 (indicating that the FBI is less concerned with Bitcoin than other types of virtual currencies). See also People v. W. Express Int'l Inc., 19 N.Y. 3d 652, 655 (N.Y. Ct. App. 2012) (discussing how Western Express utilized WebMoney and eGold as their virtual currency of choice); DOT Notice of Finding, supra note 46 (finding that Liberty reserve maintained a Dollar for Dollar and Euro for Euro exchange to back their virtual currencies) 110 Japan's ruling party won't regulate Bitcoin for now, supra note 99 (stating that Japan has no plans to regulate virtual currencies).
Since issues of money laundering and cybercrime have been around for about as long as the Internet, international methods to combat these crimes have emerged. ${ }^{111}$ However, since virtual currencies are a relatively new phenomenon, international organizations have not yet incorporated them into any current legal frameworks. This section analyzes how virtual currencies fit into the current policies and provisions of the Financial Action Task Force, the World Bank, and the International Monetary Fund. ${ }^{112}$

\subsubsection{The Financial Action Task Force}

The need for international cooperation in regulating virtual currencies is not too dissimilar from the need to regulate traditional securities internationally. ${ }^{113}$ Strong cooperation between regulators across borders is necessary for proper oversight of international entities and for effective prevention of international securities fraud. ${ }^{114}$ This international cooperation in embodied by the Financial Action Task Force, an intergovernmental body formed in 1989 by the governments of its member jurisdictions. ${ }^{115}$ It is a policy making body whose purpose is to set standards and promote effective implementation of regulatory measure to prevent terrorist financing and money laundering schemes. ${ }^{116}$ Countries ranging from Afghanistan to the Russian Federation to Mexico to the United States are members of either the Financial Action Task Force or one of its regional bodies. ${ }^{117}$

111 See generaly International Convention on Cyber Crime, Available at http://conventions.coe.int/Treaty/en/Treaties/Html/185. htm; (lacking any reference to virtual currencies); Financial Action Task Force, The FATF Recommendations infra note 128, at 116 (missing any reference to virtual currencies).

112 These Institutions are chosen as they are the principle international organizations tasked with monitoring money.

113 Ellise B. Walter, Speech by SEC Commissioner: Supervisory Cooperation: The Next Frontier for International Securities Regulation, US Securities and Exchange Comission, July 6, 2010 available at http:/ / www.sec.gov/news/speech/2010/spch070610ebw.htm (explaining that national initiatives of financial markets domestically is important, but so are broader, international financial intiatives).

114 Id. (stating that "robust cooperation among regulators is vital to the effective oversight of cross-border entities and to the prevention of international securities fraud").

115 About Us, Financial Action Task Force (Jan. 24, 2015 3:24 PM), http://www.fatf-gafi.org/pages/aboutus/ (explaining the formation of the Financial Action task Force).

116 Id. (explaining the purpose of the Financial Action Task Force).

117 Countries List, Financial Action Task Force (Feb. 21, 2015 
The Financial Action Task Force has developed recommendations that are recognized as international standards for combating terrorist financing and money laundering. ${ }^{118}$ These recommendations are the product of an international effort to combat these threats within the global financial system. ${ }^{119}$ The Financial Action Task Force monitors the progress of its members in implementing measures; reviews techniques of those who launder money or finance terrorism; promotes the implementation and adoption of measure globally; and works to identify national level vulnerabilities. ${ }^{120}$ Since the founding of the Financial Action Task Force in 1989, its recommendations have been issued five times: in 1990, 1996, 2001, 2003, and most recently in 2012. ${ }^{121}$ Recommendations are issued every few years to ensure that they are up to date and relevant since they are designed to have universal application. ${ }^{122}$

While the recommendations are useful in creating international standards and policies, the Financial Action Task Force has no enforcement mechanism to impose penalties on any non-complying nations. ${ }^{123}$ The only tool that the Financial Action Task Force has to enforce its recommendations is to publish a list of high risk and non-cooperative jurisdictions. ${ }^{124}$ Before countries are put on this list, they are notified and have the opportunity to respond to the findings. ${ }^{125}$ They may meet with an expert from the Financial Action Task Force in order to address any deficiencies or unresolved questions. ${ }^{126}$ But a country will only be taken off of the list if the Financial Action Task Force is convinced

4:05 PM), http://www.fatf-gafi.org/countries/ (listing member nations of the Financial Action Task Force).

118 About Us, Financial Action Task Force, infra note 111 (naming a few nations which are member of the Financial Action Task Force or one of its regional bodies).

119 Id. (explaining the purpose of the Financial Action Task Force recommendations).

120 Id. (stating the activities of the Financial Action Task Force). 121 Id. (listing the years that the Recommendations have been issued by the Financial Action Task Force).

122 Id. (explaining the purpose of the Financial Action Task Force recommendations).

123 Andrew Ayers, The Financial Action Task Force: The War on Terrorism Will Not Be Fought on the Battlefield, 18 N.Y.L. Sch. J. Hum. Rts. 449, 451 (2002) (describing the Financial Action Task Force as primarily a policy making body).

124 Id. at 452-53 (stating that the List of Non-Cooperative Jurisdictions is the only enforcement tool that the Financial Action Task Force holds).

125 Id. at 452-53 (explaining the development process of the List of Non-Cooperative Jurisdictions).

126 Id. at 452-53 (Describing how a nation may seek to remove itself from List of Non-Cooperative Jurisdictions). that the jurisdiction will address any shortfalls by enacting legislation and regulations. ${ }^{127}$

The 2012 recommendations do not address virtual currencies specifically. ${ }^{128}$ However, it does include one paragraph on new technologies. ${ }^{129}$ Specifically, the recommendations urge countries and financial institutions to actively identify money laundering or terrorist financing risks that may emerge out of new or developing technologies. ${ }^{130}$ After identifying such risks, countries and financial institutions should take the appropriate measures to manage and mitigate such risks. ${ }^{131}$

Furthermore, virtual currencies may fit into the definitions the Financial Action Task Force provides for the terms "funds" and "funds or other assets." This is important because the recommendations require countries to ensure funds or other assets are not used in money laundering or terrorist financing schemes. ${ }^{132}$ If a country finds that funds or other assets are being used in such schemes, the country must freeze said funds or other assets. ${ }^{133}$ The recommendations define funds to include "assets of every kind... and legal documents or instruments in any form, including electronic or digital, evidencing title to, or interest in, such assets" (emphasis added) ${ }^{134}$ The recommendations also define "funds or other assets" as,

any assets, including $[\ldots]$ property of every kind, $[\ldots]$ and legal documents or instruments in any form, including electronic or digital, evidencing title to, or interest in, such funds or other assets, including, but not limited to, bank credits, travellers cheques, bank cheques, money orders, shares, securities, bonds, drafts, or letters of credit, and any interest, dividends or other income on or value

127 See id.at 452-53 (explaining when the Financial Action Task Force may remove a nation from List of Non-Cooperative Jurisdictions).

128 See generally Financial Action Task Force, The FATF Recommendations: International Standards on Combating Money Laundering and the Financing of Terrorism \& Proliferation, Feb. 2012, available at http://www.fatf-gafi.org/media/fatf/documents/recommendations/pdfs/FATF_Recommendations.pdf (missing any mention of virtual currencies).

129 Id. at 17 (addressing new technologies and terrorist financing and money laundering).

130 Id. (suggesting nations be proactive in identifying new technologies that may assist terrorist financing or money laundering).

131 Id. (recommending nations to enact appropriate measures to manage and mitigate risks new techonolgies pose in money laundering and terrorist financing).

132 Id.at 13 (stating that nations should freeze funds or other assets of specified persons).

133 Id. (asserting that nations should freeze funds or other assets of specified persons).

134 Id. at 118 (defining the term "funds or other assets"). 
accruing from or generated by such funds or other assets. (emphasis added). ${ }^{135}$

Whether these definitions include virtual currencies depends entirely on how each jurisdiction defines the terms within the definition. For example, in the Unites States, virtual currencies are treated as property for tax purposes. ${ }^{136}$ United States courts have also held that virtual currencies are money and securities. ${ }^{137}$ Thus, within the borders of the United States, virtual currencies would easily fall under either definition as a kind of property. In the United Kingdom, Bitcoin is a type single purchase voucher subject to a value added tax and therefore may fall under the definition of "funds or other assets" as a legal document or instrument in electronic or digital form. ${ }^{138}$ However, virtual currencies other than Bitcoin likely do not fit into this definition since only Bitcoin have the status of single purchase voucher. ${ }^{139}$ On the other hand, because Japan manifestly decided to exclude virtual currencies from any regulation, virtual currencies would not likely fall under either of these definitions. ${ }^{140}$

Additionally, many of the virtual currency exchangers, which often assist cybercriminals in maintaining anonymity, may fall under the definition of a "financial institution." 141 A "financial institution is defined as "any natural or legal person who conducts as a business one or more of the following activities or operations for or on behalf of a customer: [...] Money or value transfer services". ${ }^{42}$ While the legal status of institutions may differ in varying jurisdictions, each individual participating in currency exchanges is a natural person and thus is subject to the requirement that financial institutions participate in anti-money laundering activity. ${ }^{143}$

135 Id. at 118 (defining "funds or other assets").

136 Internal Revenue Service, Notice 2014-21, available at http:/ / www.irs.gov/pub/irs-drop/n-14-21.pdf (stating that for federal tax purposes, virtual currencies are treated as property).

137 Memorandum Decision Regarding the Courts Subject Matter Jurisdiction, SEC v. Shavers, 13-cv-00416, 2014 US Dist. LEXIS 130781 (E.D. Tex. Sept. 18, 2014) (finding that virtual currencies fall under the definition of an investment contract under the Securities and Exchange Act); Ulbricht, 31 F. Supp. 3d 548 (finding that the purpose of Bitcoin is to carry value and act as a medium of exchange). 138 Skinner supra note 103 (stating that if an investor wanted to sell Bitcoin for more than $£ 77,000$, the investor would need to register for a value added tax).

139 See id. (referencing only Bitcoin).

140 Japan's ruling party won't regulate Bitcoin for now, supra note 99 (citing Japanese officials stating that Japan does not intent to enact any regulations of virtual currencies).

141 Financial Action Task Force, The FATF Recommendations supra note 128, at 116 (defining a "financial institution").

142 Id.

143 See id. (defining financial institution as any natural or legal person who operate money or value transfer services).
Despite the fact that the Financial Action Task Force was created with the intent of creating directives aimed at combating money laundering and terrorist financing activities, some of its member nations-including the United States and Canada-have been the least compliant with the recommendations. ${ }^{144}$ However, after the attacks on September 11, 2001, many nations have increased their resolve in fighting money-laundering activities. $^{145}$

\subsubsection{The World Bank and the International Monetary Fund}

The World Bank and International Monetary Fund might have a place for monitoring, regulating or utilizing virtual currencies. However, monitoring crimes facilitated by virtual currencies may be outside the scope of their functions. The World Bank was created for the purposed of financing development. ${ }^{146}$ Its first role was to provide loans for reconstruction of Europe after World War II, but since turned its attention to the world's developing nations. ${ }^{147}$ Its central purpose is to "promote economic and social progress in developing countries by helping to raise productivity so that their people may live a better and fuller life." 148 There is an argument to be made that The World Bank could utilize virtual currencies to aid its global development efforts, ${ }^{149}$ but that argument is outside the scope of this article.

At the same time The World Bank was established, the International Monetary Fund was also developed to address with the financial problems left unresolved after the Great Depression. ${ }^{150}$ The IMF's primary purpose is to monitor the international monetary system

144 Ayers, supra note 123, at 458 (explaining the challenged the Financial Action Task Force faces in completing its objectives).

145 Id. at 451 (stating that non-compliant nations saw the attacks on September 11, 2011 as a wake up call on the important of the Financial Action Task Force's work).

146 David Driscol, The IMF and the World Bank, How Do They Differ?, The International Monetary Fund, https://www.imf. org/external/pubs/ft/exrp/differ/differ.htm (explaining the differences between the World Bank and the IMF their formation).

147 Id. (explaining the evolution of the World Bank).

148 Id. (stating the purpose of the World Bank).

149 Virtual Currencies, supra note 4, at 9 (asserting that virtual currencies may be able to provide services to the un- and underbanked)

150 Driscol, supra note 146 (explaining the development of the IMF). 
of exchanges and payments. ${ }^{151}$ While the IMF has the power to; and may want to regulate virtual currencies, especially those like Bitcoin with a large market capitalization, ${ }^{152}$ the criminal aspect of virtual currency use is outside the scope of its mandate. ${ }^{153}$ The IMF has the power to gather information from member nations to discuss their monetary policy but those discussions focus on the economic, rather than the criminal aspects of money. ${ }^{154}$

\subsection{Current methods of international regulation of cybercrime and how they may apply crime facilitated by virtual currencies}

Cybercrime is unique compared to other crimes because it has the ability to transcend national borders. ${ }^{155}$ The advent of the Internet made it difficult for sovereign states to regulate criminal behavior because it is difficult to impose punishment on criminals outside of a sovereign's jurisdiction. ${ }^{156}$ This section explores how crimes facilitated by virtual currencies fit into current international efforts by nations to battle cybercrime.

\subsubsection{The International Convention on Cybercrime}

The Convention on Cybercrime is an international treaty created with the intent to harmonize the laws of nations on cyber crime and increase investigative cooperation and capabilities. ${ }^{157}$ The Convention entered

151 International Monetary Fund, The IMF at a Glance (Aug 22, 2012), available at http://www.imf.org/external/np/exr/facts/ glance.htm (visited January 24, 2015) (outlining the purpose of the IMF).

152 See Nicholas A. Plassaras, Comment, Regulating Digital Currencies: Bringing Bitcoin within the Reach of the IMF, 14 Chi. J. Int'l. L. 377 (2013) for an argument that IMF needs to regulate the exchange rates of Bitcoin.

153 IMF Mandate, available at http:/ / www.imf.org/external/np/ exr/facts/imfwb.htm (explaining the purpose of the IMF).

154 IMF Surveillance, International Monetary Fund (Oct. 3, 2014), http://www.imf.org/external/np/exr/facts/surv.htm (clarifying that the IMF's surveillance and consulting activities focus on "exchange rate, monetary, fiscal, and financial policies, as well as macro-critical structural reforms").

155 Amalie M. Weber, The Council of Europe's Convention on Cybercrime, 18 Berkeley Tech. L.J. 425, 425 (2003) (explaining the characteristics of cybercrime).

156 Id. (describing the role the internet plays in cybercrime).

157 Id. (detailing the purpose of the Convention). See also Council of Europe, Convention on Cybercrime Signatories, available at, http://conventions.coe.int/Treaty/Commun/ChercheSig. into effect in 2004 and therefore lacks any mention of virtual currencies, digital currencies or even e-currencies. ${ }^{158}$ The coordinators of the Convention recognized that the international character of cybercrime conflicted with national sovereignty and that a binding international instrument was necessary to guarantee effectiveness in combating this relatively new type of crime. ${ }^{159}$

The Convention outlines a number of cybercrime offenses that parties are responsible for addressing through legislation or other necessary measures. These offenses include, among others, crimes such as altering computer data without right, ${ }^{160}$ possession or distribution of child pornography, ${ }^{161}$ and the infringement of copy rights. ${ }^{162}$ Although there is no explicit mention of the crimes that are typically committed through the use of virtual currencies-money laundering, buying and selling of illegal goods, and fraud-it is possible, with a broad interpretation of the provisions, that some of these crimes will be covered by the language of the Convention. ${ }^{163}$ For example, Article 8 of the Convention concerns computer related fraud. ${ }^{164}$ Fraud may be subject to this provision as it is causing of a loss of property to another person through a dishonest intent of

asp?NT $=185 \& \mathrm{CM}=8 \& \mathrm{DF}=\& \mathrm{CL}=\mathrm{ENG}$ (listing signatories of the International Convention on Cyber Crime, including all of the European Union Member States but has also been ratified by Australia, the Dominican Republic, Japan, Mauritius, Panama, and the United States. ); Michael A. Vatis, The Council of Europe Convention on Cybercrime 207, 207 available at http://cs.brown.edu/courses/csci1950-p/sources/lec16/Vatis.pdf (explaining that the Convention was drafted by the council of Europe but that other non-European nations participated in negotiations).

158 See Generally International Convention on Cyber Crime, Available at http://conventions.coe.int/Treaty/en/Treaties/ $\mathrm{Html} / 185 . h t m$; (lacking any reference to virtual currencies).

159 Vatis, supra note 157, at 208 (describing the urgency in addressing the international nature of cybercrime).

160 See Convention on Cybercrime Art. 4 (referring to alteration or suppression of computer data without right).

161 Id. at Art. 9 (addressing offenses related to Child Pornography).

162 Id. at Art. 10 (referring offences related to infringements of copyright and related rights).

163 See Weber, supra note 149, at 435 (listing crimes that could be covered by the International Convention on Cybercrime. None of the crimes); but see generally SEC v. Shavers, 13-cv-00416, 2014 US Dist. LEXIS $130781 * 22$ (E.D. Tex. Sept. 18, 2014) (finding a virtual currency Ponzi scheme as a type of securities fraud).

164 See Convention on Cybercrime, Art 8 (stating the means through which a crime covered by the article must be conducted, "by: a) any input, alteration, deletion or suppression of computer data, [or] b) any interference with the functioning of a computer system, with fraudulent or dishonest intent of procuring, without right, an economic benefit.") 
procuring an economic benefit. ${ }^{165}$ However, the provision narrows itself by providing a means through which the crime may occur. For example, it seems unlikely that the conduct of Shavers in SEC v. Shavers, where a Texas man lied to investors via Internet chat rooms in a Bitcoin Ponzi scheme, would constitute an "input, alteration, deletion or suppression of computer data" or "interference with the functioning of a computer system." 166

However, a later provision may serve as a catchall for crimes not listed. ${ }^{167}$ Therefore, even though crimes usually committed through the use of virtual currencies are not explicitly listed in the Convention, these crimes might fall under the parameters of "other criminal offense committed by means of a computer system" so long as they are recognized by the relevant jurisdiction as criminal. However, this may become problematic if the domestic laws do not consider the action as criminal. For example, if Shavers, operating from within the United States, ran his Bitcoin Ponzi scheme in Japan and took Bitcoins from Japanese investors, would he face punishment since Japan does not seem to recognize virtual currencies? ${ }^{168}$ The answer is unclear and requires further analysis.

The Convention includes a provision that grants state's jurisdiction over crimes that occurred within its borders even if the perpetrator committed that offense within the borders of another sovereign. ${ }^{169}$ It also re-

165 Id. (asserting that "criminal offences [...] committed intentionally and [...] causing of a loss of property to another person by: a) any input, alteration, deletion or suppression of computer data, [or] b) any interference with the functioning of a computer system, with fraudulent or dishonest intent of procuring, without right, an economic benefit."); see also Weber, supra note 155, at 434 (listing fraud as on of the possible crimes covered by the Convention).

166 See generally, SEC v. Shavers, 13-cv-00416, 2014 US Dist. LEXIS $130781 * 22$ (E.D. Tex. Sept. 18, 2014)(outlining the facts of the case. Note the lack of any mention of any manipulation of computer data).

167 See Convention on Cybercrime Art. 14 (outlining the scope of the procedural provisions by stating "Each Party shall adopt such legislative and other measures as may be necessary to establish the powers and procedures provided for in this section for the purpose of specific criminal investigations or proceedings [...] the criminal offences established in accordance with Articles 2 through 11 of this Convention [...] [and] other criminal offences committed by means of a computer system" (emphasis added)).

168 See generally Knight, supra note 6, (stating that Japan will not take any action after more than 744,000 Bitcoins went missing from Mt. Gox, formerly the world's biggest Bitcoin exchange).

169 Explanatory Report to the Convention on Cybercrime, I 233 (stating a "Party would assert territorial jurisdiction if both the quires a state to grant jurisdiction to another state for a crime committed within the first state's borders as long as the act is a criminal offense within that jurisdiction. ${ }^{170}$ The Convention also includes mutual assistance provisions, which requires the parties to provide assistance to each other in investigations and proceedings in cases involving cyber crime. ${ }^{171}$ Furthermore, the Convention rejects the requirement of dual criminality, which requires that the two nations involved must both outlaw the action in question in order to comply with a request for assistance. ${ }^{172}$ Even though the dual criminality requirement has been praised as an innovation that eased the relatively complicated process of drafting extradition treaties, ${ }^{173}$ the drafters of the Convention argue that such a requirement would be counter productive in the context of preserving computer data, which could be quickly deleted. ${ }^{174}$

The Mutual Assistance provision and rejection of the dual criminality requirement advance the efforts of individual nations in combating cybercrime. ${ }^{175}$ For example, Western Express International member Egor Shevelev was safe in the Ukraine because there was no extradition or other agreement with the Ukraine that would have enabled the United States to assert jurisdiction over him. ${ }^{176}$ It was not until he was vacationing in

person attacking a computer system and the victim system are located within its territory, and where the computer system attacked is within its territory, even if the attacker is not.").

170 Id. I 236 (asserting that "if a national commits an offence abroad, the Party is obliged to have the ability to prosecute it if the conduct is also an offence under the law of the State in which it was committed or the conduct has taken place outside the territorial jurisdiction of any State").

171 Convention on Cyber Crime, Art. 25 (requiring parties to assist each other in " $[. .$.$] investigations or proceedings concerning$ criminal offences related to computer systems and data [...]").

172 Id. at Art. 29; Explanatory Report to the Convention on Cybercrime, 285 (arguing that the principle of dual criminality is counterproductive); Weber, supra 155, 434 (stating that the Convention rejects the requirement of dual criminality).

173 Weber, supra note 155, 434 (explaining that dual criminality has been widely lauded in the development of extradition treaties). 174 Explanatory Report to the Convention on Cybercrime, $\uparrow 285$ (asserting that dual criminality is [...] counterproductive in the context of preservation.”).

175 See DOT Notice of Finding supra, note 46, at 6 (citing the Liberty Reserve blog which stated that the purpose of the change in registration to Costa Rica was because there is no extradition treaty between the United States and Costa Rica); Manhattan DA, Western Express Cybercriminals Convicted, supra note 90 (stating that Shevelev could not be arrested in the Ukraine because there is no extradition treaty between the United States and the Ukraine).

176 Manhattan DA, Western Express Cybercriminals Convicted, supra, note 90 (stating that Shevelv could not be arrested in the 
Greece, with which the United States has an extradition agreement, that the United States was able to get Shevelev extradited. ${ }^{177}$ Additionally, Liberty Reserve moved its operation from New York to Costa Rica because there was no mutual assistance from Costa Rica and the United States. ${ }^{178}$ The inclusion of these two elements in the Convention is important but, unfortunately, the Convention is only signed by a relatively small number of nations. ${ }^{179}$

\subsubsection{Other efforts}

A common element in the cybercrime cases mentioned in section II of this article is the maintenance of anonymity and lack of oversight. By nature, virtual currencies, especially cryptocurrencies lack a central regulating authority or one that cares to validate identities of users. ${ }^{180}$ This fact makes virtual currencies especially useful to criminals but not much can be done to change this characteristic of virtual currencies. ${ }^{181}$ However, the regulation of exchangers, the people or institutions that exchange virtual currencies for fiat currencies, is a possibility. ${ }^{182}$ New York, one of the most active jurisdictions in fighting cybercrime facilitated by virtual currencies, has proposed a set of regulations, which it hopes will suppress criminal activity without stifling innovation. ${ }^{183}$ These regulations include a requirement to obtain a license to act as an exchanger or issue virtual cur-

Ukraine due the lack of an extradition treaty between the United States and the Ukraine).

177 Manhattan DA, Western Express Cybercriminals Convicted, supra, note 90 (explaining that Shevelev was arrested while on vacation in Greece).

178 DOT Notice of Finding, supra note 46, at 6 (citing Liberty Reserve's reason for moving to Costa Rica).

179 See Council of Europe Convention on Cybercrime Signatories, supra note 157 (listing all nations that are signatories to the Convention).

180 People v. W. Express Int'l Inc., 19 N.Y. 3d 652, 655 (N.Y. Ct. App. 2012) (finding that Western Express International did little to verify the identities of its users).

181 W. Express Int'l Inc., 19 N.Y. 3d at 655 (asserting that the nature of virtual currencies "recommends itself for money laundering purposes").

182 See Jacob Davidson, New York Proposes Bitcoin Regulations, Time Money, July 18, 2014, http://time.com/money/3004751/ new-york-bitcoin-regulations-benjamin-lawsky/ (explaining that the superintendent for New York's Department of Financial Services proposed new rules for regulating virtual currency businesses).

183 Id. (stating that New York proposed regulations of virtual currencies). See also People v. W. Express Int'l Inc., 19 N.Y. 3d 652, 655 (N.Y. Ct. App. 2012) (finding defendants guilty of crime facilitated through virtual currencies in New York Courts). rencies. ${ }^{184}$ The rules also require that each licensee must maintain books and records, and comply with all anti- money laundering, anti-fraud and cyber security regulations. ${ }^{185}$

While these rules may not be able to stop every instance of crime facilitated by virtual currencies, they are a good first step because they decrease the level anonymity that virtual currencies offer.

\section{Possible Channels for International Regulation of Virtual Currencies}

As discussed above, the regulation of virtual currencies might be achieved through the Financial Action Task Force, the International Convention on Cybercrime, and national regulations like those proposed by New York. However, while these three instruments are a decent starting point, the seriousness of the crimes facilitated by virtual currencies warrants action that will act as a deterrent to such crimes, rather than "might" act as a deterrent. Fortunately, the tools for cracking down on cybercrime already exist in each of these institutions and they just need to be altered and updated to reflect how the lack in regulation of virtual currencies facilitate cybercrime.

The International Convention on Cybercrime should develop an addendum to the provisions, or additional provisions that specifically outline the types of crimes that have become problematic in recent years with the growth of virtual currencies and how virtual currencies are used to carry out these crimes. To reiterate, these crimes include, but are not limited to fraud; money laundering; the buying and selling of illegal goods such as drugs, weapons, and stolen credit cards and identifying information; and dissemination of child pornography. Furthermore, it is important that the Convention is signed by additional countries in order to extend its scope.

184 New York State Department of Financial Services, Proposed New York Codes, Rules and Regulations, SS 200.2(n), 200.3, available at http://www.dfs.ny.gov/about/press2014/pr1407171-vc.pdf (requiring persons who exchange virtual currencies to obtain a license).

185 New York State Department of Financial Services, Proposed New York Codes, Rules and Regulations, \$S 200.7, 200.12 available at http://www.dfs.ny.gov/about/press2014/pr1407171-vc.pdf (explaining that each licensee must maintain their books for ten years and books must maintain information about the transaction and must provide all data to the New York Department of Finance upon request). 
Since there are so many nations that are not signatories to this Convention, there are too many places for cybercriminals to hide.

The Financial Action Task Force must also play an active role in encouraging nations to be more active in cooperating with other nations to bring cybercriminals utilizing virtual currencies to justice. The Financial Action Task Force must update its recommendations in a way that recognizes the role that virtual currencies play in financing terrorism and money laundering and how nations can work together to counter cybercrime activity. The Financial Action Task Force should also encourage nations to adopt laws and regulations similar to those that the legislature in New York State seeks to enact into law. It should also expand the definition of "financial institution" to explicitly include exchangers and the definition of "funds" or "funds or other assets" to explicitly include virtual currencies.

Even though any nation would find great difficulty in trying to directly regulate virtual currencies, especially cryptocurrencies, it is much less difficult to try to regulate those that exchange virtual currencies for fiat money. Exchangers should be regulated in the same manner as any other financial institution a nation recognizes as a legal entity. By holding an exchanger responsible for verifying the activities of those they serve, verifying the identities of their customers, and keeping standard book keeping records, the likely hood that virtual currencies will be used for criminal activity decreases significantly. If an exchanger believes that they will be held accountable for not taking to steps necessary to follow the law, they are less like to aid in cybercrime, knowingly or unknowingly. However, it is important that these regulations are enacted along side an increase in application of the Convention on Cybercrime because if, for example, an exchanger is exchanging currencies for customers in the United States in a manner that violates United States law, but is operating in a country that is not a signatory to the Convention, the United States will not have any power to hold this hypothetical person accountable.

Any nation not willing to incorporate such laws or to cooperate in international efforts to investigate and prosecute those who use virtual currencies to commit crime should be listed as a non-complying nation by the Financial Action Task Force.

\section{Final CONSIDERATIONS}

While a few nations have been working against cybercrime facilitated through the use of virtual currencies, other nations have done little if anything to regulate virtual currencies. If international efforts are not continued and strengthened, the appeal of virtual currencies for criminals will only increase, and they will find ways around what little regulation currently exists. While the institutions are currently in place to deal the old realities of money laundering, cybercrime and other related crimes, these institutions need to be updated to reflect a new reality. 


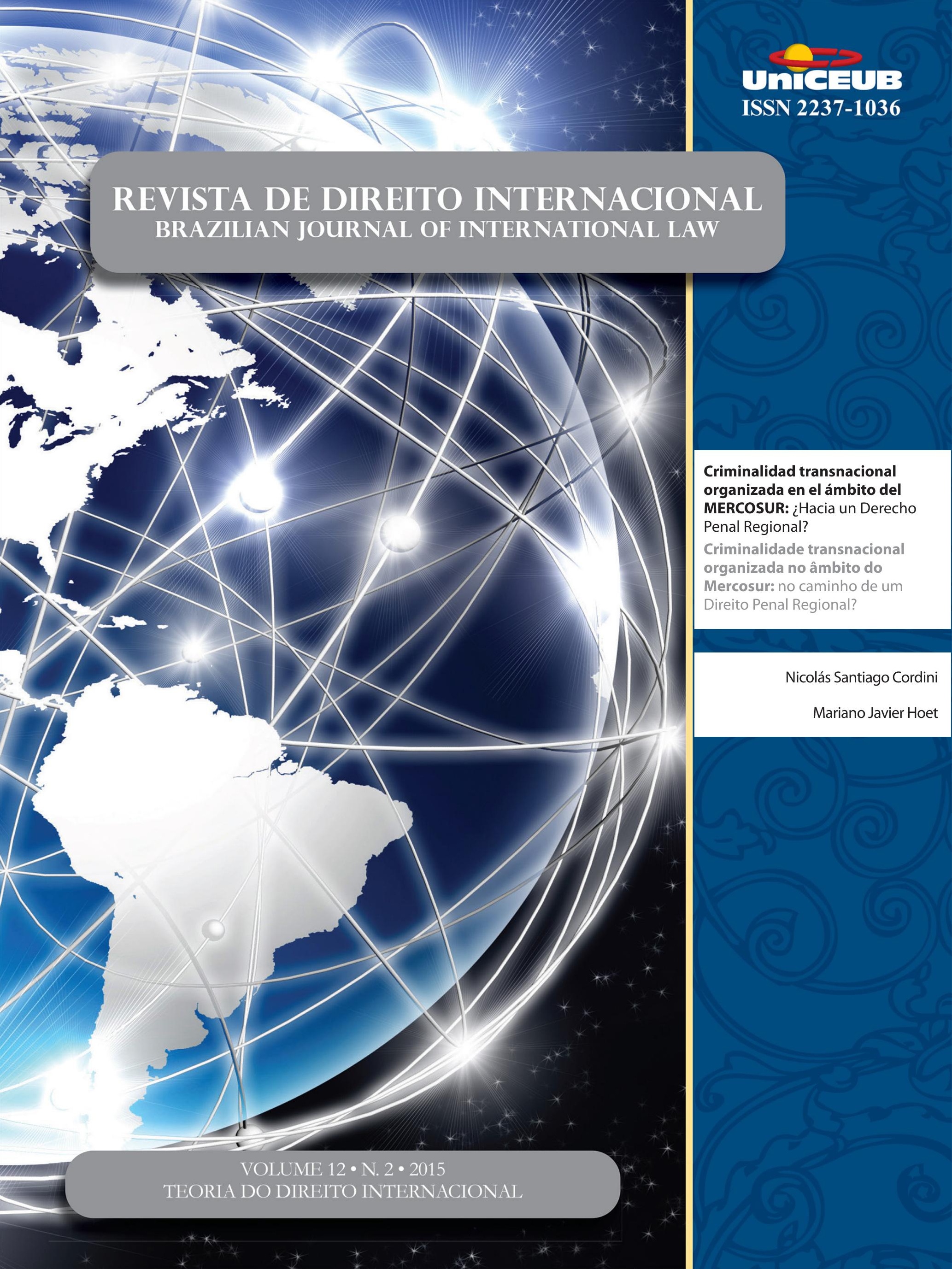




\title{
Criminalidad transnacional organizada en el ámbito del MERCOSUR: ¿Hacia un Derecho Penal Regional?*
}

\author{
Criminalidade transnacional organizada \\ no âmbito do Mercosur: no caminho de um \\ Direito Penal Regional?
}

\author{
Nicolás Santiago Cordini** \\ Mariano Javier Hoet***
}

\section{Resumen}

La criminalidad organizada no es un fenómeno reducido a la política interna de los Estados; su carácter "transnacional” provoca que las políticas criminales adoptadas aisladamente por los Estados fracasen. Si el fenómeno es regional, la respuesta que debe darse tiene que tener el mismo alcance. El objetivo central del presente trabajo es presentar los lineamientos generales de un Derecho Penal Regional tendiente a la prevención y sanción de los delitos de organización a partir del establecimiento de una Corte Penal Regional contra Crimen Transnacional Organizado. A tal fin, utilizando una metodología cualitativa, hemos comparado la legislación, tanto interna como internacional, de los Estados miembros del Mercosur, teniendo en cuenta los posibles factores facilitadores u obstaculizadores a la adopción de una política de este alcance.

Palabras claves. DELITO-ORGANIZACIÓN-TRANSNACIONALIDAD

Transnational organized crime on the MERCOSUR scale: to a Regional Criminal Law?

** Nicolás Santiago Cordini é Dr. en Derecho, Profesor Adjunto e Investigador. de Derecho Penal y Derecho Penal Internaciona da Universidad Nacional del Litoral - Argentina.

*** Mariano Javier Hoet é Profesor Adjunto de Derecho Penal y de Filosofía Social y Contemporánea. Investigador en el área de Policía y Seguridad da mesma Universidade. Emails: nicocordini@yahoo.com.ar e marianohoet@ rectorado.unl.edu.ar

\section{Abstract}

The organized crime is not a phenomena reduced to the state policies; their "transnational" nature causes that criminal policies isolated adopted by the State at the end fail. If the problem is regional, the answer that must be given has to have the same range. The central aim of the present paper is to present the general guidelines of a Regional Criminal Law in order to prevent and punish the organized crimes following the establishment of a Regional Criminal Court against the transnational organized Crime. With this aim in mind, we use a qualitative methodology in order to compare the legislation, as much national as much International, of the States members of Mercosur, taking into account the possible pros and cons in the adoption of a policy of this range. 
Key words

CRIME-ORGANIZATION-TRANSNATIONAL

\section{INTRRODUCCIÓN:}

\subsection{Marco institucional de la investigación.}

La Universidad Nacional del Litoral organiza su arquitectura institucional en materia de investigación en torno a los CAI+D (Curso de Acción para la Investigación y el Desarrollo). La mencionada política consiste básicamente en agrupar por líneas de investigación a los Proyectos de I+D (PI) en Programas de Actividades Científicas y Tecnológicas (PACT), como un modo de facilitar el logro de objetivos concurrentes de dichos proyectos y de hacer más eficientes la adquisición de equipamiento, bibliografía, etc., de uso compartido. También están previstos los denominados PI especiales que por estar orientados a la producción de conocimiento en áreas caracterizadas por la ausencia de líneas de investigación en la temática, no son agrupados en un PACT.

Dentro de la modalidad referida en último término se encuentra nuestro proyecto de investigación, denominado "Globalización y Derecho penal: el fenómeno de la criminalidad organizada. Situación en la legislación argentina y países del MERCOSUR" el cual fue aprobado mediante resolución del Consejo Superior de la UNL 205/13 y se encuentra actualmente en la fase destinada a la consolidación del equipo de investigación y al establecimiento de precisiones acerca del objeto, las fuentes, el método y las estrategias que orientarán nuestro trabajo.

El proyecto tiene como objetivo final la realización de un estudio comparativo en torno a la normativa vigente en materia de "delitos de organización" entre los países miembros del MERCOSUR y países asociados teniendo en cuenta cómo dicha nueva categoría permea la configuración del injusto generando enormes implicancias en relación con el respecto a los principios y garantías constitucionales.

Actualmente el mencionado proyecto se encuentra en la segunda etapa de desarrollo, ya se ha comparado la legislación en la materia de los Estados objeto de aná- lisis $\mathrm{y}$, consiguientemente, se ha ingresado en una etapa propositiva.

El objetivo del presente trabajo consiste en presentar, en términos generales, las estrategias de construcción normativa que, según nuestra perspectiva de análisis, resultan necesarias para abordar el fenómeno objeto de estudio.

\subsection{Los procesos de globalización y glocaliza- ción en la política criminal.}

Los tiempos que corren se encuentran fuertemente caracterizados por la concurrencia de una serie compleja de fenómenos habitualmente denominados "globalización", los que, dicho en términos sencillos refieren a la transformación de esa constelación histórica caracterizada por el hecho de que el Estado, la sociedad y el mercado son coextensivos dentro las mismas fronteras nacionales ${ }^{1}$. Es decir, la crisis de la idea de una autoridad política dominante, suprema y unificada sobre un territorio claramente demarcado ${ }^{2}$. En suma, la crisis de aquello que Weber caracterizó como una comunidad humana que en el interior de un determinado territorio reclama para sí el monopolio de la coacción física legítima (el Estado) ${ }^{3}$. Como resultado de la globalización, el sistema económico internacional en el que los Estados trazan la línea divisoria entre la economía interna y las relaciones comerciales exteriores, se está metamorfoseando en una economía trasnacional.

La globalización coloca a las funciones administrativo-materiales del Estado en contextos crecientemente volátiles que exceden en mucho la capacidad de cualquier Estado individual para influir en decisiones y resultados. Este proceso de deterioro de las fronteras no afecta únicamente a las economías; impacta también sobre las políticas internas globales, el mantenimiento de la paz y de la violencia organizada, los nuevos medios

1 Habermas, Jürgen, El valle de lágrimas de la globalización, Claves, $\mathrm{N}^{\circ}$ 109, 2001, pp. 4-5.

2 Benhabib, Seyla, (2004). Los derechos de los otros. Extranjeros, residentes y ciudadanos, Barcelona: Gedisa, 2004, p. 15.

3 Con más detalle, Heller define al Estado como una unidad de dominación, independiente en lo exterior e interior, que actúa de modo continuo, con medios de poder propios, claramente delimitada en lo personal y lo territorial, con un solo ejército que es, además, permanente, con una única y competente jerarquía de funcionarios y un orden jurídico unitario, imponiendo a los súbditos un deber de obediencia de carácter general. Heller, Hermann, Teoría del Estado, México: Fondo de Cultura Económica, 1992, pp.142-143. 
y redes de comunicación, los florecientes movimientos migratorios y las formas culturales híbridas.

En los ámbitos que la globalización quiere confiados al mercado, su propuesta político-criminal básica es la inhibición de lo público, entendida como la funcionalización del Estado a los imperativos de las estrategias que esta propone.

Sin embargo, la desregulación no puede ser total, sino que viene acompañada de políticas de contundente intervención punitiva cuando se trata de asegurar la pax publica requerida por ese mercado. La economía globalizada potencia el intervencionismo punitivo frente a sujetos o comportamientos que estima disfuncionales, criminalizando no sólo la disidencia, sino también la marginalidad provocada por el desempleo o por la inmigración. Siguiendo a Silva Sánchez, acordamos que "Criminalidad organizada, criminalidad internacional y criminalidad de los poderosos son, probablemente, las expresiones que mejor definen los rasgos generales de la delincuencia de la globalización"”.

En este marco se viene desarrollando una nueva concepción acerca de lo delictivo, centrada en elementos tradicionalmente no identificados con la delincuencia; en particular, la "organización", expresada a través de la idea de "criminalidad organizada".

Frente a este fenómeno los Estados se encuentran en una situación de dificultad (cuando no de imposibilidad) de desplegar una política criminal adecuada. El hecho de que las organizaciones operen allende las fronteras estatales, ámbito dentro del cual el Estado puede desplegar su facultad de imperio, sumado a la escasez de recursos para desarrollar las mencionadas políticas y a la connivencia que encuentran dichas organizaciones con actores que operan en diversos niveles de intervención en la prevención y sanción del delito (control de fronteras, cuerpo de policía, sistema judicial, sistema penitenciario) redunda, todo ello, en que la política criminal que se adopte se convierta en meramente simbólica.

Ante esta situación la respuesta no puede ser local, la política criminal que se desarrolle al efecto debe abarcar la misma dimensión del fenómeno que se trata de prevenir; si el fenómeno criminológico es regional, la respuesta debe tener dicho alcance. De lo contrario,

4 Silva Sánchez, Jesús-María, (1999). La expansión del Derecho penal. Aspectos de la política criminal de las sociedades postindustriales, Madrid: Civitas, 1999, p. 86. quedaría reducida a un conjunto de declaraciones de buenas intenciones.

El objetivo general de la presente investigación será determinar los lineamientos generales de una política criminal regional tendiente a la prevención y sanción de los delitos de organización a partir del establecimiento de una Corte Penal Regional contra Crimen Transnacional Organizado

\section{Metodología.}

La metodología seleccionada a los efectos de realizar el presente trabajo de investigación se basa en herramientas que se corresponden con una estrategia metodológica cualitativa. Se identifican como unidades informantes las siguientes: (i) Legislación penal de los Estados partes del MERCOSUR, en la que se recepte el elemento "organización"; demás legislación internacional en la materia (Convención de Naciones Unidas contra la Delincuencia Organizada Transnacional y sus Protocolos, Estatuto de Roma de la Corte Penal Internacional, Convención de Naciones Unidas Contra el Tráfico Ilícito de Estupefacientes y Sustancias Psicotrópicas, Convención Americana Sobre Derechos Humanos, Tratados, Protocolos y Acuerdos del MERCOSUR, etc.) y, finalmente, sentencias jurisprudenciales; (ii) Doctrina jurídica: Revistas jurídicas especializadas en la temática penal tanto nacionales como extranjeras (iii) Obras bibliográficas versadas sobre la temática de los delitos de organización y sobre jurisdicción Internacional en materia penal.

Respecto de las técnicas de investigación, recurrimos al análisis clásico de documental: análisis de contenido. Para ello se construirán una serie de instrumentos (fichas de análisis) adecuados para cada tipo de documento. Ello permitirá la sistematización de datos, posibilitando su correlación y su posterior procesamiento, a fin de constituir una muestra representativa sobre: 1) Legislación, 2) Sentencias jurisprudenciales, 3) Doctrina jurídica.

\section{Resultados.}

A continuación analizaremos los resultados alcanzados en función de los objetivos propuestos. 


\subsection{Primer objetivo: determinar el concepto de "organización": ¿De qué se trata la criminalidad organizada?}

Siguiendo a Lampe, sostenemos que al investigar en materia de "crimen organizado", no contamos con un concepto, en tanto objeto de estudio, como punto de inicio ${ }^{5}$. Por el contrario, el verdadero propósito del estudio sobre "crimen organizado" o, para ser más precisos utilizando el léxico jurídico-penal, "delitos de organización", es determinar si tal fenómeno existe o no y, en caso afirmativo, establecer "¿de qué se trata?". Una definición de "delito de organización" es, por lo tanto, un posible resultado antes que una condición previa del estudio de la criminalidad organizada ${ }^{6}$.

La existencia de delitos cometidos a través de organizaciones criminales no es un fenómeno novedoso en el Derecho Penal. Lo que resulta extraño al buen y viejo Derecho Penal liberal es la expansión de la categoría “organización” dentro de las legislaciones penales. Esta reorientación político-criminal se manifiesta a través de diversas variantes. Dichas manifestaciones no surgieron al unísono sino, por el contrario, han ido apareciendo en diversas oleadas y a través diferentes vectores que hoy pueden ser comprendidos bajo el concepto de "expansión del Derecho Penal"”.

5 Lampe, Klaus von, (2009). The study of organised crime: An assessment of the state of affairs. En Karsten Ingvaldsen, Vanja Lundgren Sørli (Eds.), Organised Crime: Norms, markets, regulation and research, Oslo: Unipub, 2009, p. 166.

6 Kelly, R.J., Criminal Underworlds: Looking Down on Society of Bellow. En Kelly R.J. (Ed.) Organized crime: Crosscultural studies. Totowa, NJ: Rowman \& Littlefield, 1986, pp. 10 y ss.

7 La denominada expansión del Derecho Penal, siguiendo a Silva Sánchez, se basa en la creación de nuevos bienes jurídico-penales (v. gr. El medio ambiente, la paz, el tráfico económico), en la ampliación de los espacios de riesgos jurídico-penalmente relevantes (disminución de los espacios de riesgo permitido), en la flexibilización de las reglas de imputación y en la relativización de los principios político-criminales.

Como causas de este fenómeno se mencionan: a) La efectiva aparición de nuevos riesgos producto de la complejización de las interacciones humanas; b) La sensación social de inseguridad que generan las dificultades de adaptación de la población a sociedades en continua aceleración; c) La configuración de una sociedad de sujetos pasivos; d) La identificación de la mayoría social con la víctima del delito, reinterpretando al ius puniendicomo "la espada de la sociedad contra la delincuencia de los poderosos"; e) El descrédito de otras instancias de protección, resignificando al Derecho penal como único instrumento eficaz de pedagogía político social; f) El surgimiento de nuevos gestores de la moral colectiva y del recurso al Derecho penal para la protección de sus respectivos intereses (organizaciones ecologistas, feministas, de consumidores, de vecinos, pacifistas o antidiscriminatorias); g) El desprecio por las formas (garantías), que responde siempre a la supuesta constatación de la
Ellos son: a) la tipificación de delitos que serían característicos de tal forma de criminalidad (p. ej. el delito de trata de personas) ${ }^{8}$; b) la introducción del elemento agravante de organización en una serie de delitos más o menos tradicionales (p. ej. el caso del delito de robo calificado 9 cuando es cometido en banda); y por último, 3) los clásicos delitos de pertenencia a una organización como es el caso del delito de asociación ilícita ${ }^{10}$.

ineficiencia de las mismas. Silva Sánchez, Jesús-María, La expansión del Derecho penal. Aspectos de la política criminal de las sociedades postindustriales, Madrid: Civitas, 1999, pp. 18-60.

Diez Ripollés rechaza la postura de Silva Sánchez considerando que la denominada "expansión del derecho penal" presenta características de dos modelos diferentes, el de la sociedad del riesgo y el de la seguridad ciudadana, que abordan realidades diferentes desde perspectivas ideológicas diversas y que, por tanto, merecen un tratamiento diferenciado. El concepto de expansión deja ya de referirse primordialmente a las nuevas formas de criminalidad propias de la sociedad del riesgo, las cuales pasan a ocupar dentro de ese nuevo concepto de expansión, un lugar marginal, tanto cuantitativa como cualitativamente Diez Ripollés, José Luis, La política criminal en la encrucijada, Buenos Aires: B de F, 2007, p. 132. En consecuencia, la identificación de la mayoría social con la víctima del delito, el descrédito de otras instancias de protección, o bien el surgimiento de nuevos gestores atípicos de la moral colectiva, entre otros, son característicos del modelo de la seguridad ciudadana y no del de la sociedad del riesgo, p. 156.

8 Artículos 142 bis y 142 ter del Código Penal argentino, artículos 231 y 231A Código penal brasileño; artículos 78, 79 y 80 Ley de migraciones 18250 de la República Oriental del Uruguay; artículo 129 del Código penal paraguayo modificado por los artículos 6, 7 y 8 Ley No 2396/04; art 41 Ley Orgánica contra la Delincuencia Organizada y Financiamiento al Terrorismo, que fue publicada en Gaceta Oficial número 39.912 del 30 de abril de 2012 de la República Bolivariana de Venezuela.

9 Así el código penal argentino art. 166 inc. $2^{\circ}$ in fine establece el supuesto en que fuese cometido en despoblado y en banda o en sentido similar el art 165 del Código penal paraguayo establece la modalidad agravada Cuando el autor hurtara (...) como miembro de una banda que se ha formado para la realización continuada de robos y hurtos... Respecto a la norma penal argentina, Boumpadre entiende que "banda" es sinónimo de asociación ilícita. Véase Boumpadre, Jorge, Derecho penal: parte especial, T. II, Corrientes: Mario A. Viera Editor, 2001, p. 74.

10 Así el artículo 210 Código Penal argentino pune al que "tomare parte de una asociación o banda de tres o más personas destinada a cometer delitos por el sólo hecho de ser miembro de la asociación"; el delito de Associação Criminosa del artículo 288 del código penal brasileño que pune cuando "Associarem-se 3 (três) ou mais pessoas, para o fim especifico de cometer crimes"; El código penal de Uruguay en su artículo 150 establece la "Asociación para delinquir" estableciendo que "Los que se asocien para cometer delitos, será castigados por el simple hecho de la asociación..."; el código penal paraguayo contiene en su artículo 239 tipifica la "Asociación criminal" en el que sanciona a "El que: 1. creara una asociación estructurada jerárquicamente u organizada de algún modo, dirigida a la comisión de hechos punibles; 2 fuera miembro de la misma o participara de ella; 3. la sostuviera económicamente o la proveyera de apoyo logístico; 4. prestara servicios a ella; o 5. la promoviera,"; por su parte el código penal venezolano contiene el delito de "agavillamiento" en su artículo 286 que se 
Conforme a las legislaciones de los Estados mercosureños (véase nota al pie n. 5) el injusto sistémico de la organización criminal (el tomar parte de la asociación o asociarse) es un injusto autónomo, independiente de los delitos concretos (delitos fines) que se puedan cometer a través de ella.

El fenómeno de la proliferación de delitos cometidos a través de una "organización" suele caracterizarse por, al menos, dos rasgos:

a) La reducción de la estructura organizativa exigida para apreciar la existencia de una "organización delictiva":

En principio, la organización criminal como sistema de injusto tiene una dimensión institucional - de institución antisocial - que hace de ella no sólo algo más que la suma de sus partes, sino también algo independiente de la suma de las partes. Siguiendo a Silva Sánchez, podemos definir a la organización criminal de la siguiente manera:

"una organización delictiva es un sistema penalmente
antijurídico (strafrechtliches Unrechtssystem), o sea, un
sistema social en el que las relaciones entre los
elementos del sistema (básicamente, personas) se
hallan funcionalmente organizadas para obtener
fines delictivos. La organización criminal como
sistema de injusto tiene una dimensión institucional
- de institución antisocial - que hace de ella no sólo
algo más que la suma de sus partes, sino también
algo independiente"11.

Es en dicha dimensión institucional donde radica su diferencia específica respecto a las meras agrupaciones coyunturales para cometer delitos.

En este sentido se manifiesta el preámbulo de la Convención de Naciones Unidas contra la Delincuencia Organizada Transnacional cuando dice:

\begin{abstract}
"Alineadas contra esas fuerzas constructivas (sociedad civil), cada vez en mayor número y con armas más potentes, se encuentran las fuerzas de lo que denomino la 'sociedad incivil'. Se trata de terroristas, criminales, traficantes de drogas,
\end{abstract}

constituye "Cuando dos o más personas se asocien con el fin de cometer delitos, cada una de ellas será penada, por el solo hecho de la asociación". Además, la Ley Orgánica contra la Delincuencia Organizada y Financiamiento al Terrorismo, que fue publicada en Gaceta Oficial número 39.912 del 30 de abril de 2012 de la República Bolivariana de Venezuela establece en su artículo Artículo 37 que "Quien forme parte de un grupo de delincuencia organizada, será penado o penada por el solo becho de la asociación".

11 Silva Sánchez, Jesús-María, (2008). La 'intervención a través de organización', ¿una forma moderna de participación en el delito? En Cancio Melia, M., et al. Delitos de organización, Buenos Aires: B de F, p. 95 tratantes de personas y otros grupos que desbaratan las buenas obras de la sociedad civil. Sacan ventaja de las fronteras abiertas, de los mercados libres y de los avances tecnológicos que tantos beneficios acarrean a la humanidad. Esos grupos prosperan en los países con instituciones débiles y no tienen escrúpulos en recurrir a la intimidación o a la violencia. Su crueldad es la verdadera antítesis de lo que consideramos civil. Son poderosos y representan intereses arraigados y el peso de una empresa mundial de miles de millones de dólares; pero no son invencibles".

Como vemos, el fundamento de su tipificación penal estaría relacionado a que dichas organizaciones suponen un incremento de la peligrosidad frente a autores individuales o concertados de modo esporádico (participación), es decir, su cualidad de disponer de multiplicación de los distintos factores de riesgo respecto de los bienes jurídicos individuales afectados por las infracciones cometidas a través de la organización.

El crimen organizado se caracteriza por ser un tipo de delincuencia que, por lo general, se presenta bajo la forma de una estructura organizada de poder, de cierta permanencia o continuidad temporal, integrada en un sistema vertical que le posibilita alcanzar cierto nivel de coordinación central en sus actividades. Según Lampe cinco requisitos fundamentales distinguen a la organización criminal de la multiplicidad de partícipes concretados de modo esporádico, ellos son: 1) ingreso de recursos que posibilitan o facilitan la comisión de hechos ilícitos; 2) una ideología de justificación de las conductas criminales; 3) un status social; 4) seguridad ante la persecución penal y 5) seguridad ante otros criminales ${ }^{12}$.

En este sentido se manifiesta la Convención de Naciones Unidas contra la Delincuencia Organizada Transnacional define "Por grupo organizado" a "un grupo estructurado de tres o más personas que exista durante cierto tiempo y que actúe concertadamente con el propósito de cometer uno más delitos graves 13 o delitos tipificados con arreglo a la presente Convención" (art. 2') Por "grupo estructurado", por su parte, la Convención lo define como "un grupo no formado fortuitamente para la comisión inmediata de un delito y en el que no necesariamente se haya asignado a sus miembros funciones formalmente definidas ni haya continuidad en la condición de miembro o exista una estructura desarrollada" (art. 2 c);

12 Lampe, Klaus von, (2013). Was ist ,Organisierte Kriminalität'?, ApuZ, 63. Jahrgang 38-39/2013, p. 6.

13 Art 2 b) Por "delito grave" se entenderá la conducta que constituya un delito punible con una privación de libertad máxima de al menos cuatro años o con una pena más grave; 
Sin embargo, el concepto de "organización" en las legislaciones nacionales tiende a ser un concepto laxo que no distingue entre la criminalidad organizada en sentido estricto (macrocriminalidad o criminalidad de los poderosos) y la mera criminalidad de bandas. El requisito que tiende a hacerse más flexible debido a que las legislaciones analizadas (véase nota al pie n. 5), no exigen la efectiva comisión de delitos sino que es requisito suficiente para punir a sus miembros la existencia de una organización "el tomar parte" de la asociación destinada a cometer delitos. Demás requisitos, por ejemplo, el contar con una de tipo estructura militar, rasgo que ostenta dentro de la organización o la finalidad específica de ésta, constituyen agravantes del delito, pero no son requisitos fundamentales para su existencia.

b) La reducción de la gravedad de los ilicitos que han de constituir el objetivo de tal organización para que ésta sea calificada como "criminal".

Si bien la Convención de Naciones Unidas contra la Delincuencia Organizada Transnacional es aplicable a ilícitos graves que ella misma define como la conducta que constituya un delito punible con una privación de libertad máxima de al menos cuatro años o con una pena más grave (art. 2 b), los ordenamientos jurídicos nacionales contienen legislaciones en la materia aplicables a delitos de criminalidad media o delitos de escasa gravedad. Basta con analizar la figura conocida "asociación ilícita" o "Asociación para delinquir", en la cual no se hace ninguna distinción en torno a la gravedad de los delitos-fines de la organización criminal ${ }^{14}{ }^{15}$.

\subsection{Segundo objetivo: Determinar el ámbito es- pacial de la solución jurídica a adoptar: el Dere- cho Penal Internacional: su status disciplinario}

La idea de un Derecho Penal Internacional como disciplina autónoma todavía sigue siendo resistida espe-

14 Es necesario destacar que la figura básica de "asociación ilícita" en nuestro ordenamiento penal es anterior a la ratificación de la Convención antes señalada por la República Argentina.

15 El hecho de que la figura de "asociación ilícita" sea susceptible de aplicación a organizaciones cuya finalidad delictiva (delitofin) lo constituyan ilícitos de escasa gravedad genera inconsistencias porque si llegase a concurrir el delito de asociación ilícita con un delito de menor gravedad, el delito de asociación ilícita - considerado como acto preparatorio independientemente penado desde la perspectiva del iter criminis - sería más relevante a los efectos penales que el delito fin efectivamente cometido y, por lo tanto, sería el artículo correspondiente a la asociación ilícita el que fijaría las reglas de concursos de delitos por ser el de mayor gravedad. cialmente por la Ciencia del Derecho Penal. Dicha resistencia se basa en que esta rama del derecho representa la máxima expresión del ejercicio soberano del Estado, que este último ejerce con exclusividad. La constitución del Derecho Penal como disciplina científica viene de la mano de formación del Estado moderno, a través de la imposición de límites al príncipe o soberano a la hora de perseguir y castigar los crímenes (ius Puniendi). Dicho en otros términos, el ejercicio de la facultad de castigar, constituye la máxima expresión del ejercicio de la soberanía.

La idea de un Derecho Penal de naturaleza internacional nació como consecuencia de los crímenes de masas cometidos durante el siglo XX. A partir de la persecución y sanción de tales delitos a través de la constitución de tribunales ad hoc y ex post facto16 se fue originando un conjunto de reglas que podríamos denominar "Derecho Penal Internacional". Sin embargo, tales reglas no están exentas de críticas, puesto que violan principios básicos del Derecho penal tales como el de legalidad o la garantía del juez natural ${ }^{17}$. Según Ambos "el carácter esencialmente retroactivo de este tipo de jurisdicción” es "el defecto congénito de los tribunales ad hoc" ${ }^{\prime 18}$. Tornándose en soluciones políticas de los vencedores sobre los vencidos en flagrante violación a las garantías básicas que otorga el Derecho Penal.

Dichas irregularidades han sido salvadas a partir del Estatuto de Roma que crea la Corte Penal Internacional (CPI), siendo el primer instrumento de tutela jurisdiccional internacional de naturaleza permanente, penal e independiente, facultado para investigar, perseguir y sancionar, de manera complementaria a los Estados Miembros, a los presuntos autores de determinados delitos a saber, aquellos que son considerados como los más graves por la Comunidad Internacional en su conjunto: genocidio, crímenes de lesa humanidad, crímenes de guerra y crimen de agresión.

16 El Tribunal Militar Internacional de Núremberg (1945); el Tribunal Militar Internacional de Tokio (1946); el Tribunal Penal Internacional para la ex-Yugoslavia, con sede en la Haya (1993), el Tribunal Militar Internacional para los crímenes cometidos en Ruanda (1994), en Arusha y el Tribunal para el Genocidio Camboyano (2006)

17 Un ejemplo claro de violación fue el Tribunal Militar Internacional de Núremberg que no garantizó (prohibiéndolo expresamente) el derecho de recusación que goza todo sujeto sometido a proceso. 18 Véase, Ambos, Kai, El derecho penal internacional en la encrucijada: de la imposición ad hoc a un sistema universal basado en un tratado internacional. Política Criminal, (vol. 5, núm. 9, 2010, págs. $237-256$ 
A partir de la conformación de la CPI podemos hablar de un "Derecho Penal Internacional" basado en los principios de legalidad, personalidad de la pena, ne bis in idem, jurisdicción complementaria, entre otros.

Esta nueva disciplina, que combina potestad punitiva con la dimensión internacional, parte de la premisa de un Derecho penal no basado en la idea de soberanía estatal, es decir un Derecho penal que ejerza el ius puniendi sin soberano. Dicha solución se hace posible a partir del desarrollo de un concepto de ciudadanía global, en nuestro caso regional, basado en la protección de los derechos humanos fundamentales garantizados por múltiples Tratados, tanto de escala universal como regional. No debemos de olvidar, sin embargo, que esta disciplina aún se encuentra en una estadio fluido y en formación.

\subsection{Tercer objetivo: determinar posibles facto- res facilitadores u obstaculizadores para la insti- tucionalización de un Derecho Penal Regional:}

A la hora de discutir la formación de un Derecho Penal de Escala Regional debemos tener en cuenta aquellos factores que sostienen nuestra línea de pensamiento y también aquellos que pudiesen constituir un obstáculo a dicha posibilidad. A continuación abordaremos los factores a favor y en contra que posee el diseño de una política de este calibre.

\section{a) Factores a favor}

\section{a.1) La Corte Penal Internacional.}

La CPI ha constituido el primer hito en la constitución de una jurisdicción permanente tendiente a juzgar y sancionar los delitos, considerados más graves por la Comunidad Internacional, cometidos por particulares. Todos los Estados objeto de Estudio han suscripto el Estatuto de Roma ${ }^{19}$ y, en consecuencia, han cedido jurisdicción en esta materia. Bien es verdad que aquí no juega el argumento a fortiori y, de hecho, los Estados parte de MERCOSUR podrían no estar interesados en ceder jurisdicción en materia de delitos menos gravosos. Sin embargo, del éxito de la CPI y de otros Tratados

19 Los Estados partes de MERCOSUR han suscripto el mencionado tratado en las siguientes fechas: Argentina: 08/02/2001; Brasil: 20/06/2002; Paraguay: 14/05/2001; Uruguay: 28/06/2002, Venezuela: 07/06/2000.
Internacionales a los que los Estados objeto de estudio han ratificado, constituyen un argumento potente para evitar el rechazo a una jurisdicción regional en materia de delitos de organización.

a.2) MERCOSUR y sus múltiples acuerdos.

Dentro de la estructura del MERCOSUR existen múltiples acuerdos celebrados entre los Estados partes y otros Estados asociados, cuyo objetivo es la cooperación internacional en materia penal. A modo de ejemplo, citamos:

_Acuerdo de Asistencia Jurídica Mutua en Asuntos Penales entre los Estados Partes del MERCOSUR, la República de Bolivia y la República de Chile (Buenos Aires, 18 de Febrero de 2002)

_Acuerdo contra el Tráfico Ilícito de Migrantes entre los Estados Partes del MERCOSUR (Belo Horizonte, 16 de diciembre de 2004).

_Acuerdo contra el Tráfico Ilícito de Migrantes entre los Estados Partes del MERCOSUR, la República de Bolivia y la República de Chile (Belo Horizonte, 16 de diciembre de 2004).

a.3) Convención de las Naciones Unidas contra la Delincuencia Organizada Transnacional y sus Protocolos.

Adoptada por la Res. 55/25 de la Asamblea General de Naciones Unidas del año 2000, la presente Convención establece el marco general de lo que debe entenderse por delincuencia organizada transnacional, a la vez que prevé medidas, tendientes a adoptar por los Estados partes, tendientes a prevenir, reprimir y sancionar los delitos definidos por la Convención y sus Protocolos.

Si bien no es objetivo de esta Convención establecer una jurisdicción internacional en la materia; esta normativa, no obstante, establece múltiples medidas de cooperación judicial, que sirven de sustento a una posible Corte Regional en la materia.

a.5) Sistemas penales similares.

Otra argumento a favor de la constitución de un Derecho Penal Regional en materia de delincuencia Transnacional Organizada, es el hecho que los Estados partes de Mercosur comparten en materia penal (tanto en lo que respecta al Derecho sustantivo como al Derecho Procesal) sistemas similares. Todos los países siguen la tradición jurídica continental europea y, en la dogmática jurídico-penal, la denominada teoría del delito Podemos 
caracterizar a la teoría del delito como un mecanismo de imputación, es decir, como un "medio técnico-jurídico para establecer a quien se debe imputar ciertos hechos y quien debe responder por ellos personalmente" ${ }^{20}$. Ahora bien, la teoría del delito no es el único mecanismo de imputación de aplicabilidad posible, por el contrario, en muchos países -por ejemplo Estados Unidos, Gran Bretaña, Francia, en alguna medida Italia, etc.- se utilizan herramientas dogmáticamente menos elaboradas, lo cual es una consecuencia de procesos históricos diferenciados con, por ejemplo, Alemania y España, países en los cuales los códigos penales aparecieron tardíamente, es decir, cuando la ciencia del derecho penal -dogmática- había alcanzado ya un grado de evolución más que considerable trabajando en la construcción de sistemas conceptuales que desbordaban los textos positivos.

El hecho que todos los Estados objeto de estudio compartan el mismo sistema de imputación constituye un factor trascendente para la consolidación de un Derecho Penal Regional. Asimismo, analizado los diversos modelos de teoría del delito, existe una gran similitud en las teorías penales propuestas por Raúl Eugenio Zaffaroni en Argentina, Juares Estevam Xavier Tabares en Brasil, Gonzalo Fernández en Uruguay ${ }^{21}$, etc., reforzando el argumento antes planteado.

A la vez, en materia Procesal Penal se observa que los diversos Estados que conforman Mercosur se encuentran en una tendencia hacia la consolidación del denominado sistema acusatorio.

La similitud de los sistemas penales constituye una gran ventaja que presenta nuestro bloque regional frente a otros, por ejemplo la Unión Europea, en los cuales paso previo a acuerdos en materia penal, deben establecer principios comunes mínimos entre los múltiples sistemas penales, lo que genera reticencias por parte de los Estados tener flexibilizar determinados postulados básicos de sus respectivos sistemas.

20 Bacigalupo, Enrique, Derecho Penal. Parte general, $2^{a}$ edición, Buenos Aires: Hammurabi, 1999, p. 197. La teoría analiza el hecho delictivo como un sistema de filtros a partir de las categorías de: acción, tipo, antijuridicidad y culpabilidad. Veáse, Murmann, Uwe, Grundkurs Strafrecht. Allgemeiner Teil, Tötungsdelikte, Körperverletzungsdelikte, $2^{\mathrm{a}}$ edición, München: C.H. Beck., 2013, pp. 50 yss.

21 Véase, ZaffaronI, Raúl, Alagia, A., et al., Derecho penal: Parte General, $2^{a}$ edición, Buenos Aires: Ediar, 2003; Tavares, Juarez Estebam Xavier, Teoría del Injusto penal, Buenos Aires: B de F, 2010; Fernández, Gonzalo, Bien jurídico y sistema del delito, Buenos Aires: B de F, 2004.

\section{b) Factores en contra.}

b.1) La cesión de soberanía.

El Derecho penal es un producto político de los Estados nacionales nacidos en el siglo XIX. Desde la perspectiva del derecho interno, aparece como el último bastión de la soberanía nacional y, en la actualidad, se afronta a un problema transnacional conocido como "criminalidad transnacional" lo que implica que los hechos ilícitos no reconocen las fronteras estatales. Ante este panorama los Estados guiados por la finalidad de evitar todo tipo de paraísos jurídicos-penales suscriben Convenciones Internacionales para rearmarse frente a modelos de delincuencia que crean una fuerte sensación de inseguridad no sólo a los ciudadanos, sino también a los mismos Estados.

Bien señala Kristen Hessler, asumir que la soberanía estatal deba incluir incluso un justificable derecho por parte de los Estados para bloquear tribunales penales internacionales está tensión con la dimensión moral de la soberanía y el proyecto de una justicia global, en la medida que se corre el riesgo de que se adopten medidas a favor del estado moralmente inaceptables tanto en la teoría como en la práctica ${ }^{22}$.

b.2) Diferencias conceptuales en la legislación de determinados delitos.

Si bien los Estados objeto de análisis comparten sistemas penales similares, difieren, no obstante, en el tratamiento específico de los delitos objeto de análisis. Así en la actualidad, determinada actividad, puede ser considerada delictiva en un Estado, y ser lícita en otro. Puesto que toda norma penal debe ser interpretada restrictivamente, excluyéndose toda extensión analógica de la misma. En la práctica, si comparamos las diversas descripciones que efectúan las distintas legislaciones, puede darse el caso, no tan infrecuente, que una determinada conducta esté prohíba conforme a la legislación de un Estado y, sin embargo, sea lícita en otro.

El objetivo de dar una respuesta uniforme a esta problemática a través de un Tratado no es fácil. A la hora de negociar una Convención, los Estados firmantes no renuncian a sus pretensiones punitivas, por lo que

22 HESSLER, Kristen, "State Sovereignty and International Juridiction" en May, Larry, Hoskins, Zachary (Eds.), International Criminal Law and Philosophy, New York: Cambridge University Press, 2000, p. 57 
el resultado de dicho acuerdo será más bien la sumatoria de dichas pretensiones que una armonización de la legislación en la materia.

Un proceso de internacionalización del Derecho Penal tal como lo planteamos, va necesariamente unido a una armonización de las legislaciones de los Estados parte. Quizás este sea el mayor desafío en aras de lograr el objetivo general.

\section{Conclusiones.}

Las conclusiones a las que hemos arribado conforman un boceto en el cual se receptan las líneas generales que consideramos que debe tener la política criminal regional tendiente al establecimiento de una "Corte Penal Regional contra el Crimen Transnacional Organizado"

\subsection{Teoría del delito como instrumento de aná- lisis:}

Las reglas de imputación, o sea, de atribución de responsabilidad, así como sus causales de exclusión (casos de error, causales de justificación, causas de exclusión de la culpabilidad, etc.) deberán estar en concordancia con los postulados de la teoría del delito. Estamos de acuerdo con Ambos, en que dicha teoría debe estar basada en un modelo político-criminal funcional ${ }^{23}$ de derecho comparado consistente en su orientación a los derechos humanos frente a un puro funcionalismo de impronta jakobsiana ${ }^{24}$.

\subsection{Sistema procesal de carácter acusatorio.}

En el que estén representadas la función judicial (el tribunal), la acusación o Fiscalía y el órgano de la Defensa. El proceso deberá ser justo, expedito y se sustanciará con ple-

23 En especial, el modelo propuesto por Claus Roxin que a las categorías básicas de la teoría del Delito, le suma las funciones de la política criminal. Véase, Roxin, Claus, Kriminalpolitik und Strafrechtssystem, $2^{a}$ edición, Berlin-New York: Walter de Gruyter, 1973; Roxin, Claus, Strafrecht: Allgemeiner Teil. Band I. Grundlagen der Aufbau der Verbrechenslehre", $4^{a}$ edición, München: C. H. Beck, 2006.

24 Ambos, Kai, La construcción de una parte general del derecho penal internacional. En Temas actuales del derecho penal internacional. Contribuciones de América Latina, Alemania y España, Jan Woischnik (Ed.), Montevideo: Konrad-Adenauer-Stiftung Verlag, 2005, p. 22. no respeto de los derechos del sujeto sometido a proceso y teniendo debidamente en cuenta la protección de los demás sujetos involucrados en el mismo, a saber, de las víctimas ${ }^{25}$ y de los testigos. Son de especial importancia en este punto las "100 Reglas de Brasilia sobre el Acceso a la Justicia de las Personas en Condición de Vulnerabilidad” adoptada por la XIV Cumbre Judicial Iberoamericana que establece reglas, entre otras, tendientes a "mitigar los efectos negativos del delito (victimización primaria) Asimismo procurarán que el daño sufrido por la víctima del delito no se vea incrementado como consecuencia de su contacto con el sistema de justicia (victimización secundaria)" (art. 5.11)

También se tendrá en cuenta los principios penales establecidos en la Convención Americana sobre Derechos Humanos las sentencias de la Corte Interamericana de Derechos Humanos en las que se ha fijado límites temporales al proceso y a las medidas cautelares (en especial, la prisión preventiva), y en los que se asegura la garantía de la defensa en juicio, la facultad amplia de apelar por parte del sujeto sometido a proceso y/o condenado, etc.

\subsection{Respeto a los principios orientadores del Derecho Penal.}

Legalidad: (nullum crimen sine lege) en función de este principio, nadie será penalmente responsable de conformidad con la Convención que lo establezca, a menos que la conducta de que se trate constituya, al momento de su realización, en un delito de la competencia de la Corte. Por lo que nadie podrá ser considerado culpable por la Corte por una conducta anterior a su entrada en vigor (irretroactividad ratione personae).

Como derivación de este principio, quien sea declarado culpable por la Corte únicamente podrá ser penado de conformidad con el Estatuto que establezca los delitos y las penas correspondientes (nulla poena sine lege).

La definición del delito siempre será interpretada

25 Siguiendo las pautas de las 100 Reglas de Brasilia: “(56) Se promoverá que las víctimas reciban información sobre los siguientes elementos del proceso jurisdiccional:

- Posibilidades de obtener la reparación del daño sufrido

- Lugar y modo en que pueden presentar una denuncia o escrito en el que ejercite una acción

- Curso dado a su denuncia o escrito

- Fases relevantes del desarrollo del proceso

- Resoluciones que dicte el órgano judicial

(57) Cuando exista riesgo para los bienes jurídicos de la víctima, se procurará informarle de todas las decisiones judiciales que puedan afectar a su seguridady, en todo caso, de aquéllas que se refieran a la puesta en libertad de la persona inculpada o condenada, especialmente en los supuestos de violencia intrafamiliar". 
restrictivamente y no se hará extensiva por analogía (probibición de interpretación analógica). En caso de ambigüedad será la norma en cuestión será interpretada en favor de la persona sometida a proceso.

Lesividad: La Corte solo puede intervenir penalmente para amenazar lesiones o puestas en peligro de bienes jurídicos, y no está facultada para castigar las acciones privadas de los hombres que de ningún modo ofendan al orden y a la moral pública, ni perjudiquen a un tercero.

Responsabilidad penal individual: la Corte tendrá competencia respecto de las personas naturales. Esto significa que solo se puede responder penalmente por los hechos en los que se ha intervenido personalmente, sea como autor, cómplice, instigador o auxiliador sub sequens. Esta garantía puede esbozarse negativamente como principio de personalidad de la pena, es decir, si solo se responde por los hechos en los que se ha participado (participación en sentido genérico) la pena no podría extenderse a quienes no han intervenido en el hecho.

Principio de culpabilidad: de él se desprenden dos consecuencias: en primer lugar, que solo se podrá castigar a un sujeto por un hecho culpable, y en segundo, que la gravedad de la pena ha de ser proporcional al grado de culpabilidad. La proporcionalidad de la pena debe darse también con respecto a la gravedad del hecho antijurídico (desvalor de acción y de resultado). A esto último se lo conoce como principio de proporcionalidad del castigo.

Estado de inocencia: fue formulado originariamente como presunción (así el art. 8 inc. 2 de la Convención Americana sobre los Derechos Humanos). Su reformulación conceptual se motivó en las observaciones de que el progreso del proceso se funda en una presunción de culpabilidad (sospecha) y no de inocencia. La mencionada reformulación se operó a partir de la distinción entre las valoraciones (presunción de culpabilidad) de los sujetos facultados para determinar el avance del proceso (y el correlativo incremento de la incriminación) y la situación en la que toda persona se encuentra, conforme a la cual, hasta el dictado por el órgano jurisdiccional competente de un pronunciamiento firme de responsabilidad penal toda persona es inocente. En lo que respecta a la proyección del principio dentro del proceso penal, entre otros aspectos importantes, nos permite explicar el alcance meramente procesal de las medidas de coerción que pueden limitar o restringir la libertad del imputado (como por ejemplo, la prisión preventiva).
Estas medidas únicamente serán legítimas cuando se orienten a evitar que el imputado rehúya la acción penal o entorpezca el desarrollo del proceso. Cualquier otra finalidad para las mismas queda excluida.

Ne bis in idem: nadie será procesado por la Corte en razón de conductas calificadas como delito por éstas por los cuales ya hubiese sido condenado o absuelto por la Corte o por un juez o tribunal estatal. La Corte, sin embargo, podrá procesar a una persona solo si el anterior proceso sustanciado en otro tribunal tuviese como propósito sustraer al acusado de su responsabilidad por crímenes de la competencia de esta Corte; o no hubiese sido instruido en forma independiente o imparcial de conformidad con las debidas garantías procesales reconocidas por el derecho internacional o lo hubiere sido de alguna manera que, en las circunstancias del caso, fuere imposible someter a la persona a la acción de la justicia.

\subsection{Competencia Material.}

La Corte tendrá competencia material para investigar y enjuiciar a los presuntos responsables, sin importar el cargo, de haber cometido manera organizada los crímenes de carácter transnacional. El ejercicio de su jurisdicción tendrá carácter complementario respecto de las jurisdicciones nacionales.

\subsubsection{Delitos comprendidos.}

Consideramos que los delitos objeto que serán objeto de persecución y sanción por la Corte serán los abordados Convención de las Naciones Unidas contra la Delincuencia Organizada Transnacional y sus Protocolos, a saber:

(i) Delito de lavado de activos.

(ii) Trata de personas

(iii) Tráfico ilícito de migrantes

(iv) Fabricación y tráfico ilícito de armas de fuego, sus piezas y componentes y municiones.

Además, pese a no ser un delito objeto del Protocolo de Palermo, consideramos necesario incluir el

(v) Tráfico de estupefacientes y sustancias psicotrópicas objeto de la Convención de Naciones 
Unidas que lleva el mismo nombre del año 1988.

Puesto que el tratado constitutivo de la Corte deberá establecer qué delitos van a ser objeto de su competencia, definiéndolos y estableciendo las penas correspondientes, en cumplimiento del principio de legalidad que rige en esta materia. Ante esta situación, los Estados deberán armonizar sus legislaciones en dicha materia a fin de evitar posibles distorsiones. Armonizar las legislaciones permitirá evitar estas lagunas de punibilidad ${ }^{26}$.

\subsection{Competencia personal:}

La Corte ejercerá su competencia sobre los delitos antes señalados que sean cometidos por personas físicas. La competencia se limitará a sólo aquellos que promuevan, dirijan u organicen la asociación. El ejercicio de la acción penal respecto de aquel que tal solo toma parte de la organización criminal o solamente cumple funciones secundarias o auxiliares es exclusiva de los Estados que tengan jurisdicción sobre el hecho. Ampliar la competencia de la Corte a todo aquel que intervenga en una organización criminal implica correr de foco el objetivo de esta institución, que no es otro que combatir la macrocriminalidad.

En debido respeto de Pactos Internacionales en la materia, la Corte no será competente respecto de los autores o partícipes que fuesen menores de 18 años en el momento de la presunta comisión del crimen.

\subsection{Competencia temporal.}

La Corte tendrá competencia únicamente respecto de crímenes cometidos después de la entrada en vigor del Estatuto que le otorgue existencia. Si un Estado se hace parte de dicho Estatuto luego de su entrada en

26 No resulta redundante aclarar que la Corte ejercerá su jurisdicción sólo cuando el delito tenga los componentes de la "organización” y "transnacionalidad". El primero ya lo hemos desarrollado en los resultados. En lo referente a la transnacionalidad seguimos la definición aportada por la Convención de las Naciones Unidas contra la Delincuencia Organizada Transnacional: "El delito será de carácter transnacional si: a) Se comete en más de un Estado; b) Se comete dentro de un solo Estado, pero una parte sustancial de su preparación, planificación, dirección o control se realiza en otro Estado; c) Se comete dentro de un solo Estado, pero entraña la participación de un grupo delictivo organizado que realiza actividades delictivas en más de un Estado; o d) Se comete en un solo Estado, pero tiene efectos sustanciales en otro Estado" (art. 3.2). vigor, la Corté sólo podrá ejercer su competencia respecto a los crímenes cometidos luego de la entrada en vigor del Estatuto respecto de ese Estado.

\subsection{Jurisdicción complementaria.}

Ante la comisión de un delito objeto de persecución por parte de la Corte, el asunto será investigado o enjuiciado por un Estado que tenga jurisdicción sobre él, salvo que no esté dispuesto a llevar a cabo las investigaciones o el juicio o no pueda realmente hacerlo.

La Corte no podrá intervenir si el asunto ya ha sido objeto de investigación por un Estado que tenga jurisdicción sobre él y éste haya decidido iniciar la acción penal contra la persona de que se trate, salvo que la decisión haya obedecido a que no esté dispuesto a llevar a cabo el juicio o no esté en condiciones de hacerlo.

\section{Referencias}

Ambos, Kai (2010). El derecho penal internacional en la encrucijada: de la imposición ad hoc a un sistema universal basado en un tratado internacional. Política Criminal, (vol. 5, núm. 9, 2010, págs. 237-256).

Ambos, Kai, (2005). La construcción de una parte general del derecho penal internacional. En Temas actuales del derecho penal internacional. Contribuciones de América Latina, Alemania y España, Jan Woischnik (Ed.), (pp. 13-40), Montevideo: Konrad-AdenauerStiftung Verlag.

Bacigalupo, Enrique (1999) Derecho Penal. Parte general, $2^{a}$ edición, Buenos Aires: Hammurabi.

Benhabib, Seyla, (2004). Los derechos de los otros. Extranjeros, residentes y ciudadanos, Barcelona: Gedisa.

Boumpadre, Jorge, (2001). Derecho penal: parte especial, T. II, Corrientes: Mario A. Viera Editor.

Cancio Melia, Manuel, Silva Sánchez, Jesús-María, (2008). Delitos de organización, Buenos Aires: B de F.

Diez Ripollés, José Luis, (2007). La política criminal en la encrucijada, Buenos Aires: B de F.

Habermas, Jürgen, (2001). El valle de lágrimas de la globalización, Claves, $\mathrm{N}^{\circ} 109$, pp. 4-10.

Fernández, Gonzalo, (2004). Bien jurídico y sistema del 
delito, Buenos Aires: B de F.

Heller, Hermann, (1992). Teoría del Estado, México: Fondo de Cultura Económica.

HESSLER, Kristen, (2000), "State Sovereignty and International Juridiction" en May, Larry, Hoskins, Zachary (Eds.), International Criminal Law and Philosophy. (pp. 39-57), New York: Cambridge University Press,

Kelly, R.J. (1986) Criminal Underworlds: Looking Down on Society of Bellow. En Kelly R.J. (Ed.) Organized crime: Crosscultural studies. (pp. 10-31) Totowa, NJ: Rowman \& Littlefield.

Lampe, Klaus von, (2013). Was ist, Organisierte Kriminalität?, ApuZ, 63. Jahrgang 38-39/2013, pp. 3-8

Lampe, Klaus von, (2009). The study of organised crime: An assessment of the state of affairs. En Karsten Ingvaldsen, Vanja Lundgren Sørli (Eds.), Organised Crime: Norms, markets, regulation and research, (pp. 165-211) Oslo: Unipub.

Murmann, Uwe, (2013). Grundkurs Strafrecht. Allge- meiner Teil, Tötungsdelikte, Körperverletzungsdelikte, $2^{\mathrm{a}}$ edición, München: C.H. Beck.

Roxin, Claus, (1973), Kriminalpolitik und Strafrechtssystem, $2^{a}$ edición, Berlin-New York: Walter de Gruyter.

Roxin, Claus, (2006). Strafrecht: Allgemeiner Teil. Band I. Grundlagen der Aufbau der Verbrechenslehre“, $4^{a}$ edición, München: C. H. Beck.

Silva Sánchez, Jesús-María, (2008). La 'intervención a través de organización', ¿una forma moderna de participación en el delito? En Cancio Melia, M., et al. Delitos de organización, (pp. 87-188). Buenos Aires: B de F.

Silva Sánchez, Jesús-María, (1999). La expansión del Derecho penal. Aspectos de la política criminal de las sociedades postindustriales, Madrid: Civitas.

Tavares, Juarez Estebam Xavier, (2010). Teoría del Injusto penal, Buenos Aires: B de F.

ZaffaronI, Raúl, Alagia, A., et al., (2003). Derecho penal: Parte General, $2^{\mathrm{a}}$ edición, Buenos Aires: Ediar. 


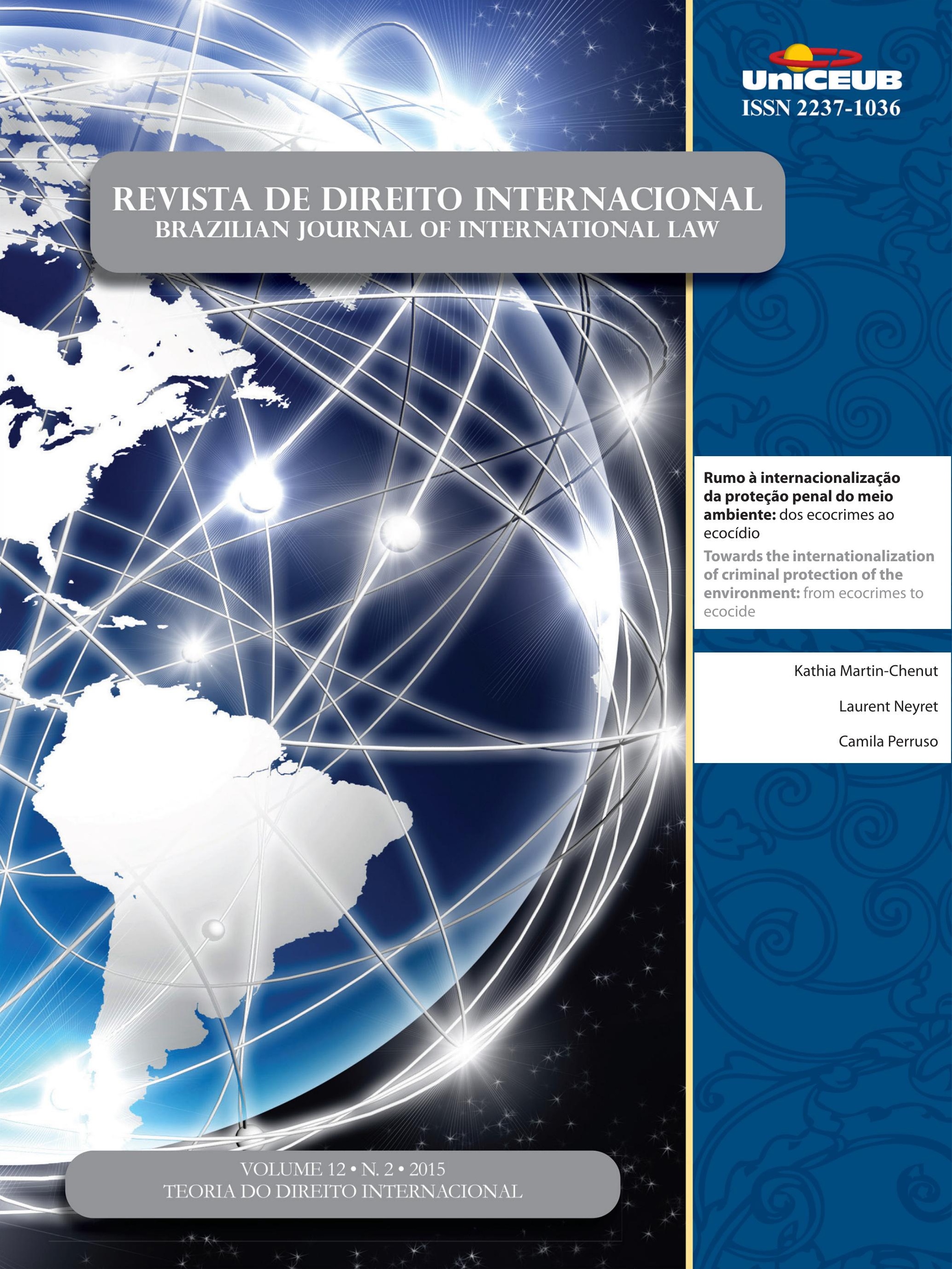




\title{
Rumo à internacionalização da proteção penal do meio ambiente: dos ecocrimes ao ecocídio*
}

\author{
Towards the internationalization of criminal \\ protection of the environment: from \\ ecocrimes to ecocide
}

Kathia Martin-Chenut ${ }^{* *}$

Laurent Neyret ${ }^{* * *}$

Camila Perruso****

* Recebido em 15/11/2015

Aprovado em 08/12/2015

** Pesquisadora do CNRS - Conselho Nacional de Pesquisa Científica - França. Codiretora da Equipe RSE UMR DRES 7453 e da pesquisa IdEx Attractivité - "Responsabilité Sociétale des Entreprises: identification et classement des outils juridiques" - (http:// dres.misha.cnrs.fr/spip.php?rubrique193). Corresponsável do módulo Law and Politics of International Courts and Tribunals do LL.M in International Law na Universidade Paris Descartes. E-mail: kmartinchenut@orange.fr.

*** Professor na Universidade de Versailles Saint Quentin - França. Diretor da pesquisa Ecocide - Mission Droit et Justice (GIP-Ministério da Justiça da França). E-mail: neyret.1@ wanadoo.fr.

**** Doutoranda em direito internacional pelas Universidades Paris Descartes e de São Paulo. Assistente de ensino e de pesquisa A.T.E.R e corresponsável do módulo Law and Politics of International Courts and Tribunals do LL.M in International Law na Universidade Paris Descartes. Pesquisadora do projeto IdEx Attractivité - "Responsabilité Sociétale des Entreprises: identification et classement des outils juridiques”. E-mail: camilaperruso@gmail.com.

\section{Resumo}

O presente artigo busca analisar o necessário movimento de apreensão da proteção penal do meio ambiente pelo direito internacional de maneira gradual e racional. Por meio da identificação das lacunas existentes nesse ramo do direito, são tecidas proposições capazes de lutar contra a criminalidade ambiental que põe em perigo a segurança do planeta, inscritas nos projetos anexos de Convenção sobre a ecocriminalidade e o ecocídio. Nesse sentido, uma renovação da ordem jurídica internacional que funda, ao lado do respeito dos direitos humanos, a proteção do meio ambiente constitui uma tendência legítima e que se inscreve em um processo de evolução dos valores comuns compartilhados pela humanidade.

Palavras-chave: Criminalidade ambiental. Direito internacional. Segurança ambiental do planeta. Intervenção penal mínima.

\section{Abstract}

This article aims to analyze the necessity to take into account the criminal protection of the environment in international law, gradually and rationally. By identifying existing gaps in this branch of law, propositions were made regarding to fight against environmental crime that endangers the safety of the planet, as it is expressed in the Convention projects on ecocriminality and ecocide attached. In this sense, a renewal of international law founded in the respect of human rights and also in the environmental protection is a legitimate process of evolution of the common values shared by humanity.

Keywords: Environmental crime. International law. Environmental security of the planet. Minimal penal intervention. 


\section{INTRODUÇÃO}

A degradação do meio ambiente apresenta-se como um desafio a diversas áreas do conhecimento, visto que os avanços proporcionados pelo progresso das ciências implicaram as necessidade de uma tomada de consciência das sociedades modernas da contradição existente entre um desenvolvimento desmedido em relação à sustentabilidade do planeta. $\mathrm{O}$ aumento das atividades humanas, visando ao crescimento econômico - muitas vezes confundido com o desenvolvimento -, aliado ao avanço da tecnologia, tem gerado impactos ambientais como a poluição, a deflorestação, as ameaças à biodiversidade e as mudanças climáticas, de maneira a exigir que a exploração pelo homem do seu babitat seja reexaminada.

Nessa perspectiva, o meio ambiente adquiriu um valor superior, considerando que sua proteção encontra seus fundamentos na segurança da humanidade presente e futura, e mais amplamente na segurança do planeta e do equilíbrio ecológico. O compartilhamento do valor atribuído ao meio ambiente pela comunidade internacional designa uma "profunda renovação dos valores essenciais, cuja violação gera uma reprovação social"1. Justifica-se, nesse ensejo, a necessidade da consagração, em direito internacional, de uma proteção penal do meio ambiente, sobretudo em virtude da disparidade das disposições nacionais e internacionais existentes visando reprimir a criminalidade ambiental.

Dessa maneira, ao mesmo tempo em que o meio ambiente passa a ser objeto de importância primordial para a comunidade internacional ${ }^{2}$, constata-se que a criminalidade ambiental ocupa o quarto lugar no âmbito internacional de atividades econômicas ilícitas, perdendo, apenas, para o tráfico de drogas, de pessoas e de objetos falsificados. Trata-se de um tipo de criminalidade caracterizada pela transnacionalidade, que permite um elevado lucro face aos baixos riscos que sofrem seus autores, considerando que a persecução e a sanção de

1 DELMAS-MARTY, Mireille. Perspectives ouvertes par le droit de l'environnement. Revue Juridique L'Environnement, Paris, v. 39, p. 7-13, 2014. Numéro spécial: Le droit répressif: quelles perspectives pour le droit de l'environnement. p. 7.

2 Diversos instrumentos internacionais têm sido adotados com vistas a estabelecer uma proteção do meio ambiente. O desenvolvimento do direito internacional do meio ambiente encontra, na adoção da Declaração de Estocolmo de 1972, um ponto crucial contribuindo à proliferação de recomendações e de convenções desse ramo do direito internacional. tais atos são raros (“low risk - bigh profit") $)^{3}$.

Por criminalidade ambiental, ou ecocriminalidade, compreende-se os "crimes que ameaçam ou prejudicam o meio ambiente, que tenham ou não repercussões sobre o homem"4. Tais crimes podem variar de uma escala de infração isolada que não engendra consequências maiores à integridade ambiental, até o crime de ecocídio que ameaça a vida humana e a segurança planetária. Nesse sentido, por "crimes comuns", contra o meio ambiente, é possível pensar na caça furtiva, no descarte de efluentes agrícolas em um rio, no abandono ilegal de resíduos na natureza. Tais crimes podem ser cometidos em virtude de ações ou omissões, de comportamentos intencionais ou negligentes, realizados por pessoas físicas ou morais, além de serem produzidos no âmbito de território nacional ou transgredir fronteiras, como também no quadro de atividades transnacionais ilícitas.

No que se refere aos "crimes fora do comum", identificam-se os comportamentos excepcionais que engendram danos irreversíveis e de extrema gravidade ao meio ambiente, que podem ocorrer em tempos de guerra ou de conflito armado ${ }^{5}$, como por exemplo a uti-

3 Comunicação da Comissão europeia sobre a abordagem adotada pela União europeia em matéria de luta contra o tráfico de espécies selvagens COM(2014) 64 final. Cf. EUROPEAN UNION'S JUDICIAL COOPERATION UNIT. Strategic Project on Environmental Crime: report. Haag: Eurojust, Nov.2014. p. 38 Available in: <http://www.eurojust.europa.eu/doclibrary/eurojust-framework/ casework/strategic $\% 20$ project $\% 20$ on $\% 20$ environmental $\% 20$ crime $\% 20$ (october $\% 202014$ )/environmental-crime-report_201411-21-en.pdf>. Access: Feb. 02, 2016. Cf. NEYRET, Laurent. La criminalité environnementale c'est gros profits pour petits risques. Disponible dans: <http://www.europe1.fr/emissions/europe-1-vous-repond/ neyret-la-criminalite-environnementale-cest-gros-profits-pour-petits-risques-2617361>. Accès: 02 Fev. 2016.

4 FOUCHARD, Isabelle; NEYRET, Laurent. 35 propositions pour mieux sanctionner les crimes contre l'environnement. In: NEYRET, Laurent (Dir.). Des écocrimes à l'écocide: le droit pénal au secours de l'environnement. Bruxelles: Bruylant, 2015. p. 305-442, p. 315. Verificar artigo XX da Proposição anexa de Convenção para os ecocrimes.

5 Estatuto de Roma do Tribunal Penal Internacional, A/CONF. 183/ 9, 17 de julho de 1998, artigo 2: "para os efeitos do presente Estatuto, entende-se por "crimes de guerra": b) Outras violações graves das leis e costumes aplicáveis em conflitos armados internacionais no âmbito do direito internacional, a saber, qualquer um dos seguintes atos: iv) Lançar intencionalmente um ataque, sabendo que o mesmo causará perdas acidentais de vidas humanas ou ferimentos na população civil, danos em bens de caráter civil ou prejuízos extensos, duradouros e graves no meio ambiente que se revelem claramente excessivos em relação à vantagem militar global concreta e direta que se previa”. NAÇÕES UNIDAS. Tribunal Penal Internacional. Estatuto de Roma. Disponível em: <http://www.un.org/ spanish/law/icc/statute/spanish/rome_statute(s).pdf>. Acesso 
lização do agente laranja durante a guerra do Vietnã, ou em tempos de paz, com atos ilícitos como o tráfico de recursos naturais e de espécies ou de substâncias perigosas como as pesticidas. Esse último tipo de criminalidade ambiental, se preencher as condições necessárias para sua qualificação como ecocídio ${ }^{6}$, é aquele que gera consequências dramáticas para as populações locais na medida em que as expõe a graves riscos sanitários. Ademais, tais atos dizem respeito a toda humanidade, visto que suas condições de existência e de desenvolvimento, das gerações presentes e futuras, são colocadas em perigo.

Partindo da constatação de que a criminalidade ambiental é um problema premente e visto que a proteção do meio ambiente é um dos imperativos atuais da comunidade internacional, uma pesquisa ${ }^{7}$ tendo como objetivo apresentar soluções jurídicas a tal fenômeno foi realizada na França. Reunindo dezesseis pesquisadores de diversas disciplinas do direito e pertencentes a diferentes tradições jurídicas, a pesquisa foi desenvolvida entre 2011 e 2014 e financiada pela Missão de Pesquisa Direito e Justiça (GIP - Ministério da justiça francês), contando ademais com o suporte de campo

em: 01 fev. 2016.

6 Verificar os elementos constitutivos do crime de ecocídio no artigo 2 da Proposição anexa de Convenção para o crime de ecocídio. O termo ecocídio, que etimologicamente faz referência ao genocídio (genos, raça em grego e occidio, massacre, carnificina), significa destruição do ecossistema. Ele foi empregado, pela primeira vez, em 1970 em uma conferência em Washington, relativa à guerra e à responsabilidade em razão da situação hostil na Indochina e no Vietnam. No ensejo desse encontro, R. Falk cunhou essa expressão por meio da elaboração de um primeiro projeto de convenção, visando que os Estados reconhecessem o ecocídio como crime internacional. Para o autor, o ecocídio seria qualificado a partir dos atos humanos que destruiriam os ecossistemas, em todo ou em parte, em tempos de guerra ou em tempos de paz (FALK, Richard. Environment warfare and ecocide: facts, appraisal and proposals. Révue Belge de Droit International, Brussels n. 11, p. 1-27, 1973. p. 21-24). Essa preocupação foi apreendida pela Subcomissão para a prevenção da discriminação e proteção de minorias da Organização das Nações Unidas (ONU) que, em 1979, cogitou inserir no escopo do crime de genocídio a proteção do meio ambiente (Relatório The Study on the Question of the Prevention and Punishment of the Crime of Genocide, E/CN.4/Sub.2/416, 4 de julho de 1979). Para um estudo dedicado à noção de ecocídio: NEYRET, Laurent. Pour la reconnaissance du crime d'écocide, Paris, v. 39, p. 179-194, 2014. Numéro spécial: Le droit répressif: quelles perspectives pour le droit de l'environnement.

7 f. NEYRET, Laurent. Des écocrimes à l'écocide, un groupe de juristes au secours de l'environnement. In: In: BRÉCHIGNAC, Catherine; BROGLIE, Gabriel de; DELMAS-MARTY, Mireille (Dir). L'environnement et ses métamorphoses. Paris: Hermann, 2015. p. 183-193. de uma equipe de jornalistas do Jornal Le Monde ${ }^{8}$, que investigaram em mais de dez países diferentes as rotas da criminalidade ambiental transnacional, enquetes que permitiram confrontar aos fatos a necessidade do desenvolvimento de um arcabouço jurídico internacional capaz de reprimir os graves danos ao meio ambiente. Nesse sentido, duas proposições de projeto de convenção internacional tratando dos crimes contra o meio ambiente foram elaboradas (conferir documentos anexos), visando à adaptação do direito penal às particularidades das duas categorias de criminalidade ambiental internacional estabelecidas: ecocrimes e ecocídio.

O presente artigo busca apresentar os resultados dessa pesquisa acadêmica, analisando as lacunas existentes em direito internacional relativas à criminalidade ambiental (1), e propondo em consequência que um regime jurídico comum, gradual e racional seja estabelecido em direito internacional com vistas a uma efetiva proteção penal ambiental (2).

\section{A IMPOTÊNCIA ATUAL DO DIREITO INTERNACIO- NAL NO TOCANTE À CRIMINALIDADE AMBIENTAL}

A criminalidade ambiental apresenta diversas faces que afetam as sociedades como um todo e faz parte da categoria de riscos globais. Ela tem consequências não somente ambientais, mas impacta os âmbitos sanitário, econômico e pode ter implicações na segurança de determinados países, como atestam casos emblemáticos de conflitos relacionados à degradação ambiental (2.1). A dificuldade de atribuir a responsabilidade dos autores dessa criminalidade evidencia as lacunas existentes em direito internacional, cujos instrumentos existentes revelam-se insuficientes. Observa-se, adicionalmente, que uma grande parte das atividades ilícitas têm, preeminentemente, em sua origem, a ação de empresas transnacionais, o que confirma a incapacidade de o direito internacional atual oferecer respostas adequadas a tal fenômeno (2.2).

8 Cf.: MARTIN-CHENUT, Kathia; FOUCHARD, Isabelle. Quelles responsabilités pour les sociétés transnationales? Le Monde, Paris, 8 Fev. 2015. Disponible à: <http://www.lemonde. $\mathrm{fr} /$ planete/visuel/2015/01/24/ecocide-episode-1-le-bois-quisaigne_4527270_3244.html\#sDDxAh2Sz0KV7qjS.99>. Accès: 2 Fev. 2015. E LE MONDE. Les Prédateurs: la nature face au crime organisé. Paris: Ateliers Henry Dougier, 2015. 


\subsection{Uma necessidade crescente de apreender a criminalidade ambiental pelo direito internacional}

Os crimes relacionados ao meio ambiente são identificados em nível internacional notadamente em razão das redes criminosas que envolvem diversos países. A título de ilustração, o comércio ilegal de madeira rosa do Madagascar ${ }^{9}$ conhece um grande sucesso dos compradores chineses, assim como o tráfico do chifre de rinocerontes de Moçambique ${ }^{10}$. Esse tipo de tráfico conta com importantes organizações criminosas, envolvendo diferentes países e pessoas de múltiplas nacionalidades.

Além dos impactos desse tipo de crime sobre a biodiversidade e o equilíbrio ecológico, os riscos relacionados aos atos criminosos têm, também, um alcance sanitário, pois é frequente que a saúde humana e mais amplamente toda a humanidade sejam submetidas aos efeitos prejudiciais causados pela degradação ambiental. Por exemplo, a descarga ilegal de lixo tóxico na Costa do Marfim por uma empresa holandesa, no famoso caso do "Probo Koala"11, teve graves repercussões ambientais, como a contaminação de águas, de solos e de ar, mas também humanas, visto que ele provocou a morte de 17 pessoas e intoxicou mais de 50.000 pessoas e não culminou na responsabilidade penal de nenhum dos agentes envolvidos.

Verifica-se que a criminalidade ambiental é intrinsecamente ligada a questões econômicas e a violação da legislação correspondente se funda na busca por uma relação

9 MARTIN-CHENUT, Kathia; FOUCHARD, Isabelle. Quelles responsabilités pour les sociétés transnationales? Le Monde, Paris, 8 Fev. 2015. Disponible à: <http://www.lemonde. $\mathrm{fr} /$ planete/visuel/2015/01/24/ecocide-episode-1-le-bois-quisaigne_4527270_3244.html\#sDDxAh2Sz0KV7qjS.99>. Accès: 2 Fev. 2016.

10 Cf. MOZAMBIQUE: le trafic à grande échelle d'ivoire et de cornes de rhinocéros continue. Le Monde, Paris, 14 Mai. 2014. Disponible à: <http://www.lemonde.fr/afrique/article/2015/05/14/ mozambique-le-trafic-a-grande-echelle-d-ivoire-et-de-cornes-derhinoceros-continue_4633777_3212.html>. Accès: 2 Fev. 2016.

11 Cf. QUEINNEC, Yann. L'affaire Probo Koala, symbole d'une responsabilité sociétale des entreprises en quête de sécurité juridique. In: GUIDICELLI-DELAGE, Geneviève; S. MANACORDA, Stefano (Dir.). La responsabilité pénale des personnes morales: perspectives européennes et internationales. Paris: Société de législation comparée, 2013. (Unité mixte de recherche de droit comparé de Paris; v. 30). p. 277-293; dossiê do caso elaborado pela Anistia internacional: AMNESTY INTERNATIONAL. Côte d'Ivoire: une vérité toxique. à propos de trafigura, du probo koala et du déversement de déchets toxiques en Côte d'Ivoire. 25 Sep. 2012. Disponible dans: <http:// www.amnesty.org/fr/documents/AFR31/002/2012/fr/>. Accès: 02 Fev. 2016. custo-benefício. Nessa direção, baseando-se em um dumping ambiental, o tráfico de lixo tóxico pode custar dez vezes menos que reciclá-lo no país de produção. E como as sanções são fracas e pouco visadas pela comunidade internacional assim como pelos Estados nacionais, o mercado criminal ambiental é muito mais lucrativo que se comparado, por exemplo, ao tráfico de drogas.

Ademais, a ecocriminalidade cometida em determinados países em desenvolvimento, notadamente africanos, diz respeito a questões de ordem da segurança nacional. A ONU e a Interpol apontam que o dinheiro dos crimes ambientais relacionado às redes organizadas pode servir a financiar grupos rebeldes ou movimentos terroristas. Existem conexões entre os conflitos armados na África e os recursos naturais, como a questão do "diamante de sangue" no Congo e a consequente desestabilização de regiões inteiras, que mostram o importante alcance geopolítico da criminalidade ambiental; ela pode assim constituir uma ameaça para a segurança nacional e para a paz.

Diante desse panorama, observa-se que os direitos nacionais são inadaptados para lidar com a criminalidade ambiental, em razão especialmente do seu caráter transnacional. Embora o direito penal como instrumento de proteção do meio ambiente tenha se desenvolvido em diversos Estados, constata-se que, de um modo geral, a legislação penal refere-se a infrações penais acessórias, subordinadas ao não respeito de regras administrativas. Além disso, verifica-se que as infrações ambientais autônomas encontram-se, também, previstas nos ordenamentos penais internos a título de crimes comuns $^{12}$ ou ainda de crimes fora do comum ${ }^{13}$. Todavia, embora direitos penais nacionais específicos à criminalidade ambiental existam, sua aplicação varia de acordo com o Estado. A disparidade do nível das sanções favorece um verdadeiro dumping ambiental e serve de catalisador para as atividades criminais. Nessa perspectiva, para que a luta contra a ecocriminalidade transnacional seja efetiva, uma harmonização das incriminações e das

12 Cf. ESTUPIÑAN-SILVA, Rosmerlin. La lutte contre la criminalité environnementale au sein des Etats. In: NEYRET, Laurent (Dir.). Des écocrimes à l'écocide: le droit pénal au secours de l'environnement. Bruxelles: Bruylant, 2015. p. 19-38.

13 Quanto aos "crimes fora do comum", notadamente o crime ecocídio, ele foi incorporado em mais de dez códigos penais de Estados, como o Vietnã, a Rússia e as antigas repúblicas soviéticas, nos quais ele é geralmente definido como o fato de destruir massivamente a flora e a fauna, de contaminar a atmosfera, as águas, e mais amplamente todo ato capaz de causar uma catástrofe ecológica. 
sanções penais entre os Estados evidencia-se necessária.

\subsection{As lacunas do direito internacional em ma- téria de criminalidade ambiental}

Se o direito internacional do meio ambiente é considerado um "direito promocional", centrado em mecanismos de prevenção, sua efetividade é constantemente questionada, sobretudo em razão das sanções correspondentes às obrigações que ele determina. Não existe a previsão de um crime ecológico geral e os instrumentos que preveem uma sanção penal a infrações setoriais encontram-se em convenções esparsas ${ }^{14}$. $\mathrm{O}$ aspecto penal do direito internacional ambiental evolui de maneira incoerente e em função de imperativos estabelecidos pela agenda diplomática dos Estados.

Assim, a questão da poluição, um dos principais aspectos prejudiciais ao meio ambiente, é considerada uma infração somente no âmbito dos mares e rios ${ }^{15}$. Além dos prejuízos diretos ao meio ambiente, há previsão em direito internacional da penalização de determinados atos que ameaçam o ecossistema, como o tráfico de resíduos perigosos e seu depósito ${ }^{16}$ ou ainda o comércio de espécies selvagens da flora e da fauna ameaçadas de extinção ${ }^{17}$. Todavia, tais obrigações de penalização são imprecisas, visto que os textos conferem uma margem de manobra importante aos Estados para sancionar os prejuízos ao meio ambiente, por meio de incriminações indiretas e fazendo referência à obrigação de "tomar medidas apropriadas" ou de "reprimir severamente",

14 BEAUVAIS, Pascal. Les limites de l'internationalisation du droit pénal de l'environnement. In: NEYRET, Laurent (Dir.). Des écocrimes à l'écocide: le droit pénal au secours de l'environnement. Bruxelles: Bruylant, 2015. p. 3-18. p. 5-11.

15 Convenção Internacional para a Prevenção da Poluição por Navios, Convenção Marpol, de 17 de fevereiro de 1973. CONVENÇÃO Internacional para a Prevenção da Poluição por Navios (MARPOL 73/78). 1973. Disponível em: <http://www.fd.unl.pt/ docentes_docs/ma/jc_MA_26322.pdf >. Acesso em: 01 fev. 2016.

16 Convenção de Basiléia. Controle dos Movimentos Transfronteiriços de Resíduos Perigosos e seu Depósito de 22 de março de 1989. CONVENÇÃO de Basileia e controle de movimentos transfronteiriços de resíduos perigosos e sua eliminação. 1989. Disponível em: <http://www.ecomodus.eu/downloads/Basel_Conventionpt.pdf>. Acesso em: 01 fev. 2016.

17 Convenção sobre o Comércio Internacional das Espécies da Fauna e da Flora Selvagens Ameaçadas de Extinção, CITES, de 23 de março de 1973. CONVENÇÃO Sobre o Comércio Internacional das Espécies Selvagens da Fauna e da Flora Ameaçadas de Extinção. 1973. Disponível em: <http://eur-lex.europa.eu/legalcontent $/ \mathrm{PT} / \mathrm{TXT} / \mathrm{PDF} /$ ?uri=CELEX:22015A0319(01)\&from= PT>. Acesso em: 01 fev. 2016. ou ainda a previsão de regras de coordenação entre os Estados dessa repressão é praticamente inexistente ${ }^{18}$.

De acordo com a repartição clássica entre o direito internacional e o direito interno no que se refere à criminalização de condutas, é necessário que seja desenvolvido no âmbito interno uma ação normativa a fim de incorporá-la no ordenamento jurídico nacional e torná-la efetiva, visto que a aplicação da norma internacional em matéria criminal não é imediata. Mas, como as determinações do direito internacional relativo à penalização dos danos ambientais é vaga, a atribuição da responsabilidade assim como as penas aplicáveis às infrações também o são. Nesse contexto de criminalidade ambiental transnacional, o direito internacional não oferece nenhuma precisão quanto aos modos de imputação do crime e, consequentemente, os agentes podem ficar ilesos à responsabilização.

Existe, assim, uma carência em direito internacional do tratamento global da criminalidade ambiental e com a ausência de um órgão internacional ${ }^{19}$ competente para verificar e julgar tais crimes, é possível inferir que tais lacunas abrem brechas para um tratamento assimétrico da repressão da ecocriminalidade. A responsabilização dos agentes constitui, dessa maneira, um ponto sensível e o fórum shopping conhece, no campo ambiental, um franco sucesso ${ }^{20}$. É prática recorrente que as empresas multinacionais transfiram suas atividades a países onde a legislação ambiental é mais permissiva. Esse fenômeno dificulta e, geralmente, impede que elas sejam responsabilizadas caso cometam graves danos ao meio ambiente ${ }^{21}$. Nessa perspectiva, a responsabilização penal dos atores privados face aos danos ecológicos é essencial ${ }^{22}$.

18 BEAUVAIS, Pascal. Les limites de l'internationalisation du droit pénal de l'environnement. In: NEYRET, Laurent (Dir.). Des écocrimes à l'écocide: le droit pénal au secours de l'environnement. Bruxelles: Bruylant, 2015. p. 3-18. p. 14.

19 Com exceção da CPI no quadro do crime de guerra supra mencionado.

20 MARTIN-CHENUT, Kathia; FOUCHARD, Isabelle. Quelles responsabilités pour les sociétés transnationales? Le Monde, Paris, 8 Fev. 2015. Disponible à: <http://www.lemonde. $\mathrm{fr} /$ planete/visuel/2015/01/24/ecocide-episode-1-le-bois-quisaigne_4527270_3244.html\#sDDxAh2Sz0KV7qjS.99>. Accès: 2 Fev. 2016.

21 Cf. MARTIN-CHENUT, Kathia; PERRUSO, Camila. L'affaire Chevron Texaco et l'apport des projets de convention écocrimes et écocide à la responsabilisation pénales des entreprises transnationales. In: NEYRET, Laurent (Dir.). Des écocrimes à l'écocide: le droit pénal au secours de l'environnement. Bruxelles: Bruylant, 2015. p. 67-86.

22 Cf. TRICOT, Juliette. Ecocrimes et écocide: quels responsa- 
Assim, a parte a necessidade de estabelecer normas gerais em direito internacional público enquadrando a criminalidade ambiental, regras internacionais de articulação de competências em matéria ambiental também são imperativas. Os pontos fracos da proteção do meio ambiente pelo direito penal são variadas: o caráter acessório das infrações em relação às regras administrativas muitas vezes variam de um Estado a outro, desvinculando-a de um valor social; a falta de legibilidade das infrações que são normalmente subordinadas a normas técnicas; a falta de coerência da noção de crime ambiental nos direitos internos e entre os Estados; a falta de vontade política ou de capacidade dos países em desenvolvimento para coibir tal crime em razão de seus aspectos lucrativos; ou a insuficiência dos meios utilizados pelos Estados desenvolvidos para combater a criminalidade ambiental, notadamente aquela praticada por suas empresas nacionais.

Nessa perspectiva, os danos causados ao meio ambiente, em virtude da criminalidade ambiental, afetam a biodiversidade e geram consequências catastróficas para o equilíbrio dos ecossistemas e do planeta, assim como à vida humana. A ausência de tratamento global à ecocriminalidade deixa um campo livre para um tratamento diferenciado de luta contra as infrações ambientais. Consequentemente, um regime jurídico coerente a ser estabelecido pelo direito internacional se impõe.

\section{A POTENCIALIDADE FUTURA DO DIREITO INTER- NACIONAL RELATIVA À CRIMINALIDADE AMBIENTAL}

O direito internacional deve apropriar-se da questão da criminalidade ambiental e instaurar um regime jurídico comum para a proteção ambiental. Ele deve ser racional, eficaz e legítimo, construído a partir de critérios determinados, tais quais a importância do valor protegido, a gravidade do dano, a ilicitude do comportamento do autor da infracção e da gravidade da sua culpa ${ }^{23}$. A racionalização da proteção penal do meio ambiente favorece desse modo dois movimentos de politica criminal: a simplificação do direito penal

bles?. In: NEYRET, Laurent (Dir.). Des écocrimes à l'écocide: le droit pénal au secours de l'environnement. Bruxelles: Bruylant, 2015. p. 141-164.

23 Cf. Ambrosio, Luca. Vers un droit pénal commun de l'environnement: critères et techniques d'incrimination. In: NEYRET, Laurent (Dir.). Des écocrimes à l'écocide: le droit pénal au secours de l'environnement. Bruxelles: Bruylant, 2015. p. 88-107. do meio ambiente e a internacionalização da proteção do meio ambiente pelo direito penal ${ }^{24}$ (3.1). Esse regime jurídico facilitaria o estabelecimento de um sistema coerente com vistas a prevenir e a reprimir, se necessário, a criminalidade ambiental (3.2).

\subsection{O estabelecimento de uma penalização comum, gradual e racional aos danos ao meio ambiente: dos ecocrimes ao ecocídio}

A criminalidade ambiental é um dos grandes desafios da comunidade internacional, haja vista a proteção do meio ambiente ser um dos principais imperativos da atualidade. Para tratar da ecocriminalidade, a determinação de uma graduação entre os tipos de crimes é fundamental. Assim, o reconhecimento de crimes comuns que devem ser melhor enquadrados por uma matriz internacional comum e de crimes ambientais graves e excepcionais que merecem uma resposta penal específica clarificariam a constituição de um sistema penal justo relativo ao meio ambiente.

A partir da análise dos textos relativos aos direitos nacionais e internacionais assim como da jurisprudência de ambos os níveis, verifica-se que seria possível classificar, hierarquicamente, dois tipos de valores protegidos que justificariam as incriminações penais ambientais: o respeito das regras administrativas e de valores respectivos e o respeito de um valor superior ligado à segurança do planeta. A adoção desses instrumentos permitiria estabelecer uma coerência da tipificação dos crimes ambientais que é atualmente esparsa, a fim de solucionar as disparidades entre os instrumentos variados de direito internacional. Vale ressaltar que a harmonização não se traduz em unificação ou uniformização; ela prevê uma aproximação em torno de princípios comuns ${ }^{25}$.

As proposições de convenção ecocrimes e ecocídio preconizam uma classificação dos crimes ambientais em nível internacional distinguindo as infrações administrativas, os ecocrimes e o ecocídio e, consequentemente,

24 FOUCHARD, Isabelle; NEYRET, Laurent. 35 propositions pour mieux sanctionner les crimes contre l'environnement. In: NEYRET, Laurent (Dir.). Des écocrimes à l'écocide: le droit pénal au secours de l'environnement. Bruxelles: Bruylant, 2015. p. 305-442. BEAUVAIS, Pascal. Les limites de l'internationalisation du droit pénal de l'environnement. In: NEYRET, Laurent (Dir.). Des écocrimes à l'écocide: le droit pénal au secours de l'environnement. Bruxelles: Bruylant, 2015. p. 3-18.

25 DELMAS-MARTY, Mireille. Préface. In: NEYRET, Laurent (Dir.). Des écocrimes à l'écocide: le droit pénal au secours de l'environnement. Bruxelles: Bruylant, 2015. p. vii-xiii. p. xi. 
buscam contribuir à descriminalização de condutas cujo valor não justificaria uma proteção penal. Assim, a fim de lutar contra o fórum shopping dos autores de atos de degradação ambiental, essa harmonização internacional de proteção penal do meio ambiente é necessária.

Os ecocrimes ${ }^{26}$ apresentam-se sob diversas formas e a determinação em um único instrumento agrupando os comportamentos aos quais deveriam corresponder respostas penais justifica-se em razão da sua contribuição ao reforço à proteção do meio ambiente do qual depende a integridade humana. Por sua vez, o ecocídio ${ }^{27}$, cometido deliberadamente como parte de uma ação generalizada ou sistemática e que pode comprometer a segurança do planeta, exige uma ação conjunta entre os Estados, razão pela qual um instrumento internacional deveria ser adotado para erigi-lo no âmbito dos crimes mais graves contra o meio ambiente.

Esse processo de internacionalização da proteção ambiental pelo direito penal encorajaria a simplificação dos direitos nacionais, por meio da descriminalização dos atos que não justificariam sua legitimidade penal, favorecendo uma melhor articulação entre as sanções civis, administrativas e penais. Ademais, ele teria por função harmonizar o direito penal relativo aos ecocrimes em nível internacional. Essa iniciativa permitiria que a margem discricionária dos Estados fosse reduzida no que se refere à persecução da criminalidade ambiental transnacional. Nesse ensejo, a adoção de mecanismos capazes de assegurar a cooperação internacional para lutar contra a grave criminalidade ambiental, por meio de órgãos internacionais independentes previstos pelo projeto de convenção internacional relativo ao ecocídio, como pela figura de um procurador internacional ${ }^{28} \mathrm{e}$ de um grupo de pesquisa e de investigação sobre o meio ambiente (GREEN) ${ }^{29}$, reforçariam esse aspecto de cooperação internacional.

Um fator essencial relativo à adoção de um instrumento internacional relativo ao ecocídio seria a possibilidade de unificar a sanção de tal crime internacional. $O$ movimento de internacionalização de um direito penal ambiental se inscreveria, enfim, na tendência atual e urgente de proteção desse bem jurídico não somente em razão de seu valor intrínseco ${ }^{30}$, mas especialmente por-

26 Cf. Projeto de Convenção contra a criminalidade ambiental. Anexo.1

27 Cf. Projeto de Convenção contra o ecocídio. Anexo 2.

28 Cf. artigo 17 do projeto de Convenção ecocídio.

29 Cf. artigo 20 do projeto de Convenção ecocídio.

30 Cf. HELLIO, Hugues. De la valeur partagée de la sûreté de que dele depende a segurança do planeta e da proteção dos direitos humanos como um todo ${ }^{31}$.

\subsection{A imperatividade da prevenção e da re- pressão da criminalidade ambiental em direito internacional}

É inegável que a proteção do meio ambiente depende da ação humana. O homem é o responsável por sua salvaguarda e, por essa razão, tem obrigações em relação a ele. Nesse sentido, não é possível fundá-la somente no princípio de não regressão adotado durante a Conferência de Rio +20 , pois as categorias jurídicas devem ser revistas à luz das práticas fatuais. Assim, "somente conceitos inovadores, 'dos ecocrimes ao ecocídio', parecem capazes de criar uma dinâmica, de iniciar processos transformadores que permitirão ampliar a visão tradicional do direito penal identificado ao Estado e limitado à proteção de valores nacionais" 32 .

O processo de internacionalização da repressão penal objetiva estabelecer meios para melhorar a sanção dos crimes ambientais, seja pela adaptação da justiça punitiva, seja pela adoção de medidas de justiça restaurativa, que implicariam a adoção de linhas diretivas que guiariam a reparação do dano ecológico, tais quais a adoção de programas de conformidade, a reparação integral ou ainda a criação de um fundo para o meio ambiente.

Ademais, as proposições de projetos de convenção ecocrimes e ecocídio visam à inibição da prática do ato ilícito, pela antecipação da responsabilidade penal. Os agentes que estariam implicados em uma infração ambiental sopesariam suas ações. Esse aspecto preventivo da repressão penal visa evitar que as pessoas físicas ou

la planète à la répression internationale de l'écocide. Une nouvelle quête. In: NEYRET, Laurent (Dir.). Des écocrimes à l'écocide: le droit pénal au secours de l'environnement. Bruxelles: Bruylant, 2015. p. 109-126.

31 Cf. DELAGE, Geneviève Giudicelli; MARTIN-CHENUT, Kathia. Humanisme et protection de la nature. In: BRÉCHIGNAC, Catherine; BROGLIE, Gabriel de; DELMAS-MARTY, Mireille (Dir.). L'environnement et ses métamorphoses. Paris: Hermann, 2015. p. 231-246; MARTIN-CHENUT, Kathia; PERRUSO, Camila. La contribution des systèmes régionaux de protection des droits de l'homme à la pénalisation des atteintes à l'environnement. In: NEYRET, Laurent (Dir.). Des écocrimes à l'écocide: le droit pénal au secours de l'environnement. Bruxelles: Bruylant, 2015. p. 39-66. 32 DELMAS-MARTY, Mireille. Préface. In: NEYRET, Laurent (Dir.). Des écocrimes à l'écocide: le droit pénal au secours de l'environnement. Bruxelles: Bruylant, 2015. p. vii-xiii. p. viii. 
morais ajam com negligência e que elas adotem uma abordagem positiva de proteção ambiental. Ademais, os projetos de convenção preveem métodos que objetivam melhorar a promoção de boas práticas assim como a formação de profissionais implicados na luta contra a ecocriminalidade.

\section{Considerações finais}

A possibilidade de apreensão da questão da criminalidade ambiental pelo direito internacional na sua vertente penal pode despertar a crítica de alguns e o ceticismo de outros. Se a crítica refere-se, sobretudo, aos importantes debates quanto a não legitimidade do direito penal como solução mágica a todos os problemas sociais, a pretensão de erigir a proteção do meio ambiente como um valor superior justificando sua tutela por meio do direito penal provoca um generalizado ceticismo.

Ora, neste trabalho de pesquisa apresentado, ao movimento de penalização da criminalidade ambiental, corresponde um movimento de descriminalização. Não se trata portanto de proposta tendente a favorecer uma hipertrofia penal. O que se busca alcançar é sobretudo uma racionalização do direito penal, que se faz necessária por meio da repressão de condutas que vão ao encontro da proteção de valores superiores. A obrigação de incriminação de certos comportamentos tidos como graves, assim como de sua persecução penal e de sanção correspondente, faz parte de um sistema democrático, visto que essa necessidade é a contrapartida natural do princípio de intervenção penal mínima. Nessa direção, o princípio de subsidiariedade que guia esse ramo do direito é garantido pelas proposições de projetos de convenção anexas ao presente artigo. Elas não somente estabelecem uma distinção entre os ecocrimes e o ecocídio, como propõem uma gradação das medidas repressivas em função da gravidade da infração. Ademais, essa perspectiva de racionalização do direito penal tem como consequência a descriminalização das infrações mais leves ${ }^{33}$.

Finalmente, imaginar uma renovação da ordem jurídica internacional, que funda, ao lado do respeito dos direitos humanos, a proteção do meio ambiente ${ }^{34}$, cons-

33 MARTIN-CHENUT, Kathia; PERRUSO, Camila. La contribution des systèmes régionaux de protection des droits de l'homme à la pénalisation des atteintes à l'environnement. In: NEYRET, Laurent (Dir.). Des écocrimes à l'écocide: le droit pénal au secours de l'environnement. Bruxelles: Bruylant, 2015. p. 39-66. p. 64-65.

34 BELAIDI, Nadia. La lutte contre les atteintes globales à l'environnement: titui uma tendência absolutamente legítima e que se inscreve em um processo de evolução dos valores comuns compartilhados pela humanidade. Nesse sentido, face a forças dogmáticas que resistiriam à possibilidade de constituição de um sistema visando à proteção penal do meio ambiente em direito internacional, cumpre relembrar que "todo grande movimento deve passar pela experiência de três etapas: o ridículo, a discussão e a adoção" 35 .

\section{REFERÊNCIAS}

AMBROSIO, Luca. Vers un droit pénal commun de l'environnement: critères et techniques d'incrimination. In: NEYRET, Laurent (Dir.). Des écocrimes à l'écocide: le droit pénal au secours de l'environnement. Bruxelles: Bruylant, 2015. p. 88-107.

AMNESTY INTERNATIONAL. Côte d'Ivoire une vérité toxique. à propos de trafigura, du probo koala et du déversement de déchets toxiques en Côte d'Ivoire. 25 Sep. 2012. Disponible dans: <http://www.amnesty.org/fr/documents/ AFR31/002/2012/fr/>. Accès: 02 Fev. 2016.

BEAUVAIS, Pascal. Les limites de l'internationalisation du droit pénal de l'environnement. In: NEYRET, Laurent (Dir.). Des écocrimes à l'écocide: le droit pénal au secours de l'environnement. Bruxelles: Bruylant, 2015. p. 3-18.

BELAIDI, Nadia. La lutte contre les atteintes globales à l'environnement: vers un ordre public écologique. Bruxelles: Bruylant, 2008.

CONVENÇÃO de Basileia e controle de movimentos transfronteiriços de resíduos perigosos e sua eliminação. 1989. Disponível em: <http://www.ecomodus. eu/downloads/Basel_Convention-pt.pdf $>$. Acesso em: 01 fev. 2016.

CONVENÇÃO Internacional para a Prevenção da Poluição por Navios (MARPOL 73/78). 1973. Disponível em: $\quad<$ http://www.fd.unl.pt/docentes_docs/ma/jc_ MA_26322.pdf>. Acesso em: 01 fev. 2016.

CONVENÇÃO Sobre o Comércio Internacional das

vers un ordre public écologique. Bruxelles: Bruylant, 2008.

35 Segundo a fórmula de J. S. Mill na obra de Tom Regan "o direito dos animais". Cf MARGUENAUD, Jean-Pierre. Une révolution théorique: l'extraction masquée des animaux de la catégorie des biens. JCP G, Paris, n. 10-11, p. 495-501, 9 Mars 2015. p. 500. 
Espécies Selvagens da Fauna e da Flora Ameaçadas de Extinção. 1973. Disponível em: <http://eur-lex.europa.eu/legal-content/PT/TXT/PDF/?uri=CELEX:2 2015A0319(01)\&from=PT> . Acesso em: 01 fev. 2016

DELAGE, Geneviève Giudicelli; MARTIN-CHENUT, Kathia. Humanisme et protection de la nature. In: BRÉCHIGNAC, Catherine; BROGLIE, Gabriel de; DELMAS-MARTY, Mireille (Dir.). L'environnement et ses métamorphoses. Paris: Hermann, 2015. p. 231-246.

DELMAS-MARTY, Mireille. Perspectives ouvertes par le droit de l'environnement. Revue Juridique L'Environnement, Paris, v. 39, p. 7-13, 2014. Numéro spécial: Le droit répressif: quelles perspectives pour le droit de l'environnement.

DELMAS-MARTY, Mireille. Préface. In: NEYRET, Laurent (Dir.). Des écocrimes à l'écocide: le droit pénal au secours de l'environnement. Bruxelles: Bruylant, 2015. p. vii-xiii.

ESTUPIÑAN-SILVA, Rosmerlin. La lutte contre la criminalité environnementale au sein des Etats. In: NEYRET, Laurent (Dir.). Des écocrimes à l'écocide: le droit pénal au secours de l'environnement. Bruxelles: Bruylant, 2015. p. 19-38.

EUROPEAN UNION'S JUDICIAL COOPERATION UNIT. Strategic Project on Environmental Crime: report. Haag: Eurojust, Nov. 2014. Available in: $<$ http://www.eurojust.europa.eu/doclibrary/eurojustframework/casework/strategic $\% 20$ project $\% 20$ on $\% 20$ environmental $\% 20$ crime $\% 20$ (october $\% 202014$ )/environmental-crime-report_2014-11-21-en.pdf $>$. Access: Feb. 02, 2016.

FALK, Richard. Environment warfare and ecocide: facts, appraisal and proposals. Révue Belge de Droit International, Brussels, n. 11, p. 1-27, 1973.

FOUCHARD, Isabelle; NEYRET, Laurent. 35 propositions pour mieux sanctionner les crimes contre l'environnement. In: NEYRET, Laurent (Dir.). Des écocrimes à l'écocide: le droit pénal au secours de l'environnement. Bruxelles: Bruylant, 2015. p. 305-442.

HELLIO, Hugues. De la valeur partagée de la sûreté de la planète à la répression internationale de l'écocide: une nouvelle quête. In: NEYRET, Laurent (Dir.). Des écocrimes à l'écocide: le droit pénal au secours de l'environnement. Bruxelles: Bruylant, 2015. p. 109-126.

LE MONDE. Les Prédateurs, la nature face au crime organisé.
Paris: Ateliers Henry Dougier, 2015.

MARGUENAUD, Jean-Pierre. Une révolution théorique: l'extraction masquée des animaux de la catégorie des biens. JCP G, Paris, n. 10-11, p. 495-501, 9 Mars 2015.

MARTIN-CHENUT, Kathia; FOUCHARD, Isabelle. Quelles responsabilités pour les sociétés transnationales? Le Monde, Paris, 8 Fev. 2015. Disponible à: <http:/ / www.lemonde.fr/planete/visuel/2015/01/24/ecocide-episode-1-le-bois-qui-saigne_4527270_3244. html\#sDDxAh2Sz0KV7qjS.99>. Accès: 2 Fev. 2015.

MARTIN-CHENUT, Kathia; PERRUSO, Camila. L'affaire Chevron Texaco et l'apport des projets de convention écocrimes et écocide à la responsabilisation pénales des entreprises transnationales. In: NEYRET, Laurent (Dir.). Des écocrimes à l'écocide: le droit pénal au secours de l'environnement. Bruxelles: Bruylant, 2015. p. 67-86.

MARTIN-CHENUT, Kathia; PERRUSO, Camila. La contribution des systèmes régionaux de protection des droits de l'homme à la pénalisation des atteintes à l'environnement. In: NEYRET, Laurent (Dir.). Des écocrimes à l'écocide: le droit pénal au secours de l'environnement. Bruxelles: Bruylant, 2015. p. 39-66.

MOZAMBIQUE: le trafic à grande échelle d'ivoire et de cornes de rhinocéros continue. Le Monde, Paris, 14 Mai. 2014. Disponible à: <http://www.lemonde.fr/ afrique/article/2015/05/14/mozambique-le-trafic-agrande-echelle-d-ivoire-et-de-cornes-de-rhinoceroscontinue_4633777_3212.html>. Accès: 2 Fev. 2016.

NAÇÕES UNIDAS. Tribunal Penal Internacional. Estatuto de Roma. Disponível em: <http://www.un.org/ spanish/law/icc/statute/spanish/rome_statute(s). pdf>. Acesso em: 01 fev. 2016.

NEYRET, Laurent. Des écocrimes à l'écocide, un groupe de juristes au secours de l'environnement. In: In: BRÉCHIGNAC, Catherine; BROGLIE, Gabriel de; DELMAS-MARTY, Mireille (Dir.). L'environnement et ses métamorphoses. Paris: Hermann, 2015. p. 183-193.

NEYRET, Laurent. La criminalité environnementale c'est gros profits pour petits risques. Disponible dans: <http://www.europe1.fr/emissions/europe-1-vousrepond/neyret-la-criminalite-environnementale-cestgros-profits-pour-petits-risques-2617361>. Accès: 02 Fev. 2016.

NEYRET, Laurent. Pour la reconnaissance du crime d'écocide, 
Paris, v. 39, p. 179-194, 2014. Numéro spécial: Le droit répressif: quelles perspectives pour le droit de l'environnement.

QUEINNEC, Yann. L'affaire Probo Koala, symbole d'une responsabilité sociétale des entreprises en quête de sécurité juridique. In: GUIDICELLI-DELAGE, Geneviève; S. MANACORDA, Stefano (Dir.). La responsabilité pénale des personnes morales: perspectives européennes et internationales. Paris: Société de législation comparée, 2013. (Unité mixte de recherche de droit comparé de Paris; v. 30). p. 277-293.

TRICOT, Juliette. Ecocrimes et écocide: quels responsables?. In: NEYRET, Laurent (Dir.). Des écocrimes à l'écocide: le droit pénal au secours de l'environnement. Bruxelles: Bruylant, 2015. p. 141-164.

\section{Anexo 1}

\section{Projeto de Convenção contra a criminalidade ambiental (Convenção Ecocrimes)}

\section{Preâmbulo}

Os Estados Partes,

Conscientes que a preservação do meio ambiente natural condiciona o futuro da humanidade,

Preocupados pela progressão das infrações contra o meio ambiente e por seus efeitos, que se estendem cada vez mais além das fronteiras dos Estados onde essas infrações são cometidas,

Preocupados pelas estreitas e crescentes relações entre a criminalidade ambiental e as outras formas de criminalidade internacional, tais quais a criminalidade transnacional organizada, os tráficos ilícitos, a lavagem de dinheiro ou ainda a corrupção e em plena conformidade com os textos já adotados relativos à matéria pela Organização das Nações Unidas, conscientes que a criminalidade ambiental tem um impacto não somente sobre o meio ambiente, mas igualmente sobre a paz, a segurança e as economias nacionais, assim como incidências nefastas sobre os planos sanitário e social, suscetíveis de comprometer o desenvolvimento sustentável,

Determinados a responder, de maneira eficaz e adaptada, a essa criminalidade que necessita uma abordagem global e multidisciplinar para preservar o meio ambiente e a saúde humana,

Conscientes que as disparidades entre as legislações e as capacidades nacionais favorecem a criminalidade ambiental e necessitando que uma importante cooperação internacional, tendo em conta as responsabilidades comuns mas diferenciadas dos Estados,

Notando que um certo número de acordos internacionais e regionais tratam da questão da proteção e da preservação do meio ambiente, mas que os sistemas de sanção existentes não são suficientes a garantir o respeito efetivo da legislação em matéria de proteção do meio ambiente,

Conscientes que esse respeito pode e deve ser reforçado pela existência de sanções penais, que refletem uma desaprovação da sociedade qualitativamente diferente daquela manifestada pelas sanções administrativas ou de indenização civil,

Notando, ademais, a existência de múltiplas convenções internacionais de cooperação penal, mas nenhuma que trate, especificamente, do meio ambiente e determinadas a reforçar o recurso ao direito penal, em suas diversas dimensões preventivas e repressivas, sem prejuízo de todos os outros meios disponíveis, civis e administrativos, a serviço notadamente da reparação dos danos ao meio ambiente e da indenização das vitimas,

Notando as iniciativas nessa direção de múltiplas organizações internacionais e notadamente do Programa das Nações Unidas para o meio ambiente, do Escritório das Nações Unidas contra a droga e o crime e da Interpol,

Afirmando que os Estados devem cumprir suas obrigações internacionais relativas à proteção e a salvaguarda do meio ambiente e são responsáveis a esse respeito em conformidade com o direito internacional,

Convencidos que as medidas eficazes, especialmente de natureza penal, devem ser tomadas com urgência para promover a cooperação, a fim de prevenir e de combater mais eficazmente a criminalidade ambiental:

Convém o seguinte: 


\section{Capítulo: Disposições gerais}

\section{Artigo 1 - Terminologia}

Para os fins da presente Convenção:

1. Por "ilícito" compreende-se:

a) todo comportamento contrário ao direito do Estado sobre o território no qual é cometido, caracterizado pela violação de uma lei, uma regra administrativa, ou uma decisão de uma autoridade competente, visando à proteção do meio ambiente;

b) O comportamento é igualmente considerado como ilícito:

i) quando os fatos foram cometidos por uma pessoa física ou jurídica estrangeira em um Estado no qual as disposições protetoras do meio ambiente estabelecem um nível de proteção manifestamente inferior ao nível estabelecido no Estado da nacionalidade da pessoa física ou naquela a pessoa jurídica tem sua sede ou ainda no Estado de onde provêm os rejeitos;

ii) quando os fatos foram cometidos com base em uma autorização ou de uma licença que foi obtida por meio da corrupção, do abuso de funções de um agente público ou por meio de ameaças, no sentido da Convenção das Nações Unidas contra a corrupção.

2. Por "ecossistemas", compreendem-se as dinâmicas complexas formadas de comunidades de plantas, de animais, de microrganismos e de se meio ambiente não vivo que, por sua interação, formam unidades funcionais.

3. Por "pessoa jurídica", compreende-se toda entidade, tendo a personalidade jurídica em virtude do direito aplicável, exceção feita aos Estados ou entidades públicas no exercício de suas prerrogativas de autoridade pública e de organizações internacionais públicas.

4. Por "pessoa jurídica estrangeira", compreende-se:

a) uma pessoa jurídica onde a sede situa-se em um Estado diferente daquele onde é realizado o comportamento proibido ou por uma de suas filiais, $\mathrm{ou}$

b) uma pessoa jurídica onde a sede é situada no
Estado onde é realizado o comportamento proibido, mas que realiza a atividade na ocasião em que se produz esse comportamento por intermédio de uma pessoa jurídica estrangeira ou de uma filial.

Para determinar a nacionalidade da pessoa jurídica, os Estados poderão levar em consideração o critério da sede, assim como do lugar onde a pessoa jurídica realiza sua atividade principal ou seu principal centro administrativo.

\section{Artigo 2 - Campo de aplicação}

1. A presente Convenção se aplica à prevenção e à repressão das infrações estabelecidas em conformidade com seus artigos 3 e 4, assim como à reparação de suas consequências.

2. A presente Convenção é sem prejuízo das normas aplicáveis ao crime de ecocídio e das normas aplicáveis às infrações às regras administrativas enquadrando a proteção do meio ambiente.

\section{Capítulo 2: Definições das infrações}

\section{Artigo 3 - dos prejuízos ao meio ambiente}

1. Cada EstadoParte adota as medidas legislativas e autras necessárias para conferir o caráter de infração penal o fato de 'colocar em perigo ${ }^{36}$ o meio ambiente que decorre de atos ilícitos, cometidos intencionalmente ou por negligência ao menos grave, como segue:

a) o rejeito, a emissão ou a introdução de uma quantidade de substâncias ou de radiações ionizantes no ar ou na atmosfera, nos solos, nas águas ou nos meios aquáticos;

b) a coleta, o transporte, a valorização ou a eliminação de lixo, inclusive a supervisão dessas operações assim como o entretenimento subsequente dos locais de descarga e notadamente as ações empreendidas como negociador ou corretor em toda atividade relacionada à gestão do lixo;

c) a exploração de uma usina naquela uma atividade perigosa é exercida ou substâncias ou preparações perigosas são estocadas ou utilizadas;

36 Em francês: mise en danger. 
d) a produção, o tratamento, a manipulação, a utilização, a detenção, a armazenagem, o transporte, a importação, a exportação ou a eliminação de matérias nucleares ou de outras substâncias radioativas perigosas;

e) a produção, a importação, a exportação, colocar à venda ou a utilização de substâncias enfraquecendo a camada de ozônio;

f) a morte, a destruição, a possessão ou a captura de espécimes de espécies selvagens da fauna e da flora salvo nos casos em que os atos portam sobre uma quantidade ínfima dessas espécimes e têm um impacto ínfimo sobre o estado de conservação da espécie;

g) o comércio de espécimes de espécies da fauna ou da flora selvagens ou de partes ou produtos delas advindos portam sobre uma quantidade ínfima dessas espécimes e têm um impacto ínfimo sobre o estado de conservação da espécie;

h) todo outro ato ilícito de caráter análogo suscetível de colocar em perigo o meio ambiente.

2. Ocorre o ato de 'colocar em perigo' o meio ambiente quando os atos enumerados no parágrafo precedente criam um risco de degradação substancial dos ecossistemas na sua composição, sua estrutura ou seu funcionamento.

3. É uma circunstância agravante o fato de causar uma degradação substancial dos ecossistemas em sua composição, sua estrutura ou seu funcionamento.

\section{Artigo 4 - das violações à pessoa}

Cada Estado-Parte adota as medidas legislativas e outras necessárias para conferir o caráter de infração penal ao fato de colocar em perigo uma outra pessoa que decorre dos atos cometidos intencionalmente ou por negligência ao menos grave, como segue:

a) o rejeito, a emissão ou a introdução de uma quantidade de substâncias ou de radiações ionizantes no ar ou na atmosfera, nos solos, nas águas ou nos meios aquáticos;

b) a coleta, o transporte, a valorização ou a eliminação de lixo, inclusive a supervisão dessas operações assim como o entretenimento subsequente dos locais de descarga e notadamente as ações empreen- didas como negociador ou corretor em toda atividade relacionada à gestão do lixo;

c) a exploração de uma usina naquela uma atividade perigosa é exercida ou substâncias ou preparações perigosas são estocadas ou utilizadas;

d) a produção, o tratamento, a manipulação, a utilização, a detenção, a armazenagem, o transporte, a importação, a exportação ou a eliminação de matérias nucleares ou de outras substâncias radioativas perigosas;

e) todo outro ato de caráter análogo que cria um risco de causar a morte ou de graves lesões às pessoas.

2. Há ato de colocar em perigo uma outra pessoa quando os atos enumerados no parágrafo precedente criam um risco de causar a morte ou graves lesões a pessoas.

3. É uma circunstância agravante o fato de causar a morte ou graves lesões a pessoas em consequência dos atos enumerados no parágrafo 1.

\section{Artigo 5 - participação às infrações}

No sentido da presente Convenção, comete uma infração penal quem:

a) Comete uma ou diversas infrações previstas nos artigos 3 e 4 da presente Convenção;

b) Organiza o cometimento de tal infração ou dá a ordem a outras pessoas de cometê-la;

c) Torna-se cúmplice de tal infração, inclusive fornindo os meios desse cometimento, notadamente pela fabricação de falsos documentos ou da falsificação de documentos;

d) Contribui de toda outra maneira ao cometimento de tal infração por um grupo de pessoas agindo em concerto. Esse concurso deve ser deliberado e, segundo o caso:

i) Visar facilitar a atividade criminal ou a arquitetura criminal do grupo, se essa atividade ou essa arquitetura comporta a execução de um crime previsto pela presente Convenção; ou

ii) Ser realizada em plena consciência da intenção do grupo de cometer esse crime. 


\section{Artigo 6 - Responsabilidade penal das pessoas morais}

1. Cada Estado-Parte, em conformidade com os seus princípios jurídicos, adota as medidas necessárias para garantir que uma pessoa jurídica possa ser responsabilizada pelas infrações estabelecidas na presente Convenção, quando cometidos em seu nome, por qualquer pessoa que exerce um poder de direção, agindo, individualmente, ou como membro de um órgão da pessoa jurídica, em virtude:

a) de um mandato da pessoa jurídica;

b) de uma autoridade para tomar decisões em nome da pessoa jurídica; ou

c) de uma autoridade para exercer um controle no seio da pessoa jurídica.

2. Cada Estado-Parte, em conformidade com os seus princípios jurídicos, adota as medidas necessárias para garantir que uma pessoa jurídica possa ser responsabilizada penalmente quando, em virtude da sua falta de vigilância ou de controle, ela tenha tornado possível a prática de uma infração estabelecida em conformidade com a presente Convenção.

3. Sob reserva dos princípios jurídicos do Estado-Parte, a responsabilidade das pessoas morais pode ser penal, civil ou administrativa.

4. A responsabilidade penal das pessoas jurídicas estabelecidas nos termos dos parágrafos 1 e 2 não prejudica a responsabilidade penal das pessoas físicas que participaram na acepção do artigo 5 , às infrações visadas pelos artigos 3 e 4 .

\section{Capítulo 3: Medidas repressivas Seção 1: Sanções}

\section{Artigo 7 - Sanções contra as pessoas físicas}

1. Os Estados-Partes adotam as medidas necessárias para punir, de maneira eficaz, proporcional e dissuasiva as pessoas físicas reconhecidamente culpadas das infrações previstas na presente Convenção e para garantir a reparação dos danos ambientais e a indenização das vítimas.

2. Os Estados-Partes fazem das infrações visadas pela presente Convenção passíveis de penas que levam em consideração sua extrema gravidade. Para a escolha e a determinação da gravidade da sanção, os Estados-Partes levam em consideração, especialmente, os seguintes critérios:

a) Os benefícios econômicos advindo da infração, incluindo neste caso as economias que puderam resultar da não adoção de medidas de proteção ambiental;

b) A posição hierárquica do autor da infração, o fato de que ele tenha cometido o crime no âmbito das atividades de uma pessoa jurídica ou o seu estatuto de funcionário público;

c) A pronta reparação dos danos e a indenização das vítimas;

d) O caráter organizado do crime.

3. A reparação de danos toma formas tais como:

a) Medidas de restauração ambiental,

b) Reparação por danos materiais e morais,

c) Programas de conformidade,

d) Provisionamento do Fundo para o meio ambiente,

e) Medidas de desenvolvimento local;

f) e, de acordo com as circunstâncias, medidas de reparação simbólica adaptadas à dimensão cultural do dano ambiental, que podem se expressar em pedidos de desculpas às comunidades locais.

\section{Artigo 8 - Sanções contra as pessoas jurídicas}

1. Os Estados-Partes adotam as medidas necessárias para sancionar, de maneira eficaz, proporcional e dissuasiva as pessoas jurídicas reconhecidamente culpadas de uma das infrações visadas pela presente Convenção e para garantir a reparação dos danos ambientais e a indenização das vítimas.

2. Os Estados-Partes adotam as medidas necessárias para punir, de maneira eficaz, proporcional e dissuasiva as pessoas morais reconhecidamente culpadas de uma das infrações visadas pela presente Convenção. Em particular, os Estados-partes consideram estabelecer as sanções seguintes:
a) Multas;
b) Proibições, notadamente: 
- A dissolução da pessoa jurídica;

- O encerramento temporário ou definitivo dos locais ou estabelecimentos da pessoa jurídica;

- A suspensão, temporária ou definitiva, do todo ou de parte da atividade da pessoa jurídica no exercício daquela foi cometida, favorizada ou dissimulada a infração;

- A retirada de licenças, autorizações ou concessões;

- A proibição de receber subsídios e financiamentos públicos e de contratar com a administração pública.

c) Publicação da condenação. Quando há uma pluralidade de vítimas não identificadas, a publicação deve garantir que elas estejam conscientes do seu direito à indemnização;

d) Nomeação de um mandatário de justiça, a fim de que a pessoa jurídica adote as medidas organizacionais de natureza a prevenir novos crimes contra o meio ambiente ou que ela ele execute com diligência as medidas de reparação ou indenização.

3. A reparação de danos assume, notadamente, a forma de:

a) Medidas de restauração ambiental;

b) Reparação por danos materiais e morais;

c) Programas de Compliance;

d) Provisionamento do Fundo para o Meio Ambiente;

e) Medidas de desenvolvimento local;

f) E, dependendo das circunstâncias, de medidas de reparação simbólica adaptadas à dimensão cultural de danos ambientais, que podem assumir a forma de um pedido de desculpas para as comunidades afetadas;

4. Os Estados membros adotam as medidas necessárias para impedir que as sanções ou as consequências danosas que delas decorrem possam ser garantidas.

\section{Artigo 9 - critérios de determinação da sanção das pessoas jurídicas}

1. Para a escolha e a determinação da sanção, con- vém priorizar a reparação do dano e a indenização das vítimas.

2. Nos casos em que a multa possa comprometer a solvência da pessoa jurídica, a segurança dos empregos ou a reparação dos danos, os Estados-Partes podem fornecer a possibilidade de parcelar o pagamento. Nesses casos e, em conformidade com o direito interno, eles poderão, também, dar prioridade para a reparação do dano pela pessoa jurídica autora da infração.

3. Os Estados-Partes levarão em conta os seguintes critérios para a escolha e a determinação da gravidade da sanção:

a) O lucro econômico da infração, incluindo neste caso as economias que resultaram da falta de adoção de medidas de proteção ambiental;

b) A ausência ou a insuficiência de medidas de controles internos que teriam permitido a prevenção da infração;

c) A reiteração de infrações contra o meio ambiente no âmbito da ou pela pessoa jurídica. Para este fim, serão consideradas as sanções impostas às pessoas jurídicas por outras autoridades;

d) A natureza organizada do crime;

e) A colaboração da pessoa jurídica no processo penal, em particular no estabelecimento da responsabilidade;

f) A reparação imediata dos danos e a assistência às vítimas;

g) A adoção imediata de medidas de controle interno para destinadas a prevenir infrações similares.

4. A dissolução da pessoa jurídica e o encerramento definitivo das suas instalações ou atividades só serão pronunciados se a pessoa jurídica tiver sido criada para cometer os fatos incriminados ou quando ela será considerada como parte de um grupo criminoso organizado, tal como definido no Convenção das Nações Unidas contra o Crime Organizado Transnacional.

\section{Artigo 10 - Suspensão da execução da sanção, provas e acordos processuais}

1. Os Estados-Partes poderão, em conformidade com os princípios fundamentais de seu direito interno, prever a possibilidade de não impor sanção, de não exe- 
cutar ou de não processar a pessoa jurídica, nos casos em que ela cumprir, corretamente, suas medidas internas de organização e de maneira voluntária e imediata:

a) Avisou as autoridades competentes do cometimento de uma das infrações definidas pela presente Convenção, cometidas por um de seus empregados ou dirigentes;

b) Reparou ou se esforçou para reparar os danos causados e, em partículas, aqueles sofridos pelas vítimas;

2. Nessas hipóteses, a decisão de não impor uma sanção, de não executar e de não processar a pessoa jurídica poderá ser subordinada à realização de certas condições, especialmente:

a) a designação de um auditor público encarregado de supervisionar a adoção de medidas de prevenção apropriadas pela entidade, assim que a reparação do dano causado ou de investigar sobre as causas estando na origem do cometimento de uma infração contra o meio ambiente;

b) O pagamento de um montante que compense o benefício que a entidade pôde obter em razão do cometimento da infração ou da falta de respeito da legislação ambiental.

\section{Artigo 11 - confisco e apreensão}

1. Os Estados Partes adotam, na medida do possível no quadro de seus sistemas jurídicos nacionais, as medidas necessárias para permitir o confisco:

a) Do produto do crime derivado de infrações previstas pela presente Convenção ou de bens cujo valor corresponda ao desse produto.

b) Dos bens, materiais ou outros instrumentos utilizados ou destinados a serem utilizados na prática das infrações previstas na presente Convenção.

2. Os Estados Partes preveem a possibilidade de apreender os produtos do crime advindo de infrações visadas pela presente Convenção. Os produtos também incluem as economias resultando da não adoção de medidas de proteção ambiental;

3. Os Estados Partes adotam as medidas necessárias para permitir a identificação, a localização, o congelamento ou a apreensão dos elementos mencionados no parágrafo 1 do presente artigo, a fim de um eventual confisco;

4. Se o produto do crime tiver sido transformado ou convertido, no todo ou em parte, em outros bens, eles estão sujeitos às medidas referidas neste artigo no lugar do produto mencionado;

5. Se o produto do crime tiver sido misturado com bens adquiridos legalmente, esses bens, sem prejuízo de todos os poderes de congelamento ou de apreensão, podem ser confiscados até ao valor estimado do produto com o qual tenha sido misturado;

6. As receitas ou outros benefícios obtidos com o produto do crime, os bens nos quais o produto tenha sido transformado ou convertido ou os bens com os quais tenha sido misturado podem, também, ser objeto das medidas referidas no presente artigo, da mesma maneira e na mesma medida que o produto do crime;

7. Para efeitos deste artigo e do artigo 17 da presente Convenção, cada Estado-Parte habilita seus tribunais ou outras autoridades competentes para ordenarem a produção ou a apreensão de documentos bancários, financeiros ou comerciais. Os Estados-Partes não podem invocar o sigilo bancário para recusar de dar cumprimento às disposições do presente parágrafo;

8. A interpretação das disposições do presente artigo não deve em nenhum caso violar os direitos de terceiros de boa-fé;

9. Nenhuma disposição do presente artigo viola o princípio segundo o qual as medidas que são visadas são definidas e executadas em conformidade com o direito interno de cada Estado parte e segundo as disposições desse direito.

\section{Seção 2: Cooperação em matéria repressiva}

\section{Artigo 12 - Competências nacionais}

1. Cada Estado-parte adota as medidas necessárias para estabelecer sua competência relativa às infrações visadas pela presente Convenção nos casos seguintes:

a) Quando os fatos tenham sido cometidos em todo o território sob a jurisdição desse Estado; ou

b) Quando o resultado da infração é realizado em todo o território sob a jurisdição desse Estado; ou

c) Quando da infração for cometida a bordo de 
um navio de seu pavilhão ou a bordo de uma aeronave matriculada no seu direito nacional no momento em que a infração é cometida; ou

d) Quando da infração for cometida por um dos seus nacionais; ou

e) Quando a infração for cometida por uma pessoa jurídica que tenha a sua sede ou o sua atividade principal ou seu principal centro administrativo no seu território; ou

f) Quando a infração for cometida contra um dos seus nacionais e que o Estado o considere apropriado.

2. Cada Estado-Parte adota, igualmente, as medidas que sejam necessárias para estabelecer sua competência nos casos em que o suposto autor de uma infração prevista pela presente Convenção encontra-se em seu território e que ele não o extradite, nos termos do artigo 15, para qualquer um dos Estados-partes que tenham estabelecido sua competência de acordo com o parágrafo 1 .

3. Quando mais de um Estado-parte declara-se competente em relação a uma infração prevista pela presente Convenção, os Estados-partes interessados se esforçam para coordenar suas ações de forma adequada, em especial no que diz respeito às condições de engajamento de persecução e de modalidades de assistência jurídica mútua.

4. Sem prejuízo das normas do direito internacional geral, a presente Convenção não exclui o exercício de qualquer competência penal estabelecida por um Estado-Parte, em conformidade com seu direito interno.

\section{Artigo 13 - Investigação e persecução penal}

1. Se considerar que as circunstâncias justificam, depois de analisar as informações de que dispõe, qualquer Estado-parte em cujo território se encontra uma pessoa suspeita de ter cometido uma infração prevista nos artigos 3 e 4, assegura a detenção dessa pessoa ou toma todas as outras medidas legais para garantir sua presença. Essa detenção e essas outras medidas devem estar em conformidade com a legislação desse Estado; elas podem ser mantidas somente durante o tempo que for necessário para permitir o estabelecimento de um processo penal ou de um processo de extradição.

2. Tal Estado procede, imediatamente, a uma investi- gação preliminar com vistas a estabelecer os fatos.

3. Qualquer pessoa detida em virtude do parágrafo 1 deste artigo poderá se comunicar, imediatamente, com o representante competente mais próximo do Estado da sua nacionalidade ou, se for um apátrida, com o representante da Estado em que resida habitualmente.

4. Quando um Estado detém uma pessoa em custódia nos termos das disposições deste artigo, ele notifica, imediatamente, a detenção e as circunstâncias que a justificam aos Estados referidos no parágrafo 1 do artigo 10. O Estado que procede à investigação preliminar prevista no parágrafo 2 do presente artigo deve comunicar, rapidamente, as suas conclusões aos citados Estados e indicará se pretende exercer sua competência.

\section{Artigo 14 - participação da sociedade civil}

Cada Estado-parte visa a favorizar, em conformidade com seu direito interno, a informação da sociedade civil e sua participação aos processos penais relativos às infrações previstas pela presente Convenção, de um grupo, de uma fundação ou uma associação que, de acordo com seu estatuto, tem por objetivo a proteção do meio ambiente.

\section{Artigo 15 - extraditar ou processar}

1. O Estado-parte sobre o território e sob a jurisdição em que se encontra o presumível autor de uma infração prevista nos artigos 3 e 4, se não o extraditar, submete o caso às suas autoridades competentes para o exercício da ação penal.

2. Essas autoridades tomarão sua decisão nas mesmas condições que para qualquer outra infração de direito comum de natureza grave nos termos do direito desse Estado.

3. Toda pessoa processada por qualquer infração prevista nos artigos 3 e 4 beneficia da garantia de um tratamento equitativo em todas as fases do processo.

\section{Artigo 16 - extradição}

1. As infrações previstas nos artigos 3 e 4 são consideradas como passíveis de extradição em qualquer tratado de extradição concluído entre os Estados-partes antes da entrada em vigor da presente Convenção. Os 
Estados-partes comprometem-se a incluir essa infração como caso de extradição em todo tratado de extradição futuramente concluído.

2. Um Estado-parte que condiciona a extradição à existência de um tratado tem a faculdade, quando receber um pedido de extradição de outro Estado-parte com o qual não está vinculado por um tratado de extradição, de considerar essa Convenção como a base jurídica para a extradição relativamente às infrações previstas nos artigos 3 e 4. A extradição é sujeita às demais condições previstas pela legislação do Estado requerido.

3. Os Estados-partes que não condicionam a extradição à existência de um tratado reconhecendo as infrações previstas nos artigos 3 e 4 como caso de extradição entre eles, sem prejuízo das condições previstas pela legislação do Estado requerido.

4. Se necessário, as infrações previstas nos artigos 3 e 4 são consideradas, para efeitos de extradição entre os Estados Partes, como cometidas tanto no lugar de sua perpetração que no território dos Estados que estabeleceram sua competência de acordo com o artigo 12 .

5. As disposições relativas às infrações previstas nos artigos 3 e 4 de todos os tratados ou acordos de extradição concluídos entre Estados-Partes devem ser modificados entre Estados-Partes na medida em que elas são incompatíveis com a presente Convenção.

5. Para fins de extradição ou assistência jurídica mútua entre os Estados-Partes, nenhuma infração prevista nos artigos 3 e 4 não pode ser considerada como uma infração política, como uma infração conexa à uma infração política ou como uma infração inspirada por motivos políticos. Por conseguinte, um pedido de extradição ou de assistência jurídica mútua com base em tal infração não poderá ser recusada pela simples razão de que se trata de uma infração política, uma infração conexa à uma infração política ou uma infração inspirada por motivos políticos.

\section{Artigo 17 - Assistência jurídica mútua}

1. Os Estados-Partes acordam, mutualmente, uma ampla assistência jurídica para as investigações, os processos e os procedimentos judiciais relativos às infrações previstas por esta Convenção.

2. A assistência jurídica mútua é baseada no princípio do reconhecimento mútuo das sentenças e decisões judiciais dos Estados-Partes.

3. A mais ampla assistência jurídica mútua possível é concedida, desde que as leis, tratados, acordos e arranjos pertinentes do Estado Parte requerido a permita, quando das investigações, processos e procedimentos judiciais relativos a infrações pelas quais uma pessoa jurídica possa ser passível de responsabilidade no Estado-Parte requerente, em conformidade com o artigo 6 da presente Convenção.

4. A assistência jurídica mútua é realizada, também, em processos por fatos puníveis nos termos do direito nacional do Estado Membro requerente ou do Estado Membro requerido, ou ambos, a titulo de violações das regras investigadas pelas autoridades administrativas, cuja decisão pode gerar um processo perante um tribunal competente, notadamente em matéria penal.

5. Os Estados-Partes poderão invocar a falta de dupla incriminação para recusar dar seguimento a um pedido de assistência nos termos do presente artigo. $\mathrm{O}$ Estado-Parte requerido poderá, contudo, quando considerar apropriado, prestar essa assistência, na medida em que ele decide, a seu critério, independentemente do fato que a conduta possa constituir ou não uma infração nos termos do direito nacional do Estado-parte requerido.

6. Cada Estado-Parte designa uma autoridade central que tem a responsabilidade e o poder de receber as demandas de assistência jurídica mútua e, seja executá-las, seja transmiti-las às autoridades competentes para execução. As autoridades centrais garantem a execução ou a transmissão rápida e em adequada forma das demandas recebidas.

7. As demandas são endereçadas por escrito ou, se possível, por todo outro meio que possa produzir um documento escrito, em uma língua aceitável para o Estado-Parte requerido, nas condições que permitem a esse Estado de estabelecer sua autenticidade. Em caso de urgência e se os Estados-Parte convêm, as demandas podem ser feitas oralmente, mas devem ser confirmadas sem prazo por escrito.

8. Toda demanda é executada em conformidade com o direito interno do Estado-Parte requerido e, na medida em que ela não contrarie o direito interno desse Estado e quando é possível, de acordo com os procedimentos especificados na demanda.

9. A assistência jurídica mútua pode ser refusada: 
a) Se a demanda não é feita em conformidade com as disposições do presente artigo;

b) Se o Estado-Parte requerido estima que a execução da demanda é suscetível de causar um prejuízo à sua soberania, à sua segurança, à sua ordem pública ou a outros interesses essenciais;

c) Caso o direito interno do Estado-Parte requerido proíba suas autoridades de tomar as medidas demandadas tratando-se de uma infração análoga tendo sido objeto de uma investigação, de um processo ou de um processo judiciário no quadro de sua própria competência;

d) Caso ele seria contrário ao sistema jurídico do Estado-Parte requerido relativamente à assistência jurídica mútua de aceitar a demanda.

10. Toda recusa de assistência jurídica mútua deve ser motivada. Antes de recusar um pedido de assistência ou adiar sua execução, nos termos do parágrafo 11, o Estado-Parte requerido deve estudar com o Estado-Parte requerente a possibilidade de conceder a assistência sob reserva das condições que ele considerar necessárias. Se o Estado-Parte requerente aceitar a assistência jurídica mútua sujeita a condições, ele deverá respeitá-las.

11. O Estado-Parte requerente deverá executar a demanda de assistência jurídica mútua o mais rapidamente possível e deverá levar em conta, na medida do possível, todos os prazos sugeridos pelo Estado Parte requerente e que estão motivados de preferência na demanda. A assistência pode ser adiada pelo Estado-Parte requerido pelo motivo que ela interfere em uma investigação em curso, uma ação judicial ou um processo judicial em curso.

\section{Capítulo 4: Medidas preventivas}

\section{Artigo 18 - Cooperação internacional em maté- ria de prevenção}

1. Os Estados-Partes cooperam para prevenir as infrações previstas na presente Convenção, adotando todas as medidas possíveis, especialmente, se necessário, adaptando sua legislação nacional, para evitar e impedir a preparação em seus respectivos territórios de infrações a serem cometidas no interior ou fora do seu território.
2. Os Estados-Partes cooperam também para a prevenção das infrações previstas na presente Convenção, por meio da troca de informações precisas e verificadas em conformidade com sua legislação interna e por meio da coordenação de medidas administrativas e de outras medidas tomadas.

3. Os Estados-Partes podem trocar informações pelo intermédio de instituições regionais e internacionais interessadas na luta contra a criminalidade ambiental, incluindo a Interpol, a Europol e o Escritório das Nações Unidas sobre drogas e crime.

4. Os Estados-Partes dispensam ou reforçam a formação adequada dos profissionais pertinentes que tratam de autores e suspeitos de terem cometido uma das infrações previstas na presente Convenção e de suas vítimas.

5. Os Estados-Partes se esforçam para sensibilizar o público quanto à existência, às causas e à gravidade da criminalidade ambiental e à ameaça que ela representa. Eles podem fazê-lo, se necessário, por intermédio dos meios de comunicação social e pela adoção de medidas destinadas a promover a participação do público nas atividades de prevenção e de repressão desse crime.

6. Os Estados-Partes informam o Secretário da presente Convenção o nome e o endereço da autoridade ou das autoridades que podem ajudar as outras Partes a desenvolver as medidas de prevenção das infrações previstas na presente Convenção.

7. Os Estados-Partes colaboram, conforme sua conveniência, entre eles e com as instituições regionais e internacionais competentes, para desenvolver e promover as medidas visadas pelo presente capítulo.

\section{Capítulo 5: aplicação da convenção}

\section{Artigo 19 - Proteção da soberania}

1. Os Estados-Partes cumprirão as obrigações decorrentes da presente Convenção em conformidade com os princípios de igualdade soberana e de integridade territorial dos Estados, assim como da não ingerência nos assuntos internos de outros Estados.

2. Nenhuma disposição da presente Convenção autoriza qualquer Estado-Parte a exercer, no território de outro Estado-Parte, uma competência ou funções, 
exclusivamente, reservadas às autoridades desse outro Estado-Parte por seu direito interno.

\section{Artigo 20 - Implementação da Convenção}

1. Cada Estado-Parte adota as medidas necessárias, incluindo legislativas e administrativas, de acordo com os princípios fundamentais de sua legislação interna, para garantir o cumprimento das suas obrigações em virtude da presente Convenção.

2. Cada Estado-Parte poderá adotar medidas mais estritas ou mais severas do que as previstas pela presente Convenção para prevenir e punir os crimes internacionais mais graves contra o meio ambiente.

3. As disposições da presente Convenção são aplicadas e interpretadas de acordo com as regras do direito internacional geral e os princípios do direito internacional do meio ambiente, notadamente o princípio de responsabilidades comuns, mas diferenciadas.

\section{Artigo 21 - Exame do cumprimento das disposi- ções}

1. A Assembleia dos Estados-Partes adota, por consenso, disposições de caráter não conflituoso, de natureza não judicial e consultiva para examinar o cumprimento das disposições da presente Convenção.

2. Essas disposições deverão permitir uma apropriada participação do público e prever a opção de se admitirem comunicações de membros do público sobre questões relacionadas à presente Convenção.

3. O procedimento adotado por consenso para o exame do cumprimento das disposições da presente Convenção aplica-se sem prejuízo do processo de resolução de litígios previstos no artigo 22. Sempre que possível, as Partes deverão utilizar procedimentos preliminares relativos ao cumprimento antes de recorrer a mecanismos de solução de disputas.

\section{Artigo 22 - Solução de controvérsias}

1. Se surgir uma controvérsia entre duas ou mais Partes quanto à interpretação ou a aplicação desta Convenção, elas devem se esforçar para resolvê-la pela via da negociação ou por qualquer outro meio de resolução de disputas que elas considerarem aceitável. Além disso, as Partes procuram a melhor solução para o estado do meio ambiente e o respeito de seus direitos, pela implementação anterior, e, na medida do que é apropriado, do procedimento de exame do respeito das disposições previsto no artigo 21.

2. Quando uma Parte assina, ratifica, aceita, aprova ou adere à presente Convenção, ou em qualquer momento posterior, ela pode declarar por escrito ao depositário que, no caso de disputas, não foram resolvidas em conformidade com o parágrafo 1 acima, ela aceita como obrigatório um dos dois ou ambos os meios de solução de controvérsias abaixo em suas relações com qualquer Parte que aceite a mesma obrigação:

a) A submissão da controvérsia à Corte Internacional de Justiça;

b) A submissão da controvérsia à arbitragem;

3. Se as Partes na controvérsia aceitarem os dois meios de solução de controvérsias referidos no parágrafo 2 acima, a controvérsia poderá ser submetida apenas à Corte Internacional de Justiça, a menos que elas acordem o contrário.

\section{Artigo 25 - Medidas cautelares}

1. Se uma corte, um tribunal ou um órgão responsável pelo exame do respeito da Convenção, regularmente invocado por uma controvérsia ou uma situação que considere, prima facie, que tem jurisdição sobre a controvérsia ou sobre a situação, em conformidade com a presente Convenção, esse tribunal ou esse órgão pode prescrever quaisquer medidas cautelares que considere apropriadas à circunstância a fim de evitar o grave prejuízo ambiente ou para preservar os direitos respectivos das Partes em litígio, aguardando a decisão final.

2. As medidas cautelares podem ser modificadas ou retiradas no momento em que as circunstâncias que as justificavam mudem ou deixem de existir.

3. Medidas cautelares podem ser prescritas, modificadas ou retiradas em virtude do presente artigo pela demanda de uma Parte à controvérsia ou de todo membro do público interessado e habilitado a apresentar comunicações. As medidas cautelares podem ser prescritas, modificadas ou retiradas somente depois que a possibilidade de ser ouvido tenha sido dada às Partes.

4. A corte, o tribunal ou o órgão responsável pelo 
cumprimento da Convenção notifica, imediatamente, as diferentes Partes à controvérsia de qualquer medida cautelar ou qualquer decisão de modificação ou de retirada e, se considerar apropriado, quaisquer outras pessoas que julgar interessada.

5. Enquanto aguarda a constituição de um tribunal arbitral para apreciar a controvérsia nos termos do artigo 22, qualquer órgão jurisdicional designado de comum acordo pelas Partes ou, na falta de acordo no prazo de duas semanas a contar da data do pedido de medidas cautelares, a Corte Internacional de Justiça pode prescrever, modificar ou revogar medidas cautelares em conformidade com o presente artigo, se considerar que, prima facie, o tribunal a ser constituído teria jurisdição e se ela estima que a urgência da situação exige. Uma vez constituído, o tribunal que julgará a controvérsia, de acordo com os parágrafos 1 a 4 , pode modificar, revogar ou confirmar essas medidas cautelares.

6. As Partes à controvérsia se conformam sem demora a todas as medidas cautelares prescritas em virtude deste artigo.

\section{Capítulo 4: Disposições finais}

$\mathrm{Na}$ ausência de especificidade própria em matéria de infrações ambientais a esse respeito, as disposições finais não serão na presente objeto de desenvolvimentos.

\section{Anexo 2 \\ Projeto de Convenção contra o ecocídio (Convenção Ecocídıo)}

\section{Preâmbulo}

Os Estados-Partes à presente Convenção,

Conscientes que todos os povos são unidos por uma solidariedade de destino e que seu meio ambiente constitui um patrimônio comum das gerações presentes e futuras, cuja proteção condiciona a sobrevivência da humanidade;

Conscientes de que o futuro da humanidade e a viabilidade do planeta relevam da responsabilidade de toda a comunidade internacional;
Preocupados com a expansão de crimes intencionais em detrimento do meio ambiente e com as consequências graves e duradouras, às vezes irreversíveis, ao equilíbrio ecológico e à humanidade;

Conscientes que as disparidades entre as legislações e as capacidades nacionais favorecem a criminalidade ambiental em escala mundial;

Notando que diversos acordos internacionais e regionais tratam da questão da proteção do meio ambiente, mas que os sistemas de sanção existentes não são suficientes para preservar a segurança do planeta;

Preocupados com os laços estreitos e crescentes entre a criminalidade ambiental e outras formas de criminalidade internacional, como a criminalidade transnacional organizada, os tráficos ilícitos, a lavagem de dinheiro ou ainda a corrupção e em plena conformidade com as disposições já adotadas nessa área pelas Nações Unidas;

Reconhecendo que os crimes mais graves contra o meio ambiente ameaçam a paz mundial, a segurança da humanidade e a segurança do planeta;

Afirmando que os crimes mais graves que ameaçam a comunidade internacional não podem ficar impunes e que sua repressão deve ser efetivamente assegurada por medidas tomadas em nível nacional e pelo reforço da cooperação internacional;

Determinados a pôr fim à impunidade dos autores desses crimes, a contribuir com a sua prevenção e com a reparação de suas consequências;

Relembrando que é dever de cada Estado de submeter à sua jurisdição penal os responsáveis por crimes internacionais;

Determinados, para essas finalidades e no interesse da segurança do planeta, a reforçar as condições de cooperação penal entre os Estados e que os crimes internacionais mais graves contra o meio ambiente, características do crime ecocídio, sejam objeto de sanções penais apropriadas;

Acordam o seguinte:

\section{Artigo 1- Campo de aplicação}

1. A presente Convenção aplica-se aos mais graves crimes contra o meio ambiente que, em tempos de paz como em tempo de conflito armado, prejudicam a segurança do planeta. 
2. A presente Convenção não se sobrepõe aos instrumentos pertinentes do Direito Internacional Humanitário que regulam os danos ambientais durante conflito armado.

\section{Capítulo 1: Medidas repressivas}

\section{Artigo 2: Definição do ecocídio}

1. Para os fins da presente Convenção, o ecocídio define-se como os atos intencionais descritos a seguir, quando eles comprometem a segurança do planeta e são cometidos no âmbito de uma ação generalizada ou sistemática:

a) O rejeito, a emissão ou a introdução de uma quantidade de substâncias ou de radiações ionizantes no ar ou na atmosfera, nos solos, nas águas e nos ambientes aquáticos;

b) A coleta, o transporte, a valorização ou a eliminação de resíduos, incluindo a fiscalização dessas operações e a posterior manutenção dos aterros e notadamente as medidas tomadas na qualidade de negociador ou corretor em qualquer atividade relacionada à gestão de resíduos;

c) A exploração de uma fábrica em que uma atividade perigosa é realizada ou substâncias ou preparações perigosas sejam armazenadas ou utilizadas;

d) A produção, o tratamento, a manipulação, a utilização, a detenção, a armazenagem, o transporte, a importação, a exportação ou a eliminação de materiais nucleares ou outras substâncias radioativas perigosas;

e) a morte, a destruição, a posse ou a captura de espécimes da fauna e da flora selvagens protegidos ou não;

f) outros atos de caráter análogo cometidos intencionalmente e que colocam em perigo a segurança do planeta.

2. Os atos referidos no parágrafo 1 afetam a segurança do planeta quando eles causam:

a) a degradação extensa, durável e grave do ar ou da atmosfera, dos solos, das águas, dos meios aquáticos, da fauna ou da flora, ou de suas funções ecológicas; ou b) a morte, a invalidez permanente ou doenças incuráveis graves a uma população, ou a desapropriação permanente dessa última de suas terras, territórios ou recursos.

3. Os atos referidos no parágrafo 1 devem ser cometidos intencionalmente e com conhecimento do caráter generalizado ou sistemático da ação em que se inserem. Esses atos são considerados como intencional quando seu autor sabia ou deveria saber que havia uma alta probabilidade de que eles afetam a segurança do planeta.

\section{Artigo 3: Participação ao crime de ecocídio}

Cada Estado-Parte adotará as medidas legislativas e outras necessárias, a fim de responsabilizar por um crime de ecocídio toda pessoa que, intencionalmente:

a) comete um tal crime, individualmente, em conjunto com uma outra pessoa, ou por intermédio de uma outra pessoa e que esta última seja ou não penalmente responsável;

b) dá a ordem, solicita ou instiga à comissão de tal crime, uma vez que haja cometimento ou tentativa de cometer esse crime;

c) com vistas a facilitar o cometimento de um tal crime, oferece sua ajuda, seu concurso ou toda outra forma de assistência para o cometimento ou a tentativa de comissão desse crime, inclusive pelo fornecimento de meios para sua comissão, particularmente pela fabricação de falsos documentos ou pela falsificação de documentos;

d) contribui de toda outra maneira para a prática ou tentativa de prática desse crime por um grupo de pessoas agindo em conjunto. Esta contribuição dever, de acordo com o caso:

i) visar a facilitar a atividade criminosa ou o propósito criminoso do grupo, quando tal atividade ou propósito envolver o cometimento de um crime de ecocídio; ou

ii) ser realizada com o conhecimento da intenção do grupo de cometer o crime;

e) tenta cometer tal crime por meio de atos que, por seu caráter substancial, constituem o começo da execução, mas sem que o crime ocorra em razão de circunstâncias independentes da sua vontade. 


\section{Artigo 4 - Imprescritibilidade}

O crime de ecocídio é imprescritível.

\section{Artigo 5 - Responsabilidade penal das pessoas morais}

1. Cada Estado-Parte, em conformidade com os seus princípios jurídicos, adota as medidas necessárias para garantir que uma pessoa jurídica possa ser responsabilizada, penalmente, por crime de ecocídio, quando cometidos em seu nome, por qualquer pessoa que exerce um poder de direção, agindo, individualmente, ou como membro de um órgão da pessoa jurídica, em virtude:

a) de um mandato da pessoa jurídica;

b) de uma autoridade para tomar decisões em nome da pessoa jurídica; ou

c) de uma autoridade para exercer um controle no seio da pessoa jurídica.

2. Cada Estado-Parte, em conformidade com os seus princípios jurídicos, adota as medidas necessárias para garantir que uma pessoa jurídica possa ser responsabilizada penalmente quando, em virtude da sua falta de vigilância ou de controle, ela tenha tornado possível a prática de um crime de ecocídio em seu nome.

3. A responsabilidade penal das pessoas jurídicas estabelecidas nos termos dos parágrafos 1 e 2 não prejudica a responsabilidade penal das pessoas físicas que participaram na acepção do artigo $3 \mathrm{em}$ um crime de ecocídio.

4. Por "pessoa jurídica", entende-se qualquer entidade dotada de personalidade jurídica nos termos da legislação aplicável, com exceção do Estado ou de entidades públicas no exercício de suas prerrogativas de autoridade pública e das organizações internacionais públicas.

\section{Artigo 6 - Sanções contra as pessoas físicas}

1. Os Estados-Partes adotam as medidas necessárias para sancionar, de maneira eficaz, proporcional e dissuasiva as pessoas físicas reconhecidamente culpadas do crime de ecocídio e para garantir a reparação dos danos ambientais e a indenização das vítimas.

2. Os Estados-Partes fazem do ecocídio um crime passível de sanções que levam em consideração sua ex- trema gravidade. Essas sanções podem assumir a forma de prisão, de multas e confisco dos benefícios, bens e valores advindos direta ou indiretamente do crime, sem prejuízo dos direitos de terceiros de boa-fé.

3. Para a escolha e a determinação da gravidade da sanção, os Estados-Partes levam em consideração especialmente os seguintes critérios:

a) Os benefícios econômicos advindo da infração, incluindo nesse caso as economias que puderam resultar da não adoção de medidas de proteção ambiental;

b) A posição hierárquica do autor da infração, o fato de que ele tenha cometido o crime no âmbito das atividades de uma pessoa jurídica ou o seu estatuto de funcionário público;

c) A pronta reparação dos danos e a indenização das vítimas;

d) O caráter organizado do crime.

4. A reparação de danos toma formas tais como:

a) Medidas de restauração ambiental,

b) Reparação por danos materiais e morais,

c) Programas de conformidade,

d) Provisionamento do Fundo para o meio ambiente,

e) Medidas de desenvolvimento local,

f) E, de acordo com as circunstâncias, medidas de reparação simbólica adaptadas à dimensão cultural do dano ambiental, que podem se expressar em pedidos de desculpas às comunidades locais.

\section{Artigo 7: Sanções contra as pessoas morais}

1. Os Estados-Partes adotam as medidas necessárias para punir, de maneira eficaz, proporcional e dissuasiva as pessoas morais reconhecidamente culpadas do crime de ecocídio e para garantir a reparação dos danos ambientais e a indenização das vítimas.

2. Os Estados-Partes adotam as medidas necessárias para punir, de maneira eficaz, proporcional e dissuasiva as pessoas morais reconhecidamente culpadas do crime de ecocídio. Em particular, os Estados-Partes consideram estabelecer as sanções seguintes:

a) Multas; 
b) Proibições, notadamente:

- A dissolução da pessoa jurídica;

- O encerramento temporário ou definitivo dos locais ou estabelecimentos da pessoa jurídica;

- A suspensão, temporária ou definitiva, do todo ou de Parte da atividade da pessoa jurídica no exercício daquela foi cometida, favorizada ou dissimulada a infração;

- A retirada de licenças, autorizações ou concessões;

- A proibição de receber subsídios e financiamentos públicos e de contratar com a administração pública.

c) Publicação da condenação. Quando há uma pluralidade de vítimas não identificadas, a publicação deve garantir que elas estejam conscientes do seu direito à indemnização;

d) Nomeação de um mandatário de justiça, a fim de que a pessoa jurídica adote as medidas organizacionais de natureza a prevenir novos crimes contra o meio ambiente ou que ela ele execute com diligência as medidas de reparação ou indenização.

3. A reparação de danos assume, notadamente, a forma de:

a) Medidas de restauração ambiental,

b) Reparação por danos materiais e morais,

c) Programas de Compliance,

d) Provisionamento do Fundo para o Meio Ambiente,

e) Medidas de desenvolvimento local,

f) E, dependendo das circunstâncias, de medidas de reparação simbólica adaptadas à dimensão cultural de danos ambientais, que podem assumir a forma de um pedido de desculpas para as comunidades afetadas.

4. Os Estados-membros adotam as medidas necessárias para impedir que as sanções ou as consequências danosas que delas decorrem possam ser garantidas.
Artigo 8 - Critérios de determinação da sanção das pessoas jurídicas

1. Para a escolha e a determinação da sanção, convém priorizar a reparação do dano e a indenização das vítimas.

2. Nos casos em que a multa possa comprometer a solvência da pessoa jurídica, a segurança dos empregos ou a reparação dos danos, os Estados-Partes podem fornecer a possibilidade de parcelar o pagamento. Nesses casos e, em conformidade com o direito interno, eles poderão, também, dar prioridade para a reparação do dano pela pessoa jurídica autora da infração.

3. Os Estados-Partes levarão em conta os seguintes critérios para a escolha e a determinação da gravidade da pena:

a) Os benefícios econômicos da infração;

b) Os benefícios econômicos da infração, incluindo nesse caso as economias que resultaram da falta de adoção de medidas de proteção ambiental;

c) A ausência ou a insuficiência de medidas de controles internos que teriam permitido a prevenção da infração;

d) A reiteração de infrações contra o meio ambiente no âmbito da ou pela pessoa jurídica. Para este fim, serão consideradas as sanções impostas às pessoas morais por outras autoridades;

e) A natureza organizada do crime;

f) A colaboração da pessoa jurídica no processo penal, em particular no estabelecimento da responsabilidade;

g) A reparação imediata dos danos e a assistência às vítimas;

h) A adoção imediata de medidas de controle interno para destinadas a prevenir infrações similares.

4. A dissolução da pessoa jurídica e o encerramento definitivo das suas instalações ou atividades só serão pronunciados se a pessoa jurídica tiver sido criada para cometer os fatos incriminados ou quando ela será considerada como parte de um grupo criminoso organizado, tal como definido no Convenção das Nações Unidas contra o Crime Organizado Transnacional. 


\section{Artigo 9 - Confisco e apreensão}

1. Os Estados-Partes devem adotar, na medida do possível em relação ao seus sistemas jurídicos nacionais, as medidas necessárias para permitir a confisco:

a) Do produto do crime derivado de infrações previstas na presente Convenção ou de bens cujo valor corresponda ao desse produto. $\mathrm{O}$ produto do crime também inclui as economias que resultam da não adoção de medidas de proteção ambiental;

b) Dos bens, equipamentos ou outros instrumentos utilizados ou destinados a serem utilizados na prática das infrações previstas na presente Convenção.

2. Os Estados-Partes adotam as medidas necessárias para permitir a identificação, a localização, o congelamento ou a apreensão dos elementos mencionados no parágrafo 1 do presente artigo, a fim de um eventual confisco.

3. Se o produto do crime tiver sido transformado ou convertido, no todo ou em parte, em outros bens, eles estão sujeitos às medidas referidas neste artigo no lugar do produto mencionado.

4. Se o produto do crime tiver sido misturado com bens adquiridos legalmente, esses bens, sem prejuízo de todos os poderes de congelamento ou de apreensão, podem ser confiscados até ao valor estimado do produto com o qual tenha sido misturado.

5. As receitas ou outros benefícios obtidos com o produto do crime, os bens nos quais o produto tenha sido transformado ou convertido ou os bens com os quais tenha sido misturado, podem também ser objeto das medidas referidas no presente artigo, da mesma maneira e na mesma medida que o produto do crime.

6. Para efeitos deste artigo e do artigo 13 da presente Convenção, cada Estado-Parte habilita seus tribunais ou outras autoridades competentes para ordenarem a produção ou a apreensão de documentos bancários, financeiros ou comerciais. Os Estados-Partes não podem invocar o sigilo bancário para recusar de dar cumprimento às disposições do presente parágrafo.

7. A interpretação das disposições do presente artigo não deve, em nenhum caso, violar os direitos de terceiros de boa fé.
8. Nenhuma disposição do presente artigo viola o princípio segundo o qual as medidas que são visadas são definidas e executadas em conformidade com o direito interno de cada Estado-Parte e segundo as disposições desse direito.

\section{Artigo 10 - Competências nacionais}

1. Cada Estado-Parte adota as medidas necessárias para estabelecer sua competência relativa ao crime de ecocídio nos casos seguintes:

a) Quando os fatos tiverem sido cometidos em todo o território sob a jurisdição desse Estado; ou

b) Quando o resultado da infração é realizado em todo o território sob a jurisdição desse Estado; ou

c) Quando a infração for cometida a bordo de um navio de seu pavilhão ou a bordo de uma aeronave matriculada no seu direito nacional no momento em que a infração é cometida; ou

d) Quando a infração for cometida por um dos seus nacionais; ou

e) Quando a infração for cometida por uma pessoa jurídica que tenha a sua sede ou o sua atividade principal ou seu principal centro administrativo no seu território; ou

f) Quando a infração for cometida contra um dos seus nacionais e que o Estado o considere apropriado.

2. Cada Estado-Parte adota, igualmente, as medidas que sejam necessárias para estabelecer sua competência nos casos em que o suposto autor de um crime de ecocídio encontra-se em seu território e que ele não o extradite, nos termos do artigo 15, para qualquer um dos Estados-Partes que tenham estabelecido sua competência de acordo com o parágrafo 1 .

3. Quando mais de um Estado-Parte declara-se competente em relação a um crime de ecocídio, os Estados-Partes interessados se esforçam para coordenar suas ações de forma adequada, em especial no que diz respeito às condições de engajamento de persecução e de modalidades de assistência jurídica mútua.

4. Sem prejuízo das normas do direito internacional geral, a presente Convenção não exclui o exercício de 
qualquer competência penal estabelecida por um Estado-Parte, em conformidade com seu direito interno.

\section{Artigo 11 - Investigação e persecução penal}

1. Se considerar que as circunstâncias justificam, depois de analisar as informações de que dispõe, qualquer Estado-Parte em cujo território se encontra uma pessoa suspeita de ter cometido um crime de ecocídio, assegura a detenção dessa pessoa ou toma todas as outras medidas legais para garantir sua presença. Essa detenção e essas outras medidas devem estar em conformidade com a legislação desse Estado; elas podem ser mantidas somente durante o tempo que for necessário para permitir o estabelecimento de um processo penal ou de um processo de extradição.

2. Tal Estado procede imediatamente a uma investigação preliminar com vistas a estabelecer os fatos.

3. Qualquer pessoa detida em virtude do parágrafo 1 deste artigo poderá se comunicar, imediatamente, com o representante competente mais próximo do Estado da sua nacionalidade ou, se for um apátrida, com o representante da Estado em que resida habitualmente.

4. Quando um Estado detém uma pessoa em custódia nos termos das disposições deste artigo, ele notifica, imediatamente, a detenção e as circunstâncias que a justificam aos Estados referidos no parágrafo 1 do artigo 10. O Estado que procede à investigação preliminar prevista no parágrafo 2 do presente artigo deve comunicar rapidamente as suas conclusões aos citados Estados e indicará se pretende exercer sua competência.

5. Este Estado deve comunicar essas informações o mais rapidamente possível ao Procurador Internacional do meio ambiente previsto no artigo 17.

\section{Artigo 12 - Participação da sociedade civil}

Cada Estado-Parte visa favorizar, em conformidade com seu direito interno, a informação da sociedade civil e sua participação aos processos penais relativos a crimes de ecocídio, de um grupo, de uma fundação ou uma associação que, de acordo com seu estatuto, tem por objetivo a proteção do meio ambiente.

\section{Artigo 13 - Extraditar ou processar}

1. O Estado-Parte, sobre o território e sob a jurisdição em que se encontra o presumível autor de um crime de ecocídio, se não o extraditar, submete o caso às suas autoridades competentes para o exercício da ação penal.

2. Essas autoridades tomarão sua decisão nas mesmas condições que para qualquer outra infração de direito comum de natureza grave nos termos do direito desse Estado.

3. Toda pessoa processada por crime de ecocídio beneficia da garantia de um tratamento equitativo em todas as fases do processo.

\section{Artigo 14 - Extradição}

1. O crime de ecocídio é automaticamente considerado como passível de extradição em qualquer tratado de extradição concluído entre os Estados-Partes antes da entrada em vigor da presente Convenção. Os Estados-Partes comprometem-se a incluir essa infração como caso de extradição em todo tratado de extradição futuramente concluído.

2. Um Estado-Parte que condiciona a extradição à existência de um tratado tem a faculdade, quando receber um pedido de extradição de outro Estado-Parte com o qual não está vinculado por um tratado de extradição, de considerar esta Convenção como a base jurídica para a extradição relativamente ao crime de ecocídio. A extradição estará sujeita às demais condições previstas pela legislação do Estado requerido.

3. Os Estados-Partes que não condicionam a extradição à existência de um tratado reconhecendo o crime de ecocídio como caso de extradição entre eles, sem prejuízo das condições previstas pela legislação do Estado requerido.

4. Se necessário, o crime de ecocídio é considerado, para efeitos de extradição entre os Estados-Partes, como cometido tanto no lugar de sua perpetração como no território dos Estados que estabeleceram sua competência de acordo com o artigo 10.

5. Para fins de extradição ou assistência jurídica mútua entre os Estados-Partes, o crime de ecocídio não pode ser considerado como uma infração política, 
como uma infração conexa à uma infração política ou como uma infração inspirada por motivos políticos. Por conseguinte, um pedido de extradição ou de assistência jurídica mútua com base em tal infração não poderá ser recusada pela simples razão de que se trata de uma infração política, uma infração conexa a uma infração política ou uma infração inspirada por motivos políticos.

\section{Artigo 15 - Assistência jurídica mútua}

1. Os Estados-Partes acordam, mutualmente, uma ampla assistência jurídica para as investigações, os processos e os procedimentos judiciais relativos ao crime de ecocídio.

2. A assistência jurídica mútua é baseada no princípio do reconhecimento mútuo das sentenças e decisões judiciais dos Estados Partes.

3. A mais ampla assistência jurídica mútua possível é concedida, desde que as leis, tratados, acordos e arranjos pertinentes do Estado-Parte requerido a permita, quando das investigações, processos e procedimentos judiciais relativos a infrações pelas quais uma pessoa jurídica possa ser passível de responsabilidade no Estado-Parte requerente, em conformidade com o artigo 5 da presente Convenção.

4. A assistência jurídica mútua é realizada, também, em processos por fatos puníveis nos termos do direito nacional do Estado-Membro requerente ou do Estado-Membro requerido, ou ambos, a titulo de violações das regras investigadas pelas autoridades administrativas, cuja decisão pode gerar um processo perante um tribunal competente, notadamente em matéria penal.

5. Os Estados-Partes poderão invocar a falta de dupla incriminação para recusar dar seguimento a um pedido de assistência nos termos do presente artigo. $\mathrm{O}$ Estado-Parte requerido poderá, contudo, quando considerar apropriado, prestar essa assistência, na medida em que ele decide a seu critério, independentemente do fato que a conduta possa constituir ou não uma infração nos termos do direito nacional do Estado-Parte requerido.

6. Cada Estado-Parte designa uma autoridade central que tem a responsabilidade e o poder de receber as demandas de assistência jurídica mútua e, seja executá-las, seja transmiti-las às autoridades competentes para execução. As autoridades centrais garantem a execução ou a transmissão rápida e em adequada forma das de- mandas recebidas.

7. As demandas são endereçadas por escrito ou, se possível, por todo outro meio que possa produzir um documento escrito, em uma língua aceitável para o Estado-Parte requerido, nas condições que permitem a esse Estado de estabelecer sua autenticidade. Em caso de urgência e se os Estados-Parte convêm, as demandas podem ser feitas oralmente, mas devem ser confirmadas sem prazo por escrito.

8. Toda demanda é executada em conformidade com o direito interno do Estado-Parte requerido e, na medida em que ela não contrarie o direito interno desse Estado e quando é possível, de acordo com os procedimentos especificados na demanda.

9. A assistência jurídica mútua pode ser refusada:

a) Se a demanda não é feita em conformidade com as disposições do presente artigo;

b) Se o Estado Parte requerido estima que a execução da demanda é suscetível de causar um prejuízo à sua soberania, à sua segurança, à sua ordem pública ou a outros interesses essenciais;

c) Caso o direito interno do Estado Parte requerido proíba suas autoridades de tomar as medidas demandadas tratando-se de uma infração análoga tendo sido objeto de uma investigação, de um processo ou de um processo judiciário no quadro de sua própria competência;

d) Caso ele seria contrário ao sistema jurídico do Estado-Parte requerido relativamente à assistência jurídica mútua de aceitar a demanda.

10. Toda recusa de assistência jurídica mútua deve ser motivada. Antes de recusar um pedido de assistência ou adiar sua execução, nos termos do parágrafo 11, o Estado-Parte requerido deve estudar com o Estado-Parte requerente a possibilidade de conceder a assistência sob reserva das condições que ele considerar necessárias. Se o Estado-Parte requerente aceitar a assistência jurídica mútua sujeita a condições, ele deverá respeitá-las.

11. O Estado-Parte requerente deverá executar a demanda de assistência jurídica mútua o mais rapidamente possível e deve levar em conta, na medida do possível, todos os prazos sugeridos pelo Estado-Parte requerente e que estão motivados de preferência na demanda. A assistência pode ser adiada pelo Estado-Parte requerido pelo motivo que ela interfere em uma investigação 
em curso, uma ação judicial ou um processo judicial em curso.

\section{Artigo 16 - Cooperação internacional}

1. Os Estados-Partes concordam, em conformidade com as disposições dos instrumentos internacionais pertinentes em matéria de cooperação internacional em matéria penal e com seu direito interno, com a mais ampla cooperação em investigações e processos judiciais relacionados com o crime de ecocídio.

2. Os Estados-Partes, na investigação e na persecução do crime de ecocídio, cooperam, ativamente, com o órgão do Procurador internacional previsto no artigo 17.

\section{Artigo 17 - Competência do Procurador Interna- cional do Meio Ambiente}

1. A Assembleia dos Estados-Partes elege por 5 anos um Procurador Internacional do meio ambiente independente, complementar às autoridades judiciais nacionais.

2. O Procurador Internacional é competente para investigar e reunir provas relativas a supostos atos de ecocídio levadas ao seu conhecimento, pelas autoridades nacionais dos Estados-Partes, por instituições regionais e internacionais interessadas na luta contra o criminalidade ambiental, pela sociedade civil ou pelo GREEN.

3. Os Estados-Partes designam um procurador nacional como correspondente do Procurador Internacional do meio ambiente.

4. O Procurador Internacional do Meio Ambiente presta apoio às autoridades nacionais e contribui para a coordenação das investigações e dos procedimentos penais.

\section{Artigo 18 - Criação de um Tribunal Penal Inter- nacional do Meio Ambiente}

Os Estados-Partes cooperam a fim de criar um Tribunal Penal Internacional para o Meio Ambiente, complementar das jurisdições nacionais, competente para julgar o crime de ecocídio.

\section{Capítulo 2: Medidas preventivas}

\section{Artigo 19 - A cooperação internacional em ma- téria de prevenção}

1. Os Estados-Partes cooperam para prevenir o crime de ecocídio, adotando todas as medidas possíveis, especialmente, se necessário, adaptando sua legislação nacional, para evitar e impedir a preparação em seus respectivos territórios de infrações a serem cometidas no interior ou fora do seu território.

2. Os Estados-Partes cooperam, também, para a prevenção do crime ecocídio, por meio da troca de informações precisas e verificadas em conformidade com sua legislação interna e por meio da coordenação de medidas administrativas e de outras medidas tomadas.

3. Os Estados-Partes podem trocar informações pelo intermédio de instituições regionais e internacionais interessadas na luta contra a criminalidade ambiental, incluindo a Interpol, a Europol e o Escritório das Nações Unidas sobre drogas e crime.

4. Os Estados-Partes dispensam ou reforçam a formação adequada dos profissionais pertinentes que tratam de autores e suspeitos de um crime de ecocídio e de suas vítimas.

5. Os Estados-Partes se esforçam para sensibilizar o público quanto à existência, às causas e à gravidade da criminalidade ambiental e à ameaça que ela representa. Eles podem fazê-lo, se necessário, por intermédio dos meios de comunicação social e pela adoção de medidas destinadas a promover a participação do público nas atividades de prevenção e de repressão desse crime.

6. Os Estados-Partes informam o Secretário da presente Convenção o nome e o endereço da autoridade ou das autoridades que podem ajudar as outras Partes a desenvolver as medidas de prevenção do crime de ecocídio.

7. Os Estados-Partes colaboram, conforme sua conveniência, entre eles e com as instituições regionais e internacionais competentes, para desenvolver e promover 
as medidas visadas pelo presente capítulo.

\section{Artigo 20 - Competência do Grupo de Pesqui- sa e de Investigação para o Meio Ambiente37 (GREEN)}

1. O Grupo de Pesquisa e de Investigação para o Meio Ambiente (GREEN) procede à constatação dos fatos materiais suscetíveis de corresponder à definição do crime de ecocídio e à formulação de opiniões sobre a criminalidade ambiental internacional.

2. O GREEN age com base na demanda de um ou mais Estados-Partes, do Secretariado da Convenção, do Procurador Internacional do Meio Ambiente, de todas as outras instituições encarregadas de lidar com os mais graves crimes ambientais ou com base em um comunicação da sociedade civil.

3. O GREEN é composto por 20 membros eleitos pelos Estados-Partes, de acordo com uma distribuição geográfica equitativa. Os membros do GREEN exercem suas funções a título individual. Eles devem gozar de caráter jurídica elevado e beneficiar de experiência reconhecida em matéria ambiental.

4. O GREEN pode solicitar aos Estados-Partes e às instituições nacionais, regionais e internacionais competentes todas as informações e toda a assistência que considerar necessárias, a fim de lhe permitir-lhe cumprir sua missão.

5. O GREEN pública, anualmente, um relatório de atividades.

\section{Capítulo 3: Aplicação da Convenção}

\section{Artigo 21 - Proteção da soberania}

1. Os Estados-Partes cumprirão as obrigações decorrentes da presente Convenção em conformidade com os princípios de igualdade soberana e de integridade territorial dos Estados, assim como da não ingerência nos assuntos internos de outros Estados.

2. Nenhuma disposição da presente Convenção autoriza qualquer Estado-Parte a exercer, no território de outro Estado-Parte, uma competência ou funções

37 Em francês: Groupe de Recherche et d'Enquête pour l'Environnement (GREEN). exclusivamente reservadas às autoridades desse outro Estado-Parte por seu direito interno.

\section{Artigo 22 - Implementação da Convenção}

1. Cada Estado-Parte adota as medidas necessárias, incluindo legislativas e administrativas, de acordo com os princípios fundamentais de sua legislação interna, para garantir o cumprimento das suas obrigações em virtude da presente Convenção.

2. Cada Estado-Parte poderá adotar medidas mais estritas ou mais severas do que as previstas pela presente Convenção para prevenir e punir os crimes internacionais mais graves contra o meio ambiente.

3. As disposições da presente Convenção são aplicadas e interpretadas de acordo com as regras do direito internacional geral e os princípios do direito internacional do meio ambiente, notadamente o princípio de responsabilidades comuns, mas diferenciadas.

\section{Artigo 23 - Exame do cumprimento das disposi- ções}

1. A Assembleia dos Estados-Partes adota, por consenso, disposições de caráter não conflituoso, de natureza não judicial e consultiva para examinar o cumprimento das disposições da presente Convenção.

2. Essas disposições deverão permitir uma apropriada participação do público e prever a opção de se admitirem comunicações de membros do público sobre questões relacionadas à presente Convenção.

3. O procedimento adotado por consenso para o exame do cumprimento das disposições da presente Convenção aplica-se sem prejuízo do processo de resolução de litígios previstos no artigo 26. Sempre que possível, as Partes deverão utilizar procedimentos preliminares relativos ao cumprimento antes de recorrer a mecanismos de solução de disputas.

\section{Artigo 24 - Solução de controvérsias}

1. Se surgir uma controvérsia entre duas ou mais Partes quanto à interpretação ou a aplicação dessa Convenção, elas devem se esforçar para resolvê-la pela via da negociação ou por qualquer outro meio de resolução de disputas que elas considerarem aceitável. Além disso, 
as Partes procuram a melhor solução para o estado do meio ambiente e o respeito de seus direitos, pela implementação anterior e, na medida do que é apropriado, do procedimento de exame do respeito das disposições previsto no artigo 25.

2. Quando uma Parte assina, ratifica, aceita, aprova ou adere à presente Convenção, ou em qualquer momento posterior, ela pode declarar por escrito ao depositário que, no caso de disputas não foram resolvidas em conformidade com o parágrafo 1 acima, ela aceita como obrigatório um dos dois ou ambos os meios de solução de controvérsias abaixo em suas relações com qualquer Parte que aceite a mesma obrigação:

a) A submissão da controvérsia à Corte Internacional de Justiça;

b) A submissão da controvérsia à arbitragem;

3. Se as Partes na controvérsia aceitarem os dois meios de solução de controvérsias referidos no parágrafo 2 acima, a controvérsia poderá ser submetida apenas à Corte Internacional de Justiça, a menos que elas acordem o contrário.

\section{Artigo 25 - Medidas cautelares}

1. Se uma corte, um tribunal ou um órgão responsável pelo exame do respeito da Convenção, regularmente invocado por uma controvérsia ou uma situação que considere, prima facie, que tem jurisdição sobre a controvérsia ou sobre a situação, em conformidade com a presente Convenção, esse tribunal ou esse órgão pode prescrever quaisquer medidas cautelares que considere apropriadas à circunstância a fim de evitar o grave prejuízo ambiente ou para preservar os direitos respectivos das Partes em litígio, aguardando a decisão final.

2. As medidas cautelares podem ser modificadas ou retiradas no momento em que as circunstâncias que as justificavam mudem ou deixem de existir.

3. Medidas cautelares podem ser prescritas, modificadas ou retiradas em virtude do presente artigo pela demanda de uma Parte à controvérsia ou de todo membro do público interessado e habilitado a apresentar comunicações. As medidas cautelares podem ser prescritas, modificadas ou retiradas somente depois que a possibilidade de ser ouvido tenha sido dada às Partes.

4. A corte, o tribunal ou o órgão responsável pelo cumprimento da Convenção notifica imediatamente as diferentes Partes à controvérsia de qualquer medida cautelar ou qualquer decisão de modificação ou de retirada e, se considerar apropriado, quaisquer outras pessoas que julgar interessada.

5. Enquanto aguarda a constituição de um tribunal arbitral para apreciar a controvérsia nos termos do artigo 26, qualquer órgão jurisdicional designado de comum acordo pelas Partes ou, na falta de acordo no prazo de duas semanas a contar da data do pedido de medidas cautelares, a Corte Internacional de Justiça pode prescrever, modificar ou revogar medidas cautelares em conformidade com o presente artigo, se considerar que, prima facie, o tribunal a ser constituído teria jurisdição e se ela estima que a urgência da situação exige. Uma vez constituído, o tribunal que julgará a controvérsia, de acordo com os parágrafos 1 a 4, pode modificar, revogar ou confirmar essas medidas cautelares.

6. As Partes à controvérsia se conformam sem demora a todas as medidas cautelares prescritas em virtude deste artigo.

\section{Capítulo 4: Disposições Finais}

$\mathrm{Na}$ ausência de especificidade própria em matéria de crime de ecocídio, as disposições finais não serão na presente objeto de desenvolvimentos. 


\title{
Engaging the U.N. Guiding Principles on Business and Human Rights: the inter- american commission on human rights \& the extractive sector*
}

\author{
Relacionando os Princípios Orientadores das \\ Nações Unidas sobre Empresas e Direitos \\ Humanos a Comissão Interamericana de \\ Direitos Humanos e o setor extrativista
}

Cindy S. Woods**

\begin{abstract}
Following the adoption of the U.N. Guiding Principles on Business and Human Rights (Guiding Principles) in 2011, states have increasingly engaged with the need to protect against and remedy corporate human rights abuses. This can be seen in the proliferation of National Action Plans (NAPs) on business and human rights (BHR). Many countries through the Americas have begun drafting BHR NAPs, and engaging in other activities to promote corporate accountability and social responsibility. As the normalization of BHR standards continues in the region, it is important for the Inter-American Commission on Human Rights (IACHR) to take a lead role in setting regional standards for the state responsibility to protect against and remedy corporate human rights abuse. This paper illustrates, through a discussion of the IACHR's mandate and functions, along with an analysis of the Commission's work in the extractive sector that the IACHR is both capable of and obliged to engage with the Guiding Principles.
\end{abstract}

Keywords:

1. Business and Human Rights

2. Inter-american Commission on Human Rights

3. Extractives

4. UN Guiding Principles

5. ESCR Unit

* Recebido em 10/09/2015

Aprovado em 06/10/2015

** J.D. Georgetown University Law Center; M.Phil., University of Cambridge; B.A., University of Oklahoma. The author would like to thank the editors of the Brazilian Journal of International Law, her family for their support, and of course, El Ruts. C 2015, Cindy S. Woods. E-mail: csw58@georgetown.edu

\section{INTRODUCTION}

In recent years, the business and human rights movement has climbed to the top of the international human rights agenda. Starting in the 1970s, as multinational corporations increased in fiscal and political power throughout the neoliberal boom of the era, and as corporate complicity in large scale human rights abuses came to light, civil society and governments alike 
began to push for increased corporate accountability. ${ }^{1}$ After multiple failed endeavors within the United $\mathrm{Na}-$ tions system at drafting a binding code of conduct for transnational corporations, in 2011, the Human Rights Council adopted the Guiding Principles on Business and Human Rights (Guiding Principles). ${ }^{2}$ These principles lay out, in three pillars, the state duty to protect individuals against human rights abuses; the corporate responsibility to respect human rights; and the need for greater access to judicial and non-judicial remedies for victims of corporate human rights abuse. ${ }^{3}$ Following the endorsement of the Guiding Principles, the subsequently created Working Group on the issue of human rights and transnational corporations and other business enterprises called upon states to begin operationalizing the Guiding Principles through the creation of National Action Plans (NAPs)_- "evolving policy strateg[ies]" aimed at creating cohesive and coherent implementation. ${ }^{4}$ Over thirty countries have committed to creating a NAP, including many within the inter-American system, signaling the region's readiness to engage with the Guiding Principles. ${ }^{5}$

1 The Bhopal gas tragedy of 1984 is probably the most cited case of corporate complicity in human rights abuse, though calls for an international code of conduct for TNCs began in the mid-seventies. See, Address Delivered by Salvador Allende Gossens, President of Chile, at the inaugural ceremony on 13 April 1973, United Nations Conference on Trade and Development, Proceedings of the United $\mathrm{Na}$ tions Conference on Trade and Development, Apr. 13-May 21, 1972, 62, U.N. Doc. TD/180 (Vol. 1), Annex VIII (1973).

2 U.N. Special Representative of the Secretary-General, Guiding Principles on Business and Human Rights: Implementing the United Nations "Protect, Respect and Remedy" Framework: Rep. of the Special Representative of the Secretary-General on the Issue of Human Rts. and Transnat'l Corp. and other Bus. Enter., John Ruggie, Annex, U.N. Doc. A/HRC/17/31 (Mar. 21, 2011) [hereinafter Guiding Principles]. For more on past attempts at drafting a binding code of conduct, see Cindy S. Woods, "It Isn't A State Problem": The Minas Conga Mine Controversy and the Need for Binding International Obligations on Corporate Actors, 46 Geo. J. Int. L. 629, 635-39 (2015).

3 Guiding Principles, supra note 2.

4 U.N. Working Group on Business and Human Rights, Guidance on National Action Plans on Business and Human Rights ii (2014) [hereinafter Working Group Guidance].

5 Compare State National Action Plans, U.N. Human Rights Office of the High Commissioners for Human Rights, http://www. ohchr.org/EN/Issues/Business/Pages/NationalActionPlans.aspx (last visited Apr. 8, 2015) with National Action Plans, Business \& Human Rights Resource Center. http://business-humanrights.org/en/ un-guiding-principles/implementation-tools-examples/implementation-by-governments/by-type-of-initiative/national-action-plans (last visited Apr. 8, 2015). Countries within the region committed to forming a NAP include, Argentina, Brazil, Chile, Colombia, Guatemala, Mexico, and the United States. Id.
The Guiding Principles were favorably received throughout the international community, not only by states, but also regional bodies; the General Assembly of the Organization of American States (OAS) endorsed the principles in June 2014. ${ }^{6}$ As the supreme organ of the OAS, the General Assembly requested the Inter-American Commission on Human Rights (IACHR) to "continue supporting states in the promotion and application of the state and business commitments in the area of human rights and business." However, the IACHR has been slow on the uptake. Some merit this lethargy to unfamiliarity on the Commission's part with the new business and human rights lexicon, while others question if the mandate of the IACHR is adequate to allow the Commission to implementation the Guiding Principles. This paper aims to put both of these mistaken assumptions to rest by illustrating that not only is the promotion of the Guiding Principles squarely within the Inter-American Commission's mandate, but also that the Commission is well-versed in issues of business and human rights, through an analysis of the inter-American human rights system's prior decisions, hearings and reports. In demonstrating the latter point, the paper will focus on the extractive industry; arguably one of the sectors most fraught with corporate human rights abuses in the Americas. Finally, the paper will go one step further, and illustrate the importance of the IACHR's engagement with the Guiding Principles.

The paper will progress as follows: Part II introduces the Guiding Principles in greater detail, before turning to a discussion regarding the implementation of the principles in domestic spheres. Part III focuses on the inter-American system, introducing the Inter-American Commission, overviewing its functions and clarifying its mandate. Part IV illustrates how the Commission has been engaging with the topic of business and human rights through its work regarding the extractive sector, focusing on three main issues: indigenous peoples' rights, criminalization of human rights defenders, and private security. Part V argues that the Commission should and must engage with the principles because it has been request to by the OAS General Assembly, has the ability to set normative standards in the field, and should seek to close gaps in accountability. Part VI

6 Organization of American States, Resolution Promotion and Protection of Human Rights in Business, OAS AG/RES. 2840 (XLIV-O/14) (June 4, 2014) [hereinafter OAS Resolution].

7 Id. at 3 . 
concludes by suggesting that the Commission can and should begin effectively and explicitly engaging the Guiding Principles within the inter-American system.

\section{The U.N. Guiding Principles on Business and Human Rights}

The U.N. Guiding Principles on Business and Human Rights were unanimously endorsed by the Human Right Council in 2011. The principles are the culmination of Professor John Ruggie's six-year mandate to identify and clarify standards of corporate responsibility and accountability for multinational corporations and explicate the duties of States in regulating and adjudicating the role of multinational corporations with regards to human rights. ${ }^{8}$

\section{A. The Three Pillars}

The Guiding Principles are based on a three-pillared "Protect, Respect, and Remedy" Framework, which establishes the (1) state duty to protect human rights; (2) the corporate responsibility to respect human rights; and (3) the need for greater access to remedy, both judicial and non-judicial, for victims of business-related abuse. ${ }^{9}$ The following is a brief discussion of each pillar, highlighting the pertinent principles for subsequent analysis.

\section{State Duty to Protect}

States are obligated to protect individuals within their jurisdiction against human rights abuses caused by corporate actors. ${ }^{10}$ This obligation requires that states take appropriate steps to "prevent, investigate, punish and redress such abuse through effective policies, legislation, regulations and adjudication." ${ }^{11}$ In part, states

8 Comm'n on Human Rights Res. 2005/69, Human Rights and Transnational Corporations and Other Business Enterprises, U.N. Doc.E/CN.4/RES/2005/69 (Apr. 20, 2005).

9 Special Rep. of the Sec'y Gen. on the issue of human rights and transnat'l corps. and other bus. enters., John Ruggie, Promotion and Protection of All Human Rights, Civil, Political, Economic, Social and Cultural Rights, Including the Right to Development: Protect, Respect and Remedy: a Framework for Business and Human Rights, U.N. Doc. A/HRC/8/5 (Apr. 7, 2008).

10 Id. princ. 1.

11 Id. should enforce de jure and de facto laws which require businesses to respect human rights, periodically reassessing the adequacy of these laws, and provide effective guidance to corporate actors regarding how to respect human rights within their operations. ${ }^{12}$ States should take additional steps to protect individuals against human rights abuses caused by parastatal corporations or other business enterprises substantially supported by the state. ${ }^{13}$ In conflict-affected areas, where the control over territory, resources or a Government itself is contested and the risk of human rights abuses is heightened, states have additional human rights duties to ensure that corporations are not involved in causing or exacerbating human rights abuses. ${ }^{14}$ These auxiliary duties include "engaging at the earliest stage possible with business enterprises to help them identify, prevent and mitigate the human rights-related risks of their activities and business relationships" and "providing adequate assistance to business enterprises to assess and address the heightened risk of abuses, paying special attention to both gender-based and sexual violence." ${ }^{15}$

\section{Corporate Responsibility to Respect}

While there is no legal obligation for corporations' to uphold human rights norms, business enterprises have a responsibility to respect internationally recognized human rights. ${ }^{16}$ This responsibility exists independently from states' ability or willingness to uphold their human rights duties, and above and beyond compliance with national laws and regulations that seek to protect human rights. ${ }^{17}$ The corporate responsibility to respect is twofold: (1) corporations should avoid infringing on the human rights of others through their activities but address such impacts when they occur and, (2) they should seek to prevent or mitigate adverse human rights impacts that are "directly linked to their operations, products or services by their business relationships," even if they have not directly contributed

\footnotetext{
12 Id. princ. 3.

13 Id. princ. 4.

14 Id. princ. 7.

15 Id.

16 Id. princ. 11. These rights are understood, at a minimum, to encompass the rights expressed in the International Bill of Human Rights and the fundamental rights protected in the International Labor Organization's (ILO) Declaration on Fundamental Principles and Rights at Work. Id. princ. 12.

17 Id. princ. $11 \mathrm{cmt}$.
} 
to the harm. ${ }^{18}$ Addressing human rights impacts means, "taking adequate measures for their prevention, mitigation and where appropriate, remediation." ${ }^{19}$ In order for corporations to identify, mitigate and account for how they address adverse human rights impacts, they should carry out human rights due diligence, which should include "assessing actual and potential human rights impacts, integrating and acting upon the findings, tracking responses, and communicating how impacts are addressed." ${ }^{20}$ Some ways to gauge human rights risks include seeking meaningful consultation with potentially affected groups and other stakeholders, and drawing on internal and independent external human rights expertise. $^{21}$

\section{Access to Remedy}

States must ensure, through judicial, administrative, legislative or other appropriate means that victims of business-related human rights abuse have access to effective remedy. ${ }^{22}$ Failure to investigate, punish and redress corporate human rights abuses renders the state duty to protect meaningless. ${ }^{23}$ States should therefore ensure the effectiveness of their domestic judicial mechanisms in the context of addressing corporate human rights abuses; this includes reducing legal, practical and other barriers that could lead to a failure by victims to access remedy. ${ }^{24}$ State-based and non-state-based grievance mechanisms can also be used as an alternative source of remedy for corporate human rights abuses. ${ }^{25}$ However, in order to be effective, these non-judicial grievance mechanisms should be legitimate, accessible, predictable, equitable, transparent, rights-compatible, and a source of continuous learning. ${ }^{26}$

\section{B. Moving Forward: Implementing the Guiding Principles}

Following its endorsement of the Guiding Principles, the Human Rights Council established a Working

$\begin{array}{ll}18 & \text { Id. princ. } 13 . \\ 19 & \text { Id. } \\ 20 & \text { Id. princ. } 17 . \\ 21 & \text { Id. princ. } 18 . \\ 22 & \text { Id. princ. } 25 . \\ 23 & \text { Id. } \\ 24 & \text { Id. princ. } 26 . \\ 25 & \text { Id. princ. } 27-31 . \\ 26 & \text { Id. princ. } 31 .\end{array}$

Group on the issue of human rights and transnational corporations and other business enterprises (Working Group), requesting it, in part, to "promote the effective and comprehensive dissemination and implementation of the Guiding Principles." ${ }^{27}$ In this regard, the Working Group has encouraged all states to develop and enact National Action Plans (NAPs), fluid policy strategies aimed at preventing corporate human rights abuses through the promotion of the Guiding Principles. ${ }^{28}$ The Working Group and a number of civil society organizations have developed guidance on the development of NAPs. ${ }^{29}$ According to the Working Group, one essential criterion for the creation of an effective NAP is the meaningful involvement of interested stakeholders in an inclusive and transparent process. ${ }^{30}$

As of April 2015, more than thirty countries have committed to or have drafted NAPs, including at least six countries within the inter-American system. ${ }^{31}$ In line with prevailing guidance, many of these countries have reached out to civil society organizations and other interested stakeholders for inputs, evaluations and guidance, including the U.S. process of public consultations in collaboration with universities and civil society organizations and the Mexican government's engagement with domestic and international civil society organizations. ${ }^{32}$ Accompanying this rising interest in and collaboration on the development of NAPs in the Western Hemisphere have come calls for the increased participation of the Inter-American Commission on Human Rights in regional NAPs processes. ${ }^{33}$ For example, in

27 Human Rights Council Res. 17/4, Human rights and transnational corporations and other business enterprises, 17th Sess., U.N. Doc. A/HRC/Res/17/4 (July 6, 2011).

28 Working Group Guidance, supra note 4 at ii.

29 See, e.g., Id.; The Danish Institute for Human Rts. \& The Int'l Corp. Accountability Roundtable, National Action Plans on Business and Human Rights: A Toolkit for the Development, Implementation and Review of State Commitments to Business and $\mathrm{Hu}-$ man Rights 16-17 (2014).

30 Working Group Guidance, supra note 4 at ii.

31 See supra note 5.

32 See, Christopher Smart, Announcement of Opportunity to Provide Input into the U.S. National Action Plan on Responsible Business Conduct, U.S. National Security Council (Nov. 20, 2014; 1:29 PM), https:// www.whitehouse.gov/blog/2014/11/20/announcement-opportunity-provide-input-us-national-action-plan-responsible-business(last visited Apr. 10, 2015); ICAR \& PODER Partner to Support the Development of a National Action Plan on Business \& Human Rights in Mexico, International Corporate Accountability Roundtable, http:// accountabilityroundtable.org/analysis/icarpoderprojectmexiconap/ (last visited Apr. 10, 2015).

33 See, e.g., Letter to the Inter-American Commission on Human Rights 
December the Chilean government announced that it had begun the NAP process and would "look to the [Inter-American] Commission for advisement throughout [the] process." ${ }^{34}$ With the growing number of countries within the inter-American system committed to drafting NAPs, it is time for the Inter-American Commission to take a leadership role in this emerging human rights movement in the region.

\section{The Inter-American Commission on Hu- MAN RIGHTS}

The Inter-American Commission on Human Rights (IACHR) was formed in 1959 by the Organization of American States as an autonomous organ tasked with the promotion and protection of human rights. Since its inception, the IACHR has monitored state activities and served as a focal point of human rights consensus within the region. As calls for increased Commission engagement with the Guiding Principles become stronger, some question whether the IACHR has the mandate or capacity to widen its scope to broader issues of business and human rights. However, an overview of the Commission's mandate and structure reveals this possibility to be well within the realm of the IACHR's authority.

\section{A. The IACHR's Mandate and Functions}

The principal function of the Commission is to "promote the observance and protection of human rights" in the Western Hemisphere. ${ }^{35}$ The American Convention on Human Rights in 1969 defines in more specific terms the functions and powers of the Com-

on Integrating Business and Human Rights, International Corporate Accountability Roundtable (Dec. 18, 2014), http://accountabilityroundtable.org/wp-content/uploads/2014/12/ICAR-Letter-toInter-American-Commission.pdf (last visited Apr. 10, 2015).

34 Id.; see also, Subsecretario Edgardo Riveros participó en Foro Anual sobre Derechos Humanos y Empresas en Naciones Unidas, Ministerio de Relaciones Exteriores de Chile (Dec. 2, 2014), http://www.minrel.gov.cl/subsecretario-edgardo-riveros-participo-en-foro-anualsobre-derechos-humanos-y-empresas-en-naciones-unidas/minrel/2014-12-03/100147.html (last visited Apr. 10, 2015).

35 Organization of American States, Charter of the Organization of American States (Signed in Bogotá in 1948 and amended by the Protocol of Buenos Aires in 1967, by the Protocol of Cartagena de Indias in 1985, by the Protocol of Washington in 1992, and by the Protocol of Managua in 1993), Apr. 30, 1948, 1609 U.N.T.S. 48. mission, which include:

(a.) to develop an awareness of human rights among the peoples of America;

(b.) to make recommendations to the governments of the member states, when it considers such action advisable, for the adoption of progressive measures in favor of human rights within the framework of their domestic law and constitutional provisions as well as appropriate measures to further the observance of those rights;

(c.) to prepare such studies or reports as it considers advisable in the performance of its duties;

(d.) to request the governments of the member states to supply it with information on the measures adopted by them in matters of human rights;

(e.) to respond, through the General Secretariat of the Organization of American States, to inquiries made by the member states on matters related to human rights and, within the limits of its possibilities, to provide those states with the advisory services they request;

(f.) to take action on petitions and other communications pursuant to its authority under the provisions of Articles 44 through 51 of this Convention; and

(g.) to submit an annual report to the General Assembly of the Organization of American States. ${ }^{36}$

These functions and powers are further refined by the Statute of the IACHR, which provides more context to the Commission's mandate, especially regarding individual petitions. ${ }^{37}$ While the IACHR mandate is quite broad, the work of the Commission generally falls within three main categories: the (1) individual petition system; (2) monitoring of Member States human rights situations; and (3) special attention to priority thematic areas.

\section{Individual Petition System}

The Commission has the authority to act on petitions containing denunciations or complaints alleging violation of the American Convention on Human Rights or the American Declaration of the Rights and Duties of Man brought by any individual, group of persons, or nongovernmental entity legally recognized

36 Organization of American States, American Convention on Human Rights, "Pact of San Jose", Costa Rica, Nov. 22, 1969, OAS Treaty Series No. 36; 1144 U.N.T.S. 123 [hereinafter Pact of San Jose].

37 Organization of American States, Statute of the Inter-American Commission on Human Rights, Oct. 1, 1979, O.A.S. Off. Rec. OEA/ Ser.P/IX.0.2/80, Vol. 1 at 88. 
in a member state. ${ }^{38}$ While the Commission's finding in any case brought before it is not considered binding, it does have the authority to forward cases of violations of the American Convention to the Inter-American Court on Human Rights, whose findings are binding on those member state that have accepted its jurisdiction. ${ }^{39}$ Through the petition system, the Commission can also call on states to adopt precautionary measure to avoid serious and irreparable harm to life and personal integrity. ${ }^{40}$

\section{Member State Monitoring}

The IACHR also monitors member states through the presentation of its Annual Report to the General Assembly and the publication of special reports on the human rights situation in member states or specific human rights problems within the region..$^{41}$ Additionally, the Commission carries out in loco visits to monitor human rights situations at the request or permission of member states to investigate specific situations or take broader stock of the general situation of human rights in the state. ${ }^{42}$

\section{Priority Thematic Areas}

In relation to priority thematic areas, the Commission maintains nine rapporteurships on broad topics of human rights. ${ }^{43}$ These rapporteurships are aimed at strengthening, promoting and systematizing the IACHR's work surrounding these groups, communities

38 American Convention on Human Rights, supra note 42 at art. 44; Statute of the Inter-American Commission on Human Rights, supra note 44 at art. 19-20.

39 Petition and Case System Informational Brocbure, Inter-American Commission on Human Rights, https://www.oas.org/en/iachr/ docs/pdf/HowTo.pdf (last visited Apr. 13, 2015).

40 Organization of American States, Rules of Procedure of the Inter-American Commission on Human Rights, Annual Report of the Inter-American Court of Human Rights, 1991, O.A.S. Doc. OEA/ Ser.L/V/III.25 doc. 7 at 18 (1992).

41 Statute of the Inter-American Commission on Human Rights, supra note 44 at art. 18 .

42 Id.

43 Themes of the rapporteurships include the freedom of expression; human rights defenders; and the rights of indigenous peoples; women; migrants; children; persons deprived of liberty; afro-descendants and against racial discrimination; lesbian, gay, trans, bisexual, and intersex persons. Thematic Rapporteurships and Units, Organization of American States, http://www.oas.org/en/ iachr/mandate/rapporteurships.asp (last visited Apr. 13, 2015). and peoples particularly at risk of human rights abuses. ${ }^{44}$ In 2012, as part of the IACHR Strengthening Process, the Commission created the Unit on Economic, Social, and Cultural Rights (ESCR Unit). ${ }^{45}$ This new thematic area has the mandate to "cooperate with the analysis and evaluation of the situation of these rights in the Americas, provide advice to the IACHR in the proceedings of individual petitions, cases and request of precautionary measures and provisional measures which address these rights, undertake working visits to the OAS Member States and prepare studies and publications." 46 Some within the organization sees the ESCR Unit as the actor most poised to engage at a high level with the business and human rights movement, especially the Guiding Principles. ${ }^{47}$ However, thus far, little has been done within the Commission to promote this new international human rights standard.

\section{B. Squaring the IACHR's functions with the Gui- ding Principles}

In 2014, the General Assembly of the OAS endorsed the Guiding Principles, vowing to continue promoting their application and urging member states to disseminate the Guiding Principles and the best practices surrounding their implementation. ${ }^{48}$ It also requested that the Inter-American Commission "continue supporting states in the promotion and application of state and business commitments in the area of human rights and business." ${ }^{\text {49 }}$ However, the Commission has been slow to take up this charge. Some question whether this relative inaction is the result of the functional inadequacy of the Commission's mandate to engage with the Guiding Principles; however, this view can be easily dismissed by

\section{Id.}

45 Unit on Economic, Social and Cultural Rights, Organization of American States, http://www.oas.org/en/iachr/desc/ (last visited Apr. 13, 2015). For more information on the Strengthening Process, see Process for Strengthening the IACHR: Methodology, Organization of American States, http://www.oas.org/en/iachr/ mandate/strengthening.asp (last visited Apr. 13, 2015).

46 Unit on Economic, Social and Cultural Rights, supra note 53.

47 See, e.g., Paulo Vannuchi, Comm'r Unit on Economic, Social and Cultural Rights, Presentation at the Special Meeting of the Permanent Council of the Organization of American States on Promotion and Protection of Human Rights in Business (Jan. 28, 2015); Interview with Paloma Munoz Quick, Consultant, Economic Social and Cultural Rights Unit, Inter-American Commission on Human Rights (Feb. 20, 2015).

48 OAS Resolution, supra note 6.

49 Id. 
the fact that (1) the Guiding Principle are a restatement of existing international human rights law and (2) the Commission maintains the express prerogative to advance human rights in the region.

\section{The Guiding Principles Create No New Internatio- nal Obligations}

The Guiding Principles do no create new international law obligations, but rather elaborate the "the implications of existing standards and practices for States and businesses." 50 This viewpoint, that the Guiding Principles are a mere restatement of current international law, is not the rhetoric of Professor Ruggie, but the consensus reached by numerous stakeholder consultations throughout the drafting process. ${ }^{51}$ As such, the IACHR is not being asked to delve into a new set of human rights standards; only to promote the improvement of sections of human rights law where the current regime falls short—a task well within its ambit of responsibilities. ${ }^{52}$ This point was cogently made at the Special Meeting on Promotion and Protection of Human Rights in Business held by the OAS Permanent Council in January 2015. According to Jorge Daniel Taillant, executive director of the Argentine-based Center for Human Rights and Environment, the business and human rights agenda is "not one more subject for the OAS" to deal with, but merely a "sophistication of [its] understanding on human rights." ${ }^{3}$ To support this claim, he cites the preamble to the Universal Declaration of Human Rights, which proclaims "every individual and every organ of society . . . shall strive by teaching and education to promote respect for these rights and freedoms [provided for by the Declaration] and by progressive measures, national and international, to secure their universal and effective recognition and observance. . . ." 54 The American Convention, in accordance with the Declaration's viewpoint, holds that "the ideal of free men enjoying freedom from fear and want can be achieved only if conditions are created whereby everyone may enjoy his economic, social, and cultural

50 Guiding Principles, supra note 2, ๆ 14.

51 Id. at $\$ 10-12$.

52 Id. at 14.

53 Jorge Daniel Taillant, Remarks at the Special Meeting on Promotion and Protection of Human Rights in Business, OAS Permanent Council (Jan. 29, 2015).

54 UN General Assembly, Universal Declaration of Human Rights, G.A. Res. 217A, Dec. 10, 1948, U.N. Doc. A/810. rights, as well as his civil and political rights" and binds state parties and the IACHR to promote the human rights enshrined within the document to this end..$^{55}$

The Guiding Principles, as a "single, logically coherent and comprehensive template" which elaborates existing standards and demonstrates "where the current regime falls short and how it should be improved" are a tool for states and regional instruments alike to effectively continue with their task of promoting the full implementation and realization of human rights, not the source of new obligations. ${ }^{56}$

\section{The IACHR Has A Mandate To Promote Human Rights}

Advising state actors on the promotion of human rights is part of the mandate of the Inter-American Commission, enshrined in its duty "to promote respect for and defense of human rights." ${ }^{57}$ As discussed in the previous section, this includes making recommendations to member state governments regarding progressive measures for the implementation and observance of human rights standards; accepting individual petitions regarding state violations of human rights; preparing studies and reports in relation to promoting respect and knowledge of human rights; and providing states with advisory services regarding human rights in the state when requested. ${ }^{58}$ As settled above, because the implementation of the Guiding Principles is geared towards closing gaps in the promotion of existing international human rights obligations within the corporate realm, it falls squarely within the Commission's mandate to engage with the movement. ${ }^{59}$ This view is bolstered by the fact that multiple member states have gestured toward the Commission regarding guidance on business and human rights topics. In April 2014, the Republic of Panama formally requested an advisory opinion from the Inter-American Commission regarding the scope and protection of the rights and obligations of "legally-recognized non-governmental entities," including corporations and private companies. ${ }^{60}$ In a less 55 American Convention on Human Rights, supra note 42.
56 Guiding Principles, supra note 2, 114 .
57 American Convention on Human Rights, supra note 42 at art. 41.
58 See supra note 43 \& accompanying text.
59 See supra note 64 \& accompanying text.
$60 \quad$ Request for an Advisory Opinion by the Government of the
Republic of Panama (Apr. 28, 2014), http://www.corteidh.or.cr/
solicitudoc/solicitud_14_11_14_ing.pdf (last visited Apr. 18, 2015). 
formal capacity, the government of Chile announced in December 2014 that it would look to the Inter-American Commission for guidance during the creation of its National Action Plan on Business and Human Rights. ${ }^{61}$ With a clearly laid out mandate and accompanying state belief that the Commission is competent to advise on issues of business and human rights there appears to be no hindrances regarding the IACHR's engagement with the Guiding Principles.

\section{The Extractive Sector: Demonstrating THE IACHR's FAMILIARITY WITH BUSINESS AND Human Rights Concepts}

While the ease with which the first rationale of Commission inaction-inadequate mandate-can be dismissed could lead one to believe the argument to be a red herring, the second line of reasoning-Commission discomfort with the new business and human rights lexicon-bears more weight. This section argues that while the Commission has been diffident regarding referencing and implementing the Guiding Principles, this wariness is unnecessary given the extent to which the Commission has already engaged with topics and principles encompassed by the Guiding Principles. The following analysis will focus on the human rights impacts of the extractive industry, an emblematic business and human rights problem in the inter-American system, to illustrate the extent to which the IACHR has spoken to and engaged with issues espoused in the Guiding Principles.

The problem of human rights abuse related to the extractives industry is one faced by the majority of countries in the region. The IACHR has long recognized this nexus through the granting of numerous public hearings, publication of reports and taking of petitions related to the topic - both before and after the OAS endorsement of the Guiding Principles. ${ }^{62}$ Specifically, the Commission has spoken considerably on the human rights requirements of states in the extractive context regarding three overlapping subjects: (1) indige-

61 Letter to the Inter-American Commission on Human Rights on Integrating Business and Human Rights, International Corporate Accountability Roundtable (Dec. 18, 2014), http://accountabilityroundtable.org/ wp-content/uploads/2014/12/ICAR-Letter-to-Inter-AmericanCommission.pdf (last visited Apr. 10, 2015).

62 See, infra subsections A-C. nous peoples' rights; (2) threats against of human rights defenders; and (3) use of private security and military forces.

\section{A. Indigenous Peoples' Rights}

The relationship between human rights abuse and the extractive sector frequently involves issues of indigenous peoples rights. Given the large population of indigenous peoples in the hemisphere, the IACHR has been very involved in the protection of these minority groups, creating the rapporteurship on the rights of indigenous peoples in $1990 .{ }^{63}$ The Commission has spoken broadly to the connection between indigenous rights and natural resources on many occasions, and more specifically on the obligation of state actors in protecting against human rights violations by extractive companies. The bulk of the inter-American human rights system's work regarding this topic has been in reference to the indigenous right to free, prior and informed consultation and/or consent (FPIC).

The FPIC standard has been established through a number of key cases decided upon by the Inter-American Court on Human Rights. ${ }^{64}$ While the Court's jurisprudence, as legally binding, lays the foundation for this right, the Commission's work leading up to recommending these emblematic cases to the Court was integral to the development of the standard in the region. ${ }^{65}$ In early cases involving indigenous land rights, the Court established that the right to property espoused in Article 21 of the American Convention protects the indigenous right to natural resources found within their territory and related to their culture and traditional uses. ${ }^{66}$ However, this property right is not absolute, and

63 Rapporteurship on the Rights of Indigenous Peoples, Organization of American States, http://www.oas.org/en/iachr/indigenous/default.asp (last visited Apr. 23, 2015).

64 See, e.g., Saramaka People v. Suriname, Merits, Reparations and Costs, Judgment, Inter-Am. Ct. H.R. (Nov. 28, 2007) [hereinafter Saramaka Case]; Kichwa Indigenous People of Sarayaku v. Ecuador, Merits and Reparations, Judgment, (June 27, 2012)[hereinafter Sarayaku Case].

65 The Commission continues to push the IACtHR to engage with issues of indigenous rights and natural resources. In February 2014, the Commission filed another case dealing with the indigenous right to FPIC. See, LACHR Takes Case involving Kalina and Lokono Peoples v. Suriname to the Inter-American Court (Feb. 4, 2014), available at http://www.oas.org/en/iachr/media_center/PReleases/2014/009. asp (last visited Apr. 23).

66 See, Sawhoyamaxa Indigenous Community v. Paraguay, Merits, Reparations and Costs, Judgment, Inter-Am. Ct. H.R. I 118 (Mar. 
a state may restrict the use and right to property where the restrictions are "(a) previously established in law; (b) necessary; (c) proportional; and (d) with the aim of achieving a legitimate objective in a democratic society" as long as it does not deny a population's survival as a tribal people. ${ }^{67}$

In 2007, the Court first spoke to the right of free, prior and informed consultation and consent in Saramaka People v. Suriname. In Saramaka, descendants of self-liberated African slaves challenged the Suriname government's granting of logging and mining concessions to extractive companies claiming rights to traditional territory for their cultural, religious and economic activities. ${ }^{68}$ The Court clarified the states obligations regarding the granting of natural resource concessions on indigenous land by holding that in order to guarantee that the property right restrictions of the Saramaka people imposed by the concessions within their territory did not amount to a denial of their survival as a tribal people, the state must, inter alia, "ensure the effective participation of the members of the Saramaka people, in conformity with their customs and traditions, regarding any development, investment, exploration or extraction plan [] within Saramaka territory." ${ }^{\circ 9}$ In order to ensure effective participation, the state "has a duty to actively consult" with the community according to their customs and traditions. ${ }^{70}$ This duty "requires the State to both accept and disseminate information, and entails constant communication between the parties." ${ }^{11}$ Additionally, consultations must be "in good faith, through culturally appropriate procedures and with the objective of reaching an agreement." ${ }^{\prime 2}$ These consultations should take place at the early stages of a development or investment plan and the state must ensure that the consulted group is aware of possible environmental and health risks in order to make a knowing and voluntary decision. ${ }^{73}$ Most importantly, the Court held that in re-

29, 2006); Yakye Axa Indigenous Community v. Paraguay, Merits, Reparations and Costs, Judgment, Inter-Am. Ct. H.R. ๆ 137 (June 17, 2005).

67 Saramaka Case, supra note 72 ฯ 127-28.

68 While the Saramaka people were not indigenous to the country, the Court found them to maintain certain tribal characteristics that made them akin to indigenous peoples and thus deserving of the same rights and protections. Id. 9 ๆ 79-86.

69 Id. 129.

$70 \quad I d .9133$.

$71 \quad I d$.

72 Id.

73 Id. gards to "large-scale development or investment projects that would have a major impact" within indigenous territory, the state has a duty not only to consult with affected indigenous communities, but to obtain their "free, prior and informed consent."

The safeguards established in the Saramaka case, especially the standards around adequate consultation, were further refined and embedded within the inter-American system in the 2012 Kichwa Indigenous People of Sarayaku v. Ecuador case. In Sarayaku, the indigenous Kichwa peoples of the Ecuadorian Amazon Basin brought a complaint against the government of Ecuador for, inter alia, granting a concession for oil exploration and exploitation on their communally titled land without their consultation and consent. ${ }^{75}$ The Court, in finding that the state obligation to consult with indigenous peoples and communities about to be affected by state action on their territory has been "clearly recognized" as a general principle of international law, went on to explicate more specifically the obligations of the state regarding advanced, informed, culturally appropriate consultations and issues of good faith. ${ }^{76}$ Additionally, according to the IACtHR, the state has a duty to "organize appropriately the entire government apparatus and, in general, all the organizations through which public power is exercised, so that they are capable of legally guaranteeing the free and full exercise of [the indigenous right to participate in decisions on matters that concern their interests and survival]." ${ }^{77}$ Because it is the state's obligation to guarantee these consultation rights, it must also "ensure that the rights of indigenous peoples are not ignored in any other activity or agreement reached with private individuals, or in the context of decisions of public authorities that would affect their rights and interests." ${ }^{.78}$ This duty therefore entails that a state must "carry out the tasks of inspection and supervision" regarding implementation of indigenous consultation. ${ }^{79}$ Similarly, the duty to consult cannot be designated to a third party, i.e. an extractive company; it is a duty of the state. $^{80}$

The Inter-American Commission has also reaffirmed the indigenous right to consultation through the issuance of number precautionary measures. For

\footnotetext{
74 Id. $\$ 134$.

75 Sarayaku Case, supra note 72.

76 Id. ๑ף 165-66, 180-203, 208-11.

77 Id. 1166.

78 Id. 9167.

79 Id.

80 Id. 203.
} 
example, in 2011 the Commission requested the state of Brazil to suspend a large-scale dam project in the Xingu river basin because the government had not consulted with the indigenous peoples living in the area affected by the mega-project. ${ }^{81}$ Similarly, in 2010, the IACHR issued a precautionary measure to protect the members of eighteen Maya indigenous communities in Guatemala from the harming environmental effects of mining in the region occurring without the indigenous population's FPIC. ${ }^{82}$ The Commission requested the state to suspend the unauthorized mining project and any other activities related to the concession granted to the extractive company. ${ }^{83}$

The IACHR also continues to raise awareness regarding indigenous rights in relation to natural resource extraction through the publication of reports and holding of public hearings. In the past two years, the Commission has held a number of hearings on the rights of indigenous people in relation to the extractive industry; in the last period of sessions alone, the IACHR conducted five hearings on the subject. ${ }^{84}$ Similarly, the Commission has recently issued a report on the rights of indigenous peoples in voluntary isolation and initial contact which identified the extraction of natural resources as a main threat to the full enjoyment of the human rights of these populations. ${ }^{85}$ Incursion into the property of indigenous peoples in voluntary isolation or initial contact can result is negative consequences more dire in scale than the effects of similar incursions on contacted indigenous groups, given not only the sustenance ties these groups have to the land, but also the fragility of

81 Indigenous Communities of the Xingu River Basin, Pará, Brazil, Inter-Am. Comm'n H.R., PM 382/10 (Apr. 1, 2011).

82 Communities of the Maya People (Sipakepense and Mam) of the Sipacapa and San Miguel Ixtahuacán Municipalities in the Department of San Marcos, Guatemala, Inter-Am. Comm'n H.R., PM 260/07 (May 20, 2010).

83 Id.

84 In the 154 Period of Sessions, the IACHR conducted the following hearings: Human Rights Situation of Leaders and Defenders of the Shuar People in Ecuador, Hearing Before the Inter-Am. Comm'n H.R (Mar. 17, 2015); Extractive Industries and Human Rights of the Mapuche People in Chile, Hearing Before the Inter-Am. Comm'n H.R (Mar. 17, 2015); Corporations, Human Rights, and Prior Consultation in the Americas, Hearing Before the Inter-Am. Comm'n H.R (Mar. 17, 2015); Human Rights and Extractive Industries in Latin America, Hearing Before the Inter-Am. Comm'n H.R (Mar. 19, 2015); The Right to Property and the Right to a Healtby Environment of Indigenous Peoples in Bocas del Toro, Panama, Hearing Before the Inter-Am. Comm'n H.R (Mar. 20, 2015)

85 Inter-American Commission on Human Rights, Indigenous peoples in Voluntary Isolation and Initial Contact in the Americas, OEA/Ser.L/V/II, Doc. 47/13 (Dec. 30, 2013) ๆף 101-14. their worldview and immune systems ${ }^{86}$ In this context, the Commission considers the principle of no contact, as an expression of the right of indigenous peoples in voluntary isolation to self-determination, essential for the protection of these special indigenous rights; it is "fundamental that every effort by made to reinforce respect for the principles of no contact" unless initiated by the peoples in isolation. ${ }^{87}$ However, because of this respect for indigenous self-determination, it is not possible for the government to conduct free, prior and informed consultations with these special indigenous groups without making contact with these peoples and violating the principle of no contact. ${ }^{88}$ Therefore, the Commission has established standards for when FPIC may be undertaken in regard to each of these groups: In relation to peoples in voluntary isolation, the main factors to analyze when considering whether consultation would be plausible are " (i) the manifest rejection of the presence of persons who are not members of their people in territories, and (ii) their decisions to remain in isolation with respect to other peoples and persons." ${ }^{\text {99 }}$ For indigenous peoples in initial contact, a state may be able to consult the group through consultation with other indigenous groups or majoritarian society members with which the group has contact with special consideration to their "particular situation of vulnerability and interdependence with their territories and natural resources, their worldview, and how they may interpret a consultation process." ${ }^{\prime 90}$ In these cases, the state is still obligated to undertake the consultation in accordance with the standards already established by the Inter-American Commission and Court. ${ }^{91}$

\section{B. Human Rights Defenders}

The Inter-American Commission has long expressed an interest in and focus on the situation of human rights defenders in the Americas. The Executive Secretariat of the IACHR created a Unit for Human Rights Defenders in 2001 and the IACHR issued its first thematic report on the issue in $2006 .{ }^{92}$ In 2011, due to the

\begin{tabular}{|c|c|}
\hline 86 & Id. \甲19-20. \\
\hline 87 & Id. ๆף 21-22. \\
\hline 88 & Id. 925. \\
\hline 89 & Id. \\
\hline 90 & Id. ๆ 26. \\
\hline 91 & Id. \\
\hline 92 & Rapporteurship \\
\hline
\end{tabular}
American States, http://oas.org/en/iachr/defenders/reports/the- 
increasing number of petitions the Commission received regarding abuses towards human rights defenders and growing interest in the subject from civil society, the IACHR created the Rapporteurship on Human Rights Defenders. ${ }^{93}$ That same year, the Second Report on the Situation of Human Rights Defenders in the Americas was released, making much mention of the role the extractive sector played in the increasing abuse towards these activists. ${ }^{94}$ Along with noting many troubling trends regarding extractive industries and human rights abuses, the Commission laid out certain state responsibilities in relation to this conflict. ${ }^{95}$

The Commission held that "attacks, aggression and harassment targeted at defenders of the environment have become more pronounced" in the region due in large part to the tensions between extractive industries and sectors that resist the implementation of such projects. ${ }^{96}$ The IACHR made a connection between failing to uphold environmental regulations, increased social protest against extractive projects, and subsequent violence against human rights defenders. The Commission noted that the majority of extractive projects are run by foreign businesses and that host states "often do not properly monitor their activities and environmental effects," especially where regulation is weak or does not exist. ${ }^{97}$ The lack of state enforcement often "pits the industries against the communities neighboring the projects." $"$ This tension has led to the harassment, abuse and murder of environmental defenders "region-wide in the case of the extractive industry," exposing the problem of State non-compliance with its obligations. ${ }^{99}$ The state is not only obligated "to adopt measures to protect the human rights of all persons," it also has "a duty to enforce the national and international environmental protection standards that they have enacted or accepted." ${ }^{100}$ Effective enforcement of environmental protection measures in relation to extractive projects "is essential to avoid the State's international responsibility for violating human rights of the communities affected

\footnotetext{
matic.asp (last visited Apr. 18, 2015).

93 Id.

94 Inter-American Commission on Human Rights, Second Report on the Situation of Human Rights Defenders in the Americas (2011) [hereinafter Second Report].

95 See, infra notes 78-80.

96 Second Report, supra note 103 at 9312.

97 Id. at 313.

98 Id. at 9316.

$99 \quad I d$. at 9317.

100 Id. at 314.
}

by activities detrimental to the environment."'101

In addition, in relation to the IACHR's concern regarding the growing abuse faced by environmental defenders who oppose extractive industry projects, the IACHR pronounced that "States are obligated to take reasonable measures to prevent the threats, assaults and harassment of human rights defenders; conduct serious investigations of the facts brought to their attention; and, where appropriate, punish those responsible and adequately redress the victim." ${ }^{102}$ Subsequent to making this clear statement regarding state obligations in relation to extractive industry violence towards environmental defenders, the Commission has confirmed this international standard by issuing a number of precautionary measures to protect defenders in this exact position. For example, in April 2007, the IACHR granted precautionary measures in favor of members of the Grupo de Formación Integral para el Desarrollo Sostenible (GRUIFIDES), a community organization dedicated to the defense of the environment and legal assistance to peasant communities around Cajamarca, Peru. ${ }^{103}$ The beneficiaries of the precautionary measure had been subject to intimidation and threats by supporters of mining in the region, where assassinations had already occurred in confrontations between mine activists and mining supporters. ${ }^{104}$ The state was requested not only to protect the life and physical integrity of the beneficiaries, but also to judicially investigate the facts giving rise to the precautionary measures. ${ }^{105}$ Similarly, in 2012, the IACHR granted precautionary measures in favor of a human rights defender in Guatemala, Telma Yolanda Oqueli Veliz, involved in opposing a mining project in the region. ${ }^{106}$ After receiving threats in relation to her anti-mine work, Ms. Oqueli Veliz was shot in the back. ${ }^{107}$ In this case, the IACHR also requested the state to adopt the necessary measures to guarantee the life and physical integrity of the beneficiary and to investigate the facts leading up to the issuing of the precautionary measure. ${ }^{108}$

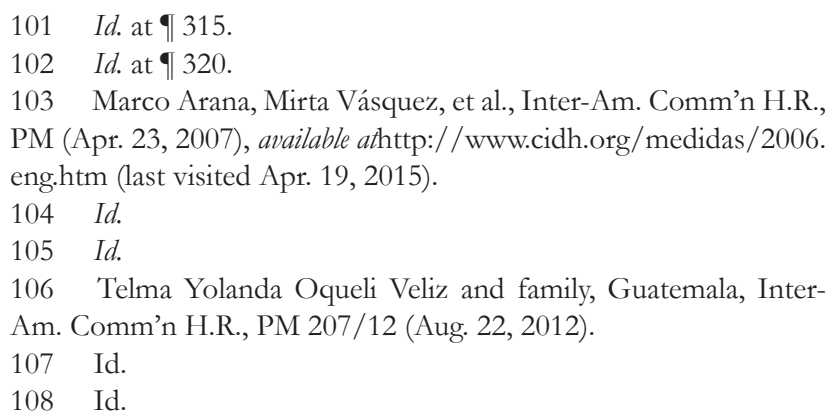
PM (Apr. 23, 2007), available athttp://www.cidh.org/medidas/2006. eng.htm (last visited Apr. 19, 2015).

104 Id.

105 Id.

106 Telma Yolanda Oqueli Veliz and family, Guatemala, InterAm. Comm'n H.R., PM 207/12 (Aug. 22, 2012).

107 Id.

108 Id. 
Lastly, the Commission has also held a number of public hearings that touch on the relationship between human rights defenders and the extractive sector. Most recently, these hearings include broad examinations of social protest in the Americas and specifically in Guatemala ${ }^{109}$; examinations of the situation of human rights defenders in the Americas in general, and Brazil, Ecuador and Guatemala, in specific ${ }^{110}$; investigations into the improper use of law to criminalize human rights defenders ${ }^{111}$; and extractive industry specific hearings regarding their impacts on general human rights. ${ }^{112}$ These hearings, granted by the IACHR mostly at the request of civil society organizations, illustrate the Commission's interest in developing awareness within the inter-American community regarding the persecution of human rights defenders in relation to the extractive sector.

\section{Private Military and Security Forces}

The use of private military and security forces (PMSCs) in the extractive sector in the inter-American region, especially in Latin America, has also put the IACHR on alert. Reports indicate that the emerging trend of extractive corporations using PMSCs to protect their operations has led to harmful human rights abuses among local populations. ${ }^{113}$ Particularly, the use of

109 Social Protest and Human Rights in the Americas, Hearing Before the Inter-Am. Comm'n H.R (Mar. 16, 2015); Human Rights and Social Protest in Guatemala, Hearing Before the Inter-Am. Comm'n H.R (Oct. 28, 2013).

110 Situation of Human Rights Defenders in Guatemala, Hearing Before the Inter-Am. Comm'n H.R (Oct. 28, 2014); Situation of Human Rights Defenders in the Americas, Hearing Before the Inter-Am. Comm'n H.R (Mar. 24, 2014); Situation of the Right to Freedom of Association and Environmental Defenders in Ecuador, Hearing Before the Inter-Am. Comm'n H.R (Mar. 28, 2014); Situation of Human Rights Defenders in Brazil, Hearing Before the Inter-Am. Comm'n H.R (Oct. 29, 2013); Situation of Human Rights Defenders in Guatemala, Hearing Before the Inter-Am. Comm'n H.R (Oct. 28, 2013).

111 Improper Use of Criminal Law to Criminalize Human Rights Defender, Hearing Before the Inter-Am. Comm'n H.R (Oct. 31, 2014).

112 Human Rights and Extractive Industries in Latin America, Hearing Before the Inter-Am. Comm'n H.R (Mar. 19, 2015); Impact of Canadian Mining Activities on Human Rights in Latin America, Hearing Before the Inter-Am. Comm'n H.R (Oct. 28, 2014); Development and Extractive Industries in Colombia, Hearing Before the Inter-Am. Comm'n H.R. (Oct. 31, 2013); Human Rights Situation of People Affected by Mining in the Americas and the Responsibilities of the Host and Home States of the Mining Companies, Hearing Before the Inter-Am. Comm'n H.R (Nov. 1, 2013).

113 Antonie Perret, Private Security Trends and Challenges in Latin America [Student's Paper Series] Western Hemisphere Security Analysis private security forces is often times linked directly to abuse towards human rights defenders. The IACHR has received numerous reports detailing instances where extractive sector businesses have hired security forces to attack, abuse and harass leaders of environmental and social movements lobbying against their operations. ${ }^{114}$ In advising states on their role in situations such as these, the Commission underscores that state failure to intervene in, prevent or investigate this type of directed violence by PMSCs could comprise the states international responsibility to prevent human rights abuses inflicted upon its citizens. ${ }^{115}$ In addition, the Commission holds that in countries that allow private security firms to operate according to the rules that govern business activity, these forces must be "properly regulated." 116 According to the IACHR, the domestic legal system "must regulate the functions that private security services can perform, the types of weapons and materials they are authorized to use, the proper mechanism to oversee their activities, introduction of licensing, and a system whereby these private security firms are required to report their contracts on a regular basis . . ."117 In addition, the public authorities should "demand compliance with selection and training requirements that individuals hired by [] private security firms must meet, specifying which public institutions are authorized to issue certifications attesting to the firms' employees." 118

\section{Discussion}

An overview of the Commission's work in the area of human rights and the extractive sector illustrates its experience with concepts covered by the Guiding Principles. First, within the Commission's engagement with the indigenous right to free, prior and informed consultation and/or consent, it has espoused various duties that the state must abide by in protecting its indigenous population from possible human rights abuse caused by extractive operations. The Commission has made clear that the state, not any individual extractive company,

Center (Aug. 1, 2011), available at http://digitalcommons.fiu.edu/ $\mathrm{cgi} /$ viewcontent.cgi? article $=1036 \&$ context $=$ whemsac.

114 Second Report, supra note 103 at $\$ 318$.

115 Inter-American Commission on Human Rights, Report on Citizen Security and Human Rights, OEA/Ser.L/V/II (Dec. 31, 2009) \ๆ 39-46 [hereinafter Report on Citizen Security].

$116 \quad$ Id. 973.

117 Id.

118 Id. 
has the international obligation to consult with, and in some cases, gain the consent of, indigenous groups when extractive operations are being planned within their traditional territory. This obligation, and the requirements that accompany it, fall within the first pillar of the Guiding Principles-the state duty to protect human rights. Also resounding within the first pillar is the Commission's guidance on the state obligation to protect against the abuse of human rights defenders and regulate and protect against abuse of PMSCs.

Similarly, within the Commission's nascent, but expanding, views on the use of PMSCs in the extractive sector, the second pillar of the Guiding Principles - the corporate responsibility to respect human rights-is also implicated. While the IACHR has mainly focused on how the states should regulate these companies, it has indicated through the types of regulation desired, its expectation for PMSCs. Also, its condemnation for the lack of state investigation and prosecution of extractive companies, which hire these forces, connotes the Commissions condemnation for these actions, signaling that extractive corporations should respect human rights, or be prosecuted for not doing so.

Lastly, the Commission speaks to the third pillar of the Guiding Principles_-access to judicial and non-judicial remedy for corporate human rights abuse-in its discourse on both PMSCs and the criminalization of human rights defenders. The IACHR has stated explicitly that the state must investigate and, where appropriate, punish those responsible for threats, assaults and harassment of human rights defenders; likewise, it must investigate directed violence by PMSCs or risk compromising its own international responsibility.

\section{Arguments for Engagement}

While the discussion above illustrates the IACHR's familiarity with business and human rights concepts, some may argue that it also demonstrates the Commission's ability to protect against human rights abuses implicated by business within its existing legal framework. Thus the question must be asked: why a need to engage with the Guiding Principles at all? The answer is threefold: the Inter-American Commission (1) has been requested to engage with the principles; (2) has the ability to set normative standards in the field; and (3) should seek to close increasing accountability gaps

\section{A. The IACHR has been requested to engage with the Guiding Principles}

The General Assembly of the OAS has explicitly requested that the Inter-American Commission engage with the Guiding Principles. The Charter of the OAS lays out the formal mandate of the commission, stating that its "principal function shall be to promote the observance and protection of human rights and to serve as a consultative organ of the [OAS] in these matters." ${ }^{119}$ Keeping in mind this function, the Generally Assembly called on the Commission to continue supporting "the promotion and application of state and business commitments in the area of human rights and business" when it formally endorsed the Guiding Principles in June 2014. ${ }^{120}$ Part of the General Assembly's own vow to support and promote the disseminate and implementation of the Guiding Principles across the Western Hemisphere was based on its assumption that it's consultative human rights arm would uphold its mandated role as promoter of human rights across the Americas. The Commission's decision whether or not to engage with the Guiding Principles is not its own to make- the General Assembly has entreated this uptake, and the Commission lacks the authority to disregard such a request.

\section{B. The IACHR has the ability to set normative standards in the field}

The Inter-American Commission maintains great influence over not only member states, but also the international community, regarding its interpretation and promotion of human rights understandings. As such, the Commission has the ability to transform the Guiding Principles clarification of state obligations and business responsibilities into region-wide normative concepts. The General Assembly recognized as much it its 2014 adoption of the Guiding Principles, citing its inspiration by "the emerging practices and progress seen in the Hemisphere with regard

119 Organization of American States, Charter of the Organization of American States (Signed in Bogotá in 1948 and amended by the Protocol of Buenos Aires in 1967, by the Protocol of Cartagena de Indias in 1985, by the Protocol of Washington in 1992, and by the Protocol of Managua in 1993), Apr. 30, 1948, 1609 U.N.T.S. 48. 120 OAS Resolution, supra note 6. 
to social responsibility an its anchoring in human rights" as one consideration in its decision to embrace and implement the new human rights framework. ${ }^{121}$ The Commission's ability to create and support normative shifts in business and human rights thinking emanate from all its designated functions, including both its individual petition system and advisory functions.

An example of the IACHR's power to influence can be seen in the Commission's work with the concept of free, prior and informed consent. As discussed in Section IV, the Commission's engagemettnt with the indigenous right to consultation and consent was the impetus for the Inter-American Court's elucidation and interpretation of this right through the hearing of multiple cases on this issue. ${ }^{122}$ While the concept of FPIC emerged in the international arena almost simultaneously with its evolution in the inter-American court system, the Commission's continued engagement with this topic through hearings and reports brought it from the fringe and into focus. ${ }^{123}$ Following the inter-American systems clarification of FPIC, multiple governments in the region have become more engaged on the topic, including the Ecuadorian government guaranteeing FPIC in its 2008 Constitution and the 2011 promulgation of the Indigenous Peoples Consultation Law in Peru. ${ }^{124}$ Today, the right to free, prior and informed consent is a clear concern for companies doing business in Latin America. ${ }^{125}$ While the region continues to define the contours of the right through legislation, litigation and advocacy, it is important to note the paradigm shift in the conversations being had-it is no longer about whether the right exists, but how the right is upheld. Similarly, other regions have continually looked to the jurisprudence and precedent set in the inter-American system for reference in their own interpretation of the right to free, prior and informed consent.

The opportunity to normalize additional human rights in the business context is ripe for the Inter-Ame-

$121 \quad I d$.

122 See, supra Section IV, part A.

123 The Inter-American Court on Human Rights ruled on the Saramaka case in 2007, the same year the U.N. General Assembly adopted the UN Declaration on the Rights of Indigenous Peoples, which espouses FPIC as a human right.

124 Constitución Política de la República de Chile [C.P.] art. 57; Law No. 29785, Sept. 7, 2011, Diario Official [D.O.] (Perú).

125 See, e.g., Steven Fox \& Trevor Sutton, Ground Rules: Cultivating Investments through Free, Prior, and Informed Consent, Veracity (2015); Amy K. Lehr \& Gare A. Smith, Implementing a Corporate Free, Prior, and Informed Consent Policy: Benefits and Challenges, Foley Hoag, LLP (2010). rican Commission. The steady increase of extractive industry investment in the region, coupled with the relative strength of the inter-American human rights system, has created a prime opportunity for the Commission to weigh in on multiple aspects of the business and human rights problem. The Commission can continue to expand it's conceptualization of State duties and corporate expectations regarding FPIC, human rights defenders, and private security forces through the taking of individual petitions, the issuance of thematic reports or other types of state guidance, including advising on the state NAP processes. It can also grow its work in the field by expanding the scope of business and human rights issues it addresses via these means. The Inter-American Commission's already existing concern over these discreet human rights concerns in the extractive sector coupled with its ability to create normative shifts in the illustrate the human rights gains to be had by the Commission's engagement with the principles.

\section{The IACHR should seek to close increasing accountability gaps}

Not only is the Inter-American Commission an important avenue for victims of corporate human rights abuse to access remedy, it is increasingly become one of the few places where such remedy is possible. Recent developments in U.S. jurisprudence have severely limited one of the main paths for victims of corporate human rights to justice, U.S. federal courts under the Alien Tort Statute (ATS). The ATS allows, in short, for non-U.S. citizens to file a case in U.S. federal court for torts committed in violation of international law. ${ }^{126}$ While historically, ATS litigation has been used by foreign plaintiffs to bring suit against foreign corporations for human rights abuses committed abroad, in 2011, the U.S. Supreme Court held in Kiobel v. Royal Dutch Petroleum that federal courts do not have jurisdiction over such cases unless such claims "touch and concern" the United States with "sufficient force." 227 While the exact contours of the "touch and concern" requirement are still being mapped out through lower court decisions, multiple suits against corporate actors for human rights abuses committed within the Americas have been thrown out of U.S. courts. ${ }^{128}$

\footnotetext{
12628 U.S.C. $\$ 1350$.

127 Kiobel v. Royal Dutch Petroleum Co., 133 S. Ct. 1658 (2013).

128 See, e.g., Elizabeth Holland, ATS Case Developments Post-Kiobel:
} 
The narrowing of this avenue of redress has had an alarming effect. For example, under the Kiobel interpretation of the ATS, the Court of Appeals for the Eleventh Circuit dismissed a lawsuit against the U.S.-based banana company Chiquita Brands International alleging torture, extrajudicial killings, war crimes and crimes against humanity for its involvement in funding the Self-Defense Forces of Colombia (AUC), a right-wing paramilitary group. ${ }^{129}$ The case was a consolidation of numerous similar cases brought in varying U.S. districts over a period of four years and compiled the claims of over 4,000 victims of grave human rights abuse caused by the AUC and allegedly supported by Chiquita. ${ }^{130}$ The circuit court, finding that it no longer had jurisdiction to hear the case under Kiobel, left thousands of victim's without remedy. While this is not to assume that the other courts of the region are not equipped to hear such cases; many times this is thought to be the case, with foreign plaintiffs' citing corruption or weak rule of law as arguments why redress is not available in their home state.

As forums within which victims of corporate human rights abuse can seek accountability constrict, it is increasingly important for the inter-American human rights system to carry more weight. In situations where corporations cannot be brought into State courts for jurisdictional or other reasons, the Inter-American Commission should look to the Guiding Principles to examine the State's breach of duty in regards to protecting against corporate human rights abuse or providing access to remedy for victims of human rights violations and to clarify its expectations for corporate behavior. This increase of engagement with the Guiding Principles is the required by the Commission in order to faithfully uphold its mandate to promote human rights in the region.

Interpreting the "Touch and Concern" Standard, Corporate Social Responsibility and the Law (Sept. 13, 2013) http://www.csrandthelaw. com/2013/09/13/case-developments-post-kiobel-interpreting-thetouch-and-concern-standard/ (last visited Sept. 27, 2015); Post-Kiobel, the Lower Courts are only Pretending to Apply the Presumption against Extraterritoriality in Alien Tort Statute Cases, The View From LL2, http:/ / viewfromll2.com/2014/07/22/post-kiobel-the-lower-courts-areonly-pretending-to-apply-the-presumption-against-extraterritoriality-in-alien-tort-statute-cases/ (last visited Sept. 27, 2015).

129 Cardona, et al. v. Chiquita Brands International, et al. No. 1214898 (11th Cir. 2014).

130 For more information relating to the history of the Chiquita case, see Chiquita lawsuits (re Colombia), Business \& Human Rights Resource Centre, http://business-humanrights.org/en/chiquitalawsuits-re-colombia (last visited Sept. 27, 2015)

\section{Final Conclusions}

Not only is it well within the Inter-American Commission's mandate and capacity to start engaging with the Guiding Principles on Business and Human Rights, there are multiple reasons why the Commission should and must engage. The Commission's mandate require it generally to promote the observance and protection of human rights by empowering the Commission to make recommendations to governments and prepare studies as it sees fit, request information from governments, and provide them with advisory serves as requested. The Guiding Principles, as a restatement of existing international human rights law, falls within the ambit of rights that the Commission should be promoting. It should therefore feel unfettered in utilizing its functions and powers to the full extent to encourage state implementation of the Guiding Principles.

Additionally, the Commission has already spoken to several duties and expectations of the state in regards to human rights and the extractive sector. As illustrated above, much of the guidance the IACHR has provided fits squarely within the framework of the Guiding Principles. The Commission need not learn a new branch of international human rights law, nor overhaul it's its current, general thinking on human rights issues within the region. Implementing the Guiding Principles requires only that the Commission, in addition to its current conceptualization of human rights and international law, layer into its analysis the Guiding Principle framework. This incorporation is not intended to displace any existing international human rights law fields with which the Commission interacts; it simple bolsters the authority of the Commission's statements and findings while also engaging with and promoting the business and human rights framework. The Commission has the mandate and the knowledge to accomplish this end.

Lastly, multiple reasons exist why the Commission should and must engage with the Guiding Principles. Foremost, the IACHR been directly requested by the OAS General Assembly to amp up its engagement with the principles. Second, it should utilize its influence and ability to normalize standards in the region to further its mission of advancing human rights promotion and protection in the Hemisphere. Moreover, as avenues for redress of corporate human rights abuse shut down or continue to be out of reach of victims in both home and host countries, the Inter-American Commission 
has a duty to take on more cases relating to business and human rights to provide access to remedy to those in the Americas that otherwise would not find justice for corporate human rights abuse.

\section{References}

Address Delivered by Salvador Allende Gossens, President of Chile, at the inaugural ceremony on 13 April 1973, United Nations Conference on Trade and Development, Proceedings of the United Nations Conference on Trade and Development, Apr. 13-May 21, 1972, I 62, U.N. Doc. TD/180 (Vol. 1), Annex VIII (1973).

U.N. Special Representative of the Secretary-General, Guiding Principles on Business and Human Rights: Implementing the United Nations "Protect, Respect and Remedy" Framework: Rep. of the Special Representative of the SecretaryGeneral on the Issue of Human Rts. and Transnat'l Corp. and other Bus. Enter., John Ruggie, Annex, U.N. Doc. A/ HRC/17/31 (Mar. 21, 2011)

Cindy S. Woods, "It Isn't A State Problem": The Minas Conga Mine Controversy and the Need for Binding International Obligations on Corporate Actors, 46 Geo. J. Int. L. 629, 635-39 (2015).

U.N. Working Group on Business and Human Rights, Guidance on National Action Plans on Business and Human Rights ii (2014)

Compare State National Action Plans, U.N. Human Rights Office of the High Commissioners for Human Rights, http://www.ohchr.org/EN/Issues/Business/Pages/ NationalActionPlans.aspx (last visited Apr. 8, 2015)

National Action Plans, Business \& Human Rights Resource Center. http://business-humanrights.org/en/ un-guiding-principles/implementation-tools-examples/implementation-by-governments/by-type-of-initiative/national-action-plans (last visited Apr. 8, 2015).

Organization of American States, Resolution Promotion and Protection of Human Rights in Business, OAS AG/RES. 2840 (XLIV-O/14) (June 4, 2014)

Comm'n on Human Rights Res. 2005/69, Human Rights and Transnational Corporations and Other Business Enterprises, U.N. Doc.E/CN.4/RES/2005/69 (Apr. 20, 2005).

Special Rep. of the Sec'y Gen. on the issue of human rights and transnat'l corps. and other bus. enters., John Ruggie, Promotion and Protection of All Human Rights, Civil, Political, Economic, Social and Cultural Rights, Including the Right to Development: Protect, Respect and Remedy: a Framework for Business and Human Rights, U.N. Doc. A/ HRC/8/5 (Apr. 7, 2008).

Human Rights Council Res. 17/4, Human rights and transnational corporations and other business enterprises, 17th Sess., U.N. Doc. A/HRC/Res/17/4 July 6, 2011).

The Danish Institute for Human Rts. \& The Int'l Corp. Accountability Roundtable, National Action Plans on Business and Human Rights: A Toolkit for the Development, Implementation and Review of State Commitments to Business and Human Rights 16-17 (2014).

Christopher Smart, Announcement of Opportunity to Provide Input into the U.S. National Action Plan on Responsible Business Conduct, U.S. National Security Council (Nov. 20, 2014; 1:29 PM), https://www.whitehouse.gov/ blog/2014/11/20/announcement-opportunity-provide-input-us-national-action-plan-responsible-business(last visited Apr. 10, 2015)

ICAR \& PODER Partner to Support the Development of a National Action Plan on Business \& Human Rights in Mexico, International Corporate Accountability Roundtable, http://accountabilityroundtable.org/analysis/icarpoderprojectmexiconap/ (last visited Apr. 10, 2015).

Letter to the Inter-American Commission on Human Rights on Integrating Business and Human Rights, International Corporate Accountability Roundtable (Dec. 18, 2014), http:/ /accountabilityroundtable.org/wp-content/ uploads/2014/12/ICAR-Letter-to-Inter-AmericanCommission.pdf (last visited Apr. 10, 2015).

Subsecretario Edgardo Riveros participó en Foro Anual sobre Derechos Humanos y Empresas en Naciones Unidas, Ministerio de Relaciones Exteriores de Chile (Dec. 2, 2014), http://www.minrel.gov.cl/subsecretarioedgardo-riveros-participo-en-foro-anual-sobre-derechos-humanos-y-empresas-en-naciones-unidas / minrel/2014-12-03/100147.html (last visited Apr. 10, 2015).

Organization of American States, Charter of the Organization of American States (Signed in Bogotá in 1948 and amended by the Protocol of Buenos Aires in 1967, by the Protocol of Cartagena de Indias in 1985, by the Protocol of Washington in 1992, and by the Protocol 
of Managua in 1993), Apr. 30, 1948, 1609 U.N.T.S. 48.

Organization of American States, American Convention on Human Rights, "Pact of San Jose", Costa Rica, Nov. 22, 1969, OAS Treaty Series No. 36; 1144 U.N.T.S. 123

Organization of American States, Statute of the InterAmerican Commission on Human Rights, Oct. 1, 1979, O.A.S. Off. Rec. OEA/Ser.P/IX.0.2/80, Vol. 1 at 88.

Petition and Case System Informational Brochure, Inter-American Commission on Human Rights, https://www.oas. org/en/iachr/docs/pdf/HowTo.pdf (last visited Apr. 13, 2015).

Organization of American States, Rules of Procedure of the Inter-American Commission on Human Rights, Annual Report of the Inter-American Court of Human Rights, 1991, O.A.S. Doc. OEA/Ser.L/V/III.25 doc.7 at 18 (1992).

Thematic Rapporteurships and Units, Organization of American States, http://www.oas.org/en/iachr/mandate/ rapporteurships.asp (last visited Apr. 13, 2015).

Unit on Economic, Social and Cultural Rights, Organization of American States, http://www.oas.org/en/iachr/ desc/ (last visited Apr. 13, 2015

Process for Strengthening the IACHR: Methodology, Organization of American States, http://www.oas.org/en/ iachr/mandate/strengthening.asp (last visited Apr. 13, 2015).

Paulo Vannuchi, Comm'r Unit on Economic, Social and Cultural Rights, Presentation at the Special Meeting of the Permanent Council of the Organization of American States on Promotion and Protection of Human Rights in Business (Jan. 28, 2015)

Jorge Daniel Taillant, Remarks at the Special Meeting on Promotion and Protection of Human Rights in Business, OAS Permanent Council (Jan. 29, 2015).

UN General Assembly, Universal Declaration of Human Rights, G.A. Res. 217A, Dec. 10, 1948, U.N. Doc. A/810.

Request for an Advisory Opinion by the Government of the Republic of Panama (Apr. 28, 2014), http:// www.corteidh.or.cr/solicitudoc/solicitud_14_11_14_ ing.pdf (last visited Apr. 18, 2015).

Letter to the Inter-American Commission on Human Rights on Integrating Business and Human Rights, International Corporate Accountability Roundtable (Dec. 18, 2014), http:/ / accountabilityroundtable.org/wp-content/
uploads/2014/12/ICAR-Letter-to-Inter-AmericanCommission.pdf (last visited Apr. 10, 2015).

Rapporteurship on the Rights of Indigenous Peoples, Organization of American States, http://www.oas.org/en/iachr/indigenous/default.asp (last visited Apr. 23, 2015).

Saramaka People v. Suriname, Merits, Reparations and Costs, Judgment, Inter-Am. Ct. H.R. (Nov. 28, 2007)

Kichwa Indigenous People of Sarayaku v. Ecuador, Merits and Reparations, Judgment, (June 27, 2012)

IACHR Takes Case involving Kalina and Lokono Peoples v. Suriname to the Inter-American Court (Feb. 4, 2014), available at http://www.oas.org/en/iachr/media_center/ PReleases/2014/009.asp (last visited Apr. 23).

Sawhoyamaxa Indigenous Community v. Paraguay, Merits, Reparations and Costs, Judgment, Inter-Am. Ct. H.R. ๆ 118 (Mar. 29, 2006); Yakye Axa Indigenous Community v. Paraguay, Merits, Reparations and Costs, Judgment, Inter-Am. Ct. H.R. ๆ 137 (June 17, 2005).

Indigenous Communities of the Xingu River Basin, Pará, Brazil, Inter-Am. Comm'n H.R., PM 382/10 (Apr. 1, 2011).

Communities of the Maya People (Sipakepense and Mam) of the Sipacapa and San Miguel Ixtahuacán Municipalities in the Department of San Marcos, Guatemala, Inter-Am. Comm'n H.R., PM 260/07 (May 20, 2010).

Human Rights Situation of Leaders and Defenders of the Shuar People in Ecuador, Hearing Before the Inter-Am. Comm'n H.R (Mar. 17, 2015)

Extractive Industries and Human Rights of the Mapuche People in Chile, Hearing Before the Inter-Am. Comm'n H.R (Mar. 17, 2015)

Corporations, Human Rights, and Prior Consultation in the Americas, Hearing Before the Inter-Am. Comm'n H.R (Mar. 17, 2015)

Human Rights and Extractive Industries in Latin America, Hearing Before the Inter-Am. Comm'n H.R (Mar. 19, 2015)

The Right to Property and the Right to a Healthy Environment of Indigenous Peoples in Bocas del Toro, Panama, Hearing Before the Inter-Am. Comm'n H.R (Mar. 20, 2015)

Inter-American Commission on Human Rights, Indigenous peoples in Voluntary Isolation and Initial Contact in the Americas, OEA/Ser.L/V/II, Doc. 47/13 (Dec. 


\section{0, 2013) ๆף 101-14.}

Rapporteurship on Human Rights Defenders, Organization of American States, http://oas.org/en/iachr/defenders/reports/thematic.asp (last visited Apr. 18, 2015).

Inter-American Commission on Human Rights, Second Report on the Situation of Human Rights Defenders in the Americas (2011)

Marco Arana, Mirta Vásquez, et al., Inter-Am. Comm'n H.R., PM (Apr. 23, 2007), available at http://www.cidh. org/medidas/2006.eng.htm (last visited Apr. 19, 2015).

Telma Yolanda Oqueli Veliz and family, Guatemala, Inter-Am. Comm'n H.R., PM 207/12 (Aug. 22, 2012).

Social Protest and Human Rights in the Americas, Hearing Before the Inter-Am. Comm'n H.R (Mar. 16, 2015)

Human Rights and Social Protest in Guatemala, Hearing Before the Inter-Am. Comm'n H.R (Oct. 28, 2013)

Situation of Human Rights Defenders in Guatemala, Hearing Before the Inter-Am. Comm'n H.R (Oct. 28, 2014)

Situation of Human Rights Defenders in the Americas, Hearing Before the Inter-Am. Comm'n H.R (Mar. 24, 2014)

Situation of the Right to Freedom of Association and Environmental Defenders in Ecuador, Hearing Before the Inter-Am. Comm'n H.R (Mar. 28, 2014)

Situation of Human Rights Defenders in Brazil, Hearing Before the Inter-Am. Comm'n H.R (Oct. 29, 2013)

Situation of Human Rights Defenders in Guatemala, Hearing Before the Inter-Am. Comm'n H.R (Oct. 28, 2013)

Improper Use of Criminal Law to Criminalize Human Rights Defender, Hearing Before the Inter-Am. Comm'n H.R (Oct. 31, 2014).

Human Rights and Extractive Industries in Latin America, Hearing Before the Inter-Am. Comm'n H.R (Mar. 19, 2015)

Impact of Canadian Mining Activities on Human Rights in Latin America, Hearing Before the Inter-Am. Comm'n H.R (Oct. 28, 2014)

Development and Extractive Industries in Colombia, Hearing Before the Inter-Am. Comm'n H.R. (Oct. 31, 2013)

Human Rights Situation of People Affected by Mining in the Americas and the Responsibilities of the Host and Home States of the Mining Companies, Hearing Before the Inter-Am. Comm'n H.R (Nov. 1, 2013)
Antonie Perret, Private Security Trends and Challenges in Latin America [Student's Paper Series] Western Hemisphere Security Analysis Center (Aug. 1, 2011), available at http://digitalcommons.fiu.edu/cgi/viewcontent.cgi?ar ticle $=1036 \&$ context $=$ whemsac .

Inter-American Commission on Human Rights, Report on Citizen Security and Human Rights, OEA/Ser.L/V/ II (Dec. 31, 2009) 9ף 39-46

Organization of American States, Charter of the Organization of American States (Signed in Bogotá in 1948 and amended by the Protocol of Buenos Aires in 1967, by the Protocol of Cartagena de Indias in 1985, by the Protocol of Washington in 1992, and by the Protocol of Managua in 1993), Apr. 30, 1948, 1609 U.N.T.S. 48.

Constitución Política de la República de Chile [C.P.] art. 57; Law No. 29785, Sept. 7, 2011, Diario Official [D.O.] (Perú).

Steven Fox \& Trevor Sutton, Ground Rules: Cultivating Investments through Free, Prior, and Informed Consent, Veracity (2015)

Amy K. Lehr \& Gare A. Smith, Implementing a Corporate Free, Prior, and Informed Consent Policy: Benefits and Challenges, Foley Hoag, LLP (2010)

28 U.S.C. $\int 1350$.

Kiobel v. Royal Dutch Petroleum Co., 133 S. Ct. 1658 (2013). Elizabeth Holland, ATS Case Developments Post-Kiobel: Interpreting the "Touch and Concern" Standard, Corporate Social Responsibility and the Law (Sept. 13, 2013) http:/ / www.csrand thelaw.com/2013/09/13/casedevelopments-post-kiobel-interpreting-the-touch-andconcern-standard/ (last visited Sept. 27, 2015)

Post-Kiobel, the Lower Courts are only Pretending to Apply the Presumption against Extraterritoriality in Alien Tort Statute Cases, The View From LL2, http://viewfromll2. com/2014/07/22/post-kiobel-the-lower-courts-areonly-pretending-to-apply-the-presumption-against-extraterritoriality-in-alien-tort-statute-cases/ (last visited Sept. 27, 2015)

Cardona, et al. v. Chiquita Brands International, et al. No. 1214898 (11th Cir. 2014).

Chiquita lawsuits (re Colombia), Business \& Human Rights Resource Centre, http://business-humanrights.org/ en/chiquita-lawsuits-re-colombia (last visited Sept. 27, 2015) 


\section{O direito humano à comunicação prévia e pormenorizada das acusações nos processos administrativos: $O$ desprezo do Superior Tribunal de Justiça ao Pacto de San José da Costa Rica e à Corte Interamericana de Direitos Humanos*}

\author{
The human right to a prior notification in \\ detail of the charges against the accused in \\ administrative proceedings: The contempt of \\ Brazilian Superior Court of Justice to The Pact of \\ San José de Costa Rica and The Inter-American \\ Court of Human Rights
}

Daniel Wunder Hachem **

Eloi Pethechust ***

* Recebido em 19.07.2015

Aprovado em 30.09.2015

** Professor do Departamento de Direito Público da Universidade Federal do Paraná e do Programa de Mestrado e Doutorado em Direito da Pontifícia Universidade Católica do Paraná (Curitiba-PR, Brasil). Doutor e Mestre em Direito do Estado pela Universidade Federal do Paraná. Diretor Acadêmico do NINC - Núcleo de Investigações Constitucionais da UFPR (www.ninc.com.br). Coordenador Executivo, pelo Brasil, da Rede Docente Eurolatinoamericana de Derecho Administrativo. Membro do Foro Iberoamericano de Derecho Administrativo. Advogado. E-mail: danielhachem@gmail. com

*** Mestrando em Direito pela Pontifícia Universidade Católica do Paraná (Curitiba-PR, Brasil), bolsista da CAPES/PROSUP. Especialista em Direito Processual Civil pelo Instituto de Direito Romeu Felipe Bacellar. Membro dos grupos de pesquisa "Direito e Economia" e "Regulação Econômica e Atuação Empresarial" do Programa de Pós-Graduação em Direito da Pontifícia Universidade Católica do Paraná. Membro da Comissão dos Advogados Iniciantes da $\mathrm{OAB} / \mathrm{PR}$. Advogado. E-mail: pethechust@hotmail.com.

\section{Resumo}

O presente artigo tem como objetivo analisar o direito dos acusados, nos processos administrativos sancionadores, a uma descrição prévia e pormenorizada das acusações que lhes são dirigidas. Com base na previsão desse direito na Convenção Americana de Direitos Humanos, no rol denominado "Garantias Judiciais", o trabalho busca realizar confronto entre o posicionamento do Superior Tribunal de Justiça brasileiro e a jurisprudência da Corte Interamericana de Direitos Humanos, a respeito da incidência de tais garantias em processos administrativos. A metodologia utilizada consistiu na análise das decisões do STJ sobre o tema nos últimos dez anos, comparando-as com as decisões da Corte Interamericana a propósito do assunto, para verificar se há consonância ou divergência entre tais tribunais. Após constatar que o Superior Tribunal de Justiça brasileiro ignora solenemente o referido direito em suas decisões, admitindo práticas administrativas totalmente contrárias ao Pacto de San José da Rica, o estudo conclui pela necessidade do STJ e da Administração Pública brasileira adequarem seu entendimento à posição consolidada pela Corte Interamericana de Direitos Humanos.

Palavras-chave: Desenvolvimento. Direitos humanos. Direitos fundamentais. Eficiência administrativa. Direito humano à ampla defesa. Processo administrativo sancionador. 
ABSTRACT

This article aims to analyze the right of the accused in administrative disciplinary proceedings to a prior notification in detail of the charges against them. From the prediction of that right in the American Convention on Human Rights, in the list called "Right to a Fair Trial", the paper aims to make a confrontation between the position of the Brazilian Superior Court of Justice and the jurisprudence of the Inter-American Court of Human Rights regarding the incidence of such guarantees in administrative proceedings. The methodology used was the analysis of STJ decisions on the subject over the past decade, comparing them with the decisions of the Inter-American Court concerning the subject, to check for compliance or inconsistency between such courts. After noting that the Brazilian Superior Court of Justice ignores solemnly this right in its decisions, accepting administrative practices totally opposite to the Pact of San José de Costa Rica, the study concludes it is necessary that the STJ and the Brazilian Public Administration suit their understanding to the consolidated position of the Inter-American Court of human rights.

Keywords: Development. Fundamental rights. Administrative efficiency. Human right to legal defense. Administrative sanctioning proceeding.

\section{INTRODUÇão}

A jurisprudência do Superior Tribunal de Justiça brasileiro (STJ) ${ }^{1}$ consolidou, nos últimos anos, entendimento segundo o qual os atos administrativos de instauração dos processos administrativos disciplinares regidos pela Lei no 8.112/90 não demandam uma descrição minudente e detalhada dos fatos imputados ao acusado. ${ }^{2}$ Ou seja: de acordo com a posição atual pacificada

1 É importante observar que na organização judiciária brasileira o Superior Tribunal de Justiça possui como principal função (além de outras) a de uniformizar a jurisprudência dos tribunais brasileiros a respeito da interpretação das leis federais. Suas competências estão estabelecidas no art. 105 da Constituição Federal. Por sua vez, o Supremo Tribunal Federal tem como função primordial — além de outras incumbências - a guarda da Constituição, atuando como Corte Constitucional no exercício do controle de constitucionalidade e como revisor das decisões de outros tribunais que ofendam a Constituição ou interpretem-na da forma inadequada. Suas atribuições estão definidas no art. 102 da Constituição Federal.

2 Algumas das diversas decisões do Tribunal representativas desse pela Corte, baseada, exclusivamente, na interpretação da legislação nacional, o acusado em processos administrativos de cunho sancionador não precisa receber, antes do exercício do seu direito ao contraditório e à ampla defesa, uma comunicação prévia e pormenorizada das acusações que lhe são assacadas.

Ocorre que a interpretação das normas legais não pode ser feita de forma isolada. Ela deve ser realizada de forma sistemática, ${ }^{3}$ levando em consideração também as previsões estabelecidas na Constituição e nos tratados internacionais. Entre os direitos e garantias albergados pela Convenção Americana sobre Direitos Humanos, também denominada Pacto de San José da Costa Rica e incorporada ao ordenamento jurídico brasileiro em 1992, encontra-se textualmente previsto em seu art. $8^{\circ}$, n. 2 , "b" o direito do acusado à prévia e pormenorizada descrição dos fatos relativos à acusação que lhe foi dirigida. A Corte Interamericana de Direitos Humanos, por sua vez, tem proferido importantes decisões a respeito do conteúdo jurídico do mencionado direito e da sua incidência nos processos administrativos, ${ }^{4}$ as quais, em princípio, parecem estar em desacordo com o posicionamento manifestado pelo Superior Tribunal de Justiça brasileiro.

O problema jurídico que surge, nessa conjuntura, é o seguinte: as "garantias judiciais" do art. $8^{\circ}$ do Pacto de San José da Costa Rica (e entre elas o direito do art. $8^{\circ}$, n. 2, "b") são aplicáveis também aos processos extrajudiciais, como é o caso dos processos administrativos sancionadores? Em caso positivo, a hierarquia de tais tratados, superior à da legislação ordinária, obriga a Administração Pública a respeitá-los mesmo nos casos em que a lei em sentido formal dispuser um procedimento que lhes seja contrário? Levando em conta tais considerações, não estaria o Superior Tribunal de Justiça supervalorizando a legislação ordinária nacional em detrimento de previsões mais protetivas inscritas em um tratado internacional de direitos humanos? Qual é a posição da Corte Interamericana de Direitos Humanos a respeito do assunto e qual deve ser o seu impacto na jurisprudência dos Tribunais Superiores nacionais?

posicionamento serão analisadas no tópico " 4 . O posicionamento do Superior Tribunal de Justiça brasileiro sobre o dever de especificação das condutas no ato de instauração do processo administrativo disciplinar". 3 FREITAS, Juarez. O intérprete e o poder de dar vida à Constituição: preceitos de exegese constitucional. A\&C - Revista de Direito Administrativo \& Constitucional, Curitiba, ano 4, n. 8, p. 13-35, 2002. 4 A análise de tais decisões será empreendida no tópico "5. A aplicação das garantias do art. $8^{\circ}$ da Convenção Americana sobre Direitos Humanos aos processos administrativos". 
Em suma, a questão essencial por trás da discussão ora iniciada consiste na relação entre o Direito Internacional dos Direitos Humanos e o Direito interno, seja no plano normativo, relativo aos impactos dos tratados sobre a legislação nacional, seja no plano jurisprudencial, referente à influência (ou ausência dela) das decisões da Corte Interamericana de Direitos Humanos sobre as posições dos tribunais brasileiros. ${ }^{5}$

Nesse contexto, com o intuito de responder as indagações acima apresentadas, o presente artigo se propõe a investigar: (i) a hierarquia dos tratados internacionais de proteção dos direitos humanos na ordem jurídica brasileira; (ii) a compatibilidade das disposições normativas pertinentes ao processo administrativo disciplinar regido pela Lei no 8.112/90 com o art. $8^{\circ}$, n. 2, "b" da Convenção Americana sobre Direitos Humanos; (iii) o atual posicionamento do STJ quanto à necessidade de constar, no ato que inaugura o processo disciplinar, a minuciosa descrição dos fatos a serem apurados; (iv) a possibilidade de aplicação das garantias do art. $8^{\circ}$ da Convenção Americana de Direitos Humanos aos processos administrativos (e não apenas aos processos judiciais); e, por fim, (v) questionar o entendimento exarado pelo STJ no que tange à (in)aplicabilidade do art. $8^{\circ}$, n. 2, "b" da Convenção Americana de Direitos Humanos aos processos administrativos, verificando se a jurisprudência do Tribunal se encontra ou não alinhada ao referido tratado internacional e ao entendimento manifestado pela Corte Interamericana de Direitos Humanos.

\section{OS DiREITOS HUMANOS COMO ELEMENTOS INTEGRANTES DO BLOCO DE CONSTITUCIONALIDADE E A HIERARQUIA DOS TRATADOS INTERNACIONAIS no Direito brasileiro}

A noção de bloco de constitucionalidade surge no Direito francês na década de 1970 , em decisão do Conselho Constitucional que admitiu a normatividade do Preâmbulo da Constituição de 1958 e das demais fontes jurídicas às quais ele se reporta. Desde então, as disposi-

5 Sobre a atualidade dessa inter-relação entre a Corte Interamericana de Direitos Humanos e a jurisdição nacional, ver: LEAL, Mônia Clarissa Hennig. Corte Interamericana de Direitos Humanos e jurisdição constitucional: judicialização e ativismo judicial em face da proteção dos direitos humanos e fundamentais? Revista de Investigações Constitucionais, Curitiba, vol. 1, n. 3, p. 123-140, set./dez. 2014. DOI: http://dx.doi.org/10.5380/rinc.v1i3.40518. ções de todos os documentos normativos referidos no Preâmbulo constitucional francês passaram a ser consideradas como normas integrantes da Constituição, tão juridicamente aplicáveis quanto as que efetivamente constam do seu corpo. A expressão "bloco de constitucionalidade", no entanto, jamais foi empregada pela jurisprudência constitucional, tendo aparecido somente no meio doutrinário a partir de um trabalho de Louis Favoreu. $^{6}$

O autor inspirou-se na locução "bloco de legalidade", habitualmente utilizada no Direito Administrativo por autores como Maurice Hauriou para aludir ao plexo de normas que não decorriam da lei formal, mas que eram igualmente de observância obrigatória para a Administração Pública (tais como os regulamentos ${ }^{7}$ e os então chamados "princípios gerais do Direito"). ${ }^{8}$ Com base na doutrina de Maurice Hauriou, Louis Favoreu transportou a ideia de "bloco" para a seara constitucional e criou a expressão "bloc de constitucionalitê", designando o grupo de normas que, juntamente com a Constituição positivada de um Estado, formam um bloco normativo de nível hierárquico constitucional. ${ }^{9}$

$\mathrm{Na}$ jurisprudência francesa, a existência de um "bloco de constitucionalidade" - ainda que sem referência a essa expressão - foi pela primeira vez reconhecida em 1971, em decisão do Conselho Constitucional, ao se admitir que no sistema jurídico francês o conjunto de normas composto pela Constituição de 1958, o Preâmbulo da Constituição de 1946, a Declaração dos Direitos do Homem e do Cidadão de 1789 e os princípios e direitos fundamentais reconhecidos pelas Leis da

6 FAVOREU, Louis. Le principe de constitutionnalité: essai de définition d'aprés la jurisprudence du Conseil constitutionnel. In: Recueil d'études en hommage à Charles Eisenmann. Paris: $\mathrm{Cu}$ jas, 1975. p. 33.

7 A respeito do tema, assim se manifestou Maurice Hauriou: "Se a violação de um regulamento orgânico enseja indenizações reparatórias de danos, se ela enseja nulidade de decisões administrativas ou reforma de julgamentos que aplicaram mal o regulamento, assim como se houvessem aplicado mal a lei, percebe-se que o regulamento orgânico penetra no bloco da legalidade por todas as vias que conduzem a isso. O regulamento orgânico se converteu, pela jurisprudência, um elemento da legalidade". HAURIOU, Maurice. Notes d'arrêts sur décisions du Conseil d'État et du Tribunal des Conflits: publiées au Recueil Sirey de 1892 à 1928. t. I. Paris: Librairie du Recueil Sirey, 1929. p. 49.

8 FAVOREU, Louis. El bloque de la constitucionalidad. Revista del Centro de Estudios Constitucionales, n ${ }^{\circ}$ 5, Madrid, Centro de Estudios Constitucionales, p. 45-68, ene./abr. 1990. p. 46-47.

9 FAVOREU, Louis. El bloque de la constitucionalidad. Revista del Centro de Estudios Constitucionales, $n^{\circ}$ 5, Madrid, Centro de Estudios Constitucionales, p. 45-68, ene./abr. 1990. p. 47. 
República compunham um bloco de princípios e regras que possuíam caráter normativo dotado de nível hierárquico constitucional. $\mathrm{Na}$ decisão, o Conselho francês reconheceu, com base no Preâmbulo da Constituição de 1958 e nas fontes jurídicas nele referidas, a liberdade de associação como um princípio fundamental presente nas Leis da República, possuindo, portanto, valor constitucional, ainda que não fosse um direito codificado no corpo da Constituição em vigor.

Atualmente, o termo "bloco de constitucionalidade" designa, no Direito francês, o conjunto de elementos normativos aos quais se reconhece hierarquia constitucional, ainda que não se encontrem formalmente escritos no texto da Constituição de 1958. Esse complexo de normas funciona como parâmetro para o controle de constitucionalidade das leis, exercido pelo Conselho Constitucional. Seus componentes são múltiplos e hodiernamente compreendem, além do próprio texto da Constituição de 1958 (inclusive seu Preâmbulo), o Preâmbulo da Constituição de 1946, a Declaração dos Direitos do Homem e do Cidadão de 1789, os ditos "princípios fundamentais reconhecidos pelas leis da República", ${ }^{10}$ outros princípios e objetivos de valor constitucional identificados pelo Conseil Constitutionnel, ${ }^{11}$ bem como a Carta do Meio-Ambiente incorporada ao Preâmbulo da Constituição vigente em 2005. Todas essas parcelas do bloco situam-se no mesmo patamar hierárquico-normativo - isto é: em nível constitucional — inexistindo relação de superioridade/inferioridade entre elas.

Essa ideia construída pioneiramente na França foi incorporada com sentido similar — ainda que adquirindo especificidades e contornos próprios - aos sistemas jurídicos de diversos Estados, tais como Espanha, ${ }^{12}$

10 VEDEL, Georges. La place de la Déclaration de 1789 dans le bloc de constitutionnalité. In: CONSEIL CONSTITUTIONNEL. La Déclaration des droits de l'homme et du citoyen et la jurisprudence: colloque des 25 et 26 mai 1989 au Conseil constitutionnel. Paris: Presses Universitaires de France, 1989. p. 52.

11 Mencione-se como exemplo o princípio da dignidade da pessoa humana, não inscrito no texto constitucional francês, mas guindado à condição de "princípio de valor constitucional" pelo Conseil Constitutionnel ao analisar as leis de bioética na decisão no 94-343/344 DC de 27 de julho de 1994. Ampliar em: GIMENO-CABRERA, Véronique. Le traitement jurisprudentiel du principe de dignité de la persone humaine dans la jurisprudence du Conseil Constitutionnel français et du Tribunal Constitutionnel espagnol. Paris: LGDJ, 2004.

12 FERNÁNDEZ, Tomás-Ramón. Las leyes orgánicas y el bloque de la constitucionalidad: en torno al artículo 28 de la Ley Orgánica del Tribunal Constitucional. Madrid: Civitas, 1981; RUBIO
Itália, ${ }^{13}$ México, ${ }^{14}$ Peru, ${ }^{15}$ Colômbia,${ }^{16}$ Argentina,${ }^{17}$

LLORENTE, Francisco. El bloque de constitucionalidad. Revista Española de Derecho Constitucional, $n^{\circ}$ 27, Madrid, Centro de Estudios Políticos y Constitucionales, p. 9-38, sep./dic. 1989; GÓMEZ FERNÁNDEZ, Itziar. Redefinir el bloque de la constitucionalidad 25 años después. Estudios de Deusto: Revista de la Universidad de Deusto, vol. 54, $\mathrm{n}^{\circ} 1$, Bilbao, Universidad de Deusto, p. 61-98, ene./jun. 2006; LORENZO RODRÍGUEZ-ARMAS, Magdalena. Reflexiones en torno al concepto del bloque de la constitucionalidad. In: MORODO LEONCIO, Raúl; VEGA GARCÍA, Pedro de (Coords.). Estudios de teoría del Estado y derecho constitucional en honor de Pablo Lucas Verdú. v. 4. Madrid: Universidad Complutense - Facultad de Derecho, 2001. p. 2609-2622.

13 ZAGREBELSKY, Gustavo. La giustizia costituzionale. 2. ed. Bologna: II Mulino, 1988. p. 123.

14 ROSARIO RODRÍGUEZ, Marcos del. De la supremacía constitucional a la supremacía de convencionalidad. La nueva conformación del bloque de constitucionalidad en México. Quid Iuris, año 8, vol. 22, Chihuahua, Tribunal Estatal Electoral de Chihuahua, p. 93-118, sep./nov. 2013; DÍAZ MADRIGAL, Ivonne Nohemí. El debido proceso en instrumentos internacionales y el nuevo bloque de constitucionalidad en el sistema jurídico mexicano. Reforma Judicial: Revista Mexicana de Justicia, nº 20, México, Instituto de Investigaciones Jurídicas - Universidad Nacional Autónoma de México, p. 167-194, jul./dic. 2012; MORALES MORALES, Alejandra Virginia. ODIMBA ON'ETAMBALAKO WETSHOKONDA, Jean Cadet. La incorporación del concepto del bloque de constitucionalidad en materia de derechos humanos en México. Revista Prolegómenos: Derechos y Valores de la Facultad de Derecho, vol. 14, n 27, Bogotá, Universidad Militar Nueva Granada, p. 135146, ene./jun. 2011.

15 HAKANSSON NIETO, Carlos. El reconocimiento judicial del bloque de constitucionalidad. Un estudio con especial referencia al ordenamiento jurídico peruano. In: FERRER MAC-GREGOR, Eduardo; ZALDÍVAR LELO DE LARREA, Arturo (Coords.) La ciencia del derecho procesal constitucional: estudios en homenaje a Héctor Fix-Zamudio en sus cincuenta años como investigador del derecho. t. IV. México: UNAM/Marcial Pons, 2008. p. 763-780.

16 REINA GARCÍA, Óscar M. Las cláusulas de apertura o reenvío hacia fuentes externas previstas en la Constitución colombiana, como criterio para delimitar el contenido del bloque de constitucionalidad. Revista Derecho del Estado, no 29, Bogotá, Universidad Externado de Colombia, p. 175-214, jul./dic. 2012; REY CANTOR, Ernesto. El bloque de constitucionalidad. Aplicación de tratados internacionales de derechos humanos. Estudios constitucionales: Revista del Centro de Estudios Constitucionales, año 4, no 2, Santiago de Chile, Universidad de Talca, p. 299-334, jul./dic. 2006; OLANO GARCÍA, Hernán Alejandro. El bloque de constitucionalidad en Colombia. Estudios constitucionales: Revista del Centro de Estudios Constitucionales, año 1, no 1, Santiago de Chile, Universidad de Talca, p. 231-242, ene./dic. 2005; RAMELLI, Alejandro. Sistema de fuentes de derecho internacional público y "bloque de constitucionalidad" en Colombia. Cuestiones constitucionales: Revista Mexicana de Derecho Constitucional, no 11, México, Instituto de Investigaciones Jurídicas - Universidad Nacional Autónoma de México, p. 157-175, jul./dic. 2004.

17 MANILI, Pablo Luis. El bloque de constitucionalidad: la recepción del derecho internacional de los derechos humanos en el derecho constitucional argentino. Buenos Aires: La Ley, 2003; CLÉRICO, Laura; RONCONI, Liliana. Impacto del bloque de constitucionalidad en la interpretación del derecho común: La interpretación amplia de los abortos permitidos en Argentina. Estudios constitucionales: Revista del Centro de Estudios Constitucionales, año 
Uruguai, ${ }^{18}$ Panamá, ${ }^{19}$ República Dominicana, ${ }^{20}$ entre outros. Na América Latina, grande parte das Constituições aderiu às cláusulas constitucionais abertas, permitindo a "integração entre a ordem constitucional e internacional, especialmente no campo dos direitos humanos, ampliando e expandindo o bloco de constitucionalidade."21

No sistema normativo brasileiro vigente, a Teoria do Bloco de Constitucionalidade foi incorporada pela via do $\$ 2^{\circ}$, do art. $5^{\circ}$ da Constituição da República Federativa do Brasil, no qual se estabelece que os direitos e garantias expressos na Constituição "não excluem outros decorrentes do regime e dos princípios por ela adotados, ou dos tratados internacionais em que a República Federativa do Brasil seja parte."

Por meio da Emenda Constitucional n ${ }^{\circ} 45 / 2004$, foi acrescido o $\$ 3^{\circ}$ ao art. $5^{\circ}$ da Constituição, o qual pode ser considerado uma norma interpretativa do disposto no $\$ 2^{\circ}$, ao estabelecer que "os tratados e convenções internacionais sobre direitos humanos que forem aprovados, em cada Casa do Congresso Nacional, em dois turnos, por três quintos dos votos dos respectivos membros, serão equivalentes às emendas constitucionais." E isso porque o novo dispositivo surgiu com o objetivo de esclarecer qual seria o patamar hierárquico no qual se

10, no 2, Santiago de Chile, Universidad de Talca, p. 193-230, jul./ dic. 2012; GUTIÉRREZ COLANTUONO, Pablo Ángel. Derecho administrativo, Constitución y derechos humanos. A\&C - Revista de Direito Administrativo \& Constitucional, $n^{\circ} 40$, Belo Horizonte, Fórum, p. 239-250, abr./jun. 2010. p. 241; CASSAGNE, Juan Carlos. La jerarquía y regulación de los Tratados en la Constitución argentina. A\&C - Revista de Direito Administrativo \& Constitucional, Belo Horizonte, ano 10, n. 40, p. 199-216, abr./jun. 2010.

18 FORMENTO, Augusto, DELPIAZZO, José Miguel. Primer reconocimiento jurisprudencial del bloque de constitucionalidad: concepto, importancia, efectos jurídicos y perspectivas. Revista de Derecho, $n^{\circ}$ 18, Montevideo, Universidad de Montevideo - Facultad de Derecho, p. 101-113, jul./dic. 2010; BARBAGELATA, Héctor-Hugo. La consagración legislativa y jurisprudencial del bloque de constitucionalidad de los derechos humanos. Derecho Laboral: Revista de doctrina, jurisprudencia e informaciones sociales, $\mathrm{n}^{\circ}$ 237, Montevideo, Fundación de Cultura Universitaria, p. 141-155, ene./mar. 2010.

19 HOYOS, Arturo. El control judicial y el bloque de constitucionalidad en Panamá. Boletín Mexicano de Derecho Comparado, $\mathrm{n}^{\circ} 75$, México, Instituto de Investigaciones Jurídicas - Universidad Nacional Autónoma de México, p. 785-807, sep./dic. 1992.

20 REPÚBLICA DOMINICANA. El bloque de constitucionalidad en la determinación de los principios fundamentales del debido proceso. Extracto de la Resolución de la Suprema Corte de Justicia, República Dominicana, 13 de noviembre de 2003. Diálogo Jurisprudencial, $\mathrm{n}^{\circ} 3$, México, Instituto de Investigaciones Jurídicas Universidad Nacional Autónoma de México, p. 27-50, jul./dic. 2007. 21 PIOVESAN, Flávia. Temas de Direitos Humanos. 7. ed. São Paulo: Saraiva, 2014. p. 139. encontram situadas as normas veiculadas por tratados internacionais de direitos humanos incorporados pelo ordenamento jurídico brasileiro.

Com base nesses dispositivos constitucionais, pode-se afirmar que, no sistema normativo pátrio, os direitos e garantias fundamentais não se encontram apenas positivados textualmente no corpo da Constituição e no catálogo do Título II ("Dos direitos e garantias fundamentais"), sendo também assegurados em normas que decorrem do regime democrático e dos princípios constitucionais, bem como naquelas sediadas em tratados internacionais sobre direitos humanos dos quais o Brasil seja signatário. Por força do art. $5^{\circ}, \$ 2^{\circ}$ da Constituição Federal, consideram-se direitos materialmente fundamentais: (i) os expressamente positivados na enumeração do Título II da CF; (ii) os implícitos e subentendidos nos enunciados normativos desse mesmo apartado da Constituição; (iii) os proclamados explicitamente em outras partes do texto constitucional que se assemelhem àqueles inscritos no rol do Título II em termos de conteúdo e importância; (iv) os previstos nos tratados internacionais de direitos humanos; (v) os que não estejam anunciados em texto normativo algum, mas que decorram dos princípios e do regime constitucionalmente adotados.

Portanto, a noção de bloco de constitucionalidade é evidentemente vigente na ordem jurídica nacional. A própria Constituição de 1988 permitiu, expressamente, a entrada no plano constitucional de normas não inscritas expressamente em seu texto. Essa abertura da normatividade constitucional é amplamente reconhecida na doutrina nacional, como se denota nos trabalhos de Ana Maria D’Ávila Lopes ${ }^{22}$, Celso $\mathrm{Lafer}^{23}$, Flávia Piovesann ${ }^{24}$, Ingo Wolfgang Sarlet ${ }^{25}$, Valerio de Oliveira Mazzuoli, ${ }^{26}$ dentre outros.

22 LOPES, Ana Maria D’Ávila. Bloco de constitucionalidade e princípios constitucionais: desafios do poder judiciário. Seqüência: Publicação do Curso de Pós-Graduação em Direito da UFSC, $\mathrm{n}^{\circ}$ 59, Florianópolis, Universidade Federal de Santa Catarina, p. 4360, jul./dez. 2009. p. 48-49.

23 LAFER, Celso. A internacionalização dos direitos humanos: Constituição, racismo e relações internacionais. Barueri: Manole, 2005. p. 15 e ss.

24 PIOVESAN, Flávia. Direitos humanos e o Direito Constitucional Internacional. 14. ed. São Paulo: Saraiva, 2013. p. 113 e ss.

25 SARLET, Ingo Wolfgang. A eficácia dos direitos fundamentais. 10. ed. Porto Alegre: Livraria do Advogado 2010. p. 78 e ss.

26 MAZZUOLI, Valerio de Oliveira. Curso de Direito Internacional Público. 2. ed. São Paulo: Revista dos Tribunais, 2007. p. 694-695. 
Nesse mesmo sentido, a jurisprudência do Supremo Tribunal Federal - em reiteradas decisões — atesta a existência, no Direito brasileiro, de um bloco normativo composto por preceitos que, embora sediados em outras fontes jurídicas que não o texto da Constituição, também integram o elenco de direitos constitucionalmente consagrados. ${ }^{27}$

Resta evidente que os tratados internacionais sobre direitos humanos incorporados ao sistema normativo nacional por meio do procedimento estabelecido no $\$ 3^{\circ}$ do art. $5^{\circ}$ da Constituição Federal — similar ao procedimento de aprovação de emendas constitucionais - gozam de hierarquia constitucional. Sobre esse ponto, parece não haver qualquer dúvida ou controvérsia, diante da literalidade do citado dispositivo constitucional. Entretanto, não se pode dizer o mesmo em relação às normas de Direito Internacional que versem sobre direitos humanos e que foram incorporadas ao ordenamento pátrio antes da Emenda Constitucional $\mathrm{n}^{\circ} 45 / 2004$ (que acrescentou o $\$ 3^{\circ}$ ao art. $5^{\circ}$ da CF) por meio do procedimento legislativo simplificado, não submetidos às regras do processo de internalização delimitadas pelo $\int 3^{\circ}$ do art. $5^{\circ}$ da $\mathrm{CF} / 88$. Nesses casos, a doutrina e jurisprudência divergem.

Dentre as duas posições mais expressivas, de um lado encontram-se os que defendem que: a) os tratados

27 Nesse sentido: BRASIL. Supremo Tribunal Federal. ADI 595/ES , Relator Min. Celso de Mello. Segunda Turma. Julgado em 18.02.2002. Disponível em: <http://www.stf.jus.br/portal/ processo $/$ verProcessoAndamento.asp?numero $=595 \&$ classe $=$ ADIMC\&codigoClasse $=0$ \&origem $=J U R \&$ recurso $=0 \&$ tipoJulgame nto $=M>$. Acesso em: 23 de jun. 2015; BRASIL. Supremo Tribunal Federal. ADI 514/PI. Relator Min. Celso de Mello. Julgado em 24.03.2008. Disponível em: <http://www.stf.jus.br/portal/ processo $/$ verProcessoAndamento.asp? numero $=514 \&$ classe $=\mathrm{A}$ DI\&codigoClasse $=0 \&$ origem $=$ JUR\&recurso $=0 \&$ tipoJulgament $\mathrm{o}=\mathrm{M}>$. Acesso em: 23 de jun. 2015; BRASIL. Supremo Tribunal Federal. ADI 4222 AgR/DF. Relator Min. Celso de Mello. Julgado em 01.08.2014. Disponível em: <http://redir.stf.jus.br/paginadorpub/paginador.jsp?doc TP $=$ TP\&docID $=6631759>$. Acesso em: 23 de jun. 2015; BRASIL. Supremo Tribunal Federal. Habeas Corpus n ${ }^{\circ}$ 91361. Relator Min. Celso de Mello. Segunda Turma. Julgado em 23.09.2008. Disponível em: <http://redir.stf.jus.br/paginadorpub/paginador.jsp?doc $T P=A C \& d o c I D=573717>. \quad$ Acesso em: 23 de jun. 2015; BRASIL. Supremo Tribunal Federal. Habeas Corpus $n^{\circ}$ 87585. Relator Min. Marco Aurélio. Tribunal Pleno. Julgado em 03.12.2008. Disponível em: < http://redir.stf.jus.br/paginadorpub/paginador.jsp?docTP $=\mathrm{AC} \&$ docID $=597891>$. Acesso em: 23 de jun. 2015; BRASIL. Supremo Tribunal Federal. Recurso Extraordinário no 466343. Relator Min. Cezar Peluso. Julgado em 03.12.2008. Disponível em: <http://redir.stf.jus.br/paginadorpub/ paginador.jsp?doc $\mathrm{TP}=\mathrm{AC} \& \operatorname{docID}=595444>$. Acesso em: $23 \mathrm{de}$ jun. 2015. internacionais de direitos humanos não incorporados pelos trâmites do $₫ 3^{\circ}$ do art. $5^{\circ}$ da CF são normas materialmente constitucionais, por força do art. $5^{\circ}, \S 2^{\circ}$ que já estava inserido na redação original da Constituição, possuindo o mesmo patamar hierárquico-normativo das demais normas constitucionais; ${ }^{28}$ e, do outro lado, aqueles que sustentam que: b) as normas internacionais de direitos humanos incorporadas pelo Direito interno sem observância das peculiaridades procedimentais do $\int 3^{\circ}$, do art. $5^{\circ}$, da CF possuem status infraconstitucional (encontram-se abaixo da Constituição), mas supralegal (estão acima da legislação ordinária). ${ }^{29}$

Apesar do $\$ 3^{\circ}$ do art. $5^{\circ}$ da Constituição Federal ter gerado essas divergências interpretativas, o Supremo Tribunal Federal brasileiro (STF) concluiu que: a) os tratados de direitos humanos aprovados nos termos do $\$ 3^{\circ}$ do art. $5^{\circ}$ da CF detêm hierarquia constitucional; b) os tratados de direitos humanos incorporados ao ordenamento sem observar o rito fixado no $\$ 3^{\circ}$ do art. $5^{\circ}$ da CF situam-se em um patamar inferior à Constituição (infraconstitucional), não podendo alterá-la, mas superior às leis (supralegal), revogando as disposições legais que lhe forem contrárias ou incompatíveis. Assim, se manifestou o STF, entendendo que "o caráter especial desses diplomas internacionais sobre direitos humanos lhes reserva lugar específico no ordenamento jurídico, estando abaixo da Constituição, porém acima da legislação interna." ${ }^{30}$

Parte da doutrina, no entanto, defende posição diversa da Suprema Corte Federal. Sustentam tais autores, como é o caso de Flávia Piovesan, que todos os tratados de direitos humanos aos quais o Estado brasileiro aderiu, independentemente de terem observado ou não os trâmites legislativos descritos no art. $5^{\circ}, \S 3^{\circ}$, da CF,

28 É a posição defendida por PIOVESAN, Flávia. Direitos humanos e o Direito Constitucional Internacional. 14. ed. São Paulo: Saraiva, 2013. p. 126-130.

29 É o entendimento adotado pelo Supremo Tribunal Federal. Ver: BRASIL. Supremo Tribunal Federal. Recurso Extraordinário $\mathrm{n}^{\circ}$. 597.285. Relator Min. Ricardo Lewandowski. Julgado em 18.05.2010. Disponível em: <http://www.stf.jus.br/portal/processo $/$ verProcessoAndamento.asp? numero $=597285 \&$ classe $=R E \&$ codigoClasse $=0$ \&origem $=J U R \&$ recurso $=0 \&$ tipoJulgamento $=\mathrm{M}>$. Acesso em: 23 de jun. 2015.

30 BRASIL. Supremo Tribunal Federal. Recurso Extraordinário $\mathrm{n}^{\circ}$ 349703. Relator Min. Carlos Britto. Relator p/ Acórdão: Min. Gilmar Mendes. Tribunal Pleno. Julgado em 03.12.2008. DJe104, divulgado em 04.06.2009 e publicado em 05.06.2009. Disponível em: <http://redir.stf.jus.br/paginadorpub/paginador. jsp?docTP=AC\&docID=595406>. Acesso em: 23 de jun. 2015. 
desfrutam, por força do $\$ 2^{\circ}$ do art. $5^{\circ}$ da $\mathrm{CF}$, de hierarquia de normas materialmente constitucionais, compondo o bloco de constitucionalidade, ao passo que os tratados de direitos humanos internalizados com base no trâmite do $\$ 3^{\circ}$ de art. $5^{\circ}$ da $\mathrm{CF}$, além de serem materialmente também são formalmente constitucionais, fato que lhes atribui as prerrogativas inerentes às emendas constitucionais. $^{31}$

Assim, "enquanto os tratados materialmente constitucionais podem ser suscetíveis de denúncia '(ato unilateral pelo qual um Estado se retira de um tratado)', os tratados material e formalmente constitucionais, por sua vez, não podem ser denunciados" ${ }^{\prime 2}$, pois equiparam-se às emendas à Constituição, que possuem processo legislativo mais rigoroso para alterações e impossibilidade de exclusão no caso de veicularem direitos fundamentais, já que esses são arrolados como cláusulas pétreas pelo texto constitucional brasileiro (art. $60, \S 4^{\circ}, \mathrm{IV}, \mathrm{CF}$ ).

Discordando-se da solução a que chegou a Suprema Corte brasileira, o presente estudo acolhe o entendimento manifestado por Flávia Piovesan de que ambas as espécies de tratados internacionais - os incorporados antes e os internalizados depois da $\mathrm{EC} \mathrm{n}^{\circ} 45 / 2004-$ veiculam direitos considerados materialmente fundamentais, motivo pelo qual todos eles integram o chamado "bloco de constitucionalidade" e posicionam-se no mesmo patamar hierárquico das normas constitucionais.

Logo, conclui-se que, existindo conflito entre as normas internacionais de direitos humanos e qualquer disciplina normativa infraconstitucional, deve prevalecer a disposição estabelecida no ato normativo internacional. Esse entendimento se baseia não apenas na construção teórica tecida até o momento, mas também nos princípios da boa-fé e do pacta sunt servanda no Direito Internacional, ${ }^{33}$ no caráter jus cogens inerente a significativa parcela das normas previstas nos tratados de direitos humanos, bem como no que dispõe o art. $27 \mathrm{da}$ Convenção de Viena sobre Direito dos Tratados ("uma parte não pode invocar disposições de seu direito interno como

31 PIOVESAN, Flávia. Temas de Direitos Humanos. 7. ed. São Paulo: Saraiva, 2014. p. 65-67; SARLET, Ingo Wolfgang. A eficácia dos direitos fundamentais. 10. ed. Porto Alegre: Livraria do Advogado 2010. p. 129.

32 PIOVESAN, Flávia. Direitos humanos e o Direito Constitucional Internacional. 14. ed. São Paulo: Saraiva, 2013. p. 145. 33 Nesse sentido dispõe a Convenção de Viena sobre o Direito dos Tratados, concluída em 1969 e ratificada pelo Brasil em 2009, em seu art. 26, que assim estabelece "Pacta sunt servanda - Todo tratado em vigor obriga as partes e deve ser cumprido por elas de boa fé". justificativa para o não cumprimento do tratado")..$^{34}$

\section{A DESCRIÇÃO PRÉVIA E PORMENORIZADA DAS CONDUTAS DO ACUSADO NO PROCESSO ADMINISTRATIVO DISCIPLINAR COMO DESDOBRAMENTO DOS DIREITOS AO CONTRADITÓRIO E À AMPLA DEFESA: ENTRE O SILÊNCIO DA LEI No 8.112/90 E A PREVISÃO expressa do Pacto de San José da Costa RICA}

A Lei $\mathrm{n}^{\circ} 8.112 / 90$, que dispõe sobre o regime jurídico dos servidores públicos civis da União, das autarquias e das fundações públicas federais, dentre suas disposições normativas disciplina o processo para apuração de condutas ilícitas praticadas pelos servidores públicos no exercício de suas funções ou em razão delas.

A lei em questão estabelece em seu art. 143 que "A autoridade que tiver ciência de irregularidade no serviço público é obrigada a promover a sua apuração imediata, mediante sindicância ou processo administrativo disciplinar, assegurada ao acusado ampla defesa". Em ambos os casos, sindicância ou processo disciplinar, a instauração se dá por meio de portaria inaugural, ato que dá início ao processo de averiguação das denúncias.

Ocorre que a Lei $\mathrm{n}^{\circ}$ 8.112/90 não estabelece quais requisitos devem estar presentes no instrumento inaugural. Com efeito, a Constituição Federal de 1988 também não possui qualquer referência explícita nesse sentido, assegurando apenas em seu art. $5^{\circ}, \mathrm{LV}$, que "aos litigantes, em processo judicial ou administrativo, e aos acusados em geral são assegurados o contraditório e ampla defesa, com os meios e recursos a ela inerentes".

Contudo, em ambos os casos, tanto o art. 143 da Lei $\mathrm{n}^{\circ} 8.112 / 90$ quanto a art. $5^{\circ}, \mathrm{LV}$ da CF asseguram ao servidor público o direito a uma "ampla defesa", e, especificamente na Constituição, a norma refere-se a uma ampla defesa com "todos os meios e recursos a ela inerentes". O art. $2^{\circ}$ da Lei n ${ }^{\circ}$ 9.784/99, que rege os processos administrativos no âmbito federal, também submete a Administração Pública aos princípios da ampla defesa e do contraditório (art. $2^{\circ}$, caput) e ao dever de respeitar

34 PIOVESAN, Flávia. Direitos humanos e o Direito Constitucional Internacional. 14. ed. São Paulo: Saraiva, 2013. p. 122. 
a "garantia dos direitos à comunicação, à apresentação de alegações finais, à produção de provas e à interposição de recursos, nos processos de que possam resultar sanções e nas situações de litígio" (art. $2^{\circ}$, parágrafo único, X). ${ }^{35}$

O direito à ampla defesa com todos os meios e recursos a ela inerentes apresenta conteúdo jurídico bastante abrangente e possui uma série de desdobramentos, os quais encontram-se previstos explícita e implicitamente na Constituição, na legislação ordinária e em tratados internacionais de direitos humanos. ${ }^{36}$ Exemplificativamente, podem-se citar alguns desses desdobramentos do direito de defesa: (i) o dever de individualização e especificação das condutas no ato de instauração do processo; (ii) o caráter prévio da defesa ${ }^{37}$; (iii) o direito de oferecer e produzir provas ${ }^{38}$; (iv) o direito à autodefesa ${ }^{39}$; (v) o direito à defesa técnica por advogado ${ }^{40}$; (vi) a concessão ao acusado do tempo adequado para a preparação da sua defesa. ${ }^{41}$

Do conjunto apresentado, verifica-se que nenhuma dessas especificações inerentes à ampla defesa consta de forma expressa, nesses exatos termos, no texto da Constituição. Contudo, podem ser deduzidas tacitamente do disposto na parte final do art. 5, LV ("com todos os meios e recursos a ela inerentes"), mediante interpretação teleológica e sistemática da ordem constitucional, bem como, em alguns casos, por estarem explicitamente positivadas em convenções internacionais de direitos

35 BACELLAR FILHO, Romeu Felipe; PIVETTA, Saulo Lindorfer. O regime jurídico do processo administrativo na Lei $\mathrm{n}^{\circ}$ 9.784/99. A\&C - Revista de Direito Administrativo \& Constitucional, Belo Horizonte, ano 14, n. 58, p. 107-135, out./dez. 2014. p. 113.

36 BACELLAR FILHO, Romeu Felipe; HACHEM, Daniel Wunder. A necessidade de defesa técnica no processo administrativo disciplinar e a inconstitucionalidade da Súmula Vinculante $n^{\circ} 5$ do STF. A\&C - Revista de Direito Administrativo \& Constitucional, $\mathrm{n}^{\circ}$ 39, Belo Horizonte, Fórum, p. 27-64, jan./mar. 2010. p. 36.

37 PIOVESAN, Flávia (coordenadora geral). Código de direito internacional dos direitos humanos anotado. São Paulo: Editora DPJ, 2008. p. 1216-1217.

38 PIOVESAN, Flávia (coordenadora geral). Código de direito internacional dos direitos humanos anotado. São Paulo: Editora DPJ, 2008. p. 1220.

39 PIOVESAN, Flávia (coordenadora geral). Código de direito internacional dos direitos humanos anotado. São Paulo: Editora DPJ, 2008. p. 1219.

40 PIOVESAN, Flávia (coordenadora geral). Código de direito internacional dos direitos humanos anotado. São Paulo: Editora DPJ, 2008. p. 1221.

41 PIOVESAN, Flávia (coordenadora geral). Código de direito internacional dos direitos humanos anotado. São Paulo: Editora DPJ, 2008. p. 1218-1219. humanos incorporadas ao Direito brasileiro. ${ }^{42}$

Alguns desses desdobramentos do direito de defesa foram comtemplados textualmente no rol de direitos humanos consagrados pela Convenção Americana sobre Direitos Humanos, também denominada Pacto de San José da Costa Rica. A Convenção Americana, formada no âmbito da Organização dos Estados Americanos, foi subscrita durante a Conferência Especializada Interamericana de Direitos Humanos, em 1969, na cidade de San José da Costa Rica. O instrumento internacional foi ratificado pelo Brasil em 1992, sendo, desde então, parte integrante do ordenamento jurídico brasileiro. Cabe acrescentar que o Brasil, ao aderir ao Pacto Internacional não subscreveu qualquer reserva em relação ao conteúdo do seu art. $8^{\circ} .^{43}$ Logo, seu conteúdo integral encontra-se vigente no Direito pátrio.

Dentre os direitos e garantias albergados pelo aludido tratado internacional, encontra-se expressamente descrito em seu art. $8^{\circ}$, n. 2, "b", o direito do acusado à prévia e pormenorizada descrição dos fatos na acusação que lhe foi dirigida. Observe-se o que dispõe o mencionado dispositivo: "Art. $8^{\circ}$. (...) n. 2. (...) Durante o processo, toda pessoa tem direito, em plena igualdade, às seguintes garantias mínimas: (...) b) comunicação prévia e pormenorizada ao acusado da acusação formulada".

Constata-se que o art. $8^{\circ}$, n. 2, "b" da Convenção especifica sem rodeios que toda pessoa possui, como garantia mínima, o direito de ser notificado/informado sobre os fatos da denúncia de forma pormenorizada, detalhada, especifica e prévia. Não se trata, pois, de qualquer notificação: o tratado exige a descrição pormenorizada de qual ou quais condutas estão sendo imputadas ao agente, bem como o seu enquadramento legal.

A Corte Interamericana de Direitos Humanos, no Caso Fermín Ramírez vs. Guatemala, sentenciado em 2005, ao interpretar o art. $8^{\circ}$, n. 2, "b" da Convenção Americana, entendeu que "la descripción material de la conducta imputada contiene los datos fácticos recogidos en la acusación, que constituyen la referencia indispensable para el ejercicio de la defensa del imputado y la consecuente consideración del juagador en la sentencia. De abi que el imputado tenga derecho a conocer, a través de una descripción clara, detallada y precisa, los hechos

42 BACELlar fIlHO, Romeu Felipe. Processo Administrativo Disciplinar. 4. ed. São Paulo: Saraiva, 2013. p. 309.

43 PIOVESAN, Flávia. Direitos humanos e o Direito Constitucional Internacional. 14. ed. São Paulo: Saraiva, 2013. p. 174 
que se le imputan". ${ }^{44}$

A descrição prévia e pormenorizada da natureza e da causa da acusação, bem como o seu respectivo enquadramento em um tipo infracional estabelecido em lei, permitem ao acusado defender-se com a precisão necessária, seja em relação ao marco fático apresentado ou à subsunção normativa da conduta. O conhecimento prévio e detalhado da acusação consiste em um pressuposto lógico do direito de defesa, afinal, ninguém pode defender-se de algo que não conhece. ${ }^{45}$ Caso o acusado não tome conhecimento prévio dos fatos materiais e de sua classificação legal, não poderá inquirir testemunhas ou produzir provas documentais e periciais que robusteçam sua defesa, já que não saberá especificamente quais provas lhe serão úteis.

Nesse sentido, merece destaque a doutrina de Pablo Ángel Gutiérrez Colantuono, ao assinalar que "lo esencial es que quien se ve afectado por la actividad persecutoria del Estado conozca oportunamente el motivo, el significado y las posibles repercusiones de esa actividad, porque sólo asi puede enfrentarla adecuadamente". E conclui o autor que "sólo resulta posible preparar adecuadamente la defensa si se conoce la acusación". ${ }^{46}$

Por fim, cabe ressaltar que o Pacto Internacional sobre Direitos Civis e Políticos, também ratificado pelo Brasil em 1992, igualmente prevê em seu art. 14, item 3, letra "a", o direito de todo acusado de ser informado de forma minuciosa dos motivos da acusação contra ele formulada. O dispositivo define que "Toda pessoa acusada de um delito terá direito, em plena igualmente, a, pelo menos, as seguintes garantias: a) De ser informado, sem demora, numa língua que compreenda e de forma minuciosa, da natureza e dos motivos da acusação contra ela formulada". A norma em questão reforça o disposto no art. $8^{\circ}$, n. 2, "b" do Pacto de San José, demonstrando a preocupação no âmbito internacional de que sejam asseguradas garantias mínimas ao cidadão acusado de ter praticado uma infração.

44 CORTE INTERAMERICANA DE DIREITOS HUMANOS. Caso Fermin Ramirez vs. Guatemala. Sentencia de 20 de junio de 2005, pars. 67 e 68. Disponível em: <http:/ /www.corteidh. or.cr/docs/casos/articulos/seriec_126_esp.pdf > . Acesso em: 23 de jun. 2015.

45 GUTIÉRrEZ COLANTUONO, Pablo Ángel; JUSTO, Juan Bautista (Colaborador). Administración Pública, juridicidad y derechos humanos. Buenos Aires: Abeledo Perrot, 2009. p. 183.

46 GUTIÉRREZ COLANTUONO, Pablo Ángel; JUSTO, Juan Bautista (Colaborador). Administración Pública, juridicidad y derechos humanos. Buenos Aires: Abeledo Perrot, 2009. p. 183.
À luz de tudo o que foi dito, infere-se que, no processo administrativo disciplinar disposto na Lei $\mathrm{n}^{\circ}$ $8.112 / 90$, deve ser observado o direito fundamental ao contraditório e à ampla defesa, com todos os desdobramentos que lhe são inerentes, entre eles a descrição prévia e pormenorizada das condutas do acusado, conforme prevê o art. $8^{\circ}$, n. 2, "b" do Pacto de San José da Costa Rica, a jurisprudência da Corte Interamericana de Direitos Humanos ${ }^{47}$ e o art. 14, item 3, letra a) do Pacto Internacional sobre Direitos Civis e Políticos.

\section{O posicionamento do Superior Tribunal DE JUSTIÇA BRASILEIRO SOBRE O DEVER DE ESPECIFICAÇÃO DAS CONDUTAS NO ATO DE INSTAURAÇÃO DO PROCESSO ADMINISTRATIVO DISCIPLINAR}

Conforme enfatizado no início do tópico antecedente, a Lei no $8.112 / 90$ prevê que a instauração da sindicância ou processo disciplinar se dá por meio de portaria inaugural, ato que dá início ao processo de averiguação das denúncias. No entanto, tal diploma legal não estabelece quais requisitos devem estar presentes no instrumento inaugural, indicando, apenas, que deve ser assegurado o direito à ampla defesa.

Diante do silêncio da Lei $\mathrm{n}^{\circ} 8.112 / 90$, o Superior Tribunal de Justiça brasileiro interpretou que para a instauração dos processos administrativos disciplinares basta a descrição, em linhas gerais, das bases fáticas que dão suporte à denúncia, não sendo necessária sequer a indicação do embasamento jurídico que dá ensejo à acusação. Segundo o STJ, é dispensável inclusive a indicação do ilícito na portaria vestibular. ${ }^{48}$

Cumpre lembrar que o processo administrativo disciplinar na esfera federal brasileira se desenvolve, nos termos da Lei no 8.112/90, em três fases: (i) instauração;

47 CORTE INTERAMERICANA DE DIREITOS HUMANOS. Caso Fermin Ramírez vs. Guatemala. Sentencia de 20 de junio de 2005, pars. 67 y 68. Disponível em: <http://www.corteidh. or.cr/docs/casos/articulos/seriec_126_esp.pdf>. Acesso em: 23 de jun. 2015.

48 BRASIL. Superior Tribunal de Justiça. RMS 39.361/MG. Rel. Ministro Humberto Martins. Segunda Turma. Julgado em 07.02.2013. Disponível em: <https://ww2.sti.jus.br/processo/revista/documento $/$ mediado/?componente $=I T A \&$ sequencial $=1207$ 937\&num_registro $=201202273227 \&$ data $=20130219 \&$ formato $=P$ DF>. Acesso em: 23 de jun. 2015. 
(ii) inquérito; e (iii) julgamento. A segunda fase - (ii) inquérito - compreende (ii.i) instrução; (ii.ii) defesa; (ii.iii) relatório (art. 151, II). Desse modo, se o acusado for esperar o final do inquérito para saber com precisão quais ilicitudes the estão sendo imputadas, jamais poderá inquirir testemunhas ou produzir provas documentais e periciais que robusteçam sua defesa, porque a oportunidade para fazê-lo já terá precluído. É mais do que evidente que o servidor só saberá quais provas lhe serão úteis quando tiver plena ciência do que está sendo acusado. De que adianta conhecer com detalhes a acusação que lhe está sendo assacada somente no indiciamento, se em tal momento já não é mais possível produzir novas provas? Mas para o STJ isso não interessa: vale mais a ordem das etapas fixada na lei do que a determinação do tratado de direitos humanos

O entendimento do Tribunal se baseia em uma interpretação equivocada dos dispositivos da Lei $\mathrm{n}^{\circ}$ 8.112/90. Segundo o STJ, o art. 161 da Lei no 8.112/90 institui que, no momento do indiciamento, será necessária a especificação dos fatos imputados ao servidor. Tal dispositivo prevê que "Tipificada a infração disciplinar, será formulada a indiciação do servidor, com a especificação dos fatos a ele imputados e das respectivas provas.”. A interpretação realizada considera que, diante da previsão do art. 161, a especificação das peculiaridades fáticas não se faz necessária em momento anterior ao indiciamento, isto é, nem na portaria de instauração, muito menos nos momentos subsequentes, sendo imprescindível somente ao final do processo investigativo.

Ou seja: o entendimento da Corte é o de que, somente após o encerramento da fase de instrução probatória, - quando todas as testemunhas já tiverem sido ouvidas e todas as provas documentais e periciais já houverem sido produzidas - é que será necessária a confecção de um termo de indiciamento, indicando as condutas, o ilícito e o enquadramento legal que estão sendo imputados ao servidor acusado. Tal fato torna a leitura do STJ bastante conflitante com a garantia do direito fundamental à ampla defesa e ao contraditório.

O Superior Tribunal de Justiça conta com múltiplos e retirados julgados nesse sentido. Apenas para fins exemplificativos, cabe citar algumas decisões da Corte. No ano de 2010, por exemplo, no julgamento do Mandado de Segurança n ${ }^{\circ}$ 13.518/DF, de relatoria do Ministro Napoleão Nunes Maia Filho, restou consignado no voto condutor do julgamento que "não se exige que a
Portaria instauradora do Processo Disciplinar contenha a minuciosa descrição dos fatos que serão apurados pela Comissão Processante, exigível apenas quando do indiciamento do servidor". ${ }^{49}$

Em outra oportunidade, o STJ entendeu que apenas a indicação das condutas imputadas ao agente, sem descrição detalhada das condições materiais, natureza, causa e enquadramento jurídico das acusações, era suficiente para dar validade jurídica a portaria de instauração de processo administrativo. Assim restou consignado no aresto em questão: "A jurisprudência do Superior Tribunal de Justiça é pacífica no sentido de que os atos administrativos de instauração dos processos administrativos disciplinares não demandam descrição minudente e detalhada, requerente somente a presença dos elementos necessários para o exercício regular da ampla defesa e do contraditório". ${ }^{50}$

Sob essa mesma perspectiva, a Ministra Maria Thereza de Assis Moura, no julgamento do Embargos de Declaração em sede de Recurso Especial n 1096274/ RJ, defendeu que a portaria inicial de instauração do processo administrativo disciplinar serve apenas para dar publicidade à constituição da Comissão Processante, nada além. De acordo com a Ministra, "considerando que a portaria inaugural do processo disciplinar tem o objetivo de conferir publicidade à constituição da Comissão Processante, apenas quando do indiciamento do servidor, posteriormente à fase instrutória do processo administrativo disciplinar, deve haver a descrição detalhada dos fatos". ${ }^{51}$

Nessa mesma esteira, o STJ em reiteradas decisões frisa que apenas referências genéricas aos fatos impu-

49 BRASIL. Superior Tribunal de Justiça. MS no 13.518/DF. Rel. Ministro Napoleão Nunes Maia Filho. Julgado em 19.12.2008. Disponível em: <https://ww2.stj.jus.br/processo/revista/documento/ mediado $/$ ?componente $=$ ITA\&sequencial $=846320 \&$ num_registro $=$ $200800875154 \&$ data $=20081219 \&$ formato $=$ PDF $>$. Acesso em: 23 de jun. 2015. Com idêntica argumentação: BRASIL. Superior Tribunal de Justiça. MS no 14.578/DF. Rel. Ministro Og Fernandes. Julgado em 25.08.2010. Disponível em: < https://ww2.stj.jus.br/ processo $/ \mathrm{revista} /$ documento $/$ mediado/?componente $=$ ITA\&sequ encial $=961788 \&$ num_registro $=200901609418 \&$ data $=20100922 \& f$ ormato=PDF $>$. Acesso em: 23 de jun 2015.

50 BRASIL. Superior Tribunal de Justiça. RMS 39.361/MG. Rel. Ministro Humberto Martins. Julgado em 07.02.2013.

51 BRASIL. Superior Tribunal de Justiça. EDcl no REsp 1096274/RJ. Rel. Ministra Maria Thereza De Assis Moura. Julgado em 25.09.2012. Disponível em: <https://ww2.stj.jus.br/processo $/$ revista $/$ documento $/$ mediado $/$ ?componente $=$ ITA\&sequencial $=$ $1181577 \&$ num_registro $=200802170819 \&$ data $=20130205 \&$ format o=PDF>. Acesso em: 23 de jun. 2015. 
tados ao servidor são suficientes para validar a portaria de instauração do processo disciplinar, pontuando que "a portaria de instauração do processo disciplinar que faz referências genéricas aos fatos imputados ao servidor, deixando de expô-los minuciosamente, não enseja sua nulidade, tendo em vista que tal exigência deve ser observada apenas na fase de indiciamento, após a instrução". ${ }^{52}$

Ainda, em outro julgado sobre a matéria, o Tribunal endossou que, na portaria inaugural, não se faz necessário sequer constar a capitulação legal da conduta praticada pelo servidor. Sustentou-se no acórdão que "a jurisprudência do STJ está assentada em considerar que não é necessária a descrição minuciosa dos fatos, tampouco de eventual capitulação legal na portaria de instauração e, logo, sua ausência não viola a amplitude de defesa". ${ }^{53}$

Conforme se observa, a jurisprudência do Superior Tribunal de Justiça é reiterada e pacífica sobre a matéria, o que se pode concluir pela enxurrada de julgados uníssonos sobre o tema: MS 15.786/DF, Rel. Min. Castro Meira, julgado em 13.4.2011; MS 15.787/DF, Rel. Ministro Benedito Gonçalves, julgado em 09.05.2012; MS 16.815/DF, Rel. Ministro Cesar Asfor Rocha, julgado em 11.04.2012; MS 9.201/DF, Rel. Ministra Laurita Vaz, julgado em 08.09.2004; MS 16.192/DF, Rel. Ministro Mauro Campbell Marques, julgado em 10.04.2013; MS 17.472/DF, Rel. Ministro Arnaldo Esteves Lima, julgado em 13.06.2012; RMS 23.974/ES, Rel. Ministra Maria Thereza de Assis Moura, julgado em 01.06.2011; RMS 24.138/PR, Rel. Ministra Laurita Vaz, julgado em 03.11.2009; MS 13.518/DF, Rel. Ministro Napoleão Nunes Maia Filho, julgado em 19.12.2008; MS 12.369/ DF, Rel. Ministro Feliz Fischer, julgado em 10.09.2007.

Essa posição do Superior Tribunal de Justiça é costumeiramente seguida pela Administração Pública brasileira no âmbito dos processos admi-

52 BRASIL. Superior Tribunal de Justiça. AgRg no RMS 23.775/ PR. Rel. Ministro Jorge Mussi. Julgado em 28.08.2012. Disponível em: <https://ww2.stj.jus.br/processo/revista/documento/med iado $/$ ?componente $=I T A \&$ sequencial $=1173623 \&$ num_registro $=20$ $0700516360 \&$ data $=20120906 \&$ formato $=$ PDF $>$. Acesso em: 23 de jun. 2015.

53 BRASIL. Superior Tribunal de Justiça. RMS 35.208/DF. Rel. Ministro Humberto Martins. Julgado em 16.02.2012. Disponível em: <https://ww2.stj.jus.br/processo/revista/documento/med iado $/$ ?componente $=I T A \&$ sequencial $=1122970 \&$ num_registro $=20$ $1101909232 \&$ data $=20120227 \&$ formato $=P D F>$. Acesso em: 23 de jun. 2015. nistrativos disciplinares na esfera federal. Pelo que se denota de tais decisões, a Administração Pública e os tribunais brasileiros insistem em ignorar solenemente o art. $8^{\circ}$, n. 2, "b" do Pacto de San José da Costa Rica, o art. 14, item 3, letra a) do Pacto Internacional sobre Direitos Civis e Políticos e como se verá a seguir - a jurisprudência da Corte Interamericana de Direitos Humanos.

\section{A APLicaÇão das GaRANTIAS do ART. $8^{\circ}$ do Pacto de San José da Costa Rica aos PROCESSOS ADMINISTRATIVOS E A JURISPRUDÊNCIA da Corte Interamericana de Direitos HuMANOS}

O texto do art. $8^{\circ}$ do Pacto de San José da Costa Rica gerou muitas polêmicas em relação ao âmbito de abrangência do dispositivo. Isso porque sua própria redação previa que se tratavam de "garantias judiciais". Nesse caso, uma interpretação literal do tratado poderia conduzir à equivocada conclusão de que a norma não se aplicaria a outras modalidades de processo, tal como o processo administrativo. Vale dizer, a hermenêutica da convenção poderia levar ao entendimento de que o elenco de garantias ali expressas incidiria apenas na esfera dos processos judiciais. ${ }^{54}$

Entretanto, felizmente a Corte Interamericana de Direitos Humanos já teve a oportunidade de se manifestar sobre o alcance das garantias previstas no art. $8^{\circ}$ da Convenção Americana de Direitos Humanos. Em suas decisões restou firmado o posicionamento de que a proteção conferida pelo dispositivo deve ser aplicar a todas as relações jurídicas processuais, sejam ela judiciais ou administrativas, desde que o ato emanado do Estado possa afetar — criando ou restringindo - direitos e obrigações ao acusado. ${ }^{55}$

54 CORTE INTERAMERICANA DE DIREITOS HUMANOS. Caso Baena, Ricardo y otros vs. Panamá, sentença de 28 de novembro de 2003. Disponível em: < http://www.corteidh.or.cr/ docs/casos/articulos/seriec_104_esp.pdf $>$. Acesso em: 23 de jun. 2015.

55 Em recente julgado da Corte Interamericana restou resumido seu o posicionamento atual no seguinte trecho: "El aspecto esencial de lo que contiene el artículo $8^{\circ}$, por ello, no reside, pues, en la naturaleza de la autoridad dentro del ordenamiento constitucional del país, sino en lo que el procedimiento busca determinar y resolver en cuanto a garantias a favor de la persona. Si el sentido de la norma es el de ofrecer ciertas garantias básicas en la determinación de derechos u obligaciones de la persona, parece claro que el aspecto 
O primeiro argumento favorável a esse entendimento reside nos próprios antecedentes históricos da criação e formulação do art. $8^{\circ}$ do Pacto de San José da Costa Rica. A redação da norma foi objeto de debates e discussões durante a Conferência Especializada Interamericana sobre Direitos Humanos, a qual deu origem à Convenção Americana. Inicialmente, o dispositivo estendia seu alcance às obrigações cíveis. Após diversas sugestões dos membros integrantes da Comissão, o raio de alcance da redação da norma passou a englobar as obrigações cíveis, laborais e fiscais. Ocorre que, ainda assim, havia uma preocupação dos membros da Comissão com possíveis restrições do âmbito de incidência da norma. Por esse motivo, ao final foi proposta pelo representante do México a inserção, ao final do enunciado normativo, do termo "ou de qualquer outra natureza". ${ }^{56}$ Percebe-se que a preocupação dos redatores do Pacto foi sempre no sentido de ampliar ao máximo o campo de incidência da norma ora discutida. Logo, em uma interpretação histórica e teleológica, pode-se concluir que a intenção dos redatores foi a de que a abrangência da norma fosse a mais ampla possível, incluindo, nesse caso, os processos administrativos.

O segundo embasamento à posição defendida encontra arrimo na interpretação sistemática da Convenção Americana. Por meio de uma leitura harmônica dos art. $1^{\circ}, 2^{\circ}$ e 29 da Convenção Americana, considera-se que a intenção mínima - o piso — do art. $8^{\circ}$ é assegurar garantias no âmbito judicial, porém sua esfera de incidência abrange todas as modalidades de processo. Essa interpretação se coaduna com o estabelecido no art. 29, c), da Convenção, ao prever que "Nenhuma disposição da presente Convenção pode ser interpretada no sentido de; (...) c) excluir outros direitos e garantias que são inerentes ao ser humano ou que decorrem da forma democrática representativa de governo”. Em ou-

medular y trascendente es éste, y no el de la naturaleza de la autoridad. Este parece ser, pues, el criterio central para establecer que es obligatorio atenerse a las exigencias del artículo $8^{\circ}$ en lo que sea pertinente a espacios extrajudiciales. En otras palabras, es claro que la Convención tiene establecido que deben garantizarse los derechos de la persona tanto en las esferas no judiciales como en las judiciales teniendo en cuenta lo que sea aplicable a un procedimiento no judicial'. CORTE INTERAMERICANA DE DIREITOS HUMANOS. Caso Barbani Duarte y otros vs. Uruguay, sentença de 13 de outubro de 2011, par. 15. Disponível em: < http://www.corteidh.or.cr/docs/ casos/articulos/seriec_234_esp.pdf>. Acesso em: 23 de jun. 2015.

56 A referência aos debates no momento de elaboração da redação do Pacto é feita por: GUTIÉRREZ COLANTUONO, Pablo Ángel; JUSTO, Juan Bautista (Colaborador). Administración Pública, juridicidad y derechos humanos. Buenos Aires: Abeledo Perrot, 2009. p. 58, nota $\mathrm{n}^{\circ} 92$. tras palavras: a alusão a "garantias judiciais" não pode ser lida como exclusão da tutela de direitos dos cidadãos frente a outras modalidades de processos, tal como o processo no âmbito administrativo. Nesse sentido expressa-se a jurisprudência da Corte Interamericana de Direitos Humanos. ${ }^{57}$

Outro ponto favorável ao entendimento esposado reside na interpretação evolutiva do preceito. A abordagem evolutiva considera tanto o texto escrito da norma quanto a finalidade da sua criação. Nos primórdios da criação do Pacto, o desafio americano era assegurar as garantias do art. $8^{\circ}$ ao menos na arena judicial. Todavia, à medida que a Convenção passou a ser aplicada, percebeu-se que as práticas estatais questionáveis não provinham apenas de atividades judiciais, mas também de outras ações ou omissões no campo administrativo. Portanto, com o passar do tempo, vencido o desafio de aplicação das garantias do art. $8^{\circ}$ no âmbito judicial, o próximo passo tornou-se ampliar seu alcance de proteção a todos os órgãos que desenvolvem funções públicas. É essa a posição acolhida pela Corte Interamericana de Direitos Humanos, ao entender que a norma do art. $8^{\circ}$ do Pacto de San José não permanece estática e que a sua imperatividade jurídica, à luz de uma interpretação evolutiva, aplica-se a novos espaços de atuação estatal nos quais a sua proteção passa a ser requerida, sendo a Administração Pública um dos principais. $^{58}$

Nesse sentido, merece destaque o seguinte trecho da sentença do caso Comunidade indígena Yakye Axa vs. Paraguai, julgado pela Corte Interamericana de Direitos

57 CORTE INTERAMERICANA DE DIREITOS HUMANOS. Caso Blake vs. Guatemala, sentença de 24 de janeiro de 1998, par. 96. Disponível em: < http://www.corteidh.or.cr/docs/ casos/articulos/seriec_36_esp.pdf $>$. Acesso em: 23 de jun. 2015.

58 CORTE INTERAMERICANA DE DIREITOS HUMANOS. Caso Hermanos Gómez Paquiyauri vs. Perú, sentença de 8 de julho de 2004, par. 165. Disponível em: <http://www.corteidh. or.cr/docs/casos/articulos/seriec_110_esp.pdf>. Acesso em: 23 de jun. 2015; CORTE INTERAMERICANA DE DIREITOS HUMANOS. Caso Comunidad Mayagna (Sumo) Awas Tingni Vs. Nicaragua, sentença de 31 de agosto de 2001, par. 146. Disponível em: <http://www.corteidh.or.cr/docs/casos/articulos/seriec_79_esp. pdf $>$. Acesso em: 23 de jun. 2015.

; CORTE INTERAMERICANA DE DIREITOS HUMANOS. Caso "Niños de la Calle" (Villagrán Morales y otros) vs. Guatemala, sentença de 19 de novembro de 1999, par. 193. Disponível em: $<$ http://www.corteidh.or.cr/docs/casos/articulos/Seriec_63_esp. pdf $>$. Acesso em: 23 de jun. 2015; EUROPEAN COURT OF HUMAN RIGHTS. Caso Tyrer vs. The United Kingdom, julgado em 25 de abril de 1978, par. 31. Disponível em: <http://hudoc.echr. coe.int/sites/eng/pages/search.aspx?i=001-57587>. Aceso em: 23 de jun. 2015. 
Humanos: "En otras oportunidades, tanto este Tribunal, como la Corte Europea de Derechos Humanos, han señalado que los tratados de derechos bumanos son instrumentos vivos, cuya interpretación tiene que acompañar la evolución de los tiempos y las condiciones de vida actuales. Tal interpretación evolutiva es consecuente con las reglas generales de interpretación consagradas en el artículo 29 de la Convención Americana, así como las establecidas por la Convención de Viena sobre el Derecho de los Tratados". ${ }^{59}$

Também cabe acrescentar, como mais um fundamento para a ampliação do espectro de incidência das garantias previstas no art. $8^{\circ}$ da Convenção Americana, o princípio "pro homine", também denominado de "propersona" ${ }^{00}$. Esse postulado anuncia que sempre deve prevalecer a aplicação da norma mais benéfica à pessoa humana. Assim, deve o intérprete sempre buscar aplicar a norma que em cada caso resulte mais favorável e mais protetiva ao ser humano, à sua liberdade e aos seus direitos. ${ }^{61}$ Logo, compete aos tribunais alargarem o campo de incidência do art. $8^{\circ}$ do Pacto de San José para a esfera administrativa, uma vez que tal postura conduz a uma aplicação mais favorável e protetiva à pessoa.

Em suma, o que se conclui, nas palavras de Agustín Gordillo, é que "en cualquier caso, no resultan admisibles interpretaciones que proponen restringir o limitar indebidamente el alcance del debido proceso. En ningún caso será legítimo prescindir de su observancia y cumplimiento". ${ }^{62}$

Ainda, mostra-se inaplicável na situação em apreço a tese de convalidação dos atos administrativos nulos

59 CORTE INTERAMERICANA DE DIREITOS HUMANOS. Caso Comunidad indígena Yakye Axa vs. Paraguay, sentença de 17 de julho de 2005, par. 125. Disponível em: <http://www.corteidh.or.cr/docs/casos/articulos/seriec_125_esp.pdf $>$. Acesso em: 23 de jun. 2015.

60 Segundo Flávia Piovesan, no sistema global de proteção dos direitos humanos pode-se encontrar tal princípio em várias convenções, tais como "art. 23 da Convenção sobre Eliminação da Discriminação contra Mulher, o art. 41 da Convenção sobre Direito da Criança, o art. 16, paragrafo $2^{\circ}$, da Convenção contra Tortura e o art. $4^{\circ}$, paragrafo $4^{\circ}$, da Convenção sobre os Direitos das Pessoas com Deficiência." PIOVESAN, Flávia. Direitos humanos e o Direito Constitucional Internacional. 14. ed. São Paulo: Saraiva, 2013. p. 172.

61 MUÑOZ (h), Ricardo Alberto. La tutela administrativa efectiva. La Ley, Tomo 2012-B, Buenos Aires, p. 1-6, mar. 2012. p. 5. Para uma leitura completa do tema ver: BIDART CAMPOS, Germán. Las fuentes del Derecho Constitucional y el principio "pro homine”. In: BIDART CAMPOS, Germán; GIL DOMINGUEZ, Andrés (coord.). El Derecho Constitucional del Siglo XXI: Diagnóstico y perspectivas. Buenos Aires: Editora Ediar, 2000. p. 11 e ss. 62 GORDILlO, Agustín. Procedimiento Administrativo. 1. ed. Buenos Aires: Depalma, 2003. p. 43. por meio de revisão judicial, segundo a qual os vícios relativos ao devido processo não justificam a anulação do processo administrativo pelo fato de que eles podem ser posteriormente corrigidos pelo Poder Judiciário. No caso Castillo Petruzzi e outros vs. Peru, a Corte Interamericana de Direitos Humanos decidiu que todos os atos que dão suporte à decisão estão integrados, guardando relação cronológica, lógica e teleológica, e que portanto, diante de um vício grave no processo administrativo, não se mostra possível convalidar a violação do direito em sede admirativa através do controle judicial. Vale dizer: o devido processo legal, quando não atendido na via administrativa, não pode simplesmente ser postergado para ser corrigido pela via judicial. Deve, de plano, o ato administrativo ser declarado nulo e repetidos todos os seus passos precedentes. ${ }^{63}$ Por consequência, no Direito brasileiro o princípio da inafastabilidade do controle judicial (art. 5 ${ }^{\circ}, \mathrm{XXXV}, \mathrm{CF}$ ) não pode ser invocado para sustentar a validade do processo disciplinar maculado por não observar as diretrizes do art. $8^{\circ}$ do Pacto de San José.

Por fim, é oportuno destacar que a jurisprudência da Corte Interamericana de Direitos Humanos endossa em reiterados julgados o posicionamento aqui defendido. Acerca do entendimento da Corte, mostra-se pertinente o seguinte trecho da sentença do caso Ruch Ivcher

63 Nesse sentido se posicionou a Corte Interamericana: "Todo proceso está integrado por actos jurídicos que guardan entre sí relación cronológica, lógica y teleológica. Unos son soporte o supuesto de los otros y todos se ordenan a un fin supremo y comin: la solución de la controversia por medio de una sentencia. Los actos procesales corresponden al género de los actos jurídicos, y por ello se encuentran sujetos a las reglas que determinan la aparición y los efectos de aquéllos. Por ende, cada acto debe ajustarse a las normas que presiden su creación y le confieren valor jurídico, presupuesto para que produzca efectos de este carácter. Si ello no ocurre, el acto carecerá de esa validezy no producirá tales efectos. La validez de cada uno de los actos jurídicos influye sobre la validez del conjunto, puesto que en éste cada uno se halla sustentado en otro precedente y es, a su turno, sustento de otros más. La culminación de esa secuencia de actos es la sentencia, que dirime la controversia y establece la verdad legal, con autoridad de cosa juggada." CORTE INTERAMERICANA DE DIREITOS HUMANOS. Caso Castillo Petruzzi y otros vs. Perú, sentença de 30 de maio de 1999, par. 218. Disponível em: < http://www.corteidh. or.cr/docs/casos/articulos/seriec_52_esp.pdf $>$. Acesso em: 23 de jun. 2015. Essa mesma postura pode ser observada no julgado do Caso Comunidad indigena Yakye Axa vs. Paraguay, no qual a Corte consignou que "Si los actos en que se sostiene la sentencia están afectados por vicios graves, que los privan de la eficacia que debieran tener en condiciones normales, la sentencia no subsistirá. Carecerá de su soporte necesario: un proceso realizado conforme a Derecho." CORTE INTERAMERICANA DE DIREITOS HUMANOS. Caso Comunidad indígena Yakye Axa vs. Paraguay, sentença de 17 de julho de 2005, par.125. Disponível em: <http://www. corteidh.or.cr/docs/casos/articulos/seriec_125_esp.pdf $>$. Acesso em: 23 de jun. 2015. 
Bronstein vs. Peru, cujo julgamento foi presidido pelo jurista Antônio A. Cançado Trindade: "la Corte estima que tanto los órganos jurisdiccionales como los de otro carácter que ejerzan funciones de naturaleza materialmente jurisdiccional, tienen el deber de adoptar decisiones justas basadas en el respeto pleno a las garantías del debido proceso establecidas en el artículo 8 de la Convención Americana". ${ }^{64}$ No mesmo sentido, manifestou-se a Corte no caso Corte Constitucional vs. Peru. ${ }^{65}$

Um dos casos paradigmáticos da jurisprudência da Corte Interamericana, por defender especificamente a extensão das garantias do art. $8^{\circ}$, n. 2, "b" da Convenção Americana ao processo administrativo sancionador, é o caso Baena Ricardo e Outros vs. Panamá (270 Trabalhaadores vs. Panamá). ${ }^{66} \mathrm{Na}$ oportunidade, a Corte afirmou que: "Si bien el artículo 8 de la Convención Americana se titula 'Garantías Judiciales', su aplicación no se limita a los recursos judiciales en sentido estricto, 'sino [al] conjunto de requisitos que deben observarse en las instancias procesales' a efectos de que las personas estén en condiciones de defender adecuadamente sus derechos ante cualquier tipo de acto del Estado que pueda afectarlos. Es decir, cualquier actuación u omisión de los órganos estatales dentro de un proceso, sea administrativo sancionatorio o jurisdiccional, debe respetar el debido proceso legal'. ${ }^{67}$

À luz do exposto, conclui-se que as garantias do art. $8^{\circ}$, n. 2, "b" do Pacto de San José da Costa Rica incidem no âmbito dos processos administrativos, ${ }^{68}$ pois o raio

64 CORTE INTERAMERICANA DE DIREITOS HUMANOS. Caso Ruch Ivcher Bronstein vs. Perú, sentença de 06 de fevereiro de 2001, par.104. Disponível em: <http://www.corteidh. or.cr/docs/casos/articulos/Seriec_74_esp.pdf>. Acesso em: 23 de jun. 2015.

65 CORTE INTERAMERICANA DE DIREITOS HUMANOS. Caso The Constitutional Court vs. Perú, sentença de 31 de janeiro de 2001, par. 69. Disponível em: <http://www.corteidh.or.cr/ docs/casos/articulos/Seriec_71_esp.pdf $>$. Acesso em: 23 de jun. 2015.

66 DURÁN MARTÍNEZ, Augusto. La jurisprudencia de la Corte Interamericana de Derechos Humanos en la perspectiva del Derecho Administrativo. Especial referencia al caso Gelman vs. Uruguay. Revista de Investigações Constitucionais, Curitiba, vol. 1, n. 2, p. 103-130, maio/ago. 2014. DOI: http://dx.doi.org/10.5380/rinc. v1i2.40512. p. 109.

67 CORTE INTERAMERICANA DE DIREITOS HUMANOS. Caso Baena Ricardo y Otros vs. Panamá, sentença de 28 de novembro de 2003, par. 124. Disponível em: <http://www.corteidh. or.cr/docs/casos/articulos/seriec_104_esp.pdf>. Acesso em: 23 de jun. 2015.

68 Posição defendida também por: ALIANAK, Raquel Cynthia. El renovado Derecho Administrativo, a la luz del control de convencionalidad. A\&C - Revista de Direito Administrativo \& Constitucional, Belo Horizonte, ano 15, n. 59, p. 29-46, jan./mar. 2015. p. 43. de alcance da norma compreende os atos emanados de qualquer autoridade pública, seja administrativa, legislativa ou judicial, desde que o ato estatal imponha obrigações ou restrinja direitos dos cidadãos.

\section{Considerações finais: A NECESSIDADE de ADEQUAÇÃO DA JURISPRUDÊNCIA DO SUPERIOR Tribunal de Justiça e da Administração Pública brasileira aO art. 80, N. 2, "B" dO Pacto de San José da Costa Rica, ao art. 14, item 3, letra a) do Pacto Internacional sobre Direitos Civis e Políticos e à JURISPRUdÊnCIA DA CORTE INTERAMERICANA DE Direitos Humanos}

Conforme se viu anteriormente, o Superior Tribunal de Justiça brasileiro, sem o menor constrangimento, consolidou uma avalanche de decisões que afirmam que "no ato que inaugura o processo disciplinar é desnecessária a minuciosa descrição dos fatos a serem apurados". ${ }^{69}$ Ou seja, entende a Corte que não é preciso, no ato de instauração do processo administrativo disciplinar, oferecer ao cidadão uma comunicação prévia e pormenorizada das acusações que lhe são dirigidas, sendo suficiente apenas indicar os membros da Comissão Processante e apontar acusações genéricas.

Essa posição do STJ, que é seguida pela Administração Pública brasileira, revela-se francamente contrária aos direitos humanos ao contraditório e à ampla defesa, e, portanto, claramente inconstitucional e inconvencional, uma vez que:

(i) ofende o art. $5^{\circ}, \mathrm{LV}$ da Constituição Federal, que assegura ao cidadão, nos processos administrativos, os direitos ao contraditório e à ampla defesa "com todos os meios e recursos a ela inerentes", visto que, no momento em que o acusado receber a comunicação com a descrição detalhada das condutas fáticas e do enquadramento legal da suposta infração cometida a fase de instrução probatória, já terá ocorrido e ele não poderá mais pro-

69 BRASIL. Superior Tribunal de Justiça. Agravo Regimental no Recurso em Mandado de Segurança n ${ }^{\circ}$ 29.595/MS. Relatora Min. Maria Thereza de Assis Moura. Sexta Turma. Julgado em 16.08.2012. DJe 27.08.2012. Disponível em: <https://ww2.stj.jus.br/processo/ revista $/$ documento $/$ mediado $/$ ?componente $=I T A \&$ sequencial $=117$ 0368\&num_registro $=200901006464 \&$ data $=20120827 \&$ formato $=P$ DF>. Acesso em: 23 de jun. 2015. 
duzir provas, elemento indispensável dos direitos fundamentais ao contraditório e ampla defesa;

(ii) infringe frontalmente o direito humano a uma "comunicaşão prévia e pormenorizada ao acusado da acusação formulada", inscrito no art. $8^{\circ}$, n. 2, "b" da Convenção Americana de Direitos Humanos — diploma que, segundo o Supremo Tribunal Federal, desfruta de hierarquia supralegal no ordenamento jurídico nacional ${ }^{70} \mathrm{e}$, portanto, se sobrepõe a qualquer previsão de leis ordinárias;

(iii) afronta o art. 14, item 3, letra a) do Pacto Internacional sobre Direitos Civis e Políticos, que assim como o Pacto de San José da Costa Rica estabelece como direito humano a garantia de "ser informado, sem demora, numa língua que compreenda e de forma minuciosa, da natureza e dos motivos da acusação contra ela formulada" e, também, goza de hierarquia supralegal no Direito brasileiro;

(iv) contraria diretamente a jurisprudência da Corte Interamericana de Direitos Humanos, que em reiterados julgados consolidou o entendimento de que as "Garantias Judiciais" do art. $8^{\circ}$ do Pacto de San José da Costa Rica - entre elas o direito à "comunicação prévia e pormenorizada ao acusado da acusação formulada" - se aplicam também aos processos administrativos (e não somente aos processos judiciais);

(v) por consequência da transgressão da Convenção Americana e do Pacto Internacional sobre Direitos Civis e Políticos, agride também o art. $5^{\circ}, \$ 2^{\circ}$ da Constituição Federal, segundo o qual os direitos previstos no texto constitucional não excluem outros, decorrentes dos tratados internacionais dos quais o Brasil seja parte, ignorando a existência de um "bloco de constitucionalidade" que ultrapassa as previsões expressas do texto constitucional e vincula todos os Poderes Públicos à sua observância e cumprimento.

Para que haja verdadeiro respeito aos direitos humanos e fundamentais estabelecidos nos tratados internacionais e nos dispositivos constitucionais acima referidos, a Administração Pública brasileira encontra-se proibida de instaurar processos disciplinares sem pormenoriz̧ar, já

70 BRASIL. Supremo Tribunal Federal. Recurso Extraordinário $\mathrm{n}^{\circ}$ 349703. Relator Min. Carlos Britto. Relator p/ Acórdão: Min. Gilmar Mendes. Tribunal Pleno. Julgado em 03.12.2008. DJe104, divulgado em 04.06.2009 e publicado em 05.06.2009. Disponível em: <http://redir.stf.jus.br/paginadorpub/paginador. jsp?docTP=AC\&docID=595406>. Acesso em: 23 de jun. 2015. no ato inaugural, as condutas supostamente ilícitas que estão sendo imputadas ao servidor público, sob pena de incorrer em violação de direitos humanos e acarretar responsabilização internacional do Estado brasileiro. ${ }^{71}$

Ao ratificar tratados de direitos humanos, o Estado Brasileiro não está apenas assumindo uma obrigação com os demais Estados que se submeteram a essa ordem normativa, mas está também adotando um compromisso com os seus próprios cidadãos. ${ }^{72}$ Logo, ignorar as convenções internacionais significa, em última análise, deslealdade com o próprio povo brasileiro e com os demais Estados signatários dos pactos.

O descumprimento da normativa internacional por parte da Administração Pública e dos juízes e tribunais brasileiros, enquanto partes integrantes do aparato do Estado, poderá implicar a responsabilização do Brasil no plano internacional. A respeito, a Corte Interamericana de Direitos Humanos no caso Almonacid Arellano e Outros vs. Chile declarou que "El cumplimiento porparte de agentes o funcionarios del Estado de una ley violatoria de la Convención produce responsabilidad internacional del Estado, y es un principio básico del derecho de la responsabilidad internacional del Estado, recogido en el Derecho Internacional de los Derechos Humanos, en el sentido de que todo Estado es internacionalmente responsable por actos $u$ omisiones de cualesquiera de sus poderes $u$ órganos en violación de los derechos internacionalmente consagrados, según el artículo 1.1 de la Convención Americana". ${ }^{73}$

Ademais, ressalta-se que o compromisso do Brasil na esfera internacional não se submete, apenas, à aplicação mecânica dos dispositivos previstos nos pactos

71 Acerca do tema, ver: RAMOS, André de Carvalho. Responsabilidade internacional por violação de direitos humanos. Rio de Janeiro: Renovar, 2004.

72 A esse respeito, segue trecho da opinião consultiva $\mathrm{n}^{\circ}$. OC2/82 de 24 de setembro de 1982 da Corte Interamericana, denominada "El Efecto de las Reservas Sobre la Entrada en Vigencia de la Convención Americana (artículos 74 y 75)", que assim dispôs "los tratados modernos sobre derechos humanos, en general, $y$, en particular, la Convención Americana, no son tratados multilaterales del tipo tradicional, concluidos en función de un intercambio reciproco de derechos, para el beneficio mutuo de los Estados contratantes. Su objeto y fin son la protección de los derechos fundamentales de los seres bumanos, independientemente de su nacionalidad, tanto frente a su propio Estado como frente a los otros Estados contratantes. Al aprobar estos tratados sobre derechos humanos, los Estados se someten a un orden legal dentro del cual ellos, por el bien común, asumen varias obligaciones, no en relación con otros Estados, sino hacia los individuos bajo su jurisdicción" (par. 29).

73 CORTE INTERAMERICANA DE DIREITOS HUMANOS. Caso Almonacid Arellano y Otros vs. Chile, sentença de 26 de setembro de 2006. Disponível em: <http://www.corteidh.or.cr/docs/ casos/articulos/seriec_154_esp.pdf>. Acesso em: 25 de jun. 2015. 
dos quais é signatário. Para além da letra fria das normas internacionais, o Estado tem a obrigação de aplicar a jurisprudência da Corte Interamericana, responsável pela interpretação em última instância da Convenção Americana de Direitos Humanos. ${ }^{74}$ O Poder Judiciário brasileiro está submetido ao império dos tratados internacionais internalizados pelo Estado e da jurisprudência que os interpretar (no caso, a Corte Interamericana de Direitos Humanos). Cabe à justiça brasileira "tener en cuenta no solamente el tratado, sino también la interpretación que del mismo ha hecho la Corte Interamericana, intérprete última de la Convención Americana". ${ }^{75}$

Portanto, cabe aos juízes e tribunais brasileiros, bem como à Administração Pública, assegurar a implementação da normativa internacional de proteção dos direitos humanos no seu âmbito interno. Não apenas a incorporação, mas sobretudo a aplicação dos tratados internacionais de proteção dos direitos humanos pelo Brasil constitui alta prioridade nos dias atuais. O próprio futuro da proteção internacional dos direitos humanos dependente em grande parte da adoção e aperfeiçoamento de medidas nacionais de implementação desses direitos no âmbito interno dos países signatários. ${ }^{76}$

A Constituição de 1988 representa um marco no tocante à concretização dos direitos humanos, pois promove abertura à conjugação do Direito interno e do Direito Internacional dos Direitos Humanos, permitindo a entrada na ordem constitucional, com paridade hierárquica, das normas internacionais de proteção dos direitos humanos, formando o chamado "bloco de constitucionalidade". Cabe aos operadores do Direito incorporar os novos valores constitucionais, propagando essa nova ordem em todas as esferas estatais, sejam elas administrativas, legislativas ou judiciárias, impedindo que se perpetuem os antigos valores do regime autoritário. ${ }^{77}$

74 SAGÜÉS, Nestor Pedro. Nuevas fronteras del control de convencionalidad: el reciclaje del derecho nacional y el control legisferante de convencionalidad. Revista de Investigações Constitucionais, Curitiba, vol. 1, n. 2, p. 23-32, maio/ago. 2014. DOI: http:// dx.doi.org/10.5380/rinc.v1i2.40509. p. 31.

75 CORTE INTERAMERICANA DE DIREITOS HUMANOS. Caso Boyce y otros vs. Barbados, julgado em 20 de novembro de 2007, par. 78. Disponível em: < http://www.corteidh.or.cr/ docs/casos/articulos/seriec_169_esp.pdf >. Acesso em: 23 de jun 2015.

76 CANÇADO TRINDADE, Antônio Augusto. A interação entre o Direito Internacional e o direito interno na proteção dos Direitos Humanos. Arquivos do Ministério da Justiça, n. 46, v. 182, p. 27-84, jul./dez. 1993.

77 PIOVESAN, Flávia. Temas de Direitos Humanos. 7. ed.
Pelo exposto, conclui-se que faz-se necessário, em caráter emergencial, a adequação da jurisprudência do Superior Tribunal de Justiça e da Administração Pública brasileira (i) ao teor do disposto no art. $8^{\circ}$, n. 2, "b" do Pacto de San José da Costa Rica; (ii) ao conteúdo do art. 14, item 3, letra a) do Pacto Internacional sobre Direitos Civis e Políticos; e (iii) à jurisprudência da Corte Interamericana de Direitos Humanos, de modo a aplicar as garantias mínimas expressas nos referidos dispositivos aos processos administrativos disciplinares que tramitam sob o regime da Lei $\mathrm{n}^{\circ} 8.112 / 90$, em especial o direito à descrição prévia e pormenorizada das condutas imputadas ao acusado.

\section{REFERÊNCIAS}

ALIANAK, Raquel Cynthia. El renovado Derecho Administrativo, a la luz del control de convencionalidad. A\&C - Revista de Direito Administrativo \& Constitucional, Belo Horizonte, ano 15, n. 59, p. 29-46, jan./mar. 2015.

BACELLAR FILHO, Romeu Felipe; HACHEM, Daniel Wunder. A necessidade de defesa técnica no processo administrativo disciplinar e a inconstitucionalidade da Súmula Vinculante n 5 do STF. A\&C - Revista de Direito Administrativo \& Constitucional, $n^{\circ} 39$, Belo Horizonte, Fórum, p. 27-64, jan./mar. 2010.

BACELLAR FILHO, Romeu Felipe; PIVETTA, Saulo Lindorfer. O regime jurídico do processo administrativo na Lei no 9.784/99. A\&C - Revista de Direito Administrativo \& Constitucional, Belo Horizonte, ano 14, n. 58, p. 107-135, out./dez. 2014.

BACELLAR FILHO, Romeu Felipe. Processo Administrativo Disciplinar. 4. ed. São Paulo: Saraiva, 2013.

BARBAGELATA, Héctor-Hugo. La consagración legislativa y jurisprudencial del bloque de constitucionalidad de los derechos humanos. Derecho Laboral: Revista de doctrina, jurisprudencia e informaciones sociales, $n^{\circ}$ 237, Montevideo, Fundación de Cultura Universitaria, p. 141-155, ene./mar. 2010.

BIDART CAMPOS, Germán. Las fuentes del Derecho Constitucional y el principio "pro homine". In: BIDART CAMPOS, Germán; GIL DOMINGUEZ, An-

São Paulo: Saraiva, 2014. p. 80. 
drés (coord.). E1 Derecho Constitucional del Siglo

XXI: Diagnóstico y perspectivas. Buenos Aires: Editora Ediar, 2000.

BRASIL. Superior Tribunal de Justiça. AgRg no RMS 23.775/PR. Rel. Ministro Jorge Mussi. Julgado em 28.08.2012. Disponível em: <https://ww2.stj.jus.br/ processo/revista/documento/mediado/?componente $=$ ITA\&sequencial $=1173623 \&$ num_registro $=2007005$ $16360 \&$ data $=20120906 \&$ formato $=P D F>$. Acesso em: 23 de jun. 2015.

BRASIL. Superior Tribunal de Justiça. Agravo Regimental no Recurso em Mandado de Segurança no 29.595/ MS. Relatora Min. Maria Thereza de Assis Moura. Sexta Turma. Julgado em 16.08.2012. DJe 27.08.2012. Disponível em: <https://ww2.stj.jus.br/processo/revista/documento/mediado/?componente $=I T A \& s e q u e n$ cial $=1170368 \&$ num_registro $=200901006464 \&$ data $=2$ 0120827\&formato=PDF $>$. Acesso em: 23 de jun. 2015.

BRASIL. Superior Tribunal de Justiça. EDcl no REsp 1096274/RJ. Rel. Ministra Maria Thereza De Assis Moura. Julgado em 25.09.2012. Disponível em: <https://ww2.stj.jus.br/processo/revista/documento $/$ mediado $/$ ?componente $=$ ITA\&sequencial $=1181577$ \&num_registro $=200802170819 \&$ data $=20130205 \&$ for mato $=$ PDF $>$. Acesso em: 23 de jun. 2015.

BRASIL. Superior Tribunal de Justiça. MS no 13.518/ DF. Rel. Ministro Napoleão Nunes Maia Filho. Julgado em 19.12.2008. Disponível em: <https://ww2.stj.jus. $\mathrm{br} / \mathrm{processo} /$ revista/documento/mediado/?compon ente $=$ ITA\&sequencial $=846320 \&$ num_registro $=2008$ $00875154 \&$ data $=20081219 \&$ formato $=P D F>$. Acesso em: 23 de jun. 2015.

BRASIL. Superior Tribunal de Justiça. MS $n^{\circ}$ MS 14.578/DF. Rel. Ministro Og Fernandes. Julgado em 25.08.2010. Disponível em: <https://ww2.stj.jus.br/ processo/revista/documento/mediado/?componente $=$ ITA\&sequencial $=961788 \&$ num_registro $=200901609$ $418 \&$ data $=20100922 \&$ formato $=P D F>$. Acesso em: 23 de jun 2015.

BRASIL. Superior Tribunal de Justiça. RMS 35.208/ DF. Rel. Ministro Humberto Martins. Julgado em 16.02.2012. Disponível em: <https://ww2.stj.jus.br/ processo/revista/documento/mediado/?componente $=$ ITA\&sequencial $=1122970 \&$ num_registro $=2011019$ $09232 \&$ data $=20120227 \&$ formato $=P D F>$. Acesso em: 23 de jun. 2015.
BRASIL. Superior Tribunal de Justiça. RMS 39.361/ MG. Rel. Ministro Humberto Martins. Segunda Turma. Julgado em 07.02.2013. Disponível em: < https://ww2. stj.jus.br/processo/revista/documento/mediado/?co mponente $=I T A \&$ sequencial $=1207937 \&$ num_registro $=201202273227 \&$ data $=20130219 \&$ formato $=$ PDF $>$. Acesso em: 23 de jun. 2015.

BRASIL. Supremo Tribunal Federal. ADI 4222 AgR/DF. Relator Min. Celso de Mello. Julgado em 01.08.2014. Disponível em: <http://redir.stf.jus.br/paginadorpub/ paginador.jsp?doc $\mathrm{TP}=\mathrm{TP} \& \mathrm{doc} \mathrm{ID}=6631759>$. Acesso em: 23 de jun. 2015.

BRASIL. Supremo Tribunal Federal. ADI 514/PI. Relator Min. Celso de Mello. Julgado em 24.03.2008. Disponível em: <http://www.stf.jus.br/portal/processo/ verProcessoAndamento.asp? numero $=514 \&$ classe $=\mathrm{AD}$ I\&codigoClasse $=0 \&$ origem $=J U R \&$ recurso $=0 \&$ tipoJul gamento $=\mathrm{M}>$. Acesso em: 23 de jun. 2015.

BRASIL. Supremo Tribunal Federal. ADI 595/ES , Relator Min. Celso de Mello. Segunda Turma. Julgado em 18.02.2002. Disponível em: <http://www. stf.jus.br/portal/processo/verProcessoAndamento. asp? numero $=595 \&$ classe $=$ ADI-MC $\&$ codigoClasse $=$ 0 \&origem $=J U R \&$ recurso $=0 \&$ tipoJulgamento $=\mathrm{M}>$. Acesso em: 23 de jun. 2015.

BRASIL. Supremo Tribunal Federal. Habeas Corpus $\mathrm{n}^{\circ}$ 87585. Relator Min. Marco Aurélio. Tribunal Pleno. Julgado em 03.12.2008. Disponível em: $<$ http://redir.stf.jus.br/paginadorpub/paginador. jsp?docTP=AC\&docID=597891 $>$. Acesso em: 23 de jun. 2015.

BRASIL. Supremo Tribunal Federal. Habeas Corpus $n^{\circ}$ 91361. Relator Min. Celso de Mello. Segunda Turma. Julgado em 23.09.2008. Disponível em: $<$ http:/ / redir.stf.jus.br/paginadorpub/paginador. jsp?docTP=AC\&docID=573717>. Acesso em: $23 \mathrm{de}$ jun. 2015.

BRASIL. Supremo Tribunal Federal. Recurso Extraordinário no 349703. Relator Min. Carlos Britto. Relator p/ Acórdão: Min. Gilmar Mendes. Tribunal Pleno. Julgado em 03.12.2008. DJe-104, divulgado em 04.06.2009 e publicado em 05.06.2009. Disponível em: < http://redir.stf.jus.br/paginadorpub/paginador. jsp?docTP=AC\&docID=595406>. Acesso em: 23 de jun. 2015. 
BRASIL. Supremo Tribunal Federal. Recurso Extraordinário $\mathrm{n}^{\circ}$ 466343. Relator Min. Cezar Peluso. Julgado em 03.12.2008. Disponível em: <http:// redir.stf.jus.br/paginadorpub/paginador. jsp?docTP $=$ AC\&docID $=595444>$. Acesso em: $23 \mathrm{de}$ jun. 2015.

BRASIL. Supremo Tribunal Federal. Recurso Extraordinário no . 597.285. Relator Min. Ricardo Lewandowski. Julgado em 18.05.2010. Disponível em: < http://www. stf.jus.br/portal/processo/verProcessoAndamento.as $\mathrm{p}$ ? numero $=597285 \&$ classe $=\mathrm{RE} \&$ codigoClasse $=0 \&$ or $\mathrm{i}$ gem $=J U R \&$ recurso $=0 \&$ tipoJulgamento $=M>$. Acesso em: 23 de jun. 2015.

CANÇADO TRINDADE, Antônio Augusto. A interação entre o Direito Internacional e o direito interno na proteção dos Direitos Humanos. Arquivos do Ministério da Justiça, n. 46, v. 182, p. 27-84, jul./dez. 1993.

CASSAGNE, Juan Carlos. La jerarquía y regulación de los Tratados en la Constitución argentina. A\&C - Revista de Direito Administrativo \& Constitucional, Belo Horizonte, ano 10, n. 40, p. 199-216, abr./jun. 2010.

CLÉRICO, Laura; RONCONI, Liliana. Impacto del bloque de constitucionalidad en la interpretación del derecho común: La interpretación amplia de los abortos permitidos en Argentina. Estudios constitucionales: Revista del Centro de Estudios Constitucionales, año $10, n^{\circ} 2$, Santiago de Chile, Universidad de Talca, p. 193-230, jul./dic. 2012.

CORTE INTERAMERICANA DE DIREITOS HUMANOS. Caso Almonacid Arellano y Otros vs. Chile, sentença de 26 de setembro de 2006. Disponível em: <http://www.corteidh.or.cr/docs/casos/articulos/seriec_154_esp.pdf $>$. Acesso em: 25 de jun. 2015.

CORTE INTERAMERICANA DE DIREITOS HUMANOS. Caso Baena, Ricardo y otros vs. Panamá, sentença de 28 de novembro de 2003. Disponível em: < http:/ / www.corteidh.or.cr/docs/casos/articulos/seriec_104_ esp.pdf>. Acesso em: 23 de jun. 2015.

CORTE INTERAMERICANA DE DIREITOS HUMANOS. Caso Barbani Duarte y otros vs. Uruguay, sentença de 13 de outubro de 2011, par. 15. Disponível em: <http://www.corteidh.or.cr/docs/casos/articulos/seriec_234_esp.pdf>. Acesso em: 23 de jun. 2015.

CORTE INTERAMERICANA DE DIREITOS HU-
MANOS. Caso Blake vs. Guatemala, sentença de 24 de janeiro de 1998, par. 96. Disponível em: <http://www. corteidh.or.cr/docs/casos/articulos/seriec_36_esp. pdf $>$. Acesso em: 23 de jun. 2015.

CORTE INTERAMERICANA DE DIREITOS HUMANOS. Caso Boyce y otros vs. Barbados, julgado em 20 de novembro de 2007, par. 78. Disponível em: < http:/ / www.corteidh.or.cr/docs/casos/articulos/seriec_169_ esp.pdf $>$. Acesso em: 23 de jun 2015.

CORTE INTERAMERICANA DE DIREITOS HUMANOS. Caso Castillo Petruzzi y otros vs. Perú, sentença de 30 de maio de 1999, par. 218. Disponível em: $<$ http://www.corteidh.or.cr/docs/casos/articulos/seriec_52_esp.pdf $>$. Acesso em: 23 de jun. 2015.

CORTE INTERAMERICANA DE DIREITOS HUMANOS. Caso Comunidad indígena Yakye Axa vs. Paraguay, sentença de 17 de julho de 2005, par. 125. Disponível em: <http://www.corteidh.or.cr/docs/casos/ articulos/seriec_125_esp.pdf $>$. Acesso em: 23 de jun. 2015.

CORTE INTERAMERICANA DE DIREITOS HUMANOS. Caso Comunidad Mayagna (Sumo) Awas Tingni Vs. Nicaragua, sentença de 31 de agosto de 2001, par. 146. Disponível em: <http://www.corteidh.or.cr/ docs $/$ casos $/$ articulos/seriec_79_esp.pdf $>$. Acesso em: 23 de jun. 2015.

CORTE INTERAMERICANA DE DIREITOS HUMANOS. Caso Fermín Ramírez vs. Guatemala. Sentencia de 20 de junho de 2005, pars. 67 e 68. Disponível em: $<$ http://www.corteidh.or.cr/docs/casos/articulos/seriec_126_esp.pdf $>$. Acesso em: 23 de jun. 2015.

CORTE INTERAMERICANA DE DIREITOS HUMANOS. Caso Hermanos Gómez Paquiyauri vs. Perú, sentença de 8 de julho de 2004, par. 165. Disponível em: <http://www.corteidh.or.cr/docs/casos/articulos/seriec_110_esp.pdf>. Acesso em: 23 de jun. 2015.

CORTE INTERAMERICANA DE DIREITOS HUMANOS. Caso "Niños de la Calle" (Villagrán Morales y otros) vs. Guatemala, sentença de 19 de novembro de 1999, par. 193. Disponível em: <http://www.corteidh.or.cr/docs/casos/articulos/Seriec_63_esp.pdf $>$. Acesso em: 23 de jun. 2015.

CORTE INTERAMERICANA DE DIREITOS HUMANOS. Caso Ruch Ivcher Bronstein vs. Perú, sentença de 06 de fevereiro de 2001, par.104. Disponível em: 
$<$ http://www.corteidh.or.cr/docs/casos/articulos/Seriec_74_esp.pdf >. Acesso em: 23 de jun. 2015.

CORTE INTERAMERICANA DE DIREITOS HUMANOS. Caso The Constitutional Court vs. Perú, sentença de 31 de janeiro de 2001, par. 69. Disponível em: $<$ http://www.corteidh.or.cr/docs/casos/articulos/Seriec_71_esp.pdf>. Acesso em: 23 de jun. 2015.

DÍAZ MADRIGAL, Ivonne Nohemí. El debido proceso en instrumentos internacionales y el nuevo bloque de constitucionalidad en el sistema jurídico mexicano. Reforma Judicial: Revista Mexicana de Justicia, $\mathrm{n}^{\circ}$ 20, México, Instituto de Investigaciones Jurídicas - Universidad Nacional Autónoma de México, p. 167-194, jul./dic. 2012.

DURÁN MARTÍNEZ, Augusto. La jurisprudencia de la Corte Interamericana de Derechos Humanos en la perspectiva del Derecho Administrativo. Especial referencia al caso Gelman vs. Uruguay. Revista de Investigações Constitucionais, Curitiba, vol. 1, n. 2, p. 103130, maio/ago. 2014. DOI: http://dx.doi.org/10.5380/ rinc.v1i2.40512

EUROPEAN COURT OF HUMAN RIGHTS. Caso Tyrer vs. The United Kingdom, julgado em 25 de abril de 1978, par. 31. Disponível em: < http://hudoc.echr.coe. int/sites/eng/pages/search.aspx?i=001-57587>. Aceso em: 23 de jun. 2015.

FAVOREU, Louis. Le principe de constitutionnalité: essai de définition d'aprés la jurisprudence du Conseil constitutionnel. In: Recueil d'études en hommage à Charles Eisenmann. Paris: Cujas, 1975.

FAVOREU, Louis. El bloque de la constitucionalidad. Revista del Centro de Estudios Constitucionales, $\mathrm{n}^{\circ}$ 5, Madrid, Centro de Estudios Constitucionales, p. 45-68, ene./abr. 1990.

FERNÁNDEZ, Tomás-Ramón. Las leyes orgánicas y el bloque de la constitucionalidad: en torno al artículo 28 de la Ley Orgánica del Tribunal Constitucional. Madrid: Civitas, 1981.

FREITAS, Juarez. O intérprete e o poder de dar vida à Constituição: preceitos de exegese constitucional. A\&C - Revista de Direito Administrativo \& Constitucional, Curitiba, ano 4, n. 8, p. 13-35, 2002.

FORMENTO, Augusto, DELPIAZZO, José Miguel. Primer reconocimiento jurisprudencial del bloque de constitucionalidad: concepto, importancia, efectos jurídicos y perspectivas. Revista de Derecho, $\mathrm{n}^{\circ}$ 18, Montevideo, Universidad de Montevideo - Facultad de Derecho, p. 101-113, jul./dic. 2010.

GIMENO-CABRERA, Véronique. Le traitement jurisprudentiel du principe de dignité de la persone humaine dans la jurisprudence du Conseil Constitutionnel français et du Tribunal Constitutionnel espagnol. Paris: LGDJ, 2004.

GÓMEZ FERNÁNDEZ, Itziar. Redefinir el bloque de la constitucionalidad 25 años después. Estudios de Deusto: Revista de la Universidad de Deusto, vol. 54, no 1, Bilbao, Universidad de Deusto, p. 61-98, ene./ jun. 2006.

GORDILlO, Agustín. Procedimiento Administrativo. 1. ed. Buenos Aires: Depalma, 2003.

GUTIÉRREZ COLANTUONO, Pablo Ángel. Derecho administrativo, Constitución y derechos humanos. A\&C - Revista de Direito Administrativo \& Constitucional, $n^{\circ}$ 40, Belo Horizonte, Fórum, p. 239-250, abr./jun. 2010.

GUTIÉRREZ COLANTUONO, Pablo Ángel; JUSTO, Juan Bautista (Colaborador). Administración Pública, juridicidad y derechos humanos. Buenos Aires: Abeledo Perrot, 2009.

HAKANSSON NIETO, Carlos. El reconocimiento judicial del bloque de constitucionalidad. Un estudio con especial referencia al ordenamiento jurídico peruano. In: FERRER MAC-GREGOR, Eduardo; ZALDÍVAR LELO DE LARREA, Arturo (Coords.) La ciencia del derecho procesal constitucional: estudios en homenaje a Héctor Fix-Zamudio en sus cincuenta años como investigador del derecho. t. IV. México: UNAM/Marcial Pons, 2008.

HAURIOU, Maurice. Notes d'arrêts sur décisions du Conseil d'État et du Tribunal des Conflits: publiées au Recueil Sirey de 1892 à 1928. t. I. Paris: Librairie du Recueil Sirey, 1929.

HOYOS, Arturo. El control judicial y el bloque de constitucionalidad en Panamá. Boletín Mexicano de Derecho Comparado, $n^{\circ} 75$, México, Instituto de Investigaciones Jurídicas - Universidad Nacional Autónoma de México, p. 785-807, sep./dic. 1992.

LAFER, Celso. A internacionalização dos direitos humanos: Constituição, racismo e relações internacionais. Barueri: Manole, 2005. 
LEAL, Mônia Clarissa Hennig. Corte Interamericana de Direitos Humanos e jurisdição constitucional: judicialização e ativismo judicial em face da proteção dos direitos humanos e fundamentais? Revista de Investigações Constitucionais, Curitiba, vol. 1, n. 3, p. 123140, set./dez. 2014. DOI: http://dx.doi.org/10.5380/ rinc.v1i3.40518.

LOPES, Ana Maria D’Ávila. Bloco de constitucionalidade e princípios constitucionais: desafios do poder judiciário. Seqüência: Publicação do Curso de PósGraduação em Direito da UFSC, no 59 , Florianópolis, Universidade Federal de Santa Catarina, p. 43-60, jul./dez. 2009.

LORENZO RODRÍGUEZ-ARMAS, Magdalena. Reflexiones en torno al concepto del bloque de la constitucionalidad. In: MORODO LEONCIO, Raúl; VEGA GARCÍA, Pedro de (Coords.). Estudios de teoría del Estado y derecho constitucional en honor de Pablo Lucas Verdú. v. 4. Madrid: Universidad ComplutenseFacultad de Derecho, 2001.

MANILI, Pablo Luis. El bloque de constitucionalidad: la recepción del derecho internacional de los derechos humanos en el derecho constitucional argentino. Buenos Aires: La Ley, 2003.

MAZZUOLI, Valerio de Oliveira. Curso de Direito Internacional Público. 2. ed. São Paulo: Revista dos Tribunais, 2007.

MORALES MORALES, Alejandra Virginia; ODIMBA ON'ETAMBALAKO WETSHOKONDA, Jean Cadet. La incorporación del concepto del bloque de constitucionalidad en materia de derechos humanos en México. Revista Prolegómenos: Derechos y Valores de la Facultad de Derecho, vol. 14, n 27, Bogotá, Universidad Militar Nueva Granada, p. 135-146, ene./jun. 2011.

MUÑOZ (h), Ricardo Alberto. La tutela administrativa efectiva. La Ley, Tomo 2012-B, Buenos Aires, p. 1-6, mar. 2012.

OLANO GARCÍA, Hernán Alejandro. El bloque de constitucionalidad en Colombia. Estudios constitucionales: Revista del Centro de Estudios Constitucionales, año 1, $\mathrm{n}^{\circ}$ 1, Santiago de Chile, Universidad de Talca, p. 231-242, ene./dic. 2005.

PIOVESAN, Flávia (coordenadora geral). Código de direito internacional dos direitos humanos anotado. São Paulo: Editora DPJ, 2008.
PIOVESAN, Flávia. Direitos humanos e o Direito Constitucional Internacional. 14. ed. São Paulo: Saraiva, 2013.

PIOVESAN, Flávia. Temas de Direitos Humanos. 7. ed. São Paulo: Saraiva, 2014.

RAMELLI, Alejandro. Sistema de fuentes de derecho internacional público y "bloque de constitucionalidad" en Colombia. Cuestiones constitucionales: Revista Mexicana de Derecho Constitucional, no 11, México, Instituto de Investigaciones Jurídicas - Universidad Nacional Autónoma de México, p. 157-175, jul./dic. 2004.

RAMOS, André de Carvalho. Responsabilidade internacional por violação de direitos humanos. Rio de Janeiro: Renovar, 2004.

REINA GARCÍA, Óscar M. Las cláusulas de apertura o reenvío hacia fuentes externas previstas en la Constitución colombiana, como criterio para delimitar el contenido del bloque de constitucionalidad. Revista Derecho del Estado, no 29, Bogotá, Universidad Externado de Colombia, p. 175-214, jul./dic. 2012.

REPÚBLICA DOMINICANA. El bloque de constitucionalidad en la determinación de los principios fundamentales del debido proceso. Extracto de la Resolución de la Suprema Corte de Justicia, República Dominicana, 13 de noviembre de 2003. Diálogo Jurisprudencial, $\mathrm{n}^{\circ}$ 3, México, Instituto de Investigaciones Jurídicas - Universidad Nacional Autónoma de México, p. 27-50, jul./ dic. 2007.

REY CANTOR, Ernesto. El bloque de constitucionalidad. Aplicación de tratados internacionales de derechos humanos. Estudios constitucionales: Revista del Centro de Estudios Constitucionales, año 4, $\mathrm{n}^{\circ}$ 2, Santiago de Chile, Universidad de Talca, p. 299-334, jul./dic. 2006.

ROSARIO RODRÍGUEZ, Marcos del. De la supremacía constitucional a la supremacía de convencionalidad. La nueva conformación del bloque de constitucionalidad en México. Quid Iuris, año 8, vol. 22, Chihuahua, Tribunal Estatal Electoral de Chihuahua, p. 93-118, sep./nov. 2013.

RUBIO LLORENTE, Francisco. El bloque de constitucionalidad. Revista Española de Derecho Constitucional, $\mathrm{n}^{\circ} 27$, Madrid, Centro de Estudios Políticos y Constitucionales, p. 9-38, sep./dic. 1989. 
SAGÜÉS, Nestor Pedro. Nuevas fronteras del control de convencionalidad: el reciclaje del derecho nacional y el control legisferante de convencionalidad. Revista de Investigações Constitucionais, Curitiba, vol. 1, n. 2, p. 23-32, maio/ago. 2014. DOI: http://dx.doi. org/10.5380/rinc.v1i2.40509.

SARLET, Ingo Wolfgang. A eficácia dos direitos fundamentais. 10. ed. Porto Alegre: Livraria do Advogado 2010.
VEDEL, Georges. La place de la Déclaration de 1789 dans le bloc de constitutionnalité. In: CONSEIL CONSTITUTIONNEL. La Déclaration des droits de l'homme et du citoyen et la jurisprudence: colloque des 25 et 26 mai 1989 au Conseil constitutionnel. Paris: Presses Universitaires de France, 1989.

ZAGREBELSKY, Gustavo. La giustizia costituzionale. 2. ed. Bologna: II Mulino, 1988. 


\section{A responsabilidade internacional do Brasil em face do controle de convencionalidade em sede de direitos humanos: conflito de interpretação entre a jurisdição da Corte Interamericana de Direitos Humanos e o Supremo Tribunal Federal quanto a Lei de anistia*}

* Recebido em 30/10/2015

Aprovado em 05/12/2015
** Doutora em Direito Público pela Pontifícia Universidade Católica de Minas Gerais. Mestre em Direito Internacional e Comunitário Pontifícia Universidade Católica de Minas Gerais (2006), especialização em Direito Processual pelo IEC/PUCMINAS(2003), e graduação em Direito pela Pontifícia Universidade Católica de Minas Gerais (2006). Professora Adjunta do Departamento de Direito Público da Universidade Federal de Minas Gerais e professora da Universidade de Itaúna. E-mail: carlavolpini@ hotmail.com

*** Graduado em Direito pela Universidade Federal de Minas Gerais (1992), Mestre em Direito pela Universidade Federal de Minas Gerais (1999) e Doutor em Direito pela Universidade Federal de Minas Gerais (2000). Atualmente é Professor Associado da Faculdade de Direito da Universidade Federal de Minas Gerais; Professor dos cursos de graduação, mestrado e doutorado em Direito da PUC MINAS; professor de Direito Constitucional e Direito Internacional da Faculdade de Direito da UNIFENAS/BH; Coordenador do Laboratório de Direito e Inovação Tecnológica da UFMG; Advogado e consultor jurídico registrado no PNUD - Programa das Nações Unidas para o Desenvolvimento. E-mail:bruno-wanderley@hotmail.com.
Carla Ribeiro Volpini Silva**

Bruno Wanderley Junior***

\section{Resumo}

O presente artigo tem por objetivo analisar o conflito entre a jurisdição da Corte Interamericana de Direitos Humanos e o Supremo Tribunal Federal brasileiro acerca da Lei de Anistia, através de um breve relato da conjuntura histórica no momento de criação da Lei da Anistia; da sentença da Corte Interamericana de Direitos Humanos no caso Gomes Lund e outros; da decisão do Supremo Tribunal Federal no sentido da constitucionalidade da lei de anistia e do controle de convencionalidade das leis. A metodologia utilizada no presente trabalho ancorou-se nos métodos histórico e indutivo que permitiram estabelecer as premissas conceituais e práticas aplicadas à análise da Lei de Anistia pela Corte interamericana de Direitos Humanos, e pelo STF através da ADPF 153, ou seja, tanto no âmbito internacional quanto nacional. Ao final, concluiu-se que a ações nas esferas internacional e nacional devem ser coordenadas, para a aplicação dos direitos humanos, evitando conflitos de interpretação e proporcionando uma resposta coerente e efetiva para as pessoas vitimadas por violações desses direitos, principalmente quando esse fato for fruto da ação direta de agentes do próprio Estado.

Palavras-chave: Anistia. Controle de convencionalidade das leis. Corte Interamericana de Direitos Humanos. 


\section{Abstract}

This article aims to analyze the conflict between the jurisdiction of the Inter-American Court of Human Rights and the Brazilian Supreme Court about the Amnesty Law, through a historical situation briefing at the time of the Amnesty Law creation; the Inter-American Court of Human Rights on the Gomes Lund's judgment; the Brazilian Supreme Court's decision about the constitutionality of the amnesty law and conventionality control. The methodology used in this study was fixed in historical and inductive methods for establishing the conceptual standards and practices applied to analyse the Amnesty Law for the Inter-American Court of Human Rights and the Brazilian Supreme Court through the ADPF 153, in other words, to the international and domestic level. We conclude that the actions in the international and national level should be coordinated, to the implementation of human rights, avoiding conflicts of interpretation and providing a coherent and effective response to those affected by human rights abuses, specially when this fact was the result of direct action of state agents.

Keywords: Amnesty. Convencionality control. InterAmerican Court of Human Rights.

\section{INTROduÇÃo}

O processo de redemocratização do Brasil, após 21 anos de Regime Militar, passou por várias etapas até sua consolidação em 1988. Desde o golpe de 1964, até as eleições presidenciais de 1985, o Regime Militar apresentou um período obscuro de violações sistemáticas dos direitos humanos e de desprezo pelos princípios e regras fundamentais das ordens interna e internacional.

Após uma sucessão de crises econômicas e políticas, que abalaram a estrutura da ditadura, esta promoveu uma abertura gradual do regime, com a distensão, abertura e com a anistia ampla, geral e irrestrita, culminando com o fim dos governos militares e a redemocratização do país. Contudo, a história cobra uma resposta às graves violações dos direitos humanos perpetradas pelos agentes da ditadura, protegidos pela mesma Lei de Anistia, que devolveu a cidadania a tantos perseguidos políticos. Mas, há vítimas que não encontraram respostas, a quem foram negadas a justiça e a paz de espírito, pois seus parentes, torturados, mortos e desaparecidos, foram esquecidos e as respostas sobre seu paradeiro nunca foram dadas.

No âmbito interno, o Supremo Tribunal Federal (STF) julgando, em 29 de abril de 2010, a Ação por Descumprimento de Preceito Fundamental (ADPF) $n^{\circ}$ $153^{1}$, considerou a mesma lei como constitucional, reconhecendo não só sua constitucionalidade, mas a validade de seus efeitos.

No âmbito regional, a Comissão Interamericana de Direitos Humanos da OEA (Organização dos Estados Americanos) investigou denúncia contra o Brasil, oferecida em 07 de agosto de 1995, pelas ONGs: CEJIL (Centro pela Justiça e o Direito Internacional) e Human Rights Watch/Americas, representando pessoas que foram vítimas de desaparecimento forçado, na chamada "Guerrilha do Araguaia". Em 31 de outubro de 2008 foi aprovado o Relatório de Mérito no 91/08 que concluiu pela responsabilização internacional do Brasil, contendo ainda recomendações para o Estado brasileiro. Apesar de ter sido notificado em novembro daquele ano, o Brasil não implementou as medidas apontadas pela Comissão Interamericana de Direitos Humanos, que decidiu representar o caso na Corte Interamericana de Direitos Humanos (CtIDH), em 26 de março de 2009. A Corte Interamericana de Direitos Humanos, julgou o caso, que ficou conhecido como caso Gomes Lund e outros, condenando o Brasil, em 24 de novembro de 2010, e considerando a Lei da Anistia inválida em face do Direito Internacional dos Direitos Humanos.

Embora a decisão da ADPF 153 tenha sido proferida sete meses antes da decisão do caso Gomes Lund e outros, pela CtIDH, ressalta-se que as discussões acerca das violações dos direitos humanos pelo governo brasileiro na guerrilha do Araguaia e sobre a validade da Lei de Anistia em face dos direitos humanos, já vinham ocorrendo, no seio da OEA, desde 1995. E o Brasil recebeu a notificação da Comissão de Direitos Humanos da OEA, sobre as recomendações apontadas no Relatório de Mérito no 91/08, baseado no art. 50 da Convenção Americana de Direitos Humanos, em outubro de 2008.

1 BRASIL. Supremo Tribunal Federal. Arguição de Descumprimento de Preceito Fundamental. ADPF 153 DF. Tribunal Pleno. Arguente: Conselho Federal da Ordem dos Advogados. Arguido: Congresso Nacional. Relator: Min. Eros Grau. Brasília, 29 de abril de 2010. Disponível em: <http://redir.stf.jus.br/paginadorpub/ paginador.jsp?docTP $=\mathrm{AC} \& \operatorname{doc} \mathrm{ID}=612960>$. Acesso em: $10 \mathrm{dez}$. 2015. 
Deste modo, o Estado brasileiro furtou-se a reconhecer a decisão do Sistema Interamericano de Direitos Humanos, sustentando-se na decisão da ADPF 153, surgindo, assim, a controvérsia entre a jurisdição internacional da CtIDH e a jurisdição constitucional do STF, envolvendo discussões acerca da soberania nacional, da Justiça de Transição, da observância da autoridade jurisdicional da Corte Interamericana e das questões sobre o controle de constitucionalidade e o controle de convencionalidade das leis pátrias em face do Direito Internacional. Todavia, o STF tem pela frente o julgamento de outra ADPF, a de $n^{\circ} 320$, criando a expectativa de uma possível mudança de posicionamento do nosso Supremo Tribunal, adotando o mesmo entendimento da CtIDH e promovendo a responsabilização dos torturadores e demais envolvidos nas violações de direitos humanos durante o Regime Militar.

Este trabalho visa, pois, analisar, através do método histórico-indutivo, o problema de conflito entre a jurisdição da Corte Interamericana de Direitos Humanos e o Supremo Tribunal Federal brasileiro, acerca da Lei de Anistia.

Em primeiro lugar, descreve-se um pequeno resumo da conjuntura brasileira à época do regime militar, apenas para situar o leitor em alguns dos fatos mais relevantes, divididos em três fases sequenciais, que antecederam e ensejaram a criação da Lei de Anistia, inicialmente pleiteada pela sociedade civil brasileira, em favor dos perseguidos políticos pela Ditadura e posteriormente utilizada pelo próprio regime militar para proteger seus agentes e esconder seus atos de violação dos direitos humanos, travestido de "anistia, ampla, geral e irrestrita”. Após esta contextualização, será apontada, a polêmica acerca da Lei de Anistia e a controvérsia entre a posição da Corte Interamericana de Direitos Humanos, no caso brasileiro e em alguns outros julgados, e a posição do Supremo Tribunal Federal acerca da constitucionalidade da Lei de Anistia.

Ao final, conclui-se almejando a harmonização das normas de direitos humanos nos planos interno e internacional acerca da lei da Anistia, através da mudança de posicionamento do STF na ADPF 320, ainda pendente de julgamento. A ADPF 320 surge como uma oportunidade para a revisão da Lei de Anistia, através da fundamentação jurídica do controle de convencionalidade, que faz prevalecer a decisão da $\mathrm{CtIDH}$, consolidando a justiça de transição no Brasil.

\section{O Regime MiLITAR DE 1964-1985 e a VIO- LAÇÃO SISTEMÁTICA DOS DIREITOS HUMANOS}

Durante todo o período do Regime Militar no Brasil, desde o golpe em 1964, até às vésperas da redemocratização, a violação dos direitos humanos foi uma constante das políticas públicas de repressão, que impuseram também a censura aos meios de comunicação e as perseguições a qualquer cidadão que se opusesse ao regime. Milhares de pessoas foram presas, torturadas, forçadas ao exílio, ou mortas. Muitos estão, até hoje, desaparecidos.

O Regime Militar durou de 31 de março de $1964^{2}$ até 15 de março de $1985^{3}$. Também chamado de Ditadura Militar, esse regime de exceção passou por três fases distintas, que representam os momentos de instalação, recrudescimento e desmonte do regime. ${ }^{4}$

Na primeira fase (1964-1968) o golpe militar derruba o governo Goulart e se instala, adotando medidas de restrição de direitos como o Ato Institucional n ${ }^{\circ} 1$, de 09 de abril de 1964, pelo qual os militares se livraram de autoridades e servidores públicos considerados indesejáveis, por meio de cassação de mandatos e de direitos políticos, aposentadorias compulsórias e demissões de servidores civis e militares.

Nesses primeiros anos, o regime endureceu gradativamente. Intervenções em Universidades, Sindicatos e Jornais, são seguidas por uma onda de prisões arbitrárias e perseguições a políticos e intelectuais que se opunham ao golpe. O governo militar tentou justificar a suposta legitimidade da autoproclamada "Revolução", com a chamada "Doutrina de Segurança Nacional". ${ }^{5}$

A segunda fase do Regime Militar se inicia ainda em 1968, ano de grandes revoltas e protestos contra o regi-

2 Dia do golpe contra o governo do Presidente João Goulart.

3 Dia da posse de José Sarney na Presidência da República Federativa do Brasil.

4 Para uma visão geral dessas fases, BRASIL. Secretaria de Direitos Humanos. Momentos da ditadura. Disponível em: <http://memoriasdaditadura.org.br/momentos-da-ditadura $>$. Acesso em: 30 out. 2015.

5 A "Doutrina de Segurança Nacional" foi elaborada pela Escola Superior de Guerra (ESG) e posta em prática durante o Regime Militar pelo General Goubery do Couto e Silva, um dos artífices do golpe de 1964 e, mais tarde, do processo de "distensão" que leva à posterior "abertura" do Regime Militar nos governos Geisel e Figueiredo. BRASIL. Comissão Especial sobre Mortos e Desaparecidos Políticos. Direito à memória e à verdade. Brasília: CEMDP, 2007. p. 20. 
me, com o Ato Institucional no 5 , de 13 de dezembro de 1968. ${ }^{6}$ Assim, o regime entrou em sua fase mais cruel.

O referido Ato Institucional no 5 , aumentava o poder de intervenção do Presidente e o autorizava a fechar o Congresso Nacional e os Poderes Legislativos dos outros entes da federação, além de ampliar a cassações políticas e subordinar o Judiciário ao poder Executivo, suspendendo a maioria das garantias constitucionais.

Em 31 de agosto de 1969 o governo do Presidente Costa e Silva chega ao fim, quando o Presidente é vítima de um derrame cerebral. Nessa situação deveria sucedê-lo o seu Vice, Pedro Aleixo. Porém, uma Junta Militar nega a posse a Pedro Aleixo e assume o poder, agravando ainda mais as relações do Regime Militar com a sociedade civil. O regime recrudesceu suas ações de violência contra os considerados inimigos da democracia, iniciando a chamada "guerra revolucionária".

O auge da política repressora do Regime Militar foi atingido sob o governo do General Médici, entre os anos de 1969 a 1974. Sucedendo-lhe no poder, o General Ernesto Geisel enfrentou uma nova crise. O chamado "milagre econômico", capitaneado pelo ajuste fiscal, aumento da presença do capital estrangeiro na economia, arrocho salarial e aumento do consumo, se transformaria em um desastre econômico, principalmente em função da crise mundial do petróleo, de 1973.

Diante de uma crise econômica internacional e de outra crise, dessa vez de caráter político e dentro do próprio Brasil, com sucessivas vitórias da oposição representada pelo Movimento Democrático Brasileiro (MDB), o governo Geisel resolve iniciar um processo lento e gradual de redemocratização, denominado "distensão". Contudo, essa política, que teoricamente ia de

6 Antes disso, com o Ato Institucional n $\mathrm{n}^{\circ}$, o Regime Militar enterrava de vez a Constituição democrática de 1946, para em seguida outorgar outra Constituição, em 24 de janeiro de 1967, que entrou em vigor em 15 de março de 1967, dia em que o General Costa e Silva tomou posse como Presidente do Brasil, tendo como VicePresidente o jurista mineiro Pedro Aleixo.

7 "A conquista de mentes a favor do regime em vigor, naquele momento, era o único caminho para impedir, diziam os doutrinadores da ESG e os condutores da ditadura, que fossem abertas quaisquer brechas para a desmoralização dos governos militares. A adesão à ditadura deveria, então, operar uma verdadeira desmoralização dos ideais comunistas. Este processo era denominado de guerra revolucionária, a qual, como parte da estratégia psicossocial, tinha a característica de uma guerra psicológica que atuaria no sentido de evitar que o regime viesse a tomar medidas mais drásticas no futuro." REZENDE, Maria José de. A ditadura militar no Brasil: repressão e pretensão de legitimidade, 1964-1984. Londrina: Eduel, 2013. p. 55. encontro à postura violenta e radical da chamada "linha dura" do regime, não mudou, na verdade, a brutalidade da repressão. Ao contrário, o governo se esforçou cada vez mais em justificar os atos de repressão, como forma de legitimar o Regime Militar como um todo.

Na visão de Maria José de Rezende, os "representantes do regime diziam-se incumbidos de satisfazer as aspirações de distensão política que emergiam naquele momento sem a quebra, porém, do padrão de domínio vigente, o que significava que os atos de exceção deveriam respaldar este processo."

Apesar das promessas de abertura gradual do regime, o governo Geisel implementou uma dura perseguição aos membros da esquerda brasileira e, diante de sucessivas derrotas políticas, fechou o Congresso Nacional em 1977, publicando um conjunto de emendas e decretos-lei conhecido como "Pacote de Abril", fechando ainda mais o regime e, dentre outras medidas, alterando a forma das eleições de 1978, que deveriam ser diretas, permanecendo sob a forma de eleições indiretas, para evitar uma derrota do governo nas urnas. ${ }^{9}$

Enquanto o Regime Militar perdia apoio internaciona ${ }^{10}$ e sofria com o aumento da força política da oposição e com a resistência dos meios intelectual e cultural no Brasil, buscava, desesperadamente, manter o apoio popular por meio de uma massiva propaganda do regime, baseada na censura à oposição e na criação de vínculos artificiais entre os líderes do governo e o homem comum, especialmente no seio da classe média.

\begin{abstract}
A pretensa ligação entre os comandantes da ditadura e a população era feita a partir da divulgação insistente, através de diversos canais, de que eles eram homens de família, do povo, religiosos, anti-comunistas, democratas, etc.. Estes traços apareciam como a ponte que os ligava aos diversos membros constituintes da sociedade brasileira. É interessante marcar que os formuladores da estratégia psicossocial labutavam para mostrar que os militares no poder se identificavam com o povo, mas de maneira que ficassem também ressaltados
\end{abstract}

8 REZENDE, Maria José de. A ditadura militar no Brasil: repressão e pretensão de legitimidade, 1964-1984. Londrina: Eduel, 2013. p. 161.

9 MOTTA, Marly. Dentro da névoa autoritária acendemos a fogueira...: a OAB na redemocratização brasileira (1974-80). Revista Culturas Jurídicas, Rio de Janeiro, v. 3, n. 1, p. 1-29, jan./jun. 2008. p. 13.

10 Especialmente após a eleição de Jimmy Carter como Presidente dos Estados Unidos, tomando posse em 1977, sendo ele um ferrenho crítico dos regimes ditatoriais, contrário ao uso da tortura e da violação dos Direitos Humanos. 
os elementos (disciplina, rigidez ética, capacidade de controle e de tutoração, dentre outros) que os qualificavam para ser os representantes máximos da nação brasileira. Em todo o período que vigorou a ditadura militar, os seus condutores buscavam reconhecimento para as suas ações e intenções pondo em relevo as qualidades dos militares no poder, tais como: caráter, compromisso cristão, amabilidade com a família e defesa da ordem e da justiça. A criação de laços entre eles e a população era pautada na insistência de que havia uma intimidade emotiva deles com a maioria dos membros da sociedade brasileira. A estratégia psicossocial destacava que o país não estava sendo governado por uma instituição (as Forças Armadas), mas por pessoas com as quais os brasileiros se identificavam. Ressaltavam, assim, que sob esse aspecto eles se diferenciavam de todos os demais grupos que já tinham estado no poder. ${ }^{11}$

A intenção do Regime Militar era a de enaltecer suas conquistas econômicas, embora estas já estivessem mitigadas totalmente pelas crises internacionais e nacionais, e passar uma ideia de proteção, estabelecendo uma dependência entre o povo e os governantes militares, pretensamente mais preparados para a tarefa de livrar a sociedade de seus inimigos (rotulados como inimigos do próprio povo, da família, da pátria e de Deus).

Maria José de Rezende afirma que a "ditadura militar potencializava esta ideia de proteção, de tutela. Ao se debater em torno da sedimentação de uma relação de tutoração, o grupo de poder se empenhava em diluir completamente os efeitos de sua política altamente repressora." 12

A censura aos meios de comunicação e a propaganda dos benefícios do Regime Militar na vida da sociedade brasileira era uma tática do governo para esconder a violação dos direitos humanos empreendidas nos porões da ditadura, com torturas físicas, mentais e morais, assassinatos e terrorismo de Estado, restrições à democracia e permissividade com a corrupção, principalmente nos contratos com o setor privado, nas concessões, na gestão das empresas estatais e nas relações com as empresas multinacionais.

General João Batista de Figueiredo. O projeto do governo não era entregar o Estado à oposição, mas garantir que a transição recairia nas mãos da parcela da

11 REZENDE, Maria José de. A ditadura militar no Brasil: repressão e pretensão de legitimidade, 1964-1984. Londrina: Eduel, 2013. p. 364.

12 REZENDE, Maria José de. A ditadura militar no Brasil: repressão e pretensão de legitimidade, 1964-1984. Londrina: Eduel, 2013. p. 365. sociedade civil que dava sustentação ao regime. Nesse processo, era de suma importância proteger o aparelho estatal de qualquer forma de contestação, presente ou futura, acerca de sua conduta e garantir a necessária empatia entre o regime e o povo. Contudo, a oposição da sociedade e a consciência dos abusos e das práticas cruéis do governo contradiziam a propaganda oficial e faziam crescer a rejeição da sociedade à ditadura e seus métodos.

A necessária estratégia de desengajamento militar posta em andamento com as políticas de distensão e abertura não significava que os condutores militares e civis do regime estavam abrindo mão de buscar adesão para o processo político, social e econômico instaurado em março de 1964. Ao contrário, havia uma clara intenção de arrefecer, assim como nos períodos anteriores, as perspectivas negativas em torno do regime; o que era dificultado cada vez mais, nos dois últimos governos da ditadura, com o florescimento de diversas formas de contestações no interior da sociedade civil. ${ }^{13}$

A terceira fase do Regime Militar vai começar no governo do Presidente Figueiredo, com a implementação da abertura iniciada no governo anterior e pela concessão da anistia a todos os políticos e cidadãos perseguidos pelo regime, ou cassados pelos Atos Institucionais. Mas, a lei da anistia não significava uma vitória da sociedade civil e, tampouco, uma resposta adequada às vítimas do Regime Militar ou às suas famílias. Estas sequer foram ouvidas.

A anistia era uma bandeira levantada pela sociedade civil e por lideranças políticas, especialmente as da oposição, para reverter as cassações e as perseguições de caráter eminentemente político, sofrida por intelectuais, autoridades e cidadãos que lutaram pela democracia e se opuseram ao Regime Militar, desde a edição do Ato Institucional $n^{\circ} 1$. Contudo, o Presidente Figueiredo enviou ao Congresso uma proposta de projeto de lei da anistia, que atingia não apenas as vítimas do regime, mas também seus algozes.

Ao proteger os agentes do Estado, que efetuaram as práticas de tortura, assassinatos políticos, e as mais cruéis formas de violação de direitos constitucionais e de direitos humanos, intentava-se proteger o próprio Regime Militar diante da história, resguardando a ilusão de seu papel protetivo dos interesses sociais.

13 REZENDE, Maria José de. A ditadura militar no Brasil: repressão e pretensão de legitimidade, 1964-1984. Londrina: Eduel, 2013. p. 370-371. 
O Presidente Figueiredo propôs, portanto, ao Congresso a criação de uma lei de anistia ampla, geral e irrestrita, afirmando que a Revolução de 1964 havia cumprido seu papel na história. No dia 28 de agosto de 1979, seria sancionada a Lei 6683/79, que passou para a história como "Lei da Anistia".

O fato da Lei da Anistia abranger a chamada "anistia recíproca", pois anistiava os que foram perseguidos pelo Regime e também aqueles que atuaram por ele, não encontrou unanimidade em nenhum dos lados. Alguns líderes da oposição alegavam que não se poderia deixar de punir os crimes contra a humanidade, configurados nos atos de tortura e assassinatos políticos e argumentavam ainda que não havia um único torturador julgado e condenado e, portanto, não poderia haver tecnicamente a sua anistia. Do lado dos militares havia os que argumentavam que anistiar os agentes do Estado seria admitir sua culpa e a própria existência da violação aos direitos humanos, então negada veementemente pelo Governo Militar. ${ }^{14}$

Ao largo dessa controvérsia, o fato é que a Lei de Anistia entrou em vigor e permitiu o retorno dos líderes políticos cassados e dos exilados, bem como a possibilidade de reintegração dos servidores aposentados ou demitidos em função dos Atos Institucionais. Contudo, muitos dos perseguidos ainda permaneceriam presos por algum tempo, enquanto os agentes da máquina de repressão foram beneficiados de imediato.

Considerado por muitos como um acordo histórico e responsável por uma transição pacífica do Regime Militar para a democracia, a Lei de Anistia, por outro lado, soterrou as chances de uma real reparação dos danos causados pela ditadura, jogando no esquecimento os mortos e desaparecidos, abandonando suas famílias na amargura da impunidade e da incerteza sobre o destino de seus entes queridos, cujas vidas foram apagadas, assim como as respostas nunca foram dadas e a justiça nunca alcançada.

O governo Figueiredo, todavia, levou o processo de abertura até o fim, reestruturando os partidos políticos (a ARENA se tornaria PDS e o MDB foi transformado em PMDB), o que promoveria o fim do bipartidarismo e a reorganização político-partidária, que permitiu, por exemplo, a fundação do Partido dos Trabalhadores em

14 FICO, Carlos. A negociação parlamentar da anistia de 1979 e o chamado "perdão aos torturadores". Revista Anistia Política e Justiça de Transição, Brasília, n. 4, p. 318-333, jul./dez., 2010.
1980, reconhecido pelo TSE em 1982, seguindo-se as eleições diretas para governadores em 1982 e o fim do regime Militar com as eleições presidenciais de 1985. A redemocratização culminou com a promulgação da Constituição da República de 1988 e o retorno definitivo do pluripartidarismo.

\section{A POLÊMICA ACERCA dA LEI DE ANISTIA E A CONTROVÉrsia ENTRE A POSIÇÃo dA CORTE IN- teramericana de Direitos Humanos e a do Supremo Tribunal Federal.}

Em qualquer sociedade civilizada, o Estado detém a exclusividade do jus puniendi, ou seja, somente o Estado pode subjetivar o direito penal, aplicando suas sanções punitivas aos indivíduos sob sua jurisdição. Mas, o direito de punir também abarca o poder de não punir, isto é, a prerrogativa de extinguir a punibilidade, por meio da previsão legal dos casos em que que o interesse ou a possibilidade de punir desaparecem. ${ }^{15}$

Dentre os casos em que o Estado decide não punir estão a anistia, a graça, o indulto, ou mesmo o perdão. Percebe-se, assim, que o Estado tem o poder de rever, em certos casos, a aplicação da sanção penal, podendo desistir de punir, por considerar que não há interesse social na punibilidade. Em todos os casos, é a lei que autoriza a medida.

A anistia, nesse sentido, é um instrumento jurídico capaz de apagar a punibilidade de um determinado crime, significando uma verdadeira renúncia do jus puniendi do Estado no caso em que ela é concedida.

Magalhães Noronha observa que a anistia "aplica-se, em regra, a crimes políticos, tendo por objetivo apaziguar paixões coletivas perturbadoras da ordem e da tranquilidade social". ${ }^{16}$

A anistia é um instituto que remonta à Antiguidade. Atribuída aos gregos, a anistia foi usada em todas as eras da civilização como um instrumento político, uma forma de apagar as penas impostas a cidadãos, por motivo

15 No Brasil, o Código Penal prevê a extinção da punibilidade em seu artigo 107. BRASIL. Decreto-Lei no 2.848, de 7 de dezembro de 1940. Disponível em: <http://www.planalto.gov.br/ccivil_03/decretolei/Del2848compilado.htm>. Acesso em: 09 fev. 2016.

16 NORONHA, Edgard Magalhães. Direito penal. 38. ed. São Paulo: Saraiva, 2004. v. 1. p. 379. 
de perseguição política, durante a vigência de regimes tirânicos. ${ }^{17}$

No Brasil, a anistia foi um instrumento adotado desde a era colonial, estando presente no Império e em diversos períodos da nossa história política republicana. ${ }^{18}$

Contudo, é na nossa história recente, em referência aos chamados "anos de chumbo", que o instituto da anistia vai alcançar um maior destaque, como demanda legítima de uma sociedade assolada pelo terror da ditadura e das violações de seus direitos fundamentais; como instrumento de transição política; e como ponto central do conflito entre a jurisdição internacional da Corte Interamericana na defesa dos direitos humanos e o Supremo Tribunal Federal em sua prerrogativa decisória constitucional.

Promulgada em agosto de 1979, a Lei 6683/79, denominada "Lei da Anistia", surgiu como um corolário do processo de abertura política, que promoveu a transição pacífica do Regime militar para a democracia. Todavia, foi no seio da sociedade civil, nos movimentos sociais, na luta dos familiares dos presos e desaparecidos, nos meios intelectuais e artísticos, nas comunidades de base, na Igreja, enfim, em diversos setores da sociedade brasileira que o clamor pela anistia germinou e floresceu, e como observa Glenda Mezarobba, a reivindicação pela anistia aos perseguidos políticos do Regime Militar "começou a ser formulada logo depois do golpe":

17 "Historicamente a anistia surgiu na Grécia, mais especificamente no período de Solon no ano de 594 a.C., Solon que institui entre os helenos um regime democrático, concede o primeiro ato de clemência que a História registra, reintegrando os direitos aos cidadãos perseguidos pelos regimes tirânicos que lhe antecedem e concede o perdão a todos os perseguidos, exceto aos condenados por traição ou homicídio. Depois foi usada também por Petroceides em 405 a.C., que, segundo Rui Barbosa, "restabeleceu com restrições a comunhão dos direitos civis e políticos, a favor de numerosos cidadãos processados e condenados, tendo ordenado a queima de todos os registros, os atenienses gratificados, fizeram um acrópole e solene juramento de reconhecimento geral" 1. Rui Barbosa se refere ainda à anistia atribuída a Trasíbulo, resultado de um acordo de paz entre atenienses e espartanos." COSTA, Homero de Oliveira. Incursões na história das Anistias políticas no Brasil. Coletivo Catarinense: Memória, Verdade e Justiça, 25 jul. 2015. Disponível em: < https:// coletivomemoriaverdadejusticasc.wordpress.com/2015/07/25/ incursoes-na-historia-das-anistias-politicas-no-brasil-homero-deoliveira-costa/>. Acesso em: 20 out. 2015.

18 COSTA, Homero de Oliveira. Incursões na história das Anistias políticas no Brasil. Coletivo Catarinense: Memória, Verdade e Justiça, 25 jul. 2015. Disponível em: <https://coletivomemoriaverdadejusticasc.wordpress.com/2015/07/25/incursoes-na-historia-das-anistias-politicas-no-brasil-homero-de-oliveira-costa/>. Acesso em: 20 out. 2015.
O primeiro a reclamá-la foi Alceu de Amoroso Lima, o Tristão de Athayde. Em dezembro de 1964, durante entrevista a uma emissora de rádio carioca, o escritor católico apelou por anistia ao presidente Castello Branco. Em seguida foi a vez do general Pery Constant Bevilacqua, ministro do Superior Tribunal Militar (STM), defender a adoção do expediente. Em 1967, um manifesto da Frente Ampla, organizada por líderes da oposição como Carlos Lacerda, Juscelino Kubitschek e João Goulart, pediria 'anistia geral, para que se dissipe a atmosfera de guerra civil que existe no país'. ${ }^{19}$

Como exemplo do engajamento da sociedade civil, em 1975, o Movimento Feminino pela Anistia, liderado por Terezinha Zerbini, inicia uma mobilização nacional pela anistia ampla, geral e irrestrita, tendo como foco os perseguidos políticos e opositores ao Regime Militar. Nos anos que se seguiram, juntamente com o Comitê Brasileiro pela Anistia, foram organizados diversos encontros, passeatas e manifestações que contavam com o apoio de setores da Igreja católica e de representantes de outras religiões, associações de direitos civis e instituições como a OAB (Ordem dos Advogados do Brasil), culminando com o Congresso Nacional pela Anistia, realizado em São Paulo em 1978, no qual as representações sociais discutiram e elaboraram suas propostas para uma lei de anistia, a ser encaminhada ao Senado da República. ${ }^{20}$

Mas a Lei da Anistia não foi fruto apenas da pressão da sociedade. O próprio Regime Militar almejava usar a lei para salvaguardar sua imagem na história, pretendendo jogar ao esquecimento as práticas de terror e violência com que tratou seus opositores.

Apesar de nascer no seio da sociedade e na luta dos movimentos sociais, a Lei de Anistia ficou longe de atender às expectativas do povo brasileiro, principalmente das vítimas e de seus familiares. Desvirtuada por um número gigantesco de emendas e substitutivos (314 ao todo), propostas, em sua maioria, por políticos da ARENA (partido do Governo), o projeto da Lei de Anistia perdeu legitimidade, refletindo-se especialmente

19 MEZAROBBA, Glenda. Um acerto de contas com o futuro anistia e suas consequências: um estudo do caso brasileiro. 2003. 206 f. Dissertação (Mestrado) - Programa de Pós-graduação em Ciência Politica, Faculdade de Filosofia, Letras e Ciências Humanas, Universidade de São Paulo, São Paulo, 2003. p. 13.

20 VARGAS, Mariluci Cardoso. O movimento feminino pela anistia como partida para a redemocratização brasileira. In: ENCONTRO ESTADUAL DE HISTÓRIA, 9., Porto Alegre, 2008. Vestígios do Passado: história e suas fontes. Porto Alegre: ANPUHS, 2008. Disponível em: <http://eeh2008.anpuh-rs.org.br/resources/content/ anais/1212369464_ARQUIVO_trabalhocompletoanpuh.pdf $>$. Acesso em: 09 fev. 2016. p. 07. 
na redação do art. $1^{\circ}$ das Lei, estendendo seus benefícios também aos agentes da repressão, mandantes e executores das violações dos direitos humanos. ${ }^{21}$

Conforme José Maria Goméz “o objetivo primordial dessa lei era absolver os agentes repressivos do Estado pela prática de torturas, assassinatos e desaparecimentos de opositores levada à frente durante as três fases distintas do longo ciclo da ditadura". ${ }^{22}$

De qualquer forma, a lei foi promulgada e entrou em vigor, atingindo seus objetivos iniciais de promover um clima de alivio na sociedade, com o retorno dos exilados e a esperança de redemocratização.

Por um certo tempo, a sociedade se entregou ao clima da transição, alimentada pelas eleições diretas para governadores em 1982 e a campanha das "Diretas Já" que, em 1984, levou milhões de brasileiros às ruas, clamando por democracia e por eleições diretas para Presidente. Mesmo com a derrota do projeto das eleições presidenciais diretas, o processo eleitoral que levou à escolha de Tancredo Neves para Presidente do Brasil, tendo José Sarney como vice, no Colégio Eleitoral no Congresso Nacional, atendeu às expectativas do povo de derrotar o candidato do Governo, Paulo Maluf, e virar a página da história, com o fim do Regime Militar e o início da tão almejada redemocratização do país.

Entretanto, do ponto de vista da justiça de transição, a nova República não respondeu aos anseios das vítimas da ditadura e de seus familiares, pois não reabriu a discussão sobre a tortura e as violações de direitos perpetradas pelo Regime Militar, além de se posicionar no sentido de inviabilizar o acesso aos documentos secretos do período da ditadura. A abertura dos arquivos da ditadura só volta à pauta das discussões oficiais efetivamente na década de 1990, conforme afirma José Maria Goméz:

\footnotetext{
No entanto, nos anos noventa, como consequência da influência crescente do tema do direito à verdade, à justiça e à memória no plano internacional, houve uma série de iniciativas parlamentares e governamentais que procuraram atenuar a política de esquecimento oficial sobre os mortos e os desaparecidos. ${ }^{23}$
}

21 SWENSSON JUNIOR, Lauro Joppert. Anistia penal: problemas de validade da lei de anistia brasileira (lei 6.683/79). Curitiba: Juruá, 2007. p. 182.

22 GOMEZ, José Maria. Globalização dos direitos humanos, legado das ditaduras militares no Cone Sul latino-americano e justiça transicional. Revista Direito, Estado e Sociedade, Rio de Janeiro, n. 33, p. 85-130, jul./dez. 2008. p. 118.

23 GOMEZ, José Maria. Globalização dos direitos humanos, le-
Foram os permanentes esforços das vítimas, familiares e organizações da sociedade civil pelos direitos humanos e a pressão de organismos internacionais, os responsáveis diretos por essa mudança de comportamento dos poderes públicos. ${ }^{24}$

Nesse sentido, em 21 de outubro de 2008, o Conselho Federal da Ordem dos Advogados do Brasil entrou com uma Arguição de Descumprimento de Preceito Fundamental (ADPF) no Supremo Tribunal Federal. O objetivo era questionar o dispositivo da Lei 6683/79, que ampliava os efeitos da anistia aos agentes da repressão, com o argumento de que não teria este sido recepcionado pela Constituição de $1988 .{ }^{25}$

Era a ADPF 153, pela qual a OAB iniciou a discussão perante a mais alta Corte do país, sobre a controversa e, para muitos, perversa Lei da Anistia. ${ }^{26}$ :

3. O arguente alega ser notória a controvérsia constitucional a propósito do âmbito de aplicação da "Lei de Anistia". Sustenta que "se trata de saber se houve ou não anistia dos agentes públicos responsáveis, entre outros crimes, pela prática de homicídio, desaparecimento forçado, abuso de autoridade, lesões corporais, estupro e atentado violento ao pudor contra opositores políticos ao

gado das ditaduras militares no Cone Sul latino-americano e justiça transicional. Revista Direito, Estado e Sociedade, Rio de Janeiro, n. 33, p. 85-130, jul./dez. 2008. p. 119.

24 "Esses esforços iam da elaboração do dossiê do Comitê Brasileiro de Anistia, passando pelo da Comissão de Familiares de Mortos e Desaparecidos Políticos, pelo da Comissão de Cidadania e Direitos Humanos da Assembleia Legislativa do Rio Grande do Sul e outros numerosos trabalhos, até culminar, em 1985, com o livro Brasil: Nunca Mais, publicado pela Comissão Justiça e Paz da Arquidiocese de São Paulo, com prefácio de Dom Paulo Evaristo Arns. Grande parte das informações sobre as vítimas e os responsáveis da repressão, foi obtida pelos ativistas, de forma secreta, a partir dos dossiês do Superior Tribunal Militar." (GOMEZ, José Maria. Globalização dos direitos humanos, legado das ditaduras militares no Cone Sul latino-americano e justiça transicional. Revista Direito, Estado e Sociedade, Rio de Janeiro, n. 33, p. 85-130, jul./dez. 2008. p. 118; nota de rodapé no 35 )

25 Lei 6683 de 28 de agosto de 1979: Art. $1^{\circ}[\ldots] \rrbracket 1^{\circ}$ - Consideram-se conexos, para efeito deste artigo, os crimes de qualquer natureza relacionados com crimes políticos ou praticados por motivação política. BRASIL. Lei no 6.683, de 28 de agosto de 1979. Disponível em: <http://www.planalto.gov.br/ccivil_03/leis/L6683. htm>. Acesso em: 09 fev. 2016.

26 Transcrição dos principais argumentos da OAB, expostos no Relatório do Ministro Eros Grau, em seu voto na a ADPF 153. BRASIL. Supremo Tribunal Federal. Arguição de Descumprimento de Preceito Fundamental. ADPF 153 DF. Tribunal Pleno. Arguente: Conselho Federal da Ordem dos Advogados. Arguido: Congresso Nacional. Relator: Min. Eros Grau. Brasília, 29 de abril de 2010. Disponível em: <http://redir.stf.jus.br/paginadorpub/paginador. jsp?docTP=AC\&docID=612960>. Acesso em: $10 \mathrm{dez} .2015$. 
regime militar" [fl. 04].

4. Afirma ainda que a controvérsia constitucional sobre a lei federal está consubstanciada na divergência de entendimentos, notadamente do Ministério da Justiça e do Ministério da Defesa, no que toca à aplicação da lei de que se cuida. Caberia ao Poder Judiciário pôr fim ao debate.

5. Daí o cabimento da ADPF, instrumento hábil a definir, com eficácia geral, se a lei federal guarda conformidade com a ordem constitucional vigente.

6. Acrescenta não ser possível, consoante o texto da Constituição do Brasil, considerar válida a interpretação segundo a qual a Lei n. 6.683 anistiaria vários agentes públicos responsáveis, entre outras violências, pela prática de homicídios, desaparecimentos forçados, abuso de autoridade, lesões corporais, estupro e atentado violento ao pudor. Sustenta que essa interpretação violaria frontalmente diversos preceitos fundamentais.

7. A eventual declaração, por esta Corte, do recebimento do $\int 1^{\circ}$ do artigo $1^{\circ}$ da Lei 6.683 implicaria, segundo o arguente, desrespeito [i] ao dever, do Poder Público, de não ocultar a verdade; [ii] aos princípios democrático e republicano; [iii] ao princípio da dignidade da pessoa humana.

8. Por fim, alega que os atos de violação da dignidade humana não se legitimam com a reparação pecuniária [Leis ns. 9.140 e 10.559] concedida às vítimas ou aos seus familiares, vez que os responsáveis por atos violentos, ou aqueles que comandaram esses atos, restariam "imunes a toda punição e até mesmo encobertos pelo anonimato".

$\mathrm{A} O A B$ requereu do STF que procedesse ao julgamento da ADPF 153, procurando uma "interpretação conforme a Constituição", ou seja, a finalidade não é a retirada do texto da lei, mas de uma interpretação que restrinja seu alcance àquele que esteja em conformidade com a Constituição, afastando qualquer outra interpretação que permita sua aplicação contrária aos princípios e regras constitucionais. De acordo com Jurgen Schwabe:

\begin{abstract}
interpretação de leis conforme a Constituição" (verfassungskonforme Auslegung) persegue o escopo de poupar a decisão legislativa, evitando a declaração de sua inconstitucionalidade ou até de nulidade da regra fixada pelo legislador, na medida em que, em havendo mais de uma interpretação possível, há de se dar prevalência àquela que for mais correspondente às normas constitucionais. ${ }^{27}$
\end{abstract}

Dessa forma, ao julgar procedente a ADPF 153, o STF afastaria a interpretação de que os agentes públicos que participaram, de qualquer forma, das torturas,

27 SCHWABE, Jürgen. Cinqüenta anos da jurisprudência do Tribunal Constitucional Alemão. Montevidéu: Fundação Konrad-Adenauer, 2005. p. 113. mortes, estupros, agressões e desaparecimentos forçados, fossem beneficiados pela Lei da Anistia. Contudo, o texto do dispositivo em comento (art. $1^{\circ}, \int 1^{\circ}$ da Lei da Anistia) não seria retirado, permanecendo em vigor em relação àqueles que são os legítimos destinatários da anistia: as vítimas da ditadura.

Não obstante o renovado clamor da sociedade por justiça e o anseio pela tardia, mas ainda necessária, punição dos responsáveis pela repressão da Ditadura Militar, o Ministro Eros Grau, relator da ADPF 153, decidiu pela improcedência do pedido, finalizando seu voto com a seguinte observação ${ }^{28}$ :

Observações finais

59. Retorno ao parecer do eminente Procurador Geral da República. Impõe-se, sim, o desembaraço dos mecanismos que ainda dificultam $O$ conhecimento do quanto ocorreu entre nós durante as décadas sombrias que conheci. Que se o faça, e se espera que isso logo ocorra, quando do julgamento da ADI n. 4077, na qual é questionada a constitucionalidade das Leis ns. 8.159/91 e 11.111/05. Transcrevo trecho desse parecer, que subscrevo: "Se esse Supremo Tribunal Federal reconhecer a legitimidade da Lei da Anistia e, no mesmo compasso, afirmar a possibilidade de acesso aos documentos históricos como forma de exercício do direito fundamental à verdade, o Brasil certamente estará em condições de, atento às lições do passado, prosseguir na construção madura do futuro democrático".

60. É necessário dizer, por fim, vigorosa e reiteradamente, que a decisão pela improcedência da presente ação não exclui o repúdio a todas as modalidades de tortura, de ontem e de hoje, civis e militares, policiais ou delinquentes.

Há coisas que não podem ser esquecidas. Em um poema, Hombre preso que mira su hijo, Mario Benedetti diz ao filho que "es bueno que conozcas/ que tu viejo calló/o puteó como un loco/que es una linda forma de callar"; "y acordarse de vos--prossegue ---/de tu carita/lo ayudaba a callar/una cosa es morirse de dolor/y otra cosa morirse de vergüenza". E assim termina este lindo poema, que de quando em quando ressoa em minha memória: "llora nomás botija/son macanas/que los hombres no lloran/aquí lloramos todos/gritamos berreamos moqueamos chillamos maldecimos/porque es mejor llorar que traicionar/porque es mejor llorar que traicionarse/llora/pero no olvides". É

28 BRASIL. Supremo Tribunal Federal. Arguição de Descumprimento de Preceito Fundamental. ADPF 153 DF. Tribunal Pleno. Arguente: Conselho Federal da Ordem dos Advogados. Arguido: Congresso Nacional. Relator: Min. Eros Grau. Brasília, 29 de abril de 2010. Disponível em: <http://redir.stf.jus.br/paginadorpub/ paginador.jsp?docTP $=\mathrm{AC} \& \operatorname{doc} \mathrm{ID}=612960>$. Acesso em: $10 \mathrm{dez}$. 2015. 
necessário não esquecermos, para que nunca mais as coisas voltem a ser como foram no passado.

Julgo improcedente a ação.

O voto do Relator, Ministro Eros Grau, pela improcedência do pedido da $\mathrm{OAB}$, na $\mathrm{ADPF}$ 153, foi acompanhado pelos ministros Cármen Lúcia, Celso de Mello, Cezar Peluso, Ellen Gracie, Gilmar Mendes e Marco Aurélio. Votaram pela procedência parcial, os Ministros Ayres Britto e Ricardo Lewandovsky. ${ }^{29}$ Com esse resultado, o STF reconheceu a compatibilidade da Lei da Anistia com o sistema constitucional de 1988 e também seu alcance amplo, com seus efeitos recaindo sobre aqueles que, representando o Estado brasileiro, praticaram toda sorte de violações de direitos humanos. Pelo Menos, por enquanto, as vítimas e parentes dos mortos, torturados e desaparecidos não encontrariam aqui uma verdadeira "justiça de transição".

Claro está, que a decisão do STF limita a possibilidade de uma justiça real e de efetividade da proteção aos direitos humanos durante o período da repressão. A Justiça de Transição, assim proclamada, é representada por um conjunto de medidas, de caráter político e jurídico, que visam reparar, no seio da sociedade, os danos sofridos em um regime de exceção, pelo regime democrático que o sucede.

Vale dizer que é uma justiça reparatória, mas não apenas no sentido de indenizar, ou reintegrar as vítimas de um regime político autoritário anterior, mas uma justiça transformadora, que exponha o passado, exorcize seus fantasmas, puna aqueles que foram agentes do terror estatal e restitua a dignidade aviltada às vítimas, para que os crimes contra elas cometidos não se perpetuem na sombra da impunidade.

Para André Ramos Tavares e Walber Angra: A justiça reparadora, de transição ou transicional se configura naqueles procedimentos que têm a finalidade de compensar abusos cometidos contra direitos humanos em regimes ditatoriais, em períodos de exceção ou de situações de anomalia constitucional..$^{30}$

29 MAFFEI, Vinicius Setubal. ADPF 153: a lei de anistia ante o Supremo Tribunal Federal. Disponível em: <http://www.egov.ufsc. $\mathrm{br} /$ portal/conteudo/adpf-153-lei-de-anistia-ante-o-supremo-tribunal-federal-uma-vis $\% \mathrm{C} 3 \% \mathrm{~A} 3 \mathrm{o}$-constitucional-penal-e-in>. Acesso em: 20 out. 2015 .

30 TAVARES, André Ramos; ANGRA, Walber de Moura. Justiça reparadora no Brasil. In: SOARES, Inês Virgínia Prado; KISHI, Sandra Akemi Shimada (Coord.). Memória e verdade: a justiça de transição no estado democrático brasileiro. Belo Horizonte: Fórum, 2009. p. 69-91. p. 71.
Flávia Piovesan entende que a "justiça de transição lança o delicado desafio de como romper com o passado autoritário e viabilizar o ritual de passagem à ordem democrática." ${ }^{\prime 1}$

Ao negar-se ao povo brasileiro o resgate de sua história e ao impedir-se que crimes contra a nação, o povo, o próprio Estado sejam investigados, julgados e eventualmente punidos, não se consagrou a anistia, mas a impunidade. Numa Justiça Transicional real e efetiva, a construção do futuro depende de como lida-se com os erros do passado. Não houve, a contento da sociedade, nenhuma punição exemplar dos violadores dos direitos humanos.

$\mathrm{Na}$ visão de Eneá Almeida e Marcelo Torelly, Justiça de Transição é vista "como o conjunto de esforços jurídicos e políticos para o estabelecimento ou restabelecimento de um sistema de governo democrático fundado em um Estado de Direito, cuja ênfase não recai apenas sobre o passado, mas também numa perspectiva de futuro". 32

E tendo na Justiça de Transição uma perspectiva de futuro, não há como aceitar uma posição do STF que olhou apenas para o passado, desconsiderando que o Estado Democrático de Direito, em um mundo globalizado, tem compromisso com a verdade, com a ética e com a prevalência dos direitos humanos, todos princípios adotados pelo Brasil em sua Constituição e em tratados internacionais já recepcionados e ratificados, portanto, obrigatórios nas ordens interna e internacional.

E foi na ordem internacional que veio uma outra resposta, uma lição sobre a Justiça de Transição e sobre o direito à verdade. Trata-se do julgamento pela Corte Interamericana de Direitos Humanos (CtIDH) do caso Gomes Lund e outros, referente à análise da conduta do aparelho de repressão do Governo do Brasil à época da ditadura, com a morte e o desaparecimento dos assim chamados "guerrilheiros" do Araguaia.

O caso Lund, julgado pela CtIDH versou sobre o massacre promovido pelo Governo da Ditadura Militar

31 PIOVESAN, Flavia. Direito internacional dos direitos humanos e a lei de anistia: o caso brasileiro. Revista da Faculdade de Direito da FMP, Porto Alegre, n. 4, 2007. p. 113.

32 ALMEIDA, Eneá S.; TORELLY, Marcelo. Justiça de transição, estado de direito e democracia constitucional: estudo preliminar sobre o papel dos direitos decorrentes da transição política para a efetivação do estado democrático de direito. Sistema Penal e Violência, Porto Alegre, v. 2, n. 2, p. 36-52, jul./dez. 2010. p. 41 
brasileira, numa localidade chamada Bico de Papagaio, perto do rio Araguaia, ao sul do Estado do Pará, contra um grupo de militantes de um núcleo de resistência rural à ditadura, organizado a partir do ano de 1966 pela ala mais radical do PCdoB, o Partido Comunista do Brasil. ${ }^{33}$

Na chamada "Operação Marajoara”, em outubro de 1973, com ordens de não fazer prisioneiros, os agentes do Estado massacraram os ditos "guerrilheiros", negando-lhes quaisquer direitos, pois não havia chance de rendição, e, como disse Emílio Meyer, "o fato é que nenhum dos guerrilheiros mortos jamais foi submetido a julgamento; nada de legalidade e, menos ainda, devido processo legal". ${ }^{34}$

Após o esgotamento dos recursos internos, em vãs tentativas de solucionar o caso nos tribunais brasileiros, a questão foi submetida à Comissão Interamericana de Direitos Humanos em 07 de agosto de 1995, que tratou do caso no âmbito de suas atribuições, resolvendo submetê-lo à Corte Interamericana de Direitos Humanos em 26 de março de 2009. ${ }^{35}$

O Brasil opôs exceções em sua defesa preliminar, na tentativa de desqualificar o julgamento pela CtIDH, argumentando, inclusive, que já havia julgado a questão da anistia aos agentes do Estado que atuaram naquele momento da história do país, reconhecendo a eles, na decisão da já mencionada ADPF 153, o direito à anistia.

Emílio Meyer comenta que a Corte Interamericana de Direitos Humanos:

decidiu que a argüição de descumprimento de preceito fundamental não era uma medida judicial à disposição dos representantes, dado que no momento em que peticionaram junto à Comissão Interamericana de Direitos Humanos, em 1996, não havia regulamentação para o procedimento

33 MONTEIRO, Adalberto. Guerrilha do Araguaia: uma epopeia pela liberdade. São Paulo: A. Garibaldi, 2005. p. 53.

34 MEYER, Emilio Peluso Neder. Responsabilização por graves violações de direitos humanos na ditadura de 1964-1985: a necessária superação da decisão do Supremo Tribunal Federal na ADPF n 153/DF pelo Direito Internacional dos Direitos Humanos. 2012. 303 f. Tese (Doutorado) - Programa de Pós-Graduação em Direito, Faculdade de Direito, Universidade Federal de Minas Gerais, Belo Horizonte, 2012. p. 208

35 MEYER, Emilio Peluso Neder. Responsabilização por graves violações de direitos humanos na ditadura de 1964-1985: a necessária superação da decisão do Supremo Tribunal Federal na ADPF n 153/DF pelo Direito Internacional dos Direitos Humanos. 2012. 303 f. Tese (Doutorado) - Programa de Pós-Graduação em Direito, Faculdade de Direito, Universidade Federal de Minas Gerais, Belo Horizonte, 2012. da argüição. Além disto, os representantes não estão legitimados a propor tal ação e ela não seria apta a definir responsabilidades individuais e nem determinar o paradeiro das vítimas desaparecidas. A CteIDH esclareceu também que não pretendia revisar a decisão do STF, mas determinar se o Brasil violou suas obrigações internacionais. De mais a mais, a Corte poderia, conforme sua jurisprudência, examinar decisões de órgãos judiciais internos, ainda que se tratasse de tribunais superiores; seu papel se destacaria em relação ao do Supremo Tribunal Federal, já que ela realizaria um controle de convencionalidade, e não de constitucionalidade. ${ }^{36}$

O resultado foi que a CtIDH condenou o Brasil, determinando a indenização aos familiares das vítimas, exigindo do Brasil o reconhecimento de sua responsabilidade histórica e declarando a Lei de Anistia inválida, em decisão francamente contrária à posição já adotada pelo STF na ADPF 153. Desse modo, o Direito Internacional responsabiliza o Estado por violações de suas obrigações internacionais, não admitindo que ele invoque seu direito interno como desculpa para este descumprimento. ${ }^{37}$

No plano interno foram implementadas inúmeras políticas de reconstrução da memória e da verdade histórica, relativa ao período do Regime Militar, com a edição de leis e criação de Comissões e Órgãos específicos para promover o processo de revisão histórica e de efetivação da justiça de transição. Um dos mais importantes organismos criados para esse fim foi a $\mathrm{Co}-$ missão Nacional da Verdade (CNV), criada pela Lei 12.528/2011, com a "finalidade apurar graves violações de Direitos Humanos ocorridas entre 18 de setembro de 1946 e 5 de outubro de 1988." ${ }^{\prime 38}$

36 MEYER, Emilio Peluso Neder. Responsabilização por graves violações de direitos humanos na ditadura de 1964-1985: a necessária superação da decisão do Supremo Tribunal Federal na ADPF n 153/DF pelo Direito Internacional dos Direitos Humanos. 2012. 303 f. Tese (Doutorado) - Programa de Pós-Graduação em Direito, Faculdade de Direito, Universidade Federal de Minas Gerais, Belo Horizonte, 2012. p. 213.

37 SANTOS, Roberto Lima. Crimes da ditadura militar: responsabilidade internacional do estado brasileiro por violação aos direitos humanos. Porto Alegre: N. Fabris, 2010.

38 A CNV funcionou de 16 de maio de 2012 a 16 de dezembro de 2014 e contou com o apoio de comissões da verdade de âmbito estadual e municipal, além de comissões criadas por diversas Universidades e pela $\mathrm{OAB}$ de vários Estados, $\mathrm{ONGs}$ e entidades públicas de toda a federação, recebendo o apoio internacional de entidades como o PNUD (Programa das Nações Unidas para o Desenvolvimento), e a UNESCO, prestando um inestimável serviço ao país e à efetivação da justiça de transição. BRASIL. Comissão Verdade. $A$ CNV. Disponível em: <http://www.cnv.gov.br/institucional-acesso-informacao/a-cnv.html>. Acesso em: 20 out. 2015; e BRASIL. Comissão da Verdade. Equipe. Disponível em: <http://www.cnv. gov.br/institucional-acesso-informacao/equipe.html>. Acesso em: 
Embora a Comissão Nacional da Verdade não tivesse competência para instaurar processos e nem o poder de punir, realizou um árduo trabalho para apurar os crimes cometidos pela ditadura e apontar seus responsáveis. Seu relatório, contundente e preciso, apesar de receber críticas de alguns setores da sociedade, trouxe de volta ao debate político e jurídico a Lei da Anistia, servindo de base para que outras instituições, como a $\mathrm{OAB}$, fundamentassem processos judiciais para questionar a validade, constitucionalidade e convencionalidade da Lei, em face dos direitos fundamentais da Constituição e dos direitos humanos consagrados pelas declarações e Convenções internacionais.

No que concerne à decisão da CtIDH, esta foi além da condenação à meras indenizações pecuniárias, mas promoveu um ajuste eficaz para a efetivação da Justiça de Transição no caso Gomes Lund e outros. Nas palavras de Hayashi:

Portanto, a sentença proferida pela CIDH, além de declarar que o Brasil violou vários direitos previstos pela Convenção Americana na situação específica da Guerrilha do Araguaia, ampliou o alcance de sua decisão, como já havia feito em relação aos casos envolvendo leis de anistia de outros países, e determinou que a Lei $n^{\circ} 6.683 / 79$ não poderia mais constituir um óbice à investigação e processamento dos agentes responsáveis pelas graves violações de direitos humanos ocorridas durante a ditadura militar nacional. ${ }^{39}$

$\mathrm{Na}$ verdade, CtIDH possui uma vasta jurisprudência de casos envolvendo Justiça de Transição e aplicação de leis de anistia que dificultam o acesso à justiça ${ }^{40}$.

20 out. 2015.

39 HAYASHI, Andrei T. Direitos bumanos e controle de convencionalidade: as justiças de transição e as leis de anistia no continente sulamericano. Curitiba: Universidade Federal do Paraná, 2014. p. 93.

40 A CtIDH jurisprudência de vários casos julgados sobre anistia e direito à verdade. Dentre eles, elenca-se alguns que contribuem para a compreensão do caso Gomes Lund:. CORTE INTERAMERICANA DE DIREITOS HUMANOS. Caso Velásquez Rodríguez us. Honduras. Presidente: Juiz Rafael Nieto Navia. San José, 27 de julho de 1988. Disponível em: <http://www.corteidh.or.cr/docs/casos/ articulos/seriec_04_esp.pdf $>$. Acesso em: 08 dez. 2015; CORTE INTERAMERICANA DE DIREITOS HUMANOS. Caso Barrios Altos vs. Peru. Presidente: Juiz Antônio Augusto Cançado Trindade. San José, 30 de novembro de 2001. Disponível em: < http://www. corteidh.or.cr/docs/casos/articulos/Seriec_75 _esp.pdf $>$. Acesso em: 08 dez. 2015; CORTE INTERAMERICANA DE DIREITOS HUMANOS. Caso "A Última Tentação de Cristo - (Olmedo Bustos e outros vs Chile). Sentencia de 5 de febrero de 2001 (Fondo, Reparaciones y Costas). Disponível em: <http://www.corteidh.or.cr/docs/casos/ articulos/Seriec_73_esp.pdf $>$. Acesso em: 20 out. 2015; CORTE INTERAMERICANA DE DIREITOS HUMANOS. Caso La Cantuta vs. Perú. Sentencia de 29 de noviembre de 2006 (Fondo, Repara-
Dentre estes casos, importante citar o caso Mapiripán, contra o Estado colombiano, onde houve condenação pela CtIDH, da Colômbia, e, posteriormente, a Corte constitucional colombiana, observando as obrigações internacionais em casos de graves violações de direitos humanos, determinou o afastamento das disposições de direito interno sobre anistia.

Figuras como as leis de ponto final, que impedem o acesso à justiça, as anistias em branco para qualquer delito, as autoanistias (ou seja, os benefícios penais que os detentores legítimos ou ilegítimos do poder concedem a si mesmos e aos que foram cúmplices dos delitos cometidos), ou qualquer outra modalidade que tenha como propósito impedir às vítimas um recurso judicial efetivo para fazer valer seus direitos, foram consideradas violadoras do dever internacional dos Estados de prover recursos judiciais para a proteção dos direitos humanos. ${ }^{41}$

$\mathrm{Na}$ jurisprudência da CtIDH sobre Justiça de Transição, o caso mais recente é o El Mozote, onde a CtI$\mathrm{DH}$, conclui que a Lei de Anistia Geral de El Salvador é incompatível com a Convenção Americana e que não pode ser um empecilho para a investigação e punição de casos de graves violações de direitos humanos:

Por outro lado, a Lei de Anistia Geral para a Consolidação da $\mathrm{Paz}$ teve como consequência a instauração e perpetuação de uma situação de impunidade devido à falta de investigação,

ciones y Costas). Disponível em: <http://www.corteidh.or.cr/docs/ casos/articulos/seriec_162_esp.pdf>. Acesso em: 30 out. 2015; CORTE INTERAMERICANA DE DIREITOS HUMANOS. Caso Gomes Lund y otros ("Guerrilha do Araguaia") vs. Brasil. Disponível em: < http://www.corteidh.or.cr/cf/Jurisprudencia2/ficha_tecnica. cfm?nId_Ficha $=342 \& l a n g=e s>$. Acesso em: 30 out. 2015; CORTE INTERAMERICANA DE DIREITOS HUMANOS. Caso Gelman vs. Uruguay. Sentencia de 24 de febrero de 2011.(Fondo y Reparaciones). Disponível em: <http://www.corteidh.or.cr/docs/casos/ articulos/seriec_221_esp1.pdf $>$. Acesso em: 30 out. 2015; CORTE INTERAMERICANA DE DIREITOS HUMANOS. Caso Masacres de el Mozote y Lugares Aledaños vs. El Salvador. Disponível em: <http:/ / www.corteidh.or.cr/docs/casos/articulos/seriec_252_esp.pdf $>$. Acesso em: 08 dez. 2015; CORTE INTERAMERICANA DE DIREITOS HUMANOS. Caso Gudiel Álvarezy otros ('Diario Militar") vs. Guatemala. Sentencia de 20 de noviembre de 2012 (Fondo, Reparaciones y Costas). Disponível em: <http://www.corteidh.or.cr/ docs/casos/articulos/seriec_253_esp1.pdf $>$. Acesso em: 30 out. 2015. Disponíveis em: <http://www. corteidh.or.cr/docs/casos>. Acesso em: 11 dez. 2015.

41 Corte Constitucional da Colômbia, Revisão da Lei 742 de 5 de junho de 2002, Expediente no LAT-223, Sentença C-578/02, de 30 de julho de 2002, seção 4.3.2.1.7 (tradução da Secretaria da Corte Interamericana). BRASIL. Ministério da Justiça. Jurisprudência da Corte Interamericana de Direitos Humanos: direito à vida, anistias e direito á verdade. Disponível em: <http://www.sdh.gov.br/assuntos/ atuacao-internacional/sentencas-da-corte-interamericana/pdf/direito-a-vida-anistias-e-direito-a-verdade>. Acesso em: 11 dez. 2015. 
persecução, captura, julgamento e punição dos responsáveis pelos fatos, descumprindo assim os artigos 1.1 e 2 da Convenção Americana, esta última norma referente à obrigação de adequar seu direito interno ao nela previsto. Dada sua manifesta incompatibilidade com a Convenção Americana, as disposições da Lei de Anistia Geral para a Consolidação da $\mathrm{Paz}$ que impeçam a investigação e punição das graves violações de direitos humanos ocorridas no presente caso carecem de efeitos jurídicos e, consequentemente, não podem seguir representando um obstáculo para a investigação dos fatos do presente caso e para a identificação, julgamento e punição dos responsáveis, nem podem ter igual ou similar impacto a respeito de outros casos de graves violações de direitos humanos reconhecidos na Convenção Americana que possam ter ocorrido durante o conflito armado em El Salvador. (grifos nossos) $^{42}$

No caso brasileiro, a controvérsia se estabeleceu e ganhou repercussão. Apesar da decisão da CtIDH, o Brasil insistiu em manter a interpretação do STF, quanto ao alcance da Lei da Anistia. Sob a alegação de que já havia exercido um controle de constitucionalidade pela mais alta Corte do país, o Brasil ignorou a necessidade de adequação desse controle a outro tão importante quanto: o controle de convencionalidade.

\section{Do CONTROLE DE CONVENCIONALIDADE DAS LEIS EM FACE DOS TRATADOS DE DIREITOS HUMANOS E SUA APLICAÇÃo NO CASO dA LEI DE ANISTIA}

A própria Constituição de 1988 está repleta de dispositivos que reconhecem aos direitos humanos o status de norma fundamental.

No art. $4^{\circ}$, II, a Constituição decreta a prevalência dos direitos humanos e no $\int 2^{\circ}$ do art. $5^{\circ}$ a Constituição admite que os tratados de direitos humanos têm status constitucional, enquanto que o $\int 3^{\circ}$ dispõe sobre a recepção desses tratados pelo quórum de votação de $3 / 5$, em dois turnos, em cada uma das Casas Legislativas (Câmara dos Deputados e Senado), dando àqueles a equivalência às emendas constitucionais.

A previsão constitucional acerca dos tratados de direitos humanos, desde a redação original da Consti-

42 BRASIL. Comissão da Anistia. Jurisprudência da Corte Interamericana de Direitos Humanos. Tradução da Corte Interamericana de Direitos Humanos. Brasília: Ministério da Justiça, 2014, p. 429. tuição de 1988 , até a inclusão do $\int 3^{\circ}$ do art. $5^{\circ}$, pela Emenda Constitucional 45 de 2004, evidencia a intenção soberana do povo brasileiro em dar aos tratados de direitos humanos um status constitucional. E, nos termos do $\int 1^{\circ}$ do mesmo art. $5^{\circ}$, com aplicação imediata. Nesse sentido, nos ensina Valério Mazzuolli, deve haver uma "compatibilidade vertical das normas do direito interno com as convenções internacionais de direitos humanos em vigor em um determinado país." ${ }^{33}$

Caso a lei interna esteja em desacordo com as normas expressas em tratados de direitos humanos, recepcionados e ratificados pelo Estado, aquela não pode prevalecer sobre estes. Para garantir que tal aberração jurídica não ocorra, apresenta-se uma nova modalidade de controle normativo: o controle de convencionalidade.

O controle de convencionalidade das leis surgiu na Europa, numa decisão do Conselho Constitucional da França, na qual este se deu por incompetente para julgar conflito de lei francesa em face Convenção europeia de Direitos Humanos, apontando a diferença entre controle de constitucionalidade e controle de convencionalidade, na decisão 74-54 DC, de 15 de janeiro de $1975 .{ }^{44}$

De acordo com Valério Mazzuoli, no julgamento do caso supracitado, o Conselho Constitucional francês

entendeu não ser competente para analisar a convencionalidade preventiva das leis (ou seja, a compatibilidade destas com os tratados ratificados pela França, notadamente - naqueles caso concreto - a Convenção Europeia de Direitos Humanos de 1950), pelo fato de não se tratar de um controle de constitucionalidade propriamente dito, o único em relação ao qual teria competência dito Conselho para se manifestar a respeito. ${ }^{45}$

Controle de Convencionalidade é, pois, o controle da compatibilidade entre as leis internas de um país e os tratados de direitos humanos dos quais este país seja parte.

43 MAZZUOLI, Valério de Oliveira. O controle jurisdicional de convencionalidade das leis. 2. ed. São Paulo: Revista dos Tribunais, 2011. p. 23.

44 FRANCE. Conseil constitutionnel. Décision n ${ }^{\circ}$ 74-54 DC du 15 janvier 1975. Disponible à l'adresse: <http://www.conseil-constitutionnel.fr/conseil-constitutionnel/francais/les-decisions/1975/7454-dc/decision-n-74-54-dc-du-15-janvier-1975.7423.html>. Consulté le: 06 Février 2016.

45 MAZZUOLI, Valério de Oliveira. O controle jurisdicional de convencionalidade das leis. 2. ed. São Paulo: Revista dos Tribunais, 2011. p. 81. 
No âmbito da Corte Interamericana de Direitos Humanos, a questão da convencionalidade das leis foi abordada, pela primeira vez em 2001, no caso "A Última Tentação de Cristo", também conhecido como Caso Olmedo Bustos e outros contra o Chile. Nesse emblemático caso, o filme "A Última Tentação de Cristo" havia sido proibido, por decisão judicial, de ser exibido no país. A decisão foi confirmada pela Corte suprema do Chile e o caso foi levado à Comissão de Direitos Humanos da OEA e posteriormente à Corte Interamericana. Em sua sentença, a CtIDH decidiu que a censura feita ao filme violava disposições do Pacto de San José da Costa Rica, determinou ao Chile providências para que seu ordenamento jurídico e suas Cortes se adequassem a esta decisão. ${ }^{46}$

Não faltam precedentes. A jurisprudência da CtIDH deixa claro seu entendimento. O problema está na sua observância pelos países membros da Corte.

As decisões da CtIDH, na proteção e consolidação dos direitos humanos no continente americano precisam ser entendidas, como afirma Nestor Pedro Sagués, como prevalentes sobre as decisões das cortes internas, sob o risco de se ver desmoronar todo o sistema regional de proteção dos direitos humanos. ${ }^{47}$

Outrossim, o $₫ 4^{\circ}$ do art. $5^{\circ}$ da Constituição de 1988 reconhece a jurisdição de Tribunal Penal Internacional, ao qual o Brasil tenha aderido, reconhecendo, dessa forma, a validade supranacional das decisões emanadas de Corte Internacional. Se a jurisdição internacional foi constitucionalizada para atender a decisões no âmbito do Direito Internacional Penal, em face do princípio da prevalência dos Direitos Humanos, devemos interpretar que se aplica a mesma lógica às decisões de Cortes internacionais de Direitos Humanos, como é o caso da CtIDH.

Nota-se ainda que o controle de convencionalidade poderia ter sido feito pelo próprio STF, pois, como observa Mazzuoli, este controle pode ser feito tanto pela

46 CORTE INTERAMERICANA DE DIREITOS HUMANOS. Caso "A Última Tentação de Cristo - (Olmedo Bustos e outros vs Chile). Sentencia de 5 de febrero de 2001 (Fondo, Reparaciones y Costas). Disponível em: <http://www.corteidh.or.cr/docs/casos/articulos/ Seriec_73_esp.pdf $>$. Acesso em: 20 out. 2015.

47 SAGUÉS, Nestor P. El control de convencionalidad em el sistema interamericano, y sus anticipos em elámbito de losderechos económico-sociales: concordâncias e diferencias com el sistema europeo. p. 384. Disponível em: <http://biblio.juridicas.unam.mx/libros/7/3063/16. pdf $>$. Acesso em: 10 dez. 2015. via difusa, incidental, como pela via concentrada, direta. $^{48}$

Nesse caso, a competência seria do Supremo Tribunal Federal e uma nova oportunidade para o STF rever sua posição em relação à Lei da Anistia surgiu, com o ajuizamento da Arguição de Descumprimento de Preceito Fundamental n. 320.

Proposta em 15 de maio de 2014, pelo Partido Socialismo e Liberdade - PSOL, a ADPF 320 chega à Suprema Corte brasileira, ao mesmo tempo que tramita no Congresso Nacional o Projeto de Lei 237/2013, que prevê a revisão da Lei da Anistia. ${ }^{49}$

A ADPF 320 foi distribuída ao Ministro Luiz Fux, relator e já recebeu o parecer do Procurador Geral da República se manifestou no sentido de ser promovida uma revisão da Lei. $^{50}$

O parecer do Procurador Geral da República explicitamente afirma que o julgamento da ADPF 320 não entrará em conflito com a decisão do Supremo Tribunal Federal sobre a ADPF 153. O Procurador, Rodrigo Janot, lembrou que o julgamento da ADPF 153 pelo Supremo Tribunal Federal se baseou no controle de constitucionalidade da Lei de Anistia, reconhecendo-a como constitucional. Contudo, a decisão da CtIDH levou em conta a (in)compatibilidade da Lei da Anistia com o Pacto de San José da Costa Rica, exercendo, portanto, outro tipo de controle, o de convencionalidade. Assim, na ADPF 320, o STF pode considerar esse fato como um argumento novo e consolidar o entendimento da CtIDH, inclusive vinculando as decisões dos órgãos judiciários inferiores.

O controle de convencionalidade é necessariamente aplicável ao caso da Lei de Anistia. O STF terá a opor-

48 MAZZUOLI, Valério de Oliveira. O controle jurisdicional de convencionalidade das leis. 2. ed. São Paulo: Revista dos Tribunais, 2011. p. 174.

49 PEDIDO de revisão da Lei da Anistia chega ao STF. Jornal Brasil 247, 16 maio 2016. Disponível em:<http://www.brasil247.com/ pt/247/140043/Pedido-de-revis\%C3\%A3o-da-Lei-da-Anistia-chega-ao-STF.htm>. Acesso em: 29 out. 2015.

50 "Na manifestação, recebida pela Suprema Corte no dia do $35^{\circ}$ ano de existência da lei, Janot sustenta que graves violações de direitos humanos cometidas durante a ditadura militar são crimes contra a humanidade e, por isso, imprescritíveis. Destaca a necessidade de cumprimento de sentença da Corte Interamericana de Direitos Humanos (CIDH) sobre o tema." BRASIL. Procuradoria Geral da República. PGR defende não aplicação de parte da Lei da Anistia. Disponível em: <pgr.jusbrasil.com. br/noticias/147876963/pgr-defende-nao-aplicacao-de-parte-da-lei-daanistia>. Acesso em: 30 out. 2015. 
tunidade de se manifestar sobre o caso e exercê-lo de modo a readequar sua jurisprudência à da CtIDH. Esse é um momento de resgate da Justiça de Transição e o Supremo Tribunal Federal tem a oportunidade de efetivá-la.

\section{Considerações finais}

Opressão, agressão, tortura, mortes, enfim, toda sorte de abusos ao longo de séculos culminaram na necessidade de codificar, promover e proteger os direitos humanos, tanto pela atuação de Organismos Internacionais, quanto pelo compromisso dos Estados de implementá-los e efetivá-los dentro e fora de seus territórios.

O Brasil é um país que busca participar, cada vez mais, desse movimento que busca dar eficácia aos direitos humanos, porém enfrenta ainda alguns obstáculos que impedem o cumprimento de seus compromissos assumidos com a sociedade internacional. Um deles é a insistência em esconder as graves violações de direitos humanos perpetradas pelos regimes ditatoriais do passado e perpetuadas, de certa forma, pelos órgãos estatais do presente.

A Justiça de Transição é um imperativo para se resgatar a dívida moral e material com as vítimas e seus familiares, das ações truculentas e criminosas dos governos ditatoriais que, num passado não tão distante, aviltaram a consciência da nação e vilipendiaram os direitos fundamentais de seus próprios cidadãos.

A Lei da Anistia, promulgada nos estertores do Regime Militar, representou a oportunidade de resgatar os perseguidos e exilados do regime, mas esconderam um dispositivo que garantiu a impunidade dos detratores da pátria, violadores contumazes dos direitos humanos e fundamentais.

A revisão desta Lei é imperiosa, para que o Brasil possa definitivamente virar essa dolorosa página da nossa história, devolvendo a dignidade roubada das vítimas dos regimes de exceção e implementando a justiça de transição e o direito à verdade e à memória.

A posição do Supremo Tribunal Federal no julgamento da ADPF 153 foi de encontro a essa aspiração do povo brasileiro e representou a perda de uma oportunidade histórica de se fazer justiça ao país e sua memória política.
Em contrapartida, a Corte Interamericana de Direitos Humanos, no julgamento do Caso Gomes Lund e outros, abriu caminho a uma revisão desse posicionamento, ao condenar o Brasil à reparação e indenização das vítimas, ao reconhecimento das violações dos direitos humanos e, sobretudo, a invalidade da Lei de Anistia, soterrando a impunidade e restituindo a mais alta acepção da justiça.

Apesar disso, o Brasil insiste em descumprir a decisão da Corte, alegando que já exerceu o controle de constitucionalidade e que a consideração da validade da Lei da Anistia em face da Constituição é irrevogável.

Contudo, a ADPF 320 abre uma nova oportunidade para a revisão da Lei de Anistia, pois traz à baila o argumento jurídico do controle de convencionalidade, que invalida esta Lei em face das convenções internacionais de direitos humanos, permitindo assim ao STF a oportunidade de se redimir com a história e a honra do Brasil, retirando os efeitos nefastos da Lei de Anistia quanto à impunidade dos torturadores e demais responsáveis pela mais obscura era de existência do Brasil enquanto nação.

\section{ReferênCIAS}

ALMEIDA, Eneá S.; TORELLY, Marcelo. Justiça de transição, estado de direito e democracia constitucional: estudo preliminar sobre o papel dos direitos decorrentes da transição política para a efetivação do estado democrático de direito. Sistema Penal e Violência, Porto Alegre, v. 2, n. 2, p. 36-52, jul./dez. 2010.

BIDNIUK, Gabriela da Rosa. Justiça de transição no Brasil. Ambito Jurídico, Rio Grande, v. 15, n. 97, fev. 2012. Disponível em: <http://www.ambito-juridico.com.br/ site/index.php?n_link=revista_artigos_leitura\&artigo_ id=11164> . Acesso em: 09 fev. 2016.

BRASIL. Comissão da Anistia. Jurisprudência da Corte Interamericana de Direitos Humanos. Tradução da Corte Interamericana de Direitos Humanos. Brasília: Ministério da Justiça, 2014.

BRASIL. Comissão da Verdade. $A C N V$. Disponível em: $\quad<$ http://www.cnv.gov.br/institucional-acessoinformacao/a-cnv.html>. Acesso em: 20 out. 2015.

BRASIL. Comissão da Verdade. Equipe. Disponível em: $<$ http://www.cnv.gov.br/institucional-acesso-informa- 
cao/equipe.html>. Acesso em: 20 out. 2015.

BRASIL. Comissão Especial sobre Mortos e Desaparecidos Políticos. Direito à Memória e à Verdade. Brasília: CEMDP, 2007.

BRASIL. Decreto-Lei no 2.848, de 7 de dezembro de 1940. Disponivel em: <http://www.planalto.gov.br/ccivil_03/decreto-lei/Del2848compilado.htm>. Acesso em: 09 fev. 2016.

BRASIL. Lei no 6.683, de 28 de agosto de 1979. Disponível em: <http://www.planalto.gov.br/ccivil_03/leis/ L6683.htm>. Acesso em: 09 fev. 2016.

BRASIL. Ministério da Justiça. Jurisprudência da Corte Interamericana de direitos humanos: direito à vida, anistias e direito á verdade. Disponível em: <http://www.sdh. gov.br/assuntos/atuacao-internacional/sentencas-dacorte-interamericana/pdf/direito-a-vida-anistias-e-direito-a-verdade.> Acesso em: 11 dez. 2015.

BRASIL. Procuradoria Geral da República. PGR defende não aplicação de parte da Lei da Anistia. Disponível em: <pgr.jusbrasil.com.br/noticias/147876963/pgr-defende-nao-aplicacao-de-parte-da-lei-da-anistia $>$. Acesso em: 30 out. 2015.

BRASIL. Secretaria de Direitos Humanos. Momentos da ditadura. Disponível em: <http://memoriasdaditadura. org.br/momentos-da-ditadura $>$. Acesso em: 30 out. 2015.

BRASIL. Supremo Tribunal Federal. Arguição de Descumprimento de Preceito Fundamental. ADPF 153 DF. Tribunal Pleno. Arguente: Conselho Federal da Ordem dos Advogados. Arguido: Congresso Nacional. Relator: Min. Eros Grau. Brasília, 29 de abril de 2010. Disponível em: <http://redir.stf.jus.br/paginadorpub/ paginador.jsp?doc'TP $=$ AC\&docID $=612960>$. Acesso em: 10 dez. 2015.

CALDAS, Roberto de Figueiredo. O Controle de Constitucionalidade de o Controle de Convencionalidade no Brasil. In: ANUARIO DE DERECHO CONSTITUCIONAL LATINOAMERICANO, Bogotá, v. 29, p. 393-415, 2013.

CORTE INTERAMERICANA DE DIREITOS HUMANOS. Caso "A Última Tentação de Cristo - (Olmedo Bustos e outros us Chile). Sentencia de 5 de febrero de 2001 (Fondo, Reparaciones y Costas). Disponível em: $<$ http://www.corteidh.or.cr/docs/casos/articulos/Seriec_73_esp.pdf $>$. Acesso em: 20 out. 2015.
CORTE INTERAMERICANA DE DIREITOS HUMANOS. Caso Barrios Altos vs. Peru. Presidente: Juiz Antônio Augusto Cançado Trindade. San José, 30 de novembro de 2001. Disponível em: <http://www. corteidh.or.cr/docs/casos/articulos/Seriec_75 _esp.pdf $>$. Acesso em: 08 dez. 2015.

CORTE INTERAMERICANA DE DIREITOS HUMANOS. Caso de la "Masacre De Mapiripán” vs. Colômbia. Disponível em: <http://www.corteidh.or.cr/docs/casos/articulos/seriec_134_esp.pdf $>$. Acesso em: 10 dez. 2015 .

CORTE INTERAMERICANA DE DIREITOS HUMANOS. Caso Gelman vs. Uruguay. Sentencia de 24 de febrero de 2011.(Fondo y Reparaciones). Disponível em: <http://www.corteidh.or.cr/docs/casos/articulos/seriec_221_esp1.pdf>. Acesso em: 30 out. 2015.

CORTE INTERAMERICANA DE DIREITOS HUMANOS. Caso Gomes Lund e Outros ("Guerrilha do Araguaia”) vs. Brasil. Presidente: Juiz Diego García- Sayán. San José, 24 de novembro de 2010. Disponível em: <http://www.corteidh.or.cr/docs/casos/articulos/seriec_219_esp.pdf>. Acesso em: 08 dez. 2015.

CORTE INTERAMERICANA DE DIREITOS HUMANOS. Caso Gomes Lund y otros ("Guerrilha do Araguaia") vs. Brasil. Disponível em: <http://www. corteidh.or.cr/cf/Jurisprudencia2/ficha_tecnica. cfm?nId_Ficha $=342 \& l a n g=e s>$. Acesso em: 30 out. 2015.

CORTE INTERAMERICANA DE DIREITOS HUMANOS. Caso Gudiel Álvarezy otros ("Diario Militar") vs. Guatemala. Sentencia de 20 de noviembre de 2012 (Fondo, Reparaciones y Costas). Disponível em: <http:// www.corteidh.or.cr/docs/casos/articulos/seriec_253_ esp1.pdf $>$. Acesso em: 30 out. 2015.

CORTE INTERAMERICANA DE DIREITOS HUMANOS. Caso La Cantuta vs. Perú. Sentencia de 29 de noviembre de 2006 (Fondo, Reparaciones y Costas) Disponível em: <http://www.corteidh.or.cr/docs/casos/articulos/seriec_162_esp.pdf $>$. Acesso em: 30 out. 2015.

CORTE INTERAMERICANA DE DIREITOS HUMANOS. Caso Masacres de el Mozote y Lugares Aledaños vs. El Salvador. Disponível em: <http://www.corteidh. or.cr/docs/casos/articulos/seriec_252_esp.pdf $>$. Acesso em: 08 dez. 2015.

CORTE INTERAMERICANA DE DIREITOS HU- 
MANOS. Caso Velásquez. Rodríguez, vs. Honduras. Presidente: Juiz Rafael Nieto Navia. San José, 27 de julho de 1988. Disponível em: <http://www.corteidh.or.cr/ docs/casos/articulos/seriec_04_esp.pdf $>$. Acesso em: 08 dez. 2015.

COSTA, Homero de Oliveira. Incursões na história das Anistias politicas no Brasil. Coletivo Catarinense: Memória, Verdade e Justiça, 25 jul. 2015. Disponível em: $<$ https:// coletivomemoriaverdadejusticasc.wordpress. com/2015/07/25/incursoes-na-historia-das-anistiaspoliticas-no-brasil-homero-de-oliveira-costa/>. Acesso em: 20 out. 2015.

FICO, Carlos. A negociação parlamentar da anistia de 1979 e o chamado "perdão aos torturadores". Revista Anistia Política e Justiça de Transição, Brasília, n. 4, p. 318333, jul./dez., 2010.

FRANCE. Conseil constitutionnel. Décision $n^{\circ}$ 74-54 DC du 15 janvier 1975. Disponible à l'adresse: <http:// www.conseil-constitutionnel.fr/conseil-constitutionnel/francais/les-decisions/1975/74-54-dc/decision-n74-54-dc-du-15-janvier-1975.7423.html>. Consulté le: 06 Février 2016.

GOMEZ, José Maria. Globalização dos direitos humanos, legado das ditaduras militares no Cone Sul latinoamericano e justiça transicional. Revista Direito, Estado e Sociedade, Rio de Janeiro, n. 33, p. 85-130, jul./dez. 2008.

HAYASHI, Andrei T. Direitos humanos e controle de convencionalidade: as justiças de transição e as leis de anistia no continente sul-americano. Curitiba: Universidade Federal do Paraná, 2014.

MAFFEI, Vinicius Setubal. ADPF 153: a lei de anistia ante o Supremo Tribunal Federal. Disponível em: <http://www.egov.ufsc.br/portal/conteudo/adpf153-lei-de-anistia-ante-o-supremo-tribunal-federaluma-vis $\%$ C3\%A3o-constitucional-penal-e-in>. Acesso em: 20 out. 2015.

MARTIN, Francisco Forrest et al. International buman rights e humanitarian law: treaties, cases and analysis. Cambridge: Cambridge University, 2006.

MAZZUOLI, Valério de Oliveira. O controle jurisdicional de convencionalidade das leis. 2. ed. São Paulo: Revista dos Tribunais, 2011.

MEYER, Emilio Peluso Neder. Responsabilização por graves violaçôes de direitos humanos na ditadura de 1964-1985: a necessária superação da decisão do Supremo Tribunal
Federal na ADPF n ${ }^{\circ}$ 153/DF pelo Direito Internacional dos Direitos Humanos. 2012. 303 f. Tese (Doutorado) - Programa de Pós-Graduação em Direito, Faculdade de Direito, Universidade Federal de Minas Gerais, Belo Horizonte, 2012.

MEZAROBBA, Glenda. Um acerto de contas com o futuro anistia e suas consequências: um estudo do caso brasileiro. 2003. 206 f. Dissertação (Mestrado) - Programa de Pósgraduação em Ciência Politica, Faculdade de Filosofia, Letras e Ciências Humanas, Universidade de São Paulo, São Paulo, 2003.

MONTEIRO, Adalberto. Guerrilha do Araguaia: uma epopeia pela liberdade. São Paulo: A. Garibaldi, 2005.

MOTTA, Marly. Dentro da névoa autoritária acendemos a fogueira...: a OAB na redemocratização brasileira (1974-80). Revista Culturas Jurídicas, Rio de Janeiro, v. 3, n. 1, p. 1-29, jan./jun. 2008.

NORONHA, Edgard Magalhães. Direito penal. 38. ed. São Paulo: Saraiva, 2004. v. 1.

PEDIDO de revisão da Lei da Anistia chega ao STF. Jornal Brasil 247, 16 maio 2016. Disponível em: <http://www.brasil247.com/pt/247/140043/Pedidode-revis $\%$ C3\%A3o-da-Lei-da-Anistia-chega-ao-STF. htm>. Acesso em: 29 out. 2015.

PIOVESAN, Flavia. Direito internacional dos direitos humanos e a lei de anistia: o caso brasileiro. Revista da Faculdade de Direito da FMP, Porto Alegre, n. 4, 2007.

REZENDE, Maria José de. A ditadura militar no Brasil: repressão e pretensão de legitimidade, 1964-1984. Londrina: Eduel, 2013.

SAGUÉS, Nestor P. El control de convencionalidad em el sistema interamericano, y sus anticipos em elámbito de losderechos económicosociales: concordâncias e diferencias com el sistema europeo. Disponível em: <http://biblio.juridicas.unam.mx/ libros/7/3063/16.pdf>. Acesso em: 10 dez. 2015.

SANTOS, Roberto Lima. Crimes da ditadura militar: responsabilidade internacional do estado brasileiro por violação aos direitos humanos. Porto Alegre: N. Fabris, 2010.

SCHWABE, Jürgen. Cinqüenta anos da jurisprudência do Tribunal Constitucional Alemão. Montevidéu: Fundação Konrad-Adenauer, 2005.

SWENSSON JUNIOR, Lauro Joppert. Anistia penal: problemas de validade da lei de anistia brasileira (lei 6.683/79). Curitiba: Juruá, 2007. 
TAVARES, André Ramos; ANGRA, Walber de Moura. Justiça reparadora no Brasil. In: SOARES, Inês Virgínia Prado; KISHI, Sandra Akemi Shimada (Coord.). Memória e verdade: a justiça de transição no estado democrático brasileiro. Belo Horizonte: Fórum, 2009. p. 69-91.

VARGAS, Mariluci Cardoso. O movimento feminino pela anistia como partida para a redemocratização brasileira. In: ENCONTRO ESTADUAL DE HISTÓRIA, 9., Porto Alegre, 2008. Vestígios do Passado: história e suas fontes. Porto Alegre: ANPUHS, 2008. Disponivel em: <http://eeh2008.anpuh-rs.org.br/resources/content/ anais/1212369464_ARQUIVO_trabalhocompletoanpuh.pdf>. Acesso em: 09 fev. 2016. 


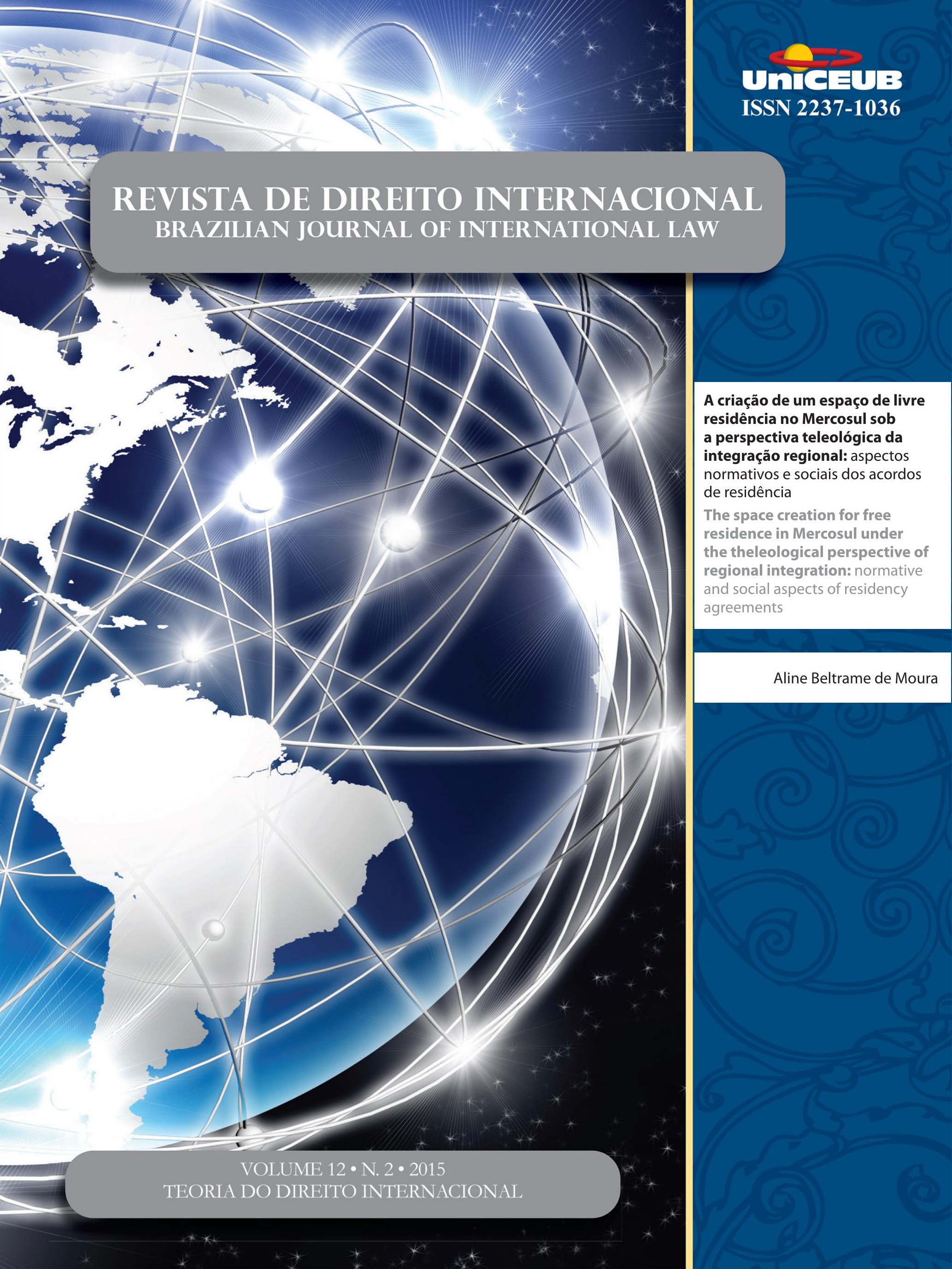




\title{
A criação de um espaço de livre residência no Mercosul sob a perspectiva teleológica da integração regional: aspectos normativos e sociais dos acordos de residência*
}

\author{
The space creation for free residence in \\ Mercosul under the theleological perspective \\ of regional integration: normative and social \\ aspects of residency agreements
}

Aline Beltrame de Moura**

\section{Resumo}

O Mercosul tem estimulado a adoção de políticas regionais tendentes à valorização da sua dimensão social, alcançando uma esfera até pouco tempo marginalizada pelo processo de integração. Nesse sentido, o cidadão emerge como o centro de diversas medidas adotadas com o escopo de tutelar seus interesses e direitos individuais e coletivos. O objetivo deste artigo consiste em verificar que a entrada em vigor dos Acordos de Residência em dez países latino-americanos simboliza e, acima de tudo, materializa os anseios de uma integração vertical, isto é, que parta da sociedade civil e alcance a esfera institucional do fenômeno regional. A dimensão teleológica da integração é observada ao se vislumbrar que não somente com base no desenvolvimento econômico se constrói o Mercosul, mas, igualmente, com base em uma matriz social cada vez mais presente no quotidiano da população. A metodologia utilizada é a bibliográfica.

Palavras-chave: Cidadania. Processo de integração regional. Mercosul. Direitos e prerrogativas. Residência e migração.

* Recebido em 13/09/2015

Aprovado em 11/10/2015

** Doutora em Direito Internacional pela Università degli Studi di Milano (UNIMI), Itália. Bolsista CAPES Doutorado Pleno no Exterior. Vencedora do Prêmio Riccardo Monaco de melhor tese de doutorado defendida na Itália em 2014 na área do Direito Internacional. Mestre em Direito nas Relações Internacionais pela Universidade Federal de Santa Catarina (UFSC), Bacharel em Direito pela mesma instituição. Pesquisadora Visitante do Max Planck Institute for Comparative and International Private Law em Hamburgo, Alemanha. Membro do Grupo de Pesquisa em Direito Internacional - UFSC/CNPq. Professora substituta da Universidade Federal de Santa Catarina, Professora da Faculdade CESUSC e da Pós-Graduação do Centro Universitário Católica de Santa Catarina. E-mail: alineb.moura@gmail.com.

\section{Abstract}

Mercosul has stimulated the adoption of regional politics aimed to valorize his social dimension, reaching a sphere until then marginalized by the integration process. Accordingly, the citizen emerges as the center of several adopted measures aiming his benefits and individual and collective rights. The purpose of this article is to analyse the Residency Agreement implementation in ten Latin American countries symbolizes, and above all, materializes the wishes of a vertical integration, this is, that departs from the civil society and reaches the institutional sphere at a regional phenomenon. The theleological integration dimension it's observed when glimpsing that not only from the economic development the Mercosul is built, but equally from a social matrix increasingly present in the population's daily basis. The used methodology it's the bibliographic. 
Keywords: Citizenship. Regional integration process. Mercosur. Rights and Prerogatives. Residence and Migration.

\section{INTRODUÇÃO}

O Mercosul se encontra em uma fase do processo de integração bastante peculiar se comparada aos anos imediatamente posteriores ao Tratado de Assunção. De um nascimento marcado pelo predomínio de fatores econômicos e de trocas comerciais, o Mercosul amadureceu, superou crises internas e se fortaleceu em um ponto inimaginável pelos seus idealizadores quando da sua criação: a dimensão social. Âmbito este ainda pouco explorado pelos estudiosos que insistem em fixar suas atenções exclusivamente às controvérsias e fragilidades da integração econômica e comercial, esquecendo que o elemento central de todo este processo é o cidadão. $\mathrm{O}$ objetivo do presente artigo, portanto, consiste em trazer à tona a discussão sobre esta nova perspectiva teleológica da integração, tentando entender e superar o estigma de ineficiência que muitas vezes circundam a análise das questões que envolvem o Mercosul.

Considerando tais premissas, o presente artigo pretende analisar as mais recentes medidas adotadas pelos órgãos do Mercosul no sentido de viabilizar a consolidação da sua dimensão social, em particular, o caminho levado até a assinatura e a entrada em vigor dos Acordos de Residência para os Cidadãos dos Estados Partes do Mercosul, os quais preveem a adoção de procedimentos diferenciados que facilitam a concessão da autorização da residência para os nacionais dos dez Estados que ratificaram tal documento, beneficiando cerca de 400 milhões de pessoas.

Ao analisarmos os benefícios e direitos previstos em tais Acordos, pretende-se verificar em que medida estaríamos diante de um verdadeiro "espaço de livre residência" no Mercosul, embora ainda subsistam os controles aduaneiros e migratórios nas fronteiras nacionais. Conforme será observado, trata-se de um percurso normativo peculiar e instigante que nos leva a refletir sobre os reais anseios e desafios do fenômeno mercosulino.

De forma a auxiliar a pesquisa, a combinação dos métodos sistemático e indutivo estabelece análise mais completa e efetiva acerca do paradigma da circulação de pessoas e da fixação da residência em países pertencen- tes ao Mercosul, haja vista que se trata de um argumento multifacetário, não exaurindo as tarefas da pesquisa apenas no campo jurídico.

\section{A CiRCULAÇÃo dAS PESSOAS NOS PROCESSOS DE INTEGRAÇÃO REGIONAL}

A fim de compreender a atual fase da integração do Mercosul $^{1}$ na perspectiva da circulação e da residência das pessoas na região, parece oportuno distinguir dois conceitos que, frequentemente, são confundidos: migração e da livre circulação. A migração conecta-se à noção de fronteiras fechadas e ao poder de um Estado de controlar o ingresso dos estrangeiros no seu território, enquanto a livre circulação invoca a ideia de fronteiras abertas e a possibilidade dos cidadãos de moverem-se livremente no espaço integrado ${ }^{2}$. Portanto, a noção de livre circulação, inerente a um processo de integração, diferencia-se da noção de migração tradicional, ou seja, daquela entre Estados, tendo em vista que "la libre movilidad migratoria constituye la principal contraparte social de las políticas económicas en espacios regionales de integración ${ }^{3 " .}$

1 O Mercosul, atualmente, possui cinco Estados-membros, quatro Estados Associados. Um se encontra em fase de adesão para se tornar membro a título pleno e dois em fase de adesão para adquirirem a condição de Estado Associado. Além dos Estados fundadores - Argentina, Brasil, Paraguai e Uruguai - também a Venezuela aderiu como Estado-membro em julho de 2012. O último Estado que assinou o Protocolo de adesão para passar da categoria de Estado Associado para Estado-membro foi a Bolívia, em dezembro de 2012, enquanto o Equador já iniciou o processo para satisfazer os requisitos exigidos à admissão. Na pendência da implementação dos mencionados procedimentos, os Estados hoje Associados são Bolívia, Chile, Peru, Colômbia e Equador; recentemente assinaram $\mathrm{o}$ ato de adesão para se tornarem Associados do Mercosul a Guina e o Suriname. Tal dinâmica de expansão, sobretudo nos últimos anos, assinala o relevante papel que está assumindo esta organização internacional na região latino-americana. Nesse sentido, ver ARIETI, Samuel A. Development: the Role of Mercosur as a Vehicle for Latin American Integration. Chicago Journal of International Law, Chigado, v. 6, n. 2, p. 761-773, Jan. 2006. p. 761 ss. Cfr. di recente NASCIMBENE, Bruno. Le droit de la nationalité et le droit des organisations d'intégration régionales. Vers de nouveaux statuts de résidents? Leide: Brill, 2014. (Recueil des Cours de l'Académie de La Haye, 367). p. 382 ss. 2 SANT'ANA, Marcílio Ribeiro de. A livre circulação de trabalhadores no Mercosul. In: Brasil, migrações internacionais e identidade. 2000. Disponível em: <http://www.comciencia.br/reportagens/ migracoes/migr08.htm>. Acesso em: 23 nov. 2014.

3 MÁRMORA, Lelio; PÉREZ, Vichich Nora. Elementos de politicas migratorias para el Mercosur: Informe Nacional de Desarrollo Humano. Buenos Aires: Senado de la Nación Argentina, 1997. p. 267. Veja-se o art. 10 do Tratado de Assunção de 1991 e o art. 3 do Protocolo de Ouro Preto de 1994. O CMC exercita, ademais, a personalidade 
Nesse sentido, a construção do Mercosul pressupõe a redefinição de certos limites. Os deslocamentos internacionais convertem-se em internos e estabelece-se um duplo jogo de fronteiras que se abre às pessoas dos Estado-membros e se fecham aos origináriios dos demais Estados ${ }^{4}$. Nesse caso, os movimentos populacionais ocorridos dentro de um processo de integração regional possuem aspecto sociocultural fundamental capaz de favorecer o aprofundamento da integração ${ }^{5}$, em particular na região do Mercosul, onde existe uma cultura histórica e linguística compartilhadas entre os povos.

De fato, a partir da configuração de uma liberdade de trânsito das pessoas entre os Estados-Partes de uma organização internacional, cujo objetivo primário é o de facilitar o atravessamento das fronteiras inicialmente apenas aqueles que vão trabalhar em um outro Estado da comunidade econômica, desenvolve-se, progressivamente, uma noção de cidadania. Esta delineia os contornos de um estatuto de cidadania no momento em que a mera liberdade de circulação e residência — agora não mais somente dos trabalhadores - se une a outros direitos e deveres que ultrapassam aqueles meramente necessários para a fruição da atividade econômica transfronteiriça $a^{6}$.

Conforme será verificado, no Mercosul é possível, atualmente, vislumbrar a consolidação de relevantes direitos nas mais variadas áreas e que têm como ponto de partida o direito à circulação e, sobretudo, o direito à residência dos cidadãos dos Estados Partes em qualquer um dos países do bloco regional.

jurídica do Mercosul (art. 8 par. 3 do Protocolo). BRASIL. Decreto $n^{\circ}$ 1.901, de 09 de maio de 1996. Disponível em: <http://www.planalto. gov.br/ccivil_03/decreto/D1901.htm>. Acesso em: 15 dez. 2015;

4 MODOLO, Vanina. La movilidad territorial en el Mercado Común Europeo y Mercosureño. In: NOVICK, Susana (Dir.). Migraciones y Mercosur: una relación inconclusa. Buenos Aires: Catálogos: 2010. p. 29-50. p. 33.

5 NOVICK, Susana (Dir.). Introdución, migraciones, políticas e integración regional: avances y desafíos. In: Migraciones y Mercosur: una relación inconclusa. Buenos Aires: Catálogos: 2010. p. 9-28. p. 10. A autora salienta a troca de bens e os movimentos populacionais nos citados territórios, fenômenos registrados antes mesmo da conquista espanhola.

6 GOIZUETA VÉRTIZ, Juana; GÓMEZ FERNÁNDEZ, Itziar; PASCUAL GONZÁLEZ, María Isabel. La libre círculación de personas en los sistemas de integración económica: modelos comparados: Unión Europea, Mercosur y Comunidad Andina. Navarra: Thomson Reuters Aranzadi, 2012. p. 13.

\section{A liberdade de CiRculação No Tratado de AssunÇÃo e NAS PRIMEIRAs dECISÕES do MER- COSUL}

Diferentemente de outros processos de integração regional, como a União Europeia ${ }^{7}$, o Tratado constitutivo do $\mathrm{Mercosul}^{8}$ não previa nenhuma disciplina relativa à liberdade de circulação dos trabalhadores e à abolição de qualquer discriminação em base à nacionalidade entre os trabalhadores dos Estados-membros. Na primeira fase da integração, a única previsão sobre a livre circulação se encontrava no art. 1 do Tratado de Assunção e dizia respeito à liberdade de circulação de bens, serviços, fatores produtivos entre os Estados, sem nenhuma referência direta ao direito de circulação e de residência dos indivíduos.

Apesar da ausência de previsão expressa, o Conselho do Mercado Comum (CMC), desde as primeiras Decisões em 1991, tem manifestado a vontade política de "avanzar en la implementación progresiva de la integración, que implica un espacio regional donde pueden circular libremente los ciudadanos y residentes de los Estados Partes del Mercado Común, asi como sus bienes, servicios y factores productivos". Portanto, o CMC já teve a oportunidade de referenciar a necessidade do estabelecimento de um espaço regional onde os indivíduos, e não somente os trabalhadores, possam livremente circular e residir nos Estados-Partes.

Na recém citada Decisão n. 12/91, os ministros dos respectivos Estados também demonstraram a intenção de criar uma maior fluidez de trânsito por meio da harmonização das leis em matéria de migração. Com tal finalidade, foi previsto a instalação de balcões preferen-

7 Como é notório, o art. 48 do Tratado de Roma de 1957 previa a livre circulação e a abolição de qualquer discriminação baseada na nacionalidade para os trabalhadores dos Estados-membros. União Europeia. 48. TRATADO que institui a Comunidade Económica Europeia ou Tratado CEE - texto original (versão não consolidada). Disponível em: <http://eur-lex.europa.eu/legal-content/PT/ TXT/HTML/?uri=URISERV:xy0023\&from=PT $>$. Acesso em: 15 dez. 2015.

8 O Tratado de Assunção, celebrado em 26 de março de 1991 entre Argentina, Brasil, Paraguai e Uruguai, entrou em vigor em 19 de novembro de 1991. BRASIL. Decreto n 1.901, de 09 de maio de 1996. Disponível em: <http://www.planalto.gov.br/ccivil_03/decreto/ D1901.htm>. Acesso em: 15 dez. 2015

9 MERCOSUl. Conselho do Mercado Comum. Decisão $n^{\circ}$ 12, de 17 de dezembro de 1991. Disponível em: <http://www.mercosur. int/msweb/portal\%20intermediario/Normas/normas_web/Decisiones/PT/CMC_1991_DEC_012_PT_TransitCiudada.PDF>. Acesso em: 15 dez. 2015. Sobre a facilitação para os cidadãos do Mercosul de 17 de dezembro de 1991 em Brasília. 
ciais nos aeroportos e nos portos para os cidadãos e para os residentes destes Países. O objetivo de tais medidas, conforme o próprio texto da Decisão nos informa, era o de contribuir "ao incremento do intercâmbio econômico e comercial e, em especial, turístico". Em outras palavras, nessa fase do processo de integração, não se pensava em facilitar ou promover as migrações propriamente ditas, mas antes em facilitar a mobilidade temporária, de natureza comercial ou turística ${ }^{10}$.

Nesse primeiro período da integração regional, o Grupo Mercado Comum (GMC) tinha elaborado uma lista de documentos de identificação pessoal válidos para a circulação das pessoas no território dos Estados Partes $^{11}$ e tinha auspicado a criação de um documento único de viagem para os seus cidadãos, razão pela qual foi estabelecido um grupo de trabalho ad hoc ${ }^{12}$ que culminou com a criação do passaporte comum do Mercosull $^{13}$ que começou a ser emitido em 2006, seguindo o modelo europeu. Na capa do passaporte, é cunhada a denominação "Mercosul" ou "Mercosur", acima daquela do nome do Estado-membro. Tal documento tem o escopo de uniformizar a qualidade técnica para fins de identificação, facilitando assim os controles. Do ponto de vista simbólico, pretende tornar identificáveis os seus cidadãos no exterior, além de mostrar a existência de uma identidade comum. A Argentina realizou um passo ulterior ao estampar também na carteira de identidade dos seus nacionais a palavra "Mercosur", todavia, não resulta que algum outro Estado-membro tenha adotado

10 AGUIRRE, Orlando; MERA, Gabriela; NEJAMKIS, Lucila. Políticas migratorias e integración regional: la libre circulación y los desafíos a la ciudadanía. In: NOVICK, Susana (Dir.). Migraciones y Mercosur: una relación inconclusa. Buenos Aires: Catálogos: 2010. p. $50-72$, p. 62.

11 MERCOSUL. Grupo Mercado Comum. Resolução n 44, de 03 de agosto de 1994. Disponível em: <http://www.mercosur.int/msweb/ Normas/normas_web/Resoluciones/PT/GMC_RES_1993038_PT_Grupo_AD_HOC_Documento_\%C3\%9Anico_Viagem. PDF>. Acesso em: 15 dez. 2015. Sobre Documentos válidos de cada Estado Parte para a circulação das pessoas no Mercosul. Os documentos válidos para este fim são as carteiras de identidade e os passaportes.

12 MERCOSUL. Grupo Mercado Comum. Resolução $n^{\circ}$ 38, de 30 de junho de 1993. Disponível em: <http://www2.uol.com.br/ actasoft/actamercosul/novo/res_44_94.htm>. Acesso em: 15 dez. 2015. sobre a criação de um Grupo ad hoc para a redação do documento único de viagem em Assunção, Paraguai.

13 MERCOSUL. Grupo Mercado Comum. Resolução n 40, de 8 de dezembro de 1998. Disponível em: <http://www.mercosur.int/ innovaportal/v/387/4/innova.front/busqueda-de-normativa $>$. Acesso em: 15 dez. 2015. Sobre Características comuns que devem ter os passaportes, de, Rio de Janeiro, Brasil. medidas do mesmo gênero ${ }^{14}$. De qualquer modo, esse documento "is a sign that MERCOSUR integration is still on course. [...] One very important feature of the MERCOSUR passport is that it enhances workeforce mobility and facilitates cultural and political integration Sometimes this form of integration comes before economic integration." 15

Outros acordos haviam sido igualmente firmados nesse período, muito embora, em âmbito mais limitado, em matéria de coordenação e cooperação entre os Estados para o controle das fronteiras ${ }^{16}$, dentre os quais se destaca o Acordo de Recife de $1993^{17}$ que consagrou

14 FLÔRES JUNIOR, Renato G. Símbolos e integrações regionais: uma breve introdução com vistas ao Mercosul. In: HOFMEISTER, Wilhelm. União Europeia e Mercosul: dois momentos especiais da integração regional. Rio de Janeiro: Fundação Konrad Adenauer no Brasil, abr. 2007. (Cadernos Adenauer, 1). p. 17-31. p. 23.

15 VALADÃO, Marcos Aurelio Pereira. Legal and institutional dimensions of reform: Washington Consensus and Latin America integration: Mercosur and the road to regional inconsistencies - to where are we going exactly?. Law and Business Review of the Americas, Dallas, v. 15, n. 1, p. 207-220, 2009. p. 216.

16 MERCOSUL. Conselho do Mercado Comum. Decisão $n^{\circ} 18$, de 07 de dezembro de 1999. Disponível em: < http://www.mercosur.int/ msweb/Normas/normas_web/Decisiones/PT/Dec_018_099_ $\mathrm{Tr} \% \mathrm{C} 3 \%$ A2nsito $\% 20$ Vicinal $\% 20$ Fronteiri $\% \mathrm{C} 3 \% \mathrm{~A} 7 \mathrm{O} \% 20 \mathrm{MCS}$ Ata\%202_99.PDF>. Acesso em: 15 dez. 2015 com relação ao Acordo sobre o trânsito vicinal transfronteiriço entre os Estados Partes do Mercosul; MERCOSUL. Conselho do Mercado Comum. Decisão $n^{\circ}$ 19, de 07 de dezembro de 1999. Disponível em: <http:// www.mercosur.int/msweb/portal\%20intermediario/Normas/normas_web/Decisiones/PT/Dec_019_099_Tr\%C3\%A2nsito\%20 Vicinal $\% 20$ Front $\% 20 \mathrm{MCS} \% 20 \mathrm{Bol} \% 20$ Chile_Ata $\% 202 \_99 . P D F>$. Acesso em: 15 dez. 2015 que estende o acordo também a Bolívia e Chile; MERCOSul. Conselho do Mercado Comum. Decisão $n^{\circ}$ 14, de 29 de junbo de 2000. Disponível em: <http://gd.mercosur.int/ SAM \%5CGestDoc\%5Cpubweb.nsf/AA30EDC2D55AF15D032 57F1D00490651/\$File/DEC_014-2000_PT_Regul\%20Reg\%20 Tr\%C6\%92nsito $\% 20$ Vicinal $\% 20$ Fronteiri $\%$ E2\%80\%A1o_Ata $\% 20$ 1_00.pdf>. Acesso em: 15 dez. 2015 que regulamenta as decisões precedentes, criando a Credencial de Trânsito Vicinal nas Fronteiras (TVF) que permite ao beneficiário permanecer no território do país vizinho por até 72 horas; MERCOSUL. Conselho do Mercado Comum. Decisão n 15, de 29 de junho de 2000. Disponível em: <http:// gd.mercosur.int/SAM\%5CGestDoc\%5Cpubweb.nsf/C53D520147 0B3A1503257F1D0049314D/\$File/DEC_015-2000_PT_Reg\%20 Tr\%C6\%92nsito $\% 20$ Vicin $\% 20$ Front $\% 20$ MCS $\% 20 B$ B $\% 20$ Chile_ Ata\%201_00.pdf>. Acesso em: 15 dez. 2015 estende esta regulamentação também à Bolívia e ao Chile.

17 MERCOSUL. Conselho do Mercado Comum. Decisão $n^{\circ}$ 05, de 22 de abril de 1993. Disponível em: <http://gd.mercosur.int/ SAM/GestDoc/PubWeb.nsf/OpenFile?OpenAgent\&base=SAM $\backslash$ GestDoc $\backslash$ DocOfic0Arch.nsf\&id=832579C700726F0D 832577 810052E8A2\&archivo=RES_005_1993-PT_Comiss\%F5es\%20 SGTs $\% 20 \mathrm{~N} \% \mathrm{~B} 0 \% 202, \% 207, \% 2010 . \mathrm{doc}>$. Acesso em: 15 dez. 2015 sobre Aplicação dos Controles integrados de Fronteiras entre os Países do Mercosul de $1^{\circ}$ de julho de 1993 em Assunção, Paraguai. Recentemente, tal disciplina foi integrada pela Dec. CMC n. 07/12 sobre a Complementação ao Acordo de Recife em matéria 
o conceito de "controle integrado de fronteiras", estabelecendo procedimentos administrativos e operativos que fossem comuns e integrados entre os Estados Partes para o controle da entrada e da saída das pessoas no seus territórios.

A dimensão migratória da integração foi contemplada pelo Programa de Ação do Mercosul de $1995^{18}$, segundo o qual o desenvolvimento do fenômeno regional no sentido de promover o mercado comum requer aprofundamento do tema das migrações nos seus diversos aspectos, dentre os quais o controle das fronteiras e o exame da possibilidade de coordenação das políticas migratórias dos Estados-Partes ${ }^{19}$.

Segundo as orientações traçadas pelo citado Programa de Ação, foi aprovada a criação de um modelo único do "Cartão de entrada e saída" ${ }^{20}$, ou seja, de uma declaração solicitada aos indivíduos que se desloquem de um Estado-Parte para outro através de meios de transporte aéreos, fluviais, marítimos e terrestres. Com relação aos aspectos institucionais e à necessidade de centralizar o sistema de troca de informações relativos à autenticidade dos documentos de viagem dos respectivos cidadãos, foi aprovada a criação dos Centros de Consulta de

migratória, adotada em 29 de junho de 2012 em Mendonça, Argentina. MERCOSUL. Conselho do Mercado Comum. Decisão $n^{\circ}$ 07, de 29 de junho de 2012. Disponível em: <http://gd.mercosur.int/ SAM\%5CGestDoc\%5Cpubweb.nsf/A2829874C636D36B03257F 1D0049FB6C/\$File/DEC_007-2012_PT_Complementacao\%20 Acordo $\% 20$ Recife $\% 20$ Materia $\% 20$ Migratoria.pdf $>$. Acesso em: 15 dez. 2015.

18 MERCOSUL. Conselho do Mercado Comum. Decisão n ${ }^{\circ}$ 9, de 5 de outubro de 1995. Disponível em: <http://gd.mercosur.int/SAM/ GestDoc/PubWeb.nsf/OpenFile?OpenAgent\&base=SAM $\backslash$ GestDoc $\backslash$ DocOfic0Arch.nsf\&id $=832579$ C700726F0D83257751006F6 800\&archivo $=$ DEC_008-1995_PT_Prot $\% 20 \mathrm{Harm} \% 20$ Norm $\% 20$ Intelect $\% 20$ Proc $\% 20$ Denom $\% 20$ Origem_Ata $\% 201$-95.doc $>$. Acesso em: 15 dez. 2015. sobre o Programa de Ação do Mercosul até o ano de 2000.

19 MERCOSUL. Conselho do Mercado Comum. Decisão n 9, de 5 de outubro de 1995. Disponível em: <http://gd.mercosur.int/SAM/ GestDoc/PubWeb.nsf/OpenFile?OpenAgent\&base=SAM $\backslash$ GestDoc $\backslash$ DocOfic0Arch.nsf\&id $=832579$ C 700726F0D83257751006F6 800\&archivo=DEC_008-1995_PT_Prot $\% 20$ Harm $\% 20$ Norm $\% 20$ Intelect $\% 20$ Proc $\% 20$ Denom $\% 20$ Origem_Ata $\% 201$-95.doc $>$. Acesso em: 15 dez. 2015.

20 MERCOSUL. Grupo Mercado Comum. Resolução nº 58, de 21 de junho de 1996. Disponível em: <http://gd.mercosur.int/SAM/ GestDoc/PubWeb.nsf/OpenFile?OpenAgent\&base $=$ SAM $\backslash$ GestDoc $\backslash$ DocOfic0Arch.nsf\&id $=832579$ C 700726F0D 8325775900 565BEF\&archivo=RES_058-1996_PT_Cart\%E3oEntrada $\% 20$ Saida\%20(CES).doc>. Acesso em: 15 dez. 2015 em Buenos Aires, Argentina. A Resolução entrou em vigor 180 dias após a data da assinatura $\left(\operatorname{art} .7^{\circ}\right)$.
Documentos Pessoais do Mercosul em 199621, os quais deveriam ter a tarefa de facilitar o controle migratório e a circulação de um modo geral. Todavia, ao verificarmos os órgãos nacionais que seriam atualmente responsáveis por esse tipo de controle ${ }^{22}$, parece que os citados Centros jamais foram efetivamente criados e colocados em funcionamento, tendo em vista que não se encontra nenhuma informação a respeito.

Nos anos 2000, foi firmado o Acordo sobre a Isenção de $\operatorname{Vistos}^{23}$, mas possuía âmbito subjetivo de aplicação limitado à categoria de trabalhadores migrantes e aos que exercitam determinadas profissões, tais como artistas, professores, cientistas, atletas, jornalistas, profissionais liberais ou técnicos especializados. O Acordo prevê que essas categorias poderiam permanecer no território de um outro Estado-membro por 90 dias (prorrogáveis pelo mesmo período) até um máximo de 180 dias por ano, sem a necessidade de visto. Resta evidente que, dessa forma, se afasta da ideia de livre circulação regional ao mesmo tempo em que se submete o tema migratório aos critérios nacionais, de caráter mais restritivo $^{24}$. Todavia, até hoje, apenas o Brasil ratificou o Acordo, não se encontrando, portanto, vigente ${ }^{25}$.

21 MERCOSUL. Grupo Mercado Comum. Resolução n 59, de 21 de junho de 1996. Disponível em: <http://gd.mercosur.int/SAM/ GestDoc/PubWeb.nsf/OpenFile?OpenAgent\&base=SAM $\backslash$ GestDoc $\backslash$ DocOfic0Arch.nsf\&id $=832579$ C700726F0D832577590057C CDC\&archivo=RES_059-1996_PT_Cria\%E7\%E3oCentrosConsu IDocuPersonales.doc >. Acesso em: 15 dez. 2015 em Buenos Aires, Argentina.

22 O art. 3 e 4 da Res. GMC n. 59/96 expressamente definiu quais deveriam ser os órgãos nacionais responsáveis pelo estabelecimento da sede e pela administração do funcionamento interno dos Centros. MERCOSUL. Grupo Mercado Comum. Resolução n 59, de 21 de junbo de 1996. Disponível em: <http://gd.mercosur.int/SAM/ GestDoc/PubWeb.nsf/OpenFile?OpenAgent\&base=SAM $\backslash$ GestDoc $\backslash$ DocOfic0Arch.nsf\&id=832579C700726F0D832577590057C CDC\&archivo=RES_059-1996_PT_Cria\%E7\%E3oCentrosConsu IDocuPersonales.doc $>$. Acesso em: 15 dez. 2015

23 MERCOSUL. Conselho do Mercado Comum. Decisão $n^{\circ} 48$, de 14 de dezembro de 2000. Disponível em: <http://gd.mercosur.int/ SAM\%5CGestDoc\%5Cpubweb.nsf/6420A63D340570CA03257 F1D004AF9BF/\$File/DEC_048-2000_PT_FERR_Acordo $\% 20$ Isen $\%$ E $2 \% 80 \% \mathrm{~A} 1 \% \mathrm{C} 3 \% 860 \% 20 \mathrm{de} \% 20$ Vistos_Ata $\% 202 \_00$. pdf > . Acesso em: 15 dez. 2015. sobre a Isenção de Vistos entre os Estados Partes do Mercosul de 14 de dezembro de 2000, adotada em Florianópolis, Brasil.

24 AGUIRRE, Orlando; MERA, Gabriela; NEJAMKIS, Lucila. Políticas migratorias e integración regional: la libre circulación y los desafíos a la ciudadanía. In: NOVICK, Susana (Dir.). Migraciones y Mercosur: una relación inconclusa. Buenos Aires: Catálogos: 2010. p. $50-72$. p. 14.

25 O art. 8 do Acordo prevê que o mesmo entrará em vigor a partir da ratificação do segundo Estado Parte, de modo bilateral, até 


\section{OS ACORDOS SOBRE MIGRAÇÃO E RESIDÊNCIA DE 2002}

O salto qualitativo na matéria de migração e circulação de pessoas dentro do espaço territorial do Mercosul ocorreu durante a XXIII Reunião do Conselho Mercado Comum entre os dias 5 e 6 de dezembro de $2002^{26} \mathrm{com}$ a assinatura de Acordos sobre a Migração e a Residência dos cidadãos dos Estados-Partes do Mercosul. Diferentemente do que se possa imaginar, esses Acordos não preveem nenhum requisito ligado à situação socioeconômica ou laboral do migrante, a condição principal para ser beneficiário desses direitos é somente aquela de ser titular da nacionalidade de um dos Estados Partes.

Para maior clareza, é oportuno precisar que dois são os Acordos sobre a Regularização das Migrações Internas dos Cidadãos do Mercosul, de idêntico conteúdo mas com Estados contraentes diferentes. O primeiro foi assinado apenas pelos Estados-membros fundadores do Mercosul; já o segundo teve a participação também da Bolívia e do Chile, ambos Estados Associados. A mesma situação constata-se com relação aos dois Acordos sobre Residência para os Cidadãos dos Estados-Parte do Mercosul, isto é, o primeiro foi assinado pelos Estados-Membros e o segundo também por Bolívia e Chile. De qualquer modo, a sua relevância consiste em acolher uma série de solicitações inerentes à necessidade de criação de um espaço integrado ${ }^{27}$, manifestadas pelos diversos atores do Mercosul desde o início do processo de integração.

Diferentemente do que possa parecer em um primeiro momento, tais Acordos não devem ser confundidos com as Decisões do Conselho Mercado Comum. Os Acordos sobre Migração e sobre Residência constituem, de fato, autênticos instrumentos internacionais

que os outros Estados realizem o procedimento de incorporação. BRASIL. Decreto $n^{\circ}$ 6.975, de 7 de outubro de 2009. Disponível em: <http://www.planalto.gov.br/ccivil_03/_Ato2007-2010/2009/Decreto/D6975.htm>. Acesso em: 15 dez. 2015.

26 Reunião ocorrida em Brasília, Brasil, entre os dias 5 e 6 de dezembro de 2002.

27 REVELEZ, Lincoln Bizzozero. La educación superior en el Sector Educativo del Mercosur: impactos en la migración intrarregional y perspectivas en el proceso de integración. In: LAS MIGRACIONES humanas en el Mercosur: una mirada desde los derechos humanos, compilación normativa. Montevideo: Observatório de Políticas Públicas de Derechos Humanos en el Mercosur, 2009. p. 35-46. p. 41. na medida em que foram elaborados e assinados pelos Chefes de Estado e de Governo. Somente com a Decisão CMC n. 28/02 28 ocorreu a incorporação dos citados Acordos e, assim, as normas internacionais se tornaram realmente direito do Mercosul. Recorda-se que, dado o caráter intergovernamental do bloco, as Decisões do CMC são, em regra, atos não vinculantes e que precisam se submeter ao procedimento de incorporação em cada Estados-Partes a fim de tornarem-se vigentes.

Considerando-se tal situação, diante do retardo do Paraguai em realizar a ratificação do Acordo sobre a Residência, os outros Estados-membros começaram a aplicá-lo de modo bilateral, por meio da troca de instrumentos das respectivas ratificações: isto ocorreu a partir de 3 de abril de 2006 entre Argentina e Brasil; de 20 de julho de 2006 entre Argentina e Uruguai; e de 23 de outubro de 2006 entre Brasil e Uruguai ${ }^{29}$. Os Acordos sobre Residência para os Cidadãos dos Estados-Partes, na qualidade de normas do Mercosul, entraram em vigor para todos os Estados-Membros somente em 28 de julho de 2009, após o depósito da ratificação pelo Paraguai.

Por sua vez, o Acordo sobre a Regularização das Migrações Internas não se encontra atualmente em vigor, pois falta a ratificação da Argentina. Todavia, tal situação não se vislumbra como um problema, uma vez que as disposições deste último repetem-se substancialmente nos Acordos sobre Residência. Oito são os artigos que compõem os Acordos sobre Migração, dos quais apenas quatro apresentam um conteúdo substancial, enquanto os outros disciplinam aspectos meramente formais, como a entrada em vigor e a possibilidade de denúncia.

Os dois Acordos sobre Migração estabelecem, nos art. 1 e 2, que o nacional de um Estado-Parte que se encontre em território de outro Estado-Parte poderá efetuar a tramitação migratória de sua residência nesse último, sem necessidade de sair deste e independente da condição migratória em que houver ingressado o

28 MERCOSUL. Conselho do Mercado Comum. Decisão n 48 , de 6 de dezembro de 2002. Disponível em: < hhttp://www.sice.oas.org/ trade/mrcsrs/decisions/dec2802p.asp>. Acesso em: 15 dez. 2015.

29 SALZMANN, Antonio Cardesa. El contenido jurídico de la libre circulación de personas en el Mercosur: balance y perspectivas. In: GOIZUETA VÉRTIZ, Juana; GÓMEZ FERNÁNDEZ, Itziar; PASCUAL GONZÁLEZ, María Isabel. La libre círculación de personas en los sistemas de integración económica: modelos comparados: Unión Europea, Mercosur y Comunidad Andina. Navarra: Thomson Reuters Aranzadi, 2012. p. 163-185. p. 169. 
peticionante, estando isento do pagamento de qualquer multas ou de outras sanções administrativas mais gravosas. Por outro lado, o art. 3 dos Acordos sobre Residência preveem a mesma regra, acrescentando que o procedimento também pode ser realizado antes do ingresso do indivíduo no território do Estado-Parte de recepção. Dessa forma, a ausência da entrada em vigor dos Acordos Migratórios é, de certa forma, compensada pela eficácia já adquirida pelas disposições contidas nos Acordos sobre Residência.

Muito embora não tenham entrado em vigor, relevante salientar que o propósito dos Acordos sobre Migração consiste em transformar "situações de fato" em "situações de direito", a fim de permitir o funcionamento dos outros dois Acordos sobre Residência ${ }^{30}$. Era necessário que os primeiros, de âmbito mais amplo e geral, fornecessem as bases para a posterior aplicação daqueles sobre a residência que, por sua vez, contém normas procedimentais e específicas, cujo escopo consistia em evitar eventuais conflitos entre as legislações internas dos Estados Partes.

Compreende-se, assim, porque os Acordos sobre Migração tenham sido elaborados com a finalidade de orientar aqueles sobre a Residência. Estes, inclusive, são claros ao afirmar que a "implementação de uma política de livre circulação de pessoas na Região é essencial" porque tem o escopo de "fortalecer e aprofundar o processo de integração, assim como os fraternais vinculos existentes entre eles31". Com tal propósito, torna-se necessário estabelecer regras co-

30 Assim REVELEZ, Lincoln Bizzozero. La educación superior en el Sector Educativo del Mercosur: impactos en la migración intrarregional y perspectivas en el proceso de integración. In: LAS MIGRACIONES humanas en el Mercosur: una mirada desde los derechos humanos, compilación normativa. Montevideo: Observatório de Políticas Públicas de Derechos Humanos en el Mercosur, 2009. p. 35-46. p. 41. O autor continua afirmando que a existência de acordos deste tipo mostra-se relevante não somente se considerado o número de imigrações. Segundo o Ministério de Interior da Argentina cerca de 300 mil argentinos vivem nos outros países do Mercosul, incluindo os Associados. Além disso, 1,2 milhão de paraguaios, 1 milhão de bolivianos, 200 mil uruguaios, 200 mil chilenos e 20 mil brasileiros vivem na Argentina, sendo que a maior parte se encontra na clandestinidade. Cf.: Terra Actualidad (2002) Habrá libertad de tránsito y residencia en el Mercosur, 9 de novembro de 2002. 31 Cfr. Preâmbulo dos Acordos sobre Residência, MERCOSUL. Conselho do Mercado Comum. Decisão n 13, de 5 de julho de 2002. Disponível em: <http://www.mercosur.int/msweb/Normas/normas_web/Decisiones/PT/Dec_013_002_Acordo\%20Antidumping\%20OMC_Ata\%201_02.PDF $>$. Acesso em: 15 dez. 2015; MERCOSUL. Conselho do Mercado Comum. Decisão n ${ }^{\circ} 14$, de 5 de julho de 2002. Disponível em: <http://www.sice.oas.org/trade/mrcsrs/ decisions/dec1402p.asp>. Acesso em: 15 dez. 2015. muns que disciplinem a situação migratória dos cidadãos dos Estados-Partes e que se apresentem, portanto, como um instrumento do início de uma livre circulação e residência de pessoas na região do Mercosul.

Superada essa questão, reforça-se que a importância dos Acordos sobre Residência é confirmada pelas posteriores aprovações dos pedidos de adesão apresentados pelo Peru ${ }^{32}$ e Equador em $2011^{33}$ e pela Colômbia em $2012^{34}$. A Venezuela é o único país que ainda não ratificou tais documentos. Dessa forma, atualmente, os Acordos sobre Residência para os Cidadãos do Mercosul estão em vigor em quatro Estados-membros e em todos os Estados Associados, totalizando nove países, cuja população beneficiada gira em torno de $500 \mathrm{mi}-$ lhões de pessoas. São eles: Argentina, Brasil, Uruguai, Paraguai, Bolívia, Chile, Peru, Equador e Colômbia.

\subsection{Os direitos e prerrogativas previstos nos acordos sobre residência para os cidadãos dos estados-parte do Mercosul}

No tocante às disposições normativas dos Acordos sobre Residência, é curioso notar que, segundo o art. 2, os seus beneficiários são os "Nacionais de uma Parte"; todavia, a definição de "nacionais" que podem gozar de tais direitos é limitada às pessoas que tenham a nacionalidade originária de um dos Estados-Partes ou a nacionalidade adquirida por naturalização há pelo menos cinco anos. Esse tratamento diferenciado poderia

32 O Peru decidiu que o acordo deveria entrar em vigor na mesma data da assinatura do ato de adesão à Dec. CMC n. 4/11, ou seja, em 28 de junho de 2011. MERCOSUL. Conselho do Mercado Comum. Decisão $n^{\circ} 4$, de 28 de junho 2011. Disponível em: <http:/ gd.mercosur.int/SAM $\% 5 C G e s t D o c \% 5 C$ pubweb.nsf/E1B5E57 FB6D43E1F03257F1D004C3DCB/\$File/DEC_004-2011_PT_ Ades $\%$ C3\%860\%20Peru $\% 20$ Acordo $\% 20$ Residen $\% 20$ Nacionais. pdf $>$. Acesso em: 15 dez. 2015.

33 O Equador assinou a Dec. CMC n. 21/11 em 28 de junho de 2011 e decidiu o acordo deveria entrar em vigor após a ratificação pela Assembleia Nacional equatoriana, ocorrida em 3 de dezembro de 2013. MERCOSUL. Conselho do Mercado Comum. Decisão $n^{\circ}$ 21, de 28 de junho 2011. Disponível em: <http://gd.mercosur.int/ SAM\%5CGestDoc\%5Cpubweb.nsf/852556C938D1A7D703257 F1D004C7D16/\$File/DEC_021-2011_PT_Ades $\%$ C3\%860\%20 Equador\%20Residen\%20Nacionais.pdf>. Acesso em: 15 dez. 2015. 34 Do mesmo modo do Peru, a Colômbia decidiu que o acordo deveria entrar em vigor na mesma data da assinatura do ato de adesão à Dec. CMC n. 20/12, ou seja, em 29 de junho de 2012. MERCOSUL. Conselho do Mercado Comum. Decisão $n^{\circ}$ 20, de 29 de junho 2012. Disponível em: < http://www.cartillaciudadania.mercosur.int/uploads/DEC_020-2012_PT_Adesao\%20Col\%20Acordo $\% 20$ Resid $\%$ C3\%AAncia.pdf>. Acesso em: 15 dez. 2015. 
suscitar questionamentos sobre uma eventual discriminação, dado que permitiria, em última análise, que dois indivíduos que tenham adquirido a nacionalidade por naturalização em um dos Estados Partes não recebam o mesmo tratamento no âmbito do Mercosul em razão do tempo transcorrido da data da conclusão do procedimento interno de naturalização ${ }^{35}$.

Com relação aos beneficiários dos direitos elencados pelos Acordos, é interessante notar que os destinatários são tanto os nacionais dos Estados Partes que tenham migrado para outro Estado-Parte quanto os seus familiares, mesmo sendo nacionais de Estados terceiros. Portanto, os familiares gozam de todos os direitos concedidos aos beneficiários primários sem que haja qualquer discriminação em relação ao tratamento oferecido a um cidadão do Mercosul ${ }^{36}$.

Nesse sentido, o art. 9, $\$ 2^{\circ}$ dos Acordos sobre Residência disciplinam acerca do reagrupamento familiar. Permite-se, portanto, aos membros da família de um cidadão do Mercosul que não tenha a nacionalidade de um destes países, a aquisição da autorização de residência idêntica ao do nacional de um Estado-Parte, desde que, é claro, não existam impedimentos de ordem pública ou segurança pública.

35 Nesse sentido, como é notório, interessante recordar que este tipo de diferenciação não encontra guarida no âmbito da União Europeia que, no art. 9 do Tratado de Lisboa, dispõe que "É cidadão da União Europeia qualquer pessoa que tenha a nacionalidade de um Estado-Membro" sem fazer alguma distinção em relação ao modo de aquisição da nacionalidade. PORTUGAL. Comissão de Assuntos Europeus da Assembleia da República. Tratado de Lisboa: versão consolidada. Disponível em: <https://www.parlamento.pt/europa/ Documents/Tratado_Versao_Consolidada.pdf $>$. Acesso em: 15 dez. 2015.

36 De modo a complementar o estudo, ressalta-se que o mesmo ocorre na União Europeia. Dentre outras prescrições europeias sobre o assunto, pode-se recordar o Considerando 20 da Diretiva n. 2004/38/CE: "Em conformidade com a proibição da discriminação em razão da nacionalidade, todos os cidadãos da União e membros das suas famílias que residam num Estado-Membro com base na presente diretiva deverão beneficiar, nesse Estado-Membro, de igualdade de tratamento em relação aos nacionais nos domínios abrangidos pelo Tratado, sob reserva das disposições específicas expressamente previstas no Tratado e no direito secundário" Nesse sentido, ver: ALEXOVIČOVÁ, Iveta. The right of citizenship of the Union and their family members to move and reside freely within the territory of the Member States. In: SCHNEIDER, Hildegard. Migration, Integration and Citizenship: a challenge for Europe's future. Maastricht: Forum Maastricht, 2005. p. 73-105; CONDINANZI, Massimo; LANG, Alessandra; NASCIMBENE, Bruno. Cittadinanza dell'Unione e libera circolazione delle persone. 2. ed. Milano: Giuffrè, 2006; PAGANO, Emmanuele. Ricongiungimento familiare, cittadinanza e residenza: dal caso Zambrano al caso Dereci. Diritto comunitario e degli scambi internazionali, v. 51, n. 3, p. 467-475, 2012. p. 467-475.
Além disso, como os destinatários de tais normas são os nacionais enquanto tais, independentemente da condição laboral, pode-se afirmar que o cerne do direito à livre residência das pessoas encontra-se no art. $9, \$ 1^{\circ}$, o qual prevê a concessão do tratamento nacional em matéria de direitos civis, sociais, culturais e econômicos aos cidadãos dos Estados-Partes e aos seus familiares. Possuem estes, portanto, o direito de associação para fins lícitos, de liberdade de pensamento e de expressão, de professar e praticar livremente a própria religião, o direito de usar a própria língua, os tratamentos relativos à segurança social, aos direitos de uma igual retribuição em condições análogas de trabalho e o direito de fundar sindicatos ou de aderir a estes.

$\mathrm{Na}$ prática, todavia, verifica-se a ausência de uma atuação mais incisiva no sentido de preconizar tais paridades de tratamento por meio de políticas nacionais com esta finalidade específica. Sob tal perspectiva, um expoente do Departamento de Direitos Humanos da Presidência da República brasileira, ao comentar as normas previstas pelo Acordo sobre Residência, manifestou a vontade de conceder aos estrangeiros do Mercosul condições mais facilitadas de ingresso e residência, incluindo os direitos relativos ao trabalho e a uma plena cidadania $^{37}$. Nesse sentido, pode ser mencionada uma iniciativa do governo do Estado de São Paulo a fim de equiparar o tratamento dispensado aos trabalhadores do Mercosul com o concedido aos cidadãos brasileiros, oferecendo programas de qualificação profissional aos trabalhadores estrangeiros que se encontrem em uma situação vulnerável, como frequentemente ocorre com nacionais bolivianos e paraguaios no Brasil ${ }^{38}$.

A igualdade de tratamento, de acordo com o art. 9, $\$ 3^{\circ}$, é também estendida a todas as questões que con-

37 Entrevista concedia por Maria do Rosario. Agência Brasil. NUNES, Maria do Rosário. Após morte de Brayan, ministra vai debater situação de bolivianos no país. Folha de São Paulo. São Paulo, 1 jul. 2013. Disponível em: <http://www1.folha.uol.com. br/cotidiano/2013/07/1304235-apos-morte-de-brayan-ministravai-debater-situacao-de-bolivianos-no-pais.shtml>. Acesso em: 10 out. 2013.

38 ROLLI, Claudia. Governo paulista pretende qualificar estrangeiros. Folha de São Paulo. São Paulo, 11 ago. 2013. Disponível em: <http://www1.folha.uol.com.br/mercado/2013/08/1324746governo-paulista-pretende-qualificar-estrangeiros.shtml>. Acesso em: 10 out. 2013. Segundo a reportagem, na região metropolitana da cidade de São Paulo vivem cerca de 275 mil bolivianos, 45 mil paraguaios e 20 mil peruanos. Estima-se que de 80 a 100 mil dos trabalhadores sul-americanos se contraem em condição irregular, tendo em vista que muitos desenvolvem atividades análogas ao de escravidão. 
cernem a aplicação da legislação em matéria de trabalho. Os Acordos têm abrangência ampla, pois se trata de um princípio que compreende os direitos de exercitar qualquer atividade, autônoma ou subordinada, nas mesmas condições dos cidadãos do País de recepção, incluindo a aplicação da legislação trabalhista, em particular a da remuneração, das condições de trabalho e de previdência social ${ }^{39}$.

Seguindo a mesma orientação, o art. $8, \S 2^{\circ}$ estabelece que as pessoas que obtenham a residência no respeito das regras estabelecidas pelos Acordos têm o direito de trabalhar e de exercitar qualquer atividade, por conta própria ou de outrem, nas mesmas condições dos cidadãos do país de acolhimento. Nesse sentido, porém, surpreende a falta de previsão de exceções ao princípio de não discriminação em base à nacionalidade para as atividades que normalmente são reservadas somente aos cidadãos natos ${ }^{40}$, tais como determinados empregos na administração pública e certas atividades que impliquem o exercício do poder público. Apesar dessas imprecisões normativas, o princípio da igualdade é considerado nos Acordos como um elemento inerente ao espaço de livre residência das pessoas no mercado co-

39 Art. 8. 2. "[os imigrantes] Têm ainda, direito a exercer qualquer atividade, tanto por conta própria, como por conta de terceiros, nas mesmas condições que os nacionais do país de recepção, de acordo com as normas legais de cada país. [...] Art. 9. 3. Igualdade de tratamento com os nacionais: Os imigrantes gozarão, no território das Partes, de tratamento não menos favorável do que recebem os nacionais do país de recepção, no que concerne à aplicação da legislação trabalbista, especialmente em matéria de remuneração, condições de trabalho e seguro social." (Grifo do Autor). MERCOSUL. Conselho do Mercado Comum. Acordo sobre residência para nacionais dos estados partes do Mercosul, Bolivia e Chile. Disponível em: <http://www.mercosur.int/innovaportal/ file/5838/1/56-acuerdoresidenciamsur-boliviaychile.pdf $>$. Acesso em: 15 dez. 2015.

40 A título exemplificativo, o Brasil no art. 222 da Constituição Federal estabelece que "A propriedade de empresa jornalística e de radiodifusão sonora e de sons e imagens é privativa de brasileiros natos ou naturalizados bá mais de dez anos, on de pessoas jurídicas constituídas sob as leis brasileiras e que tenham sede no País." Do mesmo modo, o art. $12, \$ 3^{\circ}$ prevê que "São privativos de brasileiro nato os cargos: de Presidente e Vice-Presidente da República; de Presidente da Câmara dos Deputados; de Presidente do Senado Federal; de Ministro do Supremo Tribunal Federal; da carreira diplomática; de oficial das Forças Armadas; de Ministro de Estado da Defesa." As Cartas Constitucionais dos outros Estados Partes do Mercosul preveem exceções análogas: Argentina (art. 48, 55 e 89); Paraguai (art. 162, 221, 223, 228 e 258); Uruguai (art. 90, 99, 151, 235, 242, 245, 247 e 264); Venezuela (art. 160, 188 e 227). BRASIL. Câmara dos Deputados. Constituiç̃os dos países do Mercosul, 1996-2000: textos constitucionais Argentina, Bolívia, Brasil, Chile, Paraguai e Uruguai. Brasília: Câmara dos Deputados, 2001. Disponível em: <http://www.planalto. gov.br/ccivil_03/Constituicao/Constituicao.htm>. Acesso em: 15 dez. 2015. mum, que goza de um valor jurídico mais relevante que aquele expresso na Declaração Sócio-Laboral de $1988^{41}$, dotada de um mero valor exortativo e não vinculante ${ }^{42}$.

Retomando a análise do Acordo sobre Residência, o art. 9, $₫ 5^{\circ}$ reconhece o direito de transferir dinheiro, permitindo, assim, aos imigrantes de transferir a sua renda e as suas economias ao país de origem, segundo a legislação interna de cada Estado Parte. Trata-se de um tema relevante no âmbito latino-americano e também interamericano, dado que um estudo realizado pelo Fundo Multilateral de Investimentos do Banco Interamericano de Desenvolvimento conjuntamente com o Pew Hispanic Center ${ }^{43}$, constatou que esse tipo de transferência, em certos casos, pode ultrapassar os fluxos de assistência oficial para o desenvolvimento nacional, representando, em alguns países, cerca de $15 \%$ do produto interno líquido $^{44}$ e quase a metade dos investimentos diretos que recebe a região ${ }^{45}$.

Um outro importante direito previsto pelo art. 9, $\$ 6^{\circ}$ refere-se aos filhos dos migrantes. A estes são garantidos o direito ao nome, ao registro de nascimento e à aquisição da nacionalidade, em conformidade

41 O documento, assinado em 10 de dezembro de 1998 no Rio de Janeiro estabeleceu princípios programáticos de integração regional, sendo dividido em quatro partes principais. As primeiras duas referem-se ao conteúdo privado das relações trabalhistas, ou seja, aos direitos individuais e coletivos. As últimas, por sua vez, concernem aos aspectos públicos, como os vinculados às obrigações estatais, os quais foram chamados de "outros direitos" e às regras de "aplicação e seguimento" com relação à vigência do instrumento. MERCOSUL. Declaração Sociolaboral do Mercosul. Disponível em: <http:// bd.camara.gov.br/bd/bitstream/handle/bdcamara/10092/constituicoes_mercosul.pdf $>$. Acesso em: 15 dez. 2015

42 SALZMANN, Antonio Cardesa. El contenido jurídico de la libre circulación de personas en el Mercosur: balance y perspectivas. In: GOIZUETA VÉRTIZ, Juana; GÓMEZ FERNÁNDEZ, Itziar; PASCUAL GONZÁLEZ, María Isabel. La libre círculación de personas en los sistemas de integración económica: modelos comparados: Unión Europea, Mercosur y Comunidad Andina. Navarra: Thomson Reuters Aranzadi, 2012. p. 163-185. p. 171.

43 REMITTANCE Senders and Receivers: tracking the transnational channels. Washington: Pew Hispanic Center, Nov. de 2003. Available at: <http://www.pewhispanic.org/files/reports/23.pdf>. Accessed on: 15 oct. 2015.

44 Por exemplo, o fluxo de transferência de dinheiro proveniente do exterior em El Salvador em 2002 foi de 15,1\% segundo o estudo do Pew Hispanic Center. REMITTANCE Senders and Receivers: tracking the transnational channels. Washington: Pew Hispanic Center, Nov. de 2003. Available at: <http://www.pewhispanic.org/ files/reports/23.pdf>. Accessed on: 15 oct. 2015.

45 BIZZOZERO, Lincoln; PASTORINO, Ana. Los Acuerdos Migratorios y de Circulación laboral en el ambito del Mercosur. Revista de Análise em Política Internacional, Brasília, v. 5, n. 1, p. 5-13, 2003. p. 10 . 
com as respectivas legislações internas. É reconhecido, também, o direito de acesso à educação em condições de igualdade com os cidadãos do País de recepção, independentemente da regularidade ou não da situação migratória dos genitores. Em outras palavras, o acesso ao sistema educacional público não pode ser negado ou limitado em razão da eventual clandestinidade dos pais. Em última análise, todavia, depreende-se que os direitos reservados aos filhos dos migrantes pelo Acordo do Mercosul não são mais do que a atuação de princípios de direitos humanos consagrados pelas convenções internacionais ${ }^{46}$. Nesse sentido, mesmo não sendo uma novidade em absoluto nem um privilégio para os sujeitos beneficiários, os Acordos confirmam a importância da proteção do indivíduos enquanto seres humanos e não apenas enquanto sujeito economicamente ativos, tutelando, em especial, os interesses dos menores.

Por fim, o art. 9, $\int 4^{\circ}$ refere-se às obrigações em matéria de previdência social, estabelecendo que os Estados-Partes examinarão a possibilidade de assinar acordos recíprocos neste âmbito. A ausência de conteúdo substancial desta disposição poderia ser totalmente superada com o simples reenvio ao Acordo Multilateral de Previdência Social de $1997^{47}$. Sem dúvida, perdeu-se a oportunidade de inserir as respectivas normas no novo Acordo ou de simplesmente fazer-lhe menção, mostrando, dessa forma, a coerência e o diálogo das normas emanadas no Mercosul. Além disso, o mesmo

46 Faz-se referência, por exemplo, à Declaração universal dos direitos do homem de 1948 e à Convenção internacional sobre os direitos da infância de 1989, ambas aprovadas pela Assembleia Geral das Nações Unidas.

47 MERCOSUL. Conselho do Mercado Comum. Decisão $n^{\circ}$ 19, de 15 de dezembro de 1997. Disponível em: <http://www.sice. oas.org/trade/mrcsrs/decisions/dec1997p.asp>. Acesso em: 15 dez. 2015. O Acordo reconhece os princípios materiais basilares do direito internacional em matéria de previdência social como a aplicação da lei do local da execução, a não discriminação, a conservação dos direitos adquiridos e a acumulação dos períodos de trabalho. Para aprofundamento ver: URIARTE, Ermida Oscar. La dimensión social del Mercosur. Montevideo: Fundación de Cultura Universitaria, 2004. Com relação à obrigação dos Estados-Partes de garantir a aplicação do princípio de não discriminação nessa matéria veja-se a jurisprudência argentina: Corte Suprema de Justicia de La Nación. Recurso de becho: A. 1023. XLIII, caso Alvarez, Maximiliano y otros c/ Cencosud S.A., de 7 de dezembro de 2010. ARGENTINA. Corte Suprema de Justicia de La Nación. Recurso de Hecho. Caso Alvarez, Maximiliano y otros c/ Cencosud S.A. Buenos Aires, de 7 de dezembro de 2010 Disponible en: <http://www.infojus.gob. ar/corte-suprema-justicia-nacion-federal-ciudad-autonoma-buenos-aires-alvarez-maximiliano-otros-cencosud-sa-accion-amparofa10000047-2010-12-07/123456789-740-0000-1ots-eupmocsollaf $>$. Visitado el: 15 oct. 2015. se conclui a partir da leitura atenta de outras disposições dos Acordos.

Analisando as demais disposições, pode-se igualmente observar que, apesar de o art. 2 fornecer a definição de alguns termos utilizados pelos Acordos (como "Estados-Parte", "Nacionais de uma Parte", "Imigrantes", "País de origem" e "País de recepção"), permanecem algumas imprecisões concernentes, por exemplo, à noção de "família" acolhida pelo Acordo, dado que os familiares dos cidadãos dos Estados Partes do Mercosul podem gozar dos mesmos direitos dos beneficiários primários, como previsto pelo art. $9, \S 2^{\circ}$, analisado precedentemente. Sob tal perspectiva, sobretudo em virtude da ambiguidade do termo "família", poderiam surgir problemas na medida em que não existe um órgão jurisdicional no âmbito mercosulino com competência para interpretar, na ocasião de uma eventual controvérsia, o conteúdo da condição de "familiar" de um nacional dos Estados Partes. Consequentemente, uma controvérsia deste gênero permaneceria submetida aos juízes nacionais que poderiam invocar a ordem pública nacional para limitar ou impedir o reagrupamento familiar garantido pelo Acordo, por exemplo, aos casais homoafetivos, considerando que não existe uniformidade da disciplina desta matéria nos ordenamentos jurídicos dos Estados Partes do Mercosullis.

\subsection{A criação de um espaço de livre residência no Mercosul}

De um modo geral, em relação ao conteúdo, alguns autores afirmam que esses Acordos introduziram um direito de residência, ou seja, uma "área de libre residencia"49, que é diferente de um pleno direito à livre circulação ${ }^{50}$

48 Em síntese, a Argentina e também o Uruguai e o Brasil (ambos a partir de 2013) reconhecem o direito ao matrimonio entre pessoas do mesmo sexo. O Equador e Colômbia permitem a união estável; por sua vez, o Paraguai, a Venezuela, a Bolívia, o Peru e o Chile não preveem nenhuma disciplina neste sentido. Dados disponíveis em: INTERNATIONAL LESBIAN, GAY, BISEXUAL, TRANS AND INTERESEX ASSOCIATION. Directorio LGBTI y organizaciones aliadas de ILGA. Available at: <http://ilga.org/ilga/en/ organisations/ILGA \%20LATIN\%20AMERICA $\% 20$ AND $\% 20$ CARIBBEAN>. Accessed on: 20 dec. 2014.

49 AGUIRRE, Orlando; MERA, Gabriela; NEJAMKIS, Lucila. Políticas migratorias e integración regional: la libre circulación y los desafíos a la ciudadanía. In: NOVICK, Susana (Dir.). Migraciones y Mercosur: una relación inconclusa. Buenos Aires: Catálogos, 2010. p. 50-72. p. 65.

50 VARELA, Justo Corti. Evolución de la libre circulación de personas en el Mercosur y su impacto en las políticas migratorias 
dos nacionais dos Estados-Partes. De fato, o art. 8, $\$ 1^{\circ}$ é claro ao afirmar que as pessoas que tenham obtido a residência "têm direito a entrar, sair, circular e permanecer livremente no território do país de recepção". Os Acordos, portanto, circunscrevem a aplicação e a eficácia do direito à livre circulação em um contexto estritamente "bilateral", ou seja, apenas entre o País de origem e o de recepção ${ }^{51}$. Nesses termos, efetivamente, eles não contemplam um real direito de livre circulação no território do Mercosul, mas sim um direito de residência, garantido diante da satisfação dos requisitos previstos pelos Acordos.

Com relação à residência, os Acordos preveem a concessão de dois tipos de permissão. A primeira é a "residência temporária" que, dependendo do caso, pode durar até dois anos, podendo ela ser convertida em "residência permanente", desde que o interessado efetue a solicitação dentro de noventa dias antes do vencimento da mesma. Se a pessoa não requerer a conversão e permanecer no país de recepção, o art. 6 determina que esta fica submetida à legislação migratória interna de cada Estado Parte.

Os requisitos para a concessão da residência temporária estão elencados no art. 4 dos Acordos, o qual prevê que o solicitante deve apresentar a seguinte documentação: passaporte válido, carteira de identidade ou certidão de nacionalidade; certidão de nascimento, prova do estado civil e certidão de naturalização quando for o caso; certidão negativa de antecedentes judiciais e/ou penais e/ou policiais dos últimos cinco anos; autodeclaração de ausência de antecedentes internacionais penais ou policiais; pagamento de uma taxa de serviço e um certificado médico que ateste a aptidão psicofísica do peticionante se assim exigido pela legislação interna do Estado Parte.

Atenção especial suscita a última das condições previstas no art. 4, letra "f $f$ ", segundo a qual o peticionante

nacionales. In: GOIZUETA VÉRTIZ, Juana; GÓMEZ FERNÁNDEZ, Itziar; PASCUAL GONZÁLEZ, María Isabel. La libre círculación de personas en los sistemas de integración económica: modelos comparados: Unión Europea, Mercosur y Comunidad Andina. Navarra: Thomson Reuters Aranzadi, 2012. p. 104-118. p. 151.

51 SALZMANN, Antonio Cardesa. El contenido jurídico de la libre circulación de personas en el Mercosur: balance y perspectivas. In: GOIZUETA VÉRTIZ, Juana; GÓMEZ FERNÁNDEZ, Itziar; PASCUAL GONZÁLEZ, María Isabel. La libre círculación de personas en los sistemas de integración económica: modelos comparados: Unión Europea, Mercosur y Comunidad Andina. Navarra: Thomson Reuters Aranzadi, 2012. p. 163-185. p. 166. deve apresentar um certificado médico acerca da sua "capacidade psicofísica" se assim exigido pela legislação interna do Estado-Parte de ingresso. De fato, "no resulta claro el objetivo perseguido al introducir una disposición de esta indole en un instrumento internacional que tiene por finalidad el facilitar la obtención de residencia." ${ }^{52}$. De qualquer forma, a necessidade da observância dos citados requisitos para obtenção da residência, além daquele relativo à titularidade da nacionalidade de um dos Estados Partes, é confirmada pela jurisprudência estatal ${ }^{53}$.

Com a finalidade de efetuar a conversão em residência permanente, o art. 5 exige que o interessado apresente os seguintes documentos: certidão de residência temporária; passaporte válido e vigente ou carteira de identidade; certidão negativa de antecedentes judiciais e/ou penais e/ou policiais, no país de recepção; comprovação dos meios de vida lícitos que permitam a subsistência do peticionante e de seus familiares; pagamento de uma taxa. Nota-se, portanto, que apenas para a concessão da residência permanente (após dois anos) é que as autoridades migratórias poderão exigir um comprovante de renda do peticionante. De modo diametralmente oposto, salienta-se que o cidadão da União Europeia que queira gozar do direito de residência em outro Estado-membro por um período superior a três meses deve comprovar, desde o início, a possibilidade de dispor, para si próprio e para a sua família, de recursos financeiros suficientes para a sua subsistência ${ }^{54}$.

Diante do exposto, resta evidente que os Acordos constituem respostas necessárias à determinadas situações de fato e demonstram também a capacidade do Mercosul de definir as suas políticas no âmbito político e social. Por outro lado, é inegável a presença de algumas questões críticas, tais como as circunstâncias em que

52 BIZZOZERO, Lincoln; PASTORINO, Ana. Los Acuerdos Migratorios y de Circulación laboral en el ambito del Mercosur. Revista de Análise em Política Internacional, Brasília, v. 5, n. 1, p. 5-13, 2003. p. 8.

53 BRASIL. Tribunal Regional Federal (1 Região). Embargos de Declaração em Agravo Regimental em Agravo de Instrumento EDAGA 25896 MG 2008.01.00.025896-0. Quinta Turma. Relator: Des. Federal João Batista Moreira. Brasília, 06 de maio de 2009. Disponível em: <http://trf-1.jusbrasil.com.br/jurisprudencia/4126664/embargos-de-declaracao-no-agravo-regimental-no-agedaga-25896-mg-20080100025896-0\#>. Acesso em: 15 dez. 2015. 54 Art. 7 da Diretiva 2004/38/CE. CONSELHO DA UNIÃO EUROPEIA. Directiva n. 38, de 29 de abril de 2004. Jornal Oficial da União Europeia, Bruxelas, 30 abr. 2004. Disponível em: <http:// eur-lex.europa.eu/LexUriServ/LexUriServ.do?uri=OJ:L:2004:158:0 077:0123:pt:PDF>. Acesso em: 15 dez. 2015. 
foram elaborados. Todo procedimento de preparação dos Acordos foi confiado, exclusivamente, aos Ministro de Interior. Tal escolha não se coaduna com aspectos técnicos ao considerar que os órgãos e as instituições com competência específica na matéria não foram convidados a participar dos trabalhos preparatórios. Além disso, mostra-se discutível a escolha de não adotar um instrumento orgânico em matéria de migração e circulação de pessoas, capaz de uniformizar e tornar coerente todo o sistema ${ }^{55}$.

Apesar disso, não se pode negar que se trate de instrumentos jurídicos que sinalizam o início de um percurso para a criação de um regime comum em matéria de migração e de residência no espaço mercosulino. Sob tal ponto de vista, os Acordos se apresentam como o passo mais concreto e relevante tomado até hoje em direção a uma efetiva zona de liberdade de circulação e residência das pessoas no espaço de integração regional do Mercosul.

De uma análise das sucessivas Decisões em tema de vistos adotadas pelo Conselho Mercado Comum nos últimos anos ${ }^{56}$, restam claras as dificuldades encontradas no processo de realização de uma completa liberdade de circulação de pessoas, dado que nenhuma delas foi efetivamente colocada em prática. Por estas e pelas razões já expostas, é que realmente parece estarmos

55 BIZZOZERO, Lincoln; PASTORINO, Ana. Los Acuerdos Migratorios y de Circulación laboral en el ambito del Mercosur. Revista de Análise em Política Internacional, Brasília, v. 5, n. 1, p. 5-13, 2003. p. 11.

56 MERCOSUL. Conselho do Mercado Comum. Decisão $n^{\circ}$ 16, de 15 de dezembro de 2003. Disponível em: < http://www.camara. gov.br/sileg/integras/428260.pdf>. Acesso em: 15 dez. 2015. sobre a criação do "Visto Mercosul"; MERCOSUL. Conselho do Mercado Comum. Decisão $n^{\circ}$ 10, de 20 de julho de 2006. Disponível em: $\quad<$ http://gd.mercosur.int/SAM\%5CGestDoc\%5Cpubweb. nsf/EE4C0C2AEBD99F1503257F1D00536141/\$File/DEC_0102006_PT_AcdoPrazo90DiasTuristasNacionais.pdf>. Acesso em: 15 dez. 2015. para a concessão de uma estadia de 90 dias aos turistas, cidadãos dos Estados-Partes do Mercosul e dos Estados Associados; MERCOSUL. Conselho do Mercado Comum. Decisão $n^{\circ}$ 21, de 20 de julho de 2006. Disponível em: <http://gd.mercosur. int/SAM\%5CGestDoc\%5Cpubweb.nsf/E3D6470E4AD8BD960 3257F1D00536502/\$File/DEC_021-2006_PT_FERR_AcdGratuidade $\% 20 \mathrm{de} \% 20$ Vistos.pdf $>$. Acesso em: 15 dez. 2015. sobre a gratuidade dos vistos para os estudantes e os docentes dos Estados Partes do Mercosul; MERCOSUL. Conselho do Mercado Comum. Decisão $n^{\circ}$ 53, de 16 de dezembro de 2010. Disponível em: <http:// gd.mercosur.int/SAM $\% 5$ CGestDoc $\% 5 C$ pubweb.nsf/4D7F0F7 FF4DF5FBD03257F1D0053868C/\$File/DEC_053-2010_PT_ FERR_Patente\%20MERCOSUL.pdf $>$. Acesso em: 15 dez. 2015. Salienta-se, todavia, que nenhuma destas Decisões são atualmente em vigor, em razão da falta de ratificação por alguns Estados Partes. mais próximos da consolidação de um espaço de livre residência. De qualquer modo, vale ressaltar que constituem evidentes obstáculos ao desenvolvimento do Mercosul a facilidade com que se adotam tais Decisões, a burocracia e a lentidão dos Parlamentos nacionais na sua incorporação, assim como o excesso de poder decisório nas mãos dos Estados.

Tais fatores freiam a plena realização da livre circulação dos cidadãos na região e impedem que esta se torne uma prática comum como já ocorre em outros fenômenos integracionistas ${ }^{57}$. Por tais razões, segundo alguns autores, a livre circulação nos processos de integração latino-americanos - em particular, no Mercosul - não alcançaram o nível necessário para poder configurar um estatuto de cidadão comunitário, meta que, ao contrário, foi alcançada no âmbito europeu ${ }^{58}$. Apesar disso, não restam dúvidas que o êxito do fenômeno de integração do Mercosul, mesmo sob o aspecto econômico, deva passar, inevitavelmente, pelo envolvimento dos cidadãos. Não se pode olvidar que, muito embora o Mercosul atualmente seja uma união aduaneira "imperfeita", o objetivo final do Tratado de Assunção é o aperfeiçoamento de um mercado comum. E, por sua vez, o mercado comum, enquanto fase da integração econômica, pressupõe a completa realização da livre circulação dos quatro fatores de produção: bens, serviços, capitais e pessoas.

Considerando as fontes normativas do Mercosul e, em particular, o direito derivado, observa-se que os Estados-Partes continuam a criar, gradualmente, substrato jurídico comum aparentemente capaz de abrir as portas para futuros desenvolvimentos no campo da livre circulação e residência das pessoas na região. O núcleo central seria constituído pelo reconhecimento do direito de residência e de acesso às atividades econômicas em condições paritárias com os cidadãos do Estado-membro de residência ${ }^{59}$.

57 CAMARGO, Sonia. O processo de integração regional: fronteiras abertas para os trabalhadores do Mercosul. Contexto Internacional, Rio de Janeiro, v. 32, n. 2, p. 489-517, jul./dez. 2010. p. 492.

58 GOIZUETA VÉRTIZ, Juana; GÓMEZ FERNÁNDEZ, Itziar; PASCUAL GONZÁLEZ, María Isabel. La libre círculación de personas en los sistemas de integración económica: modelos comparados: Unión Europea, Mercosur y Comunidad Andina. Navarra: Thomson Reuters Aranzadi, 2012. p. 21.

59 SALZMANN, Antonio Cardesa. El contenido jurídico de la libre circulación de personas en el Mercosur: balance y perspectivas. In: GOIZUETA VÉRTIZ, Juana; GÓMEZ FERNÁNDEZ, Itziar; PASCUAL GONZÁLEZ, María Isabel. La libre círculación de personas en los sistemas de integración económica: modelos comparados: Unión Eu- 
Insere-se em tal tendência, e ao mesmo tempo demonstra a atualidade desse tema, a recente proposta de modificação da lei sobre a imigração uruguaia ${ }^{60}$ no sentido de passar a prever a concessão da residência permanente a todos os cidadãos dos Estados Partes do Mercosul. O único requisito solicitado é a demonstração da titularidade da cidadania de um destes países. $\mathrm{Na}$ exposição de motivos, afirma-se que o projeto reflete a "vocación integracionista" do Uruguai e "se enmarca en una política migratoria basada en una perspectiva de derechos y en linea con los compromisos internacionales asumidos", dentre os quais o Acordo sobre Residência assinado em 2002 no âmbito do Mercosul, expressamente citado pelo projeto de lei. Enfim, o ato salienta ainda uma vez a intenção de reforçar e aprofundar o processo de integração por meio da implementação de uma política de livre circulação das pessoas pertencentes à região.

Apesar das dificuldades apontadas, não se pode negar um certo otimismo diante da adoção de importantes medidas destinadas, principalmente, à harmonização das normativas neste setor ${ }^{61}$. Observa-se, ademais, que a problemática migratória e o conceito de livre circulação e residência têm ganhado espaço no debate político. De fato, alguns autores sustentam que a noção restritiva de migração está gradualmente deixando espaço a uma ideia de cidadania comunitária ou regional ${ }^{62}$.

Desse modo, a entrada em vigor dos Acordos sobre Residência não são um ponto de chegada, mas antes uma porta aberta para as futuras iniciativas de integra-

ropea, Mercosur y Comunidad Andina. Navarra: Thomson Reuters Aranzadi, 2012. p. 163-185. p. 173-179.

60 Proposta n. 215074 do Ministro das Relações Exteriores do Uruguai sobre o Projeto de lei encaminhado ao Parlamento em 24 de janeiro de 2014 que propõe a modificação da lei uruguaia sobre imigração n. 18.250 de 6 de janeiro de 2008. Atualmente aguarda a provação pelos parlamentares.

61 GOIZUETA VÉRTIZ, Juana; GÓMEZ FERNÁNDEZ, Itziar; PASCUAL GONZÁLEZ, María Isabel. La libre círculación de personas en los sistemas de integración económica: modelos comparados: Unión Europea, Mercosur y Comunidad Andina. Navarra: Thomson Reuters Aranzadi, 2012. p. 17-19. De fato, os autores alegam que o distanciamento habitual entre a realidade e a norma, entre a facilidade com que se tomam decisões ambiciosas e os obstáculos para aplicar as normas, obriga a ter uma atitude muito prudente a fim de avaliar o presente e impedem de fazer previsões confiáveis para o futuro da livre circulação das pessoas no Mercosul e também na Comunidade Andina.

62 AGUIRRE, Orlando; MERA, Gabriela; NEJAMKIS, Lucila. Políticas migratorias e integración regional: la libre circulación y los desafíos a la ciudadanía. In: NOVICK, Susana (Dir.). Migraciones y Mercosur: una relación inconclusa. Buenos Aires: Catálogos: 2010. p. $50-72$. p. 68. ção da região ${ }^{63}$. Nesta mesma linha de desenvolvimento insere-se o Estatuto da Cidadania do Mercosul, um Plano de Ação adotado no final de 2010, que objetiva delinear uma nova perspectiva para o Mercosul "Social". Trata-se de um cronograma de ações que deve ser adotado a fim de estabelecer direitos mínimos, em diversos âmbitos, aos nacionais dos Estados Partes que, por sua vez, passariam a ser denominados "cidadãos do Mercosul". Ressalta-se que a análise de tal Estatuto será realizada em outro artigo destinado exclusivamente para tal fim.

\section{Considerações finais}

O direito à livre residência mostra-se como uma importante medida adotada no sentido de assegurar aos nacionais e aos familiares destes o direito de residir no território do Mercosul mediante a observância de procedimento simplificado e que procura facilitar a regularização migratória dos indivíduos que se encontrem em situação vulnerável. Trata-se de um relevante avanço tanto do ponto de vista do conteúdo substancial dos Acordos sobre Residência quanto da extensão dos sujeitos beneficiados. Conforme repetidamente salientado, não existe, ainda, uma efetiva liberdade de circulação de pessoas na região, uma vez que persistem os controles migratórios efetuados nas fronteiras estatais.

Paradoxalmente, porém, já é possível vislumbrar um direito à livre residência no âmbito do Mercosul, no qual os cidadãos dos dez Estados Partes possuem direitos e prerrogativas diferenciadas em comparação com os indivíduos provenientes de países terceiros. A facilidade para a concessão da residência provisória e permanente aos cidadãos mercosulinos que migram para outro Estado da região revela-se uma ferramenta jurídica fundamental à garantia dos direitos fundamentais destes indivíduos e, sem dúvida, sinaliza a consolidação de um primeiro acervo normativo em prol dos nacionais dos Estados-Partes do Mercosul, o qual toca mais de perto questões sensíveis do dia a dia da população.

63 SALZMANN, Antonio Cardesa. El contenido jurídico de la libre circulación de personas en el Mercosur: balance y perspectivas. In: GOIZUETA VÉRTIZ, Juana; GÓMEZ FERNÁNDEZ, Itziar; PASCUAL GONZÁLEZ, María Isabel. La libre círculación de personas en los sistemas de integración económica: modelos comparados: Unión Europea, Mercosur y Comunidad Andina. Navarra: Thomson Reuters Aranzadi, 2012. p. 163-185. p. 165. 
Unir os povos em favor de uma dimensão social que ultrapasse o aspecto puramente econômico apresenta-se como um dos escopos emergentes dos vários Países reunidos através do vínculo de um tratado internacional de integração. Os Acordos sobre Migração e Residência inserem-se, portanto, em quadro mais amplo de harmonização de políticas comuns voltadas ao estabelecimento de parâmetros mínimos de tratamento dos cidadãos dos Estados-Partes do Mercosul e de seus familiares, indicando relevante passo rumo à consolidação de um bloco regional mais consciente da sua verdadeira dimensão teleológica de integração.

\section{REFERÊNCIAS}

ABRAMOVICH,Victor. Direitos humanos no marco do processo de integração regional no Mercosul. Revista de la Secretaría del Tribunal Permanente de Revisión, Asuncion, v. 1, n. 2, p. 351-361, 2013.

ACCIOLY, Elizabeth. O Atual mecanismo de solução de controvérsias do Mercosul: o Protocolo de Olivos. Revista da Faculdade de Direito, Lisboa, v. 45, n. 13, p. 204226, Jan. 2004.

AGUIRRE, Orlando; MERA, Gabriela; NEJAMKIS, Lucila. Políticas migratorias e integración regional: la libre circulación y los desafíos a la ciudadanía. In: NOVICK, Susana (Dir.). Migraciones y Mercosur: una relación inconclusa. Buenos Aires: Catálogos, 2010. p. 50-72.

ALEXOVIČOVÁ, Iveta. The right of citizenship of the Union and their family members to move and reside freely within the territory of the Member States. In: SCHNEIDER, Hildegard. Migration, Integration and Citizenship: a challenge for Europe's future. Maastricht: Forum Maastricht, 2005. p. 73-105.

ARGENTINA. Corte Suprema de Justicia de La Nación. Recurso de Hecho. Caso Alvarez, Maximiliano y otros c/ Cencosud S.A. Buenos Aires, de 7 de dezembro de 2010. Disponible en: <http://www.infojus.gob.ar/ corte-suprema-justicia-nacion-federal-ciudad-autonoma-buenos-aires-alvarez-maximiliano-otros-cencosud-sa-accion-amparo-fa10000047-2010-12-07/123456789-740-0000-1ots-eupmocsollaf $>$. Visitado el: 15 oct. 2015.
ARIETI, Samuel A. Development: the Role of Mercosur as a Vehicle for Latin American Integration. Chicago Journal of International Law, Chigado, v. 6, n. 2, p. 761773, Jan. 2006.

BIZZOZERO, Lincoln; PASTORINO, Ana. Los Acuerdos Migratorios y de Circulación laboral en el ambito del Mercosur. Revista de Análise em Política Internacional, Brasília, v. 5, n. 1, p. 5-13, 2003.

BRASIL. Câmara dos Deputados. Constituições dos paises do Mercosul, 1996-2000: textos constitucionais Argentina, Bolívia, Brasil, Chile, Paraguai e Uruguai. Brasília: Câmara dos Deputados, 2001. Disponível em: < http:/ / www.planalto.gov.br/ccivil_03/Constituicao/Constituicao.htm>. Acesso em: 15 dez. 2015.

BRASIL. Decreto $n^{0}$ 1.901, de 09 de maio de 1996. Disponível em: <http://www.planalto.gov.br/ccivil_03/ decreto/D1901.htm>. Acesso em: 15 dez. 2015.

BRASIL. Decreto $n^{0}$ 6.975, de 7 de outubro de 2009. Disponível em: < http://www.planalto.gov.br/ccivil_03/_ Ato2007-2010/2009/Decreto/D6975.htm>. Acesso em: 15 dez. 2015.

BRASIL. Tribunal Regional Federal (1 Região). Embargos de Declaração em Agravo Regimental em Agravo de Instrumento EDAGA 25896 MG 2008.01.00.025896-0. Quinta Turma. Relator: Des. Federal João Batista Moreira. Brasília, 06 de maio de 2009. Disponível em: < http:/ / trf-1.jusbrasil.com.br/jurisprudencia/4126664/embargos-de-declaracao-no-agravo-regimental-no-ag-edaga25896-mg-20080100025896-0\#>. Acesso em: 15 dez. 2015.

CAMARGO, Sonia. O processo de integração regional: fronteiras abertas para os trabalhadores do Mercosul. Contexto Internacional, Rio de Janeiro, v. 32, n. 2, p. 489517, jul./dez. 2010.

CONDINANZI, Massimo; LANG, Alessandra; NASCIMBENE, Bruno. Cittadinanza dell'Unione e libera circolaz̧ione delle persone. 2. ed. Milano: Giuffrè, 2006.

CONSELHO DA UNIÃO EUROPEIA. Directiva n. 38, de 29 de abril de 2004. Jornal Oficial da União Europeia, Bruxelas, 30 abr. 2004. Disponível em: < http://eurlex.europa.eu/LexUriServ/LexUriServ.do?uri=OJ:L:20 04:158:0077:0123:pt:PDF>. Acesso em: 15 dez. 2015.

FLÔRES JUNIOR, Renato G. Símbolos e integrações regionais: uma breve introdução com vistas ao Mercosul. In: HOFMEISTER, Wilhelm. União Europeia e Mer- 
cosul: dois momentos especiais da integração regional. Rio de Janeiro: Fundação Konrad Adenauer no Brasil, abr. 2007. (Cadernos Adenauer, 1). p. 17-31.

FONTOURA, Jorge. A revisão institucional do Mercosul: Ouro Preto II. Revista de Estudos Europeus, Coimbra, v. 1, n. 1, p. 291-297, jan./jun. 2007.

GOIZUETA VÉRTIZ, Juana; GÓMEZ FERNÁNDEZ, Itziar; PASCUAL GONZÁLEZ, María Isabel. La libre círculación de personas en los sistemas de integración económica: modelos comparados: Unión Europea, Mercosur y Comunidad Andina. Navarra: Thomson Reuters Aranzadi, 2012.

KEGEL, Patrícia Luíza; AMAL, Mohamed. Instituições, direito e soberania: a efetividade jurídica nos processos de integração regional nos exemplos da União Europeia e do Mercosul. Revista Brasileira de Política Internacional, Brasília, v. 52, n. 1, p. 53-70, jan./jun. 2009.

MÁRMORA, Lelio; PÉREZ, Vichich Nora. Elementos de politicas migratorias para el Mercosur: Informe Nacional de Desarrollo Humano. Buenos Aires: Senado de la Nación Argentina, 1997.

MERCOSUL. Conselho do Mercado Comum. Acordo sobre residência para nacionais dos estados partes do Mercosul, Bolivia e Chile. Disponível em: <http://www.mercosur. int/innovaportal/file/5838/1/56-acuerdoresidenciamsur-boliviaychile.pdf>. Acesso em: 15 dez. 2015.

MERCOSUL. Conselho do Mercado Comum. Decisão $n^{\circ}$ 05, de 22 de abril de 1993. Disponível em: <http:// gd.mercosur.int/SAM/GestDoc/PubWeb.nsf/ OpenFile?OpenAgent\&base $=\mathrm{SAM} \backslash$ GestDoc $\backslash$ DocOfic0Arch.nsf\&id =832579C 700726F0D832577810052E 8A2\&archivo=RES_005_1993-PT_Comiss $\%$ F5es $\% 20$ SGTs $\% 20 \mathrm{~N} \%$ B0\%202,\%207,\%2010.doc>. Acesso em: 15 dez. 2015.

MERCOSUL. Conselho do Mercado Comum. Decisão $n^{\circ}$ 07, de 29 de junho de 2012. Disponível em: <http:// gd.mercosur.int/SAM\%5CGestDoc\%5Cpubweb. nsf/A2829874C636D36B03257F1D0049FB6C/\$Fi le/DEC_007-2012_PT_Complementacao\%20Acordo $\% 20$ Recife $\% 20$ Materia $\% 20$ Migratoria.pdf $>$. Acesso em: 15 dez. 2015.

MERCOSUL. Conselho do Mercado Comum. Decisão $n^{\circ}$ 10, de 20 de julho de 2006. Disponível em: <http:// gd.mercosur.int/SAM $\% 5$ CGestDoc $\% 5$ Cpubweb.nsf/ EE4C0C2AEBD99F1503257F1D00536141/\$File/
DEC_010-2006_PT_AcdoPrazo90Dias'TuristasNacionais.pdf>. Acesso em: 15 dez. 2015.

MERCOSUL. Conselho do Mercado Comum. Decisão $n^{\circ}$ 12, de 17 de dezembro de 1991. Disponível em: <http:/ / www.mercosur.int/msweb/portal\%20intermediario/ Normas/normas_web/Decisiones/PT/CMC_1991_ DEC_012_PT_TransitCiudada.PDF $>$. Acesso em: 15 dez. 2015.

MERCOSUL. Conselho do Mercado Comum. Decisão $n^{\circ}$ 13, de 5 de julho de 2002. Disponível em: <http:// www.mercosur.int/msweb/Normas/normas_web/ Decisiones/PT/Dec_013_002_Acordo\%20Antidumping\%200MC_Ata\%201_02.PDF>. Acesso em: 15 dez. 2015.

MERCOSUL. Conselho do Mercado Comum. Decisão $n^{\circ}$ 14, de 29 de junho de 2000. Disponível em: < http:/ / gd.mercosur.int/SAM\%5CGestDoc\%5Cpubweb. $\mathrm{nsf} / \mathrm{AA} 30 \mathrm{EDC}$ D 55 AF 15 D03257 F 1 D 0049 0651/\$File/DEC_014-2000_PT_Regul\%20 Reg $\% 20 \operatorname{Tr} \%$ C 6\%92n sito $\% 20 \mathrm{Vicina} 1 \% 20$ Fronteiri\%E2\%80\%A1o_Ata\%201_00.pdf>. Acesso em: 15 dez. 2015 .

MERCOSUL. Conselho do Mercado Comum. Decisão $n^{\circ}$ 14, de 5 de julho de 2002. Disponível em: <http:// www.sice.oas.org/trade/mrcsrs/decisions/dec1402p. asp>. Acesso em: 15 dez. 2015.

MERCOSUL. Conselho do Mercado Comum. Decisão $n^{\circ}$ 15, de 29 de junho de 2000. Disponível em: <http:/ / gd.mercosur.int/SAM $\% 5$ CGestDoc $\% 5$ Cpubweb.nsf/ C53D5201470B3A1503257F1D0049314D/\$File/ DEC_015-2000_PT_Reg\%20Tr\%C6\%92nsito\%20 Vicin $\% 20$ Front $\% 20$ MCS $\% 20 B o l \% 20$ Chile_Ata $\% 20$ 1_00.pdf>. Acesso em: 15 dez. 2015.

MERCOSUL. Conselho do Mercado Comum. Decisão $n^{\circ}$ 16, de 15 de dezembro de 2003. Disponível em: < http:/ / www.camara.gov.br/sileg/integras/428260.pdf $>$. Acesso em: 15 dez. 2015.

MERCOSUL. Conselho do Mercado Comum. Decisão $n^{\circ} 18$, de 07 de dezembro de 1999. Disponível em: < http:/ / www.mercosur.int/msweb/Normas/normas_web/ Decisiones/PT/Dec_018_099_Tr\%C3\%A2nsito $\% 20$ Vicinal $\% 20$ Fronteiri $\%$ C3\%A7o\%20MCS_Ata $\% 20$ 2_99.PDF>. Acesso em: 15 dez. 2015.

MERCOSUL. Conselho do Mercado Comum. Decisão $n^{\circ}$ 19, de 07 de dezembro de 1999. Disponível em: 
<http://www.mercosur.int/msweb/portal\%20intermediario/Normas/normas_web/Decisiones/PT/ Dec_019_099_Tr\%C3\%A2nsito $\% 20$ Vicinal $\% 20$ Front $\% 20 \mathrm{MCS} \% 20 \mathrm{Bol} \% 20 \mathrm{Chile} \_$Ata $\% 202 \_99 . P D F>$. Acesso em: 15 dez. 2015.

MERCOSUL. Conselho do Mercado Comum. Decisão $n^{\circ}$ 19, de 15 de dezembro de 1997. Disponível em: <http:// www.sice.oas.org/trade/mrcsrs/decisions/dec1997p. asp>. Acesso em: 15 dez. 2015.

MERCOSUL. Conselho do Mercado Comum. Decisão $n^{\circ}$ 20, de 29 de junho 2012. Disponível em: <http:// www.cartillaciudadania.mercosur.int/uploads / DEC_020-2012_PT_Adesao $\% 20 \mathrm{Col} \% 20$ Acordo $\% 20$ Resid\%C3\%AAncia.pdf>. Acesso em: 15 dez. 2015.

MERCOSUL. Conselho do Mercado Comum. Decisão $n^{\circ} 21$, de 20 de julbo de 2006. Disponível em: <http:// gd.mercosur.int/SAM\%5CGestDoc\%5Cpubweb. nsf/E3D6470E4AD8BD9603257F1D00536502/\$F ile/DEC_021-2006_PT_FERR_AcdGratuidade $\% 20$ de\%20Vistos.pdf>. Acesso em: 15 dez. 2015.

MERCOSUL. Conselho do Mercado Comum. Decisão $n^{\circ} 21$, de 28 de junho 2011. Disponível em: <http:// gd.mercosur.int/SAM\%5CGestDoc\%5Cpubweb.ns f/852556C938D1A7D703257F1D004C7D16/\$Fi le/DEC_021-2011_PT_Ades\%C3\%86o\%20Equador $\% 20$ Residen $\% 20$ Nacionais.pdf $>$. Acesso em: 15 dez. 2015.

MERCOSUL. Conselho do Mercado Comum. Decisão n 4, de 28 de junho 2011. Disponível em: <http:// gd.mercosur.int/SAM\%5CGestDoc\%5Cpubweb.nsf/ E1B5E57FB6D43E1F03257F1D004C3DCB/\$File/ DEC_004-2011_PT_Ades\%C3\%86o\%20Peru \%20 Acordo\%20Residen\%20Nacionais.pdf $>$. Acesso em: 15 dez. 2015.

MERCOSUl. Conselho do Mercado Comum. Decisão $n^{\circ} 48$, de 14 de dezembro de 2000. Disponível em: <http:// gd.mercosur.int/SAM\%5CGestDoc\%5Cpubweb. nsf/ 6420A63D340570CA03257F1D004AF9BF /\$File/DEC_048-2000_PT_FERR_Acordo\%20 Isen $\% \mathrm{E} 2 \% 80 \% \mathrm{~A} 1 \% \mathrm{C} 3 \% 860 \% 20 \mathrm{de} \% 20 \mathrm{Vistos}$ Ata\%202_00.pdf>. Acesso em: 15 dez. 2015.

MERCOSUL. Conselho do Mercado Comum. Decisão $n^{\circ} 48$, de 6 de dezembro de 2002. Disponível em: <http:/ / www.sice.oas.org/trade/mrcsrs/decisions/dec2802p. asp>. Acesso em: 15 dez. 2015.

MERCOSUL. Conselho do Mercado Comum. Decisão $n^{\circ}$ 53, de 16 de dezembro de 2010. Disponível em: <http:/ / gd.mercosur.int/SAM\%5CGestDoc\%5Cpubweb.nsf /4D7F0F7FF4DF5FBD03257F1D0053868C/\$File/ DEC_053-2010_PT_FERR_Patente\%20MERCOSUL.pdf $>$. Acesso em: 15 dez. 2015.

MERCOSUL. Conselho do Mercado Comum. Decisão $n^{\circ}$ 9, de 5 de outubro de 1995. Disponível em: <http:// gd.mercosur.int/SAM/GestDoc/PubWeb.nsf/ OpenFile? OpenAgent\&base $=\mathrm{SAM} \backslash$ GestDoc $\backslash$ DocOfic0Arch.nsf\&id =832579C700726F0D 83257751 006F6800\&archivo=DEC_008-1995_PT_Prot\%20 Harm $\% 20$ Norm $\% 20$ Intelect $\% 20$ Proc $\% 20$ Denom $\% 20$ Origem_Ata\%201_95.doc>. Acesso em: 15 dez. 2015.

MERCOSUL. Declaração Sociolaboral do Mercosul. Disponível em: <http://www.dhnet.org.br/direitos/ deconu/a_pdf/dec_sociolaboral_mercosul.pdf $>$. Acesso em: 15 dez. 2015.

MERCOSUL. Grupo Mercado Comum. Resolução n 38 , de 30 de junho de 1993. Disponível em: <http://www2. uol.com.br/actasoft/actamercosul/novo/res_44_94. htm>. Acesso em: 15 dez. 2015.

MERCOSUL. Grupo Mercado Comum. Resolução n 40 , de 8 de dezembro de 1998. Disponível em: <http://www. mercosur.int/innovaportal/v/387/4/innova.front/busqueda-de-normativa >. Acesso em: 15 dez. 2015.

MERCOSUL. Grupo Mercado Comum. Resolução n ${ }^{\circ} 4$, de 03 de agosto de 1994. Disponível em: <http://www. mercosur.int/msweb/Normas/normas_web/Resoluciones/PT/GMC_RES_1993-038_PT_Grupo_AD_ HOC_Documento_\%C3\%9Anico_Viagem.PDF $>$. Acesso em: 15 dez. 2015.

MERCOSUL. Grupo Mercado Comum. Resolução $n^{\circ}$ 59, de 21 de junbo de 1996. Disponível em: <http:// gd.mercosur.int/SAM/GestDoc/PubWeb.nsf/ OpenFile?OpenAgent\&base $=\mathrm{SAM} \backslash \mathrm{GestDoc} \backslash$ DocOfic0Arch.nsf\&id=832579C700726F0D 832577590057 CCDC\&archivo=RES_059-1996_PT_Cria\%E7\%E3 oCentrosConsulDocuPersonales.doc $>$. Acesso em: 15 dez. 2015 .

MODOLO, Vanina. La movilidad territorial en el Mercado Común Europeo y Mercosureño. In: NOVICK, Susana (Dir.). Migraciones y Mercosur. una relación incon- 
clusa. Buenos Aires: Catálogos: 2010. p. 29-50.

MONNET, Jean. Memórias: a construção da Unidade Européia. Brasilia: EdUnB, 1986.

NASCIMBENE, Bruno. Le droit de la nationalité et le droit des organisations d'intégration régionales. Vers de nowveaux statuts de résidents? Leiden: Brill, 2014. (Recueil des Cours de l'Académie de La Haye, 367).

NASCIMBENE, Bruno; ROSSI DAL POZZO, Francesco. Diritti di cittadinanza e libertà di circolazione nell'Unione europea. Padova: CEDAM, 2012.

NOVICK, Susana (Dir.). Introdución, migraciones, políticas e integración regional: avances y desafíos. In:_. Migraciones y Mercosur: una relación inconclusa. Buenos Aires: Catálogos, 2010. p. 9-28.

NUNES, Maria do Rosário. Após morte de Brayan, ministra vai debater situação de bolivianos no país. Folha de São Paulo. São Paulo, 1 jul. 2013. Disponível em: < http:/ / www1.folha.uol.com.br/cotidiano/2013/07/1304235apos-morte-de-brayan-ministra-vai-debater-situacaode-bolivianos-no-pais.shtml>. Acesso em: 10 out. 2013

PAGANO, Emmanuele. Ricongiungimento familiare, cittadinanza e residenza: dal caso Zambrano al caso Dereci. Diritto comunitario e degli scambi internazionali, v. 51, n. 3, p. 467-475, 2012.

PATRIOTA, Antônio. Para Patriota, o objetivo é estabelecer uma efetiva cidadania mercosulina. Brasília, MRE, 2011. Entrevista ao Boletim em Questão, em 26 de março de 2011. Disponível em: <http://www.itamaraty.gov. $\mathrm{br} /$ index.php?option $=$ com_content $\& v i e w=$ article $\&$ $\mathrm{id}=4588$ :para-patriota-o-objetivo-e-estabelecer-umaefetiva-cidadania-mercosulina-em-questao-secom-pr26-3-2011\&catid $=195 \&$ Itemid $=455 \&$ lang $=p t-B R>$. Acesso em: 15 ago. 2014.

PORTUGAL. Comissão de Assuntos Europeus da Assembleia da República. Tratado de Lisboa: versão consolidada. Disponível em: < https://www.parlamento.pt/europa/Documents/Tratado_Versao_Consolidada.pdf $>$. Acesso em: 15 dez. 2015.

QUEIROLO, Ilaria; SCHIANO DI PEPE, Lorenzo. Lezioni di diritto dell'Unione europea e relazioni familiari. 2. ed. Torino: Giappichelli, 2010.

QUINTÃO, Aylê-Salassié Filgueiras. Americanidade: Mercosul, passaporte para a integração. Brasília: Congresso Federal, 2010.
REMITTANCE Senders and Receivers: tracking the transnational channels. Washington: Pew Hispanic Center, Nov. de 2003. Available at: < http://www.pewhispanic.org/files/reports/23.pdf $>$. Accessed on: 15 oct. 2015.

REVELEZ, Lincoln Bizzozero. La educación superior en el Sector Educativo del Mercosur: impactos en la migración intrarregional y perspectivas en el proceso de integración. In: LAS MIGRACIONES humanas en el Mercosur: una mirada desde los derechos humanos, compilación normativa. Montevideo: Observatório de Políticas Públicas de Derechos Humanos en el Mercosur, 2009. p. 35-46.

RODRIGUES, José Noronha. Cidadania e Direitos Fundamentais. Revista Direitos Fundamentais e Democracia, Curitiba, v. 8, n. 8, p. 181-212, jul./dez. 2010.

ROLLI, Claudia. Governo paulista pretende qualificar estrangeiros. Folha de São Paulo. São Paulo, 11 ago. 2013. Disponível em: <http://www1.folha.uol.com. br/mercado/2013/08/1324746-governo-paulista-pretende-qualificar-estrangeiros.shtml $>$. Acesso em: 10 out. 2013.

SALZMANN, Antonio Cardesa. El contenido jurídico de la libre circulación de personas en el Mercosur: balance y perspectivas. In: GOIZUETA VÉRTIZ, Juana; GÓMEZ FERNÁNDEZ, Itziar; PASCUAL GONZÁLEZ, María Isabel. La libre círculación de personas en los sistemas de integración económica: modelos comparados: Unión Europea, Mercosur y Comunidad Andina. Navarra: Thomson Reuters Aranzadi, 2012. p. 163-185.

SANT'ANA, Marcílio Ribeiro de. A livre circulação de trabalhadores no Mercosul. In: Brasil, migracōes internacionais e identidade. 2000. Disponível em: <http://www. comciencia.br/reportagens/migracoes/migr08.htm>. Acesso em: 23 nov. 2014.

TRATADO que institui a Comunidade Económica Europeia ou Tratado CEE - texto original (versão não consolidada). Disponível em: <http://eur-lex.europa. eu/legal-content/PT/TXT/HTML/?uri=URISERV:x y0023\&from=PT $>$. Acesso em: 15 dez. 2015.

URIARTE, Ermida Oscar. La dimensión social del Mercosur. Montevideo: Fundación de Cultura Universitaria, 2004.

VALADÃO, Marcos Aurelio Pereira. Legal and institutional dimensions of reform: Washington Consen- 
sus and Latin America integration: Mercosur and the road to regional inconsistencies - to where are we going exactly?. Law and Business Review of the Americas, Dallas, v. 15, n. 1, p. 207-220, 2009.

VARELA, Justo Corti. Evolución de la libre circulación de personas en el Mercosur y su impacto en las políticas migratorias nacionales. In: GOIZUETA VÉRTIZ, Juana; GÓMEZ FERNÁNDEZ, Itziar; PASCUAL GONZÁLEZ, María Isabel. La libre círculación de personas en los sistemas de integración económica: modelos comparados: Unión Europea, Mercosur y Comunidad Andina. Navarra: Thomson Reuters Aranzadi, 2012. p. 104-118.

VÁZQUEZ: hay que llenar de ciudadanía al Mercosur palabras del Presidente de la República, Tabaré Vázquez, durante la Cumbre de Jefes de Estados del Mercosur en Asunción. Disponível em: <http://archivo.presidencia. gub.uy/_web/noticias/2005/06/2005062007.htm>. Acesso em: 20 dez. 2014.

WHITE, Robin Ca. Free movement, equal treatment, and Citizenship of the Union. International and Comparative Law Quarterly, Cambridge, v. 54, n. 4, p. 885-905, Oct. 2005.

WOLKMER, Antônio Carlos. Integração e direito comunitário latino-americano. In: PIMENTEL, Luiz Otávio (Org.). Mercosul no cenário internacional: direito e sociedade. Curitiba: Juruá, 1998. v. 1. p. 43-54. 


\section{A funcionalização como tendência evolutiva do Direito Internacional e sua contribuição ao regime legal do banco de dados de identificação de perfil genético no Brasil*}

\author{
The funcionalization as an evolutive \\ tendency of the Internacional Law and its \\ contribution to the brazilian genetic profile \\ database statute
}

Antonio Henrique Graciano Suxberger**

\section{Resumo}

O presente artigo analisa as tendências evolutivas de funcionalização e humanização do Direito Internacional Público. Menciona a relevância da compreensão dada pelas instâncias e organizações do Direito Internacional para a adequada compreensão de temas da legislação pátria que se referem a garantias cuja positivação interna dá-se de modo idêntico ou assemelhado ao estabelecido em Convenções internacionais. Como exemplo da relevância da funcionalização do Direito Internacional, aborda-se o tratamento legislativo dado pelo Brasil à coleta de material biológico para identificação do perfil genético, a fim de demonstrar que a compreensão das inovações legislativas observou, estritamente, às orientações emanadas, dentre outras fontes, da Corte Europeia de Direitos Humanos. O estudo realiza revisão bibliográfica e documental da doutrina pátria sobre o tema e se vale de julgados das Cortes internacionais para concluir pela compatibilidade da Lei 12.654, de 2012, com a Constituição brasileira e, também, com as Convenções de Direitos Humanos sobre o tema. A importância do trabalho reside no fato de que, de modo geral, a doutrina brasileira tem sustentado a inconstitucionalidade da previsão legislativa de coleta de material para perfil genético, desconsiderando, assim, o importante papel do Direito Internacional para a construção de soluções interpretativas aos problemas do direito interno.

Palavras-chave: Tendências do Direito Internacional. Banco de dados de perfil genético. Intimidade. Garantia de não autoincriminação. Presunção de Inocência.

\section{Abstract}

This paper analyses the functionalization and humanization as evolutive tendencies of International Law. It argues the relevance of the interpretation provided by organisms of International Law to the strict and correct comprehension of subjects presented in the internal Law on rights and privileges stated similar or even identical to Internacional Human Rights Conventions.
** Artigo convidado. Professor do Programa de Mestrado e Doutorado do Centro Universitário de Brasília — UniCEUB. Doutor em Direitos Humanos e Desenvolvimento pela Universidade Pablo de Olavide (Sevilha, Espanha, 2009) e Mestre em Direito, Estado e Constituição pela Universidade de Brasília (2005). Email: suxberger@gmail.com
Recebido em 31/10/2015

Aprovado em 02/11/2015. 
As an example of the International Law's functionalization, the paper assays the genetic profile database and its legal treatment in Brazil, in order to demonstrate that the brazilian Act (Federal Statute 12.654/2012) is strictly according to the standards established by the European Court of Human Rights. From a literature review and document analysis about the subject, this paper also considers cases from the European Court of Human Rights and Inter-American Court of Human Rights to conclude that Federal Statute 12.654 is according to the brazilian Constitution and the International Conventions of Human Rights. The importance of this essay lies on the consideration that the majority of brazilian authors have been challenged the constitutionality of the genetic profile database statute, disregarding the International Law's contribution to interpretative solutions to internal legal issues.

Keywords: Internacional Law tendencies. Genetic profile database. Intimicy. Privilege against self-incrimination. Presumption of innocence.

\section{SUMÁRIO}

1. Considerações iniciais. 2. O banco de dados de perfil genético e a crítica generalizada à coleta do material biológico no Brasil. 3. A juridicidade da coleta compulsória de material genético para fins criminais. 4. Dos contornos fixado ao tema pela Lei 12.654. 5. A compatibilidade da coleta do material genético do condenado com as garantias do direito ao silêncio e da presunção de inocência. Referências.

\section{INTRODUÇÃO'}

O estudo do Direito Internacional tem apresentado tendências usualmente indicadas como evolutivas. ${ }^{2}$ Essas tendências são assim compreendidas a partir da

1 O autor agradece as contribuições iniciais de Rejane Zenir Jungbluth Teixeira Suxberger, que resultaram num melhor aclaramento das ideias sustentadas neste artigo, e as sempre valorosas sugestões de Bruno Amaral Machado quando da conclusão do artigo.

2 MIRANDA, Jorge. A incorporação ao direito interno de instrumentos jurídicos de Direito Internacional Humanitário e Direito Internacional dos Direitos Humanos. Revista CEJ, v. 4, n. 11, p. 23-26, maio/ago. 2000. Disponível em: <http://www.jf.jus.br/ojs2/index. $\mathrm{php} / \mathrm{revcej} /$ article/view/344/546>. Acesso em: 2 out. 2015. universalização do Direito das Gentes, quando se deixa de observar um Direito Internacional unicamente euro-americano para alcançar uma pretensão efetivamente universalizante. Seguidamente, mereceu destaque a tendência de regionalização do Direito Internacional, compreendida como a criação de espaços regionais nos quais as comunidades políticas e de Estados encontram formas de solidariedade e de cooperação qualificadas. A institucionalização guarda referência à consolidação de organismos internacionais e, por conseguinte, a maior presença do Direito Internacional por intermédio desses organismos. A funcionalização refere-se ao fato de que o Direito Internacional cada vez mais extrapola o plano estritamente internacional para prestar-se igualmente a tratar das relações jurídicas internas, isto é, "assume tarefas de regulamentação e de solução de problemas, como a saúde, o trabalho, o ambiente etc.". 3 A bumanização do Direito Internacional faz-se presente por intermédio da Declaração Universal de 1948, da Convenção Europeia de Direitos Humanos e da Convenção Americana sobre Direitos Humanos, respectivamente de 1950 e de 1969, e da criação (e consolidação) da Justiça Penal Internacional.

Além dessas cinco tendências evolutivas, Valério Mazzuolit acrescenta a objetivação, a codificação e a jurisdicionalização. A objetivaşão do Direito Internacional é compreendida como a superação do dogma voluntarista presente nos arranjos havidos entre Estados. A codificação do Direito Internacional mostra-se pungente na positivação de diversos textos pela Comissão de Direito Internacional. Por fim, a jurisdicionalização do Direito Internacional é consectário da criação de diversos Tribunais, de variadas naturezas, cuja submissão dá-se por cláusulas facultativas com forte tendência a se tornarem mandamentos de observância obrigatória pelos Estados.

Dentre essas tendências, interessa revisitar, de modo particular, os fenômenos da funcionalização e da bumanização como tendências atuais do Direito Internacional. Com efeitos, as Cartas Constitucionais hoje vigentes, indiscutivelmente, guardaram inspiração recíproca que,

3 MIRANDA, Jorge. A incorporação ao direito interno de instrumentos jurídicos de Direito Internacional Humanitário e Direito Internacional dos Direitos Humanos. Revista CEJ, v. 4, n. 11, p. 23-26, maio/ago. 2000. Disponível em: <http://www.jf.jus.br/ojs2/index. $\mathrm{php} / \mathrm{revcej} /$ article/view/344/546>. Acesso em: 2 out. 2015.

4 MAZZUOLI, Valério de Oliveira. Curso de direito internacional público. 7. ed. São Paulo: Revista dos Tribunais, 2013. p. 70. 
muitas vezes, se valeram de experiências comparadas e situadas no mesmo contexto histórico e social para a consagração de garantias e direitos.

Para além das próprias Cartas Constitucionais, é inegável a influência igualmente exercida pelos Tratados e Convenções de Direitos Humanos na elaboração do rol de direitos e garantias fundamentais consagrados nas Constituições. A Constituição brasileira é exemplo disso, ao espelhar o estado do debate sobre diversas garantias no direito comparado e positivá-las em atenção a essas discussões e proposições já insculpidas em normas internacionais. De modo particular, as discussões havidas em meados da década de 1980 no Brasil não descuraram do que trouxeram a Declaração Universal dos Direitos Humanos de 1948, a Convenção Europeia de Direitos Humanos de 1950, a Convenção Americana sobre Direitos Humanos de 1969, o Pacto Internacional sobre os Direitos Econômicos, Sociais e Culturais de 1966, entre outros.

A título ilustrativo, dois exemplos se prestam a essa constatação. O primeiro deles refere-se ao estabelecimento pela Constituição brasileira ${ }^{5}$ da dignidade humana como fundamento da própria República (artigo 1. ${ }^{\circ}$, inciso III). Se, na ordem constitucional anterior Constituição de $1967^{6}$ —, essa relevante expressão se referia à ordem econômica e, particularmente, à valorização do trabalho (artigo 160, inciso II), a Carta de 1988 estabelece-a como fundamento da República e da própria afirmação do Estado Democrático de Direito, de modo a bem espelhar a influência do debate de sua positivação na Declaração Universal de 1948, isto é, como fundamento reconhecido e inerente à própria qualidade humana. O segundo exemplo refere-se ao destaque atribuído pela Constituição brasileira aos direitos sociais como direitos fundamentais (Capítulo II do Título II da Constituição). Essa afirmação topográfica e inegavelmente valorativa buscou superar ou obviar todo o debate sobre o caráter de fundamentalidade desses direitos já reconhecidos no âmbito internacional. Se essa opção de positivação representou maior efetividade ou concreção desses direitos e garantias, isso é tema que

5 BRASIL. Constituição (1988). Constituição da República Federativa do Brasil. Disponível em: <http://www.planalto.gov.br/ccivil_03/ constituicao/ConstituicaoCompilado.htm>. Acesso em: 2 out. 2015.

6 BRASIL. Constituição (1967). Constituição da República Federativa do Brasil. Disponível em: <http://www.planalto.gov.br/ccivil_03/ Constituicao/Constituicao67.htm>. Acesso em: 2 out. 2015. escapa ao estudo proposto neste artigo. Por ora, basta afirmar a influência recíproca inegável desses diplomas normativos internacionais na consolidação dos direitos e garantias fundamentais na ordem jurídica interna.

Com base nessa constatação, vê-se que os temas que guardam identidade de positivação, isto é, que guardam preceitos positivados de modo assemelhado ou mesmo idêntico nas Convenções internacionais e Constituições nacionais reclamam igual consideração recíproca nas construções atinentes à definição de seu sentido e alcance. Justamente por isso, a funcionalização do Direito Internacional busca servir de ponte à construção de soluções e à oferta de ferramentas interpretativas para a consolidação de interpretações jurídicas que, devidamente contextualizadas, não se afastem por completo da consideração última de que também a ordem constitucional interna, notadamente em relação aos direitos e garantias, hão de guardar um mínimo de consonância com sua leitura na ordem internacional.

Desse modo, o tópico das relações entre o Direito Internacional Público e o Direito interno estatal merece revisitação, a fim de que, para além do debate a respeito do status das normas internacionais ou mesmo do diálogo entre normas internas e internacionais, igualmente se preste à construção de soluções interpretativas que considerem a experiência comparada como fonte ou gênese na leitura do sentido e do alcance de direitos e garantias constitucionalmente assegurados.

Esse esforço atende à percepção de que os limites entre direito nacional e direito internacional encontram-se mais tênues, por força do adensamento das tradicionais fontes do direito internacional. A internacionalização do direito, entendida como processo de operacionalização comum do fenômeno jurídico por diferentes atores, em diferentes territórios, é indicada por Marcelo Dias Varella como o modo pelo qual o direito internacional é hoje construído a partir de macro e microprocessos de expansão de suas fontes e sujeitos tradicionais. ${ }^{7}$

Defende-se, pois, uma interpretação constitucionalmente adequada de preceitos da ordem jurídica interna que, se resultantes da reprodução ou de aproximação de enunciados igualmente presentes na ordem internacional, observe o sentido e o alcance estabelecidos pelas instâncias formalizadas do Direito das Gentes sobre

7 VARELLA, Marcelo Dias. Internacionalizą̧ão do direito: direito internacional, globalização e complexidade. Brasília: UniCEUB, 2103. p. 14-23. 
esses mesmos preceitos. Afinal, se a característica de universalização dos direitos e garantias passa por sua humanização, não se mostra adequada a maior ou menor garantia de implementação a depender dos influxos dessa ou daquela ordem interna que positiva, em seus textos normativos, preceitos de forma assemelhada ou idêntica a que fazem as Convenções e Tratados firmados pelos Estados. Nisso reside a relevância da funcionalização do Direito Internacional, a permitir o socorro interpretativo a respeito do sentido e do alcance de normas e garantias internas ainda que cotejadas com diplomas igualmente internos.

A ordem jurídica brasileira trouxe exemplo recente da necessidade dessa funcionalização do Direito Internacional justamente por meio do aprimoramento da identificação por meio do perfil genético em casos de investigação criminal e composição de banco de dados. Como se verá a seguir, a consideração do tema pela Corte Europeia de Direitos Humanos assegura instrumental adequado a melhor interpretação dos institutos positivados na ordem interna e consentaneidade com as demandas mais atuais a respeito do uso da tecnologia quando em aparente confronto com o direito à intimidade.

Trata-se da Lei 12.654, de 28 de maio de 2012, que altera a Lei de Identificação Criminal e a Lei de Execução Penal, "para prever a coleta de perfil genético como forma de identificação criminal, e dá outras providências". 8 Ao prever a possibilidade de submissão da pessoa para coleta de material biológico e documentação do perfil genético, seja para fins de identificação criminal, seja para inserção em banco de dados de perfil genético, diversas vozes, na doutrina nacional, indicaram a inconstitucionalidade do diploma legal por contrariedade a preceitos da Constituição brasileira que encontram previsões assemelhadas, quando não idênticas, a enunciados constantes de Convenções e Tratados Internacionais. O Direito Internacional pode, pois, prestar instrumental interpretativo para a correta compreensão das inovações trazidas pela Lei 12.654? Responder a essa pergunta é o objetivo do presente artigo.

Para tanto, buscar-se-á o estado do tema - a cole-

8 BRASIL. Lei $n^{0}$ 12.654, de 28 de maio de 2012. Altera as Leis nos 12.037, de 1 o de outubro de 2009, e 7.210, de 11 de julho de 1984 - Lei de Execução Penal, para prever a coleta de perfil genético como forma de identificação criminal, e dá outras providências. Disponível em: <http://www.planalto.gov.br/ccivil_03/_Ato20112014/2012/Lei/L12654.htm>. Acesso em: 2 out. 2015. ta de material biológico para fins de documentação do perfil genético para fins de identificação criminal e sua possível inserção em banco de dados genéticos — nas Cortes Europeia e Americana de Direitos Humanos. Na sequência, com base na leitura dos institutos trazidos pela nova legislação, buscar-se-á indicar sua compatibilidade ou não com os preceitos constitucionais - e por sinédoque - e das Convenções e Tratados de Direitos Humanos, em particular a dignidade da pessoa, a garantia da não autoincriminação e a presunção de inocência. A metodologia utilizada foi a de análise documental das decisões dos mais relevantes Tribunais internacionais e do percurso por eles trilhado no enfrentamento do tema, além de revisão bibliográfica da doutrina específica sobre o tema. A revisão da totalidade dos casos que versaram sobre a identificação criminal por meio do perfil genético demandou análise dos casos já submetidos à Corte Europeia de Direitos Humanos e à Corte Interamericana de Direitos Humanos. O tema insere-se no debate mais amplo que coloca, de um lado, a demanda por uma intervenção penal eficaz, isto é, orientada por um consequencialismo, e de outro lado a promoção das garantias penais construídas a partir do Direito Penal liberal.

Conquanto a Lei tenha sido editada em 2012, somente no ano de 2015 o tema ganhou relevância prática, com a paulatina instalação dos bancos de dados de perfil genético a partir do material coletado nos estabelecimentos prisionais. Por isso, a atualidade da discussão, especialmente porque os Tribunais brasileiros estão sendo iterativamente instados a dizer da conformidade das disposições legais com a Constituição.

\section{O banco de dAdos de PERFIL GenÉtico e a CRÍTICA GENERALIZADA À COLETA DO MATERIAL BIOLÓGICO NO BRASIL}

A Lei 12.654 teve tramitação célere no Poder Legislativo. Originou-se de projeto apresentado no Senado Federal, autuado sob o número 93, de autoria do parlamentar Ciro Nogueira, no ano de 2011 (PLS 93/2011). Sem maiores considerações sobre a compatibilidade das inovações trazidas com o ordenamento pátrio, o PLS 93/2011 justifica-se por meio da proliferação dos bancos de dados de perfil genético nos países desenvolvidos e, por conseguinte, a necessidade de o Brasil 
igualmente incorporar essa inovação tecnológica útil ao aprimoramento da persecução penal. ${ }^{9}$

A notícia do primeiro banco de dados de perfil genético é da Islândia, ainda na década de 1990. O banco de dados lá instalado recebeu recursos públicos e dados do setor sanitário, como coleções de tecidos heterogêneos acumulados em hospitais, universidades e pesquisas de organizações comerciais. A finalidade inicial da organização desses dados era a criação de dados terapêuticos. Por isso, o estabelecimento de parcerias com grandes laboratórios. Com essa mesma concepção, vários países, igualmente, iniciaram ações para formação de bancos de dados genético, a exemplo do Reino Unido, Estônia, Japão, Suécia, Singapura, Áustria. ${ }^{10}$

A extensão do uso dos dados para fins de investigação criminal deu-se na sequência da ampliação do uso dos meios tecnológicos na persecução penal. Os Estados Unidos, por exemplo, dispõem de banco de dados com mais de dez milhões de perfis genéticos de indivíduos condenados. Vinte e seis dos cinquenta estados, além da coleta de amostras de condenados, também coletam material para levantamento do DNA de detidos ou suspeitos. A maior parte dos países integrantes do Conselho da Europa já admitem a coleta compulsória de material biológico para inclusão em banco de dados de perfil genético. Os bancos nacionais encontram-se hoje previstos na Áustria, Bélgica, República Checa, Dinamarca, Estônia, Finlândia, França, Alemanha, Grécia, Hungria, Irlanda, Itália, Letônia, Luxemburgo, Países Baixos, Noruega, Polônia, Espanha, Suécia e Suíça. Como se verá a seguir, a coleta e o armazenamento de perfis de DNA de pessoas condenadas são permitidos, como regra geral, por períodos limitados de tempo após a condenação.

A recepção da Lei 12.654 pela doutrina no Brasil, em geral, não foi positiva. A título ilustrativo, veja-se a abordagem de Diogo Machado de Carvalho, quando afirma que o banco de dados genéticos tem finalidade duvidosa e carrega nítido objetivo determinista. Carvalho asse-

9 BRASIL. Senado Federal. Projeto de Lei ño 93, de 2011. Estabelece a identificação genética para os condenados por crime praticado com violência contra pessoa ou considerado hediondo. Autor da proposição: Senador Ciro Nogueira. Disponível em: <http://http:// www25.senado.leg.br/web/atividade/materias/-/materia/99463>. Acesso em: 15 fev. 2016.

10 GUEDES, Gabriel Pinto; FELIX, Yuri. A identificação genética na lei no 12.654/2012 e os princípios de direito processual penal no estado democrático de direito. Revista de Estudos Criminais, Porto Alegre, v. 12, n. 53, p. 157-179, abr./jun. 2014. p. 160. vera que a intervenção corporal obrigatória, despida de um concreto fim processual obrigatório, "não encontra consonância com um juízo de proporcionalidade apto a amparar a obrigatoriedade de tamanha intromissão". ${ }^{11}$

Também Alberto Ribeiro Mariano Júnior, em artigo específico sobre o tema, entende que a coleta de material para identificação do perfil genético não se mostra compatível com os preceitos estabelecidos na Constituição brasileira de 1988, notadamente os postulados da presunção de inocência e da proibição de autoincriminação. ${ }^{12}$ No mesmo sentido, é o pensamento de Wagner Marteleto Filho, para quem as restrições advindas das garantias contra a autoincriminação e a cooperação inconsciente desautorizam as previsões da Lei $12.654 .{ }^{13}$

Especificamente sobre a coleta de material biológico de condenados definitivamente para exame e alimentação de banco de dados de perfis genéticos, André Nicolliti visualiza contrariedade aos incisos III, XLVII e XLIX do artigo $5 .^{\circ}$ da Constituição brasileira. Nicolliti sustenta que a coleta do material implica, assim, hipótese de tortura, aproxima-se da proibição de pena de morte e contraria a garantia da integridade física e moral, por entender que tais garantias projetam "dimensão que se traduz na vedação a qualquer pena corporal, ou seja, traça uma esfera de proteção do corpo, esfera esta incompatível com a submissão coercitiva a uma intervenção corporal". ${ }^{14}$

Mohamad Ale Hasan Mahmoud e Maria Thereza Rocha de Assis visualizam, em relação às inovações trazidas pela Lei 12.654, reflexos jurídico-penais da ideia de uma modernidade líquida, tal como mencionada por Baumann, e concluem que as previsões legais contrariam, frontalmente, a dignidade humana tal como consagrada pela Constituição brasileira. ${ }^{15}$

11 CARVALHO, Diogo Machado de. As intervenções corporais no processo penal: entre o desprezo, o gozo e a limitação de direitos fundamentais. Rio de Janeiro: Lumen Juris, 2014. passim.

12 MARIANO JÚNIOR, Alberto Ribeiro. A (des)regularização da obtenção do material genético no processo penal brasileiro. Revista Magister de Direito Penal e Processual Penal, Porto Alegre, v. 11, n. 63, p. 78-92, dez./jan. 2014.

13 MATELETO FILHO, Wagner. O direito à não autoincriminação no processo penal contemporâneo. Belo Horizonte: Del Rey, 2012.

14 NICOLLITI, André. Banco de dados de perfis genéticos (DNA): as inconstitucionalidades da Lei 12.654/2012. Boletim do IBCCRIM, São Paulo. n. 245, p. 15-16, abr. 2013. p. 16.

15 MAHMOUD, Mohamad Ale Hasan; MOURA, Maria Thereza Rocha de Assis. A Lei 12.654/2012 e os direitos humanos. Revista Brasileira de Ciências Criminais, v. 20, n. 98, p. 339-358, set./out. 2012. 
De um modo geral, a Lei 12.654 foi recebida com muitas críticas pela doutrina, que, de modo majoritário, entende que a previsão do banco de dados de perfil genético mostra-se incompatível com preceitos da Constituição brasileira. Os preceitos indicados pelos autores que sustentam a inconstitucionalidade da Lei, contudo, guardam semelhança, ou mesmo identidade, com preceitos insculpidos tanto na Convenção Europeia de Direitos Humanos quanto na Convenção Americana de Direitos Humanos. Os Estados compromissados com essas Cartas, ao contrário do que sustentado pelos mencionados autores à luz da Constituição brasileira, não só positivam a possibilidade de coleta do material biológico para perfil genético, como igualmente trazem a previsão do respectivo banco de dados. Afinal, os preceitos invocados pelos críticos da Lei 12.654 guardam distinção substancial na positivação brasileira ou a intelecção dada a eles afastou-se da necessária funcionalização e da humanização do Direito Internacional Público que devem influenciar o modo de leitura dos preceitos garantidores estabelecidos na ordem interna? ${ }^{16}$

\section{A JURIDICIDADE DA COLETA COMPULSÓRIA DE MATERIAL GENÉTICO PARA FINS CRIMINAIS}

A coleta de material biológico para documentação do perfil genético, como forma de identificação criminal, conquanto só tenha sido positivada no direito pátrio no ano de 2012, como visto, já vem sendo tratada amiúde no direito comparado há, aproximadamente, uma década. Reino Unido, Estados Unidos da América, Alemanha, Itália e outros países centrais, com base nos incrementos permitidos pelos avanços tecnológicos a influenciar sobremaneira a investigação criminal e a formação de provas para a persecução penal, depararam-se com a temática da coleta obrigatória de perfil genético ainda na década de 2000 .

Interessa neste artigo, especialmente, a discussão instaurada sobre os limites da coleta e da mantença de dados de perfil genético na Corte Europeia de Direitos Humanos (CEDH).

16 BRASIL. Lei $n^{\circ}$ 12.654, de 28 de maio de 2012. Altera as Leis nos 12.037, de 1 o de outubro de 2009, e 7.210, de 11 de julho de 1984 - Lei de Execução Penal, para prever a coleta de perfil genético como forma de identificação criminal, e dá outras providências. Disponível em: <http://www.planalto.gov.br/ccivil_03/_Ato20112014/2012/Lei/L12654.htm>. Acesso em: 2 out. 2015.
Em 4 de dezembro de 2008, a CEDH julgou o caso que ficou conhecido como $S$. and Marper versus United Kingdom. ${ }^{17}$ Tratava-se de caso que mencionava duas situações ocorridas no Reino Unido (Applicattions n. 30562/04 e 30566/04), mais especificamente na Grã-Bretanha e na Irlanda do Norte.

$\mathrm{O}$ primeiro, referente à criança identificada como S., cuidava de pessoa nascida no ano de 1989 que, no ano de 2001 (quando, então, contava 11 anos de idade), foi detida pela prática de fato equiparado a roubo. Suas impressões papiloscópicas (digitais) e material genético foram colhidos. S. foi absolvido (acquitted) em 14/6/2001. Já Michael Marper, nascido em 1963, foi preso em 13/3/2001 e acusado de assediar sua parceira (o fato guardaria tipicidade assemelhada ao constrangimento ilegal acrescido de violência real no direito brasileiro). Igualmente, suas impressões papiloscópicas e material genético foram colhidos. A persecução penal de Marper não foi adiante, uma vez que ele e sua parceira se reconciliaram, fato que ensejou, por força das disposições do ordenamento britânico, a "descontinuidade" da persecução penal.

S. e Marper formularam, expressamente, pedido para descarte (destruição) das impressões papiloscópicas e dos materiais genéticos colhidos, mas o pleito foi recusado pela Polícia. Essa recusa foi, então, judicializada por S. e Marper. O caso chegou até a Casa dos Lordes (House of Lords), instância máxima do Judiciário britânico em 22 de julho de 2004.

Quando o tema foi analisado pela Corte Europeia de Direitos Humanos, a Grande Sala do Tribunal Europeu fixou que a mantença "ilimitada e indiscriminada" de dados genéticos (DNA) equivale a uma ingerência desproporcional na vida privada daquelas pessoas a que pertencem os dados tomados. A Corte destacou o fato de que o material colhido foi mantido "indefinidamente", independentemente da natureza ou da gravidade do delito imputado ao investigado/acusado.

Convém destacar que o parâmetro de controle para a apreciação da CEDH foi justamente o artigo $8 .^{\circ}$ da Convenção Europeia de Direitos Humanos ${ }^{18}$, cujo teor

17 CORTE EUROPEIA DE DIREITOS HUMANOS. Caso $S$. and Marper vs. Reino Unido (n. 30562/04 e n. 30566/04). Sentença de 4 de dezembro de 2008. Disponível em: <https://www.coe.int/t/ dghl/standardsetting/dataprotection/Judgments/S. $\% 20$ AND $\% 20$ MARPER $\% 20 \mathrm{v} . \% 20$ THE \%20UNITED \%20KINGDOM $\% 20$ EN. pdf $>$. Acesso em: 2 out. 2015.

18 CONSELHO DA EUROPA. Convenção para a Proteç̧ão dos Di- 
abaixo se transcreve ${ }^{19}$ :

Direito ao respeito pela vida privada e familiar

1. Qualquer pessoa tem direito ao respeito da sua vida privada e familiar, do seu domicílio e da sua correspondência.

2. Não pode haver ingerência da autoridade pública no exercício desse direito senão quando essa ingerência estiver prevista na lei e constituir uma providência que, numa sociedade democrática, seja necessária para a segurança nacional, para a segurança pública, para o bem-estar econômico do país, a defesa da ordem e a prevenção das infracções penais, a proteção da saúde ou da moral, ou a proteção dos direitos e das liberdades de terceiros.

A decisão da Corte Europeia destacou a importância da utilização de meios tecnológicos avançados, como o confronto de perfil genético, para o enfrentamento do crime. No entanto, delimitou a apreciação do caso quanto à justificativa para a mantença dos dados de perfil genético. Convém transcrever alguns excertos da decisão:

106. However, while it recognises the importance of such information in the detection of crime, the Court must delimit the scope of its examination. The question is not whether the retention of fingerprints, cellular samples and DNA profiles may in general be regarded as justified under the Convention. The only issue to be considered by the Court is whether the retention of the fingerprint and DNA data of the applicants, as persons who had been suspected, but not convicted, of certain criminal offences, was justified under Article 8 \ 2 of the Convention. ${ }^{20}$

reitos do Homem e das Liberdades Fundamentais (Convenção Europeia de Direitos Humanos). Roma, 4 nov. 1950. Disponível em: <http://www. echr.coe.int/Documents/Convention_POR.pdf>. Acesso em: 2 out. 2015.

19 CORTE EUROPEIA DE DIREITOS HUMANOS. Caso $S$. and Marper vs. Reino Unido (n. 30562/04 e n. 30566/04). Sentença de 4 de dezembro de 2008. Disponível em: <https://www.coe.int/t/ $\mathrm{dghl} /$ standardsetting/dataprotection/Judgments/S.\%20AND $\% 20$ MARPER $\% 20 \mathrm{v} . \% 20$ THE $\% 20$ UNITED $\% 20$ KINGDOM $\% 20 \mathrm{EN}$. pdf>. Acesso em: 2 out. 2015.

20 Tradução: "entretanto, embora se reconheça a importância dessa informação [uso do DNA para prova criminal] para a configuração do crime, a Corte precisa delimitar o escopo desse exame. A questão não é se a mantença de digitais, amostras de células ou perfil de DNA podem, em geral, ser tida como justificada nos termos da Convenção. A única questão a ser considerada pelo Tribunal é se a retenção das impressões digitais e do perfil de DNA dos recorrentes, como pessoas que foram consideradas suspeitas, mas não condenadas, por certos crimes, justiça-se à luz do Artigo 8. $.^{\circ}, \int 2 .^{\circ}, \mathrm{da}$ Convenção". CORTE EUROPEIA DE DIREITOS HUMANOS. Caso S. and Marper vs. Reino Unido (n. 30562/04 e n. 30566/04). Sentença de 4 de dezembro de 2008. Disponível em: <https://www. coe.int/t/dghl/standardsetting/dataprotection/Judgments/S. $\% 20$ AND $\% 20$ MARPER $\% 20 \mathrm{v} . \% 20$ THE $\% 20$ UNITED $\% 20$ KINGDOM\%20EN.pdf>. Acesso em: 2 out. 2015. $[\ldots] 108$. As regards, more particularly, cellular samples, most of the Contracting States allow these materials to be taken in criminal proceedings only from individuals suspected of having committed offences of a certain minimum gravity. In the great majority of the Contracting States with functioning DNA databases, samples and DNA profiles derived from those samples are required to be removed or destroyed either immediately or within a certain limited time after acquittal or discharge. A restricted number of exceptions to this principle are allowed by some Contracting States (see paragraphs 47-48 above). ${ }^{21}$

$[\ldots] 125$. In conclusion, the Court finds that the blanket and indiscriminate nature of the powers of retention of the fingerprints, cellular samples and DNA profiles of persons suspected but not convicted of offences, as applied in the case of the present applicants, fails to strike a fair balance between the competing public and private interests and that the respondent State has overstepped any acceptable margin of appreciation in this regard. Accordingly, the retention at issue constitutes a disproportionate interference with the applicants' right to respect for private life and cannot be regarded as necessary in a democratic society. This conclusion obviates the need for the Court to consider the applicants' criticism regarding the adequacy of certain particular safeguards, such as too broad an access to the personal data concerned and insufficient protection against the misuse or abuse of such data.

126. Accordingly, there has been a violation of Article 8 of the Convention in the present case. ${ }^{22}$

21 Tradução: "relativamente, de modo mais particular, às amostras de células, a maioria dos Estados-partes permitem que esses materiais sejam colhidos no curso de persecução penal apenas de indivíduos suspeitos de terem cometido infrações com certa gravidade mínima. $\mathrm{Na}$ grande maioria dos Estados-partes com bancos de dados de perfil genético em funcionamento, amostras de perfil genético devem ser retiradas ou destruídas, imediatamente, ou em determinado lapso temporal limitado após a absolvição ou extinção do processo [sem condenação]. Um número limitado de exceções a esse princípio são permitidos por alguns Estados-partes (ver parágrafos 47-48 acima)". CORTE EUROPEIA DE DIREITOS HUMANOS. Caso $S$. and Marper vs. Reino Unido (n. 30562/04 e n. 30566/04). Sentença de 4 de dezembro de 2008. Disponível em: <https://www.coe.int/t/ $\mathrm{dghl} /$ standardsetting/dataprotection/Judgments/S.\%20AND $\% 20$ MARPER \%20v.\%20THE\%20UNITED \%20KINGDOM $\% 20$ EN. pdf>. Acesso em: 2 out. 2015 .

22 Tradução: "125. Em conclusão, o Tribunal considera que a abrangente e indiscriminada natureza dos poderes de retenção das impressões digitais, amostras de células e perfis de DNA de pessoas suspeitas, mas não condenadas por crimes, como ocorre no presente caso dos recorrentes, peca por violar um justo equilíbrio entre o interesse público e o interesse particular e que o Estado demandado ultrapassou qualquer margem aceitável de consideração a esse respeito. Consequentemente, a retenção em causa constitui uma ingerência desproporcional ao direito dos recorrentes de respeito à vida privada e não pode ser tida como necessária numa sociedade democrática. Essa conclusão afasta a necessidade da Corte apreciar 
O controle de convencionalidade atentou-se para a legislação britânica (Criminal Justice and Police Act 2001) em face da Convenção Europeia de Direitos Humanos. O caso S. e Marper versus Reino Unido é o mais importante precedente sobre a normatização da coleta e mantença de banco de dados de perfil genético no mundo ocidental.

A Corte Interamericana de Direitos Humanos $(\mathrm{CIDH})$, instalada nos termos do Pacto de São José da Costa Rica, internalizado no Brasil por meio do Decreto $678 / 1992^{23}$, ainda não teve oportunidade de enfrentar o tema de modo tão minudente como fez o Conselho da Europa. É certo que a CIDH já decidiu temas atinentes ao uso da prova que verse sobre perfil genético. Por exemplo, no caso Fornerón e bija versus Argentina, julgado em 27 de abril 2012, a CIDH tratou do uso de material genético para fins de prova de paternidade ${ }^{24}$. A CIDH, igualmente, já tratou do uso de material genético como prova especialmente nos casos que versam sobre desaparecimentos forçados e outros crimes próprios de regimes políticos de exceção (por exemplo, Caso de las Hermanas Serrano Cruz versus El Salvador ${ }^{25}$, Caso Rochac Hernández y otros versus El Salvador ${ }^{20}$ ). Contudo, especificamente sobre a coleta de material genético para alimentação e mantença de banco de dados genéticos, com finalidade de subsidiar apurações criminais, ainda

as críticas dos recorrentes dirigidas à adequação de certas garantias específicas, como o acesso demasiado amplo aos dados pessoais e a proteção insuficiente contra o mau uso ou abuso dessas informações. 126. Assim, houve violação ao Artigo $8 .^{\circ}$ da Convenção no presente caso". CORTE EUROPEIA DE DIREITOS HUMANOS. Caso $S$. and Marper vs. Reino Unido (n. 30562/04 e n. 30566/04). Sentença de 4 de dezembro de 2008. Disponível em: <https://www.coe.int/t/ $\mathrm{dghl} /$ standardsetting/dataprotection/Judgments/S.\%20AND $\% 20$ MARPER \%20v.\%20THE\%20UNITED \%20KINGDOM $\% 20$ EN. pdf $>$. Acesso em: 2 out. 2015.

23 BRASIL. Decreto $n^{\circ}$ 678, de 6 de novembro de 1992. Promulga a Convenção Americana sobre Direitos Humanos (Pacto de São José da Costa Rica), de 22 de novembro de 1969. Disponível em: <http://www.planalto.gov.br/ccivil_03/decreto/D0678.htm>. Acesso em: 2 out. 2015.

24 CORTE INTERAMERICANA DE DIREITOS HUMANOS. Caso Fornerón e bija vs. Argentina. Sentença de 27 de abril de 2012. Disponível em: < http://corteidh.or.cr/docs/casos/articulos/seriec_242_esp.pdf $>$. Acesso em: 2 out. 2015.

25 CORTE INTERAMERICANA DE DIREITOS HUMANOS. Caso de las Hermanas Serrano Cruz vs. El Salvador. Sentença de 1 de março de 2005. Disponível em: < http://www.corteidh.or.cr/docs/ casos/articulos/seriec_120_esp.pdf>. Acesso em: 2 out. 2015.

26 CORTE INTERAMERICANA DE DIREITOS HUMANOS. Caso Rochac Hernández y otros vs. El Salvador. Sentença de 14 de outubro de 2014. Disponível em: <http://www.corteidh.or.cr/docs/casos/articulos/seriec_285_esp.pdf>. Acesso em: 2 out. 2015. não há manifestação expressa e conclusiva da CIDH.

Por isso, a relevância da decisão proferida pela Corte Europeia de Direitos Humanos, até mesmo como orientação para a consideração do tema na legislação pátria, conquanto não se submeta o Brasil à Convenção Europeia de Direitos Humanos. A funcionalização do Direito Internacional não apenas autoriza, mas, igualmente, reclama que a compreensão do tema guarde solução aproximada entre os diplomas internacionais que versam sobre idênticas garantias.

\section{Dos contornos fixados ao tema pela LeI 12.654}

No Brasil, o tema da identificação criminal, que conforma a garantia constitucional que proíbe a identificação criminal da pessoa civilmente identificada (artigo 5. ${ }^{\circ}$, inciso LVIII), exige tratamento por lei ordinária e tal tarefa é hoje desincumbida pela Lei 12.037 , de $1 .^{\circ}$ de outubro de $2009 .{ }^{27}$

A Lei 12.654/201228 prevê a "coleta do perfil genético" como modo ou instrumento de identificação criminal. Nesse ponto o diploma legal incorre numa impropriedade técnica. O próprio artigo 2. ${ }^{\circ}$ da Lei de 2012 menciona que "os dados relacionados à coleta do perfil genético deverão ser armazenados em banco de dados de perfis genéticos”. A coleta, entretanto, só pode ser do material biológico. É a partir desse material biológico que se extraem as informações que identificam o perfil genético da pessoa. Desse modo, perfil genético não se "coleta"; ele é obtido, justamente, por meio de exame genético cujas informações são armazenadas em banco de dados. ${ }^{29}$

27 BRASIL. Lei no 12.037, de 01 de outubro de 2009. Dispõe sobre a identificação criminal do civilmente identificado, regulamentando o art. $5^{\circ}$, inciso LVIII, da Constituição Federal. Disponível em: <http://www.planalto.gov.br/ccivil_03/_Ato2007-2010/2009/ Lei/L12037.htm>. Acesso em: 2 out. 2015.

28 BRASIL. Lei $n^{0} 12.654$, de 28 de maio de 2012. Altera as Leis nos 12.037 , de 1 o de outubro de 2009 , e 7.210 , de 11 de julho de 1984 - Lei de Execução Penal, para prever a coleta de perfil genético como forma de identificação criminal, e dá outras providências. Disponível em: < http://www.planalto.gov.br/ccivil_03/_Ato20112014/2012/Lei/L12654.htm>. Acesso em: 2 out. 2015.

29 SILVA, Emílio de Oliveira e. Identificação genética para fins criminais: análise dos aspectos processuais do banco de dados de perfil genético implementado pela Lei n. 12.654/2012. Belo Horizonte: Del Rey, 2014. 
Como já destacado, a Lei 12.654 promoveu modificações tanto na Lei de Identificação Criminal (12.037) quanto na Lei de Execução Penal (Lei 7.210, de 1984). Uma vez que o assunto não recebeu regulamentação num único diploma legal, sua compreensão reclama a consideração de todo o regime legal do banco de dados de perfil genético, a fim de se evitar conclusões açodadas sobre a eventual incompatibilidade com o programa constitucional brasileiro e com as disposições consagradas nas Convenções de Direitos Humanos que versam sobre o tema.

O enfrentamento do tema, na ordem a seguir, conquanto reclame a referência concomitante às diversas leis envolvidas, mostra-se como alternativa mais clara ao tema. São três os pontos que versam sobre a coleta do material genético e a mantença dos dados de perfil genético: (a) a coleta do material para fins de identificação criminal; (b) a coleta de material daqueles condenados definitivamente; (c) o regime de acesso ao banco de dados.

\subsection{Coleta de material genético para identifica- ção criminal}

A primeira delas refere-se à possibilidade de realização da coleta de material genético da pessoa submetida à identificação criminal por meio de decisão judicial. Confira-se a redação do art. 5. ${ }^{\circ}$ da Lei 12.037 , com destaque à redação estabelecida ao parágrafo único do dispositivo justamente por força da Lei 12.037:

\footnotetext{
Art. $5^{\circ} \mathrm{A}$ identificação criminal incluirá o processo datiloscópico e o fotográfico, que serão juntados aos autos da comunicação da prisão em flagrante, ou do inquérito policial ou outra forma de investigação.

Parágrafo único. $\mathrm{Na}$ hipótese do inciso IV do art. 3. ${ }^{\circ}$, a identificação criminal poderá incluir a coleta de material biológico para a obtenção do perfil genético. $[\mathrm{NR}]^{30}$
}

O dispositivo legal define a abrangência da identificação criminal no Brasil, para afirmar que ela abrange a coleta das impressões papiloscópicas e, também, a identificação fotográfica (novidade da Lei 12.037 em relação ao regime legal anterior da identificação criminal). Somente à luz do banco de dados de perfil genético a

30 BRASIL. Lei no 12.037, de 01 de outubro de 2009. Dispõe sobre a identificação criminal do civilmente identificado, regulamentando o art. $5^{\circ}$, inciso LVIII, da Constituição Federal. Disponível em: <http://www.planalto.gov.br/ccivil_03/_Ato2007-2010/2009/ Lei/L12037.htm>. Acesso em: 2 out. 2015. previsão inserta no artigo 3. ${ }^{\circ}$, inciso IV, da Lei 12.037, passa a guardar sentido normativo. Diz o referido inciso que a identificação criminal da pessoa civilmente identificada dar-se-á quando "a identificação criminal for essencial às investigações policiais, segundo despacho da autoridade judiciária competente, que decidirá de ofício ou mediante representação da autoridade policial, do Ministério Público ou da defesa". É dizer: trata-se de identificação criminal determinada judicialmente. A ordem, por óbvio, sobrepõe-se a eventual recusa da pessoa submetida à identificação, até porque a ausência de identificação criminal da pessoa autoriza, no ordenamento pátrio, a providência extrema da prisão processual, nos termos do parágrafo único do artigo 313 do Código de Processo Penal.

Ora, só faz sentido exigir a manifestação do Poder Judiciário, para fins de determinação de identidade, naqueles casos em que a coleta do material para essa identificação flexibilize, toque, vulnere ou atinja temas ou valores hábeis a receber a chamada cláusula de reserva de jurisdição. Não é demais afirmar o dever de evitar a banalização da manifestação jurisdicional, que, na investigação criminal, há de ser reservada aos casos de proteção de direitos e garantias fundamentais do investigado ou suspeito. Vale frisar que, nesse aspecto, a Constituição brasileira, por mandamento expresso, guarda previsão até mais rígida que muitos dos países submetidos à Convenção Europeia de Direitos Humanos ou à Convenção Americana de Direitos Humanos, pois diversos países autorizam a determinação de custódia independentemente de comando judicial. Exemplo de tal peculiaridade encontra-se no ordenamento norte-americano, que, nesse ponto, equilibra-se com a necessidade de pronta apresentação do detido à autoridade judicante.

É possível, decerto, que a simples coleta de impressões papiloscópicas ou mesmo a fotografia do investigado ou suspeito derive de decisão judicial. A previsão do inciso IV do artigo $3 .^{\circ}$ da Lei 12.037, contudo, parece efetivamente vocacionada aos casos em que haja necessidade de decisão judicial para sobreposição da vontade ou de submissão do particular à atuação do Estado orientada, no caso específico, pela presença de interesse público que precede a recusa do particular para sua identificação.

De modo mais simples, naqueles casos em que a atuação estatal invasiva mostre-se essencial (e, por isso, submetida a cláusula de subsidiariedade), reclama-se a 
decisão judicial. Não é por outra razão que a hipótese de realização da identificação criminal, por força do inciso IV do artigo $3 .^{\circ}$, mostra-se aberta: a decisão judicial que aprecia a efetiva imprescindibilidade da identificação à investigação criminal é medida dirigida justamente à tutela dos direitos do investigado ou suspeito e, por isso mesmo, substancia garantia desse investigado ou suspeito.

\subsection{Coleta de material genético de pessoas con- denadas definitivamente}

A Lei 12.654 estabeleceu a obrigatoriedade de coleta de material genético de condenados definitivamente por crimes dolosos praticados com grave violência a pessoa ou por crimes hediondos ou a eles equiparados. Confira-se a redação do artigo 9. ${ }^{\circ}$-A da Lei de Execução Penal, com sua redação determinada pela Lei 12.654, cuja inconstitucionalidade muitas vezes é indicada na doutrina pátria:

Art. 9. ${ }^{\circ}$-A. Os condenados por crime praticado, dolosamente, com violência de natureza grave contra pessoa, ou por qualquer dos crimes previstos no art. 1 o da Lei no 8.072, de 25 de julho de 1990, serão submetidos, obrigatoriamente, à identificação do perfil genético, mediante extração de DNA ácido desoxirribonucleico, por técnica adequada e indolor.

$\int 1 .^{\circ}$ A identificação do perfil genético será armazenada em banco de dados sigiloso, conforme regulamento a ser expedido pelo Poder Executivo.

$\int 2 .^{\circ}$ A autoridade policial, federal ou estadual, poderá requerer ao juiz competente, no caso de inquérito instaurado, o acesso ao banco de dados de identificação de perfil genético. ${ }^{31}$

A leitura do dispositivo legal autoriza algumas assertivas sobre o seu sentido e alcance.

A primeira delas refere-se ao momento de coleta do material genético. Uma vez que, após o julgamento do HC 84.078 pelo Supremo Tribunal Federal no ano de $2009^{32}$, não mais se admite o início da execução da pena

31 BRASIL. Lei $n^{\circ}$ 12.654, de 28 de maio de 2012. Altera as Leis nos 12.037, de 1 o de outubro de 2009, e 7.210, de 11 de julho de 1984 - Lei de Execução Penal, para prever a coleta de perfil genético como forma de identificação criminal, e dá outras providências. Disponível em: <http://www.planalto.gov.br/ccivil_03/_Ato20112014/2012/Lei/L12654.htm>. Acesso em: 2 out. 2015.

32 BRASIL. Supremo Tribunal Federal. Habeas Corpus. HC 84.078-7/ MG. Tribunal Pleno. Paciente: Omar Coelho Vitor. Coator: Superior Tribunal de Justiça. Relator: Min. Eros Grau. Brasília, 5 de fevereiro de 2009. Disponível em: <http://www.stf. antes do trânsito em julgado da sentença penal condenatória, nota-se que a coleta do material genético dá-se, apenas, após o trânsito em julgado da sentença condenatória que reconheceu a prática de crime doloso com violência de natureza grave contra pessoa ou de crime hediondo ou a esse equiparado.

Convém repetir com ênfase: a coleta só se dá após o trânsito em julgado da sentença que reconheceu a pessoa submetida ao fornecimento de material genético como incursa em crime hediondo, a esse equiparado, ou em crime doloso praticado com violência grave contra pessoa. Não se trata, pois, de qualquer crime, mas, efetivamente, dos crimes mais graves previstos na legislação interna. Não se trata, ainda, de pessoa suspeita, indiciada ou acusada, mas de pessoa definitivamente condenada como incursa nesses crimes gravíssimos (os mais graves, repita-se, da legislação pátria). Não se trata de coleta no curso de processo pendente de decisão definitiva, mas de coleta realizada por ocasião da classificação do sentenciado por ocasião do início do cumprimento de sua reprimenda. Veja-se que o artigo 9. ${ }^{\circ}$-A da Lei de Execução Penal insere-se no Título II (Do Condenado e do Internado), Capítulo I (Da Classificação), o que só ocorre, repita-se, após a definitividade da sentença condenatória.

Veja-se que, atualmente, a técnica de extração de material para elaboração do perfil genético dá-se com um bastonete, com algodão, que recolhe saliva do sentenciado. A saliva colhida, de modo indolor e minimamente invasivo, basta à realização da identificação e delineamento do perfil genético. $\mathrm{O}$ avanço tecnológico mostra-se, enfim, menos oneroso ao sentenciado que a usual coleta das impressões papiloscópicas.

\subsection{Acesso ao banco de dados de perfil genético}

Se o regime legal de identificação criminal por coleta de material para obtenção do perfil genético da pessoa civilmente identificada reclama sempre decisão judicial e, mais, se somente a pessoa definitivamente condenada pelos crimes mais graves previstos na legislação pátria fornecerá material genético para "alimentar" banco de dados de perfil genético, pergunta-se: qual o regime legal de acesso a esse banco de dados de perfil genético?

jus.br/arquivo/cms/noticiaNoticiaStf/anexo/ementa84078.pdf>. Acesso em: 20 jan. 2016. 
A resposta encontra-se nos artigos $5 .^{\circ}-\mathrm{A}, 7 .^{\circ}-\mathrm{A}$ e $7 .^{\circ}-$ $\mathrm{B}$, da Lei de Identificação Criminal, com a redação determinada pela Lei 12.654. Mostra-se útil transcrever o texto legal, pois a discussão sobre seu sentido normativo reclama a compreensão literal do preceito:

'Art. 5o-A. Os dados relacionados à coleta do perfil
genético deverão ser armazenados em banco de
dados de perfis genéticos, gerenciado por unidade
oficial de perícia criminal.
$\int 1$ o As informações genéticas contidas nos bancos
de dados de perfis genéticos não poderão revelar
traços somáticos ou comportamentais das pessoas,
exceto determinação genética de gênero, consoante
as normas constitucionais e internacionais sobre
direitos humanos, genoma humano e dados
genéticos. $\int 20$ Os dados constantes dos bancos de dados de perfis genéticos terão caráter sigiloso, respondendo civil, penal e administrativamente aquele que permitir ou promover sua utilização para fins diversos dos previstos nesta Lei ou em decisão judicial.

$\int 30$ As informações obtidas a partir da coincidência de perfis genéticos deverão ser consignadas em laudo pericial firmado por perito oficial devidamente habilitado.'

'Art. 7o-A. A exclusão dos perfis genéticos dos bancos de dados ocorrerá no término do prazo estabelecido em lei para a prescrição do delito.'

'Art. 7o-B. A identificação do perfil genético será armazenada em banco de dados sigiloso, conforme regulamento a ser expedido pelo Poder Executivo. ${ }^{.33}$

O banco de dados de perfil genético, portanto, insere-se na incumbência de órgão oficial de perícia. $\mathrm{O}$ legislador brasileiro teve o cuidado de restringir a finalidade do banco de dados de perfil genético: trata-se de banco de dados dirigido estritamente à identificação criminal. Não se admite qualquer utilização para fins etiológicos, de definição comportamental ou para fins de eugenia ou de definição criminológica ou criminógena do sujeito ali identificado.

Os dados têm caráter sigiloso, isto é, a fixação do sigilo é estipulada legalmente e funda-se — vale destacar — na conformação legal do direito constitucional à intimidade (ou à vida privada), tal como positivado no inciso $\mathrm{X}$ do artigo 5..$^{\circ}$ da Constituição, também na

33 BRASIL. Lei $n^{\circ} 12.654$, de 28 de maio de 2012. Altera as Leis nos 12.037, de 1 o de outubro de 2009, e 7.210, de 11 de julho de 1984 - Lei de Execução Penal, para prever a coleta de perfil genético como forma de identificação criminal, e dá outras providências. Disponível em: <http://www.planalto.gov.br/ccivil_03/_Ato20112014/2012/Lei/L12654.htm>. Acesso em: 2 out. 2015.
Convenção Europeia de Direitos Humanos de 1950 e na Convenção Americana de Direitos Humanos.

A previsão inserta na Lei $12.037^{34}$ (com a redação estabelecida pela Lei 12.654) substancia verdadeira garantia legal de salvaguarda da intimidade daquela pessoa submetida à identificação criminal por meio da coleta de material para documentação do perfil genético. Tal assertiva, decerto, vai na contramão do que sustentam os autores mencionados no item dois do presente trabalho. Isso porque a previsão legal, que assegura o caráter de oficialidade do banco, estabelece a finalidade desse banco e ainda exige a manifestação jurisdicional para o cotejo do dado com o banco. Tais cuidados - ou elementos que dificultam o acesso ao banco - protegem, salvaguardam e garantem a intimidade do particular em face da atuação persecutória do Estado. Não houvesse essa previsão legal, aí sim se poderia cogitar de malferimento do direito à intimidade, o qual, aliás, projeta-se em diversas outras garantias de igual ou maior jaez: como o sigilo bancário, o sigilo fiscal, etc.

O legislador interno indicou, ainda, que o cotejo dos dados extraídos do banco de perfil genético dá-se apenas e tão-somente por meio de perícia oficial. Demais disso, atento às diretrizes internacionais - máxime o caso aqui mencionado da Corte Europeia de Direitos Humanos - ocupou-se de não manter indefinidamente o dado de perfil genético. Ao revés, fixou limite temporal para o dado a ser mantido no banco de perfis genéticos (prazo prescricional do delito).

O caráter sigiloso do banco de dados, uma vez mais, em iteração que bem demonstra a preocupação do legislador ordinário com a salvaguarda dos direitos constitucionais do investigado ou suspeito submetido à identificação criminal e a tendência de funcionalização do Direito Internacional, é estabelecido no artigo $7 .^{\circ}-\mathrm{B}$ da Lei $12.037^{35}$, embora isso já pudesse ser extraído de disposições lidas diretamente da Constituição brasileira.

34 BRASIL. Lei no 12.037, de 01 de outubro de 2009. Dispõe sobre a identificação criminal do civilmente identificado, regulamentando $\mathrm{o}$ art. $5^{\circ}$, inciso LVIII, da Constituição Federal. Disponível em: <http://www.planalto.gov.br/ccivil_03/_Ato2007-2010/2009/ Lei/L12037.htm>. Acesso em: 2 out. 2015.

35 BRASIL. Lei $n^{0} 12.037$, de 01 de outubro de 2009. Dispõe sobre a identificação criminal do civilmente identificado, regulamentando o art. $5^{\circ}$, inciso LVIII, da Constituição Federal. Disponível em: <http://www.planalto.gov.br/ccivil_03/_Ato2007-2010/2009/ Lei/L12037.htm>. Acesso em: 2 out. 2015. 


\section{A COMPATIBILIDADE DA COLETA DO MATERIAL GENÉTICO DO CONDENADO COM AS GARANTIAS DO DIREITO AO SILÊNCIO E DA PRESUNÇÃO DE INOCÊNCIA}

Fixado o regime legal dos bancos de dados de perfil genético pela ordem jurídica interna, vê-se, agora de modo claro, que o tema não admite tratamento solitário ou isolado da previsão inserta no art. 9. ${ }^{\circ}$-A da LEP. É dizer: não há como ler o dispositivo de modo dissociado das previsões insertas na Lei de Identificação Criminal. Isso porque não há sentido jurídico ao se afirmar a inconstitucionalidade (máxime se o parâmetro de confronto encontra positivação assemelhada em Convenções internacionais) da coleta de material de perfil genético se não se tem em conta o modo pelo qual esses dados serão acessados posteriormente.

O regime legal da coleta de material de perfil genético guarda absoluta consonância com a previsão constitucional - e internacional — da presunção de inocência. A presunção de inocência guarda positivação tanto na Convenção Americana de Direitos Humanos (artigo 8. . número 2) quanto na Convenção Europeia de Direitos Humanos (artigo 6.', número 2. ${ }^{\circ}$ ), cujos textos, aliás, guardam estrita similitude ("Toda pessoa acusada de um delito tem direito a que se presuma sua inocência, enquanto não for legalmente comprovada sua culpa").

A fórmula dúbia e truncada estabelecida no texto constitucional brasileiro - "ninguém será considerado culpado até o trânsito em julgado de sentença penal condenatória" $" 36$ - acabou sendo consolidada nos anos de jurisprudência que se seguiram após a Constituição de 1988 e, também, pela dicção inequívoca do Pacto de São José da Costa Rica, o que mais uma vez mostra a importância da funcionalização e da humaniz̧ação do Direito Internacional na compreensão das garantias fundamentais estabelecidas no ordenamento interno.

A presunção de inocência, de qualquer modo, por mais alargada que seja a compreensão que se dê a esse postulado, só tem lugar até o trânsito em julgado de sentença penal condenatória. Ora, a legislação interna impõe a coleta do material de perfil genético somente após a definitividade da condenação criminal. E, como já destacado, não se trata de qualquer condenação cri-

36 Artigo 5. ${ }^{\circ}$, inciso LVII. BRASIL. Constituição (1988). Constituição da República Federativa do Brasil. Disponível em: < http://www. planalto.gov.br/ccivil_03/constituicao/ConstituicaoCompilado. htm>. Acesso em: 2 out. 2015. minal. O legislador atentou para a orientação indicada pela CEDH para que a providência extremada ocorra, apenas, em casos de considerável gravidade.

Veja-se a parcimônia do legislador brasileiro: a coleta do material para banco de dados de perfil genético só ocorre nas condenações definitivas dos crimes mais graves da legislação nacional, isto é, crimes dolosos praticados com violência grave contra a pessoa ou crimes hediondos ou a esses equiparados. A inclusão em banco de dados de perfil genético, repita-se, não se dá para qualquer pessoa, mas apenas daquela reconhecidamente condenada como incursa nos crimes mais graves da legislação interna.

Pelo raciocínio sustentado por aqueles que sustentam a inconstitucionalidade da submissão do condenado ao fornecimento do material biológico, não só a coleta de material genético vulneraria a presunção de inocência, mas igualmente as impressões dactilares (ou papiloscópicas), se colhidas sem o consentimento do condenado. É que a garantia, segundo quem assim sustenta, não se refere ao grau de invasão ou submissão do condenado ao fornecimento do dado de identificação, mas sim ao fornecimento da identificação em si. Como se observa, entretanto, o argumento não resiste a um confronto detido sobre o tema.

Atende ao interesse público primário - mediante condições prévia e juridicamente estabelecidas por lei e com a devida observância da cláusula de reserva de jurisdição - a mantença de dados (dentre eles, os indicativos do perfil genético) que identifiquem aqueles que incorram (isso reconhecido de modo definitivo por decisão judicial) na prática dos crimes mais graves da legislação interna. E, de qualquer sorte, a mantença desses dados dar-se-á, apenas, e tão-somente enquanto presente o interesse do Estado na punição do fato ensejador da grave condenação.

Por conseguinte, não há que se falar de violação da presunção de inocência. Tal garantia já não mais assiste ao condenado definitivamente. A mantença do dado de perfil genético dar-se-á na medida exata em que se mantiver o poder-dever de punir do Estado em relação ao fato praticado. Por fim, aqui se está a tratar daqueles crimes mais graves da legislação interna, assim inclusive reconhecidos pelo constituinte originário (os chamados hediondos e a eles equiparados). 
Já em relação ao direito ao silêncio ${ }^{37}$, positivado no inciso LXIII do art. 5. ${ }^{\circ}$ da Constituição, que abrange o privilégio de não ser compelido a produzir prova contra si mesmo (Nemo tenetur se detegere ou Nemo tenetur se ipsum accusare ou Nemo tenetur se ipsum prodere), igualmente não se vislumbra qualquer vulneração pelo artigo 9.'-A da Lei de Execução Penal.

Não se cuida de compelir o condenado a produzir prova contra sua própria autodeterminação. A garantia do Nemo tenetur implica a impossibilidade de se exigir condutas ativas ou a colaboração do próprio acusado na produção de provas contra si no curso de persecução penal. Não é o caso do mencionado artigo 9. ${ }^{\circ}$-A da LEP $^{38}$, uma vez que o fornecimento do material de perfil genético não se presta, no momento de sua coleta, para qualquer persecução penal em seu desfavor. Ao contrário, cuida-se de procedimento realizado por ocasião da classificação do condenado para início do cumprimento de sua reprimenda.

A eventual utilização do material coletado pode se dar por ocasião de investigação criminal que coteje material próprio da investigação com aquele mantido no banco de dados de perfil genético (alimentado, repita-se, com o material fornecido pelo condenado definitivo). Não há como estender o Nemo tenetur à coleta do material fornecido pelo condenado definitivo porque a abrangência da garantia do Nemo tenetur refere-se, por óbvio, à produção de provas ou elementos de informação de investigações ou persecuções penais em curso. $\mathrm{O}$ regime legal, nesse último caso, é diverso. Ele não se refere ao artigo 9. ${ }^{\circ}$-A da Lei de Execução Penal, mas sim aos já mencionados artigos $5 .^{\circ}$, parágrafo único, $5 .^{\circ}$-A, 7. ${ }^{\circ}$-A e $7 .^{\circ}-\mathrm{B}$ da Lei de Identificação Criminal. ${ }^{39}$

Veja-se que o sujeito submetido a identificação criminal por meio de material coletado, para extração do perfil genético, não terá suas informações inseridas no banco de dados de perfil genético. Um exemplo ilustra bem essa assertiva, que encontra lastro exatamente

37 BRASIL. Constituição (1988). Constituição da República Federativa do Brasil. Disponível em: <http://www.planalto.gov.br/ccivil_03/ constituicao/ConstituicaoCompilado.htm>. Acesso em: 2 out. 2015.

38 BRASIL. Lei $n^{\circ}$ 7.210, de 11 de julho de 1984. Institui a Lei de Execução Penal. Disponível em: <http://www.planalto.gov.br/ ccivil_03/LEIS/L7210.htm>. Acesso em: 2 out. 2015.

39 BRASIL. Lei n $n^{\circ}$ 12.037, de 01 de outubro de 2009. Dispõe sobre a identificação criminal do civilmente identificado, regulamentando o art. $5^{\circ}$, inciso LVIII, da Constituição Federal. Disponível em: <http://www.planalto.gov.br/ccivil_03/_Ato2007-2010/2009/ Lei/L12037.htm>. Acesso em: 2 out. 2015. na literalidade da Lei 12.654: se Mévio é investigado e essa investigação reclama sua identificação criminal, nos termos da Lei 12.037, por meio de coleta de material biológico, para extração de seu perfil genético, ainda que seja ele ao final condenado, esse material coletado não será considerado para fins de inclusão no banco de dados de DNA. A regulação presente na Lei de Execuções Penais, inserta pela Lei 12.654, claro, restringe-se aos crimes ali mencionados e, por conseguinte, ao final do processo em que restou condenado José, fora das hipóteses descritas no artigo 9. ${ }^{\circ}$-A da Lei de Execução Penal, seus dados serão excluídos. ${ }^{40}$

A incidência do Nemo tenetur, assim, refere-se à eventual determinação judicial de cotejo de material coletado em investigação (não necessariamente do investigado ou mesmo contra sua própria autodeterminação) com aquele constante em banco de dados de perfil genético.

Por ocasião da incidência do art. 9. ${ }^{\circ}$-A da LEP, não se trata de obrigar a pessoa a produzir prova contra si mesma, pois não se obriga o acusado a fornecer material genético para ser confrontado no caso em que está sendo processado. $\mathrm{O}$ fornecimento obrigatório só acontecerá se o indivíduo for definitivamente condenado. E, nesse caso, ficará "identificável” até a exclusão do perfil genético do banco, isto é, até a extinção da punibilidade do fato ensejador da condenação definitiva.

De qualquer sorte, o direito de não produzir provas contra si mesmo pode e deve ser usado em um processo ou investigação penal, mas jamais pode servir como um "salvo-conduto" para não identificá-lo em caso de prática de novos delitos. O investigado ou acusado, segundo o Nemo tenetur, não pode ser compelido a fornecer material enquanto estiver processado. A obrigação de fornecimento de material para perfil genético, nos termos legais, é posterior, opera-se, apenas, após o trânsito em julgado da sentença condenatória, e poderá servir como prova em eventuais processos futuros.

\section{Considerações finais}

A solução para a compatibilidade do regime legal da coleta de material genético para fins de identificação criminal

40 HAMMERSCHMIDT, Denise. Identificación genética, discriminación y criminalidad: un análisis de la situación jurídico penal en España y en Brasil. Curitiba: Juruá, 2012. p. 156. 
com a Constituição brasileira mostra-se como exemplo do fenômeno indicado pelos internacionalistas de aumento da complexidade do Direito das Gentes. A compreensão do tema reclama especificação ou objetivação da internacionalização do direito ou, em outros termos, ilustra exemplo próprio da funcionalização do Direito Internacional Público como instrumento de compreensão adequada dos problemas do ordenamento interno.

Por um lado, o exame de DNA, vale dizer, nunca será, isoladamente, prova cabal de culpa. Prestar-se-á, quando muito, para comprovar a presença do indivíduo no local do crime ou mesmo que são deles os vestígios materiais lá deixados (em situações de delitos não-transeuntes, isto é, que deixam vestígios materiais). São circunstâncias que não conduzem, ipso facto, a juízo condenatório. Por outro lado, o exame de DNA pode prestar-se como prova, aí sim, cabal de inocência do acusado, ainda que isoladamente.

O ponto crucial, portanto, refere-se ao fornecimento do material genético como forma de identificação genética. Isso, contudo, ocorrerá, apenas, e tão-somente enquanto presente o jus puniendi ou jus punitionis do fato ensejador da condenação daquele sentenciado. Veja-se que o acesso a esse banco de dados de perfil genético dar-se-á justamente com observância de decisão judicial, a qual, por sua vez, deverá indicar a imprescindibilidade de tal providência para a investigação criminal (artigo 5. ${ }^{\circ}-\mathrm{A}, \S 2 .^{\circ}$, parte final).

Afirmar a inviabilidade desse cotejo por inconstitucionalidade implicaria assumir esfera intocável por decisão judicial ou, em outras palavras, afirmar o caráter absoluto da intangibilidade do material atinente ao perfil genético. A tanto não se chega, decerto. Aliás, cabe o destaque de que nenhum país do mundo dá caráter absoluto à intimidade para afirmar que o material para definição do perfil genético é intangível.

O destaque e a ênfase deduzidos prestam-se, apenas, para sublinhar a necessidade de que o tema seja apreciado e compreendido de modo sistemático e em cotejo com todo o regime legal da coleta de dados para banco de perfil genético. Mais do que isso, é preciso que o tema observe justamente o importante instrumental prestado pelo Direito das Gentes, dado que suas instâncias formalizadas já prestaram relevante contribuição à conformação do tema à luz do melhor direito.

Interpretações isoladas ou herméticas dos dispositivos que cuidam da coleta do material, da compulso- riedade de identificação criminal ou do regime jurídico dos bancos respectivos podem conduzir, por equívoco, à conclusão de que os preceitos legais trazidos pela Lei 12.654 seriam incompatíveis com a ordem constitucional ou mesmo com as Convenções de que o Brasil é signatário.

Ao contrário, a positivação do tema na legislação pátria atentou — com bastante parcimônia, permita-se a qualificação - justamente aos standards fixados pela Corte Europeia de Direitos Humanos e, por conseguinte, à funcionalização do Direito Internacional. Ademais da consideração própria da análise comparada, vê-se que o regime legal tal como estabelecido para o tema guardou consonância com o sentido e o alcance dados à intimidade, à presunção de inocência e ao direito ao silêncio, seja no direito interno, seja no Direito Internacional.

\section{ReferênCias}

BRASIL. Constituição (1988). Constituição da República Federativa do Brasil. Disponível em: < http: / www.planalto.gov.br/ccivil_03/constituicao/ConstituicaoCompilado.htm>. Acesso em: 2 out. 2015.

BRASIL. Constituição (1967). Constituição da República Federativa do Brasil. Disponível em: <http://www.planalto.gov.br/ccivil_03/Constituicao/Constituicao67. htm>. Acesso em: 2 out. 2015.

BRASIL. Decreto no 678, de 6 de novembro de 1992. Promulga a Convenção Americana sobre Direitos Humanos (Pacto de São José da Costa Rica), de 22 de novembro de 1969. Disponível em: <http://www.planalto.gov. br/ccivil_03/decreto/D0678.htm>. Acesso em: 2 out. 2015.

BRASIL. Decreto-lei ñ 3.689, de 3 de outubro de 1941. Código de Processo Penal. Disponível em: < http://www. planalto.gov.br/ccivil_03/decreto-lei/Del3689Compilado.htm>. Acesso em: 2 out. 2015.

BRASIL. Lei no 7.210, de 11 de julho de 1984. Institui a Lei de Execução Penal. Disponível em: <http://www. planalto.gov.br/ccivil_03/LEIS/L7210.htm>. Acesso em: 2 out. 2015.

BRASIL. Lei no 12.037, de 01 de outubro de 2009. Dispõe sobre a identificação criminal do civilmente identificado, regulamentando o art. $5^{\circ}$, inciso LVIII, da Consti- 
tuição Federal. Disponível em: <http://www.planalto. gov.br/ccivil_03/_Ato2007-2010/2009/Lei/L12037. htm>. Acesso em: 2 out. 2015.

BRASIL. Lei $n^{\circ}$ 12.654, de 28 de maio de 2012. Altera as Leis nos 12.037, de 1o de outubro de 2009, e 7.210, de 11 de julho de 1984 - Lei de Execução Penal, para prever a coleta de perfil genético como forma de identificação criminal, e dá outras providências. Disponível em: <http://www.planalto.gov.br/ccivil_03/_Ato20112014/2012/Lei/L12654.htm>. Acesso em: 2 out. 2015.

BRASIL. Senado Federal. Projeto de Lei no 93, de 2011. Estabelece a identificação genética para os condenados por crime praticado com violência contra pessoa ou considerado hediondo. Autor da proposição: Senador Ciro Nogueira. Disponível em: <http://http:// www25.senado.leg.br/web/atividade/materias/-/materia/99463>. Acesso em: 15 fev. 2015.

BRASIL. Supremo Tribunal Federal. Habeas Corpus. HC 84.078-7/ MG. Tribunal Pleno. Paciente: Omar Coelho Vitor. Coator: Superior Tribunal de Justiça. Relator: Min. Eros Grau. Brasília, 5 de fevereiro de 2009. Disponível em: < http://www.stf.jus.br/arquivo/cms/ noticiaNoticiaStf/anexo/ementa84078.pdf >. Acesso em: 20 jan. 2016.

CARVALHO, Diogo Machado de. As intervenções corporais no processo penal: entre o desprezo, o gozo e a limitação de direitos fundamentais. Rio de Janeiro: Lumen Juris, 2014.

CONSELHO DA EUROPA. Convenção para a Proteç̧ão dos Direitos do Homem e das Liberdades Fundamentais (Convenção Europeia de Direitos Humanos). Roma, 4 nov. 1950. Disponível em: <http://www.echr.coe.int/Documents/Convention_POR.pdf $>$. Acesso em: 2 out. 2015.

CORTE INTERAMERICANA DE DIREITOS HUMANOS. Caso de las Hermanas Serrano Cruz vs. El Salvador. Sentença de 1 de março de 2005. Disponível em: $<$ http://www.corteidh.or.cr/docs/casos/articulos/seriec_120_esp.pdf >. Acesso em: 2 out. 2015.

CORTE INTERAMERICANA DE DIREITOS HUMANOS. Caso Fornerón e hija vs. Argentina. Sentença de 27 de abril de 2012. Disponível em: <http://corteidh.or.cr/docs/casos/articulos/seriec_242_esp.pdf>. Acesso em: 2 out. 2015.

CORTE INTERAMERICANA DE DIREITOS HU-
MANOS. Caso Rochac Hernández y otros vs. El Salvador. Sentença de 14 de outubro de 2014. Disponível em: <http://www.corteidh.or.cr/docs/casos/articulos/seriec_285_esp.pdf>. Acesso em: 2 out. 2015.

CORTE EUROPEIA DE DIREITOS HUMANOS. Caso S. and Marper vs. Reino Unido (n. 30562/04 e n. 30566/04). Sentença de 4 de dezembro de 2008. Disponível em: <https://www.coe.int/t/dghl/ standardsetting/dataprotection/Judgments/S. $\% 20$ AND \%20MARPER \%20v. \%20THE\%20UNITED $\% 20$ KINGDOM $\% 20$ EN.pdf>. Acesso em: 2 out. 2015.

GUEDES, Gabriel Pinto; FELIX, Yuri. A identificação genética na lei $\mathrm{n}^{\circ}$ 12.654/2012 e os princípios de direito processual penal no estado democrático de direito. Revista de Estudos Criminais, Porto Alegre, v. 12, n. 53, p. 157-179, abr./jun. 2014.

HAMMERSCHMIDT, Denise. Identificación genética, discriminación y criminalidad: un análisis de la situación jurídico penal en España y en Brasil. Curitiba: Juruá, 2012.

MARIANO JÚNIOR, Alberto Ribeiro. A (des)regularização da obtenção do material genético no processo penal brasileiro. Revista Magister de Direito Penal e Processual Penal, Porto Alegre, v. 11, n. 63, p. 78-92, dez./jan. 2014.

MATELETO FILHO, Wagner. O direito à não autoincriminação no processo penal contemporâneo. Belo Horizonte: Del Rey, 2012.

MAHMOUD, Mohamad Ale Hasan; MOURA, Maria Thereza Rocha de Assis. A Lei 12.654/2012 e os direitos humanos. Revista Brasileira de Ciências Criminais, São Paulo, v. 20, n. 98, p. 339-358, set./out. 2012.

MAZZUOLI, Valério de Oliveira. Curso de direito internacional público. 7. ed. São Paulo: Revista dos Tribunais, 2013.

MIRANDA, Jorge. A incorporação ao direito interno de instrumentos jurídicos de Direito Internacional Humanitário e Direito Internacional dos Direitos Humanos. Revista CEJ, v. 4, n. 11, p. 23-26, maio/ago. 2000. Disponível em: <http://www.jf.jus.br/ojs2/index.php/ revcej/article/view/344/546>. Acesso em: 2 out. 2015.

NICOLITTI, André. Banco de dados de perfis genéticos (DNA). As inconstitucionalidades da Lei 12.654/2012. Boletim do IBCCRIM, São Paulo. n. 245, p. 15-16, abr. 2013. 
SILVA, Emílio de Oliveira e. Identificação genética para fins criminais: análise dos aspectos processuais do banco de dados de perfil genético implementado pela Lei n. 12.654/2012. Belo Horizonte: Del Rey, 2014.

VARELLA, Marcelo Dias. Internacionalização do direito: direito internacional, globalização e complexidade.

Brasília: UniCEUB, 2103. 


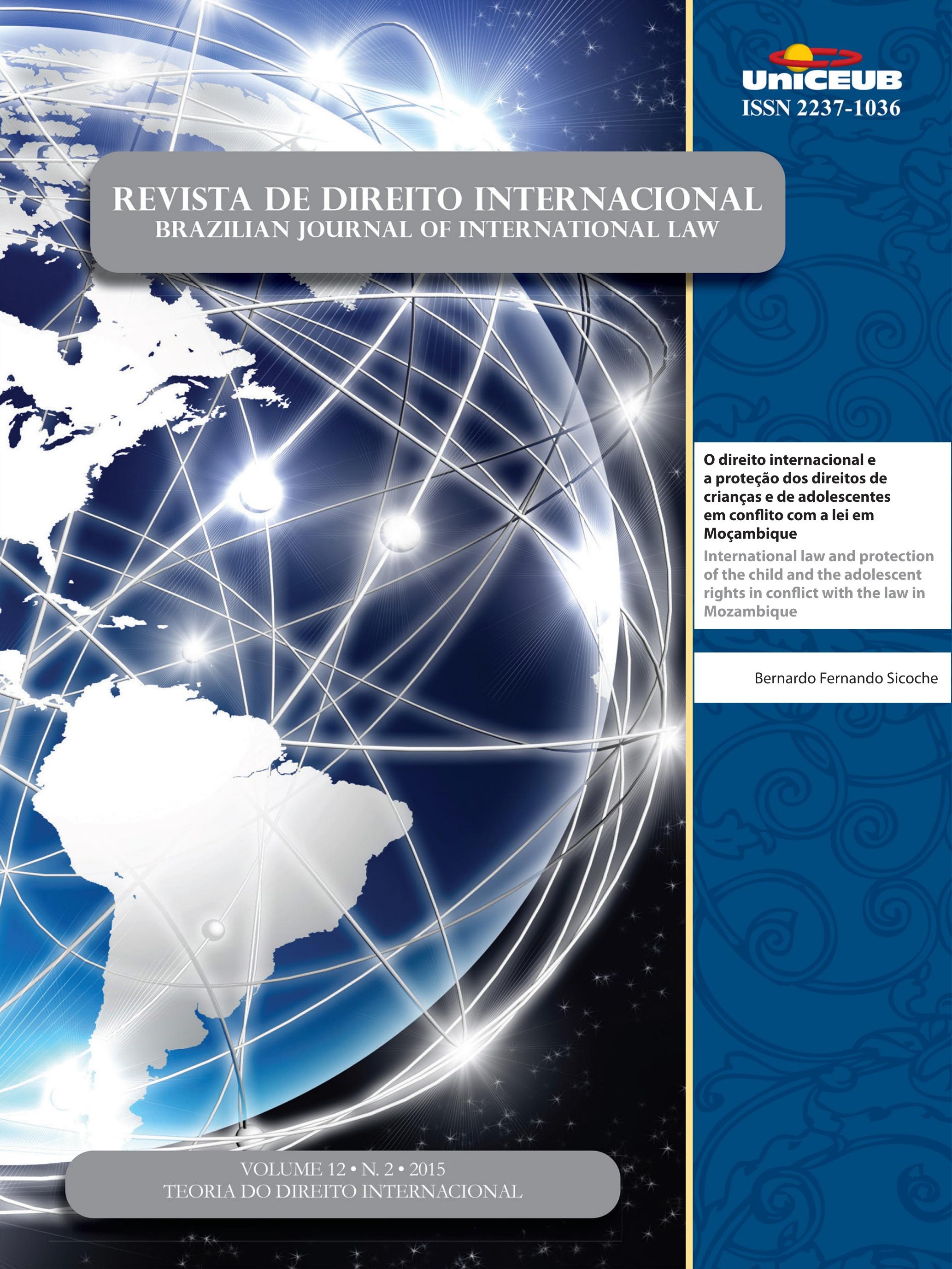




\title{
O direito internacional e a proteção dos direitos de crianças e de adolescentes em conflito com a lei em Moçambique*
}

\author{
International law and protection of the child \\ and the adolescent rights in conflict with the \\ law in Mozambique
}

Bernardo Fernando Sicoche ${ }^{* *}$

\section{Resumo}

O objetivo deste artigo é analisar os mecanismos e os instrumentos de proteção da criança e do adolescente em conflito com a lei em Moçambique, à luz das leis internas e do Direito Internacional. O enfoque é propor mecanismos de apoio e de promoção da melhoria do atendimento da criança e do adolescente em conflito com a lei penal em Moçambique, no que concerne aos procedimentos socioeducativos e processuais. Primeiramente, abordam-se aspectos conceptuais, os fundamentos teóricos e jurídicos de proteção da criança e do adolescente em conflito com a lei. Em seguida faz-se analisam-se instrumentos internacionais de proteção das crianças e dos adolescentes autores de ato infracional, alguns deles ratificados pelo governo de Moçambique. Analisa-se, também, o impacto dessas normas na realidade moçambicana. Finalmente, discutem-se os procedimentos adotados na justiça infantil, atualmente, com vista a proteção das crianças e adolescentes em Moçambique. Em termos metodológicos, optou-se pela pesquisa bibliográfica (coleta de dados secundários - materiais analisados, relatórios, revistas, artigos, leis, estatutos, livros e folhetos). A conclusão, que se chega neste artigo, é de que existem vários instrumentos internacionais e nacionais que visam à proteção de crianças e adolescentes em conflito com a lei. Contudo, a inobservância dessas leis pelos agentes encarreguem para velar sobre a justiça infantil, devido, por um lado, ao desconhecimento dessa matéria, por outro lado, devido à falta de coordenação e cooperação no âmbito da execução dos procedimentos tendentes a proteção dos menores visados; à falta de alternativas de detenção para menores ofensores; e à falta de acesso à justiça juvenil. A formação e a capacitação jurídica em matéria do direito da criança e do adolescente, aos agentes ligados ao setor da justiça de menores, podem contribuir para uma maior observância e respeito pelas normas nacionais e internacionais sobre os direitos da criança e a respectiva justiça infantil.

* Recebido em 03/09/2015 Aprovado em 07/12/2015

** Doutorando em Ciência Política na Universidade Federal do Rio Grande do Sul. Mestre em Direito pela Universidade Federal do Rio Grande do Sul. Bolsista do Programa Estudantes-Convênio de Pós-Graduação PEC-PG, da CAPES/CNPq - Brasil. E-mail: bernardosicoche@yahoo.com.br.
Palavras-chave: Criança e adolescente em conflito com a lei. Direitos da criança e do adolescente. Direito internacional. Justiça de menores. 


\section{Abstract}

The objective of this paper is to analyze the mechanisms and child protection instruments and teenagers in conflict with the law in Mozambique, in the light of domestic laws and international law. The focus is to propose mechanisms to support and promote improved child care and adolescents in conflict with the law in Mozambique, with regard to youth and procedural requirements. First, we discuss conceptual aspects, theoretical and legal foundations child protection and adolescents in conflict with the law. Then makes an analysis of international instruments for the protection of children and teenager who infraction, some of them ratified by the Government of Mozambique. It analyzes also the impact of these standards on the Mozambican reality. Finally, the procedures adopted are discussed in children's justice, currently, in order to protect children and teenagers in Mozambique. In terms of methodology we were chosen literature (secondary data collection - analyzed materials, reports, journals, articles, laws, statutes, books and leaflets). The conclusion that is reached in this study is that there are several international and national instruments aimed at protecting children and teenagers in conflict with the law. However, the non-observance to comply with these laws by responsible officers to watch over the children's justice, because on the one hand, the ignorance of this matter, on the other, due to lack of coordination and cooperation in the implementation of procedures to protect the targeted children; the lack of alternatives to detention of minor offenders; and lack of access to juvenile justice. Training and legal training in the field of child and adolescent rights, the agents of the juvenile justice sector can contribute to better compliance and respect for national and international standards on children's rights and their children's justice.

Keywords: Children and Adolescents in conflict with the law. Rights of the child and the adolescent. International law. Minors justice.

\section{INTRODUÇÃO}

A proteção internacional da criança e do adolescente em conflito com a lei na sociedade moderna é um tema de indiscutível centralidade, quer pelo caráter passional dos direitos da criança e interesse que desperta na sociedade, quer pela importância que lhe é devida por cada um dos países e governos signatários da Declaração Universal dos Direitos da Criança. O presente artigo tem como tema "o Direito Internacional e a proteção dos direitos da criança e do adolescente em conflito com a lei em Moçambique" e foi elaborado no âmbito da preocupação pelas atuais formas de tratamentos de menores em conflito com a lei.

A motivação para o tema surge no âmbito das constatações de que, nos últimos anos, nas cadeias moçambicanas, existe a predominância de muitos reclusos com idade inferior a 16 anos. Um estudo realizado pelo Ministério da Justiça de Moçambique em coordenação com o Fundo das Nações Unidas para a Infância (UNICEF), em 2003, revelou que foram visitados 20 estabelecimentos penitenciários e algumas esquadras da polícia. Nesses locais foram entrevistados um total de 106 reclusos com menos de 21 anos de idade, sendo 75 com menos de 18 e 37 com menos de 16 anos de ida$\mathrm{de}^{1}$. Segundo os pesquisadores, entre os entrevistados, estavam ainda "duas crianças de 12 anos de idade na província de Nampula, uma delas estava detida há 16 dias, por posse de droga (marijuana)"'2.

$\mathrm{Na}$ visão de Baleira, os dados estatísticos não espelham de uma forma
clara a magnitude e as características do problema,
mas dentro desse quadro teórico conceitual, os
dados colhidos apontam para a existência de um
número expressivo - entre 25 e $30 \%$ - e cada vez
maior de crianças em situação de conflito com a lei ${ }^{3}$.

Outro estudo sobre as crianças em conflito com a lei, levado a cabo pelo $\mathrm{UNICEF}^{4}$ em 2006, revela que "pelo menos $25 \%$ de todos os reclusos inquiridos tinham menos de 18 anos de idade, e 18\% tinham menos de 16". À luz da lei moçambicana (art. 46 do Código Penal), os menores de 16 anos gozam de uma inimpu-

1 BALEIRA, Sérgio (Coord.). Relatório preliminar da pesquisa sobre "A Criança em Conflito com a Lei". Moçambique: [S.n], abr.de 2003. Consultoria com Save The Children Norway. p. 8.

2 BALEIRA, Sérgio (Coord.). Relatório preliminar da pesquisa sobre "A Criança em Conflito com a Lei". Moçambique: [S.n], abr.de 2003. Consultoria com Save The Children Norway. p. 8.

3 BALEIRA, Sérgio (Coord.). Relatório preliminar da pesquisa sobre "A Criança em Conflito com a Lei". Moçambique: [S.n], abr.de 2003. Consultoria com Save The Children Norway. p. 8

4 FUNDO DAS NAÇÕES UNIDAS PARA A INFÂNCIA. Proteção da criança. Moçambique: UNICEF, 2014. Disponível em: <http://www.unicef.org/mozambique/pt/protection.html $>$. Acesso em 27 set. 2014. 
tabilidade absoluta.

Paralelamente aos dados acima, também foram relatadas várias constatações ligadas à violação dos direitos da criança e do adolescente em conflito com a lei. Dentre vários problemas constatados, destaca-se o descumprimento das normas nacionais e internacionais; a existência de muitas crianças nas cadeias moçambicanas; violação policial contra as crianças e os adolescentes autores de ato infracional; existência de crianças e de adolescentes "sem voz" que passam injustiças graves no seu tratamento e falta de proteção e apoio; inexistência de processos legais claros para casos em que há menores envolvidos; falta de alternativas de detenção para menores ofensores; falta de acesso à justiça juvenil; e a junção de adolescentes e adultos nas mesmas cadeias ${ }^{5}$.

De acordo com Miguel,

em 2013, cerca de 2.300 crianças e adolescentes em conflito com a lei foram mantidos em regime de reclusão, pese embora os crimes de que são acusados sejam considerados de pequena dimensão. Todavia, eles estão a beneficiar de assistência jurídica acompanhada pelos técnicos da justiça moçambicana e do UNICEF. Segundo o Ministério da Justiça, em Moçambique existem 17.000 crianças e adolescentes detidos e o número tende a aumentar, segundo estudos efetuados a nível local e internacional, os quais demonstram ainda que grande parte desse grupo encontra-se nos centros de reabilitação. Enquanto isso, Koenraad Vanormelingen, representante da UNICEF em Moçambique disse que 700.000 crianças vivem em situação de vulnerabilidade no país. O UNICEF está a desenvolver um programa que em parte pretende sensibilizar as comunidades a perceberem que a criança não pode ser vista como criminosa ${ }^{6}$.

Com base nesses dados, verifica-se que o índice dos casos de crianças e de adolescentes autores de ato infracional presos nas cadeias moçambicanas tende a subir. Em relação à ideia de proteção dos direitos da criança e do adolescente, percebe-se que, apesar dos esforços empreendidos, tem fracassado o papel do Estado na busca e proteção dos direitos humanos da criança, na medida em que, os procedimentos atualmente adotados, com vista a aplicação da justiça infantil, no País, co-

5 BALEIRA, Sérgio (Coord.). Relatório preliminar da pesquisa sobre "A Criança em Conflito com a Lei". Moçambique: [S.n], abr.de 2003. Consultoria com Save The Children Norway. p. 6.

6 MANGUE, Reginaldo. Milhares de crianças estão em conflito com a lei no país.Jornal@Verdade, Moçambique, 27 mar. 2014. Disponível em: <http://www.verdade.co.mz/nacional/45093milhares-de-criancas-estao-em-conflito-com-a-lei-no-pais $>$. Acesso em: 10 set. 2014. lidem com as normas internacionais do Direito Público sobre a proteção da criança e adolescente em conflito com a lei.

Por essa razão, neste artigo procura-se relacionar as normas do Direito Internacional com a estrutura e a atuação das instituições moçambicanas encarreguem pela proteção de criança e adolescente em conflito com a lei, num Estado de Direito Moçambicano, segundo consagra a Constituição da República de Moçambique (CRM) de 2004. Nesse sentido, dá-se enfoque à percepção de que, só assegurando a ampla e profunda integração das políticas governamentais e a efetiva articulação dessas políticas com o Direito Internacional e a sociedade civil, pode-se conquistar avanços significativos na realização dos direitos da criança e do adolescente em Moçambique. Ou seja, uma proteção efetiva da criança e do adolescente pode mitigar os riscos e as vulnerabilidades que contribuem para os abusos da justiça infantil.

A Convenção sobre os Direitos da Criança de 1989 reafirma o fato de as crianças, devido à sua vulnerabilidade, necessitarem de uma proteção e de uma atenção especial e, sublinha de forma particular a responsabilidade fundamental do Estado, no que diz respeito aos cuidados e proteção. Dispõe, ainda, a necessidade de proteção jurídica e não jurídica de adolescentes e o papel vital da cooperação internacional para que os direitos da criança e de adolescente sejam uma realidade.

A necessidade de garantir uma proteção especial à criança foi enunciada, pela primeira vez, na Declaração de Genebra de 1924 sobre os Direitos da Criança e seguidamente na Declaração dos Direitos da Criança adotada pelas Nações Unidas em 1959. Também foi reconhecida pela Declaração Universal dos Direitos do Homem; pelo Pacto Internacional sobre os Direitos Civis e Políticos; pelo Pacto Internacional sobre os Direitos Econômicos, Sociais e Culturais (art. 10); e pelos estatutos e instrumentos pertinentes das agências especializadas e organizações internacionais que se dedicam ao bem-estar da criança.

Assim, na busca pela garantia dos direitos da criança e do adolescente em conflito com a lei, estabelece-se como prioridade, no presente artigo, a atenção no estudo de mecanismos de apoio e de promoção da melhoria do atendimento da criança e do adolescente em conflito com a lei penal. O enfoque é propor mecanismos de reforço da justiça de menores em conflito com a lei, no que concerne aos procedimentos socioeducativos e 
processuais.

Dessa forma, traçou-se os seguintes objetivos como linhas de orientação para a materialização do artigo: $O b$ jetivo Geral: analisar o sistema de atendimento sociopedagógico e protetivo às crianças e aos adolescentes em conflito com a lei em Moçambique, a luz das normas nacionais e internacionais; Objetivos Especificos: avaliar os mecanismos nacionais e internacionais do Direito Internacional para a proteção da criança e do adolescente; propor algumas medidas para o melhoramento de atendimento a criança e ao adolescente infrator.

Este artigo está estruturado em quatro seções: na primeira abordam-se aspectos conceptuais e os fundamentos teóricos e jurídicos de proteção da criança e do adolescente em conflito com a lei; na segunda seção, descreve-se os instrumentos internacionais de proteção da criança e do adolescente em conflito com a lei e seus respectivos impactos na realidade moçambicana; a terceira seção aborda a justiça infantil e sua proteção em crianças e adolescentes em Moçambique; na quarta e última seção apresenta-se as considerações finais que resultam da inferência feita com base nas constatações da pesquisa e nas referências bibliográficas consultadas.

\section{Conceito e fundamentos teóricos e JURÍDICOS DE PROTEÇÃO DA CRIANÇA E DO ADOLESCENTE EM CONFLITO COM A LEI}

O termo 'criança em conflito com a lei' "é uma expressão conceitual que envolve elementos que representam realidades sociais de grande complexidade, nomeadamente a 'criança', a 'lei' e, entre estes, o próprio 'estado de conflito' que o significado da expressão encerra"7. As Regras de Beijing, que não só estabelecem garantias de proteção aos jovens, como também um sistema justo, humano e digno para todos menores, na sua Regra 2.2, consideram criança ou adolescente autor de ato infracional "qualquer criança ou jovem acusado de ter cometido um delito ou considerado culpado de ter cometido um delito" ${ }^{8}$.

7 BALEIRA, Sérgio (Coord.). Relatório preliminar da pesquisa sobre "A Criança em Conflito com a Lei”. Moçambique: [S.n], abr.de 2003. Consultoria com Save The Children Norway. p. 25.

8 ASSEMBLEIA GERAL DAS NAÇÕES UNIDAS. Regras minimas das Nações Unidas para a administração da justiça de menores (Regras de Beïing). 1985. Disponível em: <http://www.gddc.pt/direitos-
Segundo Baleira,

o estado de conflito com a lei representa, a priori, a não conformidade entre a conduta ou comportamento do indivíduo com as regras ou normas formal ou informalmente institucionalizadas numa sociedade ou comunidade?

Assim, considera-se que "a criança está em conflito com a lei quando esta rompe com as leis estabelecidas e/ou adquire um comportamento que não corresponde às expectativas da sociedade" ${ }^{" 10}$. Ao passo que o conceito de menor, criança e adolescente varia de um país para o outro. Algumas nações tendem a fazer coincidi-lo com a definição adotada por algumas organizações internacionais e outros tendem a separar os três termos.

Nas teorias modernas, alguns autores tendem, também, a estabelecer diferenças concepcionais entre criança e adolescente. Por exemplo, Frota afirma que,

de um modo geral, existe a compreensão de que ser criança resume-se em ser feliz, alegre, despreocupado, ter condições de vida próprias ao seu desenvolvimento, ou seja, a infância é considerada o melhor tempo da vida [...]. Já que a adolescência se configura como um momento em que, naturalmente, o indivíduo tornase alguém muito chato, difícil de se lidar e que está sempre criando confusão e vivendo crises [...]. Deste modo, existe uma leitura de senso comum que costuma colocar a criança vivendo o melhor momento da vida e o adolescente, uma fase difícil para ele e para quem convive com ele. ${ }^{11}$

Frota, ainda explica que etimologicamente "a palavra infância vem do latim, infância, e refere-se ao indivíduo que ainda não é capaz de falar. Essa incapacidade, atribuída à primeira infância, estende-se até os sete anos, que representa a idade de razão"12. Com mesmo entendimento Àries esclarece que:

a primeira idade é a infância que planta os dentes, e essa idade começa quando a criança nasce e dura

humanos/textos-internacionais-dh/tidhuniversais/dhaj-NOVOregrasBeijing.html>. Acesso em: 01 fev. 2016.

9 BALEIRA, Sérgio (Coord.). Relatório preliminar da pesquisa sobre "A Criança em Conflito com a Lei”. Moçambique: [S.n], abr.de 2003. Consultoria com Save The Children Norway. p. 29.

10 BALEIRA, Sérgio (Coord.). Relatório preliminar da pesquisa sobre "A Criança em Conflito com a Lei”. Moçambique: [S.n], abr.de 2003. Consultoria com Save The Children Norway. p. 29.

11 FROTA, Ana Maria Monte Coelho. Diferenças concepções da infância e adolescência: a importância da historicidade para sua construção. Estudos e Pesquisas em Psicologia, Rio de Janeiro, v. 7, n. 1, p. 147-160, abr. 2007. p. 148.

12 FROTA, Ana Maria Monte Coelho. Diferenças concepções da infância e adolescência: a importância da historicidade para sua construção. Estudos e Pesquisas em Psicologia, Rio de Janeiro, v. 7, n. 1, p. 147-160, abr. 2007. p. 150. 
até os sete anos, e nessa idade aquilo que nasce é chamado enfant (criança), que quer dizer não falante, pois nessa idade a pessoa não pode falar bem nem formar perfeitamente suas palavras, pois ainda não tem seus dentes bem ordenados nem firmes. Após a infância, vem a segunda idade, que chama-se puerita e é assim chamada porque nessa idade a pessoa é ainda como a menina do olho, e essa idade dura até os 14 anos. $^{13}$

Em relação ao termo adolescente, Eisenstein, explica que

os limites cronológicos da adolescência são definidos pela Organização Mundial de Saúde (OMS) entre 10 e 19 anos (adolescentes) e pela Organização das Nações Unidas (ONU) entre 15 e 24 anos (youth), critérios estes usados principalmente para fins estatísticos e políticos ${ }^{14}$.

Seguidamente, essa autora esclarece que "na maioria dos países, o conceito de maioridade do ponto de vista legal é estabelecido aos 18 anos, mas outros critérios existem e permanecem flexíveis e confusos, de acordo com os costumes e culturas locais" ${ }^{\prime 15}$.

Autores como Marcelli e Braconnier definem a adolescência como uma "fase, um período, uma passagem da infância à fase adulta" ${ }^{16}$. Ideias semelhantes são expressas por Habigzang e Caminha na assertiva segundo a qual:

a infância e a adolescência são etapas do ciclo de vida nas quais o indivíduo desenvolve as capacidades cognitivas, afetivas e físicas [...] habilidades sociais [...]. Crianças e adolescentes são considerados sujeitos em condição peculiar de desenvolvimento, necessitando cuidados especiais que garantam a sua proteção e o desenvolvimento de suas potencialidades. ${ }^{17}$

Nos termos da Convenção sobre os Direitos da Criança adotada pela Assembleia Geral das Nações Unidas em 20 de novembro de 1989, a criança é definida

13 ARIÈS, Philippe. História social da criança e da família. Tradução de Dora Flaksman. 2. ed. Rio de Janeiro: LTC, 1981. p. 36.

14 EISENSTEEIN, Evelyn. Adolescência: definição, conceitos e critérios. Adolescência \& Saúde, Rio de Janeiro, v. 2, n. 2, p. 1-6, jun. 2005. p. 6.

15 EISENSTEEIN, Evelyn. Adolescência: definição, conceitos e critérios. Adolescência \& Saúde, Rio de Janeiro, v. 2, n. 2, p. 1-6, jun. 2005. p. 6

16 MARCELLI; BRACONNIER, 1986 apud JACOBINA, Olga Maria Pimentel; COSTA, Liana Fortunato. Para não ser bandido: Trabalho e Adolescentes em conflito com a lei. Cadernos de Psicologia Social do Trabalho, São Paulo, v. 10, n. 2, p. 95-110, 2007. p. 97.

17 HABIAGZANG, Luísa Fernanda; CAMINHA, Renato Maiato. Abuso sexual contra crianças e adolescentes: conceituação e intervenção clínica. São Paulo: Casa do Psicólogo, 2004. p. 19. como todo o ser humano com menos de dezoito anos de idade, exceto se a lei nacional confere a maioridade mais cedo. Neste instrumento internacional, sublinha-se a necessidade de "a idade limite abaixo da qual não deve ser permitido privar uma criança de liberdade deve ser fixada em lei"18. Notou-se, também, nessa Convenção que o termo "criança" é utilizado sem distinção com o de menor e de adolescente.

Situação idêntica verifica-se nas Regras Mínimas das Nações Unidas para a Administração de Justiça de Menores (Regras de Beijing). Essa norma internacional opta por usar o termo "menor", entendido como "qualquer criança ou jovem que, em relação ao sistema jurídico considerado, pode ser punido por um delito, de forma diferente da de um adulto", ao passo que as Regras Mínimas das Nações Unidas para a proteção dos jovens privados de liberdades usam o termo "jovem", compreendido como "uma pessoa de idade inferior a 18 anos". Contudo, destaca-se nessa norma a necessidade de em cada país a lei estabelecer de forma explícita a idade-limite antes da qual o jovem não poderá ser privado de sua liberdade individual.

Em alguns países, faz-se uma distinção clara entre os termos menor, criança e adolescente. Por exemplo, o Estatuto da Criança e do Adolescente ${ }^{19}$ do Brasil (ECA) que dispõe sobre a proteção integral à criança e ao adolescente, estabelece uma diferença explícita entre criança e adolescente. À luz do ECA “considera-se criança, a pessoa até doze anos de idade incompletos e, adolescente aquela entre doze (completos) e dezoito anos de idade" (art. 2 ${ }^{\circ}$ ECA). O parágrafo único deste artigo estabelece que, nos casos expressos em lei, aplica-se excepcionalmente o ECA às pessoas entre dezoito e vinte e um anos de idade.

Noutros países, como é o caso de Moçambique, não se faz distinção clara, confundindo-se os três termos, como sinônimos, a semelhança com o conceito adotado na Carta Africana dos Direitos e Bem-Estar da Criança. $\mathrm{O}$ art. $3^{\circ}$ da Lei n. ${ }^{\circ}$ 7/2008, dispõe que, se considera criança, toda pessoa menor de dezoito anos de idade. Mas, nos casos expressamente previstos, a mesma lei aplica-se, também, aos menores com mais de dezoito e

18 ASSEMBLÉIA GERAL DAS NAÇÕES UNIDAS. Regras das Nações Unidas para a proteção dos menores privados de liberdade. Disponível em: <http://www.rolim.com.br/2002/_pdfs/066.pdf>. Acesso em: 20 set. 2014.

19 BRASIL. Estatuto da Criança e do Adolescente. 7. ed. Brasília: Câmara dos Deputados, 2010. 
menos de vinte e um anos de idade. Esta definição está em conformidade com os princípios do Direito Internacional, como explica Issá, ao aludir que:

No que se refere ao conceito de criança, depois
de considerados vários fatores atinentes ao
desenvolvimento da criança e ao estabelecimento
na Convenção sobre os Direitos da Criança,
decidiu-se acolher a regra estabelecida no Direito
Internacional, que considera criança, todo o menor
de 18 anos. Entendeu-se, entretanto, que deveria
estender a aplicação da lei aos maiores de 18 e
menores de 21 , sempre que se justifique. ${ }^{20}$

A Resolução n 32/2006 de Conselho de Ministros de Moçambique, que define "Estratégia de Desenvolvimento Integral da Juventude", estabelece uma diferenciação dos termos criança e jovem. Consta nessa resolução que jovem é todo o indivíduo moçambicano que se encontra na faixa etária de 15 a 35 anos de idade, o que se subentende que indivíduo com idade inferior a 15 anos seja considerado criança. No entanto, é importante destacar que o Código Civil de Moçambique (CC) define a maioridade civil em 21 anos (art. 130 do CC). Antes de se completar esta idade, salvo algumas exceções admitidas pelo art. 124 do CC, o exercício de direitos civis carece de consentimento dos representantes legais.

A Constituição da República de Moçambique (CRM) fixa a maioridade política em 18 anos - idade pela qual uma pessoa tem o dever e o direito de votar e de ser votada (exercício da cidadania). Contudo, no que diz respeito à responsabilidade criminal, que se traduz na imputabilidade ou inimputabilidade criminal, o Código Penal moçambicano (CP), determina que gozam de inimputabilidade absoluta "Os menores de 16 anos" (alínea a, do art. 46 do CP). E possuem a inimputabilidade relativa, "Os menores que, tendo dezesseis anos e menos de vinte e um, tiverem precedido sem discernimento" (alínea a, n. ${ }^{\circ}$, art. 47 do CP).

Pires e Nery Filho relacionam a questão de imputabilidade à responsabilidade. $\mathrm{Na}$ visão desses autores, "a imputação, ou imputabilidade, estabelece uma relação causal entre um sujeito e uma ação, no caso uma ação delituosa. [...]. Por sua vez, a responsabilidade, por outro lado, relaciona-se às consequências legais do ato praticado" 21 . Entretanto, o legislador moçambicano fi-

20 ISSÀ, Abdul Carimo Mahomed. Lei de base de proteção da criança, lei da organização jurisdicional de menores e lei sobre o tráfico de pessoas. Maputo: Central Impressora e Editora de Maputo, 2008. p. 18.

21 PERES, Maria Fernanda Tourinho; NERY FILHO, Antônio. A doença mental no direito penal brasileiro: inimputabilidade, irre- xou em 16 anos a maioridade criminal (a imputabilidade), que se entende como sendo a idade a partir da qual se considera que a criança já goza da necessária liberdade e inteligência para distinguir entre o bem e o mal. Nesse sentido, Marques, afirma que:

O menor, pelo seu desenvolvimento mental ainda incompleto, não possui a maturidade suficiente para dirigir a sua conduta com poder de autodeterminação em que se descubra, em pleno desenvolvimento, os fatores intelectivos e volitivos que devem nortear o comportamento humano. Daí entender-se que o menor não deve considerar-se um imputável. ${ }^{22}$

A nível teórico defende-se que o conceito da criança é refletido por uma visão subjetiva, segundo a qual, o ser criança pode significar, antes de mais nada, a incapacidade biológica e/ou psicológica de um indivíduo, de realizar determinado tipo de atividades classificadas sociológica e/ou legalmente como sendo de adultos e por essa razão, não se lhe deve atribuir tal responsabilidade $^{23}$. À luz da Legislação moçambicana (Código Penal e Civil), encontram-se, objetivamente, três classes ou categorias de crianças ou de adolescentes, nomeadamente: criança menor de 16 anos de idade - legalmente inimputável; criança maior de 16 e menor de 18 anos de idade - penalmente imputável com pena diminuída e civilmente inimputável; criança maior de 18 e menor de 21 anos de idade - penalmente imputável e civilmente inimputável ${ }^{24}$.

Essas divisões em categorias provêm do entendimento de que a pessoa, em certa idade, ainda não goza de uma sanidade mental apta para responder com as suas responsabilidades, como afirma Bitencourt:

A falta de sanidade mental ou a falta de maturidade
mental, que é a hipótese da menoridade (18 anos),
podem levarao reconhecimento dainimputabilidade,
pela incapacidade da culpabilidade. [...]. A
imaturidade mental, isoladamente, esgota o conceito
da inimputabilidade, porque, por presunção
legal, o menor de dezoito anos é mentalmente
imaturo e, consequentemente, incapaz de qualquer

sponsabilidade, periculosidade e medida de segurança. História, Ciências, Saúde - Manguinhos. Rio de Janeiro, v. 9, n. 2, p. 335-355, maio/ ago. 2002. p. 339.

22 MARQUES, José Frederico. Tratado de direito penal. Campinas: Bookseller, 1997. p. 222.

23 BALEIRA, Sérgio (Coord.). Relatório preliminar da pesquisa sobre "A Criança em Conflito com a Lei”. Moçambique: [S.n], abr.de 2003. Consultoria com Save The Children Norway. p. 25.

24 BALEIRA, Sérgio (Coord.). Relatório preliminar da pesquisa sobre "A Criança em Conflito com a Lei”. Moçambique: [S.n], abr.de 2003. Consultoria com Save The Children Norway. p. 27. 
culpabilidade. Nessa hipótese, é suficiente que se faça a comprovação da idade do menor, isto é, do aspecto puramente biológico. ${ }^{25}$

Couto compartilha também com a ideia de imputabilidade da criança, ao afirmar que "[...] a inimputabilidade em razão da idade se fundamenta nesta falta de maturidade emocional a par de uma incapacidade de controle de impulso de acordo com os valores adequados" ${ }^{26}$. Em outras palavras, Couto destaca que "a censura jurídico-penal do adulto possuidor de uma personalidade totalmente formada não existe para o menor, no qual se verifica uma certa falta de maturidade e entendimento de estruturas e valores ético-sociais" ${ }^{27}$.

$\mathrm{O}$ ato criminal praticado pela criança ou adolescente pode ser uma experiência de busca de sentido e de limite, da mesma maneira que pode ser um equivalente depressivo, uma maneira de disfarçar a depressão decorrente de abandono afetivo, emocional e familiar do menor infrator ${ }^{28}$. Daí decorre inimputabilidade em razão da menoridade.

\section{INSTRUMENTOS INTERNACIONAIS DE PROTEÇÃO DA CRIANÇA E DO ADOLESCENTE EM CONFLITO COM A LEI}

A necessidade e a exigência de reconhecimento da garantia de uma proteção especial à criança foram enunciadas, pela primeira vez, na Declaração de Genebra de 1924 sobre os Direitos da Criança. Mas, a partir da Declaração Universal dos Direitos Humanos, adotada em 1948, que comunidade internacional, por intermédio da Organização das Nações Unidas (ONU), vem construindo uma série de instrumentos normativos, em que são registrados mecanismos de controle e cooperação, visando assegurar a não violação dos direitos fundamentais do ser humano, em especial da criança.

25 BITENCOURT, Cezar Roberto. Código Penal comentado. São Paulo: Saraiva, 2002. p. 103.

26 COUTO, Isabel Luís do. O problema da idade da imputabilidade penal. 2012. 56 f. Tese (Mestrado) - Programa de Pós-Graduação do Centro Regional do Porto, Escola de Direito, Universidade Católica Portuguesa, Porto, 2012. p. 40.

27 COUTO, Isabel Luís do. O problema da idade da imputabilidade penal. 2012. 56 f. Tese (Mestrado) - Programa de Pós-Graduação do Centro Regional do Porto, Escola de Direito, Universidade Católica Portuguesa, Porto, 2012. p. 41.

28 TRINDADE, Jorge. Delinquência juvenil: competência transdisciplinar. 3. ed. Porto Alegre: Livraria do Advogado, 2002. p. 74.
É nessa perspectiva que o artigo 10 do Pacto Internacional de Direitos Econômicos, Sociais e Culturais, adotado pela Assembleia Geral das Nações Unidas em 1966, determina claramente que os Estados “devem adotar medidas especiais de proteção e de assistência que devem ser tomadas em benefício de todas as crianças e adolescentes, sem discriminação alguma derivada de razões de paternidade ou outras". Já o artigo 10 do Pacto Internacional sobre os Direitos Civis e Políticos de 1966 faz referências explícitas às crianças e aos adolescentes em conflito com a lei e, estabelece de forma clara os mecanismos de tratamento aos jovens nas mãos da justiça, aguardando o julgamento e julgados, como pode se observar na assertiva abaixo:

\section{As pessoas jovens processadas deverão ser separadas das adultas e julgadas o mais rápido possível. O regime penitenciário consistirá em um tratamento cujo objetivo principal seja a reforma e a reabilitação moral dos prisioneiros. Os delinquentes juvenis deverão ser separados dos adultos e receber tratamento condizente com sua idade e condição jurídica ${ }^{29}$.}

No entanto, o principal o instrumento jurídico mais transcendente, construído pela comunidade internacional para proteger os menores de idade autores de ato infracional é a Convenção Internacional sobre os Direitos da Criança, adotada pela Assembleia Geral da ONU em 1989. Esta Convenção dispõe sobre a Doutrina da Proteção Integral, demandando a observância dos princípios da excepcionalidade e brevidade da privação de liberdade da criança e do adolescente e a instituição da justiça juvenil.

A Convenção sobre os Direitos da Criança (CDC), a Carta Africana sobre os Direitos e Bem-estar da Criança apresentam uma ampla análise da necessidade de proteção da criança. Estes ordenamentos jurídicos reconhecem que as crianças são vulneráveis a violações dos seus direitos humanos básicos, e, consequentemente, lhes concede o direito fundamental à proteção jurídica e social, antes e após o nascimento.

De acordo com Tânia da Silva Pereira, a Convenção representa "um consenso de que existem alguns direitos básicos universalmente aceitos e que são essenciais para o desenvolvimento completo e harmonioso

29 ORGANIZAÇÃO DAS NAÇÕES UNIDAS. Pacto Internacional dos Direitos Civis e Politicos (1966). Disponível em: <http://www. oas.org/dil/port/1966\%20Pacto $\% 20$ Internacional $\% 20$ sobre $\% 20$ Direitos $\% 20$ Civis $\% 20 \mathrm{e} \% 20 \mathrm{Pol} \% \mathrm{C} 3 \%$ ADticos.pdf>. Acesso em: 25 jun. 2012. 
da criança" ${ }^{30}$. Para essa autora, a Convenção também "representa, em definitivo, o instrumento jurídico internacional mais transcendente para a promoção e o exercício dos direitos da criança" ${ }^{31}$. Na mesma perspectiva se insere a Veronese, ao dispor que o cumprimento das normas constantes naquela Convenção é de caráter obrigatório pelos Estados, porque a norma nela instituída "tem natureza coercitiva e exige de cada Estado-Parte que a subscreve e ratifica um determinado posicionamento. [...] tem força de lei internacional e, assim, cada Estado não poderá violar seus preceitos, como também deverá tomar as medidas positivas para promovê-los" ${ }^{\prime 32}$.

A Convenção sobre os Direitos da Criança (CDC) $)^{33}$ estabelece alguns princípios basilares que norteiam o tratamento das crianças e dos adolescentes em conflito com a lei. Estes podem se encontrar em situação de detidos em prisão preventiva ou que estejam na iminência de ser detidos. Dentre vários princípios, destaca-se os seguintes:

- A não discriminação da criança em relação a raça, cor, sexo, língua, religião, opinião política ou outra da criança, de seus pais ou representantes legais, ou da sua origem nacional, étnica ou social, fortuna, incapacidade, nascimento ou de qualquer outra situação (art. $2^{\circ}$, da CDC);

- Interesse superior da criança $\left(\operatorname{artigo~} 3^{\circ}\right)$;

- Direito à vida, à sobrevivência e ao desenvolvimento $\left(\operatorname{artigo} 6^{\circ}\right)$;

- Respeito pelas opiniões da criança (artigo 12\%);

- O dever de a custódia ou a detenção ser usada

30 PEREIRA, Tânia da Silva. A Convenção e o Estatuto: um ideal comum de proteção ao ser humano em vias de desenvolvimento. In: (Coord.). Estatuto da Criança e do Adolescente: Lei 8.069/90: "estudos sócio-jurídicos". Rio de Janeiro: Renovar, 1992 p. 67-115. p. 68.

31 PEREIRA, Tânia da Silva. A Convenção e o Estatuto: um ideal comum de proteção ao ser humano em vias de desenvolvimento. In: __ (Coord.). Estatuto da Criança e do Adolescente: Lei 8.069/90: "estudos sócio-jurídicos". Rio de Janeiro: Renovar, 1992 p. 67-115. p. 68 .

32 VERONESE, Josiane Rose Petry. Humanismo e infância: a superação do paradigma da negação do sujeito. In: MEZZAROBA, Orides (Org.) Humanismo latino e Estado no Brasil. Florianópolis: Fundação Boiteux, 2003. p. 421-452. p. 434.

33 ORGANIZAÇÃO DAS NAÇÕES UNIDAS. A Convenção sobre os Direitos da Criança: adoptada pela Assembleia Geral nas Nações Unidas em 20 de novembro de 1989 e ratificada por Portugal em 21 de setembro de 1990. Disponível em: <https://www.unicef. pt/docs/pdf_publicacoes/convencao_direitos_crianca2004.pdf $>$. Acesso em: 27 set. 2014 como último recurso (art. 37, da CDC);

- A proibição de torturas e outras formas de tratamento cruel, desumano e degradante ou punição - (alínea a, art. 37, da CDC);

- A proibição da detenção irregular e ilegal, incluindo detenção sem acusação formada ou sem suspeita de envolvimento no cometimento de ofensa criminal (alínea b, art. 37, da CDC);

- A proibição de aplicação de penas de morte e de prisão perpétua aos menores de 18 anos de idade ou de impor estas penas devido aos crimes cometidos antes de 18 anos (alínea a, art. 37, da CDC);

- O dever da separação do recinto da detenção ou prisão dos menores de idade com os adultos, em todas as fases do processo (alínea c, art. 37, da CDC);

- O direito a condições humanas de detenção, incluindo a manutenção do contato com os membros da sua família (alínea c, art. 37, da CDC).

Para as crianças e os adolescentes que tenham que depor em casos como testemunhas, vítimas ou perpetradoras de violação, deve se assegurar o respeito pelos seguintes princípios e direitos: direito à privacidade, direito a proteção, apoio psicológico, direito a assistência legal, excepcionalidade, brevidade e respeito à condição peculiar de pessoa em desenvolvimento (art. 40, da CDC). Em suma, a criança tem o direito de ser protegida contra todas as formas de exploração prejudiciais a qualquer aspecto do seu bem-estar (art. 36, da CDC).

Ainda em relação à preocupação pela proteção dos direitos da criança e do adolescente, especificamente, em conflito com a lei, há outros instrumentos internacionais que servem de referência para o atendimento e a aplicação da justiça juvenil. Nas Regras Mínimas das Nações Unidas para Administração da Justiça da Infância e da Juventude, por exemplo, são detalhadas as diretrizes para a instalação de justiças especializadas e as garantias mínimas que devem ser conferidas à criança e ao adolescente acusado de prática infracional.

A Declaração Universal dos Direitos da Criança, a Convenção Americana de Direitos Humanos, as Diretrizes das Nações Unidas para a Prevenção da Delinquência Juvenil, e as Regras Mínimas das Nações Unidas para a Proteção dos Jovens Privados de Liberdade (Regras de Beijing), são outros instrumentos legais estatuídos pela comunidade internacional a favor dos direi- 
tos da criança e do adolescente, envolvidos em atos criminais. O conteúdo dessas normas permeia a legislação moçambicana relativa à problemática em análise.

Decorrente da Convenção Americana de Direitos Humanos (1969) - Pacto de San José da Costa Rica, no artigo 19, de forma pouco descritiva está plasmado que "Toda criança terá direito às medidas de proteção que a sua condição de menor requer, por parte da sua família, da sociedade e do Estado". A Declaração Universal dos Direitos das Crianças de 20 de novembro de 1959 estabeleceu 10 princípios de proteção da criança e do adolescente. Dentre eles podem-se destacar os seguintes:

\begin{abstract}
Princípio I - A criança desfrutará de todos os direitos enunciados nesta Declaração. Estes direitos serão outorgados a todas as crianças, sem qualquer exceção, distinção ou discriminação [...]. Princípio II - Direito à especial proteção para o seu desenvolvimento físico, mental e social e, disporá de oportunidade e serviços, a serem estabelecidos em lei por outros meios [...]. Ao promulgar leis com este fim, a consideração fundamental a que se atenderá será o interesse superior da criança. Princípio X - A criança deve ser protegida contra as práticas que possam fomentar a discriminação racial, religiosa, ou de qualquer outra índole. Deve ser educada dentro de um espírito de compreensão, tolerância, amizade entre os povos, paz e fraternidade universais e com plena consciência de que deve consagrar suas energias e aptidões ao serviço de seus semelhantes. ${ }^{34}$
\end{abstract}

O $8^{\circ}$ Congresso das Nações Unidas sobre a Prevenção do Delito e Tratamento do Delinquente, criado por meio da resolução $n^{\circ}$ 45/112, de 14 de Dezembro de 1990, e as Diretrizes das Nações Unidas para a Prevenção da Delinquência Juvenil - Diretrizes de Riad, estabelecem políticas e medidas progressistas de prevenção da delinquência juvenil, que se traduzem na participação dos adolescentes nos programas de serviços comunitários, de autoajuda e de indenização e assistência nos casos em que aparecem como vítimas. Ainda no $8^{\circ}$ congresso, foram estabelecidas "Regras das Nações Unidas para a Proteção dos Menores Privados de Liberdade" 35 , tidas como princípios basilares para a consideração da prisão da criança e adolescente em conflito com a lei,

34 FUNDO DAS NAÇÕES UNIDAS PARA A INFÂNCIA. Declaração Universal dos Direitos das Crianças. Disponível em: <http:/ / www.mp.go.gov.br/portalweb/hp/8/docs/declaracao_universal_ dos_direitos_da_crianca.pdf $>$. Acesso em: 27 set. 2014.

35 ASSEMBLÉIA GERAL DAS NAÇÕES UNIDAS. Regras das Nações Unidas para a proteção dos menores privados de liberdade. Disponível em: <http://www.rolim.com.br/2002/_pdfs/066.pdf>. Acesso em: 20 set. 2014. em medida excepcional e no menor espaço de tempo. Estabeleceu-se, também, que deveria ser evitada, ao máximo possível, a ação coercitiva às crianças e aos adolescentes.

A finalidade das regras criadas é de "estabelecer normas mínimas aceitas pelas Nações Unidas para a proteção dos jovens privados de liberdade em todas as suas formas, de maneira compatível com os direitos humanos e liberdades fundamentais e, com vista a se opor aos efeitos prejudicais de todo tipo de detenção [...]" Consta nessas regras que "o sistema de justiça de menores deve respeitar os direitos e a segurança dos menores e promover o seu bem-estar físico e mental. A prisão deverá constituir uma medida de último recurso" ${ }^{37}$.

Relativamente à legislação e administração da justiça da infância e da adolescência, o $8^{\circ}$ Congresso das Nações Unidas sobre prevenção do delito e tratamento do delinquente, deliberou as seguintes regras:

50. Os governos deverão promulgar e aplicar leis e procedimentos especiais para fomentar e proteger os direitos e o bem-estar de todos os jovens. 51. Deverá ser promulgada e aplicada uma legislação que proíba a vitimização, os maus-tratos e a exploração das crianças e dos jovens. 52. Nenhuma criança ou jovem deverá ser objeto de medidas severas ou degradantes de correção ou castigo no lar, na escola ou em qualquer outra instituição. 54. Com o objetivo de impedir que se prossiga à estigmatização, à vitimização e à incriminação dos jovens, deverá ser promulgada uma legislação pela qual seja garantido que todo ato que não seja considerado um delito, nem seja punido quando cometido por um adulto, também não deverá ser considerado um delito, nem ser objeto de punição quando for cometido por um jovem. 55. Poderá ser considerada a possibilidade de se estabelecer um escritório de "proteção da infância e da adolescência” (ombudsman) ou um escritório análogo independente que garanta o respeito da condição jurídica, dos direitos e dos interesses dos jovens e, também, a possibilidade de remeter casos aos serviços disponíveis. Do mesmo modo, deverão ser estabelecidos serviços de

36 ASSEMBLÉIA GERAL DAS NAÇÕES UNIDAS. Regras das Nações Unidas para a proteção dos menores privados de liberdade. Disponível em: <http://www.rolim.com.br/2002/_pdfs/066.pdf>. Acesso em: 20 set. 2014.

37 ASSEMBLÉIA GERAL DAS NAÇÕES UNIDAS. Regras das Nações Unidas para a proteção dos menores privados de liberdade. Disponível em: <http://www.rolim.com.br/2002/_pdfs/066.pdf>. Acesso em: 20 set. 2014. 
defesa jurídica da criança. 56. O pessoal, de ambos os sexos, da polícia e de outros órgãos de justiça deverão ser capacitados para atender às necessidades especiais dos jovens; essa equipe deverá estar familiarizada com os programas e as possibilidades de remessa a outros serviços, e devem recorrer a eles sempre que possível, com o objetivo de evitar que os jovens sejam levados ao sistema de justiça penal. 57. Leis deverão ser promulgadas e aplicadas, estritamente, para proteger os jovens do uso indevido das drogas e de seus traficantes ${ }^{38}$.

Diretrizes semelhantes foram estabelecidas pela Carta Africana dos Direitos e Bem-Estar da Criança, ao dispor no artigo 17 de uma "Administração da Justiça Juvenil" e determinando que "Cada criança ou acusados culpados de terem violado o direito penal terão direito a tratamento especial, de forma coerente com a criança o sentido de dignidade e valor e que reforça a criança o respeito pelos direitos humanos e liberdades fundamentais ${ }^{39}$ ".

A Organização de Unidade Africana (OUA), criada a 25 de maio de 1963 em Addis Abeba, Etiópia, substituída pela União Africana (UA) a 9 de julho de 2002, determina também que os Estados-Membros dessa Carta, em especial devem: assegurar que nenhuma criança que esteja detida ou presa ou de outra forma privada da sua liberdade deva ser submetida a tortura, tratamento desumano ou degradante ou punição; assegurar que as crianças sejam separadas dos adultos em seu local de detenção ou prisão; assegurar que cada criança acusada de violar a lei penal deva ser presumida inocente até devidamente reconhecidos culpados; oferecer assistência jurídica e outras, adequadas para a preparação e apresentação de sua defesa; determinar o assunto a criança o mais rapidamente possível, por um tribunal imparcial e se considerado culpado, tem direito a um recurso apresentado por um tribunal superior; e proibição da imprensa e ao público publicar imagens e julgamento da criança.

Moçambique ratificou diversos instrumentos internacionais que estabelecem garantias de proteção dos direitos da criança e do adolescente em conflito com

38 ORGANIZAÇÃO DAS NAÇÕES UNIDAS. Diretrizes das Nações Unidas para Prevenção da Delinquência Juvenil, Diretrizes de Riad. Disponível em: < http://www.dhnet.org.br/direitos/sip/onu/c_a/ lex45.htm>. Acesso em: 20 set. 2014.

39 ORGANIZAÇÃO DE UNIDADE AFRICANA. Carta Africana dos Direitos e Bem-Estar da Criança. Disponível em: <http:/ / www. didinho.org/CartaAfricDirBEC.pdf>. Acesso em: 20 set. 2014. a lei. São eles: Convenção sobre os Direitos da Criança de 1989; Carta Africana dos Direitos e Bem-Estar da Criança de 1990; Protocolo Adicional à Convenção das Nações Unidas contra Criminalidade Organizada Transnacional, relativo à Prevenção e Punição do Tráfico de Pessoas, em especial Mulheres e Crianças de 2000, ratificados em 1989, 1980 e 2001, respectivamente. Também ratificou as seguintes legislações internacionais: a Declaração Universal dos Direitos do Homem; o Pacto Internacional Sobre Direitos Civis e Políticos; a Carta Africana dos Direitos do Homem e dos Povos; e a Carta dos Direitos Fundamentais, outorgada pela SADC. Essa ação simboliza o compromisso do Governo de Moçambique para com a harmonização da legislação nacional com as normas internacionais.

No entanto, como pode se perceber, há muitos instrumentos internacionais que estabelecem, de uma forma clara, princípios de proteção à criança e ao adolescente em conflito com a lei, tanto a nível internacional, assim como em Moçambique. Contudo, esses instrumentos continuam sendo violados pelas entidades responsáveis pela justiça infantil ou dos que velam sobre a matéria do direito da criança. Por exemplo, no Relatório da Amnistia Internacional de 2012 consta que "durante a sua visita a centros de detenção, encontraram vários jovens que afirmaram e aparentavam ser menores de 16 anos de idade. Alguns, [...], declararam que na altura da sua detenção tinham menos de 16 anos de idade" ${ }^{\prime 4}$.

Em setembro de 2013, “o Diretor Nacional Adjunto dos Serviços Prisionais comunicou que havia 15.663 presos, incluindo 618 prisioneiras e 5.108 menores na faixa etária dos 16 aos 18 anos de idade em prisões projetadas para alojar apenas 7.804"41. Esse cenário revela que as crianças são vulneráveis á violação dos seus direitos humanos básicos. Essas crianças não têm sido colocadas em penitenciárias específicas, ou seja, separadas com os adultos. Estas e outras práticas violam o artigo 37 da CDC, ao dispor que "Nenhuma criança deve ser

40 AMNISTIA INTERNACIONAL. Aprisionando os meus direitos prisão e detenção arbitrária e tratamento dos reclusos em Moçambique. Maputo: Amnesty International, nov. de 2012. Disponível em: $<$ http://www.amnistia-internacional.pt/files/Noticias_anexos/ novembro2012/Mocambique_Aprisionando_os_meus_direitos_ embargado_01h00_de_dia_22nov2012.pdf>. Acesso em: 01 fev. 2016. Índice: AFR 41/001/2012. p. 34.

41 RELATÓRIO dos direitos humanos: Moçambique de 2013. Disponível em: <http://photos.state.gov/libraries/mozambique/19452/pdfs/mozambiquehrrfinal.pdf>. Acesso em: 27 maio 2014. 
submetida à tortura, a penas ou tratamentos cruéis, à prisão ou detenção ilegal [...]. A criança privada de liberdade deve ser separada dos adultos, [...]”.

Todavia, o governo moçambicano mostra-se preocupado com a situação que as crianças e adolescentes em conflito com a lei estão sendo expostas, ou seja, denotam-se ações que evidenciam o compromisso no melhoramento da situação. Por exemplo, ao nível legislativo e em respeito pelas Convenções Internacionais ratificadas no País, o governo estatuiu o conjunto de disposições relativas à proteção jurídica e social à criança e adolescente suspeitos de prática do crime. São eles:

a. A Lei n. ${ }^{\circ} 8 / 2008$, de 15 de julho, que aprova "A organização Tutelar de Menores". Está Lei estabelece o regime jurisdicional aplicáveis à criança que comete um ato tipificado como crime;

b. A Lei no 7/2008, de 9 de julho, Lei de Bases de Promoção dos Direitos da Criança em Moçambique;

c. A Lei no 29/2009, de 29 de setembro, Lei da Violência Doméstica de 2009, que não só tem por objetivo de reforçar a proteção das mulheres, como também de crianças contra o abuso e a exploração sexual em casa e nas comunidades;

d. Lei n ${ }^{\circ} 23 / 2007$, de 1 de agosto, Lei do Trabalho que pró́be especificamente as piores formas de trabalho infantil para as crianças menores de 18 anos, independentemente do local que o menor se encontre (penitenciaria ou casa);

e. Lei $\mathrm{n}^{\circ}$ 10/2004, de 25 de agosto, Lei da Família, que dispõe novas normas jurídicas para responsabilidades parentais, guarda, adoção e herança;

f. Decreto $n^{\circ} 5 / 89$, de 10 de abril, que dispõe sobre a tramitação processual relativa à concessão da adoção e tutela de menores; e;

g. Lei n. ${ }^{\circ}$ 4/2007 de 7, Lei de Proteção Social, que estabelece a necessidade e a exigência da provisão de segurança social básica a pessoas pobres e crianças em situações difíceis.

O dever de observância estrita dos princípios internacionais e nacionais de proteção da criança e do adolescente em conflito com a lei em Moçambique re- cai, não só às entidades públicas (Ministério da Justiça, Conselho Nacional da Criança, Ministério da Mulher e da Ação Social, Ministério do Interior, Tribunal de Menores, Serviço Nacional das Prisões), como também ás organizações não governamentais (UNICEF, UNICRI, SAVE THE CHILDREN etc), por meio de sistemas e serviços legislativos, sociais e administrativos apropriados de apoio e assistência social, com finalidade de diminuir os riscos de violação dos direitos da criança e do adolescente.

\section{JUSTIÇA INFANTIL E A PROTEÇÃO DE CRIANÇAS em Moçambique}

A Lei n. ${ }^{\circ}$ 8/2008, de 15 de julho, que aprova "A organização Tutelar de Menores" e a Lei no 7/2008, de 9 de julho, Lei de Bases de Promoção dos Direitos da Criança, constituem, praticamente, o quadro legal da justiça de menores em Moçambique. A aplicação dessas leis é feita em harmonia com os instrumentos internacionais ratificados em Moçambique (Convenção sobre os Direitos da Criança de 1989; Carta Africana dos Direitos e Bem-Estar da Criança; Protocolo Adicional à Convenção das Nações Unidas contra Criminalidade Organizada Transnacional, relativo à Prevenção e Punição do Tráfico de Pessoas, em especial Mulheres e Crianças de 2000; e demais legislações de proteção à criança e ao adolescente).

A aprovação desses instrumentos legais em 2008 simbolizava o nascimento de um sistema de proteção infantil em Moçambique. Não obstante, reconhece-se a existência neles de certas incongruências, pois não está bem claro a competência de algumas instituições neles elencados. Na percepção de Issá:

Os dois instrumentos legais acima mencionados [encontram-se] em muitos dos seus aspectos, ultrapassados e reajustados à realidade. Por outro lado, em muitas vertentes, o Estatuto e seu Regulamento não [chegam] a ter qualquer aplicação prática, designadamente, no que dissesse respeito aos serviços de assistência social, de observação e aos estabelecimentos de prevenção criminal previstos no Estatuto e regulamento. $\mathrm{Na}$ verdade, aqueles serviços e instituições nunca chegaram a funcionar tal como foram concedidos ${ }^{42}$.

42 ISSÀ, Abdul Carimo Mahomed. Lei de base de proteção da criança, lei da organização jurisdicional de menores e lei sobre o tráfico de pessoas. Maputo: Central Impressora e Editora de Maputo, 2008. p. 69. 
É de concordar com Issá, pois naqueles instrumentos legais, por exemplo, não constam de uma forma explícita os mecanismos e procedimentos claros da competência exclusiva da instituição policial. Esse fato faz com que, em algumas vezes, as crianças permaneçam muito tempo sob custódia policial, já que o primeiro contato entre os menores em conflito com a lei e a justiça infantil é quase atribuído à Polícia da República de Moçambique (PRM), por meio do Departamento de Atendimento à Mulher e Criança Vítimas de Violência Doméstica - Setor que atende as queixas relacionadas com a violência praticada contra a mulher e criança, no domínio das relações domésticas e familiares, e de que não resulte à morte. Esse departamento tem um papel preponderante no atendimento, assistência, registro e encaminhamento dos menores em conflito com a lei à justiça de menores, para além de outras ações que a lei confere.

A juíza-presidente do Tribunal de Menores em Moçambique, Manuela de Oliveira, falando em Maputo num encontro de avaliação da implementação do projeto de reabilitação juvenil, que inclui medidas alternativas à detenção de crianças em conflito com a lei, citada pelo Jornal Notícias de Moçambique, no dia 28 de março de 2014, afirmou que "a manutenção de crianças detidas por muitos dias nas esquadras policiais é uma das contrariedades que dificultam a aplicação de penas alternativas à prisão e, consequentemente, a totalidade do processo de regeneração de menores em conflito com a lei" ${ }^{43}$. Muito recentemente assistiu-se esse tipo de situação. Foi no dia 08 de novembro de 2014, quando "um grupo de nove crianças, com idades compreendidas entre 14 e 15 anos, foi detido [...] em Maputo, acusado de protagonizar roubos na via pública com recurso a armas brancas"44. De acordo com o Jornal@Verdade, os menores foram encarcerados na $12^{\mathrm{a}}$ Esquadra da Polícia em Maputo, onde aguardam pelo seguimento dos trâmites legais. A Polícia da República de Moçambique (PRM) justificou a prisão dos menores nos seguintes

43 EM conflito com a lei: Ilegalidades dificultam regeneração de crianças. Noticias on-line, Maputo, 28 mar. 2014. Disponível em: $<$ http://www.jornalnoticias.co.mz/index.php/sociedade/13119em-conflito-com-a-lei-ilegalidades-dificultam-regeneracao-de-criancas>. Acesso em: 01 fev. 2016.

44 NOVE crianças detidas por roubo na via pública em Maputo.Jornal@Verdade, Moçambique, 18 nov. 2014. Disponível em: $<$ http://www.verdade.co.mz/newsflash/50307-nove-criancas-detidas-por-roubo-na-via-publica-em-maputo->. Acesso em: 23 out. 2015. termos:

A detenção ocorreu graças a denúncia de populares, por várias vezes foram ameaçados por aqueles menores com recurso a navalhas, facas e outros instrumentos contundentes, para além de terem perdido os seus pertences. "Esperamos que a detenção sirva de lição para estes e outros menores que enveredam pelo mesmo caminho deixem o mundo do crime e voltem a integrar-se nas suas famílias e tornem-se seres humanos decentes e úteis para a sociedade" ${ }^{45}$.

Manuela de Oliveira entende que "No lugar de manter as crianças nas esquadras por muito tempo o ideal, [...], seria o seu encaminhamento imediato ao Tribunal de Menores, entidade legitimada para tratar todos os procedimentos necessários". Continuamente afirma a juíza que "Esta ilegalidade cometida nas esquadras cria embaraços na aplicação das medidas alternativas à prisão por parte de alguns juízes, fato que compromete o processo de reabilitação dos menores" ${ }^{46}$. Manuela de Oliveira afirma ainda que:

[...] a Polícia tem ficado com os menores por muito tempo, acabando por resolver o problema a seu jeito, sem seguir os procedimentos que estão previstos na lei. Por seu turno, o Vice-Ministro da Justiça, Alberto Nkutumula, confirmou que o procedimento policial é inadequado, fato que compromete todo o processo de condução do menor até ao devido tratamento legal. Joaquim Nhampossa, do Ministério do Interior, reconheceu as falhas cometidas pela Polícia, muitas das quais estão, segundo ele, relacionadas com o desconhecimento da matéria por parte dos agentes ${ }^{47}$.

Dessa forma, alguns pesquisadores veem o fenômeno de existência de crianças e adolescentes em conflito com a lei como sendo um problema derivado da má atuação das autoridades governamentais e não governamentais:

45 NOVE crianças detidas por roubo na via pública em Maputo.Jornal@Verdade, Moçambique, 18 nov. 2014. Disponível em: $<$ http://www.verdade.co.mz/newsflash/50307-nove-criancas-detidas-por-roubo-na-via-publica-em-maputo->. Acesso em: 23 out. 2015.

46 NOVE crianças detidas por roubo na via pública em Maputo.Jornal@Verdade, Moçambique, 18 nov. 2014. Disponível em: $<$ http://www.verdade.co.mz/newsflash/50307-nove-criancas-detidas-por-roubo-na-via-publica-em-maputo- $>$. Acesso em: 23 out. 2015.

47 NOVE crianças detidas por roubo na via pública em Maputo.Jornal@Verdade, Moçambique, 18 nov. 2014. Disponível em: $<$ http://www.verdade.co.mz/newsflash/50307-nove-criancas-detidas-por-roubo-na-via-publica-em-maputo->. Acesso em: 23 out. 2015. 
Quanto aos casos de menores em conflito com a lei, a ausência pode ser explicada, por um lado, pela inexistência de instituições adequadas para lidar com aquele tipo de questões em Moçambique. A precariedade da oferta jurídica e judiciária afasta uma parte considerável da procura potencial. Por outro lado, há muitos casos de menores em conflito com a lei que recebem tratamento inadequado por parte das instituições judiciárias, particularmente a polícia, sendo-lhes aplicadas medidas carcerárias ${ }^{48}$.

Em razão disso, atualmente, o sistema de justiça criminal moçambicano, no que toca às crianças e aos adolescentes em conflito com a lei, carece severamente de uma abordagem centrada no respeito pelos direitos da criança, tal como é requerido pelos instrumentos nacionais e internacionais de Direito Público. $\mathrm{O}$ artigo $1^{\circ}$ da Lei n. ${ }^{\circ} 7 / 2008$, de 09 de julho, é claro neste assunto, ao dispor que o objeto daquela Lei é a proteção da criança e visa, essencialmente, promover e proteger os direitos da criança, tal como se encontram definidos na Constituição da República de Moçambique de 2004 (CRM), na Convenção sobre os Direitos da Criança (CDC), na Carta Africana sobre os Direitos e Bem-estar da Criança e nas demais legislações de proteção à criança.

Esse entendimento mostra que Moçambique recebe e aceita as normas do Direito Internacional e que estas devem ser respeitadas. Aliás, a CRM já dispõe, de forma explicita, no n. 2 do art. 17 que "A República de Moçambique aceita, observa e aplica os princípios da Carta da Organização das Nações Unidas e da Carta da União Africana”. Ademais, estabelece no n. ${ }^{\circ} 1$ do art. 18 CRM que "Os tratados e acordos internacionais, validamente aprovados e ratificados, vigoram na ordem jurídica moçambicana após a sua publicação oficial e enquanto vincularem internacionalmente o Estado de Moçambique". Assim, as normas internacionais "têm na ordem jurídica interna o mesmo valor que assumem os atos normativos infraconstitucionais emanados da Assembleia da República e do Governo, consoante a sua respectiva forma de recepção" (n. ${ }^{\circ} 2$, art. 18 da CRM). É importante ressaltar que a Convenção dos Direitos da Criança (CDC) foi ratificada pela Resolução no 19/90 da Assembleia da República de Moçambique de 23 de outubro.

No entanto, essas normas continuam sendo violadas, como se observa nos procedimentos e tratamentos atuais aos menores em conflito com a lei no País.

48 FUMO, Joaquim; JOSÉ, André Cristiano; SAMO, Saturnino. Estudo diagnóstico da justiça de menores. Maputo: CEIDIMA, 2012. p. 44.
Dessa forma, fica violado o n. $^{\circ} 1$ do artigo $3^{\circ}$ da CDC, ao dispor que: "Os Estados-Partes comprometem-se a garantir à criança a proteção e os cuidados necessários ao seu bem-estar, tendo em conta os direitos e deveres dos pais, representantes legais ou outras pessoas que a tenham legalmente a seu cargo [...]".

No estágio atual que o sistema de justiça de menores em Moçambique apresenta, é correto afirmar que há um grande desconhecimento dos procedimentos para o tratamento correto da justiça de menores, como estabelecem as normas internacionais. Este fator resulta no tratamento inadequado da criança e do adolescente por parte das instituições judiciárias. Estas práticas impróprias têm outras consequências na vida da criança ou do adolescente:

Os adolescentes julgados nos tribunais se distinguem significativamente dos outros adolescentes em muitas das escalas de medida da regulação familiar. As famílias dos adolescentes julgados e internados em instituições são mais desfavorecidas no plano estrutural e que os laços entre os pais e o adolescente são fracos assim como a supervisão parental. ${ }^{49}$

O envolvimento da família constitui um ato muito importante para a repressão da conduta delitiva da criança ou do adolescente em conflito com a lei, nos processos decisórios da justiça criminal.

Dado o seu papel central na socialização das crianças e adolescentes, a família tem sido considerada um fator decisivo no desenvolvimento da delinquência juvenil. Assim, não é por acaso que muitas teorias da delinquência juvenil se centram na estrutura familiar, na interação pais-filhos e nos estilos educativos dos pais ${ }^{50}$.

Nesse entendimento, McCord afirma que "A presença dos pais é reforçada pela comunicação que permite ao adolescente conhecer as opiniões e as expectativas parentais. $\mathrm{O}$ adolescente torna-se então consciente das potenciais consequências que a sua conduta ilícita tem nas suas relações com os pais" "51. Contudo, essa visão, as vezes, é ignorada pelas comunidades, pois, há ocasiões

49 MCCORD, Joan. Forjar criminosos na família. In: FONSECA, António Castro. Comportamento anti-social e familia: uma abordagem científica. Coimbra: Almedina, 2002. p. 15-36. p. 57.

50 NAPLAVA, Thomas; OBERWITTLER, Dietrich. Fatores familiares e delinquência juvenil: resultados da investigação sociológica na Alemanha. In: FONSECA, António Castro. Comportamento anti-social e família: uma abordagem científica. Coimbra: Almedina, 2002, p. 157-180. p. 157.

51 MCCORD, Joan. Forjar criminosos na família. In: FONSECA, António Castro. Comportamento anti-social e família: uma abordagem científica. Coimbra: Almedina, 2002. p. 15-36. p. 41. 
em que, a população sai ao público pressionando ou mesmo criticando a polícia por não manter sob custódia policial as crianças e adolescentes autores de infrações criminais. Nessa perspectiva, as crianças são vistas pelos populares como os principais protagonistas do crime e da insegurança pública que criam pânico no seio das comunidades. A conduta da população pode também significar o desconhecimento dos procedimentos legais que a lei moçambicana e do Direito Público oferece para a garantia dos direitos da criança em conflito com a lei, como por exemplo, a Lei n. ${ }^{\circ}$ 7/2008, de 09 de julho, que contempla vários mecanismos sobre a imputabilidade da criança e adolescente em conflitos com a lei.

Nos termos do artigo 82 da Lei n. ${ }^{\circ} 7 / 2008$, de 09 de julho, a imputabilidade criminal da criança deve ser definida na lei criminal. Dessa forma, em Moçambique, a criança com menos de 16 anos não pode ser sujeita a medidas de privação de liberdade, apenas se lhe podendo aplicar as medidas tutelares previstas por lei (art. 83). Também, a criança maior de 16 anos e menor de 18 que cometa crime de pequena gravidade deve aplicar-se, sempre que possível medida alternativa a de prisão (art. 84). Entretanto, não é o que se observa nos tribunais moçambicanos. Pode-se notar, em relação aos dados apresentados na parte introdutória deste artigo, em que do universo de crianças em conflito com a lei, inquiridas pela UNICEF em 2006, pelo menos 25\% tinham menos de 18 anos de idade, e 18\% tinham menos de 16 . O número cresceu em 2013, em que dados divulgados por Mangue (2013) apontavam para cerca de 2300 crianças e adolescentes em conflito com a lei, estavam mantidos em regime de reclusão, vivendo uma situação de vulnerabilidade no País. Estes fatos violam, não só a própria lei nacional, como também as normas internacionais de direitos da criança.

Que se diga de passagem que a lei moçambicana sobre está matéria apresenta muitas lacunas. Dispõe o n. ${ }^{\circ} 1$, do art. 85 da lei n. ${ }^{\circ} 7 / 2008$, de 09 de julho que, "Salvo o disposto na lei, nenhuma criança criminalmente inimputável será privada da sua liberdade senão em flagrante delito ou por ordem escrita e fundamentada da autoridade judiciária competente". Esse dispositivo legal dá a entender que os menores de 16 anos de idade em Moçambique podem ser presos, desde que seja em flagrante delito ou com um mandato judicial. É este artigo que legitima os agentes da autoridade pública em prender menores inimputáveis, violando as normas internacionais. Se a lei fala de inimputabilidade absoluta dos menores de 16 anos (art. 46 do Código Penal), não há razão para estes serem presos. É necessário aplicar-lhes medidas socioeducativas, o que não necessariamente é sinônimo de prisão.

$\mathrm{O}$ art. 28 da Lei 8/2008, de 15 de julho, elenca uma série de medidas socioeducativas que podem ser aplicadas a crianças e adolescentes em conflito com a lei, das quais se destacam as seguintes: repreensão registrada; entrega à responsabilidade dos pais, tutor, família de acolhimento ou pessoas encarregadas pela sua guarda; acolhimento em instituições de proteção; liberdade assistida da criança; assistência médico-psicológica; colocação em família idônea ou em estabelecimento oficial de educação, em regime de semiaberto; colocação, em regime de internamento, em escolas de formação vocacional; e internamento em estabelecimento de recuperação juvenil.

Uma vez que o n. ${ }^{\circ} 1$ do art. 85, da Lei n. ${ }^{\circ}$ 7/2008, de 09 de julho, autoriza, de forma explicita, a prisão de menores, os números subsequentes deste artigo estabelecem alguns procedimentos que devem ser observados no momento da detenção. É o caso de, em situações que a criança seja privada de sua liberdade, dever-se-á separar dos adultos e se respeitar o direito de manter contatos regulares com a sua família (n. ${ }^{\circ}$, art. 85). Nesses termos, o menor privado de liberdade é assegurado pelo Estado pronto acesso a assistência judiciária e garantido tratamento, com humanidade e com o respeito devido à dignidade da pessoa humana, de forma consentânea às necessidades da sua pessoa e idade (n. ${ }^{\circ} 4$, art. 85).

A prisão de qualquer criança e o local onde se encontre detida devem ser comunicados imediatamente à autoridade judiciária competente e à família do menor detido ou à pessoa por ele indicada (art. 86). Nenhuma criança ou adolescente é privada da sua liberdade sem que exista processo instaurado nos termos da lei (art. 90). As crianças que estiverem em prisão preventiva devem beneficiar-se de todos os direitos e garantias previstas nas Regras Mínimas das Nações Unidas para tratamento de menores em conflito com a lei. Nessas regras, destaca-se a necessidade de as crianças ou os adolescentes estarem separados dos adultos.

O outro direito que se assiste aos menores é a vedação da divulgação de atos judiciais, policiais e administrativos que digam respeito à criança a quem seja atribuída autoria de ato delitivo (art. 94, da Lei n. 7 /2008, de 09 de julho) assim como nenhuma criança pode ser 
sujeita a tratamento negligente, discriminatório, violento e cruel, nem ser objeto de qualquer forma de exploração ou opressão. Sendo punidos por lei todos os atos que se traduzam em violação dos direitos ora estabelecidos (art. $7^{\circ}$ da Lei n..$^{\circ}$ 7/2008, de 09 de julho).

Independentemente das dificuldades e contradições que ainda marcam o processo de proteção da criança e do adolescente em conflito com a lei em Moçambique, parece inquestionável que o governo moçambicano assumiu tarefas de grandes proporções (criação de um quadro jurídico favorável à realização dos direitos da criança), com vista a inverter o cenário, o que muitas vezes contrasta com a sua capacidade de dar respostas com a efetividade esperada. Os mecanismos já estão criados na lei, nota-se, nesse momento, a falta de políticas e infraestruturas adequadas para a internação de crianças autores de ato infracional. Não menos importante constata-se, também, a fraca formação do pessoal que lida com matérias do gênero, de modo a dotá-los de conhecimentos básicos que os permitam lidar com os menores sem violar as normas internas e internacionais.

\section{Considerações finais}

Das análises e interpretações feitas neste artigo, é correto afirmar que vários são os instrumentos internacionais de proteção às crianças e aos adolescentes em conflito com a lei, ratificados pelo governo de Moçambique. Essas normas, equacionadas com as leis nacionais, são suficientes para a garantia dos direitos dos visados. Mas o problema continua sendo a inobservância destes instrumentos. Como forma de superar esse problema, a tese de uma formação e capacitação jurídica em matéria do direito da criança aos agentes ligados ao setor da justiça de menores, seja a mais correta.

Outrossim, com base em uma análise restrita aos argumentos apresentados, conclui-se que, apesar dos importantes avanços alcançados no campo da legislação e das políticas de proteção social dos direitos da criança em Moçambique, aprovados a nível nacional, ainda são vários os problemas ligados à proteção das crianças e do adolescente em conflito com a lei, no País. As leis nacionais e internacionais continuam sendo violadas, devido aos maus procedimentos dos agentes responsáveis por esta matéria. Por exemplo, a prisão de menores de 16 anos; falta de coordenação entre as entidades responsável (Polícia, Tribunal, Ministério Público, entre outras) em manter os primeiros contatos, fazer diligências e encaminhar os menores ao tribunal ou instituições vocacionadas à proteção das crianças; o tratamento inadequado de menores; a demora em entregar os menores detidos ao tribunal para a decretação de medidas cautelares diversas da prisão; entre outras práticas contrárias a legislações internas e do Direito Internacional, constituem fenômenos sociais que continuam abalando o sistema de proteção das crianças e adolescentes autores de ato infracional, no País.

No entanto, muitos ainda são os desafios que o governo de Moçambique tem para a cabal proteção e respeito pelos direitos e liberdade dos menores vulneráveis a sanções penais. Para o efeito, é importante que se diga que dentro das instituições do Estado comprometidas com a causa da criança e do adolescente, é indispensável a criação de instituições vocacionadas, não só para aplicar os princípios estabelecidos na lei, como também para socializar, reabilitar, ou mesmo melhorar o tratamento das crianças e dos adolescentes em conflito com a lei. Também, não menos importante, a ampliação das instituições ligadas à assistência médico-psicológica e de internamento para a recuperação juvenil; a aplicação de medidas cautelares diversas da prisão, como por exemplo, a libertação sob advertência, entregando a criança aos cuidados de um progenitor, familiar ou tutor, entre outras medidas diversas da prisão.

\section{ReferênCias}

AMNISTIA INTERNACIONAL. Aprisionando os meus direitos prisão e detenção arbitrária e tratamento dos reclusos em Moçambique. Maputo: Amnesty International, nov. de 2012. Disponível em: < http://www.amnistia-internacional.pt/files/Noticias_anexos/novembro2012/ Mocambique_Aprisionando_os_meus_direitos_ embargado_01h00_de_dia_22nov2012.pdf>. Acesso em: 01 fev. 2016.

ARIÈS, Philippe. História social da criança e da família. Tradução de Dora Flaksman. 2. ed. Rio de Janeiro: LTC, 1981.

ASSEMBLÉIA GERAL DAS NAÇÕES UNIDAS. Regras das Nações Unidas para a proteção dos menores privados de liberdade. Disponível em: <http://www.rolim.com. br/2002/_pdfs/066.pdf>. Acesso em: 20 set. 2014. 
ASSEMBLEIA GERAL DAS NAÇÕES UNIDAS. Regras minimas das Nações Unidas para a administração da justiça de menores (Regras de Beijing). 1985. Disponível em: <http://www.gddc.pt/direitos-humanos/textosinternacionais-dh/tidhuniversais/dhaj-NOVO-regrasBeijing.html>. Acesso em: 01 fev. 2016.

BALEIRA, Sérgio (Coord.). Relatório preliminar da pesquisa sobre "A Criança em Conflito com a Lei". Moçambique: [S.n], abr.de 2003. Consultoria com Save The Children Norway.

BITENCOURT, Cezar Roberto. Código Penal comentado. São Paulo: Saraiva, 2002.

BRASIL. Estatuto da Criança e do Adolescente. 7. ed. Brasília: Câmara dos Deputados, 2010.

COUTO, Isabel Luís do. O problema da idade da imputabilidade penal. 2012. 56 f. Tese (Mestrado) - Programa de Pós-Graduação do Centro Regional do Porto, Escola de Direito, Universidade Católica Portuguesa, Porto, 2012.

EISENSTEEIN, Evelyn. Adolescência: definição, conceitos e critérios. Adolescência \& Saúde, Rio de Janeiro, v. 2, n. 2, p. 1-6, jun. 2005.

EM conflito com a lei: Ilegalidades dificultam regeneração de crianças. Noticias on-line, Maputo, 28 mar. 2014. Disponível em: <http://www.jornalnoticias.co.mz/ index.php/sociedade/13119-em-conflito-com-a-lei-ilegalidades-dificultam-regeneracao-de-criancas $>$. Acesso em: 01 fev. 2016.

FROTA, Ana Maria Monte Coelho. Diferenças concepções da infância e adolescência: a importância da historicidade para sua construção. Estudos e Pesquisas em Psicologia, Rio de Janeiro, v. 7, n. 1, p. 147-160, abr. 2007.

FUMO, Joaquim; JOSÉ, André Cristiano; SAMO, Saturnino. Estudo diagnóstico da justiça de menores. Maputo: CEIDIMA, 2012.

FUNDO DAS NAÇÕES UNIDAS PARA A INFÂNCIA. Declaração Universal dos Direitos das Crianças. Disponível em: <http://www.mp.go.gov.br/portalweb/ hp/8/docs/declaracao_universal_dos_direitos_da_ crianca.pdf>. Acesso em: 27 set. 2014.

FUNDO DAS NAÇÕES UNIDAS PARA A INFÂNCIA. Proteção da criança. Moçambique: UNICEF, 2014. Disponível em: <http://www.unicef.org/mozambique/pt/protection.html>. Acesso em: 27 set. 2014.
HABIAGZANG, Luísa Fernanda; CAMINHA, Renato Maiato. Abuso sexual contra crianças e adolescentes: conceituação e intervenção clínica. São Paulo: Casa do Psicólogo, 2004.

ISSÀ, Abdul Carimo Mahomed. Lei de base de proteção da criança, lei da organização jurisdicional de menores e lei sobre o tráfico de pessoas. Maputo: Central Impressora e Editora de Maputo, 2008.

JACOBINA, Olga Maria Pimentel; COSTA, Liana Fortunato. Para não ser bandido: trabalho e adolescentes em conflito com a lei. Cadernos de Psicologia Social do Trabalho, São Paulo, v. 10, n. 2, p. 95-110, 2007.

MANGUE, Reginaldo. Milhares de crianças estão em conflito com a lei no país.Jornal@Verdade, Moçambique, 27 mar. 2014. Disponível em: <http://www.verdade. co.mz/nacional/45093-milhares-de-criancas-estao-emconflito-com-a-lei-no-pais>. Acesso em: 10 set. 2014.

MARQUES, José Frederico. Tratado de direito penal. Campinas: Bookseller, 1997.

MCCORD, Joan. Forjar criminosos na família. In: FONSECA, António Castro. Comportamento anti-social e família: uma abordagem científica. Coimbra: Almedina, 2002. p. 15-36.

MOÇAMBIQUE. Código de Processo Penal. Maputo: Ministério da Justiça, 1993.

MOÇAMBIQUE. Constituição (2004). Constituição da República de Moçambique. Maputo: Imprensa Nacional, 2004.

MOÇAMBIQUE. Lei n. 7, de 09 de julho de 2008. Lei de Promoção e Proteção do Direito da Criança. Coletânea de legislação nacional de protecção da criança. Maputo: Fundação para o Desenvolvimento da Comunidade, 2009.

MOÇAMBIQUE. Lei n. 8, de 15 de junho de 2008. Lei da Organização Tutelar de Menores. Coletânea de legislação nacional de proteçãa da criança. Maputo: Fundação para o Desenvolvimento da Comunidade, 2009.

MOÇAMBIQUE. Resolução no 32, de 21 de setembro de 2006. Boletim da República, maputo, n. 38, $1^{\text {a }}$ Série, set. 2006. Suplemento.

NAPLAVA, Thomas; OBERWITTLER, Dietrich. Fatores familiares e delinquência juvenil: resultados da investigação sociológica na Alemanha. In: FONSECA, 
António Castro. Comportamento anti-social e família. Coimbra: Almedina, 2002. p. 157-180.

NOVE crianças detidas por roubo na via pública em Maputo. Jornal@Verdade, Moçambique, 18 nov. 2014. Disponível em: <http://www.verdade.co.mz/ newsflash/50307-nove-criancas-detidas-por-roubo-navia-publica-em-maputo->. Acesso em: 23 out. 2015.

ORGANIZAÇÃO DA UNIDADE AFRICANA. Carta Africana dos Direitos Humanos e dos Povos, (1981). Disponível em: <http://a5i.org/wp-content/ uploads /2014/03/12-Ap\%C3\%AAndice-3-CaADHP. pdf >. Acesso em: 22 mar. 2012.

ORGANIZAÇÃO DAS NAÇÕES UNIDAS. A Convenção sobre os Direitos da Criança: adoptada pela Assembleia Geral nas Nações Unidas em 20 de novembro de 1989 e ratificada por Portugal em 21 de setembro de 1990. Disponível em: <https://www.unicef.pt/docs/ pdf_publicacoes/convencao_direitos_crianca2004. pdf $>$. Acesso em: 27 set. 2014.

ORGANIZAÇÃO DAS NAÇÕES UNIDAS. Diretriżes das Nações Unidas para Prevenção da Delinquência Juvenil, Diretrizes de Riad. Disponível em: <http://www.dhnet. org.br/direitos/sip/onu/c_a/lex45.htm>. Acesso em: 20 set. 2014.

ORGANIZAÇÃO DAS NAÇÕES UNIDAS. Pacto Internacional dos Direitos Civis e Políticos (1966). Disponível em: <http://www.oas.org/dil/port/1966\%20Pacto $\% 20$ Internacional $\% 20$ sobre $\% 20$ Direitos $\% 20$ Civis $\% 20 \mathrm{e} \% 20$ Pol\%C3\%ADticos.pdf>. Acesso em: 25 jun. 2012.

ORGANIZAÇÃO DAS NAÇÕES UNIDAS. Pacto In- ternacional sobre os Direitos Econômicos, Sociais e Culturais. 1966. Disponível em: <http://www.unfpa.org.br/Arquivos/pacto_internacional.pdf $>$. Acesso em: 25 jun. 2012.

ORGANIZAÇÃO DE UNIDADE AFRICANA. Carta Africana dos Direitos e Bem-Estar da Criança. Disponível em: <http://www.didinho.org/CartaAfricDirBEC. pdf $>$. Acesso em: 20 set. 2014.

PEREIRA, Tânia da Silva. A Convenção e o Estatuto: um ideal comum de proteção ao ser humano em vias de desenvolvimento. In: (Coord.). Estatuto da Criança e do Adolescente: Lei 8.069/90: "estudos sóciojurídicos". Rio de Janeiro: Renovar, 1992. p. 67-115.

PERES, Maria Fernanda Tourinho; NERY FILHO, Antônio. A doença mental no direito penal brasileiro: inimputabilidade, irresponsabilidade, periculosidade e medida de segurança. História, Ciências, Saúde - Manguinhos. Rio de Janeiro, v. 9, n. 2, p. 335-355, maio/ago. 2002.

RELATÓRIO dos direitos humanos: Moçambique de 2013. Disponível em: <http://photos.state.gov/libraries/mozambique/19452/pdfs/mozambiquehrrfinal. pdf>. Acesso em: 27 maio 2014.

TRINDADE, Jorge. Delinquência juvenil: competência transdisciplinar. 3. ed. Porto Alegre: Livraria do Advogado, 2002.

VERONESE, Josiane Rose Petry. Humanismo e infância: a superação do paradigma da negação do sujeito. In: MEZZAROBA, Orides (Org.) Humanismo latino e estado no Brasil. Florianópolis: Fundação Boiteux, 2003. p. 421-452. 


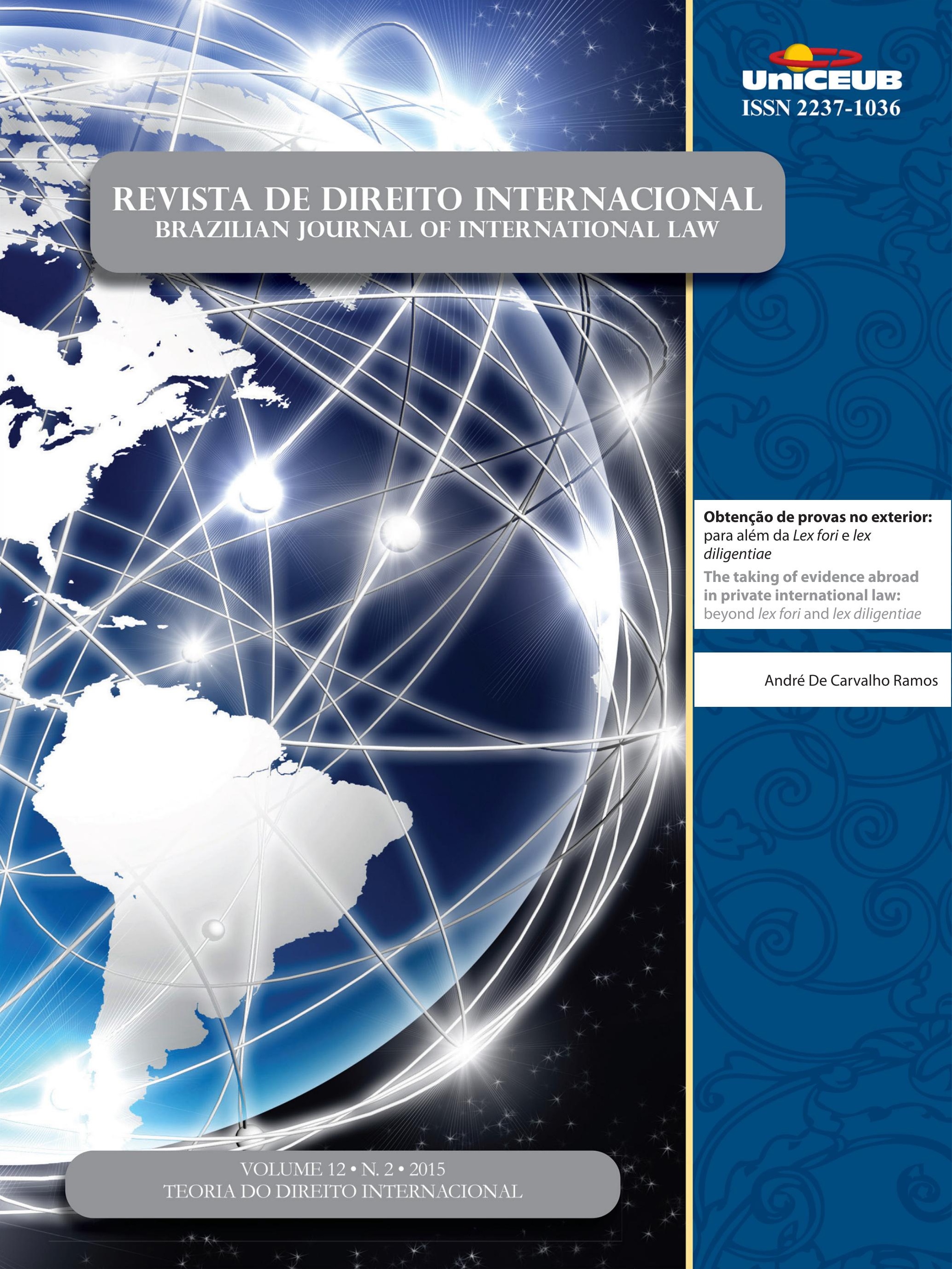




\section{Obtenção de provas no exterior: para além da Lex fori e lex diligentiae*}

\section{The taking of evidence abroad in private international law: beyond lex fori and lex diligentiae}

André De Carvalho Ramos**

\section{Resumo}

$\mathrm{O}$ artigo analisa a regência normativa da produção probatória no exterior, buscando superar o cisma tradicional envolvendo a temática, entre o uso da lex fori ou da lex diligentiae para regular as regras a serem aplicadas em matéria de prova. O artigo objetiva demonstrar que, acima da divisão entre a lex fori e a lex diligentiae, há a disputa na interpretação dos direitos envolvidos em matéria de prova, expondo os modelos pelos quais é possível interpretar e ponderar os conflitos de interesses entre as partes em um determinado processo. O âmbito de análise o artigo centra-se na Lei de Introdução às Normas do Direito Brasileiro (LINDB), no Código de Bustamante, na Convenção da Haia sobre a Obtenção de Provas no Exterior em Matéria Civil e Comercial e também na jurisprudência brasileira. Propõe-se a mudança no foco da temática para que sejam explicitados os modelos de definição de direitos envolvidos na produção probatória no exterior. São expostos os seguintes modelos de com foco no parâmetro de interpretação a ser utilizado: o modelo nacional (ou da lex fori), o modelo estrangeiro (ou da lex causae) ou, finalmente, o modelo universalista (ou da interpretação internacionalista).

Palavras-chave: Direito internacional privado. Lei de introdução às normas do direito brasileiro. Direitos humanos. Lex fori. Lex diligentiae. Lex causae.

\section{Abstract}

This article analyzes the rules on the taking of evidence abroad, seeking to overcome the traditional divergence between the use of the lex fori or the lex diligentiae. The aim is to demonstrate that beyond this division, there is a dispute concerning the rights related to the taking of evidence, exposing the models to the interpretation and weigh of the conflicting interests of the parties. With this objective, the Law of Introduction to the Brazilian Legal Statutes, the 1928 Convention on Private International Law (Bustamante Code), the Hague Convention on the Taking of Evidence Abroad in Civil and Commercial Matters and also on the Brazilian case-law are examined. Moreover, a change of focus on the matter is proposed, aiming the explanation of the models of determination of rights related to the taking of evidence abroad. Focusing on the parameter of interpretation to be used, three

** Professor de Direito Internacional e Direitos Humanos da Faculdade de Direito da USP. Contato principal para correspondência. Email: carvalhoramos@usp.br.
* Recebido em 05/11/2015. Aprovado em 02/02/2016. 
models are examined: the national (lex fori), the foreign (lex causae) or, finally, the universalist (internationalist interpretation).

Keywords: Private international law. Law of introduction to the brazilian legal statutes. Human rights. Lex fori. Lex diligentiae. Lex causae.

\section{SUMÁRIO}

1 Introdução. 2 Produção probatória no exterior e o direito internacional privado. 3 Provas e a ordem pública. 4 A "lex diligentiae" na lei de introdução às normas do direito brasileiro e no código bustamante: o risco do retorno à lex fori. 5. A "lex diligentiae" na Convenção da Haia sobre a obtenção de provas no exterior em matéria civil e comercial (1970). .6 A prática brasileira. 7 As deficiências da dicotomia "lex fori" $\mathrm{x}$ "lex diligentiae". 8 O giro copernicano: os modelos para aferir o respeito aos direitos envolvidos na produção probatória no exterior. 9 Conclusão. Referências.

\section{INTRODUÇÃo}

A necessidade de realização de diligências probatórias em Estado estrangeiro é um tema habitual no Direito Internacional Privado, possuindo imenso potencial de divergência e debates. As diferenças de leis materiais e processuais regendo a prova, bem como o conflito entre o direito à prova e outros direitos (como, por exemplo, o direito à intimidade) geram inúmeras controvérsias no tratamento dos fatos transnacionais.

Essas polêmicas podem implicar em violação do devido processo legal tanto no caso de impedimento à realização de determinada prova (levando ao perecimento do bem da vida a ser protegido) quanto na realização de determinada diligência de modo ofensivo à dignidade humana e aos direitos humanos dos envolvidos (partes, testemunhas, assistentes, etc).

São dois os critérios mais utilizados para a escolha da lei de regência da prova processual: (i) a lei do Estado no qual o processo original se desenvolve ("lex fori regit processum") e (ii) a lei do Estado estrangeiro no qual a diligência será realizada (a "lex diligentiae"). Mesmo que a lei estrangeira seja escolhida e regule a produção da prova no exterior, o julgador nacional pode descartar a diligência por ter sido violada a ordem pública do foro, centrada no respeito a direitos dos envolvidos na controvérsia. Como exemplo desse uso da gramática dos direitos humanos para conformar o conceito de ordem pública no Direito Internacional Privado, foi introduzida no regimento interno do Superior Tribunal de Justiça a hipótese de não homologação de sentença estrangeira por ofensa à dignidade humana. ${ }^{1}$

Percebe-se que a temática da regência normativa da produção probatória ultrapassa a visão tradicional de escolha da lei aplicável às diligências no exterior. Não se trata de se optar pela (i) lex fori ou pela (ii) lex diligentiae na regulação da produção probatória no exterior, porque esse cisma pode ser superado pelo uso da cláusula de proteção da "ordem pública", dando-se preferência às normas probatórias do foro (lex fori). Mesmo quando o Direito Internacional Privado no Brasil impõe, inicialmente, o uso da lex diligentiae como regra geral para a regência da prova realizada no exterior, é possível que tal lei estrangeira seja considerada ofensiva à ordem pública e a prova seja descartada. Há um "eterno retorno" à lei do foro, com base na tradicional cláusula de proteção da ordem pública.

O cerne da temática consiste, então, em entender como são traçados o conteúdo e limites dos direitos envolvidos na produção da prova, uma vez que o fantasma da ofensa à ordem pública de Direito Internacional Privado ameaça o uso da "lex diligentiae", acarretando insegurança jurídica e o consequente risco de xenofobia e chauvinismo jurídicos.

Propõe-se, então, um giro copernicano na temática, uma vez que o foco da matéria deve ser os modelos de determinação dos direitos envolvidos para a aceitação ou descarte da lei estrangeira, buscando assim o parâmetro de interpretação a ser utilizado: se o parâmetro nacional (modelo nacional ou da lex fori), o parâmetro do Estado no qual a diligência será realizada (modelo estrangeiro ou da lex causae) ou, finalmente, o parâmetro universal (modelo universalista ou da interpretação internacionalista).

1 Emenda Regimental n. 19, de 11 de novembro de 2015, que introduziu o art. 216-F: "Não será homologada a sentença estrangeira que ofender a soberania nacional, a dignidade da pessoa humana e/ ou a ordem pública.". BRASIL. Superior Tribunal de Justiça. Emenda Regimental $n^{\circ}$ 19, de 11 de novembro de 2015. Disponível em: <http://dj.stj.jus.br/20151120.pdf>. Acesso em: 08 fev. 2016. 
Para tanto, será analisada, inicialmente, a regulação da produção probatória no exterior tanto na Lei de Introdução às Normas do Direito Brasileiro (Lei 12.376/10 - LINDB) ${ }^{2}$, no Código Bustamante ${ }^{3}$ e ainda na Convenção da Haia sobre obtenção de prova no exterior em matéria civil e comercial ${ }^{4}$, maior tratado multilateral sobre a temática recentemente ratificado pelo Brasil. Após, as opções brasileiras referentes a obtenção da prova serão cotejadas à luz da jurisprudência dos tribunais superiores (em casos cíveis ou criminais), bem como serão esmiuçados os modelos para aferição da validade da produção da prova no exterior, expondo-se suas principais características, diferenças e críticas.

\section{Produção probatória No eXterior e o di- REITO INTERNACIONAL PRIVADO}

Para o Direito Internacional, a jurisdição de um Estado consiste no poder de regência estatal sobre pessoas, entes e bens. Utiliza-se o termo jurisdição internacional em sentido estrito (ou jurisdição de adjudicação ou de julgamento) para denominar o poder do Judiciário nacional de conhecer e solucionar as controvérsias. ${ }^{5}$

A existência desse poder é emanação da própria soberania do Estado, pois, como já decidiu a Corte

2 BRASIL. Decreto-Lei $n^{\circ} 4.657$, de 4 de setembro de 1942. Disponível em: <http://www.planalto.gov.br/ccivil_03/Decreto-Lei/ Del4657.htm>. Acesso em: 08 fev. 2016; BRASIL. Lei $n^{\circ}$ 12.376, de 30 de dezembro de 2010. Disponível em: <http:/ /www.planalto. gov.br/ccivil_03/_Ato2007-2010/2010/Lei/L12376.htm>. Acesso em: 08 fev. 2016.

3 CONFERÊNCIA INTERNACIONAL AMERICANA, 6., 1928, Havana. Direito Internacional Privado: Convenção de Direito Internacional Privado (Código de Bustamante). Disponível em: <http://www.faccamp.br/apoio/LuciaSirleneCrivelaroFidelis/ direitoInternacional/cOdigo_de_bustamente.pdf>. Acesso em: 08 fev. 2016.

4 HAGUE CONFERENCE ON PRIVATE INTERNATIONAL LAW, 20., 1970, Hague. Convention on the taking of evidence abroad in civil or commercial matters. Available in: <https://assets. hcch.net/docs/dfed98c0-6749-42d2-a9be-3d41597734f1.pdf>. Access: Feb. 08, 2016.

5 No sentido amplo, a jurisdição internacional pode ser dividida em três subespécies: (i) a jurisdição normativa (ou jurisdição para prescrever), (ii) a jurisdição de implementação ou de execução e (iii) a jurisdição de adjudicação ou jurisdição em sentido estrito. A jurisdição normativa consiste no poder do Estado de criar normas de regência sobre a conduta social. Já a jurisdição de implementação consiste no poder de aplicar as regras estabelecidas. Não trataremos da outra acepção de jurisdição no plano internacional, que vem a ser a jurisdição dos tribunais internacionais.
Permanente de Justiça Internacional, "[...] a jurisdição é uma das formas mais óbvias de exercício do poder soberano". Há regras nacionais sobre jurisdição estatal que determinam sua extensão e seus limites diante das demais jurisdições dos Estados estrangeiros. ${ }^{7} \mathrm{Na}$ medida em que a jurisdição estatal encontra limites, em geral atrelados ao seu território, surge a necessidade do Estado contar com a colaboração dos demais para fazer valer suas decisões sobre pessoas, bens e condutas localizados ou realizados fora do seu território, no que se denomina cooperação jurídica internacional. Nesse sentido, a cooperação jurídica internacional consiste no conjunto de regras internacionais e nacionais que rege atos de colaboração entre Estados, ou mesmo entre Estados e organizações internacionais, com o objetivo de facilitar o acesso à justiça. ${ }^{8}$

Esses atos de colaboração envolvem atividades de solicitação e cumprimento de medidas extrajudiciais (por exemplo, a solicitação de informação do Direito vigente em um Estado) e judiciais. Nesse último caso, a cooperação jurídica internacional abrange a colaboração para o cumprimento de medidas pré-processuais, de desenvolvimento regular de um processo e de execução.

A cooperação jurídica internacional é indispensável no caso de determinado litígio possuir vínculos de internacionalidade ou estraneidade que exijam a prática de atos no estrangeiro, como medidas preparatórias diversas, citações, notificações, atos instrutórios e, por fim, atos executórios dos efeitos da decisão.

Como já visto, o presente artigo visa a análise da produção de prova no exterior, ou seja, em Estado distinto daquele que conduz o processo. A prova em matéria processual consiste em um conjunto de atividades de verificação e demonstração aptas a convencer o Estado-Juiz da validade das proposições que foram impugnadas em um processo. ${ }^{9}$ A ação de provar englo-

6 CORTE PERMANENTE DE JUSTIÇA INTERNACIONAL. Caso do Estatuto legal da Groelândia Oriental (Dinamarca vs. Noruega). Julgamento de 5 de abril de 1933. (Séries A/B, n. 53). p. 48.

7 MESQUITA, José Ignácio Botelho de. Da competência internacional e dos princípios que a informam. Revista de Processo, n. 50, p. 51-71, abr./jun. 1988. p. 51.

8 Sobre a cooperação jurídica internacional, conferir RAMOS, André de Carvalho; MENEZES, Wagner. Direito internacional privado e a nova cooperação jurídica internacional. São Paulo: Arraes, 2014.

9 MARINONI, Luiz Guilherme; ARENHART, Sergio Cruz. Prova. São Paulo: Revista dos Tribunais, 2010. p. 57. 
ba um conjunto de atos praticados pelas partes e pelo juiz para a verificação da veracidade de uma afirmação de fato. ${ }^{10} \mathrm{O}$ termo "prova" origina-se de probare, que pode ser entendido como equivalente de demonstrar ou mesmo persuadir.

O objeto da prova é todo fato ou ato relevante para a solução da controvérsia. As fontes de prova representam os elementos externos a um processo que, quando examinadas adequadamente, revelam a realidade, sendo fontes de prova as pessoas (fontes pessoais) e as coisas (fontes reais). Já os meios de prova, termo usado na Lei de Introdução às Normas do Direito Brasileiro (LINDB), consistem em instrumentos e técnicas de uso das fontes de prova, de modo a extrair delas os dados e informações necessários para uma decisão. ${ }^{11}$ Ainda, o modo de produção da prova é a forma processual de aplicação dos meios de prova. Por exemplo: determinada pessoa é fonte de prova, sendo o seu testemunho um meio de prova lícito e previsto no Brasil; se for ouvida em um processo judicial, o modo de produção da prova será testemunhal, regulado na lei processual, que contém o seu passo a passo.

No caso dos processos com vínculos de estraneidade, surge a dúvida sobre qual deve ser a lei apta a regular a legitimidade de uma fonte de prova, bem como os meios de prova lícitos ou o modo adequado de sua produção: a lei do Estado que conduz o processo ("lex fori”) ou a lei do local no qual a produção probatória será realizada, abrangendo também a fonte de prova e os meios de prova ("lex diligentiae").

Resta definir a relação entre a temática das provas (fonte, meio e modo de produção) e a da ordem pública, que tem impacto no eventual afastamento da lei estrangeira (por ofensa à ordem pública) e na prevalência da lei brasileira.

\section{Provas e a ordem pública}

$\mathrm{Na}$ ótica do Direito Internacional Privado, a ordem pública consiste no conjunto de valores essenciais defendidos por um Estado, que impede (i) a aplicação de lei estrangeira eventualmente indicada pelos critérios de

10 BADARÓ, Gustavo Henrique Righi Ivahy. Ônus da prova no processo penal. São Paulo: RT, 2003. p. 158.

11 DINAMARCO, Cândido Rangel. Instituições de direito processual civil. 5. ed. São Paulo: Malheiros, 2005. v. 2. p. 615-616. conexão; (ii) a prorrogação ou derrogação da jurisdição e, finalmente, (iii) a cooperação jurídica internacional pretendida. É um instituto que restringe a própria atuação do DIPr para preservar os valores defendidos pelo Estado do foro. ${ }^{12}$

O limite ao uso do direito estrangeiro em virtude de violação de valores essenciais defendidos no foro é tema tradicional do DIPr no Brasil. O primeiro diploma a mencionar expressamente o limite da ordem pública ao direito estrangeiro foi o Decreto n ${ }^{\circ} 6.982$ de 1878, que tratou do reconhecimento e execução de sentença estrangeira. $\mathrm{O}$ art. $2^{\circ}$ do Decreto estabeleceu quatro causas de denegação do reconhecimento, a saber: (i) ofensa à soberania; (ii) leis ditas como obrigatórias e de ordem pública; (iii) leis que regulam a organização da propriedade territorial; e (iv) moralidade pública. ${ }^{13}$ Após, a Lei no 221 de 1894 reduziu esses casos a dois: ofensa à ordem pública e ao direito público, o que mostra a confusão ainda reinante entre a ordem pública interna (normas cogentes nacionais, como as de direito público) e a ordem pública de direito internacional privado (normas contendo valores essenciais defendidos pelo Estado).

No Esboço de Teixeira de Freitas, houve a expressa exclusão do direito estrangeiro nos casos em que sua aplicação fosse contrária ao direito público e criminal do Império, à tolerância dos cultos, à moral e aos bons costumes. Como exemplo de lei estrangeira ofensiva aos direito público e criminal, foram elencadas aquelas que permitissem a poligamia e quanto à tolerância dos cultos, foram apontadas as leis que considerassem incapazes judeus e apóstatas, entre outros exemplos. ${ }^{14}$

12 Dolinger, em sua tese apresentada no concurso para a cátedra de Direito Internacional Privado da Universidade do Estado do Rio de Janeiro, definiu a ordem pública como sendo o "anjo da guarda do sistema jurídico de determinada sociedade. Sua aplicação varia de acordo com os graus de intensidade em que os princípios fundamentais do sistema venham a ser feridos". Para Valladão, a ordem pública contempla os princípios essenciais da ordem jurídica do foro, fundados no conceitos de justiça, de moral, de religião, de economia e mesmo de política, que ali orientam a respectiva legislação. Conferir respectivamente em DOLINGER, Jacob. A evolução da ordem pública no direito internacional privado. Rio de Janeiro: Luna, 1979. p. 41 e VALLADÃO, Haroldo. Direito internacional privado. 2. ed. Rio de Janeiro: F. Bastos, 1977. v. 1. p. 496.

13 BRASIL. Câmara dos Deputados. Decreto no 6.982, de 27 de julho de 1878. Disponível em: < http://www2.camara.leg.br/legin/ fed/decret/1824-1899/decreto-6982-27-julho-1878-547801-publicacaooriginal-62676-pe.html>. Acesso em: 08 fev. 2016.

14 Art. $5^{\circ}$ da parte geral do Esboço. Ver em FREITAS, Augusto Teixeira de. Código civil: esboço. Rio de Janeiro: Universal de Laem- 
O projeto de Código Civil de Clóvis Beviláqua continha, em seu artigo 18, a proibição à aplicação de lei estrangeira contrária à soberania nacional, ofensiva dos bons costumes ou diretamente incompatível com lei federal brasileira fundada em motivo de ordem pública. Após os longos debates no Congresso Nacional, a introdução ao Código Civil de 1916 foi aprovada com redação diferente no tocante à matéria, unindo artigos que estavam separados no projeto: "as leis, atos, sentenças de outro país, bem como as disposições e convenções particulares, não terão eficácia, quando ofenderem a soberania nacional, a ordem pública e os bons costumes" (art. 17) ${ }^{15}$. Eduardo Espínola e Eduardo Espínola Filho criticaram esse dispositivo, fruto da influência do Código Civil italiano, pois teria unido em um único artigo a ordem pública nacional (na hipótese da restrição à autonomia da vontade - "disposições e convenções particulares") com a ordem pública internacional (de direito internacional privado), no caso das "leis, atos sentenças de outro país". ${ }^{16}$

Por seu turno, o artigo 17 da LINDB possui redação quase que idêntica: "As leis, atos e sentenças de outro país, bem como quaisquer declarações de vontade, não terão eficácia no Brasil, quando ofenderem a soberania nacional, a ordem pública e os bons costumes.". Substituiu-se, somente, a expressão "disposições e convenções particulares" de 1916 pela "quaisquer declarações de vontade" de 1942. Para Gama e Silva não houve inovação e foi mantido o mesmo princípio consagrado no direito positivo e na jurisprudência nacional pretérita. ${ }^{17}$

A LINDB utilizou três expressões de limite ao direito estrangeiro: soberania nacional, ordem pública e bons costumes. Para Dolinger, esses termos utilizados representam uma ressalva à aplicação da lei normalmen-

mert, 1860. p. 5-6.

15 BRASIL. Lei $n^{o}$ 3.071, de 1 de janeiro de 1916. Disponível em: <http://www.planalto.gov.br/ccivil_03/leis/L3071impressao. htm>. Acesso em: 08 fev. 2016.

16 In verbis: "Nesse ponto é que se mostra a inconveniência de unir, no mesmo dispositivo de lei, a regra de direito civil relativa ao respeito, que devem as disposições e convenções particulares às normas legais de ordem pública, e a regra de direito internacional privado relativa à inadmissibilidade de aplicação de leis estrangeiras, que ofendem aos nossos princípios de ordem pública”. ESPÍNOLA, Eduardo; ESPÍNOLA FILHO, Eduardo. Tratado de direito civil brasileiro: do direito internacional privado brasileiro: parte geral. Rio de Janeiro: F. Bastos, 1941. v. 2. p. 588.

17 SILVA, Luis Antonio Gama e. A ordem pública em direito internacional privado. 1994. Monografia (Livre Docência) - Faculdade de Direito, Universidade de São Paulo, São Paulo, 1944. p. 139. te competente de acordo com o sistema de direito internacional privado, podendo ser abrangidos no conceito amplo de "ordem pública". ${ }^{18}$ Apesar de reconhecer que todos os termos poderiam ser resumidos na expressão "ordem pública", Serpa Lopes buscou definir separadamente cada um dos dois outros termos da LINDB em relação à limitação ao uso do direito estrangeiro: (i) ofensa à soberania consiste naquilo que fere o jus imperii do Estado brasileiro, tal qual a lei estrangeira que venha a ferir a competência dos tribunais brasileiros em julgar nacionais; (ii) ofensa aos bons costumes retrata o conjunto de princípios éticos contemporâneos próprios do seu povo e país. ${ }^{19}$

Também Espínola reconheceu a amplitude da "ordem pública", em cujo objeto os autores em geral inserem o respeito à soberania e aos bons costumes. ${ }^{20}$ Amílcar de Castro considerou o uso dos termos "soberania" e "bons costumes" supérfluos, pois bastaria a menção à ordem pública. ${ }^{21}$ Corrêa de Brito, ao tratar da redundância do uso dos três termos ("soberania", "ordem pública" e "bons costumes") defende a prevalência do termo mais genérico da ordem pública, que envolve os outros dois. $^{22}$

No plano convencional, o artigo $4^{\circ}$ do Código de Bustamante estabelece que "os preceitos constitucionais são de ordem pública internacional”. Novamente, há a confusão entre as normas imperativas ou de ordem pública interna e as normas de ordem pública de direito internacional privado.

Já o artigo $5^{\circ}$ da Convenção Interamericana sobre Normas Gerais de Direito Internacional Privado determina que a lei declarada aplicável poderá não ser aplicada no território do Estado parte que a considerar manifestamente contrária aos princípios de sua ordem públi$\mathrm{ca}^{23}$ Nesse ponto, a Convenção inclina-se a favor do

18 DOLINGER, Jacob. A evolução da ordem pública no direito internacional privado. Rio de Janeiro: Luna, 1979. p. 117.

19 LOPES, Miguel Maria Serpa. Comentários à lei de introdução ao código civil. 2. ed. Rio de Janeiro: F. Bastos, 1959. v. 3. p. 300-301. 20 ESPÍNOLA, Eduardo. Elementos de direito internacional privado. Rio de Janeiro: J. R. dos Santos, 1925. p. 341.

21 Amílcar de Castro prefere o termo "ordem social" ao invés de "ordem pública", uma vez que esta última é ambígua, podendo significar a manutenção da paz e da segurança. CASTRO, Amílcar de. Direito internacional privado. 5. ed. Rio de Janeiro: Forense, 2000. p. 292.

22 BRITO, Luiz Araújo Corrêa de. Do limite à extraterritorialidade do direito estrangeiro no Código Civil Brasileiro. São Paulo: Escolas Profissionais Salesianas, 1952. p. 100.

23 In verbis: "A lei declarada aplicável por uma convenção de Di- 
reconhecimento da interpretação restritiva da cláusula de ordem pública, sendo necessário que a lei estrangeira seja "manifestamente" contrária aos princípios da ordem pública defendida pelo Estado. Essa interpretação advém do risco de seu uso abusivo redundar em xenofobia jurídica, em desfavor de um Direito Internacional Privado que aceita a pluralidade de valores que informa o mundo contemporâneo. Por sua vez, os tratados que cuidam da cooperação jurídica internacional contam, em geral, com cláusula de denegação da cooperação em virtude de ofensa à ordem pública, soberania, segurança e outros interesses essenciais do Estado requerido. ${ }^{24}$

Resta determinar a inclusão da matéria referente a provas no alcance da ordem pública de direito internacional privado (DIPr) no Brasil. Inicialmente, a leitura do conceito de ordem pública no DIPr demonstra que esta é caracterizada pela indeterminação e, consequentemente, é instável, podendo variar ao sabor da mudança dos valores essenciais defendidos pelo Estado.

Essa instabilidade faz com que sua densificação seja sempre contemporânea, dependente da atualidade dos valores nela contidos. ${ }^{25}$ Por isso, a primeira orientação para a determinação do conteúdo da ordem pública para o DIPr é não confundi-lo com o conteúdo da ordem pública interna. A qualidade de norma de ordem

reito Internacional Privado poderá não ser aplicada no território do Estado Parte que a considerar manifestamente contrária aos princípios da sua ordem pública.” ORGANIZAÇÃO DOS ESTADOS AMERICANOS. Convenção Interamericana sobre Normas Gerais de Direito Internacional Privado. Disponível em: <http://www. oas.org/juridico/portuguese/treaties/b-45.htm>. Acesso em: 08 fev. 2016.

24 Conforme ensina Denise Neves Abade, em obra sobre cooperação jurídica internacional, citando, o artigo 3.1 "e" do Tratado entre a República Federativa do Brasil e a República Italiana sobre Cooperação Judiciária em Matéria Penal: “e) se a Parte requerida considerar que a prestação da cooperação pode comportar prejuízo à própria soberania, segurança ou a outros interesses nacionais essenciais"; o artigo V, 1. "d" do Acordo de Cooperação Judiciária e Assistência Mútua em Matéria Penal entre o Governo da República Federativa do Brasil e o Governo da República da Colômbia, que impede o cumprimento do pedido caso este seja contrário "à segurança, à ordem pública ou a outros interesses essenciais da Parte Requerida"; o artigo III, 1. 'b” do Acordo de Assistência Judiciária em Matéria Penal entre o Governo da República Federativa do Brasil e o Governo dos Estados Unidos da América, entre outros. Conferir em ABADE, Denise Neves. Direitos fundamentais na cooperação jurídica internacional. São Paulo: Saraiva, 2013. p. 240.

25 DOLINGER, Jacob. Direito internacional privado: parte geral. 10. ed. Rio de Janeiro: Forense, 2011. p. 389. Conferir também DOLINGER, Jacob. A ordem pública internacional em seus diversos patamares. Revista dos Tribunais, São Paulo, v. 93, n. 828, p. 33-42, out. 2004. pública no foro (norma cogente, aquela que não pode ser derrogada pela vontade das partes) não implica, necessariamente, que essa norma impedirá a aplicação do direito estrangeiro, a não ser que este se choque, de modo grave, com os valores essenciais defendidos pelo Estado brasileiro. ${ }^{26}$

Um dos fatores importantes para a fixação da temática das provas dentro do alcance do conceito de ordem pública do Direito Internacional Privado é o seu claro envolvimento com a gramática dos direitos humanos, considerados um conjunto de direitos essenciais para uma vida do ser humano pautada na liberdade, igualdade e dignidade ${ }^{27}$.

Ora, a essencialidade dos direitos humanos habilita-os a serem considerados parte integrante dos valores protegidos pela ordem pública do DIPr no Brasil. Para Ada Pellegrini Grinover, a cooperação jurídica internacional deve levar em consideração "a consciência cada vez mais profunda de que os direitos fundamentais devem colocar-se como termo de referência nessa matéria". ${ }^{28}$ Como salienta Abade, a proteção de direitos humanos está entre os valores essenciais defendidos pelo Estado do foro ao invocar a cláusula de ordem pública. ${ }^{29}$ Nesse sentido, há uma impregnação jusfundamentalista do conceito de ordem pública.

De todos os ângulos, há direitos humanos relacionados à produção probatória: devido processo legal, direito à prova, igualdade, intimidade, integridade física (vedação às provas oriundas de tortura, por exemplo), entre outros direitos. A produção de provas deve ser feita conforme os direitos humanos envolvidos, não se admitindo fontes, meios ou modos de produção de prova que os violem (os fins não justificam os meios). Havendo violação, essas provas são consideradas ilícitas e não podem contribuir para o deslinde da causa. Nessa

26 Nesse sentido, Dolinger defende que “[...] Não é toda lei local, cogente, das que não podem ser derrogadas pela vontade das partes no plano interno, que não poderá ser substituída por lei estrangeira diversa, no plano do Direito Internacional Privado. [...] A norma estrangeira, indicada pelo DIP, deverá chocar a nossa ordem pública de forma mais grave para que sal aplicação seja rejeitada". DOLINGER, Jacob. Direito internacional privado: parte geral. 10. ed. Rio de Janeiro: Forense, 2011. p. 397.

27 RAMOS, André de Carvalho. Teoria geral dos direitos humanos na ordem internacional. 5. ed. São Paulo: Saraiva, 2015.

28 GRINOVER, Ada Pellegreni. As garantias processuais na cooperação internacional em matéria penal. Revista Forense, Rio de Janeiro, v. 373, p. 03-18, maio/jul. 2004. p. 03.

29 ABADE, Denise Neves. Direitos fundamentais na cooperação jurídica internacional. São Paulo: Saraiva, 2013. p. 104. 
linha, a Constituição brasileira prevê serem inadmissíveis, em qualquer espécie de processo, as provas obtidas por meios ilícitos (art. 5, LVI - "são inadmissíveis, no processo, as provas obtidas por meios ilícitos"). Há duas espécies de provas ilícitas: a) prova ilícita em sentido estrito, que é aquela que foi obtida em violação de regra de direito material e b) a prova ilegítima, que foi obtida em violação a regra processual.

Interessam ao DIPr as hipóteses de prova ilícita em sentido estrito, pois são justamente aquelas produzidas no Estado estrangeiro (fora de um processo nacional) e que podem gerar dúvida sobre a possibilidade da lei estrangeira dispor de modo diferente do direito brasileiro no tocante às diligências probatórias. No Brasil, são hipóteses de ilicitude da prova em sentido estrito: (i) violação indevida do domicílio (art. $5^{\circ}, \mathrm{XI}, \mathrm{da} \mathrm{CF}^{30}$ ), (ii) interceptação indevida das comunicações (art. $5^{\circ}$, XII, da $\mathrm{CF}^{31}$ ), (iii) uso de tortura ou maus-tratos (art. $5^{\circ}$, III, da $\mathrm{CF}^{32}$ ), (iv) violação do sigilo de correspondência (art. $5^{\circ}, \mathrm{XII}^{33}$ ), por violação do direito à intimidade (caso de quebra do sigilo bancário e fiscal de modo não apropriado), entre outras ${ }^{34}$.

Contudo, essa é a concepção brasileira de prova ilícita que pode não ser compatível com a visão estrangeira,

$30 \quad$ In verbis: " $\mathrm{XI}$ - a casa é asilo inviolável do indivíduo, ninguém nela podendo penetrar sem consentimento do morador, salvo em caso de flagrante delito ou desastre, ou para prestar socorro, ou, durante o dia, por determinação judicial;”. BRASIL. Constituição (1988). Constituição da Republica Federativa do Brasil. Disponível em: <http://www.planalto.gov.br/ccivil_03/Constituicao/Constituicao.htm>. Acesso em: 08 fev. 2016.

31 In verbis: "XII - é inviolável o sigilo da correspondência e das comunicações telegráficas, de dados e das comunicações telefônicas, salvo, no último caso, por ordem judicial, nas hipóteses e na forma que a lei estabelecer para fins de investigação criminal ou instrução processual penal”. BRASIL. Constituição (1988). Constituição da Republica Federativa do Brasil. Disponível em: <http://www.planalto.gov.br/ccivil_03/Constituicao/Constituicao.htm>. Acesso em: 08 fev. 2016.

32 In verbis: "III - ninguém será submetido a tortura nem a tratamento desumano ou degradante;". BRASIL. Constituição (1988). Constituição da Republica Federativa do Brasil. Disponível em: $<$ http://www.planalto.gov.br/ccivil_03/Constituicao/Constituicao. htm >. Acesso em: 08 fev. 2016.

33 In verbis: XII - é inviolável o sigilo da correspondência e das comunicações telegráficas, de dados e das comunicações telefônicas, salvo, no último caso, por ordem judicial, nas hipóteses e na forma que a lei estabelecer para fins de investigação criminal ou instrução processual penal;". BRASIL. Constituição (1988). Constituição da Republica Federativa do Brasil. Disponível em: <http://www.planalto.gov.br/ccivil_03/Constituicao/Constituicao.htm>. Acesso em: 08 fev. 2016.

34 Por todos, GOMES FILHO, Antonio Magalhães. Direito à prova no processo penal. São Paulo: RT, 1997. porque a conformação de direitos pode variar, mesmo em Estados democráticos. Não há homogeneidade no mundo dos direitos. A retórica da proteção de direitos pode ser invocada ainda por titulares distintos: o indivíduo interessado na produção probatória (ou a coletividade, no caso de direitos difusos ou macroindividuais) pode alegar que seu direito à prova foi violado, caso a diligência produzida no exterior seja considerada ilícita; já o indivíduo interessado em impedir que a prova seja considerada admissível no processo brasileiro, pode alegar a violação de outro direito, como, por exemplo, o direito à privacidade (no caso clássico de quebra de sigilo bancário por meio diferente do admitido pela visão brasileira). Não há, assim, somente um único indivíduo a ser prejudicado por diferenças de visões e interpretações dos direitos humanos.

Assim, a diferença entre a visão brasileira e a do Estado estrangeiro sobre as chamadas "provas ilícitas" pode levar a "batalhas judiciais" no Brasil sobre a inadmissibilidade dessas provas por ofensa a normas constitucionais ou legais. Surgem, então, os seguintes questionamentos: (i) as provas ilícitas em sentido estrito de acordo com a visão brasileira podem ou não ser transplantadas para a produção probatória no exterior; (ii) caso o Estado estrangeiro, burocraticamente, cumpra a diligência de acordo com sua lei (respeitando, então, os direitos humanos de acordo com a visão estrangeira), pode ou não o juiz brasileiro determinar sua exclusão, por ofensa à ordem pública.

Sendo a aplicação do direito estrangeiro descartada por ofensa à ordem pública, a prática brasileira inclina-se pelo uso da lei do foro (lex fori) sem maior preocupação com eventual norma alternativa. Nesse ponto, é importante analisar a disputa entre a "lex diligentiae" e a "lex fori" na regência das temática das provas produzidas no exterior. Caso a "lex diligentiae" seja considerada ofensiva à ordem pública brasileira, será aplicada - tout court - a lei nacional. Há, assim, no cisma doutrinário entre a "lex fori" e a "lex diligentiae", a prevalência da "lex fori".

Antes, então, de avançarmos sobre a temática do senhor da interpretação dos direitos humanos envolvidos na produção probatória, veremos abaixo os principais delineamentos do uso da "lex fori" e da "lex diligentiae". 


\section{A "LeX diLigentiae" Na LeI de INTROdução ÀS NORMAS DO DIREITO BRASILEIRO E NO CÓDIGO BUSTAMANTE: O RISCO DO RETORNO À LEX FORI}

$\mathrm{O}$ art. 13 da Lei de Introdução às Normas do Direito Brasileiro (LINDB) dispõe que "A prova dos fatos ocorridos em país estrangeiro rege-se pela lei que nele vigorar, quanto ao ônus e aos meios de produzir-se, não admitindo os tribunais brasileiros provas que a lei brasileira desconheça". ${ }^{35}$

Trata-se da prova dos fatos ocorridos no estrangeiro e que venha a ser lá produzida, não afetando a produção probatória de fato ocorrido no estrangeiro que venha a ser realizada no Brasil. Assim, caso uma testemunha de fato ocorrido no estrangeiro se encontre no Brasil e seja ouvida aqui em processo judicial, aplicam-se as regras sobre a prova testemunhal da lei processual brasileira (lex fori regit processum). Nesse sentido, a Convenção Panamericana de Direito Internacional Privado, também denominada Código Bustamante ${ }^{36}$, dispõe que "a forma por que se há de produzir qualquer prova regula-se pela lei vigente no lugar em que for feita" (art. 400).

A LINDB, então, adotou a lei do lugar no qual ocorreu o fato ou ato (lex diligentiae) para reger (i) os meios de prova e (ii) o ônus da produção da prova. Essa solução consta também do Código Bustamante, cujo art. 399 estabelece que a lei do lugar em que se realizar o ato ou fato que se trate de provar deve reger os meios de prova, salvo se esses meios não forem autorizados pela lei do lugar do processo (lex fori).

Já o artigo 12 da antiga introdução ao Código Civil de 1916 era mais lacônico, prevendo apenas que os meios de prova seriam regulados conforme a lei do lugar, onde se passou o ato, ou fato, que se tem de provar, sem a especificação referente aos "meios de prova" e ao "ônus da produção da prova", constantes agora do art. $13 .{ }^{37}$

35 BRASIL. Decreto-Lei $n^{\circ} 4.657$, de 4 de setembro de 1942. Disponível em: <http://www.planalto.gov.br/ccivil_03/Decreto-Lei/ Del4657.htm >. Acesso em: 08 fev. 2016.

36 Incorporado internamente pelo Decreto $\mathrm{n}^{\circ} 18.871$, de 13 de agosto de 1929. BRASIL. Câmara dos Deputados. Decreto $n^{\circ}$ 18.871, de 13 de agosto de 1929. Disponível em: <http://www2. camara.leg.br/legin/fed/decret/1920-1929/decreto-18871-13-agosto-1929-549000-norma-pe.html>. Acesso em: 08 fev. 2016.

37 Nesse sentido, LOPES, Miguel Maria Serpa. Comentários à lei de introdução ao código civil. 2. ed. Rio de Janeiro: F. Bastos, 1959. v. 3. p. 160.
Para Tenório, o ônus probatório é matéria decorrente do fato que se constituiu e do direito que o disciplinou na formação e nos efeitos. Assim, não deve ser regido pela lex fori, mas sim pela lex loci actus. ${ }^{38}$ Por outro lado, no curso de um processo, o ônus da prova consiste em faculdade processual que, se não exercida, pode acarretar prejuízo à parte. Nesse último sentido (processual), é utilizada a lei processual do foro (lex fori regit processum).

Há uma restrição ao final da redação do art. 13 da LINDB: não se admite no Brasil provas que a lei brasileira (lex fori) desconheça. Ocorre que esse conceito aberto de "prova desconhecida" só seria concretamente aplicável caso o ordenamento brasileiro não aceitasse as chamadas provas atípicas ou livres (aquelas não enumeradas expressamente na lei processual - provas típicas). No processo civil brasileiro, as partes têm o direito de empregar (i) todos os meios legais (provas típicas), bem como (ii) os moralmente legítimos, ainda que não especificados (provas atípicas), para provar a verdade dos fatos em que se funda o pedido ou a defesa e influir eficazmente na convicção do juiz (art. 369 do novo Código de Processo Civil - CPC, de 2015).

Assim, eventual meio de prova da lei estrangeira, mesmo que desconhecido expressamente no Brasil, pode ser aqui aceito caso seja "moralmente legítimo" na dicção do art. 369 do novo CPC, uma vez que será considerado como prova atípica lícita. A prova estrangeira desconhecida será inadmitida somente se for "moralmente ilegítima", o que, em outros termos, implica em reconhecer a ofensa à ordem pública brasileira.

Quanto às provas típicas, o CPC/2015 enumera como meios de prova típicos a ata notarial (art. 384), o depoimento pessoal (art. 385), a confissão (art. 389), a exibição de documento ou coisa (art. 396), a prova documental (art. 405 e seguintes), a prova testemunhal (art. 442 e seguintes), a inspeção judicial (art. 481 e seguintes) e a prova pericial (art. 464 e seguintes a 439). ${ }^{39}$

A princípio, todos esses meios de prova típicos são conhecidos e devem ser aceitos de acordo com a forma de realização prevista na lei estrangeira. Por sua vez,

38 TENORIO, Oscar. Lei de introdução ao Código Civil Brasileiro. 2. ed. Rio de Janeiro: Borsói, 1955. p. 406. Nesse sentido, o Código Civil brasileiro regula as provas do casamento nos artigos 1.543 e seguintes.

39 BRASIL. Lei $n^{\circ} 13.105$, de 16 de março de 2015. Disponível em: < http://www.planalto.gov.br/ccivil_03/_ato2015-2018/2015/ lei/113105.htm>. Acesso em: 08 fev. 2016. 
o documento redigido em língua estrangeira somente poderá ser juntado aos autos quando acompanhado de versão para a língua portuguesa tramitada por (i) via diplomática ou (ii) pela autoridade central ${ }^{40}$, ou (iii) firmado por tradutor juramentado (art. 192, parágrafo único, do CPC/2015). O próprio interessado pode providenciar a comunicação e entrega de atos realizados em uma jurisdição para utilização como prova em outra. É possível, por exemplo, que determinado documento seja obtido pelo interessado em Estado estrangeiro e, após a sua legalização, seja utilizado em matéria probatória no Brasil. De fato, no caso de documentos públicos, há a exigência de certificação que é feita, salvo acordo internacional em contrário, pela legalização ${ }^{41}$.

A finalidade do uso da lex diligentiae como regra geral da LINDB e do Código Bustamante é dar segurança jurídica aos que necessitam provar fatos transnacionais. Evita-se a situação kafkiana de determinada pessoa realizar um ato no estrangeiro, confiando na lei local sobre

40 A autoridade central é um órgão de comunicação inserido em cada Estado e necessariamente previsto em tratados internacionais. Possui, em geral, três funções básicas: (i) gerenciar e agilizar o trâmite dos pleitos cooperacionais, recebendo-os e enviando-os a outro Estado, dispensando-se a via diplomática; (ii) zelar pela adequação das solicitações enviadas e recebidas aos termos do tratado e (iii) capacitar as autoridades públicas envolvidas, de modo a aperfeiçoar os pedidos emitidos. BRASIL. Lei no 13.105, de 16 de março de 2015. Disponível em: <http://www.planalto.gov.br/ccivil_03/_ato20152018/2015/lei/113105.htm>. Acesso em: 08 fev. 2016.

41 A legalização de documentos públicos estrangeiros consiste em uma sequência de certificações, para assegurar a autenticidade do documento. Inicialmente, os documentos públicos originais (e, eventualmente, suas traduções juramentadas) devem ser levados ao próprio Ministério das Relações Exteriores do país emitente para que seja atestada a sua origem e as assinaturas nacionais. Depois, o documento é levado para a repartição consular do país no qual o interessado deseja a utilização, para que seja, por sua vez, também atestada a autenticidade por meio da certificação da assinatura do representante diplomático do Estado de origem do documento. Após esse trâmite, o documento está legalizado e pode ser utilizado no outro país. Em 2015, o Congresso Nacional aprovou o texto da Convenção sobre a Eliminação da Exigência de Legalização de Documentos Públicos Estrangeiros, celebrada na Haia, em 5 de outubro de 196, pelo Decreto Legislativo n. 148. Em 29 de janeiro de 2016, foi editado o Decreto n. 8.660 promulgando internamente o tratado. Essa convenção, também chamada de "Convenção da Apostila" substitui a legalização pela "apostila", que consiste em certificação emitida em um documento público que atesta sua autenticidade, reconhecendo-se a assinatura do emissor do documento público e sua função desempenhada (art. $3 .^{\circ}$ da Convenção). HAGUE CONFERENCE ON PRIVATE INTERNATIONAL LAW, 20., 1970, Hague. Convention on the taking of evidence abroad in civil or commercial matters. Available in: <https://assets.hcch.net/docs/ dfed98c0-6749-42d2-a9be-3d41597734f1.pdf $>$. Access: Feb. 08, 2016. como provar esse ato (meios de prova) e depois vir a ser surpreendida com novas exigências fruto da lex fori.

Para Dolinger e Tiburcio, a maior razão para a adoção da lex diligentiae para reger a produção probatória no exterior é o respeito à soberania do Estado estrangeiro, cujas leis determinam a forma e o modo da realização da produção probatória, uma vez que as leis do Estado do processo são limitadas ao seu próprio território. $^{42}$

Em que pese a opção brasileira pela "lex diligentiae", há a prevalência da lei nacional (lex fori), na hipótese da lei estrangeira ser considerada ofensiva à ordem pública de Direito Internacional Privado no Brasil, como prevê a cláusula da ordem pública inserida no art. 17 da LINDB.

Com isso, caso a lei estrangeira tenha - de acordo com a ótica do intérprete local - ofendido normas essenciais do foro (informadoras da ordem pública), a prova será descartada, em nome da prevalência da lex fori. Há um retorno à lei do foro, em que pese a regra geral da "lex diligentiae".

Esse "predomínio oculto" da "lex fori" é grave porque é feito pelas mãos da cláusula da ordem pública, que, como visto, é instável e indeterminada. Mesmo que a ordem pública seja determinável conforme aos direitos humanos (a impregnação jusfundamentalista), há ainda dúvidas sobre a visão de direitos humanos que deve imperar.

\section{A "lex diligentiae" na Convenção da Haia SOBRE A OBTENÇÃO DE PROVAS NO EXTERIOR EM MATÉRIA CIVIL E COMERCIAL (1970)}

Os trabalhos preparatórios da Convenção da Haia sobre a Obtenção de Provas no Exterior em matéria civil e comercial indicam que seu objetivo principal era a modernização das antigas Convenções da Haia sobre Processo Civil Internacional de 1905 e 1954, para atender as crescentes demandas de cooperação jurídica internacional entre

42 DOLINGER, Jacob; TIBURCIO, Carmen. The forum law rule in international litigation: lex fori or lex diligentiae? Unresolved Choice-of-law issues in the transnational rules of civil procedure. Texas International Law Journal, v. 33, n. 3, p. 425-461, summer 1998. p. 434. 
os Estados ${ }^{43}$. Essas demandas de cooperação originam-se da maior intensidade dos fluxos comerciais e civis do capitalismo contemporâneo, com a expansão da atividade das empresas multinacionais, levando ao crescimento de litígios com elementos de estraneidade, como, por exemplo, réu domiciliado em Estado estrangeiro, documentos na posse de empresas sediadas em outro Estado e testemunhas que devem ser ouvidas no estrangeiro. Por isso, no preâmbulo da Convenção, fica claro que seu objetivo é facilitar a transmissão e o cumprimento de cartas rogatórias e promover a harmonização dos diversos métodos por eles utilizados para tais fins, bem como tornar mais eficiente a cooperação jurídica internacional em matéria civil ou comercial.

Desde sua entrada em vigor em 1972, a Convenção de 1970 é o instrumento multilateral de maior abrangência em cooperação jurídica internacional em matéria civil e comercial, possuindo 58 Estados partes ${ }^{44}$, entre eles vários dos parceiros comerciais do Brasil, como Alemanha, Argentina, França, Estados Unidos, bem como todos os demais membros dos BRICs (Rússia, China, Índia e África do Sul ${ }^{45}$. Além disso, sua elaboração foi expressamente voltada a atender tanto a visão processual dos países de tradição romano-germânica (civil law) quanto a dos países de tradição voltada aos precedentes judiciais e ao direito consuetudinário (common law), de forma a acelerar a obtenção de provas no exterior $^{46}$.

43 AMRAM, Philip W. Explanatory report on the Hague Convention of 18 March 1970 on the taking of evidence abroad civil or commercial matters. Available in: <http://www.hcch.net/upload/ expl20e.pdf>. Access: Out. 30, 2015.

44 Dados disponibilizados pela Conferência da Haia de Direito Internacional Privado, HAGUE CONFERENCE ON PRIVATE INTERNATIONAL LAW, 20., 1970, Hague. Members of the Organisation. Available in: <https://www.hcch.net/en/instruments/ conventions/status-table/print/?cid=82>. Access: Feb. 08, 2016.

45 Sobre o BRIC, ver CASELLA, Paulo Borba. BRIC: Brasil, Rússia, China e África do Sul: uma perspectiva de cooperação internacional. São Paulo: Atlas, 2011.

46 Sua elaboração motivou também a adoção de tratados na Organização dos Estados Americanos (OEA). Há duas outras convenções elaboradas no seio das Conferências Interamericanas sobre Direito Internacional Privado (CIDIP's), a saber: (i) a Convenção Interamericana sobre Obtenção de Provas no Estrangeiro e a (ii) Convenção Interamericana sobre Cartas Rogatórias, ambas elaboradas na CIDIP-I (Panamá, 1975). A Convenção sobre Cartas Rogatórias já foi ratificada e incorporada internamente ao ordenamento brasileiro (Decreto n. 1.898, de 9 de maio de 1996), bem como seu Protocolo Adicional elaborado em Montevidéu em 1979 (Decreto n. 2.022, de 7 de outubro de 1996). Contudo, no que tange ao objeto deste artigo (a obtenção de provas no exterior), a específica Convenção Interamericana sobre Obtenção de Provas no Estrangeiro ainda não foi ratificada pelo Brasil.
A Convenção possui 42 artigos, divididos em três partes, referentes a (i) cartas rogatórias (14 artigos), (ii) obtenção de provas por representantes diplomáticos, agentes consulares ou comissários (7 artigos) e (iii) disposições gerais (21 artigos). Não foi definida o que vem a ser uma "matéria civil ou comercial", o que implica na possibilidade de seu uso amplo, excepcionando-se somente a temática criminal. ${ }^{47}$

No Capítulo II, a Convenção inova ao instituir a possibilidade de obtenção de provas no exterior por intermédio da atividade de diplomatas, cônsules e comissários. Buscou-se formalizar a atuação da via diplomática ou consular na obtenção de prova no interesse de processos instaurados no Estado acreditante, a qual tem a vantagem de não necessitar de investimento adicional ou de novos órgãos. Já o comissário seria um passo adicional, rumo à especialização de um agente na cooperação jurídica internacional, na medida em que é um indivíduo expressamente designado para obter provas no interesse de processo instaurado em outro Estado Contratante. Caso haja necessidade, os agentes diplomáticos, consulares ou o comissário podem pedir assistência local para obter provas com coação (art. 18). ${ }^{48}$

É de se salientar, contudo, que a atividade probante da autoridade estrangeira no outro Estado foi regulada, tendo a Convenção o cuidado de diferenciar a (i) obtenção de prova sem coação da (ii) obtenção de prova com coação; neste último caso, a assistência das autoridades locais seria indispensável. Mesmo assim, essa atuação probante no território nacional de autoridades estrangeiras fez com que a maioria dos Estados contratantes impusesse reserva ao Capítulo II da Convenção ${ }^{49}$.

No caso brasileiro, a reserva foi sugerida, inicialmente, pelo Ministério das Relações Exteriores em termos mais restritos, englobando somente uma reserva ao artigo 16, parágrafo $2^{\circ}$ (as provas previstas não poderão ser obtidas sem

47 HAGUE CONFERENCE ON PRIVATE INTERNATIONAL LAW, 20., 1970, Hague. Convention on the taking of evidence abroad in civil or commercial matters. Available in: <https://assets. hcch.net/docs/dfed98c0-6749-42d2-a9be-3d41597734f1.pdf>. Access: Feb. 08, 2016.

48 HAGUE CONFERENCE ON PRIVATE INTERNATIONAL LAW, 20., 1970, Hague. Convention on the taking of evidence abroad in civil or commercial matters. Available in: <https://assets. hcch.net/docs/dfed98c0-6749-42d2-a9be-3d41597734f1.pdf>. Access: Feb. 08, 2016

49 HAGUE CONFERENCE ON PRIVATE INTERNATIONAL LAW, 20., 1970, Hague. Members of the Organisation. Available in: <https://www.hcch.net/en/instruments/conventions/statustable/print/?cid=82>. Access: Feb. 08, 2016. 
autorização prévia de autoridade brasileira competente) e ainda reservas aos artigos 17 e 18 (levando o Brasil a não se vincular à obtenção de provas por comissário sem coação e por representantes diplomáticos, funcionários consulares e comissários com coação). Após o trâmite congressual, ficou assentada a reserva a todo Capítulo $\mathrm{II}^{50}$, o que foi concretizado na ratificação brasileira. ${ }^{51}$

O diálogo entre o sistema da "civil law" e da "common law" foi obstaculizado pela previsão do art. 23, que dispôs que os Estados Contratantes podem, no momento da assinatura, ratificação ou adesão, declarar que não cumprirão as Cartas Rogatórias que tenham sido emitidas com o propósito de obterem o que é conhecido, nos países de Common Law, pela designação de "pre-trial discovery of documents". O Brasil fez tal declaração, o que significa que o Estado não aceitará cartas rogatórias que tenham por objeto atos processuais a ser praticados na chamada fase de "discovery", ou seja, durante a investigação e obtenção de provas antes mesmo de o processo (trial) ser iniciado perante o juízo competente. Aqui, a razão para o rechaço está na falta de similaridade com o processo brasileiro, o que demonstra a dificuldade do Direito Internacional Privado em contornar a desconfiança com instituições desconhecidas, mesmo aquelas oriundas de Estados Democráticos e que respeitam o devido processo legal.

No que tange à regência normativa da produção probatória, o art. $9^{\circ}$ prevê que a autoridade judicial aplicará a legislação de seu país no que diz respeito às formalidades a serem seguidas na obtenção da prova. Entretanto, essa autoridade atenderá ao pedido do Estado requerente de que se proceda de forma especial, a não ser que tal procedimento seja (i) incompatível com a legislação do Estado requerido ou que (ii) sua execução não seja possível, quer em virtude da prática judicial

50 Vide parecer do Senador Anibal Diniz. Em: COMISSÃO DE RELAÇÕES EXTERIORES E DEFESA NACIONAL. Parecer de 2011: o Projeto de Decreto Legislativo n ${ }^{\circ} 638$, de 2010 (n 2.438, de 2010, na origem), da Comissão de Relações Exteriores e de Defesa Nacional da Câmara dos Deputados, que aprova, com ressalvas, o texto da Convenção sobre a Obtenção de Provas no Estrangeiro em Matéria Civil ou Comercial, assinada em Haia, em 18 de março de 1970. Disponível em: < http://legis.senado.leg.br/mateweb/arquivos/mate-pdf/96771.pdf>. Acesso em: 30 out. 2015.

51 A convenção entrou em vigor para o Brasil no dia 08 de junho de 2014. Conferir em HAGUE CONFERENCE ON PRIVATE INTERNATIONAL LAW, 20., 1970, Hague. Convention on the taking of evidence abroad in civil or commercial matters. Available in: <https://assets.hcch.net/docs/dfed98c0-6749-42d2-a9be3d41597734f1.pdf>. Access: Feb. 08, 2016. seguida, quer de dificuldades de ordem prática.

$\mathrm{Na}$ mesma linha do uso da lex diligentiae, o artigo 10 prevê que a autoridade do Estado Requerido utilizará os meios de coação apropriados e previstos por sua legislação para a execução de decisões proferidas por suas próprias autoridades ou de pedidos formulados por uma parte em processo interno.

Ficaram estabelecidas as duas opções mais conhecidas de norma de regência da produção probatória no exterior. De um lado, a regra geral do uso da lex diligentiae, que concretiza a máxima da lei local rege o ato (locus regit actum $)^{52}$. Por outro lado, há o uso excepcional da lex fori objetivando que haja o uso de modo de produção probatória ou meios de prova conhecidos pelo Estado do foro.

Com essas duas opções, a Convenção da Haia de 1970 objetivou conciliar as duas fórmulas principais que regem a produção probatória no exterior, evitando rigidez na opção por uma ou outra. Houve um avanço em relação à LINDB e do Código Bustamante, que - como visto - desembocam no "predomínio oculto" da lex fori. De acordo com a Convenção da Haia, caso o Estado Requerente tenha uma visão própria sobre a temática probatória, deve informar previamente ao Estado Requerido e solicitar que seus procedimentos sejam seguidos, evitando o uso futuro da cláusula de ordem pública para descartar a diligência probatória estrangeira.

Todavia, essa fórmula conciliatória nem sempre será possível: o uso excepcional da lei do Estado Requerente para reger a produção probatória a ser realizada no Estado Requerido depende, de acordo com a Convenção da Haia, de duas circunstâncias: (i) não ser incompatível com o direito do Estado Requerido ou (ii) não ser sua execução impossível por violação da prática judicial local ou por razões práticas. Assim, em que pese o avanço, a Convenção da Haia não eliminou o risco de batalhas judiciais sobre a admissibilidade ou não das provas realizadas no exterior.

\section{A PRÁtICA BRASILEIRA}

A prática brasileira indica o reiterado uso da lex diligentiae quando o Brasil está na posição de Estado

52 NAZO, Nicolao. A Regra "Locus Regit Actum". Revista da Faculdade de Direito da Universidade de São Paulo, São Paulo, v. 30, p. 128-140, 1934. p. 128-140. 
requerido, no cumprimento de pedidos cooperacionais oriundos de Estado estrangeiro, sem maior consideração sobre as leis e práticas do Estado Requerente de origem do processo (lex processum). Como visto, a Convenção da Haia de 1970 reconhece importante exceção ao uso da lex diligentiae, que vem a ser o uso da lei do Estado Requerente caso este insista em determinada forma ou modo especial para a realização probatória, o que ainda não tem gerado abalos no cotidiano forense nacional.

De fato, a jurisprudência brasileira sobre a aplicação da lex diligentiae é farta, como se vê, por exemplo, na exigência da aplicação da lex diligentiae (no caso, a lei brasileira) para a realização da citação de indivíduo domiciliado no Brasil. Tanto o Supremo Tribunal Federal quanto o Superior Tribunal de Justiça usualmente não aceitam o uso de modos citatórios estrangeiros no Brasil, exigindo que a citação seja feita pela forma conhecida, qual seja, por intermédio de carta rogatória.

Nesse sentido, o uso do instrumento anglo-saxônico do affidavit foi considerado, em diversas ocasiões, como sendo ofensivo à soberania brasileira, tendo o Superior Tribunal de Justiça decidido que a "citação do réu domiciliado no Brasil para responder a demanda ajuizada no exterior deve se processar por carta rogatória". ${ }^{53}$ A citação realizada por meio do affidavit não foi aceita, mesmo sendo realizada em mãos dos representantes legais norte-americanos de réus domiciliados no Brasil. ${ }^{54}$

Outro caso marcante do uso da lex diligentiae pelo Brasil ocorreu no Caso Amia, no qual o Poder Judiciá-

53 BRASIL. Superior Tribunal de Justiça. Sentença Estrangeira Contestada. SEC 1.483/LU. Corte Especial. Requerente: Cláudia Sofia Duarte Mendes. Requerido: Carlos Alberto Mendes. Relator: Min. Ari Pargendler. Brasília, 12 de abril de 2010. Disponível em: <http://stj.jusbrasil.com.br/jurisprudencia/9119789/sentencaestrangeira-contestada-sec-1483-lu-2006-0176892-5/inteiro-teor-14265081>. Acesso em: 08 fev 2016.

54 BRASIL. Superior Tribunal de Justiça. Sentença Estrangeira Contestada. SEC 684/EUA. Corte Especia. Requerente: Doorway Investiments Ltd. Requerido: SMV Participações e Empreendimentos Ltda. Relator: Min. Castro Meira. Brasília, 01 de julho de 2010. Disponível em: < http://stj.jusbrasil.com.br/jurisprudencia/9119789/ sentenca-estrangeira-contestada-sec-1483-lu-2006-0176892-5/ inteiro-teor-14265081>. Acesso em: 08 fev 2016. Nesse sentido, em precedente mais recente. BRASIL. Superior Tribunal de Justiça. Sentença Estrangeira Contestada. SEC 8800/EX. Corte Especial. Requerente: T A V S. Requerido: C DA F C B. Relator: Min. Napoleão Nunes Maia. Brasília, 18 de dezembro de 2013. Disponível em: $<$ http://stj.jusbrasil.com.br/jurisprudencia/24912482/sentencaestrangeira-contestada-sec-8800-ex-2013-0055111-5-stj/relatorio-evoto-24912484>. Acesso em: 08 fev 2016. rio argentino solicitou, por carta rogatória, que a oitiva de testemunha no Brasil sobre o atentado ao prédio da Asociación Mutual Israelita Argentina - Amia fosse feita por juiz argentino e na sua Embaixada em Brasilia. O Supremo Tribunal Federal indeferiu o pleito, em nome da soberania brasileira, mandando aplicar a legislação brasileira (lex diligentiae) para os atos aqui realizados, o que implicou na realização da oitiva da testemunha perante juiz brasileiro em sua sede ${ }^{55}$.

Por sua vez, o Supremo Tribunal Federal indeferiu o pedido de coleta de sangue compulsória para instruir ação de investigação de paternidade ${ }^{56}$, bem como a oitiva de corréu como testemunha. Novamente, foram aplicadas as vedações da lex diligentiae, ou seja, o ordenamento brasileiro não admite a intervenção corpórea mínima compulsória, bem como a oitiva - como testemunha e com o dever de dizer a verdade - do corréu ${ }^{57}$.

Nesses casos, há o reforço à supremacia da lei nacional, uma vez que a lei do local da diligência é a lei brasileira, sendo desnecessário o apelo às cláusulas de ordem pública. No caso de pedido do Estado estrangeiro para que seja seguido determinado procedimento probatório (exceção à regra da lex diligentiae, admitida em tratados como a Convenção da Haia de 1971), a cláusula do respeito à ordem pública de Direito Internacional Privado do local do foro pode servir para justificar a denegação de tal pleito (como ocorreu no caso Amia). Ou seja, novamente, há o retorno à lex fori.

Por outro lado, o Estado brasileiro, quando deve implementar as medidas probatórias realizadas no exterior, sujeita-se, via de regra, à lei local estrangeira que

55 BRASIL. Supremo Tribunal Federal. Carta Rogatória. CR 8577 / AT. Relator: Min. Celso de Mello. Brasília, 19 de fevereiro de 1999. Disponível em: <http://stf.jusbrasil.com.br/jurisprudencia/19162300/carta-rogatoria-cr-8577-stf $>$. Acesso em: $08 \mathrm{fev}$. 2016. Conferir também o caso AMIA em ABADE, Denise Neves. Direitos fundamentais na cooperação jurídica internacional. São Paulo: Saraiva, 2013. p. 346.

56 BRASIL. Supremo Tribunal Federal. Carta Rogatória. CR 8443. Relator: Min. Celso de Mello Brasília, 03 de setembro de 1998. Disponível em: <http://stf.jusbrasil.com.br/jurisprudencia/19162569/carta-rogatoria-cr-8443-stf $>$. Acesso em: 08 fev. 2016.

57 BRASIL. Supremo Tribunal Federal. Habeas Corpus. HC 87759/DF. Primeira Turma. Paciente: Achille Lollo. Impetrante: Técio Lins e Silva e outros. Relator: Min. Marco Aurélio. Brasília, 26 de fevereiro de 2008. Disponível em: < http://stf.jusbrasil.com. br/jurisprudencia/754245/habeas-corpus-hc-87759-df>. Acesso em: 08 fev. 2016. Ambos os casos detalhados por ABADE, Denise Neves. Direitos fundamentais na cooperação jurídica internacional. São Paulo: Saraiva, 2013. p. 344-346. 
rege tal produção probatória, devendo ser seguido o art. 13 da LINDB, que dispõe que os fatos e atos realizados no estrangeiro não precisam, para serem provados, obedecer necessariamente a todas as formalidades e restrições da lex fori, bastando que cumpram as exigências da lei estrangeira, a lex diligentiae ${ }^{58}$. No máximo, pode o Estado brasileiro solicitar que seja seguido procedimento específico previsto em sua lei nacional, mas tal pleito sujeita-se à aprovação do Estado do local da realização da diligência, conforme prega, por exemplo, a Convenção da Haia sobre Obtenção de Provas no exterior.

Contudo, a prática brasileira demonstra que o ataque à lex diligentiae ocorre sempre que a regra estrangeira é diferente da regra brasileira sobre provas. Nesse momento, surge a ameaça do uso da cláusula de ordem pública, prevista no art. 17 da Lei de Introdução às Normas do Direito Brasileiro.

A temática da quebra do sigilo bancário - por ser prova corriqueira em casos cíveis ou criminais - exemplifica bem a situação: o Estado estrangeiro, realiza a quebra do sigilo de acordo com suas regras (lex diligentiae), o que pode envolver - ou não - a necessidade de autorização do juiz brasileiro. Pela regra do art. 13 da LINDB, o correntista brasileiro no exterior não possui a extensão extraterritorial da exigência de ordem judicial brasileira (lex fori brasileira) para a quebra do sigilo bancário.

Há precedente do Superior Tribunal de Justiça no caso Igreja Universal do Reino de Deus, no qual se alegou a necessidade de ordem judicial brasileira para a quebra do sigilo bancário em outro país, não bastando o pedido do Ministério Público, uma vez que, no Brasil, tal órgão público somente pode ordenar a quebra do sigilo bancário em casos envolvendo verbas públicas ${ }^{59}$. Ou seja, buscou-se estender ao Estado estrangeiro as formalidades probatórias brasileiras. O Superior Tribunal de Justiça entendeu que esse tipo de extensão das formalidades da lex fori não é cabível, devendo prevalecer a lex diligentiae (no caso, a legislação norte-americana).

58 DOLINGER, Jacob; TIBURCIO, Carmen. The forum law rule in international litigation: lex fori or lex diligentiae? Unresolved Choice-of-law issues in the transnational rules of civil procedure. Texas International Law Journal, v. 33, n. 3, p. 425-461, summer 1998. p. 425 e seguintes.

59 Sobre a necessidade de ordem judicial para a quebra do sigilo bancário e a hipótese de cabimento de ordem realizada pelo Ministério Público, ver RAMOS, André de Carvalho. Curso de direitos humanos. 2. ed. São Paulo: Saraiva, 2015. p. 546 e seguintes.
Nos termos da decisão, “[...] Na espécie, a solicitação do Ministério Público do Estado de São Paulo foi dirigida à autoridade dos Estados Unidos da América do Norte. Nada importa, para esse efeito, o que a legislação brasileira dispõe a respeito. As investigações solicitadas serão realizadas, ou não, nos termos da legislação daquele País".(grifo nosso)..$^{60}$

Outro precedente sobre a temática ocorreu no Caso Alstom, no qual a Defesa de investigado procurou declarar nula a remessa de informação proveniente da Suíça porque o Judiciário suíço teria declarado ilícito (de acordo com o direito suíço) o modo de obtenção de tais informações. O Superior Tribunal de Justiça rechaçou tal pleito, por vários motivos (inclusive a ausência de vínculo da ilicitude detectada na Suíça com as informações efetivamente repassadas ao Brasil), enfatizando-se - em trecho do voto do Relator, Ministro Noronha - o uso da lex diligentiae: "O importante frisar é que a Suíça considera tal produção de prova em termos diferentes do nosso. O envio ao Brasil de prova assim obtida não seria ilícita, porque obtida de maneira conforme à legislação local". ${ }^{61}$

Também no Superior Tribunal de Justiça, no Caso Ruedas Bustos, foi debatida a oitiva de testemunha perante autoridade não judicial (a "deposition" norte-americana), o que violaria o devido processo legal. O Relator Min. Gilson Dipp sustentou a regularidade da coleta, pois foi cumprido o disposto na lei do Estado estrangeiro (lex diligentiae) e houve ciência da defesa para apresentação de quesitos. ${ }^{62}$ Para o STJ, então, tais solicitações devem ser executadas de acordo com as leis do Estado Requerido ${ }^{63}$. Nos Tribunais Regionais Fede-

60 BRASIL. Superior Tribunal de Justiça. Suspensão de Segurança. AgRg no AgRg na SS 2382 -SP. Agravante: Igreja Universal do Reino de Deus. Agravado: Ministério Público do Estado de São Paulo. Relator: Min. Presidente Ari Pargendler. Brasília, 26 de outubro de 2010. Disponível em: <http://stj.jusbrasil.com.br/jurisprudencia/17419981/suspensao-de-seguranca-agrg-no-agrg-na-ss-2382>. Acesso em: 08 fev. 2016.

61 BRASIL. Superior Tribunal de Justiça. Agravo Regimental no Inquérito. AgRg no Inq 417 PA 2003/0150299-1. Segunda Turma. Agravante: Rosa Maria Portugal Gueiros. Agravado: Justiça Pública. Relator: Min. João Otávio de Noronha. Brasilia, 21 de setembro de 2015. Disponível em: <http://sti.jusbrasil.com.br/jurisprudencia/19242370/ agravo-regimental-no-inquerito-agrg-no-inq-417-pa-2003-0150299-1/ inteiro-teor-19242371>. Acesso em: 08 fev. 2016.

62 Consta do acórdão que a Defesa foi intimada a apresentar perguntas, mas recusou.

63 BRASIL. Superior Tribunal de Justiça. Habeas Corpus. HC 128590/PR. Quinta Turma. Impetrante: Alberto Zacharias Toron e Outros. Impetrado: Tribunal Regional Federal Da 4a Região. Relator: Min. Gilson Dipp. Brasília, 15 de fevereiro de 2011. Disponível em: <http://stj.jusbrasil.com.br/jurisprudencia/18447585/habeas- 
rais, há precedente (Caso Hourcade) sobre a adequação do uso da "lex diligentiae" em casos de interrogatório em Estado estrangeiro no qual não é imprescindível a presença de defensor. ${ }^{64}$

No Supremo Tribunal Federal, há interessante debate sobre o modo de requerer a produção probatória (sobre a possibilidade do Ministério Público suíço requerer diretamente carta rogatória para produção de provas ou se esta deveria ser emitida por autoridade judicial, tal qual ocorre no Brasil $\left.^{65}\right)$ e ainda sobre acesso aos autos de diligências (que teria sido negada na França, mas que é direito de qualquer parte no Brasil ${ }^{66}$ ). Em ambos os casos, o STF acabou, ao final, fazendo prevalecer a "lex diligentiae".

Não está claro, entretanto, que a aceitação da "lex diligentiae" pode ser considerada uma tendência no Superior Tribunal de Justiça ou no Supremo Tribunal Federal. A incerteza e a indeterminação da cláusula de ordem pública podem acarretar a impugnação de determinada diligência probatória produzida no exterior por ofensa ao devido processo legal e a outros direitos envolvidos.

\section{As DEFICIÊNCIAS DA DICOTOMIA "LEX FORI"X "LEX DILIGENTIAE"}

O tratamento normativo do cisma (ou dicotomia) entre a "lex fori" e a "lex diligentiae" para a regência da

corpus-hc-128590-pr-2009-0026980-2/inteiro-teor-18447586>. Acesso em: 08 fev. 2016.

64 BRASIL. Tribunal Regional Federal (4. Região). Apelação Criminal n. 2003.71.00.035503-8/RS Oitava Turma. Apelante: Attilio Giacoboni Hourcade. Apelado: Ministério Público Federal. Relator: Juiz Federal Sebastião Ogê Muniz. Porto Alegre, 17 de julho de 2012. Disponível em: <http://www.radaroficial.com.br/d/4976686>. Acesso em: 08 fev. 2016. Consta da ementa do acórdão: "Em sede de cooperação jurídica internacional, os atos processuais praticados no exterior devem ser realizados segundo as normas vigentes no Estado Requerido. Hipótese em que inexiste nulidade no interrogatório realizado, no Estado Requerido, sem a presença de defensor.".

65 BRASIL. Supremo Tribunal Federal. Embargos de Declaração em Habeas Corpus. HC 91002 RJ. Primeira Turma. Embargante: Ministério Público Federal. Embargado: Sergio do Rego Macedo. Relator: Min. Marco Aurélio. Brasília, 24 de março de 2009. Disponível em: < http://stf.jusbrasil.com.br/jurisprudencia/14714850/embdeclno-habeas-corpus-hc-91002-rj>. Acesso em: 08 fev. 2016.

66 BRASIL. Supremo Tribunal Federal. Habeas Corpus. HC 97511 SP. Primeira Turma. Paciente: Paulo Salim Maluf. Impetrante: José Roberto Leal de Carvalho. Relator: Min. Ricardo Lewandowski. Brasília, 10 de agosto de 2010. Disponível em: <http://www.stf. jus.br/arquivo/cms/noticiaNoticiaStf/anexo/HC_97_511.pdf>. Acesso em: 08 fev. 2016. produção probatória no exterior não gerou segurança jurídica e respeito aos direitos humanos.

De um lado, a opção da LINDB, do Código Bustamante, da Convenção da Haia de 1970, bem como de diversos tratados, pela "lex diligentiae", não eliminou a possibilidade do retorno à "lex fori”" pelas mãos da cláusula da ordem pública. Esse retorno foi denominado inclusive de "predomínio oculto" da "lex fori", o que implica em insegurança jurídica. A parte interessada na produção probatória e que cumpriu a "lex diligentiae", pode ser surpreendida depois pela alegação de ofensa à ordem pública, com o descarte da prova ("prova ilícita").

Nesse sentido, mesmo a fórmula conciliatória da Convenção da Haia de 1970 não é certa: o Estado do processo principal pode pedir ao Estado estrangeiro que a diligência probatória siga as regras do processo principal, mas dispõe a própria Convenção que tal pleito pode ser recusado por motivos genéricos.

Se a opção pela "lex diligentiae" é tíbia, por que os Estados não retrocedem e confessam a preferência pela "lex fori’'? A resposta é simples: porque o Estado do local da realização da diligência tradicionalmente resiste ao uso de regras de outro país sobre a regência de provas. O Caso Amia no Supremo Tribunal Federal (STF) brasileiro exemplifica a situação: mesmo diante do pleito de um Estado Democrático, vizinho ao Brasil e de intensa parceria e confiança (membros originários de um ambicioso projeto de integração, o Mercosul), o STF simplesmente indeferiu o pedido de aplicação da lei do processo principal (lei argentina), sob a alegação genérica de respeito à soberania nacional.

O cerne do debate, então, deve sofrer um giro copernicano: não mais ser concentrado no cisma entre "lex diligentiae" e "lex fori" e sim em como interpretar os direitos envolvidos que possibilitam a aplicação da cláusula da ordem pública em matéria probatória. Só assim será lograda segurança jurídica e, ao mesmo tempo, respeito aos direitos de todos os envolvidos nesse complexo problema da produção probatória no exterior.

\section{O GIRO COPERNICANO: OS MODELOS PARA AFERIR O RESPEITO AOS DIREITOS ENVOLVIDOS NA PRODUÇÃO PROBATÓRIA NO EXTERIOR}

Tendo em vista as falhas da tradicional dicotomia entre a "lex fori" e a "lex diligentiae", propõe-se o es- 
tudo de um modo de definir os direitos dos envolvidos na produção probatória no exterior, objetivando evitar a insegurança jurídica até então reinante e, concomitantemente, promover os direitos envolvidos.

De início, descarta-se o uso da fórmula da "primazia da norma probatória mais favorável ao indivíduo" como modo de escolha da lei para reger a produção probatória no exterior. Grosso modo, a "primazia da norma mais favorável ao indivíduo" levaria à escolha do ordenamento (lex fori ou lex diligentiae) que fosse mais protetivo aos direitos humanos na temática probatória. Não haveria a prevalência mecânica da norma brasileira ou da norma estrangeira, mas, casuisticamente, prevaleceria a norma mais favorável ao indivíduo.

Contudo, a produção probatória no exterior envolve conflito de direitos de indivíduos distintos ou mesmo entre direitos difusos e direitos individuais. De modo conciso, em um processo (cível ou criminal) há aquele que tem interesse na produção da prova (para demonstrar sua tese) e aquele que terá um ganho processual se a prova não for produzida ou se for considerada "ilícita". Há choque de interesses, que será traduzido em choque de direitos. Assim, impossível definir qual seria a norma "favorável", pois determinado indivíduo ou indivíduos (mesmo que indeterminados, como é o caso da sociedade na temática criminal, que é representada pelo Ministério Público) seriam prejudicados. ${ }^{67}$

Por isso, urge definir os parâmetros para aferir o conteúdo e os limites dos direitos humanos envolvidos na produção probatória no exterior. Há três modelos possíveis: (i) o modelo nacional (ou da lex fori); (ii) o modelo estrangeiro (ou da lex causae) e o (iii) modelo universalista (ou da interpretação internacionalista).

O modelo nacional (ou da lex fori) consiste em determinar o conteúdo e limites dos direitos envolvidos de acordo com a visão de direitos humanos do Estado do processo principal (Estado do foro, no qual o processo é realizado). Esse modelo é o mais acessível ao intérprete e ainda tem a seu favor o seu uso tradicional no que tange ao conteúdo da cláusula de "ordem pública", que representa o "anjo da guarda" (expressão de Dolin$\left.\operatorname{ger}^{68}\right)$ dos valores do foro. Porém, ao se exigir a repro-

67 Sobre a crítica ao uso da "primazia da norma mais favorável ao indivíduo" na seara dos direitos humanos, ver RAMOS, André de Carvalho. Teoria geral dos direitos humanos na ordem internacional. 5. ed. São Paulo: Saraiva, 2015. p. 143 e seguintes.

68 DOLINGER, Jacob. A evolução da ordem pública no direito dução na íntegra de todo o arcabouço nacional referente à produção de provas, suas formas e meios, pode o Estado estrangeiro (do local da realização da diligência) simplesmente não concordar. Sem essa concordância, haverá a denegação de justiça (a prova não será produzida), gerando, paradoxalmente, violação de direitos (a começar pelo direito de acesso à justiça). Essa postura gera o aumento da xenofobia e chauvinismo jurídicos e ameaça a tolerância e a diversidade que o DIPr almeja.

O modelo estrangeiro (ou da lex causae) consiste na aceitação da formatação dos direitos envolvidos na produção probatória de acordo com a concepção do Estado no qual a diligência será realizada. Há, inicialmente, a facilidade na produção da prova (repete-se aquilo que o Estado estrangeiro está habituado a fazer), o que reforça o direito de acesso à justiça. Também há confiança no ordenamento estrangeiro, reforçando o espírito de cooperação do DIPr, a qual pode estar, inclusive, embasada na existência consolidada do regime democrático e protetor de direitos humanos no Estado estrangeiro. Contudo, mesmo Estados democráticos podem desrespeitar direitos ou podem passar por momentos de histeria e pânico. Essa "cegueira deliberada" do Estado do foro em analisar como a prova foi produzida no exterior pode prejudicar, em um caso concreto, determinado direito.

Por fim, há o modelo universalista (ou da interpretação internacionalista), que busca aferir o conteúdo e os limites dos direitos protegidos de acordo com parâmetros internacionais, extraídos do intenso cipoal de decisões de órgãos internacionais de direitos humanos, como a Corte Europeia de Direitos Humanos, Corte Interamericana de Direitos Humanos, entre outros ${ }^{69}$.

Esse último modelo é o que mais se aproxima da essência de tolerância e diversidade do Direito Internacional Privado, disciplina que tem sua alma mater na possibilidade de uso de regras estrangeiras, distintas das regras locais. Por sua vez, o modelo universalista também atende ao próprio desenho contemporâneo dos direitos humanos, que não é mais localista e, sim, internacional. ${ }^{70} \mathrm{~A}$ principal deficiência desse modelo

internacional privado. Rio de Janeiro: Luna, 1979. p. 41.

69 Sobre essas Cortes Internacionais e seus processos internacionais de direitos humanos, ver RAMOS, André de Carvalho. Processo internacional de direitos humanos. 4. ed. São Paulo: Saraiva, 2015.

70 Sobre a evolução histórica da proteção internacional dos direitos humanos, ver RAMOS, André de Carvalho. Teoria geral dos direitos humanos na ordem internacional. 5. ed. São Paulo: Saraiva, 
seria a falta de decisões internacionais que forneçam a interpretação internacionalista dos direitos envolvidos na produção probatória no exterior. Se essa deficiência ocorria no passado, isso não é mais verdadeiro no presente. Há já milhares de precedentes da Corte Europeia de Direitos Humanos e mesmo a Corte Interamericana de Direitos Humanos já possui quase 300 casos aprecia$\operatorname{dos}^{71}$. Cada vez mais, a interpretação internacionalista dos direitos humanos impõe-se.

Exemplo do impacto da adoção de determinado modelo de aferição de direitos humanos deu-se no julgamento de homologação no Brasil de sentença russa, versando sobre a declaração de nulidade de cláusula de estatuto social, referente à utilização da marca da vodca russa "Stolichnaya". Em suas contestações, as interessadas no indeferimento da homologação alegaram ofensa à ordem pública brasileira, em especial por violação de direitos como o devido processo legal, o contraditório e a ampla defesa. O Min. Relator Fernando Gonçalves fez constar de seu voto que a sentença russa já havia sido considerada adequada à luz dos direitos humanos pela Corte Europeia de Direitos Humanos, ocasião em que não foi detectada qualquer violação à Convenção Europeia de Direitos Humanos ${ }^{72}$. Assim, de modo pioneiro, houve certa aproximação em direção ao modelo universalista.

\section{Considerações finais}

O debate envolvendo o uso da "lex fori regit processum" ou da "lex diligentiae" na produção de provas no exterior retrata um dos problemas centrais do Direito Internacional Privado do século XXI: como evitar que as diferenças de interpretação dos direitos humanos envolvidos em um fato transnacional gerem alegações de desrespeito à ordem pública, redundando em um nova era de territorialismo e rechaço ao direito estrangeiro?

2015.

71 Sobre os números atualizados dos órgãos internacionais de direitos humanos, ver RAMOS, André de Carvalho. Processo internacional de direitos humanos. 4. ed. São Paulo: Saraiva, 2015.

72 BRASIL. Superior Tribunal de Justiça. Sentença Estrangeira Contestada. SEC $n^{\circ}$ 269. Corte Especial. Requerente: Empresa Estatal Federal Fkp Soiuz Plodoimport e Outros. Requerido: Instituto Nacional de Propriedade Industrial. Relator: Min. Fernando Gonçalves. Brasília, 03 de março de 2010. Disponível em: < http://www. stf.jus.br/arquivo/cms/noticiaNoticiaStf/anexo/HC_97_511. pdf>. Acesso em: 08 fev. 2016.
As soluções prevista na Lei de Introdução às Normas do Direito Brasileiro, no Código Bustamante e mesmo na Convenção da Haia de 1970 são insuficientes e geram insegurança jurídica, pelo "predomínio oculto" da lex fori e pela instabilidade e indeterminação da cláusula de ordem pública. O problema maior continua sendo as diferentes concepções sobre os direitos envolvidos na produção probatória: enquanto um Estado pode dar maior peso ao direito de acesso à justiça e, com isso, ser mais permissivo quanto aos modos de produção da prova, outro Estado pode optar por dar preferência a outros direitos (direito à intimidade, direito a não produzir prova contra si mesmo, etc) e, consequentemente, criar uma série de entraves à produção probatória (barreiras à quebra do sigilo bancário, vedação ao uso de gravação ambiental, etc).

Por isso, propôs-se o abandono da ênfase no tradicional cisma entre os critérios da lex fori e a lex diligentiae para que seja focado no modelo de determinação dos direitos humanos envolvidos na produção probatória no exterior.

Descartou-se o uso da fórmula da "primazia da norma probatória mais favorável ao indivíduo", por ser inviável em um cenário de conflito de direitos envolvidos na temática. Depois, propostos três modelos possíveis de regência da produção probatória no exterior, fica evidente a superioridade do modelo universalista, pela sua coerência e consistência com a concepção internacionalista dos direitos humanos (que não é mais local, dada a consagração da internacionalização desses direitos) e pela existência de decisões internacionais densificando os direitos envolvidos na produção probatória no exterior.

\section{ReferênCiAs}

ABADE, Denise Neves. Direitos fundamentais na cooperação jurídica internacional. São Paulo: Saraiva, 2013.

AMRAM, Philip W. Explanatory report on the Hague Convention of 18 March 1970 on the taking of evidence abroad civil or commercial matters. Available in: $<$ http://www.hcch.net/upload/expl20e.pdf>. Access: Oct. 30, 2015.

ARAÚJO, Nadia de; POLIDO, Fabrício Bertini Pa- 
squot. Reconhecimento e execução de sentenças estrangeiras: análise do projeto em andamento na Conferência da Haia de direito internacional privado. Revista Brasileira de Direito Internacional, v. 11, n. 1, p. 20-42, 2014.

BADARÓ, Gustavo Henrique Righi Ivahy. Ônus da prova no processo penal. São Paulo: RT, 2003.

BRASIL. Câmara dos Deputados. Decreto $n^{\circ} 18.871$, de 13 de agosto de 1929. Disponível em: < http://www2. camara.leg.br/legin/fed/decret/1920-1929/decreto18871-13-agosto-1929-549000-norma-pe.html>. Acesso em: 08 fev. 2016.

BRASIL. Câmara dos Deputados. Decreto $n^{\circ}$ 6.982, de 27 de julho de 1878. Disponível em: <http://www2. camara.leg.br/legin/fed/decret/1824-1899/decreto-6982-27-julho-1878-547801-publicacaooriginal62676-pe.html>. Acesso em: 08 fev. 2016.

BRASIL. Constituição (1988). Constituição da Republica Federativa do Brasil. Disponível em: < http://www. planalto.gov.br/ccivil_03/Constituicao/Constituicao. htm>. Acesso em: 08 fev. 2016.

BRASIL. Decreto-Lei $n^{\circ} 4.657$, de 4 de setembro de 1942. Disponível em: <http://www.planalto.gov.br/ ccivil_03/Decreto-Lei/Del4657.htm>. Acesso em: 08 fev. 2016.

BRASIL. Lei $n^{\circ}$ 3.071, de 1 de janeiro de 1916. Disponível em: <http://www.planalto.gov.br/ccivil_03/ leis/L3071impressao.htm>. Acesso em: 08 fev. 2016.

BRASIL. Lei $n^{\circ}$ 12.376, de 30 de dezembro de 2010. Disponível em: <http://www.planalto.gov.br/ccivil_03/_ Ato2007-2010/2010/Lei/L12376.htm>. Acesso em: 08 fev. 2016.

BRASIL. Lei $n^{\circ}$ 13.105, de 16 de março de 2015. Disponível em: < http://www.planalto.gov.br/ccivil_03/_ ato2015-2018/2015/lei/113105.htm>. Acesso em: 08 fev. 2016..

BRASIL. Superior Tribunal de Justiça. Agravo Regimental no Inquérito. AgRg no Inq 417 PA 2003/01502991. Segunda Turma. Agravante: ROSA Maria Portugal Gueiros. Agravado: Justiça Pública. Relator: Min. João Otávio de Noronha. Brasília, 21 de setembro de 2015. Disponível em: <http://stj.jusbrasil.com.br/ jurisprudencia/19242370/agravo-regimental-no-inquerito-agrg-no-inq-417-pa-2003-0150299-1/inteiroteor-19242371>. Acesso em: 08 fev. 2016.

BRASIL. Superior Tribunal de Justiça. Emenda Regi- mental $n^{\circ} 19$, de 11 de novembro de 2015. Disponível em: <http://dj.stj.jus.br/20151120.pdf>. Acesso em: 08 fev. 2016.

BRASIL. Superior Tribunal de Justiça. Sentença Estrangeira Contestada. SEC 1.483/LU. Corte Especial. Requerente: Cláudia Sofia Duarte Mendes. Requerido: Carlos Alberto Mendes. Relator: Min. Ari Pargendler. Brasília, 12 de abril de 2010. Disponível em: < http:/ / stj.jusbrasil.com.br/jurisprudencia/9119789/sentencaestrangeira-contestada-sec-1483-lu-2006-0176892-5/ inteiro-teor-14265081>. Acesso em: 08 fev 2016.

BRASIL. Superior Tribunal de Justiça. Sentença Estrangeira Contestada. SEC 684/EUA. Corte Especia. Requerente: Doorway Investiments Ltd. Requerido: SMV Participações e Empreendimentos Ltda. Relator: Min. Castro Meira. Brasília, 01 de julho de 2010. Disponível em: <http://stj.jusbrasil.com.br/jurisprudencia/9119789/sentenca-estrangeira-contestadasec-1483-lu-2006-0176892-5/inteiro-teor-14265081>. Acesso em: 08 fev 2016.

BRASIL. Superior Tribunal de Justiça. Sentença Estrangeira Contestada. SEC 8800/EX. Corte Especial. Requerente: T A V S. Requerido: C DA F C B. Relator: Min. Napoleão Nunes Maia. Brasília, 18 de dezembro de 2013. Disponível em: <http://stj.jusbrasil.com.br/ jurisprudencia/24912482/sentenca-estrangeira-contestada-sec-8800-ex-2013-0055111-5-stj/relatorio-e-voto-24912484>. Acesso em: 08 fev 2016.

BRASIL. Superior Tribunal de Justiça. Sentença Estrangeira Contestada. SEC 269. Corte Especial. Requerente: Empresa Estatal Federal Fkp Soiuz Plodoimport e Outros. Requerido: Instituto Nacional de Propriedade Industrial. Relator: Min. Fernando Gonçalves. Brasília, 03 de março de 2010. Disponível em: <http://www. stf.jus.br/arquivo/cms/noticiaNoticiaStf/anexo/ HC_97_511.pdf>. Acesso em: 08 fev. 2016.

BRASIL. Superior Tribunal de Justiça. Suspensão de Segurança. AgRg no AgRg na SS 2382 -SP. Agravante: Igreja Universal do Reino de Deus. Agravado: Ministério Público do Estado de São Paulo. Relator: Min. Presidente Ari Pargendler. Brasília, 26 de outubro de 2010. Disponível em: <http://sti.jusbrasil.com.br/jurisprudencia/17419981/suspensao-de-seguranca-agrgno-agrg-na-ss-2382>. Acesso em: 08 fev. 2016.

BRASIL. Supremo Tribunal Federal. Carta Rogatória. CR 8443. Relator: Min. Celso de Mello Brasília, 03 de 
setembro de 1998. Disponível em: <http://stf.jusbrasil. com.br/jurisprudencia/19162569/carta-rogatoria-cr8443-stf>. Acesso em: 08 fev. 2016.

BRASIL. Supremo Tribunal Federal. Carta Rogatória. CR 8577 / AT. Relator: Min. Celso de Mello. Brasília, 19 de fevereiro de 1999. Disponível em: <http://stf. jusbrasil.com.br/jurisprudencia/19162300/carta-rogatoria-cr-8577-stf>. Acesso em: 08 fev. 2016.

BRASIL. Supremo Tribunal Federal. Habeas Corpus. HC 87759/DF. Primeira Turma. Paciente: Achille Lollo. Impetrante: Técio Lins e Silva e outros. Relator: Min. Marco Aurélio. Brasília, 26 de fevereiro de 2008. Disponível em: <http://stf.jusbrasil.com.br/jurisprudencia/754245/habeas-corpus-hc-87759-df >. Acesso em: 08 fev. 2016.

BRASIL. Supremo Tribunal Federal. Habeas Corpus. HC 97511 SP. Primeira Turma. Paciente: Paulo Salim Maluf. Impetrante: José Roberto Leal de Carvalho. Relator: Min. Ricardo Lewandowski. Brasília, 10 de agosto de 2010. Disponível em: < http://www.stf.jus.br/arquivo/cms/noticiaNoticiaStf/anexo/HC_97_511.pdf $>$. Acesso em: 08 fev. 2016.

BRASIL. Supremo Tribunal Federal. Habeas Corpus. HC 97511 SP. Primeira Turma. Paciente: Paulo Salim Maluf. Impetrante: José Roberto Leal de Carvalho. Relator: Min. Ricardo Lewandowski. Brasília, 10 de agosto de 2010. Disponível em: < http://www.stf.jus.br/arquivo/cms/noticiaNoticiaStf/anexo/HC_97_511.pdf > . Acesso em: 08 fev. 2016.

BRASIL. Superior Tribunal de Justiça. Habeas Corpus. HC 128590/PR. Quinta Turma. Impetrante: Alberto Zacharias Toron e Outros. Impetrado: Tribunal Regional Federal Da 4a Região. Relator: Min. Gilson Dipp. Brasília, 15 de fevereiro de 2011. Disponível em: < http:/ / stj.jusbrasil.com.br/jurisprudencia/18447585/habeas-corpus-hc-128590-pr-2009-0026980-2/inteiro-teor-18447586>. Acesso em: 08 fev. 2016.

BRASIL. Tribunal Regional Federal (4. Região). Apelação Criminal n. 2003.71.00.035503-8/RS Oitava Turma. Apelante: Attilio Giacoboni Hourcade. Apelado: Ministério Público Federal. Relator: Juiz Federal Sebastião Ogê Muniz. Porto Alegre, 17 de julho de 2012. Disponível em: <http://www.radaroficial.com. br/d/4976686>. Acesso em: 08 fev. 2016.

BRITO, Luiz Araújo Corrêa de. Do limite à extraterri- torialidade do direito estrangeiro no Código Civil Brasileiro. São Paulo: Escolas Profissionais Salesianas, 1952.

CASELLA, Paulo Borba. BRIC: Brasil, Rússia, China e África do Sul: uma perspectiva de cooperação internacional. São Paulo: Atlas, 2011.

CASTRO, Amílcar de. Direito internacional privado. 5. ed. Rio de Janeiro: Forense, 2000.

COMISSÃO DE RELAÇÕES EXTERIORES E DEFESA NACIONAL. Parecer de 2011: o Projeto de Decreto Legislativo n 638, de 2010 (n 2.438, de 2010, na origem), da Comissão de Relações Exteriores e de Defesa Nacional da Câmara dos Deputados, que aprova, com ressalvas, o texto da Convenção sobre a Obtenção de Provas no Estrangeiro em Matéria Civil ou Comercial, assinada em Haia, em 18 de março de 1970. Disponível em: <http://legis.senado.leg.br/mateweb/arquivos/mate-pdf/96771.pdf $>$. Acesso em: 30 out. 2015.

CONFERENCIA INTERNACIONAL AMERICANA, 6., 1928, Havana. Direito Internacional Privado: Convenção de Direito Internacional Privado (Código de Bustamante). Disponível em: <http://www.faccamp.br/apoio/LuciaSirleneCrivelaroFidelis/direitoInternacional/cOdigo_de_bustamente.pdf $>$. Acesso em: 08 fev. 2016.

CORTE PERMANENTE DE JUSTIÇA INTERNACIONAL. Caso do Estatuto legal da Groelândia Oriental (Dinamarca vs. Noruega). Julgamento de 5 de abril de 1933. Local: editora, 1933. (Séries A/B, n. 53).

DINAMARCO, Cândido Rangel. Instituições de direito processual civil. 5. ed. São Paulo: Malheiros, 2005. v. 2.

DOLINGER, Jacob. A evolução da ordem pública no direito internacional privado. Rio de Janeiro: Luna, 1979.

DOLINGER, Jacob. A ordem pública internacional em seus diversos patamares. Revista dos Tribunais, São Paulo, v. 93, n. 828, p. 33-42, out. 2004.

DOLINGER, Jacob. Direito internacional privado: parte geral. 10. ed. Rio de Janeiro: Forense, 2011.

DOLINGER, Jacob; TIBURCIO, Carmen. The forum law rule in international litigation: lex fori or lex diligentiae? Unresolved Choice-of-law issues in the transnational rules of civil procedure. Texas International Law Journal, v. 33, n. 3, p. 425-461, summer 1998. 
ESPÍNOLA, Eduardo. Elementos de direito internacional privado. Rio de Janeiro: J. R. dos Santos, 1925.

ESPÍNOLA, Eduardo; ESPÍNOLA FILHO, Eduardo. Tratado de direito civil brasileiro: do direito internacional privado brasileiro: parte geral. Rio de Janeiro: F. Bastos, 1941. v. 2.

FREITAS, Augusto Teixeira de. Código Civil: esboço. Rio de Janeiro: Universal de Laemmert, 1860.

GOMES FILHO, Antonio Magalhães. Direito à prova no processo penal. São Paulo: RT, 1997.

GRINOVER, Ada Pellegreni. As garantias processuais na cooperação internacional em matéria penal. Revista Forense, Rio de Janeiro, v. 373, p. 03-18, maio/jul. 2004.

HAGUE CONFERENCE ON PRIVATE INTERNATIONAL LAW, 20., 1970, Hague. Convention on the taking of evidence abroad in civil or commercial matters. Available in: <https://assets.hcch.net/docs/ dfed98c0-6749-42d2-a9be-3d41597734f1.pdf $>$. Access: Feb. 08, 2016.

HAGUE CONFERENCE ON PRIVATE INTERNATIONAL LAW, 20., 1970, Hague. Members of the Organisation. Available in: <https://www.hcch.net/en/instruments/conventions/status-table/print/?cid $=82>$. Access: Feb. 08, 2016.

KROSKA, Renata Caroline. Da desnecessidade de inadimplemento essencial para aplicação do art. 74 da CISG e dos danos efetivamente recuperáveis. Revista Brasileira de Direito Internacional, v. 11, n. 1, p. 179201, 2014.

LOPES, Inez. O direito internacional privado e a responsabilidade civil extracontratual por danos ambientais causados por transportes marítimos à luz do direito brasileiro. Revista Brasileira de Direito Internacional, v. 12, n. 1, p. 217-239, 2015.

LOPES, Miguel Maria Serpa. Comentários à lei de introdução ao código civil. 2. ed. Rio de Janeiro: F. Bastos, 1959. v. 3.

MARINONI, Luiz Guilherme; ARENHART, Sergio
Cruz. Prova. São Paulo: Revista dos Tribunais, 2010.

MÉRIDA, Carolina Helena. Sequestro interparental: princípio da residência habitual. Revista Brasileira de Direito Internacional, v. 8, n. 1, p. 255-272, 2011.

MESQUITA, José Ignácio Botelho de. Da competência internacional e dos princípios que a informam. Revista de Processo, n. 50, p. 51-71, abr./jun. 1988.

MONTAGNER, Angela Christina Boelhouwer. A adoção internacional e a nacionalidade da criança adotada. Revista Brasileira de Direito Internacional, v. 6, n. 1, p. 399-419, 2009.

NAZO, Nicolao. A Regra "Locus Regit Actum". Revista da Faculdade de Direito da Universidade de São Paulo, São Paulo, v. 30, p. 128-140, 1934.

ORGANIZAÇÃO DOS ESTADOS AMERICANOS. Convenção Interamericana sobre Normas Gerais de Direito Internacional Privado. Disponível em: <http:// www.oas.org/juridico/portuguese/treaties/b-45.htm>. Acesso em: 08 fev. 2016.

RAMOS, André de Carvalho. Curso de direitos humanos. 2. ed. São Paulo: Saraiva, 2015.

RAMOS, André de Carvalho. Processo internacional de direitos humanos. 4. ed. São Paulo: Saraiva, 2015.

RAMOS, André de Carvalho. Teoria geral dos direitos humanos na ordem internacional. 5. ed. São Paulo: Saraiva, 2015.

RAMOS, André de Carvalho; MENEZES, Wagner. Direito internacional privado e a nova cooperação jurídica internacional. São Paulo: Arraes, 2014.

SILVA, Luis Antonio Gama e. A ordem pública em direito internacional privado. 1994. xx f. Monografia (Livre Docência) - Faculdade de Direito, Universidade de São Paulo, São Paulo, 1944.

TENORIO, Oscar. Lei de introdução ao Código Civil Brasileiro. 2 ed. Rio de Janeiro: Borsói, 1955.

VALLADÃO, Haroldo. Direito internacional privado. 2. ed. Rio de Janeiro: F. Bastos, 1977. v. 1. 


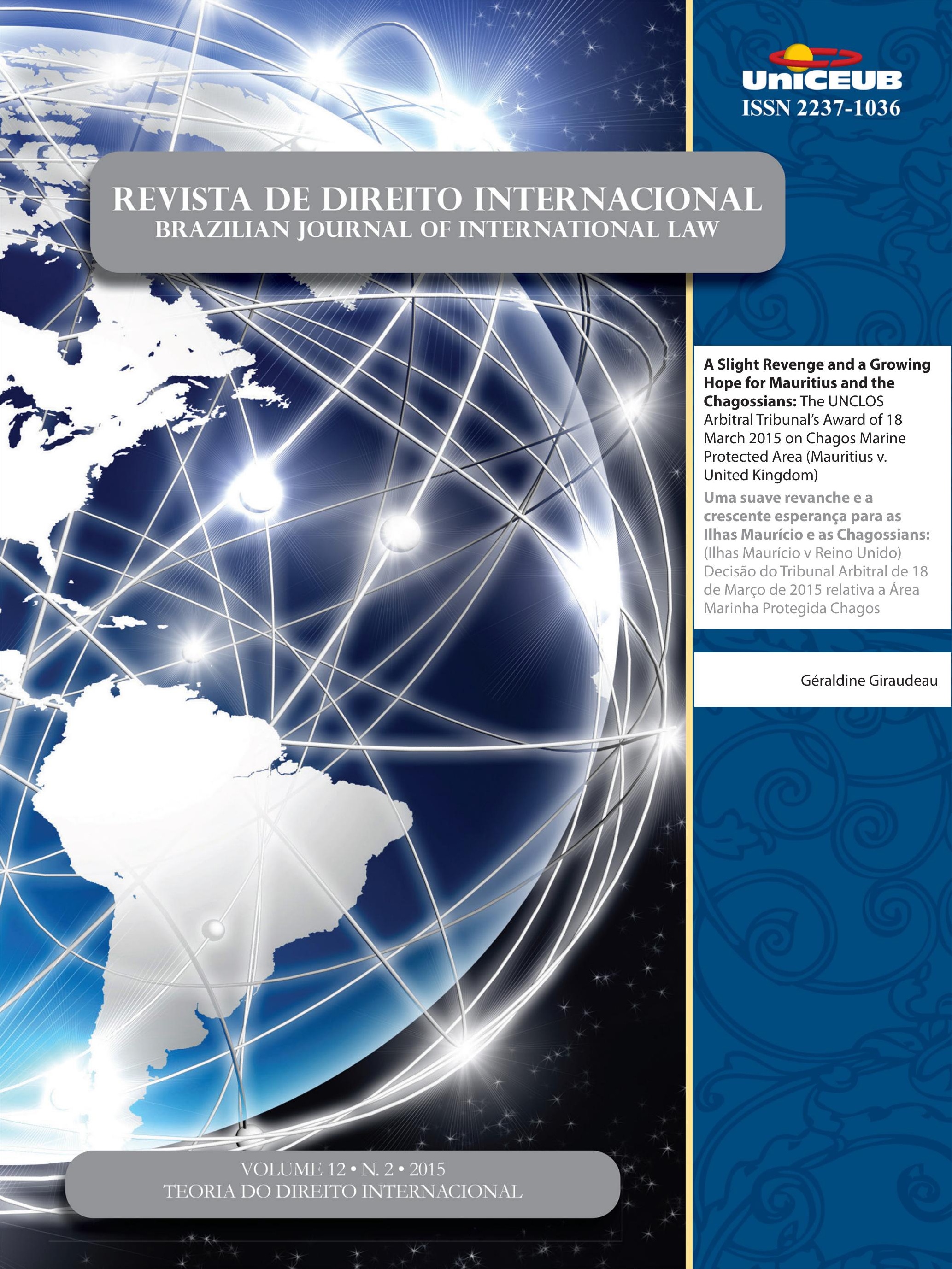




\section{A Slight Revenge and a Growing Hope for Mauritius and the Chagossians: The UNCLOS Arbitral Tribunal's Award of 18 March 2015 on Chagos Marine Protected Area (Mauritius v. United Kingdom)*}

\author{
Uma suave revanche e a crescente esperança \\ para as Ilhas Maurício e as Chagossians: (Ilhas \\ Maurício v Reino Unido) Decisão do Tribunal \\ Arbitral de 18 de Março de 2015 relativa a Área \\ Marinha Protegida Chagos
}

Géraldine Giraudeau**
Recebido em 08/10/2015 Aprovado em 23/11/2015

** Professor of Public Law at the University of Perpignan Via Domitia (Professeur agrégé de droit public), Ph.D. (Paris 1 Panthéon-Sorbonne and Carlos III Madrid). The author is grateful to Ines El Hayek, Ph.D. student at Paris 1 Panthéon-Sorbonne, for her linguistic corrections and comments. E-mail: ggiraudeau@ yahoo.fr

\section{Abstract}

The recent award of 18 March 2015 puts an end to the arbitration established under Part XV of the United Nations Convention of the Law of the Sea and its Annex VII, about the creation, by the United Kingdom, of a huge marine protected area around the Chagos islands. The proceedings - initiated by Mauritius- constitute a new page, this time at an international level, of the already very furnished litigation arising from the scandalous detachment of this isolated archipelago from the territory of the former British colony, and the removal of its entire population for defence interests. The award is substantially favourable to Mauritius and unanimously recognizes the incompatibility of the marine protected area (MPA) with articles 2(3), 56(2) and 194(4) UNCLOS. Even if it does not directly address the dispute regarding the sovereignty on the islands, it creates some fundamental consequences on the whole issue, by declaring the Lancaster House Undertakings legally binding. It also brings an essential enlightenment on the interpretation of the rights and the compulsory dispute settlement mechanisms provided by the Montego Bay Convention. This article analyses the award and the reasoning followed by the panel, in connexion with the whole dispute and the law of the sea. It also pretends to demonstrate the important consequences of the decision.

Keywords: International arbitration-Law of the Sea- Interpretation of UNCLOS

\section{INTRODUCTION}

There is little doubt about the difficulty of judging, particularly when it is about deciding in the tense context of an international dispute, and especially when a question of territorial sovereignty is - directly or indirec- 
tly- at stake. The case of the Chagos Marine Protected Area ${ }^{1}$ makes no exception. Indeed, the role of the five members of the arbitral tribunal - constituted on the basis of Article 287 of the United Nations Convention on the Law of the Sea ${ }^{2}$ and Article 1 of Annex VII can certainly be qualified as a very delicate one. Four years after Mauritius started proceedings on December 2010, the panel unanimously decided that the establishment of the MPA surrounding the small isolated atoll was violating the provisions of articles 2(3), 56(2) and 194(4) UNCLOS 3 . The recognition of the responsibility of the UK for having breached its obligations under international law towards its former colony, emerged into a complex long term dispute between the two states on the sovereignty over the islands, and the rights of the Chagossians to return to their homeland. Indeed, the history of the Chagos archipelago is not a common one, and was the object in the 1960's of some scandalous strategies between the UK and the USA which implied the forced exile of the indigenous inhabitants of this tiny and fragmented piece of territory lost in the middle of the Indian Ocean. At that time, the Chagos islands were part of the British colony of Mauritius, but the central government of the UK excised them from that territory in 1965, before Mauritius' independence, and created the BIOT ${ }^{4}$. The UK and the USA had agreed that the land was strategic and suitable for the establishment of a security base. For that reason, the two states planned the illegal detachment of the archipelago, which was condemned by UN resolutions and domestic decisions ${ }^{5}$. Both states reached the deal that the southest and principle island of Diego Garcia would be available for the US, where the Americans built an important military base which is still functioning, and playing a key role during the campaigns in the Middle East. Following the project established by London and Washington, the entire local population of the Chagos islands, some 1800 individuals, were secretly removed from their land and mainly displaced to Mauritius and the Seychelles between 1967 and 1973. Various procedures were engaged by the exiled Chagossians and

1 Hereafter « MPA».

2 Hereafter «UNCLOS».

3 PCA, Chagos Marine Protected Area Arbitration (Mauritius v. United Kingdom), Award of 18 march 2015, 217 p., available on the website of the Permanent Court of Arbitration: http://www. pca-cpa.org/.

4 Stands for «British Indian Ocean Territory», created by the BIOT Order 1965, and administered as an overseas territory.

5 In this article, II. their descendants before English domestic courts. The dispute reached the European Court of Human Rights and concerned the right for the outer Chagossians to return to their homeland ${ }^{6}$.

However, the present case brought before the UNCLOS tribunal is related to the more recent decision of UK, taken on 1 April 2010, establishing a Marine Protected Area around the archipelago, covering a surface that goes up to 200 miles from the baselines and representing more than half a million square kilometers ${ }^{7}$. According to Mauritius, the British decision violated the Convention on the Law of the Sea, as the UK was not entitled to take these actions since it is not the "coastal state" in the meaning of the convention, and because of the undertakings it took towards Mauritius at the time of the detachment ${ }^{8}$. It contended that the MPA was incompatible with the rights provided for by the Convention, especially the fishing rights of Mauritius regarding the Chagos waters, and with the obligations of consultation and cooperation with other states. It also asked the tribunal to declare that the UK could not prevent the United Nations Commission on the Limits of the Continental Shelf from making some recommendations about the petition of Mauritius for an extended Continental shelf surrounding the Chagos archipelago. In response, the UK challenged the jurisdiction of the tribunal in all aspects. London presented the creation of the MPA as a necessary measure regarding the protection of the environment, and pretended that the proceedings were an "attempt by Mauritius to construct a case under the Convention in order to bring a dispute concerning sovereignty over the Chagos Archipelago within the jurisdiction of the Tribunal". The decision of the tribunal intervened in an political and legal imbroglio with questions and principles as important as the history of colonialism and self-determination, the preservation of environment, the interpretation of

6 See ALLEN, S. International Law and the Resettlement of the (Outer) Chagos Islands. Human Rights Law Review, Oxford, v. 8, n. 4, p. 683-702, 2008. From the same author: The Chagos Islanders and International Law, Oxford, Hart Publishing, 308 p.

7 Award, para. 5, p. 1. On the special nature of the MPA, see MONEBHURRUN, N. Creating Marine Protected Areas to assert territorial jurisdiction against the Right of Abode of Native Populations: The Case of the Chagos Archielago. In: GÓMEZ, E. M. Vásquez; CINELLI, C. (Ed.). Regional Strategies to Maritime Security. A Comparative Perspective. Valence: Tirant Lo Blanch, 2014. p. $79-100$.

8 See after «the Lancaster House Undertakings».

9 Award, para. 12, p. 2. 
UNCLOS, and the scope of the jurisdiction provided by Part XV of the Convention. By three votes to two, the tribunal decided to dismiss Mauritius on its first and second demands, unanimously, to declare that there was no dispute about the CLCS and, last but not least, unanimously, after having recognized its jurisdiction on this question, to declare the incompatibility between the MPA and the Convention in its articles 2(3), 56(2), and 194(4). This long award - 217 pages - has some important legal and political consequences. It brings some precious clarifications on the UNCLOS, and will oblige Mauritius and the UK to renegotiate about the creation of a protected area around Chagos. It also recognizes the binding nature of the Lancaster House Undertakings of 1965, which will be of great significance for Mauritius' claim on the islands, and for the Chagossians' struggle for their right to be resettled.

\section{BACKGROUND}

\section{A. Situation and history of the Chagos islands}

The Chagos archipelago is constituted by coral atolls and islands situated in the middle of the Indian Ocean ${ }^{10}$. It counts more than 60 individuals islands among which Diego Garcia is the largest one ${ }^{11}$. The Chagos archipelago is one of the most isolated island groups in the world, located about $2200 \mathrm{kms}$ from the main island of Mauritius, $1780 \mathrm{kms}$ from Sri Lanka, and $1513 \mathrm{kms}$ from Malé ${ }^{12}$. It was discovered during the $16^{\text {th }}$ century and claimed by France which administered it as a dependency of "Ile de France", as was named Mauritius at that time. The British captured the "Ile de France" in 1810 and the territory, henceforth "Mauritius", was officially ceded by France through the treaty of 30 May 1814. The Chagos archipelago was then administered by the UK as a dependency of Mauritius till $1965^{13}$.

10 Award, para 55, p. 13

11 San Diego is about 27.20 square kilometres. Then come respectively Eagle (Great Chagos Bank, 2.45 square kilometres), île Pierre (Peros Banhos, 1.50 square kilometres), Eastern Egmont (Egmont Islands, 1.50 square kilometres), île du Coin (Peros Banhos, 1. 28 square kilometres) and île Boddam (Salomon Islands, 1.08 square kilometres): Mauritius' Memorial, para. 2.6, p. 10. All the writings and hearing transcripts quoted are available on the PCA website.

12 Mauritius' memorial, p.10, and Preliminary Objections from United Kingdom, para. 2.5, p. 5.

13 On that early history, see Award, para. 56-61, p. 13-14.
In the second half of the XXth century, following the international dynamic of decolonization, Mauritius started to move towards independence. Meanwhile, the United Kingdom and the United States engaged in negotiations on the possibility to detach the Chagos archipelago from Mauritius, in order to establish a security zone in the Indian Ocean. The United States' plan was to create a military base and San Diego appeared as the good place for that, after a survey. While arranging the modalities of that shared defense strategy, the two states arrived to the conclusion that the UK would lend San Diego for the use of Washington, after having detached the entire archipelago from Mauritius, put it under UK administration, and displaced the entire local population to ensure the security facilities ${ }^{14}$. The UK and the USA also discussed the terms of compensation which would be submitted to the local politics. The formal proposal was officially sent by the Governor of Mauritius to the Mauritius Council of Ministers on 19 July 1965. The issue at that point was about how far this proposal was a real one, and not an element of blackmail in the achievement of independence. For that reason, writings of Mauritius in the MPA case, as well as the award of 18 march 2015, present in details the records of the meetings that took place between Mauritian political leaders and representatives of English government, especially the Secretary of State for the Colonies, Anthony Greenwood. Among these discussions, the most important is the Lancaster House Meeting of 23 September 1965, since Sir Seewoosagur Ramgoolam and his colleagues reached an agreement with the Secretary of State about the detachment of the Chagos islands, under some conditions clearly expressed in the draft record $^{15}$. Here is reproduced part of this record, as the undertakings are of great importance for the solution reached by the tribunal:

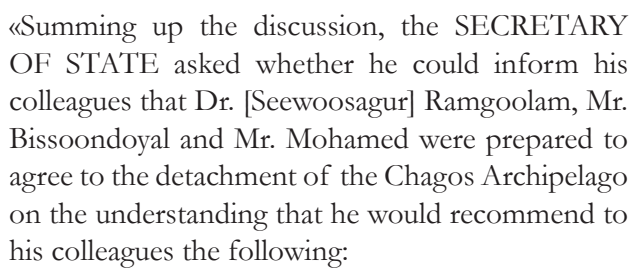

14 See Award para 69-99, p. 21-37. San Diego was supposed to be lent without charge, but United States agreed to contribute to the costs of establishing the BIOT for an amount of 5 millions pounds, "to be paid by waiving United Kingdom payments in respect of joint missile development programmes": award para. 89, p. 33-34. 15 Award para. 74, p. 24. The Lancaster House conditions will be of great importance in the solution voted by the tribunal: this article, IV. 
(i) negotiations for a defence agreement between Britain and Mauritius;

(ii) in the event of independence an understanding between the two governments that they would consult together in the event of a difficult internal security situation arising in Mauritius;

(iii) compensation totalling up to [illegible] Mauritius Government over and above direct compensation to landowners and the cost of resettling others affected in the Chagos Islands;

(iv) the British Government should use its good offices with the United States Government in support of Mauritius' request for concessions over sugar imports and the supply of wheat and other commodities;

(v) that the British Government would do their best to persuade the American Government to use labour and materials from Mauritius for construction work in the islands;

(vi) that if the need for the facilities on the islands disappeared the islands should be returned to Mauritius.

SIR S. RAMGOOLAM said that this was acceptable to him and Messrs. Bissoondoyal and Mohamed in principle but he expressed the wish to discuss it with his other ministerial colleagues. $\rangle^{16}$

It quickly appeared that the detachment of the Chagos archipelago and the forced removal of its population would violate the international obligations of the UK. When it was publically announced, the question was raised before the Special Committee on the Situation with regard to the Implementation of the Declaration on the Granting of Independence to Colonial Countries and Peoples. Also, the General Assembly of the United Nations adopted three resolutions condemning the UK's behavior. The first one is resolution 2066(XX) of 16 December 1965, which, recalling resolution 1514(XV) notes "with deep concern that any step taken by the administering Power to detach certain islands from the Territory of Mauritius for the purpose of establishing a military base would be in contravention of the Declaration..." ${ }^{17}$. The second and third ones are resolutions 2232(XXI) of 20 December 1966 and 2357(XXII) of 19 December 1967, which do not concern only Mauritius, but also deplore the conduct of administering powers towards various territories under foreign administration ${ }^{18}$. Ignoring these recommenda-

16 Reproduced from para. 74 , p. 24 of the award.

17 United Nations General Assembly Resolution 2066(XX).

18 United Nations General Assembly Resolution 2232(XXI) and tions, the UK enacted the BIOT Order 1965 detaching the islands from Mauritius, and organized the removal of the entire Chagossian population between 1968 and $1973^{19}$. The BIOT Commissioner passed on 16 April 1971 the Immigration Ordinance prohibiting the entry or presence in the archipelago without a nominative permit ${ }^{20}$. For mere compensation, Mauritius received 650000 pounds to be able to organize the resettlement of the displaced individuals ${ }^{21}$.

The award on the MPA dispute recalls precisely these events, as it is not possible to evaluate the present dispute without these information. Almost one third of the decision is actually dedicated to the history and factual background, including the facts surrounding the establishment of the MPA ${ }^{22}$. It is of importance to consider that from these events emerged at least two different litigations. One is about the illegal removal of the Chagossians and their right to return. The other one is the dispute at the international level between Mauritius and the UK regarding the sovereignty over the Chagos islands, and further the establishment of the MPA. These are two different disputes, but closely linked (for instance some domestic decisions concerning the Chagos were mentioned during the MPA procedure, to explain the UK's behaviour about fishing rights ${ }^{23}$ ). For that reason, we'll start with a short reminder of the proceedings regarding the right of return of the Chagossians, mostly raised before English domestic courts, and then present the procedure at the international level.

\section{B. Adjudication on compensation and right of return for the Chagossians}

A few years after the forced removal of the entire Chagossian population, former residents and their descendants used their British citizenship to present their claim before the English domestic courts. The cases "Vincatassin", "Bancoult I", "Bancoult II", and "Bancoult III" about Chagossians' rights regarding national and international law, made the issue publically known. The struggle of the native population for the recognition of the injustice their suffered and their right to re-

United Nations General Assembly Resolution 2357(XXII).

19 Award para 90, p. 34.

20 Award, para. 90.

21 Award, para. 91.

22 Award, p. 1-69.

23 See UK's counter memorial, para. 3.33, p. 71-72. 
turn on the island, gained each day more importance in the UK media, above all in the last years.

\section{The Vencatassen case}

Litigation started in 1975, when Mr Michel Ventacassen, a former resident of the Chagos archipelago, initiated a claim for compensation in front of the courts of England and Wales ${ }^{24}$. The UK government was directly accused, and finally settled the case through its engagement to pay 4 millions pounds to the "fund for the former residents of the Archipelago" 25 . Mauritius and the UK then signed an arrangement on 7 July 1982 which mentions that the 4 millions pounds, together with the 650000 ones already paid" ${ }^{26}$, "shall be in full and final settlement of all claims (arising from the removal or resettlement of the population of the Chagos Archipelago)"27. The recipients of the fund have been asked to sign a paper redacted in English where they renounced to their rights for future claims ${ }^{28}$.

\section{The Bancoult I case}

It's only in 1998 that the issue concerning the islanders came back under the light. Another former resident, and leader of the Chagossians' revendications, Mr Olivier Bancoult, instituted a claim in front of the courts of England and Wales. He asked for judicial review of the section 4 of the BIOT Immigration Ordinance, $1971^{29}$. The High Court declared the removal of the Chagossian people unlawful, and recognized their right to abode in the $\mathrm{Chagos}^{30}$. A new ordinance was then enacted in 2000 , including an exception to the restricted access to the archipelago for the entry of the Chagossians, except for Diego Garcia ${ }^{31}$.

24 UK's counter memorial para. 92, p. 34.

25 UK's counter memorial, para. 92.

26 See this article, introduction.

27 Agreement between the Government of the United Kingdom of Great Britain and Northern Island and the Government of Mauritius concerning the Ilois, Port Louis, 7 July 1982, with amending Exchange of Notes, Port Louis, 26 octobre 1982, Cmnd. 8785, 1316 UNTS 128. Quoted in the Award, para. 92. The agreement was implemented in Mauritius by the Ilois Trust Fund Act of 30 July 1982. 28 See Chagos Islanders v. Attorney General [2003] EWHC 2222 (Ouseley J). The question is about whether the persons concerned understood the paper they signed.

29 See this article, A.

$30 R$ (Bancoult) v. Secretary of State for foreign and Commonwealth Affairs (N. 1) [2001] QB 1067 (Laws LJ and Gribbs J).

31 Inmigration Ordinance 2000, see R (Bancoult) v. Secretary of

\section{The Chagossians collective claim}

Another claim was brought in 2002 by 4959 former residents of the Chagos and their descendants, against the Attorney general of England and Wales and the BIOT Commissioner, for compensation and restoration of property rights. However, on 9 October 2003, the action was dismissed by the High Court on the grounds "that no tort at common law was committed by the removal of the Chagossian population and that further compensation for property loss was precluded by the Limitation Act. 1980 and the Claimants' renunciation in exchange for the compensation provided in 1982"'32.

\section{The Bancoult II case}

Meanwhile, the government also conducted some studies in order to determine the feasibility of a resettlement in the archipelago ${ }^{33}$. The conclusion reached in 2002 of such study was that it was not feasible to resettle the Chagossian population, and, on that basis, the British government denied another time access of the Chagossians to the archipelago and right of abode ${ }^{34}$. $\mathrm{Mr}$ Bancoult asked for the judicial review of the two Orders enacted in that sense. The "Bancoult II" claim was favourably received by the High Court and the Court of Appeal $^{35}$, but the House of Lords allowed an appeal and held, in a controversial decision, that, regarding the studies on the feasibility of a resettlement and the practical difficulties of such a measure (in particular economic ones), it was "impossible to say, taking fully into account the practical interests of the Chagossians, that the decision to reimpose immigration control on the islands was unreasonable or an abuse of power" ${ }^{36}$. The claim

State for Foreign and Commonwealth Affairs (No. 2) [2008] QB 365, para. 18.

32 Award, para. 95, p. 35-36. Chagos Islanders v. Attorney General [2003] EWHC 2222 (Ouseley J). The Court of appeal denied leave of appeal on 22 July 2004, Chagos Islanders v. Attorney General [2004] EWCA Civ 997 (Sedley LJ).

33 ALLEN, S. "International Law and the Resettlement of the (Outer) Chagos Islands". Human Rights Law Review, Oxford, v. 8, n. 4, p. 683-702, 2008. p. 685.

34 BIOT (Constitution) Order, 2004 and BIOT (Immigration) Order, 2004.

$35 R$ (Bancoult) v. Secretary of State for Foreign and Commonwealth Affairs (No. 2) [2006] EWCH 1038 (Admn.) and R (Bancoult) v. Secretary of State for Foreign and Commonwealth Affairs (No. 2) [2008] QB 365.

$36 R$ (Bancoult) v. Secretary of State for Foreign and Commonwealth Affairs (No. 2) [2009] 1 AC 453 (Hoffmann LJ). Quoted in 
was then introduced by Mr Bancoult and other Chagossians to the European Court of Human Rights, but the latter declared it inadmissible, on the basis of the 1982 agreement, in a decision of 12 December $2012^{37}$.

\section{The Bancoult III case}

Simultaneously, a third round of litigation emerged in this already long and complex dispute, through the "Bancoult III" procedure. This new case constituted, in the own words of the High Court, "a further chapter in the history of litigation arising out of the removal and subsequent exclusion of the local population from the Chagos Archipelago in the British Indian Ocean Territory ("BIOT")"38. The demand was introduced by $\mathrm{Mr}$ Bancoult after the official proclamation of the MPA around the Chagos islands on 1 April $2010^{39}$. He challenged the Foreign Secretary's decision on the following grounds:

«(1) an improper motive, namely an intention to create an effective long-term way to prevent Chagossians and their descendants from resettling in BIOT;

(2) the failure to reveal, as part of the consultation preceding the decision, that the Foreign Secretary's own consultants had advised that resettlement of the population was feasible;

(3) the failure to disclose relevant environmental information in the course of the consultation;

(4) the failure to disclose that the MPA proposal, in so far as it prohibited all fishing, would adversely affect the traditional and/or historical rights of Chagossians to fish in the waters of their homeland, as both Mauritian citizens and as the native population of the Chagos Islands;

(5) breach of the obligations imposed on the United Kingdom under Article 198 of the Treaty on the Functioning of the European Union ("the TFEU"), which relates to the association of overseas territories with the European Union. $»^{40}$

The Court dismissed the Claimant's case in its entirety in its decision of 6 June $2013^{41}$. An appeal was then

the Award, para. 97, p. 36-37.

37 Chagos Islanders v. United Kingdom, no. 35622/04, para. 81, 12 December 2012

$38 R$ (Bancoult) v. Secretary of State for Foreign and Commonwealth Affairs (N. 3) [2013] EWHC 1502 (Admin) (Richards LJ), para. 1.

39 See above A.

40 R (Bancoult) v. Secretary of State for Foreign and Commonwealth Affairs (N. 3) [2013] EWHC 1502 (Admin) (Richards LJ), para. 2.

41 Ibid., para. 77 .The claimant evidenced this first ground on a lodged with the Court of Appeal on 23 August 2013, but dismissed by a decision of 23 may $2014^{42}$.

Surprising is the fact that the award of 18 March 2015 doesn't mention this proceeding in the part of the decision dedicated to the litigation in front of domestic courts. The Bancoult III was however mentioned several times by the UK during the pleadings, in some occasions to reinforce some of its arguments, especially about fishing rights ${ }^{43}$. However, it was above all pointed by Mauritius to denounce a retention and redaction of documents. Reminding in its reply, that "this case has proceeded in parallel to a domestic judicial review before the English courts", Mauritius advised the tribunal "that a great number of UK government documents were disclosed in those proceedings - in relation to the internal decision-making process - and that the UK consciously chose not to make this relevant material available to the Tribunal in these proceedings" ${ }^{44}$. Mauritius counsels finally had access to these documents after having asked them to the solicitors representing $\mathrm{Mr}$ Bancoult. The state concluded, after consultation of this material, that not only did the UK not disclose all the available information, but also chose to add unfounded redaction to several documents ${ }^{45}$. The UK was then asked to submit unredacted documents ${ }^{46}$. This accusation became a real incident of procedure when the issue couldn't be solved despite several letters exchanged by the two parties on that aspect. The tribunal had to inter-

document published by Wikileaks recording meeting with BIOT officials. The preliminary decision ruled that the Wikileaks' document was inadmissible as a copy of an authentic US Embassy cable under the Vienna Convention on Diplomatic Relations of 1961.

42 R (Bancoult) v. Secretary of State for Foreign and Commonwealth Affairs (N. 3) [2014] EWCA CIV 708.

43 In its counter memorial, UK underlines in a foot note that "The basis of the judicial review proceedings in $\mathrm{R}$ (Bancoult) $\mathrm{v}$. Secretary of State for Foreign and Commonwealth Affairs [2013] EWHC 1502 (Admin) was the Claimant's contention that there was a sufficient argument concerning the existence of Mauritian fishing rights in respect of BIOT waters as to require mention to be made of it in the consultation document if the consultation was to be lawful: the Court concluded there was not (paras. 153-156). This did not require the Court to determine whether as a matter of international law, Mauritius had such rights which it indicated it would have declined to do on the basis of non-justiciability and other principled grounds (see para. 153) (Authority 43)", UK's counter memorial, footnote 224, p. 75. See also footnotes 239, 261, 268, 278.

44 Mauritius's reply, para. 1.11, p.2.

45 The ones set out in Annex 185 of the Uk's counter memorial. These documents, according to Mauritius, clearly show the dissension existing between the UK foreign minister and the other actors at the time of creating the MPA, see after, C.

46 Mauritius'reply, para. 1.11 to 1.21 , p. 2-5. 
vene, by urging the UK "to remove all redactions that were not strictly required on the grounds of irrelevancy or legal professional privilege" ${ }^{47}$. After several intents and the removal of some of the redactions, the tribunal decided to examine the documents with remaining ones, in advance of the hearing, and found that there were justified ${ }^{48}$.

\section{The claim in front of the UK Supreme Court}

In 2014, there was a new turning point in the Chagos litigation, through the notification formulated in front of the UK Supreme Court, on the basis of the discovery of documents regarding the feasibility of the resettlement of the Chagossian people in the archipelago, which had not been disclosed at the time of the procedure. The issue raised by the claimant is formally "whether the judgment of the House of Lords in R (on the application of Bancoult No 2) v Secretary of State for Foreign and Commonwealth Affairs should be set aside on the alleged ground of material non-disclosure by the respondent and, if so, whether the appellant should be permitted to adduce fresh evidence at the rehearing of the appeal» ${ }^{49}$. The UK Supreme Court's decision is still expected while this article is redacted.

\section{The Interstate Dispute over the Chagos islan- ds and the proceedings about the MPA}

The Mauritian pretentions on Chagos islands appeared in the 1980's, after several years of silence ${ }^{50}$. The manifestation of this pretention was made through the adoption of different texts expressively incorporating the Chagos in the Mauritian territory ${ }^{51}$, by the es-

47 Award of 18 March 2015, para. 38, p. 8.

48 The President of the tribunal and the Registar attented an ex parte meeting in Istanbul on 21 April 2014. Award, para. 48-49, p. 10.

$49 \mathrm{R}$ (on the application of Bancoult No 2) (Appellant) v Secretary of State for Foreign and Commonwealth Affairs (Respondent), Case ID: UKSC 2015/0021, case summary. Available on the:<https:// www.supremecourt.uk/cases/uksc-2015-0021.html>

50 Mauritius explains this silence by the political and socio economic context. Mauritius underlined this reliance on UK in its writings, especially in its Reply, para. 2. 94, see also award, para. 100. While UK sees in it the recognition of the British sovereignty on the territory, para. 2. 61 of UK's Rejoinder, quoted by para. 100 of the award.

51 The Award in its para. 100-111 mentions for instance the Interpretation and General Clauses (Amendment Act, 1982), the formulation adopted in the 1992 Constitution of Mauritius, the Mari- tablishment of special entities ${ }^{52}$, and by the means of some official public declarations ${ }^{53}$. Meanwhile, the British Government never denied its sovereignty over the BIOT, and there was no doubt about the existence of a territorial dispute between the two states regarding the Chagos archipelago.

Mauritius asserts it only became aware of the planned creation of the MPA after the publication of an article in The Independant on 9 February $2009^{54}$. In reaction, Mauritius insisted on its sovereignty over the Chagos islands through correspondence, and during the joint talks with the UK (under a sovereignty umbrella) ${ }^{55}$. While the UK and Mauritius were exchanging some views, the UK initiated a public consultation about the creation of the MPA. These exchanges by phone and letter are mentioned in detail in the award ${ }^{56}$. Another important talk took place on November 2009 between the two respective prime ministers of Mauritius and the UK (Navinchandra Ramgoolam and Gordon Brown), both present at the Commonwealth Heads of Government Meeting, although the two parties still disagree on the content of this exchange ${ }^{57}$. Meanwhile, the public consultation was still running until 5 March 2010. Documents show that the decision of the Foreign Secretary to create the MPA was taken despite the contrary advice of the British officials in charge of the BIOT, especially the BIOT Commissioner, and the BIOT Administrator ${ }^{58}$. Nevertheless, the MPA was officially established by the Proclamation of 1 April 2010. Mauritius protested by a verbal note ${ }^{59}$.

After the issue was unsuccessfully raised in some meetings ${ }^{60}$, Mauritius initiated an arbitral proceeding

time Zones Act (1977), the Maritime Zones (Exclusve Economic Zones) Regulations (1984), The Maritime Zones Act (2005) and the Maritime Zones Act(2005). Some of these texts provoked opposition by the British Government.

52 As the Select Committee on the Excision of the Chagos Archipelago created by the Mauritian Parliament on 21 July 1982.

53 See the declarations of the Mauritius Government in front of the General Assembly of United Nations, in Mauritius' reply para. 2.85, quoted by the Award in its para. 103, p. 38 .

54 The article in question was written by S. Gray and titled «Giant Marine Park plan for Chagos».

55 These talks had already planned in order to discuss the Chagos issue and the demands to adress to the Commission on the Limits of the Continental Shelf: award, para 110, p. 41; and para. 128, p. 47.

56 Award, para. 131-134, p. 49-52.

57 Award, para. 135.

58 Award, para. 150, p. 61.

59 Award, para 153, p. 64-65.

60 Award, p. 66. 
against the UK by a notification of 20 December 2010, on the basis of article 287 UNCLOS and article 1 of the annex VII to the Convention. The notification appoints Judge R. Wolfrum (a German national) as a member of the tribunal ${ }^{61}$. On 19 January 2011, the UK appointed Judge Ch. Greenwood (a British national) as another member of the tribunal ${ }^{62}$. Because of the disagreement between the parties regarding the appointment of the other members, Mauritius asked the President of the International Tribunal of the Law of the Sea to make a decision, in conformity with article 3(e) of Annex VII UNCLOS. The president of the ITLOS nominated judges J. Kateka (a Tanzanian national), A. Hoffmann (a South African national) as arbitrators, and I. Shearer (an Australian national) as arbitrator and president of the tribunal ${ }^{63}$. It was settled that the Permanent Court of Arbitration would serve as Register for the proceedin$\mathrm{gs}^{64}$. Mauritius decided to challenge the appointment of judge Greenwood, for insufficient guarantees of independence with the British government ${ }^{65}$. The tribunal (constituted of four members for the occasion) held a hearing on that issue and dismissed the challenge ${ }^{66}$.

On the other side, the UK decided to first raise preliminary objections to the jurisdiction of the tribunal, and to ask for the bifurcation of these proceedings. That is to say that the UK requested the tribunal to treat the jurisdictional objections as a preliminary matter and to organise a separate hearing on the question of bifurcation $^{67}$. As the British Counsels were challenging the

61 Para. 10 of the notification, in accordance with article 3(b) of annex VII to the Convention.

62 In accordance of article 3(c) of annex VII to the Convention.

63 Award para. 15-18, p. 5.

64 Award, para. 18.

65 "On 19 May 2011, Mauritius requested additional disclosure from Judge Greenwood (the "Request for Additional Disclosure"). Mauritius expressed concern at the "long-standing" and "close working" character of the relationship between Judge Greenwood and the Government of the United Kingdom and also at the fact that Judge Greenwood had advised the United Kingdom "on many of the most sensitive issues of international law and foreign policy". Considering the "strategic importance for the United Kingdom" of the issues raised in the case brought before the Tribunal, Mauritius requested further disclosure": PCA, Chagos Marine Protected Area (Mauritius v. United Kingdom), Decision on challenge of $30 \mathrm{No}$ vember 2011, para. 10.

66 PCA, Chagos Marine Protected Area (Mauritius v. United Kingdom), Decision on challenge of 30 November 2011, para. 10. The decision of almost 40 pages is interesting regarding application of standards to the appointment of international judges and arbitrators.

67 Award, para. 28-34, p. 7. jurisdiction of the tribunal in all aspects, they were arguing among other things that in the case of a decision in the UK's favour, this would "eliminate the need to proceed to what would be a costly and wide-ranging (in terms of both facts and law) merits phase" ${ }^{\prime 68}$. Rules of procedure had upstream been adopted by the tribunal and the parties, and contained in detail the procedure to follow in case of the submission of some preliminary objections ${ }^{69}$. On that basis, the tribunal issued on 15 January 2013 an Order rejecting the UK's demand for bifurcation and decided that the objections would be considered during the proceedings on the merits ${ }^{70}$.

These incidental proceedings, added to the already mentioned incident about the documents disclosed in annex 185 of the UK's counter memorial ${ }^{71}$, and to the various requested extensions of time to submit the written pieces $^{72}$, considerably postponed the hearings on the merits. They finally took place from 22 April 2014 to 9 May 2014 in Istanbul.

The final submissions of the parties are redacted as follows:

For Mauritius:

"On the basis of the facts and legal arguments
presented in its Memorial, Reply, and during the
oral hearings, Mauritius respectfully requests
the Arbitral Tribunal to adjudge and declare,
in accordance with the provisions of the 1982
United Nations Convention on the Law of the
Sea ("the Convention"), in respect of the Chagos
Archipelago, that:

(1) the United Kingdom is not entitled to declare an "MPA" or other maritime zonesbecause it is not the "coastal State" within the meaning of inter alia Articles 2, 55,56 and 76 of the Convention; and/or

(2) having regard to the commitments that it has made to Mauritius in relation to theChagos Archipelago, the United Kingdom is not entitled unilaterally to declare an "MPA" or other maritime zones because Mauritius has rights as a "coastal State"within the meaning of inter alia Articles 56(1)(b)(iii) and 76(8) of the Convention;and/or

(3) the United Kingdom shall take no steps that may

68 United Kiingdom's Preliminary objections, para. 6. 16, p. 74-75. 69 Award para. 24- 27, p. 6.

70 CPA, Chagos Marine Protected Area (Mauritius v. United Kingdom), Procedural Order n², 15 January 2015.

71 See this article, B.

72 Award para. 32-34, p. 7. 
prevent the Commission on theLimits of the Continental Shelf from making recommendations to Mauritius inrespect of any full submission that Mauritius may make to the Commissionregarding the Chagos Archipelago under Article 76 of the Convention;

(4) The United Kingdom's purported "MPA" is incompatible with the substantive andprocedural obligations of the United Kingdom under the Convention, including interalia Articles 2, 55, 56, 63, 64, 194 and 300, as well as Article 7 of the Agreement forthe Implementation of the Provisions of the United Nations Convention on the Lawof the Sea of 10 December 1982 Relating to the Conservation and Management ofStraddling Fish Stocks and Highly Migratory Fish Stocks of 4 August 1995.

For the United Kingdom:

"For the reasons set out in the Counter-Memorial,
the Rejoinder and these oral pleadings, the United
Kingdom of Great Britain and Northern Ireland
respectfully requests the Tribunal:
(i) to find that it is without jurisdiction over each of
the claims of Mauritius;
(ii) in the alternative, to dismiss the claims of
Mauritius.
In addition, the United Kingdom of Great Britain
and Northern Ireland requests the Tribunal to
determine that the costs incurred by the United
Kingdom in presenting its case shall be borne by
Mauritius, and that Mauritius shall reimburse the
United Kingdom for its
share of the expenses of the Tribunal".

\section{DECISION ON JURISDICTION AND CLARIFICATION ON PART XV UNCLOS}

The UK's objection to the tribunal's jurisdiction constituted a valuable opportunity for the arbitrators to bring some substantial interpretation of the United $\mathrm{Na}-$ tions Convention on the Law of the Sea. For the United Kingdom, there was no such legal ground in the concerned provisions, and, additionally, it contended that the procedural requirements of the previous exchange of views provided in article 283 UNCLOS hadn't been met $^{73}$. As set out in brief by the tribunal itself, "Mauritius considere[d] that the United Kingdom beare[d] the burden of establishing that an express exception to the

73 See United Kingdom's counter memorial, chapters IV and V.
Tribunal's jurisdiction, such as those set out in Articles

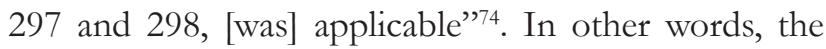
issue for the tribunal was about choosing an extensive or a restrictive interpretation of the UNCLOS articles establishing the compulsory procedures of dispute settlement. Prevalence of the objectives pursued by the Convention would lead to the first option, but there is no surprise in the tribunal's decision to not threaten the states' sovereignty by preferring a strict lecture of the will of the parties, at least regarding the jurisdiction on land disputes ${ }^{75}$. The tribunal decided to deal with this question through its own approach, by examining its jurisdiction regarding Mauritius' first and second submissions, then Mauritius' fourth submission about the compatibility of the MPA to the Convention, after that Mauritius' third submission about CLCS, and by deciding finally on article 283 requirements.

\section{A. Tribunals under UNCLOS have no jurisdiction on land disputes}

\section{Legal aspects at stake}

The main arguments of UK regarding the alleged lack of jurisdiction of the tribunal towards Mauritius' first and second submissions turned logically around the issue of land sovereignty disputes and their treatment by the Montego Bay Convention. According to the UK, the notification presented by Mauritius was an attempt to requalify what was in reality a land dispute, and the sovereignty over the Chagos archipelago constituted "the real issue in the case" ${ }^{76}$. A formulation that voluntarily referred to the important assertion of the International Court of Justice in the Nuclear Tests Award: "it is the Court's duty to isolate the real issue in the case and to identify the object of the claim" 77 . But these assertions raised three main legal points.

74 Award para. 161, p. 71.

75 It is useful to remind that the preamble of the Convention expresses these objectives with proper reference to the sovereignty of states, mentioning their desire to establish "through this Convention, with due regard for the sovereignty of all States, a legal order for the seas and oceans which will facilitate international communication, and will promote the peaceful uses of the seas and oceans, the equitable and efficient utilization of their resources, the conservation of their living resources, and the study, protection and preservation of the marine environment ...".

76 United Kingdom's counter memorial, para. 4.3-4.9, quoted by the Award para. 164, p. 72.

77 Nuclear Tests (New Zealand v. France), Judgment, I.C.J. Reports 1974, para. 30, p. 466. 
1.1. The first question was about the scope of the compulsory jurisdiction under article 286 and 288 of the Convention, which respectively provide that:

Article 286

Application of procedures under this section

Subject to section 3, any dispute concerning the interpretation or application of this Convention shall, where no settlement has been reached by recourse to section 1 , be submitted at the request of any party to the dispute to the court or tribunal having jurisdiction under this section

Article 288

Jurisdiction

1. A court or tribunal referred to in article 287 shall have jurisdiction over any dispute concerning the interpretation or application of this Convention which is submitted to it in accordance with this Part.

2. A court or tribunal referred to in article 287 shall also have jurisdiction over any dispute concerning the interpretation or application of an international agreement related to the purposes of this Convention, which is submitted to it in accordance with the agreement.

$[\ldots]$

The UK argued that these provisions had to be understood in a restrictive way, with careful interpretation, and could not serve as a general basis to settle all kinds of international disputes. It contained that the real issue in the case was the question of sovereignty over the islands, which could not be identified as a dispute concerning the interpretation or application of UNCLOS. In their demonstration, the British counsels took the precaution to explain, that by maintaining this position, they were not trying to say that it was impossible for a tribunal to deal with some land issues when these aspects would be incidental or in the case of "mixed disputes" about maritime boundaries ${ }^{78}$. For Mauritius, the case was limited to the interpretation of the Convention, for the starting point of the claim was indeed in it, and the question was about the notion of "coastal state" $"$.

1.2. Another element discussed between the parties was the relevance of article 293 of the Convention and the implication of the application of "other rules of

78 United Kingdom's counter memorial, p. 101-103; Award para. 166-174, p. $72-75$.

79 Mauritius' reply, para 7.5-7.28, p. 191-201; Award para. 175179, pp 76-77. international law not incompatible" with it ${ }^{80}$. Mauritius was pretending that on that basis, "issues closely linked or ancillary to questions arising directly under the Convention are also questions 'concern[ing] the interpretation or application of the Convention" $" 81$ and (ironically quoting A. Boyle's academic writings, in this case acting as counsel for the UK) that "in compulsory jurisdiction cases, the tribunal may have to decide matters of general international law that are not part of the law of the sea and Article 293(1) allows for this" $"$. To what the UK answered substantially that article 293 could not in any case serve to extend the jurisdiction allowed by the Convention $^{83}$.

1.3. The third point concerned the relevance of article 298(1)(a)(i) of the Convention, and the question to know whether or not these provisions "excluding a dispute concerning sovereignty over land territory from compulsory conciliation implies a contrario that such a dispute would be subject to compulsory dispute resolution in the absence of such a declaration" $" 84$. For Mauritius, mainly, an a contrario understanding of the article stayed in the following reasoning: "If, indeed, mixed disputes were not otherwise covered by the Convention's jurisdiction, there would have been no need for the

80 The entire article sets out: " 1 . A court or tribunal having jurisdiction under this section shall apply this Convention and other rules of international law not incompatible with this Convention. 2. Paragraph 1 does not prejudice the power of the court or tribunal having jurisdiction under this section to decide a case ex aequo et bono, if the parties so agree."

81 Final transcript 446:2-4, quoted by the Award para. 182, p. 7778.

82 Ibid., 435:13-15. Ph. Sands here quotes during the public hearings A. Boyle, reminding a assertion already made in the writings and furnished in the Annex 103 of Mauritius' reply, p. 49.

83 United Kingdom's counter memorial, p. 121.

84 Award, para. 188, p. 79. Article 298(1)(a)(i) sets out: "1. When signing, ratifying or acceding to this Convention or at any time thereafter, a State may, without prejudice to the obligations arising under section 1, declare in writing that it does not accept any one or more of the procedures provided for in section 2 with respect to one or more of the following categories of disputes: (a) (i) disputes concerning the interpretation or application of articles 15,74 and 83 relating to sea boundary delimitations, or those involving historic bays or titles, provided that a State having made such a declaration shall, when such a dispute arises subsequent to the entry into force of this Convention and where no agreement within a reasonable period of time is reached in negotiations between the parties, at the request of any party to the dispute, accept submission of the matter to conciliation under Annex V, section 2; and provided further that any dispute that necessarily involves the concurrent consideration of any unsettled dispute concerning sovereignty or other rights over continental or insular land territory shall be excluded from such submission". 
specific exclusion in the last clause of Article 298(1)(a) (i) "85. Instead, the UK was underlining the specific nature of mixed disputes, and the fact that the Chagos case had nothing to do with a maritime boundary issue ${ }^{86}$.

2. The tribunal's prudent approach on the compulsory settlement of disputes The reasoning adopted by the tribunal is in our point of view a reasonable one. Though the international judge can sometimes fulfill its mission with audacity in order to serve the necessary peaceful settlement of international disputes, it would have been adventurous to conclude from the Convention on the jurisdiction of the tribunal, on what was certainly mainly a land dispute. It would have indeed truncated the initial will of the parties to the Convention. The tribunal concluded that the first two submissions of Mauritius were related to the question of sovereignty on the Chagos islands, and that it had no jurisdiction on this aspect. It was somehow impossible to completely avoid this issue, since the decision on Mauritius' fourth submission does have some legal consequences on the territorial dispute between Mauritius and the UK about the Chagos islands.

2.1. The use of the notion of "coastal state" couldn't hide that the submissions were about land sovereignty. As the Convention does not "provide guidance on the identification of "the coastal state" in cases where sovereignty over the land territory fronting a coast is disputed" $" 87$, the question, in the tribunal's point of view, "hing[ed] entirely on whether the issues raised in Mauritius' first submission [and therefore second submission] represent a dispute "concerning the interpretation or application" of the Convention" $" 88$. It had then to decide upstream on the nature of the dispute raised by the first submission. According to the decision, there was no doubt on the existence of a dispute between the parties with respect to sovereignty over the Chagos islands, nor was there any doubt about the existence of a dispute between the parties with respect to the manner in which the MPA was declared ${ }^{89}$. Hence the issue raised was at this point formulated in this way by the tribunal:

\footnotetext{
"Is the Parties' dispute primarily a matter of the interpretation and application of the term "coastal state", with the issue of sovereignty forming one
}

85 Final Transcript, 450:23-24, quoted by the Award para. 191, p. 80 .

86 Although, as noticed by Mauritius, submissions have been presented to the CLTS.

87 Award para. 203, p. 85.

88 Award, para. 206, p. 86.

89 Award para. 209-210, p. 87 aspect of a larger question? Or does the Parties' dispute primarily concern sovereignty, with the United Kingdom's actions as a "coastal State" merely representing a manifestation of that dispute?"90

The impressive amount of documents and evidential material furnished by the parties was not able to bring a clear answer to this question. A bit surprisingly, the judges focused on the consequences which could emerge from their decision. Mauritius' counsels, aware of that aspect, had actually already formulated them, rolling the dice, with the will to make these consequences less frightening: to state the UK is not the costal state would

"do no more than state that Mauritius is "the coastal state" in relation to the Chagos Archipelago and that the Chagos Archipelago forms an integral part of the Republic of Mauritius. [...] The British [would] leave. The former residents of the Chagos Archipelago who wish to return finally [would] be free to do so and their exile would come to an end. [...] Those are the consequences of applying the law, from exercising jurisdiction and interpreting and applying the words that sit in the Convention"'91.

But the demonstration did not have the expected impact, since the tribunal drew the opposite conclusion by stating in a very direct manner that these conclusions were "not the sort of consequences that follow from a narrow dispute regarding the interpretation of the words "coastal state" for the purposes of certain articles of the Convention" trated that the dispute related to the first submission was "characterized as relating to land sovereignty over the Chagos Archipelago"

2.2. What failed to be demonstrated was then the scope of jurisdiction allowed by the Convention and the measure to which it would cover "a dispute over land sovereignty when [...] that disputes touches some ancillary manner on matters regulated by the Convention"94. The parties had exchanged long argumentation on this aspect, but the decision brushes off these considerations by establishing that the Convention gives no clue about the jurisdiction on land disputes, for the mere rea-

90 Award, para. 211, p. 87.

91 Final Transcript, 1030:13-21, quoted in the Award para. 211, p. 88 .

92 Award para. 211, p. 88.

93 Award para. 211.

94 Award para. 212. 
son "that none of the Convention participants expected that a long-standing dispute over territorial sovereignty would ever be considered to be a dispute "concerning the interpretation or application of the Convention"'"95.

To interpret the intent of the parties to the Convention, it was necessary, indeed, as underlined by the award, to refer to the evident major "sensitivity" of states when questions of territorial sovereignty are at stake $^{96}$. In a provocative but pertinent question, the decision asks:

"[...] if the drafters of the Convention were sufficiently concerned with the sensitivities involved in delimiting maritime boundaries that they included the option to exclude such disputes from compulsory settlement, is it reasonable to expect that the same States accepted that more fundamental issues of territorial sovereignty could be raised as separate claims under Article 288(1)?"'97

The tribunal obviously answered "no" by considering that a reading of article 298(1)(a)(i) as it would cover matters of land sovereignty would "do violence to the intent of the drafters of the Convention..."98 and concluded on the interpretation of part XV of UNCLOS:

\footnotetext{
"As a general matter, the Tribunal concludes that, where a dispute concerns the interpretation or application of the Convention, the jurisdiction of a court or tribunal pursuant to Article 288(1) extends to making such findings of fact or ancillary determinations of law as are necessary to resolve the dispute presented to it (see Certain German Interests in Polish Upper Silesia, Preliminary Objections, Judgment of 25 August 1925, P.C.I.J. Series A, No. 6, p. 4 at p. 18). Where the "real issue in the case" and the "object of the claim" (Nuclear Tests (New Zealand v. France), Judgment, I.C.J. Reports 1974 , p. 457 at p. 466, para. 30) do not relate to the interpretation or application of the Convention, however, an incidental connection between the dispute and some matter regulated by the Convention is insufficient to bring the dispute, as a whole, within the ambit of Article 288(1)"'99
}

It however took the precaution to precise, that through this declaration,

" $[t]$ he Tribunal does not categorically exclude that in some instances a minor issue of territorial sovereignty

95 Award para. 215.

96 See Award para. 216, p. 89. The tribunal takes in account "the inherent sensitivity of States to questions of territorial sovereignty".

97 Award para. 216.

98 Award para. 219, p. 90

99 Award para. 220. could indeed be ancillary to a dispute concerning the interpretation or application of the Convention."'100

An hypothesis that did not correspond to the Chagos islands case, for what the decision excludes the jurisdiction of the tribunal towards Mauritius' first submission. It also excludes jurisdiction towards the second submission, after having considered it distinct, but nevertheless referring in the same way to a territorial dispute over land ${ }^{101}$.

This conclusion was the only one not unanimously shared by the panel and was voted by three arbitrators $^{102}$. The opposition of judges Kateka and Wolfrum on this question motivated the redaction of a joint dissenting and concurring opinion explaining the reasons of this disagreement ${ }^{103}$. To them, the qualification of the dispute deserved to focus clothier on the formulation of the submission made by Mauritius, and some elements showed that into the strict mark of the MPA case, the first concern of Mauritius was not the sovereignty claim $^{104}$. They both argued for a limited scope of Mauritius' first submission, and an apprehension of the second submission, as it was not a question of sovereignty but a dispute as to whether the United Kingdom has ceded one or more rights as a coastal State in the commitments made in the Lancaster House Undertakings ${ }^{105}$.

It is true that "the Tribunal missed the opportunity to deal with the separation of the Chagos Islands from Mauritius and the circumstances surrounding this separation" 106 , but on a justified motivation. Moreover, as already mentioned, the award partly addresses the question on land sovereignty, since the decision on Mauritius' fourth submission has some important consequences ${ }^{107}$. Another solution would have supposed to decide on the existence of a legal title of the UK on the Chagos islands, which would have meant to decide on a

100 Award para. 221.

101 Award para. 228-230, p. 94-95.

102 Dispositif of the award, para. 547, p. 215.

103 The opinion also raises grounds of discordance on the relevant reasoning about the jurisdiction of the tribunal on Mauritius' third and fourth submissions.

104 Dissenting and concurring opinion of judges James Kateka and Rüdiger Wolfrum, para. 3-17.

105 Dissenting and concurring opinion of judges James Kateka and Rüdiger Wolfrum, para. 19.

106 Dissenting and concurring opinion of judges James Kateka and Rüdiger Wolfrum, para. 67.

107 On that question, this article, IV. 
land dispute independent from a question of interpretation of the Convention. It was not possible to give a statement on the competence about the MPA without deciding on the question of the territorial title. The judges couldn't ignore that the MPA issue was one facet of a larger dispute. It is logical that states voluntarily reduce the scope of an issue when they bilaterally submit it to an international settlement. It would however not be acceptable that one state could submit a dispute to such international mechanism without the consent, previous or present, of the other state, by focusing the initial claim on one consequence of the main issue. Pretending that the UNCLOS could serve as a conventional basis for the jurisdiction to deal with land disputes not even linked with maritime boundaries would be far from the drafters' intent, and would be contrary to the general rules of interpretation provided by international law.

\section{B. The MPA is not only about fisheries and the tribunal has jurisdiction over issues related to these other aspects}

\section{Identification of the legal reasoning}

The issue on the tribunal's jurisdiction with regard to Mauritius' fourth claim on the compatibility of the MPA with the Convention represents a large part of the award ${ }^{108}$. The tribunal's jurisdiction on that aspect was related to the relevance of article 297 UNCLOS. This long article establishes grounds and exceptions to compulsory jurisdiction and was then crucial for both parties. In substance, there was a dissension in the manner to present the nature of the MPA. The UK presented it as a measure concerning above all fisheries, and was then rejecting the establishment of the tribunal on the grounds of article 297(1)(c) relating to the preservation of the environment, as Mauritius conten$\operatorname{ded}^{109}$. It argued for the same reason that the jurisdiction of the tribunal was excluded by article 297(3)(a) UNCLOS which precludes compulsory proceeding for disputes relating to the sovereign rights of the coastal state "with respect to the living resources in the exclusive economic zone or their exercise..." $"$. The UK was

108 See Award p. 93-130.

109 On that question, Mauritius' memory p. 88-89 and UK's counter-memorial, p. 160-169.

110 Article 297(3)(a) UNCLOS. See again UK's counter-memorial, p. $160-169$. also denying the tribunal's jurisdiction towards Mauritius' claims about cooperation with respect to highly migratory fish stocks (articles 63 and 64 UNCLOS and 1995 Fish Stocks Agreement) ${ }^{111}$, access to the territorial sea fish stock and to the exclusive economic zone fish stock (articles 2(3), 55 and 56(2) UNCLOS) ${ }^{112}$, harvesting of sedentary species of the continental shelf (article 78 UNCLOS) ${ }^{113}$, marine pollution (article 194 UNCLOS $)^{114}$, and the abuse of rights alleged by Mauritius (article 300 UNCLOS) ${ }^{115}$.

The tribunal found it had jurisdiction on these claims, except on those excluded by article 297(3)(a) for being related to fisheries. It exposed its decision in a three parts reasoning, respectively dedicated to the scope and character of the MPA, the scope and character of Mauritius' rights, and the articulation with article 297 (1) (c) UNCLOS.

1.1. The first question is quickly treated in the award by an efficient application of estoppel, without, however, naming the principle:

"[h]aving argued for the necessity and importance
of the MPA by reference to environmental
concerns that extend well beyond the management
of fisheries, it is not now open to the United
Kingdom to limit the jurisdiction of this Tribunal
with the argument that the MPA is merely a fisheries
measure"116

The decision reaches this conclusion from the official declarations of the British government around the establishment of the MPA, which let no doubt about the way the UK presented the creation of the area ${ }^{117}$.

1.2. The second part of the reasoning turning around the scope of Mauritius' rights brings a classification between the articles of the Convention invoked. As mentioned above, Mauritius contented that the MPA was incompatible with the UK's obligations under articles 2, $55,56,63,64,194$, and 300 UNCLOS $^{118}$. To determine

111 The following claims are detailed in Mauritius' memorial p. 124-153. For the arguments of UK on this point: UK's counter memorial p. 156-159 and p. 170.

112 Award, p. 154-156 and p. 173.

113 Award, p. 155. Mauritius raised the question of sedentary species but did not claim a violation of article 78 in the final submissions, as reminds the note 370 of the award.

114 Award, p. 159.

115 Award, p. 174. For more details about the arguments of these ultimate claims, see Award p. 100-111.

116 Award para. 291, p. 113.

117 Award para. 286-291, p. 111-113.

118 Award para. 294, p. 114. 
the scope of Mauritius' rights, the decision establishes three categories among this list of dispositions.

On one side, articles 2(3) and 56(2) regarding the exercise of sovereignty or sovereign rights over the territorial sea and the exclusive economic zone refer respectively to "other rules of international law" 119 and to an obligation "to have due regard to the rights and duties of other states"120. The tribunal considered then "the rights in issue to be those originating in the Lancaster House Undertakings" 121 . The question of the binding nature of these rights was let for the merits, the question was at that point if they could "justify the provisional conclusion that they may have been binding as a matter of international law and relevant to the application of Articles 2 and 56"122. The tribunal found the test satisfied ${ }^{123}$. The rights related to fisheries were clearly identified like falling under the exclusion of article 297(3) (a) ${ }^{124}$, but the panel found that the undertakings relating to the return of the Archipelago (when no longer needed for defense purposes), and to the benefit of oil and mineral resources ${ }^{125}$, were linked to the creation of the MPA and not covered by any exception. "The MPA's very existence bears upon the choices that Mauritius will have open to it when the Archipelago is eventually returned" expressed the tribunal ${ }^{126}$, and "the benefit of the minerals and oil in the surrounding [...] may be significantly affected by the MPA" in such a situation $^{127}$.

On the other side, articles 63, 64 and 194 of the Convention directly create some rights to Mauritius by imposing some obligations to the $\mathrm{UK}^{128}$. There was no much doubt about the fact that articles 63 and 64 (as well as the 1995 Fish Stocks Agreement) concerned fisheries and would fall under the exclusion of article

119 Article 2(3) UNCLOS sets out: "The sovereignty over the territorial sea is exercised subject to this Convention and to other rules of international law".

120 Article 56(2) UNCLOS sets out: "In exercising its rights and performing its duties under this Convention in the exclusive economic zone, the coastal State shall have due regard to the rights and duties of other States and shall act in a manner compatible with the provisions of this Convention".

121 Award, para. 294.

122 Award, para. 296, p. 115.

123 Award para. 296.

124 Award para. 297, p. 116.

125 Undertakings vii et viii.

126 Award, para. 298, p. 116.

127 Award, para. 298.

128 Award, para. 293, p. 114. 297(3)(a), even if subtle distinctions had been opposed by Mauritius ${ }^{129}$. However, article 194 on marine pollution doesn't fall under exception, and the claim based on this article was actually not really opposed under the scope of jurisdiction ${ }^{130}$.

Finally, articles 55 and 300 UNCLOS constitute for the tribunal a special kind of dispositions that don't add anything to the scope of Mauritius' rights: article 55 describes the exclusive economic zone ${ }^{131}$ and article 300 about abuse of rights is necessarily linked to the invocation of another article ${ }^{132}$.

To the panel, the claims could not be entirely excluded by the article 297(c)(a) exception, since the scope of Mauritius' alleged rights went beyond the strict mark of fisheries.

1.3. According to the previous steps of the demonstration, the tribunal concluded that it had jurisdiction to consider Mauritius' fourth submission and the compatibility of the MPA with articles 2(3), 56(2), 194 and 300 $\mathrm{UNCLOS}^{133}$. But it reaffirmed its jurisdiction, prior to this conclusion, by identifying the dispute as entering into the scope of article 297(1)(c) UNCLOS ${ }^{134}$. The articulation established between the dispute and this tortuous article of the Montego Bay Convention, as the last part of the reasoning, implies here some more explanations.

2. The inclusive interpretation of article 297(1) UNCLOS and its consequences on the tribunal's jurisdiction

The MPA case was a good opportunity to bring some enlightening on the enigmatic article 297(1) UNCLOS and the tribunal dedicated some important deve-

129 Award para. 300-301, p. 117. Mauritius had for example tried to demonstrate that the Convention doesn't exclude jurisdiction on dispute about rights of fisheries in the territorial sea by a similar reading of the dispositions of the first and third paragraphs of article 297: Mauritius' memorial, p. 88-89.

130 Award, para 302.

131 "The exclusive economic zone is an area beyond and adjacent to the territorial sea, subject to the specific legal regime established in this Part, under which the rights and jurisdiction of the coastal State and the rights and freedoms of other States are governed by the relevant provisions of this Convention."

132 "States Parties shall fulfil in good faith the obligations assumed under this Convention and shall exercise the rights, jurisdiction and freedoms recognized in this Convention in a manner which would not constitute an abuse of right."

133 Award, para 323, p. 129-130.

134 Award, para. 319. 
lopments to it. Mauritius had invoked article 297(1) to find some ground of its claim, but the tribunal chose to offer here a general reading of these dispositions, through an analyze of the textual construction and the relationship between articles 288(1) and 297(1)(c), and through the drafting history of the article.

2.1. A classical application of the rules of interpretation of conventional instruments imposes to start by studying the formulation of the dispositions whose meaning raises some question, as well as their situation in the whole text. Even without naming these evident rules of international law codified by the Vienna Convention on treaties, the panel did so by having a cloth look on article 297(1)(c) and its articulation with other dispositions of the Convention of Montego Bay. The question was about whether or not the first paragraph oh article 297 could limit the jurisdiction of the tribunal, and the panel answered through a more general one: can potentially article 297(1)(c) limit the jurisdiction of a tribunal? As a matter of fact, article 297(1) is phrased in affirmative terms and includes no exceptions ${ }^{135}$, which would lead to a negative answer. As mentioned by the tribunal, it "does not state that disputes concerning the exercise of sovereign rights and jurisdiction are only subject to compulsory settlement in the enumerated cases" ${ }^{136}$, which pleads for a lecture in the sense of an unlimited list. In this direction also goes the comparison with article 297(3), which would be unnecessary with another reading of article 297(1), and with article 297(2), which would be in contradiction with article 297(1), in the case of an exclusive lecture of the last mentioned dispositions ${ }^{137}$.

Regarding these observations, "article 297(1) reaffir$\mathrm{ms}$, but does not limit, the Tribunal's jurisdiction pursuant to article $288(1){ }^{\prime 138}$. Still, the problem also came from the place in the whole text and the subtitle of article 297: "Limitations on applicability of section 2" (a section dedicated to "compulsory procedures entailing binding decision"). Article 297(2) and 297(3) indeed express some limitations. Article 297(1) is located in section 3 of Part XV UNCLOS, a section reserved to "limitations and exceptions of section 2". Because of "the apparent ambiguity of including a jurisdiction-affirming provision in an article otherwise devoted to limitations

135 Award para. 307, p. 119.

136 Award para. 308.

137 Award para. 308.

138 Award para 308. on the exercise of compulsory dispute settlement"139, the tribunal decided to have a look on the draft history of the article.

2.2. Article 297 has a complex history. The decision recalls the 1976 draft version, the 1977 draft version, the 1979 draft version, and the nearly final $1980 \mathrm{draft}$ version $^{140}$. This makes the text of the award a bit cumbersome, but shows the difficulties the drafters met to find a satisfactory formulation of these dispositions. It is interesting to read that the first intent was effectively to formulate a limitation on the submission to compulsory settlement of disputes, but was then omitted in the final text ${ }^{141}$. The Commentary of the Convention explains this change ${ }^{142}$. To the tribunal, the historical also shows that "the placement of the jurisdiction affirming Article 297(1) within an Article devoted to limitations on the compulsory settlement of disputes is explained by the procedural safeguards that were briefly introduced into the Article and which ultimately became Article 294" "143. These considerations lead to the conclusion of the tribunal:

\footnotetext{
"The Tribunal considers that the drafting history confirms the conclusion it reached from the textual construction of Article 297. Article 297(1) reaffirms a tribunal's jurisdiction over the enumerated cases and (through Article 294) imposes additional safeguards; it does not restrict a tribunal from considering disputes concerning the exercise of sovereign rights and jurisdiction in other cases. Where a dispute concerns "the interpretation or application" of the Convention, and provided that none of the express exceptions to jurisdiction set out in Article 297(2) and 297(3) are applicable, jurisdiction for the compulsory settlement of the dispute flows from Article 288(1). It is not necessary that the Parties' dispute also fall within one of the cases specified in Article 297(1)"144
}

\section{The "exchange of views" requirement of arti- cle 283 UNCLOS is a procedural condition and must be interpreted with flexibility}

After Mauritius' third submission about petition to CLCS was quickly set aside for absence of dispute ${ }^{145}$,

139 Award para. 308.

140 Award p. 120-126.

141 Award, para. 314, p. 126-127.

142 Award para. 314.

143 Award., para. 315.

144 Award, para. 317.

145 There's no need to recall such part of the decision in details. 
the tribunal still had to examine the UK's transversal argument on the unfulfilment of article 283. This article of part XV of the Convention contains general dispositions about the settlement of disputes between the parties, and provides that:

"1. When a dispute arises between States Parties concerning the interpretation or application of this Convention, the parties to the dispute shall proceed expeditiously to an exchange of views regarding its settlement by negotiation or other peaceful means.

2. The parties shall also proceed expeditiously to an exchange of views where a procedure for the settlement of such a dispute has been terminated without a settlement or where a settlement has been reached and the circumstances require consultation regarding the manner of implementing the settlement."

To the UK, the exchange of views was a precondition to the jurisdiction under the Convention, which hadn't been met in the case regarding the fourth submission. It argued that the requirement of article 283 differed from the general international law obligation to negotiate, and must be read as a higher standard ${ }^{146}$. It was then "not sufficient to meet the requirements of article 283(1) simply to point to a stream of communications with the respondent State, even if they refer to an existing longstanding sovereignty claim"147. Whereas Mauritius pretended that "the requirements of article 283 (were) not particularly onerous" and "(did) not need lengthy exchanges"148.

It was here another opportunity for the tribunal to bring some substantial elements on the application of

The tribunal unanimously recognized that Mauritius' and the UK's officials were having talks on the question of the submission to the CLCS. The issue emerged during the exchange of writings, when the UK raised some objections, but in the mark of a general argumentation about the MPA case. During the hearings, the UK expressed its will to cooperate, and Mauritius accepted the UK's proposition to organize the talks under a sovereign umbrella. Then the tribunal, by encouraging the parties to exchange their views on that question, contributed in resolving the dispute without a binding decision. See Award p. 130-139.

146 See UK's rejoinder, p. 105-125. The rejoinder, in para. 6.7, quotes judges Wolfrum and Treves, who had already concluded to this deviation from the general procedure in international law (The $M / V$ "Louisa" Case (Saint Vincent and the Grenadines v. Kingdom of Spain), Provisional Measures case, Order of 23 December 2010, Dissenting Opinion of Judge Wolfrum, paras. 28-29, and Dissenting Opinion of Judge Treves, para. 10.)

147 Award, para. 6.52, p. 124.

148 Final transcript 402:1-6, quoted by the Award para. 360, p. 142. the Convention. This issue was developed quite in details, to conclude that the requirement was met $^{149}$. To do so, the panel established a distinction between a requirement about exchanging views regarding the means for resolving the dispute, and a requirement about negotiating on the substance of the dispute ${ }^{150}$. Article 283 would then relate to procedure, not to substance, as indicated by the textual structure of the provisions ${ }^{151}$.

Two points were then analyzed. Firstly, the absence of requirement in the Convention for substantive negotiations. Nevertheless, "to the extent that such a requirement could be considered to be implied from the structure of sections 1 and 2 of Part XV", there would be for the tribunal "no hesitation" that Mauritius met it, regarding the talks that had been engaged ${ }^{152}$. The references to the furnished jurisprudence of general international law justified the conclusion ${ }^{153}$. Secondly, the procedural requirement of article 283 UNCLOS should not be interpreted in a too formalistic manner, as it had been already set in the Barbados/Trinidad and Tobago $\operatorname{award}^{154}$ :

\footnotetext{
"Article 283 forms part of the Convention and was intended to ensure that a State would not be taken entirely by surprise by the initiation of compulsory proceedings. It should be applied as such, but without an undue formalism as to the manner and precision with which views were exchanged and understood. In the Tribunal's view, Article 283 requires that a dispute have arisen with sufficient clarity that the Parties were aware of the issues in respect of which they disagreed"155
}

149 Award p. 147-152.

150 Award, para. 378, p. 147.

151 Award.

152 Award para. 378, p. 147-148.

153 For instance, the decision quotes: Application of the International Convention on the Elimination of All Forms of Racial Discrimination (Georgia v. Russian Federation) Preliminary Objections, Judgment, I.C.J. Reports 2011, p. 70 at p. 85, para. 30; see also Military and Paramilitary Activities in and against Nicaragua (Nicaragua v. United States of America), Jurisdiction and Admissibility, Judgment, I.C.J. Reports 1984, p. 392 at p. 428-429; Mavrommatis Palestine Concessions, Jurisdiction, Judgment of 30 August 1924, PCIJ Series A, No. 2, p. 6 at p. 13, 15

154 Award of 11 April 2006, PCA Award Series, p. 94-96, RIAA, Vol. XXVII, p. 147 at p. 206-207, paras. 201-205, quoted by the Award, para. 381, p. 149.

155 Award, para. 382, p. 149. 
In the present case, the tribunal considered that the parties had engaged "in some exchange of views regarding the means to settle that dispute", as shown by the correspondence of December 2009 relative to the settlement of the dispute ${ }^{156}$, and had then met the article 283 requirement.

\section{THE BREACH OF UNCLOS DISPOSITIONS}

After so many considerations on background and jurisdiction, the award finally dedicates a short part to merits (60 pages on 217)- a paradox existing in many international rulings. The tribunal first had to determine "the content of Mauritius' rights, both pursuant to the Convention and otherwise, in the territorial sea, exclusive economic zone, and continental shelf areas affected by the MPA" 157 . That raised a delicate legal issue regarding the nature of the agreement reached between the British government and the representatives of Mauritius before its independence. Then, it had to examine whether the declaration of the MPA was breaching the UK's obligations under the Convention.

\section{A. The Lancaster House Undertakings are now international obligations}

Two points needed to be apprehended by the judges when considering the scope of Mauritius' rights. Firstly, the nature of the Lancaster House Undertakings, and secondly, the specific rights regarding fisheries mentioned in the above-mentioned agreement ${ }^{158}$.

\section{The legal nature of the Lancaster House Undertakings}

Regarding the first and main point, Mauritius contended that the British undertakings drew their binding nature from the repetition of their expression by the UK government. Indeed, Mauritius maintained that no valid agreement had been reached in 1965, since

"the United Kingdom was in violation of its obligations with respect to self-determination, the

156 Ibid., para. 383-384.

157 Award, para. 389, p. 153.

158 Mauritius was also contending the existence of traditional rights of fisheries apart from the Lancaster House Agreement, but having decided that the rights about fisheries mentioned in the Agreement had some legal effects, there was no need for the tribunal to examine them. linkage between detachment and independence imposed by the United Kingdom put the Mauritius Council of Ministers under duress, and any purported consent "was not given in accordance with the applicable standards for the treatment of a colonizer towards an independence movement."'”159

The UK's position was that the nature of the undertakings had to be examined exclusively under British law, and that the government had never intended to be bound by them ${ }^{160}$.

As recalled by the decision itself, the legal effect of the Lancaster House Undertakings was actually central in Mauritius' fourth submission, but also in the first and second ones ${ }^{161}$. Was the inclusion of such an observation a way for the tribunal to express its contribution to the "Chagos resettlement issue", by deciding on the legal nature of the agreement, even having precluded its jurisdiction on the Mauritius' submissions linked to the question of sovereignty over the Chagos islands? It might be so, as the conclusion of the internationally binding nature of these undertakings is of a great importance in the whole dispute. The recognition of the UK's obligation to return the islands when there is no more need of defense consideration will certainly have some consequences in the way the dispute between the two states can be solved, and also on the way the last Chagossians claim will be heard by the British Supreme Court if it is reopened.

To treat this delicate issue, the tribunal adopted a four steps reasoning that consisted in recognizing that the British officials had made an offer with the intent to be bound, that the 1965 had become a matter of international law after the independence of Mauritius, that the 1965 undertakings had been repeated by the UK government, and finally that the British government was estopped from denying the binding effect of the undertakings ${ }^{162}$.

\subsection{The parties' intent}

The tribunal extracted two conclusions from the detailed record of the meetings surrounding the Lancaster House meeting. On one hand, the fundamental impor-

159 Award para. 393, p. 154. The sentence quotes Final Transcript, 977:17-19. On the binding nature of the undertakings, see also Mauritius' Reply p. 49-65.

160 On these legal aspects, see Uk's counter memorial p. 212-219, the arguments are resumed in the para. 399-406 of the award.

161 Award., para. 418-419, p. 163.

162 Award p. 163-179. 
tance the undertakings recovered in Mauritius' "agreement" to detachment. On the other hand, the intent, by the UK officials, to be bound by the undertakings ${ }^{163}$. This is a convincing demonstration, seeing the whole record, the context, and the details of negotiations. The tribunal also mentioned the language used as an evidential element for the UK's intent to be bound ${ }^{164}$.

\subsection{The nature of the Undertakings}

This said, the place of the "agreement" in international law was very uncertain. It had been concluded between the British government and a non-self-governing territory, for what it should exclusively respond to British law, which precludes any effect in the international order for such agreement, as it would be in any other state $^{165}$. To the panel, however, the event of the independence of Mauritius propelled the undertakings to the international level. To the tribunal, "[t]he independence of Mauritius in 1968, however, had the effect of elevating the package deal reached with the Mauritian Ministers to the international plane and of transforming the commitments made in 1965 into an international agreement" ${ }^{\prime 166}$.

The judges concluded that the "1965 agreement" became a matter of international law ${ }^{167}$. It took for that in account the context of the commitment:

"The Parties did not themselves characterize the status of the 1965 Agreement either at its conclusion or at the moment of Mauritian independence. The Tribunal, in turn, does not consider the circumstances in which the Agreement was initially framed-as a matter between the United Kingdom and its colony-to be determinative of the Parties' intent with respect to its eventual status. Objectively, the Tribunal considers the subject matter of the 1965 Agreement- an agreement to the reconstitution of a portion of a soon-to-

163 Award, para. 421-423, p. 164-167. We put the word agreement between comas for the issue there is around the validity of the consent by Mauritius officials. The words of the tribunal in paragraph 422 are the following: "Without yet passing on the legal nature of these commitments or the validity of Mauritian consent, the Tribunal is confident that, without the United Kingdom's undertakings, neither Sir Seewoosagur Ramgoolam nor the Mauritius Council of Ministers would have agreed to detachment". Mauritius uses the word agreement bewteen comas in its memorial, see p. 117 .

164 Award, para. 423.

165 Award, para. 425. The tribunal refers to I. Hendry and S. Dickson, British Overseas Territories Law (2011), p. 261.

166 Award, para. 425, p. 167.

167 Award, para. 428, p. 168. -be-independent colony as a separate entity in exchange for compensation and a series of detailed undertakings - to be more in the nature of a legal agreement than otherwise. And, as set out above, the Tribunal sees no hint in the course of negotiations or in the language used in 1965 that anything less than a firm commitment was intended $\gg^{168}$

The decision is less clear on the conditions that would permit to identify the expression of the undertakings and the following detachment of the Chagos islands as an "agreement". It was actually a big issue, for Mauritius' and the Chagossians' argument precisely denunciated the nullity of such an "agreement" concluded, to them, under duress. During the proceeding, Mauritius presented the Lancaster House Undertakings more as an international promise than an agreement for that reason. And the decision is someway ambiguous when it starts to use the term "1965 agreement". It was impossible for the tribunal, however, to totally escape from this important legal and political issue, resolved in the award by the recognition that the commitments had been renewed.

\subsection{The repetition of the Undertakings}

The decision manoeuvres a bit quickly but skilfully on the issue above mentioned, admitting that "the United Kingdom's repetition of the undertakings, and Mauritius' reliance thereon, suffices to resolve any concern that defects in Mauritian consent in 1965 would have prevented the Lancaster House Undertakings from binding the United Kingdom"169. The undertakings, at least those concerned by the establishment of the MPA, actually were repeated, as a whole or separately, on numerous occasions ${ }^{170}$, as Mauritius had contended ${ }^{171}$.

The repetition of the Lancaster House engagements is then a fundamental point in the reasoning, for resolving any concern about the validity of consent of Mauritius in 1965, and for entering into the tribunal's approach to conclude that UK was estopped by their formulation.

\subsection{The application of estoppel}

To bring an even more complete demonstration, the

168 Award, para. 427.

169 Award, para. 428, p. 168.

170 Award, para. 429-433.

171 Mauritius' memorial, p. 117. 
decision enters at that level to a detailed application of the classical estoppel. It makes a doctrinal parenthesis with the definition of the principle and a rich recall of the jurisprudential application of it, from which the tribunal drew four conditions:

\begin{abstract}
«Further to this jurisprudence, estoppel may be invoked where (a) a State has made clear and consistent representations, by word, conduct, or silence; (b) such representations were made through an agent authorized to speak for the State with respect to the matter in question; (c) the State invoking estoppel was induced by such representations to act to its detriment, to suffer a prejudice, or to convey a benefit upon the representing State; and (d) such reliance was legitimate, as the representation was one on which that State was entitled to rely» ${ }^{172}$
\end{abstract}

The two first conditions were already answered by the previous observations, the tribunal examined then "whether Mauritius relied to its detriment on the United Kindgom's representations", and "whether Mauritius was entitled to rely upon the United Kingdom's representations" $" 173$. To the arbitrators, the following analysis grid had to be applied. Firstly, about the existence of the reliance, they considered that "evidence of opportunities foregone in reliance upon a representation constitutes one of the clearest forms of detrimental reliance, although a benefit conveyed on the representing State will also suffice" ${ }^{174}$. And, specified, about the entitlement on reliance that:

"[...] Not all reliance, even to the clear detriment of a State, suffices to create grounds for estoppel. A State that elects to rely to its detriment upon an expressly non-binding agreement does not, by so doing, achieve a binding commitment by way of estoppel. Such reliance is not legitimate. Nor does a State that relies upon an expressly revocable commitment render that commitment irrevocable."

At the same time, the Tribunal does not consider that a representation must take the form of a binding unilateral declaration before a State may legitimately rely on it. To consider otherwise would be to erase any distinction between estoppel and the doctrine on binding unilateral acts" ${ }^{175}$.

It answered positively to both questions. On the first issue, it relied, among other elements, on Mauritius' denial to have formalized the undertakings in a treaty in

172 Award para. 438, p. 174

173 Award, p. 175-178.

174 Award, para. 440, p. 175.

175 Award, para. 445-446, p. 177.
2009 because it considered the existent ones were sufficient $^{176}$. It also explained Mauritius' temporary silence about the sovereignty claim on the Chagos islands on this way:

"Had the package of undertakings not been given,
the Tribunal considers it beyond question that
Mauritius would have asserted its claim to the
Archipelago earlier and more directly, and would
have withheld its cooperation in other areas of the
Parties' bilateral relations, as indeed occurred in
2009 and 2010 when the United Kingdom appeared
(at least to Mauritius) to have set aside its concern
for Mauritian rights in favour of the pursuit of the
MPA"177

On the second issue, the tribunal considered that Mauritius was entitled to rely on the UK's undertakings, particularly after their reiteration, and had no reason to think they were revocable ${ }^{178}$. The recall at that point of the Lac Lanoux case and the fact that "bad faith is not presumed", sounds like a reproving message addressed to the British government.

\section{The fishing rights.}

An ancillary issue was the need to clarify the containing of the fishing rights, since the parties had a different interpretation on that point. Mauritius had logically a broad understanding of them, considering that Mauritius vessels could fish "anywhere in the Chagos waters except in the immediate vicinity of Diego Garcia Island, and for any species, subject only to the requirement that they obtain fishing licences, which were is-

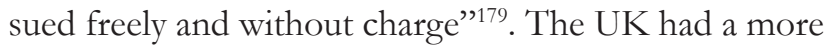
restrictive view limited to "preferential fishing rights"

The tribunal finally chose an intermediate way, between these two extreme lectures, of some fishing rights but with limitations. References were here again made to the terms of the undertakings and to the record of the officials exchanges. The UK, regarding the text of the undertaking, still has the margen of appreciation to decide on the manner it has to ensure that Mauritius' rights remain avalaible ${ }^{181}$.

176 Award, para. 440

177 Award, para. 442.

178 Award, para. 447, p. 178

179 Final Transcript 167:11-13, quoted by the Award, para. 408, p. 160.

180 Final Transcript 595:18-20, quoted by the award para. 411, p. 161.

181 Award, p. 181. 


\section{B. The interpretation of articles 2(3), 56(2), 194, and 300 UNCLOS}

Mauritius' claim implied a separate analysis of each article and the respective arguments of the parties. Nevertheless, the most important dissension about interpretation concerned article 2(3), which deserves for that reason a special mention. The tribunal then applied articles 2(3) and 56(2), affirmed apart the incompatibility of the MPA with article 194, and dismissed Mauritius regarding the claim on article 300.

\section{Article 2(3) creates a general obligation}

Regarding article 2(3), the parties were differing on whether it creates an obligation for the states. The decision reveals a substantive work of interpretation, as well as a classical application of the dispositions of the Vienna Convention on Treaties. A cloth examination of the words of the article, including a comparison to non-English version ${ }^{182}$, an analysis of the whole structure of the Convention ${ }^{183}$, and a (too) long regard to the origin of the dispositions ${ }^{184}$, lead the tribunal to a positive answer. To the pane, article 2(3) creates a general obligation to exercise sovereignty subject to the general rules of international law. It's a mere obligation, not an obligation of compliance ${ }^{185}$. In this case, it would mean that the UK had "to act in good faith in its relations with Mauritius, including with respect to undertakings" $" 186$.

2. The application of the Convention to the establishment of the MPA

The tribunal first applied article 2(3) in connexion with article 56(2) UNCLOS. There was no much doubt about the text of article 56(2), except about the implications of the expression "due regard" 187 . The two articles

182 The English and French versions make no distinction.

183 For instance, the article 87 about High seas makes a difference between the expressions "is exercised" and "shall be exercised", as mentioned by the award in note 654 .

184 It finds its origin in the 1958 Geneva Convention on the Territorial Sea and the Contiguous Zone.

185 Award, para. 516, p. 201-202.

186 Award, para. 517.

187 Para. 519, p. 202, of the decision sets out: "In the Tribunal's view, the ordinary meaning of "due regard" calls for the United Kingdom to have such regard for the rights of Mauritius as is called for by the circumstances and by the nature of those rights. The Tribunal declines to find in this formulation any universal rule of conduct. The Convention does not impose a uniform obligation to avoid any impairment of Mauritius' rights; nor does it uniformly permit the United Kingdom to proceed as it wishes, merely noting such rights. Rather, the extent of the regard required by the Conven- were applied together since the requirements they both establish were considered by the tribunal "to be, for all intents and purposes, equivalent" ${ }^{188}$. The reasoning is developed in details in the award, based on the record of talks and correspondence, but paragraph 535 says it all:

\begin{abstract}
"The Tribunal also concludes that the United Kingdom failed properly to balance its own rights and interests with Mauritius' rights arising from the Lancaster House Undertakings. Not only did the United Kingdom proceed on the flawed basis that Mauritius had no fishing rights in the territorial sea of the Chagos Archipelago, it presumed to concludewithout ever confirming with Mauritius - that the MPA was in Mauritius' interest. This approach is to be contrasted with the one adopted with respect to the United States, as another State with rights and interests in the Archipelago. There, the record demonstrates a conscious balancing of rights and interests, suggestions of compromise and willingness to offer assurances by the United Kingdom, and an understanding of the United State's concerns in connection with the proposed activities. All these elements were noticeably absent in the United Kingdom's approach to Mauritius"
\end{abstract}

The formulation of this conclusion, as well as the comparison established with UK's behaviour towards United States, are not neutral. It shows that this decision is not only about applying the technical law of the sea, but also about rending justice in a very wider context of postcolonialism policy. The judicial demonstration sounds like a general "remonstrance" to the UK, and a condemnation of the double standards behaviour adopted at an international level towards the most powerful ones and the less powerful states.

The judges made somehow a more flexible application of article 194. They distinguished for that articles 194(1) and 194(4). The first dispositions, on one hand, would only be prospective and require UK's "best efforts"189. Seing "the limited life of the MPA"190, UK would not have violated this obligation. The dispositions of article 194(4), on the other hand, establishing a obligation to "refrain from unjustifiable interference", would create a requirement "functionnaly equivalent to

tion will depend upon the nature of the rights held by Mauritius, their importance, the extent of the anticipated impairment, the nature and importance of the activities contemplated by the United Kingdom, and the availability of alternative approaches. In the majority of cases, this assessment will necessarily involve at least some consultation with the rights-holding State".

188 Award, para. 520, p. 203.

189 Award, para. 539, p. 211.

190 Award, para. 539. 
the obligation of "due regard", set out in Article 56(2), or the obligation of good faith that follows from Article $2(3)$ "191. It would then require in the same way "a balancing act between competing rights, based upon an evaluation of the extent of the interference, the availability of alternatives, and the importance of the rights and policies at issue" ${ }^{\prime 192}$. However, the article specifies that this obligation is reserved towards the "activities carried out by other States", so the application of article 194(4) was here reserved to the activities of fisheries in the territorial sea. For the same reasons explained regarding the application of articles 2(3) and 56(2), the tribunal concluded to a violation of the Convention ${ }^{193}$.

Despite the clear condemnation of UK's behaviour, the claim on article 300 was dismissed by the arbitrators, who, haven already recognized the UK's infringement of its international commitments, saw no need to enter in a new polemic. The Mauritius' claim about the alleged abuse of rights was indeed essentially based on an exchange of notes verbales between Colin Roberts, Director of the Overseas Territories Department at the FCO, and a Political Counsellor at the US Embassy, in London, on 12 May 2009. The outcome of the exchange would have been recounted in a cable from the US Embassy addressed to the US Secretary of State, and published on the "Wikileaks" website in December $2010^{194}$

\section{Final COnCLUSions}

The award of 18 March 2015 on the MPA around Chagos islands has a great importance legally and politically speaking.

Regarding the legal aspect, it brings some substantial elements on the interpretation of the United Nations Convention on the Law of the Sea on rights and obligations, and on the scope of the jurisdiction provided by Part XV. It was only the twelfth case treated by a tribunal constituted under the Annex VII of the Con-

191 Award, para. 540, p. 211.

192 Award.

193 Award, para. 541, p. 212.

194 Mauritius' memorial, p. 72 and 148. The cable published by Wikileaks mentioned the British and American commune intent to preserve their interests and to put a stop to the Chagossians claim for resettlement. The English domestic courts already refused to receive the Wikileaks document as a piece of proof: this article, II. vention, and each proceeding creates high expectations. The panel fulfilled the challenge by publishing a rich, and, in some aspects, an audacious decision, which also contributes to defuse the threat of the fragmentation of international law, by referring to numerous decisions of arbitral tribunals and of the International Court of Justice. It also made some detailed application of classical concepts of general international law, as estoppel, and brought a singular reasoning on the international effects of the 1965 "arrangement" between the British government and the not yet independent Mauritian political leaders.

In terms of judicial policy, it was everything except easy to intervene in the context of this long standing dispute, and to decide on a case involving considerations as essential as the respect of human rights and the protection of the environment. By unanimously condemning the establishment of the MPA by the UK, the tribunal ran the risk to treat the protection of the environment on a secondary level. That's why the judges chose to express their concern in some "final observations" to underline that the decision was about 'the manner in which the MPA was established, rather than its substance" ${ }^{195}$. They also called the parties to a necessary negotiation in order to achieve "a mutually satisfactory arrangement for protecting the marine environment..." $"$. The award therefore found its place into the continuity of the diplomatic process ${ }^{197}$.

In that sense, it must be noted that the tribunal constituted under the UNCLOS provisions dismissed Mauritius' submissions related to the claim of sovereignty on the Chagos islands, but couldn't avoid to face the nature of the whole issue. It had to manage with the sensibilities of the parties, exaggerated by the dimension of the territorial dispute and the context of the Chagossians struggle for resettlement. The decision voted only partially, although substantially, satisfies Mauritius ${ }^{198}$. It is at the same time an audacious award, by expressing a clear condemnation of the UK's behaviour, and by declaring the binding effect of the Lancaster House Undertakin-

195 Award para. 544, p. 212.

196 Award, para. 544.

197 On that question see WELLENS, K. Negociations in the Case Law of the International Court of Justice: a Functional Analysis. Ashgate, 2014. p. 358.

198 The tribunal qualifies itself the decision as substantially satisfying for Mauritius in the paragraph 546 of the award. In the mark of this will to not aggravate the dispute enters the decision for the costs to be equally shared, para. 546, p. 213 of the award. 
gs. As a matter of fact, despite the strategic interests at stake, domestic or international jurisdictions that would have in the future to reconsider the Chagossians' claim or to settle the territorial dispute between Mauritius and UK, would not be able to ignore the legal obligations of the British government as they were recognized in this award, especially the commitment "to return the Archipelago to Mauritius when no longer needed for defense purposes".

\section{References}

ALLEN, S. International Law and the Resettlement of the (Outer) Chagos Islands. Human Rights Law Review, Oxford, v. 8, n. 4, p. 683-702, 2008.

Chagos Islanders v. Attorney General [2003] EWHC 2222 (Ouseley J).

Chagos Islanders v. Attorney General [2004] EWCA Civ 997 (Sedley LJ).

ECHR, Chagos Islanders v. United Kingdom, n. 35622/04, 12 December 2012.

MONEBHURRUN, N. Creating Marine Protected Areas to assert territorial jurisdiction against the Right of Abode of Native Populations: The Case of the Chagos Archielago. In: GÓMEZ, E. M. Vásquez; CINELLI, C. (Ed.). Regional Strategies to Maritime Security. A Comparative Perspective. Valence: Tirant Lo Blanch, 2014. p. 79-100.

ONU. United Nations Convention on the Law of the Sea, 1982.
ONU. United Nations General Assembly Resolution 2066(XX).

ONU. United Nations General Assembly Resolution 2232(XXI).

ONU. United Nations General Assembly Resolution 2357(XXII).

PCA, Chagos Marine Protected Area Arbitration (Mauritius v. United Kingdom), Award of 18 march 2015, 217 p. Available on the: <http://www.pca-cpa.org. Hearing transcripts and documents available at the same address.

$R$ (Bancoult) v. Secretary of State for foreign and Commonwealth Affairs (n. 1) [2001] QB 1067 (Laws LJ and Gribbs J).

$R$ (Bancoult) v. Secretary of State for Foreign and Commonwealth Affairs (n. 2) [2006] EWCH 1038 (Admn.) $-R$ (Bancoult) v. Secretary of State for Foreign and Commonwealth Affairs (n. 2) [2008] QB 365.

$R$ (Bancoult) v. Secretary of State for Foreign and Commonwealth Affairs (n. 2) [2009] 1 AC 453 (Hoffmann $\mathrm{LJ})$.

$R$ (Bancoult) v. Secretary of State for Foreign and Commonwealth Affairs (n. 3) [2013] EWHC 1502 (Admin) (Richards LJ).

$R$ (Bancoult) v. Secretary of State for Foreign and Commonwealth Affairs (n. 3) [2014] EWCA CIV 708.

Vienna Convention on Diplomatic Relations of 1961.

WELLENS, K. Negociations in the Case Law of the International Court of Justice: a Functional Analysis. Ashgate, 2014. 


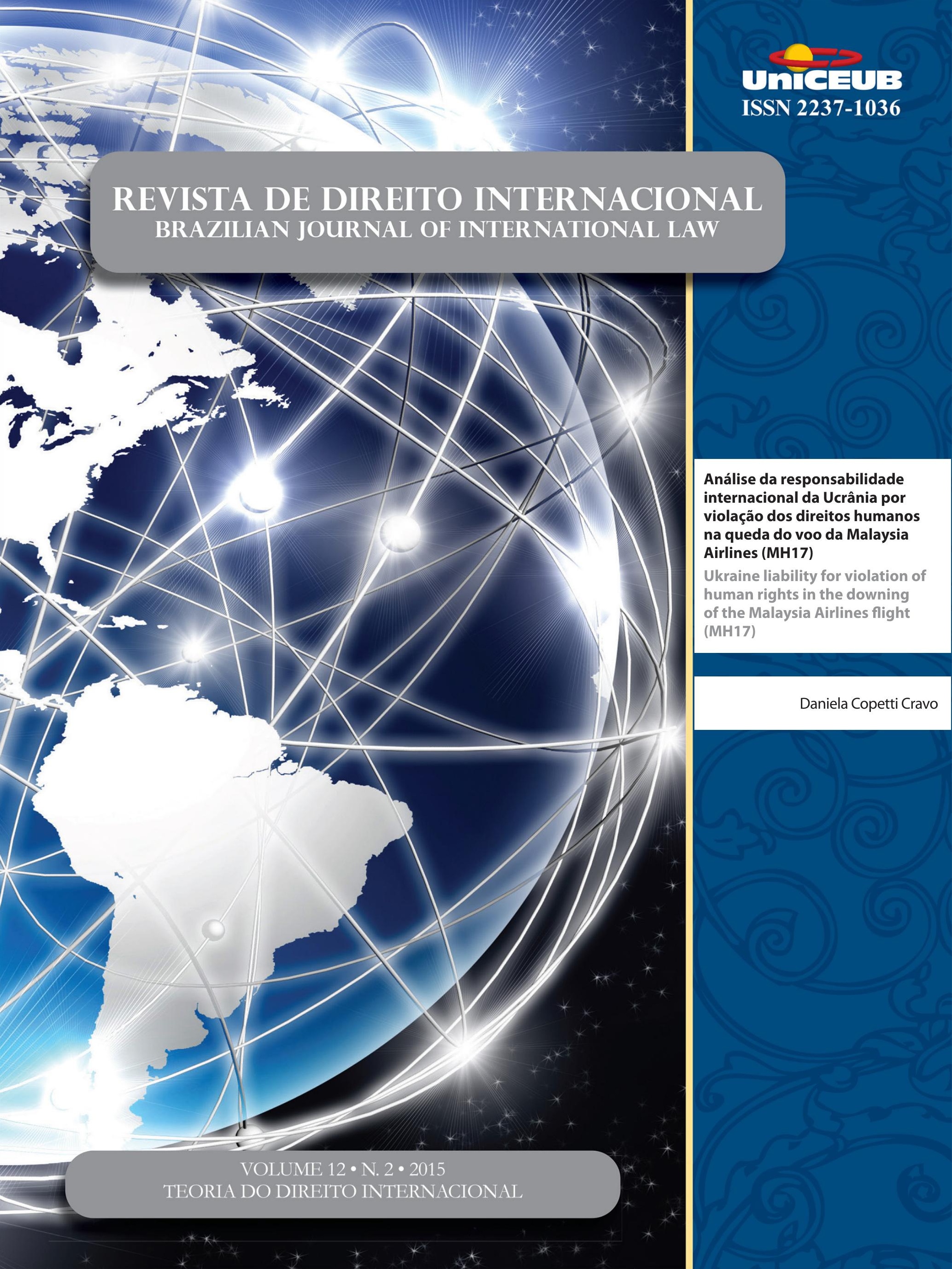




\title{
Análise da responsabilidade internacional da Ucrânia por violação dos direitos humanos na queda do voo da Malaysia Airlines (MH17)*
}

\author{
Ukraine liability for violation of human \\ rights in the downing of the Malaysia Airlines \\ flight (MH17)
}

Daniela Copetti Cravo**

\section{Resumo}

Sequer as investigações oficiais do abate do Voo MH17 no espaço aéreo da Ucrânia foram finalizadas, mas o caso já chegou à Corte Europeia de Direitos Humanos, por meio de ação movida por familiares de vítimas. Esses buscam a responsabilização da Ucrânia por violação dos direitos humanos; mas será que esta pode ser responsabilizada? Houve omissão pelo não fechamento do espaço aéreo? E, em caso positivo, qual é o fórum mais oportuno para buscar tal responsabilização? Não se deve falar em responsabilidade extraterritorial da Rússia? O propósito desse estudo, que se apoia no método dedutivo de abordagem de dados, consiste em tecer algumas possíveis respostas a tais questões, as quais apontam, como conclusão, para a responsabilidade da Ucrânia pela sua omissão ao não prudentemente fechar o seu espaço aéreo.

Palavras-chave: Voo MH17. Responsabilidade internacional. Corte Europeia de Direitos Humanos.

\section{Abstract}

Notwithstanding that not even the official investigations concerning the attack on the MH17 Flight around the Ukrainian airspace were concluded, the case has already arrived at the ECHR (European Court of Human Rights), through a lawsuit filed by the victim's families. Such lawsuit seeks to promote the responsibility of Ukraine for violating human rights. The issues that arise in this context are: is it possible to hold Ukraine accountable for this situation? Was there an omission by Ukraine's authorities for not shutting down it's airspace? Regarding this possibility, is the ECHR the most convenient forum to seek such responsibility? Could the extraterritorial responsibility of the Russian Federation be considered? Thus, the main purpose of this study, which relies on a deductive approach, is to bring forth some possible answers to this issue. Our efforts, therefore, point out to the plausibility of the accountability of Ukraine for failing to not act prudently and for not closing it's airspace during this conjuncture.

** Mestre e Doutoranda em Direito pela UFRGS. E-mail: danielacopetticravo@hotmail. com.
Recebido em 02/08/2015

Aprovado em 09/09/2015 
Keywords: MH17 flight. International responsibility. European Court of Human Rights.

\section{INTRODUÇão}

A Ucrânia, logo após decidir não assinar acordo com a União Europeia em 2013, passou a vivenciar sua maior crise desde a independência. O movimento que começou com protestos em Kiev, rapidamente se espalhou pelo país inteiro, tendo como pauta principal a mudança de regime e o protesto contra a corrupção.

Nessa senda, o governo se desestabilizou e os conflitos sociais evoluíram. Abriu-se, pois, uma janela de oportunidade para a região da Crimeia ${ }^{1}$ tão próxima cultura e etnicamente da Rússia ${ }^{2-3}$, sair do controle jurisdicional da Ucrânia.

Assim, no desenrolar de toda instabilidade institucional e social, houve a anexação formal pela Rússia da Crimeia. Essa, muito embora tenha sido referendada pela população local ${ }^{4-5}$, foi considerada ilegal no âmbito da ONU, por meio de adoção de Resolução pela Assembleia Geral (A/RES/68/262).

A anexação foi - justamente - o gatilho das lutas entre os movimentos pró-Rússia, que ganharam corpo em várias outras regiões da Ucrânia além da Crimeia e as forças ucranianas, mobilizadas por decreto do Presidente Ucraniano para conter as ameaças e agressões à integridade territorial do país.

1 MARXSEN, Christin. The crimea crisis: an international law perspective. Zeitschrift ausländisches öffentliches Recht und Völkerrecht, Heidelber, v. 74, n. 2, p. 367-391, 2014.

2 DUMONT, Gérard-François. L'Ukraine, une terre étrangère pour la Russie? Géostratégiques, Paris, n. 43, p. 69-90, nov. 2014.

3 MCGEE, Robert. Should crimea secede from Ukraine and become part of Russia (Again)? Journal of Accounting, Ethics and Public Policy, v. 2, n. 2, p. 1- 7, March 2, 2014.

4 ENGLE, Eric. A New Cold War? Cold Peace. Russia, Ukraine, and NATO. The University of St. Thomas Law Journal, Houston, n. 59, p. $97-174,2015$.

5 Nesse sentido, coloca Christakis: “Or, c'est précisément l'illicéité de l'intervention militaire russe en Crimée qui rend le processus de sécession et son annexion illicites. La conséquence qui en résulte est une obligation de non-reconnaissance de la nouvelle situation". Tradução livre autora: "Mas é precisamente a ilegalidade da intervenção militar russa na Crimeia que torna o processo de secessão e sua anexação ilegal. A conseqüência é uma obrigação de não reconhecimento da nova situação." CHRISTAKIS, Theodore. Les Conflits de Sécession en Crimée et dans l'Est de l'Ukraine et Le Droit International. Journal du Droit International, p. 23-48, 2014.
No meio desse conflito, o Voo comercial da Malaysia Airlines MH17 é abatido no leste da Ucrânia, em uma zona controlada pelos separatistas pró-Rússia. Todas as 298 pessoas a bordo, das mais diversas nacionalidades, morreram.

Muito embora as investigações oficiais, realizadas sob o manto da Resolução n. ${ }^{\circ} 2166$ do Conselho de Segurança da ONU, sequer tenham sido finalizadas, familiares de vítimas da queda do voo, invocando violações a direitos humanos, acionaram a Ucrânia perante a Corte Europeia de Direitos Humanos.

Mas quais seriam os fundamentos jurídicos e fáticos existentes no caso em apreço, que respaldam e dão sustento à ação dos familiares de vítimas? Preliminarmente, é necessário sopesar a própria legitimidade processual da Ucrânia, no polo passivo, para, num segundo momento, verificar a sua responsabilidade internacional por violação a direitos humanos.

Isso porque os dados oficiais até o momento informam que o abate ocorreu em uma zona controlada por separatistas pró-Rússia. Assim, caso seja comprovado um efetivo controle pelo governo russo desse movimento, com base no teste desenvolvido pela Corte Internacional de Justiça (CIJ) originariamente no Caso Nicarágua v. Estados Unidos da América 1986 ria uma responsabilidade extraterritorial da Rússia pelo ocorrido.

No entanto, além de o teste ser bastante rigoroso, como se verá ao longo desse estudo, seria bastante difícil afastar a obrigação primária da Ucrânia de garantir o gozo e a observância dos direitos humanos em seu território, nomeadamente no seu espaço aéreo, já que, assim, ela se comprometeu internacionalmente por meio da Convenção Europeia de Direitos Humanos.

Destarte, considerando-se a ausência de um due diligence pela Ucrânia, que mesmo depois de ter 4 aviões militares seus abatidos dias antes do Voo MH17, nada fez no sentido de fechar o seu espaço aéreo, como não a considerar parte legitima e cobrar sua responsabilidade, com fundamento na proteção internacional dos direitos humanos?

6 INTERNATIONAL COURT OF JUSTICE. Nicaragua vs. United States of America. Sentence on June 27, 1986. Available at: $<$ http: $/ /$ www.icj-cij.org/docket $/$ ?sum $=367 \& p 1=3 \& p 2=3 \&$ case $=7$ 0\&p3=5>. Access on: 16 dec. 2015. 
Destaca-se que essa proteção nasce para superar o próprio problema gerado pela positivação nacionalista, que deu respaldo às terríveis atrocidades cometidas no século XX, bem como para evitar que a interpretação unilateral dos direitos humanos pelos Estados seja usada como um instrumento para violações disfarçadas.

A proteção internacional é, portanto, subsidiária, a fim de que os Estados, ao falharem em promover os direitos humanos, inclusive no seu dever de prevenção e due diligence, sejam responsabilizados internacionalmente. Ou seja, quando esgotadas as vias internas, a tutela no âmbito internacional emerge com base no caráter objetivo que possuem tais direitos.

Para bem operacionalizar tal proteção internacional, vivenciou-se a criação de mecanismos, tanto de cunho global quanto regional, de natureza judicial ou quase judicial. Alguns desses, e é o que mais se deve dar destaque, possibilitam o acesso direto pelos indivíduos, sem qualquer necessidade de proteção diplomática, de cunho extremamente político, baseada — ademais na nacionalidade.

É com foco nessa valorização dos indivíduos na ordem internacional que houve a possibilidade de os familiares de vítimas do Voo MH17 recorrerem à Corte Europeia de Direitos Humanos, para responsabilizar a Ucrânia. Mas será que estariam, ademais, preenchidos os requisitos necessários para isso? Diante das peculiaridades do caso, quando pode ser considerado que houve um esgotamento das vias internas? E quais seriam essas?

Dessa feita, o estudo apresentado neste artigo, que se apoia no método dedutivo de abordagem de dados, busca apresentar fundamentos, com base na doutrina, em instrumentos normativos e na jurisprudência de Cortes Internacionais, da responsabilidade internacional da Ucrânia pela violação a direitos humanos perpetuada no seu espaço aéreo, afastando, pois, a responsabilidade extraterritorial da Rússia. Pretende-se, ademais, verificar como a Corte Europeia de Direitos Humanos pode ser considerada o fórum mais conveniente para apreciação do caso envolvendo o Voo MH17, apontando quais seriam os requisitos necessários para tanto. Em termos de utilidade e contribuição prática, a proposta deste trabalho consiste em, em última análise, fazer uma exposição indutiva da proteção internacional dos direitos humanos, partindo de um caso concreto; e uma releitura da responsabilidade estatal por omissão, confrontando, para tanto, diferentes decisões das cortes internacionais, mais especificamente as da Corte Internacional de Justiça, da Corte Europeia de Direitos Humanos e do Tribunal Penal para a ex-Iugoslávia.

\section{Teste do EFETIVo CONTROle: AFASTANDO A RESPONSABILIDADE EXTRATERRITORIAL DA RÚSSIA}

Em 9 de setembro de 2014, foi apresentado o relatório preliminar da investigação ${ }^{7}$ sobre a queda do avião na Ucrânia. Este concluiu que o Voo MH17 da Malaysia Airlines explodiu no ar provavelmente como resultado de um dano estrutural causado por um grande número de objetos de alta-tensão que penetraram, a partir do ambiente externo, o avião. Não há indícios de que a queda do avião teria sido causada por uma falha técnica ou por ações da tripulação.

Segundo Bachmann ${ }^{8}$, pode-se, nesse caso, estar diante de crime de guerra, genocídio ou até terrorismo. Com relação a essa última possibilidade, o caso do Voo MH17 traz alguma semelhança com o Caso Lockerbie, já que esse também versou sobre a explosão de avião civil, que, segundo investigações dos Estados Unidos e da Escócia, decorreu de ato terrorista?

7 KINGDOM OF NETHERLANDS. Dutch Safety board releases preliminary report on flight $M H 17$. Available at: <http://www.thenetherlands.org/news/2014/09/mh17-preliminary-report.html > . Access on: 30 jul. 2015.

8 BACHMANN, Sascha-Dominik Oliver Vladimir. Malaysia airlines flight MH17: the day Russia became a state sponsor of terrorism. Amicus Curiae, London, n. 95, p. 1-3, Aug. 2013.

9 Em 21 de dezembro de 1988, uma bomba no Voo 103 da Pan Am, que sobrevoava a cidade de Lockerbie na Escócia, explodiu, matando 259 passageiros e tribulantes, bem como 11 residentes da cidade de Lockerbie. Tanto o Lord Advocate of Scotland e o Grand Jury of US acusaram dois cidadãos líbios como responsáveis pela explosão. Consequentemente, tanto o Reino Unido, quanto os Estados Unidos, requisitaram à Líbia a extradição dos nacionais, para que a prossecução criminal ocorresse alternativamente em algum desses Estados. Alegando que em conformidade com a Convenção de Montreal as autoridades libanesas teriam jurisdição sobre o caso, a Líbia acionou a Corte Internacional de Justiça em 1971 (INTERNATIONAL COURT OF JUSTICE. Libya vs. United States of America. Sentence on Sept 23, 1971. Available at: $<$ http:/ $/$ www.icj-cij.org/docket/index.php?sum $=460 \&$ code $=$ lus\& $\mathrm{p} 1=3 \& \mathrm{p} 2=3 \&$ case $=89 \& \mathrm{k}=82 \& \mathrm{p} 3=5>$. Access on: $16 \mathrm{dec}$. 2015; e INTERNATIONAL COURT OF JUSTICE. United Kingdom of Great Britain and Northern Ireland v. Albania. 1948. Sentence on Mars 25, 1948. Available at: <http://www.icj-cij.org/docket/index. php?p1 $=3 \& p 2=3 \&$ case $=1 \& p 3=4>$. Access on: 16 dec. 2015). Em 2003, as partes notificaram a CIJ da celebração de acordo, no sentido de extinguir o processo. Os acusados foram julgados, pois, em um 
Apesar, então, de não se ter nenhuma conclusão (até o momento) acerca da autoria dos fatos ${ }^{10}$, muitas acusações preliminares foram tecidas aos insurgentes pró-Rússia, grande parte fundadas na própria declaração dada por esses ${ }^{11,}$ de que teriam abatido o Voo MH17 por engano. Será que nessa hipótese pode-se falar em responsabilidade da Rússia, pelo controle exercido sobre esses insurgentes? Está-se diante de uma responsabilidade extraterritorial?

A jurisprudência internacional vem sustentando há tempos que, para configurar a responsabilidade extraterritorial, se faz necessário o efetivo controle por parte do terceiro Estado, que no caso seria a Rússia. Nesse sentido, não se pode deixar de citar o caso Nicarágua v. Estados Unidos da América, julgado pela Corte Internacional de Justiça (CIJ) em $1986^{12}$.

O caso versa sobre a queda do regime ditatorial na Nicarágua, por meio de movimento popular, que levou ao poder a oposição socialista, do movimento sandinista. Em contraposição a esses, havia o CONTRAS (denominação dada ao grupo contrarrevolucionário da Nicarágua), integrado, inclusive, por facções leais à ex-ditadura. Esses eram financiados pelo governo dos Estados Unidos, primeiramente com financiamento direto e, quando esse foi proibido pelo Congresso da Nicarágua, indireto, por meio da venda de armas.

Por tal financiamento, Nicarágua submeteu o caso à Corte Internacional de Justiça em face dos Estados Unidos da América, alegando que esse país teria violado a sua soberania. Ademais, ao encorajar o CONTRAS (denominação dada ao grupo contrarrevolucionário da Nicarágua) a praticar violações aos direitos humanos (tais como, assassinatos e sequestros de cidadãos da Ni-

tribunal neutro na Holanda, composto por cinco juízes escoceses. 10 A previsão de divulgação oficial das investigações está prevista para outubro de 2015 DUTCH SAFETY BOARD. Investigation Crash MH17. July, 2014. Available at: < http://www.onderzoeksraad. $\mathrm{nl} /$ en/onderzoek/2049/investigation-crash-mh17-17-july-2014/ inzage/1643/progress-of-the-mh17-investigation\#fasen>. Access on: 16 dec. 2015.

11 HALL, John. We shot down MH17 thinking it was Ukrainian cargo plane'. MailOnline, London, July 24, 2014. Available at: <http://www.dailymail.co.uk/news/article-2703873/We-shotMH17-thinking-Ukrainian-cargo-plane-Sensational-admission-proRussian-says-realised-mistake-came-bodies-children-not-militarycrew.html>. Access on: 16 dec. 2015.

12 INTERNATIONAL COURT OF JUSTICE. Nicaragua vs. United States of America. Sentence on June 27, 1986. Available at: $<$ http: $/ /$ www.icj-cij.org $/$ docket $/$ ?sum $=367 \& p 1=3 \& p 2=3 \&$ case $=7$ $0 \& p 3=5>$. Access on: 16 dec. 2015. carágua), deveria ser condenado e responsabilizado por tais atos.

Essa última alegação é a mais pertinente à investigação da teoria do efetivo controle. E sobre esta, analisando o caso, a CIJ distinguiu em duas classes os grupos como o CONTRAS (denominação dada ao grupo contrarrevolucionário da Nicarágua), que não são juridicamente vinculadas a um Estado, mas podem atuar em nome destes. Assim, têm-se aqueles que são totalmente dependentes do Estado estrangeiro, inclusive com planejamento e direção; e outros que, embora financiados, mantêm certo grau de independência do Estado financiador.

Com base em tal distinção, a CIJ entendeu que o CONTRAS caracterizava-se como esse segundo grupo. Assim, não houve o efetivo controle de suas ações pelos Estados Unidos, uma vez que inexistiu a emissão de instruções em relação a operações específicas, nem o controle da execução dessas, com a pressão necessária para que fossem realizadas, razão pela qual a CIJ afastou a responsabilização do Estado americano. Essa análise ficou conhecida como teste do efetivo controle.

Esse teste foi posteriormente revisto pelo Tribunal Penal Internacional para a ex-Iugoslávia no caso Tadić $^{13}$, de uma maneira mais ampla do que o aplicado no caso acima mencionado. No entanto, Cassese ${ }^{14}$ destaca que o teste foi utilizado para justificar a competência do Tribunal e a configuração dos crimes como internacionais, razão pela qual essa amplitude deve ser interpretada com ressalva, ainda mais porque o caso não versou sobre responsabilidade Estatal.

Mais recentemente, cita-se a utilização do teste pela CIJ quando do julgamento do genocídio ocorrido em Srebrenica pelas forças armadas do Exército servo-bósnio em 1995, atribuído à República Federal da Iugoslávia ${ }^{15}$. Nessa oportunidade, a Corte reafirmou o teste nos moldes originais, rechaçando aquele utilizado pelo Tribunal Penal para a ex-

13 UNITED NATIONS. International Tribunal for the Prosecution of Persons Responsible for Serious Violations of International Humanitarian Law Committed in the Territory of the Former Yugoslavia since 199. Prosecutor v. Du[Ko Tadi]. Sentence on July 15, 1999. Available at: <http://www.icty.org/x/cases/tadic/acjug/en/tad-aj990715e. pdf $>$. Access on: 16 dec. 2015.

14 CASSESE, Antonio. The Nicaragua and tadić tests revisited in light of the ICJ judgment on genocide in Bosnia. The European Journal of International Law, Oxford, v. 18 n. 4, p. 649-668, 2007.

15 INTERNATIONAL COURT OF JUSTICE. Case Bosnia and Herzegovina vs. Serbia and Montenegro. Sentence on July 11, 2006. Available at: <http://www.icj-cij.org/docket/files/91/13687.pdf>. Access on: 16 dec. 2015. 
-Iugoslávia. Nesse sentido, Gill ${ }^{16}$ esclarece:

On this point, the Court did not follow the ICTY's standard of overall control in relation to Yugoslavia/Serbia's relationship to the Bosnian Serb armed forces and militias, instead it reiterated its own standard of effective control which it had first put forward in its 1986 Nicaragua decision. Yugoslavia's responsibility was limited to its failure to (attempt to) prevent the massacre and did not encompass direct responsibility for either the commission of genocide or complicity in the commission of genocide ${ }^{17}$.

Assim, para que a Rússia possa ser considerada responsável no caso em apreço, há a necessidade de comprovação de que, além do abate do Voo ter sido provocado pelo movimento pró-Rússia, esses agiram sob o efetivo controle ${ }^{18}$ da Rússia, considerado de maneira mais estrita do que no caso Tadić.

Destarte, sem um relatório final das investigações, não há como sustentar a priori tal responsabilidade. No mesmo sentido recentes posicionamentos da Corte Europeia de Direitos Humanos que afastam o teste do efetivo controle.

Nesse sentindo, a Corte tem entendido como responsável o Estado onde foram perpetuadas as violações aos direitos humanos, independentemente de ter ocorrido controle ou apoio de outro Estado na prática do ato. Esse é o precedente estampado no caso Ilascu v. Moldova e Rússia julgado em $2004^{19}$. O caso é decorrente da Guerra da Transnístria, em que por meio de um sentimento separatista, apoiado pela Rússia, essa região desejava ser independente e se separar da Moldá-

16 GILL, T. D. The genocide case: reflections on the ICJ's decision in Bosnia-Herzegovina v Serbia. Available at: <http://www.haguejusticeportal.net/index.php?id=7266> . Access on: 16 july 2015 .

17 Tradução livre autora: Nesse ponto, a Corte não seguiu o teste do Tribunal Penal para a ex-Iugoslávia de controle total em relação ao relacionamento entre Iugoslávia/Sérvia para as forças armadas servo-bósnias e milícias; em vez disso, reiterou o seu próprio padrão de controle efetivo apresentado pela primeira vez na sua decisão sobre Nicarágua em 1986. A responsabilidade da Iugoslávia foi limitada à sua incapacidade de (tentar) evitar o massacre e não abrange a responsabilidade direta com a realização do genocídio ou com a sua cumplicidade em relação a essa realização. GILL, T. D. The Genocide case: reflections on the ICJ's decision in Bosnia-Herzegovina v Serbia. Available at: <http://www.haguejusticeportal.net/index. php?id=7266> . Access on: 16 july 2015 .

18 Destaca-se que o efetivo controle também está previsto no Projeto da Comissão de Direito Internacional das Nações Unidas sobre Responsabilidade Internacional dos Estados de 2001.

19 EUROPEAN COURT OF HUMAN RIGHTS. Ilascu v. Moldova and Russia. Sentence on July 08, 2004. Available at: <http:// hudoc.echr.coe.int/eng?i=001-59454>. Access on: 16 dec. 2015. via. A corte, assim, estabeleceu:

quando um Estado contratante éimpedido de exercer a sua autoridade sobre a totalidade do seu território por uma situação de fato constrangedora, como quando um regime separatista está configurado, seja ou acompanhado por uma ocupação militar do outro Estado, não por isso deixa de ter jurisdição na acepção do artigo $1^{\circ}$ da Convenção sobre a parte do seu território temporariamente sujeita a uma autoridade local sustentada por forças rebeldes ou por outro Estado. [...]. O Estado em questão deve esforçar-se, com todos os meios legais e diplomáticos à sua disposição vis-à-vis Estados estrangeiros e organizações internacionais, para continuar a garantir o gozo dos direitos e liberdades definidos na Convenção ${ }^{20 .}$

No entanto, entende-se não ser cabível aplicar nesse contexto o recente precedente do caso Cyprus v Turkey $^{21}$, uma vez que nesse houve efetiva invasão militar por parte da Turquia em Cyprus. Dessa feita, veja-se como a Ucrânia poderia ter impedido as violações que ocorreram no espaço aéreo sobre sua soberania, o que faz emergir a sua responsabilidade.

\section{RESPONSABILIDAdE da UCRÂNIA PELO NÃO FECHAMENTO DO SEU ESPAÇO AÉREO}

Muito pouco antes da queda do Voo MH17, 4 aviões militares ucranianos já tinham sido abatidos desde de junho de 2014 pelos insurgentes ${ }^{22}$. Dois desses foram abatidos em alta altitude, caso similar ao que ocorreu com o Voo MH17.

Será que, diante desse cenário, não seria previsível o evento danoso? E caso fosse, teria a Ucrânia, por meio de obrigações assumidas no plano internacional, obrigação de evitar tal dano, empreendendo esforços para que esse não ocorresse? Há responsabilidade internacional? Qual é a responsabilidade primária?

Acredita-se que sim, já que houve descumprimento de dever previamente assumido. Veja-se, a Ucrânia, por ser membro do Conselho Europeu, participa do sistema

20 Tradução livre autora.

21 EUROPEAN COURT OF HUMAN RIGHTS. Cyprus v. Turkey, 2014. Sentence on May 10, 2001. Available at: < http://hudoc. echr.coe.int/eng?i=001-59454>. Access on: 16 dec. 2015.

22 WHY WAS MH17, a Civilian Airliner, Flying over a War Zone? The Economist, London, July 21, 2014. Available at: < http://www. economist.com/blogs/economist-explains/2014/07/economistexplains-14>. Access on: 16 dec. 2015. 
europeu de proteção aos direitos humanos e está vinculada à Convenção Europeia de Direitos Humanos.

E quais os deveres previstos na Convenção que foram violados? $\mathrm{O}$ direito à vida, previsto no artigo $2^{\circ}$, e o direito ao respeito pela vida privada e familiar, previsto no artigo $8^{\circ}$. Mas será que esses deveres existem também no que toca à prevenção e independem de culpa ou dolo? Trata-se de uma responsabilidade objetiva?

Nessa perspectiva, este artigo assenta-se nas lições de Cançado Trindade ${ }^{23}$, referentes ao fato de que a responsabilidade no que toca aos direitos humanos é objetiva ou absoluta, calcada no elemento do risco, não sendo necessário identificar erro ou dolo. Conclui Cançado Trindade ${ }^{24}$ :

no meu entendimento, a responsabilidade internacional do estado está configurada desde o momento que esse falha em cumprir com uma obrigação internacional, independente da verificação do erro ou da culpa de sua parte, e a ocorrência de um dano adicional. No lugar de uma atitude psicológica presumida ou erro por parte dos agentes públicos, o que realmente determina é a conduta objetiva do Estado ( a due diligence para evitar às violações aos direitos humanos). Pode-se, assim, chegar no estabelecimento de uma objetiva ou absoluta responsabilidade do Estado a partir da violação de suas obrigações internacionais convencionais de proteção dos direitos humanos. Nessa responsabilidade objetiva reside o dever de prevenção 25 .

Destarte, a Ucrânia tinha sim o dever de prevenir o ocorrido, não empreendendo a due diligence que lhe era exigida. Reforça esse posicionamento o próprio Projeto da Comissão de Direito Internacional das Nações Unidas sobre Responsabilidade Internacional dos Estados de $2001^{26}$, ao prever a responsabilidade Estatal por atos omissivos.

Nesse mesmo projeto, há previsão de exclusão de responsabilidade por força maior, no artigo $23^{27}$, no se-

23 TRINDADE, Antônio Cançado. The construction of a bumanized international law. Leiden: Brill, 2014.

24 TRINDADE, Antônio Cançado. The construction of a bumanized international law. Leiden: Brill, 2014. p. 254.

25 Tradução livre autora.

26 UNITED NATIONS. Draft Articles on Responsibility of States for Internationally Wrongful Acts, with Commentaries. Available at: $<$ http://legal.un.org/ilc/texts/instruments/english/commentaries/9_6_2001.pdf>. Access on: 16 dec. 2015.

27 UNITED NATIONS. Draft Articles on Responsibility of States for Internationally Wrongful Acts, with Commentaries. Available at: $<$ http://legal.un.org/ilc/texts/instruments/english/commentaries/9_6_2001.pdf>. Access on: 16 dec. 2015. guinte sentindo:

the wrongfulness of an act of a State not in conformity with an international obligation of that State is precluded if the act is due to force majeure, that is the occurrence of an irresistible force or of an unforeseen event, beyond the control of the State, making it materially impossible in the circumstances to perform the obligation ${ }^{28}$.

Acredita-se que, pelo nível de agravamento que os conflitos encontravam-se no território ucraniano, não se pode dizer que o abate do Voo foi totalmente imprevisto. Há relatos que a Eurocontrol, organização que gerencia o espaço aéreo europeu, teria instado, muito embora sem força vinculativa, o governo ucraniano para que este fechasse o seu espaço aéreo, após as reiteradas quedas de aviões militares ucranianos por parte dos rebeldes pró-Rússia ${ }^{29}$.

Diante de todo cenário, outra conclusão não há de que a Ucrânia efetivamente assumiu o risco de que violações como as perpetuadas com o abate do Voo MH17 ocorressem. Especula-se que houve interesse financeiro por parte da Ucrânia, já que essa recebia taxas pelo trânsito aéreo, cerca de 700 voos por dia, o que equivale, aproximadamente, a muitos milhões por mês ${ }^{30}$.

Com base no que foi anteriormente exposto nesse estudo, não há como, pois, afastar a responsabilidade da Ucrânia. Além disso, não podemos deixar de mencionar um importante precedente da Corte Internacional de Justiça no Caso do Canal de Corfu, que versa igualmente sobre atos omissivos para parte da Albânia ${ }^{31}$, uma vez que dois destroyers britânicos explodiram por causa de minas nas águas territoriais da Albânia, em 1945, o que

28 Tradução livre autora: "A ilicitude de um ato de um Estado que não esteja em conformidade com uma obrigação internacional desse Estado está excluída se o ato é devido a força maior, que é a ocorrência de uma força irresistível ou de um imprevistoevento, fora do controle do Estado, tornando materialmente impossível nas circunstâncias cumprir a obrigação".

29 PANCEVSKI, Bojan. Kiev Was Urged to Close Airspace Days Before MH17 Tragedy. Russia Insider, Greenwich, Dec. 8, 2014. Available at: <http://russia-insider.com/en/ukraine/2014/12/08/0323-34pm/kiev_was_urged_close_airspace_days_mh17_tragedy $>$. Access on: 16 dec. 2015.

30 HUDSON, Alexandra. MH17 Victim's Mum is Suing Ukraine for $\$ 1 \mathrm{~m}$ : for Failing to Close Country's Airspace. Mirror, Liverpool, Nov 30. 2014. Available at: <http://www.mirror.co.uk/news/ world-news/mh17-victims-mum-suing-ukraine-4724052>. Access on: 16 dec. 2015.

31 INTERNATIONAL COURT OF JUSTICE. United Kingdom of Great Britain and Northern Ireland v. Albania. 1948. Sentence on Mars 25, 1948. Available at: <http://www.icj-cij.org/docket/index. php?p1 $=3 \& p 2=3 \&$ case $=1 \& p 3=4>$. Access on: 16 dec. 2015. 
acarretou a morte dos tripulantes, além dos danos materiais.

A CIJ expressou, em tal ocasião, que cada Estado não pode permitir que seu território seja utilizado para a prática de atos contrários aos direitos dos outros estados. Assim, mesmo que os responsáveis pelas minas não tenham sido identificados, a Albânia seria, sim, responsável, no seguinte sentido:

\begin{abstract}
as obrigações que incumbiam as autoridades albanesas consistiam em fazer conhecida, no interesse da navegação em geral, a existência de um campo de minas nas águas territoriais albanesas e em advertir os navios de guerra britânicos, no momento de sua aproximação, do perigo iminente ao qual os expunha esse campo de minas. Essas obrigações fundam-se não na Convenção VIII de Haia de 1907, que é aplicável em tempos de guerra, mas sobre certos princípios gerais e bem reconhecidos, tais como as considerações elementares de humanidade, mais absolutas ainda em tempo de paz do que em tempo de guerra; o princípio da liberdade das comunicações marítimas; e a obrigação de todo Estado de não permitir que seu território seja utilizado para o fim de atos contrários aos direitos dos outros Estados ${ }^{32}$.
\end{abstract}

Fundamentadas as razões pelas quais a Ucrânia pode ser responsabilizada pelo dever de ter prevenido o ocorrido, vejamos qual seria o fórum mais adequado para tanto.

\section{Forum Conveniens: Corte Europeia de Direitos Humanos}

Em face dessa possível responsabilidade da Ucrânia, ao falhar em prevenir violações aos direitos humanos, qual seria o fórum mais conveniente para julgá-la? Está-se diante de um Grotian Moment, para criação de um novo foro?

Uma proposta de criação de um Tribunal Internacional Criminal para o Voo MH17 da Malaysia Airlines foi apresentada em julho 2015 ao Conselho de Segurança das Nações Unidas. No entanto, não foi possível a adoção desta, já que houve o veto da Rússia ${ }^{33 .}$

32 INTERNATIONAL COURT OF JUSTICE. United Kingdom of Great Britain and Northern Ireland v. Albania. 1948. Sentence on Mars 25, 1948. Available at: <http://www.icj-cij.org/docket/index. php?p1 $=3 \& p 2=3 \&$ case $=1 \& p 3=4>$. Access on: 16 dec. 2015.

33 UNITED NATIONS. Security Council fails to adopt proposal to create tribunal on crash of Malaysian Airlines flight MH17. Available at: $<$ http://www.un.org/apps/news/story.asp?NewsID=51530>. Access on: 16 dec. 2015
O veto foi recebido com desapontamento, especialmente por parte da Malásia. A proposta de tribunal, que seria aprovada por meio de resolução, possibilitaria uma investigação e um posterior julgamento criminal do caso $^{34}$.

Mas, então, tendo com base as cortes internacionais já existentes, quais poderiam ser instadas a se manifestar sobre o caso? Primeiramente, fala-se na CIJ, que é a mais alta corte no sistema das Nações Unidas.

Esta, no entanto, não está aberta a petições de vítimas, nem sequer tem a capacidade de promover persecuções criminais individuais. Possui, por outro lado, atribuição para determinar quando Estados são responsáveis por certos atos, como pelo financiamento de grupos armados (Rússia) ${ }^{35}$ ou pela falha de não fechar o seu espaço aéreo (Ucrânia).

Ocorre que essa submissão à jurisdição da CIJ não é compulsória, deve haver um reconhecimento da sua competência contenciosa. André de Carvalho Ramos ${ }^{36}$ menciona que esse reconhecimento pode ocorrer de quatro formas: (a) cláusula Raul Fernandes, (cláusula facultativa de jurisdição obrigatória), (b) previsão em acordos específicos, (c) reconhecimento para o caso, e (d) prorrogação da competência.

Nesse sentido, destaca-se que nem a Rússia nem a Ucrânia aderiram à cláusula Raul Fernandes. E, da mesma forma, supõe-se que seja bastante improvável que essas venham a reconhecer caso eventualmente acionadas para o deslinde do caso em apreço.

Outra corte que pode assumir um papel interessante é o Tribunal Penal Internacional, responsável por julgar certos crimes internacionais, nomeadamente aqueles considerados como contra a humanidade. Nesse sentido, é essencial definir e caracterizar os atos que ocasionaram o abate dos $\mathrm{MH} 17$, até mesmo porque esse tribunal não possui competência no que toca a atos de terrorismo ${ }^{37}$.

34 UNITED NATIONS. Security Council fails to adopt proposal to create tribunal on crash of Malaysian Airlines flight MH17. Available at: $<$ http://www.un.org/apps/news/story.asp?NewsID=51530>. Access on: 16 dec. 2015.

35 AUSTRALIAN NATIONAL UNIVERSITY. MH17: the legal path to justice. Available at: <https://law.anu.edu.au/news/law/ mh17-legal-path-justice>. Access on: 2 aug. 2015.

36 RAMOS, André de Carvalho. Processo internacional de direitos bumanos. São Paulo: Saraiva, 2014.

37 AUSTRALIAN NATIONAL UNIVERSITY. MH17: the legal path to justice. Available at: <https://law.anu.edu.au/news/law/ 
No entanto, cabe ressaltar que nem a Rússia nem a Ucrânia são partes do Estatuto de Roma. Esses dois Estados o assinaram, mas não ratificaram. Ainda que seja possível o reconhecimento da jurisdição por não membros, conforme o artigo 12 do Estatuto de Roma, nada garante que esse reconhecimento seja de fato exercido ${ }^{38}$.

Ao lado dessas Cortes, há aquelas decorrentes dos sistemas regionais de proteção aos direitos humanos, tais como a Corte Europeia de Direitos Humanos. O grande destaque que deve ser dado é que essa, diferentemente das apontadas acima, permite o acesso direto por individuais.

Segundo André de Carvalho Ramos ${ }^{39}$, a apresentação de petições individuais teve início com o Protocolo 11. Em 2010, a Corte Europeia totalizou um número de recebimento de mais de 61 mil petições ${ }^{40}$, o que é deveras expressivo.

Esse modelo de petições constitui uma valorização do indivíduo na ordem internacional fantástico, que deve ser bem elogiado. É adotado, ademais, nos mecanismos quase judiciais, tais como os comitês de tratados específicos.

Um destaque importante refere-se ao fato de que a Corte Europeia não exige que o autor tenha nacionalidade do Estado réu ou a estadia regular neste. Essa possibilidade é muito importante, especialmente no caso em apreço, já que nenhuma das vítimas do Voo MH17 eram ucranianas.

André de Carvalho Ramos ${ }^{41}$ enumera fatores que podem gerar a inadmissibilidade da petição:

os motivos da inadmissibilidade são os seguintes:
1) ausência de esgotamento dos recursos internos;
2) perda do prazo de seis meses a contar da data
da decisão interna definitiva para peticionar à Corte
EDH; 3) anonimato da petição; 4) coisa julgada,
caso a petição seja essencial, idêntica a uma petição
anteriormente examinada pela Corte ou já submetida

mh17-legal-path-justice>. Access on: 2 aug. 2015.

38 DOBRIANSKY, Paula J. Russia should be prosecuted for its crimes against humanity. The Washington Post, Washington, Feb. 12, 2015. Available at: <https://www.washingtonpost.com/ opinions/the-icc-must-prosecute-russia/2015/02/12/1755105cb2c0-11e4-827f-93f454140e2b_story.html>. Access on: $16 \mathrm{dec}$. 2015.

39 RAMOS, André de Carvalho. Processo internacional de direitos bumanos. São Paulo: Saraiva, 2014.

40 RAMOS, André de Carvalho. Processo internacional de direitos humanos. São Paulo: Saraiva, 2014.

41 RAMOS, André de Carvalho. Processo internacional de direitos bumanos. São Paulo: Saraiva, 2014. a outra instância internacional de direitos humanos sem qualquer fato novo; 5) teor incompatível com o disposto na Convenção ou manifestamente mal fundada ou com caráter abusivo; e, finalmente, 6) não ocorrência de qualquer prejuízo significativo ou matéria de grave indagação, salvo se o respeito pelos direitos exigir uma apreciação da petição.

Assim, faz-se necessário, dentre os requisitos, o prévio esgotamento dos recursos internos, para que a Corte Europeia de Direitos Humanos possa ser acionada. Mas, no caso do Voo MH17, quais seriam esses recursos internos? Seriam os da Ucrânia ou os do país de residência das vítimas e/ou seus familiares?

Como o "crime" ocorreu no seu espaço aéreo, evidente que a Ucrânia, de qualquer forma, teria jurisdição para a persecução. Mas diante de toda a fragilidade institucional com as disputas que vêm ocorrendo no local, será que é possível imaginar que essa persecução efetivamente ocorra?

Ademais, considerando as dimensões internacionais, pode-se visualizar a competência de Estados como Holanda, Malásia, Austrália e outros para julgar o caso, com base na jurisdição universal, respaldada na Convenção de Montreal sobre atos ilícitos contra a aviação civil ${ }^{42}$.

Veja-se que dessa forma é muito complicado prever qual seria o esgotamento prévio que os familiares das vítimas deveriam recorrer antes de chegarem até a Corte Europeia de Direitos Humanos. Por outro lado, a própria situação delicada e os inúmeros elementos internacionais do caso não podem servir como entraves à reparação desses familiares. Dessa feita, o caso já instaurado perante a Corte Europeia de Direitos Humanos sem dúvida será paradigmático, até mesmo nas questões preliminares que terá que enfrentar.

\section{Considerações finais}

Ainda que a Rússia pudesse vir a ser responsabilizada com base no teste do efetivo controle cunhado pela CIJ no caso Nicarágua v. Estados Unidos da América $(1986)^{43}$ e revisto, mais recentemente, no caso Bósnia

42 AUSTRALIAN NATIONAL UNIVERSITY. MH17: the legal path to justice. Available at: <https://law.anu.edu.au/news/law/ mh17-legal-path-justice>. Access on: 2 aug. 2015.

43 INTERNATIONAL COURT OF JUSTICE. Nicaragua vs. United States of America. Sentence on June 27, 1986. Available at: $<$ http: $/ /$ www.icj-cij.org $/$ docket $/$ ?sum $=367 \& \mathrm{p} 1=3 \& \mathrm{p} 2=3 \&$ case $=7$ 
e Herzegovina v. Sérvia e Montenegro (2006) ${ }^{44}$, não há como afastar a responsabilidade primária da Ucrânia por violações aos direitos humanos ocorridos no seu espaço aéreo, muito embora essas tenham sido provocadas por insurgentes. Nesse sentido, exalta-se o entendimento da Corte Europeia de Direitos Humanos (Ilascu v. Moldávia e Rússia, 2004) ${ }^{45}$ de que determinado Estado, mesmo que possua em seu território um regime separatista configurado, deve esforçar-se, por todos os meios legais e diplomáticos disponíveis, para continuar a garantir os direitos previstos na Convenção Europeia de Direitos Humanos.

Assim, houve falha da Ucrânia no seu dever de proteção e due diligence, fazendo emergir a sua responsabilidade. Essa independe de culpa ou dolo por parte do Estado violador, sendo, pois, objetiva e, até mesmo, absoluta.

O não fechamento do espaço aéreo da Ucrânia, mesmo após ter vários aviões seus abatidos, constitui uma grave omissão. A responsabilidade internacional por atos omissivos já foi apreciada no caso Reino Unido da Grã Bretanha e Irlanda do Norte v. Albânia julgado pela CIJ, cuja conclusão aplica-se analogicamente ao caso do Voo MH17: "é obrigação de todo Estado de não permitir que seu território seja utilizado para o fim de atos contrários aos direitos dos outros Estados" ${ }^{\prime 4}$.

Em última análise, havendo fundamentos para sustentar a responsabilidade internacional da Ucrânia por violações a direitos humanos, verificou-se, ao longo desse estudo, que a Corte Europeia de Direitos Humanos é o fórum mais conveniente para que essa seja apurada, especialmente considerando-se o acesso a esta por meio dos indivíduos prejudicados pela falha da Ucrânia no seu dever de prevenir. Questão controversa, no entanto, que dependerá de um juízo da Corte, diz respeito ao esgotamento dos recursos internos. Espera-se, todavia, que esse não seja utilizado como entrave à reparação

0\&p3=5>. Access on: 16 dec. 2015.

44 INTERNATIONAL COURT OF JUSTICE. Case Bosnia and Herzegovina vs. Serbia and Montenegro. Sentence on July 11, 2006. Available at: <http://www.icj-cij.org/docket/files/91/13687.pdf>. Access on: 16 dec. 2015

45 EUROPEAN COURT OF HUMAN RIGHTS. Ilascu v. Moldova and Russia. Sentence on July 08, 2004. Available at: <http:// hudoc.echr.coe.int/eng?i=001-59454>. Access on: 16 dec. 2015. 46 INTERNATIONAL COURT OF JUSTICE. United Kingdom of Great Britain and Northern Ireland v. Albania. 1948. Sentence on Mars 25, 1948. Available at: <http://www.icj-cij.org/docket/index. php?p1 $=3 \& p 2=3 \&$ case $=1 \& p 3=4>$. Access on: 16 dec. 2015. dos danos sofridos com o abate, especialmente considerando as grandes peculiaridades do caso.

\section{ReferênCias}

AUSTRALIAN NATIONAL UNIVERSITY. MH17: the legal path to justice. Available at: <https://law.anu. edu.au/news/law/mh17-legal-path-justice $>$. Access on: 2 aug. 2015.

BACHMANN, Sascha-Dominik Oliver Vladimir. Malaysia airlines flight MH17: the day Russia became a state sponsor of terrorism. Amicus Curiae, London, n. 95, p. 1-3, Aug. 2013.

CASSESE, Antonio. The Nicaragua and tadić tests revisited in light of the ICJ judgment on genocide in Bosnia. The European Journal of International Law, Oxford, v. 18 n. 4, p. 649-668, 2007.

CHRISTAKIS, Theodore. Les Conflits de Sécession en Crimée et dans l'Est de l'Ukraine et Le Droit International. Journal du Droit International, p. 23-48, 2014.

DOBRIANSKY, Paula J. Russia should be prosecuted for its crimes against humanity. The Washington Post, Washington, Feb. 12, 2015. Available at: < https://www. washingtonpost.com/opinions/the-icc-must-prosecute-russia/2015/02/12/1755105c-b2c0-11e4-827f93f454140e2b_story.html>. Access on: 16 dec. 2015.

DUMONT, Gérard-François. L'Ukraine, une terre étrangère pour la Russie? Géostratégiques, Paris, n. 43, p. 69-90, nov. 2014.

DUTCH SAFETY BOARD. Investigation Crash MH17. July, 2014. Available at: <http://www.onderzoeksraad.nl/en/onderzoek/2049/investigation-crashmh17-17-july-2014/inzage/1643/progress-of-themh17-investigation\#fasen>. Access on: 16 dec. 2015.

ENGLE, Eric. A New Cold War? Cold Peace. Russia, Ukraine, and NATO. The University of St. Thomas Law Journal, Houston, n. 59, p. 97-174, 2015.

EUROPEAN COURT OF HUMAN RIGHTS. Cyprus v. Turkey, 2014. Sentence on May 10, 2001. Available at: <http://hudoc.echr.coe.int/eng?i=001-59454>. Access on: 16 dec. 2015.

EUROPEAN COURT OF HUMAN RIGHTS. Ilascu v. Moldova and Russia. Sentence on July 08, 2004. Availa- 
ble at: <http://hudoc.echr.coe.int/eng?i=001-59454>. Access on: 16 dec. 2015.

GILL, T. D. The Genocide case: reflections on the ICJ's decision in Bosnia-Herzegovina v Serbia. Available at: <http://www.haguejusticeportal.net/index. php?id $=7266>$. Access on: 16 july 2015.

HALL, John. We shot down MH17 thinking it was Ukrainian cargo plane'. MailOnline, London, July 24, 2014. Available at: < http:/ /www.dailymail.co.uk/news/ article-2703873/We-shot-MH17-thinking-Ukrainiancargo-plane-Sensational-admission-pro-Russian-saysrealised-mistake-came-bodies-children-not-militarycrew.html>. Access on: 16 dec. 2015.

HUDSON, Alexandra. MH17 Victim's Mum is Suing Ukraine for $\$ 1 \mathrm{~m}$ : for Failing to Close Country's Airspace. Mirror, Liverpool, Nov 30. 2014. Available at: <http://www.mirror.co.uk/news/world-news/mh17victims-mum-suing-ukraine-4724052>. Access on: 16 dec. 2015.

INTERNATIONAL COURT OF JUSTICE. Líbya vs. United States of America. Sentence on Sept 23, 1971. Available at: <http://www.icj-cij.org/docket/index.ph $\mathrm{p}$ ? sum $=460 \&$ code $=$ lus \&p $1=3 \& \mathrm{p} 2=3 \&$ case $=89 \& \mathrm{k}=82$ \&p3=5>. Access on: 16 dec. 2015.

INTERNATIONAL COURT OF JUSTICE. United Kingdom of Great Britain and Northern Ireland v. Albania. 1948. Sentence on Mars 25, 1948. Available at: <http://www.icj-cij.org/docket/index. php?p1 $=3 \& \mathrm{p} 2=3 \&$ case $=1 \& \mathrm{p} 3=4>$. Access on: $16 \mathrm{dec}$. 2015.

INTERNATIONAL COURT OF JUSTICE. Case Bosnia and Herzegovina vs. Serbia and Montenegro. Sentence on July 11, 2006. Available at: <http://www. icj-cij.org/docket/files/91/13687.pdf>. Access on: 16 dec. 2015.

INTERNATIONAL COURT OF JUSTICE. Líbya vs. United Kingdom. Sentence on Sept 23, 1971. Available at: <http://www.icj-cij.org/docket/index.php?sum $=46$ $0 \& \mathrm{p} 1=3 \& \mathrm{p} 2=3 \& \mathrm{k}=82 \&$ case $=88 \& \mathrm{p} 3=0>$. Access on: 16 dec. 2015.

INTERNATIONAL COURT OF JUSTICE. Nicaragua vs. United States of America. Sentence on June 27, 1986. Available at: <http://www.icj-cij.org/docket/?s $\mathrm{um}=367 \& \mathrm{p} 1=3 \& \mathrm{p} 2=3 \&$ case $=70 \& \mathrm{p} 3=5>$. Access on: 16 dec. 2015.
KINGDOM OF NETHERLANDS. Dutch Safety board releases preliminary report on flight MH17. Available at: <http://www.the-netherlands.org/ news/2014/09/mh17-preliminary-report.html $>$. Access on: 30 july 2015.

MARXSEN, Christin. The crimea crisis: an international law perspective. Zeitschrift ausländisches öffentliches Recht und Völkerrecht, Heidelber, v. 74, n. 2, p. 367-391, 2014.

MCGEE, Robert. Should crimea secede from Ukraine and become part of Russia (Again)? Journal of Accounting, Ethics and Public Policy, v. 2, n. 2, p, 1-7, March 2, 2014.

PANCEVSKI, Bojan. Kiev Was Urged to Close Airspace Days Before MH17 Tragedy. Russia Insider, Greenwich, Dec. 8, 2014. Available at: <http://russiainsider.com/en/ukraine/2014/12/08/03-23-34pm/ kiev_was_urged_close_airspace_days_mh17_tragedy $>$. Access on: 16 dec. 2015.

RAMOS, André de Carvalho. Processo internacional de direitos humanos. São Paulo: Saraiva, 2014.

TRINDADE, Antônio Cançado. The construction of a humanized international law. Leiden: Brill, 2014.

UNITED NATIONS. Draft Articles on Responsibility of States for Internationally Wrongful Acts, with Commentaries. Available at: <http://legal.un.org/ilc/texts/ instruments/english/commentaries/9_6_2001.pdf>. Access on: 16 dec. 2015.

UNITED NATIONS. International Tribunal for the Prosecution of Persons Responsible for Serious Violations of International Humanitarian Law Committed in the Territory of the Former Yugoslavia since 199. Prosecutor v. Du[Ko Tadi]. Sentence on July 15, 1999. Available at: <http://www.icty.org/x/cases/tadic/ acjug/en/tad-aj990715e.pdf>. Access on: 16 dec. 2015.

UNITED NATIONS. Security Council fails to adopt proposal to create tribunal on crash of Malaysian Airlines flight MH17. Available at: < http://www.un.org/ apps/news/story.asp?NewsID $=51530>$. Access on: 16 dec. 2015.

WHY WAS MH17, a Civilian Airliner, Flying over a War Zone? The Economist, London, July 21, 2014 Available at: <http://www.economist.com/blogs/economistexplains/2014/07/economist-explains-14>. Access on: 16 dec. 2015. 


\section{Natureza jurídica do desenvolvimento sustentável no direito internacional*}

\section{The legal status of sustainable development in international law}

Pedro Ivo Diniz**

\section{Resumo}

O artigo tem como objetivo a verificação da natureza jurídica do desenvolvimento sustentável no intuito de determinar sua qualidade normativa. Aplicar-se-á, nesse sentido, o método hipotético-dedutivo desenvolvido por meio de pesquisa bibliográfica e documental, envolvendo vasta revisão da literatura especializada aliada à análise da jurisprudência internacional e dos instrumentos legais sobre o tema. O estabelecimento de parâmetros para a determinação da natureza jurídica de um conceito permitirá a verificação da proposta defendida por parte dos internacionalistas de que o desenvolvimento sustentável possui a qualidade de norma de direito internacional, impondo um compromisso vinculante a todos os Estados. Buscar-se-á, assim, estabelecer a existência de uma obrigação decorrente da noção de desenvolvimento sustentável. Embora ainda paire incertezas que dificultem a determinação de um dever de desenvolver, de forma sustentável, encontra-se consagrado, no seio da sociedade internacional, um compromisso de dedicar determinados esforços para alcançar esse objetivo. $\mathrm{O}$ preceito oriundo do conceito de desenvolvimento sustentável, portanto, remete a uma obrigação de meio. O estudo demonstra-se relevante, portanto, na medida em que fundamenta e corrobora um posicionamento vanguardista e coerente para o enfrentamento de dilemas globais eminentes. Com efeito, a validação da exigibilidade jurídica de comportamentos relacionados ao desenvolvimento sustentável enseja a utilização do arcabouço institucional do direito internacional na busca pela realização desse precípuo objetivo global.

Palavras-chave: Desenvolvimento Sustentável, Natureza Jurídica, Direito Internacional do Meio Ambiente.

* Recebido em 30/10/2015 Aprovado em 30/12/2015

** Doutor em Direito Internacional. Professor e Coordenador do Curso de Direito. Coordenador do Núcleo de Estudos em Direito e Relações Internacionais. Email: pedroivodiniz@gmail.com

\section{Abstract}

The article aims to verify the legal status of sustainable development in order to determine its normative quality. It will be applied, in that sense, hypothetical-deductive method developed through bibliographical and documentary research, involving extensive review of the literature combined with the analysis of international jurisprudence and legal instruments on the subject. The establishment of parameters for the determination of the legal status of a concept will allow the verification of the proposal advocated by some internationalists that sustainable development has the quality of a rule 
of international law, imposing a binding commitment to all States. The article is intended thus to establish the existence of an obligation under the notion of sustainable development. Although there are still uncertainties that make it difficult to determine a duty to develop in a sustainable way, it is enshrined in the international society a commitment to devote determined efforts to achieve this goal. The precept originated from the concept of sustainable development, therefore, refers to an obligation of means. The study shows its relevance, therefore, because underlies and supports an avant-garde and consistent positioning for coping with eminent global dilemmas. Indeed, the validation of the legal enforceability of behaviors related to sustainable development entails the use of the institutional framework of international law in the pursuit of achieving that preciput global goal.

Keywords: Sustainable Development, Legal Status, International Environmental Law

\section{INTRODUÇÃo}

Para que se possa compreender as questões centrais do debate sobre o desenvolvimento sustentável no direito internacional, faz-se necessário o estudo de sua natureza jurídica. Com efeito, prévia a qualquer discussão sobre sua aplicabilidade deve-se estabelecer se, de fato, trata-se de um objeto pertinente ao campo do direito internacional e se uma obrigação jurídica pode ser imposta aos sujeitos em razão desse conceito. Tal reflexão se justifica em razão da ampla utilização do termo "desenvolvimento sustentável”, nos mais variados contextos, em uma gama diversa de especialidades científicas em diferentes áreas de conhecimento. ${ }^{1} \mathrm{~A}$ apropriação e absorção em debates acadêmicos distintos levaram, entre outras importantes consequências, a um questionamento entre os juristas internacionais se o desenvolvimento sustentável enquadra-se, de alguma forma, entre os

1 "O desenvolvimento sustentável tornou-se um paradigma inevitável que deve, como comumente aceito, sustentar a maioria das, se não todas as, ações humanas. Ele permeia os discursos ambientais, sociais, políticos, econômicos e culturais do âmbito local até o 'global', tanto pelo setor público e como pelo privado. O desenvolvimento sustentável também penetrou amplamente o domínio jurídico.” BARRAL, Virginie. Sustainable Development in International Law: Nature and Operation of an Evolutive Legal Norm. The European Journal of International Law. Vol. 23, n. 2, julho 2012, p. 377, tradução nossa. institutos do direito, ou se remete apenas a uma noção exógena com relevância política e social, mas sem conteúdo estritamente jurídico.

Mesmo quando inserido no escopo do direito internacional, a flexibilidade do conceito e sua utilização maleável resultam em compreensões conflitantes sobre sua natureza jurídica. ${ }^{2}$ Pode-se defender que sua elaborada ambiguidade foi justamente o que garantiu seu amplo e difuso acolhimento. ${ }^{3}$ Contudo, apesar do “(...) desenvolvimento sustentável ter recebido 'aceitação universal', isto na verdade não afirma que ele tenha qualidade normativa."

O desenvolvimento sustentável encontra-se, como visto, presente em um número expressivo de instrumentos jurídicos internacionais. Permeia debates globais ambientais, econômicos, de direitos humanos, entre tantos, além de figurar em decisões de cortes e outros organismos internacionais. ${ }^{5}$ Nesse sentido, o "desenvolvimento sustentável, sem surpresa, interessa juristas internacionais, mas a incerteza quanto a sua natureza também desperta sua perplexidade."

2 "A ampla disseminação do desenvolvimento sustentável no direito internacional tem gerado interesse acadêmico considerável. No entanto, por causa do conteúdo evasivo e flexível do que tem sido chamado pela CIJ um conceito no caso Gabcíkovo-Nagymaros, e, mais recentemente, um objetivo no caso Pulp Mills, comentários acadêmicos muitas vezes se debatem para determinar a natureza jurídica do desenvolvimento sustentável, que revelou-se uma noção desafiadora à qualificação jurídica.” BARRAL, Virginie. Sustainable Development in International Law: Nature and Operation of an Evolutive Legal Norm. The European Journal of International Law. Vol. 23, n. 2, julho 2012, p. 377, tradução nossa.

3 Ver, nesse sentido, HUNTER, David; SALZMAN, James; ZAELKE, Durwood. International Environmental Law and Policy. Nova York: Thomson Reuters/Foundation Press, 2011, p. 180.

4 ATAPATTU, Sumudu A. Emerging Principles of International Environmental Law. New York: Transnational Publishers, 2007, p. 186, tradução nossa. [While this seems to indicate that] sustainable development has received "universal acceptance," it does not actually state that it has normative quality.

5 Até o ano de 2014, tem -se 134 tratados que se tem evado o termo desenvolvimento sustentável. Nessa seara, também pode citar que ele está presente em contextos de direitos humanos, como o artigo 19 do Protocolo à Carta Africana dos Direitos Humanos e dos Povos sobre os Direitos das Mulheres em África, na Carta dos Direitos Fundamentais da União Europeia. Além de estar presenter em tratados acerca do comércio internacional como o NAFTA (North American Free Trade Agreement) e o Acordo de Cotonou de 2000.

6 BARRAL, Virginie. Sustainable Development in International Law: Nature and Operation of an Evolutive Legal Norm. The European Journal of International Law. Vol. 23, n. 2, julho 2012, p. 378, tradução nossa. Sustainable development unsurprisingly interests international lawyers, but the uncertainty surrounding its nature also sparks their perplexity. 
Nesse ensejo, a questão da natureza jurídica do desenvolvimento sustentável deve ser abordada para que se possa, por um lado, evidenciar a importância do tema para o direito, não apenas como um conceito ou objetivo, mas com a natureza jurídica de norma e, por outro lado, destacar a importância do direito para o tema, que assume, nesse cenário, função primordial na busca da implementação do desenvolvimento sustentável. ${ }^{7}$ Em outras palavras, a caracterização do desenvolvimento sustentável como norma jurídica internacional, não apenas justifica a discussão no campo do direito, mas possui desdobramentos relevantes na esfera da responsabilidade internacional e na possibilidade de utilização dos instrumentos institucionais internacionais de enforcement para a garantia do cumprimento de tal norma. A determinação do status normativo do desenvolvimento sustentável torna-se fundamental para que se possa analisar formas de se exigir sua implementação.

Evidentemente, a efetivação de uma obrigação jurídica perpassa premissas e institutos distintos daqueles relacionados a uma tendência - enquanto prenúncio de uma regra futura ainda não consagrada, ${ }^{8}$ ou a um objetivo estritamente político. Não obstante, pretende-se demonstrar neste trabalho que é aquela categoria que se enquadra a noção de desenvolvimento sustentável e, com efeito, sua caracterização como uma obrigação de direito internacional e a compreensão das particularidades que envolvem esse preceito deverão pautar qualquer abordagem congruente para a realização do desenvolvimento sustentável.

Para tanto, serão discutidos os contornos do debate específico da natureza jurídica (2) que, assim como tudo aquilo que envolve "desenvolvimento sustentável", estão permeados por complexas divergências. Buscar-se-á, dessa forma, a reunião de elementos para a analisar a natureza jurídica do desenvolvimento sustentável (3)

7 "O Direito funciona como o mecanismo formal para a criação e manutenção de ordem social, como visto no mundo ocidental. Todas as sociedades possuem algum grau de ordem, que permite a interação social sustentada dentro de um período de tempo. A forma de ordem que existe depende da sociedade em particular e as necessidades percebidas por aquela sociedade. Assim, quando as necessidades do ambiente são acolhidas como um componente necessário da ordem social, o Direito assume um papel de destaque na formação dessa forma de ordem." RAMLOGAN, Rajendra. Sustainable Development - Towards a Judicial Interpretation. Leiden: Brill, 2010 p. 29, tradução nossa.

8 DIHN, Nguyen Quoc; DAILLIER, Patrick; PELLET, Alain. Direito Internacional Público. $2^{\mathrm{a}}$ ed. Braga: Fundação Calouste Gulbenkian, 2003, p. 327. e sustentar a hipótese de que, além e mais relevante do que sua eminente função de influenciar o processo de interpretação judicial, o desenvolvimento sustentável pode ser enquadrado nas categorias tradicionais de normatividade. Trata-se, com efeito, de uma obrigação de meio (4). Tendo como referência a obra de Virginie Barral, buscar-se-á, neste trabalho, em última análise, corroborar a proposição do desenvolvimento sustentável como uma obrigação relativa por meio de uma análise de sua normatividade e de sua relação com as fontes formais do direito internacional.

\section{Contornos do debate}

O debate acerca da natureza jurídica do desenvolvimento sustentável abarca opiniões destoantes e, por vezes, opostas, que transitam entre a caracterização do termo como um mero ideal político até a sua afirmação como norma de direito consuetudinário. Nesse contexto, é possível identificar quatro correntes que resumem e representam o amplo espectro de argumentos divergentes acerca da temática, agrupados entre aqueles que defendem que o desenvolvimento sustentável é um conceito exógeno ao direito (2.1); aqueles que o caracterizam como uma "matriz conceitual" (2.2); aqueles que o classificam como uma norma intersticial (2.3); e, por fim, aqueles que sustentam que se trata de uma obrigação de meio

\section{(4).}

Os primeiros - que negam sua relação com o direito - reconhecem sua relevância filosófica ou política, mas sem atribuir qualquer valor jurídico. Não existe, portanto, afinidade direta com o direito, à exceção do fato de que pode contribuir para a formação de norma, enquanto um objetivo político.

O segundo grupo compreende aqueles que evitam o debate apontando para a sua falta de relevância. Nessa linha de pensamento, as discussões sobre classificação do desenvolvimento sustentável como norma jurídica internacional seriam inócuas, devendo o foco estar no estudo dos vários princípios essenciais para a sua realização que se agregam em torno dessa "matriz

9 Ver BARRAL, Virginie. Sustainable Development in International Law: Nature and Operation of an Evolutive Legal Norm. The European Journal of International Law. Vol. 23, n. 2, julho 2012. 
conceitual". ${ }^{10}$ Nesse sentido:

Sem minimizar a importância essencial do desenvolvimento sustentável no direito internacional ambiental e reconhecendo o amplo espectro de consequências jurídicas daí decorrentes, o princípio em questão tem sido descrito como "um conceito amplo de integração", cujo estatuto jurídico concreto ainda é incerto. ${ }^{11}$

Insere-se nesse grupo as correntes teóricas que não reconhecem seu status normativo per se, mas o transcendem a um novo ramo: o direito internacional do desenvolvimento sustentável.

Um terceiro grupo pode ser destacado no debate comportando aqueles que apoiam a concepção do desenvolvimento sustentável como "norma intersticial", no sentido de que sua relevância jurídica remete a sua influência exercida no processo de raciocínio judicial.

Por fim, uma quarta corrente sustenta que o desenvolvimento sustentável possui o status de norma jurídica, enquadrando-se, particularmente, como uma obrigação de meio. Tal abordagem será defendida no presente trabalho como a leitura mais pertinente da natureza jurídica do desenvolvimento sustentável, sendo as razões para tal conclusão desenvolvidas ao longo desta seção. Antes, contudo, serão explanados os principais argumentos dos demais grupos mencionados $(2.1 ; 2.2$ e 2.3$)$ para, em seguida, identificar critérios que permitem estabelecer a natureza jurídica de determinada noção (3) e, então, concluir este estudo com a caracterização do desenvolvimento sustentável como obrigação de meio (4).

\subsection{Desenvolvimento Sustentável como concei- to exógeno ao Direito}

O ponto convergente entre os argumentos resumidos neste artigo remete à percepção de que o desenvolvimento sustentável não possui qualquer natureza jurídica, não sendo capaz de criar obrigações legais. A

10 Expressão consagrada na obra de DUPUY, Pierre-Marie. Où en est le droit international de l'environnement à la fin du siècle? Revue General de Droit International Public, v. 4, 1997, p. 886.

11 JUSTE-RUIZ, José. The Implications of the Principle of Sustainable Development in Internationa Environmental Law. In: CONSTANTINIDES, Aristotle; ZAIKOS, Nikos. The Diversity of International Law. Leiden: Brill, 2009, p. 641, tradução nossa. Without minimizing the essential importance of sustainable development in international environmental law, and recognizing the wide spectrum of legal consequences arising from it, the principle at hand has been described as "an integrative umbrella concept" whose concrete legal status is still uncertain. sua relevância, portanto, justifica-se sob perspectivas políticas, sociológicas ou filosóficas. Tal linha de argumentação não nega a influência exógena que a noção pode exercer na conduta dos Estados e, até mesmo, na elaboração de normas e documentos internacionais. A noção, no entanto, per se, seria, apenas, um conceito, um objetivo político comum ou uma tendência, sendo incapaz de criar obrigações ou ensejar responsabilidade aos sujeitos envolvidos em um possível descumprimento de determinado padrão de conduta.

A dificuldade de determinação de um padrão de conduta preciso é, inclusive, o fundamento recorrente para sustentar essa linha de argumentação.

A incerteza normativa, juntamente com a ausência de
padrões judiciáveis de revisão, sugerem fortemente
que não há até agora nenhuma obrigação legal
internacional de que o desenvolvimento deva ser
sustentável, e que as decisões sobre o que constitui
sustentabilidade resta principalmente aos governos
individuais. $^{12}$

Os defensores dessa corrente recorrem a determinadas decisões da Corte Internacional de Justiça (CIJ) no intuito de corroborar suas conclusões. Nesse sentido, o acórdão de 25 de setembro de 1997 da Corte sobre o caso Gabcíkovo-Nagymaros não reconheceu a natureza jurídica do desenvolvimento sustentável ao caracterizá-lo como um "conceito", furtando-se a consagrá-lo com o status de norma de direito internacional. O texto do acórdão assim estabelece: "esta necessidade de conciliar o desenvolvimento econômico com a proteção do meio ambiente é adequadamente expressa no conceito de desenvolvimento sustentável."13

No caso das Papeleiras de 2010, entre Argentina e Uruguai, a Corte retomou suas conclusões do caso Gabcíkovo-Nagymaros, mas foi além, atribuindo ao

12 BIRNIE, Patricia; BOYLE, Alan. International Law and the Environment. Oxford: Oxford University Press, 2002 apud ATAPATTU, Sumudu A. Emerging Principles of International Environmental Law. New York: Transnational Publishers, 2007, p. 190, tradução nossa. [N] ormative uncertainty, coupled with the absence of justiciable standards for review, strongly suggest that there is as yet no international legal obligation that development must be sustainable, and that decisions on what constitutes sustainability rest primarily with individual governments.

13 CORTE INTERNACIONAL DE JUSTIÇA (CIJ). Projeto Gabcikovo-Nagymaros (Hungria v. Eslováquia). Reports of Judgments, Advisory Opinions and Orders, 25 de setembro de 1997b, p. 78, tradução nossa Disponível em: http://www.icj-cij.org/docket/ files/92/7375.pdf . Acesso em: 05 jan. 2015. This need to reconcile economic development with protection of the environment is aptly expressed in the concept of sustainable development. 
desenvolvimento sustentável a condição de "objetivo". A Corte afirmou que: “(...) a necessidade de encontrar um equilíbrio entre o uso das águas e a proteção do rio [é] consistente com o objetivo do desenvolvimento sustentável." ${ }^{14}$ Apesar do relativo avanço, a CIJ ficou aquém de reconhecer uma obrigação legal relativa ao desenvolvimento sustentável.

Portanto, apesar de a Corte não discutir diretamente a natureza jurídica do desenvolvimento sustentável, seu posicionamento evasivo possibilita sua utilização como amparo ao argumento que nega qualquer status normativo a esse simples conceito ou objetivo.

Deve-se destacar, no entanto, que essa linha de argumentação, embora encontre respaldo em leituras céticas das decisões da CIJ, é geralmente fragilizada por alegações pragmáticas. Mesmo que se discuta sobre sua "normatividade", 15 a análise do contexto internacional sugere fortemente que não se trata apenas de uma noção abstrata ou um instrumento de discurso, mas que possui um papel importante na integração de três áreas centrais e, muitas vezes, conflitantes, do direito internacional, quais sejam, o desenvolvimento econômico, a proteção ambiental e o desenvolvimento social. Em outras palavras, o desenvolvimento sustentável é "mais do que um mero conceito pela simples razão de que os Estados cada vez mais olham para ele em relação às atividades de desenvolvimento e tem influenciado muito o processo de tomada de decisão." ${ }^{\text {16 }}$

Frente a essas questões, emerge um segundo grupo que reconhece uma relevância mais significativa do desenvolvimento sustentável no direito internacional, sem, contudo, enfrentar a questão de sua natureza jurídica. A análise dos argumentos desta corrente é o objeto da próxima seção.

14 CORTE INTERNACIONAL DE JUSTIÇA (CIJ). Caso Relativo às Fábricas de Celulose no Rio Uruguai (Argentina v. Uruguai). Reports of Judgments, Advisory Opinions and Orders, 20 de abril de 2010a, p. 74, tradução nossa. Disponível em: http://www.icj-cij.org/ docket/files/135/15877.pdf . Acesso em: 05 jan. 2015. [Regarding Article 27, it is the view of the Court that its formulation reflects not only the need to reconcile the varied interests of riparian States in a transboundary context and in particular in the use of a shared natural resource,] but also the need to strike a balance between the use of the waters and the protection of the river consistent with the objective of sustainable development.

15 O conceito será desenvolvido na seção 3 deste trabalho.

16 ATAPATTU, Sumudu A. Emerging Principles of International Environmental Law. New York: Transnational Publishers, 2007, p. 187188, tradução nossa. [It is] more than a mere concept for the reason that states increasingly look to it in relation to development activities and it has greatly influenced the decisionmaking process.

\subsection{Desenvolvimento Sustentável como “Matriz Conceitual"}

O segundo conjunto de argumentos agrupados nesta seção divergem dos primeiros ao contestar a ideia de que o desenvolvimento sustentável resume-se a um conceito exógeno ao direito. $\mathrm{O}$ expressivo volume de documentos internacionais que se referem ao desenvolvimento sustentável indica que uma descrição do desenvolvimento sustentável como um objetivo político internacional vazio de qualquer valor jurídico seria imprópria. ${ }^{17}$

No entanto, estes se aproximam daqueles no que tange ao posicionamento evasivo em relação ao reconhecimento de um status de norma ao desenvolvimento sustentável. A noção careceria de qualidade normativa para que se pudesse classificá-la como princípio jurídico. Se assim o fosse, seu descumprimento poderia acarretar na responsabilização do Estado transgressor. Para evitar essa inferência e as complexas consequências que dela seriam oriundas, ${ }^{18}$ essa corrente esquiva-se da afirmação de que o desenvolvimento sustentável constitui, atualmente, um único princípio de direito internacional ou uma norma do costume internacional que deve ser aceito como obrigatório por todos os Estados. ${ }^{19}$ Entende-se, com efeito, que não haveria prática estatal consistente ou opinio juris que assegurasse ao desenvolvimento sustentável um lugar no rol de normas consuetudinárias do direito internacional. ${ }^{20}$

A natureza jurídica do desenvolvimento sustentável seria, nesse viés, incerta e, em última análise, pouco relevante. Seja ele um novo ramo autônomo do direito internacional, com princípios e regras específicos comportados em seu arcabouço teórico, ou uma "matriz conceitual" ampla, que, da mesma maneira, só adquire forma por meio dos princípios ${ }^{21}$ e procedimentos que

17 SEGGER, Marie-Claire Cordonier; KHALFAN, Ashfaq. Sustainable Development Law - Priciples, Practices, \& Prospects. Oxford: Oxforf University Press, 2006.

18 Ver seção 4 deste trabalho.

19 SEGGER, Marie-Claire Cordonier; KHALFAN, Ashfaq. Sustainable Development Law - Priciples, Practices, \& Prospects. Oxford: Oxforf University Press, 2006, p. 45.

20 ATAPATTU, Sumudu A. Emerging Principles of International Environmental Law. New York: Transnational Publishers, 2007, p. 187.

21 Os princípios que se relacionam com o desenvolvimento sustentável não serão abordados neste artigo. Mas uma breve análise pode concluir princípios integram a noção geral de desenvolvimento sustentável pela sua relação complementar com os princípios da integração e da equidade inter e intrageracional, como por exemplo, 
a integram, a discussão sobre a natureza jurídica perde significância na medida em que tais princípios e procedimentos assumiriam o foco do estudo sobre desenvolvimento sustentável. Nessa lógica, se somente por meio desses institutos - dotados, esses sim, de qualidade jurídica - é que o desenvolvimento sustentável se manifesta no campo do direito ou pode ser aplicado na sociedade internacional, ${ }^{22}$ então é, por meio do estudo desses princípios e procedimentos, que o desenvolvimento sustentável será compreendido.

Nesse caminho, diversas formas de se referir ao desenvolvimento sustentável são cunhadas, sem, contudo, acrescentar algo sobre sua natureza jurídica. Tem-se, por exemplo, a referência a um "termo legal" 23 que abarcaria os princípios, procedimentos e objetivos, mas também os acordos internacionais sobre meio ambiente, economia e direitos humanos. Não seria, assim, um corpo autônomo de regras, mas se apoiaria em princípios e arranjos institucionais existentes para alcançar sua realização.

O epíteto distinto não atribui ao "termo legal" características significativamente distintas daquelas da "matriz conceitual" aqui descritas - irresoluto no que tange à determinação de seu caráter normativo mas contundente em sua valoração como algo além de um simples conceito ou um objetivo político. Parece, para os defensores dessa linha de argumentação, ser satisfatório enquadrar o desenvolvimento sustentável em uma grande área cinzenta existente entre a ideia de "conceito" e a condição de "norma jurídica”. Assim, “(...) não seria um corpo autônomo de princípios, mas nos

princípio da precaução, princípio do poluidor-pagador, da participação publica e outros.

22 Em que pese as divergentes alusões a sociedade ou a comunidade internacional pelos autores de Direito Internacional, adotarse-á, neste trabalho, o termo "sociedade internacional". "Existem, por certo, entre todos os Estados, interesses materiais comuns, provenientes dos laços que a civilização técnica forjou. Mas uma comunidade deve também assentar numa base espiritual que, nesse caso, falta. Um vínculo comunitário só poderia nascer de relações entre Estados que apresentassem analogias profundas para favorecerem a eclosão desse elemento subjectivo necessário. (...) Esta objecção assenta essencialmente na distinção estabelecida por uma teoria sociológica alemã, entre 'comunidade' (Gemeinschaft) e 'sociedade' (Gesellschaft). (...) À escala universal, só o conceito de sociedade internacional assim seria concebível, não o de comunidade internacional". DIHN, Nguyen Quoc; DAILLIER, Patrick; PELLET, Alain. Direito Internacional Público. $2^{\mathrm{a}}$ ed. Braga: Fundação Calouste Gulbenkian, 2003, p. 40.

23 SANDS, Philippe. International Law in the Field of Sustainable Development. British Year Book of International Law, v. 65, p. 303381, 1994, p. 379. obriga a aplicar os princípios existentes, regras e mecanismos institucionais de forma integrada." $24 \mathrm{O}$ cerne da discussão é impelido, nesse sentido, para a questão dos componentes do desenvolvimento sustentável, que constituem o caminho para alcançar a sua realização. ${ }^{25}$

Interessante notar que as decisões da Corte, em especial no caso da Papeleiras, são igualmente utilizadas pelos defensores dessa corrente para sustentar seus argumentos. Fundamenta-se que o desenvolvimento sustentável como "objetivo" situa-se, justamente, entre o conceito e a norma jurídica, orientando as ações internacionais por meio dos princípios e procedimentos que o compõe, sem, contudo, ter atingido ainda um conteúdo jurídico preciso.

Ele pode ser caracterizado principalmente como um objetivo, uma estratégia, um arquétipo ou um paradigma operatório, mas ainda não como regra consolidada do direito internacional consuetudinário. Como está atualmente, ele expressa um objetivo que deve ser articulado por meio de princípios mais específicos, regras e instituições, a fim de desenvolver plenamente o seu potencial normativo inerente. ${ }^{26}$

Apesar das diferentes análises que se convergem sob essa zona incerta acerca da natureza jurídica do desenvolvimento sustentável, estas parecem malograr o objetivo de contribuir de forma assertiva para esse debate específico. Nesse sentido, uma perspectiva certamente mais profícua e que tem alcançado importante aceitação remete à caracterização do desenvolvimento sustentável como "norma intersticial", atribuindo ao termo qualidade jurídica certa, mesmo que frágil e incipiente. Portanto, a próxima seção se dedica ao estudo dessa linha de argumentação.

24 ATAPATTU, Sumudu A. Emerging Principles of International Environmental Law. New York: Transnational Publishers, 2007, p. 188, tradução nossa. (...) it is not a free-standing body of principles but requires us to apply the existing principles, rules and institutional arrangements in an integrated manner.

25 "Na medida em que os componentes do desenvolvimento sustentável adquiriram status normativo - e alguns componentes têm - não dar-lhes efeito poderia acarretar responsabilidade." ATAPATTU, Sumudu A. Emerging Principles of International Environmental Law. New York: Transnational Publishers, 2007, p. 187, tradução nossa. 26 JUSTE-RUIZ, José. The Implications of the Principle of Sustainable Development in Internationa Environmental Law. In: CONSTANTINIDES, Aristotle; ZAIKOS, Nikos. The Diversity of International Law. Leiden: Brill, 2009, p. 642, tradução nossa. It can be primarily characterized as an objective, a strategy, an archetype or an operative paradigm, but not yet as a consolidated rule of customary international law. As the principle stands today, it expresses an objective which shall be articulated through more specific principles, rules and institutions in order to fully develop its inherent normative potential. 


\subsection{Desenvolvimento Sustentável como Norma Intersticial}

Os defensores do argumento de que o desenvolvimento sustentável deve ser entendido como uma norma intersticial adotam uma interessante perspectiva sobre a natureza jurídica do termo. Tem-se como ponto de partida a negação do caráter de regra primária ${ }^{27}$ do desenvolvimento sustentável, rejeitando, assim, seu status de norma consuetudinária. Possui, contudo, certa qualidade normativa, sendo considerado um elemento do processo de raciocínio judicial. O desenvolvimento sustentável seria, portanto, um "meta-princípio" que age em outras regras e princípios jurídicos redefinindo limites de normas primárias quando estas se encontrarem em situação de possível conflito ou sobreposição entre elas. ${ }^{28} \mathrm{Em}$ outras palavras, um conceito jurídico que exerce uma espécie de normatividade intersticial. ${ }^{29}$

Essas normas intersticiais atuam como agentes livres modificadores, podendo combinar com outras regras primárias para alterá-las. Não regulam diretamente a conduta dos sujeitos, mas se relacionam com normas primárias - estas, sim, destinadas a determinar o padrão de comportamento juridicamente aceitável. ${ }^{30}$ Tais normas intersticiais irão adquirir sua normatividade quando servirem de ferramenta no processo judicial, podendo atuar como um padrão em relação ao qual as condutas serão avaliadas. ${ }^{31}$ Ao atribuir novos contornos às nor-

27 Nos termos definidos por Hart, diferenciando as regras primárias, sendo aquelas que prescrevem um comportamento, das regras secundárias, as quais não visam regular a conduta, mas se relacionam com as normas primárias, alterando os efeitos jurídicos destas. HART, H. L. A. O conceito de direito. São Paulo: Martins Fontes, 2009.

28 LOWE, Vaughn. Sustainable Development and Unsustainable Arguments. In: BOYLE, Alan; FREESTONE, David (eds.). International Law and Sustainable Development: Past Achievements and Future Challenges. Oxford: Oxford University Press, 1999.

29 BARRAL, Virginie. Sustainable Development in International Law: Nature and Operation of an Evolutive Legal Norm. The European Journal of International Law. Vol. 23, n. 2, julho 2012, p. 389.

30 "Exemplos de tais normas, juntamente com o desenvolvimento sustentável, incluem a regra da razão, a ponderação de interesses, e o teste de homem razoável, que são 'aspectos das regras primárias sobre as quais elas são parasitas', mas que tem 'uma vitalidade além de qualquer norma primária específica’.” BARRAL, Virginie. Sustainable Development in International Law: Nature and Operation of an Evolutive Legal Norm. The European Journal of International Law. Vol. 23, n. 2, julho 2012, p. 389, tradução nossa.

31 Elas podem representar padrões de avaliação utilizados pelos Estados para justificar suas ações e criticar as dos demais. Elas definem os termos de discussões internacionais e servem de quadro para as negociações. Ver, nesse sentido, ATAPATTU, Sumudu A. Emerging Principles of International Environmental Law. New York: mas primárias, a norma intersticial será capaz de afetar a decisão em casos apreciados por tribunais internacionais. "Nesta análise, o desenvolvimento sustentável seria um instrumento judicial puramente hermenêutico, vazio de qualquer conteúdo vinculante que pretenda regular a conduta dos sujeitos jurídicos." ${ }^{32}$

Não obstante a sua possível aplicação pelos tribunais, essas "normas modificadoras" não necessitam de prática estatal ou opinio iuris para ter reconhecido seu status jurídico. Assim, a qualidade jurídica de uma norma intersticial dispensa uma análise de seu caráter consuetudinário. Não sendo uma norma primária, ela não estabelece um padrão de conduta específico que deve ser obedecido. Torna-se, portanto, despropositada uma análise da conduta estatal para avaliar a observância da norma intersticial. Da mesma forma, a análise da opinio iuris pressupõe a aceitação, como norma vinculante, de uma conduta específica estabelecida, que também não se aplica às normas intersticiais. Ao atuar apenas modificando as normas primárias, seu caráter normativo não está relacionada com a prescrição de uma conduta, mas com a releitura de padrões preexistentes. São, desse modo, conceitos jurídicos que não dependem da prática estatal ou da opinio iuris da mesma forma que as normas primárias consuetudinárias necessitam..$^{33}$

É, em grande parte, por essa razão que a abordagem do desenvolvimento sustentável como "norma modificadora” tem recebido considerável apreço, já que consegue precisar sua natureza jurídica, reconhecendo seu status normativo, mesmo que secundário, sem, no entanto, avançar para a temida assunção de que o desenvolvimento sustentável possui os elementos para ser considerado uma obrigação internacional primária.

Tal receio em apontar sua consagração consuetudinária dá-se não apenas pela resistência da Corte Internacional

Transnational Publishers, 2007, p. 184-185. Ver, igualmente, LOWE, Vaughn. Sustainable Development and Unsustainable Arguments. In: BOYLE, Alan; FREESTONE, David (eds.). International Law and Sustainable Development: Past Achievements and Future Challenges. Oxford: Oxford University Press, 1999, p. 34.

32 BARRAL, Virginie. Sustainable Development in International Law: Nature and Operation of an Evolutive Legal Norm. The European Journal of International Law. Vol. 23, n. 2, julho 2012, p. 389, tradução nossa. On this analysis, sustainable development would be a purely hermeneutical judicial tool, empty of any binding content purporting to regulate legal subjects' conduct.

33 Ver LOWE, Vaughn. Sustainable Development and Unsustainable Arguments. In: BOYLE, Alan; FREESTONE, David (eds.). International Law and Sustainable Development: Past Acbievements and Future Challenges. Oxford: Oxford University Press, 1999, p. 33. 
de Justiça em reconhecer o desenvolvimento sustentável como um costume internacional vinculante; mas, principalmente, por que assumir essa proposição significa enfrentar seus desdobramentos, que envolvem definir em relação a qual conduta os sujeitos estão obrigados e, logo, quais seriam consideradas violações, ensejando a responsabilização internacional, além de ter que identificar a prática estatal e opinio iuris que corroborem o argumento. Em suma, envolve a necessidade de estabelecer a capacidade do desenvolvimento sustentável em produzir efeito jurídico enquanto norma e seu enquadramento em uma das fontes reconhecidas do direito internacional público. Esses desdobramentos, de fato, não são simples.

Nesse sentido, sua aceitação como componente do raciocínio judicial tem um apelo evidente: trata-se de um objeto pertinente ao campo do direito internacional, sendo justificável sua presença constante em documentos e decisões internacionais, podendo, inclusive, ser útil e influenciar o resultado em tribunais. Não obstante, não se trata de uma norma vinculante que regule a conduta dos Estados. Sendo assim, não há descumprimento possível de tal norma, evitando-se o desgaste político inerente a uma obrigação jurídica imposta a sujeitos em um ambiente anárquico. $\mathrm{O}$ desenvolvimento sustentável parece enquadrar-se no conceito de norma intersticial, assumindo o importante papel de modificar o efeito de normas primárias existentes no intuito de conciliar o desenvolvimento econômico, desenvolvimento social e a proteção ambiental. ${ }^{34}$

$\mathrm{O}$ argumento que pretende-se defender neste trabalho, no entanto, segue o caminho diverso das três linhas expostas até aqui, quais sejam, da negação de qualquer relação direta do desenvolvimento sustentável com o direito (2.1), de sua caracterização como uma "matriz conceitual", sem enfrentar a questão de sua natureza jurídica (2.2), e de seu status de norma intersticial, que modifica normas primárias, com grande valor hermenêutico, podendo influenciar o processo judicial, porém, não estabelecendo uma conduta obrigatória aos sujeitos (2.3). A hipótese remete ao desenvolvimento sustentável como norma primária, ou seja, que cria uma obrigação aos sujeitos em relação a determinada conduta. Trata-se, todavia, de uma obrigação de meio.

Para chegar a essa conclusão, consistentemente aludida por Virginie Barral (2012), deve-se, antes, identi-

34 ATAPATTU, Sumudu A. Emerging Principles of International Environmental Law. New York: Transnational Publishers, 2007, p. 186. ficar os elementos que atribuem a natureza jurídica de determinada noção. Conforme mencionado anteriormente, reconhecer que o desenvolvimento sustentável possui natureza jurídica de norma vinculante significa afirmar que ele é jurídico em seu escopo, ou seja, é capaz de produzir efeitos jurídicos, além de se inserir nas fontes formais reconhecidas pelo direito internacional. Portanto, a próxima seção será dedicada a análise da natureza jurídica do desenvolvimento sustentável.

\section{Análise da natureza JuRídica}

A presente análise é dedicada ao estudo da natureza jurídica do desenvolvimento sustentável no intuito de compreender a sua condição dentro do direito internacional. Nesse sentido, a seção 2 dedicou-se aos contornos do debate, reunindo para fins didáticos, em três grupos, os principais argumentos sobre a temática. Uma quarta linha, no entanto, pode ser identificada e é precisamente a defendida neste trabalho. Ela se destaca das demais por afirmar que o desenvolvimento sustentável constitui, com efeito, uma norma vinculante de direito internacional público, capaz de gerar efeitos jurídicos e de se enquadrar entre as fontes desse ramo do direito. Todavia, tal assertiva não pode ser estabelecida sem que a noção a qual se pretende atribuir a natureza jurídica de norma seja confrontada com critérios para que essa qualidade normativa seja reconhecida.

Assim, a presente seção visa estabelecer um esquema apropriado para avaliar o status jurídico do desenvolvimento sustentável, que culminará na hipótese defendida de que se trata, de fato, de uma norma jurídica internacional que impõe uma obrigação de meio.

Para tanto, critérios devem ser definidos no sentido de precisar a natureza jurídica de determinada noção.

Para avaliar a qualidade, a função e os efeitos
de um determinado conceito ambíguo, duas
perguntas devem ser respondidas. Em primeiro
lugar, o conceito disputado é estruturado de tal
forma que ele pode ter uma qualidade normativa
('normatividade') - ou seja, a capacidade para dirigir
direta ou indiretamente, o comportamento dos seus
destinatários? E em segundo lugar, é concebido e
estabelecido adequadamente, de tal modo que o
mesmo constitui uma norma vinculante?

35 BEYERLIN, Ulrich. Different Types of Norms in International Environmental Law. Policies, Principles and Rules. In: BODANSKY, D. et al. (eds.), The Oxford Handbook of International En- 
Partindo das diretrizes desse esquema descrito, a análise da natureza jurídica do desenvolvimento sustentável dependerá de duas questões distintas. Por um lado, o desenvolvimento sustentável deve apresentar uma qualidade normativa, uma capacidade de produzir efeitos jurídicos, de regular o comportamento de seus destinatários ou, em outras palavras, apresentar "normatividade". Essa normatividade, portanto, remete ao "escopo jurídico" do desenvolvimento sustentável, ${ }^{36}$ que restrinja o comportamento dos sujeitos, e que seja regido em termos normativos. ${ }^{37}$

Por outro lado, para que seja reconhecido o status normativo de desenvolvimento sustentável, esse deve enquadrar-se em uma das fontes reconhecidas pelo direito internacional público, constituindo, dessa maneira, uma norma vinculante estabelecida de acordo com os requisitos formais consagrados.

Nesse contexto, as próximas seções estão voltadas para a análise da natureza jurídica do desenvolvimento sustentável, por meio da averiguação de suas características frentes aos critérios de "normatividade" (3.1) e de pertencimento às fontes formais do direito internacional (3.2).

\section{1. "Normatividade"}

A questão da "normatividade" remete, em última análise, à reunião de elementos normativos suficientes que constituam uma regra jurídica capaz de prescrever, per se, um comportamento concreto aos seus destinatários. ${ }^{38}$ É necessário, por conseguinte, avaliar se o

vironmental Law. Oxford: Oxford University Press, 2007, p. 428 apud JUSTE-RUIZ, José. The Implications of the Principle of Sustainable Development in Internationa Environmental Law. In: CONSTANTINIDES, Aristotle; ZAIKOS, Nikos. The Diversity of International Law. Leiden: Brill, 2009, p. 640, tradução nossa. To evaluate the quality, function and effects of a given ambiguous concept, two questions must be answered. First, is the disputed concept structured in such a way that it may have normative quality ('normativity') - that is, the capacity to directly or indirectly steer the behavior of its addressees? And second, is it designed, and accordingly established, in such a way as it constitutes a legally binding norm?

36 BARRAL, Virginie. Sustainable Development in International Law: Nature and Operation of an Evolutive Legal Norm. The European Journal of International Law. Vol. 23, n. 2, julho 2012, p. 383.

37 LOWE, Vaughn. Sustainable Development and Unsustainable Arguments. In: BOYLE, Alan; FREESTONE, David (eds.). International Law and Sustainable Development: Past Acbievements and Future Challenges. Oxford: Oxford University Press, 1999, p. 24.

38 BEYERLIN, Ulrich. Different Types of Norms in International Environmental Law. Policies, Principles and Rules. In: desenvolvimento sustentável é capaz de expressar uma conduta determinada em relação a qual os sujeitos de direito internacional encontram-se obrigados.

A dimensão variável atribuída à definição de desenvolvimento sustentável torna-se, para aqueles que negam seu caráter jurídico, um entrave. A flexibilidade com que se tem referido ao conceito impediria que este prescrevesse uma conduta precisa aos destinatários. Em suma, se não se sabe precisamente o conteúdo do desenvolvimento sustentável, não se pode criar uma obrigação de alcançá-lo, pois, sem um padrão de conduta determinado, não existe conduta diversa que configure um descumprimento. O desenvolvimento sustentável seria, nessa perspectiva, incapaz de criar efeitos jurídi$\cos$ e, portanto, não teria normatividade.$^{39}$ Ele agiria, ao contrário, como um simples "guia de ação para aquele fim." ${ }^{40}$ Deve-se averiguar, nesse sentido, se essa noção prescreve um curso preciso de conduta que dele oriunda direitos e obrigações aos sujeitos e cria bases para a responsabilização em caso de descumprimento.

Parece razoável inferir que o desenvolvimento sustentável, enquanto norma de direito internacional, não é mais abstrato nem mais ambíguo do que outras normas consagradas, como a paz e a segurança internacionais ou o respeito pelos direitos humanos ${ }^{41}$ apesar dos diferentes estágios de reconhecimento dessas normas pela sociedade internacional. ${ }^{42}$ Este não seria, assim, um im-

BODANSKY, D. et al. (eds.), The Oxford Handbook of International Environmental Law. Oxford: Oxford University Press, 2007, p. 428 apud JUSTE-RUIZ, José. The Implications of the Principle of Sustainable Development in Internationa Environmental Law. In: CONSTANTINIDES, Aristotle; ZAIKOS, Nikos. The Diversity of International Law. Leiden: Brill, 2009, p. 640.

39 "Nesse ponto, a flexibilidade com a qual, até agora, se refere ao conceito já não pode ser ocultada. O desenvolvimento sustentável não pode ser um norma de restrição de comportamento. Tal norma deve ser redigida em termos normativos." LOWE, Vaughn. Sustainable Development and Unsustainable Arguments. In: BOYLE, Alan; FREESTONE, David (eds.). International Law and Sustainable Development: Past Achievements and Future Challenges. Oxford: Oxford University Press, 1999, p. 24.

40 BEYERLIN, Ulrich. Different Types of Norms in International Environmental Law. Policies, Principles and Rules. In: BODANSKY, D. et al. (eds.), The Oxford Handbook of International Environmental Law. Oxford: Oxford University Press, 2007, p. 428 apud JUSTE-RUIZ, José. The Implications of the Principle of Sustainable Development in Internationa Environmental Law. In: CONSTANTINIDES, Aristotle; ZAIKOS, Nikos. The Diversity of International Law. Leiden: Brill, 2009, p. 640, tradução nossa.

41 SCHRIJVER, Nico. The Evolution of Sustainable Development in International Law: Inception, Meaning and Status. A Haia: Hague Academy of International Law, 2008, p. 219.

42 "No entanto, é preciso reconhecer que a sustentabilidade, e 
peditivo para o reconhecimento da normatividade do desenvolvimento sustentável. Esta será atribuída, decerto, a uma proposição formulada de tal maneira que vise alterar a ordem jurídica existente ou alcance esse resultado por meio de sua efetiva aplicação. ${ }^{43} \mathrm{E}$ sob esse ponto de vista, a normatividade do desenvolvimento sustentável é perfeitamente concebível. Cita-se, nesse intuito, a Declaração do Rio (1992) que serve de referência para o estudo do desenvolvimento sustentável no direito internacional. Nesse documento, o desenvolvimento sustentável encontra-se formulado em termos de direitos e obrigações por meio de linguagem prescritiva. É perceptível a intenção neste e em tantos outros documentos (vinculantes ou não) que tratam do tema, ${ }^{44} \mathrm{de}$ produzir efeitos na ordem jurídica internacional. ${ }^{45}$

Em grande parte dos tratados internacionais que versam sobre a questão, o desenvolvimento sustentável está definido como um objetivo; ${ }^{46}$ em outros, os Estados-parte comprometem a promover, alcançar, garantir, conseguir, favorecer, contribuir ou trabalhar para o desenvolvimento sustentável. ${ }^{47}$ Nesse contexto, comportamentos específicos são impostos aos Estados para que possam alcançar o objetivo. Cita-se a equidade intra e intergeracional e a integração entre as dimensões social, ambiental e econômica como condutas consideradas indispensáveis a fim de lograr o desenvolvimento

também a democracia, não desfrutam, no momento, do mesmo grau de reconhecimento no direito internacional como outras normas gerais, tais como a paz e a segurança e a humanidade (como refletido na legislação de direitos humanos e direito internacional humanitário). (SCHRIJVER, 2008, p. 220, tradução nossa).

43 BARRAL, Virginie. Sustainable Development in International Law: Nature and Operation of an Evolutive Legal Norm. The European Journal of International Law. Vol. 23, n. 2, julho 2012, p. 383.

44 Cita-se como mais importantes os documentos finais das conferências de Estocolmo (1992), do Rio de Janeiro (1992) e de Joanesburgo (2002 que são transcrições da evolução do conceito até se tornar tema central da Conferência do Rio de 2012. Por certo, os dois documentos mais citados no intuito de se traçar o conteúdo do desenvolvimento sustentável são o Relatório Bundtland e a Declaração do Rio.

45 BARRAL, Virginie. Sustainable Development in International Law: Nature and Operation of an Evolutive Legal Norm. The European Journal of International Law. Vol. 23, n. 2, julho 2012, p. 383.

46 Como, por exemplo, a Convenção-Quadro das Nações Unidas sobre Mudança do Clima; o Acordo de Cotonu para a redução da pobreza e a integração progressiva dos Estados da África, do Caribe e do Pacífico; e o Acordo Constitutivo da Organização Mundia do Comércio (OMC).

47 Exemplos incluem a Convenção sobre Diversidade Biológica; a Convenção Internacional de Combate à Desertificação nos Países afetados por Seca Grave e/ou Desertificação; e o Protocolo de Quioto. sustentável. Por conseguinte, apesar do conteúdo flexível e variável do desenvolvimento sustentável, alguns elementos fundamentais estão sempre presentes, independente do contexto em tela. ${ }^{48}$ "Como resultado, seu caráter indeterminado será claramente muito menor do que o caráter indeterminado do que é 'razoável' (um exemplo de normas intersticiais Lowe)." ${ }^{\prime 4}$

Não obstante certa flexibilidade conceitual, o desenvolvimento sustentável tem como objetivo a regulação de conduta. Não se trata de exercer influência ou modificar o efeito de normas primárias, ${ }^{50}$ mas sim estabelecer um padrão de comportamento obrigatório. Sua observância poderá ser avaliada por meio de seus elementos constitutivos essenciais.

Uma vez que é um objetivo que tem um teor material flexível mas identificável, pelo menos em certa medida, não pode ser um acessório simples de regras primárias com uma função processual ou estritamente hermenêutica. Pelo contrário, ele é capaz de regular e pretende regulamentar conduta diretamente e tem implicações jurídicas diretas e propriamente materiais. É uma norma primária do direito internacional. ${ }^{51}$

48 "Muitos argumentam que o status jurídico está intimamente relacionado com a questão da definição: se o conceito não tem uma definição adequada, como ele pode ter qualquer efeito vinculante? $\mathrm{O}$ problema é mais complexo, no entanto. (...) O desenvolvimento sustentável é um termo genérico que contém ambos os componentes materiais e procedimentais. A fim de decidir se o desenvolvimento sustentável tem qualquer efeito normativo, é necessário avaliar o estado de cada um dos componentes que vêm sob o guarda-chuva. Se essa abordagem for tomada, torna-se óbvio que algumas vertentes do desenvolvimento sustentável, de fato, tem efeito normativo." ATAPATTU, Sumudu A. Emerging Principles of International Environmental Law. New York: Transnational Publishers, 2007, p. 182, tradução nossa.

49 BARRAL, Virginie. Sustainable Development in International Law: Nature and Operation of an Evolutive Legal Norm. The European Journal of International Law. Vol. 23, n. 2, julho 2012, p. 389, tradução nossa. As a result, its indeterminate character will be very clearly less than the indeterminate character of what is 'reasonable' (one example of Lowe's interstitial norms).

50 “(...) ele pode ter essa função, mas apenas como um corolário da sua função principal.” BARRAL, Virginie. Sustainable Development in International Law: Nature and Operation of an Evolutive Legal Norm. The European Journal of International Law. Vol. 23, n. 2, julho 2012, p. 390, tradução nossa.

51 BARRAL, Virginie. Sustainable Development in International Law: Nature and Operation of an Evolutive Legal Norm. The European Journal of International Law. Vol. 23, n. 2, julho 2012, p. 390, tradução nossa. Because it is an objective which has a flexible but identifiable material content, at least to some extent, it cannot be a simple accessory to primary rules having a strictly procedural or hermeneutical function. On the contrary, it is capable of regulating and purports to directly regulate conduct and has properly material and direct legal implications. It is a primary norm of international law. 
Conclui-se, desse modo, que o desenvolvimento sustentável é dotado de "normatividade" suficiente para se colocar no âmbito das normas primárias de direito internacional. Contudo, o alcance jurídico per se não é suficiente para que seja atribuído ao desenvolvimento sustentável qualidade jurídica. Ele deve, igualmente, ser reconhecido como uma regra válida e obrigatória de direito. Esse reconhecimento ocorre por meio da identificação em uma das fontes formais de direito internacional. A próxima seção, destarte, trará uma breve explanação dessas fontes, naquilo que importa para a definição da qualidade jurídica do desenvolvimento sustentável.

\subsection{Norma Formal Vinculante}

O conteúdo flexível, porém identificável, usualmente concebido por meio de linguagem jurídica e prescritiva, destinada a causar efeitos jurídicos e criar obrigações a seus destinatários indica que a "normatividade" não é um obstáculo para que se reconheça a qualidade jurídica do desenvolvimento sustentável. Resta, portanto, a necessidade de se averiguar seu pertencimento às fontes formais ${ }^{52}$ do direito internacional, sendo estas "os processos de elaboração do direito, as diversas técnicas que autorizam a considerar que uma regra pertence ao direito positivo." ${ }^{53}$ Essas fontes são relevantes na medida em que garantem maior estabilidade e oponibilidade do direito internacional, justificando sua força obrigatória aos destinatários desse direito.

A referência consagrada para aludir às fontes formais é, certamente, o Estatuto da Corte Internacional de Justiça, que em seu artigo 38 estabelece que:

1. A Corte, cuja função é decidir de acordo com o direito internacional as controvérsias que lhe forem submetidas, aplicará:

a) as convenções internacionais, quer gerais, quer especiais. que estabeleçam regras expressamente

52 Estas se diferem das fontes materiais que “(...) constituem os fundamentos sociológicos das normas internacionais, a sua base política, moral ou econômica mais ou menos explicitada pela doutrina ou pelos sujeitos de direito. As fontes materiais, traduções diretas das estruturas internacionais e ideologias dominantes, têm uma dinâmica que as fontes formais, simples processos técnicos, não podem ter." DIHN, Nguyen Quoc; DAILLIER, Patrick; PELLET, Alain. Direito Internacional Público. $2^{\mathrm{a}}$ ed. Braga: Fundação Calouste Gulbenkian, 2003, p. 113.

53 DIHN, Nguyen Quoc; DAILLIER, Patrick; PELLET, Alain. Direito Internacional Público. $2^{\mathrm{a}}$ ed. Braga: Fundação Calouste Gulbenkian, 2003, p. 113. reconhecidas pelos Estados litigantes;

b) o costume internacional, como prova de uma prática geral aceita como sendo o direito;

c) os princípios gerais de direito reconhecidos pelas Nações civilizadas;

d) sob ressalva da disposição do art. 59, as decisões judiciárias e a doutrina dos publicistas mais qualificados das diferentes Nações, como meio auxiliar para a determinação das regras de direito.

2. A presente disposição não prejudicará a faculdade da Corte de decidir uma questão ex aeque et bano, se as partes com isto concordarem..$^{54}$

$\mathrm{O}$ artigo 38 representa um conjunto de fontes universalmente aceito, não só devido à adesão formal de praticamente todos os Estados, ${ }^{55}$ mas pela reprodução dos termos do artigo em outros tratados sobre resolução pacífica de controvérsias. ${ }^{56}$ Isso não o torna, entretanto, imune a críticas. Algumas de suas formulações são questionadas pela sua inexatidão e o rol apresentado, de fato, não é exaustivo no que tange às fontes formais de direito internacional, não havendo menção para fontes já consagradas como as decisões das Organizações Internacionais e os atos estatais unilaterais.

Não obstante, têm-se como fontes primárias preponderantes de direito internacional os tratados, os costumes e os princípios gerais de direito. ${ }^{57}$ Sob uma perspectiva prática, as duas primeiras destacam-se por integrarem o cerne da produção normativa internacional e, por tal razão, será por meio destas que se buscará

54 BRASIL. Decreto No 19.841. Promulga a Carta das Nações Unidas, da qual faz parte integrante o anexo Estatuto da Corte Internacional de Justiça, assinada em São Francisco, a 26 de junho de 1945, por ocasião da Conferência de Organização Internacional das Nações Unidas. 22 out. 1945. Disponível em: http://www.planalto. gov.br/ccivil_03/decreto/1930-1949/d19841.htm . Acesso em: 07 jan. 2015.

55 "Com efeito, todos os Estados membros das Nações Unidas, praticamente todos os países do mundo, são ipso facto, partes do Estatuto da Corte e ligados por ele." DIHN, Nguyen Quoc; DAILLIER, Patrick; PELLET, Alain. Direito Internacional Público. $2^{\mathrm{a}}$ ed. Braga: Fundação Calouste Gulbenkian, 2003, p. 115.

56 Ver DIHN, Nguyen Quoc; DAILLIER, Patrick; PELLET, Alain. Direito Internacional Público. $2^{\mathrm{a}}$ ed. Braga: Fundação Calouste Gulbenkian, 2003, p. 115.

57 "Mas o Estatuto também faz referencia às decisões judiciarias e às doutrinas dos publicistas, consideradas como meios auxiliares nas busca da comprovação da existência de determinada regra de direito. Assim, as "decisões judiciarias" e as "doutrinas dos publicistas", a que o artigo faz referencia, esclareça-se, não são fontes de direito como tal, constituindo-se validamente, entretanto, com meios de auxílio a definir o direito aplicável." MAZZUOLI, Valerio de Oliveira. Curso de Direito Internacional Público. São Paulo: Revista dos Tribunais, 2011a, p. 113. 
atribuir o caráter jurídico vinculante - formal e positivo - do desenvolvimento sustentável. Faz-se necessário, igualmente, compreender a relação do desenvolvimento sustentável com os princípios gerais de direito, não apenas pela paridade desses últimos com as demais fontes formais consagradas no Estatuto da Corte Internacional de Justiça, mas também para esclarecer em que medida a recorrente menção ao desenvolvimento sustentável como princípio remete a essas fonte.

\subsubsection{Direito Internacional Escrito}

Os tratados ainda constituem a principal fonte formal do Direito Internacional e são, com efeito, o ponto de partida lógico para analisar a qualidade jurídica do desenvolvimento sustentável. Esta seção remete, porém, de forma mais abrangente, ao direito internacional escrito. Isto porque o desenvolvimento sustentável consagrou-se em um vasto número de documentos jurídicos internacionais não vinculantes. Apesar destas manifestações não constituírem, tecnicamente, uma fonte formal de Direito, sua relevância não pode ser negligenciada pois "influenciam os processos jurídicos que concretizam as fontes formais". Nesse contexto, "as resoluções não obrigatórias deverão, por exemplo, ser tomadas em consideração para compreender o processo contemporâneo de criação de uma regra convencional ou consuetudinária." ${ }^{" 58}$ Ademais, instrumentos não vinculantes podem prover "a confirmação necessária de uma obrigação legal (opinio juris) para evidenciar o costume emergente e assistem no estabelecimento do conteúdo da norma." $" 59$

Destaca-se, ainda, que a distinção entre instrumentos chamados de "bardlaw" e aqueles apontados como "softlaw" está se tornando cada vez mais difícil. Nem mesmo as provisões internas dos documentos são suficientemente contrastivas. Nesse sentido:

recentemente, órgãos de fiscalização foram criados para supervisionar o cumprimento das normas não vinculantes. A Comissão de Desenvolvimento

58 DIHN, Nguyen Quoc; DAILLIER, Patrick; PELLET, Alain. Direito Internacional Público. $2^{\mathrm{a}}$ ed. Braga: Fundação Calouste Gulbenkian, 2003, p. 114.

59 SHELTON, Dinah. International Law and "Relative Normativity". In.: EVANS, Malcolm D. International Law. Oxford: Oxford University Press, 2003, p. 166, tradução nossa. [Non-binding instruments sometimes have provided] the necessary statement of legal obligation (opinion juris) to evidence the emergent custom and have assisted to establish the content of the norm.
Sustentável, por exemplo, supervisiona a implementação da Agenda 21, o plano de ação adoptado em 1992 na Conferência do Rio sobre Meio Ambiente e Desenvolvimento. Em outros casos, os Estados foram convidados a apresentar relatórios sobre o cumprimento declarações e programas de ação, de uma maneira que imita, se não duplica, os mecanismos utilizados nos tratados. $^{60}$

O desenvolvimento sustentável encontra-se, dessa forma, manifesto em incontáveis declarações, resoluções, programas de ação e códigos de conduta. ${ }^{61}$ Não obstante, são vários os tratados que consagram a expressão. No início de $2015,{ }^{62}$ o termo encontrava-se expresso em 134 tratados registrados nas Nações Unidas. No entanto, algumas pesquisas apontam um número ainda mais expressivo. ${ }^{63}$ Esses dados indicam a ampla aceitação do desenvolvimento sustentável e o reconhecimento de sua importância como objetivo consensual da sociedade internacional. Entre esses, destaca-se a reincidência da caracterização do desenvolvimento sustentável como objetivo, com a indicação dos tipos de ações que devem ser conduzidas para alcançá-lo. $\mathrm{Na}$

60 SHELTON, Dinah. International Law and "Relative Normativity". In.: EVANS, Malcolm D. International Law. Oxford: Oxford University Press, 2003 , p. 165 , tradução nossa. [Recently, the budies of supervision be created to oversee compliance with the non-binding standards. The Sustainable Development Commission, for example, oversee the Agenda 21's implantation, the action plan adopted in 1992 in Conference of Rio about Environmental. In other cases, the States were invited for show the reports about the greeting declarations and actions programs in a way that mimics, if not duplicates, the mechanisms used in the Treaties

61 O termo se encontra, até em 2015, expresso em 134 tratados, 33 desses tratados se referem ao termo com um objetivo da sociedade internacional. Outrossim, a adoção do conceito de desenvolvimento sustentável pode ser ilustrada, também, por tratados regionais para além dos multilaterais com participação do mundo todo. A exemplo, cita-se os Tratados de Maastricht e Amsterdã. Nesse sentido, também, cita-se que o conceito de desenvolvimento sustentável se insere em cartas constitutivas de organizações internacional, como ocorre na Organização Mundial do Comércio (OMC) que destaca o desenvolvimento sustentável em seu preâmbulo. Dessa forma, também o conceito aparece em várias declarações e documentos não vinculantes

62 Pesquisa realizada para os fins desse trabalho. Foram analisados todos os tratados publicados pelo secretariado geral da ONU, até a data de 7 de janeiro de 2015, que mencionam as palavras: desenvolvimento, durável e sustentabilidade. Exceto aqueles cujo texto não é publicado em respeito ao artigo 102 da Carta das Nações Unidas.

63 "Na virada da década, mais de 300 convenções incluíam o desenvolvimento sustentável em seu texto, sendo 112 de caráter multilateral e ao menos 30 destes com participação universal." BARRAL, Virginie. Sustainable Development in International Law: Nature and Operation of an Evolutive Legal Norm. The European Journal of International Law. Vol. 23, n. 2, julho 2012, p. 384. 
maioria desses tratados, ${ }^{64} \mathrm{o}$ desenvolvimento sustentável está na parte dispositiva do texto, tecnicamente vinculante, portanto, e não apenas em seu preâmbulo - parte sem força obrigatória. ${ }^{65}$

Se, por um lado, a penetrabilidade do desenvolvimento sustentável no direito dos tratados é evidente, por outro lado, a flexibilidade de sua formulação nesses documentos é inegável. Diferentemente de alguns instrumentos não vinculantes, como a Declaração do Rio, os tratados trazem disposições marcadas por expressões vagas, pelo uso do condicional, “(...) muitas vezes mais perto da definição de um incentivo do que pretendendo ser estritamente restritiva." ${ }^{66}$

A imprecisão de uma obrigação, no entanto, não é suficiente para obstaculizar a validade e a natureza jurídica vinculante de uma norma. Existem diversas disposições convencionais que estabelecem incentivos (no sentido de que as partes deverão promover ou se esforçar para) e constituem, ainda assim, normas jurídicas perfeitas. ${ }^{67} \mathrm{~A}$ natureza jurídica dessas normas não é contestada simplesmente por sua imprecisão. ${ }^{68}$ Posto isso, tem-se que o caráter mais brando do desenvolvimento sustentável não impede que este seja uma norma válida de direito internacional. Significa, apenas, que existirá uma maior margem de apreciação pelas partes do tratado no momento da execução de suas obrigações. ${ }^{69}$

Conclui-se que, de fato, o caráter vago das dispo-

64 "Todavia, uma análise empírica mostra que 207 dessas referências encontram-se na parte dispositiva das convenções (...)." BARRAL, Virginie. Sustainable Development in International Law: Nature and Operation of an Evolutive Legal Norm. The European Journal of International Law. Vol. 23, n. 2, julho 2012, p. 384, tradução nossa.

65 Ver, nesse sentido, MAZZUOLI, Valerio de Oliveira. Curso de Direito Internacional Público. São Paulo: Revista dos Tribunais, 2011a, p. 186.

66 BARRAL, Virginie. Sustainable Development in International Law: Nature and Operation of an Evolutive Legal Norm. The European Journal of International Law. Vol. 23, n. 2, julho 2012, p. 384, tradução nossa. (...) often closer to setting out an incentive than purporting to be strictly constraining.

67 Ver BARRAL, Virginie. Sustainable Development in International Law: Nature and Operation of an Evolutive Legal Norm. The European Journal of International Law. Vol. 23, n. 2, julho 2012, p. 384. 68 A imprecisão, com efeito, é característica de uma norma mais branda, e trará consequências na sua implementação. Ver, nesse sentido, LAGE, Délber A. A Jurisdicionalização do direito internacional. Belo Horizonte: Del Rey, 2009. O argumento aqui é que tal particularidade não implica, per se, ausência de natureza jurídica etc.

69 Para mais sobre os efeitos do caráter brando de uma norma, ver LAGE, Délber A. A Jurisdicionalização do direito internacional. Belo Horizonte: Del Rey, 2009. sições convencionais relativas ao desenvolvimento sustentável dificultam a imposição de uma obrigação de desenvolver de forma sustentável..$^{70}$ Isso não impede, contudo, que uma obrigação seja imposta aos Estados para que eles "se esforcem para alcançar" ou "promovam" o desenvolvimento sustentável. São nesses termos que o desenvolvimento sustentável é usualmente consagrado no texto dos instrumentos internacionais e isso não afasta seu caráter normativo. Ao contrário, impõe uma obrigação de meio que, diferente daquelas que estabelecem o dever de alcançar determinado resultado (obrigação de fim), impõe aos Estados-parte o exercício de condutas que devem ser praticadas na tentativa de alcançar determinado objetivo. Infere-se, assim, com base nesses dispositivos convencionais, amplamente difundidos em tratados de abrangência universal, não apenas a consagração do desenvolvimento sustentável em uma das fontes formais do direito internacional, mas a reafirmação de sua normatividade.

Destaca-se, porém, que, de acordo que os pressupostos consagrados do direito dos tratados, a obrigação convencional - oriunda da celebração de um tratado vincula tão somente as partes signatárias desses instrumento. ${ }^{71}$ Para que se possa afirmar um alcance normativo erga omnes, relacionada à comunidade internacional como um todo, devido à importância do direito envolvido $^{72}$ e independente de um consentimento expresso, o desenvolvimento sustentável deve integrar a ordem jurídica internacional como um princípio geral ou uma norma de direito consuetudinário. Parte-se, então, para o estudo do desenvolvimento sustentável dentro das demais fontes primárias reconhecidas pelo direito internacional.

\subsubsection{Princípio como Fonte de Direito Interna- cional}

70 É esse o argumento de Lowe para sustentar que o desenvolvimento sustentável não pode ser considerado uma norma primária que visa restringir comportamento. LOWE, Vaughn. Sustainable Development and Unsustainable Arguments. In: BOYLE, Alan; FREESTONE, David (eds.). International Law and Sustainable Development: Past Achievements and Future Challenges. Oxford: Oxford University Press, 1999.

71 Ver, nesse sentido, REZEK, José Francisco. Direito Internacional Público. São Paulo: Saraiva, 2011, p. 42.

72 Essa caracterização foi feita pela Corte Internacional de Justiça no caso Barcelona Traction de 1970. Ver SHELTON, Dinah. International Law and "Relative Normativity". In.: EVANS, Malcolm D. International Law. Oxford: Oxford University Press, 2003, p. 145. 
As discussões sobre a natureza jurídica do desenvolvimento sustentável, no que tange a sua relação com as fontes formais de Direito Internacional, são, em sua grande maioria, voltadas para os tratados e o costume internacional. Os princípios gerais de direito, nesse contexto, são colocados à margem do debate. Isso se justifica não apenas pela aparente dificuldade, por parte da doutrina, de caracterizar um princípio como fonte de direito sem passar pelo crivos utilizados para a identificação de um costume internacional, "mas também em razão das diferentes concepções ainda contidas na teoria geral do direito internacional sobre a própria noção de 'princípios.." ${ }^{73}$ Nesse contexto:

\footnotetext{
alguns autores recusam ver nos princípios gerais de direito uma "terceira" fonte, distinta do costume ou da convenção. Estas posições explicam-se, mas assentam sobre uma confusão: o que visam na realidade estes autores, são os princípios gerais do direito internacional, o mesmo será dizer as regras gerais deduzidas do espíritos dos costumes e das convenções em vigor; a este título enobrecem bem o direito consuetudinário. Mas eles devem ser nitidamente distinguidos dos princípios gerais de direito. $^{74}$
}

Fato é que, mesmo nos trabalhos em que o desenvolvimento sustentável é tratado como um princípio jurídico, a argumentação acerca de seu status se aproxima de forma quase indiscriminada dos fundamentos daqueles que o caracterizam como norma geral consuetudinária. ${ }^{75}$ Em uma perspectiva prática, parece que parte da doutrina, mesmo reconhecendo o desenvolvimento sustentável como princípio geral, carece de uma comprovação de sua qualidade jurídica por meio dos elementos necessários para a consagração de uma norma do costume internacional - quais sejam, a prática estatal

73 BEYERLIN, Ulrich. Different Types of Norms in International Environmental Law. Policies, Principles and Rules. In: BODANSKY, D. et al. (eds.), The Oxford Handbook of International Environmental Law. Oxford: Oxford University Press, 2007, p. 428 apud JUSTE-RUIZ, José. The Implications of the Principle of Sustainable Development in Internationa Environmental Law. In: CONSTANTINIDES, Aristotle; ZAIKOS, Nikos. The Diversity of International Law. Leiden: Brill, 2009, p. 639-640, tradução nossa. (...) but also to the different conceptions still held in the general theory of international law about the

very notion of 'principles'.

74 DIHN, Nguyen Quoc; DAILLIER, Patrick; PELLET, Alain. Direito Internacional Público. $2^{\mathrm{a}} \mathrm{ed}$. Braga: Fundação Calouste Gulbenkian, 2003, p. 355.

75 Ver CORTE INTERNACIONAL DE JUSTIÇA (CIJ). Parecer Dissidente do Juiz. Antônio Augusto Cançado Trindade. Caso Relativo às Fábricas de Celulose no Rio Uruguai (Argentina v. Uruguai), 20 de abril de 2010b. Disponível em: http://www.icj-cij.org/docket/ files/135/15885.pdf . Acesso em: 08 jan. 2015. reiterada e a opinio iuris. Todavia, a resistência à autonomia dos princípios gerais de direito enquanto fonte destoa do texto do artigo 38 do Estatuto da CIJ que os consagra de forma independente e inequívoca.

Ademais, a delimitação do que deve ser compreendido por princípios gerais de direito é igualmente objeto de debates. Em que pese a compreensão dominante de que se trata "essencialmente dos princípios de direito interno, vigentes in foro domestico" ${ }^{976}$, parte da doutrina defende que os princípios gerais específicos do direito internacional devem ser igualmente considerados: "como estes princípios nascem diretamente da ordem internacional, sua aplicação pela CIJ deve ser imediata, não havendo que se discutir sobre sua juridicidade e sobre o seu caráter de fonte do Direito Internacional Público". ${ }^{77}$

Nesse ensejo, o juiz Cançado Trindade, da Corte Internacional de Justiça, no caso das Papeleiras sobre o rio Uruguai, abordou diretamente a questão. O juiz brasileiro sustenta, em seu parecer dissidente, que os princípios gerais de direito são uma importante (e independente) fonte de direito internacional do meio ambiente. Ele estabelece, por conseguinte, os fundamentos para o reconhecimento do desenvolvimento sustentável como princípio jurídico, independentemente de seu caráter consuetudinário. Apesar do argumento ter sido subjugado na decisão final do caso, suas alegações merecem destaque.

O Juiz Cançado Trindade afirma, inicialmente, a autonomia dos princípios gerais de direito interno e internacional, sendo estes de grande importância no alargamento do corpo juris do direito Internacional na atualidade. ${ }^{78} \mathrm{O}$ juiz critica a falta de diligência e zelo

76 DIHN, Nguyen Quoc; DAILLIER, Patrick; PELLET, Alain. Direito Internacional Público. $2^{a}$ ed. Braga: Fundação Calouste Gulbenkian, 2003 , p. 355. Os autores continuam: "O poder concedido ao juiz não passa de um poder de verificação de princípios estabelecidos, já existentes nas ordens jurídicas nacionais."

77 MAZZUOLI, Valerio de Oliveira. Curso de Direito Internacional Público. São Paulo: Revista dos Tribunais, 2011a, p. 128. Essa opinião é acompanhada por autores clássicos: “Certos autores vão mais longe e consideram que os princípios de direito podem derivar tanto da ordem internacional como das ordens internas (Verdross, Hudson, Rousseau)." DIHN, Nguyen Quoc; DAILLIER, Patrick; PELLET, Alain. Direito Internacional Público. $2^{\mathrm{a}}$ ed. Braga: Fundação Calouste Gulbenkian, 2003, p. 357.

78 Ver CORTE INTERNACIONAL DE JUSTIÇA (CIJ). Parecer Dissidente do Juiz. Antônio Augusto Cançado Trindade. Caso Relativo às Fábricas de Celulose no Rio Uruguai (Argentina v. Uruguai), 20 de abril de 2010b, p. 137. Disponível em: http://www.icj-cij.org/docket/files/135/15885.pdf . Acesso em: 08 jan. 2015. 
dedicada aos princípios gerais de direito por parte da Corte que, segundo ele, no julgamento do caso das $\mathrm{Pa}-$ peleiras, apenas os mencionou in passim e sem a devida elaboração. ${ }^{79}$ Enfrentando diretamente a questão sobre a possibilidade (ou o dever) da CIJ de recorrer aos princípios do direito ambiental, nos termos do artigo 38 (1) (c) do seu Estatuto, o juiz confirma expressamente que “esses princípios constituem uma 'fonte' (formal) de direito internacional, independentemente, sem necessariamente ser incluído nos costumes ou tratados." $\$ 00$

\begin{abstract}
A atitude de parte da literatura especializada contemporânea, de tentar ver se um determinado princípio alcançou o 'status' de uma 'norma' de direito internacional consuetudinário, ou foi 'reconhecido' no direito internacional convencional, simplesmente foge da questão essencial, e é conceitualmente equivocada. Tal atitude deixa de entender que um princípio geral de direito é suficientemente distinto de uma regra de direito internacional consuetudinário ou uma norma de direito internacional convencional. ${ }^{81}$
\end{abstract}

O fato do Estatuto da Corte não equiparar os princípios gerais de direito ao costume ou aos tratados significa que estes devem ser considerados uma categoria própria, distinta das demais fontes. Nesses termos, os

79 "Sinto-me, portanto, obrigado, no presente parecer dissidente, a tentar restabelecer o equilíbrio, ao concentrar os meus pensamentos em princípios legais e, em especial os aplicáveis no caso em questão. Faço-o com um espírito construtivo, na esperança (poderia eu me atrever a alimentá-la?) de que a Corte seja mais sensíveis aos princípios legais em suas decisões futuras (...)." CORTE INTERNACIONAL DE JUSTIÇA (CIJ). Parecer Dissidente do Juiz Antônio Augusto Cançado Trindade. Caso Relativo às Fábricas de Celulose no Rio Uruguai (Argentina v. Uruguai), 20 de abril de 2010b, p. 138, tradução nossa. Disponível em: http://www.icj-cij.org/docket/ files/135/15885.pdf . Acesso em: 08 jan. 2015.

80 CORTE INTERNACIONAL DE JUSTIÇA (CIJ). Parecer Dissidente do Juiz. Antônio Augusto Cançado Trindade. Caso Relativo às Fábricas de Celulose no Rio Uruguai (Argentina v. Uruguai), 20 de abril de 2010b, p. 142, tradução nossa. Disponível em: http://www. icj-cij.org/docket/files/135/15885.pdf . Acesso em: 08 jan. 2015. (...) those principles constitute a (formal) "source" of international law, on their own, not necessarily to be subsumed under custom or treaties.

81 CORTE INTERNACIONAL DE JUSTIÇA (CIJ). Parecer Dissidente do Juiz Antônio Augusto Cançado Trindade. Caso Relativo às Fábricas de Celulose no Rio Uruguai (Argentina v. Uruguai), 20 de abril de 2010b, p. 142, tradução nossa. Disponível em: http:/ /www. icj-cij.org/docket/files/135/15885.pdf . Acesso em: 08 jan. 2015. The attitude of part of contemporary expert writing, of trying to see if a given principle has attained the "status" of a "norm" of customary international law, or has been "recognized" in conventional international law, simply misses the point, and is conceptually flawed. Such attitude fails to understand that a general principle of law is quite distinct from a rule of customary international law or a norm of conventional international law. princípios gerais de direito constituem uma das fontes formais do direito internacional, independente e autônoma, a qual o juiz pode recorrer diante de um caso um específico, contrariando, assim, a perspectiva positivista típica, que defende a necessidade de manifestação por meio de tratados ou costume.

O juiz Cançado Trindade, então, cita como exemplo para ilustrar seu argumento os princípios do direito internacional do meio ambiente. Para ele, o reconhecimento gradual desses princípios reflete a emergência de uma consciência acerca da necessidade de proteger o meio ambiente, não só em razão de sua vulnerabilidade, mas pelas consequências nefastas e irreparáveis que está sujeito se a devida atenção não for dada a sua tutela. Essa consciência foi fundamental para a consolidação desses princípios. Entre eles, o desenvolvimento sustentável pode ser destacado. Trindade afirma que, não obstante as correntes ainda hesitantes que se referem ao desenvolvimento sustentável apenas como "conceito", parte da doutrina já avançou no sentido de admiti-lo como um princípio geral de direito internacional do meio ambiente e, de fato, existem fortes razões para esse reconhecimento. ${ }^{82}$

Todavia, a caracterização do desenvolvimento sustentável como manifestação de fontes formais, tais quais os tratados e os princípios gerais de direito, permanece, com efeito, secundária nos trabalhos acadêmicos que discutem sua natureza jurídica, embora por razões distintas. Os tratados, por um lado, criam vínculos jurídicos restritos aos Estados signatários do instrumento, não criando, via de regra, obrigações para um terceiro Estado sem o seu consentimento, nos termos do artigo 34 da Convenção de Viena sobre Direito dos Tratados. Nesse sentido, na ausência de

82 Ver CORTE INTERNACIONAL DE JUSTIÇA (CIJ). Parecer Dissidente do Juiz. Antônio Augusto Cançado Trindade. Caso Relativo às Fábricas de Celulose no Rio Uruguai (Argentina v. Uruguai), 20 de abril de 2010b, p. 187, tradução nossa. Disponível em: http://www. icj-cij.org/docket/files/135/15885.pdf . Acesso em: 08 jan. 2015. Os princípios são, com efeito, os fundamentos de qualquer sistema legal e não podem ser negligenciados. Atribuir ao desenvolvimento sustentável a condição de princípio geral de direito, no entanto, não significa dizer que o desenvolvimento sustentável é uma regra de direito internacional que prescreve obrigações aos Estados. No mesmo parecer, o juiz Cançado Trindade ressalta que um princípio não se confunde com uma norma ou uma regra, "estes últimos são inspirados no primeiro, e obedecem aquele.” CORTE INTERNACIONAL DE JUSTIÇA (CIJ). Parecer Dissidente do Juiz Antônio Augusto Cançado Trindade. Caso Relativo às Fábricas de Celulose no Rio Uruguai (Argentina v. Uruguai), 20 de abril de 2010b, p. 142, tradução nossa. Disponível em: http://www.icj-cij.org/docket/ files/135/15885.pdf . Acesso em: 08 jan. 2015. 
um tratado global com a previsão expressa da obrigação de promover o desenvolvimento sustentável, a afirmação da existência de uma norma geral de direito internacional relativa ao desenvolvimento sustentável com base exclusivamente nessa fonte será continuamente (e compreensivelmente) alvo de resistência. Por outro lado, as divergências relacionadas aos princípios gerais de direito enquanto fonte formal autônoma de direito internacional consistem em embaraços potenciais para a determinação de uma obrigação relativa ao desenvolvimento sustentável assentada tão somente nessa fonte. Por essas razões, a discussão sobre a existência de uma norma consuetudinária concernente ao desenvolvimento sustentável permanece preponderante nos debates acerca de sua natureza jurídica.

Os argumentos até aqui apresentados demonstram que o desenvolvimento sustentável encontra-se inserido e reconhecido tanto como norma convencional em diversos tratados internacionais, assim como um princípio geral de direito internacional do meio ambiente, em sua compreensão mais abrangente. A sua identificação como norma costumeira, contudo, se faz importante para que se possa estabelecer a existência de uma obrigação oponível aos sujeitos independentemente de anuência expressa em determinado tratado ou de divergências teóricas acerca da serventia dos princípios enquanto fonte formal autônoma de direito internacional. Nesse contexto, parte-se para a análise do desenvolvimento sustentável enquanto norma internacional de direito consuetudinário.

\subsubsection{Direito Internacional Costumeiro}

O costume internacional mantém sua grande relevância como fonte de direito internacional, não apena pela ausência na sociedade internacional de uma produção normativa centralizada e integrada, mas igualmente, por viabilizar a consolidação de regras gerais de direito com aplicabilidade universal. ${ }^{83} \mathrm{O}$ artigo $38, \int 1^{\circ}$, alínea $b$, do Estatuto da Corte Internacional de Justiça define o costume internacional como "prova de uma prática geral aceita como sendo o direito" ${ }^{84}$ Uma norma

83 Ver, nesse sentido, MAZZUOLI, Valerio de Oliveira. Curso de Direito Internacional Público. São Paulo: Revista dos Tribunais, 2011a, p. 116.

84 BRASIL. Decreto $N^{o}$ 19.841. Promulga a Carta das Nações Unidas, da qual faz parte integrante o anexo Estatuto da Corte Internacional de Justiça, assinada em São Francisco, a 26 de junho de 1945, por ocasião da Conferência de Organização Internacional das Nações Unidas. 22 out. 1945. Disponível em: http://www.planalto. consuetudinária, portanto, remete a uma conduta dos Estados, geral e consistente, por estes respeitadas e aplicadas pelo entendimento aceito de que se trata de uma obrigação legal.

Infere-se dessa definição os dois elementos necessários para se configurar o costume. É necessário, por um lado, a prática reiterada por parte dos Estados de determinado comportamento (elemento objetivo) e, por outro lado, o reconhecimento de tal prática como juridicamente vinculante (elemento subjetivo). No que tange ao elemento objetivo, mesmo que a adesão universal de uma prática não seja necessária, esta deve ser consistente. Assim, condutas contrárias isoladas devem ser interpretadas como violações e não como a emergência de uma nova prática. Para essa identificação, a CIJ tem analisado diversos elementos, como declarações, conferências, votos dos Estados em organizações internacionais etc. ${ }^{85}$

Contudo, a repetição uniforme e consistente de determinados atos pelos Estados, ${ }^{86}$ apesar de indicar a construção de um costume, não é, per se, capaz de estabelecer uma norma consuetudinária. Isso porque, diferente do simples uso, o costume exige uma consciência, por parte dos atores que praticam aquela conduta, de se tratar de uma obrigação oriunda de uma regra jurídica e, por conseguinte, passível de sanção em caso de não observância. Essa convicção necessária para o reconhecimento de um costume é conhecida como opinio juris.

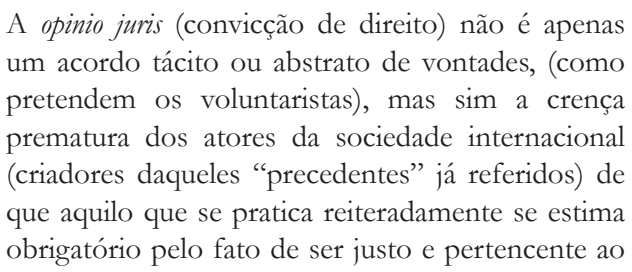

gov.br/ccivil_03/decreto/1930-1949/d19841.htm . Acesso em: 07 jan. 2015 .

85 Ver, nesse sentido, ATAPAT'TU, Sumudu A. Emerging Principles of International Environmental Law. New York: Transnational Publishers, 2007, p. 183.

86 Tradicionalmente (e sob uma perspectiva pragmática) é a parte Estatal, aliada ao elemento subjetivo, que é capaz de criar uma norma costumeira. Existe, contudo, autores que discorrem sobre a possibilidade dos demais sujeitos de direito internacional, em especial, as Organizações Internacionais, de, por meio de uma prática reiterada, incitar a formulação de um costume. Neste trabalho, para caracterização do desenvolvimento sustentável como costume, apesar da constante movimentação das organizações internacionais em prol do desenvolvimento sustentável, será analisada sob a ótica da conduta dos Estados. Para mais sobre essa discussão, ver MAZZUOLI, Valerio de Oliveira. Curso de Direito Internacional Público. São Paulo: Revista dos Tribunais, 2011a, p. 116-125. 


\section{universo do Direito. ${ }^{87}$}

A categorização dos elementos que compõem o costume, no entanto, não se traduz em uma facilidade na classificação de uma norma como tal. A referência à jurisprudência de cortes internacionais para a identificação da natureza consuetudinária de determinada proposição ganha relevância, nesse contexto, no intuito de garantir um grau de segurança para as questões jurídicas. Devido à dificuldade de se provar a existência de um costume, recorre-se à autoridade das decisões judiciais, em especial da Corte Internacional de Justiça. Mas, justamente em razão dessa autoridade, a CIJ tem adotado cautela para não reconhecer a existência de uma norma consuetudinária como muita celeridade. ${ }^{88}$ Isso se justifica pois tal autoridade só é mantida na medida em que as decisões permanecem aceitáveis aos Estados. De fato, uma afirmação precipitada acerca do caráter consuetudinário de determinada noção poderia gerar um desgaste político para a Corte. Essa conduta excessivamente precatada pode ser percebida em relação à natureza potencialmente costumeira do desenvolvimento sustentável.

Não obstante o reconhecimento contínuo das decisões judiciais acerca da importância do desenvolvimento sustentável no direito internacional, os juízes (com destaque para os da CIJ) ainda hesitam em afirmar claramente o seu caráter consuetudinário. A CIJ, como visto, consagrou a relevância do desenvolvimento sustentável independentemente de sua inclusão em tratado. Assim o fez no caso Gabcíkovo-Nagymaros, ao afirmar a necessidade expressa no conceito de desenvolvimento sustentável de conciliar o desenvolvimento econômico com a proteção ambiental, ${ }^{89}$ como também o fez no caso das Papeleiras, ao analisar a consistência dos dispositivos do tratado então em disputa de acordo com o objetivo do desenvolvimento sustentável. ${ }^{90}$ Ainda as-

87 MAZZUOLI, Valerio de Oliveira. Curso de Direito Internacional Público. São Paulo: Revista dos Tribunais, 2011a, p. 119.

88 Ver BARRAL, Virginie. Sustainable Development in International Law: Nature and Operation of an Evolutive Legal Norm. The European Journal of International Law. Vol. 23, n. 2, julho 2012.

89 Ver CORTE INTERNACIONAL DE JUSTIÇA (CIJ). Projeto Gabcikovo-Nagymaros (Hungria v. Eslováquia). Reports of Judgments, Advisory Opinions and Orders, 25 de setembro de 1997b, p. 78. Disponível em: http://www.icj-cij.org/docket/files/92/7375.pdf . Acesso em: 05 jan. 2015.

90 Ver CORTE INTERNACIONAL DE JUSTIÇA (CIJ). Caso Relativo às Fábricas de Celulose no Rio Uruguai (Argentina v. Uruguai). Reports of Judgments, Advisory Opinions and Orders, 20 de abril de $2010^{a}$, p. 74. Disponível em: http://www.icj-cij.org/docket/ sim, a Corte ficou aquém de determinar sua natureza consuetudinária.

Deve-se ressaltar, todavia, o parecer dissidente do Juiz Weeramentry no caso Gabcíkovo-Nagymaros. Nessa ocasião o então vice-presidente adrede afirmou o caráter normativo do desenvolvimento sustentável:

o princípio do desenvolvimento sustentável é, portanto, uma parte do direito internacional moderno em razão não apenas da sua necessidade lógica inescapável, mas também devido à sua ampla e geral aceitação pela comunidade global. ${ }^{91}$

O juiz afirmou, nesse ensejo, que existem indícios abundantes de reconhecimento geral entre os Estados da prática do desenvolvimento sustentável como obrigatória, suficiente para que lhe seja atribuída a natureza de direito consuetudinário. ${ }^{92}$ Cabe mencionar que uma das consequências diretas da ampla aceitação do desenvolvimento sustentável no direito internacional foi a incorporação da noção em legislações nacionais, o que corrobora a ideia de uma prática estatal nesse sentido. Com efeito, o desenvolvimento sustentável é introduzido como prioridade nos sistemas legais dos Estados, que reorganizam suas estruturas institucionais considerando esse objetivo. Exemplos, não exaustivos, de países que adotam explicitamente a noção em suas legislações e instituições incluem a Argentina, a Austrália, a Noruega e a Nova Zelândia. ${ }^{93}$

files/135/15877.pdf . Acesso em: 05 jan. 2015.

91 CORTE INTERNACIONAL DE JUSTIÇA (CIJ). Caso Relativo às Fábricas de Celulose no Rio Uruguai (Argentina v. Uruguai). Reports of Judgments, Advisory Opinions and Orders, 20 de abril de 2010a, p. 95, tradução nossa. Disponível em: http://www.icj-cij.org/docket/files/135/15877.pdf . Acesso em: 05 jan. 2015.The principle of sustainable development is thus a part of modern international law by reason not only of its inescapable logical necessity, but also by reason of its wide and general acceptance by the global community. 92 Ver CORTE INTERNACIONAL DE JUSTIÇA (CIJ). Caso Relativo às Fábricas de Celulose no Rio Uruguai (Argentina v. Uruguai). Reports of Judgments, Advisory Opinions and Orders, 20 de abril de $2010^{a}$, p. 104. Disponível em: http://www.icj-cij.org/docket/ files/135/15877.pdf . Acesso em: 05 jan. 2015.

93 A Argentina, por exemplo, possui uma Secretaria para o Desenvolvimento Sustentável e Meio Ambiente, dentro do Ministério do Meio Ambiente. A Austrália refere-se explicitamente ao "desenvolvimento ecologicamente sustentável”, como consta do art. 1 (b) do Ato de Proteção Ambiental e Conservação da Biodiversidade de 1999. A Noruega adotou a Política Ambiental para o Desenvolvimento Sustentável, e a Nova Zelândia publicou em 2003 o Programa de Ação para Desenvolvimento Sustentável. Para mais, ver Voigt (2008, p. 23-24). Ver, igualmente, Schrijver (2008, p. 153-154): “O fato de que 24 constituições nacionais contêm referências ao desenvolvimento sustentável, visto em conjunto com a ampla adoção do conceito em tratado-lei internacional, demonstra ainda mais o peso do princípio do desenvolvimento sustentável." Para exemplos 
No entanto, apesar do posicionamento assertivo do vice-presidente Weeramentry, a Corte não o confirmou na decisão. Com isso, a inserção do desenvolvimento sustentável no rol das normas consuetudinárias de direito internacional permanece como objeto de apreciação de juristas internacionais. A jurisprudência da CIJ volta a ser referência, se não estabelecendo claramente o status normativo do desenvolvimento sustentável, ao menos provendo elementos para a identificação de uma regra geral costumeira.

Em sua decisão nos casos da Plataforma Continental do Mar do Norte, a Corte estabelece que uma provisão, para formar a base de uma regra geral de direito, deve possuir um caráter fundamental de criar normas ("norm-creating character"). ${ }^{94} \mathrm{E}$ essa passagem tem sido usada como fundamento para negar a existência de uma norma costumeira relativa ao desenvolvimento sustentável. ${ }^{95}$

O argumento, contrário às conclusões do Juiz Weeramantry, é de que, na vasta gama de disposições de tratados, declarações e toda a sorte de documentos internacionais que adotam o termo "desenvolvimento sustentável”, não há evidências claras de que a noção tenha força de regra de direito internacional consuetudinário. ${ }^{96}$ Essas disposições não seriam capazes, nessa linha de argumentação, de limitar a conduta dos Estados, pois o desenvolvimento sustentável não teria o referido caráter de criar normas. Esse caráter só poderia ser admitido diante de uma formulação como: "os Estados devem desenvolver de forma sustentável". ${ }^{97}$

detalhados ver páginas 154 e seguintes.

94 Conforme descrito na referida decisão. CORTE INTERNACIONAL DE JUSTIÇA (CIJ). Casos da Plataforma Continental do Mar do Norte (República Federal da Alemanha / Dinamarca; República Federal da Alemanha / Países Baixos). Reports of Judgments, Advisory Opinions and Orders, 20 de fevereiro de 1969, p. 42. Disponível em: http://www.icj-cij.org/docket/files/52/5561.pdf . Acesso em: 09 jan. 2015.

95 Ver JUSTE-RUIZ, José. The Implications of the Principle of Sustainable Development in Internationa Environmental Law. In: CONSTANTINIDES, Aristotle; ZAIKOS, Nikos. The Diversity of International Law. Leiden: Brill, 2009, p. 640 e ATAPATTU, Sumudu A. Emerging Principles of International Environmental Law. New York: Transnational Publishers, 2007, p. 183.

96 Ver LOWE, Vaughn. Sustainable Development and Unsustainable Arguments. In: BOYLE, Alan; FREESTONE, David (eds.). International Law and Sustainable Development: Past Acbievements and Future Challenges. Oxford: Oxford University Press, 1999. p. 24.

97 LOWE, Vaughn. Sustainable Development and Unsustainable Arguments. In: BOYLE, Alan; FREESTONE, David (eds.). International Law and Sustainable Development: Past Achievements and Future Challenges. Oxford: Oxford University Press, 1999, p. 25.
Infere-se, desse modo, que, na busca identificar a natureza consuetudinária do desenvolvimento sustentável, estes autores tentam constatar se existe uma obrigação geral de desenvolver de forma sustentável, e a resposta para esse questionamento é, com efeito, negativa. ${ }^{98} \mathrm{~A}$ análise da prática estatal, por meio dos eventos e documentos internacionais em que o desenvolvimento sustentável é tratado, de fato, não indica expressamente que os Estados têm o dever de se desenvolverem sustentavelmente. "As formulações flexíveis relacionadas ao desenvolvimento sustentável significam que a evidência de opinio juris e prática estatal acerca de uma obrigação de desenvolver de forma sustentável é impossível de determinar." ${ }^{\prime 9}$

Porém, isso não significa que o desenvolvimento sustentável não se encontra refletido no costume internacional. $O$ fato de não existir uma obrigação clara de desenvolver de forma sustentável não implica que não exista uma obrigação de implementar medidas destinadas ao desenvolvimento sustentável, ou de promover o desenvolvimento sustentável. Nos dois contextos, a natureza jurídica é a mesma, o que altera é a categoria normativa que cada uma pertence. Uma obrigação de fim, que impõe o dever aos Estados de alcançar o desenvolvimento sustentável, pode não estar evidente na prática internacional; o mesmo, entretanto, não se pode asseverar sobre uma obrigação de meio, que vincule os sujeitos a dedicarem esforços e adotar ações para buscar o desenvolvimento sustentável.

Outrossim, na ausência de um reconhecimento expresso por parte da CIJ, a natureza consuetudinária dessa proposição pode ser averiguada frente aos elementos objetivos e subjetivos do costume, ou seja, a prática estatal e a opinio juris. Interessante notar que o desenvolvimento sustentável, assim como grande parte do direito internacional do meio ambiente, surge de forma peculiar nesse contexto, a partir da crença difundida entre os Estados da necessidade de se criar a regra em vez de declarar sua existência. Essa vontade reiterada de instituir uma norma pode, com efeito, resultar em um

98 Ver BARRAL, Virginie. Sustainable Development in International Law: Nature and Operation of an Evolutive Legal Norm. The European Journal of International Law. Vol. 23, n. 2, julho 2012, p. 386. 99 BARRAL, Virginie. Sustainable Development in International Law: Nature and Operation of an Evolutive Legal Norm. The European Journal of International Law. Vol. 23, n. 2, julho 2012, p. 386, tradução nossa. The flexible formulations relating to sustainable development mean that evidence of opinio juris and state practice of an obligation to develop sustainably is impossible to ascertain. 
costume. $^{100}$

A negociação, a adoção, a reafirmação de proposições semelhantes em diferentes instâncias internacionais podem irradiar as noções legais ali expressas para além do escopo inicial daqueles instrumentos. Dessa forma, a prática dos Estados reproduzirá estas proposições, emanando da opinio juris em vez de preceder a sua formação. ${ }^{101}$ A opinio juris, nesse caso, é resultado dos inúmeros instrumentos internacionais e nacionais que formulam o desenvolvimento sustentável em termos legais semelhantes. ${ }^{102}$ Apesar da flexibilidade marcante do desenvolvimento sustentável, cujas abordagens variam de um instrumento para o outro, não se pode negar uma coerência global entre elas no sentido de defini-lo como um objetivo a aspirar.

Se, por um lado, a aceitação do caráter legal da proposição do desenvolvimento sustentável pode ser inferido dos diversos atos jurídicos em que ele é abordado, esses mesmos atos, por outro lado, indicam igualmente uma prática geral reiterada relacionada a essa opinio juris. Além de celebrarem diversos documentos internacionais, tanto de caráter obrigatório como recomendatório, se reunirem em conferências, criarem organismos internacionais, tendo todas essas ações o desenvolvimento sustentável como objeto, ${ }^{103}$ os Estados ainda reportam à Comissão de Desenvolvimento Sustentável, implementam estratégias nacionais de desenvolvimento sustentá-

100 Ver SHELTON, Dinah. International Law and "Relative Normativity". In.: EVANS, Malcolm D. International Law. Oxford: Oxford University Press, 2003, p. 167.

101 BARRAL, Virginie. Sustainable Development in International Law: Nature and Operation of an Evolutive Legal Norm. The European Journal of International Law. Vol. 23, n. 2, julho 2012, p. 388. 102 "A opinio juris dos Estados sobre o carácter vinculante do desenvolvimento sustentável pode, assim, resultar da riqueza de resoluções, declarações, acordos de cavalheiros, programas de ação, decisões judiciais internacionais e nacionais, legislação nacional e as disposições convencionais referentes a ele, pelo menos na medida em que estas formulações possuam a forma de normas legais suficientemente semelhantes." BARRAL, Virginie. Sustainable Development in International Law: Nature and Operation of an Evolutive Legal Norm. The European Journal of International Law. Vol. 23, n. 2, julho 2012, p. 388, tradução nossa.

103 Como já expresso em nota anterior, a evocação do conceito de desenvolvimento sustentável, até no ano de 2015, teve referências em 134 tratados. Além dos tratados multilaterais que promover acordos em âmbitos globais, há os regionais como o de Maastricht e Amsterdã. Também pode-se perceber a presença desse conceito em cartas constitutivas como a da Organização Mundial do Comércio (OMC). Conclui-se, assim, que desenvolvimento sustentável é rememorado em diversos contextos, não se restringindo apenas o supracitados. vel e impõem a avaliação de impacto ambiental como procedimento obrigatório no intuito de alcançar o desenvolvimento sustentável. ${ }^{104}$

Pode-se questionar que a ausência de uniformidade dessas ações as desqualificam como precedentes de uma prática estatal consistente. No entanto, deve-se ressaltar que a própria noção de desenvolvimento sustentável impõe condutas variadas que devem ser adotadas para que se possa alcançá-lo, pois se trata de uma obrigação de meio, exigindo a implementação de diferentes tipos de esforços no intuito de se buscar o objetivo.

\begin{abstract}
Assim, condutas que visem alcançar o desenvolvimento sustentável, mesmo sem uniformidade, ainda podem formar precedentes válidos que constituem a prova da existência de uma prática geral dos Estados. Apesar da ausência de confirmação judicial clara, portanto, pode-se concluir que o desenvolvimento sustentável, como um objetivo, já constitui um princípio do direito consuetudinário, mesmo este princípio sendo muito geral, com um alto grau de abstração e que exige uma fundamentação caso a caso. ${ }^{105}$
\end{abstract}

A natureza jurídica do desenvolvimento sustentável encontra-se, destarte, refletida nas diferentes fontes formais do direito internacional. É claro que não se pode negar a existência de particularidades e arestas inerentes à proposição. Estas, no entanto, não retiram a qualidade jurídica do desenvolvimento sustentável, mas devem ser, de fato, compreendidas para que não se tornem impedimentos para a aplicação dessa obrigação — que tem sido caracterizada até aqui como sendo "de meio". Faz-se necessário, assim, explanar o significado dessa obrigação relativa, bem como as implicações do enquadramento nessa categoria normativa específica, sendo este, portanto, o objeto da próxima seção.

104 Ver BARRAL, Virginie. Sustainable Development in International Law: Nature and Operation of an Evolutive Legal Norm. The European Journal of International Law. Vol. 23, n. 2, julho 2012, p. 388. 105 BARRAL, Virginie. Sustainable Development in International Law: Nature and Operation of an Evolutive Legal Norm. The European Journal of International Law. Vol. 23, n. 2, julho 2012, p. 388 , tradução nossa. Hence, conduct aimed at achieving sustainable development, even if lacking uniformity, can still form valid precedents constituting evidence of the existence of a general practice of states. Despite clear judicial confirmation, it can thus be concluded that sustainable development, as an objective, already constitutes a principle of customary law, even if this principle is a very general one, with a high degree of abstraction and which requires case by case substantiation. 


\section{Desenvolvimento sustentável como uma OBRIGAÇÃO DE MEIO}

A caracterização do desenvolvimento sustentável como uma obrigação jurídica implica, necessariamente, o reconhecimento de sua natureza jurídica normativa, que visa regular o comportamento e que enseja responsabilização internacional pelo seu descumprimento. Assim, afirmar que o desenvolvimento sustentável constitui uma obrigação (seja de meio ou de fim) significa atribuir a essa noção o caráter de norma geral de direito internacional.

Um assertiva tão sólida sobre um tema tão permeado por imprecisões, de fato, encontra resistências das mais variadas ordens. Como visto, existem aqueles que se apoiam nas incertezas envolvendo a noção para negar qualquer qualidade jurídica ao desenvolvimento sustentável. No entanto, isso seria uma negligência em relação à presença constante, consistente e global da noção no direito internacional nos últimos 40 anos. Outros, nesse cenário, desconstroem a relevância da discussão, afirmando se tratar de uma matriz conceitual (ou, até mesmo, um novo ramo de direito internacional) composto por diversos princípios, esses sim, com qualidade jurídica. Apesar de amplamente difundida, essa perspectiva não é capaz de resolver o status do desenvolvimento sustentável no direito internacional. Nesses termos, os Estados não teriam um compromisso com o desenvolvimento sustentável, mas apenas com outros princípios autônomos de direito internacional do meio ambiente. O desenvolvimento sustentável permaneceria, assim, sem uma qualificação jurídica no direito internacional. Por fim, tem-se a compreensão do desenvolvimento sustentável como norma modificadora que age alterando normas primárias alterando seus efeitos jurídicos sendo, com isso, importante ferramenta hermenêutica para as instâncias judiciais internacionais. Sua normatividade estaria, assim, restrita a sua influência exercida nas cortes e tribunais, mas não seria capaz de regular a conduta dos sujeitos.

A função interpretativa do desenvolvimento sustentável é, decerto, de grande relevância, sendo capaz de "legitimar o recurso à interpretação evolutiva dos tratados, atuar como regra de resolução de conflitos e, até mesmo, redefinir obrigações convencionais." ${ }^{106}$

106 BARRAL, Virginie. Sustainable Development in International Law: Nature and Operation of an Evolutive Legal Norm.
Uma análise da qualidade jurídica do desenvolvimento sustentável não poderia, pois, ignorar essa função. No entanto, em que pese essa conveniente e relevante papel, o desenvolvimento sustentável não se limita apenas a uma ferramenta interpretativa, mas se propõe a regular a conduta dos sujeitos de direito internacional. A imprecisão que permeia a noção não retira da noção seu caráter de norma primária, mas limita, com efeito, sua caracterização como obrigação absoluta. Trata-se, portanto, de uma obrigação relativa de se alcançar o desenvolvimento sustentável, ou, em outras palavras, uma obrigação de meio em que Estados são obrigados a promover o desenvolvimento sustentável. Essa seção, por conseguinte, conclui a análise da natureza jurídica do desenvolvimento sustentável explanando as minúcias dessa obrigação de meio e as implicações de caracterizá-lo como tal.

$\mathrm{Na}$ tentativa de identificar a natureza jurídica do desenvolvimento sustentável, estabeleceram-se dois critérios necessários para que se pudesse atribuir status normativo à noção, a saber, ser capaz de produzir efeitos jurídicos e estar refletida em uma das fontes formais de direito internacional. Em relação ao segundo critério, as diversas manifestações em diferentes fontes, como o costume e os tratados, indicam que o desenvolvimento sustentável apresenta inegável qualidade jurídica.

No que concerne ao primeiro critério, apesar da flexibilidade de seu conteúdo material, este é, em certa medida, identificável, tendo em vista a caracterização amplamente aceita do desenvolvimento sustentável como um objetivo composto por elementos fundamentais que se repetem independentemente do contexto em que a proposição aparece. São justamente esses elementos que indicam os esforços que devem ser adotados e, portanto, as condutas prescritas na busca do objetivo do desenvolvimento sustentável. Ele é formulado, portanto, no sentido de regular a conduta dos sujeitos, i.e., prescrever determinando comportamento criando uma obrigação aos Estados em relação a ele. As implicações jurídicas do desenvolvimento sustentável, nesses termos, vão além de sua utilização interpretativa, modificando obrigações já existentes ou determinando seus efeitos, mas impõem um dever, o dever de promover o desenvolvimento sustentável. O cumprimento dessa

The European Journal of International Law. Vol. 23, n. 2, julho 2012, p. 377 , tradução nossa. (...) legitimize recourse to evolutive treaty interpretation, as a rule of conflict resolution, and even to redefine conventional obligations. 
obrigação pode ser verificado, com efeito, frente aos elementos constitutivos essenciais da proposição. Em outras palavras, os Estados estão obrigados a seguir condutas para promover o desenvolvimento sustentável, vinculando-se aos meios para buscar esse objetivo e não com o resultado em si. Isso porque se trata de uma obrigação relativa, ou obrigação de meio.

Esse aspecto peculiar não afeta a natureza jurídica do desenvolvimento sustentável, mas apenas o tipo normativo em que se enquadra. As regras que prescrevem um comportamento, conhecidas como regras primárias, ${ }^{107}$ podem se apresentar em diversas conformações, dentre as quais se insere a obrigação de meio.

Tal classificação remete a um expediente, usualmente adotado pelo direito privado, em especial na Teoria das Obrigações, no intuito de reforçar a efetividade de um dever em relação ao qual o compromisso com o resultado se mostra de difícil comprovação. Não é, contudo, um expediente de origem legal específico do direito civil, mas uma construção teórica perfeitamente transportável para o contexto das obrigações dos Estados no direito internacional.

A contraposição entre a obrigação de meio e de resultado, que encontra inspiração na doutrina francesa e respaldo nos sistemas jurídicos derivados do direito romano, ${ }^{108}$ remete à ambivalência entre o dever de realizar uma conduta ou de alcançar um resultado específico. Diante de uma obrigação de resultado, os destinatários da regra poderão ser exigidos pelo cumprimento de um objetivo final, enquanto a obrigação de meio impõe certos comportamentos que devem ser observados, determinados esforços que precisam ser envidados, sem, contudo, estarem vinculado a um resultado preciso. ${ }^{109}$

Desse modo, não existe uma obrigação absoluta de alcançar um desfecho específico. Sendo o resultado imprevisível ou incerto, fugindo ao controle de quem realiza a conduta exigida, seu dever só pode ser, pois, relativo, no sentido de garantir o emprego dos meios cabíveis, independentemente de um fim predeterminado. Frente ao exposto, a caracterização da obrigação de meio abarca a condição jurídica do desenvolvimento

107 Ver HART, H. L. A. O conceito de direito. São Paulo: Martins Fontes, 2009.

108 Ver CORDEIRO, António Menezes. Tratado de direito civil português. Coimbra: Almedina, 2009, p. 443.

109 Ver PEREIRA, Caio Mário da Silva. Instituições de Direito Civil - Teoria Geral das Obrigações. Rio de Janeiro: Forense, 2014, p. 132. sustentável com significativa consistência. As manifestações do desenvolvimento sustentável, tanto nos tratados como no costume internacional, são, em sua grande maioria, formuladas como um objetivo que os Estados devem se esforçar para alcançar. Assim como deve ser em uma obrigação de meio, o objeto dessa obrigação é justamente adotar condutas no intuito de buscar um objetivo, o qual servirá de referência para avaliar se os meios implementados são os adequados para cumprir a obrigação. ${ }^{110}$ Essa atuação como referência teleológica que valida os meios adotados diferencia a abordagem aqui defendida da lógica do desenvolvimento sustentável como uma matriz conceitual.

O desenvolvimento sustentável não se limita, por certo, a um conjunto de princípios conexos, porém independentes que podem ou não regular a conduta dos sujeitos. Refere-se a uma regra jurídica de conteúdo flexível, contudo identificável, que estabelece uma obrigação aos Estados de promover o desenvolvimento sustentável, por meio de esforços específicos e verificáveis. A pertinência dessas condutas para a busca do objetivo do desenvolvimento sustentável será justificada pela alusão à própria proposição, enquanto arquétipo teleológico do comportamento dos Estados. ${ }^{11}$

Tem-se, por conseguinte, que, dos Estados, deve ser exigido afinco na batalha pelo desenvolvimento sustentável, como consequência da obrigação relativa estabelecida. Por não consistir em uma obrigação absoluta, os sujeitos não estão obrigados a alcançá-lo, mas estão impelidos a tentar. Essa compreensão é confirmada pela International Law Association (ILA), por meio de seu Comitê de Recursos Hídricos, em seu quarto relatório, ao analisar as regras de Berlim sobre recursos hídricos. Nesse documento, o comitê afirma que:

a sustentabilidade não é uma obrigação absoluta.
(...) [E]m muitas situações, se um determinado uso
é sustentável será altamente discutível. Ao invés
de tentar estabelecer uma obrigação absoluta,
teoricamente, que, muitas vezes, será violada
na prática, esta regra identifica a obrigação de
tomar as medidas apropriadas para assegurar a
sustentabilidade - uma obrigação de "due diligence"
em relação a qual espera-se que os Estados se

110 BARRAL, Virginie. Sustainable Development in International Law: Nature and Operation of an Evolutive Legal Norm. The European Journal of International Law. Vol. 23, n. 2, julho 2012, p. 390. 111 Ver BARRAL, Virginie. Sustainable Development in International Law: Nature and Operation of an Evolutive Legal Norm. The European Journal of International Law. Vol. 23, n. 2, julho 2012, p. 390. 


$$
\text { conformem. }{ }^{112}
$$

Os Estados encontram-se, assim, compelidos a implementar ações que promovam o desenvolvimento sustentável. Nesse contexto, cabe aos sujeitos de direito internacional criar condições que facilitem a emergência dessa nova situação. Por certo, essa proposição não impõe uma obrigação absoluta de que o desenvolvimento seja sustentável. A prática estatal, não obstante, deve estar condicionada de tal forma que caminhe na direção desse objetivo. Para isso, parâmetros precisam ser identificados para que se possa avaliar a adequação do comportamento estatal adotado em relação a sua obrigação de promover o desenvolvimento sustentável. Isso porque o resultado final não é assegurado por aquelas condutadas, mas apenas pretendido. O sucesso dessas ações não pode, assim, ser avaliado pelo fim em si mesmo, mas devem ser constantemente apreciadas diante do objetivo desejado - o próprio desenvolvimento sustentável. Diante da impossibilidade de se avaliar a conduta do Estado de forma objetiva e direta com base na fruição de um desenvolvimento sustentável, faz-se imperativa a determinação de parâmetros.

A necessidade dessa verificação contínua por meio de parâmetros ocorre não apenas na medida em que a prática vai revelando aquelas mais ou menos adequadas ao propósito almejado, mas igualmente pela compreensão dos diferentes e complexos contextos nos quais pretende-se aplicar a regra do desenvolvimento sustentável. Nesse sentido, dois conjuntos podem ser distinguidos e merecem ser destacados, nomeadamente, os parâmetros de composição e os parâmetros de realização.

Dessa maneira, ressalta-se que os parâmetros de composição concernem, em grande parte, às questões oriundas da estruturação conceitual do desenvolvimento sustentável. Os elementos essenciais que constituem a noção compõem não apenas o conceito mas os meios próprios para alcançar aquele fim. Nesse sentido, princípios como o da integração, da equidade inter e intra-

112 INTERNATIONAL LAW ASSOCIATION (ILA). The Berlin Rules On Water Resources. Fourth Report of the Water Resources Committee, 2004, p. 16, tradução nossa. Disponível em: http://internationalwaterlaw.org/documents/intldocs/ILA_Berlin_Rules-2004.pdf . Acesso em: 13 jan. 2015. Yet sustainability is not an absolute obligation. (...) []n too many situations whether a particular use is sustainable will be highly debatable. Rather than attempt to lay down a theoretically absolute obligation that often will be breached in practice, this Rule identifies an obligation of to take appropriate measures to assure sustainability - a due diligence obligation to which States can be expected to conform. geracional, além de outros princípios conexos, como a avaliação do impacto ambiental, os princípios da precaução e participação, por exemplo, são, por um lado, denominadores comuns na busca de uma delimitação ao conceito e, por outro lado, padrões de conduta que devem ser respeitados para a promoção do desenvolvimento sustentável.

Os parâmetros de realização, por sua vez, aludem a questões pragmáticas que afetam a aplicabilidade da obrigação. Nesse sentido, a verificação da pertinência dos meios estabelecidos em relação ao fim desejado dependerá de questões como o grau de desenvolvimento dos Estados envolvidos, a consistência dos indicadores adotados ou o arcabouço institucional existente para assegurar o cumprimento da regra. As condutas relacionadas à obrigação de se promover o desenvolvimento sustentável devem ser, nesse sentido, identificáveis, para que possam ser exigíveis, porém capazes de se adaptar à complexa realidade global na qual pretende gerar efeitos. Assim, mais uma vez conclui-se que a concepção de parâmetros se torna fundamental para que se possa avaliar estas intricadas condições que se exige dos meios para buscar o desenvolvimento sustentável.

\section{Considerações finais}

Dentre os inúmeros institutos consagrados nas últimas décadas em matéria de direito internacional do meio ambiente, o desenvolvimento sustentável certamente se destaca, tanto pela função paradigmática a que se propõe como pela complexidade e as controvérsias que o acompanha. Nesse contexto, a determinação de sua natureza jurídica apresenta-se como tarefa fundamental para inferir possibilidades do direito internacional contribuir para a realização da noção, na medida em que institutos distintos implicam efeitos divergentes, especialmente no que tange sua exigibilidade por meio instrumentos jurídicos existentes. Se o conceito não possui qualquer inserção no universo do direito, sua efetivação escapa ao valimento do direito internacional. Ademais, qualquer proposta relacionada à aplicação do desenvolvimento sustentável deve estabelecer a natureza jurídica do conceito como premissa, na medida em que tal determinação irá condicionar as formas possíveis de implementar e superar os desafios de efetivação.

Dessa forma, a afirmação do desenvolvimento sus- 
tentável como uma obrigação de meio não é apenas uma construção coerente e propícia, mas estabelece, de forma clara, sua posição e seu caráter em relação ao direito internacional. Em que pese as variadas medidas e os diversos princípios envolvidos em sua consecução, os Estados têm, de fato, o dever de promover o desenvolvimento sustentável. Este trabalho buscou, nesse sentido, corroborar a abordagem sustentada por Virginie Barral de reconhecer a natureza jurídica de obrigação relativa ao desenvolvimento sustentável. Para esse propósito, foram estabelecidos critérios para a caracterização de uma norma de direito internacional, colocando à prova a "normatividade" do conceito e verificando sua relação com as diferentes fontes formais do direito internacional. Não obstante sua presença em instrumentos internacionais e sua recorrente menção enquanto princípio geral de direito, é precisamente como norma internacional consuetudinária que a noção se consolida enquanto uma obrigação imposta aos Estados.

No entanto, compreender as particularidades dessa obrigação é igualmente necessário para que a flexibilidade atribuída ao conceito não se confunda com uma impossibilidade de verificação da obrigação. A complexidade que envolve o tema, com efeito, impede uma imposição de se desenvolver sustentavelmente. Mas a consagração do desenvolvimento sustentável como um dos temas centrais da agenda internacional implica que os devidos esforços sejam sempre adotados para a consecução desse objetivo. Em outras palavras, a norma relativa ao desenvolvimento sustentável não estabelece um comportamento único esperado, mas que todo comportamento seja condicionado no intuito de alcançar esse objetivo primordial da sociedade internacional.

\section{ReferênCIAS}

ATAPATTU, Sumudu A. Emerging Principles of International Environmental Law. New York: Transnational Publishers, 2007.

BANCO MUNDIAL. Making Sustainable Commitments: An Environment Strategy for the World Bank. Washington: Banco Mundial, 2001.

BANCO MUNDIAL. World Development Report 2003. Sustainable Development in a Dynamic World. Transforming Institutions, Growth and Quality of Life. Washington: Banco Mundial, 2003.
BARRAL, Virginie. Sustainable Development in International Law: Nature and Operation of an Evolutive Legal Norm. The European Journal of International Law. Vol. 23, n. 2, p. 377-400, julho 2012.

BEYERLIN, Ulrich. The Concept of Sustainable Development. In: WOLFRUM, Rüdiger (ed.) Enforcing Environmental Standards: Economic Mechanisms as viable Means? Berlin: Springer, 1996.

BIRNIE, Patricia; BOYLE, Alan. International Law and the Environment. Oxford: Oxford University Press, 2002.

BODANSKY, Daniel. The Legitimacy of International Governance: A Coming Challenge for International Environmental Law? American Journal of International Law, v. 93, n. 3, p. 596-624, 1999.

BORDIN, Fernando Lusa. Justiça entre Gerações e a Proteção do Meio Ambiente: Um Estudo do Conceito de Equidade Intergeracional em direito internacional Ambiental. Revista de Direito Ambiental, vol. 52, p. 37, Out / 2008.

BOYLE, Alan; FREESTONE, David (eds.). International Law and Sustainable Development: Past Achievements and Future Challenges. Oxford: Oxford University Press, 1999.

BRANT, Leonardo Nemer Caldeira. A Corte Internacional de Justiça e a Construção do direito internacional. Belo Horizonte: O Lutador, 2005.

BRASIL. Decreto $N^{o}$ 19.841. Promulga a Carta das Nações Unidas, da qual faz parte integrante o anexo Estatuto da Corte Internacional de Justiça, assinada em São Francisco, a 26 de junho de 1945, por ocasião da Conferência de Organização Internacional das Nações Unidas. 22 out. 1945. Disponível em: http://www.planalto.gov.br/ccivil_03/decreto/1930-1949/d19841. htm Acesso em: 07 jan. 2015.

BRASIL. Decreto $N^{o}$ 7.030. Promulga a Convenção de Viena sobre Direito dos Tratados, concluída em 23 de maio de 1969, com reserva aos Artigos 25 e 66.14 dez. 2009. Disponível em: http://www.planalto.gov.br/ccivil_03/_Ato2007-2010/2009/Decreto/D7030.htm. Acesso em: 11 jan. 2015.

CAMERON, James; RODERICK, Peter; WERKSMAN, Jacob. Improving Compliance with International Environmental Law. Oxford: Routledge, 2014.

CANÇADO TRINDADE, Antônio Augusto. Direitos Humanos e Meio Ambiente: Paralelo dos Sistemas de Proteção Internacional. Porto Alegre: Fabris, 1993. 
CANÇADO TRINDADE, Antônio Augusto. Environment and Development: Formulation and Implementation of the Right to Development as a Human Right. In: TRINDADE, Antônio Augusto Cançado. Human Rights, Sustainable Development and the Environment. Brasília: IIDH/BID, 1992.

CANOTILHO, José Joaquim Gomes. Sustentabilidade Um Romance de Cultura e de Ciência para Reforçar a Sustentabilidade Democrática. In: Boletim da Faculdade de Direito. Universidade de Coimbra. Vol. LXXXVIII, Tomo I, 2012, pp. 1-12.

COMISSÃO DAS NAÇÕES UNIDAS SOBRE DESENVOLVIMENTO SUSTENTÁVEL (CNUDS). Report of the Expert Group Meeting on Identification of Principles of International Law for Sustainable Development, 1995. Disponível em:

http://www.un.org/documents/ecosoc/cn17/1996/ background/ecn171996-bp3.htm Acesso em: 22 jan. 2015.

COMISSÃO MUNDIAL SOBRE MEIO AMBIENTE E DESENVOLVIMENTO. Report of the World Commission on Environment and Development: Our Common Future, 1987. Disponível em: http://www.un-documents.net/ our-common-future.pdf Acesso em: 05 jan. 2015.

CORDEIRO, António Menezes. Tratado de direito civil português. Coimbra: Almedina, 2009.

CORTE INTERNACIONAL DE JUSTIÇA (CIJ). Caso Relativo às Fábricas de Celulose no Rio Uruguai (Argentina v. Uruguai). Reports of Judgments, Advisory Opinions and Orders, 20 de abril de 2010a. Disponível em: http://www.icj-cij.org/docket/files/135/15877.pdf Acesso em: 05 jan. 2015.

CORTE INTERNACIONAL DE JUSTIÇA (CIJ). Casos da Plataforma Continental do Mar do Norte República Federal da Alemanha / Dinamarca; República Federal da Alemanha / Paises Baixos). Reports of Judgments, Advisory Opinions and Orders, 20 de fevereiro de 1969. Disponível em: http://www.icj-cij.org/docket/ files/52/5561.pdf . Acesso em: 09 jan. 2015.

CORTE INTERNACIONAL DE JUSTIÇA (CIJ). Opinião Consultiva - Legalidade da Ameaça on Uso de Armas Nucleares. Reports of Judgments, Advisory Opinions and Orders, 08 de julho de 1996a. Disponível em: http://www.icj-cij.org/docket/files/95/7495.pdf . Acesso em: 04 fev. 2015.
CORTE INTERNACIONAL DE JUSTIÇA (CIJ). Parecer Dissidente do Juiz, Antônio Augusto Cançado Trindade. Caso Relativo às Fábricas de Celulose no Rio Uruguai (Argentina v. Uruguai), 20 de abril de 2010b. Disponível em: http://www.icj-cij.org/docket/files/135/15885. pdf . Acesso em: 08 jan. 2015.

CORTE INTERNACIONAL DE JUSTIÇA (CIJ). Parecer Dissidente do Juiz. Weeramantry. Opinião Consultiva sobre a Legalidade da Ameaça e do Uso de Armas Nucleares, 08 de julho de 1996b. Disponível em: http:/ / www.icj-cij.org/docket/files/95/7521.pdf . Acesso em: 03 fev. 2015.

CORTE INTERNACIONAL DE JUSTIÇA (CIJ). Parecer Dissidente Conjunto dos Juizes Awn Shawkat Al-Khasawneh e Bruno Simma. Caso Relativo às Fábricas de Celulose no Rio Uruguai (Argentina v. Uruguai), 20 de abril de 2010c. Disponível em: http://www.icj-cij.org/docket/ files/135/15879.pdf . Acesso em: 29 jan. 2015.

CORTE INTERNACIONAL DE JUSTIÇA (CIJ). Parecer Dissidente do Vice-presidente Weeramantry. Projeto Gabcíkovo-Nagymaros (Hungria v. Eslováquia), 25 de setembro de 1997a. Disponível em: http://www.icjcij.org/docket/files/92/7375.pdf . Acesso em: 09 jan. 2015.

CORTE INTERNACIONAL DE JUSTIÇA (CIJ). Projeto Gabcíkovo-Nagymaros (Hungria v. Eslováquia). Reports of Judgments, Advisory Opinions and Orders, 25 de setembro de 1997b. Disponível em: http://www.icjcij.org/docket/files/92/7375.pdf . Acesso em: 05 jan. 2015.

CORTE PERMANENTE DE ARBITRAGEM (CPA). Arbitragem relativa à ferrovia Iron Rhine (Bélgica v. Holanda). 24 de maio de 2005. Disponível em: http://www.pcacpa.org/showfile.asp?fil_id=377 . Acesso em: 17 mar. 2015.

CRETELLA NETO, José. Curso de Direito Internacional do Meio Ambiente. São Paulo: Saraiva, 2012.

DENTERS, Erik; GINTHER, Konrad; WAART, P.J.M. de (eds.). Sustainable Development and Good Governance. Dordrecht: Martinus Niijhoff, 1995.

DIHN, Nguyen Quoc; DAILLIER, Patrick; PELLET, Alain. Direito Internacional Público. $2^{\mathrm{a}}$ ed. Braga: Fundação Calouste Gulbenkian, 2003.

DINIZ, Pedro Ivo R.; LAGE, Délber Andrade. Evolução e Perspectivas do direito internacional do meio 
ambiente. In: DINIZ, Pedro Ivo R. (Org.). Direito Ambiental - Aspectos introdutórios. Lavras: Ed. UFLA, 2014.

DUPUY, Pierre-Marie. Où en est le droit international de l'environnement à la fin du siècle?. Revue General de Droit International Public, v. 4, 1997, pp. 873-903.

ELLIS, Jay. Sustainable Development and Fragmentation in International Society. In: FRENCH, Duncan. Global Justice and Sustainable Development. Leiden: Martiunus Eijhoff Publishers, 2010. ISBN: 9789004188228

EWALL, Mike. Legal Tools for Environmental Equity vs. Environmental Justice. Sustainable Development Law \& Policy. Hagerstown, Vol. XIII, n. 1, p. 4-14, abril 2013.

FITZMAURICE, Malgosia A. International Protection of the Environment. Collected Courses of the Hague Academy of International Law. Boston: Brill / Nijhoff, 2001.

FREITAS, Juarez. Sustentabilidade: Direito ao Futuro. Belo Horizonte: Fórum, 2012.

FUENTES, Ximena. International law-making in the field of sustainable development: the unequal competition between development and the evironment. In: SCHRIJVER, Nico; WEISS, Friedl. International law and sustainable development - principles and practice. Leiden: Martinus Nijhoff, 2004. 711 p.

GIBBS, David; KRUEGER, Rob (ed.). The Sustainable Development Paradox. Nova York: The Guilford Press, 2007.

GIORGETTA, Sueli. The Right to a Healthy Environment. In: SCHRIJVER, Nico; WEISS, Friedl. International Law and Sustainable Development: Principles and Practice. Leiden: Martinus Nijhoff Publishers, 2004.

GUIMARÃES, Roberto. FONTOURA, Yuna. Desenvolvimento sustentável na Rio+20: discursos, avanços, retrocessos e novas perspectivas. Cad. EBAPE.BR, v. 10, $\mathrm{n}^{\circ}$ 3, artigo 3, Rio de Janeiro, Set. 2012.

HART, H. L. A. O conceito de direito. São Paulo: Martins Fontes, 2009.

HUNTER, David; SALZMAN, James; ZAELKE, Durwood. International Environmental Law and Policy. Nova York: Thomson Reuters/Foundation Press, 2011.

INTERNATIONAL LAW ASSOCIATION (ILA). International Law on Sustainable Development - Fifth and Final Report. Conferência de Sofia, 2012. Disponível em: <file:///Users/cbo/Downloads/Final_Report_So- fia_2012.pdf>. Acesso em: 05 fev. 2015.

INTERNATIONAL LAW ASSOCIATION (ILA). International Law on Sustainable Development - Second Report. Conferência de Toronto, 2006. Disponível em: <file:///Users/cbo/Downloads/report_2006.pdf>. Acesso em: 05 fev. 2015.

INTERNATIONAL LAW ASSOCIATION (ILA). Legal Aspects of Sustainable Development - Fifth and Final Report. Conferência de Nova Deli, 2002. Disponível em: file:///Users/cbo/Downloads/sustainable_development_final_report_2002.pdf . Acesso em: 05 fev. 2015.

INTERNATIONAL LAW ASSOCIATION (ILA). The Berlin Rules On Water Resources. Fourth Report of the Water Resources Committee, 2004. Disponível em: http://internationalwaterlaw.org/documents/intldocs/ ILA_Berlin_Rules-2004.pdf . Acesso em: 13 jan. 2015.

JUSTE-RUIZ, José. The Implications of the Principle of Sustainable Development in Internationa Environmental Law. In: CONSTANTINIDES, Aristotle; ZAIKOS, Nikos. The Diversity of International Law. Leiden: Brill, 2009.

KHALFAN, Ashfaq; SEGGER, Marie-Claire Cordonier. Sustainable Development Law: Principles, Practices, \& Prospects. Oxford: Oxford University Press, 2006.

KISS, Alexandre; SHELTON, Dinah. International Environmental Law. Nova York: Trasnational Publishers, 2004.

KOSKENNIEMI, Martti. What is international law for? In.: EVANS, Malcolm D. International Law. Oxford: Oxford University Press, 2003.

LAGE, Délber A. A Jurisdicionalização do direito internacional. Belo Horizonte: Del Rey, 2009.

LEARY, David; PISUPATI, Balakrishna. The Future of International Environmental Law. Tóquio: United Nations University Press, 2010.

LOWE, Vaughn. Sustainable Development and Unsustainable Arguments. In: BOYLE, Alan; FREESTONE, David (eds.). International Law and Sustainable Development: Past Achievements and Future Challenges. Oxford: Oxford University Press, 1999.

MALJEAN-DUBOIS, Sandrine. Environnement, développement durable et droit international. De Rio à Johannesburg: et au-delà? Annuaire Français de Droit Inter- 
national, Paris, v. 48, p. 592-623, 2002.

MATHIS, Klaus. Efficiency, Sustainability, and Justice to Futures Generations. Nova York: Springer Verlag, 2013.

MATSUI, Yoshiro. The Principle of "Commom but Differentiated Responsabilities". In SCHRIJVER, Nico; WEISS, Friedl. International Law and Sustainable Development: Principles and Practice. Leiden: Martinus Nijhoff Publishers, 2004.

MAZZUOLI, Valerio de Oliveira. Curso de Direito Internacional Público. São Paulo: Revista dos Tribunais, 2011a.

MAZZUOLI, Valério de Oliveira. O Novo Direito Internacional do Meio Ambiente. Curitiba: Juruá, 2011b.

MEADOWS, D.H. et al. The Limits to Growth: A Report for the Club of Rome's Project on the Predicament of Mankind. Nova York: Universe Books, 1972.

MENEGHETTI, Francis Kanashiro; SEIFERT, Rene Eugenio; VIZEU, Fabio. Por uma crítica ao conceito de desenvolvimento sustentável. Cad. EBAPE.BR, v. 10, $\mathrm{n}^{\circ}$ 3, artigo 6, Rio de Janeiro, Set. 2012. pp. 569-583.

MUNASINGHE, Mohan. Sustainable Development in Practice. Cambridge: Cambridge University Press, 2009.

NUSDEO, Fábio. Sustentabilidade. In: MARQUES, José Roberto. Sustentabilidade e Temas Fundamentais de Direito Ambiental. Campinas: Millennium, 2009.

OKOWA, Phoebe. Procedural Obligations in International Envrionmental Agreements. British Yearbook of International Law, v. 67, n. 1, p. 276-336, jan. 1997.

ONG, David M. Procedural International Environmental Justice? The Evolution of Procedural Means for Environmental Protection: From Inter-State Obrigations to Individual-State Rights. In: FRENCH, Duncan. Global Justice and Sustainable Development. 2010.

ORGANIZAÇÃO DAS NAÇÕES UNIDAS (ONU). Declaração do Rio sobre Meio Ambiente e Desenvolvimento. Rio de Janeiro, 1992. Disponível em: http:/ / www.unep.org/ Documents.Multilingual/Default.asp?documentid $=78$ \&articleid=1163 . Acesso em: 17 jan. 2015.

ORGANIZAÇÃO DAS NAÇÕES UNIDAS (ONU). Indicators of Sustainable Development: Guidelines and Methodologies. Nova York: United Nations, 2007.

ORGANIZAÇÃO DAS NAÇÕES UNIDAS (ONU). The Future We Want. Rio de Janeiro, 2012. Disponível em: http://www.uncsd2012.org/content/ documents / 727The $\% 20$ Future $\% 20 \mathrm{We} \% 20$ Want $\% 20$ 19\%20June\%201230pm.pdf . Acesso em: 14 fev. 2015.

PEEL; Jacqueline; SANDS, Philippe. Principles os International Environmental Law. Cambridge: Cambridge University Press, 2012.

PEREIRA, Caio Mário da Silva. Instituicôes de Direito Civil - Teoria Geral das Obrigaçôes. Rio de Janeiro: Forense, 2014.

PEVATO, Paula M. International Environmental Law - vol. I. Hants: Ashgate, 2003a.

PEVATO, Paula M. International Environmental Law - vol. II. Hants: Ashgate, 2003b.

PROGRAMA DAS NAÇÕES UNIDAS PARA O DESENVOLVIMENTO (PNUD). Governance for Sustainable Development Integrating Governance in the Post-2015 Development Framework, 2014. Disponível em: http:// www.undp.org/content/dam/undp/library/Democratic\%20Governance/Discussion-Paper--Governancefor-Sustainable-Development.pdf . Acesso em: 09 fev. 2015.

RAMLOGAN, Rajendra. Sustainable Development - Towards a Judicial Interpretation. Leiden: Brill, 2010.

REDCLIFT, M. Reflections on the "Sustainable Development" Debate. International Journal of Sustainable Development and World Ecology, vol. 1, 1994.

REZEK, José Francisco. Direito Internacional Público. São Paulo: Saraiva, 2011.

ROTA, Demetrio Loperena. Desarrollo Sostenible y Globalización. Navarra: Thomson-Aranzadi, 2003.

SANDS, Philippe. International Law in the Field of Sustainable Development. British Year Book of International Law, v. 65, p. 303-381, 1994.

SCHRIJVER, Nico; WEISS, Friedl. International Law and Sustainable Development: Principles and Practice. Leiden: Martinus Nijhoff Publishers, 2004.

SCHRIJVER, Nico. The Evolution of Sustainable Development in International Law: Inception, Meaning and Status. A Haia: Hague Academy of International Law, 2008.

SEGGER, Marie-Claire Cordonier; KHALFAN, Ashfaq. Sustainable Development Law - Priciples, Practices, \& Prospects. Oxford: Oxforf University Press, 2006.

SHELTON, Dinah. International Law and "Relative Normativity". In.: EVANS, Malcolm D. International 
Law. Oxford: Oxford University Press, 2003.

SIMMA, Bruno. Foreword. In: SCHRIJVER, Nico; WEISS, Friedl. International Law and Sustainable Development: Principles and Practice. Leiden: Martinus Nijhoff Publishers, 2004.

SOARES, Guido Fernando Silva. A Proteção Internacional do Meio Ambiente. Barueri: Manole, 2003.

SMOUTS, Marie-Claude. Le Developpement Durable: Les Termes du Débat. Paris: Armand Colin - Dalloz, 2005.

TLADI, Dire. Sustainable Development, Integration and The Conflation of Values: The Fuel Reailers Case. In: FRENCH, Duncan. Global Justice and Sustainable Development. Leiden: Martiunus Eijhoff Publishers, 2010. ISBN: 9789004188228
VEIGA, José Eli da. Sustentabilidade: A Legitimação de um Novo Valor. São Paulo: Ed. Senac, 2010.

VERSCHUUREN, J. Principles of Environmental Law: The Ideal of Sustainable Development and the Role of Principles in International, European and National Law. Baden-Baden: Nomos, 2003.

VOIGT, Christina. Sustainable Development as a Principle of International Law: Resolving Conflicts between Climate Measures and WTO Law. Leiden: Martinus Nijhoff: , 2008.

WOLFRUM, Rüdiger. Means of Ensuring Compliance with and Enforcement of International Environmental Law. Collected Courses of the Hague Academy of International Law. Boston: Brill / Nijhoff, 1998. 


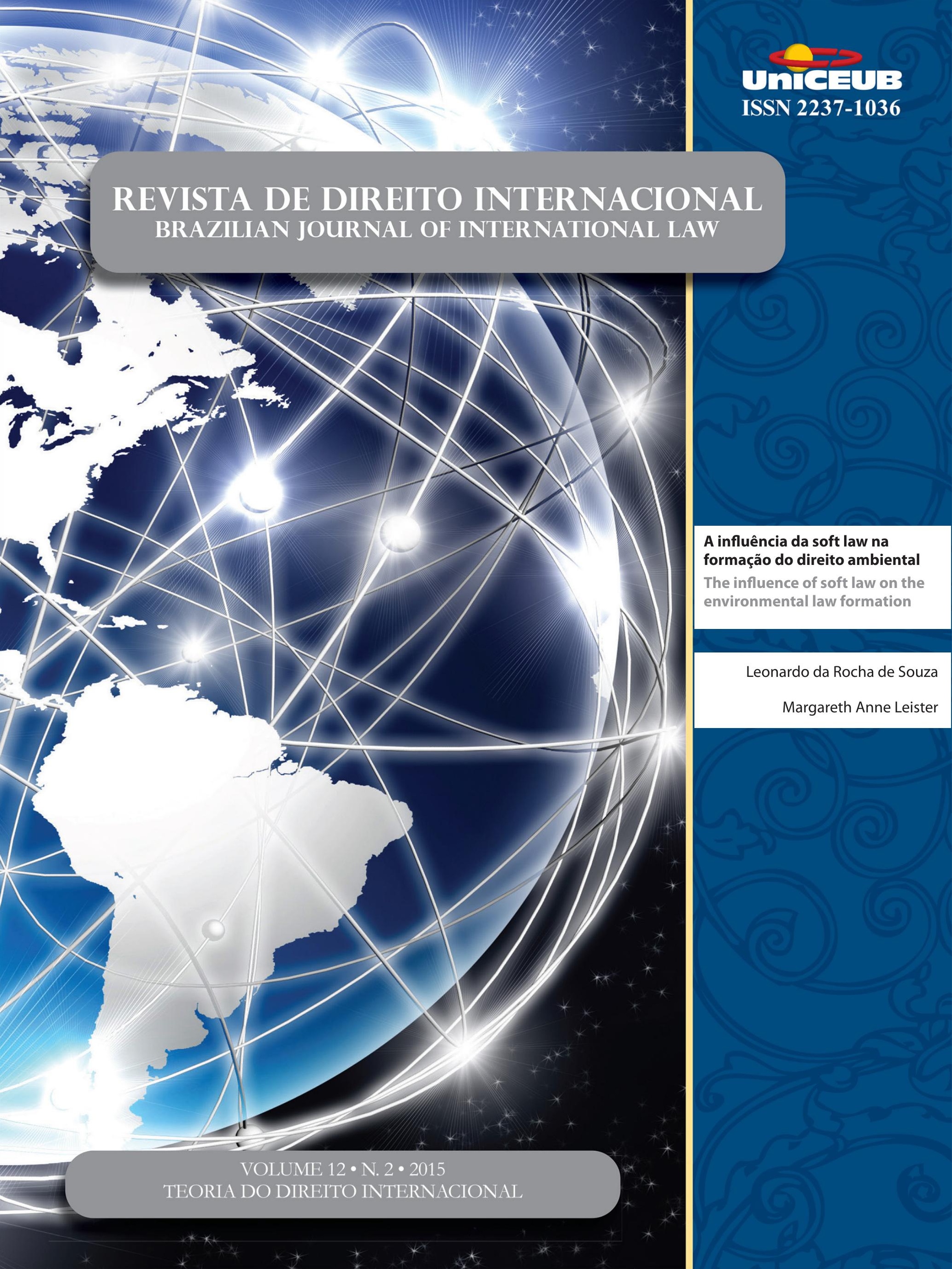




\section{A influência da soft law na formação do direito ambiental*}

\author{
The influence of soft law on the \\ environmental law formation
}

Leonardo da Rocha de Souza**

Margareth Anne Leister***

\section{Resumo}

Este artigo aborda a formação das normas de direito ambiental com destaque para as soft laws, explorando as influências do direito internacional e da opinião pública na definição da legislação ambiental nacional. $O$ objetivo específico consiste em analisar os conceitos jurídicos aplicados à legislação ambiental no âmbito global. O Direito Internacional do Ambiente tem como premissa a cooperação e a responsabilidade partilhada, é composto de sistemas jurídicos nacionais e internacionais, com vários níveis de interação e aplicação restrita pelos tribunais internacionais ou internos. Seu desenvolvimento se deu mediante princípios tais como o desenvolvimento sustentável, o princípio da precaução, a equidade e adversidade cultural. Este texto pretende responder às perguntas: Por qual razão Estados aprovam instrumentos com conteúdo indefinido e instrumentos brandos? Há instrumental ambiental internacional obrigatório e exequível? Como caracterizá-los e torná-los aplicáveis no direito interno? A abordagem metodológica é a fundamentação teórica realizada mediante levantamento e análise da literatura e fatos sobre o tema, sob enfoque jurídico. Como resultado, defende-se a importância de se formar uma esfera pública no interior de cada Estado, capaz de gerar uma opinião pública que influencie o governante a assumir compromissos internacionais que resultem em soft laws e que estas sejam internalizadas no ordenamento jurídico pátrio.

Palavras-chave: Normas ambientais. Soft Law. Direito Internacional Ambiental. Opinião pública.

\section{Abstract}

This paper addresses the issue of the soft law rules in environmental law. It explores the influences of international Lawand public opinion in shaping the domestic environmental Law.A specific objective intends to analyze soft law concepts applied to environmental law. International Environment Law, as premised on cooperation and shared responsibility, has little involvement of international or internal judicial organizations, and is composedof several multi-levelled and interacting international and national legal systems. Its development is grounded in principles such as sustainable development, the precautionary principle, international equity, and cultural diversity. The 
goal is to answer the following questions: What motivates states to endorsesoftinstruments and instruments with soft content? What is mandatory and enforceable international rules? How to characterize them and make them enforceable under domestic Law? The methodological approach is theoretical foundation through the survey and analysis of the literature on the subject, factual and legal aspects.It is proposed that, as a result, the importance of forming a public sphere within each State, able to generate a public opinion to influence the governor to take on international commitments that result in soft laws, and that thesesoft laws are internalized in the home legal system.

Keywords: Environmental Rules. Soft Law. International Environmental Law. Public opinion.

\section{INTRODUÇÃO}

Este estudo aborda a questão da formação de normas no Direito Ambiental, destacando-se as soft law. Nesse sentido, pretende-se investigar a influência das normas internacionais e da opinião pública na formação do direito ambiental interno. No tocante aos objetivos específicos, pretende-se analisar os conceitos de soft law aplicados ao Direito Ambiental. Com base na realidade do alcance dos riscos globais, verificar-se-á a forma resultante da busca de deliberações ambientais que não sejam plenamente exigíveis e que, por essa razão, não são consideradas cogentes. Este texto trata, assim, da necessidade de instâncias que influenciem o sistema global e promovam a executoriedade das normas internacionais em matéria ambiental.

Justifica-se a escolha do tema pela relevância teórica perante a comunidade científica e acadêmica no aperfeiçoamento dos estudos sobre o tema, o que é demonstrado nesse texto por meio de aplicações de soft laws e da análise de casos judiciais. Nesse sentido, propõe-se responder a questionamentos tais como: o que motiva os Estados a firmarem instrumentos considerados soft? O que motiva os Estados a firmarem instrumentos com conteúdo soft? O que significa obrigatoriedade e executoriedade das normas internacionais e como caracterizá-las e torná-las exequíveis no direito interno?

A metodologia adotada aproxima a metodologia usual da disciplina do Direito e tem por base a fundamentação teórica por meio do levantamento e análise da bibliografia acerca do tema, de forma lógico-dedutiva. Para tanto, utiliza-se investigação de cunho teórico-bibliográfico, partindo de uma concepção geral das formas normativas em matéria ambiental para uma concepção específica do que seja norma ou instrumento de soft law e as consequências da adoção desse modelo. Para uma análise mais completa e detalhada do assunto, é necessário recorrer ao método analítico transdisciplinar, que perpassa a política e afilosofia.

Inevitavelmente será enfrentada a questão da codificação das normas no direito ambiental, nos planos internacional e interno, bem como a questão da opinião pública enquanto formadora de valores ambientais. Será visto, assim, como encarar as manifestações da soft law e quais os efeitos que se lhes podem ser atribuídos no Direito Ambiental.

$\mathrm{O}$ artigo inicia identificando a soft law como característica da pós-modernidade (2). Após, analisa a influência das soft law na formação de normas ambientais internacionais e na formação do direito ambiental interno (3). Realiza, ainda, uma breve análise da internalização de normas internacionais no Direito brasileiro (4), passando a uma abordagem da influência da opinião pública na formação dos valores ambientais (5).

A proposta final é incentivar a construção de uma esfera pública cosmopolita ecológica, trazendo os ensinamentos de Jürgen Habermas a respeito da formação da opinião e da vontade. Essa esfera pública formará uma espécie de caixa de ressonância, que transmitirá aos deliberantes os valores ambientais que devem ser incorporados nas soft laws e, depois, internalizados como normas obrigatórias.

\section{Riscos globais e a Soft law como carac- TERÍSTICA DA PÓS-MODERNIDADE}

O risco ambiental global busca novos caminhos para inverter as tendências não sustentáveis e encontrar formas de desacelerar as atividades destrutivas em curso. Para tanto, os sistemas de conhecimento devem possibilitar a identificação e caracterização de tais riscos. Risco ambiental global, potencial ou efetivo, é a ameaça de efeitos adversos nos organismos e vivendo ambiente de efluentes, emissões, resíduos, recursos esgotamento, etc., decorrentes de uma organização e de atividades econômicas e sociais. São riscos ambientais 
globais aqueles que têm categorias relevantes de dano, impactos globais e cuja cadeia de danos inclui efeitos ambientalmente relevantes.

A pós-modernidade, seu conceito, seu alcance e suas características, tem sido objeto de muitos estudos acadêmicos e de muitas abordagens dos meios de comunicação de massa ${ }^{1}$. Nesse tópico, a tentativa consiste em aproximar alguns pontos de vista teóricos sobre o assunto com a temática proposta neste artigo, iniciando-se com uma breve análise dos riscos globais da degradação ambiental (2.1), realizando uma introdução das fontes do direito internacional e trazendo conceitos iniciais sobre a soft law (2.2), relacionando-a como uma característica da pós-modernidade proposta por Erik Jayme (2.3).

\subsection{Riscos globais e degradação ambiental}

A degradação ambiental transcende as fronteiras dos países que a perpetraram, podendo atingir o território de outro Estado, animais migratórios e espaços sem incidência de uma soberania nacional, como a Antártida, o alto-mar e a estratosfera. ${ }^{2}$ Por isso, o meio ambiente é uma preocupação global, sem restrição aos interesses de um Estado, devendo-se ampliar ao interesse do planeta ${ }^{3}$. Vale dizer, a preocupação ambiental surge como pauta de discussões em termos mundiais. Conforme Enrique Leff ${ }^{4}$,

a crise ambiental é a crise do nosso tempo. O risco ecológico questiona o conhecimento do mundo. Esta crise se apresenta a nós como um limite no real que re-significa e re-orienta o curso da história: limite do crescimento econômico e populacional; limite dos desequilíbrios ecológicos e das capacidades de sustentação da vida; limite da pobreza e da desigualdade social. Mas também crise do pensamento ocidental: da "determinação

1 A expressão pós-modernidade não tem um sentido unívoco, mas costuma significar uma superação à modernidade ou algo que vem após a modernidade, podendo, até mesmo, ser utilizada como equivalente ao pós-industrialismo. Para uma primeira leitura sobre o tema, cf. DINIZ, Antonio Carlos. Pós-modernismo (verbete). In: BARRETO, Vicente de Paulo (coord.) Dicionário de Filosofia do Direito. São Leopoldo, RS: Editora Unisinos; Rio de Janeiro: Editora Renovar, 2006. p. 647-650.

2 SOARES, Guido Fernando Silva. Direito internacional do meio ambiente: emergência, obrigações e responsabilidades. 2. ed. São Paulo: Atlas, 2003, p. 217, 335.

3 Marcelo Dias. Direito Internacional Público. 2.ed. São Paulo: Saraiva, 2010, p. 241.

4 LEFF, Enrique. Pensar a Complexidade Ambiental. In: LEFF, Enrique (org). A Complexidade Ambiental. São Paulo: Cortez, 2003, p. 15-16. metafísica" que, ao pensar o ser como ente, abriu a via da racionalidade científica e instrumental, que produz a modernidade como uma ordem coisificada e fragmentada, como forma de domínio e controle sobre o mundo.

O conceito de sociedade do risco, de Ulrich Beck, estimula a percepção da previsibilidade do risco inerente à atividade humana ${ }^{5}$. O argumento central de Beck é que a sociedade industrial foi substituída pela sociedade de risco, na qual o desenvolvimento da ciência e da técnica não poderiam mais prever e controlar os riscos para os quais contribuiu decisivamente para criar: "perigos são fabricados de forma industrial, exteriorizados economicamente, individualizados no plano jurídico, legitimados no plano das ciências exatas, e minimizados no plano político". Esse risco, localizado no futuro, deve estimular as pessoas a vislumbrá-lo a ponto de modificar suas atitudes para evitá-lo. Mas a incerteza em relação ao futuro não deve nos levar à estagnação pelo medo de suas consequências ${ }^{6}$; ao contrário, o resultado deve proporcionar criatividade no desenvolvimento de atividades que não sofram riscos inesperados. Assim, o alerta sobre os riscos globais deve ter uma função esclarecedora, e não transmitir a ideia de que a ruína é inevitável. ${ }^{7}$

A consequência do risco para o direito é o protagonismo da incerteza científica é o que José Esteve Pardo ${ }^{8}$ chama de "solidão do direito": os órgãos jurídicos

5 Sobre o tema cf.: SILVEIRA, Clóvis Eduardo Malinverni da. A teoria da sociedade de risco como instrumento para a compreensão da emergência dos movimentos urbanos no Brasil: um contraponto crítico. Revista Quaestio Iuris, v. 8, p. 1913-1948, 2015.

6 Nas palavras de Hans Jonas, "O medo que faz parte da responsabilidade não é aquele que nos aconselha a não agir, mas aquele que nos convida a agir" (O princípio responsabilidade, p. 351).

7 BECK, Ulrich. Sociedade de Risco: Rumo a uma outra modernidade. Trad. Sebastião Nascimento. São Paulo: Editora 34, p. 361.Para que o risco tenha essa função esclarecedora é preciso dar-se conta de seu papel de antever a catástrofe para provocar uma ação que leve a evitar determinadas decisões, calculando e controlando as incertezas. No entanto, as causas e as consequências dos riscos (a) não se limitam a um local ou espaço geográfico, (b) não podem ser calculadas com precisão e (c) não podem ser compensadas. (BECK, Ulrich. Sociedade de Risco, p. 362-364). O risco pode ser percebido como resultado da produção capitalista que gera a apropriação de recursos naturais (Beck), de forma que os riscos criados nesta geração não foram enfrentados pelas anteriores (Giddens), até mesmo diante da cibernética e das novas tecnologias (Forrester). (WEDY, Gabriel de Jesus Tedesco. Os fundamentos do princípio da precaução. Juris Plenum Direito Administrativo, Caxias do Sul, ano II, n. 8, p. 109-138, out./dez. 2015, p. 111).

8 PARDO, José Esteve.O desconcerto do Leviatã: política e direito perante as incertezasda ciência. Coordenador [da série] José Rubens Morato Leite. Trad. Flávia França Dinnebier, Giorgia Sena Martins. 
são chamados a decidir mesmo quando a ciência não os instrumentaliza suficientemente. As instâncias jurídicas e políticas precisariam de pronunciamentos seguros da ciência capazes de fundamentar suas decisões. Como nem sempre isso ocorre, essas instâncias precisam decidir com base em probabilidades. Essa relação entre o risco e o direito afeta diretamente a formação de soft laws ambientais, pois, quando a ciência avança em seus estudos e alcança novos conhecimentos científicos, os países se movimentam para adotar uma série de acordos e decisões na esfera internacional, como ocorre com as mudanças climáticas e as emissões de gases de efeito estufa. ${ }^{?}$

Percebe-se, assim, que os riscos ambientais globais exercem uma pressão sobre os países para que se reúnam e firmem compromissos ambientais uns com os outros em tratados e declarações internacionais, de forma que as deliberações realizadas entre os países em eventos internacionais tornem-se realidade no interior de cada nação. Todavia, dada a complexidade das relações internacionais contemporâneas, a figura da soft law é necessária para regulamentar as dimensões diversas do mundo pós-moderno.

\subsection{Fontes do direito internacional e soft law}

Os pilares e a estrutura do direito internacional tradicional, baseado no consentimento dos Estados como instrumento de legitimação, têm sido relativizados por outras influências. Os instrumentos de codificação do Direito internacional estão sendo alterados, neste século XXI, por novas alternativas de cooperação transfronteiriça, com processo legiferante informal. $\mathrm{O}$ modelo no qual somente a manifestação do consentimento dos Estados, mediante tratados e reconhecimento dos costumes, cria a norma internacional e vem sendo superado na doutrina.

São Paulo: Instituto O Direito por um Planeta Verde, 2015, p. 36-38. 9 PARDO, José Esteve.O desconcerto do Leviatã, p. 37. "[...] a evolução da ciência do climatem reforçado o caráter universal das mudanças climáticas, seja porque suas causas antrópicas estão no cernedo atual modo de produção e consumo no planeta, sejaporque a gravidade de seus impactos será sentida em todosos níveis da sociedade - do local ao global -, e sobas diferentes nuances - ambientais, sociais, econômicas epolíticas (REI, Fernando; SETZER, Joana; CUNHA, Kamyla Borges. A Rio+20 e o quadro institucional pelo desenvolvimento sustentável: o papel dos governos subnacionais na governança ambiental global. Revista de Direito Internacional, Brasília, v. 9, n. 3, 2012, p. 134).
A ideia tradicional das fontes do direito internacional foi desafiada por processos informais de criação de regras, problema da chamada soft law. Sua concepção é derivada do expressivo aumento de agências internacionais regulatórias que, desprovidas de poder para criação e imposição coercitiva, desenvolveram o conceito. Conforme Salem H. Nasser, a soft lawrelevante está relacionada com a transformação dos modos de produzir direito internacional, ou seja, a utilização de mecanismos soft nos processos de criação do direito internacional, "em instrumentos concertados que não são, a priori, obrigatórios", e "a inclusão desses instrumentos num mundo jurídico de que constituem a parte soft, dificulta a própria conceituação do direito e a delimitação da fronteira entre este e o não direito. Ela cria a possibilidade de graus de juridicidade, de mais direito e menos direito". ${ }^{10}$ Por essa razão, há várias categorias e graduações de soft law, com base na distinção entre o negotium e o instrumentum: quando se diz respeito ao conteúdo do seu acordo, que é o negotium, refere-se a um ato jurídico ${ }^{11}$.

O poder legiferante em matéria internacional pode optar por "suavizar" o instrumento para que o seu acordo ambiental seja expedido, decidindo por um instrumento que não configure, formalmente, um tratado ou uma declaração unilateral. Ou, inversamente, optar por recorrer a um instrumento jurídico formal enquanto "suaviza" seu conteúdo, ao adotar um discurso não-normativo, ou que não forneça qualquer diretiva precisa quanto ao comportamento a que os seus autores estão obrigados. Outra opção é a previsão de renúncia facilitada.

Nota-se a modificação dos atores e dos processos na ordem jurídica internacional, contestando a legitimidade dos processos jurídicos internacionais. Como normas de conteúdo vago, sua implementação pode se

10 NASSER, Salem H. Desenvolvimento, Costume Internacional e Soft law. In: AMARAL JÚNIOR, Alberto do. (Org.). Direito Internacional e Desenvolvimento. 1 ed. Barueri: Manole, 2005, p. 201-218 Disponível em https://gedirj.files.wordpress.com/2008/02/desenvolvimentocostumeinternacionaloftlawalemnasser.pdf

11 Alguns consideram indevida a distinção entre codificação e desenvolvimento progressivo, mas apontam necessidade de equilíbrio entre estabilidade e mudança. Codificação sugere higidez, ao passo que o desenvolvimento progressivo do Direito se dá com o surgimento de novas problemáticas que influenciam as manifestações de poder decisório por parte dos Estados. Para desenvolvimento, ver LEISTER, Margareth. Estado de Direito e Codificação do Direito Internacional. In: POMPEU, G.; SAMPAIO, Natercia; MENEZES, Wagner (org.) Comércio, Globalização e Formação do Capital Social. Belo Horizonte: Arraes Editores, 2015, p. 684-693. 
tornar ineficaz em razão da inexistência de sanção e/ ou de órgão competente para sua aplicação em caso de não cumprimento da norma. Para Guido Soares, nessa mesma linha de raciocínio, o reconhecimento de normas flexíveis que constituam regras jurídicas de conduta dos Estados, mas cuja inadimplência é governada por um sistema de sanções distintas daquelas previstas nas normas tradicionais, difere das obrigações versadas nos sistemas obrigacionais internos dos Estados ${ }^{12}$.Para um conceito de soft law, adota-se a definição de Valério de Oliveira Mazzuoli:

[...] pode-se afirmar que na sua moderna acepção ela [soft law] compreende todas as regras cujo valor normativo é menos constringente que o das normas jurídicas tradicionais, seja porque os instrumentos que as abrigam não detêm o status de 'norma jurídica', seja porque os seus dispositivos, ainda que insertos no quadro dos instrumentos vinculantes, não criam obrigações de direito positivo aos Estados, ou não criam senão obrigações pouco constringentes.

Nessa senda, qualquer instrumento regulatório dotado de força normativa limitada, que, em princípio, não é vinculante, configura a soft law. A exemplo, os termos da Declaração Universal dos Direitos Humanos, das Regras Mínimas para o Tratamento dos Presos, adotadas pelo I Congresso das Nações Unidas para a Prevenção do Crime e para o Tratamento de Delinquentes, da Declaração de Helsink sobre Segurança e Cooperação na Europa, as decisões da Comissão de Direitos Humanos das Nações Unidas, as decisões do Tribunal Internacional de Justiça (CIJ), têm caráter quasilegal.

O conceito de soft law amplamente aceito é o de normas que não são juridicamente obrigatórias, mas não são desprovidas de força legal. Assim, soft law refere-se às normas do direito internacional que não são obrigatórias, de per si, mas que desempenham um papel interpretativo importante na construção e interpretação dos princípios e normas do direito internacional ambiental formal. No âmbito do Direito Internacional Ambiental, law entende-se como as declarações não vinculantes dos Estados, princípios reconhecidos em Conferências multilaterais e os relatórios de Organizações não governamentais. "Tais princípios soft law podem vir a ser reconhecidos" como costume internacional se e quando "adotados pela prática dos estados e se entendidos como criando obrigações vinculantes. Inversamente,

12 SOARES, Guido Fernando Silva. Curso de Direito Internacional Público. 2.ed. São Paulo: Atlas, 2003. alguns princípios soft law foram incluídos em tratados, se transformando, assim, em Direito Internacional vinculante" ${ }^{13}$

A despeito de as soft law não serem juridicamente vinculativas, verifica-se sua influência na tomada de decisões no espaço público. Esses modos de cooperação informal podem ser tão cogentes quanto os tratados, especialmente em setores que tentam a harmonização normativa. O Supremo Tribunal já declarou que a soft law é norma jurídica não vinculante indicativa de amplo consenso internacional. ${ }^{14}$

Kenneth Abbott e Duncan Snidal ${ }^{15}$, para quem o domínio da soft law se inicia com o abrandamento de regimes jurídicos, informam o que deve ser avaliado para verificar se uma norma é hard ou soft law: a clareza das normas, capazes de reduzir o espaço interpretativo; a obrigatoriedade das disposições, eventualmente postas para gerar obrigações e responsabilidade para as partes; e a delegação a terceiro para decidir a respeito do sentido e das obrigações derivadas das normas em questão.

Uma característica inicial da soft law é a ampliação do espaço interpretativo pela ambiguidade de seus termos. Ainda, o fato de não serem vinculantes. São afirmações realizadas pelos Estados em eventos oficiais internacionais, que podem gerar declarações escritas, geralmente principiológicas, contendo intenções de atuação dos atores envolvidos.

No direito internacional contemporâneo, tanto o instrumentum quanto o negotium podem ser amenizados. A suavidade do instrumentum ocorre pela escolha, feita pelos signatários, de um instrumento que se encontra fora do âmbito da lei desprovido de executoriedade.

Para Fernando Rei e Maria Luiza Granziera, “os problemas ambientais em geral [...] somente podem encontrar soluções satisfatórias se negociados e regulamentados pelo conjunto dos Estados, sem desconsiderar o papel de novos atores no cenário internacional,

13 BENJAMIN, Antonio Herman de Vanconcellos e; MARQUES, Claudia Lima; TINKER, Catherine. O gigante da água desperta: uma visão geral do direito das águas no Brasil. In: MARQUES, Claudia Lima (Coord.). O novo direito administrativo, ambiental e urbanistico: estudos em homenagem à Jacqueline Morand-Deviller. São Paulo: Editora Revista dos Tribunais, 2010, p. 232, nota de rodapé 241.

14 STF, MS 30894-DF, Rel. Ministro Ricardo Lewandowski, julgado em 20/09/2011, DJe-183 23/09/2011

15 ABBOT'T Kenneth; SNIDAL, Duncan. Hard and Soft Law in International Governance. International Organization, v. 54, n. 3. Cambridge, Ma: IO Foundation and the MIT, summer 2000. 
que articulam interesses numa dinâmica mais eficiente

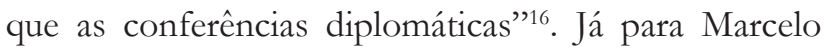
Varella, "a formação do Direito Internacional do Meio Ambiente não é nem linear, nem organizada. Há uma sucessão de normas de diferentes níveis de hierarquia, de obrigatoriedade e de lógicas subjacentes". ${ }^{17}$ Ao que parece, essa multiplicidade de normas, com diferentes graus de aplicabilidade e de força normativa, está associada à pós-modernidade, que será vista no próximo tópico sob a ótica de Erik Jayme.

\subsection{Pós-modernidade e soft law}

Pode-se relacionar as soft law com as normas narrativas de Erik Jayme que, estudando a pós-modernidade, encontrou quatro características: o pluralismo, a comunicação, a narração e o retorno dos sentimentos ${ }^{18}$. A função das normas narrativas (advindas da narração como característica da pós-modernidade) é projetar os valores que determinada sociedade considera importantes. ${ }^{19}$ Quando determinado Estado concorda com prin-

16 REI, Fernando Cardozo Fernandes; GRANZIERA, Maria Luiza Machado. Direito Ambiental Internacional: Novos olhares para a ciência do direito, 2014.

17 VARELLA, Marcelo. O surgimento e a evolução do Direito Internacional do Meio Ambiente: da proteção da natureza ao desenvolvimento sustentável. In: VARELLA, Marcelo D.; BARROSPLATIAU, Ana Flavia (org.). Proteção internacional do meio ambiente. Brasília: Unitar, UniCEUB e UnB, 2009, p. 6-25.

18 Na obra Identitéculturelle et integration, trabalhada por MARQUES, Cláudia Lima (Direito na pós-modernidade e a teoria de Erik Jayme), MIRAGEM, Bruno (Conteúdo da ordem pública e os direitos humanos) e MOROSINI, Fábio (Globalização e novas tendências....). Para uma análise das quatro características da pós-modernidade segundo Erik Jayme aplicadas ao direito ambiente cf. SOUZA, Leonardo da Rocha de. A Pós-Modernidade em Erik Jayme e a Participação Popular na Elaboração de Normas Ambientais. Direitos Culturais. Revista do Programa de Pós-Graduação em Direito - Mestrado da URI Santo Ângelo - RS, v. 5, n. 8, jan./jun. 2010, p. 193-202. Nesse texto, realiza-se uma aplicação das teorias de Erik Jayme ao direito ambiental, explicando que, de acordo com ele, "a pós-modernidade caracteriza-se pelo pluralismo, comunicação, narração e retorno dos sentimentos [...] A pluralidade de sujeitos pressupõe a diversidade de ações sobre o meio ambiente e de soluções para a sua proteção. Para que essas ações e soluções sejam analisadas é necessário que se crie oportunidades para o diálogo, suprido de informações corretas sobre suas consequências. Uma legiferação participativa permite à comunidade transmitir seus valores aos aplicadores do direito, estabelecendo as normas narrativas. Tais valores envolvem aspectos sociais, psicológicos, ideológicos e religiosos que empreendem a aplicação dos sentimentos dos participantes na elaboração das normas." (SOUZA. A Pós-Modernidade em Erik Jayme e a Participação Popular na Elaboração de Normas Ambientais, p. 193).

19 MIRAGEM, Bruno. Conteúdo da ordem pública e os direitos humanos, p. 334. cípios ambientais constantes de textos internacionais, está incluindo neles os valores que pretende desenvolver, levando o direito a adaptar-se à sua função social, à promoção humana ${ }^{20} \mathrm{e}$, por conseguinte, à proteção ambiental.

A esperança é que os valores ambientais presentes nas normas narrativas "reoriente[m] os comportamentos individuais e coletivos, relativamente às práticas de uso dos recursos naturais e energéticos", levando os agentes sociais a se tornarem mais vigilantes em relação aos impactos e riscos ambientais; fazendo com que a sociedade civil se organize para defender a proteção ambiental; e permitindo que as comunidades participem da gestão dos bens naturais. ${ }^{21}$

Os valores ambientais presentes nas normas narrativas devem servir de guia para a criação do direito ambiental, pois a normas narrativas são declarações de vontade do legislador, revelando os objetivos que ele deseja perseguir ${ }^{22}$. No entanto, não se espera que as normas narrativas tenham a mesma estrutura das normas jurídicas, pois as normas narrativas servem para inspirar e orientar a interpretação e aplicação do direito ${ }^{23}$, "possibilitando ao intérprete ou aplicador do direito perceber o que a comunidade espera dele na aplicação do direito" 24 . O objetivo das normas narrativas é fazer "um apelo à consciência”, sem coerção ou ordem ${ }^{25}$, traçando os objetivos, princípios e finalidades ${ }^{26}$ desejados pela comunidade. Quando os valores ambientais de uma comunidade são inseridos nas soft law, percebe-se sua inserção nas normas ambientais internacionais, conforme analisaremos no próximo tópico.

20 MIRAGEM, Bruno. Conteúdo da ordem pública e os direitos humanos, p. 333 e 334.

21 Enrique Leff. Ecologia, Capital e Cultura: racionalidade ambiental, democracia participativa e desenvolvimento sustentável, 2000, p. 123.

22 MOROSINI, Fábio. Globalização e Novas Tendências em Filosofia do Direito Internacional, p. 553.

23 MIRAGEM, Bruno. Conteúdo da ordem pública e os direitos humanos, p. 334 e 335.

24 SOUZA, Leonardo da Rocha de. A Pós-Modernidade em Erik Jayme e a Participação Popular na Elaboração de Normas Ambientais, p. 199.

25 JAYME, Erik. Visões para uma teoria pós-moderna do Direito Comparado, p. 32.

26 MARQUES, Cláudia Lima. Direito na pós-modernidade e a teoria de Eric Jayme, p. 29. 


\section{A influênCia das Soft law na formação de NORMAS AMBIENTAIS INTERNACIONAIS E DO DIREI- TO AMBIENTAL INTERNO}

Inicialmente, os valores ambientais inseridos nas soft law configuravam princípios voltados à cooperação internacional. O objetivo desses princípios era controlar, prevenir, reduzir e eliminar os efeitos ambientais adversos resultantes das atividades econômicas, na tentativa de afirmar a responsabilidade dos Estados no controle dos atos realizados por pessoas com vínculo político (nacionais, estrangeiros estabelecidos, empresas, navios ou aeronaves registrados no seu território) e que estejam sob sua jurisdição. A proposta inicial contemplava a exigência de o Estado indenizar qualquer dano verificado em seu território, estabelecendo a responsabilização objetiva por danos ambientais. Todavia, atores influentes do cenário internacional entenderam que a responsabilidade de pagar uma compensação só existiria onde tinha havido negligência imputável ao Estado. O Princípio 24 da Declaração de Estocolmo, então, define o papel das organizações internacionais: a coordenação dinâmica.

Para Esty e Ivanova, o atual regime do meio ambiente internacional é débil, fragmentado, carente de recursos e prejudicado por uma limitada incumbência ${ }^{27}$. O regime é composto por normas consideradas "narrativas", e exemplos de soft law são os princípios elaborados nas diversas Conferências das Nações Unidas. Em decorrência de catástrofes ambientais ocorridas na década de 1980 (como o vazamento de gás tóxico da Union Carbide, na Índia, a poluição transfronteiriça em rios internacionais - como a derrama de produtos químicos pela Sandaz no Rio Reno, e os acidentes com os superpetroleiros como o Exxon Valdéz, e os riscos demonstrados das usinas nucleares como Chernobyl e ThreeMileIsland), ocorreu a Agenda 21 Global (ECO 92 - Rio), 20 anos após a Conferência de Estocolmo que estabeleceu os princípios do direito ambiental.

Como exemplo, verifica-se que o princípio $21 \mathrm{da}$ Declaração de Estocolmo é retomado pelo princípio 2 da Declaração do Rio, reconhecendo a soberania dos Estados na exploração de recursos próprios desde que ausentes danos ambientais em outros Estados ou em

27 ESTY, Daniel C.; IVANOVA, Maria H. Revitalização da Governança Ambiental Global: um enfoque baseado em funções, p. 208. In: Governança Ambiental Global: opções e oportunidades. São Paulo: Editora Senac, 2005. locais sem jurisdição nacional. ${ }^{28}$

As soft law elaboradas nas Conferências das Nações Unidas, além de influenciarem as Conferências seguintes, têm importante papel na criação de outras normas e orientação da atuação dos países. Olivier Mazaudoux realizou um importante estudo, no qual analisa a influência de diversos princípios da Declaração do Rio em convenções internacionais e nas práticas dos Estados, que pode ser resumido na lista abaixo ${ }^{29}$ :

a) o princípio 10, sobre informação, participação e acesso à justiça em matéria ambiental, influenciou, por exemplo, a Convenção-Quadro das Nações Unidas sobre Mudanças Climáticas, de 1992;

b) o princípio 11, que incentiva a adoção de legislações protetivas do meio ambiente, influenciou a formação de leis em diversos Estados;

c) o princípio 14, sobre substâncias perigosas, influenciou a Conferência de Roterdã;

d) o princípio 15 , sobre precaução, teve influência sobre a Convenção sobre a Diversidade Biológica;

e) o princípio 16, que trata da regra do poluidor-pagador, teve impacto na proposta contida nos Tratados de Maastricht e de Amsterdã;

f) o princípio 17 , sobre estudos de impacto ambiental, influenciou a Comissão Norte-Americana para a Cooperação Ambiental;

g) o princípio 18, sobre notificação e auxílio aos outros Estados em caso de catástrofe natural, influenciou o texto da Convenção de Nova York de 1997;

h) o princípio 19, que trata da prevenção aos outros Estados para que não sofram efeitos transfronteiriços nocivos ao meio ambiente, influenciou a Convenção de Sofia, de 1994;

i) o princípio 7, que trata das responsabilidades comuns dos Estados, mas diferenciadas de acordo com o grau de desenvolvimento, aparece, por exemplo, na Convenção das Nações Unidas para a Luta Contra a Desertificação e na Convenção-Quadro das Nações Unidas Sobre Mudanças Climáticas.

28 Olivier Mazaudoux, Política internacional, direito ambiental e questões institucionais, p. 262.

29 Olivier Mazaudoux, Política internacional, direito ambiental e questões institucionais, p. 263-267. A análise realizada por Olivier Mazaudoux também é trabalhada em SOUZA, Leonardo da Rocha de. $A$ consideração dos ausentes..., p. 194 e ss. 
Esse resumo da análise feita por Mazaudoux demonstra a importância de tornar a proteção ambiental um assunto que vai além das conferências internacionais, pois a discussão ajuda na tomada de consciência dos problemas e na busca de soluções, gerando um guia de valores ambientais para a interpretação e aplicação do direito. As soft law têm sido adotadas por convenções, mas ainda não atingiram o status de hard law, vale dizer, normas jurídicas que criem vínculo obrigacional entre Estados, providas não só de obrigatoriedade, mas de executoriedade.

As declarações conjuntas em conferências, além de influenciarem a formação de normas, têm influência na formação do direito ambiental interno de cada país, como analisado a seguir. Via de regra, considera-se que um direito mais duro (hard law) tem maior chance de cumprimento voluntário internacional.

A inserção das normas narrativas em documentos internacionais foi influenciada pelo conhecimento a respeito dos problemas ambientais e de suas consequências internacionais. Percebeu-se que algumas atitudes geravam efeitos que ultrapassavam as fronteiras de cada Estado, de forma que "os danos à camada de ozônio, a perda da diversidade biológica e o efeito estufa requerem respostas planetárias e pedem, portanto, uma cooperação maior entre Estados e a disponibilização de recursos suficientes". ${ }^{30}$

Prova de que a proteção da camada de ozônio ultrapassa os limites de um Estado está na "Convenção de Viena para a Proteção da Camada de Ozônio" e no "Protocolo de Montreal sobre Substâncias que Destroem a Camada de Ozônio". Essas normas internacionais tiveram influência na formação do direito ambiental brasileiro: a Convenção e o Protocolo foram aprovados pelo Congresso Nacional por meio do Decreto Legislativo $\mathrm{n}^{\circ} 91$, de 15 de dezembro de 1989, e promulgados pelo Presidente da República por meio do Decreto $\mathrm{n}^{\circ}$ 99.280, de 6 de junho de 1990.

A Convenção de Viena para a Proteção da Camada de Ozônio retoma, em seu Preâmbulo, o Princípio 21 da Declaração da Conferência das Nações Unidas sobre o Meio Ambiente Humano (em Estocolmo), que dispõe:

os Estados, de acordo com a Carta das Nações Unidas e os princípios do direito internacional, têm o direito soberano de explorar seus próprios

30 Olivier Mazaudoux, Política internacional, direito ambiental e questões institucionais, p. 268. recursos, nos termos de suas próprias políticas ambientais, e a responsabilidade de assegurar que atividades dentro da área de sua jurisdição ou controle não causem dano ao meio ambiente de outros Estados ou de áreas além dos limites da jurisdição nacional. ${ }^{31}$

Assim, o Princípio 21 da Declaração da Conferência das Nações Unidas sobre o Meio Ambiente Humano (norma considerada soft law), influenciou o texto da Convenção de Viena para a Proteção da Camada de Ozônio (uma norma internacional), que foi internalizado no Brasil por meio do Decreto Legislativo $n^{\circ}$ 91, de 15 de dezembro de 1989, e promulgados pelo Presidente da República por meio do Decreto no 99.280, de 6 de junho de 1990 (uma norma interna). Esse caminho para a internalização de normas internacionais no Direito brasileiro será tratado a seguir.

\section{A INTERNALIZAÇÃO DE NORMAS INTERNACIO- NAIS NO DIREITO BRASILEIRO}

No direito brasileiro, a Constituição Federal previu a possibilidade de os tratados internacionais terem seu conteúdo elevado a direitos fundamentais. Seu art. 5. é o único artigo no Capítulo "Dos Direitos e Deveres Individuais e Coletivos", e contém uma grande lista de direitos e deveres considerados fundamentais, destinados a garantir o direito à vida, à liberdade, à igualdade, à segurança e à propriedade, conforme previsto em seu caput. Esse mesmo artigo prevê que seu rol de direitos e deveres não é taxativo, admitindo outros provenientes "dos tratados internacionais em que a República Federativa do Brasil seja parte" $\left(\$ 2 .^{\circ}\right)$.

Existe, até mesmo, a possibilidade de "os tratados e convenções internacionais sobre direitos humanos" serem considerados "equivalentes às emendas constitucionais", se adotados os procedimentos previstos no \$3. . Assim, mesmo que não sejam inseridos na Constituição Federal por meio de uma Emenda Constitucional, os tratados podem ter o mesmo status de uma emenda constitucional. Para isso, o texto constitucional aponta dois requisitos:

31 BRASIL. Decreto no 99.280, de 6 de junho de 1990. Promulgação da Convenção de Viena para a Proteção da Camada de Ozônio e do Protocolo de Montreal sobre Substâncias que Destroem a Camada de Ozônio. Diário Oficial da União de 7 de junho de 1990. 
a) que os tratados e convenções internacionais versem sobre direitos humanos;

b) que sejam aprovados, em cada Casa do Congresso Nacional, em dois turnos, por três quintos dos votos dos respectivos membros.

$\mathrm{O} \int 3 .^{\circ}$ foi inserido no art. $5 .^{\circ}$ da Constituição Federal por meio da Emenda Constitucional n. ${ }^{\circ} 45$, de 30 de dezembro de 2004. Nadia de Araújo aponta a evolução que essa norma do $\$ 3 .^{\circ}$ trouxe ao ordenamento jurídico:

\begin{abstract}
Não há dúvida de que houve uma evolução no sistema, pois agora há uma nova classe de tratados que serão alçados ao patamar constitucional, a critério do Poder Executivo (pois lhe cabe definir por que procedimento vai enviar os tratados), desde que respeitado o novo iter de aprovação (quorum especial e a votação em dois turnos). ${ }^{32}$
\end{abstract}

Essa evolução, no entanto, não impede a existência de diversas dúvidas, relacionadas: aos tratados adotados antes da EC 45/2004; à ratificação do tratado (as emendas constitucionais não são promulgadas pelo Presidente da República, mas o tratado precisa ser ratificado por ele); à denúncia dos tratados recepcionados de forma qualificada (já que, nos tratados comuns, o Poder Executivo não precisa de autorização do Poder Legislativo para renunciá-los). ${ }^{33}$

Valerio de Oliveira Mazzuoli comenta a posição do Supremo Tribunal Federal (STF) em relação aos tratados não aprovados com a maioria qualificada exigida pelo \$3..$^{\circ}$ do art. 5. ${ }^{\circ}$ da Constituição: eles seriam considerados norma de caráter supralegal (acima das normas infraconstitucionais, mas abaixo da Constituição). Esse entendimento foi firmado no Recurso Extraordinário 466.343-1/SP, que discutiu “a questão da prisão civil por dívida nos contratos de alienação fiduciária em garantia" 34 .

Essa decisão restou assim ementada:

PRISÃO CIVIL. Depósito. Depositário infiel. Alienação fiduciária. Decretação da medida coercitiva. Inadmissibilidade absoluta. Insubsistência da previsão constitucional e das normas subalternas. Interpretação do art. $5^{\circ}$, inc. LXVII e $\iint 1^{\circ}, 2^{\circ}$ e $3^{\circ}$, da CF, à luz do art. $7^{\circ}, \S 7$, da Convenção Americana de Direitos Humanos (Pacto de San José da Costa Rica). Recurso improvido. Julgamento conjunto do RE $\mathrm{n}^{\circ} 349.703$ e dos HCs $\mathrm{n}^{\circ} 87.585$ e $\mathrm{n}^{\circ}$ 92.566. É ilícita a prisão civil de

32 Nadia de Araujo, Direito internacional privado, p. 178-181.

33 Nadia de Araujo, Direito internacional privado, p. 178-181.

34 Valerio de Oliveira Mazzuoli, Curso de direito internacional público, p. 373. depositário infiel, qualquer que seja a modalidade do depósito.

Em resumo, discutia-se a colisão entre a norma do art. 5', LXVII, da Constituição Federal (que admite a prisão civil do depositário infiel) e o art. $7^{\circ}, \int 7$, do Pacto de San José da Costa Rica (que impede a prisão civil por dívida).

Dessa forma, os tratados internacionais que versam sobre direitos humanos "não estão (...) nem aquém nem além da Constituição, mas colocados no mesmo patamar hierárquico dos demais comandos da Carta Magna e automaticamente inseridos no texto constitucional." 35 No mesmo sentido explica Valerio de Oliveira Mazzuoli:

[...] uma vez aprovados pelo quorum que estabelece o $\int 3^{\circ}$ do $\operatorname{art.} 5^{\circ}$ da Constituição, os tratados de direitos humanos ratificados integrarão formalmente a Constituição, uma vez que serão equivalentes às emendas constitucionais. Contudo, frise-se que essa integração formal dos tratados de direitos humanos no ordenamento brasileiro não abala a integração material que esses mesmos instrumentos já apresentam desde a sua ratificação e entrada em vigor no Brasil. Dizer que um tratado equivale a uma emenda constitucional significa dizer que ele tem a mesma potencialidade jurídica que uma emenda. E o que faz uma emenda? Uma emenda reforma a Constituição, para melhor ou para pior. Portanto, o detalhe que poderá passar despercebido de todos (e até agora também não vimos ninguém cogitá-lo) é que atribuir equivalência de emenda aos tratados internacionais de direitos humanos, às vezes, pode ser perigoso, bastando imaginar o caso em que a nossa Constituição é mais benéfica em determinada matéria que o tratado ratificado. ${ }^{36}$

Assim, considerando-se a proteção ambiental como direito humano, os tratados que tratam dessa matéria podem ter a mesma força que os direitos fundamentais positivados pela Constituição. No entanto, tomando-se por base o ordenamento jurídico brasileiro, normalmente os tratados são equivalentes às leis, inclusive no que tange à análise de sua constitucionalidade, sendo incorporados após uma série de procedimentos. Foi em relação a essa espécie de tratados que Hans Kelsen asseverou:

35 Odete Novais Carneiro Queiroz. Prisão Civile Direitos Humanos, p. 72 .

36 O novo $\int 3^{\circ}$ do art. $5^{\circ}$ da Constituição e sua Eficácia, p. 107 e Curso de direito internacional público, p. 837-838. Mazzuoli critica a redação do $\$ 3 .^{\circ}$ por entender (entre outras coisas) que o $\$ 2 .^{\circ}$ do art. $5 .^{\circ}$ já prevê os tratados como normas com status constitucional. Menciona entendimento do STF favorável à sua tese, no Habeas Corpus 87.5858, que conta com voto-vista do Ministro Celso de Melo, baseado, dentre outras obras, no Curso de Direito Internacional Público de Mazzuoli. (Curso de direito internacional público, p. 373-374). 
Os tratados internacionais devem ser considerados como mantendo com a Constituição exatamente a mesma relação que as leis. Eles podem ser imediatamente inconstitucionais, seja formalmente, por causa da sua elaboração, seja materialmente, por causa do seu conteúdo.

No entanto, o lugar do tratado internacional no edifício da ordem jurídica não se deixa determinar de maneira perfeitamente unívoca. Só se pode interpretá-lo como norma imediatamente subordinada à Constituição e determinada por ela, supondo-se que a Constituição seja um grau supremo, isto é, do ponto de vista do primado do direito interno. ${ }^{37}$

Com esse ensinamento, Kelsen abre a possibilidade de o tratado internacional deixar de ser equivalente a uma lei infraconstitucional, se assim o definir o direito interno de uma determinada nação. No caso do Brasil, a Constituição está, "no edifício da ordem jurídica", em um "grau supremo" em relação à maioria dos tratados.

É possível considerar, porém, “o tratado internacional como pertencente a uma ordem jurídica superior aos Estados contratantes, criada de acordo com uma regra do direito das gentes por um órgão próprio da comunidade internacional formado por representantes desses Estados" caso em que o tratado teria "preponderância quanto à lei e mesmo quanto à Constituição". Nesse caso, continua Kelsen: "se uma lei, mesmo uma lei constitucional, contradiz um tratado, ela é irregular, a saber, contrária ao direito internacional. Ela vai imediatamente contra o tratado, e mediatamente contra o princípio pacta sunt servanda." ${ }^{38}$

O que pode ser similar, no Brasil, com essa construção apontada por Kelsen, está no $₫ 4 .^{\circ}$, do art. $5^{\circ}$ da Constituição Federal. Esse dispositivo legal, incluído pela Emenda Constitucional n. ${ }^{\circ} 45$, de 08 de dezembro de 2004, diz que "O Brasil se submete à jurisdição de Tribunal Penal Internacional a cuja criação tenha manifestado adesão". ${ }^{39}$ Essa previsão constitucional, implantada em 2004, reconheceu uma superioridade do direito internacional em relação à ordem jurídica interna brasileira, ao menos na matéria de competência do Tribunal Penal Internacional. Com isso, temos dois extremos presentes na ordem jurídica brasileira: tratados que são equivalentes a uma lei infraconstitucional e tratado(s)

37 Hans Kelsen, Jurisdição Constitucional, p. 137.

38 Hans Kelsen, Jurisdição Constitucional, p. 137-138.

39 O Tratado que previu a adesão do Brasil ao Tribunal Penal Internacional foi internalizado por meio do Decreto n. ${ }^{\circ} 4388$, de 25 de setembro de 2002 . que são superiores à ordem jurídica interna. Entre esses dois extremos estão os tratados que são equivalentes à norma constitucional.

Há uma obrigatoriedade de cumprimento dos Tratados Internacionais, de forma que, enquanto não vem um tratado internacional revogar ou modificar o anterior, este continua valendo, pois,

[...] segundo as regras do direito internacional, um tratado só pode perder sua força obrigatória em virtude de outro tratado ou de certos outros fatos determinados por ele, mas não por ato unilateral de uma das partes contratantes, notadamente, não por uma lei. ${ }^{40}$

O tratado não pode, portanto, sermodificado senão por outro tratado ou por condições nele previsto. Enquanto estão em vigor, os tratados mantêm sua força obrigatória, havendo o impedimento de um ato unilateral de um dos países contratantes modificar o tratado. Podemos acrescentar, nesse sentido, que nenhum ato ou omissão unilateral pode retirar do tratado sua força obrigatória e sua eficácia. Isso implica em dizer que, firmado o tratado e tendo ele ingressado no ordenamento jurídico da parte contratante, seu conteúdo deve ser colocado em prática, devendo ser considerado descumprimento do tratado as ações que lhe são contrárias e a omissão que não o aplica. Portanto, a deliberação ambiental que não leva em conta os deveres de proteção insculpidos nos tratados os está descumprindo.

A primeira sanção pelo descumprimento deve provir da Corte Constitucional. Kelsen, reportando-se à Constituição federal austríaca de $10^{\circ}$ de outubro de 1920, ensina que o mencionado órgão "decide sobre recursos contra violação, dos direitos constitucionalmente garantidos, por ato de autoridade administrativa". ${ }^{41}$ Assim, se ato de autoridade administrativa proveniente do Poder Executivo violar direitos previstos em tratados constitucionalmente garantidos, caberá recurso à Corte Constitucional.

Kelsen acrescenta, ainda:

a Corte Constitucional pode decidir também sobre a violação de direitos constitucionalmente garantidos ocorrida através de atos que se enquadram no poder discricionário das autoridades administrativas [... e essas...] decisões da Corte Constitucional têm caráter simplesmente cassatório. ${ }^{42}$

Mas a hipótese de garantir a proteção ambiental proveniente de um compromisso internacional depende de o Es-

\footnotetext{
$40 \quad$ Hans Kelsen, Jurisdição..., p. 138.

41 Jurisdição Constitucional, p. 29, destaque no original.

42 Jurisdição Constitucional, p. 31.
} 
tado optar por fazer parte da convenção ou tratado internacional, atribuição que, no Brasil, pertence, privativamente, ao Presidente da República, e que está sujeita a referendo do Congresso Nacional (art. 84, VIII, da Constituição Federal). Guido Fernando Silva Soares ensinava:

\begin{abstract}
o juízo sobre a conveniência de assinar tratados ou convenções internacionais é de competência exclusiva do Presidente da República, e nem mesmo, acredita-se, haveria a possibilidade de medidas judiciais que, com legitimidade, o forçassem a assinar tratados ou convenções internacionais contra sua determinação política de não fazê-lo (por via de mandados de injunção, ou outros meios admitidos pela Constituição Federal) ${ }^{43}$
\end{abstract}

Para que haja referendo do Congresso Nacional, o Presidente da República encaminha uma Mensagem ao Presidente da Câmara dos Deputados, expondo e justificando "os juízos de conveniência de o país figurar como parte naqueles tratados ou convenções internacionais". A Mensagem enviada pelo Presidente tem o objetivo de convencer "sobre a necessidade e oportunidade de o Brasil cingir-se às obrigações internacionais instituídas e a consequente introdução daqueles atos internacionais, no ordenamento jurídico brasileiro". ${ }^{44}$

Assim, a soberania nacional impede que um organismo internacional imponha sanções ao país que não aderiu ao compromisso internacional. Se a submissão de um Estado ao Tribunal Penal Internacional ou a outro organismo internacional depende de sua aceitação expressa, fica reduzida a possibilidade de responsabilizá-lo por ato antijurídico, culpável e/ou punível. Ressalte-se, no entanto, que a responsabilidade internacional ambiental não precisa, necessariamente, estar prevista em uma lei ou tratado. Segundo Guido Soares, a responsabilidade internacional,

\begin{abstract}
[...] nos primórdios de sua formulação no Direito Internacional, fora grandemente apoiado na doutrina, sua grande fonte de inspiração, além de um exercício de dedução dos princípios gerais de direito. Em particular após a segunda metade do século XIX, passou a basear-se num costume internacional, inferido de precedentes da jurisprudência arbitral dos litígios havidos entre Estados, em decorrência de violações de direitos de estrangeiros [...].
\end{abstract}

[Assim], salvo nos raros casos em que existem normas escritas entre os Estados, o estudo da

43 Direito Internacional do Meio Ambiente, p. 187-188.

44 Direito Internacional do Meio Ambiente, p. 187-188. Esse procedimento tem algumas exceções apontadas pelo autor à p. 189 da mesma obra. responsabilidade internacional dos Estados tem constituído uma penosa tarefa, dado o casuísmo em seu tratamento. ${ }^{45}$

No que se refere ao Direito Internacional do Meio Ambiente, no entanto, surgiram tratados e convenções multilaterais que passaram a servir de jus scriptum para a responsabilização internacional ambienta ${ }^{46}$. Isso facilita sua aplicação e diminui discussões relacionadas à legitimidade de decisões baseadas, por exemplo, em costumes ou princípios gerais de direitos. Todavia, Norma Sueli Padilha entende que:

[...] apesar da confirmação em Johanesburgo, dos princípios fundamentais sugeridos na Rio/92, bem como no Programa da Agenda 21, na verdade, não houve nenhum avanço efetivo quanto a um programa de ações concretas, para lograr o desenvolvimento sustentável global, o que seria de sua importância para o avanço na questão da problemática ambiental que só tem se agravado na década que separa a Conferência do Rio da de Johanesburgo. Tampouco possuem tais instrumentos força jurídica. ${ }^{47}$

Assim, tendo em vista que os tratados internacionais dependem da vontade política do governante, propõe-se, no tópico seguinte, que essa vontade política seja influenciada pela opinião pública, e que essa volte-se à formação de valores ambientais.

\section{INFLUÊNCIA DA OPINIÃO PÚBLICA NA FORMA- ÇÃO DOS VALORES AMBIENTAIS}

A internalização dos compromissos firmados pelos países em tratados e declarações internacionais influencia a formação das demais normas ambientais internas. Mas esses instrumentos dependem da aquiescência da nação para aceitar os termos do tratado e para internalizá-lo, além de ser necessário verificar a hierarquia que teria o tratado no direito interno. Some-se a isso a crítica que se faz ao sistema de governança internacional do meio ambiente, considerado fraco, fragmentado, sem visão, sem autoridade e sem legitimidade. "Essa deficiência de instituições internacionais tem uma grande quota de responsabilidade para o agravamento da crise ecológica mundial" ${ }^{48}$

45 Direito Internacional do Meio Ambiente, p. 724-725

46 Guido Soares, Direito Internacional do Meio Ambiente, p. 724-725.

47 PADILHA, Norma Sueli. Fundamentos Constitucionais do Direito

Ambiental Brasileiro. Rio de Janeiro: Elsevier, 2010. p. 99

48 MONT'ALVERNE, Tarin Cristino Frota; PEREIRA, Ana 
Assim, é necessária uma esfera pública interna ao Estado que forme uma opinião pública apta a influenciar o governante a querer contrair obrigações em um ato internacional. Isso permitiria que o "poder legítimo produzido comunicativamente" influenciasse o "sistema político" por meio de argumentos que tornem racionais as decisões administrativas. O caminho para essa influência exige a "democratização dos [...] processos de formação da opinião e da vontade", geradores de argumentos normativos que obtenham "um efeito regulador indireto" sobre as decisões dos governantes. A formação da opinião e da vontade exige, no entanto, "um alto nível de educação para todos e liberdade para manifestações teóricas da opinião e para propaganda". ${ }^{49}$

Teríamos, assim, o que Habermas denominou de "soberania popular procedimentalizada", cujo desenvolvimento depende de uma cultura política na qual a população está " acostumada com a liberdade política: não pode haver formação política racional da vontade sem a contrapartida de um mundo da vida racionalizado", que permita vários degraus e fragmentos na formação da opinião e da vontade. Diversas esferas públicas seriam formadas, sensíveis aos problemas da sociedade como um todo, construindo, modificando e filtrando os temas, os valores e os argumentos que influenciariam as decisões governamentais, "formando uma caixa de ressonância". Os governantes atenderiam essa ressonância por receio de receber a crítica dos seus eleitores e, consequentemente, de serem "punidos" nas urnas. $\mathrm{E}$ os discursos só conseguiriam ter essa influência se permitissem "uma participação ampla, ativa e difusora", desenvolvida no "pano de fundo de uma cultura política igualitária, destituída de todos os privilégios oriundos da formação e amplamente intelectualizada". ${ }^{0}$

Forma-se, assim, uma esfera pública cosmopolita ecológica, conectada ao reconhecimento do meio am-

Carolina Barbosa. Refugiados ambientais e tutela jurídicainternacional: algumas considerações. Revista de Direito Internacional, Brasília, v. 9, n. 3, 2012, p. 53. Nesse texto, as autoras apresentam como proposta ao problema dos refugiados ambientais, a construção de novas estruturas de governança internacional ambiental (como "a criação de uma Organização Mundial para o MeioAmbiente, o fortalecimento do PNUMA e a criação deum Conselho para o desenvolvimento sustentável"), tendo como objetivo "consolidar os diversos organismosinternacionais competentes em matéria ambiental." (MONT'ALVERNE; PEREIRA, Refugiados ambientais e tutela jurídicainternacional..., p. 53).

49 Jürgen Habermas, Direito e Democracia, v. II, p. 270-271, 262.

50 Jürgen Habermas, Direito e Democracia, v. II, p. 274-275, 277 (destaque no original). biente como valor comum da humanidade, sem limite de fronteiras geográficas. ${ }^{51}$ Como resultado, um Estado não pode tratar os bens naturais do seu território sem considerar os interesses dos demais Estados, graças à conhecida influência global produzida por um ato local.

Ao reconhecer o meio ambiente como valor inerente a toda a humanidade, percebe-se, como consequência lógica, que a preservação ambiental é dever da comunidade internacional ${ }^{52}$. A Corte Internacional de Justiça, no caso Papeleras (Argentina v. Uruguai) ${ }^{53}$, ainda que decidisse que não houve violação de obrigação substantiva assumida pelo Uruguai, lamentou que "a obrigação de proteger e preservar, estabelecido na alínea 'a' do artigo 41 do Estatuto deve ser interpretado de acordo com a prática amplamente aceita pelos Estados nos últimos anos ${ }^{54 \%}$. Em voto dissidente, o juiz Raúl Vinuesa registrou que a CIJ deixou de aplicar o princípio da precaução para evitar adequadamente a poluição e preservar o ambiente aquático do rio Uruguai em conformidade com o Estatuto 1975 e direito internacional geral. E considerou: “[...] o princípio da precaução não é uma abstração ou um componente acadêmico de soft law desejável, mas norma de direito internacional geral [...]. O direito que um Estado tem de que os demais Estados preservem o meio ambiente de seus territórios implica no seu dever de fazer o mesmo". ${ }^{55}$ Como bem defendeu Sebastián López Escarcena,

[...] a importância deste processo reside no desenvolvimento jurisprudencial de certos conceitos que garantem um lugar de destaque na história do direito ambiental internacional, particularmente em relação aos princípios da prevenção e da precaução, e a obrigação de realizar estudo de impacto ambiental. [...]

51 MAZAUDOUX, Olivier. Política internacional, direito ambiental e questões institucionais: defesa de uma ecologização das relações de força internacionais. In: D'ISEP, Clarissa Ferreira Macedo; NERY JUNIOR, Nelson; MEDAUAR, Odete (coord.). Politicas Públicas Ambientais: Estudos em homenagem ao Professor Michel Prieur. São Paulo: Editora Revista dos Tribunais, 2009, p. 259.

52 Olivier Mazaudoux, Política internacional, direito ambiental e questões institucionais: defesa de uma ecologização das relações de força internacionais, p. 259.

53 CIJ. Caso Papeleras. Argentina vs. Uruguay, Judgment, I.C.J. Reports 2010, p. 14. Disponível em: http://www.icj-cij.org/docket/index.php?p1 $=3 \& \mathrm{p} 2=3 \&$ case $=135 \& \mathrm{p} 3=4$. Acesso em: 19 de janeiro 2015.

54 CIJ. Caso Papeleras. Argentina vs. Uruguay, Judgment, I.C.J. Reports 2010, \204. Disponível em: http://www.icj-cij.org/docket/ index.php?p1 $=3 \& \mathrm{p} 2=3 \&$ case $=135 \& \mathrm{p} 3=4$.Acesso em: 19 dejaneiro 2015.

55 CIJ. Caso Papeleras. Argentina vs. Uruguay, Judgment, I.C.J. Voto Dissidente Juiz RaúlVinuesa, p. 293. Disponível em: http:/ / www.icjcij.org/docket/files/135/15893.pdf . Acesso em 16/09/2015. 
$\mathrm{Na}$ sua análise, a CIJ se baseia nos "Objetivos e Princípios do Impacto Ambiental", aprovados em 1987 pelo Programa das Nações Unidas para o Meio Ambiente, notando que é um guia / orientação de um organismo internacional de caráter técnico e, como tal, deve ser levado em conta pelas partes do Estatuto de 1975 para adotar medidas reguladoras internas. Estes objetivos e princípios exigem que o EIA deve conter, ao menos, uma descrição de alternativas possíveis e adequadas. ${ }^{56}$

Ademais, "a solução dos problemas ambientais globais requer a construção de uma governança global, por meio da qual as diferentes formas e níveis de enfrentamento dos problemas passam a coexistir numa dinâmica de complementaridade" ${ }^{57}$. Para isso, é necessário desenvolver uma opinião pública internacional que promova um controle social criador de regras emanadas de sua própria vontade. No entanto, o caminho para a formação dessa vontade exige que os atores sociais reconheçam como valores a paz, os direitos humanos e a preservação ambiental, acima dos interesses egoístas de seus Estados. Claro que esse reconhecimento ocorre lentamente, mas, espera-se, de forma progressiva. Aos poucos, conferências e convenções discutem o tema e estabelecem princípios, a seguir, compromissos e tratados são firmados, até chegar-se à incorporação desses valores e princípios no ordenamento jurídico de cada Estado. $^{58}$

Os tratados e declarações internacionais ainda recebem interpretações controversas a respeito de sua aplicabilidade, e ainda dependem da aquiescência dos Estados $^{59}$. Mas a própria discussão dos seus temas já

56 ESCARCENA, Sebastián López. El asunto de las plantas de celulosa sobre elríoUruguay. Revista Chilena de Derecho, vol. $39 \mathrm{~N}^{\circ} 3$, 2012 , p. 854 e 857.

57 REI, Fernando; SETZER, Joana; CUNHA,Kamyla Borges. A Rio+20 e o quadro institucional pelodesenvolvimento sustentável: o papeldos governos subnacionais na governançaambiental global. Revista de Direito Internacional, Brasília, v. 9, n. 3, 2012, p. 131.

58 Olivier Mazaudoux, Política internacional, direito ambiental e questões institucionais: defesa de uma ecologização das relações de força internacionais, p. 259-260.

59 Isso sem falar no alerta de Antonio Herman Benjamin de que "nem sempre os países menos desenvolvidos são chamados a opinar e participar da elaboração de tratados e acordos internacionais que, diretamente, lhes dizem respeito.” A própria Agenda 21, em seu capítulo 39, reconhece essa situação. "Consequentemente, suas realidades [dos países subdesenvolvidos], com peculiaridades e dificuldades próprias, deixam de ser levadas em consideração, dificultando a execução dos documentos internacionais eventualmente assinados." Some-se a isso a escassez de recursos desses países para implementar as políticas ambientais definidas nos tratados e convenções internacionais. (A proteção do meio ambiente nos países menos desenvolvidos: o caso da América Latina, p. 91, nota de rodapé 41). permite uma evolução no seu tratamento. Se um conjunto de Estados delibera a respeito de mecanismos de proteção ambiental já se percebe um grande avanço, pois isso levará ao debate desse assunto nos meios de comunicação, no Poder Público e em fóruns paralelos. Diversas informações serão pesquisadas, produzidas e divulgadas, o que permitirá à população dos Estados formarem suas opiniões. E, se todo esse processo ocorrer de acordo com a ética do discurso de Jürgen Habermas (sem coações externas, em um processo racional de argumentação e contra argumentação), poder-se-á chegar a uma ética cosmopolita ambiental. ${ }^{60}$

\section{Considerações finais}

As ações ou omissões que influenciam o meio ambiente não ficam adstritas ao território do país em que ocorreram. Essa realidade incentiva os países a firmarem instrumentos internacionais que reconheçam o alcance dos danos ambientais, prevenindo sua ocorrência ou sancionando-a. Este artigo pretendeu destacar a realidade do alcance global da degradação ambiental, o que motiva os países a firmarem instrumentos configurados como soft laws que, ao serem internalizados, tornam-se condutores das deliberações ambientais.

A necessidade de equilíbrio entre desenvolvimento econômico e proteção ambiental transforma as relações internacionais, que passam a buscar uma parceria mundial entre Estados, organizações não-governamentais e povos. A busca pelo bem-estar de todos surge como um novo interesse da humanidade fundamentado na solidariedade, "na cooperação, na luta por um destino comum". ${ }^{61}$

As organizações e demais atores internacionais têm importante papel no incentivo a uma deliberação que considere os ausentes, tanto no que se refere a instituições oficiais que congregam Estados, como em relação a outras organizações sem vínculo estatal que promovem o debate e a formação de opinião pública ambientalmente correta. Essas influências têm mais força quando internalizadas pelos Estados por meio de compromis-

60 Esse assunto é abordado em SOUZA, Leonardo da Rocha de. A consideração dos ausentes..., p. 127 e ss.

61 Olivier Mazaudoux, Política internacional, direito ambiental e questões institucionais: defesa de uma ecologização das relações de força internacionais, p. 276-277, 280. 
sos firmados em tratados e declarações internacionais, pois isso confere aos demais signatários a possibilidade de exigir os termos do acordo firmado. Quando os Estados estão dispostos a assumirem compromissos ambientais internacionais com outras nações, as deliberações que ocorrem no seu interior recebem a coação do direito para que promovam a proteção ambiental.

Para que os Estados assumam compromissos ambientais internacionais, é necessário o reconhecimento de sua inserção em uma realidade que transcende suas fronteiras, formando uma comunidade internacional que tem como vontade comum a preservação do meio ambiente. Para isso, os cidadãos de todas as nações devem assumir a proteção ambiental como algo que têm em comum e que, por isso, deve ser reconhecido como tema que une a todos.

Um dos entraves para que isso ocorra é a tendência que cada Estado tem de buscar seus próprios interesses, desenvolvendo suas economias internas e mantendo-se competitivos no cenário internacional. Em virtude dessa competição, alguns Estados tendem a subjugar direitos humanos e a utilizar os bens naturais de forma irresponsável, sem abertura a uma gestão democrática que permita a influência de seus cidadãos na tomada de decisões.

Diante disso, tornam-se necessárias instâncias supranacionais que influenciem o sistema global e a formação de uma identidade coletiva global, que gerem uma coesão social e uma solidariedade que supere os limites do Estado Nacional. Surgiria um contexto comunicacional que não precisa do sistema político para ser criado, mas que depende de uma "autocompreensão ético-política dos cidadãos" que forme "um contexto intersubjetivamente partilhado de entendimentos possíveis". Para que essa opinião pública não fique adstrita ao Estado nacional, deve ser formada em uma arena internacional, em um "contexto comunicacional que avance para além das fronteiras de opiniões públicas de inserção meramente nacional". ${ }^{2}$

O papel inicial das organizações supranacionais seria promover uma obediência dos Estados-membros às normas de proteção ambiental de forma heterônoma. Após, ocorreria a formação de cidadãos cosmopolitas que se preocupam com os interesses dos ausentes, formando uma solidariedade que supere os limites do ter-

62 JürgenHabermas, $A$ inclusão do outro, p. 180-181, 183. ritório de seu Estado. Essa solidariedade fica mais clara quando se trata da matéria ambiental, pois ela forma um contexto intersubjetivamente partilhado entre os cidadãos de todas as nações.

Habermas cita alguns exemplos de pressões que a ONU tem realizado sobre os países em temas que devem formar uma opinião pública planetária: "a ONU organizou uma série de conferências sobre questões de abrangência planetária envolvendo a ecologia (no Rio de Janeiro), os problemas do crescimento populacional (na cidade do Cairo), da pobreza (em Copenhague) e do clima (em Berlim)". O simples fato de essas "cúpulas mundiais" trazerem à discussão esses temas demonstra sua importância para a comunidade política internacional, gerando uma "opinião pública mundial" que, no mínimo, exerce "uma pressão política sobre os governos". ${ }^{63}$

Também são destacadas as pressões de atores internacionais não governamentais ${ }^{64}$ como o Greenpeace e a Anistia Internacional, que mobilizam para a formação “de uma opinião pública supranacional”. São instituições que "ganham influência crescente na imprensa, como forças que fazem frente aos Estados, surgidas a partir de algo semelhante a uma sociedade civil internacional, integrada em rede." ${ }^{65}$

Qualquer pressão de órgão internacional, no entanto, não pode ser fundamentada no poder militar, que pode significar ao Estado uma afronta à sua soberania, gerando uma aversão a essa intervenção. Ao contrário, deve haver uma influência para que os Estados sejam autônomos no desenvolvimento autossustentável de relações sociais aceitáveis sob o ponto de vista da paz, levando os Estados a desenvolverem "a participação democrática, a tolerância cultural e a condição efetiva de um Estado de direito." Com isso, estariam presentes "estratégias não violentas em favor de processos de democratização" que levariam os Estados a se tronarem mais sensíveis “ao poder 'brando' de influências indiretas". ${ }^{66}$

Parece, assim, que as pressões dos atores internacionais seriam um importante incentivo para mudar a

63 Jürgen Habermas, A inclusão do outro, p. 197.

64 Sobre a influência das organizações internacionais não-governamentais em matéria ambiental, cf. o artigo As ONGs e o direito internacional do meio ambiente, no qual Guido F. S. Soares analisa as mudanças havidas no Direito Internacional no século XX, a influência e o status de organizações internacionais na proteção ambiental. 65 Jürgen Habermas, $A$ inclusão do outro, p. 198.

66 Jürgen Habermas, $A$ inclusão do outro, p. 208-209. 
opinião pública no interior de cada Estado rumo a uma esfera pública cosmopolita ecológica. Em decorrência, são necessárias instâncias que influenciem o sistema global e avançam na execução das normas internacionais em matéria ambiental.

Se isso ocorrer, será natural a cada nação assumir compromissos internacionais como tratados e declarações que as vincule juridicamente, internalizando esses pactos como normas a serem seguidas no interior de cada Estado.

\section{REFERÊNCIAS}

ARAUJO, Nadia de. Direito internacional privado: teoria e prática brasileira. 5.ed. atual. eampl. Rio de Janeiro: Renovar, 2011.

BECK, Ulrich. Sociedade de Risco: Rumo a uma outra modernidade. Trad. Sebastião Nascimento. São Paulo: Editora 34, 2010.

BECK, Ulrich. A política na sociedade de risco. Idéias, Campinas-SP, n. 1, nova série, $2^{\circ}$ semestre, 2010.

BENJAMIN, Antonio Herman Vasconcellos e. A proteção do meio ambiente nos países menos desenvolvidos: o caso da América Latina. Revista de Direito Ambiental, São Paulo: RT, n. 0, abr./jun. 1995, p. 83-105.

BENJAMIN, Antonio Herman de Vanconcellos e; MARQUES, Claudia Lima; TINKER, Catherine. O gigante da água desperta: uma visão geral do direito das águas no Brasil. In: MARQUES, Claudia Lima (Coord.). O novo direito administrativo, ambiental e urbanístico: estudos em homenagem à Jacqueline Morand-Deviller. São Paulo: EditoraRevista dos Tribunais, 2010, p. 208-249.

BLUTMAN, L. In the trap of a legal metaphor: international soft law. The International and Comparative Law Quarterly, Oxford, v. 59, n. 3, p. 605-624, 072010.

BRASIL. Supremo Tribunal Federal. Ementa: Depositário infiel - Prisão. A subscrição pelo Brasil do Pacto de São José da Costa Rica, limitando a prisão civil por dívida ao descumprimento inescusável de prestação alimentícia, implicou a derrogação das normas estritamente legais referentes à prisão do depositário infiel. Habeas Corpus 87585. Paciente e impetrante: Alberto de Ribamar Ramos Costa. Coator: Superior Tribunal de Justiça. Relator: Min. Marco Aurélio, Tribunal Pleno, julgado em 03/12/2008, Diário de Justiça Eletrônico (DJe) [Brasília] 118, divulgado em 25/06/2009, publicado em 26/06/2009, ementa vol. 02366-02, p. 00237.

BRASIL. Supremo Tribunal Federal. Ementa: Prisão civil. Depósito. Depositário infiel. Alienação fiduciária. Decretação da medida coercitiva. Inadmissibilidade absoluta. Insubsistência da previsão constitucional e das normas subalternas. Interpretação do art. $5^{\circ}$, inc. LXVII e $\iint 1^{\circ}, 2^{\circ}$ e $3^{\circ}$, da CF, à luz do art. $7^{\circ}, \int 7$, da Convenção Americana de Direitos Humanos (Pacto de San José da Costa Rica). Recurso improvido. Julgamento conjunto do RE no 349.703 e dos HCs no 87.585 e $\mathrm{n}^{\mathrm{o}}$ 92.566. É ilícita a prisão civil de depositário infiel, qualquer que seja a modalidade do depósito. Recurso Extraordinário no ${ }^{\circ}$ 466343. Recorrente: Banco Bradesco S/A. Recorrido: Luciano Cardoso Santos. Relator: Min. Cezar Peluso, Tribunal Pleno, julgado em 03/12/2008, Diário de Justiça Eletrônico (DJe) [Brasília] 104, divulgado em 04/06/2009, publicado em 05/06/2009, ementa vol. 02363-06, p. 01106; Revista Trimestral de Jurisprudência [Brasília], vol. 00210-02, p. 00745.

CÁRDENAS CASTAÑEDA, Fabián Augusto. A call for rethinking the sources of international law: soft law and the other side of the coin. Anuario Mexicano de Derecho Internacional, vol. XIII, 2013, p. 355-403.

CORTE INTERNACIONAL DE JUSTIÇA (CIJ). Caso Papeleras. Uruguayvs Argentina, Judgment, I.C.J. Reports 2010, p. 14. Disponível em: http://www.icj-cij. org $/$ docket $/$ index.php?p1 $=3 \& \mathrm{p} 2=3 \&$ case $=135 \& \mathrm{p} 3=4$ . Acesso em: 19 de janeiro 2015.

DECLARAÇÃO DE ESTOCOLMO SOBRE O MEIO AMBIENTE HUMANO (1972), In: MAZZUOLI, Valerio de Oliveira (org.). Coletânea de Direito Internacional, Constituição Federal. 10. ed. rev. ampl. e atual. São Paulo: Editora Revista dos Tribunais, 2012. p. 11331137.

DECLARAÇÃO DO RIO DE JANEIRO SOBRE MEIO AMBIENTE E DESENVOLVIMENTO (1992), In: MAZZUOLI, Valerio de Oliveira (org.). Coletânea de Direito Internacional, Constituição Federal. 10. ed. rev. ampl. e atual. São Paulo: Editora Revista dos Tribunais, 2012. p. 1137-1140.

DINIZ, Antonio Carlos. Pós-modernismo (verbete). In: BARRETO, Vicente de Paulo (coord.) Dicionário de Filosofia do Direito. São Leopoldo, RS: Editora Unisinos; Rio de Janeiro: Editora Renovar, 2006. p. 647-650. 
ELLIS, J. Shades of Grey: Soft Law and the Validity of Public International Law. Leiden Journal of International Law, Cambridge, v. 25, n. 2, p. 313-334, 062012.

ESCARCENA, SebastiánLópez. El asunto de las plantas de celulosa sobre el río Uruguay. Revista Chilena de Derecho, vol. 39, n. 3, 2012, p. 849-860.

GERSEN, J.E.; POSNER, E.A. Soft law: lessons from congressional practice. Stanford law review, Stanford, v. 61, n. 3, p. 573-627, 122008.

GOLDMANN, M. We Need to Cut Off the Head of the King: Past, Present, and Future Approaches to International Soft Law. Leiden Journal of International Law, Cambridge, v. 25, n. 2, p. 335-368, 062012.

Guzman, Andrew T. and Meyer,Timothy L. International Soft Law, 2 J. Legal Analysis 171 (2010). Disponível em: http://scholarship.law.berkeley.edu/facpubs/695, acesso em 14/10/2015.

HABERMAS, Jürgen. $A$ inclusão do outro: estudos de teoria política. Tradução: George Sperber e Paulo AstorSoethe. São Paulo: Edições Loyola, 2002.

HABERMAS, Jürgen. Direito e Democracia: entre facticidade e validade, volumes I e II, 2.ed.; tradução: Flávio BenoSiebeneichler. Rio de Janeiro: Tempo Brasileiro, 2003.

JAYME, Erik. Visões para uma teoria pós-moderna do Direito Comparado. Revista dos Tribunais, a. 88, v. 759, jan. 1999, p. 24-40.

JAYME, Erik. O Direito Internacional Privado do novo milênio: a proteção da pessoa humana face à globalização. In: MARQUES, Cláudia Lima; ARAÚJO, Nadia de (orgs.). O Novo Direito Internacional - Estudos em homenagem a Erik Jayme. Rio de Janeiro: Renovar, 2005, p. 3-20.

JONAS, Hans. O princípio responsabilidade: ensaio de uma ética para a civilização tecnológica. Trad. Marijane Lisboa, Luiz Barros Montez. Rio de Janeiro: Contraponto, Ed. PUC-Rio, 2006.

KELSEN, Hans. Jurisdição Constitucional. Trad. do alemão Alexandre Krug; trad. do italiano Eduardo Brandão; trad. do francês Maria Ermantina Galvão. Intr. e revisão técnica Sérgio Sérvulo da Cunha. São Paulo: Martins Fontes, 2003.

LEFF, Enrique. Ecologia, capital e cultura: racionalidade ambiental, democracia participativa e desenvolvimento sustentável. Trad. Jorge Esteves da Silva. Blumenau: Ed. da FURB, 2000.

LEFF, Enrique. Pensar a Complexidade Ambiental. In: LEFF, Enrique (org). A Complexidade Ambiental. São Paulo: Cortez, 2003.

MARQUES, Cláudia Lima. Direito na pós-modernidade e a teoria de Eric Jayme. In: OLIVEIRA JUNIOR, Jose Alcebíades de. (Org.). Faces do multiculturalismo: teoria - política - direito. Santo Ângelo: EDIURI, 2007, v. 1, p. 21-36.

MAZAUDOUX, Olivier. Política internacional, direito ambiental e questões institucionais: defesa de uma ecologização das relações de força internacionais. In: D'ISEP, Clarissa Ferreira Macedo; NERY JUNIOR, Nelson; MEDAUAR, Odete (coord.). Políticas Públicas Ambientais: Estudos em homenagem ao Professor Michel Prieur. São Paulo: Editora Revista dos Tribunais, 2009, p. 258-283.

MAZZUOLI, Valerio de Oliveira. Curso de direito internacional público. 5.ed. rev., atual. eampl. São Paulo: Editora Revista dos Tribunais, 2011.

MAZZUOLI, Valerio de Oliveira. O novo $\int 3^{\circ}$ do art. $5^{\circ}$ da Constituição e sua Eficácia. Revista de Informação Legislativa. Brasília, a. 42, n. 167, p. 93-114, jul./set. 2005.

MIRAGEM, Bruno. Conteúdo da ordem pública e os direitos humanos. Elementos para um direito internacional pós-moderno. In: MARQUES, Cláudia Lima; ARAÚJO, Nadia de (orgs.). O Novo Direito Internacional - Estudos em homenagem a Erik Jayme. Rio de Janeiro: Renovar, 2005, p. 307-354.

MONT'ALVERNE, Tarin Cristino Frota; PEREIRA, Ana Carolina Barbosa. Refugiados ambientais e tutela jurídica internacional: algumas considerações. Revista de Direito Internacional, Brasília, v. 9, n. 3, 2012, p. 45-55.

MOROSINI, Fábio. Globalização e Novas Tendências em Filosofia do Direito Internacional: a Dicotomia entre Público e Privado da Cláusula de Estabilização. In: MARQUES, Cláudia Lima; ARAÚJO, Nadia de (orgs.). O Novo Direito Internacional - Estudos em homenagem a Erik Jayme. Rio de Janeiro: Renovar, 2005, p. 549-572.

NASSER, Salem H. Fontes e Normas do Direito Internacional - Um Estudo Sobre a Soft Law. São Paulo: Editora Atlas, 2006.

NASSER, Salem H. Desenvolvimento, Costume Internacional e Soft law. In: Alberto do Amaral Júnior. 
(Org.). Direito Internacional e Desenvolvimento. 1 ed. Barueri: Manole, 2005, p. 201-218. Disponível em https:// gedirj.files.wordpress.com/2008/02/desenvolvimentocostumeinternacionaloftlawalemnasser.pdf, acesso em 14/10/2015.

PARDO, José Esteve. O desconcerto do Leviatãa: política e direito perante as incertezas da ciência. Coordenador [da série] José Rubens Morato Leite. Trad. Flávia França Dinnebier, Giorgia Sena Martins. São Paulo: Instituto O Direito por um Planeta Verde, 2015

QUEIROZ, Odete Novais Carneiro. Prisão Civil e Direitos Humanos. São Paulo: Revista dos Tribunais, 2004.

REI, Fernando Cardozo Fernandes; GRANZIERA, Maria Luiza Machado. Direito Internacional do Meio Ambiente (DIMA) e Direito Ambiental Internacional (DAI): Novos atores em cena. In: SORTO, Fredys Orlando; DEL'OLMO, Florisbal de Souza (coord.). Direito internacional I [Recurso eletrônico on-line] organização CONPEDI/UFPB. Florianópolis: CONPEDI, 2014. p. 320-341. Disponível em: http://publicadireito. com.br/artigos/?cod=16e62507eba0d973, acesso em 14/10/2015.

REI, Fernando; SETZER, Joana; CUNHA, Kamyla Borges. A Rio+20 e o quadro institucional pelo desenvolvimento sustentável: o papel dos governos subnacionais na governança ambiental global. Revista de Direito Internacional, Brasília, v. 9, n. 3, 2012, p. 129-140

SHAFFER, G.C.; POLLACK, M.A. Hard versus Soft law in internationalsecurity. Boston College. Law School. Boston College Law Review, Newton Centre, v. 52, n. 4, p. 1147-1241, 092011.

SILVEIRA, Clóvis Eduardo Malinverni da. A teoria da sociedade de risco como instrumento para a compreensão da emergência dos movimentos urbanos no Bra- sil: um contraponto crítico. Revista Quaestio Iuris, v. 8, p. 1913-1948, 2015.

SOARES, Guido Fernando Silva. As ONGs e o direito internacional do meio ambiente. Revista de Direito Constitucional e Internacional, São Paulo: RT, a. 9, n. 34, jan./ mar. 2001, p. 7-51.

SOARES, Guido Fernando Silva. Direito internacional do meio ambiente: emergência, obrigações e responsabilidades. 2.ed. São Paulo: Atlas, 2003.SOUZA, Leonardo da Rocha de. A Consideração dos Ausentes à Deliberação Ambiental: uma proposta a partir da ética do discurso de Jürgen Habermas. Rio de Janeiro: Lumen Juris, 2013.

SOUZA, Leonardo da Rocha de. A Pós-Modernidade em Erik Jayme e a Participação Popular na Elaboração de Normas Ambientais. Direitos Culturais. Revista do Programa de Pós-Graduação em Direito - Mestrado da URI Santo Ângelo - RS, v. 5, n. 8, jan./jun. 2010, p. 193-202.

UNITED NATIONS. Report of the World Summit on Sustainable Development. A/CONF.199/20, New York, 2002.

VARELLA, Marcelo Dias. Direito Internacional Público. 2.ed. São Paulo: Saraiva, 2010.

VARELLA, Marcelo. O surgimento e a evolução do Direito Internacional do Meio Ambiente: da proteção da natureza ao desenvolvimento sustentável. In: VARELLA, Marcelo D.; BARROS-PLATIAU,Ana Flavia (org.). Proteção internacional do meio ambiente. Brasília: Unitar, UniCEUB e UnB, 2009, p. 6-25.

WEDY, Gabriel de Jesus Tedesco. Os fundamentos do princípio da precaução. Juris Plenum Direito Administrativo, Caxias do Sul, ano II, n. 8, p. 109-138, out./dez. 2015. 


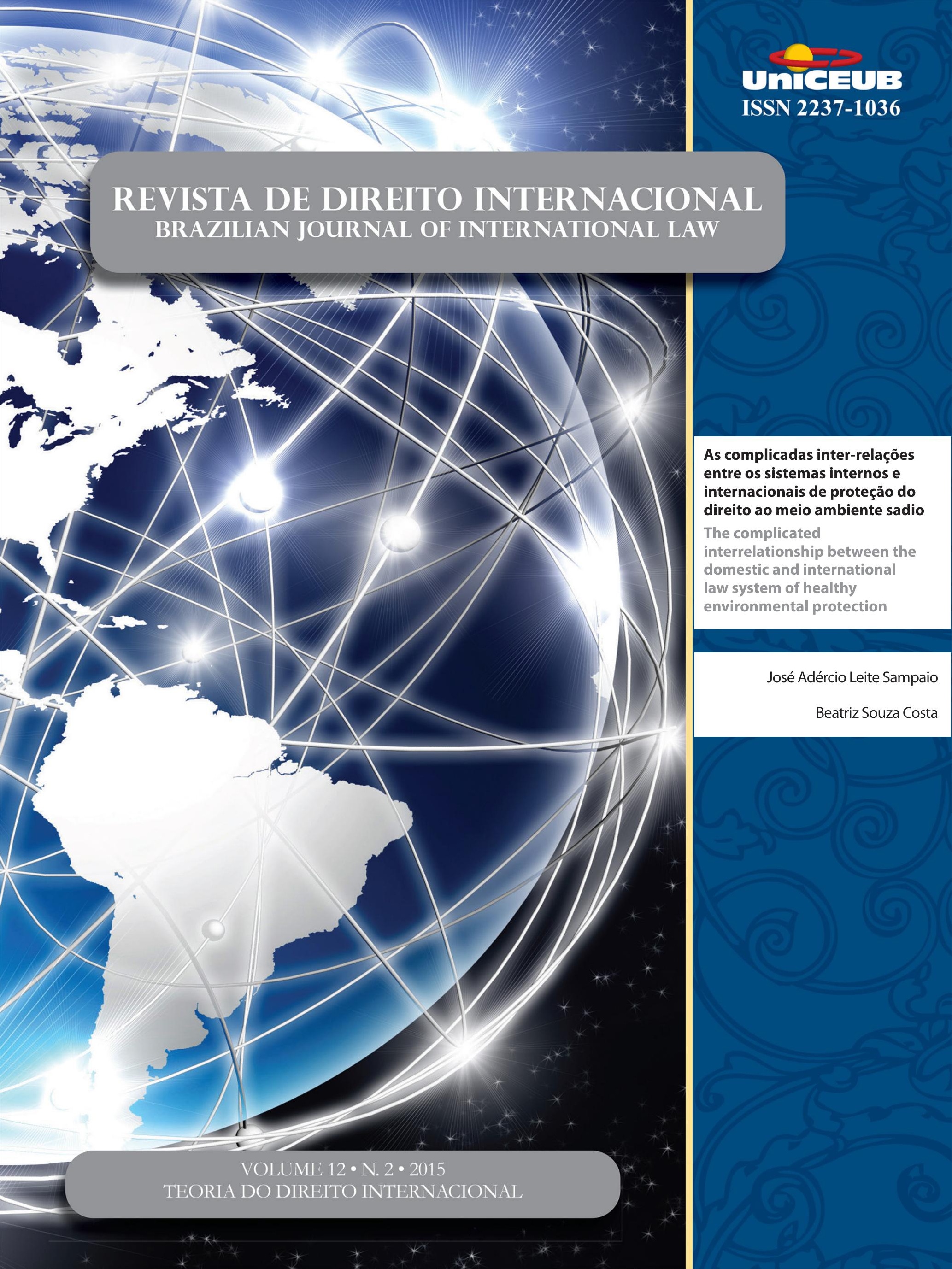




\section{The complicated interrelationship between the domestic and international law system of healthy environmental protection}

\section{Resumo}

Este artigo tem como objetivo analisar as inter-relações entre os sistemas interno e internacional de proteção do meio ambiente. Embora a definição dessa proteção como objeto de um direito humano ou fundamental encontre argumentos morais e jurídicos que superam teses contrárias, o seu reconhecimento pelos Estados e pela comunidade internacional ainda revela déficits de normatividade e de eficácia. A economia é quase sempre chamada a justificar esse fenômeno. É preciso, todavia, explorar os elementos internos e externos que contribuem para esta justificativa e para aquele déficit. $\mathrm{O}$ artigo procurar avaliar ainda os fatores que podem atuar, pelo menos, normativamente, no sentido da convergência dos sistemas para promover A efetiva proteção ambiental. Utilizou-se a metodologia jurídico-teórica, dedutiva e com técnica bibliográfica, para o desenvolvimento da pesquisa, assim como em sites relativos ao tema.

Palavras-chave: Meio Ambiente Sadio; Sistema Global de Proteção de Direitos Humanos; OMC; Direitos Humanos.

* Recebido em 10/11/2015 Aprovado em 09/02/2016

** Mestre e Doutor em Direito Constitucional pela UFMG. Professor do Mestrado em Direito Ambiental e Desenvolvimento Sustentável da Escola Superior Dom Helder Câmara. Professor da PUC-MG. Procurador da República.

*** Mestre e Doutora em Direito Constitucional pela UFMG. Professora de Direito Ambiental Constitucional do Curso de Pós-Graduação em Direito Ambiental e Desenvolvimento Sustentável da Escola Superior Dom Helder Câmara. Pró-Reitora de Pesquisa da ESDHC.

\section{Abstract}

This article aims to examine the interrelations between domestic and international systems of protection of the healthy environment. Although the definition of such protection as the object of a human or fundamental right finds moral and legal arguments that outweigh opposing views, their recognition by States and the international community reveals normative and effective deficits. Economics is often called upon to justify this phenomenon. It must be explored, however, the internal and external elements that contribute to this justification and for that deficit. The article also evaluates the factors, such as social participation, that can act, at least, normatively towards convergence of effective protection systems.

Keywords: Healthy environment; Global System of Human Rights Protection; WTO; Human Rights. 


\section{INTRODUÇÃO}

O meio ambiente é o mundo em que se vive. Afirmação prosaica, todavia pertinente à consideração de que a humanidade é moradora do mesmo espaço e usuária - pelo menos potencial - dos mesmos recursos.

A degradação ambiental não é um fenômeno que importe a um país somente nem a um continente ou hemisfério terrestre. Essa conexão objetiva remete a uma intersubjetividade necessária na forma de compreender e lidar com o problema gerado pela atividade humana. Intersubjetividade que, todavia, esbarra nas fronteiras políticas e no interesse econômico. Se os Estados, segundo sua conveniência e demandas, tenderem a regulamentar a matéria como mônadas, a tarefa será destinada ao fracasso. A questão exige convergência das demais nações e povos para solução de estabelecimento de bases para o desenvolvimento sustentável.

Está posta a indagação que se formula no trabalho: como os sistemas nacionais e internacional operam na proteção do meio ambiente? Em se tratando de uma abordagem jurídica, a pergunta formulada exige uma resposta prévia sobre o status que se confere à proteção ambiental, a sua subjetividade como poder ou direito atribuída a todos sobre o bem comum da humanidade, ou seja, um ambiente sadio e ecologicamente equilibrado.

Sustenta-se no trabalho a natureza de direito humano ou fundamental, do meio ambiente, como expressão de uma necessidade básica para indivíduos, grupos, nações, um pluridireito, uma multissubjetividade que requer atendimento por um regime de proteção, interna e internacional, que atenda à sua indivisibilidade. Todavia, há barreiras que se impõem à inter-relação entre os sistemas dessa proteção, interna e internacional, dificultando o necessário tratamento da indivisibilidade de fenômenos como aquecimento global, depleção da camada de ozônio, poluição dos mares, do ar e da terra.

Há, todavia, elementos que facilitam o encontro dos dois sistemas. Elementos que tentam recuperar o sentido da unidade imposta pela moradia comum sobre o mesmo planeta. Procuram-se identificar os argumentos que ajudem a entender por que os Estados relutam contra o óbvio. O estudo, adotando a metodologia jurídico-teórica com técnica de pesquisa bibliográfica, revela a predominância de interesses estratégicos e econômicos no desenvolvimento desses papeis, secundada por um discurso de proteção jusambiental e por pressões da so- ciedade civil de âmbito interno e internacional.

Aliam-se como fatores que dificultam as inter-relações efetivas de proteção interna e internacional a fragmentação das normas regionais e globais sobre o assunto, a dificuldade de o direito internacional dos direitos humanos incluir o direito ao meio ambiente sadio em seu repertório de discurso e prática, além de uma jurisprudência internacional, caracterizada por certa vacilação e óbices à sua efetividade. De um modo geral, porém, pode-se afirmar que a orientação das cortes regionais de direitos humanos, notadamente nas Américas e Europa, parece mitigar a leitura da predominância econômica sobre interesses ambientais. Mas, mesmo nesses domínios, não faltam indicativos de que os argumentos morais e jurídicos tendem, pelo menos, a se somar à defesa de mercados, de competitividade e de lucro. O crescimento econômico ainda seduz o imaginário como horizonte de promessas de um mundo mais livre, mais próspero e mais, talvez, feliz.

Preferiram-se destacar mais, por seu traço paradigmático, as orientações que se firmaram na Organização Mundial do Comércio (OMC). Criada em 1995, a OMC tem entre seus consideranda que a atividade econômica deve dar com "utilização ótima dos recursos mundiais em conformidade com o objetivo de um desenvolvimento sustentável e buscando proteger e preservar o meio ambiente" . O relato não será menos elusivo: o direito ao meio ambiente sadio ainda tem um longo caminho a percorrer.

Somam-se a esses elementos de direito supranacional aspectos internos que se projetam para fora das fronteiras, contribuindo para o déficit de proteção jusambiental. A estrutura constitucional dos Estados, seja pelos instrumentos de nacionalização dos tratados, seja pela articulação nem sempre fácil entre unidades territoriais de poder, sobretudo em Estados descentralizados e federais, tendem a criar óbices de aplicação das normas internas e internacionais.

Há, todavia, elementos que lançam no horizonte promessas de alteração desse cenário. Elementos que se projetam no sentido tanto da comunidade internacional para os Estados como dos Estados para a comunidade internacional. Trata-se da "cidadania ambiental" que adquire papel relevante no esforço de contrabalançar o

1 ORGANIZAÇÃO MUNDIAL DO COMÉRCIO. Marrakesh Agreement Establishing WTO, 15/4/1995. Disponível em: <http:// bit.ly/1wgdiM2>. Acesso em: 03 fev. 2015. 
poderoso empenho dos interesses econômicos. Essa cidadania acena com a possibilidade de uma cooperação entre as nações que estabeleça um equilíbrio dinâmico entre desenvolvimento e sustentabilidade.

\section{DiReito ao meio ambiente SADIO: UM DIREITO HUMANO E DIREITO FUNDAMENTAL ${ }^{2}$}

Há argumentos dogmáticos e materiais que sustentam a definição do direito ao meio ambiente sadio ou, na dicção do direito constitucional brasileiro, ecologicamente equilibrado tanto como direitos humanos, em sua perspectiva internacional, quanto como direitos fundamentais, em sua dimensão interna. Os argumentos dogmáticos valem-se da existência de diversos acordos, declarações, pactos e tratados internacionais que o reconhecem em aspectos gerais ${ }^{3}$ e específicos ${ }^{4}$; assim como de sua previsão nos textos das Constituições ou a sua afirmação pela jurisprudência constitucional de diversos Estados 5 .

Os fundamentos materiais são identificados pelo consenso formado no âmbito dos Estados, e também da comunidade internacional, interpretando o meio ambiente como um valor moral que requer a devida proteção pelos sistemas jurídicos. Esse valor moral ora é

2 Utilizaremos indistintamente "direito ao meio ambiente sadio ou saudável" e "direito ao meio ambiente ecologicamente equilibrado", terminologia empregada pela Constituição brasileira de 1988. 3 Vejam-se, por exemplo, os instrumentos regionais de direitos humanos, tais como o Protocolo Adicional à Convenção Interamericana de Direitos Humanos sobre Direitos Econômicos, Sociais e Culturais, a Carta Africana dos Direitos Humanos e seu Protocolo Adicional sobre os Direitos das Mulheres. No âmbito das Nações Unidas, a Declaração Universal dos Direitos Humanos (DUDH), o Pacto Internacional sobre os Direitos Econômicos e Sociais e Culturais (PIDESC) e a Convenção sobre os Direitos da Criança (CDC) estabelecem o direito ao mais alto nível possível de saúde. Sob o PIDESC, o direito à saúde inclui a obrigação de promover a saúde ambiental, de modo a proteger os cidadãos contra os riscos ambientais para a saúde, para garantir condições de trabalho saudáveis e assegurar o direito à alimentação segura e à água potável.

4 Dentre vários documentos, citem-se a Convenção sobre o Comércio Internacional de Espécies Ameaçadas de Fauna e Flora Silvestres (CITES), Convenção-Quadro sobre Mudança do Clima (UNFCCC), Convenção sobre o Acesso à Informação e Participação Pública no Processo Decisório e Acesso à Justiça em Matéria Ambiental (Convenção de Aarhus)

5 SAMPAIO, José Adércio L. Constituição e Meio Ambiente na Perspectiva do Direito Constitucional Comparado. In SAMPAIO, José Adércio L.; WOLD, Chris; NARDY, Afrânio. Princípios de Direito Ambiental na Dimensão Internacional e Comparada. Belo Horizonte: Del Rey, 2003, p. 37-115. p. 37 e ss. apresentando como primário, a reconhecer o ambiente como um bem valioso em si mesmo na linha defendida pela variedade de correntes que compõem as orientações biocêntricas ou a chamada "ecologia profunda"; ora é defendido como um valor secundário ou instrumental, todavia jurídica e politicamente essencial, em razão de sua indispensabilidade para a vida humana na Terra $^{6}$.

Haveria, porém, dificuldades de ordem liberal à sua categorização, sobretudo, em nível de direito fundamental. Em se tratando de um "direito coletivo" ou "bem comunitário", o meio ambiente sadio não poderia ser considerado tecnicamente um direito de status fundamental. A prova disso seria dada pela impossibilidade de, como bem de todos, ser salvaguarda da minoria em contraposição à maioria.

Essas dificuldades são, todavia, enfrentadas pela constatação de que os efeitos nocivos da degradação ambiental recaem especialmente sobre as pessoas mais vulneráveis, incluindo populações mais pobres, comunidades tradicionais e indígenas, minorias étnicas, mulheres, idosos e crianças. Haveria uma espécie de divisão social do dano ambiental ou do ambiente poluído?

Nessa esteira, e diante de consequências difusas como o aquecimento global e o buraco da camada de ozônio, pelo menos no curto prazo, pessoas de maior poder aquisitivo poderiam, senão neutralizá-las, pelo menos, minorar seus malefícios. Enfim, trata-se de uma crítica liberal que não desnatura outras possíveis interpretações teóricas, a exemplo da comunitarista e mesmo certas correntes republicanistas, que não refutam o caráter de fundamentalidade a direitos de titularidade coletiva. ${ }^{8}$

Na prática, entretanto, os governos e agências internacionais ou não enquadram as questões ambientais no

6 BENSON, John. Environmental Ethics: An Introduction with Readings. New York: Routledge, 2000; KELLER, David R. (ed). Environmental Ethics: The Big Questions. Chichester; Malden: Wiley-Blackwell, 2010.

7 ADEOLA, Francis O. Cross-National Environmental Injustice and Human Rights Issues A Review of Evidence in the Developing World. American Behavioral Scientist, v. 43, n. 4, p. 686-706, 2000. São vários os estudos que demonstram essa divisão social perversa. Vejam-se, dentre outros: HUMAN RIGHTS WATCH. "What Will Happen if Hunger Comes?" Abuses against the Indigenous Peoples of Ethiopia's Lower Omo Valley. Junho de 2012. Disponível em: < http://bit. ly/1weM9sI>. Acesso em: 08 fev. 2014.

8 SAMPAIO, José Adércio L. Teoria da Constituição e dos Direitos Fundamentais. Belo Horizonte: Del Rey, 2013. 
âmbito dos direitos humanos e fundamentais, cada um no seu nível, ou o fazem de modo superficial, quando não diversionista. As leis e os regulamentos internacionais são importantes ferramentas para proteger o meio ambiente, mas, geralmente, quando tratam do assunto, tendem a se concentrar em aspectos técnicos de regulação e dos processos ecológicos determinados. ${ }^{9}$

Essa ambiguidade foi retratada pela nomeação, apenas em 2012, pelo Conselho de Direitos Humanos da ONU (CDH) de seu primeiro perito independente para desenvolver estudos e relatórios sobre o cumprimento das obrigações de direitos humanos relacionadas ao gozo de um ambiente seguro, limpo, saudável e sustentável. Talvez a mais importante de suas tarefas seja ajudar o Conselho a definir o conteúdo do direito humano a um meio ambiente saudável, bem como definir instrumentos que assegurem seu efetivo exercício ${ }^{10}$. Antes tarde do que nunca.

Sem embargo das dificuldades apontadas, é crescente a tendência de tratamento do meio ambiente no âmbito dos direitos humanos e constitucionais. As inter-relações entre esse fenômeno, no âmbito das nações e no plano internacional, são notáveis e esperadas. É certo que contextos locais e mesmo circunstâncias históricas modulam a intensidade e a forma que o Estado contribui neste processo de afirmação internacional de um direito ao meio ambiente sadio. Por outro, lado em

9 Um exemplo sempre lembrado é o da Convenção de Estocolmo sobre os Poluentes Orgânicos Persistentes. Ver: KARLAGANIS, Georg et al. The elaboration of the 'Stockholm convention'on persistent organic pollutants (POPs): a negotiation process fraught with obstacles and opportunities. Environmental Science and Pollution Research, v. 8, n. 3, p. 216-221, 2001. No caso brasileiro, há um um relativo consenso, firmado pela jurisprudência e doutrina, de se tratar de um direito fundamental: COSTA, Beatriz Souza. Meio Ambiente como Direito à Vida: Brasil, Portugal e Espanha. 2. ed. Rio de Janeiro: Lumen Juris, 2013. p. 43.

10 ORGANIZAÇÃO DAS NAÇÕES UNIDAS. Conselho de Direitos Humanos. 19a Sessão. A/HRC/RES/19/10, 19/04/2012. Disponível em: <http://bit.ly/1FrWGRi>. Acesso em: 15 fev. 2014. De se notar que, desde 1972, existe no âmbito da ONU o Programa das Nações Unidas para o Meio Ambiente ou PNUMA, autodenominada principal autoridade global em meio ambiente, sendo responsável por promover a conservação ambiental e o uso eficiente de recursos no contexto do desenvolvimento sustentável. ORGANIZAÇÃO DAS NAÇÕES UNIDAS. Programa das Nações Unidas para o Meio Ambiente ou PNUMA. Disponível em: < http://bit. ly/1Wu1rB9 >. Acesso em: 15.fev.2015. Para muitos, o PNUMA foi uma resposta simbólica da ONU ao problema ambiental, sem contornos de uma instituição com poderes efetivos: IVANOVA, Maria. Designing the United Nations Environment Programme: a story of compromise and confrontation. International Environmental Agreements: Politics, Law and Economics, v. 7, n. 4, p. 337-361, 2007. sentido inverso, sofre influxos de avanços e retrocessos verificados internacionalmente. $\mathrm{O}$ exame do tema se limitará, todavia, aos Estados Unidos e ao Brasil. Uma circunscrição, porém, que pode auxiliar à compreensão do que sucede em outros lugares, dadas as convergências e distinções entre os dois países.

\section{As INTER-RELAÇõES ENTRE PROTEÇÃO INTERNA E INTERNACIONAL DO DIREITO AO MEIO AMBIENTE SADIO}

Em um mundo globalizado é praticamente impossível que os Estados tomem decisões de política ambiental sem levar em conta o cenário e contextos internacionais. Razões técnicas e econômicas explicam esse comportamento. Em geral, a adoção de instrumentos mais rigorosos de proteção ambiental, no âmbito doméstico, suscita duas grandes preocupações. Uma delas, a primeira, sobre a eficácia das medidas; outra, a segunda, sobre o impacto que produz na competitividade do país e de suas empresas ${ }^{11}$.

A primeira se funda na limitação que têm os Estados para enfrentar isoladamente problemas como o aquecimento global, a poluição do ar ou a destruição da camada de ozônio. A segunda se reporta ao aumento relativo dos custos operacionais e de produção de bens e serviços, para as empresas sediadas no Estado que adota medidas ambientais mais restritivas, correndo o risco de verem seus produtos encarecerem no mercado interno e externo, e, com isso, perderem negócios ${ }^{12}$.

O comportamento dos agentes políticos e econômicos internamente acaba produzindo significativos efeitos no plano internacional; assim também ações e medidas regulamentares adotadas pela comunidade internacional terminam produzindo consequências importantes no âmbito doméstico; algumas, por vezes, além do razoavelmente previsível. Exemplifica-se a questão com uma história do final dos anos 1980 e início dos 1990: foram apresentados mais de trinta projetos de lei no Congresso dos Estados Unidos, destina-

11 O'CONNELL, Mary E. Using Trade to Enforce International Environmental Law: Implications for United States Law. Global Legal Studies Journal, v. 1 ,1994, p. 273-291.

12 SPRINZ, Detlef; VAAHTORANTA, Tapani. The InterestBased Explanation of International Environmental Policy. International Organization, v. 48, n. 1, p. 77-105, 1994. 
dos a alterar as leis comerciais, diante da percepção e queixas de que a legislação ambiental em vigor estava reduzindo a competitividade dos bens produzidos no país. Em geral, os projetos visavam obrigar outros países a adotarem, de modo efetivo, normas de proteção ambiental semelhantes às norte-americanas ou ainda às aprovadas internacionalmente. A sanção podia bem ser a impossibilidade de acesso ao mercado estadunidense ou a elevação dos encargos de importação ${ }^{13}$.

A maioria dessas iniciativas não evoluiu. Algumas, porém, foram convertidas em lei. Uma delas foi a que promoveu a alteração da lei de proteção aos mamíferos marinhos (Marine Mammal Protection Act - MMPA). Aprovada em 1972, a MMPA causou impacto sobre os pescadores do país, ao limitar o número de golfinhos que podiam ser abatidos anualmente em decorrência da pesca de atum. Essa limitação motivara a queixa dos pescadores que se diziam prejudicados pela importação de pescados de lugares onde não havia semelhante restrição. Com alterações formuladas na MMPA, sobretudo em 1988, passou-se a proibir a entrada, em território estadunidense, de pescados oriundos de países que não adotassem medidas restritivas de proteção dos golfinhos.

O governo norte-americano, premido por uma ordem judicial, embargou as importações de atum capturado por pescadores mexicanos ${ }^{14}$. Em vista do embargo, o México recorreu ao GAT'T, alegando a violação do Acordo Geral sobre Tarifas e Comércio. A decisão lhe foi favorável, obrigando os Estados Unidos a levantarem o embargo. A unilateralidade da medida adotada pelos Estados Unidos, independentemente do seu acerto, do ponto de vista ambiental, era prejudicial ao livre comércio e, portanto, inadmissível ${ }^{15}$.

Esse caso balizou diversos outros julgamentos pelo GATT e por sua sucessora, a OMC. Note-se como uma

13 LEVIN, Geoffrey W. Levin. The Environment and Trade: A Multilateral Imperative, Minnesota. Journal of Global Trade, v. 1, p. 231267, 1992.

14 Veja-se a decisão em: ESTADOS UNIDOS. Corte do Nono Circuito, n. 90-16581 (929 F.2d 1449) (9th Cir. April 11, 1991). Disponível em: <http://bit.ly/1GTWrjc>. Acesso em: 15 fev. 2015. A liminar havia sido concedida por uma Corte Distrital da Califórnia em 1990 (Earth Island Institute v. Mosbacher, 746 F. Supp. 964 (N.D. Cal. 1990)) e fora objeto de recurso pelo governo norte-americano. Em vão.

15 ORGANIZAÇÃO MUNDIAL DO COMÉRCIO. Mexico versus Estados Unidos - Caso Golfinho - Atum I. Julgado em 03/09/1991. Disponível em: <http://bit.ly/1x1Y0FG>. Acesso em: 11 nov. 2014. convergência de interesses egoístas e altruístas, de reserva de mercado e de proteção ambiental, acabou produzindo uma série de eventos relevantes para o sistema de proteção interna e internacional do meio ambiente. De forma positiva, mas também em sentido contrário.

O estudo das razões de convergência entre sistemas normativos aponta para elementos multifatoriais com maior ou menor tendência emulativa ou mimética ou à submissão coercitiva entre eles ${ }^{16}$. Assim como a existência de redes de comunicação, interação ${ }^{17}$, de pressões políticas e econômicas cruzadas ${ }^{18}$. Essas orientações teóricas se somam a outras tantas, de viés econômico ou construtivista, quando se tentam encontrar as razões para o comportamento dos Estados na criação de um sistema integrado de proteção ambiental, interno e internacional. ${ }^{19}$

Sem embargo da complexidade dos mecanismos que relacionam os dois sistemas de proteção, podem-se divisar duas ordens de dificuldades de obtenção de isomorfismo institucional, normativo inclusivamente, com fins meramente indicativos: uma mais destacadamente oriunda da comunidade internacional, denominada de dificultadora centrípeta; outra, decorrente do ambiente interno dos Estados ou, por paralelo, chamada de dificultadora centrífuga. Há, todavia, um elemento importante de contraposição às forças dissipativas do encontro entre os dois sistemas: a sociedade civil também interna e transfronteira, que mobiliza a cooperação entre os Estados, atuando as duas, para manter a metáfora, como facilitadoras pluridirecionais.

16 DiMAGGIO, Paul J.; POWELL, Walter W. The Iron Cage Revisited. Institutionalized Isomorphism and Collective Rationality in Organizational Fields. In: DiMAGGIO, Paul J.; POWELL, Walter W. (eds). The New Institutionalism in Organizational Analysis, Chicago: Chicago University Press, 1991, p. 63-82.

17 SIMMONS, Beth A.; ELKINS, Zachary. The Globalization of Liberalization: Policy Diffusion in the International Political Economy. American Political Science Review, v. 98, p. 171-189, 2004.

18 HOBERG, George. Globalization and Policy Convergence: Symposium Overview. Journal of Comparative Policy Analysis: Research and Practice, v. 3, p. 127-32, 2001.

19 Vejam-se, dentre outros estudos e perspectivas, HOPF, Ted. The Promise of Constructivism in International Relations Theory. International Security, v. 23, n. 1, p. 171-200, 1998; WÆVER, Ole. Four Meanings of International Society: A Trans-Atlantic Dialogue. International Society and the Development of International Relations Theory, v. 2, p. 80-144, 1998; ROBERTS, J. Timmons; PARKS, Bradley C.; VÁSQUEZ, Alexis A. Who Ratifies Environmental Treaties and Why? Institutionalism, Structuralism and Participation by 192 nations in 22 treaties. Global Environmental Politics, v. 4, n. 3, p. 22-64, 2004. 


\subsection{As forças dificultadoras centrípetas}

Em nível internacional, o direito ao meio ambiente sadio se submete às vicissitudes de um tratamento pouco sistemático do direito internacional dos direitos humanos, expressão do sistema internacional de proteção, e, ao mesmo tempo, sujeito às ordens da lógica da economia, principalmente no âmbito da Organização Mundial do Comércio.

\subsubsection{O direito ao meio ambiente sadio em sede do direito internacional dos direitos humanos}

O sistema global de proteção de direitos não tem dado tratamento adequado ao direito ao ambiente sadio. É certo que ele também tem suas dificuldades, mas ao não incluir, de modo mais consistente, em seu discurso a proteção ambiental como expressão de um direito humano acaba por reduzir espaços argumentativos e práticos importantes. E diminuir-se a si mesmo.

Os problemas ambientais repercutem em diversos domínios da vida humana, da liberdade à igualdade, da saúde à educação. Mesmo que não fossem considerados no âmbito de um direito próprio, teriam de ser avaliados como elementos, por vezes, nucleares daqueles direitos.

Pessoas que vivem em área ambientalmente degradada não têm a sua dignidade devidamente respeitada. A imprecisão do tratamento do tema acaba repercutindo na baixa sistematicidade dos acordos e tratados internacionais aprovados. Não raramente, encontram-se áreas tanto lacunosas, quanto sobrepostas, gerando perda de conteúdo normativo e de eficácia. Se a complexidade da matéria já cria obstáculos ao estabelecimento de unidades conceituais, a falta de sintonia normativa os tornam ainda mais difíceis de superação.

Não se pode perder de vista que a multiplicidade dos documentos internacionais acarreta onerosidade adicional à administração dos Estados, não só por exigirem trabalhos extraordinários para coordená-los internamente, como por demandarem ações de acompanhamento e negociações no âmbito dos organismos internacionais e regionais ${ }^{20}$. A atuação de organismos

20 NEUHAUS, Eesther; BORN, Rubens H. Governança Ambiental Internacional: Perspectivas, Cenários e Recomendações. Brasília/São Paulo: Fórum Brasileiro de ONGs e Movimentos Sociais para o Meio Ambiente e o Desenvolvimento, 2007. Disponível em: <http://bit. das Nações Unidas como os Conselhos de Direitos Humanos; dos Direitos Econômicos, Sociais e Culturais; sobre a Eliminação da Discriminação Contra a Mulher e dos Direitos das Crianças procuram extrair um dever estatal de proteção ambiental nas respectivas áreas de atuação, embora o façam de maneira tímida e valendo-se de um fundamento por derivação: o direito à vida, o direito à cultura ou à alimentação, por exemplo, exigiriam medidas contra a degradação do meio ambiente ${ }^{21}$.

Quando as petições que lhes são formuladas conseguem superar o obstáculo quase intransponível da admissibilidade, acabam, em geral, sucumbindo a proclamações mais retóricas do que efetivas de um direito atrelado a uma soft law. ${ }^{22}$ A contribuição das cortes regionais de direitos humanos, por sua vez, embora possa até funcionar como indutora de mobilização social e de iniciativas de aperfeiçoamento normativo ou mesmo do reconhecimento de um direito processual ao meio ambiente sadio, ainda não foi capaz de superar o déficit de organicidade e sistematicidade normativa nos respectivos ambientes em que atuam ${ }^{23}$.

As decisões proferidas, por vezes, envoltas com declarações nem sempre claras de um direito básico ao meio ambiente saudável, acabam padecendo da mesma dispersão de proteção, induzida pela resolução de questões concretas e majoritariamente pontuais como acesso à água limpa, a poluição atmosférica ou o direito de povos indígenas. Não é incomum, ainda, que se tenham de valer de um malabarismo argumentativo para extrair a proteção a partir de outros direitos consagrados, como sucede, particularmente, no âmbito europeu, com o recurso ao direito à informação ou ao direito à vida privada e familiar, assegurados, respectivamente, pelos artigos 8 e 10 da Convenção Europeia de Direitos Humanos $^{24}$. Sem falar das pressões de ordem política e

ly/1Gu8N3X>. Acesso em: 15 fev. 2015.

21 SHELTON, Dinah. Human Rights, Health and Environmental Protection: Linkages in Law and Practice. Health and Human Rights Working Paper Series, v. 1, p. 3-24, 2002.

22 SHELTON, Dinah. Environmental rights and Brazil's obligations in the Inter-American human rights system. George Washington Int'l Law Review, v. 40, p. 733-777, 2008.

23 CICHOWSKI, Rachel A. The European Court and Civil Society: Litigation, Mobilization and Governance. Cambridge: Cambridge University Press, 2007.

24 MOWBRAY, Alastair. The Creativity of the European Court of Human Rights. Human Rights Law Review, v. 5, n. 1, p. 57-79, 2005. A atuação do Tribunal de Justiça se tem dado a favor do reconhecimento de um direito processual ambiental: KOPPEN, Ida J. The Role of the European Court of Justice. In: JORDAN, Andrew 
econômica que sofrem aqueles tribunais que, se não inibem seus proferimentos, tendem a reduzir seu impacto prático $^{25}$.

O tratamento fragmentário do problema, como se faz hoje, apenas adia a inevitável consideração do meio ambiente como um verdadeiro direito humano. E o tempo perdido poderá cobrar um preço adicional. Cabe ao direito internacional dos direitos humanos trazer de vez para si a tarefa de precisar o conteúdo e a estrutura do direito ao meio ambiente sadio, reforçando a sua institucionalidade, por meio do estabelecimento de mecanismos de responsabilização de pessoas, grupos ou Estados que, por ato ou omissão, desencadeiam crises ambientais $^{26}$.

Enquanto o direito internacional dos direitos humanos falha nessa missão, a proteção do meio ambiente em nível global se sujeita às intempéries e vontades da economia revelada pela experiência do GAT'T e de sua sucessora, a OMC.

\subsubsection{O direito ao meio ambiente sadio em sede da Organização Mundial do Comércio}

Os esforços, liderados pelos Estados Unidos, de reconstrução dos laços comerciais entre as nações após a Segunda Guerra Mundial resultaram na celebração do Acordo Geral sobre Comércio e Tarifas (General Agreement on Trade and Tariffs - GATT). Esse acordo estabeleceu um conjunto de normas que se destinavam a acabar ou, pelo menos, reduzir as barreiras tarifárias para o comércio em nível global.

Nesse documento a única menção ao meio ambiente se encontrava no artigo XX do GATT como exceção às regras do livre comércio. De acordo com o artigo, os países podiam impor medidas "necessárias para proteger a vida e a saúde humana, animal ou vegetal" ou "re-

(ed). Environmental Policy in the European Union. Actors, Institutions \& Processes. London: Earthscan, p. 67-86, 2005. Para uma visão da jurisprudência interamericana: MOTTA, Thalita L. Um Panorama Jurisprudencial da Proteção do Direito Humano ao Meio Ambiente Ecologicamente Equilibrado no Sistema Interamericano de Direitos Humanos. Veredas do Direito, v. 6, n. 12, p. 9-24, 2009.

25 STEPHENS, Tim. International Courts and Environmental Protection. Cambridge; New York: Cambridge University Press, 2009, p. 359 et seq

26 KIPPENBERG, Juliane; COHEN, Jane. Lives in the Balance: The Human Cost of Environmental Neglect. In: HUMAN RIGHTS WATCH. World Report 2013. 2013, p. 41-50. Disponível em: <http://bit.ly/15LXCUF>. Acesso em: 11 jan. 2014. p. 42. lacionadas com a conservação de recursos naturais não renováveis", desde que essas medidas não equivalessem a uma discriminação injusta contra produtos estrangeiros ou operassem de forma restritiva e dissimuladas sobre o comércio.

Observa-se que a menção foi pequena e adormeceu até os anos 1970, quando o assunto ingressou de fato nas preocupações do GATT, principalmente com a criação do Grupo sobre Medidas Ambientais (Group on Environmental Measures and International Trade) ou, simplesmente, "EMIT Group"; com a elaboração do documento intitulado "Controle da Poluição Industrial e Comércio Internacional" e com os debates e resultados da Rodada de Tóquio de negociações comerciais (19731979). Entretanto, a preocupação não era exatamente com a proteção ambiental, mas com os impactos negativos que as medidas de proteção que, aos poucos, vinham sendo adotadas pelos Estados, poderiam acarretar sobre o comércio internacional. As exceções do artigo XX, agora, em foco, deveriam ser adequadamente tratadas para evitar que se transformassem em regras ${ }^{27}$.

Outra mostra dessa preferência, do comércio sobre o ambiente, pode ser identificada nas decisões tomadas na solução de conflitos entre os países. O caso dos golfinhos entre Estados Unidos e México, mencionado precedentemente, dá o tom da preferência. Segundo o painel que o decidiu, as exceções ao comércio, previstas no artigo XX, deveriam ser interpretadas de forma restritiva. Ademais, os Estados Unidos não tinham provado que a proibição da importação do atum era "necessária", quer dizer, era a forma menos restritiva ao comércio para proteger os golfinhos.

O país poderia ter obtido o mesmo objetivo por meio de acordos com outros países. Enfim, os norte-americanos não poderiam usar as exceções do Artigo XX para regular os recursos naturais fora de suas fronteiras. Em resumo: Os Estados Unidos haviam adotado uma medida discriminatória injustificada contra os mexicanos. A conclusão poderia ter sido outra, se a proteção ambiental fosse prioridade ou, pelo menos, situada

27 WATSON, James. The WTO and the Environment: Development of Competence beyond Trade. New York: Routlege, 2013. p. 156-157; VARELLA, Marcelo D. O Acúmulo de Lógicas Distintas no Direito Internacional: Conflitos entre Comércio Internacional e Meio Ambiente. In: SHIMADA, Sandra A. et al (org.). Desafios do Direito Ambiental no Século XXI. Estudos em Homenagem a Paulo Affonso Leme Machado. São Paulo: Malheiros, 2005. 
no mesmo nível da promoção do $\operatorname{comércio~}^{28} 29$.

A Organização Mundial do Comércio (OMC) foi criada em de janeiro de 1995, sendo uma das principais medidas da última rodada do GATT, realizada no Uruguai entre 1986 e 1994. Entre os órgãos que compõem a estrutura da OMC está o Comitê de Comércio e Meio Ambiente (Committee on Trade and Environment CTE), com o objetivo de conciliar demandas de comércio com a proteção do meio ambiente, de modo a possibilitar a promoção do desenvolvimento sustentável.

Desde a criação da OMC já ocorreram oito Conferências Ministeriais a exemplo de Cingapura, em 1996; Genebra, em 1998; Seattle, em 1999; Doha, em 2001; Cancún, em 2003; Hong Kong, em 2005; Genebra em 2009 - 2011 e Bali em 2013 ${ }^{30}$. Em nenhuma delas, porém, as recomendações do CTE, embora consideradas, levaram a modificações do sistema multilateral de comércio, que fossem significativas para o meio ambiente. É certo que, já na primeira delas, foi reafirmado o compromisso com o uso sustentável dos recursos naturais e o desenvolvimento econômico limpo, ao tempo que se estimulava a cooperação entre organizações ambientais intergovernamentais a exemplo o Programa das Nações Unidas para o Meio Ambiente - PNUMA.

As rodadas de negociações que a sucederam, porém, apenas fizeram apelos retóricos à promoção de um comércio mundial compatível com as exigências do desenvolvimento sustentável. Os resultados práticos foram insatisfatórios. A prova disso é que, embora esti-

28 MUSGRAVE, R. Kenton; STEPHENS, Garland. GATT-Tuna Dolphin Dispute: An Update, The. Natural Resources Journal, v. 33, p. $957-975,1993$.

29 De acordo com o painel: "The Panel considered that if the broad interpretation of Article XX(b) suggested by the United States were accepted, each contracting party could unilaterally determine the life or health protection policies from which other contracting parties could not deviate without jeopardizing their rights under the General Agreement. The General Agreement would then no longer constitute a multilateral framework for trade among all contracting parties but would provide legal security only in respect of trade between a limited number of contracting parties with identical internal regulations".

30 A Conferência Ministerial, integrada pelos membros da OMC, é o órgão que toma as decisões mais importantes no âmbito da Organização, podendo compreender os assuntos de qualquer dos Acordos Comerciais Multilaterais. SEK, Lenore. The World Trade Organization: Background in Issues. In BABKINA, A. M. (ed). World Trade Organization: Issues and Bibliography. Huntington: Nova Science Publ. 2000, p. 7-14. p. 08; ORGANIZAÇÃO MUNDIAL DO COMÉRCIO. Marrakesh Agreement Establishing WTO, 15/4/1995. Disponível em: <http://bit.ly/1wgdiM2>. Acesso em: 03 fev. 2015. mulados pela $\mathrm{OMC}$, os acordos multilaterais sobre meio ambiente até hoje não recebem tratamento normativo no âmbito da Organização. Não integram o Anexo I ao Acordo que a criou e, embora pudessem vir a ser incluídos na sua ordem jurídica, por meio da aplicação do art. V do Acordo, os membros até gora se abstiveram de fazê-lo. Esse déficit de normatividade se reflete nos casos apreciados no contencioso da OMC, sendo raro o fundamento da decisão recorrer a um desses acordos.

Já foi visto anteriormente, que a proteção ambiental é interpretada pelo art. XX do GATT, como uma exceção ao livre comércio. O caso do atum entre Estados Unidos e México mostrou como essa natureza excepcional atrai interpretação restritiva em prejuízo do meio ambiente. A orientação não mudou mesmo com a OMC se tendo comprometido também com a causa ambiental.

Muito recentemente, o tema voltou a exame em nova reclamação formulada pelo México contra os Estados Unidos. A questão, agora, era saber se a exigência norte-americana, na qual as embalagens de atum, vendidas no país, contivessem informações de que fora pescado sem provocar risco aos golfinhos, violavam as normas do livre comércio. O painel entendeu que a rotulagem exigida era mais restritiva ao comércio do que o necessário para cumprir os objetivos legítimos de (i) assegurar que os consumidores não fossem enganados ou iludidos sobre a mortandade de golfinhos acarretada pela pesca de atum; e (ii) contribuir para a proteção dos golfinhos, assegurando que o mercado estadunidense não fosse usado para incentivar as frotas de pesca a capturar atum com riscos de vida aos golfinhos ${ }^{31}$.

No caso "Venezuela e Brasil versus Estados Unidos", a reclamação se fundava numa regulamentação aprovada pela Agência de Proteção Ambiental norte-americana (EPA), a Regulation of Fuels and Fuel Additives, com base no Clean Air Act de 1990, que estabelecia os níveis-base de toxicidade da gasolina importada, deixando para as refinadoras do país a fixação de tais níveis, o que acarretaria, na prática, um tratamento diferenciado e mais gravoso para o produto externo comparativamente ao interno.

Nesse caso provocaria a violação ao artigo III:4 do GATT-94. Os Estados Unidos se defenderam sob o

31 ORGANIZAÇÃO MUNDIAL DO COMÉRCIO. Mexico versus US - Caso Atum II. Julgado em setembro 2014. Disponível em: < http://bit.ly/1G8FkJt>. Acesso em: 15 mar. 2015. 
argumento de que a medida era necessária para reduzir a emissão, na atmosfera, de substâncias tóxicas resultantes da combustão da gasolina. A OMC, todavia, deu ganho de causa aos reclamantes. Os norte-americanos não teriam provado que a exceção ambiental imposta era o meio menos restritivo possível ao comércio. E ainda haviam promovido uma discriminação injustificada entre o produto nacional e o importado. Segundo a Organização, a medida, a pretexto de promover o meio ambiente, criava uma restrição disfarçada e injustificável do comércio internacional ${ }^{32}$.

Nem tudo são trevas, porém. Em outro caso apreciado pela Organização, os Estados Unidos foram questionados por alguns países, dentre eles a Malásia e Tailândia. Os reclamantes impugnavam a legislação estadunidense que, dentre outras restrições, proibia a venda de camarões que fossem capturados por redes que não permitissem a fuga de tartarugas marinhas, eventualmente, recolhidas por elas. Para os Estados Unidos, a exigência era instrumento necessário para proteger as tartarugas marinhas que estavam na lista de espécies em perigo de extinção de uma convenção internacional, a CITES. Para os reclamantes, tratava-se de uma medida unilateral e contrária ao GATT. Não foi esse o entendimento da OMC, todavia. A unilateralidade não era razão bastante para declarar a medida impugnada inconsistente com o GATT, tampouco se via nela discriminação injustificada. E mais: diferentemente do Caso Golfinho-Atum I, permitiu-se restringir uma importação com base no seu processo de produção e não no produto em si ${ }^{33}$. Ademais, a Organização fez uso de um Acordo Multilateral de defesa do meio ambiente, fato raro de acontecer e, portanto, motivo de destaque.

Algum tempo depois, o Brasil foi acionado pela União Europeia, por ter proibido a importação de pneus usados e reformados. A vedação não se aplicava aos países do Mercosul. O Brasil alegava defender o meio ambiente e justificava a exceção no pequeno número de importados oriundos do Mercosul. A OMC reconheceu que a proibição de importação de pneus usados ou reformados era justificável em razão da pro-

32 ORGANIZAÇÃO MUNDIAL DO COMÉRCIO. Venezuela, Brazil versus US: Gasoline, Case n. 2 and 4. Julgado em 20/05/1996. Disponível em: <http://bit.ly/1DTtT5K>. Acesso em: 11 fev. 2015.

33 ORGANIZAÇÃO MUNDIAL DO COMÉRCIO. Malásia, Indonésia versus Estados Unidos. Julgamento final em 19/09/2001. Disponível em: <http://bit.ly/1Gs2U7m>. Acesso em: 15 fev. 2015. teção à saúde humana e ao meio ambiente. Não aceitou, porém, a exceção que fazia ao Mercosul, por se tratar de uma discriminação injustificável ${ }^{34}$.

É cedo ainda para afirmar que a Organização se tenha rendido à evidência do problema ambiental. Razões econômicas e pragmáticas continuam a prevalecer sobre a orientação de proteger o meio ambiente. O número limitado de casos a favor das questões ecológicas e a falta de normatividade, dentro da Organização, de pactos e convenções internacionais sobre o assunto, dão ainda razões para conclusões pessimistas que, diante das frustações da Rodada de Doha, em que se tentava uma aproximação entre os acordos da OMC e os de outros organismos internacionais com objetivo ambiental, ainda não têm perspectiva de reversão ${ }^{35}$.

A deficitária interlocução entre tais organismos é problemática para obtenção de, ao menos, níveis razoáveis de proteção ambiental. Que dirá de reconhecer um direito ao meio ambiente sadio. As iniciativas de aproximação entre a OMC, os órgãos regionais e das Nações Unidas de direitos humanos ainda são tímidas diante do tamanho do desafio que têm pela frente. Sem meias palavras, é uma questão de sobrevivência.

\subsection{As forças dificultadoras centrífugas}

A proteção internacional do direito ao meio ambiente sadio encontra também dificuldades oriundas dos países. Interesses econômicos e geopolíticos tendem a orientar a política externa de cada um deles, interferindo nas orientações assumidas nos fóruns internacionais. Assim também peculiaridades dos sistemas jurídicos e políticos dos Estados podem dificultar a internação das normas e parâmetros ambientais que eles se comprometeram a cumprir internacionalmente.

A diversidade de estágios de maturidade das insti-

34 ORGANIZAÇÃO MUNDIAL DO COMÉRCIO. U.E. versus Brasil. Julgamento final em 07/12/2007. Disponível em: <http:// bit.ly/1x292L6>. Acesso em: 15 fev. 2015.

35 SHAW, Sabrina. Trade and Environment in WTO. In BRACK, Duncan (ed). Trade and Environment: Conflict Or Compatibility. London; New York: Routledge, 2013, p. 140-147. Para um conhecimento de casos que envolvem questões ambientais, ver: ORGANIZAÇÃO MUNDIAL DO COMÉRCIO. Chronological List of Disputes Cases, atualizado em 02/02/2015. Disponível em: < http://bit. ly/1BTZ1pk>. Acesso em: 11 mar. 2015. Numa perspectiva mais otimista, veja-se PIFFER, Carla. Comércio Internacional e Meio Ambiente: A OMC como Locus de Governança Ambiental. Veredas do Direito, v. 8, n. 15, p. 111-132, 2011. 
tuições jurídicas, associada a culturas políticas, é outro elemento que, se não impede, delonga a harmonização dos mecanismos de proteção. O tema, por certo, exigiria mais aprofundamento, mas, para os propósitos do trabalho, atenta-se para as relações entre União e entidades subnacionais, e entre Executivo, Legislativo e Judiciário, na definição e execução de políticas públicas ambientais. O reconhecimento de um direito fundamental ao meio ambiente sadio é outro elemento que pode interferir no processo. A Constituição, portanto, é uma peça-chave no estabelecimento ou, pelo menos, na canalização das forças que atuam na inter-relação entre o sistema interno e o sistema internacional de proteção do meio ambiente.

\subsubsection{O federalismo ambiental}

Tanto nos Estados Unidos quanto no Brasil, a atuação da União e dos Estados para defesa do meio ambiente se tem dado de forma cooperativa, o que é um elemento positivo para internação de compromissos internacionalmente assumidos. Todavia não são incomuns as ocorrências de conflitos. No País do Norte, a crescente regulamentação federal sobre o tema é objeto de sérias críticas, oriundas, sobretudo, de autoridades estaduais. Tome-se o exemplo da competência para disciplinar a extração do óleo de xisto. Os Estados reivindicaram a atribuição exclusiva sobre o assunto, protestando de modo veemente contra a intenção de federalizá-la ${ }^{36}$.

Em geral, afirma-se que a hipertrofia da União impede uma adequada e eficiente gestão das políticas ambientais por parte dos Estados e poderes locais. A centralização da política ambiental, todavia, não preclui a competência estadual, desde que as normas suplementares estabeleçam padrões mais rigorosos de proteção. Mais recentemente, e como resposta às queixas estaduais, passaram-se a adotar fórmulas de articulação e incentivos para que as legislações estaduais sigam o modelo federal, sobretudo naqueles campos em que a cláusula do comércio não esteja envolvida ${ }^{37}$.

36 LIN, Albert C. Fracking and Federalism: A Comparative Approach to Reconciling National and Subnational Interests in the United States and Spain. Environmental Law, v. 44, p. 1039-1219, 2014.

37 WILLIAMS III, Robertson C. Growing State-Federal Conflicts in Environmental Policy: The Role of Market-Based Regulation. Journal of Public Economics, v. 96, 2012, p. 1092-1099.
O federalismo executivo ambiental tem sido criticado pelas despesas que acarreta aos entes subnacionais. Calcula-se que, entre 2000 e 2010, os cofres estaduais foram onerados com pelo menos US $\$ 23$ bilhões apenas com as principais regulamentações adotadas pela Agência Federal para o Meio Ambiente, a EPA, naquele período ${ }^{38}$. A Suprema Corte tem sido chamada a se pronunciar sobre eventuais excessos centralizadores da União, mas, de modo geral, tem mantido as normas federais aprovadas ${ }^{39}$.

No Brasil, não é diferente. A Constituição atribui a todos os entes federais a tarefa de promover um meio ambiente sadio. A competência legislativa ambiental também é compartilhada, cabendo a União dispor sobre normas gerais e aos Estados e Municípios, no que couber, a competência suplementar.

Essa competência, todavia, acha-se significativamente reduzida, em virtude de a Constituição atribuir privativamente à União leis sobre direito civil, direito comercial, direito processual, dentre tantos outras. Em virtude disso, muitas leis estaduais, algumas com disciplina mais rigorosa que a federal, têm sido declaradas inconstitucionais pelo Supremo Tribunal Federal ${ }^{40}$.

No entanto, essa tendência centralizadora no campo das competências materiais têm sido seriamente reduzidas, por meio de leis federais que remetem a sua execução, inclusive processos de licenciamento ambiental, para os Estados e para os Municípios. Essa transferência ou "devolução" de competência nem sempre é acompanhada de alocação de recursos, o que tem gerado fortes críticas dos governos locais. Para setores ambientalistas, essa descentralização executiva pode agravar os déficits de efetividade das normas ambientais tanto as previstas em legislação doméstica quanto às assumidas externamente ${ }^{41}$.

38 ROSENBAUM, Walter A. Environmental Politics and Policy. Washington, D.C.: Sage, 2014. p.42.

39 O'LEARY, Rosemary. The Impact of Federal Court Decisions on the Policies and Administration of the U.S. Enviornmental Protection Agency. Administrative Law Review, v. 41, n. 4, 1989, p. 549574; ZIMMERMANN, Joseph F. Contemporary American Federalism: The Growth of National Power. Albany, State University of New York Press, 2008. p. 83 e ss.

40 BRASIL. Supremo Tribunal Federal. Pleno. ADPFMC. Julgamento em 28/09/2011. Disponível em: < http://bit. ly/1Bh4BBp>. Acesso em: 15 fev. 2015; SAMPAIO, Jose Adércio L. A Constituição Reinventada pela Jurisdição Constitucional. Belo Horizonte: Del Rey, 2002. p. 633/634.

41 SCARDUA, Fernando P; BURSZTYN, Maria A. Almeida. Descentralização da política ambiental no Brasil. Sociedade e Estado, v.18, 
Devido a esse fato, alega-se que a descentralização se tem feito de forma desordenada, sem planejamento ou articulação entre as três esferas de governo. $\mathrm{O}$ quadro se agrava quando se leva em conta a existência de diferenças significativas entre os sistemas normativos e de administração dos diversos entes federativos, algumas, sem estrutura para cumprir a tarefa, além de uma facilidade maior para cooptação do processo decisório pelo poder econômico ${ }^{42}$.

A dependência do Legislativo para aperfeiçoamento dos compromissos ambientais de nível internacional é outro elemento que tende tanto a dificultar a internação daquelas já assumidas, quanto a promover mudanças de orientação da política externa sobre o assunto. À semelhança dos Estados Unidos, no Brasil, um tratado ou acordo ambiental depende de sua aprovação do Congresso Nacional para passar a compor à ordem jurídica interna. Afora isso, há sempre a possibilidade de o Legislativo aprovar leis que se desviem dos parâmetros internacionais de proteção do meio ambiente, inclusive para pior.

A hierarquia dos tratados internamente pode agravar este quadro. Em não havendo hierarquia, a lei posterior revoga eventual disposição constante de tratado integrado na ordem jurídica. O tema é sensível nos Estados Unidos, pelo apego ao princípio da soberania popular ${ }^{43}$.

No Brasil a situação é menos problemática. Os tratados de direitos humanos, se não forem incorporados como emenda constitucional, têm uma posição supralegal, impedindo que as leis os revoguem ${ }^{44}$. A questão considerada é saber que disciplina sobre o meio ambiente integra o direito ao meio ambiente sadio ou ecologicamente equilibrado e, portanto, colocada fora da disposição legislativa, e qual se reporta apenas a tarefas meramente administrativas que po-

n.1-2, p. 291-314, 2003.

42 AFONSO, José. Descentralizar e depois Estabilizar: A Complexa Experiência Brasileira. Revista do BNDES, v. 3, n. 5, p. 31-62, 1996. p. 32; SOUZA, Celina. Federalismo e Gasto Social no Brasil: Tensões e Tendências. Revista Lua Nova, v. 52, p. 5-28, 2001. p. 19; BROSE, Markus. Descentralização e Good Government. Como Aperfeiçoar o Desempenho dos Governos locais?. Revista do Serviço Público, n. 3, Jul-Set 2002, p. 95-138.

43 MERON, Theodor. On a hierarchy of international human rights. American Journal of International Law, v. 80, p. 1, 1986; JACKSON, John H. Status of Treaties in Domestic Legal Systems: A Policy Analysis. American Journal of International Law, v. 86, p. 310340, 1992.

44 BRASIL. Supremo Tribunal Federal. Pleno. RE 349703/ RS. Julgamento em 03/02/2008. Disponível em: < http://bit. ly/1Bh4BBp>. Acesso em: 15/02/2015. deriam, em tese, ser alteradas. É crescente no país, especialmente no âmbito doutrinário, a adoção do princípio da não retroatividade socioambiental que, em sua perspectiva mais exigente, impede mudanças que agravem direta ou indiretamente o sistema de proteção ambiental. ${ }^{45}$ Não é, todavia, seguro universal contra alterações legislativas, notadamente em períodos de crise econômica.

É preciso levar em consideração, ainda, que o reconhecimento constitucional expresso do direito ao meio ambiente sadio ou ecologicamente equilibrado tende a reduzir as exigências argumentativas para aprovação de medidas que se destinem a proteger os processos ecológicos, e promover o desenvolvimento sustentado. Nos Estados Unidos, não há dispositivo nesse sentido, nem reconhecimento por construção interpretativa da Suprema Corte, não se tratando, por conseguinte, de um direito constitucional. No Brasil, o art. 225 da Constituição Federal de 1988 expressa:

Todos têm direito ao meio ambiente ecologicamente equilibrado, bem de uso comum do povo e essencial à sadia qualidade de vida, impondo-se ao Poder Público e à coletividade o dever de defendê-lo e preservá-lo para as presentes e futuras gerações. ${ }^{46}$

É, sem dúvida, uma contribuição jurídica importante para estimular os governantes a assumirem externamente compromissos com a proteção do meio ambiente, bem como um facilitador para sua eventual integração à ordem doméstica. A política, todavia, nem sempre se resume ao direito.

\subsection{As forças facilitadoras pluridimensionais}

Direito e política ambientais tendem a avançar, quando há o envolvimento da sociedade civil e, ao mesmo tempo, quando os Estados se propõem a colaborar mais do que a competir.

\subsubsection{A participação da sociedade civil}

Confiar os destinos da humanidade a representantes institucionalizados do poder estatal, como visto, não é

45 SAMPAIO, José Adércio L. Da Cláusula do Não Retrocesso Social à Proibição de Reversibilidade Socioambiental. In: ANJOS FILHO, Robério N. (org). Direitos Humanos e Direitos Fundamentais: Diálogos Contemporâneo. Salvador: Juspodium, 2013.

46 BRASIL. Constituicão Federal de 1988. Disponível em: <http://www.planalto.gov.br/ccivil_03/Constituicao/ConstituicaoCompilado.htm>. Acesso: 23 mar.2015. 
garantia de que se venha a adotar um eficiente sistema de proteção internacional do meio ambiente. Afora os elementos críticos do próprio mecanismo de representação popular, os interesses econômicos e geopolíticos dos Estados acabam por interferir nos processos deliberativos. A redescoberta da sociedade civil como um instrumento indispensável não apenas à legitimação democrática, mas também para controle e efetividade das execução de políticas públicas é nota de encontro de teses liberais e republicanistas. $\mathrm{O}$ fenômeno não se restringe apenas aos Estados, mas se expressa internacionalmente ${ }^{47}$.

O avanço da tecnologia de comunicação tem propiciado a criação de fóruns e redes de discussões e articulações sobre os mais variados assuntos, ambientais inclusive, facilitando a difusão de informações e, notadamente, a organização de eventos concomitantes em todas as partes do planeta, uma pauta de reivindicação relativamente comum e o fortalecimento de movimentos ambientais globalizados ${ }^{48}$. Se antes defendiam-se espaços não formais, de circulação de ideias, e projetos coletivos para contra-arrestar o corporativismo dos parlamentos nacionais, com ganhos democráticos, hoje se pode dizer o mesmo para a comunidade internacional em face dos organismos multilaterais e empresas multinacionais.

Esse estímulo à participação social pode ser reforçada pelas Constituições dos países. No Brasil, o texto constitucional cria verdadeiras tarefas sociais de participação e de promoção dos direitos, notadamente, os de índole social como saúde e educação, bem como de feição coletiva. Assim também se dá com o direito ao meio ambiente ecologicamente equilibrado. Ademais, atribuem-se poderes aos cidadãos para peticionar, representar, controlar atos dos agentes públicos e, inclusive, impugná-los judicialmente por violação aos deveres de proteção ambiental, por meio da ação popular.

Por sua vez, a Constituição norte-americana também estimula a ampla participação de indivíduos e grupos nos processos deliberativos do país. Não o faz de

47 FRANK, David J. The Social Bases of Environmental Treaty Ratification, 1900-1990. Sociological Inquiry, v. 69, n. 4, p. 523-550, 1999.

48 CAMMAERTS, Bart. Lógicas de protesto e a estrutura de oportunidade de mediação. MATRIZes, v. 7, n. 2, p. 13-36, 2013; LEE, Francis LF. Internet, Citizen Self-Mobilisation, and Social Movement Organisations in Environmental Collective Action Campaigns: Two Hong Kong Cases. Environmental Politics, p. 1-18, 2014. modo expresso, senão por meio do reconhecimento da liberdade de expressão e imprensa, da liberdade de reunião, liberdade de associação e do direito de petição, associados a uma cultura de reivindicação e de defesa do que Tocqueville chamava de "interesse bem compreendido" $"$.

É certo que esses loci de participação também se acham disponíveis à ocupação pelos vícios dos processos deliberativos formais. E a explicação não é das mais complicadas. No exercício das competências participativas, entrecruzam-se interesses os mais diversos tanto de natureza moral e altruísta, quanto de feitio econômico e egoísta. Os formuladores de políticas ambientais não podem desconsiderar essa pluralidade de vozes, o que leva, em certo grau, à redução das expectativas de resultados dos projetos e planos originalmente traçados. Em vez de solução tecnicamente ideal para os problemas, acaba-se obtendo um produto híbrido de arranjos, compromissos e consensos dos diversos atores e interesses envolvidos $^{50}$.

Esse ambiente de diálogo e conflagração tem levado os próprios ambientalistas a adotarem estratégias de negociações com uma certa dose de pragmatismo, de modo a conseguirem a alternativa mais benéfica, ainda que não ideal, à preservação ambiental. Abandonar a mesa de negociação é fórmula de fracasso da política pretendida, mas nela manter-se é sinal da agonia da política idealizada ${ }^{51}$.

Isso ocorre não apenas no processo legislativo, como dá conta de exemplo o atual Código Florestal brasileiro, Lei 12.651/2012, mas também no curso da execução das leis, o que se mostra mais visível no centro das audiências públicas ambientais que, no mais das vezes, reduzem, mas não impedem, prejuízos ambientais em decorrência de empreendimentos que, sob o olhar estrito da proteção ambiental, não deveriam ser licenciados.

Mesmo com esse viés de pragmatismo, os movimentos sociais são indispensáveis à promoção de políticas de defesa do meio ambiente interna e internacional-

49 TOCQUEVILle, Alexis. A Democracia na América. Trad. Eduardo Brandão. Vol. II. São Paulo: Martins Fontes, 2000. p. 148-149. 50 ALLISON, Graham. The Essence of Decision. Boston: Little Brown, 1971.

51 LINDBLOM, Charles A; WOODHOUSE, Edward J. The Policy Making Process. Englewood Cliffs: Prentice Hall, 1993; SPETH, James G. Environmental Failure: A Case for the New Green Politics. Environment360, 20/10/2008. Disponível em: < http://bit. ly/1KDMVGx>. Acesso em: 15 nov. 2014. 
mente. As dificuldades enfrentadas e desvios desse movimento tendem a ser superados pela aprendizagem que o próprio processo deliberativo fornece. $\mathrm{O}$ encontro de meio ambiente e democracia é esperança de um mundo melhor.

\subsubsection{A cooperação internacional}

Os problemas ambientais, como a redução da camada de ozônio e a perda da biodiversidade, são resultados da ação humana e seus impactos também se fazem sentir em todo o mundo. O seu enfrentamento ou o seu gerenciamento dependem da cooperação de todos os países. Os déficits de interlocução entre as agências internacionais de proteção ao meio ambiente conspiram contra a eficiência de suas normativas e políticas, propiciando que a lógica econômica prevaleça sobre as necessidades de eco-proteção.

A teoria e prática econômicas ensinam que, na ausência de cooperação, cada país, assim como cada agente econômico, tenderá a maximizar seus próprios benefícios líquidos de redução dos custos com a adoção de políticas ambientais e, ao fazê-lo, estimulam uma competição internacional de consequências deletérias ao meio ambiente ${ }^{52}$. Diversos estudos indicam que a escassez de recursos naturais e a degradação ambiental podem ser causas de conflitos e até mesmo guerras, mas também contribuem para estimular a cooperação entre os países. E tanto maior tende a ser a cooperação quanto maior for o dano e menor a disponibilidade de recursos $^{53}$. Há, ainda, a variável imposta pelo maior ou menor retorno desses recursos, de modo que insumos lucrativos tendem a estimular atitudes cooperativas com vistas a estabilizar mercados e preços ${ }^{54}$.

Nesse passo existe também um ingrediente aportado pelas diversidades de sistemas e estruturas políticos

52 BARRETT, Scott. The problem of global environmental protection. Oxford Review of Economic Policy, v. 6, n. 1, p. 68-79, 1990; LUCAS, Robert EB; WHEELER, David; HETTIGE, Hemamale. Economic Development, Environmental Regulation, and the International Migration of Toxic Industrial Pollution, 1960-88. World Bank Publications, 1992.

53 DINAR, Shlomi. Resource Scarcity and Environmental Degradation. Analysing International Conflicts and Cooperation. In DINAR, Shlomi (ed). Beyond Resource Wars: Scarcity, Environmental Degradation, and International Cooperation. Cambridge: MIT Press, 2011, p. 3-22.

54 HVEEM, Helge. Minerals as a Factor in a Strategic Policy and Action. In: WESTING, Arthur H. (ed). Global Resources and International Conflict. Oxford: Oxford University Press, 1986, p. 55-84. p. 71. e normativos entre os países, do qual se tratou precedentemente ${ }^{55}$. Essas leituras econômicas e institucionais requisitam, no entanto, um complemento fornecido por uma cultura de convivência humana que não se fundamenta apenas no homo oeconomicus. As motivações do agir humano e, por via indutiva, dos Estados podem se dar por outras razões, morais e políticas, por exemplo ${ }^{56}$.

Independente da orientação que se possa seguir, é ponto assente que a cooperação fomentada pelos organismos internacionais deve ocorrer sobre bases igualitárias, sempre levando em conta as diferenças de desenvolvimento econômico e social existentes entre países. As assimetrias devem ser levadas em conta necessariamente para coordenação das ações dos players internacionais. Adoção de posições hegemônicas de Estados mais desenvolvidos acaba por inviabilizar acordos ou a sua efetividade ${ }^{57}$.

A paralisia da OMC, nessa esteira, na rodada de Doha é um exemplo. Não se pode perder de vista que a inclusão do setor privado neste cenário é salutar, desde que seus interesses econômicos não se sobreponham à finalidade de proteção e à voz dos países em desenvolvimento. Adoção de certificações de "empresas amigas do meio ambiente", por meio de expediente como a ISO 14000 , tende a contribuir com o processo, desde que não importe uma privatização dos próprios parâmetros de proteção, em prejuízo ao poder deliberativo dos Estados, principalmente dos mais pobres, e aos reclames da sociedade civil mundializada ${ }^{58}$.

A cooperação internacional é causa e efeito, como se nota, da aproximação dos sistemas de proteção do direito ao meio ambiente sadio, internos e internacional.

55 LEEDS, Brett A. Domestic Political Institutions, Credible Commitments, and International Cooperation. American Journal of Political Science, v. 43, n. 4, p. 979-1002, 1999.

56 MEYER, John et. al. The Structuring of a World Environmental Regime, 1870-1990. International Organization, v. 51, p. 623-651, 1997; FRANK, David J. The Social Bases of Environmental Treaty Ratification, 1900-1990. Sociological Inquiry, v. 69, n. 4, p. 523-550, 1999.

57 BODANSKY, Daniel. The Legitimacy of International Governance. A Coming Sharing of International Environmental Law. American Journal of International Law, v. 93, n. 3, p. 596-624. p. 603/604; SUSSKIND, Lawrence. Environmental Diplomacy; Negotiating More Effective Global Agreements. Oxford: Oxford University Press, 1994. p. 18.

58 CLAPP, Jennifer. The privatization of global environmental governance: ISO 14000 and the developing world. Global Governance, p. 295-316, 1998; FRANK, David J. The Social Bases of Environmental Treaty Ratification, 1900-1990. Sociological Inquiry, v. 69, n. 4, p. 523-550, 1999. 


\section{Considerações finais}

Com a tendência teórica de tratamento do meio ambiente no âmbito dos direitos humanos e constitucionais, seria de pensar que a proteção desse bem estivesse garantido pelos Estados e pela comunidade internacional. Pensamento vão, todavia. A realidade aponta, senão o oposto, pelo menos um quadro menos otimista.

A consideração do direito ao meio ambiente sadio como um direito humano, em sede global e regional, ou como um direito fundamental, pelos Estados, ainda encontra óbices de efetividade. As inter-relações entre os sistemas internos e internacionais, que deveriam sinergicamente promovê-lo, encontram obstáculos que se entrecruzam centrípeta e centrifugamente, vale dizer, da comunidade internacional para os Estados e destes para aquela.

O tratamento fragmentário da proteção ambiental pelo sistema global de direitos e a ambiguidade do direito internacional dos direitos humanos em incluir o direito ao meio ambiente sadio em seu temário e prática lançam sinais pouco alentadores para a criação de um regime mais uniforme (e efetivo) de proteção jusambiental. A jurisprudência internacional, notadamente das cortes regionais, não tem sido bastante para reverter decisivamente o quadro. No âmbito da Organização Mundial do Comércio, é notória a predominância dos interesses econômicos sobre as demandas ambientais.

A proteção internacional do direito ao meio ambiente sadio encontra também dificuldades oriundas dos Estados. Interesses econômicos e geopolíticos tendem a orientar a política externa de cada um deles, interferindo nas orientações assumidas nos fóruns internacionais. Assim também peculiaridades dos sistemas jurídicos e políticos dos Estados podem dificultar a internação das normas e parâmetros ambientais que eles assumiram internacionalmente.

Destacam-se as formas diversificadas de articulação entre o direito dos tratados e o direito constitucional e, dominantemente, a submissão daquele a este. Assim também as relações entre as unidades territoriais de poder, sobretudo nos Estados descentralizados ou federais, geram custos adicionais aos mecanismos de uniformização e efetividade do direito ao meio ambiente sadio.

Há, por outro lado, as "forças facilitadoras pluridimensionais", assim denominados os fatores que tanto se projetam da comunidade internacional para dentro dos Estados, quanto na direção inversa, facilitando o processo (ou ainda projeto) de promoção do ambiente sadio ou equilibrado. Direito e política ambientais tendem a avançar, quando há o envolvimento da sociedade civil e, ao mesmo tempo, quando os Estados se propõem a colaborar mais do que a competir. Os dois fatores se estimulam reciprocamente e são os instrumentos mais eficazes para superar os óbices, as forças dissipadoras de integração dos sistemas de proteção.

\section{ReferênCIAS}

ADEOLA, Francis O. Cross-National Environmental Injustice and Human Rights Issues A Review of Evidence in the Developing World. American Behavioral Scientist, v. 43, n. 4, p. 686-706, 2000.

AFONSO, José. Descentralizar e depois Estabilizar: A Complexa Experiência Brasileira. Revista do BNDES, v. 3, n. 5, p. 31-62, 1996.

ALLISON, Graham. The Essence of Decision. Boston: Little Brown, 1971.

BARRETT, Scott. The problem of global environmental protection. Oxford Review of Economic Policy, v. 6, n. 1, p. 68-79, 1990.

BENSON, John. Environmental Ethics: An Introduction with Readings. New York: Routledge, 2000.

BODANSKY, Daniel. The Legitimacy of International Governance. A Coming Sharing of International Environmental Law. American Journal of International Law, v. 93 , n. 3, p. 596-624.

BOUCHER, Doug; ELIAS, Pipa; FAIRES, Jordan; SMITH, Sharon. Report: Deforestation Success Stories.Tropical Nations Where Forest Protection and Reforestation Policies Have Worked. Union of Concerned Scientists, 2014, disponível em: http://bit.ly/1GTWrjc, acesso em: 1 mar. 2015.

BRASIL. Constituição Federal de 1988. Disponível em:< http:/ /www.planalto.gov.br/ccivil_03/Constituicao/ ConstituicaoCompilado.htm>. Acesso: 23 mar. 2015.

BRASIL. Supremo Tribunal Federal. Pleno. ADPF-MC , julgamento em 28/9/2011, disponível em http://bit. ly/1Bh4BBp, acesso em: 15 fev. 2015. 
BRASIL. Supremo Tribunal Federal. Pleno. RE 349703/ RS, julgamento em 3/2/2008, disponível em http://bit. ly/1Bh4BBp, acesso em: 15 fev.2015.

BROSE, Markus. Descentralização e Good Government. Como Aperfeiçoar o Desempenho dos Governos locais? Revista do Serviço Público, n. 3, Jul-Set 2002 , p. 95138.

CAMMAERTS, Bart. Lógicas de protesto e a estrutura de oportunidade de mediação. MATRIZes, v. 7, n. 2, p. 13-36, 2013.

CERVO, Amado L. Brazil in the current World Order. Austral: Brazilian Journal of Strategy \& International Relations, v. 1, n. 2, p. p. 35-57, 2012.

CICHOWSKI, Rachel A. The European Court and Civil Society: Litigation, Mobilization and Governance. Cambridge: Cambridge University Press, 2007.

CLAPP, Jennifer. The privatization of global environmental governance: ISO 14000 and the developing world. Global Governance, p. 295-316, 1998.

COSTA, Beatriz Souza. Meio Ambiente como Direito à Vida: Brasil, Portugal e Espanha.2. ed. Rio de Janeiro:Lumen Juris, 2013.

DAUVERGNE, Peter; BL FARIAS, Déborah. The rise of Brazil as a global development power. Third World Quarterly, v. 33, n. 5, p. 903-917, 2012.

DI LEO, Louis A. The Polar Bear Ethic: From the Reactionary Trend in Environmental Lawmaking to the Climate Change Imperative. Journal of Environmental Law \& Litigation, v. 28, p. 347, 2013.

DiMAGGIO, Paul J.; POWELL, Walter W. The Iron Cage Revisited. Institutionalized Isomorphism and Collective Rationality in Organizational Fields. In: DiMAGGIO, Paul J.; POWELL, Walter W. (eds). The New Institutionalism in Organizational Analysis, Chicago: Chicago University Press, 1991, p. 63-82.

DINAR, Shlomi. Resource Scarcity and Environmental Degradation. Analysing International Conflicts and Cooperation. In DINAR, Shlomi (ed). Beyond Resource Wars: Scarcity, Environmental Degradation, and International Cooperation. Cambridge: MIT Press, 2011, p. 3-22.

ESTADOS UNIDOS. Corte do Nono Circuito, n. 90-16581 (929 F.2d 1449) (9th Cir. April 11, 1991), disponível em: http://bit.ly/1GTWrjc, acesso em: 15 fev. 2015.

FRANK, David J. The Social Bases of Environmental
Treaty Ratification, 1900-1990. Sociological Inquiry, v. 69, n. 4, p. 523-550, 1999.

GOLDENBERG, Jose. The Road to Rio. In: KELLÉN, Bo; MINTZER, Irving M.; LEONARD, J. Amber; CHADWICK, Michael (eds). Negotiating Climate Change: The Inside Story of the Rio Convention. Cambridge: Cambridge Univ. Press; Stockholm : Stockholm Environment Institute, 1994, p. 175-185.

HOBERG, George. Globalization and Policy Convergence: Symposium Overview. Journal of Comparative Policy Analysis: Research and Practice, v. 3, p. 127-32, 2001.

HOPF, Ted. The Promise of Constructivism in International Relations Theory. International Security, v. 23, n. 1, p. 171-200, 1998.

HOVI, Jon; SPRINZ, Detlef F; BANG, Guri. Why the United States did not become a party to the Kyoto Protocol: German, Norwegian and US perspectives. European Journal of International Relations, p. 1-22, 2010.

HUMAN RIGHTS WATCH. What Will Happen if Hunger Comes? Abuses against the Indigenous Peoples of Ethiopia's Lower Omo Valley, junho de 2012, disponível em: http:/ / bit.ly/1weM9sI, acesso em: 10 ago. 2014.

HUMAN RIGHTS WATCH. World Report 2013, 2013, disponível em: http://bit.ly/1E2Vmoe, acesso em: 1 mar. 2015.

HUMAN RIGHTS WATCH. World Report 2014, 2014, disponível em: http:/ / bit.ly/1kTnFzd, acesso em: 1 mar. 2015.

HVEEM, Helge. Minerals as a Factor in a Strategic Policy and Action. In: WESTING, Arthur H. (ed). Global Resources and International Conflict. Oxford: Oxford University Press, 1986, p. 55-84.

INSTITUTO BRASILEIRO DE GEOGRAFIA E ESTATÍSTICA (IBGE). Perfil dos Municípios Brasileiros: Meio Ambiente 2012. Rio de Janeiro: IBGE, 2013.

JACKSON, John H. Status of Treaties in Domestic Legal Systems: A Policy Analysis. American Journal of International Law, v. 86, p. 310-340, 1992.

IVANOVA, Maria. Designing the United Nations Environment Programme: a story of compromise and confrontation. International Environmental Agreements: Politics, Law and Economics, v. 7, n. 4, p. 337-361, 2007.

JACOBSON, Harold. Climate Change, Unilateralism, Realism and Two-Level Games. In: FORMAN, She- 
pard; STEWART, Patrick (eds.), Multilateralism and US Foreign Policy. Boulder: Lynne Rienner. 2002, p. 415-436.

KARLAGANIS, Georg et al. The elaboration of the 'Stockholm convention'on persistent organic pollutants (POPs): a negotiation process fraught with obstacles and opportunities. Environmental Science and Pollution Research, v. 8, n. 3, p. 216-221, 2001.

KELEMEN, Daniel; VOGEL, David. Trading Places: The Role of the United States and the European Union in International Environmental Politics. Comparative Political Studies, v. 20, n. 10, 2009, p.1-30.

KELLER, David R. (ed). Environmental Ethics: The Big Questions. Chichester; Malden: Wiley-Blackwell, 2010.

KIPPENBERG, Juliane; COHEN, Jane. Lives in the Balance: The Human Cost of Environmental Neglect. In: HUMAN RIGHTS WATCH. World Report 2013, 2013, p. 41-50, disponível em: http://bit.ly/15LXCUF, acesso em: 11 mar. 2014.

KOPPEN, Ida J. The Role of the European Court of Justice. In: JORDAN, Andrew (ed). Environmental Policy in the European Union. Actors, Institutions \& Processes. London: Earthscan, p. 67-86, 2005.

LAGO, André A. C. Estocolmo, Rio, Joanesburgo: o Brasil e a Três Conferências Ambientais das Naçôes Unidas. Brasília: Instituto Rio Branco/FUNAG, Fundação Alexandre de Gusmão, 2007.

LEE, Francis LF. Internet, Citizen Self-Mobilisation, and Social Movement Organisations in Environmental Collective Action Campaigns: Two Hong Kong Cases. Environmental Politics, p. 1-18, 2014.

LEEDS, Brett A. Domestic Political Institutions, Credible Commitments, and International Cooperation. American Journal of Political Science, v. 43, n. 4, p. 9791002, 1999.

LEVIN, Geoffrey W. Levin, The Environment and Trade: A Multilateral Imperative, Minnesota. Journal of Global Trade, v. 1, p. 231-267, 1992.

LIN, Albert C. Fracking and Federalism: A Comparative Approach to Reconciling National and Subnational Interests in the United States and Spain. Environmental Law, v. 44, p. 1039-1219, 2014.

LINDBLOM, Charles A; WOODHOUSE, Edward J. The Policy Making Process. Englewood Cliffs: Prentice Hall, 1993.
LUCAS, Robert EB; WHEELER, David; HET'TIGE, Hemamale. Economic Development, Environmental Regulation, and the International Migration of Toxic Industrial Pollution, 1960-88. World Bank Publications, 1992.

MARTINS, Clitia Helena B. et al. Da Rio-92 à Rio+ 20: Avanços e Retrocessos da Agenda 21 no Brasil. Indicadores Econômicos FEE, v. 42, n. 3, p. 97-108, 2015.

MERON, Theodor. On a hierarchy of international human rights. American Journal of International Law, v. 80, p. $1,1986$.

MEYER, John; FRANK, David J.; HIRONAKA, Ann, SCHOFER, Evan; TUMA, Nancy. The Structuring of a World Environmental Regime, 1870-1990. International Organization, v. 51, p. 623-651, 1997.

MOTTA, Thalita L. Um Panorama Jurisprudencial da Proteção do Direito Humano ao Meio Ambiente Ecologicamente Equilibrado no Sistema Interamericano de Direitos Humanos. Veredas do Direito, v. 6, n. 12, p. 9-24, 2009.

MOWBRAY, Alastair. The Creativity of the European Court of Human Rights. Human Rights Law Review, v. 5, n. 1, p. 57-79, 2005.

MUSGRAVE, R. Kenton; STEPHENS, Garland. GATT-Tuna Dolphin Dispute: An Update, The. Natural Resources Journal, v. 33, p. 957-975, 1993.

NEUHAUS, Eesther; BORN, Rubens H. Governança Ambiental Internacional: Perspectivas, Cenários e Recomendações. Brasilia/São Paulo: Fórum Brasileiro de Ongs e Movimentos Sociais para o Meio Ambiente e o Desenvolvimento, 2007, disponível em: http://bit.ly/1Gu8N3X, acesso em: 5 fev. 2015.

O'CONNELL, Mary E. Using Trade to Enforce International Environmental Law: Implications for United States Law. Global Legal Studies Journal, V. 1 ,1994, p. 273291.

O'LEARY, Rosemary. The Impact of Federal Court Decisions on the Policies and Administration of the U.S. Enviornmental Protection Agency. Administrative Law Review, v. 41, n. 4, 1989, p. 549-574.

ORGANIZAÇÃO DAS NAÇÕES UNIDAS. Conselho de Direitos Humanos. 19a. Sessão. A/HRC/ RES/19/10, 19/4/2012, disponível em: http://bit. ly/1FrWGRi, acesso em: 15 fev. 2014.

ORGANIZAÇÃO DAS NAÇÕES UNIDAS. Con- 
selho de Direitos Humanos. Country Mandates. 2012. Disponível em: http://bit.ly/192ZgmW, acesso em: 29 mar. 2014.

ORGANIZAÇÃO DAS NAÇÕES UNIDAS. Programa das Nações Unidas para o Meio Ambiente - PNUMA. Disponível em: < http://bit.ly/1Wu1rB9>. Acesso em: 15.fev.2015.

ORGANIZAÇÃO MUNDIAL DO COMÉRCIO. 2015. Chronological List of Disputes Cases, atualizado em 2/2/2015, disponível em: http://bit.ly/1BTZ1pk, acesso em: 11 mar. 2015.

ORGANIZAÇÃO MUNDIAL DO COMÉRCIO. Malásia, Indonésia versus Estados Unidos, Julgamento final em 19/9/2001, disponível em: http://bit.ly/1Gs2U7m, acesso em: 5 fev. 2015.

ORGANIZAÇÃO MUNDIAL DO COMÉRCIO. Marrakesh Agreement Establishing WTO, 15/4/1995, disponível em: http://bit.ly/1wgdiM2, acesso em: 03 fev.2015.

ORGANIZAÇÃO MUNDIAL DO COMÉRCIO. Mexico versus Estados Unidos - Caso Golfinho - Atum I, julgado em 3/9/1991, disponível em: http://bit. ly/1x1Y0FG, acesso em: 11 nov. 2014.

ORGANIZAÇÃO MUNDIAL DO COMÉRCIO. Mexico versus US - Caso Atum II, julgado em setembro 2014, disponível em: http:/ / bit.ly/1G8FkJt, acesso em: 5 mar. 2015.

ORGANIZAÇÃO MUNDIAL DO COMÉRCIO. U.E. versus Brasil, Julgamento final em 7/12/2007, disponível em: http://bit.ly/1x292L6, acesso em: 5 fev. 2015.

ORGANIZAÇÃO MUNDIAL DO COMÉRCIO. Venzuela, Brazil versus US: Gasoline, Case n. 2 and 4, julgado em 20/5/1996, disponível em: http://bit. ly/1DTtT5K, acesso em: 11 fev. 2015.

PIFFER, Carla. Comércio Internacional e Meio Ambiente: A OMC como Locus de Governança Ambiental. Veredas do Direito, v. 8, n. 15, p. 111-132, 2011.

PRESTOWITZ, Clyde. Rogue Nation. New York: Basic Books, 2003.

ROBERTS, J. Timmons, PARKS, Bradley; VASQUEZ, Alexis. Who Ratifies Envi- ronmental Treaties and Why? Global Environmental Politics, v. 4, n. 3, p. 22-64, 2004.

ROSENBAUM, Walter A. Environmental Politics and Po- licy. Washington, D.C.: Sage, 2014.

SAMPAIO, Jose Adercio L. A Constituição Reinventada pela Jurisdição Constitucional. Belo Horizonte: Del Rey, 2002.

SAMPAIO, José Adércio L. Constituição e Meio Ambiente na Perpectiva do Direito Constitucional Comparado. In SAMPAIO, José Adércio L.; WOLD, Chris; NARDY, Afrânio. Princípios de Direito Ambiental na Dimensão Internacional e Comparada. Belo Horizonte: Del Rey, 2003, p. 37-115.

SAMPAIO, José Adércio L. Da Cláusula do Não Retrocesso Social à Proibição de Reversibilidade Socioambiental. In: ANJOS FILHO, Robério N. (org). Direitos Humanos e Direitos Fundamentais: Diálogos Contemporâneo. Salvador: Juspodium, 2013.

SCARDUA, Fernando P; BURSZTYN, Maria A. Almeida. Descentralização da política ambiental no Brasil. Sociedade e Estado, v.18, n.1-2, p. 291-314, 2003.

SCHREURS, Miranda. Global Environment Threats in a Divided Northern Community. International Environmental Agreements, v. 5, p. 349-376, 2005.

SEK, Lenore. The World Trade Organization: Background in Issues. In BABKINA, A. M. (ed). World Trade Organization: Issues and Bibliography. Huntington: Nova Science Publ. 2000, p. 7-14.

SHAW, Sabrina. Trade and Environment in W'TO. In BRACK, Duncan (ed). Trade and Environment: Conflict Or Compatibility. London; New York: Routledge, 2013, p. 140-147.

SHELTON, Dinah. Human Rights, Health and Environmental Protection: Linkages in Law and Practice. Health and Human Rights Working Paper Series, v. 1, p. 3-24, 2002.

SHELTON, Dinah. Environmental rights and Brazil's obligations in the Inter-American human rights system. George Washington Int'l Law Review, v. 40, p. 733-777, 2008.

SILVA, José Irivaldo A. O. Ecologização de Megaprojetos Hídricos: O Caso da Transposição do Rio São Francisco. Agua y Territorio, v. 1, n. 4, p. 59-69, 2014.

SILVA, Mayane Bento; HERREROS, Mário Miguel Amin Garcia; BORGES, Fabricio Quadros. Análise dos Aspectos Econômicos e Socioambientais no Projeto Hidrelétrico Belo Monte, Pará, Revista de Ciências Ambientais, v. 8, n. 1, p. p. 15-27, 2014. 
SIMMONS, Beth A. ; ELKINS, Zachary. The Globalization of Liberalization: Policy Diffusion in the International Political Economy. American Political Science Review, v. 98, p. 171-189, 2004.

SOUZA, Celina. Federalismo e Gasto Social no Brasil: Tensões e Tendências. Revista Lua Nova, v. 52, p. 5-28, 2001.

SPETH, James G. Environmental Failure: $A$ Case for the New Green Politics. Environment360, 20/10/2008, disponível em: http://bit.ly/1KDMVGx, acesso em: 5 nov. 2014.

SPRINZ, Detlef; VAAHTORANTA, Tapani. The Interest-Based Explanation of International Environmental Policy. International Organization, v. 48, n. 1, p. 77-105, 1994.

STEPHENS, Tim. International Courts and Environmental Protection. Cambridge; New York: Cambridge University Press, 2009.

SUSSKIND, Lawrence. Environmental Diplomacy; Negotiating More Effective Global Agreements. Oxford: Oxford University Press, 1994.

TOCQUEVILle, Alexis. A Democracia na América. Trad. Eduardo Brandão. Vol. II. São Paulo: Martins Fontes, 2000.

VILANI, Rodrigo M.; MACHADO, Carlos José S. Justiça social e ambiental: reflexão sobre os megaeventos esportivos no Rio de Janeiro. Sustentabilidade em Debate, v. 5, n. 3, p. 245-264, 2014.

WÆVER, Ole. Four Meanings of International Society: A Trans-Atlantic Dialogue. International Society and the Development of International Relations Theory, v. 2, p. 80144, 1998

WATSON, James. The WTO and the Environment: Development of Competence beyond Trade. New York: Routlege, 2013.

WILLIAMS III, Robertson C. Growing State-Federal Conflicts in Environmental Policy: The Role of MarketBased Regulation. Journal of Public Economics, v. 96, 2012, p. 1092-1099.

VARELLA, Marcelo D. O Acúmulo de Lógicas Distintas no Direito Internacional: Conflitos entre Comércio Internacional e Meio Ambiente. In: SHIMADA, Sandra A. et al (org.). Desafios do Direito Ambiental no Século XXI. Estudos em Homenagem a Paulo Affonso Leme Machado. São Paulo: Malheiros, 2005.

VISENTIN, M. Alice Dias Rolim. Acesso ao Recursos Genéticos, repartição de Benefícios e propriedade intelectual: A conservação da Biodiversidade e os direitos de patentes. Revista Veredas do Direito, Belo Horizonte, n. 17, v. 09, p.163-179, jan/jun, 2012.

ZIMMERMANN, Joseph F. Contemporary American Federalism: The Growth of National Power. Albany, State University of New York Press, 2008. 


\section{Normas Editoriais}

1. Serão aceitas colaborações inéditas e a publicação de um artigo está condicionada à sua adequação às normas editoriais, e seu simples recebimento desobriga a sua publicação. Revista de Direito Internacional classificará as colaborações de acordo com as seguintes seções:

1.1 Artigos: compreende textos que contenham relatos completos de estudos ou pesquisas concluídas, matérias de caráter opinativo, revisões da literatura e colaborações assemelhadas.

1.2 Resenhas: compreende análises críticas de livros, de periódicos recentemente publicados, dissertações e teses.

2. Excepcionalmente, a comissão editorial poderá aceitar a submissão de trabalhos que já tenham sido publicados e caso isso ocorra, serão submetidos ao mesmo processo de avaliação pelos pares que aqueles inéditos. $\mathrm{O}$ autor deverá apresentar autorização por escrito do editor da revista na qual seu trabalho tenha sido originalmente publicado, acompanhado de cópia do mesmo.

3. O processo de avaliação dos artigos e resenhas compreende duas fases: a primeira destinada à análise da adequação do trabalho à linha editorial da revista (Comissão Editorial) e a segunda referente à avaliação do conteúdo e qualidade dos trabalhos. Esta segunda fase é realizada mediante o processo de avaliação pelos pares, ou seja, os artigos serão submetidos à aprovação de no mínimo 2 pareceristas adhoc.

4. Os trabalhos serão enviados para a avaliação sem a identificação de autoria

5. Os trabalhos devem ser enviados no seguinte padrão:

$1^{a}$ Página: Começar com o título do título do trabalho, seguido do texto. Não inseriro nome dos autores ou outros elementos queidentifiquem a autoria. A autoria do artigo e a qualificação dos autores são inseridas nos campos específicos do formulário eletrônico. O objetivo aqui é garantir uma avaliação cega por pares. Os textos deverão ser digitados em Arial 12, espaço 1,5 margem de 2,5 $\mathrm{cm}$, numeração arábica das páginas no ângulo superior direito, em programa compatível com o World para Windows.

Título do trabalho: o título deve ser breve e suficientemente específico e descritivo para representar o conteúdo do texto e deverá ter a sua tradução para o inglês.

Resumo: em todos os artigos submetidos deve ser incluído um resumo informativo com o máximo de 250 palavras e espaço entre linhas simples. O resumo deve ser estruturado com as seguintes informações:

Objetivo do artigo (obrigatório);

Metodologia (obrigatório);

Conclusões (obrigatório);

Limitações da pesquisa e suas implicações (se aplicável);

Limitações práticas (se aplicável)

Originalidade ou valor (obrigatório); 
Destacar no mínimo três e no máximo seis palavraschave que representem o conteúdo do texto. O resumo e as palavras-chave deverão ter a sua tradução para o inglês.

Agradecimentos: agradecimentos a auxílios recebidos para a elaboração do trabalho deverão ser mencionados no final do artigo.

Notas: notas referentes ao corpo do artigo deverão vir no rodapé do texto.

Apêndices: apêndices podem ser empregados no caso de listagens extensivas, estatísticas e outros elementos de suporte.

Materiais gráficos: fotografias nítidas e gráficos (estritamente indispensáveis à clareza do texto) poderão ser aceitos e cada fotografia ou gráfico deverá vir no texto e além disso cada um deverá ser enviado em arquivo separado. Se as ilustrações enviadas já tiverem sido publicadas, mencionar a fonte e a permissão para reprodução.

Quadros: os quadros deverão ser acompanhados de cabeçalho que permita compreender o significado dos dados reunidos, sem necessidade de referência ao texto. Assinalar, no texto, pelo seu número de ordem, os locais onde os quadros devem ser intercalados.

Referências: as referências redigidas segundo a norma NBR 6023/2002 da Associação Brasileira de Normas Técnicas (ABNT), deverão ser apresentadas por ordem alfabética e constituir uma lista única no final do artigo. A exatidão e adequação das referências a trabalhos que tenham sido consultados e mencionados no texto do artigo são da responsabilidade do autor. Informações procedentes de comunicação pessoal, de trabalhos em andamento ou não publicados não devem ser incluídas na lista de referências, mas indicada em nota de rodapé.

Não utilizar o sistema Autor data para citações. O formato utilizado pela revista é o sistema numérico, onde a citação é indicada por número sobrescrito e a referência mencionada em nota de rodapé.

Recomendações: recomenda-se que se observem as normas da ABNT referentes à apresentação de artigos em publicações periódicas (NBR 6022/2002), apresen- tação de citações em documentos (NBR 10520/2002), apresentação de originais (NBR 12256), norma para datar (NBR 892), numeração progressiva das seções de um documento (NBR 6024/2003) e resumos (NBR $6028 / 2003)$.

A revista se reserva o direito de efetuar nos originais alterações de ordem normativa, ortográfica e gramatical, com vistas a manter o padrão culto da língua, respeitando, porém, o estilo dos autores.

A partir de 2009, consideramos útil formular algumas sugestões (não obrigatórias) aos autores, com base nos principais motivos por recusa de artigos nos anos anteriores.

7. Com a publicação do artigo o autor receberá cinco exemplares da revista. No caso de resenha o autor receberá dois exemplares.

8. Responsabilidades e conflitos de interesse: A responsabilidade pelas informações e opiniões indicadas nos artigos é exclusiva dos autores. Eventuais conflitos de interesse serão de responsabilidade dos próprios autores e não do periódico.

\section{Envio dos trabalhos:}

1. Os trabalhos deverão ser enviados para a equipe editorial da revista no endereço eletrônico www.rdi.uniceub.br

2. Cada autor deve enviar declaração de responsabilidade nos termos abaixo:

“Eu XXXX certifico que participei da concepção do trabalho tornar pública minha responsabilidade pelo seu conteúdo, que não omiti quaisquer ligações ou acordos de financiamento entre os autores e companhias que possam ter interesse na publicação deste artigo."

3. Para as colaborações inéditas, cada autor deve enviar a transferência de direitos autorais nos termos abaixo:

"Eu XXXX declaro que em caso de aceitação do artigo inédito, a Revista de Direito Internacional passa a ter os direitos autorais a ele referentes. 
V. 12, n.2 